\title{
Hanford Waste Vitrification Plant Technical Manual
}
D. E. Larson, Editor
R. A. Watrous
O. L. Kruger
J. L. Nelson
L. A. Fort
S. O. Bates

A. J. Schmidt

M. R. Elmore

M. E. Peterson

R. D. Scheele

R. K. Nakoka

S. M. Barnes

J. M. Perez

R. A. Brouns

G. J. Sevigny

J. L. Scott

R. W. Goles

Flour Technology

March 1996

Prepared for

the U.S. Department of Energy

under Contract DE-AC06-76RLO 1830

Pacific Northwest National Laboratory

Richland, Washington 99352 



\section{Hanford Waste Vitrification Plant Technical Manual}
D. E. Larson, Editor
A. J. Schmidt
M. R. Elmore
R. A. Watrous
M. E. Peterson
R. D. Scheele
O. L. Kruger
R. K. Nakaoka
S. M. Barnes
J. L. Nelson
J. M. Perez
R. A. Brouns
L. A. Fort
G. J. Sevigny
J. L. Scott
S. O. Bates
R. W. Goles
Flour Technology

March 1996

Prepared for

the U.S. Department of Energy

under Contract DE-AC06-76RLO 1830

Pacific Northwest National Laboratory

Richland, Washington 99352 



\section{DISCLAIMER}

This report was prepared as an account of work sponsored by an agency of the United States Government. Neither the United States Government nor any agency thereof, nor Battelle Memorial Institute, nor any of their employees, makes any warranty, express or implied, or assumes any legal liability or responsibility for the accuracy, completeness, or.usefulness of any information, apparatus, product, or process disclosed, or represents that its use would not infringe privately owned rights. Reference herein to any specific commercial product, process, or service by trade name, trademark, manufacturer, or othenwise does not necessarily constitute or imply its endorsement, recommendation, or favoring by the United States Government or any agency thereof, or Battelle Memorial Institute. The views and opinions of authors expressed herein do not necessarily state or reflect those of the United States Government or any agency thereof.

\section{PACIFIC NORTHWEST NATIONAL LABORATORY operated by \\ BATTELLE \\ for the \\ UNITED STATES DEPARTMENT OF ENERGY under Contract DE-AC06-76RLO 1830}

Printed in the United States of America

Available to DOE and DOE contractors from the

Office of Scientific and Tecrnical Information, P.O. Box 62, Oak Ridge, TN 37831;

prices, available from (615) 576-8401.

Available to the public from the National Technical Information Service, U.S. Departmest of Commerce, 5285 Port Royal Rd., Springtield, VA 22161 


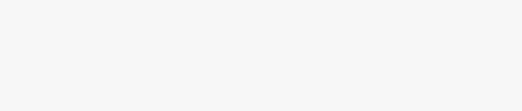




\section{PREFACE}

The December 1987 edition of the Hanford Waste Vitrification Plant Technical Manual (HWVP-88-V110205A) has been updated. The following sections were revised:

- 4.1 Waste Form Development

- 4.3 Feed Preparation

- 4.5 Melter/Turntable

- 4.6 Melter off Gas

- 4.7 Equipment Construction Materials (new section).

In addition, Appendix A, HWVP Process Stream Chemical Compositions and Properties, and Appendix C, PNL Melter Off-Gas Treatment Development Data, were revised. Appendix B, Ruthenium Properties and Decontamination Properties, was replaced with a new appendix, Glass Electrical Conductivity Constraints. 


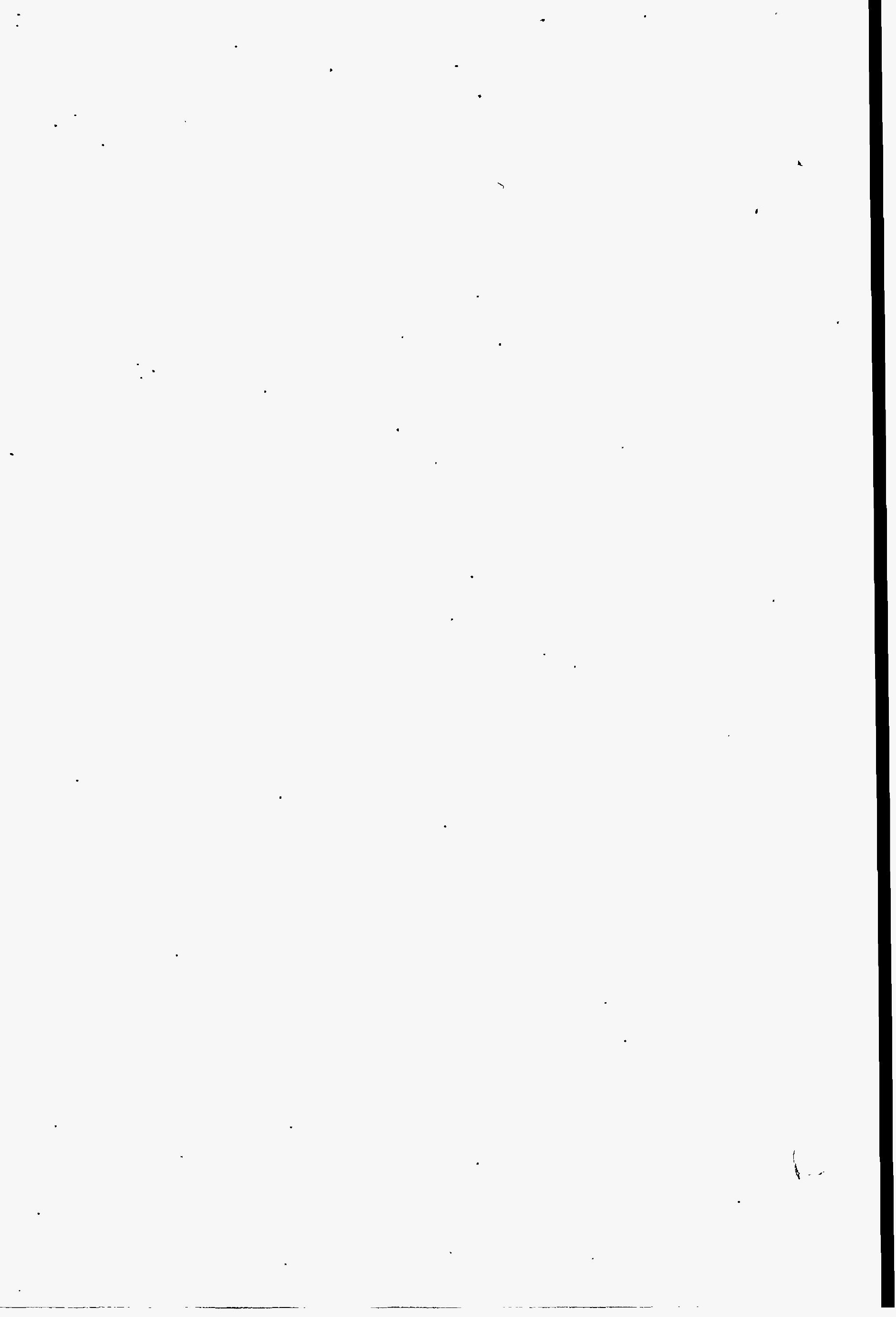




\section{ACKNOWLEDGMENTS}

Primary contributors to the technical manual are as follows:

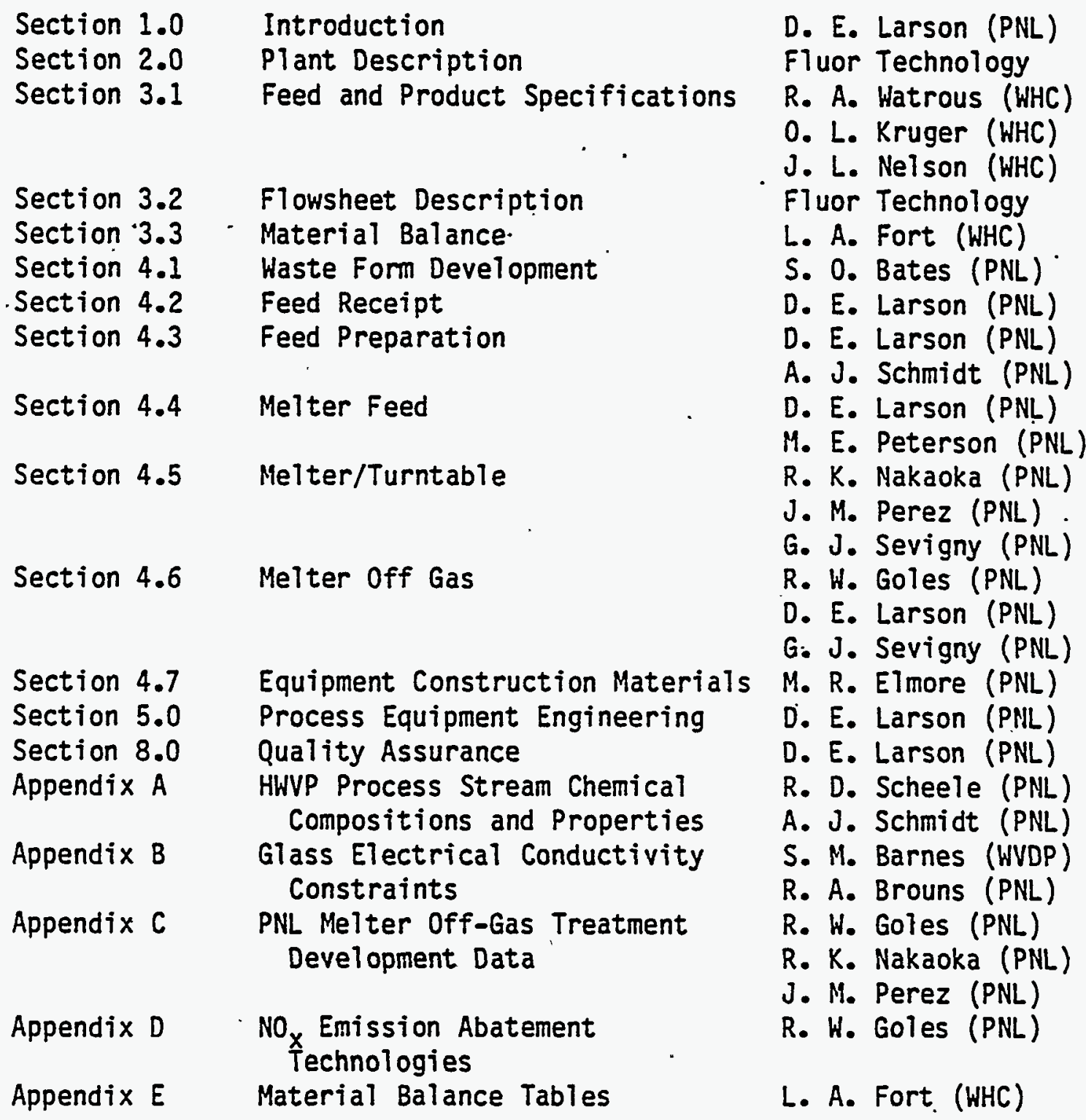

The technical and editorial input of the following people contributed substantially to the content and quality of this manual:

J. L. Scott (WHC)

0. L. Kruger (WHC) 
- The following document production staff at PNL are gratefully acknowledged for their contributions to this manual:

$$
\begin{aligned}
& \text { D. K. Hilliard, Editor } \\
& \text { S. C. Cozad, Word Processor } \\
& \text { K. K. Chase, Word Processor }
\end{aligned}
$$




$\begin{array}{ll}\text { AA } & \text { atomic absorption } \\ \text { AES } & \text { Auger electron spectroscopy } \\ \text { AFF } & \text { Aromatic Flavors and Fragrances, Inc. } \\ \text { ALARA } & \text { as low as reasonably achievable } \\ \text { CAW } & \text { current acid waste } \\ \text { CC } & \text { complexant concentrate } \\ \text { CCTV } & \text { closed circuit television } \\ \text { CDC } & \text { canister decontamination cell } \\ \text { CDMC } & \text { contact decontamination and maintenance cell } \\ \text { COD } & \text { chemical oxygen demand } \\ \text { CPC } & \text { chemical praocess cell } \\ \text { CRW } & \text { coating removal waste } \\ \text { CVS } & \text { composition variability study } \\ \text { D\&D } & \text { decontamination and decommissioning } \\ \text { DBA } & \text { design basis accident } \\ \text { DCS } & \text { distributed control system } \\ \text { DF } & \text { decontamination factor } \\ \text { DOE } & \text { Department of Energy } \\ \text { DOE-RL } & \text { DOE-Richland Operations Office } \\ \text { DSC } & \text { differential scanning calorimetry } \\ \text { DST } & \text { double-shell tank } \\ \text { DWPF } & \text { Defense Haste Processing Facility } \\ \text { DWTT } & \text { decontamination waste treatment tank } \\ \text { E\&I } & \text { electrical and instrument } \\ \text { ESCII } & \text { Engineering-Scale Ceramic Melter } \\ \text { EVS } & \text { ejector/venturi scrubber } \\ \text { ETF } & \text { Engineering Test Facility } \\ \text { FAVC } & \text { formic acid vent condenser } \\ \text { FAVH } & \text { formic acid vent header } \\ \text { FC } & \text { film cooler } \\ \text { FPO } & \text { fission product oxides } \\ \end{array}$




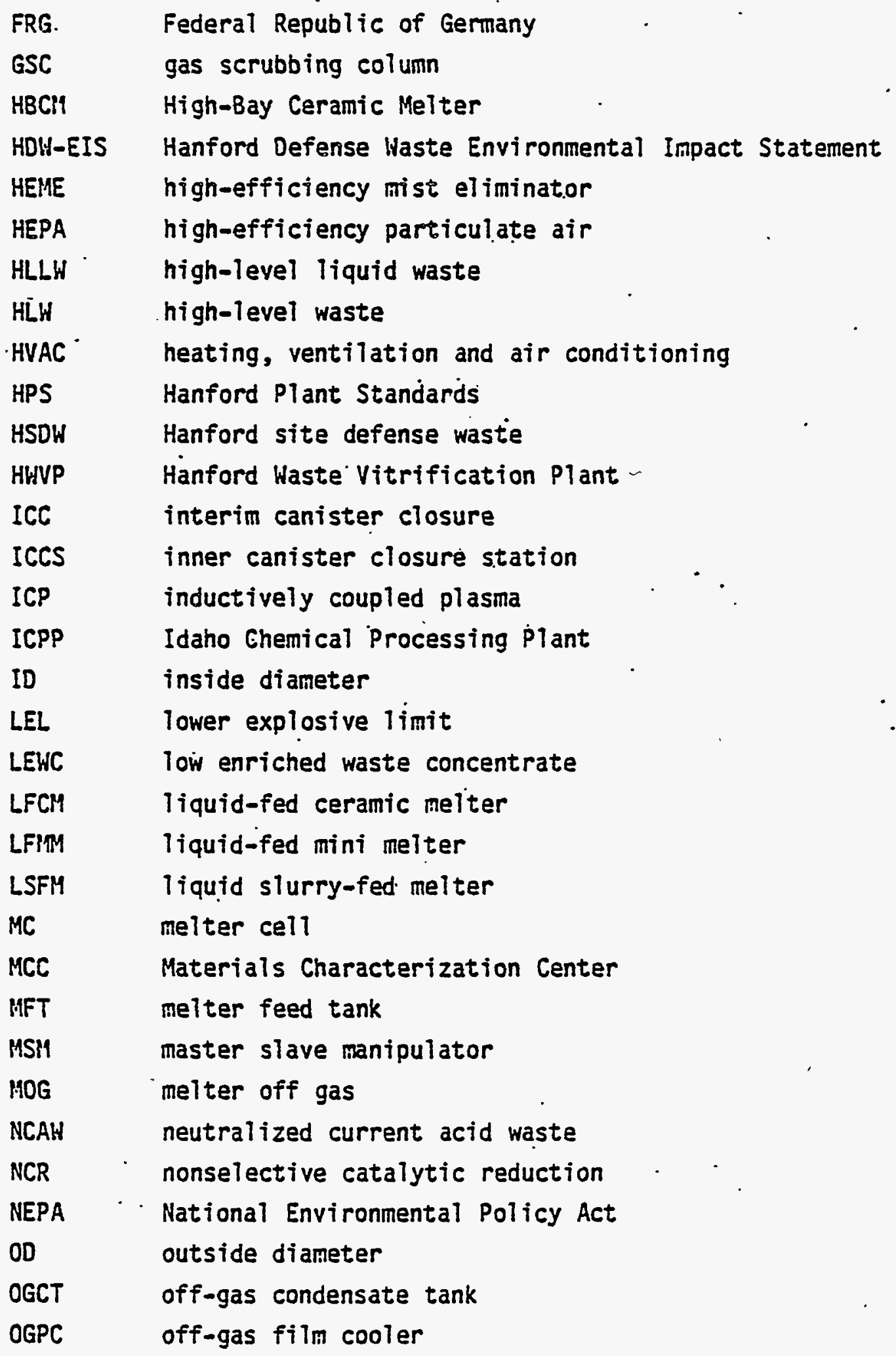




$\begin{array}{ll}\text { PAT } & \text { phosphoric acid treated } \\ \text { PCU } & \text { pound centigrade unit } \\ \text { P\&ID, } & \text { piping and instrumentation diagram } \\ \text { PDC } & \text { preliminary decontamination chamber } \\ \text { PFP } & \text { Plutonium Finishing Plant } \\ \text { PNL } & \text { Pacific Northwest Laboratory } \\ \text { PSCM } & \text { Pilot-Scale Ceramic Melter } \\ \text { RCT } & \text { recycle collection tank } \\ \text { RDCT } & \text { regulated drains collection tank } \\ \text { REDC } & \text { remote equipment decontamination cell } \\ \text { RLFS } & \text { recirculation loop feed system } \\ \text { RLFCM } & \text { Radioactive Liquid Fed Ceramic Melter } \\ \text { RLST } & \text { receipt and lag storage tank } \\ \text { RPL } & \text { RSL program language } \\ \text { RPWCT } & \text { radioactive process waste collection treatment } \\ \text { RSDA } & \text { relative standard deviation for analysis } \\ \text { RSDS } & \text { relative standard deviations for sampling } \\ \text { RST } & \text { receiving and storage tank } \\ \text { SAS } & \text { steam atomizing scrubber } \\ \text { SA } & \text { ratio of surface area to volume } \\ \text { SBS } & \text { submersed bed scrubber } \\ \text { SCR } & \text { selective catalytic reduction } \\ \text { SEM } & \text { scanning electron microscopy } \\ \text { SFHT } & \text { spent frit hold tank } \\ \text { SHT } & \text { slurry hold tank } \\ \text { SIB } & \text { siliceous insulation brick } \\ \text { SME } & \text { slurry mix evaporator } \\ \text { SMECT } & \text { slurry mix evaporator condensate tank } \\ \text { SNR } & \text { selective noncatalytic reduction } \\ \text { SPA } & \text { special pump alloy } \\ \text { SPTF } & \text { Slurry Pump Test Facility } \\ \text { SRAT } & \text { slurry receipt and adjustment tank } \\ \text { SRL } & \text { Savannah River Laboratory } \\ & \end{array}$




$\begin{array}{ll}\text { SS } & \text { site specific } \\ \text { SS } & \text { stainless steel } \\ \text { SST } & \text { single-shell tank } \\ \text { ST } & \text { scrubber tank } \\ \text { STS } & \text { smear test station } \\ \text { TOSF } & \text { Savannah River waste - formated } \\ \text { TOSM } & \text { Savannah River waste - modified } \\ \text { TMA } & \text { thermomechanical analysis } \\ \text { TO } & \text { total oxide } \\ \text { TOC } & \text { total organic carbon } \\ \text { TRU } & \text { transuranic } \\ \text { TIT } & \text { time-temperature transformation } \\ \text { UPS } & \text { uninterruptible power supply } \\ \text { VCC } & \text { vertical cantilevered-shaft centrifugal } \\ \text { WVS } & \text { vessel vent system } \\ \text { WAC } & \text { waste acceptance comittee } \\ \text { HAC } & \text { waste acceptance criteria } \\ \text { WAPS } & \text { waste acceptance preliminary specifications } \\ \text { WAS } & \text { Waste Acceptance Specifications } \\ \text { WCF } & \text { Waste Calcining Facility } \\ \text { WCP } & \text { Waste form compliance plan } \\ \text { WFD } & \text { waste form development } \\ \text { WFQ } & \text { waste form qualification } \\ \text { WFQP } & \text { waste form qualification plan } \\ \text { WQR } & \text { waste form qualification report } \\ \text { WSEP } & \text { waste solidification engineering program } \\ \text { WTC } & \text { weld test cell } \\ \text { WVDP } & \text { West Valley Demonstration Project } \\ \text { WVSP } & \text { West Valley Support Project } \\ \text { WO } & \text { waste oxides } \\ \text { XRD } & \text { x-ray diffraction } \\ \text { XRF } & \text { x-ray fluorescence } \\ \end{array}$




\section{CONTENTS(a)}

1.0 INTRODUCTION

1.1 BACKGROUND .................. 1-1

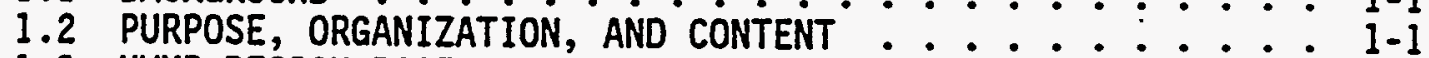

1.3 HWVP DESIGN BASES ..................... 1 . . . . 1 .

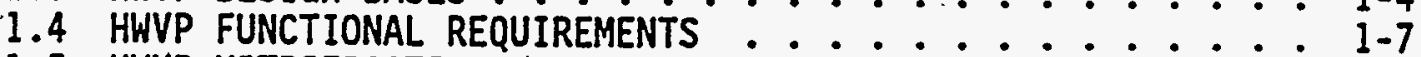

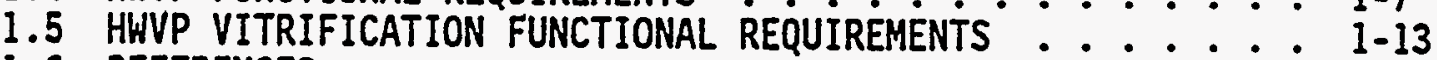

1.6 REFERENCES .................... 1 . . 122

2.0 HWVP PLANT DESCRIPTION

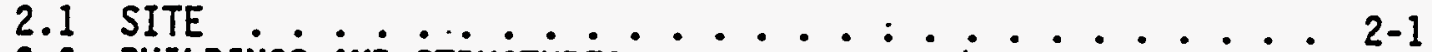

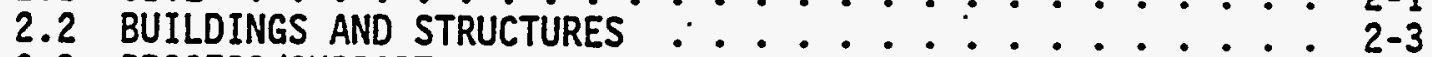

2.3 PROCESS/SUPPORT EQUIPMENT .............. 2-. 2 . . . . . .

3.0 PROCESS DESCRIPTION

3.1 FEED AND PRODUCT SPECIFICATIONS . . . . . . . . . 3-1

3.2 FLOWSHEET DESCRIPTION ................... $3-35$

3.3 MATERIAL BALANCE ................... $3-50$

3.4 PROCESS TIME CYCLE (Future Inciusion) ........ $3-54$

3.5 REFERENCES .................. $3-57$

4.0 PROCESS EQUIPMENT AND TECHNOLOGY

4.1 HASTE FORM DEVELOPMENT . . . . . . . . . . . 4.1-1

REFERENCES .............................. 4.108

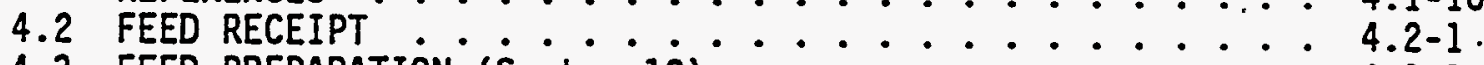

4.3 FEED PREPARATION (System 12) . . . . . . . . . . . . . . . . . .

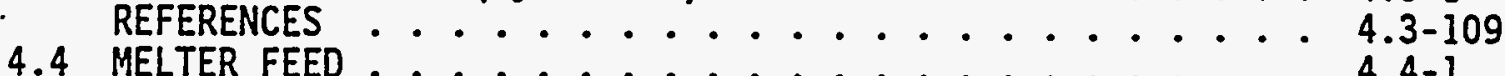

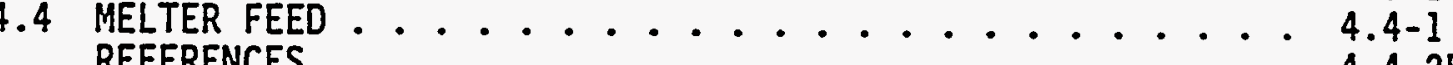

4.5 MELTER/TURNTABLE $($ System 13 ) * * . . . . . . . 4.4-25

REFERENCES ....................... . . . $4.5-75$

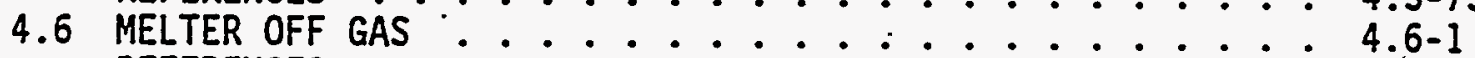

REFERENCES ..................... 4.6-154

4.7 EQUIPMENT CONSTRUCTION MATERIALS . . . . . . . . . . . . $4.7-1$

REFERENCES .................. 4...7-65

4.8 VESSEL VENT (System 15) . . . . . . . . . . . .

4.9 RADIOACTIVE PROCESS WASTE COLLECTION AND TREATMENT

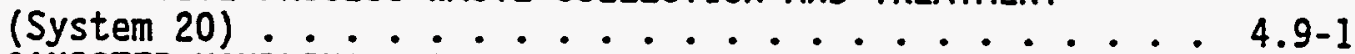

4.10 CANISTER HANDLING AND INSPECTION (System 23) . . . . $4.10-1$

4.11 CANISTER CLOSURE (System 17) . . ........... . 4.11-1

4.12 CANISTER DECONTAMINATION (System 16) . . . . . . . . 4.12-1

4.13 INTERIM CANISTER STORAGE (System 18) . . . . . . . . . . 4.13-1

4.14 CANISTER LOADOUT (System 19) .............. . . . . . . . . . .

4.15 CHEMICAL MAKEUP AND TRANSFER (Systems 54 and 58) . . . 4.15-1

4.16 HWVP VENTILATION ................. 4.16-1

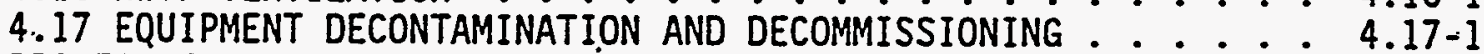

5.0 PROCESS EQUIPMENT

5.1 TANKS/AGITATION . . . . . . . . . . . . . 5-1

5.2 HEAT TRANSFER ..................... 5 . . . . .

(a) A detailed table of contents section is included at the beginning of each section. 
6.0 SAFETY (Future Inciusion)

7.0 HASTE FORM QUALIFICATION (Future IncTusion)

8.0 QUALITY ASSURANCE

QUALITY ASSURANCE ............ . . . . . . . .

APPENDIX A - HWVP PROCESS STREAM CHEMICAL COMPOSITIONS AND

PROPERTIES . . . . . . . . . A-1

APPENDIX B - GLASS ELECTRICAL CONDUCTIVITY CONSTRAINTS . . . . B-I

APPENDIX $C$ - PNL MELTER OFF-GAS TREATMENT DEVELOPMENT DATA $\ldots \ldots c-1$

APPENDIX D - NO EMISSION ABATEMENT TECHNOLOGIES ........ D-1

APPENDIX E - MATERIAL BALANCE TABLES ............ E- $1 . \ldots$ 


\section{SECTION 1.0}

INTRODUCTION 



\subsection{INTRODUCTION}

\section{CONTENTS}

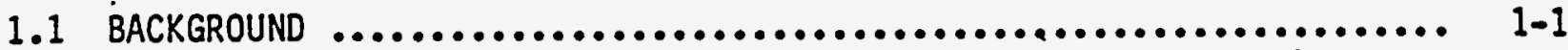

1.2 PURPOSE, ORGANIZATION, AND CONTENT $\ldots \ldots \ldots \ldots \ldots \ldots \ldots \ldots \ldots \ldots \ldots \ldots, 1-2$

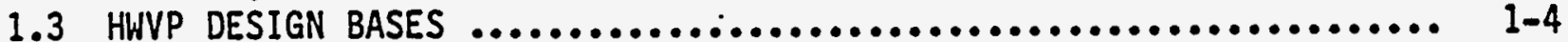

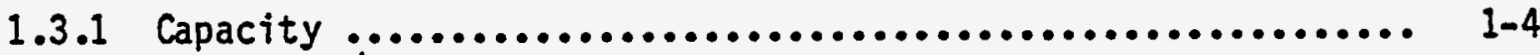

1.3.2 Feed Composition ......................................... 1-5

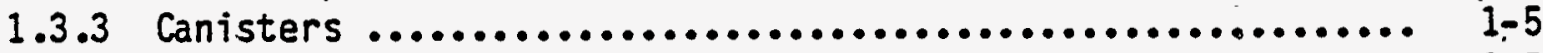

1.3 .4 Fléxibility $\ldots \ldots \ldots \ldots \ldots \ldots \ldots \ldots \ldots \ldots \ldots \ldots \ldots \ldots \ldots \ldots \ldots \ldots, 1-5$

1.3 .5 Safety .............................................. 1-6

1.4 HWVP FUNCTIONAL REQUIREMENTS $\ldots \ldots \ldots \ldots \ldots \ldots \ldots \ldots \ldots \ldots \ldots \ldots \ldots \ldots, 1-7$

1.4.1 Site Integration ..................................... 1-7

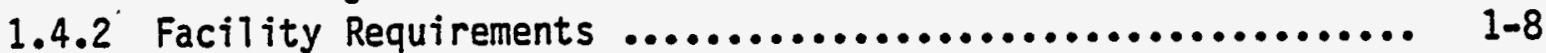

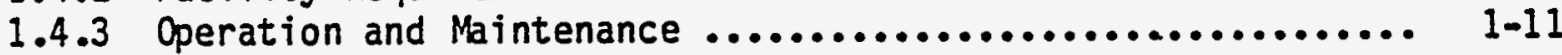

1.4.4 Decommissioning ....................................... $1-12$

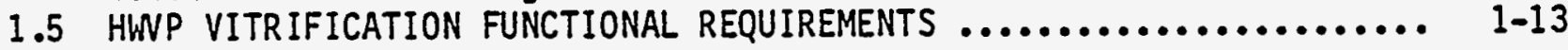

1.5.1 General ............................................ 1-13

1.5.2 System Equipment Functional Requirements $\ldots \ldots \ldots \ldots \ldots \ldots \ldots . .1$.15

1.6 REFERENCES $\ldots \ldots \ldots \ldots \ldots \ldots \ldots \ldots \ldots \ldots \ldots \ldots \ldots \ldots \ldots \ldots \ldots \ldots \ldots \ldots, 1-22$

FIGURE:

1-1 Vitrification Process Biock Diagram ..................... 1-14 

The background design bases and functional requirements of the Hanford Waste Vitrification Plant are discussed in this section. In addition, the purpose, organization, and content of the HWVP Technical Manual are presented.

\section{$1.1 \cdot$ BACKGROUND}

The U.S. Department of Energy (DOE) program to dispose of defense highlevel waste is formally described in the Defense Waste Management Plan (Ref. 1-1) submitted to Congress in 1983. This plan outlines the strategy of sequencing the disposal efforts at.the three DOE sites that have high-level waste: Savannah River, Hanford, and Idaho. Sequencing the effort will enable the Hanford Site to take advantage of the development work and operating experience gained at the Savannah River site.

A key element of the Hanford waste management strategy is the construction of a new facility, the Hanford Waste Vitrification Plant (HWVP), to vitrify existing and future liquid high-level waste produced by defense activities at the Hanford Site. The HWVP mission is to vitrify pretreated waste in borosilicate glass, cast the glass into stainless steel canisters, and store the canisters at the Hanford Site until they are shipped to a federal geological repository. The mission for the HWVP was developed as a part of the Interim Hanford Waste Management Plan (Ref. 1-2). This Hanford site-specific plan responded to general program guidance provided by the DOE in the Defense Waste Management Plan (Ref. 1-1). The Interim Hanford Waste Management Plan provides a reference $\mathrm{plan}$ for Hanford Site Defense Waste (HSDW) management for future planning purposes. Implementation of a HSDH management strategy requires awaiting a record-of-decision for the National Environmental Policy Act (NEPA) process currently in progress. The draft Environmental Impact Statement (HDW-EIS) (Ref. 1-3) has been issued, and comments are being received. The NEPA process is expected to be completed in 1987. Until then, options in the HDW-EIS are to remain open.

In the Interim Hanford Waste Management Plan, the strategy gives highest priority to double-shell tank (DST) wastes to minimize the need for new tank construction. A major objective of the waste management. program is to dispose of new wastes, such as PUREX coating removal waste (CRH) and Neutralized Current Acid Haste (NCAW), as quickly after their production as possible. DoubleShell Tank wastes include treated CRW, NCAW, Complexant Concentrate (CC), and Plutonium Finishing Plant (PFP) wastes. Single-Shell Tank (SST) waste may also become a candidate for waste vitrification. 
The annual production of the facility will be 145 to 175 canisters. The HWVP will be located in the 200 East Area of the Hanford Site, approximately 25 miles north of Richland, Washington.

The DOE Richland Operations Title II Office (RL) is requesting Plant and Capital Equipment (PACE) funding to start design in Fiscal Year (FY) 1990. Hot startup is currently targeted for FY 1999. Fluor Technology, Inc. (Fluor) of Irvine, California; selected by $D O E / R L$ as the Architect/Engineer (A/E) to perform design services, has completed a Reference Conceptual Design (RCD). An Advanced Conceptual Design (ACD) has been initiated, leading into PACE-funded preliminary design, detailed design, procurement, plant construction, and finally plant startup operations. The Preliminary Safety Analysis Report (PSAR) will be issued prior to the start of construction.

To support the HWWP design process, HWVP will establish a qualified waste form. To support the subsequent HWVP operations, a HWVP process technology must be established. The HWWP vitrification process, plant design, and overall operation of the plant are based on 20 years of vitrification process development and the design/construction at the Defense Waste Processing Facility (DWPF) in Savannah River at the West Valley Demonstration Project (WVDP), and at the Pacific Northwest Laboratory. Application of the vitrification technology being used in the United States is internationaliy known; production. plants are already in operation in Belgium and France.

The HWWP technology approach is to identify key HWVP waste form qualification (WFQ) and design issues, identify sources of applicable verification technology, and maximize the use of existing DOE vitrification technology and design resources. The HWVP issues will be resolved through technology exchange, support from other Hanford waste management programs, and a limited HWW applied technology development effort. Using DWPF and WVDP technology as a basis, HWVP applied technology efforts have established a reference Hanford pretreated high-level waste feed, borosilicate glass, vitrification flowsheet, and a data base to support detailed design. Key feed and glass properties as well as vitrification process parameters have been characterized. A preliminary waste form description and a WFQ plan have been prepared.

\subsection{PURPOSE, ORGANIZATION, AND CONTENT}

The HWVP Technical Manual (Manual) documents the technical bases of the current HWVP process and provides a physical description of the related equipment and the plant. The immediate purpose of the document is to provide the technical bases for preparation of project baseline documents that will be used to direct the Titie I and Title II design by the A/E, Fluor. Documents that will interface with the Manual include, but are not limited to 
- Hanford Waste Vitrification Plant Functional. Design Criteria

- Hanford Waste Vitrification Plant Technical Data Package

- Flowsheet.

The process, equipment, and plant descriptions included in this document are at the $90 \%$ completion status based on the latest HWVP Reference Conceptual Design Report. The technical data presented in this document have been collected through technology exchange with other vitrified waste producers, support from other Hanford waste management programs, or the HWVP applied technology development efforts. The technical data presented is current through September 1987.

This document will be updated periodically with the latiest technical information available to provide the technical bases throughout the design process. The process, equipment, and plant descriptions will also be updated to reflect the latest design information. Once the design process is complete, the purpose of the Manual will shift from a design basis document to an operational support document. As an operation support document, the Manual is intended for use in training and educating personnel unfamiliar with the process and as a reference handbook for personnel responsible for the startup and operation of the piant.

The content of the Manual is organized in the following manner.

Chapter 1.0 contains the background and context within which the HWVP was designed. An outline of the Manual is provided as a guide to the user.

Chapter 2.0 describes the site, plant, equipment and supporting services and provides the context for application of the process information in the Manual.

Chapter 3.0 provides plant feed and product requirements, which are primary process bases for plant operation. Plant process operations are described, including the reference process material balance.

Chapter 4.0 summarizes the technology for each plant process. This information is generally described by providing the following information on each major plant process: function, operational requirements, process chemistry, and technology deveropment.

Chapter 5.0 describes the engineering principles for designing major types of HWVP equipment. 
Chapter 6.0 describes the general safety aspects-of the plant and process to assist in safe and prudent facility operation. Safety areas considered include radiation protection, shielding, criticality, decontamination/ decommissioning, industrial safety, and chenical processes.

Chapter 7.0 includes a description of the waste form qualification program and data.

Chapter $\mathbf{8 . 0}$ indicates the current status of quality assurance requirements for the Manual.

The Appendices provide data that are too extensive to be placed in the main text, such as extensive tables and sets of figures.

Two systems are used for noting references. Where references are not publicly available, the reference location is noted with a lower case letter in parentheses and provided at the bottom of the page. References readily available to the pubtic are noted with a number in parentheses and included in a reference section.

Information may not be complete in some manual sections. This incomplete information will be provided in future Manual updates.

\subsection{HWVP DESIGN BASIS (Exerpt from HIVP Functional Design Criteria)(a)}

The HWVP shall be designed to vitrify pretreated Hanford defense liquid high-level and transuranic wastes using a remote process cell/canyon concept. This concept shall enable the process cells to be serviced by manipulators, incell cranes, and a canyon crane. If cell covers are provided, they shall be removable to permit access by the canyon crane.

\subsubsection{Capacity}

The facility shall be designed to achieve an average glass production rate of $100 \mathrm{lb} / \mathrm{h}$, and an annual production of $610,000 \mathrm{lb}$, based on operating $70 \%$ of the time over a 3-yr. melter life. The design shall be based on 25 wt\% waste loading in the product glass.

(a) Functional Design Criteria, Hanford Waste Vitrification PIant, Project B-595, HWV-FDC-001, Rev. 2, Rockwell Hanford Operations, Richland, Washington (1986). 


\subsubsection{Feed Composition}

The HWV shall be designed to process a reference feed. The characteristics of the feed are described in the Hanford Waste Vitrification Plant Technical Data Package. ${ }^{\text {a) }}$

\subsubsection{Canisters}

The canisters will be constructed of stainless steel. The maximum length of the canister shall be $10 \mathrm{ft}$ and the maximum diameter $2 \mathrm{ft}$. Each canister shall have a unique and permanent identification marking.

\subsubsection{Flexibility}

The design concept shall facilitate, to the extent practical, modifications required to allow the HWVP to augment and support future DOE programs.

Typically, the following flexibility features shall be provided:

- remote equipment installation and removal and the decontamination and decommissioning (D\&D) capabilities for remotely maintained equipment and facilities

- provisions for wall blanks in the process cells for future installation of shielded windows and/or manipulators

- spare pipe routings

- spare electrical wall nozzles

- capability to provide additional interim canister storage space

- spare nozzles on process vessels.

(a) HWVP Design Staff/B. K. Schroeder, Hanford Waste Vitrification Plant Technical Data Package, SD-HWV-DP-001 Rev: 2, Rockwel1 Hanford Operations, Richland, Washington (May 1986). 


\subsubsection{Safety.}

1.3.5.1 - Criticality Safety. Criticality safety, shall comply with DOE Order $5480.1 \mathrm{~A}$ (Ref. 1-4) as implemented by RHO-MA-136. (a)

1.3.5.2. Shielding. The most radioactive material described in the Technical Data Package (D) shielding requirements. to meet as low as reasonably achievable (ALARA) guidelines acfording to DOE Order 5480.1A (Ref. 1-4), DOE/EV/1830, (c) and RHO-MA-278 R.1.(d). Quantities and locations of radioactive materials shall be assumed such that the largest credible dose is the design.basis. The process streams resulting from the feed shall also be considered in the shielding calculations.

1.3.5.3 Contamination Control. Facility design features shall confine contamination to the vicinity of the source and minimize contamination spread. Containment shall be done in shielded process cells, the canyon, high-integrity process vessels, and leakproof canisters. Confinement shall be achieved by ventilation control (differential pressure), by directing air from uncontaminated areas toward areas of higher contamination, by high efficiency particulate air (HEPA) or equivalent filtration or equivalent backflow isolation, and by the use of control.7ed personnel traffic patterns. The cross-contamination of process cells by airflow shall be minimized.

1.3.5.4 Abnormal Operations. The facility design shall include provisions to monitor and alarm on detection of abnormal conditions such as radioactive particulate release, liquid and gaseous release, abnormal radiation levels, fires, and overheating or pressurization. Process and facility systems shall be designed to assure safe channeling of energy and material flows (e.g., rupture discs, seal pots, electrical ground fault detection circuitry, siphon breaks, ete.).

1.3.5.5. Design Basis Accidents. The HWVP shall be designed to withstand the effects of design basis accidents (DBA) as delineated in DOE Order 6430.1 (Ref. 1-5), without loss of containment and with confinement of radioactive and (a) Nuclear Criticality Safety Standards, RHO-MA-136, Rockwell Hanford

(b) HWVP Design Staff/B. K. Schroeder, HWVP. Technical Data Package, SD-HWV-DP-001 Rev. 2, Rockwell Hanford Operations (May 1986).

(c). A Guide for Reducing Radiation to As Low as Reasonably Achievable (ALARA),

(d) ALARA Program (As Low as Reasonably Achievable), RHO-MA-278 R.1, Rockwel1 Hanford Operations, June 19, 1985. 
toxic materials within allowable limits. Simultaneous occurrences of more than one DBA shall be considered when a joint occurrence, casually related to a common-mode failure, is possible.

1.3.5.6 Component Failure Analysis. The design shall be such that no single credible component failure will result in unacceptable safety consequences. Unacceptable safety consequences to be evaluated include the following:

- fire (other than localized minor fire such as caused by shorting of electrical equipment)

- explosion

- criticality

- instantaneous release of radioactivity from the facility in excess of 5,000 times DOE Order 5480.1A (Ref. 1-4), Chapter XI, Table II values, at point of discharge

- exposure of personnel to ionizing radiation in excess of DOE Order 5480.1A (Ref. 1-4), Chapter XI values

- exposure of personnel to toxic chemical agents in excess of ceiling threshold limit value of the American Conference of Governmental Industrial Hygienists.

The effects of component failure, including control and monitoring, and utilities failure (such as power sources, air and vacuum supplies) shall be evaluated for unacceptable consequences.

1.4 HWWP FUNCTIONAL REQUIREMENTS (Exerpt from HWVP FunctionaT Design Criteria (a)

\subsubsection{Site Integration}

The HWVP shall be located in accordance with guidelines in DOE Order 6430.1 (Ref. 1-5) and DOE-Richland Operations Office (DOE-RL) Order 4320.2B (Ref. 1-6).

(a) Functional Design Criteria, HWVP, Project B-595, HWV-FDC-001 Rev. 2, Rockwell Hanford Operations (1986). 
The site integration criteria are listed below.

1. The HWVP shall be located to permit convenient tie-in to existing railroads, roadways, utilities, and waste disposal facilities.

2. The HWVP shall be located to minimize interference with existing underground encasements and piping.

3. The following specific site factors shall be evaluated in siting the HWVP according to guidelines contained in DOE Order 6430.1 (Ref. 1-5) and DOE-RL Order 4320.2B (Ref. 1-6):

- proximity of radioactive feeds to HWVP

- utilities/site services

- HWVP process waste streams

- HWVP effiuent streams

- site interferences

- site expansion

- environmental and safety considerations

- cost.

\subsubsection{Facility Requirements}

1.4.2.1 Chemicals and Materials Receipt and Storage. The facility will have the capability to receive and store all chemicals and materials necessary to operate and maintain the plant.

1.4.2.2 Maintenance and Decontamination. Facilities shall be provided for both radioactive and nonradioactive equipment maintenance to support plant operations and to minimize facility equipment downtime. The radioactive equipment maintenance area shall be provided with appropriate decontamination facilities and shall accomodate remote and contact maintenance.

1.4.2.3 Mechanical Support. Mechanical support shall be provided as part of the facility. Such ițems as the canyon crane, process cell cranes, canister and cask loading equipment, rail facilities, and truck loading docks shall be provided to meet process and facility operation requirements.

1.4.2.4 Support Services. Support services in the form of electrical power, standby power, uninterruptible power supply (UPS) teleconmunications, compressed gases, sanitary water, raw water, sewers, and steam shall be provided as part of the facility. 
1.4.2.5 P.rocess Control. A distributed control system (DCS) shall be provided to monitor and control the facility process operations, HVAC, support services and to provide product quality control. The DCS shall have a data acquisition mode to retain a documented history of the operations. This information shall be sufficient to support product qualification requirements. This system shall involve both automatic and manual data input and control functions to provide a single operating and process control data base.

1.4.2.6 Administrative Support. Administrative support needs, including lockers, showers, and health physics areas, shall be provided to accormodate workers, Offices/work areas shall be provided for all plant support personnel including systems support, process engineering, radiation monitoring, shift administration, and maintenance personnel.

1.4.2.7 Vessel Vent System (VVS). A separate VVS shail be provided for vapors and off gas from those process vessels not served by the melter off-gas treatment system. These gases shall be collected in a common header, treated, and routed to the facility exhaust ventilation system. The VVS shall be capable of decontaminating the vapors and off gas so that component concentrations, following filtration in the facility exhaust system, shall meet requirements for stack release to an uncontrolled area as defined in RHO-MA-139. (a) The purpose of this system is to prevent hydrogen buildup in vessels due to radiolysis, decontaminate the gases for release to the facility exhaust system, and maintain a differential pressure sufficient to maintain containment. Process vessels shall be maintained at a pressure less than that of the ambient atmosphere, and backflow prevention devices shall be provided at each contaminated noncontaminated material interface boundary.

The hydrogen generation rates in the process vessels shall be calculated as part of the design process, and, if any possibility of reaching explosive concentrations exists, a monitoring and associated concentration control system shall be provided.

1.4.2.8 Heating, Ventilating and Air Conditioning (HVAC). An HVAC system or systems shall be provided to ensure safe operation of the facility. Process cells shall vent into the contaminated zone of the facility HVAC exhaust system. The HVAC system shall be designed to maintain airflow from noncontaminated to progressively more contaminated areas. Consideration shall be given to providing separate HVAC supply systems for contaminated and noncontaminated areas. The HVAC system shall meet applicable requirements in DOE Orders 6430.1 (Ref. 1-5) and 5480.1A (Ref. 1-4), and pertinent Hanford Plant Standards (HPS). (a) Environmental Protection Manual, RHO-MA-139, Rockwell Hanford Operations 
Concentrations of radionuclides at the point of release stack shall meet DOE Order 5480.1A (Ref. 1-4), Table II concentration guidelines.

1.4.2.9 Solid Haste Handling. Generation of solid wastes within the facility shall be minimized. Radioactive solid wastes generated within the facility shall be contained, decontaminated (where applicable), packaged, and stored while awaiting release to burial. On release to burial, the waste shall be transported to the 200 Area burial grounds through the HWV rail/truck unloading area. All radioactive solid waste shall be handled in accordance with the Hanford Site solid waste requirements described in RHO-MA-222. (a)

1.4.2.10 Liquid. Waste Handling. The volume of radioactive liquid waste produced as the. result of facility and processing operations shall be minimized. Where appropriate, radioactive liquid waste shall be recycied through the vitrification process. Radioactive liquid waste shall be collected, analyzed, and transferred from the facility for. further processing or storage.

1.4.2.11 Liquid Effluent Handling. Liquid effluents are the steam condensate, cooling water, chemical; and sanitary waste streams that are produced within HWYP as a result of processing activities. Liquid effluent handling systems shall be provided for handling these effluent streams. The system shall be capable of analyzing and diverting potentially contaminated effluent streams to suitable retention facilities.

Chemical wastes from HWVP shall be separated into nonhazardous and hazard-. ous waste streams. The nonhazardous chemical waste consists of caustic and acid waste streans which shall be neutralized within the HWVP facility. and routed for disposal.

The HWVP shall either chemically or thermally convert hazardous chemical wastes to nonhazardous wastes or provide all. facilities and equipment to handle, store, treat, or ship the hazardous waste to a hazardous waste storage facility for subsequent shipment to a permitted transfer, treatment, storage, or disposal facility. Hazardous chemical waste treatment and handling shall be in accordance with applicable state and federal regulations.

Hazardous chemical wastes shall be chemically or thermally converted to nonhazardous wastes or shall be loaded out for shipment to the Hanford Dangerous Waste Storage Facility for subsequent shipment to a permitted transferr,

(a) Hanford Solid Waste Packaging, Storage, and Disposal Requirements, 
treatment, storage, or disposal facility. Hazardous chemical waste treatment and handling shall be in accordance with applicable state and federal regulations.

1.4.2.12 Canister Interim Storage. A filled and decontaminated canister storage system shall be provided to perform, as a minimum, the following functions:

- Provide storage for 5 years of plant production. .

- Enable remote handling, placement, and retrieval of individual canisters.

- Provide for detection and safe recovery of failed canisters.

- Provide for canister retrieval and inspection.

- Ensure the canister glass centerline temperature does not exceed $932^{\circ} \mathrm{F}\left(500^{\circ} \mathrm{C}\right)$.

- Monitor canister cooling air for contamination and temperature.

- Provide for canister recovery, inspection, and shipment to another

- facility/repository.

- Provide a mechanism to weigh each canister before shipment.

The design shall provide for the capability to expand the storage for an additional 5 years of production.

1.4.2.13 Process Sampling Systems. Process sampling systems shall be provided for process control, accountability, diagnosis, and. waste form qualification. Analytical capability shall be provided within the HWVP to meet processing and waste form qualification requirements.

1.4.2.14 Interim Failed Equipment Storage. Space shall be provided to store failed radioactive equipment prior to removal from the facility. The space shall be sufficient to minimize adverse impact on plant operations.

\subsubsection{Operation and Maintenance}

The HWWP vitrification processing areas shall be designed for remote operation and maintenance to attain ALARA goals for personnel radiation exposure while being cost effective to operate and maintain in accordance with 
DOE Orders 6430.1.(Ref. 1-5) and 5480.1A (Ref. 1-4). In special circumstances, contact maintenance shall be provided within ALARA guidelines as stated in RHOMA-278 Rev 1. (a) Visual access shall be attained through the use of shielded viewing windows and remote controlled devices such as closed circuit television (CCTV). Equipment shall be remotely removable for decontamination, maintenance, and replacement.

\subsubsection{Decommissioning}

The design of the HWV shall facilitate decontamination so that the facility can be decommissioned at a future date. Guidance for process equip- . ment design to facilitate eventual decomissioning shall be obtained from American National Standard Institute (ANSI) N300 (Ref. 1-7). The following principles shall be employed to the extent practicable.

- Filters shall be placed as near as practical to the source of contamination to minimize contamination of ductwork.

- Areas subject to contamination shall be designed to facilitate decontamination. Liners and coatings shall be selected to withstand decontaminating agents and radiation degradation throughout the life - of the plant.

- Process cell penetrations shall be designed to minimize technical and construction problems in the structural closing and sealing of these penetrations at the time of decomissioning.

- Surfaces shall be free of crevices, ledges, and/or protrusions which could collect radioactive material.

- Penetrations shall be waterproofed for protection during decontamination efforts.

- Fixtures and outlets shall be sealed.

- Floors shall be monolithic, nonporous, and sloped toward drains.

- Drains and similar piping shall have physical provisions for cleaning.

(a) ALARA Program (As Tow as Reasonably Achievable), RHO-MA-278 Rev. 1, Rockwell Hanford Operations, June 19, 1985. 
- Piping systems shall be sloped and free of traps except as required for process isolation.

- Adequate overhead clearance shall be provided for remote transfer of equipment over installed piping.

- Aisles shall be wide enough to facilitate movement of equipment.

1.5 HWVP VITRIFICATION PROCESS FUNCTIONAL REQUIREMENTS (EXerpt from HWVP Functional Design Criteria) (a)

\subsubsection{General}

The vitrification process block flow diagram is shown in Figure 1-1 and the process functions include the following:

- feed receipt and storage

- initial feed chemical treatment and concentration

- final feed makeup and concentration

- melter feeding

- vitrification

- canister handling, filling, and cooling

- canister decontamination and inspection

- canister closure and inspection

- process off-gas treatment:

The vitrification system equipment shall include all required process tanks and components, in-cell remote piping and electrical jumpers, related instrumentation and control systems, and support equipment necessary to install the equipment in the facility. The in-cell process equipment, jumpers, and support shall be designed to allow remote installation and removal using the in-cell and/or canyon crane. Vitrification system components that may credibly have an operational life shorter than the facility life shall be designed to be remotely replaceable. The capability shall be provided to perform a preliminary decontamination, where practical, of equipment before removal. The need for ready access to components requiring frequent replacement shall be considered during design and development of vitrification process equipment. Services and utilities required to support operation of the vitrification system equipment will be provided.

(a) Functional Design Criteria, HWVP, Project B-595, HWV-FDC-001 Rev. 2, Rockwel1 Hanford Operations (1986). 


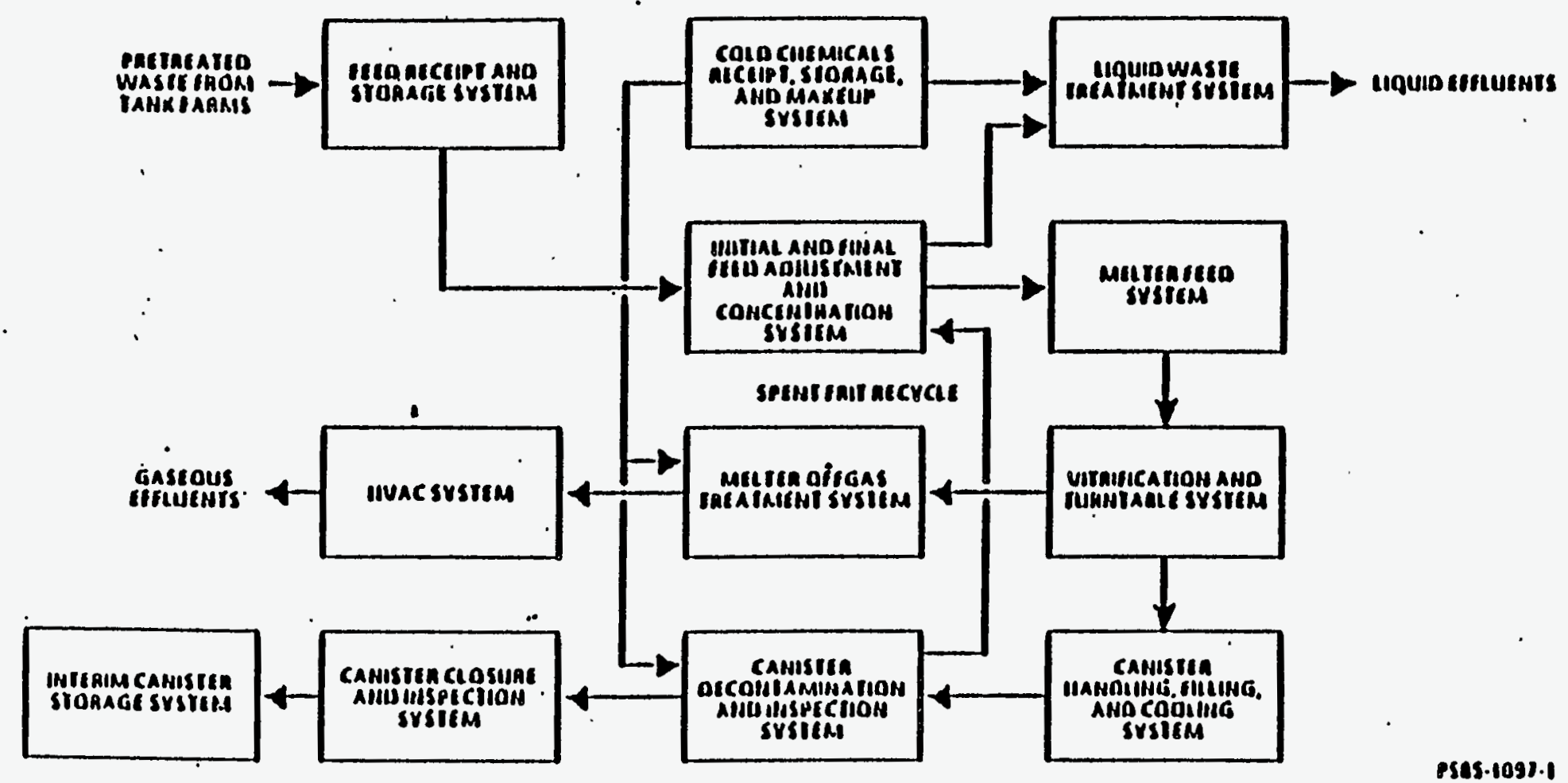

Figure 1-1. Vitrification Process Block Diagram 
Where practicable, replaceable vitrification-system process components and equipment shall be designed for a 20-yr life, and nonreplaceable components and equipment shall be designed for a 40-yr life. Components such as the melter will not meet this requirement. Current technology indicates that a 3-yr lifetime can be expected for the melter electrodes and refractory. Other melter components, such as thermowells and overflow heaters, may fail more often and must be remotely replaceable without replacing the melter.

\subsubsection{System Equipment Functional Requirements}

1.5.2.1 Feed Receipt and Storage. Lag storage for the HWVP feed received from the 200 East tank farms shall be provided by a tank (the receiving and lag storage tank [RLST]) capable of storing enough feed for a suitable plant operating period.

The RLST shall include components to perform, as a minimum, the following functions:

- Receive and hold the HWVP feed.

- Transfer the feed slurry to the melter feed makeup system as required.

- Provide agitation to maintain homogeneity.

- Sample the feed.

- Condense overhead vapors and recycle the condensate.

- Flush and clean tank.

The RLST will be the main tank located at the HWVP facility for receipt of feeds to be processed at the HWVP. The RLST will provide constant agitation of the slurry to maintain homogeneity and suspension of the contents. Adequate cooling shall be provided to maintain contents at, or cool contents to, $95^{\circ} \mathrm{F}$ in a reasonable time. Collected condensable overheads shall be routed to the facility waste handling system or recycled to the RLST as deemed appropriate. The pumping system shall provide controlled and measured fiow with minimum dilution of feed. The pump shall be remotely replaceable. The vessel shall be maintained at a vacuum relative to the ambient during operation. Capability shall be provided to decontaminate the vessel. The tank shall be designed for an operating life of 40 years and shall be a double-shell tank. 
1-5.2.2 Initial Feed Adjustment and Concentration System. - The function of the initial feed adjustment system is to treat the feed with formic acid and other chemicals as required and to concentrate and blend with other process streams if required.

The feed adjustment system will include components to perform, as a minimum, the following functions:

- Receive and hold feed and other streams as necessary.

- React the feed with formic acid or other chemical additives.

- Concentrate the treated feed.

- Monitor chemical reaction and feed concentration processes.

- Sample the concentrate.

- Condense the concentrator overheads.

- Refiux or transport condensate.

- Sample and recycle or dispose of condensate.

- Transport the concentrate to other vessels for further processing.

The adjustment system will be capable of reacting the HWV feed with formic acid at appropriate temperatures and then concentrating the feed and recycled overheads. The system will be sized to support melter operation at a maximum design feed rate. All tanks shall be provided with-agitators to maintain solids in constant suspension and uniform temperatures in the slurry. The chemical reaction and concentrator tank shall have the capability to heat and control the feed temperatures during the formic acid addition. The acid shall be added at a controlled and variable rate below the surface of the slurry. The vapors from the reaction during acid addition and digestion shall be fully or partially refluxed. The tank will have the capability to boil the treated feed for digestion and concentration. Adequate cooling shall be provided with agitators to maintain or cool contents to approximately $95^{\circ} \mathrm{F}\left(35^{\circ} \mathrm{C}\right)$ in reasonable time period. The feed hold tank may receive feed from a variety of sources as deemed appropriate, and the concentrate hold tank shall supply feed to the feed makeup systerl. Collected condensate shall be routed to the facility waste handling system or recycled to the feed concentration system as deemed appropriate. All vessels shall be maintained at a pressure less than that of the cell during operation. Multiple process functions may be performed in a single vessel as deemed appropriate. Capability will be provided to perform a preliminary decontamination of the vessels before removal.

1.5.2.3 Final Feed Makeup and Concentration System. The function of the final feed makeup system is to prepare feed for vitrification by adding glass-forming and other chemical additives as appropriate.

As a minimum, the feed makeup system shall include components to perform the following functions: 
- Receive a batch of feed from the initial feed adjustment system.

- Make up a batch of feed in a tank.

- Add contaminated recycled frit to the final feed makeup tank.

- Add required glass forming materials as frit to the final feed makeup tank.

- Add, at a controlled rate, required feed rheology modification chemicals to the feed makeup tank.

- Add, at a controlled rate, required redox control chemicals to the feed makeup tank.

- Digest and/or concentrate the melter feed.

- Lag store prepared melter feed until required for melter feeding.

- Sample prepared feed.

Concentrated feed will be transferred from the initial feed adjustment system to the final feed makeup tank. The tank will have the capability to heat the feed to boiling. Appropriate quantities of glass-forming and other feed adjustment chemicals are added at controlled rates. Equipment for storing, makeup, and transfer of nonradioactive feed makeup chemicals shall be located in a nonradiation, noncontaminated area. The system will provide heat for concentration and digestion; agitation to ensure a uniform dispersion of additives, heat, suspension of solids; and a sampling system to obtain a representative sample of the feed. The capacity of the makeup system shall be sized to allow continuous melter operations at maximum rates and simultaneous feed makeup. Cooling shall also be provided to the makeup tank to cool and maintain feed temperatures to less than approximately $95^{\circ} \mathrm{F}\left(35^{\circ} \mathrm{C}\right)$. The feed makeup vessel shall be maintained at a vacuum relative to the cells and will be capable of being decontaminated before removal. The feed makeup process can be conducted in a vessel performing other process functions if all other criteria can be met. The feed makeup system shall be capable of transferring feed to the melter feed system, to the process waste system, or to the initial feed adjustment system.

1.5.2.4 Melter Feed System. The function of the melter feed system is to transfer the prepared feed slurry to the melter at a controlled rate. The melter feed system shall include components to perform the following functions as a minimum: 
- Hold the prepared feed in the tank that feeds the melter.

- Sample the prepared feed.

- Agitate to achieve homogeneity.

- Feed the melter at a controlied rate.

- Measure and control the flow rate of the melter feed.

- Flush the melter feed transfer system to prevent and/or clear obstructions in the feed system including the line, transfer device, and melter feed nozzle.

- Cool the feed nozzle.

- Provide cooling to maintain feed at a set temperature.

- Add chemicals.

- Filter the inlet to the feed system to prevent plugging nozzles.

The melter feed system shall be designed to continuously feed makeup slurry to the melter at a controlled and measured rate. The controlled rate shall range from $20 \%$ to $100 \%$ of the maximum melter design capacity. The melter feed tank shall be located close to the melter. The melter feed tank shall be provided with agitation to maintain a uniform feed to the melter and with cooling to maintain the feed slurry temperature below approximately $95^{\circ} \mathrm{F}\left(35^{\circ} \mathrm{C}\right)$. The melter feed tank shall be maintained at a pressure less than that of the cell and allow for sampling the contents. The feed lines shall be as short as practical, minimizing the number of bends, and the bends shall be long radius. Cooling shall be provided to the feed nozzle to inhibit plugging. Provisions shall be made for flushing the feed pump, feed line, and feed nozzles.

1.5.2.5 Melter System. The function of the melter system is to convert feed slurry components into molten glass and discharge the glass into canisters.

The system shall be designed around a joule-heated liquid-fed ceramic meiter (LFCM). The melter system shall. include components to perform; as a minimum, the following functions:

- Operate for a minimum of 3 years.

- Cool by a jacket to minimize heat transfer to the cell. 
- Provide redundant and independent overflow sections.

- Operate continuously, if necessary.

- Stop and start remotely.

- Vent to the off-gas system.

- Operate under vacuum relative to the cell under both normal and off-

- standard operating conditions.

- Operate with glass temperatures up to $2280^{\circ} \mathrm{F}\left(1250^{\circ} \mathrm{C}\right)$.

- Have continuous or batch overfiow.

- IdTe.

- Replace components having an expected life less than that of the melter design life.

- Capable of containing/relieving anticipated pressure surges from offgas flows.

- Empty the melter:

- View the melter cold cap with a CCTV.

The melter feed slurry shall be fed directly into the melting cavity through a cooled feed nozzle in the 1id. The feed nozzle shall be remotely replaceable and be cooled to minimize the solids plugging potential. The off gas resulting from the melter operation shall be directed to the off-gas port which is equipped with devices to minimize solids buildup in the port and clean out the port should it become plugged. The molten glass is transferred from the molten pool through a heated overflow section and allowed to fall by gravity into a canister. The overflow section is heated to maintain the glass in a flowable condition. An airlift system is required to initiate flow through the overflow section and to draw down the liquid level in the melter such that it will not overflow until desired. The overflow sections will have a remotely replaceable sleeve should it become plugged by glass during canister filling. The melter overflow section shall be sealed to the canister or canisterhandling device during operation to minimize air inleakage into the melter. The CCTV shall be provided for adequate remote viewing of the LFCM interior.

1.5.2.6 In-Cell Canister Handling, Filling, Cooling and Lag Storage Systems. The function of the in-cell canister handling, glass level detection, and lag 
storage systems is to provide for physical movement; positioning, and monitoring of the canisters in the vitrification processes and facility. All special tools and mechanisms shall be designed to be remotely inștalled and operated using an overhead or cell crane.

As a minimum, the in-cell canister handling system shall include equipment to perform the following functions as a minimum:

- Move empty canisters into process cells.

- Move empty canisters between canister process celts.

- Store a limited number of empty and filled canisters in the melter cell.

- Store a limited number of canisters in the decontamination and weld cell.

- Provide a mechanism to receive a filled canister and position it as required to enable lid welding and subsequent lid weld inspection.

- Provide a system to introduce canister lids into the process cell and handle then in the cell to enable welding onto the canister.

- Provide a mechanism to handle canister under melter which will enable movement of canister under melter for filling; during filling and venting, provide a seal with the melter to minimize air inleakage to the melter and direct gases and fumes into the off-gas system or the main melter cavity; cool the canister at a defined rate; and move the canister from under the melter for unloading and subsequent handling.

- Provide two independent and reliable methods to determine the glass fill level in the canister.

1.5.2.7 Canister Decontamination. Preliminary canister decontamination shall be performed in the melter cell after inner canister closure to remove looselyadhered contaminants from the outside surface of each canister. The capability to measure canister surface temperature prior to decontamination shall be provided to verify that temperatures are below $212^{\circ} \mathrm{F}\left(100^{\circ} \mathrm{C}\right)$. .

An air-injected frit slurry blasting technique has been developed and shall be used for the final canister decontamination process. The entire external surface of each canister shal1 be decontaminated to less than 220 and 2,200 disintegrations per minute/15.5 square inches for alpha and beta-ganma contaminants, respectively. Two identical decontamination chambers shall be 
located in the canister decontamination cell (CDC). Filled canisters shall be transported to the CDC and placed in a chamber using an in-cell crane. . A lidf canister grapple apparatus shall be placed on the chamber to seal the chamber from the surrounding cell. Following a frit slurry blast cycle, residual slurry or water shall be removed from the surface of the canister and the canister transported from the chamber to a smear test station. Canisters which exceed the surface contamination limits specified above shall be returned to a chamber for further decontamination.

Canister decontamination equipment shall be designed for remote operation and maintenance or replacement. Each decontamination chamber shall be connected to the facility vessel ventilation system to provide a negative pressure in the chamber with respect to the surrounding cell. Canister movement inside the chamber shall be independent of the in-cell crane. Capability to rinse the interior surfaces of the chambers shall be provided. Spent decontamination filuids, frit slurry, and contaminants shall be transferred to the final feed makeup system for vitrification.

1.5.2.8 Canister Closure System. The canister closure system shall provide a welded 1 id closure on the filled and decontaminated canisters with an integrity equivalent to the canister wall. The welder shall be a resistance welder and operate in a fully remote manner inside a shielded process cell. A resistance canister closure welding process has been developed and shall be used for the canister closure system. Remote viewing of. the process shall be provided. All handling of canisters and lids shall be done using remote methods and in-cell handling equipment. The welder shall be contact maintained.

The canister lid closure configuration and the welding system equipment shall permit inspection, rework, and/or repair of the 1 id weld if required. The welding system and weld repair methods shall minimize or eliminate grinding and chip producing operations inside the process cell.

A temporary inner canister closure system shall be provided to prevent decontamination agents from entering the filled canisters during preliminary and final decontamination and before final canister welding operations. The temporary system shall not utilize bolted or welded closure mechanisms. The closure shall be temporary and shall be impervious to decontamination agents. The inner cariister closure system shall include features to assure seal integrity.

1.5.2.9 Process Off-Gas Treatment System. The process off-gas system treats melter off gas to reduce radioactive and toxic materials to within allowable limits for stack release. 
The process off-gas treatment system shall discharge to the facility exhaust systen upstream of the facility filter. The off-gas treatment system shall decontaminate the melter off-gas so that component concentrations, following filtration in the facility exhaust system, shall meet requi rements for stack release to an uncontrolled area as defined in RHO-MA-139.(a) Stack release conditions shall be based on airborne emissions from the total of the facility. operation systems. The off-gas treatment system shall be designed to remove condensables, heat, solid particles, semi-volatile radionuclides, and hazardous chemicals from the melter off-gas. The capability shall be provided to recycle the condensate collected from the vitrification process off-gas system to the feed concentration system for reprocessing or dispose of it to the process waste system. The system shall maintain the melter and all compo- nents within the process off-gas system.at a negative pressure with respect to the cell. Provisions shall also be made to maintain the melter at a negative pressure with respect to the cell and meet facility emission requirements should the off-gas system be out of service.

The process off-gas system shall be designed to accommodate effluent surge conditions that occur during operation of the melter. The surges are the result of rapid steam generation that occurs when the slurry feed contacts the molten glass through fissures in the cold cap. The system shall be designed to maintain a vacuum relative to the cell under maximum surge condition.

The process off-gas system components requiring frequent replacement shall be designed to provide ready access. In addition to the components that may require frequent replacement, all process off-gas system equipment must be designed for remote installation and removal.

\subsection{REFERENCES}

- 1-I Defense Waste Management PIan. U.S. Department of Energy, Washington, D.C. (1983).

1-2 Interim Hanford Waste Management Plan. Department of Energy. - Richland Operations Office, Richland, Washington (1985).

- 1-3. Draft Environmental Impact Statement-Disposal of Hanford Defense HighLevel, Transuranic, and Tank Wastes. DOE/EIS-0113, U.S. Department of Energy, Hashington, D.C. (1986).

(a) Environmental Protection Manual, RHO-MA-139, Rockwel1 Hanford Operations (May 8, 1978). 
1-4 DOE Order 5480.1A, "Evironmental Protection, Safety, and Health Protection Program for DOE Operations," Department of Energy, Washington, D.C. (August 13, 1981).

1-5 DOE Order 6430.1, "General Design Criteria Manual," Department of Energy, Washington D.C. (December 12, 1983).

1-6 DOE-RL Order 4320.2B, "Site Selection," Department of Energy - Richland Operations Office, Richland, Washington (April 1, 1986).

1-7 "Design for Decommissioning of Nuclear Fuel Reprocessing Plants," American National. Standards Institute. 

SECTION 2.0

HWVP PLANT DESCRIPTION 



\title{
2.0 HWVP PLANT DESCRIPTION
}

\author{
CONTENTS
}

2.1 SITE $\ldots \ldots \ldots \ldots \ldots \ldots \ldots \ldots \ldots \ldots \ldots \ldots \ldots \ldots \ldots \ldots \ldots \ldots \ldots \ldots \ldots \ldots \ldots \ldots \ldots \ldots$

2.1.1 Site Description ........................................

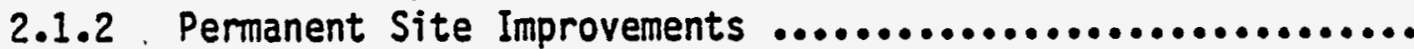

2.2 BUILDINGS AND STRUCTURES

2.2.1 Vitrification Building ...............................

2.2.2 Manipulator Repair Building ..............................

2.2 .3 Support Building

..............

PROCESS/SUPPORT EQUIPMENT

HWVP Reference Site in 200E Area..................... HWVP Site Plan ............................................ Utility Site Plan ........................................ 
2-13b. Coil Assembly: SME, SRAT (PTan View) ................. 2-46

2-14a Transfer Pump (Elevation) .......................... 2-47

2-14b Transfer Pump (Plan View and Detail of. Settiing

Chamber .......................................... 2-48

2-15a Sample Pump (Elevation) .......................... 2-49

215b Sample Pump (Plan View) ............................. 2-50

2-16a Agitator (Elevation) ............................ 2-5I

2-16b Agitator (Plan View and Guide Pin Detaj1) ............... 2-52

2-17a Melter Feed Pump (Elevation) ............................. 2-54

2-17b Melter Feed Pump (Plan View and Detail of Screen

Installation) ...................................... 2-55

2-18 Melter .......................................... 2-57

2-19 Turntabie ..................................... 2-58

\section{TABLES:}

2-1 Building and Area Dimensions ........................ 2-10

2-2 Process Tank Description .............................. 2-31

2-3 Heating/Cooling Coils Description .................... 2-31

2-4 Agitator Description ............................... 2-32

2-5 Condenser Description .............................. 2-32

2-6 Pump Description ................................. 2-33 


\section{SECTION 2.0 - HWVP PLANT DESCRIPTION}

FLUOR TECHNOLOGY, INC.

The HWVP plant description section provides a summary technical description of the plant site (Section 2.1), buildings and structures (Section 2.2), and process/support equipment (Section 2.3). More detail on HWV design features can be obtained from the Reference Conceptual Design documentation. (a)

\subsection{SITE}

The reference HWV site is described below.

\subsubsection{Site Description}

The reference site selected for the HWVP is located within the 200 East Area (Figure 2-1) on undeveloped land, approximately 2,000 ft west of the B-Plant 221-B canyon building. The 200 East Area of the Hanford Site is located approximately 25 miles northwest of the city of Richland, Washington. The reference site has access to existing railroads, utilities, and required waste pipeline tie-ins, and has potential for expansion. The reference site land area is approximately 1,200 ft by 1,200 ft (35 acres).

The site is located on a terrace, locally referred to as the "200 Area Plateau," near the center of the Hanford Site. From the 200 Area Plateau, the ground surface slopes gently toward the Columbia River. The climate is arid to semiarid as a result of being in the rain shadow of the Cascade mountain range. Because of the arid environment and prevailing winds, the Hanford Site is blanketed by a thin veneer of wind-blown sediments. Hater erosion on the plateau is minor because of the minimal precipitation, high soil porosity, and relatively flat topography.

There are several portions of the site that cannot be disturbed. An existing encasement to the southeast contains six waste-transfer lines, is approximately $7 \mathrm{ft}$ below grade, and must not be disturbed. A 24-in. concrete export waterline to the southwest is approximately $3 \mathrm{ft}$ below grade and is not to be moved. An existing railroad track to the east of the site provides rail entrance and exit for HWVP.

(a) Fluor Technology, Inc., Reference Conceptual Design, Hanford Waste Vitrification Plant, Technical Descriptions and Drawings. SD-HWV-TI-007, Rev. 0, for Westinghouse Hanford Company, Richland, Washington (April 1987). 


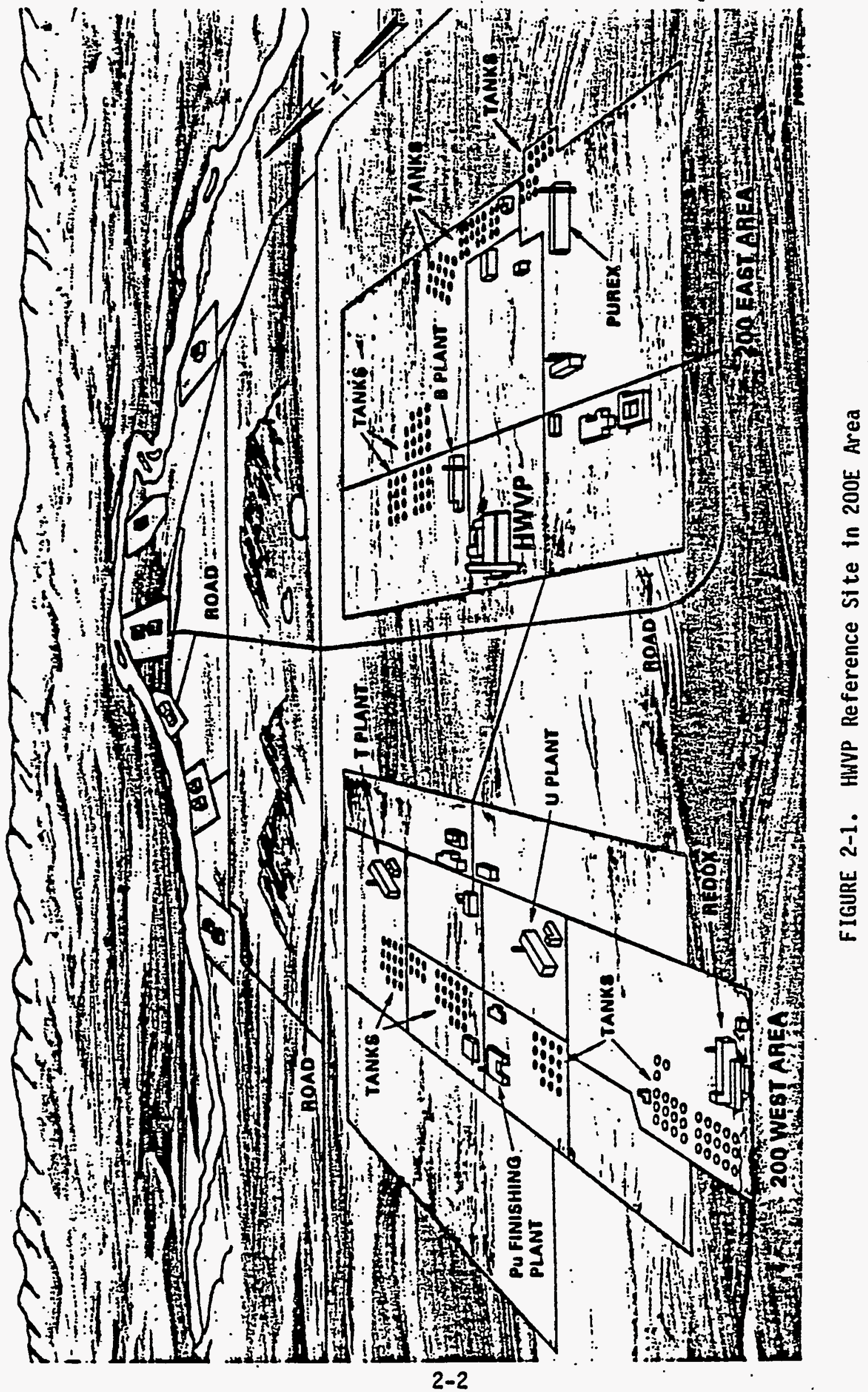


The vegetation on the site consists of sagebrush and other. common central Washington desert plant species. The soil is classified as sandy gravel with excellent drainage characteristics. The site is relatively level with about a $1-1 / 2 \%$ slope from the northeast to southwest.

Approximately 35 acres of land is to be cleared and graded for construction of the HWVP, access roads, and railroad spurs. Except for the export waterline, roads, railroads and waste-transfer encasement, the site is undisturbed.

\subsubsection{Permanent Site Improvements}

The HWVP Site Plan and HWVP buildings are shown in figure 2-2. Improvements to the site include providing pedestrian, vehicle, and railroad access. In addition, the following civil activities are required.

\subsubsection{Excavation and Backfill}

Excavation is required for the facility. The process cell and canyon area excavations for the Vitrification Building are about $15 \mathrm{ft}$ deep with a small portion being approximately $30 \mathrm{ft}$ deep. An excavation side slope of $1.5: 1$ is used to el iminate the need for shoring. The bottom of the excavation is wide enough to provide work space and construction access roads between the toe of the cut slope and the building foundation. Excavated material is stockpiled for use as backfill.

\subsubsection{Trenching}

Trenching is required for the underground utilities and for the feed transfer 7 ines as shown in Figure 2-3. All lines are routed to minimize interference with existing utilities. Shoring may be required to install utilities and process transfer lines.

\subsubsection{Finish Grading}

Finish grading blends the facility into the existing topography and provides drainage away from all buildings. Other areas disturbed during construction have their original contours and grades restored, as much as possible, and are stabilized with gravel. 


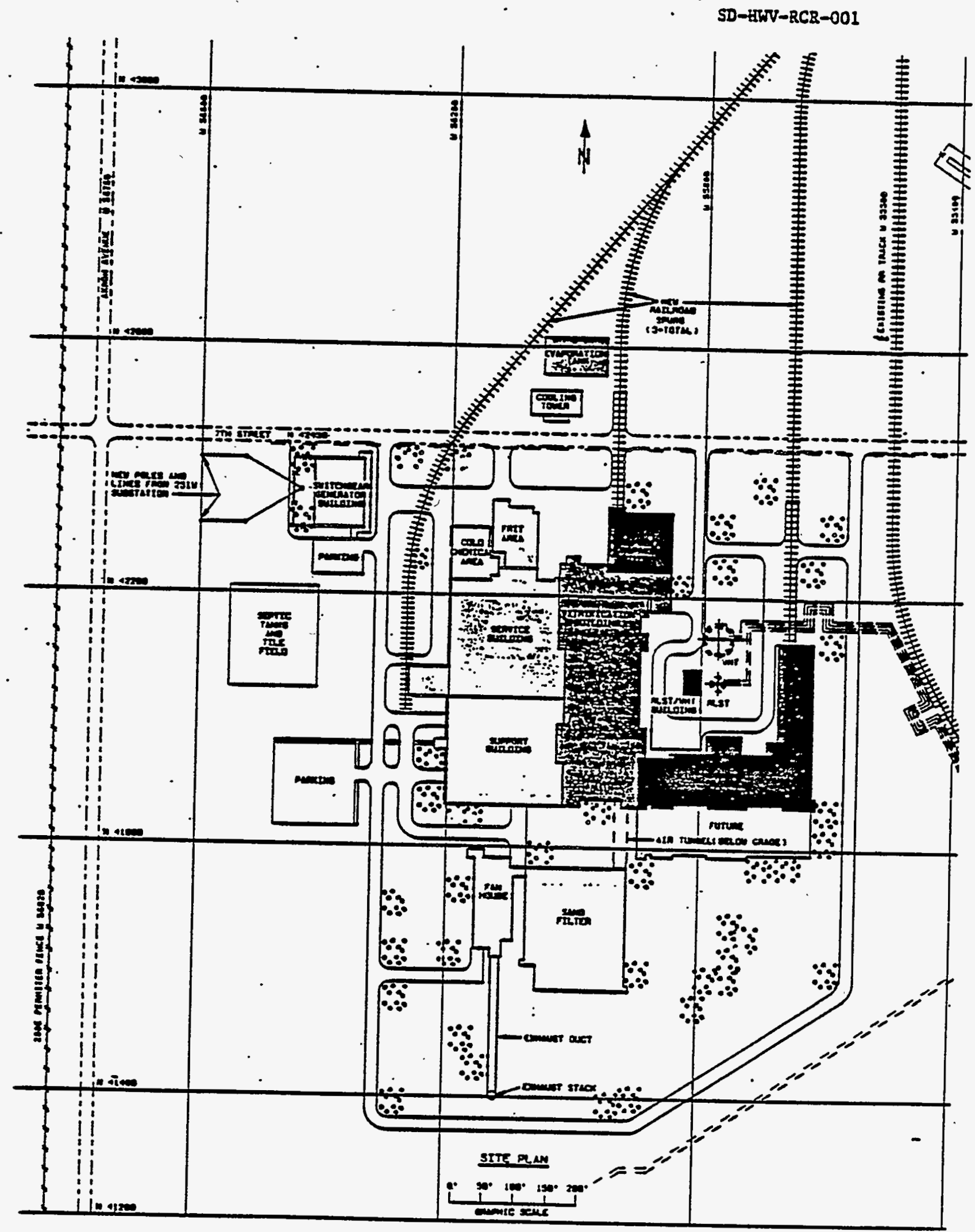

FIGURE 2-2. HWVP Site Plan 


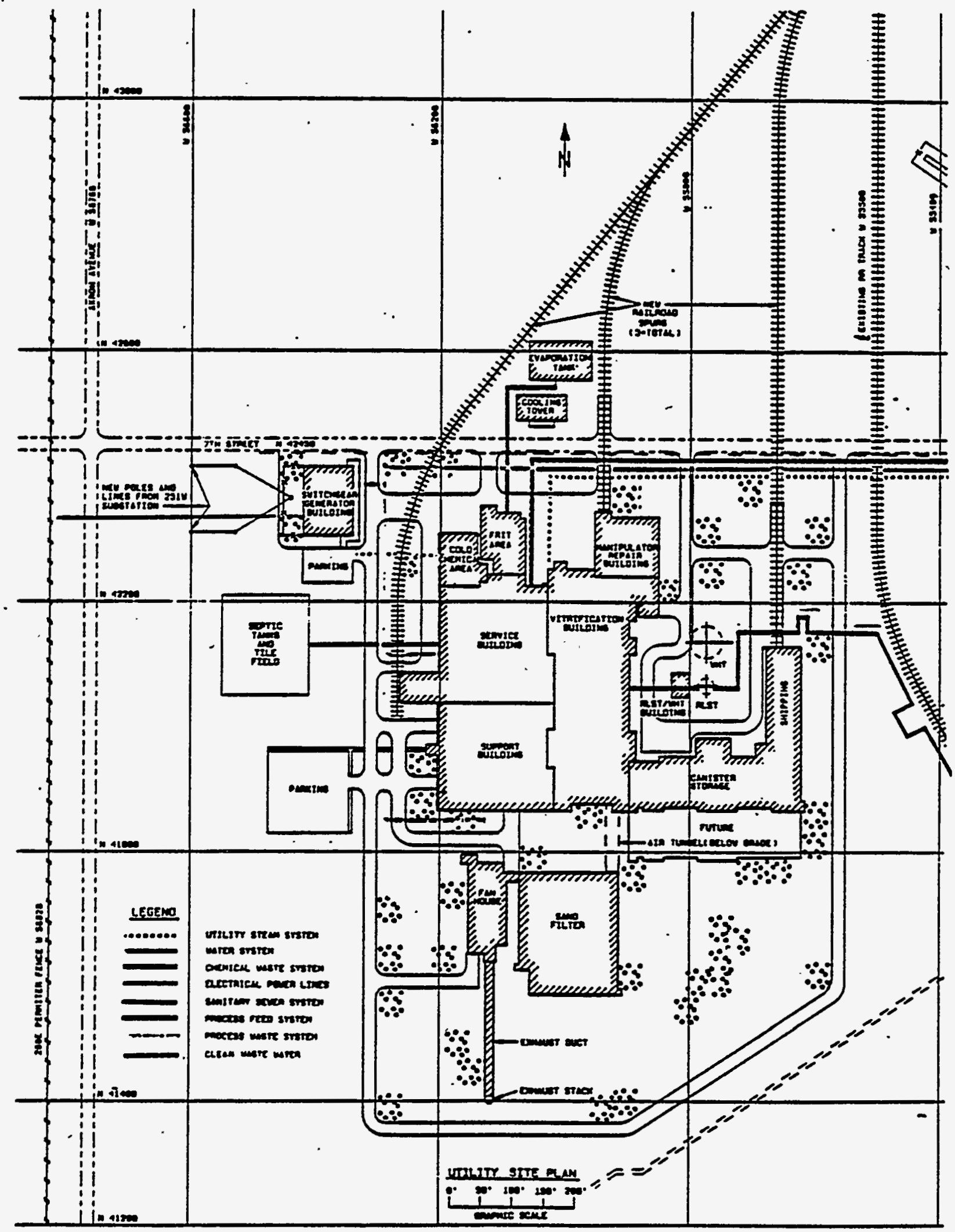

FIGURE 2-3. Utility Site Plan 


\subsubsection{Paved Access}

- Paved-access roads, including a 2,800-ft-long perimeter road, are shown on Figure 2-3. Additional. paving is required for access to individual buildings. A paved lot with spaces for automobiles, motorcycles, and handicapped parking is provided for HWVP personnel. The existing paved roads provide satisfactory al1-weather access.

\subsubsection{Rait Access}

Approximately 4,000 ft of new railroad track are required for the HWVP. From a single tie-in point with the existing Hanford mainline, three spurs provide access to the railroad well in the vitrification building, the service area loading dock, and the cask loadout and shipping area.

\subsection{BUILDINGS AND STRUCTURES (SYSTEM 01)}

The plant buildings and structures consist of either reinforced concrete structures or standard steel-framed structures. Existing utility distribution systems, with some upgrading, accomnodate the new plant. The design life of the HWVP is 40 years. Materials of construction are noncombustible and are provided with protective coatings resistant to corrosion.

The HWVP facility is divided into three major types of construction: Category I - reinforced poured-in-place concrete structures; Non-Category I steel framed structures; and Non-Category I - reinforced poured-in-place concrete structures.

The Category I, reinforced poured-in-place concrete structures include:

- the Vitrification Building (except for the HVAC room on the fourth floor)

- the Canister Storage Building (except for the railroad airlock/washdown area, the personnel and equipment facility, and the HVAC room on the second floor

- the Sand Filter Building

- the Fan House Building

- the Switchgear/Generator Building

- the RLST/WHT Vautts 
- the RLST/WHT Building.

The Non-Category I, steel framed structures include:

- the HVAC room on the fourth floor of the Vitrification Building

- the Manipulator, Repair Building .

- the Support Building

- the Service Building .

- the railroad airlock/washdown area, personnel and equipment facility, and the HVAC room on the second floor of the Canister Storage Building

- exhaust stacks ( 3 total)

- miscellaneous pipe supports including supports for a 6-in. 225 ib overhead steam line.

The Non-Category I, reinforced poured-in-place concrete structures include:

- cooling tower foundation

- solar evaporation tank

- regulated drains collection tank vault.

\subsubsection{Vitrification Building}

The Vitrification Building is a 5-story, poured-in-place reinforced concrete structure. The fourth floor supports a 2-story concrete building located on the extreme south end and a 1-story metal building on the remainder. The main process cells are located on the tunnel floor ( $8 \mathrm{ft}$ below adjacent grade), with support systems housed at various levels throughout, except for the HVAC system (System 05), which is housed primarily on the fourth floor and covered with a metal building as shown in Figures 2-4 and 2-5. The dimensions of the HWVP buildings and service areas are included in the list of building and area dimensions in Table 2-1. 

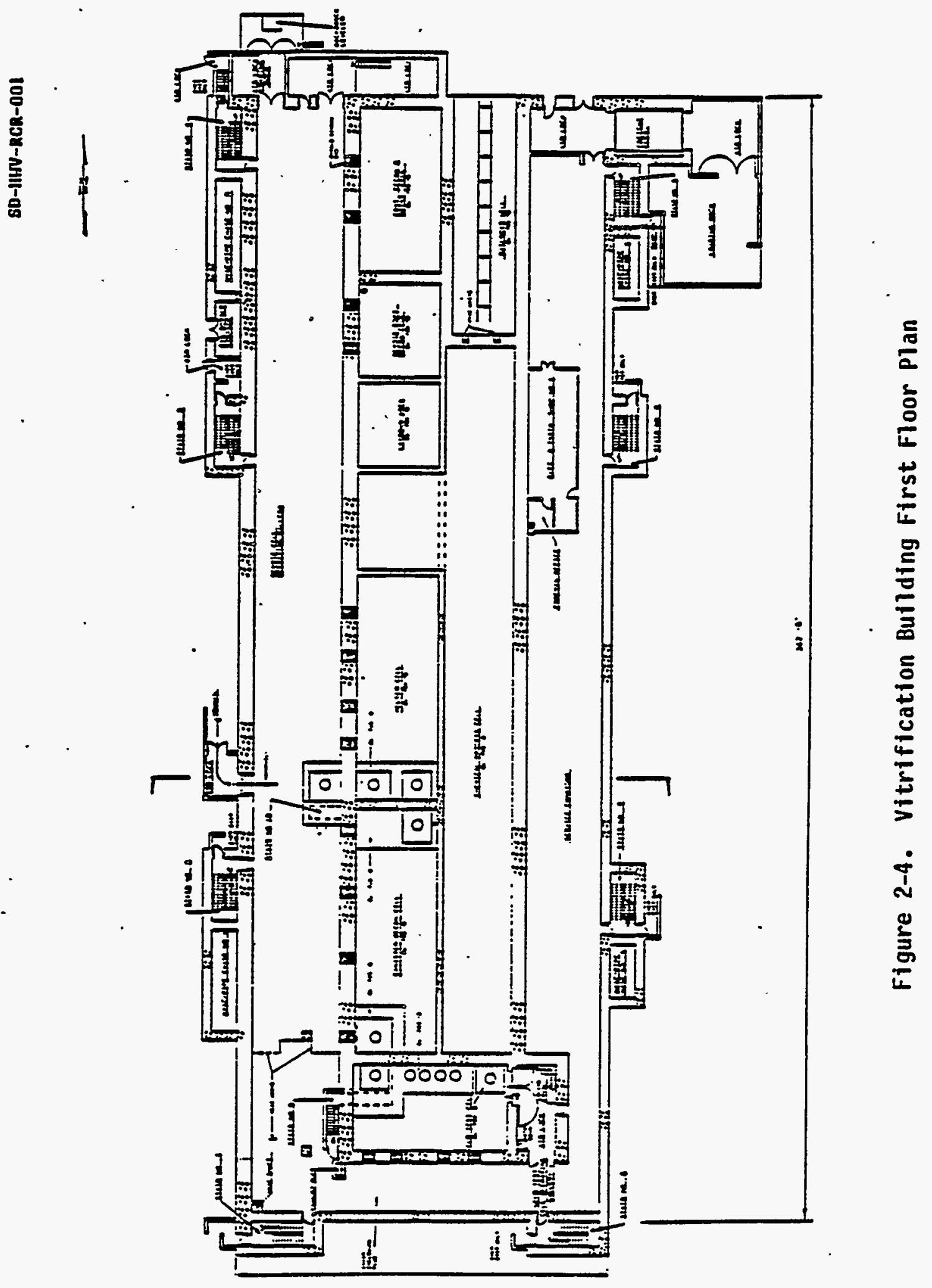


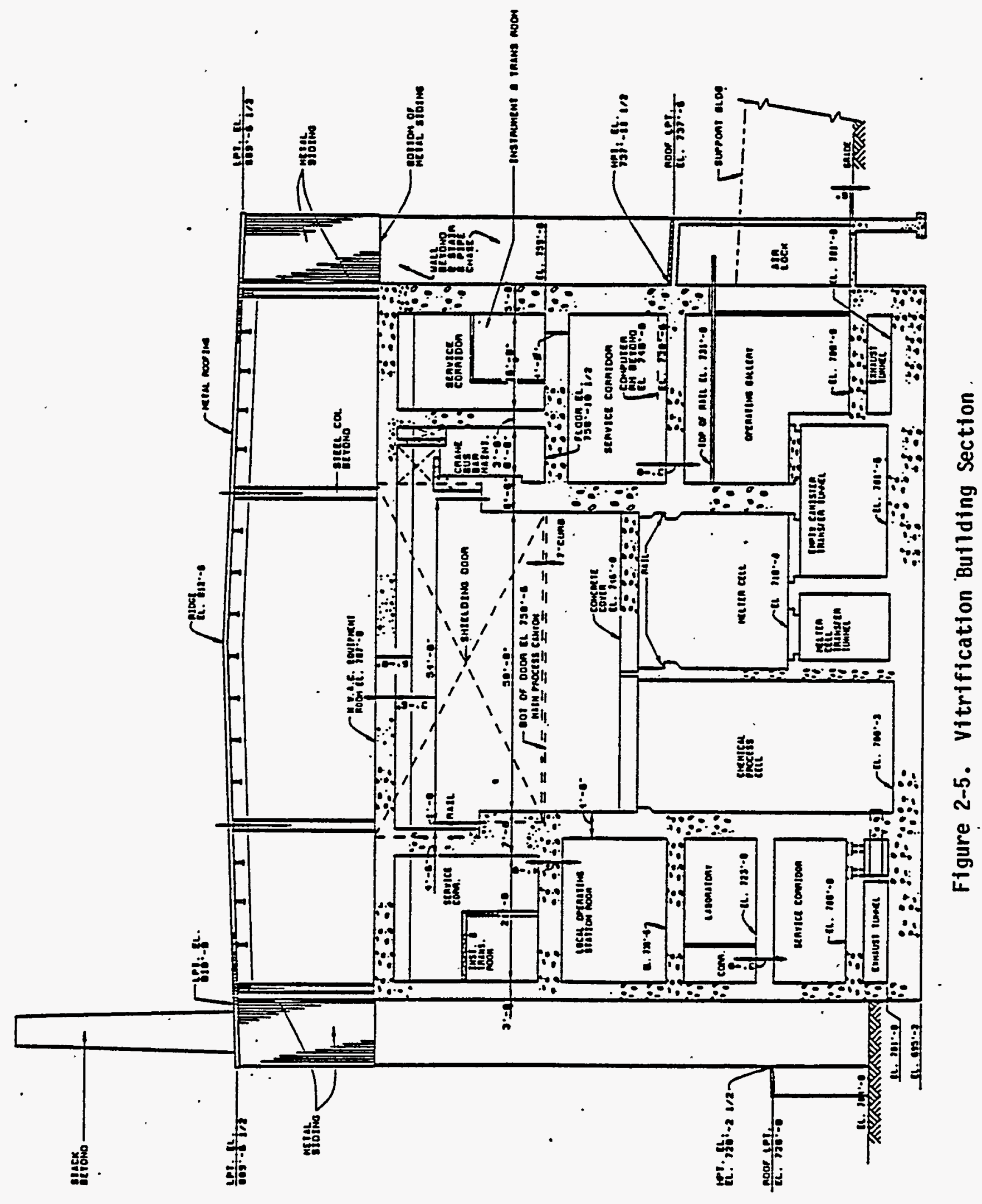


TABLE 2-1. Building and Area Dimensions

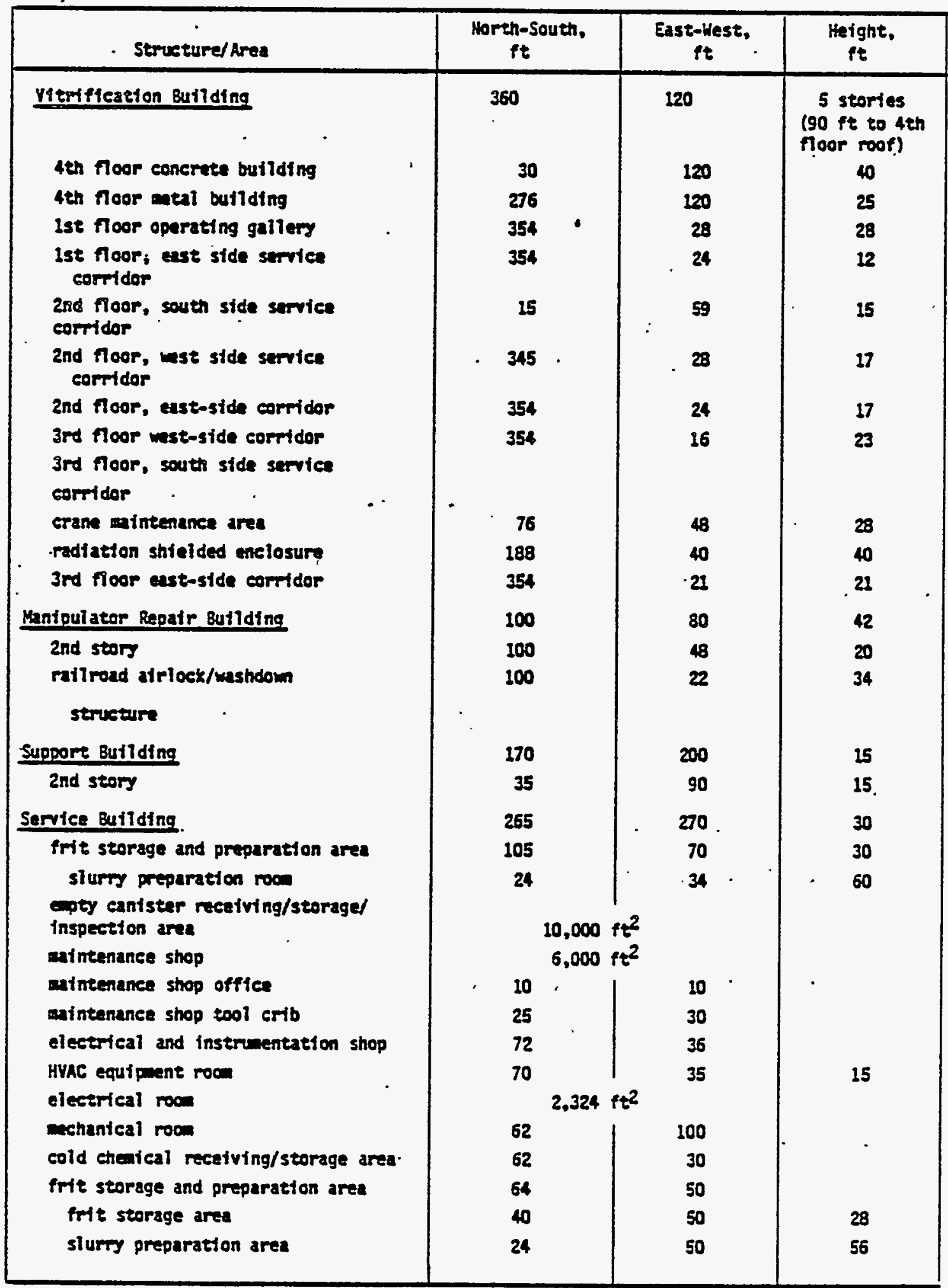


TABLE 2-1. (contd).

\begin{tabular}{|c|c|c|c|}
\hline Structure/Area & $\begin{array}{c}\text { North-South, } \\
\text { ft }\end{array}$ & $\begin{array}{c}\text { East-Hest, } \\
\text { ft }\end{array}$ & $\begin{array}{c}\text { Height. } \\
\text { ft. }\end{array}$ \\
\hline 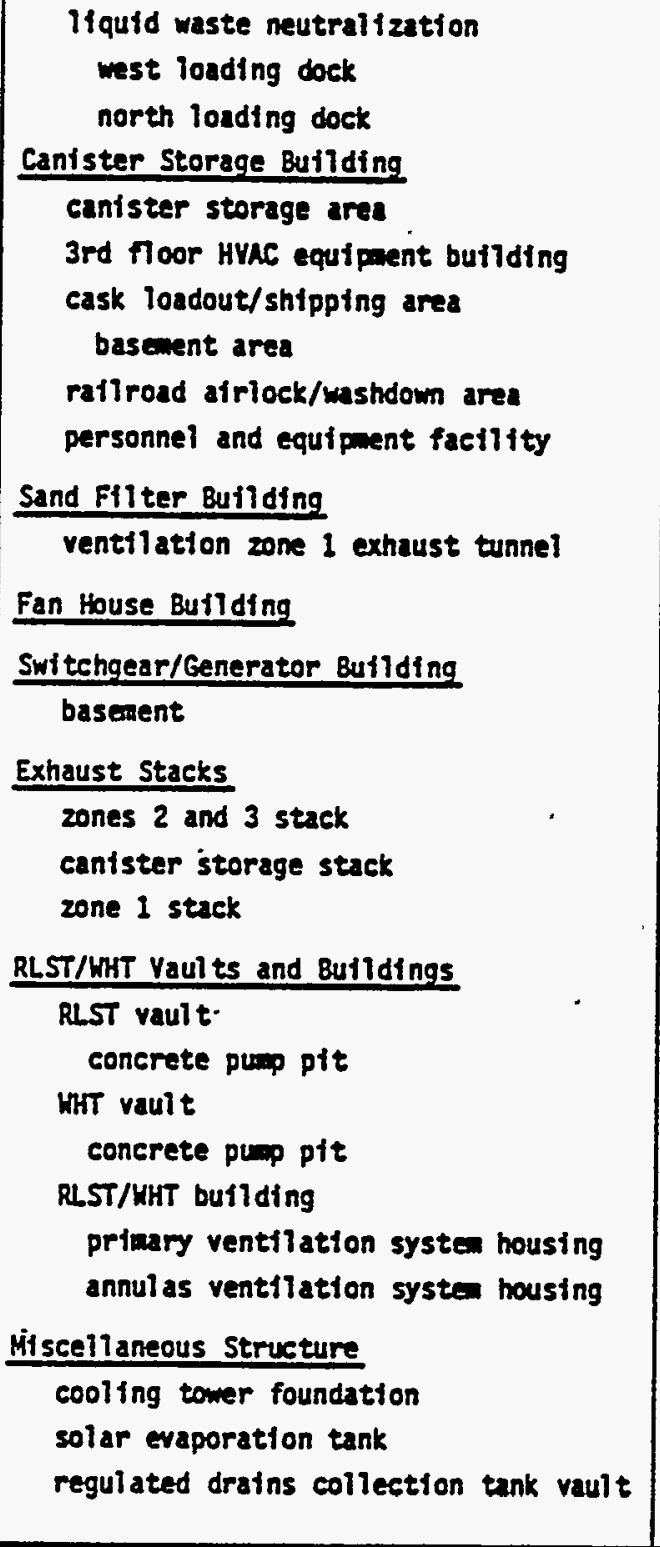 & $\begin{array}{r}50 \\
72 \\
80 \\
80 \\
100 \\
32 \\
80 \\
35 \\
200 \\
100 \\
200 \\
100 \\
40 \\
\\
\quad 8 \text {-ft } \\
6 \text {-ft } \\
16 \text {-ft }\end{array}$ & $\begin{array}{r}34 \\
18 \\
\\
274 \\
250 \\
56 \\
30 \\
56 \\
55 \\
160 \\
17 \\
160 \\
80 \\
50 \\
\\
\end{array}$ & $\begin{array}{l}49 \\
18 \\
46 \\
21 \\
24 \\
15 \\
27 \\
10 \\
27 \\
22 \\
10\end{array}$ \\
\hline
\end{tabular}


2.2.1.1 Facility Descriptions. The Vitrification Building is considered to have. four major functional areas: 1) process cell and canyon area; 2) operating galleries;. 3) service corridors; and 4) major HVAC equipment area.

2.2.1.1.1 Process Cell and Canyon Area. The process cell and canyon area is a canyon-type shielded area with concrete cover blocks. The canyon is designed for remote operation and includes the following cells or areas: the chemical process cell (CPC); melter cell (MC); canister decontamination cell (CDC); remote equipment decontamination cell (REDC); weld test cell (WTC); contact decontamination and maintenance cell (CDMC); laydown area; railroad well; and the canister transfer tunnels.

Equipment in the CDMC is remotely or contact operated and maintained. Equipment in the canister transfer tunnels and the WTC is remotely operated but contact maintained (excluding the MC/CDC tunnels, which are remotely maintained). All other cells or areas in the canyon are remotely operated and maintained, except the railroad well. Remote maintenance is performed using the canyon crane.

2.2.1.1.1.1 Meltex ceiz. The melter, canister handling equipment, inner canister, closure station, temperature survey, prel iminary canister decontamination system, the off-gas quenchers, and an in-cell crane are located in the melter cell (MC). The MC is isolated from the chemical process cell (CPC) by seismically designed concrete walls. Major maintenance operations are performed using the canyon crane to remove the shielding cover blocks and failed equipment. Empty canisters enter the MC via a canister transfer tunnel connected to the first-level operating gallery. Filled canisters are delivered to the canister decontamination cell (CDC) via a canister transfer tunnel.

2.2.1.1.1.2 Contact Decontamimation and vointerance Cell.. Decontamination of failed equipment is performed in the contact decontamination and maintenance cell (CDMC). Both the walls and the cell cover blocks are designed to provide shielding and structural strength. Equipment is decontaminated and maintained either remotely or by direct contact (i.e., authorized personnel enter the cell). Process equipment is removed and replaced by the canyon crane.

2.2.1.1.1.3 Chemricat Enocess Cell. The CPC is an enclosed cell and contains the melter feed system, the liquid waste system, the vessel-vent system, and a portion of the off-gas process equipment. There is a lay-down area next to the CPC for storing equipment during maintenance operations. A beam structure supports the rack piping and cover blocks that separate the CPC into the east side and west side. 
2.2.1.1.1.4. Remote Equipment Decontamination Cell. Facilities for decontaminating failed equipment are located in the remote equipment decontamination cell (REDC). Wall and cell cover construction is similar to the MC. All operations are performed remotely. In-cell equipment to be decontaminated is removed and returned by the canyon crane.

2.2.1.1.1.5 Canister Decontamination Cell. Associated with the canister decontamination cel1 (CDC) are the final canister decontamination systems, an enclosed and shielded smear test station, and an in-cell crane. The CDC is isolated from the CPC by solid walls and removable cover blocks. Canister decontamination equipment is remotely maintained except for the smear test station located in the tunnel between the CDC and the. HTC. The tunnel is contact maintained.

2.2.1.1.1.6 Railroad Weil. The railroad well is located in the Vitrification Building and is provided with concrete cover blocks. Process equipment is delivered to and removed from the Vitrification Building via the railroad well.

The walls and removable cover blocks provide shielding and structural strength. The railroad well serves as an inner airlock between the railroad airlock and the process cell and canyon area. There is a ventilation control door and shielding door between the railroad well and the railroad airlock.

2.2.1.1.1.7 Weld Test Celz. The WTC is a shielded process cell and is not serviced by the canyon crane. Equipment for welding the canister plug, space for a future overpack welder, the final smear test station, and two in-cell cranes are located in the WTC. The equipment is remotely operated, but contact maintained. Canisters enter the WTC via a canister transfer tunnel from the $C O C$ and leave via a second canister transfer tunnel connected to the canister storage area. Canisters are removed from the transfer tunnel by a crane in the canister storage area.

The walls and ceiling of the WTC provide shielding and structural strength. Personnel and equipment enter and exit through an airlock. A plug is provided in the ceiling of the WTC to access an in-cell crane trolley in the event of double failure.

2.2.1.1.1.8 Exhaust Tunnels. Ventilation Zone 1 exhaust tunnels are located below the first-level operating gallery and service corridors on the east, west, and south sides of the process cells. The tunnels are normally 4-ft high and extend from the wall of the process cells to the outside wall of the Vitrification Building. The ventilation Zone 1 exhaust tunnels connect to the main exhaust tunnel at the southeast corner of the building and continue to the sand filter and exhaust stack. 
2.2.1.1.2 Operating Galleries. . There are two operating gaileries--the first-level west gallery and the mezzanine-level east gallery. Both galleries are regulated because they are subject to possible contamination.

2.2.1.1.2.1 First-Floor Operatina Gallery. The gallery floor is $8 \mathrm{ft}$ above the floor of the process cells. Viewing windows and operating stations for the CDC, MC, REDC, CDMC, and WTC are located in the gallery. The cold frit tank, pumps for the canister decontamination system, the melter closed loop cooling water system, and the decontamination cell acid. tanks are also located on the gallery level. Empty canisters from the service area enter the process cell and canyon area at this level through an airlock (transported by monorail).

2.2.1.1.2.2 Mezzanine-Level Operating Gallery. The sample cells, with their viewing windows and operating stations, are located at the mezzanine level, which is between the first and second levels.

2.2.1.1.3 Service Corridors. There are service corridors on each floor that surround or partly surround the process cell area. The first and third floor service corridors are regulated. The second floor corridors are clean areas since there are electrical penetrations from the second floor corridors into the process-cell areas. A 7-ft-wide passageway on the second and third. floors connects the east and west corridors at the north end of the process cell.

2.2.1.1.3.1 Eirgt-Floor Service Comidor. The service corridor on the east side of the first floor contains:

- liquid-waste catch tanks that are accessible from the first-level east corridor but are located on the tunnel level below this corridor

- exhaust fans for the sample-cel1s' entry hoods

- electrical and instrumentation shop No. 1

- health protection system vacuum exhaust blowers

- process steam condensate delay system.

2.2.1.1.3.2 Mezzamine Level. Local HEPA filters and exhaust fans for the WTC are located in the southwest portion of the mezzanine level.

The welder power packs are located in a clean area in the southern portion of the mezzanine level. 
2.2.1.1.3.3. Second-Floor Service Corridor. The service corridor on the west side of the second floor and contains:

- local operating stations, the emergency back-up console for the DCS, and CCTV distribution cabinets

- electrical substations

- air handling units

- motor control center (MCC) and switchgear for all eléctrical services on the west side of the building

- electrical and instrumentation shop No. 2

- emergency breathing-air bottles

- plant and instrument air compressors and receivers, and the instrument air dryers.

The service corridor on the south side of the second floor contains:

- welder substation and MCC

- rectifier drive cabinet

- remote CCTV equipment cabinet.

The corridor on the east side of the second floor contains:

- Tocal operating station for central control system

- motor control center for all equipment on the east side of the process area

- electricar substations.

2.2.1.1.3.4 Third-Floor Service Corridors. The third floor service corridors are regulated. Most service piping and control valves supplying cold chemicals, steam, cooling water, air, and electrical services to the in-cell equipment are located in the east and west side of the third floor service corridors. Located in the west-side corridor are the maintenance shop; airlocks (entries into the main process cell crane bus bar corridor); and the process closed-loop cooling and chilled water systems. 
The crane maintenance area is located on the third floor in the south side service corridor. A 30-in.-thick concrete door shields the crane maintenance area from the process cell and canyon area. A radiation-shielded enclosure is provided above the shielding door. The enclosure is a two-level structure that houses the door lifting hoists and a maintenance crane. Space is provided to raise the door.

In addition to the service piping and controls in the east side service corridor, there is an electrical and instrumentation shop (No. 3), a viewing window for the crane maintenance area, an airlock, cold chemical feed tanks, and the process frit slurry systen.

2.2.1.1.4 Major HVAC Equipment Area. The major HVAC equipment is housed in the metal building located on the fourth floor.

In addition, there are two loading docks servicing the Vitrification Building. Both docks are enclosed by concrete walls and/or missile resistant doors to protect the access doors from potential tornado-generated missiles. One loading dock is located at the northwest corner of the process cell and canyon area, and the other is located at the northwest end of the area next to the manipulator repair shop and freight elevator. Also, there is a freight elevator located near the northeast corner of the Vitrification Building. The elevator services three levels, including the mezzanine and the roof. The elevator cab has a double entrance at the first level and is large enough to carry any equipment or pieces of equipment used in the area served.

\subsubsection{Manipulator Repair Building}

The Manipulator Repair Building is actually two structures separated by a seismic separation joint. The building is located at the north end of the Vitrification Building. The manipulator repair area is a two-story metal building. The second story is a partial floor located on the west side of the second floor. The second floor has a concrete slab because of the HVAC equipment criteria.

The second structure is a railroad airlock/washdown area. This one-story metal building is located adjacent to the west wall of the manipulator repair area.

The manipulator repair area is used for repair of failed master slave manipulators (MSMs) and Electro-Mechanical Manipulators (EMMs) and includes a separate decontamination area for MSMs. The manipulators are brought from the Vitrification Building for repair, and returned along a service corridor on the first floor of the Vitrification Building. The railroad airlock/washdown area 
is an extension of the railroad well within the Vitrification Building. It provides a transition between the open environment and the inside of the Vitrification Building.

2.2.2.1 Facility Descriptions The Manipulator Repair Building may be considered to have five major functional areas: 1) manipulator repair shop; 2) new parts assembly room; 3), decontamination area; 4) HVAC room; and 5) railroad airlock/washdówn area.

2.2.2.1.1 Manipulator Repair Shop. The manipulator repair shop includes - a machine shop, storage rooms, and personnel offices. A truck loading dock and airlock provide outside access to the manipulator repair and machine shop.

2.2.2.1.2 New Parts Assembly Room. The new parts assembly room includes work benches and tools for the assembly of new manipulators.

2.2.2.1.3 Decontamination Area. The decontamination area contains both a contaminated lag area and an MSM decontamination room with hot manipulator repair shop glove boxes. A monorail system services both the hot manipulator repair and machine shops.

2.2.2.1.4 HVAC Room. The HVAC room is the second floor of the manipulator repair area and contains the major HVAC equipment for the manipulator repair shop, railroad airlock/washdown, and the railroad well within the Vitrification Building.

2:2.2.1.5 Railroad Airlock/Hashdown Area. The railroad airlock/washdown is a transition between the outside and the Vitrification Building. The railcars receive a washdown in this area after leaving the Vitrification Building and before entering the outside environment.

\subsubsection{Support. Bujlding}

The Support Building is a one-story metal building located adjacent to the southwest quadrant of the Vitrification Building. There is a partial second story located along the east wall and $30 \mathrm{ft}$ from the south wall. The second floor has a concrete slab to accommodate major HVAC equipment. Most of the offices and the control room.for the Vitrification Building, plus the health protection facilities, are housed in this building. The Support Building is separated from the Service Building by a 4-h fire wall and provides access to the Vitrification Building through regulated and clean entrances. Health protection services, changerooms, and toilets are provided in the regulated sections, which are separated from the clean section by airlocks. The clean 
section contains showers, toilets, lockers, clothing storage, offices, a lunchroom, a supply and reproduction room, a conference room, and space for control functions, which in general provide administrative support and control systems . for the Vitrification Building.

2.2.3.1 Facility Descriptions. The Support Building has six major functional areas: 1) office area; 2) computer rooms; 3) control rooms; 4) clean entrance; 5) regulated entrance; and 6) HVAC room.

2.2.3.1.1 Office Area. The office area occupies approximately $60 \%$ of the first floor and includes various types of offices (single occupancy, double occupancy, and bull-pen), traditional office area rooms (conference, reproduction, supply, medical, communications, training, etc.), plus the main entrance and vestibule. In addition, speciality areas for a model room, design area, and an electrical and instrument shop are provided.

2.2.3.1.2 Computer Rooms. Special computer rooms are provided for computer-aided design personal computers, teminals, software, storage, health protection, and computer aided design system.

2.2.3.1.3 Control Rooms. Specific control rooms are provided for crane, central control, and supervisor console.

2.2.3.1.4 Clean Entrance. The clean entrance into the Vitrification Building includes showers, toilets, lockers, clothing storage, laundry area, and changerooms. These facilities are also available to the other functional areas except the regulated entrance.

2.2.3.1.5 Regulated Entrance. The regulated entrances from the Vitrification Building include health protection services, changerooms, toilets, and a decontamination shower. equipment.

2.2.3.1.6 HVAC Room. The entire partial second floor is for HVAC

\subsubsection{Service Building}

The Service Building is actually two structures separated by a seismic separation joint. The building is located adjacent to the northwest quadrant of the Vitrification Building and to the north end of the Support Building. The service area is a one-story metal building. The frit storage and preparation area is a one-story metal building except for the slurry preparation room, which contains a bucket elevator and has a roof height of $60 \mathrm{ft}$. 
The service area provides operational support functions for the Vitrification Building, including empty canister storage and inspection, maintenance shops, and cold chemical storage. The frit storage and preparation area is used for storage of the frit tote-bins and preparation of the slurry.

\subsubsection{Facility Descriptions. The Service Building has 10 major functional} areas: 1) empty canister receiving/storage/inspections; 2) maintenance shop; 3) electrical and instrumentation shop No. 5; 4) HVAC equipment room; 5) electrical room; 6) mechanical room; 7) cold chemical receiving/storage area; 8) pipeway; 9) frit storage and preparation area; and 10) liquid waste neutratization area.

2.2.4.1.1 Empty Canister Receiving/Storage/Inspection Area. The empty canister receiving, storage, and inspection facility is an integral part of the Service Building. Empty canisters and overpacks are unloaded from a railroad car or truck by a forklift. The forklift performs all canister and overpack handling operations along the length of the canister storage corridors. After the canisters and overpacks are unloaded from the railcar or truck, they are deposited in canister/overpack racks or in a laydown area on the loading dock. An airlock with roll-up doors separates the canister inspection area from the canister ștorage area. A loading dock around the empty canister storage area and an overhead door provide access to the building for receipt of equipment and canisters.

The canisters and overpacks are subjected to nondestructive testing in the inspection area before entering the process cell and canyon area. The canisters and overpacks are handled by a forklift in the inspection area and are. then transferred to the process cell and canyon area by a 2-ton monorail. The Taydown area, empty canister storage area, plug storage area, office area, airlock, $x$-ray area, and inspection area measure approximately $10,000 \mathrm{ft}^{2}$.

2.2.4.1.2 Maintenance Shop. The $6,000 \mathrm{ft}^{2}$ maintenance shop includes a fabrication and repair area that contains welding, cutting, and grinding equipment. The fabrication area is serviced by a one-ton monorail hoist with a 20- $\mathrm{ft}$ extension. A pipe storage rack accommodates 20- $\mathrm{ft}$ lengths of pipe. A drill press, hydraulic press, pipe bending machine, and a pipe threading machine are located in this area, which also contains an office and a tool crib with tool closet.

2.2.4.1.3 Electrical and Instrumentation Shop No. 5. The electrical and instrument (E\&I) shop No. 5 is used for the repair of all uncontaminated electrical equipment and instrumentation. A $10-\mathrm{ft}$ wide access corridor provides service access to this shop. 
2.2.4.1.4 HVAC Equipment Room. The HVAC equipment room is located on a mezzanine. The mezzanine has a concrete floor slab to accommodate the equipment.

2.2.4.1.5 Electrical Room. The electrical room houses a local operating station, motor control center, starters, and a substation with switchgear and an airbrake.

2.2.4.1.6 Mechanical Room. The mechanical room houses the water chillers for Zone 2 and Zone 3 HVAC supply units. The mechanical room al so houses a breathing-air compressor, chilled-water pumps, moisture separator, hot water storage tank and pump, reciprocating water chillers, pump, air compressor, after cooler, moisture separator, and storage tank. A monorail system is provided in the mechanical roon for maintenance and repair.

2.2.4.1.7 Cold Chemical Receiving/Storage Area. A chemical storage area is provided in the northwest corner of the service area and is attached to the cold chemical area. Bags and drums of cold chemicals are stored in this area. Two offices, men/women toilet facilities, and local operating stations are located in this area.

Forklift access to the chemical storage area, the mechanical room, E\&I shop No. 5, and the electrical room is provided by a 10-ft-wide corridor connecting these rooms. Before personnel exit the building, they are monitored for contanination.

Also included in this area is a cold feed storage area containing various tanks for receiving and mixing chemicals prior to their transfer via pipeline to the Vitrification Building.

2.2.4.1.8 Pipeway. The three-level pipeway located in the center of the cold chemical receiving/storage area is the primary route into the Vitrification Building for cold chemicals and frit slurry.

2.2.4.1.9 Frit Storage and Preparation Area. The frit storage and preparation area is located north of the service area and east of the chemical storage area. The building is a standard steel-framed structure with metal

exterior walls and roof, a reinforced concrete slab foundation, and an attached loading dock. The frit storage area is used for storage of 30 frit totebins. The slurry preparation area of the building houses the slurry makeup equiprent.

2.2.4.1.10 Liquid Waste Neutralization. The Tiquid waste neutralization area contains several tanks and is located adjacent to the frit storage and preparation area. 
Two concrete loading docks service these functional areas. One is located west of the empty canister storage area, with a canopy extending over the railroad unloading area. The other is located north of the empty canister storage area and west of the maintenance aea. Both loading docks have canopies that extend from the service area roof. The two loading docks are connected by an 8-ft-wide personnel access way. The loading docks are $4 \mathrm{ft}$ above ground.

\subsubsection{Canister Storage Building}

The Canister Storage Building is actually three distinct structures separated by seismic separation joints, located adjacent to the southwest corner of the Vitrification Building. The canister storage area is a two-story pouredin-place reinforced concrete structure approximately $28 \mathrm{ft}$ above grade to the second floor, with an additional $21 \mathrm{ft}$ below grade. The second floor supports a one-story metal building to house the building's major HVAC equipment as shown in Figures 2-6 and 2-7.

The cask loadout/shipping and railroad airlock/washdown area is actually two structures separated by seismic separation joints, located adjacent to the northwest quadrant of the canister storage area. The cask loadout/shipping area is, a one-story poured-in-place reinforced concrete structure with a partial basement area. The basement accommodates a cask pit for work with the loadout tunnel and test station in the canister storage area. The cask loadout/shipping structure abuts with a one-story metal railroad airlock/washdown building.

The third structure is a one-story metal personnel and equipment facility located midway along the north side of the canister storage area. This structure also contains the regulated entrance to the canister storage area.

The Canister Storage Building serves as a storage location for canisters . of vitrified waste. The facilities receive and store canisters filled with the vitrified product that have been sealed, decontaminated, and characterized; remove the radioactive decay heat generated by the canisters by air ventilation that is HEPA filtered before discharge; and house support systems and electri-cal distribution system components required for the building and its equipment.

The cask loadout/shipping and railroad airlock/washdown areas of the Canister Storage Building provide a facility for transfer of the canisters from the storage area into a cask and onto a raillcar for shipment to a final repository. 


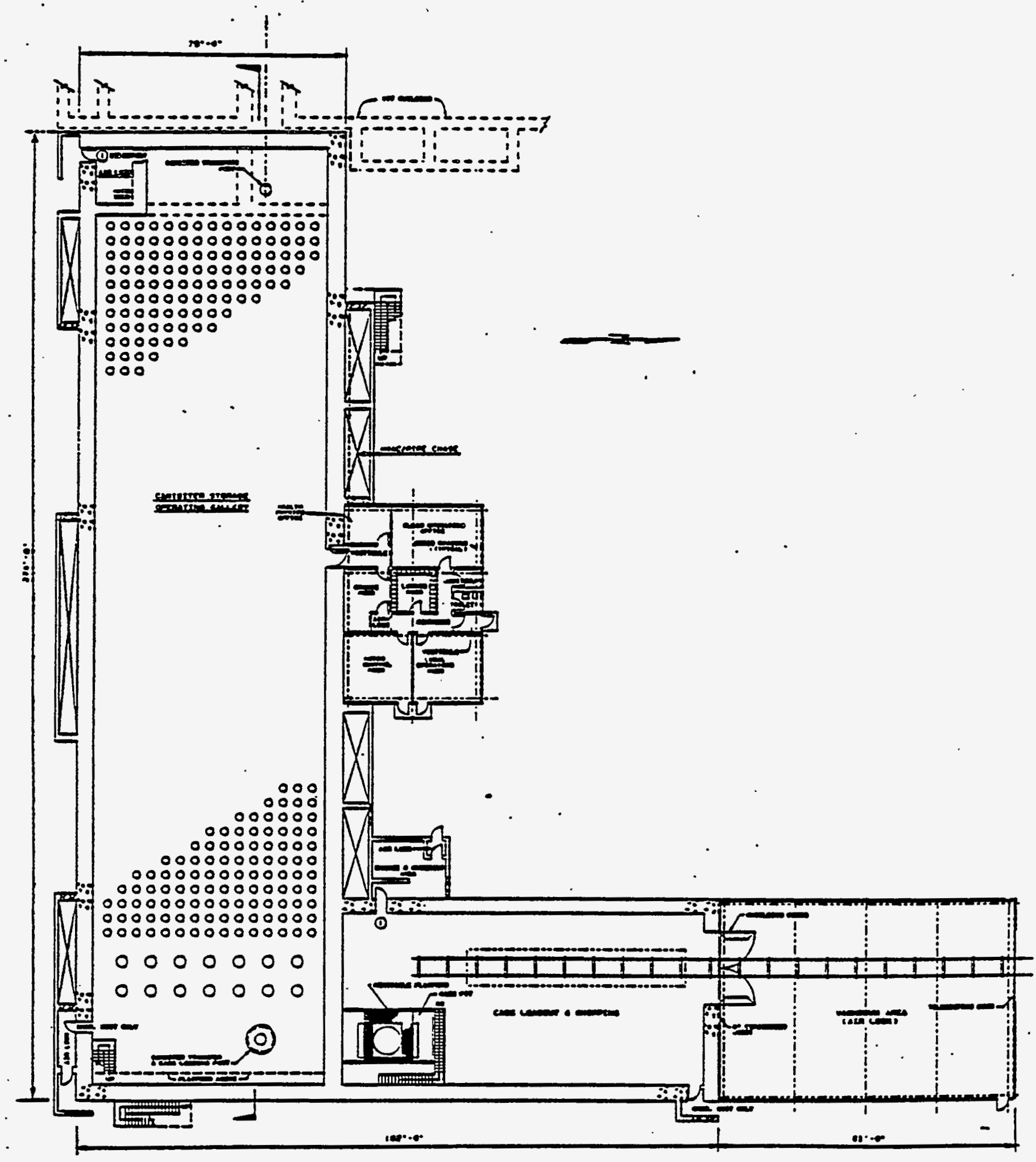

FIGURE 2-6. Canister Building First Floor PTan 
웅

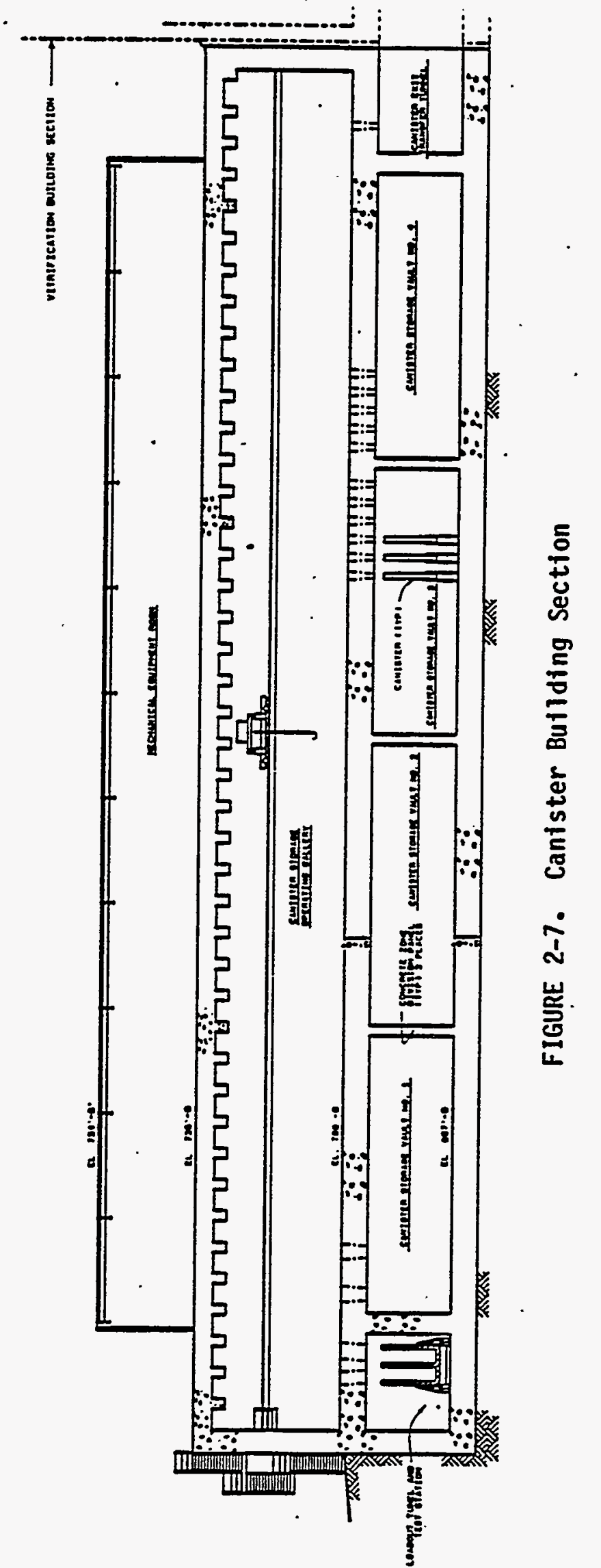

2-23 
2.2.5.1 Facility Descriptions. The Canister. Storage-Building has six major functional areas: 1) storage area; 2) operating area; 3) HVAC equipment room; 4). personnel and equipment facility;. 5) cask loadout/shipping area; and 6) railroad airlock/washdown area.

2.2.5.1.1 Storage Area. This Category I area, including the below-grade air supply, exhaust air, and transfer tunnel structures, stores filled canisters and provides protection for operating personnel and the surrounding environment.

The stored canisters are protected against external damage. The canister supports and plenum boundaries are seismic resistant structures fabricated from large diameter pipe sections and anchored to steel plates in the floor. The space between the pipes is sealed off by a galvanized horizontal steel plate to form air inlet and air outlet plenums.

A canister transfer and cask loading tunnel connects the east end of the canister storage area to the cask loadout and shipping area. At the south end of the tunnel is a knockout for future expansion of the canister storage area.

At the west end of the canister storage area is a canister exit transfer tunnel from the weld test cell in the Vitrification Building.

2.2.5.1.2 Operating Area. The operating area located over the storage area has a 5-ft-thick poured-in-place reinforced concrete floor slab. It has hatch openings that are closed by removable precast shielding plugs. There are 750 standard and 14 oversized openings, each identified with an embedded plate. The openings in the standard panels are laid out in a grid pattern, measuring $3 \mathrm{ft}, 6$ in. square. The plugs are removed by an overhead traveling crane.

2.2.5.1.3 HVAC Equipment Room. The HVAC equipment room is on the second floor over the operating area. Air intake and exhaust shaft extend from the HVAC building down the side of the operating and storage areas and are designed to be a part of the building. They: meet Category I design criteria. The HVAC air supply originates, and the exhaust shafts terminate, on the roof over the canister storage area. The HEPA filters are housed in a steel-framed and insulated building with metal siding. This building is designed to facilitate the changing of the HEPA filters.

A concrete stack is also located on the roof over the canister storage area on the east side of the Vitrification Building.

2.2.5.1.4 Personnel and Equipment Facility. The personnel and equipment facility is centrally located on the north side of the operating area to allow 
easy access to the operating floor area. Personnel access to the area is limited and is not allowed during movement of the unshielded canisters. Access to the operating area is through a regulated entrance that includes health protection services, a change room, and a locker room. Also included in this facility are a clean operating office, a local operators room, and a motor control room, which is separated by a $2-h$ fire wall.

2.2.5.1.5 Cask Loadout/Shipping Area. The cask loadout and shipping area is a concrete Category I structure located on the northeast side of the canister storage area and attached. to a common cask transfer tunnel. The cask moves between the canister storage area and the loadout area by a remotely operated cart or rail system. Personnel are allowed to enter the loadout area through a change and checkout area. After the cask is loaded and-inspected, the cask is removed from the cart by an overhead crane and loaded onto a flat bed railcar.

2.2.5.1.6 Railroad Airlock/Washdown. The railroad airlock/washdown area is a metal building located north of the cask loadout/shipping area. This area serves as a washdown area for incoming railcars. The railcars are backed into the washdown area and pulled into the cask loadout and shipping area with a car puller.

\subsubsection{Sand Filter Building}

The Sand Filter Building is a one-story below-grade poured-in-place reinforced concrete building. It is located approximately $100 \mathrm{ft}$ due south of the Vitrification Building. A ventilation Zone 1 exhaust tunnel (approximately $17 \mathrm{ft}^{\prime}$ wide and $10 \mathrm{ft}$ high inside cross section) runs from the northeast corner of the Sand Filter Building to the southeast corner of the Vitrification Building. This tunnel is part of the Sand Filter Building.

The Sand Filter Building houses a sand filter to filter Zone 1 exhaust gas.

2.2.6.1 Facility Descriptions. The Sand Filter Building is considered to have three major functional areas: 1) sand filter; 2) exhaust tunnel; and 3 ) temporary bypass.

2.2.6.1.1 Sand Filter. The sand filter consists of an air intake and distribution system, the filter bed, and an air exit system. The filter bed consists of graded layers of rock and sand designed to remove a minimum of $99.95 \%$ of the radioactive particulates at an air velocity of $5 \mathrm{ft} / \mathrm{min}$. The air exit system discharges the filtered air to the exhaust stack. 
Space is reserved on the east side of the sand filter facility for the future replacement of the sand filter and for extension of the filter tunnels in the event of particulate loading, excessive pressure drops, or the need for greater air filtration capacity necessitates expansion.

2.2.6.1.2 Exhaust Tunnel. The exhaust tunnel is approximately $100 \mathrm{ft}$ in length and provides a passage for exhaust vessel vent system and melter off-gas air from the Vitrification Building to the sand filter.

2.2.6.1.3 Temporary Bypass. The temporary bypass is a metal HVAC duct passing over the. top of the sand filter and designed to route Vitrification Building air around the sand filter until hot startup of the system. Design of the bypass ensures that unfiltered air cannot bypass the sand filter after hot startip.

\subsubsection{Fan House Building}

The Fan House Building is a two-stage poured-in-place reinforced concrete building located approximately $100 \mathrm{ft}$ south of the southwest corner of the Vitrification Building.

The Fan House Building contains fan. inlet plenums, fan discharge plenums, exhaust fans, and associated electrical equipment and is unattended during normal operations. Personnel are not assigned to the fan house building on a full-time basis. Personnel access is only necessary for maintenance. Equi.pment operations are monitored from the control room in the Vitrification Building.

2.2.7.1 Facility Description. The Fan House Building has four major functional areas: 1) HVAC tunnels and fan room; 2) HVAC equipment and storage room; 3) HVAC sampling station; and 4) electrical equipment room.

2.2.7.1.1 HVAC Tunnels and Fan Room. The HVAC intake tunnel from the Sand Filter Buitding and the exhaust tunnel to the stack are located on the first floor directly below the HVAC fan room on the second floor.

2.2.7.1.2 HVAC Equipment and Storage Room. The HVAC equipment and storage room on the second floor, contains ventilation equipment for the electrical equipment, local operating station, and battery room. Fan house building inlet and exhaust tunnels are located under the fan room for the Zone 1 exhaust. 
2.2.7.1.3 HVAC Sampling Station. The HVAC sampling station is located on the second floor over the exhaust tunnel and contains computers, analyzers, processors, and related equipment necessary to sample and maintain a record. of the emissions through the stack.

2.2.7.1.4 Electrical Equipment Room. The electrical equipment room provides the power for the HVAC fans and contains a load center, motor control center, battery room, and local operator's station.

\subsubsection{Switchgear/Generator Building}

The Switchgear/Generator Building is a one-story poured-in-place reinforced concrete building with a partial basement for an electrical vault located in the center of the building. This building is located approximately $100 \mathrm{ft}$ north and $150 \mathrm{ft}$ west of the northwest corner of the service building.

The Switchgear/Generator Building houses the incoming power distribution system switchgear and the standby engine-generators.

2.2.8.1 Facility Description. The Switchgear/Generator Building has two major functionat areas: 1) incoming power distribution and 2) standby engine generators.

2.2.8.1.1 Incoming Power Distribution. The center half of the building houses the incoming power distribution system switchgear ( 2 units) that is located on the first floor directly over the basement electrical vault.

2.2.8.1.2 Standby Engine Generators. The outer one-quarter at both the north and south ends of the building houses the standby engine-generators that supply the standby power for essential facility equipment.

\subsubsection{Exhaust Stacks}

The exhaust stacks include; 1) two metal stacks attached to the Vitrification Building and 2) one freestanding stack and the above-grade exhaust duct from the Fan House Building to this freestanding stack. The Zone 2 and 3 stack is a metal stack approximately $8 \mathrm{ft}$ in base diameter and $60 \mathrm{ft}$ high, located at the northwest corner of the fourth floor of the Vitrification Building. The canister storage building stack is a metal stack approximately $6 \mathrm{ft}$ in base diameter and $40 \mathrm{ft}$ high attached to a concrete chase extending $20 \mathrm{ft}$ above the fourth floor of the Vitrification Building. The Zone 1 stack is a metal stack approximately $16 \mathrm{ft}$ in base diameter and $150 \mathrm{ft}$ high, located 200 feet due south of the Fan House Building. 
The function of these exhaust stacks is to disperse filtered air to the atmosphere.

2.2.9.1 Facility Description. The function of the following three exhaust stacks is to disperse filtered air from various locations to the atmosphere:

2.2.9.1.1 Zone 2 and 3 Stack. The Zone 2 and 3 stacks disperse filtered air to the atmosphere from Zones 2 and 3 within the Vitpification Building, the Manipulator Repair Building, and the regulated areas of the Support Building.

\subsection{Canister Storage Stack. The canister storage stack disperses} filtered air from the Canister Storage Building. It is constructed in two segments. The first segment is a concrete chase extending above the northwest corner of the canister storage building and supported from the Vitrification Building. The second segment is a metal stack that extends from the chase. above the adjacent roof.

2.2.9.1.3 Zone 1 Stack. The Zone 1 stack disperses filtered air to the atmosphere from the Zone 1 area of the Vitrification Building.

\subsubsection{RLST/WHT Vauits and Building}

There are three separate structures included within this section. The receipt and $\mathrm{lag}$ storage tank (RLST) vault is a 20-ft high double-wall tank with another 20-ft concrețe pump pit extending above the top of the tank. the entire assembly is below grade and located approximately $122 \mathrm{ft}$ north of the canister storage area and $96 \mathrm{ft}$ west of the canister shipping area. The primary tank is stainless steel; the secondary tank is carbon steel. The secondary tank is the inter-form for a concrete shell that surrounds the secondary tank and is an integral part of the pump pit.

The waste hold tank (WHT) vault is a 20-ft high double-wall tank with another 20-ft concrete pump pit extending above the top of the tank. The entire assembiy is below grade and located approximately $192 . \mathrm{ft}$ north of the canister storage area and $96 \mathrm{ft}$ west of the canister shipping area. The construction of this vautt is similar to that of the RLST vault described above.

The RLST/WHT Building is a one-story building located approximately $332 \mathrm{ft}$ north of the canister. storage area, and $76 \mathrm{ft}$ west of the canister shipping area.

This building is actually two structures separated by a seismic separation joint. The primary ventilation system is housed in a one-story reinforced 
poured-in-place concrete structure. The annulus ventilation system is housed in a one-story metal building. The two adjacent buildings are arranged to form a $40 \mathrm{ft}$ by $60 \mathrm{ft}$ footprint.

\subsubsection{Facility Description. The primary function of each of these} structures is as follows:

2.2.10.1.1 RLST Vault. The receipt and lag storage tank (RLST) vault houses the feed RLST. The primary purpose of this tank system is to receive HWV feed from the tank farm and provide lag storage before processing. This tank system is al so capable of receipt of the transuranic (TRU) recycle stream from the decontamination waste treatment tank (DWTT) located in the CPC.

2.2.10.1.2 WHT Vault. The waste hold tank (WHT) vault houses the WHT. The primary purpose of this tank system is to provide lag storage of the radioactive process waste to meet tank farm transfer scheduling requirements.

2.2.10.1.3 RLST/WHT Building. The RLST/WHT Building is located at grade. The primary purpose of this building is to house the RLST and WHT primary and annulus ventilation sampling and transmitting systems.

\subsubsection{Miscellaneous Structures}

There are three additional poured-in-place reinforced concrete structures that have sufficient merit to be mentioned. These are the cooling tower foundation, the solar evaporation tank, and the regulated drains collection tank (RDCT) vault. The cooling tower foundation is approximately $4 \mathrm{ft}$ high and located approximately $240 \mathrm{ft}$ due north of the Vitrification Building. The solar evaporation tank is located approximately $300 \mathrm{ft}$ due north of the Vitrification Building. The RDCT is located $10 \mathrm{ft}$ due south of the Service Building.

2.2.11.1 Facility Description. The primary function of each of these miscellaneous structures is as follows:

2.2.11.1.1 Cooling Tower Foundation. The cooling tower foundation supports an induced draft timber cooling tower that is purchased in three cells as a package unit for field erection. The cooling tower provides cooling water to the Vitrification and Service Buildings.

2.2.11.1.2 Solar Evaporation Tank. The solar evaporation tank services the liquid waste neutralization tanks located in the Service Building. The tank consists of a metal tank centered within a concrete basin of sufficient volume to contain the contents of the tank in the event of a tank rupture. 
2.2.11.1.3 Regulated Drains Collection Tank. The RDCT services the support Building personnel decontamination area drains. The tank is contained within a vault that is primarily below grade.

\subsection{PROCESS/SUPPORT EQUIPMENT (Partial.7y Completed Section)}

A summary of equipment process engineering data for various equipment pieces is provided in Tables 2-2 through 2-6 (Section 2.3.1). This-section also generally describes the equipment: Assembly drawings of representative equipment items are provided (Section 2.3.2) to graphically show equipment features.

\subsubsection{Process Equipment Engineering Data}

A compilation of process engineering features for the process equipment is provided in the following tables:

Equipment

Process Tanks Description

Heating/Cooling Coils Description

Agitator Description

Condenser Description

Pump Description
Table Number

$2-3$

$2-4$

2-5

$2-6$

A brief general description is provided of the equpment in each classification. 
TABLE 2-2. Process Tank Description

\begin{tabular}{|c|c|c|c|c|c|c|c|c|c|c|}
\hline \multirow[b]{2}{*}{$\begin{array}{l}\text { Equipment } \\
\text { Hunher }\end{array}$} & \multirow[b]{2}{*}{ Equi ment Hame } & \multirow[b]{2}{*}{ Function } & \multirow[b]{2}{*}{$\begin{array}{l}\text { Morking } \\
\text { Volume } \\
\text { (gal) }\end{array}$} & \multirow[b]{2}{*}{$\begin{array}{l}\text { Overall } \\
\text { olmensions } \\
\text { I.D. } \times \text { HT }\end{array}$} & \multirow[b]{2}{*}{$\begin{array}{c}\text { Construction } \\
\text { Materlal }\end{array}$} & \multicolumn{4}{|c|}{ Design } & \multirow[b]{2}{*}{ Features } \\
\hline & & & & & & Pressure (ps|g) & $\begin{array}{l}\text { Vacuum } \\
\text { (ps/g) }\end{array}$ & $\begin{array}{l}\text { Hax } \\
\text { L Lquidd } \\
\text { Level } \\
\text { (ft) }\end{array}$ & $\begin{array}{l}\text { Speclffec } \\
\text { Gravity }\end{array}$ & \\
\hline 12A-1T-TK-1100 & $\begin{array}{l}\text { Slurry Recelpt } \\
\text { Adjustment Tank } \\
\text { (SRAT) }\end{array}$ & $\begin{array}{l}\text { Chemically } \\
\text { adjust, } \\
\text { transfer. } \\
\text { and con- } \\
\text { centrate }\end{array}$ & $8,600^{\circ}$ & $\begin{array}{c}12^{\circ}-0^{*} \times x \\
19^{4}-1^{\prime \prime}\end{array}$ & Alloy 20 & $50 \bullet 275^{\circ} \mathrm{F}$ & -- & 11.5 & $1.21 \cdot 100^{\circ} \mathrm{F}$ & 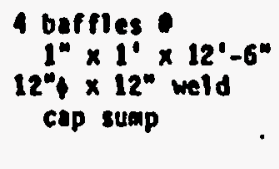 \\
\hline $12 A-1 T-T K-1200$ & $\begin{array}{l}\text { Slurry MIX } \\
\text { Evaporator } \\
\text { (sHE) }\end{array}$ & $\begin{array}{l}\text { Makeup and } \\
\text { concentrate } \\
\text { melter }\end{array}$ & 8,600 & $\begin{array}{l}12^{\circ}-0^{\prime \prime} \times x \\
19^{\circ}-1^{\prime \prime}\end{array}$ & Alloy 20 & $50 \bullet 215^{\circ} \mathrm{F}$ & m- & 11.5 & $\begin{array}{l}1.21 \bullet 100^{\circ} \mathrm{F} \\
\operatorname{sump}\end{array}$ & $\begin{array}{l}4 \text { baffles } \\
1 " \times 1^{\prime \prime} \times 12^{\prime}-6^{\prime \prime} \\
122^{\prime \prime} \times 12^{\prime \prime} \text { weld cap cop }\end{array}$ \\
\hline
\end{tabular}

TABLE 2-3. Heating/Cooling Colls Description

\begin{tabular}{|c|c|c|c|c|c|c|c|c|c|}
\hline $\begin{array}{l}\text { Equipment } \\
\text { Hunher }\end{array}$ & Equit pment Heme & Function & Capacity (Btu/h) & $\begin{array}{l}\text { Heat Transfer } \\
\text { Area }\left(\left|t^{2}\right|\right.\end{array}$ & Plpe & $\begin{array}{c}\text { Hunber of } \\
\text { Rows }\end{array}$ & Materfal & $\begin{array}{c}\text { Design } \\
\text { Pressure } \\
\text { (pstg) }\end{array}$ & Fentures \\
\hline $11 A-90-E-1003$ & RLST cooling coll & Cool tank contents & Coolfing 350,000 & Heat-transfer-160 & $2^{\mu}$ HPS Seh 40 & 18 & 31655 & $150 \cdot 250^{\circ} \mathrm{F}$ & \\
\hline $12 \Lambda-1 T-E-112$ & SRAT heatIng coll & $\begin{array}{l}\text { Heat/boll tank } \\
\text { contents }\end{array}$ & Heating $6,000,000$ & 340 & 2" APS Sch 10 & 18 & Alloy 20 & $200 \bullet 100^{\circ} \mathrm{F}$ & 2 colls \\
\hline $12 A-1 T-E-1103$ & SRAT coolling coll & Cool tank contents & Coolling 260,000 & 140 & $2^{\prime \prime}$ hips $\operatorname{sech} 10$ & 18 & Alloy 20 & $200 \bullet 400^{\circ} \mathrm{F}$ & 1 coll. \\
\hline $120-1 T-E-1202$ & SHE heatIng coll & $\begin{array}{l}\text { Heat/bofl tank } \\
\text { contents }\end{array}$ & llesting $6,000,000$ & 340 & $2^{n}$ HPS Sch 40 & 18 & Alloy 20 & $200 \bullet 400^{\circ} \mathrm{F}$ & 2 colls \\
\hline $12 n-11-E-1203$ & SHE cooling coll & Cool tank contents & Cooling 960,000 & 140 & $2^{\prime \prime}$ HPS Sch 40 & 18 & Alloy 20 & $200 \ominus 400^{\circ} \mathrm{F}$ & $1 \operatorname{coll}$ \\
\hline
\end{tabular}


TABLE 2-4. Agitator Description

\begin{tabular}{|c|c|c|c|c|c|c|c|c|c|}
\hline $\begin{array}{l}\text { Equlponent } \\
\text { Nusuber }\end{array}$ & Equilpriment Mane & Function & $\begin{array}{c}\text { Capactiyy } \\
\text { (gpm) }\end{array}$ & Material & Aplisator & $\begin{array}{l}\text { Pover } \\
\text { (V/I/III) }\end{array}$ & $\begin{array}{l}\text { Agitstor } \\
\text { Cength/ola } \\
\text { (Ifi) }\end{array}$ & Halght & Feature \\
\hline $\begin{array}{c}\text { IIA-90-P-1001 } \\
.\end{array}$ & ALst igltator pump & Agltate lank slurry & $210 \bullet 80 \mathrm{psl}$ & J1a 35 & $\begin{array}{l}\text { Hotor } \\
\text { 50/1160 }\end{array}$ & $240 / 3 / 60$ & $-25^{\prime}$ (pumpl & $\therefore$ & 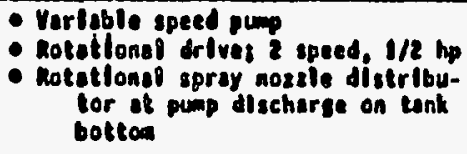 \\
\hline $12 A-11-A G-1104$ & SAAT eglteftor & Agltate contents & -- & Alloy 20 & $\begin{array}{l}100 / 130 \\
50 / 65\end{array}$ & $400 / 3 / 60$ & $17^{\circ} 6^{\circ} / 3^{\prime}$ & 9120 & 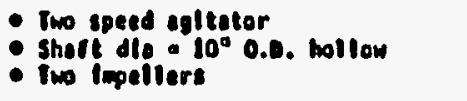 \\
\hline $12 a-11-A G-1204$ & sik egltetor & Agltote contents & -- & Alloy 20 & $\begin{array}{l}100 / 130 \\
50 / 65^{\circ}\end{array}$ & $460 / 3 / 160$ & $11 \cdot 0 \times / 3$ & 1120 & 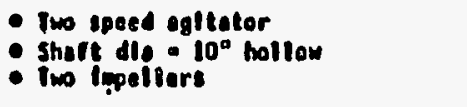 \\
\hline
\end{tabular}

岕

TABLE 2-5. Condenser Description

\begin{tabular}{|c|c|c|c|c|c|c|c|c|}
\hline & Equlpaent Hame & Function & $\begin{array}{l}\text { Capaclty } \\
\text { (atu/hr) }\end{array}$ & $\begin{array}{l}\text { Theat Iransfor } \\
\text { Aree }\left(1 t^{2}\right)\end{array}$ & $\begin{array}{l}\text { Olmenslons, } \\
\text { die } x \text { he }\end{array}$ & $\begin{array}{c}\text { Destgn Pressure, } \\
\text { psis }\end{array}$ & Passes & Fentures \\
\hline $12 A-11-C D-1101$ & sant condenser & $\begin{array}{l}\text { Condense concentrator } \\
\text { vapor }\end{array}$ & $5,330,000$ & 416 & $2^{\prime} 0^{\prime} \times 13^{\prime} 6^{\circ}$ & $\begin{array}{l}\text { Shell } 200 \div 150^{\circ} \mathrm{F} \\
\text { Twbe } 500250^{\circ} \mathrm{F}\end{array}$ & $\begin{array}{l}\text { Shell }-1 \\
\text { Itbe }-2\end{array}$ & 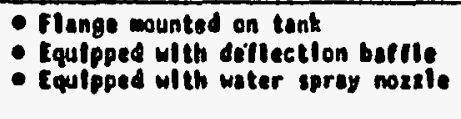 \\
\hline $128-11-C D-1201$ & SHEll condenser & $\begin{array}{l}\text { Condense concentrator } \\
\text { vapor }\end{array}$ & $5,310,000$ & 118 & $20^{\circ} \times 13^{\circ} 5^{\circ}$ & $\begin{array}{l}\text { Shell } 100: 150^{\circ} \mathrm{F} \\
\text { Tube } 50: 250^{\circ} \mathrm{F}\end{array}$ & $\begin{array}{l}\text { Shell - I } \\
\text { tube - } 2\end{array}$ & $\begin{array}{l}\text { - Ilange nounted on tenk } \\
\text { - Equlpped wleh deflectlon ballle } \\
\text { - Equipped with water sproy nozzle }\end{array}$ \\
\hline
\end{tabular}


TABLE 2-6. Pump Description

\begin{tabular}{|c|c|c|c|c|c|c|c|c|}
\hline $\begin{array}{l}\text { Equipment } \\
\text { Mumber }\end{array}$ & EquIpnent Hame & Function & Copactey (gpm) & Hoterial & Pump $\mathrm{rpm}_{\mathrm{pm}}$ & $\begin{array}{l}\text { Power } \\
\text { (V/H/Hz) }\end{array}$ & $\begin{array}{l}\text { Pump. } \\
\text { Lenpiti } \\
\text { lifil }\end{array}$ & Features \\
\hline iin-90-p-1008 & RLST agleator pump & Agltate tenk slurry & $210000 \mathrm{ps1}$ OP & 3162 & $50 / 1150$ & $240 / 3 / 60$ & 25 & 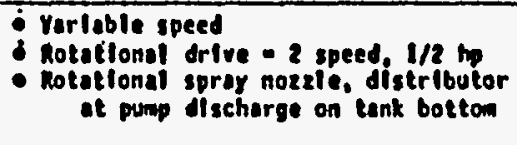 \\
\hline $11 n-90-P-1005$ & RLst semple punp & Semple tenk slurry & 100.45 pst or & 301L. & $20 / 1750$ & $220 / 3 / 60$ & 25 & 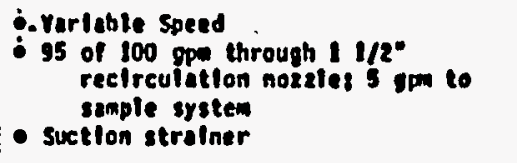 \\
\hline 11A-90-P-1005 & $\begin{array}{l}\text { MLSI transfer pump } \\
\text {. }\end{array}$ & $\begin{array}{l}\text { Irañater leed to } \\
\text { sant }\end{array}$ & & 3042 & $20 / 1800$ & $220 / 3 / 60$ & 25 & - Varlable speed \\
\hline $11 A-90-P-1008$ & RLSI annulus pump & $\begin{array}{l}\text { Iransfer tonk slurry } \\
\text { leakage }\end{array}$ & $50 \bullet 40 \mathrm{pst}$ & 3012 & $10 / 1150$ & $220 / 3 / 60$ & 25 & - self priming \\
\hline $11 n-90 \cdot r-1009$ & $\begin{array}{l}\text { RLsI leak detection } \\
\text { plt pump }\end{array}$ & $\begin{array}{l}\text { Iransler tonk slurry } \\
\text { leakage }\end{array}$ & $5 \bullet 50$ psI op & 3042 & $5 / 1150$ & $220 / 3 / 60$ & 40 & - sell priming \\
\hline
\end{tabular}




\subsubsection{Process Equipment Assembly Drawings}

Assembly drawings are provided of key Defense Waste Processing Facility (DWPF) process equipment. It is currently anticipated that the HWVP equipment will be similar. These assembly drawings provide a graphic illustration of equipment design features.

\section{$\therefore$ Equipment Requirements Orawing}

High Efficiency Mist Eliminator

Thermowave Assembly

SME/SRAT/DWTT Condenser

Coil Assembly-Melter Feed Tank.

Steam Atomi zed Scrubber Assembiy

Coil Assembly - DWTT

Off Gas Condenser

Formic Acid Vent Condenser

Tank A'ssembly-SMECT

Tank Assembly-OGCT

Tank Assembly-SFHT

Tank Assembly-RCT

Tank Assembly-SME, SRAT, MFT, DWTT

Coil Assembly SME/SRAT

Remote Process.Cell-Transfer Pump

DWPF Centrifugal Sample Pump

Process Cell Agitator Slurry Service

DHPF Canister Assembly and Details

Melter Feed Pump

0il Drain Catch Tank

RLST/WHT Arrangement

Melter

Turntable
DWPF

Drawing

H752125

W752129

W752132

W752133

W752135

W752139

W752182

W752183

W752142

W752189

W752190

W752191

W752193

W752197

W752260

W752270

W752280

W752311.

W752272

W752134
Figure

Number

2-8

2-9

2-10

2-11

2-12

2-13

2-14

2-15

2-16

2-17

2-18

2-19 


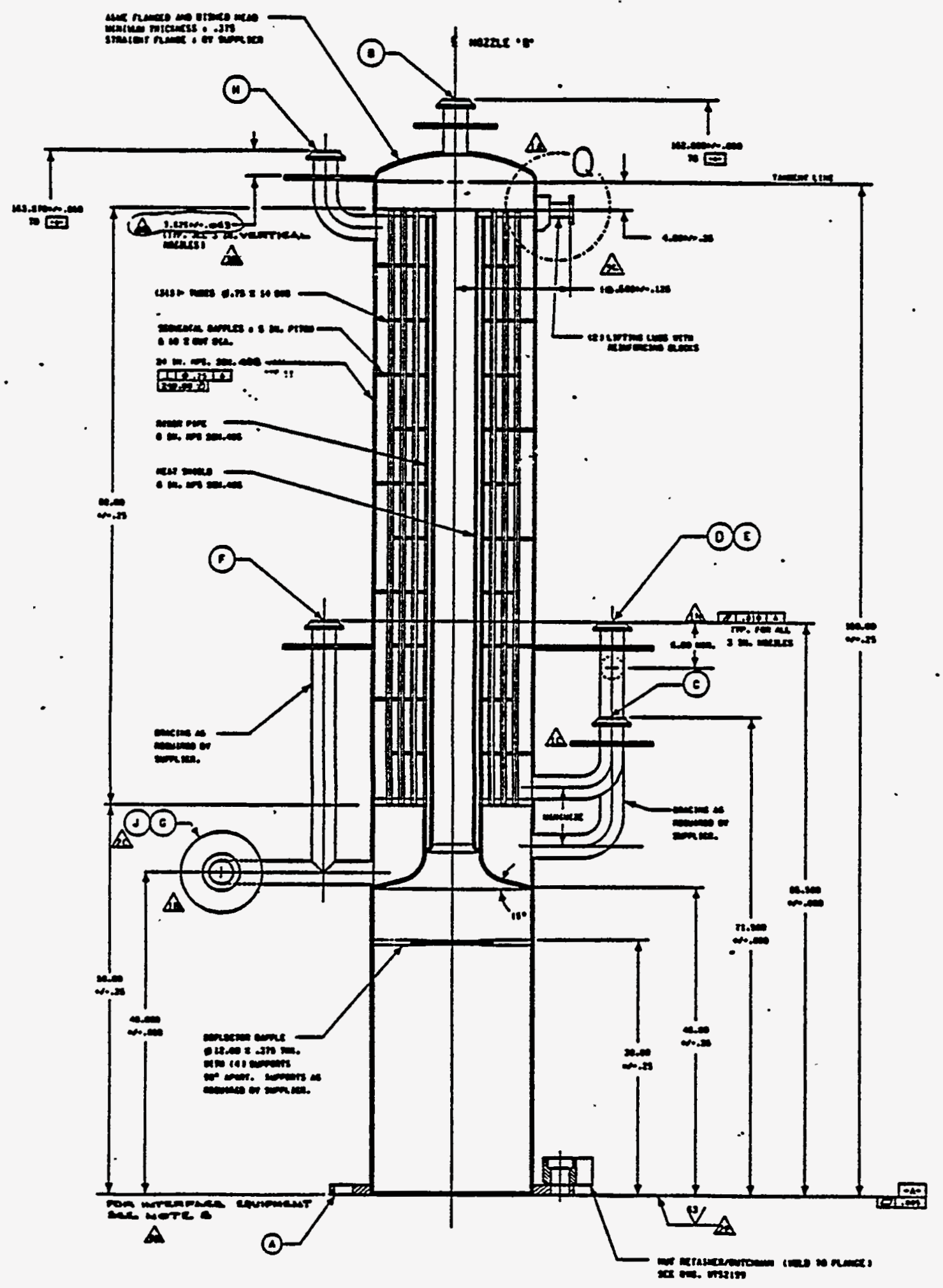

FIGURE 2-8a. Condenser: SME, DWTT, SRAT (Elevation) 


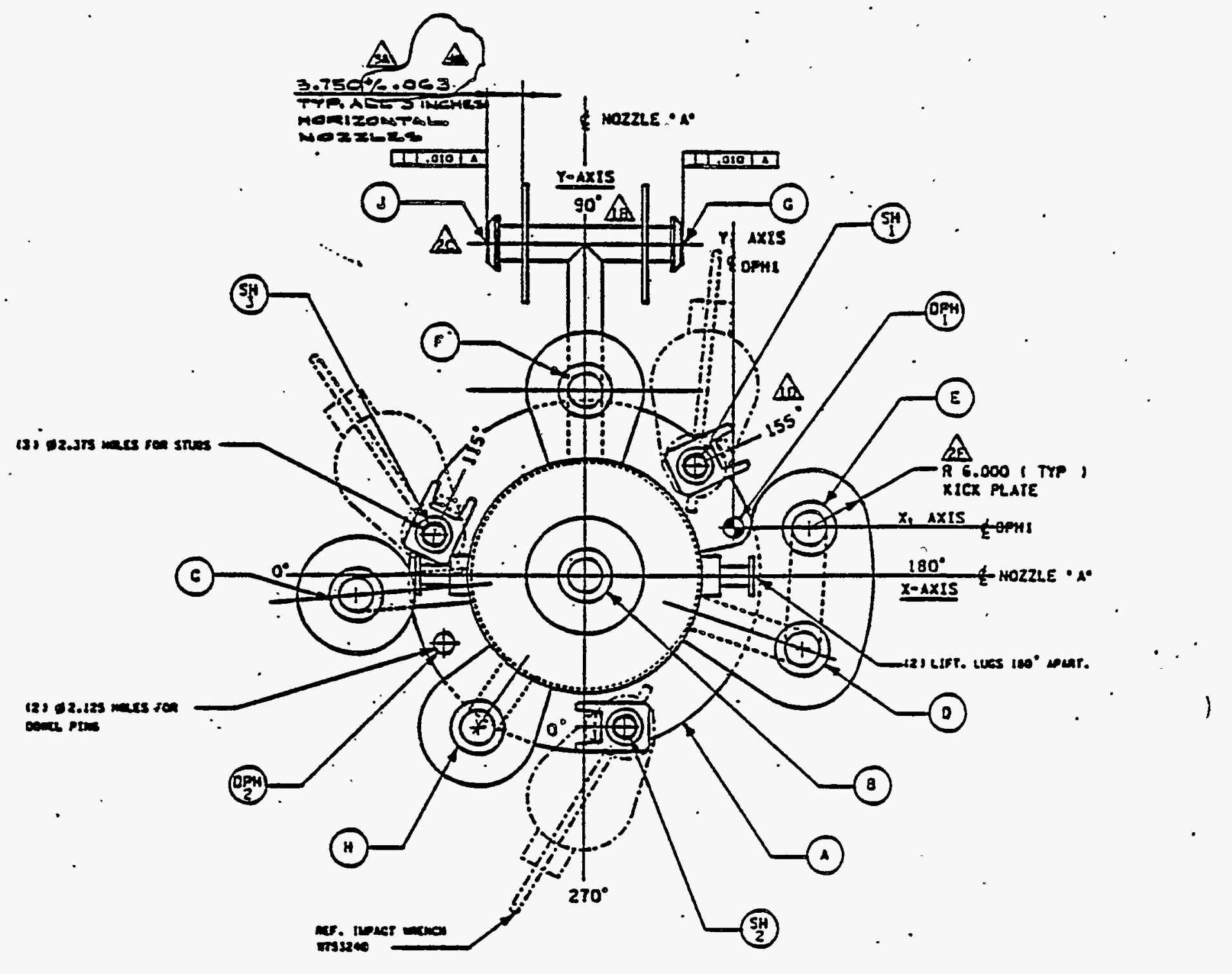

FIGURE 2-8b. Condenser: SME, DWTT, SRAT (Plan View) 


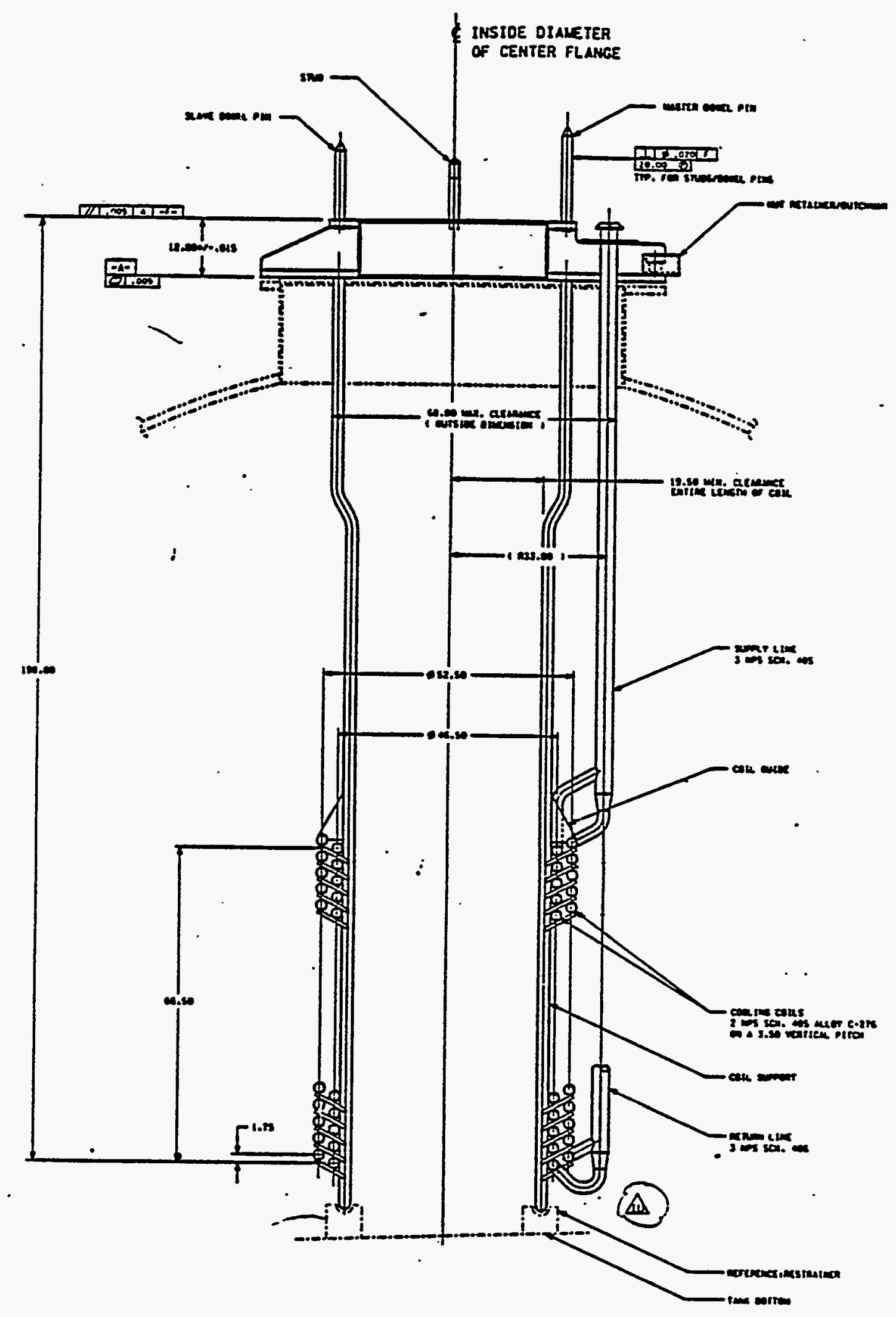

FIGURE 2-9a. Coil Assembly: Melter Feed Tank (Elevation) 


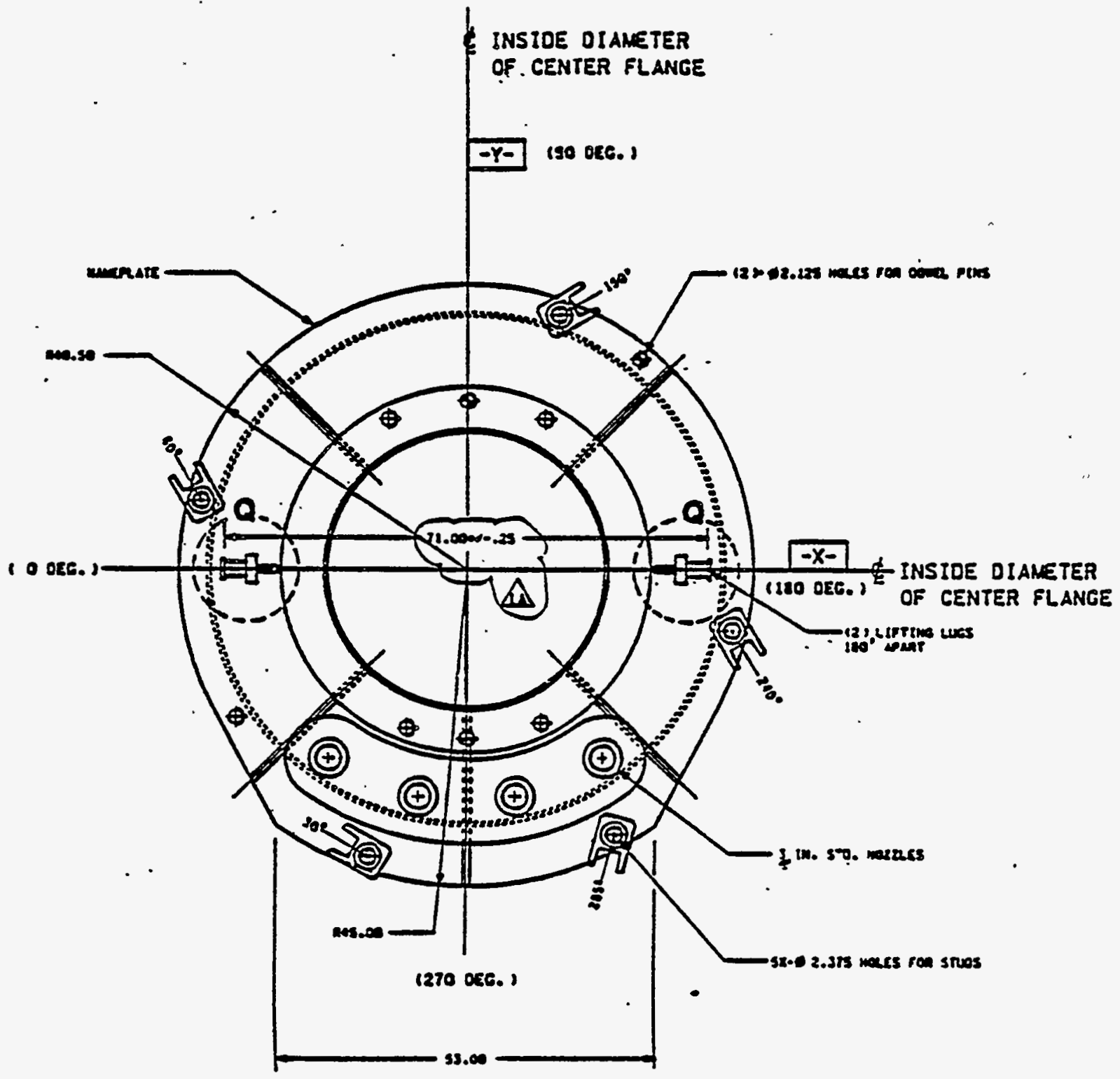

FIGURE 2-9b. Coil Assembly: Melter Feed Tank (Plan View) 


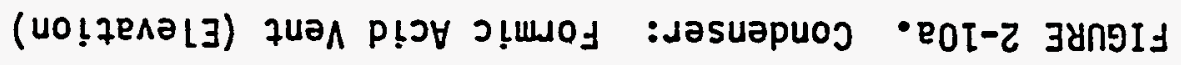

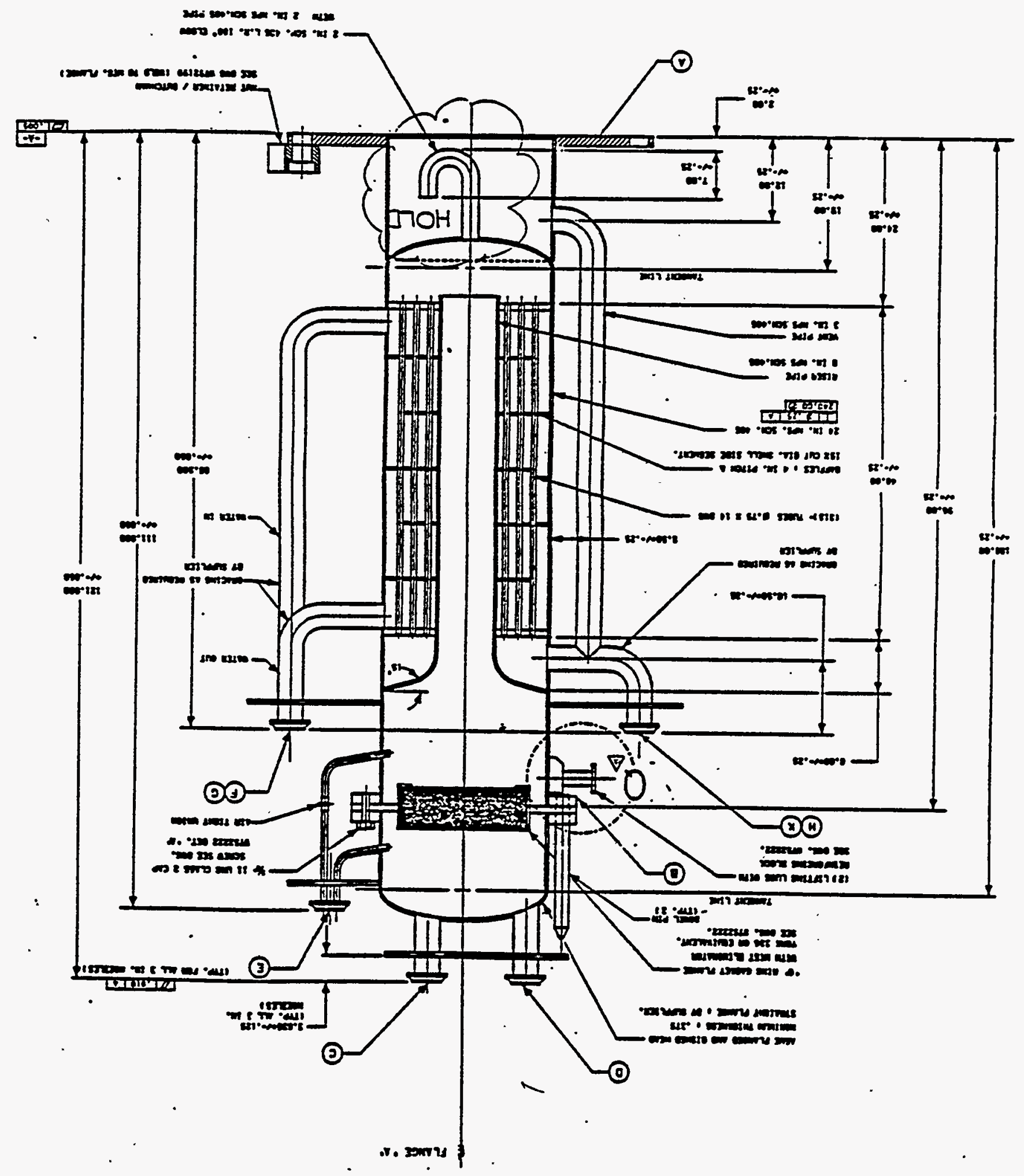




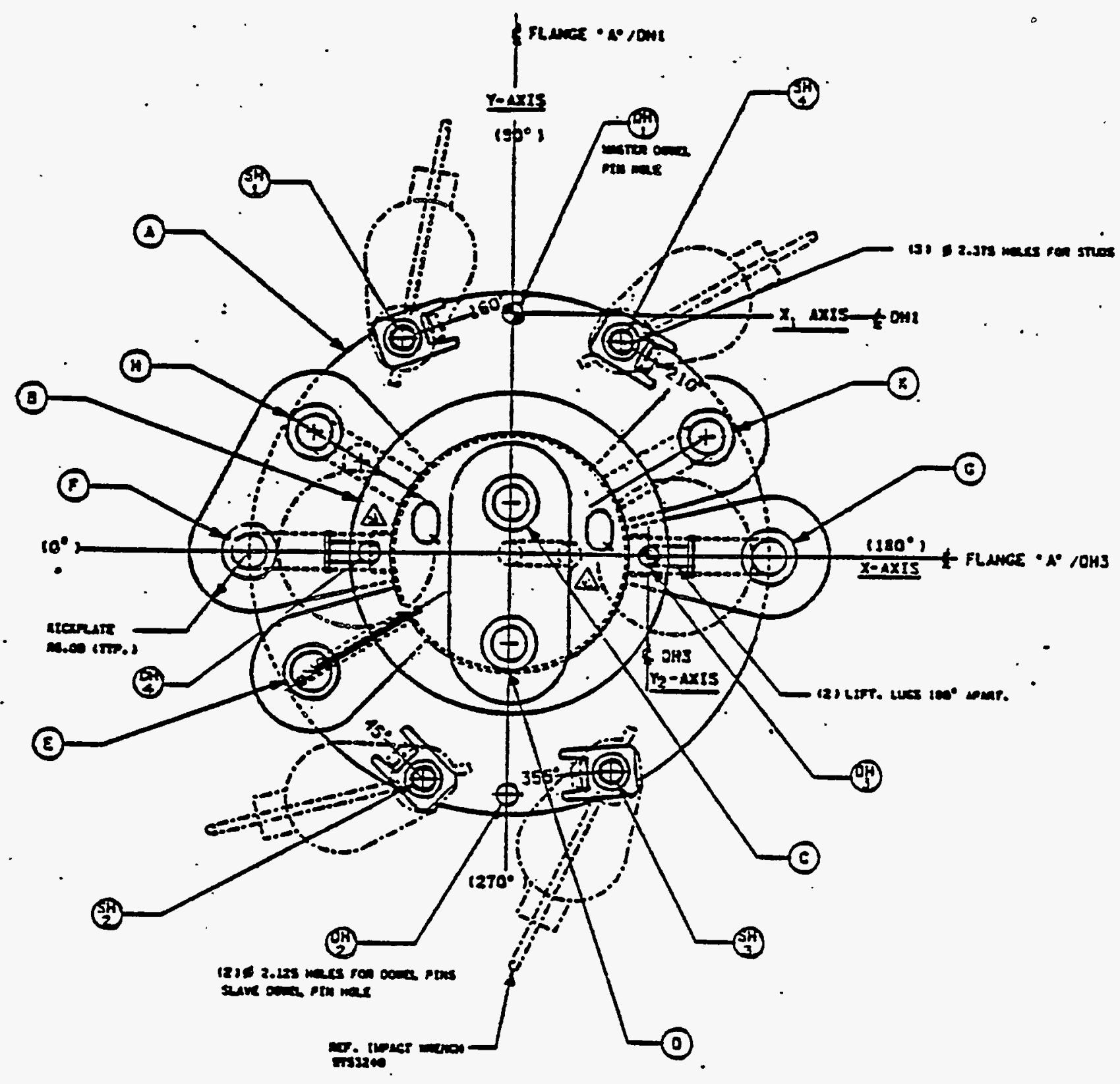

FIGURE 2-10b. Condenser: Formic Acid Vent (Plan View) 


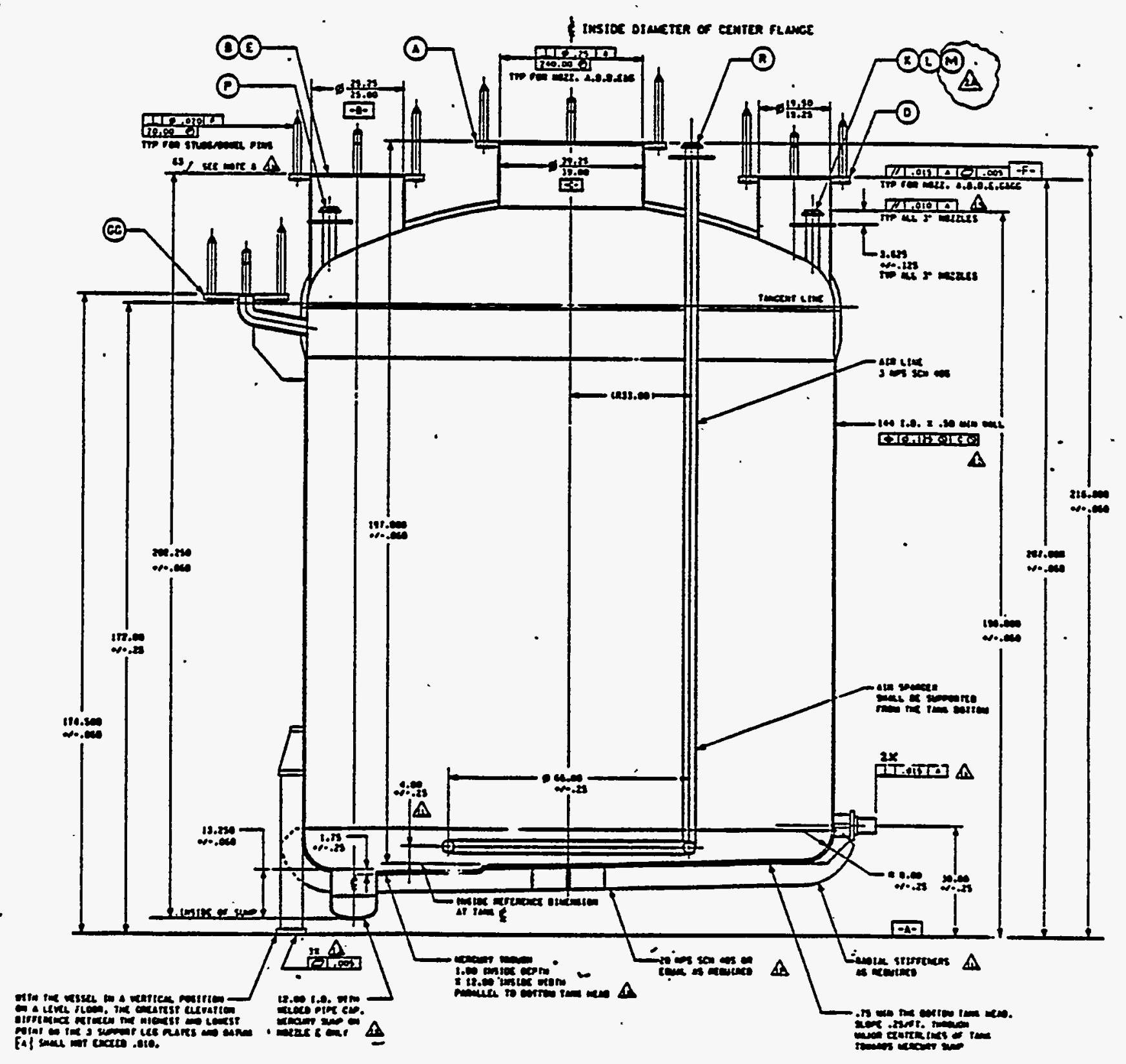

FIGURE 2-11a. Tank Assembly: SMECT (Elevation) 


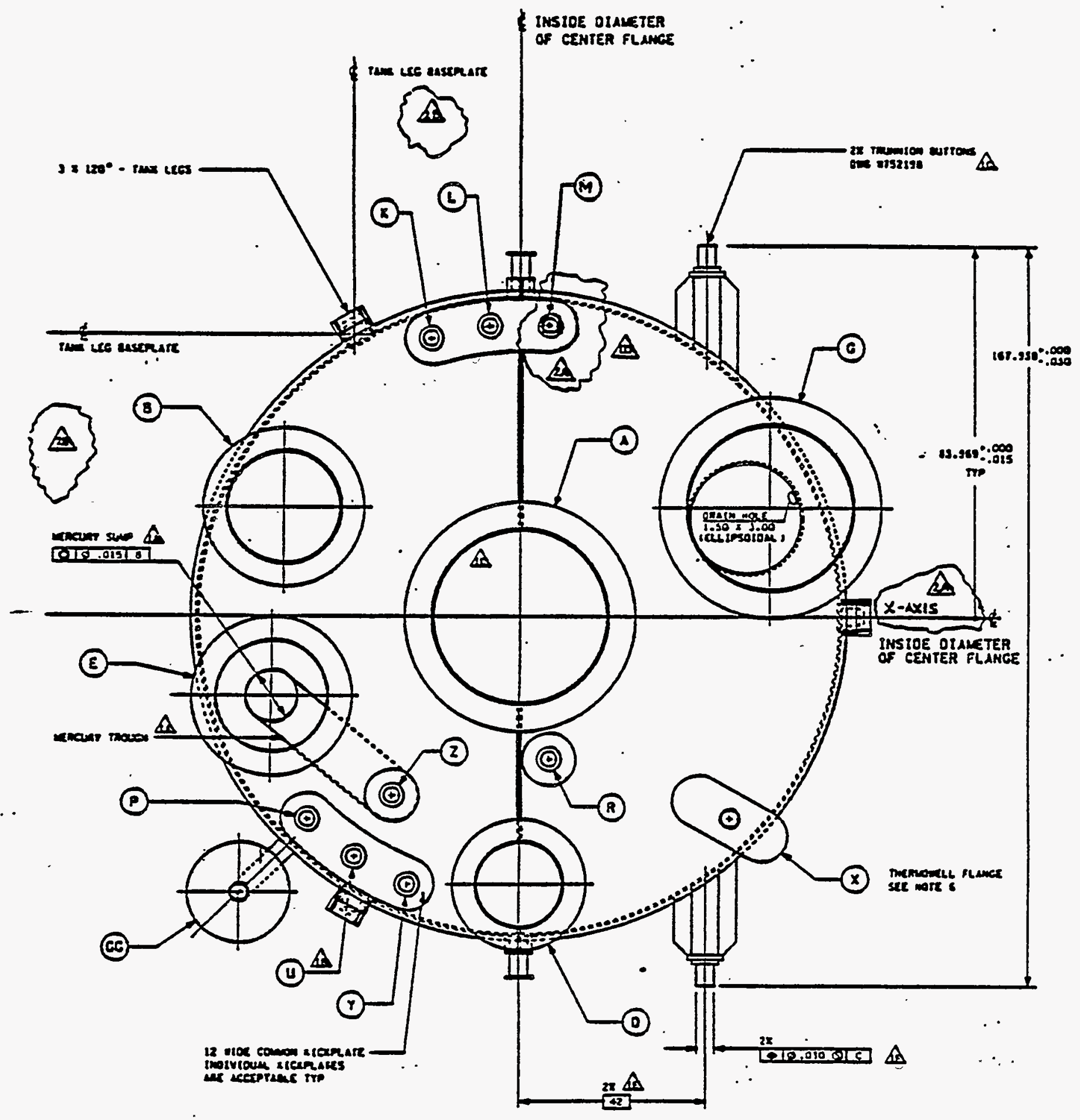

FIGURE 2-11b. Tank Assembiy: SMECT (Plan View) 


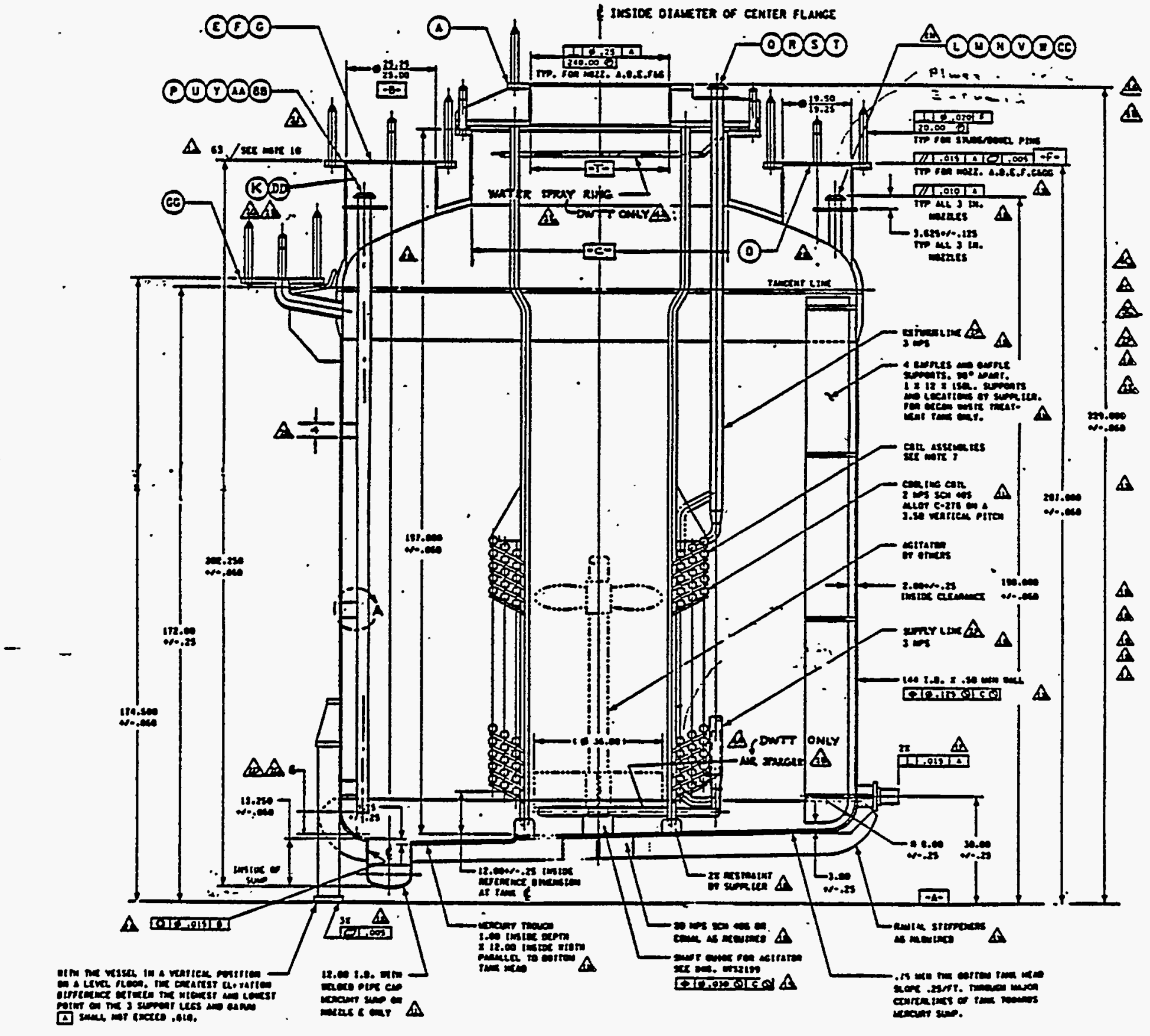

FIGURE 2-12a. Tank Assembly: SME, SRAT, MFT, DWTT (ETevation) 


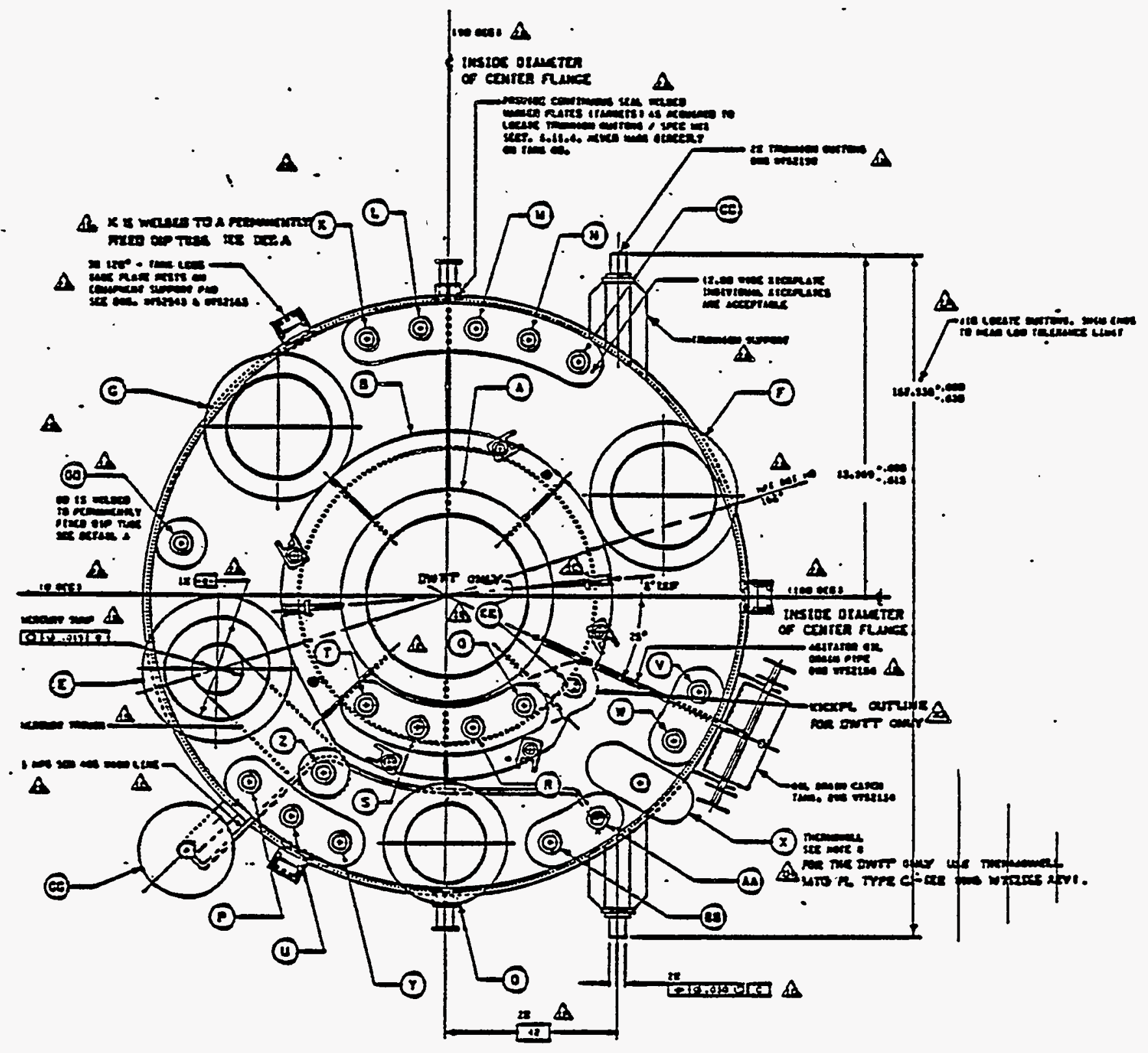

FIGURE 2-12b. Tank Assembly: SME, SRAT, MFT, DHTT (Plan View) 


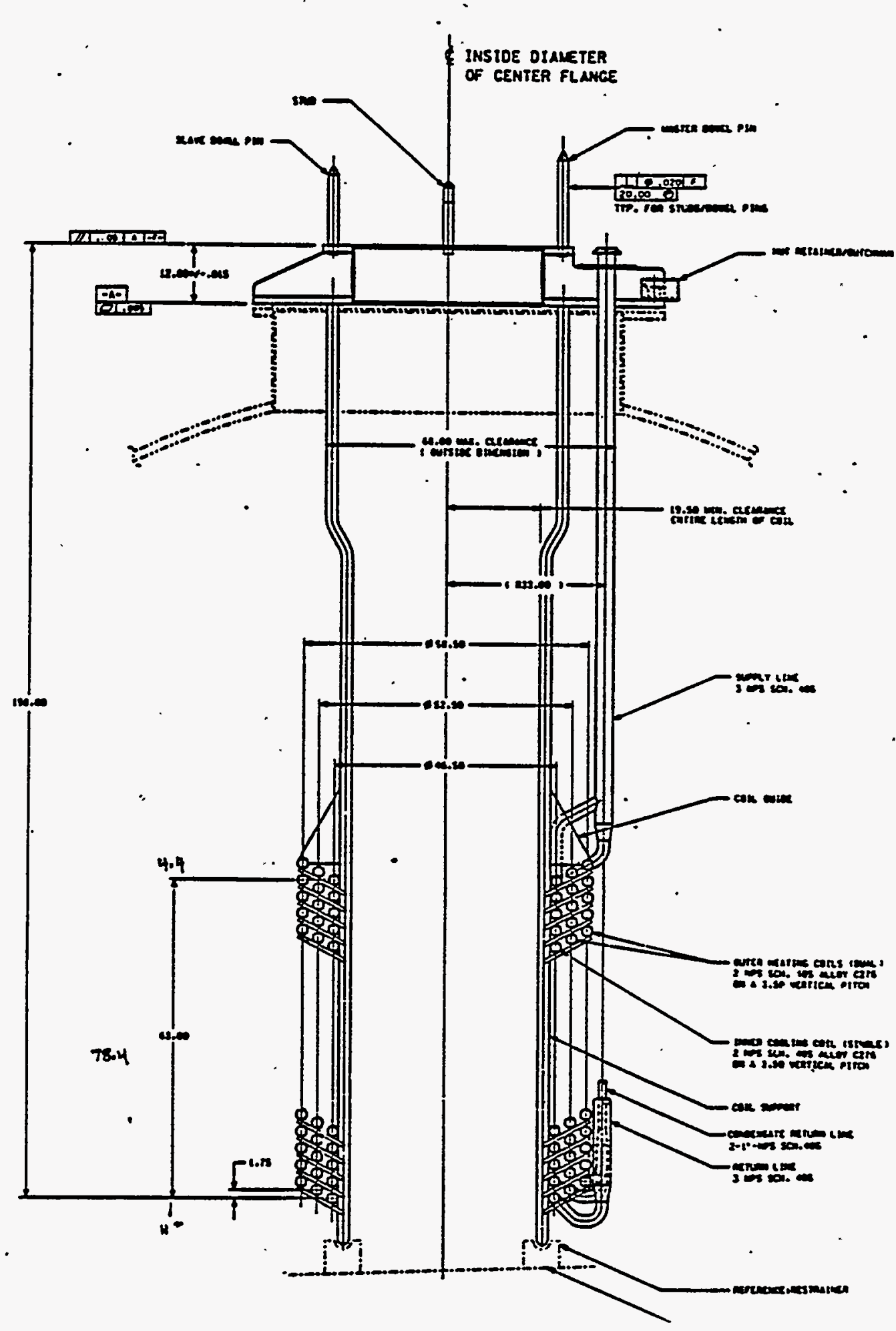

FIGURE 2-13a. Coil Assembly: SME, SRAT (Elevation) 


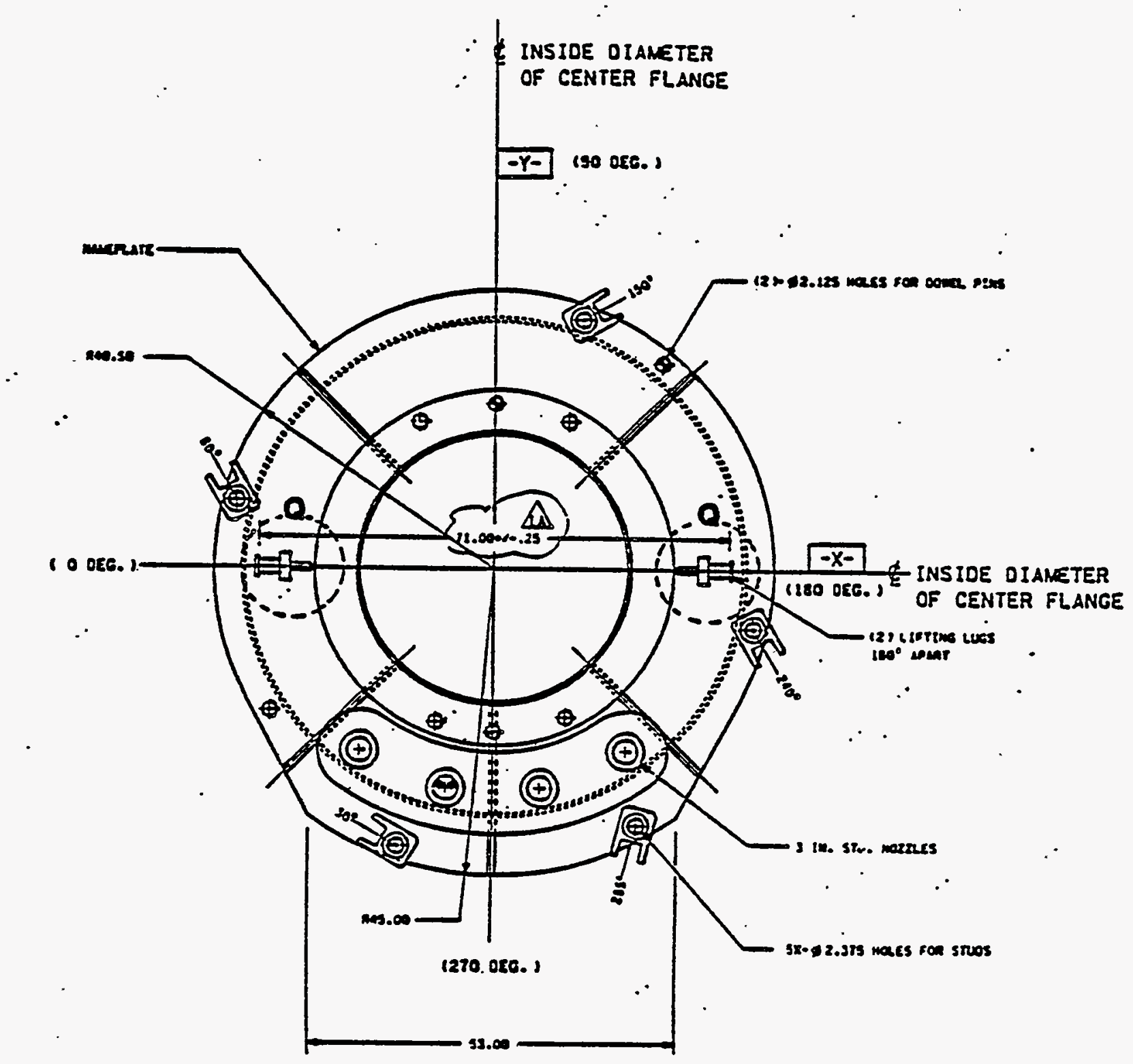

FIGURE 2-13b. Coil Assembly: SME, SRAT (PTan View) 


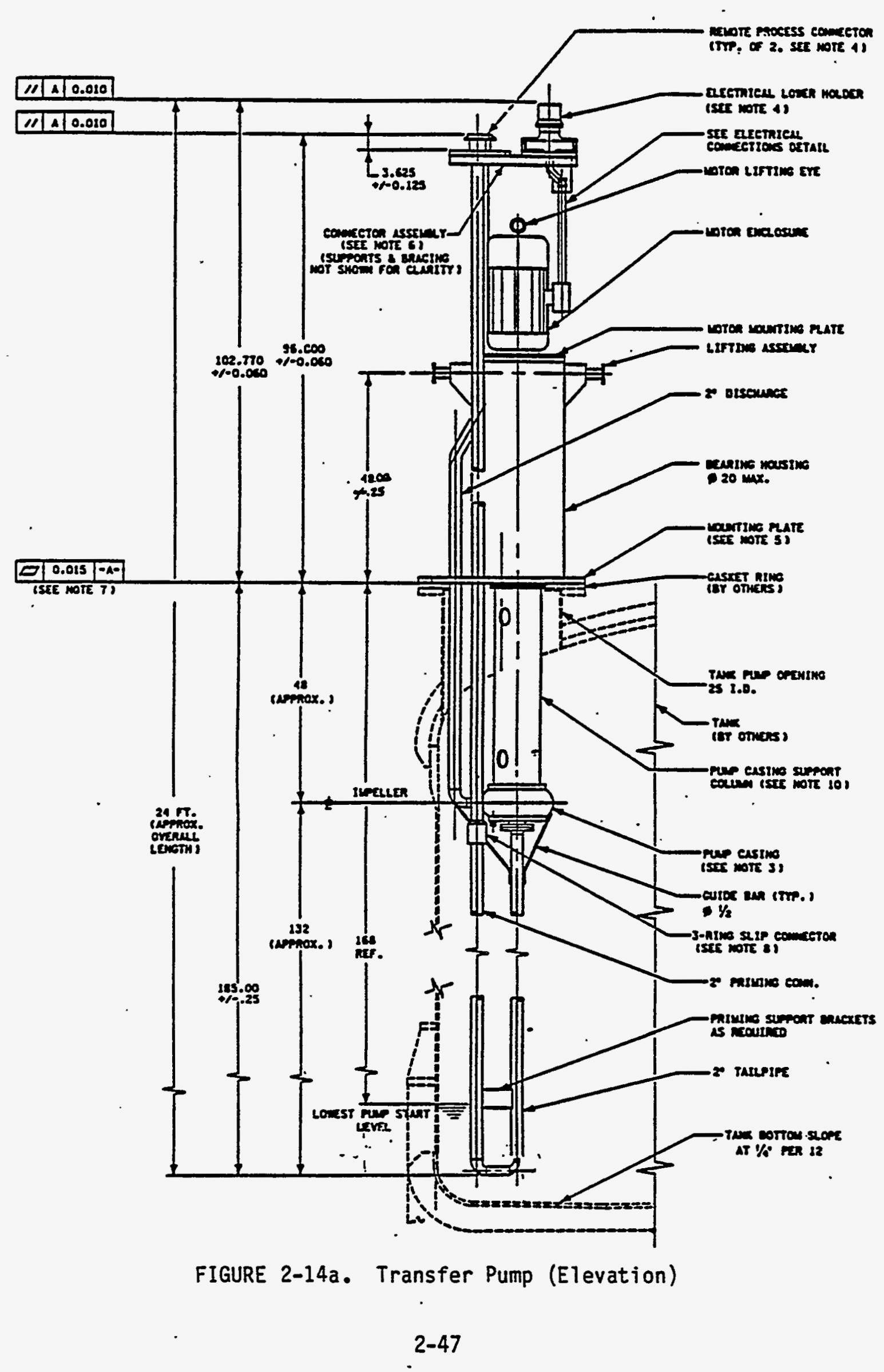




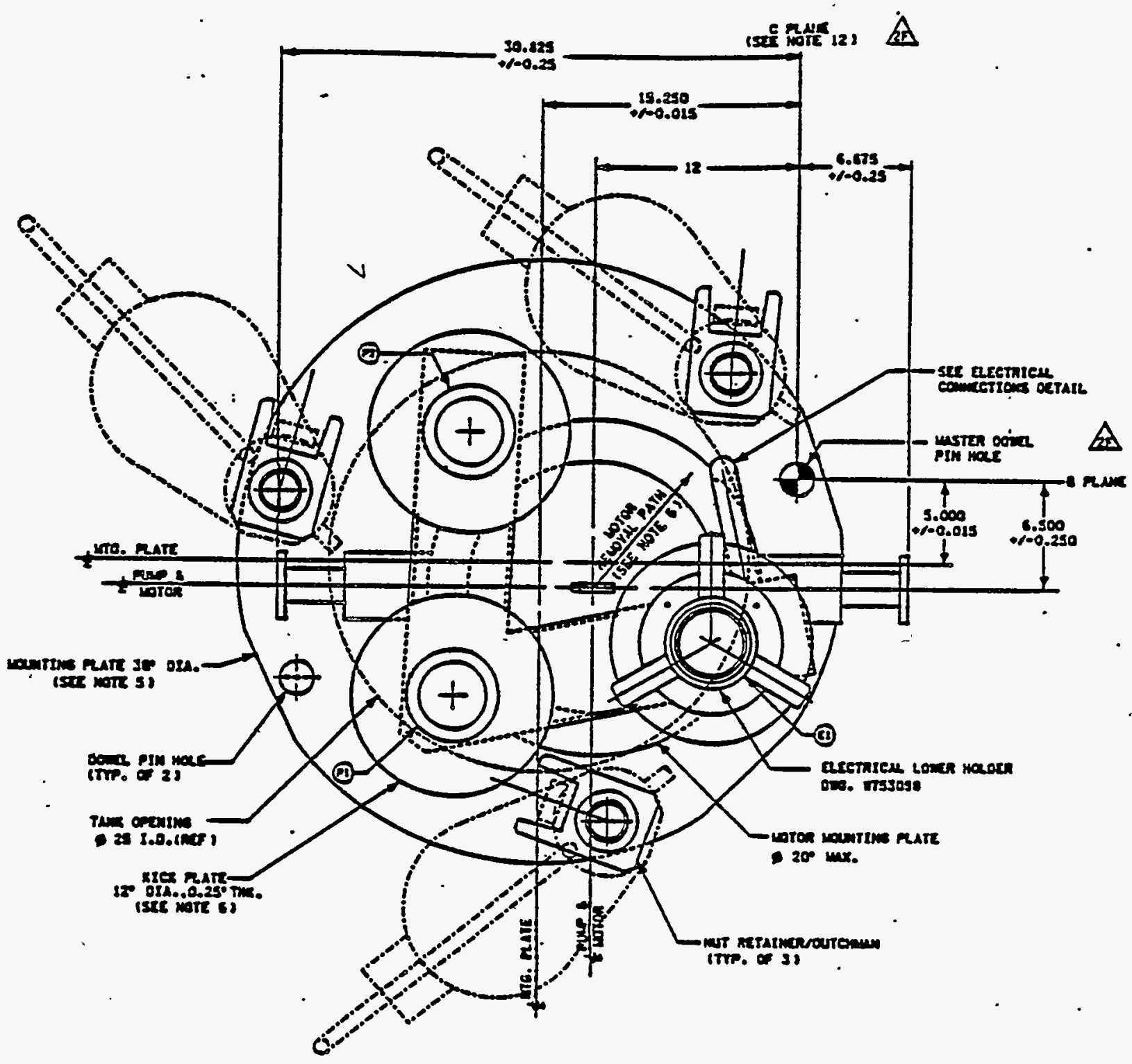

FIGURE 2-14b. Transfer Pump (P1an View and Detail of Settling Champber) 


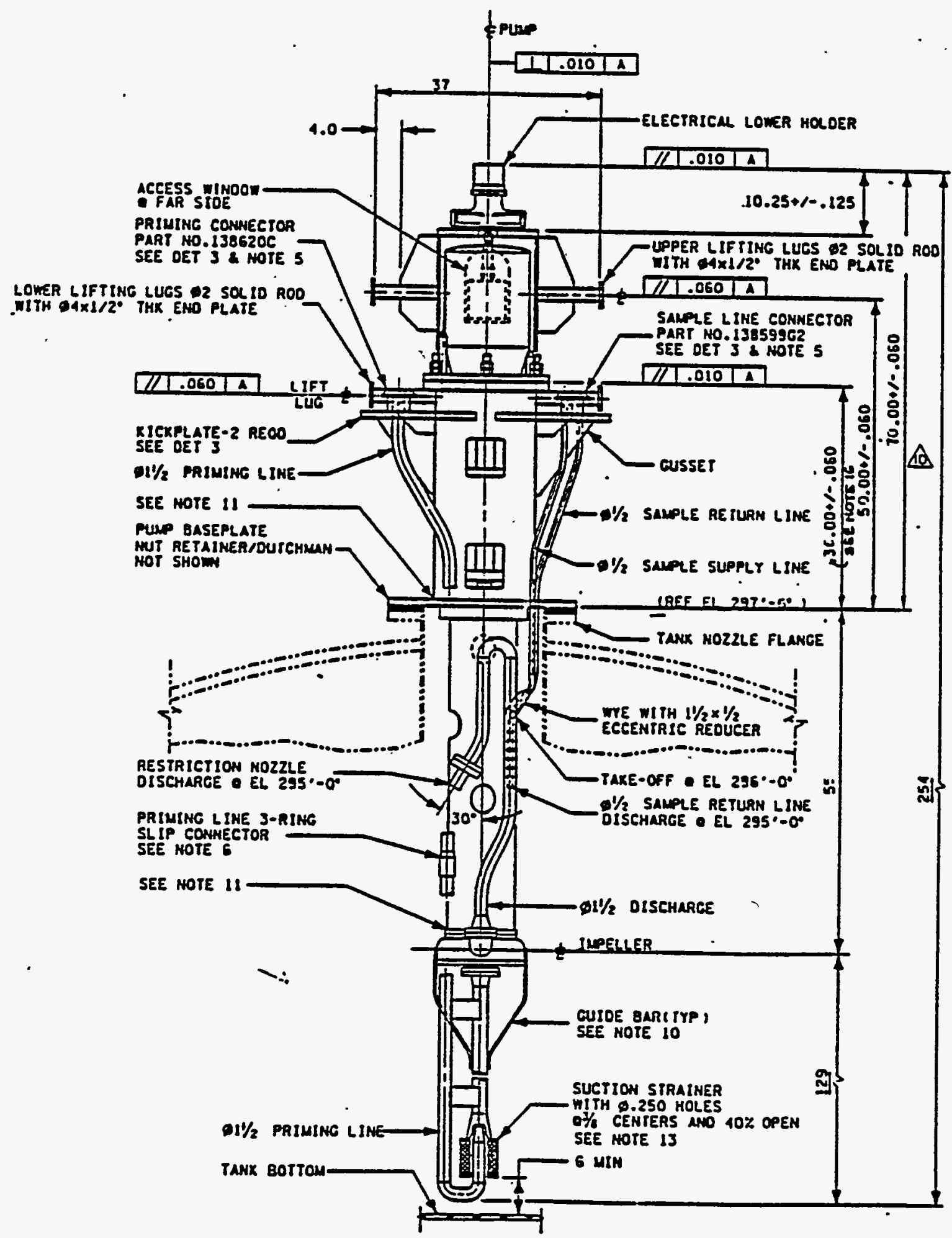

FIGURE 2-15a. Sample Pump (Elevation) 


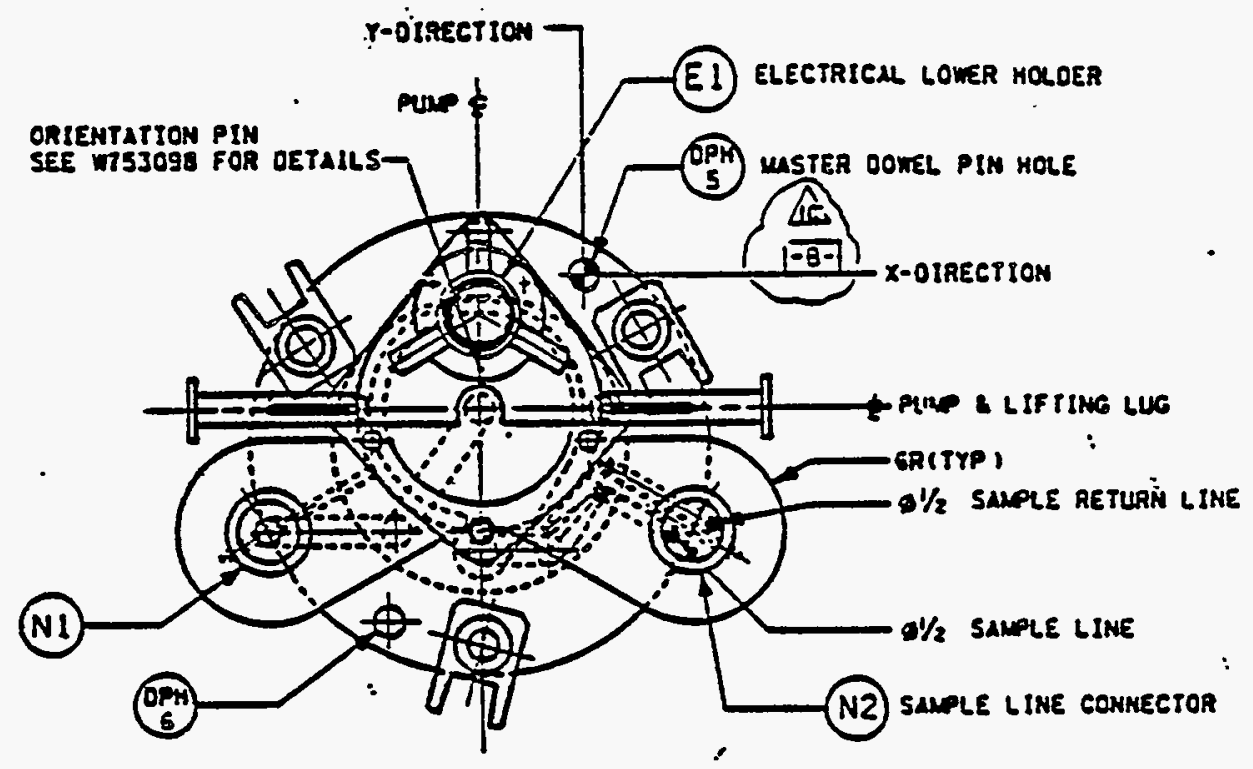

FIGURE 2-15b. Sample Pump (P1an View) 


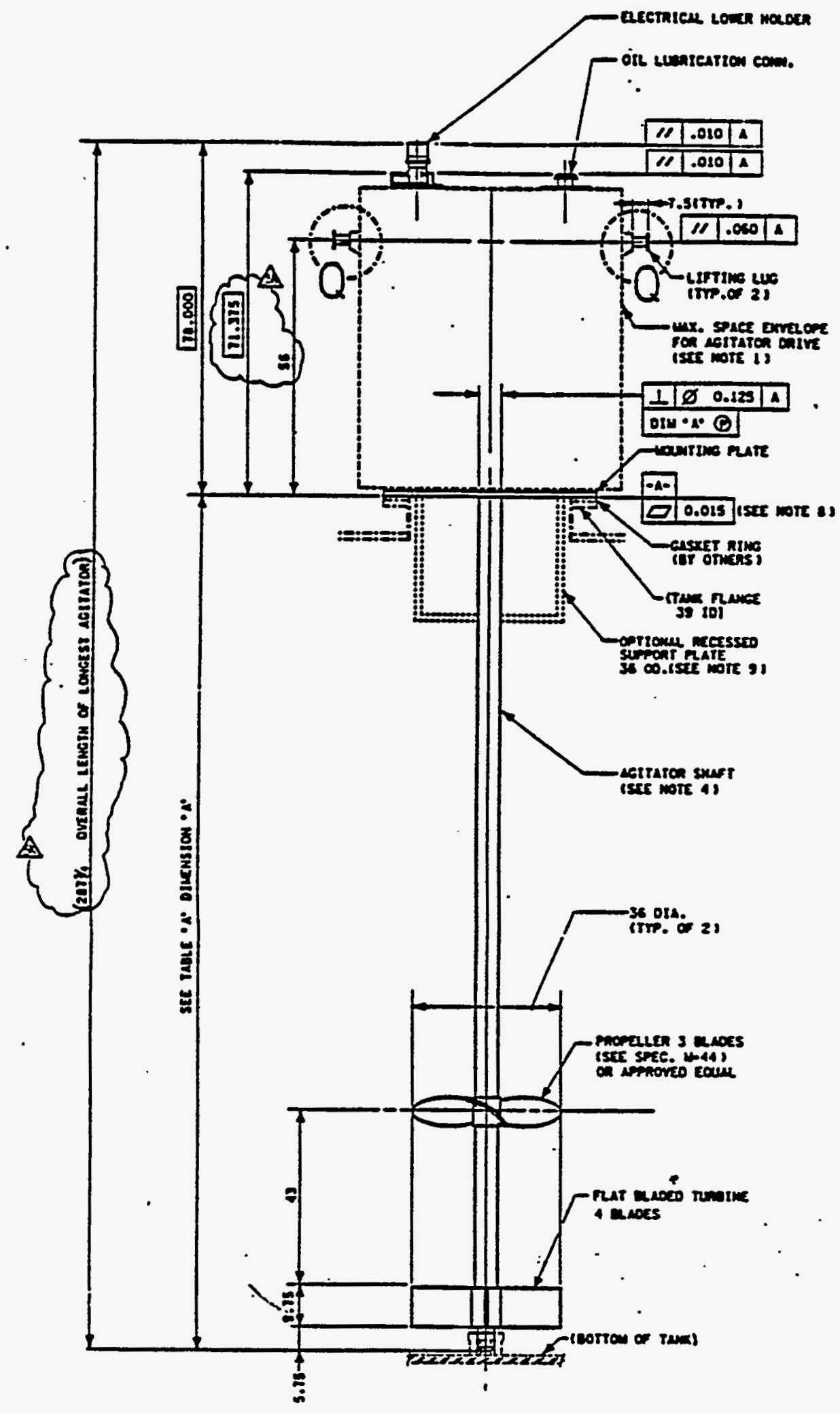

FIGURE 2-16a. Agitator (Elevation) 


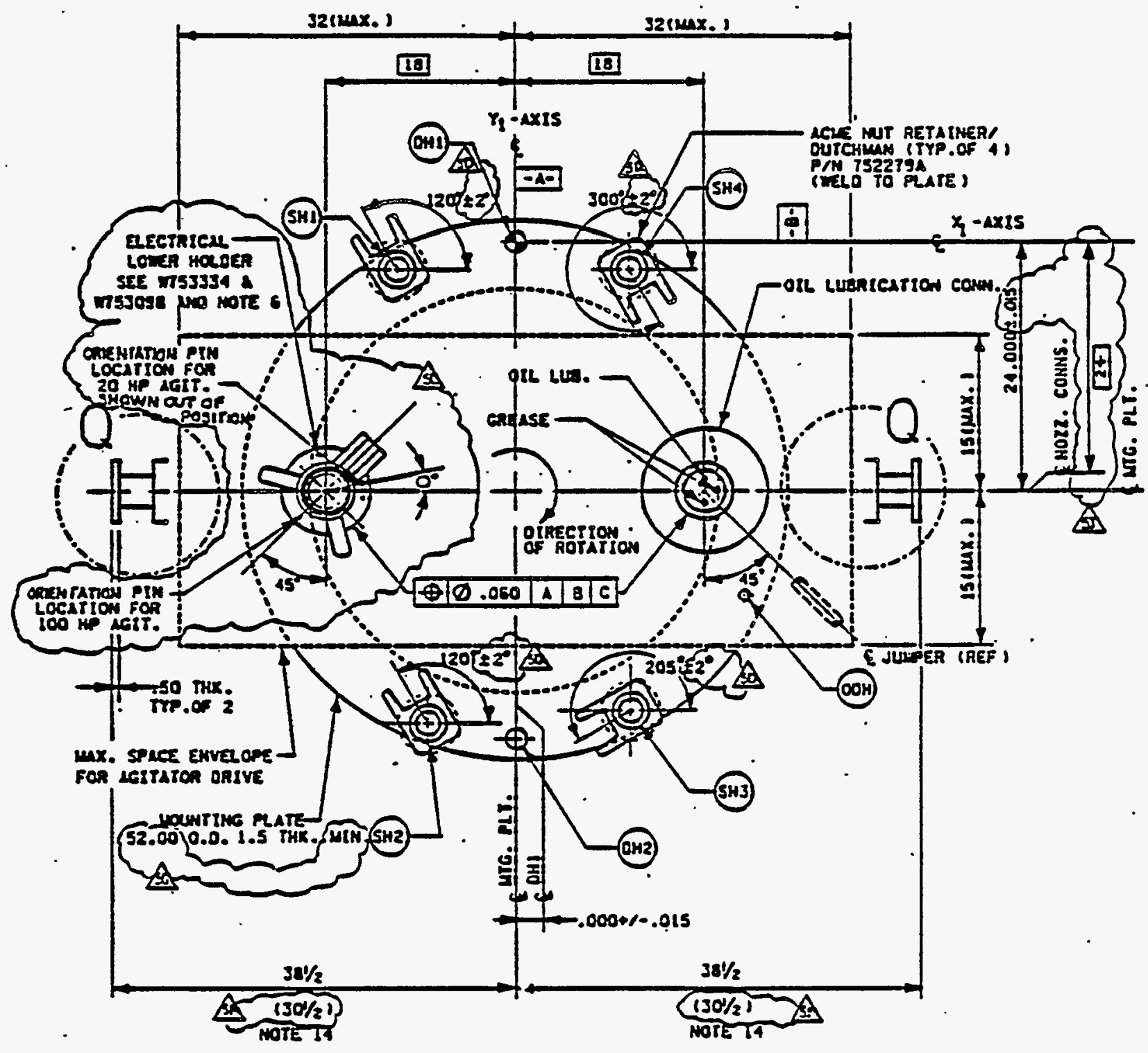

FIGURE 2-16b. Agitator (P1an View and Guide Pin Detail) 


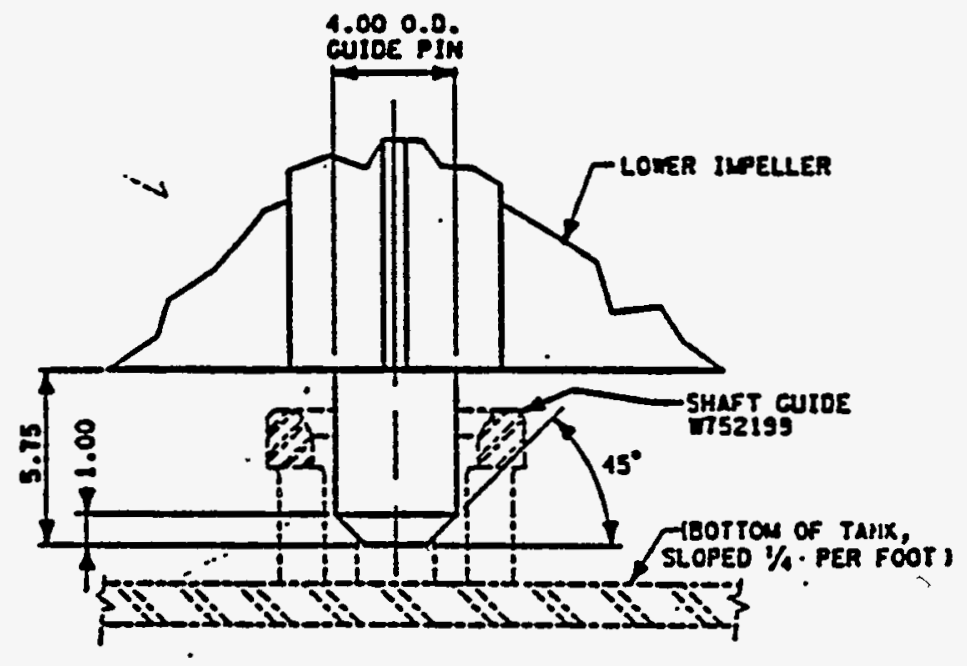

FIGURE 2-16b. (contd) 


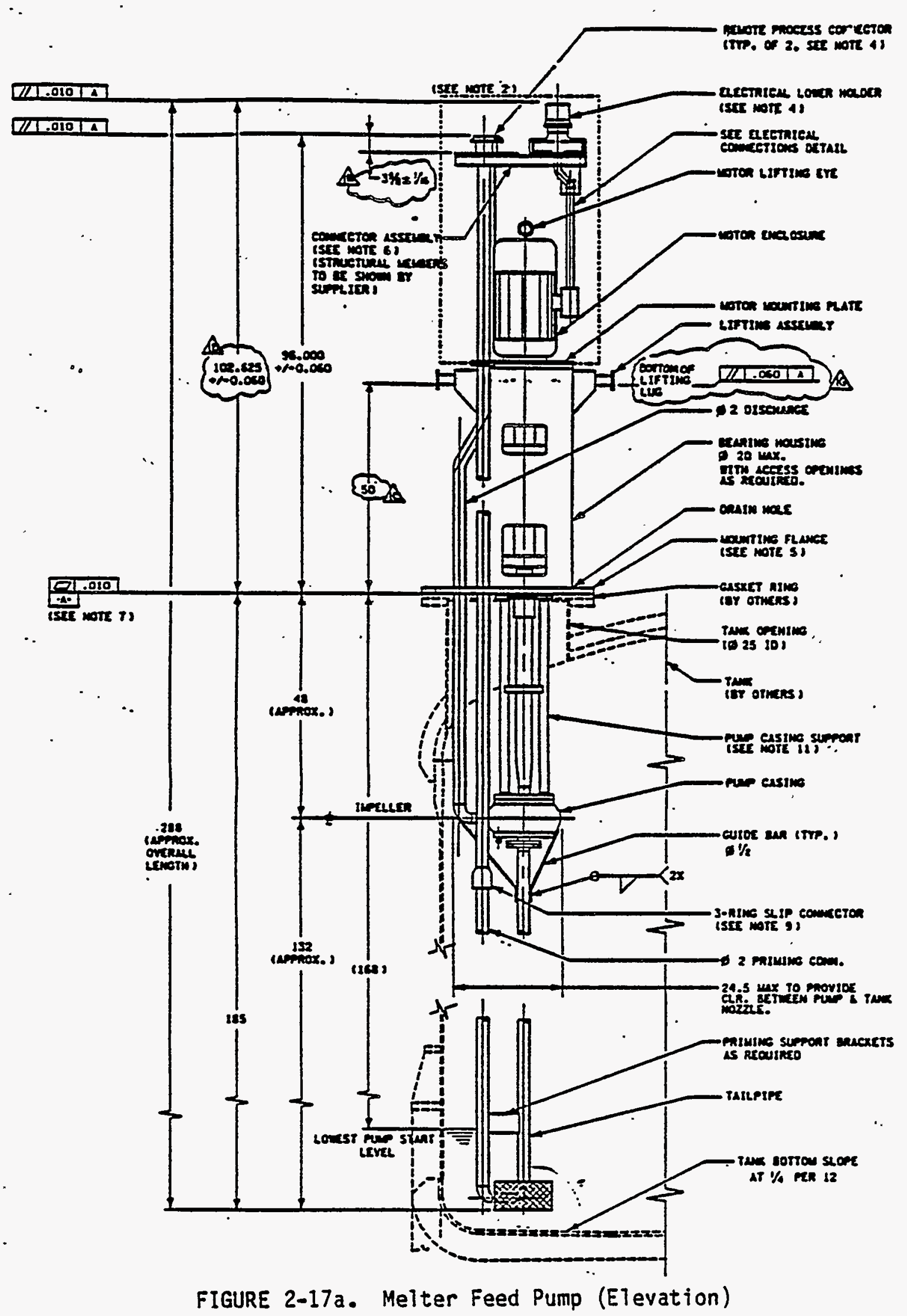




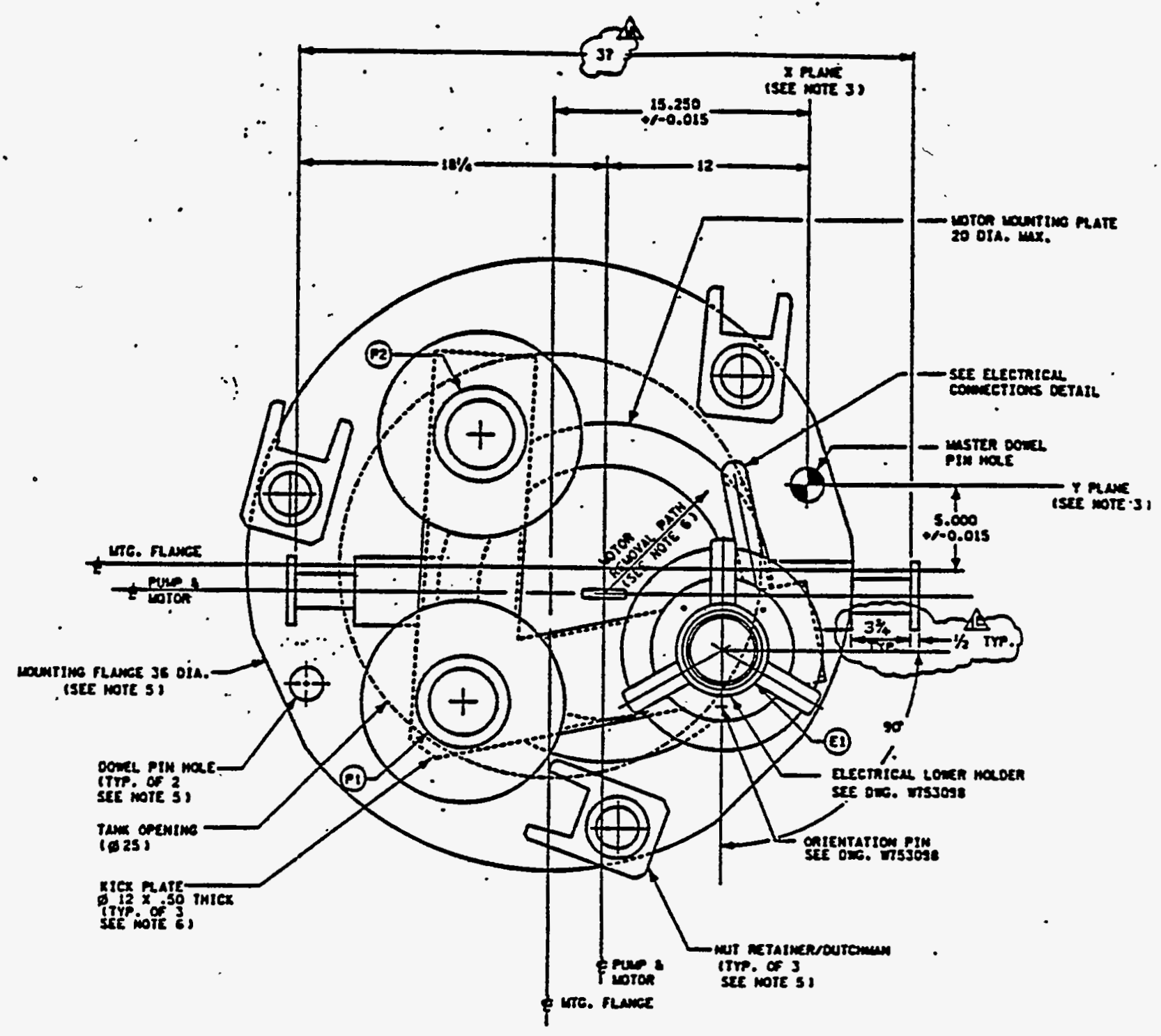

FIGURE 2-17b. Melter Feed Pump (Plan View and Detail of Screen Installation) 


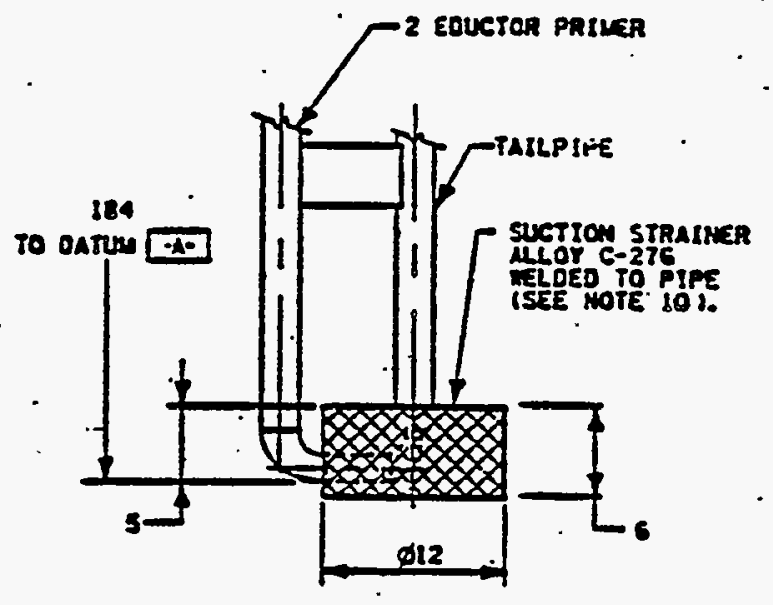

FIGURE 2-17b. (contd) 


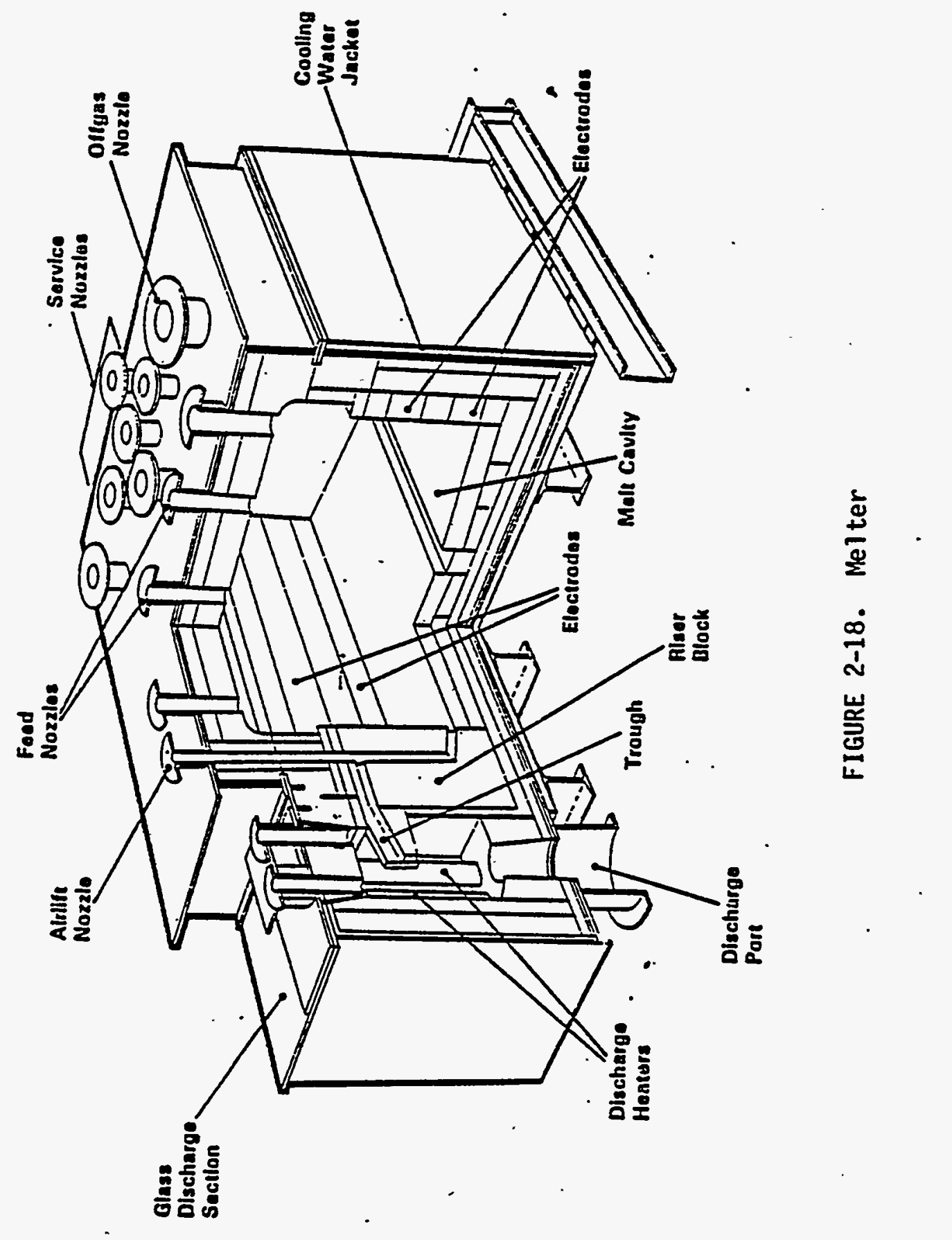




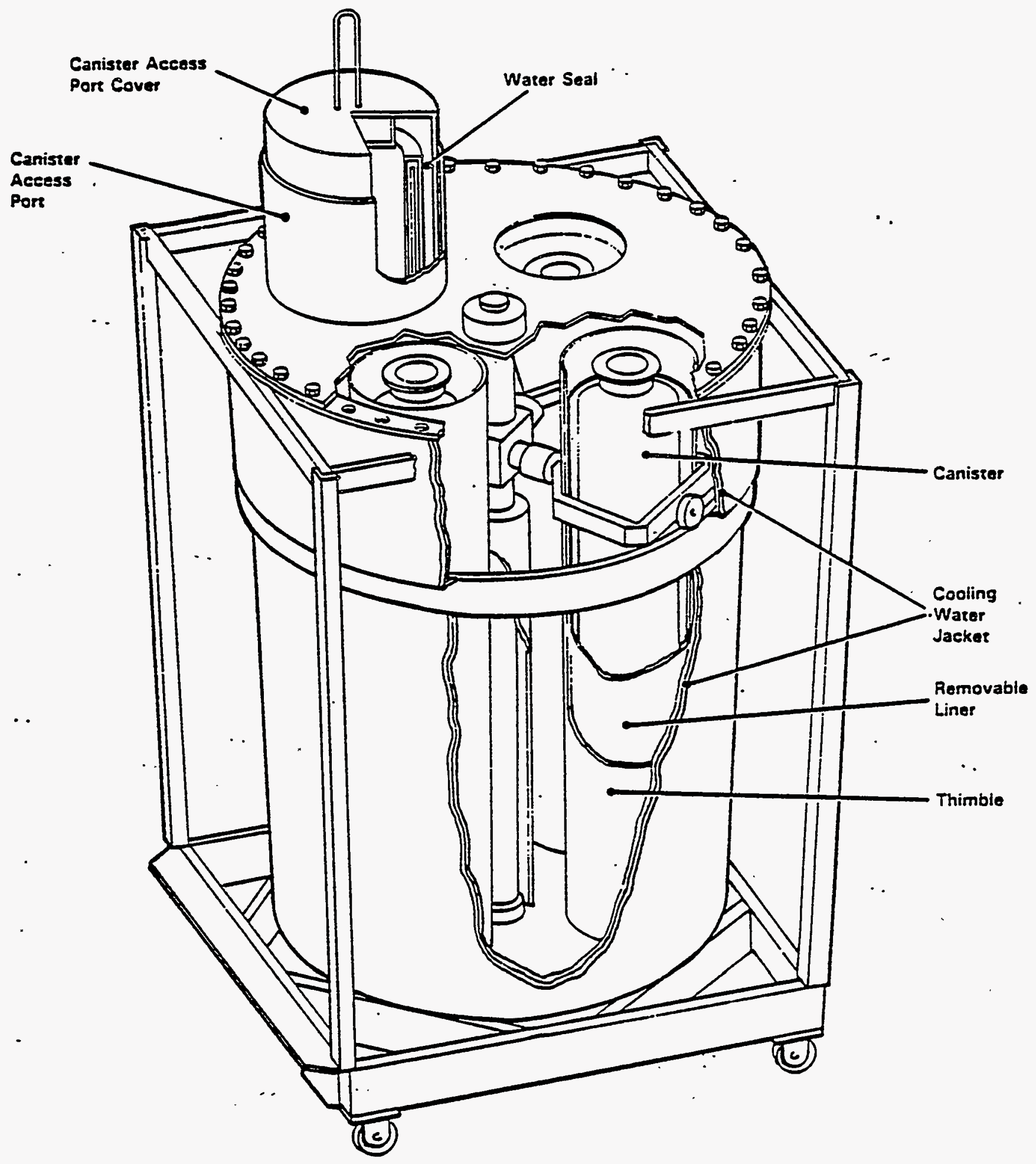

FIGURE 2-19. Turntable 
SECTION 3.0

PROCESS DESCRIPTION 


\subsection{PROCESS DESCRIPTION}

\section{CONTENTS}

3.1 FEED AND PRODUCT SPECIFICATIONS .......................... 3-1

3.1.1 HWVP Reference NCAW Feed Specification ....................

3.1.2 Preliminary HWVP Product Specification .....................

3.2 FLOWSHEET DESCRIPTION $\ldots \ldots \ldots \ldots \ldots \ldots \ldots \ldots \ldots \ldots \ldots \ldots \ldots \ldots \ldots \ldots \ldots \ldots$

3.2 .1 Feed Receipt System .................................

Feed Preparation System $\ldots \ldots \ldots \ldots \ldots \ldots \ldots \ldots \ldots \ldots \ldots \ldots \ldots \ldots \ldots \ldots \ldots$

3.2 .3

Melter Feed

3-37

3.2 .4

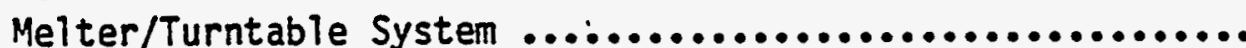

3-38

3.2 .5

Meiter Off-Gas System

$3-39$

3.2 .6

Vessel Vent Systen

3-41

3.2 .7

Radioactive Process Waste Collection and

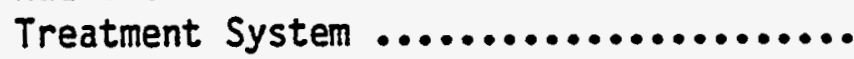

$3-41$

3.2 .8

Canister Handling and Inspection System

$3-42$

3.2 .9

Canister Closure System

3.2 .10

Canister Decontamination System

$3-43$

3.2 .11

Canister Decontamination System .........................

3.2 .12

Interim Canister Storage System

$3-45$

$3-46$

3.2 .13

Canister Loadout System

$3-47$

3.2 .14

Canister Receipt and Handling System

$3-47$

3.2 .15

Frit Receipt and Makeup System

$3-48$

$3-50$

$3-50$

$3-50$

3.3 .1

Chemical
BALANCE

3.3 .2

Description of HWVP Flowsheet Model

$3-54$

$3-54$

3.4

PROCESS TIME CYCLE (Future Inclusion) 


\section{FIGURES}

3-1 Hanford Haste Vitrification Plant Process Key Diagram ........ 3-36

\section{TABLES}

3-1 HWVP Reference Feed Composition for G1ass Retained. Components and Acceptable Composition Ranges for Vitrification

3-2 Composition Limits for Non-Glass Componenits in Hanford Waste Vitrification Plant Neutralized Current Acid Waste Feed, as Received from Tank Farms ........................ 3-8

3-3 Composition of Hanford Waste Vitrification PTant Reference Waste and Glass .................................. $3-20$

3-4 Unique Process Features of Chemical Receipt, Makeup, and Distribution Subsystems ............................ 3-51

3-5 Decontamination Factor Values Used for the Melter and Off Gas Equipment ....................................... 3-55

3-6 Input Parameters for Material Balance Computer Program ...... 3-56 
This section of the Manual describes the various steps and material flows throughout the HWVP process. To provide the framework for process operations, the feed and product specifications are presented in Section 3.1. The flowsheet is then described in Section 3.2. The reference material balance is provided, Section 3.3, including engineering conditions, mass balance, chemical balance, oxide balance, radiochemical balance, and a feed/effluent characteri- . zation summary. Process element time cycles. will be provided in Section 3.4

\subsection{FEED AND PRODUCT SPECIFICATIONS}

The HWVP feed and product specifications are described in this section to provide a context and guidelines for flowsheet operations. These specifications are evolving and require periodic updating. The feed specification is for pretreated NCAW. Other plant feed specifications will be added as available. The HWVP product specifications are similar to those for the DWPF (Ref. 3-1).

\subsubsection{HWVP Reference NCAW Feed Specification (a)}

The HWWP feed specification defines acceptable composition ranges for components present in pretreated (washed) NCAW to be stored in underground tanks for processing in the HWVP. The following information is provided:

- reference pretreated NCAW feed composition

- acceptable limits for waste components

- discussion of the effects of various waste components.

The NCAW solids product from B Plant will be mixed in tank farms with storage tank heels and dilute waste of uncertain compositions. Thus, the final point of application of this specification should be at the tank farm vessels used to store the HWVP feed. However, the B Plant pretreatment process will exert the primary influence on the HWVP feed composition; therefore, this specification should also be used as a criteria for B Plant NCAW processing.

(a) R. A. Watrous and 0. L. Kruger, Hanford Waste Vitrification Plant Feed Specification: Pretreated Neutralized Current Acid Waste Feed, SD-HWV-OCD-001 Rev. 1, Westinghouse Hanford.Company, Richland, Washington (September 1987). 
The feed compositional requirements for NCAW washed sludge are based on the known allowable concentration ranges. of waste components in HW39 glass (the HWVP reference NCAW glass formulation) and upon consideration of waste processability and envifonmental release constraints. For many of these stated requirements, however, absolute limits are as yet unknown; some requirements are based on expected nominal concentrations plus a safety factor. The consequence of exceeding one of these requirements would likely be an engineering evaluation to determine the impact to HWVP operations.

These specifications cover only part of the overall HIVP mission. Several waste types are scheduled for vitrification in the HWVP: NCAW, complexant concentrate (CC), Plutonium Finishing Plant (PFP) waste, and possibly transuranic contaminated cladding waste or waste sludges from single-shell tanks (SST). Of these, NCAH is scheduled to be processed first. For this reason and because of the uncertainty in composition of the other waste types, the scope of this discussion is limited to addressing compositional specifications for the NCAW oniy.

This revision of the HWVP NCAW feed specification incorporates data obtained from glass development activities conducted during FY 1987. (a) These. data were added to the base of information al ready set forth, (b) which was based on earlier glass formulation studies. $(\dot{c})$

Also, note that while fission product mass yalues are included in the ref$\therefore$ erence feed composition, curie values are not given. A separate document (Ref. 3-2), aimed at defining a HWVP feed composition to be used for plant shielding design, gives curie values for various PUREX and process facility modifications (PFM) operating scenarios.

3.1.1.1 Specifications. Currently, glass formulations developed for NCAW and vitrification plant design aspects are based on the expectation that future NCAW washed sludge compositions will fall close to the reference composition (NCAW '87) given in Table 3-1. This NCAW reference feed composition is based

(a) S. 0. Bates, Interim Milestone HWVP-87-V110202C - Report on FY87 Glass Variability Testing Conducted for the Hanford Waste Vitrification Program, Pacific Northwest Laboratory, Richland, Washington (July 1987).

(b) R. N. Hagner, Hanford Waste Vitrification Plant Feed Specification; Pretreated Neutralized Current Acid Waste Feed, SD-HWV-0CD-001, Rev . 0 (September 1986).

(c) S. 0. Bates and W. M. Bowen, Interim Milestone HWVP-86-V1122C - Report on Composition Variability Testing Conducted. for the Hanford Waste Vitrification Program, Pacific-Northwest Laboratory, Richland, Washington (September 1986). 
on evaluations of the PUREX and B Plant flowsheets. (a) Values selected for specific waste components are the best estimates of the composition as determined from modeling of various process alternatives including adjustments to accommodate future processing variations and specific analytical data. The reference composition values for each component generally fall within the range anticipated for the first HWVP NCAW feed tank (101-AZ) and the projected compositions of subsequent NCAW feed tanks. (a) To date, there has been only partial analytical verification of the reference feed composition.

Glass formulation developmental work is performed using a weight percent oxide basis for expression of glass component concentrations. However, B Plant and tank farm operating specifications usually refer to the acceptable component concentration ranges on an elemental mole percent basis. Component molarity values cannot be given at this time because the quantity of solids that will be present in HWVP feed from underground storage is unknown.

3.1.1.1.1 Limitations on Component Variability. Pretreated NCAW composition ranges are provided in Table 3-1 for components in the HWVP feed stream that remain in the glass after the feed has been processed through the HWVP melter. These are the compositional ranges of waste oxides in pretreated NCAW feed that are acceptable to HWVP with no modifications to the HW39 glass formulation, frit composition, waste loading level, or facility design. These compositional limits are based on simulant testing to evaluate the effects of compositional variability on feed processing and melter operations and on glass product quality. Information sources are referenced by footnotes for the specified composition ranges, and further explanations of component effects are given in Section 3.1.1.2.

Table 3-2 gives feed compositional limits for components such as TOC, nitrates, and halides, and environmentally sensitive radionuclides which are volatile under melter operating conditions. These limits are derived from consideration of melter operability and the amount of the various components that can be effectively removed or released by the current design of the HWWP melter off-gas system. If these limits are exceeded engineering evaluation will be required to determine the impact on the HWVP design and operations. For example, ${ }^{14} \mathrm{C}$ or ${ }^{129}$ I concentrations in excess of the Table 3-2 limits may require the installation of additional off-gas control equipment.

(a) R. A. Watrous and 0. L. Krueger, Hanford Waste Vitrification Plant Feed Specification: Pretreated Neutralized Current Acid Waste Feed, SD-HWV-OCD-001, Rev. 1, Westinghouse Hanford Company, Richland, Washington (September 1987). 
TABLE 3-1. HWVP Reference Feed Composition for GTass Retained Components and-Acceptable Composition Ranges for Vitrification

\begin{tabular}{|c|c|c|}
\hline $\begin{array}{l}\text { Component } \\
\text { (oxide) }\end{array}$ & $\begin{array}{l}\text { Reference Feed } \\
\text { (NCAH 1987) (wt\%) }\end{array}$ & $\begin{array}{l}\text { Acceptable Feed } \\
\text { Range (wt\%) }\end{array}$ \\
\hline $\mathrm{Fe}_{2} \mathrm{O}_{3}$ & 28.0 & $8-60(b, c, d)$ \\
\hline $\mathrm{Al}_{2} \mathrm{O}_{3}$ & 9.0 & $2-26(e)$ \\
\hline $\mathrm{Na}_{2} \mathrm{O}$ & 17.5 & $4.5-22(e ; f)$ \\
\hline $\mathrm{Cr}_{2} \mathrm{O}_{3}$ & 0.5 & $0-2.0(e, g, j)$ \\
\hline $\mathrm{SiO}_{2}$ & 4.0 & $0-17,5(e, f, h)$ \\
\hline $\mathrm{ZrO}_{2}$ & 15.0 & $0-40^{(e)}$ \\
\hline$(\mathrm{La}, \mathrm{Nd})_{2} \mathrm{O}_{3}$ & 4.5 & $0-8(e, i)$ \\
\hline $\mathrm{SO}_{3}$ & 1.8 & $0-2^{(j, k)}$ \\
\hline $\mathrm{U}_{3} \mathrm{O}_{8}$ & $4: 7$ & $0-32(e, i)$ \\
\hline$F(v)$ & 1.2 & $0-6.9^{(b, j, 1)}$ \\
\hline$P_{2} O_{5}$ & 0.4 & $0-4(j, m)$ \\
\hline $\mathrm{Cs}_{2} \mathrm{O}$ & 0.6 & $(n)$ \\
\hline Sro & 0.4 & $(n)$ \\
\hline $\mathrm{CaO}$ & 0.3 & $0-20(b, f)$ \\
\hline MgO & 0.2 & $(f, p)$ \\
\hline $\mathrm{TiO}_{2}$ & 0.01 & $0-4^{(m)}$ \\
\hline TOC & $-(q)$ & $-(q)$ \\
\hline NiO & 2.3 & $0-8^{(b, j)}$ \\
\hline $\mathrm{B}_{2} \mathrm{O}_{3}$ & 0.1 & $(f)$ \\
\hline $\mathrm{MnO}_{2}$ & 0.6 & $0-20^{(b, j)}$ \\
\hline $\mathrm{MoO}_{3}$ & 1.2 & $0-8^{(b, i)}$ \\
\hline $\mathrm{K}_{2} \mathrm{O}$ & 0.05 & $(e, r)$ \\
\hline $\mathrm{Li}_{2} \mathrm{O}$ & 0.0 & $(e, f, r)$ \\
\hline $\mathrm{BaO}$ & 0.4 & $0-20(b, i)$ \\
\hline CdO & 3.0 & $0-10(p)$ \\
\hline $\mathrm{RuO}_{2}$ & 0.6 & $(p, s, t)$ \\
\hline
\end{tabular}


TABLE 3-1. (contd).

\begin{tabular}{|c|c|c|}
\hline $\begin{array}{l}\text { Component } \\
\text { (oxide) }\end{array}$ & $\begin{array}{l}\text { Reference Feed } \\
\text { (NCAW 1987) (wt\%) }\end{array}$ & $\begin{array}{l}\text { Acceptable Feed } \\
\text { Range (wt\%) }\end{array}$ \\
\hline $\mathrm{PdO}$ & 0.2 & $(p, t)$ \\
\hline $\mathrm{Rh}_{2} \mathrm{O}_{3}$ & 0.2 & $(p, t)$ \\
\hline $\mathrm{TC}_{2} \mathrm{O}_{7}$ & 0.4 & (s) \\
\hline $\mathrm{CeO}_{2}$ & 0.6 & (u) \\
\hline CuO & 0.6 & (u) \\
\hline $\mathrm{Pr}_{6} \mathrm{O}_{11}$ & 0.4 & (u) \\
\hline $\mathrm{Rb}_{2} \mathrm{O}$ & 0.2 & (u) \\
\hline $\mathrm{Sm}_{2} \mathrm{O}_{3}$ & 0.2 & (u) \\
\hline $\mathrm{Y}_{2} \mathrm{O}_{3}$ & 0.2 & (u) \\
\hline $\mathrm{NpO}_{2}$ & 0.1 & (u) \\
\hline $\mathrm{Pm}_{2} \mathrm{O}_{3}$ & 0.1 & (u) \\
\hline $\mathrm{TeO}_{2}$ & 0.1 & (u) \\
\hline Beo & 0.1 & (u) \\
\hline $\mathrm{PbO}_{2}$ & 0.05 & (u) \\
\hline $\mathrm{Ta}_{2} \mathrm{O}_{5}$ & 0.03 & (u) \\
\hline $\mathrm{SeO}_{2}$ & 0.03 & (u) \\
\hline $\mathrm{SnO}_{2}$ & 0.04 & (u) \\
\hline $\mathrm{Am}_{2} \mathrm{O}_{3}$ & 0.02 & (u) \\
\hline $\mathrm{Eu}_{2} \mathrm{O}_{3}$ & 0.02 & (u) \\
\hline $\mathrm{PuO}_{2}$ & 0.02 & (u) \\
\hline $\mathrm{Ag}_{2} \mathrm{O}$ & 0.01 & (u) \\
\hline $\mathrm{Gd}_{2} \mathrm{O}_{3}$ & 0.01 & (u) \\
\hline $\mathrm{Nb}_{2} \mathrm{O}_{5}$ & 0.01 & $(u)$ \\
\hline TOTAL & 100.00 & \\
\hline
\end{tabular}

(a) Specification is based on $25 \mathrm{wt} \%$ waste loading in the glass with HW39 frit (S. O Bates, Baseline Milestone V110202B - Update of Glass Composition Boundaries of the Hanford Waste Vitrification Plant Reference Glass HW39. Pacific Northwest Laboratory, Richland, Washington (August 1987). 
TABLE 3-1. (contd)

Footnotes (contd)

(b) FY 1987 glasș development work (S. O. Bates, Interim Milestone HWVP-87-V110202C - Report on FY87 G1ass Variability Testing Conducted for the Hanford Haste Vitrification Program, Pacific Northwest Laboratory, Richland, Washington (JuTy 1987).

(c) Sufficient $\mathrm{Fe}_{2} \mathrm{O}_{3}$ should be maintained in the glass to act as a redox buffer to protect against Uranium +5 reduction to Uranium +4 .

(d) With 0.13 wt\% $\mathrm{Cr}_{2} \mathrm{O}_{3}$ in glass.

(e) FY 1986 glass development work (S. O. Bates and W. M. Bowen, Interim Milestone HWVP-86 V1122C Report on Composition Variability Testing Conducted for the Hanford Waste Vitrification Program, Pacific Northwest Laboratory, Richland, Washington (September 1986).

(f) Component added as glass former.

(g) FY 1985 glass development work (S. O. Bates, Hanford Waste Vitrification Plant Interim Milestone HWVP-85-020202C: Results of Composition Variability Studies (CVS) to Date, Pacific Northwest Laboratory, Richland, Washington (September 1985).

(h) Lower limit is the minimum tested. Range could be extended lower.

(i) Negligible effect on glass properties over range tested; range could be expanded.

(j) Critical glass limit; no potential for increase.

(k) FY 1985 glass development work (S. O. Bates, D. S. Goldman, and W. C. Richey, HWVP Basel ine Milestone 020207A, A Letter Report Summarizing the Sulfate/Redox Relationship to Glass Melting Chemistry and Behavior, Pacific Northwest Laboratory, Richland, Washington (September 1985).

(1) Reference 3-3.

(m) Predicted range based on extrapolation of DWPF data.

(n) No range established based upon glass properties; may be constrained by canister heat loading.

(p) Component effect may be studied in future glass development/waste variability work. 
TABLE 3-1. (Contd)

References (contd)

(q) Carbon has been excluded from the oxide basis composition since it does not remain in the glass after melting. See Table 3-2 for specifications for non-glass waste components.

(r) Can be partially substituted for $\mathrm{Na}_{2} \mathrm{O}$ on a molar basis.

(s) May be limited by off-gas handling constraints.

(t) Due to formation of nonsoluble phases in the melter, the noble metals should be maintained as low as possible. Noble metals in a concentration of approximately 1 to 2 wt\% for the PAMELA feed processed using a $10 \%$ waste loading in the glass were a major contributor to the melter furnace.

(u) Components are minor constituents that are not expected to affect glass properties.

(v) Fluorine is not a metal oxide but is listed here since it is retained in borosilicate glass with a significant acceptable feed range. Note that in calculating the total weight of "waste oxides" as described. in Section 3.1.1.1.3, there is a minor inconsistency in treating fluorine as an elemental component; in actuality, fluorine displaces oxygen assumed to be present in other oxide compounds.

- Limitations given for single component variations (Table 3-1) have been developed with the understanding that as the concentration of one component rises the concentrations of all other waste components will drop correspondingly, remaining present in the same proportions relative to each other. However, strong chemical interactions exist between iron and chromium, as well as between sulfate and organic carbon. Thus, variations within the acceptable concentration ranges for these constituents cannot be considered independently.

Additionally, the cumulative effects on glass properties must be considered when multiple components are allowed to vary from their nominal compositions. Major changes in multiple components should be considered collectively rather than individual1y. The HWVP Process Technology. Unit must be contacted whenever this feed specification is applied to a NCAW waste composition that differs markediy from the nominal reference feed (see Table 3-1). 
TABLE 3-2. Composition Limits for Non-Glass Components in Hanford Waste Vitrification Plant Neutralized Current Acid Waste Feed, as Received from Tank Farms

\begin{tabular}{|c|c|c|}
\hline Component & Units. & Limit \\
\hline $\begin{array}{l}\mathrm{TOC} \\
\mathrm{NO}_{3}, \mathrm{NO}_{2} \\
\mathrm{CT} \\
{ }^{14} \mathrm{C} \\
{ }^{121_{\mathrm{I}}}\end{array}$ & $\begin{array}{l}\text { ( } \mathrm{g} / \mathrm{g} \text { nonvolatile waste oxides) } \\
\text { ( } \mathrm{g} \text { moles/g nonvolatile waste oxides) } \\
\text { ( } \mathrm{g} / \mathrm{g} \text { nonvolatile waste oxides) } \\
\text { ( } \mu \mathrm{Ci} / \mathrm{g} \text { nonvolatile waste oxides) } \\
\text { ( } \mu \mathrm{Ci} / \mathrm{g} \text { nonvolatile waste oxides) }\end{array}$ & $\begin{array}{l}<0.02^{(a)} \\
<0.0032^{(b)} \\
<0.003^{(c)} \\
<1.1^{(d)} \\
<3.0 E-4)^{(d)}\end{array}$ \\
\hline
\end{tabular}

(a) Limit is derived from 1987 feed rheology work, and corresponds to $3 \mathrm{~g}$ TOC (not including formic acid additions) per liter of concentrated melter feed (at $150 \mathrm{~g}$ waste oxides per liter). (R. K. Farnsworth, Basel ine Milestone HWVP-87-V110203A - The Effect of Feed Composition and Formic Acid Addition on G7ass Redox State, Pacific Northwest Laboratory, Richland, Washington [August 1987].)

(b) Limit is derived from a letter from K. R. Shah to F. G. Brooks, "Guidance on NO Abatement" (JuTy 7, 1987) and a private communication from G. E. Stegen to R. A. Watrous (September 24, 1987). The limit corresponds to an annual allowable release from the HWVP stack of $3.6 \mathrm{E}+4 \mathrm{~kg} \mathrm{NO} / \mathrm{yr}$ assuming an off-gas system of 1.0 . An annual glass production rate of $525 \mathrm{t} / \mathrm{yr}(1.31 \mathrm{E}+8 \mathrm{~g}$ waste oxides/yr) was also assumed. Allowance was. made for $1.7 \mathrm{E}+4 \mathrm{~kg} \mathrm{NO} 2 / \mathrm{yr}$ to be released from decontamination operations.

(c) Limit estimated from letter from R. W. Wagner to J. R. Baker, "Levels of $\mathrm{NO}_{3}, \mathrm{NO}_{2}, \mathrm{Cl}^{-}$, and $\mathrm{F}^{-}$in NCAW Feed to HWVP" (January 2, 1987).

(d) Limits are derived from Derived Concentration Guide values and the design flow rate for the HWV stack (100,000 CFM) assuming a safety factor of 5 and decontamination factors of 1.0 and 2.0 for ${ }^{14} \mathrm{C}$ and 129 , respectively. When both $14 \mathrm{C}$ and $129 \mathrm{I}$ are present in the HWVP feed, the "sum of fractions" method should be used in applying these limits (i.e., $C / 1.1+I / 3.0 E-4<1.0--$ where $C$ and I represent concentrations of ${ }^{14} \mathrm{C}$ and 129 in units of microcuries per gram of nonvolatile waste oxides). Note also that the limit for ${ }^{129}$ I appears to be on the edge of analytical detection. 
Ranges are not specified in Table 3-1 for components that are expected to be present in minor quantities and have negligible effects upon glass properties over the range of expected variability. The ranges of components that. have not been studied as part of the HWVP glass studies, but which may impact glass processability and/or durability, were extrapolated from DWPF work or taken from commercial glass literature (where available). Some of these comonents may be potential candidates for further waste variability studies.

3.1.1.1.2 Limitations on Bulk Properties. Several bulk properties of the washed sludge, total heat generation and total solids content, are of concern. Limit values are given in the discussions, below.

- Heat Generation - Fission product decay heat in washed sludge must not exceed a ratio of 3.4 watts per $\mathrm{kg}$ of nonvolatile. waste oxide components without further engineering study.

This limit is based on limiting glass canister heat to less than 1400 watts per canister, a value slightly less than the acceptance specification of 1500 watts per canister for a repository in salt. (a) The heat limit is calculated assuming the canister contains $1650 \mathrm{~kg}$ of $\mathrm{glass}$ at a waste loading of $25 \mathrm{wt} \%$ waste oxides. Although canister decay heat at the time of filling is not expected to approach 1400 watts for normal NCAW waste, the possibility exists that the blending of segregated Cs concentrates or "returned" Cs/Sr capsule materials into a single aging waste tank could create abnormally high heat loads in the glass made from that tank.

If an abnormal heat load from short lived fission products must be evaluated, extended storage (estimated to be 5 to 15 years) of the glass canisters would likely be considered to lower the heat load to less than 1500 watts per canister at the time of shipping. However, at no time during storage can a canister contain in excess of 6500 watts. This limit is designed to keep glass centerline temperatures safely below the $490^{\circ} \mathrm{C}$ glass transition temperature of HW39 glass (Ref. 3-2). Additionally, further study may be needed to evaluate the convective cooling capability of the HWVP canister storage facility. The waste feed heat value corresponding to 6500 watts per canister is 16 watts per $\mathrm{kg}$ of waste oxides.

- Solids Content - The concentration of total solids in the washed sludge slurry must be limited to control pumpability and at the same

(a) Letter from J. L. Nelson to B. A. Wolf, "Repository Waste Package Rock Thermal Limits" (February 17, 1986). 
time avoid excessive dilution which would cause reduced processing rate problems at the HWVP. Thus, the slurry of washed sludge solids must be controlled within the range of 3 to $19 \mathrm{wt} . \%$ solids. (a) A solids content greater than 4 wt\% is desired.

- Separable Organic Phase - The HWVP design does not allow for the presence of a separate organic phase in the feed. At this time the HWVP feed specification can allow no second organic phase. However, if such a condition were to be viewed as more than a remote possibility, further engineering studies would be required to better define the plants actual tolerance for trace organic phases.

3.1.1.1.3. Bases for Compositions. The high operating temperature of the HWV melter drives off-all water and many volatile chemical species. Thus, for this HWVP feed specification, the waste components present in the HWVP NCAW feed have been divided into two catagories as follows:

A. Components that are retained in the glass matrix to any appreciable extent. These components are shown in Table 3-1 and make up the bulk of the HWVP feed stream.

B. Components that volatilize or chemically react under high temperatures to form volatile species, thus exiting the melter via the offgas system. These components are given in Table 3-2, and include TOC, nitrate, nitrite, chloride, and certain radioisotopes.

The components in the two catagories affect the HWVP feed properties and feed preparation process in different ways. The concentrations of Category A components directly determine the processability of the feed slurry and glass meit and the final properties of the solidified glass waste form.

Although Category B components have an appreciable bearing on the feed and glass processability, they affect the properties of the glass only indirectly. These components can also have a major impact on the design bases for the HWVP off-gas and waste treatment systems. Organic carbon is one of the most important of these components; its effects are discussed in Section 3.1.1.2 Excessive levels of nitrate and nitrite could result in off-gas problems since $\mathrm{NO}_{x}$ emissions to the environment are limited. Nitrate and chloride are both corrosive to the feed preparation system and off-gas system equipment; they may require the use of more-expensive alloys for equipment fabrication, or may adversely affect equipment and facility life.

(a) Fluor Technology, Inc., Hanford Waste Vitrification Plant -- Engineering Study - Recycle of Liquid Radwaste Study" (February 1987). 
Since the Category A components are controlling in terms of glass formulation, their concentrations are expressed in oxide basis weight percents. That is, given a list of elemental waste components from an inductively coupled plasma (ICP) analysis of a potential HWVP feed stream, the data must be manipulated before the waste can be evaluated for glass formulation purposes.

These specifications do not take into account decontamination factors for some of the volatile elements during processing in the melter and potential recycle of constituents collected in the off-gas treatment system to the HWVP feed stream. Recycle of the volatile species is under evaluation and may be added at a later date. The impact of recycle would be to reduce the allowable limit for some specific volatile feed components.

3.1.1.2 Pretreated NCAW Component Limit Bases. A brief sumary of the effects on glass processability and quality and the bases for established limits is presented below for each of the most important feed components.

Iron - The $\mathrm{Fe}^{+3}$ in the glass acts as a redox buffer that protects against reduction of $U$, transition metals, and the noble metal group. The lower limit is based upon the need to maintain sufficient $F e$ to be relatively certain that $u^{+5}$ will not be reduced to $U^{+4}$. The upper 1 imit is the maximum allowable without' an abrupt change in glass durability (leach resistance).

Aluminum - This component increases glass durability and raises the melt viscosity. Too much aluminum will result in the formation of an aluminum crystalline phase. The upper limit is based on the maximum allowable viscosity of the glass without an adjustment of the frit composition.

Silicon, Zirconium - Both constituents increase melt viscosity and glass durability. Too much of either element will produce a melt too viscous to process (basis for the upper limits). Additionally, a zirconium silicate phase may form if too much $\mathrm{Zr}$ is present.

Sodium and Other Alkali - Melt viscosity is lowered and melt electrical conductivity increases with additions of these elements. Excess $\mathrm{Na}$ severely reduces glass leach resistance. Potassium and Li have essentially the same effects and can be partially substituted for $\mathrm{Na}$ on a molar basis. The upper and lower bounds for.alkali constituents are established by melt viscosity limits. An additional $15 \mathrm{wt} \% \mathrm{Na}_{2} \mathrm{O}$ in the feed could be accommodated by adjustment of the frit composition. Often, a combination of the alkalis (the "mixed alkali effect") allows an acceptable processing temperature without as much degradation of chemical durability as would result from the use of a single alkali. 
Chromium - The Cr-combines with $\mathrm{Fe}$ and $\mathrm{Ni}$ to form spinel crystals. The crystals are not soluble in the glass and settle to the melter floor. This behavior reduces the effective melter volume by accumulation, and has the potential for electrically shorting the melter. The upper $\mathrm{Cr}$ limit is established by the chromium solubility limit in borosilicate glass.

Lanthanum, Neodymium - These rare earth elements have been found to have negligible effects on glass or melt properties over the range tested. . This range, 0 to 8 wt\% oxide in the feed at 25 wt\% oxide waste laading, encompasses a much wider range than is expected from pretreated NCAW: If necessary, this range could likely be extended by conducting further waste variability testing.

Noble Metals - At melter operating temperatures (approximately $1150^{\circ} \mathrm{C}$ ), noble metals (Ru, Rh, and $P d$ ) are only slightly soluble in waste glass. The solubility of Ru has been observed to be less than 0.001 wt\% in borosilicate melts. Most of the $R u$ remains as oxide crystals (except under very reducing conditions when ruthenium metal can form); Rh. and Pd remain alloyed in the metallic state. Rhodium may also be present as part of iron spinel phases. In borosilicate glass, noble metals provide nucleation sites for growth of more major phases and may cause significant sludge formation. If significant quantities of highly conductive noble metals accumulate on the melter floor, shorting of the melter electrodes could occur. Preliminary studies indicate the expected concentration of noble metals in pretreated NCAW waste could lead to processing problems in the melter.

Sulfate - The limited solubility of this constituent in the melt is the basis for the upper limit. The $\mathrm{SO}_{4}^{-2}$ converts to $\mathrm{SO}_{3}$ in the melter. Excess $\mathrm{SO}_{3}$ results in the formation of a molten sulfate phase on the surface of the melt. This sulfate phase also enhances the volatility of radionuclides in the melter.

Sulfate solubility is strongly affected by the glass melt redox state (measured by the ferrous to ferric ratio), which is in turn affected by the amount of organic carbon in the feed. Sulfate solubility is greatest when ferrous-toferric ratios are below about 0.3 ; the redox state of $\mathrm{Fe}$ in the HWVP melter will be maintained below this level. (a)

Carbon - Organic carbon is added to melter feed to control the glass melt redox state. A certain amount of organic carbon is needed for this purpose; however,

(a) S. O. Bates, D. S. Goldman, and W. C. Richey, HWVP Basel ine Milestone 020207A: A Letter Report sumnarizing the Sulfate/Redox Relationship to Glass Melting Chemistry and Behavior, Pacific Northwest Laboratory, Richland, Hashington (1985). 
formic acid, which contains organic carbon, must be added during melter feed preparation to adjust feed rheology for processability. Thus, the majority of the carbon needed for redox control comes from the formic acid. Excessive organic carbon in HWVP feed will result in a melt which is too reducing, and could cause metal precipitation and melter electrode shorting. Additionally, a melt ferrous-to-ferric ratio greater than 0.3 will decrease sulfate solubility with the consequences discussed above for sulfate. Excess organic carbon could cause, soot formation in the melter and may impact the feed processing rate with the HWVP meiter design. Organic species can also affect feed processing (e.g.; foaming); this impact may be species dependent and is not considered in setting the $0.02 \mathrm{~g} / \mathrm{g}$ TOC limit given in Table 3-2.

Non-organic carbon as carbonate ion will not alter the feed redox state, but will increase melter off-gas and may impact the melter feed preparation rheology and processing rate. However, carbonate is expected to be converted to $\mathrm{CO}_{2}$ and be driven of during feed preparation.

Phosphate - This component increases the corrosiveness of the glass melt, enhances crystallization and reduces glass durability. Also a refractory calcium/rare earth/phosphate phase can form the surface of the melt, which slows processing rates. The upper limit is the maximum allowable to maintain glass durability and to guard against feed processing problems in the melter.

Uranium - Like the rare earth elements ( $L a, N d)$, U has little effect on the glass over the range tested. The range of $\mathrm{U}_{3} \mathrm{O}_{8}$ in the feed could be extended; however, $U$ levels of this magnitude in pretreated NCAW are not expected.

Fluorine and Other Halogens - Fluorine readily replaces 0 in the glass molecular structure because the two elements have similar ionic sizes. However, because $F$ is monovalent, it breaks up the glass structure and causes undesirable phase separation. The upper limit for $F$ was established through variability studies that showed loss of durability from postulated liquid-liquid phase separation. All of the halogens tend to be volatile from the glass melt to some extent. These elements can cause severe corrosion, especially in the presence of $\mathrm{SO}_{2}$ that necessitates the use of expensive materials and design for the off-gas and instrumentation systems. Radioisotopic iodine is a particular off-gas effluent concern and may require a special absorbing system for the HWVP.

Cesium, Strontium - Radioisotopic $\mathrm{Cs}$ and $\mathrm{Sr}$ increase the fission product heat Toading of the glass. Although the levels of $\mathrm{Cs}$ and $\mathrm{Sr}$ are expected to be within acceptable heat loading limits in HWVP feed, the possibility exists that excessive heat-producing fission products could require the waste loading in the glass to be lowered such that canister centerline temperatures remain below limits set by waste form qualification requirements. 
Calcium - This constituent acts as a fluxing agent. and enhances melting. The upper limit is the maximum allowable without exceeding the lowest acceptable viscosity for the glass. An excess of calcium will increase devitrification of the glass waste form.

Nickel - In sufficient quantities, this transition metal will alloy with Fe and Cr to form Fe-Cr-Ni spinel crystals. The upper limit is the maximum tested and could be extended with additional variability testing of the glass.

Manganese - Like $\mathrm{Fe}$, the +2 and +3 states of Mn form a major redox couple that . influences the processing stability of the melter feed during both feed preparation and meiting. Additional Mn could be accomnodated beyond the maximum range evaluated through further glass and feed process variability testing.

Molybdenum - This transition metal decreases the glass waste form durability but the range could be expanded from the maximum amount tested through additional glass variability studies.

Cadmium - Preliminary glass testing indicates that CdO is soluble at levels up to 2.5 wt\% in glass at a $\mathrm{Fe}^{+2} / \mathrm{Fe}^{+3}$ ratio of 0.18 . Cadmiun volatility under these conditions is also found to be minimal.

\subsubsection{Preliminary HWVP Product Specifications}

The preliminary HWV product specifications describe the specifications and approach planned to ensure that the vitrified Hanford defense high-level wastes will meet the acceptance requirements of the candidate geologic repositories for nuclear waste. Those acceptance requirements are being defined through negotiation with the candidate repositories, under guidance from the U.S. Department of Energy. Although the specific requirements for the vitrified Hanford waste have not yet been defined, they are expected to be very similar to those requirements defined for the waste vitrified at the DWPF, located at the Savannah River Plant in South Carolina. These specifications and the associated Waste Form Qualification Plan (Ref. 3-4) are based on the OWPF requirements. The content of this HWVP pian is based on the assumption that the HWVP high-level waste form will be disposed of in one of the geologic repository projects defined by the Nuclear Waste Policy Act of 1982 . Proposed legislation currently under consideration by Congress may change or delay the repository site selection process. The impacts of this change will be assessed as details of the new legislation become available.

The approach to waste form qualification at the HWVP is based upon the following concepts: 1) defining the requirements for the HWVP product, 
2) designing the process and product to show compliance with the requirements, 3) analyzing and testing the process and product to show compliance with the requirements, and 4) operating the facility within the limitations of the verified process.

Where possible, compliance with the repository waste acceptance specifications will be achieved by direct measurement of the appli.cable process or product variable and administrative control of the HWVP. Where direct measurement is not possible or practical (i.e., glass crystallinity), translation of available measurements (i.e., feed composition) to the specific waste acceptance specifications will be achieved through process and product models.

The data collected during nonradioactive process and product tests is being used to develop predictive models and to evaluate the consequences of variations in plant operating conditions and feed composition on glass composition and quality. The process and product models will then be used to predict product quality for comparison to the specific repository acceptance requirements. This approach is proposed to minimize sampling of the actual vitrified waste, to reduce overall HWVP and operating expenses, and to reduce personnel radiation exposure. The product quality analyses and actual operating data would then constitute the product quality control records.

The complete text of each of the Waste Acceptance Preliminary Specification (WAPS) for the DWPF HLW Form is contained below. Following each of the specifications is a discussion of the HWVP compliance strategy development activities. All bolded items are directly from the WAPS (Ref. 3-1) and have not been edited or changed in any way. Although the HWVP is currently basing its planning on the DWPF WAPS, the HWVP reserves the right to renegotiate each of the specifications when HWVP-specific WAPs are prepared.

\subsubsection{Chemical Specification (WAPS 1.1). The waste form for DWPF is boro- silicate waste glass.}

\subsection{Chemical Composition Projections (WAPS 1.1.1). The producer} shall include in the Haste Form Qualification Report (HQR) sufficient chenical and microstructural data to characterize the elemental composition and crystalline phases for the product of the waste production facility and expected variations in the product due to process variations during the life of the facility. The method to be used to make these projections shall be described by. the producer in the Haste Form Compliance PIan (KCP).

3.1.2.2 Radionuclide Inventory Specification (WAPS 1.2). For all radionuclide inventory estimates required by this specification, the producer shall report ali radioisotopes that have half-lives longer than $10 \mathrm{yr}$ and are present in 
concentrations greater than $0.05 \%$ of the total radioactive inventory in curies (in the aggregate or in the canistered waste form, as applicable) at any time up to $1,100 \mathrm{yr}$ after production.

3.1.2.2.1 Radionuclide Inventory Projections (WAPS 1.2.1). The producer shall provide in the $K Q R$ estimates of the total quantities of individual radionuclides to be shipped to the repository and of the uncertainties in the expected values. The producer shall also provide in the HQR estimates of the inventories of individual radionuclides expected to be present in each canistered waste form produced at the facility and the expected range of variations due to process variations during the life of the facility. These estimates shall be calculated for the year 2025. The method used to make these projections shall be described by the producer in the HCP.

3.1.2.2.2 Compliance Strategy. Both the chemical and radionuclide inventory projection specifications (1.1.1 and 1.2 .1 ) will be satisfied by the same steps and logic. The activities to be undertaken for these specifications are discussed concurrently. Specifications 1.1 .2 and 1.2 .2 on chemical and radionuclide inventory during production will similarly be satisfied by the same basic activities and are discussed concurrently in Section 3.1.2.2.5.

This specification shall provide the following.

1. Allow the repository to conduct site-specific waste form testing for performance assessment.

2. Provide a benchmark against which actual production glass can be evaluated to show that production chemical compositions are within characterized ranges.

3. Provide information on the total chemical and radionuclide loading to be provided to the repository during the life of the waste production process.

Current estimates of elemental composition and crystalline phases for the HWVP reference waste form and ranges. are provided in the HWVP Preliminary Description of Haste Form and Canister (Ref. 3-2). The accuracy of these. estimates is contingent on a number of variables, including the production reactor operating mission, plutonium-uranium extraction (PUREX) operating efficiency, and pretreatment washing efficiency.

Additionally, even if all wastes to be processed are well characterized, other variables will influence the composition of individual canistered waste forms. These include blending of different waste streams and glass former batching variability. 
As the HWVP nears production, both the range of uncertainty and expected variability will decrease. Nonetheless, there always remain enough uncertainty in the expected compositions that the HWVP will necessarily qualify a range of glass compositions. This range will encompass all compositions to be produced by the HWVP.

The following activities have been identified as necessary to provide the information required by this specification:

- Characterize the composition of existing waste through tank sampling and flow sheet analyses.

- Determine the volume of existing waste.

- Estimate future waste generation composition and volume.

- Document pretreatment effects on waste volume and composition.

- Estimate total volume and composition of waste to be processed by HWVP after pretreatment.

- Estimate waste biending schemes.

- Establish glass forms (frit) compositions.

- Establish glass. composition and ranges.

- Estabiish credible thermal histories for production canisters.

- Characterize glass crystallinity versus composition and thermal history.

Results of these activities will be reported in the WQR and regular updates of the WFD.

3.1.2.2.3 Chemical Composition During Production (WAPS 1.1.2). For the canistered waste forms the producer shall include in the production records the elemental composition of the glass waste form for all elements, excluding oxygen, present in concentrations greater than $20.5 \%$ by weight. The producer shall describe the method to be used for compliance in the HCP. An estimate of the precision and accuracy and the basis for the estimate of the precision shall be reported in the IUCP. 
3.1.2.2.4 Radionuclide Inventory During Production (WAPS 1.2.2). At the time of shipment, the producer shall provide in the production records estimates of inventories of individual radionuclides in each canistered waste form. The producer shall also report the expected precision and accuracy of these estimates in the HCP.

3.1.2.2.5 Compliance Strategy. Specifications 1.1 .2 and 1.2 .2 on chemical and radionuctide inventory during production will be satisfied by the same steps and logic. The activities undertaken for the specifications are discussed concurrently in 4.2.5. Specifications 1.1 .1 and 1.2 .1 on chemical and radionuclide inventory projections were discussed in Section 3.1.2.2.2.

Accurate knowledge of the chemical and radionuclide content of the waste form during production is critical to the HWVP approach to WFQ. Chemical and radionuclide compositions are used to provide the basis for assertions that other characteristics (such as crystallinity and thermial output) of the waste form are known.

The general compliance approach to determine the composition of the glass during production is as follows:

- The vitrification process will be operated within established operating limits.

- Samples of the melter feed tank, feed preparation tanks, and glass pour stream will be taken on a designated schedule.

- Operating parameters and analytical results will be applied to the process and product models.

The development activities required to successfully fulfill this approach are as follows:

- Establish a plant process control strategy that identifies critical control parameters and deviations from control limits during operations.

- Continue developing, validating, and verifying process models.

- Identify the required sampling schedule to support process control and accountability needs.

- Develop analytical techniques adequate to provide the required chemical and radionuclide resolution. 
Development of the process model is a continuing effort. The model will be verified during nonradioactive operations of the HWVP. The precision and accuracy of the assessment of glass composition during production will be calculated based on the results of nonradioactive operations and will be reported in the WOR.

Accounting for composition of the waste form will involve sampling of both the feed preparation tanks and the glass product. Although no strong technical reason exists for the sampling of the actual vitrified product, the NRC has mandated that product sampling will be required. The HWVP has undertaken a preliminary evaluation to assess the minimum amount of sampling required to achieve compliance with this specification. Strict adherence to the specification would require that only 11 chemical components of the HWVP reference glass composition (shown in Table 3-3) be reported. However, because the concentrations in Table 3-3 are early estimates with, in some cases, broad ranges expected due to variability in the wastes, all 25 elements may require reporting in the WQR. Additionally, 20 radionuclides in the HWVP reference glass meet the reportability requirements of the specification. A listing of the 20 radionuclides with activities greater than $0.01 \%$ follows (at any time in the first 1,100 yr after canister production and with half-lives greater than $10 \mathrm{yr})$ :

$\begin{array}{rrrr}137 \mathrm{Cs} & 241_{\mathrm{Pu}} & 126 \mathrm{Sn} & 14 \mathrm{C} \\ 90 & 99_{\mathrm{Sr}} & 79 \mathrm{Se} & 242 \mathrm{~m}_{\mathrm{Am}} \\ 151_{\mathrm{Sm}} & 239_{\mathrm{Pu}} & 135 \mathrm{Cs} & 107 \mathrm{Pd} \\ 241_{\mathrm{Am}} & 63_{\mathrm{Ni}} & 237_{\mathrm{Np}} & 240 \mathrm{Pu} \\ 154_{\mathrm{Eu}} & 93_{\mathrm{Zr}} & 243_{\mathrm{Am}} & 59_{\mathrm{Ni}}\end{array}$

The required number and location of samples throughout the process and the number of analyses per sample are directly related to the required precision. As the number of samples or analyses increases, the precision is improved. The relationship between sampling and analytical schemes and the precision of the combined estimate of glass composition will be examined further. As a part of this examination, the mass balance model must be defined, expressions for obtaining the uncertainty associated with predictions from the mass balance model must be determined, and uncertainties associated with the sampling and analysis of glass samples must be quantified.

Based on estimates of the precision and accuracy of current chemical and radiochemical analysis techniques, a preliminary mass balance model around the melter, and a statistical propagation of errors analysis, a number of samplingschedules can be prepared. The required number of samples from the SME, MFT, 
TABLE 3-3. Composition of Hanford Waste Vitrification Plant Reference Haste and Giass (Ref. 3-2)

\begin{tabular}{|c|c|c|c|c|c|}
\hline Oxide & $\begin{array}{l}\text { Normalized } \\
\text { Waste } \\
\text { (wt\% oxide) }\end{array}$ & Range & $\begin{array}{c}\text { Frit } \\
\text { (wt\% oxide) }\end{array}$ & $\begin{array}{l}\text { wt\% } \\
\text { oxide }\end{array}$ & $\begin{array}{c}\text { wt: } \\
\text { Element }\end{array}$ \\
\hline $\mathrm{SiO}_{2}$ & 2.9 & $0--16$ & 67.25 & 51.2 & 23.9 \\
\hline $\mathrm{B}_{2} \mathrm{O}_{3}$ & 0.0 & - & 12.75 & 9.6 & 3.0 \\
\hline $\mathrm{Na}_{2} \mathrm{O}$ & 10.5 & $0--20$ & 10.75 & 10.7 & 7.9 \\
\hline $\mathrm{Li}_{2} \mathrm{O}^{\circ}$ & 0.0 & $-\infty$ & 5.00 & 3.8 & 1.7 \\
\hline $\mathrm{CaO}$ & 0.3 & - & 3.75 & 2.9 & 2.1 \\
\hline $\mathrm{MgO}$ & 0.2 & $\infty$ & 1.00 & 0.8 & 0.5 \\
\hline $\mathrm{Fe}_{2} \mathrm{O}_{3}$ & 44.0 & $30--60$ & - & 11.0 & 7.7 \\
\hline $\mathrm{Al}_{2} \mathrm{O}_{3}$. & 17.0 & $2--26$ & - & 4.3 & 2.2 \\
\hline $\mathrm{Cr}_{2} \mathrm{O}_{3}$ & 5.3 & $0--2$ & - & 1.3 & 0.9 \\
\hline$\dot{\mathrm{Z}} \mathrm{rO}_{2}$ & 2.3 & $0--40$ & - & 0.6 & 0.4 \\
\hline NiO & 2.3 & -- & - & 0.6 & 0.5 \\
\hline $\mathrm{La}_{2} \mathrm{O}_{3}$ & 2.2 & - & - & 0.6 & 0.5 \\
\hline $\mathrm{SO}_{4}$. & 1.8 & $0--2$ & $\infty$ & 0.5 & 0.2 \\
\hline $\mathrm{Nd}_{2} \mathrm{O}_{3}$ & 1.7 & - & $-\infty$ & 0.4 & 0.4 \\
\hline $\mathrm{MOO}_{3}$ & 1.2 & - & - & 0.3 & 0.2 \\
\hline$F$ & 1.2 & TBD & - & 0.3 & 0.3 \\
\hline CuO & 0.6 & $-\infty$ & - & 0.2 & 0.1 \\
\hline TOC & 0.6 & $0--5$ & - & 0.0 & 0.0 \\
\hline $\mathrm{MnO}_{2}$ & 0.6 & - & - & 0.2 & 0.1 \\
\hline $\mathrm{CeO}_{2}$ & 0.6 & -- & - & 0.2 & 0.1 \\
\hline $\mathrm{RuO}_{2}$ & 0.5 & - & - & 0.2 & 0.1 \\
\hline $\mathrm{U}_{3} \mathrm{O}_{8}$ & 0.6 & $0--32$ & - & 0.2 & 0.1 \\
\hline $\mathrm{Cs}_{2} \mathrm{O}$ & 0.5 & -- & - & 0.2 & 0.1 \\
\hline $\mathrm{P}_{2} \mathrm{O}_{5}$ & 0.02 & $0--5$ & - & 0.0 & 0.0 \\
\hline $\mathrm{TiO}_{2}$ & 0.01 & $0--4$ & - & 0.0 & 0.0 \\
\hline
\end{tabular}


or glass depends on the required precision for the estimate of glass composition. By examining the precision of the glass estimate for various combinations of significant factors, an acceptable sampling schedule can be determined.

In addition to statistical analysis providing the basis for establishing the product composition sampling plan, the HWVP is considering the use of statistical process control (SPC) techniques during operation.

The SPC is a procedure for monitoring a process in the presence of natural process uncertainty and producing information about the process that can be used to make decisions. Under SPC, inherent, expected variation is allowed, whereas shifts or variances above those expected under normal operating conditions are detected. Typically, the average measured value and the variability of the process characteristic to be controlled are. both used to assess process control. Application of SPC analyses at HWVP is in the early stages of development.

\subsubsection{Specification for Radionuclide Release Properties (WAPS 1.3)}

3.1.2.3.1 Control of Radionuclide Release Properties (WAPS 1.3.1). The producer shall demonstrate that the radionuclide release properties of the waste form can be controlled during production. The producer shall relate the method of control to the repository site-specific tests TBD [R2] or perform the repository site-specific tests TBD [R2]. The producer shall describe the intended method for demionstrating compliance in the WCP. Supporting technical documentation for the selected method of control shall be included in the WQR.

3.1.2.3.2 Compliance Strategy. The HWVP will relate radionuclide release properties to glass product composition through the use of the product models. Glass development studies indicate that radionuclide release can be controlled by controlling the product composition. Other variables, such as residence time in the melter and melt temperature, do not appear to be important factors to durability, although their effects will be assessed. The activities described under specifications 1.1 and 1.2 for determining and controlling product composition are critical to the satisfaction of this specification.

The HWVP will relate the results of current and future nonrepository-sitespecific durability testing. to site-specific test procedures as they become available. Current testing is performed through a statistically based study in deionized water using procedures modified from Materials Characterization Center-1 (MCC-1) and MCC-3.

The following activities have been identified as necessary to fulfill the requirements of this specification: 
- Identify repository site-specific testing requirements.

- Identify repository performance objectives for test results.

- Develop product model correlating durability to composition.

- Develop giass to optimize durability.

3.1.2.3.3 Verification of Radionuclide Release Properties (WAPS 1.3.2). The producer shal1. document that the canistered waste form at the time of production met the limits of specification 1.3.1. The producer shall describe the method for demonstrating compliance in the WCP. Documentation supporting the selected method of verification and the verification results shall be included in the production records.

3.1.2.3.4 Compliance Strategy. The HWVP will control radionuclide release properties during production by controlling product composition. If other variables are identified as having significant impacts on product durability, such effects will be documented and controlled during plant operation.

It is not planned that the HWVP will conduct regular durability tests on actual production glass. However, if it is determined that a glass has been produced that is not within identified composition boundaries and cannot be = accommodated by the product model, verification testing of radionuclide release properties will be performed.

The following activities have been identified as necessary to achieve compliance with this specification.

- Develop product model correlating composition to radionuclide release properties.

- Identify verification testing protocol.

3.1.2.4 Specification for Chemical and Phase Stability (WAPS 1.4). The producer shall provide the following data on the borosilicate glass waste form:

(a) The transition temperature where the slope of the thermal expansion versus temperature curve shows a sharp increase.

(b) A time-temperature-transformation (TIT) diagram that identifies temperatures and the duration of exposure at the temperature that causes significant changes in either the phase structure or the phase compositions of the borosilicate glass waste form. The producer shall provide $T I T$ diagrams characteristic of the expected range of waste form composition. The waste form radionuclide release properties called for under specifications 
1.3 shall also be provided for representative samples covering the same ranges of temperature, duration of exposure, and waste form composition.

The requested data, analysis, and appropriate technical support shall be provided in the KQR. The method used to produce these data shall be described in the HCP.

At the time of shipment, the producer shall certify that the maximum waste form temperature is at least $100^{\circ} \mathrm{C}$ below the transition temperature in $1.4(\mathrm{a})$ above. In addition, the producer shall certify that after the initial cooldown, the canistered waste forms to be'shipped have been handled and stored in a manner such that the maximum temperature of the waste form has not exceeded the transition temperature specified in specification 1.4(a). The producer shall also describe the method of certification in the VCP. The canistered waste forms shall be transported under conditions that ensure that the transition temperature of specification 1.4(a) above is not exceeded; certification that this has been accomplished will be required on receipt at the repository.

\subsection{Compliance Strategy. The transition temperatures and TTT} diagrams will be determined for the reference glass compositions identified. Standard dilatometric and/or thermal analyses will be used to determine transition temperatures. The $\Pi \pi T$ diagrams will be developed using methods employed by the DWPF.

The HWV has performed preliminary $\pi$ TT studies on the reference glass composition. Extensive $T \pi$ versus composition and thermal history testing will not be initiated until the repository site-specific radionuclide release tests have been identified.

The HWVP storage facility for canistered waste forms is designed so that, after initial cooldown, the maximum temperature of the canistered waste form will not exceed the glass transition temperature. Transportation is not the responsibility of the HWVP. The transporting organization will be responsible for certifying compliance during transport of the canistered waste form to a federal repository.

The following activities have been identified as required for achieving compliance with this specification:

- Identify reference product composition boundary envelopes.

- Prepare TIT diagrams for reference glasses.

- Measure transition temperatures for composition envelope glasses. 
- Document that radionuclide release properties for all composition envelope glasses are acceptable.

- Document that the design of the storage facility meets specification.

3.1.2.5 Material Specification (WAPS 2.1). The waste form canister and any secondary canisters applied by the producer shall be fabricated from austenitic stainless steel. The ASTM alloy specification and the composition of the canister material, the secondary canister material, and any filler material used in welding shall be included in the ICP.

3.1.2.5.1 Compliance Strategy. The HWVP will use administrative controls on the procurement documents to achieve compliance with this specification. All materials used in the fabrication of the canisters will have ASTH designations, with certification provided for each lot and heat used. The canister will be inspected and documentation verified before shipment to the HWV.

The following activities are required to achieve compliance with specification:

- Prepare canister procurement documents specifying appropriate materials of construction

- Verify canister materials of construction before shipment to the HWVP.

As a minimum, the production record for each canistered waste form will include the following information:

- the ASTM alloy specifications of the canister materials

- the vendor

- identification of the heat

- certificate(s) of anaiysis

- identification of inspection records.

3.1.2.6 Fabrication and Closure Specifications (WAPS 2:2). The canister fabrication methods, as well as those for any secondary canister applied by the producer, shall be identified in the MCP and documented in the WQR. The outermost closure shall be leaktight in accordance with the definition of "Teaktightness" in ANSI M14.5-1977, "American National Standard for Leakage Tests on Packages for Shipment of Radioactive Materials." The method for demonstrating compliance shall be described by the producer in the WCP and documented in the WQR. 
3.1.2.6.1 Compliance Strategy. The reference process for final closure of the HWVP canister is to upset resistance weld a 5-in.-diameter, 1/2-in.thick 304L stainless steel plug into the canister neck. The approximate weld conditions are a force of $70,000 \mathrm{lb}$ and a current of $230,000 \mathrm{~A}$ for $1.5 \mathrm{~s}$. Parametric testing of the welder will be done to identify the range of process conditions (force, amps, and time) to be. used in the HWVP that will give a leaktight weld. The quality of the final closure weld will be assured through control of the process parameters, visual inspection of the final weld, and measurements of the displacement of the plug in the final weid.

The HWVP is considering the use of other closure techniques for the canister. Discussions are in progress with the repository projects and the Waste Acceptance Committee to assess the feasibility of this option.

All welding, welding procedure qual ifications, repair,.electrodes, and welder performance tests used in the fabrication of the canisters, will be performed in accordance with ASME Section IX, Summer 1983 Addenda - Welding and Brazing Qualifications, unless otherwise specified in the canister procurement document. The canister fabrication welds are made according to drawing and procedural specifications. An HWVP QA representative will conduct inspections at the vendor shop to verify that the procedures are followed.

The WQR will include a more-detailed description of the canister fabrication methods as specified in the canister procurement documents. The WQR will also include a report on the testing of the closure conditions and associated leak rates and validation of the testing during HWVP cold operations.

The production record for each canistered waste form will verify that the fabrication welds were made according to the drawings and the procedures. The production record will also include the values of the actual closure conditions to verify that the final closure was made within the prescribed limits.

\subsubsection{Identification and Labeling Specifications (WAPS 2.3).}

3.1.2.7.1 Identification (WAPS 2.3.1). The producer shall assign an alphanumeric code to each canister or secondary canister, if one is used, that is produced. This alphanumeric code shall appear on the labels of the canistered waste form and on all documentation pertinent to that particular canistered waste form.

3.1.2.7.2 Labeling (WAPS 2.3.2). Each canister shall be labeled with the identification code specified above. Two labels shall be firmly affixed, with one visible from the top and one from the side of the canister. The identification code shall be printed in a type size of at least 92 point using a sans serif type face (Megaron Bold Condensed or equivalent). A proposed layout 
shall be provided in the ICP. Labels, meeting the requirements above, shall be applied to the exterior of the outermost canister. Labels affixed to the outside of the outermost canister shall not cause dimensional limits of specification 3.11 to be exceeded. The label materials and method of attachment shall be selected to be compatible with the canister material. The label shall be designed to withstand filling and storage at the producer's facility, shipment to the repository, and possibie lag storage at the repository prior to final packaging. The producer shall describe the label materials and method of attachment in the KCP. The producer shall estimate the service life of the label and provide a strategy for meeting that estimate in the WCP.

3.1.2.7.3 Compliance Strategy. The HWV will use an alphanumeric code on labels affixed to the top and side of the canister. Labeiing will be in the manner identified by the DWPF. Future updates of the HWVP WFQ PIan wilT provide the final design of the label lettering and estimates of the service life.

3.1.2.8 Free Liquid Specification (WAPS 3.1). After closure the canistered waste form shall not contain free liquids that could be drained from the canister either initially or after having been subjected to the transition.tem-. perature of Specification 1.4(a). The producer shall describe the method of compliance in the ICP and provide documentation in the HQR.

3.1.2.8.1 Compliance Strategy. The vitrification process, operating at $-2100^{\circ} \mathrm{F}\left(-1150^{\circ} \mathrm{C}\right)$, with a nominal residence time of $65 \mathrm{~h}$, will evaporate all free liquids from the waste feed stream as. the waste is converted into molten glass. The glass pouring into the canister will be at a temperature of about $1830^{\circ} \mathrm{F}\left(1000^{\circ} \mathrm{C}\right)$, and the canister under a vacuum. Thus, free 1 iquids wilt not enter the canister with the glass, and any liquids in the canister are unlikely to remain there due to the heat of the pouring glass stream and the vacuum.

The most likely source of free liquids is the water/frit slurry used to decontaminate the canister. A shrink-fit seal has been developed to ensure that this slurry does not enter the canister. This temporary canister closure seal will be inserted into the canister neck after filling, and before canister decontamination, to prevent inleakage of the decontamination slurry. Every temporary canister closure will be tested to ensure that it is watertight. Administrative controls will be used to prevent the introduction of any free liquids into the canisters before or after filling the canister with glass.

The WQR will include a report on the absence of liquid in borosilicate waste glass. The WQR will also include a report on the controls used to keep free liquids out of the canistered waste form, including data from nonradioactive testing on the leak rate of the temporary canister closure. 
The production record for each canistered waste form will include the results of leak testing the temporary canister closure of that canistered waste form before decontamination. The production record will also certify that appropriate controls were used to prevent the introduction of free liquids into the canistered waste form.

3.1.2.9 Gas Specification (WAPS 3.2). After closure, the canistered waste form shall not contain free gas other. than cover and radiogenic gases. Cover gases shal1 be helium, argon, other inert gases, or air, or combinations thereof. The maximum internal gas pressure immediately after closure shall be $7 \mathrm{psig}$ at $25^{\circ} \mathrm{C}$. The producer. shall describe the method of compliance in the WCP and shall document in the WQR the quantities and compositions of any gases that might accumulate inside the canister after the canister has been subjected to temperatures up to the transition temperature of Specification 1.4(a).

The producer shall also document in the WQR the quantities and compositions of any gases that might accumulate inside the canisters as a result of radioactive decay.

3.1.2.9.1. Compliance Strategy. Borosilicate waste glass does not contain free gas. The canister is filled with glass, and the temporary canister c10sure is emplaced in the air atmosphere of the HWVP melt cell. Because the canister has not completely cooled from filling when the temporary seal is emplaced, the canistered waste form is under a slight vacuum due to contraction of the air inside.

Administrative controls will be used to prevent the introduction of any gases into the canisters after filling and sealing. The maximum internal gas pressure, expected immediately after closure, will be calculated. The gases that might be generated at temperatures up to the transition temperature will be determined from either available technical literature or new experimental evidence as necessary. The amounts of gases generated due to radioactive decay will be calculated.

3.1.2.10 Specification for Explosiveness, Pyrophoricity, and Combustibility (WAPS 3.3). After closure the canistered waste form shall not contain explosive, pyrophoric, and combustible materials. The producer shall describe in the UCP those administrative controls and other factors that prevent the introduction of explosive, pyrophoric, or combustible materials into canistered waste forms. The producer shall present in the MQR an evaluation of the canistered waste form to demonstrate that, for the range of material compositions, it remains nonexplosive, nonpyrophoric, and noncombustible after having been subjected to temperatures up to the transition temperature of specification $1.4(a)$. 
3.1.2.10.1 Compliance Strategy. Borosilicate waste glass is not explosive, pyrophoric, or combustible because all components of the glass have already been oxidized. The canister manufacturer will clean and degrease the canister and cover the opening with a gasketed metal cap for shipment, preventing the introduction of such materials during transportation and storage. Administrative controls will be-used to preclude the introduction of these materials after the cap is removed at the plant. The canister internals will also be inspected for debris before entry into the melt cell. After filling with glass, the temporary canister closure prevents unwanted materials from entering the canister.

3.1.2.11 Organic Materials Specification (WAPS 3.4). After closure the canistered waste form shall not contain organic materials. The producer shall describe the wethod for complying with this specification in the WCP and document the detection limit for the organic materials in the MQR.

13.1.2.11.1 Compliance Strategy. Borosilicate waste glass is an inorganic material, thus introducing no organic materials into the canister. The canisters themselves will be degreased by the manufacturer prior to receipt at the HWVP. The canister will be inspected after the cap is removed at the plant. The vitrification process, operating at $-1150^{\circ} \mathrm{C}$, will volatilize any organics that are present in the waste feed stream. Administrative controls will be used to prevent the introduction of organics into the canisters either before or after filling the canister with glass.

3.1.2.12 Free Volume-Specification (WAPS 3.5). After closure, the free-volume within the canistered waste form shall not exceed $20 \%$ of the total internal rotume of an enpty canister. The producer shall identify the nominal free volune and expected range of variation in the WCP and describe the method of compliance in the WCP. The producer shall also provide in the WCP the expected frequency distribution of free volumes in the canistered waste forms. The free volume within the canistered waste form shall be reported in the production records.

3.1.2.12.1 Compliance Strategy. The HWV canistered waste forms will be filled as full as is practicable to minimize the number of canistered waste forms produced. At the beginning of radioactive operations, the nominal free volume at the completion of filling will be $\leq 15 \%$. The free volume is expected to decrease as experience. is gained in operation of the HWVP equipment.

The glass level will be monitored by gamma emission and neutron transmission and will be compared with the glass level as calculated from the weight of the glass to assure control of the fill level. The free volume will be calculated based on the level of the glass attained during pouring. A small number 
of canistered waste forms will have free volumes in excess of $20 \%$. These canisters could be produced as a result of a process upset, draining the melter at the end of its life, equipment failures, or operated error. It is not possible to estimate the number of such events at this time. A frequency distribution based on experience with prototypic equipment will be provided in the WQR.

3.1.2.13 Specification for Removable Radioactive Contamination of External Surfaces (WAPS 3.6 ). The level of removable radioactive contamination on all external surfaces of each canistered waste form shall not exceed the following limits:

\section{A7pha radiation: $\quad 220 \mathrm{dpm} / 100 \mathrm{~cm}^{2}$ \\ Beta and Gamna radiation: 2,200 dpm/100 $\mathrm{cm}^{2}$.}

In addition, the producer shall visually inspect the canistered waste forms and remove visible waste glass on the exterior of the canistered waste form before shipment. The producer shall also provide in the MCP an estimate of the amount of canister material that is removed during the decontamination and the basis for that estimate. The producer shall describe the method of compliance in the ICP and provide supporting documentation in the MQR.

3.1.2.13.1 Compliance Strategy. The canistered waste. form will be decontaminated by slurry frit blasting as developed by the DWPF. The canistered waste forms will be visually inspected for waste glass on the exterior of .the canistered waste form. Assurance that the canistered waste forms do not exceed the above contamination levels will be provided by a smear. test of the canister external surfaces.

Based on process development work at the Savannah River Laboratory (SRL), a single slurry frit'blasting cycle from DWPF type decontamination will remove $50 \mathrm{~g}$ of canister material (metal and contaminated oxides), or approximately $7 \mathrm{mg} /$ in. $^{2}$. of canister surface area. The SRL has shown that a conservative estimate of the minimum metal removal required to achieve the specified level of decontamination is $5 \mathrm{mg} / \mathrm{in}^{2}$.

3.1.2.14 Heat Generation Specification (WAPS 3.7). The canistered waste form shall not exceed a total heat generation rate of $800 \mathrm{~W} /$ canister at the time of shipment to the repository.

3.1.2.14.1 Heat Generation Projections (WAPS 3.7.1). The producer sha11. document in the WRR the expected thermal output and the range of expected variation due to process variation during the life of the production facility. The method to be used in making these projections shall be described by the producer in the WCP. 
3.1.2.14.2. Compliance Strategy. Current estimates indicate that thermal outputs of up to $\mathrm{I.2} \mathrm{kW}$ per canister will be achieved by the HWVP. The HWVP will negotiate the approximate thermal output limit for HWV-canistered waste forms during preparation of the HWVP specific WAPS.

The expected thermal output and the range of expected variations for the canistered waste forms. will be calculated based on the radionuclide inventory projections described in specification 1.2 .

3.1.2.14.3 Heat Generation During Production (WAPS 3.7.2). The producer shall. specify in the production records the. heat generation rate and its accuracy to $\pm 15 \%$ for canistered waste forms at time of shipment. The expected accuracy of the heat generation rates shall be supplied in the HCP. The waste producer shall describe the plan for compliance in the KCP.

\subsection{Compliance Strategy.}

The heat generation rate of each canistered waste form will be calculated based on the radionucilide inventory described for specification 1.2.2. If a canistered waste form is produced with a heat generation rate exceeding the limit, the repository will be contacted and disposition determined. In the - event the repository will not accept the canister, it will be stored at the production site until sufficient radioactive decay has occurred such that the heat generation limit is not exceeded.

3.1.2.15 Specification for Maximum Dose Rates (WAPS 3.8). At the time of Eshipment the canistered waste form shall not exceed a maximum surface gamma = dose rate of $10^{5} \mathrm{rem} / \mathrm{h}$ and a maximum neutron dose rate of $10^{3} \mathrm{rem} / \mathrm{h}$.

3.1.2.15.1 Projections of Maximum Dose Rates (WAPS 3.8.1). The producer shall specify in the WQR the expected values and the range of expected variation for both ganma and neutron dose rates. The producer shall describe in the HCP the method to be used in making these projections.

3.1.2.15.2 Compliance Strategy. The HWVP will negotiate the appropriate dose rates for HWVP canistered waste forms during preparation of the HWVP specific HAPS.

The projected dose rates will be calculated based on the projections of composition and radionuclide inventory described in specification 1.2.2.

3.1.2.15.3 Maximum Dose Rates at Time of Shipment (WAPS 3.8.2). The producer shall provide in the production records the gamma and neutron dose rates for the canistered waste forms at. the time of shipment. The producer shall describe the method of compliance in the UCP. 
3.1.2.15.4 Compliance Strategy. The gamma and neutron dose rates of each canistered waste form will be determined before shipment. The radionuclide inventory determined for specification 1.2 .2 will be used for this calculation.

3.1.2.16 Chemical Compatibility Specification (WAPS 3.9). The contents of the canistered waste form shall not Tead to internal corrosion of the canister such thiat there will be an adverse effect on normal handling during storage, transportation, and repository operation. The producer shall describe the method of compliance in the HCP and document in the MQR the extent of corrosiveness and chemical reactivity among the waste form, the canister, and any filler materials. Corrosion, chemicai interactions, and any reaction products generated within the canistered waste forms after exposure to temperatures up to the transition temperature of specifications 1.4(a) shall be evaluated in the KQR.

3.1.2.16.1 Compliance Strategy. The extent of chemical reactivity among the borosilicate waste glass, the canister, the gas in the void space, and the volatiles from the waste glass will be determined from either available technical literature or new experimental evidence, as necessary. It is currently believed that the canistered waste form will not lead to internal corrosion of the canister such that there would be an adverse effect on normal handling, as long as there is no liquid water inside the canistered waste form. Administrative controls will be developed to prevent liquid water from entering the canistered waste form.

3.1.2.17. Subcriticality Specification (WAPS 3.10). The producer shall ensure that the canistered waste form will remain subcritical under all credible conditions likely to be encountered from production through receipt at the repository. The calculated effective neutron multiplication factor, keff; shall be sufficiently below unity to show at least a $5 \%$ margin after allowance for the bias in the method of calculation and the uncertainty in the experiments used to validate the method of calculation. The producer shall describe the method of compliance in the WCP and provide supporting documentation in the WQR. The IQR shall also include sufficient information on the nuclear characteristics of the canistered waste form to enable the repository designer to confirm subcriticality under repository storage and disposal conditions.

3.1.2.17.1 Compliance Strategy. A bounding calculation will be performed on the basis of the radionuclide inventory of specification 1.2.2 to show that the effective multiplication factor of a canistered waste form will be much less than 1.

3.1.2.18 Specifications for Height, Length, Diameter, and Overall Dimensions (WAPS 3.11). The configuration, dimensions, and weights of the canistered waste form shall be controlled as indicated below, and the following parameters of the canistered waste form shall be documented at the time of shipment. 
3.1.2.18.1 Weight Specification (WAPS 3.11.1). The weight of the canistered waste form shall not exceed $3,000 \mathrm{~kg}$. The measured weight shall be reported in the production records, accurate to within $\pm 5 \%$.

3.1.2.18.2 Length Specification (HAPS 3.11.2). The overal1 length of the final canistered waste form at the time of shipment shall be $3.000 \mathrm{~m}(+.005 \mathrm{~m}$, $-.020 \mathrm{~m})$.

3.1.2.18.3 Diameter Specification (WAPS 3.11.3). The outer diameter of the canistered waste form shall be $61.0 \mathrm{~cm}(+1.5 \mathrm{~cm},-1.0 \mathrm{~cm})$. The minimum wall thickness of the enpty canister shall be $0.85 \mathrm{~cm}$. The producer shall state in the ICP the minimum canister wall thickness of the filled canister, and the thickness of any secondary canisters, along with their technical bases.

3.1.2.18.4 Specification for Overall Dimensions (WAPS 3.11.4). The dimensions of the canistered waste form shall be controlled so that, at the time of shipment to a repository, the canistered waste form will stand upright without support on a flat horizontal surface and will fit without forcing wen lowered vertically into a right-circular, cylindrical cavity, $64.0 \mathrm{~cm}$ in diameter and $3.01 \mathrm{~m}$ in length.

3.1.2.18.5 Compliance Strategy. The final weight of each canistered waste form will be measured before shipment to a repository. The dimensions of the canister will be controlled by the canister manufacturer. Any effects of the vitrification process on the length, diameter, or wall thickness will be determined from measurements of nonradioactive canistered waste forms produced during nonradioactive operation. Data available from the DWPF indicates that the minimum wall thickness will be $0.89 \mathrm{~cm}$, and the average wall thickness will be $0.95 \mathrm{~cm}$. The weld plug will extend $-0.002 \mathrm{~m}$ above the nominal $3 \mathrm{~m}$ of canister length.

3.1.2.19 Drop Test Specification (WAPS 3.12). The canistered waste form at time of shipment shall be capable of withstanding a drop of 7 w onto a flat, essentially unyielding surface without breaching. The producer shall describe the method of compliance in the WCP and present the supporting documentation of analysis and test results in the WQR. The test results shall include information on measured canister leak rates and canister deformation after the drop test.

3.1.2.19.1 Compliance Strategy. Nonradioactive canistered waste forms will be shown to successfully pass the required drop test. Also, a model of the drop test response will be developed by the DWPF and the confidence level in the canister integrity determined. 
3.1.2.20 Handling Features Specification (WAPS 3.13). The canistered waste form shall have a neck with a lifting flange. The lifting flange geometry and maximum loading capacity shall be described in the MCP.

The producer shall design the lifting flange and a suitable grapple, which could be used at the repository, that meets applicable codes and standards for use at the repository. The grapple and the flange shall be designed to satisfy the following requirements:

(a) The grapple shall be capable of being remotely engaged and disengaged from the flange.

(b) The grapple, when attached to a suitable hoist (to be supplied by the repository), and when engaged with the flange, shall be capable of raising and lowering a canistered waste form in a vertical direction.

(c) The grapple, in the disengaged position, shall be capable of being inserted into and withdrawn in a vertical direction from a right- circular cylindrical cavity with diameter equal to that of the canistered waste form.

The design of the flange and grapple shall be capable of fulfilling the requirements of $3.13(a)$ through $3.13(\mathrm{c})$ without contacting or penetrating the walls of an imaginary right-circular, cylindrical cavity with a diameter equal to that of the canistered waste form, coaxial with the canistered waste form, and extending for a height of $0.7 \mathrm{~m}$ above the highest point on the canistered waste form. The design of the grapple shall include features that will prevent an inadvertent release of a suspended canistered waste form when the grapple is engaged with the flange. The producer shall describe the grapple and the flange design concepts in the ICP and provide the designs in the. MQR.

3.1.2.20.1 Compliance Strategy. The HWVP reference canister and grapple are the same as those developed for the DWPF. Should deviation from the DWPF design be required, appropriate design and testing activities will be initiated.

3.1.2.21 Quality Assurance Specification (WAPS 4.0). The producer shall establish, maintain, and execute a QA program that complies with $0 G R / B-3$ (a) as augmented by Supplement No. 11. The QA program shall be applied to all testing and analysis activities that provide information to be included in WQRs. The

(a) U.S. Department of Energy, "Quality Assurance Plan for High-Level Radioactive Waste Repositories," ORG/B-3, DOE/RW-0095. 
WCPs shall be prepared in accordanice with the QA program; however, existing data generated prior to the inception of the subject QA program may be included in the WCP so long as the specific QA measures that were in effect when the data were generated are described. The QA program shall also be applied to all activities that could effect conpliance with waste acceptance specifications during waste form production, handling, storage, preparation for shipment, and shipment to the repository. The producer shall describe his QA program in the HCP and certify cospliance with it in the WQR, and in production records.

3.1.2.21.1 Compliance Strategy. The requirements for the waste producer's QA program are currently stated in the Quality Assurance (QA) plan for High-Level Radioactive Waste Repositories (OGR/B-3), OOE/RW-0j095 as augmented by Supplement No. 11 .

These documents, in their present form, do not clearly delineate the relationship between the waste producers and the repository program. The application of the requirements of these documents needs clarification. For this reason, a working group made up of representatives from potential waste producer project offices has developed detailed quality requirements for waste acceptance process activities.

The OGR/B-3 document states that the project offices and contractors are to use NQA-1 and its addenda as the principal means for complying with the 18 criteria of Appendix B of 10 CFR 50. The draft QA requirements for waste acceptance process activities al so 1 ist NQA-1 as one of basic requirements along with 14 supplemental requirements. Other basic requirements also exist.

The Westinghouse Hanford Company (WHC) has a QA program in place that addresses the 18 requirements specified in ANSI/ASME NQA-1. The HWVP project has a $Q A$ Program Plan that specifies the QA requirements for the project, including direction to all of the project participants.

Activities currently ongoing within the project are performed in accordance with practices and procedures that are part of the responsible contractor's QA program. These activities are monitored through independent reviews, surveillances, and audits to verify conformance to the applicable QA program. The results of the monitoring process are documented and filed as quality records.

The existing QA programs do not address all the requirements stated in the draft waste form production $Q A$ requirements document. That means that some activities, although performed under a currently approved QA program wi11 not conform to the supplemental requirements of the draft document. The HWVP QA program plan will be revised to reflect the requirements of the QA plan for 
waste form production when issued by DOE/RW. At that time the Waste Form Compliance Plan will contain a detailed QA program to ensure that these requirements are met.

\subsection{FLOWSHEET DESCRIPTION}

The HWVP process flowsheet is described in this section for the current reference NCAW feed. The associated process key diagram is shown in Figure $3-1$.

\subsubsection{Feed Receipt System (System 11).}

The feed receipt system consists of a stainless steel tank housed underground in a concrete vault. The vault is lined with a secondary carbon steel tank. The RLST is fed with pretreated NCAW seed from the tank farms through the system-encased pipeline that interfaces at the ER-154 diversion box. The RLST receives and cools the HWVP feed, and provides necessary lag storage before processing. Constant agitation is provided to maintain the feed solids in homogenous suspension, which allows material balance sampling and uniform composition feed to the feed preparation system in the CPC of the Vitrification Building. The RLST has adequate volume to provide sufficient feed for at least one batch of made-up melter feed. The HWVP in this tank is sampled and thoroughiy characterized for any potential processing adjustments.

The initial batch transfer into the slurry receipt and adjustment tank (SRAT) for a feed makeup cycle is made with the RLST transfer pump through an encased pipeline. After transfers the lines are flushed forward to remove solids. Continuous feeding of the SRAT follows the batch transfer at flow rates necessary to maintain constant liquid levels in the evaporator through the use of the sample pump and a diversion valve on the RLST sampling pipeline.

The RLST has leak detection systems and pumps both in the annulus and in an adjacent leak detection well. These systems provide leak detection and control for both the primary and secondary tanks.

The primary vessel is vented to the Category I RLST/WHT vessel vent in the RLST/WHT Building. Air is drawn through the annulus space and vented through the Non-Category I RLST/WHT annulus vent subsystem in the RLST/WHT Building. 


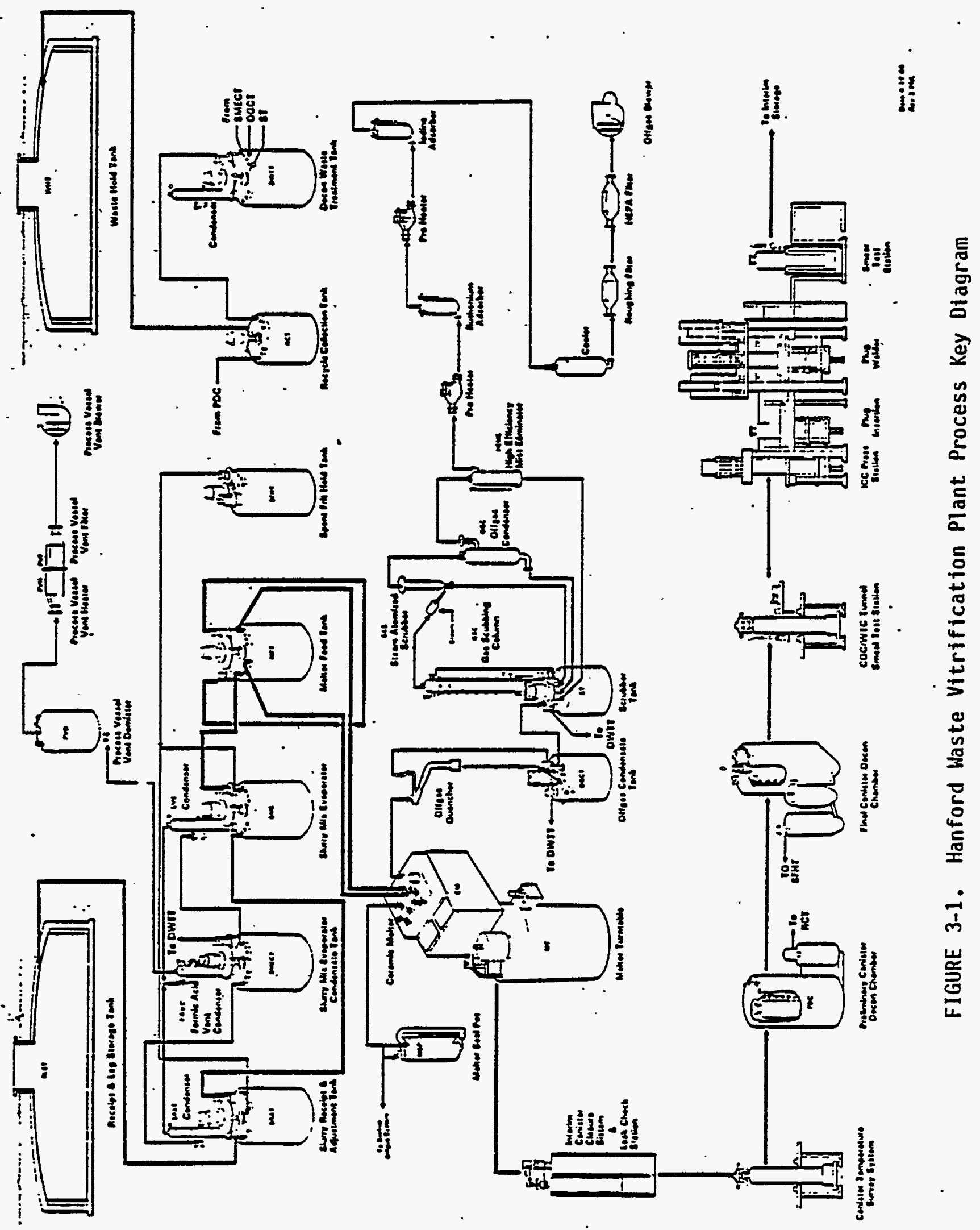




\subsubsection{Feed Preparation System (System 12)}

The feed preparation.system includes two evaporators, the slurry receipt and adjustment tank (SRAT) and the slurry mix evaporator (SME). It aiso includes the slurry mix evaporator condensate tank (SMECT) and the spent frit hold tank (SFHT).

The SRAT receives the HWVP feed from the RLST. Initially a batch transfer is made to fill the tank to its operating level. After initiation of boiling, feed is continuously pumped to the SRAT for operation at a constant level. The feed transfer lines are flushed after each transfer. The slurry is agitated continuously to keep it well mixed and to improve heat transfer. The vapors are condensed in the SRAT condenser and drained to the SMECT. The additional volume of HWVP feed needed to make one melter feed tank (MFT) batch is added as required. The SRAT batch is cooled to about $200^{\circ} \mathrm{F}\left(95^{\circ} \mathrm{C}\right)$, and formic acid is added at a controlled rate. After addition of the required formic acid, the slurry is boiled under complete reflux conditions to complete the formating reactions. The slurry is then cooled, sampled, and further adjusted as needed.

Next, the slurry is batch transferred to the slurry mix evaporator (SME). The required amount of spent frit slurry from canister decontamination is added from the spent frit hold tank (SFHT) with continuous agitation. Some evaporation is performed to reduce volume. This allows room for addition of the required process frit slurry to reach the final glass-forming frit/waste-oxide ratio. The evaporation process continues until the required total oxides. concentration for melter feed is obtained. The condensates from the slurry mix evaporator condenser also drain to the SMECT. The slurry is then cooled and sampled, and final adjustments are made. At the required time, the batch is batch transferred to the melter feed system. The condensates in SMECT are batch transferred to DWTT in System 20, as required.

All vents from the tanks in the feed preparation system pass through the formic acid vent condenser, which acts as a chiller to lower total condensables including organics in these vented gases. The condensate from the formic acid vent condenser drains to the SMECT. The noncondensables are vented to the vessel vent system (System 15).

\subsubsection{Melter Feed (System 22)}

The melter feed system consists of the MFT and its associated equipment. The MFT receives the slurry from the slurry mix evaporator in System 12. The slurry is continuousiy agitated to provide a well-mixed tank of uniform composition for sampling and feed to the melter. The slurry is cooled to maintain temperature to prevent cavitation in the sample and feed pumps. 
After each batch addition, the slurry mix is sampled for accountability to determine the composition and radionuclide content of the glass waste.

The slurry is fed continuously to the melter through two independent recirculating feed loops with controlled flow side streams into the melter cell and the melter, respectively. Either loop is capable of supplying the feed at nominal production pate independently. Automatic flushing occurs in both the loops and side stream pipes whenever the feed flow drops below preset values while the feed pump is in operation.

Feed flow is monitored by flow elements in both the pump loop and side. stream to the melter. Liquid level in the MFT is monitored to check flow rates to the melter.

Process frit slurry, sugar solution, formic acid solution, and potassium hydroxide (KOH) frit modifier can all be added to the MFT in a controlled manner, if required.

\subsubsection{Melter/Turntable System (System 13)}

The meiter receives a continuous feed of waste/glass frit slurry at a reference rate of about $0.5 \mathrm{gpm}$ at $3.1 \mathrm{lb}$ to $\mathrm{TO} / \mathrm{gal}(400 \mathrm{~g} \mathrm{TO} / \mathrm{L}$ solids. The resulting glass production is $100 \mathrm{pph}$.

The melter is operated at "steady state" with a crust (cold cap) composed of waste calcine and frit that covers about 90 percent of the melt surface. This cold cap may range in thickness from 1 to 6 in. The feed siurry is introduced onto the top of the cold cap where water is evaporated and drawn into the off-gas system. The glass melt beneath the cold cap is at a temperature of approximately $2100^{\circ} \mathrm{F}\left(1150^{\circ} \mathrm{C}\right)$, which enables the cold cap to melt from the bottom and form the waste borosilicate glass.

Adequate mixing and residence time in the melter after melting and before pouring into the canister allow the glass to. homogenize. Mixing is achieved by convection caused by thermal gradients throughout the melt. The minimum residence time of $12 \mathrm{~h}$ is attained by sizing the melt chamber.

The molten glass then flows through a heated pouring section (riser and trough) and into stainless steel canisters. The canisters are filled to approximately 90 in.

Glass is withdrawn from the melter into the canisters by overflow of the glass through the pour spout. Airlifting is also used for pouring, which 
lowers the molten glass level in the melter. Stopping the airlift stops the flow of glass, allowing the canisters to be rotated in the turntable while melter feeding continues.

Electrodes are used to provide electrical energy, which is converted to heat by Joule's Law ( $I^{2} R$ ) to bring the melt temperature to approximately $2100^{\circ} \mathrm{F}$ $\left(1150^{\circ} \mathrm{C}\right)$. Because of the high resistivity of glass at room temperature, it is . necessary to heat the interior of the melter to greater than $1200^{\circ} \mathrm{F}\left(650^{\circ} \mathrm{C}\right)$ before significant joule heating of the glass is established. Heaters will be inserted through the lid of the melter for startup and removed when joule heating is established.

The turntable-is a containment vessel that provides the housing for a 4-position canister carousel. One position is used for canister loading/ unloading; a second position is for canister filling; a third position is for canister cooling; and the fourth position is for canister holding and can be used as an alternate fill position. The containment vessel of the turntable is located under and connected to the two overflow ports of the melter with bellows. The carousel is rotated with a drive mechanism and positioned under the desired station by a turntable positioning device.

Filled canisters are removed from the turntable through a port seaied from the turntable atmosphere and replaced by empty canisters using a remotely operated crane in the melter cell.

In the event of a major failure or at the end of its useful life, evacuated canisters will be used to remove as much glass from the melter as possible prior to removal from the melter cell.

Operation of the system to produce between 135 and $180 \mathrm{pph}$ of glass will be possible by increasing slurry feed rate and oxide. content.

\subsubsection{Melter Off-Gas System (System 14)}

The melter off gas (MOG) system consists of two identical subsystems (trains). The back-up train is maintained in a fully operating standby mode. The MOG system maintains the melter at a negative pressure relative to the melter cell. After removing water, entrained particulate, acid gases, ruthenium, and iodine, the MOG System discharges decontaminated melter off gas to the Zone 1 facility exhaust tunnel.

The MOG is drawn from the melter through a film cooler/brush assembly that cools and dilutes the off gas with air and prevents plugging of the off-gas exit line from the melter. An ejector. venturi scrubber (quencher) further 
cools the off gas, condenses water vapor, and removes larger particulates. quenched off gas and quench solution flow into the off-gas condensate tank (OGCT) where the liquid is de-entrained and recirculated to the quencher. Periodically, accumulated condensate is withdrawn from the OGCT and routed to the DWTT in Systen 20.

Gas is drawn from the OGCT vapor space into the gas .scrub column (GSC) where it is contacted countercurrently with liquid from the scrub tank (ST). Chemicals may be added to the GSC and ST from the chemical receipt, makeup, and distribution system. - The GSC removes acid gases and some particulates. The scrubbed gas exits the column through a de-entrainment pad and is drawn into the steam atomized scrubber (SAS).

In the SAS, the gas is contacted with a stream of steam-atomized liquid from the ST. The high-energy contact allows removal of very small particulates. The gas and liquid streams are separated in a cyclone that is part of the SAS. Liquid is returned to the ST, and the gas is routed to the off-gas condenser.

The off-gas condenser cools the off-gas stream for dehumidification and residual formic acid vapor removal. This increases the efficiency and life of the adsorbers, and protects the HEPA filters. Condensate flows to the ST and the off gas exits the condenser through a de-entrainment pad and is routed to the high-efficiency mist eliminator (HEME).

Fine mists and particulates are removed from the cooled off gas in the HEME. The HEME elements are washed with demineralized water to improve efficiency and control pressure drop. Hash solution drains to the ST and the off gas flows to the Ru adsorbers.

An electric heater preheats the off gas to about $120^{\circ} \mathrm{F}\left(70^{\circ} \mathrm{C}\right)$ before it is decontaminated in the Ru adsorber bed. Following Ru adsorption, the off gas is further heated to about $300^{\circ} \mathrm{F}\left(150^{\circ} \mathrm{C}\right)$ before being passed through one of the two parallel iodine adsorbers.

The off gas is then cooled and filtered before being discharged to the vent tunnel through the MOG induction draft blower. Filtration is accomplished by a series arrangement of a roughing and two HEPA filters in a remotely replaceable pretested assembly.

The exit gas'from each major process component can be sampled. 


\subsubsection{Vessel Vent System (System 15)}

The vessel vent system (VVS) is composed of three major subsystems. These subsystems include:

- vent gas collection

- vent gas filtration

- vent gas discharge.

Vent gas collection is performed by the vessel vent header in the Vitrification Building. The header runs the length of the CPC and CDC and collects. vent gases from the process vessels and decontamination chambers. It is sloped so that all liquids flow to the formic acid vent condenser (FAVC).

Vent gases are heated by an electrical heater to a relative humidity of less than 85 percent before being filtered. Filtration is done is series by a roughing and two HEPA filters in a remotely replaceable, tested assembly. Following filtration, the vent gas may be sampled before discharge to the vent tunnel via the WVS exhausters.

Induced draft motive force for the VVS is provided-by a low pressure (20 in. W.G.) centrifugal fan. A redundant exhauster is installed in parallel and instrumented for either manual or automatic switchcover should the primary exhauster fail. Either exhauster may be remotely replaced without impairing normal WVS operation.

\subsubsection{Radioactive Process Waste Collection and Treatment System (System 20)}

The radioactive process waste collection and treatment (RPWCT) system consists of an evaporator decontamination waste treatment tank (DWTT), a recycle collection tank (RCT) for DWTT condensates. and non-TRU radioactive wastes, a waste hold tank (WHT) to provide lag storage for non-TRU wastes between HWVP and the tank farms, and many associated collection headers and pumps.

The DWTT collects TRU waste from the feed preparation system condensates and the melter off gas system condensates and scrubber solutions. Sumps are routed to DWTT, as are decontamination wastes requiring chemical treatment for chemical adjustment before their transfer to the tank farms.

The RCT collects the condensates from DWTT and other radioactive wastes that are below TRU waste levels. These wastes are sampled, then neutralized and chemicaliy adjusted to tank farm requirements. They are then transferred to the WHT where they are stored until sufficient volume is collected to 
warrant transfer to the tank farms through the ER-152 diversion box. The WHT transfer pump can be used to back flush the RLST feed line to the ER-154 diversion box through a valve manifold.

The vents from RCT and DWTT connect to the FAVC in System 12. The primary vent from WHT connects to the Category I. RLST/WHT vent in the RLST/WHT building.

The WHT annulus vent system is Non-Category I. It draws air through the annulus space and vents to the RLST/WHT annulus vent subsystem in the RLST7WHT building.

\subsubsection{Canister Handling and Inspection System (System 23)}

The canister handling and inspection system includes equipment for moving canisters between cells and to different stations within a cell. Canister transport between cells, including transport of empty canisters to the melter cell from the Service Building and from the WTC to interim canister storage, is done by motorized transfer cars located in transfer tunnels or by cranes. The cars move on tracks mounted on the sides of the tunnel walls. The canisters are loaded into the transfer cars using a cell crane with a canister grapple. The same type grapple and a crane are used to transport the canister to different stations within a cell. The grapple has no motors; is positive locking, and has a minimum of moving parts. The grapple is engaged and disengaged by the crane.

Storage racks in the melter, canister decontamination and weld test cells are provided as a buffer so that operations in the cells may proceed somewhat independent of the operations in adjacent cells: i.e., final decontamination of a canister need not be performed immediately when it enters the cell, but may be delayed for hours until convenient for the area operator.

The systen also includes the CDC and WTC smear test stations, which are equipped with turntables and lifting grapples as required to give access to all canister surfaces by the smear test master slave manipulator tools. In-cell cranes are used to place canisters into and remove them from the smear test stations. 


\subsubsection{Canister Closure System (System 17)}

The HWVP canister closure system is a multi-step process featuring the use of a temporary interim canister closure (ICC) plug to permit canister decontamination prior to welding. Canister decontamination operations, although performed in conjunction with canister closure operations, are not considered a part of the canister closure system.

Key steps in the canister closure process after canister filling operations in the melter/turntable are as follows:

- canister transfer to the ICC system

- installation of a temporary ICC plug in the canister

- Teak testing the temporary canister closure

- temperature survey of canister surface

- removal of the canister from the CDC/WTC tunnel into the WTC (after decontamination, smear testing, and transfer operations by the canister decontamination system)

- insertion of the canister into the closure plug welder system

- displacement of the ICC plug down into the neck of the canister to permit installation of the final closure plug

- insertion of the canister (with welded closure) to the WTC test station for final inspections and surface contamination checks.

The canister is transferred from either the turntable or in-cell storage rack to the interim canister closure system (ICCS). The ICCS is mounted atop a stainless steel frame capable of holding one canister. The ICCS consists of a canister flange heater and a leak test system mounted on pivoting arms for positioning over the canister. At the ICCS, the canister neck is heated to 300 to $400^{\circ} \mathrm{F}$. The ICC plug is inserted into the canister opening with a master slave manipulator (MSM).

Verification that the ICC plug is properly installed is required. This may be done visually, or may require some special equipment such as a gauge. The canister neck is allowed to cool in order to make a water-tight seal by a shrink-fit between the ICC plug and a sleeve installed in the canister neck during canister fabrication. After cooling, the ICC plug is helium leak tested at $100 \mathrm{lb} / \mathrm{in}^{2}$. The leak test is performed by pressurizing a container 
installed around the. canister neck and monitoring any pressure decay. Canis-. ters passing the leak test $\left(2 \times 10^{-4} \mathrm{sTO} \mathrm{cm}^{3} / \mathrm{s}\right.$ per atmosphere). are transferred to the decontamination system in the MC.

The ICCS is equipped to rework ICC plugs that are not watertight (do not pass the leak test) by reheating the canister flange, displacing the failed plug and canister sleeve into the canister, and inserting a repair plug in the neck of the canister for shrink fitting and by cleaning canister. sealing surfaces of surface deposits prior to ICC operations. Any glass particles must be collected.

The plug welder system performs two basic functions in the final closure of the canisters: 1) the ICC is pressed down in the neck of the canister a sufficient distance so it will not interfere with the insertion and welding of the weld plug but still maintains a seal with the inside diameter of the canister; and 2) the weld plug is welded into the neck of the canister by a resistance welder. The plug welder assembly, which is mounted on a structural steel framework, consists of a canister insertion position, hydraulic press station for pressing the ICC, a resistance welder station, and a trolley for moving the canister between stations.

After the WTC crane places the canister in the insertion position of the plug welder system, the trolley transports the canister to the ICC press station. A hydraulic ram exerting a force of 300,000 to $400,000 \mathrm{lb}$ is used to press the ICC down into the canister neck. After the press function is complete, the ram is retracted and the canister is moved back to the canister insertion position. The surface to be welded is visually examined to ensure there is no interference with the insertion of the closure.plug or achievement of a satisfactory weld. The examination includes an ICC position check to inspect for final closure plug position, presence of foreign material on flange or neck of canister, and unacceptable deformation of nozzle opening or canister flange bottom surface. An MSM is used to.place the weld plug into the canister neck. The plug protrudes approximately $1 / 2$ in. above the canister neck. After the closure plug is inserted, and just prior to welding, a visual examination is performed to verify that the plug is correctly positioned. The trolley then moves the canister into the welding station where the canister flange is seated and supported on a split-bottom electrode.

A pneumatically operated upper electrode is used to press down on the weld plug with $75,000 \mathrm{lb}$ of force to achieve electrical contact, thus completing the circuit through the upper electrode, the piug, the canister fiange, and the grounding plates. Circuit resistance is measured to ensure adequate continuity before the actual weld. With the ram force maintained, a weld current of 240,000 amps for $1.5 \mathrm{~s}$ is applied. As the metal. at the plug/canister interface heats, plastic deformation occurs and the plug is forced about $1 / 2$ in. into the 
canister neck, forming a solid-state weld. The ram is retracted, and the trolley is used to move the canister back to the canister insertion position. The WTC crane is used to transfer the canister to the WTC smear test station for final inspection and surface contamination checks.

\subsubsection{Canister Decontamination System (System 16)}

The preliminary canister decontamination station receives a canister and manipulates it through hot water spray and air dry cycles. The sequence of operations is as follows:

1. Canister is placed into the chamber by the MC crane with a grapple.

2. Canister manipulating mechanism is placed on top of the chamber.

3. Canister is engaged by the canister manipulating mechanism.

4. Spray is turned on.

5. Canister is lifted and rotated.

6. Once the spray cycle is complete, the canister is air-dried.

7. Canister manipulating mechanism is disengaged from canister.

8. Canister manipulating mechanism is removed from the chamber.

9. Canister is lifted from the chamber with the MC crane and a grapple and placed in the MC/COC transfer tunnel.

10. Canister manipulating mechanism is placed back on the chamber.

11. Water used for decontamination is pumped to the recycle collection tank (RCT).

The final canister decontamination station receives a canister and manipulates it through a frit slurry blast cycle followed by water rinse and air drying cycles. The sequence of operation is as follows:

1. Canister is removed from the MC/CDC transfer tunnel with the CDC crane and a contaminated grapple and placed in a CDC final decontamination chamber. 
2. Canister manipulating mechanism is placed on the chamber and engages the canister.

3. Canister is raised and rotated while frit slurry is directed at the canister flange through the frit blast nozzles.

4. The canister is lowered to the support and the canister manipulating mechanismi grapple is disengaged, raised, and frit blasted.

5. The canister manipulating mechanism is lowered and engages the canister again at a different flange location.

6. The remainder of the frit blast cycle is performed.

7. Once the frit blast cycle is complete, the canister and canister support are rinsed by air-injected water through the same nozzles.

8. Canister is air-dried.

9. Canister manipulating mechanism is disengaged from the canister.

10. Canister is removed from the final decontamination chamber'with a CDC crane and a clean grapple and placed in the smear test station - located in the COC/WTC transfer tunnei.

11. Final decontamination chamber canister manipulating mechanism is replaced.

12. Spent frit and rinse water are pumped to the spent frit holding tank (SFHT).

\subsubsection{Interim Canister Storage System (System 18)}

The interim canister storage system includes the Interim Canister Storage Building and all its equipment. General requirements for its design are:

- Store 5-year production of canisters.

- During normal operation, remove radioactive decay heat by convection of air. The maximum allowable centerline temperature for the glassform waste in storage is $932^{\circ} \mathrm{F}\left(500^{\circ} \mathrm{C}\right)$.

- Provide biological shielding for personnel, assuming all vault storage spaces are filled with canisters of waste. 
- Contain airborne contamination resulting from a design basis tornado or design basis earthquake.

- Provide capability to retrieve canisters for future shipment to a federal repository.

- Provide space for future expansions up to a total of a 10-yr production.

- Building expansion increment(s) should operate independently. Ventilation systems for each building added will operate independently of the system provided on the original project.

\subsubsection{Canister Loadout System (System 19)}

The canister loadout system provides for the receiving, loading, closure, cleaning, and inspection of transport casks for offsite shipment of filled canisters. Casks received by rail car are handled using a 117-ton crane (with a 10-ton auxiliary hoist to remove the cask's lid) and moved from the rail car to a transfer car that travels in a tunnel between the rail car area and the Interim Canister Storage Building. When the car is under the Interim. Canister Storage Building, the interim canister storage crane unloads canisters from . their storage position into the cask through a floor plug. The transfer car, cask, and floor plug system is designed such that all canister positions in the cask are filled.

The loaded canister transport cask passes an inspection point that permits remote inspection of the canister's external surface to assure cleanliness. Shield doors separate the cask loadout tunnel from the rail car area and also the rail car area from the washdown area.

Once a cask has been loaded, crane and transfer car contirol changes from direct pendant control to remote control while the cask is still on the transfer car. Remote control continues until the cask lid has been placed over the canisters. The 1 id is then bolted in place and the entire cask is moved back onto the rail car where final radiation surveys, smear checks, and overall inspections are made per shipping regulations in effect.

\subsubsection{Canister Receipt and Handling System (System 57)}

Components are delivered to the Service Building by truck or rail. Each canister is fastened in a wooden shipping cradle. Plugs are received in boxes on pallets. On the loading dock canisters are removed from the cradies, and 
protective covers are removed from the nozzles. Each canister receives a visual inspection for damage incurred during shipment or handling. Overpacks are handled similar to the canisters. Depending on final design, overpack covers may be handled similar to plugs.

Quality examinations for canisters and plugs include tests and inspections performed by Service Building personnel. Additional tests are performed by the vendor and by operating contractor for informational purposes. A sample of metal from each meit or fabrication lot for laboratory analys is is received before each shipment.

A statistically sufficient percentage of the components from each shipment are transferred directly to the inspection area for an audit of the vendor's certification. Following the audit inspections, these components are transferred to storage. The remainder are transferred directly from the receiving inspection to storage. When a given lot is released (based on the results of Taboratory examinations and the audit inspection), components are removed from storage. At the in-process inspection, all components are inspected for the following items:

- cleantiness

- damage incurred in handling or storage

- dimensions eritical to operations in the process cells.

At in-process inspection, soiled components are hand-cleaned. Those with minor surface damage are dressed, using hand tools, to meet specifications. Each canister. and each overpack has an identifying number (in addition to the vendor's lot number) to provide a sequential number for processing.

The acceptance/rejection criterion for leak testing canisters and overpacks is a leak rate of $1 \times 10^{-6} \mathrm{STD} \mathrm{cm}^{3} / \mathrm{s}$ helium.

Rejected canisters and overpacks are returned to the vendor; packaged as they are received.

\subsubsection{Frit Receipt and Makeup System (System 58)}

Frit received into the bins is removed batchwise by mechanically inverting and puncturing the bin 1id. Frit flows by gravity into a close coupled, fixedspeed screw conveyor that directly feeds a fixed-speed bucket elevator. The bucket elevator carries the frit vertically to sufficient height which enables gravity flow through the following conditioning equipment: 
a) a magnetic chute capable of removing all tramp iron and ferrous materials

b) a lump breaker capable of crushing agglomerated lumps of glass frit to the required particle size for processing, i.e., $-80 /+200$ mesh

c) a scalping screen capable of removing oversize particles.

Conditional frit bearing the scalping falls into an activated weigh bin capable of handling two tote bin batches. The weigh bin is capable of measuring and delivering glass frit accurately to a screw conveyor that feeds the dry glass frit to the frit slurry makeup tank. The entire dry frit conveying system is vented to a common exhaust header. Exhausted air is filtered by a dust collector prior to atmospheric release.

In the frit slurry makeup tank, the glass frit is mixed with dilute formic acid and water as necessary to create a 2600-galion batch of 60 wt\% slurry. The slurry batch is constantly agitated to maintain solids in a uniform suspension. A sample pump/recirculation loop is provided locally with a sample top to provide for batch composition verification.

A transfer pump is provided to pump slurry to either of two receiving vessels in the Vitrification Building: the process frit slurry feed tank or the decontamination frit slurry feed tank. Transfer lines are flushed immediately upon completion of batch transfers. Process frit transfer flushes are routed back to the frit slurry makeup tanks so as not to.dilute the transferred slurry. The transfer fiush water for the decontamination frit slurry flushes forward, providing a part of the dilution water, required for slurry preparation prior to its use for canister decontamination.

The process frit slurry tank acts oniy as a batching tank for supplying feed preparation tanks in the chemical. processing cell. The tank is equipped with a sample pump/recirculation loop with sample top to verify composition and a mechanical agitator to maintain uniform suspension. A transfer pump is provided to feed the required slurry to the CPC through a final slurry filtration step. This step ensures that no oversize particles reach the cell equipment.

The decontamination frit slurry tank receives $60 \mathrm{wt} \%$ slurry and performs a dilution step to $8 \mathrm{wt} \%$ for canister decontamination. The tank is equipped with a sample pump/recirculation loop with sample top to verify composition and a mechanical agitator to maintain uniform suspension. A recirculation pump is provided to recirculate the slurry through a filter to remove any oversize particles. This recirculation header connects to and feeds each of the nozzle feed pumps in the canister decontamination system. 
Each of the slurry tanks is equipped with air spargers that automatically activate on agitator failure to prevent slurry settling and spray rings to facilitate efficient tank flushes and internal cleaning.

\subsubsection{Chemical Receipt, Makeup, and Distribution System (System 54)}

The chemical receipt, makeup, and distribution system includes all facilities required to receive and prepare solutions and to feed cold chemical solutions to the process and to neutralization and decontamination facilities. 'The general process design philosophy for each chemical makeup and distribution system is to provide a makeup tank into which bulk chemicals are mixed with process water on a batch basis to prepare solutions of required concentration. Mixing and dissolution of chemicals is aided by an agitator, heaters (where necessary), and a transfer pump that recirculates solutions back to the makeup tank during batching operations. Cold chemical solutions are sampled and anaiyzed prior to transfer from the makeup tanks. Solutions are transferred from the makeup tank in the Service Building on a batch basis. Cold samplers are generally used to obtain samples of chemical solutions in the feed tanks in the Vitrification Building. All tank overflow lines have loop seals to minimize air in leakage into the tanks. Unique process features for individual subsystems are given in Table 3-4.

\subsection{MATERIAL BALANCE(a)}

A computer model has been developed to simulate the overall processing of NCAH in the HIVP. This model calculates material balances and tracks given components throughout the various process steps and main items of equipment within the plant and associated ventilation system. (b)

\subsubsection{Description of HWVP Flowsheet Model}

The HWV flowsheet model is a process simulation code that uses a technique known as sequential modular modeling. The simulation program itself does

(a) Internal memo from L. A. Fort to K. R. Shah, September 23, 1987, "Internal Letter Report - Hanford Waste Vitrification Plant Heat and Material Balance Computer Program Modifications, Fiscal Year 1987," 65651-87-079.

(b) A detailed description of the model and its use is provided in L. A. Fort and D. J. Honeyman, HWWP Heat and Material Balance Computer Program User Guide, SD-HWV-UM-002, Westinghouse Hanford Company, Richland, Washington (1987). 
TABLE 3-4. Unique Process Features of Chemical Receipt, Makeup, and Distribution Subsystems

\begin{tabular}{|c|c|}
\hline Subsystem & Unique Process Features \\
\hline Oxalic Acid Decon Feed System & None \\
\hline Sugar Solution Feed System & None \\
\hline $\begin{array}{l}\text { Off-Gas Treatment Chemical Feed } \\
\text { System }\end{array}$ & $\begin{array}{l}\text { The off-gas treatment chemical feed tank } \\
\text { in the Vitrification Building has an agi- } \\
\text { tator to aid in tank mixing. }\end{array}$ \\
\hline $\mathrm{KOH} /$ Frit Modifier Feed System & $\begin{array}{l}\text { The } \mathrm{KOH} / \text { frit modifier feed tank in the } \\
\text { Vitrification Building has an agitator to } \\
\text { aid in tank mixing. }\end{array}$ \\
\hline Flush Water Feed System & $\begin{array}{l}\text { Only a single tank in the Vitrification } \\
\text { Building is provided. The tank is pres- } \\
\text { surized by critical plant air, and trans- } \\
\text { fer is accomplished via pneumatic pressure } \\
\text { from critical plant air system. }\end{array}$ \\
\hline Caustic Storage System & $\begin{array}{l}\text { Two fully redundant } 50 \% \text { capacity storáge } \\
\text { tanks are provided. The system includes } \\
\text { unloading pump for transfer of bulk } \\
\text { caustic from tank truck to storage tanks. }\end{array}$ \\
\hline $90 \%$ Formic Acid Storage System & $\begin{array}{l}\text { Two fully redundant } 50 \% \text { capacity storage } \\
\text { tanks are provided. The system includes } \\
\text { unloading pump for transfer of bulk } \\
\text { concentrated formic acid from tank truck } \\
\text { to storage tanks. The vent from each tank } \\
\text { has a nitrogen blanket and conservation } \\
\text { breather. }\end{array}$ \\
\hline $\begin{array}{l}\text { Formic Acid Dilution and Dilute } \\
\text { Formic Acid Feed Tank System }\end{array}$ & $\begin{array}{l}\text { Formic acid dilution tank uses } 90 \% \text { formic } \\
\text { acid from storage system for makeup } \\
\text { instead of bulk chemicals. }\end{array}$ \\
\hline Nitric Acid Storage System & $\begin{array}{l}\text { Two fully redundant } 50 \% \text { capacity starage } \\
\text { tanks are provided. The system includes } \\
\text { unloading pump for transfer of bulk } \\
\text { concentrated acid from tank truck to } \\
\text { storage tanks. }\end{array}$ \\
\hline
\end{tabular}


not perform all of the functions required to produce the flowheet product. Rather, the HWVP flowsheet model is a package of software that includes the simulation program, associated programs, and the data file drivers that are required to run those programs. Using these programs separately allows the user flexibility in producing the desired flowsheet output.

For the purposes of process evaluation and plant design, the HWVP model has features that allow for variations in feed composition, glass production rate, product composition, effluent compositions, and flow rates. The HWVP model calculates a material balance for the HWVP process. for a given feed strean composition at a set of processing assumptions. The building blocks of the HWVP model are subroutines that describe the various unit operations employed in the process. An equipment change, for example, can be evaluated by modifying an existing subroutine or writing a new one and "plugging it in." Also, new data or improved calculational methods for describing the performance of a particular operation can be incorporated by modifying an existing subroutine and placing the new code into the model. The HWVP model has undergone several modifications since it was first generated and is expected to continue to evolve throughout the plant design process.

The individual programs that make up the software package are listed below. Modeling alternative processing schemes requires slight alteration and variation in the main program logic. There is currently only one version of the HWVP computer program. This version is based on the RCD $(a)$ flow sheet and has been designated as the September 1987 version.

1. Main Program - This program calls the programs to read data inputs, performs the process simulation to calculate a flowsheet, then stores the results in an output data file..

2. Unit Operation Subroutines - These subroutines are called by the main program and essentially. simulate the performance of the individual process operations.

3. Report Writer - This program reads the output data file generated by the main program, performs desired unit conversions, and produces a printout of the flowsheet.

(a) HWVP, Hanford Waste Vitrification Plant Reference Conceptual Design Report, SD-HWV-TI-007, Westinghouse Hanford Company, Rockwell Hanford Operations, Richland, Washington (1987). 
4. Graphical Output - This software generates a diagram of the process and is capable of tabulating flow sheet values generated by the main program.

The work of determining a material balance for any process involves making a series of assumptions/conistraints for each of the process unit operations involved. Detailed technical assumptions with respect to the unit operations. that make up the HWVP process were used to formulate the subroutines that model those operations. Descriptions of those subroutines and their supporting assumptions are subsequentiy addressed. Calculations are constrained by specified values for the following key process variables: 1) SRAT specific gravity, 2) SRAT/SME batch cycles, 3) spent frit usage for canister decontamination, 4) glass product waste loading, and 5) overall glass production rate.

\subsubsection{SRAT Specific Gravity. Prior to the vitrification subroutine, the} program first determines if the SRAT bottoms specific gravity is greater than a set maximum. If the specific gravity of the SRAT bottoms is greater than the specified maximum, the boildown volume of SRAT condensate is adjusted accordingly and the program iterates through the boildown subroutine again until the values agree within 0.001 . If the specific gravity of the SRAT bottoms is less than the specified maximum, the program checks to assure that there is SRAT condensate and readjusts the batch volumes between the SRAT the the SME.

3.3.1.2 SRAT/SME Batch Cycles. The efficiency of the feed treatment portion of the HWVP process is affected by batch operations in the SRAT and SME. However, neither the SRAT nor the SME operations is the limiting factor at the $-45 \mathrm{~kg} / \mathrm{h}$ glass production rate. The minimum number of batch cycles per unit of glass production is achieved by maintaining the maximum volumes in the SRAT and SME prior to concentration. The relative volumes in these tanks can be con-. trolled by varying the extent of concentration of material in the SRAT. The extent of concentration of material in the SME is not variable; it is concentrated to a set total oxides for feed to the melter $(-400 \mathrm{~g} / \mathrm{L})$. The controlling variable is the SRAT specific gravity. The program compares maximum volumes in the SRAT and SME and adjusts the SRAT condensate volume accordingly until the batch volumes are within approximately $0.01 \%$.

3.3.1.3 Spent Frit. The amount of spent frit available for blending into the SME at steady state is dependent on a given rate per canister. The amount frit used per canister decontamination is constant and is simply subtracted from the frit required to comply with the waste loading and production constraints.

3.3.1.4 Glass Product Waste Loading. After the vitrification subroutine is calculated, it compares the weight percent of waste oxides in the glass product, or waste loading, to the desired value. If the values do not agree 
within. $0.1 \%$, the ratio of frit to oxides added to the SME is adjusted and iterates from the frit addition subroutine through the vitrification subroutine until the criterion is met. The weight percent of the waste components in the glass is set at $25 \%$.

3.3.1.5 Overall Glass Production Rate. The target value for glass production rate (designated as.TRGET in the main program) in $\mathrm{kg} / \mathrm{h}$ is specified early in the progran. After the program completes the vitrification subroutine, it first determines the waste loading within the glass and then calculates the glass production rate and compares. it to the desired value. If the values do not agree within $0.01 \mathrm{~kg} / \mathrm{h}$, the program adjusts the rate of feed to the SRAT and iterates from the HWVP feed subroutine through the vitrification subroutine until the $0.01 \mathrm{~kg} / \mathrm{h}$ criterion is met. Target giass production rate is currently set at $45.36 \mathrm{~kg} / \mathrm{h}(100 \mathrm{lb} / \mathrm{h})$.

The progran basis is $1 \mathrm{~h}, \mathrm{~g} / \mathrm{L}$, and $\mathrm{L} / \mathrm{h}$. The decontamination factors (DFs), also the designation for separation factors, for the melter and off-gas equipment used by the model appear in Table 3-5. Temperatures are constant and set at $50^{\circ} \mathrm{C}$ and $25^{\circ} \mathrm{C}$ for the feed and chemicals, respectively. The input parameters are listed in Table 3-6.

\subsubsection{Material Balance Calculations}

The HWVP Heat and Material Balance Computer Program (HMBCP) block flow diagram is shown in Appendix E, Figure E-1. Each process stream is identified with a number in Table E-1. These numbers provide traceability to the material balance calculations shown in Table E-2. The various streams and units for the material and heat balance calculations are identified in the table.

\subsection{PROCESS TIME CYCLE}

(Future Inciusion) 
TABLE 3-5. Decontamination Factor (or separation factor) Values Used for the Melter and Off Gas Equipment $(a, b)$

\begin{tabular}{|c|c|c|c|c|c|c|c|c|c|c|}
\hline & $\begin{array}{c}\text { Partic- } \\
\text { ulate }\end{array}$ & Boron & Cs & 1 & Cl & ${ }^{\text {No }} x$ & $\mathrm{RuO}_{2}$ & $\mathrm{RuO}_{4}$ & so $_{x}$ & $F$ \\
\hline Molter & $\begin{array}{l}100 \\
(200)\end{array}$ & $\begin{array}{l}0 \\
\text { (1) }\end{array}$ & $\begin{array}{l}10 \\
(27)\end{array}$ & $\begin{array}{l}10 \\
(1.2)\end{array}$ & $\begin{array}{l}1 \\
(2.7)\end{array}$ & $\begin{array}{l}1 \\
\text { (1) }\end{array}$ & $\begin{array}{l}10 \\
\text { (4) }\end{array}$ & $\begin{array}{l}\text { IE9 } \\
\text { (23) }\end{array}$ & $\begin{array}{l}10 \\
(10)\end{array}$ & $\begin{array}{l}3 \\
\text { (3) }\end{array}$ \\
\hline Quencher & $\begin{array}{l}3.7 \\
(10)\end{array}$ & $\begin{array}{l}0 \\
\text { (12) }\end{array}$ & $\begin{array}{l}1.4 \\
(1.7)\end{array}$ & $\begin{array}{l}2 \\
(2)\end{array}$ & $\begin{array}{l}2 \\
(4,1)\end{array}$ & $\begin{array}{l}1 \\
(2)\end{array}$ & $\begin{array}{l}3.7 \\
(10)\end{array}$ & $\begin{array}{l}1 \\
(100)\end{array}$ & $\begin{array}{l}2 \\
\text { (2) }\end{array}$ & 2 \\
\hline GAC & $\begin{array}{l}1 \\
(1)\end{array}$ & $\begin{array}{l}0 \\
\text { (1) }\end{array}$ & $\begin{array}{l}1 \\
\text { (1). }\end{array}$ & $\begin{array}{l}1 \\
(20)\end{array}$ & $\begin{array}{l}50 \\
(10)\end{array}$ & $\begin{array}{l}3 \\
(10)\end{array}$ & $\begin{array}{l}1 \\
\text { (1) }\end{array}$ & $\begin{array}{l}1 \\
\text { (1) }\end{array}$ & $\begin{array}{l}3 \\
(10)\end{array}$ & $\begin{array}{l}100 \\
\text { (1) }\end{array}$ \\
\hline SAS & $\begin{array}{l}5 \\
(10)\end{array}$ & $\begin{array}{l}0 \\
(1)\end{array}$ & $\begin{array}{l}5 \\
(7.2)\end{array}$ & $\begin{array}{l}1 \\
(3.0)\end{array}$ & $\begin{array}{l}1 \\
\text { (1) }\end{array}$ & $\begin{array}{l}1 \\
\text { (1) }\end{array}$ & $\begin{array}{l}5 \\
(7.4)\end{array}$ & $\begin{array}{l}1 \\
\text { (i) }\end{array}$ & $\begin{array}{l}1 \\
(1)^{\circ}\end{array}$ & $\begin{array}{l}1 \\
(3.5)\end{array}$ \\
\hline HEME & $\begin{array}{l}10 \\
(10)\end{array}$ & $\begin{array}{l}0 \\
\text { (1) }\end{array}$ & $\begin{array}{l}10 \\
(14.5)\end{array}$ & $\begin{array}{l}1 \\
\text { (1) }\end{array}$ & $\begin{array}{l}1 \\
(7.5)\end{array}$ & $\begin{array}{l}1 \\
(1)\end{array}$ & $\begin{array}{l}10 \\
(21)\end{array}$ & $\begin{array}{l}1 \\
(1)\end{array}$ & $\begin{array}{l}1 \\
\text { (1) }\end{array}$ & $\begin{array}{l}1 . \\
(6.1)\end{array}$ \\
\hline RUADS & $\begin{array}{l}1 \\
\text { (1) }\end{array}$ & $\begin{array}{l}0 \\
\text { (1) }\end{array}$ & $\begin{array}{l}1 \\
\text { (1) }\end{array}$ & $\begin{array}{l}1 \\
\text { (1) }\end{array}$ & $\begin{array}{l}1 \\
\text { (1) }\end{array}$ & $\begin{array}{l}1 \\
\text { (1) }\end{array}$ & $\begin{array}{l}1 \\
\text { (1) }\end{array}$ & $\begin{array}{l}100 \\
(1000)\end{array}$ & $\begin{array}{l}1 \\
\text { (1) }\end{array}$ & $\begin{array}{l}1 \\
\text { (1) }\end{array}$ \\
\hline I2ADSI & $\begin{array}{l}0 \\
\text { (1) }\end{array}$ & $\begin{array}{l}1 \\
\text { (1) }\end{array}$ & $\begin{array}{l}100 \\
(1)\end{array}$ & $\begin{array}{l}1 \\
(500)\end{array}$ & $\begin{array}{l}1 \\
(1)\end{array}$ & $\begin{array}{l}1 \\
(1)\end{array}$ & $\begin{array}{l}1 \\
\text { (1) }\end{array}$ & $\begin{array}{l}1 \\
\text { (1) }\end{array}$ & $\begin{array}{l}1 \\
\text { (1) }\end{array}$ & (1) \\
\hline HEPA & $\begin{array}{l}\text { IE4 } \\
(1 E 6)\end{array}$ & $\begin{array}{l}0 \\
\text { (1) }\end{array}$ & $\begin{array}{l}1 E 4 \\
(1 E 6)\end{array}$ & $\begin{array}{l}1 \\
(1)\end{array}$ & $\begin{array}{l}1 \\
\text { (1) }\end{array}$ & $\begin{array}{l}1 \\
\text { (1) }\end{array}$ & $\begin{array}{l}1 E 4 \\
(1 E 6)\end{array}$ & 1 (1) & $\begin{array}{l}1 \\
\text { (1) }\end{array}$ & $\begin{array}{l}1 \\
\text { (1) }\end{array}$ \\
\hline $\begin{array}{l}\text { Sond } \\
\text { Filiter }\end{array}$ & IE3 & 0 & IE3 & 1 & 1 & 1 & IE3 & 1 & 1 & 1 \\
\hline
\end{tabular}

(a) Default values are in parentheses.

(b) Decontanination factors are tentative. 
TABLE 3-6. Input Parameters for Material Balance Computer Program

Transfer volume to SME, gal

Maximum SRAT specific grayity

Formic acid conc., wt\%

SME batch volume, gal

Process frit conc., wt\%

Spent frit per canister, 1b

Decon. water per canister, gal

Canister waste loading, wt\%

Melter feed concentration, g-oxide/L

Pressure controi air, scin to the film cooler

DWTT bottoms conc., wt\% oxide basis

Evaporation rate, $i b / h$

Flush water rate, $\%$ of stream flow

Concentrator separation factor

Process steam pressure, psig

SRAT/SME/DWTT finat cool down temp., ' $\mathrm{F}$

Grams sugar added per liter of SiUE concentrate $\mathrm{pH}$ of the final feed adjustment

Target glass rate, $\mathrm{kg} / \mathrm{h}$

SRAT, SME, SMECT, MFT, DWTT, RLST vessel vent. scfin

SFHT and HHT vessel vent., scfm

Boiling tanks separation factor

Ambient vessel with condenser separation factor

Frit percentage factor, $\mathrm{Na}_{2} \mathrm{O}$

Frit percentage factor, formate

Frit percentage factor, $\mathrm{SiO}_{2}$

Frit percentage factor, $\mathrm{CaO}^{2}$

Frit percentage factor, $\mathrm{B}_{2} \mathrm{O}_{3}$

Frit percentage factor, $\mathrm{MgO}^{3}$

Frit percentage factor, $\mathrm{Li}_{2} \mathrm{O}$

Frit rejection percentage, $\%$

Decon. solution, sumps and chemical waste, gpm

$\mathrm{KMnO}_{4}$ in decon. chemicals, $\mathrm{lb} / \mathrm{h}$

$\mathrm{HNO}_{3}$ in decon. chemicals, $\mathrm{Ib} / \mathrm{h}$

$\mathrm{H}_{2} \mathrm{C}_{2} \mathrm{O}_{4}$ in decon. chemicals, $\mathrm{Tb} / \mathrm{h}$

Frit composition:

\begin{tabular}{cr} 
Component & wt\% \\
\cline { 1 - 1 } $\mathrm{SiO}_{2}$ & 67 \\
$\mathrm{~B}_{2} \mathrm{O}_{3}$ & 13 \\
$\mathrm{Na}_{2}$ & 10 \\
$\mathrm{Li}_{2}$ & 5 \\
$\mathrm{CaO}_{\mathrm{MgO}}$ & 4 \\
$\mathrm{Mg}$ & 1
\end{tabular}

Formate concentration in the frit is $1 \mathrm{wt} \%$
12350

1.05

90

7700

60

189

457

25

400

125.4

2

5000

1

1000

150 (default set at 150)

122 (default set at 122)

0

4.5

45.36

20

50

10

1E6

0.1

0.01

0.67

0.04

0.13

0.01

0.05

0.05

0.906

0.00021

0.0094

0.0027 


\subsection{REFERENCES}

3-1 Waste Acceptance Committee, Waste Acceptance Preliminary Specifications for the Defense Waste Processing Facility High Level Waste Form, U.S. Department of Energy, Office of Civitian Radioactive Haste Management, Washington, D.C. (Apri] 1986).

3-2 D. E. Mitchell, Hanford Waste Vitrification Plant Preliminary Description of Waste Form and Canister, WHC-EP-008, Hestinghouse Hanford Company (September 1987).

3-3 M. B. Voif, Chemical Approach to Glass, Volume 7 of American Ceramic Society series on Glass Science and Technology (1984).

3-4 J. L. Nelson, Preliminary Hanford Waste Vitrification Plant Waste Form Qualification Plan, WHC-ED-0045, Westinghouse Hanford Company, Richland, Washington (September 1987).

3-5 10 CFR 50, United States Code of Federal Regulations, Chapter 10, Part 50, 


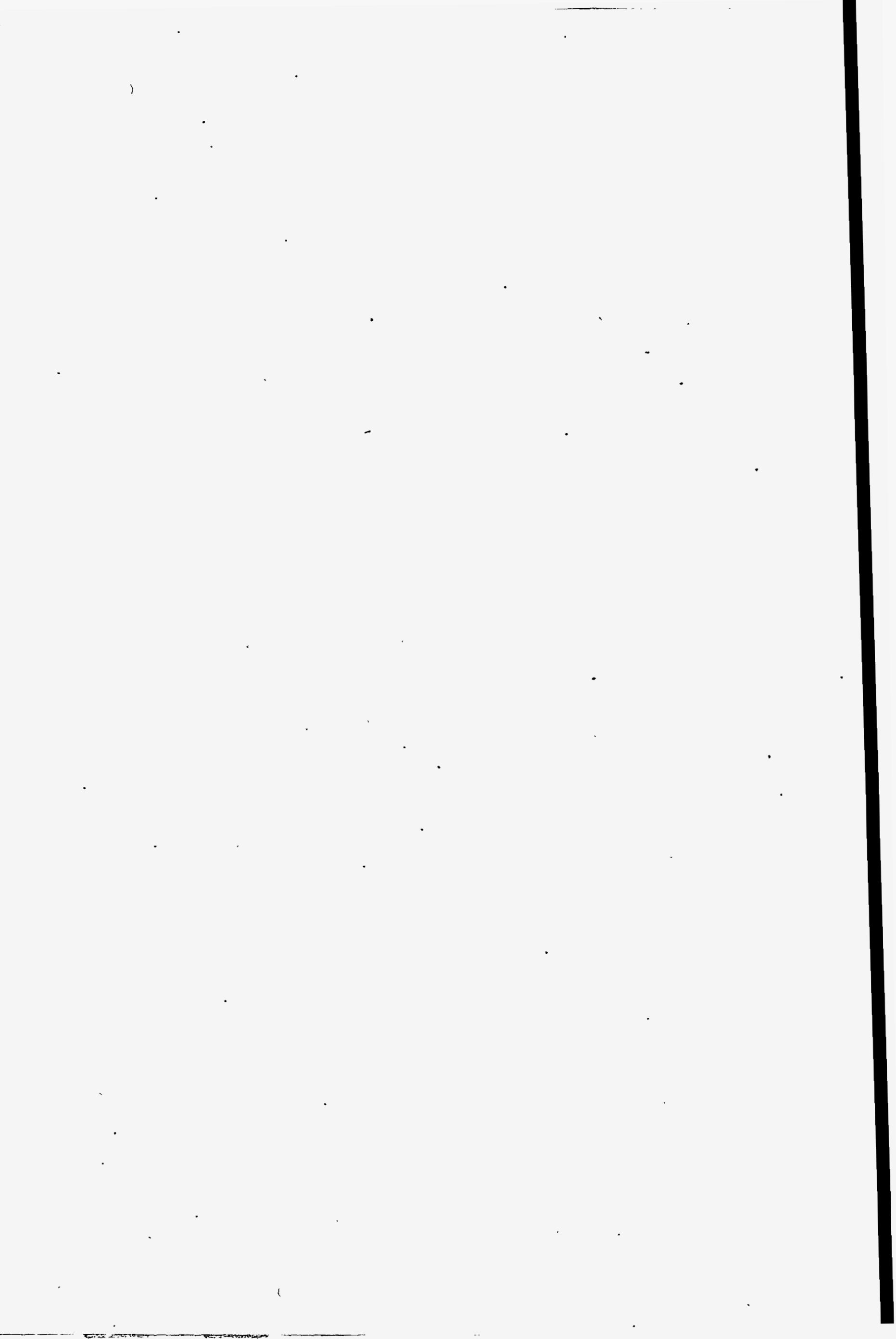


SECTION 4.0

PROCESS AND EQUIPMENT TECHNOLOGY 



\subsection{PROCESS AND EQUIPMENT TECHNOLOGY}

\section{CONTENTS}

4.1 WASTE FORM DEVELOPMENT .............. 4.1-1

4.1.1 G7ass Waste Property Requirements ....... 4.1-1

4.1.1.1 GTass and Melt Processing Requirements... 4.1-2

4.1.1.2 Waste Acceptance Preliminary Specifi- . . 4.1-4 cation. (HAPS) Requirements

4.1.2 Reference Glass Development ......... 4.1-5

4.1.2.1 Reference G] ass Development Background . . 4.1-6

4.1.2.2 Reference HWVP Glass Formulation ...... 4.1-8

4.1.2.3 Waste Form Product Qualification Leach

Testing of HW39-1 Glass ....... 4.1-48

4.1.3 Composition Variability Effects ......... 4.1-58

4.1.3.1 Variability Study Feed Compositions ... 4.1-58

4.1.3.2 Sulfate Variability Studies ....... 4.1-59

4.1.3.3 NCAW 84--High-Chrome Feed Glass

Variability Studies ........ 4.1-62

4.1.3.4 NCAW 84--Low-Chrome Feed Glass

Variability Studies ......... 4.1-82

4.1.3.5 Noble Meta7s Behavior in HWVP 84-.
Low-Chrome Feed Glass, HW39-2 .... 4.1-98

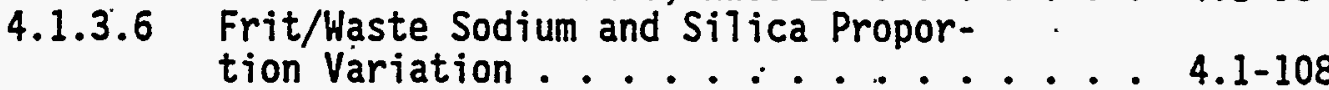

REFERENCES ........................117

4.2 FEED RECEIPT . . . . . . . . . . . . . 4.2-1

4.2:1 Function .................... 4.2-1

4.2.2 Operational Requirements ............ 4.2-1

4.2.3 Process Chemistry . . . . ...... 4.2-1

4.2.4 Technology Development ........... 4.2-2

4.3 FEED PREPARATION (System 12) . . ......... 4.3-1

4.3.1 Function ....................... 4-1

4.3.2 Operational Requirements ........... 4.3-1

4.3.3 Process Chemistry ............. 4.3-1

4.3.3.1 STurry Receipt and Adjustment Tank .... 4.3-1

4.3.4 4.3.3.2 Slurry Mix Evaporator ....... 4.3-12

Process Development ${ }_{4.3}$ HWVP Process slurry characterization $\cdots 4.3-15$

4.3.4.2 HWVP Feed Redox Adjustment with Formic

$4.3-15$

Acid and Sugar ........... 4.3-134

4.3.4:3 Off-Gas Characterization from HWVP Feed

Formating ........... 4.3-159

4.3.4.4 HWVP Pilot-Scale SRAT Study (Formating

Foaming and Heat Transfer During

Concentration) . . . . . . . 4.3-167

4.3.4.5 Ful7-Scale SRAT/SME Process Tests - SRL • 4.3-172 
4.4 MELTER FEED ................... . . 4.4-1

4.4.1 Function .........................

4.4.2 Operational Requirements ............ 4.4-1

4.4.3 Process Chemistry ............ 4... . . . .

4.4.4 DWPF Mel.ter Feed System Testing ......... 4.4-1

4.4.4.1 Equipment and Description ....... 4.4.4

4.4.4.2 Testing ............ 4..... 4...

4.4.4.3 Performance ............. 4.4-9

4.4.4.4 Wear Results ........... 4.4-21

4.4.4.5 Straining ............ 4...4-23

4.4.4.6 Conclusions .............. 4.4-24

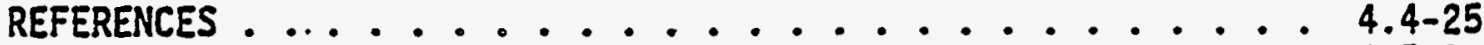

4.5 MELTER/TURNTABLE (System 13) ........... 4. . . . .

4.5.1 Function ................... 4.5-1

4.5.2 Operationar Requirements . . . . . . . 4.5-1

4.5.3 Process Chemistry ............ 4.5-1

4.5.3.1 Cold Cap and plenum Chemistry ..... 4.5-1

4.5.3.2 Glass Chemistry .......... 4. 4. . 16

4.5.4 Technology Development ........... 4.5-16

4.5.4.1 Nonradioactive Testing Equipment ..... 4.5-16

4.5.4.2 HWVP Melter Experiments $\ldots \ldots$ 4.5-20

4.5.4.3 Reference Feed Variability ...... 4.5-55

4.5.4.4 Formation and Settling of Chromite

Spinel Crystal ........ 4. 4. . . 61

4.5.4.5 Redox State of Melter Giass ...... 4.5-64

4.5.4.6 Glass Discharge System Performance for
HWVP-15. Testing ......... 4.5-68

REFERENCES ......................... 45

4.6 MELTER OFF GAS .................... $4.6-1$

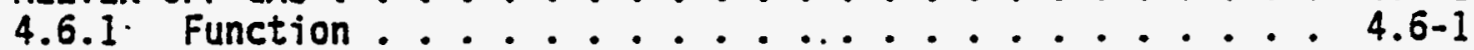

4.6.2 Operational Requirements ......... 4.6-4

4.6.3 Process Chemistry ............. 4.6-4

4.6.3.1 Film Cooter ........... 4.6-6

4.6.3.2 Submerged Bed Scrubber . . . . . . . 4.6-7

4.6.3.3 Demister............. 4.6-7

4.6.3.4 Quencher ........... 4.6-9

4.6.3.5 Gas Scrubbing Column ......... 4.6-9

4.6.3.6 Steam Atomized Scrubber ....... 4.6-10

4.6.3.7 Condenser ........... 4.6-10

4.6.3.8. High-Efficiency Mist El iminator .... 4. 4.6-10

4.6.3.9 Iodine Adsorber . . . . . . . . 4.6-12

4.6.3.10 Roughing and HEPA Fi7ters ....... 4.6-12

4.6.3.11 NOx Selective Catalytic Reduction $\therefore .4 .6-12$

4.6.4 Technology Development ........... 4.6-13

4.6.4.1 Melter Emissions . . . . . . . . . 4.6-14

4.6.4.2 File Cooler ............ 4.6-46

4.6.4.3 Submerged Bed Scrubber.......... 4.6-50

4.6.4.4 Chevron Demister .......... 4.6-87

4.6.4.5 Ejector Venturi Scrubber....... 4.6-92

4.6.4.6 Gas Scrubbing Column . . . . . 4.6-100

4.6.4.7 Steam Atomized Scrubber. ....... 4.6-104 
4.6.4.8 Condenser . . . ... 4.6-111

4.6.4.9 High-Efficiency Mist Eliminator $\therefore . .4$ 4.6-112

4.6.4.10 Ruthenium Adsorber ............4.6-135

4.6.4.11 Iodine Adsorber . . . . . . . . . 4.6-139

4.6.4.12 Filters ............ 4.6.144

4.6.4.13 Technetium Volatility ......... 4.6.145

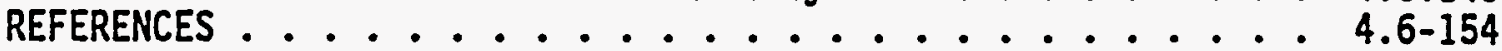

4.7 EQUIPMENT CONSTRUCTION MATERIALS . . .

4.7.1 Function ..................... 4.1

4.7.2 Operational Requirements ............... 4.1

4.7.3 Corrosion/Erosion Chemistry ......... 4.7-2

4.7.4 Technology Development .......... 4. ..7-6

4.7.4.2 PNL Materials Tests . . . ...... 4.7-8

4.7.4.3 Cost Evaluation of Using Alloy 20 and

C-276 for Equipment Fabrication ... 4. 4-37

4.7.4.4 Melter Materials Evaluation ...... 4.7-41

REFERENCES ..................... 4.7-65

4.8 VESSEL VENT (System 15) . . . . . . . . . . . . . 4.8-1

4.8.1 Function .................... 4. . . . . . .

4.9 RADIOACTIVE PROCESS WASTE COLLECTION AND TREATMENT

(System 20) . . . . . . . . . . . . . . . 4.9-1

4.9.1 Function ................ 4.9-1

4.10 CANISTER HANDLING AND INSPECTION (System 23) $\quad . . . . . . .4 .10-1$

4.10.1 Function ................. 4.10-1

4.11 CANISTER CLOSURE (System 17)

4.11.1 Function ................... 4.11-1

4.12 CANISTER DECONTAMINATION (System 16) . . . . . . . . 4.12-1

4.12.1 Function ........... 4.12-1

4.13 INTERIM CANISTER STORAGE (System 18) . . . . . . . . 4.13-1

4.13.1 Function .......................... 43-1

4.14 CANISTER LOADOUT (System 19) . . . . . . . . . . . 4.14-1

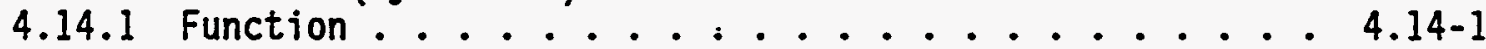

4.15 CHEMICAL MAKEUP AND TRANSFER (Systems 54 and 58) . . . . . $4.15-1$ 4.15.1 Function ................. 4.15-1

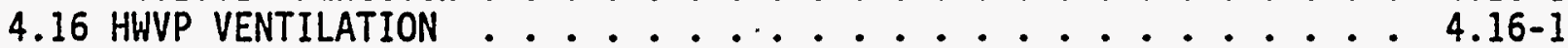

4.17 EQUIPMENT DECONTAMINATION AND DECOMMISSIONING . . . . . . . $4.17-1$

\section{FIGURES}

4.1-1 Glass/Feed Development Flowsheet 4.1-6

4.1-2 Viscosity of Reference HWVP Glass (HW39-1) ..... . 4.1-17

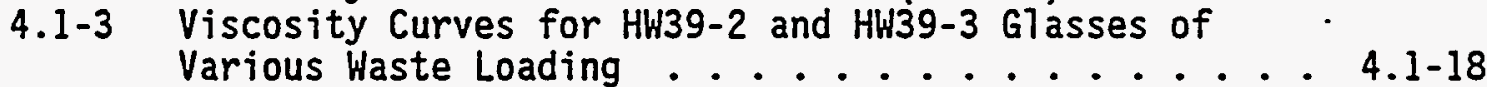

4.1-4 Viscosity Curves for HWVP Glasses HW39-2 and

4.1-5 Electrical Conductivity of Reference HWVP Giass

4.1-6 Electrical Conductivity curves for $\dot{H}+\dot{3} 9-2$ and

4.1-7 Electrical Conductivity Curves for HWVP Giasses

HW39-2, and HW39-4................. 4.1-22 
4.1-8 Prel iminary Time-Temperature-Transformation Diagram for the HWVP Reference Glass, HW39-1 . . . . . . 4.1-33

4.1-9 Predicted Centerline Canister Cooling Rates of the Open and Closed Canister Turntable Designs .... . 4.1-34

4.1-10 Predicted Centerline Canister Cooling Rates of the Open and Closed Canister Turntable Designs..... 4.1-40

4.1-11 Thermal Expansion Curve and Determination of the Glass Transition Temperature for the HWVP Reference Glass, HW39-1 ................... 4.43

4.1-12 Calculated Density of HWVP Reference Glass, HW39-1 . . . . . . . . . . . . . . . . . . .

4.1-13 Measured Heat Capacity $\left(C_{p}\right)$ from $0 \cdot \dot{c}$ to $4000^{\circ} c$ for the HWVP Reference Glass, HW39-1 . . . . . 4.1-45

4.1-14 Measured Thermal Diffusivity from $450 \mathrm{~K}$ to $825 \mathrm{~K}$ $\left(1777^{\circ} \mathrm{C}\right.$ to $552^{\circ} \mathrm{C}$ ) for the HWVP Reference Glass, HW39-1 .................... 4.1-46

4.1-15 Thermal Expansion Curve and Determination of the HW39-3 Glass Transition Temperature for HW43

GTass Produced from NCAW 86 Waste ...... 4.1-47

4.1-16 HWVP Reference Canister ........... 4.1-49

4.1-17 Turntable Canister Cooling ........... 4.1-50

4.1-18 Resuitant $\log (S A / V \cdot d a y s)$ Values for Each Type of Test in the Test Matrix ........ 4.1-55.

4:1-19 Plot of Normal ized Boron Concentration Versus

t.(SA/V) Values from HW39-1 Leach Tests
4.1-20 The Sulfate Concentration Versus the $\mathrm{Fe}^{+2} / \mathrm{Fe}^{+3}$ in
Glasses Produced from the 0.5 wt\% $\mathrm{SO}_{3} \mathrm{Feed}^{\circ}$

4.1-21 The Sulfate Concentration Versus the $\mathrm{Fe}^{+2} / \mathrm{Fe}^{+3}$ in Glasses. Produced from the 1 wt\% $\mathrm{SO}_{3}$ Feed . . . . . 4.1-63

4.1-22 Effects Plot of Predicted 100 Poise Temperature (TIOOP) . 4.1-66

4.1-23 Effects Pjot of Predicted Electrical Conductivity at $11500^{\circ} \mathrm{C}(E 1150) \ldots \ldots$ 4.1-66

4.1-24 Effects Plot of Predicted Normal ized Release for

Boron from MCC-3 Testing . . ...... 4.1-67

4.1-25 Contour Plot of Predicted Tioop in $c . \ldots 4.1 .69$

4.1-26 Contour Plot of Predicted ElI50 in $\mathrm{ohm}^{-1} \mathrm{~cm}^{-1}$... 4.1-70

4.1-27 Contour Plot of Predicted 28-Day MCC-1 Normalized Boron Release in $\mathrm{g} / \mathrm{m} 2 \ldots . . . . . .24-71$

4.1-28 The Effects Plot of Components on Tioop . . . . 4.1-75

4.1-29 The Effects Plot of Components E1150 ...... 4.1-75

4.1-30 Viscosity. of HW39-1 Glass Versus $\mathrm{Cr}_{2} \mathrm{O}_{3}$ Content . . 4.1-77

4.1-31 Temperature of 100 Poise Melt Viscosity (TI0OP) Versus $\mathrm{Cr}_{2} \mathrm{O}_{3}$ Content in HW39-1 Glass.... 4.1-78

4.1-32 Electrical Conductivity Curve of HH39-1 Giasses

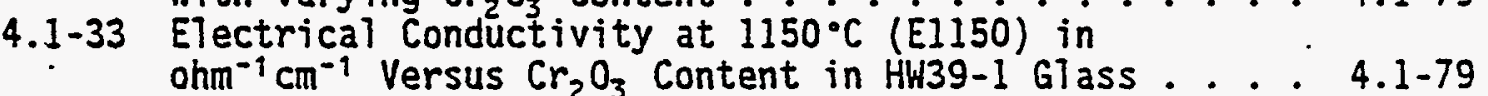

4.1-34 Testing Envelope and Test Compositions for Iron - . . 4.1-93
Calcium Variability Test . . . . . . . 4.1-79

4.1-35 Contour Plot of Predicted 100 Poise Temperature (TIOOP) for the Iron-Calcium Variability Test... 4.1-97 
4.1-36 Effects Plot of Predicted 100 Poise Temperature (TIOOP) for the Iron-Calcium Variability Test . . . 4.1-98

4.1-37 Contour Plot of Predicted Electrical Conductivity at $1150^{\circ} \mathrm{C}$ (E1150) for the Iron/Calcium Variability Test . . . . . . . . . . . . . . . . . . .

4.1-38 Effects Piot of Predicted Electrical Conductivity at $115^{\circ} \mathrm{C}$ (E1150) for the Iron/Calcium Variability Test . . . . . . . . . . . . 1-100

4.1-39 Contour Piot of Predicted 28-Day MCC-3 Boron Release for the Iron-Calcium Variability Test . . . 4.1-101

4.1-40 Effects Plot of Predicted 28-Day MCC-3 Boron. Release for the Iron - Calcium Variability Test ...................... 4.1-102

4.1-41 Compositional Ratios for HWVP Giasses Versus T100P ........................ 415

4.3-1 Manganese During Formic Acid Refluxing - DWPF . . 4:3-8

4.3-2 Effect of Formic Acid Addition ( $90 \mathrm{wt} \%$ ) on the Redox State of Various Feed Compositions . . . . 4.3-9

4.3-3 Change of Potential with Concentration of $\mathrm{H}^{+}$for Pertinent Feed Formating Components . . . . . 4.3-11

4.3-4 BoiTing Temperature of Synthetic HWVP Feed (HWS6). . 4 4.3-27

4.3-5 Specific Gravity of Synthetic HWVP Feed (HWS6) . . 4.3-28

4.3-6 Solids/Supernate Distribution in Synthetic HWVP Feed (HWS6) : ................... 4-28

4.3-7 Solids Content in Synthetic HWVP Feed (HWS6) . . . 4.3-29

4.3-8 pH and Alkalinity of Synthetic HWVP Feed (HWS6) . . 4.3-29

4.3-9 Apparent Viscosity of Synthetic HWVP Feed (HWS6) at Various Temperatures ............ 4-30

4.3-10 Yield Stress of Synthetic HWVP Feed (HWS6) at Various Temperatures ........... 4.3-30

4.3-11 Sett7ing Rate of Synthetic HWVP Feed (HWS6), $17 \mathrm{~g} \mathrm{HO} / \mathrm{L}$. . . . 4.3-31

4.3-12 Synthetic HWVP Feed (HWS6) Particle-Size Distribution at $198 \mathrm{~g} \mathrm{HO} / \mathrm{L}$. . . . . . . . 4.3-31

4.3-13 Oxides in Synthetic HWVP Feed (HWS6) . . . . . 4.3-32

4.3-14 Boiling Temperature of Synthetic Formated HWVP Feed (HWS6) ................ 4.3-32

4.3-15 Specific Gravity of Synthetic Formated HWVP Feed (HWS6) ....... 4.3-33

4.3-16 Solids/Supernate Distribution in Synthetic Formated HWVP Feed (HWS6) ........ 4.3-33

4.3-17 Solids Content in Synthetic Formated HWVP Feed (HWS6) . . . . . . . . . 4.3-34

4.3-18 $\mathrm{pH}$ and Alka7inity of Synthetic Formated HWVP Feed (HWS6) ................. 4.34

4.3-19 Apparent Viscosity of Synthetic Formated HWVP Feed (HWS6) at Various Temperatures ...... 4.3-35

4.3-20 Yield Stress of Synthetic Formated HWVP Feed (HWS6) at Various Temperatures ........ 4.3-35

4.3-21 Settling Rate of Synthetic Formated HWVP Feed (HWS6) ................. 4.3-36 
4.3-22 Synthetic Formated HWVP Feed (HWS6) Particle

Size Distribution at $151 \mathrm{~g} \mathrm{WO} / \mathrm{L} \ldots . . .3-36$

4.3-23 0xides in Synthetic Formated HWVP Feed (HWS6). . . . 4.3-37

4.3-24 Specific Gravity of Synthetic Formated HWVP

Feed (HWS6) at Various Formic Acid Additions . . . . 4.3-37

4.3-25 Solids/Supernate Distribution in Synthetic

Formated HWVP Feed (HWS6) at Various Formic

Acid Additions ........ 4.3-38

4.3-26 Solids Content in Synthetic Formated HWVP Feed

(HWS6) at Various Formic Acid Additions ..... 4.3-38

4.3-27 pH and Alkal inity of Synthetic Formated HWVP

Feed (HWS6) at Various Formic Acid Additions . . . . 4.3-39

4.3-28 Sett7ing Rate of Synthetic-Formated HWVP Feed

(HWS6) at Various Formic Acid Additions . . . . . 4.3-39

4.3-29 Apparent Viscosity and Yield Stress of Synthetic

Formated HWVP Feed (HWS6) at Various Formate

4.3-30

Additions

$4.3-40$

4.3-31

Effect of Time on $\mathrm{pH}$ of HWVP STurries

$4.3-40$

Boiling Temperature of Synthetic Melter Feed

$4.3-32$

(HWS6) T. .

4.3-41

$4.3-33$

Specific Gravity of Synthetic Meiter Feed (HWS6) . . . 4.3-41

Solids/Supernate Distribution in Synthetic Melter

4.3-34

Feed (HWSE)

$4.3-42$

Solids Content in Synthetic Melter Feed (HWS6) . . 4.3-42

4.3-35 pH and Alkalinity of Synthetic Melter

Feed (HWS6)

4.3-36 Apparent Viscosity of Synthetic Melter Feed (HWS6)

$4.3-43$ at Various Temperatures

4.3-37 Yield Stress of Synthetic Melter Feed (HWSG) at

Various Temperatures . . . . . . . 4.3-44

4.3-38 Settling Rate of Synthetic Meiter Feed (HWS6) $\ldots$ 4.3-44

4.3-39 Oxides in Synthetic Melter Feed (HWS6) .... 4.3-45

4.3-40 pH as a Function of Time for Synthetic Melter

Feed (HWS6) . . . . . . . . . . . . . . .

4.3-41 Apparent Viscosity and Yield Stress of Synthetic

Melter Feed (HWS6) at Various Formate Additions . . 4.3-46

4.3-42 Boiling Temperature of Frit (HH39) Slurries ... 4.3-46

4.3-43 Specific Gravity of Frit (HW39) S7urries . . . . . 4.3-47

4.3-44 Solids/Supernate Distribution in Frit (HW39)

$4.3-45$ Solids content of Frit inw3 siurries.........3.47

4.3-46 pH of Frit (HW39) Slurry as a Function of Time ... 4.3-48

4.3-47 0xides in Frit HWVP (HW39) Feed S7urries . . . . 4.3-49

4.3-48 Settling Behavior of Frit (HW39) Slurries . . 4.3-49

4.3-49 Vapor Pressure of Formic Acid - DWPF . . . . . . 4.3-50

4.3-50 Formic Acid Vapor/Liquid Equilibrium Curves .... 4.3-51

4.3-5I OutTine of Feed Preparation Scoping Study .... 4.3-56

4.3-52 Proposed Test Matrix for Feed Process Variable

Testing .................... 41

4.3-53 Particle Size Distributions for Synthetic

HWVP Feeds RBPS -2 and RBPS-3 ........ 4.3-73 
4.3-54 Densities (NCAH 84, high chromium) of Simulated HWVP Synthetic B-Plant Feed, HWVP-13 and HWVP-14 Feeds and Simulation HWS6.Versus S7urry Concentration Before Formic Acid Treatment . . . . . . . 4.3-84

4.3-55 Apparent Viscosity of Synthetic B-Piant Feed, HWVP-13 and HWVP-14 Feeds, and Simulation HWS6 Versus Siurry Concentration Before Formic Acid Treatment

4.3-56 Yield Stress of Synthetic B-Plant Feed, HWVP-13 and HWVP-14 Feeds, and Simulation HWS6 Versus S7urry Concentration Before Formic Acid Treatment . . . . 4.3-86

4.3-57 Procedure for Preparation of Hydroxides from Nitrates .............. 4.3-95

4.3-58 Average Apparent Viscosities as a Function of Shear Rate for PSCM-23 Samples 28, 39, and 42 . . . 4.3-96

4.3-59 Solubilization of Ions in HWVP Feed During Formating, Concentrating, and Frit Addition ... 4.3-101

4.3-60 Total Solids Concentration as a Function of Waste Oxide Concentration of Simulate HWVP Feed ..... 4.3-106

4.3-61 Density of Simulated (NCAW 84, high chromium)

HWVP Feeds as a Function of the of the Waste

Oxide Concentration ........... 4.3-107

4.3-62 Changes in the Yield Stress of Simulated (NCAW 84, high chromium) HWVP Feeds During Concentration ... 4.3-108

4.3-63 Changes in the Apparent Viscosity of Simulated (NCAW 84, high chromium) HWVP Feeds During

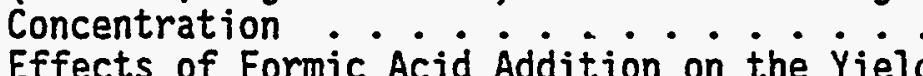

4.3-64 Effects of Formic Acid Addition on the Yield
Stress of Simulated HWVP. Feed Concentration (HWS6-NCAW 84, high chromium) ........ 4.3-110

4.3-65 Effect of Formic Acid Addition on Yield Stress for Varying Waste Oxide Concentrations . . . . . 4.3-111

4.3-66 Effects of Formic Addition on the Apparent Viscosity of Simulated HWVP Feed Concentrates . . . 4.3-113

4.3-67 Ratio of Dissolved Solids to Total Solids at Various $\mathrm{pH}$ Values During Concentration, Low Agitation .................... 4-114

4.3-68 Variation of $\mathrm{pH}$ During Concentration for Low-Agitation Batches ......... 4.3-115

4.3-69 Effect of Varying Agitation on Yield Stresses of Samples .....................116

4.3-70 Effect of Varying Agitation on the Apparent Viscosity ......... 4.3-117

4.3-71 Effect of Varying $\mathrm{pH}$ on Yieid Stress Samples (HWS7-HW 84, high chromium) Formated at $50 \mathrm{~g}$ WO/L with Low Agitation .......... 4.3-118

4.3-72 Effect of Varying $\mathrm{pH}$ on Apparent Viscosity (at $468 \mathrm{~s}^{-1}$ ) for Samples Formated at $50 \mathrm{~g}$ WO/L with Yow Agitation Stress as a Function of concentration for

4.3-73 Yield Stress as a Function of Concentration for
Meiter Feeds (HWS5-NCAW 84, high chromium) That. Were Boiled and Those That Were Not Boiled ... . 4.3-120 
4.3-74 Apparent Viscosity as a Function of Concentration for Melter Feeds (HHS5-NCAN 84, high chromium) That Were Boiled and Those That Here not Boiled

4.3-75 Yield Stress Values of Simulated, NCAW 84, High Chromium Melter Feed Prepared for Laboratory Simulation HWSE and HWVP-13 AND HWVP-14 Feed Versus Slurry Concentration .......... 4.3-122

4.3-76 Apparent Viscosities of Simulated, NCAN 84, High Chromium Melter Feeds Prepared for Laboratory Test Batches and HWVP-13 and HWVP-14 Feed Samples Versus STurry Concentration :........... 4.3-123

4.3-77 Apparent Viscosity Values, at $183 \dot{\mathrm{sec}}$, of HHVP Feed S7urries HWS7 (NCAW 84, high chromium), HHS9 (NCAW 86), and PSCM-23 (NCAW 87)

4.3-78 Yield Stress VaTues of HWVP STurries HWS7 (NCAN 84, high chromium), HWS9 (NCAN 86), and PSCM-23 (NCAN 87) ............. 4.3-127

4.3-79 Density Versus Weight Percent Haste Oxides for HWS7 (NCAH 84, high chromium), HWS9 (NCAH 86) and PSCM-23 (NCAN 87)

4.3-80 Weight Percent Dissolved Sotids Fraction Versus Weight Percent Total Solids Fraction for Samples Prepared from Laboratory Simulations HWST (NCAH 84, high chromium) and HWS9 (NCAH 86) . . . 4.3-129.

4.3-81 Weight Percent Total Solids Values Versus Weight Percent Waste Oxide Values for Samples Prepared from Laboratory Simulations HWS7 (NCAW 84, high chromium) and HWS9 (NCAH 86) .........

4.3-82 Effect of Formic Acid Addition ( 90 wt $\%$ ) on the Apparent Viscosity of Various NCAW 84 Low-Chromium Feed Compositions and NCAW 86 Feed . . . . . . . 4.3-131

4.3-83 Effect of Formic Acid Addition ( $90 \mathrm{wt} \%$ ) on the Yield Stress of Various NCAW 84 Low-Chromium Feed Compositions and NCAW 86 Feed .......... . 4.3-132

4.3-84 Effect of Formic Acid Addition (90 wt\%) on the Redox State of Various Feed Compositions (NCAW 86 and NCAW 84, low chromium) ....... 4.3-137

4.3-85 Effect of Formic ACid Addition on pH of NCAW 84,

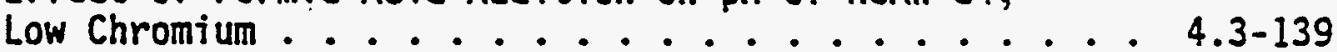

4.3-86 Effect of Formic Acid Addition on the $\mathrm{pH}$

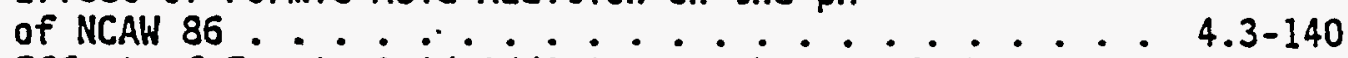

4.3-87 Effect of Formic Acid Addition on the $\mathrm{pH}$ of the High Iron Composition .............. 4.3-141

4.3-88 Effect of Formic Acid Addition. on the $\mathrm{pH}$ of the

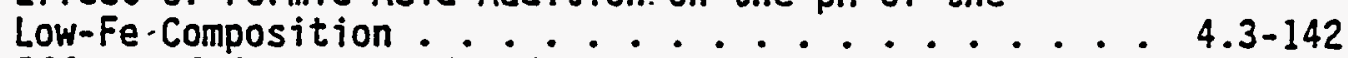

4.3-89 Effect of Formic Acid Addition on the $\mathrm{pH}$ of the High Aluminum Composition ............ 4.3-143

4.3-90 Effect of Formic Acid Addition on the $\mathrm{pH}$ of the Low Aluminum Composition .............. 4.3-144

4.3-91 Effect of Formic Acid Addition on the $\mathrm{pH}$ of the High Sodium Composition 
4.3-92 Effect of Formic Acid Addition on the $\mathrm{pH}$ of the Low Sodium Composition :................. 4-146

4.3-93 Effect of Formic Acid Addition on the $\mathrm{pH}$ of the High Zirconium Composition ........... 4.3-147

4.4-94 $\mathrm{Fe}^{+2} / \mathrm{Fe}^{+3}$ of Glass and Feed Samples from HWVP-11 . . 4.3-151

4.3-95 Feed Redox Curve for $1 / 3$ Frit - 2/3 Unreacted

Chemical Feed .............4.3-153

4.3-96 Laboratory Redox Curve . . . . . . . . 4.3-154

4.3-97 Redox Response of PSCM-22 Feeds and Giasses .... 4.3-155

4.3-98 $\mathrm{Fe}^{+2} / \mathrm{Fe}^{+3}$ Versus the Total Organic Carbon in

Pre-PSCM-23 Slurry Feeds ........... 4.3-158

4.3-99 Gas Concentration of $\mathrm{CO}_{2}$ as a Function of

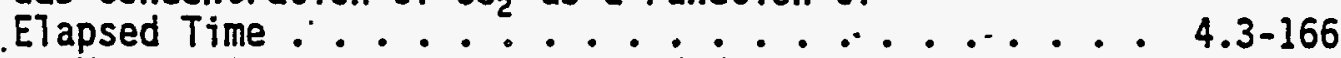

4.3-100 pH Versus Amount Formic Acid Added . . . . . . . 4.3-168

4.3-101 Post Treatment pH Change . . . . . . . . 4.3-168

4.3-102 Cross Sectional View of the TNX Fuli-Scale

SRAT/SME . . . . . . . . . . . . . . . .

4.3-103 Overhead Schematic of the TNX Fuli-Scale SRAT/SME

Showing Nozzle Orientations ........ 4.3-175

4.3-104 Schematic of the TNX Ful7-Scale SRAT/SME Coil

Assembly . . . . . . . . . . 4.3-177

4.3-105 S7udge-Oniy Process Flow Diagram for Full-Scale

SRAT/SME . . . . . . . . . . . 4.3-182

4.3-106 The Effect of Slurry Density on Agitator Power . . . 4.3-184

4.3-107 Effect of STurry Yield Stress on Boiling Heat

Transfer Coefficients ......... . . 4.3-186

4.3-108 Pump Curve for SRAT/SME Transfer Pump with SME

SME Material . . . . . . . . . . 4.3-194

4.3-109 Isolated Bubbler Pressure (Leve1) Sensor . . . . . 4.3-198

4.3-110 Effect of Slurry Temperature on Isolated Bubbler

Pressure (Leve1) Sensor Measurements . . . . . . 4.3-199

4.3-111 Temperature Calibration for Holledge PB-35 Gauge .. 4.3-200

4.3-112 Hydraguard Sampler... . . . . . . . . . 4.3-200

4.3-113 TNX FuT1-Scale SRAT/SME - DWPF . ....... 4. . . . 3-201

4.3-114 TNX Agitator Impeller Erosion Rate Measurements -

DWPF . . . . . . . . . 4.3-203

4.3-115 TNX SRAT/SME Lower Impel1er ........ 4.3-204

4.3-116 (BEFORE) Sketch Showing Original Thicknesses and Locations of Measurements on TNX SRAT/SME

Tank Bottom ......... . . . . . . . . . . 206

4.3-117 (AFTER) Sketch Showing Thicknesses and Locations

of Measurements on TNX SRAT/SME Tank Bottom

After Testing ............ 4. 4. . . . 207

4.4-1 Recirculation Loop Feed System - DWPF ...... 4.4-3

4.4-2 Fixed Restrictor - DWPF ........... 4.4-6

4.4-3 Variable Restrictor - DWPF . . . . . . . . 4.4-7

4.4-4 Pump Speed Versus Melter Flow, 11-1/4-in.

Impeller - DWPF ................... 40

4.4-5 Pump Speed Versus Melter Flow, 7-7/1 in. . . . . 4.4-11
Impeller - DWPF . . . . . .

4.4-6 Melter Feed Head Versus Fiow - DWPF .... $. .4 .4-12$ 
4.4-7 Pressure Difference Downstream Restrictor Versus FTow - DHPF ..................4-14

4.4-8 Pressure Difference Upstream Restrictor and Piping Versus Flow - DWPF ......... 4. 4. . . . 15

4.4-9 Pressure Difference Upstream Restrictor Versus

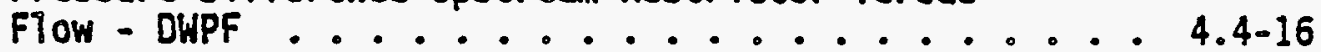

4.4-10 Lawrence Pump Test Performance Curve 1 - DWPF ... 4.4-17 4.4-11 Lawrence Pump Test Curve 2 - DWPF ....... 4.4-18 4.5-1 Standard Gibbs Free Energy of Formation of Oxides, as a Function of Temperature . . . . . . . 4.5-14

4.5-2 High-Bay Ceramic Melter - HWVP .......... 4.5-18

4.5-3 PSCM and Associated Off-Gas Treatment Equipment -

4WVP .................... 4.5-19

4.5-4 PSCM Process F7owsheet ........... 4.5-21

4.5-5 The Pilot-Scale Ceramic Melter......... 4.5-22

4.5-6 Instrument Locations for HWVP-15 . . . . . . . .

4.5-7 Operational Control Parameters for the First $200 \mathrm{~h}$ of the PSCM Experiment - HWVP ......... 4.5-30

4.5-8 Operational Control Parameters for the Final $200 \mathrm{~h}$ of the PSCM Experiment - HWVP ........ 4.5-30

4.5-9 Effect of Feed Concentration on Melter Process Rate for HWVP-13 ............ 4.5-34

4.5-10 Effect of Water Loading on Meiter Process Rate for HWVP-13 ...... 4.5-35

4.5-11 Effect of S7urry Total wt\% Solids on Meiter Process Rate for HWVP-13 . . . . . . . 4.5-35

4.5-12 Comparison of HWVP and SRL Studies of the Effect of Sol ids Loading on Glass Production Rates .. . . . 4.5-36

4.5-13 Optima1 GTass Production Rate as a Function of Melter Feed Concentration for HWVP-13 ..... 4.5-36

4.5-14 PSCM Average Bulk Glass Temperature ....

4.5-15 PSCM Average Melter Feed Rate ......... 4.5-41

4.5-16 PSCM Plenum Temperature ........... 4.5-42

4.5-17 PSCM Pienum Pressure . . . . . . . . . 4.5-42

4.5-18 PSCM ETectrode Power .............. 4.5-43

4.5-19 PSCM Electrode Resistance .......... 4.5-43

4.5-20 PSCM Electrode Current . . . . . . . . 4.5-44

4.5-21 PSCM North Electrode Temperature . . . . . . . 4.5-44

4.5-22 PSCM South Electrode Temperature . . . . . 4. 4-45

4.5-23 PSCM GI ass Discharge Trough Block Temperature ... 4.5-45

4.5-24 PSCM Glass Discharge Face Area Temperature . . . . 4.5-46

4.5-25 PSCM Glass Discharge Trough Area Temperature.... 4.5-46

4.5-26 PSCM Glass Discharge Face Heater Power ...... . 4.5-47

4.5-27 PSCM G7ass Discharge Trough Heater Power . . . . . 4.5-47

4.5-28 Comparison of Production Performance for PNL

and SRL Melters ................. 4-49

4.5-29 Viscosity Curves for HWVP Gi asses HW39-2,

4.5-30 Electrical Conductivity Curves for HWVP Giasses HW39-2, HW39-4, and PSCM-23 (HW39-4) ...... 4.5-52

4.5-31 Total Oxide Concentration of PSCM-23 Melter Feed Samples 
4.5-32 PSCM Modified Overflow Trough

Time Dependent Behavior of Melter Generated Gases

4.6-11 Noncondensible Off-Gas Composition Preceding and

4.6-12 Compositional Behavior of Exhaust Stream Feed

During Melter Reboil 1.6 4.6-35

Melter Off-Gas Compositional Behavior Associated

Hith Feed Termination

Emission Characteristics of Nitrogen and Sulfur

Emission Characteristics of Boron, ChTorine, and

4.6-18 Off-Gas Surges in Savannah River Laboratory LSFM:

DWPF

Typical Off-Gas Flow Rate Behavioral Patterns

Associated with Liquid-Fed Melters

Influence of Inlet Concentration on SBS

Performance

Influence of Steam on SBS Performance $\left(\mathrm{T}_{i} \mathrm{O}_{2}\right) \cdots \ldots$

$4.6-23$

4.6-24

Influence of Bed Diameter on SBS Performance.

Predicted Interaction Between Bed Diameter and

Steam-to-Air Ratio at a Superficial Velocity

of $0.3 \mathrm{~m} / \mathrm{s}$

4.6-25

Collection Efficiency as a Function of Particie

Diameter

Influence of Packing Size on SBS Performance

Outlet Concentration Due to Re-Entrainment as

a Function of Time

$4.6-65$

4.6-29

Effect of Scrubbing-Solution Concentration on

4.6-30 Particle Size Distribution of $\mathrm{TiO}_{2}$ Suspended in

$4.6-31$ the Scrubbing Water

Effect of Gas Velocity on Re-Entrainment 
4.6-34 SBS Concentration Bui7dup of Cations ....... 4.6-78

4.6-35 Total Elemental Concentration Buildup in SBS

Versus Theoretical Prediction ........ 4.6-79

4.6-36 SBS Bed Temperature 2 Feet Below Surface . . . . 4.6-80

4.6-37. SBS Ted Temperature 4 Feet Below Surface ..... 4.6-81

4.6-38 SBS Decontamination Factors Versus Gas Velocity . 4. 4.6-85

4.6-39 Size Distribution of Off-Gas Aerosols as

Collected on Cascade Impactor Stages . . . . . 4. 4.6-88

4.6-40 Theoretical Collection Efficiency for a 12-in.

Ejector Venturi Scrubber . . . . . . . . 4.6-94

4.6-41 Aerosol Distribution of Quenched Meiter Off-Gas

DHPF

4.6-42 Family of Theoretical Collection Efficiency

Curves at Constant Liquid/Gas Ratio and Various

Motive Pressures . . 4.6. . . . . . . .

4.6-43 Family of Theoretical Collection Efficiency

Curves at Constant Motive Pressure and Various

Liquid/Gas Ratios

4.6-44 Relationship Between Inlet Aerosol Concentration

and Aerosol Capture Efficiency for the EVS -

HWVP

4.6-45 Effect of $\mathrm{NO}_{2}$ Inlet Concentration on Plate

Absorption Efficiencies in a Bubble-Cap Column -

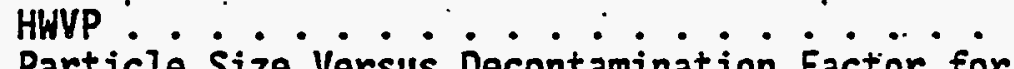

4.6-46 Particle Size Versus Decontamination Factor for

Hydrosonic Scrubber - HWVP . . . . . . . . 4.6-105

4.6-47 Outlet Concentrations from the Super Sub Scrubber

as a Function of Pressure Loss for Several Indus-

trial Applications .............. 4.6-107

4.6-48 Outlet Concentrations for a Hydrosonic Gas

Cleaner for Recycled and Once-Through Hater

Operation Modes ............. 4.6-108

4.6-49 Comparison of Scrubber Performance . . . . . 4.6-112

4.6-50 Decontamination Factor as a Function of Droplet

Size for a High-Efficiency Mist E7 iminator. . . . . 4.6-113

4.6-51 Number, Area, and Volume Distributions of Aerosols

Exiting the High-Efficiency Mist El iminator During

PSCM-15

4.6-52 Cross-Sectional View of the High-Efficiency Mist

$4.6-114$

El iminator. . . . . . . . . 4.6-116

4.6-53 Measured Pressure Drop Across the HEME - HWVP $\because \ldots 4.6-117$

4.6-54 HEME Differential Pressure and Face Velocity . . . . 4.6-123

4.6-55 Inlet Temperature to the HEME ........ 4.6-124

4.6-56 Water Collected from HEME When No Spray Was Used . . 4.6-125

4.6-57. Water Collected from HEME When Spray Was Used . . 4.6-126

4.6-58 pH of HEME Fluid .............. . . 4.6-128

4.6-59 Effect of Inlet Water Spray on HEME Performance . . 4.6-130

4.6-60 Effect of Air Flow on HEME Performance ..... 4.6-131

4.6-61 Collection Efficiency and Pressure Drop of a

Fiber Mist Eliminator as a Function of Gas

Velocity Through Fiber Packing.

$4.6-132$ 
4.6-62 Description of the Experimental System.Used by

Klein et al. ....................... 4-137

4.6-63 Air Flow Rates Through HEPA Filter ........ 4.6-138

4.6-64 Pressure Drop Across HEPA Filter Housing . . . . . 4.6-147

4.6-65 Inlet Temperature to HEPA Fi7ter ....... 4.6-148

4.7-1 Test Apparatus Used for Immersion-Type Coupon

Corrosion Tests .............. 4-12

4.7-2 Sketch of Test Specimens Used in the Abrasive

Slurry Tests ............ 4. . . . . . . . .

4.7-3 Sketch of ASTM Abrasive Siurry Testing Machine . . . 4.7-16

4.7-4 Pitting Scan for ALLCORR in Scoping Study Test

4.7-5 Sketches of the Types of Corrosion Coupons Used . . 4.7-19

for the FY 1988 HWVP TRU-Recycle Corrosion

Testing, Including Standard Coupons, Crevice

Corrosion Coupons, and Welded U-Bend Coupons . . . 4.7-25

4.7-6. Test Schematic Showing Test Solutions, TRU-Recycle

Versus Nonrecycle Conditions, Test Materials,

and Number and Types of Coupons ....... 4. 4-26

4.7-7 Test Apparatus Used for Laboratory Immersion-Type

Corrosion Tests ............ 4. 4-27

4.7-8 Electrodes Modified for Side Bus Entry . . . . . . 4.7-45

4.7-9 Condition of Electrodes as Removed. from the

PSCM During the 1985 Inspection ....... 4.7-47

4.7-10 Appearance of Melter Tank After 1982 Shutdown

and After 1985 Shutdown ........... 4. 4-48

4.7-11 Electrodes After Sand Blasting . . . . . . . 4.7-49

4.7-12 Front View of the South Electrode . . . . . . 4.7-50

4.7-13 Lid Refractory . . . . . . . . . . . 4.7-53

4.7-14. East Wa 17 of Me7ter Tank . . . . . . . . . 4.7-54

4.7-15 Changes in Melter Wall Measurements ...... 4.7-55

4.7-16 Total Change in Melter Hall Measurements . . . . 4. 4-56

4.7-17 Riser Block Measurements . . . . . . . . 4.7-58

4.7-18 Riser BTock Throat Entrance After 1982 Shutdown

and After the Riser Block was Removed in 1985 . . . 4.7-59

4.7-19 Glass Discharge Trough as Installed (1980) and

After the 1985 Shutdown .......... 4. 7-60

TABLES

4.1-1 Composition of the HWVP Reference Waste (NCAW 84

High-Chromium), Substituted Waste, and HW39-1

Glass at a 25 wt\% Oxide Waste Loading ....... 4.1-10

4.1-2 Compositions of NCAW 84 Reduced Cr203 Reference

Waste and HW39-2 Glass at a 25 wt\% Oxides Waste

Loading ...................... 411

4.1-3 Updated NCAW Waste Composition, HW39-3 Glass

Development (with Noble Metals), All Values

in oxide wt\%

4.1-4 Oxide Compositions of NCAW 87, HW39-4 Frit,

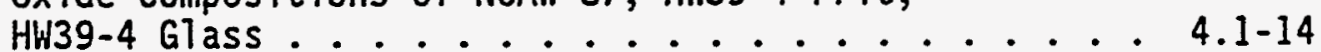


4.1-5 Composition of NCAN 86 GTass and HW39 LOW-C $\mathrm{Cr}_{2} \mathrm{O}_{3}$

4.1-6 Summary of GTass. and Meit Properties for NCAW 86

$4.1-16$

(HW39-3) and HW39-2 LOW-Cr, $\mathrm{O}_{3}$ G7 asses ....... 4.1-18

4.1-7 28-Day MCL-1 Leaching Results for the HWVP

Reference GTass HW39-1 .......... 4.1-23

4.1-8 28-Day MCC-3 Leaching Results for the HWVP

Reference Glass HW39-1............ 4.1-23

4.1-9 Normalized Elemental Mass Release from 7-day

MCC-1 for $\Pi T$ HW39-1 Glass Samples, SA/V =

$10 \mathrm{~m}^{-1}, 90^{\circ} \mathrm{C}$, in Deionized Water . . . . . 4.1-25

4.1-10 Normat ized Elemental. Mass Release from 28-day

MCC-1 for TTT HW39-1 Glass Samples, $S A / V=$

$10 \mathrm{~m}^{-1}, 90^{\circ} \mathrm{C}$, in Deionized Water ...... 4.1-25

4.1-11 Normalized Ejemental Mass Releases from 28-day

MCC-3 for ITT HH39-1 Glass Samples, 0.45-

micron filtered, $S A / V=178 \mathrm{~m}^{-1}, 90^{\circ} \mathrm{C}$, in

Deionized Water ............ 4.1-27

4.1-12 Normal ized Elemental Mass Releases from 28-day

MCC-3 for TTT HW39-1 Glass Samples, 18-Angstrom

filtered, $S A / V=1780 \mathrm{~m}^{-1}, 90^{\circ} \mathrm{C}$, in Deionized

Water

4.1-13 Normal ized Elemental Mass Releases from 28-day

MCC-1 Leaching Tests for HW39-3 Glasses, Surface

Area/Volume $=10 \mathrm{~m}^{-1}$, Temperature $=90^{\circ} \mathrm{C}$,

Leachate $=$ Deionized Hater ....... 4.1-29

4.1-14 Comparison of Normalized ReTease from 7-Day

MCC-1 Leach Testing for HWVP G7 asses HW39-4

and HH39-2 ...... 4. 4. . . . . . . . . . . .

4.1-15 Comparison of Normal ized Release from 28-Day

MCC-1 Leach Testing for HWWP GT asses HW39-4

and $H W 39-2 \ldots \ldots$. . . . . . . . . . . . .

4.1-16 Comparison of: Normal ized Rè lease from 7-Day

MCC-3 Leach Testing with $0.45-\mu \mathrm{m}$ Filtrate for

HWVP Giasses

$4.1-30$

4.1-17 Comparison of Normalized Reiease from 7-Day

MCC-3 Leach Testing with 18-Angstrom Filtrate

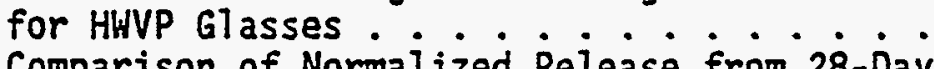

4.1-18 Comparison of Normal ized Release from 28-Day

MCC -3 Leach Testing with 0.45- $\mu \mathrm{m}$ Filtrate for

HWVP Glasses $\cdot$ Comparison of Norma $i$ ized Reiease from 28 -Day

4.1-19 Comparison of Normal ized Release from 28-Day
MCC-3 Leach Testing with 18-Angstrom Filtrate

for HWVP Glasses Conditions: MCC-3 in DIH,

$S A / N=2000 \mathrm{~m}^{-1}, 90^{\circ} \mathrm{C}$

4.1-20 HW39-1 Time-Temperature-Transformation Test

Matrix ....... 4.1-35

4.1-21 Composition of HW39-1 Glass Batched for TTT

Study :......................... 46

4.1-22 Maximum Percent Deviation of Major Components

From TTT Target Values ........... 4.1-38

4.1-23 Redox Response of TTT Samples ....... 4.1-39 
4.1-24 Calculated Density Versus Temperature for

HW39-1 Glass .................. 4.1-44

4.1-25 Filled HWVP Reference Canister Properties ..... 4.1-51

4.1-26 Composition of the HWVP Reference Waste (NCAW 84,

$53 \mathrm{wt} \% \mathrm{Cr}_{2} \mathrm{O}_{3}$ ), Substituted Waste, and Glass (HW39-1)

at a 25 wt\% Oxide Waste Loading ......... 4.1-52

4.1-27 Leaching Test Matrix for HWVP Waste Form

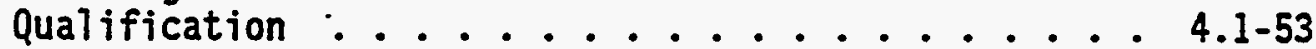

4.1-28 Proposed SA/V and Time to Test Matrix with

the Resultant $\log (t \cdot S A / V)$ Values ......... 4.1-54

4.1-29 G7ass and Leachate Amount Used to Produce

Required SA/V Ratios in MCC-3 Testing ....... 4.1-56

4.1-30 Composition of Simulated Melter Feed S1urry . . . 4.1-60

4.1-31 Experimental Ranges for the Zirconium and

Waste-Loading Variability Study ......... 4.1-65

4.1-32 Experimental Ranges for Mixed Alkali

Variability Study .................. 4.68

4.1-33 Test Compositions for the $\mathrm{U}_{3} \mathrm{O}_{8}$ Variability

Study .................... 4.1-72

4.1-34 Summary of Results From Uranium Variability

Study for Viscosity, Electrical Conductivity . . . . 4.1-72

4.1-35 Summary of 7-day MCC-1 Leaching Results from

HWVP Uranium Variability Study......... 4.1-73

4.1-36 Summary of 28-day MCC-1 Leaching Resuits

from HWVP Uranium Variability Study ........ 4.1-73

4.1-37 Ranges of Waste Components in the Multiple

Haste Component Variability Test ......... 4.1-74

4.1-38 Summary of the Results from Composition

Variability Study for HW39-1 Glass with

Varying $\mathrm{Cr}_{2} \mathrm{O}_{3}$ Content

4.1-39 Oxide Composition of Meiter Feeds Prepared

for the HWVP Feed Composition Variables Tests . . 4 4.1-81

4.1-40 Predicted and Actual T100P Values for HWVP-14

Melter Test Glass Compositions: ........ 4.1-82

4.1-41 Compositions of NCAW 84 Reduced $\mathrm{Cr}_{2} \mathrm{O}_{3}$ Ref-

erence Waste and HW39-2 Glass at a 25 wt\%

Oxides Haste Loading ............. 4.1-84

4.1-42 Summary of Glass Compositions Used in Vari-

ability Scoping Tests ........... 4.1-85

4.1-43 Summary of Viscosity and Electrical Con-

ductivity Data for Scoping Test Glasses . . . . 4.1-85

4.1-44 Fluorine Variability Studies Target Fluorine

Concentrations, and Analyzed F Concentrations . . 4.1-87

4.1-45 Summary of Viscosity and Electrical Conduc-

tivity Data for Fluorine Variability Glasses . . . 4.1-87

4.1-46 MCC-1 Leaching Results for Fluorine Variability

Testing ............... 4.1-89

4.1-47 MCC-3 Leaching Resuits for Fluorine Variability

4.1-48 Composition of Waste Mix and Modified Frit for

Iron and Calcium Variability Study....... 4.1-91 
4.1-49 Ranges of Waste Components in the Component Variability Test .....................92

4.1-50 Test Matrix of Glasses to be Used in the $\mathrm{Fe} / \mathrm{Ca} . . .4 .1-94$

4.1-51 Summary of Viscosity (TIOOP) and Electrical Conductivity (E1150) Data for Iron and Calcium Variability Study ............ 4.1-94

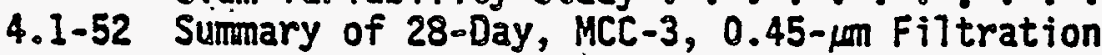
Leaching Data for Iron/Calcium Variability Study

4.1-53 Sumary of 28-Day, MCC-3, 18-Angstrom Filtration Leaching Data for Iron/Calcium Variability Study

4.1.54 Composition of the HWVP NCAW 84 (Low Chrome) Reference Waste, Substituted Waste; and Glass (HW39-2) at a 25 wt\% Oxides Waste Loading . . . . . 4.1-103

4.j-55 Composition of the HWVP NCAW 84 (Low Chrome)

Reference Haste, Substituted Waste, and Glass

(HW39-2) at a 25 wt\% Oxides Waste Loading ..... 4.1-104

4.1-56 Summary of Crucible Variability Studies

$4.1-106$

$4.1-57$ Compositions of Test Frits Compositions of Glasses Used in Compositional

4.1-58 Ratio Evaluation HWVP-14 Melter Test Glass

4.1-59 Compositional Ratios and TIOOP Values for Evaluated Giass Compositions. . . . . . . . 4.1-114

4.1-60 Estimated Change in T100P Per wt\% Change in

4.2-1 Receipt and Lag storage Tank Operationai

$4.1-116$

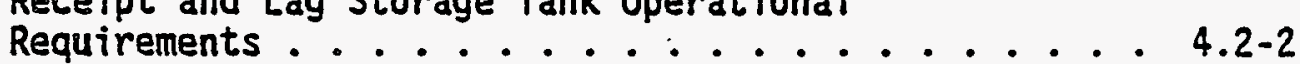

4.2-2 Washed Slurry Physicaj and Rheologicaj-Properties $: 4.2-3$

4.3-1 SRAT Operational Requirements ........ 4.3-2

4.3-2 SME Operational Requirements . . . . . . . . 4.3-3

4.3-3 SMECT Operational Requirements . . . . . . . 4.3-4

4.3-4 Formating Reaction Stoichiometry, Siudge-Oniy

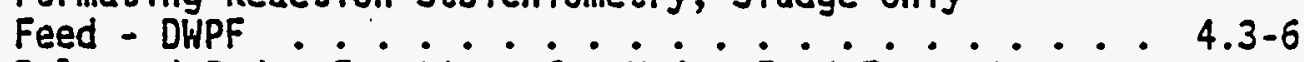

4.3-5 Bal anced Redox Equations for Major Feed Formating Reactions ................... 411

4.3-6 Properties of DWPF Reference Meiter Feed . . . . 4.3-13

4.3-7 Melter Feed Makeup Frit Slurry Requirements DWPF . . . . . . . . 4.3-14

4.3-8 Reference Haste Oxide Feed Compositions . . . . 4.3-17

4.3-9 NCAW Reference Wastes Used for Slurry Studies/Tests ............... 4.3-18

4.3-10 Key to HWVP Process siurry Properties: Tabies and Figures Based on HWS6 NCAW 84 High Chromium Composition .................. 4-19

4.3-11 Heat Capacity for Synthetic HWVP Slurries ... 4.3-22

4.3-12 Shear Strength of Settled Solids in Synthetic HWVP Slurries .................... 4-23

4.3-13 Volume Percent and Specific Gravity of Synthetic HWVP Slurries ............ 4.3-24

4.3-14 Physical Properties of 90 wt\% Formic Acid - DWPF . . 4.3-25 
4.3-15 Vapor-Liquid Equilibria for Formic Acid/Water

System at $760 \mathrm{~mm} \mathrm{Hg}$ - DWPF ....... 4.3-25

4.3-16 Frit (HW39) Physical Properties and Chemical

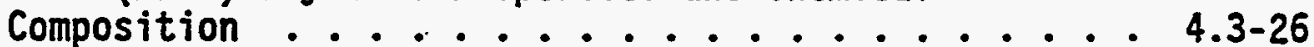

4.3-17 Vapor Pressure of Formic Acid in Dilute Aqueous

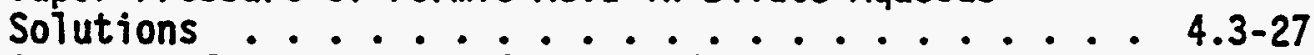

4.3-18 Summary of Properties of HWVP Reference Feed

Simulation HWS4 (NCAH 84, high chromium)

Concentration as a Function of the Amount of

Formic Acid ............... 4.3-52

4.3-19 Matrix of Laboratory Batches of Melter Feeds

Prepared to Evaluate Effects of Boiling ..... 4.3-54

4.3-20 Properties of Simulated Melter Feed (NCAH 84,

high chromium) Batches Prepared to Evaluate

the Effects of Boiling ..................... 455

4.3-21 Properties of HWS6 (NCAW 84, high chromium) During

the Concentration Phase ............. 4.3-57

4.3-22 Properties of Simulated HWVP Feed (NCAW 84, high

chromium) Concentrates Before and After Treatment

with Formic Acid . . . . . . . . . . . 4.3-57

4.3-23 Rheological Properties of HWSE (NCAW 84, high

chromium) Samples Treated with Formic Acid Before

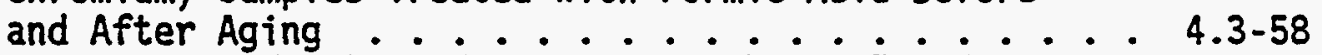

4.3-24 Properties of Melter Feeds Made with SimuTated

HWVP Feed Concentrates (NCAW 84, high chromium)

as the Concentrations and .pH Here Adjusted .... 4.3-59

4.3-25 Data for HWVP Variability Study on Reference Feed

Batch HWS7 (NCAW, high chromium) Test ..... 4.3-63

4.3-26 - Chemicals Used to Generate Synthetic CAW

for RBPS-3 . . . . . . . . . . . . . . . . . .

4.3-27 Summary of the Physical Characteristics of Each

Phase During the Settle-Decant Washing Procedure . . 4.3-69

4.3-28 Mass Accounting of the Original Elements Used to

Generate RBPS-3 CAW at Various Points in the

RBPS-3 Processing Procedure ........ 4.3-70

4.3-29 Distribution of the Original Amount of Each

Element Among the Two Supernatant Fractions and

the Hashed Solids ................... 41

4.3-30 Composition of Washed Synthetic B-piant Feeds

RBPS-2 and RBPS-3 Compared to the Reference . . . 4.3-72

4.3-31 Properties of Synthetic HWVP Feed RBPS-2 as the

Concentration was Increased by Boiling . . . . . 4.3-74

4.3-32 Properties of Synthetic HWVP Feed RBPS-3 as the

Concentration was Increased by Boiling . . . . . 4.3-75

.4.3-33 Range of Major Component Concentrations,

NCAH Waste................. 4-76

4.3-34 Waste Oxide Composition of Simulated NCAW Feeds
Used for Farnsworth Study ... 4.3-77

4.3-35 Compound Concentrations of Simulants Used to . . . 4.3-78

4.3-36 Sample Properties: HWVP Redox Control Studies . . 4.3-79 
4.3-37 Properties of Samples Taken During Processing of Simulated Feeds (NCAH 84, high chromium) for the HWVP-13 Run ............... 4.3-81.

4.3-38 Oxide Compositions of Various Melter Feeds Prepared for the HWVP-14 Feed Composition Variables Tests . . . 4.3-82

4.3-39 Rheological and Physical Properties Data for NCAW 86 Simulant HWS9 .................. 4-87

4.3-40 Comparison of Target Composition and Actual Composition of NCAH 86 (HWS11) Simulated Feed . ... 4.3-90

4.3-41 Properties of Simulated Feed (NCAW 86) Prepared by Precipitating Nitrate Salts with Sodium Hydroxide ........ 4. 4. . . . . . . . 22 4.3-42 PSCM-23 MeTter Feed Composition ........ 4.3-94 4.3-43 Properties of PSCM-23 Feed (NCAN 87) . . . . . . 4.3-95 4.3-44 Supernate and S7udge Data ........... 4.3-97 4.3-45 Potential Ionic Species Contributing to Supernate

4.3-46 Chenical Composition of Selected PSCM-23

4.377 Feed Samples . . . . . . . . 4.3-99

4.3-47 HWVP PSCM-23 Feed Anion Concentration During Formating, Concentrating and Frit Addition . . . . 4.3-102

4.3-48 HWVP PSCM-23 Feed Carbon Content During Formating, Concentrating, and Frit Addition ....... 4.3-103

4.3-49 Range of Formic Acid Additions For Acceptable Adjustment of the Redox States of Various Feeds . . 4.3-138

4.3-50 Physical Property Ranges Encountered by the 32 Melter Feeds ............ 4.3-148

4.3-51 Glass-Forming Fraction in Melter Feed siurry . . 4.3-150 4.3-52 Summary of Laboratory Melter Feed Formating Tests . 4.3-157 4.3-53 Summary of Test Runs . . . . . . . . . 4.3-160 4.3-54 Sunmary of Experimental observations . . . . . . 4.3-162 4.3-55 Experimental Parameters and Data Summary for the

4.3-56 Summary of Formic Acid Observations Preparation for PSCM-23 .................. 4-171

4.3-57 Estimation of the Average Overail Heat Transfer Coefficient During Concentration ....... 4.3-173 Comparison of Boiling Heat Transfer Coefficients... Nozzle Schedule for the TNX Full-Scale SRAT/SME Sludge/Frit Composition for SRAT Batch \#1 .... 4.3-179

4.3-62 Sludge-Only Glass Frit Chemical Compositions and Specifications . .......... 4.3-181

4.3-63 Average Boiling Heat Transfer Coefficients for Water Runs and SRAT/SME \#1 and \#2 ....... 4.3-185

4.3-64 Heat Transfer Results from Water Run and SRAT/SME \#7 and \#8............ 4.3-187

4.3-65 Average Transient Heat Transfer Coefficients for SRAT/SME \#2 ................. 4-188

4.3-66 The Effect of Boi $T$-Up Rate on Condenser DP During Full-Scale SRAT/SME Water Runs ........ 4.3-190 4.3-67 Major Formic Acid Reactions ......... 4.3-191. 
4.3-68 Conversion of Manganese, Nickel and Calcium from the

- Insoluble to the Soluble State for SRAT Batch \#2 .

4.3-69 Slurry Design Bases ........... 4.3-193

4.3-70 Slurry History for SRAT/SME Batch \#1 ....... 4.3-195

4.3-71. SRAT/SME Component Wear Test History - DWPF .... 4.3-202

4.3-72 TNX Pump Hear Measurements (for pump operation

4.4-1 Melter Feed System Operationai Requirements -

4.3-208

4.4-2 HWVP

4.4-2

$4.4-3$

Catalog of Pump Tests - DWPF .

4.4-8

$4.4-4$

Major Pump Parts--Weight Losses for DWPF

4.4-22

4.4-5

Piping Thickness Measurements, mils - DHPF

4.4-23

$4.5-1$ Strainer Data -.DWPF

4.4-24

$4.5-2$

Melter/Turntable Operational Requirements

4.5-2

$4.5-3$

Melter Process Bases - HWVP

4.5-4

Melter Stoichiometry - DHPF

Details of the Melter Runs: HWVP-11, - $12,-13$,

$4.5-5$

and -15

$4.5-6$

$4 \cdot 5-6$

Simulated Waste Fraction of Melter Feed siurry

4.5-7

4.5-7

HWVP Melter Feed Composition

$4.5-24$

Glass-Forming Fraction in Melter Feed siurry

4.5-8

HWVP.

$4.5-25$

. $4.5-27$

$4.5-9$

Summary Data of HBCM Experiment - HWVP

$4.5-27$

4.5-10

Summary Data of PSCM Experiment - HWVP

$4.5-29$

4.5-11

Comparison of Processing Rates Obtained During

HWVP Melter Testing with NCAW-HWVP ........ 4.5-33

$4.5-12$

PSCM Process Flowsheet--Period One.

$4.5-38$

$4.5-13$

PSCM-23 Process Flowsheet--Period Two

$4.5-39$

4.5-14

PSCM-23 Process Flowsheet--Period Three

$4.5-40$

Composition of Melter Feed Samples Taken During

4.5-15

the HWVP-15 Test

$4.5-54$

Composition of Melter Glass Samples Taken During

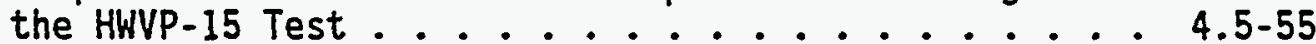

4.5-16 Summary of HWVP Feeding Interruptions ..... 4.5-56

4.5-17 Melter Feed Compositions Tested During HWVP-14 . . 4.5-59

4.5-18 Processing Summary for HWVP-14 ....... 4.5-60

4.5-19 HWVP-15 Giass Pouring Data .......... 4.5-70

4.6-1 Melter Off-Gas System Operational Requirements . . 4. 4-6-4

4.6-2 Calculation of Composite Lower Explosive Limit... 4.6-5

4.6-3 Hanford Waste Vitrification Plant Nominal

Decontamination Factors ........ 4.6-15

4.6-4 Pilot-Scale Ceramic Melter Operating Conditions .. 4.6-16

4.6-5. Size Distribution of Aerosols in PSCM Exhaust

Gas ................... 4.6-17

4.6-6 Elemental Size Distribution Across the Cyclonic

Sampling System - HWVP .......... 4.6-18

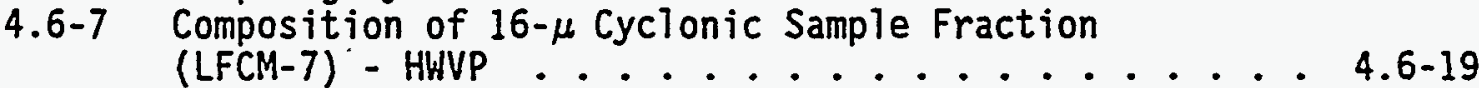

4.6-8 Submicron Particulate Composition (PSCM-4) - ... 4.6-19

4.6-9 Emission Data from LFCM Tests Under Various
Conditions - HWVP ..... 4.6-20 
4.6-10 HWVP-15 Decontamination Factors for Melter

Aerosol ...................... 4-22

4.6-11 WVSP Semivolatile El ement Decontamination Factor . . 4.6-25

4.6-12 WVSP Semivolatile El ement Decontamination Factor.
Results, PSCM-15 . . 4.6.26

4.6-13 WVSP Semivolatile Element Decontamination Factor

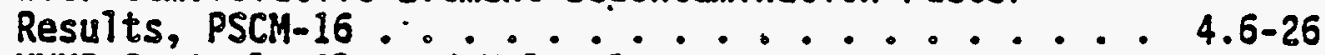

4.6-14 HWVP Semivolatile and Volatile Decontamination

Factor Results - HWVP-12, HWVP-15, HWVP-11 .... 4.6-28

4.6-15. Melter Off-Gas Composition .............6-29

4.6-16 Volatile Melter Effluent Losses ........ 4.6-32

4.6-17. Percent Volatile Melter Effluent Losses . . . . 4.6-32

4.6-18 Qualitative Relationship Between LFCM Feed Types

and Presence of Exhaust-Gas Constituents - HWVP . . 4.6-37

4.6-19 Melter-Generated Off-Gas Components (formate) -

4.6-20 Melter Idiing Deposits - HWVP $4.6-40$

4.6-21 Size Distribution of Melter Aerosols . . . . . . 4.6-44

4.6-22 Comparison Between Compositions of Off-Gas

Jumper Deposits and the Glass .......... 4.6-49

4.6-23 Values for Experimental Parameters . . . . . 4.6-51

4.6-24 Parameter Estimates . . . . . . . . . 4.6-53

4.6-25 Influence of Aerosol on SBS Performance ..... 4.6-54

4.6-26 Experiments Conducted at Intet Temperatures

4.6-28 SBS Gaseous Decontamination Factors . . . . 4.6-82

4.6-29 Volatile SBS Effiuent Losses . . . . . . . 4.6-83

4.6-30 Individual Element Decontamination Factors for

SBS Aerosol .............. 4.6-84

4.6-31 SBS Total Decontamination Factors ...... 4.6-89

4.6-32 Comparative Quench Scrubber Decontamination . . . 4.6-90

4.6-33 Comparison of Compositions of Chevron Demister

and SBS Overflow Solutions ........... 4.6-91

4.6-34 Chevron Demister Hater Collection Rates ...... 4.6-91

4.6-35 Gas Handling Capacities--Type 7014 Systems with ${ }^{\text {Large Nozzles . . . 4.6-93 }}$

4.6-36 Average Operating Conditions for the EvS During HWVP-12 EVS: $6^{\text {"1 }}$ SS Shutte \& Koerting 7014

Ejector Venturi - HWVP . . . . . . . . . 4.6-98

4.6-37 Average Operating Conditions for the $\mathrm{NO}_{x}$ Column

During HWVP-12 - HWVP ...... 4. . . . . . . . 103

4.6-38. Average Operating Conditions for the HSS During HWVP-12 ................... 4.6-106

4.6-39 Hydrosonic Decontamination Factors ...... 4.6-109

4.6-40 Performance Test Results of Single-Stage, Air-

Aspirated Scrubber . . . . . . . . 4.6-110

4.6-41 Average Operating Conditions for the HEME During HWVP-12 - HWVP .............. 4.6-118

4.6-42 HEME Aerosol Decontamination Factors - HWVP ... 4.6-120 
4.6-43 HEME Design Specifications and Operating

Conditions Used in HWVP-15 ......... 4. . . . 6-122

4.6-44 El emental Concentration of HEME Liquid Drain

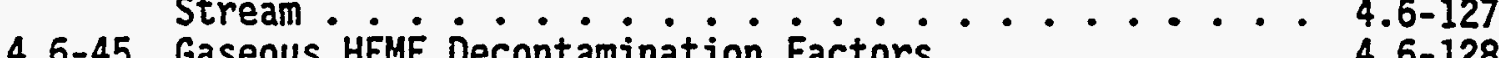

Gaseous HEME Decontamination Factors

4.6-46 HEME Effluent Losses for Condensible Gas Phase

4.6-47 Melter and $\dot{0} \dot{f} \dot{f}-\dot{G} a \dot{s}_{\text {Component Aerosoi Mass }}$

Decontamination Factors ......... 4. . . . . . 129

4.6-48 Individual Element Decontamination Factors for

HEME Aerosol ............... 4.6-133

4.6-49 HEME Total Decontamination Factors ....... 4.6-134

4.6-50 Fractional Penetration of Dry-Process Poly-

disperse Aerosol Through Various HEPA Filter

4.6-5I Composition of the HWVP NCAH 84 (Low Chromium)

Reference Waste, Substituted Haste, and GTass at

4.6-52

a 25 wt\% Oxides Waste Loading

(4.6-150

4.6-53

Elemental DF Values for the Sugar Loadings in the

4.6-54

Four Experiments ............ 4. 4-152

$4.7-1$

Distribution of Iodine in the off-Gas Components

$4.6-153$

$4.7-2$

Compositions of Solutions Used for FY 1987

Corrosion Tests .............. 4-10

4.7-3

Composition of Simulated HWVP Feed, HWS-7

$4.7-11$

Compositions of Candidate Alloys for FY 1987

Corrosion Tests ................ 4-14

4.7-4 Composition of Abrasion Test Siurries .... 4.7-15

4.7-5 Corrosion Rates for Prel iminary Scoping Tests ... 4.7-17

4.7-6 Corrosion Rates for Simulated Welded Coupons . . . 4.7-18

4.7-7 Corrosion Rates for Coupons in Simulated Feed

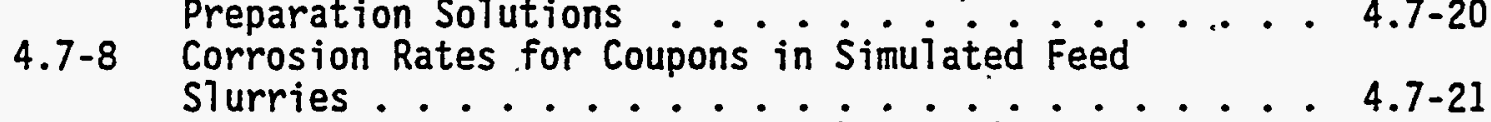

4.7-9 Coupons Corrosion Rates in Simuiated off-Gas

Condensate Solutions ............ 4. 4-22

4.7-10 Wear Rates of Alloy in Abrasive Siurry Tests . . . 4.7-22

4.7-11 Composition of DHTT Simulant Solution . . . . 4.7-28

4.7-12 Corrosion Rates for Materials in Unneutral ized

(pH<1) DWTT Simulant for Anticipated TRU-Recycle

Conditions . . . . . . . . . . 4.7-29

4.7-13 Composition of Neutralized DWTT Simulant Solution . 4.7-30

4.7-14 Corrosion Rates for Materials in Neutralized

(pH-4) DWTT Simulant for Anticipated TRU-Recycle

Conditions ........................ 40

4.7-15 Composition of the Feed Siurry Simulant Chemicaily

Adjusted to Simulate TRU-Recycle Conditions ... . 4.7-31

4.7-16 Corrosion Rates for Materials in Simulated Feed

STurry Under Anticipated TRU-Recycle Conditions . . . 4.7-31

4.7-17 Comparison of DWPF and HWVP Corrosion Test Results . 4.7-33

4.7-18 Materials Selected for the PSCM-23 Materials

Evaluation Tests ................... 4-34 
4.7-19 Coupon Exposure Schedule for PSCM-23 Materials.

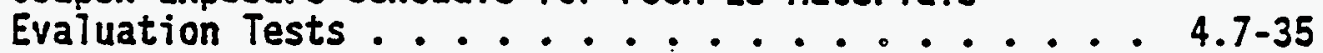

4.7-20 Materials, Conditions, and Corrosion Data for

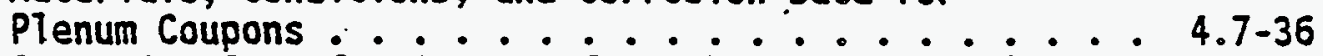

4.7-21 Corrosion Data for Coupons from the SBS Materiai

Evaluation Test ............... 4.36

4.7-22 Estimates of Equipment Fabrication Material Costs : 4.7-38

4.7-23 Operational History of PSCM ......... 4.7-42

4.7-24 Comparative Static Corrosion Rates of Candidate

4.7-25 Analysis of Electrode Corrosion Products $\therefore . \therefore$ 4.7-51

4.7-26 Reference Points for Wall Corrosion Measurements . . 4.7-57

4.7-27 Chosen Conditions for SRL Prel iminary and

Verification Tests ........... 4.7-61

4.7-28 DHPF Cost Estimates for Selected Process Equipment . 4.7-63

4.7-29 Installed Costs of Corrosion-Resistant Piping ... 4.7-63 


\subsection{PROCESS AND EQUIPMENT TECHNOLOGY}

The technology developed for HWVP process and equipment systems is described in this section of the Manual. This description generally follows the format below for each equipment system.

- Function - Presents a statement of the equipment system function.

- Operation Requirements - Indicates process and equipment conditions needed for suitable process operation.

- Process Chemistry - Describes the system process chemistry together with the related reactions and associated conditions

- Process Development - Describes the process and equipment development that has been performed on each equipment system. This includes HWVP, DWPF, WVDP, and other related work.

There are some variations to this format, such as Section 4.1, Waste Form Development, which describes development efforts to determine the chemistry and properties of the glass waste form. 



\subsection{WASTE FORM DEVELOPMENT}

Borosilicate glass has been chosen as the reference waste form for the immobilization of high-level waste (Ref. 4.1-1, 4.1-2). Glass is an amorphous material made of a random network of coordinated structural units. In the case of borosilicate glasses, these networks are composed of silica and boron oxygen polyhedra. Elements, such as $S i$ and $B$, that form the network of the glass are termed network (glass) formers. Elements such as the alkalis (e.g., Li, $\mathrm{Na}$, and $\mathrm{K}$ ) and alkaline earths (e.g., $\mathrm{Mg}$ and $\mathrm{Ca}$ ) provide additional oxygen ions, which modify the network structure and are called network modifiers. Cations of higher valence and lower coordination number than the alkalis and alkaline earths may, either reinforce or further loosen the network and are referred to as intermediates. High-level nuclear waste is generally made up of glass modifiers and intermediates. The principle major waste components incorporated into the glass include $\mathrm{Na}, \mathrm{Fe}, \mathrm{Al}, \mathrm{Cr}, \mathrm{Ni}, \mathrm{Si}$, $\mathrm{Zr}$, Rare Earths, and Mo. The waste also contains a number of important minor components which have only a very limited solubility in glass including $S$, $\mathrm{Cr}$, halides, and noble metals. Some metals, such as $\mathrm{Cs}$ and $\mathrm{Ru}$, have limited volatility at glass processing temperatures. The concentrations of these waste components varies with the waste source and history. Glass formers ( $\mathrm{Si}$ and $B$ in frit) are added to the waste in sufficient quantities to produce the gilass network necessary to incorporate and immobilize the modifier and intermediates from the waste. The frit also contains additional modifiers including $\mathrm{Na}, \mathrm{Li}, \mathrm{Ca}, \mathrm{Mg}$, to adjust glass properties such as viscosity and electrical conductivity to meet processing requirements.

The purpose of the HWVP is to stabilize high-level nuclear defense waste located at the Hanford site into a borosilicate glass waste form. This glass waste form must meet the property requirements established for waste form qualification (Section 3.1.2) and be compatible with plant equipment required for processing glass. Melt property requirements are presented below with a description of the reference glass development process and the current HWVP reference glass. The composition of the waste feed is limited by the definition of acceptable properties and composition range of the glass that will be produced. These feed composition limitations result in HWVP feed specifications for HWVP pretreatment (Section 3.1.1). A summary of feed/glass composition variability effects is also presented.

\subsubsection{Giass Waste Property Requirements.}

This section describes the properties required for processing HWVP HLW glass waste forms. There are two areas of meit and glass property limitations of concern in HLH vitrification: 1) those required for HWVP melter processability, and 2) those required for waste form qualification/repository acceptance of the glass. Nuclear waste glass compositions must have acceptable high-temperature properties for efficient melter performance and must have acceptable product properties for storage, transportation, and repository disposal. Key waste form properties and their acceptance criteria are shown below: 
Process Property.

Viscosity (100 poise temperature)

Electrical conductivity (at $1150^{\circ} \mathrm{C}$ )

Phase Behavior

Liquidus

Phase Separation

S7udge Formation (crystals)

Melting Behavior

Low foaming tendency

Acceptable processing rate

$-\frac{\cdots}{-}$

Waste Acceptance Property

Durabitity

$\mathrm{MCC}-1$

PCT

Glass transition temperature

Devitrification
Criteria

$1050-1150^{\circ} \mathrm{C}$

$0.18-0.5(\mathrm{ohm}-\mathrm{cm})^{-1}$

$\leq 1050^{\circ} \mathrm{C}$

No Tiquid phase separation

(Element concentration limits individualiy determined in laboratory studies)

$\mathrm{Fe}^{++} / \mathrm{Fe}^{+++}<0.3$ (Minimize melter metals and sludge formation)

$\mathrm{Fe}^{++} / \mathrm{Fe}^{+++}>0.005$

Determined in pilot scale studies

Criteria

$\leq 1 \mathrm{~g} / \mathrm{m}$-day, 28-day MCC-1,10m-1 none

descriptive

Time/temperature/transformation descriptions

4.1.1.1 Glass and Melt Processing Requirements. Key properties for vitrification processing in currently designed joule-heated ceramic melters are discussed below.

4.1.1.1.1 Viscosity. For melter operation, the temperature at which the glass has a viscosity of 100 poise (TIOOP) should be between $1050^{\circ} \mathrm{C}$ and $1150^{\circ} \mathrm{C}$. In the glass industry and based on melter operation experience at PNL, melting of glasses at economical rates ordinari.ly proceeds at the T100P. (a) (b) However, because at higher T100P the glass tends to have

(a) H. E. Hagy, et aI., "Physical Properties of GTass." Chapter 17 in The Handbook of Glass Manufacture, ed. F. V. Tooley, pp. 933-937, Books for Industry, Inc. New York (1974).

(b) L. A. Chick, J. L. Swanson, and D. S. Goldman, "Nuclear Waste Glass Composition Limitations." In Proceedings of Fuel Reprocessing and Waste Management, Vol. 1. American Nuclear Society, Inc. LaGrange Park, Illinois (1944). 
greater durability. For this reason, it is important to process the glass at as high a temperature as possible to lower the release of radionuclides.

Because the operating temperature of the melter and bottom drain has been set at 1050 to $1150^{\circ} \mathrm{C}$, the glass must have the required viscosity in this temperature region. The $1150^{\circ} \mathrm{C}$ T100P upper limit is the same as the DWPF upper limit of 100 poise at $1150^{\circ} \mathrm{C}$. The lower 7 imit of a $1050^{\circ} \mathrm{C}$ T100P is approximately the same as DWPF's 20 poise at $1150^{\circ} \mathrm{C}$. While the slope of glass viscosity versus temperature can vary somewhat, it is similar for most glasses of the type to be processed within the HWVP. Therefore, a glass with a T100P of $1050^{\circ} \mathrm{C}$ will have a $1150^{\circ} \mathrm{C}$ viscosity of approximately 20 to 40 poise. The use of T100P allows for changing the standard operating temperature of the melter to temperatures 10 wer than the maximum of $1150^{\circ} \mathrm{C}$ if needed. The T100P requirement has been used and. tested in pilot- and engineering-scale melters and is maintained to draw on the vast melter experience which has been generated at PNL.

If the T100P is outside this range, processing problems may be encountered in the melter. If the viscosity of the glass is too low, glass penetration into the melter bricks and increased corrosion of melter tank components (due to high convection currents) may occur. If the viscosity is too high, the interaction between the glass melt and the cold cap may be reduced, thus slowing the processing rate. A. high-viscosity glass would also be more difficult to pour from the melter and may not form a consolidated monolith in the canisters. The glass viscosity should also remain stable with time to allow stable melter operation.

\subsection{Electrical Conductivity. In joule-heated ceramic melters} designed at PNL, the electrical conductivity of the glass melt should be 0.18 to $0.5 \mathrm{ohm}^{-1} \mathrm{~cm}^{-1}$ at $1150^{\circ} \mathrm{C}$ (see Appendix B). (a) If the electrical conductivity of the glass is too high, the current required to heat the glass will exceed the recommended maximum current density for the melter electrodes. If the electrical conductivity of the glass is too low, the resulting voltage potential of the electrodes would be such that conduction could occur within the melter glass pool: Low electrical conductivity could also cause melter start-up difficulties unless undesirably large electrical power systems are supplied.

4.1.1.1.3 Phase Behavior. No excessive crystallization or phase separation should be present in the melter glass. Inhomogeneous phases may occur in the melter and glass in two ways: material from the melter feed failing to melt and dissolve into the glass, and/or the solubility of a phase in the glass melt may be exceeded resulting in a formation of crystalline or 7 iquid phases. The presence of insoluble and non-molten phases may increase the rate at which a sludge forms on the bottom of the melter, clogging areas within the melter, and/or cause shorting the melter electrodes. No significant liquid-liquid phase separation should be present in the glass produced. A liquid-liquid phase, such as an alkali-sulfate phase, may result in the segregation of radionuclides such as cesium into a less durable phase. These

(a) HWVP Monthly Report from PNL to Rockwe]1 Hanford Company (December 1984). 
Tiquid-Tiquid phases may interrupt or interfere with processing due to excessive volatility causing off-gas system problems, electrical shorting through the phase due to increased electrical conductivity, and/or increase corrosion to refactories or metal melter components.

The minimum temperature at which the waste and frit are molten with only minor crystalline phases present (such as the insoluble noble metals) is called the liquidus temperature. The DWPF criteria for liquidus is $\leq 1050^{\circ} \mathrm{C}$. The criteria set by DWPF has been adopted by HWVP. The amount of crystallinity that can be tolerated with the melter has not yet been determined. There should be no detectible liquid-liquid phase separation. PNL experience (a) indicates that the redox state $\left(\mathrm{Fe}^{++} / \mathrm{Fe}^{+++}\right)$of the glass. should be maintained below 0.3 to minimize sludge (metal and perhaps crystalline) formation in the melter bottom.

4.1.1.1.4 Melter Behavior. The glass in the melter must not foam such that the foam will impair melter processing capacity and operation. PNL experience indicates that significant foaming will not occur if the redox state $\left(\mathrm{Fe}^{++} / \mathrm{Fe}^{+++}\right)$of the glass is maintained $\geq 0.005$. Using the redox criterion, metals such as $\mathrm{Cn}, \mathrm{Mn}$, and other transition metals that can release oxygen in the melt on being reduced, causing foaming (reboil), are reduced in feed preparation (formating) or the melter cold cap. Thus, significant foaming is avoided.

It is also necessary to perform pilot-scale melting tests to ensure that the melter feed can be processed at an adequate rate $\left(1 / \mathrm{h} \cdot \mathrm{m}^{2}\right)$ to satisfy plant production requirements of vitrified glass. For example, if the glass production requirement is $50 \mathrm{~kg} / \mathrm{h}$, the melter surface area is $2 \mathrm{~m}^{2}$, and the reference melter feed total oxide loading is $0.5 \mathrm{~kg} / \mathrm{L}$, then pilot-scale tests would need to demonstrate a processing rate of $\geq 50-L$ feed $/ h \cdot m^{2}$.

\subsubsection{Haste Acceptance Preliminary Specification (WAPS) Requirements.}

GIass properties requirements specified in the WAPS(D) are of two types: specifications for radionuclide release properties (durability), and specifications for chemical and phase stability. These two requirements are discussed separately below.

4.1.1.2.1 Radionuclide Release Properties. The HAPS will require HWVP to document the radionuclide release properties of the HWVP waste form. At this time, the specific leach test(s) and maximum limits for elemental releases have not been estabi ished. The DWPF HAPS currently requires that the waste form be capable of limiting normalized elemental release rates for

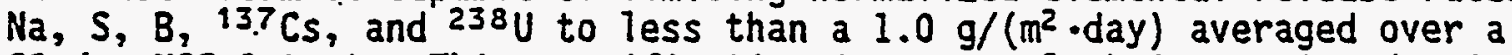
28-day MCC-1 test. This specification is currently being reviewed. Once the WAPS release limits are established, the reference glass composition envelope can be defined with respect to dissolution properties. The MCC-1 leach test

(a) S. O. Bates, B. S. Goldman, and W. C. Richey, HWVP Baseline Milestone HWVP-85-020207A A Letter Report Summarizing the Sulfate/Redox Relationship to Glass Melting Chemistry and Behavior. PNL, Richland, Washington (1985).

(b) J. L. Nelson, Preliminary HWVP Waste Form Qualification Plan - FY 1988 Update. HHC-EP-0045, HHC, Richland, Hashington (1988). 
procedure, issued by the Materials Characterization Center (MCC) (a) is widely used, and is expected to fulfill the durability testing requirements of the HAPS.

4.1.1.2.2 HAPS Chemical and Phase Stability. Devitrification of the glass can also affect the glass durability. Currently, there is no limitation specified in the WAPS as to the amount of crystali ine material allowable in the glass produced. However, the phases present must be characterized. Glasses will be evaluated under a heat-treatment that simulates the nominal canister centerline thermal conditions expected during the cooling of the filled HWVP canister in the reference open canister turntable. Timetemperature-transformation information for the HWVP glass product is required by the WAPS but no limiting conditions (other than the release properties mentioned above) have been specified. Because HWVP is qualifying a large compositional region as its reference glass, the $\Pi T$ characteristics may vary significantly over the established reference glass envelope.

\subsubsection{Reference Glass Development}

The HWVP reference glass is the nominal target composition for the glass waste form expected to be produced in the HWVP from the vitrification of pretreated NCAW. The development of a reference glass is an iterative process involving interaction between waste/feed pretreatment, glass formulation and characterization, feed melting chemistry and rheology, and short- and longterm melter tests. The development procedure (Figure 4.1-1) starts with the establishment of a front-end process and waste composition that determines the composition of the pretreated HWVP feed. Using the nominal pretreated waste composition, a glass oxide composition is developed based on laboratory melts. Properties such as melt viscosity, electrical conductivity, phase behavior, waste loading, and chemical durability (leach testing) are evaluated. These properties do not significantly depend on the chemical form of the starting materials but rather on the final oxide composition of the glass.

Economics must also be considered when developing nuclear waste products and processes. Key economic factors are the waste content in the glass product (waste loading) and the melting behavior of the feed. The waste loading determines the quantity of glass to be produced and transported for disposal. The lower the waste loading, the greater will be the number of filled canisters that will have to be disposed of. for a given quantity of waste. Melting efficiency determines melter processing rate, and thus the duration of the processing campaign. Elements that produce crystallinity (i.e., $\mathrm{Fe}, \mathrm{Al}$, $\mathrm{Cr}$, and noble metals) gerierally limit the waste loading for defense wastes. These waste loadings fall in the narrow range from 22 to 33 wt\%. Noble metals have a negligible solubility in glass. However, these compositions are for streams that were already pretreated to yield reasonable waste loadings and manageable glass volumes.

(a) Operated by the Pacific Northwest Laboratory, Richland, Washington. 


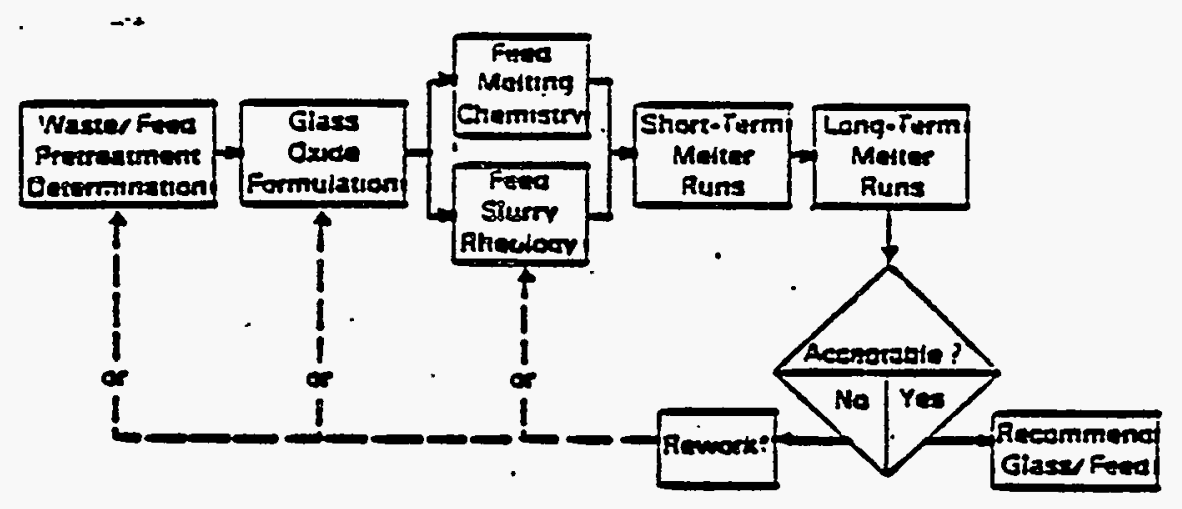

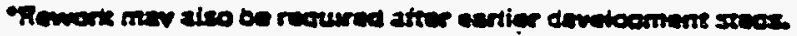

FIGURE 4.1-1. G7ass/Feed Development Flowsheet

Once an acceptable oxide glass composition is developed, properties that depend on the chemical form of the starting materials are tested using a simulated slurry melter feed. Melt redox response, melting behavior, and rheological properties are tested and adjusted in candidate feed slurry simulations made in the Taboratory. Once a slurry feed composition is developed that has acceptable rheological and Taboratory melting properties, short- and long-term engineering-scale melter tests are conducted. The processing characteristics of the feed simulation and the glass composition are evaluated under engineering-scale processing conditions.

In summary, the task of the nuclear waste glass developer is to formu- Tate a glass that can be processed with a balance of properties.. The glass requires the an acceptable waste loading and melting behavior to produce a solid product with high chemical durability.

4.1.2.1 Reference Glass Development Background. Reference NCAW glass development was initiated in 1984 using a NCAW composition provided by Rockwell based on PUREX and B-Plant flowsheet estimates. (a) This composition, NCAH 84 with high chrome waste, served as the reference waste feed for reference waste glass development in fiscal years 1985, 1986, and part of 1987 . A reference glass, designated as HW39-1, was developed that meets waste form product quality requirements.(b) (c) The HH39 glass showed significant

(a) Letter from K. R. Shah to J. E. Minor, "Recommended NCAW/CRW Blend Feed Stream Composition and Range for PNL, FY 1985 HWVP Glass Formulation. Studies," R84-3725 (October 1984).

(b) S. 0. Bates, Baseline Milestone HWVP-85-V020202B: Issue a Recommended HWVP Glass Composition for Future Hork. Pacific Northwest Laboratory, Richiland, Washington (1985).

(c) S. O. Bates and M. A. Reimus, HWVP Baseline Milestone HWVP-86-V1122B: Hanford Haste Vitrification Program Reference Glass Development FY 1986 Summary Report. Pacific Northwest Laboratory, Richland, Washington (1986). 
crystallinity due to the relatively high $\mathrm{Cr}_{2} \mathrm{O}_{3}$ concentration in the HH39-1 glass composition $\left(1.33 \mathrm{wt} \% \mathrm{Cr}_{2} \mathrm{O}_{3}\right)$. The crystals present were a cubic spinel $\left(\mathrm{FeC}_{2} \mathrm{O}_{4}\right)$ phase. Another $\mathrm{Cr}$ phase, hexagonal platelets of $\mathrm{Cr}_{2} \mathrm{O}_{3}$, was also observed in some laboratory meits and melter-produced glasses when the maximum melt temperature approached or exceeded $1250^{\circ} \mathrm{C}$.

A supernate sample from HLH storage tank 101-AZ was taken in 1985 and evaluated. (a) The evaluation indicated that the major fraction of chromium in the tank, 85 to $96 \mathrm{wt \%}$, could be in the supernate and waste pretreatment solids wash solution. Initial studies $(b)$ indicated that the chromium in the stored HLH would be essential7y insoluble. Limited PNL screening studies (c) were performed to assess the effects of chromium reduction from 1.33 wt\% in glass from NCAW 84--high chrome waste to 0.14 wt\% using the same waste loading and HW39 frit. This pretreated HWVP low-chrome waste was designated as NCAW 84--10W chrome waste. A FY 1987 study of the NCAW 84--10w chrome waste base case evaluated the effects on viscosity, efectrical conductivity, and phase behavior of varying $\mathrm{Fe}$ with low $\mathrm{Cr}, \mathrm{Ca}, \mathrm{F}, \mathrm{Ba}, \mathrm{Mn}, \mathrm{Mo}$, and $\mathrm{Ni}$. The NCAW 84-- - T Ow chrome waste provided an acceptable glass, HH39-2, where the only crystalline phases were associated primarily with noble metals ( $R u$, $R h$, and $\mathrm{Pd}$ ).

Further analyses of the Rockwell waste and PNL glass development data provided the bases for the initial HWVP feed specification. (d) This feed specification modified the reference HWVP waste feed composition, NCAW 86, that was used as the bases for further reference glass development by PNL. The NCAW 86 composition provided the bases for reference waste glass devel-. opment in FY 1987. A 1jmited characterization of the glass, HW39-3, from NCAW 86 waste was made. (e) The data base for glass characteristics using NCAW 86 waste and HW39 frit is not as comprehensive as that developed for the previous reference glass HW39-1, based on NCAW 84--high-chrome waste. Thus, where glass properties are needed for design and engineering studies, and are not available for glass from NCAW 86 waste, the HW39-1 glass properties

(a) Internal letter from J. L. Scott to J. J. Zimmer, "Potentially High Chromium Levels in Grout Facility Feed," 65652-86-030, Rockwell Hanford Operations, Richl and, Hashington (ApriT 26, 1986).

(b) Letter from W. A. Robertson to M. W. Gibson, "NCAW Sludge Washing Studies: Analys is of Laboratory Data," Rockwell Hanford Operations, Richland, Washington. (August 7, 1985).

(c) . S. 0. Bates, Interim Milestone HWVP-87-V110202C - Report on FY 1987 G]ass Variability Testing Conducted for the Hanford Waste Vitrification Program. Pacific Northwest Laboratory, Richland, Washington (JuTy 1987).

(d) R. N. Wagner, Hanford Haste Vitrification Plant Feed Specification. SD-HWV-OCD-001, Rev. 0, Rockwell Hanford Operations, Richland, Washington (September 1986).

(e) S. 0. Bates, Baseline Milestone HWVP-87-V110202A - Haste Form Evaluation of the Updated NCAW Composition. Pacific Northwest Laboratory, Richland, Washington (April 1987). 
should be used. These properties are felt to be similar to the properties of the reference glass generated from NCAN 86 feed and are acceptable for preliminary design.

Continuing studies by WHC have further defined the reference waste composition. (a) The evaluation of FY 1986 aging waste samples, the development of computer model material balance flowsheets for PUREX waste and NCAH pretreatment at B Plant, and the results of the B Plant NCAN process test have provided an additional data base. This information was used to develop an updated reference pretreated NCAW waste composition, NCAW 87, which is provided in the revised waste feed specification for HWVP. (a) The primary differences between the NCAN 86 and NCAN 87 waste compositions are as follows:

\begin{tabular}{|c|c|c|}
\hline \multirow[b]{3}{*}{$\begin{array}{l}\mathrm{SiO}_{2} \\
\mathrm{U}_{3} \mathrm{O}_{8} \\
\mathrm{P}_{2} \mathrm{O}_{5} \\
\mathrm{CdO}^{-}\end{array}$} & \multicolumn{2}{|c|}{ wt\% Haste Oxide } \\
\hline & NCAH 86 & NCAH 87 \\
\hline & $\begin{array}{l}9.0 \\
0.7 \\
0.02 \\
0.02\end{array}$ & $\begin{array}{r}4.0 \\
4.7 \\
0.4 \\
3.0\end{array}$ \\
\hline
\end{tabular}

Limited glass product development(b) was performed using the NCAW 87 waste composition to provide a product formulation for the pilot-scale ceramic melter test No. 23 performed in FY 1988, HW39-4.

- There are a variety of other potential waste feed streams to the HWVP which have only been partially characterized, sych as complexant concentrate (CC) and plutonium finishing plant (PFP) waste. (C) Characterization of single shell tank (SST) waste for processing in HWVP is in a very early

= stage. There has been no product development effort on these waste streams.

= 4.1.2.2 Reference HWUP Glass Formulation. Laboratory programs have been performed to formulate and characterize nominal reference HHVP glass product based on several HWVP NCAW feed compositions. The nomenclature for reference glasses has been established as HW39-x, where $x$ is a numerical identifier indicative of an established HWVP feed composition. Laboratory test glasses are also used to investigate various glass characteristics. These test glasses are called out as $H H-x x$, where $x x$ is a numerical identified exclusive to that test glass composition.

(a) J. D. Hright, HWVP Technical Data Package. SD-HWV-DP-001, Westinghouse Hanford Company, RịchTand, Hashington (1988).

(b) R. H. Goles et al., Hanford Waste Vitrification Program, Pilot-Scale Ceramic Melter Test Number 23. HWVP-89-IVJ0010100B, Pacific Northwest Laboratory, Richland, Hashington (September 1988).

(c) J. M. Perez et al., Update Evaluation on Characterization of the Potential Complexant Concentrate and Plutonium Finishing Plant HWVP Feed Streams. HWVP-87-V110201A, Pacific Northwest Laboratory, Richland, Washington (September 1987). 
Nominal

Reference

Class

HWVP Waste Feed

HW39-1 The glass is prepared from NCAH 84 (high chromium) reference HWVP feed and the HH39 frit. Previous nomenclature was HW39 (high chromium) glass.

HW39-2 The glass is prepared from the NCAW 84 (Tow chromium) reference feed and HW39 frit. The previous nomenclature was HW39 (Jow chromium) feed and HW39 frit.

HW39-3 The glass is prepared from the nominal NCAH 86 feed and HW39 frit. There was no previousiy assigned nomenclature for this glass.

HW39-4 This glass composition was developed for the FY 1988 Pilot-Scale Ceramic Melter run, previously called HW46. The HW46 g7ass was based on the NCAW 87 reference feed in combination with a new HH46 frit. Four HWVP reference glass formulation efforts are discussed in the following sections.

4.1.2.2.1 Reference Glass Composition. The initial neutraljzed current acid waste (NCAH) (Table 4.1-1) composition was received by PNL (a) in October 1984. A simulated waste was developed for use in glass development by substitution for or deleting some waste components. Substitutions were made on a molar basis for radioactive and/or hazardous materials (Table 4.1-1). Waste components with very low concentrations in the waste were deleted. Some of the noble metals were also deleted due to their low concentrations, high costs, and relatively inert behavior on borosilicate glasses. A refer; ence glass formulation was developed in FY 1985 and is designated HW39-1. (b) The waste loading of this glass is 25 wt\% oxides. Tabie 4.1-1 shows the NCAW reference feed and the frit composition required to produce the HW39-1 nominal reference glass composition.

The nominal compositions of the reference NCAW waste (NCAH 84) with reduced $\mathrm{Cr}_{2} \mathrm{O}_{3}$ and HW39-2 glass are shown in Table 4.1-2. (c) In 1986, it was determined that approximately nine-tenths of the chrome in the NCAW would be

(a) Letter, K. R. Shah to J. E. Minor, "Recommended NCAW/CRW Blend Feed Stream Composition and Range for PNL, FY 1985. HWVP Glass Formulation Studies." Letter R84-3725, Pacific Northwest Laboratory, Richland, Washington (October 18, 1984).

(b) S. 0. Bates, Recommended HWVP Glass Composition for the NCAW-CRH Stream for Future Work. HWVP Basel ine Milestone 020202B, Pacific Northwest Laboratory, Richl and, Washington (1985).

(c) S. 0. Bates, HWVP DOE Milestone: Issue Glass Formulation of Neutralized Current Acid Waste (NCAW). Pacific Northwest Laboratory, Richland, Washington (1986). 
TABLE 4.1-1. Composition of the HWVP Reference Haste (NCAW 84 HighChromium).; Substituted Waste, and HW39-1 Glass at a 25 wt\% Oxide Waste Loading HWVP-88-V110205A

\begin{tabular}{|c|c|c|c|c|}
\hline Oxide & $\begin{array}{l}\text { Normalized } \\
\text { Waste } \\
\text { Wt\% Oxide }\end{array}$ & $\begin{array}{l}\text { Substituted } \\
\text { Waste Nor. } \\
\text { Wt\% Oxide }\end{array}$ & $\begin{array}{c}\text { Frit } \\
\text { Wt\% Oxide }\end{array}$ & $\begin{array}{c}\text { Glass } \\
\text { Wt\% Oxide }\end{array}$ \\
\hline 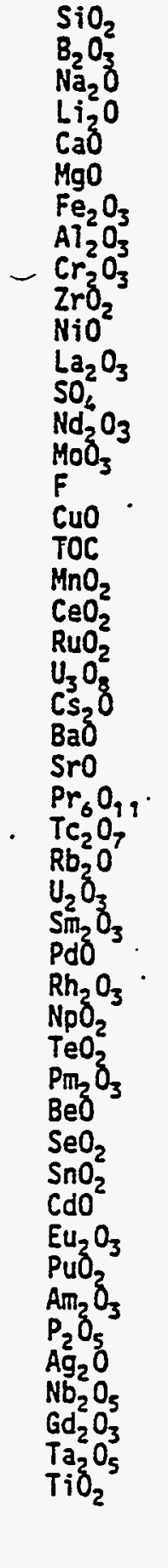 & $\begin{array}{r}2.9 \\
0.0 \\
10.5 \\
0.0 \\
0.3 \\
0.2 \\
44.0 \\
17.0 \\
5.3 \\
2.3 \\
2.3 \\
2.3 \\
1.2 \\
1.8 \\
1.7 \\
1.2 \\
1.2 \\
0.6 \\
0.6 \\
0.6 \\
0.6 \\
0.6 \\
0.6 \\
0.6 \\
0.6 \\
0.4 \\
0.4 \\
0.4 \\
0.4 \\
0.4 \\
0.2 \\
0.2 \\
0.2 \\
0.2 \\
0.2\end{array}$ & $\begin{array}{c}3.0 \\
0.0 \\
0.7 \\
10.7 \\
0.0 \\
0.3 \\
0.3 \\
44.4 \\
17.2 \\
5.3 \\
2.4 \\
2.4 \\
2.2 \\
1.8 \\
2.1 \\
1.2 \\
1.2 \\
0.6 \\
0.6 \\
0.7 \\
0.7 \\
0.6 \\
\text { SUB Nd } \\
1.0 \\
0.4 \\
0.4 \\
0.4 \\
\text { SUB Mn } \\
\text { SUB CS } \\
0.2 \\
0.2 \\
D E L \\
D E L \\
\text { SUB Ce } \\
D E L \\
\text { SUB Nd } \\
\text { SUB Mg } \\
D E L \\
D E L \\
D E L \\
\text { SUB Nd } \\
\text { SUB Ce } \\
\text { SUB Nd } \\
D E L \\
D E L \\
\text { SUB HO } \\
0.01 \\
D E L \\
D E L \\
100.00 \\
\text { SOL }\end{array}$ & $\begin{array}{l}67.25 \\
12.75 \\
10.25 \\
5 \\
3.75 \\
1\end{array}$ & $\begin{array}{r}51.3 \\
9.6 \\
10.4 \\
3.8 \\
2.9 \\
0.8 \\
11.1 \\
4.3 \\
1.3 \\
0.6 \\
0.6 \\
0.5 \\
0.4 \\
0.5 \\
0.3 \\
0.3 \\
0.1 \\
0.2 \\
0.2 \\
0.1 \\
0.2 \\
0.1 \\
0.1 \\
0.1 \\
\\
\\
0.04 \\
0.04\end{array}$ \\
\hline
\end{tabular}


TABLE 4.1-2. Compositions of NCAW 84 Reduced Cr203 Reference Haste and HW39-2 Glass at a 25 wt\% Oxides Waste Loading HWVP-87-VI1202C

\begin{tabular}{|c|c|c|c|c|c|c|c|}
\hline Oxide & $\begin{array}{c}\text { As-Received } \\
\text { (kg/MTU) }\end{array}$ & $\begin{array}{l}\text { Normalized } \\
\text { Haste } \\
\text { (wt\% oxide) }\end{array}$ & $\begin{array}{c}\text { Substituted } \\
\text { Waste } \\
\text { (wt\% oxide) }\end{array}$ & $\begin{array}{l}\text { Substituted } \\
\text { Waste Hor. } \\
\text { (wt\% oxide) }\end{array}$ & $\begin{array}{l}\text { Substituted } \\
\text { Haste Nor. } \\
\text { Ho TOC }\end{array}$ & $\begin{array}{l}\text { HW39 Frit } \\
\text { (wt\% oxide) }\end{array}$ & $\begin{array}{c}\text { Glass } \\
\text { (wt: oxide) }\end{array}$ \\
\hline 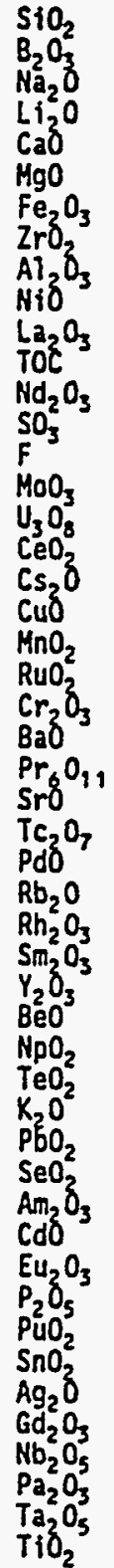 & $\begin{array}{l}0.50 \\
0.00 \\
1.8 \\
0.00 \\
0.05 \\
0.04 \\
7.5 \\
0.4 \\
2.9 \\
0.40 \\
0.37 \\
0.10 \\
0.29 \\
0.25 \\
0.20 \\
0.20 \\
0.10 \\
0.10 \\
0.10 \\
0.10 \\
0.10 \\
0.10 \\
0.09 \\
0.07 \\
0.06 \\
0.06 \\
0.06 \\
0.03 \\
0.04 \\
0.03 \\
0.03 \\
0.03 \\
0.01 \\
0.02 \\
0.02 \\
0.00 \\
0.00 \\
0.01 \\
0.00 \\
0.00 \\
0.00 \\
0.00 \\
0.00 \\
0.00 \\
0.00 \\
0.00 \\
0.00 \\
0.02 \\
0.00 \\
0.00 \\
\end{array}$ & $\begin{array}{c}3.09 \\
0.01 \\
11.1 \\
0.00 \\
0.31 \\
0.25 \\
46.3 \\
2.5 \\
17.9 \\
2.47 \\
2.28 \\
0.62 \\
1.79 \\
1.54 \\
1.23 \\
1.23 \\
0.62 \\
0.62 \\
0.62 \\
0.62 \\
0.62 \\
0.62 \\
0.56 \\
0.43 \\
0.37 \\
0.37 \\
0.37 \\
0.19 \\
0.25 \\
0.19 \\
0.19 \\
0.19 \\
0.06 \\
0.12 \\
0.12 \\
0.00 \\
0.00 \\
0.03 \\
0.02 \\
0.02 \\
0.02 \\
0.02 \\
0.02 \\
0.02 \\
0.01 \\
0.01 \\
0.01 \\
0.12 \\
0.01 \\
0.01 \\
\end{array}$ & 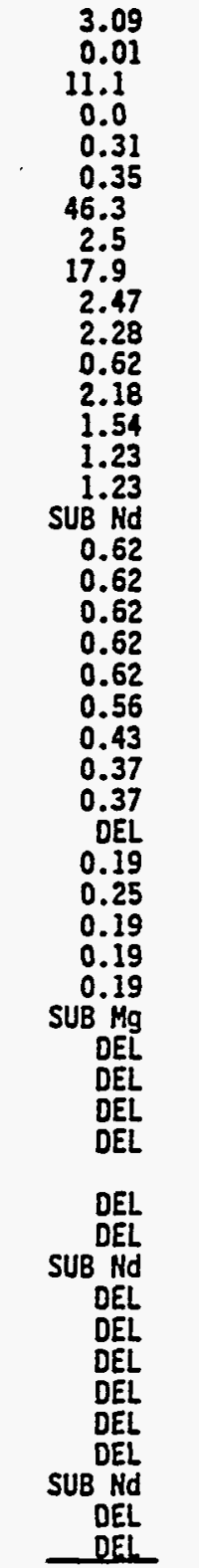 & $\begin{array}{c}3.12 \\
0.01 \\
11.2 \\
0.0 \\
0.31 \\
0.35 \\
46.8 \\
2.5 \\
18.1 \\
2.50 \\
2.31 \\
0.62 \\
2.20 \\
1.56 \\
1.25 \\
1.25 \\
\text { SUB Nd } \\
0.62 \\
0.62 \\
0.62 \\
0.62 \\
0.62 \\
0.56 \\
0.44 \\
0.37 \\
0.37 \\
D E L \\
0.19 \\
0.25 \\
0.19 \\
0.19 \\
0.19 \\
\text { SUB Mg } \\
\text { DEL } \\
0 E L \\
D E L \\
D E L \\
D E L \\
D E L \\
D D E \\
\text { DUB Nd } \\
D E L \\
0 E L \\
D E L \\
D E L \\
0 E L \\
D E L \\
\text { SUB Nd } \\
0 E L \\
D E L \\
\end{array}$ & 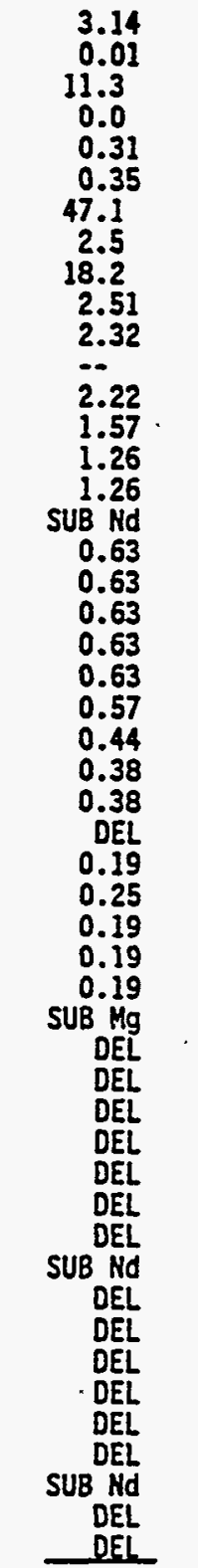 & $\begin{array}{c}67.25 \\
12.75 \\
10.25 \\
5.00 \\
3.75 \\
1.00\end{array}$ & $\begin{array}{r}51.22 \\
9.56 \\
10.51 \\
3.75 \\
2.89 \\
0.84 \\
11.78 \\
0.63 \\
4.55 \\
0.63 \\
0.58 \\
0.00 \\
0.55 \\
0.39 \\
0.31 \\
0.31 \\
0.16 \\
0.16 \\
0.10 \\
0.16 \\
0.16 \\
0.14 \\
0.11 \\
0.09 \\
0.09 \\
0.05 \\
0.05 \\
0.06 \\
0.05 \\
0.05 \\
0.05\end{array}$ \\
\hline & 16.203 & 100.000 & 98.969 & 100.000 & 100.000 & 100.000 & 100.000 \\
\hline
\end{tabular}


washed out during pretreatment. (a) When the low- $\mathrm{Cr}_{2} \mathrm{O}_{3}$ NCAW 84 is added to the reference frit, HW39, at a 25 wt\% oxides waste loading as shown in Table 4.1-2, the glass composition HW39-2 is produced.

The composition of the NCAW. 86 waste was received from Rockwell in November 1986. Using the NCAH 86 waste composition, a substituted waste composition was calculated for laboratory glass development and slurry rheology studies (Table 4.1-3). In the substituted composition, minor components (s0.I wt\% in the waste) and TC were deleted from the waste. Because no adequate substitute for Tc was identified, Tc was deleted rather than adding a nonrepresentative substitute. The total weight percent of deleted components is 0.91 wt\% of the waste. Uranium was replaced on a molar basis with Nd to eliminate the difficulties associated with working with radioactive compositions. Haste variability scoping studies have indicated that the effects of $\mathrm{U}_{3} \mathrm{O}_{8}$ and rare earth oxides on glass viscosity and electrical conductivity are very similar. (b) Neodymium was also used as a substitute for other minor rare earth oxides (except La) for simplicity. Magnesium. was substituted for $\mathrm{Be}$ on a molar basis because of the toxicity of $\mathrm{Be}$. These substitutions have been used in previous HWVP glass variability studies.

A glass/frit composition was formulated for the updated neutralized current acid waste (NCAH 87) composition. (C) The composition modification was necessary due to differences between the updated NCAW composition (NCAW 87) and the previous NCAH composition (NCAH 84), which affected the glass processing properties, such as viscosity, when using the associated NCAK 84 glass frit. The major differences between the two waste compositions are lower concentrations of $\mathrm{Fe}_{2} \mathrm{O}_{3}, \mathrm{AT}_{2} \mathrm{O}_{3}$, and $\mathrm{Cr}_{2} \mathrm{O}_{3}$, and higher concentrations of $\mathrm{Na}_{2} \mathrm{O}, \mathrm{ZrO}_{2}$, and CdO in NCAH 87. Glass formulation for the PSCM-23 test was based on the NCAW 87 composition. The resultant glass/frit composition has been designated HW39-4. The compositions of NCAH 87, the HW39-4 frit, and resulting HW39-4 glass are presented in Table 4.1-4.

Because of the lower total concentrations of transition metals in the composition of NCAH 86 compared with NCAN 84, particularly $\mathrm{Cr}_{2} \mathrm{O}_{3}$, it was felt that the NCAW 86 waste loading could be increased significantly. The transition metals are the common sources of significant dense phase formation in waste glass melts. The $\mathrm{Cr}_{2} \mathrm{O}_{3}$ concentration was reduced to 0.5 wt\% in NCAH 86 compared with 5.3 wt\% in NCAH 84, and the $\mathrm{Fe}_{2} \mathrm{O}_{3}$ concentration was reduced to 28 wt\% compared with 44 wt\%. Any increase in the waste loading of the glass

(a) R. N. Hagner, Hanford Waste Vitrification Plant Feed Soecifications: Pretreated NCAW Feed. RHO SD-HWV-OCD-001 Rev. 0., Rockwell Hanford Operations, Richland, Hashington (1986).

(b) S. 0. Bates and H..M. Bowen, Interim Milestone HWVP-86-V1122C Report on Composition Variabi.lity Testing Conducted for the Hanford Waste Vitrification Program. Pacific Northwest Laboratory, Richland, Washington (1986).

(c) G. D. Hright, Hanford Waste Vitrification Plant Technical Data Package. SD-HWV-DP-001, Rev. 4, Westinghouse Hanford Company, Richland, Washington (1988). 
TABLE 4.1-3. Updated NCAW Waste Composition, HH39-3 GTass Development (with Noble Meta7s), All Values in Oxide wt\% HWVP-87-V110202A

\begin{tabular}{|c|c|c|c|c|c|}
\hline \multirow[b]{2}{*}{ Oxide } & \multirow[b]{2}{*}{ As-Received } & \multirow{2}{*}{$\begin{array}{l}\text { NCAW } 86 \\
\text { Normalized } \\
\text { Waste }\end{array}$} & \multicolumn{3}{|c|}{ Substituted } \\
\hline & & & Waste & with TOC & No TOC \\
\hline 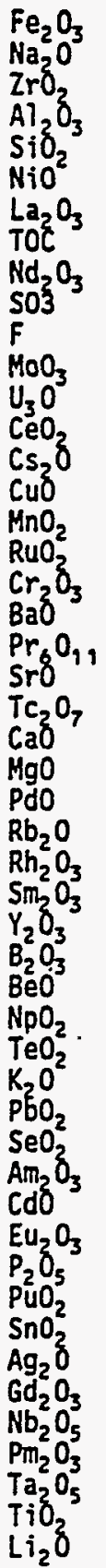 & $\begin{array}{l}28.0 \\
17.5 \\
15.0 \\
10.0 \\
9.00 \\
2.30 \\
2.00 \\
2.00 \\
1.90 \\
1.80 \\
1.20 \\
1.20 \\
0.70 \\
0.60 \\
0.60 \\
0.60 \\
0.60 \\
0.60 \\
0.50 \\
0.40 \\
0.40 \\
0.40 \\
0.40 \\
0.30 \\
0.20 \\
0.20 \\
0.20 \\
0.20 \\
0.20 \\
0.20 \\
0.10 \\
0.10 \\
0.10 \\
0.10 \\
0.05 \\
0.05 \\
0.03 \\
0.02 \\
0.02 \\
0.02 \\
0.02 \\
0.02 \\
0.02 \\
0.01 \\
0.01 \\
0.01 \\
0.01 \\
0.01 \\
0.01 \\
0.00\end{array}$ & $\begin{array}{l}28.0 \\
17.5 \\
15.0 \\
10.0 \\
9.01 \\
2.30 \\
2.00 \\
2.00 \\
1.90 \\
1.80 \\
1.20 \\
1.20 \\
0.70 \\
0.60 \\
0.60 \\
0.60 \\
0.60 \\
0.60 \\
0.50 \\
0.40 \\
0.40 \\
0.40 \\
0.40 \\
0.30 \\
0.20 \\
0.20 \\
0.20 \\
0.20 \\
0.20 \\
0.20 \\
0.10 \\
0.10 \\
0.10 \\
0.10 \\
0.05 \\
0.05 \\
0.03 \\
0.02 \\
0.02 \\
0.02 \\
0.02 \\
0.02 \\
0.02 \\
0.01 \\
0.01 \\
0.01 \\
0.01 \\
0.01 \\
0.01 \\
0.00 \\
\end{array}$ & $\begin{array}{c}28.0 \\
17.5 \\
15.0 \\
10.0 \\
9.01 \\
2.30 \\
2.00 \\
2.00 \\
2.21 \\
1.80 \\
1.20 \\
1.20 \\
\text { SUB Nd } \\
0.60 \\
0.60 \\
0.60 \\
0.60 \\
0.60 \\
0.50 \\
0.40 \\
0.40 \\
0.40 \\
D E L \\
0.30 \\
0.36 \\
0.20 \\
0.20 \\
0.20 \\
0.20 \\
0.20 \\
0.10 \\
\text { SUB } \mathrm{Hg} \\
D E L \\
D E L \\
D E L \\
D E L \\
D E L \\
D E L \\
D E L \\
\text { SUB Nd } \\
D E L \\
D E L \\
D E L \\
D E L \\
D E L \\
D E L \\
\text { SUB Nd } \\
D E L \\
D E L \\
D E E L \\
\end{array}$ & $\begin{array}{c}28.4 \\
17.7 \\
15.2 \\
10.1 \\
9.12 \\
2.33 \\
2.03 \\
2.03 \\
2.24 \\
1.82 \\
1.22 \\
1.22 \\
\text { SUB } N d \\
0.61 \\
0.61 \\
0.61 \\
0.61 \\
0.61 \\
0.51 \\
0.41 \\
0.41 \\
0.41 \\
D E L \\
0.30 \\
0.37 \\
0.20 \\
0.20 \\
0.20 \\
0.20 \\
0.20 \\
0.10 \\
\text { SUB } \mathrm{Hg} \\
\text { DEL } \\
D E L \\
D E L \\
\text { DEL } \\
D E L \\
D E L \\
D E L \\
D E L \\
\text { SUB Nd } \\
D E L \\
D E L \\
D E L \\
D E L \\
D E L \\
D E L \\
D E L \\
\text { SUB Nd } \\
D E L \\
D E L \\
D E L\end{array}$ & $\begin{array}{c}29.0 \\
18.1 \\
15.5 \\
10.3 \\
9.31 \\
2.38 \\
2.07 \\
. . \\
2.28 \\
1.86 \\
1.24 \\
1.24 \\
\text { SUB } N d \\
0.62 \\
0.62 \\
0.62 \\
0.62 \\
0.62 \\
0.52 \\
0.41 \\
0.41 \\
0.41 \\
D E L \\
0.31 \\
0.37 \\
0.21 \\
0.21 \\
0.21 \\
0.21 \\
0.21 \\
0.10 \\
\text { SUB } \mathrm{Hg} \\
\text { OEL } \\
D E L \\
D E L \\
D E L \\
D E L \\
D E L \\
D E L \\
\text { SUB Nd } \\
D E L \\
D E L \\
D E L \\
D E L \\
D E L \\
D E L \\
\text { SUB Nd } \\
D E L \\
D E L \\
D E L \\
\end{array}$ \\
\hline & 99.91 & 100.00 & 98.76 & 100.00 & 100.00 \\
\hline
\end{tabular}


TABLE 4.1-4. Oxide Compositions of NCAH 87, HW39-4 Frit, HW39-4 G7ass HWVP-89-IVJ0010100B

\begin{tabular}{|c|c|c|c|c|}
\hline Oxide & $\begin{array}{l}\text { NCAH 87, } \\
\text { wt\% Oxide }\end{array}$ & $\begin{array}{l}\text { Substituted } \\
\text { Waste, wt\% Oxide }\end{array}$ & $\begin{array}{l}\text { HW39-4 Frit, } \\
\text { wt\% Oxide }\end{array}$ & $\begin{array}{l}\text { HW39-4 Glass, } \\
\text { wt\% Oxide }\end{array}$ \\
\hline 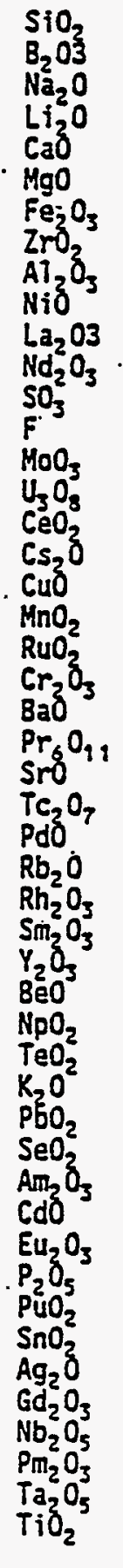 & $\begin{array}{c}4.00 \\
0.10 \\
17.5 \\
0.00 \\
0.30 \\
0.20 \\
28.0 \\
15.0 \\
9.0 \\
2.30 \\
2.50 \\
2.00 \\
1.80 \\
1.20 \\
1.20 \\
4.70 \\
0.60 \\
0.60 \\
0.60 \\
0.60 \\
0.60 \\
0.50 \\
0.40 \\
0.40 \\
0.40 \\
0.40 \\
0.20 \\
0.20 \\
0.20 \\
0.20 \\
0.20 \\
0.10 \\
0.10 \\
0.10 \\
0.05 \\
0.05 \\
0.03 \\
0.02 \\
3.00 \\
0.02 \\
0.40 \\
0.02 \\
0.04 \\
0.01 \\
0.01 \\
0.01 \\
0.10 \\
0.03 \\
0.01 \\
100.0\end{array}$ & 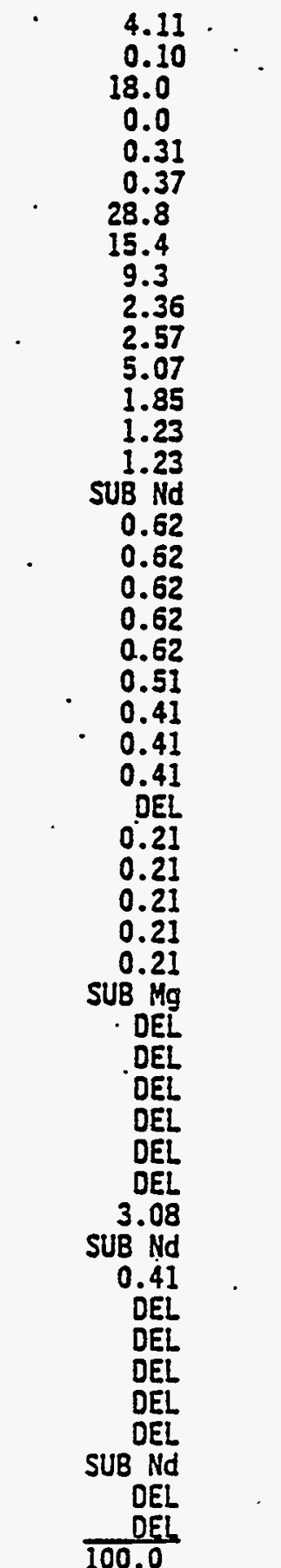 & 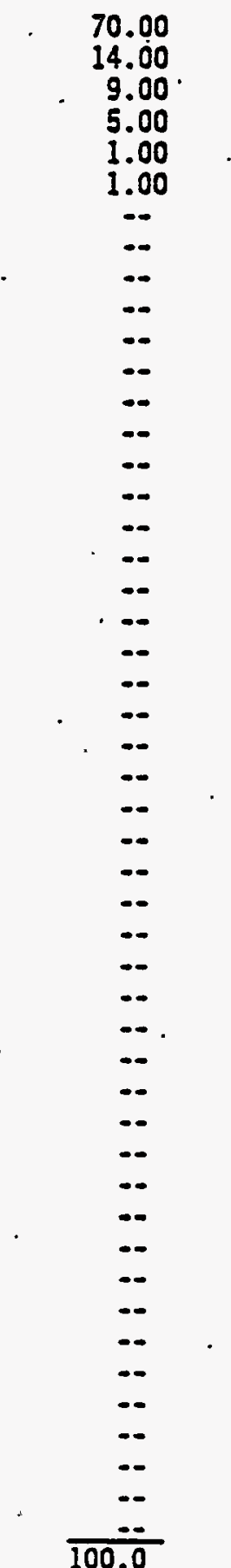 & 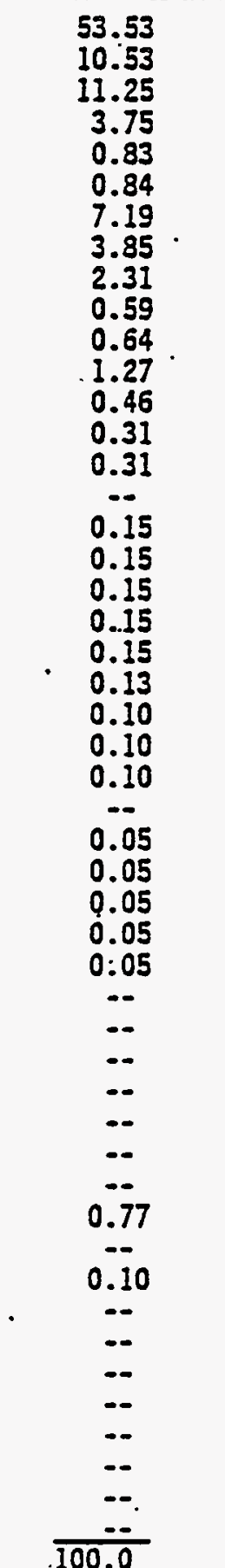 \\
\hline
\end{tabular}


would have significant beneficial economic effects by reducing the number of canisters required to contain the vitrified waste. For example, an increase in the waste loading from 25 to 30 wt\% would reduce the number of canisters by $17 \%$. In the evaluation of the NCAW 86 waste, waste loadings of 25,30 , and 35 wt\% were evaluated. The compositions of these three glasses (HW43, HW44, and HH45, respectively) are shown in Table 4.1-5.

To determine if the HH39-4 frit composition could be produced commercially, the melting behavior of the frit alone was evaluated. Carbonate and oxide components of the frit were found to melt very well at $1150^{\circ} \mathrm{C}$. Therefore, commercial frit producers should have no problem producing this frit. composition.

4.1.2.2.2 Laboratory Evaluation. The Taboratory testing was used to determine viscosity, electrical conductivity, crystallinity and devitrification, chemical durability, glass transition temperature $\left(T_{g}\right)$, and thermal expansion of the waste glasses.

4.1.2.2.2.1 Viscosity. The results for the viscosity studies on the nominal reference glass composition are presented below.

HW39-1: The HW39-1 glass has a 100-poise temperature (T100P) of 2057 $\mathrm{F}$ $\left(1124^{\circ} \mathrm{C}\right)$, and yiscosity is stable with time from $\left(950^{\circ} \mathrm{C}\right.$ to $\left.1200^{\circ} \mathrm{C}\right)$ in 7 aboratory tests. (a) (b) The value is within the 1740 to $2100^{\circ} \mathrm{F}$ (1070 to $1150^{\circ} \mathrm{C}$ ) T100p limit required for melter operation. Viscosity measurements were made using a rotating spindle technique with a Brookfield viscometer. The viscosity versus temperature curve for HW39 is shown in Figure 4.1-2.

HW39-2: The HW39-2 glass has a 100 poise temperature (T1OOP) of $1975^{\circ} \mathrm{F}$ $\pm 18^{\circ} \mathrm{F}\left(1081^{\circ} \mathrm{C} \pm 10^{\circ} \mathrm{C}\right)$ and is shown in Figure 4.1 .3 .

HW/39-3: Melt viscosity curves were determined for the. NCAW 86 glasses and are presented in Figure $4.1-3$, along with the viscosity curve of an HW39-2 glass, which contained low $\mathrm{Cr}_{2} \mathrm{O}_{3}(0.13$ wt\%) for comparison. Viscosity measurements indicated that the T100Ps for the 25, 30, and 35 wt\% waste loading were $1086^{\circ} \mathrm{C}, 1078^{\circ} \mathrm{C}$, and $1074^{\circ} \mathrm{C}$, respectively (see Table 4.1-6). This compares well with the $1081^{\circ} \mathrm{C}$ ' T100P for the HH39-2 with 0.13 wt\% $\mathrm{Cr}_{2} \mathrm{O}_{3}$ present, but it is approximately $40^{\circ} \mathrm{C}$ lower than HH39-1 with the NCAW 84 high- $\mathrm{Cr}_{2} \mathrm{O}_{3}$ level ( $1.34 \mathrm{wt} \%$ in the glass).

(a) S. 0. Bates, Recommended HWVP Glass Composition for the NCAW-CRW Stream for Future Work. HWVP Baseline Milestone 020202B, Pacific Northwest Laboratory, Richland, Washington (1985).

(b) S. G. Bates, Interim Milestone HWVP-87-V110202C - Report on FY 1987 Glass Variability Testing Conducted for the Hanford Waste Vitrification Program. HWVP-87-V110202C, Pacific Northwest Laboratory, Richland, Washington (1987). 
TABLE 4.1-5. Composition of NCAW 86 G7ass and HW39 LOW-C $\mathrm{r}_{2} \mathrm{O}_{3}$ G7ass, HW39-2 HWVP-87-V110202A

\begin{tabular}{|c|c|c|c|c|c|}
\hline Oxide & $\begin{array}{l}\text { Substituted } \\
\text { Nor. Waste. } \\
\text { No TOC }\end{array}$ & Frit & $\begin{array}{l}H W 43 \\
25 \text { wt\% }\end{array}$ & $\begin{array}{c}\text { HWA4 } \\
30 \text { wt\% }\end{array}$ & $\begin{array}{l}\text { HWw45 } \\
35 \text { wt\% }\end{array}$ \\
\hline 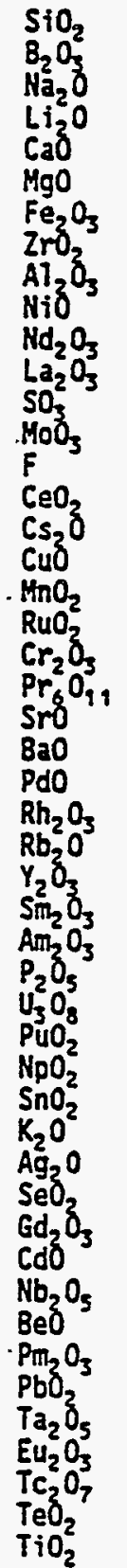 & 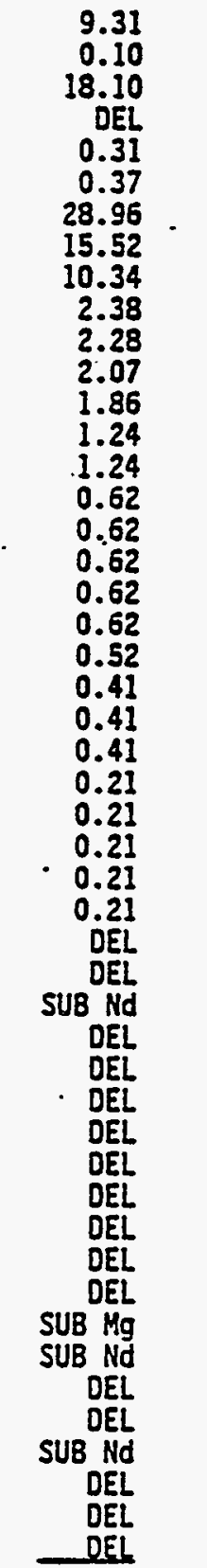 & $\begin{array}{c}67.25 \\
12.75 \\
10.25 \\
5.00 \\
3.75 \\
1.00 \\
.\end{array}$ & $\begin{array}{r}52.77 \\
9.59 \\
12.21 \\
3.75 \\
2.89 \\
0.84 \\
7.24 \\
3.88 \\
2.59 \\
0.59 \\
0.57 \\
0.52 \\
0.47 \\
0.31 \\
0.31 \\
0.16 \\
0.16 \\
0.16 \\
0.16 \\
0.16 \\
0.13 \\
0.10 \\
0.10 \\
0.10 \\
0.05 \\
0.05 \\
0.05 \\
0.05 \\
0.05\end{array}$ & $\begin{array}{r}49.87 \\
8.96 \\
12.61 \\
3.50 \\
2.72 \\
0.81 \\
8.69 \\
4.66 \\
3.10 \\
0.71 \\
0.69 \\
0.62 \\
0.56 \\
0.37 \\
0.37 \\
0.19 \\
0.19 \\
0.19 \\
0.19 \\
0.19 \\
0.16 \\
0.12 \\
0.12 \\
0.12 \\
0.06 \\
0.06 \\
0.06 \\
0.06 \\
0.06\end{array}$ & $\begin{array}{r}46.97 \\
8.32 \\
13.00 \\
3.25 \\
2.55 \\
0.78 \\
10.14 \\
5.43 \\
3.62 \\
0.83 \\
0.80 \\
0.72 \\
0.65 \\
0.43 \\
0.43 \\
0.22 \\
0.22 \\
0.22 \\
0.22 \\
0.22 \\
0.18 \\
0.14 \\
0.14 \\
0.14 \\
0.07 \\
0.07 \\
0.07 \\
0.07 \\
0.07\end{array}$ \\
\hline & 100 & 100 & 100 & 100 & 100 \\
\hline
\end{tabular}




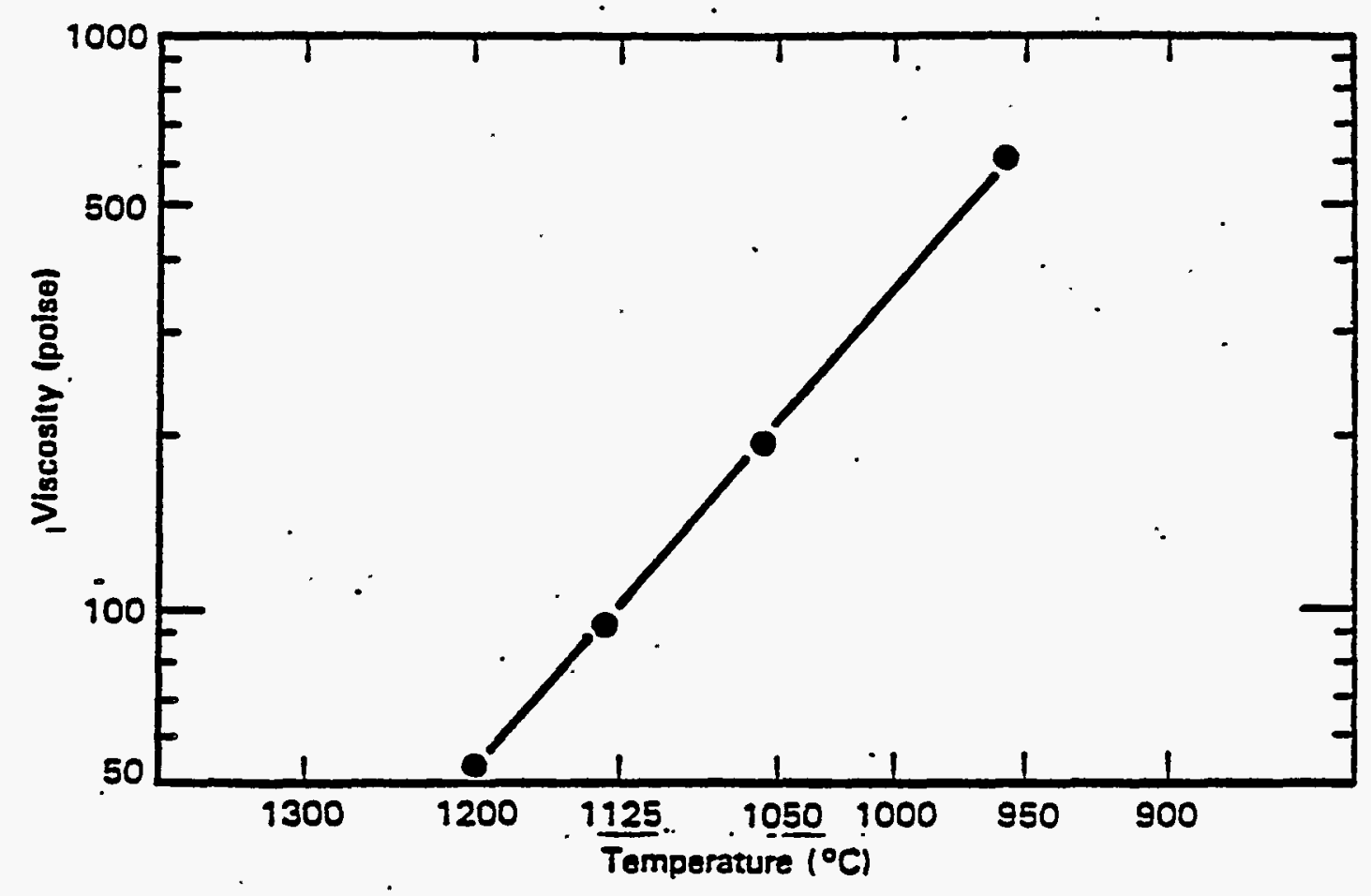

FIGURE 4.1-2. Viscosity of Reference HWVP Glass (HW39-1)

The slightly negative effect on T100P with increasing waste loadings of NCAH 86 gontrasts with the slight7y positive effect of waste loading with NCAW 84. (a) This difference is due to the increased alkali and reduced $\mathrm{Cr}_{2} \mathrm{O}_{3}$ in NCAW 86.

If the final update of the NCAW composition also has a similar level of alkali, the increased alkali could easily be compensated for by the reduction of alkali in the frit. Such a reduction would increase the TlOOP of the nominal glass composition to nearer the center of the $1070^{\circ} \mathrm{C}$ to $1150^{\circ} \mathrm{C}$ range required for HWVP processing and would allow for more flexibility in the melt viscosity because the composition would be more variable.

A small amount of very fine-grained crystalline material was observed at all three waste loadings. The crystals were very smali and did not have an observable effect on the viscosity of the me1t. The phase behaviors of the glass compositions are discussed in Section 4.1.2.2.6.

(a) S. 0. Bates and W. M. Bowen, Interim Milestone HWVP-86-V1122C - Report on Composition Variability Testing Conducted for the Hanford Haste Vitrification Program. Pacific Northwest Laboratory, Richland, Washington (1986). 


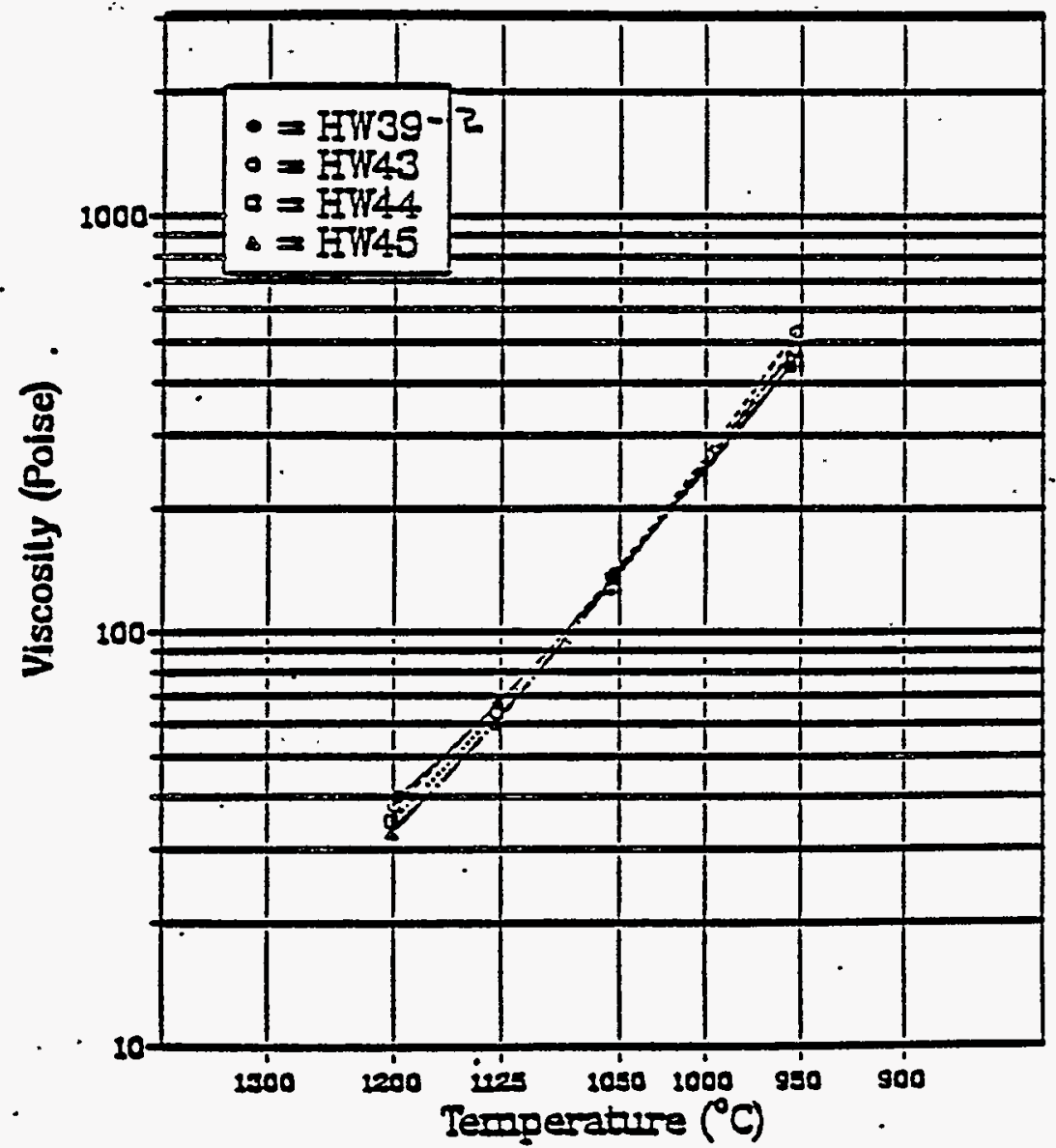

FIGURE 4.1-3. Viscosity Curves for HW39-2 and HH39-3 Glasses of Various Haste Loading HWVP-87-V1120202A

TABLE 4.1-6 Summary of Glass and Melt Properties for NCAW 86 (HH39-3)

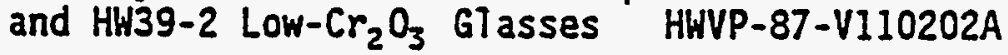

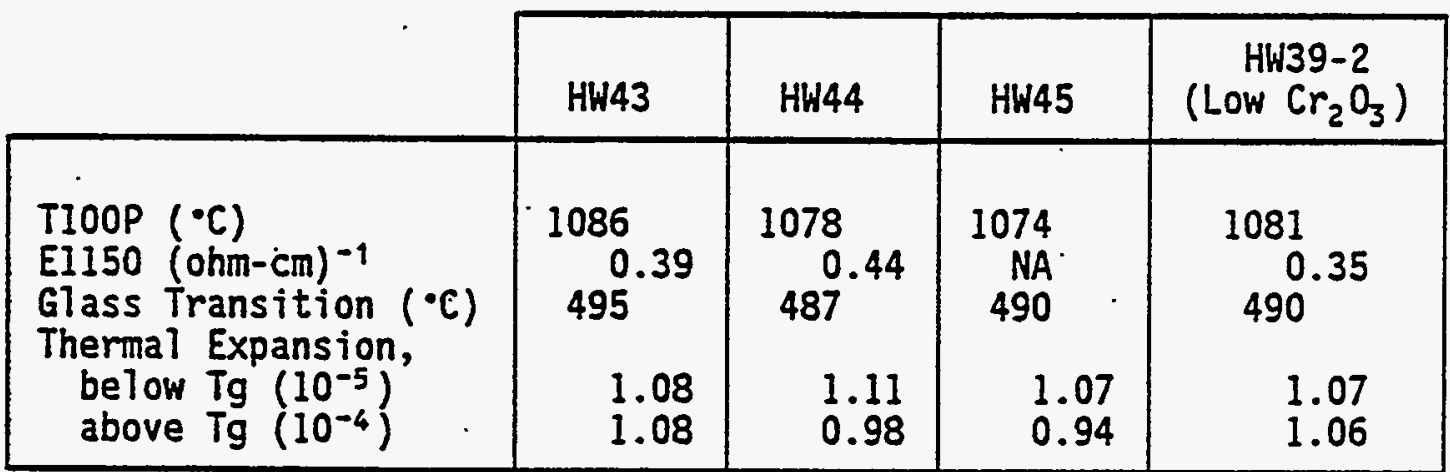


HW39-4: The. T100P of the HW39-4 glass has been determined to be $1106^{\circ} \mathrm{C}$ $\pm 10^{\circ} \mathrm{C}$. The viscosity curve or HW39-4 is shown in Figure 4.1-4 along with that of HH39-2 for comparison. The viscosity was stable with respect to time.

4.1.2.2.2.2 Conductivity. The results for the electrical conductivity studies on the nominal reference glass composition are presented below.

HW39-1: The electrical conductivity of the HW39-1 glass at 2100 $\mathrm{F}$ $\left(1150^{\circ} \mathrm{C} \text { ) is } 0.30 \text { (ohm-cm) }{ }^{-1} \text {, which is within the } 0.18 \text { to } 0.5 \text { (ohm-cm) }\right)^{-1}$ limit required for melter operation. (a) The electrical conductivity of a glass was measured using a two-probe method. The electrical conductivity versus temperature curve for HW39 is shown in Figure 4.1-5.

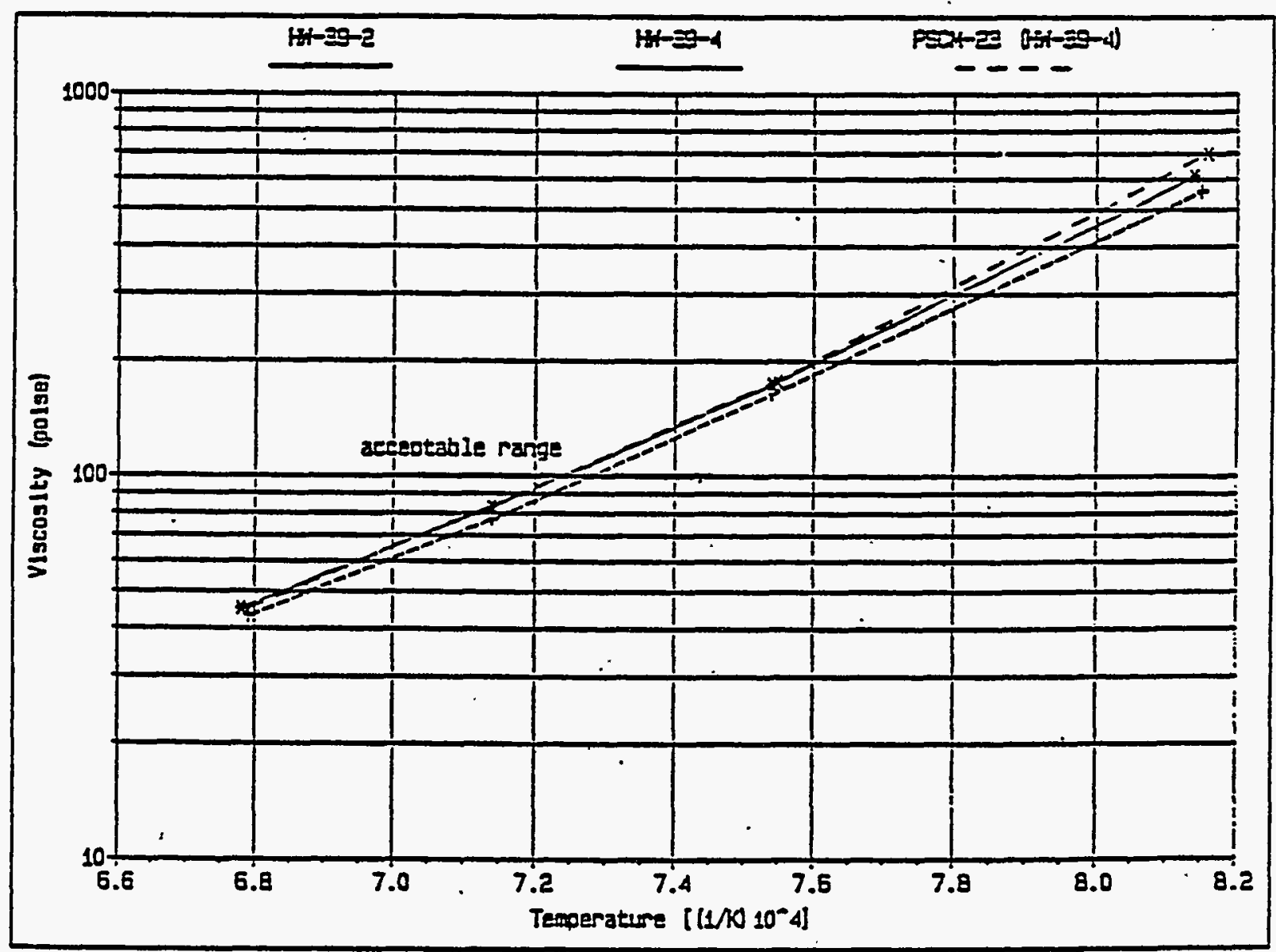

FIGURE 4.1-4. Viscosity Curves for HWVP Glasses HW39-2 and HW39-4, HWVP-89-IVJ0010100B

(a) G. J. Sevigny and D. Berger, Hanford Waste Vitrification Project Melter/Turntable Conceptual Desian Report. HWVP-8GV1142B, Pacific Northwest Laboratory, Richland, Washington (1985). 


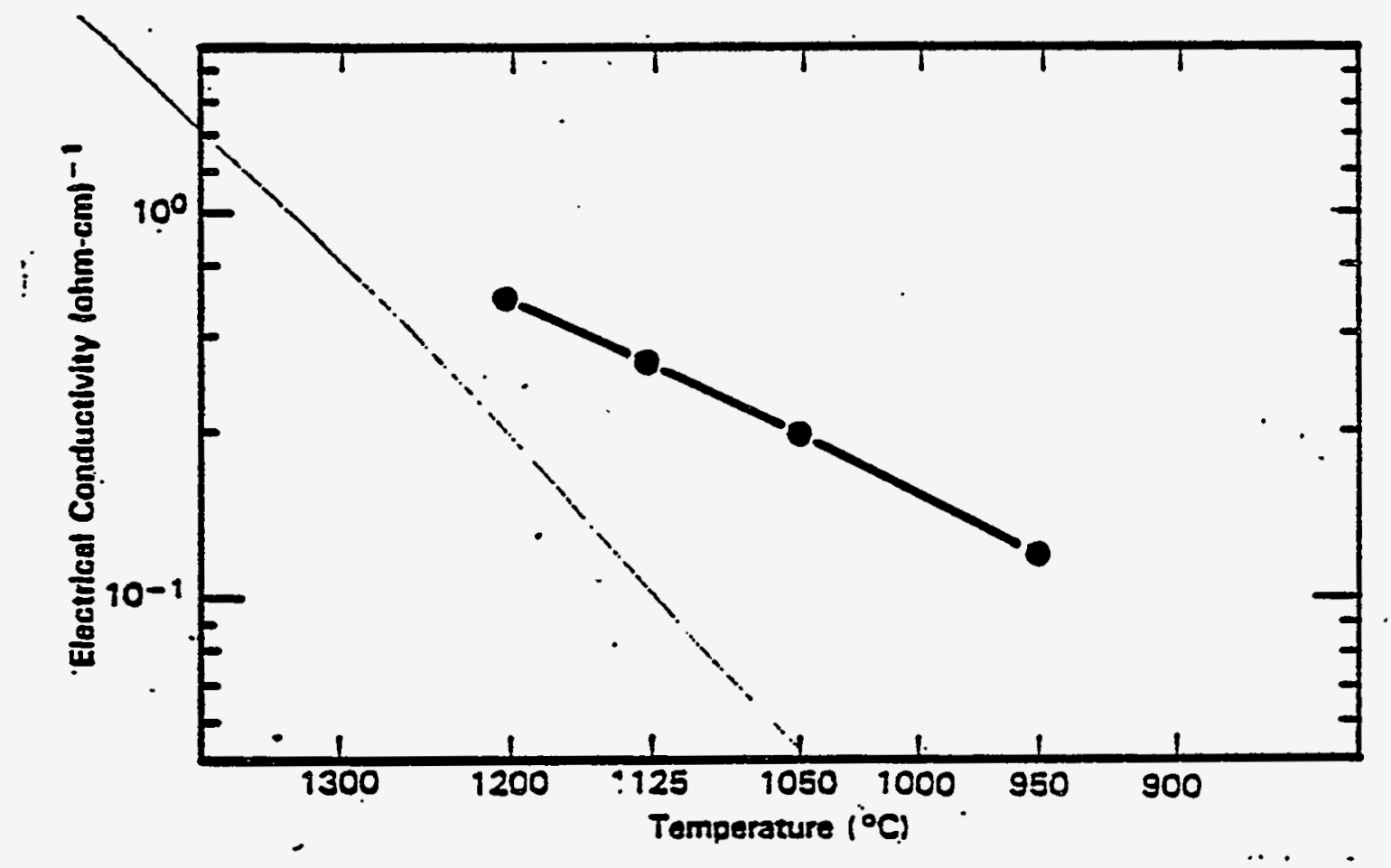

FIGURE 4.1-5. Electrical Conductivity of Reference HWVP Glass (HW39-1)

HW39-2: The HW39-2 glass has an electrical conductivity (E1150) of $0.29(\mathrm{ohm}-\mathrm{cm})^{-1}$ at $1150^{\circ} \mathrm{C} \pm 0.02(\mathrm{ohm}-\mathrm{cm})^{-1}$ and is shown in Figure 4.1-6.

HW39-3: The electrical conductivity of the NCAW 86 glasses HW43 and HW44 was measured. The electrical conductivity curves are presented in Figure 4.1-6 along with the electrical conductivity data for the HW39-2 (low$\mathrm{Cr}_{2} \mathrm{O}_{3}$ ) glass for comparison. The electrical conductivity of $\mathrm{HW} 45$ was not. determined, as the glass sample was destroyed by a furnace malfunction. The electrical conductivities at $1150^{\circ} \mathrm{C}$ (E1150). for the NCAW $86 \mathrm{gl}$ asses and the HW39 (low- $\mathrm{Cr}_{2} \mathrm{O}_{3}$ ) glass are shown in Table 4.1-6. Even without the HW45 electrical conductivity measurement, the trend of increasing electrical conductivity with increased waste loading of NCAN 86 was apparent. The increased alkali content in the NCAW 86 was responsible for this increase in E1150 with waste loading. It is possible that, at 35 wt\% waste loading (HW45), the El150 of the melt could be higher than the 0.5 (ohm-cm) $)^{-1}$ limit set for HWVP processing. If the final update of the NCAW has higher levels of alkali, the increased alkali could easily be compensated for by the reduction of alkali in the frit. Alkali reduction would reduce the El150. of the nominal glass composition to nearer the center. of the 0.18 to 0.5 (ohm $-\mathrm{cm})^{-1}$ range required for HWVP processing and could also allow for increased waste loadings. 


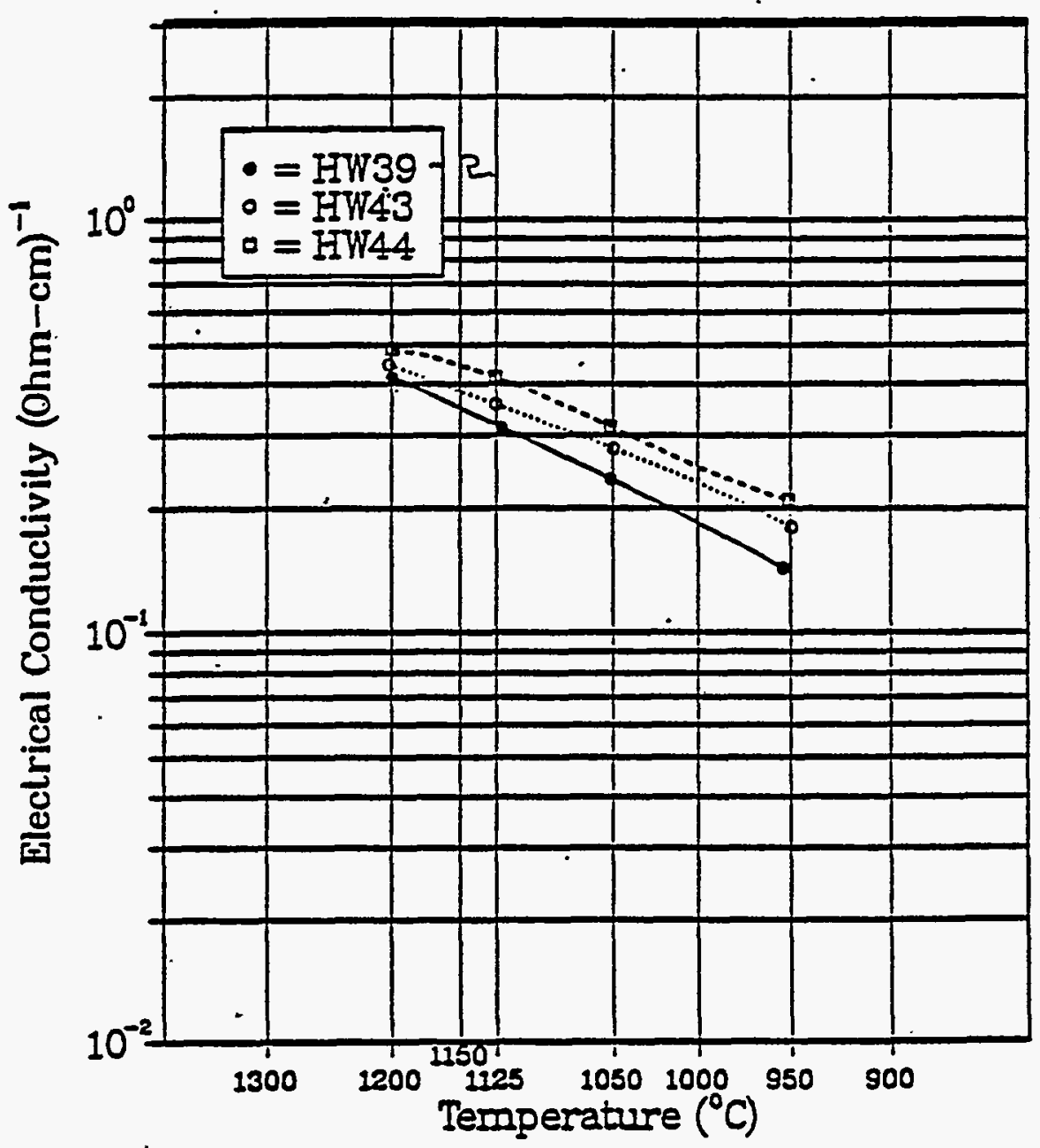

FIGURE 4.1-6. Electrical Conductivity Curves for HW39-2 and HW39-3 Glasses of Various Haste Loading HWVP-87-VI10202A

HW39-4: The electrical conductivity at $1150 \cdot \mathrm{C}$ (EI150) of HW39-4 is $0.26 \pm 0.02(\mathrm{ohm}-\mathrm{cm})^{-1}$. The electrical conductivity curve for the HW39-4 is shown in Figure 4.1-7 along with that of HW39-2 for comparison.

4.1.2.2.2.3 Leaching. . The results for the leaching studies on the nominal reference glass composition are presented below. 


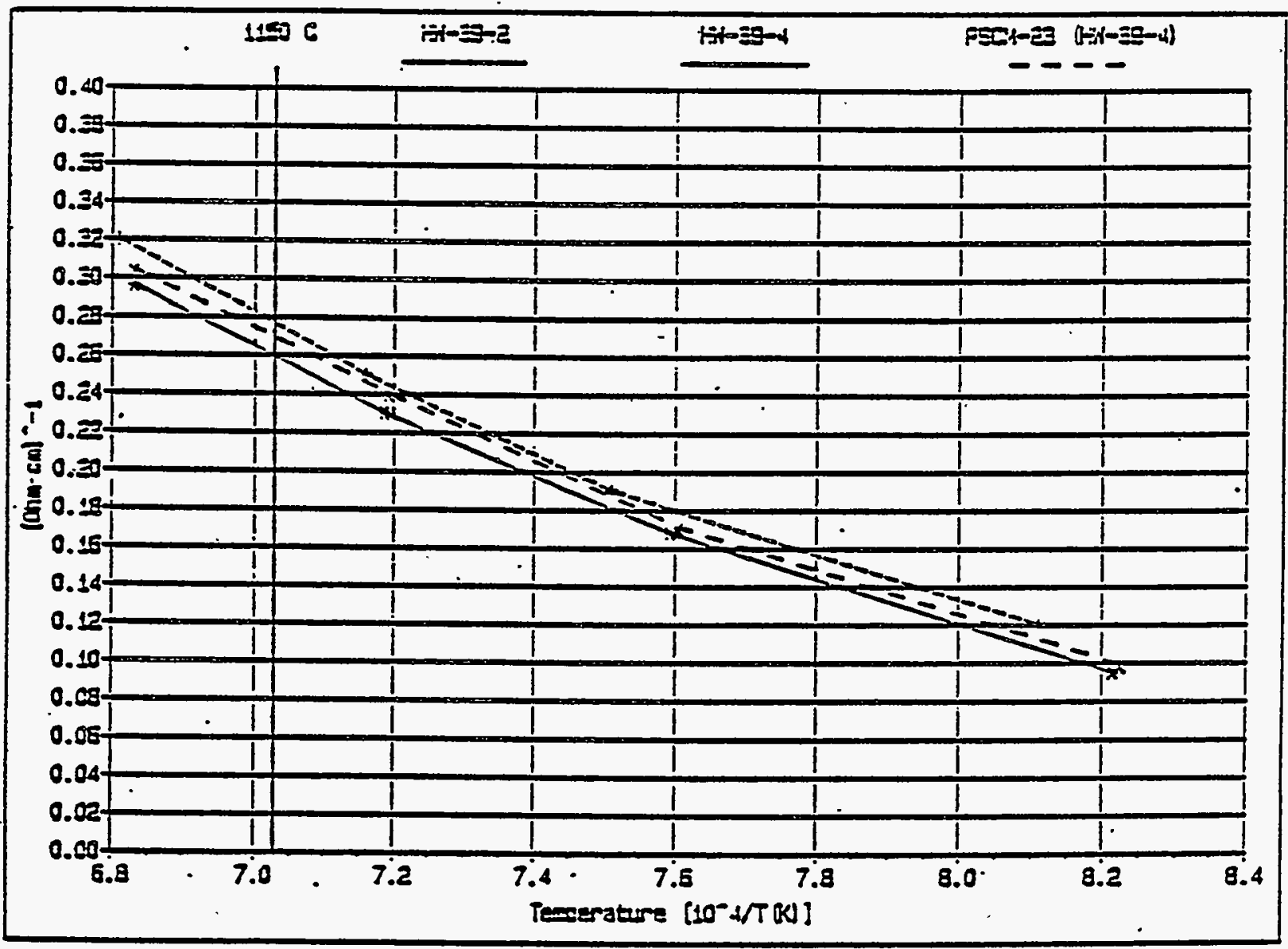

FIGURE 4.1-7. E]ectrical Conductivity Curves for HWVP GIasses HW39-2, and HW39-4 HWVP-89-IVJ0010100B

HW39-1: Results from 28-day MCC-1 and MCC-3 Teach tests(a)(b) of the HWWP reference glass, HW39-1, are summarized in Tables 4.1-7 and 4.1-8. In Table 4.1-7, the results shown are 28-day MCC-1 static leach tests in deionized water at $200^{\circ} \mathrm{F}\left(90^{\circ} \mathrm{C}\right.$ ) with a SA/N (surface area-to-volume ratio) of $\left.10 \mathrm{~m}^{-1}\right)$. The MCC-1 test is the most widely used test for comparing leaching performance.

In MCC-3 leaching tests, elemental concentrations in the leachate are representative of longer-term extrapolation of MCC-1 test results and provide an indication of the upper concentration limits under saturation conditions (see Table 4.1-8). Saturation is achieved more rapidly in MCC-3 test due to higher $S A / V$ ratios than those used in $M C C-1$ tests (approximately

(a) Materials Characterization Center, MCC-1P Static Leach Test Method, Rev. 1. Pacific Northwest Laboratory, Richland, Washington (1983).

(b) Materials Characterization Center, MCC-3S Agitated Powder Leach Test Method. Pacific Northwest Laboratory, Richland, Washington (1984). 
TABLE 4.1-7. 28-Day MCC-1 Leaching Results for the HWVP Reference Glass HW39-1

\begin{tabular}{|c|c|}
\hline Normalized Elemental Release $\left(\mathrm{g} / \mathrm{m}^{2}\right)$ \\
\hline Element & $($ HH39-1) \\
\hline Al & 10 \\
B & 15 \\
Ca & 6.8 \\
CS & 13 \\
Fe & 0.32 \\
Li & 15 \\
Na & 15 \\
Si & 14 \\
Sr & 5.7 \\
Final pH & 9.3 \\
\hline
\end{tabular}

(a) Conditions: deionized water, $90^{\circ} \mathrm{C}$, $S A / V=10 / m$.

TABLE 4-1-8. 28-Day MCC-3 Leaching Results for the HWVP Reference Glass HW39-1

\begin{tabular}{|c|c|c|}
\cline { 2 - 3 } \multicolumn{1}{c|}{} & \multicolumn{2}{c|}{ Normalized Elemental Release $\left(\mathrm{g} / \mathrm{m}^{2}\right)$} \\
\hline Element & $18 \AA$ Filter & $45-\mu$ Filter \\
\hline $\mathrm{Al}$ & 0.05 & 0.15 \\
$\mathrm{~B}$ & 0.48 & 0.48 \\
$\mathrm{Ca}$ & 0.01 & 0.06 \\
$\mathrm{CS}$ & 0.07 & 0.15 \\
$\mathrm{Fe}$ & 0.01 & 0.15 \\
$\mathrm{Li}$ & 0.57 & 0.59 \\
$\mathrm{Mg}$ & 0.01 & 0.28 \\
$\mathrm{Na}$ & 0.45 & 0.46 \\
$\mathrm{Si}$ & 0.26 & 0.28 \\
$\mathrm{Sr}$ & 0.01 & 0.04 \\
Final pH & & \\
\hline
\end{tabular}

(a) Conditions: deionized water, $90^{\circ} \mathrm{C}$, $S A / V=1780 / \mathrm{m}$. 
$1800 \mathrm{~m}^{-1}$ compared with $\left.10 \mathrm{~m}^{-1}\right)$. The near-saturated conditions in the MCC-3 are thought to more closely approach the expected repository environment.

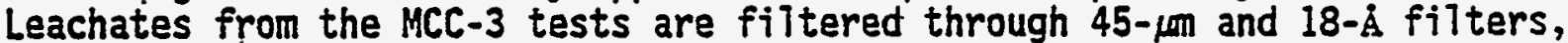
and each fittrate is analyzed. The analysis of the $45-j \mathrm{~m}$ filtrate indicates the amount of material that is in solution or is colloidal. Passing through an 18- $\AA$ filter, the colloidal material is removed from the filtrate, and ICP analysis of the filtrate provides the amount of material truly in solution and available for transport.

The tests used to assess chemical durability of thermally treated HW39-1 were 7-and 28-day MCC-1, and 28-day MCC-3 using -100+200 mesh glass

powder. (a) Samples $B 4\left(750^{\circ} \mathrm{C}, 300-\mathrm{h}\right.$ holding time), $\mathrm{C}$ and $\mathrm{C} 4\left(600^{\circ} \mathrm{C}, 30\right.$, and $300-h$ holding times, respectively), and the prepared standard were tested. Al7 tests were performed in deionized water (DIW) at $90^{\circ} \mathrm{C}$. The results are given in terms of normalized elemental mass release. This is calculated with use of the following equation:

$$
N R_{i}=m_{i} /\left(F_{i} \times S A\right)
$$

where $N R_{j}=$ normalized mass release of element $i\left(\mathrm{~g} / \mathrm{m}^{2}\right)$

$$
\begin{aligned}
& m_{j}=\text { mass of element } i \text { in leachate ( } g \text { ) } \\
& F_{j}=\text { fraction of element } i \text { in glass (dimensionless) } \\
& S A=\text { surface area of monolith }\left(\mathrm{m}^{2}\right)
\end{aligned}
$$

The results of the $M C C-1,7$-day tests are given in Table 4.1-9. The elemental mass releases of samples $C 3$ and $C 4\left(600^{\circ} \mathrm{C}, 30\right.$ - and $300-\mathrm{h}$ holding times,-respectively) show similar leaching behavior with respect to the standard. Calcium elemental release is a little lower for the $C$ samples, which may. be caused by the increased stability of the calcium in pyroxene crystals. The other elemental releases are comparabie within experimental error.

Comparing sample $\mathrm{B} 4\left(750^{\circ} \mathrm{C}, 300^{-h}\right.$ holding time) with the standard suggests slightiy different leaching behavior. The elemental releases of $B, L i$, $\mathrm{Mo}$, and $\mathrm{Na}$ are twice as large for $\mathrm{B} 4$ as for the standard. The release of $\mathrm{Si}$ is also slight7y elevated. Sample $B 4$ does not appear to be as chemically durable as the standard. The releases of $\mathrm{Ba}, \mathrm{Ca}$, and $\mathrm{Mg}$ are significantiy reduced for $B 4$, suggesting that these elements are perhaps stabilized by pyroxene formation. The fact that the two $300-h$ samples leach differently seens to indicate that the differing crystalline phases being formed affect glass durability differently. Here, the phase richer in augite $\left(750^{\circ} \mathrm{C}\right.$ samples) has the greater adverse effects on glass durability.

The results of the MCC-1, 28-day tests are given in Table 4.1-10. It is easily seen that the treated samples are less durable than the standard.

(a) S. 0. Bates and M. A. Reimus, Baseline Milestone V1122B - Hanford Waste Vitrification Plant Reference GTass Development - FY 1986 Summary - Report. HWVP-86-V1122B, P.acific Northwest Laboratory, Richland, Hashington. (1986). 
TABLE 4.1-9. Normalized Elemental Mass Release from 7-day MCC-1 for TTT HW39-1 Glass Samples, $S A / V=10 \mathrm{~m}^{-1}, 90^{\circ} \mathrm{C}$, in Deionized Hater HWVP-86-V1122B

\begin{tabular}{|c|r|r|r|r|}
\cline { 3 - 5 } \multicolumn{2}{c|}{} & \multicolumn{1}{c|}{$750^{\circ} \mathrm{C}$} & \multicolumn{2}{c|}{$600{ }^{\circ} \mathrm{C}$} \\
\hline \multirow{2}{*nyyy}{ Element } & Std & $\begin{array}{c}300 \mathrm{~h} \\
\mathrm{~B} 4\end{array}$ & $\begin{array}{c}30 \mathrm{~h} \\
\mathrm{C3}\end{array}$ & \multicolumn{1}{c|}{$\begin{array}{c}300 \mathrm{~h} \\
\mathrm{C}\end{array}$} \\
\hline $\mathrm{A1}$ & 7.74 & 14.66 & 10.11 & 9.50 \\
$\mathrm{~B}$ & 10.56 & 27.43 & 10.62 & 10.27 \\
$\mathrm{Ca}$ & 6.47 & 0.89 & 2.27 & 2.35 \\
$\mathrm{Cs}$ & 12.22 & 17.43 & 13.04 & 12.70 \\
$\mathrm{Fe}$ & 0.37 & 0.22 & 0.20 & 0.27 \\
$\mathrm{Li}$ & 10.26 & 22.87 & 9.63 & 9.35 \\
$\mathrm{Mg}$ & 3.13 & 0.00 & 2.99 & 1.72 \\
$\mathrm{Mn}$ & 0.28 & 0.38 & 0.47 & 0.59 \\
$\mathrm{Mo}$ & 10.81 & 24.46 & 11.56 & 11.13 \\
$\mathrm{Na}$ & 10.50 & 20.24 & 8.16 & 7.41 \\
$\mathrm{Si}$ & 8.83 & 12.87 & 7.29 & 6.76 \\
$\mathrm{Sr}$ & 5.91 & 1.28 & 8.08 & 8.61 \\
$\mathrm{pH}$ & 9.31 & 10.36 & 9.32 & 8.82 \\
\hline
\end{tabular}

TABLE 4.1-10. Normalized Elemental Mass Release from 28-day MCC-1 for TTT HW39-1 GTass Samples, $S A / V=10 \mathrm{~m}^{-1}, 90^{\circ} \mathrm{C}$, in Deionized Water HWVP-86-V1122B

\begin{tabular}{|l|r|r|r|r|}
\cline { 3 - 5 } \multicolumn{2}{c}{} & \multicolumn{1}{c|}{$750{ }^{\circ} \mathrm{C}$} & \multicolumn{2}{c|}{$600{ }^{\circ} \mathrm{C}$} \\
\hline & & \multicolumn{1}{c|}{$300 \mathrm{~h}$} & \multicolumn{1}{c|}{$30 \mathrm{~h}$} & \multicolumn{1}{c|}{$300 \mathrm{~h}$} \\
Element & Std, & \multicolumn{1}{c|}{$\mathrm{B} 4$} & \multicolumn{1}{c|}{$\mathrm{C} 3$} & $\mathrm{C} 4$ \\
\hline $\mathrm{Al}$ & 8.81 & 17.63 & 17.44 & 20.07 \\
$\mathrm{~B}$ & 14.07 & 114.46 & 23.48 & 31.54 \\
$\mathrm{Ca}$ & 6.80 & 0.31 & 1.20 & 1.05 \\
$\mathrm{Cs}$ & 13.85 & 15.05 & 22.24 & 23.91 \\
$\mathrm{Fe}$ & 0.27 & 1.44 & 0.48 & 0.25 \\
$\mathrm{Li}$ & 13.46 & 94.50 & 21.62 & 27.94 \\
$\mathrm{Mn}$ & 0.37 & 3.46 & 1.79 & 1.85 \\
$\mathrm{Mo}$ & 18.73 & 114.50 & 28.76 & 37.28 \\
$\mathrm{Na}$ & 13.88 & 82.69 & 19.45 & 24.15 \\
$\mathrm{Si}$ & 11.34 & 39.35 & 15.00 & 18.12 \\
$\mathrm{Sr}$ & 5.76 & 0.28 & 2.99 & 2.19 \\
$\mathrm{pH}$ & 9.96 & 10.24 & 9.98 & 10.05 \\
\hline
\end{tabular}


Once again, sample $\mathrm{B} 4\left(750^{\circ} \mathrm{C}, 300-\mathrm{h}\right.$ holding time) is the least durable. The formation of a pyroxene crystaliine phase definitely causes a decrease in glass durability.

Comparing the two $C$ samples $\left(600^{\circ} \mathrm{C}, 30\right.$ - and $300-h$ holding times, respectively), shows that the durability is decreased with holding time. Holding time was shown earlier to increase pyroxene formation without affecting the overali composition of the glass. Thus, the increasing amount pyroxene probably caused this observed decrease in chemical durability. As. in the MCC-1, 7-day test, Ca release is significantly lower for $\mathrm{B} 4\left(750^{\circ} \mathrm{C}, 300-\mathrm{h}\right.$ holding time) than for the standard. This is also true for the $C$. samples. The identical discrepancy between $\mathrm{B4}\left(750^{\circ} \mathrm{C}, 300 \mathrm{~h}\right)$ and $\mathrm{C} 4\left(600^{\circ} \mathrm{C}, 300 \mathrm{~h}\right)$ releases exists here as in the MCC-1, 7-day test.

The results of the MCC -3, 28 day tests are given in Tables 4.1-11 and 4.1-12. Tabie 4.1-11 lists $0.45 \mathrm{~km}$ filtered leachate data; Table 4.1-12 lists 18-angstrom filtered data. The normalized releases obtained using the MCC-3 leach test seem low compared with the MCC-1 data, but this is caused by the much higher SA/V ratio in the MCC-3 test, which results in the leachant saturating more rapidly. MCC-3 results can be used for long-term extrapolation of MCC-I test resuits and to define maximum upper concentration 7 imits under closed system, static conditions.

In Table 4.1-11, it is seen that the treated samples are less durable than the standard. Interestingly, the trend seen earlier, the $C$ samples $\left(600^{\circ} \mathrm{C}\right)$ being more chemically durable than the $B\left(750^{\circ} \mathrm{C}\right)$ sample, is reversed here. This indicates that the crystalline product richer in augite (formed
at $750^{\circ} \mathrm{C}$ ) is more chemically durable over the long term than that formed at $600^{\circ} \mathrm{C}$. It has been shown earlier that the product formed at $600^{\circ} \mathrm{C}$ is more chemically durable over the short term. However, pyroxene formation decreases the overall glass product durability.

Table 4.1-12 lists those normalized elemental releases obtained from 18-angstrom filtered leachate. A comparison of these releases with those obtained from $0.45-\mu \mathrm{m}$ filtered leachate is used to determine if colloids are being formed. Comparing Table 4.1-11 with Table 4.1-12 indicates there is no significant colloid formation.

HW39-2: No leaching studies were performed on the HW39-2 glass.

HW39-3: To provide a preliminary evaluation of the durability of glasses produced from the NCAW 86 waste, 28-day MCC-1 leaching tests were conducted. All tests were performed with a surface area/volume of $10 \mathrm{~m}^{-1}$ in deionized water at $90^{\circ} \mathrm{C}$ using quenched and annealed glass samples. For comparison of glasses of different composition, the results are given in terms of normalized elemental mass release. 
TABLE 4.1-11.. Normalized Elemental Mass Releases from 28-day MCC-3 for TTT HW39-1 G7ass Samples, 0.45-micron filtered, $S A / V=1780 \mathrm{~m}^{-1}, 90^{\circ} \mathrm{C}$, in Deionized Water HWVP-86-V1122B

\begin{tabular}{|c|c|c|c|c|}
\cline { 3 - 5 } \multicolumn{2}{c}{} & $750{ }^{\circ}$ & \multicolumn{2}{c|}{$600 \cdot \mathrm{C}$} \\
\hline & & $300 \cdot h$ & $30 \mathrm{~h}$ & $300 \mathrm{~h}$ \\
Element & Std & $\mathrm{B} 4$ & $\mathrm{C} 3$ & $\mathrm{C} 4$ \\
\hline $\mathrm{Al}$ & 0.14 & 0.08 & 0.03 & 0.02 \\
$\mathrm{~B}$ & 0.50 & 1.84 & 4.63 & 5.83 \\
$\mathrm{Ca}$ & 0.05 & 0.01 & 0.01 & 0.01 \\
$\mathrm{Fe}$ & 0.14 & 0.09 & 0.02 & 0.00 \\
$\mathrm{Li}$ & 0.59 & 1.53 & 4.02 & 4.79 \\
$\mathrm{Mg}$ & 0.26 & 0.22 & 0.07 & 0.01 \\
$\mathrm{Mn}$ & 0.18 & 0.31 & 0.12 & 0.03 \\
$\mathrm{Mo}$ & 0.46 & 1.46 & 3.47 & 4.22 \\
$\mathrm{Na}$ & 0.49 & 1.27 & 2.70 & 3.16 \\
$\mathrm{Si}$ & 0.29 & 0.39 & 0.79 & 0.85 \\
$\mathrm{Sr}$ & 0.04 & 0.01 & 0.02 & 0.02 \\
$\mathrm{Zr}$ & 0.01 & 0.04 & 0.03 & 0.01 \\
$\mathrm{pH}$ & 10.69 & 10.44 & 10.65 & 11.11 \\
\hline
\end{tabular}

TABLE 4.1-12. Normalized Elemental Mass Releases from 28-day MCC-3 for TTT HW39-1 Glass Samples, 18-Angstrom filtered, $S A / V=1780 \mathrm{~m}^{-9}, 90^{\circ} \mathrm{C}$, in Deionized Water HWVP-86-V1122B

\begin{tabular}{|c|c|c|c|c|}
\cline { 3 - 5 } \multicolumn{2}{c|}{} & \multicolumn{1}{c|}{$750{ }^{\circ} \mathrm{C}$} & \multicolumn{2}{c|}{$6000^{\circ} \mathrm{C}$} \\
\hline Element & Std & $\begin{array}{c}300 \mathrm{~h} \\
\mathrm{~B} 4\end{array}$ & $\begin{array}{c}30 \mathrm{~h} \\
\mathrm{C3}\end{array}$ & $\begin{array}{c}300 \mathrm{~h} \\
\mathrm{C} 4\end{array}$ \\
\hline $\mathrm{AT}$ & 0.05 & 0.01 & 0.02 & 0.02 \\
$\mathrm{~B}$ & 0.51 & 1.86 & 4.63 & 5.67 \\
$\mathrm{Ca}$ & 0.01 & 0.01 & 0.01 & 0.01 \\
$\mathrm{Fe}$ & 0.00 & 0.00 & 0.00 & 0.00 \\
$\mathrm{Li}$ & 0.55 & 1.48 & 3.84 & 4.73 \\
$\mathrm{Mn}$ & 0.00 & 0.00 & 0.00 & 0.00 \\
$\mathrm{Mo}$ & 0.48 & 0.99 & 3.45 & 4.19 \\
$\mathrm{Na}$ & 0.48 & 1.21 & 2.64 & 3.16 \\
$\mathrm{Si}$ & 0.23 & 0.34 & 0.79 & 0.85 \\
$\mathrm{Sr}$ & 0.00 & 0.00 & 0.01 & 0.02 \\
$\mathrm{PH}$ & 10.69 & 10.44 & 10.65 & 11.11 \\
\hline
\end{tabular}


A summary of the 28-day MCC-1 leach testing results for the HW39-3 glasses is presented in Table 4.1-13. The results of 28-day MCC-1 leach testing of the HWVP reference glass, HW39-1, are also presented for comparison. Based on these test results, the glasses made from NCAW 86 were as durable as the HH39-I reference glass. The increased $\mathrm{ZrO}_{2}$ was thought to be the major cause of the increase in durability, offsetting any decrease in durability due to the increased amount of $\mathrm{Na}_{2} \mathrm{O}$ in the waste and glass.. Any modifications to the frit to adjust the T100P or E1150 to nearer the center of the HWVP operation ranges, most probably a reduction of the $\mathrm{Na}_{2} \mathrm{O}$ content in the frit, should improve the glass durability.

HW39-4: Durability testing was conducted on the HW39-4 glass for 7 and 28 days using .MCC-1 and MCC -3 leaching procedures. The test resuTts are summarized in Tables 4.1-14 and 4.1-15 for the MCC-1 tests, and Tables 4.1-16 through 4.1-19 for the MCC-3 tests. Leach testing for HW39-2 glass (a) are presented for comparison. To compare the relative durability of different glasses, elemental glass components that do not precipitate after being rèleased from the glass should be compared, such as B, and the alkalies (Li and $\mathrm{Na)}$ to a slightly lesser degree.

In the 7- and 28-day MCC-1 test, the normalized $B$ releases for the HW39-4 and HW39-2 glasses were found to be similar, with slightly higher releases from HW39-4 in the 28-day test. Both of these giasses were below $=\quad$ the proposed tuff geologic repository $B$ 1imit of $28 \mathrm{~g} / \mathrm{m}^{2}$ for a 28 -day MCC-1 test.

The results from the MCC -3 tests were significantly different. The MCC -3 leach test is very similar to the MCC-1 test procedure with two exceptions; the glass is in a powdered form, and glass powder and leachant are agitated by rotating the container. The elemental leachate concentrations from MCC-3 tests approximate Tong-term extrapolation of MCC-1 test results and assess the glass dissolution properties when.glass components may be saturated in the leachant.

In the 7-day MCC-3 tests, the normalized B release from HW39-4 was -5 times higher than the normalized boron release from HW39-2. In the 28-day MCC-3 tests the normalized boron release was -8 times higher. The reason for this significant increase of glass dissolution under MCC-3 conditions in not clear. The final $\mathrm{pH}$ for the HW39-4 leachant was slightly lower than for HW39-2; generally, the higher the $\mathrm{pH}$ the greater the dissolution of the glass. The differences in the two glass composition do not suggest any large change in durability. Calculating the free energies of hydration for the two glasses using a DWPF model (Ref. 4.1-7) indicated that the HW39-4 glass should be more durable than the HH39-2 glass.

(a) S. O. Bates et al., Interim Milestone HWVP-88-V320301A - Supplemental Report on Leach Testing of Simulated Hanford Waste Vitrification Plant Reference Glass, HW39. Pacific Northwest Laboratory, Richl and, Washington (1988). 
TABLE 4.1-13. Normalized Elemental Mass Releases from 28-day MCC-1 Leaching Tests for HW39-3 Giasses, Surface Area/ Volume $=10 \mathrm{~m}^{-1}$, Temperature $=90^{\circ} \mathrm{C}$; Leachate $=$ Deionized Hater HWVP-87-V110202A

\begin{tabular}{|c|r|r|r|r|}
\hline Element & HW43 & \multicolumn{1}{|c|}{$H W 44$} & \multicolumn{1}{|c|}{ HW45 } & . HW39 \\
\hline $\mathrm{Si}$ & 11.66 & 9.97 & 9.21 & 12.18 \\
$\mathrm{~B}$ & 16.24 & 13.51 & 13.22 & 14.49 \\
$\mathrm{Li}$ & 16.60 & 13.80 & 13.00 & 14.94 \\
$\mathrm{Na}$ & 15.47 & 13.59 & 13.05 & 14.62 \\
$\mathrm{Ca}$ & 4.48 & 3.47 & 2.48 & 7.13 \\
$\mathrm{Mo}$ & 15.96 & 14.99 & 12.90 & $\mathrm{NA}$ \\
$\mathrm{Sr}$ & 2.96 & 2.36 & 1.60 & 6.19 \\
$\mathrm{~A} 7$ & 7.24 & 7.04 & 7.04 & 9.16 \\
$\mathrm{Fe}$ & 0.30 & 0.15 & 0.10 & 0.46 \\
$\mathrm{CS}$ & 16.97 & 12.24 & 12.73 & 17.13 \\
Final pH & 9.63 & 9.63 & 9.64 & 9.65 \\
\hline
\end{tabular}

TABLE 4.1-14. Comparison of Normalized Release from 7-Day MCC-1 Leach Testing for HWVP Glasses HW39-4 and HW39-2. Conditions: $M C C-1$ in DIH, SA $/ \mathrm{V}=10^{-1}, 90^{\circ} \mathrm{C}$ HWVP-89-IVJ00100B

\begin{tabular}{|c|c|c|}
\cline { 2 - 3 } \multicolumn{1}{c|}{} & \multicolumn{2}{c|}{ Normalized } \\
Elementa7 \\
\cline { 2 - 3 } ReTease $\left(\mathrm{g} / \mathrm{m}^{2}\right)$
\end{tabular}


TABLE 4.1-15. Comparison of Normalized Release from 28-Day MCC-1 Leach Testing for HWVP GTasses HW39-4 and HW39-2. Conditions: MCC-1 in DIW, SA $/ V=10^{-1}, 90^{\circ} \mathrm{C}$ HWVP-89-IVJ0010100B

\begin{tabular}{|c|c|c|}
\cline { 2 - 3 } \multicolumn{1}{c|}{} & \multicolumn{2}{c|}{ Norma] ized } \\
\multicolumn{1}{c|}{ Elemental Release $\left(\mathrm{g} / \mathrm{m}^{2}\right)$} \\
\hline Element & HW39-4 & $H H-39-2$ \\
\hline Si & 13.34 & 11.20 \\
$\mathrm{~B}$ & 19.31 & 14.83 \\
$\mathrm{Li}$ & 16.50 & 15.01 \\
$\mathrm{Na}$ & 15.95 & 13.54 \\
$\mathrm{Ca}$ & 0.23 & 7.23 \\
$\mathrm{MO}$ & 16.74 & 13.94 \\
$\mathrm{Sr}$ & 0.89 & 5.72 \\
Al & 9.61 & 9.11 \\
$\mathrm{Fe}$ & 0.22 & 0.00 \\
$\mathrm{CS}$ & 20.68 & 16.22 \\
Final pH & 9.41 & 9.32 \\
\hline
\end{tabular}

TABLE 4-1-16. Comparison of Normal ized Release from 7-Day MCC-3 Leach Testing with $0.45-\mu \mathrm{m}$ Filtrate for HWVP Glasses. Conditions: $M C C-3$ in DIH, 7 days, $S A / V=2000 \mathrm{~m}^{-1}$, $90^{\circ} \mathrm{C} \quad$ HWWP-89-IVJ0010100B

\begin{tabular}{|c|c|c|}
\cline { 2 - 3 } \multicolumn{1}{c|}{} & \multicolumn{2}{c|}{ Normalized } \\
\cline { 2 - 3 } Elemental Release $\left(\mathrm{g} / \mathrm{m}^{2}\right)$ \\
\hline Si & HW39-4 & HH39-2 \\
B & 0.60 & 0.21 \\
$\mathrm{Li}$ & 2.19 & 0.44 \\
$\mathrm{Na}$ & 1.81 & 0.49 \\
$\mathrm{Ca}$ & 1.58 & 0.40 \\
$\mathrm{Sr}$ & 0.02 & 0.04 \\
$\mathrm{Al}$ & 0.02 & 0.03 \\
$\mathrm{Fe}$ & 0.04 & 0.12 \\
$\mathrm{Mg}$ & 0.18 & $<0.01$ \\
$\mathrm{CS}$ & 0.39 & 0.25 \\
Final pH & 0.21 & 0.13 \\
\hline
\end{tabular}


TABLE 4.1-17. Comparison of Norma7 ized Release from 7-Day MCC-3. Leach Testing with 18-Angstrom Fi7trate for HWVP Glasses. Conditions: $M C C-3$ in DIW, SA/V $=2000 \mathrm{~m}^{-1}, 90^{\circ} \mathrm{C}$ HWVP-89-IVJ0010100B

\begin{tabular}{|c|c|c|}
\cline { 2 - 3 } \multicolumn{1}{c|}{} & \multicolumn{2}{c|}{ Normalized } \\
\multicolumn{1}{c|}{ Elemental Release $\left(\mathrm{g} / \mathrm{m}^{2}\right)$} \\
\hline Element & $H W 39-4$ & $H H 39-2$ \\
\hline $\mathrm{Si}$ & 0.52 & 0.20 \\
$\mathrm{~B}$ & 2.19 & 0.45 \\
$\mathrm{Li}$ & 1.75 & 0.47 \\
$\mathrm{Na}$ & 1.54 & 0.39 \\
$\mathrm{Ca}$ & 0.01 & $<0.01$ \\
$\mathrm{Sr}$ & $<0.01$ & $<0.01$ \\
$\mathrm{Al}$ & 0.01 & 0.04 \\
$\mathrm{Fe}$ & 0.15 & $<0.01$ \\
$\mathrm{Mg}$ & $<0.01$ & $<0.01$ \\
$\mathrm{CS}$ & 0.17 & 0.05 \\
Final pH & 10.18 & 10.38 \\
\hline
\end{tabular}

TABLE 4-1-18. Comparison of Normalized Release from 28-Day MCC-3 Leach

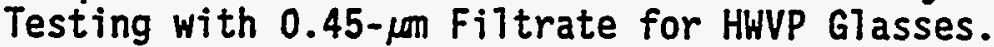
Conditions: MCC -3 in DIH, $S A / V=2000 \mathrm{~m}^{-1}, 90^{\circ} \mathrm{C}$ HWVP-89-IVJ0010100B.

\begin{tabular}{|c|c|c|}
\cline { 2 - 3 } \multicolumn{1}{c|}{} & \multicolumn{2}{c|}{ Normalized } \\
\multicolumn{1}{c|}{} & Elemental \\
\hline Element & HH39-4 & HW39-2 \\
\hline Si & 0.64 & 0.25 \\
$\mathrm{~B}$ & 4.29 & 0.53 \\
$\mathrm{Li}$ & 2.90 & 0.62 \\
$\mathrm{Na}$ & 2.74 & 0.52 \\
$\mathrm{Ca}$ & 0.01 & 0.07 \\
$\mathrm{Sr}$ & $<0.01$ & 0.05 \\
$\mathrm{AT}$ & $<0.01$ & 0.17 \\
$\mathrm{Fe}$ & 0.04 & $<0.01$ \\
$\mathrm{Mg}$ & 0.08 & 0.36 \\
$\mathrm{CS}$ & 0.19 & 0.23 \\
Final.pH & 10.41 & 10.55 \\
\hline
\end{tabular}


TABLE 4.1-19. Comparison of Normalized Release from 28-Day MCC-3 Leach Testing with 18-Angstrom Filtrate for HWVP Glasses. Conditions: $M C C-3$ in $D I H, S A / V=2000 \mathrm{~m}^{-1}, 90^{\circ} \mathrm{C}$ HWVP-89-IVJ0010100B

\begin{tabular}{|c|c|c|}
\hline \multirow[b]{2}{*}{ Element } & \multicolumn{2}{|c|}{$\begin{array}{l}\text { Normal ized } \\
\text { Elemental Release }\left(\mathrm{g} / \mathrm{m}^{2}\right)\end{array}$} \\
\hline & HW39-4 & HW39-2 \\
\hline $\begin{array}{l}\mathrm{Si} \\
\mathrm{B} \\
\mathrm{Li} \\
\mathrm{Na} \\
\mathrm{Ca} \\
\mathrm{Sr} \\
\mathrm{AT} \\
\mathrm{Fe} \\
\mathrm{Mg} \\
\mathrm{Cs}\end{array}$ & $\begin{array}{r}0.69 \\
4.29 \\
2.93 \\
2.77 \\
0.03 \\
<0.01 \\
<0.01 \\
<0.01 \\
<0.01 \\
0.19 \\
\end{array}$ & $\begin{array}{r}0.22 \\
0.53 \\
0.58 \\
0.50 \\
0.01 \\
<0.01 \\
0.04 \\
<0.01 \\
<0.01 \\
0.09 \\
\end{array}$ \\
\hline Final $\mathrm{pH}$ & 10.41 & 10.55 \\
\hline
\end{tabular}

4.1.2.2.2.4 Phase Behavior. The results for the phase behavior studies on the nominal reference glass composition are presented below.

HW39-I: (a) Nuclear waste glasses can devitrify at and below melter - processing temperatures. Devitrification is indicated by the formation of - crystals in the glass. Crystal formation leads to inhomogeneity of the glass product and, in some cases, a decrease in chemical durability, as was observed, for example, when acmite crystals formed in SRL-165 glass (Ref. 4.1-8).

The formation of crystals believed to be pyroxenes, as well as spinel crystals, has been observed in HW39-1 glass. (b) Pyroxene is a family of silicate minerals which may contain $\mathrm{Ca}, \mathrm{Na}, \mathrm{Mg}, \mathrm{Fe}$, and/or $\mathrm{Al}$, of which acmite $\left(\mathrm{NaFeSi}_{2} \mathrm{O}_{6}\right)$ and augite $\left[(\mathrm{Ca}, \mathrm{Fe}, \mathrm{Mg}) \mathrm{Si}_{2} \mathrm{O}_{6}\right]$ are members. The formation of pyroxenes crystals in HW39-1 glass has a similar effect on chemical durability as that of acmite in SRL-165.

(a) S. O. Bates and M. A. Reimus, Basel ine Milestone V1122B - Hanford Waste Vitrification Plant Reference Glass Development - FY 1986 Summary Report. HWVB-86-V1122B, Pacific Northwest Laboratory, Richland, Washington (1986).

(b) Hanford Waste Vitrification Program Monthiy Report, AR05-15-10, Design and Fabrication Section (September 1985). 
The spinel crystals present in $\mathrm{HW39-1}$ are a chromite spinel ( $\mathrm{FeCr}_{2} \mathrm{O}_{4}$ ) phase. This spinel phase is due to the relatively high $\mathrm{Cr}_{3} \mathrm{O}_{3}$ concentration in the HW39 glass composition (1.33 wt\% $\mathrm{Cr}_{2} \mathrm{O}_{3}$ ). The solubility of $\mathrm{Cr}_{2} \mathrm{O}_{3}$ in typical borosilicate waste glasses is $<0.5 \mathrm{wt \%}$. The spinel phase has been determined to have no significant affect on the durability of the glass. (a)

The formation of a crystalline phase during melter processing, or after the glass is placed in the waste form canister, can significantly affect the quality and/or processability of the glass product. The draft of the Waste Acceptance Preliminary Specifications for DWPF (Ref. 4.1-9) requires that a time-temperature-transformation (TTT) diagram of the glass product be reported. Time-Temperature-Transformation diagrams are isothermal. transformation piots. Isothermally heat-treated specimens of material are prepared so that any thermaliy-activated transformations that occur in the materia1 can be identified and characterized. In glass waste forms, the possible transformations of concern are partial devitrification of the glass into one or more crystalline products. Specimens may be prepared with isothermal heat treatment to determine the effects, if any, of the transformations on other physical properties such as leach rates. A simplified TTT diagram of HW39-1 glass has been generated to gain insight into devitrification behavior, given in Figure 4.1-8. The glass was also subjected to simulated closed canister.

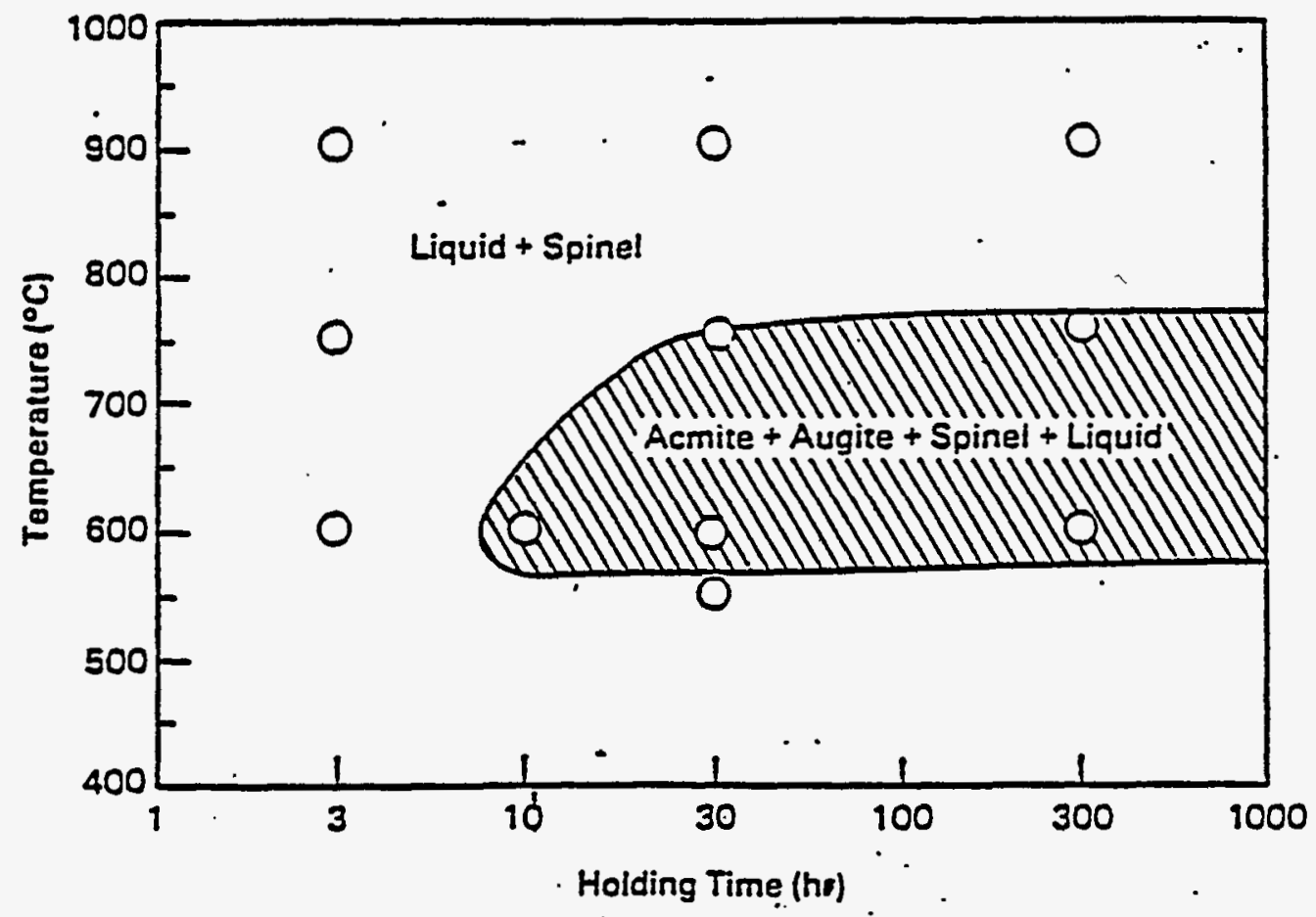

FIGURE 4.1-8. Preliminary Time-Temperature-Transformation Diagram for the HWVP Reference Glass, HW39-1 HWVP-86-V1122B

(a) S. 0. Bates, Results of Composition Variability Studies to Date. HWVP-85-020202-C, Pacific Northwest Laboratory, Richland, Washington (1985). 
turntable cooling rates (refer to Figure 4.1-9) to evaluate the reference glass devitrification characteristics: Because of the relatively high $\mathrm{Cr}_{2} \mathrm{O}_{3}$ content in the current reference glass, chromite spinel crystals are present at melter processing temperature. Using data generated during two melter tests (HBCM-85 and PSCM-22) conducted during FY 1986, an evaluation of the effects of the spinel crystais on the processability have been evaluated.

The objectives of the study were to 1) create a simplified timetemperature-transformation (TT) diagram of HW39-1 glass, and 2) determine the effect of pyroxene formation on HW39-1 chemical durability. Analysis of the $\pi$ diagram gives insight of HW39 devitrification behavior. Study of the time-temperature-transformation of this glass determined the thermal conditions that should be avoided to prevent formation of undesirable devitrification products. Determination of the effect of pyroxene formation on HW39-1 chemical durability indicated that pyroxenes decrease product quality. This knowledge may be used to indicate possible problems and glass cooling limitations.

To develop the TT diagram, a procedure developed by the Materials Characterization Center (MCC), designated as MCC-7S(a) for determining

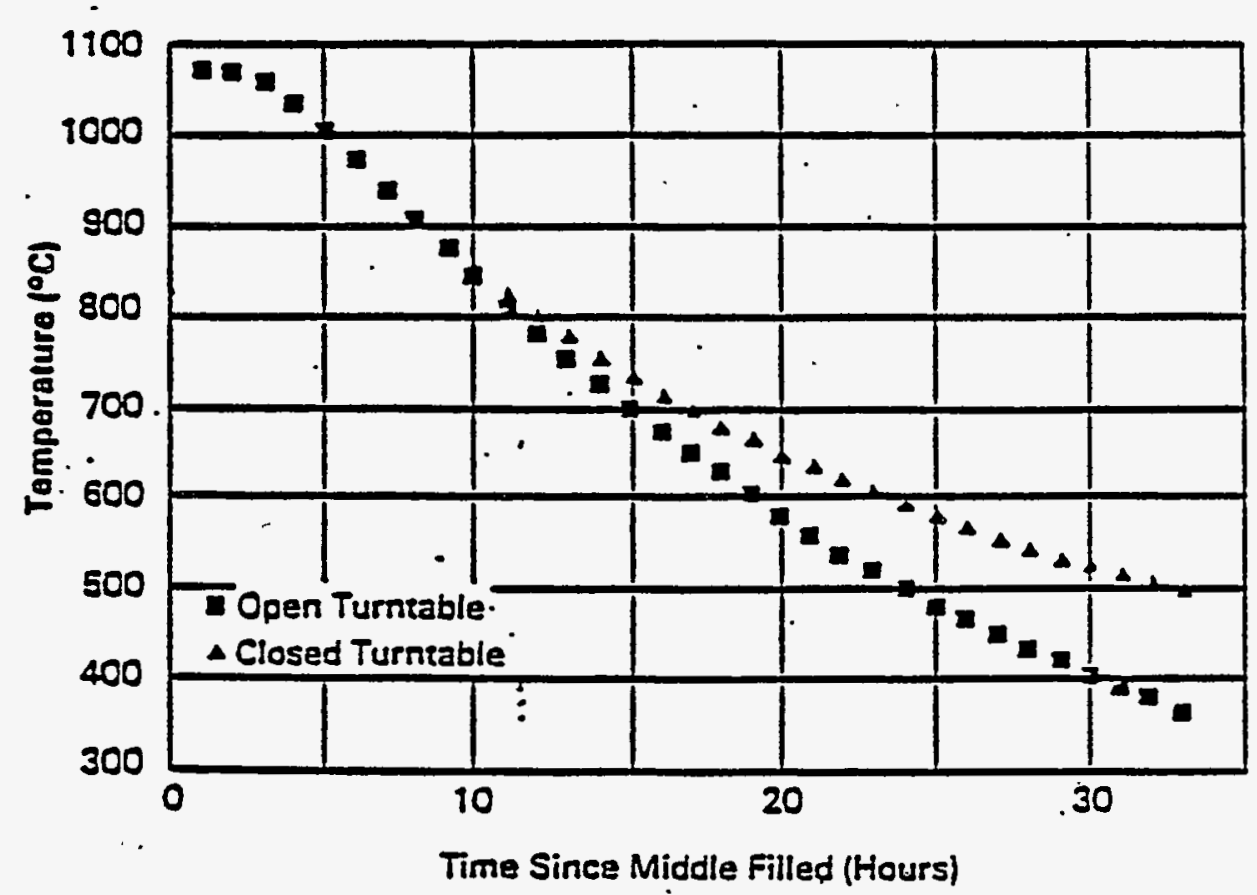

FIGURE 4.1-9. Predicted Centerline Canister Cooling Rates of the Open and Closed Canister Turntable Designs HWVP-85-V1122B

(a) Materials Characterization Center, MCC-7S Method for Preparation of Isothermal7y Heat-Treated Waste Forms. Pacific Northwest Laboratory, Richland, Washington (1984). 
transformation kinetics in solids was employed. This procedure consists of isothermally heat-treating specimens over a specific range of temperatures for specific time periods that are identified in a test matrix. Analysis of the chemical durability was based on MCC-1 and MCC-3 leach testing results.

The test matrix used is given in Table 4.1-20. It is a simplified matrix consisting of 11 test points with three duplicates (total of 14 test points). Three holding temperatures and three holding times are utilized. The matrix was originally designed for "scoping" purposes. Test points C5 and DI were added to further define where the leading edge of the TT diagram fe11. The HH39-1 glass was batched from oxides and carbonates. The target glass composition and inductively coupled plasma (ICP) analysis of the batch are. given in Tàble 4.1-21.

The testing also followed MCC-7S test procedures. For each test point, $150 \mathrm{~g}$ of milled glass and $0.38 \mathrm{~g}$ of graphite (for redox control) were added to a fused silica crucible, melted at $1150^{\circ} \mathrm{C}$ for $1 \mathrm{~h}$ in a furnace, then removed from the furnace and placed in an oven at the specified holding temperature and holding time. The crucible was then removed and annealed at $470^{\circ} \mathrm{C}$ for $2 \mathrm{~h}$, cooled slowly, then core-drilled. A standard with which to compare experimental results was also produced. It was treated in the same manner as the test samples but was not heat treated prior to annealing at $470^{\circ} \mathrm{C}$.

TABLE 4.1-20. HH39-1 Time-Temperature-Transformation Test Matrix HWVP-86-V1122B

\begin{tabular}{|c|c|c|}
\hline Test No. & Holding Temperature & $\begin{array}{c}\text { Holding Time } \\
(\mathrm{h})\end{array}$ \\
\hline STD & N/A $)$ & 0 \\
A1 & 900 & 3 \\
A2 & 900 & 30 \\
A3 & 900 & 300 \\
A4 & 900 & 300 \\
B1 & 750 & 3 \\
B2 & 750 & 30 \\
B3 & 750 & 30 \\
B4 & 750 & 300 \\
C1 & 600 & 3 \\
C2 & 600 & 3 \\
C3 & 600 & 30 \\
C4 & 600 & 300 \\
C5 & 600 & 10 \\
D1 & 550 & 30 \\
\hline
\end{tabular}


TABLE 4.1-21. Composition of HH39-1 Glass Batched for TTT Study HWVP-8G-V1122B

\begin{tabular}{|c|c|c|c|c|}
\hline \multirow[b]{2}{*}{ Oxide } & \multicolumn{2}{|c|}{ ICP wt\% } & \multirow[b]{2}{*}{ Avg } & \multirow{2}{*}{$\begin{array}{c}\text { Normal ized } \\
\text { wt\% }\end{array}$} \\
\hline & HW39A & HW39B & & \\
\hline 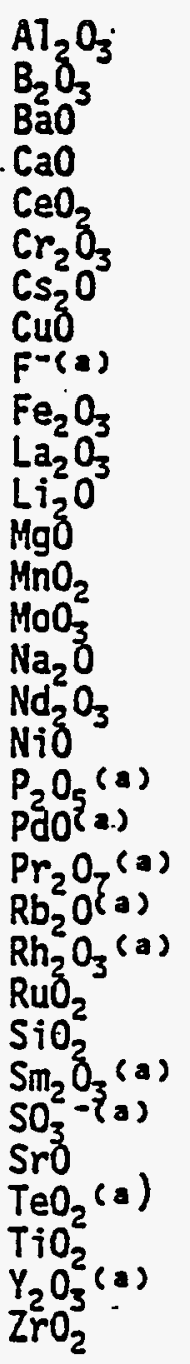 & $\begin{array}{r}4.27 \\
9.50 \\
0.09 \\
3.11 \\
0.24 \\
1.21 \\
0.11 \\
0.12 \\
0.30 \\
10.80 \\
0.57 \\
3.52 \\
0.82 \\
0.16 \\
0.26 \\
9.73 \\
0.47 \\
0.57 \\
0.02 \\
0.03 \\
0.09 \\
0.01 \\
0.04 \\
0.14 \\
48.50 \\
0.04 \\
0.45 \\
0.08 \\
0.03 \\
0.03\end{array}$ & $\begin{array}{r}4.45 \\
9.78 \\
0.10 \\
3.02 \\
0.24 \\
1.29 \\
0.13 \\
0.13 \\
0.30 \\
11.10 \\
0.59 \\
3.61 \\
0.86 \\
0.17 \\
0.28 \\
10.20 \\
0.48 \\
0.57 \\
0.02 \\
0.03 \\
0.09 \\
0.01 \\
0.04 \\
0.15 \\
49.90 \\
0.04 \\
0.45 \\
0.08 \\
0.03 \\
0.02 \\
0.05 \\
0.59 \\
\end{array}$ & $\begin{array}{r}4.36 \\
9.64 \\
0.09 \\
3.07 \\
0.24 \\
1.25 \\
0.12 \\
0.13 \\
0.30 \\
10.95 \\
0.58 \\
3.57 \\
0.84 \\
0.17 \\
0.27 \\
9.97 \\
0.48 \\
0.57 \\
0.02 \\
0.03 \\
0.09 \\
0.01 \\
0.04 \\
0.15 \\
49.20 \\
0.04 \\
0.45 \\
0.08 \\
0.03 \\
0.03 \\
0.05 \\
0.59\end{array}$ & $\begin{array}{r}4.48 \\
9.90 \\
0.10 \\
3.15 \\
0.25 \\
1.28 \\
0.12 \\
0.13 \\
0.31 \\
11.25 \\
0.60 \\
3.66 \\
0.86 \\
0.17 \\
0.28 \\
10.23 \\
0.49 \\
0.59 \\
0.02 \\
0.03 \\
0.09 \\
0.01 \\
0.04 \\
0.15 \\
50.53 \\
0.04 \\
0.46 \\
0.08 \\
0.03 \\
0.03 \\
0.05 \\
0.61 \\
\end{array}$ \\
\hline TOTAL & 95.95 & 98.80 & 97.38 & 100.00 \\
\hline
\end{tabular}

(a) Not analyzed....assumed target. 
Following heat treatment, thin sections of the core samples were made and examined with transmitted and reflected light microscopy for initial determination of crystalline content. When crystals were observed, the thin sections were examined with scanning electron microscopy/energy-dispersive $x$-ray (SEM/EDX) for qualitative analysis. A portion of the sample was also submitted for $X$-ray diffraction (XRD) analysis.

MCC-1 and MCC-3 leach tests ( 7 and 28 day) were performed on glass samples in which pyroxene formation was observed. Leach testing was performed on samples with differing crystalline compositions and on the prepared standard to determine if the chemical durability of HW39-I is dependent upon crystalline composition and/or amount.

The time-temperature-transformation (TTT) diagram (Figure 4.1-8) was derived based on the results of optical microscopic observation, SEM/EDX, and XRD. All treated samples and the standard contained spinel crystals as expected. Pyroxene crystals were observed in samples treated over $3 \mathrm{~h}$ at 600 and $750^{\circ} \mathrm{C}$. The Teading edge of the diagram is located at slightly less than $10 \mathrm{~h}, 600^{\circ} \mathrm{C}$. It should be noted that al though the diagram was derived from observations taken at eleven test points and is extrapolated, it provides a good basis for evaluating TT effects in HW39-1 glass.

Samples held at $900^{\circ} \mathrm{C}$ showed that the spinel crystals had agglomerated and settled within the crucible with time. SEM/EDX data indicate that the crystals have a high $\mathrm{Cr}$ and $\mathrm{Fe}$ content and also contain a small quantity of $\mathrm{Ni}$. The individual crystals grow with holding time, from approximately 1:7 $\mu \mathrm{m}$ to 2 to $2.7 \mu \mathrm{m}$ over a $300-\mathrm{h}$ period. XRD data show no indication of the amount of crystalline material increasing with time, or being any larger than that of the standard. With simultaneous crystal formation and dissolution, larger crystals are being preferentially formed over time.

Samples held at $750^{\circ} \mathrm{C}$ showed that pyroxene formation occurred sometime around $30-h$ holding time along with the ever-present spinels. The crystals, which were first observed at $30-h$ holding time via optical microscope and SEM, have a rectangular shape. SEM/EDX data indicate that these crystals contain $\mathrm{Si}, \mathrm{Ca}, \mathrm{Fe}$, and small amounts of $\mathrm{Na}, \mathrm{Mg}, \mathrm{Al}, \mathrm{Cr}$, and $\mathrm{Ni}$. XRD data indicate that these crystals are an acmite/augite solid solution. The presence of these crystals was not indicated by XRD at $30-h$ holding time, which suggests that the crystalline content at this point was less than 5 wt\% (XRD detection 7 imit). These pyroxene crystals, large in comparison with the spinel crystals, measure approximately $53 \mathrm{\mu m}$ across at $30 \mathrm{~h}$ and grow with increasing holding times to 100 to $150 \mu \mathrm{m}$ at $300 \mathrm{~h}$. The glass matrix was partially depleted of $\mathrm{Si}, \mathrm{Ca}, \mathrm{Fe}, \mathrm{Ni}, \mathrm{Mg}$, and $\mathrm{Na}$ with holding time, indicating that the pyroxene content increases with time. The crystals appear to nucleate homogeneously. The amount of spinels remains relatively constant with time.

Samples held at $600^{\circ} \mathrm{C}$ showed that pyroxene formation occurred sometime between 3 - and 10-h holding time. The crystalline phase was shown by SEM/EDX to contain $\mathrm{Si}, \mathrm{Fe}, \mathrm{Ca}$ and small amounts of $\mathrm{Ni}, \mathrm{Na}, \mathrm{Mg}$, and $\mathrm{Al}$. XRD data indicate that this phase is an acmite/augite solid solution. XRD peak intensities indicate that the phase formed at $600^{\circ} \mathrm{C}$ contains less augite than the 
phase formed at. $750^{\circ} \mathrm{C}$. . The crystals formed at $600^{\circ} \mathrm{C}$ are dendritic and appear to be nucleated by the spinels present. This indicates that the crystalline formation is primarily heterogeneous in nature, which is faster than homogeneous formation. The crystalline density in the glass increases with holding time as indicated by microscopic/SEM examination. The crystals grow with holding time from approximately 3 to $10 \mathrm{\mu m}$ across. The glass matrix is observed to be partially depleted of $\mathrm{Ca}, \mathrm{Fe}, \mathrm{Mg}$, and $\mathrm{Si}$ with time, also indicating crystal growth. The spinel content appears to remain constant over time.

To verify that the compositions of the samples were not changing with holding time through volatility losses, ICP analysis was performed on all samples after heat treatment, annealing, and core drilling. The major giass components and their percent maximum deviations from the target composition are listed in Table 4.1-22. With the exception of $\mathrm{Fe}_{2} \mathrm{O}_{3}$ and $\mathrm{CaO}$, the major components were within $5 \%$ of the target values. The $\mathrm{Fe}_{2} \mathrm{O}_{3}$ and $\mathrm{CaO}$ varied less than 7\%. Variations were random and not related to the time of heat treatment. No loss of components over time as a result of volatility was observed. Volatile species, such as $\mathrm{Na}$, did not deviate more than nonvolatile species in the analysis.

The redox state of the samples was also determined as it too has been shown to affect the durability of nuclear waste glasses. Table 4.1-23 lists the ferrous/ferric ratio of the samples and the standard. This ratio varied from 0.15 to $0: 32$. The only set of samples shown to possibly become more oxidized over time are those treated at $900^{\circ} \mathrm{C}$. The samples that underwent leach testing--STD, B4, C3 and C4--have comparable redox ratios, and consequentiy the redox. state of these glasses was not a factor that affected durability performance.

TABLE 4.1-22. Maximum Percent Deviation of Major Components From TTT Target Values HWVP-86-VI122B

\begin{tabular}{|c|c|c|}
\hline Component & Target wt\% & $\begin{array}{c}\text { Maximum \% Deviation } \\
\text { of Target }\end{array}$ \\
\hline $\mathrm{SiO}_{2}$ & 51.51 & 2.23 \\
$\mathrm{Na}_{2} \mathrm{O}$ & 10.36 & 5.02 \\
$\mathrm{Fe}_{2} \mathrm{O}_{3}$ & 11.14 & 6.64 \\
$\mathrm{~B}_{3} \mathrm{O}_{3}$ & 9.56 & 3.45 \\
$\mathrm{Al}_{2} \mathrm{O}_{3}$ & 4.31 & 4.18 \\
$\mathrm{CaO}$ & 2.87 & 6.27 \\
$\mathrm{Li}_{2} \mathrm{O}$ & 3.75 & 2.93 \\
\hline
\end{tabular}


TABLE 4:1-23. Redox Response of TTT Samples HWVP-86-V1122B

\begin{tabular}{|l|c|c|}
\hline Sample & Holding Time $(\mathrm{h})$ & $\mathrm{Fe}^{2+} / \mathrm{Fe}^{3+}$ \\
\hline STD & N/A & 0.27 \\
A1 & 3 & 0.23 \\
A2 & 30 & 0.26 \\
A3 & 300 & 0.13 \\
A4 & 300 & 0.15 \\
B1 & & 0.16 \\
B2 & 3 & 0.23 \\
B3 & 30 & 0.22 \\
B4 & 30 & 0.32 \\
C1 & 300 & 0.16 \\
C2 & 3 & 0.24 \\
C3 & 3 & 0.28 \\
C4 & 30 & 0.32 \\
C5 & 300 & 0.32 \\
D1 & 10 & 0.15 \\
\hline
\end{tabular}

HW39-2: Optical evaluation of thin sections of quenched samples of glass and fibers pulled during viscosity measurements found no observable changes in the amounts or types of crystalline material in all the glasses compared with the HW39-2 reference glass. The crystals present in the glass are the noble metal ( $R u, R h$, and $P d$ ) phases. Analysis by $X$-ray diffraction (XRD) found no detectable crystalline phases except in the $5 \mathrm{wt} \%$ fluorine glass, which contained between 5 and $10 \mathrm{wt} \%$ of a crystalline material identified by XRD as $\mathrm{CaF}_{2}$. The detection limit for XRD is approximately 5 wt\%.

HW39-3: The phase behavior of the NCAH 86 waste was evaluated in quenched and heat-treated glasses. The evaluation consisted of the examination of thin sections of the glasses with transmitted and reflected light microscopy for initial determination of crystalline content. When crystals were observed, the thin sections were examined with scanning electron microscopy/energy-dispersive $x$-ray (SEM/EDX) for qualitative analysis. Powder portions of each glass were also submitted for $X$-ray diffraction (XRD) analysis.

Optical evaluation of the quenched NCAH 86 glasses revealed a small amount of very fine grain crystalline material at all three waste loadings. The large amounts of chromite spinel observed in the HW39-1 glass were not present in the NCAW 86 because of the reduced $\mathrm{Cr}_{2} \mathrm{O}_{3}$ level. The amounts of crystall ine material observed were approximately the same in the $H W 43$ and an HW39-2 glass, both of which had the same $\mathrm{Cr}_{2} \mathrm{O}_{3}$ level and waste loading. The amount of crystalline material increased slightly as the waste loading 
increased in HW44:and HW45. Analysis by SEM/EDX indicated that the crystalline phases were comprised of $\mathrm{Ru}, \mathrm{Rh}$, and Pd. Analysis by XRD could not detect these crystalline phases, indicating that the amount of each crystalline phase was less than 5 wt\%. This was typical of what had been observed in the HH39-2 glass using the NCAW 84 waste composition. At melter operating temperatures (approximately $1150^{\circ} \mathrm{C}$ ), noble metals (Ru, $\mathrm{Rh}$, and Pd) are only slightly soluble in borosilicate glasses. The solubility of Ru has been observed to be less than 0.001 wt\% in borosilicate melts (Ref. 4.1-6). The Ru will usually exist as oxide crystals except under very reducing conditions when $\mathrm{Ru}$ metal can form. Rhodium and $\mathrm{Pd}$ typically remain alloyed in the metallic state.

To evaluate the devitrification behavior of NCAN 86 glasses, a heat treatment was conducted on each giass to simulate the canister cool-down conditions. Canister cooling curves were derived from data generated from the TEMPEST computer code used to model the fontinuous filling and cooling of canisters in an open and closed turntable. (a) The cooling curve is given in Figure 4.1-10. The closed turntable curve was used for conservative case simulation because greater devitrification takes place with slower cooling rates.

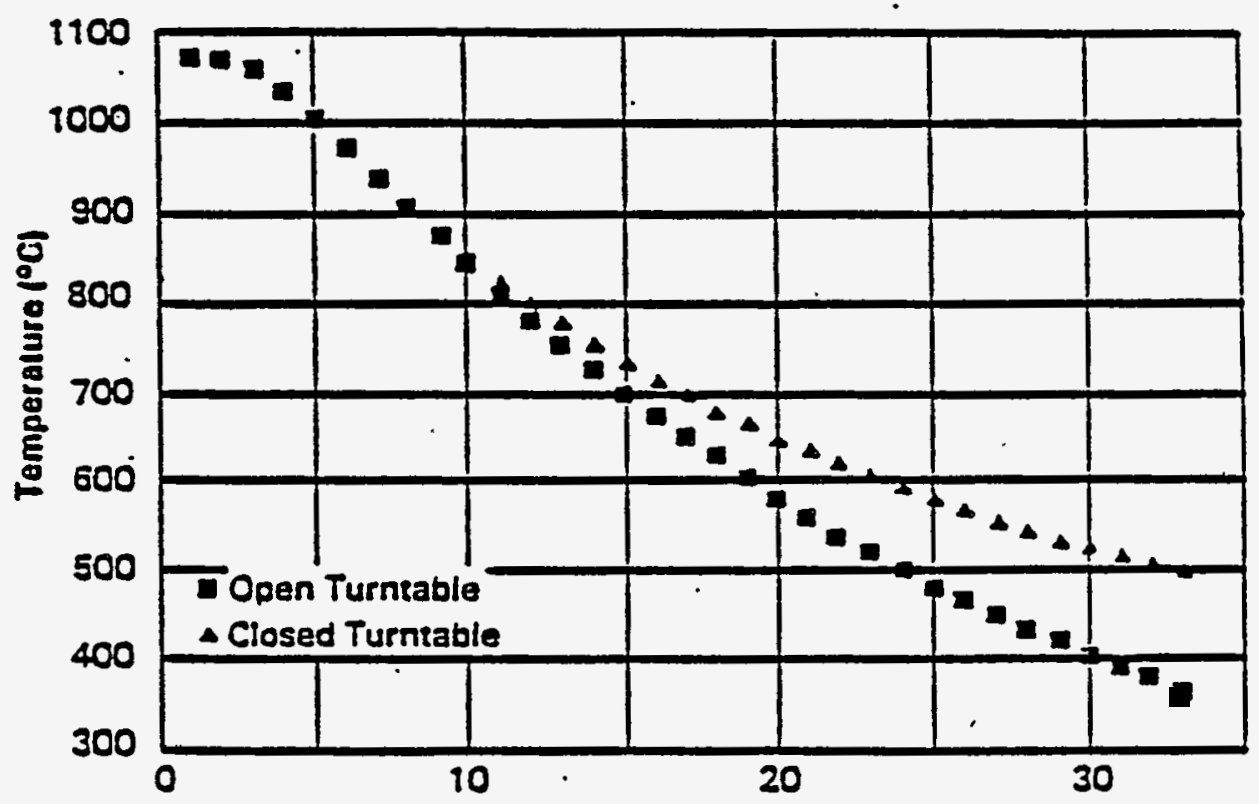

Time Since Middle Filled

FIGURE 4.1-10. Predicted Centerline Canister Cooling Rates of the Open and Closed Canister Turntable Designs HWVP-87-V110202A

(a) M. R. Elmore, Evaluation of Turntable Desion Concepts for the HWVP. HWVP-86-V1132A, Pacific Northwest Laboratory, Richland, Washington (1986). 
To simulate the cool-down, a furnace was programmed to perform a series of linear cooling rate steps, very closely simulating the model cooling curve. A powdered sample of each glass was placed in an alumina crucible, placed in the furnace at $1150^{\circ} \mathrm{C}$, allowed to melt for $1 \mathrm{~h}$, then allowed to cool at the programmed cooling rate. The crucible was then halved vertical7y; a thin section of the glass was made from one half and an XRD powder sample was taken from the other.

The XRD analysis detected no devitrification products in the HW43 or HW39-2 $\left(0.13\right.$ wt\% $\left.\mathrm{Cr}_{2} \mathrm{O}_{3}\right)$ glass samples but indicated that between $5 \%$ and $10 \%$ devitrification occurred in HW44 and. HW45. AnaTysis by SEM/EDX found two devitrification products. Iron-chromium-nickel spinel crystals were observed to have nucleated off the noble metal crystals. Iron- calcium silicate (pyroxene) crystals were observed to have both nucleated on the spinel crystal's and to have homogeneously nucleated resulting in their independent existence in the melt. The fact that the pyroxenes nucleated on spinel crystals indicates that the spinels formed first, followed by the pyroxenes at lower temperatures. Because these devitrification products occur after the glass is in the canister, the observed devitrification presents no processing problems. However, the pyroxenes have been observed to affect the durability of the waste form. (a) Due to presence of pyroxenes, any increase in waste loading over 25 wt\% waste oxide could affect durability and could also affect compliance with durability limits established by the WAC.

HW39-4: The phase behavior of HW39-4 was evaluated by optical and SEM/EDAX analyses of thin sections of quenched and heat-treated glass. The gross diversification behavior was evaluated by subjecting the glass to a $900^{\circ} \mathrm{C}$ 3-day isotherm anneal and a simulated canister heat-treatment. In the quenched and isothermal heat-treated glass, the only crystalline phases present were the oxide and metal7 ic phases of noble metal (Ru, Rh, and Pd) which were expected due to the negligible solubility of the noble metals. In the simulated canister heat-treated glass, small amounts of nickel-ironchrome spinel crystals, $(\mathrm{Ni}, \mathrm{Fe})(\mathrm{Fe}, \mathrm{Cr})_{2} \mathrm{O}_{4}$, were al so observed (estimated $\leq 5 \mathrm{wt} \%$ ). As subsequently indicated, no crystalline phases were observed in the PSCM-23 melter glass, and there was no indication of sludge (crystalline phase) formation in the melter when the melter bottom was physically probed after the run.

\subsection{Thermal Properties. The results from the thermal property} testing studies on the nominal reference glass composition are presented below. No thermal properties testing studies have been performed on the HW39-2 or HW39-4 compositions.

HW39-1: (a) HW39 glass monoliths (approximately $1 \mathrm{~cm} \times 1 \mathrm{~cm} \times 2 \mathrm{~cm}$ ) were cut from an annealed glass bar, then annealed at $475^{\circ} \mathrm{C}$ for $2 . \mathrm{h}$ and furnace

(a) S. 0. Bates and M. A. Reimus, HWVP Baseline Milestone HWVP-86-V1122B: Hanford Waste Vitrification Program Reference Glass Development FY 1986 Summary Report. Pacific Northwest Laboratory, Richland, Washington. 
cooled at $\leq 1 \cdot \mathrm{C} / \mathrm{min}$. The glass monoliths were heated at a rate of $200^{\circ} \mathrm{C} / \mathrm{min}$. The resuiting thermal expansion of HW39-1 glass is shown in figure 4.1-1I.

The thermal coefficient of linear expansion is the fractional change of a linear dimension per unit increase in temperature; $\left(1 / l_{0}\right)(\Delta l / \Delta t)$ where $1_{0}$ is the original length of the sample and $\Delta l$ and $\Delta t$ are the changes in the length and temperature, respectively. The low thermal coefficient of linear expansion describes the thermal expansion below $\mathrm{T}_{\mathrm{g}}$ and the high thermal coefficient of 7 inear expansion describes thermal expansion above $T_{g}$. From the curve shown in Figure 4.1-11, the low thermal coefficient of 1inear expansion is determined to be $8.4 \times 10^{-6} /{ }^{\circ} \mathrm{C}$, and the high thermal coefficient of Tinear expansion, $97.2 \times 10^{-6} / \cdot \mathrm{C}$.

The glass transition temperature of HW39-1 glass was determined by . extending the two linear rates of thermal expansion as shown in Figure 4.1-11. The intersection of extensions of the two linear rates defines the glass transition temperature. The $T_{g}$ for HW39-1 glass is $914^{\circ} \mathrm{F}\left(490^{\circ} \mathrm{C}\right)$. In Figure 4.1-11, the rate of the change in sample length with temperature begins to decrease at approximately $540^{\circ} \mathrm{C}$. This change was due to penetration of the probe into the sample and not a change of the rate of thermal expansion. This peak in length is called the dilatometric softening temperature, which for HW39-I glass is $550^{\circ} \mathrm{C}$.

The density of the reference glass from room temperature to the glass transition temperature $914^{\circ} \mathrm{F}\left(490^{\circ} \mathrm{C}\right)$ was calculated by using the low thermal expansion coefficient to calculate the change in volume with temperature (assuming no change in sample weight). About $T_{g}$, the high thermal expansion coefficient was used to calculate the change in volume/ ${ }^{\circ} \mathrm{C}$. The calculated values for the density of $\mathrm{HH} 39-1$ from $20^{\circ} \mathrm{C}$ to $1200^{\circ} \mathrm{C}$ are shown. in Figure 4.1-12 and Tabie 4.1-24.

The heat capacity of HW39-1 glass was determined using DSC. This technique subjects a glass sample and a reference material to closely controlled programmed temperature profiles. In the event of any change $C_{p}$ of the glass, or other transition such as a phase change, the amount of thermal energy. required to maintain both the sample and the reference material at the same temperature is measured. Because the energy input is equivalent to the energy absorbed, the heat capacity of the glass can be determined.

Five samples of powdered HW39-1 glass were used for the DSC analysis to determine $C_{p}$. Figure 4.1-13 shows the average $C_{p}$ of the five samples plotted against temperature up to $400^{\circ} \mathrm{C}$. . Using least squares linear regression, a line was fitted to the data with a coefficient of determination $\left(R^{2}\right)$ of 0.99 . The equation of the fitted line is:

$$
C_{p}=0.1709+\left(3.389 \times 10^{-4}\right) t
$$

where $C_{p}$ is in $\operatorname{cal} /\left(g \cdot{ }^{\circ} \mathrm{C}\right)$ and $t$ is the temperature between $0^{\circ} \mathrm{C}$ and $400^{\circ} \mathrm{C}$. 


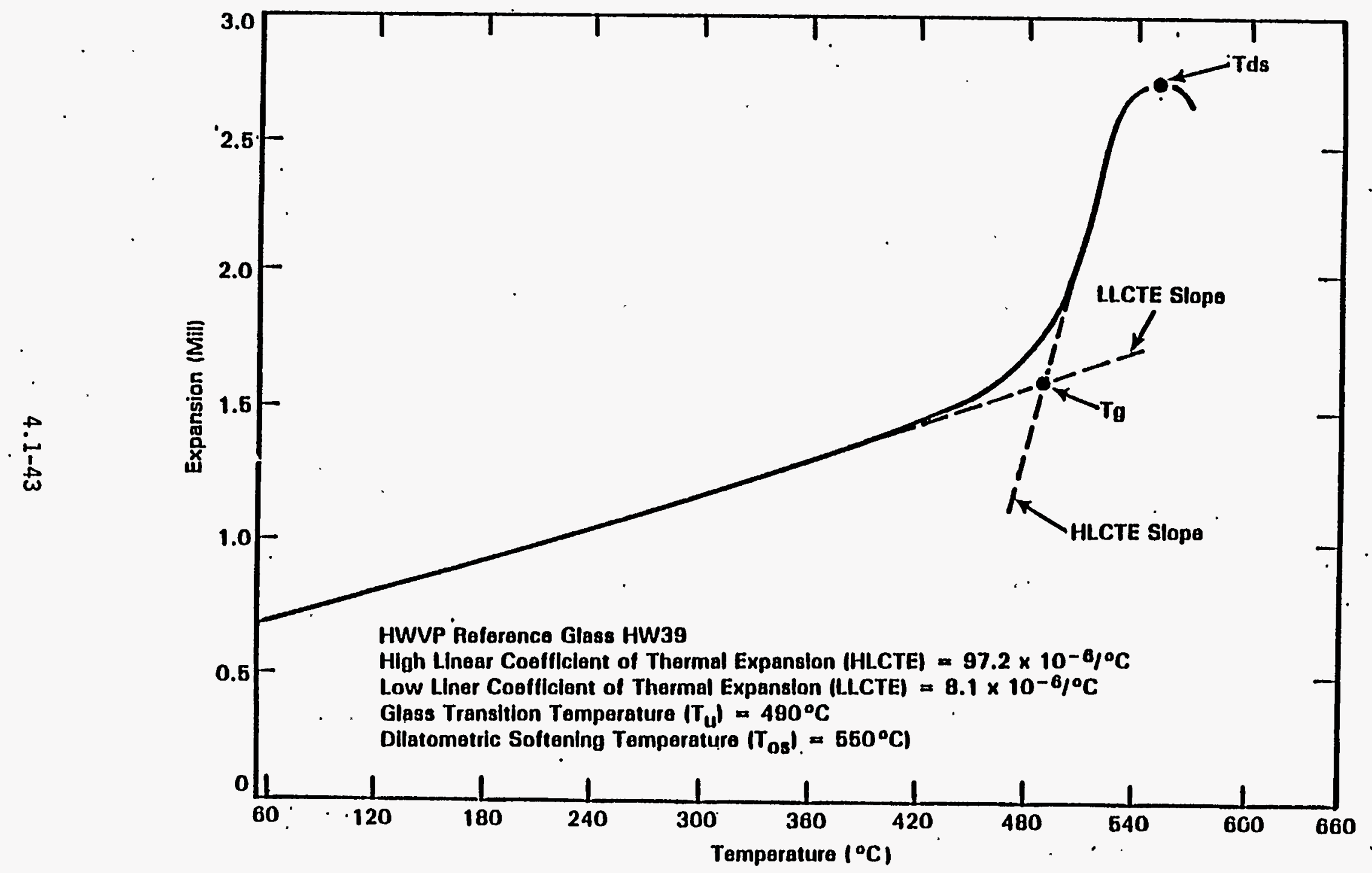

FIGURE 4.1-11. Thermal Expansion Curve and Determination of the Glass Transition Temperature for the HWVP Reference Glass, HW39-1 HWVP-86-V1122B 


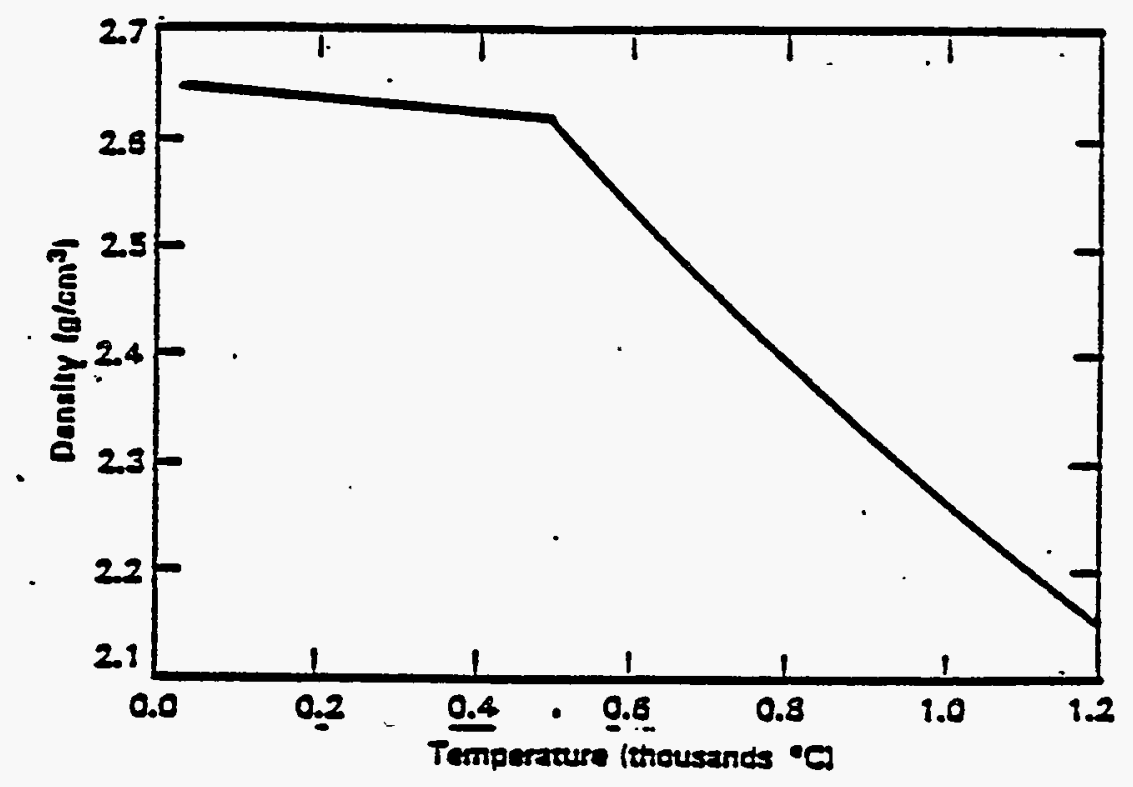

FIGURE 4.1-12. Calculated Density of HWVP Reference Glass, HW39-1 HWVP-86-V1122B

TABLE 4.1-24: Calculated Density Versus Temperature for HW39-1 Glass HWVP-86-V1122B

Lower Coefficient of Linear Expansion $=8.40 \times 10^{-6}$

High Coefficient of Linear Expansion $=97.2 \times 10^{-6}$

Density at $20^{\circ} \mathrm{C}=2.65 \mathrm{~g} / \mathrm{cm}:^{3}$

\begin{tabular}{|c|c|}
\hline Temperature & CaTculated Density \\
\hline 20 & 2.65 \\
100 & 2.64 \\
200 & 2.64 \\
300 & 2.63 \\
400 & 2.62 \\
$490\left(T_{g}\right)$ & 2.62 \\
500 & 2.61 \\
600 & 2.54 \\
700 & 2.46 \\
800 & 2.40 \\
900 & 2.33 \\
1000 & 2.27 \\
1050 & 2.23 \\
1100 & 2.20 \\
1150 & 2.17 \\
1200 & 2.14 \\
\hline
\end{tabular}




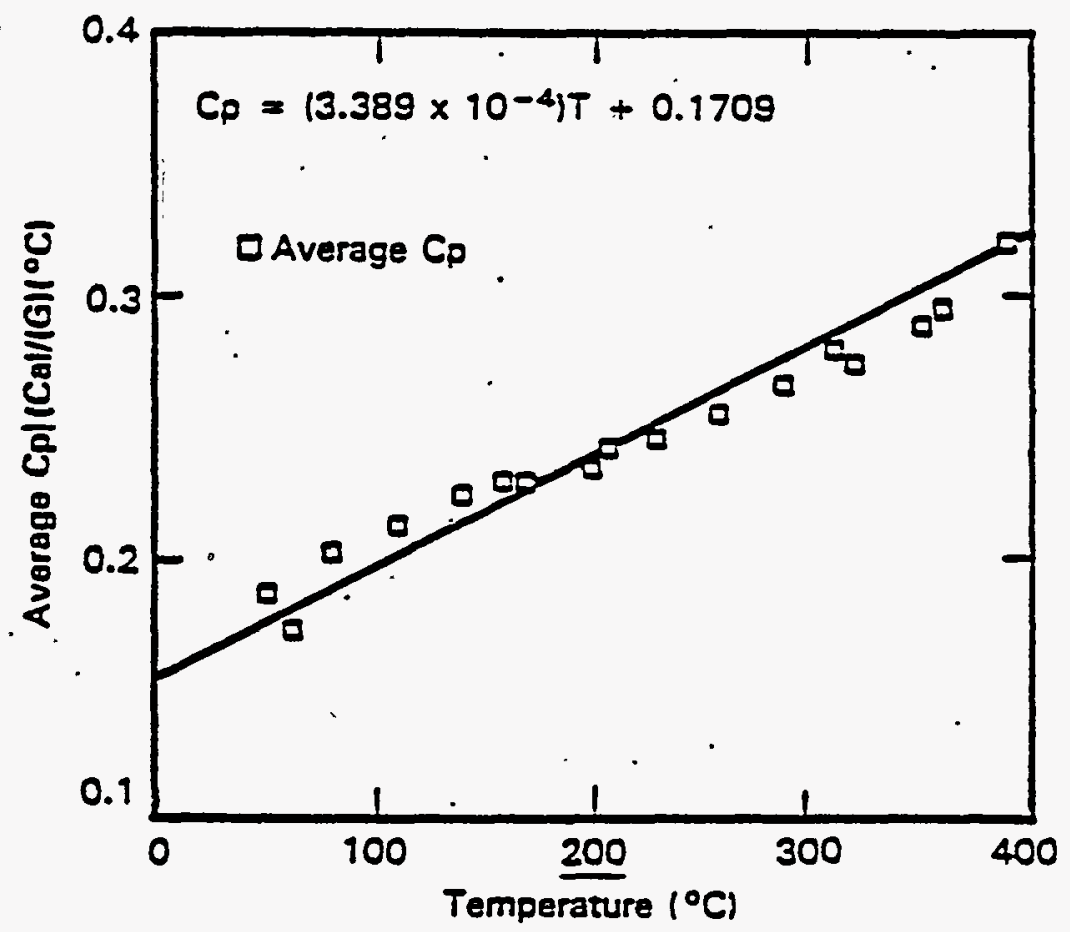

FIGURE 4.1-13. Measured Heat Capacity $\left(C_{p}\right)$ from $0^{\circ} \mathrm{C}$ to $400^{\circ} \mathrm{C}$ for the HWVP Reference G7ass, HW39-1 HWVP-86-V1122B

The thermal conductivity $(\cdot k)$ of HW39-1 can be calculated using the glass density $(\rho)$, heat capacity $\left(C_{p}\right)$, and thermal diffusivity $(\alpha)$ of the reference glass. Thermal diffusivity is defined as the ratio of thermal conductivity to the heat capacity per unit volume, $k / \rho C_{p}$. The thermal diffusivity for HW39-1 is shown in Figure 4.1-14.

HW39-3: (a) The preliminary HWVP WFQP (Ref. 4.1-5) requires that the glass transition temperature $\left(T_{g}\right)$ be reported. Below the glass transition temperature, rearrangement of the glass structure is severely limited, resulting in the glass structure being essentially independent of time and temperature. Thermomechanical Analysis (TMA) was used to determine the $\mathrm{Tg}$ and the linear thermal expansion coefficient.

The glass transition temperatures for the NCAW 86 glasses were determined by extending the two linear rates of thermal expansion as shown in Figure 4.1-15, which is the TMA curve for HW43. The intersection of extensions of the two linear rates defines the glass transition temperature. In Figure 4.1-15, the rate of the change in sample length with temperature begins

(a) S. 0. Bates, Baseline Milestone HWVP-87-V110202A: Waste Form Evaluation of the Updated NCAW Composition Report. Pacific Northwest. Laboratory, Richland, Washington (1987). 


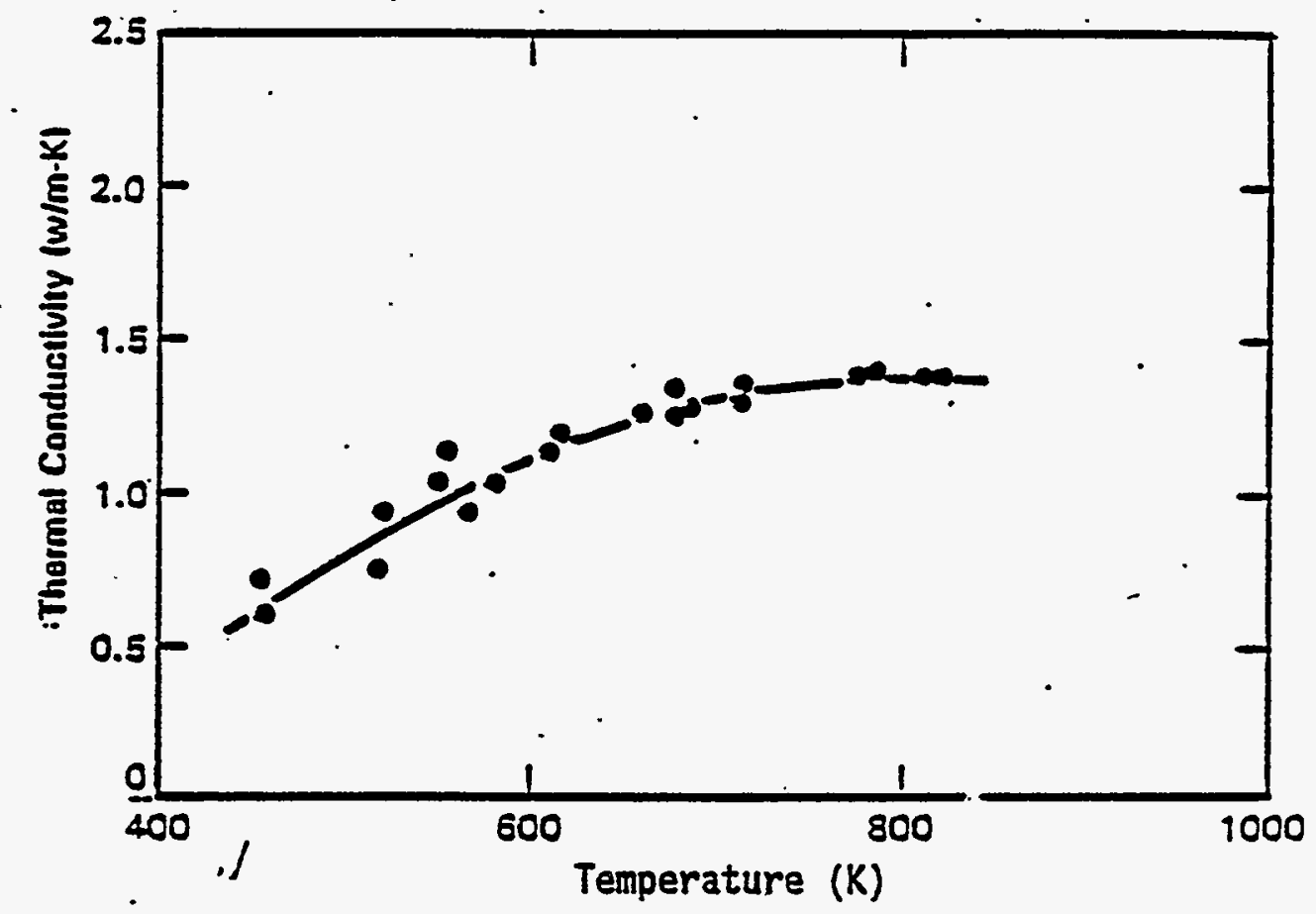

FIGURE 4.1-14. Measured Thermal Diffusivity from $450 \mathrm{~K}$ to $825 \mathrm{~K}$ $\left(177^{\circ} \mathrm{C}\right.$ to $552^{\circ} \mathrm{C}$ ) for the HWVP Reference GTass; HWH39-1 HWVP-86-VI122B

to decrease at approximately $540^{\circ} \mathrm{C}$. This change was due to penetration of the probe into the sample and not to a change in the rate of thermal expansion. The Tgs for all the NCAN 86 glasses are approximately $490^{\circ} \mathrm{C}$. This was the same value measured for the HW39-1 reference glass.

The thermal expansion coefficients for the NCAW 86 glasses are presented in Figure 4.1-15. The coefficient of linear thermal expansion is the fractional change of a linear dimension per unit increase in temperature:

$\left(1 / l_{0}\right)(\Delta 7 / \Delta t)$, where $l_{0}$ is the original length of the sample and $\Delta 1$ and $\Delta t$ are the changes in the length and temperature, respectively. The low coefficient of linear thermal expansion describes the thermal expansion below $T_{g}$, and the high coefficient of linear thermal expansion describes thermal expansion above $T_{g}$. Both low and high coefficients of thermal expansion for the NCAW 86 glasses were approximately the same as HW39-1. Both $T_{q}$ and thermal expansion were very insensitive to the composition changes in NCAW feed for HW39-1 and HW39-3 glasses. 


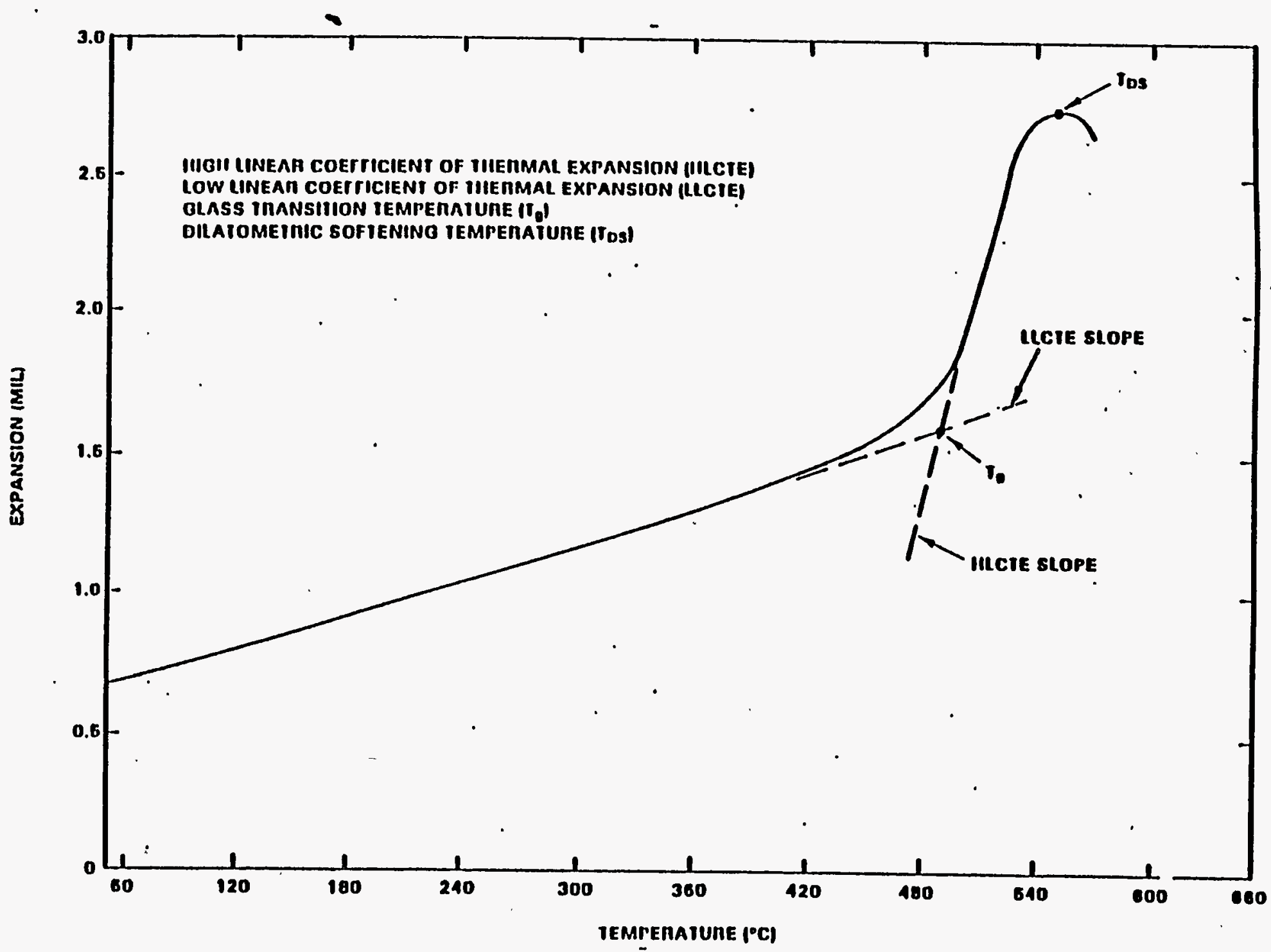

FIGURE 4.1-15. Thermal Expansion Curve and Determination of the HW39-3 Glass Transition Temperature for HW43 Glass Produced from NCAW 86 Haste HWVP-87-V110202A 
4.1.2.2.2.6 Mechanical Properties. Limited mechanical property testing has been performed on HW39-1 glass only. Prel iminary compressive strength and Young's moduius(a) of HW39-1 are as follows:
Compressive Strength
Young's Modulus
$6 \times 10^{4}$ psi
$2.8 \times 10^{8} \mathrm{psi}$

The following mechanical properties for the SRL composite glass(a) should be used as the standard reference where HWVP data are not available.

$\begin{array}{ll}\text { Young's Modulus } & 9 \times 10^{6} \mathrm{psi} \\ \text { Tensile Strength } & 9 \times 10^{3} \mathrm{psi} \\ \text { Compressive Strength } & 1 \times 10^{5} \mathrm{psi} \\ \text { Poisson's Ratio } & 0.2\end{array}$

4.1.2.2.2.7 HWVP Reference Canister Glass Canister. Characteristic properties of the reference HWVP canisters are provided as shown in the table below:

\begin{tabular}{|c|c|}
\hline Item & Table/Figure \\
\hline HWVP Reference Canister & Figure 4.1-16 \\
Centerline and Canister Surface Cooling & Figure 4.1-17 \\
Filled HWVP Reference Canister Properties & Table 4.1-25 \\
\hline
\end{tabular}

4.1.2.3 Haste Form Product Qual ification Leach Testing of HW39-1 Glass. (b) The HWVP Waste Form Qualification Leach Test P1an $(C)$ has been developed to provide glass durability information pertinent to the WAS. However, the nonradioactive, $90^{\circ} \mathrm{C}$ testing temperature portion of the leach test $\mathrm{plan}$ was conducted in deionized water to evaluate the proposed testing methodology and to provide an initial data base on the long-term durability of the HWVP reference glass.

(a) R. G. Baxter, Description of Defense Haste Processing Facility Reference Waste Form and Canister. DP-1606, Rev. 1, P. 43, E.I. du Pont deNemours and Company, Savannah River Plant, Aiken, South Carolina (1983).

(b) S. 0. Bates et al., Baseline Milestone HWVP-87-V110705A - Report on Leach Testing of Simulated Hanford Waste Vitrification P7ant Project Reference Glass HW39. HWVP-87-V110705A, Pacific Northwest Laboratory, Richland, Washington (September 1987).

(c) S. 0. Bates, HWVP Baseline Milestone HWVP-86-HLV32: The Hanford Waste Vitrification Program Waste-Form Qualification Leach Test Plan. Pacific Northwest Laboratory, Richland, Washington (1985). 


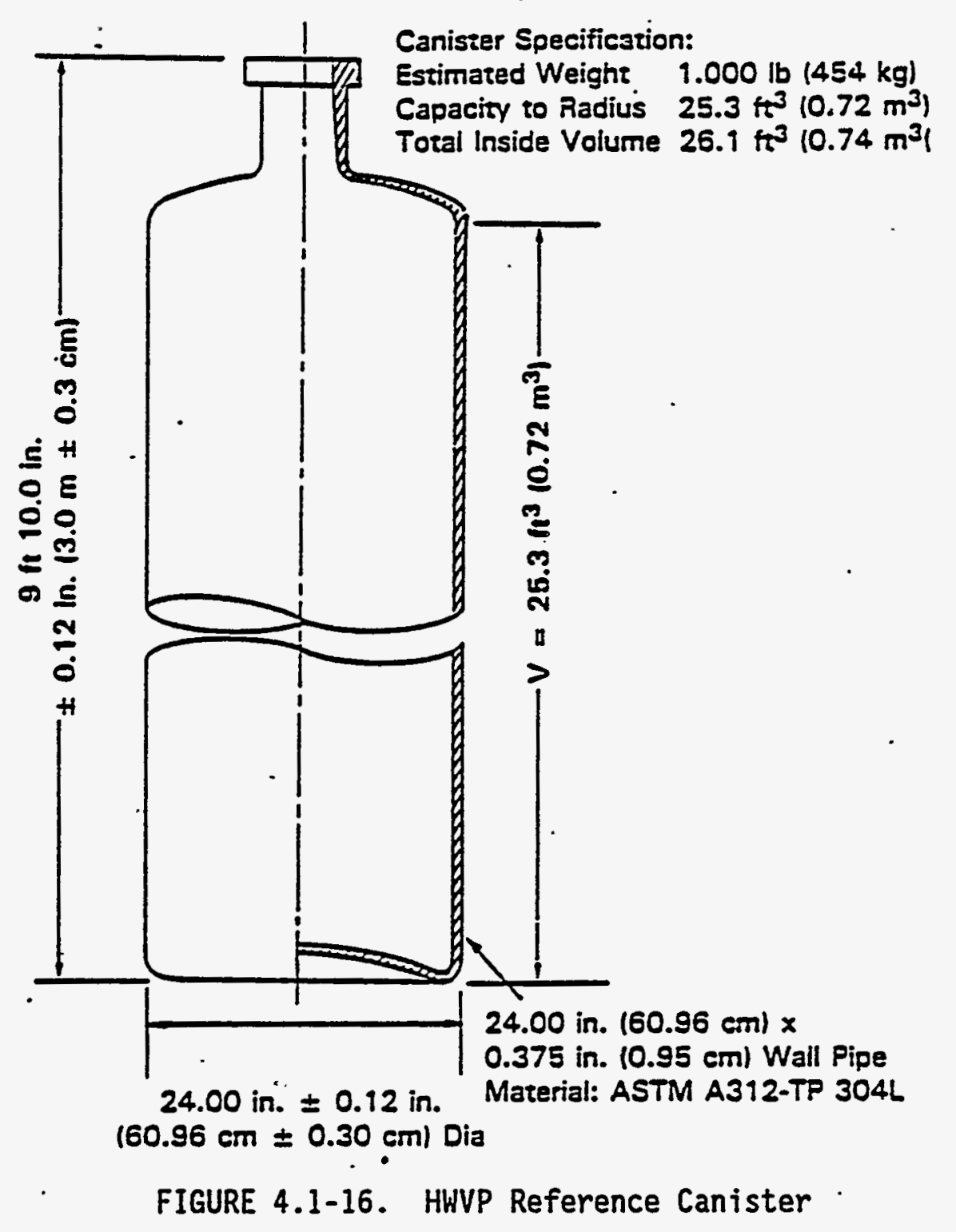

4.1.2.3.1 Technical Approach. Testing was conducted using a nonradioactive HWVP reference glass, HW39-1 (1.3 wt\% $\left.\mathrm{Cr}_{2} \mathrm{O}_{3}\right) .(\mathrm{a})(\mathrm{b})$ The compositions of the NCAW 84 (high- $\mathrm{Cr}_{2} \mathrm{O}_{3}$ ) waste and HW39 glass are shown in Table 4.1-26.

The MCC-1 leach test measures the elemental mass loss. from a monolith sample of glass as a function of time. A glass sample is suspended in a

(a) S. 0. Bates, Baseline Milestone HWVP-85-V020202B: Issue a Recommended HWVP Glass Composition for Future Work. Pacific Northwest Laboratory, Richland, Hashington (1985).

(b) S. 0. Bates and M. A. Remus, HWVP Basel ine Milestone HWVP-86-V1122B: HWVP Reference Glass Development - FY 1986 Summary Report. Pacific Northwest Laboratory, Richland, Washington (1986). 


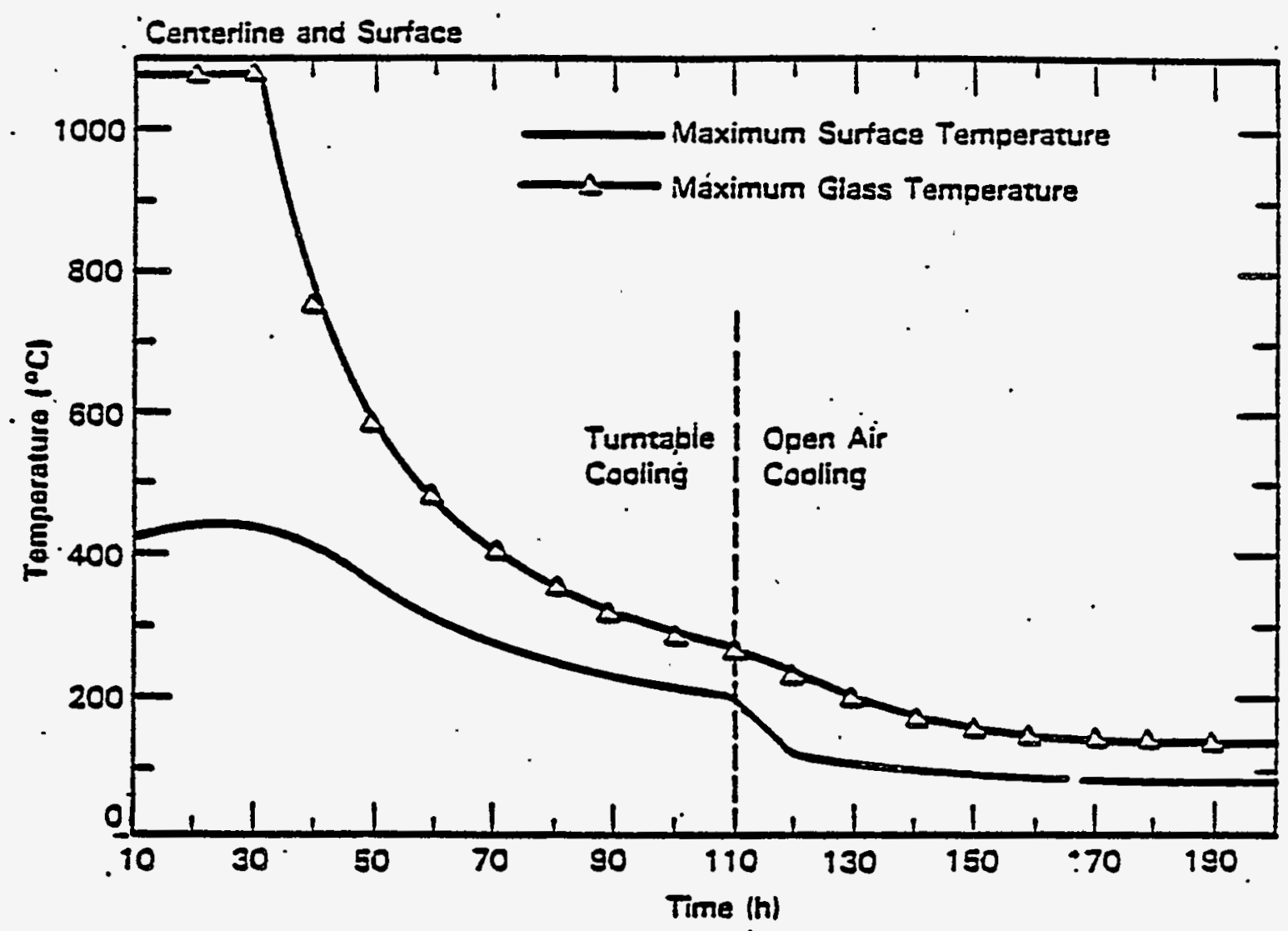

FIGURE 4.1-17. Turntable Canister Cooling. The expected maximum canister surface temperature and maximum internal glass temperature are shown as a function of time from filling in a closed turntable and removal at $110 \mathrm{~h}$ to continued cooling in open air. (Decay heat $=1.5 \mathrm{~kW}$ )

Teflon(a) support and sealed in a Teflon container. The SA/V ratio (surface area of sample/volume of leachant) used was $10 \mathrm{~m}^{-9}$. The leachant in either MCC-1 or MCC-3 tests can be a synthetic silicate ground water, a synthetic brine, or deionized water. Tests reported herein were conducted using deionized water as the leachant.

The MCC -3 test uses powdered glass instead of the monolith sample used in the MCC-1 test. The MCC-3 tests are intended to yield results that would be similar to results from monolith tests conducted for extended periods of time. All MCC-3 tests were conducted using the same 100 to 200 mesh-size powders.

(a) Tefion is a registered trademark of the E.I. du Pont deNemours and Company. 
TABLE 4.1-25. Filled HWVP Reference Canister Properties

G7ass:

Height $7.5 \mathrm{ft}$ cold glass

$\left(22.2 \mathrm{ft}^{3}\right) /\left(2.95 \mathrm{ft}^{2}\right)=7.5 \mathrm{ft}$

(volume) $/($ cross section area $)=$ height $\frac{\text { ref. canister }}{\text { canister ID }=23.25 \text { in. }}$ cross section area $=2.95 \mathrm{ft}^{2}$

Volume $22.2 \mathrm{ft}^{3}$

$(0.85)\left(26.1 \mathrm{ft}^{3}\right)=22.2 \mathrm{ft}^{3}$

(fill $\%$ (volume) $=$ fill volume

Weight $3660 \mathrm{~Tb}$

$\left(22.2 \mathrm{ft}^{3}\right)\left(165 \mathrm{lb} / \mathrm{ft}^{3}\right)=3650 \mathrm{lb}$

(fill volume)(glass density) $=$ glass weight at $38^{\circ} \mathrm{C}$

Percent canister fill $85 \%$ of total volume reference

Surface temperature $-80^{\circ} \mathrm{C}$ of total volume reference

Centerline temperature $f 130^{\circ} \mathrm{C}$ midheight

Heat generation $1.5 \mathrm{~kW}$

Filled canister:

Height $9 \mathrm{ft} 10 \mathrm{in.}$ (cold, no lid) (ref. HWVP canister)

Volume $26.1 \mathrm{ft}^{3}$ (ref. HWVP canister)

Weight $4660 \mathrm{lb}$ (1000 $\mathrm{lb}$ ref. canister $+3630 \mathrm{lb}$ glass $=4660$ total)

Surface temperature $75^{\circ} \mathrm{C}$ midheight

4.1.2.3.2 Test Matrix. The test matrix, given in Table 4.1-27, shows the number of replicates and blanks at each time and SA/V ratio.

Table 4.1-28 shows the resultant $\log (t \cdot S A / V)$ values for each test. The overlap of $\log (t \cdot S A / V)$ values provided by the test matrix is shown in Figure 4.1-18. All tests were conducted in Teflon PFA leach containers cleaned according to MCC-1P procedures. The temperatures within the ovens were maintained at $90 \pm 1^{\circ} \mathrm{C}$. Oven temperatures were continuously monitored with calibrated thermistors and recorded throughout the tests.

The MCC -3 tests were conducted at SA $/ V$ ratios of 475,1780 , and $17,800 \mathrm{~m}^{-1}$. The powders for all the MCC-3 testing were sieved, using nyion screens, to retain the -100 -mesh $(149 \mathrm{\mu m})+200$-mesh $(74 \mathrm{\mu m})$ size particle sizes. The $S A / V$ ratios were adjusted by varying the amount of leachant and powdered glass in the leaching vessel as shown in Table 4.1-29. Three replicates and a blank were run at each point of the test matrix. The blanks were used to determine if sources of contamination were present. 
TABLE 4.1-26. "Composition of the HWVP Reference Waste (NCAH 84, 5.3 wt\% $\mathrm{Cr}_{2} \mathrm{O}_{3}$ ), Substituted Waste, and Glass (HW39-1) at a 25 wt\% Oxide Waste Loading HWVP-87-V110705A

\begin{tabular}{|c|c|c|c|c|}
\hline Oxide & $\begin{array}{l}\text { Normalized } \\
\text { Haste } \\
\text { (wto Oxide) }\end{array}$ & $\begin{array}{l}\text { Subst tuted } \\
\text { Yaste Nor. } \\
\text { (wte Oxide) }\end{array}$ & $\begin{array}{c}\text { Frit } \\
\text { (wto oxidel }\end{array}$ & $\begin{array}{c}\text { Glass } \\
\text { (wto Oxide) }\end{array}$ \\
\hline 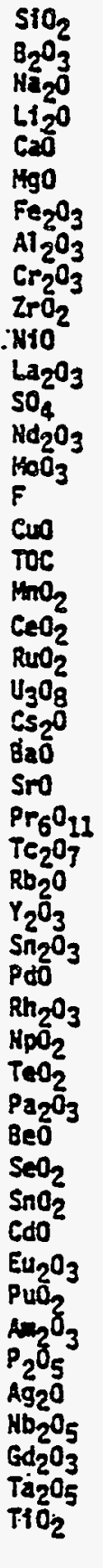 & $\begin{array}{r}2.9 \\
0.0 \\
10.5 \\
0.0 \\
0.3 \\
0.2 \\
44.0 \\
17.0 \\
5.3 \\
2.3 \\
2.3 \\
2.3 \\
1.8 \\
1.7 \\
1.2 \\
1.2 \\
0.6 \\
0.6 \\
0.6 \\
0.6 \\
0.6 \\
0.6 \\
0.6 \\
0.4 \\
0.4 \\
0.4 \\
0.4 \\
0.4 \\
0.2 \\
0.2 \\
0.2 \\
0.2 \\
0.2 \\
0.1 \\
0.1 \\
0.1 \\
0.1 \\
0.03 \\
0.02 \\
0.02 \\
0.02 \\
0.02 \\
0.02 \\
0.02 \\
0.01 \\
0.01 \\
0.01 \\
0.01 \\
0.01 \\
100.00\end{array}$ & 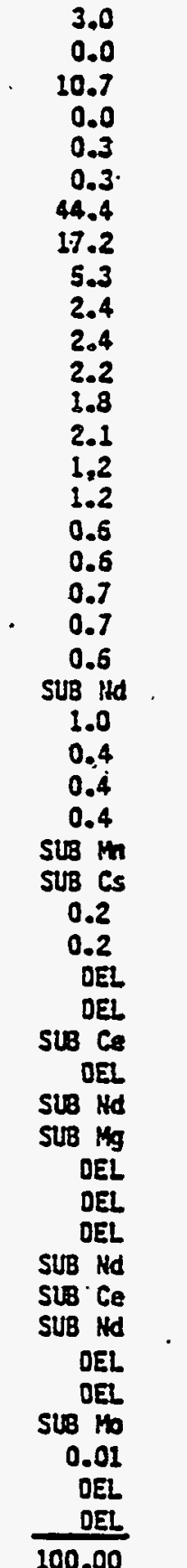 & $\begin{array}{c}67.25 \\
12.75 \\
10.25 \\
5 \\
3.75 \\
1\end{array}$ & $\begin{array}{r}51.3 \\
9.5 \\
10.4 \\
3.8 \\
2.9 \\
0.8 \\
11.1 \\
4.3 \\
1.3 \\
0.6 \\
0.5 \\
0.5 \\
0.4 \\
0.5 \\
0.3 \\
0.3 \\
0.1 \\
0.2 \\
0.2 \\
0.1 \\
0.2 \\
0.1 \\
0.1 \\
0.1 \\
\\
\\
0.04 \\
0.04\end{array}$ \\
\hline
\end{tabular}


TABLE 4.1-27. Leaching Test Matrix for HHVP Waste Form Qualification. Each value in the matrix indicates the number of replicates. HWVP-87-V110705A

\begin{tabular}{|c|c|c|c|c|c|c|c|c|c|c|c|}
\hline & \multicolumn{11}{|c|}{ Test Duration In Days } \\
\hline Test & 0.25 & 0.5 & 1 & 3 & 7 & 14 & 28 & 56 & 91 & 182 & 360 \\
\hline $\begin{array}{l}M C C-1 \\
S A / V=10 \mathrm{~m}^{-1} \\
\text { BTanks }\end{array}$ & $\begin{array}{c}\text { Temp }=90^{\circ} \mathrm{C} \\
3 \\
1\end{array}$ & $\begin{array}{l}3 \\
1\end{array}$ & $\begin{array}{l}3 \\
1\end{array}$ & $\begin{array}{l}3 \\
1\end{array}$ & $\begin{array}{l}3 \\
1\end{array}$ & $\begin{array}{l}3 \\
1\end{array}$ & $\begin{array}{l}3 \\
1\end{array}$ & $\begin{array}{l}3 \\
1\end{array}$ & $\begin{array}{l}3 \\
1\end{array}$ & $\begin{array}{l}6 \\
1\end{array}$ & $\begin{array}{l}6 \\
1\end{array}$ \\
\hline $\begin{array}{l}M C C-3 \\
S A / V=475 \mathrm{~m}^{-1} \\
\text { Blanks }\end{array}$ & $\begin{array}{l}3 \\
1\end{array}$ & $\begin{array}{l}3 \\
1\end{array}$ & $\begin{array}{l}3 \\
1\end{array}$ & $\begin{array}{l}3 \\
1\end{array}$ & $\begin{array}{l}3 \\
1\end{array}$ & $\begin{array}{l}3 \\
1\end{array}$ & $\begin{array}{l}3 \\
1\end{array}$ & $\begin{array}{l}3 \\
1\end{array}$ & $\begin{array}{l}3 \\
1\end{array}$ & $\begin{array}{l}6 \\
1\end{array}$ & $\begin{array}{l}6 \\
1\end{array}$ \\
\hline $\begin{array}{l}M C C-3 \\
S A / V=1780 \mathrm{~m}^{-1} \\
\text { BTanks }\end{array}$ & $\begin{array}{l}3 \\
1\end{array}$ & $\begin{array}{l}3 \\
1\end{array}$ & $\begin{array}{l}3 \\
1\end{array}$ & $\begin{array}{l}3 \\
1\end{array}$ & $\begin{array}{l}3 \\
1\end{array}$ & $\begin{array}{l}3 \\
1\end{array}$ & $\begin{array}{l}3 \\
1\end{array}$ & $\begin{array}{l}3 \\
1\end{array}$ & $\cdot \begin{array}{l}3 \\
1\end{array}$ & $\begin{array}{l}6 \\
1\end{array}$ & $\begin{array}{l}6 \\
1\end{array}$ \\
\hline $\begin{array}{l}\text { MCC }-3 \\
\text { SA } / V=17800 \mathrm{~m}^{-1} \\
\text { Blanks }\end{array}$ & $\begin{array}{l}3 \\
1\end{array}$ & $\begin{array}{l}3 \\
1\end{array}$ & $\begin{array}{l}3 \\
1\end{array}$ & $\begin{array}{l}3 \\
1\end{array}$ & $\begin{array}{l}3 \\
1\end{array}$ & $\begin{array}{l}3 \\
1\end{array}$ & $\begin{array}{l}3 \\
1\end{array}$ & $\begin{array}{l}3 \\
1\end{array}$ & & - & \\
\hline
\end{tabular}

At the end of each test, a chemical analysis of the leachants was conducted. The analyses for dissolved cations were conducted using inductively coupled plasma atomic absorption (AA).

4.1.2.3.3 Results. Normalized elemental concentrations were calculated using the following equation:

$$
N C_{i}=m_{i} / F_{i}
$$

where $N C_{i}=$ normalized concentration of element $i\left(\mathrm{~g} g 7 \mathrm{ass} / \mathrm{m}^{3}\right)$

$m_{i}=$ concentration of element $i$ in leachate $\left(\mathrm{g} i / \mathrm{m}^{3}\right)$

$F_{j}=$ weight fraction of element $i$ in $g$ lass $(g \mathrm{i} / \mathrm{g}$ glass).

An important event occurs at the highest $t \cdot S A / V$ value for the test with an $S A / V$ ratio of $17,800 \mathrm{~m}^{-1}$. A dramatic decrease in the concentrations of $\mathrm{Al}, \mathrm{Ca}, \mathrm{Cs}, \mathrm{Sr}$, and $\mathrm{Si}$ indicates a large increase in their precipitation rates. The $\mathrm{pH}$ also increases at this point in time, possibly due to the precipitation of the silicate, which acts as a buffer. Silica concentration plays a key role in the rate of glass dissolution, and thus the precipitation of silica may have a significant impact on the final rate of dissolution.

The release rates of HW39-1 were compared with an estimate of the 10 CFR 60 (Ref. 4.1-10) criterion. The 10 CFR 60 criterion estimate assumes a repository boundary release rate of less than 1 part in $10^{5}$ per year. This rate corresponds to an approximate dissolution rate of $0.01 \mathrm{~g} /\left(\mathrm{m}^{2} \mathrm{~d}\right)$. The 
TABLE 4.1-28. Proposed SA/V and Time to Test Matrix with the Resultant Log(t.SA/V) Values. HWVP-87-V110705A

\begin{tabular}{|c|c|c|c|}
\hline Test & $S A / V\left(m^{-1}\right)$ & Time (days) & $\log (t \cdot S A / V)$ \\
\hline $\begin{array}{l}\text { MCC-1 } \\
\text {. } \\
\text {. }\end{array}$ & $\begin{array}{l}10 \\
10 \\
10 \\
10 \\
10 \\
10 \\
10 \\
10 \\
10 \\
10 \\
10\end{array}$ & $\begin{array}{r}0.25 \\
0.50 \\
1 \\
3 \\
7 \\
14 \\
28 \\
56 \\
91 \\
182 \\
364\end{array}$ & $\begin{array}{l}0.40 \\
0.70 \\
1.00 \\
1.48 \\
1.85 \\
2.15 \\
2.45 \\
2.75 \\
2.96 \\
3.26 \\
3.56\end{array}$ \\
\hline$M C C-3$ & $\begin{array}{l}475 \\
475 \\
475 \\
475 \\
475 \\
475 \\
475 \\
475 \\
475 \\
475 \\
475\end{array}$ & $\begin{array}{r}0.25 \\
0.50 \\
1 \\
3 \\
7 \\
14 \\
28 \\
56 \\
91 \\
182 \\
364\end{array}$ & $\begin{array}{l}2.07 \\
2.38 \\
2.68 \\
3.15 \\
3.52 \\
3.82 \\
4.12 \\
4.42 \\
4.64 \\
4.94 \\
5.24\end{array}$ \\
\hline . & $\begin{array}{l}1780 \\
1780 \\
1780 \\
1780 \\
1780 \\
1780 \\
1780 \\
1780 \\
1780 \\
1780 \\
1780\end{array}$ & $\begin{array}{r}0.25 \\
0.50 \\
1 \\
3 \\
7 \\
14 \\
28 \\
56 \\
91 \\
182 \\
364\end{array}$ & $\begin{array}{l}2.65 \\
2.95 \\
3.25 \\
3.73 \\
4.10 \\
4.40 \\
4.70 \\
5.00 \\
5.21 \\
5.51 \\
5.81\end{array}$ \\
\hline . & $\begin{array}{l}17800 \\
17800 \\
17800 \\
17800 \\
17800\end{array}$ & $\begin{array}{r}1 \\
3 \\
14 \\
28 \\
56\end{array}$ & $\begin{array}{l}4.25 \\
4.73 \\
5.40 \\
5.70 \\
6.00\end{array}$ \\
\hline
\end{tabular}




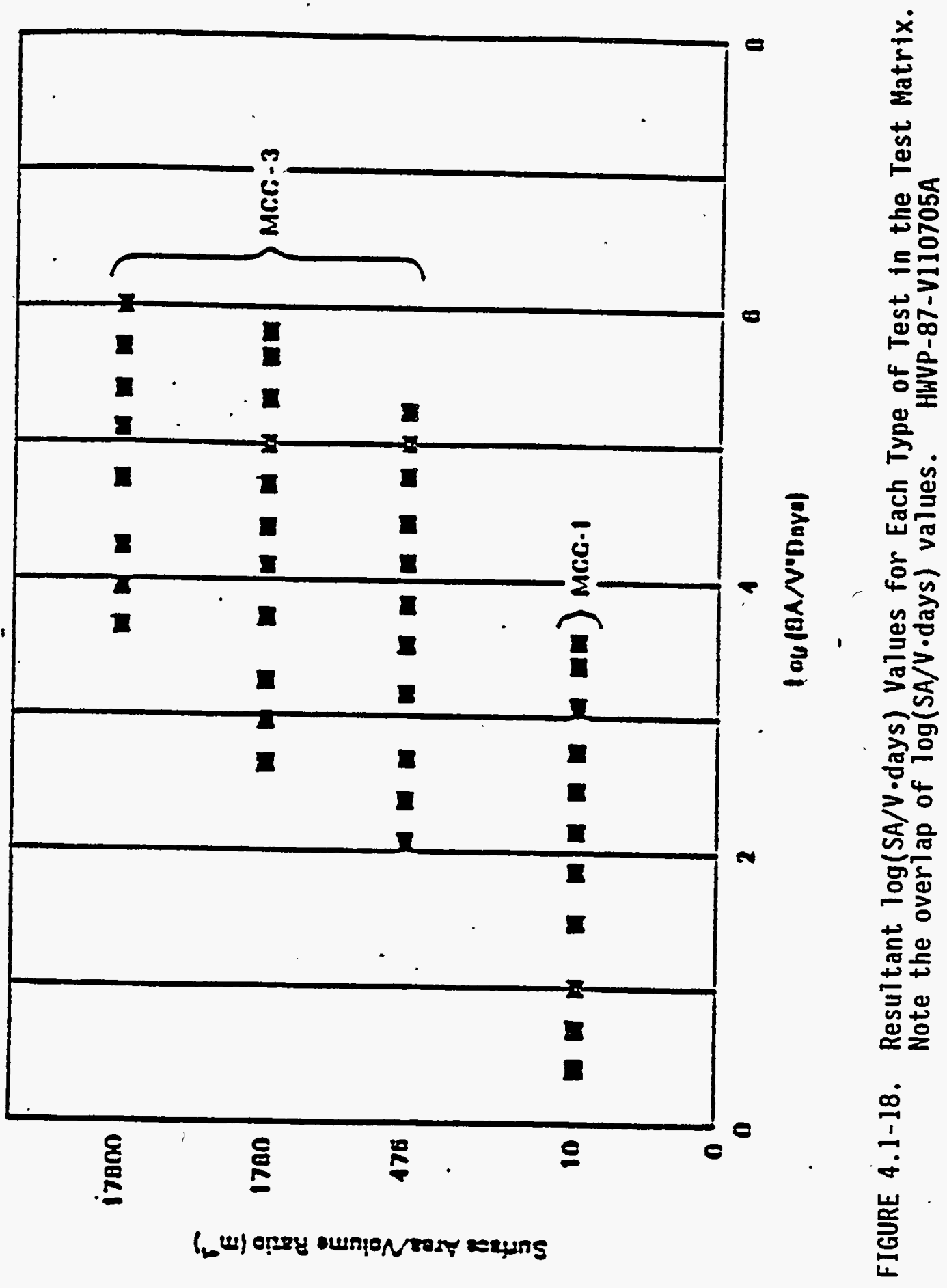

4.1-55 
TABLE 4.1-29. GTaSS and Leachate Amount Used to Produce Required SA/N Ratios in MCC-3 Testing

\begin{tabular}{|c|c|c|}
\hline$S A / V\left(\mathrm{~m}^{-1}\right)$ & Glass $(\mathrm{g})$ & Leachate $(\mathrm{mL})$ \\
\hline 475 & 1.067 & 40 \\
1780 & 4.00 & 40 \\
17800 & 10.00 & 10 \\
\hline
\end{tabular}

estimation of the 10 CFR 601 imit assumes that a standard HWVP canister (containing a glass gy inder with a diameter of $0.61 \mathrm{~m}, 2.84 \mathrm{~m}$ long is $85 \%$ full of HW39-1 glass. (a)

Figure 4.1-19 shows a $\log -\log$ plot of the normalized B concentration versus $t \cdot S A / V$ values for all SA/V ratios. Concentration data from the MCC-1 0.25 - and 0.5 -day tests indicate that the dissolution rate, as determined from the 0.25-day B concentration, is lower than the rate obtained from the 0.5 -day data. This low rate at very early times is in disagreement with the general7y accepted understanding of these systems. The dissolution rate should constantly decrease with time until the final rate is obtained. The mechanism for this initial rate increase is not yet understood but corresponds to an increase in the $\mathrm{pH}$ of the leachate. Results from the MCC -3 tests do not show this initial rate increase, but this result may be due to a lack of early time data. The 0.25 -day data was not used-in determining the forward rate of dissolution because of the initial rate discrepancy. The $0.5-$ and 1-day MCC-1 data lie on a line of unit slope, tangent to the concentration curve. The tangent intercept indicates a forward rate of dissolution of approximately $3 \mathrm{~g} /\left(\mathrm{m}^{2} \mathrm{~d}\right)$.

Although a final steady-state dissolution rate was not reached, a conservative estimate of the final rate can be made by determining the intercept of the unit slope tangent shown in Figure 4.1-19. The unit slope line passes through the B concentration of the MCC-3 182-day test at an SA/N of $1780 \mathrm{~m}^{-1}$. Using the intercept of this line, the final rate of dissolution is estimated to be approximately $0.01 \mathrm{~g} /\left(\mathrm{m}^{2} \mathrm{~d}\right)$. This estimated rate is the same as the $0.01 \mathrm{~g} /\left(\mathrm{m}^{2} \mathrm{~d}\right)$ estimate for the regulatory 1 imit.

In a repository environment, the groundwater is often saturated with silica. This saturation causes the final rate of glass dissolution to be reached soon after the groundwater comes in contact with the glass. Saturation of many elements in the leachant will lower their release rates below the release criterion. Only radioactive elements with high solubilities, such as $\mathrm{Te}$ (under oxidizing conditions), are likely to behave like the $\mathrm{B}$ data in Figure 4.1-19.

(a) S. 0. Bates and M. A. Reimus, HWWP Basel ine Milestone HWVP-86-VI122B: HWVP Reference Glass Development - FY 1986 Summary Report. Pacific Northwest Laboratory, Richland, Washington (1986). 
$\left\langle S-I^{\circ}\right\rangle$

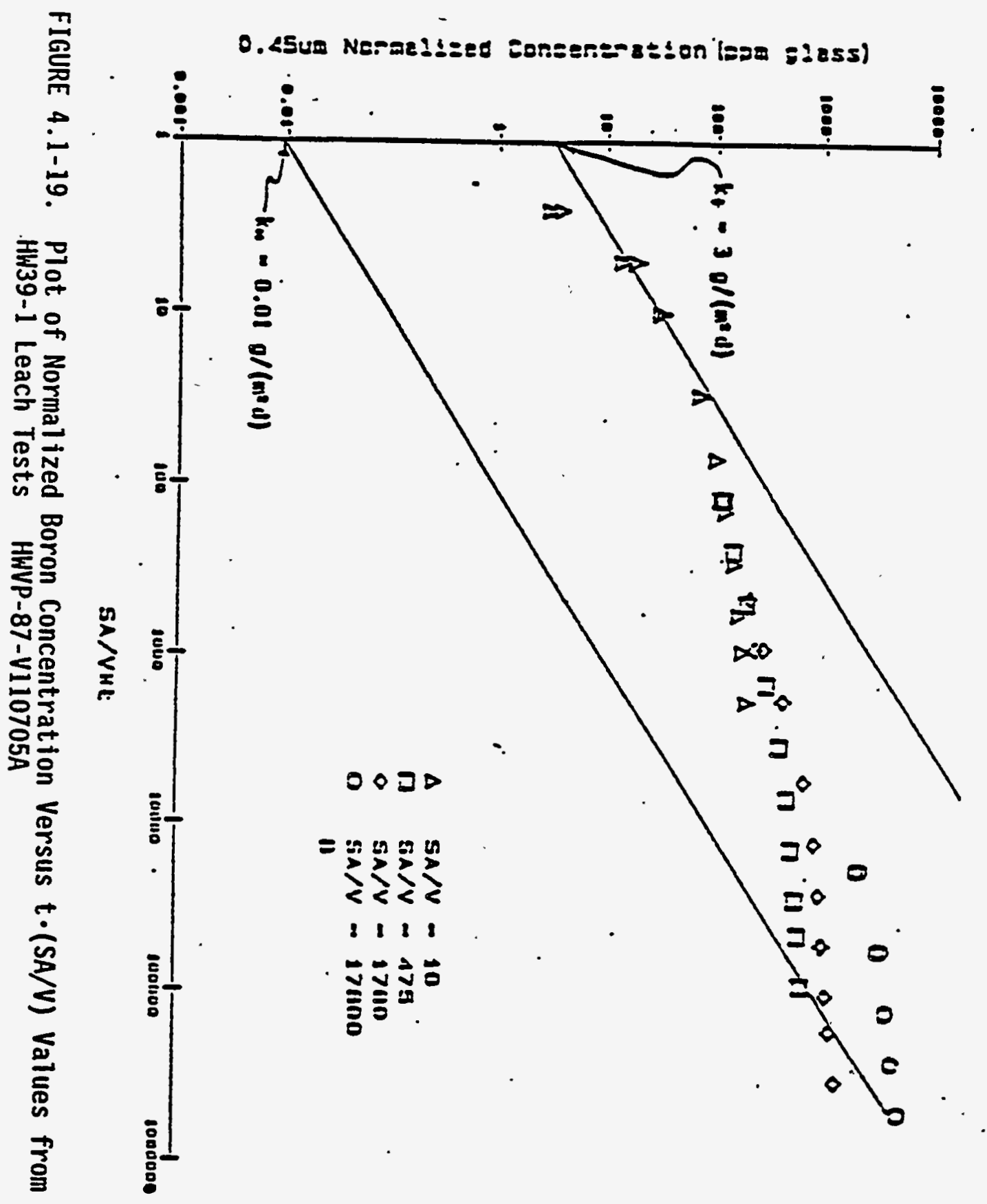




\subsubsection{Composition Variability Effects}

Because of its amorphous structure, silicate-based glass can incorporate a wide variety of elements, often in significant quantities. This attribute and the demonstrated durability of glass are the major advantages of glass as a nuclear waste form. However, the property constraints discussed previously can eventualiy limit the concentration of elements that can be incorporated into waste glass. The chemical composition of the first of the Hanford wastes to be processed through the HWVP, the NCAW, is expected to vary. The resulting glass product will therefore deviate from the nominal composition of the reference glass. Although borosilicate glasses are generally forgiving, changes in the glass composition resulting from variation in the feed composition can affect the physical and chemical properties of the glass. Changes in key glass physical properties such as melt viscosity, electrical conductivity, and phase behavior (crystallinity) can affect the processability of the giass in.the melter. The chemical durability (leaching characteristics) of the glass product can also be affected and possibiy impact the acceptability of the glass for geologic isolation.

Scoping studies have been conducted to determine candidate glass components to include in a composition variability study (CVS) as part of the waste-form qualification process. (a) The CVS will be conducted to model important glass and melt properties over the composition envelope defined by the ranges of waste component variability. This model will be used to determine the region of the envelope that will produce acceptable glass and melt properties for HWVP Liquid Fed Ceramic Melter (LFCM) processability and meet the requirements of the Waste Acceptance Specification (WAS). The scoping tests will indicate whether or not changes over a glass component's predicted variance ranges will produce significant changes in the critical glass and melt properties and predict what extremes are allowaple. These composition variability studies have provided the primary bases(b) for developing the HHVP feed specifications. (Section 3.1.1). The scoping studies also provide preliminary information on the effects and limitations of waste components to aid in waste pretreatment and waste-form development.

4.1.3.1 Variability Study Feed Compositions. The composition variability testing completed as of August 1987 establishes a preliminary evaluation glass components comprising approximately 97\% of the NCAW 84--high-chrome waste. The results of these scoping tests are subsequentiy summarized here. The variability studies in FY 1985 for $\mathrm{Cr}$ and $\mathrm{Zr}$ were expanded and included in the FY 1986 variability study test results. The study results are not entirely self consistent because different base case feed compositions may

(a) S. 0. Bates, The HWup Statistical Variability Study Test Plan. Interim Milestone HWVP-86-V1122A, draft for RHO comment, Pacific Northwest Laboratory, Richland, Hashington (1986).

(b) S. 0. Bates, Baseline Milestone HWVP-87-V11202B - Update of Glass Composition Boundaries of the Hanford Waste Vitrification Plant Project Reference Glass, HW39. Pacific Northwest Laboratory, Richland, Washington (August 1987). 
have been used. For all variability studies, the same frit composition, HW39, was used except where indicated.

4.1.3.2 Sulfate Variability studies. (2) If the solubility limit of $\mathrm{SO}_{3}$ in a glass melt is exceeded, an undesirable molten sulfate layer will occur on the melt surface. This molten sulfate layer will readily incorporate radionuc-

lides, principaliy cesium, that could volatilize and enter the off-gas system of the melter. If the molten sulfate is entrained in the glass melt and transported through the melter, a highly soluble cesium-enriched sulfate phase could be deposited in the canister. To reduce the possibility of a sulfate layer, the $\mathrm{SO}_{3}$ concentration in the waste should be such that the solubility limit of $\mathrm{SO}_{3}$ in the waste glass is not exceeded.

The solubility of $\mathrm{SO}_{3}$ in borosilicate glasses is known to depend on the oxidation state of the glass. Furthermore, the solubility of sulfur decreases as the glass becomes more reduced and then increases under strongly reducing conditions. Thus, $\mathrm{SO}_{3}$ solubility (and the amount of washing required in the waste treatment process to remove sulfate) will depend on the oxidation state of the glass.

This study determined the solubility of sulfate in the HWVP initial reference glass (HW39-1) and determined the relationship between sulfate solubility and the redox state of the glass.

4.1.3.2.1 Approach. Using a bottom-heated crucible furnace, two simulated HWVP melter feeds (NCAW 84--high chrome, Table 4.1-30) with 0.5 and $1.0 \mathrm{wt} \% \mathrm{SO}_{3}$ were used to produce glass samples that were adjusted with sugar to redox states corresponding to ferrous/ferric ratios ranging from 0.00 to 2.5. Sulfate concentrations within these glasses were determined using a LECO CS244 sulfur analyzer.

4.1.3.2.2 Results. In glass samples made from the 0.5 wt\% sulfate feed, the sulfate content in the glass decreased as the ferrous/ferric ratio increased. No sulfate layer was observed on the top of the glass surface after the crucible was removed from the furnace. The change in glass sulfate concentration versus ferrous/ferric ratio is shown in Figure 4.1-20. In the expected range of ferrous/ferric ratios considered appropriate for melter operation $(0.001$ to 0.3$)$, little or no effect on the sulfate level was observed. As the ferrous/ferric ratio was increased beyond 0.4 , the sulfate level decreased by more than a factor of two to a minimum $\mathrm{SO}_{3}$ solubility of approximately 0.15 . Each cut glass sample had a uniform texture, a shiny. surface, and no visible metals on any of the exposed surfaces.

All glass samples produced from the 1 . wt\% $\mathrm{SO}_{3}$ feed had a yellow layer on the glass surface when removed from the furnace. When a positive ferrous/ ferric ratio was achieved, the yellow surface layer changed to a white layer

(a) S. O. Bates, D. S. Goldman, and W. C. Richey, HWVP Baseline Milestone HWVP-85-020207A: A Letter Report Summarizing the Sulfate/Redox Relationship to Glass Melting Chemistry and Behavior. Pacific Northwest Laboratory, Richland, Washington (1985). 
TABLE 4.1-30. Composition of Simulated Melter Feed Slurry HWVP-85-02027A

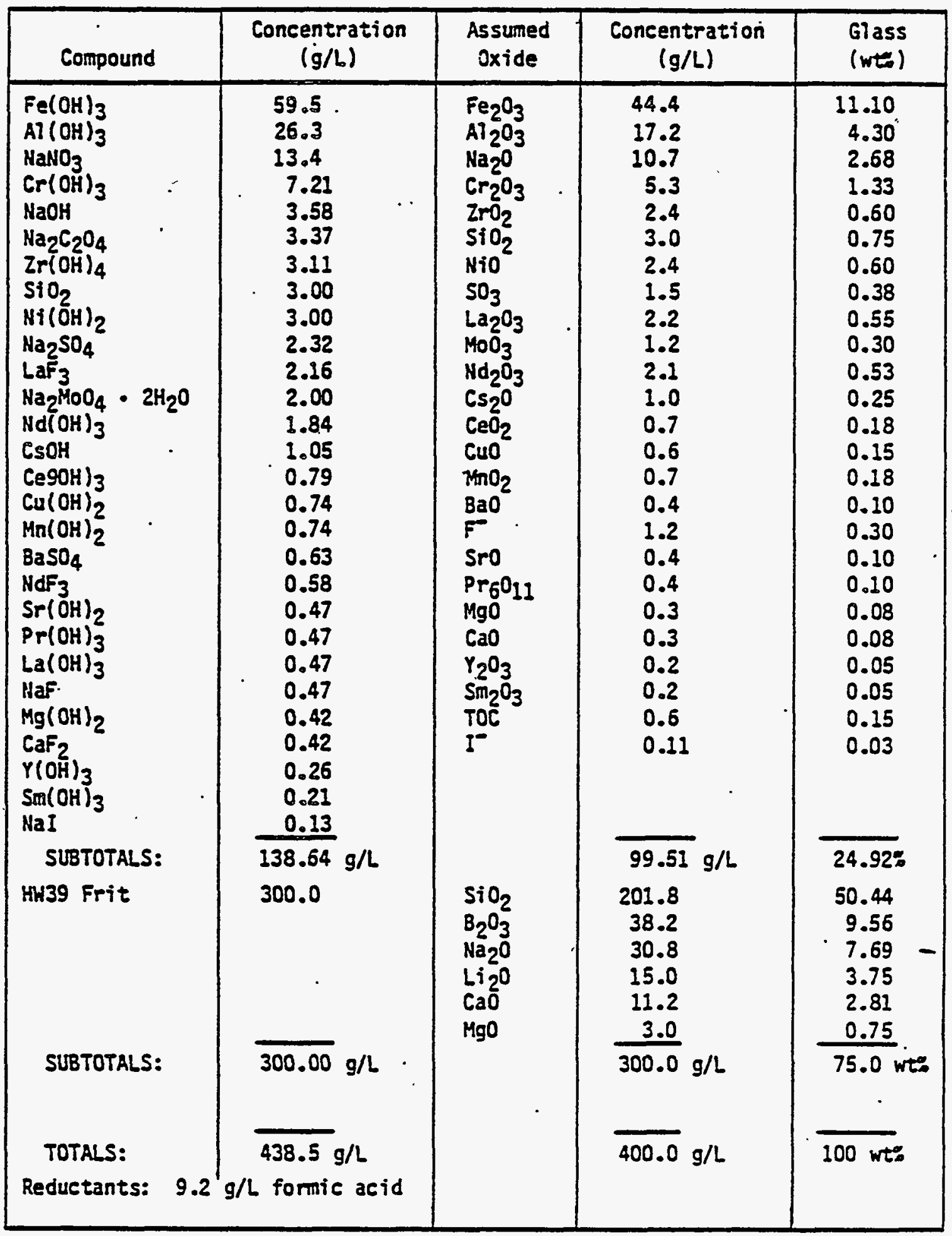




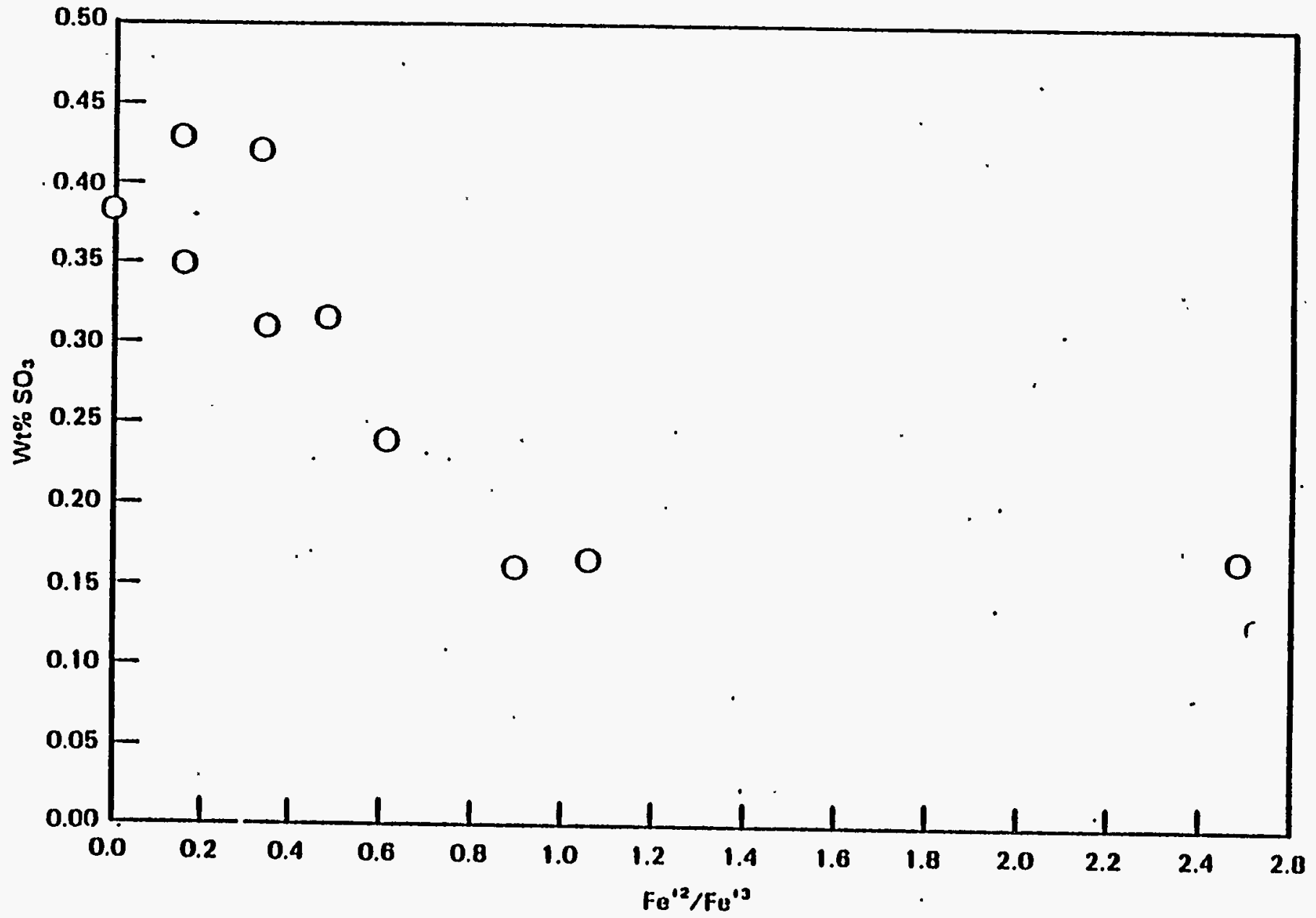

FIGURE 4.1-20. The Sulfate Concentration Versus the $\mathrm{Fe}^{+2} / \mathrm{Fe}^{+3}$ in Glasses Produced from the
0.5 wt\% $\mathrm{SO}_{3}$ Feed HWVP-85-02027A 
on the reduced glasses. These surface layers were water soluble and disappeared during the wet cutting procedure. Analysis of the water-soluble surface layers using inductively coupled plasma/atomic emission spectroscopy (ICP/AES) indicated a high concentration of sulfur in the layer. The presence of a sulfate layer on the surface of the glass indicates that the sulfate solubility of the glass was exceeded. Thus, the amount of $\mathrm{SO}_{3}$ measured in the glass at or near. oxidizing conditions was the maximum solubility of $\mathrm{SO}_{3}$. in the $\mathrm{HW} 3 \mathrm{~g}$ glass. The $\mathrm{SO}_{3}$ concentration at oxidizing or low ferrous/ ferric ratios was approximately $0.9 \mathrm{wt} \%$ in the glass (3.6 oxide wt\% in the waste assuming a 25 oxide wt\% waste loading). This is the maximum concentration allowable in the glass. The design guideline for $\mathrm{SO}_{3}$ in the waste should be low.enough to provide for possible variations in the $\mathrm{SO}_{3}$ concentration. To allow for possible temperature and redox excursions during melter operation, a flowsheet goal of 0.5 wt\% 503 in the glass (2:0 oxide wt\% in the waste assuming a 25 oxide wt\% glass waste loading) is recommended.

The glasses produced from the 1 wt\% sulfate feed exhibited much the same behavior as did the 0.5 wt\% sulfate glasses when the ferrous/ferric ratio was increased (Figure 4.1-21). At ferrous/ferric ratios of 0.0 to 0.4 , the sulfate level remained relatively unchanged. Again, as the ferrous/ferric ratio increased beyond 0.4 , the corresponding level. of sulfate decreased by more than a factor of 2. Each cut glass sample again had a uniform texture, shiny surface, and no visible metals on any of the exposed surfaces.

\subsubsection{NCAW 84--High-Chrome Feed Glass Variability Studies. (a) Scoping} studies were performed in FY 1985 and FY 1986 to determine the effects of waste and glass component compositions on HWVP glass (HW39-1) made from NCAH 84--high-chrome waste. The variable chemical components were $\mathrm{Zr}$, waste loading, type of alkali ( $\mathrm{Li}, \mathrm{Na}, \mathrm{K}$ ), $\mathrm{Na}, \mathrm{Fe}, \mathrm{AT}$, Si, rare earths, $\mathrm{U}$, and $\mathrm{Cr}$. These components were chosen based on their expected ranges of variability and/or their potential to affect glass properties.

4.1.3.3.1 Waste Glass Composition. HWVP variability scoping studies were conducted using reference NCAW 84--high-chrome feed and HW39-1.glass. The oxide compositions of the NCAW waste and the reference glass are shown in Table 4.1-26. All variability studies except the uranium variability study were conducted using this simulated nonradioactive composition. For the uranium test, no substitution for $U_{3} \mathrm{O}_{8}$ was made. The composition ranges for the waste components were set with input from Rockwell Hanford Operations.

In all tests except for the $Z r$ minus waste loading variability study, the total waste loading (the sum of the varying and nonvarying components) was maintained at the reference waste loading of 25 wt\% oxides.

(a) S. O. Bates and W. M. Bowen, Interim Milestone HWVP-86-V1122C - Report on Composition Variability Testing Conducted for the Hanford Waste Vitrification Program. Pacific Northwest Laboratory, Richland, Washington (September 1986). 
占

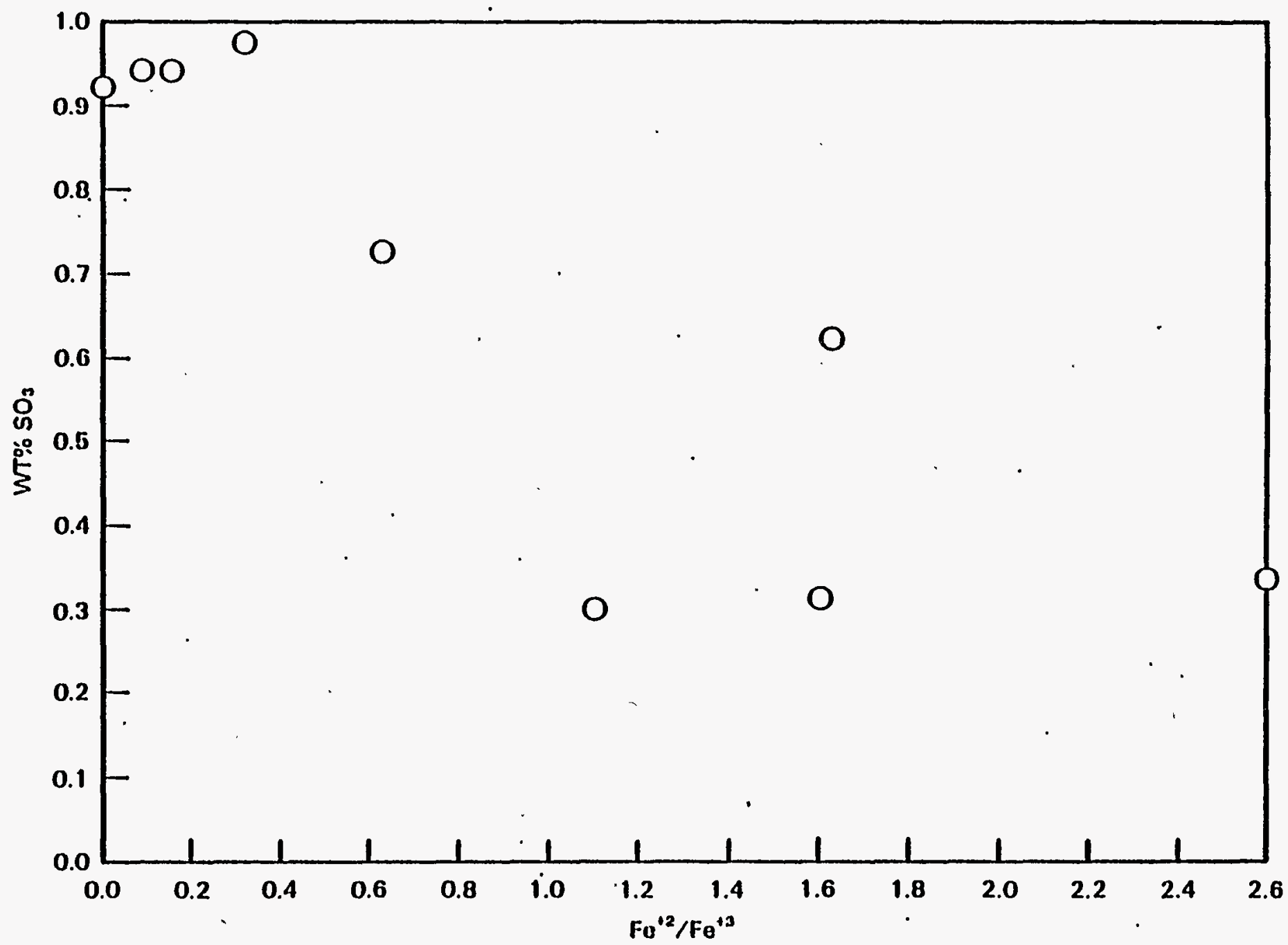

FIGURE 4.1-21. The Sulfate Concentration Versus the $\mathrm{Fe}^{+2} / \mathrm{Fe}^{+3}$ in Glasses Produced from the $1 \mathrm{wt} \% \mathrm{SO}_{3}$ Feed 
4.1.3.3.2 Glass Property Measurement. The physical properties measured and modeled were viscosity, electrical conductivity, and chemical durability. Chemical durability was evaluated using standard Materials Characterization Center (MCC) - 1 and MCC-3 leach tests. Described below is a summary of processing limitations and techniques used to evaluate each of these properties.

4.1.3.3.2.1 Viscosity. Viscosity measurements were made using a rotating spindle technique. A glass was heated in a platinum crucible to $1200^{\circ} \mathrm{C}$ and allowed to reach thermal stability. A viscosity reading was then taken. The melt was held at temperature for $30 \mathrm{~min}$ and then a second viscosity measurement was taken. The temperature was lowered to $1125^{\circ} \mathrm{C}$ and the procedure was repeated. Viscosity measurements were also taken at $1050^{\circ} \mathrm{C}$ and $950^{\circ} \mathrm{C}$. The stability of the viscosity was determined by comparing the two viscosities measured at each temperature. The results were plotted as log viscosity versus inverse absolute temperature. From this plot, the Tloop of the glass was determined.

4.1.3.3.2.2 Electrical Conductivity. The electrical conductivity of a glass was measured using a two-probe method. Electrical conductivity measurements were made at the same temperatures used for the viscosity. measurements $1200^{\circ} \mathrm{C}, 1125^{\circ} \mathrm{C}, 1050^{\circ} \mathrm{C}$, and $950^{\circ} \mathrm{C}$. Two platinum- $10 \%$ gold blades were inserted into the glass at each temperature to a known depth. The resistance of the glass between the blades was measured using an impedance bridge, and the electrical conductivity was calculated.

4.1.3.3.2.3 Leaching Characteristics. The glass quality was evaluated based on the glass dissolution (leaching) behavior determined using standard MCC -1 and MCC-3 leaching tests.

The MCC-1 static leach test measured the elemental mass loss of a monoTith sample of glass as a function of time. A glass sample was suspended within a sealed Teflon container by a Tefion monofilament. The surface area to volume ratio (surface area of sample/volume of leachant) of $10 \mathrm{~m}^{-1}$ was selected for all MCC-1 variability leach testing. The leachant used in all tests was deionized water. The sealed containers were maintained at $900^{\circ} c$ for 7 or 28 days. The results of the tests were based on an elemental analysis of the leachate by ICP atomic emission spectroscopy from which were determined the total elemental concentrations of materials dissolved from the sample.

4.1.3.3.3 $\mathrm{ZrO}_{2}$ and Haste-Loading Variability. The reference NCAW waste level for $\mathrm{ZrO}_{2}$ was 2.3 wt\% oxides. Preliminary analyses of the actual NCAW waste stream indicate that the level of $\mathrm{ZrO}_{2}$ in the waste may be as high as 45 wt\% oxides. Zirconium is known to have significant effects on the viscosity, electrical conductivity, and durability of borosilicate glasses. Because $\mathrm{Zr}$ has a potentially wide range of variability and potential to affect glass properties, a $Z r$ variability scoping study was initiated.

The effects of varying the total waste loading $\left(\mathrm{ZrO}_{2}+\mathrm{a} l 1\right.$ other nonvarying waste components) of the glass were also investigated. The waste 
loading of the glass is also an important economic factor for the HWVP. If the waste loading could be increased from 25 to $30 \mathrm{wt \%}$, the number of canisters could be reduced by $20 \%$.

Changes in critical glass and melt properties due to variations in the $\mathrm{ZrO}_{2}$ content and waste loading of NCAW in the HW39-1 glass (Table 4.1-31) were determined to provide the following observations:

- Assuming a 25 wt\% total waste loading $\left(\mathrm{ZrO}_{2}+\right.$ waste) and using the model developed from data to evaluate the T100P (Figure 4.1-22), it is predicted that the glass could contain up to $10 \% \mathrm{ZrO}_{2}$ (40 wt\% in the waste) before the T100P of the glass exceeds $1150^{\circ} \mathrm{C}$, which is the upper limit for melter operation. If all the $\mathrm{ZrO}_{2}$ is removed from the glass, a T100P of approximately $1100^{\circ} \mathrm{C}$ is predicted.

- The waste loading of the glass, with the reference level 0.6 wt\% $\mathrm{ZrO}_{2}$, could be increased to 30 wt\%. Increasing the waste loading to 30 wt\% would also increase the amount of crystalline material in the glass.

- The electrical conductivity of the glass does not exceed the range recommended for melter operation over the ranges of compositions tested as shown by the model (Figure 4.1-23) developed from experimental data. Within the more restrictive composition range required to produce an acceptable T100P, the EI150 of the glass melt is well within the required range.

- The addition of $\mathrm{ZrO}_{2}$ to the glass over the range tested increases the durability of the glass as shown in Figure 4.1-24.

- In glasses with 20 to 30 wt\% waste loading, the release rates for $\mathrm{B}, \mathrm{Ca}$, $\mathrm{Na}, \mathrm{Si}$, and $\mathrm{CS}$ are similar to the release rates of the HH39-1.

TABLE 4.1-31. Experimental Ranges for the Zirconium and Waste-Loading Variability Study

\begin{tabular}{|l|c|c|}
\hline Component & Minimum Wt\% & Maximum Wt\% \\
\hline Glass formers & 70 & 85 \\
$\mathrm{ZrO}_{2}$ & 0 & 15 \\
Waste minus $\mathrm{ZrO}_{2}$ & 0 & 30 \\
\hline
\end{tabular}




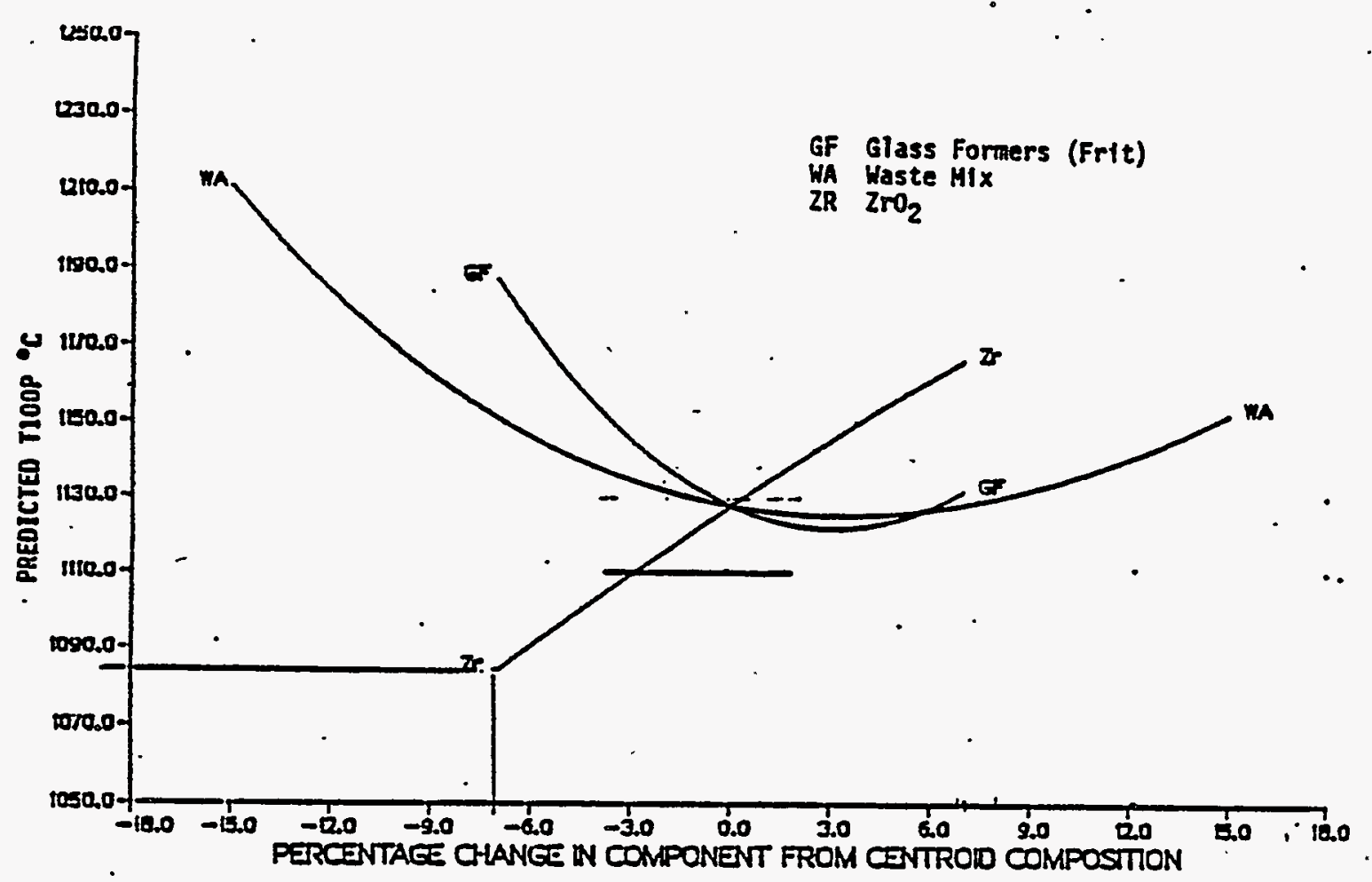

FIGURE 4.1-22. Effects Plot of Predicted 100 Poise Temperature (T100P) HWVP-87-V110202C

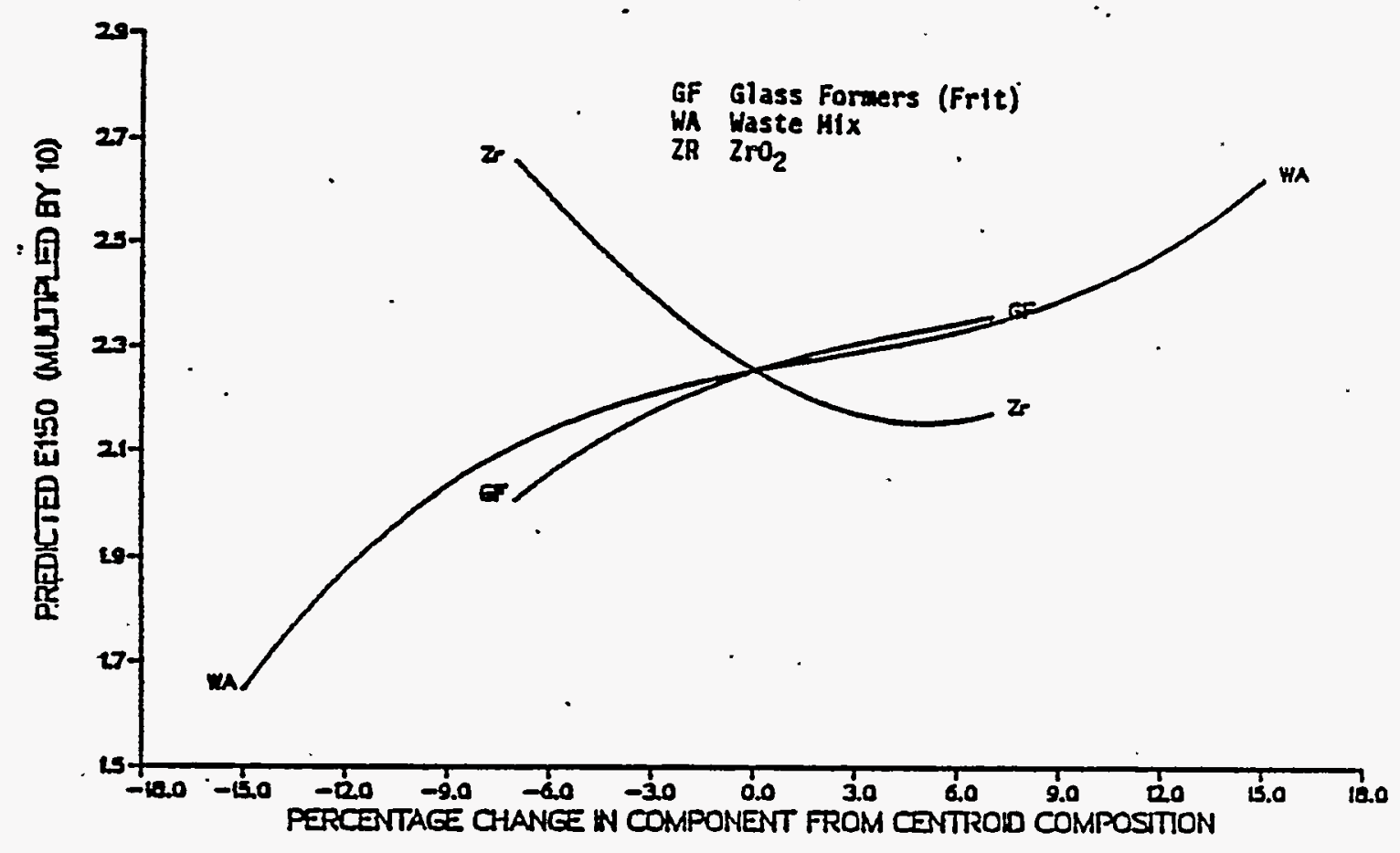

FIGURE 4.1-23. Effects Plot of Predicted Electrical Conductivity at $11500^{\circ} \mathrm{C}$ (E1150) HWVP-87-V110202C 


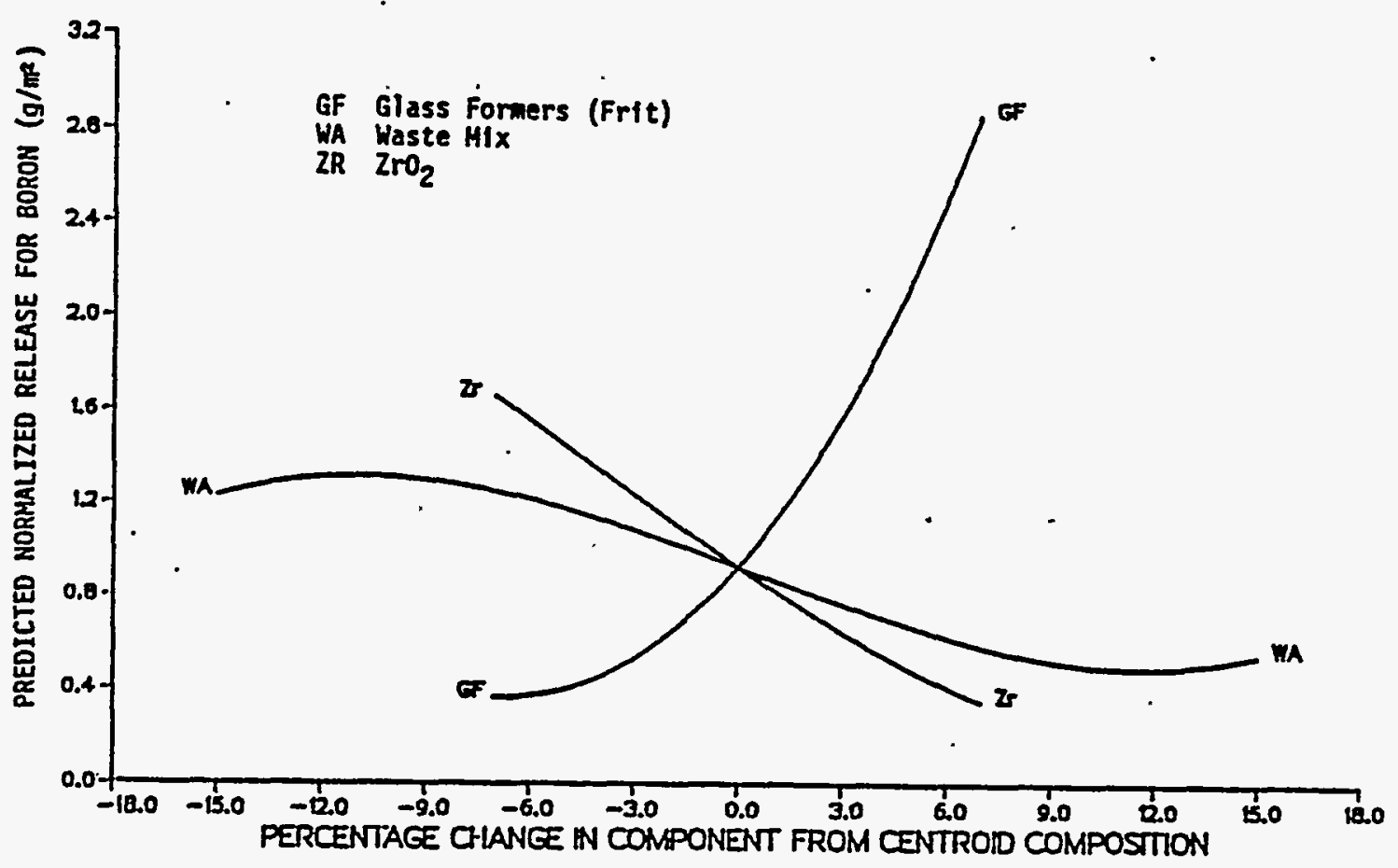

FIGURE 4.1-24. Effects P1ot of Predicted Normalized Release for Boron from HCC-3 Testing (28-day, $90^{\circ} \mathrm{C}, S A / V=1780 \mathrm{~m}^{-1}$ ) HWVP-87-V110202C

4.1.3.3.4 Mixed Alkali Variability. The alkali oxides are an essential component of borosilicate waste glasses. They serve as network modifiers, lowering the viscosity of the melt and thus the temperature required to process the glass melt. In addition, the alkali ions are the major charge carriers responsible for electrical conductivity of the glass melt. The alkalies are also one of the main components in determining not only the processability but also the chemical durability of glasses. For these reasons, proper adjustment of the alkali content is one of the most critical tasks of glass development. The HW39-1 reference glass formulations contain 14.2 wt\% (19.2 mol\%) alkali oxides.

Often, a combination of the alkalis is used for network modification. Utilization of the "mixed alkali. effect" allows an acceptable processing temperature without as much degradation of chemical durability as would result from the use of a single alkali. Sodium is the predominant alkali used. Sodium is a major component of both the NCAW waste and the glass frit, which is added to the waste to produce the HW39 composition. $\mathrm{Li}_{2} \mathrm{O}$ is also added to the glass via frit addition to the waste. Potassium compounds have been considered for use in the production and pretreatment of NCAW waste and could be present in the NCAW waste. This mixed alkali variability study was conducted to evaluate the effect of the ratios of these three alkali oxides on glass and melt properties. 
The study evaluated the changes in critical glass and melt properties resulting from variations in the type and relative amounts of the major alkalies comprising the total alkali fraction of the HWVP HH39-1 glass. The effects were evaluated by varying the moTar ratio of $\mathrm{Li}_{2} \mathrm{O}, \mathrm{Na}_{2} \mathrm{O}$, and $\mathrm{K}_{2} \mathrm{O}$ used to make up the total alkali mole fraction, which was held constant at the reference value of $19.2 \mathrm{mo} 1 \%$ in HW39-1 glass (Table 4.1-32).

-From this study, the following observations are made:

- At the current HW39-1 mole fraction of 19.2 mol\% total alkali, a range of about 4 to $8 \mathrm{~mol} \% \mathrm{~K}_{2} \mathrm{O}$ can be accommodated, depending on the ratio of $\mathrm{Li}_{2} \mathrm{O}$ to $\mathrm{Na}_{2} \mathrm{O}$, without unacceptably altering the viscosity (Figure 4.1-25) or electrical conductivity (Figure 4.1-26) of the glass melt.

- The addition of $\mathrm{K}_{2} \mathrm{O}$ to the glass generally. decreases the durability of the glass (Figure 4.1-27). The resulting increases in elemental release observed are largest for cesium.

- With respect to reducing the viscosity of the melt, the relative strengths of the individual alkalies are $\mathrm{Li}_{2} \mathrm{O}>\mathrm{Na}_{2} \mathrm{O} \gg \mathrm{K}_{2} \mathrm{O}$ (Figure 4.1-25).

- With respect to increasing the electrical conductivity of the melt, the relative strengths of the individual alkalies are $\mathrm{Li}_{2} \mathrm{O}>\mathrm{Na}_{2} \mathrm{O}>$ $\mathrm{K}_{2} \mathrm{O}$ (Figure 4.1-26).

4.1.3.3.5 Uranium Variability. To evaluate the effects of uranium variability on important glass properties, the concentration of $\mathrm{U}_{3} \mathrm{O}_{8}$ was varied in the waste fraction of the HWVP reference glass $\mathrm{HW} 39-1$. The $\mathrm{U}_{3} \mathrm{O}_{8}$ variability in the NCAW is expected to range from less than $0.5 \mathrm{wt} \%$ to $20 \mathrm{wt \%}$

(0.1 to 5 wt\% in the glass). The $\mathrm{U}_{3} \mathrm{O}_{8}$ level in the HH39-1 reference glass is $0.15 \mathrm{wt \%}$. The effects of uranium variability on glass properties were evaluated separately from the other components to reduce the number of radioactive melts and the resulting time and expense associated with working with radioactive glasses in the laboratory.

TABLE 4.1-32. Experimental Ranges for Mixed A7kali Variability Study HWVP-87-V110202C

\begin{tabular}{|c|c|c|}
\hline Component & Minimum Mo $7 \%$ & Maximum Mo $7 \%$ \\
\hline $\mathrm{K}_{2} \mathrm{O}$ & 0 & 19.2 \\
$\mathrm{Li}_{2} \mathrm{O}$ & 0 & 19.2 \\
$\mathrm{Na}_{2} \mathrm{O}$ & 0 & 19.2 \\
\hline
\end{tabular}




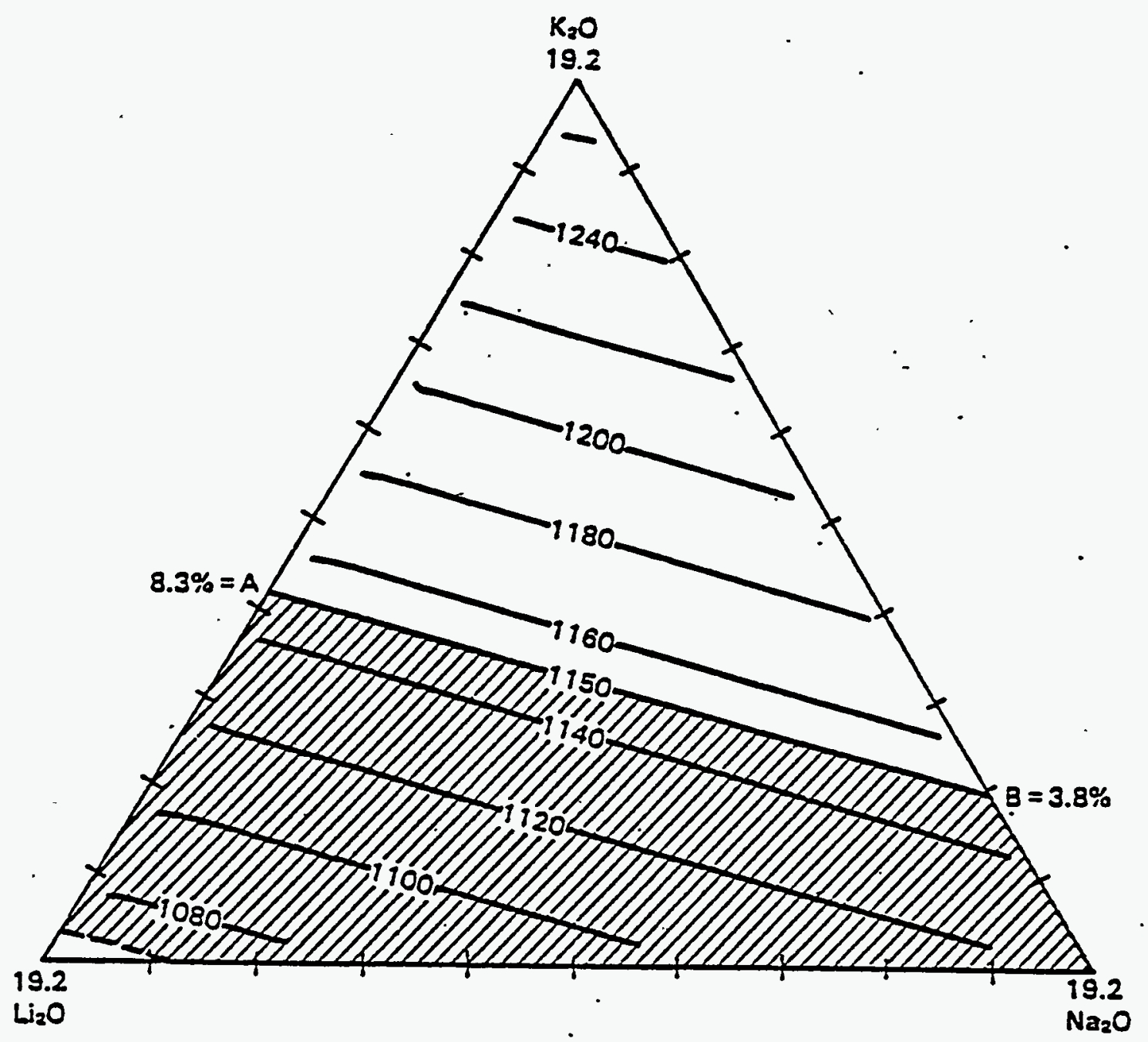

FIGURE 4.1-25. Contour PTot of Predicted T100P in ${ }^{\circ} \mathrm{C}$. The shaded area indicates the region of predicted T100P values that are within the currently established limits for T100P (1070$1150^{\circ} \mathrm{C}$ ). Al! axis compositions are given in mol\%. HWVP-87-V110202C 


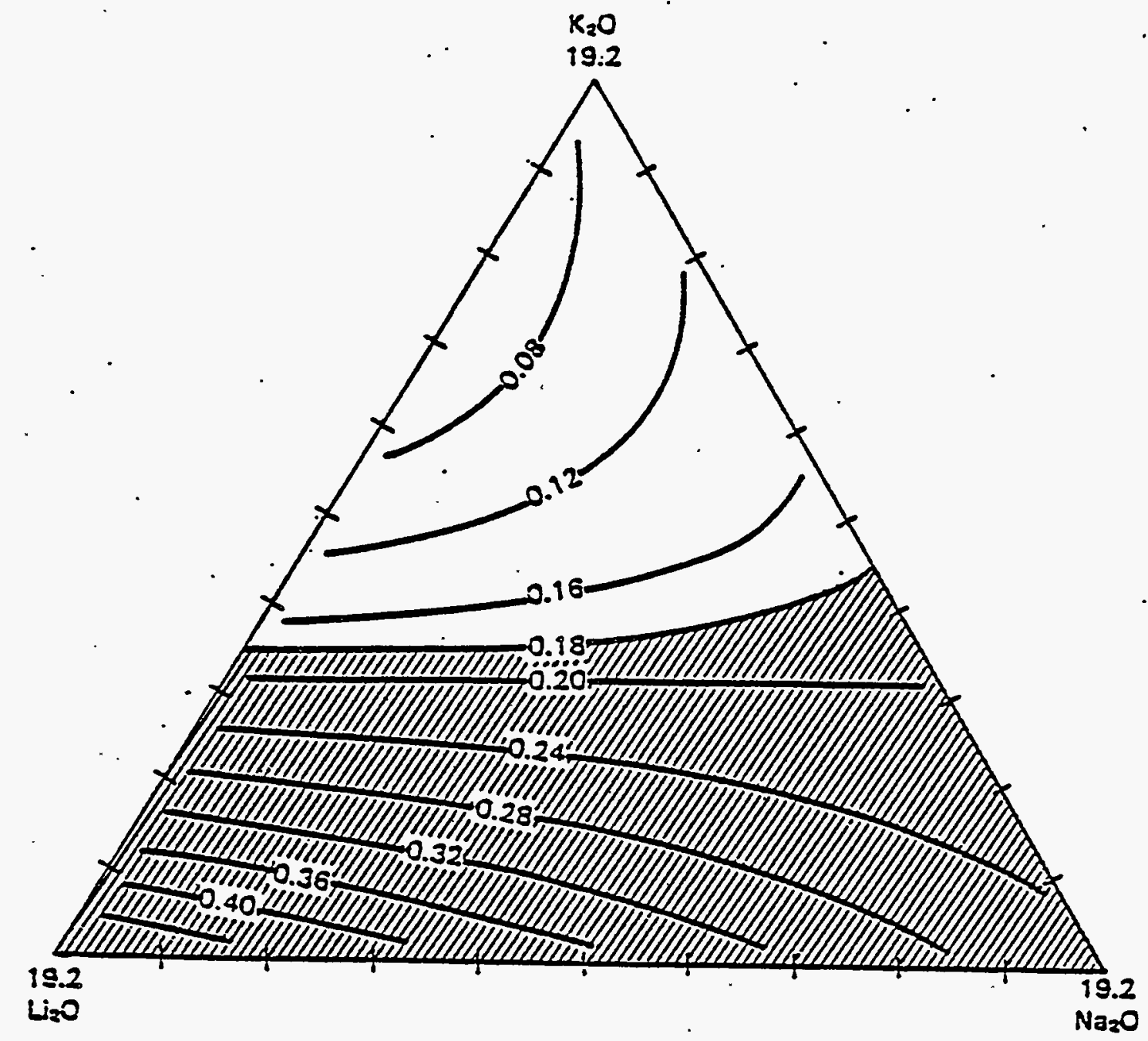

FIGURE 4.1-26. Contour Plot of Predicted El150 in $\mathrm{ohm}^{-1} \mathrm{~cm}^{-1}$. The shaded area -indicates the region of predicted E1150 values that are within the currently established limits of 0.18 $0.5 \mathrm{ohm}^{-1} \mathrm{~cm}^{-1}$. All axis compositions are given in mo1\%. HWVP-87-V110202C 


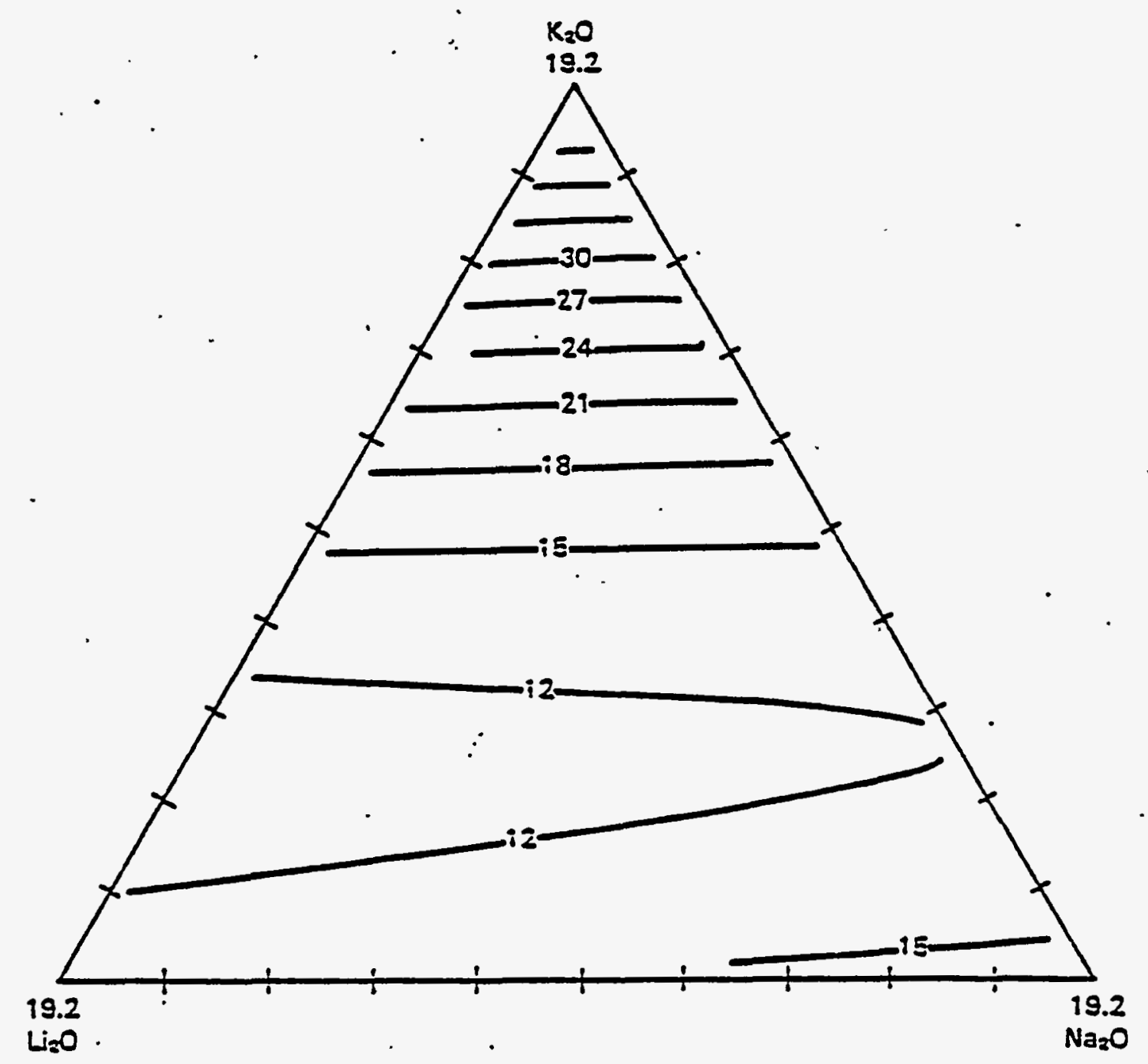

F.IGURE 4.1-27. Contour P7ot of Predicted 28-Day MCC-1 Normalized Boron ReTease in $\mathrm{g} / \mathrm{m2}$. Al1 axis compositions are given in mol\%

An evaluation of the changes in critical glass and melt properties due to varying $\mathrm{U}_{3} \mathrm{O}_{8}$ content in the total waste fraction of HW39-1 glass was conducted as a single component variability test. The range for $\mathrm{U}_{3} \mathrm{O}_{8}$ variabi7ity in this test was 0 to $8 \mathrm{wt} \%$ in the glass; the total waste loading $\left(\mathrm{U}_{3} \mathrm{O}_{8}+\right.$ nonvarying waste components) was maintained at $25 \mathrm{wt} \%$ (Table $4.1-33$ ). The upper 1 imit was expanded to $8 \mathrm{wt} \%$ from the expected $5 \mathrm{wt} \%$ maximum in an attempt to exceed the solubility limit of $\mathrm{U}_{3} \mathrm{O}_{8}$ in the glass so that the upper $\mathrm{U}_{3} \mathrm{O}_{8}$ concentration 7 imit can be established. Six glasses with $\mathrm{U}_{3} \mathrm{O}_{8}$ levels of $0,0.15,2,4,6$, and $8 \mathrm{wt} \% \mathrm{U}_{3} \mathrm{O}_{8}$ were evaluated. study:

The following observations were made based on this $U_{3} O_{8}$ variability

- The viscosity (TIOOP) of the reference glass was not affected significantly over the range of 0 to $8 \mathrm{wt} \% \mathrm{U}_{3} \mathrm{O}_{8}$ in the glass (Tabie 4.1-34). 
TABLE 4.1-33. Test Compositions for the $U_{3} \mathrm{O}_{8}$ Variability Study

\begin{tabular}{|l|c|c|c|}
\hline Melt Number & $U_{3} O_{8}$ (wt\%) & Waste Mix (wt\%) & Frit \\
\hline 1 & 0 & 25 & 75 \\
2 (reference) & 0.15 & 24.85 & 75 \\
3 & 2 & 23 & 75 \\
4 & 4 & 21 & 75 \\
5 & 6 & 19 & 75 \\
6 & 8 & 17 & 75 \\
\hline
\end{tabular}

TABLE 4.1-34. Summary of Results From Uranium Variability Study for Viscosity, Electrical Conductivity

\begin{tabular}{|l|l|l|l|l|l|l|c|}
\hline \multicolumn{7}{c|}{} & \multicolumn{7}{|c|}{ Wt\% $U_{3} \mathrm{O}_{8}$ in Glass } \\
\cline { 2 - 8 } & 0.0 & 0.15 & 2.0 & 4.0 & 6.0 & 8.0 & HW39-1 \\
\hline TI00P $\left({ }^{\circ} \mathrm{C} \pm 10^{\circ} \mathrm{C}\right)$ & 1103 & 1080 & 1109 & 1103 & 1113 & 1109 & 1124 \\
E1150 $\left(\mathrm{ohm}^{-1} \mathrm{~cm}^{-1}\right)$ & 0.25 & 0.28 & 0.27 & 0.28 & 0.27 & 0.25 & 0.27 \\
\hline
\end{tabular}

- The electrical conductivity of the reference glass at $1150^{\circ} \mathrm{C}$ was not affected significantiy over the range of 0 to $8 \mathrm{wt} \% \mathrm{U}_{3} \mathrm{O}_{8}$ in the glass (Table 4.1-34).

- For 0 to $8 \mathrm{wt} \% \mathrm{U}_{3} \mathrm{O}_{3}$ in the glass, the $U$ was observed to be incorporated into the glass matrix with no uranium phase separation.

- As the level of $\mathrm{U}_{3} \mathrm{O}_{8}$ increased in the glass, the amount of $\mathrm{Fe}$ in the chromite spinel phiase $\left[\mathrm{Fe}(\mathrm{Fe}, \mathrm{Cr})_{2} \mathrm{O}_{4}\right]$ was observed to decrease. Above $2 \mathrm{wt} \% \mathrm{U}_{3} \mathrm{O}_{3}$, the chrome crystalline phase was thought to be $\mathrm{Cr}_{2} \mathrm{O}_{3}$.

- The amount of uranium variation expected in the NCAW will not significantly affect the viscosity, electrical conductivity, or durability (Table 4.1-35 and 4.1-36) of the glass.

4.1.3.3.6 Multiple Component Waste Variability Test. The following oxides have al so been identified as having a high potential for variation in the waste composition and can significantly affect the physical and chemical properties of borosilicate glasses: $\mathrm{Na}_{2} \mathrm{O}, \mathrm{Fe}_{2} \mathrm{O}_{3}, \mathrm{Al}_{2} \mathrm{O}_{3}$, SiO $\mathrm{Si}_{2}$, and $\mathrm{RE}_{2} \mathrm{O}_{3}$ (rare earth oxides; $\mathrm{La}_{2} \mathrm{O}_{3}$ and $\mathrm{Nd}_{2} \mathrm{O}_{3}$ ). These five components represent 80 wt\% of the reference waste as oxides; therefore, the variation in the concentrations of these components will have the greatest potential for impact on the makeup of the waste and glass. 
TABLE 4.1-35. Summary of 7-day MCC-1 Leaching Results from HWVP Uranium Variability Study. MCC-1 conditions:

$S A / V=10 \mathrm{~m}^{-1}, 90^{\circ} \mathrm{C}$, in deionized water.

\begin{tabular}{|c|c|c|c|c|c|c|c|}
\hline \multirow[b]{2}{*}{ Element } & \multicolumn{7}{|c|}{$\begin{array}{l}\text { Normalized Elemental Release } \\
\text { for Various wt\% } U_{3} O_{8} \text { in Glass }\left(\mathrm{g} / \mathrm{m}^{2}\right)\end{array}$} \\
\hline & 0.0 & 0.15 & 2.0 & 4.0 & 6.0 & 8.0 & HW39-1 \\
\hline $\begin{array}{l}\mathrm{Si} \\
\mathrm{B} \\
\mathrm{Li} \\
\mathrm{Na} \\
\mathrm{Ca} \\
\mathrm{Sr} \\
\mathrm{Al} \\
\mathrm{Fe} \\
\mathrm{U}\end{array}$ & $\begin{array}{c}8.2 \\
10 \\
9.6 \\
9.7 \\
5.5 \\
5.1 \\
7.2 \\
0.12 \\
\text { NP(a) }\end{array}$ & $\begin{array}{c}9.1 \\
11 \\
11 \\
11 \\
5.7 \\
5.0 \\
7.8 \\
0.10 \\
1.4\end{array}$ & $\begin{array}{l}9.5 \\
12 \\
11 \\
11 \\
5.9 \\
5.2 \\
8.5 \\
0.11 \\
1.2\end{array}$ & $\begin{array}{l}9.9 \\
12 \\
12 \\
11 \\
6.1 \\
4.6 \\
9.1 \\
0.13 \\
0.81\end{array}$ & $\begin{array}{l}8.9 \\
11 \\
10 \\
10 \\
6.1 \\
4.5 \\
8.6 \\
0.13 \\
0.74\end{array}$ & $\begin{array}{l}9.6 \\
11 \\
11 \\
11 \\
6.1 \\
3.7 \\
9 \\
0.14 \\
0.88\end{array}$ & $\begin{array}{c}8.7 \\
9.7 \\
10 \\
9.7 \\
5.9 \\
5.5 \\
7.3 \\
0.20 \\
\text { NP(a) }\end{array}$ \\
\hline Final pH & 9.6 & 9.6 & 9.6 & 9.7 & 9.5 & 9.6 & 9.7 \\
\hline
\end{tabular}

(a) $N P=$ not present in this glass composition.

TABLE 4.1-36. Summary of 28-day MCC-1 Leaching Results from HWVP Uranium Variability Study. MCC-1 conditions: $S A / V=10 \mathrm{~m}^{-1}, 90^{\circ} \mathrm{C}$, in deionized water.

\begin{tabular}{|c|c|c|c|c|c|c|c|}
\hline \multirow[b]{2}{*}{ Element } & \multicolumn{7}{|c|}{$\begin{array}{l}\text { Normalized Elemental Release } \\
\text { for Various wt\% } \mathrm{U}_{3} \mathrm{O}_{8} \text { in Glass }\left(\mathrm{g} / \mathrm{m}^{2}\right)\end{array}$} \\
\hline & 0.0 & 0.15 & 2.0 & 4.0 & 6.0 & 8.0 & HW39-1 \\
\hline $\begin{array}{l}\mathrm{Si} \\
\mathrm{B} \\
\mathrm{Li} \\
\mathrm{Na} \\
\mathrm{Ca} \\
\mathrm{Sr} \\
\mathrm{AT} \\
\mathrm{Fe} \\
\mathrm{U}\end{array}$ & $\begin{array}{l}12 \\
14 \\
14 \\
13 \\
5.8 \\
4.7 \\
8.4 \\
0.14 \\
\text { NP(O) }\end{array}$ & $\begin{array}{l}12 \\
15 \\
15 \\
14 \\
5.9 \\
4.5 \\
8.9 \\
0.19 \\
2.4\end{array}$ & $\begin{array}{l}12 \\
16 \\
15 \\
15 \\
6.1 \\
4.7 \\
9.5 \\
0.16 \\
3.0\end{array}$ & $\begin{array}{l}13 \\
17 \\
16 \\
15 \\
6.6 \\
4.3 \\
10.3 \\
0.23 \\
4.3\end{array}$ & $\begin{array}{c}13 \\
16 \\
15 \\
15 \\
7.1 \\
4.8 \\
10.5 \\
0.20 \\
4.5\end{array}$ & $\begin{array}{l}14 \\
17 \\
16 \\
16 \\
7.1 \\
4.2 \\
.11 .3 \\
0.30 \\
5.1\end{array}$ & $\begin{array}{c}12 \\
14 \\
16 \\
15 \\
6.6 \\
5.5 \\
9.2 \\
0.40 \\
N P(a)\end{array}$ \\
\hline Final $\mathrm{pH}$ & 9.6 & 9.6 & 9.4 & 9.5 & 9.4 & 9.4 & 9.7 \\
\hline
\end{tabular}

(a) NP: not present in this glass composition. 
A multiple component waste variability study was conducted to characterize and produce a first-order model of the effects on glass and melt properties due to varying the proportions of $\mathrm{Na}_{2} \mathrm{O}, \mathrm{Fe}_{2} \mathrm{O}_{3}, \mathrm{Al}_{2} \mathrm{O}_{3}, \mathrm{SiO}_{2}$, and rare earth oxides $\left(\mathrm{RE}_{2} \mathrm{O}_{3}\right)$ in the waste fraction of the glass (Table 4.1-37). In this test, the. composition range for each oxide exceeds the variation currently expected in the HWVP process. The first-order models produced do not predict leaching results well, and further testing to develop a second-order model would be required to adequately predict leaching performance.

From this study the following observations are made:

- For all five oxides tested, the viscosity of the melt (Figure 4.1-28), rather than the electrical conductivity (Figure 4.1-29), was the limiting factor. In other words, if the viscosity of the composition is acceptable, the electrical conductivity is atso.

- For $\mathrm{Na}_{2} \mathrm{O}$, the range of acceptable variability was from 8.8 to $13.2 \mathrm{wt} \%$ in the glass. The concentration of $\mathrm{Na}_{2} \mathrm{O}$ in the reference glass is 10.4 wt\%.

- For $\mathrm{Fe}_{2} \mathrm{O}_{3}$, the range of acceptable variability was from $7.3 \mathrm{wt} \%$ in the glass to the maximum wt\% $\mathrm{Fe}_{2} \mathrm{O}_{3}$ evaluated in the test, 15 wt\%. The concentration of $\mathrm{Fe}_{2} \mathrm{O}_{3}$ in the reference glass is 11.1 wt\%.

- For $\mathrm{Al}_{2} \mathrm{O}_{3}$, the range of acceptable variability was from 0.4 to 6.5 wt\% in the glass. The concentration of $\mathrm{Al}_{2} \mathrm{O}_{3}$ in the reference glass is 4.3 wt\%.

- For $\mathrm{SiO}_{2}$, the upper limit of acceptable variability was 54.8 wt\% in the glass. At the lowest level of $\mathrm{SiO}_{2}$ tested (50.4 wt\%), the glass properties were still acceptable. This lowest level represents $0 \mathrm{wt} \% \mathrm{SiO}_{2}$ in the waste. The concentration of $\mathrm{SiO}_{2}$ in the reference glass is 51.3 wt\%.

TABLE 4.1-37. Ranges of Haste Components in the MuTtiple Haste Component Variability Test

\begin{tabular}{|l|c|c|}
\hline \multicolumn{1}{|c|}{ Oxide } & $\begin{array}{c}\text { Range of Oxide wt\% in the } \\
\text { Haste Fraction of the Glass }\end{array}$ & $\begin{array}{c}\text { Range of Oxide wt\% } \\
\text { in the Glass }\end{array}$ \\
\hline $\mathrm{Na}_{2} \mathrm{O}$ & $0-10$ & $7.7-17.7$ \\
$\mathrm{Fe}_{2} \mathrm{O}_{3}$ & $5-15$ & $5.0-15.0$ \\
$\mathrm{Al}_{3} \mathrm{O}_{3}$ & $0-8$ & $0.0-8.0$ \\
$\mathrm{SiO}_{2}$ & $0-5$ & $50.4-55.4$ \\
$\mathrm{RE}_{2} \mathrm{O}_{3}$ & $0-2$ & $0.0-2.0$ \\
Haste mix & $0-20$ as required & $16.6-36.9$ \\
\hline
\end{tabular}




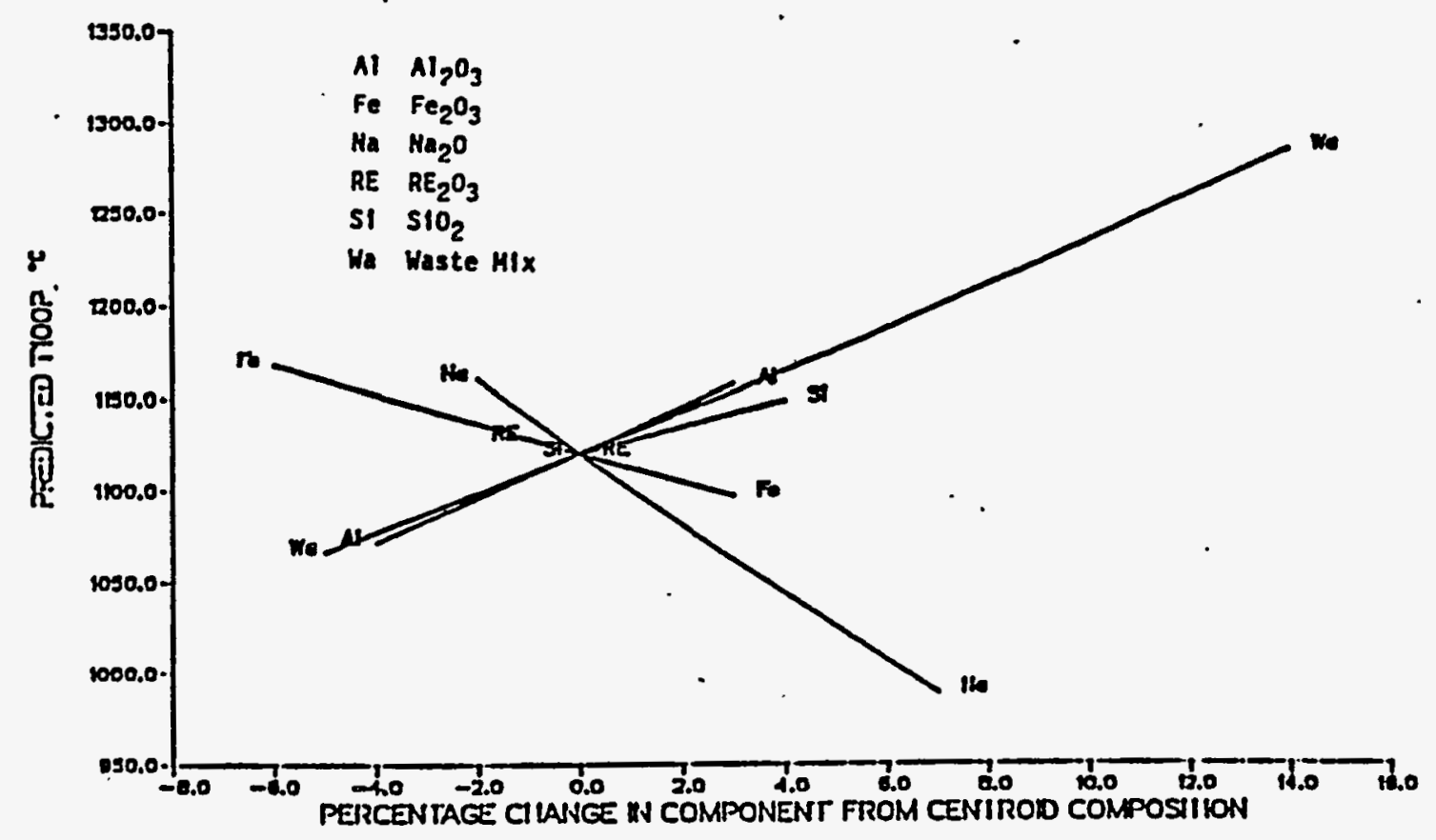

FIGURE 4.1-28. The Effects Plot of Components on T100P. The HWVP reference glass, HW39-1, is the centroid composition.

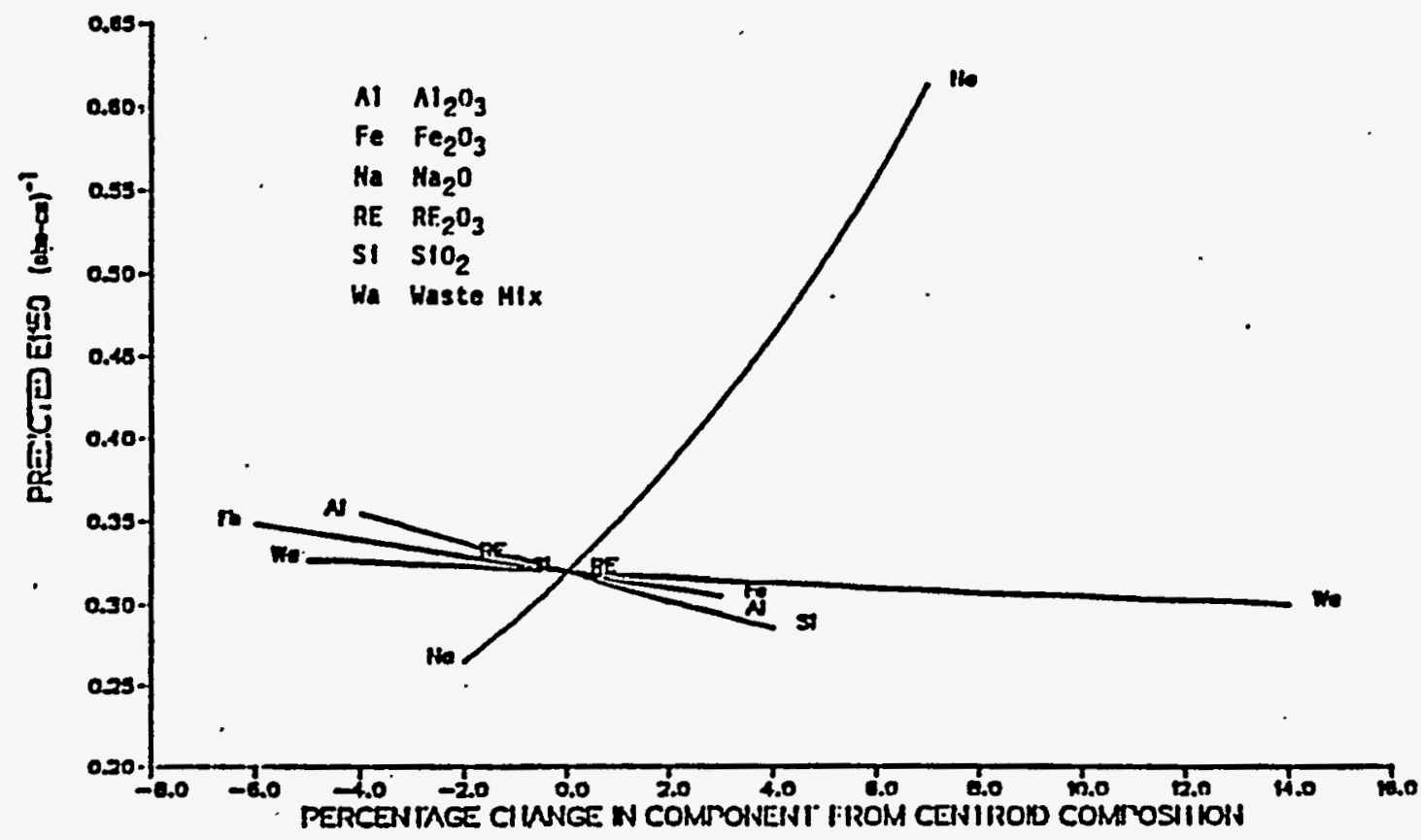

FIGURE 4.1-29. The Effects Plot of Components El150. The HWVP reference glass, HW39-1, is the centroid composition. 
- For the rare-earth oxides $\left(\mathrm{RE}_{2} \mathrm{O}_{3}\right)$, the glass properties were acceptable over the complete range tested, 0.0 to $2.0 \mathrm{wt} \%$ in the glass. Therefore, although the lower limit of $\mathrm{RE}_{2} \mathrm{O}_{3}$ in the glass was 0.0 wt\%, the upper variability limit was undetermined at some concentration $>2.0$ wt\% in the glass. The concentration of $\mathrm{SiO}_{2}$ in the reference glass is $51.3 \mathrm{wt} \%$.

- The effects of rare-earths (1anthanum and neodymium) on the viscosity and electrical conductivity of the glass due to varying the rare earth oxide from 0 to 2 wt\% were not significant.

4.1.3.3.7 Chrome Variability. Chrome variability was chosen for study because earlier work with borosilicate waste glasses had shown that small changes ( 0 to 1 wt\%) in $\mathrm{Cr}_{2} \mathrm{O}_{3}$ concentration can have a significant effect on the amount and type of the crystalline material within the glass. The solubility of $\mathrm{Cr}_{2} \mathrm{O}_{3}$ in the HW39-1 glass composition is approximately $0.5 \mathrm{wt} \%$. Above 0.5 wt\%, chromite spinel $\left[\mathrm{Fe}(\mathrm{Cr}, \mathrm{Fe})_{2} \mathrm{O}_{4}\right]$ and $\mathrm{Cr}_{2} \mathrm{O}_{3}$ crystals are present in the glass. Because the $\mathrm{Cr}_{2} \mathrm{O}_{3}$ concentration in the reference glass is 1.34 wt\%, these crystalline phases are present in the glass. These crystalline phases have been observed during reference glass development to affect the viscosity of the melt.

A single component variability study was conducted to evaluate the effects of chrome variability. The $\mathrm{Cr}_{2} \mathrm{O}_{3}$ concentration in HW39-1 glass varied from 0.0 to 2.0 wt\%. Glasses with $\mathrm{Cr}_{2} \mathrm{O}_{3}$ concentrations of $0.0,0.5$, $1.0,1.34$, and 2.0 wt\% were tested. Although the variation of $\mathrm{Cr}_{2} \mathrm{O}_{3}$ content. within HW39-1 gTass was observed to have minor effects on viscosity and elec-. trical conductivity, the changes in physical properties were not large enough to affect the processability of the glass within the meiter. A7though the increase in crystalline material with increasing $\mathrm{Cr}_{2} \mathrm{O}_{3}$ content did not adversely affect the physical or leaching properties of the glass, increased crystalline content could cause processing problems within the melter, due to settling and sludge formation. The settling potential was evaluated in the HWVP -12 and HWVP-13 melter tests (HW39-1 glass with 1.34 wt\% $\mathrm{Cr}_{2} \mathrm{O}_{3}$ ). The results of these melter evaluations are reported elsewhere (Ref. 4.1-11). (a)

The results obtained from the $C r$ variability study are summarized in Table 4.1-38. Variations in $\mathrm{Cr}_{2} \mathrm{O}_{3}$ concentration affected the viscosity, electrical conductivity, and the crystallinity of the glass. No significant effects were observed in the leachability of the glasses over the $\mathrm{Cr}_{2} \mathrm{O}_{3}$ range tested. An ICP analysis found all five glasses to be equivalent with the exception of the $\mathrm{Cr}_{2} \mathrm{O}_{3}$ concentration.

4.1.3.3.7.1 Yiscosity (T100P). The viscosity curves of the five glasses are shown in Figure 4.1-30. As the $\mathrm{Cr}_{2} \mathrm{O}_{3}$ concentration increased in the glass, the viscosity increased slightly. A plot of the T100P versus

(a) R. K. Nakaoka et al., Hanford Haste Vitrification Program Milestone HWVP-HLVID: Nonradioactive LFCM Testing Results in FY 1986 Under the Hanford Waste Vitrification Program. Pacific Northwest Laboratory, Richland, Hashington (1986). 
TABLE 4.1-38. Summary of the Results from Composition Variability Study for HW39-1 Glass with Varying $\mathrm{Cr}_{2} \mathrm{O}_{3}$ Content. MCC-1 Conditions: 28 days, DI water, $90^{\circ} \mathrm{C}, S A / F=10 \mathrm{~m}^{-1}$.

\begin{tabular}{|c|c|c|c|c|c|}
\hline \multirow[b]{2}{*}{ Element } & \multicolumn{5}{|c|}{$\begin{array}{l}\text { Normalized Elemental Release for Various } \\
\qquad \begin{array}{c}\mathrm{Wt} \% \mathrm{Cr}_{2} \mathrm{O}_{3}\left(\mathrm{~g} / \mathrm{m}^{2}\right)\end{array}\end{array}$} \\
\hline & 0.0 & 0.5 & 1.0 & 1.34 & 2.0 \\
\hline 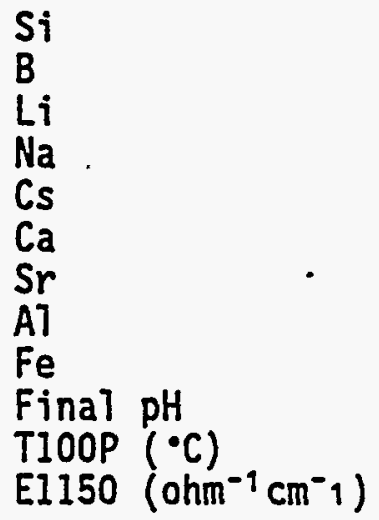 & $\begin{array}{c}12 \\
14 \\
15 \\
15 \\
20 \\
6.9 \\
5.9 \\
9.0 \\
0.4 \\
9.7 \\
1077 \\
0.35\end{array}$ & $\begin{array}{c}12 \\
15 \\
16 \\
15 \\
21 \\
6.6 \\
5.5 \\
9.2 \\
0.4 \\
9.7 \\
1088 \\
0.29\end{array}$ & $\begin{array}{c}12 \\
15 \\
15 \\
15 \\
18 \\
6.8 \\
5.7 \\
9.2 \\
0.2 \\
9.7 \\
1101 \\
0.26\end{array}$ & $\begin{array}{c}12 \\
14 \\
15 \\
15 \\
17 \\
7.1 \\
6.2 \\
9.2 \\
0.5 \\
9.7 \\
1097 \\
0.27\end{array}$ & $\begin{array}{c}11 \\
14 \\
14 \\
14 \\
17 \\
6.8 \\
6.9 \\
8.6 \\
0.2 \\
9.7 \\
1116 \\
0.27\end{array}$ \\
\hline
\end{tabular}

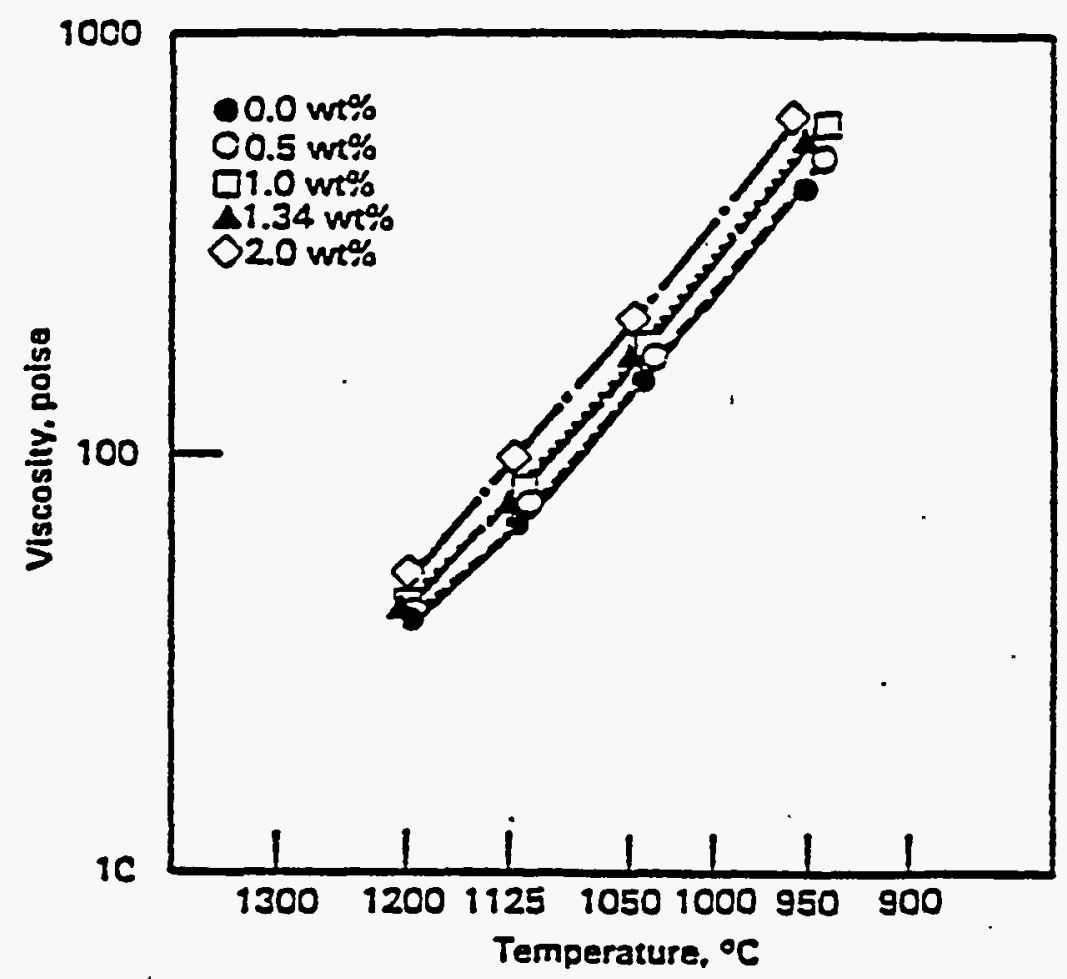

FIGURE 4.1-30. Viscosity of HW39-1 Giass Versus $\mathrm{Cr}_{2} \mathrm{O}_{3}$ Content 
$\mathrm{Cr}_{2} \mathrm{O}_{3}$ content is shown in figure 4.1-31. The viscosities were stable with time for all glass compositions tested except the $2.0 \mathrm{wt} \% \mathrm{Cr}_{2} \mathrm{O}_{3} \mathrm{gl}$ lass. At $9500^{\circ} \mathrm{C}$, the viscosity of the $2.0 \mathrm{wt} \% \mathrm{Cr}_{2} \mathrm{O}_{3}$ glass increased slowly. The increase in $7100 \mathrm{P}$ was roughly linear within the range of $\mathrm{Cr}_{2} \mathrm{O}_{3}$ concentrations tested. Although the viscosities did vary, the viscosities of all the glasses tested were within the limits required for melter operation, TI00P from $1070^{\circ} \mathrm{C}$ to $1150^{\circ} \mathrm{C}$.

\subsection{Electrical Conductivity (E1150). The electrical conduc-} tivity of the HW39-1 glass was affected by variations in $\mathrm{Cr}_{2} \mathrm{O}_{3}$ content. Electrical conductivity curves for the five glasses are shown in Figure 4.1.32. A plot of E1150 versus $\mathrm{Cr}_{2} \mathrm{O}_{3}$ content in the glasses is shown in Figure 4.1.33. The electrical conductivity of the glasses increased significantly when the $\mathrm{Cr}_{2} \mathrm{O}_{3}$ concentration was less than $0.5 \mathrm{wt} \%$. This increase was not large enough to cause the electrical conductivity of the glass. to exceed the 7 imits set for acceptable melter processing $\left(0.18\right.$ to $0.5 \mathrm{ohm}^{-1} \mathrm{~cm}^{-1}$ at $\left.1150^{\circ} \mathrm{C}\right)$.

4.1.3.3.7.3 Phase Behavior. As found in previous work, (a) the amount of crystali ine material within the glass is directiy related to the $\mathrm{Cr}_{2} \mathrm{O}_{3}$

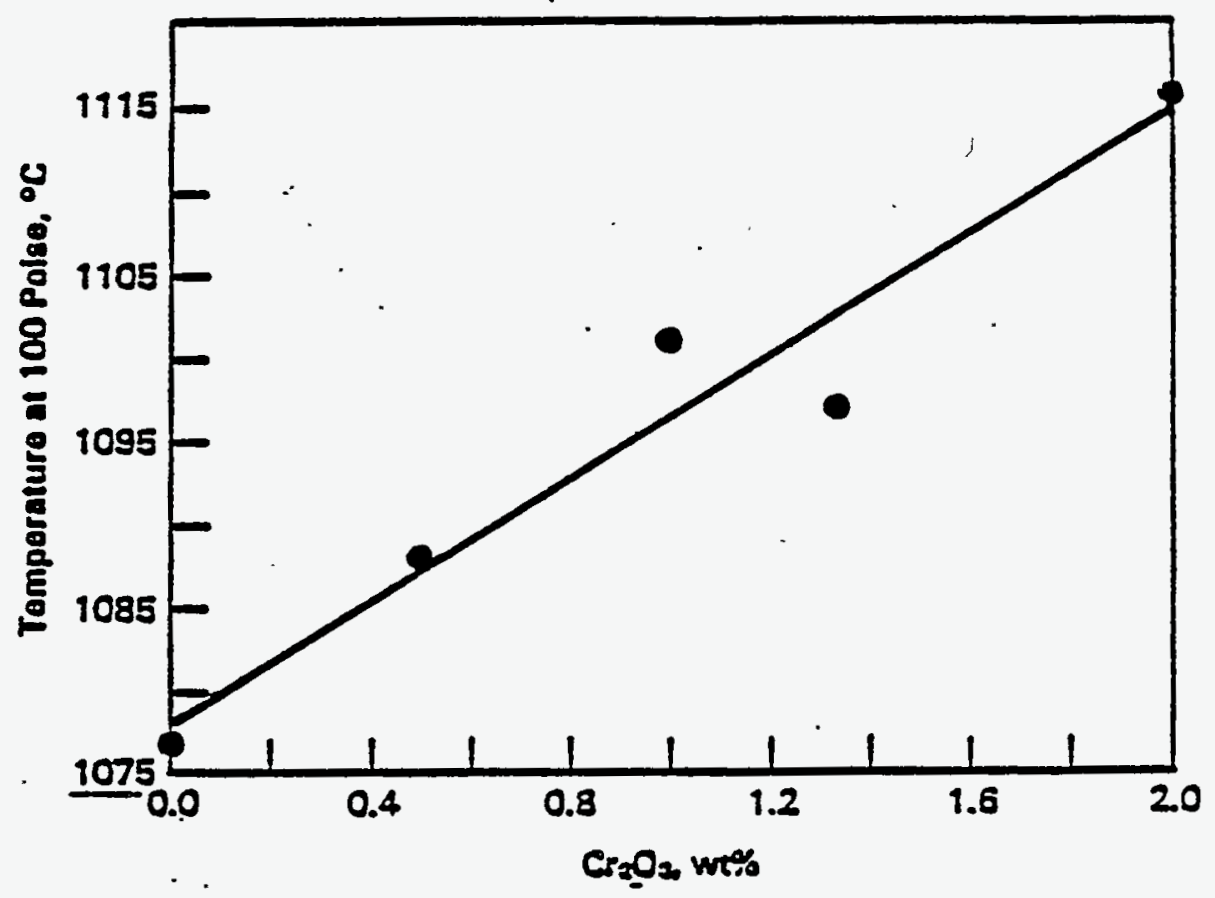

FIGURE 4.1-31. Temperature of 100 Poise Melt Viscosity (TI00P) Versus $\mathrm{Cr}_{2} \mathrm{O}_{3}$ Content in HW39-1 Glass

(a) S. 0. Bates, HWUP Baseline Milestone V11020202B: Issue a Recommended HWVP Glass Composition for Future Work. Pacific Northwest Laboratory, Richland, Washington (1985). 


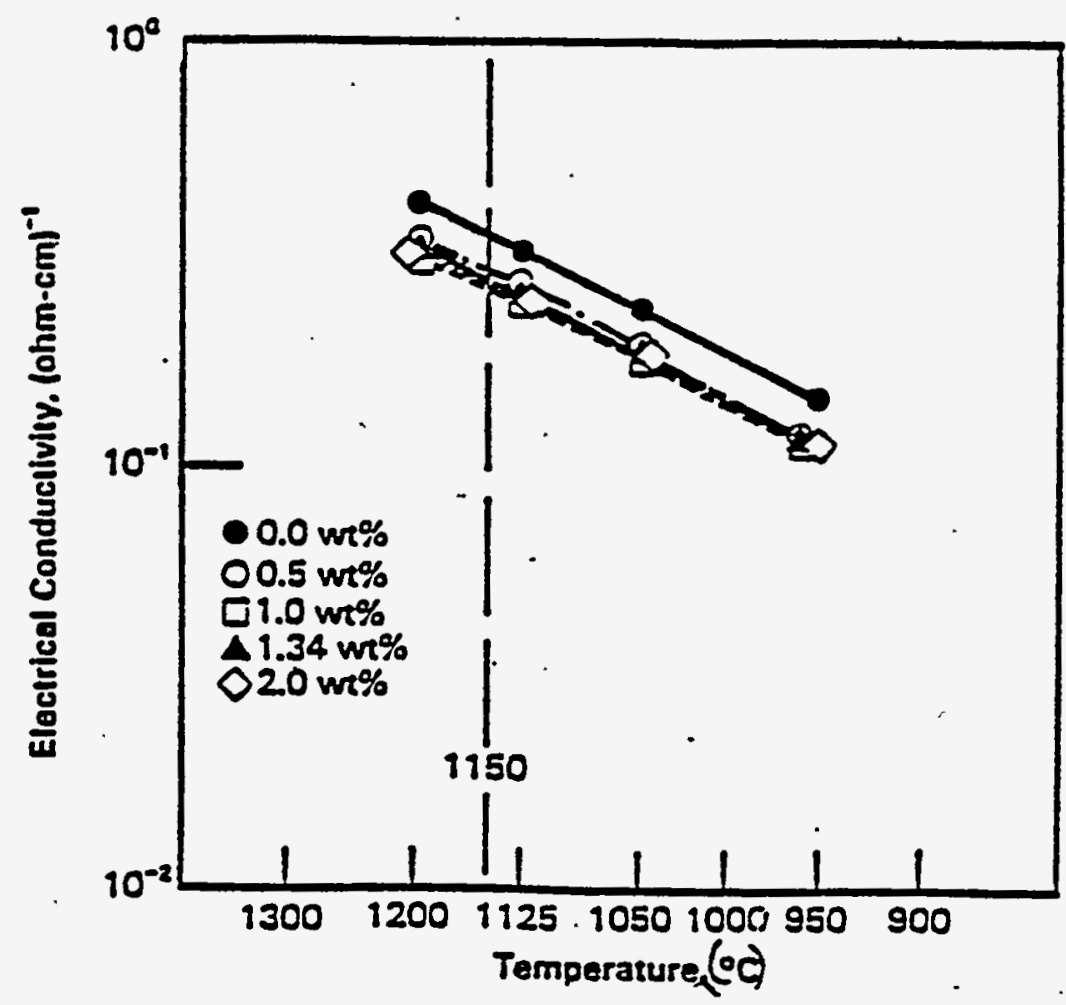

FIGURE 4.1-32. Electrical Conductivity Curve of HH39-1 Glasses with Varying $\mathrm{Cr}_{2} \mathrm{O}_{3}$ Content HWVP-87-V110202C

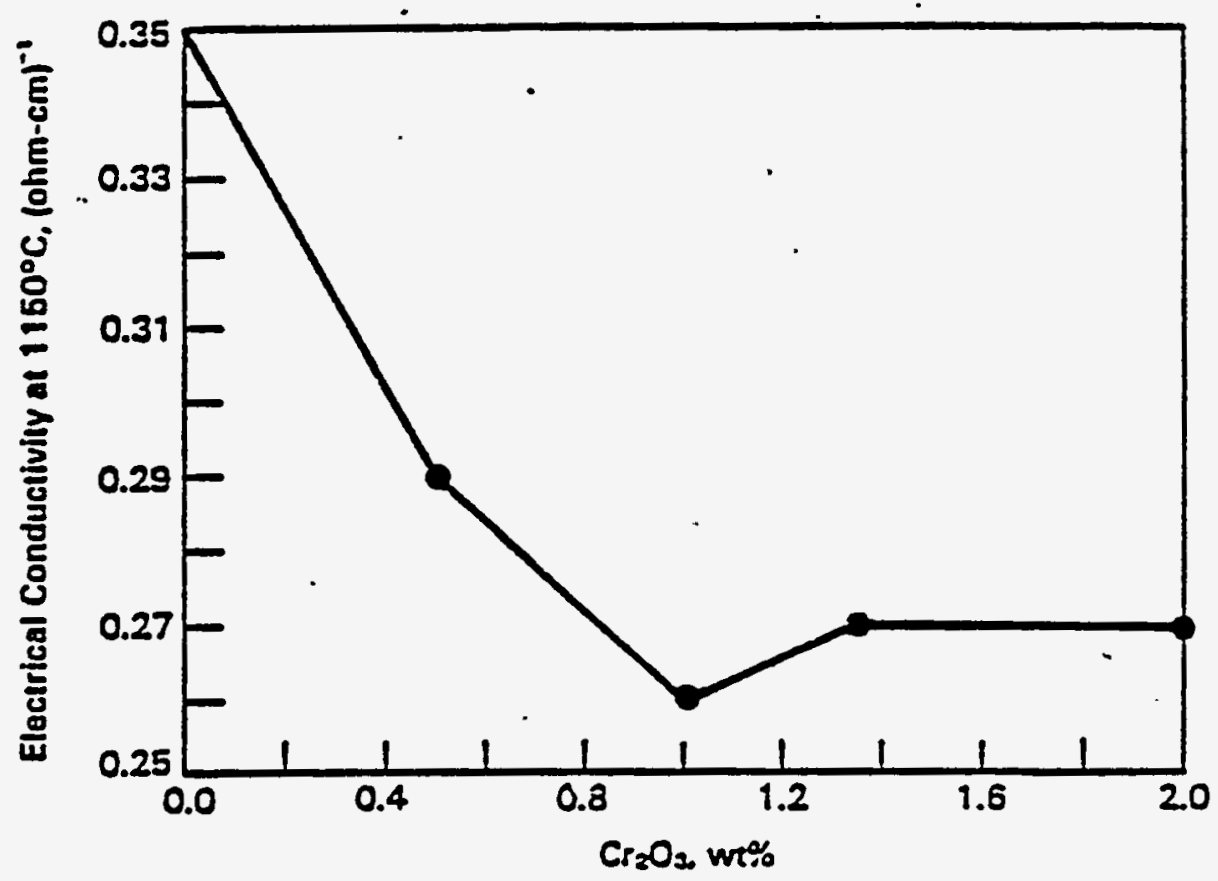

FIGURE 4.1-33. Electrical Conductivity at $1150^{\circ} \mathrm{C}$ (E1150) in $\mathrm{ohm}^{-1} \mathrm{~cm}^{-1}$ Versus $\mathrm{Cr}_{2} \mathrm{O}_{3}$ Content in HW39-1 GTass HWVP-87-V110202C 
concentration. No crystalline material was observed in the 0.0 wt\% $\mathrm{Cr}_{2} \mathrm{O}_{3}$ glass. With $\mathrm{Cr}_{2} \mathrm{O}_{3}$ concentrations of 0.5 to $2.0 \mathrm{wt} \%$, a significant amount (1 to $5 \mathrm{wt \%}$ ) of crystalline phase was observed. The amount of crystalline phase observed increased directly with the increase in $\mathrm{Cr}_{2} \mathrm{O}_{3}$ content in the glasses with 0.5 wt\% $\mathrm{Cr}_{2} \mathrm{O}_{3}$ and above. This indicated that the $\mathrm{Cr}_{2} \mathrm{O}_{3}$ solubility in HW39-1 glass was less than 0.5 wt\%. This has also been found to be the case with other borosilicate waste glasses from earlier HWVP, DHPF, and WVDP work. The only crystalline phase observed in the test glasses with $\mathrm{Cr}_{2} \mathrm{O}_{3}$ concentration of 1.0 wt\% or greater was the cubic spinel, $\mathrm{FeCr}_{2} \mathrm{O}_{4}$, about 5 $\mathrm{m}$ in size. At 0.5 wt\% $\mathrm{Cr}_{2} \mathrm{O}_{3}$ concentration, hexagonal platelets of the sesquioxide $(\mathrm{Fe}, \mathrm{Cr})_{2} \mathrm{O}_{3}$ about $35 \mathrm{~mm}$ in size were also present with the spinel in the glass.

4.1.3.3.7.4 Leaching Results. The durability of the glasses was evaluated using a 28-day MCC-1 Teaching test. A summary of the test results is found in Table 4.1-38. Each value listed is an average of three test samples. No significant difference in the normalized elemental release was observed in any of the test glasses. The durability of HW39-1 glass is unchanged with variations in the $\mathrm{Cr}_{2} \mathrm{O}_{3}$ concentration range of 0.0 to 2.0 wt\%.

4.1.3.3.8 Variability Melter Testing. Some testing of HWV composition variability has been completed in engineering-scale Liquid-Fed Ceramic Helters (LFCM). Of the waste composition extremes determined in the $\mathrm{ZrO}_{2}$ variability tests and multiple component variability, the following scenarios were selected as the most.representative for HWVP-14 melter testing: Tow Fe, low Al, high $\mathrm{Zr}$, and high $\mathrm{Na}$. The first three compositions follow the trend of actual aging-waste samples; the last one is a reflection of the washing step of the pretreatment sequence: The observations made during laboratory glass development of the compositions used in HWVP-14 are reported below. The results for the HWWP-14 melter test are reported in a milestone report by Nakaoka et a7. (a)

The oxide compositions evaluated for HWVP-14 are presented in Table 4.1-39 along with the reference glass compositions. The extreme compositions were batched in the laboratory using compounds in the oxide form. Each composition was melted and the glass viscosity determined. The TIOOP values for high $\mathrm{Na}_{2} \mathrm{O}$, low $\mathrm{Al}_{2} \mathrm{O}_{3}$, and high $\mathrm{ZrO}_{2}$ compositions of the four compositions agreed well with the predicted values from the waste variability study models. However, the low Fe composition T100P was substantialiy lower than predicted $\left(1104^{\circ} \mathrm{C}\right.$ versus $\left.1145^{\circ} \mathrm{C}\right)$.

The major difference between the waste variability study composition for low $\mathrm{Fe}$ and the batched gilass composition was a higher (reference) chrome level used in the variability studies. Based on recent indications, the chrome level in HWVP reference feed is substantially lower than previously thought. In an effort to reflect this anticipated change and to limit the

(a) R. K. Nakaoka et al., Hanford Waste Vitrification Program Milestone HWVP-HLV1D: Nonradioactive LFCM Testing Results in FY 1986 Under the Hanford Waste Vitrification Program. Pacific Northwest Laboratory, Richland, Hashington (1986). 
TABLE 4.1-39. Oxide Composition of Melter Feeds. Prepared for the HWVP Feed Composition Variables Tests

\begin{tabular}{|c|c|c|c|c|c|c|}
\hline \multirow[b]{2}{*}{ Oxide } & \multicolumn{6}{|c|}{ Oxide Composition (wt\%) } \\
\hline & Reference & Low AT & High $\mathrm{Zr}$ & High Na & Low $\mathrm{Fe}$ & Low $\mathrm{Fe}_{2}$ \\
\hline $\begin{array}{l}\mathrm{Al}_{2} \mathrm{O}_{3} \\
\mathrm{BaO}_{2} \\
\mathrm{CaO}^{2} \\
\mathrm{CeO}_{2} \mathrm{CO}_{2} \\
\mathrm{Cr}_{2} \mathrm{O}_{3} \\
\mathrm{CSO}_{2} \\
\mathrm{CuO} \\
\mathrm{Fe}_{2} \mathrm{O}_{3} \\
\mathrm{MgO}_{3} \\
\mathrm{MnO}_{2} \\
\mathrm{MOO}_{3} \\
\mathrm{NiO} \\
\mathrm{Pr}_{6} \mathrm{O}_{11} \\
\mathrm{SiO}_{2} \\
\mathrm{Sm}_{2} \mathrm{O}_{3} \\
\mathrm{SrO}_{3} \\
\mathrm{Y}_{2} \mathrm{O}_{3} \\
\mathrm{Zr}_{2} \mathrm{O}_{3} \\
\mathrm{La}_{2} \mathrm{O}_{3} \\
\mathrm{Na}_{2} \mathrm{O} \\
\mathrm{Nd}_{2} \mathrm{O}_{3} \\
\mathrm{~F}_{2} \mathrm{SO}_{3} \\
\mathrm{SO}_{3}- \\
\mathrm{TOC}\end{array}$ & $\begin{array}{r}4.32 \\
0.10 \\
0.08 \\
0.18 \\
1.34 \\
0.25 \\
0.15 \\
11.15 \\
0.08 \\
0.18 \\
0.30 \\
0.60 \\
0.10 \\
0.76 \\
0.05 \\
0.10 \\
0.05 \\
0.60 \\
0.55 \\
2.70 \\
0.53 \\
0.30 \\
0.38 \\
0.15 \\
\end{array}$ & $\begin{array}{l}0.40 \\
0.13 \\
0.10 \\
0.23 \\
0.16 \\
0.31 \\
0.19 \\
14.08 \\
0.10 \\
0.23 \\
0.38 \\
0.76 \\
0.13 \\
0.96 \\
0.06 \\
0.13 \\
0.06 \\
0.76 \\
0.70 \\
3.41 \\
0.67 \\
0.38 \\
0.48 \\
0.19 \\
\end{array}$ & $\begin{array}{c}2.79 \\
0.07 \\
0.05 \\
0.12 \\
0.08 \\
0.16 \\
0.10 \\
7.20 \\
0.05 \\
0.12 \\
0.20 \\
0.39 \\
0.07 \\
0.49 \\
0.02 \\
0.07 \\
0.02 \\
10.00 \\
0.36 \\
1.75 \\
0.34 \\
0.20 \\
0.25 \\
0.10 \\
\end{array}$ & $\begin{array}{r}4.00 \\
0.10 \\
0.07 \\
0.17 \\
0.11 \\
0.23 \\
0.14 \\
10.30 \\
0.07 \\
0.17 \\
0.28 \\
0.55 \\
0.10 \\
0.70 \\
0.04 \\
0.10 \\
0.04 \\
0.55 \\
0.51 \\
5.50 \\
0.49\end{array}$ & $\begin{array}{l}5.80 \\
0.14 \\
0.10 \\
0.24 \\
0.17 \\
0.33 \\
0.20 \\
8.00 \\
0.01 \\
0.24 \\
0.41 \\
0.81 \\
0.14 \\
1.02 \\
0.06 \\
0.14 \\
0.06 \\
0.81 \\
0.74 \\
3.65 \\
0.72 \\
0.41 \\
0.51 \\
0.20 \\
\end{array}$ & $\begin{array}{l}6.66 \\
0.16 \\
0.12 \\
0.28 \\
0.19 \\
0.38 \\
0.24 \\
5.50 \\
0.12 \\
0.28 \\
0.47 \\
0.92 \\
0.16 \\
1.17 \\
0.07 \\
0.16 \\
0.07 \\
0.92 \\
0.85 \\
4.16 \\
0.82 \\
0.47 \\
0.59 \\
0.24\end{array}$ \\
\hline $\begin{array}{l}\text { TOTALS } \\
\text { FRIT HW39 }\end{array}$ & $\begin{array}{l}25.00 \\
75.00\end{array}$ & $\begin{array}{l}25.00 \\
75.00\end{array}$ & $\begin{array}{l}25.00 \\
75.00\end{array}$ & $\begin{array}{l}25.00 \\
75.00\end{array}$ & $\begin{array}{l}25.00 \\
75.00\end{array}$ & $\begin{array}{l}25.00 \\
75.00\end{array}$ \\
\hline
\end{tabular}

formation of chromite spinel crystals in the melter glass, the level of chrome in HWVP-14 feeds was reduced by an order of magnitude from 1.34 wt\% to $0.13 \mathrm{wt} \% \mathrm{Cr}_{2} \mathrm{O}_{3}$.

The compositions tested in the waste variability study, on the other hand, reflected the chrome level of the reference feed. Removing this amount of $\mathrm{Cr}_{2} \mathrm{O}_{3}$ from the glass had the predicted effect of lowering the TloOP approximately $20^{\circ} \mathrm{C}$, as shown in Table 4.1-40, except in the low-Fe glass composition.

An effort was made to adjust the low-Fe composition to counteract the effect of removing a majority of the chrome on the TIOOP of the glass. The concentration of $\mathrm{Fe}$ in the low-Fe composition was further reduced from $8.0 \mathrm{wt} \%$ in the glass to $5.5 \mathrm{wt} \%$ to produce a predicted TIOOP of approximately 
TABLE 4.1-40. Predicted and Actual TIOOP Values for HWVP-14 Melter Test Glass Compositions HWVP-86-HLV1D

\begin{tabular}{|c|c|c|}
\hline Composition & $\begin{array}{c}\text { Predicted T100P } \\
(\cdot \mathrm{C})\end{array}$ & $\begin{array}{c}\text { Measured TIO0P } \\
(\cdot \mathrm{C})\end{array}$ \\
\hline High $\mathrm{ZrO}_{3}$ & 1150 & 1158 \\
High $\mathrm{Na}_{2} \mathrm{O}$ & 1050 & 1048 \\
Low $\mathrm{Al}_{2} \mathrm{O}_{3}$ & 1075 & 1063 \\
Low $\mathrm{Fe}_{2} \mathrm{O}_{3}$ & 1130 & 1104 \\
\hline
\end{tabular}

$1145^{\circ} \mathrm{C}$. This composition was batched in the laboratory, melted, and the T100P was determined. However, dropping the $\mathrm{Fe}_{2} \mathrm{O}_{3}$ to 5.5 wt\% had little effect on the T100P, which only increased from $1104^{\circ} \mathrm{C}$ to $1111^{\circ} \mathrm{C}$. This minor increase in the viscosity, due to reducing the amount of $\mathrm{Fe}_{2} \mathrm{O}_{3}$ at relatively low $\mathrm{Cr}_{2} \mathrm{O}_{3}$ concentrations, was similar to the results observed in other low $\mathrm{Cr}_{2} \mathrm{O}_{3}$ waste glasses (Ref. 4.1-12). The glass viscosity of the $5.5 \mathrm{wt} \% \mathrm{Fe}_{2} \mathrm{O}_{3}$ composition was within the acceptable range for LFCM processing $\left(1111^{\circ} \mathrm{C}\right.$ ) but still does not reflect the predicted results of the waste variability study model. These results indicate that the relative effect on viscosity, due to the variation of iron content, increases in the presence of higher chrome levels. This effect probably is due to the formation of the iron-chrome crystalline phases formed at the higher $\mathrm{Cr}_{2} \mathrm{O}_{3}$ concentration. Additional work is needed to improve the predictive model so that the interaction between $\mathrm{Fe}$ and $\mathrm{Cr}$ concentration can be incorporated.

The following observations are made based on the above work.

- The models produced for $\mathrm{Zr}, \mathrm{Na}, \mathrm{Al}$, and chrome variability accurately predict the changes in T100P with $10^{\circ} \mathrm{C}$.

- The relative effect on viscosity due to the variation of $\mathrm{Fe}$ content increases in the presence of higher chrome levels.

- For $\mathrm{Fe}_{2} \mathrm{O}_{3}$, the lower limit of acceptable variability can be extended to at least $5.5 \mathrm{wt} \%$ in the glass if the $\mathrm{Cr}_{2} \mathrm{O}_{3}$ content in the glass is near 0.1 wt\%. Further testing is required to define the lowest limit.

4.1.3.4 NCAW 84--Low-Chrome Feed G1ass Variability Studies. (a) The nominal compositions of the reference NCAW waste (NCAW 84) with reduced $\mathrm{Cr}_{2} \mathrm{O}_{3}$ and

(a) S. 0. Bates, Interim Milestone HWVP-87-V110202C - Report on FY 1987 Glass Variability Testing Conducted for the Hanford Waste Vitrification Program. Pacific Northwest Laboratory, Richland, Washington (July 1987). 
HH39-2 glass are shown in Table 4.1-41.(a)(b) In 1986, it was determined that approximately nine tenths of the chrome in the NCAW would be washed out during pretreatment. (c) When the low $\mathrm{Cr}_{2} \mathrm{O}_{3}$ NCAW 84 is added the reference frit composition at a $25 \mathrm{wt} \%$ oxides waste loading as shown in Table 4.1-41, the glass composition used in the testing is produced.

In this series of tests, additional glass components were evaluated, and the effects of $\mathrm{Fe}_{2} \mathrm{O}_{3}$ variability were re-evaluated because of the reduction of $\mathrm{Cr}_{2} \mathrm{O}_{3}$ in the waste. The effect of $\mathrm{Fe}_{2} \mathrm{O}_{3}$ on the temperature at which the viscosity of the glass is 100 poise (T10OP) is reduced with $10 \mathrm{~W}-\mathrm{Cr}_{2} \mathrm{O}_{3}$ levels; therefore, the acceptable $\mathrm{Fe}_{2} \mathrm{O}_{3}$ range of variation needed to be re-evaluated. The components selected for evaluation in this variability study were $\mathrm{Fe}$ with Tow $\mathrm{Cr}, \mathrm{Ca}, \mathrm{F}, \mathrm{Ba}, \mathrm{Mn}, \mathrm{Mo}$, and $\mathrm{Ni}$.

4.1.3.4.1 Scoping Studies (F, BaO, $\left.\mathrm{MnO}_{2}, \mathrm{MOO}_{3}, \mathrm{NiO}\right)$. Scoping tests were conducted at a concentration beyond the expected range of variability in the NCAN waste. In these scoping tests, the compositions of the glasses assumed a total waste loading of $25 \mathrm{wt} \%$, with the remaining portion of the waste being made up of the nonvarying waste components held at a constant proportion to one another. Glasses with 5 wt\% fluorine, 5 wt\% BaO, 5 wt\% $\mathrm{MnO}_{2}, 2 \mathrm{wt} \% \mathrm{MoO}_{3}$, and $2 \mathrm{wt} \% \mathrm{NiO}$ were tested in scoping tests. A summary of these glass compositions is presented in Table 4.1-42. Scoping tests were not conducted for $\mathrm{Fe}$ and $\mathrm{Ca}$ because previous studies and experience had shown that both elements can significantly effect glass properties over the ranges to be tested.

With the exception of $F$, no waste component had any major effects on the viscosity, electrical conductivity, phase behavior, and durability properties of the HW39-2 glass composition. At 5 wt\% F, a crystalline phase separation was observed in the glass. Because of potential incongruent changes in viscosity, electrical conductivity, or durability that can be associated with phase separation, the variability evaluation of fluorine was conducted separately. Because of the high levels of $\mathrm{Fe}_{2} \mathrm{O}_{3}$ and $\mathrm{CaO}$ in the glass scoping tests were not need for these components. Iron and $\mathrm{Ca}$ were included together in a single variability test. The results of the $5 \mathrm{wt} \% \mathrm{BaO}, 5 \mathrm{wt} \% \mathrm{MnO}_{2}$, $2 \mathrm{wt} \% \mathrm{MoO}_{3}$, and 2 wt\% $\mathrm{NiO}$ scoping tests are presented together. The results of the $\mathrm{F}$ testing and the $\mathrm{Fe} / \mathrm{Ca}$ testing are presented separately.

4.1.3.4.1.1 Viscosity Results. A summary of the T100p values for each of the scoping test glasses is presented in Table 4.1-43. Over the ranges tested, none of the waste components produced any major change in the TIOOP

(a) Letter from K. R. Shah to J. E. Minor, "Recommended (NCAW/CRW Blend) Feed Stream Composition and Range for PNL FY 1985 HWVP Glass Formation" (October 18, 1984).

(b) S. 0. Bates, HWUP DOE Milestone: Issue GTass Formulation of Neutralized Current Acid Waste (NCAW). Pacific Northwest Laboratory, Richland, Washington (1986).

(c) R. N. Wagner, Hanford Waste Vitrification Plant Feed Specification: Pretreated NCAW Feed. RHO-SD-HWV-OCD-001 Rev. 0, Rockwe11 Hanford Operations, Richland, Washington. 
TABLE 4.1-41. Compositions of NCAW 84 Reduced $\mathrm{Cr}_{2} \mathrm{O}_{3}^{\circ}$ Reference Waste and HH39-2 Glass at a 25 wt\% Oxides Waste Loading HWVP-87-V110202C

\begin{tabular}{|c|c|c|c|c|c|c|c|}
\hline oxide & $\begin{array}{l}\text { As Rerefved } \\
\text { (Kg/MTU) }\end{array}$ & $\begin{array}{l}\text { Mormalized } \\
\text { Haste } \\
\text { (wte axide) }\end{array}$ & $\begin{array}{l}\text { Substi tuted } \\
\text { Haste } \\
\text { (wth Oxide) }\end{array}$ & $\begin{array}{l}\text { Substituted } \\
\text { Haste Hor. } \\
\text { (wte Oxide) }\end{array}$ & $\begin{array}{l}\text { Substi tuted } \\
\text { Haste Hor. } \\
\text { Ho TOC }\end{array}$ & $\begin{array}{l}\text { Hu39 Frit } \\
\text { (wte Oxide) }\end{array}$ & $\begin{array}{c}\text { Giass } \\
\text { wts Oxide }\end{array}$ \\
\hline 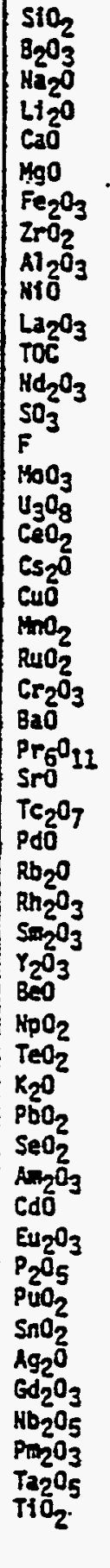 & $\begin{array}{l}0.50 \\
0.00 \\
1.8 \\
0.00 \\
0.05 \\
0.04 \\
7.5 \\
0.4 \\
2.9 \\
0.40 \\
0.37 \\
0.10 \\
0.29 \\
0.25 \\
0.20 \\
0.20 \\
0.10 \\
0.10 \\
0.10 \\
0.10 \\
0.10 \\
0.10 \\
0.09 \\
0.07 \\
0.06 \\
0.06 \\
0.06 \\
0.03 \\
0.04 \\
0.03 \\
0.03 \\
0.03 \\
0.01 \\
0.02 \\
0.02 \\
0.00 \\
0.00 \\
0.01 \\
0.00 \\
0.00 \\
0.00 \\
0.00 \\
0.00 \\
0.00 \\
0.00 \\
0.00 \\
0.00 \\
0.02 \\
0.00 \\
0.00 \\
16.203 \\
\end{array}$ & $\begin{array}{c}3.09 \\
0.01 \\
11.1 \\
0.00 \\
0.31 \\
0.25 \\
46.3 \\
2.5 \\
17.9 \\
2.47 \\
2.28 \\
0.62 \\
1.79 \\
1.54 \\
1.23 \\
1.23 \\
0.62 \\
0.62 \\
0.62 \\
0.62 \\
0.62 \\
0.62 \\
0.56 \\
0.43 \\
0.37 \\
0.37 \\
0.37 \\
0.19 \\
0.25 \\
0.19 \\
0.19 \\
0.19 \\
0.06 \\
0.12 \\
0.12 \\
0.00 \\
0.00 \\
0.03 \\
0.02 \\
0.02 \\
0.02 \\
0.02 \\
0.02 \\
0.02 \\
0.01 \\
0.01 \\
0.01 \\
0.12 \\
0.01 \\
0.01 \\
100.000\end{array}$ & 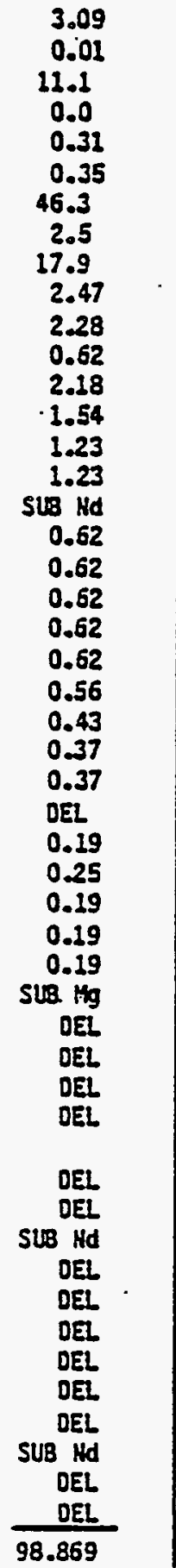 & 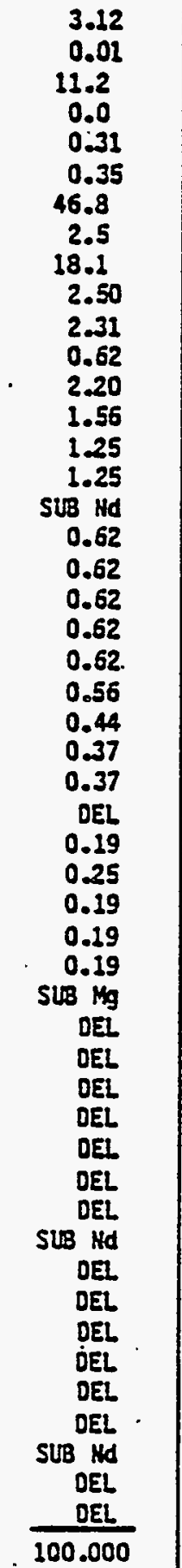 & 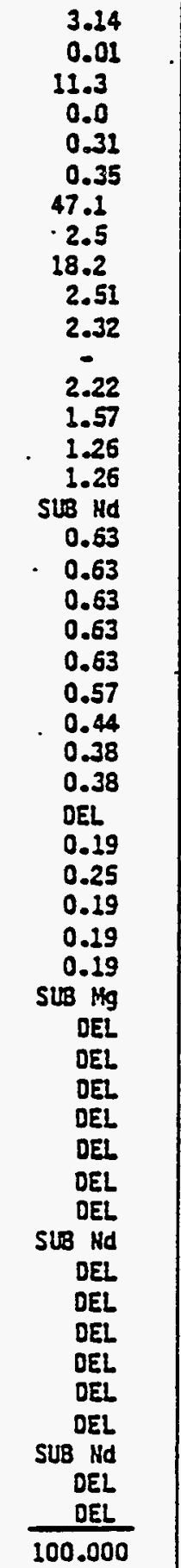 & $\begin{array}{r}67.25 \\
12.75 \\
10.25 \\
5.00 \\
3.75 \\
1.00\end{array}$ & $\begin{array}{r}51.22 \\
9.56 \\
10.51 \\
3.75 \\
2.89 \\
0.84 \\
11.78 \\
0.63 \\
4.55 \\
0.63 \\
0.58 \\
0.00 \\
0.55 \\
0.39 \\
0.31 \\
0.31 \\
0.16 \\
0.16 \\
0.16 \\
0.16 \\
0.16 \\
0.14 \\
0.11 \\
0.09 \\
0.09 \\
0.05 \\
0.06 \\
0.05 \\
0.05 \\
0.05\end{array}$ \\
\hline
\end{tabular}


TABLE 4.1-42. Summary of Glass Compositions Used in Variability Scoping Tests HWVP-87-V110202C

\begin{tabular}{|c|c|c|c|c|c|}
\hline & $5 \% \mathrm{Ba}$ & $5 \% \mathrm{Hn}$ & $2 \%$ Mo & $2 \% \mathrm{Ni}$ & HW39-2 \\
\hline 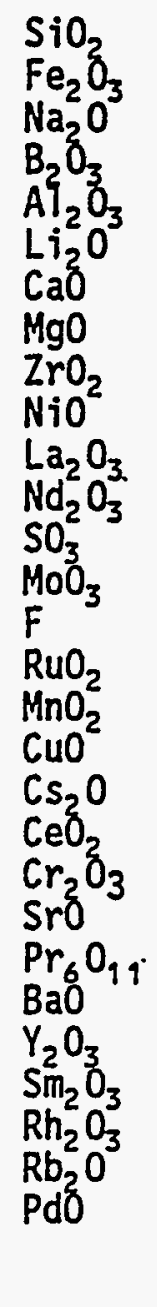 & $\begin{array}{r}51.06 \\
9.46 \\
9.94 \\
9.56 \\
3.65 \\
3.75 \\
2.88 \\
0.83 \\
0.49 \\
0.49 \\
0.47 \\
0.42 \\
0.32 \\
0.26 \\
0.26 \\
0.13 \\
0.13 \\
0.13 \\
0.13 \\
0.13 \\
0.11 \\
0.09 \\
0.09 \\
5.00 \\
0.04 \\
0.04 \\
0.04 \\
0.04 \\
0.04 \\
\\
100.00\end{array}$ & $\begin{array}{r}51.07 \\
9.54 \\
9.96 \\
9.56 \\
3.69 \\
3.75 \\
2.88 \\
0.83 \\
0.50 \\
0.50 \\
0.48 \\
0.43 \\
0.33 \\
0.26 \\
0.26 \\
0.13 \\
5.00 \\
0.13 \\
0.13 \\
0.13 \\
0.11 \\
0.09 \\
0.09 \\
0.09 \\
0.04 \\
0.04 \\
0.04 \\
0.04 \\
0.04 \\
\\
100.00\end{array}$ & $\begin{array}{r}51.16 \\
10.97 \\
10.31 \\
9.56 \\
4.24 \\
7.50 \\
2.89 \\
0.84 \\
0.57 \\
0.57 \\
0.55 \\
0.49 \\
0.37 \\
2.00 \\
0.30 \\
0.15 \\
0.15 \\
0.15 \\
0.15 \\
0.15 \\
0.12 \\
0.10 \\
0.10 \\
0.10 \\
0.05 \\
0.05 \\
0.05 \\
0.05 \\
0.05 \\
100.00\end{array}$ & $\begin{array}{r}51.17 \\
11.10 \\
10.34 \\
9.56 \\
4.29 \\
3.75 \\
2.89 \\
0.84 \\
0.58 \\
2.00 \\
0.56 \\
0.50 \\
0.38 \\
0.30 \\
0.30 \\
0.15 \\
0.15 \\
0.15 \\
0.15 \\
0.15 \\
0.13 \\
0.10 \\
0.10 \\
0.10 \\
0.05 \\
0.05 \\
0.05 \\
0.05 \\
0.05 \\
100.00\end{array}$ & $\begin{array}{l}51.21 \\
11.77 \\
10.50 \\
9.56 \\
4.55 \\
3.75 \\
2.89 \\
0.85 \\
0.62 \\
0.62 \\
0.59 \\
0.53 \\
0.40 \\
0.32 \\
0.32 \\
0.16 \\
0.16 \\
0.16 \\
0.16 \\
0.16 \\
0.13 \\
0.11 \\
0.11 \\
0.11 \\
0.05 \\
0.05 \\
0.05 \\
0.05 \\
0.05 \\
\end{array}$ \\
\hline
\end{tabular}

TABLE 4.1-43 Summary of Viscosity and Electrical Conductivity Data for Scoping Test Glasses HWVP-87-V110202C

\begin{tabular}{|c|c|c|c|c|c|}
\hline Glass & $5 \% \mathrm{BaO}$ & $5 \% \mathrm{MnO}_{2}$ & $2 \% \mathrm{MoO}_{3}$ & $2 \% \mathrm{NiO}$ & $\begin{array}{c}\mathrm{HW} 39-2 \\
(\mathrm{TOW} \mathrm{Cr})\end{array}$ \\
\hline T100P $\left[{ }^{\circ} \mathrm{C} \mathrm{( \pm 10^{ \circ } \mathrm { C } )}\right]$ & 1067 & 1058 & 1091 & 1082 & 1081 \\
E1150 (ohm-Cm) & -1 \\
{$\left[ \pm 0.02(\mathrm{ohm}-\mathrm{Cm})^{-1}\right]$} & 0.29 & 0.30 & 0.30 & 0.29 & 0.29 \\
\hline
\end{tabular}


from the value for the HW39-2 (low Cr) glass. The 5 wt\% variations in BaO and $\mathrm{MnO}_{2}$ produced the largest variance but, in both cases, $\triangle T 100 \mathrm{P}$ values were less than $30^{\circ} \mathrm{C}$. Considering that a $5 \mathrm{wt} \%$ change in the waste component in the glass (20 wt\% in the waste). was required to produce this $\Delta T 100 P$, none of the waste components tested were judged to significantly affect the viscosity enough to justify including these components in further detailed variability testing.

\subsection{Electrical Conductivity Results. The El150 values for} the scoping glasses are also presented in Table 4.1-43. The electrical conductivities of 217 the glasses were found to be unchanged by any of the variations tested. This is in agreement with previous variability studies that indicated that, in most cases, if the TI00P of the glass is acceptable, the electrical conductivity will also be acceptable and will not be a. 1 imiting factor.

4.1.3.4.1.3 Phase Behavior Results. Optical evaluation of thin sections of quenched samples of glass and fibers pulled during viscosity measurements found no observable changes in the amounts or types of crystalline material in a.1 $19^{\text {the }}$ glasses compared to the HW39-2 (10w $\mathrm{Cr}$ ) reference glass. The crystals present in the glass are the noble metal ( $R u, R h$, and $P d$ ) phases. Analysis by XRD found no detectable crystalline phases except in the 5 wt\% $F$ glass which contained between 5 and 10 wt\% of a crystalline material, identified by XRD as $\mathrm{CaF}_{2}$. The detection 7 imit for XRD is approximately 5 wt\%.

4.1.3.4.2 Fiuorine Variability. The behavior of $F$ in borosilicate glasses differs in many respects from the other halogens. Therefore, the behavior of the other halogens should not be inferred from this study. The effective radius of $F$ is. very close to that of oxygen, permitting $F$ to partially replace oxygen in the glass. The other halogens are larger and much less stable as components in the glass structure. Because of the ability to replaced oxygen in the glass, $F$ has a higher solubility in the glass than the other halogens. Generally, most clear commercial glasses contain at the most 0.6 wt\% F compared to 0.1 wt\% Cl (Ref. 4.1-13). Above the solubility limit, both liquid and crystalline phase separation occurs causing opacity. The presence of elements such as $A T$ and $B$ in the glass increases the solubility of $F$ in the glass somewhat.

The 5 wt\% $F$ glass evaluated in the scoping test was observed (by XRD) to have phase separation that is not acceptable because of potential degradation of the glass durability and potential impacts on melter operation. Because phase separation can have incongruent effects on the properties such as viscosity or electrical conductivity, the $F$ variability was evaluated independently of $\mathrm{Fe}$ and $\mathrm{Ca}$. The range of $\mathrm{F}$ variability investigated was from the current reference level of 0.3 to 5 wt\% $F$ in the glass. To cover this range, glasses with $F$ concentrations of $0.3,2,3,4$, and 5 wt\% were tested. The waste loading of each glass remained constant at $25 \mathrm{wt} \%$, with the nonvarying components remaining in the same relative wt\% proportions to each other.

During the melting of these glasses; off-gassing of $F$ was observed by the technician (due to the odors given off). Analyses of the glasses found 
that the amount of $F$ retained in the glass ranged from 60 to $80 \mathrm{wt} \%$ of the target values. (see Table 4.1-44). The amount of fluorine retained in the glass appears to have a time-at-melting-temperature dependence. When melting the 3 wt\% target $F$ glass, the melting crucible cracked which required the glass to be transferred to another crucible. This resulted in a $20 \%$ increase. in the standard melting time of $2 \mathrm{~h}$ at which the glass was at the melting temperature of $1150^{\circ} \mathrm{C}$.

4.1.3.4.2.1 Viscosity Results. The effect of $F$ on the melt viscosity is shown in Table 4.1-45. From 0.3 to 1.5 wt\% $F$ in the glass, the T100P of the glass remains unchanged. However, between 1.5 and $1.73 \mathrm{wt} \% \mathrm{~F}$, the TIOOP drops $18^{\circ} \mathrm{C}$ and continues to decrease as the $\mathrm{F}$ content increases. While the magnitude of the change in T100P is not great, the drop in T100P between 1.5 and 1.73-wt\% $F$ may have been due to the presence of a $F$ liquid-7iquid phase. separation in the glass.

TABLE 4.1-44. Fluorine Variability Studies Target Fluorine Concentrations, and Analyzed F Concentrations HWVP-87-V110202C

\begin{tabular}{|c|c|c|}
\hline F Target (wt\%) & F Analyzed (wt\%) & F Retained (\%) \\
\hline 0.31 & na & na \\
2 & 1.5 & 75 \\
3 & 1.73 & $58(\mathrm{a})$ \\
4 & 3.0 & 75 \\
5 & 4.26 & 85 \\
\hline
\end{tabular}

(a) Melting time not standard (20\% longer) due to crucible failure.

TABLE 4.1-45. Summary of Viscosity and Electrical Conductivity Data for Fluorine Variability Glasses. HWVP-87-V110202C

\begin{tabular}{|c|c|c|c|c|c|}
\hline & \multicolumn{5}{|c|}{ As-Analyzed F (wt\%) } \\
\hline & 0.3 & 1.5 & 1.73 & 3.0 & 4.3 \\
\hline $\begin{array}{l}\text { T100P }\left[\cdot \mathrm{C}\left( \pm 10^{\circ} \mathrm{C}\right)\right] \\
\text { E1150 (ohm-cm) } \\
{\left[ \pm 0.02(\mathrm{ohm}-\mathrm{cm})^{-1}\right]}\end{array}$ & $\begin{array}{l}1081 \\
0.29\end{array}$ & $\begin{array}{l}1085 \\
0.31\end{array}$ & $\begin{array}{l}1067 \\
0.31\end{array}$ & $\begin{array}{l}1059 \\
0.32\end{array}$ & $\begin{array}{l}\text { NA } \\
\text { NA }\end{array}$ \\
\hline
\end{tabular}


4.1.3.4.2.2 'Electrical Conductivity Results. The El150 values for the $F$ glasses are also presented in Table 4.1-45. The electrical conductivities of all the glasses were found to be unchanged due to any of the variations tested. This is in agreement with previous variability studies that indicated that, in most cases, if the TIOOP of the glass is acceptable, the electrical conductivity will be also and will not be a limiting factor in variability limits.

4.1.3.4.2.3 Phase Behavior Results. Optical analysis of the quenched glass samples found little change in the phase behavior of the glasses with 1.75 wt\% or less F. The glasses with 3.0 and 4.26 wt\% $F$ appeared darker in color. No gross immiscibility was observed optically in any of the glasses. However, regions of 7 iquid-1iquid phase separation can be very small $(\leq 0.01 \cdot \mu \mathrm{m})$. Examination of possible $F$ immiscibility regions would require special techniques such as carbon replica preparation of fracture surface (Ref. 4.1-14, 4.1-15) or ion milling. The noble metal phases were consistently present in all the glasses at the same levels observed in the reference composition.

$X$-ray diffraction analysis was conducted on all the $F$ glasses. A crystalline phase was observed in only the glass containing 4.8 wt\% $F$. The detection Timit for XRD for most crystall ine phases is approximately 5 wt\%. The 4.8 wt\%.F glass contained between 5 and 10 wt\% of a crystalline material which was identified by XRD as $\mathrm{CaF}_{2}$. The 3 wt\% $F$ glass may have contained some $\mathrm{CaF}_{2}$ but at levels below the XRD detection limit.

4.1.3.4.2.4 Durability Results. - The results of 28-day MCC-i and MCC-3 testing for the $F$ glasses are shown in Tables 4.1-46 and 4.1-47. The MCC-1 data indicates no significant changes in durability for any of the glasses. However, in the MCC-3 data the releases for the 3.0 wt\% F glass are two to six times higher than for $B, N a$, and $L i$. The releases for the 4.8 wt\% $F$ glass in both the MCC-1 and MCC -3 tests are the same as observed for a 11 other glasses except the 3.0 wt\% F glass. Duplicate $M C C-1$ and $M C C-3$ tests were conducted for the 3.0 and 4.8 wt\%. F glasses. A duplicate ICP analysis of the 3.0 wt\% $F$ glass confirmed that the require target composition had been obtained.

The reason for the increase in releases at $3.0 \mathrm{wt} \% \mathrm{~F}$ and the decrease to previous levels at $4.8 \mathrm{wt} \%$ is not known. A possible theory is that a liquidliquid phase separation had occurred in the 3.0 wt\% $F$ glass (possibiy an alkali-fluorine and/or a boron-fluorine phase) that is not present in the 4.8 wt\% $\mathrm{F}$ glass due to $\mathrm{CaF}_{2}$ formation. This also corresponds to the small but measurable drop in the TI0OP between 1.73 and $3.0 \mathrm{wt} \% \mathrm{~F}$ and the observed color change in the 3.0 and 4.8 wt\% $F$ glasses. The larger increases in releases observed in the MCC-3 compared to $M C C-1$ tests could be due to the greatiy increased glass surface area in contact with the leachate. Because of the higher glass surface area, more of a separated phase would be exposed. This would explain the higher releases. Between 3.0 and 4.8 wt\% $\mathrm{F}$, the $\mathrm{CaF}_{2}$ would then form; locking up the $F$ and restricting the formation of the lessdurable alkali-fluorine and/or a $B / F$ phase. 
TABLE 4.1-46. MCC-1 Leaching Results for Fluorine Variability Testing. Test Conditions: MCC-1, 28-day, Deionized Water, $90^{\circ} \mathrm{C}$, $S A / V=10 \mathrm{~m}^{-1}$ HWVP-87-V110202C

\begin{tabular}{|c|c|c|c|c|c|c|}
\hline \multirow[b]{2}{*}{ Chemical } & \multirow[b]{2}{*}{ Element } & \multicolumn{5}{|c|}{$\begin{array}{l}\text { Target Normal ized Mass Loss at wt\% } \\
\text { (actual F wt\%) }\left(\mathrm{g} / \mathrm{m}^{2}\right)\end{array}$} \\
\hline & & $0.3 \%(0.3)$ & $2 \%(1.5)$ & $3 \%(1.7)$ & $4 \%(3.0)(a)$ & $5 \%(4.3)(8)$ \\
\hline $\begin{array}{l}\mathrm{SiO}_{2} \\
\mathrm{~B}_{2} \mathrm{O}_{3} \\
\mathrm{Li}_{2} \mathrm{O} \\
\mathrm{Na}_{2} \mathrm{O} \\
\mathrm{CaO} \\
\cdot \mathrm{MoO}_{3} \\
\mathrm{SrO} \\
\mathrm{Al}_{2} \mathrm{O}_{3} \\
\mathrm{Fe}_{2} \mathrm{O}_{3}\end{array}$ & $\begin{array}{l}\mathrm{Si} \\
\mathrm{B} \\
\mathrm{Li} \\
\mathrm{Na} \\
\mathrm{Ca} \\
\mathrm{Mo} \\
\mathrm{Sr} \\
\mathrm{Al} \\
\mathrm{Fe}\end{array}$ & $\begin{array}{c}13.6 \\
14.5 \\
14.9 \\
14.6 \\
6.81 \\
16.3 \\
5.74 \\
9.54 \\
0.32\end{array}$ & $\begin{array}{c}13.7 \\
18.7 \\
18.2 \\
16.6 \\
5.87 \\
17.2 \\
3.69 \\
9.05 \\
0.18\end{array}$ & $\begin{array}{c}11.53 \\
14.92 \\
13.7 \\
14.3 \\
8.20 \\
15.6 \\
5.91 \\
9.14 \\
0.52\end{array}$ & $\begin{array}{c}13.3 \\
17.0 \\
16.5 \\
16.7 \\
7.02 \\
19.2 \\
5.57 \\
9.86 \\
0.34\end{array}$ & $\begin{array}{c}11.4 \\
14.2 \\
14.2 \\
13.0 \\
3.2 \\
11.4 \\
3.21 \\
10.2 \\
0.30\end{array}$ \\
\hline $\mathrm{pH}^{-}$ & $\begin{array}{l}\text { INITIAL } \\
\text { FINAL }\end{array}$ & - & $\begin{array}{l}5.64 \\
9.59\end{array}$ & $\begin{array}{l}5.69 \\
9.44\end{array}$ & $\begin{array}{l}5.67 \\
9.52\end{array}$ & $\begin{array}{l}5.60 \\
9.18\end{array}$ \\
\hline
\end{tabular}

(a) Average of duplicate leaching tests.

4.1.3.4.2.5 Discussion. Viscosity and electrical conductivity data. require no limitation of the $F$ concentration in the glass up to $4.3 \mathrm{wt} \%$. However, to preclude the formation of any additional crystalline phases in the glass, it is recommended that a level of $4.3 \mathrm{wt} \% \mathrm{~F}$ be considered unacceptable. Because of the increase of releases at $3.0 \mathrm{wt} \% \mathrm{~F}$, it is recommended that the $3.0 \mathrm{wt} \% \cdot \mathrm{F}$ be considered unacceptable and the maximum allowable $F$ limit in the HWVP reference glass be set at the last acceptable F level: 1.73 wt\% in the glass.

For comparison, the $\mathrm{F}$ level in the DWPF reference glass is less than $0.1 \mathrm{wt} \% \mathrm{~F}$ (Ref. 4.1-16). The low enriched waste concentrate (LEWC) being vitrified at the PAMELA plant contains $6.8 \mathrm{wt} \% \mathrm{~F}$ but with a maximum waste loading of only $14 \mathrm{wt} \%$ oxides. This results in a $0.95 \mathrm{wt} \% \mathrm{~F}$ concentration in the glass (Ref. 4.1-17). The nominal $F$ level in glass with a 25 wt\% waste loading of HWVP NCAW 86 is $0.31 \mathrm{wt} \%$.

4.1.3.4.3 Iron and Calcium Variability. There are a number of assumptions and general conditions assumed for this variability test. Because CaO is a component of the reference frit, reducing the $\mathrm{CaO}$ in the waste to $0 \mathrm{wt} \%$ would still leave $2.81 \mathrm{wt} \% \mathrm{CaO}$ in the glass. To better evaluate the effects of $\mathrm{CaO}$ on glass properties, $\mathrm{CaO}$ was removed from the frit composition which was then renormalized $(w t \%)$. The $2.81 \mathrm{wt} \% \mathrm{CaO}$ that would have been provided by the frit was added to the total waste loading of the glass, increasing the total waste loading from the reference level of $25 \mathrm{wt} \%$ to $27.81 \mathrm{wt} \%$. The total waste loading, the sum of the varying component(s) and the nonvarying waste components, was held at 27.81 oxide wt\% in the glass. Although the 
TABLE 4.1-47:" MCC-3 Leaching Results for Fluorine Variability Testing. Test Conditions: $\mathrm{MCC}-3,28-$ day, Deionized Hater, $90^{\circ} \mathrm{C}$, $S A / V=1780 / m^{-1} \quad$ HIVP-87-V110202C

\begin{tabular}{|c|c|c|c|c|c|c|}
\hline \multicolumn{7}{|c|}{$0.45 \mu \mathrm{m}$ Filtration } \\
\hline & & \multicolumn{5}{|c|}{$\begin{array}{l}\text { Target Normal ized Mass Loss at wt\% } \\
\text { (actual } F \text { wt\%) }\left(\mathrm{g} / \mathrm{m}^{2}\right)\end{array}$} \\
\hline Chemical & Element & $0.3 \%(0.3)$ & $2 \%(1.5)$ & $3 \%(1.7)$ & $4 \%(3.0)(a)$ & $5 \%(4.3)^{(. a)}$ \\
\hline $\begin{array}{l}\mathrm{SiO}_{2} \\
\mathrm{~B}_{2} \mathrm{O}_{3} \\
\mathrm{Li}_{2} \mathrm{O} \\
\mathrm{Na}_{2} \mathrm{O} \\
\mathrm{CaO} \\
\mathrm{MoO}_{3} \\
\mathrm{SrO} \\
\mathrm{Al}_{2} \mathrm{O}_{3} \\
\mathrm{Fe}_{2} \mathrm{O}_{3}\end{array}$ & $\begin{array}{l}\mathrm{Si} \\
\mathrm{B} \\
\mathrm{Li} \\
\mathrm{Na} \\
\mathrm{Ca} \\
\mathrm{Mo} \\
\mathrm{Sr} \\
\mathrm{Al} \\
\mathrm{Fe}\end{array}$ & $\begin{array}{l}0.28 \\
0.48 \\
0.59 \\
0.46 \\
0.06 \\
N A \\
0.04 \\
0.15 \\
0.15\end{array}$ & $\begin{array}{l}0.27 \\
0.51 \\
0.59 \\
0.46 \\
0.06 . \\
0.37 \\
0.00 \\
0.16 \\
0.19\end{array}$ & $\begin{array}{l}0.23 \\
0.47 \\
0.55 \\
0.45 \\
0.07 \\
0.46 \\
0.05 \\
0.16 \\
0.19\end{array}$ & $\begin{array}{l}0.32 \\
1.08 \\
3.88 \\
1.14 \\
0.04 \\
0.91 \\
0.02 \\
0.11 \\
0.14\end{array}$ & $\begin{array}{l}0.23 \\
0.45 \\
0.65 \\
0.37 \\
0.05 \\
0.39 \\
0.02 \\
0.17 \\
0.13\end{array}$ \\
\hline $\mathrm{pH}$ & $\begin{array}{l}\text { INITIAL } \\
\text { FINAL }\end{array}$ & $\begin{array}{r}5.72 \\
10.35\end{array}$ & $\begin{array}{r}5.64 \\
10.25\end{array}$ & $\begin{array}{r}5.35 \\
.10 .04\end{array}$ & $\begin{array}{r}5.40 \\
10.01\end{array}$ & $\begin{array}{l}5.64 \\
9.70\end{array}$ \\
\hline \multicolumn{7}{|c|}{18 Angstrom Filtration } \\
\hline $\begin{array}{l}\mathrm{SiO}_{2} \\
\mathrm{~B}_{2} \mathrm{O}_{3} \\
\mathrm{Li}_{2} \mathrm{O} \\
\mathrm{Na}_{2} \mathrm{O} \\
\mathrm{CaO} \\
\mathrm{MoO}_{3} \\
\mathrm{SrO} \\
\mathrm{Al}_{2} \mathrm{O}_{3} \\
\mathrm{Fe}_{2} \mathrm{O}_{3}\end{array}$ & $\begin{array}{l}\mathrm{Si} \\
\text { B } \\
\mathrm{Li} \\
\mathrm{Na} \\
\mathrm{Ca} \\
\mathrm{Mo} \\
\mathrm{Sr} \\
\mathrm{Al} \\
\mathrm{Fe}\end{array}$ & $\begin{array}{l}0.26 \\
0.48 \\
0.57 \\
0.45 \\
0.01 \\
\text { NA } \\
0.00 \\
0.05 \\
0.00\end{array}$ & $\begin{array}{l}0.23 \\
0.51 \\
0.56 \\
0.45 \\
0.01 \\
0.34 \\
0.00 \\
0.05 \\
0.00\end{array}$ & $\begin{array}{l}0.20 \\
0.47 \\
0.52 \\
0.44 \\
0.01 \\
0.44 \\
0.00 \\
0.04 \\
0.00\end{array}$ & $\begin{array}{l}0.30 \\
1.09 \\
3.84 \\
1.13 \\
0.02 \\
1.17 \\
0.00 \\
0.03 \\
0.00\end{array}$ & $\begin{array}{l}0.19 \\
0.45 \\
0.63 \\
0.36 \\
0.01 \\
0.35 \\
0.00 \\
0.06 \\
0.00\end{array}$ \\
\hline $\mathrm{pH}$ & $\begin{array}{l}\text { INITIAL } \\
\text { FINAL }\end{array}$ & $\begin{array}{r}5.72 \\
10.35\end{array}$ & $\begin{array}{r}5.64 \\
10.25\end{array}$ & $\begin{array}{r}5.35 \\
10.04\end{array}$ & $\begin{array}{l}5.35 \\
9.99\end{array}$ & $\begin{array}{l}5.6 \\
9.68\end{array}$ \\
\hline
\end{tabular}

(a) Average of duplicate leaching tests.

amount of the nonvarying waste components, hereafter referred to as the waste mix, was varied in the different test melts, the oxide proportions within the waste mix remained fixed at the (wt\%) proportions found in the reference waste composition. The waste mix was treated as a single component in this test. The compositions of the waste mix and modified frit are shown in Table 4.1-48. The composition of glass-forming oxides (minus $\mathrm{CaO}$ ), hereafter referred to as frit, was the normalized HWVP reference glass frit composition minus $\mathrm{CaO}$, shown in Table 4.1-41, and will make up the remaining 72.19 wt\% of the glass. The range of variablity for $\mathrm{Fe}_{2} \mathrm{O}_{3}, \mathrm{CaO}$, waste mix, and frit are 
TABLE 4.1-48. Composition of Waste Mix and Modified Frit for Iron and Calcium Variability Study HWVP-87-V110202C

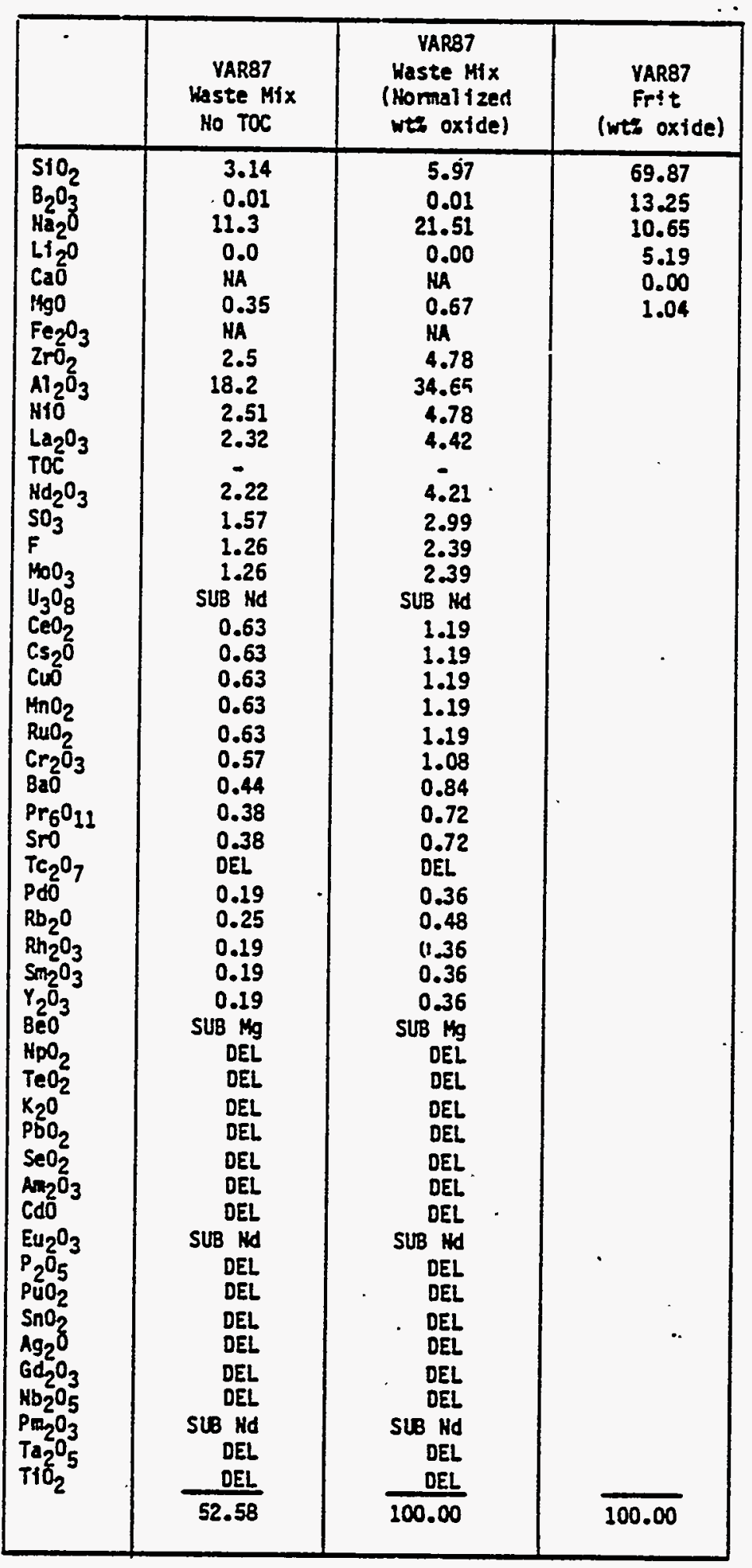


shown in Table 4.1-49. These ranges and constraints established the extreme vertices, edge centroids, and overall centroid of the mixture region which determined the melt compositions included in this test as shown in Figure 4.1-34. The test matrix for this test is shown in Table 4.1-50.

Each of the glass mixtures selected was evaluated to determine T100P, El150, and 28-day MCC-3 leaching.

A summary of the viscosity and electrical conductivity data for the $\mathrm{Fe}$ and $\mathrm{Ca}$ variability study is found in Table 4.1-51. Summaries of MCC-3 leaching data are presented in Tables 4.1-52 and 4.1-53.

4.1.3.4.3.1 Iron and Calcium Viscosity. Figure 4.1-35 is the contour plot of the test region and Figure 4.1-36 is the effects plot for T100P. Using the model generated for T100P, the extreme composition variations allowable with only acceptable alteration of the viscosity were estimated. The T100P of the HW39-2 (0.14 wt\% $\left.\mathrm{Cr}_{2} \mathrm{O}_{3}\right)$ reference glass, $1976{ }^{\circ} \mathrm{F}\left(1081^{\circ} \mathrm{C}\right)$, is at the low end of the melter operating range. of $1958^{\circ} \mathrm{F}$ to $2100^{\circ} \mathrm{F}\left(1070^{\circ} \mathrm{C}\right.$ to $\left.1150^{\circ} \mathrm{C}\right)$. The estimates of the extreme composition limits were set at T100Ps of $100^{\circ} \mathrm{F}\left(40^{\circ} \mathrm{C}\right)$ from $1976^{\circ} \mathrm{F}\left(1081^{\circ} \mathrm{C}\right), 1900^{\circ} \mathrm{F}$ to $2050^{\circ} \mathrm{F}\left(1040^{\circ} \mathrm{C}\right.$ to $\left.1120^{\circ} \mathrm{C}\right)$. Because the concentrations in the waste of $\mathrm{Fe}, \mathrm{Ca}$, and the remainder of the waste components are not related, the extreme limits for each component were estimated by holding the waste loading at 25 wt\% and keeping the proportions of all but the composition. The concentrations of the $\mathrm{Fe}$ or $\mathrm{Ca}$ were then varied until the minimum and maximum limits for TI0OP were predicted by the model.

The maximum for $\mathrm{Fe}_{2} \mathrm{O}_{3}$ in the glass was predicted to be 22 wt\%. The minimum amount of $\mathrm{Fe}_{2} \mathrm{O}_{3}$ was predicted to be 2 wt\% in the glass. Based on viscosity data only, these values are recommended as the extreme 1 imits to be allowed in the feed specification for $\mathrm{Fe}_{2} \mathrm{O}_{3}$.

The maximum for $\mathrm{CaO}$ in the glass was predicted to be $5 \mathrm{wt} \%, 20 \mathrm{wt} \% \mathrm{CaO}$ in the waste at a 25 wt\% waste loading. The minimum amount of CaO was predicted to be 0 wt\% in the glass. Based on viscosity data only, these values are also recommended as the extreme limits to be allowed in the feed specification for $\mathrm{CaO}$.

TABLE 4.1-49. Ranges of Haste Components in the Component Variability Test HWVP-87-V110202C

\begin{tabular}{|l|c|}
\hline \multicolumn{1}{|c|}{ Oxide } & : Range of Oxide wt\% in the Glass \\
\hline $\mathrm{Fe}_{2} \mathrm{O}_{3}$ & $0-27.81$ \\
$\mathrm{CaO}^{2}$ & $0-12.81$ \\
Waste mix & As required \\
Frit & 72.19 \\
\hline
\end{tabular}




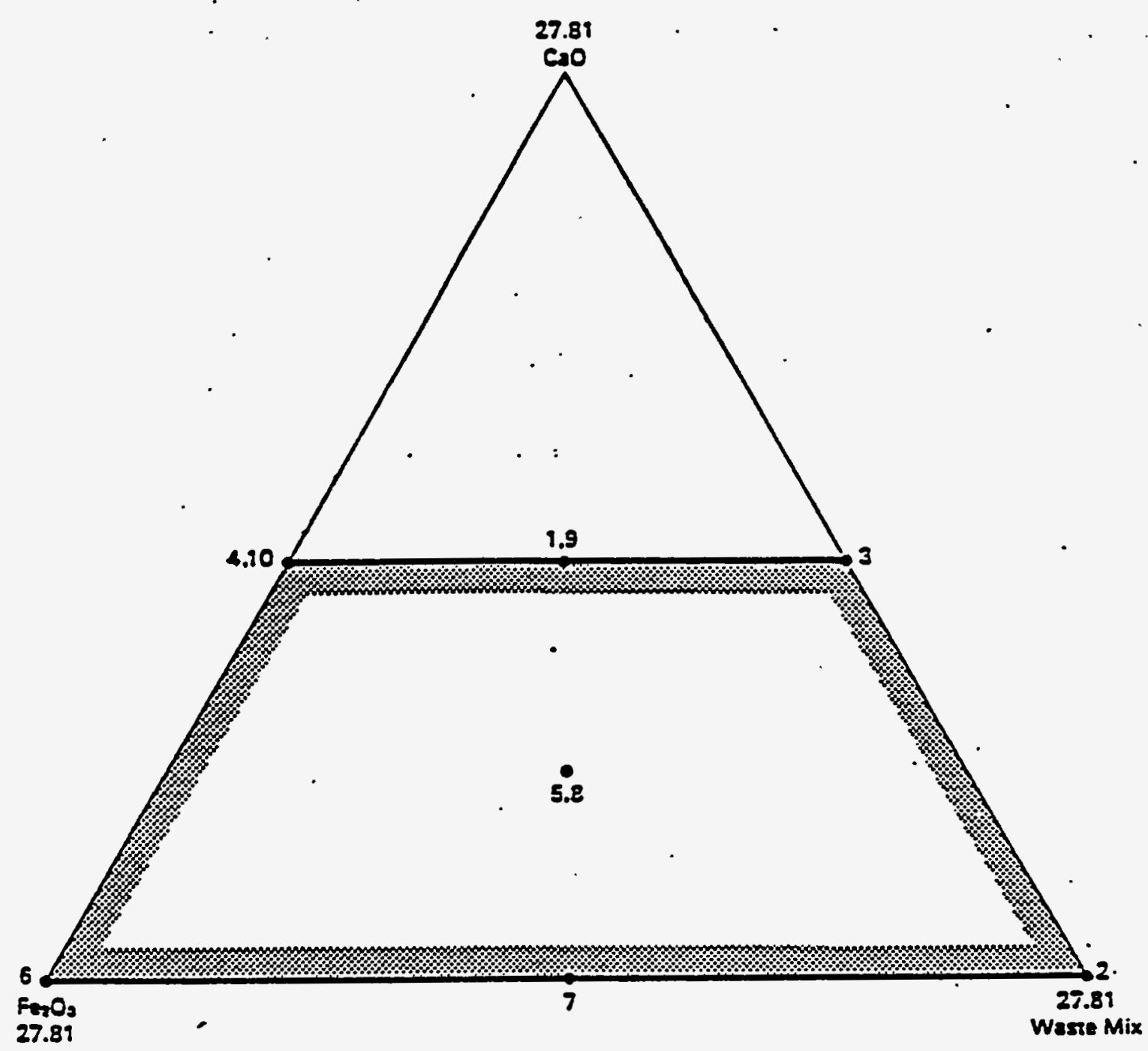

FIGURE 4.1-34. Testing Envelope and Test Compositions for Iron - Calcium Variability Test. Ternary Diagram is of the $27.81 \mathrm{wt} \%$ of nonfrit components. HWVP-87-V110202C

4.1.3.4.3.2 Iron and Calcium Electrical Conductivity. Figure 4.1-37 is the contour plot of the experimental region and Figure $4.1-38$ is the effects plot for E1150. Using the model generated for E1150, the extreme composition variation allowable with acceptable alteration the viscosity were estimated. The same methodology used to evaluate TIOOP data was used to evaluate E1150. The values for E1150 over the entire composition region tested ranged from a 0.23 to 0.33 (ohm-cm $)^{-1}$. Alt these values are well within the 0.18 to 0.5 (ohm- $\mathrm{cm})^{-i}$ range currently established for melter operation. These results confirm results from previous studies indicating that in most cases if the viscosity of this type of glasses is acceptable, the electrical conductivity will be also. 
TABLE 4.1-50. Test Matrix of Glasses to be Used in the $\mathrm{Fe} / \mathrm{Ca}$ Variability Study HWVP-87-V110202C

\begin{tabular}{|c|c|c|c|c|}
\cline { 2 - 5 } \multicolumn{1}{c|}{} & \multicolumn{4}{c|}{ Composition (wt\% Oxide) } \\
\hline Glass ID\# & $\mathrm{Fe}_{2} \mathrm{O}_{3}$ & $\mathrm{CaO}$ & Waste Mix & Frit \\
\hline 1 & 7.51 & 12.79 & 7.51 & 72.19 \\
2 & 0 & 0 & 27.81 & 72.19 \\
3 & 0 & 12.79 & 15.02 & 72.19 \\
4 & 15.02 & 12.79 & 0 & 72.19 \\
5 & 10.71 & 6.4 & 10.71 & 72.19 \\
6 & 27.81 & 0 & 0 & 72.19 \\
7 & 13.91 & 0 & 13.91 & 72.19 \\
8 & 10.71 & 6.4 & 10.71 & 72.19 \\
9 & 7.51 & 12.79 & 7.51 & 72.19 \\
10 & 15.02 & 12.79 & 0. & 72.19 \\
\hline
\end{tabular}

TABLE 4.1-51. Summary of Viscosity (T100P) and Electrical Conductivity (E1150) Data for Iron and Calcium Variability Study HWVP-87-V110202C

\begin{tabular}{|c|c|c|}
\hline G1ass ID\# & T100P $^{\circ} \mathrm{C}$ & E1150 $(\text { ohm- Cm })^{-1}$ \\
\hline 1 & 1041 & 0.26 \\
2 & 1161 & 0.35 \\
3 & 1030 & 0.28 \\
4 & 967 & 0.25 \\
5 & 1039 & 0.27 \\
6 & 1093 & 0.25 \\
7 & 1105 & 0.33 \\
8 & 1042 & 0.28 \\
9 & 977 & 0.25 \\
10 & 1012 & 0.24 \\
\hline
\end{tabular}


TABLE 4.1-52. Summary of 28-Day, MCC-3, 0.45- $\mu \mathrm{m}$ Filtration Leaching Data for Iron/Calcium Variability Study. All tests were conducted at $90^{\circ} \mathrm{C}$ with surface area/ volume $=1780 / \mathrm{m}^{-1}$ in deionized water. HWVP-87-V110202C

\begin{tabular}{|c|c|c|c|c|c|c|c|c|c|c|c|}
\hline \multirow[b]{3}{*}{ Chemical } & \multirow[b]{3}{*}{ Element } & \multicolumn{10}{|c|}{ Normalized Mass Release $\left(\mathrm{g} / \mathrm{m}^{2}\right)$} \\
\hline & & \multicolumn{10}{|c|}{ Glass No. } \\
\hline & & 1 & 2 & 3 & 4 & 5 & 6 & 7 & 8 & 9 & 10 \\
\hline $\mathrm{SiO}_{2}$ & St & 0.24 & 0.17 & 0.14 & 0.16 & 0.67 & NA & 0.57 & 0.68 & 0.24 & 0.18 \\
\hline $\mathrm{B}_{2} \mathrm{O}_{3}$ & B & 0.51 & 0.37 & 0.22 & 0.30 & 2.31 & NA & 0.47 & 2.53 & 0.51 & 0.32 \\
\hline $\mathrm{LI}_{2} \mathrm{O}$ & Li & 0.83 & 0.40 & 0.41 & 0.49 & 2.25 & NA & 0.60 & 2.43 & 0.84 & 0.53 \\
\hline $\mathrm{Na}_{2} \mathrm{O}$ & $\mathrm{Na}$ & 0.75 & 0.37 & 0.40 & 0.41 & 2.09 & NA & 0.37 & 2.03 & 0.61 & 0.31 \\
\hline $\mathrm{CaO}$. & $\mathrm{Ca}$ & 0.05 & 0.00 & 0.11 & 0.06 & 0.01 & NA & 0.00 & 0.01 & 0.05 & 0.06 \\
\hline $\mathrm{MoO}_{3}$ & Mo & 0.55 & 0.25 & 0.22 & 0.00 & 2.46 & NA & 0.41 & 2.54 & 0.52 & 0.00 \\
\hline Sro & $\mathrm{Sr}$ & 0.00 & 0.02 & 0.10 & 0.02 & 0.02 & NA & 0.12 & 0.01 & 0.06 & 0.14 \\
\hline $\mathrm{Al}_{2} \mathrm{O}_{3}$. & A1 & 0.01 & 0.17 & 0.03 & 0.00 & 0.01 & NA & 0.33 & 0.01 & 0.01 & 0.00 \\
\hline $\mathrm{Fe}_{2} \mathrm{O}_{3}$ & $\mathrm{Fe}$ & 0.00 & 0.04 & 0.00 & 0.00 & 0.00 & NA & 0.47 & 0.00 & 0.00 & 0.00 \\
\hline $\mathrm{pH}$ & $\begin{array}{l}\text { Initial } \\
\text { Final }\end{array}$ & $\begin{array}{r}5.52 \\
11.59\end{array}$ & $\begin{array}{r}5.52 \\
10.65\end{array}$ & $\begin{array}{r}5.52 \\
11.47\end{array}$ & $\begin{array}{r}5.52 \\
11.09\end{array}$ & $\begin{array}{r}5.52 \\
11.33\end{array}$ & $\begin{array}{l}5.52 \\
9.98\end{array}$ & $\begin{array}{r}5.52 \\
10.35\end{array}$ & $\begin{array}{r}5.52 \\
11.26\end{array}$ & $\begin{array}{r}5.52 \\
11.34\end{array}$ & $\begin{array}{r}5.52 \\
10.93\end{array}$ \\
\hline
\end{tabular}


TABLE 4.1-53. Summary of 28-Day; MCC-3, 18-Angstrom Filtration Leaching Data for Iron/Calcium Variability Study. All tests were conducted at $90^{\circ} \mathrm{C}$ with surface area/ volume $=1780 / \mathrm{m}^{-1}$ in deionized water. HWVP-87-V110202C

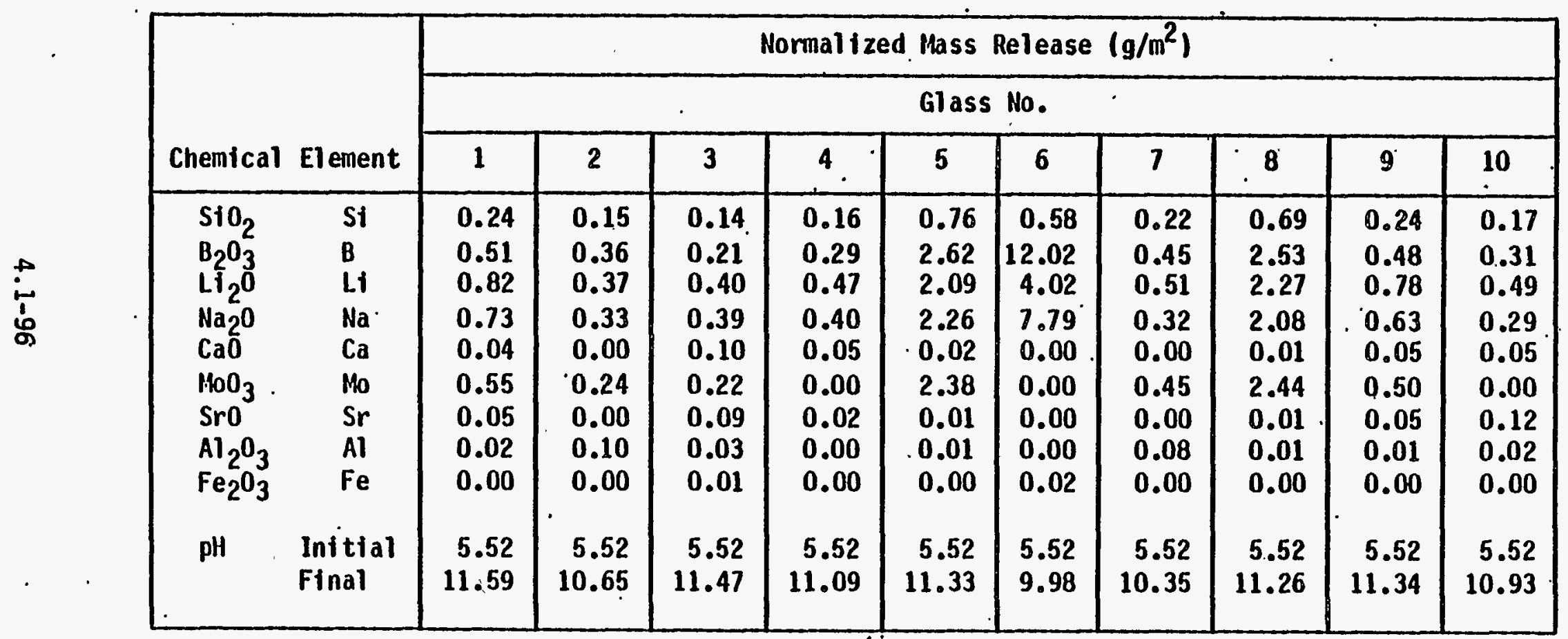




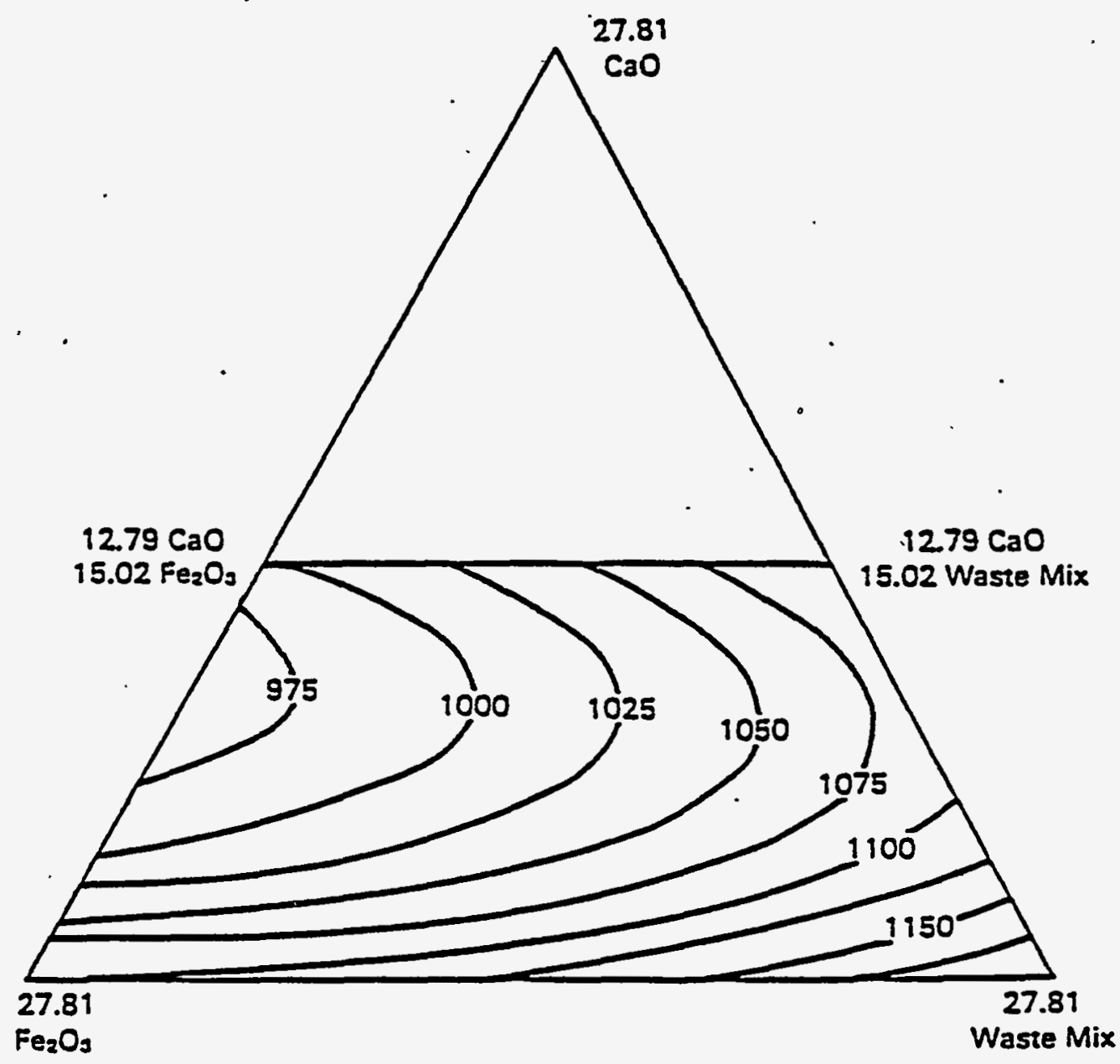

FIGURE 4.1-35. Contour Plot of Predicted 100 Poise Temperature (T100P) for the Iron-Calcium Variability Test HWVP-87-V110202C

4.1.3.4.3.3 Iron and Calcium Durabi7ity. Figure 4.1-39 is the contour plot and Figure 4.1-40 is the effects plot for B release from 28-day MCC-3 testing. Boron is presented as a general example for the results of all the leaching data. Although the fitted model has an adjusted $R^{2}$ value of 0.88 , the LOF of 3933.39 is very high and significant. The reason for the high $\mathrm{R}^{2}$ but high LOF also is the high $\mathrm{Fe}_{2} \mathrm{O}_{3}$ glass (G7ass \#6) had releases much greater than the other glasses. The model tends to see the glasses other than glass \#6 in a cluster with glass \#6 being another point. This is like fitting a line through only 2 points. Thus, the fitted model should be useful only for predicting the most general trends in durability as the three components are varied over the experimental region. 


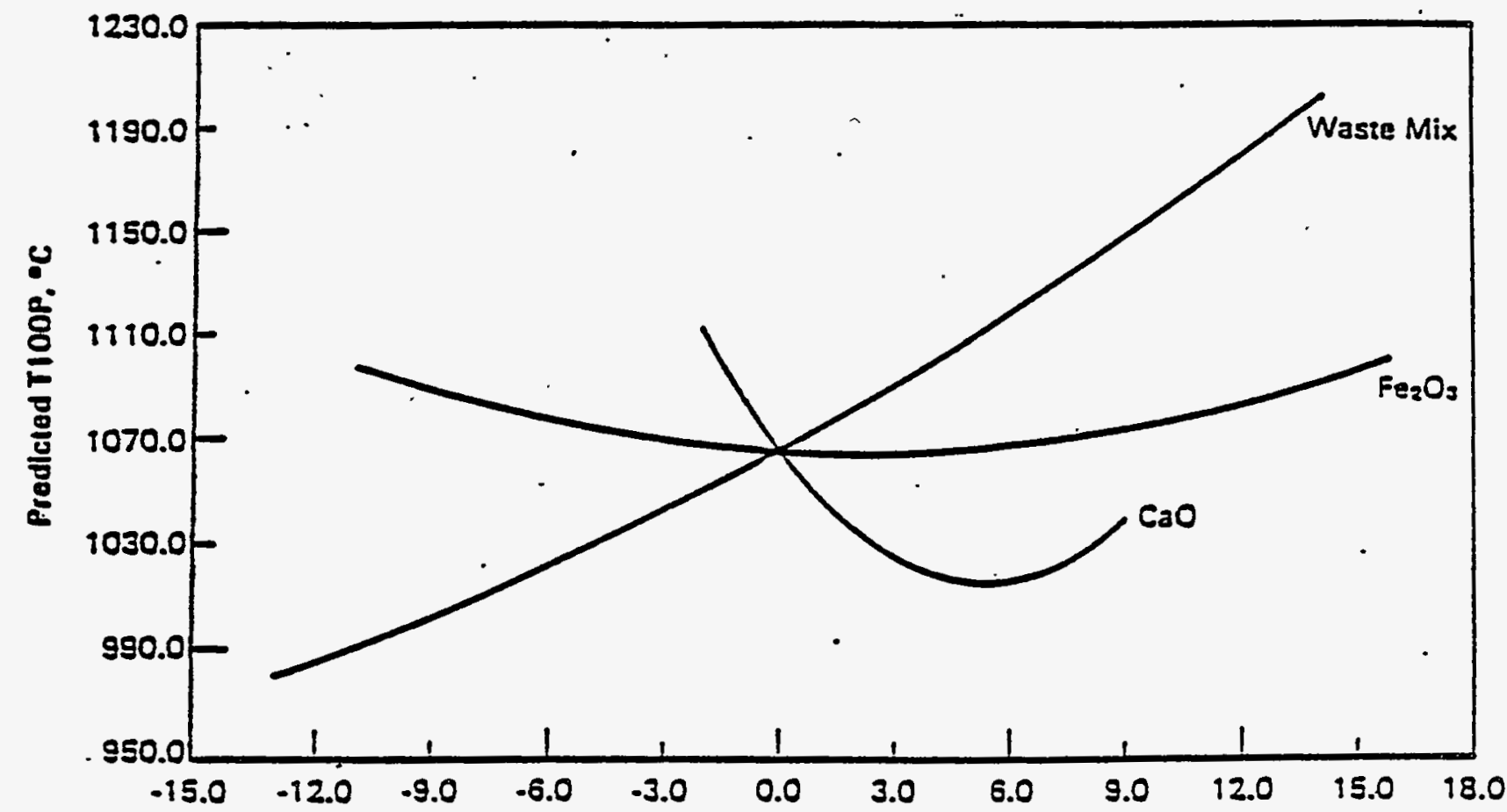

Pereentage Change in Combonent From Centroid Composition

FIGURE 4.1-36. Effects PTot of Predicted 100 Poise Temperature (T100P) for the Iron-Calcium Variability Test HWVP-87-V110202C

Figure 4.1-39 shows the release of $B$ (the other elements exhibited the same type of release trends) generally increasing as $\mathrm{Fe}_{2} \mathrm{O}_{3}$ increases. However, from $15 \mathrm{wt} \% \mathrm{Fe}_{2} \mathrm{O}_{3}$ in the $\mathrm{glass}$ to $27.81 \mathrm{wt} \% \mathrm{Fe}_{2} \mathrm{O}_{3}$ the release rates increase significantly. Because there is no specific release limit currently established, a definite composition limit cannot be set. However, because of the rapidly increasing release rates above $15 \mathrm{wt} \% \mathrm{Fe}_{2} \mathrm{O}_{3}$, it is recommend that 15 wt\% $\mathrm{Fe}_{2} \mathrm{O}_{3}$ be maintained at the upper limit for the HWVP feed specification despite the fact that the viscosity based 7 imit is higher.

4.1.3.5 Noble Metals Behavior in HWVP 84--10w-Chrome Feed Glass, HW39-2. (a) At meiter operating temperatures (approximately $1150^{\circ} \mathrm{C}$ ), noble metals (Ru, $\mathrm{Rh}$, and $\mathrm{Pd}$ ) are only slightly soluble in borosilicate nuclear waste glasses. The soiubility of Ru has been observed to be less than 0.001 wt\% in borosilicate melts (Ref. 4.1-6).

(a) R. W. Geldart, S. 0. Bates, and S. J. Jette, Basel ine Milestone HWVP-87V110202F - Prel iminary Evaluation of Noble Metal Behavior in the. Hanford Waste Vitrification Plant Reference Glass - HW39. Pacific Northwest Laboratory, Richland, Washington (September 1987). 


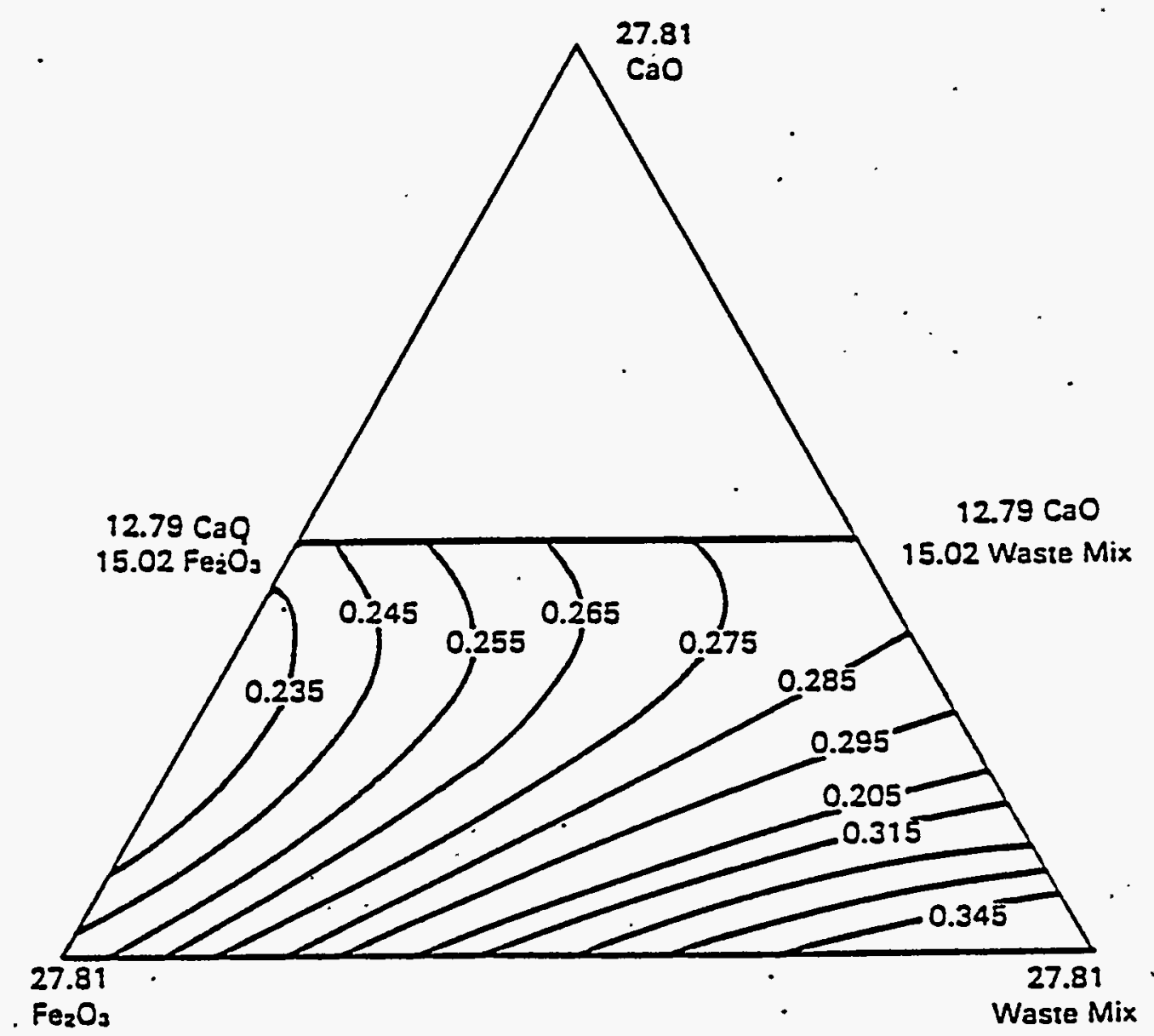

FIGURE 4.1-37. Contour Plot of Predicted Electrical Conductivity at $1150^{\circ} \mathrm{C}$ (E1150) for the Iron/Calcium Variability Test HWVP-87-V110202C

The presence of noble metals in nuclear. waste glasses has also been observed in Targe-scale vitrification plants in the Federal Republic of Germany (FRG) and Japan. In the case of the FRG PAMELA melter; the noble metal phases caused a viscous, conductive sludge to accumulate at the bottom of the melter. The sludge caused short-circuiting of the lower melter electrodes and failure of the bottom drain of the melter. (a) The HWVP reference glass composition (HW39) for pretreated NCAH has approximately the same concentration of total noble metals as is found in the glass processed in the FRG PAMELA me7ter. Therefore, conditions similar to those.observed in PAMELA could occur in the HWVP melter.

A study was conducted to determine if there is a potential for the formation of a noble metal sludge in the HWVP melter. Extensive accumulation of noble metals in the HWVP melter will impact both melter design and operation.

(a) M. Stehle, technical exchange package between DWK-PAMELA and HWVP (April 13-14, 1987). 


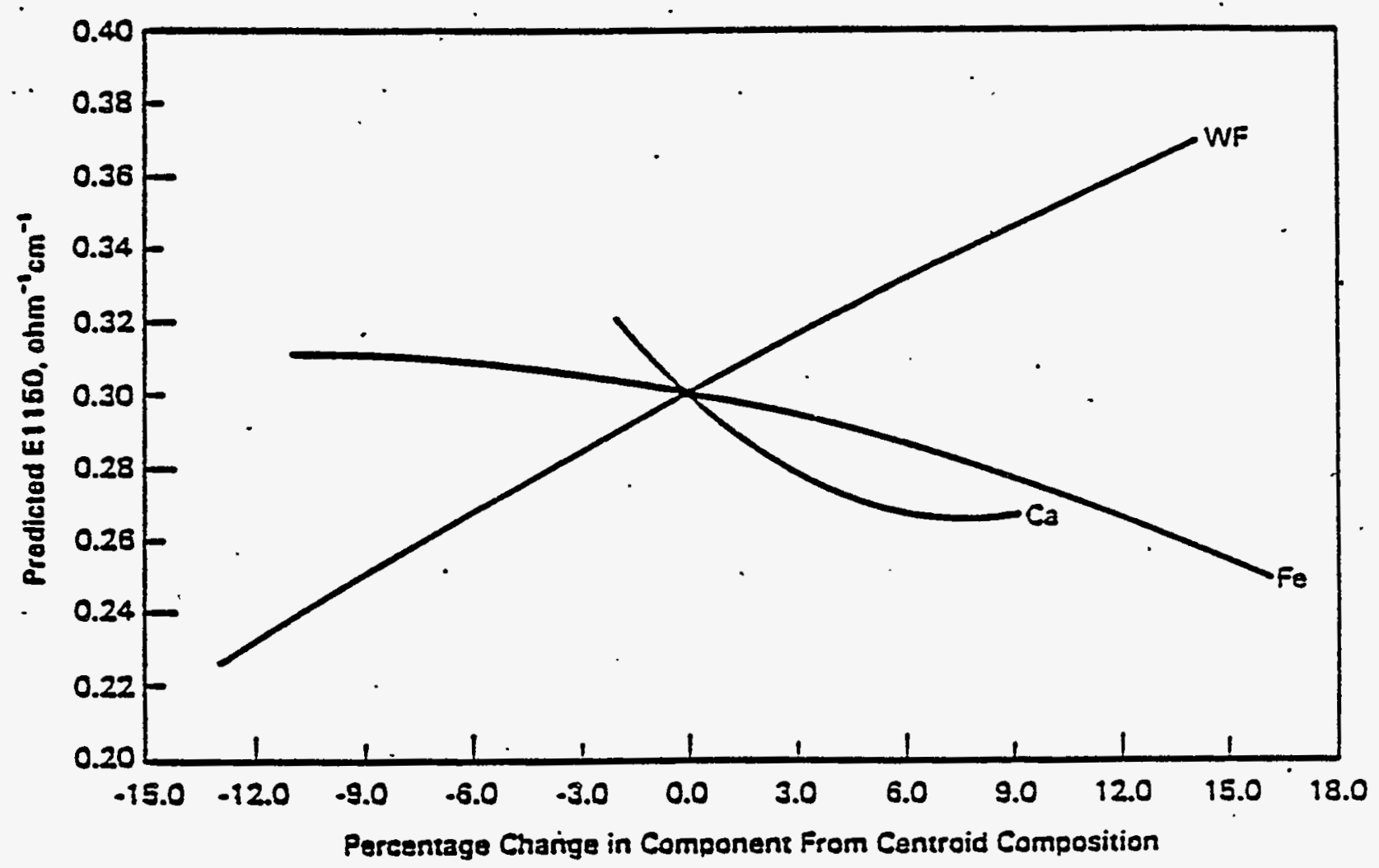

FIGURE 4.1-38. Effects PTot of Predicted E]ectrical Conductivity at $115^{\circ} \mathrm{C}$ (E1150) for the Iron/Calcium Variability .Test HWVP-87-V110202C

Noble metals have been included in some laboratory-scale testing for HWVP reference glass development. Particles of Pd metal and $\mathrm{RuO}_{2}$.crystals have been observed in previous laboratory melts.

The effects of glass redox conditions, noble metal concentrations, temperature and time were studied using both crucible glass melts and the liquid-fed minimelter (LFMM). Crucible glass melts were used to characterize the precipitation, agglomeration, and settling behavior of the noble metals. The LFMM was used to study noble metal precipitation in a smal7-scale continuous feed process designed to partially simulate the conditions of the larger-scale ceramic melters.

4.1.3.5.1 Technical Approach. The behavior of noble metals was studied using two different melt processes. These processes were crucible melts and the LFMM. The glass composition used for all testing was the HWVP reference glass HW39-2 incorporating NCAW 84--1 OW chrome waste. The oxide compositions of the waste and resulting glass are presented in Table 4.1-54. The formulation used to make the waste slurry feed is shown in Table 4.1-55. Crucible melts have benefits in their simplicity but can not incorporate the dynamics 


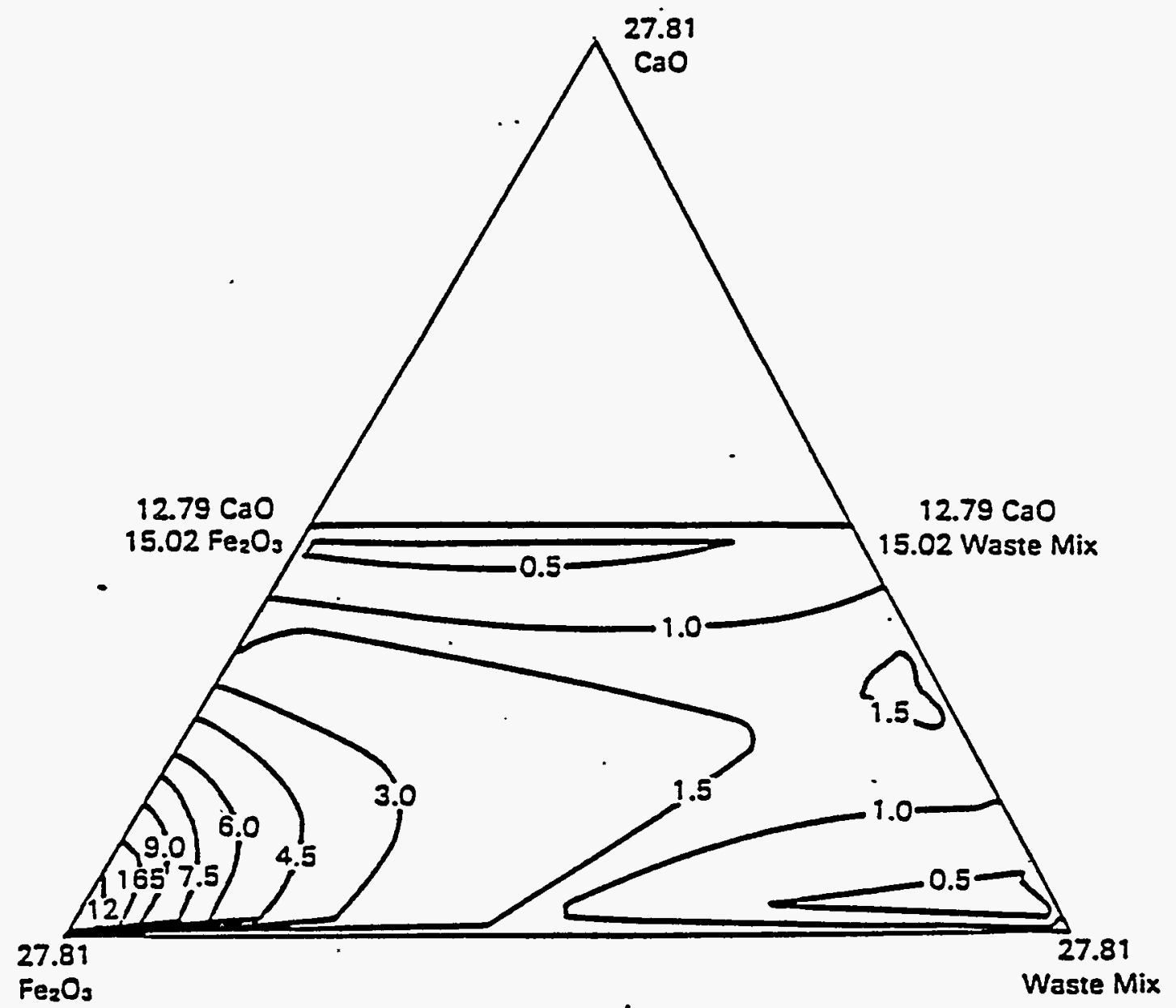

FIGURE 4.1-39. Contour Plot of Predicted 28-Dáy MCC-3 Boron Release for the Iron-Calcium Variability Test HWVP-87-V110202C

of a continuously-fed system. The LFMM was used to provide a more representative comparison to large-scale melters. Operation of the LFMM was limited to studying glass redox conditions and time-related agglomeration.

4.1.3.5.1.1 Crucible Melt Tests. The melt was begun by placing the crucible in the hot furnace and bringing the crucible to the required operating temperature. The melt temperature was measured by placing a Type-K thermocouple at the base of the crucible. Fifty $\mathrm{mL}$ of a simulated slurry were poured into the crucible in three aliquots over a 30 -min period. The $\mathrm{Ru}, \mathrm{Rh}$, and $\mathrm{Pd}$ were added to the feed as the oxides, $\mathrm{RuO}_{2}, \mathrm{Rh}_{2} \mathrm{O}_{3}$, and $\mathrm{PdO}$. Their average particle sizes were measured to be approximately $15 \mu \mathrm{m}, 5 \mu \mathrm{m}$, and $2 \mu \mathrm{m}$, respectively. After the feeding period was completed, the glass was stirred and allowed to melt for an additional $30 \mathrm{~min}$. The crucible was then removed from the meit furnace and transferred to an annealing oven. The glass was annealed at $930^{\circ} \mathrm{F}\left(500^{\circ} \mathrm{C}\right)$ and oven-cooled over night to ambient conditions. 


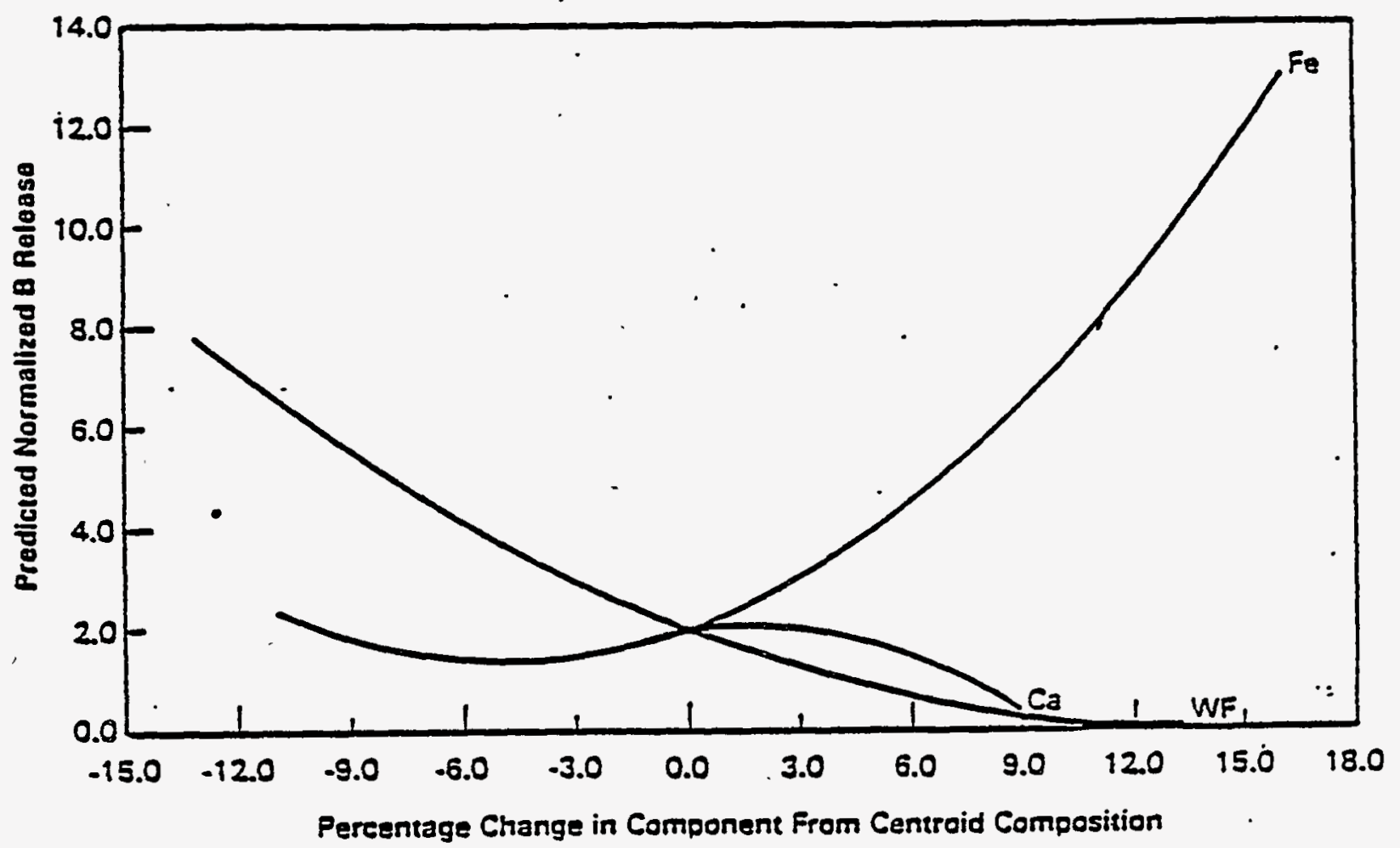

FIGURE 4.1-40. Effects Plot of Predicted 28-Day MCC-3 Boron Release for the Iron - Calcium Variability Test HWVP-87-V110202C

The glass depth in each crucible was approximately 8 to $10 \mathrm{~mm}$. Thin sections of the annealed glass were cut along the axial length of the crucible. Sections were polished and then analyzed by scanning electron spectroscopy (SEM/EDAX). A sample of the glass produced in the crucible was crushed and powdered in an agate disc mill and used to determine the glass redox and composition. ICP mass spectroscopy and XRF were used to analyze the glass compositions.

4.1.3.5.1.2 LFMM Melts. Several different LFMM experiments were performed. Each experiment used a simulated feed slurry to obtain the reference level HW39-2 low-chrome glass composition shown in Table 4.1-54. The Ru, Rh, and $\mathrm{Pd}$ were added to the feed as the oxides, $\mathrm{RuO}_{2}, \mathrm{Rh}_{2} \mathrm{O}_{3}$, and $\mathrm{PdO}$. Their average particle sizes were measured to be approximately $15 \mu \mathrm{m}, 5 \mathrm{\mu m}$, and $2 \mu \mathrm{m}$, . respectively. The redox conditions for each glass were adjusted by adding sugar as a reducing agent to the reference level formated feed. Pre7 iminary crucible melts were used to determine sugar additions necessary to achieve glass redox ratios between 0.03 and 0.3 . The range of the slurry feed rate was $180 \mathrm{~mL} / \mathrm{h}$ to $300 \mathrm{~mL} / \mathrm{h}$. The steady state glass depth in the LFMM crucible was approximately $10 \mathrm{~cm}$. The bottom temperature of the LFMM crucible fluctuated from $2000^{\circ} \mathrm{F}$ to $2100^{\circ} \mathrm{F}\left(1095^{\circ} \mathrm{C}\right.$ to $\left.1150^{\circ} \mathrm{C}\right)$, and the temperature 
TABLE 4.1-54: Composition of the HWVP NCAW 84 (Low Chrome) Reference Haste, Substituted Waste, and GTass (HW39-2) at a 25 wt\% Oxides Haste Loading

\begin{tabular}{|c|c|c|c|c|c|c|}
\hline Oxide & $\begin{array}{l}\text { Hormal ized } \\
\text { Haste } \\
\text { (wtw Oxide) }\end{array}$ & $\begin{array}{l}\text { Substituted } \\
\text { Haste } \\
\text { (weth Oxidel }\end{array}$ & $\begin{array}{l}\text { Substituted } \\
\text { Naste Ho"*. } \\
\text { (wt: Cxide) }\end{array}$ & $\begin{array}{l}\text { Sub!:t: tuted } \\
\text { Waste Hor. } \\
\text { No ToC }\end{array}$ & $\begin{array}{l}\text { HW39 Frit } \\
\text { (wt: Oxide) }\end{array}$ & $\begin{array}{c}\text { HKas } \\
\text { Giass } \\
\text { (wto Oxide) }\end{array}$ \\
\hline 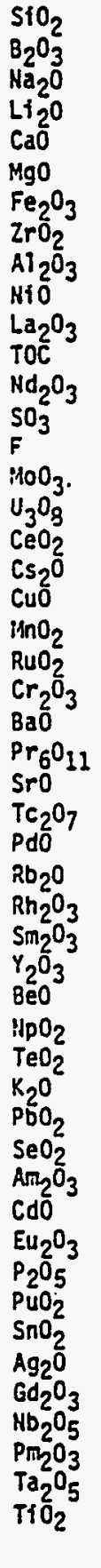 & $\begin{array}{c}3.09 \\
0.01 \\
11.1 \\
0.00 \\
0.31 \\
0.25 \\
46.3 \\
2.5 \\
17.9 \\
2.47 \\
2.29 \\
0.62 \\
1.79 \\
1.54 \\
1.24 \\
1.24 \\
0.62 \\
0.62 \\
0.62 \\
0.62 \\
0.62 \\
0.62 \\
0.56 \\
0.43 \\
0.37 \\
0.37 \\
0.37 \\
0.19 \\
0.25 \\
0.19 \\
0.19 \\
0.19 \\
0.06 \\
0.12 \\
0.12 \\
0.00 \\
0.00 \\
0.03 \\
0.02 \\
0.02 \\
0.02 \\
0.02 \\
0.02 \\
0.02 \\
0.01 \\
0.01 \\
0.01 \\
0.01 \\
0.01 \\
0.01 \\
100.0\end{array}$ & 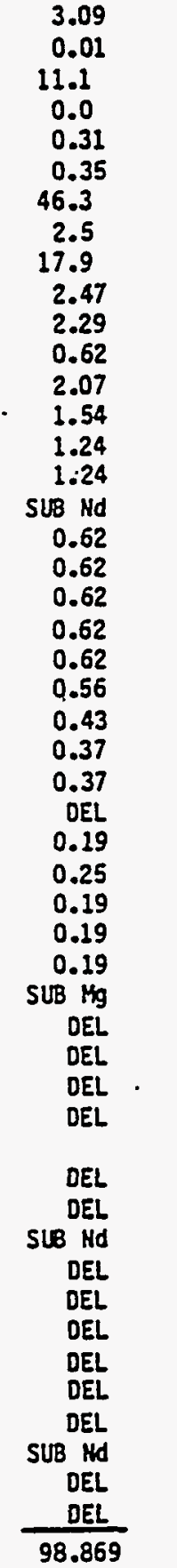 & $\begin{array}{c}3.12 \\
0.01 \\
11.2 \\
0.0 \\
0.31 \\
0.35 \\
46.9 \\
2.5 \\
18.1 \\
2.50 \\
2.31 \\
0.62 \\
2.09 \\
1.56 \\
1.25 \\
1.25 \\
S U B \quad N d \\
0.62 \\
0.62 \\
0.62 \\
0.62 \\
0.62 \\
0.56 \\
0.44 \\
0.37 \\
0.37 \\
D E L \\
0.19 \\
0.25 \\
0.19 \\
0.19 \\
0.19 \\
S U B M g \\
D E L \\
D E L \\
D E L \\
D E L \\
D E L \\
D E L \\
D E L \\
S U B N d \\
O E L L \\
D E L \\
D E L \\
D E L \\
D E L L \\
D E L L \\
S U B N d \\
D E L \\
O E L \\
100.0 \\
\end{array}$ & 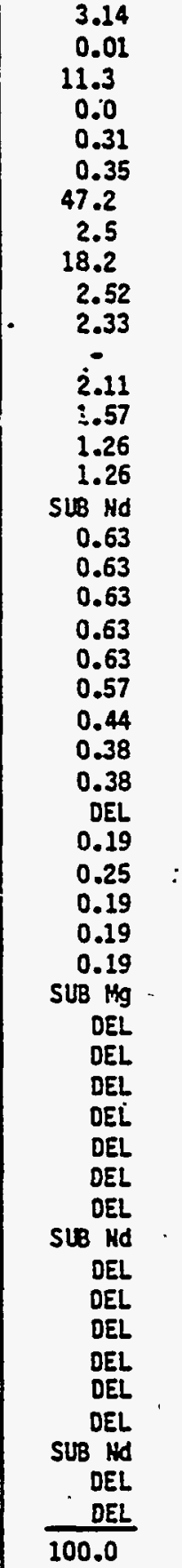 & $\begin{array}{r}67.25 \\
12.75 \\
10.25 \\
5.00 \\
3.75 \\
1.00\end{array}$ & $\begin{array}{r}51.22 \\
9.56 \\
10.52 \\
3.75 \\
2.89 \\
0.84 \\
11.79 \\
0.63 \\
4.56 \\
0.63 \\
0.58 \\
0.00 \\
0.53 \\
0.39 \\
0.31 \\
0.31 \\
\\
0.16 \\
0.16 \\
0.16 \\
0.16 \\
0.16 \\
0.14 \\
0.11 \\
0.09 \\
0.09 \\
0.05 \\
0.06 \\
0.05 \\
0.05 \\
0.05\end{array}$ \\
\hline
\end{tabular}


TABLE 4.1-55. Compositions of HWUP LOW-Chrome Reference Level Haste Slurry HWVP-87-V110202F

\begin{tabular}{|c|c|}
\hline Compound & g Compound/L \\
\hline 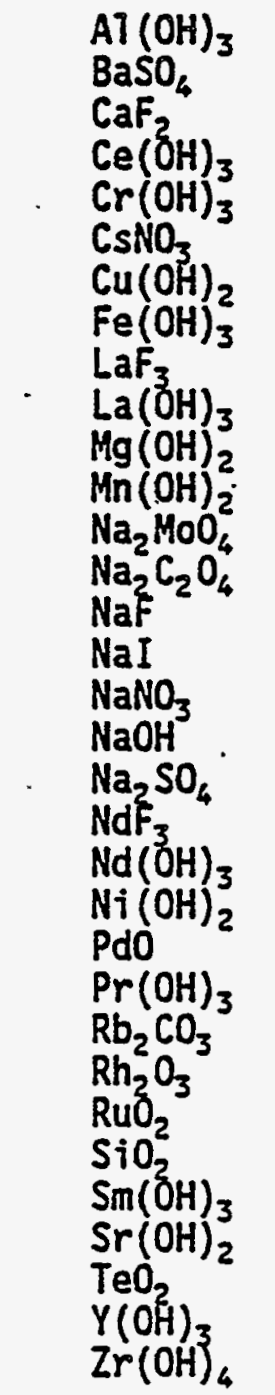 & $\begin{array}{r}125.67 \\
3.03 \\
1.95 \\
3.15 \\
3.48 \\
3.93 \\
3.48 \\
1203.3 \\
6.69 \\
5.73 \\
2.28 \\
2.90 \\
8.07 \\
15.87 \\
5.04 \\
2.10 \\
34.17 \\
26.25 \\
10.74 \\
1.8 \\
9.9 \\
14.07 \\
0.87 \\
1.92 \\
1.34 \\
0.87 \\
2.85 \\
14.16 \\
0.99 \\
4.39 \\
0.43 \\
1.05 \\
14.58\end{array}$ \\
\hline
\end{tabular}

at the top of the melt from $1220^{\circ} \mathrm{F}\left(660^{\circ} \mathrm{C}\right)$ to $1890^{\circ} \mathrm{F}\left(1030^{\circ} \mathrm{C}\right)$, depending upon the proximity of the cold cap to the thermowell. LFMM output glasses were analyzed by XRF, SEM/EDAX, and ICP. A giass core was drilled in the glass remaining in the LFMM following completion of the LFMM experiments.

4.1.3.5.2. Observations and Conclusions. The following observations were made during the noble metals behavior study: 
Crucible Studies (Table 4.1-56). Based on the crucible melt tests, the following observations were made regarding the effects of temperature, time, noble metal concentrations, and redox environment on noble metal precipitation.

- Nobie metal phases observed in the crucible study included $\mathrm{Fe}-\mathrm{Cr}-\mathrm{Ni}$ spinel with varying amounts of $\mathrm{Ru}, \mathrm{Rh}$, and $\mathrm{Pd}$. Metallic-appearing nodules of $\mathrm{Pd}, \mathrm{Ru}$, and $\mathrm{Rh}$ and various combinations of all three noble metals were observed in some of the melts. Many of these nodules often had traces of $\mathrm{Cu} ; \mathrm{Fe}, \mathrm{Ni}$, and $\mathrm{Cr}$. Palladium was observed to alloy with $\mathrm{Te}$ in some cases. Besides the metallic-like nodules, some noble metal oxides $\left(\mathrm{RuO}_{2}\right.$ and $\left.\mathrm{RhO}_{2}\right)$ were observed by XRD.

- In the temperature range planned HWVP melter operation, temperature played a role in the agglomeration and settling behavior of the predominant iron-spinel crystals. However, agglomerations of the crystals increased in both size and number as the temperature decreased.

- Both the settling and agglomeration behavior of the noble metal phases were observed to vary with time. The size of the spinel crystals in the agglomerates increased with time. As time increased, Pd was transported to the surface of the crucible. The mechanism for this transport was not determined.

- The only effect observed when the concentration of noble metals was increased was an increase in the quantity of the noble metal particulate throughout the melt.

- For redox conditions expected in the HWVP melters, redox conditions affected both the quantity and type of particulate observed. Glasses with ferrous/ferric ratios of 0.0 and 0.03 displayed large quantities of spinel crystals that contained small quantities of $\mathrm{Ru}, \mathrm{Rh}$ and $\mathrm{Pd}$. No spinel crystals were observed at ferrous/ferric ratios of 0.27 . At this ferrous/ferric ratio, each of the noble metals agglomerated in high-purity particulates, with little mixing of elements. These high-purity noble metal agglomerates were not observed at the lower ferrous/ferric ratios.

- When sugar was used to obtain a glass with a ferrous/ferric ratio of 0.65 , spinel crystals were observed. However, spinel crystals were no longer observed at a ferrous/ferric ratio above 0.27 when formic. acid was used as a reducing agent.

- The cold cap sample from a crucible melt did not reveal any excessive formation of noble metals in the cold cap. 
TABLE 4.1-56. Summary of Crucible Variability Studies

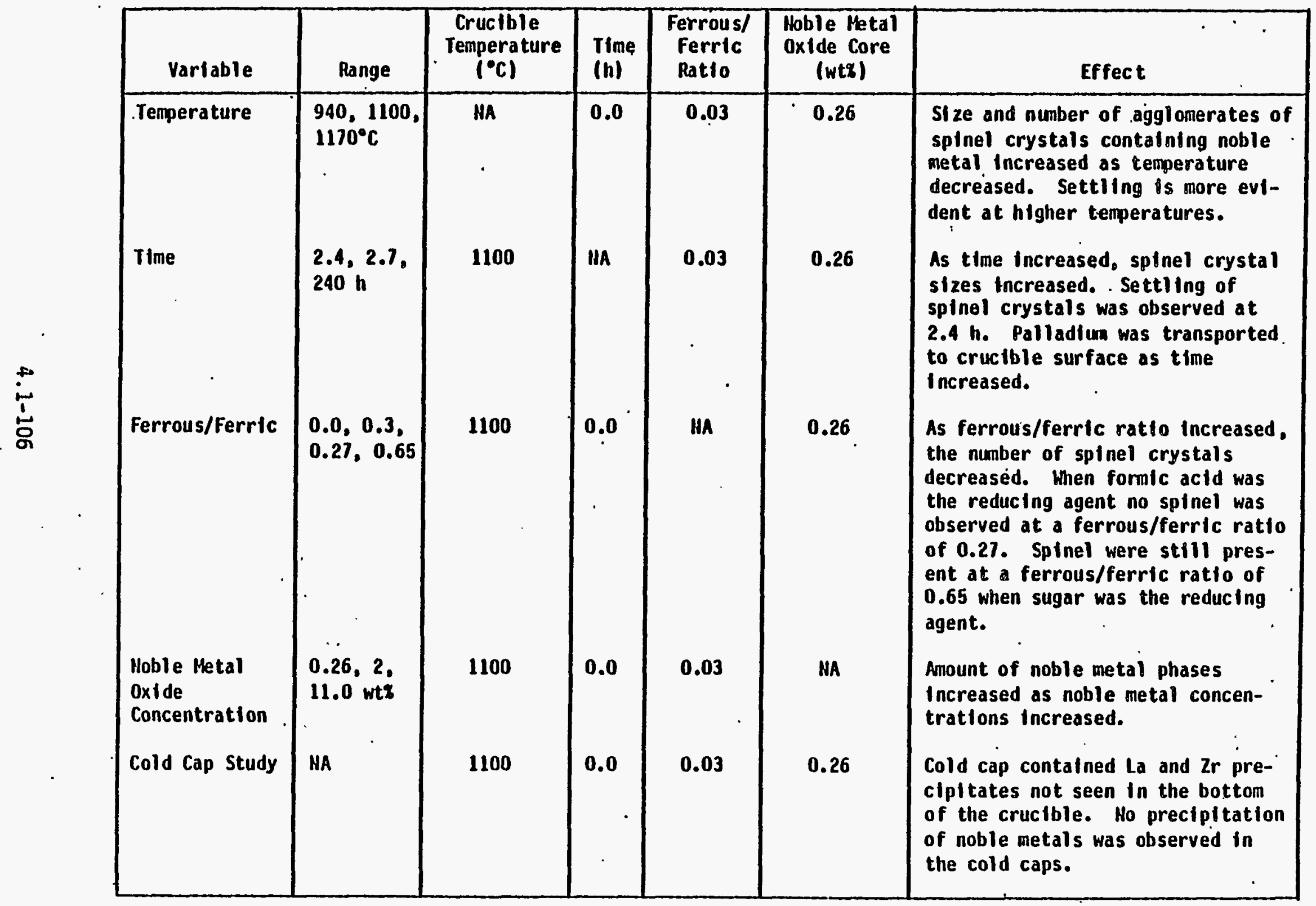


- Ruthenium was observed (possibly as $\mathrm{RuO}_{2}$ ) to adhere to bubbles present in the glass melt. These bubbles act as a transport mechanism to bring. the Ru to the surface of the melt where it was observed to accumulate. Palladium also accumulated at the surface of the crucible melts. These observations are consistent with observations made by the Japanese (Ref. 4.1-18). The wetting and surface tension properties of the noble metals and the glass may be responsible for the accumulation.

- Ruthenium and Rh phases acted as nucleating agents for other particulates. They were often present. in large agglomerates of spinel and other noble metal particulates.

LFMM Studies. The following observations were made from the LFMM experiments.

- Large noble metal nodules were observed in the LFMM. Some of the high-Ru, $-\mathrm{Pd}$, and $-\mathrm{Rh}$ noble metal nodules were as large as $0.5 \mathrm{~cm}$ in diameter. Many of the nodules accumulated near the end of an Inconel thermowell, indicating possible catalysis by the Inconel.

- The glass redox state of the minimelter output glass could not be controlled satisfactorily by sugar addition presumably because of the corrosion of the Inconel. Thus, it is unlikely that the LFMM conditions are representative of those expected in the large-scale HWVP melters.

- High-chrome spinel crystals-in-agglomeration sizes up to $100 \mu \mathrm{m}$ were abundant in the output glass of each minimelter test. These spinels were likely the result of corrosion of the Inconel vessel. Although particulates containing $\mathrm{Ru}$ and $\mathrm{Pd}$ were observed in the output glass, these particulate were usually under 1 m in diameter.

Based on the above observations, the following conclusions can be made:

\section{Crucible Testing}

- A wide variety of noble metal phases may form at conditions expected in HWVP melter using the reference level HWVP low-chromium glass compositions. These phases included a variety of iron-chrome-noble metal spinel phases, metallic-like nodules which included various combinations of $\mathrm{Ru}, \mathrm{Rh}$, and $\mathrm{Pd}$ and agglomerates of submicron $\mathrm{Ru}$ crystals. The exact form of the Ru is unknown. All the phases have the potential to settle in stagnant glass melts.

- The crucible tests indicate that noble metal concentrations, temperature, time, glass redox conditions, and type of reducing agent may all affect noble metal behavior under HWVP melter operating conditions. 
- Based on crucible. testing, there is the potential for formation of noble metal sludges in the HWVP melter. Further testing in engineer-and pilot-scale melters are needed to assess the sludge formation potential.

\section{LFMM Studies}

- The LFMM results were affected by the corrosion of the Inconel vesse?.

- Noble metal concentrations in the reference level HWVP low-chrome glass were sufficient to cause precipitation of noble metals in the LFMM. Although the conditions in the LFMM are only partially representative of those in the large- scale HWVP melter, these results indicate that precipitation of noble metals could occur in the HWVP melters.

4.1.3.6 Frit/Waste Sodium and Silica Proportion Variation. (a) A study was performed to assess the viability of potential scenarios for expanding the current specifications of waste and frit components to allow for greater pretreatment and processing flexibility.

The HW39-2 reference glass, frit, and NCAN $84\left(0.13 \mathrm{wt} \% \mathrm{Cr}_{2} \mathrm{O}_{3}\right)$ waste compositions (see Tabie 4.1-54) were used as a basis for these tests to allow for the use of models and data generated in previous variability testing. Where applicable, conclusions and comments with regard to the modified reference waste (NCAH 86) composition are also made.

The two methods of providing additional process adjustment evaluated in this study were 1) the adjustment of the frit to allow for additional $\mathrm{Na}$ from the waste and 2) the use of $\mathrm{SiO}_{2}$ or $\mathrm{Na}$ additions in place of some portion of the frit to adjust the temperature at which the viscosity of the melt is 100 poise (T100P). The use of compositional ratios such as the (alkali) ${ }_{2} \mathrm{O} / \mathrm{SiO}_{2}$ in a glass composition to predict the TlOOP of a melt based on composition was also evaluated as a method of controlling process adjustments.

These studies were based on glass and frit compositions and properties only. The processability of the scenarios must be verified in slurry feed rheology and melter tests before being considered fully acceptable.

4.1.3.6.1. Frit Adjustment. Because the reference glass composition consists of $25 \mathrm{wt} \%$ waste and $75 \mathrm{wt} \%$ frit, frit modification can provide a large amount of flexibility for variability in the waste. At a 25 wt\% waste loading, every $1 \mathrm{wt} \%$ of frit component modified provides for a $4 \mathrm{wt} \%$ change in the same component in the waste. At this time, most of the frit

(a) S. 0. Bates, Interim Milestone HWVP-87-V110202E - Composition Variability Studies to Increase Processing Flexibility for the Hanford Waste Vitrification Plant. Pacific Northwest Laboratory, Richland, Washington (September 1987). 
components are not in the waste or have small expected variabilities. The exception is $\mathrm{Na}$. Changes in washing efficiency at B.Plant significantly affect the amount of $\mathrm{Na}$ in.the waste. Laboratory tests were conducted to determine the minimum amount of $\mathrm{Na}_{2} \mathrm{O}$ required in the frit. This allowed the determination of the amount of flexibility possible for increasing the amount of $\mathrm{Na}$ in the waste by the removal of $\mathrm{Na}_{2} \mathrm{O}$ from the frit.

For large-scale commercial frit producers, the frit composition must be workable below $2280^{\circ} \mathrm{F}\left(1250^{\circ} \mathrm{C}\right)$. A good indication of workability is the temperature at which the viscosity of the glass is 100 poise (T100P). Other factors, such as the rate the viscosity of the frit increases with decreasing temperature and the devitrification characteristics, are also important. Furthermore, the frit composition must be submitted to commercial frit producers to determine if the frit can be produced. For this study, it was assumed that if a frit composition had a T100P of below $2280^{\circ} \mathrm{F}\left(1250^{\circ} \mathrm{C}\right)$, it would be considered viable. However, even if a frit can be produced, it would not necessarily have the processing qualities required for the HWVP process. Factors such as melting behavior, cold cap morphology, and melting rates must be confirmed in engineering-scale melter tests. The HH39 reference frit has a T100P of $2025^{\circ} \mathrm{F}\left(1108^{\circ} \mathrm{C}\right)$ and has been shown to be very processable in melter tests.

To initiate testing, a frit composition was formulated by removing all the $\mathrm{Na}_{2} \mathrm{O}$ from the $\mathrm{HW} 39$ reference frit and renormalizing the modified frit composition to $100 \%$. This frit composition was designated Frit \#1 and is presented in Table 4.1-57. The melting point of Frit \#1 was between 2280 $\mathrm{F}$ and $2370^{\circ} \mathrm{F}\left(1250^{\circ} \mathrm{C}\right.$ and $\left.1300^{\circ} \mathrm{C}\right)$. At $2270^{\circ} \mathrm{F}\left(1300^{\circ} \mathrm{C}\right)$ the viscosity of the melt was approximately 200 poise. As the Frit \#I melt was removed from the furnace to be poured into bars, the viscosity was observed to increase very rapidly and glass crystallized immediately. The melt temperature had to be increased to $2550^{\circ} \mathrm{F}\left(1400^{\circ} \mathrm{C}\right)$ so that a melt could be easily poured from the melt crucible. The bars of Frit \#l appeared to be a totally crystalline white ceramic similar to porcelain in appearance. Frit \#l was deemed unacceptable based on the required melting temperature and viscosity properties.

TABLE 4.1-57. Compositions of Test Frits

\begin{tabular}{|l|r|r|r|}
\hline Oxide & HW39 & Frit \#1 & Frit \#2 \\
\hline $\mathrm{SiO}_{2}$ & 67.25 & 74.93 & 70.98 \\
$\mathrm{~B}_{2} \mathrm{O}_{3}$ & 12.75 & 14.21 & 13.46 \\
$\mathrm{Na}_{2} \mathrm{O}$ & 10.25 & 0.00 & 5.28 \\
$\mathrm{Li}_{2} \mathrm{O}$ & 5.00 & 5.57 & 5.28 \\
$\mathrm{CaO}$ & 3.75 & 4.18 & 3.96 \\
$\mathrm{MgO}$ & 1.00 & 1.11 & 1.06 \\
\hline
\end{tabular}


For Frit $\# 2,-$ approximately half of the $\mathrm{Na}_{2} \mathrm{O}$. (5 wt\% of the reference 10.25 wt\% total) was removed from the HW39 reference frit and the composition was renormalized to 100 wt\%. This frit composition is al so presented in Table 4.1-57. Frit $\frac{\| 12}{\pi 2}$ melted at approximately $2190^{\circ} \mathrm{F}\left(1200^{\circ} \mathrm{C}\right)$, but it was necessary to raise the temperature of the meit to $2370^{\circ} \mathrm{F}\left(1300^{\circ} \mathrm{C}\right)$. to allow for the fining of a large number of bubbles in the melt. The T100P of Frit \#2 was determined to be $2210^{\circ} \mathrm{F}\left(1211^{\circ} \mathrm{C}\right)$. The rate of increase in the viscosity as the melt was poured was much less than Frit \#1, and the melt poured easi7y at $2370^{\circ} \mathrm{F}\left(1300^{\circ} \mathrm{C}\right)$. Aithough the air-quenched glass remained vitreous, the annealed bar was observed to have only a small amount of crystallization. Based on the melting point and viscosity of this frit, this frit composition was judged to be acceptable.

Contact with a commercial frit producer provided a tentative confirmation that Frit $\$ 2$ would be viable. (a) The general guideline obtained from the frit producer for a producible frit was that the $\mathrm{SiO}_{2}$ remain below 72 to 73 wt\%. Frit \#2 meets this criterion. However, frits with $\mathrm{SiO}_{2}$ concentrations above 68 wt\% become difficult to produce because of the "shortness" of the glass (the greater the change in viscosity versus temperature, the "shorter" the glass). The frit producer would have to conduct some limited testing before a bid would be made to produce frit $\# 2$.

Removing up to $5 \mathrm{wt} \% \mathrm{Na}_{2} \mathrm{O}$ from the frit provides for the potential addition of $\mathrm{Na}$ in the waste from $\mathrm{O}$ to $20 \mathrm{wt} \%$ as $\mathrm{Na}_{2} \mathrm{O}$. For the NCAH 84 waste, this addition would mean a $\mathrm{Na}_{2} \mathrm{O}$ increase of from 11.1 to as high as 31.1 wt\% in the waste. The latest update of the NCAW composition, NCAW 86, has higher concentrations of $\mathrm{Na}_{2} \mathrm{O}$ and $\mathrm{ZrO}_{2}$ but lower concentrations of $\mathrm{Fe}_{2} \mathrm{O}_{3}$, and $\mathrm{Al}_{2} \mathrm{O}_{3}$. Al] other oxide concentration differences are too small to be of major sig-

- nificance in the glass. At a 25 wt\% waste loading of NCAW 86, and using the HW39 reference frit composition, the T100P of the resulting giass was $1985^{\circ} \mathrm{F}$ $\left(1086^{\circ} \mathrm{C}\right) .(\mathrm{b})$

Because the above potential modifications to the waste and frit would resuit in no net change in the finat glass composition, glass variability, ranges identified in previous variability studies would still be valid. (c)(d) The glass flexibility provides for an addition 2.7 wt\% increase in $\mathrm{Na}_{2} \mathrm{O}$ in the glass (10.8 wt\% in the waste) before the Tl00p limits are exceeded. At

(a) Personal communication with. Bob Long of American Porcelain Enamel Co., Muskegon, Michigan, on July 17, 1987.

(b) S. 0. Bates, HWVP Basel ine Milestone HWVP-87-V110202A: Waste Form Evaluation of the Uodated NCAW Composition. Pacific Northwest Laboratory, Richland, Washington (1987).

(c) S. 0. Bates and W. M. Bowen, Interim Milestone HWVP-86-V1122C - Report on Composition Variability Testing Conducted for the Hanford Waste Vitrification Program. Pacific Northwest Laboratory, Richland, Washington (1986).

(d) S. 0. Bates, Baseline Milestone HWVP-87-V110202B - Update of GlasS Composition Boundaries of the Hanford Waste Vitrification Program Reference Glass, HW39. Pacific Northwest Laboratory, Richland, Washington (1987.). 
an extreme, the glass flexibility and the frit adjustment could both be used to accommodate a maximum of approximately $42 \mathrm{wt} \% \mathrm{Na}_{2} \mathrm{O}$ in the NCAW 84 waste. The processability of the modified waste and frit compositions still needs to be verified in an engineering-scale melter test.

The removal of $\mathrm{Na}_{2} \mathrm{O}$ from the frit would result in a harder, more-durable frit. The rheology properties of the frit in the melter feed should be very similar to the reference frit.

4.1.3.6.2 Melter Feed Adjustments. If for some reason the composition of the waste varies to the point where critical glass processing properties will not be met, it may be possible to add certain elements to the melter feed to modify the feed and resulting glass composition such that the out-oflimits glass property would be adjusted to an acceptable value. Variability studies have shown that, in most cases, the limiting glass property is the viscosity of the melt and, if the viscosity of any of this family of waste glasses is acceptable, the rest of the required processing properties will be acceptable also. For this reason, the two main scenarios evaluated were for a low- and high-viscosity waste/glass composition. To keep process additions as simple as possible, only two types of additives were considered: one to raise melt viscosity $\left(\mathrm{SiO}_{2}\right.$ addition) and one to lower melt viscosity ( $\mathrm{Na}$ addition).

4.1.3.6.2.1 Viscosity Prediction. The SRL is evaluating the alkali/Si ratio as a method of maintaining a constant melt viscosity in the DHPF and determining the amount of prefipitate hydrolysis waste (high in alkali) to. add to the sludge and frit. (a) The alkali/Si ratio is not planned to be used to adjust for composition variations in the DWPF sludge.

To evaluate if a compositional ratio similar to the alkali/si ratio could be used to predict the viscosity of HWVP glass compositions, various compositional ratios were plotted against measured T100P values. The following composition ratios were evaluated:

- a $\mathrm{k}_{2} \mathrm{O} / \mathrm{SiO}_{2}$ molar basis

- alk $\mathrm{K}_{2} \mathrm{O} \mathrm{SiO}_{2}$ wt\% basis

- alk/Si molar basis

- al $\mathrm{k}_{2} \mathrm{O} /\left(\mathrm{SiO}_{2}+\mathrm{Al}_{2} \mathrm{O}_{3}+\mathrm{ZrO}_{2}\right)$ molar basis

- $a 7 k^{2} /(S i+A T+Z r)^{2}$ molar basis

- $27 \mathrm{k}_{2} \mathrm{O} /\left(\mathrm{SiO}_{2}+\mathrm{Al}_{2} \mathrm{O}_{3}+\mathrm{ZrO}_{2}\right)$ wt\% basis

where alk is the sum of the $\mathrm{Li}$ and $\mathrm{Na}$ concentrations. The glasses used for this evaluation were previously studied HWVP glasses that had low $\mathrm{Cr}_{2} \mathrm{O}_{3}$ concentrations $(\approx 0.13 \mathrm{wt} \%)$. No high- $\mathrm{Cr}_{2} \mathrm{O}_{3}$ HWVP glasses were used to avoid the higher unstable viscosities caused by the presence of chrome crystalline phases. The glasses used are presented below, and the glass compositions are 7isted in Tabie 4.1-58.

- HW39-2, the HWVP $\left(0.13 w t \% \mathrm{Cr}_{2} \mathrm{O}_{3}\right)$ reference glass incorporating the NCAW 84 waste at a 25 wt\% waste loading.

(a) 0. L. Kruger, Trip Report 65652-TR-87-003, "HWVP-PNL-DWPF Technology Exchange," Savannah River Laboratory/DWPF, Aiker, South Carolina (March 11 and 12 , 1987). 
TABLE 4.1-58. Compositions of G7asses Used in Compositional Ratio Evaluation HWVP-14 Melter Test Glass

HWVP-87-V110202E

\begin{tabular}{|c|c|c|c|c|c|c|c|c|}
\hline \multirow[b]{2}{*}{ Oxide } & \multirow[b]{2}{*}{ HH39 } & \multirow[b]{2}{*}{ HW43 } & \multirow[b]{2}{*}{ HH44 } & \multirow[b]{2}{*}{ HW45 } & \multicolumn{4}{|c|}{ HWVP-14 Melter Test Glass } \\
\hline & & & & & $\begin{array}{l}\text { Low } \\
\mathrm{AT}_{2} \mathrm{O}_{3}\end{array}$ & $\begin{array}{l}\mathrm{High} \\
\mathrm{ZrO}_{2}\end{array}$ & $\begin{array}{l}\mathrm{High} \\
\mathrm{Na}_{2} \mathrm{O}\end{array}$ & $\begin{array}{l}\text { Low } \\
\mathrm{Fe}_{2} \mathrm{O}_{3}\end{array}$ \\
\hline 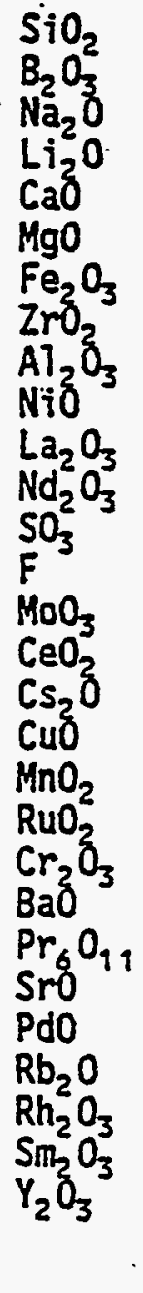 & $\begin{array}{r}51.21 \\
9.56 \\
10.48 \\
3.7 \\
2.89 \\
0.85 \\
11.72 \\
0.61 \\
4.53 \\
0.61 \\
0.59 \\
0.56 \\
0.48 \\
0.32 \\
0.32 \\
0.16 \\
0.16 \\
0.16 \\
0.16 \\
0.16 \\
0.14 \\
0.11 \\
0.11 \\
0.11 \\
0.05 \\
0.05 \\
0.05 \\
0.05 \\
0.05 \\
100.00\end{array}$ & $\begin{array}{r}52.76 \\
9.59 \\
12.21 \\
3.75 \\
2.89 \\
0.84 \\
7.23 \\
3.87 \\
2.58 \\
0.59 \\
0.52 \\
0.61 \\
0.46 \\
0.31 \\
0.31 \\
0.15 \\
0.15 \\
0.15 \\
0.15 \\
0.15 \\
0.13 \\
0.10 \\
0.10 \\
0.10 \\
0.05 \\
0.05 \\
0.05 \\
0.05 \\
0.05 \\
100.00\end{array}$ & $\begin{array}{r}49.86 \\
8.96 \\
12.60 \\
3.50 \\
2.72 \\
0.81 \\
8.68 \\
4.65 \\
3.10 \\
0.71 \\
0.62 \\
0.73 \\
0.56 \\
0.37 \\
0.37 \\
0.19 \\
0.19 \\
0.19 \\
0.19 \\
0.19 \\
0.15 \\
0.12 \\
0.12 \\
0.12 \\
0.06 \\
0.06 \\
0.06 \\
0.06 \\
0.06 \\
100.00\end{array}$ & $\begin{array}{r}46.97 \\
8.32 \\
12.99 \\
3.25 \\
2.55 \\
0.78 \\
10.12 \\
5.42 \\
3.62 \\
0.83 \\
0.72 \\
0.85 \\
0.65 \\
0.43 \\
0.43 \\
0.22 \\
0.22 \\
0.22 \\
0.22 \\
0.22 \\
0.18 \\
0.14 \\
0.14 \\
0.14 \\
0.07 \\
0.07 \\
0.07 \\
0.07 \\
0.07 \\
100.00\end{array}$ & $\begin{array}{r}51.37 \\
9.56 \\
11.05 \\
3.75 \\
2.91 \\
0.87 \\
14.08 \\
0.74 \\
0.40 \\
0.74 \\
0.70 \\
0.67 \\
0.58 \\
0.38 \\
0.38 \\
0.19 \\
0.19 \\
0.19 \\
0.19 \\
0.19 \\
0.17 \\
0.13 \\
0.13 \\
0.13 \\
0.06 \\
0.06 \\
0.06 \\
0.06 \\
0.06 \\
100.00\end{array}$ & $\begin{array}{r}50.91 \\
9.56 \\
9.41 \\
3.75 \\
2.86 \\
0.81 \\
7.20 \\
10.00 \\
2.78 \\
0.38 \\
0.36 \\
0.34 \\
0.29 \\
0.20 \\
0.20 \\
0.10 \\
0.10 \\
0.10 \\
0.10 \\
0.10 \\
0.09 \\
0.07 \\
0.07 \\
0.07 \\
0.03 \\
0.03 \\
0.03 \\
0.03 \\
0.03 \\
100.00\end{array}$ & $\begin{array}{r}51.12 \\
9.56 \\
13.18 \\
3.75 \\
2.88 \\
0.83 \\
10.29 \\
0.54 \\
3.98 \\
0.54 \\
0.51 \\
0.49 \\
0.42 \\
0.28 \\
0.28 \\
0.14 \\
0.14 \\
0.14 \\
0.14 \\
0.14 \\
0.12 \\
0.09 \\
0.09 \\
0.09 \\
0.05 \\
0.05 \\
0.05 \\
0.05 \\
0.05 \\
100.00\end{array}$ & $\begin{array}{r}51.43 \\
9.56 \\
11.27 \\
3.75 \\
2.91 \\
0.87 \\
8.00 \\
0.78 \\
5.79 \\
0.78 \\
0.75 \\
0.71 \\
0.61 \\
0.41 \\
0.41 \\
0.20 \\
0.20 \\
0.20 \\
0.20 \\
0.20 \\
0.18 \\
0.14 \\
0.14 \\
0.14 \\
0.07 \\
0.07 \\
0.07 \\
0.07 \\
0.07 \\
100.00\end{array}$ \\
\hline
\end{tabular}


- HW43, the HW39 reference frit and the NCAH 86 waste at a 25 wt\% waste loading.

- HW44, the HW39 reference frit and the NCAW 86 waste at a 30 wt\% waste loading.

- HW45, the HW39 reference frit and the NCAW 86 waste at a 35 wt\% waste loading.

- HWVP-14 melter test glasses based on the HW39 glass composition (25 wt\% waste loadings):(a)

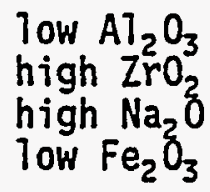

A summary of the measured TIOOP values and the compositional ratios is presented in Table 4.1:59. Figure 4.1-41 is a plot of the compositional ratios versus T100P. Figure 4.1-41 shows that the alk $\mathrm{O} /\left(\mathrm{SiO}_{2}+\mathrm{Al}_{2} \mathrm{O}_{3}+\mathrm{ZrO}_{2}\right)$ molar ratio, the alk/(Si+Al+Zr) molar ratio, and $a 7 k_{2} 0 /\left(\mathrm{SiO}_{2}+\mathrm{Al}_{2} \mathrm{O}_{3}+\mathrm{ZrO}_{2}\right)^{2} \mathrm{Wt} \%$ ratio appear to have the best linear fit to TlOOP. The alk $\mathrm{K}_{2} \mathrm{O} /\left(\mathrm{XS}_{\mathrm{SO}}+\mathrm{yAT}_{2} \mathrm{O}_{3}+\right.$ $\left.\mathrm{ZZrO}_{2}\right)$ ratio will be discussed later and is a weighted $\mathrm{al}_{2} \mathrm{O} /\left(\mathrm{SiO}_{2}+\mathrm{Al}_{2} \mathrm{O}_{3}+\right.$

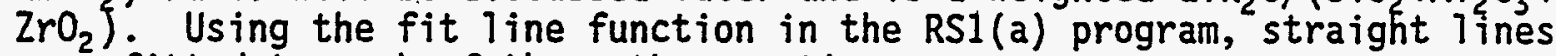
were fitted to each of these three ratios.

Caution should be used with any of the above ratios to estimate Tloop when the major changes in composition are not $\mathrm{Na}_{2} \mathrm{O}, \mathrm{SiO}_{2}, \mathrm{Al}_{2} \mathrm{O}_{3}$, or $\mathrm{ZrO}_{2}$. The fact that these elements are the only ones used in the ratios may not account for other elemental variations. The HW43, HW44, and HW45 glasses are based on NCAW 86 instead of NCAW 84, but the TlOOPs for these giasses are predicted well by the fitted lines. However, the only major. differences between these two waste compositions are the $\mathrm{Na}_{2} \mathrm{O}, \mathrm{Al}_{2} \mathrm{O}_{3}, \mathrm{ZrO}_{2}$, and $\mathrm{Fe}_{2} \mathrm{O}_{3}$ concentrations. Iron has been foynd to have only minor effects on viscosity at the lower $\mathrm{Cr}_{2} \mathrm{O}_{3}$ concentration. $(\mathrm{b})$

The above composition ratio/viscosity relationships also assume that the relative effect on viscosity of each of the components is the same and that the effect of $\mathrm{Na}_{2} \mathrm{O}$ on viscosity per wt\% has the same magnitude but in the opposite direction. Variability scoping tests that have evaluated $\mathrm{Na}_{2} \mathrm{O}$, $\mathrm{SiO}_{2}, \mathrm{Al}_{2} \mathrm{O}_{3}$, and $\mathrm{ZrO}_{2}$ have shown that each component will affect the meit viscosity to a different degree per wt\% change in concentration. Using the

(a) R. K. Nakaoka, J. M. Perez, W. C. Buchmiller, R. W. Goles, and S. O. Bates; Nonradioactive LFCM Testing Results in FY 1986 Under the HWVP. HWVP-86-HLVID, Pacific Northwest Laboratory, Richland, Washington.

(b) S. 0. Bates, Interim Milestone HWVP-87-V11202C - Report on FY 87 Glass Variability Testing Conducted for the Hanford Waste Vitrification Program. Pacific Northwest Laboratory, Richland, Washington (1987). 
TABLE 4.1-59. Compositional Ratios and T100P Values for Evaluated Glass Compositions HWVP-87-V110202E

\begin{tabular}{|c|c|c|c|c|c|c|c|c|}
\hline Ratios & HW39 & HH43 & HW44 & HW45 & $\begin{array}{l}\text { Low } \\
\mathrm{Al}_{2} \mathrm{O}_{3}\end{array}$ & $\begin{array}{l}\mathrm{High} \\
\mathrm{ZrO}_{2}\end{array}$ & $\begin{array}{l}\mathrm{High} \\
\mathrm{Na}_{2} \mathrm{O}\end{array}$ & $\begin{array}{l}\text { Low } \\
\mathrm{Fe}_{2} \mathrm{O}_{3}\end{array}$ \\
\hline 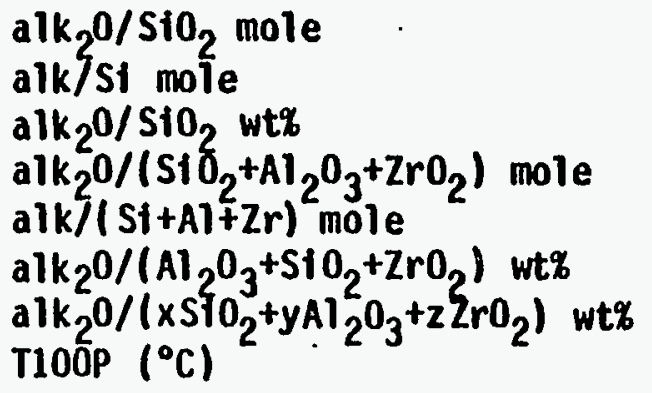 & $\begin{array}{r}0.3457 \\
0.7959 \\
0.2779 \\
0.3268 \\
0.5935 \\
0.2526 \\
0.8987 \\
1081\end{array}$ & $\begin{array}{r}0.3672 \\
0.8763 \\
0.3024 \\
0.3449 \\
0.6568 \\
0.2695 \\
0.9014 \\
1086\end{array}$ & $\begin{array}{r}0.3861 \\
0.9423 \\
0.3228 \\
0.3568 \\
0.6774 \\
0.2794 \\
0.9236 \\
1078\end{array}$ & $\begin{array}{r}0.4073 \\
1.0164 \\
0.3458 \\
0.3697 \\
0.6982 \\
0.2900 \\
0.9464 \\
1074\end{array}$ & $\begin{array}{r}0.3553 \\
0.8284 \\
0.2881 \\
0.3513 \\
0.7272 \\
0.2818 \\
0.9826 \\
1075\end{array}$ & $\begin{array}{r}0.3272 \\
0.7333 \\
0.2584 \\
0.2901 \\
0.4601 \\
0.2065 \\
0.6359 \\
1158\end{array}$ & $\begin{array}{r}0.3976 \\
0.9654 \\
0.3313 \\
0.3783 \\
0.7485 \\
0.3044 \\
1.0820 \\
1048\end{array}$ & $\begin{array}{r}0.3590 \\
0.8410 \\
0.2920 \\
0.3343 \\
0.6010 \\
0.2589 \\
0.9229 \\
1104\end{array}$ \\
\hline
\end{tabular}




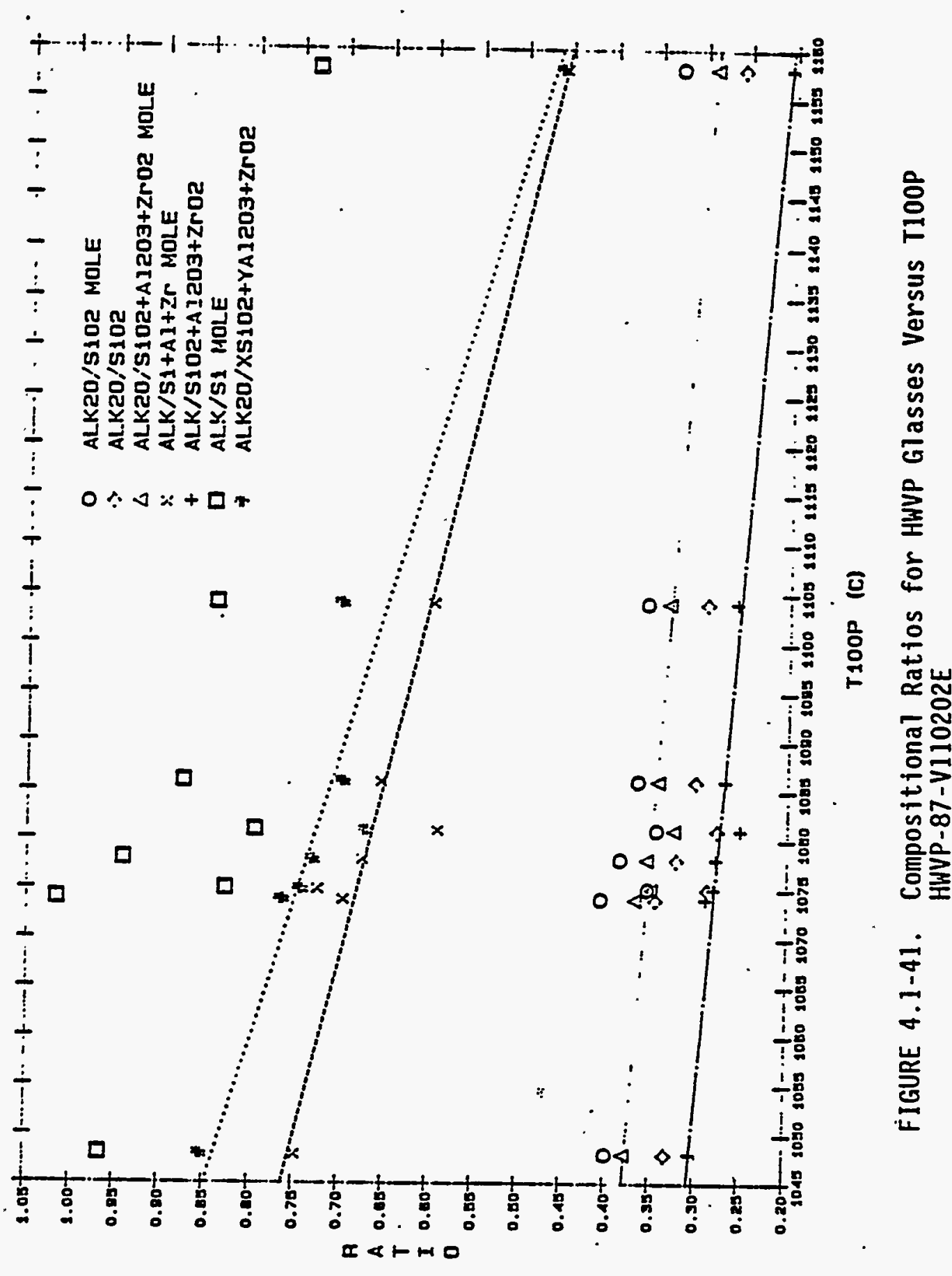


models developed from the variability scoping. studies, (a) the change in. TIOOP per wt\% change in each of the components was estimated. These estimates were made by maintaining a 25 wt\% waste loading and exchanging each component individually with frit until a 1 wt\% increase of the component was achieved in the glass composition. The predicted T100P was then subtracted from the predicted TI00P for the reference glass to calculate the $\Delta T 100 P /$ wt\% oxide for each component. These estimates of $\Delta T 100 P / w t \%$ oxide values are summarized in Table 4.1-60.

To compensate for the different $\Delta T 100 \mathrm{P} /$ wt\% oxide for each component, the alk $\mathrm{K}_{2} \mathrm{O} /\left(\mathrm{SiO}_{2}+\mathrm{Al}_{2} \mathrm{O}_{3}+\mathrm{ZrO}_{2}\right)$ relationship was modified by multiplying the wt\% of each component by its $\triangle T I O O P / w t \%$ oxide ( $i . e .$, onty the $\mathrm{Na}_{2} \mathrm{O}$ in the $a l \mathrm{k}_{2} \mathrm{O}$ was multiplied by 24). The compositional relationship now becomes

$$
\frac{\left(a 7 k_{2} \mathrm{O} \cdot 24\right)}{\left.\left.\left(\mathrm{SiO}_{2} \cdot 7\right)+\mathrm{Al}_{2} \mathrm{O}_{3} \cdot 5\right)+\mathrm{ZrO}_{2} \cdot 13\right)}
$$

The resulting values for the above ratio for each glass are plotted in Figure 4.1-41. Therefore, it can be concluded that the weighted ratio is only slightly better in predicting T100P than the other ratios evaluated.

4.1.3.6.3. Frit/Haste Variation Conclusions. Based on the study of $\mathrm{Na}$ and $S i$ proportions in the frit and waste, the foljowing conclusions are made:

- Up to $5 \mathrm{wt \%} \mathrm{Na}_{2} \mathrm{O}$ can be removed from the HW39 reference frit while maintaining a processable frit composition. In turn, the potential addition of 0 to $20 \mathrm{wt} \% \mathrm{Na}_{2} \mathrm{O}$ in the waste would be possible. For the NCAH 84 waste, this would mean a $\mathrm{Na}_{2} \mathrm{O}$ increase of from 11.1 to as high as 31.1 wt\% in the waste. For NCAW 86 waste this would mean a $\mathrm{Na}_{2} \mathrm{O}$ increase from 17.5 to approximately $33.5 \mathrm{wt} \%$.

TABLE 4.1-60. Estimated Change in T100P Per wt\% Change in Glass Components HWVP-87-V110202E

\begin{tabular}{|c|r|}
\hline Component & $\Delta T 100 \mathrm{P} /$ wt\% Oxide $(\cdot \mathrm{C})$ \\
\hline $\mathrm{Na}_{2} \mathrm{O}$ & -24 \\
$\mathrm{SiO}_{2}$ & 7 \\
$\mathrm{Al}_{2} \mathrm{O}_{3}$ & 5 \\
$\mathrm{ZrO}_{2}$ & 13 \\
\hline
\end{tabular}

(a) S. 0. Bates and W. M. Bowen, Interim Milestone HWVP-86-V1122C - Report on Composition Variability Testing Conducted for the Hanford Waste Vitrification Program. Pacific Northwest Laboratory; Richland, Washington (1986). 
- The additional $\mathrm{Na}$ allowable in the waste as the result of $\mathrm{Na}_{2} \mathrm{O}$ removal from the frit could provide additional flexibility in the B-plant washing-efficiency specifications.

- The existing flexibility of the reference glass composition can handle the normal fluctuation in the NCAW composition. The above modifications provide additional process flexibility for other waste being considered and for abnormal waste batched.

- Compositional ratios, the ratios of different glass components or the ratios of the sums of difference glass components, can be used to estimate the T100P of glass melts based on composition. The ratios using the total wt\% alkali oxides over the sum of the wt\%'s - of $\mathrm{SiO}_{2}, \mathrm{Al}_{2} \mathrm{O}_{3}$, and $\mathrm{ZrO}_{2}$ were found to predict the TIOOP well.

- The addition of $\mathrm{SiO}_{2}$ or sodium as partial replacement for frit, provides a method of adjusting the viscosity of abnormal waste batches or possible other wastes to within operating specifications.

\section{REFERENCES}

4.1-1 The Evaluation and Selection of Candidate High-Level Waste Forms. U.S. Department of Energy Savannah River Operations Office, Report DOE/TIC 11611 (March 1982).

4.1-2 Environmental Assessment: Haste Form Selection for SRP High-Level Waste. U.S. Department of Energy Report DOE/EA-0179 (JuTy 1982).

4.1-3 J. Stanek, Electric Melting of Glass, pp. 55-81. Elsevier/NorthHol land, Inc., New York, New York (1977).

4.1-4 C. L. Babcock, Silicate Glass Technology Methods, pp. 222-237. John Wiley \& Sons, New York (1977).

4.1-5 J. L. Ne7son, Preliminary Harford Waste Vitrification Plant Waste Form Qualification Plan. WHC-EP-0045, Hestinghouse Hanford Company, Richland, Washington (September 1987).

4.1-6 H. D. Schrieber, F. A. Sett7e, Jr., P. L. Jamison, J. P. Eckenrode, and G. W. Headley, "Ruthenium in Glass-Forming Borosilicate Melts." Jour. Less-Common Meta7s 115:145-154 (1985).

4.1-7 M. J. Plodinec, C. M. Jantzen, and G. C. Hicks, "Thermodynamịc Approach to Prediction of the Stability of Proposed Radwaste Giasses." In Nuclear Waste Management: Advances in Ceramics, Vol. 8, eds. G. C. Wicks and W. A. Ross, pp. 991-995, American Ceramic Society, Columbus, Ohio (1984). 
4.1-8 C. M. Jantzen, D. F. Bickford, and D. G. Karraker, "Time-TemperatureTransformation Kinetics in SRL Waste Glass." In Nuclear Waste Management: Advances in Ceramics, Vol. 8, eds. G. C. Hicks and W. A. Ross, pp. 30-38, American Ceramic Society, Columbus, Ohio (1984).

4.1-9 U.S. Department of Energy, Waste Acceptance Pre].iminary Specifications for the Defense Waste Processing Facjlity High Level Haste Form. ORG/B-8, draft for concurrence, U.S. Department of Energy, Washington, D.C. (1986).

4.1-10 Code of Federal-Regulations, "Disposal of High-Level Radioactive Waste in Geological Laboratories: Technical Criteria." 10 CFR 60, Nuclear Regulatory Comnission, Washington D.C. (1983).

4.1-11 J. M. Perez, Jr., and R. K. Nakaoka, "Vitrification Testing of Simulated High-Level Radioactive Haste at Hanford." Proceedings of Symposium on Waste Management ' 86 , Tucson, Arizona, eds. R. G. Post and M. E. Hacks, Vo7. II, pp. 495-505.

4.1-12 L. A. Chick and G. F. Piepel, "Statistical Designed Optimization of a Glass Composition." Am. Cer. Soc., Vol. 67(11):763-768.

4.1-13 M. B. Volf, Chemical Approach to Glass, Vol. 7 of Glass Science and Technology. ETsevier, New York (1984).

4.1-14 D.E. Brad7ey, Br. J. Physics 11:506-509 (1986).

4.1-15 W. Vogel, Chemistry of Glass, Trans. N. Kreidl. The American Ceramic Society, Inc., Columbus, Ohio (1985).

4.1-16 C. M. Jantzen, D. F. Bickford, and D. G. Karraker, "Time-Temperature Transformation Kinetics in SRL Waste Glass." In Nuclear Waste Management: Advances in Ceramics, Vol. 8, eds. G. C. Hicks and W. A. Ross, pp. 30-38, American Ceramic Society, Columbus, Ohio (1984).

4.1-17 E. Schiewer, "The Borosilicate Glass for PAMELA." Radioactive Waste Management and the Nuclear Fuel Cycle 7(2):121-138 (1985).

4.1-18 H. Mitamura et al., "Segregation of the Elements of the P7 atinum Group in a Simulated High-Level Waste Glass." Nuclear and Chemical Haste Management 4:245-251 (1983). 


\subsection{FEED RECEIPT (System 11)}

The feed receipt section summarizes the process technology related to feed receipt, lag storage, and transfer to the SRAT in HWVP.

\subsubsection{Function}

The primary purposes of this tank system, including pipelines and spares from diversion box ER-154, are to receive HWVP feed from the tank farms and to provide feed lag storage before processing. This tank system also provides receipt and recycle of the TRU bottoms stream from the DWTT located in the CPC of the Vitrification Building via the radioactive process waste collection and treatment system. This blended feed is transferred to the feed preparation system for melter feed makeup.

\subsubsection{Operational Requi rements}

The operational requirements of the RLST are provided in Table 4.2-1.

\subsubsection{Process Chemistry}

No chemical processes are performed in this tank.

\section{4:2.4 Technology Development}

There is no technology development for the RLST. There are no chemical processes in the RLST. The major concern in the RLST is the ability to homogenize the tank contents.

Bases for the agitation design requirements to achieve homogeneous RLST contents can be provided by the physical and rheological properties of the slurry. Applicable properties and a comparison with available DWPF washed slurry properties are provided in Table 4.2-2.

The slow initial settling rate $(8 \mathrm{~cm} / \mathrm{h})$, relatively high settled solids volume percent (21 v07\%), and low settled solids shear strength (20 dynes/cm) for the $1.7 \mathrm{wt} \%$ solids slurry suggest that the solids are easily homogenized and easily.resuspended with a suitably designed tank mixing system. The low yield stress ( 0 to 1 dynes $/ \mathrm{cm}^{2}$ ) and consistency suggest that the slurry may be regarded as a neutonian fluid for design purposes. Standard desiign practices for siurry suspension or homogenization can be used for equipment design. As the solids content in the slurry increases the slurry becomes increasingly pseodoplastic, and greater care is required in designing the agitation system. 
TABLE 4.2-1. Receipt and Lag Storage Tank Operational Requirements

- recaive Hiv feed from tank farm at a transfer rate up to $100 \mathrm{gpm}$

- receive TRU waste from orst at a transfer rate up to $100 \mathrm{gpm}$

- routing flexibifity to necive hyp radipactive process wate from int at a transfer rate up to $100 \mathrm{gpm}$

- routing flexibtitity to restive seat enin coneents at a raes up to 100 gom

- winime full working volue of 50,000 gal

- cool and mintain contentes at $95 \%\left(35^{\circ} \mathrm{C}\right)$. Tank contentes nomaliy cooled to $122^{\circ} \mathrm{F}\left(50^{\circ} \mathrm{C}\right)$.

- dissipate radionucl fde decay heat

- reference - stu/h

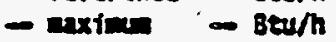

- aineain homgineous hMP fand coneentration through agitation

- transfer representative supie of tank contents to saple call

- bateh transfer hinP feed to SRat at a rate of up to $100 \mathrm{gpm}$

- continuously transfer Miv fead to SRAT at a controlled rate of 1 to $10 \mathrm{grm}$

- routing flextbitity to bateh transfor hip feed to sie at a rate of up to $100 \mathrm{gim}$

- routing flexibility to continuousiy transfer hap feed to ShE at a controlled rate of 1 to 10. $\mathrm{gin}$

- Aush al1 transfer linas

- detect leaks from primary tank

- datece leaks from secondary tank

- pup ifquid fro secondary tante to primary tank

- Eaineain vecum contor in prinary tant

- untntain vecui control in secondary tank

- monter redfation level in' secondary ents

- receive pumpout fron leak detecsion mil

- provide suffictent air inleakage to prevent explosive hydrogen concentration butidup

- RLST instrumeation

- Itquid level: 2 to 188 in.

- temperature:. 20 to $220^{\circ} 8$ (-7 to $\left.105^{\circ} \mathrm{C}\right)$

- spectfle gravity: 0.9 to 1.4

- vecuu

- wonftor radiction levei in leak detection wil

- leak detection mll pup pit instrumentation

- Itqutd level

- temerature

- spectifle gravity 
TABLE 4.2-2. Washed STudge STurry Physical and Rheological Properties

\begin{tabular}{|c|c|c|}
\hline Characteristic & $\begin{array}{c}\text { Synthetic } \\
\text { HWVP }\end{array}$ & $\begin{array}{l}\text { Synthet ic } \\
\text { DWPF }\end{array}$ \\
\hline Wt\% solids & $\begin{array}{r}1.7^{(a)}(b) \\
6(b)\end{array}$ & $\begin{array}{l}5 \text { (except as noted } \\
\text { DPSTD-84-100) }(C)\end{array}$ \\
\hline $\begin{array}{l}\text { Slurry yield stress } \\
\left.\text { (dynes } / \mathrm{cm}^{2}\right)\end{array}$ & $\begin{array}{l}1.9 \text { @ } 50^{\circ} \mathrm{C}(\mathrm{a}) \\
10 \mathrm{Rm} \operatorname{temp}(\mathrm{b})\end{array}$ & Negligible ${ }^{(c)}$ \\
\hline $\begin{array}{l}\text { Consistency } \\
\text { Apparent viscosity } \\
\text { (Cp) }\end{array}$ & $\begin{array}{l}2.9 \text { @ } 50^{\circ} \mathrm{C}, 183^{5^{-1}}(\mathrm{a}) \\
3 \text { \& Rm Temp, } 183^{-1}(b)\end{array}$ & Negl igible $e^{(c)}$ \\
\hline $\begin{array}{l}\text { Initial settling } \\
\text { rate }(\mathrm{cm} / \mathrm{h})\end{array}$ & $8.3 \ominus \mathrm{Rm}$ Temp (a) & $\begin{array}{l}6.40{ }^{-1} \text { wt\% insoluble } \\
\text { solids }(c)\end{array}$ \\
\hline Final volume \% & $21(a)$ & $\begin{array}{l}140-1 \text { wt\% insoluble } \\
\text { solids }(c)^{\text {rt }}\end{array}$ \\
\hline $\begin{array}{l}\text { Shear strength of } \\
\text { settled solids } \\
\text { (dynes } / \mathrm{cm}^{2} \text { ) }\end{array}$ & $20(a)$ & $-\infty$ \\
\hline $\begin{array}{l}\text { Slurry specific } \\
\text { gravity }\end{array}$ & $\begin{array}{l}1.04(a) \\
1.05(b)\end{array}$ & $1.03(c)$ \\
\hline
\end{tabular}

(a) Appendix A. This settling rate may not conform to maximum free settling rate of largest particles. This is likely the solids/ liquid interface initial movement rate.

(b) R. Farnsworth et al., "HWVP Feed Process Variability Testing for Fiscal Year 1986," RHO-RE-CR-16P/HWVP-V1123C, Pacific Northwest Laboratory, Richland, Washington (September 17, 1986).

(c) T. Motyka, "Technical Data Summary for In-Tank Sludge Processing, DPSTD-84-100, Savannah River Laboratory, Aiken, South Carolina (Apri7 1984). 



\subsection{FEED PREPARATION (System 12)}

The feed preparation section summarizes process technology related to concentrating and formating HWVP feed together with meiter feed makeup.

\subsubsection{Function}

The primary purposes of this multi-tank feed preparation system is to receive the HWVP feed from the receipt and Tag storage tank (RLST), make up the HWVP feed to the melter feed specifications, and transfer the prepared slurry to the melter feed system.

\section{3:2 Operational Requirements}

The operational requirements for the SRAT, SME, and SMECT are provided in Tables 4.3-1, 4.3-2, and 4.3-3, respectively.

\subsubsection{Process Chemistry}

The process chemistry for the SRAT and the SME is described in this section.

4.3.3.1 Slurry Receipt and Adjustment Tank. The primary chemistry in the SRAT is the adjustment of the HWVP feed rheological and redox properties through feed concentration and formating reactions. The formating reaction was original7y developed at SRL to reduce mercury from an oxide to a metal for removal from the melter feed. It was found that the formating reaction al so adjusts the concentrated feed rheology to reduce the yield point, the apparent viscosity, and solids settling rate in the non-Newtonian feed to make the feed easier to process. Also, the formating reaction chemically reduces some metals to lower valence states. The formate supplies adequate carbon to keep the atmosphere in the melter and glass reducing to inhibit releases of oxygen in the molten glass, which prevents the molten glass in the melter from foaming. There is likely additional metal reduction in the melter crust to prevent oxygen release in the melt.

The stoichiometry for the formating reactions proposed by.SRL(a) for DWPF feed is indicated in Table 4.3.4. The reactions are primarily acid base neutralization reactions with carbonate decomposition on the acid side. There are also limited reduction reactions such as on $\mathrm{Mn}^{+4}, \mathrm{Hg}^{+2}, \mathrm{Ag}^{+1}, \mathrm{Pd}^{+2}$, $\mathrm{Rh}^{+4}$, and $\mathrm{Cr}^{+6}$. The reaction stoichiometry is affected by feed composition and process conditions. The reaction definition is based on chemical and thermodynamic considerations but have not been well defined.

(a) E.I. du Pont de Nemours \& Company, Basic Data Report - DWPF-STudge Plant, SRP-200-S Area. DPSP 80-133, Savannah River Plant, Aiken, South Carolina, (April 1985). 


\section{TABLE 4.3-1. SRAT Operationat Requirements}

The operational requirements of the SRAT are as follows:

- receive HWV feed ( 2 to 15 wt\% total solids) from RLST at a transfer rate up to $100 \mathrm{gpm}$ and a controlied feed rate of 2 to $10 \mathrm{gpm}$

- maximum operating volume 9400 gal of hwVp or formated HWVP feed

- concentrate hWWP feed at a rate of up to $10 \mathrm{gpm}$

- route concentration overheads to a tank mounted SRAT condenser

- SRAT condenser condensate routed to SHECT and the off gas is routed to the vessel vent systen

- cool and maintain formated HWV feed at $95^{\circ} \mathrm{F}\left(35^{\circ} \mathrm{C}\right)$ [normally cooled to $\left.122^{\circ} \mathrm{F}\left(50^{\circ} \mathrm{C}\right)\right]\left(35^{\circ} \mathrm{C}\right.$ based on flexibility for jet transfer, $50^{\circ} \mathrm{C}$ based on DHPF puap transfer)

- dissipate radionuclide decay heat

- maintain homogeneous tank contents through agitation

- add 90 wt: formic acid to tank at a controlled rate of 2 gpm, control pange 0.5 - 5 gpa

- maintain tank.contents temperature. at $199{ }^{\circ} \mathrm{F}\left(93^{\circ} \mathrm{C}\right)$, range $194^{\circ} \mathrm{F}$ $\left(90^{\circ} \mathrm{C}\right)$ - $208^{\circ} \mathrm{F}\left(98^{\circ} \mathrm{C}\right)$ to provide flexibility for formating

- boil tank contents under full condensate reflux conditions

- sample tank conterits (representative sample)

- batch transfer formated HWWP feed to SME at a rate up to $100 \mathrm{gpm}$

- monitor contents and status

-1 lquid level: 2.to 155 in. (instrument range: 0 to 160 in.)

- specific gravity: 0.9 to 1.5

- temperature: 30 to $230 \circ \mathrm{F}$

-- vaculan: > cell vacuum

-. (pH: 2 to 13)

- add chemicals solutions/siurries at a controlled rate of 2 up to 50 gpar

- provide routing flexibility to add spent frit slurry and process frit from the PFSFT in the cold chemical area of the vitrification building

- provide routing flexibility to batch transfer SRAT contents to the MFT

- provide routine flexibility to return SRAT contents to the RLST

- provide tank ventilation/overfiow control to cell

- monitor condenser condensate and effluent temperature

- provide routing flexibility for SRAT to receive contents of SHE and MFT

- provide sufficient air inleakage to prevent explosive hydrogen concentration buildup

- flush tank mounted condenser with water or chemicals

- receive TRU recycle slurry at rates up to $100 \mathrm{gpm}$ 


\section{TABLE 4.3-2. SME Operational Requirements}

The operational requirements of the SME are as follows:

- receive feed from the SRAT at a transfer rate up to $100 \mathrm{gpm}$

- maximum operating volume $9400 \mathrm{gal}$ of formated HWP feed or made-up . melter feed

- concentrate melter feed at a rate of up to $10 \mathrm{gpm}$

- route concentration overheads to a tank mounted SHE condenser

- SME condenser condensate routed to SMECT and the off gas is routed to the vessel vent system

- cool and maintain made-up melter feed at $95^{\circ} \mathrm{F}\left(35^{\circ} \mathrm{C}\right)$ (nomally cooled to $122^{\circ} \mathrm{F}\left(50^{\circ} \mathrm{C}\right)\left(35^{\circ} \mathrm{C}\right.$ based on flexibility for jet transfer; $50^{\circ} \mathrm{C}$ based on DWPF pump transfer)

- dissipate radionuclide decay heat

- maintain homogeneous tank contents through agitation

- add spent frit slurry to SME at a controlled rate up. to $100 \mathrm{gpm}$

- add process frit slurry from PFSFT to SHE at a controlled rate up to $50 \mathrm{gpm}$

- sample tank contents

- batch transfer made-up melter feed to MFT at a rate up to $100 \mathrm{gpm}$

- monitor contents and status

$\therefore$ liquid level: 2 to 155 in (instrument range: ' 0 to 160 in.)

-. specific gravity: 0.9 to 1.5

-- temperature: ( 30 to $2300^{\circ} F$ )

-. vacuum: > cell vacuum

-. (pH: 2 to 13)

- add chemicais, solutions/slurries at a controlled rate of 2 up to $50 \mathrm{gpm}$

- add $90 \mathrm{wt \%}$ formic acid to tanks at a controlled rate of $2 \mathrm{gpm}$, control range 0.5 to $5 \mathrm{gpm}$

- provide routing flexibility to batch transfer SME contents to RLST

- provide routing flexibility to batch (100 gpm) and controlled $\left(2\right.$ to ${ }^{\circ}$ $10 \mathrm{gpm}$ ) transfer from RLST to SHE

- provide routing flexibility to batch transfer SME contents to SRAT

- provide ventilation/overfiow control to cell

- provide routing flexibility to transfer MFT contents to SHE

- provide capability to fully recycle SHE condenser condensate .

- provide sufficient air inleakage to prevent explosive hydrogen con-. centration buildup

- flush tank-mounted condenser with water or chemicals

- monitor condenser exit air and condensate temperature

- provide routing flexibility to receive TRU recycle slurry at rates up to $100 \mathrm{gpm}$ 
TABLE 4.3-3. SMECT Operational Requirements

The operational requirements of the SMECT are as follows:

SMECT

- receive condensate from SRAT condenser and SME condenser

- maximum operating volume $9400 \mathrm{gal}$ of condensate

- sample tank contents

- monitor contents and status

-- liquid level: 2. to 155

- specific gravity: 0.9 to 1.5

- temperature: 30 to $230 . \%$

-. vacuum: > cell vacuum

-- (pH: 2 to 13 )

- add chemicals as solutions

- vent to the vessel vent system

- batch transfer condensate to DWTT at rates up to $100 \mathrm{gpm}$

- provide ventilation/overflow control to cell 
At SRL, the quantity of $\mathrm{HCOOH}$ added to the SRAT is based on the quantity required to satisfy 90\% of the stoichiometry in Table 4.3-4 (assuming each reaction goes to completion). The precipitate product is neglected.(a) Selected reactions do not go to completion with stoichiometric addition of formic acid, as indicated by the percentages following the last reaction product. The formic acid strength used is $90 \mathrm{wt} \%$. SRL studies(b) showed that addition of $120 \%$ of the stoichiometry caused an excessive reducing condition in the melter, where some metals precipitated out:

The formating reaction is begun at an elevated temperature $\left[185^{\circ} \mathrm{F}\right.$ to $200{ }^{\circ} \mathrm{F}\left(85^{\circ} \mathrm{C}\right.$ to $\left.\left.93^{\circ} \mathrm{C}\right)\right]^{(\mathrm{C})}$ with agitation to rapidiy initiate the reaction and provide suitable reaction kinetics. Most of the reactions occur during the formic acid addition. (c) On completion of the formic acid addition the slurry is heated to boiling with full reflux to increase the reaction kinetics and to complete slow reactions such as the $\mathrm{MnO}_{2}$ conversion. The concentrator overheads are completely refluxed during the reaction to minimize formic acid loss. The limiting reaction rate appears to be the $\mathrm{Mn}^{+4} \rightarrow$ $\mathrm{Mn}^{+2}$ conversion. This reaction progress is shown in Figure 4.3-1, which indicates that most of the reaction is completed after 2 to $4 \mathrm{~h}$.

Studies at SRL(a) have indicated that the reaction can be suitably controlled by regulating the addition rate of the $90 \mathrm{wt} \%$ formic acid. The addition of formic acid at a $2 \mathrm{gpm}$ rate in the DWPF to $13 \mathrm{wt} \%$ solids feed produces a controllable reaction without excessive foaming or vessel pressurization. Vessel off-gas flow (vacuum decrease) and $\mathrm{pH}$ change could be used as indications of reaction completion. PNL studies with synthetic HWVP feed (NCAW 84 high chromium) show that there is a mild tendency to foam while formating and adding the acid slowiy, but the foaming tendency is not significant.

The formate addition experience at SRL (d) indicates that the amount of formic acid required is the stoichiometric quantity to react with the calcium, manganese, nicke1, and mercury present in the DWPF feed. Based on this information, the quantity of formic acid for the HWVP reference feed simulation was estimated as the amount needed to stoichiometrically react with the

(a) F. D. Nankani, "Trip Conference-Report - HWVP/DWPF Technical Exchange Meeting - Slurry Feed Preparation and Melter Feed System," 65651-TCR86-002, Rockwe 17 Hanford Operations, January 1, 1980.

(b) Memorandum from E. J. Weber to M. D. Boersma, "Progress of Large-Scale SRAT/SME Study," DPST-82-733, Savannah River Laboratory, Aiken, South Carolina, dated July $21,1982$.

(c) E.I. du Pont de Nemours \& Company, Basic Data Report - DWPF-STudge Plant, SRP-200-S Area. DPSP 80-133, Savannah River P1ant, Aiken, .South Carolina, (April 1985).

(d) Memorandum from R. E. Eibling to R. B. Ferguson, "Results of Mercury Reduction with Formic Acid," DPST-83-1047, Savannah River Laboratory, Aiken, South Carolina, dated December 1, 1983. 
TABLE 4.3-4. Formating Reaction Stoichiometry, Sludge-Only Feed - DWPF. Each reaction goes to completion unless otherwise noted: (E.I. du Pont de Nemours \& Company, Basic Data Report DWPF-STudge PTant, SRP 200-S Area, DPSP 80-133, Apri7 1985)

\begin{tabular}{|c|c|}
\hline Reactants & Products \\
\hline 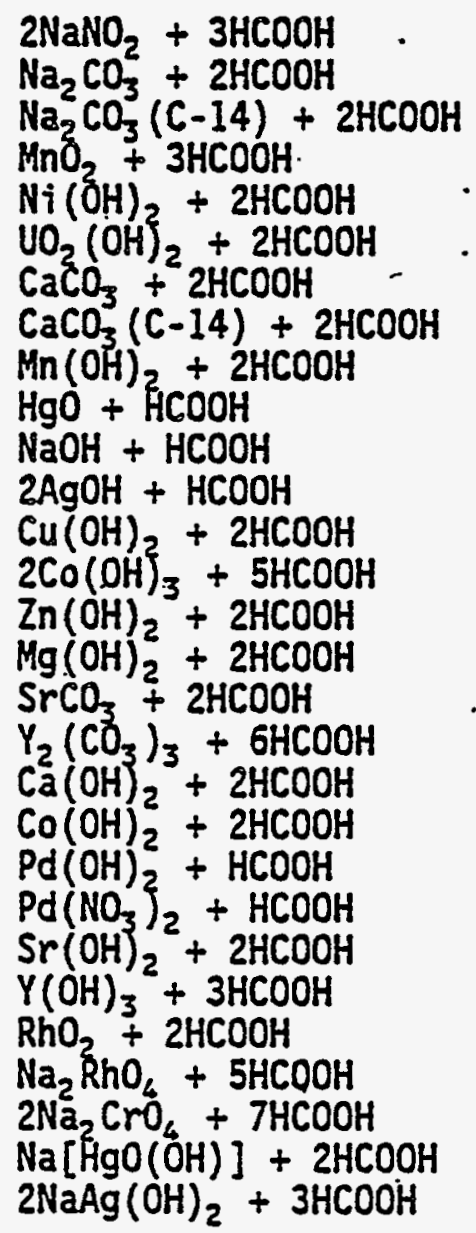 & 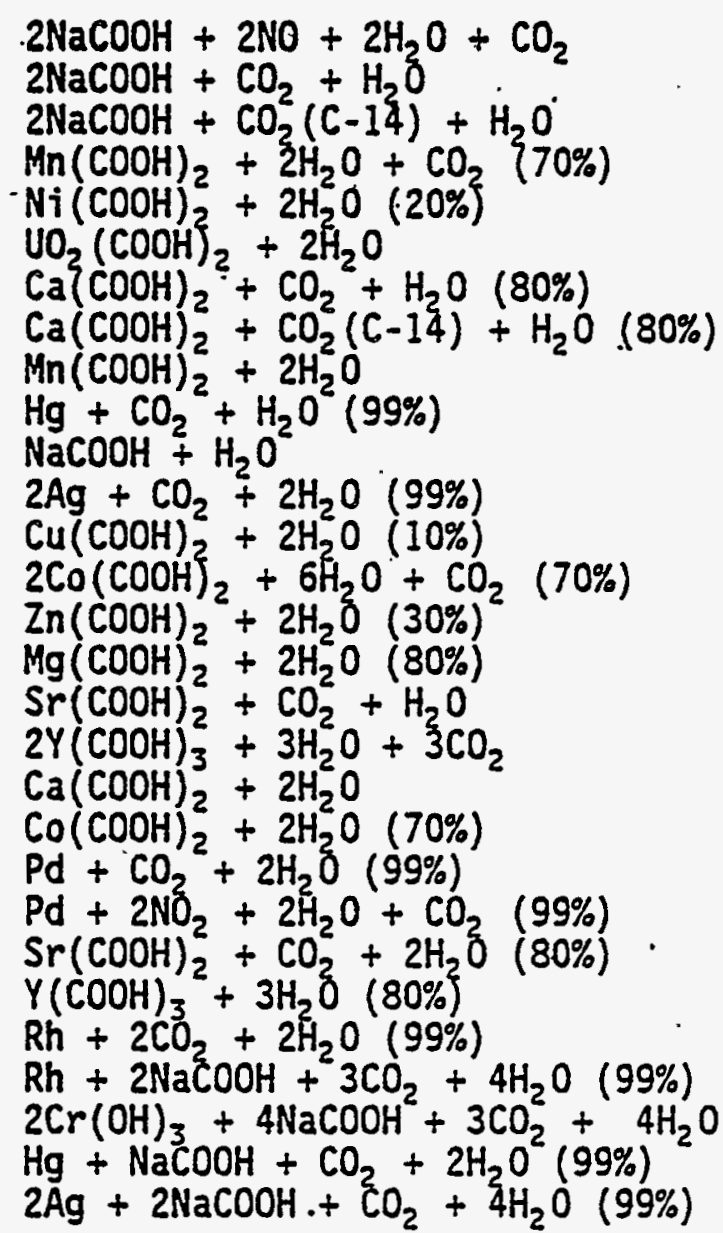 \\
\hline
\end{tabular}


NOTES:

1. A71 percentages for partial reactions are based on the reference feed blend and consequently subject to shift with overall composition changes between feed types.

2. Group $A$ includes $\mathrm{Cd}, \mathrm{Mo}, \mathrm{Rb}, \mathrm{Se}, \mathrm{Tc}, \mathrm{Te}$.

3. Group B includes $\mathrm{Ag}, \mathrm{Am}, \mathrm{Ca}, \mathrm{Cm}, \mathrm{Co}, \mathrm{Cr}, \mathrm{Eu}, \mathrm{La}, \mathrm{Nb}, \mathrm{Nd}, \mathrm{Np}, \mathrm{Pm}, \mathrm{Pr}$, $\mathrm{Sb}, \mathrm{Sm}, \mathrm{Sn}, \mathrm{Tb}, \mathrm{T} 7, \mathrm{Zr}$.

4. The following feed components do not react:

\begin{tabular}{|c|c|c|c|}
\hline Soluble Solids & Soluble Solids & Insoluble Solids & Insoluble Solids \\
\hline $\begin{array}{l}\mathrm{Ba}\left(\mathrm{NO}_{3}\right)_{2} \\
\mathrm{CaSO}_{4} \\
\mathrm{CsNO}_{3} \\
\mathrm{Group} \mathrm{A} \\
\mathrm{Group}_{\mathrm{B}} \mathrm{B} \\
\mathrm{NH}_{4} \mathrm{NO}_{3} \\
\mathrm{Na}_{2} \mathrm{C}_{2} \mathrm{O}_{4} \\
\mathrm{Na}_{2} \mathrm{MoO}_{4} \\
\mathrm{Na}_{2} \mathrm{PuO}_{2}(\mathrm{OH})_{2} \\
\mathrm{Na}_{2} \mathrm{RuO}_{4} \\
\mathrm{Na}_{2} \mathrm{SO}_{4}\end{array}$ & $\begin{array}{l}\mathrm{Na}_{2} \mathrm{SiO}_{3} \\
\mathrm{Na}_{3} \mathrm{PO}_{4} \\
\mathrm{NaAT}(\mathrm{OH})_{4} \\
\mathrm{NaCl} \\
\mathrm{NaF} \\
\mathrm{NaI} \\
\mathrm{NaNO}_{3} \\
\mathrm{Sr}_{3}\left(\mathrm{NO}_{3}\right)_{2} \\
\mathrm{Tritium}_{3} \\
\mathrm{Y}\left(\mathrm{NO}_{3}\right)_{3}\end{array}$ & $\begin{array}{l}\mathrm{Al}(\mathrm{OH})_{3} \\
\mathrm{BaSO}_{4} \\
\mathrm{Ca}_{3}\left(\mathrm{PO}_{4}\right)_{2} \\
\mathrm{CaC}_{2} \mathrm{O}_{4} \\
\mathrm{CaF}_{2} \\
\mathrm{CaSO}_{4} \\
\mathrm{Carbon} \\
\mathrm{Co}(\mathrm{OH})_{3} \\
\mathrm{CrOH})_{3} \\
\mathrm{CSNN}{ }_{3} \\
\left.\mathrm{Fe}_{3} \mathrm{OH}\right)_{3} \\
\text { Group A } \\
\text { Group B } \\
\mathrm{KNO}_{3}\end{array}$ & $\begin{array}{l}\mathrm{Na}_{2} \mathrm{SO}_{4} \\
\mathrm{Na}_{3} \mathrm{PO}_{4} \\
\mathrm{NaCl}_{4} \\
\mathrm{NaF} \\
\mathrm{NaI} \\
\mathrm{NaNO}{ }_{3} \\
\mathrm{PbCO}_{3} \\
\mathrm{PbSO}_{4} \\
\mathrm{PuO}_{2} \\
\mathrm{RuO}_{2} \\
\mathrm{SiO}_{2} \\
\mathrm{ThO}_{3} \\
\mathrm{UO}_{2}\left(\mathrm{OH}_{2}\right. \\
\mathrm{ZeO} \text { ite }\end{array}$ \\
\hline
\end{tabular}

mono- and divalent hydroxides and all the carbonates in the simulation. The $100 \%$ stoichiometric concentration is 1.87 moles of formic acid per liter for the DWPF feed, while $0.43 \mathrm{moles} / \mathrm{L}$ is the stoichiometric quantity for the initial HWVP reference feed simulation. The difference between the DWPF feed and HWVP reference feed simulations is that the latter contains no calcium and mercury and much less nickel and manganese. The stoichiometric quantity of formic acid for the more rigorous HWVP reference feed simulation is only $0.29 \mathrm{moles} / \mathrm{L}$ of concentrate, because there are no carbonates in this simulation $(0.092 \mathrm{~g} \mathrm{HCOOH} / \mathrm{g}$ waste oxides).

The effects of formating on the rheoiogy and physical properties of HWVP feed in the make-up melter feed are fully discussed in Section 4.3.4.

The primary criteria developed at PNL for formic acid addition to HWV. feeds is adequate formic acid addition to assure the glass produced from melter feed is in the proper redox control range (glass $\mathrm{Fe}^{+2} / \mathrm{Fe}^{+3}$ between 0.005 and 0.3 ). This formic acid addition amount has been shown to control 


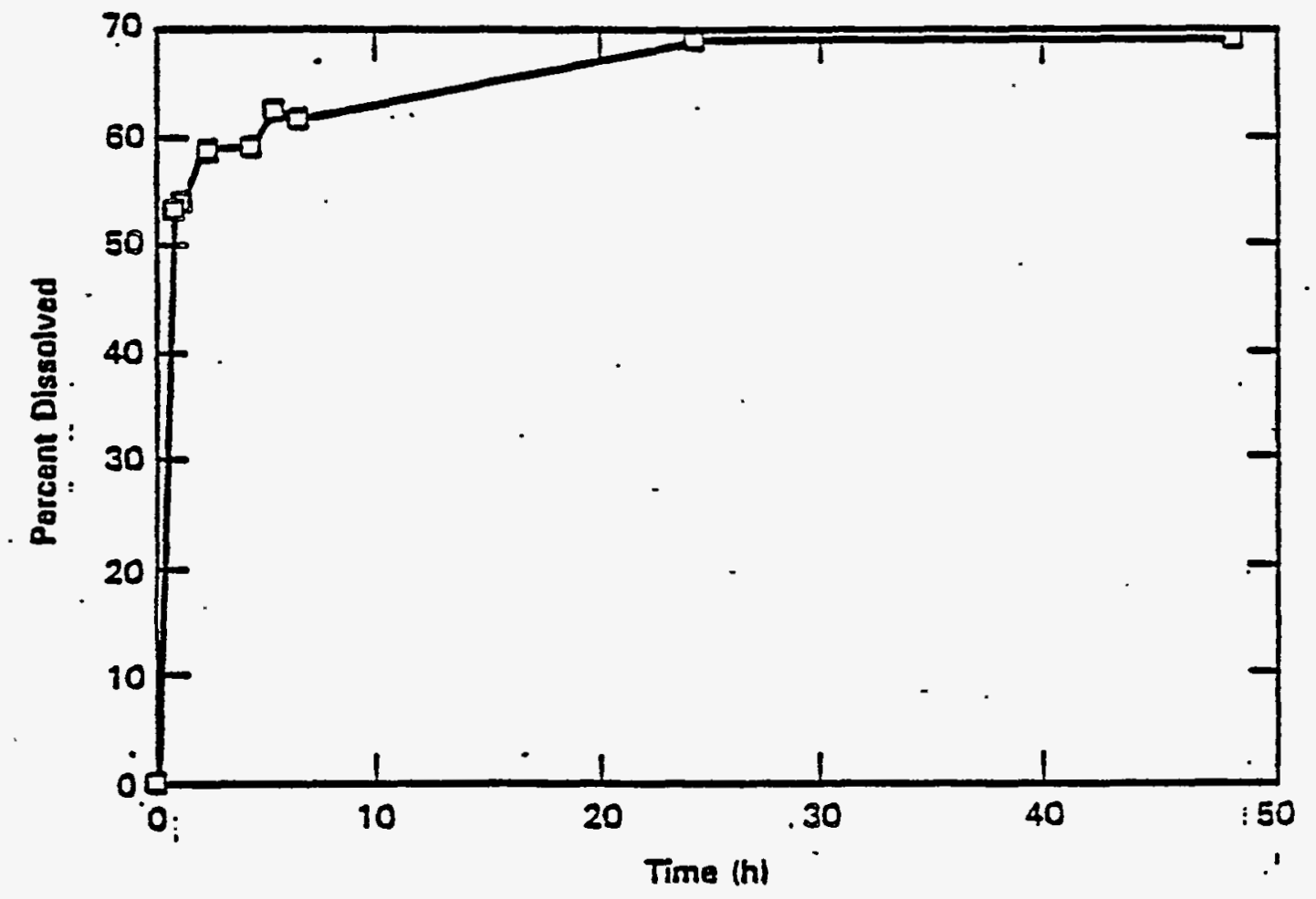

FIGURE 4.3-1. Manganese During Formic Acid Refluxing - DWPF

melter foaming from redox reactions and produce process slurries with acceptable rheology for plant processing. This criteria results in adding similar stoichiometry amounts of formic acid as for DWPF feeds. The chemical reactions of formating HWVP feeds have not been fully characterized, but are presumed to be similar to DHPF accounting for feed composition differences. For HWVP it is assumed that $\mathrm{Sm}, \mathrm{Pr}$, and Ce hydroxides are neutralized by formic acid because these elements are rare earth hydroxides that should be easily neutralized.

The amount of formic acid addition required to achieve acceptable redox conditions in variations of HWVP feed compositions is shown in Figure 4.3-2. Data from Figure 4.3-2 show that:

- Increasing the feed's $\mathrm{Zr}$ concentration increases the redox state of the glass if equivalent amounts of formic acid have been added.

- Increasing the feed's $\mathrm{Na}$ concentration increases the redox state of the glass if equivalent amounts of formic acid have been added.

- Decreasing the feed's aluminum concentration increases the redox state of the glass if equivalent amounts of formic acid addition have been added. 


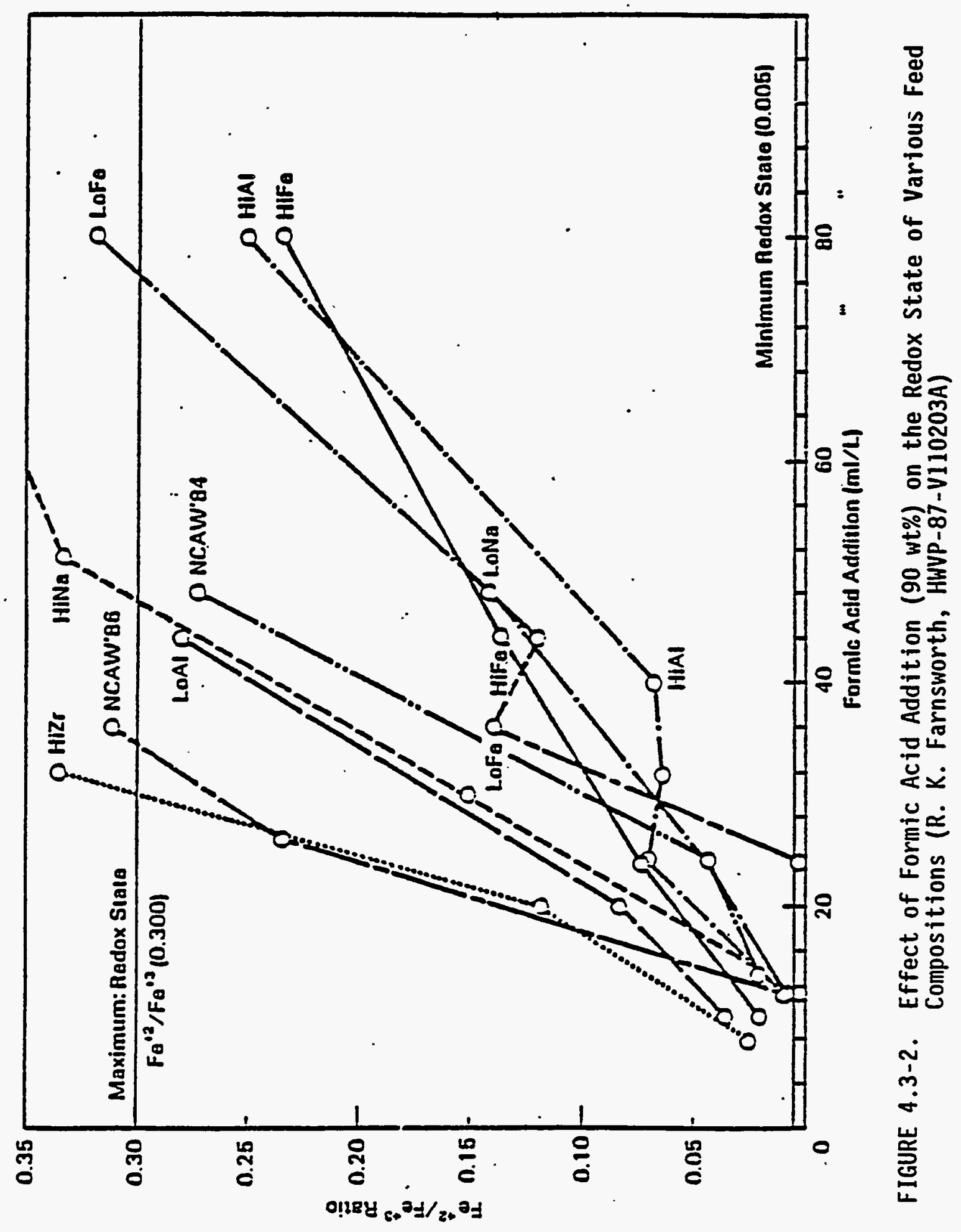


Changing the Fe concentration in the feed results in a decrease in the redox state of the glass. Reasons for this change are not readily apparent.

The predominant gas constituent released during feed formating is carbon dioxide $\left(\mathrm{CO}_{2}\right)$. (a) Most of the $\mathrm{CO}_{2}$ is predicted to be produced by the reduction of. ferric ion by formic acid as represented in equation (1).

$$
2 \mathrm{Fe}^{+3}+\mathrm{H}_{2} \mathrm{CO}_{2}=2 \mathrm{Fe}^{+2}+\mathrm{CO}_{2}+2 \mathrm{H}^{+}
$$

The detection of $\mathrm{NO}_{\mathrm{x}}$ during a PNL study(a) indicates that nitrate ions may also be reduced by formic acid. This redox reaction also produces $\mathrm{CO}_{2}$ in accordance with the following redox equation:

$$
2 \mathrm{NO}_{3}^{-}+3 \mathrm{H}_{2} \mathrm{CO}_{2}+2 \mathrm{H}^{+}=2 \mathrm{NO}+3 \mathrm{CO}_{2}+4 \mathrm{H}_{2} \mathrm{O}
$$

- Carbon dioxide $\left(\mathrm{CO}_{2}\right)$ may also be produced by decomposition of formic acid, particularly in the presence of noble metal catalyst. The decomposition reaction also produces $\mathrm{H}_{2}$

$$
\mathrm{HCOOH}=\mathrm{CO}_{2}+\mathrm{H}_{2}
$$

PNL studies show that the gasses released during the feed formating process are dependent upon the activity of redox reactions. Figure $4.3-3$ i7lustrates the theoretical pH dependence of the reactions pertinent to the feed formating process; namely those involving the production of $\mathrm{CO}_{2}, \mathrm{H}_{2}$, $\mathrm{NO}$, and $\mathrm{N}_{2} \mathrm{O}$ from $\mathrm{Fe}$, formic acid, nitrate, and water redox reactions. Other potential feed component redox reactions may influence the net amount of gases released; however, for the present treatment these reactions are considered insignificant relative to iron and nitrate activity based on redox behaviors and respective concentrations in the simulant feed. Indirectiy, the feed formating reactions may be influenced kinetically by changes in the physical nature of the feed caused by the formation of sols, e.g., hydrated zirconium hydroxides, as indicated by changes in the feed viscosity during the formating process.

For comparison, the balanced redox equations involving formic acid, water, iron, and nitrate and their respective redox potentials are given in Table 4.3-5.

The reduction of $\mathrm{Fe}^{+3}$ to $\mathrm{Fe}^{+2}$ by formic acid becomes thermodynamically more favorable between the $\mathrm{pH}$ range of 7 to 1. Similar, but less extreme behavior is exhibited for $\mathrm{NO}_{3}{ }^{-}$to $\mathrm{N}_{2} \mathrm{O}$ redox reactions. A s.light favorable increase in the thermodynamics, favorable for production of $\mathrm{H}_{2}$, occurs as the $\mathrm{pH}$ decreases from 7 to $\mathrm{I}$. Maximum release rates and amounts of $\mathrm{CO}_{2}$ were

(a) K. D. Wiemers et al., Evaluation of Process Off-Gases Released During Formating of an HWVP Feed Simulant. HWVP-87-V110203G, Pacific Northwest Laboratory, Richland, Washington (September 1987). 


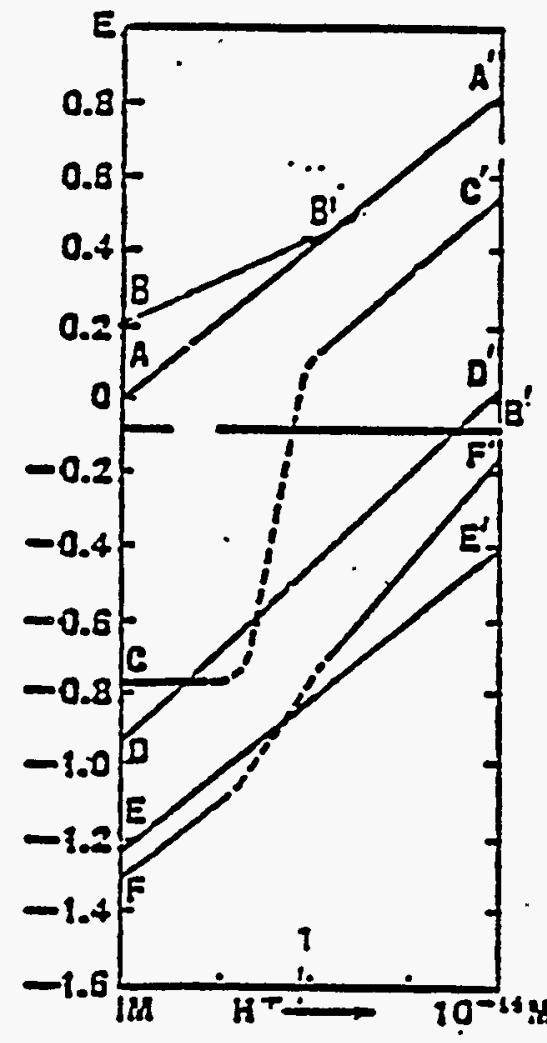

$$
\begin{aligned}
& \text { A } 1 / 2 \mathrm{H}_{2}=\mathrm{H}^{+}+\mathrm{e}^{-} \\
& \mathrm{A}^{\prime} \mathrm{I} / 2 \mathrm{H}_{2}+\mathrm{OH}^{-}=\mathrm{H}_{2} \mathrm{O}+\mathrm{e}^{-} \\
& \text {B } \mathrm{HCO}_{2} \mathrm{H}^{2}=\mathrm{CO}_{2}+2 \mathrm{H}^{2}+2 e^{-} \\
& \mathrm{B}^{\prime} \mathrm{HCO}_{2}^{-}+\mathrm{OH}^{2} \rightarrow \mathrm{CO}_{2}+2 \mathrm{H}_{2} \mathrm{O}+2 \mathrm{e}^{-} \\
& \text {C } \mathrm{Fe}^{++}=\mathrm{Fe}^{+++}+\mathrm{e}^{2} \\
& \mathrm{C}^{\prime} \mathrm{OH}^{-}+\mathrm{Fe}(\mathrm{OH})_{2}=\mathrm{Fe}(\mathrm{OH})_{3}+\mathrm{e}^{-} \\
& \text {D } 2 \mathrm{H}_{2} \mathrm{O}+\mathrm{NO}=\mathrm{NO}_{3}+4 \mathrm{H}^{+}+3 e^{-} \\
& D^{\prime} 40 \mathrm{H}+\mathrm{NO}=\mathrm{NO}_{3}{ }^{-}+3 \mathrm{e}^{-} \\
& \text {E } \mathrm{H}_{2} \mathrm{O}=1 / 2 \mathrm{O}_{3}+2 \mathrm{H}^{+}+2 \mathrm{e}^{-} \text {. } \\
& \mathrm{E}^{\prime} 2 \mathrm{OH}^{-}=1 / 2 \mathrm{O}_{2}+\mathrm{H}_{2} \mathrm{O}+2 \mathrm{e}^{-} \\
& \text {F } \mathrm{N}_{2} \mathrm{O}+3 \mathrm{H}_{2} \mathrm{O}=2 \mathrm{HNO}_{2}+4 \mathrm{H}^{+}+4 \mathrm{e}^{-} \\
& F^{\prime} \mathrm{N}_{2}^{2} \mathrm{O}+6 \mathrm{OH}^{-}=2 \mathrm{NO}_{2}^{2}+3 \mathrm{H}_{2} \mathrm{O}+4 \mathrm{e}^{-}
\end{aligned}
$$

FIGURE 4.3-3. Change of Potential with Concentration of $\mathrm{H}^{+}$for Pertinent Feed Formating Components (Ref. 4.3-1)

TABLE 4.3-5. Balanced Redox Equations for Major Feed Formating Reactions

\begin{tabular}{|l|c|}
\hline Balanced Redox Equation & $\begin{array}{c}\text { Net } \\
\text { Potential }\end{array}$ \\
\hline $\mathrm{Fe}+3+\mathrm{H}_{2} \mathrm{CO}_{2} \rightarrow 2 \mathrm{Fe}^{+2}+\mathrm{CO}_{2}+\mathrm{H}^{+}$ & 1.74 \\
$2 \mathrm{Fe}(\mathrm{OH})_{3}+\mathrm{H}_{2} \mathrm{CO}_{2}^{-}+2 \mathrm{Fe}(\mathrm{OH})_{2}+\mathrm{CO}_{2}+\mathrm{H}_{2} \mathrm{O}$ & -0.68 \\
$2 \mathrm{NO}_{3}+3 \mathrm{H}_{2} \mathrm{CO}_{2}+2 \mathrm{H}^{+}-2 \mathrm{NO}+3 \mathrm{CO}_{2}+8 \mathrm{H}_{2} \mathrm{O}$ & 2.52 \\
$2 \mathrm{NO}_{3}+\mathrm{HCO}_{2}-\mathrm{H}_{2} \mathrm{O} \rightarrow 2 \mathrm{NO}_{3}+3 \mathrm{CO}_{2}+\mathrm{OH}^{-}$ & 2.26 \\
$\mathrm{H}_{2} \mathrm{CO}_{2} \rightarrow \mathrm{H}_{2}+\mathrm{CO}_{2}$ & 0.2 \\
$\mathrm{HCO}_{2}+\mathrm{H}_{2} \mathrm{O} \rightarrow \mathrm{CO}^{2}+\mathrm{H}_{2}+\mathrm{OH}^{-}$ & 0 \\
\hline
\end{tabular}

observed in this $\mathrm{pH}$ range ( $\mathrm{pH}$ 5-7). A test that exhibited the maximum $\mathrm{CO}_{2}$ release rates and amounts was maintained in this $\mathrm{pH}$ range through most of the observed formating process. This correlation lends support to the implication that the release of $\mathrm{CO}_{2}$ is directly related to the redox of $\mathrm{Fe}$ and nitrates. Release of $\mathrm{H}_{2}$ is most predominant during post heat treatment. Longer duration of post heat treatment periods would be beneficial to evaluate the extent of formic acid reactions. 
Releases of gases from the formating process are thus a result of the desired redox process, i.e., obtaining a specific $\mathrm{Fe}^{+2} / \mathrm{Fe}^{+3}$ ratio and minimizing $\mathrm{NO}_{x}$.releases in the melter.

4.3.3.2 STurry Mix Evaporator. No del iberate chemical reactions occur in the SME. The frit slurry is added to the formated HWVP feed, and any other concentration and chemical adjustments are made to ensure that the melter feed conforms to the melter feed requirements provided in Table 4.3-6. These requirements are based on those established by SRL for DWPF melter feed. Since, in essence, the HWWP process and equipment (except for the melter/ turntabie) and product requirements are currentiy similar to those for DHPF, it was felt that the process properties of process slurries should be simi$7 \mathrm{ar}$. These requirements may be altered if process verification demonstrates that the process and equipment can handle HWVP slurries with properties that vary from the properties of DWPF slurries or if the HWVP melter feed properties cannot conform to these requirements.

Making up meiter feed consists of adding spent frit siurry as available from canister decontamination. (The frit slurry compositions and properties are given in Section 4.3.4.1.) Then the balance of required frit is added as a fresh 60 wt\% slurry to produce a frit/waste slurry that has 25 wt\% waste oxides in the glass. The quantities of fresh frit used are shown in Table 4.3-7. The frit slurries contain 1 wt\% formic acid based on the frit content. The purpose of the formic acid is to facilitate resuspension of the frit solids should they inadvertentiy settle out due to loss of agitation. (a) The formic acid'will react with the sodium oxide in the frit to partially dissolve the frit and neutralize the formic acid according to the reaction:

$$
2 \mathrm{HCOOH}+\mathrm{Na}_{2} \mathrm{O} \rightarrow 2 \mathrm{NaCOOH}+\mathrm{H}_{2} \mathrm{O}
$$

(assumed to have occurred in cold feed makeup facilities)

This reaction is slow and will manifest itself as a pH increase in the made-up melter feed. The made-up feed is usually at a pH of 4.0 to 4.5. SRL experience has shown that over a period of weeks the $\mathrm{pH}$ will slowly increase to over 8. The DWPF has a melter feed requirement to maintain the feed $\mathrm{pH}<8$ to minimize the potential for frit solids consolidation. Thus, if the melter feed $\mathrm{pH}$ rises to 8 or greater, the feed is neutralized with formic acid.

The made-up HWVP feed is sampled and analyzed to verify that it is adequate to obtain a suitable composition for glass processing and properties. Analyses performed include determining that the $3 / 1$ frit/waste oxide composition is appropriate and that the composition of the waste components in the

(a) PNL experience has shown that if the frit settles without formic acid over a period of hours, the frit can consolidate into a mass that cannot be resuspended. SRL experience has demonstrated that addition of formic acid can facilitate resuspension of settled frit. 
TABLE 4.3-6. Properties of DHPF Reference Melter Feed(a)

\begin{tabular}{|l|l|}
\hline \multicolumn{1}{|c|}{ Property } & \multicolumn{1}{|c|}{ Acceptable Range } \\
\hline Density (g/mL) & $1.29-1.46$ \\
$\mathrm{pH}$ & Less than 8. \\
Concentration (wt\% total solids) & $40-50$ \\
(dried at <100 $\mathrm{C}$ ) & \\
Transport velocity (ft/s) & $3-10$ (except in the feed line \\
Consistency (cP) & $10-40$ \\
Yield point (dynes $\left./ \mathrm{cm}^{2}\right)$ & $25-150$ \\
Range & $80-$ \\
Design value & \\
\hline
\end{tabular}

(a) H. T. Blair, et al., Status of Melter Feed Rheology Evaluation for Melter Feed Selection. HWVP-85 020203A, Pacific Northwest Laboratory, Apri1 1985.

waste has not change significantly to cause processing or glass quality problems. Another key analysis performed is whether there is sufficient nonvolatile carbon in the feed makeup such that the atmosphere in the melter and the glass will be reducing. This analysis is performed by making a test melt in the laboratory and verifying that the $\mathrm{Fe}^{+2} / \mathrm{Fe}^{+3}$ ratio is between 0.005 and 0.3 . If there is not sufficient carbon in the feed $\left(\mathrm{Fe}^{+2} / \mathrm{Fe}^{+3}<0.005\right)$, then more organic is added as formic acid or sugar solutions. If the melter feed is too reducing $\left(\mathrm{Fe}^{+2} / \mathrm{Fe}^{+3}>0.3\right.$ ), then more feed and/or frit may be added. A feed that is too oxidizing has the potential for foaming resulting from oxygen release. A feed that over-reduces could reduce metals such as $\mathrm{Ni}$ and perhaps $\mathrm{Fe}$ and $\mathrm{Cr}$ to $\mathrm{Ni}$ or spinel alloys in the bottom of the meiter; these could short out the melter.

The made-up feed is boiled up to reach the final concentration for melter feeding. It is desirable to have the final feed as concentrated as possible, compatible with feed handling, to minimize using the melter as a concentrator and to increase melter processing rates.

In evaporating the feed, SRL experience(a) has indicated that the feed will cake at air/siurry interfaces and on the walls where there is splashing. The heating coils should not be exposed to the air during heating, as they can build up a hard layer if exposed to slurry and allowed to dry. Experience at SRL $(a)$ also has shown that the solids buildup on coil surfaces may be removed by covering the coils with slurry and agitating for some time.

(a) Memorandum from E. J. Weber to M. D. Boersma, "Progress of Large Scale SRAT/SME Study," DPST-82-733, Savannah River Laboratory, Aiken, South Carolina, dated JuTy 21, 1982. 
TABLE 4.3-7. Melter Feed Makeup Frit STurry Requirements - DWPF $(a, b)$

\begin{tabular}{|c|c|c|c|c|}
\hline \multicolumn{5}{|c|}{$\begin{array}{l}\text { Final Canister Decontamination } \\
\text { Agent Requirement }\end{array}$} \\
\hline \multirow[b]{2}{*}{ Process Step } & \multicolumn{4}{|c|}{ Quantities per Canister } \\
\hline & Ib Frit & Tb $\mathrm{HCOOH}$ & gal $\mathrm{H}_{2} \mathrm{O}$ & SCF Air \\
\hline $\begin{array}{l}\text { Initial cleaning } \\
\text { Rinse } \\
\text { Vessel flush } \\
\text { Spot cleaning } \\
\text { Rinse } \\
\text { Vessel flush } \\
\text { Total }\end{array}$ & $\begin{array}{c}500(2) \\
30 \\
530\end{array}$ & $\begin{array}{l}0.3 \\
5: 3\end{array}$ & $\begin{array}{l}540(a) \\
180 \\
25 \\
32(a) \\
35 \\
5 \\
817\end{array}$ & $\begin{array}{r}8,400 \\
4,200 \\
560 \\
800 \\
13,960\end{array}$ \\
\hline
\end{tabular}

\section{Oxide Removal}

- Quantity $=0.11 \mathrm{lb} /$ canister.

- Composition: $\mathrm{Fe}_{2} \mathrm{O}_{3}=74.3$ wt\%; $\mathrm{NiO}=7.2 \mathrm{wt \%} \mathrm{Cr}_{2} \mathrm{O}_{3}=18.5$ w.t\%.

\begin{tabular}{|l|c|c|c|c|}
\hline \multicolumn{5}{|c|}{ Initial Canister Decontamination } \\
Agent Requirement \\
\hline \multirow{4}{*}{ Process Step } & \multicolumn{4}{|c|}{ Quantities per Canister } \\
\cline { 2 - 5 } & Ib Frit & 16 HCOOH & gal $\mathrm{H}_{2} \mathrm{O}$ & SCF Air \\
\hline Initial cleaning & 0 & 0 & 210 & 8,400 \\
Rinse & & & 180 & 4,200 \\
Vessel flush & & 0 & 25 & 12,600 \\
Total & 0 & 0 & 415 & 12,000 \\
\hline
\end{tabular}

(a) F. D. Nankani, "Trip, Conference Report - HWWP/DWPF Technical Exchange Meeting - Siurry Feed Preparation and Melter Feed System," 65651-TCR86-002, Rockwel1 Hanford Operations, January 1, 1980.

(b) E.I. du Pont de Nemours \& Company, Basic Data Report - DWPF-siudge Plant, SRP 200-S Area, DPSP 80-133 (Apri1 1985). 
TABLE 4.3-7. Melter Feed Makeup Frit STurry Requirements - DHPF (contd)

Oxide Removal: None.

\begin{tabular}{|l|c|c|c|c|}
\hline \multicolumn{5}{|c|}{ Fresh Frit Addition } \\
\hline \multirow{3}{*}{ Process Step } & \multicolumn{4}{|c|}{ Quantities per Canister } \\
\cline { 2 - 5 } & Tb Frit & Ib HCOOH & gal $\mathrm{H}_{2} \mathrm{O}$ & SCF Air \\
\hline & & & & \\
Fresh frit add & 1989 & 29.5 & 161 & \\
Line flush & 0 & 0 & 20 & 0 \\
Total & 1989 & 29.5 & 181 & 0 \\
\hline
\end{tabular}

However, it is not clear to what extent this cake removal procedure is reliable. It is therefore prudent to minimize the exposure of equipment to caking conditions. Equipment surfaces that cake should be covered with slurry or water to inhibit cake hardening and improve the potential for cake removal.

In concentration, the condenser is operated at $122^{\circ} \mathrm{F}\left(50^{\circ} \mathrm{C}\right)$, and condensate is assumed to have entrainment of $2 \mathrm{ppm}$ in the tank vapor space and $1 \mathrm{ppm}$ in the vapor effluent.

\subsubsection{Process Development}

Studies have been completed and documented on feed preparation chemistry and process development that are applicable to HWVP. These studies includelaboratory efforts on HWVP process siurry and feed formating process characterization. Large-scale process studies at SRL have been performed to evaluate process and equipment performance that are applicable to HWVP. The results of these studies are subsequentiy summarized.

4.3.4.1 HWVP Process STurry Characterization (PNL). (a)(b)(c)(d) A series of studies have been performed to characterize HWVP process slurries, i.e., HWVP

(a) R. K. Farnsworth et al., Feed Process Variability Testing for Fiscal Year 1986, RHO-RE-CR-16P/HWVP-86-V1123C, Rockwe11 Hanford Operations, Richland, Washington (November 17, 1986).

(b) G. T. Thornton, Evaluation and Comparison of HWVP Reference Feed Composition and Updated Neutralized Current Acid Waste Composition Simulants, HWVP-87-V110203C, Pacific Northwest Laboratory, Richland, Washington (Aprit 1987).

(c) K. D. Hiemers et a1., Evaluation of Process Off-Gases Released During Formatting of an HWVP Feed Simulant. HWVP-87-V110203G, Pacific Northwest Laboratory, Richiand, Washington (September 1987).

(d) R. D. Scheele et al., "Characterization of Simulated Hanford Waste Vitrification Program Feed and Concentrates," Pacific Northwest Laboratory, Richland, Washington (1986). 
feed, formated HWVP feed, HWVP melter feed and frit slurries as a function of a variety of process variables that could affect physical or process properties. This section summarizes the test results by indicating the methods used to make the various slurries and presenting the characterization data. The techniques used to develop the data are outiined; and then the associated results are discussed. Variables studied include the following:

- composition

- method of HWVP synthetic feed preparation

- slurry concentration

- amount of formic acid addition

- boiling

- agitation rate

- sTurry aging.

Slurry characteristics evaluated for the test compositions include:

- total oxides

- total solids

- dissolved solids

- density

- $\mathrm{pH}$

- apparent viscosity

- yield stress.

Since 1984, five feed compositions have been designated as reference NCAW feeds for the HWVP. The rationales for developing and changing these compositions are presented in Section 4.1.2.1 of the Technical Manual. Physical and process properties of slurry feeds are to some extent dependent upon the feed composition. Therefore, when reviewing data from HWVP simulated slurry studies, it is important to note which NCAH reference feed compositions were used for the studies.

Table 4.3-8 lists the target waste oxide compositions for NCAW reference feeds. Table 4.3-9 indicates which reference compositions were used for each study discussed in Section 4.3.4.1. Because of variations in.compositions, and since not all simulated feeds matched the target NCAH compositions, the actual compositions for slurry feed studies have been included in Appendix $A$.

4.3.4.1.1. Synthetic HWVP Process Slurries/Properties. The general procedure for preparing an HWVP feed simulant is to first mix together the hydroxides, sulfates, fluorides, and nitrates. The waste slurry is then diluted or concentrated to its desired starting concentration. For rheology and redox modification, a suitable amount of $90 \mathrm{wt} \%$ formic acid solution is added to format the HWVP feed. This enables further waste concentration if desired for testing. The glass frit is finally added dry, or perhaps as a slurry, to produce the HWVP melter feed. The glass frit is predominantly silica and has a particle size distribution between 80 and 200 mesh ( 74 to $177 \mathrm{\mu m}$ ). A smal7 amount of formic acid, equivalent to 1.0 wt\% of the frit addition, is also added to prevent frit agglomeration in the slurry. Then the simulated HWVP melter feed can be diluted or concentrated for testing. 
TABLE 4.3-8. Reference Haste Oxide Feed Compositions

\begin{tabular}{|c|c|c|c|c|c|}
\hline oxide & $\begin{array}{c}\text { Reference } \\
\text { NCAW } 84 \\
\text { High } \\
\text { Chromium } \\
\text { Waste( }=1)\end{array}$ & $\begin{array}{l}\text { Reference } \\
\text { NCAW } 84 \\
\text { Low } \\
\text { Chromium(b) } \\
\text { Waste }\end{array}$ & $\begin{array}{l}\text { Reference } \\
\text { NCAW } 86 \\
\text { Waste( } \$)\end{array}$ & $\begin{array}{l}\text { Reference } \\
\text { NCAW } 87 \\
\text { Waste (c) }\end{array}$ & $\begin{array}{l}\text { Reference } \\
\text { NCAW } \\
\text { Sept. } 88 \\
\text { Waste(d) }\end{array}$ \\
\hline 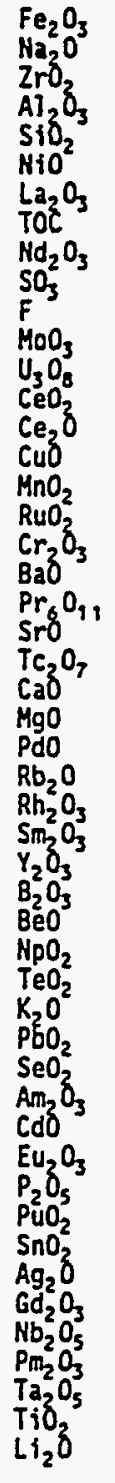 & 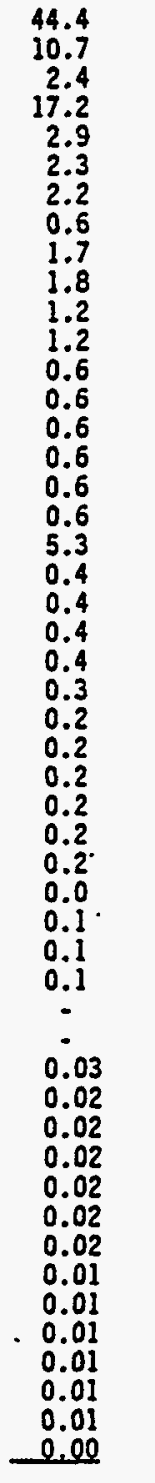 & $\begin{array}{l}46.3 \\
11.1 \\
2.5 \\
17.9 \\
3.1 \\
2.5 \\
2.3 \\
0.6 \\
1.8 \\
1.5 \\
1.2 \\
1.2 \\
0.6 \\
0.6 \\
0.6 \\
0.6 \\
0.6 \\
0.6 \\
0.6 \\
0.4 \\
0.4 \\
0.4 \\
0.4 \\
0.3 \\
0.2 \\
0.2 \\
0.3 \\
0.2 \\
0.2 \\
0.2 \\
0.0 \\
0.1 \\
0.1 \\
0.1 \\
0.00 \\
0.00 \\
0.03 \\
0.02 \\
0.02 \\
0.02 \\
0.02 \\
0.02 \\
0.02 \\
0.01 \\
0.01 \\
0.01 \\
0.1 \\
0.01 \\
0.01 \\
0.00\end{array}$ & $\begin{array}{l}28.0 \\
17.5 \\
15.0 \\
10.0 \\
9.0 \\
2.3 \\
2.0 \\
2.0 \\
1.9 \\
1.8 \\
1.2 \\
1.2 \\
0.7 \\
0.6 \\
0.6 \\
0.6 \\
0.6 \\
0.6 \\
0.5 \\
0.4 \\
0.4 \\
0.4 \\
0.4 \\
0.3 \\
0.2 \\
0.2 \\
0.2 \\
0.2 \\
0.2 \\
0.2 \\
0.1 \\
0.1 \\
0.1 \\
0.1 \\
0.05 \\
0.05 \\
0.03 \\
0.02 \\
0.02 \\
0.02 \\
0.02 \\
0.02 \\
0.02 \\
0.01 \\
0.01 \\
0.01 \\
0.01 \\
0.01 \\
0.01 \\
0.00 \\
\end{array}$ & $\begin{array}{c}28.0 \\
17.5 \\
15.0 \\
9.0 \\
4.0 \\
2.3 \\
2.3 \\
0.3 \\
2.2 \\
1.8 \\
1.2 \\
.1 .2 \\
4.7 \\
0.6 \\
0.6 \\
0.6 \\
0.6 \\
0.6 \\
0.5 \\
0.4 \\
0.4 \\
0.4 \\
0.4 \\
0.3 \\
0.2 \\
0.2 \\
0.2 \\
0.2 \\
0.2 \\
0.2 \\
0.1 \\
0.1 \\
0.1 \\
0.1 \\
0.05 \\
0.05 \\
0.03 \\
0.02 \\
3.0 \\
0.02 \\
0.4 \\
0.02 \\
0.04 \\
0.01 \\
0.01 \\
0.01 \\
0.01 \\
0.03 \\
0.01 \\
0.00 \\
\end{array}$ & 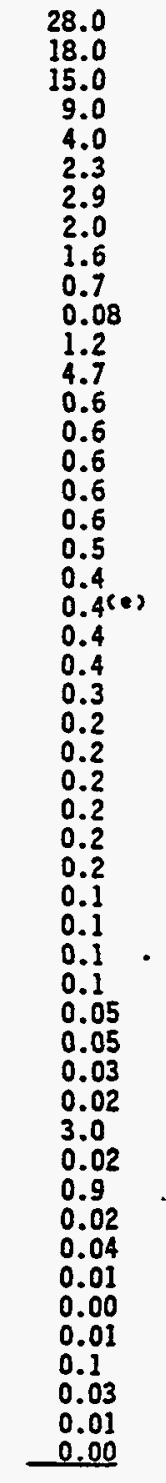 \\
\hline & 100.00 & 100.00 & 100.00 & 100.00 & 100.00 \\
\hline
\end{tabular}

(a) Technical Manual pg. 4.1-12.

(b) Technical Manual pg. 4.1-61.

(c) R. A. Watrous and 0. L. Kruger, "HWVP Feed Specification: Pretreated Neutralized Current Arid Waste Feed," SD-HWV-OCD-001, Rev. 1, Westinghouse Hanford Company, Richland, Washington (1987).

(d) HWYP Technical Data Package, SO-HWV-DP-001, Rev. 4, Hestinghouse Hanford Company, Richland, Washington (1988).

(e) $\mathrm{Pr}_{6} \mathrm{O}_{11}$ as $\mathrm{Pr}_{2} \mathrm{O}_{3}$. 
TABLE 4.3-9. NCAW Reference Wastès Used for S7urry Studies/Tests

\begin{tabular}{|l|l|}
\hline Study-Test Feed & NCAW Reference Feed \\
\hline HWS4 & NCAW 84 high chromium \\
HWS5 & NCAW 84 high chromium \\
HWS6 & NCAW 84 high chromium \\
HWS7 & NCAW 84 high chromium \\
RBPS-2 & NCAW 84 high chromium \\
RBPS-3 & NCAW 84 high chromium \\
HWS9 & NCAW 86 Composition Variations \\
Farnsworth Study & NCAW 84 high chromium \\
Thornton Study & and NCAW 86 \\
Wiemers Study & NCAW 86 \\
HWWP-11/HBCM-85-1. & NCAW 84 high chromium \\
HWVP-13/HBCM-86-2 & Composition Variations \\
HWWP-14/HBCM-86-3 & NCAW 84 high chromium \\
HWWP-11/HBCM-85-1 & NCAW 84 high chromium \\
HWVP-12/PSCM-22 & NCAW 87 \\
HWWP-15/PSCM-23 & \\
\hline
\end{tabular}

To make the NCAN feed slurries more representative of actual waste, recent studies (RBPS-L, RBPS-3, Wiemers, and HWVP-15) have included major hydroxide metallic chemicals ( $\mathrm{Fe}, \mathrm{Zr}$, solutions. ) precipitated from nitrate

4.3.4.1.1.1. NCAW 84 High-Chromium Physical and Rheological Properties. A study was performed to determine the physical and rheological properties of HWVP process slurries (HWVP. feed, formated HWVP feed, melter feed, frit, and formic acid) using NCAH 84 high-chromium feed. The specific feed composition and method of makeup is included in Appendix A (Table A.2) together with the techniques used for property measurements. In laboratory studies, the synthetic HWVP slurry did not show a tendency to foam during boiling while being stirred under low boiling rates. Solids tended to build up on the glassware and the metal stirrer during boiling at about $200 \mathrm{~g} \mathrm{HO} / \mathrm{L}$. The process stream properties are provided in the Tables and Figures listed in Table 4.3-10 and subsequently included. 
TABLE 4.3-10. Key to HWVP Process S7urry Properties: Tables and Figures Based on HWS6 NCAW 84 High .Chromium Composition(a)

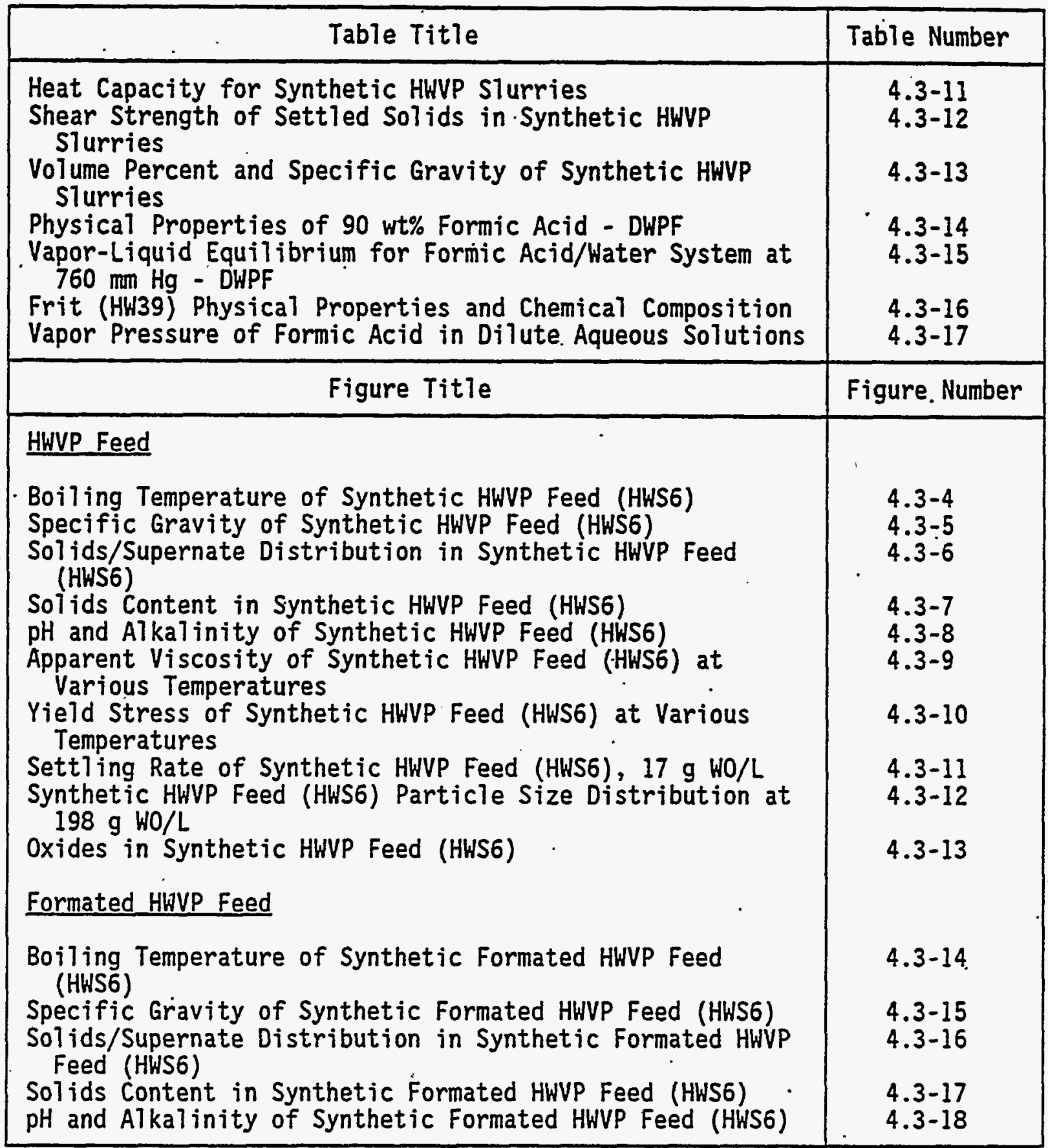

(a) R. D. Scheele et al., "Characterization of Simulated Hanford Waste Vitrification Program Feed and Concentrates, "Pacific Northwest Laboratory, Richiand, Washington (1986). 
TABLE 4.3-10. Key to HWVP Process S7urry Properties: Tables and Figures Based on HWS6 NCAW 84 High Chromium Composition (contd)

\begin{tabular}{|c|c|}
\hline Figure Title & Figure Number \\
\hline $\begin{array}{l}\text { Formated HWVP Feed (contd) } \\
\text { Apparent Viscosity of Synthetic Formated HWVP Feed (HWS6) } \\
\text { at Various Temperatures } \\
\text { Yield Stress of Synthetic Formated HWVP Feed (HWS6) } \\
\text { at Various Temperatures } \\
\text { Settling Rate of Synthetic Formated HWVP Feed (HWS6) } \\
\text { Synthetic Formated HWVP Feed (HWS6) Particle Size } \\
\text { Distribution at } 151 \mathrm{~g} \text { WO/L } \\
\text { Oxides in Synthetic Formated HWVP Feed (HWS6) } \\
\text { Specific Gravity of Synthetic Formated HWVP Feed (HWS6) } \\
\text { at Various Formic Acid Additions } \\
\text { Solids/Supernate Distribution in Synthetic Formated HWWP } \\
\text { Feed (HWS6) at Various Formic Acid Additions } \\
\text { Sol ids Content in Synthetic Formated HWVP Feed (HWS6) at } \\
\text { Various Formic Acid Additions } \\
\text { pH and Alkalinity of Synthetic Formated HWVP Feed (HWS6) } \\
\text { at Various Formic Acid Additions } \\
\text { Settling Rate of Synthetic Formated HWVP Feed (HWS6) at } \\
\text { Various Formic Acid Additions } \\
\text { Apparent Viscosity and Yield Stress of Synthetic Formated } \\
\text { HWVP Feed (HWS6) at Various Formated Additions } \\
\text { Effect of Time on pH of HWVP Slurries } \\
\text { Minton }\end{array}$ & $\begin{array}{l}4.3-19 \\
4.3-20 \\
4.3-21 \\
4.3-22 \\
4.3-23 \\
4.3-24 \\
4.3-25 \\
4.3-26 \\
4.3-27 \\
4.3-28 \\
4.3-29 \\
4.3-30\end{array}$ \\
\hline 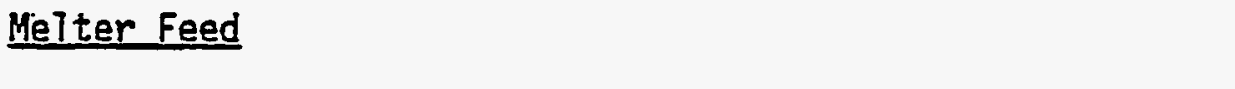 & \\
\hline $\begin{array}{l}\text { Boiling Temperature of Synthetic Melter Feed (HWS6) } \\
\text { Specific Gravity of Synthetic Melter Feed (HWS6) } \\
\text { Solids/Supernate Distribution. in Synthetic Melter Feed } \\
\text { (HWS6) }\end{array}$ & $\begin{array}{l}4.3-31 \\
4.3-32 \\
4.3 .33\end{array}$ \\
\hline $\begin{array}{l}\text { Solids Content in Synthetic Melter Feed (HWS6) } \\
\text { pH and Alkalinity of Synthetic Melter Feed (HWS6) } \\
\text { Apparent Viscosity of Synthetic Melter Feed (HWS6) at } \\
\text { Various Temperatures } \\
\text { Yield Stress of Synthetic Melter Feed (HWS6) at Various } \\
\text { Temperatures }\end{array}$ & $\begin{array}{l}4 \cdot 3-34 \\
4 \cdot 3-35 \\
4.3-36 \\
4 \cdot 3-37\end{array}$ \\
\hline $\begin{array}{l}\text { Settling Rate of Synthetic Melter Feed (HWS6) } \\
\text { oxides in Synthetic Melter Feed (HWS6) } \\
\text { pH as a Function of Time for Synthetic MeTter Feed (HWS6) } \\
\text { Apparent Viscosity and Yield Stress of Synthetic Melter } \\
\text { Feed (HWS6) at Various Formate Additions }\end{array}$ & $\begin{array}{l}4 \cdot 3-38 \\
4 \cdot 3-39 \\
4.3-40 \\
4.3-41\end{array}$ \\
\hline
\end{tabular}

\section{$4.3-20$}


TABLE 4.3-10. Key to HWVP Process Slurry Properties: Tables and Figures Based on HWSG NCAW 84 High Chromium Composition (contd).

\begin{tabular}{|l|c|}
\hline \multicolumn{1}{|c|}{ Figure Title } & Figure Number \\
\hline Frit Slurries & \\
Boiling Temperature of Frit (HW39) Slurries & $4.3-42$ \\
Specific Gravity of Frit (HW39) Slurries & $4.3-43$ \\
Solids/Supernate Distribution in Frit (HH39) Slurries & $4.3-44$ \\
Solids Content of Frit (HW39) Slurries & $4.3-45$ \\
pH of Frit (HW39) Slurry as a Function of Time & $4.3-46$ \\
Oxides in Frit (HW39) STurries & $4.3-47$ \\
Settling Rate of Frit (HW39) Slurries & $4.3-48$ \\
Essential Materials Properties & \\
Vapor Pressure of Formic Acid - DHPF & \\
Formic Acid Vapor/Liquid Equilibrium Curves & $4.3-49$ \\
\hline
\end{tabular}


TABLE 4:3-11. Heat Capacity for Synthetic HWVP s7urriẹs

\begin{tabular}{|c|c|}
\hline Sample & $\begin{array}{l}\text { Heat Capacity }(a) \\
\left(\text { Cal } /{ }^{C}-g\right)\end{array}$ \\
\hline $\begin{array}{l}\text { HWVP Feed } \\
19 \mathrm{~g} \mathrm{WO} / \mathrm{L} \\
100 \mathrm{~g} \text { WO/L }\end{array}$ & $\begin{array}{l}0.88 \\
0.83\end{array}$ \\
\hline $\begin{array}{l}\text { Formated HWVP Feed } \\
100 \mathrm{~g} \mathrm{HO} / \mathrm{L} \text {. } \\
(0.092 \mathrm{~g} \text { formic/g } \mathrm{WO})\end{array}$ & 0.92 \\
\hline $\begin{array}{l}100 \mathrm{~g} \mathrm{HO} / \mathrm{L} \\
(0.189 \mathrm{~g} \text { formic/g HO) }\end{array}$ & 0.90 \\
\hline $\begin{array}{l}125 \mathrm{~g} \mathrm{WO} / \mathrm{L} \\
(0.092 \mathrm{~g} \text { formic/g WO) }\end{array}$ & 0.82 \\
\hline $\begin{array}{l}151 \mathrm{~g} \mathrm{WO} / \mathrm{L} \\
(0.092 \mathrm{~g} \text { formic/g WO) }\end{array}$ & $\quad 0.80$ \\
\hline $\begin{array}{l}\text { Melter Feed } \\
\quad 100 \cdot \mathrm{g} W 0 / \mathrm{L}+0: 092 \mathrm{~g} \\
\text { formic } / \mathrm{g} \mathrm{WO}+300 \mathrm{~g} \text { Fit } / \mathrm{L}\end{array}$ & 0.76 \\
\hline $\begin{array}{l}125 \mathrm{~g} \mathrm{WO} / \mathrm{L}+0.092 \mathrm{~g} \\
\text { formic/g WO }+275 \mathrm{~g} \text { Frit } / \mathrm{L}\end{array}$ & 0.76 \\
\hline $\begin{array}{l}\text { Frit STurry } \\
4 \text { wt\% Frit }+0.01 \mathrm{~g} \\
\text { formic/g Frit }\end{array}$ & 0.97 \\
\hline$\underset{\text { HW39 }}{\text { Frit }}$ & $\begin{array}{l}0.26 @ 50^{\circ} \mathrm{C} \\
0.21 \mathrm{e70} 0^{\circ} \mathrm{C} \\
0.15 @ 90^{\circ} \mathrm{C}\end{array}$ \\
\hline
\end{tabular}

(a) 45 to $100^{\circ} \mathrm{C}$. 
TABLE 4:3-12. Shear Strength of Settled Solids in Synthetic HWVP STurries(a)

\begin{tabular}{|c|c|}
\hline Sample & $\begin{array}{l}\text { Shear strength } \\
\left(\text { dyne } / \mathrm{cm}^{2}\right)\end{array}$ \\
\hline $\begin{array}{l}\text { HHVP Feed } \\
17 \mathrm{~g} W 0 / \mathrm{L} \\
100 \mathrm{~g} \mathrm{WO} / \mathrm{L} \\
198 \mathrm{~g} \mathrm{WO} / \mathrm{L}\end{array}$ & $\begin{array}{r}20.3 \\
23.4 \\
481\end{array}$ \\
\hline $\begin{array}{l}\text { Formated HWVP Feed } \\
100 \mathrm{~g} \mathrm{WO} / \mathrm{L} \\
(0.046 \mathrm{~g} \text { formic/g } \mathrm{WO})\end{array}$ & - 19.1 \\
\hline $\begin{array}{l}100 \mathrm{~g} \mathrm{HO} / \mathrm{L} \\
(0.092 \mathrm{~g} \text { formic/g } \mathrm{HO})\end{array}$ & 27.4 \\
\hline $\begin{array}{l}100 \mathrm{~g} \mathrm{HO} / \mathrm{L} \\
(0.138 \mathrm{~g} \text { formic } / \mathrm{g} \mathrm{HO})\end{array}$ & 37.5 \\
\hline $\begin{array}{l}100 \mathrm{~g} \mathrm{HO} / \mathrm{L} \\
(0.184 \mathrm{~g} \text { formic/g WO })\end{array}$ & 35.9 \\
\hline $\begin{array}{l}125 \mathrm{~g} \mathrm{HO} / \mathrm{L} \\
(0.092 \mathrm{~g} \text { formic/g WO) }\end{array}$ & 30.9 \\
\hline $\begin{array}{l}151 \mathrm{~g} \mathrm{WO} / \mathrm{L} \\
0: 092 \mathrm{~g} \text { formic/g WO) }\end{array}$ & 85.7 \\
\hline $\begin{array}{l}\text { Melter Feed } \\
\quad \text { Formated } 100 \mathrm{~g} \mathrm{WO} / \mathrm{L} \\
+ \text { Formated } 300 \mathrm{~g} \text { Frit/L }\end{array}$ & 217 \\
\hline $\begin{array}{l}125 \mathrm{~g} \mathrm{wO} / \mathrm{L} \\
+ \text { Unformated } 275 \mathrm{~g} \mathrm{Frit/L}\end{array}$ & 180 \\
\hline $\begin{array}{l}\text { Frit slurry } \\
60 \mathrm{wt} \% \text { Frit } \\
(0.01 \mathrm{~g} \text { formic } / \mathrm{g} \text { Frit })\end{array}$ & $\begin{array}{r}3702 \\
\leq 6108\end{array}$ \\
\hline
\end{tabular}

(a) Solids allowed to settle for $2 d$. 
TABLE 4.3-13. Volume Percent and Specific Gravity of Synthetic HWVP STurries

\begin{tabular}{|c|c|c|}
\hline S7urry & $\begin{array}{l}\text { Volume Percent } \\
\text { Settled Solids }\end{array}$ & $\begin{array}{l}\text { Settled Solids } \\
\text { Density }(\mathrm{g} / \mathrm{mL})\end{array}$ \\
\hline $\begin{array}{l}\text { HWVP Feed } \\
17 \mathrm{~g} \text { WO/L }\end{array}$ & 20.6 & 1.16 \\
\hline $\begin{array}{l}\text { Formated HWVP Feed } \\
100 \mathrm{~g} \mathrm{HO} / \mathrm{L} \\
(0.046 \mathrm{~g} \text { formic } / \mathrm{g} \text { WO })\end{array}$ & 71.9 & 1.09 \\
\hline $\begin{array}{l}\text { Formated HWVP Feed } \\
100 . \mathrm{g} \mathrm{HO} / \mathrm{L} \\
(0.138 \mathrm{~g} \text { formic } / \mathrm{g} \mathrm{WO})\end{array}$ & 65.5 & 1.10 \\
\hline $\begin{array}{l}\text { Formated HWVP Feed } \\
100 \mathrm{~g} \mathrm{HO} / \mathrm{L} \\
(0.184 \mathrm{~g} \text { formic } / \mathrm{g} \mathrm{HO})\end{array}$ & 65.3 & 1.10 \\
\hline $\begin{array}{l}\text { Frit Siurry } \\
\text { Formated } 100 \mathrm{~g} \mathrm{WO} / \mathrm{L} \\
\text { + Formated } 300 \mathrm{~g} \text { Frit/L }\end{array}$ & 72.8 & 1.26 \\
\hline $\begin{array}{l}\text { Frit Slurry } \\
\quad \text { Formated } 100 \mathrm{~g} \mathrm{WO} / \mathrm{L} \\
\quad+\text { Formated } 300 \mathrm{~g} \text {.Frit/L }\end{array}$ & 75.5 & 1.30 \\
\hline $\begin{array}{l}\text { Melter Feed } \\
\quad \text { Formated } 125 \mathrm{~g} \text { WO/L }+ \\
\text { Unformated } 275 \text { Frit/ }\end{array}$ & 81.9 & 1.23 \\
\hline $\begin{array}{l}\text { Melter Feed } \\
\quad \text { Formated } 125 \mathrm{~g} \mathrm{WO} / \mathrm{L} \\
\quad+\text { Formated } 375 \mathrm{~g} \text { Frit/L }\end{array}$ & 87.4 & 1.35 \\
\hline $\begin{array}{l}\text { Formated HWVP Feed } \\
\quad 151 \mathrm{~g} \mathrm{WO} / \mathrm{L}\end{array}$ & 96.9 & 1.13 \\
\hline $\begin{array}{l}\text { Formated HWVP Feed } \\
100 \mathrm{~g} \mathrm{WO} / \mathrm{L} \\
(0.092 \mathrm{~g} \text { formic/g WO) }\end{array}$ & 67.0 & 1.09 \\
\hline
\end{tabular}


TABLE 4.3-14. Physical Properties of $90 \mathrm{wt} \%$ Formic Acid - DHPF

\begin{tabular}{ll|}
\hline Temperature & $-20{ }^{\circ} \mathrm{C}$ \\
Specific Gravity & -1.2044 \\
Grams of HCOOH/Liter & -1084 \\
$1 \mathrm{~b} / \mathrm{ft}^{3}$ & -67.67 \\
ib/ga7 & -9.046
\end{tabular}

TABLE 4.3-15. Vapor-Liquid Equilibria for Formic Acid/Water System at $760 \mathrm{~mm} \mathrm{Hg}$ - DWPF (E.I. du Pont de Nemours \& Co., "Basic Data Report - DWPF - STudge PI ant - SRP, 200-S Area," DPSP 80-133, SRP)

\begin{tabular}{|c|c|c|}
\hline \multirow[b]{2}{*}{ Temperature $\left({ }^{\circ} \mathrm{C}\right)$} & \multicolumn{2}{|c|}{ Wt\% Water } \\
\hline & Liquid & Vapor \\
\hline $\begin{array}{l}100.0 \\
100.4 \\
101.0 \\
101.5 \\
102.0 \\
102.5 \\
103.3 \\
103.7 \\
104.4 \\
105.1 \\
106.1 \\
106.6 \\
107.1 \\
107.4 \\
107.3 \\
106.8 \\
100.6\end{array}$ & $\begin{array}{r}100.0 \\
92.6 \\
86.1 \\
77.7 \\
72.3 \\
66.6 \\
59.4 \\
56.7 \\
51.6 \\
46.3 \\
38.6 \\
34.7 \\
29.9 \\
24.5 \\
19.3 \\
15.8 \\
0.0\end{array}$ & $\begin{array}{r}100.0 \\
96.5 \\
92.6 \\
88.2 \\
84.4 \\
80.2 \\
73.6 \\
70.9 \\
65.3 \\
56.3 \\
47.2 \\
40.6 \\
33.3 \\
25.3 \\
18.0 \\
13.3 \\
0.0\end{array}$ \\
\hline
\end{tabular}


TABLE 4.3-16. Frit (HW39) Physical Properties and Chemical Composition(a)

Supplier: American Porcelain Enamel Company

1285 East Keating Avenue

Muskegon, Michigan

(616) $726-4756$

Lot No.: M7673 (Used for PSCM-22)

Specified Size: $-80 /+200$ mesh

Bulk Properties Measured:

Aerated bulk density:

Packed bulk density:

Average bulk density:

Angle of repose:

Specific density:

Particle size distribution: Sieve Size

U.S. Std. Mesh

$1.14 \mathrm{~g} / \mathrm{cm}^{3}$

$1.37 \mathrm{~g} / \mathrm{cm}^{3}$

$1.26 \mathrm{~g} / \mathrm{cm}^{3}$

$38^{\circ}$

2.49 to $2.51 \mathrm{~g} / \mathrm{cm}^{3}$

Cumulative Wt\%

Under Size

800

97.

100

73

120

140

170

200

.50

23

9

Mean particle size:

120 mesh

Chemical Composition(b):

\begin{tabular}{crr} 
Chemical & & Wt $\%$ \\
\cline { 1 - 1 } & & \\
$\mathrm{SiO}_{2}$ & & 67.3 \\
$\mathrm{~B}_{2} \mathrm{O}_{3}$ & & 12.7 \\
$\mathrm{Na}_{2} \mathrm{O}$ & & 10.3 \\
$\mathrm{Li}_{2} \mathrm{O}$ & 5.0 \\
$\mathrm{CaO}$ & 3.7 \\
$\mathrm{MgO}$ & & 1.0
\end{tabular}

(a) Letter (December 13, 1985) from J. E. Minor to R. C. Liikala HWVP Monthly Report - November 1985," H. T. Blair, Feed Processing, Pacific Northwest Laboratory, Richland, Washington.

(b) Letter (October 18, 1984) from K. R. Shah (RHO) to J. E. Minor (PNL), "Recommended NCAW/CRW Blend Feed Stream Composition and Range for PNL, FY 1985 HWVP Glass Formulation Studies, "Letter R84-3725, Pacific Northwest Laboratory, Richiand, Washington. 

TABLE 4.3-17. Vapor Pressure of Fprmic Acid in Dilute
Aqueous Solutions (a)

\begin{tabular}{|c|cc|}
\hline \multirow{2}{*}{$\begin{array}{c}\text { Solution } \\
\text { Temperature }( \pm 0.2 \cdot \mathrm{C})\end{array}$} & \multicolumn{2}{|c|}{$\begin{array}{c}\text { Formic Acid Vapor Phase } \\
\text { Concentration }(\mathrm{ppm})\end{array}$} \\
\cline { 2 - 3 } Concentration $( \pm 0.02 \mathrm{wt \%})$ & $\begin{array}{c}\text { Experimental } \\
( \pm 1 \mathrm{ppm})(\mathrm{s})\end{array}$ & Empirical(b) \\
\hline $10^{\circ} \mathrm{C} / 0.54 \mathrm{wt \%}$ & 11 & 22 \\
$10^{\circ} \mathrm{C} / 0.99 \mathrm{wt \%}$ & 17 & 41 \\
$50^{\circ} \mathrm{C} / 0.54 \mathrm{wt \%}$ & 66 & 102 \\
$50^{\circ} \mathrm{C} / 0.99 \mathrm{wt \%}$ & 267 & 186 \\
\hline
\end{tabular}

(a) Based on duplicate chromatographic runs of each sample, a $95 \%$ confidence interval for the analytical results was calculated to be $\pm \mathrm{ppm}_{\mathrm{y}}$ for the vapor samples. Evaluation of the vapor phase sampling calibration run data indicated an accuracy of $2 \%$ for the vapor phase sampling procedure.

(b) Vapor phase concentrations estimated by interpolation of WHC data for the appropriate vapor temperature and solution concentrations. The pertinent WHC spreadsheets are provided in Appendix A.

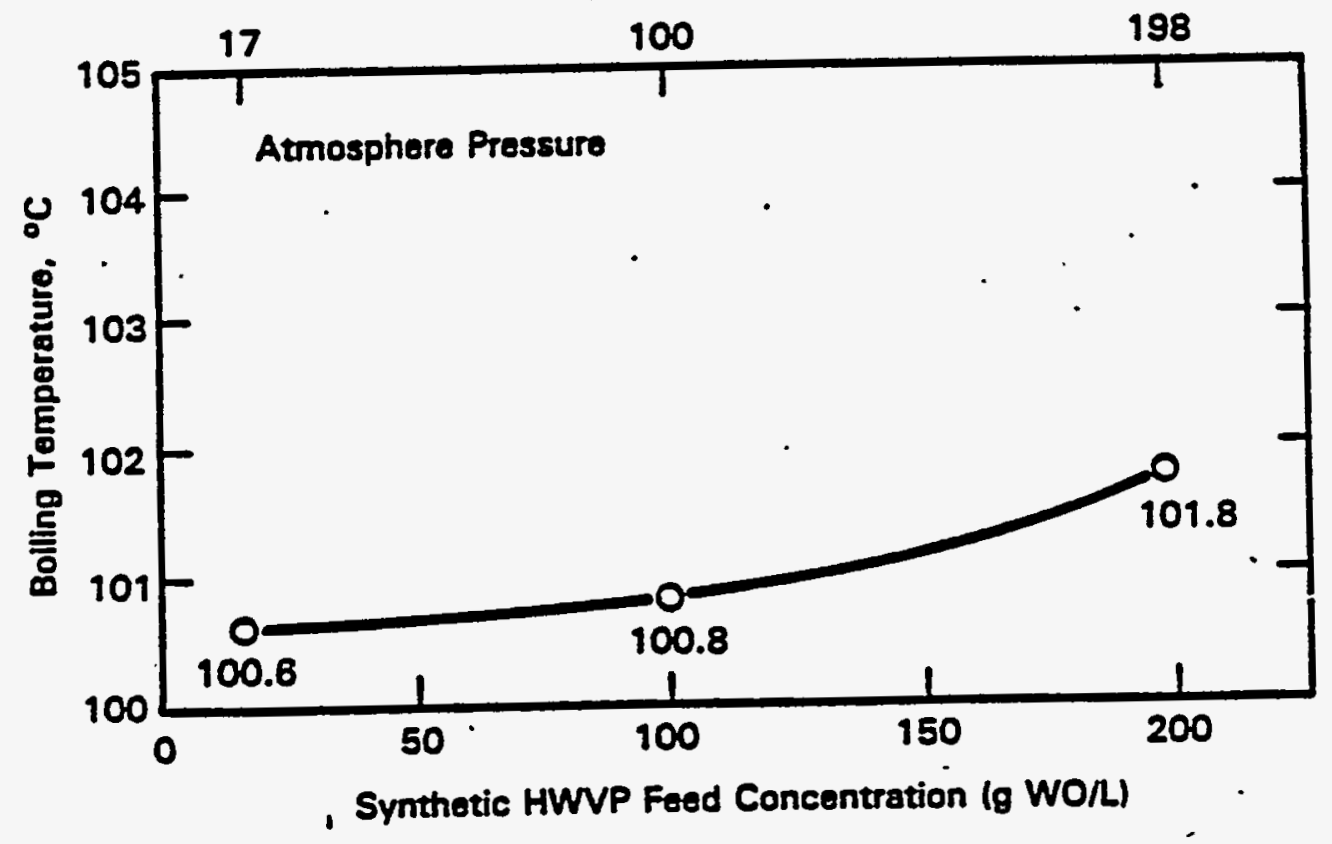

FIGURE 4.3-4. Boiling Temperature of Synthetic HWVP Feed (HWS6)

(a) K. D. Hiemers, May 1988, "Formic Acid Phase Concentrations Over Dilute Aqueous Solutions at the Proposed HWVP Condenser Operating Temperatures," HWVP-88-V110203A, Pacific Northwest Laboratory, Richland, Washington. 


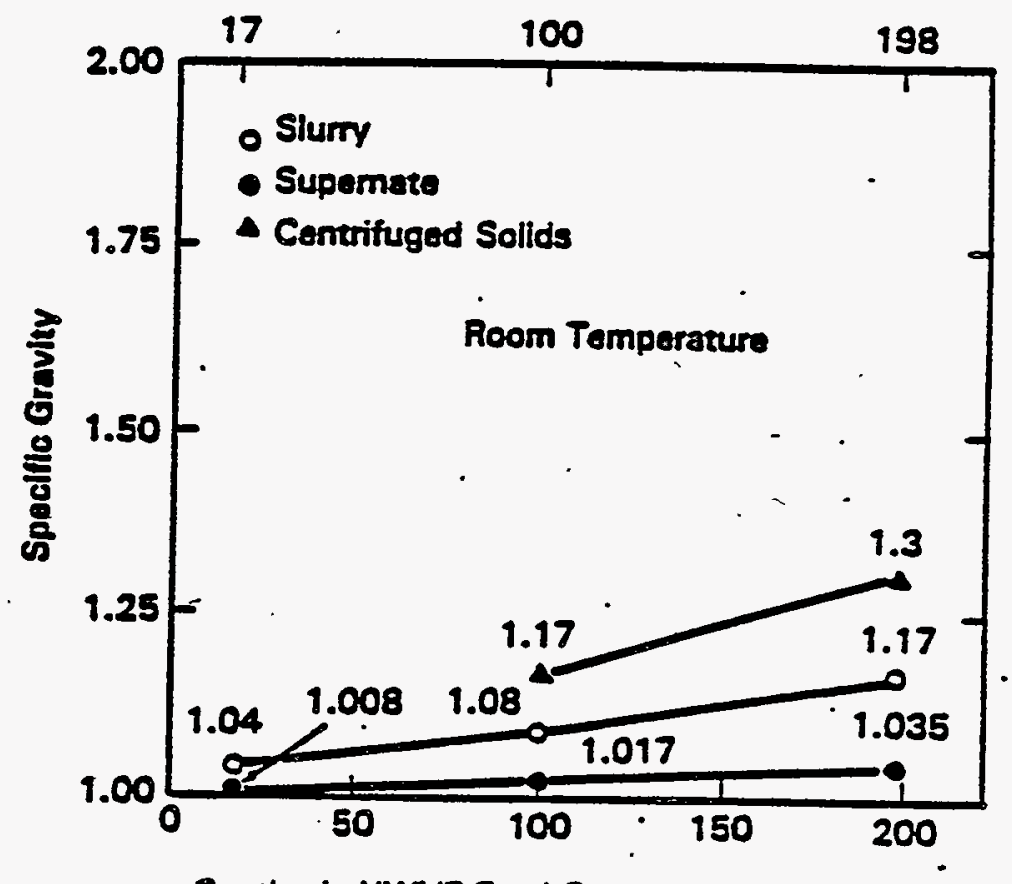

Synthetic HWVP Feed Concentration (g WO/L)

FIGURE 4.3-5. Specific Gravity of Synthetic HWVP Feed (HWS6)

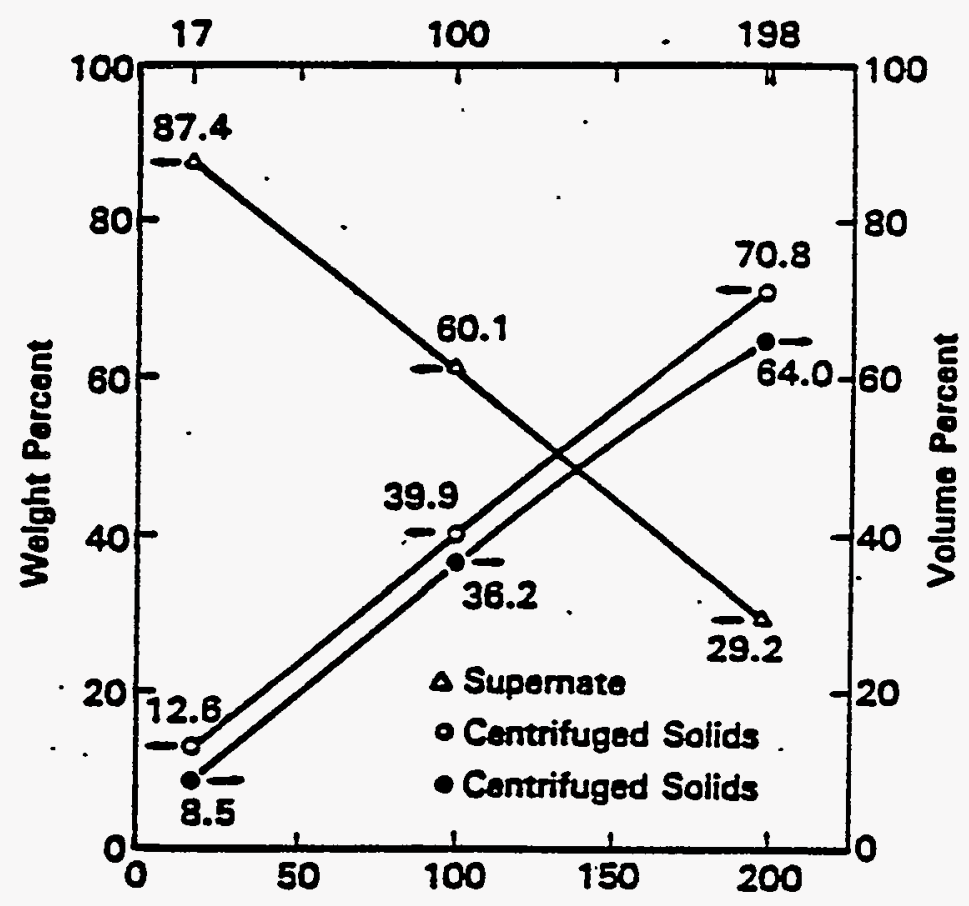

Synthetic HWVP Feed Concentration, (g WO/L)

FIGURE 4.3-6. Solids/Supernate Distribution in Synthetic HWVP Feed (HWS6) 


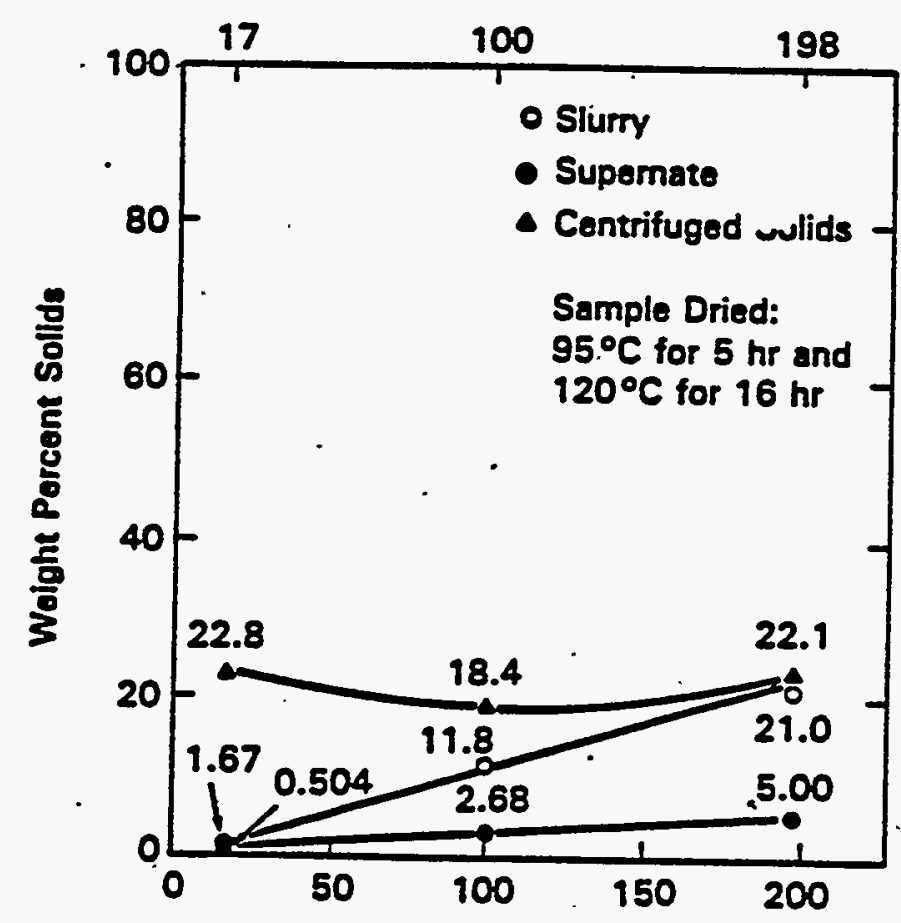

Synthetic HWVP Feed Concentration, (g WO/L)

FIGURE 4.3-7. Solids Content in Synthetic HWVP Feed (HWS6)

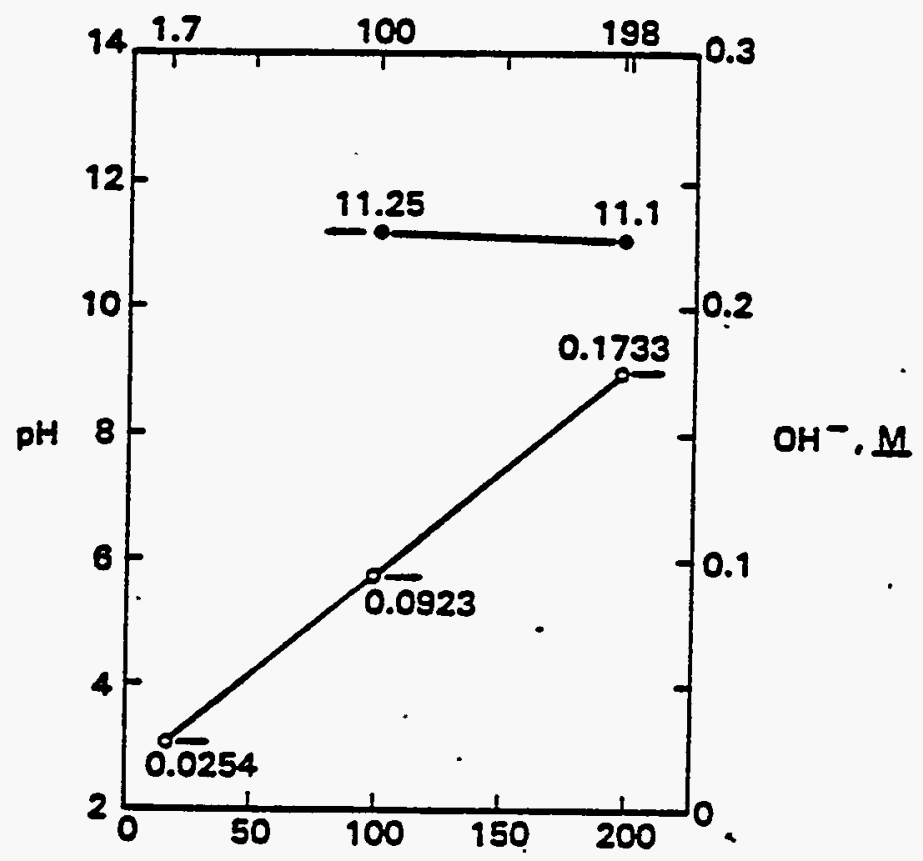

Synthetic HWWP Foed Concentration, (g WO/L)

FIGURE 4.3-8. pH and ATkalinity of Synthetic HWVP Feed (HWS6) 


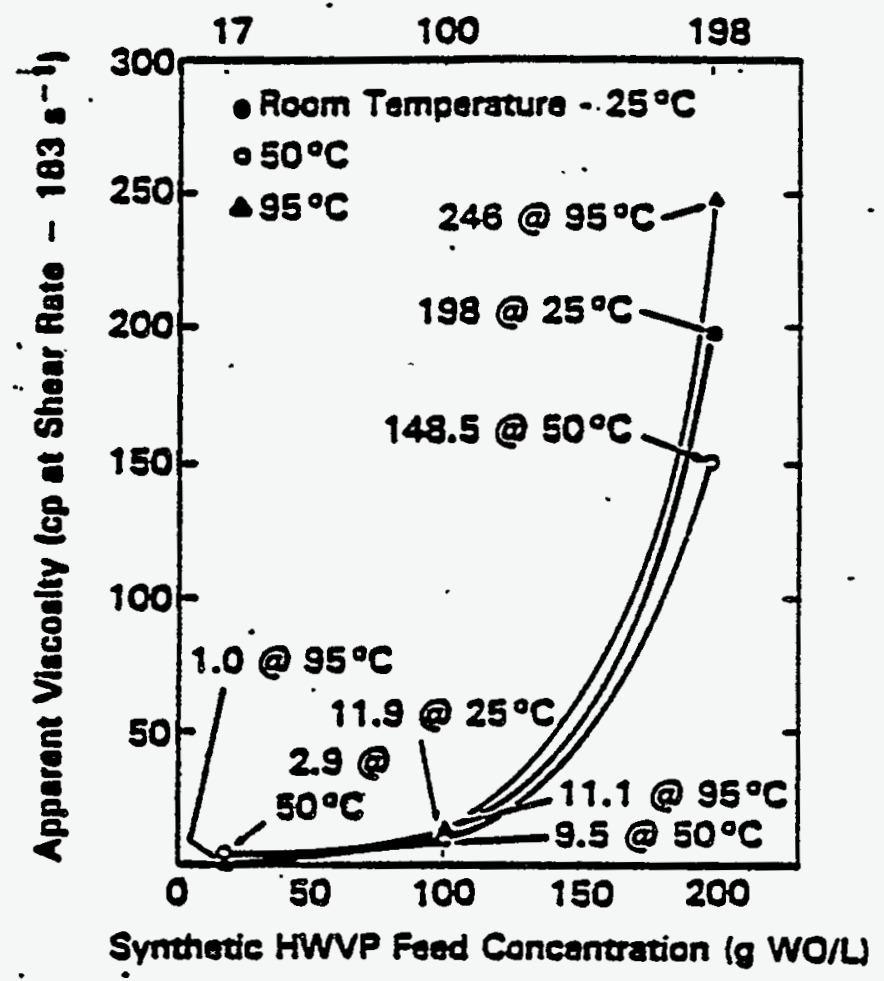

FIGURE 4.3-9. Apparent Viscosity of Synthetic HWVP Feed (HHS6) at Various Temperatures

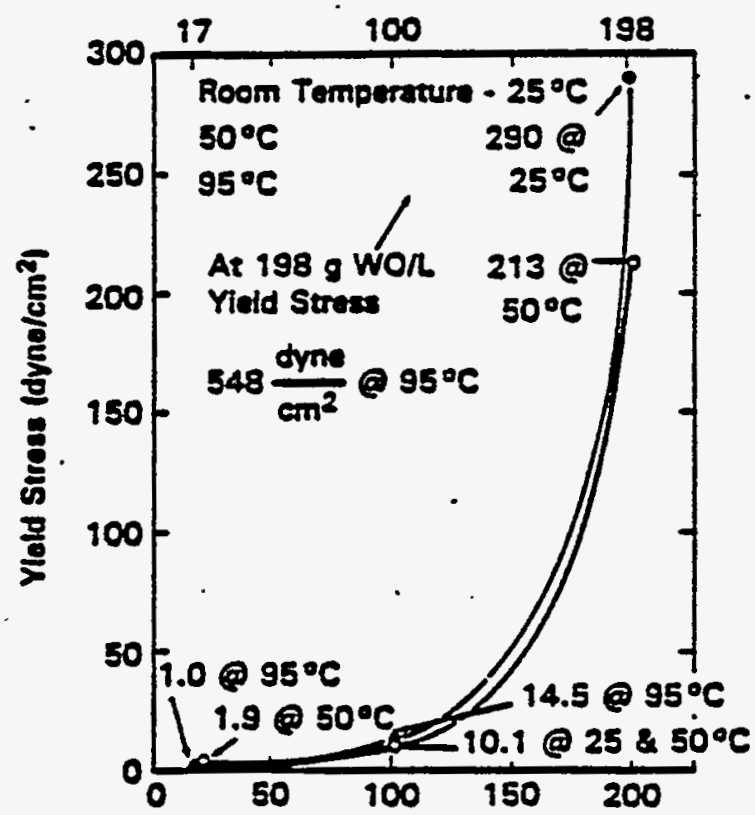

Symtheric HWVP Foed Concentration (g WO/L)

FIGURE 4.3-10. Yield Stress of Synthetic HWVP Feed (HWS6) at Various Temperatures 


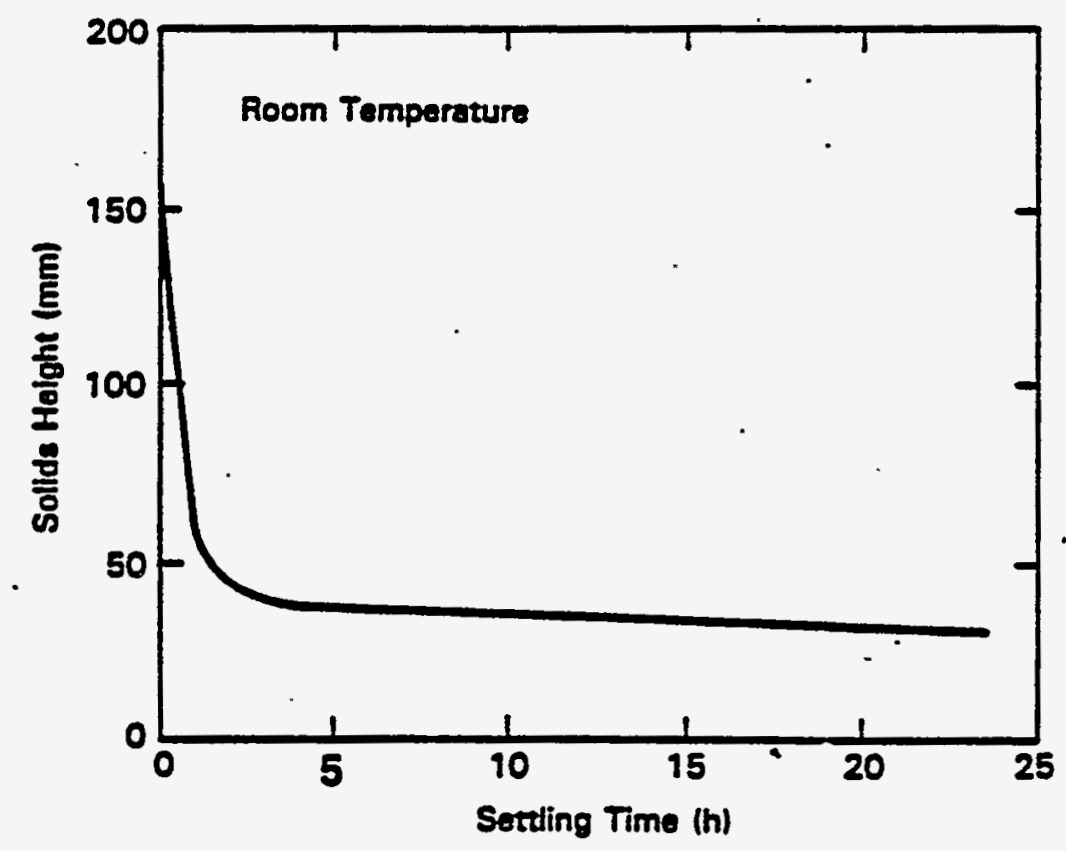

FIGURE 4.3-11. Settling Rate of Synthetic HWVP Feed (HWS6), $17 \mathrm{~g} \mathrm{HO} / \mathrm{L}$

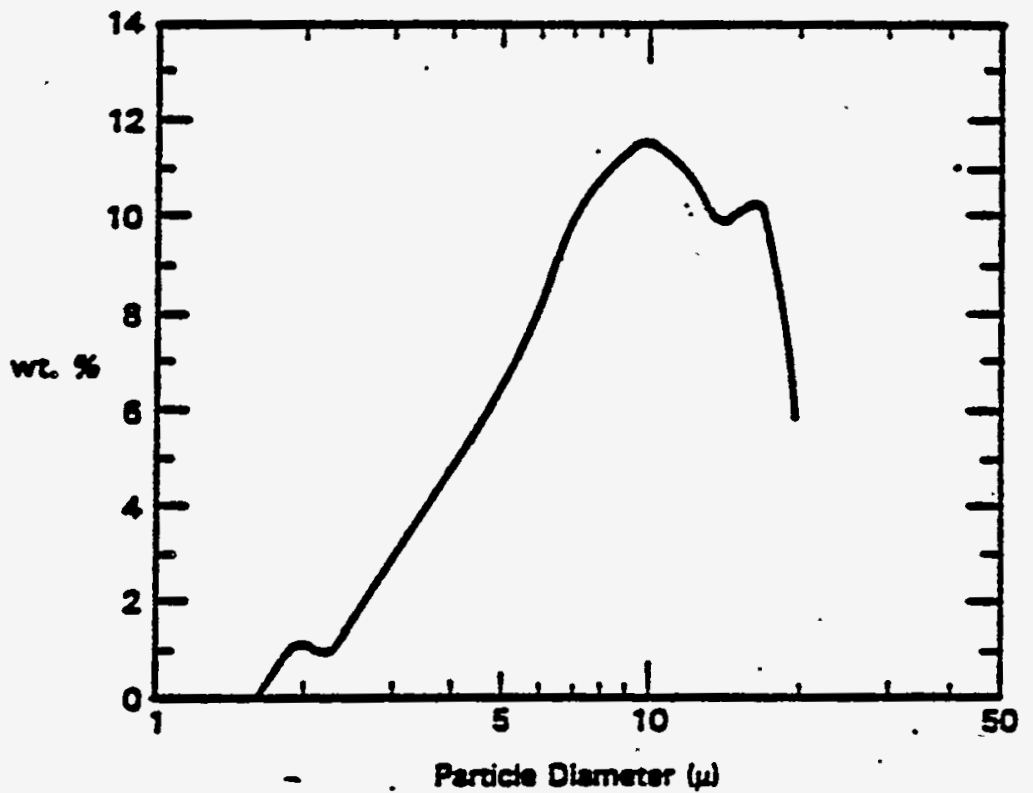

FIGURE 4.3-12. Synthetic HWVP Feed (HWS6) Particle-Size Distribution at $198 \mathrm{~g} \mathrm{HO} / \mathrm{L}(\mathrm{a})$

(a) Letter (March 10, 1986) from H. T. B7air/J. M. Perez to J. E. Minor, "February 1986 Monthly Report - HWVP Task V112," Pacific Northwest Laboratory, Richland, Washington. 


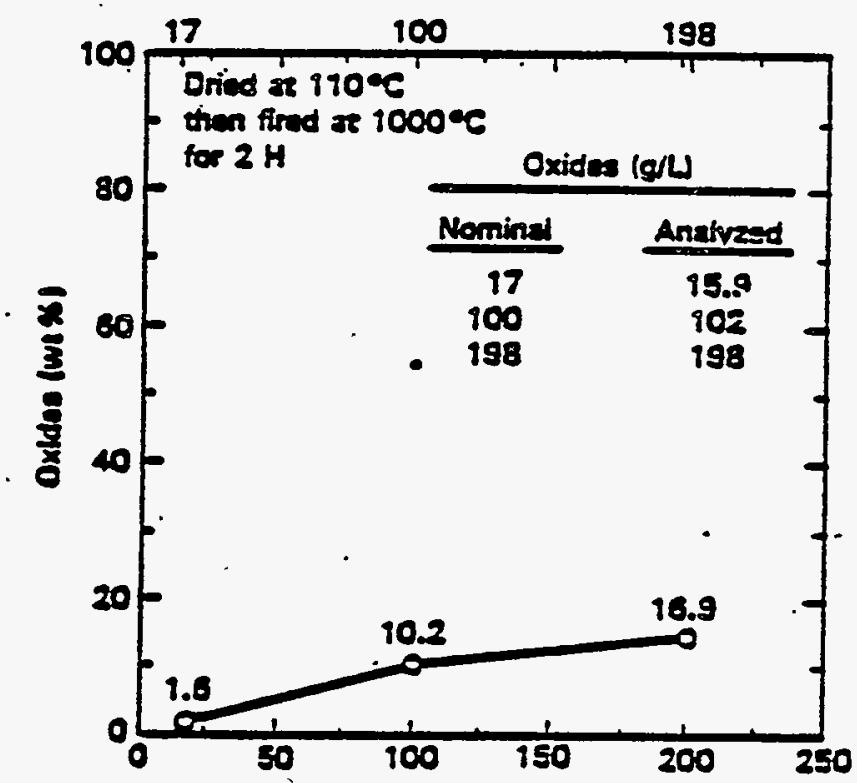

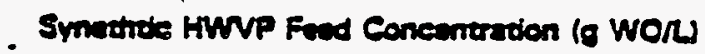

FIGURE 4.3-13. - Oxides in Synthetic HWVP Feed (HWS6)

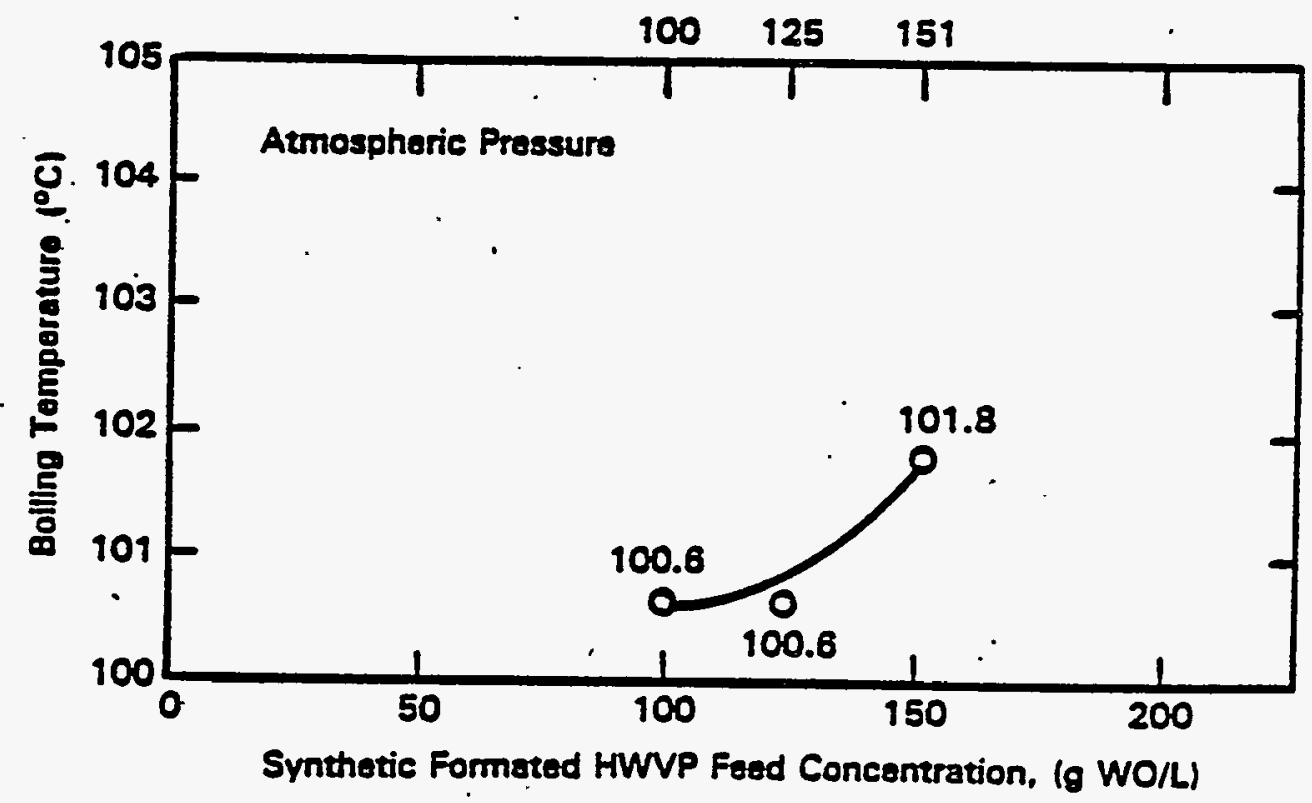

FIGURE 4.3-14. Boiling Temperature of Synthetic Formated HWVP Feed (HWS6). 


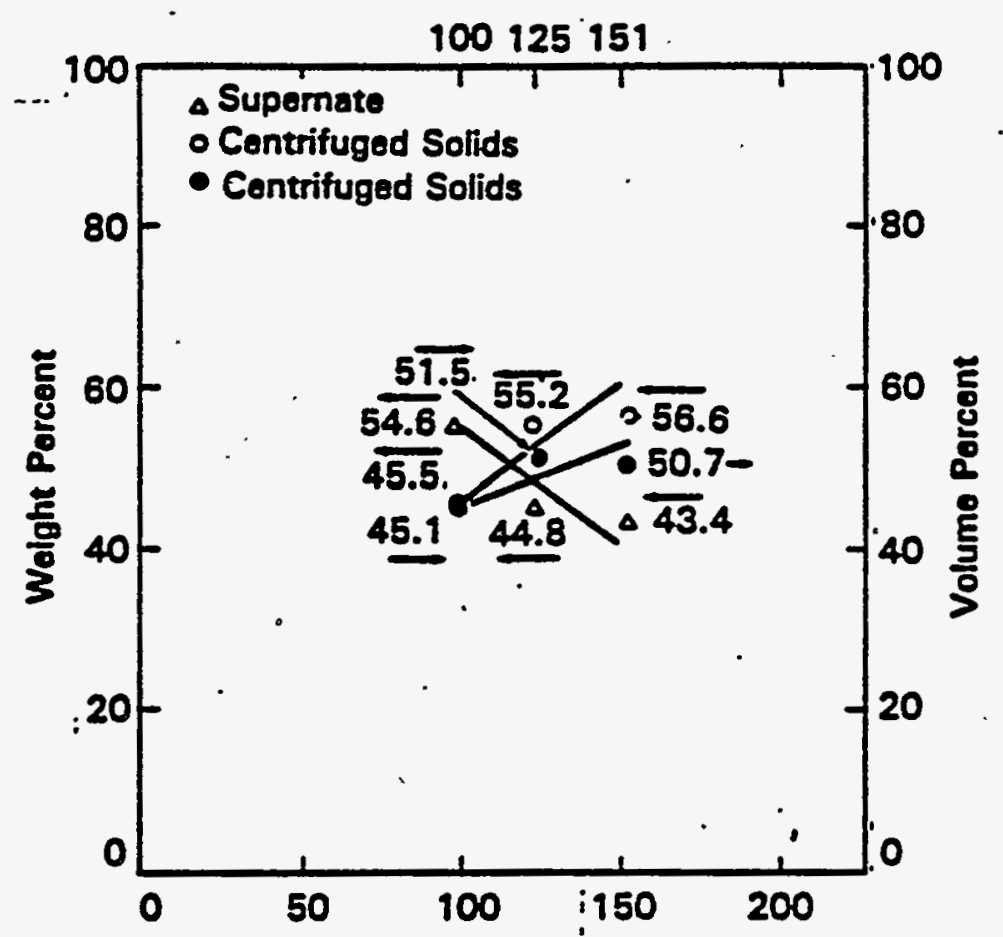

Synthetic Formated HWWP Feed Concentration, g (WO/L)

FIGURE 4.3-15. Specific Gravity of Synthetic Formated HWVP Feed (HWS6)

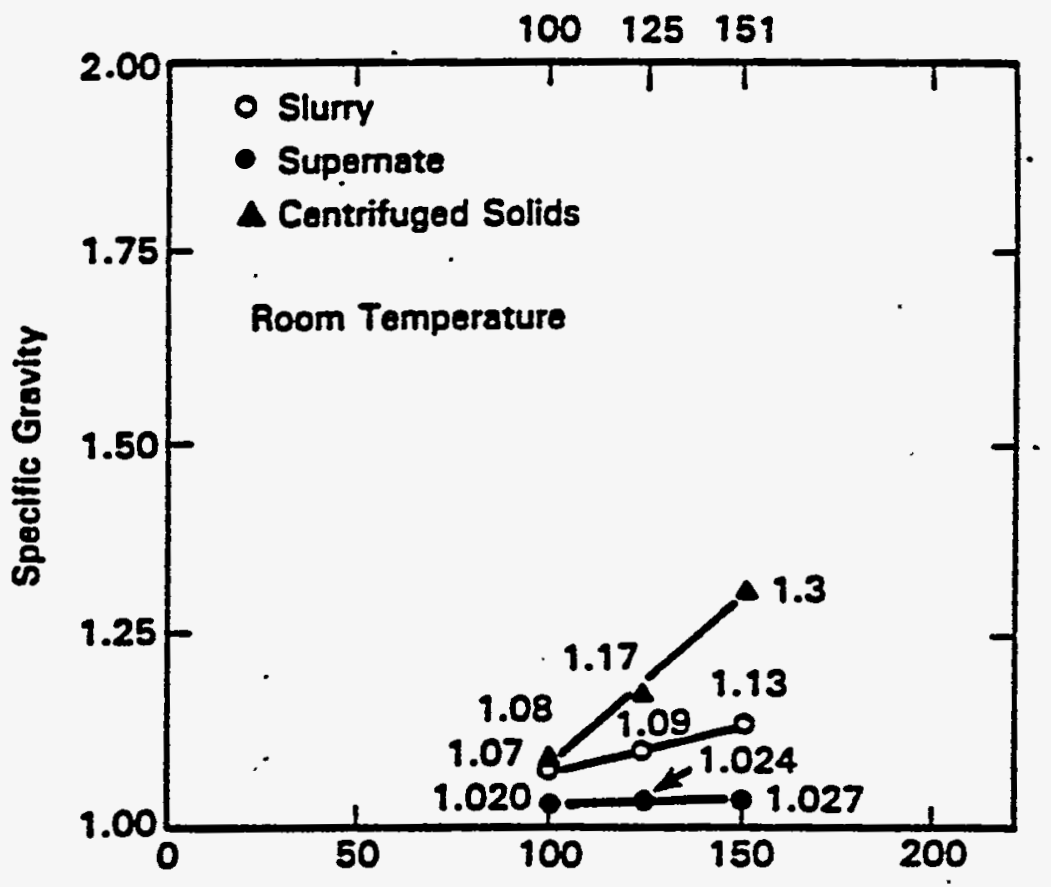

Synthetic Formated HWVP Feed Concentration (g WO/L)

FIGURE 4.3-16. Solids/Supernate Distribution in Synthetic Formated HWVP Feed (HWS6) 


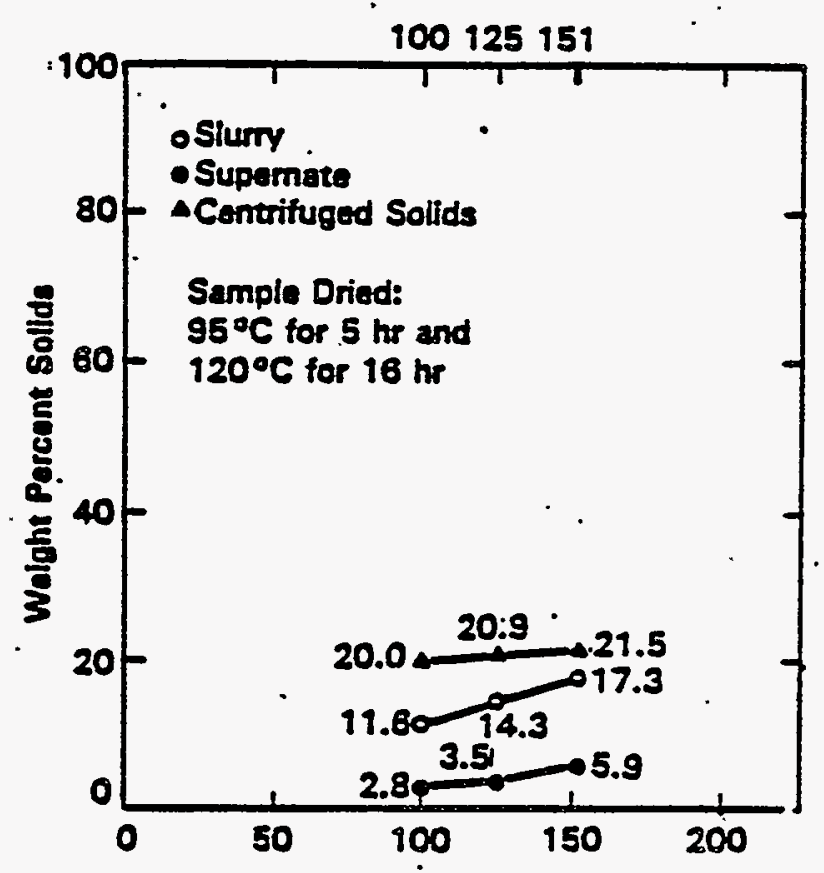

Symthric Formatgd HWVP Foed Concentration. g (WO/L)

FIGURE 4.3-17. Solids Content in Synthetic Formated HWVP Feed (HWSE)

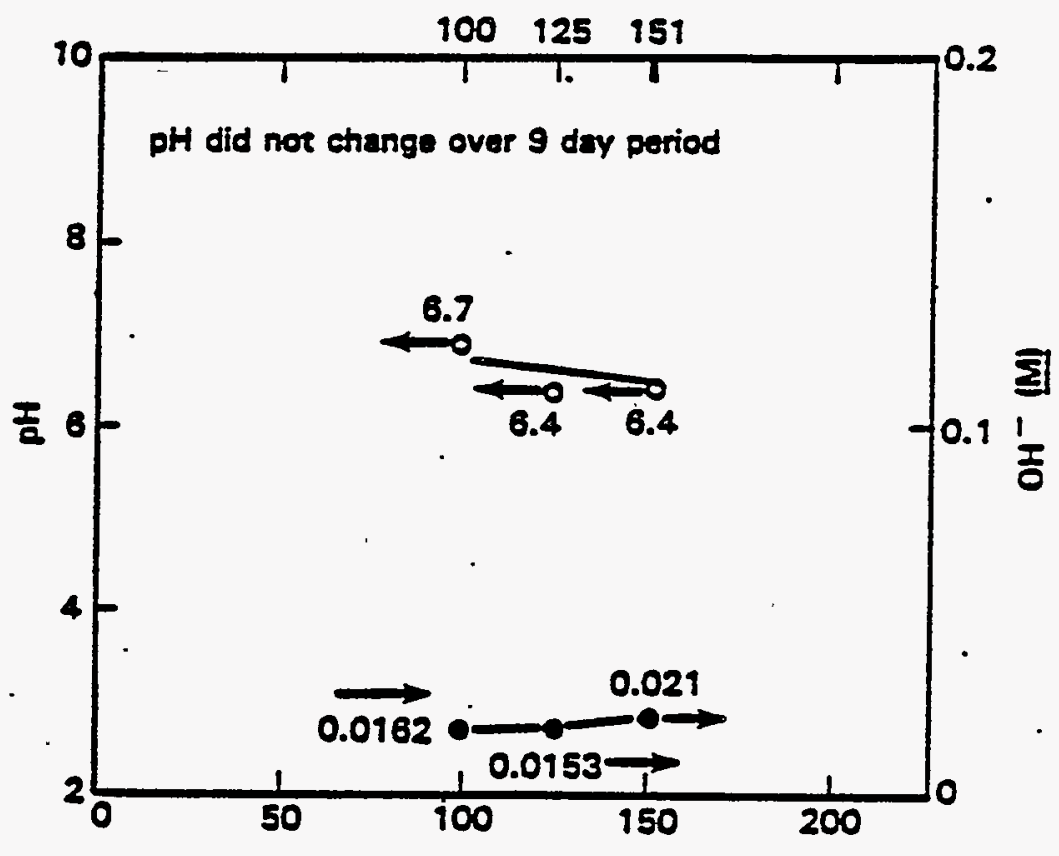

Synthetic Formated Foed Concentration (s WO/L)

FIGURE 4.3-18. pH and ATkalinity of Synthetic Formated HWVP Feed (HHS6) 


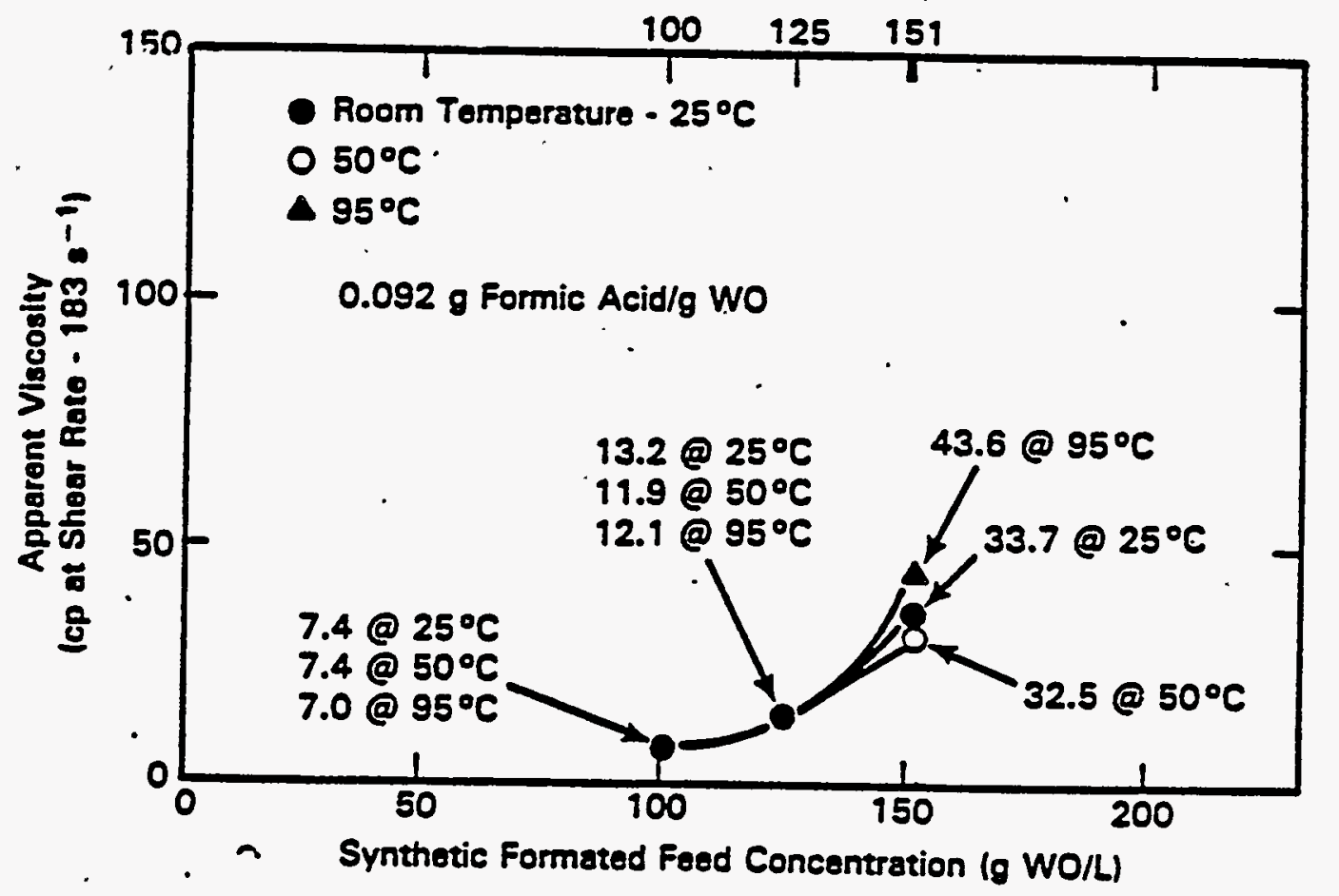

FIGURE 4.3-19. Apparent Viscosity of Synthetic Formated HWVP Feed (HWS6) at Various Temperatures

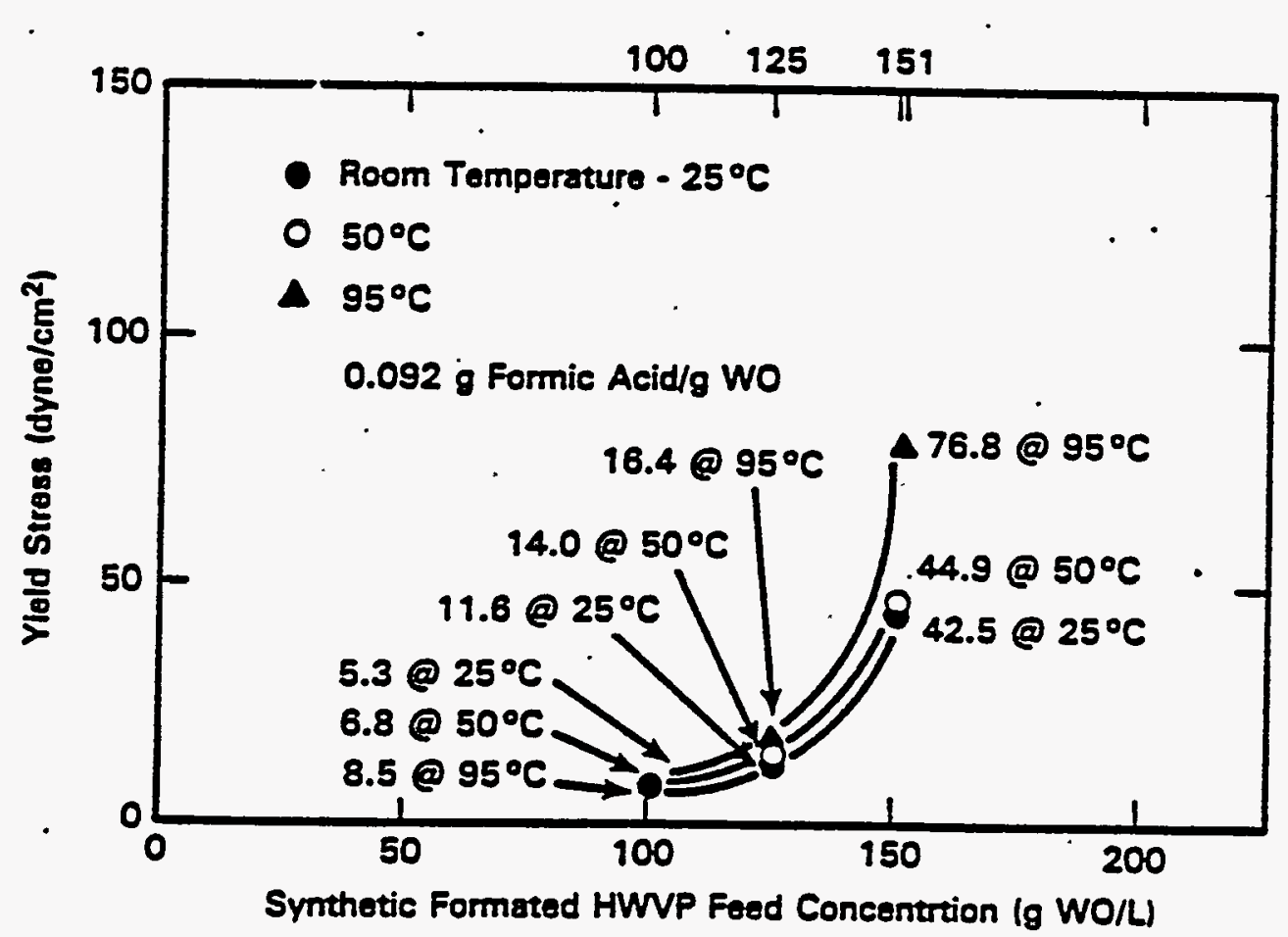

FIGURE 4.3-20. Yield Stress of Synthetic Formated HWVP Feed (HWS6) at Various Temperatures 


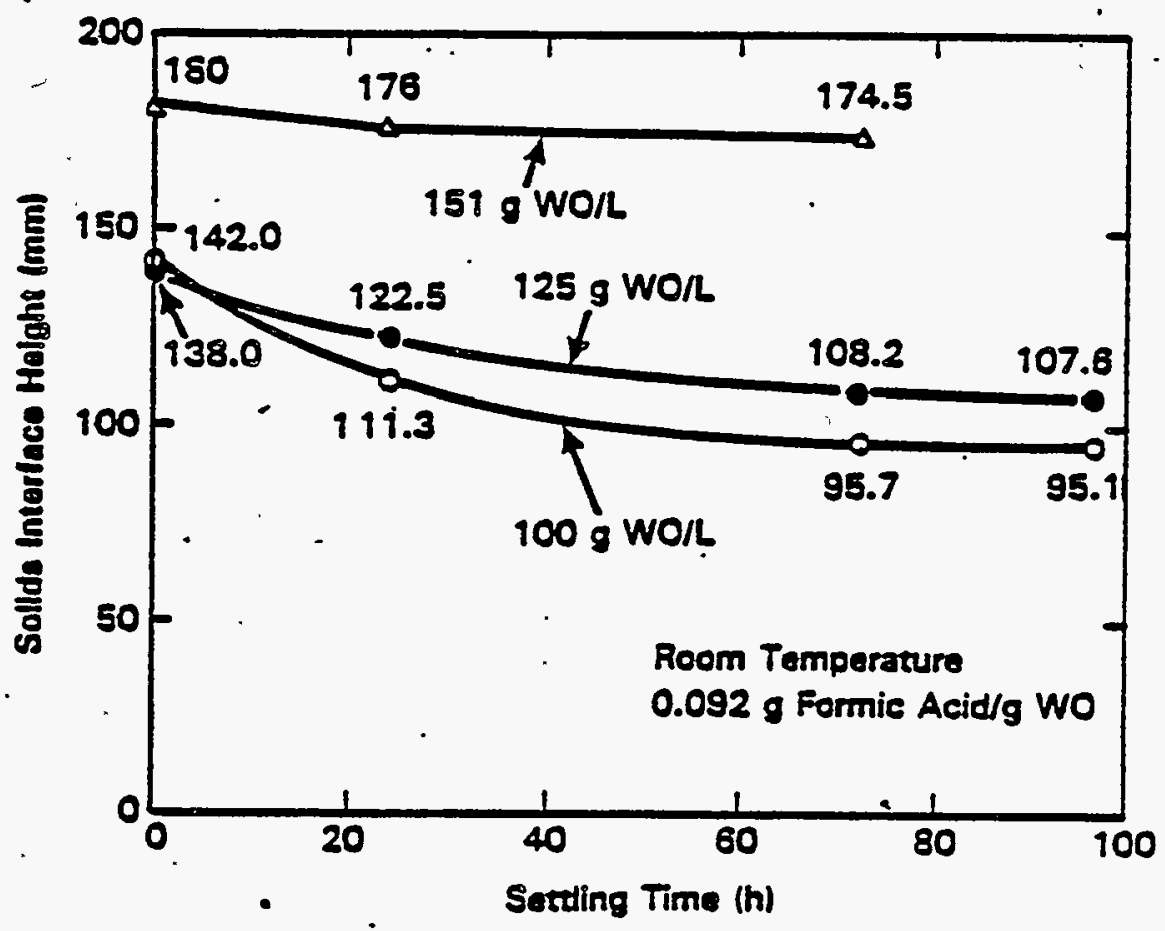

FIGURE 4.3-21. Settling Rate of Synthetic Formated HWVP Feed (HWS6)

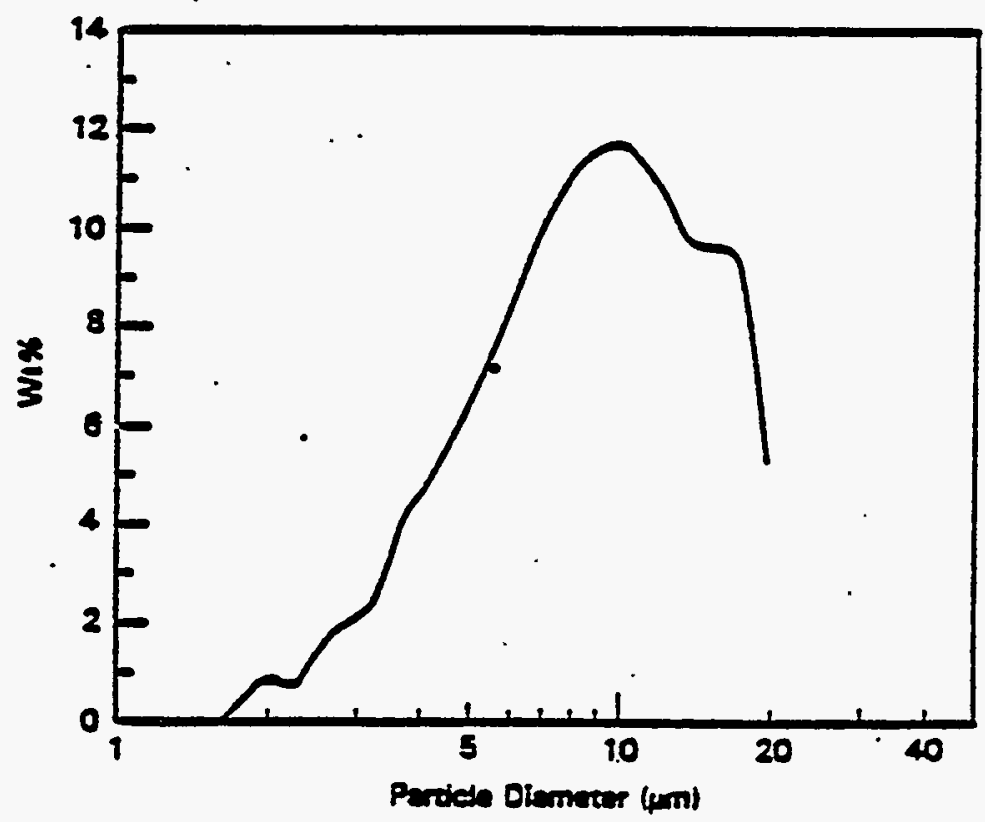

FIGURE 4.3-22. Synthetic Formated HWVP Feed (HWS6) Particle Size Distribution at $151 \mathrm{~g} \mathrm{WO} / \mathrm{L}^{(\mathrm{a})}$

(a) Letter (March 10, 1986) from H. T. B7air/J. M. Perez to J. E. Minor, "February 1986 Month7y Report - HWVP Task V113, " Pacific Northwest Laboratory, Richland, Washington. 


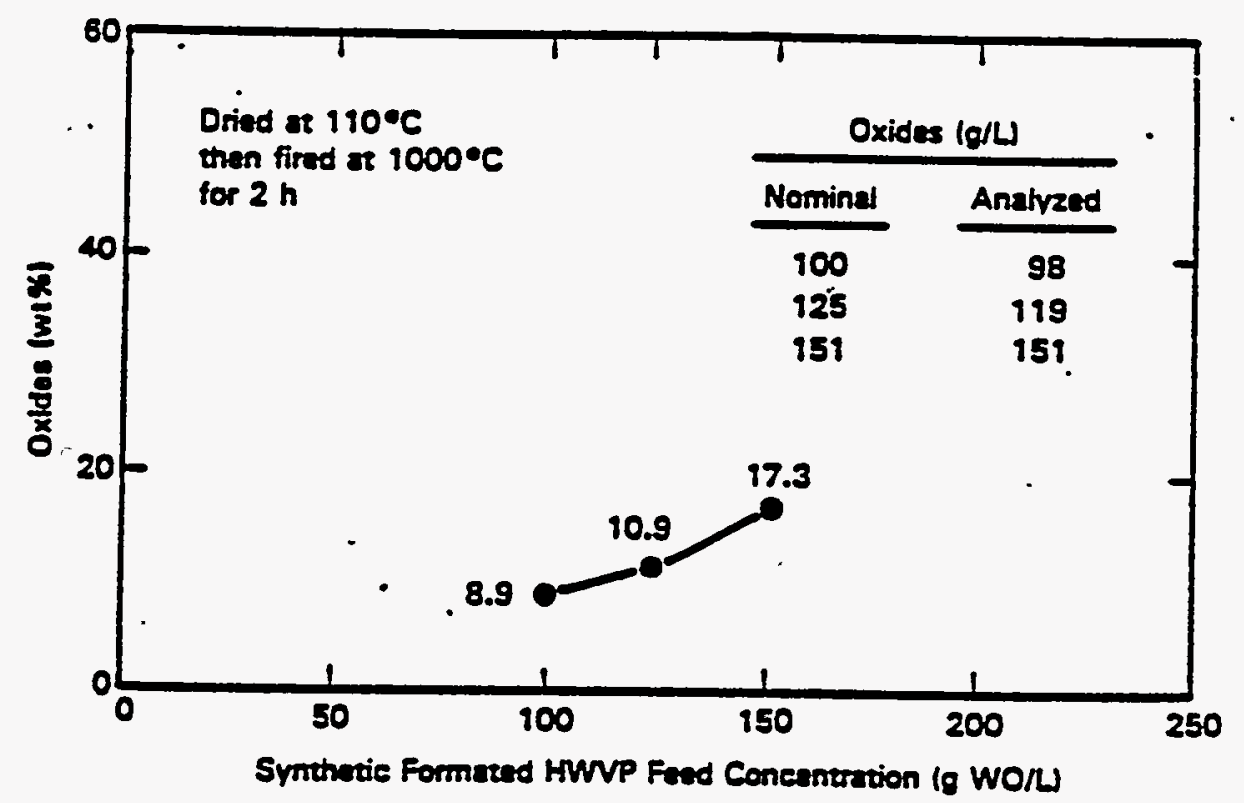

FIGURE 4.3-23. Oxides in Synthetic Formated HWVP Feed (HWS6)

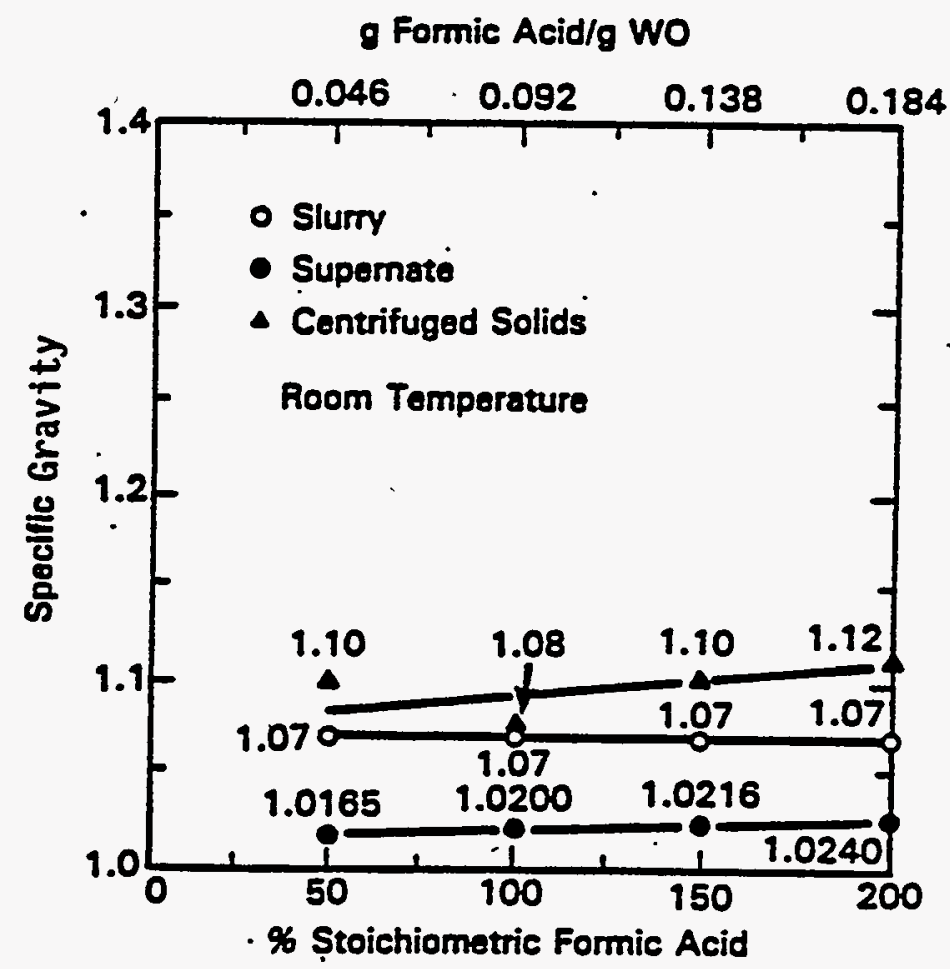

FIGURE 4.3-24. Specific Gravity of Synthetic Formated HWVP Feed (HWS6) at Various Formic Acid Additions 


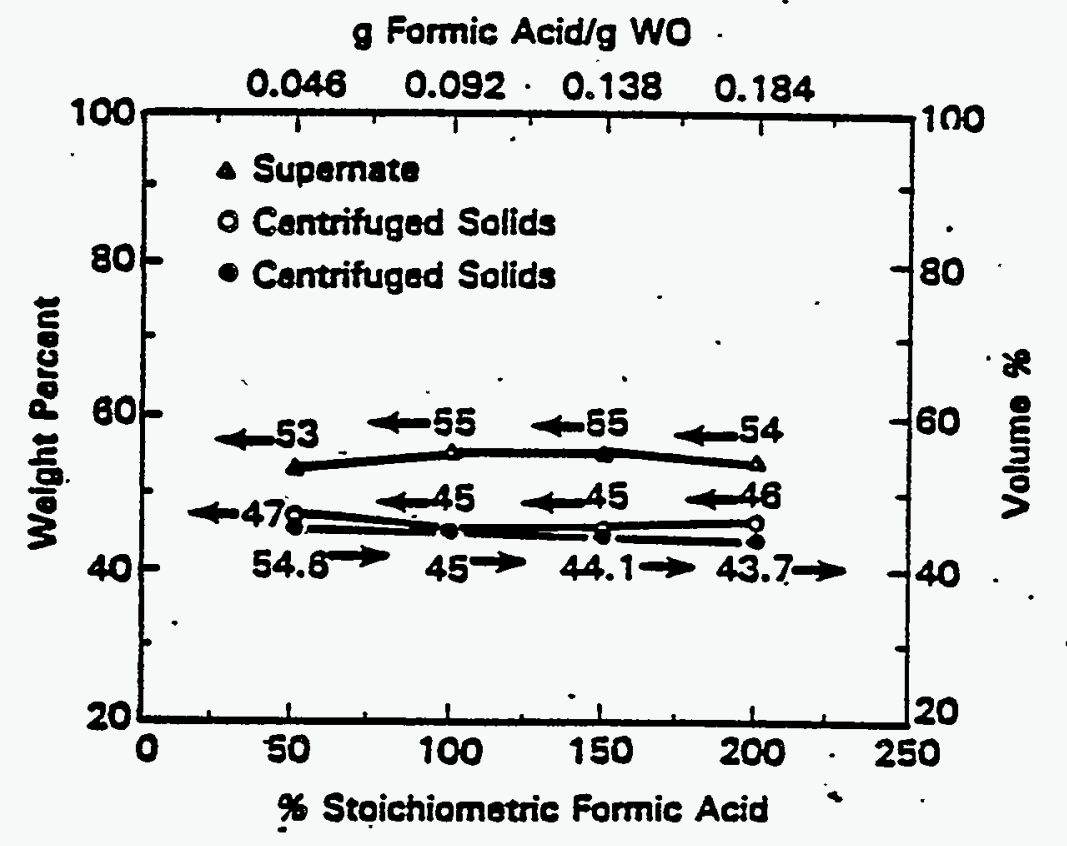

FIGURE 4.3-25. Solids/Supernate Distribution in Synthetic Formated HWVP Feed (HWSE) at Various Formic Acid Additions

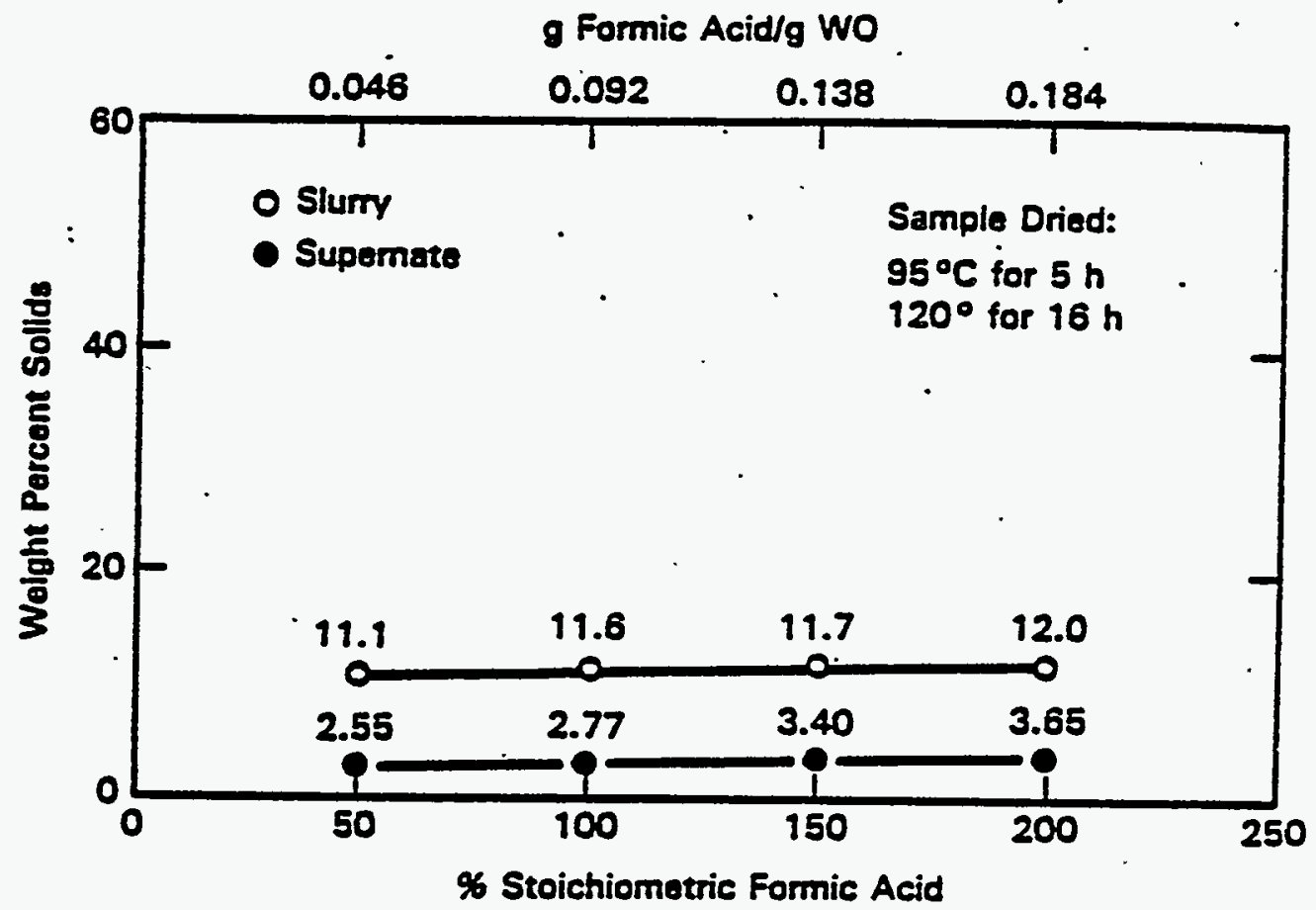

FIGURE 4.3-26. Solids Content in Synthetic Formated HWVP Feed (HWS6) at Various Formic Acid Additions 


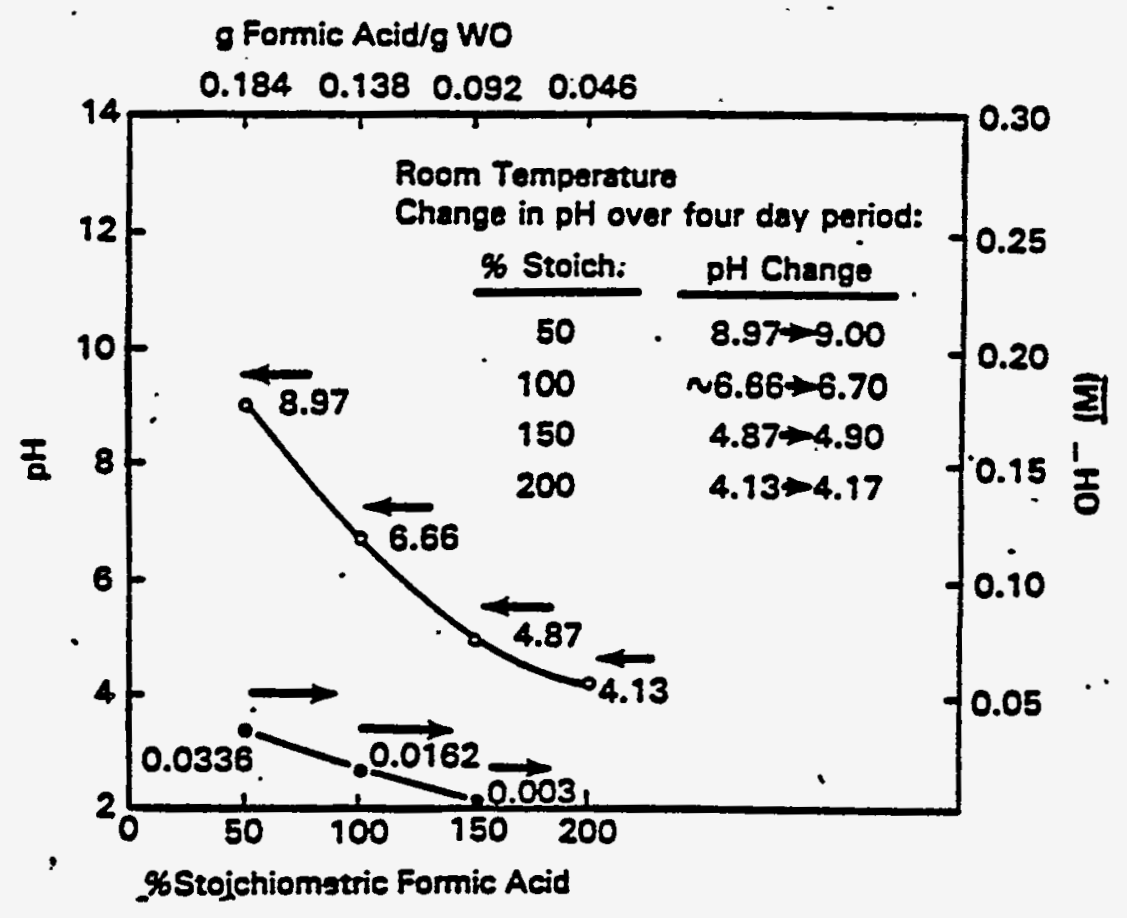

FIGURE 4.3-27. $\mathrm{pH}$ and ATkalinity of Synthetic Formated HWVP Feed (HWS6) at Various Formic Acid Additions

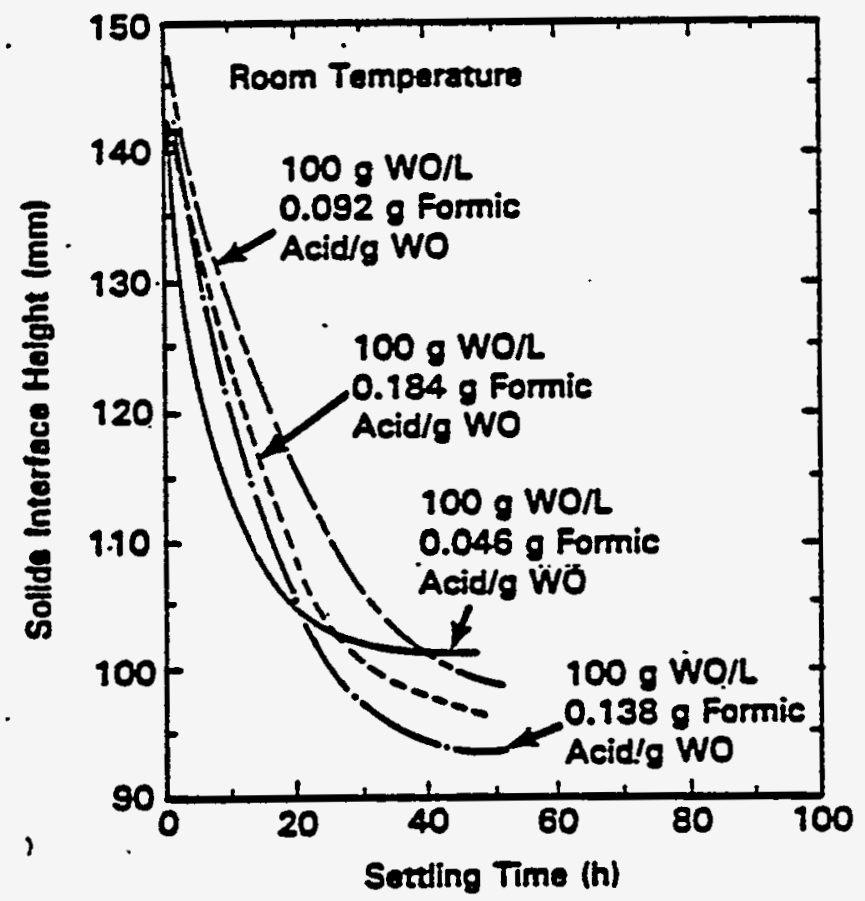

FIGURE 4.3-28. Sett7ing Rate of Synthetic Formated HWVP Feed (HWS6) at Various Formic Acid Additions 


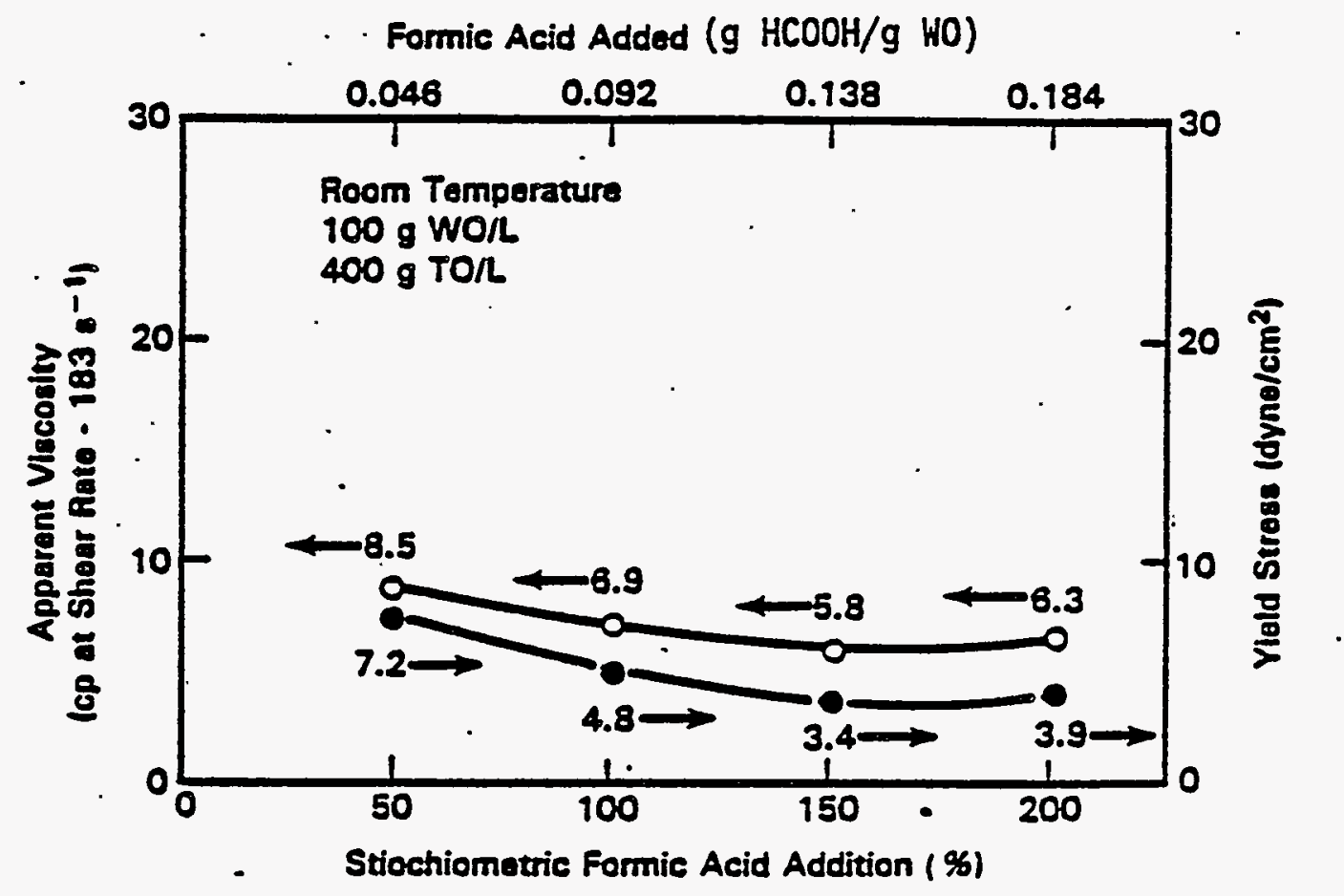

FIGURE 4.3-29. Apparent Viscosity and Yield Stress of Synthetic Formated HWVP Feed (HWS6) at Various Formate Additions

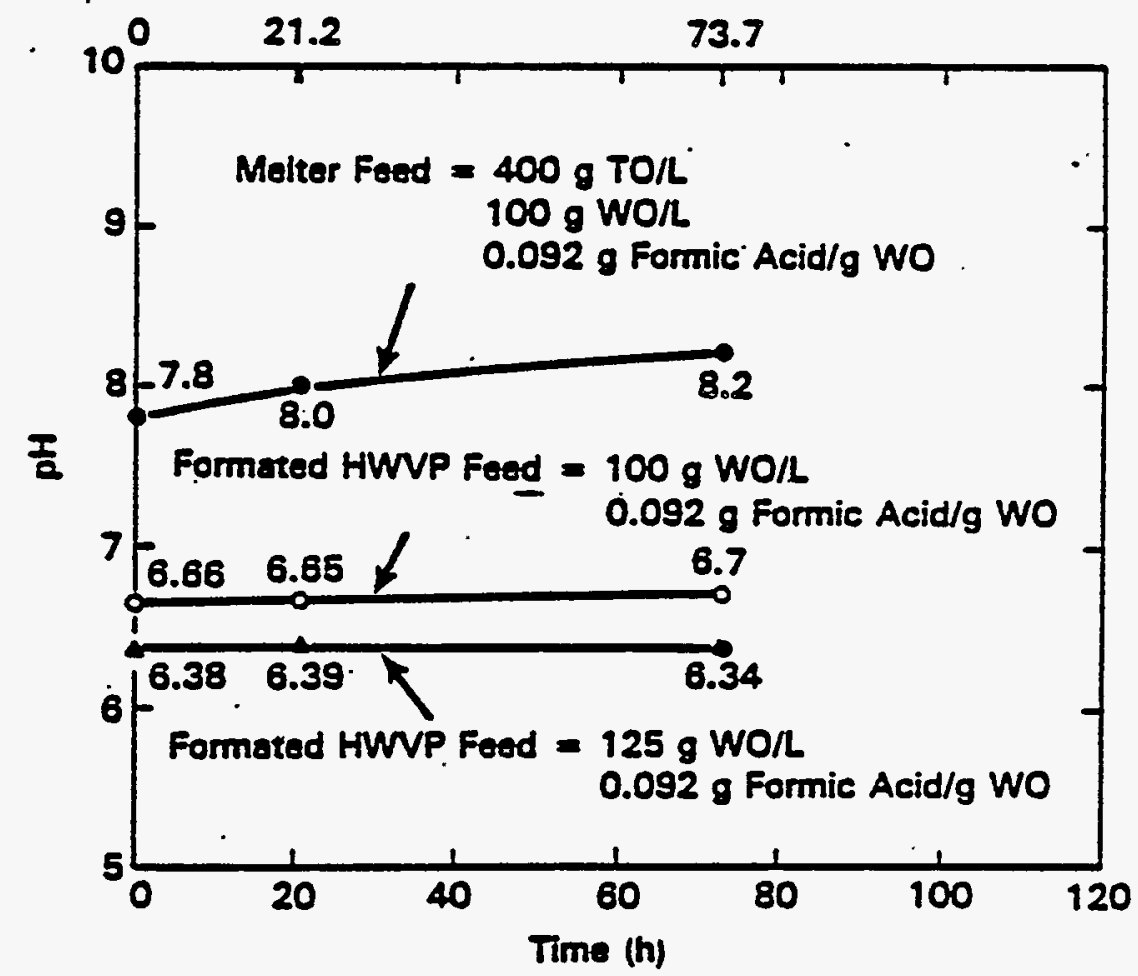

FIGURE 4.3-30. Effect of Time on $\mathrm{pH}$ of HWVP Slurries 


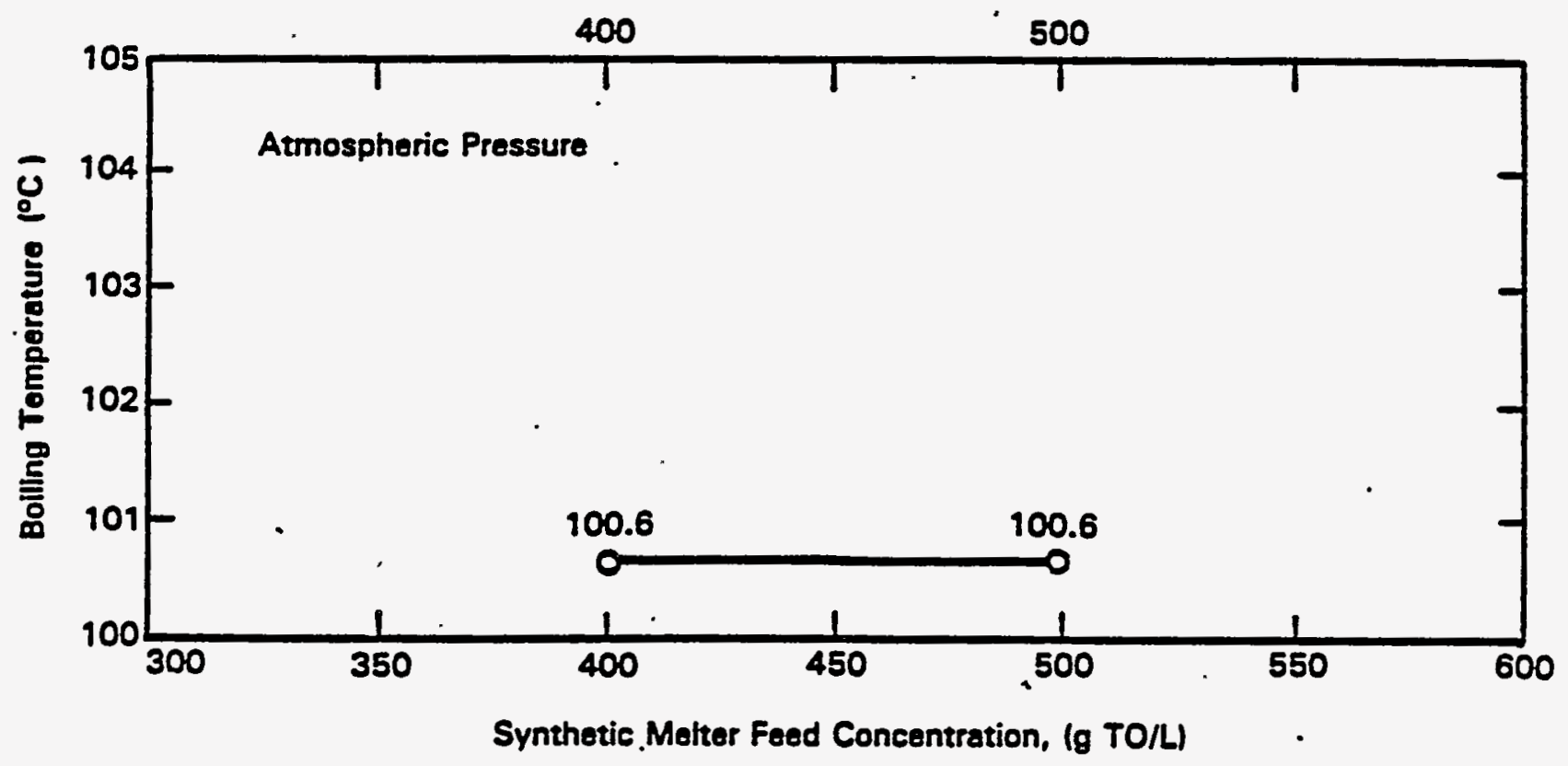

FIGURE 4.3-31. Boiling Temperature of Synthetic Melter Feed (HWS6)

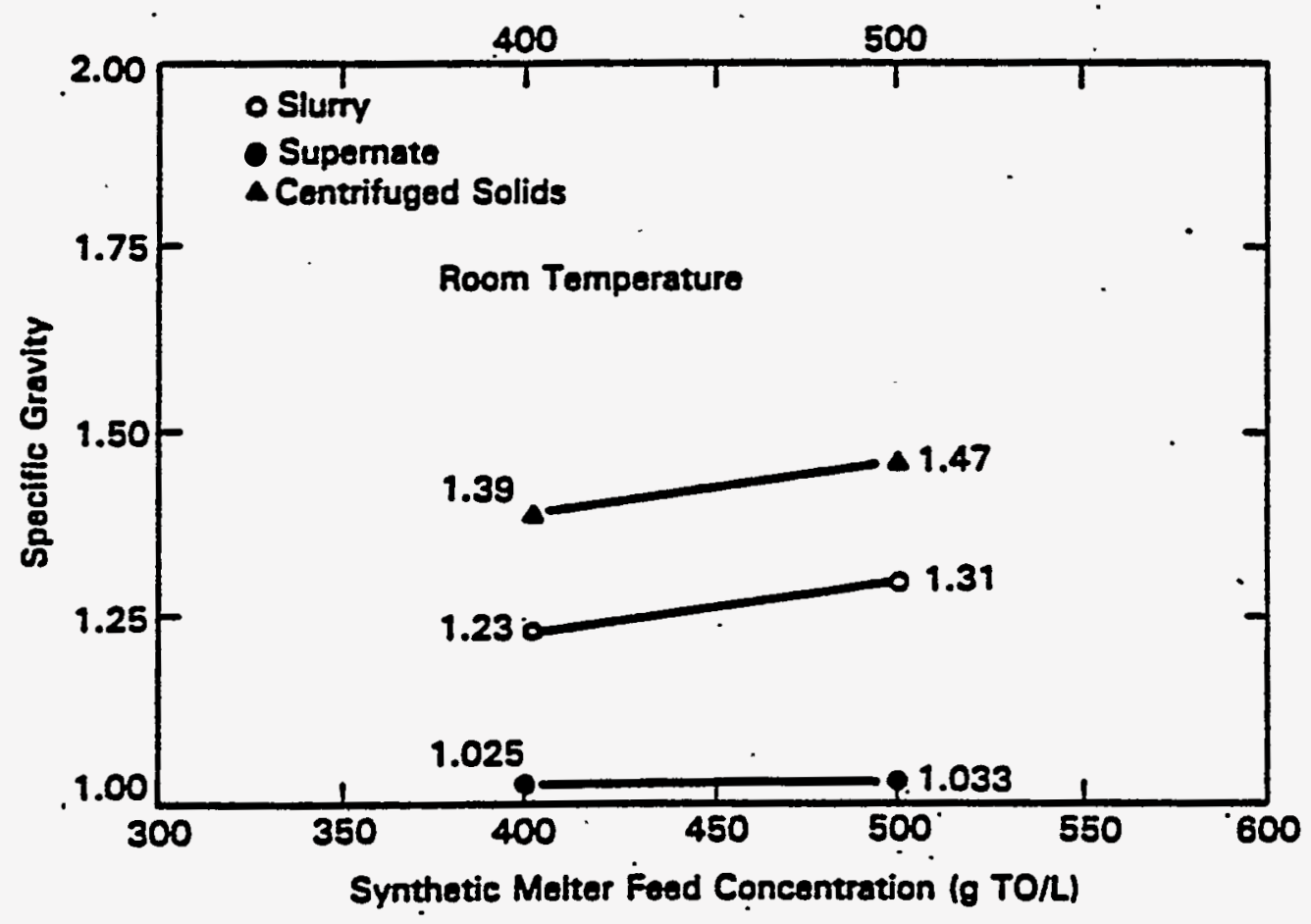

FIGURE 4.3-32. Specific Gravity of Synthetic Melter Feed (HWS6) 


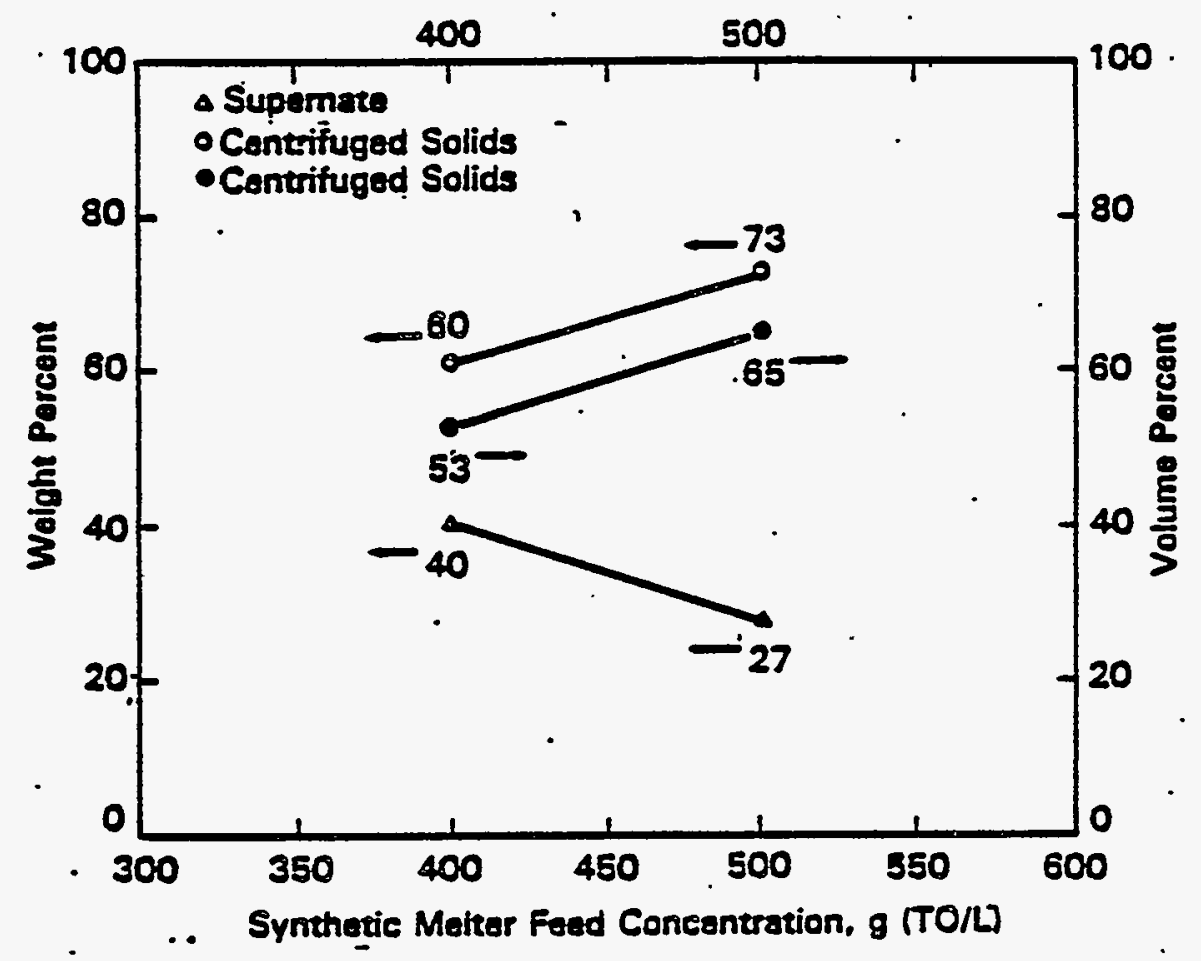

FIGURE 4.3-33. Solids/Supernate Distribution in Synthetic He]ter Feed (HWS6)

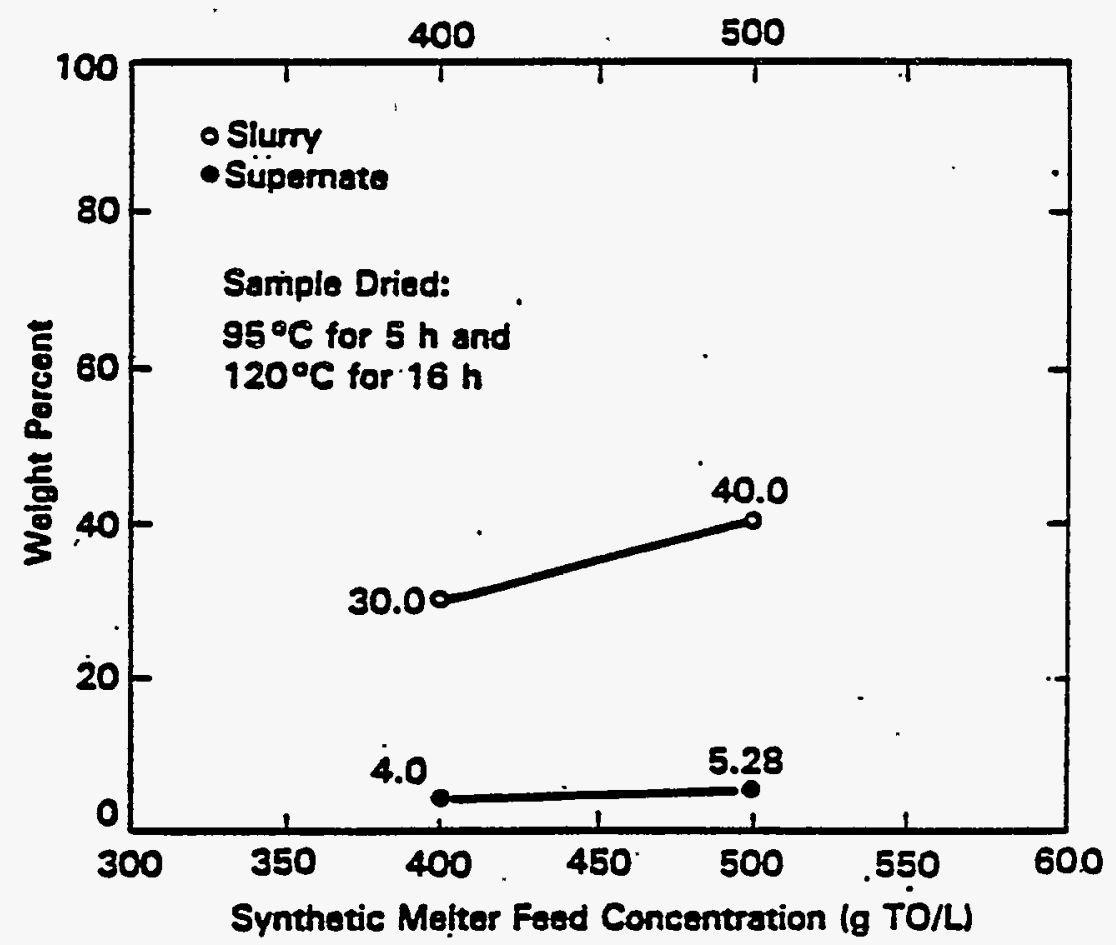

FIGURE 4.3-34. Solids Content in Synthetic Melter Feed (HWS6) 


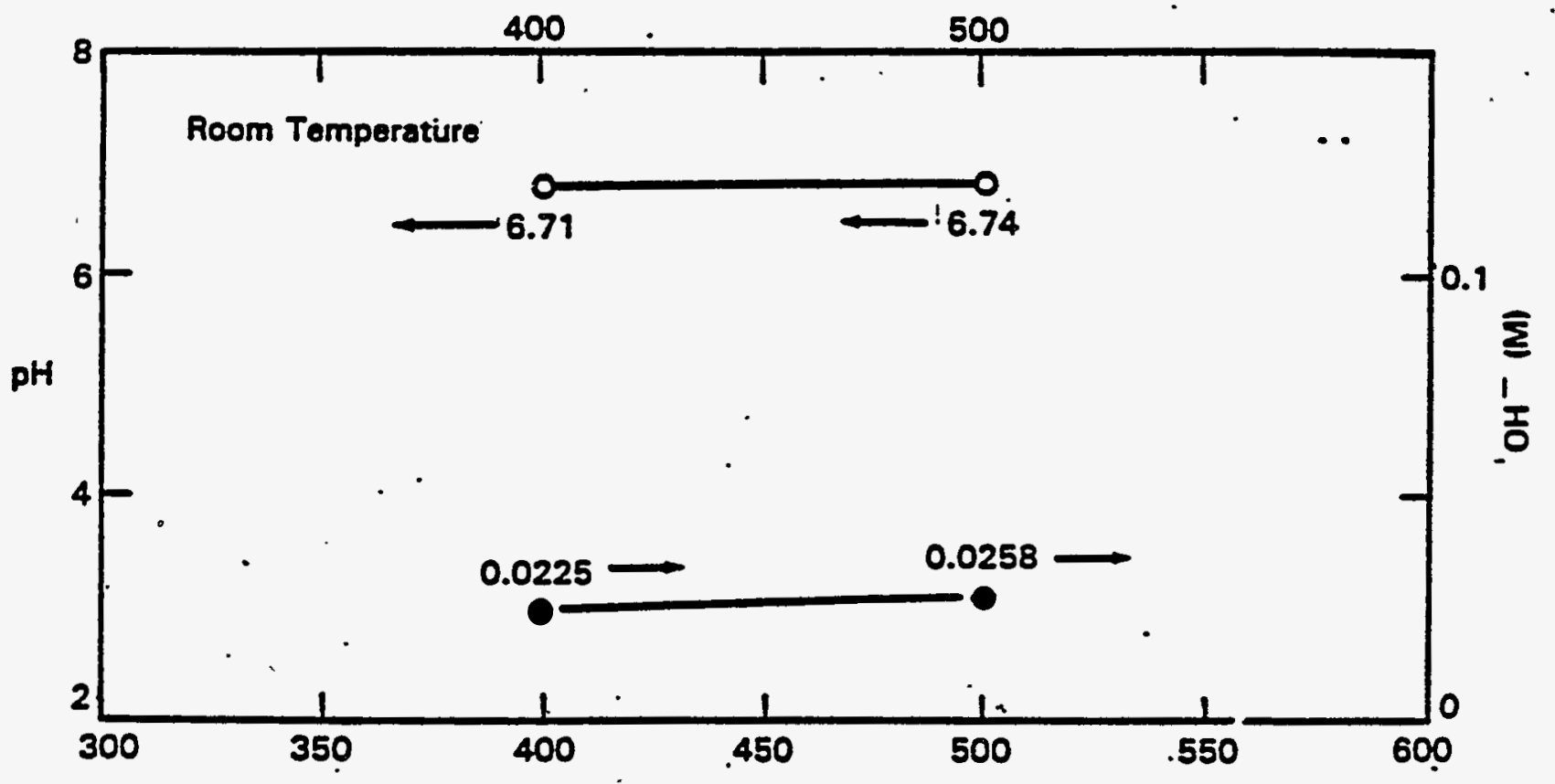

FIGURE 4.3-35. $\mathrm{pH}$ and Alkalinity of Synthetic Melter Feed (HWS6)

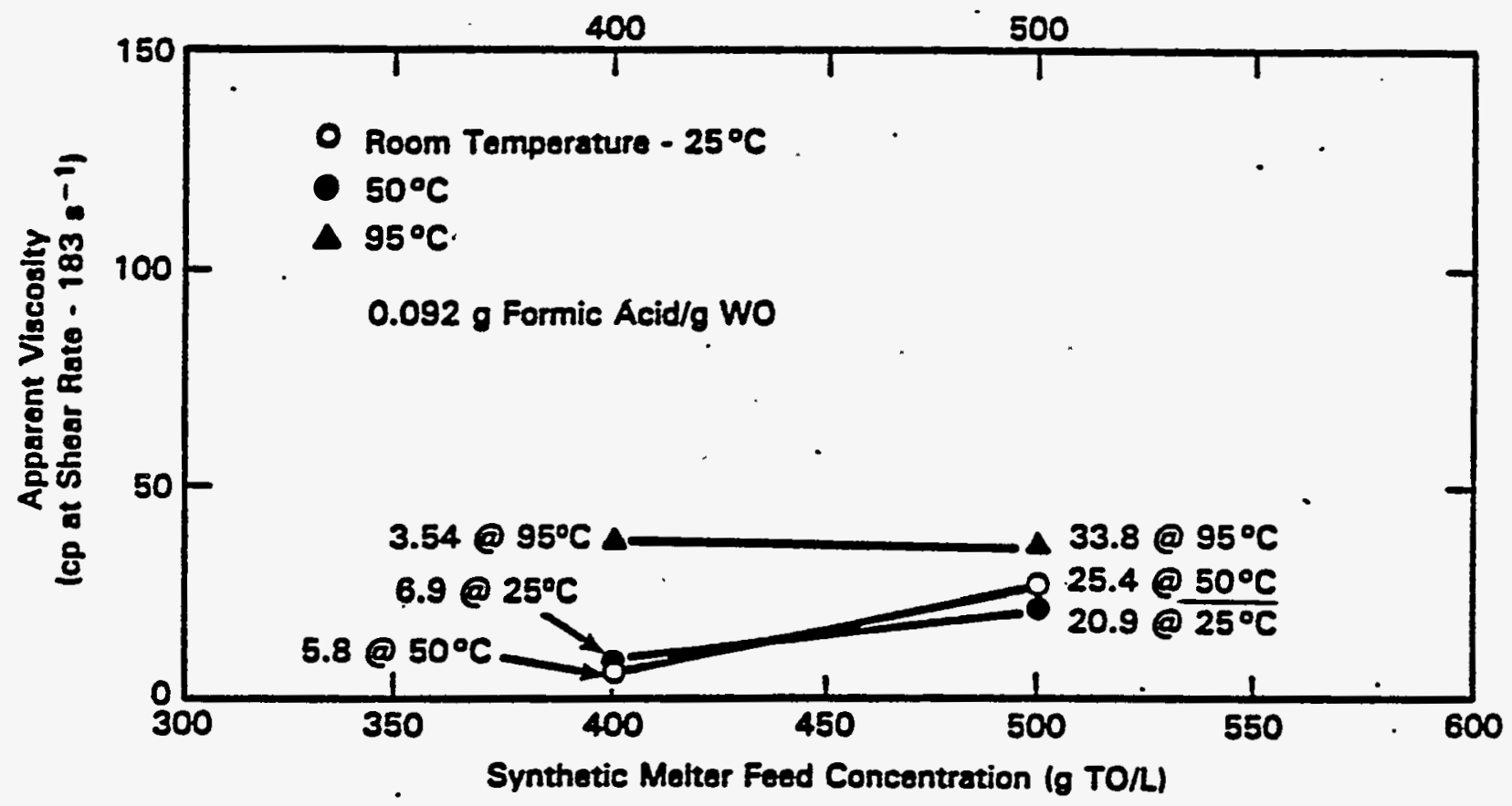

FIGURE 4.3-36. Apparent Viscosity of Synthetic Melter Feed (HWS6) at Various Temperatures 


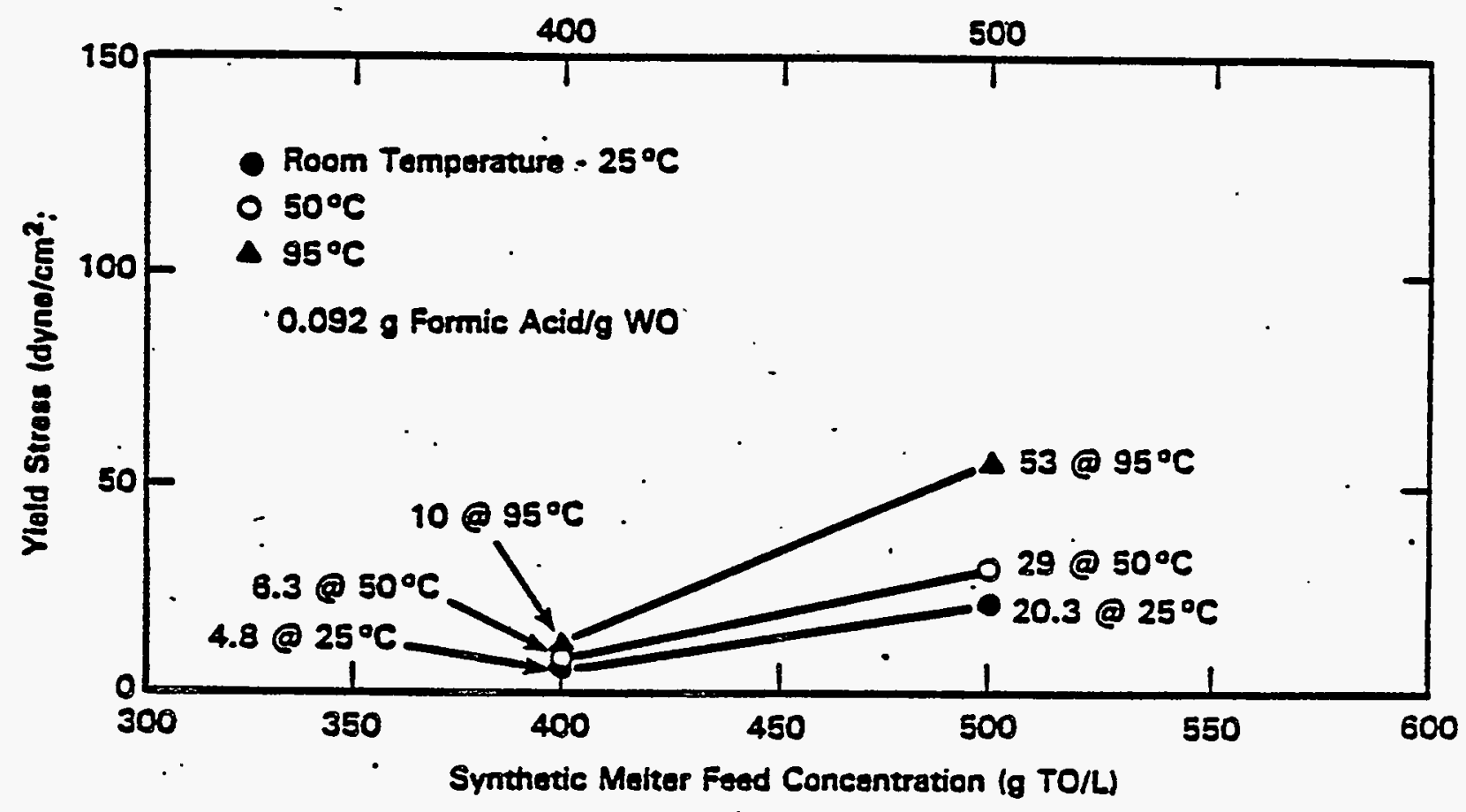

FIGURE 4.3-37. Yield Stress of Synthetic Melter Feed (HWS6) at Various - Temperatures

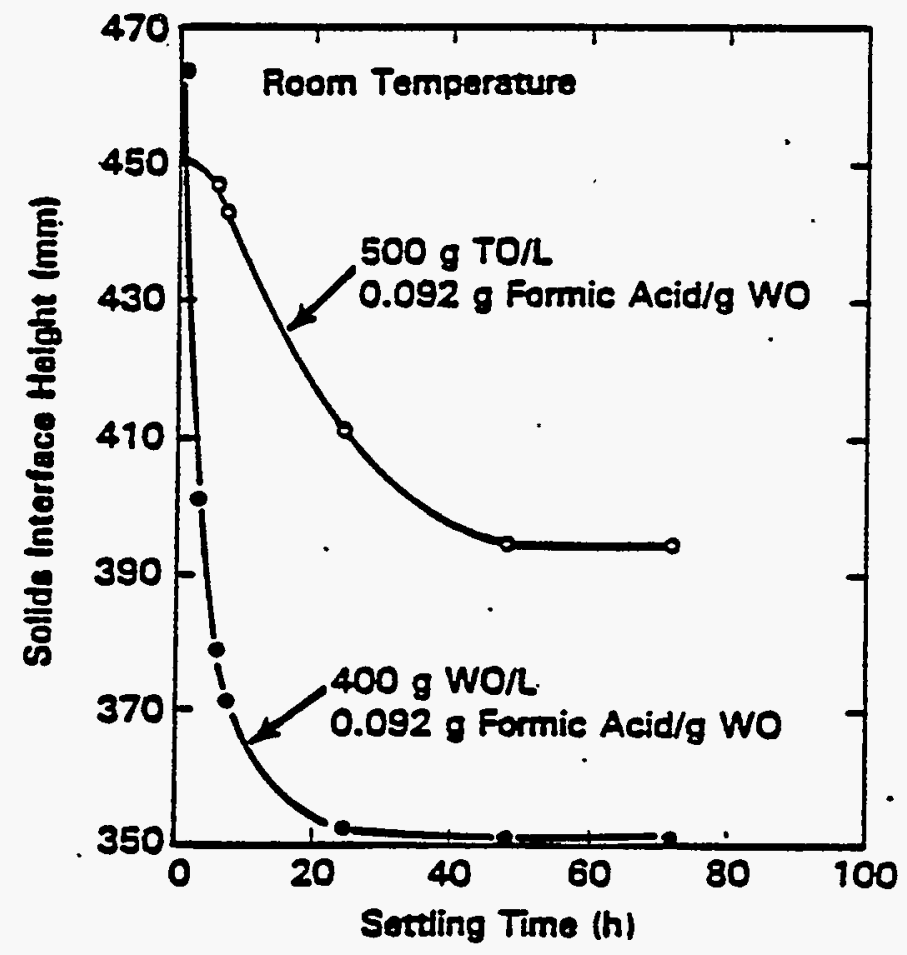

FIGURE 4.3-38. Settling Rate of Synthetic Melter Feed (HWS6) 


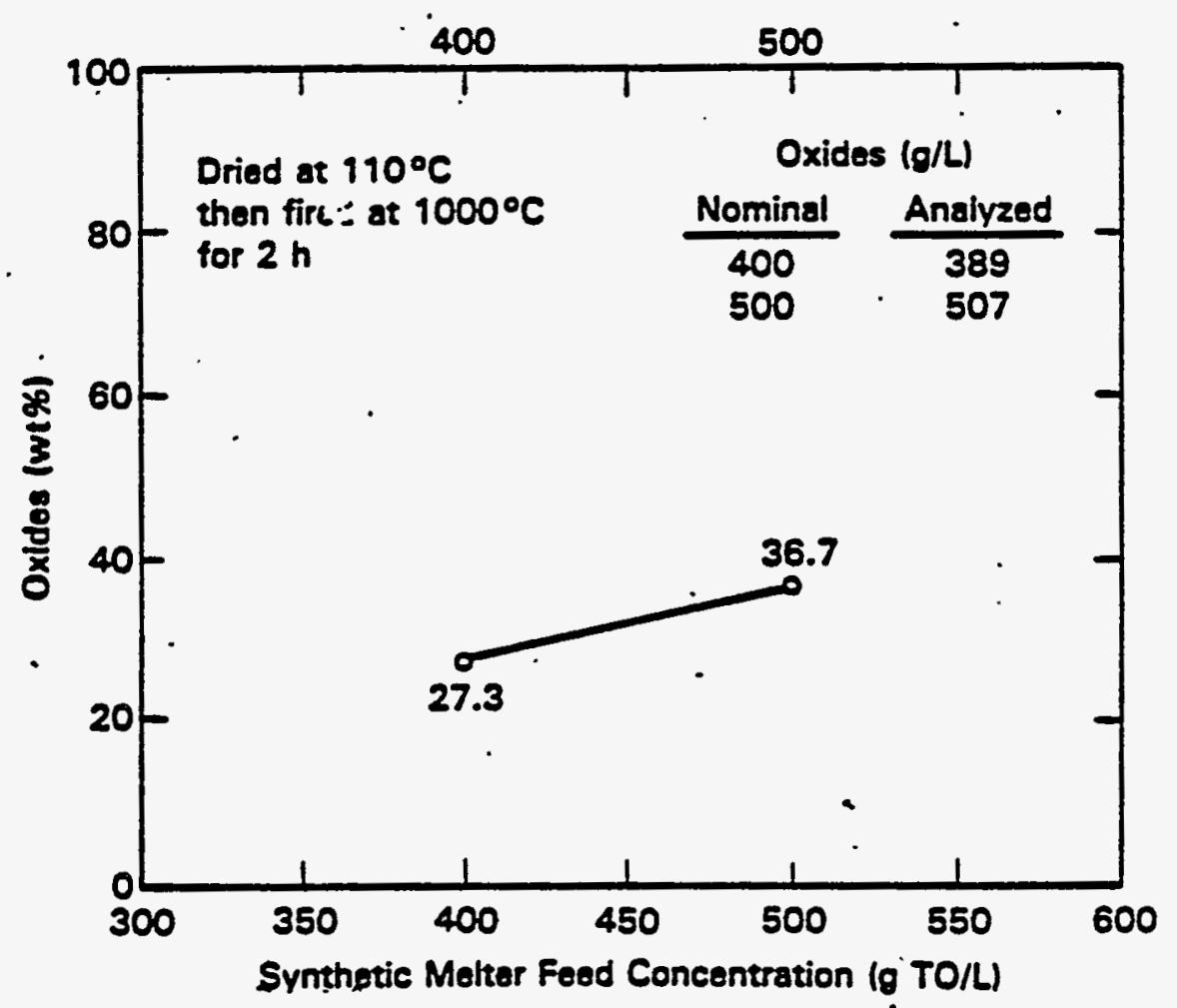

FIGURE 4.3-39. Oxides in Synthetic Me7ter Feed (HWS6)

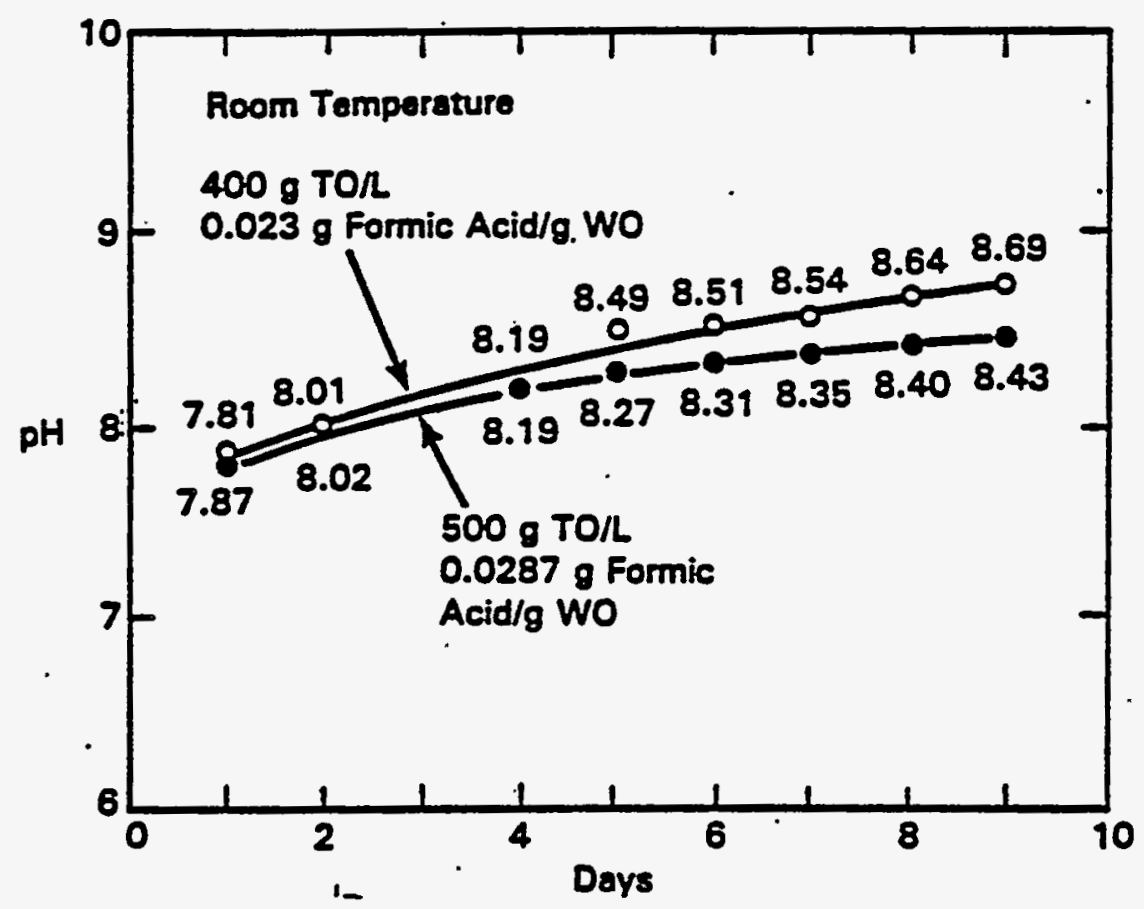

FIGURE 4.3-40. $\mathrm{pH}$ as a Function of Time for Synthetic Me7ter Feed (HWS6) 
Formic Acid Added (g HCOOHig WO)

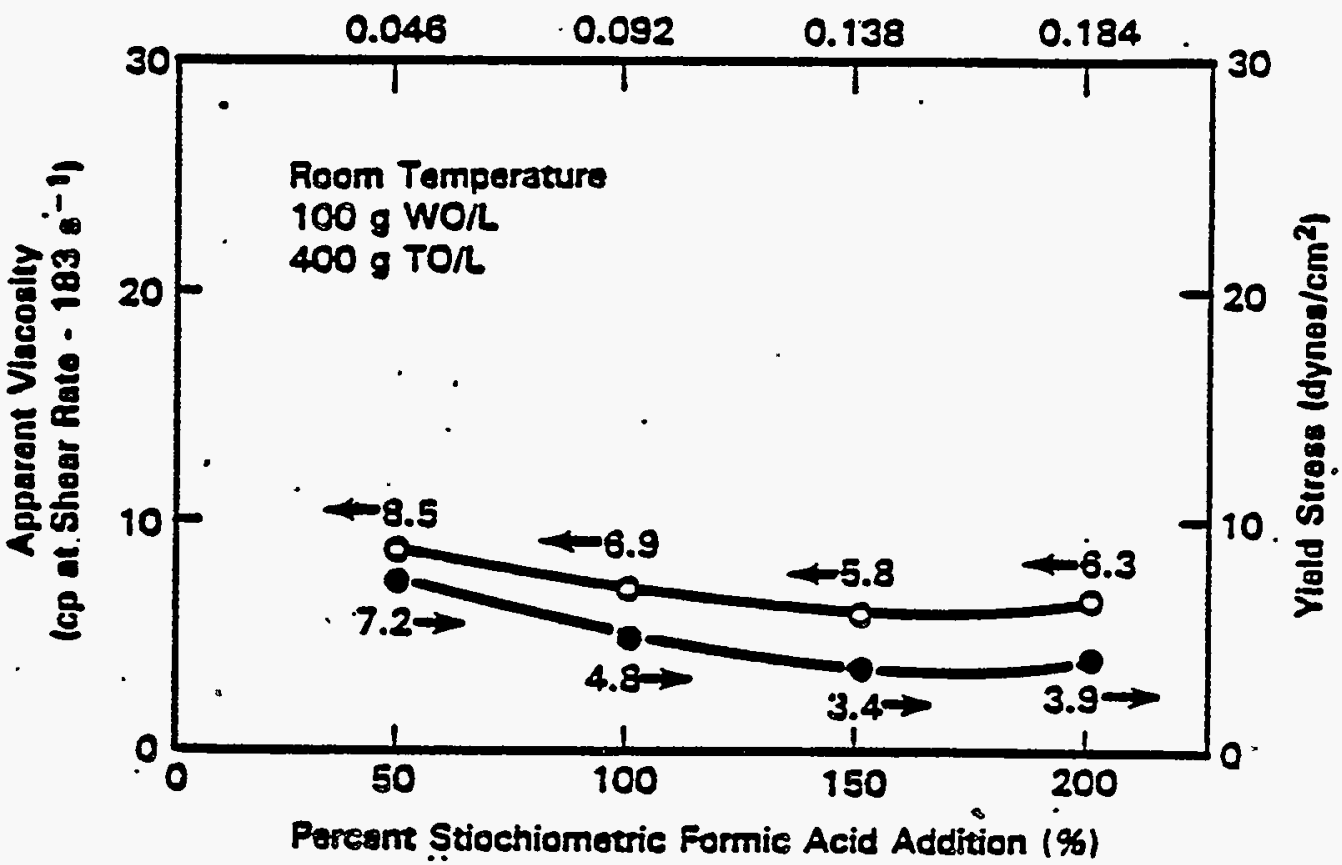

FIGURE 4,3-41. Apparent Viscosity and Yield Stress of Synthetic Melter Feed (HHSG) at Various Formate Additions

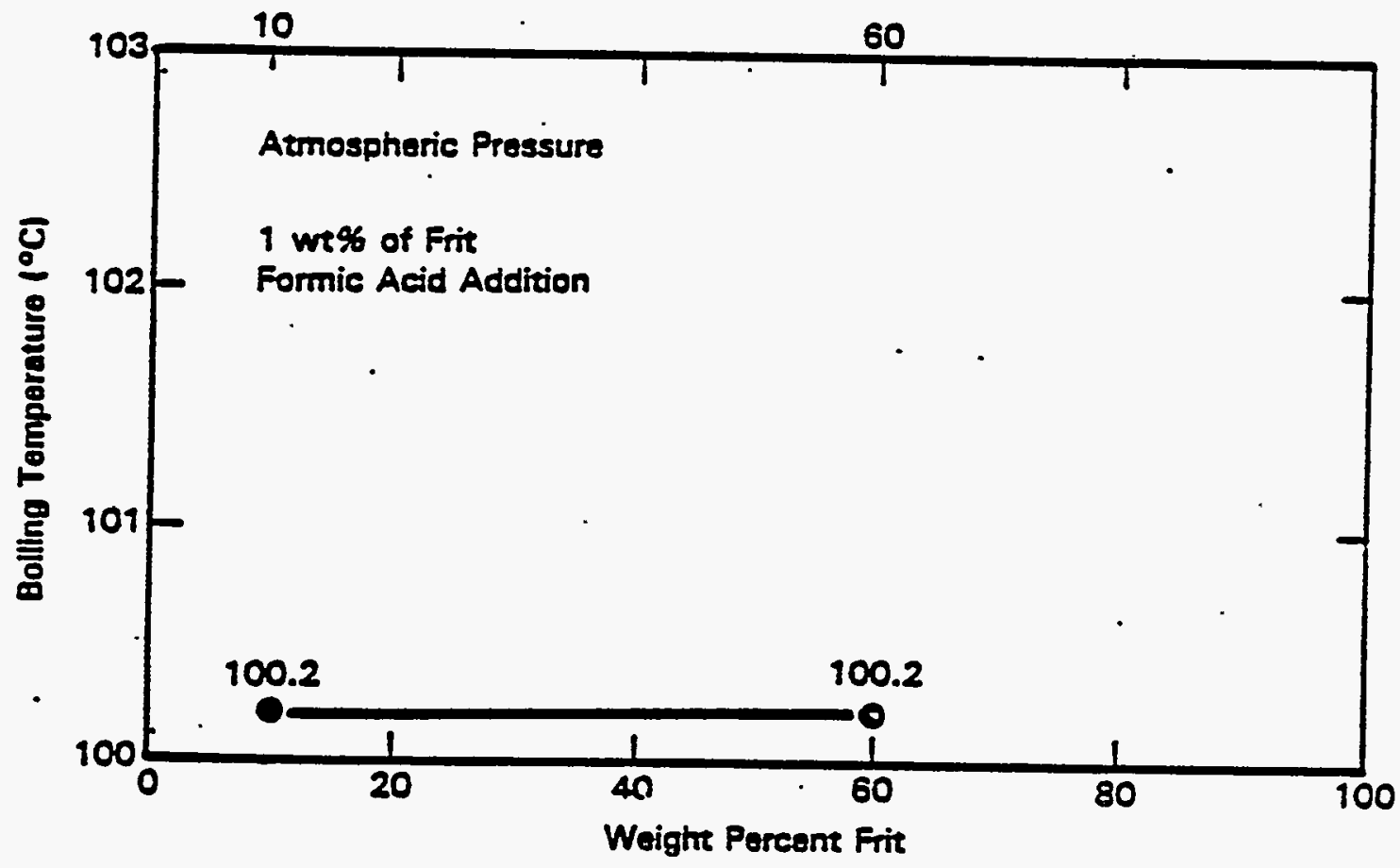

FIGURE 4.3-42. Boiling Temperature of Frit (HW39) STurries 


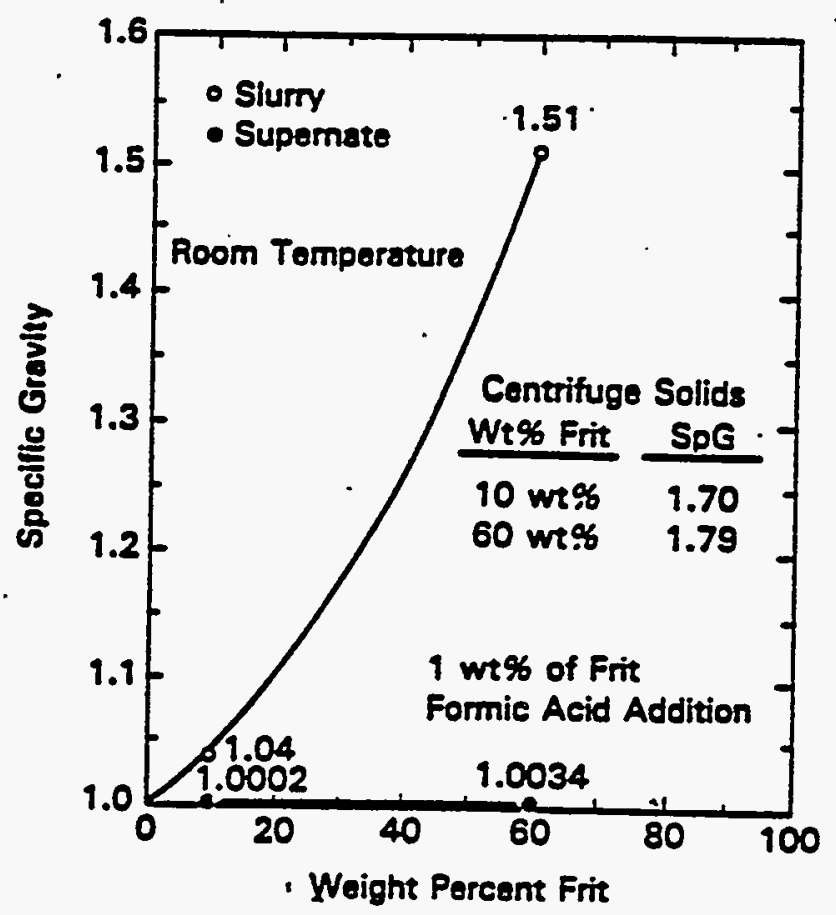

FIGURE 4.3-43. Specific Gravity of Frit (HW39) Slurries

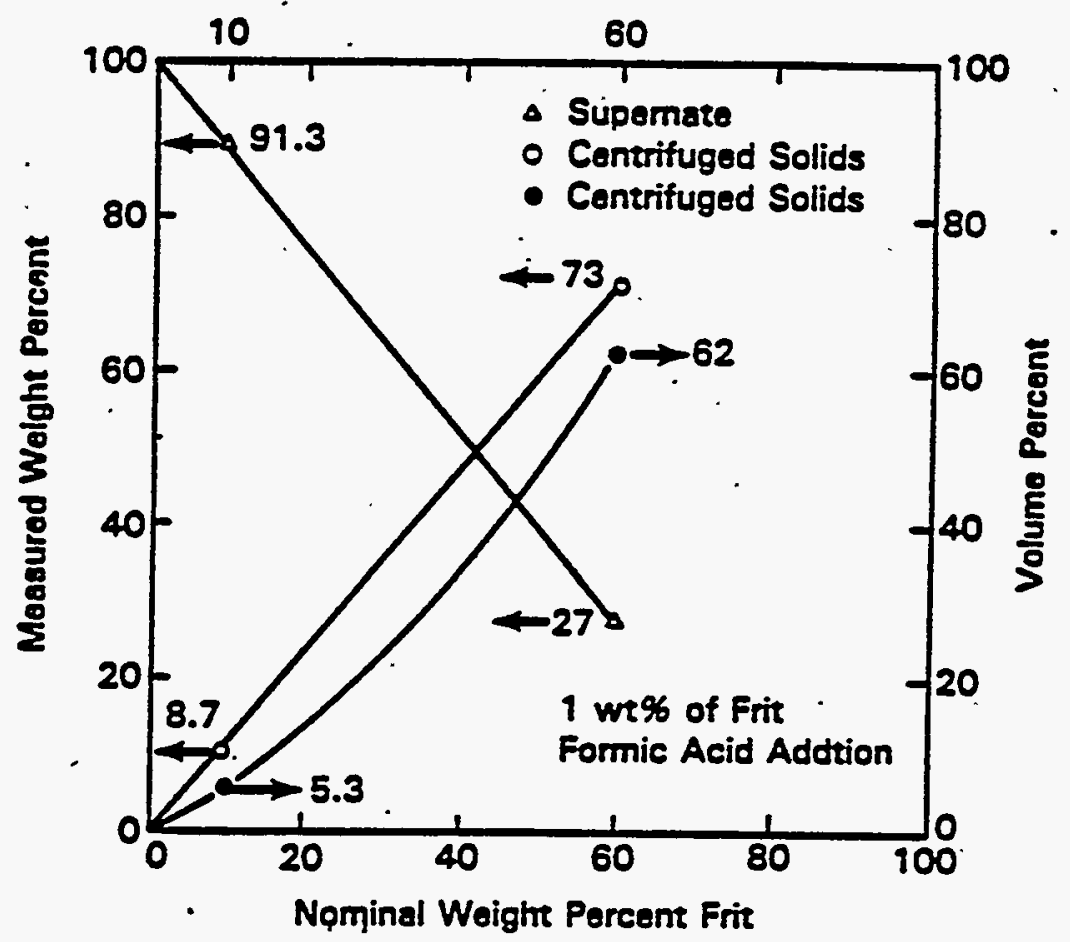

FIGURE 4:3-44. Solids/Supernate Distribution in Frit (HW39) STurries 


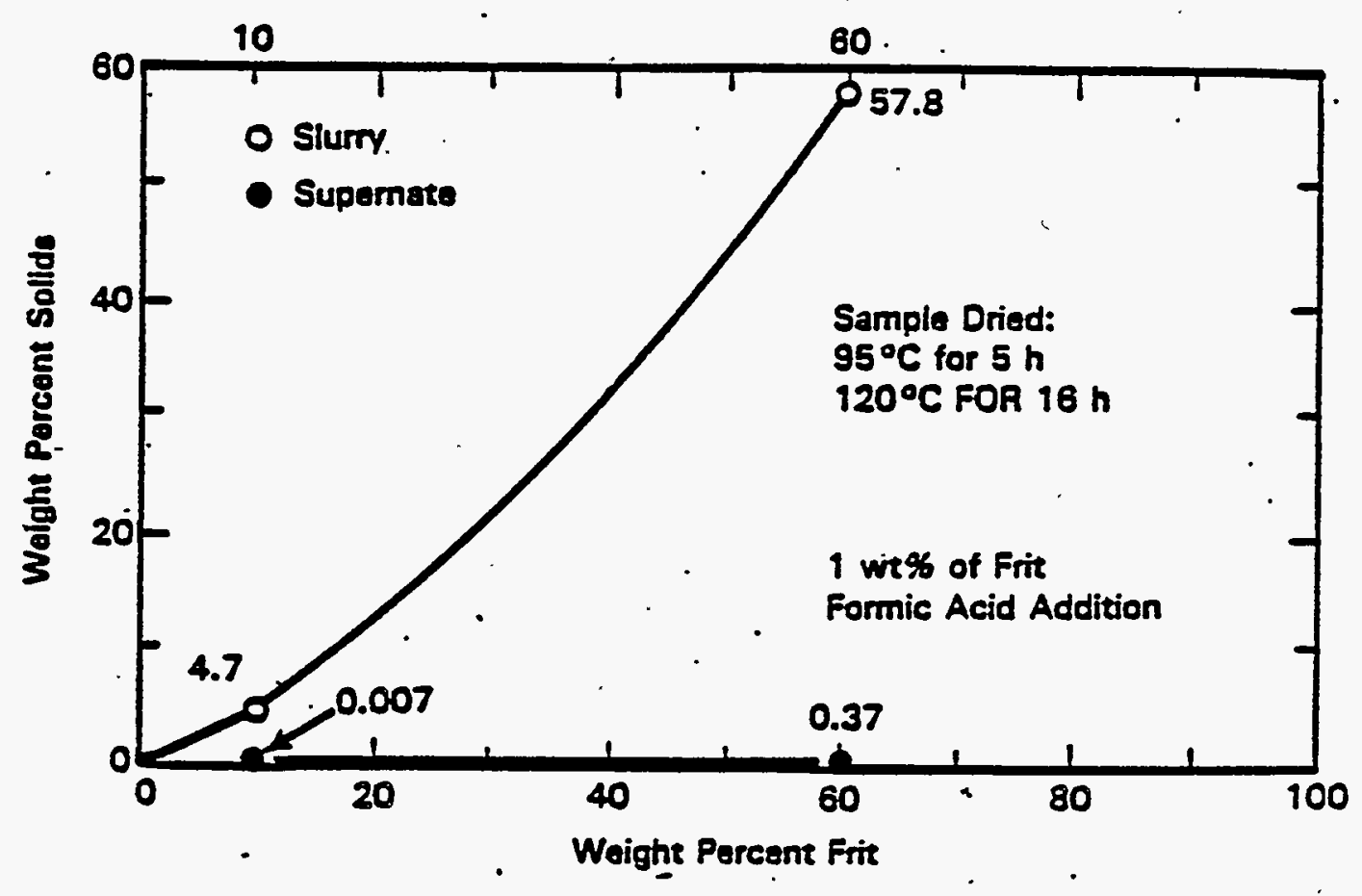

FIGURE 4.3-45. Solids Content of Frit (HH39) Slurries

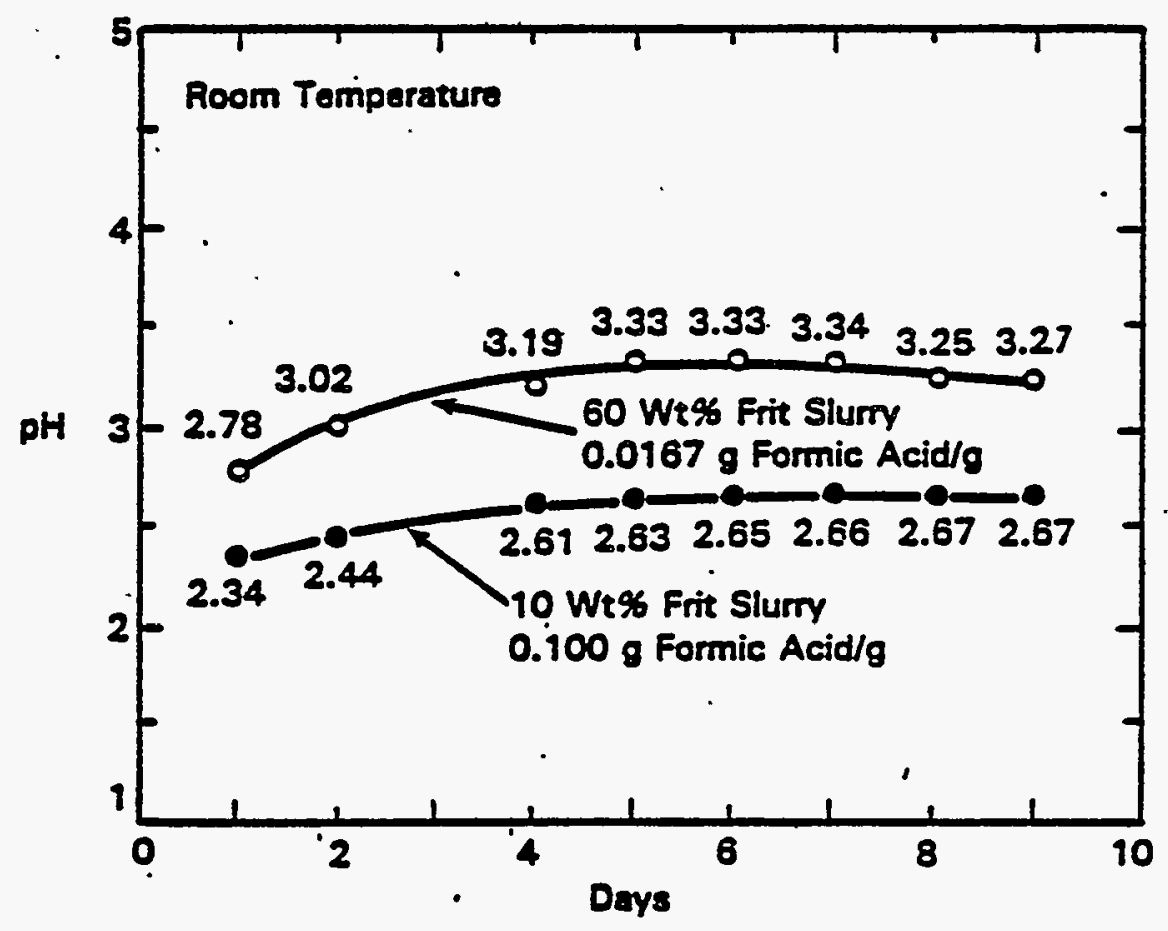

FIGURE 4.3-46. pH of Frit (HH39) Slurry as a Function of Time 


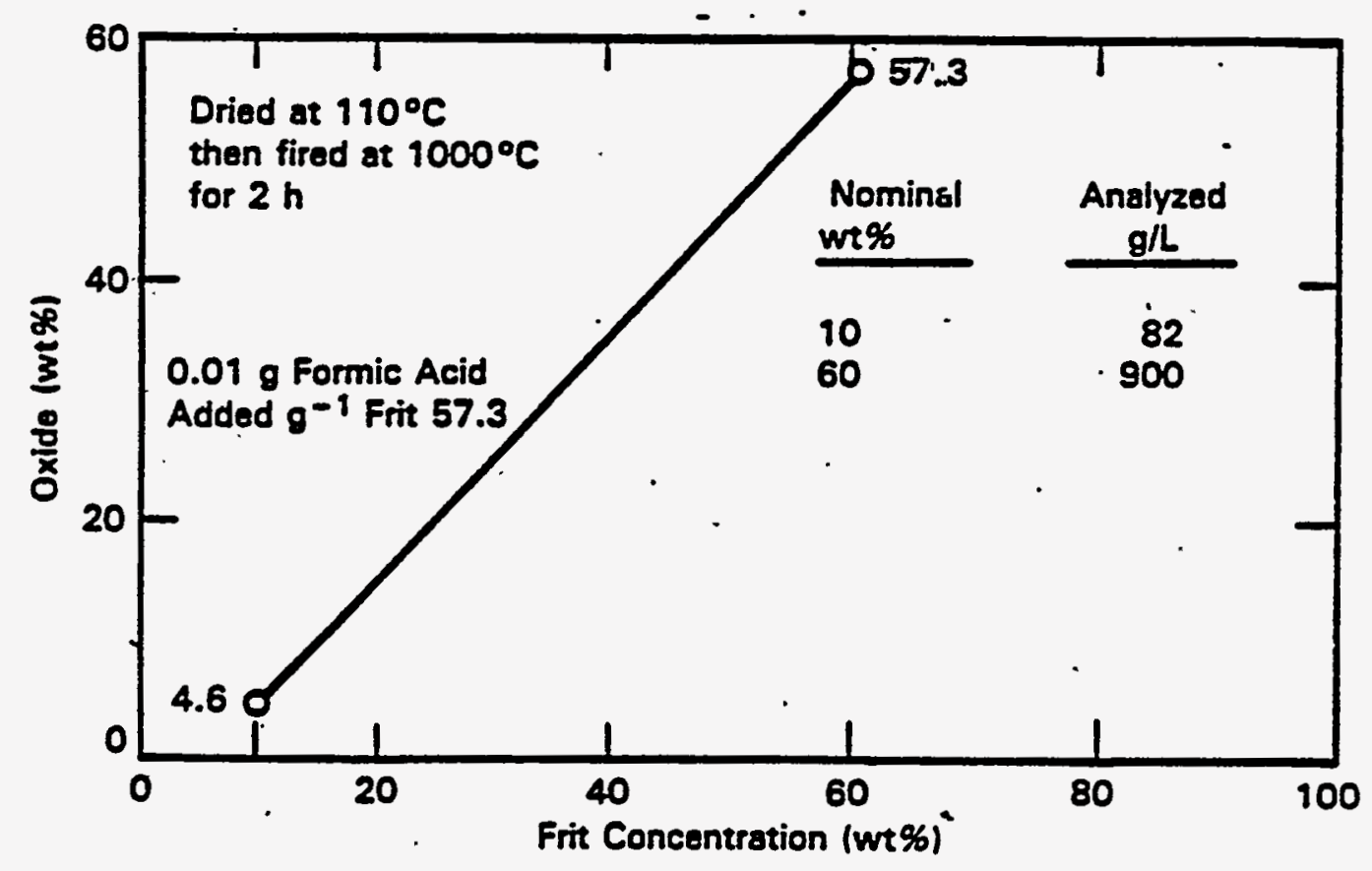

FIGURE 4.3-47. Oxides in Frit HWVP (HW39) Feed Slurries

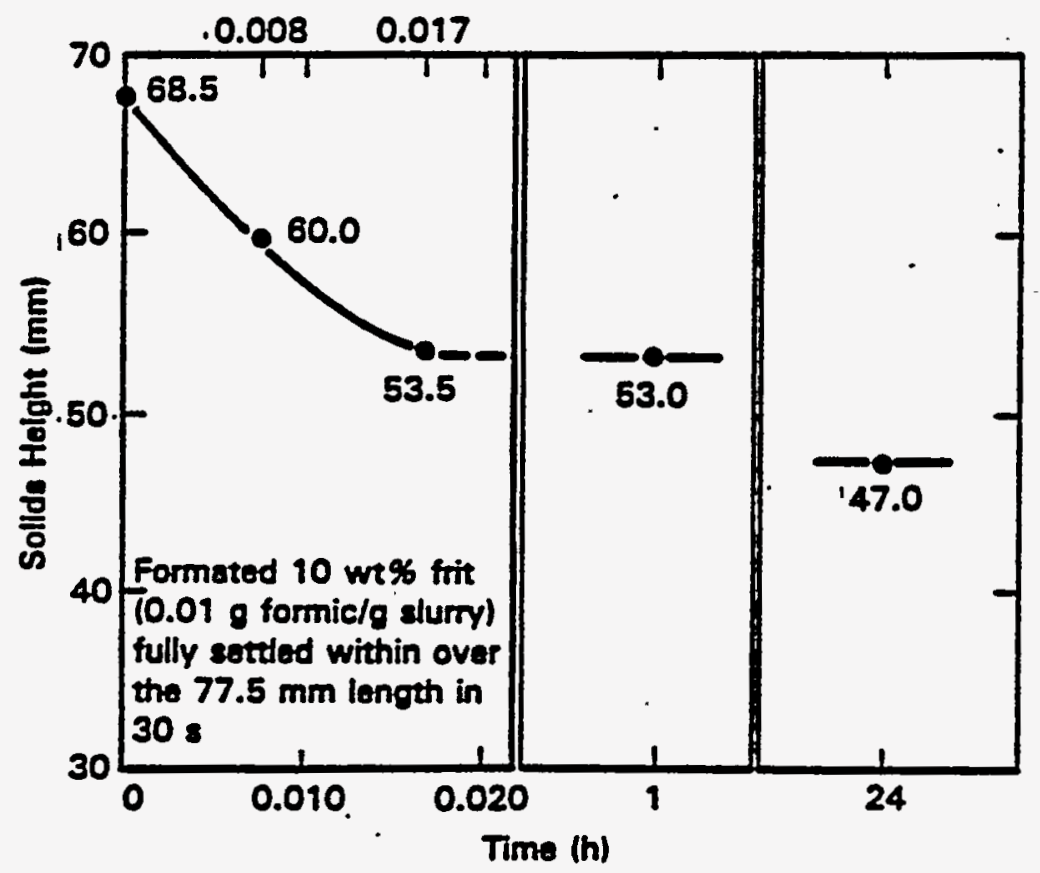

FIGURE 4.3-48. Settling Behavior of Frit (HW39) S7urries 


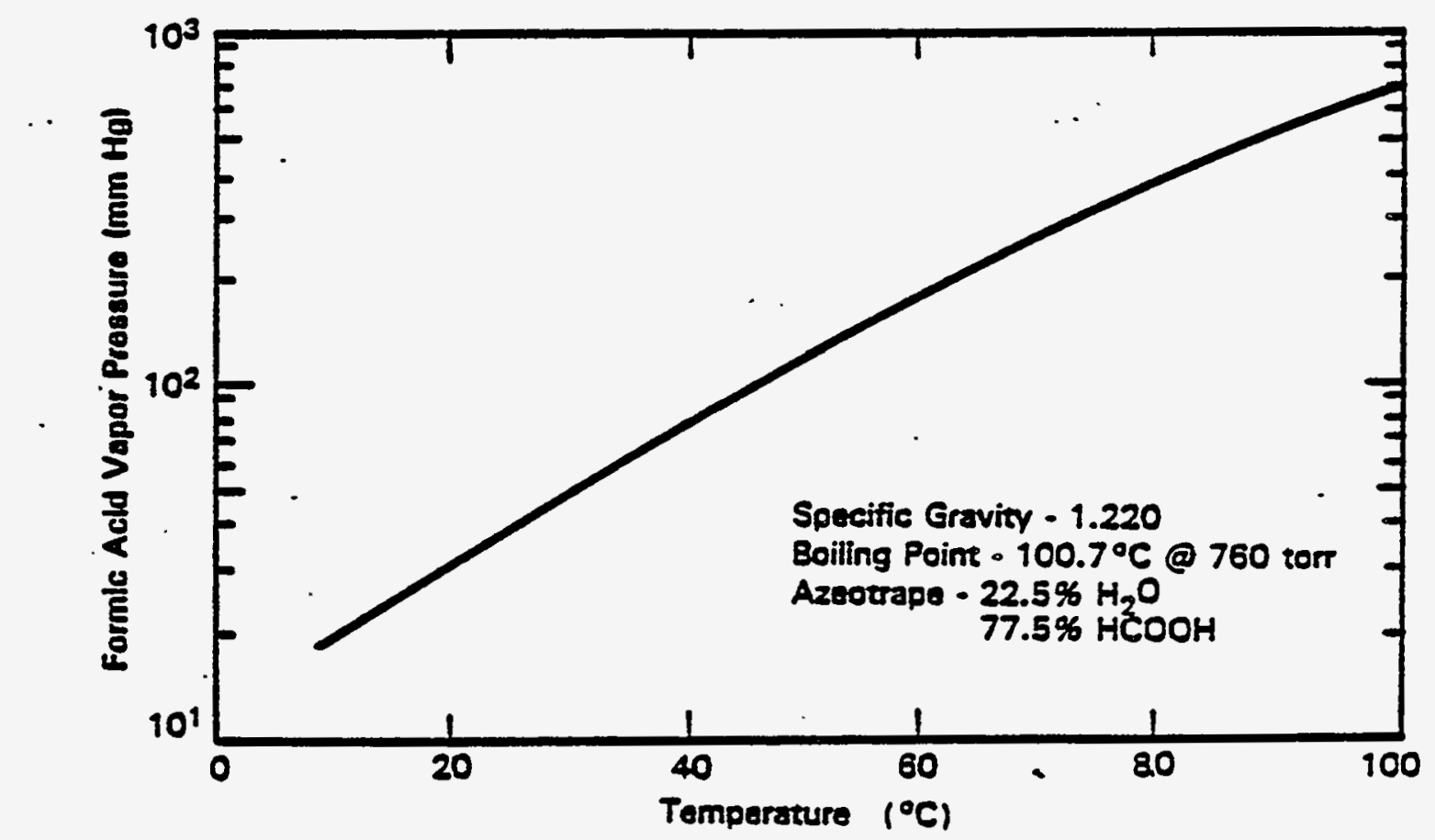

FIGURE 4.3-49. Vapor Pressure of Formic Acid - DWPF (E.I. du Pont de Nemours \& Co., "Basic Data Report.- DWPF -

Sludge Plant - SRP, 200-S Area," DPSP 80-133, SRP)

\subsubsection{1,1.2 HWVP Feed Evaluation (Concentration, Boiling, Formic Acid}

Additionl. (a) An eariy simulated NCAW 84 high chromium slurry used for testing is identified as HWS4. A compositional recipe for the HWS4 simulation is shown in Appendix $\dot{A}$ (Table $A-6)$. Preparation consisted of mixing in each specified component in the order shown in the table to achieve a concentration of approximately $140 \mathrm{~g} \mathrm{WO} / \mathrm{L}$. Three levels of formic acid addition were tested on each of the two different waste slurry concentrations. Three small batches of the HWS4 slurry at a concentration of $140 \mathrm{~g} \mathrm{HO} / \mathrm{L}$ were treated with. $1,2.5$ and 5 times the stoichiometric amount of formic acid. Three other batches of the HWS4 slurry were first concentrated to $190 \mathrm{~g} \mathrm{WO} / \mathrm{L}$ and then treated with $1,1.5$, and 2 times the stoichiometric amount of formic acid. After formic acid addition, the rheological properties of each batch were determined. The stoichiometric value of formic acid addition represents the amount of formic acid required to react with al] potential monovalent and divalent cations in the waste slurry. Data from the study are presented in Table 4.3-18.

(a) "HWVP Feed Process Variability Testing for Fiscal Year 1986," RHO-RE-CR-16P/HWVP-86-V1123C, Pacific Northwest Laboratory, Richland, Washington (1986). 

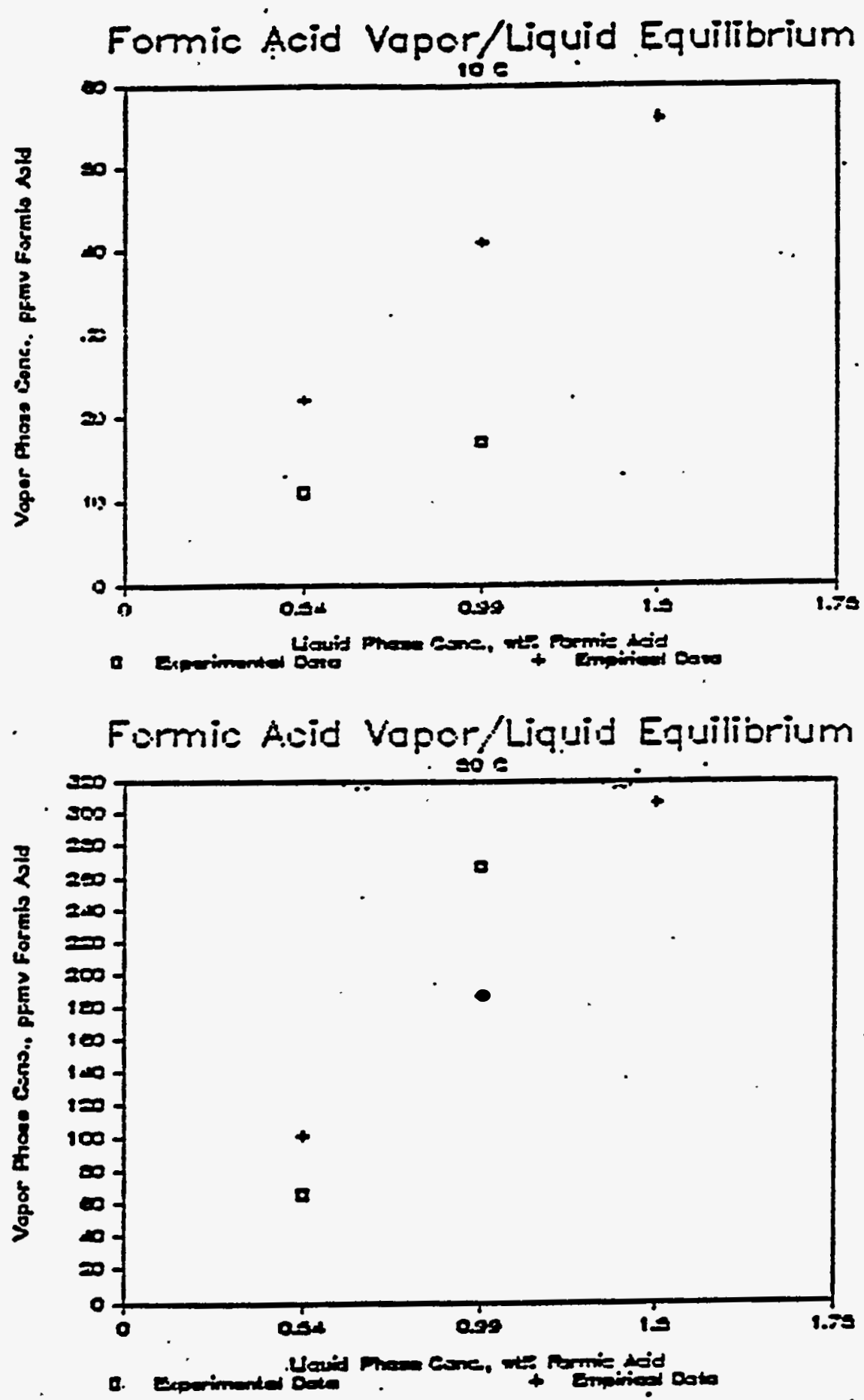

FIGURE 4.3-50. Formic Acid Vapor/Liquid Equilibrium Curves(a)

(a) K. D. Heimers, May 1988, "Formic Acid Vapor Phase Concentrations Over Dilute Aqueous Solutions at the Proposed HWVP Condenser Operating Temperatures," HWVP-88-V110203A, Pacific Northwest Laboratory, Richland, Washington. 
Table 4.3-18. Summary of Properties of HWVP Reference Feed Simulation HWS4 (NCAW 84, high chromium) Concentration as a Function of the Amount of Formic Acid RHO-RE-CR-16P/HWVP-86-V1123C

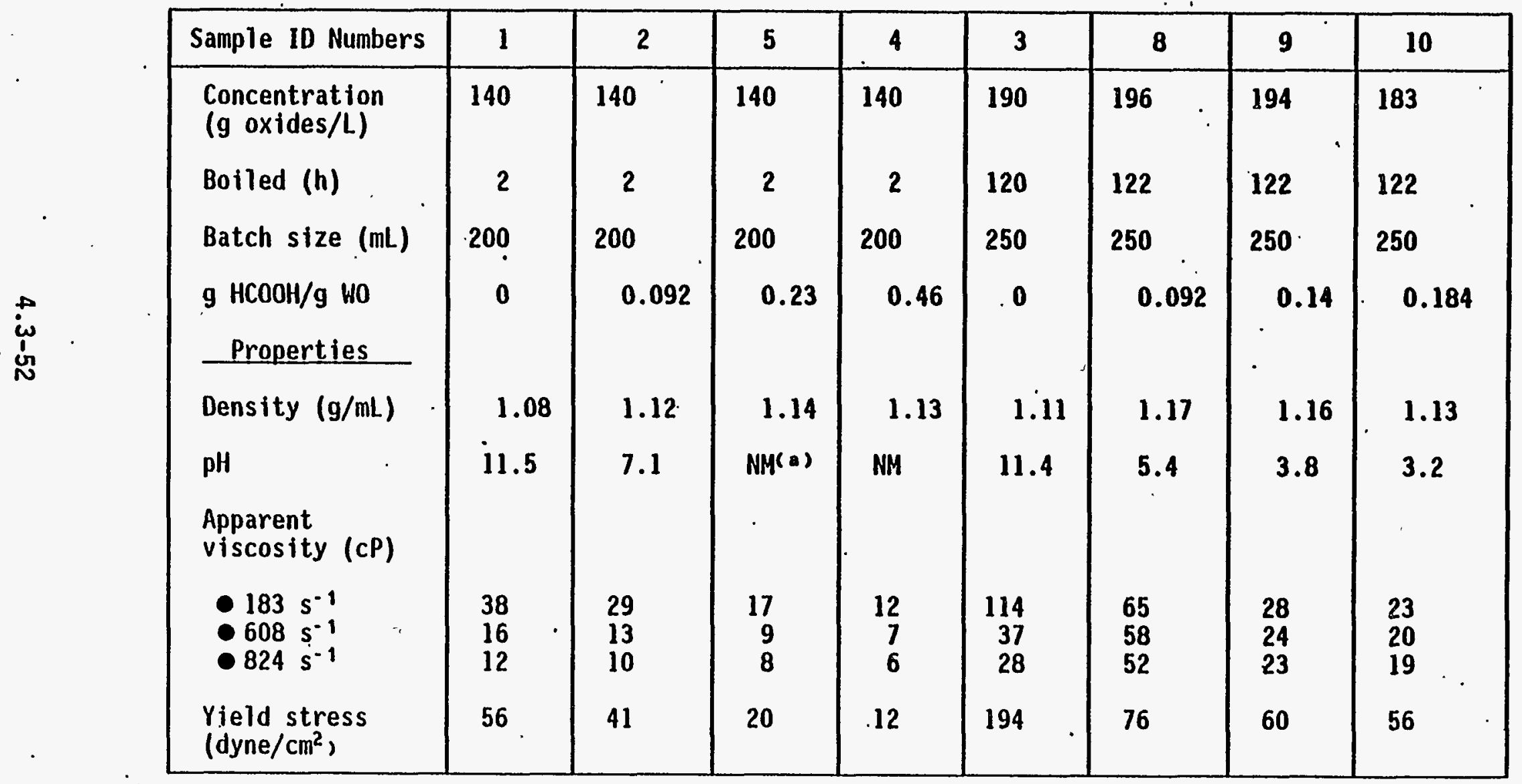

(a) $N M=$ Not measured. 
4.3.4.1.1.3. Melter Feed Evaluation (Concentration, Boiling, Formic Acid Addition). (a) Eight batches were prepared as shown in the matrix in Table 4.3-19 to evaluate the effects of slurry boiling on melter feed rheoTogy. The test batches were obtained from a simulated (NCAW-84, high chromium, master batch (identified as HWS5) that was prepared using the composition identified in Appendix A. (Tabie A-6). Six of the eight batches were treated with a stoichiometric amount of formic acid $(0.092 \mathrm{~g} \mathrm{HCOOH} / \mathrm{g} \mathrm{WO}$ ) and then concentrated from $140 \mathrm{~g} \mathrm{HO} / \mathrm{L}$ to $187 \mathrm{~g} \mathrm{WO} / \mathrm{L}$. The two batches not treated with formic acid served as control batches.

Following this process, dry frit (HW39) and an amount of formic acid equivalent to 1 wt\% of the frit were added to each of the batches. Physical properties and compositions of the HW39 frit are shown in Table 4.3-16. This procedure produced melter feeds at a concentration of approximately $600 \mathrm{~g}$ TO/L. One each of the boiled and unboiled batches (HWS5-3-6 and HWS5-3-5, respectively) were left at a concentration of $600 \mathrm{~g} \mathrm{TO} / \mathrm{L}$. The other batches were diluted to concentrations of $400 \mathrm{~g} \mathrm{TO} / \mathrm{L}$ and $500 \mathrm{~g} \mathrm{TO} / \mathrm{L}$.

- Melter feed batches HWS5-3-2, $-3-4 ;-3-6$, and $-3-8$ were then boiled with full reflux for $6 \mathrm{~h}$. Selection of a $6-\mathrm{h}$ boiling period was based on the batches used in the initial FY 1985 concentration study (Ref. 4.3-2). The rheological and chemical properties of each batch were measured within $24 \mathrm{~h}$ after the final step in the preparation of each batch, to minimize any effects of aging. Table 4.3-20 summarizes the results of the bqiling study.

4.3.4.1.1.4. HWVP Feed Makeup Techniques. (a) A variation of the above procedure, as shown in Figures 4.3-51, was implemented to perform studies to evaluate the effects of various feed makeup techniques on NCAW 84, high chromium, slurry properties. Each makeup approach simulated the anticipated plant processes to varying extents. The feed codes are also identified in Figure 4.3-51 for reference in reviewing the test results. The composition of this simulated HWVP reference feed HWS6 batch is provided in Appendix A (Table A-7).

Characterization data of samples during the concentration of HWVP feed, HWS6, are presented in Table 4.3-21.

The data presented in Table 4.3-22 allow comparison of the initial unformated and formated characterization samples for batches $C(150 \mathrm{~g} \mathrm{WO} / \mathrm{L})$ and $D(200 \mathrm{~g} \mathrm{WO} / \mathrm{L})$ to those of the unboiled control batches prepared at $150 \mathrm{~g}$ WO/L (unformated and formated).

Effects of the four- to eleven-day aging period (before frit addition) are shown in Tabie 4.3-23. Aging after treatment with formic acid resulted in rheological property changes ranging from $0 \%$ to $12 \%$. Such changes in

(a) "HWVP Feed Process Variability Testing for Fiscal Year 1986," RHO-RE-CR-16P/HWVP-86-V1123C, Pacific Northwest Laboratory, Richland, Washington (1986). 
TABLE 4.3-19. Matrix of Laboratory Batches of Meiter Feeds Prepared to Evaluate Effects. of Boiling (NCAW 84, high chromium) RHO-RE-CR-16P/HWVP-86-V1123C

\begin{tabular}{|c|c|c|c|c|}
\cline { 2 - 5 } \multicolumn{1}{c|}{} & \multicolumn{4}{c|}{ Batch Numbers } \\
\hline \multirow{2}{*}{$\begin{array}{c}\text { Concentration } \\
\text { (g TO/L)(a) }\end{array}$} & \multicolumn{2}{|c|}{ Not Boiled } & \multicolumn{2}{c|}{ Boiled $6 \mathrm{~h}$} \\
\cline { 2 - 5 } & With HCOOH & Without HCOOH & With HCOOH & Without HCOOH \\
\hline 400 & HWS5-3-1 & HWS5-3-7 & $\begin{array}{c}\text { HWS5-3-2 } \\
\text { HWS5-3-4 }\end{array}$ & HWS5-3-8 \\
500 & HWS5-3-3 & HWS5-3-6 & \\
\hline
\end{tabular}

(a) $\cdot \mathrm{g} T \mathrm{O} / \mathrm{L}=$ grams total oxide (including frit and waste), per liter of melter feed.

waste characteristics are not likely to have a significant effect on the process operations. The effect of aging over longer periods was not addressed here.

Physical and rheological characterizations of samples from all three process batches are shown in Table 4.3-24.

4.3.4.1.1.5. HWVP Feed Makeup Techniques. (a) A subsequent series of tests was then conducted to evaluate the effects of variables on simulated HWVP (NCAW 84, high chromium) slurry properties. The variables examined were waste oxide concentration before formic acid addition, the amount of formic acid addition to the waste slurry (function of final $\mathrm{pH}$, agitator shear during waste simulant processing, and aging. The composition of the simuTated HWVP reference feed batch, HWS7, used for the test has been included in Appendix A, Table A-8. The test matrix and changes in feed parameters are shown in Figure 4.3-52.

The data for this variable test is indexed and presented below.

During all variable tests, the sample taken from each required step was identified with the following sample identification system:

$$
\text { HWS7 - [1] [2] [3] - [4]. }
$$

(a) "HWVP Feed Process Variability Testing for Fiscal Year 1986," RHO-RE-CR-16P/HWVP-86-V1123C, Pacific Northwest Laboratory; Richl and, Washington (February 17, 1986). 
TABLE 4.3-20. Properties of Simulated Melter Feed (NCAW 84, high chromium) Batches Prepared to Evaluate the Effects of Boiling RHO-RE-CR-16P/HWVP-86-V1123C

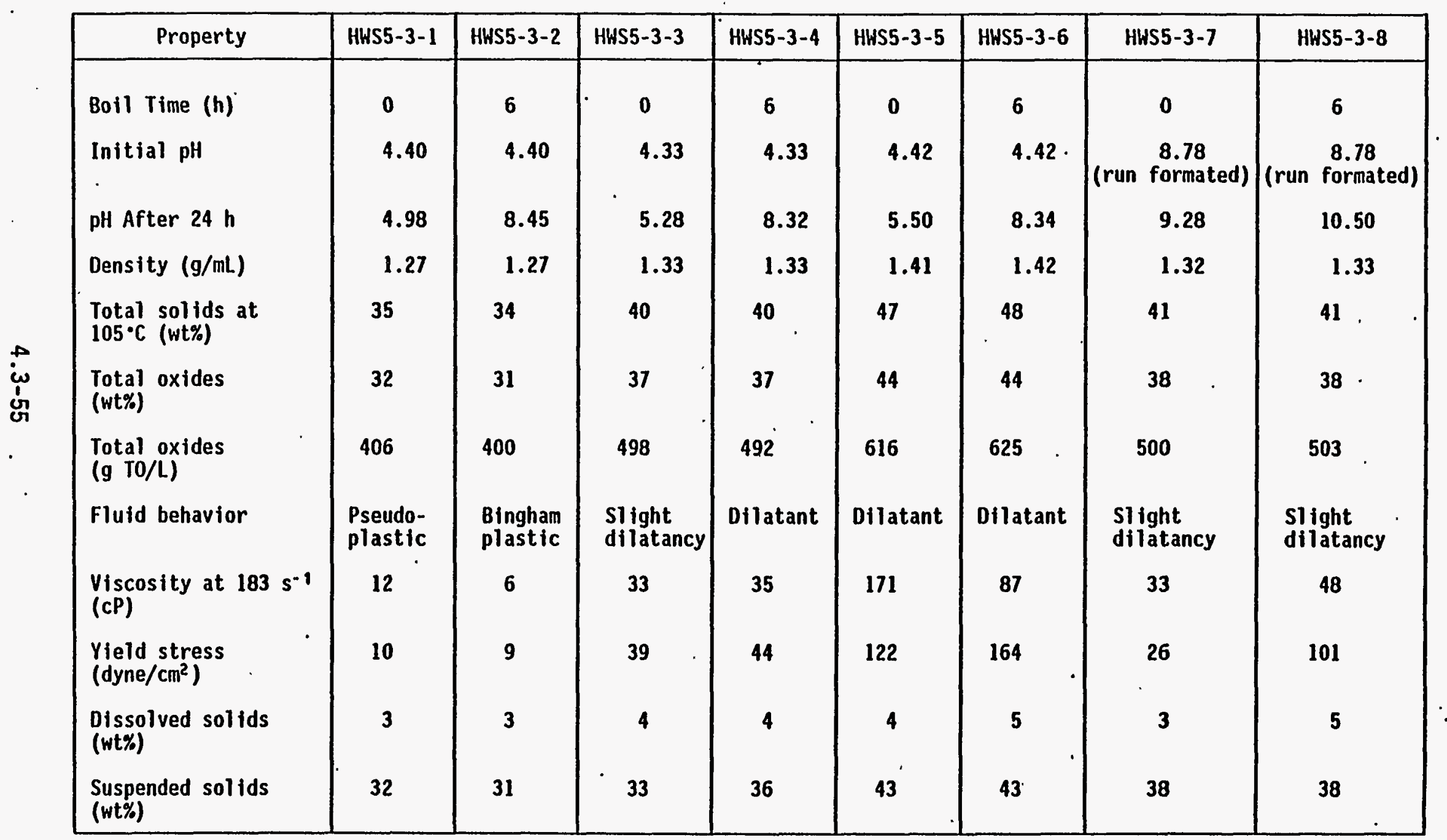




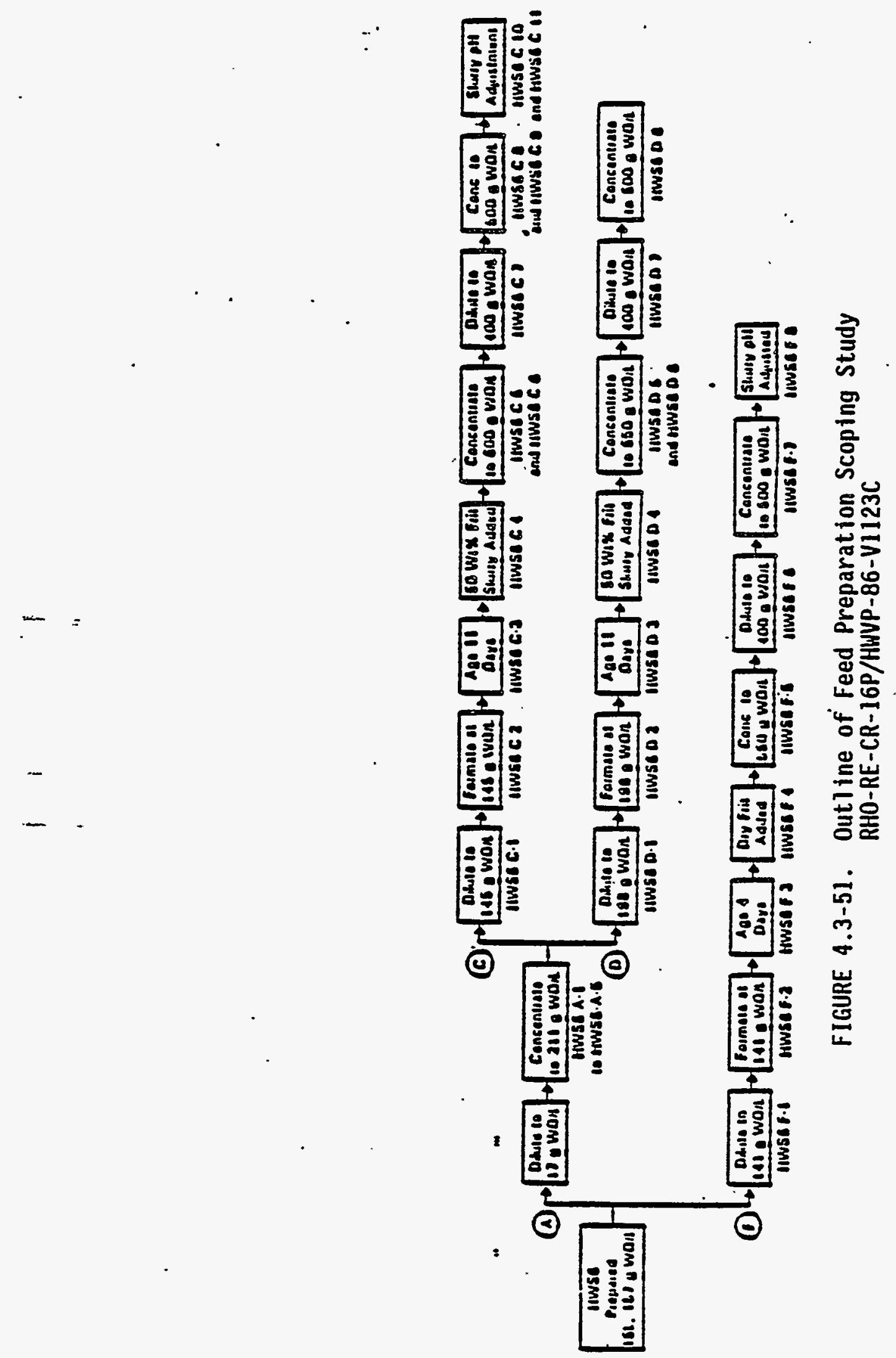

4.3-56 
TABLE 4.3-21. Properties of HWS6 (NCAW 84, high chromium) During the Concentration Phase RHO-RE-CR-16P/HWVP-86-V1123C

\begin{tabular}{|c|c|c|c|c|c|c|c|}
\hline & \multicolumn{7}{|c|}{ Batch and Boiling Cycle Number, HWS6- } \\
\hline Slurry Property & $A-1$ & $A-2$ & $A-3$ & $A-4$ & $A-5$ & $C-1$ & $D-1$ \\
\hline Total oxides $(g / L)$ & 46 & 84 & 91. & 109 & 211 & 145 & 198 \\
\hline Total oxides (wt\%) & 4 & 8 & 9 & 10 & 18 & 13 & 17 \\
\hline Total solids (wt\%) & 6 & 10 & 11 & 12 & 23 & 16 & -21 \\
\hline Density $(\mathrm{g} / \mathrm{mL})$ & 1.05 & 1.06 & 1.08 & 1.09 & 1.17 & 1.13 & 1.17 \\
\hline $\mathrm{pH}$ & 11.3 & 11.2 & 11.0 & 11.3 & 11.4 & 11.3 & 11.1 \\
\hline $\begin{array}{l}\text { Apparent viscosity } \\
\text { at } 183 \mathrm{~s}-1 \text { (CP) }\end{array}$ & 3 & 10 & 15 & 13 & 279 & 40 & 198 \\
\hline $\begin{array}{l}\text { Yield stress } \\
\text { (dyne } / \mathrm{cm} 2\end{array}$ & 1 & 8 & 10 & 11 & 421 & 39 & 290 \\
\hline
\end{tabular}

TABLE 4.3-22. Properties of Simulated HWVP Feed (NCAW 84, high chromium) Concentrates Before and After Treatment with Formic Acid RHO-RE-CR-16P/HWVP-86-V1123C

\begin{tabular}{|c|c|c|c|c|c|c|}
\hline \multirow[b]{2}{*}{ STurry Property } & \multicolumn{6}{|c|}{ Batch Number, HWS6- } \\
\hline & $C-1$ & $C-2$ & $\begin{array}{c}\text { F-1 } \\
\text { (Control) }\end{array}$ & $\begin{array}{c}F-2 \\
\text { (Control) }\end{array}$ & $0-1$ & $D-2$ \\
\hline Formic acid addition & Before & After & Before & After & Before & After \\
\hline Total oxides $(\mathrm{g} / \mathrm{L})$ & 145 & 151 & 141 & 152 & 198 & 216 \\
\hline Total oxides (wt\%) & 13 & 13 & 13 & 13 & 17 & 18 \\
\hline Total solids (wt\%) & 16 & 17 & 16 & 17 & 21 & 24 \\
\hline Density $(\mathrm{g} / \mathrm{mL})$ & 1.13 & 1.13 & 1.10 & 1.14 & 1.17 & 1.19 \\
\hline pH & 11.3 & 6.4 & 11.8 & 6.8 & 11.1 & 6.9 \\
\hline $\begin{array}{l}\text { Apparent viscosity } \\
\text { at } 183 \mathrm{~s}-1 \text { (cP) }\end{array}$ & 40 & 34 & 52 & 37 & 198 & 176 \\
\hline $\begin{array}{l}\text { Yield stress } \\
\text { (dyne } / \mathrm{cm}^{2} \text { ) }\end{array}$ & 39 & 43 & 70 & 46 & 290 & 239 \\
\hline
\end{tabular}


TABLE 4.3-23. Rheological Properties of HWS6. (NCAW 84, high chromium) Samples Treated with Formic Acid Before, and After Aging RHO-RE-CR-16P/HWVP-86-V1123C

\begin{tabular}{|c|c|c|c|c|c|c|}
\hline \multirow[b]{2}{*}{ Slurry Property } & \multicolumn{6}{|c|}{ Sample Number } \\
\hline & $c-2$ & $6-3$ & $D-2$ & $D-3$ & $F-2$ & $F-3$ \\
\hline Approx. aging time (h) & 0 & 260 & 0 & 260 & 0 & 96 \\
\hline $\begin{array}{l}\text { Apparent viscosity } \\
\text { at } 183 \mathrm{~s}^{-1} \text { (cP) }\end{array}$ & 34 & 36 & 176 & 190 & 37. & 37 \\
\hline $\begin{array}{l}\text { Yield stress } \\
\left(\text { dyne } / \mathrm{cm}^{2}\right)\end{array}$ & 43 & 48 & 239 & 235 & 46 & 48 \\
\hline
\end{tabular}

The first character represents the approximate stock concentration during formic acid treatment and can be one of the following three numbers:

- 50, for $-50 \mathrm{~g} W 0 / \mathrm{L}$

- 100 , for - $g$ HO/L

- 200, for - 9 W0/L.

The second character represents the rate of agitation that the waste is subjected to during formating, concentration, and frit addition, and can be one of the following two letters:

- L, far low

- $H$, for high agitation rates.

The third character represents the approximate $\mathrm{pH}$ level to which each sample is formated and can be one of the following three values:

- 8, for samples formated to a pH of 8

- 6 , for samples formated to a $\mathrm{pH}$ of 6

- 4, for samples formated to a pH of 4.

Finally, the fourth character represents the approximate concentration or frit addition level for each sample, and can take one of the following values:

- 50, for formated samples with an approximate concentration of $50 \mathrm{~g} / \mathrm{HO} / \mathrm{L}$

- 100, for formated samples with an approximate concentration of $100 \mathrm{~g} / \mathrm{WO} / \mathrm{L}$ 
TABLE 4.3-24. Properties of Melter Feeds Made with Simulated HWVP Feed Concentrates (NCAH 84, high chromium) as the Concentrations and $\mathrm{pH}$ Here Adjusted RHO-RE-CR-16P/HWVP-86-V1123C

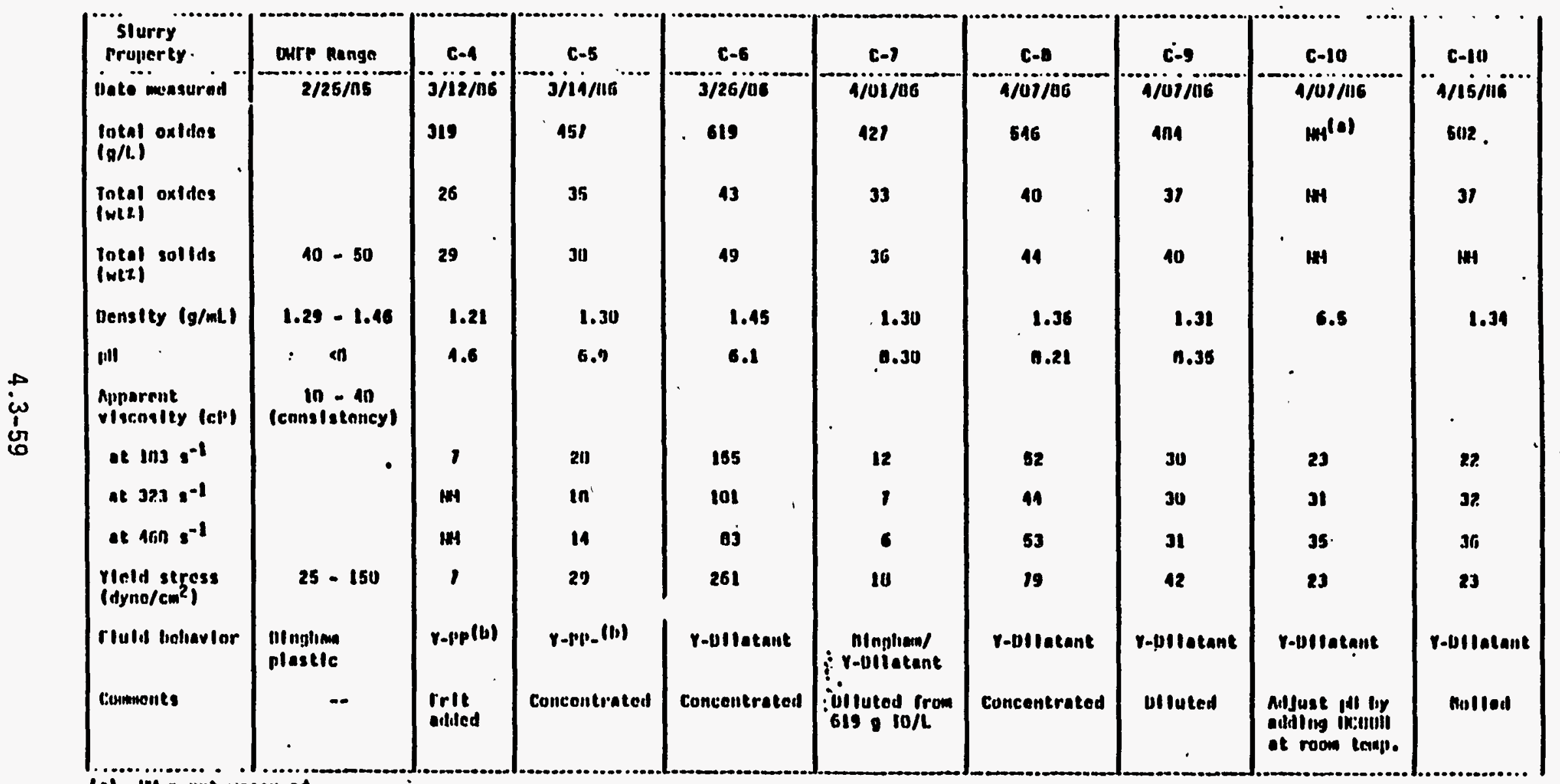

(ii) $\mathrm{WH}-\mathrm{not}$ mensured.

(b) r-pp • yleld-pseurioplastic. 


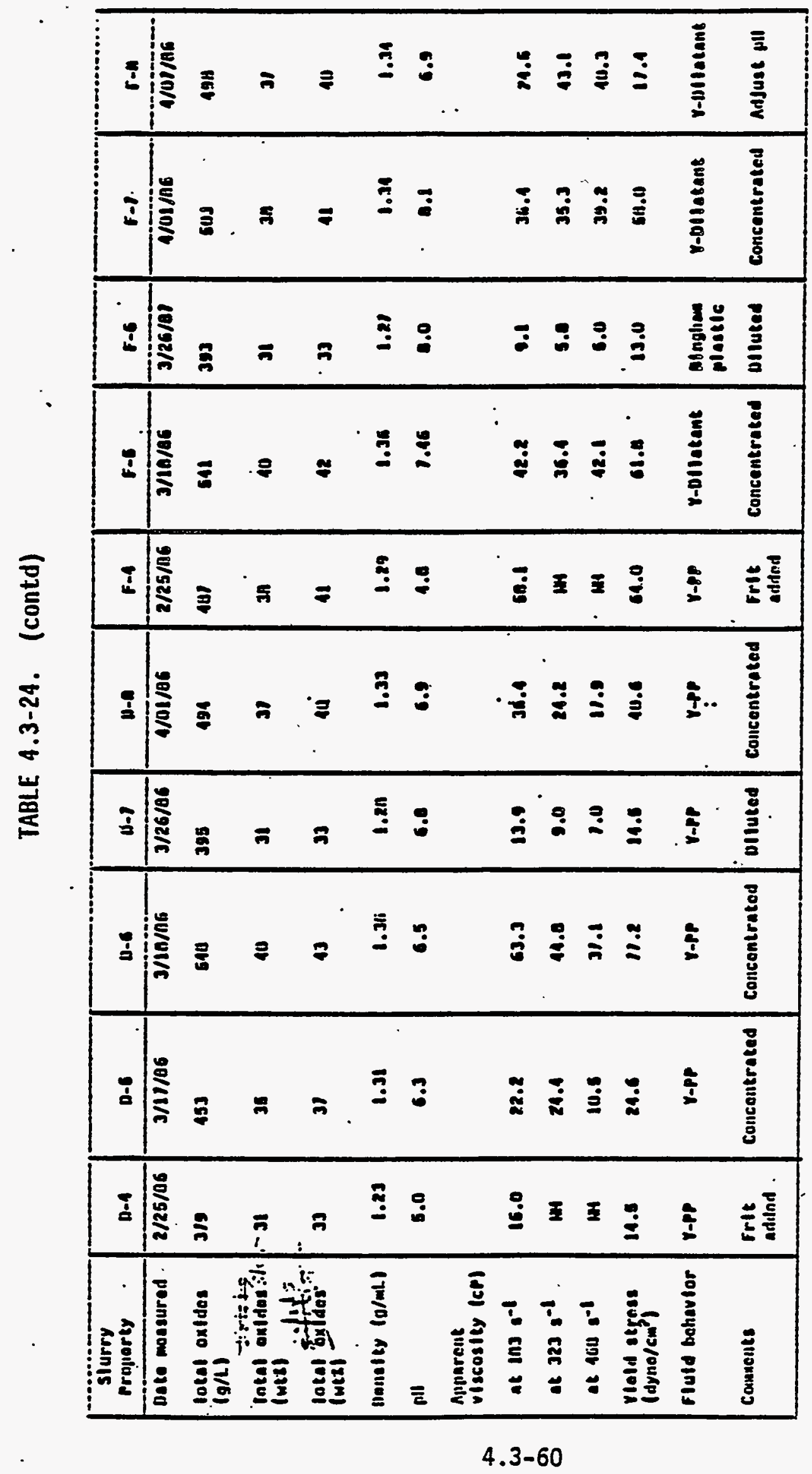




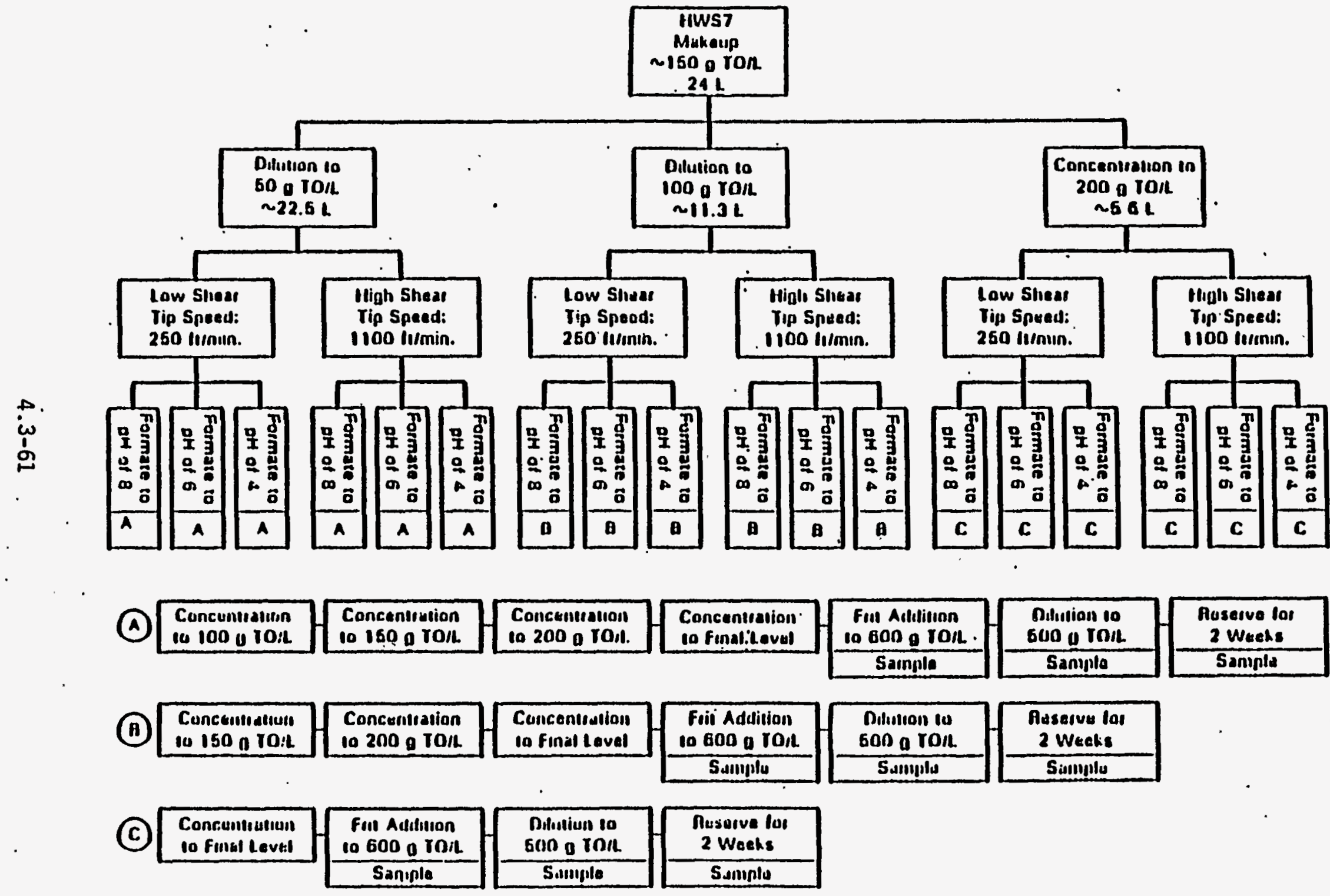

FIGURE 4.3-52. Proposed Test Matrix for Feed Process Variable Testing RHO-RE-CR-16P/HWVP-86-V1123C 
- 150, for formated samples with an approximate concentration of $150 \mathrm{~g} \mathrm{WO} / \mathrm{L}$

- 200, for formated samples with an approximate concentration of $200 \mathrm{~g} \mathrm{HO} / \mathrm{L}$

- 250, for formated samples with an approximate. concentration of $250 \mathrm{~g} \mathrm{HO} / \mathrm{L}$

- FC, for formated samples upon the completion of concentration

- 600F, for concentrated samples with frit added to approximately $600 \mathrm{~g} \mathrm{TO} / \mathrm{L}$

- 500F, for concentrated samples with frit added to approximately $500 \mathrm{~g} \mathrm{TO} / \mathrm{L}$

- 500FA, for concentrated samples with frit added to approximately $500 \mathrm{~g} \mathrm{TO} / \mathrm{L}$ and aged for two weeks.

Before formating, four other characterization samples were taken. Identification of these samples were as follows:

- HWS7-MU, for a sample of the HWS7 makeup at approximately $150 \mathrm{~g}$ WO/L

- HWS7-100U, for a 100-g-W0/L sample that is unformated

- HWS7-200U, for a 200-g-WO/L sample that is unformated.

The data from the HWVP feed process variable-testing are presented in Table 4.3-25.

4.3.4.1.1.6 B-Plant Synthetic HWVP Feed Characterization and Comparison with Pilot Scale Test Feeds. (a) An additional series of tests was performed to compare the characteristics of previousiy described synthetic slurries with slurry simulations that were made up to simulate the actual waste processing from operations in PUREX through receipt in the HWVP.

Rockwell provided two batches of synthetic CAW that had been denitrated and treated with caustic to become NCAW 84, high chromium. Synthetic CAW was batched from nitrate compounds dissolved in an acid solution. The CAW was denitrated using sugar and then neutralized with sodium hydroxide. The resulting synthetic NCAW was transferred to PNL, where the solids were separated and washed following the standard settle-decant procedure. The washed synthetic NCAW solids should be representative of actual HWVP feed.

The first batch of NCAW 84, high chromium, Rockwell B-Plant Simulant \#2 (RBPS-2), consisted of approximately $16 \mathrm{~L}$, which resulted in approximately $3.5 \mathrm{~L}$ of synthetic HWV feed after the settle-decant procedure. This amount

(a) "HWVP Feed Process Variability Testing for Fiscal Year 1986," RHD-RE-CR-16P/HWVP-86-VI123C, Pacific Northwest Laboratory, Richland, Washington (1986). 
TABLE 4.3-25. Data for HWVP Variability Study on Reference Feed Batch HWS7 (NCAH 84, high chromium) Test HWVP-86-V1123B

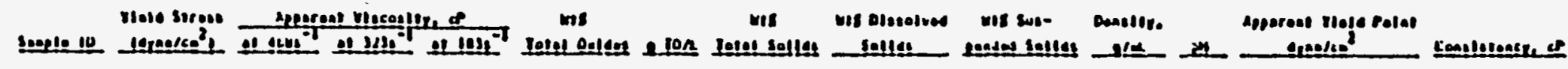

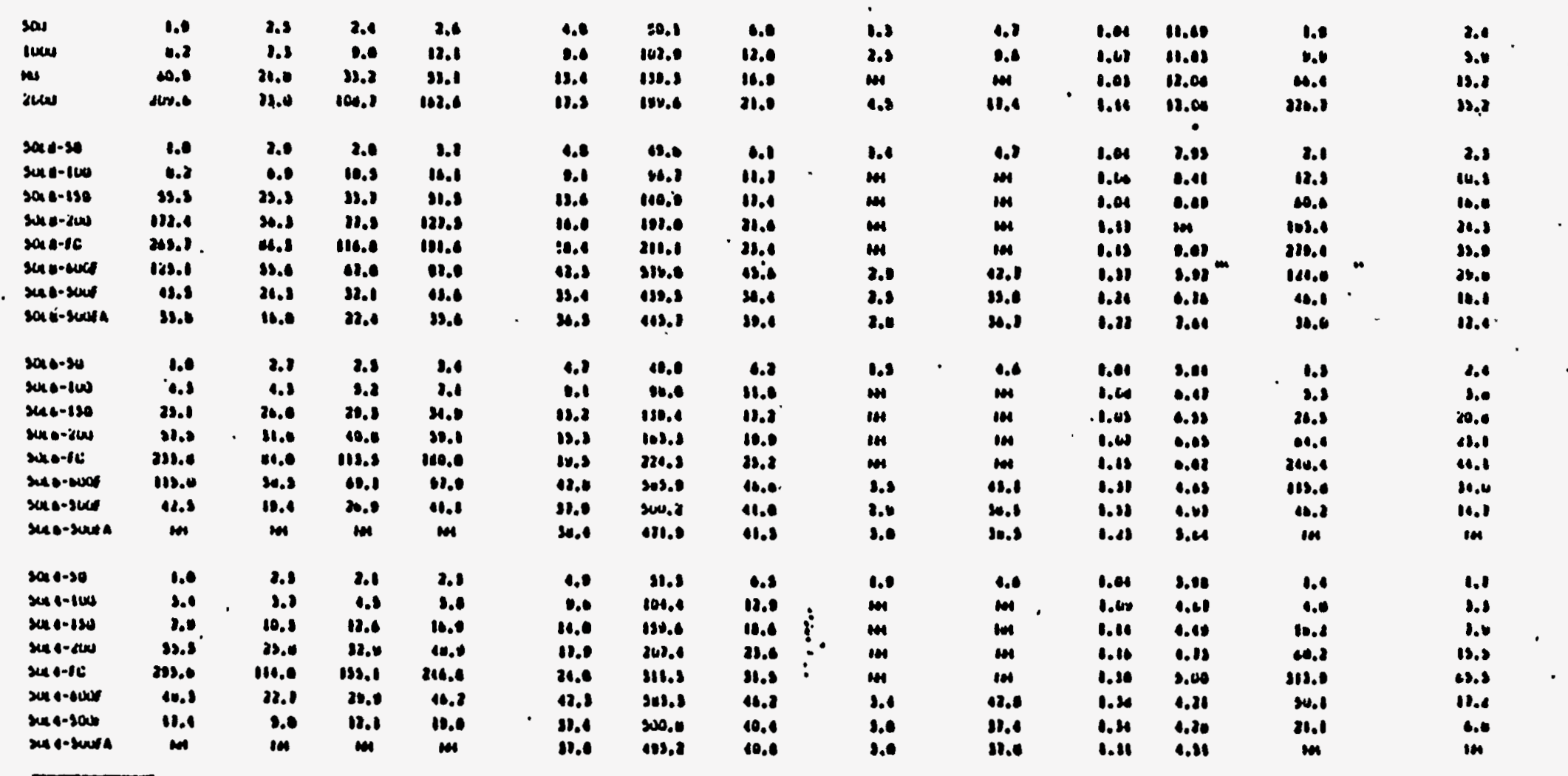

in. nis custurm. 


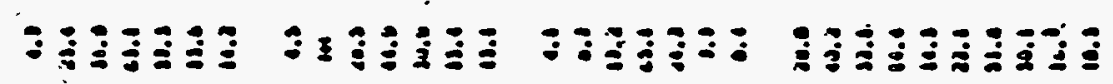

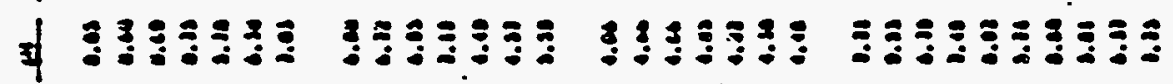

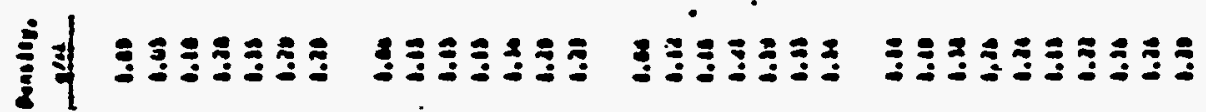

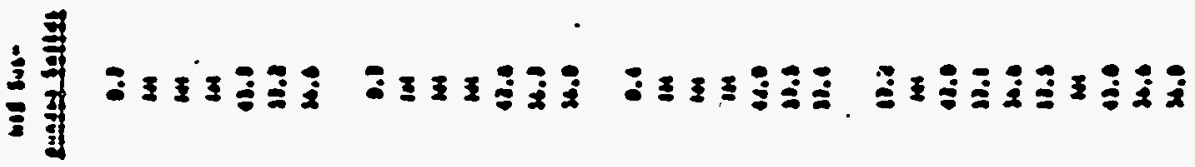

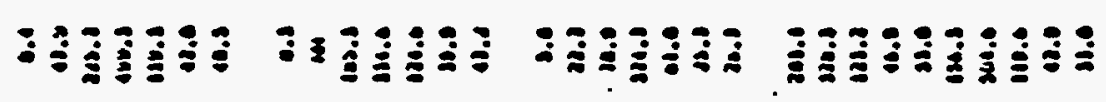

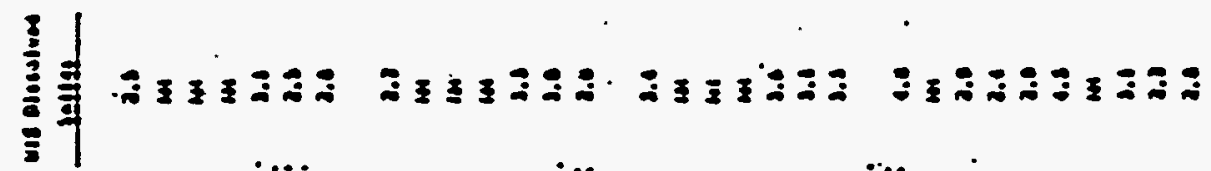

空

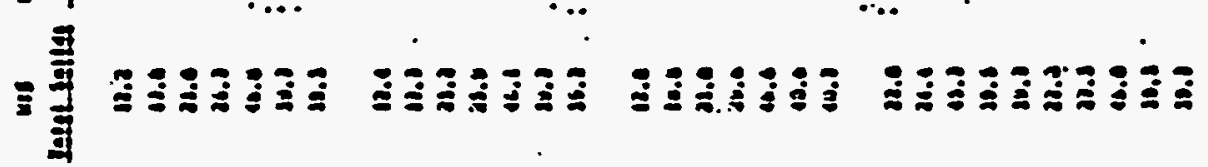

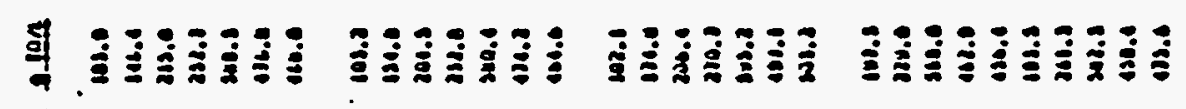

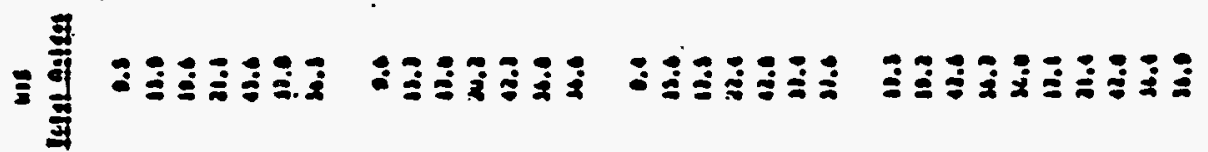

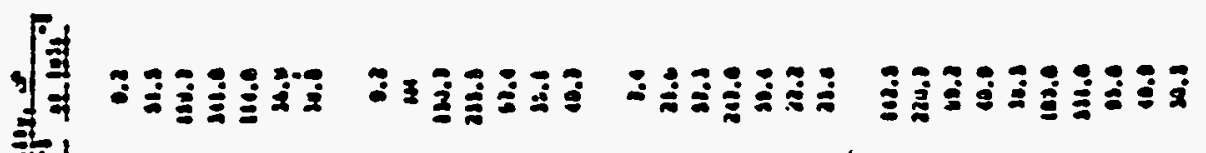

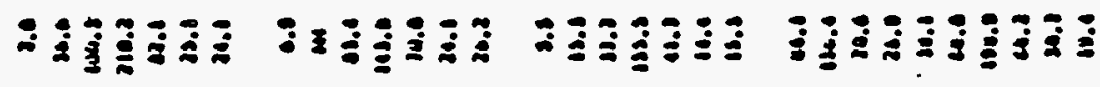

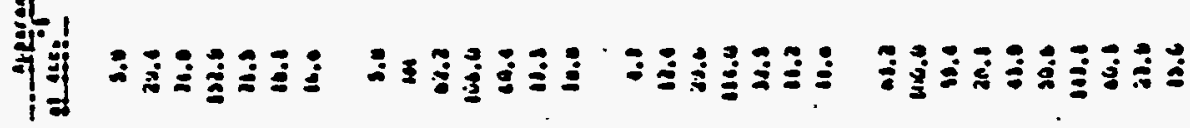

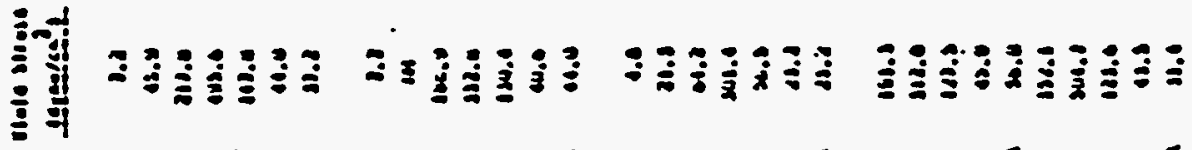

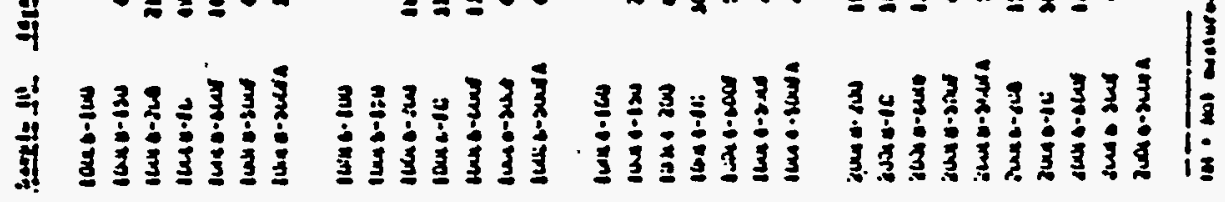




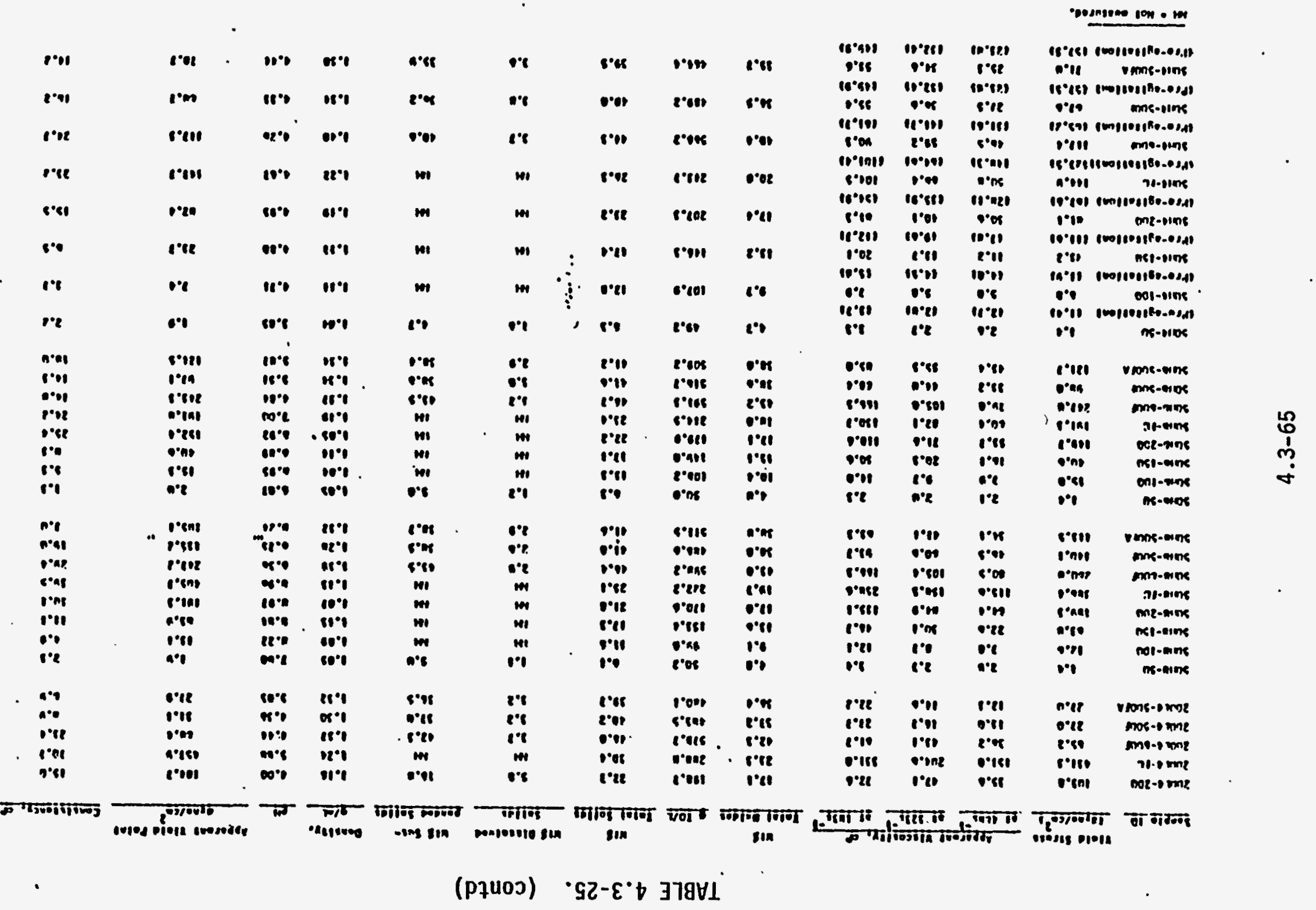




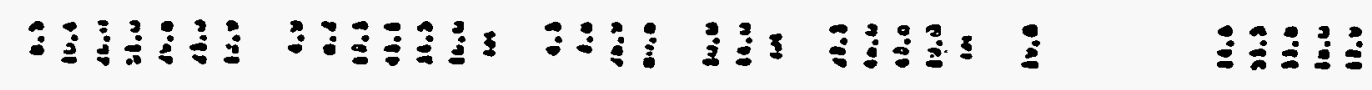

|

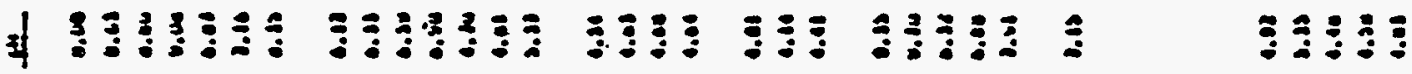

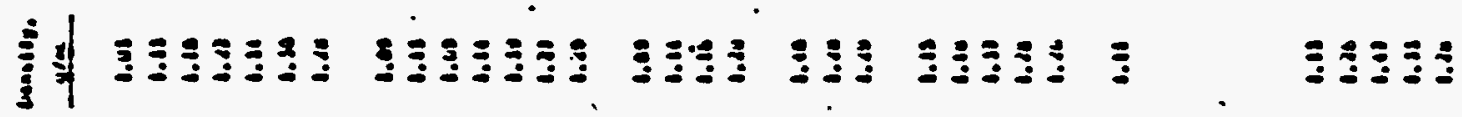

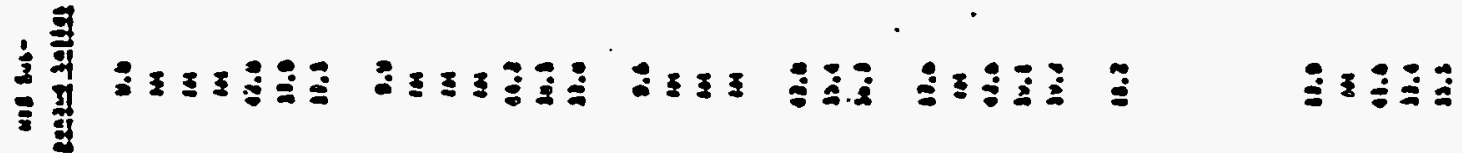

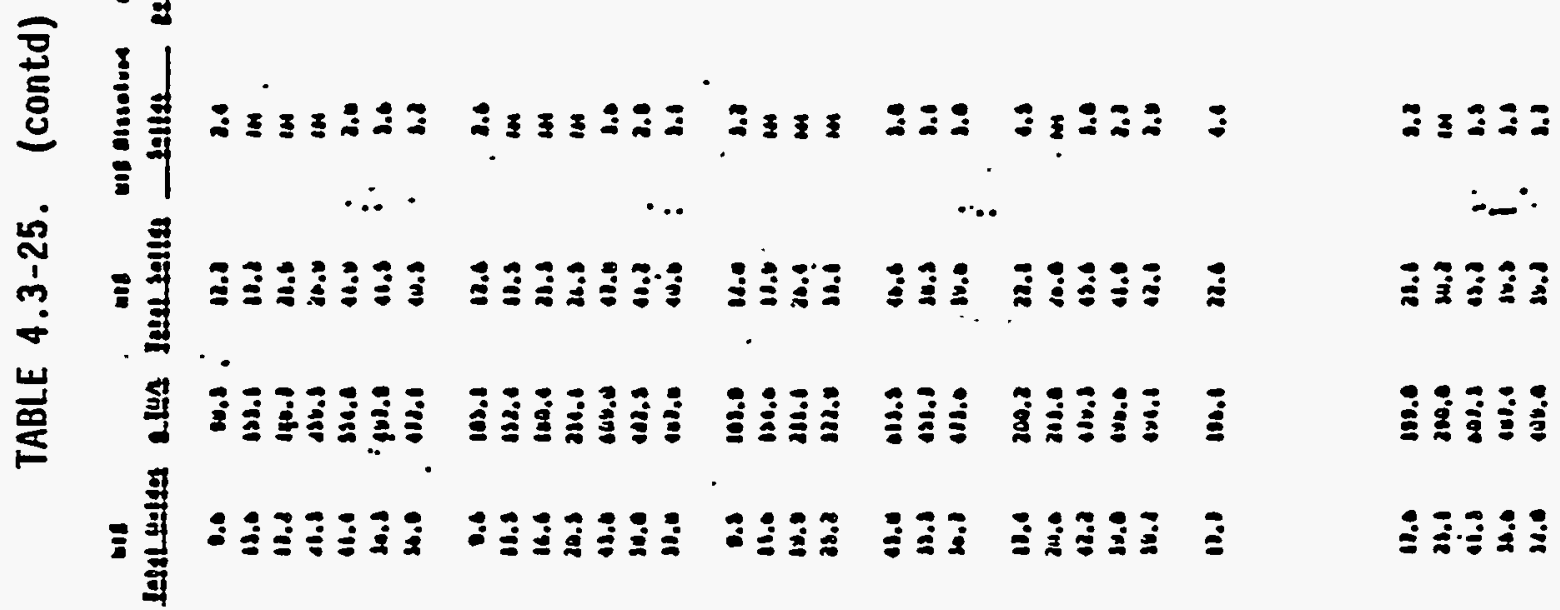

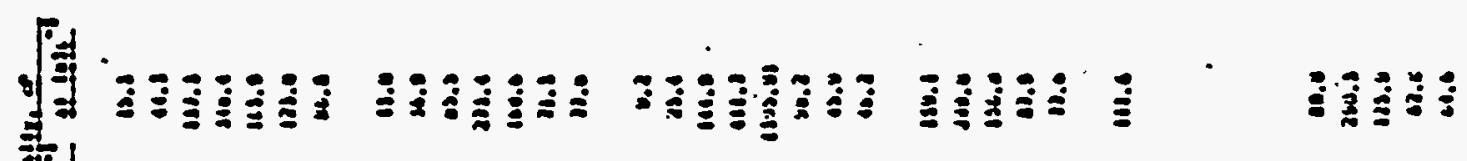

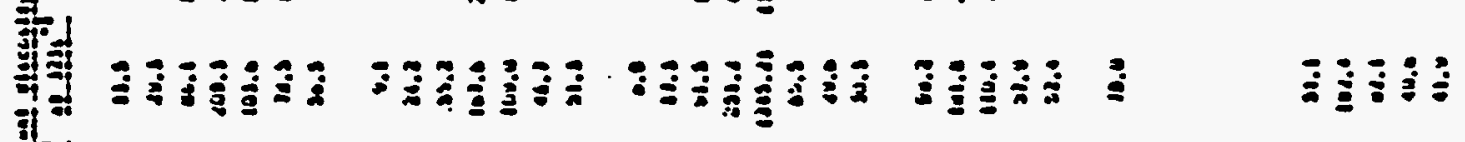

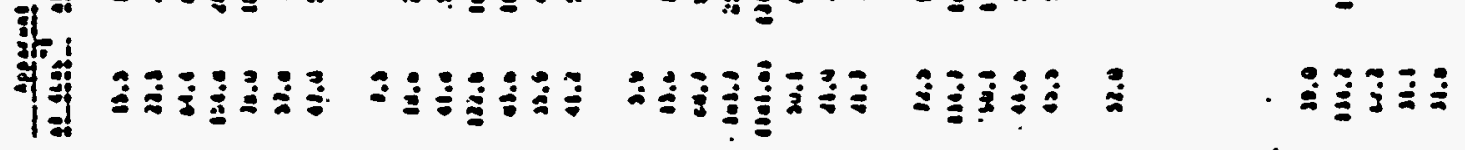

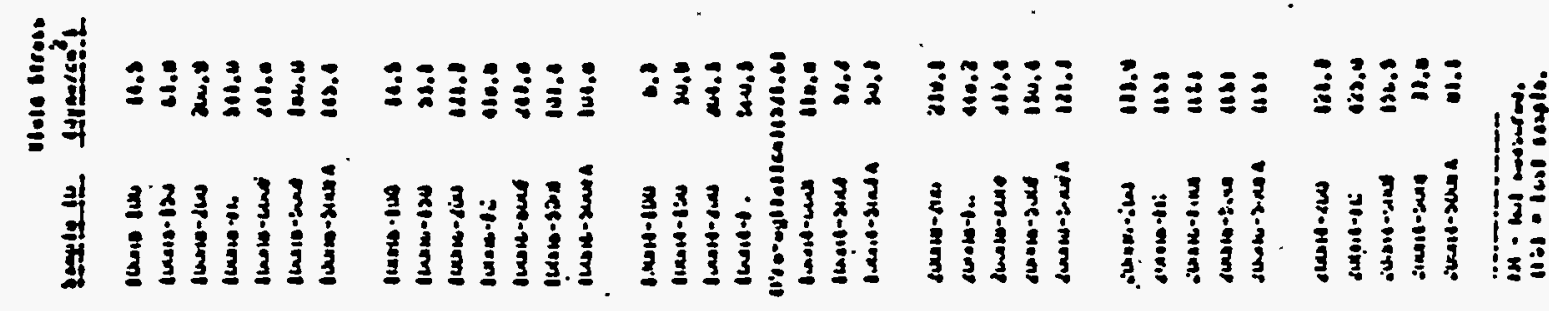


of material was insufficient to perform a complete characterization of the synthetic waste as it was taken through the melter feed workup procedure. A second batch, Rockwell B-Plant Simulant \#3 (RBPS-3), consisted of approximately $180 \mathrm{~L}$ of synthetic NCAW 84 . The composition of the RBPS-3 is shown in Table 4.3-26.

The synthetic CAW used to prepare RBPS-3 was formed by dissolving representative chemicals in -a nitric acid solution. The compounds used to produce RBPS-3 and the amount of each chemical added are shown in Table 4.3-26. A solution of $0.7 \mathrm{M}$ sucrose with $0.005 \mathrm{M}$ sodium hydroxide $(2.33 \mathrm{~kg}$ sucrose and $1.93 \mathrm{~g} \mathrm{NaOH}$ dissolved in $9.67 \mathrm{~L}$ of water) was added to the synthetic CAW at a flow rate of $13.5 \mathrm{~mL} / \mathrm{min}$ over a $12-\mathrm{h}$ period to denitrate the waste. The denitration process was conducted at $98^{\circ} \mathrm{C}$. The solution was then neutralized at $75^{\circ} \mathrm{C}$ with $75 \mathrm{~L}$ of $19 \mathrm{M}$ sodium hydroxide. The sodium hydroxide was added in one batch, as quickly as possible. The NCAW was then allowed to digest for two days at $50+^{\circ} \mathrm{C}$-before being transferred to PNL, where the settledecant washing procedure was performed.

TABLE 4.3-26. Chemicals Used to Generate Synthetic CAW for RBPS-3 (NCAW 84, high chromium) RHO-RE-CR-16P/HWVP-86-VI123C

\begin{tabular}{|c|c|c|c|c|}
\hline Compound Added & $\begin{array}{l}\text { Amount } \\
\text { Added (g) }\end{array}$ & $\begin{array}{l}\text { Element of } \\
\text { Interest }\end{array}$ & $\begin{array}{c}\text { Percent of } \\
\text { Molecular } \\
\text { Height }\end{array}$ & $\begin{array}{l}\text { Amount of } \\
\text { Element } \\
\text { Added (g) }\end{array}$ \\
\hline $\begin{array}{ll}\mathrm{NaNO}_{3} & \\
\mathrm{Al}\left(\mathrm{NO}_{3}\right)_{3} & 9 \mathrm{H}_{2} \mathrm{O} \\
\mathrm{Fe}\left(\mathrm{NO}_{3}\right)_{3} & 9 \mathrm{H}_{2} \mathrm{O} \\
\mathrm{Cr}\left(\mathrm{NO}_{3}\right)_{3} & 9 \mathrm{H}_{2} \mathrm{O} \\
\mathrm{Na}_{2} \mathrm{CrO}_{4} & 4 \mathrm{H}_{2} \mathrm{O}\end{array}$ & $\begin{array}{r}1,870 \\
33,011 \\
8,727 \\
320.1 \\
129.6\end{array}$ & $\begin{array}{l}\mathrm{Na} \\
\mathrm{Al} \\
\mathrm{Fe} \\
\mathrm{Cr}(\mathrm{III}) \\
\mathrm{Cr}(\mathrm{VI})\end{array}$ & $\begin{array}{l}0.271 \\
0.072 \\
0.138 \\
0.130 \\
0.222\end{array}$ & $\begin{array}{r}506 \\
2,377 \\
1,206 \\
41.6 \\
28.8\end{array}$ \\
\hline $\begin{array}{ll}\mathrm{SiO}_{2} & \\
\mathrm{Ni}\left(\mathrm{NO}_{3}\right)_{2} & 6 \mathrm{H}_{2} \mathrm{O} \\
\mathrm{ZrO}\left(\mathrm{NO}_{3}\right)_{2} & \\
\mathrm{Cu}\left(\mathrm{NO}_{3}\right)_{2} & 3 \mathrm{H}_{2} \mathrm{O} \\
\mathrm{Mn}\left(\mathrm{NO}_{3}\right)_{2} & 6 \mathrm{H}_{2} \mathrm{O}\end{array}$ & $\begin{array}{r}66 \\
247.2 \\
101.9 \\
43.5 \\
51.7\end{array}$ & $\begin{array}{l}\mathrm{Si} \\
\mathrm{Ni} \\
\mathrm{Zr} \\
\mathrm{Cu} \\
\mathrm{Mn}\end{array}$ & $\begin{array}{l}0.467 \\
0.199 \\
0.388 \\
0.259 \\
0.189\end{array}$ & $\begin{array}{r}30.8 \\
49.2 \\
62.8 \\
11.3 \\
9.8\end{array}$ \\
\hline $\begin{array}{l}\mathrm{MgSO}_{4} \quad \mathrm{HH}_{2} \mathrm{O} \\
\mathrm{MoO} \\
\mathrm{Ca}\left(\mathrm{NO}_{3}\right)_{2} \\
\mathrm{CsNO}_{3} \\
\mathrm{SrF}_{2} .\end{array}$ & $\begin{array}{l}37.0 \\
66.2 \\
19.7 \\
54.6 \\
22.6\end{array}$ & $\begin{array}{l}\mathrm{Mg} \\
\mathrm{Mo} \\
\mathrm{Ca} \\
\mathrm{Cs} \\
\mathrm{Sr}\end{array}$ & $\begin{array}{l}0.099 \\
0.666 \\
0.385 \\
0.682 \\
0.698\end{array}$ & $\begin{array}{r}3.6 \\
44.1 \\
7.6 \\
37.2 \\
15.8\end{array}$ \\
\hline $\begin{array}{l}\mathrm{BaSO}_{4} \\
\mathrm{Rare} \text { earth nitrates } \\
\mathrm{HF}(49 \%) \\
\mathrm{H}_{2} \mathrm{SO}_{4}(98 \%) \\
\mathrm{HNO}_{3}(70 \%)\end{array}$ & $\begin{array}{r}32.7 \\
44.0 \\
413.0 \\
3,292 \\
4,112\end{array}$ & $\mathrm{Ba}$ & 0.588 & 19.2 \\
\hline
\end{tabular}


At PNL the NCAH was agitated for $4 \mathrm{~h}$ before a sample of the waste was collected. The NCAN slurry was then alTowed to settie for $63 \mathrm{~h}$ before approximately $158 \mathrm{~L}$. of supernatiant was separated from the settled solids. This volume corresponded to approximately $99 \%$ of the supernatant layer actually present in the settling drum. Approximately $30.4 \mathrm{~kg}$ of residual sludge remained after the initial settle-decant. The residual sludge was washed with water in an amount equaling 12.5 times its own volume (275 $\mathrm{L}$ of wash water). The wash slurry was then agitated for $4.8 \mathrm{~h}$ before a sample was collected. The wash slurry was allowed to settle for $62 \mathrm{~h}$. Again, approximately $99 \%$ of the supernant layer $(270 \mathrm{~L})$ was siphoned from the settling drum. Approximately $19.5 \mathrm{~kg}$ of washed solids, or synthetic HWVP feed, remained after the wash. supernatant had been decanted.

The first batch of synthetic NCAN, RBPS-2, was only a smalt fraction of a batch of approximately $2000 \mathrm{~L}$ generated by Rockwell. The actual amounts. of each component added were not recorded, but the recipe used to generate RBPS-2 was the same as for RBPS-3. Two known differences in preparation existed between the two batches. These were: 1) ten times too much nickel was added to RBPS-2 in a batching error, and 2) the sodium hydroxide was added in several small batches during the neutralization of RBPS-2, as opposed to one large batch during RBPS-3 neutralization.

The data from the B-Plant simulations are summarized below.

Mass, volume, and specific gravity measurements (Table 4.3-27), were taken of each phase (homogeneous slurry, supernatant, and settled-solids) during the settle-decant washing procedure so that an overall material balance could be performed for RBPS -3 .

The results of the component material balances for RBPS- 3 are summarized in Table 4.3-28. An attempt was made to account for all of the starting material for each component at various stages of the waste processing procedure. The results show that the average amount accounted for, of each element, is within $13 \%$ of the actual amount added except for magnesium and silicon.

Table 4.3-29 shows the percentage of the total amount of each element present in the NCAW 84, high chromium supernatant, wash supernatant, and washed sludge for both B-Plant synthetics.

The original synthetic B-Plant feeds were fairly close in composition, aside from the differences in the amounts of $\mathrm{Ni}$ and $\mathrm{Na}$. The percentages of each element washed out of the solids (Table 4.3-30) were al so very similar. The compositions of the washed solids were vastly different, however. The difference is largely due to the fact that $2 \%$ of the sodium in batch RBPS-2 remained in the washed solids, whereas only. $1 \%$ remained for batch RBPS-3. 
- TABLE 4.3-27. Summary of the Physical Characteristics of Each Phase During the Settle-Decant Washing Procedure(a) (RBPS-3) RHO-RE-CR-16P/HWVP-86-V1123C

\begin{tabular}{|c|c|c|c|c|}
\hline & Mass (kg) & Volume (L) & Density $(g / c c)$ & $\mathrm{pH}$ \\
\hline $\begin{array}{l}\text { CAW before } \\
\text { denitration }\end{array}$ & & 109 & 1.19 & 0.50 \\
\hline CAW & & 116 & 1.23 & 0.36 \\
\hline $\begin{array}{l}\text { NCAW received } \\
\text { from Rockwell }\end{array}$ & $238.7(19.1)$ & $179(16.3)^{(b)}$ & $1.322(1.17)$ & $13.38(13.66)$ \\
\hline $\begin{array}{l}\text { NCAW } \\
\text { supernatant }\end{array}$ & $207.2(15.3)$ & $159(13.2)^{(b)}$ & $1.308(1.16)$ & $13.30(13.64)$ \\
\hline $\begin{array}{l}\text { Residual } \\
\text { solids }\end{array}$ & $30.4(3.8)$ & $21.5(3.1)^{(b)}$ & $1.413(1.24)$ & $13.31(13.63)$ \\
\hline $\begin{array}{l}\text { Wash water } \\
\text { added }\end{array}$ & 267.6 & 268 & 0.998 & 7.67 \\
\hline Wash slurry & 298.0 & 290 & $1.037(1.01)$ & 13.15 \\
\hline $\begin{array}{l}\text { Wash } \\
\text { supernatant }\end{array}$ & 276.4 & 270 & $1.027(1.01)$ & $13.18(12.67)^{\circ}$ \\
\hline $\begin{array}{l}\text { Wash } \\
\text { solids } \\
\text { (HWVP feed) }\end{array}$ & $19.5(3.7)$ & $14(3.5)$ & $1.140(1.05)$ & $13.19(12.64)$ \\
\hline
\end{tabular}

(a) Values corresponding to RBPS-2 are in parentheses.

(b) Estimated volume (mass/density).

Particle size distributions were measured for the two synthetic HWVP feeds, RBPS-2 and RBPS-3, using a HIAC computerized instrumental particle analyzer. The results are shown in Figure 4.3-53. Both feeds exhibited a mean particle size of 4 to $5 \mathrm{~lm}$ in diameter, but there was a larger portion of particles with diameters $>10 \mu m$ for RBPS-3.

- Pacific Scientific Co., HIAC Instruments Div., Montclair, California. 
TABLE 4.3-28. Mass Accounting of the Original Elements Used to Generate RBPS-3 CAH at Various Points in the RBPS-3 Processing Procedure

RHO-RE-CR-16P/HWVP-86-V1123C

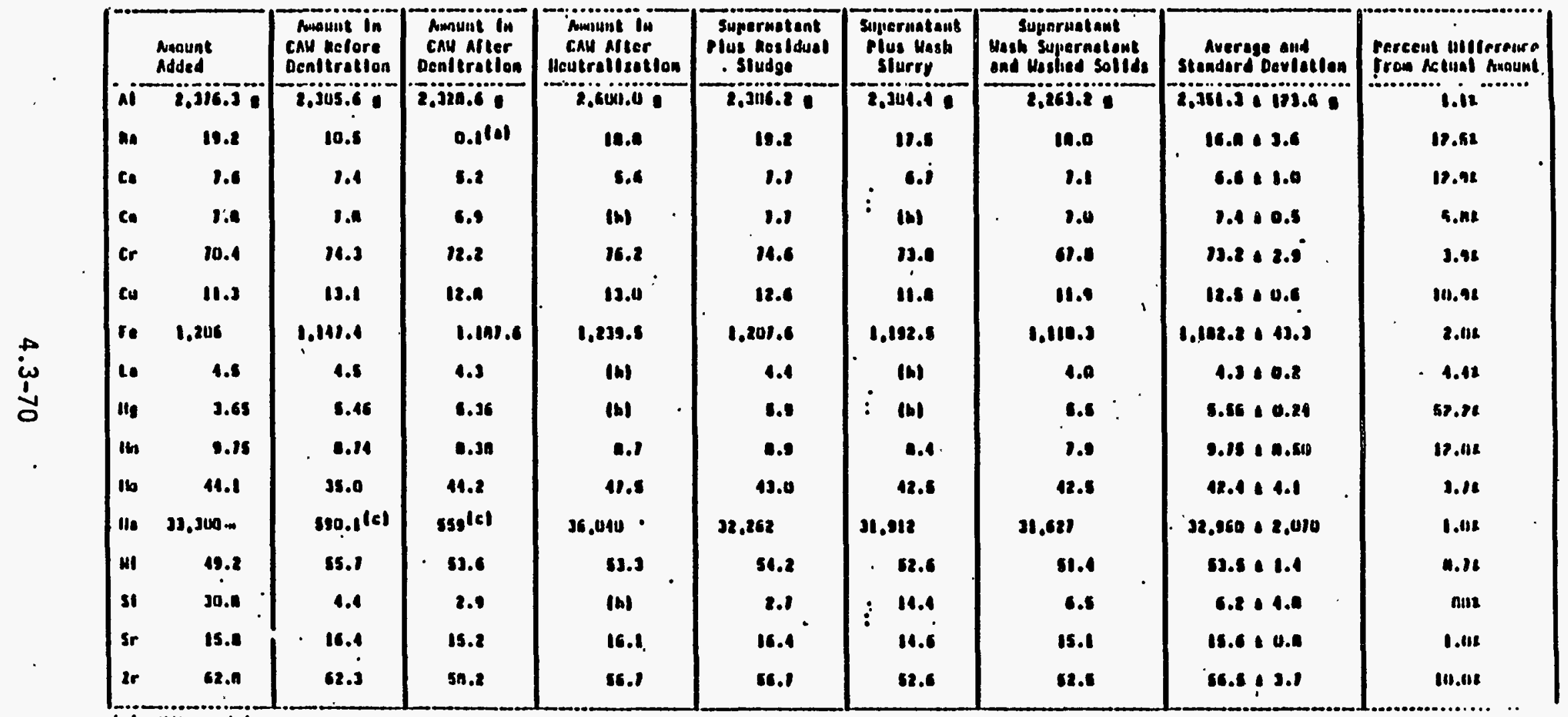

(a) llöt used in everase.

(i) Caillil unt be calculoled.

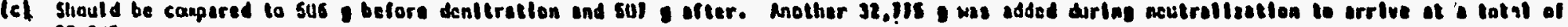
33,300 s. 
TABLE 4.3-29. Distribution of the Original Amount of Each Element Among the Two Supernatant Fractions and the Hashed Solids( $)$ RHO-CE-CR-16P/HWVP-86-V1123C

\begin{tabular}{|c|c|c|c|c|c|c|}
\hline \multirow[b]{2}{*}{$\begin{array}{l}\mathrm{A} 1 \\
\mathrm{~B} \\
\mathrm{Ba} \\
\mathrm{Ca} \\
\mathrm{Ce}\end{array}$} & \multicolumn{2}{|c|}{$\begin{array}{l}\text { Wt\% in NCAN } \\
\text { Supernatant }\end{array}$} & \multicolumn{2}{|c|}{$\begin{array}{l}\text { Wt\% in Wash } \\
\text { Supernatant }\end{array}$} & \multicolumn{2}{|c|}{$\begin{array}{l}\text { Wt\% in Washed } \\
\text { Solids }\end{array}$} \\
\hline & $\begin{array}{r}88.0 \% \\
-- \\
0.0 \% \\
12.7 \% \\
0 \%\end{array}$ & $\begin{array}{r}(78.3 \%) \\
(81.4 \%) \\
(0.0 \%) \\
(18.3 \%) \\
(0 \%)\end{array}$ & $\begin{array}{c}10.3 \% \\
-\overline{0.0 \%} \\
2.8 \% \\
0 \%\end{array}$ & $\begin{array}{r}(16.5 \%) \\
(13.2 \%) \\
(0.0 \%) \\
(26.4 \%) \\
(13.4 \%)\end{array}$ & $\begin{array}{r}1.7 \% \\
- \\
100 \% \\
84.5 \% \\
100 \%\end{array}$ & $\begin{array}{l}(5.2 \%) \\
(5.4 \%) \\
(100 \%) \\
(55.3 \%) \\
(86.6 \%)\end{array}$ \\
\hline $\begin{array}{l}\mathrm{Cr} \\
\mathrm{Cu} \\
\mathrm{Fe} \\
\mathrm{La} \\
\mathrm{Mg}\end{array}$ & $\begin{array}{r}8.8 \% \\
43.7 \% \\
0.2 \% \\
0 \% \\
0 \%\end{array}$ & $\begin{array}{r}(16.9 \%) \\
(16.1 \%) \\
(0.7 \%) \\
(0 \%) \\
(0 \%)\end{array}$ & $\begin{array}{r}1.2 \% \\
0 \% \\
0 \% \\
0 \% \\
0 \%\end{array}$ & $\begin{array}{r}(11.6 \%) \\
(3.5 \%) \\
(0.6 \%) \\
(9.9 \%) \\
(37.6 \%)\end{array}$ & $\begin{array}{r}90.0 \% \\
56.3 \% \\
99.8 \% \\
100 \% \\
100 \%\end{array}$ & $\begin{array}{l}(71.5 \%) \\
(80.4 \%) \\
(98.7 \%) \\
(90.1 \%) \\
(62.4 \%)\end{array}$ \\
\hline $\begin{array}{l}\text { Mu } \\
\text { Mo } \\
\mathrm{Na} \\
\mathrm{Ni} \\
\text { Si }\end{array}$ & $\begin{array}{r}1.3 \% \\
83.1 \% \\
87.0 \% \\
0 \% \\
-\end{array}$ & $\begin{array}{r}(4.9 \%) \\
(83.9 \%) \\
(80.4 \%) \\
(0.2 \%) \\
(0 \%)\end{array}$ & $\begin{array}{r}0 \% \\
10.1 \% \\
12.0 \% \\
0 \% \\
--\end{array}$ & $\begin{array}{c}(0 \%) \\
(14.5 \%) \\
(17.6 \%) \\
(0.2 \%) \\
(0 \%)\end{array}$ & $\begin{array}{r}98.7 \% \\
6.8 \% \\
1.0 \% \\
100 \% \\
--\end{array}$ & $\begin{array}{r}(95.1 \%) \\
(1.6 \%) \\
(1.9 \%) \\
(99.6 \%) \\
(100 \%)\end{array}$ \\
\hline $\begin{array}{l}5 r \\
Z u \\
Z r\end{array}$ & $\begin{array}{r}1.3 \% \\
= \\
18.1 \%\end{array}$ & $\begin{array}{r}(4.6 \%) \\
(56.5 \%) \\
(40.9 \%)\end{array}$ & $\begin{array}{c}0 \% \\
-- \\
0.4 \%\end{array}$ & $\begin{array}{r}(0 \%) \\
(0 \%) \\
(5.5 \%)\end{array}$ & $\begin{array}{c}98.7 \% \\
-\overline{81.5 \%}\end{array}$ & $\begin{array}{l}(95.4 \%) \\
(43.5 \%) \\
(53.6 \%)\end{array}$ \\
\hline
\end{tabular}

(a) Values corresponding to RBPS-2 are in parentheses.

The physical properties of the synthetic feeds were frequentiy measured during. the concentration process. Tables 4.3-31 and 4.3-32 list the results for samples taken from batches RBPS-2 and 3, respectively.

\subsection{Concentration Variations of Major Components in HWVP Feed} (Farnsworth Study). (a) A study was conducted to determine the effect of HWVP feed composition and formic acid addition on the redox state of the resultant glass. Although the primary purpose of this study was to examine factors influencing glass redox states, physical and rheological-properties were determined for each melter feed sample.

(a) R. K. Farnsworth, The Effect of Feed Composition and Formic Acid Addition on G7ass Redox State. HWVP-87-V110203A, Pacific Northwest Laboratory, Richland, Washington (1987). 
TABLE 4:3-30. Composition of Washed Synthetic B-P7ant Feeds RBPS- 2 and RBPS -3 Compared to the Reference (NCAW 84, high chromium) RHO-RE-CR-16P/HWVP-86-V1123C

\begin{tabular}{|c|c|c|c|}
\hline \multirow[b]{2}{*}{ Oxide } & \multirow{2}{*}{$\begin{array}{l}\text { Reference } \\
\text { Amount (wt\%) }\end{array}$} & \multicolumn{2}{|c|}{ Wt\% } \\
\hline & & RBPS-2 & RBPS-3 \\
\hline $\begin{array}{l}\mathrm{Al}_{2} \mathrm{O}_{3} \\
\mathrm{~B}_{2} \mathrm{O}_{3} \\
\mathrm{BaO} \\
\mathrm{CaO} \\
\mathrm{CeO}_{2}\end{array}$ & $\begin{array}{r}17.2 \\
0.0 \\
0.4 \\
0.3 \\
0.7\end{array}$ & $\begin{array}{r}12.90 \\
0.02 \\
0.45 \\
0.44 \\
0.30\end{array}$ & $\begin{array}{l}3.05 \\
0.05 \\
0.83 \\
0.62 \\
0.35\end{array}$ \\
\hline $\begin{array}{l}\mathrm{Cr}_{2} \mathrm{O}_{3} \\
\mathrm{CuO} . \\
\mathrm{Fe}_{2} \mathrm{O}_{3} \\
\mathrm{La}_{2} \mathrm{O}_{3} \\
\mathrm{MgO}\end{array}$ & $\begin{array}{r}5.3 \\
0.6 \\
44.4 \\
2.2 \\
0.3\end{array}$ & $\begin{array}{r}1.01 \\
0.44 \\
33.27 \\
0.16 \\
0.41\end{array}$ & $\begin{array}{r}3.68 \\
0.35 \\
65.78 \\
0.20 \\
0.45\end{array}$ \\
\hline $\begin{array}{l}\mathrm{MrO}_{2} \\
\mathrm{MoO}_{3} \ldots . \\
\mathrm{Na}_{2} \mathrm{O} \\
\mathrm{Nd}_{2} \mathrm{O}_{3} \\
\mathrm{NiO}^{2}\end{array}$ & $\begin{array}{c}0.7 \\
1.2 \ldots \\
10.7 \\
2.1 \\
2.4\end{array}$ & $\begin{array}{c}0.36 \\
0.07 \\
27.78 \\
0 \\
20.15\end{array}$ & $\begin{array}{r}0.51 \\
0.18 \\
17.58 \\
0.09 \\
2.70\end{array}$ \\
\hline $\begin{array}{l}\mathrm{SiO}_{2} \\
\mathrm{irO}^{2} \\
\mathrm{ZrO}_{2}\end{array}$ & $\begin{array}{l}3.0 \\
0.4 \\
2.4\end{array}$ & $\begin{array}{l}0.19 \\
0.57 \\
1.48\end{array}$ & $\begin{array}{l}0.47 \\
0.73 \\
2.38\end{array}$ \\
\hline
\end{tabular}




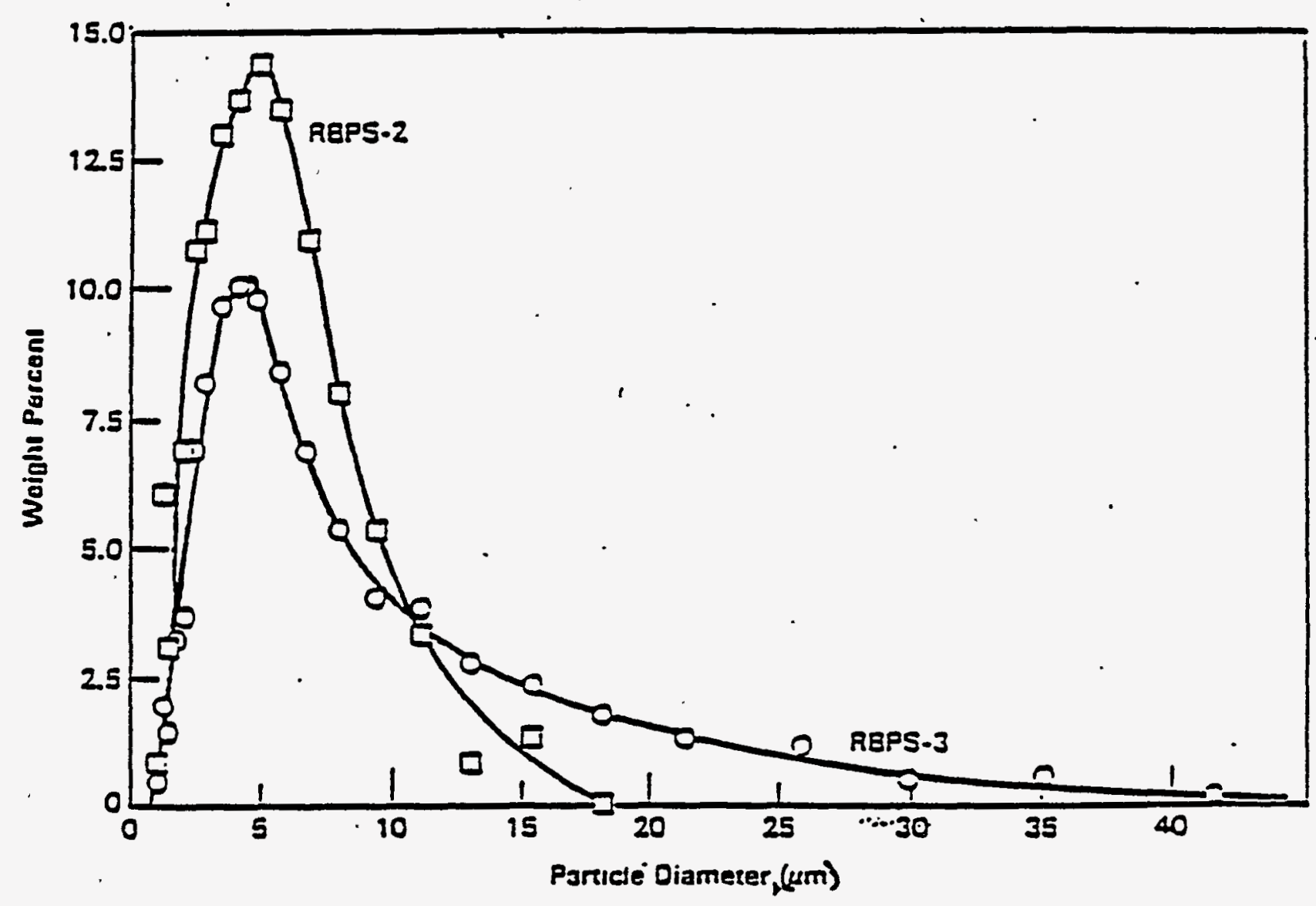

FIGURE 4.3-53. Particle Size Distributions for Synthetic HWVP Feeds RBPS-2 and RBPS-3 (NCAW 84, high. chromium) RHO-RE-CR-16P/HWVP-86-V1123C

Nine waste compositions encompassing expected HWVP waste feed variations tested in this study were chosen based on the concentration ranges for the major components in the pretreated NCAW 1984 10W-Cr waste composition shown in Table 4.3-33. A waste component is determined to be a major component if its nominal concentration based on the 1986 NCAW update (a) exceeds 5 wt\%. An exception to this requirement is silica (14 wt\% in the 1986 NCAW updated composition). Silica is not considered in this study because of its relative inertness as a major component.

The nine different waste compositions were prepared at concentrations of approximately $150 \mathrm{~g} \mathrm{WO} / \mathrm{L}$. They were prepared to evaluate the physical and rheological properties and redox state resulting from the different compositions. One composition was based on the 1984 low chromium NCAW HWWF feed.

(a) R. N. Wagner, Hanford Waste Vitrification Feed Specifications: PreTreated NCAW Feed. RHO-SD-HWV-CD-001, Rev. 0, Rockwell Hanford Operations, Richiand, Washington (1986). 


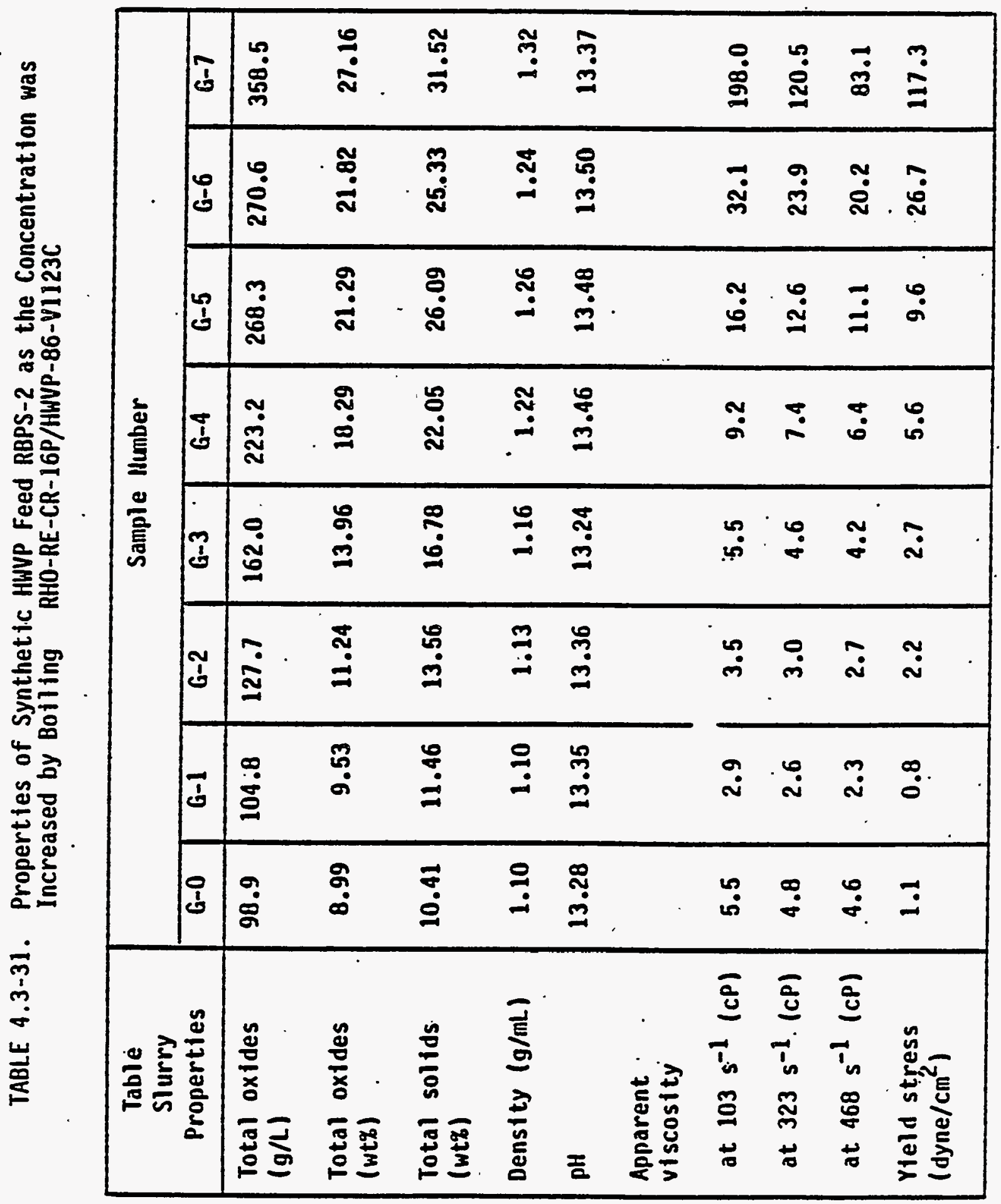




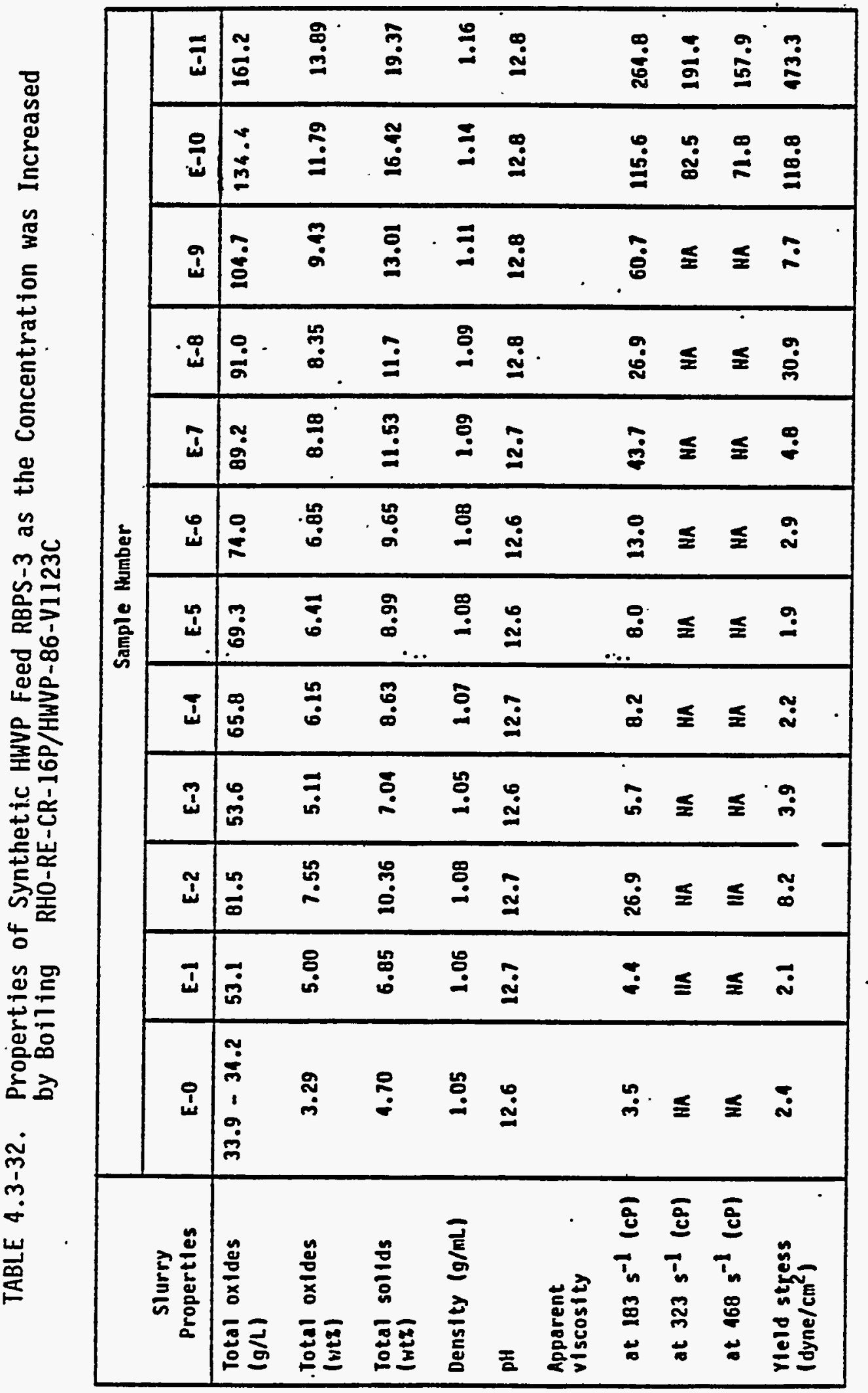


TABLE 4.3-33. Range of Major Component Concentrations, NCAW Haste (R. K. Farnsworth, HWVP-87-V110203A, 1987)

\begin{tabular}{|c|c|}
\hline Component 0xide & Concentration (wt\% total oxides) \\
\hline $\mathrm{Fe}_{2} \mathrm{O}_{3}$ & $12.0-66.0$ \\
$\mathrm{Al}_{2} \mathrm{O}_{3}$ & $1.6-26.0$ \\
$\mathrm{Na}_{2} \mathrm{O}$ & $4.5-22.0$ \\
$\mathrm{ZrO}_{2}$ & $0.0-40.0$ \\
\hline
\end{tabular}

Another reference simulant evaluated in this study was the 1986 NCAW composition. The other seven waste compositions were based on modifications of the 1984 low- chromium composition for the NCAW. To evaluate the composition limits, one major component in each of the seven batches was raised or lowered to one of the concentration limits shown in Table 4.3-33. The feed was then renormalized to maintain the same relative concentrations of the other components. The compositions for each of these feeds are provided in Tables 4.3-34 and 4.3-35. Brackets around any of the compounds shown in these tables indicate that the compound was used to balance more than one feed component. The amount of bracketed compound added is listed el sewhere on. the table. A Tow-Zr composition was not evaluated because of the presence of low-Zr concentrations in the NCAW 84, low chromium composition.

Nitrates were added to each of the feed compositions to simulate the amount of nitrates remaining in the NCAW when it is introduced to the HWVP. The nitrate level is important because of the effect of formic acid as a denitrator. To keep the denitration reaction from influencing the results, the amount of nitrates in each feed composition was set according to the amount expected in each feed upon entering the HWVP.

After confirming the various component concentrations by ICP analysis, selected samples of each waste composition were processed into melter feeds. Different amounts of formic acid were added to the waste, followed by the addition of glass-forming frit, additional formic acid, and water (if necessary). The resultant melter feeds had a total oxide concentration of $500 \mathrm{~g}$ $\mathrm{TO} / \mathrm{L}$, and an approximate waste oxide concentration of $25 \mathrm{wt} \%(125 \mathrm{~g} \mathrm{HO} / \mathrm{L})$. The meiter feeds were then physically and rheologically characterized, and the ferrous-to-ferric ratios of the resultant glasses were determined. Furthermore, each of the nine waste compositions were evaluated at three to five different levels of formic acid addition.

Specific details of the formic acid addition are provided in Section 4.3.4.2.1, "Laboratory Study of Redox Adjustment with Formic Acid."

Tabie 4.3-36 provides a summary of the characterized properties for each melter feed. Included in this table are the ferrous-to-ferric ratios for each melter feed. The ratio of ferrous- to-ferric ions in the resultant glass of each melter feed sample provided a good basis for evaluating the redox state of the feed as a function of formic acid addition. 
TABLE 4.3-34. Haste Oxide Composition of Simulated NCAW Feeds Used for Farnsworth Study (R. K. Farnsworth, HWVP-87-V110203A, 1987)

\begin{tabular}{|c|c|c|c|c|c|c|c|c|c|}
\hline & NCAH 86 & NCAN 84 & $\begin{array}{c}\text { NCAH } 84 \\
\text { Low } \\
\text { Chromium }\end{array}$ & $\begin{array}{l}\text { MCAW } 84 \\
\text { Low } \\
\text { Chromium }\end{array}$ & $\begin{array}{l}\text { NCAN } 84 \\
\text { Low Chromium }\end{array}$ & $\begin{array}{l}\text { NCAH } 84 \\
\text { Low Chromium }\end{array}$ & $\begin{array}{l}\text { NCAH } 84 \\
\text { Low Chromium }\end{array}$ & $\begin{array}{l}\text { NCAN } 84 \\
\text { LOW Chromiug }\end{array}$ & $\begin{array}{l}\text { NCAN } 84 \\
\text { Low Chromium }\end{array}$ \\
\hline $\begin{array}{l}\text { Waste } \\
\text { Oxide }\end{array}$ & $\begin{array}{l}\text { Reference } \\
\text { Wt\% }\end{array}$ & $\begin{array}{l}\text { Low Chromium } \\
\text { wt\% }\end{array}$ & $\begin{array}{c}\text { Low Iron } \\
\text { wt\% }\end{array}$ & $\begin{array}{c}\text { High Iron } \\
\text { wt\% }\end{array}$ & Low $\underset{\text { wt\% }}{\text { Aluminum }}$ & $\begin{array}{c}\text { High Aluminum } \\
\text { wt\% }\end{array}$ & $\begin{array}{l}\text { Low Sodium } \\
\text { wt\% }\end{array}$ & $\begin{array}{l}\text { High Sodium } \\
\text { wt\% }\end{array}$ & $\begin{array}{l}\text { High Zirconium } \\
\text { wt\% }\end{array}$ \\
\hline$A l_{2} \mathbf{O}_{3}$ & 10.34 & 18.25 & 30.44 & 13.81 & 1.60 & 26.07 & 19.66 & 16.05 & 11.21 \\
\hline $\begin{array}{l}\mathrm{BaO} \\
\mathrm{CaO} \\
\mathrm{CeO} \\
\mathrm{Cr}_{2} \mathrm{O}_{3} \\
\mathrm{Cs}_{2} \mathrm{O} \\
\mathrm{CuO} \\
\mathrm{F} \\
\mathrm{Fe}_{2} \mathrm{O}_{3} \\
\mathrm{La}_{2} \mathrm{O}_{3}\end{array}$ & $\begin{array}{r}0.41 \\
0.31 \\
0.62 \\
0.52 \\
0.62 \\
0.62 \\
1.24 \\
29.10 \\
2.08\end{array}$ & $\begin{array}{r}0.44 \\
0.31 \\
0.63 \\
0.57 \\
0.63 \\
0.63 \\
1.26 \\
17.23 \\
2.33\end{array}$ & $\begin{array}{r}0.73 \\
0.52 \\
1.04 \\
0.94 \\
1.04 \\
1.04 \\
2.10 \\
12.06 \\
3.89\end{array}$ & $\begin{array}{r}0.33 \\
0.24 \\
0.48 \\
0.43 \\
0.48 \\
0.48 \\
0.95 \\
60.05 \\
1.76\end{array}$ & $\begin{array}{r}0.53 \\
0.38 \\
0.76 \\
0.68 \\
0.76 \\
0.76 \\
1.51 \\
56.86 \\
2.81\end{array}$ & $\begin{array}{r}0.40 \\
0.28 \\
0.57 \\
0.51 \\
0.57 \\
0.57 \\
1.14 \\
42.72 \\
2.11\end{array}$ & $\begin{array}{r}0.47 \\
0.34 \\
0.68 \\
0.61 \\
0.68 \\
0.68 \\
1.35 \\
50.86 \\
2.51\end{array}$ & $\begin{array}{r}0.39 \\
0.28 \\
0.55 \\
0.50 \\
0.55 \\
0.55 \\
1.10 \\
41.52 \\
2.05\end{array}$ & $\begin{array}{r}0.27 \\
0.19 \\
0.39 \\
0.35 \\
0.39 \\
0.39 \\
0.77 \\
29.03 \\
1.43\end{array}$ \\
\hline $\begin{array}{l}\mathrm{MgO} \\
\mathrm{MnO}_{2} \\
\mathrm{MoO}_{3} \\
\mathrm{Na}_{2} \mathrm{O} \\
\mathrm{Nd}_{2} \mathrm{O}_{3}\end{array}$ & $\begin{array}{r}0.37 \\
0.62 \\
1.24 \\
18.16 \\
2.29\end{array}$ & $\begin{array}{r}0.35 \\
0.63 \\
1.26 \\
11.33 \\
2.23\end{array}$ & $\begin{array}{r}0.59 \\
1.04 \\
2.10 \\
18.89 \\
3.71\end{array}$ & $\begin{array}{l}0.27 \\
0.48 \\
0.95 \\
8.61 \\
1.68\end{array}$ & $\begin{array}{r}0.42 \\
0.76 \\
1.51 \\
13.64 \\
2.68\end{array}$ & $\begin{array}{r}0.32 \\
0.57 \\
1.14 \\
10.23 \\
2.01\end{array}$ & $\begin{array}{l}0.38 \\
0.68 \\
1.35 \\
4.51 \\
2.40\end{array}$ & $\begin{array}{r}0.31 \\
0.55 \\
1.10 \\
22.06 \\
1.96\end{array}$ & $\begin{array}{l}0.22 \\
0.39 \\
0.77 \\
7.01 \\
1.36\end{array}$ \\
\hline $\begin{array}{l}\mathrm{N1O} \\
\mathrm{PdO} \\
\mathrm{Pr}_{6} \mathrm{O}_{11} \\
\mathrm{Rh}_{2} \mathrm{O}_{3} \\
\mathrm{RuO}_{2} \\
\mathrm{SO}_{3}\end{array}$ & $\begin{array}{l}2.39 \\
0.21 \\
0.41 \\
0.21 \\
0.62 \\
1.87\end{array}$ & $\begin{array}{l}2.52 \\
0.19 \\
0.38 \\
0.19 \\
0.63 \\
1.57\end{array}$ & $\begin{array}{l}4.20 \\
0.31 \\
0.63 \\
0.31 \\
1.04 \\
2.62\end{array}$ & $\begin{array}{l}1.90 \\
0.14 \\
0.29 \\
0.14 \\
0.48 \\
1.19\end{array}$ & $\begin{array}{l}3.03 \\
0.23 \\
0.45 \\
0.23 \\
0.76 \\
1.90\end{array}$ & $\begin{array}{l}2.28 \\
0.17 \\
0.34 \\
0.17 \\
0.57 \\
1.42\end{array}$ & $\begin{array}{l}2.72 \\
0.20 \\
0.41 \\
0.20 \\
0.68 \\
1.70\end{array}$ & $\begin{array}{l}2.22 \\
0.17 \\
0.33 \\
0.17 \\
0.55 \\
1.57\end{array}$ & $\begin{array}{l}1.55 \\
0.12 \\
0.23 \\
0.12 \\
0.39 \\
0.97\end{array}$ \\
\hline $\begin{array}{l}\mathrm{SiO}_{3} \\
\mathrm{Sm}_{2} \mathrm{O}_{3} \\
\mathrm{SrO} \\
\mathrm{Y}_{2} \mathrm{O}_{3} \\
\mathrm{ZrO}_{2}\end{array}$ & $\begin{array}{r}9.34 \\
0.21 \\
0.41 \\
0.21 \\
15.55 \\
\end{array}$ & $\begin{array}{l}3.15 \\
0.19 \\
0.38 \\
0.19 \\
2.51\end{array}$ & $\begin{array}{l}5.24 \\
0.31 \\
0.63 \\
0.31 \\
4.22 \\
\end{array}$ & $\begin{array}{l}2.38 \\
0.14 \\
0.29 \\
0.14 \\
1.90 \\
\end{array}$ & $\begin{array}{l}3.79 \\
0.23 \\
0.45 \\
0.23 \\
3.01 \\
\end{array}$ & $\begin{array}{r}2.85 \\
0.17 \\
0.34 \\
0.17 \\
2.31 \\
\end{array}$ & $\begin{array}{l}3.39 \\
0.20 \\
0.41 \\
0.20 \\
2.71\end{array}$ & $\begin{array}{r}2.77 \\
0.17 \\
0.33 \\
0.17 \\
2.21 \\
\end{array}$ & $\begin{array}{r}1.93 \\
0.12 \\
0.23 \\
0.12 \\
40.04 \\
\end{array}$ \\
\hline $\begin{array}{l}\text { Total } \\
\text { TOC(A) } \\
\mathrm{NO}_{3}^{-}\end{array}$ & $\begin{array}{r}100.00 \\
2.08 \\
7.13\end{array}$ & $\begin{array}{r}100.00 \\
0.63 \\
5.80\end{array}$ & $\begin{array}{r}100.00 \\
1.04 \\
9.64\end{array}$ & $\begin{array}{r}100.00 \\
0.48 \\
4.40\end{array}$ & $\begin{array}{r}100.00 \\
0.76 \\
4.19\end{array}$ & $\begin{array}{r}100.00 \\
0.57 \\
6.55\end{array}$ & $\begin{array}{r}100.00 \\
0.68 \\
4.51\end{array}$ & $\begin{array}{r}100.00 \\
0.55 \\
7.82\end{array}$ & $\begin{array}{r}100.00 \\
0.39 \\
3.58\end{array}$ \\
\hline
\end{tabular}

(a) Iotal Qrganic Carbon. 
TABLE 4.3-35. Compound Concentrations of Simulants Used to Prepare NCAH Feeds for Farnsworth Study (R. K. Farnsworth, HWVP-87-V110203A, 1987)

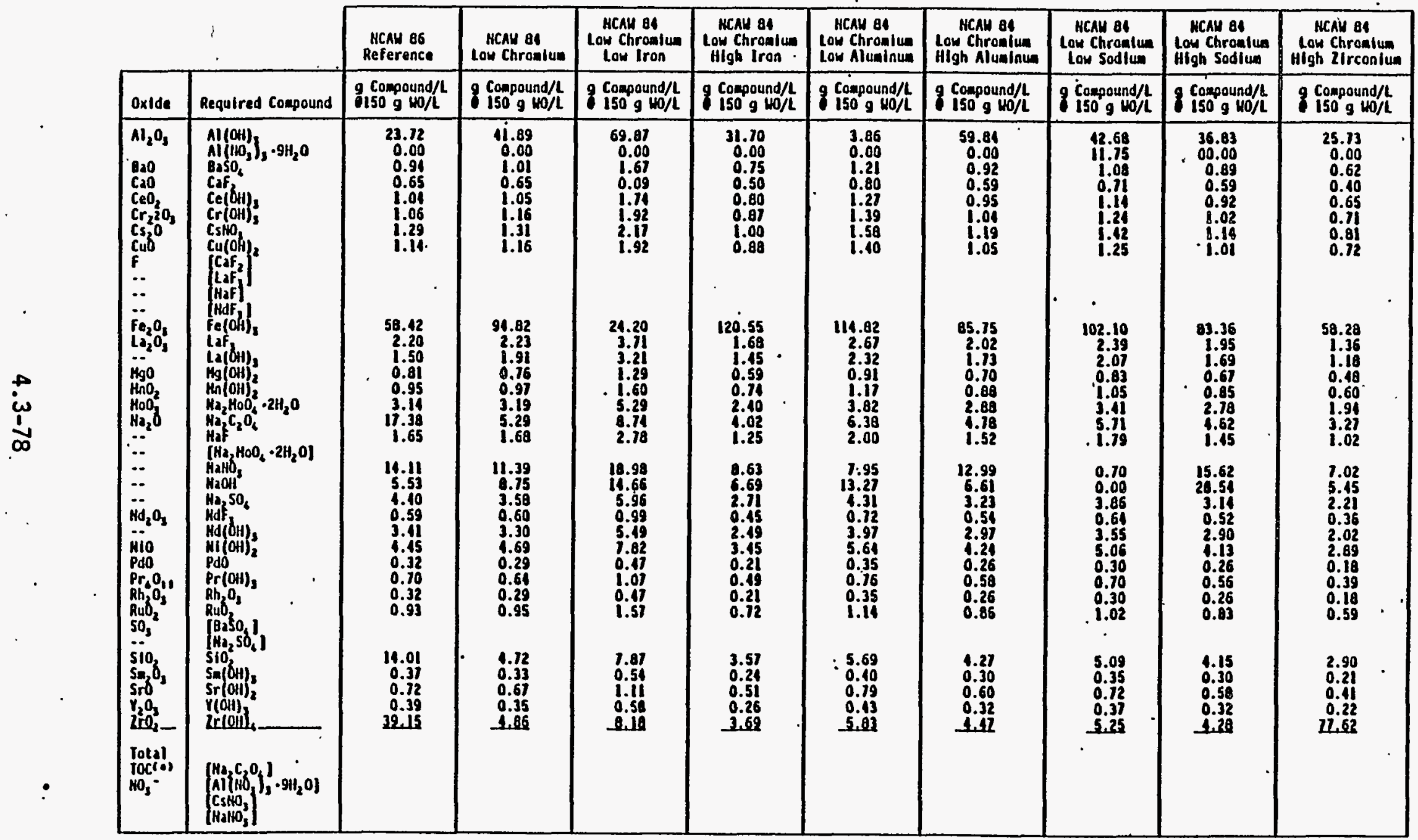

(a) Iotal grganic Garbon. 


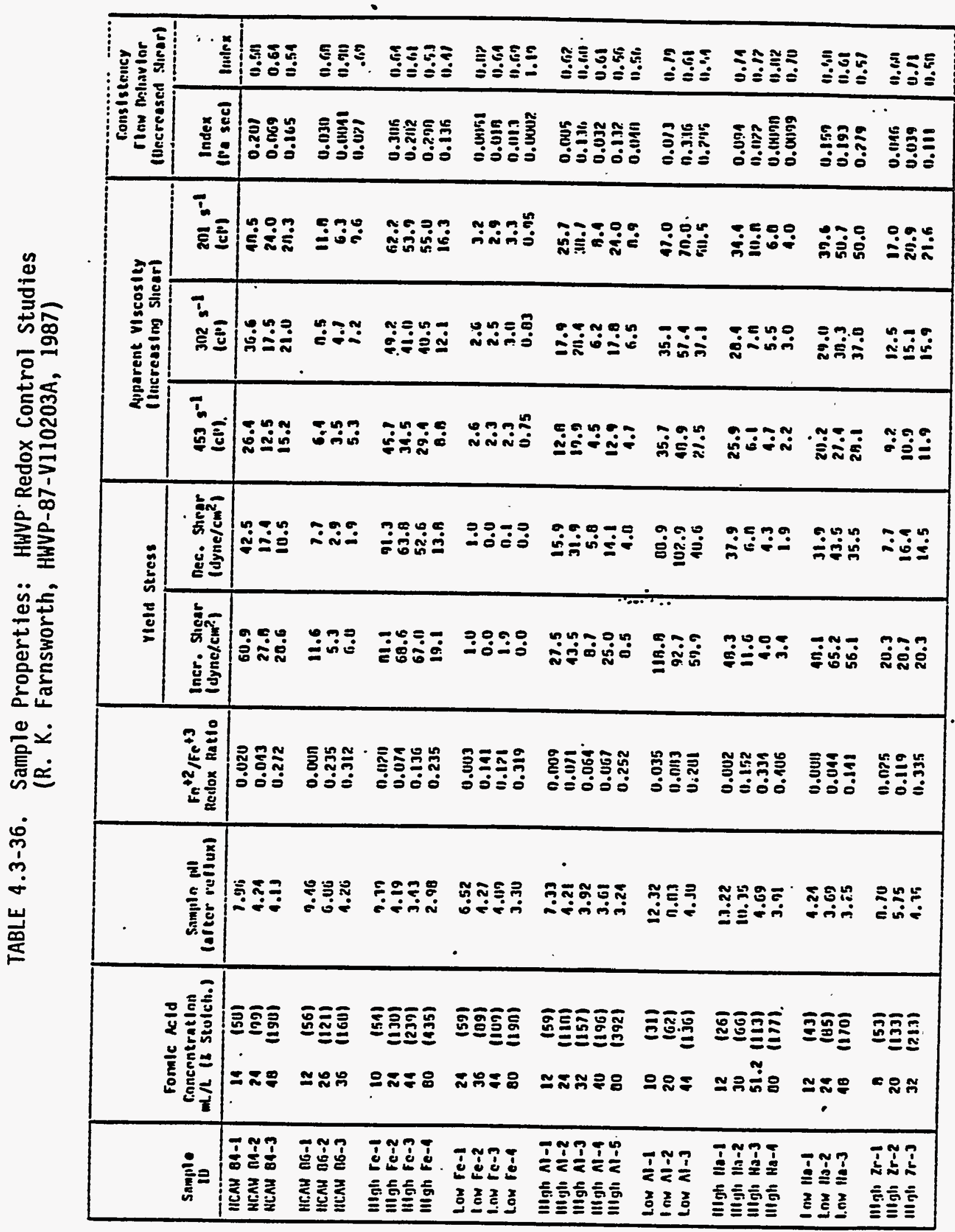




\subsection{HWVP Melter Feed Characterization for Pilot-Scale Melter} Run HWVP-13 and HWVP-14. (a) The preparation of melter feed slurries for large-scale melter experiments requires the use of a number of tanks. For runs HWVP-13 and -14, a master batch of HWVP reference feed NCAW 84 high chromium was prepared in Tank 311, a 2500-L tank. Tank 311 is equipped with internal steam coils that were used to heat the waste slurry during formic acid addition. Once the waste batch was prepared, it was then recirculated through a Tecmaro inline homogenizer to break down any agglomerated particles. The silicon dioxide and glass-former frit were not added to Tank 311 to prevent excessive wear to the grinding heads in the homogenizer. Following homogenization of the waste, the slurry was reacted with formic acid. This required heating the slurry to approximately $95^{\circ} \mathrm{C}$ before metering in the formic acid. Once the formic acid treatment was completed, the slurry was transferred to an intermediate makeup tanks (Tank 60) or Tank HB, 11). Frit and silica and additional formic acid, equivalent to 1 wt\% of the frit, were added to the slurry and agitated until the slurry was transferred to the melter feed tank for use. Slurry was transferred in batches to the melter feed tank, Tank HB 21.

The major objective of the HWVP-13 melter test was to evaluate processing characteristics of melter feed slurries having different total oxide loadings. Therefore, for this experiment, a single waste slurry batch was prepared. The batch was then separated into three fractions to which the silica, frit, 1 wt\% formic acid and required dilution water were added. The three melter feed concentrations tested were 415,515 , and $654 \mathrm{~g} \mathrm{TO} / \mathrm{L}$. For the case of $654 \mathrm{~g} \mathrm{TO} / \mathrm{L}$, the waste fraction was concentrated to a value higher than initially achieved in order to reach the target melter feed oxide concentration. Physical and rheological properties of each sample taken were characterized during the various stages of melter feed preparation (see Table 4.3-37).

The major test objective of the HWVP-14 experiment was to evaluate the processing characteristics of different slurry compositions. Each composition represented a possible variation in waste composition coming to the HWVP. Initially, five different compositions were considered. Therefore, five slurry batches were prepared in the laboratory and characterized. Three of these five composition were prepared for the HWVP-14 experiment.

The oxide compositions of the five batches of simulated HWVP feed considered for HWVP-14 are presented in Table 4-3.38 They included feeds containing: 1) the minimum level of Al expected, 2) the maximum level of $\mathrm{Zr}$ expected, 3) the maximum level of $\mathrm{Na}$ expected, and 4) two different low levels of $\mathrm{Fe}$. The other waste components were adjusted so that the total oxide concentration in the HWVP feed remained constant (25 wt\%) despite the large change in the level of the elements of interest. Preparing the simulated feeds in this way resulted in large variations in the concentrations of

\footnotetext{
(a) "HWVP Feed Process Variability Testing for Fiscal Year 1986," RHO-RE-CR-16P/HWVP-86-V1123C, Pacific Northwest Laboratory, Richland, Hashington (1986).

- Tecmar Inc., Cleveland, Ohio, 44122
} 
TABLE 4.3-37. Properties of Samples Taken During Processing of Simulated Feeds (NCAW 84, high chromium) for the HWVP-13 Run RHO-RE-CR-16P/HWVP-86-V1123C

\begin{tabular}{|c|c|c|c|c|c|c|c|c|c|c|c|c|c|}
\hline \multirow[b]{2}{*}{$\begin{array}{l}\text { Slurry } \\
\text { Property }\end{array}$} & \multicolumn{13}{|c|}{ Sanple Hunber } \\
\hline & 11 & 8 & 9 & 10 & 11 & 15 & 23 & 33 & 34 & 134 & 136 & 219 & \\
\hline Slurry type & $\mathrm{Fe}(\mathrm{OH})_{3}$ & $\begin{array}{l}\text { Maste } \\
\text { only }\end{array}$ & $\begin{array}{l}\text { ICCOOII } \\
\text { added }\end{array}$ & $\begin{array}{l}\text { Bolled } \\
\text { I h }\end{array}$ & $\begin{array}{l}\text { olled } \\
2 \mathrm{~h}\end{array}$ & $\begin{array}{l}\text { Frit } \\
\text { added }\end{array}$ & $\begin{array}{l}\text { Frit } \\
\text { added }\end{array}$ & Dlluted & Diluted & $\begin{array}{l}\text { Frlt } \\
\text { added }\end{array}$ & $\begin{array}{l}\text { Frit } \\
\text { added }\end{array}$ & $\begin{array}{l}\text { Concen- } \\
\text { trated }\end{array}$ & $\begin{array}{l}\text { Concen- } \\
\text { trated }\end{array}$ \\
\hline $\begin{array}{l}\text { Total oxides } \\
(g / L)\end{array}$ & 112.3 & 136 & 172 & -- & 188 & 470 & 478 & 456 & 424 & 476 & 163 & 624 & 649 \\
\hline $\begin{array}{l}\text { Total oxides } \\
\text { (wts) }\end{array}$ & 10.2 & 12.2 & 15.6 & -- & 26.2 & 35.9 & 36.2 & 34.9 & 33.0 & 36.0 & 36.0 & 43.4 & 45.3 \\
\hline $\begin{array}{l}\text { Total solfds } \\
\text { (ntz) }\end{array}$ & 11.1 & 19.9 & 28.7 & -- & 21.5 & 39.2 & 39.6 & 31.2 & 35.4 & 39.5 & 39.5 & 97.5 & 49.3 \\
\hline Densfty (g/mL) & 1.11 & 1.11 & 1.12 & 1.15 & 1.16 & 1.31 & 1.32 & 1.31 & 1.29 & 1.32 & 1.31 & .1 .44 & 1.43 \\
\hline pHI. & $\cdots$ & 12.3 & 7.0 & 7.5 & 7.6 & 8.0 & 8.0 & 8.5 & 0.5 & 0.0 & 8.0 & 1.2 & 1.2 \\
\hline $\begin{array}{l}\text { Apparent } \\
\text { viscosity }\end{array}$ & & & & & & & & & & & & & \\
\hline at $183 \mathrm{~s}^{-1}$ & 41.5 & 40.0 & 21.4 & 30.1 & 42.3 & 20.6 & 27.7 & 9.9 & 10.3 & 32.5 . & 30.9 & 18.3 & 17.5 \\
\hline et $323 \mathrm{~s}^{-1}$ & 30.5 & 26.5 & 15.7 & 20.7 & 28.5 & 12.6 & !. 10.0 & 6.3 & 6.7 & 24.7 & 19.8 & 33.2 & 31.6 \\
\hline at $468 \mathrm{~s}^{-1}$ & 22.9 & 20,4 & 13.9 & 16.7 & 22.8 & 9.3 & 12.1 & 5.3 & 5.6 & 20.1 & 14.9 & 29.1 & 25.7 \\
\hline $\begin{array}{l}\text { Yield stress } \\
\left.\text { (dyne } / \mathrm{cm}^{2}\right)\end{array}$ & 78.2 & 47.1 & 23.2 & 31.7 & 51.4 & 24.6 & 34.0 & $14.5^{\circ}$ & 14.5 & 43.5 & 12.0 & 66.7 & 69.6 \\
\hline
\end{tabular}


TABLE 4.3-38 Oxide Compositions of Various Me7ter Feeds Prepared for the HWVP-14 Feed Composition Variables Tests

RHO-RE-CR-16P/HWVP-86-VI123C

\begin{tabular}{|c|c|c|c|c|c|c|}
\hline \multirow[b]{2}{*}{ Oxide } & \multicolumn{6}{|c|}{ Melter Feed, wt\% To } \\
\hline & $\begin{array}{c}\text { Reference } \\
\text { (NCAH 84, } \\
\text { high } \\
\text { chromium) }\end{array}$ & Low AT & High Zr & High $\mathrm{Na}$ & Low Fe & Low Fe2 \\
\hline $\begin{array}{l}\mathrm{Al}_{2} \mathrm{O}_{3} \\
\mathrm{BaO}_{3} \\
\mathrm{CaO}_{2} \\
\mathrm{CeO}_{2} \\
\mathrm{Cr}_{2} \mathrm{O}_{3}\end{array}$ & $\begin{array}{l}4.32 \\
0.10 \\
0.08 \\
0.18 \\
1.34\end{array}$ & $\begin{array}{l}0.40 \\
0.13 \\
0.10 \\
0.23 \\
0.16\end{array}$ & $\begin{array}{l}2.79 \\
0.07 \\
0.05 \\
0.12 \\
0.08\end{array}$ & $\begin{array}{l}4.00 \\
0.10 \\
0.07 \\
0.17 \\
0.11\end{array}$ & $\begin{array}{l}5.80 \\
0.14 \\
0.10 \\
0.24 \\
0.17\end{array}$ & $\begin{array}{l}6.66 \\
0.16 \\
0.12 \\
0.28 \\
0.19\end{array}$ \\
\hline $\begin{array}{l}\mathrm{CsO}_{2} \\
\mathrm{CuO} \\
\mathrm{Fe}_{2} \mathrm{O}_{3} \\
\mathrm{MgO}_{3} \\
\mathrm{MnO}_{2}\end{array}$ & $\begin{array}{r}0.25 \\
0.15 \\
11.15 \\
0.08 \\
0.18\end{array}$ & $\begin{array}{r}0.31 \\
0.19 \\
18.08 \\
0.10 \\
0.23\end{array}$ & $\begin{array}{l}0.16 \\
0.10 \\
7.20 \\
0.05 \\
0.12\end{array}$ & $\begin{array}{r}0.23 \\
0.14 \\
10.30 \\
0.07 \\
0.17\end{array}$ & $\begin{array}{l}0.33 \\
0.20 \\
8.00 \\
0.10 \\
0.24\end{array}$ & $\begin{array}{l}0.38 \\
0.24 \\
5.50 \\
0.12 \\
0.28\end{array}$ \\
\hline $\begin{array}{l}\mathrm{MoO}_{3} \\
\mathrm{NiO} \\
\mathrm{Pr}_{6} \mathrm{O}_{11} \\
\mathrm{SiO}_{2} \\
\mathrm{Sm}_{2} \mathrm{O}_{3}\end{array}$ & $\begin{array}{l}0.30 \\
0.60 \\
0.10 \\
0.76 \\
0.05\end{array}$ & $\begin{array}{l}0.38 \\
0.76 \\
0.13 \\
0.96 \\
0.06\end{array}$ & $\begin{array}{l}0.20 \\
0.39 \\
0.07 \\
0.49 \\
0.02\end{array}$ & $\begin{array}{l}0.28 \\
0.55 \\
0.10 \\
0.70 \\
0.04\end{array}$ & $\begin{array}{l}0.41 \\
0.81 \\
0.14 \\
1.02 \\
0.06\end{array}$ & $\begin{array}{l}0.47 \\
0.92 \\
0.16 \\
1.17 \\
0.07\end{array}$ \\
\hline $\begin{array}{l}\mathrm{SrO} \\
\mathrm{Y}_{2} \mathrm{O}_{3} \\
\mathrm{ZrO}_{2} \\
\mathrm{La}_{2} \mathrm{O}_{3} \\
\mathrm{Na}_{2} \mathrm{O}\end{array}$ & $\begin{array}{l}0.10 \\
0.05 \\
0.60 \\
0.55 \\
2.70\end{array}$ & $\begin{array}{l}0.13 \\
0.06 \\
0.76 \\
0.70 \\
3.41\end{array}$ & $\begin{array}{r}0.07 \\
0.02 \\
10.00 \\
0.36 \\
1.75\end{array}$ & $\begin{array}{l}0.10 \\
0.04 \\
0.55 \\
0.51 \\
5.51\end{array}$ & $\begin{array}{l}0.14 \\
0.05 \\
0.81 \\
0.74 \\
3.65\end{array}$ & $\begin{array}{l}0.16 \\
0.07 \\
0.92 \\
0.85 \\
4.16\end{array}$ \\
\hline $\begin{array}{l}\mathrm{Nd}_{2} \mathrm{O}_{3} \\
\mathrm{~F}^{-\mathrm{C}} \\
\mathrm{SO}_{3}^{-} \\
\mathrm{TOC}^{-}\end{array}$ & $\begin{array}{l}0.53 \\
0.30 \\
0.38 \\
0.15\end{array}$ & $\begin{array}{l}0.67 \\
0.38 \\
0.48 \\
0.19\end{array}$ & $\begin{array}{l}0.34 \\
0.20 \\
0.25 \\
0.10\end{array}$ & $\begin{array}{l}0.49 \\
0.28 \\
0.35 \\
0.14\end{array}$ & $\begin{array}{l}0.72 \\
0.41 \\
0.51 \\
0.20\end{array}$ & $\begin{array}{l}0.82 \\
0.47 \\
0.59 \\
0.24\end{array}$ \\
\hline TOTALS & 25.00 & 25.00 & 25.00 & 25.00 & 25.00 & 25.00 \\
\hline $\begin{array}{l}\text { FRIT } \\
\text { HW39 }\end{array}$ & 75.00 & 75.00 & 75.00 & 75.00 & 75.00 & 75.00 \\
\hline
\end{tabular}

other elements as well as those elements that are the object of this study. of particular interest with respect to the rheological properties is the change in the iron content of the test batches because of the perceived influence of ferric hydroxide. 
Each of the five different feed batches was characterized at three phases of the melter feed preparation: 1) as the simulated HWVP feed was prepared before formic acid was added, 2) after the formic acid treatment, and 3) after the frit was added. The three compositions selected for melter testing were: 1) high zirconium; 2). high sodium; and 3) low iron, denoted as Fe2. Because of the significant differences in composition from the reference waste composition, it was also of interest to evaluate the change in physical and rheological properties with respect to the simulated slurries studied up to this point.

Plots of siurry density, apparent viscosity, and yield stress, respectively, versus waste oxide composition are plotted in Figures 4.3-54, 4.3-55, and 4.3-56, respectively. These plots are for waste slurries prior to treatment with formic acid. The density results are not surprising in that the density of the low-Al batch is greater than many of the others because it contains the greatest iron concentration. It is not clear, however, why the low-iron batch, Fe2, has the highest density. These relatively smail density differences between the various samples are not a concern from a slurry preparation standpoint. However, they do give an indication of the effect that composition will have on specific-gravity measurements of actual feeds in the HWVP tank, and will have to be considered from a process-control point of view.

\subsection{Characterization of NCAW 86 HWVP P7ant Feed. (a) The} HWVP-RF composition was updated in FY 1986 to better characterize the NCAW feed expected to be received in the HWVP. A study(a) was performed to 1) determine the rheological and physical properties of NCAW 86 composition siurry simulants, 2) identify the effects of the composition change on these properties, and 3) determine if changes in. these properties comprise the validity of the existing feed processing data base: A simulated NCAW 86 feed (HWS9) was prepared (Table A-5, Appendix A) and processed by sequential dilution, concentration, formating and further concentration: Rheological (apparent viscosity and yield stress) and physical properties (all other properties measured such as $\mathrm{pH}$, solids loading and oxide loading) were measured for HWS9 at various processing stages (Table 4.3-39). The sample(s) taken at each processing step was identified with. the following sample identification system. (a)

$$
\text { HWS9 - [1] [2] [3] }
$$

The first character represents the target concentration at that processing step. The concentration is given in $\mathrm{g} W 0 / \mathrm{L}$.

(a) G. T. Thornton, Evaluation and Comparison of HWVP Reference Feed Composition and Updated Neutralized Current Acid Waste Composition Simulants, HWVP-87-V110203C, Pacific Northwest Laboratory, Richland, Washington (Apri1 1987). 


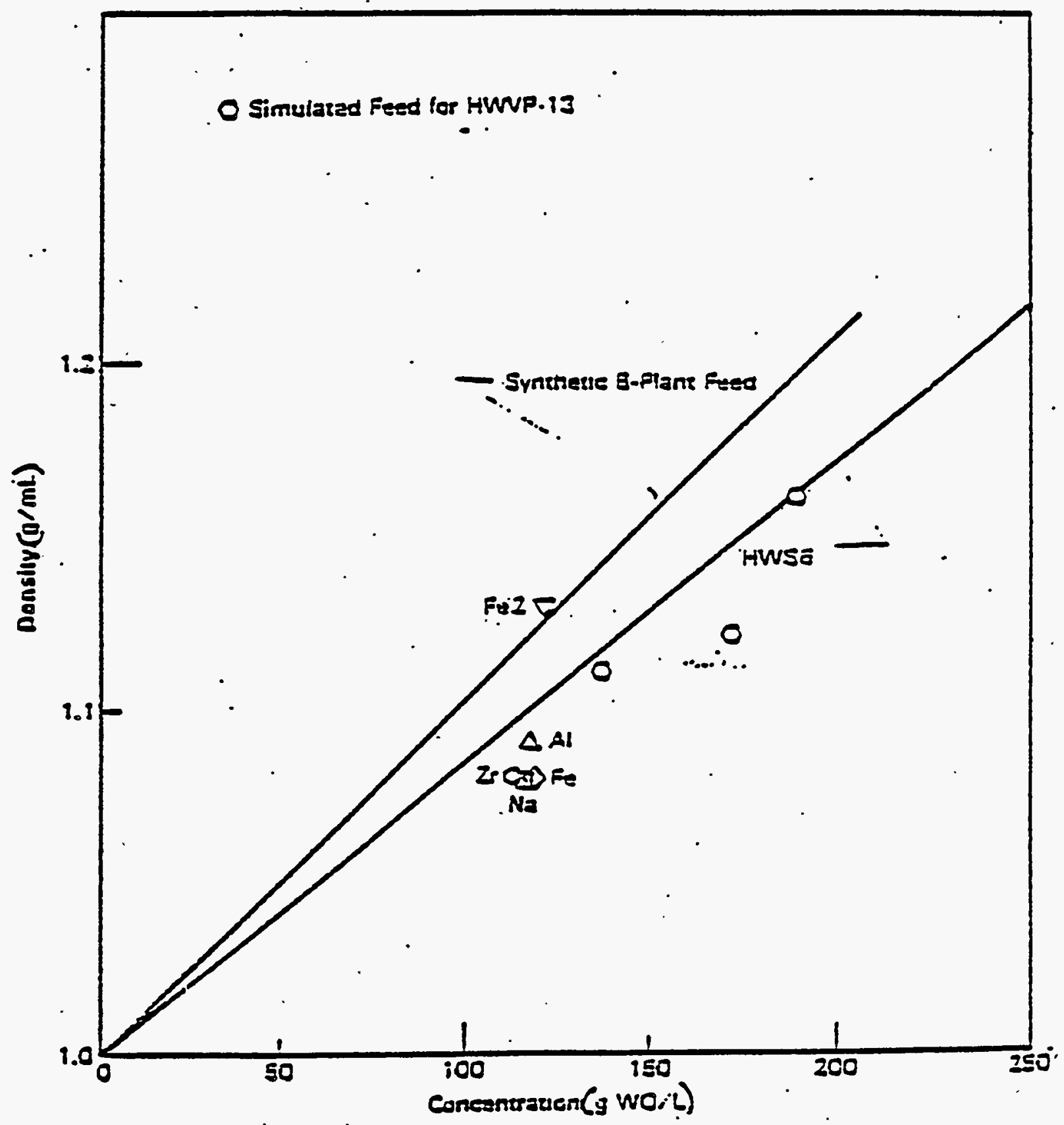

FIGURE 4.3-54. Densities (NCAW 84, high chromium) of Simulated HWVP Synthetic B-P7 ant Feed, HWVP-13 and HWVP-14 Feeds and Simulation HWS6 Versus Slurry Concentration Before Formic Acid Treatment RHO-RE-CR-16P/HWVP-86-V1123C 


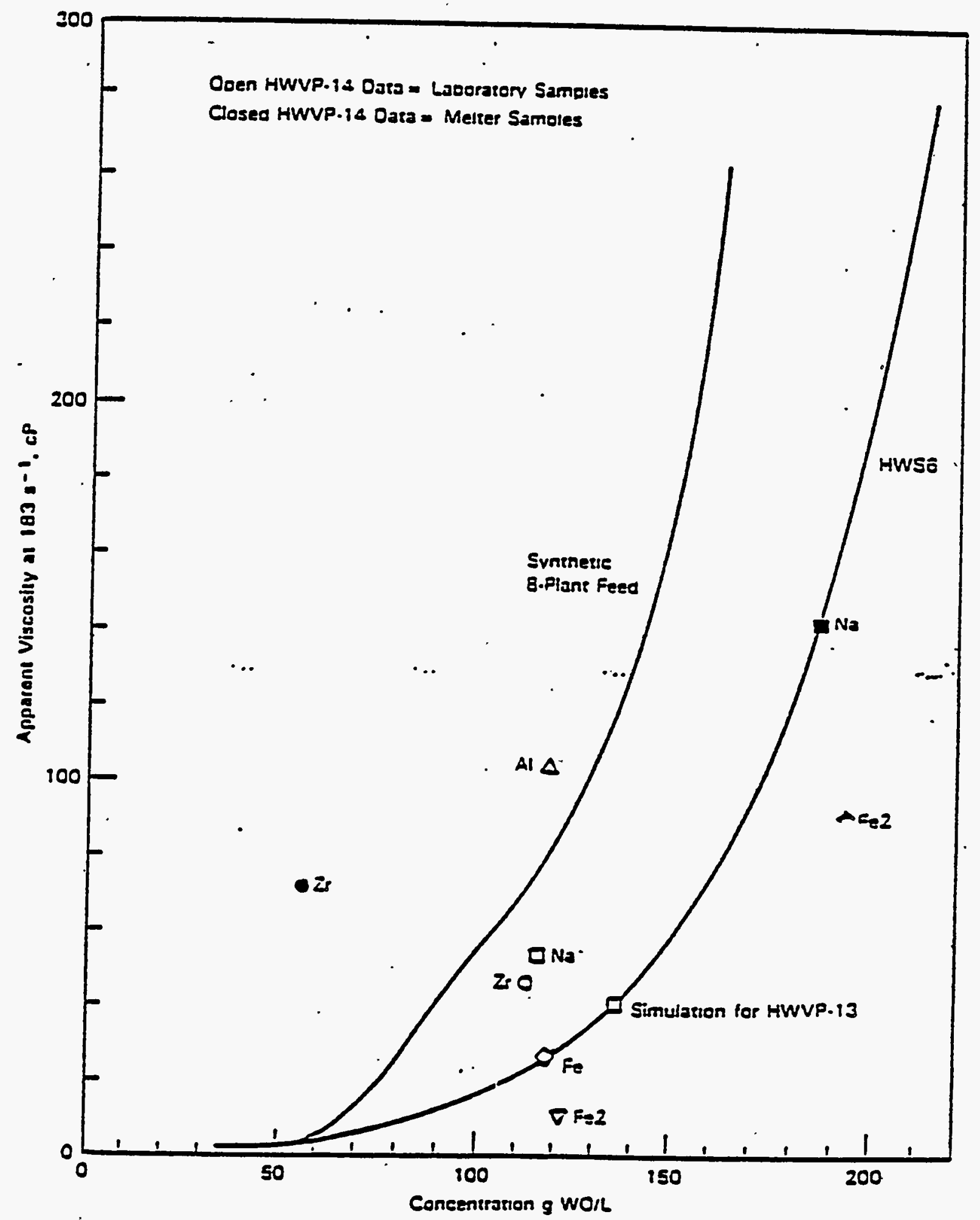

FIGURE 4.3-55. Apparent Viscosity of Synthetic B-Plant Feed, HWVP-13 and HWVP-14 Feeds, and Simulation HWS6 Versus Slurry Concentration Before Formic Acid Treatment

RHO-RE-CR-16P/HWVP-86-V1123C 


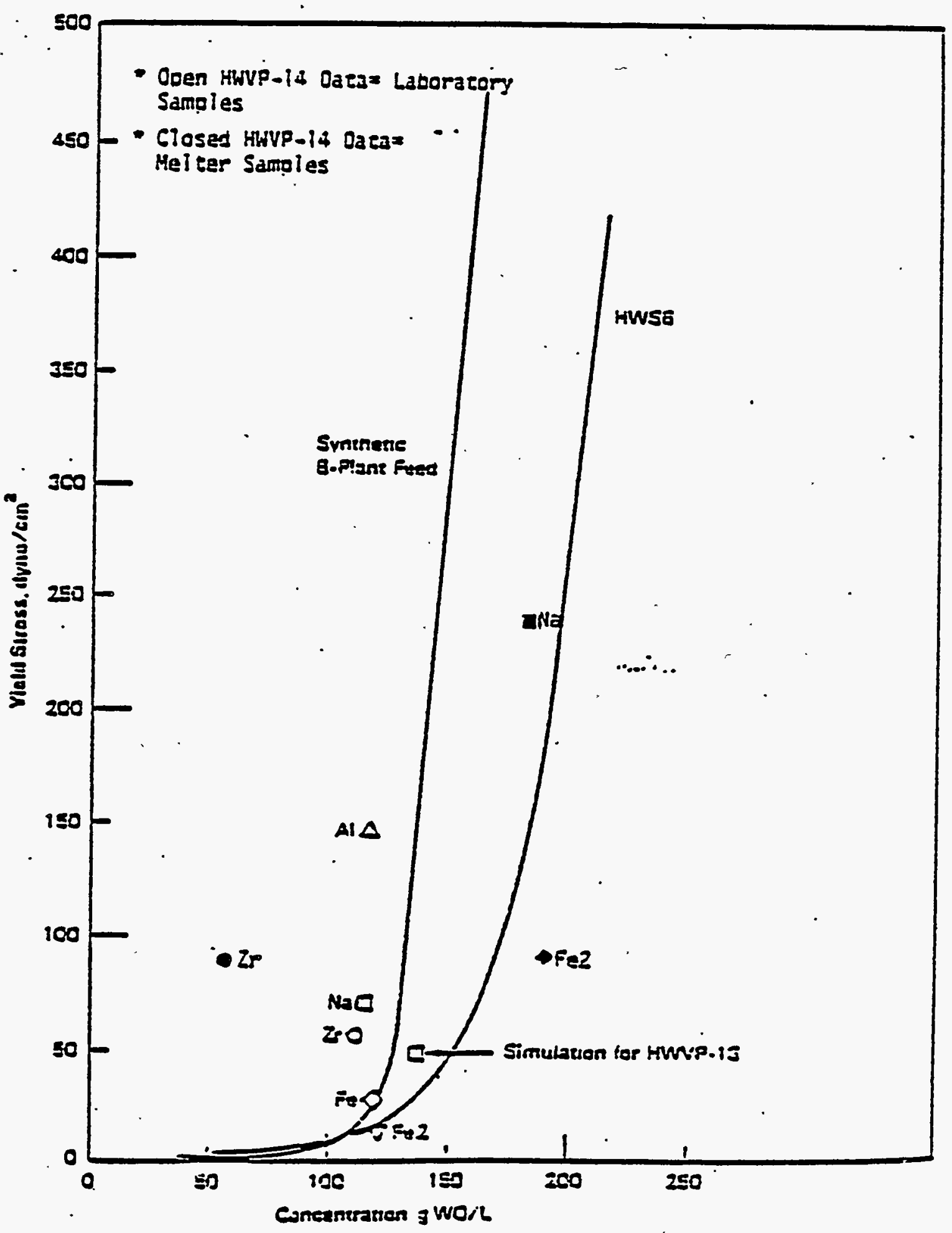

FIGURE 4.3-56. Yield Stress of Synthetic B-Plant Feed, HWVP-13 and HWVP-14 Feeds, and Simulation HWS6 Versus STurry Concentration Before Formic Acid Treatment RHO-RE-CR-16P/HWVP-86-V1123C 


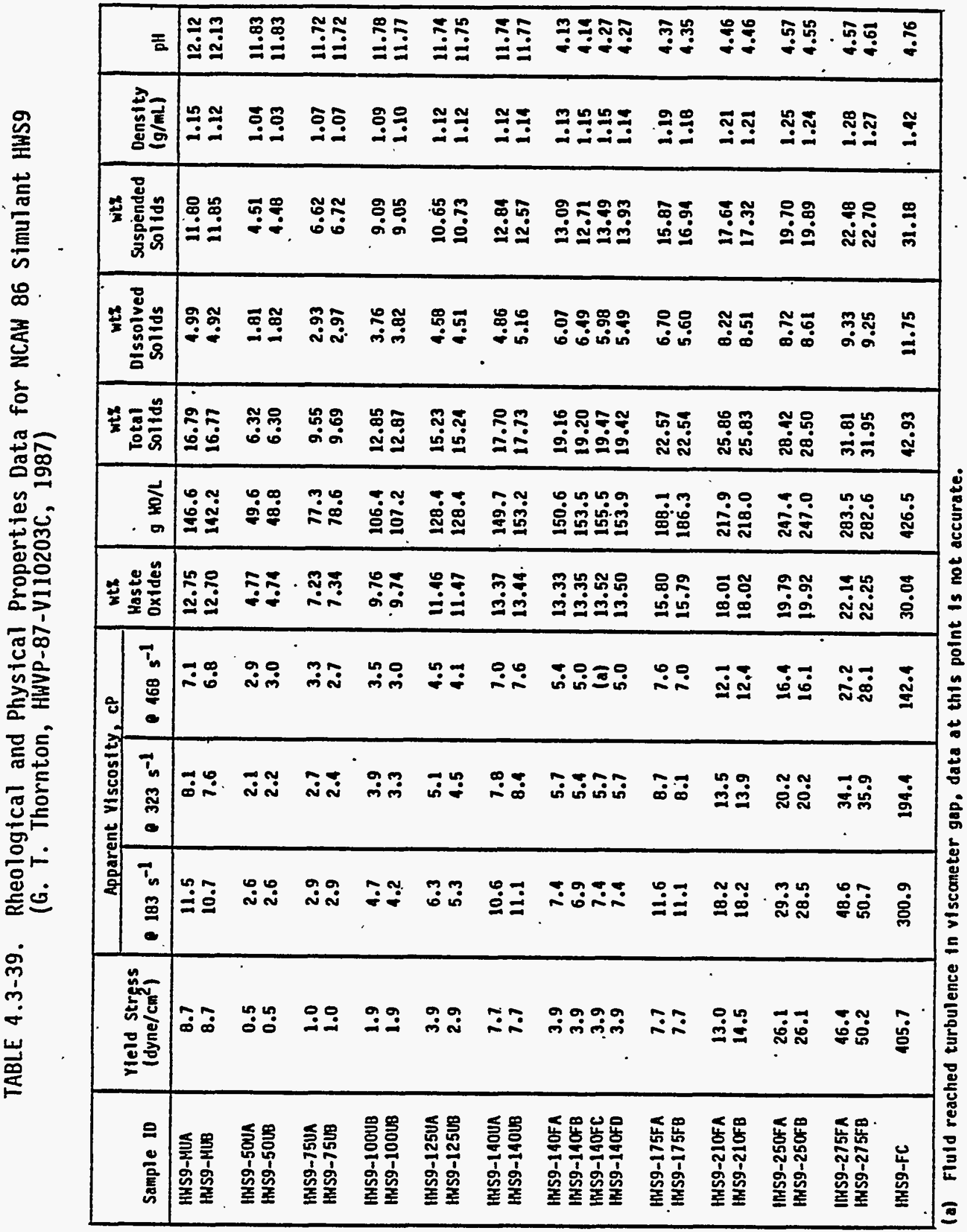


The second character defines whether or not the sample has been formated and can be one of the two following letters:

- U, for samples of unformated HWS9

- F, for samples of formated HWS9.

The third and final character designates replicate subsamples taken at the same point in processing and is the letter $A$ or $B$.

Groups of samples that do not fall directly into the above sample numbering systems are identified as follows:

HWS9-MU, for the HWS9 stock slurry as-prepared.

HWS9-140FC and HWS9-140FD, for formated HWS9 slurry samples prepared according to the reference procedure and heat treated for 2 hours after formating. These samples are for comparison with HWS9-140A and HWS9-140B, which did not receive the 2-hour heat treatment. This comparison provided an evaluation of the benefits of the standard 2-hour post-formating heat time.

HWS9-FC, for the highest oxide concentration reached during HWS9 processing, reached this step marked the end of HWS9 processing.

A small scoping test was carried out to evaluate the benefits of the standard $2 \mathrm{~h}$ post-formating heat treatment. Samples HWS9-140FC and B received no post-formating heat treatment and samples HWS9-140FC and D received the reference $2 \mathrm{~h}$ heat treatment period. As can be seen in Table 4.3-42, no rheological benefits in the form of reduced yield stress or apparent viscosity values were obtained by performing this heat treatment. In fact, no rheological differences at all are seen between heat-treated and non-heat-treated samples of formated HWS9. The only differences seen in physical properties are a slight concentration effect with heat treatment resulting from imperfect refluxing apparatus and a slight rise in $\mathrm{pH}$.

\subsection{Synthetic HWVP NCAW 86 Feed Makeup From Precipitated}

Hydroxides. (a) Seven test runs were performed using a simulated NCAW 86 feed composition to characterize HWVP feed formating off-gas release. For preparation of this feed a new procedure was developed at PNL in which nitrate salts were neutralized with sodium hydroxide to produce the hydroxide feed. This procedure better simulated the actual processing of the radioactive NCAW. Preyious simulants were prepared by blending chemical hydroxides together. (b)

(a) K. D. Hiemers et al., Evaluation of Process off Gases Released During Formatting of an HWVP Feed Simulant, HWVP-87-VI10203G, Pacific Northwest Laboratory, Richland, Washington (September 1987).

(b) R. K. Farnsworth, The Effect of Feed Composition and Formic Acid Addition on Glass Redox State, HWVP-87-V110203A, Pacific Northwest Laboratory, Richland, Washington (August 1987). 
During the test runs formic acid was added at three different stoichiometric amounts and at three different rates. Feed elemental composition was determined for the respective samples. The physical and rheological properties of the simulated feed were measured for comparison with the properties of previous simulants.

Feed Preparation. Nitrate salts of $\mathrm{Fe}, \mathrm{Zr}, \mathrm{AT}$, and $\mathrm{Ni}$ were dissolved in individual tanks and neutralized using sodium hydroxide. The hydroxide precipitates were subsequently allowed to settle and were then washed to remove the excess $\mathrm{Na}$. Removal of the excess $\mathrm{Na}$ was required to achieve the target composition. After washing, the solids were sampled and chemically analyzed.

A group of the minor feed components was added as nitrates to a fifth tank, followed by the addition of water. This tank was also neutralized with sodium hydroxide and the solids were sampled and chemically analyzed. The solids in tank \#5 were not washed and the sodium which was added for neutralization was the total amount of sodium required for the target composition.

A sixth tank contained the remaining feed components, which were added as sulfates, oxides, or fluorides. This tank was not neutralized and the contents of this tank were sampled and chemically analyzed.

The resulting simulated HWVP feed was prepared by blending the contents of all six tanks together in the appropriate quantities based on the resuits of the chemical analysis for each tank. After the final blending, the resulting simulated NCAW feed was sampled and chemically analyzed.

The feed was below the $150 \mathrm{~g}$ WO/L (actual $90 \mathrm{~g}$ WO/L) target concentration and was concentrated by heating to remove the excess water. After final chemical analysis, sugar and silica ( -325 mesh) were added to the simulated feed. The sugar was added to obtain the target TOC concentration. No excess nitrate was added to the simulated feed because it was expected that nitrate would remain in the feed as a result of neutralization and associated inefficiencies in the feed preparation process. Chemical analysis confirmed the expected behavior.

The amount of sodium hydroxide added to Tanks 1 through 5 was twice the stoichiometric amount required to precipitate the nitrate salts. Comparisons of the actual and target feed compositions are shown in Table 4.3-40.

The amount of formic acid was varied between $70 \%$ and $130 \%$ of the calculated stoichiometric amount required to convert the hydroxides to formate salts. Formic acid added at $50 \%$ of the stoichiometric amount was visually observed in past studies to generate insignificant quantities of gases. The component $"$ in the feed that were assumed to react completely with formic acid and were used to calculate the stoichiometric addition of formic acid were $\mathrm{Ce}(\mathrm{OH})_{3}, \mathrm{Mg}(\mathrm{OH})_{2}, \mathrm{Mn}(\mathrm{OH})_{2}, \mathrm{NaOH}, \mathrm{Nd}(\mathrm{OH})_{3}, \mathrm{Ni}(\mathrm{OH})_{2}, \operatorname{Pr}(\mathrm{OH})_{3}, \mathrm{Sm}(\mathrm{OH})_{3}, \mathrm{Sr}(\mathrm{OH})_{2}$, and $\mathrm{Y}(\mathrm{OH})_{3}$. The 100\% stoichiometric amount required approximately 0.50 moles of formic acid per liter of feed $(19.1 \mathrm{~mL} 90 \mathrm{wt} \% \mathrm{HCOOH} / \mathrm{L}$ feed). The $130 \%$ stoichiometric addition required $24.8 \mathrm{~mL} 90 \mathrm{wt} \% \mathrm{HCOOH} / \mathrm{L}$ feed and the $70 \%$ stoichiometric addition required $13.4 \mathrm{~mL} 90 \mathrm{wt} \% \mathrm{HCOOH} / \mathrm{L}$ feed. 
TABLE 4.3-40. Comparison of Target Composition and Actual Composition of NCAW 86 (HWS11) Simulated Feed (Wiemers et al., HWVP-87-V110203G, 1987)

\begin{tabular}{|c|c|c|c|c|c|c|c|c|c|c|c|c|c|}
\hline \multirow[b]{2}{*}{ Oxide } & \multirow{2}{*}{$\begin{array}{l}\text { Turget } \\
\text { (wtx) }\end{array}$} & \multirow{2}{*}{$\begin{array}{c}\text { Target } \\
(\mathrm{g} \mathrm{Ho/L)}\end{array}$} & \multirow[b]{2}{*}{ Elements } & \multicolumn{2}{|c|}{ Im g Element/L } & \multirow{2}{*}{$\begin{array}{l}\text { Target } \\
\text { Element } \\
\text { (wtt) }\end{array}$} & \multirow{2}{*}{$\begin{array}{l}\text { El exent } \\
\text { Mormal } \\
\text { Target } \\
\text { (wts) }\end{array}$} & \multirow{2}{*}{$\begin{array}{l}\text { Initial } \\
\text { Feed in } \\
\text { Element } \\
\text { (wtx) }\end{array}$} & \multirow{2}{*}{$\begin{array}{c}\text { Init|al } \\
\text { Foed } 12 \\
\text { Element } \\
\text { (wtx) }\end{array}$} & \multirow{2}{*}{$\begin{array}{c}\text { Inttlal } \\
\text { Feed I3 } \\
\text { El ement } \\
\text { (wtx) }\end{array}$} & \multirow{2}{*}{$\begin{array}{l}\text { Average } \\
\text { Initial } \\
\text { feed } \\
\text { (wtx) }\end{array}$} & \multirow{2}{*}{$\begin{array}{l}\text { Actual } \\
\text { Element } \\
\text { Mormal } \\
\text { (wtx) }\end{array}$} & \multirow[b]{2}{*}{$8 \mathrm{DeV}$. } \\
\hline & & & & Elenent & Target & & & & & & & & \\
\hline $\begin{array}{l}\mathrm{Al}_{2} \mathrm{O}_{3} \\
\mathrm{BaO}_{3} \\
\mathrm{~B}_{2} \mathrm{O}_{3}\end{array}$ & $\begin{array}{r}10.150 \\
0.110 \\
0.100\end{array}$ & $\begin{array}{r}15.225 \\
0.615 \\
0.150\end{array}$ & $\begin{array}{l}A 1 \\
B a \\
B\end{array}$ & $\begin{array}{r}26.982 \\
137.340 \\
10.810\end{array}$ & $\begin{array}{l}8.058 \\
0.551 \\
0.047\end{array}$ & $\begin{array}{l}7.617 \\
0.521 \\
0.044\end{array}$ & $\begin{array}{l}8.340 \\
0.570 \\
0.049\end{array}$ & $\begin{array}{l}0.672 \\
0.050 \\
0.026\end{array}$ & $\begin{array}{l}0.672 \\
0.051 \\
0.009\end{array}$ & $\begin{array}{l}0.678 \\
0.050 \\
0.000\end{array}$ & $\begin{array}{l}0.671 \\
0.050 \\
0.012\end{array}$ & $\begin{array}{l}8.418 \\
0.629 \\
0.146\end{array}$ & $\begin{array}{r}0.9 \\
10.0 \\
198.0\end{array}$ \\
\hline $\begin{array}{l}\mathrm{C}_{2} \mathrm{O} \\
\mathrm{CeO}_{2} \\
\mathrm{Cr}_{2} \mathrm{O}_{3} \\
\mathrm{Cs}_{2} \mathrm{O} \\
\mathrm{CuO} \\
\mathrm{Fe}_{2} \mathrm{O}_{3}\end{array}$ & $\begin{array}{r}0.300 \\
0.610 \\
0.510 \\
0.610 \\
0.610 \\
28.410\end{array}$ & $\begin{array}{r}0.450 \\
0.915 \\
0.765 \\
0.915 \\
.0 .915 \\
12.615\end{array}$ & $\begin{array}{l}\text { Ce } \\
\text { Ce } \\
\text { Cr } \\
\text { Cs } \\
\text { Cu } \\
\text { Fe }\end{array}$ & $\begin{array}{r}40.080 \\
140.120 \\
51.996 \\
132.905 \\
63.546 \\
55.841\end{array}$ & $\begin{array}{r}0.322 \\
0.745 \\
0.523 \\
0.863 \\
0.731 \\
29.806\end{array}$ & $\begin{array}{r}0.304 \\
0.704 \\
0.494 \\
0.816 \\
0.691 \\
28.176\end{array}$ & $\begin{array}{r}0.333 \\
0.771 \\
0.541 \\
0.893 \\
0.757 \\
-30.849\end{array}$ & $\begin{array}{l}0.041 \\
0.041 \\
0.043 \\
0.047 \\
0.043 \\
2.700\end{array}$ & $\begin{array}{l}0.050 \\
0.050 \\
0.044 \\
0.041 \\
0.044 \\
2.730\end{array}$ & $\begin{array}{l}0.046 \\
0.047 \\
0.044 \\
0.047 \\
0.044 \\
2.720\end{array}$ & $\begin{array}{l}0.046 \\
0.046 \\
0.044 \\
0.047 \\
\cdot 0.044 \\
2.717\end{array}$ & $\begin{array}{c}0.570 \\
0.574 \\
0.545 \\
0.587 \\
0.545 \\
33.929\end{array}$ & $\begin{array}{r}71.0 \\
26.0 \\
0.7 \\
34.0 \\
28.0 \\
10.0\end{array}$ \\
\hline $\begin{array}{l}\mathrm{C}_{2} \mathrm{O}_{3} \\
\mathrm{H}_{2} \mathrm{O} \\
\mathrm{H} \mathrm{O}_{2} \\
\mathrm{HoO}_{3} \\
\mathrm{Ha}_{2} \mathrm{O} \\
\mathrm{Hd}_{2} \mathrm{O}_{3} \\
\mathrm{H}^{\circ} \mathrm{O}\end{array}$ & $\begin{array}{r}2.030 \\
0.370 \\
0.610 \\
1.220 \\
11.160 \\
2.240 \\
2.410\end{array}$ & $\begin{array}{r}3.045 \\
0.555 \\
0.915 \\
1.830 \\
26.640 \\
3.360 \\
3.615\end{array}$ & $\begin{array}{l}\mathrm{La} \\
\mathrm{Hg} \\
\mathrm{HI} \\
\mathrm{Ho} \\
\mathrm{Ha} \\
\mathrm{HId} \\
\mathrm{HI}\end{array}$ & $\begin{array}{r}138.906 \\
24.305 \\
54.938 \\
95.940 \\
22.990 \\
114.240 \\
58.710\end{array}$ & $\begin{array}{r}2.596 \\
0.335 \\
0.578 \\
1.220 \\
19.763 \\
2.881 \\
2.841\end{array}$ & $\begin{array}{r}2.451 \\
0.317 \\
0.516 \\
1.153 \\
18.682 \\
2.723 \\
2.686\end{array}$ & $\begin{array}{r}2.687 \\
0.347 \\
0.598 \\
1.263 \\
20.454 \\
2.982 \\
2.940\end{array}$ & $\begin{array}{l}0.152 \\
0.034 \\
0.032 \\
0.101 \\
1.620 \\
0.171 \\
0.238\end{array}$ & $\begin{array}{l}0.159 \\
0.036 \\
0.033 \\
0.106 \\
1.720 \\
0.181 \\
0.276\end{array}$ & $\begin{array}{l}0.154 \\
0.038 \\
0.033 \\
0.105 \\
1.730 \\
10.192 \\
0.236\end{array}$ & $\begin{array}{l}0.155 \\
0.036 \\
0.033 \\
0.104 \\
1.690 \\
0.178 \\
0.250\end{array}$ & $\begin{array}{r}1.936 \\
0.450 \\
0.400 \\
1.299 \\
21.107 \\
2.223 \\
3.122\end{array}$ & $\begin{array}{r}28.0 \\
30.0 \\
32.0 \\
3.0 \\
3.0 \\
25.0 \\
6.0\end{array}$ \\
\hline $\begin{array}{l}\mathrm{Pr}_{6} \mathrm{O}_{11} \\
\mathrm{PdO}^{2} \mathrm{P}^{2} \\
\mathrm{Rh}_{2} \mathrm{O} \\
\mathrm{Rh}_{2} \mathrm{O}_{3} \\
\mathrm{Ru}_{2} \mathrm{O}_{2}\end{array}$ & $\begin{array}{l}0.410 \\
0.200 \\
0.200 \\
0.200 \\
0.610\end{array}$ & $\begin{array}{l}0.615 \\
0.300 \\
0.300 \\
.0 .300 \\
0.915\end{array}$ & $\begin{array}{l}\mathrm{Pr} \\
\mathrm{Pd} \\
\mathrm{RD} \\
\mathrm{Ph} \\
\mathrm{Ru}\end{array}$ & $\begin{array}{r}140.908 \\
106.400 \\
85.470 \\
102.905 \\
101.070\end{array}$ & $\begin{array}{l}0.509 \\
0.261 \\
0.274 \\
0.243 \\
0.695\end{array}$ & $\begin{array}{l}0.401 \\
0.247 \\
0.259 \\
0.230 \\
0.657\end{array}$ & $\begin{array}{r}\mathrm{HI} \\
\mathrm{HI} \\
\mathrm{MI} \\
\mathrm{HI} \\
0.119\end{array}$ & 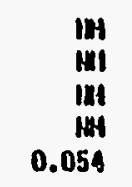 & 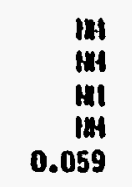 & 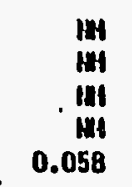 & 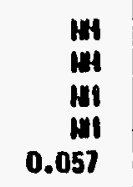 & 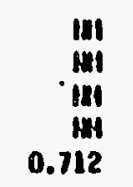 & $\begin{array}{l}H I \\
H I \\
H I \\
H I \\
I .0\end{array}$ \\
\hline $\begin{array}{l}\mathrm{SlO}_{2} \\
\mathrm{Sm}_{2} \mathrm{O}_{3} \\
\mathrm{SrO}^{2} \\
\mathrm{r}_{2} \mathrm{O}_{3} \\
\mathrm{ZrO}_{2}\end{array}$ & $\begin{array}{r}9.140 \\
0.200 \\
0.410 \\
0.200 \\
15.220\end{array}$ & $\begin{array}{r}13.710 \\
0.300 \\
0.615 \\
0.300 \\
22.830\end{array}$ & $\begin{array}{l}S 1 \\
S m \\
S r \\
y \\
Z r\end{array}$ & $\begin{array}{r}28.086 \\
150.400 \\
97.620 \\
88.906 \\
91.220\end{array}$ & $\begin{array}{r}6.109 \\
0.259 \\
0.520 \\
0.236 \\
16.901\end{array}$ & $\begin{array}{r}6.058 \\
0.245 \\
0.492 \\
0.223 \\
15.971\end{array}$ & $\begin{array}{r}6.633^{\circ} \\
\text { HI } \\
0.538 \\
0.241 \\
17.492\end{array}$ & $\begin{array}{r}0.528 \\
\text { H } \\
0.045 \\
0.020 \\
1.270\end{array}$ & $\begin{array}{r}0.469 \\
\text { MII } \\
0.042 \\
0.020 \\
1.330\end{array}$ & $\begin{array}{r}0.505 \\
114 \\
0.042 \\
0.020 \\
1.180\end{array}$ & $\begin{array}{r}0.501 \\
\text { If } \\
0.043 \\
0.020 \\
1.260\end{array}$ & $\begin{array}{r}6.253 \\
14 \\
0.537 \\
0.250 \\
15.736\end{array}$ & $\begin{array}{r}6.0 \\
H I \\
0.2 \\
2.1 \\
10.0\end{array}$ \\
\hline $\begin{array}{l}\mathrm{TOC} \\
\mathrm{CI} \\
\mathrm{F} \\
\mathrm{HO}_{3} \\
\mathrm{SO}_{3}\end{array}$ & $\begin{array}{l}2.030 \\
0.000 \\
1.220 \\
0.000 \\
1.830\end{array}$ & $\begin{array}{l}3.045 \\
0.000 \\
1.830 \\
0.000 \\
2.745\end{array}$ & $\begin{array}{l}\mathrm{C} \\
\mathrm{Cl} \\
\mathrm{F} \\
\mathrm{HD}_{3} \\
\mathrm{SO}_{4}\end{array}$ & $\begin{array}{l}12.011 \\
35.453 \\
18.998 \\
62.005 \\
96.058\end{array}$ & $\begin{array}{l}3.045 \\
0.000 \\
1.830 \\
0.000 \\
2.345\end{array}$ & $\begin{array}{l}2.878 \\
0.000 \\
1.730 \\
0.000 \\
2.595\end{array}$ & $\begin{array}{l}\text { III } \\
\text { HI } \\
\text { III } \\
\text { HI } \\
\text { NI }\end{array}$ & $\begin{array}{r}m I \\
0.063 \\
0.034 \\
\mathbf{j . 4 2 0} \\
0.270\end{array}$ & $\begin{array}{r}\text { InI } \\
0.062 \\
0.033 \\
3.500 \\
0.274\end{array}$ & $\begin{array}{c}m \\
0.063 \\
0.032 \\
3.430 \\
0.263\end{array}$ & $\begin{array}{r}14 \\
0.063 \\
0.033 \\
3.450 \\
0.269\end{array}$ & $\begin{array}{l}\text { MH } \\
\text { HI } \\
\text { HI } \\
\text { HI } \\
\text { III }\end{array}$ & $\begin{array}{l}\text { HI } \\
\text { HI } \\
\text { HI } \\
\text { MII } \\
\text { HI }\end{array}$ \\
\hline TOtal & 100.200 & 150.300 & & & 105.787 & 100.000 & 100.001 & 11.715 & 11.991 & 11.747 & 11.020 & 99.975 & \\
\hline
\end{tabular}


For the formating process, approximately $2 L$ of feed were heated to $190^{\circ} \mathrm{F}$ to $205^{\circ} \mathrm{F}\left(90^{\circ} \mathrm{C}\right.$ to $\left.95^{\circ} \mathrm{C}\right)$ and $90 \mathrm{wt} \%(23 \mathrm{M})$ formic acid was added beneath the feed surface at a constant fTow rate. Gas sample buTbs and a series of gas scrubbers were used to collect gas samples. Samples were collected before formic acid addition, after one-half and all of the formic acid was added, and at the completion of the post-heat-treatment period. In the postheat-treatment period, the feed was heated for $2 \mathrm{~h}$ at $205^{\circ} \mathrm{F}\left(95^{\circ} \mathrm{C}\right)$. Feed samples were withdrawn from the vessel after one-half and all the formic acid had been added and after the post-heat-treatment period.

The results of the physical and rheological characterization are summarized in Table 4.3-41. The physical properties measured for the feed used in the process off-gas study were not significantly different from the previous measurements.

The rheological measurements presented in Table 4.3-41 is for feed samples taken after the $2-h$ heat treatment. The rheological properties for the simulant prepared by nitrate precipitation for this study are significantly different from those measured previously. A significant difference in the rheological behavior of the nitrate precipitated feed is that the yield stress and apparent viscosity increased after the addition of formic acid. The viscosity visually appeared to decrease during the 2-h heat treatment. The addition of formic acid between $70 \%$ and $130 \%$ of the stoichiometric requirement (Runs $3,4,5$ ) did not significantiy affect the apparent viscosity and yield stress of the feed. As expected, the apparent viscosity and yield stress did not change significantly as a result of formic acid addition rate (Runs 3, 6, 7). Previous studies using other feed simulants (made from hydroxides) and compositions have shown that formic acid was an effective rheological modifier and resulted in decreasing the apparent viscosity and yield stress.

The rheological behavior observed may be attributed to the method of simulant preparation. The viscosity of the feed is a function 1) the viscosity of the fluid medium, 2) the concentration of the suspended material, 3 ) the size and shape of the suspended particles, and 4) the forces of interaction between the particles. The size and shape of the suspended particles and the forces of interaction between the particles are expected to be the most significant differences between this feed simulant and previous simulants. The precipitation of the hydroxides of $\mathrm{La}, \mathrm{Ce}, \mathrm{Mn}$, Noble Metals, Fe, $\mathrm{Cu}$, and $\mathrm{Zr}$ using sodium hydroxide is known to form gelatinous precipitates. In addition, many of the precipitates form polymers with time. The size and shape of the particles are different because they are the result of precipitation. The interactions between the particles are stronger if indeed gelatinous precipitates and polymers are forming. The higher viscosity measurements strongly suggest that the attractive forces between the particles are higher. 
TABLE 4.3-41. Properties of Simulated Feed (NCAW 86) Prepared by Precipitating Nitrate Salts with Sodium Hydroxide (Hiemers et al., HWVP-87-110203G, 1987)

\begin{tabular}{|c|c|c|c|c|c|c|c|c|c|c|}
\hline Test Number & \multicolumn{3}{|c|}{$\begin{array}{c}\text { Initlal Feed } \\
\text { Average }\end{array}$} & $\begin{array}{l}\text { Run } 11 \\
\text { Final }\end{array}$ & $\begin{array}{l}\text { Run } 12 \\
\text { Final }\end{array}$ & $\begin{array}{l}\text { Run } 13 \\
\text { Final }\end{array}$ & $\begin{array}{l}\text { Run } 14 \\
\text { Final }\end{array}$ & $\begin{array}{l}\text { Run } 15 \\
\text { Rinal }\end{array}$ & $\begin{array}{l}\text { Run } 16 \\
\text { Final }\end{array}$ & $\begin{array}{l}\text { Run } 17 \\
\text { Final }\end{array}$ \\
\hline $\begin{array}{l}\text { Formic acid } \\
\text { addition rate } \\
\text { (mL/min) }\end{array}$ & \multicolumn{3}{|c|}{0} & i & 1 & 1 & $\cdot 1$ & 1 & 1.5 & 0.5 \\
\hline $\begin{array}{l}\text { Amount formic } \\
\text { acid added } \\
\text { ( } \% \text { stoichiometric) }\end{array}$ & \multicolumn{3}{|c|}{$0 \%$} & $100 \%$ & $100 \%$ & $100 \%$ & $70 \%$ & $130 \%$ & $100 \%$ & $100 \%$ \\
\hline $\begin{array}{l}\text { Density } \\
\text { pH } \\
\text { wt\% total solids } \\
\text { g WO/L }\end{array}$ & \multicolumn{3}{|c|}{$\begin{array}{l}1.13 \\
11.9 \\
18.32 \\
144\end{array}$} & $\begin{array}{c}1.10 \\
5.4 \\
16.40\end{array}$ & $\begin{array}{l}1.10 \\
4.7 \\
17.13\end{array}$ & $\begin{array}{r}1.10 \\
4.3 \\
17.42\end{array}$ & $\begin{array}{l}1.14 \\
5.5 \\
17.76\end{array}$ & $\begin{array}{l}1.13 \\
4.4 \\
17.54\end{array}$ & $\begin{array}{l}1.12 \\
4.2 \\
17: 90\end{array}$ & $\begin{array}{l}1.10 \\
5.0 \\
17.93\end{array}$ \\
\hline $\begin{array}{l}\text { Yield stress } \\
\text { (dynes/cm })\end{array}$ & 51.7 & 55.5 & 50.7 & 96.6 & 120.75 & 115.9 & 115.9 & 120.75 & 149.7 & 149.7 \\
\hline $\begin{array}{l}\text { Apparent } \\
\text { viscosity (cP) }\end{array}$ & & & & & & & & & & \\
\hline $\begin{array}{l}\text { at } 183 \mathrm{~s}^{-1} \\
\text { at } 323 \mathrm{~s}^{-1} \\
\text { at } 468 \mathrm{~s}^{-1}\end{array}$ & $\begin{array}{l}46.2 \\
31.0 \\
23.2\end{array}$ & $\begin{array}{l}46.2 \\
29.9 \\
23.2\end{array}$ & $\begin{array}{l}46.2 \\
31.0 \\
23.7\end{array}$ & $\begin{array}{l}71.3 \\
43.4 \\
31.0\end{array}$ & $\begin{array}{l}89.7 \\
55.3 \\
40.8\end{array}$ & $\begin{array}{l}87.1 \\
52.3 \\
39.2\end{array}$ & $\begin{array}{l}92.4 \\
57.6 \\
42.8\end{array}$ & $\begin{array}{l}95.0 \\
58.3 \\
42.8\end{array}$ & $\begin{array}{r}110.90 \\
65.80 \\
47.50\end{array}$ & $\begin{array}{c}113.50 \\
68.80 \\
49.5\end{array}$ \\
\hline $\begin{array}{l}\text { Amount formic } \\
\text { actd added } \\
\text { (mL } \mathrm{HCOOH} / \mathrm{L} \text { feed) }\end{array}$ & $\mathbf{0}$ & 0 & $\mathbf{0}$ & 19.1 & 19.1 & 19.1 & 13.4 & 24.8 & 19.1 & 19.1 \\
\hline
\end{tabular}


4.3.4.1.1.11 HWVP Slurry Characterization for Pilot-Scale Melter Run 23. (a) The melter feed processed during PSCM-23 was a simulated .HWVP composition consisting of pretreated neutralized current acid waste (NCAW 1987) and a premade glass-forming frit. The basis for the waste oxide composition was the FY 1987 HWVP feed pretreatment specifications for NCAW. (b) Based on this composition, a npnradioactive waste oxide composition was determined by Bates et a1. (1988). (c) The chemicals used to batch the melter feed and the associated glass oxide composition are presented in Table 4.3-42.

The major constituents of the melter feed, $\mathrm{Fe}(\mathrm{OH})_{3}, \mathrm{Al}(\mathrm{OH})_{3}, \mathrm{Zr}(\mathrm{OH})_{4}$, and $\mathrm{Ni}(\mathrm{OH})_{2}$, were supplied by an offsite vendor in a blended slurry form that was to be prepared using the procedure outlined in Figure 4.3-57. However, due to excessively slow settling rates, the settle/decant procedure was replaced by a filtration procedure. The remaining melter feed components were combined with the mixed hydroxide slurry and a compositional analysis was performed. Based on the results of this analysis, adjustments were made as needed to reach the target composition. The feed was then heated to between $90^{\circ} \mathrm{C}$ and $95^{\circ} \mathrm{C}$, and $23.2 \mathrm{~g}$ of $90 \mathrm{wt} \%$ formic acid and $10 \mathrm{~g}$ sugar were added per liter of melter feed slurry. Following completion of the formic acid treatment, the temperature of the feed was increased to approximately $100^{\circ} \mathrm{C}$ and held there for $2 \mathrm{~h}$ to ensure that all chemical reactions had reached equilibrium.

Four PSCM-23 feed samples were selected for further characterization: samples 13 and 28 representing initial feed; sample 39 representing concentrated and formated feed; and sample 42, a concentrated, formated feed to which frit was added. The characterization effort included the collection and evaluation of the following data: $\mathrm{pH}$, density, rheology, supernate/ sludge volume ratio, wt\% water in the sludge fraction, and analys is of feed fractions by IC, ICP, and carbon analyses. Table 4.3-43 summarizes the $\mathrm{pH}$, density, and rheological data collected for the selected PSCM-23 feed samples.

The $\mathrm{pH}$ of the feed prior to formating is approximately 9 and after formating approximately 4 . The initial pH of the PSCM-23 samples is lower than measured for previous feed simulants ( $\mathrm{pH}>11)$. The final $\mathrm{pH}$ of approximately 4 indicates that an acceptable amount of formic acid has been added based on past studies. A significant increase in density is observed for sample 42 (after frit addition). Samples 13,28 , and 39 have yield stresses of approximately $3 \mathrm{~Pa}$ and are somewhat pseudoplastic (flow behavior index, $n=0.8$; where $n=1$ is Newtonian). The average apparent viscosities as a function of

(a) R. H. Goles and R. K. Nakaoka, HWVP Pilot-Scale Ceramic Melter Test 23, HWVP-89-IVJ0010100B, Pacific Northwest Laboratory, Richland, Washingtion (January 1989).

(b) R. A. Watrous and 0. L. Kruger, "Hanford Waste Vitrification Plant Feed Specification: Pretreated NCAW Feed," RHO-SD-HWV-OCD-001 Rev. 1, Hestinghouse Hanford Company, Richtand, Washington (1987).

(c) S. 0. Bates et a7., "Interim Milestone HWVP-88-V320301A - Supplemental Report on Leach Testing of Simulated HWVP Reference Glass HW-39,"

Pacific Northwest Laboratory, Richland, Washington (1988).

$$
4.3-93
$$


TABLE 4.3-42. PSCM-23 Me]ter Feed Composition HWVP-89-IVJ0010100B

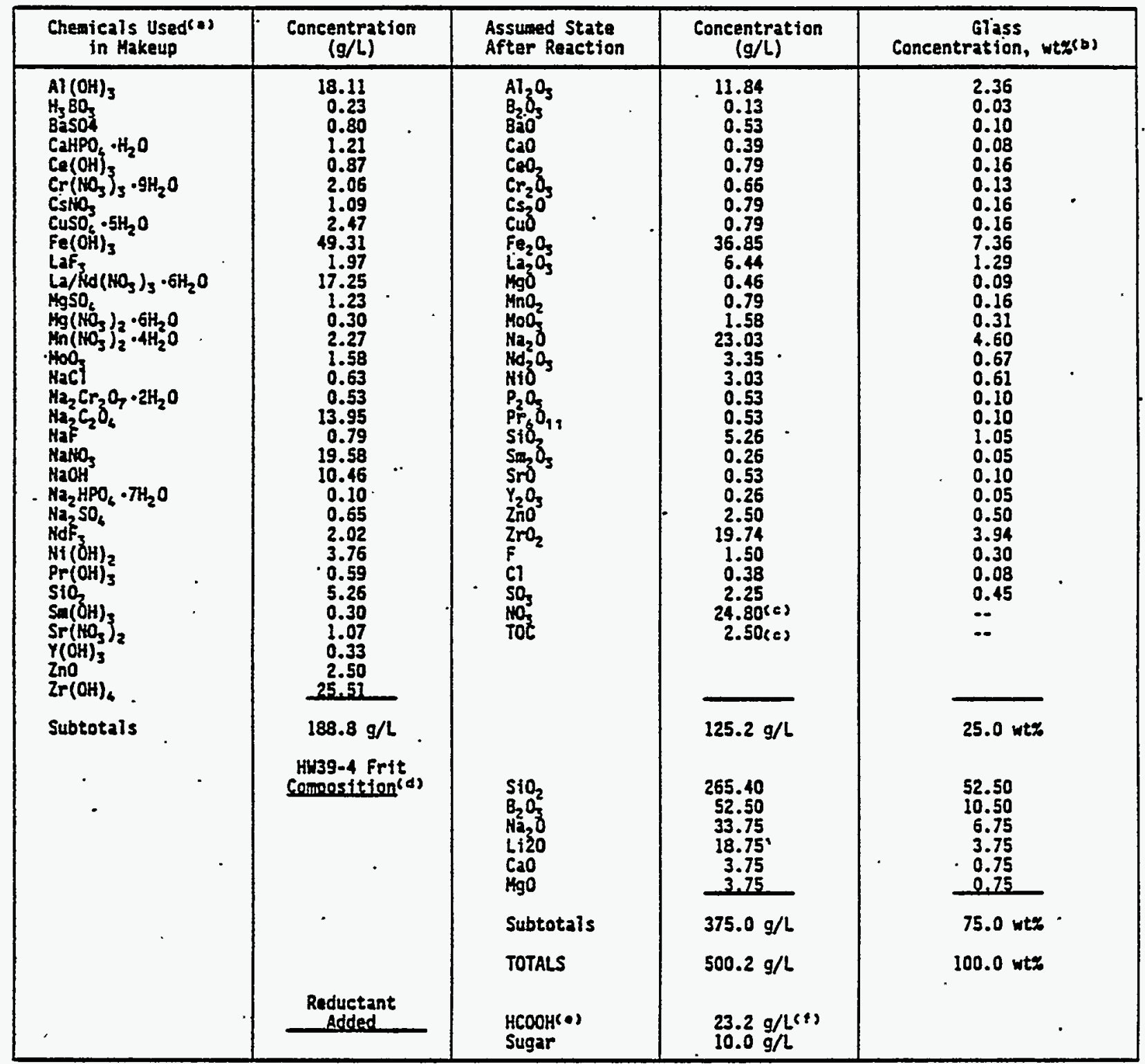

(a) Prior to formic actd treatment.

(b) Values assume no volatility losses.

(c) Yalue is not included in subtotal values.

(d) Size distribution of frit was $-80 /+200$ mesh with a maximum of 10 wt\% -200 mesh.

(e) Value given is for a $90 \mathrm{wt \%}$ solution of $\mathrm{HCOOH}$.

(f) Value includes $90 \mathrm{wtz} \mathrm{HCOOH}$ added with frit, equivalent to 1 wts of frit added, or $4.2 \mathrm{~g} / \mathrm{h}$. 


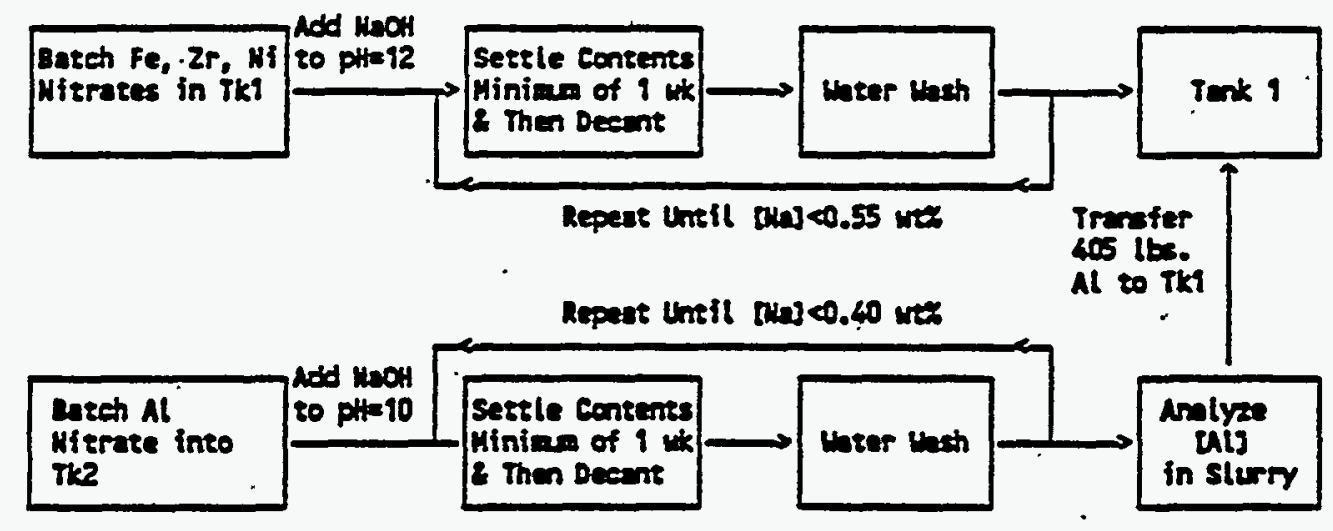

FIGURE 4.3-57. Procedure for Preparation of Hydroxides from Nitrates HWVP-89-IVJ0010100B

TABLE 4.3-43. Properties of PSCM-23 Feed (NCAW 87) HWVP-89-IVJ0010100B

\begin{tabular}{|c|c|c|c|c|}
\hline Sample & $\begin{array}{l}\text { PSCM-23-13 } \\
\text { (unformated) }\end{array}$ & $\begin{array}{l}\text { PSCM-23-28 } \\
\text { (unformated) }\end{array}$ & $\begin{array}{l}\mathrm{PSCM}-23-39(\bullet) \\
\text { (formated) }\end{array}$ & $\begin{array}{l}\text { PSCM-23-42 } \\
\text { (unformated and } \\
\text { frit added) }\end{array}$ \\
\hline Total oxides $(g / L)$ & 148 & 140 & 199 & 621 \\
\hline Total oxides (wt\%) & 12.4 & 12.1 & - $\quad 16.1$ & 42.2 \\
\hline Density $(\mathrm{g} / \mathrm{ml})$ & 1.19 & 1.16 & 1.24 & 1.47 \\
\hline $\mathrm{pH}$ & 8.95 & 8.94 & 4.16 & 4.42 \\
\hline $\begin{array}{l}\text { Yield stress } \\
\left(\text { dyne } / \mathrm{cm}^{2}\right)\end{array}$ & 3.2 & 3.67 & 2.71 & (b) \\
\hline Apparent viscosity $\left(C_{p}\right)$ & & & & \\
\hline $\begin{array}{l}183 s^{-1} \\
303 s^{-1} \\
468 s^{-1}\end{array}$ & $\begin{array}{l}30.7 \\
19.8 \\
17.9\end{array}$ & $\begin{array}{l}34.0 \\
22.1 \\
19.9\end{array}$ & $\begin{array}{l}17.9 \\
20.0 \\
18.1\end{array}$ & $\begin{array}{l}\text { (b) } \\
\text { (b) } \\
\text { (b) }\end{array}$ \\
\hline
\end{tabular}

(a) Rheological values may be somewhat higher due to concentrating of sample after formating.

(b) Data not availabie. 
shear rate are shown graphically in Figure 4.3-58. In a shear rate range of 200 to $468 \mathrm{~s}^{-1}$ the average apparent viscosities range from 30 to $18 \mathrm{cP}$. Insufficient sample volume was available for rheological measurements of sample 42.

The rheological properties of the feed are greatly dependent on feed preparation due in part to the formation of age and $\mathrm{pH}$ dependent hydrolyzed polymeric colloids by three of the major constituents: ferric ion, aluminum ion, and zirconium ion. Other constituents (e.g., nickel and cupric ions) may also contribute to the polymeric concentration. The physical state of the feed influences both the agitation and pumping requirements and potentially the kinetics of the formating reactions.

A $20 \mathrm{~mL}$ aliquot of the slurry from each sample was centrifuged and the supernate and sludge recovered. Observations and the chemical composition of these phases are discussed below.

The sludge was dried at $105^{\circ} \mathrm{C}$ for $20 \mathrm{~h}$. This temperature was selected to evaporate water without decomposing the organics. Tabie 4.3-44 presents the ratio of supernate to sludge recovered, qualitative observations concerning the supernate and sludge, and wt\% of water in the sludge.

- The supernate to sludge ratio was approximately 50/50 up to addition of frit: Concentrating. and dilution steps were not apparent from these data. As one might predict, the ratio of supernate to sludge decreased to $35 / 65$ after the addition of frit.

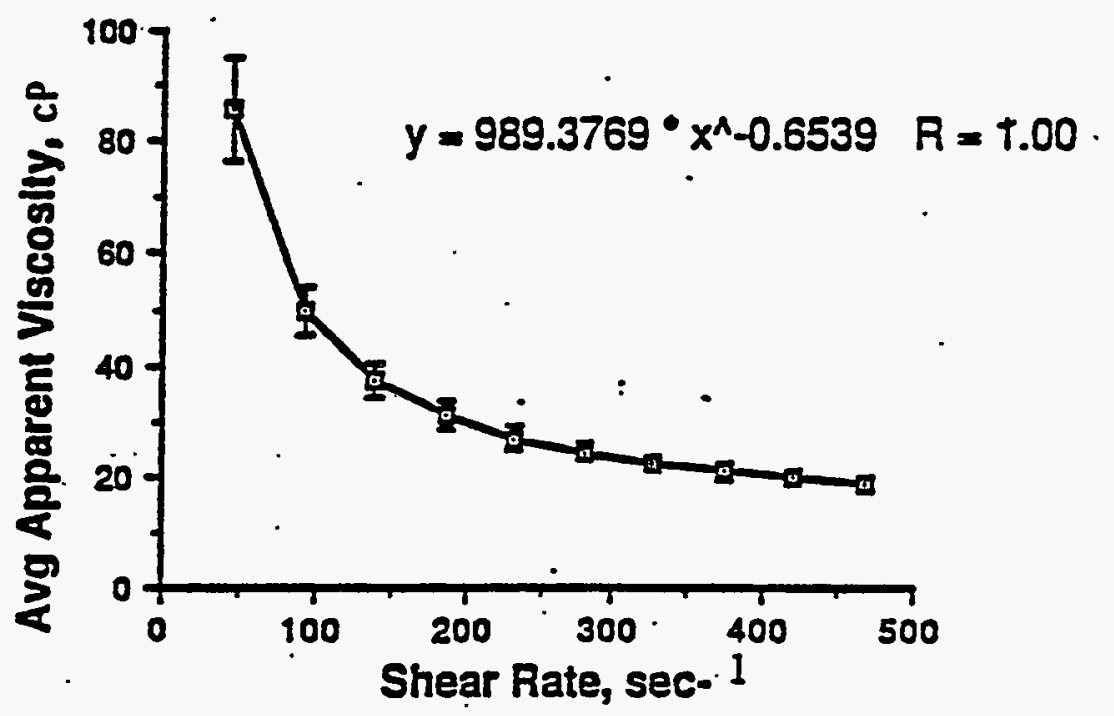

FIGURE 4.3-58. Average Apparent Viscosities as a Function of Shear Rate for PSCM-23 Samples 28, 39, and 42 HWVP-89-IVJ0010100B 
TABLE 4.3-44. Supernate and S7udge Data HWVP-89-IVJ0010100B

\begin{tabular}{|c|c|c|c|}
\hline Sample Label & $\begin{array}{l}\text { Vor. Ratio: } \\
\text { Supernate/ } \\
\text { S7udge }\end{array}$ & $\begin{array}{l}\text { wt\% Water } \\
\text { in Sludge }\end{array}$ & Qualitative Observations \\
\hline PSCM-23-13 & $50 / 50$ & 71 & $\begin{array}{l}\text { Supernate - yellow color; } \\
\text { Sludge }-2 \text { distinct layers }\end{array}$ \\
\hline PSCM-23-28 & $50 / 50$ & 71 & $\begin{array}{l}\text { Supernate - yellow color; } \\
\text { Sludge }-2 \text { distinct layers }\end{array}$ \\
\hline PSCM-23-39 & $45 / 55$ & 64 & $\begin{array}{l}\text { Supernate - blue color; } \\
\text { Sludge }-2 \text { distinct layers }\end{array}$ \\
\hline PSCM-23-42 & $35 / 65$ & 39 & $\begin{array}{l}\text { Supernate - blue color, } \\
\text { less intense than }-39 ; \\
\text { sludge - } 3 \text { distinct layers }\end{array}$ \\
\hline
\end{tabular}

The supernates were observed to be two different colors, the alkaline supernates being yeillow and the acidic supernates being blue. Table 4.3-45 Tists ionic species which may potentially contribute to the observed coloring. The yellow color observed. in the alkaline supernate may be due to a hydrolysis product of ferric ion. Hydrated ferrous and cupric ions are : likely candidates for the blue color in the acid supernate. The presence of copper in the alkaline supernate was confirmed by ICP analysis as discussed later. Although somewhat unstable in an oxidizing environment, ferrous ion may be present as a product of reduction of ferric ion by formic acid.

Between two and three different fractions of particle densities were observed in the sludges recovered from centrifugation. The three layers may be due to 1) gelatinous polymers, 2) precipitated salts, and 3) frit. Samples 13, 28, and 39 had two distinct layers after centrifugation. The top layer composed approximately 95\% of the total sludge volume and was a dark brick red color. The second, bottom layer was a light orange-sand color and contained visible black particulate, approximately $0.5 \mathrm{~mm}$ in diameter. The bottom layer appeared to be more compact, containing less water. An additional third layer beneath the orange-sandy colored layer was observed in sample 42 . In sample 42 the top Tayer composed approximately $30 \%$ of the total sludge volume; the orange sandy layer composed approximately $4 \%$ and the third layer, an orange brick color, made up the remaining $66 \%$. The additional third layer was relatively grainy compared to the other two layers, perhaps because it contained most of the frit. Each of these centrifuged samples was homogenized prior to drying.

The amount of water loss on drying the sludge fractions from samples 13 and 28 was 71 wt\%. The wt\% water in the sludge decreased after formating and concentrating to $64 \mathrm{wt} \%$. Sludge containing the frit contained the least amount of water. 
TABLE 4.3-45. Potential Ionic Species Contributing to Supernate Color HWVP-89-IVJ0010100B

\begin{tabular}{|c|c|}
\hline Ionic Species & Characteristic Color \\
\hline $\begin{array}{l}{\left[\mathrm{Cr}\left(\mathrm{H}_{2} \mathrm{O}_{6}\right]^{+2}\right.} \\
{\left[\mathrm{Cr}\left(\mathrm{H}_{2} \mathrm{O}\right)_{6}\right]^{+3}} \\
{\left[\mathrm{Cr}\left(\mathrm{H}_{2} \mathrm{O}\right)_{4 \mathrm{Cl}_{2}}\right]^{+}} \\
{\left[\mathrm{Ni}\left(\mathrm{H}_{2} \mathrm{O}\right)_{6}\right]^{+2}} \\
{\left[\mathrm{Cu}\left(\mathrm{H}_{2} \mathrm{O}\right)_{6 .}\right]^{+2}} \\
{\left[\mathrm{Fe}\left(\mathrm{H}_{2} \mathrm{O}\right)_{6}\right]^{+2}} \\
{\left[\mathrm{Fe}\left(\mathrm{H}_{2} \mathrm{O}\right)_{6}\right]^{+3}} \\
{\left[\mathrm{Fe}\left(\mathrm{H}_{2} \mathrm{O}\right)_{5 \mathrm{OH}}\right]^{+2}} \\
\mathrm{MOO}_{2}(\mathrm{OH})^{+2} \\
\mathrm{MoO}_{2.5}(\mathrm{OH})_{0.5}\end{array}$ & $\begin{array}{l}\text { Blue (presence of } \mathrm{Cr}^{+2} \text { uncertain) } \\
\text { Violet } \\
\text { Green } \\
\text { Green } \\
\text { Blue } \\
\text { Blue-green } \\
\text { Pale purple (exists only at } \mathrm{pH}=0 \text { ) } \\
\text { Yellow } \\
\text { Blue } \\
\text { Blue }\end{array}$ \\
\hline
\end{tabular}

The chemical composition of the supernate fraction and total slurry as determined by ICP analysis is compiled in Table 4.3-46. This supernate data is appticable with the assumption that the concentration of ions in the water contained in the sludge is not significantly different from the concentration in the supernate recovered via centrifugation.

The solubility behavior of lithium (observed only after frit addition) and those ions associated primarily with one fraction (concentration ratios $<0.001)$ throughout the formating and frit addition are outlined below:

Ion

barium
cerium
iron

lithium

sodium

silica

titanium zirconium
Associated fraction(a)

solids; $0.2 \%$ in supernate after formating solids; solids;

$0.3 \%$ in supernate after formating

$0.002 \%$ in supernate prior to formating $0.01 \%$ in supernate after formating

solids; $2.4 \%$ in supernate (observed only after frit addition)

supernate solids (prior to formating);

$0.2 \%$ in supernate after formating

$0.01 \%$ in supernate after frit addition

solids

solids;

(a) \% refers to the ratio: grams in fraction divided by total grams present. 
TABLE 4.3-46. Chemical Composition of Selected PSCM-23 Feed Sámples HWVP-89-IVJ0010100B

\section{Conoesition o/L}

\begin{tabular}{|c|c|c|c|c|c|c|c|c|}
\hline $\begin{array}{l}\text { Elenent } \\
\text { os Dxide }\end{array}$ & $\begin{array}{l}\text { PSC } \\
\text { total }\end{array}$ & $\begin{array}{l}\text { 1-23-13 } \\
\text { euparnate }\end{array}$ & $\begin{array}{l}\text { Psat-8 } \\
\text { total }\end{array}$ & $\begin{array}{l}23-28 \\
\text { exporate }\end{array}$ & $\begin{array}{l}\text { Pselt } \\
\text { total }\end{array}$ & $\begin{array}{l}\text { 23-39 } \\
\text { apermate }\end{array}$ & $\begin{array}{l}\text { Psen } \\
\text { total }\end{array}$ & $\begin{array}{l}-23-12 \\
\text { suparnato }\end{array}$ \\
\hline $\mathrm{Al}_{2} \mathrm{O}_{3}$ & 25.5 & $\left\langle\left. d\right|^{(a)}\right.$ & 14.7 & (d) & 21.0 & 1.53 & 28.6 & 0.68 \\
\hline $\mathrm{B}_{2} \mathrm{O}_{3}$ & 0.28 & .068 & 0.18 & & 9.35 & 9.31 & 75.8 & 1.58 \\
\hline$B=0$ & 5.67 & nd $(b)$ & 0.83 & nd & 0.87 & 1..4682 & 1.86 & 0.0882 \\
\hline CaO & 8.58 & .842 & 0.53 & .42 & 5.72 & 0.88 & 5.61 & 0.73 \\
\hline $\mathrm{CaO}_{2}$ & 6.94 & (d) & 5.80 & (d) & 1.98 & 0.843. & 1.97 & 5.512 \\
\hline $\mathrm{Cr}_{2} \mathrm{O}_{3}$ & 0.93 & 6.26 & 6.88 & 6.15 & 3.25 & 5.12 & 1.92 & 5.858 \\
\hline Culo & 2.05 & $\langle d|$ & 2.18 & 5.512 & 2.37 & 5.27 & 1.97 & 6.21 \\
\hline $\mathrm{Fe}_{2} \mathrm{O}_{3}$ & 46.1 & $0.8 B 1$ & 43.5 & I.EI & 89.1 & 1.488 & 42.8 & 5.1.13 \\
\hline $\mathrm{La}_{2} \mathrm{O}_{3}$ & 8.86 & 0.862 & 8.28 & 9.581 & 11.1 & 1.29 & $8 . \pi 7$ & 1.22 \\
\hline $\operatorname{Li}_{2} \mathrm{O}$ & 〈d) & $\langle d|$ & $\langle d|$ & $\left\langle\mathbf{d i}^{\circ}\right.$ & (d) & $1 . .183$ & 24.8 & 5.888 \\
\hline UgO & 9.69 & 0.628 & 5.85 & 1.28 & 9.89 & 1.98 & 5.22 & 1.91 \\
\hline $\mathrm{HnO}_{2}$ & 1.24 & ldi & 1.16 & (d) & 1.81 & 1.13 & 1.24 & 1.24 \\
\hline $\mathrm{Hol}_{3}$ & 2.52 & 0.83 & 1.90 & 9.63 & 2.84 & (d) & 1.94 & $\langle d|$ \\
\hline $\mathrm{H}_{2} \mathrm{O}$ & 28.3 & 28.2 & 25.8 & 28.2 & 41.9 & 36.9 & 48.8 & 81.2 \\
\hline $\mathrm{Hd}_{2} \mathrm{D}_{3}$ & 3.92 & $\langle d|$ & 3.18 & (dI & 4.71 & 0.15 & 3.50 & 6.899 \\
\hline MiO & 3.92 & $\langle d|$ & 3.75 & (d) & 5.87 & 1.48 & 3.71 & 9.851 \\
\hline $\mathrm{SiO}_{2}$ & 6.79 & 〈d। & 8.69 & |d। & $9.14^{\circ}$ & $0.81 ?$ & 365 & 6.035 \\
\hline Sro & 5.74 & 5.821 & 9.71 & S.811 & 1.95 & 8.54 & 9.88 & 1.51 \\
\hline $\mathrm{TiO}_{2}$ & 0.11 & $\langle d|$ & 0.20 & $\langle d|$ & 9.15 & 〈d। & 0.57 & $\langle d|$ \\
\hline$Y_{2} O_{3}$ & 0.38 & (d) & 0.38 & $\langle d|$ & 5.48 & 5.18 & 0.36 & 5.16 \\
\hline $\operatorname{Zno}$ & 3.28 & $\langle d|$ & 3.10 & $\langle d|$ & 4.24 & 0.888 & 3.28 & 9.887 \\
\hline $2 \mathrm{rO}_{2}$ & 23.8 & $\langle d|$ & 23.1 & (d) & 31.8 & c.8.81 & 23.8 & (1.881 \\
\hline $\begin{array}{ll}\text { (a) } & \text { <dl } \\
\text { (b) nd }\end{array}$ & $\begin{array}{l}=b e \\
=\text { not }\end{array}$ & fet & cti & $1 \mathrm{im}$ & & & & \\
\hline
\end{tabular}


of the five major constituents, four remain primarily with one fraction throughout the formating process: iron, zirconium, and silica remain with. the solids and sodium with the supernate. Prior to formating the remaining major constituent aluminum, is contained in the solids fraction. After formating $8 \%$ of the aluminum is solubilized.

The significant solubilization changes of HWVP feed ions observed during formating, concentrating and frit. addition are illustrated graphically in Figure 4.3-59. These data are derived from ICP analyses of supernate and slurry samples. The behavior of these ions is described below by contrasting solubilities before and after the addition of formic acid and frit.

\section{Ions with Increase in Solubility After Formating}

- Significant change (ratio supernate/total after formating >0.5)

boron

calcium

magnesium

strontium

- STight change (ratio supernate/total after formating >0:1)

copper

yttrium

zinc

- Relatively small change, however, detectable (ratio supernate/total $<0.1$, i.e., <10 wt\% solubilized)
aluminum
Tithium
neodymium
nickel

Ions with Decrease in Solubility After Formating

chromium - from $16 \%$ to $9 \%$ of total (by wt) in supernate

molybdenum - from $33 \%$ to $<0.1 \%$ of total (by wt) in supernate

Ions with Increase in Solubility After Frit Addition

boroṇ

calcium

magnesium

a) uminum

chromium

Ions with Decrease in Solubility After Frit Addition

manganese

strontium. 

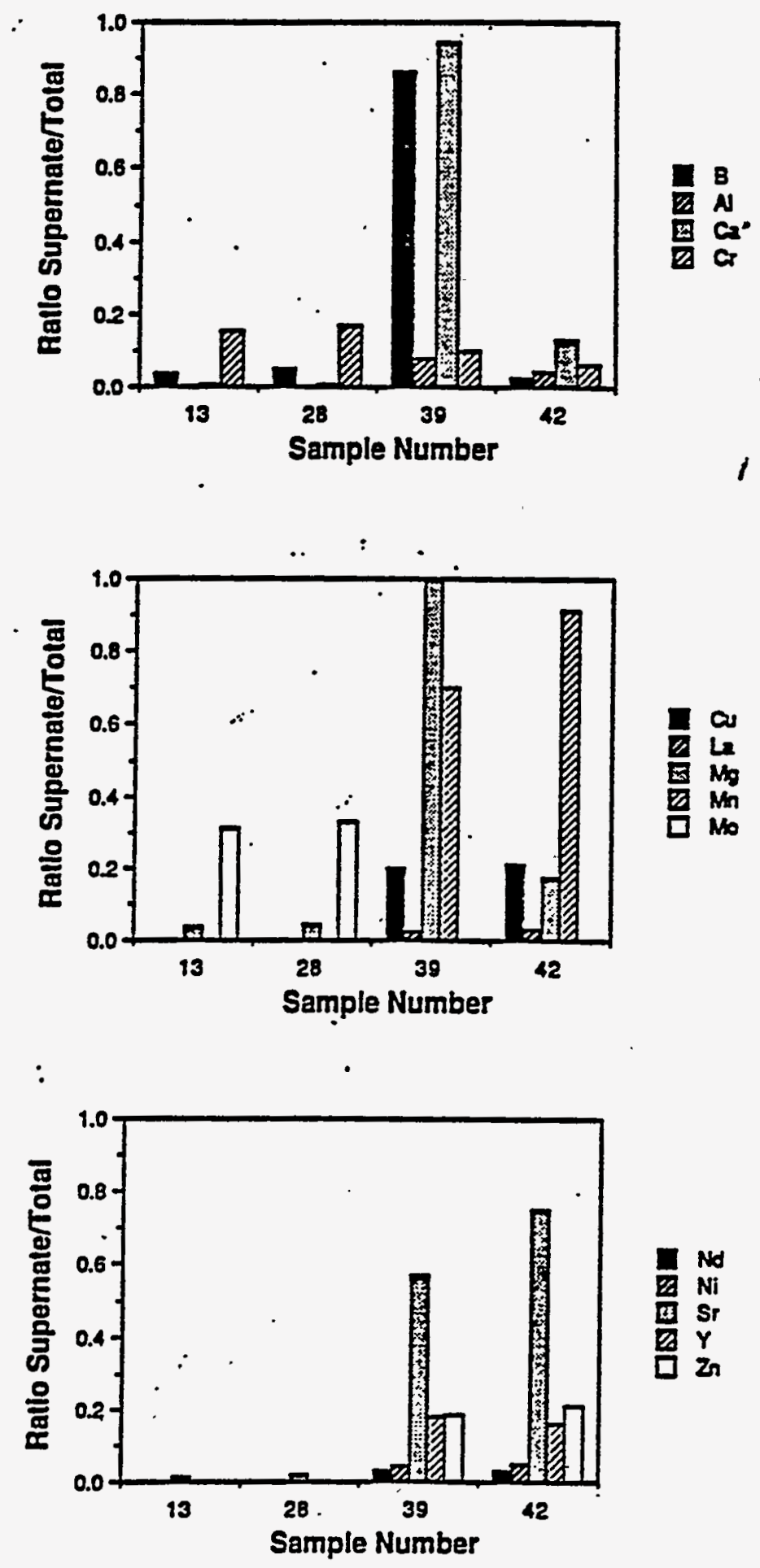

FIGURE 4.3-59. Solubilization of Ions in HWVP Feed During Formating, Concentrating, and Frit Addition HWVP-89-IVJ0010100B 
The increase.-in solubility after formating may be due to the neutralization of slightiy insoluble hydroxide species, forming soluble formates:

$$
\mathrm{M}(\mathrm{OH})_{n}+\mathrm{nHCOOH} \rightarrow \mathrm{M}^{+n}+\mathrm{nHCOO}^{-}+\mathrm{nH}_{2} \mathrm{O}
$$

As a first approximation of the observed solubilization, ratios as given in Figure 4.3-59 may represent the extent to which individual neutralization reactions have occurred.

An explanation for the absence of moiybdenum and chromium in the supernate after formating will require further consideration. Molybdenum and chromium are both transition metals, members of the VIA subgroup. However, aside from their compounds with pi-acid ligands (formate being a possibility), the lower oxidation states $(+2$ and +3$)$ do not have much in common.

The large decrease in the supernate/total weight ratio for boron, calcium, and magnesium ions and the relatively smaller decrease for aluminum and chromium ions after frit addition (sample 42) is attributed to the addition of these ions to the solid fraction via the frit matrix. The observed increase solubility of manganese and strontium after frit addition is not presentiy understood.

The concentration of soluble fluoride, chloride, nitrate, sulfate, and formate as determined from IC analysis is reported in Table 4.3-47. Evaluation of these data include the following:

After concentration (assume 1.35 concentration factor) and formating steps (sample 28 compared with sample 39):

- The concentration of sulfate decreases by $42 \mathrm{wt \%}$ (approximately $1.44 \mathrm{~g} / \mathrm{L}$ ) sulfate. This may be due to the reduction of sulfate to gaseous sulfur oxides via formic acid.

- The concentration of nitrate decreases by 3 wt\% (approximately $1.90 \mathrm{~g} / \mathrm{L}$ ). Reduction of nitrate to gaseous oxides of nitrogen ( $\mathrm{NO}, \mathrm{NO}_{2}$, $\mathrm{N}_{2} \mathrm{O}$ ) by formic acid may account for this loss.

TABLE 4.3-47. HWVP PSCM-23 Feed Anion Concentration During Formating, Concentrating and Frit Addition HWVP-89-IVJ0010100B

\begin{tabular}{|c|c|c|c|c|l|}
\hline $\begin{array}{c}\text { Sample } \\
\text { Number }\end{array}$ & $\begin{array}{c}\text { FTuoride } \\
(\mathrm{g} / \mathrm{L})\end{array}$ & $\begin{array}{c}\text { Chloride } \\
(\mathrm{g} / \mathrm{L})\end{array}$ & $\begin{array}{c}\text { Nitrate } \\
(\mathrm{g} / \mathrm{L})\end{array}$ & $\begin{array}{c}\text { Sulfate } \\
(\mathrm{g} / \mathrm{L})\end{array}$ & $\begin{array}{c}\text { Formate } \\
(\mathrm{g} / \mathrm{L})\end{array}$ \\
\hline 13 & 19.2 & 0.58 & 49.4 & 2.58 & $<\mathrm{d} 7(\mathrm{a})$ \\
28 & 18.7 & 0.58 & 48.6 & 2.53 & $<\mathrm{d} 1$ \\
39 & 49.1 & 0.82 & 63.7 & 1.98 & 20.9 \\
42 & 36.7 & 0.77 & 61.3 & 1.91 & 20.0 \\
\hline
\end{tabular}

(a) $\langle$ dl $=$ detection limit 
- The fluoride concentration increases by $95 \mathrm{wt} \%(0.023 \mathrm{~g} / \mathrm{L})$. One source of excess fluoride may be as a contaminant in the formic acid.

- The concentration of soluble formate was $20900 \mathrm{ppm}(5.6 \mathrm{~g} \mathrm{C} / \mathrm{L})$.

Carbon analyses were performed on the supernate and dried sludge fractions. Table 4.3-48 summarizes the carbon data. Evaluation of these data indicates the following:

- No insoluble carbonates are observed throughout the formating, concentrating and frit addition steps.

- The carbon content prior to formating and concentrating, $6.5 \mathrm{~g} \mathrm{C} / \mathrm{L}$, is in agreement with that reported in Section $4.1 ; 2.5 \mathrm{~g} \mathrm{C} / \mathrm{L}$ as oxalate and $4.0 \mathrm{~g} \mathrm{C} / \mathrm{L}$ as sugar $\left(\mathrm{C}_{6} \mathrm{H}_{12} \mathrm{O}_{6}\right)$.

- After formating and concentrating the supernate contains carbonate. This is potentially derived from the oxidation of formic acid or decomposition of formic acid, sugar and/or oxalate.

- After frit addition the concentration of formate, chloride, nitrate, and sulfate ions increase by 26 to $28 \mathrm{wt} \%$ based on a 0.75 dilution factor. The formate is introduced as formic acid with the frit. The remaining ions may have been introduced as contaminants during the frit addition phase.

TABLE 4.3-48. HWVP PSCM-23 Feed Carbon Content During Formating, . Concentrating, and Frit Addition HWVP-89-IVJ0010100B

\begin{tabular}{|c|c|c|c|c|c|c|}
\cline { 2 - 7 } \multicolumn{1}{c|}{} & \multicolumn{3}{c|}{ Total Organic Carbon(a,b) } & \multicolumn{2}{c|}{ Total Inorganic Carbon } \\
\hline $\begin{array}{c}\text { Sample } \\
\text { Number }\end{array}$ & $\begin{array}{c}\mathrm{mg} \mathrm{C} \\
\mathrm{g} \text { Solids }\end{array}$ & $\begin{array}{c}\text { mg C } \\
\text { STudge(c) }\end{array}$ & / $\mathrm{g}$ siudge(d) & /L Supernate & /g Solid & /L Supernate \\
\hline 13 & 17.3 & 5.0 & 6.9 & 0.38 & 0 & 0 \\
28 & 17.0 & 4.9 & 6.5 & 0.37 & 0 & 0 \\
39 & 34.0 & 12.2 & 17.5 & 5.2 & 0 & 0.34 \\
42 & 13.8 & 8.4 & 14.4 & 5.0 & 0 & 0.17 \\
\hline
\end{tabular}

(a) To convert $\mathrm{g} \mathrm{C/L}$ to $\mathrm{g}$ oxalate/L multiply by 90/24. To convert $\mathrm{g} \mathrm{C} / \mathrm{L}$ to $\mathrm{g}$ formate/L multiply by $45 / 12$.

(b) Concentration in terms of $g$ formate or oxalate/L feed was calculated using the supernate/sludge ratios given in Table 4.3-44. Based on ICP data a 1.35 concentration factor was assumed between samples 28 and 29.

(c) Wt\% water as presented in Table 4.3-44 used for conversion from dried solids to sludge.

(d) Density of sludge estimated based on supernate/siudge ratio given in Table 4.3-44 and the density of the feed slurry given in Table 4.3-43. 
- Based on carbon analyses the feed formate concentration is $27 \mathrm{~g} / \mathrm{L}$ $(6.9 \mathrm{~g} \mathrm{C} / \mathrm{L}$ feed) after formating and concentrating. Assuming a 1.35 concentration factor the concentration of formate in the initial. feed would be $20 \mathrm{~g} / \mathrm{L}$. . This formate concentration is equivalent to the addition of $19 \mathrm{~mL}$ ( $90 \mathrm{wt \%}, 23 \mathrm{M}$ ) formic acid/L feed. The sludge fraction contains $33 \mathrm{~g}$ formate/ $\mathrm{L}$. The supernate concentration is $18 \mathrm{~g}$ formate/L.

- The carbon and IC values for soluble formate are in good agreement: rsd $=4.4 \%$ (assuming all soluble carbon is formate). The amount of formate observed is in agreement with the amount of formic acid added as reported in Table 4.3-42. (23.2 - $0.01 \times 375=19.5 \mathrm{~g}$ formic acid/L).

- A significant decrease in total carbon content $(9.8$ to $3.2 \mathrm{~g} \mathrm{C/L} \mathrm{feed)}$ was observed after frit addition. This decrease is greater than can be accounted for by dilution factors and is currently attributed to changes in the oxalate and sugar composition as the formate concentration is relatively stable.

4.3.4.1.2 Laboratory Equipment and Techniques. HWVP simulated slurries were generaliy prepared in the following equipment except as previously indicated:

- Feed makeup and process tanks consisted of 2- or 4- $L$ glass bottles with 1.ids, agitators, and agitator shaft seal attachments.

- Heating systems are standard $2-L$ heating manties that jacket the lower portion of the feed tanks.

- The agitation system was a standard variable-speed lab stirrer.

- Formating was accomplished using a buret for formic acid addition.

- Slurry sampling was accomplished by removing the tank lid and removing a sample portion.

- The offgas system was a glass condenser that condensed tank vapors (mostly water) and could either be disposed of or refluxed.

Laboratory rheological data (yield stress, apparent viscosity, and consistency) were obtained using a Haake RV 100 viscometer -equipped with a M150 measuring/drive head and the MVI sensor system. Slurry density and pH were obtained using standard laboratory procedures. Accurate density determinations were sometimes difficult because of the presence of a tenacious foam in many samples. Total solids are determined by drying a sample of the slurry with known mass for $24 \mathrm{~h}$ at $105^{\circ} \mathrm{C}$ and then reweighing the sample for the calculation. Total oxides are obtained by firing the sample at $>1000^{\circ} \mathrm{C}$ for over 30 min and then reweighing the sample for the calculation.

( Haake, Inc., Saddle Brook, New Jersey. 
Weight percent dissolved solids data are obtained by vacuum filtering a sample of slurry through a membrane filter with a pore size of $0.45 \mu \mathrm{m}$. A known mass of this filtrate is then dried at $220^{\circ} \mathrm{F}\left(105^{\circ} \mathrm{C}\right)$ for $24 \mathrm{~h}$. The weight of the dry filtrate is then divided by the weight of the water lost during drying to obtain the "filtrate solids to filtrate water" ratio. This ratio, multiplied by the wt\% of water in the total slurry, gives the wt\% of dissolved solids. The wt\% of suspended solids equals the wt\% of total solids minus the wt\% of dissolved solids.

Redox measurements are performed by melting the slurry into glass, then determining the amounts of ferrous and ferric ions present to arrive at a ferrous-to-ferric ion ratio.

Particle size distribution was determined using a HIAC(a) computerized instrumental particle size analyzer. The suspending or carrier fluid used in the particle size analysis was water.

After the waste was prepared from hydroxides, a determination of the actual concentration of cations was needed. This was performed by inductively coupled plasma (ICP) anatysis.

4.3.4.1.3 HWVP Process Slurry Characterization Results. The results and conclusions that can be reached from these studies are summarized below. As expected, there is some scatter in data because of differences in makeup methods, chemical composition, sampling, and analyses differences.

HWVP Feed

- The total solids concentration of HWVP feed increases linearly with waste oxide concentration (Figure 4.3-60).

- The density of HWVP feed increases linearly with waste oxide (solids) content (Figure 4.3-54 and 4.3-61).

- The yield stress increases exponentially with waste oxide concentration (Figure 4.3-62). Below about $50 \mathrm{~g}$ WO/L, the slurry behaves as a non-yield slurry. The concentration at which the yield point begins to increase significantiy depends on the makeup approach and is between 100 to $150 \mathrm{~g} \mathrm{WO} / \mathrm{L}$.

- The apparent viscosity at $183 \mathrm{~S}^{-1}$ behaves similarly to the yield point. The viscosity increases exponentially with concentration (Figure 4.3-63). Below $50 \mathrm{~g}$ WO/L, the apparent viscosity is only modestiy above that of water. Between 100 and $150 \mathrm{~g} \mathrm{WO} / \mathrm{L}$ the apparent viscosity increases substantially.

- The $g$ WO/g TS per unit of feed is 0.78 .

(a) Pacific Scientific Co., HIAC Instruments Division, Montclair, California. 


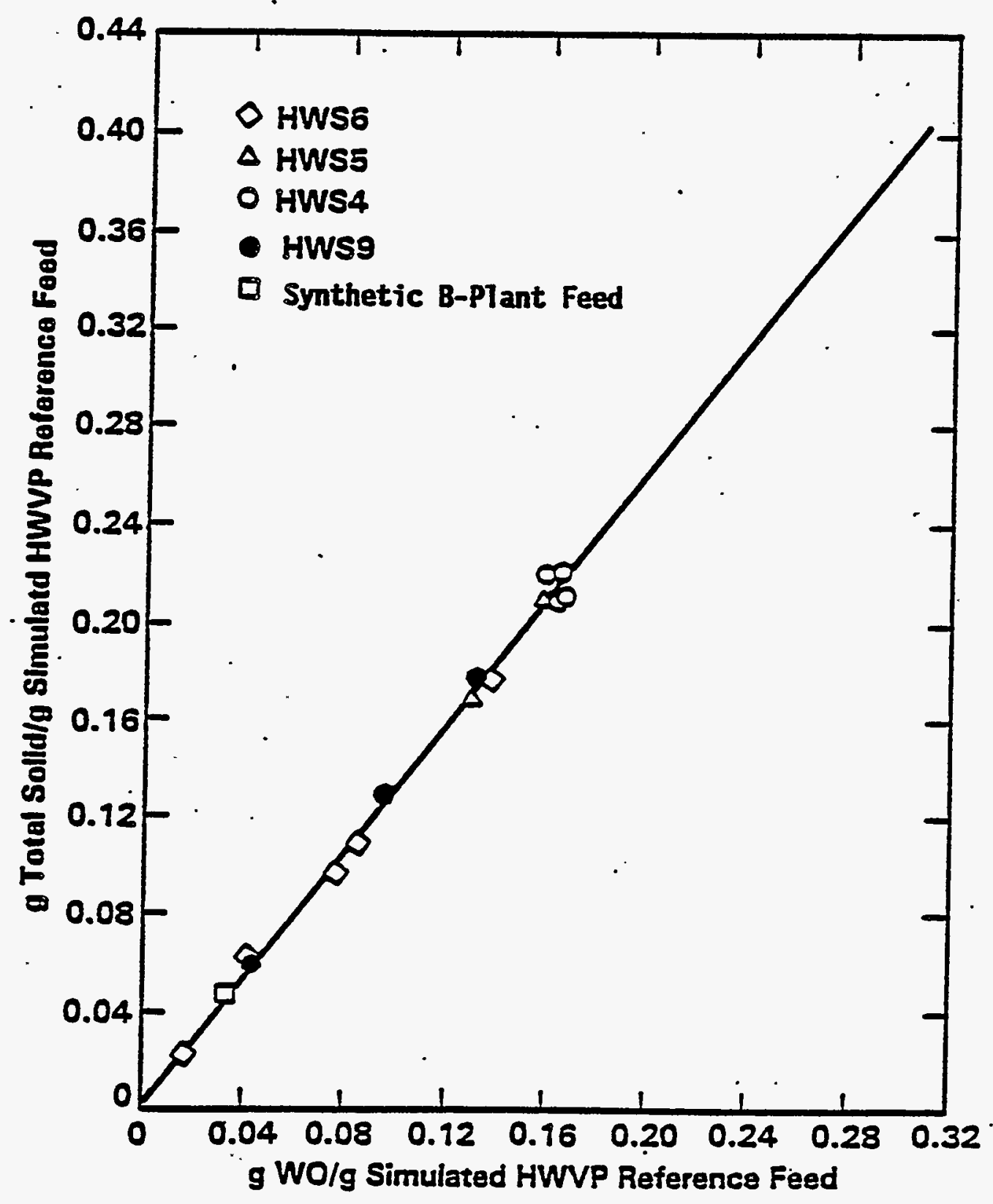

FIGURE 4.3-60. Total Solids Concentration as a Function of Waste Oxide Concentration of Simulate HWVP Feed

(NCAW 84--HWS4, HWS5, HWS6, Synthetic B P1ant

Feed; NCAW 86--HWS9) RHO-RE-CR-16P/HWVP-86-V1123C 


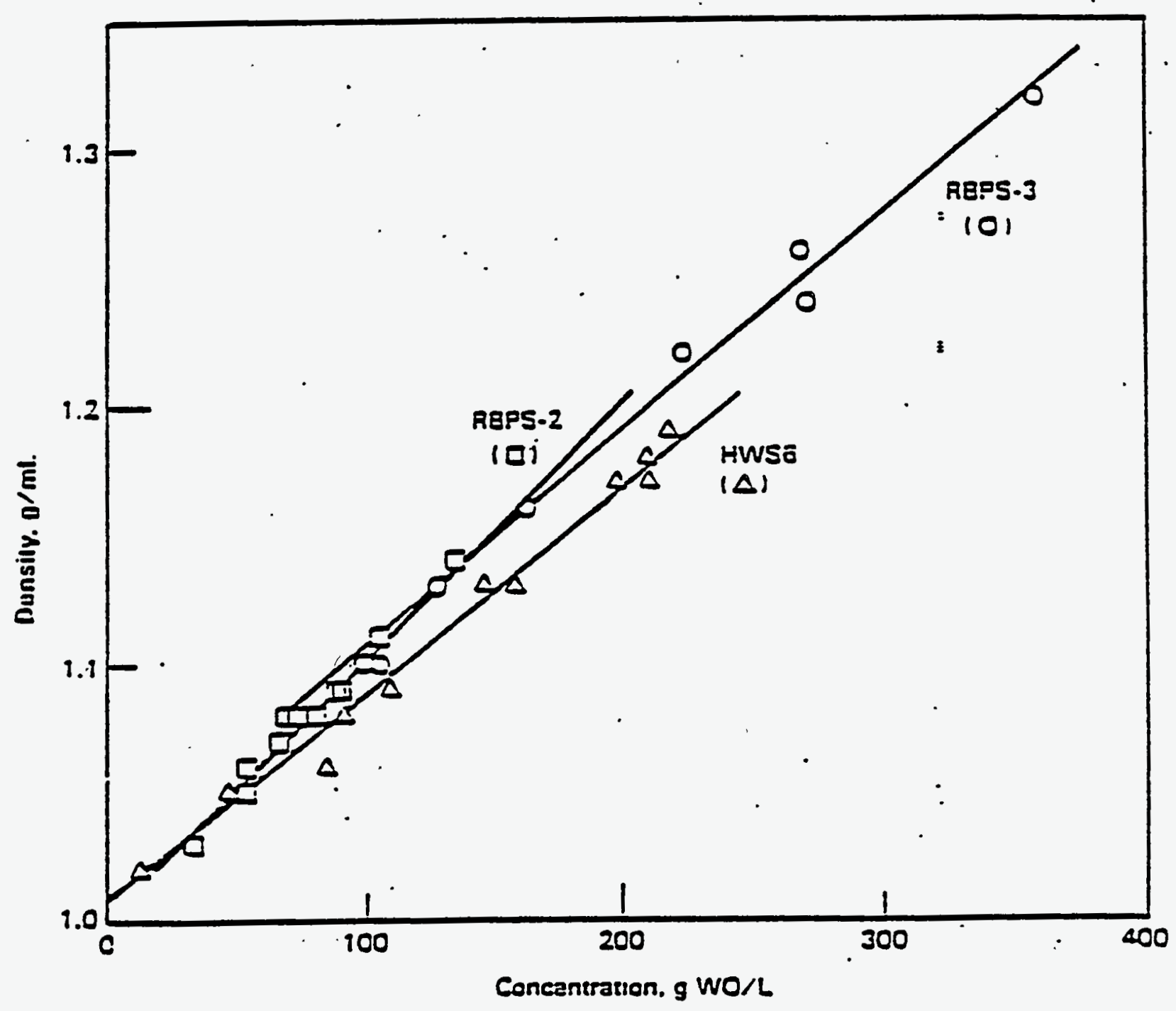

FIGURE 4.3-61. Density of Simulated (NCAW 84, high chromium) HWWP Feeds as a Function of the of the Waste Oxide Concentration RHO-RE-CR-16P/HWVP-86-V1123C

\section{Formated HWVP Feed}

- The yield stress decreases exponentially with the amount of formic acid added (Figure 4.3-64). The data al so indicates that up to half of the stoicheometric amount of formic acid add may be necessary before the yield stress decrease begins (Figure 4.3-65). Also, the rate of decrease decreases exponentially with the waste oxide concentration, based on formic acid added per $g$ WO (Figure 4.3-65). 


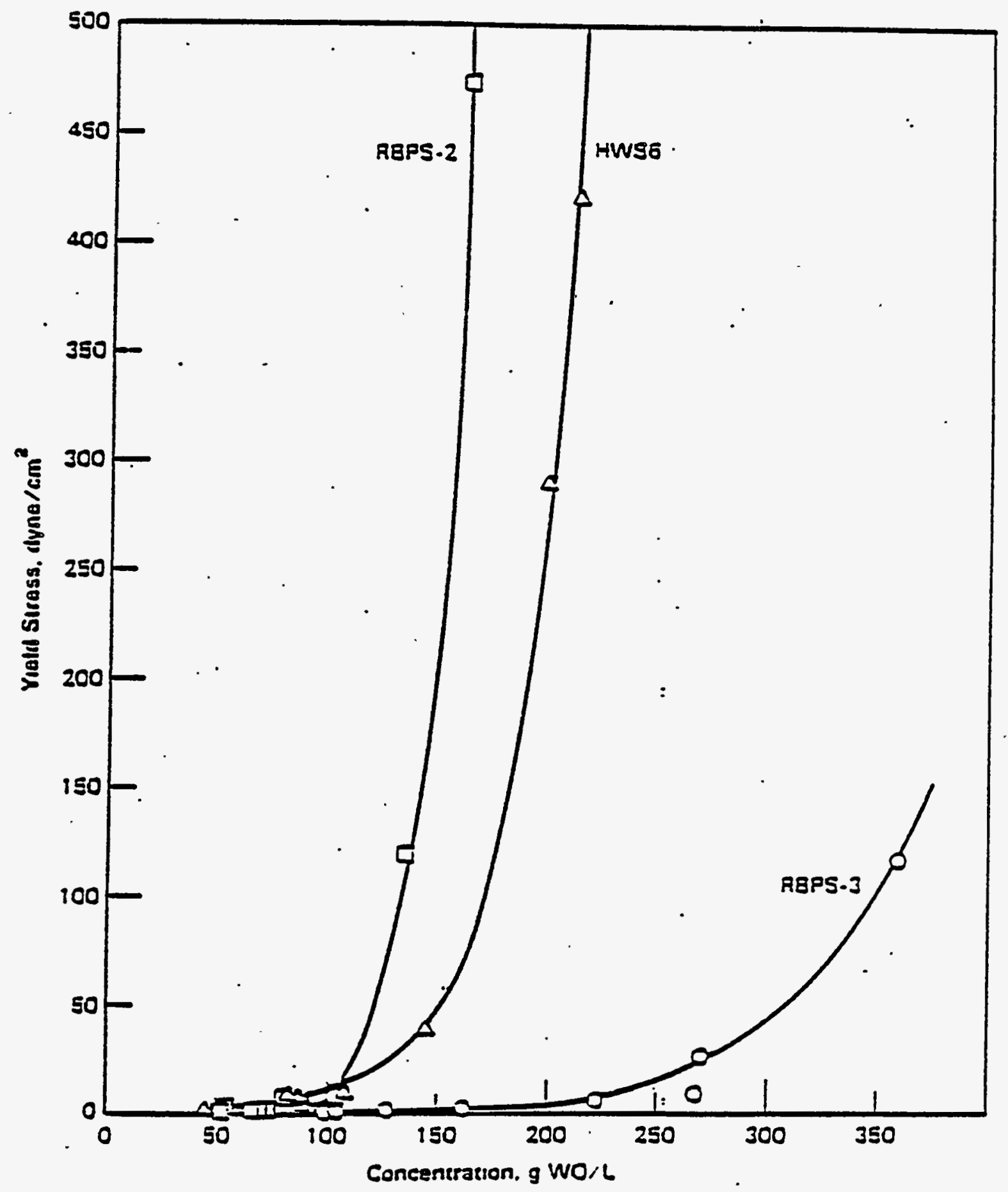

FIGURE 4.3-62. Changes in the Yield Stress of Simulated (NCAW 84, high chromium) HWVP Feeds During Concentration RHO-RE-CR-16P/HWVP-86-V1123C 


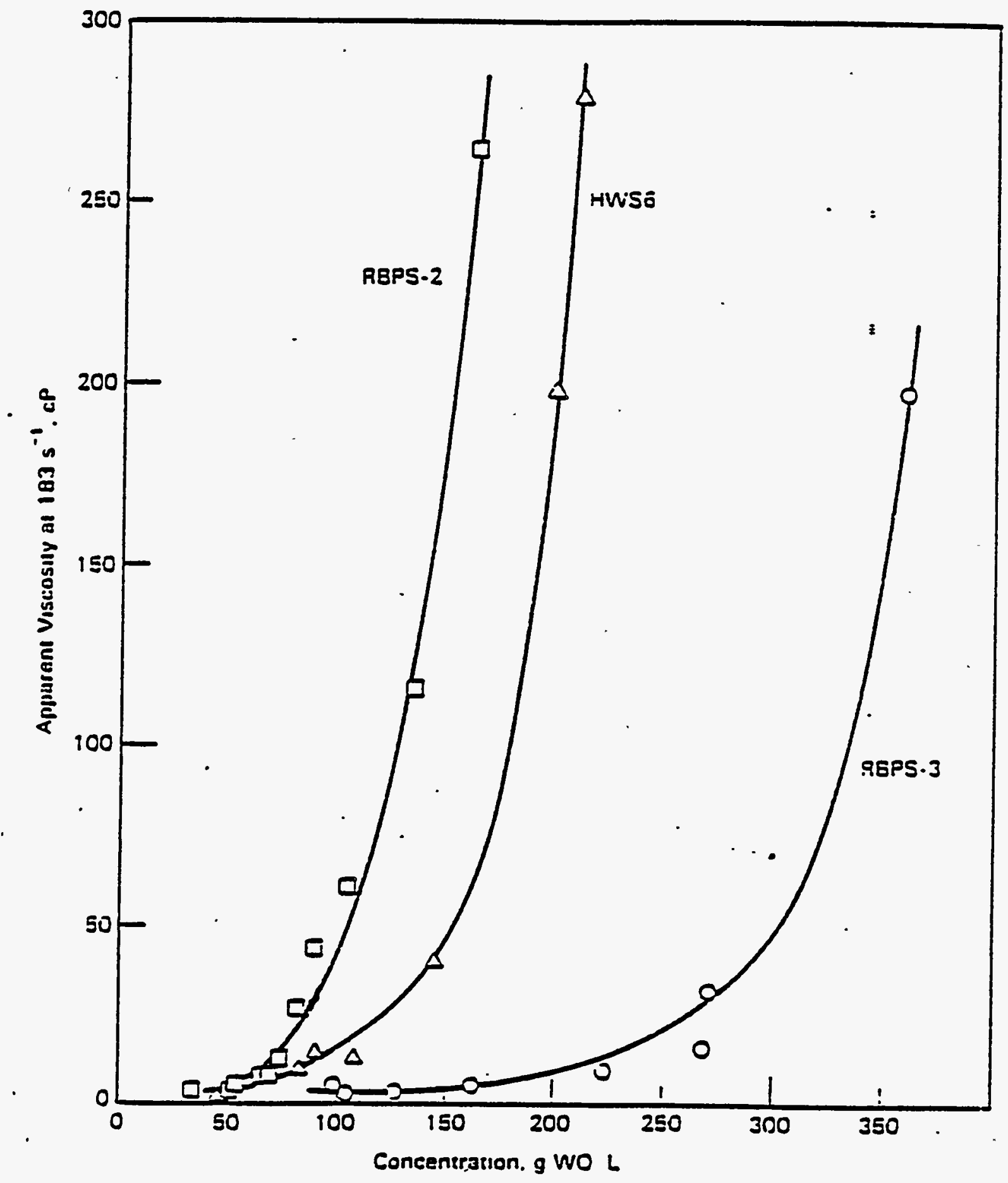

FIGURE 4.3-63. Changes in the Apparent Viscosity of Simulated. (NCAW 84, high chromium) HWVP Feeds During Concentration

RHO-RE-CR-16P/HWVP-86-V1123C 


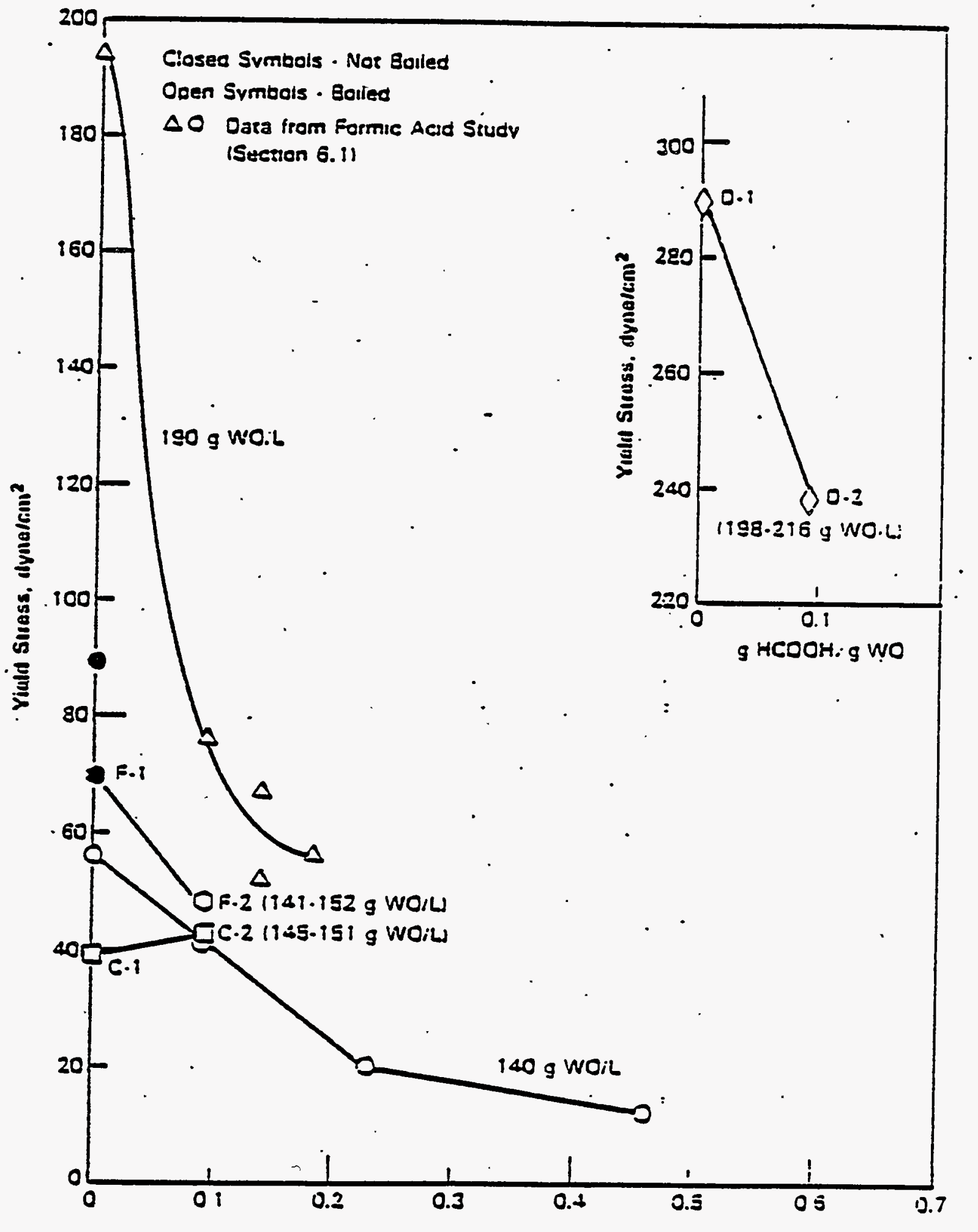

Antroune of Formic Aca Auded. gis Waste Oxides (WO)

FIGURE 4.3-64. Effects of Formic Acid Addition on the Yield Stress of Simulated HWVP Feed Concentration (HWS6-NCAW 84, high chromium) RHO-RE-CR-16P/HWVP-86-V1123C 


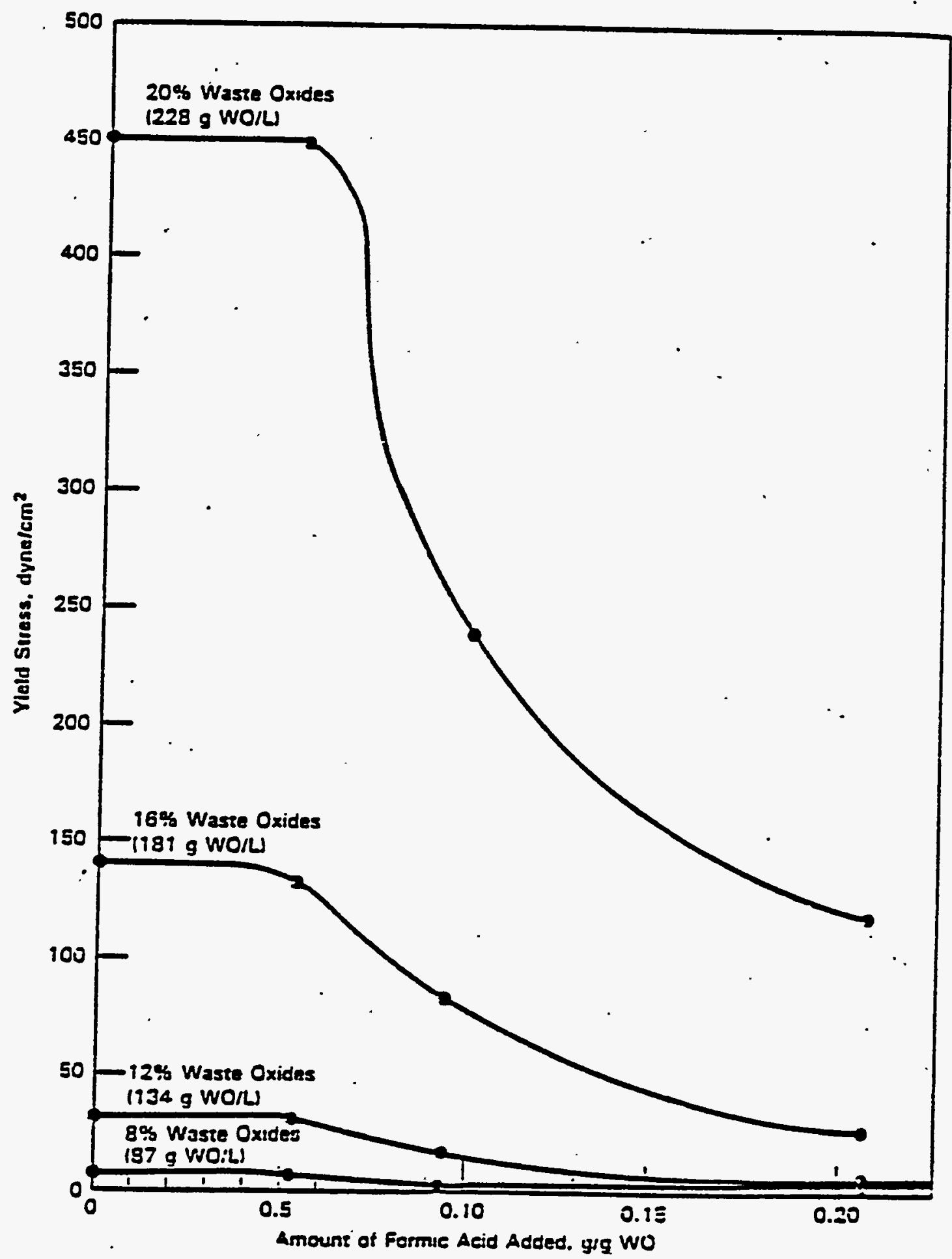

FIGURE 4.3-65. Effect of Formic Acid Addition on Yield Stress for Varying Haste Oxide Concentrations (formated at $50 \mathrm{~g} \mathrm{HO} / \mathrm{L}$, low agitation, HWS7-NCAW 84, high chromium)

RHO-RE-CR-16P/HWVP-86-VI123C 
- In a parallel manner to yield stress the apparent viscosity decreases exponentialiy with the amount of formic acid added (Figure 4.3-66). The rate of apparent viscosity decrease also decreases exponentialiy with the waste oxide concentration (Figure 4.3-66).

- Higher acid concentrations (lower final $\mathrm{pH}$ ) in the final formated product accompany the higher fractions of dissolved solids to total solids (Figure 4.3-67). (Explanation for point 200 $\mathrm{L}$ is not evident.)

- Allowing the formated slurry to set to $260 \mathrm{~h}$ does not have any significant effect on the yield stress or the apparent viscosity (Table 4.3-23). The maximum change was <12\% and generally much Tess.

- The data suggests that when the formic acid is added before boiling, the formic acid is not evaporated during subsequent concentration even when the formic acid addition exceeded stoichiometric amounts (Figure 4.3-68). This conclusion is inferred from the observation that the $\mathrm{pH}$ curves do not converge as the slurry is concentrated.

- Increases in the agitation rate increase the yield stress and apparent'viscosity of the formated slurry (Figures 4.3-69 and 4.3-70). These effects appeared to be long term.

\section{Melter Feed}

- Addition of frit to formated HWWP feed significantly reduces the yield stress and the apparent viscosity (Figures 4.3-71 and 4.3-72).

- For synthetic melter feed makeups, boiling the makeup did not significantly affect the yield stress or viscosity except at high melter feed concentrations (Figures 4.3-73 and 4.3-74). Boiling did significantly increase the slurry $\mathrm{pH}$.

- There is a slight dialatant fluid behavior at melter feed concentrations of 500 and $600 \mathrm{~g} \mathrm{WO} / \mathrm{L}$.

- The yield stress generally increases exponentially with wO concentration (Figure 4.3-75). The significant rate of increase begins at a WO concentration of about $550 \mathrm{~g} \mathrm{HO} / \mathrm{L}$.

- The viscosity generally increases exponentially with concentration (Figure 4.3-76). The rate of increase of viscosity increases significantly at a waste oxide concentration of about $550 \mathrm{~g} \mathrm{HO} / \mathrm{L}$. 


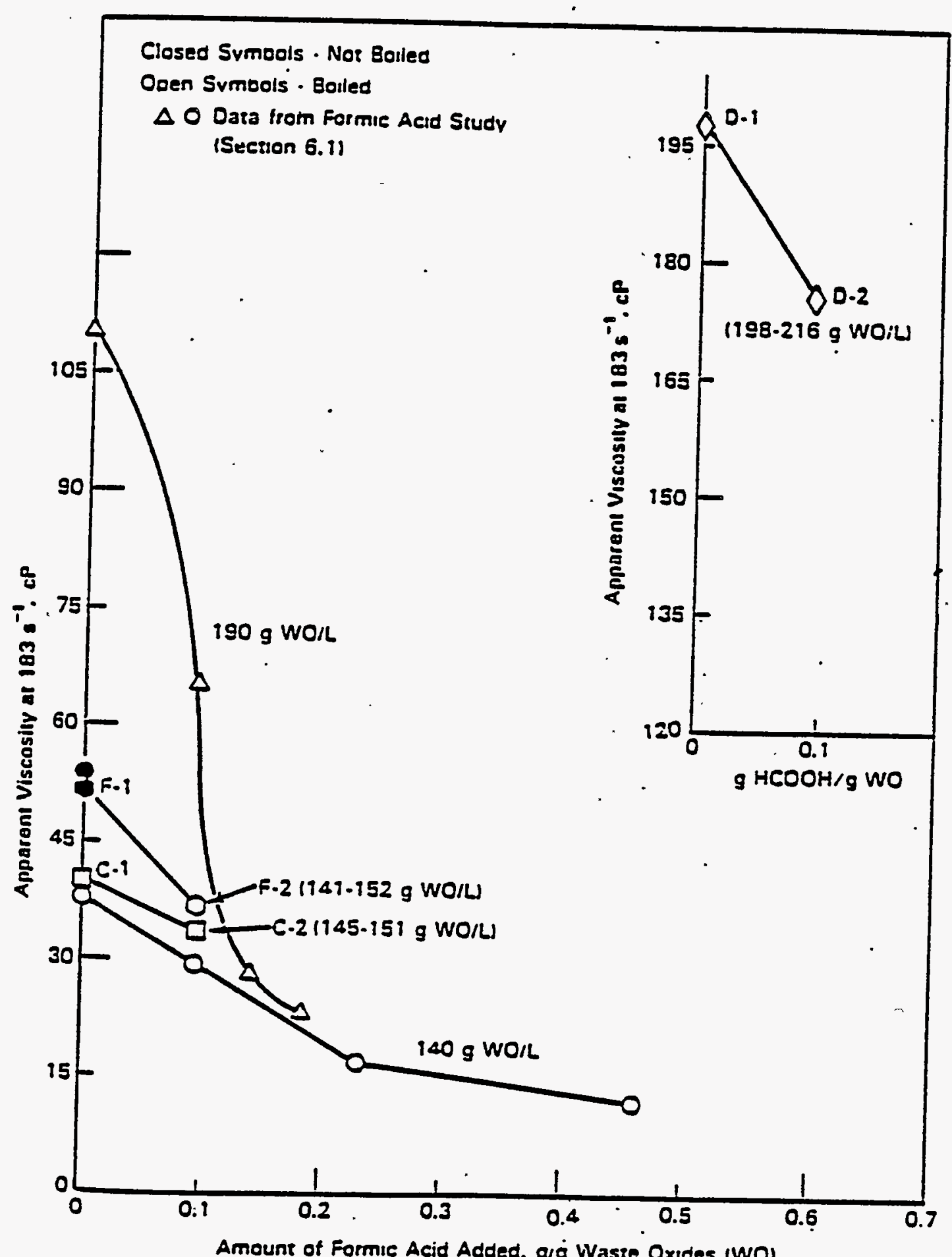

FIGURE 4.3-66. Effects of Formic Addition on the Apparent Viscosity of Simulated HWVP Feed Concentrates (HWS6-NCAW 84, high chromium) RHO-RE-CR-16P/HWVP-86-VI123C 


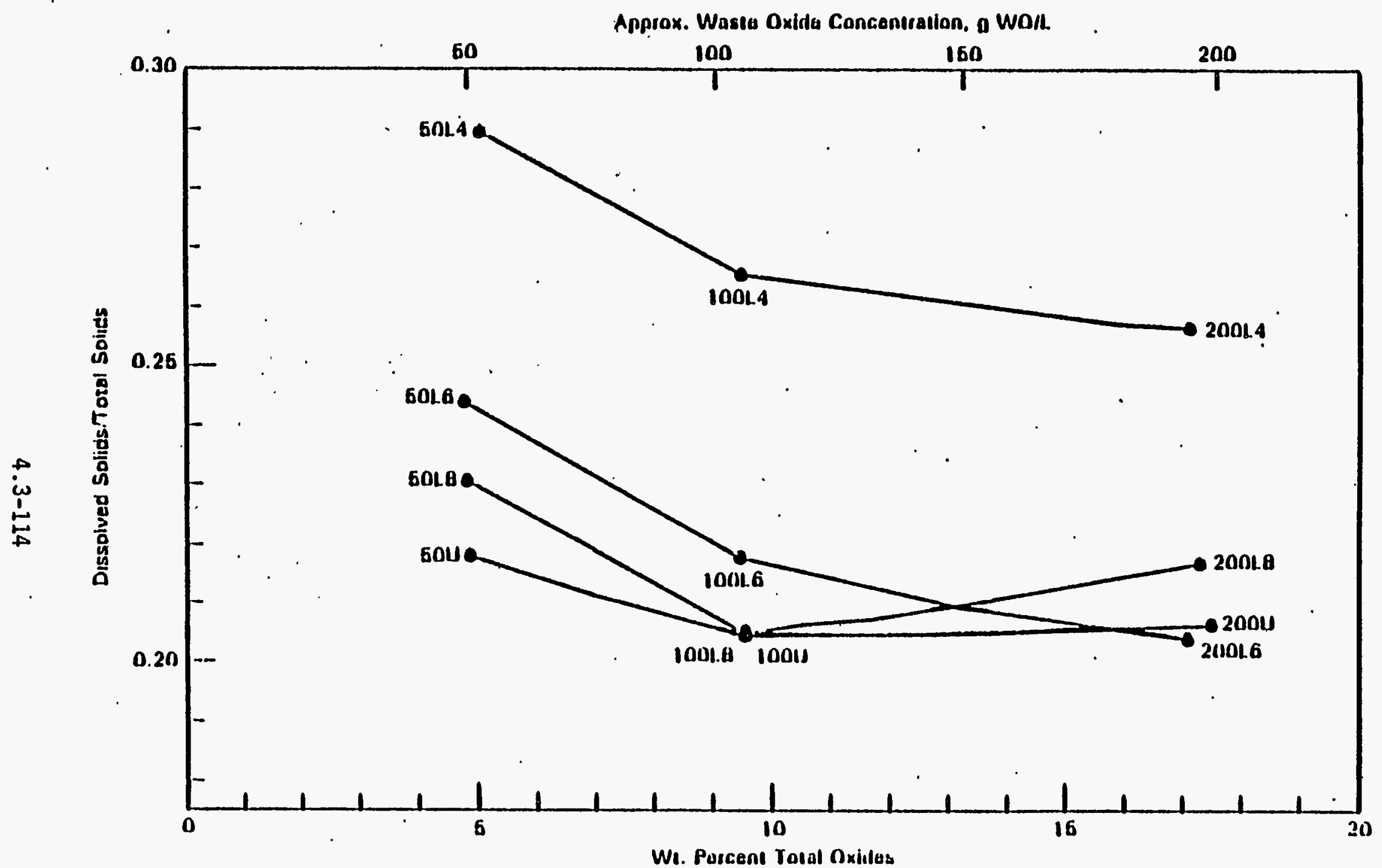

FIGURE 4-3-67. Ratio of Dissolved Solids to Total Solids at Various pH Values During Concentration, Low Agitation (HWST7-NCAH 84, high chromium) RHO-RE-CR-16P/HWVP-86-V1123C 


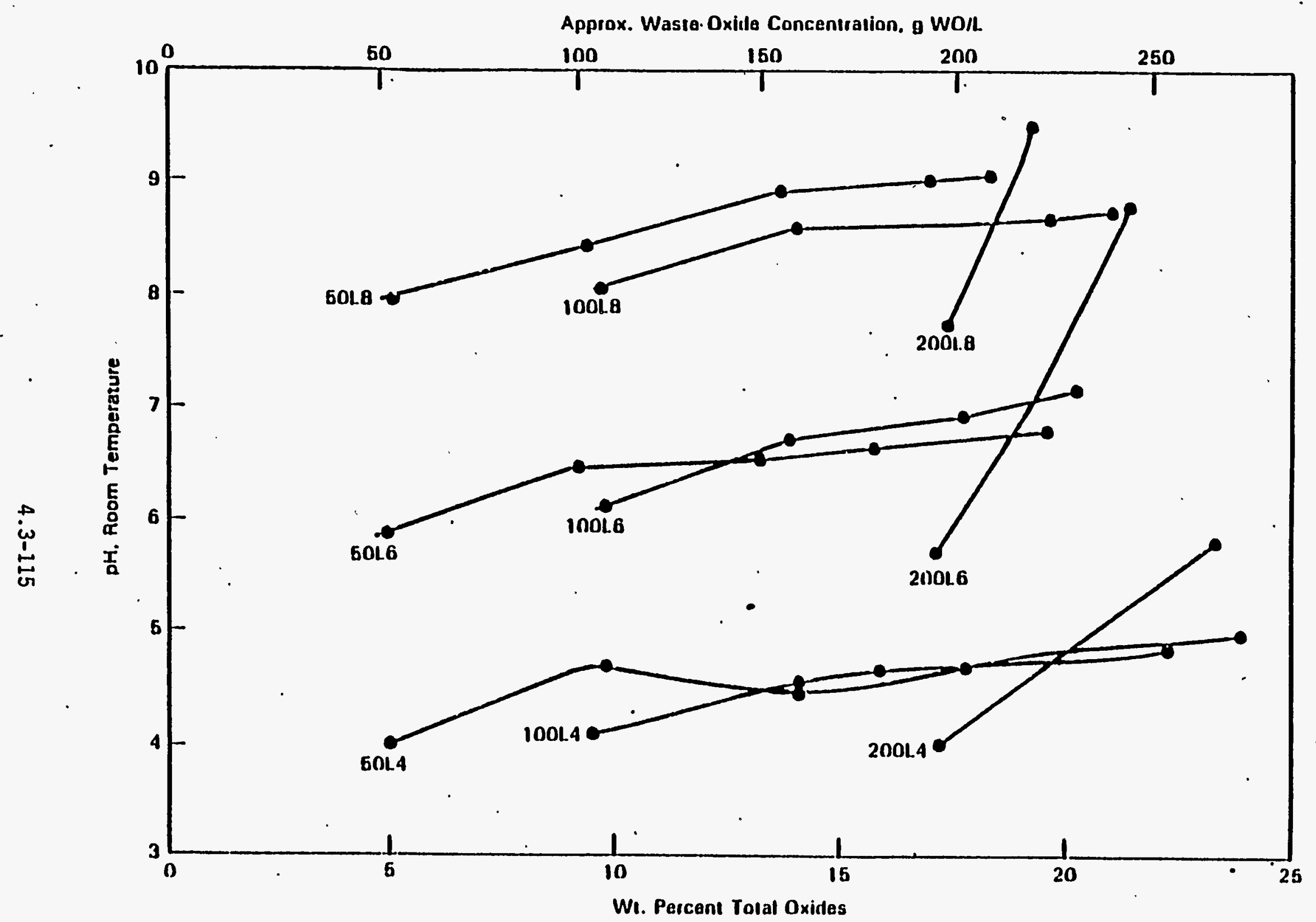

FIGURE 4.3-68. Variation of pH During Concentration for Low-Agttation Batches (HWS7-NCAW 84, high chromium) RHO-RE-CR-16P/HWVP-86-V1123C 


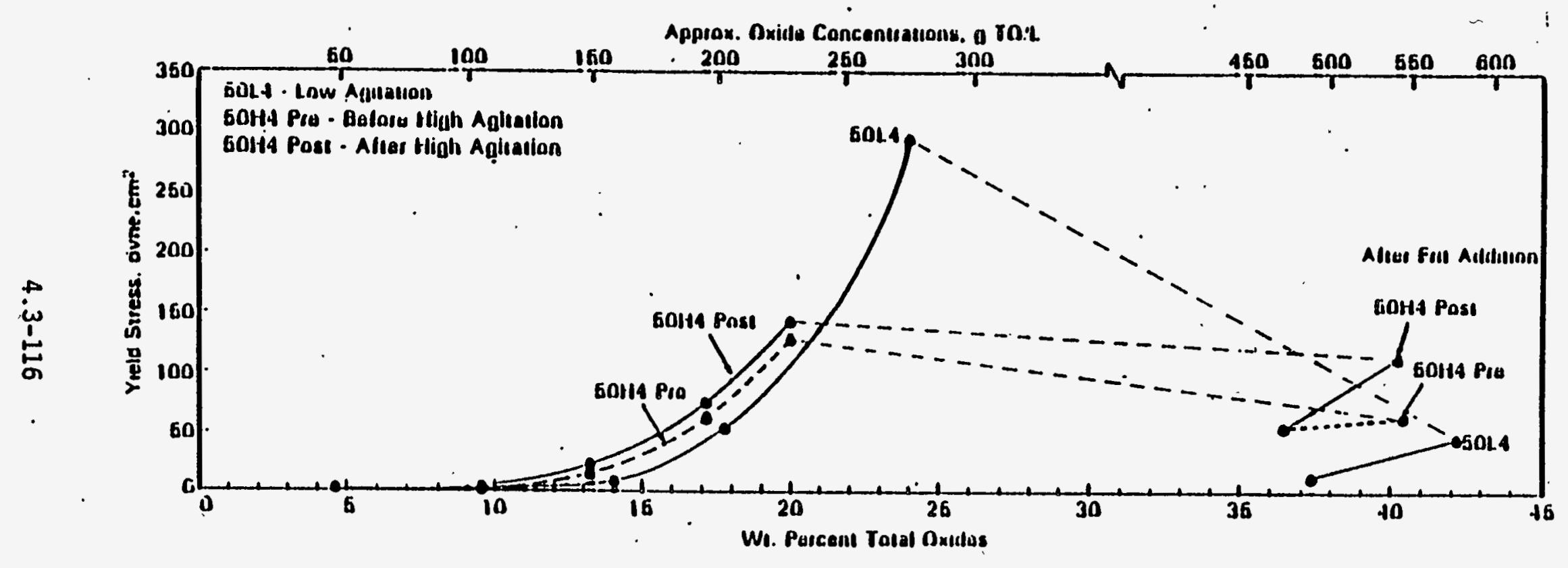

FIGURE 4.3-69. Effect of Varying Agitation on Yield Stresses of Samples (HWS7-NCAW 84, high chromium) at $50 \mathrm{~g} \mathrm{HO} / \mathrm{L}$ to a $\mathrm{pH}$ of 4 - HWVP RHO-RE-CR-16P/HWVP-86-V1123C 


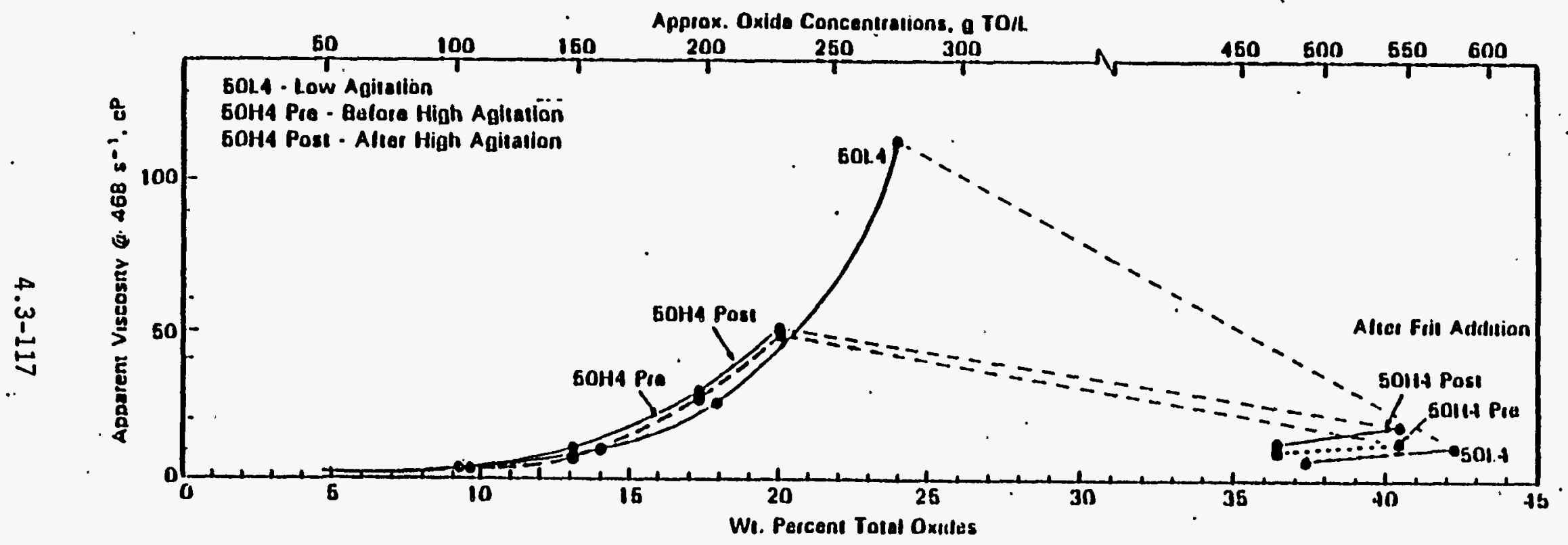

FIGURE 4.3-70. Effect of Varying Agitation on the Apparent Viscosity (at $468 s^{-1}$ ) of Samples (HWS7-NCAW 84, high chromium) RH0-RE-CR-16P/HWVP-86-V1123C 


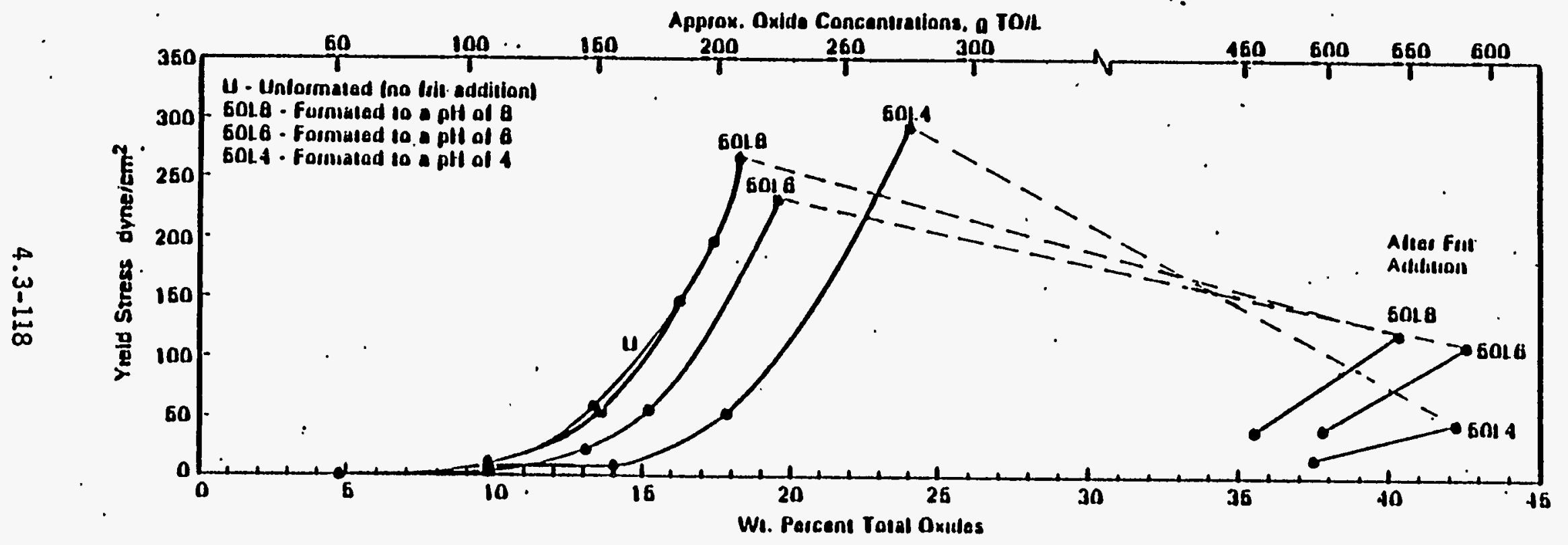

FIGURE 4.3-71. Effect of Varying pH on Yield Stress Samples (HWS7-HW 84, high chromium) Formated at $50 \mathrm{~g}$ WO/L with Low Agitation RHO-RE-CR-16P/HWVP-86-V1123C 


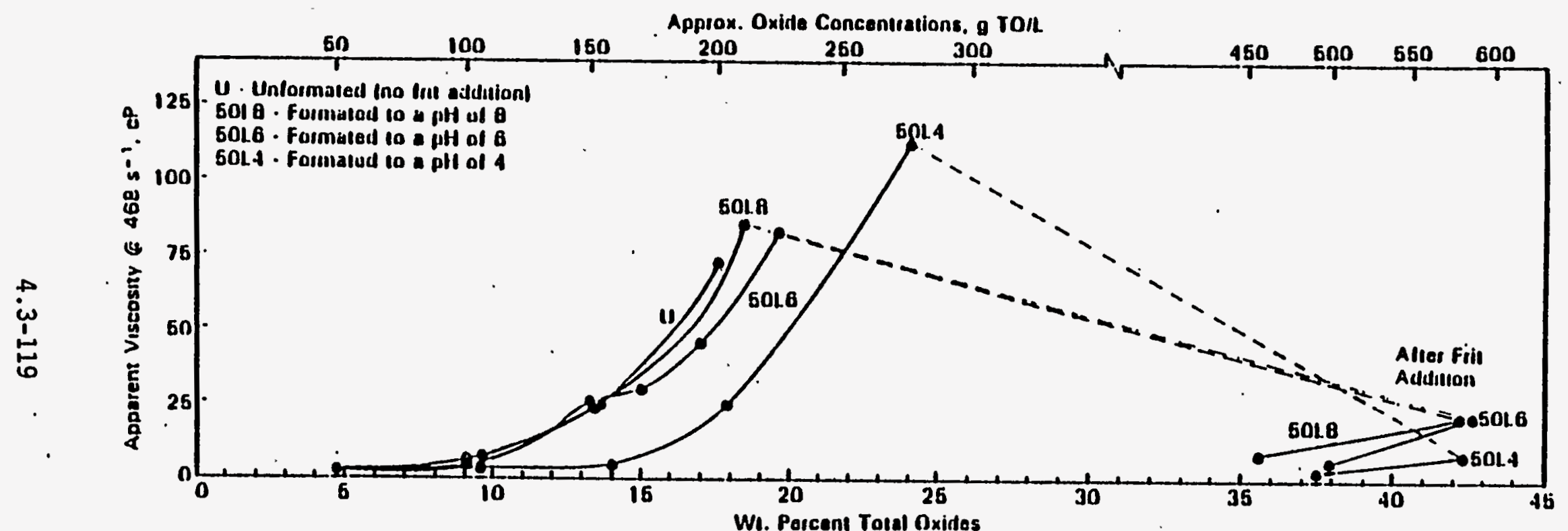

FIGURE 4.3-72. Effect of Varying $\mathrm{pH}$ on Apparent Viscosity (at $468 \mathrm{~s}^{-1}$ ) for Samples Formated at $50 \mathrm{~g} \mathrm{WO/L}$ with Low Agitation (HWS7-NCAW 84, high chromium) RH0-RE-CR-16P/HWVP-86-V1123C 


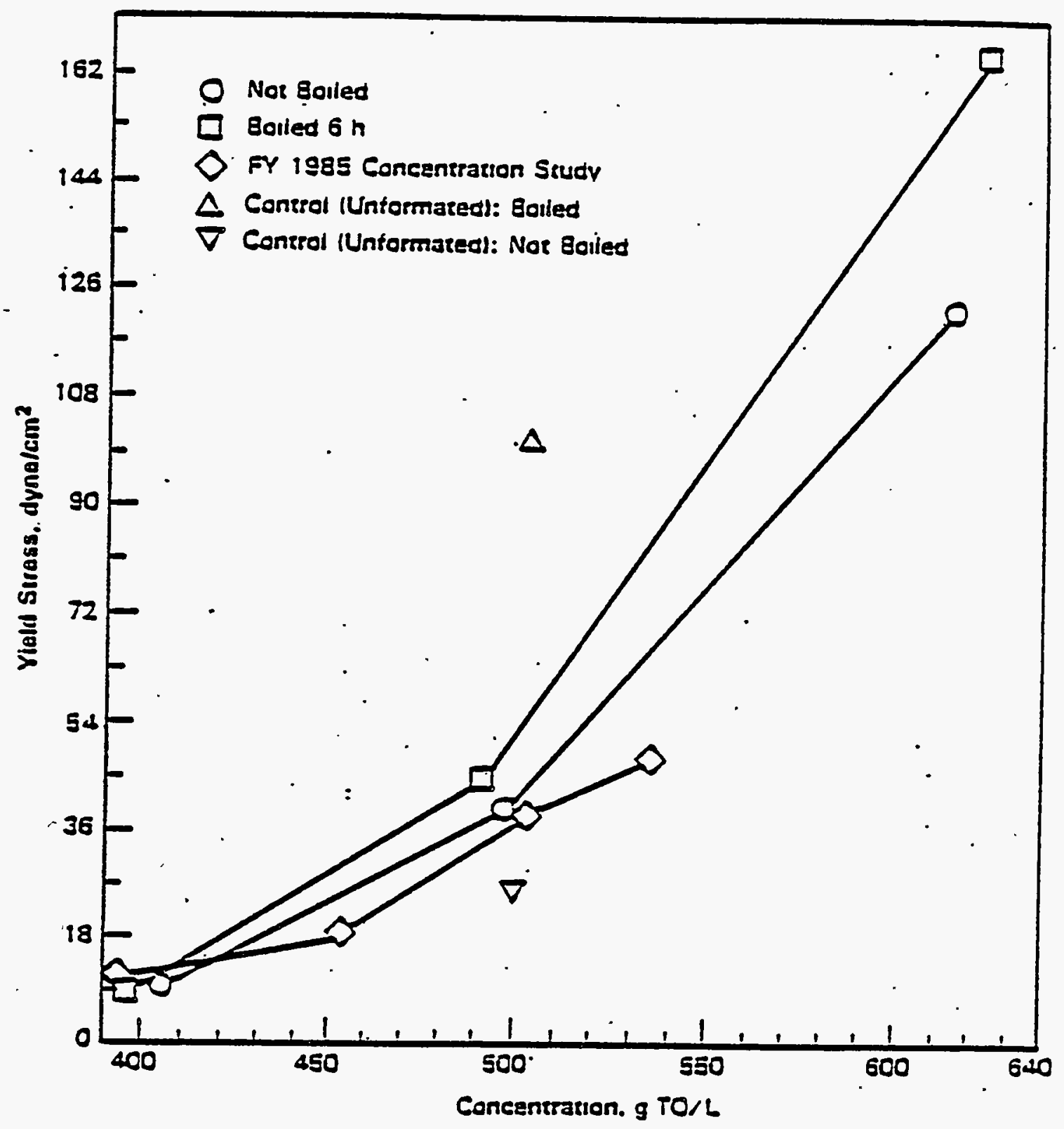

FIGURE 4.3-73. Yield. Stress as a Function of Concentration for Melter Feeds (HWS5-NCAW 84, high chromium) That Were Boiled and Thosse That Here Not Boiled RHO-RE-CR-16P/HWVP-86-V1123C 


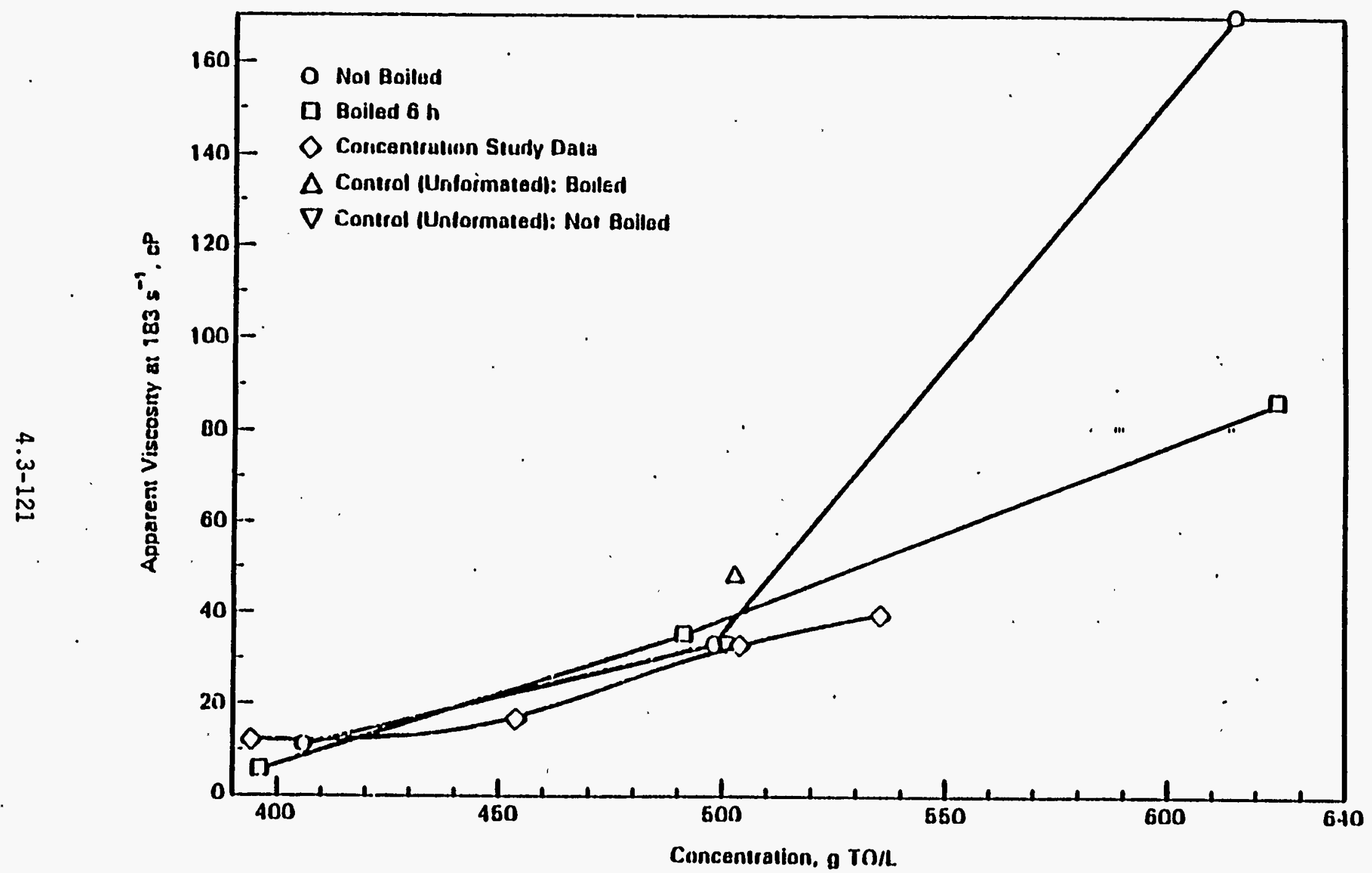

FIGURE 4.3-74. Apparent Viscosity as a Function of Concentration for Melter Feeds (HWS5-NCAW 84, high chromium) That Were Boiled and Those That Here Not Boiled RH0-RE-CR-16P/HWVP-86-V1123C 


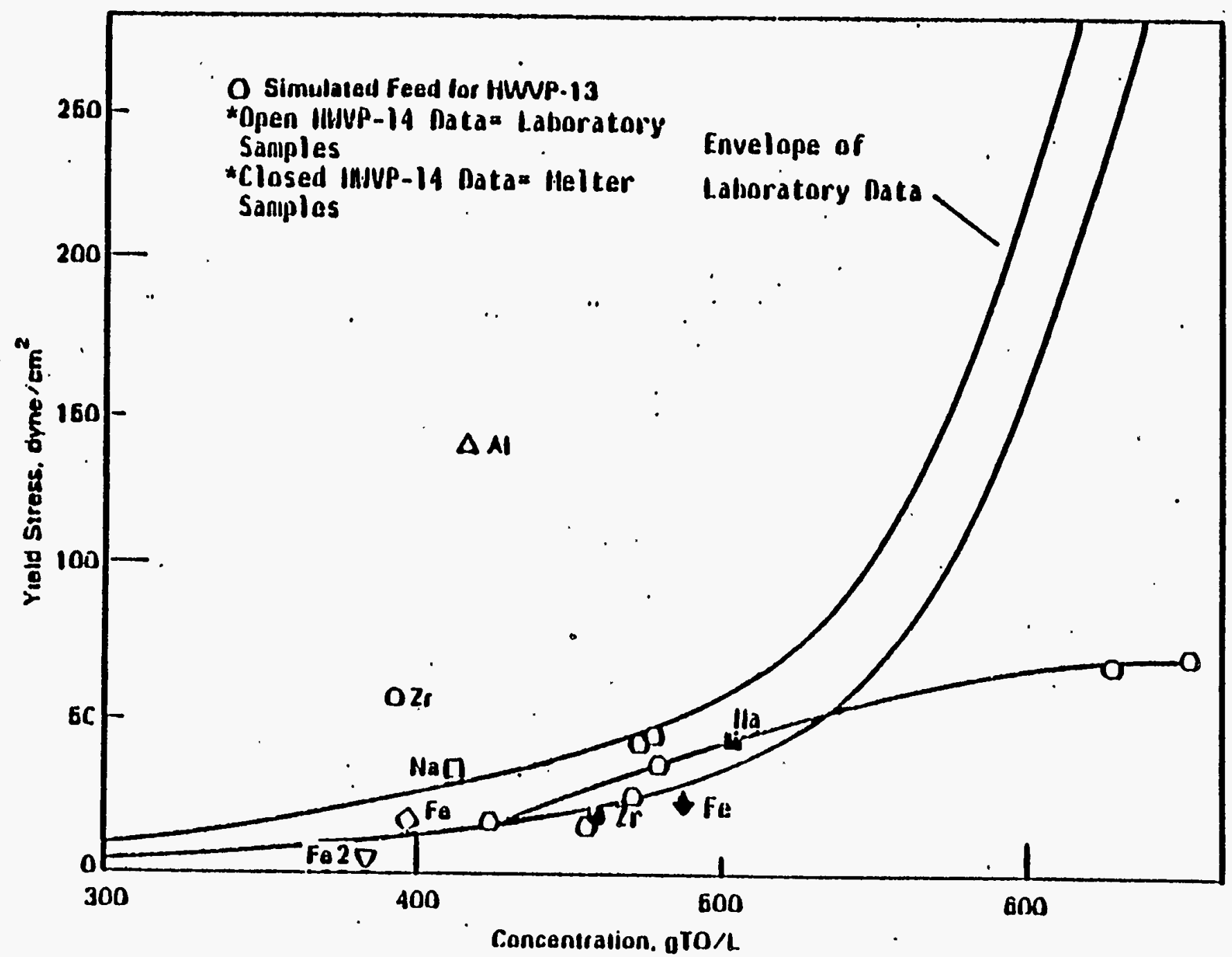

FIGURE 4.3-75. Yield Stress Values of Simulated, NCAW 84, High Chromium Melter Feed Prepared for Laboratory Simulation HWS6 and HWWP-13 and HWWP-14 Feed Versus Slurry Concentration RHO-RE-CR-16P/HWVP-86-V1123C 


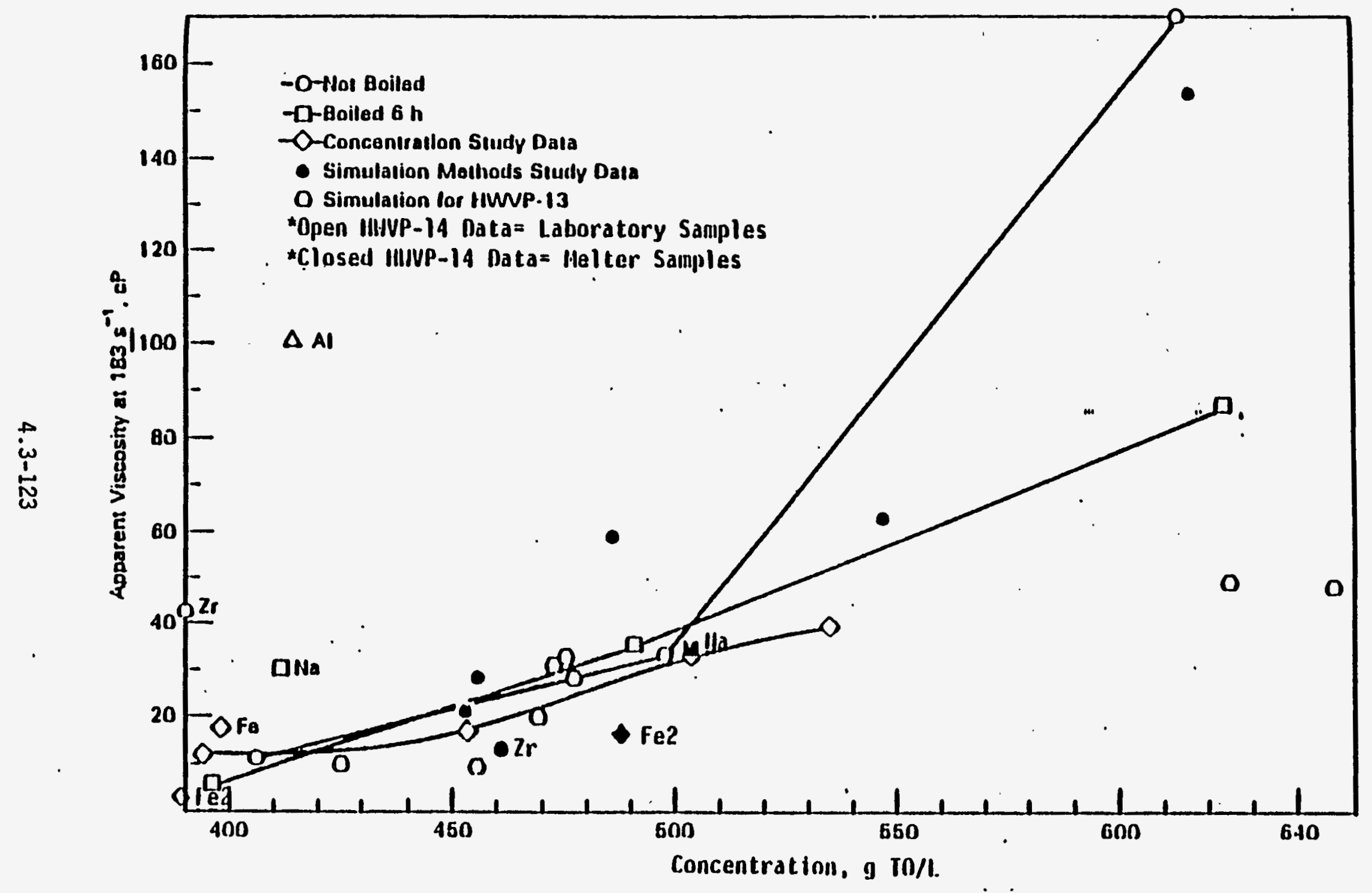

FIGURE 4.3-76. Apparent Viscosities of Simulated, NCAW 84, High Chromium Melter Feeds Prepared for Laboratory Test Batches and HWVP-13 and HWVP-14 Feed Samples Versus Slurry Concentration RHO-RE-CR-16P/HWVP-86-V1123C 
- Yield stress and viscosity properties were similar for melter feed slurry samples prepared from difute and concentrated waste slurries. However, melter feed slurries prepared from dilute waste slurries appear to be more sensitive to shear rate than are melter feed slurries prepared from more-concentrated waste slurry.

- The yield stress of melter feed decreases with increased addition of formic acid to the formated HWVP waste (Figure 4.3-71).

- The apparent viscosity of melter feed also decreases somewhat with increased addition of formic acid. to the formated HWWP waste (Figure 4.3-72).

- The effect of agitation level on yield stress and apparent viscosity is more significant after frit is added to the formated HWVP slurry (Figures 4.3-69 and 4.3.70).

- The effects of aging on melter feed yield stress and apparent viscosity do not conform to a simple. trend. The general effects appear to be negligible to modest (Table 4.3-25).

\section{Feed Composition}

Extensive feed processing development work has been performed on NCAH 84, high chromium. In 1986, the reference feed composition was modified (NCAN 86). The primary changes in NCAN composition from NCAH 84, high chromium, to NCAH 86 are as follows:

\section{wt\% Waste Oxides}

\section{NCAW 84,} high chromium

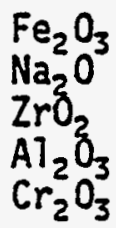

44.4

10.7

2.4

17.2

5.3
NCAW 86

28.0

17.5

15.0

10.0

0.50

In 1987, a study(a) was conducted to evaluate the rheological and physical characteristics of NCAW 86 , and to compare the characteristics of NCAW 86 to NCAW 84, high chromium. The primary conclusions of this study are as follows:

(a) G. T. Thornton, Evaluation and Comparison of HWVP Reference Feed Composition and Updated Neutralized Current Acid Waste Composition Simulants. HWVP-87-V110203C, Pacific Northwest Laboratory, Richland, Washington (Aprit 1987). 
- Rheological information contained in the HWVP feed processing data base (from NCAW 84, high chromium simulant) cannot be applied directiy to NCAW 86 slurry simulants. However, if the data base was only utilized for design purposes, it would prove to be conservative with reference to NCAW 86 simulant HWS9.

- The change in the NCAH composition from NCAH 84 (high chromium) to NCAW 86 resulted in reduced apparent viscosity and yield stress values for all concentrations of both unformatted and formated HWVP feed simulants (Figures 4.3-77 and 4.3-78). The observed reductions in rheological values may be due to the lower ferric hydroxide content of the NCAW 86 simulant compositions.

- The change in the NCAW composition from NCAW 84, high chromium, to NCAW 86 had 1 ittle effect on the physical properties of HWVP feed simulants (Figures 4.3-79, 4.3-80, and 4.3-81).

- Physical property information contained in the HWVP feed processing data base for NCAW 84, high chromium, is valid when applied to NCAW 86 simulants.

- Treatment with formic acid (formating) to a $\mathrm{pH}$ of 4 benefited the rheology of NCAW 84, high chromium simulants more than that of NCAW 86 simulants.

- Heat treatment (after formating) of simulated NCAW 86 s7urry for the reference $2-h$ period had no significant effect on rheological or physical properties (Table 4.3-39).

- NCAW 86 simulants contained a higher ratio of dissolved solids to total solids than simulations of NCAW 84 (Figure 4.3-80).

- A greater increase in the ratio of total solids to total oxides occurred upon formic acid treatment of NCAW 86 . simuiants than with NCAW 84, high chromium simulants Figure 4.3-81).

A study was conducted in 1987 (a) to evaluate the effects of formic acid on various NCAW 84--10w chromium and NCAW 86 feed compositions. From this study, the following conclusions can be made:

- Apparent viscosity and yield stress are significantly influenced by feed composition changes and by formic acid addition (Figures $4.3-82$ and $4.3-83$.

- The yield stress and apparent viscosity for the NCAW 86 simulant were lower than those obtained for the NCAW 84--10w chromium simulant feed (Figures $4.3-82$ and 4.3-83).

(a) Farnsworth et al., HWVP-87-V110203A (1987). 


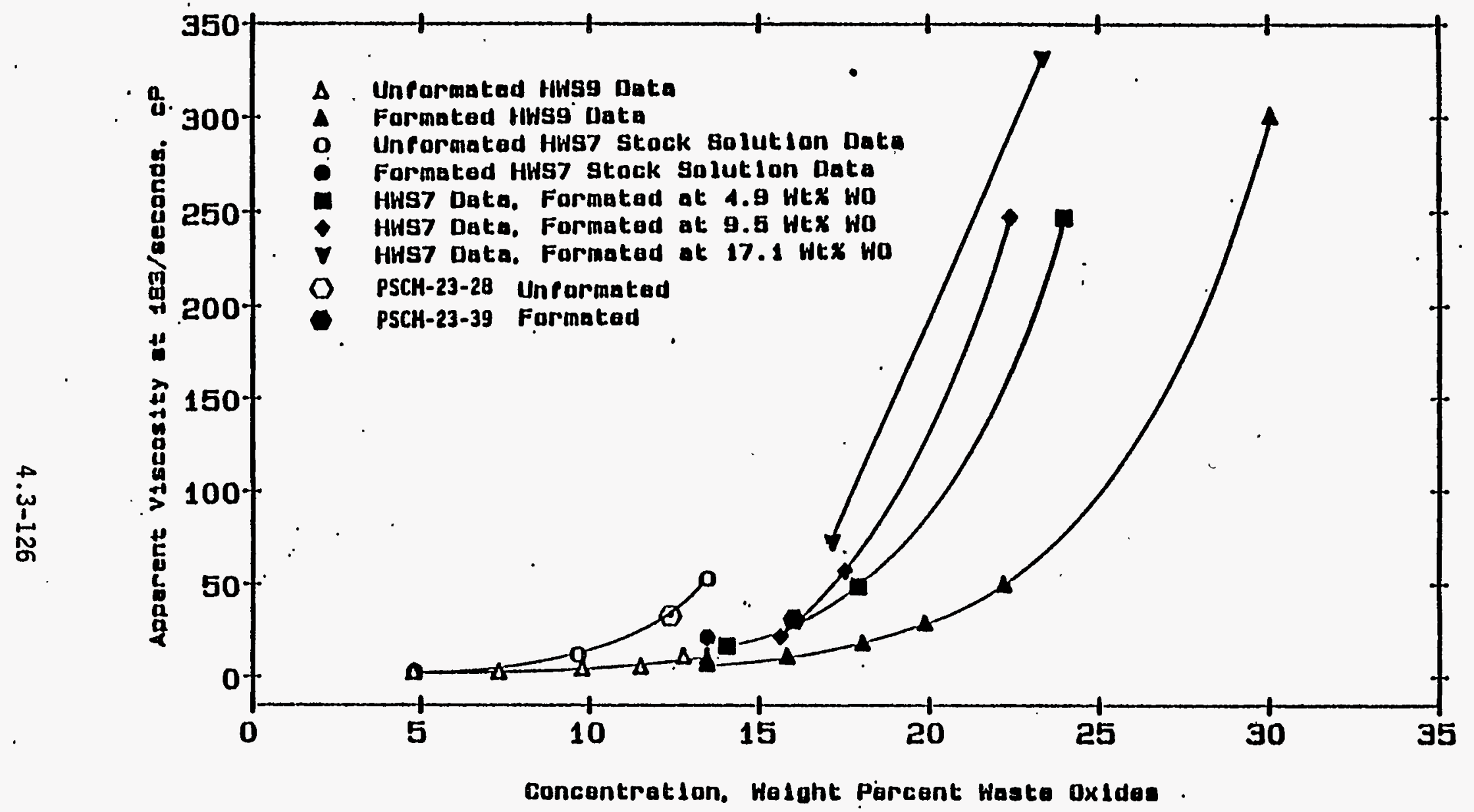

FIGURE 4.3-77. Apparent Viscosity Values, at 183/sec, of HWVP Feed Slurries HWS7 (NCAW 84, high chromium), HWS9 (NCAW 86), and PSCH-23 (NCAH 87).

(G. T. Thornton, HWVP-87-V110203C) 


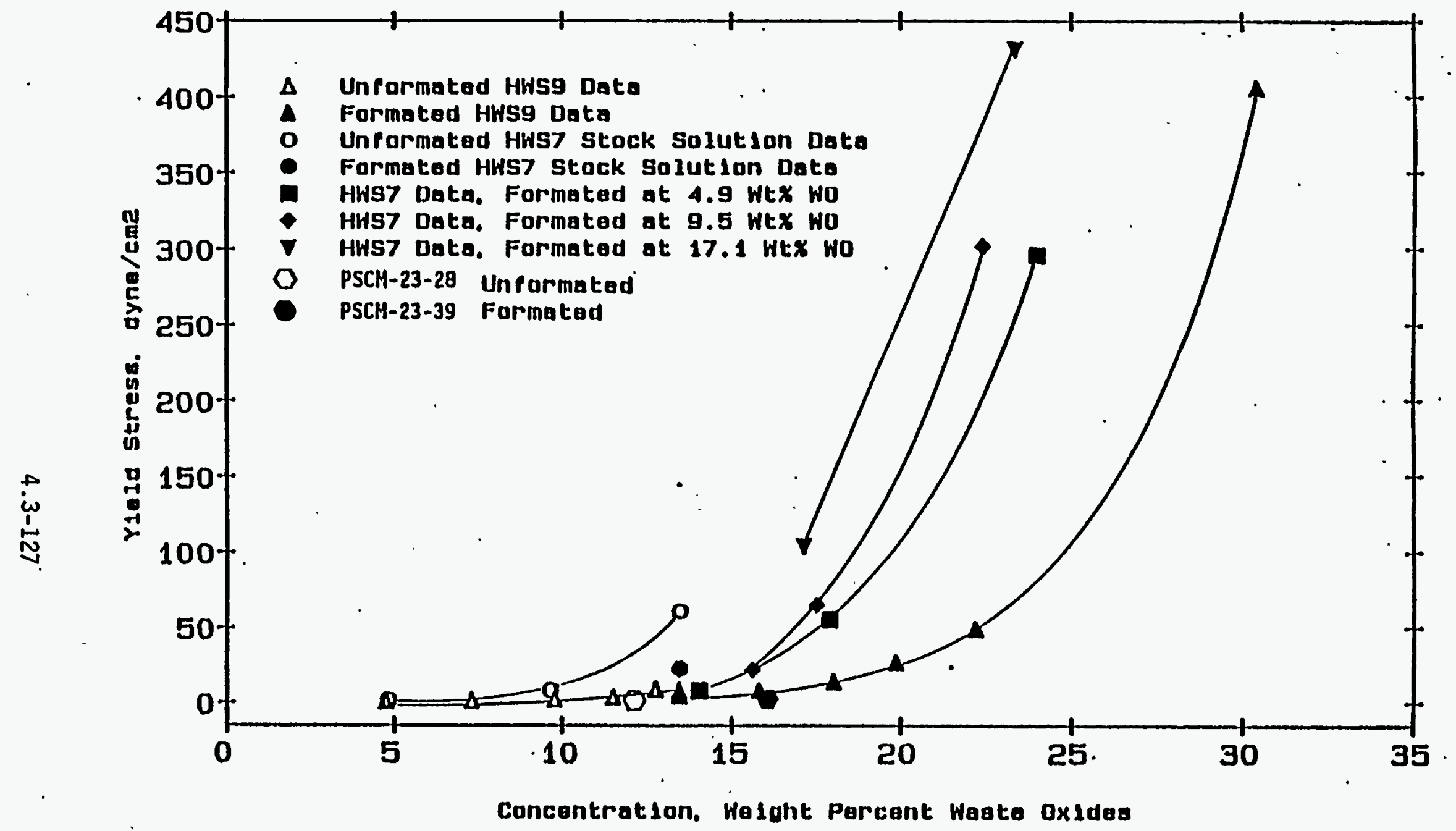

FIGURE 4.3-78. Yield Stress Values of HWVP Slurries HWS7 (NCAW 84, high chromium), HWS9 (NCAW 86), and PSCM-23 (NCAW 87) HWVP-V110203C 


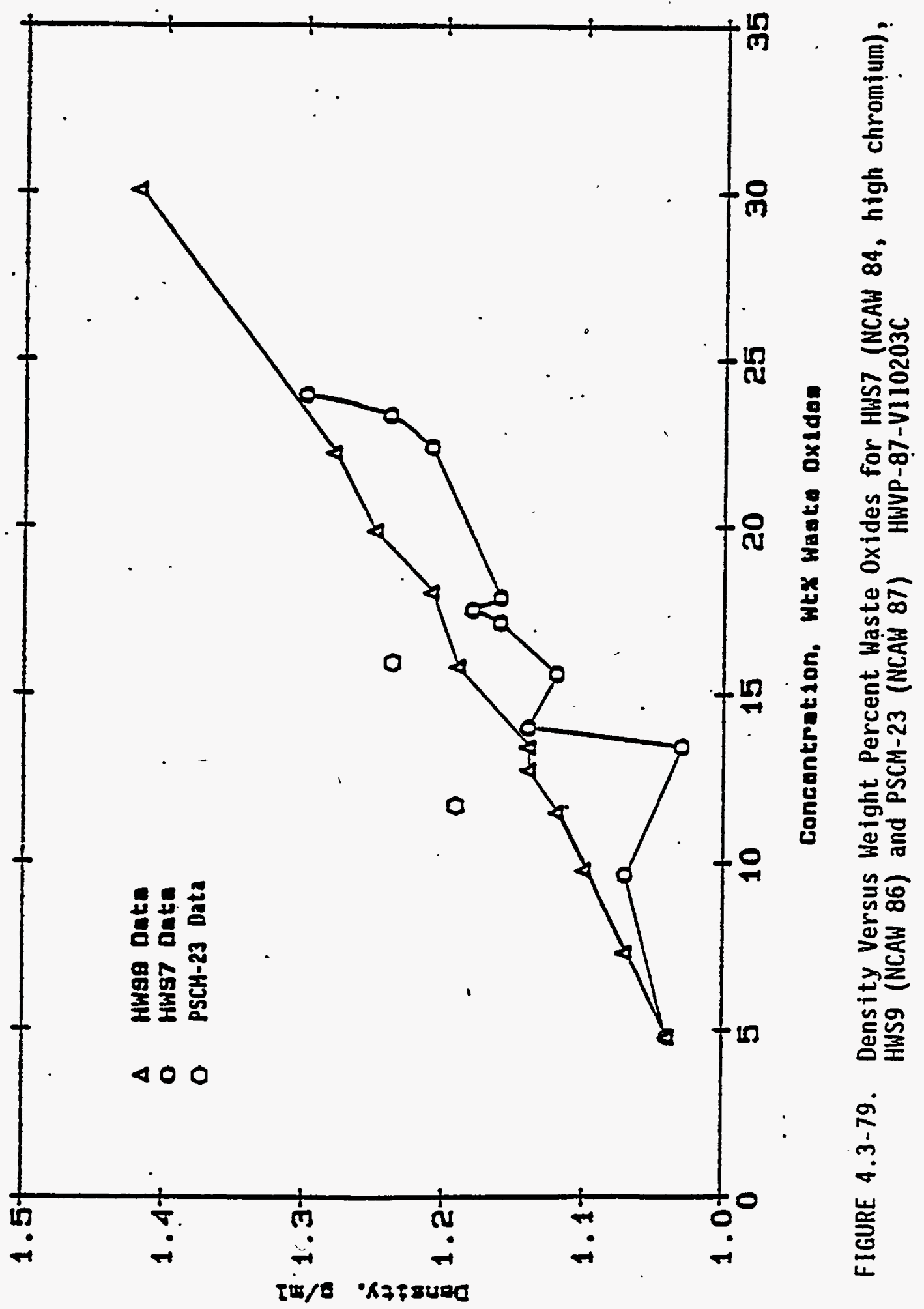




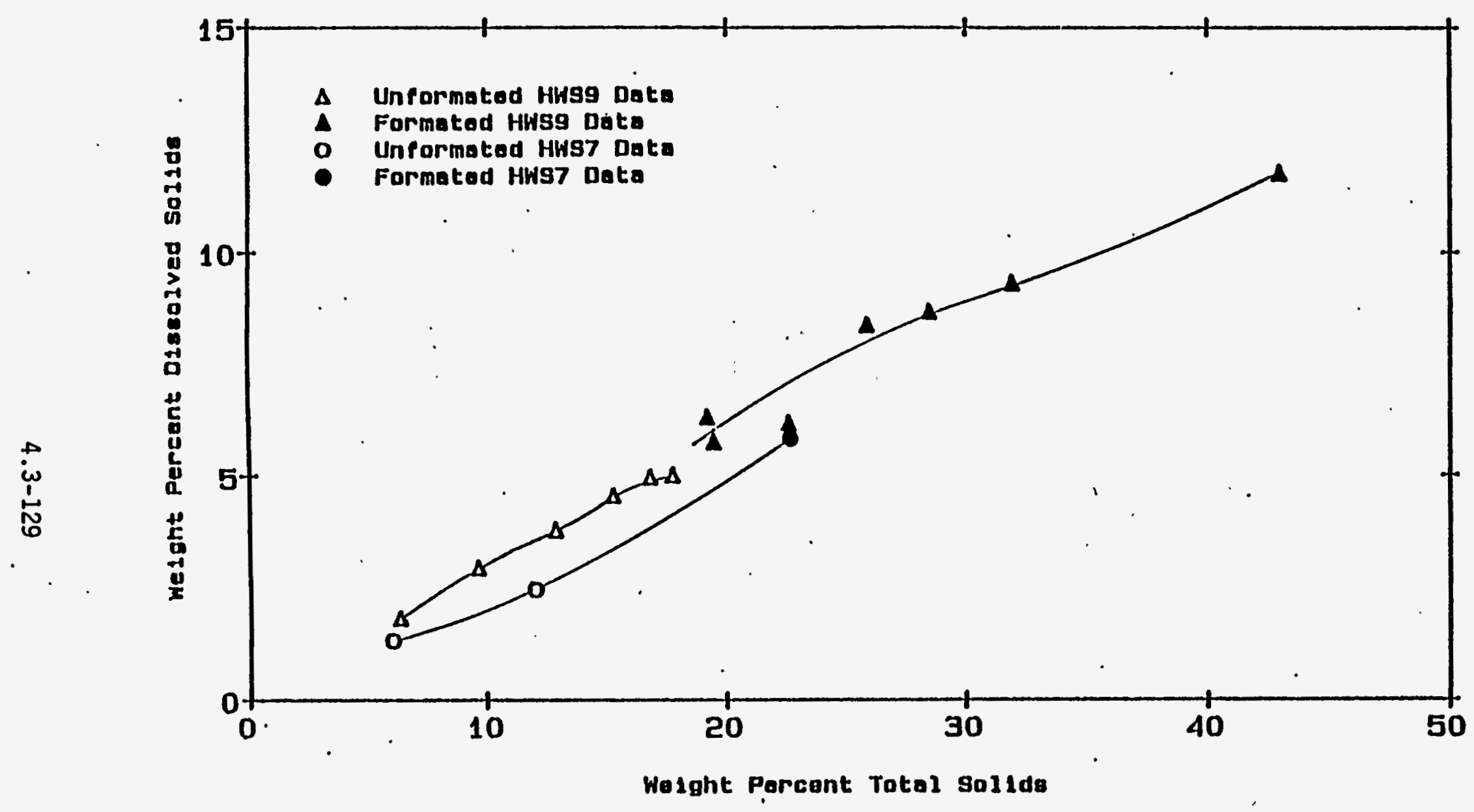

FIGURE 4.3-80. Height Percent Dissolved Solids Fraction Versus Weight Percent Total Solids Fraction for Samples Prepared from Laboratory Simulations HWS7 (NCAH 84, high chromium) and HWS9 (NCAW 86) HWVP-87-V110203C 


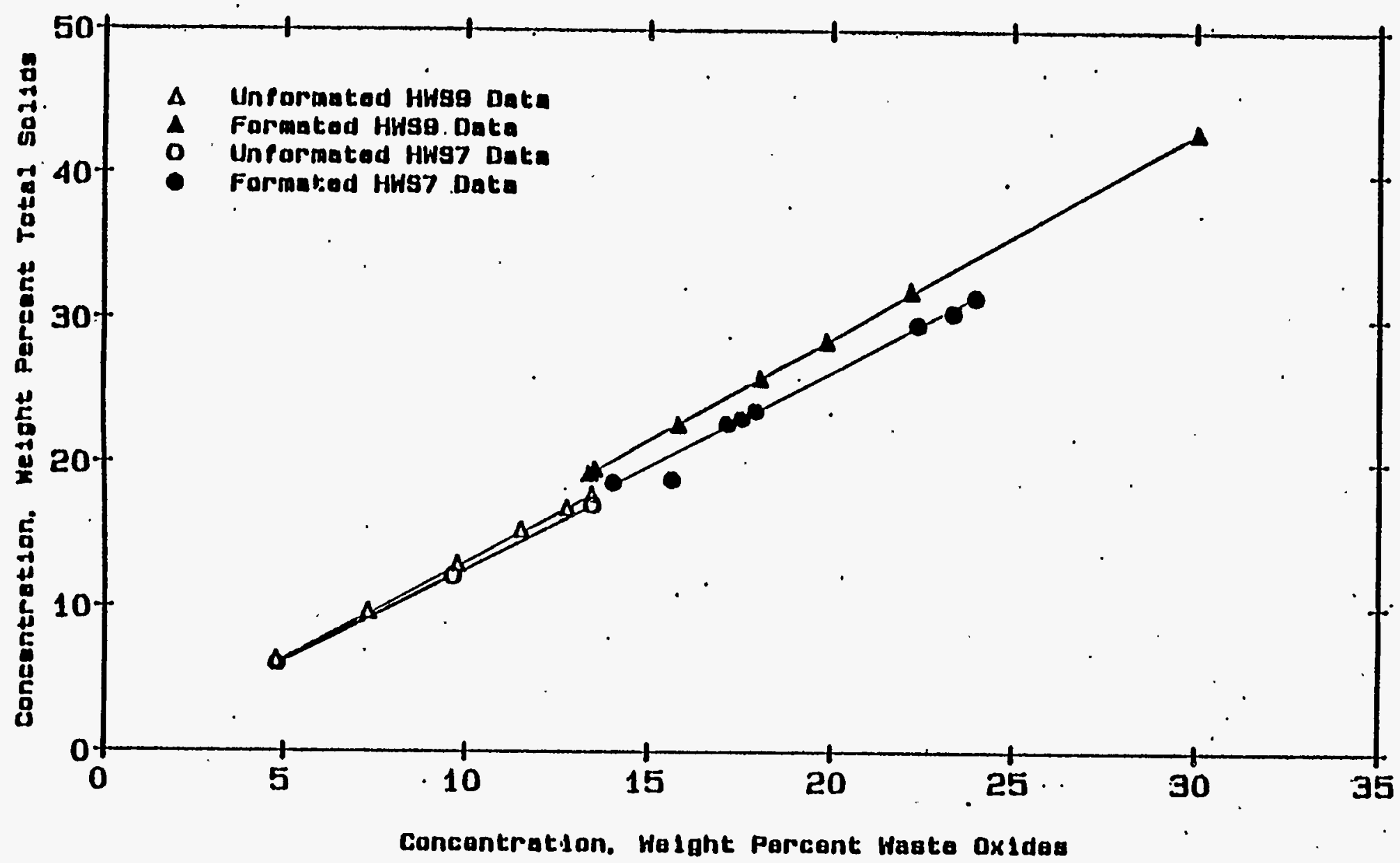

FIGURE 4.3-81. Weight Percent Total Solids Values Versus Height Percent Haste Oxide Values for Samples Prepared from Laboratory Simulations HWS7 (NCAW 84, high chromium) and HWS9 (NCAW 86) HWVP-87-V110203C 


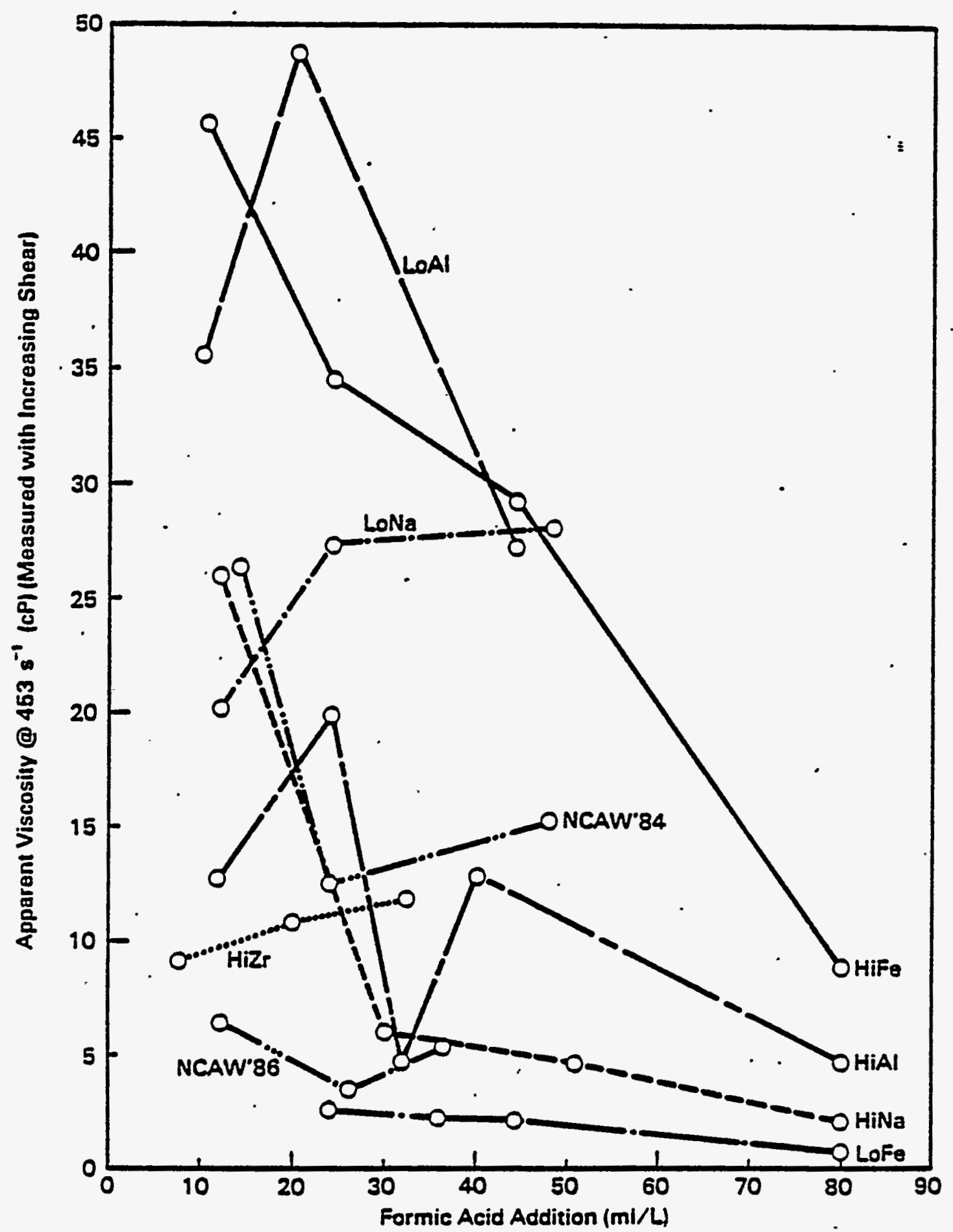

FIGURE 4.3-82. Effect of Formic Acid Addition ( $90 \mathrm{wt} \%$ ) on the Apparent Viscosity of Various NCAW 84 Low-Chromium Feed Compositions and NCAW 86 Feed HWVP-87-VI10203A 


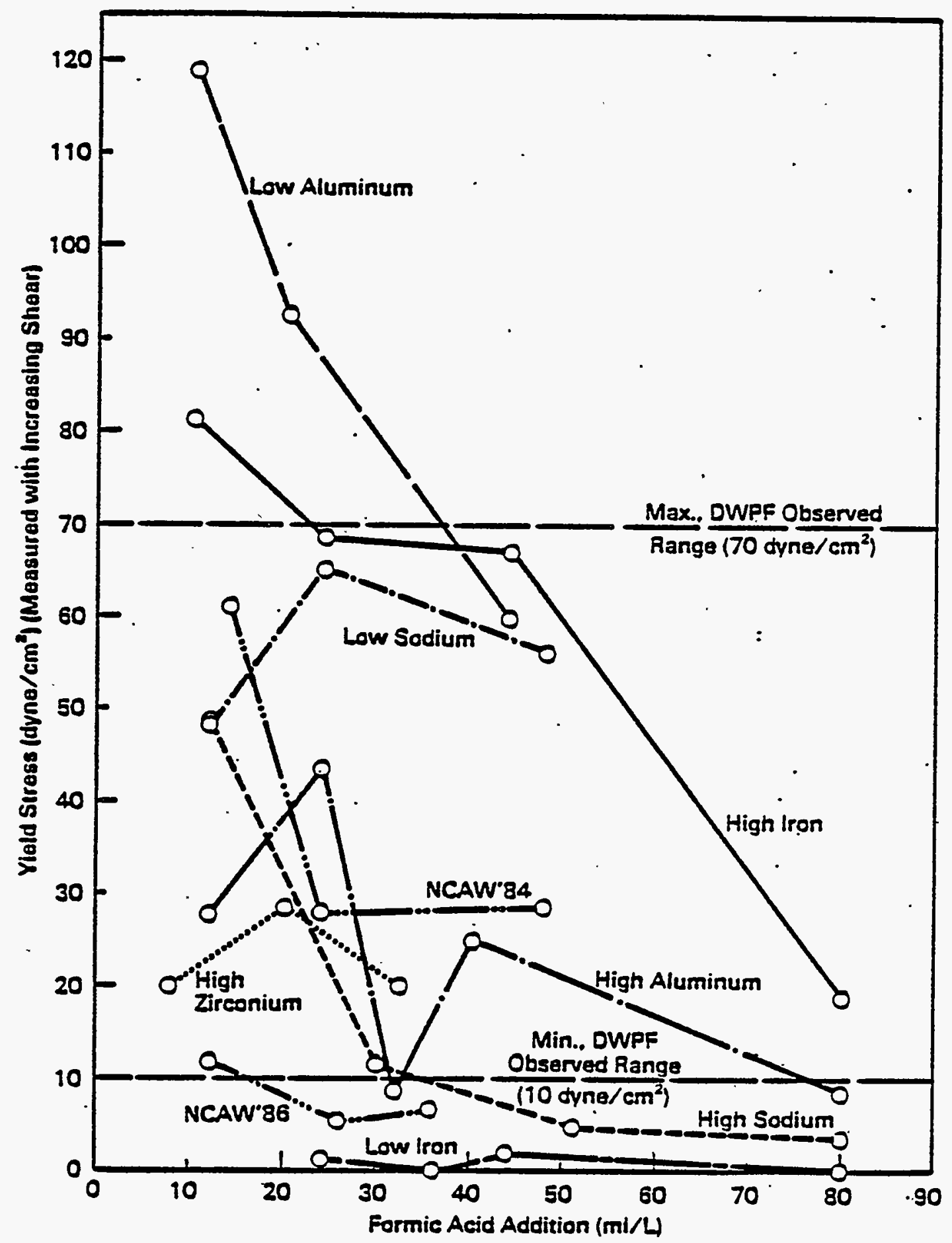

FIGURE 4.3-83. Effect of Formic Acid Addition (90 wt\%) on the Yield Stress of Varjous NCAW 84 Low-Chromium Feed Compositions and NCAH 86 Feed HWVP-87-V110203A 
- Yield stress and apparent viscosity appear to increase with increasing iron concentrations in the simulant HWVP feeds (Table 4.3-36, Figures 4.3-82 and 4.3-83).

In 1987, the HHVP reference feed composition was updated. The primary changes from NCAH 86 to NCAH 87 are as follows:

$\frac{w t \% \text { Waste Oxides }}{\text { NCAW } 86}$

$\begin{array}{lll}\mathrm{SiO}_{2} & 9.0 & 4.0 \\ \mathrm{U}_{3} \mathrm{O}_{8} & 0.7 & 4.7 \\ \mathrm{P}_{2} \mathrm{O}_{5} & 0.02 & 0.4 \\ \mathrm{CdO}^{2} & 0.02 & 3.0\end{array}$

During the PSCM-23 run, NCAW 87 was used as the feed composition. RheoTogical data from this run have been included in Figures 4.3-77, 4.3-78, and 4.3-79. These few data points do not indicate that he rheological properties of NCAW 87 are significantly different from NCAW 86.

- In 1988, the composition of NCAW 87 was updated. The most significant changes are as follows:

$\frac{\text { Wt\% Waste Oxides }}{\text { NCAW } 87}$

$\begin{array}{lll}\mathrm{SO}_{3} & 1.8 & 0.7 \\ \mathrm{~F} & 1.2 & 0.08\end{array}$

No testing has been performed on NCAW 88 , and minimal feed processing development work has been performed on NCAW 87. However, because the compositions do not vary greatly, the properties and characteristics of NCAW 88 are expected to be similar to those of NCAW 87 and NCAW 86.

\section{Feed Makeup Procedures}

The procedures used for making up the HWVP (combining metal hydroxides versus precipitating hydroxides) can effect the slurry rheology. The feed used in the Wiemers study(a) and the feed used for PSCM-23 were prepared by precipitation of nitrate salts with sodium hydroxides. Although the feed compositions were similar (NCAW 86 and NCAW 87), the rheological.properties obtained during the Wiemers study varied significantly from those obtained during PSCM-23 (Tables 4.3-44 and 4.3-46).

Rheological data obtained during PSCM-23 were included on Figures $4.3-77,4.3-78$, and 4.3-79. The other data on those figures are from simulated feeds (NCAW 84, high chromium and NCAW 86) that were prepared by

(a) Wiemers et a1., HWVP-87-V110203G (1987). 
combining. metal hydroxides. From those figures, it cannot be concluded that feed makeup procedure significantiy influences siurry rheology.

4.3.4.2 HWUP Feed Redox Adjustment with Formic Acid and Sugar. The effect of formic acid and sugar addition to HWVP feed to adjust the redox state of the resultant glass has been studied in the laboratory and during melter test runs. The results of these studies and evaluations are presented in the following sections.

\subsection{Laboratory Study of Redox Adjustment with Formic Acid. (a)} The effects of HWVP feed composition and formic acid addition on the resultant glass redox state and characteristics of the melter feed were examined. In addition, the physical and rheological properties of each melter feed sample were also determined. The study determined whether formic acid addition alone is sufficient to achieve an acceptable redox state without adversely affecting the physical and rheological properties of the melter feed.

\subsection{Feed Preparation. Nine waste compositions encompassing} expected HWVP waste feed variations were tested in this study. The compositions of these feeds, and the rationales for selecting these compositions, are discussed in Section 4.3.4.1.1.7. In addition, physical and rheological properties are also discussed in Section 4.3.4.1.1.7.

\subsection{Feed Processing. Selected samples of each waste composi-} tion were processed into melter feeds. Different amounts of formic acid were added to the waste, followed by the addition of glass-forming frit, additional formic acid, and water (if necessary). The resultant melter feeds had a total oxide concentration of $500 \mathrm{~g} \mathrm{TO} / \mathrm{L}$, and an approximate waste oxide coricentration of $25 \mathrm{wt} \%(125 \mathrm{~g}$ WO/L). The melter feeds were then physical7y and rheologically characterized, and the ferrous-to-ferric ratios of the resultant glasses were determined.

Each of the nine waste compositions were evaluated at three to five different levels of formic acid addition. The evaluation of formic acid addition was performed in three stages.

In the first stage of the study, the amount of formic acid added to each waste composition was that required to obtain a pH of 4 . The earlier studies had shown that the addition of formic acid to a $\mathrm{pH}$ of 4 reduced the yield stresses. and apparent viscosities of the NCAW 84 , high chromium feed composition.

In the second stage, the amount of formic acid added to eight of the nine waste compositions was based on a percentage of the calculated stoichiometric amount of formic acid required to convert the reactive hydroxides to

(a) R. K. Farnsworth, The Effect of Feed Composition and Formic Acid Addition on Glass Redox State. HWVP-87-V110203A, Pacific Northwest Laboratory, Richland, Washington (August 1987). 
formates. The amount of formic acid added was $80 \%$ of the "stoichiometric" amount of formic acid required for the following HWVP component reactions: (a)

$$
\begin{aligned}
& \mathrm{Cu}(\mathrm{OH})_{2}+2 \mathrm{HCOOH} \rightarrow \mathrm{Cu}(\mathrm{COOH})_{2}+2 \mathrm{H}_{2} \mathrm{O} \\
& \mathrm{Mg}(\mathrm{OH})_{2}+2 \mathrm{HCOOH} \rightarrow \mathrm{Mg}(\mathrm{COOH})_{2}+2 \mathrm{H}_{2} \mathrm{O} \\
& \mathrm{Mn}(\mathrm{OH})_{2}+2 \mathrm{HCOOH} \rightarrow \mathrm{Mg}(\mathrm{COOH})_{2}+2 \mathrm{H}_{2} \mathrm{O} \\
& \mathrm{NaOH}+\mathrm{HCOOH} \rightarrow \mathrm{NaCOOH}+\mathrm{H}_{2} \mathrm{O} \\
& \mathrm{Ni}(\mathrm{OH})_{2}+2 \mathrm{HCOOH} \rightarrow \mathrm{Ni}(\mathrm{COOH})_{2}+2 \mathrm{H}_{2} \mathrm{O} \\
& \mathrm{Sr}(\mathrm{OH})_{2}+2 \mathrm{HCOOH} \rightarrow \mathrm{Sr}(\mathrm{COOH})_{2}+2 \mathrm{H}_{2} \mathrm{O} \\
& \mathrm{Y}(\mathrm{OH})_{3}+3 \mathrm{HCOOH} \rightarrow \mathrm{Y}(\mathrm{COOH})_{3}+3 \mathrm{H}_{2} \mathrm{O} \\
& \mathrm{RhO}_{2}+2 \mathrm{HCOOH} \rightarrow \mathrm{Rh}+2 \mathrm{CO} 2+2 \mathrm{H}_{2} \mathrm{O}
\end{aligned}
$$

Originally, these were the only components in the HWVP waste simulants that were identified as reacting with formic acid. Further investigation has determined that the rare earth hydroxides may react with formic acid, according to the following reactions:

$$
\begin{aligned}
& \mathrm{La}(\mathrm{OH})_{3}+3 \mathrm{HCOOH} \rightarrow \mathrm{La}(\mathrm{COOH})_{3}+3 \mathrm{H}_{2} \mathrm{O} \\
& \mathrm{Nd}(\mathrm{OH})_{3}+3 \mathrm{HCOOH} \rightarrow \mathrm{Nd}(\mathrm{COOH})_{3}+3 \mathrm{H}_{2} \mathrm{O} \\
& \mathrm{Ce}(\mathrm{OH})_{3}+3 \mathrm{HCOOH} \rightarrow \mathrm{Ce}(\mathrm{COOH})_{3}+3 \mathrm{H}_{2} \mathrm{O} \\
& \mathrm{Pr}(\mathrm{OH})_{3}+3 \mathrm{HCOOH} \rightarrow \mathrm{Pr}(\mathrm{COOH})_{3}+3 \mathrm{H}_{2} \mathrm{O} \\
& \mathrm{Sm}(\mathrm{OH})_{3}+3 \mathrm{HCOOH} \rightarrow \mathrm{Sm}(\mathrm{COOH})_{3}+3 \mathrm{H}_{2} \mathrm{O}
\end{aligned}
$$

The increased formic acid requirements for the rare earth hydroxide reactions reduced the amount of formic acid added in stage two to approximately $60 \%$ of the actual stoichiometric level.

The amount of formic acid added in Stage 2 to the low-Na composition was not based on the $60 \%$. level of stoichiometric addition of the other eight waste compositions. This change was made because the stoichiometric amount of formic acid added to the low-Na composition in Stage 1 was only $43 \%$, and the resultant ferrous-to-ferric ratio in the glass was $0.008(0.005$ is the lower limit). Therefore, the amount of formic acid added to the second stage low-Na sample was doubled, to obtain a low-Na glass with a much higher ferrous-to-ferric ratio.

In the third stage, one to three levels of formic acid addition were selected for each waste composition. The purpose of this stage was to obtain complete redox curves for the amount of formic acid added versus the resultant ferrous-to-ferric ratio of each composition.

The formic acid was added to each sample in small (0.5 to $1.0 \mathrm{~mL}$ ) increments while the waste was maintained at $195^{\circ} \mathrm{F}$ to $205^{\circ} \mathrm{F}\left(90^{\circ} \mathrm{C}\right.$ to $\left.95^{\circ} \mathrm{C}\right)$. After the formic acid had been added, the waste was refluxed for at least $2 \mathrm{~h}$ to allow the formic acid to completely react with the components in the waste. In particular, the reaction of manganese hydroxide with formic acid is very

(a) E.I. du Pont de Nemours \& Co., Basic Data Report - DWPF Sludge Plant, SRP-200-S Area. DPSP 80-133, Savannah River Laboratory, Aiken South Carolina (April 1985). 
s7ow. Experience at SRP has suggested a $4-h$ reflux period is required for $\mathrm{Mn}$ conversion. However, since $M_{n}$ is only a minor component in the HWVP simulants and does not exist in a +4 valence state, a $2-h$ reflux period was. used.

After reflux boiling, glass frit was added. An additional amount of formic acid, equivalent to 1 wt\% of the frit, was also added to the melter feed. This level simulates the proposed HWVP and DHPF processes. (a) In the proposed process, the 1 wt\% formic acid added to the frit prevents frit coagulation should it settle.

After processing, each melter feed sample was melted in a crucible and the redox state of each glass sample was determined.

4.3.4.2.1.3 Redox State Evaluations. Figure 4.3-84 shows the ferrousto-ferric ratios of all nine feed compositions, as a function of the volume of 90. wt\% formic acid added to each liter of feed. As shown in the figure' composition greatiy influences the Tevel of formic acid required to achieve a desired redox state. The acceptable redox state limits established for HWVP glass are also shown. An acceptable range of formic acid addition for each feed composition can be established by interpolating and extrapolating each curve in Figure 4.3-84, until they intersect the acceptable redox state boundaries of 0.005 and 0.3 . This is shown in Table 4.3-49. Based on these results, a range of 90 wt\% formic acid addition between 25 and $30 \mathrm{~mL} / \mathrm{L}$ of waste was found to effectively adjust the redox potential of all nine feed compositions. Without knowing the feed composition explicitly, this range of formic acid addition should satisfactority adjust the HWVP (NCAH 84, low chromium and NCAN 86) feed without the use of sugar.

Figure 4.3-84 also shows the influence of the major component concentrations on the ferrous-to-ferric ratio of the HWVP glass. The ferrous-toferric ratio of each feed composition was compared with the ratio for the NCAH 84 composition. Based on this comparison. The following conclusions have been made.

- Increasing the feed's Ir concentration increases the redox state of the glass if equivalent amounts of formic acid have been added (see high-Zr versus NCAH low-Cr 84 curves).

- Increasing the feed's Na concentration increases the redox state of the glass if equivalent amounts of formic acid have been added (see high-Na and Tow-Na versus NCAW low-C̣r 84 curves).

- Decreasing the feed's Al concentration increases the redox state of the glass if equivalent amounts of formic acid addition have. been added (see high-AT and low-AT versus NCAW $10 w-C r 84$ curves).

(a) E.I. du Pont de Nemours \& Co., Basic Data Report - DWPF Sludge Plant, SRP-200-S Area. DPSP 80-133, Savannah River Laboratory, Aiken, South Carotina (April 1985). 


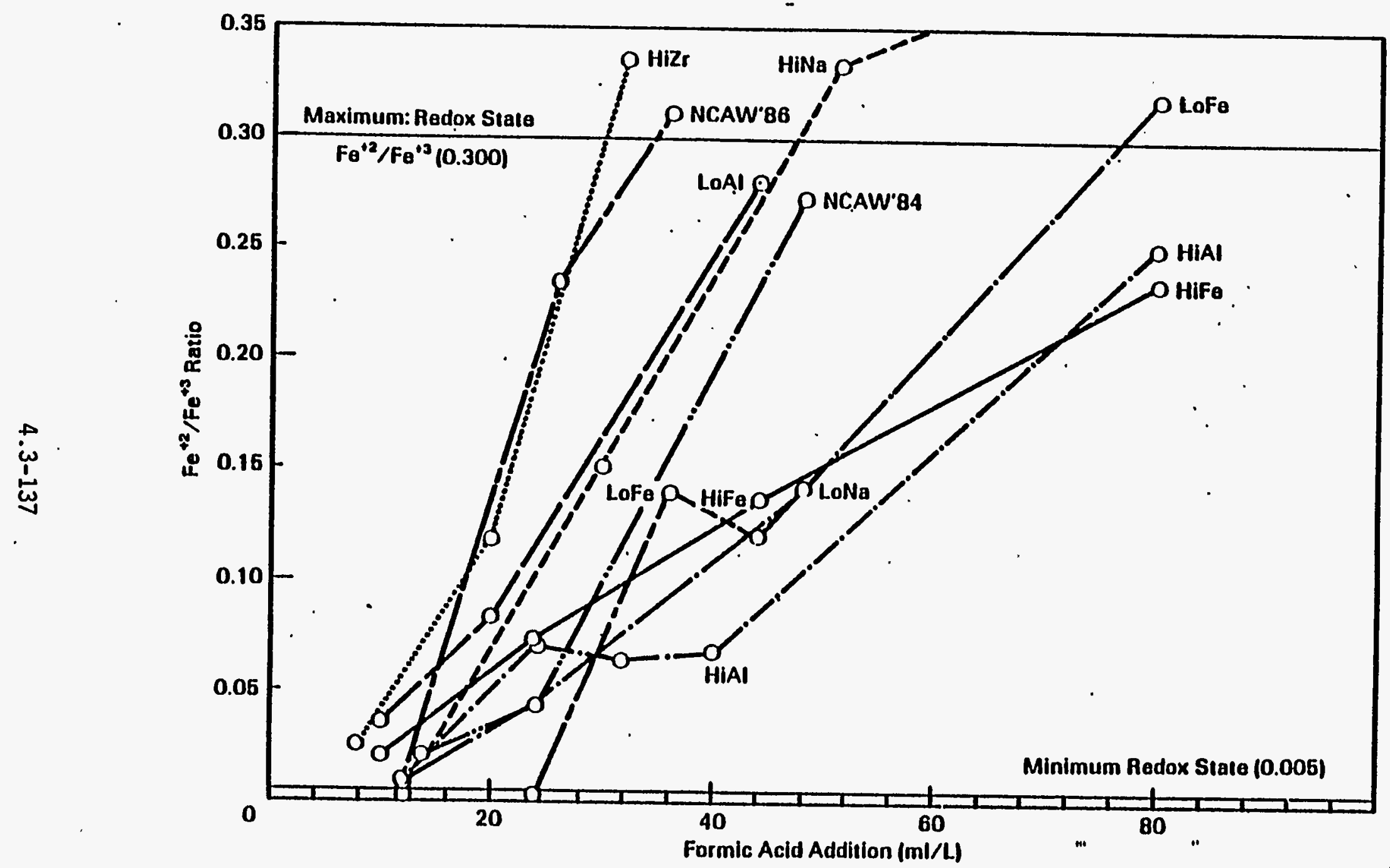

FIGURE 4.3-84. Effect of Formic Acid Addition ( $90 \mathrm{wt} \%$ ). on the Redox state of Various Feed Compositions (NCAW 86 and NCAW 84, low chromium) HWVP-87-V110203A 
TABLE 4.3-49. Range of Formic Acid Additions For Acceptable Adjustment of the Redox States of Various Feeds (R. K. Farnsworth, HWVP-87-V110203A, 1987)

\begin{tabular}{|l|c|}
\hline Feed Composition & $\begin{array}{c}\text { Approximate Formic Acid } \\
\text { Addition (mL/L) }\end{array}$ \\
\hline NCAH 84 composition(a) & 8 to 50 \\
NCAH 86 composition & 12 to 34 \\
Low-Fe composition'a) & 25 to 76 \\
High-Fe composition's) & 6 to $>80$ \\
Low-A7 composition(a). & 4 to 46 \\
High-Al composition(a) & 12 to $>80$ \\
Low-Na composition(a) & 12 to $>50$ \\
High-Na composition(a) & 13 to 47 \\
High-Zr.composition(a) & 5 to 30 \\
Alt Compositions(a) & 25 to 30 \\
\hline
\end{tabular}

(a) Composition is based upon NCAW 84--7ow-chromium.

- Changing the Fe concentration in the feed results in a decrease in the redox state of the glass. Reasons for this change are not readily apparent (see high-Fe and low-Fe versus NCAW 84 low-Cr curves).

A definite relationship is the effect of formic acid stoichiometry on the resultant $\mathrm{pH}$ of the feed. This effect was determined by measuring the $\mathrm{pH}$ of each feed at numerous points during formic acid addition. The results were evaluated by plotting each feed as a function of its formic acid concentration. The results are shown in Figures 4.3-85 through 4.3-93. The formic acid concentration necessary to achieve a $100 \%$ stoichiometric formic acid reaction is also plotted on each figure.

On some of the figures, there exists a flat profile as formic acid is initially added to the waste. The initial flatness is believed to be due to a buffering effect of the formic acid reaction. The size of the buffer may be caused by the amount of free hydroxide ion in the waste, and the resultant acid/base neutralization reaction that initially occurs between the formic acid and the free hydroxide ion. This is supported by examining the highand low-Na curves (Figures 4.3-91 and 4.3-92). $\mathrm{NaOH}$ is the primary source of free hydroxide in the HWVP feed. The results show that the low-Na composition, with its low level of free hydroxide ion, has essentialiy no buffer (Figure 4.3-92). However, the high-Na composition with its high concentration of free hydroxide ion, has an extremely large buffer.

Eventually the $\mathrm{pH}$ curve begins a steep decent with increased formic acid addition. This is observed in all of the figures: It is at this point that the formic acid reaction is thought to be occurring. The steep decent continues until a level near the $100 \%$ stochiometric level is reached. At this 


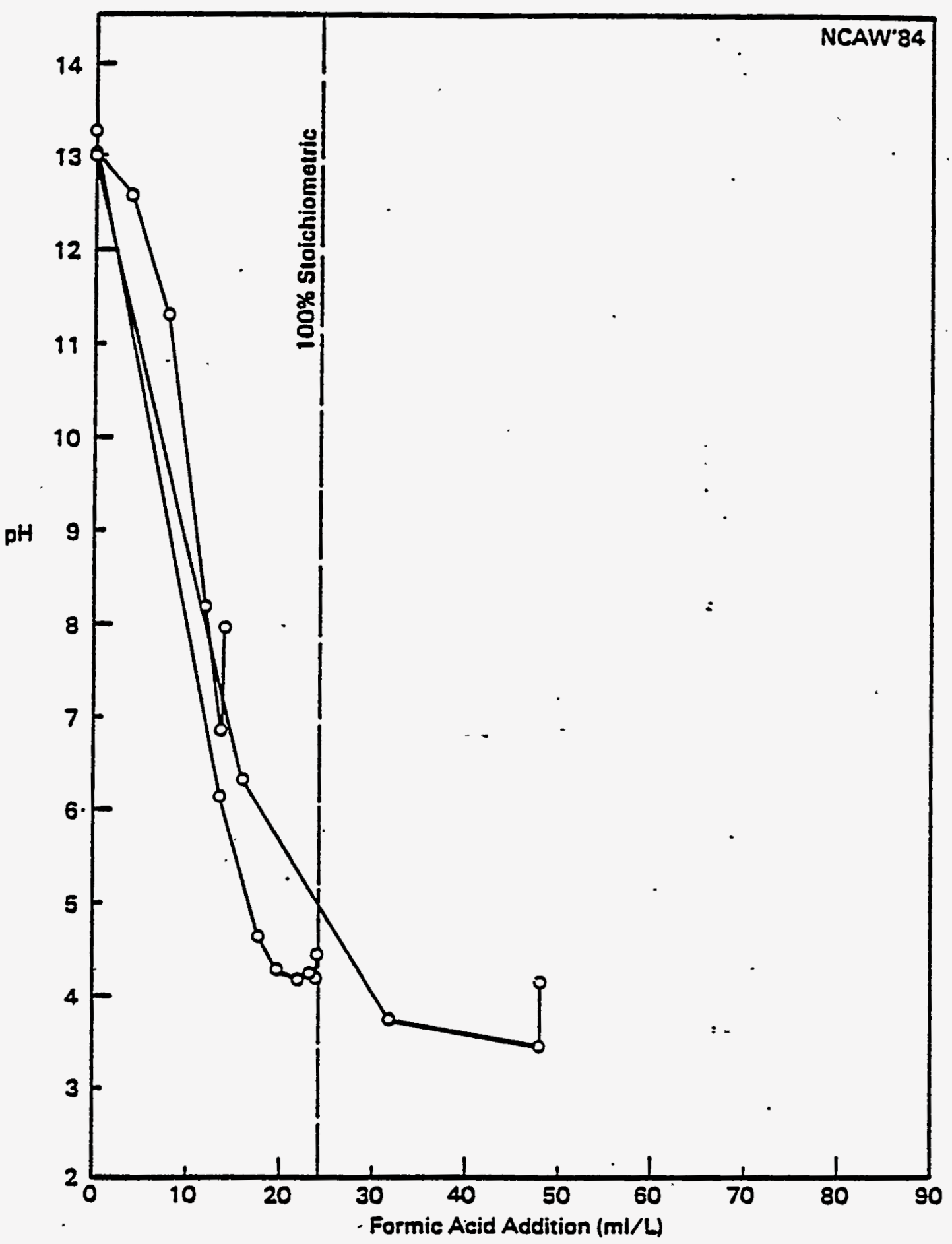

FIGURE 4.3-85. Effect of Formic Acid Addition on pH of NCAW 84, Low Chromium HWVP-87-V110203A 


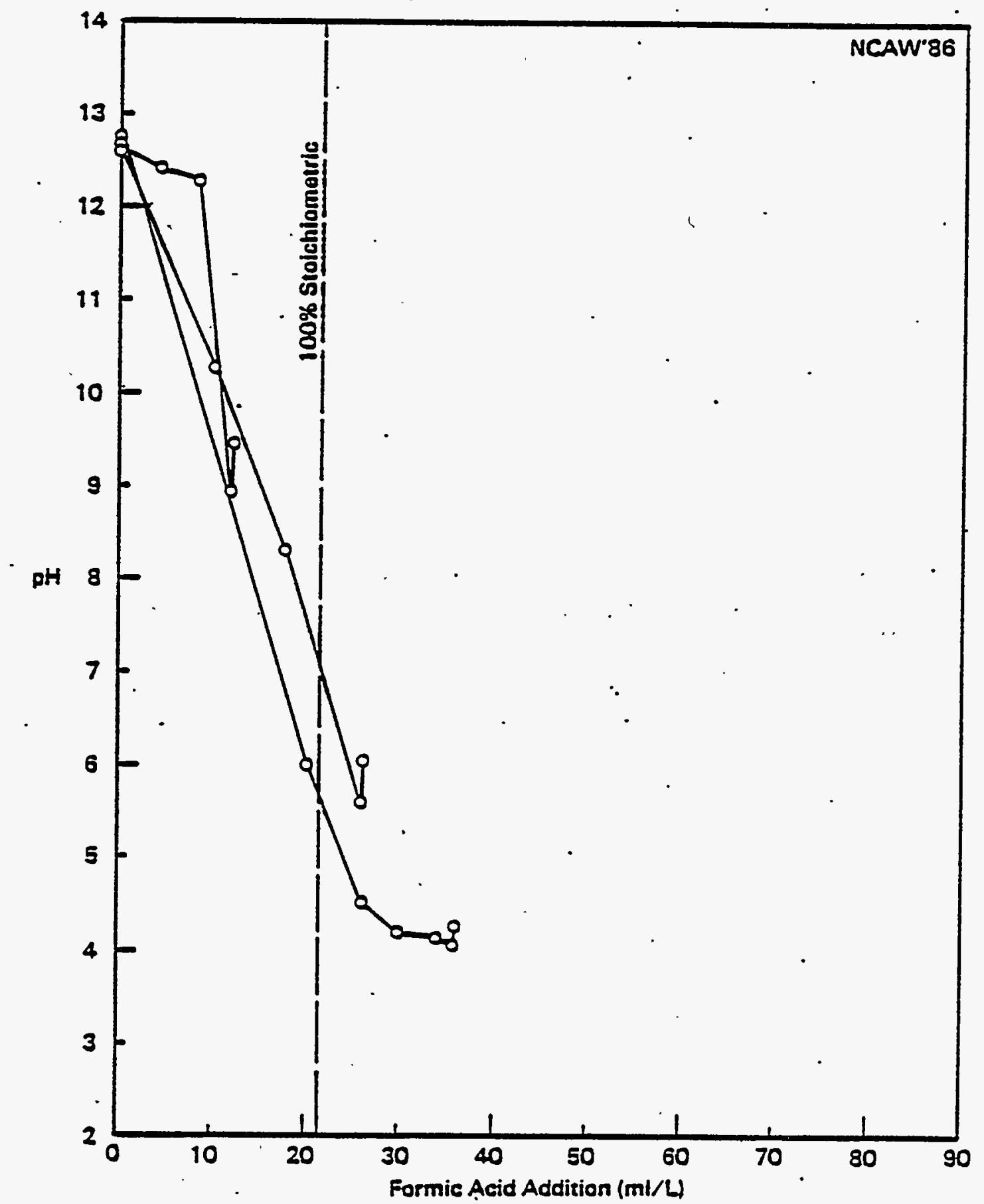

FIGURE 4.3-86. Effect of Formic Acid Addition on the pH of NCAW 86 HWVP-87-110203A 


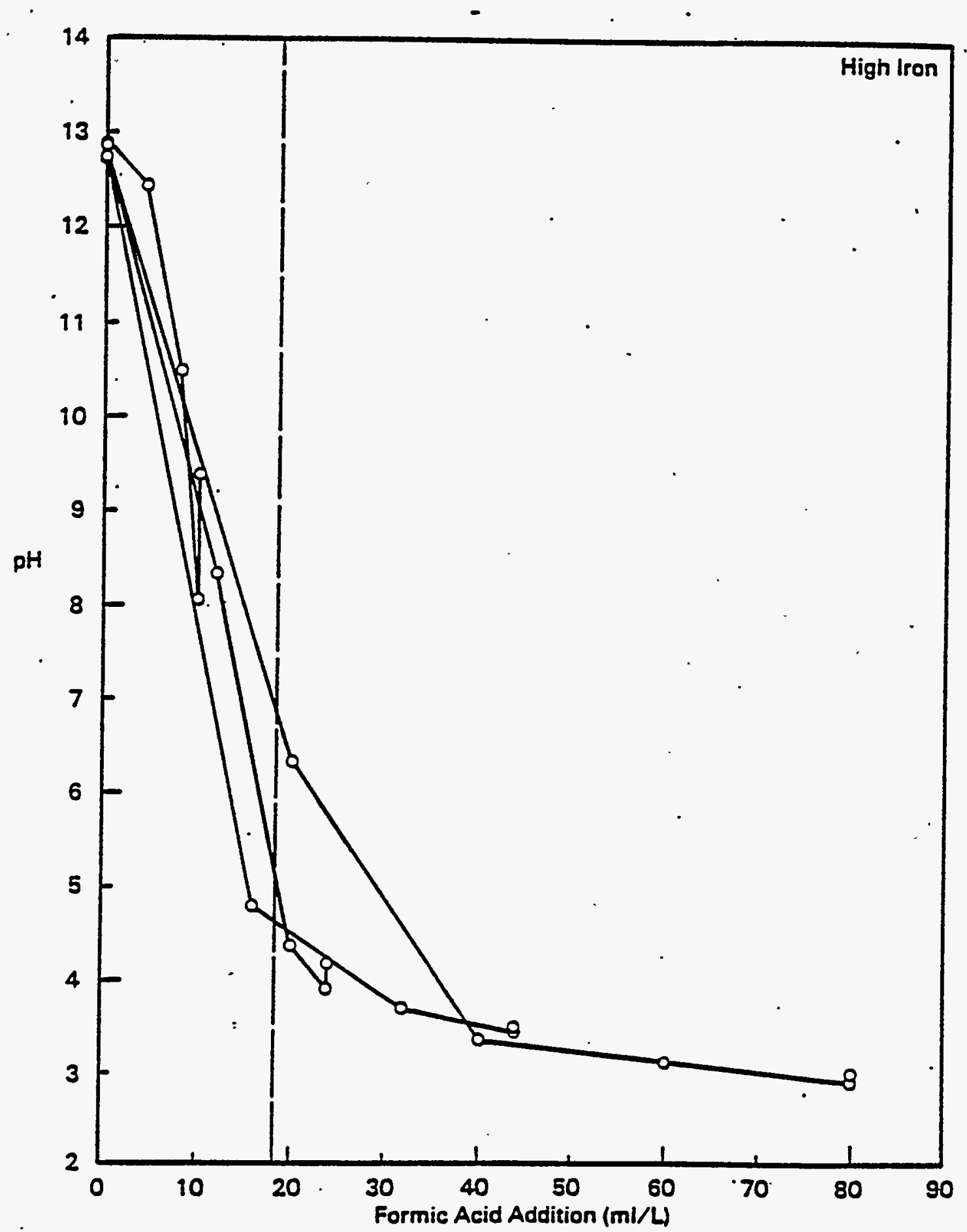

FIGURE 4.3-87. Effect of Formic Acid Addition on the $\mathrm{pH}$ of the High Iron Composition (R. K. Farnsworth, HWVP-87-110203A, PNL, 1987) 


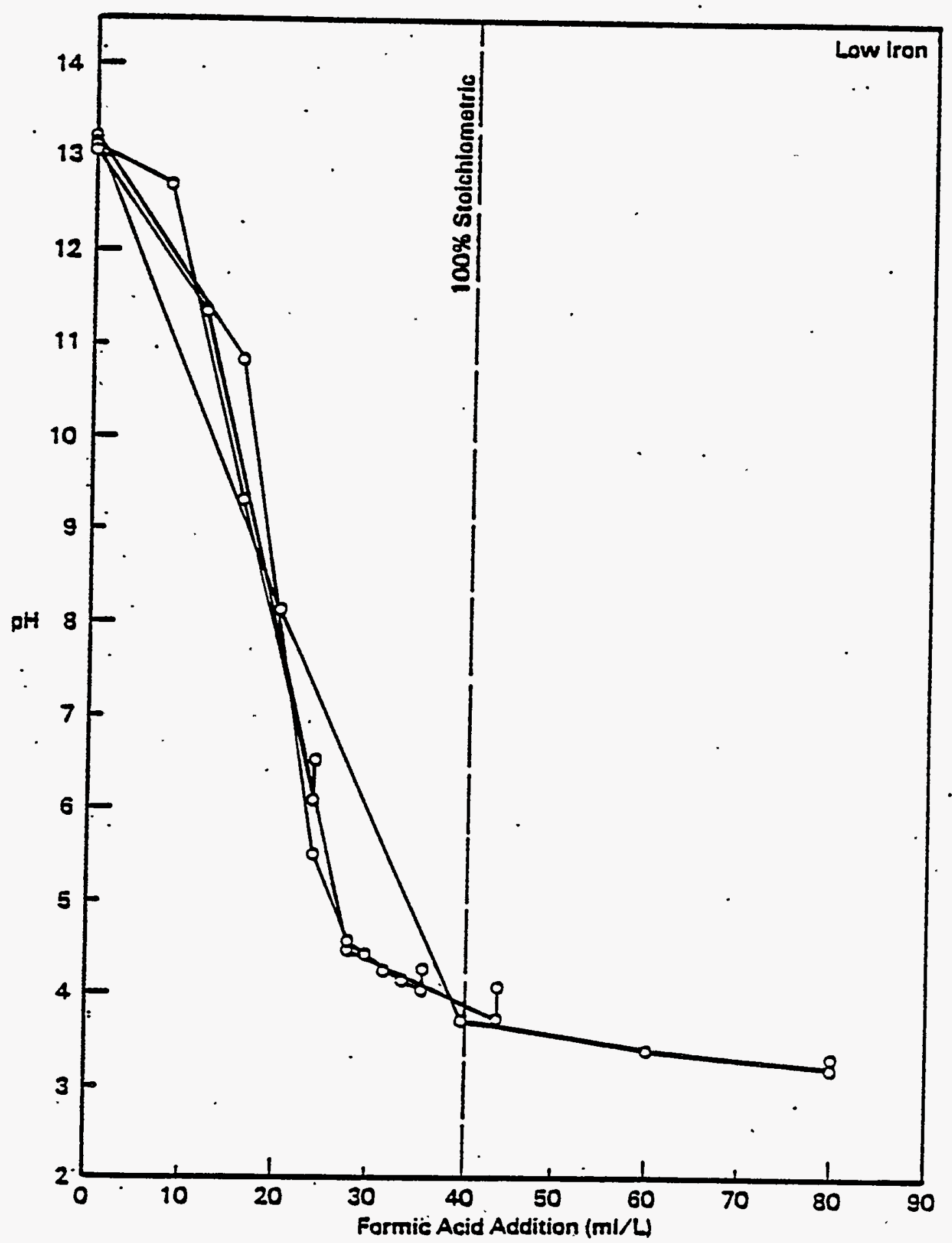

FIGURE 4.3-88. Effect of Formic Acid Addition on the $\mathrm{pH}$ of the Low-Fe Composition (R. K. Farnsworth, HWVP-87-V110203A, PNL, 


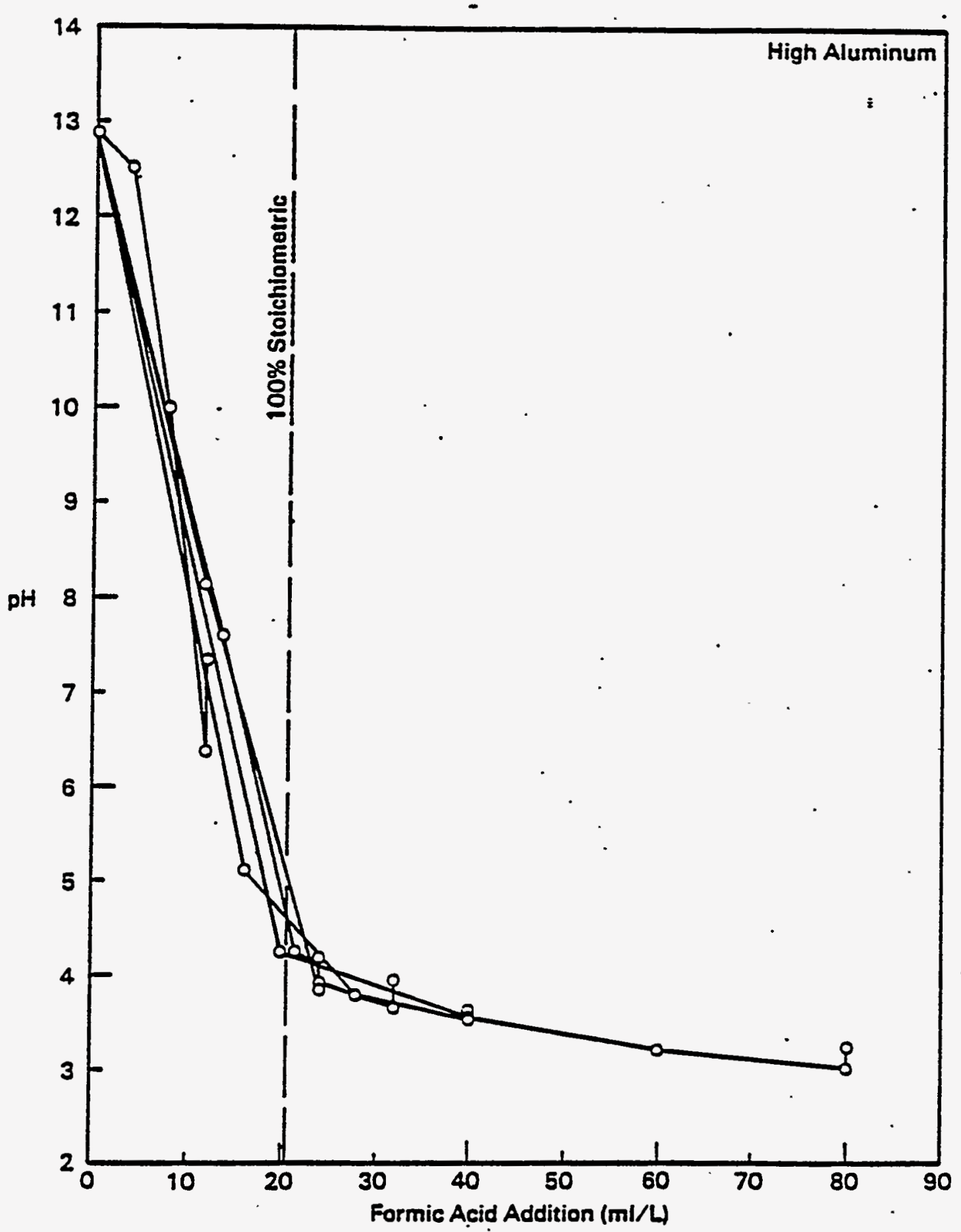

FIGURE 4.3-89. Effect of Formic Acid Addition on the $\mathrm{pH}$ of the High Aluminum Composition (R. K. Farnsworth, HWVP-87-VI10203A PNL, 1987) 


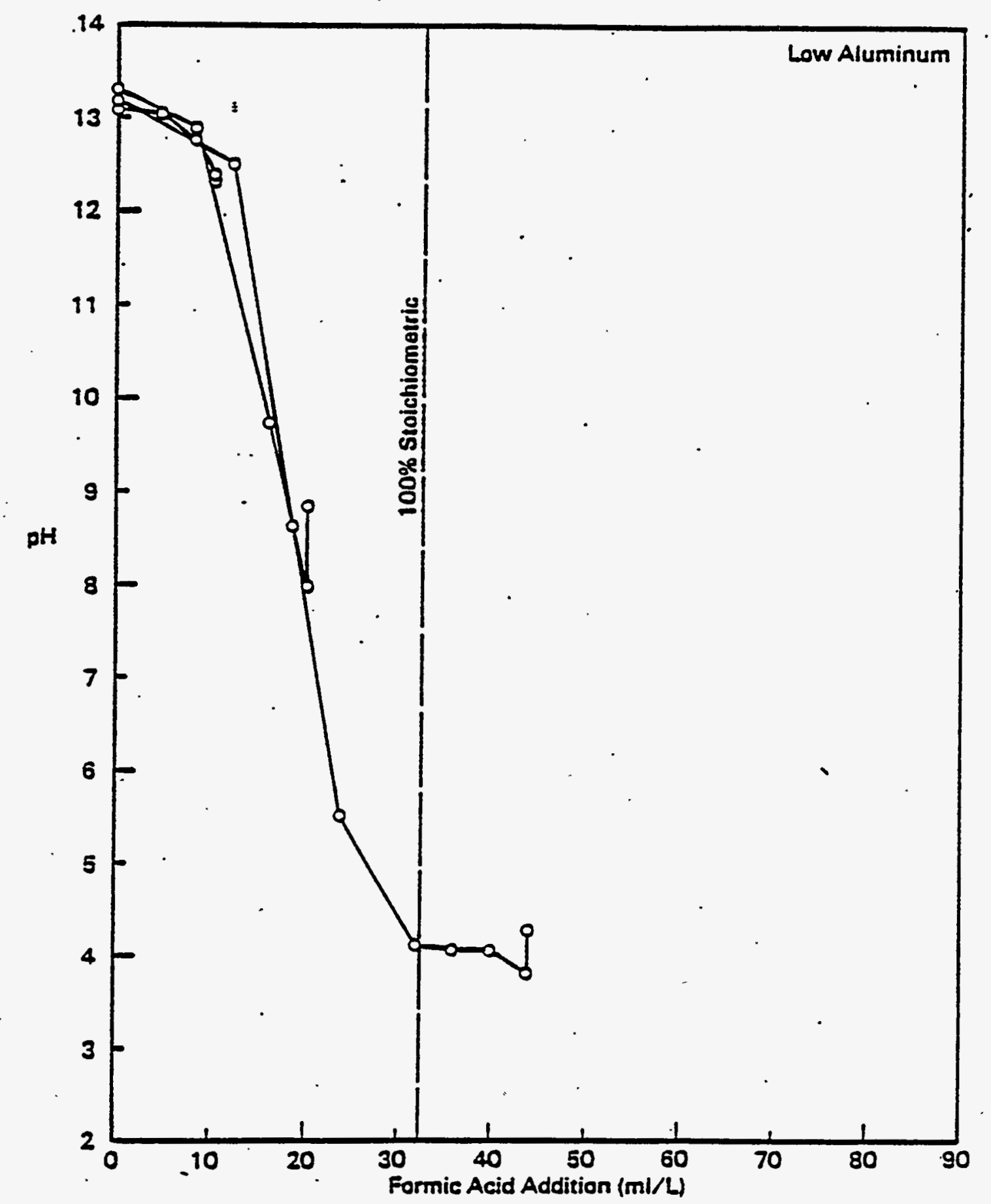

FIGURE 4.3-90. Effect of Formic Acid Addition on the $\mathrm{pH}$ of the Low Aluminum Composition (R. K. Farnsworth, HWVP-87-V110203A; PNL, 1987.) 


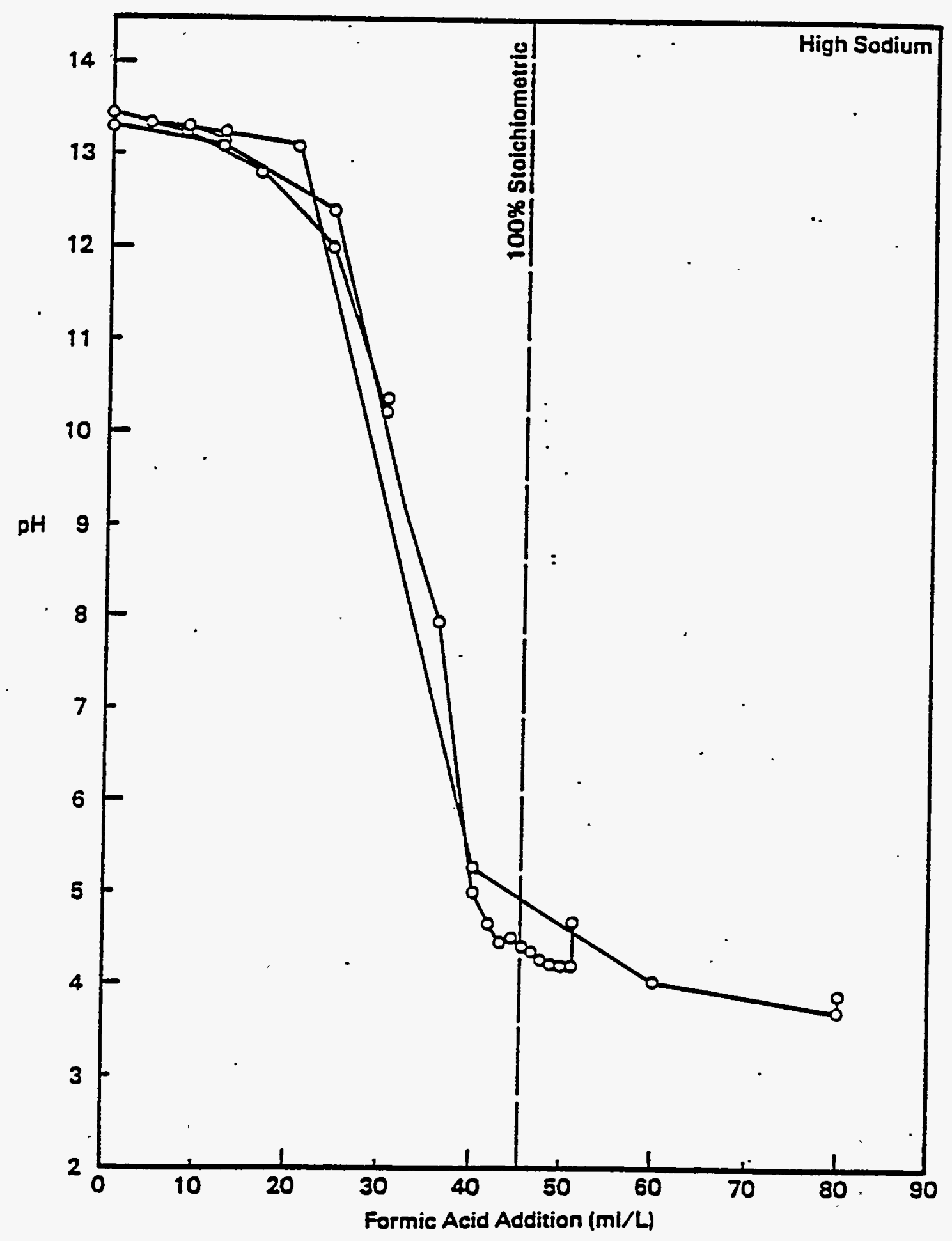

FIGURE 4.3-91. Effect of Formic Acid Addition on the $\mathrm{pH}$ of the High Sodium Composition (R. K. Farnsworth, HWVP-87-V110203A, PNL, 1987) 


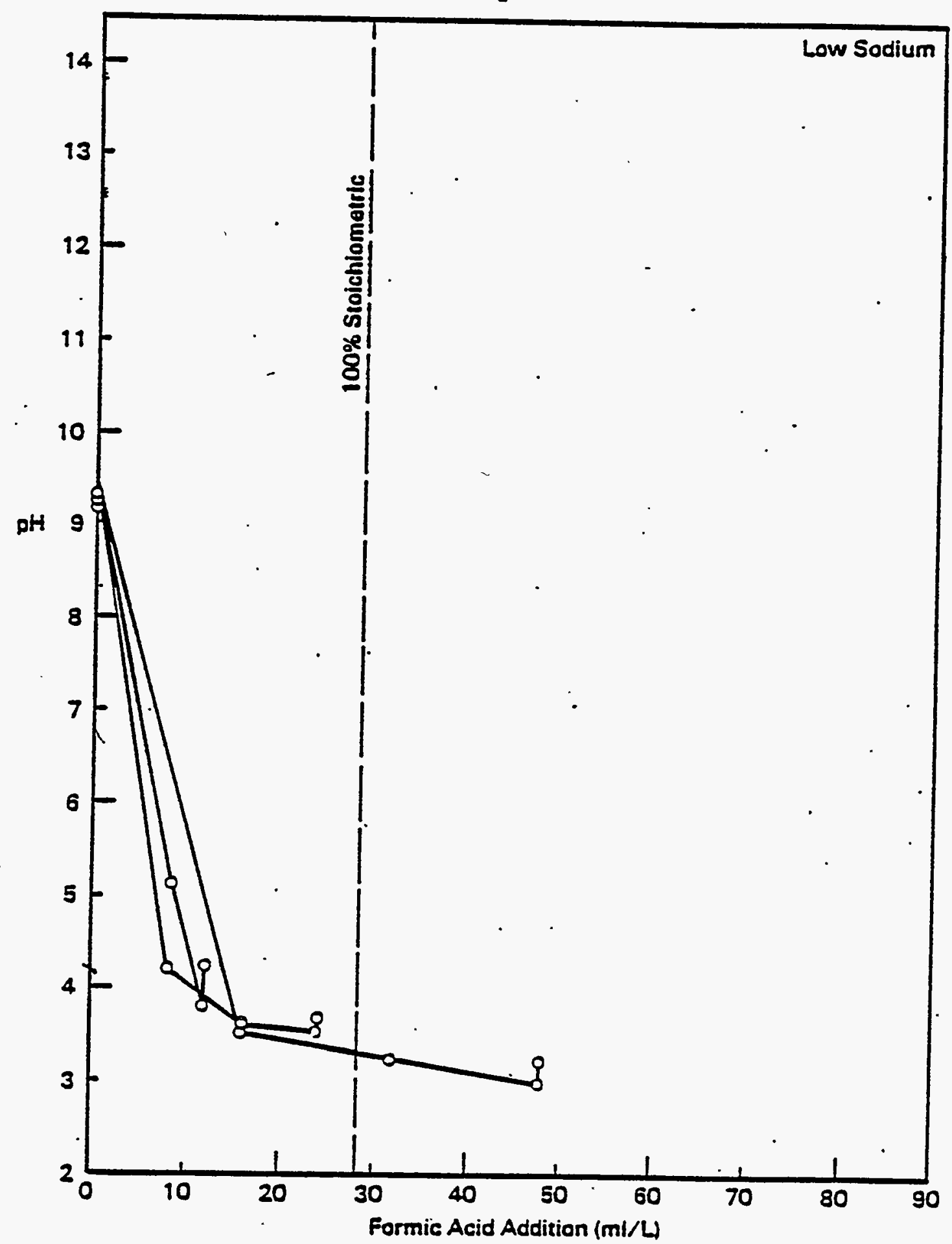

FIGURE 4.3-92. Effect of Formic Acid Addition on the $\mathrm{pH}$ of the Low Sodium Composition (R. K. Farnsworth, HWVP-87-V110203A, PNL, 1987) 


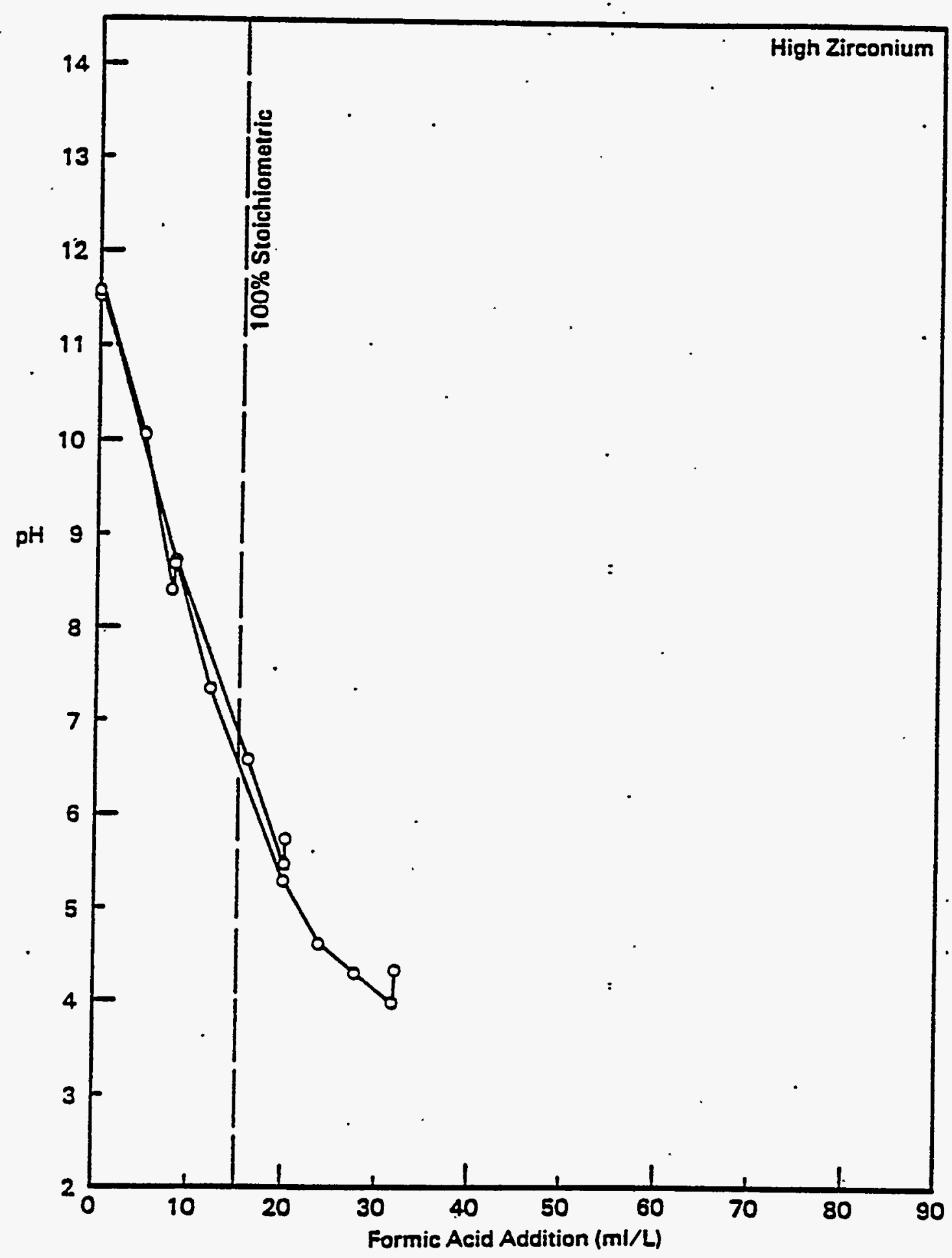

FIGURE 4.3-93. Effect of Formic Acid Addition on the $\mathrm{pH}$ of the High Zirconium Composition (R. K. Farnsworth, HWVP-87-V110203A, PNL, 1987) 
point, the reaction is essentially complete, and the pH curve flattens out again. This trend was observed in all but the high-Zr composition. The result suggests an influence of formic acid stoichiometry on $\mathrm{pH}$. Monitoring the $\mathrm{pH}$ may be a good method of monitoring the progress of the formic acid reaction in the feed preparation system and controlling its rate of addition.

The study was performed while keeping the total oxide concentration of each melter feed between 475 and $525 \mathrm{~g} \mathrm{TO} / \mathrm{L}$. The concentration of total oxides in the feed ( $\mathrm{g}$ TO/L) directly influences all of the other physical properties measured, except pH. As a result, the density, wt\% total solids, wt\% total oxides, and total oxide concentration were relatively constant for all of the melter feed samples, and were not included in the listing of sample properties shown in. Tabie 4.3-36. The physical property ranges encountered by the 32 melter feeds are shown in Table 4.3-50.

TABLE 4.3-50. Physical Property Ranges Encountered by the 32 Melter Feeds HWVP-87-V110203A

\begin{tabular}{|l|c|}
\hline \multicolumn{1}{|c|}{ Physical Property } & Property Range \\
\hline Density & $1.30-1.36$ \\
wt\% total solids & $39: 6-42.7$ \\
wt\% total oxides & $36.5-39.6$ \\
Total oxide concentration $(\mathrm{g} / \mathrm{TO} / \mathrm{L})$ & $480-525$ \\
\hline
\end{tabular}


4.3.4.2.2 Redox Results from HWVP Melter Runs. HWVP feed was evaluated during melter test runs to determine the quantity of formic acid and sugar that must be added to obtain a desirable redox state in the resultant giass. The results from these redox evaluations are presented in the following sections.

\subsection{Redox Resuits from HWVP-11/HBCH-85-1. In April 1985, the} High-Bay Ceramic Melter (HBCM) was operated for five days to evaluate the processibility and product quality of reference glass HW39 and NCAH 1984, high chromium feed. (a) The use of-formic acid and sugar to control the redox. state of the glass was also evaluated during the test run.

Two options for glass-former addition were tested during HWVP-11/ HBCM-85-1. For the first three days of the run the feed consisted of waste simulant and $100 \%$ of the glass formers added as frit (100\% frit feed). The remaining two days were devoted to using a feed in which the glass formers were added as $1 / 3$ frit - $2 / 3$ unreacted chemicals ( $1 / 3$ frit feed). Table 4.3-51 lists the chemical compositions for the glass forming fractions of the melter feed for both feed preparation options.

Previous laboratory and melter testing has shown that the foaming tendency of melter glass can be lowered if the redox state of the glass is reducing. Carbon from the formated wastes, along with sugar added to the melter feed, can be used to reduce the glass to a redox state corresponding to a ferrous-to-ferric ratio of 0.005 to 0.3 . Laboratory tests on simulated feeds prepared with laboratory chemicals indicated that approximately $6 \mathrm{~g} / \mathrm{L}$ sugar should be added to both the $100 \%$ frit feed and the $1 / 3$ frit-2/3 unreacted chemical feed to achieve the desired redox response. To confirm these results, laboratory tests using the bottom-heated crucible technique were repeated using samples of actual melter. feed. The laboratory tests indicated that $3 . \mathrm{g} / \mathrm{L}$ and $4.5 \mathrm{~g} / \mathrm{L}$ should be added to the $100 \%$ frit and the $1 / 3$ frit-2/3 unreacted chemical feeds, respectively, to maintain a ferrous-to-ferric ratio between 0.005 and 0.3 .

Samples of melter feed obtained throughout the run were melted in bottom-heated crucibles and the ferrous-to-ferric ratios were performed on glass samples taken at various times during the run. The results of these determinations are summarized in Figure 4.3-94.

The ferrous-to-ferric ratios of the $100 \%$ frit feed were within the desired range $(0.005$ too 0.3$)$, the feed redox state was sufficiently reduced to control foaming. Glass redox reached an equilibrium value of approximately 0.04 during this portion of the test with no foaming incidents observed. A ferrous-to-ferric ratio of 0.05 or lower is sufficient to lower the foaming tendency of the glass to an acceptable level. This redox ratio may not be acceptable because the determination of ferrous-to-ferric ratios below 0.05 is more difficult when radioactive glasses are analyzed using

(a) R. K. Nakaoka and S. 0. Bates, May 1985, High-Bay Ceramic Melter Run Summary, HWVP-11/HBCM-85-1, 7H35-85-23, Pacific Northwest Laboratory, Richland, Washington. 
TABLE 4.3-51. Glass-Forming Fraction in Melter Feed S1urry HWVP-1985-7H35-85-23

Case 1: 100\% Frit

\begin{tabular}{|c|c|c|c|c|}
\hline Compound & $\begin{array}{c}\text { Concentration } \\
\mathrm{a} / \mathrm{L} \\
\end{array}$ & $\begin{array}{l}\text { Oxide } \\
\text { Form } \\
\end{array}$ & $\begin{array}{c}\text { Concentration } \\
\mathrm{g} / \mathrm{L}\end{array}$ & $\begin{array}{c}\text { Glass } \\
\text { wt\% }\end{array}$ \\
\hline \multirow[t]{6}{*}{ HW39 Frit(a) } & 300.0 & $\mathrm{SiO}_{2}$ & 201.8 & 50.44 \\
\hline & & $\mathrm{B}_{2} \mathrm{O}_{3}$ & 38.2 & 9.56 \\
\hline & & $\mathrm{Na}_{2} \mathrm{O}$ & 30.8 & 7.69 \\
\hline & & $\mathrm{Li}_{2} 0$ & 15.0 & 3.75 \\
\hline & & $\mathrm{CaO}$ & $11.2^{\circ}$ & 2.81 \\
\hline & $\dot{-}$ & $\mathrm{MgO}$ & 3.0 & 0.75 \\
\hline Subtotals & $300.0 \mathrm{~g} / \mathrm{L}$ & & $300.0 \mathrm{~g} / \mathrm{L}$ & 75.0 wt\% \\
\hline
\end{tabular}

Case 2: 1/3 Frit: 2/3 Unreacted Chemicals

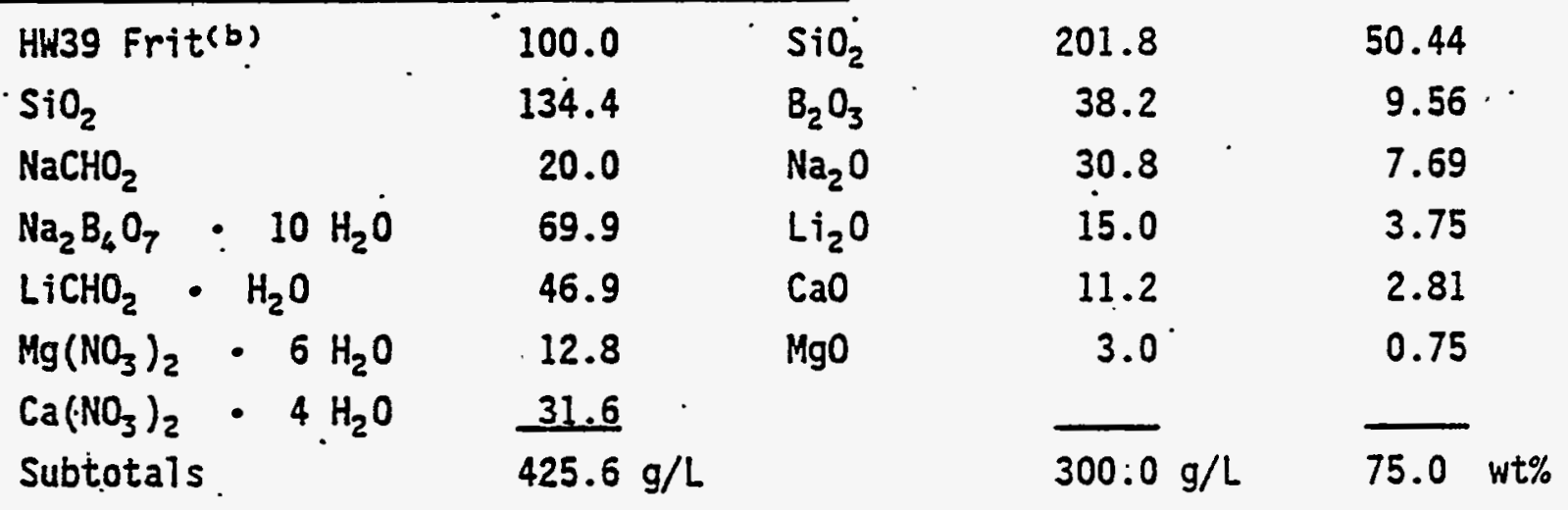
(a) HH39 frit size distribution as follows: $1 / 3$ to be $-80+200$ mesh.
(b) $2 / 3$ to be -200 mesh.
(b) HW39 frit size distribution as follows: $-80+200$ mesh. .

the current reference technique, Mossbauer spectroscopy. Ferrous-to-ferric ratios of nonradioactive glasses are measured using a compleximetric, colorimetric wet chemical method that can detect $\mathrm{Fe}^{+2} / \mathrm{Fe}^{+3}$ as 10 w as 0.005 .

Laboratory tests are used to determine what concentration of sugar is needed to reach a target redox level. Actual samples of melter feed are mixed with differing amounts of sugar and the redox is determined for each sugar level. The laboratory curve for the $100 \%$ frit feed was essentially a straight line. The concentration of sugar used for the $100 \%$ frit feed was essentially a straight line. The concentration of sugar used for the $100 \%$ frit feed was $3.0 \mathrm{~g} / \mathrm{L}$, which was one of the points tested during the laboratory tests (ferrous-to-ferric ratio from the laboratory curve was 0.116 ). 


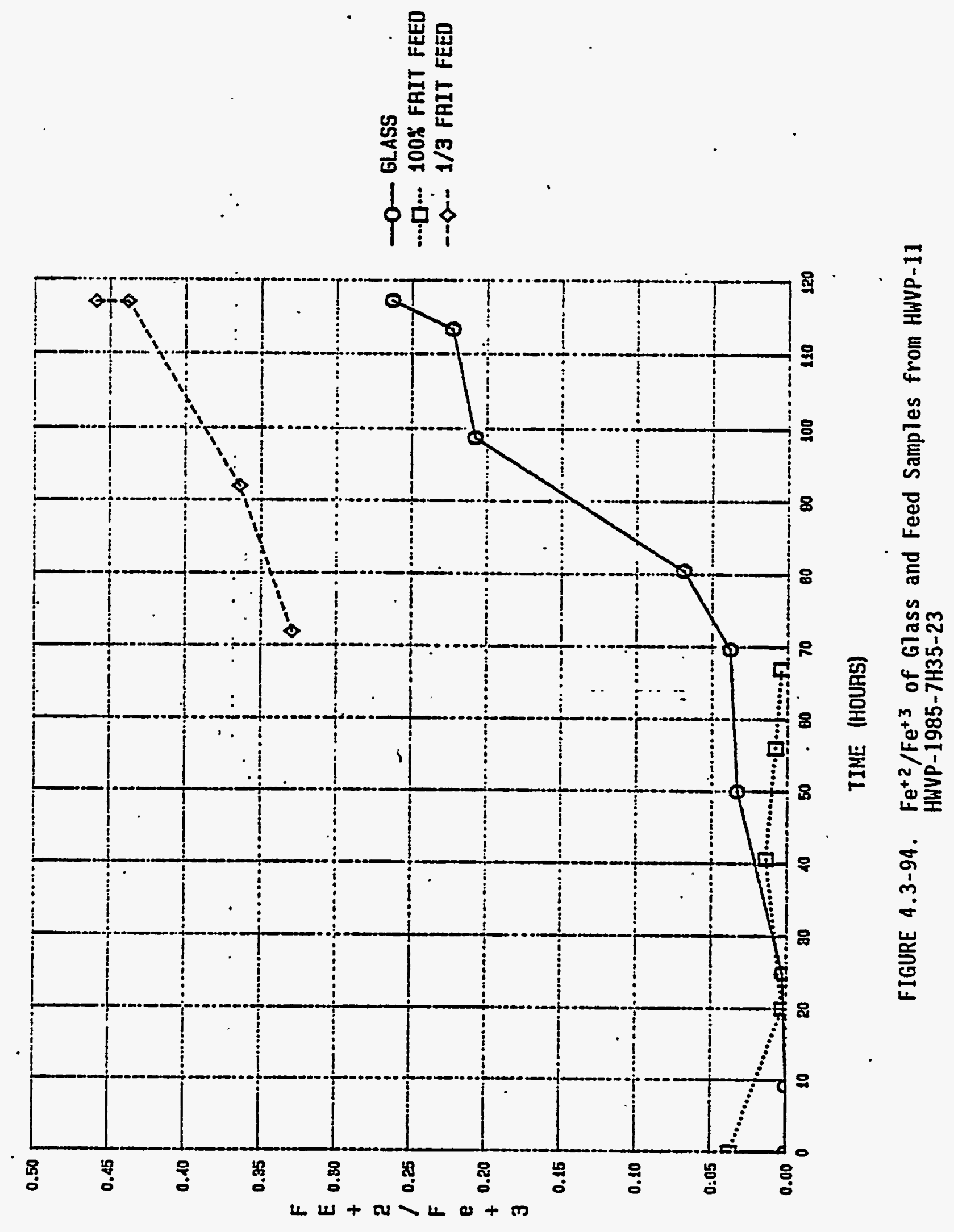


The redox response of the $1 / 3$ frit-2/3 unreacted chemical feed rose from 0.33 at the beginning to 0.46 at the end of the run. Figure 4.3-95 shows the redox curve generated in the laboratory. using $1 / 3$ frit-2/3 unreacted chemical feed. The small number of experimental points for this segment of the test introduced substantial error into the prediction of an appropriate sugar Tevel.

Redox versus time behavior of the feed and the short duration of the test did not allow the glass to reach an equilibrium state. The ferrous-to-ferric ratio of the glass increased from 0.04 to 0.26 and was increasing at the end of the run (see Figure 4.3-94).

The reason for the drift of ferrous-to-ferric ratio upward with time during the $1 / 3$ frit-2/3 unreacted chemical feed is not known. This phenomenon has not been experienced in prior melter experiments. It is possible that the combination of glass forming chemicals, formic acid, and sugar results in unanticipated reactions within the feed that cause a loss of formic acid or carbon. Also, because of differences in the environments in the bottom-heated crucible tests used in the $1 \mathrm{ab}$ and the melter, an exact correlation between HBCM and the lab has not been fully established. This fact may account for some of the offset in the laboratory redox predictions and the actual melter response.

4.3.4.2.2.2 Redox Results from HWVP-12/PSCM-22. The PSCM-22 experiment was designed to evaluate the behavior of the HW39 glass composition (NCAH 84, high chromium feed) under long-term, pilot-scale conditions. (a) For the duration of the melter run $(427 \mathrm{hr}$ ), the waste was formated with $10.2 \mathrm{~g} / \mathrm{L}$ of 90 wt\% formic acid. During the initial 187 hours (approximately 8 days) of PSCM-22, the melter feed being processed contained added sugar. Sugar has been shown to raise the redox potential of borosilicate glass, which in turn decrease the melt tendency to foam. The amount of reductant (sugar) added to the feed was $3.5 \mathrm{~g} / \mathrm{L}$. The feed processed for the next 210 hours of the run contained no sugar. During the final $30 \mathrm{hrs}$ of the run, the feed composition was changed (Auxiliary feed) and no sugar was added.

The target $\mathrm{Fe}^{+2} / \mathrm{Fe}^{+3}$ ratios for the two types of feed (with and without added sugar) tested during the run were 0.10 and 0.0 , respectively. As in past experiments, a sample of melter feed was sent for laboratory analysis prior to the start of each segment.

Bottom-heated crucible techniques were used to determine the concentration of sugar needed to achieve the desired ferrous-to-ferric ratio for the first segment of the test. Figure 4.3-96 shows the curve that was used in choosing the value of $3.5 \mathrm{~g}$ sugar/ $\mathrm{L}$ feed for this segment of the test. The laboratory curve was well defined by the number of experimental points, and $3.5 \mathrm{~g} / \mathrm{L}$ predicted a ferrous-to-ferric ratio of 0.116 . Figure 4.3-97, which is a plot of ferrous-to-ferric ratio versus run time for feed and glass

(a) R. K. Nakaoka, et al., Pilot-Scale Melter Experiment, Run Summary, HWVP-12/PSCM-22, December 1985, HWVP-86-V1124A, Pacific Northwest Laboratory, Richland, Washington. 


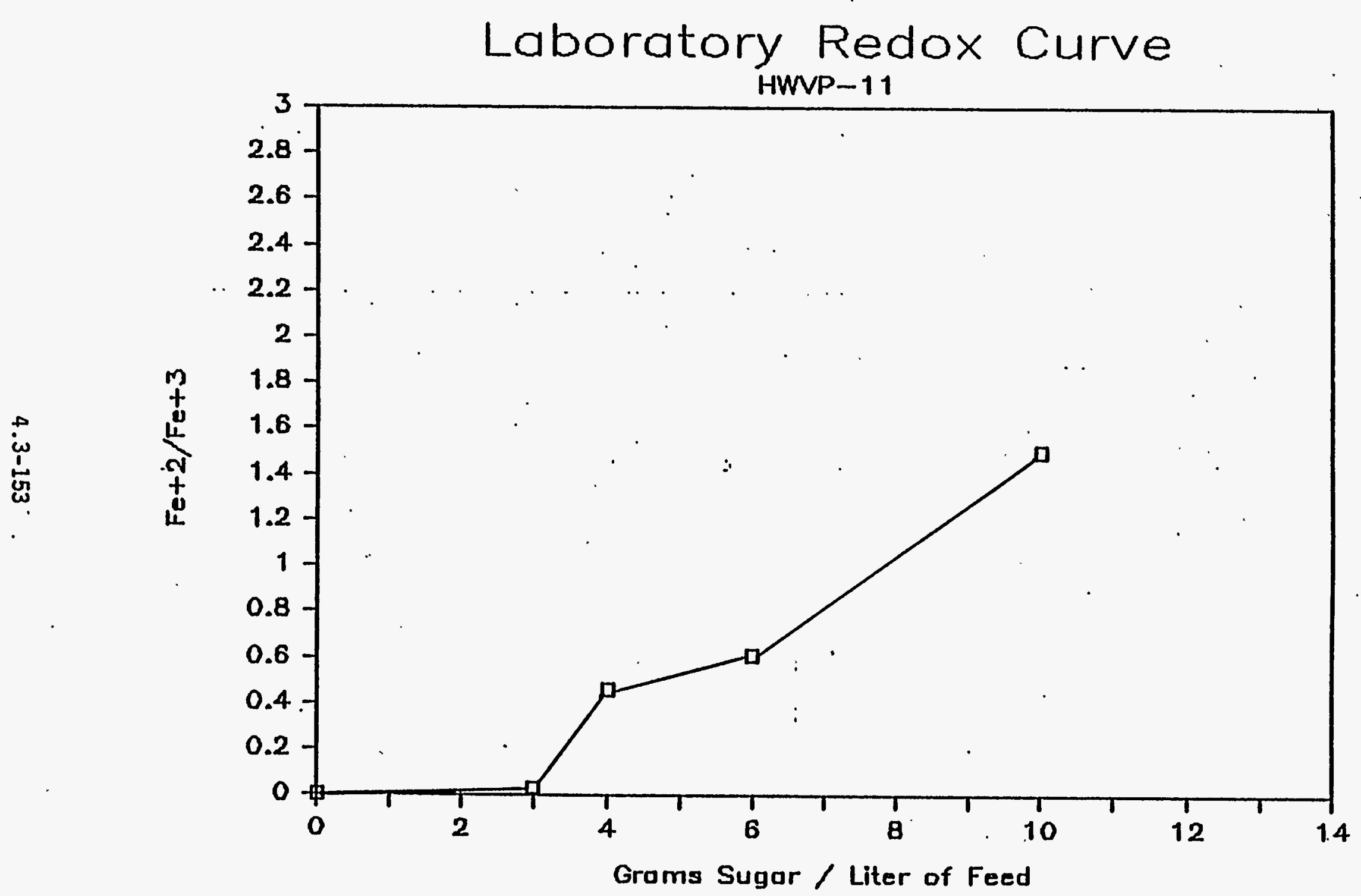

FIGURE 4.3-95. Feed Redox Curve for $1 / 3$ Frit - 2/3 Unreacted Chemical Feed HWVP-1985-7H35-85-23 


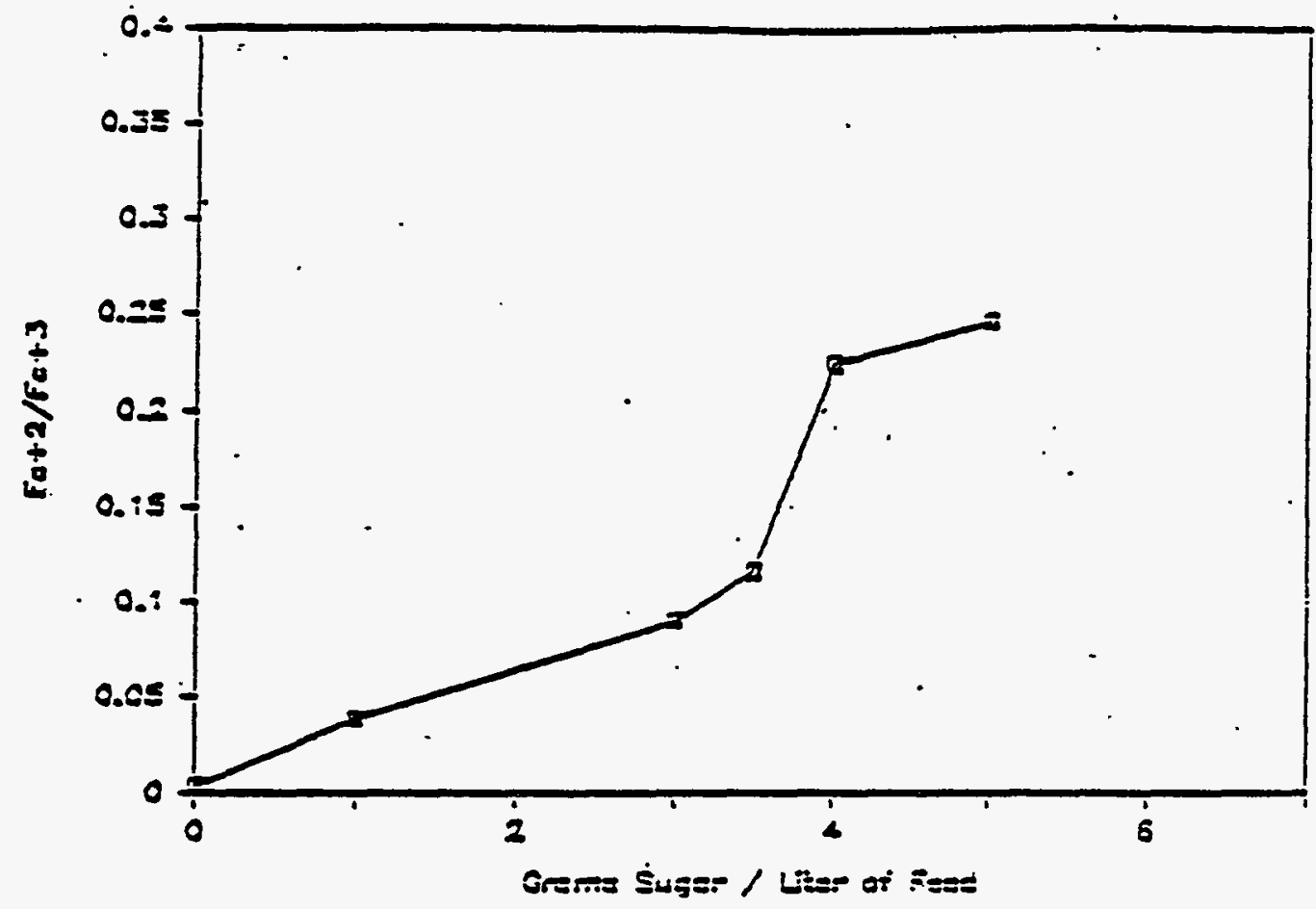

FIGURE 4.3-96. Laboratory Redox Curve (STurry with Added Sugar) HWVP-1986-V1124A

samples, shows that the ratio for the feed was very close to this value (mean value for the feed with added sugar segment of the run was $0: 106$ ). This agreement between the laboratory prediction and actual feed redox potential is in contrast to HWVP-1I. The predicted sugar concentration for the April 1985 High-Bay test $(3.0 \mathrm{~g} / \mathrm{L})$ did not sufficiently reduce the feed. Again, the laboratory predicted a ferrous-to-ferric ratio of 0.116 while the actual feed ratio ranged from 0.004 to 0.04 .

This is thought to be due to uncompleted chemical reactions of the waste components with the formic acid. (a reductant). Haste used in the makeup of feed for the actual $\mathrm{HBCM}-11$ melter test was heated to $90^{\circ} \mathrm{C}$ until the addition of formic acid was completed, about two hours. It is now thought that the formating reactions were not fully completed at this time and temperature. The changes in the redox response with time observed in both HBCM-11 feeds during the melter test support the thesis that ongoing chemical reactions were occurring in the feeds and resulted in the changing redox response.

In contrast to the HBCM-11 melter test, waste used in PSCM-22 melter feed was heated to $90^{\circ} \mathrm{C}$, the formic acid was added over a two-hour period, and the mixture was heated to $101^{\circ} \mathrm{C}$ and held at that temperature for an additional two hours. Laboratory tests indicated that the addition of 3.5 grams of sugar to each liter of melter feed would be required to achieve the target ferrous-to-ferric ratio of 0.1 for PSCM-22. Figure 4.3-97 shows that PSCM-22 melter feed did have a stable redox response at approximately the 0.1 ferrous-to-ferric level during the first 200 hours of the run. When the 


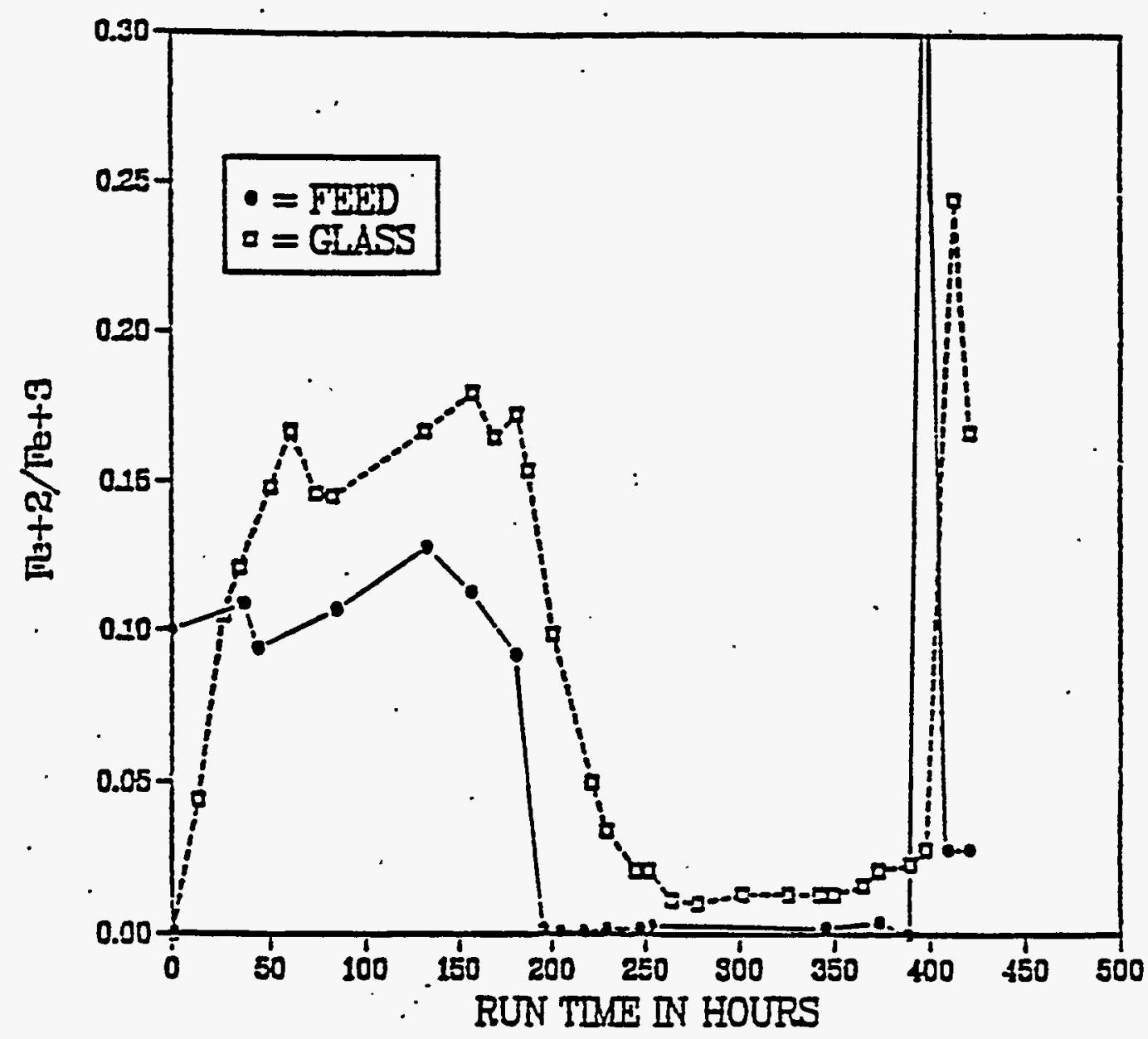

FIGURE 4.3-97 Redox Response of PSCM-22 Feeds and Glasses HWVP-1986-V1124A

sugar was removed from the feed, the feed ferrous-to-ferric ratio dropped to approximately 0.004 . Figure 4.3-97 also indicates that the ferrous-to-ferric ratio of the melter output glass closely paralleled the glass produced from melter feed in the laboratory but was offset to slightly higher values. Part of this offset can be attributed to the higher average bulk glass temperatures found during the PSCM-22 melter test $\left(1180^{\circ} \mathrm{C}\right)$. As the temperature increases in this range, the ferrous-to-ferric equilibrium in the in the glass is shifted toward the ferrous state. The offset between feed and glass could be reduced by increasing the temperature of the crucible test. As shown in Figure 4.3-97, the offset between the ferrous-to-ferric response of the feed and the melter glass is consistent and could be compensated for with a correction factor.

During the second segment of the test (no sugar), an evaluation of the stability of the melter under oxidizing conditions was made. Laboratory tests prior to the segment showed that the feed without added sugar was slightly reducing (ferrous-to-ferric ratio of 0.002 ). The formating step 
used during reference feed preparation introduced sufficient TOC to maintain a reducing feed. The mean $\mathrm{Fe}^{+2} / \mathrm{Fe}^{+3}$ of the feed of the feed for this segment of the test was 0.002 and the glass generated never went. below 0.01 (mean ratio was 0.016 ). Figure 4.3-97 shows the $\mathrm{Fe}^{+2} / \mathrm{Fe}^{+3}$ as a function of time for this feed. It appears, based on melter stability and the higher feed rates obtained during this segment of the test, that a minimal $\mathrm{Fe}^{+2} / \mathrm{Fe}^{+3}$ is desired. It may be decided that reductant additions will be made only as necessary to adjust for variation in waste stream composition.

Chloride contamination of the $\mathrm{Fe}(\mathrm{OH})_{3}$ used in the Auxiliary melter feed was sufficient to raise the ferrous-to-ferric ratio of this feed to 1.2 (no sugar was added to the Auxiliary feed). Because processing a melter feed with a low redox potential (high $\mathrm{Fe}^{+2} / \mathrm{Fe}^{+3}$ ) was not an objective of this test, adjustments to the feed were made in an effort to correct this situation. The hypothesis was made that the majority of the chloride in the feed was in the form of $\mathrm{FeCl}_{3}$. Based on this assumption, $\mathrm{NaNO}_{3}$ was added to the feed in a stoichiometric $1: 1$ molar ratio. The nitrate salt addition was made to oxidize the $\mathrm{FeCl}_{3}$ to $\mathrm{Fe}_{2} \mathrm{O}_{3}$ and thus raise the redox potential to a more desirable value (see equation).

$$
2 \mathrm{FeCl}_{3}+2 \mathrm{NaNO}_{3}=\mathrm{Fe}_{2} \mathrm{O}_{3}+\mathrm{Na}_{2} \mathrm{O}+2 \mathrm{NO}+3 \mathrm{Cl}_{2}
$$

Subsequent analysis of feed samples showed that the addition was successful. The ferrous-to-ferric ratio of the feed was lowered to 0.028 for the remainder of the run. The $\mathrm{Fe}^{+2} / \mathrm{Fe}^{+3}$ of the glass melt increased from 0.023 to 0.245 . because of the reducing nature of the initial Auxiliary feed. Once the adjustment of the feed was made, the ratio in the giass started to decline. Because of the termination of the run, the melt redox did not return to an equilibrium state.

Based on the events of PSCM-22, desired $\mathrm{Fe}^{+2} / \mathrm{Fe}^{+3}$ in actual HWVP melter feeds may be obtainable using only minimal additions of oxidizing $\left(\mathrm{NaNO}_{3}\right.$ or more suitable oxidizers) or reducing (sugar of other reductant) agents. Formating the waste stream during feed preparation may be sufficient to obtain the desired ratio in the feed and variations in the waste stream may be compensated for with the addition of the appropriate agent.

4.3.4.2.2.3 Redox Results firom PSCM-23. (a) The melter feed processed during PSCM-23 consisted of a simulated NCAH-87 composition, and a premade glass forming frit. The composition of the feed, physical characteristics, and rheological parameters, have been described in Section 4.3.4.1.1.7.

During the preparation of the melter feed, it was determined that $23.2 \mathrm{~g} / \mathrm{L}$ of $90 \mathrm{wt} \%$ formic acid and $10 \mathrm{~g} / \mathrm{L}$ sugar should be added to the feed .

(a) R. W. Goles and R. K. Nakaoka, HWVP Pilot-Scale Ceramic Melter Test 23, Draft, December 1988, HWVP-89-IVJ0010100B, Pacific Northwest Laboratory, Richland, Washington. 
to obtain a desirable $\mathrm{Fe}^{+2} / \mathrm{Fe}^{+3}$ ratio. The addition of the above quantities of reductant (formic acid and sugar) resulted in an average ferrous-to-ferric ratio in the PSCM-23 glass of 0.055 .

Formic acid(a) and sugar were added to the waste feed to determine a suitable combination to be used for PSCM-23 feed redox adjustment. The feed redox adjustment testing was required by. the higher-than-expected nitrate (oxidant) concentration in the simulated waste feed received from the vendor. The first batch of simulated HWVP feed tested was formated by adding $20 \mathrm{~mL}$ formic acid per liter of waste (Table 4.3-52). This level of formating was chosen to convert a maximum quantity of hydroxides that would participate. in formate reactions to formate salts. Testing demonstrated that 15 to $20 \mathrm{~g}$ of sugar were required to adjust the glass redox to within the required range. Sugar addition has been observed to reduce melting-rates (Perez and Nakaoka 1986). Therefore, further testing was conducted to determine if the amount of sugar added could be reduced or eliminated by increasing the amount of formic acid added to the HWVP feed. Glasses were produced from slurry batches formated using 10 to $40 \mathrm{~mL} / \mathrm{L}$ formic acid and with sugar additions of 0 to $20 \mathrm{~g} / \mathrm{L}$. The results from these tests are presented in Table $4.3-52$ and Figure 4.3-98. Figure 4.3-98 is a plot of total organic carbon in the feed versus the $\mathrm{Fe}^{+2} / \mathrm{Fe}^{+3}$ of the glass.

TABLE 4.3-52 Summary of Laboratory Melter Feed Formating Tests

\begin{tabular}{|c|c|c|c|c|}
\hline Sample \# & $\begin{array}{c}\text { Formic Acid, } \\
\mathrm{mL} / \mathrm{L}\end{array}$ & $\begin{array}{c}\text { Sugar, } \\
\mathrm{g} / \mathrm{L}\end{array}$ & $\begin{array}{c}\text { TOC, }(\mathrm{a}) \\
\mathrm{g} / \mathrm{L}\end{array}$ & $\mathrm{Fe}^{+2} / \mathrm{Fe}^{+3}$ \\
\hline GD11 & 10 & 15 & 8.6 & 0.000 \\
GD1 & 20 & 0 & 5.2 & 0.000 \\
GD7 & 20 & 15 & 11.5 & 0.039 \\
GD6 & 20 & 20 & 13.6 & 0.210 \\
GD2 & 30 & 0 & 7.8 & 0.000 \\
GD3 & 30 & 5 & 9.9 & 0.000 \\
GD4 & 30 & 10 & 12.0 & 0.000 \\
GD8 & 30 & 15 & 14.1 & 0.063 \\
GD5 & 30 & 20 & 16.2 & 0.305 \\
GD9 & 40 & 0 & 10.4 & 0.000 \\
GD10 & 40 & 10 & 14.4 & 0.009 \\
\hline
\end{tabular}

(a) Total Organic Carbon

(a) Quantities of formic acid described throughout this report refer to use of a 90 wt\% formic acid solution. The phrase "formic acid" is used for brevity. 


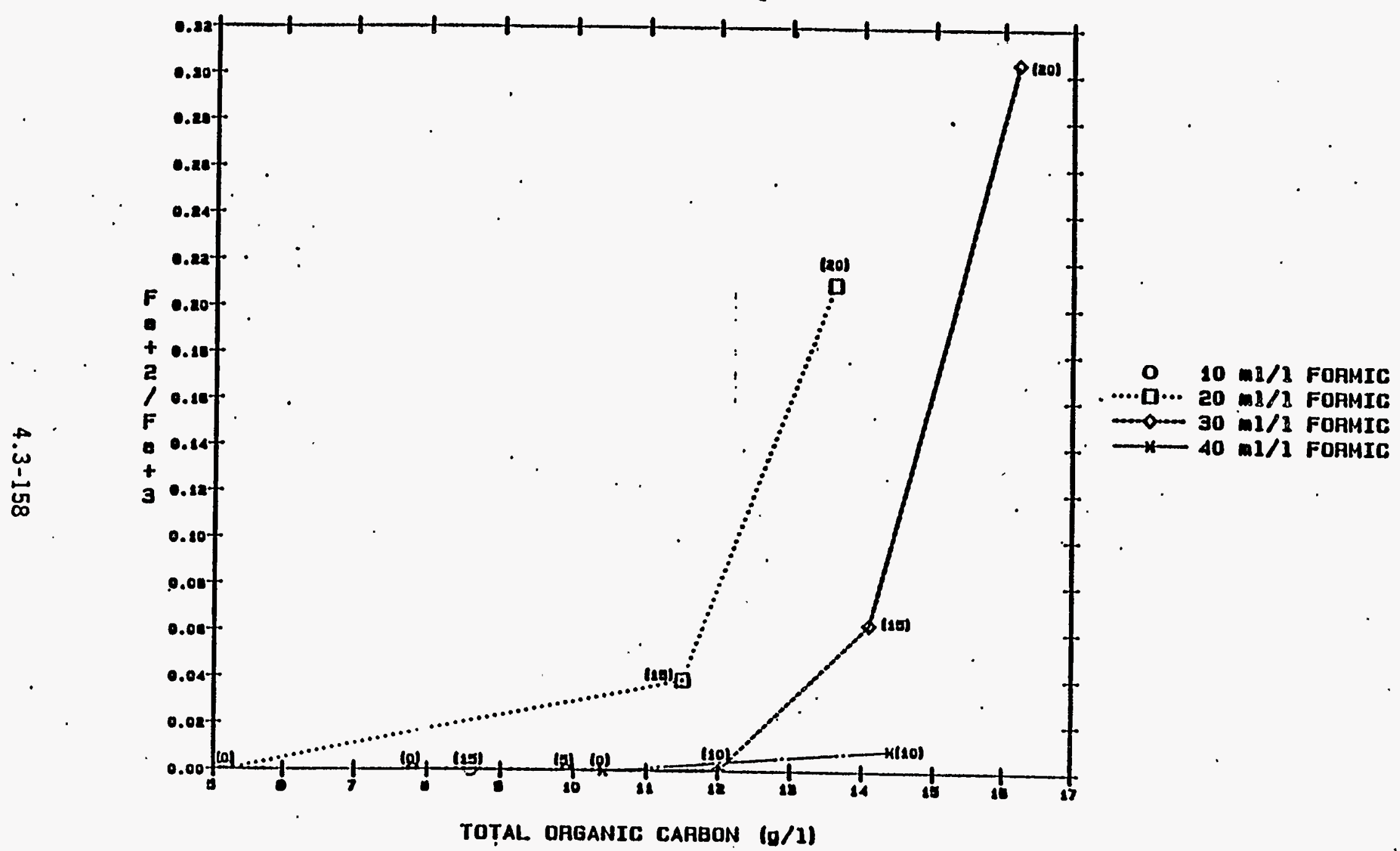

FIGURE 4.3-98. $\mathrm{Fe}^{+2} / \mathrm{Fe}^{+3}$ Versus the Total Organic Carbon in Pre-PSCM-23 Slurry Feeds. TOC is the total amount of carbon from formating the waste (each curve) plus the addition of sugar (the value in parentheses). 
The results show that up to $40 \mathrm{~mL} / \mathrm{L}$ formic acid did not provide enough reductant to reduce the giass to a measurable $\mathrm{Fe}^{+2} / \mathrm{Fe}^{+3}$ ratio, and additional reductant (sugar) needed to be added. Sugar levels of $-15 \mathrm{~g} / \mathrm{L}$ were required to reduce the glass in the laboratory. A slightly lower level $(10 \mathrm{~g} / \mathrm{L})$ was expected to be required in the HWVP-15 test due to the "closed" nature of the meiter.

In the previous melter run, HWVP-12, no sugar was required to achieve a reduced glass (see Section 4.3.4.2.2.2). However, approximately $3.5 \mathrm{~g} / \mathrm{L}$ of sugar were added during a part of the HWVP-12 test to intentionally achieve a more reduced $\mathrm{Fe}^{+2} / \mathrm{Fe}^{+3}$ state ratio (see. Figure 4.3-97). The major contributing factor for increased TOC requirement for the HWVP-15 feed is the large increase in the amount of nitrate (i.e., oxidant) in the NCAW 1987 composition $(36 \mathrm{~g} / \mathrm{L})$ compared to NCAH 1984 feed used in HWVP-12 $(10 \mathrm{~g} / \mathrm{L})$.

\subsubsection{Off-Gas Characterization from HWVP Feed Formating. (a) This feed formating process off-gas study evaluated the gas released throughout the formating process.}

4.3.4.3.1 Feed Preparation. The feed formating process off-gas study was conducted using a simulated NCAW 86 composition. The off gases generated from the feed during the formating process are dependent on the composition and physical chemistry of the feed. Noble metals were included in the feed because they are known catalysts and may affect the generation of gases during the formating process. The HWVP feed target for NCAW 86 is shown in wt\% oxides in Table 4.3-40. This feed was designated in the laboratory as HWS11.

\subsection{Feed Formating and Sampling. The feed formating process} off-gas study for FY 1987 consisted of a series of scoping studies and three test runs. A summary of the test runs is given in Table 4.3-53. The amount of formic acid was varied between $70 \%$ and $130 \%$ of the calculated stoichiometric amount required to convert the hydroxides to formate salts. Formic acid added at 50\% of the stoichiometric amount was visual7y observed in past studies to generate insignificant quantities of gases. The components in the feed that were assumed to react completely with formic acid and were used to calculate the stoichiometric addition of formic acid were $\mathrm{Ce}(\mathrm{OH})_{3}, \mathrm{Mg}(\mathrm{OH})_{2}$, $\mathrm{MnOH}_{2}, \mathrm{NaOH}, \mathrm{Nd}(\mathrm{OH})_{3}, \mathrm{Ni}(\mathrm{OH})_{2}, \operatorname{Pr}(\mathrm{OH})_{3}, \mathrm{Sm}(\mathrm{OH})_{3}, \mathrm{Sr}(\mathrm{OH})_{2}$, and $\mathrm{Y}(\mathrm{OH})_{3}$. The $100 \%$ stoichiometric amount required approximately 0.50 moles of formic acid per liter of feed $(19.1 \mathrm{~mL} 90 \mathrm{wt} \% \mathrm{HCOOH} / \mathrm{L}$ feed). The $130 \%$ stoichiometric acid required $24.8 \mathrm{~mL} 90 \mathrm{wt} \% \mathrm{HCOOH} / \mathrm{L}$ feed and the $70 \%$ stoichiometric addition required $13.4 \mathrm{~mL} 90 \mathrm{wt} \% \mathrm{HCOOH} / \mathrm{L}$ feed.

The effect of formic acid addition rate was evaluated at $0.5,1.0$ and $1.5 \mathrm{~mL} / \mathrm{min}$ formic acid $(0.006,0.012$, and $0.017 \mathrm{moles} \mathrm{HCOOH} / \mathrm{L}$ feed-min, respectively). These addition rates were selected on the basis of previous

(a) K. D. Wiemers et al., Evaluation of Process Off-Gases Released During Formating of an HWVP Feed Simulant. HWVP-87-V110203G, Pacific Northwest Laboratory, Richland, Washington (1987). 
TABLE 4.3-53. Summary of Test Runs (K. D. Hiemers et al., HWVP-87-V110203G, PNL, 1987)

\begin{tabular}{|c|c|c|c|c|c|}
\hline \multirow[b]{2}{*}{$\begin{array}{l}\text { Test } \\
\text { No. }\end{array}$} & \multirow[b]{2}{*}{ Run No. } & \multirow[b]{2}{*}{ Objective } & \multirow[b]{2}{*}{$\begin{array}{c}\text { Stoichiometry } \\
(\%)\end{array}$} & \multicolumn{2}{|c|}{ Formic Acid Addition } \\
\hline & & & & $\begin{array}{c}\text { Rate } \\
\text { mmoles/ } \\
\text { Lfeed-min }\end{array}$ & $\begin{array}{c}\text { Total } \\
\text { Amount, } \\
\text { moles/Lfeed }\end{array}$ \\
\hline $\begin{array}{r}1 \\
2 \\
2 \\
3 \\
3 \\
3\end{array}$ & $\begin{array}{c}1,2,3 \\
4 \\
5 \\
6 \\
7\end{array}$ & $\begin{array}{l}\text { Replicatesial } \\
\text { Amount formic acid } \\
\text { Amount formic acid } \\
\text { Formic acid addition rate } \\
\text { Formic acid addition rate }\end{array}$ & $\begin{array}{r}100 \\
70 \\
. \quad 130 \\
100 \\
. \quad 100\end{array}$ & $\begin{array}{r}12 \\
12 \\
12 \\
18 \\
6\end{array}$ & $\begin{array}{r}0.42 \\
0.30 \\
0.55 \\
.0 .42 \\
0.42\end{array}$ \\
\hline
\end{tabular}

(a) The intent of Runs $1, \cdot 2$, and 3 was to determine the reproducibility of the data gathered during the formating process. Howeyer, adjustments in operating parameters (agitation, purging, etc.) resulted in non-replicated runs. Therefore, Run 3, alone, was used for the gas analysis data evaluation.

laboratory-scale feed studies. (a)(b) The upper limit was restricted by the amount of foaming that was observed during previous feed formating studies.

For the formating process, approximately $2 \mathrm{~L}$. of feed were heated to $90^{\circ} \mathrm{C}$ to $95^{\circ} \mathrm{C}$ and $90 \mathrm{wt \%}(23 \mathrm{M})$ formic acid was added beneath the feed surface at a constant flow rate. Gas sample bulbs and a series of gas scrubbers were used to collect gas samples. Samples were collected before formic acid addition, after one-half and all of the formic acid was added, and at the completion of the post heat treatment period. In the post-heat-treatment period, the feed was heated for $2 \mathrm{~h}$ at $95^{\circ} \mathrm{C}$. Feed samples were withdrawn from the vessel after one-half and all the formic acio had been added and after the postheat-treatment period.

4.3.4.3.3 Experimental Equipment. The simulant feed was placed in a 3-L glass kettle. A cover gas consisting of air was directed over the feed surface through a $3 / 16$ in. I.D. adjustable glass tube that entered the side of the kettle. The kettle was placed in a temperature-controlled heating mantle that supplied heat for the formating process. The standard kettle 1id was modified; modifications included joints for the gas and feed thermo:couples, a glass tube for withdrawing feed samples, a formic acid addition tube, a pH electrode and automatic temperature compensator, the agitator

(a) R. K. Farnsworth, The Effect of Feed Composition and Formic Acid Addition on G7ass Redox State. HWVP-87-V110203A, Pacific Northwest Laboratory, Richland, Washington (1987).

(b) G. T. Thornton, Evaluation and Comparison of HWVP Reference Feed Composition and Undated Neutralized Current Acid Waste Composition Simulants. HWVP-87-V110203C, Pacific Northwest Laboratory, Richland, Wastington (Aprit 1987). 
shaft, and an off-gas exit port, which was connected to the condenser and bypass. adaptor. The formic acid was added under the feed surface through a teflon tube using a peristalic pump. A vacuum system was used to pull the sample from the feed tank into the sample collection vessel. The process off-gas was routed through the condenser. A vacuum pump with a mass flowmeter and controller was connected to the system after the final gas scrubber and was used to pull cover and process gases through the system at approximately $100 \mathrm{~mL} / \mathrm{min}$. (a)

A series of teflon valves provides for the collection of noncondensible off-gases in $125 \mathrm{~cm}^{3}$ glass sample bulbs and in a series of three $250 \mathrm{~mL}$ gas scrubbing vessels. The scrub vessels were filled with $100 \mathrm{~mL}$ solution of $1.85 \mathrm{mM} \mathrm{Na} \mathrm{CO}_{3}+1.75 \mathrm{mM} \mathrm{NaHCO}$. A computer-controlled data acquisition system monitored the feed and plenum temperatures, solution pH and cover gas flowrate.

4.3.4.3.4 Off-gas Characterization. Process off-gas samples collected in gas sample bulbs and gas scrubbers were analyzed for gas composition by mass spectrometry and ion chromatography, respectively. Specific gas components of interest included hydrogen, nitrogen oxides, fluorine, chlorine, inorganic sulfur, carbon monoxide/dioxide, and simple organic species related. to formic acid chemistry. The selected gas scrubber solution (1.85 $\mathrm{mM} \mathrm{Na} \mathrm{CO}_{3}$ $+1.75 \mathrm{mM} \mathrm{NaHCO}$ ) provided minimum interference with the ion chromatographic methods.

4.3.4.3.5 Formic Acid Specifications. During a scoping study designed to determine the vapor composition of formic acid heated to the formating temperature $\left(90^{\circ} \mathrm{C}\right.$ to $95^{\circ} \mathrm{C}$ ), methyl formate (approximately $1 \mathrm{mo} / \%$ in the formic acid stock solution) was detected at a level of $23 \mathrm{~mol} \%$ in the vapor phase.

It is noted here that DWPF/SRL procures $99 \mathrm{wt} \%$ formic acid which is then diluted with deionized water to produce the 90 wt\% formic acid solution used in the feed formating process. The advantage of diluting a high purity formic acid is the minimization of any undesirable impurities such as methy] formate.

4.3.4.3.6 Experimental Observations. Operating parameters (agitation and purge gas flow rate) and experimental observations (temperature changes and feed behàvior) are herein summarized (see Table 4.3-54).

The experimental variables for Runs I through 3 were constant. However, during Run 3 very slight foaming was noted relative to Runs 1 and 2 . The more-controlled reaction rate observed in Run 3 may have been due to the use

(a) K. D. Wiemers, Gas Release During Formating of a Simulated Hanford Waste Vitrification Plant Feed, August 1988, PNL-SA-15965, Pacific Northwest Laboratory, Richland, Hashington. 

TABLE 4.3-57. Summary of Experimental Observations (K. D. Heimers, HWUP-87-V110203G,

\begin{tabular}{|c|c|c|c|c|c|c|c|c|c|c|c|}
\hline \multirow{2}{*}{$\begin{array}{l}\text { Run } \\
\text { Ho. }\end{array}$} & \multirow{2}{*}{$\begin{array}{c}\text { Forralc Acld } \\
\text { Additlon Rate } \\
\text { (me/min) }\end{array}$} & \multirow{2}{*}{$\begin{array}{c}\text { Agltator } \\
\text { (no. blades) }\end{array}$} & \multicolumn{2}{|c|}{ Set Polnt } & \multicolumn{2}{|c|}{$\begin{array}{c}\text { Cover Gas } \\
\text { Flow Rate } \\
\text { II full Scalel } \\
\end{array}$} & \multicolumn{2}{|c|}{$\begin{array}{l}\text { Temperature } \\
\text { Feed }\left({ }^{\circ} \mathrm{C}\right)\end{array}$} & \multirow{2}{*}{$\begin{array}{l}\text { Reaction } \\
\text { IvisualI }\end{array}$} & \multirow{2}{*}{$\begin{array}{l}\text { Color of } \\
\text { Feed After } \\
\text { formating }\end{array}$} & \multirow{2}{*}{$\begin{array}{l}\text { Amount } \\
\text { of formlc Acid } \\
\text { (is Stolchlometry) }\end{array}$} \\
\hline & & & $\mathrm{HIn.}$ & Hax. & HIn. & Hax. & HIn. & Hax. & & & \\
\hline 1 & 1 & 1 & 4 & 4.5 & 20 & 20 & 93 & 95 & Sentulolent & $\begin{array}{l}\text { From brown to } \\
\text { seaweed green }\end{array}$ & 100 \\
\hline 2 & 1 & 1 & 6 & 10 & 20 & 18 & 90 & 100 & $\begin{array}{l}\text { Very violent } \\
\text { IIght green }\end{array}$ & $\begin{array}{l}\text { From brown to } \\
\text { IIght green }\end{array}$ & 100 \\
\hline 3 & 1 & 2 & 3.5 & .5 & 20 & 80 & $\dot{92}$ & 95 & $\begin{array}{l}\text { Sl Ight } \\
\text { bolling }\end{array}$ & $\begin{array}{l}\text { Ho change } \\
\text { Brown }\end{array}$ & 100 \\
\hline 1 & 1 & 2 & 4 & 1 & 20 & 80 & 93 & 94 & $\begin{array}{l}\text { Mone } \\
\text { apparent }\end{array}$ & $\begin{array}{l}\text { Ho chunge } \\
\text { Brawn }\end{array}$ & 70 \\
\hline 5 & 1. & 2 & 4 & 7 & 20 & 50 & $\begin{array}{l}91 \\
\vdots\end{array}$ & 95 & $\begin{array}{l}\text { Mone } \\
\text { apparent . }\end{array}$ & $\begin{array}{l}\text { From brown to } \\
\text { dark greenlsh } \\
\text { brown }\end{array}$ & $\begin{array}{l}130 \\
.\end{array}$ \\
\hline 6 & 1.5 & 2 & 4 & 1 & 20 & 80 & 92 & 94 & $\begin{array}{l}\text { Hone } \\
\text { apparent }\end{array}$ & $\begin{array}{l}\text { Ho change } \\
\text { Brown }\end{array}$ & 100 \\
\hline 1 & 0.5 & 2 & 5 & 7 & 20 & 80 & 92 & 95 & $\begin{array}{l}\text { Hone } \\
\text { apparent }\end{array}$ & $\begin{array}{l}\text { Ho change } \\
\text { Orown }\end{array}$ & 100 \\
\hline
\end{tabular}


of dual impeller.agitation in place of single impeller agitation. Single impeller agitation used in Runs 1 and 2 did not provide for adequate mixing as observed by the lack of feed particle circulation within the reaction kettle. The insufficient agitation resulted in sudden foaming and (approximately 1:5 in. of foam on top of the feed surface) during formic acid addition. Application of the dual impeller agitator provided more homogeneous blending of the formic acid and feed, uniform heat distribution throughout the feed, and maintained a more uniform gas evolution during the reaction periods. Changes in the agitator set point throughout the formating process were required to compensate for changes in feed viscosity. Between approximately $50 \%$ and $100 \%$ stoichiometric formic acid addition the agitator set point was increased. During the post-heat treatment period the viscosity decreased slightly and the agitator speed was decreased. The average minimum and maximum speeds for the dual impeller. were 480 and 840 rpms.

Increases in temperature were noted during the most reactive periods (between $50 \%$ and $100 \%$ stoichiometric formic acid addition). This implies that the reactions taking place are exothermic. The most significant temperature change ( +10 degrees) was observed during the most reactive feed behavior (Run 2). Of the runs with adequate agitation (Runs 3 through 7 ), Run 5 was observed to have the largest temperature change ( 4 degrees). This may have been due to the amount of formic acid added ( $130 \%$ stoichiometric).

Color changes were observed during formating without adequate agitation (Runs 1 and 2) and during the addition of excess (130\% stoichiometric) formic acid. These changes qualitatively indicate changes in chemical equilibria, most likely those of complexes with transitional metals and lanthanides.

The resuits from runs number 1 and 2 are suspect because they were conducted for initial shakedown in which process operation and control were often erratic and unstable. Also, the type of agitation may have affected the resuits.

4.3.4.3.7 Gas Release. Samples of gases released during formic acid addition and the 2-h post-heat-treatment period were collected, analyzed, and evaluated with respect to composition, rate of release and amount released.

The gases released during the formating process are a result of redox reactions and are thus related to the feed redox state prior to its entry into the melter. The major contributor to the redox activity is Fe due to its large contribution to the feed composition (23 mol\% based on cations) and due to its unique redox behavior in the $\mathrm{pH}$ range in which maximum gas releases were observed. The likelihood for redox reactions to occur in the feed and the rate at which they take place are dependent upon a combination of the following factors: component concentration, temperature, $\mathrm{pH}$, entropy and enthalpy changes between the product and reactants, physical nature of the components, presence of catalyst, and physical parameters such as agita: tion, purge gas flow rate, and surface area to volume of the feed.

Table 4.3-55 presents a summary of the feed formating off-gas experimental conditions and results. 
TABLE 4.3-55. Experimental Parameters and Data Summary for the Feed Formating Off-Gas Studies (K. D. Hiemers et a1., HWVP-87-V110203G, PNL, 1987)

\begin{tabular}{|c|c|c|c|c|c|c|c|c|c|}
\hline \multirow[b]{2}{*}{$\begin{array}{l}\text { Auin } \\
\text { Ho. }\end{array}$} & \multicolumn{3}{|c|}{ Total mount Fonalc Acld Added } & \multicolumn{3}{|c|}{ Foimlc Aeld Addielon hate } & \multicolumn{2}{|c|}{ pll Range } & \multirow[b]{2}{*}{ 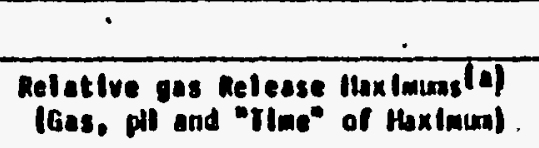 } \\
\hline & $\begin{array}{c}\text { Stolechlonatrle } \\
|z|\end{array}$ & $\begin{array}{l}\text { moles/l } \\
\text { Feed }\end{array}$ & $\begin{array}{l}\text { Relative } \\
\text { Range }\end{array}$ & $m / m / n$ & $\begin{array}{l}\text { moles/l } \\
\text { fọ. }-m / n\end{array}$ & $\begin{array}{l}\text { Relat lve } \\
\text { Range }\end{array}$ & $\begin{array}{l}\text { Formle Acld } \\
\text { Additlon Perlod }\end{array}$ & $\begin{array}{l}\text { Post Ileat } \\
\text { Jreatment }\end{array}$ & \\
\hline 3 & 100 & 0.12 & ald & 1.0 & 0.012 & ild & 11.6 to 4.3 & 4.3 to 1.3 & Ho relative gas release maxlanum. \\
\hline 4 & 10 & 0.30 & Jow & 1.0 & 0.012 & uld & 12 to 5.5 & 5.5 to 6.2 & 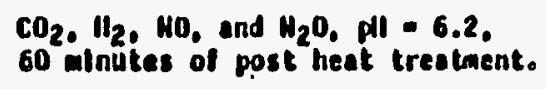 \\
\hline 6 & $\mathbf{1 3 0}$ & 0.65 & hlgh & 1.0 & 0.012 & wid & 11.0 to 4.2 & 4.2 to 7.4 & $\begin{array}{l}\text { 112. pll - 1.2, beglnnIng of post } \\
\text { heet trentment. }\end{array}$ \\
\hline 6 & 100 & 0.12 & mid & 1.5 & 0.018 & hlgh & 11.9 to 4.2 & 4.2 to 1.3 & Ho relative gas release maximuan. \\
\hline 1 & 100 & 0.42 & nld & 0.5 & 0.005 & Iow & 12.2105 & $5 \cdot 107.5$ & 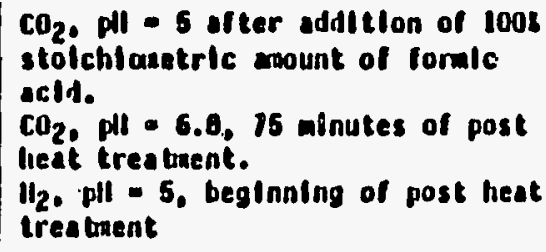 \\
\hline
\end{tabular}


4.3.4.3.7:1 $\mathrm{CO}_{2}$ Release. The concentration of $\mathrm{CO}_{2}$ in the gas phase as a function of the elapsed time for formating is shown graphicaliy in Figure 4.3-99. The general trend observed for $\mathrm{CO}_{2}$ is the presence of a maximum in gas concentration approximately 30 minutes after the beginning of formic acid addition. Depending upon the formic acid addition rate this time for maximum $\mathrm{CO}_{2}$ gas concentration corresponds to a formic acid addition between 0.2 and 0.4 moles formic acid per liter of feed. (a) Maximum concentrations of $\mathrm{CO}_{2}$ released, 85 and $65 \mathrm{~mol} \%$, were observed in Runs 4 and 5. The $85 \mathrm{~mol} \%$ is equivalent to a maximum $\mathrm{CO}_{2}$ generation rate of $0.0014 \mathrm{~g} \mathrm{~mol} / \mathrm{min} \cdot \mathrm{Lfeed}$. For all runs the $\mathrm{CO}_{2}$ gas release rate decreased during the last half of the reflux phase.

An indication of the experimental variability can be ascertained by comparing the initial $\mathrm{CO}_{2}$ behavior of Runs 3;4, and 5. With these runs, the formic acid addition rates were equal (12 mmoles/Lfeed-min), while the total formic acid added was varied. Formic acid addition ceased after approximately 25 minutes for Run 4, 35 minutes for Run 3, and 46 minutes for Run 5 . Therefore, comparison of the data from these runs for the initial 25 minutes on Figure 4.3-99 provides an indication of the experimental variability.

From Figure 4.3-99, it is apparent that the initial $\mathrm{CO}_{2}$ release behavior of Runs 4 and 5 are similar, while that of Run 3 varies to some extent:. The differences between these runs could possibly be attributed to 7 imited data, and a very fast reaction that is 7 imited by mass transfer. The foaming that was observed at lower agitation rates during Runs 1 and 2 is also indicative of mass transfer limitations. Furthermore, increasing the formic acid feed rate from $12 \mathrm{mmol} / \mathrm{min}$ to $18 \mathrm{mmol} / \mathrm{min}$ (Run 6) did not result in increased $\mathrm{CO}_{2}$ releases, which also suggests that mass transfer was rate controlling at those acid addition rates.

4.3.4.3.7.2 $\mathrm{H}_{2}$ Release. Initial release of $\mathrm{H}_{2}$ was observed after 0.3 moles $/ L$ feed ( $70 \%$ stoichiometric amount) of formic acid had been added to the feed. The most significant $\mathrm{H}_{2}$ releases were observed during the post heat treatment period. The maximum concentration of $\mathrm{H}_{2}$ observed in the feed formating off-gas was $1.63 \mathrm{mo} 7 \%$.

Based on the constant purge-gas flowrate of $100 \mathrm{ml} / \mathrm{min}$ and the formating temperature of $90^{\circ} \mathrm{C}$, the maximum hydrogen gas generation rate of the study was approximately $2.7 \times 10^{-5} \mathrm{~g} \mathrm{~mol} \mathrm{H}_{2} /$ Lfeed $\cdot$ min. One of the vessel ventilation design requirements is to ensure that the concentration of flammable components in the vapor space of the vessels and associated equipment do not exceed $50 \%$ of the lower explosive limits. (b) For hydrogen gas in air, the lower limit of ignitability (lower explosive 7 imit) is $4.00 \%$ by volume. (c)

(a) K. D. Wiemers, PNL-SA-15965, 1988.

(b) HWVP Technical Data Package, SD-HWV-DP-001, Rev. 4, September 1988, Section 3, Item 700 , pg. I.

(c) CRC Handbook of Chemistry and Physics, 59th ed., pg. D-160, CRC Press, West Palm Beach, Florida, 33409. 
co2 Gas Sehavior During Formating

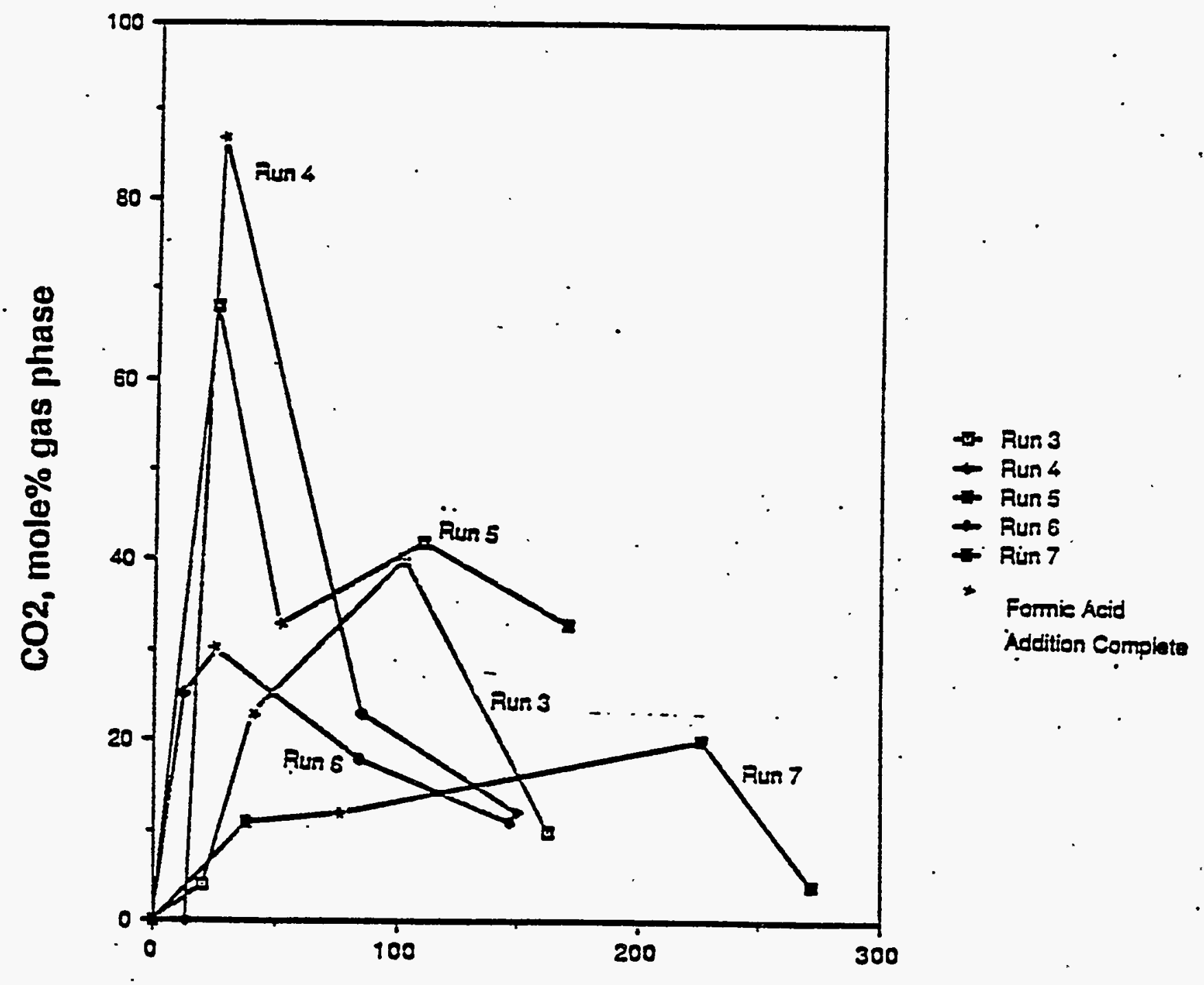

\section{Elapsed Time, mins}

FIGURE 4.3-99. Gas Concentration of $\mathrm{CO}_{2}$ as a Function of Elapsed Time 
Therefore, from the results of this study, and the design criterion, the criterion, the air-inleakage rate during the formating process would have to be; at a minimum, $1.4 \times 10^{-3} \mathrm{~g} \mathrm{~mol}$ air/Lfeed $\cdot \mathrm{min}$.

4.3.4.3.7.3 $\frac{\mathrm{NO}}{x}$ and $\mathrm{N}_{2} O$ Release. Maximum release of $\mathrm{NO}_{x}$ was observed between $50 \%$ and $130 \%$ stoichiometric addition of formic acid. Release of $\mathrm{NO}_{x}$ decreased but did continue throughout the post-heat treatment period. $\mathrm{N}_{2} \mathrm{O}$ was observed during post-treatment at a maximum concentration of 1.39 mol\%.

4.3.4.3.7.4 Formic Acid in the off-Gas. Formic acid was not detected in the off-gas downstream from the $15^{\circ} \mathrm{C}$ condenser by either mass spectrometry or ion chromatographic analysis.

4.3 4.3.7.5 $\mathrm{pH}$ Changes. The $\mathrm{pH}$ change during formic acid addition and post heat treatment is il7ustrated in Figures $4.3-100$ and $4.3-101$, respectively. Not shown in these figures is the decrease in the feed $\mathrm{pH}$ from 12 to approximately 10.5 observed during initial heating of the feed from ambient temperature to $90^{\circ} \mathrm{C}$. This decrease may have been due to the temperature dependence of hydrogen ion based equitibria.

In general, the $\mathrm{pH}$ decreased from 11 to 4 during formic acid addition and increased to approximately 7.5 during post heat treatment. Addition of formic acid at the maximum flow rate (Run 6) resulted in somewhat lower pH values (4.2) at $50 \%$ stoichiometric addition. Addition of formic acid at the minimum formic acid addition rate (Run 7) resulted in somewhat higher $\mathrm{pH}$ values (7.3) at 50\% stoichiometric addition. During Run 4 , in which the minimum amount of formic acid was added (70\% stoichiometric amount), the pH was maintained in a relatively narrow range (5.8 to 6.6 ) from $50 \%$ stoichiometric addition throughout the post-heat- treatment period. Comparison of Figures 4.3-100 and 4.3-101 with Figure 4.3-99 shows that the maximum release rates and amounts occurred in the feed $\mathrm{pH}$ range of 5.6 and 7 .

\subsubsection{HWVP Pilot-Scale SRAT Study (Formating Foaming and Heat Transfer} During Concentration). (a) Feed preparation studies for the HWVP-15 test were designed to qualitatively investigate the effects of formic acid addition rate and slurry agitation on the generation of the foam layer associated with the reaction of formic acid and selected slurry components. Characterization of the effects. of these operational parameters on the generation and stability of the foam layer was based on visual observations made during the feed preparation process. The overall boiling heat-transfer coefficient was calculated for the pilot-scale equipment using simulated HWVP feed. This value was compared to the HWVP design value and other available design/test values.

(a) R. W. Goles et a1., January 1989, "Hanford Waste Vitrification Program Pilot-Scale Ceramic Melter Test Number 23. HWVP-89-IVJ0010100B, Pacific Northwest Laboratory, Richland, Washington. 


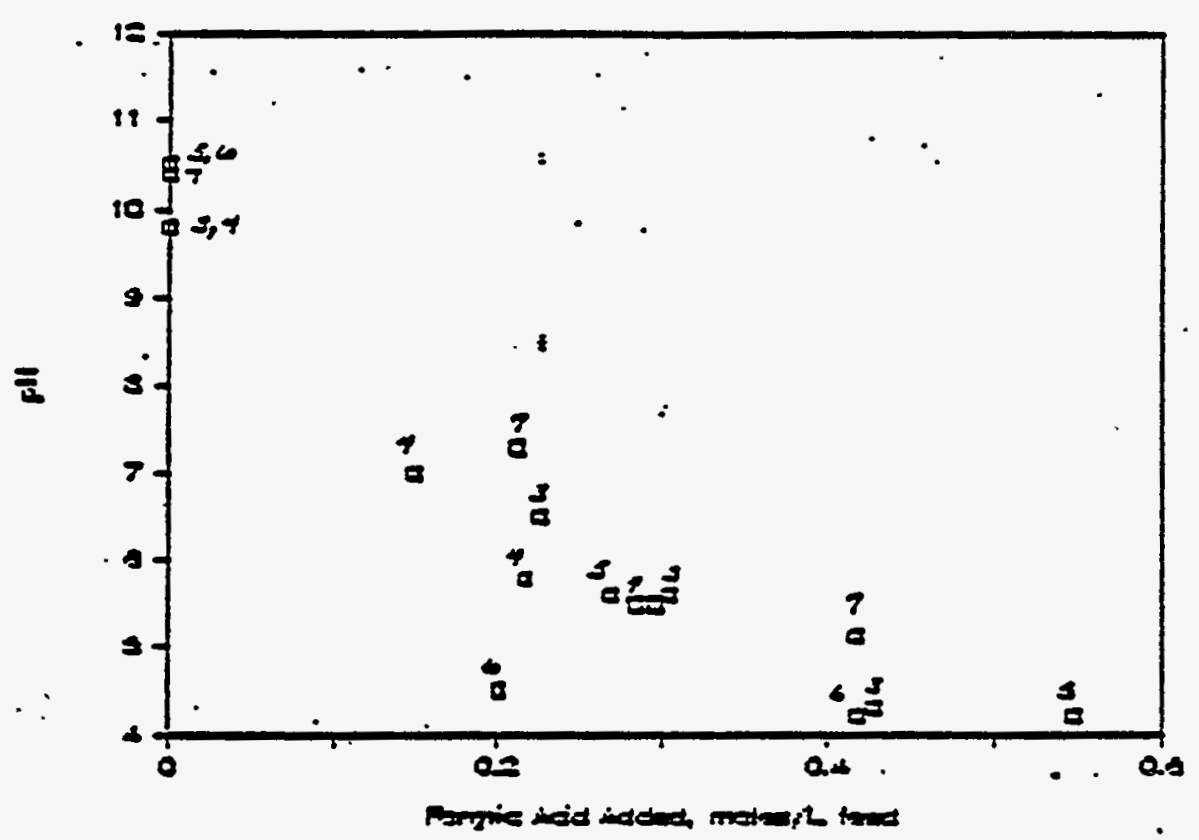

FIGURE 4.3-100. pH Versus Amount Formic Acid Added. Numbers above data points refer to run numbers. (K. D. Wiemers et a7., HWVP-87-V110203G, PNL, 1987)

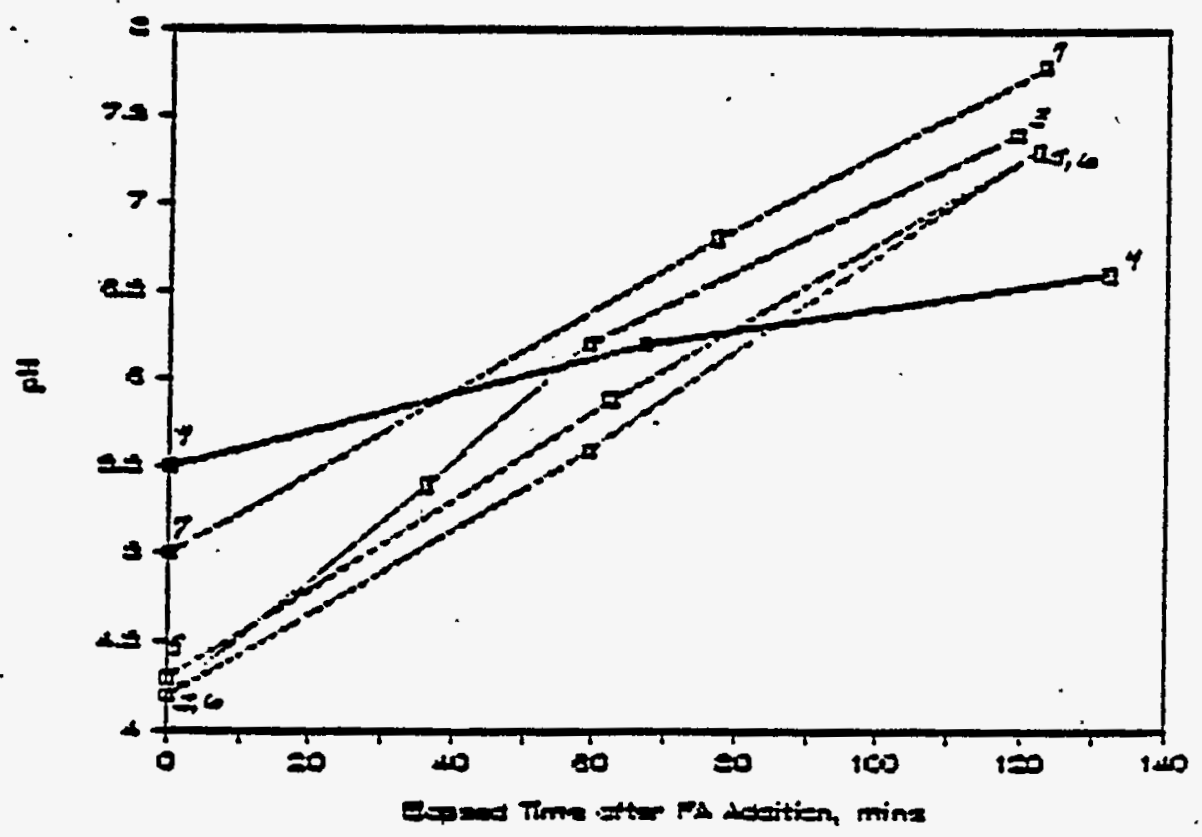

FIGURE 4.3-101. Post Treatment pH Change. Numbers above data points points refer to run numbers. (K. D. Wiemers et al., HWVP-87-V110203G, PNL, 1987) 
4.3.4.4.1 Test Equipment. Two stainless steel process tanks, having similar dimensions and agitation systems, were used to prepare feed for the HWVP-15 test. The tanks have a diameter of $165 \mathrm{~cm}$ (65 in.), a total height of $147 \mathrm{~cm}$ (58 in.), and a capacity of approximately $3000 \mathrm{~L}$ (790 gal). Agitation in both tanks is provided by two $91-\mathrm{cm}$ ( 36 in.) diameter impellers which are powered by a 7.5-hp motor coupled with a variable speed controller. The top impeller is a $45^{\circ}$ pitched blade and the bottom impeller is a four-bladed paddle. Heating of the feed is accomplished with an internal steam coil constructed of $2.5-\mathrm{cm}\left(1-\right.$ in. $_{\text {. }}$ nominal stainless steel pipe. The total heat transfer area of the coil is approximately $2.7 \mathrm{~m}^{2}\left(28.9 \mathrm{ft}^{2}\right)$, and the maximum steam pressure for the system is 100 psig. For this test, formic acid was introduced under the surface $(-50 \mathrm{~cm}$ under surface) of the feed. Temperature of the feed was monitored using a Type $K$ thermocouple and a chart recorder.

4.3.4.4.2 Experimental Procedure. The approach for evaluating the feed preparation parameters (formic acid addition rate and level of agitation). was to increase the acid addition rate with each subsequent batch of feed until an excessive and stable foam layer occurred. The slurry agitation level was then increased and the conditions of the previous batch were repeated. In this manner, the maximum rate of acid addition would be established and the effects of slurry agitation evaluated.

The qualitative characterization of the effects of operational parameters on foam generation during HWVP-15 feed preparation was based on visual observations. These observations included the presence of foam, foam thickness and density, and the rate of foam accumulation. The operational parameters evaluated during the process were formic acid addition rate and slurry agitation. During the formic acid addition procedure, the required amount of acid was initially transferred from a storage drum to a container located on a piatform scale. The acid was then pumped from the container to the process vessel, and the addition rate was determined by observing the weight change over a given time period. Agitation in the process vessel was evaluated based on observations of slurry surface movement. The controller setpoint of the variable speed system was used to quantify agitation. Approximate measurements of agitator rotational speed using a hand-held tachometer were also taken on a single batch of feed following formic acid addition and heat treatment.

Measurements of tank volume were taken before and after the unformated feed was concentrated. These values were used to determine the amount of water that was boiled off during the activity. Steam pressure and feed temperature were also monitored during the process.

Tank level was measured using a dipstick and feed volume determined from a tank calibration. Boil-off rate as a function of concentration time was not determined due to the fact that process condensate could not be collected. The difference in tank volume before and after concentration was used to calculate an overali boiling heat-transfer coefficient.

4.3.4.4.3 Experimental Observations. A total of five batches of feed were prepared in support of the HWVP-15 test. A summary of the operational parameters and observations made during the formic acid treatment activity is 
presented in Table 4.3-56. The formic acid addition rate for the initial 60 wt\% of formic acid was set at approximately $60 \mathrm{~L} / \mathrm{h}$. This rate corresponded to the maximum rate for the peristaltic addition pump used initially.

Inconsistencies created by equipment problems and preparation conditions between batches limit the number of conclusions that can be drawn from the formic acid treatment activities of this test. Varying amounts of dilution water used to rinse the precipitated slurry drums resulted in the concentration of feed undergoing formic acid treatment to vary as much as $25 \%$ from batch to batch. In addition, the control of the formic acid addition pump was less than optimum. The addition rate tended to decrease over time and had to be adjusted frequently. Many times during adjustment, the addition rate was increased above the target.

Foam was observed during the addition of the initial 60 wt\% of acid for the last three batches of feed (foaming during treatment of Batch \#3 was very light). No foam was observed during the addition of the final 40 .wt\% of acid, except for Batch $\# 5$. Prior to this.test, foaming incidents had been observed only after the initial 60 wt\% of the required formic acid had been added. (a) The formic acid concentration at the beginning of the foaming incidents encountered during the treatment of Batch \#3 and Batch \#5 was calculated to be approximately $0.3 \mathrm{M}$. A review of the data revealed that the concentration of formic acid at the initiation of the foaming incident observed during the preparation of HWVP-13 feed was approximately $0.3 \mathrm{M}$. This data suggests that formic acid concentration should be used as the benchmark for controlling foam generation instead of the percent of total acid required. A correlation to the $\mathrm{pH}$ of the feed cannot be established as measurements of this parameter were not taken.

Although the results of these tests are inconclusive, it appears that the degree of slurry. agitation may have accounted for the fact that no foaming was observed during the formic acid treatment of the first two batches. The volume of feed for these batches was approximately $25 \%$ lower than that of the final three batches. The initial controller setpoint for the agitator motor was approximately $70 \%$ for all five batches. Therefore, the relativeagitation and surface turbulence during the formic acid treatment of the first two batches was higher than the final three batches. In general, increased agitation was unsuccessful in dissipating an established foam 7 ayer while acid addition was in progress.

The observations made during the acid treatment of Batch $\# 5$ cannot be explained at this time. This batch was prepared by shift operators while the HWVP-15 test was in progress and foam was observed during most of the formic acid treatment sequence. The initial formic acid addition rate of $40 \mathrm{~L} / \mathrm{h}, a$ $33 \%$ reduction over Batch \#3 and Batch \#4, was selected in an attempt to prevent foaming. Relative agitation during the treatment of this batch was similar to that used in the treatment of the previous two batches. The acid

(a) R. K. Nakaoka et al., Pilot-Scale Ceramic Melter Experiment Run Summary HWUP-12/PSCM-22. HWVP-86-V1124A, Pacific Northwest Laboratory, Richland, Washington (1985): 
TABLE 4.3-56. Summary of Formic Acid Observations Preparation for PSCM-23 HWVP-89-IVJ0010100B

Conditions During the Addition of the Initial 60 utX of Formic Acid

\begin{tabular}{|c|c|c|c|c|}
\hline Batch \# & $\begin{array}{l}\text { Target } \\
\text { Rate, } \\
\mathrm{L} / \mathrm{h} \\
\end{array}$ & $\begin{array}{l}\text { Actual } \\
\text { Rate, } \\
\text { L/h } \\
\end{array}$ & $\begin{array}{c}\text { Agitator } \\
\text { Controller } \\
\text { Setpoint, } \\
x \\
\end{array}$ & $\begin{array}{c}\text { Rotational (a } \\
\text { Speed, } \\
\text { rom }\end{array}$ \\
\hline 1 & 60 & 63 & 70 & 85 \\
\hline 2 & 60 & 60 & 70 & 85 \\
\hline 3 & 60 & $61-35$ & $70-80$ & $85-100$ \\
\hline 4 & 60 & $60-43$ & $70-80$ & $85-100$ \\
\hline 5 & 40 & 38 & $75-85$ & $90-110$ \\
\hline
\end{tabular}

Observations

Conditions During the Addition of Final $40 \mathrm{wtX}$ of Formic Acid

\begin{tabular}{|c|c|c|c|c|c|}
\hline Batch \# & $\begin{array}{l}\text { Target } \\
\text { Rate, } \\
\text { L/h } \\
\end{array}$ & $\begin{array}{l}\text { Actual } \\
\text { Rote, } \\
\text { L/h } \\
\end{array}$ & $\begin{array}{c}\text { Agitator } \\
\text { Controller } \\
\text { Setpoint, } \\
x \\
\end{array}$ & $\begin{array}{c}\text { Rotational (a) } \\
\text { Speed, } \\
\text { rom } \\
\end{array}$ & Observat lons \\
\hline 1 & 20 & 18 & 70 & 85 & Ho form observed. \\
\hline 2 & 25 & 8 & 70 & 85 & Target rate of $25 \mathrm{~L} / \mathrm{h}$ was unattainable due to pump - no foam ob \\
\hline 3 & 25 & 20 & 80 & 100 & Rate reduced due to foaming during addition of initial $60 \mathrm{wt} \%$. \\
\hline 4 & 30 & 30 & 85 & 110 & Ho foan observed. \\
\hline $\mathbf{5}$ & 35 & 23 & 85 & 110 & Three-in. layer of foam observed throughout addition - stable. \\
\hline
\end{tabular}

(a) Rotational speed values are approximate.

Measurements taken on Batch $\$ 5$ following formic acid addition and heat treatment.

Tank volume $=2488 \mathrm{~L}$.

No foem observed.

No foum observed.

Three-in. foam layer observed after 46 wtX of required formic acid added - increasing. Pump shut off, agitation increased, and foam allowed to dissipate.

Addition rate decreased to $35 \mathrm{~L} / \mathrm{h}$ and pump turned on..

Three-in. foan layer observed - stable.

One-in. foam layer observed after 32 utX of required formic acid added - stable.

increased agi tation to dissipate foom.

Rate decl ined to $43 \mathrm{L/h}$ during addition.

Four-in. foam layer observed of ter 55 uty of required formic acid added - increasing

increased, and foan alloued to dissipate.

Pump on at same rate, three-in. foam layer observed - stable.

Three-in. layer of foam observed throughout addition - stable. 
addition rate for the final 40 wt\% of formic was inconsistent due to the loss of pump prime on a number of occasions:

\subsection{Heat Transfer Evaluation. A batch of feed was concentrated} from approximate $7 y$ $190 \mathrm{~g}$ of waste oxide per liter (WO/L) to $225 \mathrm{~g} \mathrm{WO} / \mathrm{L}$. The feed concentration required $3.4 \mathrm{~h}$ and was conducted prior to formic acid addition. An evaluation of the effects of steam pressure on boiling action was also conducted by varying the pressure over the range of 35 to 62 psig during concentration. The overall heat transfer coefficient for boiling was determined by estimating an average steam pressure, establishing the boiling temperature of the feed, and measuring the volume change that occurred during the process. Combined with the properties associated with these parameters and the dimensions of the equipment, the overall heat transfer coefficient for the concentration of NCAN-87 feed in the pilot-scale process vessel was calculated to be $88 \mathrm{Btu} / \mathrm{h} \cdot \mathrm{ft}^{2}$. $\cdot \mathrm{F}$ (see Table 4.3-57). Heat losses from the tank to the surroundings were calculated to account for $14 \%$ of the heat input. - An estimate of error for this calculation suggests that it could vary as much as $50 \%$. The majority of the error is associated with the inaccuracy of the feed volume measurement $( \pm 0.5$ in.).

The boiling action during the concentration of the feed became more vigorous as steam pressure was increased. Based on observations, it did not appear that the boiling mechanism changed over the steam pressure range tested ( 35 to $62 \mathrm{psig}$ ). The shift from nucleate to transition boiling is generally marked by a decrease in the random generation of bubbles and the appearance of vapor jets.

The value for the overall heat transfer coefficient currently being used to estimate cycle time for concentration of HWVP feed is the DWPF design value of $120 \mathrm{Btu} / \mathrm{h} \cdot \mathrm{ft}^{2}$. $\mathrm{F}$ (see Table 4.3-58). This value seems to be appropriate, based on DWPF test results. However, further testing with HWVP feed under design conditions will be required to establish a suitable boiling heat transfer coefficient for the concentration of HWVP feed as demonstrated by the significant differences between the HWVP-15 and the SRAT tests. The PSCM-23 and HWVP bench-scale test heat transfer values are not representative of plant equipment due to scale and design differences. However, the importance of these values in achieving HWVP process capacities warrants additional consideration.

\subsubsection{Full-Scale SRAT/SME Process Tests - SRL. (a) A Full-Scale SRAT/SME} Demonstration Facility has been constructed and operated at the Engineering Test Facility (ETF) of the Savannah River Laboratory in Building 672-T. The two canyon vessels are identical in design. so one tank was used at the ETF to simulate both processing steps. Two runs have been completed and evaluated to demonstrate critical design, fabrication, and operating features of the DWPF SRAT and SME.

(a) Memorandum from M. R. Baron to C. T. Randal1, "Summary of Fabrication, Start-Up, and Runs \#1 and \#2 of the DWPF FUTi-Scale SRAT/SME", DPST-87-794, Savannah River Laboratory, Aiken, South Carolina, date December 31, 1987. 
TABLE 4.3-57. Estimation of the Average Overal1 Heat Transfer Coefficient During Concentration HWVP-89-IVJ0010100Bi

$$
q=U_{0} A_{0} \Delta T=U_{0} A_{0}\left(T_{s}-T_{f}\right)
$$

where $q=$ heat rate, 8 tu/h

$U_{0}=$ overall heat transfer coefficient, Btwh-ft $t^{2} \cdot{ }^{-p}$

$A_{0}=$ heat transfer area, $f t^{2}$

$T_{s}=$ stean tenperature, $\circ$.

$T_{f}=$ feed temperature, $\cdot F$

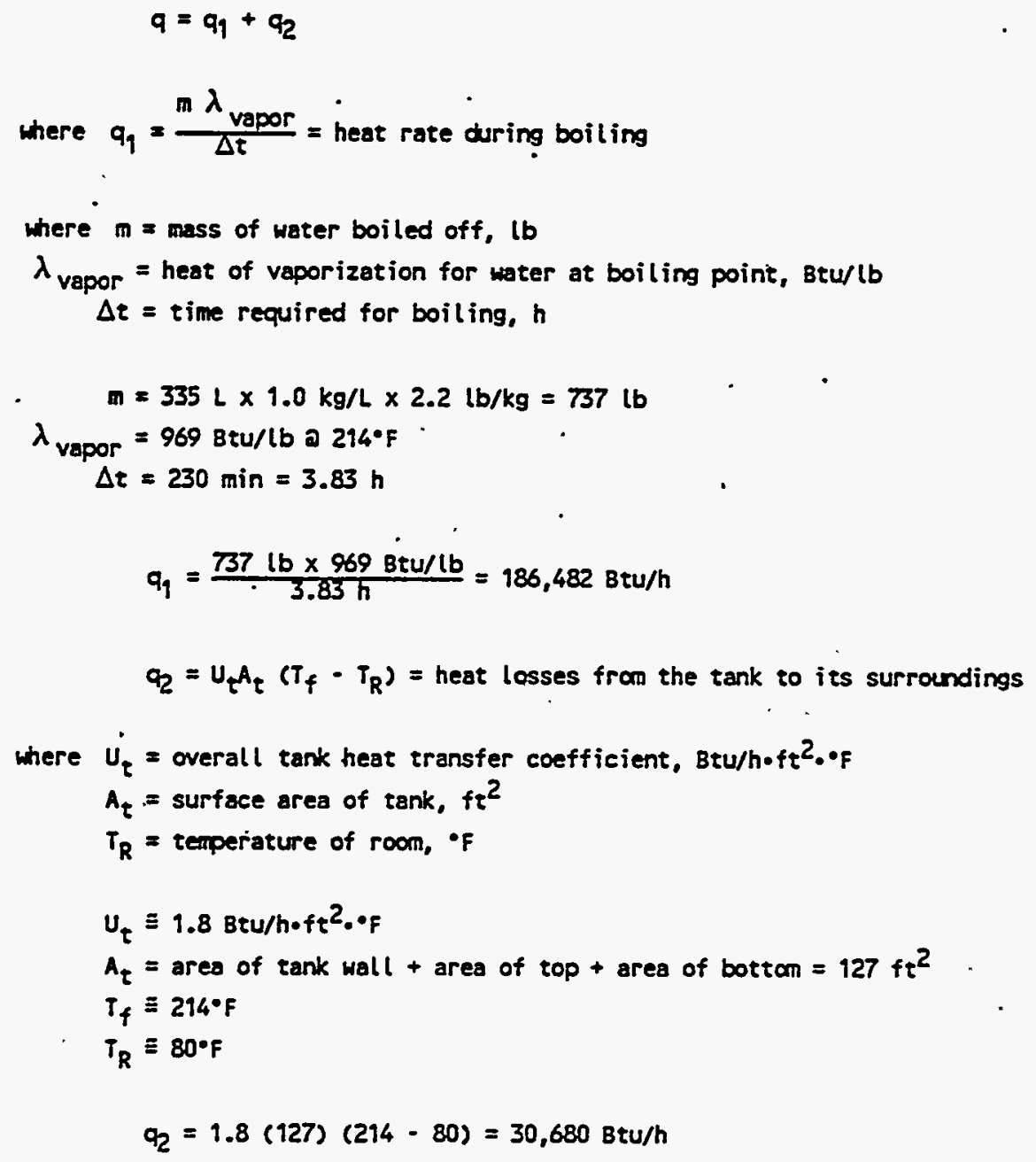

Therefore, $q=186,482 \mathrm{Btu} / \mathrm{h}+30,680 \mathrm{Btu} / \mathrm{h}=217,162 \mathrm{Btu} / \mathrm{h}$

$$
\begin{aligned}
q= & U_{0} A_{0}\left(T_{s}-T_{f}\right) \\
U_{0}=\frac{q}{A_{0}\left(T_{s}-T_{f}\right)} & =\frac{217.162}{28.9(299-214)} \\
U_{0} & =87.9 \mathrm{Btu} / \mathrm{h} \cdot \mathrm{ft}^{2} . \cdot \mathrm{F}
\end{aligned}
$$


TABLE 4.3-58. Comparison of Boiling Heat Transfer Coefficients HWVP-89-IVJ0010100B

\begin{tabular}{|l|c|c|}
\hline & $\begin{array}{c}\text { Steam } \\
\text { Pressure, } \\
\text { psig }\end{array}$ & $\begin{array}{c}\text { Heat-Transfer } \\
\text { Coefficient, } \\
\text { Btu/h-ft } \cdot \bullet \mathrm{F}\end{array}$ \\
\hline HWVP-15 & 52 & 88 \\
HWVP Bench-Scale Tests & 50 & 85 \\
DWPF SRAT Tests & 150 (max) & 127 \\
HHC Process Guidelines & 150 (max) & 120 \\
\hline
\end{tabular}

Specific topics discussed in the following sections include agitation, heating and cooling, evaporation and condensation, formic acid addition, slurry transfer, slurry rheology, and coil fouling. Many of the results are directly applicable to the. DWPF and may be useful for the design of the HWVP.

4.3.4.5.1 Test Equipment. The Design Demonstration SRAT/SME is $17.5 \mathrm{ft}$ in height (from the vessel bottom to the highest elevation nozzle face) and $12 \mathrm{ft}$ in outer diameter. A cross sectional view of the vessel is shown in Figure 4.3-102. The vessel is constructed of A77oy 20 , which is a high chrome and nickel ferrous based stainless steel containing molybdenum and copper.

The SRAT/SME head section has a minimum thickness of $1 / 2$ in and includes 27 nozzles for the agitator, coil assembly, instrumentation dip legs and process flows. Figure 4.3-103 is an overhead schematic of the tank showing the nozzle orientations. Table 4.3-59 lists the corresponding nozzle schedule including the nozzle's coordinates, size and purpose.

The tank wall has a minimum thickness of $3 / 8$ in and includes two nozzles. The first non-prototypic nozzle is located near the bottom of the tank and is used both as the tank overflow and conservation vent for pressure and vacuum relief.

The tank bottom has a minimum thickness of $3 / 4$ in and slopes $1 / 4 \mathrm{in} / \mathrm{ft}$. The low point is under the mercury pump flange (nozzle $C$ on Figure 4.3-103) and the high point is under transfer pump flange (nozzle $D$ on Figure $4.3-103$ ). A $1 \mathrm{ft}^{3}$ mercury sump is located at the low point of the tank. In the DWPF, this sump will be used to collect elemental mercury. The FullScale SRAT/SME does not contain a mercury trough which in the DWPF will be used in conjunction with the sump for mercury collection and detection.

The FuT7-Scale SRAT/SME agitation system is similar to that of the DWPF. As in the DWPF system, the agitator has a two-speed 100 hp motor. High speed for the Ful7-Scale System is $125 \mathrm{rpm}$ while low speed is $84 \mathrm{rpm}$. In the DWPF, high speed is $130 \mathrm{rpm}$ while. low speed is $65 \mathrm{rpm}$. However, the Ful1-Scale System is equipped with a set of change gears to reduce the agitator speeds to 100 and $67 \mathrm{rpm}$ to enable testing over the fuil range of DWPF conditions. 


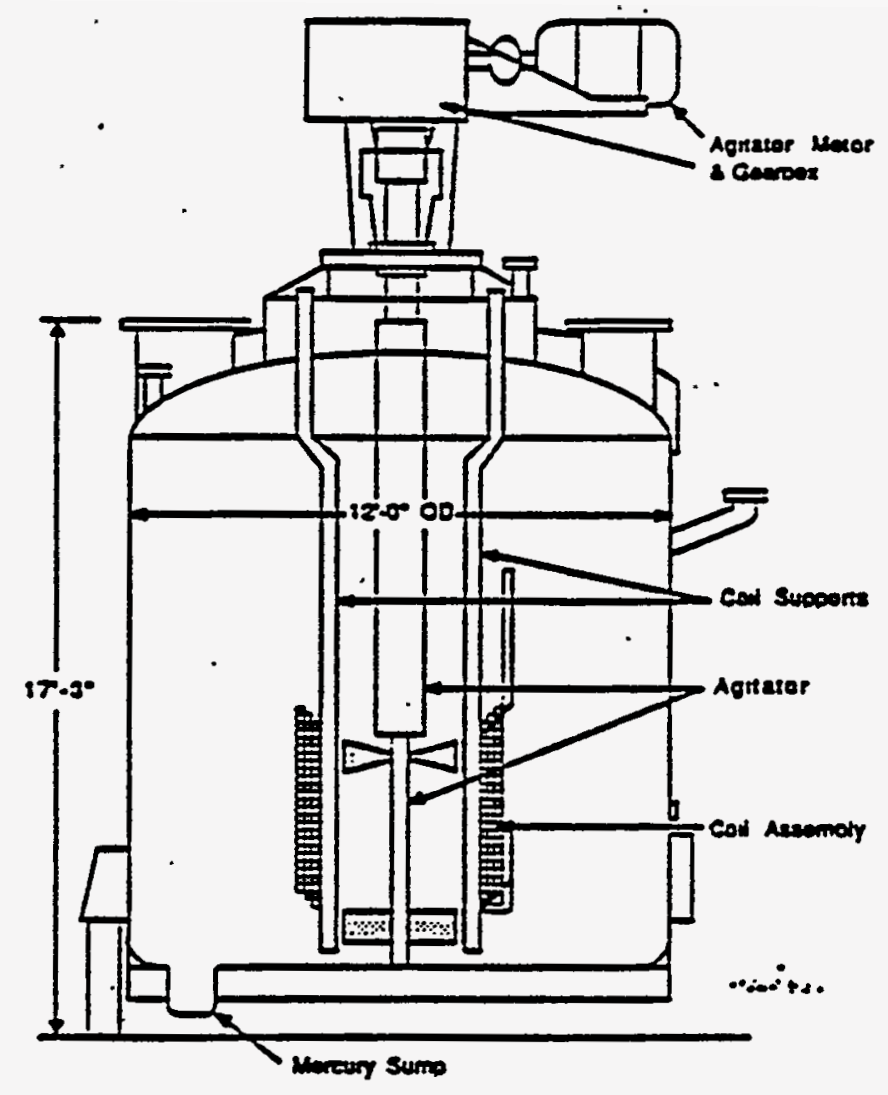

FIGURE 4.3-102. Cross Sectional View of the TNX Full-Scale SRAT/SME (Memorandum from M. R. Baron to C. T. Randall, DPST-87-794, December 31, 1987)

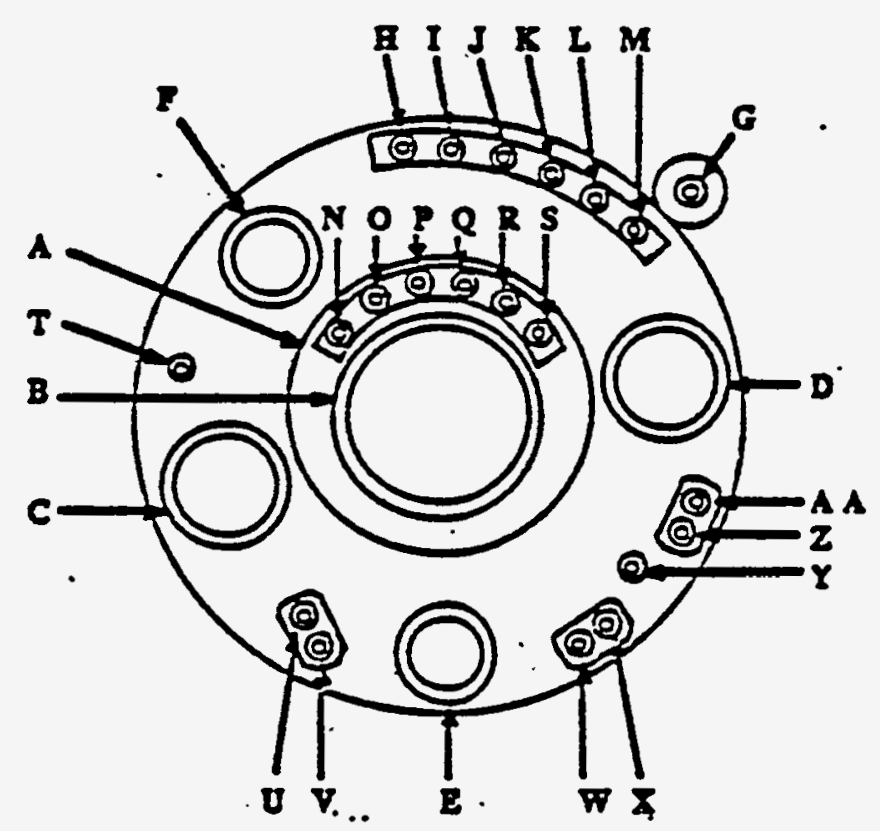

FIGURE 4.3-103. Overhead Schematic of the TNX Fu17-Scale SRAT/SME Showing Nozzle Orientations (Memorandum from M. R. Baron to C. T. Randa71, DPST-87-794, December 31, 1987) 
TABLE 4.3-59. Nozzle Schedule for the TNX FuT7-Scale SRAT/SME (Memorandum from M. R. Baron to C. T. Randa TT, DPST-87-794, December 31, 1987)

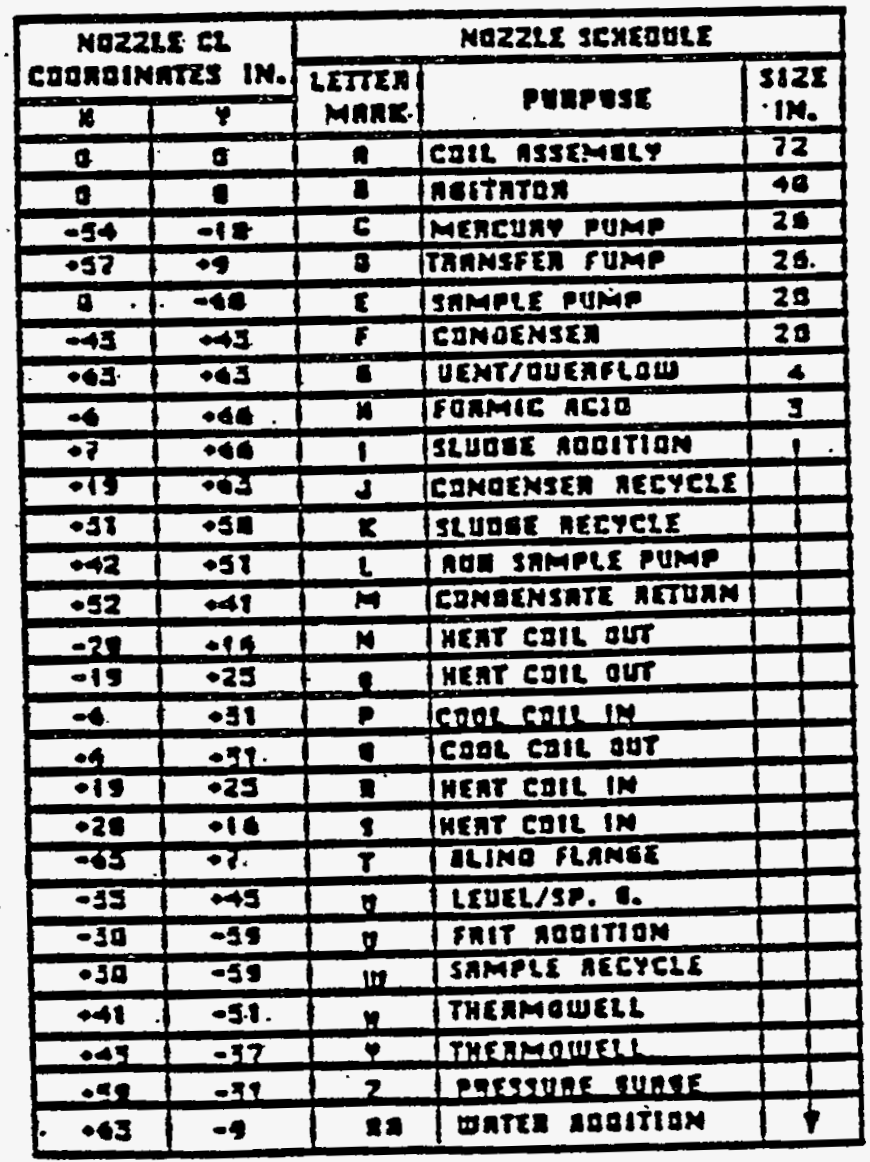

Both the DWPF and Full-Scale agitation systems are comprised of upper and lower impellers. The upper is a four-blade pitched turbine impeller. The lower is a four-blade flat turbine impeller that acts as a sweeper to keep solids from depositing on the bottom of the tank. Both impellers have a diameter of 36 in. to facilitate removal through a 40 -in. top flange. The impellers are positioned inside of the vessels heating and cooling coil assembly with about a 3 -in. clearance between the coil assembly and the impeller blades.

Heating and cooling of the SRAT/SME contents is accomplished using two heating coils and one cooling coil (Figure 4.3-104). The coil arrangement 
is a close-packed arrangement of 2-in. schedule 80, Hastelloy C-276 pipe (0. D. 2.375 in.) on $31 / 2$ in. centers. The total coil surface area available for heating is $357 \mathrm{ft}^{2}$. while the cooling surface area is $151 \mathrm{ft}^{2}$. Saturated steam is used as a heating medium while water doped with $\mathrm{NaOH}$ to inhibit corrosion is supplied from a cooling. tower for cooling. The agitator fits snugiy inside the two heating and cooling coils. The coil arrangement was originally held in place by tight tolerances and no welds were used to attach the coils to the support assembiy. It is important to note that during SRAT/SME Runs \#1 and \#2, the steam traps on the steam condensate return lines (heating coil exit) were at ground level, compared to elevated steam traps in the DWPF design. The DHPF elevated steam trap design was instalied after SRAT/SME Run \#2, and tested during SRAT/SME Run \#3 and subsequent Full-Scale Runs.

4.3.4.5.2 Test STurry. The sludge used in Full-Scale SRAT/SME Processing was prepared by an outside vendor, ARomatic Flavors and Fragrances (AFF), in a precipitation process similar to that which the radioactive sludge undergoes in the Chemical Separations Areas. Sludge was delivered to the ETF via tank trucks and was stored in the SRT until use in the SRAT/SME. The chenical compositions for SRAT/SME Batches \#1 and \#2 are found in Tables 4.3-60 and 4.3-61. The batch compositions in Tables 4.3-60 and 4.3-61 do not reflect the formic acid addition and reactions.

The amount of frit added in a particular batch depends on the sludge composition and is calculated to yield a final glass oxide/waste oxide weight $\%$ ratio of -2.5 . Therefore, the desired amount of waste forming oxides in the glass is 25 to 31 wt\%. This value is referred to as the percent waste loading.

19,050 1bs of Frit 168 was added to SME Batch \#1 as. two equal batches of frit/water. 25,900 1bs of Frit 165 was added to SME Batch \#2 in three batches of frit/water. Average compositions and specifications for Frit 165 and. 168 are found in Table 4.3-62. The amount of frit added in SME Batch \#1 was calculated to yield a final waste loading in the glass of 27 wt\%. The amount of frit added in SME Batch \#2 was calculated to yield a final waste loading in the glass of 28 wt\%.

\subsection{Test Procedure. The ETF Full-Scale SRAT/SME Cycles for} Runs \#1 and \#2 differ from the DWPF SRAT and SME Cycles in several aspects. A principal difference, which has already been stated, is that only one processing vessel is used in the Full-Scale System as both the SRAT and SME compared to a separate SRAT and SME vessel in the DWPF. Other major differences resulted from changes in the composition of the waste simulation.

Sludge consists of a water slurry of mainly the insoluble waste components in the SRP high-level waste and is composed primarily of the hydroxides of iron, aluminum and sodium, the oxides of manganese and silica and calcium carbonate. The sludge simulation used at the ETF was prepared by an outside vendor through a precipitation process similar to that which the radioactive sludge undergoes in the Chemical Separations Areas. Unlike the 
TABLE .4.3-60. S7udge/Frit Composition for SRAT Batch \#1

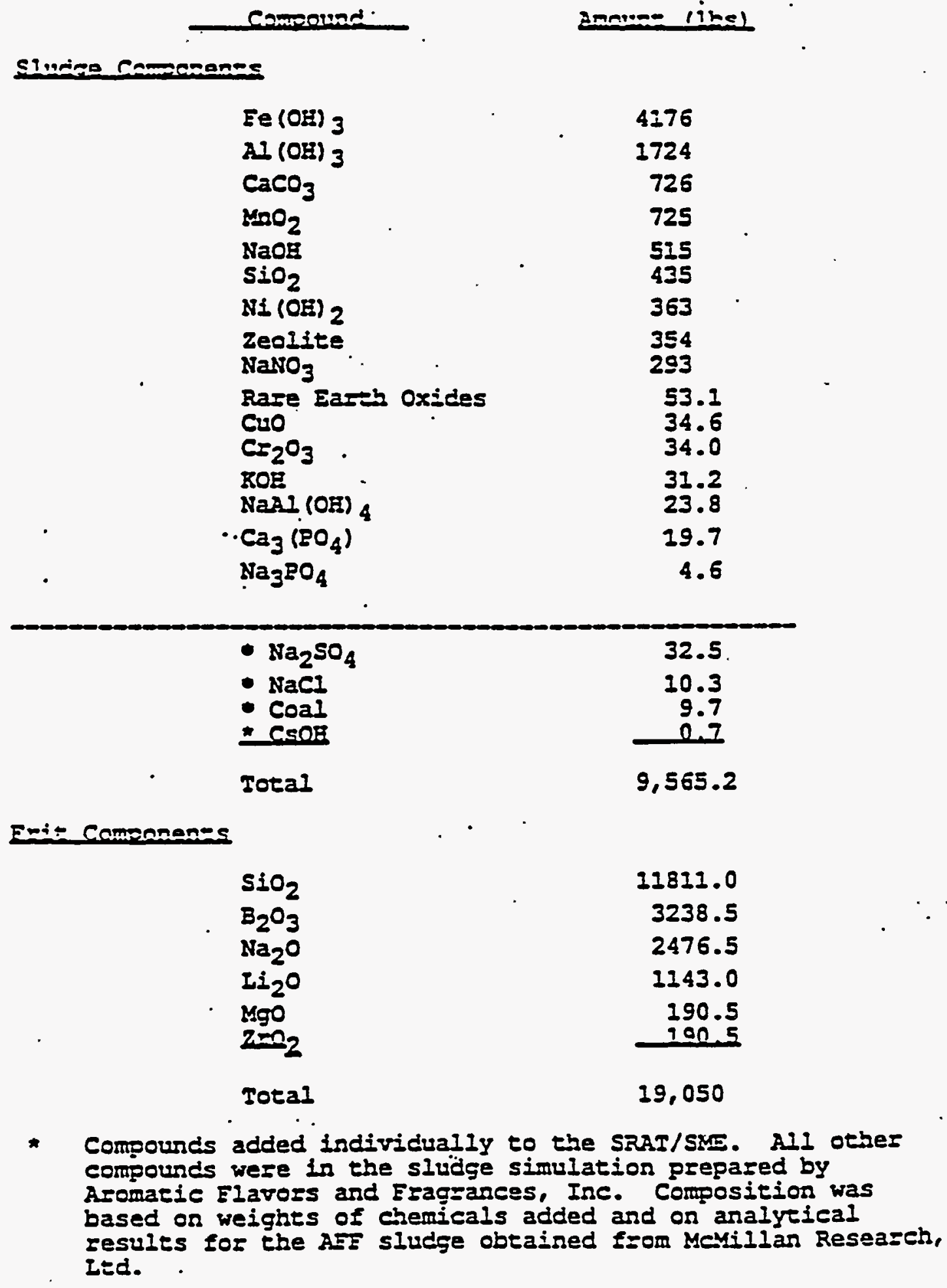


TABLE 4.3-61. STudge/Frit Composition for SRAT Batch \#2

ermocend

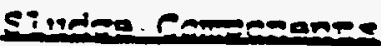

Es (Cㅍㄱ 3

$A I$ (OE) 3

$\mathrm{MeO}_{2}$

$\mathrm{CaCO}_{3}$

$\mathrm{SLO}_{2}$

NaOz.

$\mathrm{NI}$ (OE) 2

$\mathrm{NaNO}_{3}$

zeolite

Rase Eart Oxides

020

$\mathrm{Cr}_{2} \mathrm{O}_{3}$

ROE

$\mathrm{NaAl}_{\text {(OE) }}$

$\mathrm{Ca}_{3}\left(\mathrm{EO}_{4}\right)_{2}$

$\mathrm{Na}_{3} \mathrm{EO}_{4}$

- ivái

- $\mathrm{CaSO}_{4}$

$-\mathrm{Na}_{2} \mathrm{SO}_{4}$

- $\mathrm{CaF}_{2}$

- $\mathrm{SLCO}_{3}$

- Coal (tize)

- Mas

- $\operatorname{csNO}_{3}$

- NaT

Total 2ander 19hel

6513.1

2689.3

1284.8

1007.4

818.3

722.7

584.0

514.6

351.9

82.8 (Note 1)

54.0

53.1

49.1

39.9

30.7

7.3

175.0

60.0

40.0

24.2

20.0

20.0

16.5

15.0

30

$15,173.7$

E-it Camenanate
17,612

3,367

2.590

1,183

259

250

25,900 
TABLE 4.3-61. (contd)

Note 1: Rare Earth Oxide Composition - $50 \% \mathrm{CeO}_{2}$. 25\% $\mathrm{La}_{2} \mathrm{O}_{3}$ and 258 $\mathrm{Nd}_{2} \mathrm{O}_{3}$. .

* Compounds added individually to the sMe with the frit/slurny. All other compounds were in the sludge simulation prepared by Aromatic Elavors and Fragrances, Inc. Composition was based on weighes of chemicals added and on analytical results for the AFE sludge obrained from Mevillan Researeh. Itd.

TABLE 4.3-62. Sludge-OnTy Glass Frit Chemical. Compositions and Specifications.

\begin{tabular}{|c|c|c|}
\hline componeat & E-it 155 & E-it 168 \\
\hline $\mathrm{SiO}_{2}$ & $68.0 \pm 1.0$ wts & $62.0 \pm 1.0 \mathrm{wcs}$ \\
\hline $\mathrm{Na}_{2} \mathrm{O}$ & $13.0 \pm 1.0$ wts & $13.0 \pm 1.0$ wt \\
\hline $\mathrm{B}_{2} \mathrm{O}_{3}$ & $10.0 \pm 1.0$ wts & $17.0 \pm 1.0$ wes \\
\hline $\mathrm{Ii}_{2} \mathrm{O}$ & $7.0 \pm 1.0 \mathrm{wts}$ & $6.0 \pm 1.0$ wts \\
\hline $\mathrm{M}_{\mathrm{g}} \mathrm{O}$ & $1.0 \pm 0.5 \mathrm{kcs}$ & $1.0 \pm 0.5$ wts \\
\hline $2=\mathrm{O}_{2}$ & $1.0 \pm 0.5$ wt. & $1.0 \pm 0.5$ wet \\
\hline
\end{tabular}

Unzequested Components: total less than 2.0 wt?

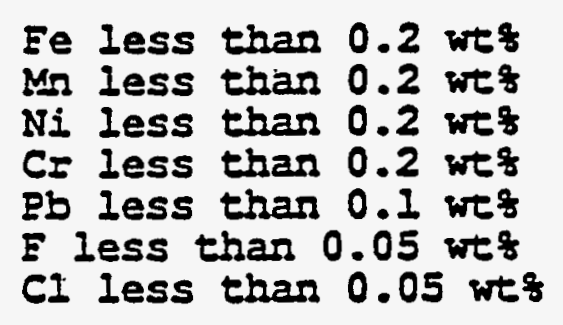

Eree metals, C, organic, less than 0.1 wt? total Moisture - less than 0.18

MESa SIZE: 0.08 retained on 80 mesh sieve. Equal to or greater than 90.08 retained on 200 mesh sieve. 
actual material which will be processed in the DWPF, the sludge simulation used at the ETF contained no radionuclides or mercury due to containment and environmental concerns.

A process flow diagram for the Full-Scale SRAT/SME System is included as Figure 4.3-105. Slurry feed preparation was initiated by transferring a siudge batch from the SRT to the SRAT/SME (SRAT Cycle). The 6000 galion batch was approximately 13 wt\% solids, had a density of $1.10-1.20 \mathrm{~g} / \mathrm{cc}$ and a $\mathrm{pH}$ of $11-13$. After a sample was taken, the s7udge was heated to $93^{\circ} \mathrm{C}$. The sludge was then adjusted by adding. a calculated amount of $90 \%$ formic acid solution. To control the rate of off-gas evolution from the siudge/formic reaction, the sludge temperature was maintained between $90{ }^{\circ} C$ and $96^{\circ} \mathrm{C}$ and the formic acid addition rate controlled at $2 \mathrm{gpm}$. At the end of the formic acid addition step, the sludge temperature was increased to boiling, $-103^{\circ} \mathrm{C}$, and the sludge was refluxed for four hours to complete the sludge/formic acid reaction. In the sludge-oniy process the addition of formic acid accomplishes the following:
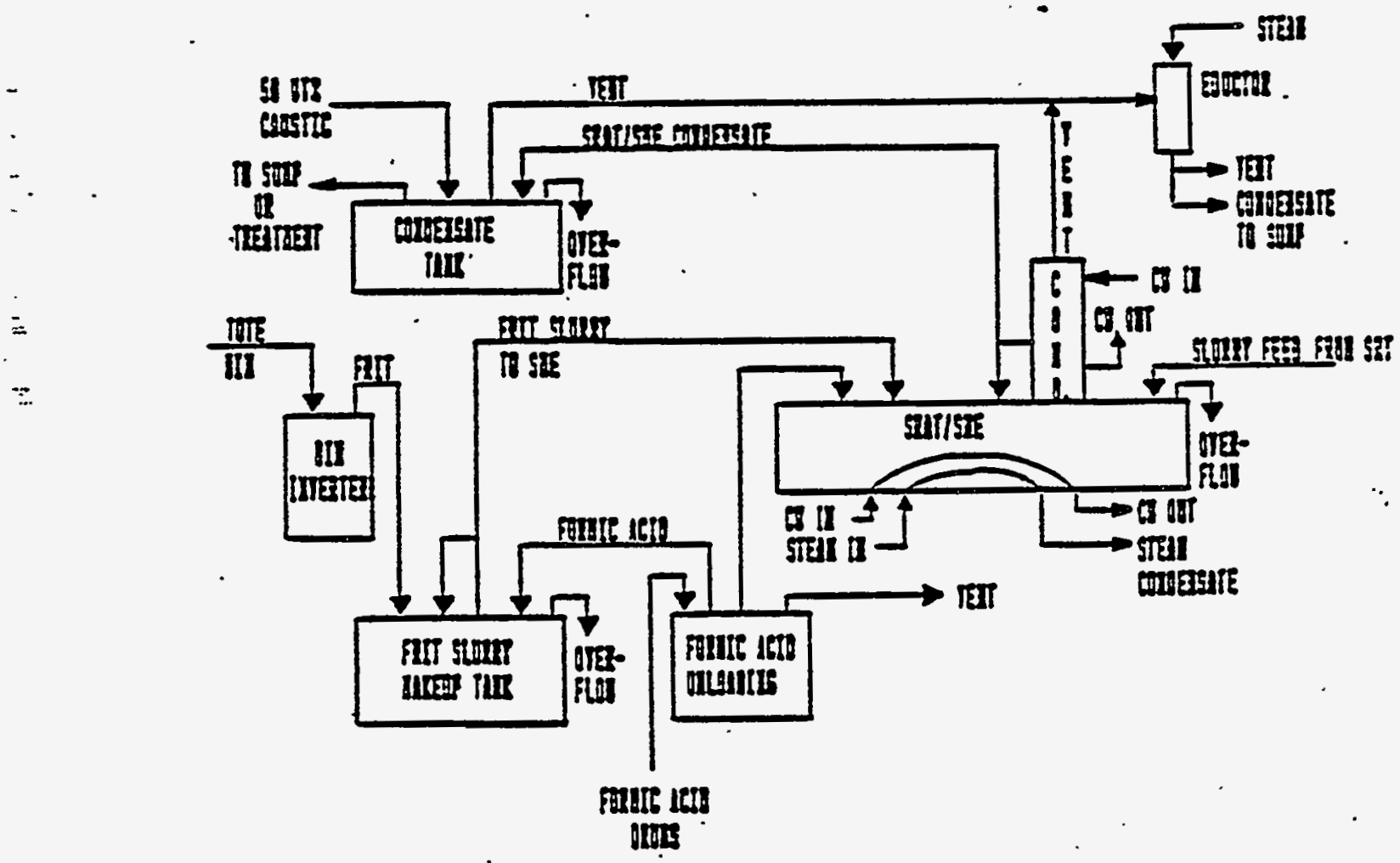

FIGURE 4.3-105. Sludge-Only Process Flow Diagram for Full-Scale SRAT/SME (Memorandum from M. R. Baron to C. T. Randa11, DPST-87-794, December 31, 1987) 
- Converts some insoluble hydroxides, oxides and carbonates to soluble formates improving the rheological properties of the slurry for more efficient pumping and mixing.

- Controls the redox reactions in the melter cold cap. This is critical to prevent foaming in the melter and to limit the reduction of compounds to their metaliic form and the deposition of these metals on the floor of the melter.

At this point, the contents were cooled and sampled to determine the effectiveness of the formic acid addition. This was determined by measuring the sludge $\mathrm{pH}$ and the percent conversion of selected sludge components from the insoluble to the soluble state (formates). If the formic acid reaction went to the desired completion, the tank contents were once again heated to boiling. The formated sludge was concentrated to a final endpoint of $19 \mathrm{wt} \%$ solids. The condensed overheads were diverted to the SMECT. Condensate collected in the SMECT was neutralized to a pH between 6 and 9 with 50 wt\% NaOH and was pumped to the building sump. The SRAT/SME contents were then cooled and sampled to determine the batch rheology and the amount of frit required during the SME cycle.

In the SRAT/SME (SME Cycle), frit was normally added as a $60 \mathrm{wt} \%$ frit/water slurry. The frit slurry was prepared in the FSMT and transferred to the SRAT/SME. The Dry Frit Handling System was used to transfer the dry frit from Tote bins to the FSMT. The amount of frit added was calculated to produce a glass product with a nominal 72 wt\% glass forming oxides and 28 wt\% waste forming oxides. After all of the frit was added, the resulting slurry was concentrated to 40 to 45 wt\% solids. The concentrated slurry was then sampled to confirm the concentration endpoint, the batch rheology and the $\mathrm{Fe}^{+2} / \mathrm{Fe}^{+3}$ ratio. If the analyses were within the desired specifications, the slurry was transferred to the Melter Feed Tank (MFT) for vitrification in the SGM.

4.3.4.5.4 Effect of STurry Density on Agitator Power. During normal heating and evaporation cycles high agitator speed was used to increase the mass transfer in the slurry and thus increase the heat transfer and boil up rate. The amount of power required by the agitator motor appeared to be more dependent upon the density of the material in the tank than on the rheology of the material. The effect of slurry density on the agitator power is shown in Figure 4.3-106. As the density of the agitated material increased, the agitator power required increased proportionately. Therefore, in the DWPF the SME and MFT agitator motors will normally run at a higher power level than the SRAT due to the higher density material in these vessels.

4.3.4.5.5 Heat Transfer Testing Results. The history of the coil heat transfer coefficients during boiling periods for initial water runs and 


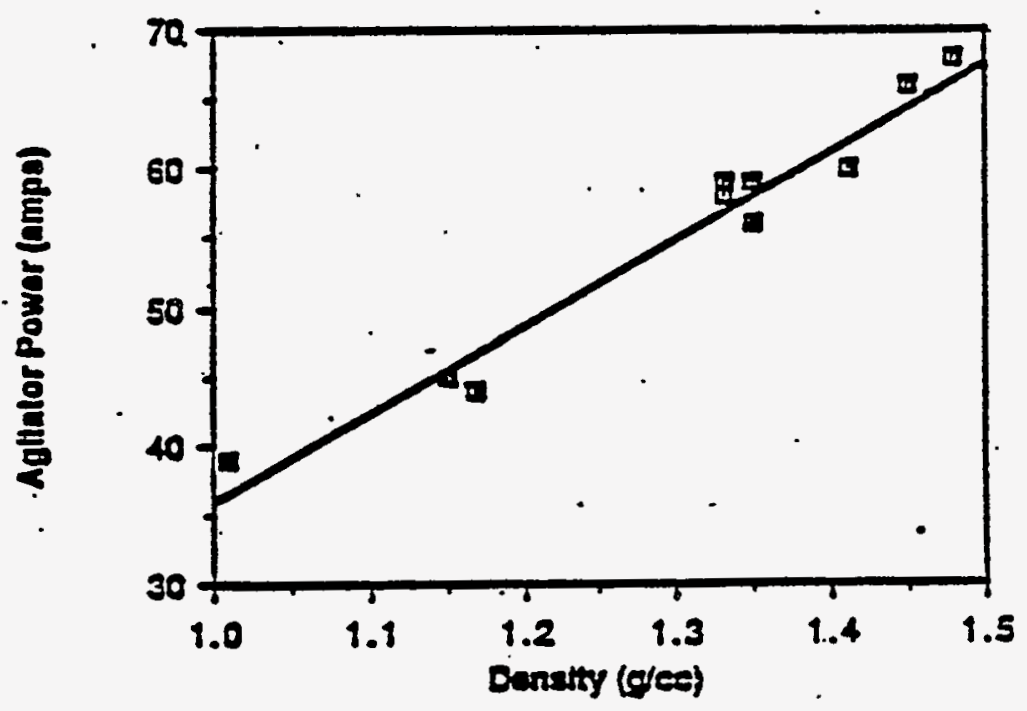

Agitater Power

FIGURE 4.3-106. The Effect of STurry Density on Agitator Power (Memorandum from M. R. Baron to C. T. Randall, DPST-87-794, December 31, 1987)

SRAT/SME Batches \#1 and \#2 are shown in Table 4.3-63. The design DWPF boiling heat transfer coefficients of $120 \mathrm{BTU} / \mathrm{hr}-\mathrm{ft}^{2} \cdot \mathrm{F}$ for the SRAT and $100 \mathrm{BTU} / \mathrm{hr}^{-\mathrm{ft}^{2}}$ of for the SME were exceeded during both SRAT/SME Runs \#1 and \#2. The heat transfer coefficients in Table 4.3-63 were calculated with an average steam supply of approximately $5000 \mathrm{pph}$ and $90 \mathrm{psig}$ inlet pressure (before the steam control valve): The Full-Scale SRAT/SME boiling heat transfer coefficients were calculated using the following formula:

$Q=m \Delta H_{\text {vap }}=U A \Delta T$

where $\quad Q=$ Evaporative heat rate

$m=$ Mass flowrate of overheads (1b/hr)

$\Delta H_{v a p}=$ Latent heat of vaporization of water (BTU/Tb)

= Heat transfer coefficient (BTU/hr-ft' $\left.{ }^{2} \cdot F\right)$

$A=$ Surface area of heating coils $\left(\mathrm{ft}^{2}\right)$

$\Delta T=$ Coil steam inlet - vessel contents $(\bullet F)$

The use of the above formula for boiling heat transfer is based on the following boundary conditions and processing experience:

- The mass flow rate of condensed overheads is conservatively used for the $\mathrm{m}$ term. Since greater than $99 \%$ of the condensed overheads are water, the latent heat of vaporizaton for water at atmospheric pressure ( $970 \mathrm{BTU} / \mathrm{Tb})$ is used for the $\Delta H_{\text {vap }}$ term.

- A small amount of water in the overheads is lost in the saturated vapor stream from the condenser. However, this amount of water is negligible and tends to make the calculation of boiling heat transfer coefficient conservative. 
TABLE 4.3-63. Average Boiling Heat Transfer Coefficients for Water Runs and SRAT/SME \#1 and \#2

(Memorandum from M. R. Baron to C. T. Randa11, DPST-87-794, December 31, 1987)

\begin{tabular}{|l|c|}
\hline \multicolumn{1}{|c|}{ Processing Cycle } & $U\left(B T U / \mathrm{hr}^{-\mathrm{ft}^{2}-\bullet F}\right.$ ) \\
\hline Water Runs (Initial) & 180 \\
SRAT \#1 & 160 \\
SME \#1 & 140 \\
Water Runs (JuTy 1985) & 180 \\
SRAT \#2 & 135 \\
SME \#2 & 115 \\
\hline
\end{tabular}

- The values were calculated for a given time period during which the $\Delta T$ between the steam inlet and the vessel contents was relatively constant.

The overall boiling heat transfer coefficients were found to decrease as the yield stress increased as is shown in Figure 4.3-107. Yield stress measurements were made with a Haake ${ }^{m}$ rotational viscometer. As water was removed from the slurry during concentrating, the yield stress increased. In the DWPF, the heat transfer coefficient at boiling can be continuously monitored to predict and maintain the minimum acceptable yield stress in the slurry. Additionaliy, a decrease in this heat transfer coefficient over time may be an indication of coil fouling in the DWPF. 


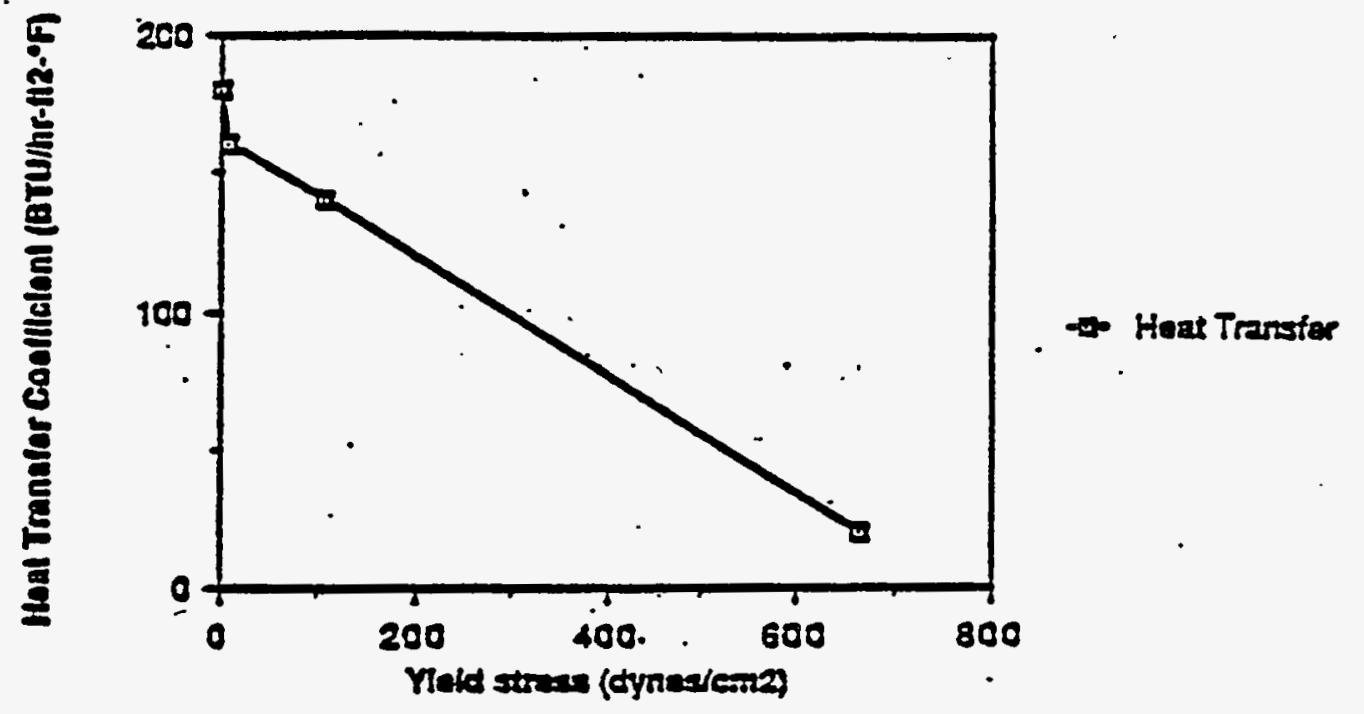

FIGURE 4.3-107. Effect of STurry Yield Stress on Boiling Heat Transfer Coefficients (Memorandum from

M. R. Baron to C. T. Randal1, DPST-87-794, December 31,1987 )

Additional heat transfer data (Table 4.3-64) from Runs 7 and 8 of the Full-Scale SRAT/SME were obtained during technical exchange between DWPF and HWVP at the Savannah River Plant. The values for the heat transfer coefficients in Table 4.3-64 are comparable to those in Table 4.3-63. A significantly lower heat transfer coefficient was obtained for water in Table 4.3-64, which could be the result of fouling. It is important to note that the heat transfer coefficients for the slurries in Runs 7 and 8 do not vary much from the heat transfer coefficient obtained for water (see Table 4.3-64). Therefore, for heat transfer purposes it is conceivable that the SRAT and the SME could be designed and modeled by using the properties of water to approximate the properties of the slurry. In Runs 7 and 8 the acid hydrolysis product was also included as part of the feed makeup for the SRAT. 
TABLE 4.3-64. Heat Transfer Resu7ts from Water Run and SRAT/SME \#7 and \#8. (T. T. Trinh, Presentation: DWPF Liquid Samping Station/ Everlasting Valves, Coil Heat Transfer Coefficients, Vessel/Component Hear, DWPF and HWVP-Technical Exchange, January 9-13, 1989, Savannah River Project, Aiken, South Carolina, dated January 12, 1989)

\begin{tabular}{|c|c|c|c|c|c|}
\hline & & \multicolumn{2}{|c|}{ SRAT/SME \#7 } & \multicolumn{2}{|c|}{ SRAT/SME \#8 } \\
\hline PARAMETER & HATER & $\begin{array}{l}\text { SRAT, } \\
10 \mathrm{wt} \%\end{array}$ & $\begin{array}{l}\text { SME, } \\
43 \text { wt\% }\end{array}$ & $\begin{array}{l}\text { SRAT, } \\
22 \text { Wt\% }\end{array}$ & $\begin{array}{l}\text { SME, } \\
44 \text { wt\% }\end{array}$ \\
\hline $\begin{array}{l}\text { Steam Flow } \\
\text { (pph) }\end{array}$ & 5000 & 5000 & 5000 & 5000 & 5000 \\
\hline 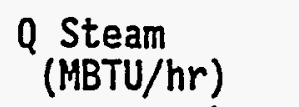 & 4.54 & 4.54. & 4.54 & 4.59 & 4.6 \\
\hline $\begin{array}{l}\text { H.T. Coeff. } \\
\text { BTU/hr-ft' }\end{array}$ & 132 & 123 & 129 & 142 & 144 \\
\hline $\begin{array}{l}\text { Boil-Up } \\
\text { (gpm) }\end{array}$ & 9.6 & 9.6 & 9.5 & 9.3 & 9.4 \\
\hline $\begin{array}{l}\text { Hboil-Up } \\
\text { (MBTU/hr) }\end{array}$ & 4.66 & 4.66 & 4.60 & 4.51 & 4.55 \\
\hline $\begin{array}{l}\text { H.T. Area } \\
\left(\mathrm{ft}_{2}\right)\end{array}$ & 357 & 357 & 357 & 357 & 357 \\
\hline $\begin{array}{c}\text { Chest } T \\
(\cdot F)\end{array}$ & 312 & 319 & 319 & 305 & 307 \\
\hline Chest $P$ & 65 & 74 & 74 & 57 & 60 \\
\hline
\end{tabular}

The transient heat transfer coefficients were calculated for SRAT/SME Run \#2 and the results are shown in Table 4.3-65. The heat transfer coefficients in Table 4.3-65 were calculated with an average steam supply of approximately $5000 \cdot \mathrm{pph}$ and $90 \mathrm{psig}$ inlet pressure (before the steam control valve). These heat transer coefficients were calculated using the following formula:

$$
\ln \frac{\left(T-t_{1}\right)}{\left(T-t_{2}\right)}=\frac{U A}{m C}(\phi)
$$


TABLE 4.3-65. Average Transient Heat Transfer Coefficients for SRAT/SME \#2 (Memorandum from M. R. Baron to C. .T. Randa17, DPST-87-794, December 11, 1987)

\begin{tabular}{|c|c|}
\hline Processing Cycle & U (BTU/hr- $\left.\mathrm{ft}^{2}-\circ \mathrm{F}\right)$ \\
\hline SRAT \#2 & 100 \\
SHE \#2 & 90 \\
\hline
\end{tabular}

where $T=$ Coil steam temperature $(\cdot F)$

$t_{1}=$ Initial temperature of vessel contents $(\cdot F)$

$t_{2}=$ Final temperature of vessel contents $(\cdot F)$

$\mathrm{m}=$ Weight of vessel contents $(\cdot F)$

$C_{p}=$ Specific heat of vessel contents $\left({ }^{\circ} F\right)$

$\phi=$ Heating interval time (hours)

$U=$ Heat transfer coefficient (BTU/hr-ftz $-\cdot F$ )

$A=$ Surface area of heating coils $\left(\mathrm{ft}^{2}\right)$

The use of the above formula for transient heat transfer coefficients is based on the following boundary conditions and processing experience:

- The values were calculated for a given time period during which the

. steam inlet temperature was relatively constant.

- An average temperature for the steam inlet can be used over a given time frame for $T$ providing that the difference between the coil exit and coil inlet temperatures is not greater than $10 \%$ of the $\Delta T$ log mean between the average coil temperature and the temperature of the tank contents.

- The specific heat data for formated acidic sludge and SME slurry were based on calorimetric studies of simulated waste sludges, representing different stages of melter feed preparation, which were completed at Du Pont's Engineering Test Center. The heat capacities of these slurries varied by less than $4 \%$ over the 30 to $110^{\circ} \mathrm{C}$ testing range therefore, an average heat capacity value was used for a specific wt\% slurry, independent of the slurry temperature. The heat capacity value for alkal ine sludge was based on reference compositions and wt\% solids. This heat capacity value was utilized since the alkaline sludge behaves exothermaliy when heated above $40^{\circ} \mathrm{C}$, and, therefore, accurate heat capacity data could not be obtained through calorimetric studies. This exotherm may be by a reaction between the free caustic and the alumina trihydrates present in the alkaline sludge. The following heat capacity values were used: 
Incoming Alkaline Sludge $=0.89$ BTU/7b- $\cdot-F$

Formated Acidic Sludge $=0.90$ BTU/7b- -F (16 wt\% solids)

SME STurry

$=0.79 \mathrm{BTU} / \mathrm{Tb}-{ }^{\circ} \mathrm{F}$ ( $40^{\circ} \mathrm{wt} \%$ solids)

The effect of agitator speed on the slurry cool down cycle was determined. SME slurry was cooled from $103^{\circ} \mathrm{C}$ (boiling) to $50^{\circ} \mathrm{C}$ (maximum design DWPF sampling temperature) using water through the coils as the cooling medium. The inlet temperature of the cooling water, was an average of 24 to $30^{\circ} \mathrm{C}$ with an average flow of about $100 \mathrm{gpm}$. The slurry cooling cycle was completed using both high and low agitation. This test was designed to determine the proper agitator speed to minimize the amount of cool down time necessary in the DWPF.

The test determined that the amount of cool down time necessary with high and low agitation (125 and $84 \mathrm{rpm}$ ) was approximately equal, both cases requiring about three hours. The cooling heat transfer coefficient increased as the higher agitator speed increased the mass transfer in the slurry. However, this higher speed also increased the amount of heat transmitted from the agitator shaft into the slurry due to friction.

Thus, for time and attainment considerations, either high or low agitator speed could be used in the DWPF for cooling of the SME and the MFT. For agitator wear considerations low speed agitation is recommended. It is important to note that this test was performed with approximately $6000 \mathrm{gal}$ lons of SME slurry with a density of $1.35 \mathrm{~g} / \mathrm{cc}$ and a yield stress of about 110-120 dynes $/ \mathrm{cm}^{2}$. The cooling time cycles will vary for different tank volumes (weights) and different slurry consistencies and densities.

After the conclusion of SME operation, SRAT/SME Batch \#I was allowed to remain in the tank for several weeks to acquire run time on the transfer pump and agitator. During this time, the cooling water to the cooling coil and condenser was valved off. The agitator maintained a vessel temperature $>70^{\circ} \mathrm{C}$ with the SME material with no cooling water flow through the coil and condenser. Therefore, the DWPF will need to operate the cooling coils in the Melter Feed Tank to stay below their maximum design pumping temperature of $50^{\circ} \mathrm{C}$.

4.3.4.5.6 SRAT/SME Condenser Testing Results. The FuT7-SCaTe SRAT/SME condenser is used to remove condensibles from the overheads and concentrate the tank contents. The condenser is mounted vertically onto the SRAT/SME and is similar to the DWPF design. During SRAT/SME Batches \#1 and \#2, the co01ing water through the condenser was nominally at an inlet temperature of $20^{\circ} \mathrm{C}$ (idle) to $35^{\circ} \mathrm{C}$ (boiling) and a flow of 400 to $460 \mathrm{gpm}$. The increase in the condenser cooling water inlet temperature at boiling compared to idle was due to the inability of the cooling tower to handle the increased heat load. 
An 8-in. diameter doubie lined updraft tube in the center of the condenser carries the overheads to the top of the condenser. The overheads experience minimal cooling and condensation passing through this updraft tube. At the top of the condenser, the overheads turn $180^{\circ}$ and flow down the 314, 3/4-in. diameter tubes, which are in contact with the cooling water. The vapor is cooled as it passes down these tubes and the condensibies (primarily water) collect in a dish located near the base of the condenser. The condensed overheads overfiow from this dish into the condensate line while the noncondensibles are pulled into the vacuum line. The vacuum line connects to the dish several inches higher than the condensate line to ensure adequate separation of the condensible and non-condensible streams. A 6-in. diameter baffle plate was centered directiy under the updraft tube in place of a demister pad to minimize entrainment.

The measured pressure drop through the condenser and the corresponding steam supply and boil-up rates are shown in Table 4.3-66. The maximum recorded pressure drop was 7-8 in. of water during evaporation at $5000 \mathrm{lb} / \mathrm{hr}$ overheads flow. This is in line with the DWPF design maximum condenser pressure drop of $10 \mathrm{in.}$. water.

Condensate samples taken from the SMECT reflux line during SRAT/SME Batches \#1 and \#2 were clear and had minimal amount of suspended solids. The SRAT/SME contents. were heated with steam at 5000 to $6000 \mathrm{pph}$ and $90 \mathrm{psig}$ inlet pressure (before the steam control valve) throughout the majority of

$\therefore \quad$ SRAT/SME Batches \#I and \#2. The condensate samples from Batch \#I were taken

$\because \quad$ with a minimum SRAT/SME freeboard under the condenser inlet/vessel top head

$\therefore \quad$ interface of about $49 \mathrm{in.}$ ( -8100 gallons tank volume). During SRAT/SME

$\because \quad$ Batch \#2, the minimum freeboard corresponding to condensate sampling was about 31 in. under the condenser inlet/vessel top head interface ( $-9300 \mathrm{gal}$ -

$=$ lons tank volume). Entrainment was minimal based on condensate samples,

TABLE 4.3-66. The Effect of Boi7-Up Rate on Condenser DP During Full-Scale SRAT/SME Water Runs

\begin{tabular}{|c|c|c|c|}
\hline $\begin{array}{c}\text { Steam Flow } \\
(1 \mathrm{~b} / \mathrm{h})\end{array}$ & $\begin{array}{c}\text { Steam Coil } \\
\text { Inlet Pressure } \\
\text { (after control valve) }\end{array}$ & $\begin{array}{c}\text { Condensate } \\
\text { Take-Off Rate }\end{array}$ & $\begin{array}{c}\text { Condenser } \\
\text { Pressure Drop }\end{array}$ \\
\hline 4200 & $45 \mathrm{psig}$ & $6.9 \mathrm{gpm}$ & 5 in. wC \\
5200 & $59 \mathrm{psig}$ & $8.4 \mathrm{gpm}$ & 7 in. wC \\
6150 & $75 \mathrm{psig}$ & $10.0 \mathrm{gpm}$ & $8 \mathrm{in.wC}$ \\
\hline
\end{tabular}

(Memorandum from M. R. Baron to C. T. Randa17, DPST-87-794, December 31, 1987) 
unlike experiences seen during subsequent Ful7-Scale SRAT/SHE Runs. Additionally, changes in the amount of freeboard under the condenser did not appear to significantly affect the amount of entrainment.

The nominal pH of the condensate from SRAT/SME Batch \#1 was between 3 and 4 and did not appear to be significantly affected by the freeboard in the SRAT/SME. The condensate samples taken during SRAT/SME \#2 had a slightly lower $\mathrm{pH},-2$ to 3 , than those from Batch $\# 1$. This. is theorized to be the result of the larger amount of formic acid which was added during SRAT/SME Batch \#2 compared to Batch \#1.

4.3.4.5.7 Results of Formic Acid Addition. The amount of formic acid added to SRAT Batch \#I was based on earlier work done in the $1 / 3$ Scale SRAT/SME. (a) During operation of the $1 / 3$ ScaTe SRAT/SME, the formic acid requirement was calculated using the bases of $90 \%$ of the stochiometric amount needed to satisfy the reactions found in Table 4.3-67 (assuming each reaction goes to completion) or $2.5 \mathrm{~g}$-mole of formic acid per $1 \mathrm{~b}$ of alkaline sludge solids whichever was less. The reduction of mercuric oxide and sodium nitrite are shown in TabTe 4.3-67 for reference. However, these reactions did not occur in SRAT/SME Batches \#1 and \#2 due to the absence of mercury compounds and nitrites in the simulated waste streams.

TABLE 4.3-67. Major Formic' Acid Reactions

Reareants

$\mathrm{MnO}_{2}+3 \mathrm{ECOOE}$

$\mathrm{Ni}(\mathrm{OB})_{2}+2 \mathrm{ECOOE}$

$\mathrm{CaCO}_{3}+2 \mathrm{FCOOH}$

$\mathrm{NaOH}+\mathrm{ICOOE}$

$\mathrm{KOH}+\mathrm{ECOOH}$

$\mathrm{SrCO}_{3}+2 \mathrm{ECOOE}$

$2 \mathrm{NaNO}_{2}+3 \mathrm{FCOOH}$

$\mathrm{BgO}+\mathrm{ECOOH}$
Dondaras

$\mathrm{M}(\mathrm{COOE})_{2}+2 \mathrm{~F}_{2} \mathrm{O}+\mathrm{CO}_{2}$

$\mathrm{Ni}(\mathrm{COOB})_{2}+2 \mathrm{E}_{2} \mathrm{O}$

$\mathrm{Ca}(\mathrm{COOE})_{2}+\mathrm{E}_{2} \mathrm{O}+\mathrm{CO}_{2}$

$\mathrm{NaCOOE}+\mathrm{E}_{2} \mathrm{O}$

$\mathrm{KCOOE}+\mathrm{E}_{2} \mathrm{O}$

$\mathrm{SI}(\mathrm{COOE})_{2} \pm \mathrm{H}_{2} \mathrm{O}+\mathrm{CO}_{2}$

$2 \mathrm{NaCOOE}+2 \mathrm{NO}+2 \mathrm{E}_{2} \mathrm{O}+\mathrm{CO}_{2}$

$\mathrm{Eg}+\mathrm{E}_{2} \mathrm{O}+\mathrm{CO}_{2}{ }^{*}$

* for reference only

(Memorandum from M. R. Baron to C. T. Randa11, DPST-87-794, December 31, 1987)

(a) Memorandum from E. J. Weber to M. D. Boersma, "Progress of Large-Scale SRAT/SME Study," DPST-82-733, Savannah River Laboratory, Aiken, South Carolina, dated JuTy $21,1982$. 
For SRAT/SME Batch \#1, formic acid was added based on the ratio of 2.5 g-mole of formic acid per lb of alkal ine sludge solids. This corresponded to 255 gallons of formic acid added in the SRAT. This amount of formic acid satisfied onty 78\% of the stoichiometry found in the TabTe 4.3-70 reactions. The total addition time was about $31 / 2$ hours including drum flushes and changes. When adding, the addition rate averaged $2 \mathrm{gpm}$. For a similar amount of formic acid, the addition time would be less for DWPF since in the DWPF formic acid addition system drum changes and flushes will not be necessary. The tank contents were continuousiy maintained between 90 to $96^{\circ} \mathrm{C}$ during the formic acid addition.

During SRAT \#1 formic acid addition, the condenser pressure drop was monitored for pressure spikes indicating $\mathrm{CO}_{2}$ evolution. One pressure spike was recorded after 100 gallons of formic acid had been added and another occurred after 160 gallons had been added. The maximum pressure drop through the condenser during formic and addition was about 3 in. of water.

For SRAT/SME \#2 the quantity of formic acid added to the SRAT was based on that required to satisfy $90 \%$ of the stoichiometry shown in the Table 4.3-67 reactions. The addition rate was maintained, as during SRAT/SME $\# 1$, at $2 \mathrm{gpm}$ and 375 gallons of formic acid were added. Off-gas evolution during the addition resulted in a maximum condenser pressure drop of 5 to 6 in. of water. One pressure spike was recorded after approximately 90 gallons of formic acid had been added. The final pH of the slurry was 3.8 after four hours of refluxing.

The conversion of selected sludge components from the insoluble to the soluble (formate) state was used to determine the degree to which the sludge and formic acid reacted. The conversion results are shown in Table 4.3-68 for SRAT Batch \#2. The DWPF Basic Data Report (a) reference conversion values are shown in parenthesis.

4.3.4.5.8 SRAT/SME Slurry Transfer Pump. Slurry was transferred from the Full-Scale-SRAT/SME using a vertical cantilever centrifugal pump similar in hydraulic characteristics to DWPF design. The design basis from the DWPF Basic Data Report(b) for slurry processing are found in Table 4.3-69.

Run time equivalent to one year of DWPF operation was completed on the transfer pump after SRAT/SME \#1. For each cycle the pump was run at $900 \mathrm{rpm}$ with a resulting flow of $100 \mathrm{gpm}$ for one hour in the recycle mode. Seventyfive cycles, the anticipated number of DWPF SRAT/SME batches per year, were completed. The pump had also been tested during water runs for over 100 hours of operation. The minimum prime required to start the pump with a

(a) DWPF Basic Data Report, DPSP-80-1033, Rev. 90; Part 19, Item 300, October 1984.

(b) DHPF Basic Data Report; DPSP-80-1033, Appendix I, Table 21-3, Rev. 10, September 1983. 
TABLE 4.3-68. Conversion of Manganese, Nickel and Calcium from the Insoluble to the Soluble State for SRAT Batch \#2

\begin{tabular}{|lcc|c|}
\hline \multicolumn{2}{|c|}{$\begin{array}{l}\text { Conversion Reactions } \\
\text { (for complete reactions see } \\
\text { Table 4.3-70) }\end{array}$} & $\begin{array}{l}\text { Percent Completion } \\
\text { Insoluble }\end{array}$ & Soluble SRAT \#2 \\
\hline $\mathrm{MnO}_{2}$ & to & $\mathrm{Mn}(\mathrm{COOH})_{2}$ & $55(70)$ \\
$\mathrm{Ni}(\mathrm{OH})_{2}$ & to & $\mathrm{Ni}(\mathrm{COOH})_{2}$ & $24(20)$ \\
$\mathrm{CaCO}_{3}$ & to & $\mathrm{Ca}(\mathrm{COOH})_{2}$ & $78(80)$ \\
\hline
\end{tabular}

(Memorandum from M. R. Baron to C. T. Randa11, DPST-87-794, December 31, 1987)

TABLE 4.3-69. STurry Design Bases

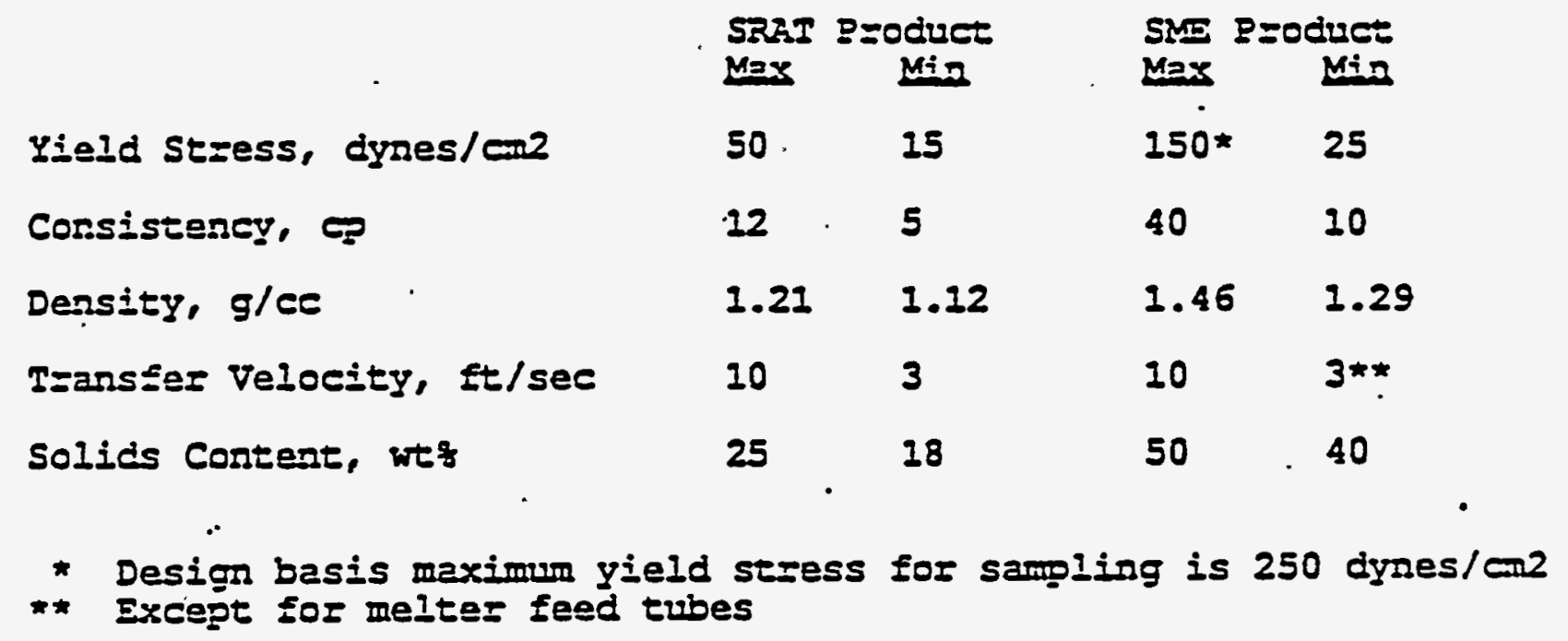

(Memorandum from M. R. Baron to C. T. Randa17, DPST-87-794, December 31, 1987) 
normal operating level of slurry (6000 gallons) was 10 to 15 gallons. As the tank level decreased the amount of prime water required increased to a maximum of about 30 to 40 gallons.

Inspection of the impeller casing revealed some wear at the slurry discharge of the casing. The semi-open faced impeller showed minimal wear. The impeller and the impeller casing for the Full-Scale SRAT/SME transfer pump were both constructed of Special Pump Alloy Modified (SPAM) as opposed to Hastelloy C-276 (SRAT) and Stellite 6 (SME) in the DWPF.

A pump curve for SME processing, shown in Figure 4.3-108, revealed that the pump performed per design. The siurry tested for this pump curve had a yield' stress of 18 dynes $/ \mathrm{cm}^{2}$, consistency of $7.5 \mathrm{cp}$ and a density of. $1.28 \mathrm{~g} / \mathrm{cc}$.

4.3.4.5.9 Ful1-Scale SRAT/SME Product RheologY. Upon completion of SME \#1, the slurry product remained in the SRAT/SME for continued testing, including observations of the $\mathrm{pH}$ drift, rheology and heat transfer characteristics. Table 4.3-70 shows this history of the slurry for SRAT/SME Batch \#1. Included are the type of material, percent solids, $\mathrm{pH}$, consistency, yield stress, density and heat transfer characteristics.

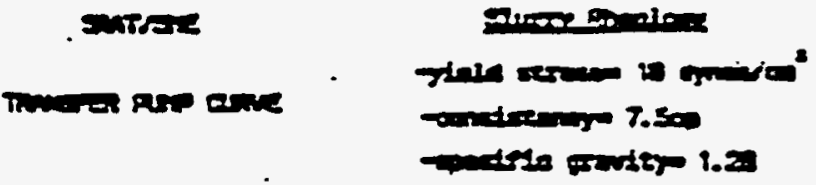

ito (re lings)

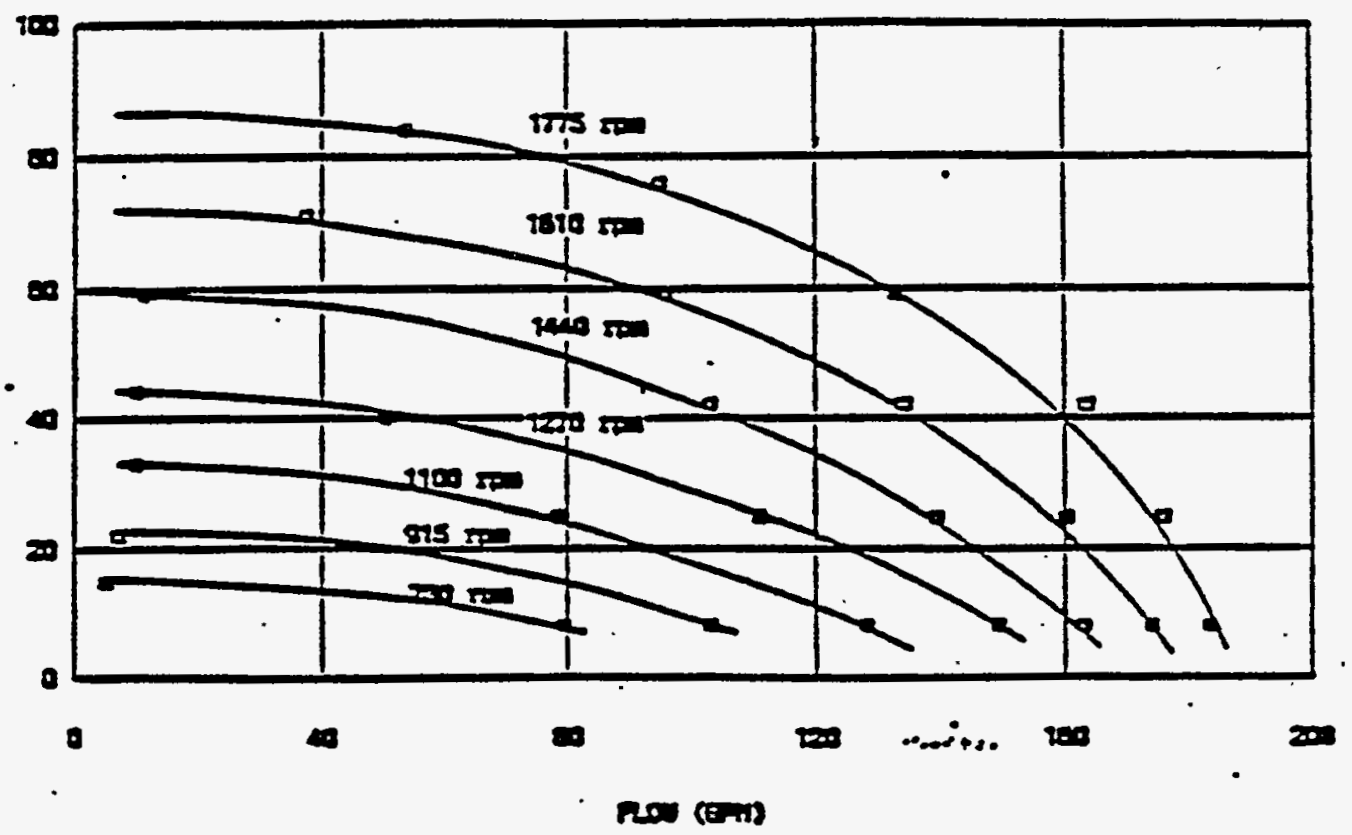

FIEURE 4.3-108. Pump Curve for SRAT/SME Transfer Pump with SME SME Material (Memorandum from M. R. Baron to C. T. Randa17, DPST-87-794, December 11, 1987) 
TABLE 4:3-70. S7urry History for SRAT/SME Batch \#1

\begin{tabular}{|c|c|c|c|c|c|c|}
\hline $\begin{array}{l}\text { MaEerial } \\
\text { S Data }\end{array}$ & $\begin{array}{l}\text { Percent } \\
\text { solids. }\end{array}$ & Des & Consistency & $\begin{array}{c}\text { Yield } \\
\text { Stzess } \\
\text { dunes/ena }\end{array}$ & $\begin{array}{r}\text { Density } \\
\text { gle }\end{array}$ & $\begin{array}{l}\text { Heas Transfog } \\
\text { BTy/h=-6+2-0 }\end{array}$ \\
\hline Warez & - & - & 1 & - & 1.01 & 180 \\
\hline $\begin{array}{l}\text { Tnzomated } \\
\text { 5!udge } \\
3 / 10 / 85\end{array}$ & 16.4 & 12.7 & 2 & 7 & 1.17 & 160 \\
\hline $\begin{array}{l}\text { Eodared } \\
\text { SIudge } \\
3 / 29 / 85\end{array}$ & 16.6 & 5.8 & 2 & 7 & 1.15 & - \\
\hline $\begin{array}{l}E=i t / S I U==9 \\
4 / 15 / 85\end{array}$ & 39.2 & 7.7 & $2-3$ & 105 & 1.33 & 140 \\
\hline $\begin{array}{l}E=\vdots-5 / \text { SIu }==y \\
4 / 25 / 85\end{array}$ & 43.1 & 7.9 & 15 & 250 & 1.41 &.- \\
\hline $\begin{array}{l}F=\dot{E}=/ \text { SIU }==9 \\
4 / 30 / 85\end{array}$ & 47.6 & 8.0 & 27 & 330 & 1.45 & - \\
\hline $\begin{array}{l}E=\vdots E / \text { SIU }==y \\
5 / 2 / 85\end{array}$ & 48.6 & 8.2 & ... 43 & - & 1.48 & $<20$ \\
\hline $\begin{array}{l}E=i t / \text { SIur }=Y^{1} \\
5 / 3 / 85\end{array}$ & 39.5 & 8.3 & 13 & 120 & 1.33 & 70 \\
\hline $\begin{array}{l}E=\dot{t}=/ \text { SIU }==9 \\
5 / 7 / 85\end{array}$ & 39.5 & 8.1 & 14 & 156 & 1.35 & - \\
\hline $\begin{array}{l}\text { E=iヒ/S1ur }=y^{2} \\
5 / 15 / 85\end{array}$ & 39.3 & 7.0 & 11 & 57 & 1.35 & 100 \\
\hline $\begin{array}{l}E=i t / \text { SIu }==y \\
5 / 29 / 85\end{array}$ & 39.1 & 7.9 & - 11 & 105 & 1.35 & - \\
\hline $\begin{array}{ll}1 & \text { Pzocess wat } \\
2 & \text { Twenty-five }\end{array}$ & $\begin{array}{l}\text { Eer added } \\
\text { g gallons }\end{array}$ & of 1 & ormic acid & added & & \\
\hline
\end{tabular}


The principal cause for the exceedingly high yield stress seen in SME Batch \#1 samples several weeks after frit addition (665 dynes $/ \mathrm{cm}^{2}$ ) is believed to be the extended storage time coupled with the concentration of the SME slurry from 39.2 to 48.6 wt\%. solids. The reconmended SME concentration end point for DHPF sludge-onty feed is 40 to $45 \mathrm{wt} \%$ solids. Higher concentrations (i.e., 48 wt\%) result in higher yield stresses which may be outside of the recommended processing limits.

Another contributing factor for the high yield stress is believed to be the shortage in the formic acid addition for SRAT \#1. As previousiy noted - (Section 3.4.3.5.7) , $2.5 \mathrm{~g}$-mole/7b alkaline sludge solids was used to determine the formic acid requirement for SRAT Batch $\# 1$. This was equivalent to an amount which satisfied only 78\% of the Table 4.3-67 reactions. This shortage of formic acid increased the alkali leach rate from the frit and resulted in the reformation of hydroxides in the slurry. As the $\mathrm{pH}$ and yield stress steadily increased over time, the heat transfer coefficient decreased eventually reaching less than $20 \mathrm{BTU} / \mathrm{hr}-\mathrm{ft}^{2}-\mathrm{OF}$ as is shown in Table 4.3-70.

Adding water to the high yield stress material to dilute it to its original concentration significantly decreased the siurry yield stress to -120 . dynes $/ \mathrm{cm}^{2}$. However, the boiling heat transfer coefficient for the coils

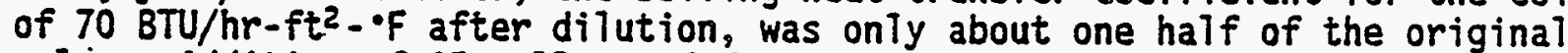
value. Addition of 25 gallons of formic acid decreased the yield stress from 156 to 57 dynes $/ \mathrm{cm}^{2}$. However, this still did not fully recover the boiling heat transfer for the coils as is seen in Table 4.3-70.

In the DWPF, a SME batch of feed will normally be processed through the melter shortly after frit addition, unlike Full-Scale SME Batch \#1. This should not allow sufficient time for an appreciable amount of alkali to leach from the frit to reform hydroxides and increase the $\mathrm{pH}$ and yield stress.

4.3.4.5.10 Coil Fouling. After the conclusion of SME operation, SRAT/SME Batch \#1 was allowed to remain in the tank for several weeks to acquire run time on the transfer pump and agitator. During that time, the contents were concentrated from 39.2 to $48.6 \mathrm{wt \%}$ solids in approximately three weeks due to agitation alone. Formic acid was then added (25. gallons), and the majority of the product from SRAT/SME Batch \#1 was transferred to another tank using the centrifugal transfer pumip. Approximately a 12-in. heel of SME material was left remaining in the tank to simulate DWPF processing strategy. Visual examination of the SRAT/SME through a top flange revealed sludge impaction around the heating coils. Sludge bridging is a concern for DWPF due to the closed packed arrangement of the coils. The theorized cause for the sludge impaction was the exceedingly high yield stress in the SME \#I slurry. In order to clean the coils, sufficient water was added to the 12-in. SME slurry heel to cover the coils. The vessel was agitated for 20 hours to remove sludge scale. The extra water was boiled off returning the tank to the 12-in. level with only a slight recoating of the coils.

The boiling heat transfer for water processing after this cleaning was found to be equivalent to earlier SRAT/SME water runs (approximately 


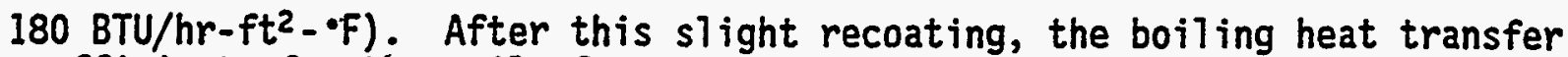
coefficients for the coils for SRAT/SME \#2 decreased; however, they were still above the DWPF design bases. A close visual inspection of the coils still showed some sludge impaction between the two heating coils, but apparently not enough to significantly hinder heat transfer.

4.3.4.5.11 Level Measurement. (a) Level measurement is critical for waste form qualification and for process control. The volume, specific gravity, and elemental concentrations of a slurry are used to inventory the chemical components within the feed preparation area.

Dip tube bubblers are frequently used to measure liquid levels in radioactive service. Dip tube bubblers bleed a small flow of air out of a set of open tubes into the fiuid. The tubes are at different fiuid heights which cause a change in the pressure on the air flowing from each individual tube. The differences in pressures are transiated into a level measurement.

DHPF employs a Holledge level sensor that uses the same principle as a dip tube bubbler except that a thin metal diaphragm separates the air from the slurry. The air does not enter the slurry, and the diaphragm prevents solids from plugging the tube. The sensing unit is constructed of all metal. (b) A needle vaive is positioned above a valve seat which is attached to the metal diaphragm. The close tolerance between the valve and the valve seat restricts the purge air flow and causes the purge air back pressure to increase an amount proportional to the diaphragm deflection. The needle valve is factory set so that at the specified purge rate the process fluid pressure deflecting the diaphragm equals the purge air supply pressure.

A cross section of the isolated bubbler sensor is shown in Figure 4.3-109. A D/P cel1 was used to measure the purge air pressure required to maintain constant flow and this signal was equated to a tank leve?.

-Two isolated bubbler assemblies were installed, one in the FSMT and the other in the SRAT/SME. The FSMT probe consisted of two sensors, white the SRAT/SME probe consisted of three. During water runs, which lasted one month, the sensors performed poorly. The level signal fluttered due to agitation effects and the changes in the specific gravity signal were even more dramatic since that output is the difference between the erratic

(a) E. O. Jones and M. E. Peterson, Evaluation of the Adaptability of the DWPF Feed Preparation System to the HWVP. HWVP-87-V110302A, Pacific Northwest Laboratory, Richland, Washington (July 1978).

(b) Memorandum from M. R. Baron to C. T. Randall, "Summary of Fabrication, Start-Up, and Runs \#1 and \#2 of the DHPF FuTi-Scale SRAT/SME," DPST-87-794, Savannah River Laboratory, Aiken, South Carol ina, dated December 31, 1987. 


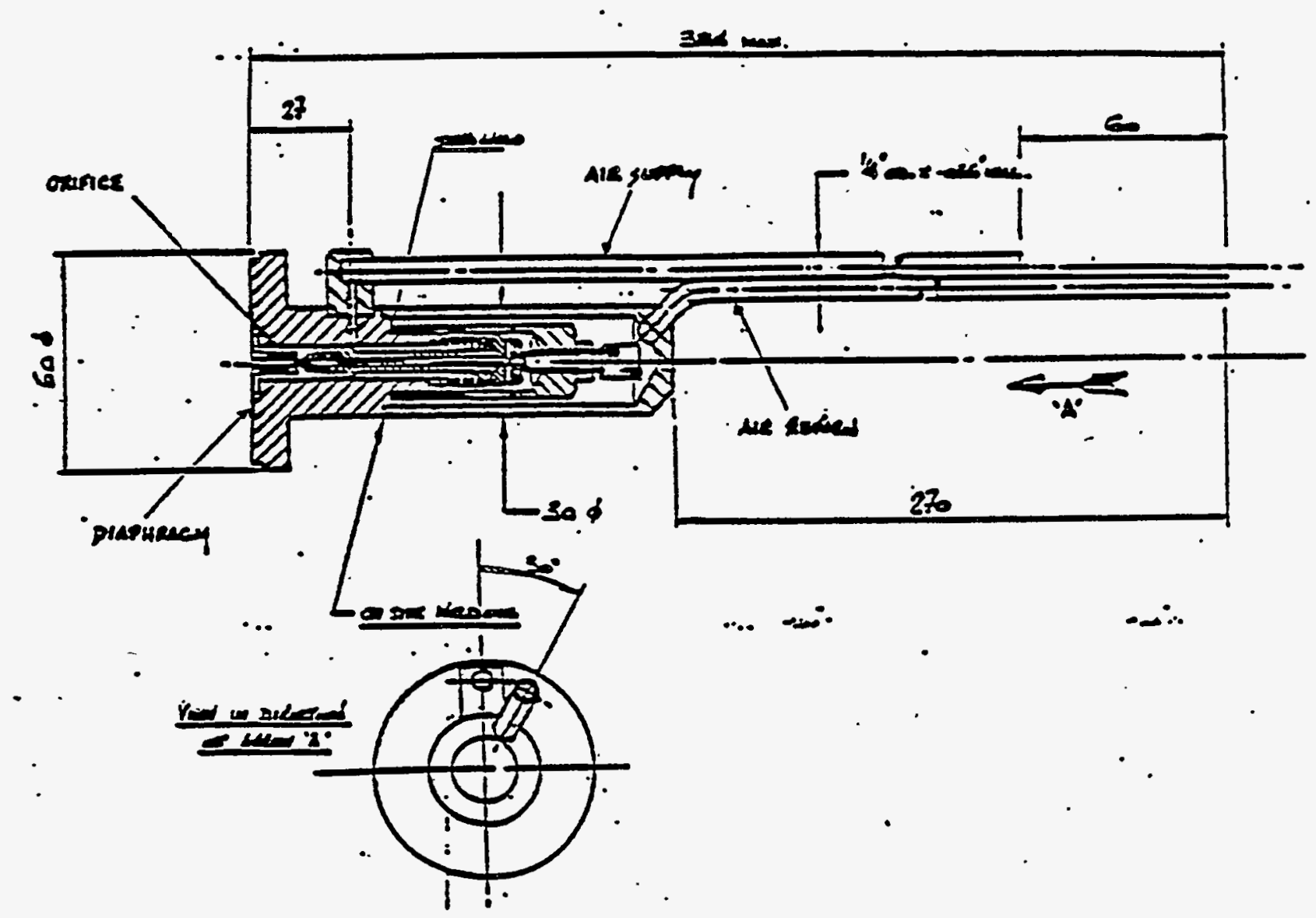

FIGURE 4.3-109. Isolated Bubbler Presșure (Level) Sensor (Memorandum from M. R. Baron to C. T. Randaiti, DPST-87-794, December 31, 1987)

readings from two sensors. The specific gravity would vary on the average from 0.94 to 1.10 as the level in the tank changed. This was caused by nonTinearity of the sensors primarily at the low end.

The isolated bubbler sensors also showed erroneous level increases during vessel heating as shown in Figure 4.3-110. As air was passed down the inside of the sensor supply tubing, the heated vessel caused the air to expand and also become more viscous. This resulted. in a greater pressure drop across the orifice; therefore, the higher level indication. 


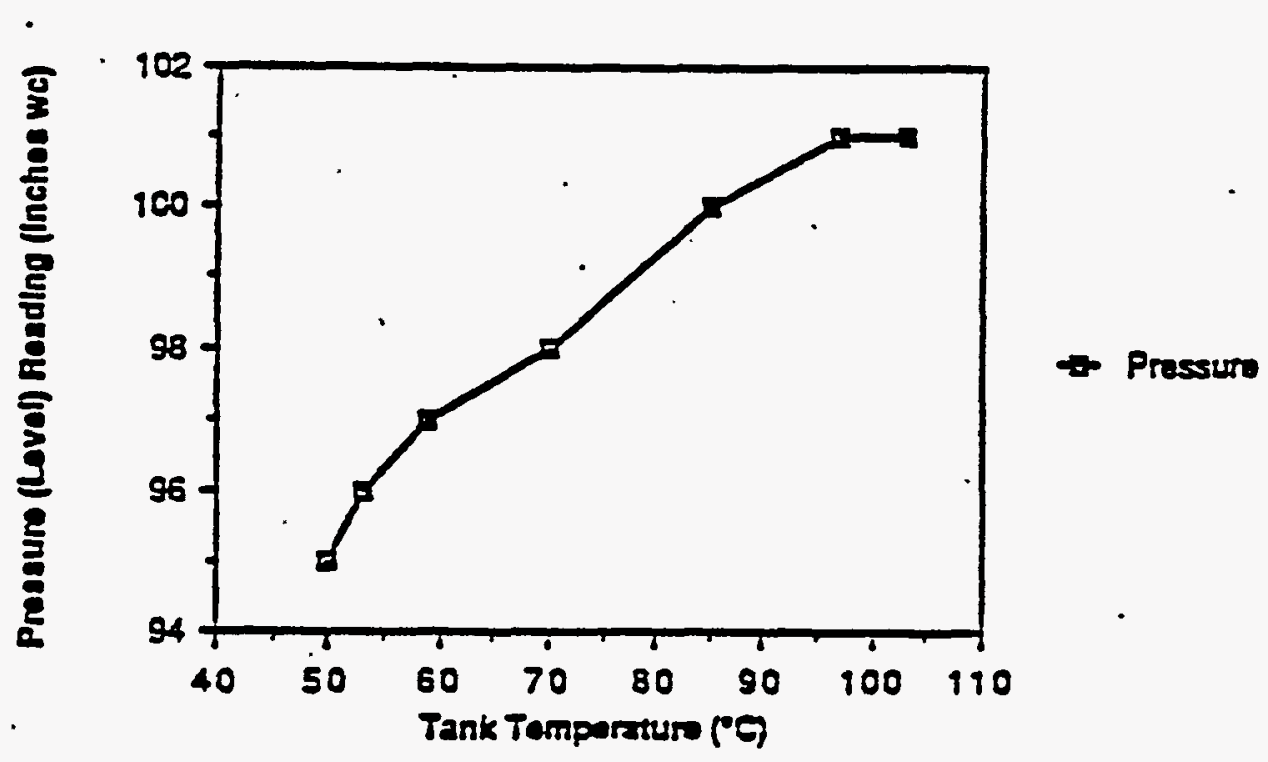

FIGURE 4.3-110. Effect of Slurry Temperature on Isolated Bubbler Pressure (Leve1) Sensor Measurements (Memorandum from M. R. Baron to C. T. Randa 17, DPST-87-794, December 31, 1987)

During a technical exchange(a) between HWWP and DWPF at the Savannah River Plant (January 9-13, 1989) results from testing the Holledge PB-35 liquid level measurement gauge were reported. Previous testing of the gauge during Full-Scale SRAT/SME runs indicated that the gauge had a nonlinear response to temperature changes, and large errors were made in the calculated density. To address these probiems, the spacing between was increased between the two transmitters to provide a larger pressure differential, and the device was calibrated as a function of temperature. Pressure calibration curves at various temperatures for the PB-35 are shown in Figure 4.3-111. After increasing the separation between the transmitters and integrating a temperature correction algorithm into the distributed control system, the gauge was retested in the SRAT/SME. From the testing results, it was determined that the operational volume of the SRAT/SME can be measured to an accuracy of $1.6 \%$ at a $95 \%$ confidence 1 evel.

4.3.4.5.12 Slurry Sampling. Sampling is necessary for process control and waste form specifications. The DWPF sampler design continuously recirculates the slurry past a sample device. The sample device (Hydraguard) ${ }^{\circ}$ diverts a part of the stream to a flush line or sample container as seen in Figure 4.3-112. Testing at TNX has demonstrated the ability of the hydraguard sampler to extract representative samples from all DWPF slurries.

(a) George Heeks, Presentation: "Holledge Liquid Level Technology Accuracy -Test," DWPF and HWVP Technical Exchange, January 9-13, 1989, Savannah River Project, Aiken, South Carolina.

(1) Hydraguard is a registered trademark of Hinds International, Hillsborough, Oregon. 


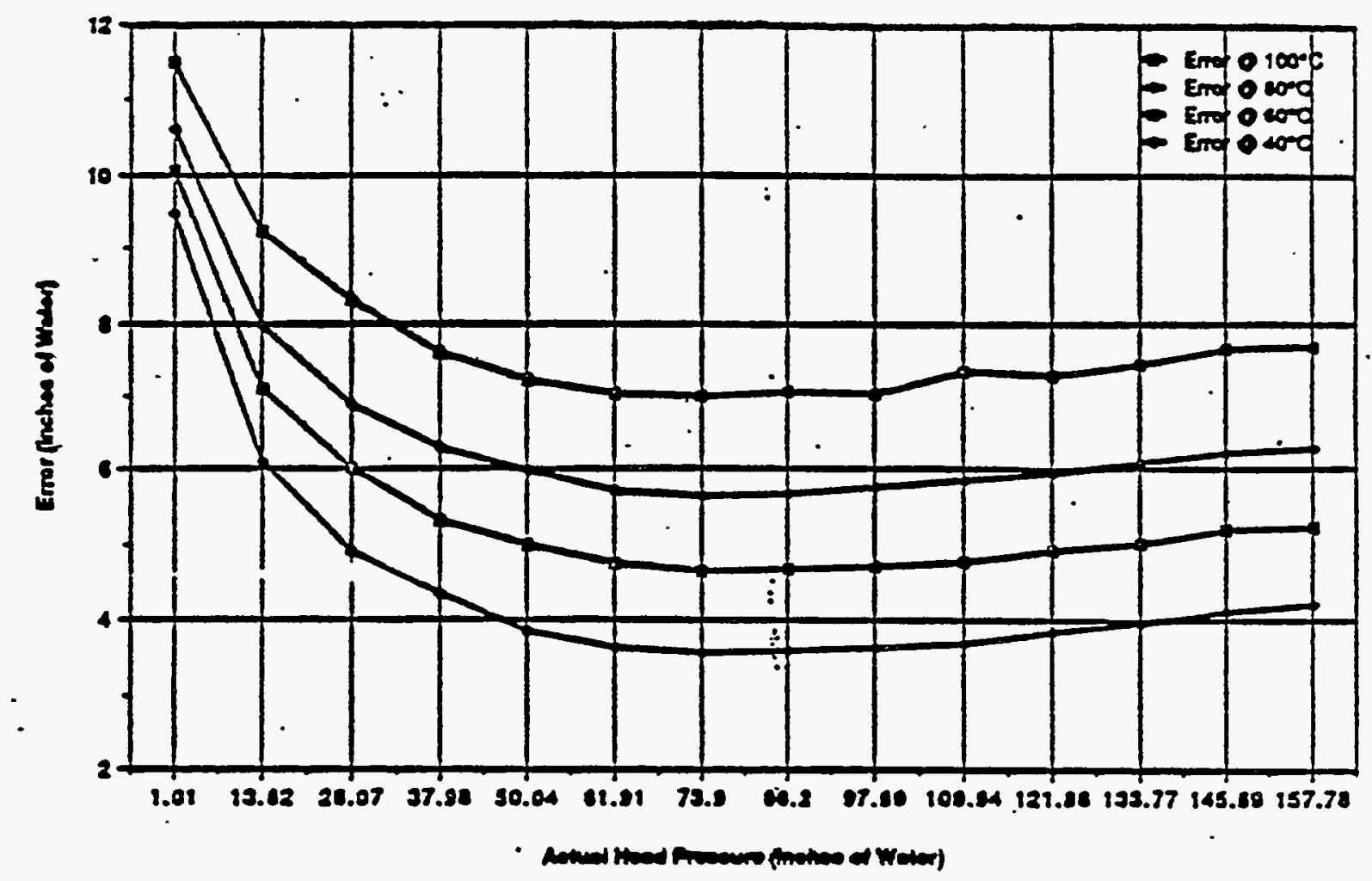

FIGURE 4.3-111. Temperature Calibration for Holledge PB-35 Gauge (George Weeks, Presentation: "Holledge Liquid Level Technology Accuracy Test, " DWPF and HWVP Technical Exchange, January 9-13, 1989, Savannah River Project, Aiken, South Carolina)

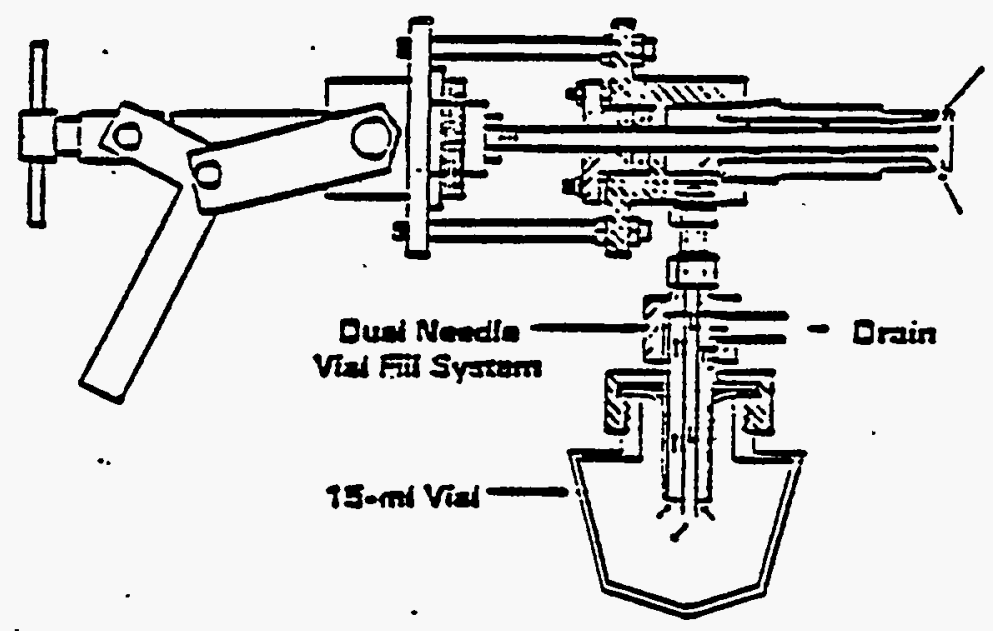

FIGURE 4.3-112. Hydraguard Sampler 
Data(a) obtained on wt\% solids was analyzed to show that the sampling precisions for the SRAT and SME are $98.56 \%$ and $95.20 \%$, respectively. The top-to-bottom homogeneity (short and long dip legs, Figure 4.3-113) for the SRAT is $0.5 \%$ and the SME is $2.5 \%$. The true value elemental segregation was not determined in these tests.

SAMPLE IINE ARRANGEMENT FOR ELEMENTAI SAMPLING ACCE:ACY IEST

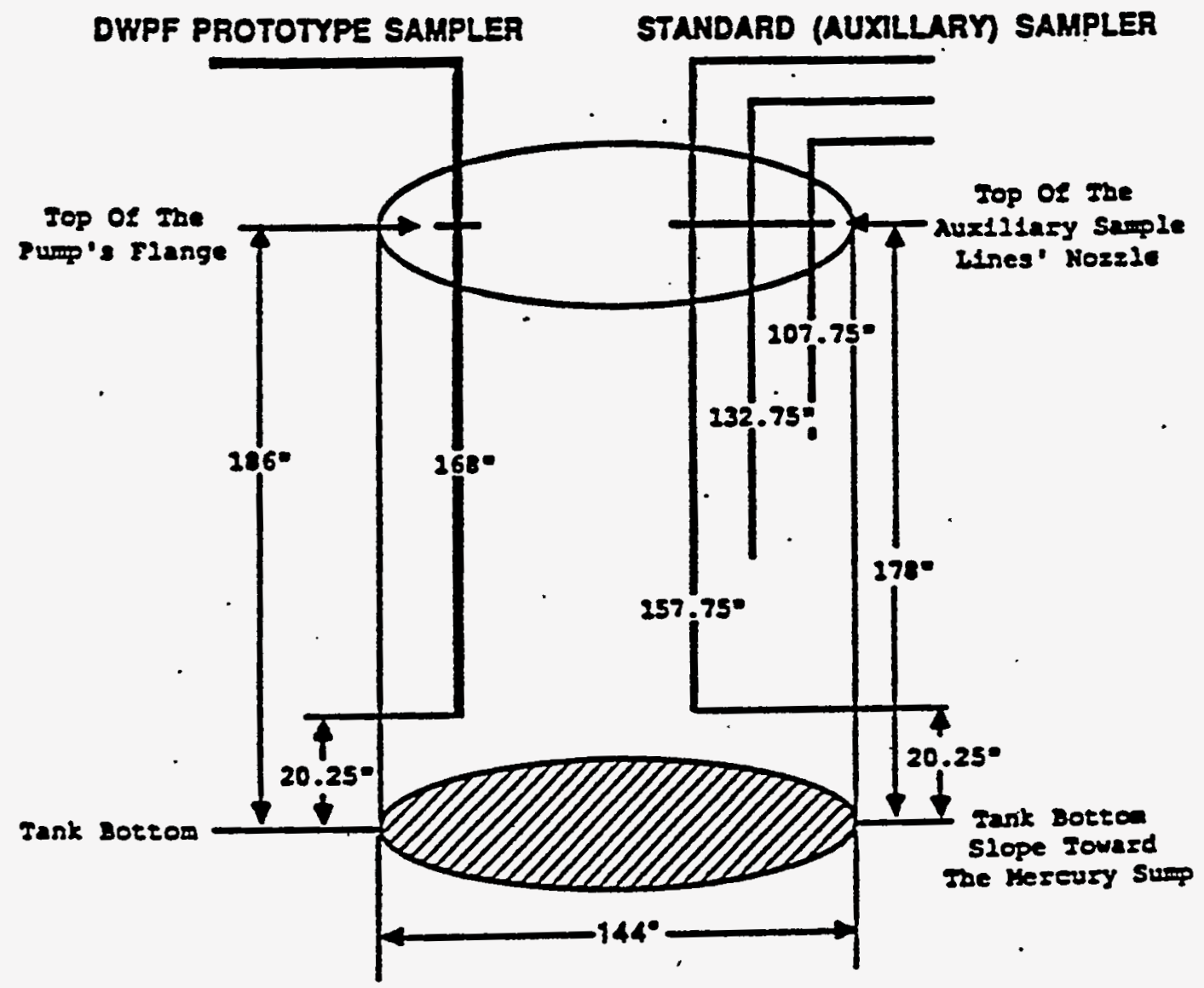

FIGURE 4.3-113. TNX FU17-SCaTe SRAT/SME - DHPF

(a) John Jenkins, presentation: "SRAT/SME Sampling Program," DWPF and HWVP Technical Exchange, Savannah River Laboratory, Aiken, South Carolina (January 9-13, 1989). 
Testing(a) of Everlasting valves as a replacement for the leaking Fujikin valves in the sampling system has been successful. Tests were conducted at a flow rate of $3 \mathrm{ft} / \mathrm{sec}$ using $30 \mathrm{wt} \% \mathrm{glass}$ frit in a $0.5 \mathrm{in}$. Tine. There were no leaks and the valves were immune to radiation. The reason the Everlasting valves were not originaliy selected was that the piping layout was complete based on the Fujikin valves; the Everlasting valves were not the same size and the orientation was different. Also, the force required to operate the vaive was not acceptable. Design modifications were completed to allow fit-up of the Everlasting valves, and the internal spring load was redesigned. Testing was completed using $47 \mathrm{wt} \%$ frit slurry at $6 \mathrm{ft} / \mathrm{sec}$ flow. Results confirmed there were no leaks and no sludge/slurry residue in the valve after flushing. The spring force remained a problem for 3-way/all-way valves; $26 \mathrm{lb}$ force was required compared to $12 \mathrm{lb}$ operating force for master slave manipulators (MSM). A tool was designed to increase the leverage for the valve operation using the MSM, and the valve is now acceptable. Valve replacement as a station module is preferred for maintenance.

4.3.4.5.13 SRAT/SME Equipment Hear(a) SRAT/SME wear on equipment components has been evaluated during the ful1-scale equipment testing at TNX. Table 4.5-71 provides a test history. Equipment components examined for wear include the agitator impeller, the heat transfer coil; the tank floor and SME transfer pump. Component wear data is subsequentiy provided.

TABLE 4.3-71. SRAT/SME Component Hear Test History - DHPF

\begin{tabular}{|c|c|c|}
\hline January 1985 & Original Construction & \\
\hline March 1985-August 1986 & SRAT/SME runs 1,$2 ; 3$ & $\begin{array}{l}(2000 \text { SRAT } h, \\
7000 \text { SME h) }\end{array}$ \\
\hline November 1986 & $\begin{array}{l}\text { Vessel Entry } \\
\text { Severe Erosion Found }\end{array}$ & \\
\hline January 1987 & Modified to DWPF design & \\
\hline February 1987-September 1987 & SRAT/SME runs $4,5,6$ & $\begin{array}{l}\text { (750 SRAT } h, \\
1215 \text { SME } h \text { ) }\end{array}$ \\
\hline November 1987 & $\begin{array}{l}\text { Vessel Entry } \\
\text { Slight Wear found }\end{array}$ & \\
\hline
\end{tabular}

(a) T. T. Trinh, presentation: "DWPF Liquid Sampling Station/Everlasting Valves, Coil Heat Transfer Coefficients, Vessel/Component Wear, "DWPF and HWVP Technical Exchange, Savannah River Laboratory, Aiken, South Carol ina (January 12, 1989). 
4.3.4.5.13.1 Aqitator Impe7ler Wear. Measurements made on the impeller are shown in Figure 4.3-114. It was observed that the erosion is greatest in areas of step changes in thickness. The wear mechanism is believed to be erosion, not cavitation. The projected impeller lifetime is $>5$ yr for a nominal 0.5-in.-thick blade. A stellite overlay is not recommended. For future impellers, it is recommended to el iminate the ear (i.e., step change), and increase overall thickness. Also, as shown in Figure 4.3-115, overlap of the impeller blade with the shaft guide can also cause wear.

4.3.4.5.13.2 Heat Transfer Coil Wear. A number of wear measurements have been taken on the full-scale SRAT/SME coils. The uitrasonic thickness of coil walls at numerous locations were as follows (EED):

\begin{tabular}{|c|c|c|}
\hline Coil & Before (in.) & After (in.) \\
\hline $\begin{array}{l}\text { Inner (cooling water) } \\
\text { Center (steam) } \\
\text { Outer (steam) }\end{array}$ & $\begin{array}{l}0.215 \text { to } 0.230 \\
0.200 \text { to } 0.215 \\
0.210 \text { to } 0.215\end{array}$ & $\begin{array}{l}0.210 \text { to } 0.218 \\
0.210 \text { to } 0.215 \\
0.210 \text { to } 0.215\end{array}$ \\
\hline
\end{tabular}

The average wear on inner coil is $8.5 \mathrm{mil}$ in 1215 SME hours equals $0.05 \mathrm{in./}$ yr. Inner coils had a polished appearance near the location of the lower impeller. For DWPF nominal thickness of 0.054 in., the projected coil 1 ifetime equals. $3 \mathrm{yr}$.

Other observations made on the coils during testing were: 1) DHPF welded coil support design el.iminated abrasion, 2) erosion of the inner coil does occur near lower impeller, and 3) projected life of inner coil is $3 \mathrm{yr}$. It was recommended that for future coils, inner coil should be fabricated of thicker pipe.

A number of observations were also made on coil positioning: 1) original TNX pin and hole design abraded to fai7ure, 2) DWPF feet and guide design, with stellite overlay, showed no abrasion, and stellite overlay was cracked, but this appeared to be of no consequence. It was recommended that no further change was needed.

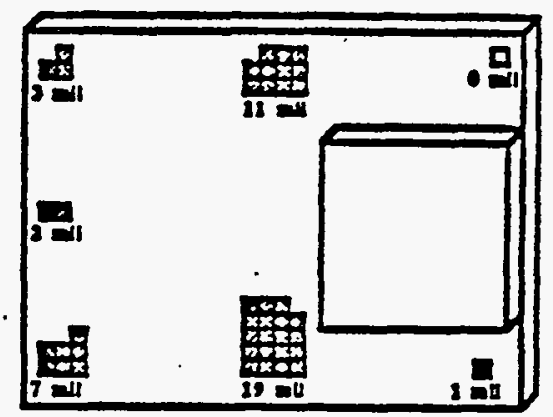

Q 1 m nll eroded

2315 ant bourn

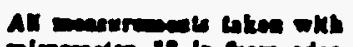

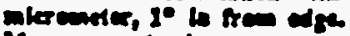

Mosurcanes shewe are

averags of i blader.

FIGURE 4.3-114. TNX Agitator Impeller Erosion Rate Measurements DWPF 
Crose secllon of lower Impeller, shall, and gulde.

Two blades omilled for clarliy.

AS DESIGNED

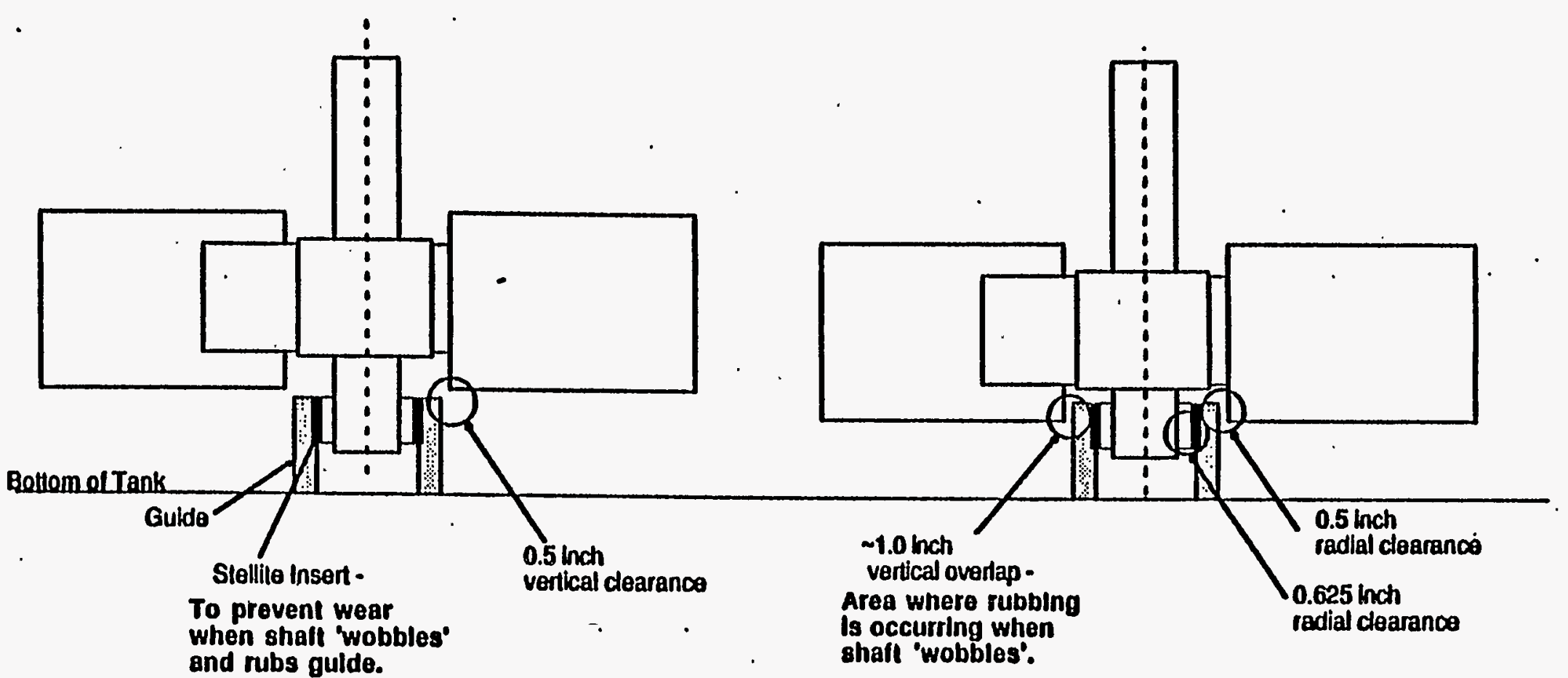

FIGURE 4.3-115. TNX SRAT/SME Lower Impeller - DWPF . 
4.3.4.5.1.13.3 Tank Floor Hear. Tank floor measurements were made by ultrasonic thicknesses at different locations and were highiy variable.

Figures 4.3-116 and 4.3-117 show tank thickness measurements before and after testing, respectively. It was difficult to measure at exact locations after a year of operation. There was inconclusive evidence for wear rates.

4.3.4.5.13.4 SHE PUmp Hear. Measurements were made on the SME transfer pump after $15 \mathrm{~h}$ of operations. This wear information is included in Table 4.3-72.

4.3.4.5.14 SRAT/SME Melter Feeding Process Operations. Testing at TNX has shown that the heel volume at pump cutout is a function of agitator speed. At $130 \mathrm{rpm}$ agitator speed, the heel will be about $3000 \mathrm{gal}$. At $87 \mathrm{rpm}$ agitator speed, the heel will be about 1500 gal. Settling tests have shown that the slurry can be transferred without agitation at the end of transfer to minimize heel volume. The minimum heel will be about $800 \mathrm{gal}$ without agitation. The wt\% solids increased from 23 to 25.7 for the SRAT slurry over a period of $24 \mathrm{~h}$ with the agitator stopped. Under this condition (no agitation) an increase from 48.3 to 50.7 wt\% solids was found after $24 \mathrm{~h}$ for the SME.

The DWPF reference time cycle for the SRAT is $57 \mathrm{~h}$; this was confirmed by TNX operational data that showed the cycle could be completed in $59 \mathrm{~h}$. Difficulties in preparing the frit slurry make-up at TNX resulted in a time cycle of $91 \mathrm{~h}$ for the SME, which was about three times the DWPF reference cycle of $31 \mathrm{~h}$. The TNX difficulties would not be expected to impact plant operation.

The Dow Corning Antifoams 544 and 2410 have been successfully tested and are acceptable for acid and basic solutions and for high and low temperature application in the SRAT. Visual observation at TNX has shown that foaming totaliy disappears for up to $24 \mathrm{~h}$. Current plans are to add $2.5 \mathrm{lb}$ of antifoam at each step of processing. This material is a silicon base and should have no impact to the process. Further studies are being conducted to assess entrainment to other processing vessels.

Plugging encountered with the melter feed system occurred at the feed tube discharge to the melter. A total of seven plugs occurred over six scale glass melter (SGM) campaigns ( $1200 \mathrm{~h}$ total feed time). All plugs were due to improper flushing. The newly developed operating strategy calls for flushing the melter feed tube with water prior to feeding slurry during pump startup. There will be no periodic flushing while melter feeding is in progress. If the pump is shut down, then an automatic water flush of $0.5-0.7 \mathrm{gpm}$ will be initiated for $15 \mathrm{sec}$. The strainer will also be flushed at the same rate and for the same period. No flushing of the feed recirculation line is anticipated. A melter feed rate of $0.2 \mathrm{gpm}$ was tested during the SGM-9 run that indicates the DWPF melter feed system will be satisfactory for the HWVP $100 \mathrm{ppm}$ melter. Feed concentrations above 60 wt\% solids will be a problem and should be avoided. 


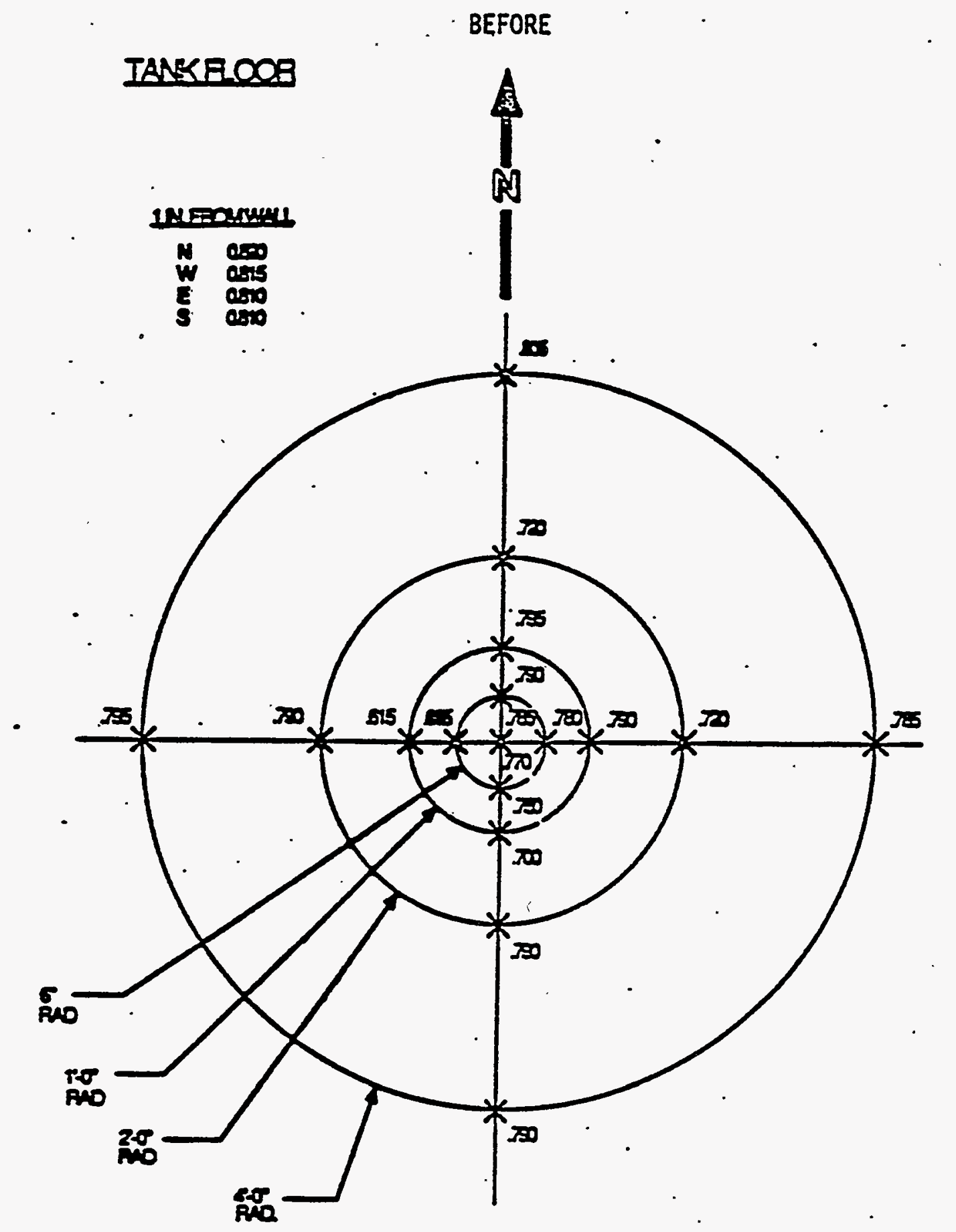

FIGURE 4.3-116. Sketch Showing Original Thicknesses and Locations of Measurements on TNX SRAT/SME Tank Bottom. Measurements in inches. The UT instrument was calibrated with stainless steel - DWPF. 


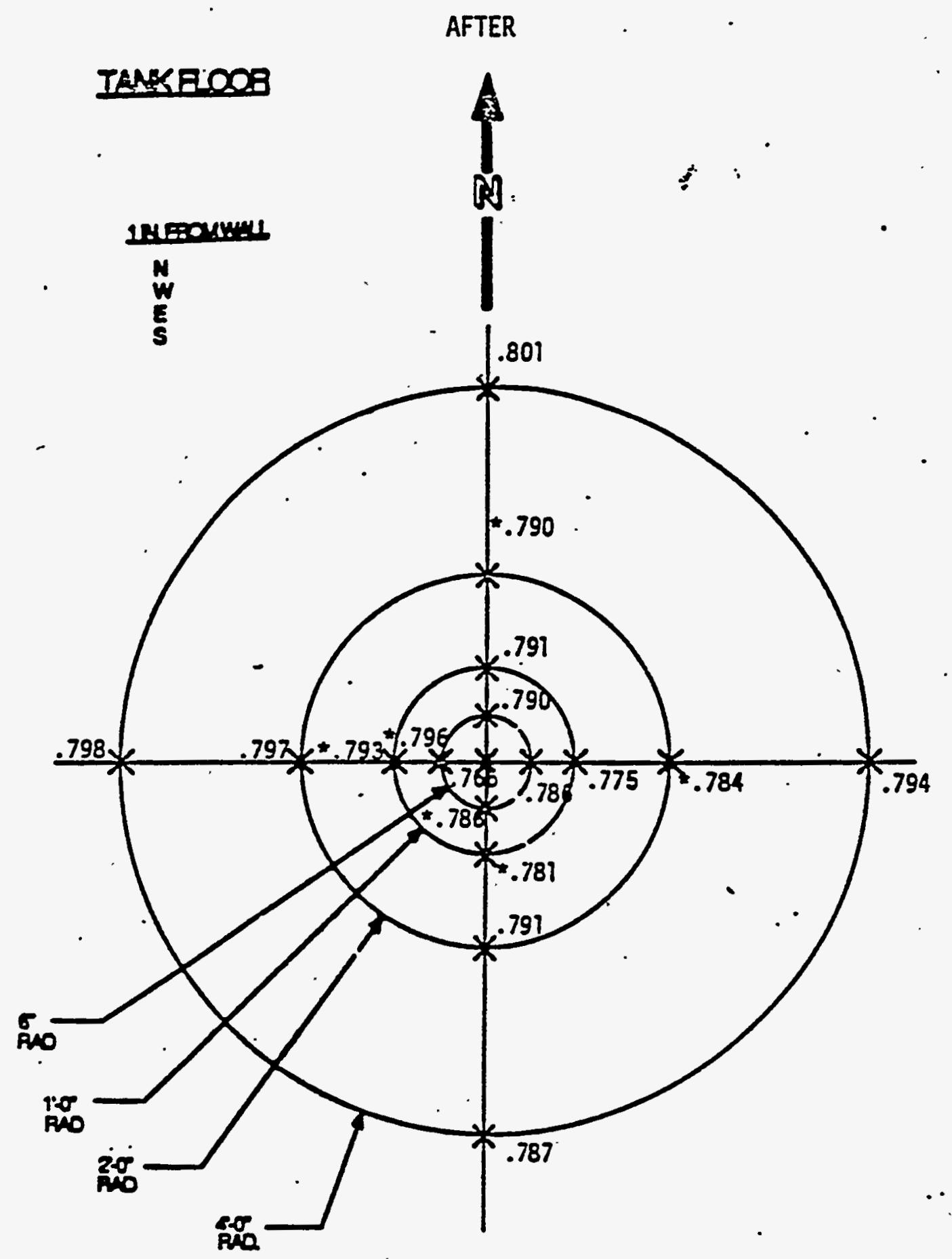

FIGURE 4.3-117. Sketch Showing Thicknesses and Locations of Measurements on TNX SRAT/SME Tank Bottom After Testing. Measurements in inches. The UT Instrument was calibrated with stainless steel - DWPF.

*Increase in thickness from previous measurements 
TABLE 4.3-72. TNX Pump Wear Measurements (for pump operation with SME Slurry)

\begin{tabular}{|c|c|c|c|}
\hline Discharge Orifice & $\begin{array}{l}t=0 h \\
(g)\end{array}$ & $t=\underset{(g)}{(g) h}$ & $\begin{array}{l}\text { Hear Rate } \\
(g / h)\end{array}$ \\
\hline $\begin{array}{l}1 \text { in. solid piece } \\
\text { Taper } \\
\text { Sleeve }\end{array}$ & $\begin{array}{l}387.4 \\
289.3 \\
150.7\end{array}$ & $\begin{array}{l}384.5 \\
286.4 \\
150.2\end{array}$ & $\begin{array}{l}0.193 \\
0.193 \\
0.033\end{array}$ \\
\hline Impel1er & 5516.2 & 5296.4 & 14.653 \\
\hline Discharge Orifice & $\begin{array}{c}T-0 h \\
(\text { in.) }\end{array}$ & $\begin{array}{c}t=15 \mathrm{~h} \\
(\text { in. })\end{array}$ & $\begin{array}{c}\text { Wear Rate } \\
\text { (in./h) }\end{array}$ \\
\hline $\begin{array}{l}\text { Diameter of inlet opening } \\
\text { to impeller }\end{array}$ & 3.1213 & 3.1400 & 0.00125 \\
\hline Impeller ring diameter & 4.6230 & 4.6200 & 0.0002 \\
\hline Impeller wall thickness & 0.16 & 0.15 & 0.00067 \\
\hline
\end{tabular}




\section{REFERENCES}

4.3-1 H. M. Latimer and J. H. Hildebrand, Reference Book of Inorganic Chemistry, third edition. The Mcltitian Company, New York (1951).

4.3-2 H. T. BTair and A. H. McMakin, MMdification of the Rheological Properties of Melter Feed for the Hanford Waste Vitrification Plant." In Proc. of the Symposium on Waste Management '86, Tucson, Arizona, eds. R. G. Post, M. E. Wacks, Vo7. II, pp. 489-494 (1986).

4.3-3 R. K. Farnsworth, C. M. Ruecker, J. M. Perez, Jr., H. T. Blair, and G. T. Thornton, Hanford Waste Vitrification Plant Feed Process Variability Testing for Fiscal Year 1986. RHO-RE-CR-16P, Prepared for Rockwe 71 Hanford Operations by Pacific Northwest Laboratory, Richiand, Washington.

4.3-4 C. L. Fow et a]., Rheological Evaluation of Simulated NCAW Transuranics. PNL-5902, Pacific Northwest Laboratory, Richland, Washington (1986). 



\subsection{MELTER FEED (System 22)}

The melter feed section summarizes process technology related to feeding the melter. -

\subsubsection{Function}

The purposes of the melter feed system is to receive the prepared melter feed slurry from the feed preparation system and deliver a homogeneous slurry at a controlled rate to the melter in the melter/turntable system.

\subsubsection{Operational Requirements}

The operational requirements of the MFT are provided in Table 4.4-1.

\subsubsection{Process Chemistry}

There is no process chemistry in the MFT.

If the feed is allowed to sit in the tank over extended periods, the $\mathrm{pH}$ is monitored and adjusted, if necessary, with formic acid to maintain the feed $\mathrm{pH}$ between 4.0 and 8.0. This range minimizes potential for frit agg7omeration and changes in feed rheology.

\subsubsection{DUPF Meiter Feed System Testing (Ref. 4.4-1)}

The purpose of the DWPF melter feed system is to transport sludge-frit slurry from the melter feed tank to the melter at a controlled low flow rate of 0.4 to $0.7 \mathrm{gpm}$.

The recirculation loop feed system (RLFS) concept uses a vertical cantiTevered-shaft centrifugal (VCC) pump to develop head in a short 2-in.-diameter recirculation pipe loop with an end restriction. A small side draw stream is taken off upstream of the restriction to feed the melter (Figure 4.4-1). Typical flow rates in the recircutation loop may be as high as $200 \mathrm{gpm}$. Flow in the side draw stream is controlled by the pump motor speed between 0.4 and $0.7 \mathrm{gpm}$. 
TABLE 4.4-1. Melter Feed System Operational Requirements - HWVP

- receive melter feed from the SME at a transfer rate of up to $100 \mathrm{gpm}$

- waximum operating volune (80z overflow with internals) of 8600 gal

- cool and maintain meiter feed at $95^{\circ} \mathrm{F}\left(35^{\circ} \mathrm{C}\right)$ [normally cooled to $122^{\circ} \mathrm{F}$ $\left.\left(50^{\circ} \mathrm{C}\right)\right]$

- dissipate radionuclide deçay heat

-- Average: Btu/h

-. Maximun: Btu/h

- maintain howogenous tank contents concentration through agitation

- sample tank contents

- provide capability to flush melter feed lines.

- feed the melter through two simitar recirculation feed systems at a controlled rate over a range of 0.12 to $0.67 \mathrm{gpm}$ each

- monitor contents and status

- liquid leyel

- specific gravity $(0.9$ to 1.4$)$

- temperature (20 to $220^{\circ} \mathrm{F}$ )

- vacuum:

-- (pH: 2 to 10)

- add chemical solutions/slurries at a controlled rate of 2 - $25 \mathrm{gpm}$

- provide capability to add 90 wt: formic acid to tank at a controlled rate of 0.5 to $5 \mathrm{gpm}$

- provide tank ventilation/overflow control to cell

- provide routing flexibility to receive melter feed from SRAT at a transfer rate up to $100 \mathrm{gpm}$

- vent tank to faVH

- provide routing flexibility to transfer MFT contents to SRAT

- provide routing flexibility to transfer MFT contents to SME

- provide capability to add process frit slurry to MFT

- provide sufficient air inleakage to prevent explosive hydrogen concentration buildup. 


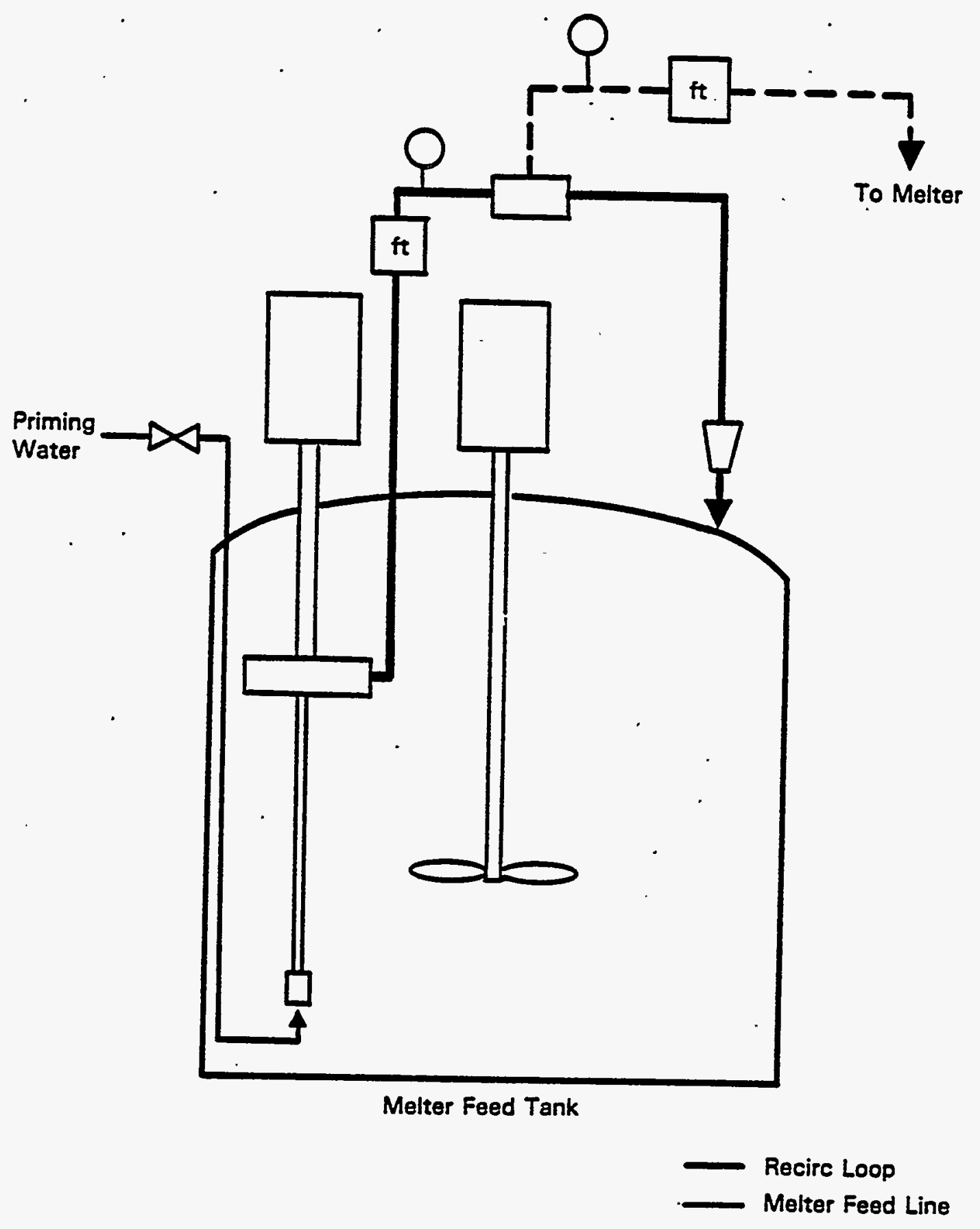

FIGURE 4.4-1. Recirculation Loop Feed System - DWPF (Ref. 4.4-1) 
below:

The specific.objectives of the melter feed system testing are listed

1. Design a recirculation loop feed system to deliver sludge frit slurry at DWPF feed rates over the range of DWPF slurry rheologies.

2. Demonstrate controliability of the melter feed flow rate by varying pump speed using a closed-loop controller.

3. Determine wear characteristics of a VCC pump over $4000 \mathrm{~h}(1 / 2 \mathrm{yr})$ in sludge-frit slurry.

4. Determine wear characteristics of the feed line, recirculation line, and restrictors.

5. Test and evaluate different types of strainers in a melter feed system.

6. Examine other general performance characteristics such as plugging, vibration, and drainage.

\subsubsection{Equipment and Description.}

4.4.4.1.1 Pump and Accessories. The melter feed pump is a VCC pump manufactured by Lawrence Pumps, Inc. It was originally tested for $1300 \mathrm{~h}$ in simulated cell transfer service with sludge-frit slurry. After the testing period, the pump was disassembled for inspection, and then reassembled and reinstalled in the Slurry Pump Test Facility (SPTF) without any changes.

Important features of the pump are listed below:

$\begin{array}{ll}\text { Nominal capacity a } 1200 \mathrm{rpm} & 140 \mathrm{gpm} \\ \text { Suction/discharge line size } & 2 \mathrm{in} . \\ \text { Casing design } & \text { single volute } \\ \text { Impeller diameter } & 11-1 / 4 \mathrm{in} . ; 7-7 / 8 \mathrm{in} . \\ \text { Impeller design } & \mathrm{closed,} \mathrm{external} \mathrm{vanes} \\ \text { Shaft length below mounting flange } & 4 \mathrm{ft} 6 \mathrm{in} \text {. } \\ \text { Tail pipe length } & 10-1 / 2 \mathrm{ft} \\ \text { Motor } & 25 \mathrm{hp} \text {, variable speed, } \\ & \text { direct drive } \\ \text { Wet end material } & \text { special pump alloy (SPA) } \\ \text { Primer type } & \text { water jet }\end{array}$


4.4.4.1.2. Piping and Instrumentation. The piping system is fabricated from 2 in. ScheduTe 80, 304L SS with five elbows. Its total length is approximately $75 \mathrm{ft}$ including equipment and instrumentation. The pipe discharges from the pump casing, exits the tanks through the pump support plate, and then returns via a $2-i n$. nozzle. Included in the line (in order of direction of flow) are the following:

- blanked tee with a Rosemount pressure transducer in the tee section

- two-in. magnetic flowmeter (originally Fischer and Porter, then changed to Krohne)

- upstream fixed restrictor spooipiece (restrictions sometimes inserted); the restrictiors are discussed further under restrictors

- upstream variable restrictor block

- enlarged tee section with an in-line strainer and the melter feed ( $3 / 8$ in.) piping take-off

- two-in. red valve pressure sensor and gauge

- downstream fixed restrictor spoolpiece (restrictor sometimes inserted)

- downstream variable restrictor block with vent to the top of Tank 0 .

The 3/8-in. melter feed line is manufactured from Schedule 80, Type 304L SS pipe with seven elbows; one mitre 90 turn simulating a Hanford connector, and a total length of $45 \mathrm{ft}$. The line runs from the 2 -in. take-off tee at the strainer back into the tank. Included in the line (in the direction of flow) are the following:

- one-half-inch red valve pressure sensor and gauge

- one-half-inch Whitey ball valve

- tee section with $3 / 8-$ in. flush water piping

- one-half inch Whitey ball valve

- mitre 90 angle simulating a Hanford connector 
- sloped with $1 / 2$ in. Fischer and Porter magnetic flowmeter

- split flex hose clamped to the pipe above the tank (at simulated melter level) to act as a siphon break.

4.4.4.1.3 Fixed Restrictors. Each fixed restrictor consists of three segments that fit inside a 2-in.-diameter spoolpiece (Figure 4.4-2). The first segment is simply a sleeve with an OD to match the ID of 2-in. pipe, and an ID of $1.78 \mathrm{in.}$ The second piece is a straight bore section that tapers from 1.78 in. to the desired restrictor nominal size at a $30^{\circ}$ angle. The final piece is a straight bore at the desired nominal restrictor size. A short (1. in.) tapered section at the inlet and outlet to the spoolpiece was used to reduce any entrance/exit effects.

The fixed restrictors were the primary means used for restricting flow in the recirculation loop' because of the Pump Composite Group's preference for a non-moving type of restriction device.

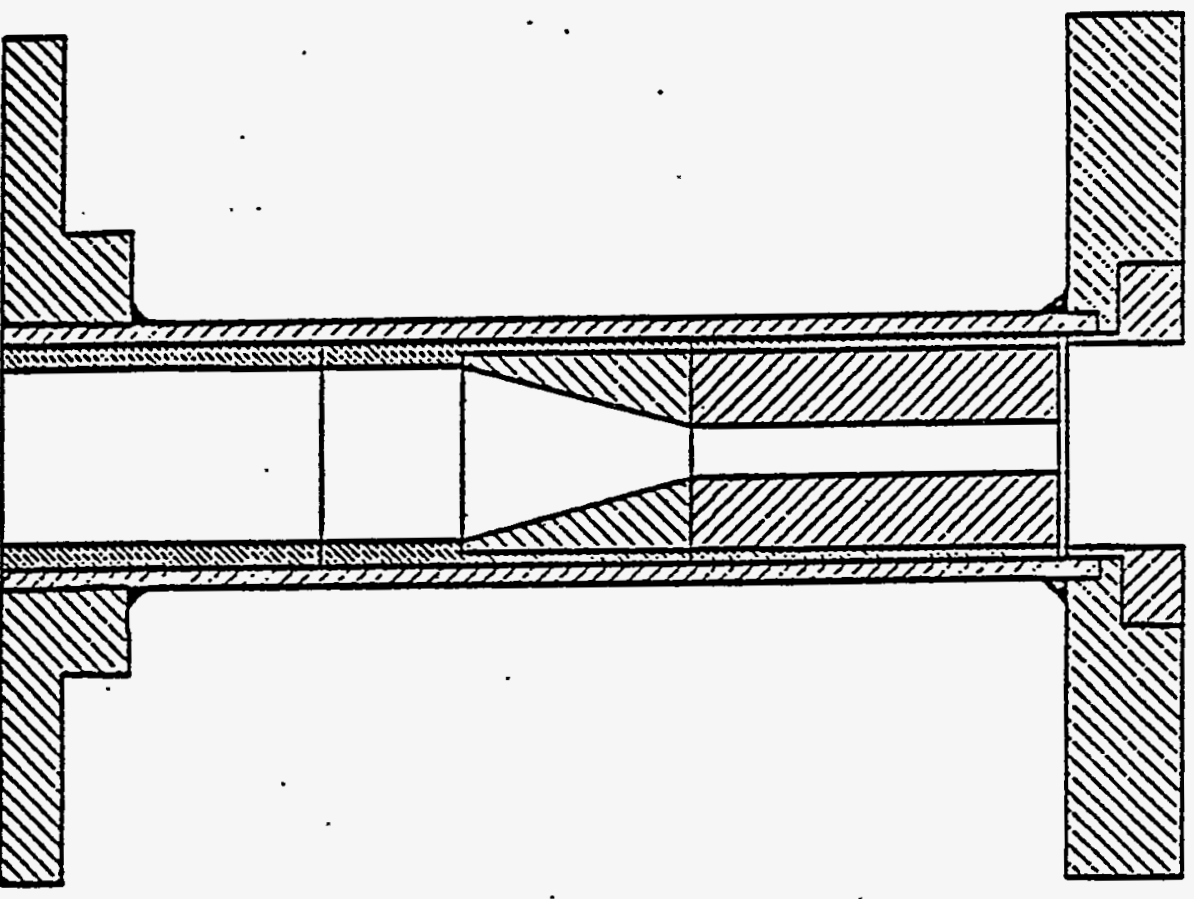

FIGURE 4.4-2 Fixed Restrictor - DWPF (Ref. 4.4-1) 
4.4:4.1.4 Variable Restrictors. The variable restrictors consist of a large cylindrical chamber with a movable impingement block mounted on a threaded shaft (Figure 4.4-3). The shaft permits the block to be moved in toward the fixed restrictor discharge until the block touches the exit of the fixed restrictor.

Both variable restrictors are mounted immediately downstream of the fixed restrictor spoolpieces, where slurry velocity is highest. In addition, both variable restrictors block flow in the horizontal direction and convert it to flow in the downward vertical direction.

4.4.4.2 Testing. Testing of the melter feed system occurred over a 10-month period. The pump was tested in sludge-frit slurry in a cell transfer application before melter feed system testing.

The following equipment and material variables were changed during testing:

- slurry rheology

- pump impeller diameter

- restrictor sizes/types/locations

- strainer sizes.

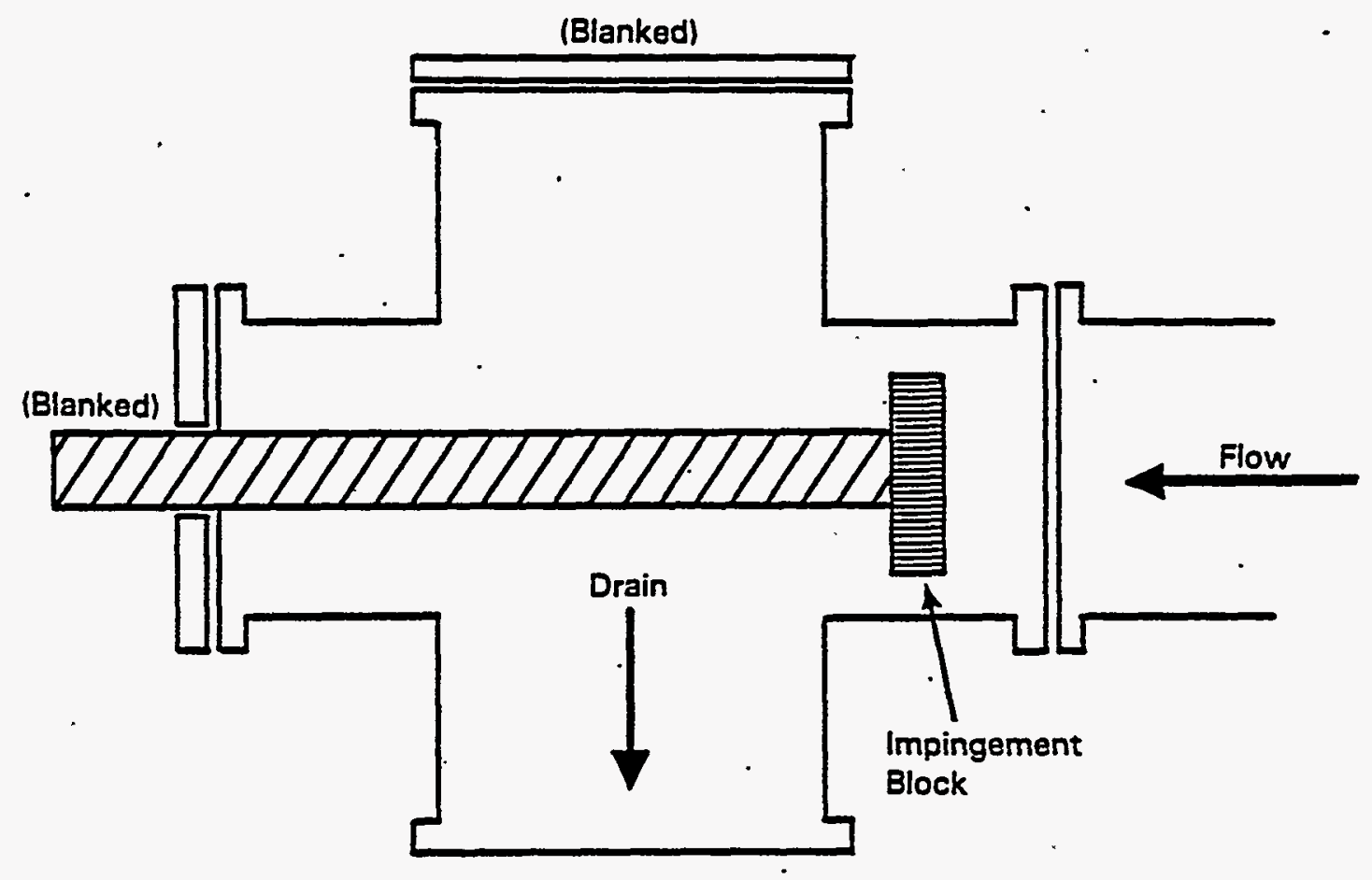

FIGURE 4.4-3. Variable Restrictor - DWPF (Ref. 4.4-1) 
Siurry rheologies tested varied from water to greater than 50 wt\% slurry with yield stress greater than the DWPF maximum of 150 dynes $/ \mathrm{cm}^{2}$. S7urry conditions evaluated during the testing period are listed in Table 4.4-2.

TABLE 4.4-2 Catalog of Pump.Tests - DWPF (Ref. 4.4-1)

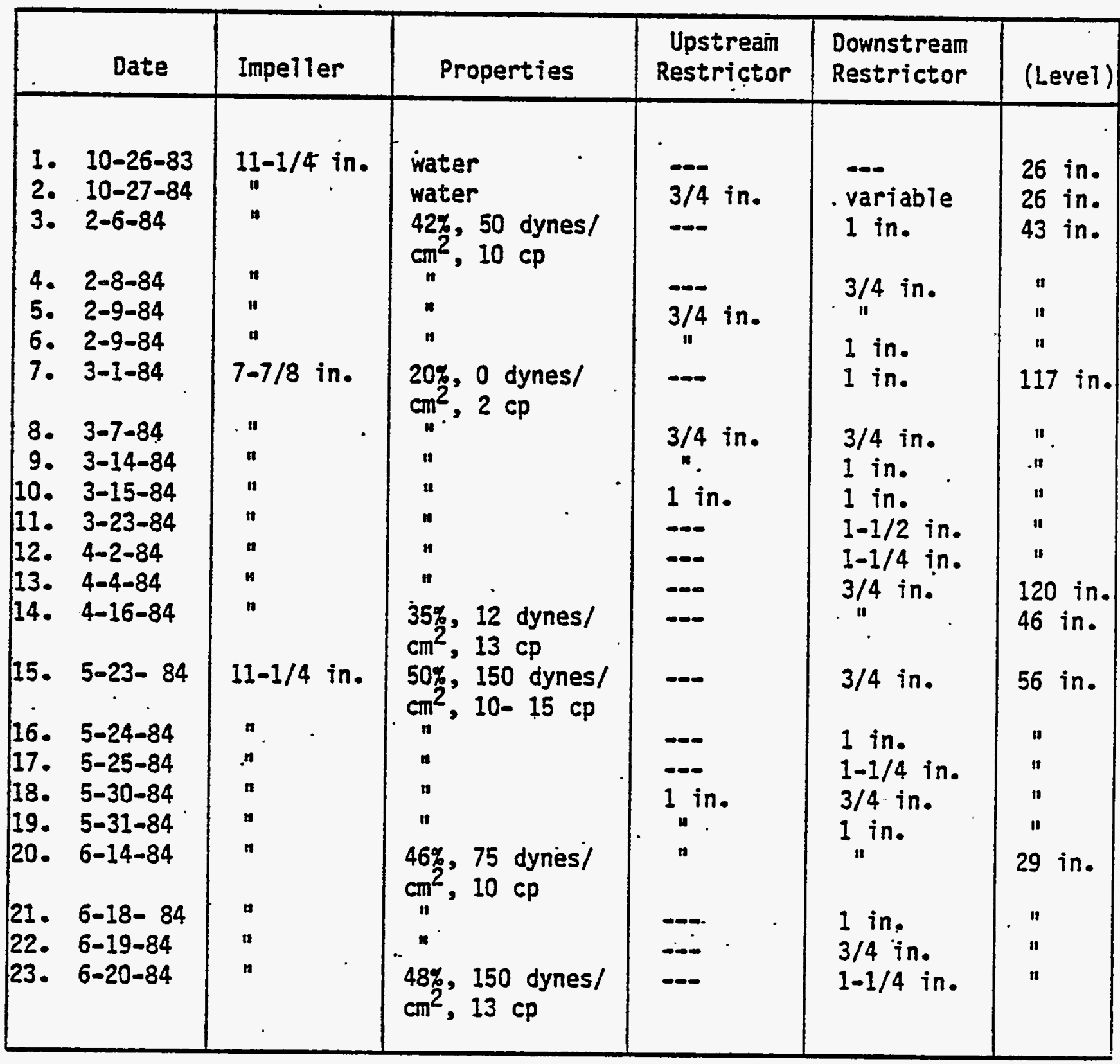


Two pump impellers, both fabricated of SPA material, were tested. The original impeller used in transfer pump testing measured 11-1/4 in. in diameter. The second impeller, 7-7/8 in. diameter, was purchased after it became apparent that a smaller impeller would better fit the required system heads, particulariy with low-rheology siurry.

Several fixed restrictors, varying in size from 3/4-in. to 1-1/2 in. in diameter, were used in both upstream and downstream fixed restrictor spoolpieces. Emphasis was placed on testing a single fixed restrictor in the downstream location only.

Two strainer sizes were tested at the melter feed take-off tee to determine the effect of strainer size on line plugging and strainer plugging.

\subsubsection{Performance.}

4.4.4.3.1 Restrictor Sizing. The RLFS provided the OWPF basic data melter flow rate of 0.4 to $0.7 \mathrm{gpm}$ for all slurry rheologies in the basic data range.

Although there were apparent advantages to using two fixed restrictors, one upstream and one downstream, only the downstream fixed restrictor was required to achieve the DWPF basic data flow rates for all applicable slurry rheologies tested. Furthermore, one, or at most two, fixed restrictor sizes will be capable of covering the entire DHPF flow and slurry range. Flow rates of 0.45 to $.90 \mathrm{gpm}$ were achieved at 645 to $850 \mathrm{rpm}$ pump motor speed with lowrheology, 42 wt\% slurry, using a 1-in. restrictor in the downstream position and an 11-1/4 in. impeller. With the same restrictor and impeller, but highrheology, $50 \mathrm{wt} \%$ slurry, flow rates of 0.11 to $0.95 \mathrm{gpm}$ were achieved at 1130 to $1205 \mathrm{rpm}$ pump motor speed. Thus, a single restrictor slightly larger than 1 in. might have permitted a flow rate as low as $0.40 \mathrm{gpm}$ with lowrheology slurry while only slightly increasing the speeds required with highrheology slurry. Figures 4.4-4 and 4.4-5 show melter flow rate versus pump motor speed for the 11-1/4-in. and 7-7/8-in. impellers, respectively.

4.4.4.3.2 Pressure/Flow Relationships. Pressure/flow relationships in the RLFS were essentially as predicted based on thermodynamic and fluid flow calculations.

Frictional losses in the 45-ft-long, 3/8-in.-diameter melter feed line were measured using the pressure gauge located in the melter feed line $1 \mathrm{ft}$ downstream of the strainer/take-off tee. The resulting pressure differences are lower than predicted by the Buckingham Equation for laminar flow based on Haake rheometer data (Figure 4.4-6). The deviation is due to a $20 \%$ lower 


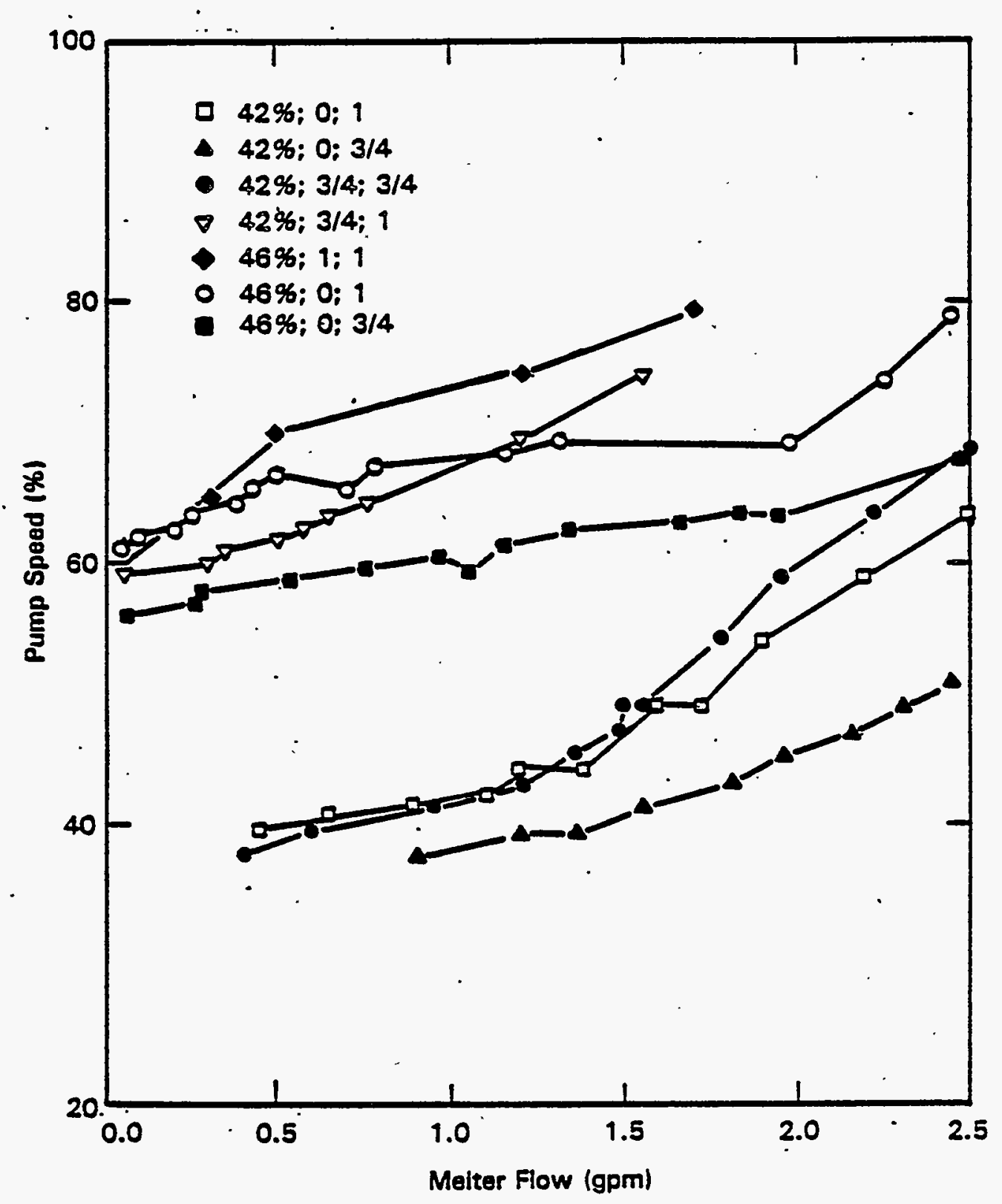

FIGURE 4.4-4. Pump Speed Versus Melter Flow, 11-1/4-in. Impeller DWPF (Ref. 4.4-1) 


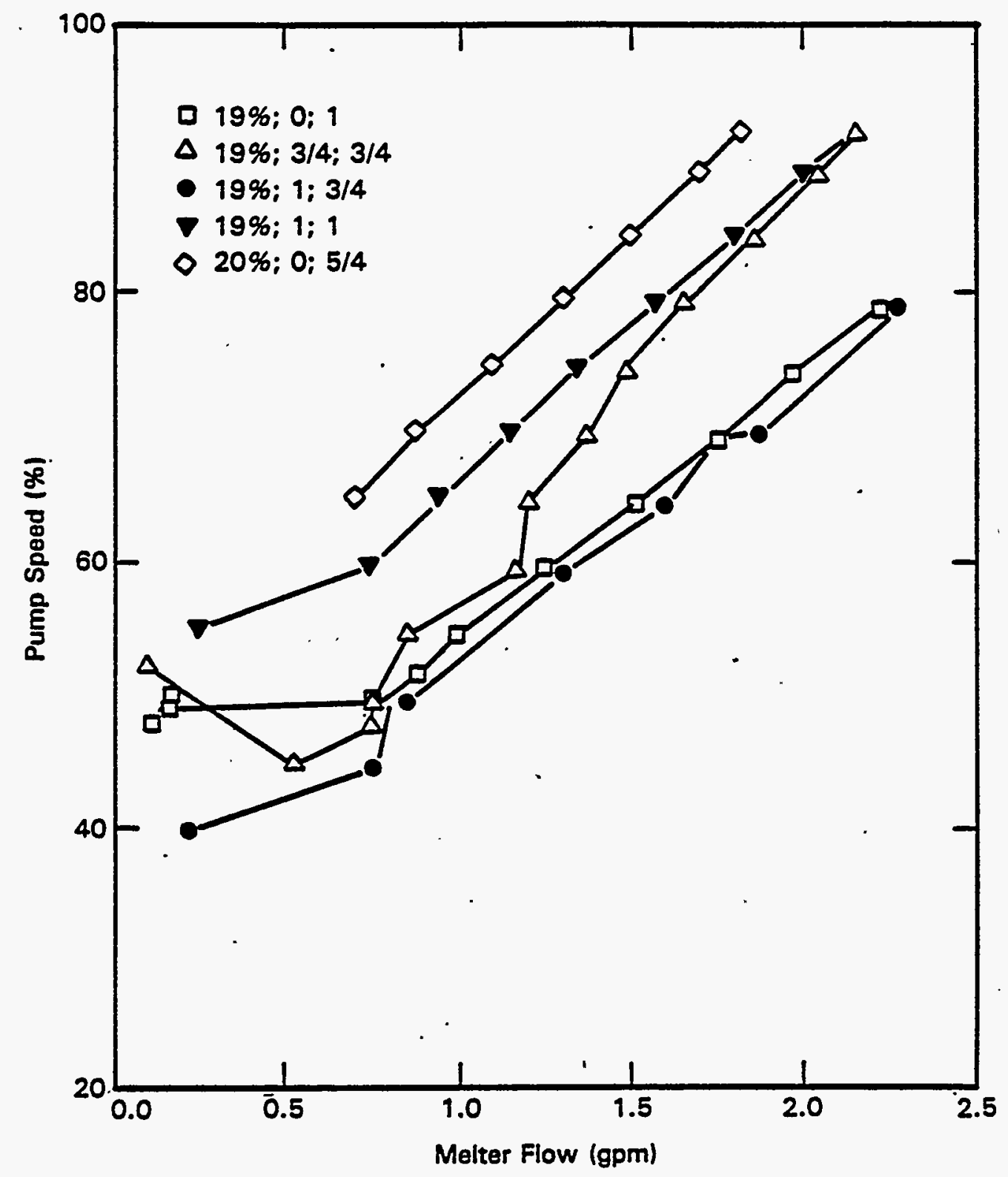

FIGURE 4.4-5. Pump Speed Versus Melter Flow, 7-7/8-in. Impeller DWPF (Ref. 4.4-1) 


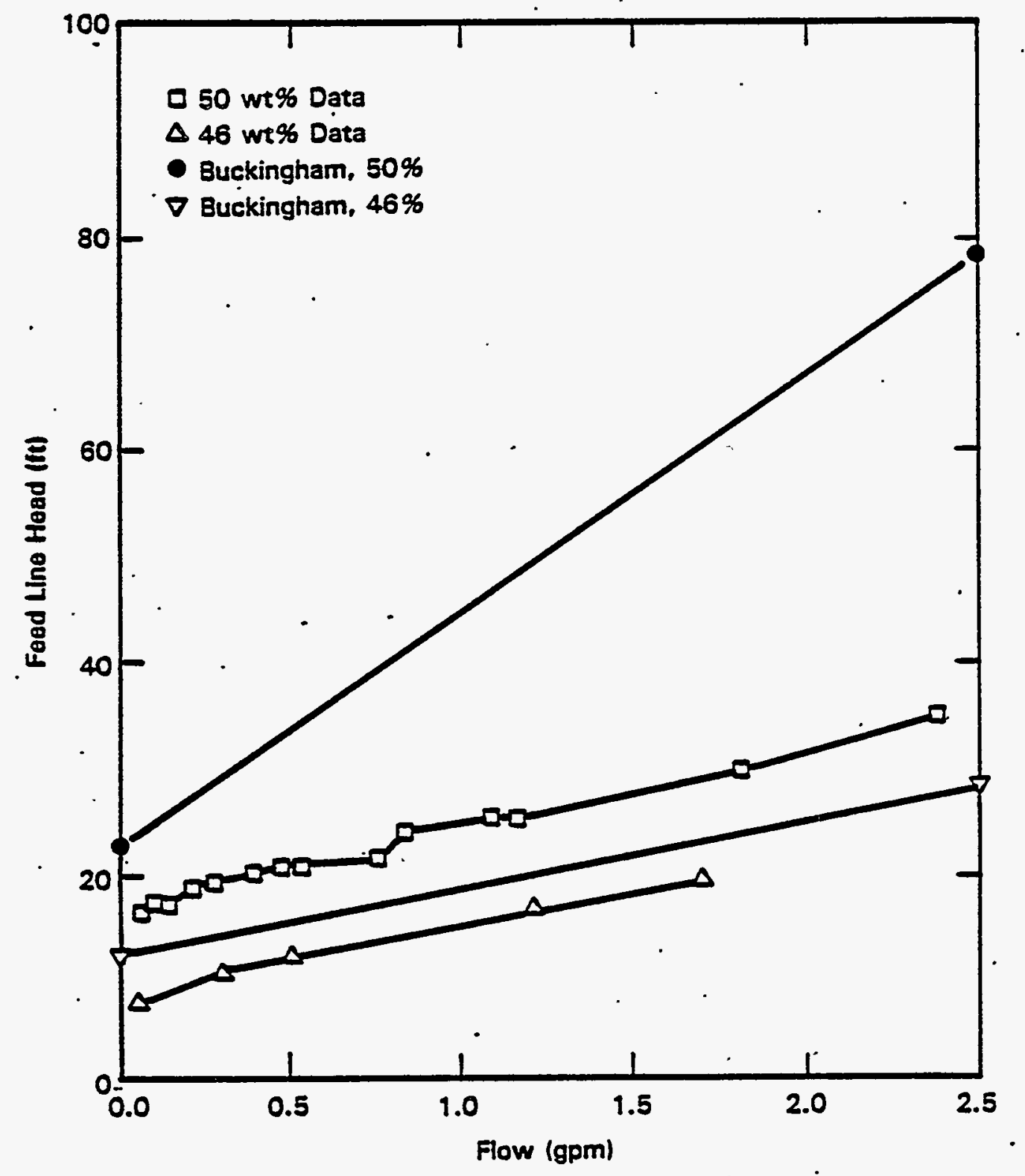

FIGURE 4.4-6. Melter Feed Head Versus Flow - DWPF (Ref. 4.4-1) 
yield stress and as much as $50 \%$ 10wer consistency than predicted by the Haake rheogram. Similar deviations from the Haake rheology were also seen by C. R. Pound in early slurry flow testing with the air-pressurized tank. Based on the RLFS data, the highest delta $P$ in the 50-ft equivalent length DWPF me1ter feed line with maximum rheology slurry and $0.7 \mathrm{gpm}$ flow rate is $38 \mathrm{ft}$ versus $45 \mathrm{ft}$ of slurry head predicted by the Buckingham Equation.

Pressure loss across the downstream restrictor was measured by using the pressure gauge located $2 \mathrm{ft}$ upstream of the restrictor. The downstream variable restrictor, unlike the upstream variable restrictor, was vented to the top of the pump tank (atmospheric). Pressure differences measured across the 3/4-in. and I-in. restrictors were $20 \%$ to $30 \%$ lower than predicted at recirculation flow rates greater than 50 gpa (Figure 4.4-7). At flow rates lower than $50 \mathrm{gpm}$, the measured pressure difference was approximately $50 \%$ lower than predicted, although the absolute discrepancy was less than at higher flow rates. Pressure difference across the 11-1/4-in. restrictor was over 50\% lower than predicted, but with an absolute discrepancy of only 3 psi at a 100-gpm flow rate. The large percentage pressure difference discrepancies versus the predicted values all occurred at relatively low restrictor exit velocities (10w flow; large restrictor) and low total pressures.

Pressure loss measured across the upstream restrictor more closely matched the predicted values. Pressure difference was measured by taking the difference between the pump discharge pressure and the pressure $4 \mathrm{ft}$ downstream of the restrictor. The effect of each fixed restrictor was calculated by subtracting the same pressure difference (at similar flow conditions) when no upstream restrictor was in use to negate the common effect of pipe frictional losses (Figures 4.4-8 and 4.4-9).

Frictional losses in the 2-in. recirculation loop could only be measured using the same gauges as for the upstream restrictor pressure difference. The total line length between the gauges was short $(<20 \mathrm{ft})$, with many potential interferences such as flowmeter, 3-way valve, gate valve, fixed-restrictor spoolpiece, variable-restrictor block, 3-in. to 2-in. adapter at the base of the variable restrictor, cross flow strainer, and five flow direction changes. The equivalent line length calculated at $100 \mathrm{gpm}$ using the measured pressure difference is greater than $40 \mathrm{ft}$. Thus, extrapolation of these measurements for predicting frictional losses in 2-in. line is probably reliable. 


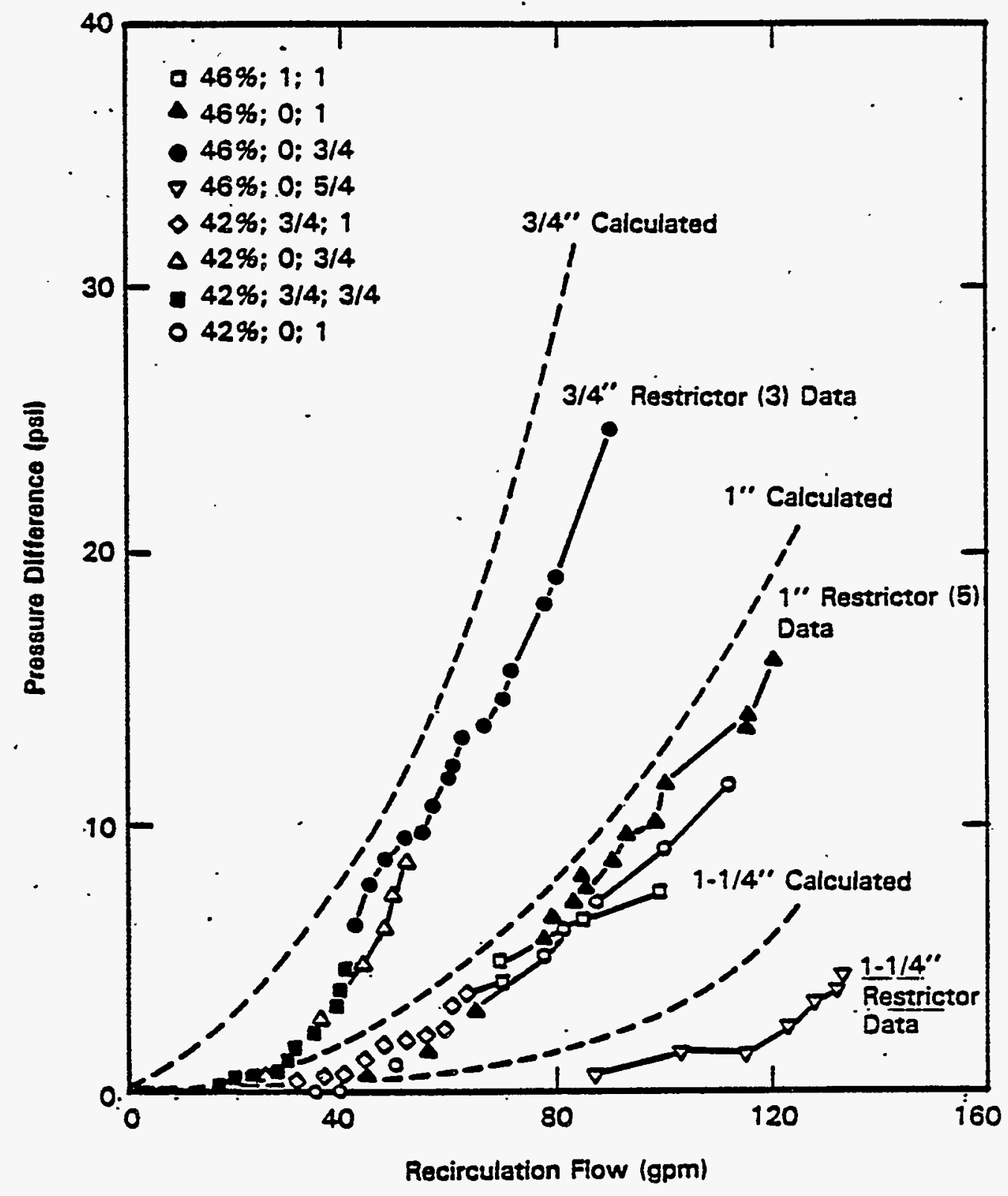

FIGURE 4.4-7 Pressure Difference Downstream Restrictor Versus Flow DWPF (Ref. 4.4-1) 


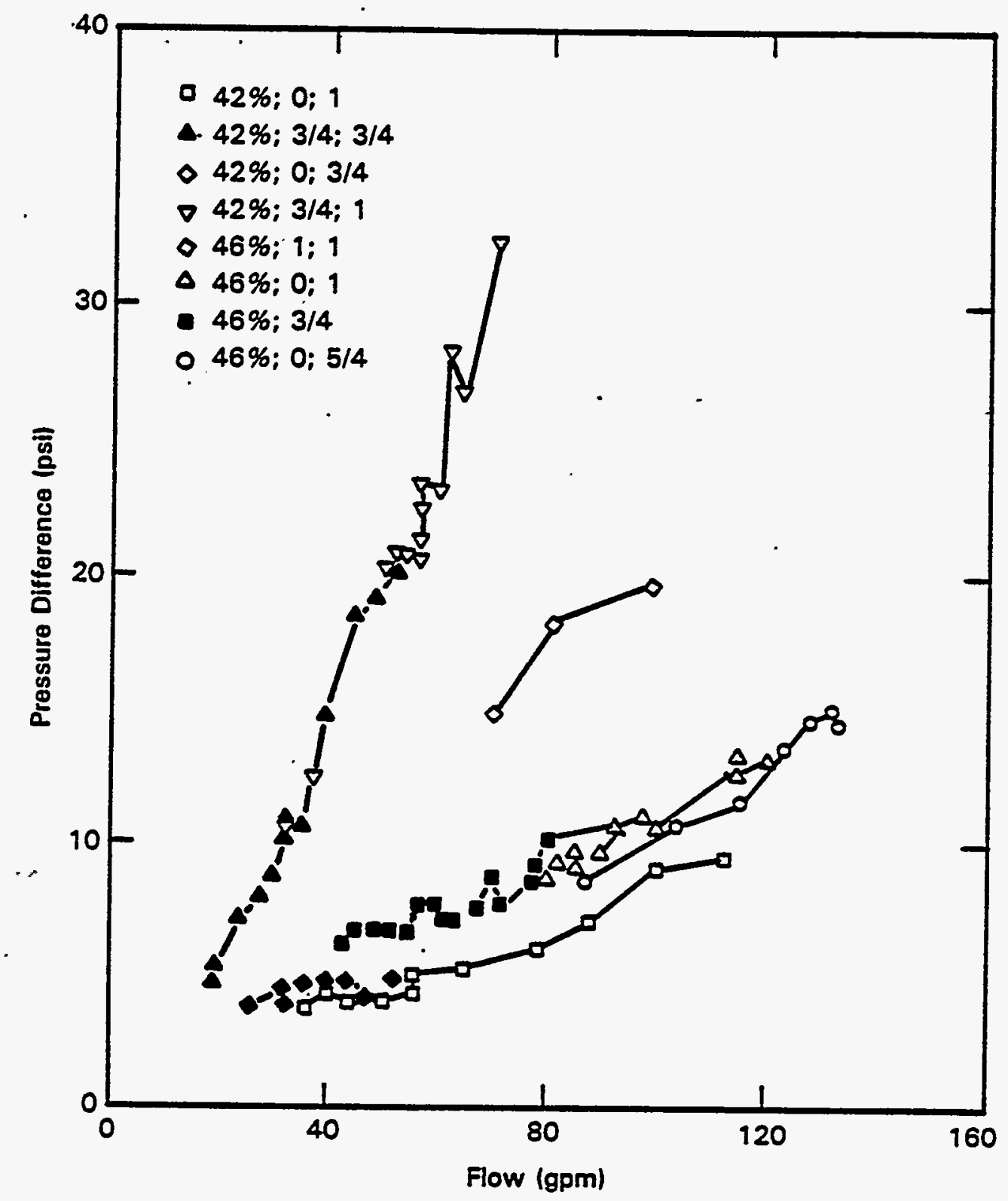

FIGURE 4.4-8. Pressure Difference Upstream Restrictor and Piping Versus Flow - DWPF (Ref. 4.4-1) 


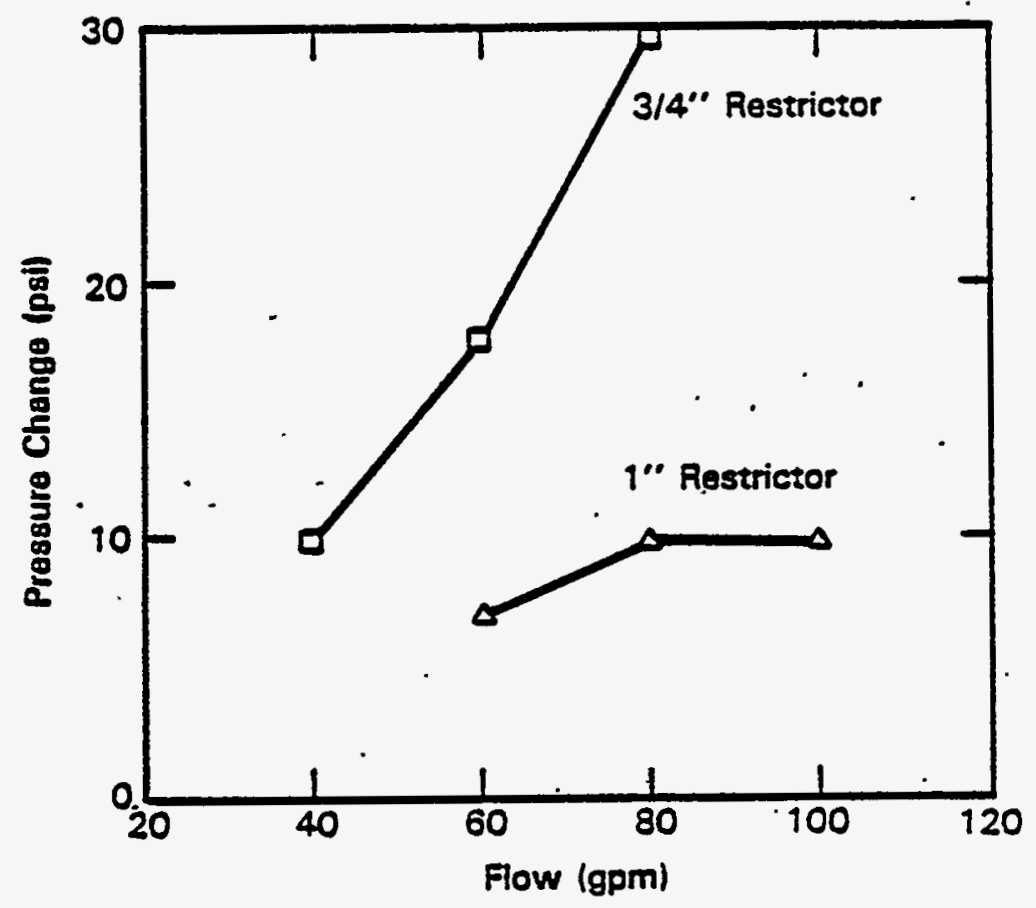

FIGURE 4.4-9. Pressure Difference Upstream Restrictor Versus Flow - DWPF (Ref. 4.4-1)

4.4.4.3.3 Pump Efficiency. Pump curves with the 11-1/4-in. impeller developed with 42 and 46 wt\% slurry at 1500 and $3800 \mathrm{~h}$ total wear time, respectively, indicate that there was some loss in pumping performance over the period of the melter feed test. The decrease, howeyer, was only 10\%, and did not have any effect other than reducing pump discharge heads. The following discussion is specific to pump operation with the 11-1/4-in. impeller.

Pump curves were developed at $900 \mathrm{rpm}$ and $1185 \mathrm{rpm}$ to match curves supplied by the vendor (Lawrence) and subsequently checked at the ETF in transfer pump testing with high-rheology (150 dynes/ $\mathrm{cm}^{2}$ yield stress, $25 \mathrm{cP}$ consistency) slurry and with water. The melter feed system curves were $5 \%$ to $20 \%$ below the vendor's water pump curves (Figures 4.4-10 and 4.4-11) uncorrected for slurry frictional losses in the suction tailpipe and 2-in. discharge piping upstream of the discharge pressure gauge, and approximately $10 \%$ below curves taken with high-rheology slurry during transfer pump testing at ETF.

Despite the loss in efficiency, the pump continued to operate well throughout the test period, excluding the final $100 \mathrm{~h}$, when a 2-ft section of heavy-gauge electrical wire became trapped in the eye of the impeller. Excepting that period, the pump was easily primed, maintained prime continuously while unattended, and, in general, ran smoothly. 


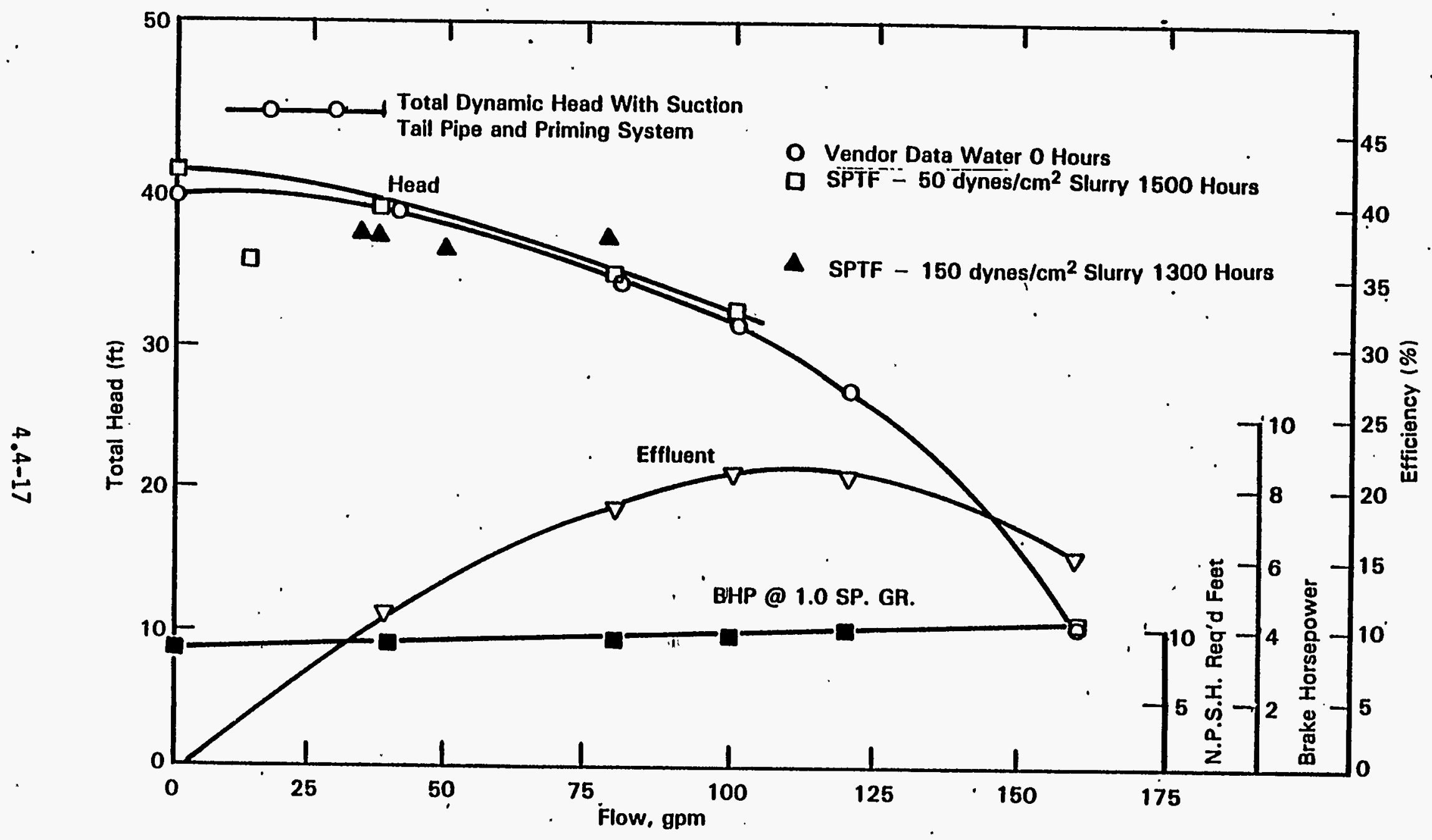

FIGURE 4.4-10. Lawrence Pump Test Performance Curve 1-DWPF (Ref. 4.4-1) 


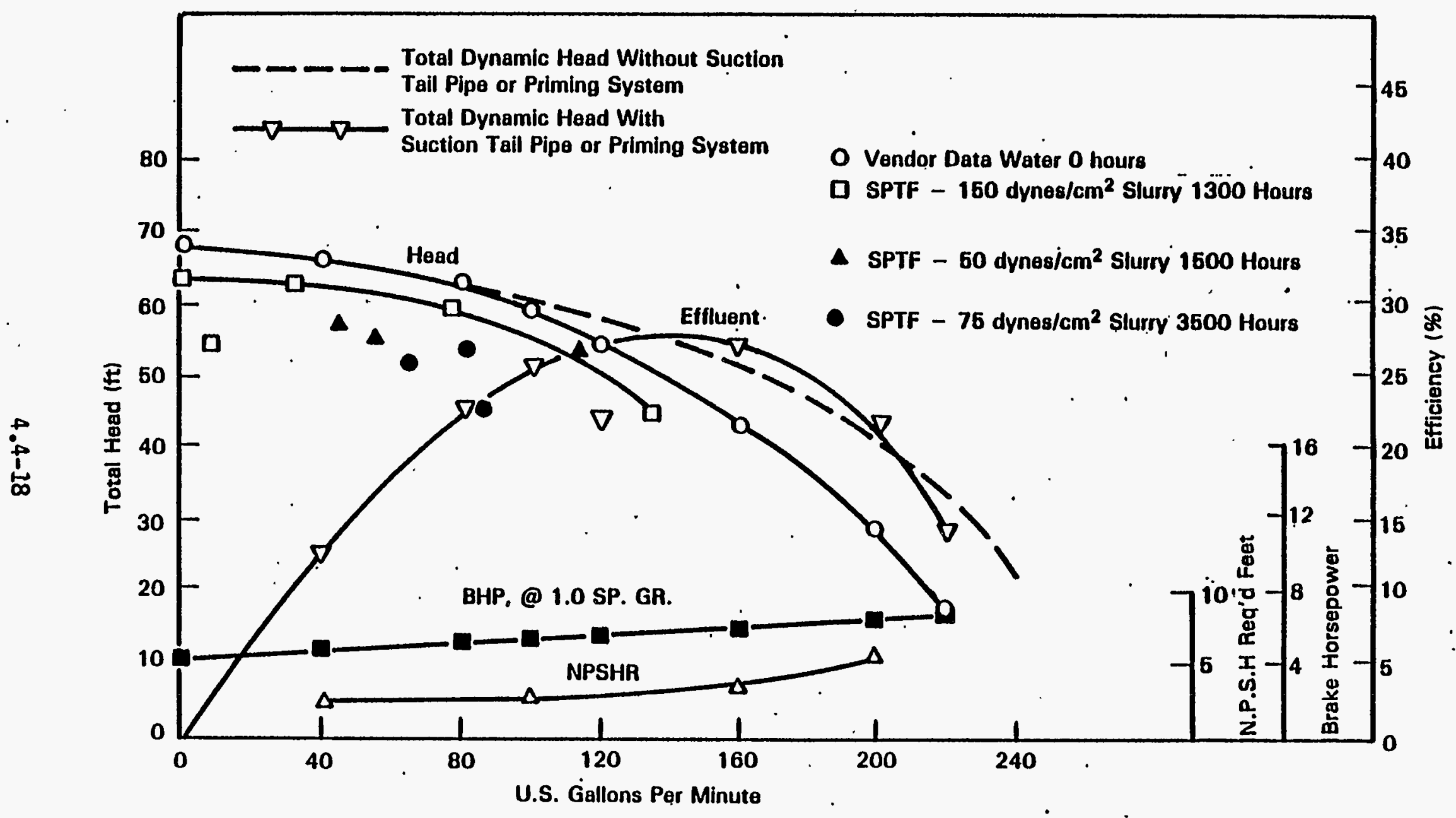

FIGURE 4.4-11. Lawrence Pump Test Performance Curve 2 - DWPF (Ref. 4.4-1) 
- Operation with the 7-7/8-in. impeller was more limited than with the 11-1/4 in.-impeller. The impeller was operated for only $1200 \mathrm{~h}$, for the most part in $20 \mathrm{wt} \%$. slurry due to inadvertent dilution while changing out impellers. Pump curves were not developed with this impeller because the 2-in. magnetic sideways flowmeter failed in service during installation of the impeller and because the replacement flowmeter did not work, causing some delay until another 2-in. flowmeter could be located the following month. However, comparing total dynamic head at the beginning and end of the 7-7/8-in. impeller testing in similar. low-flow/high-head regions of the pump curve indicates that there was no reduction in performance over the $1200 \mathrm{~h}$.

\subsection{Priming. The priming method used during RLFS testing was a} water jet. Priming was tested at length during transfer testing at ETF. Thus, the pump was primed only as necessary to complete other work test work during melter feed system testing. Priming was, in general, easily accomplished, with the following exceptions.

1. The water priming line plugged twice, the second time within an hour of an earlier successful start/prime while using 42 wt\% slurry. In each case, the plug had to be cleared by inserting a hose inside the water line and flushing the plug out with pulsating water flow. Priming line water pressure was not sufficient to remove the plug. After the second plug was cleared, the slurry was inadvertentiy diluted to $20 \mathrm{wt} \%$, probably by water coming through a leaking valve in the priming line. There was no further plugging of the line regardless of slurry rheology/wt\%. The closest subsequent slurries used were $35 \mathrm{wt} \%$ and $46 \mathrm{wt} \%$.

2. During operation with the 7-7/8-in.-diameter impeller, the pump would not maintain prime below $1130 \mathrm{rpm}$ using $35 \mathrm{wt} \%$ solids slurry. It would not stay primed at any speed up to $1850 \mathrm{rpm}$ with 50 wt\% slurry. It was operated as $10 \mathrm{w}$ as $750 \mathrm{rpm}$ with $20 \mathrm{wt} \%$ slurry. It is possible that the large gap between the impeller outer diameter and pump casing (2.7-in.) allowed air inleakage into the pump casing, causing the loss of prime. A second possibility is that the reduced impeller vane length (the impeller was originally an 11-1/4-in. casting ground down to 7-7/8-in.) reduced the available suction lift capability of the pump.

A smaller pump casing and specially designed small impeller with increased vane length to fit the existing pump have been ordered from the vendor for later use in the DWPF scale glass melter. 
3. During the final $100 \mathrm{~h}$ of operation with the 11-1/4-in. impeller, the pump repeatediy lost prime, and finally could not be primed or operated for more than a few minutes. The cause was found to be heavygauge wire that had become knotted in the impeller.

4.4.4.3.5 Vibration. Pump vibration worsened by $30 \%$-during melter feed system operation compared to measurements made at the end of transfer testing $(1300 \mathrm{~h})$. Vibration measurements made at $3400 \mathrm{~h}$ with the 7-7/8-in. impeller indicated the same basic pattern as at $1300 \mathrm{~h}$--three peak vibration frequencies between 700 to $1800 \mathrm{rpm}$. Whereas the previous peak vibration velocity was $0.50 \mathrm{in.} / \mathrm{s}$ at $720 \mathrm{rpm}$, and $0.48 \mathrm{in.} / \mathrm{s}$ at 1185 and $1620 \mathrm{rpm}$, at $3400 \mathrm{~h}$ peak velocities were $0.62,0.65$, and $0.63 \mathrm{in.} / \mathrm{s}$ at 850,1040 , and $1540 \mathrm{rpm}$, respectively. Immediately following these vibration measurements, the impeller was changed out. Later vibration measurements were excessively high due to the wire trapped in the impeller.

During and just before the $3400 \mathrm{~h}$ impeller changeout, the following vibration maintenance items were checked:

- motor shaft-to-pump shaft alignment

- pump shaft run-out

- motor vibration uncoupled from the pump

- bearings changed out.

None of the above items were outside of the DuPont Standards Specifications. The bearings were inspected and were determined not to be faulty.

It is recommended that the pump impeller and shaft be dynamically balanced and that a suction strainer be installed on the tailpipe before reinstallation in the pump tank, and that further vibration measurements be made to confirm that the recent major vibration problem was due to debris trapped in the impeller.

4.4.4.3.6 Control. Automatic control of the melter flow rate was not adequately demonstrated during the test period due to equipment problems. with the variable speed drive, and then due to high vibration and priming problems with the pump caused by large debris in the impeller. Thus, flow control was manual for all but $18 \mathrm{~h}$ of melter feed testing. The flow rate could be controlled manually to within $+0.03 \mathrm{gpm}$ of desired set point in all but a few cases as follows:

1. With 20 wt\% slurry and flow rates less than $0.75 \mathrm{gpm}$, flow was erratic and uncontrollable, usually decreasing to zero over a 5 to 15-min period. When speed was increased by a small increment, flow would ramp up quickly to $>0.75 \mathrm{gpm}$. Flow in the 2 -in. recirculation 
line continued steady (based on pressure gauges; 2-in. flowmeter was broken). This was either due to settling or to a transition in flow regime for turbulent to laminar in the 3/8-in. line. The settling concept is more plausible because of the low flow rates, thin slurry, and slow transition from normal flow to zero flow. This is not a major concern in either case because slurry weight percent solids and rheology were both well below DWPF minimums. (Melter feed flow is always laminar in the DHPF basic data rheology range.)

2. While using the variable restrictor as the primary restrictor, the flow rate was generally stable, varying $\pm 0.03 \mathrm{gpm}$. However, the. flow would occassionally change erratically by as much as $0.5 \mathrm{gpm}$ without a change in pump motor speed. Flow controllability improved again when the variable restrictor impingement block was backed out (less restriction). This problem was not seen during the use of fixed restrictors only.

3. After pump vibration became excessively high, flow controllability in both manual and automatic modes was $\pm 0.1 \mathrm{gpm}$ with cycles of approximately $4 \mathrm{~s}$. After the pump was disassembled at $3850 \mathrm{~h}$, a 2-ft section of heavy gauge wire was found inside the impeller, probably causing the vibration and the control problems.

It is expected that automatic flow control will be at least as good as manual control in any condition. Low controller proportional gain, low reset time (large integral gain), and high derivative time were found to give the best control during the short testing period with the automatic controller. These observations should be reconfirmed, however, when the pump vibration is reduced.

\subsubsection{Wear Results.}

4.4.4.4.1 Pump. Run conditions for testing are summarized in Table 4.4-1. Melter feed testing began after the pump had $1300 \mathrm{~h}$ of operation with sludge-frit slurry. Because nominal flow rates used during the transfer testing are similar to those expected in service, these hours are valid for consideration of total pump wear in service.

The original 11-1/4-in.-diameter impeller was in service for 2650 of the 3850 total hours; the 7-7/8-in.-diameter impeller was in service for $1200 \mathrm{~h}$. The following discussion summarizes wear after $1300,2200,3400$, and $3850 \mathrm{~h}$ operation in sludge-frit slurry.

Total wear at $3850 \mathrm{~h}$ was moderate. Weight loss of all major SPA components was less than 5\%, as shown in Table 4.4-3. 
TABLE 4.4-3, Major Pump Parts--Weight Losses for DWPF (Ref. 4.4-1)

\begin{tabular}{|l|c|c|c|}
\hline & $\begin{array}{c}\text { Original } \\
\text { Weight (7b) }\end{array}$ & $\begin{array}{c}1300 \mathrm{~h} \\
\text { Weight (1b) }\end{array}$ & $\begin{array}{c}3850 \mathrm{~h} \\
\text { Weight (7b) }\end{array}$ \\
\hline & & & \\
Casing & 96.9 & 95.9 & 95.4 \\
Suction disk & 55.4 & 54.1 & 53.5 \\
Impeller & & & 1 \\
(11-1/4 in.) & 23.0 & 22.3 & $21.9(\mathrm{a})$ \\
\hline
\end{tabular}

(a) $2650 \mathrm{~h}$ service.

The most significant wear was gouging of the casing volute entrance. This was also the highest wear point after 600 and $1300 \mathrm{~h}$. The probable cause of the high wear at this point is the flow splitting effect of the volute tongue, where a small burr or irregularity could cause local turbulence immediately downstream of the entrance. After $3850 \mathrm{~h}$, the depth, width, and length of the gouges had increased significantly compared to the $1300 \mathrm{~h}$ inspection to 5/16-in., 1-3/4-ino, and 2-in.,. respectively. However, based on visual inspection and thickness measurements, it appears that the volute could last an additional $4000 \mathrm{~h}$ before completely gouging through. The top face of the casing appeared smooth with no apparent wear.

After $2650 \mathrm{~h}$, the 11-1/4-in. impeller showed some pitting and light gouging behind the external vanes. Both effects were noted at $1300 \mathrm{~h}$. Neither seemed to have significantly increased during MFS testing.

The 7-7/8-in. impeller revealed light pitting and gouging after $1200 \mathrm{~h}$.

After $3850 \mathrm{~h}$, the suction disc was gouged, most severely at the inner radius to a depth of $1 / 8-i n$. versus $<1 / 8-i n$. at $1300 \mathrm{~h}$. The disc was also gouged at points at the extreme outer radius, matching points where the disc aligned with the casing volute entrance. This wear is probably not serious when compared to the 2-in. depth of the disc.

The shaft adapter showed no wear after. $3200 \mathrm{~h}$, nor did the lower shaft close to the wet end and exposed to slurry relief flow out of the casing. The upper shaft, however, was slightly scored by the packing or trapped particles in-the packing in the stuffing box at the tank mounting flange. 


\subsection{Piping and Restrictors: Pipe thickness measurements}

(Table 4.4-4) were taken three times during testing: at $0 \mathrm{~h}, 1400 \mathrm{~h}$, and $2500 \mathrm{~h}$. Measurements were conducted with an ultrasonic thickness detector. Results, however, are difficult to interpret because pipe thickness appears to have increased over the test period. This may be due to residual sludge in the piping, or poor instrument operation or calibration. After $1400 \mathrm{~h}$, both the 3/8-in. and 2-in. piping had worn 4 mils in the straight sections, a rate of $25 \mathrm{mils} / \mathrm{yr}$. This value roughly corresponds to data collected at the ETF with 304L SS in erosion tests.

Several fixed-restrictor pieces of boron carbide, an extremely hard material, and stainless steel were used in both upstream and downstream restrictor spoolpieces. None of the restrictor pieces, including both the straight bore and tapered pieces, showed significant wear. The long straight bore was. designed to minimize erosion wear effects at the exit of the tapered piece.

4.4.4.5 Straining. Two strainer sizes of the same design were used during testing. No plugs occurred in either of the strainers or in the 3/8-in. melter-feed line during this period. A comparison of strainer sizes and effectiveness, including strainers used while feeding the liquid slurry-fed melter (LSFM), is given in Table 4.4-5.

The cross-flow tapered slot design appears to be effective in preventing strainer plugs while straining slurry from the melter feed line. However, further strainer testing should be conducted while feeding an operating melter however, to verify strainer performance at elevated temperatures. Most plugs

TABLE 4.4-4. Piping Thickness Measurements, mils - DWPF (Ref. 4.4-1)

\begin{tabular}{|l|l|l|l|}
\hline \multicolumn{1}{|c|}{ Items } & Original & $\begin{array}{l}\text { After } \\
1450 \mathrm{~h}\end{array}$ & $\begin{array}{l}\text { After } \\
2500 \mathrm{~h}\end{array}$ \\
\hline 2-in. Sch. 40 & 0.154 & 0.150 & 0.159 \\
3/8-in. Sch. 80 & 0.126 & 0.122 & 0.131 \\
$\begin{array}{l}\text { 2-in. elbow } \\
\text { (top; center) }\end{array}$ & 0.135 & 0.165 & 0.165 \\
\hline
\end{tabular}


TABLE 4.4-5. Strainer Data - DWPF (4.4-1)

\begin{tabular}{|c|c|c|c|c|c|}
\hline $\begin{array}{l}\text { Opening } \\
\text { size (in.) }\end{array}$ & $\begin{array}{l}\text { Total No. } \\
\text { of Openings }\end{array}$ & $\begin{array}{c}\text { Open } \\
\text { Area } \\
\left(\text { in. }^{2}\right)\end{array}$ & $\begin{array}{l}\text { Flow } \\
\text { Rate (gpm) }\end{array}$ & $\begin{array}{l}\text { No. of } \\
\text { Feed } \\
\text { Nozzle } \\
\text { Plugs }\end{array}$ & $\begin{array}{l}\text { Interval } \\
\text { Between } \\
\text { Strainer } \\
\text { Plugs }\end{array}$ \\
\hline $\begin{array}{l}14 \text { mesh } \\
0.052 \text { sq }\end{array}$ & $-\infty$ & 25 & 0.4 & 1 & days-weeks \\
\hline $\begin{array}{l}25 \text { mesh } \\
0.034 \mathrm{sq}\end{array}$ & $-\infty$ & 9 & 0.4 & 0 & minutes \\
\hline $\begin{array}{l}\text { Round (ara) } \\
0.041 \\
0.062 \\
0.082 \\
0.082\end{array}$ & $\begin{array}{r}91 \\
91 \\
91 \\
300\end{array}$ & $\begin{array}{l}0.12 \\
0.27 \\
0.48 \\
1.58\end{array}$ & $\begin{array}{l}0.2-1.0 \\
0.2-1.0 \\
0.2-1.0 \\
0.2-1.0 .\end{array}$ & $\begin{array}{l}0 \\
0 \\
0 \\
0\end{array}$ & $\begin{array}{l}\text { 1-4 hours } \\
\text { 1-2 days } \\
\text { days-weeks } \\
\text { days-weeks }\end{array}$ \\
\hline $\begin{array}{l}0.082(a) \\
0.141(a)\end{array}$ & $\begin{array}{l}40 \\
40\end{array}$ & $\begin{array}{l}4.1 \\
7.1\end{array}$ & $\begin{array}{l}0.2->2.5 \\
0.2->2.5\end{array}$ & $\begin{array}{l}0 \\
0\end{array}$ & $\begin{array}{l}\text { none } \\
\text { none }\end{array}$ \\
\hline
\end{tabular}

(a) The 0.082-in. slots were in service for $500 \mathrm{~h}$; the $0.141 \mathrm{in}$. slots, for $2050 \mathrm{~h}$.

that occurred while feeding the LSFM were located close to the melter where high temperatures were encountered. In addition, more debris and hardened sludge agglomerates were encountered in feeding the LSFM than in the melter feed systen testing.

4.4.4.6 Conclusions. A recirculation feed loop system was designed, installed, and tested. Performance was generaliy as predicted by fluid dynamic and thermodynamic calculations. Wear was significant in certain areas of the pump, but was not serious enough to drastically reduce pump performance. Thus, the RLFS appears adequate for DWPF melter feed service provided that automatic control can be successfully demonstrated, and that recent high pump vibration problems are solved. 


\section{REFERENCES}

4.4-1 R. K. Steidlitz and D. M. Grimm, DWPF Melter Feed System Testing, DPST-894-649, Savannah River Laboratory, Aiken, South Carolina (1984).

4.4-2 J. M. Perez, Jr., and R. R. Nakaoka, "Vitrification Testing of Simulated High-Level Radioactive Waste at Hanford," PNL-SA-13360, Presented at Haste Management 86 Symposium, Pacific Northwest Laboratory, Richland, Washington (March 1986). 



\subsection{MELTER/TURNTABLE (System 13)}

The melter/turntable section summarizes process technology related to feeding the melter.

\subsubsection{Function :}

The purposes of the melter/turntable system is to receive slurry feed from the melter feed system and convert the feed into molten glass that is poured into a canister for solidification. The turntable handles the canister under the melter while containing any fumes from the canister and controls the glass cooling rate. The melter vents the process off gas to the melter off gas systém.

\subsubsection{Operational Requirements}

The operational requirements of the melter/turntable are provided in Table 4.5-1.

\subsubsection{Process Chemistry}

In the melter, the feed reacts at elevated temperatures to form molten glass and a process off gas. The bases for the flowsheet and operational analyses in the melter are provided in Tables 4.5-1 and 4.5-2. The stoichiometry and chemical reactions of the HWVP feed in the melter are shown in Table 4.5-3.

4.5.3.1 Cold Cap and Plenum Chemistry. In the simulated melter feed, most of the metals exist as metal formates, hydrated oxides, hydroxides, and nitrates with some small amounts of sulfates, fluorides, and silicates. Some semivolatile species, such as ruthenium, technetium, and halides, may exist as anions. In the melter, the formates, hydrated oxides, hydroxides, and nitrates decompose to metal oxides, generating water and hydrogen as gases. The sulfates may partially decompose, generating $\mathrm{SO}_{x}$, which is assumed to be $\mathrm{SO}_{2}$ or $\mathrm{SO}_{3}$. Then organic formates and sugar decompose to $\mathrm{CO}_{x}, \mathrm{H}_{2} \mathrm{O}$, and $\mathrm{H}_{2}$. Nitrates decompose to $\mathrm{NO}_{x}$. Semivolatile materials partially vaporize through partial conversion to a volatile form such as $\mathrm{RuO}_{4}$ or a high-vapor-pressure compound such as an oxide of Cs, Cd, Te, or B. Chemistry in the cold cap depends to a large extent on chemical composition, operating temperatures, and oxygen partial pressure. The metal halides are thought to partially react and 
TABLE 4.5-1. Melter/Turntable Operational Requirements

Melter

- The average glass instantaneous production rate is $100 \mathrm{lb} / \mathrm{h}$ with a feed containing 3.3 lb TO/gal.

- The maximum glass production is $220 \mathrm{lb} / \mathrm{h}$ with a feed containing. 4.1 Ib TO/gal.

- The minimum melter design life is $3 \mathrm{yr}$.

- The average waste residence time in the melter is greater than $12 \mathrm{~h}$.

- All melter components with an ariticipated life of less than 3 yr must be designed for remote replacement by the canyon'in-cell crane and impact wrench.

' The melter can be started and restarted remotely.

- Feed nozzles at the melter are cooled to prevent boiling and shouid be designed to prevent plugging in the line. Cooling of the feed nozzles during placement or replacement is required to prevent thermal-shock cracking.

- The melter is operated at a vacuum to the cell under normal and off-standard operating conditions. The off gas is vented to the melter primary or backup melter off-gas system.

- Canisters must be vented to the off-gas systen during pouring for a minimum of $0.5 \mathrm{~h}$ after the completion of pouring. The canisters may then. be exposed to the MC environment.

- Pouring will be accomplished by overflow or airlifting.

- Melter external body surface temperature (not including lid and overflow wall) should be $120^{\circ} \mathrm{F}$ maximum, to minimize cell updrafts when the cell covers are removed for melter repair. 
TABLE 4.5-1. (contd) .

- Normal melt surface coverage during feeding operations should be $60-80 \%$ and not exceed $90 \%$.

- The melt surface cold cap should be about 2-5 cm thick, be flexible, and vent easily. .

- Components that contact the giass will be electrically hot. Jumpers for these components must be electrically isolated.

- The melter must be capable of being installed and removed remotely.

- The melter bulk glass temperature is controlled to $2100^{\circ} \mathrm{F} \pm 40^{\circ} \mathrm{F}$ $\left(1150^{\circ} \mathrm{C} \pm 17^{\circ} \mathrm{C}\right)$. However, a minimum glass temperature of $1900^{\circ} \mathrm{F}$ $\left(1035^{\circ} \mathrm{C}\right)$ is acceptable adjacent to the refractory walls of the melter.

- Seals on the melter must minimize off-gas vapor releases during a pressure excursion.

- Interlocks shall be provided to stop melter feed and put the melter in an "idle mode" when required.

- Glass melt temperature will be measured at three depths in three locations. Depths at each location should be similar to each other. As many thermocouples as practical will be used at each level to provide redundancy.

- The vapor space temperature will be measured at approximately $15 \mathrm{in}$. above nominal glass melt line in one location (redundant thermocouple).

- Instrumentation is needed to indicate when foam or cold cap is too high.

- Viewing of the glass melt surface must be provided to determine cold cap distribution. The viewing area should include as much of the two feed entry points, the cold cap between one feed point and the nearest sidewall, and a portion of the sidewall, as possible. The cameras proposed for the melter require cooling at all times, including during installation and removal. 
TABLE 4.5-1. (contd).

- The glass level must be measured.

- Provide venting between the melter cavity and the melter overflow section.

- Provide heating to the melter overflow section to maintain the glass temperature at greater than $1050^{\circ} \mathrm{C}$.

- Provide for melter vapor space vacuum measurement.

- Melter pressure relief shall be by a seal pot. To reduce entrance, line, and exit losses, the pot shall be close coupled to melter and ducts.

- A method must be provided for sampling the glass.

\section{Turntable}

- A remotely breakable seal is required between the melter and the canister or turntable to minimize air in-leakage.

- The turntabie must provide accurate indexing of canisters into and out of either of two overflow positions during filling.

- Canister insertion and removal from the turntabie must be accomplished with the MC crane.

- The turntabie will require four canister positions; the first for loading and unloading, the next two for filling, and the fourth for cooling.

- The turntable must be removable with the melter in a standby or molten condition.

- The turntable or the canister in the filling position must be vented to control contamination.

- Venting shall not deflect or cool the falling glass stream. 
TABLE 4.5-1. (contd)

- The glass must be prevented from contacting and adhering to the external surface of the canister.

- Provide capability to weigh the canister being filled.

- Provide indication of canister pod position in turntable.

- Provide indication of temperature in turntable.

- Provide instrumentation to detect canister fill level by radiation detection:

The following are required for a closed turntable:

- Provide capability to cool turntable with a water-cooled jacket.

- Provide a capability to add water/chemical solutions to turntable. .

- Provide liquid level measurements in turntable.

- Provide route to transfer water from turntable to DWTT.

- Vent turntable to melter overflow section. 
TABLE 4.5-2. Melter Process Bases - HWVP

\section{Entrainment}

- $0.3 \%$ of the melter feed sludge components (metal oxide basis) and frit are entrained in the melter off gas.

Melter Vapor Space Operating Pressure ${ }^{(a)}$

- -5-in. $\mathrm{H}_{2} \mathrm{O}$ relative to the cell.

Purges and Air In-Leakage ${ }^{(a)}$

- Melter in-leakage air - $160 \mathrm{lb} / \mathrm{h}$.

- Backup film cooler purge. air - $200 \mathrm{lb} / \mathrm{h}$.

- TV camera lens purge - $60 \mathrm{lb} / \mathrm{h}$.

- Melter dip tubes air - $1 \mathrm{lb} / \mathrm{h}$.

- Prinary film cooler air - $700 \mathrm{lb} / \mathrm{h}$.

- Primary film cooler steam - $270 \mathrm{lb} / \mathrm{h}$. .

Design bases and maintain film cooler outlet air below $660^{\circ} \mathrm{F}$ and above $270^{\circ} \mathrm{F}$ with a linear flow rate $>50 \mathrm{ft} / \mathrm{s}$ in a pipe with a nominal

. diameter $>5.5 \mathrm{in}$. The pipe temperature downstream of the film cooler is to be $\geq 50^{\circ} \mathrm{F}$.

The melter and associated melter off-gas system should be designed to maintain a vacuum when flow surges equal to 7 times the normal rate of steam production and 3 times the normal rate of noncondensable gas production from evaporation and melting of the melter feed without venting through the backup film cooler.

\section{Canister Capacity}

- 3630 ib of waste glass/canister.

(a) Letter: R. B. Morson and R. A. Smith, WHC, to R. N. Gibbons, Fluor, December 9, 1988, "Melter Off Gas. Film Cooler Technical Information, HWVP/FLU.V-88-132. 
TABLE 4.5-3. Melter Stoichiometry - DWPF(a)

Each reaction goes to completion unless otherwise noted. The actual degree of completion of many reactions is dependent on the operation of the melter because the degree of completion is a strong function of the partial pressure of oxygen in the melter.

Sulfate content in the glass is limited to $0.3 \mathrm{wt} \%$. Sulfate compounds are incorporated in the glass as follows:

$$
\begin{aligned}
& \mathrm{PbSO}_{4}=100 \% \text { (subsequently decomposes to } \mathrm{PbS} \text { and } \mathrm{O}_{2} \\
& \mathrm{BaSO}_{4}=100 \% \\
& \mathrm{CaSO}_{4}=80 \% \\
& \mathrm{Na}_{2} \mathrm{SO}_{4}-60 \%
\end{aligned}
$$

until the 0.3 wt\% criterion is attained; at that point any remaining sulfate compounds react per the indicated stoichiometry.

The maximum percentage of iron (III) hydroxide to be reacted to Fe0 is $33 \%$. If insufficient $\mathrm{NaCOOH}$ is available, the unreduced $\left(\mathrm{Fe}(\mathrm{OH})_{3}\right.$ decomposes to $\mathrm{Fe}_{2} \mathrm{O}_{3}$ and $\mathrm{H}_{2} \mathrm{O}$.

The maximum halide content in the glass is $0.25 \mathrm{wt} \%$. Sodium halides are incorporated in the glass as follows:

$$
\begin{aligned}
& \mathrm{NaF}-67 \% \\
& \mathrm{NaCl}-50 \%
\end{aligned}
$$

until the 0.25 wt\% criterion is attained; then any remaining halide compounds are reacted per the indicated stoichiometry.

Semivolatile components are labeled with "(SV)" and volatile components are labeled with "(V)."

(a) E.I. duPont de Nemours \& Company, "Basic Data Report--DWPF-STudge Plant, SRP 200-5 Area," DPSP 80-1033 (April 1985). 
TABLE 4.5-3. (contd)

\begin{tabular}{|c|c|}
\hline Reactants & Products \\
\hline 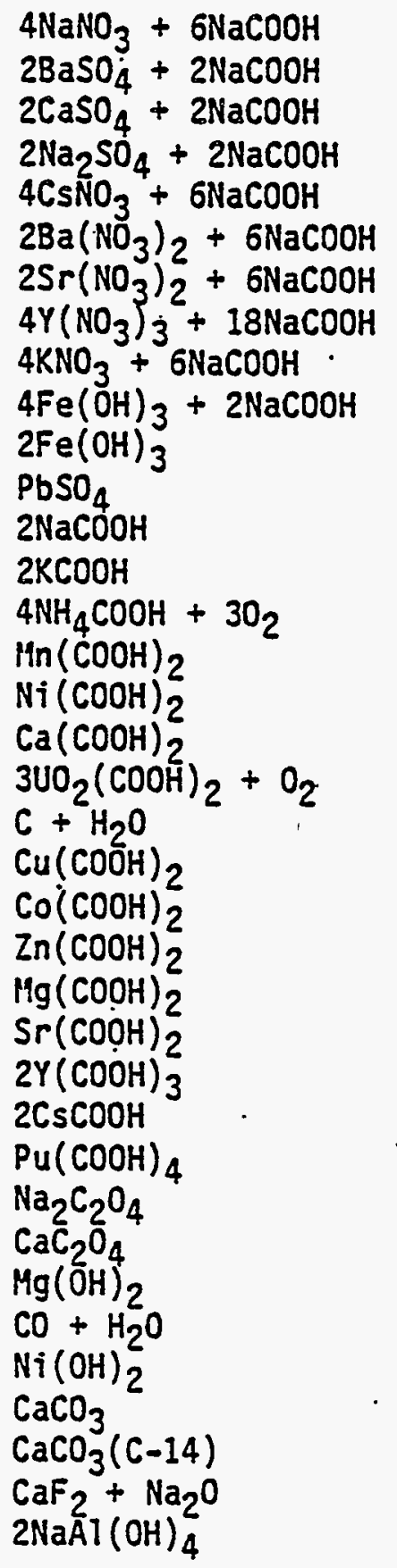 & 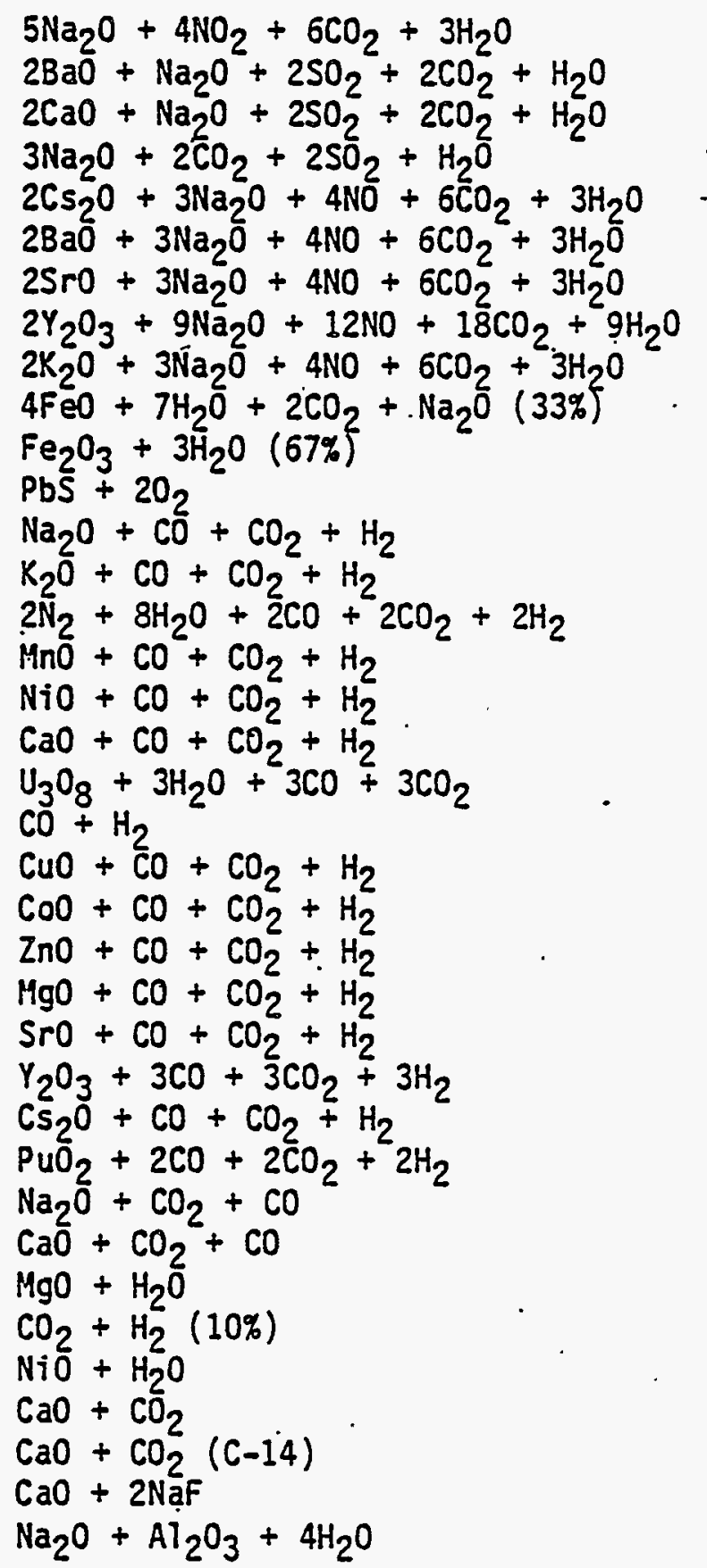 \\
\hline
\end{tabular}


TABLE 4.5-3. . (contd)

\begin{tabular}{|c|c|c|}
\hline Reactants & Products & \\
\hline 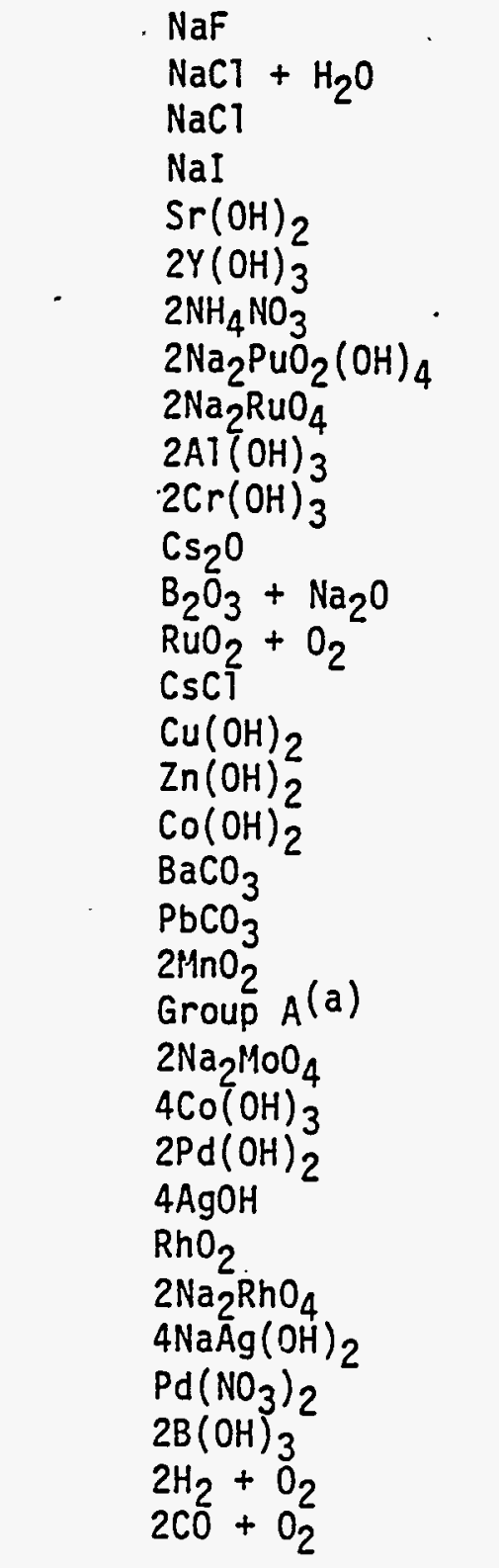 & 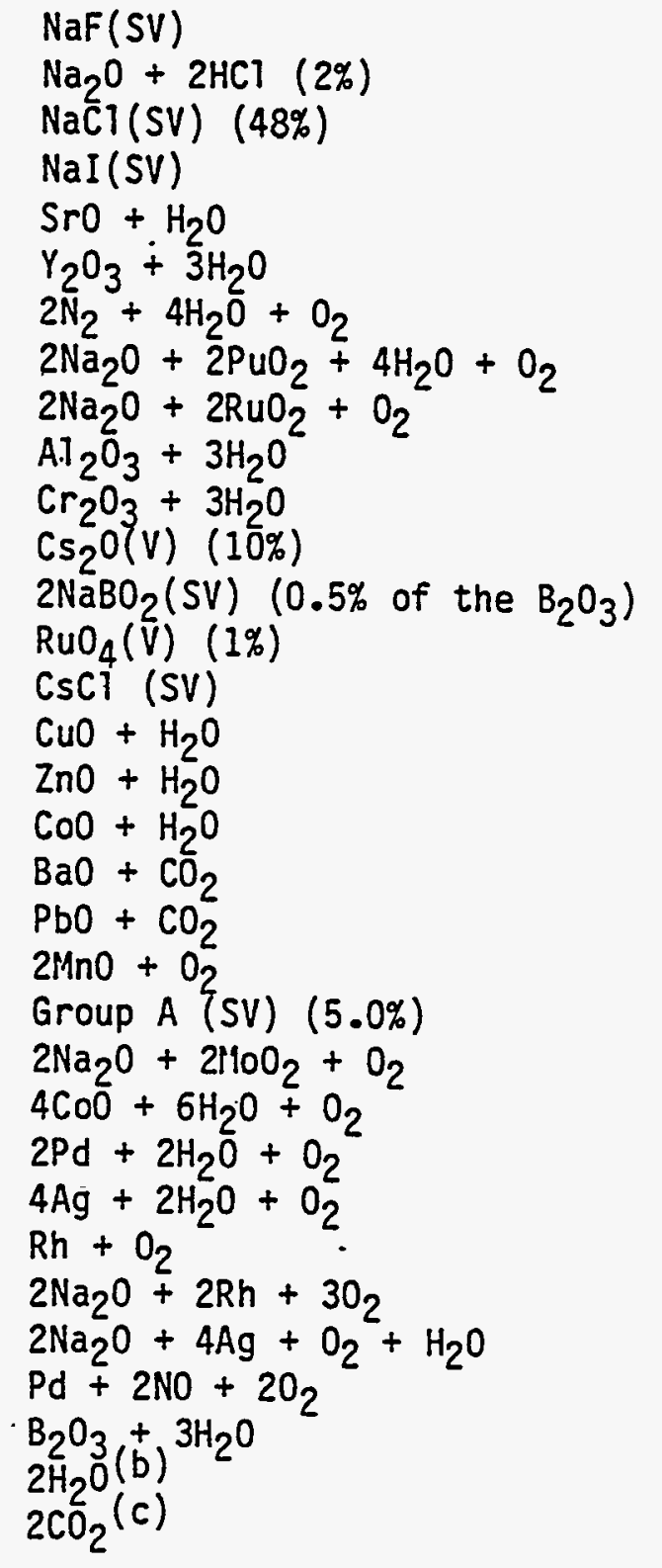 & $\cdot$ \\
\hline
\end{tabular}


TABLE 4.5-3. (contd)

Vapor Phase Stoichiometry in the Melter Plenum

\begin{tabular}{|l|l|}
\hline \multicolumn{1}{|c|}{ Reactants } & \multicolumn{1}{|c|}{ Products } \\
\hline $4 \mathrm{NaI}(\mathrm{SV})+\mathrm{O}_{2}$ & $2 \mathrm{I}_{2}+2 \mathrm{NaO}$ (SV) (1\%) \\
$2 \mathrm{NaF}(\mathrm{SV})+\mathrm{H}_{2} \mathrm{O}$ & $2 \mathrm{HF}^{2}+\mathrm{Na}_{2} \mathrm{O}(\mathrm{SV}) .(25 \%)$ \\
$\left.\mathrm{CS} \mathrm{O}_{2} \mathrm{O}\right)+2 \mathrm{NaCL}(\mathrm{SV})$ & $2 \mathrm{CsCl}(\mathrm{SV})+\mathrm{Na}_{2} \mathrm{O}(\mathrm{SV})$ \\
$4 \mathrm{NaBO}_{2}(\mathrm{SV})$ & $\mathrm{Na}_{2} \mathrm{~B}_{4} \mathrm{O}_{7}(\mathrm{SV})+\mathrm{N}_{2} \mathrm{O}(\mathrm{SV})$ \\
$\mathrm{RuO}_{2}($ entrained) & $\mathrm{RuO}_{2}(\mathrm{SV})$ \\
$\mathrm{RuO}_{4}(\mathrm{~V})$ & $\mathrm{RuO}_{2}(\mathrm{SV})+\mathrm{O}_{2}$ \\
$2 \mathrm{NO}_{2}+\mathrm{O}_{2}$ & $2 \mathrm{NO}_{2}(10 \%)$ \\
$2 \mathrm{H}_{2}+\mathrm{O}_{2}$ & $2 \mathrm{H}_{2} \mathrm{O}(\mathrm{d})$ \\
$2 \mathrm{CO}+\mathrm{O}_{2}$ & $2 \mathrm{CO}_{2}(\mathrm{P})$ \\
\hline
\end{tabular}

Vapor Phase - Stoichiometry Off-Gas Film Cooler (but prior to introduction of control air)

\begin{tabular}{|l|l|}
\hline \multicolumn{1}{|c|}{ Reactants } & \multicolumn{1}{c|}{ Products } \\
\hline $2 \mathrm{SO}_{2}+\mathrm{O}_{2}$ & $2 \mathrm{SO}_{3}$ \\
$\mathrm{SO}_{3}+\mathrm{H}_{2} \mathrm{O}$ & $\mathrm{H}_{2} \mathrm{SO}_{4}(\mathrm{~V})$ \\
$\mathrm{H}_{2} \mathrm{SO}_{4}(\mathrm{~V})+2 \mathrm{NaCL}(\mathrm{SV})$ & $\mathrm{NaSO}_{4}(\mathrm{SV})+2 \mathrm{HCl}$ \\
\hline
\end{tabular}

(a) Group $A$ is $\mathrm{Cd}$, Mo, Rb, Se, Tc, and Te.

(b) Reaction completion calculated to show 25\% of the total hydrogen from formates and hydroxides leaving the melter cold cap as $\mathrm{H}_{2}$.

(c) Reaction completion calculated to show $15 \%$ of the total carbon from organics and carbonates leaving the cold cap as $\mathrm{CO}$.

(d) Reaction completion calculated to show $1 \%$ of total carbon in plenum vapor space as $\mathrm{CO}$. 
volatilize some halide as gaseous elementary material $\left(I_{2}\right)$ or hydrogen halides ( $\mathrm{HCl}$ and $\mathrm{HF})$. Some alkali halides are generated as semivolatile materials ( $\mathrm{NaCl}, \mathrm{NaF})$. In the process of boiling off the water and generating process off gases, some solids are entrained into the off gases.

The principal loss mechanism for airborne solids escape are volatilization of semivolatiles (associated primarily with $\mathrm{B}, \mathrm{Na}, \mathrm{Sb}, \mathrm{Ru}, \mathrm{Te}$, and $\mathrm{Cs}$ ) and par: ticulate entrainment (due to vigorous steam generation and noncondensable flow), which accounts for loss of unmelted slurry feed. For the alkaline and neutralized hydroxide-type feeds (DWPF), mass DFs are in the range of 490 to 1200 based on PNL data from the Pilot-Scale Ceramic Melter (PSCM). Nitrate feed (WVSP) DFs are more similar to HWVP waste streams; these exhibits lower DFs that range from about 160 to 420. The particulate decontamination factor for the HWVP reference feed range from 330 to 1500 . These DFs are timeaveraged values for each run; individual values during the run may vary considerably. The differences in particulate DFs between DWPF and other testing have not been yet satisfactorily explained. It is anticipated that particulate losses may be related to the reducing potential of the feed, which affects the amount of semivolatile losses and amount of volatile species that may affect particulate entrainment. Decontamination factors for semivolatile chemicals are a function of the chemical characteristics of the chemical and melter operating conditions (see Section 4.6).

Goldman and Chick(a) and Plodjnec(b) provide detailed information on how redox state affects glass quality. (c) During the decomposition reactions (which primarily occur in the cold cap above the glass surface), water vapor and oxygen are released from the waste. Upon fusing, the newly molten glass is also capable of releasing some of the oxygen still present in the glass. This is assumed to be caused by the reduction of some of the oxide components in the glass. Under most conditions the gases released in the glass will also be released from the melt. These released gases will result in foam accumulation at the melt surface, due to the viscous nature of the glass. The foam creates a thermal insulating layer between the molten glass and the incoming feed that

(a) D. S. Goldman and L. A. Chick, West Valley Support Program: Progress Report on Glass Characterization and Process Chemistry, Pacific Northwest Laboratory, Richland, Washington (1984).

(b) M. J. Plodinec, Effects of Surface Forces on Glass Melting - II - Foaming and Batch Melting. DPST-82-784, Savannah River Laboratory, Aiken, South Carolina (1982).

(c) R. K. Farnsworth, August 1987, "The Effect of Feed Composition and Formic Acid Addition on Glass Redox State," HWVP-87-V110203A, Pacific Northwest Laboratory, Richland, Washington. 
reduces the melting 'rate and raises the melt temperature below the foam. Foaming also increases the melt volume by decreasing its density, and can have an effect on the electrical power distribution in the melter. Frequent foaming can result in melter downtime and therefore must be minimized.

One way to prevent glass foaming is by adding reducing agents to the feed. The reducing agents provide a strong oxidation reaction that can be used to reduce certain feed components to lower, more stable valences. The presence of reducing agents causes many of the oxidation/reduction reactions to take place in the melter cold cap, where any resultant gas releases will not affect foaming. The reduction. in the cold cap reduces the amount of oxygen released from the melt, preventing glass foaming. Organic compounds, such as formate salts or sugar, have been shown to be excel-lent reducing agenț.

As increasing levels of reducing agent are added to the waste, additional oxidation/reduction reactions occur. Controlling the amount of reduction experienced is necessary to prevent the reduction of certain metal oxides to their metallic state. This concern is.especially present for noble metals reduction and nickel sulfide formation. The reduced metals, having a higher density than glass, would then settle to the bottom of the melter. This settling over time could lead to short circuiting of the electrical path in the melter glass. Therefore, the amount of reducing agent in the feed must be minimized to prevent metals reduction, but must be sufficient to prevent glass foaming in the melter.

The extent to which the oxides in the glass are reduced is based on the Gibbs free energy potential for each reduction reaction, and theoretically, could be predicted beforehand. The Gibbs free energy potential for a particular reaction is determined from the molal enthalpy and entropy of the reactions products and reactants, according to the equation:

$$
\Delta G=\Delta H-T \cdot \Delta S
$$

where: $\Delta G=$ Gibbs free energy potential for a particular reaction

$\Delta H=$ Molal Enthalpy difference between the reaction's products and reactants.

$\Delta S=$ Molal Entropy different between the reaction's products and reactants

$T=$ Temperature, ${ }^{\circ} \mathrm{K}$.

In addition, the Gibbs free energy is also related to the equilibrium constant for a particular reaction; according to the equation:

$\Delta G=-R T \cdot \ln K$ 
where: $\Delta G=$ Gibbs free energy for a particular reaction

$R=$ Universal constant

$T=$ Temperature, ${ }^{\circ} \mathrm{K}$

$K=$ Equilibrium constant for the particular reaction

It is this equation that relates Gibbs free energy to the extent of reaction for each potential reduction.

The Gibbs free energy is related to the thermodynamic favorability that a reaction will occur. 'If the Gibbs free energy is negative, the reaction is favored to occur over time. If the Gibbs free energy is positive, the reaction will not occur over time, unless a reducing agent is present with a more negative Gibbs free energy that supplies enough energy to force the reduction reactions to occur.

The order in which the reduction reactions occur in the feed is based on the temperature at which the oxidation/reduction reactions become thermodynami cally favorable. At the point of thermodynamic favorability, the products resulting from a reduction reaction are favored over the reactants and reaction occurs. Increases in temperature will increase the extent of the reduction reaction. This relationship is due to the reaction's corresponding decrease in Gibbs free energy, which increases the reaction's equilibrium constant.

Figure 4.5-1 shows a typical plot of the Gibbs free energy of various oxides as a function of temperature. The negative energies shown in this figure indicate that for most temperatures, the oxides are thermodynamically favored. As an example, the figure shows ferric oxide as a thermodynamically .. stable component until a temperature of $-2700^{\circ} \mathrm{F}\left(-1480^{\circ} \mathrm{C}\right)$ occurs (where it reduces to magnetite). However, the presence of a reducing agent in the feed (such as carbon oxidizing to carbon dioxide) will substantially lower the temperature required for reduction to occur (see Figure 4.5-1).

This principle can be extended to the evaluation of HWV melter feed reduction provided that the following assumptions are correct. First, the glass vitrification must be slower than the reaction kinetics of each feed reduction. This assumption is necessary to assure that each melter feed component reaches its equilibrium state of reduction before the glass is cooled. Second, the environment surrounding each reduction must be favorable enough that the reduction reactions will be driven to equilibrium, regardless of their surroundings. Because of the oxygen release accompanying each reduction, this assumption is valid. Next, the difference in Gibbs free energy between oxidizing carbon and oxidizing formate salts needs to be negligible. Finally, most of the reduction reactions in the feed are assumed to occur after the 


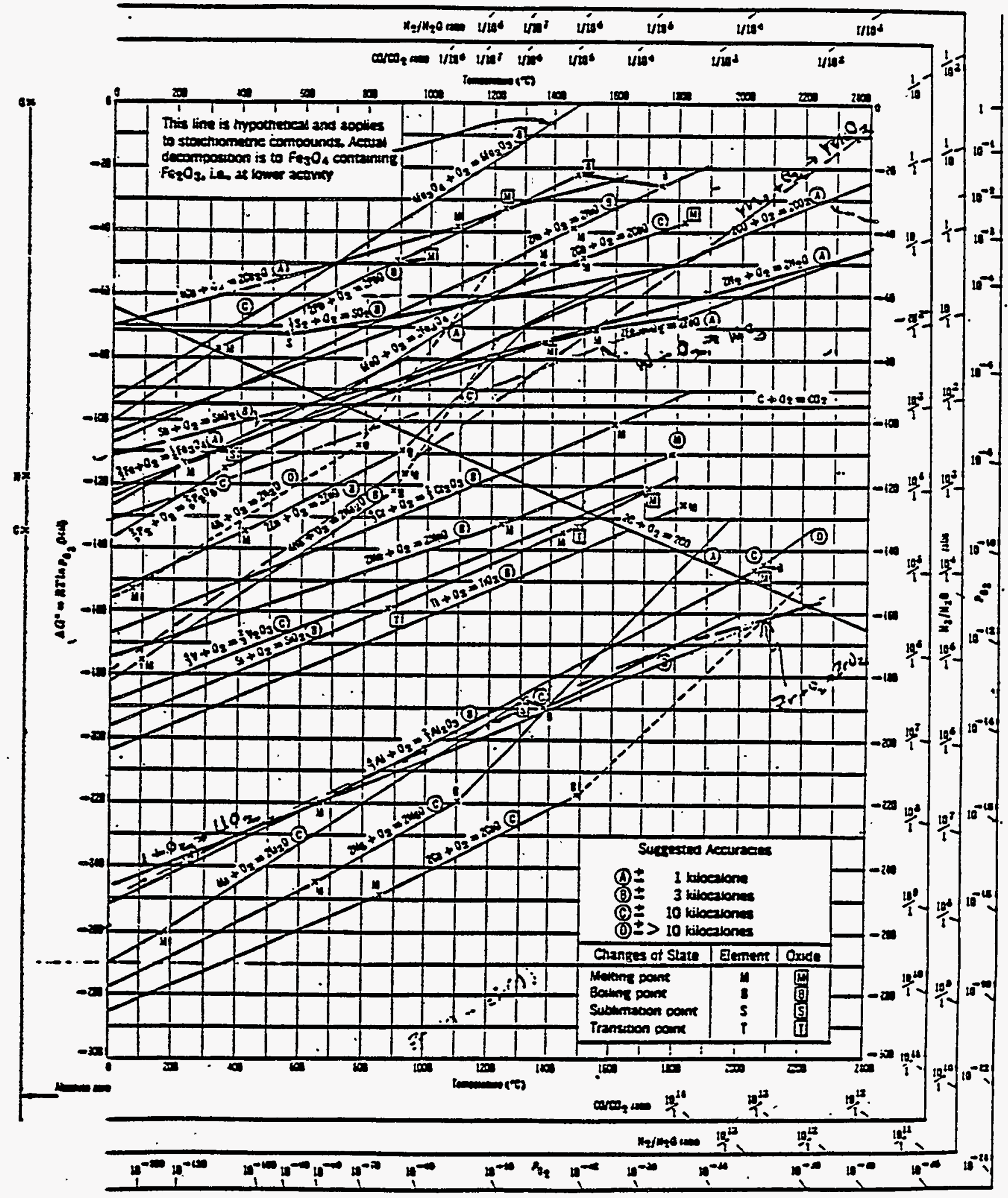

FIGURE 4.5-1. Standard Gibbs Free Energy of Formation of Oxides, as a Function of Temperature (Ref. 4.5-2 and 4.5-3) 
components have decomposed into oxides (but before fusion if a reducing agent is present). The last two assumptions are only necessary in order to use Figure 4.5-1 in this evaluation.

In the HWVP simulants, reduction is initiated by the reduction of high valence oxides (such as $\mathrm{Cr}_{2} \mathrm{O}_{7}$ and $\mathrm{MnO}_{2}$ ) to lower valence oxides $\left(\mathrm{Cr}_{2} \mathrm{O}_{3}\right.$ and $\mathrm{MnO}$ ). Hithout the presence of reducing agents, these reductions would occur at high temperatures, after the oxides have fused into the glass. The oxygen release accompanying reduction in the glass would then cause glass foaming in the melter. However, the presence of formates in the simulant will act as a reducing agent and lower the temperature at which the components can start to reduce. For the high-valence components in the HWVP simulant, the temperature at which reduction starts is 'well below the glass fusion temperature, and the oxygen released will not cause foaming.

In the HWVP simulants, the order of reduction (at temperatures below fusion) will proceed from the top of Figure 4.5-1 to the reduction reactions just above the carbon oxidation reaction, at $-95 \mathrm{kcal}$ (see Figure 4.5-1). The . extent of reduction is determined by the amount of reducing agent in the feed. Following the reduction of high valence components $\left(\mathrm{Cr}_{2} \mathrm{O}_{7}, \mathrm{MnO}_{2}\right)$, further formic acid additions will result in the reduction of ferric ion in the feed simulant (see figure 4.5-1). Increased formic acid additions will then increase the amount of ferric oxide reduction in the simulant. However, after 25 to $45 \%$ of the ferric ion has been reduced, increased formic acid additions will start to reduce some of the other simulant oxides, such as noble metal oxides, to their neutral metallic state.

The ratio of ferrous ion $\left(\mathrm{Fe}^{+2}\right)$ to ferric ion $\left(\mathrm{Fe}^{+3}\right)$ in the glass is used to indicate the redox state of the HWVP glass. The ferrous-to-ferric ratio is a measure of the reduction of ferric ion to ferrous ion in the glass, and can be determined using standard analytical methods. The ferrous-to-ferric ratio provides a quantitative indication of potential foaming or metals dropout tendencies in the melt. An acceptable ferrous-to-ferric ration of 0.005 to 0.3 has been established for the HWWP glass by Goldman. The basis for the high and low limits are as follows.

- The minimum ferrous-to-ferric ratio of 0.005 has been established based on the accuracy of the colorimetric technique used to measure ferrous-to-ferric ratios. The minimum ratio guarantees that some ferrous ion. is present in the glass. The present of ferrous ions in the HWVP feed guarantees that the feed will not be too oxidizing. 
- The maximum ferrous-to-ferric ratio of 0.3 is based on detailed analyses of HWVP simulant glasses. These glasses had been analyzed in enough detail to guarantee that metal reduction would not occur at a ferrous-to-ferric ratio of 0.3 or below. Higher levels have not been examined for HWVP glasses. However, other glasses have shown noble metal reductions at a ferrous-to-ferric ratio of 0.8 .

\subsubsection{Glass Chemistry. (See Section 4.1, Waste Form Development)}

\subsubsection{Technology Development (Ref. 4.5-1, 4.5-4)}

Development of vitrification processes for HLW has been ongoing since 1966. Vitrification is the reference technology for HLW immobilization in the United States as well as in Japan, Hest Germany, France, Great Britain, and Canada. The direct slurry-fed ceramic melter is the current reference process for vitrifying HLW in the United States. Nonradioactive testing of a jouleheated, ceramic-lined melter was first performed at PNL in 1973. Experimentation and development of direct liquid feeding of a mixture of waste and glass formers to a ceramic melter began in 1975. Pilot-scale liquid feeding tests were initiated in 1977. Attempts to feed liquid waste and frit as separate streams to a melter proved to be unsatisfactory. After only a short time it was found that the frit would settle through the slurry and melt rapidly; meanwhile, the waste would calcine and form a cake or crust that would not melt well in the absence of the fluxing agents in the frit. Since 1975, extensive testing has been conducted in support of numerous Department of Energy programs to provide vitrification technology to SRL, West Valley Demonstration Project (WVDP), and the HWVP. Since 1980 , over $60,000 \mathrm{~kg}$ of simulated HLW glass has been produced at PNL in engineering- and pilot-scale melters during about 4,000 $h$ of operation.

The liquid-fed ceramic melter (LFCM) process is an adaptation of commercial glass making technology. Glass becomes a very good electrical conductor once the glass temperature rises above its liquidus point. At operating temperatures an alternating current is passed through the melt between sets of electrodes located at opposite ends of the melt tank. By Joule's law, heat energy is liberated within the glass melt: Heat is then transferred to the feed material, primarily by convection cells that are established within the glass melt.

4.5.4.1 Nonradioactive Testing Equipment Description. The basic design of the ceramic melter is based on the extensive PNL testing and development. The primary mission of nonradioactive testing conducted under the HWVP is to develop process and characterization data on the reference flowsheet compositions and the effects of composition variability, slurry variability, and processing 
conditions on the performance of the LFCM, feed preparation systems and off-gas treatment systems. Testing is performed using two PNL melters: the engineering-scale high-bay ceramic melter (HBCM) and the pilot-scale ceramic melter. (PSCM).

The HBCM is shown in Figure 4.5-2. The glass tank has an exposed glass surface of $0.25 \mathrm{~m}^{2}$, which is $1 / 10$ scale of the proposed HWVP melter. The slurry processing capacity of the $\mathrm{HBCM}$ is in the range of 15 to $20 \mathrm{~L} / \mathrm{h}$. The melter front and back walls slope from $40.6 \mathrm{~cm}$ apart at the glass overflow level to $31.8 \mathrm{~cm}$ apart along the floor. During operation, the normal glass depth is $21.6 \mathrm{~cm}$. The resulting melt volume is approximately $55 \mathrm{~L}$ (138 $\mathrm{kg}$ at a $\mathrm{gl}$ ass density of $2.5 \mathrm{~kg} / \mathrm{L}$ ). Two Inconel 690 electrodes on opposing walls provide an electrical current through the glass melt to achieve the joule-heating effect.

Glass generated during the experiment is periodically transferred from the melt tank up a discharge riser using an airlift bubbler. Air is bubbled into the riser causing the air/glass mixture to rise into the overflow section discharge trough. The glass flows down the trough and off the face block into receiving drums.

During HBCM experiments, the use of operating constraints provides guidance for the operation of the melter system. Some of the important operating constraints follow.

- The melter is to be operated at an average bulk glass temperature of $2100^{\circ} \mathrm{F} \pm 90^{\circ} \mathrm{F}\left(1150^{\circ} \mathrm{C} \pm 50^{\circ} \mathrm{C}\right)$.

- Electrode temperatures are to be maintained below $1830^{\circ} \mathrm{F}\left(1000^{\circ} \mathrm{C}\right)$.

- Melter vacuum is to be maintained at $5 \mathrm{in.}(12.7 \mathrm{~cm}) \mathrm{WG}$ (water gage).

- The overflow section temperature is to be maintained at $1965^{\circ} \mathrm{F} \pm 45^{\circ} \mathrm{F}$ $\left(1075^{\circ} \mathrm{C} \pm 25^{\circ} \mathrm{C}\right)$.

The PSCM and associated support equipment before the PSCM-23 test run are shown in Figure 4.5-3. The glass tank had an exposed glass surface of $0.73 \mathrm{~m}^{2}$, which is at almost one-third scale. The melt tank is rectangular with dimensions of $69 \mathrm{~cm}$ wide by $104 \mathrm{~cm}$ between the two electrodes. At a normal glass overflow depth of $37 \mathrm{~cm}$, the melt volume was $270 \mathrm{~L}$. The electrodes were single, 5-cm-thick Inconel 690 plates with 5-cm-thick feet that extend $13 \mathrm{~cm}$ into the melt. The feet cause the electrical current flux to be skewed slightly toward the floor of the melt tank. The additional heating helps to prevent spinel sludge from forming. 

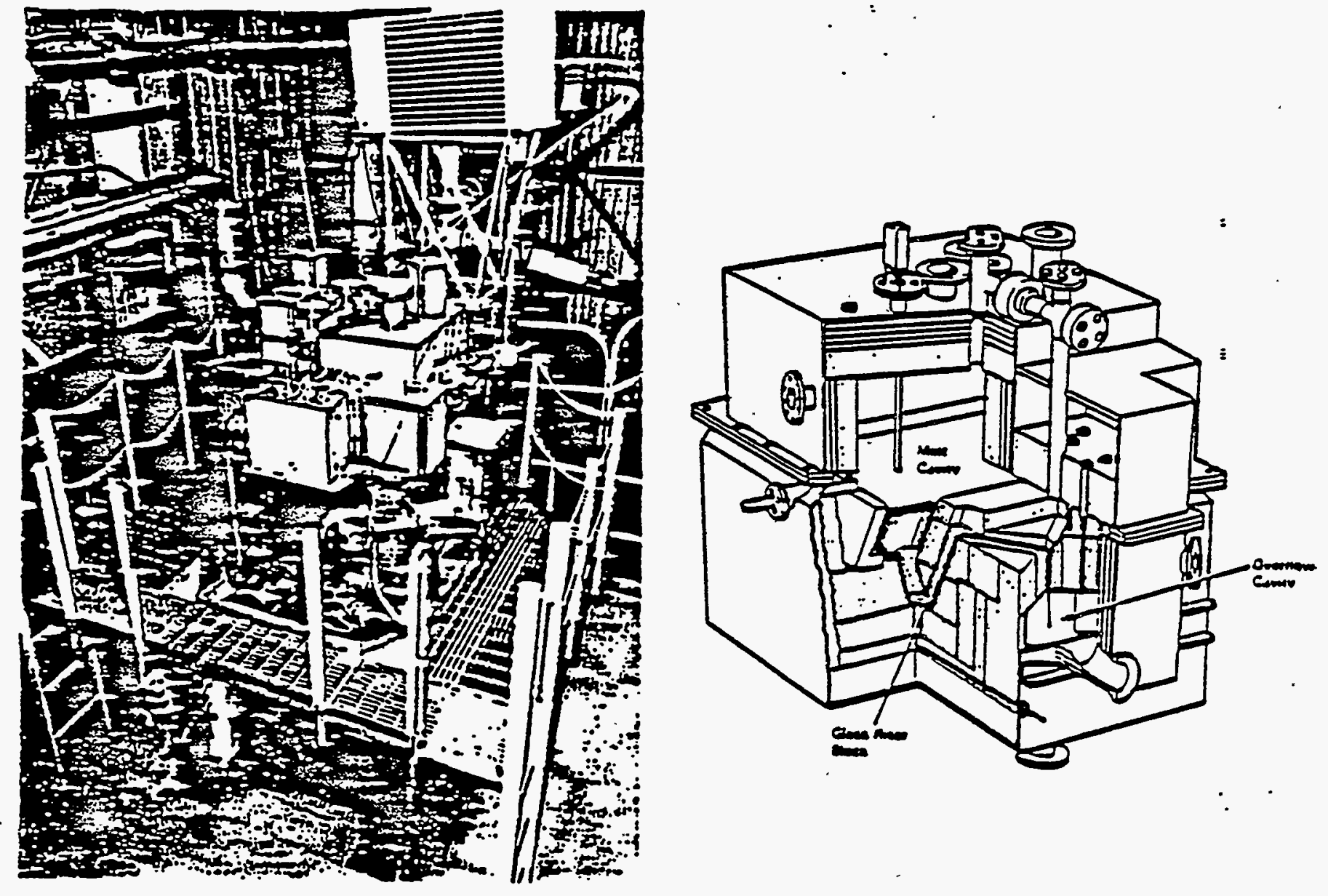

FIGURE 4.5-2. High-Bay Ceramic Melter - HWVP

The. glass was discharged from the tank through a $7.6-\mathrm{cm}$ riser port located near the melter floor in the center of the refractory wall. Glass from the melter could be discharged continuously or in batches via an airlift bubbler. Glass flowed from the riser, down the discharge trough, and off the face block. The glass product was received in either 55-gal drums or instrumented canisters. The overflow glass discharge section was maintained at 1830 .to $2010^{\circ} \mathrm{F}$ (1000 to $1100^{\circ} \mathrm{C}$ ) by six spiral bayonet-type silicon carbide heating elements.

Operating constraints for PSCM experiment are similar to those in the HBCM experiments. Additional constraints are as follows:

- During attainment and operation at design processing rates, the plenum temperature does not drop below $420^{\circ} \mathrm{F} \pm 45^{\circ} \mathrm{F}\left(275^{\circ} \mathrm{C} \pm 25^{\circ} \mathrm{C}\right)$. 


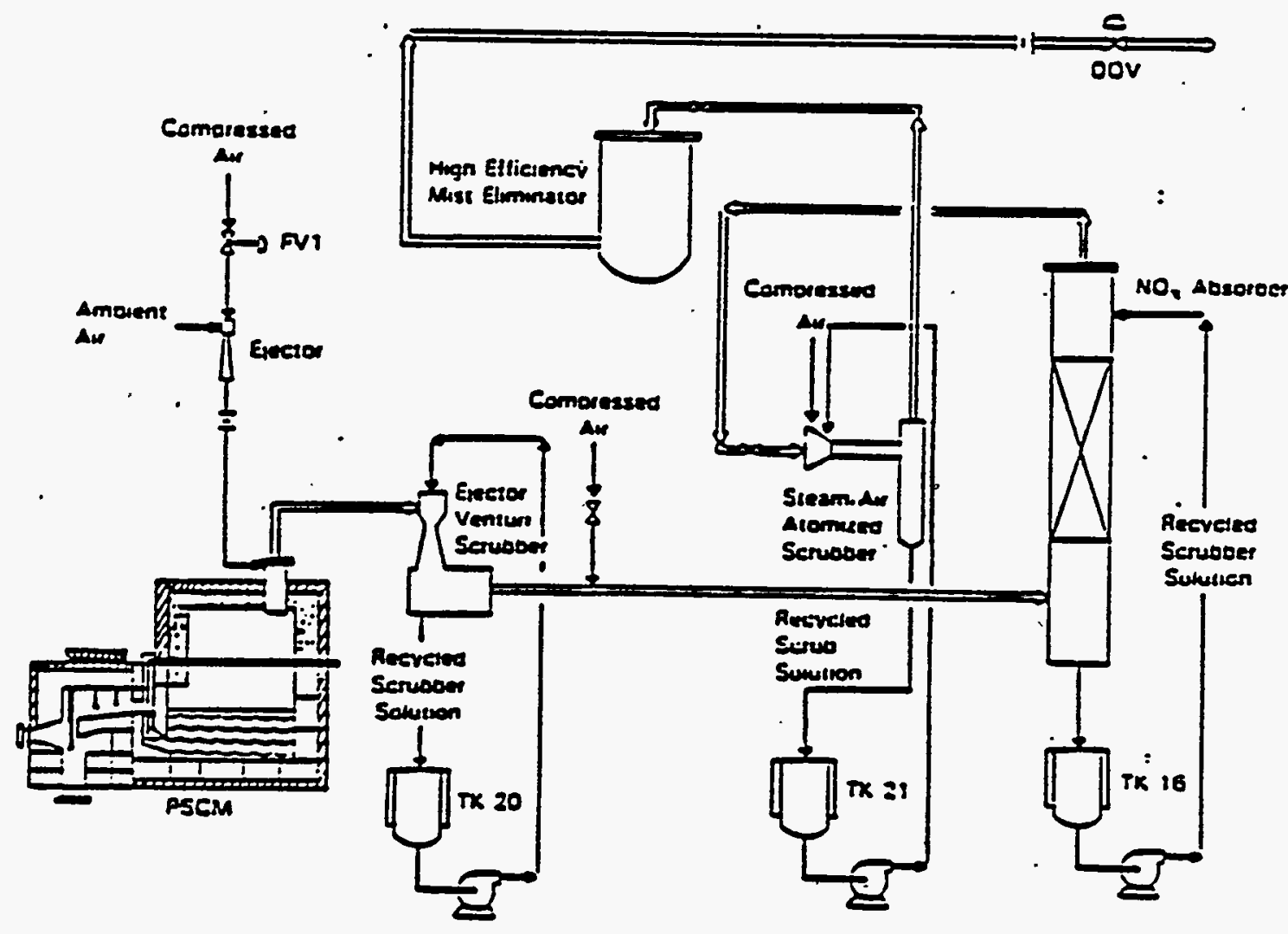

FIGURE 4.5-3. PSCM and Associated Off-Gas Treatment-Equipment - HWVP

- During operation at maximum rates, the plenum temperature does not drop below $435^{\circ} \mathrm{F} \pm 45^{\circ} \mathrm{F}\left(225^{\circ} \mathrm{C} \pm 25^{\circ} \mathrm{C}\right)$.

The PSCM systen was modified prior to the HWVP-15 run.(a) The PSCM system used for testing is schematically illustrated in Figure 4.5-4. A cut away view of the melter is presented in Figure 4.5-5. The melt cavity of the PSCM measures $74 \mathrm{~cm}$ by $102 \mathrm{~cm}$ with an exposed glass surface area of $0.76 \mathrm{~m}^{2}$. Operating at a nominal vacuum of $12.7 \mathrm{~cm} \mathrm{W.C.,} \mathrm{the} \mathrm{melter} \mathrm{has} \mathrm{a} \mathrm{glass} \mathrm{depth} \mathrm{of}$ $38 \mathrm{~cm}$ and a volume of $288 \mathrm{~L}$. Based on a density of $2.5 \mathrm{~kg} / \mathrm{L}$, this volume corresponds to an inventory of $720 \mathrm{~kg}(1584 \mathrm{lb})$ of glass. The plenum space height above the glass is $60 \mathrm{~cm}$. The melter lid is a one piece unit which covers both the melt cavity and the overflow section. Figure 4.5-6 presents the locations of specific instrumentation for the HWVP-15 test.

(a) R. W. Goles et al., Hanford Waste Vitrification Program Pilot-Scale Ceramic Melter Test Number 23. HWVP-89-IVJ0010100B, Pacific Northwest Laboratory, Richland, Washington (1989). 
During the test, melter feed was transferred from the MFT to the melter through a 0.78-cm I.D. feed line connected to a water cooled feed nozzle. Both a Moyno progressive cavity and an air displacement slurry. (ADS) pump were used during HWVP-15. Each pump was used for an approximately equal amount of time.

Glass produced during the HWVP-15 test was periodically airlifted from the melter into 55-gal drums. The quality of the stream associated with glass pours was assessed by the consistency in which the stream passed through an 11.4-cm ring placed in the opening of the receiving drum.

\subsubsection{HWVP Melter Experimerits. Melter studies of the reference NCAW Compo-} sition began in FY 1985 following laboratory development of the waste form and conditioning of the slurry redox and rheology. These two areas are covered in depth in other chapters of this Manual. Two engineering-scale and two pilotscale melter experiments have been conducted to date to evaluate the reference HWVP feed. Specific objectives for evaluating the reference composition were to evaluate the processing characteristics of the melter feed slurry, detemine the nominal and maximum processing rates of the feed, determine whether glass frit or unreacted glass-forming chemicals were the preferred method of adding the glass former material, and determine the optimum slurry oxide loading for achieving maximum glass production rates. Other objectives of the experiments are presented in later sections of this chapter. The four experiments, or "melter runs," were HWVP-11, HWVP-12, HWVP-13 and HWVP-15. Details of the four melter runs are given in Table 4.5-4. A fifth engineering scale melter was run - (HWVP-14) to assess the effects of melter feed composition variability on melter processing.

The initial tests, HWVP-11 and HWVP-12, were conducted to determine basic fundamentals such as selecting the method of adding glass formers (HWVP-11), observing the processing characteristics of the cold cap/glass interaction (HWVP-11 and -12), and determining the nominal and maximum processing rates (HWVP-11 and -12). Following this initial development, the third melter run, HWVP-13, was performed to determine the optimum slurry oxide loading in order to achieve the maximum glass production rate. HWVP-15 testing was performed primarily to evaluate the HWVP melter off-gas treatment system at steady-state melter operating conditions; however, the nominal processing characteristics of the feed in the melter were also evaluated. HWVP tests $-11,-12$, and -13 of the melter runs were conducted using the HWVP feed composition and glass composition shown in Table 4.5-5. The HWVP-15 test, was conducted within the feed and glass compositions shown in Table 4.5-6. Detailed results from these melter runs are presented in the following sections. 


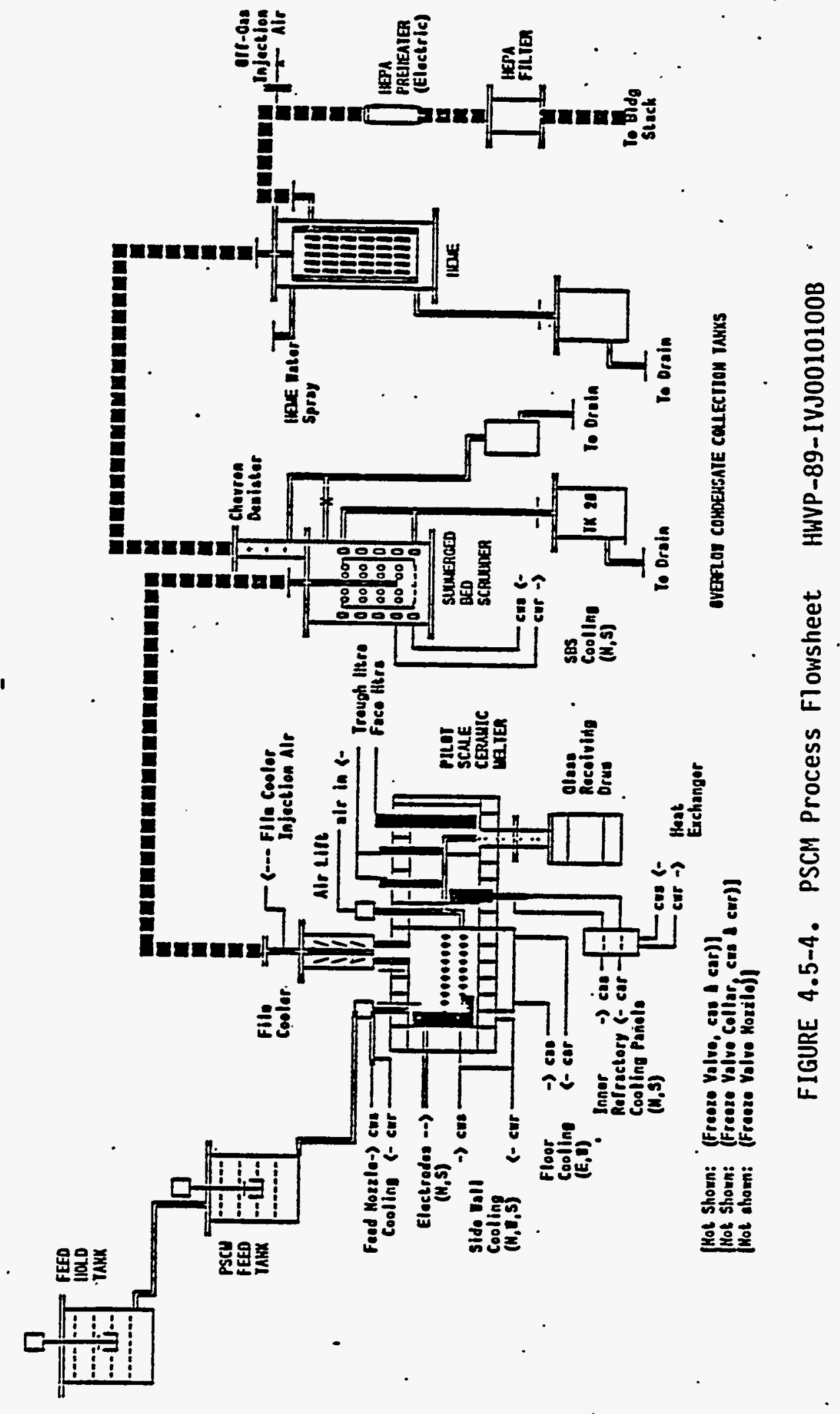




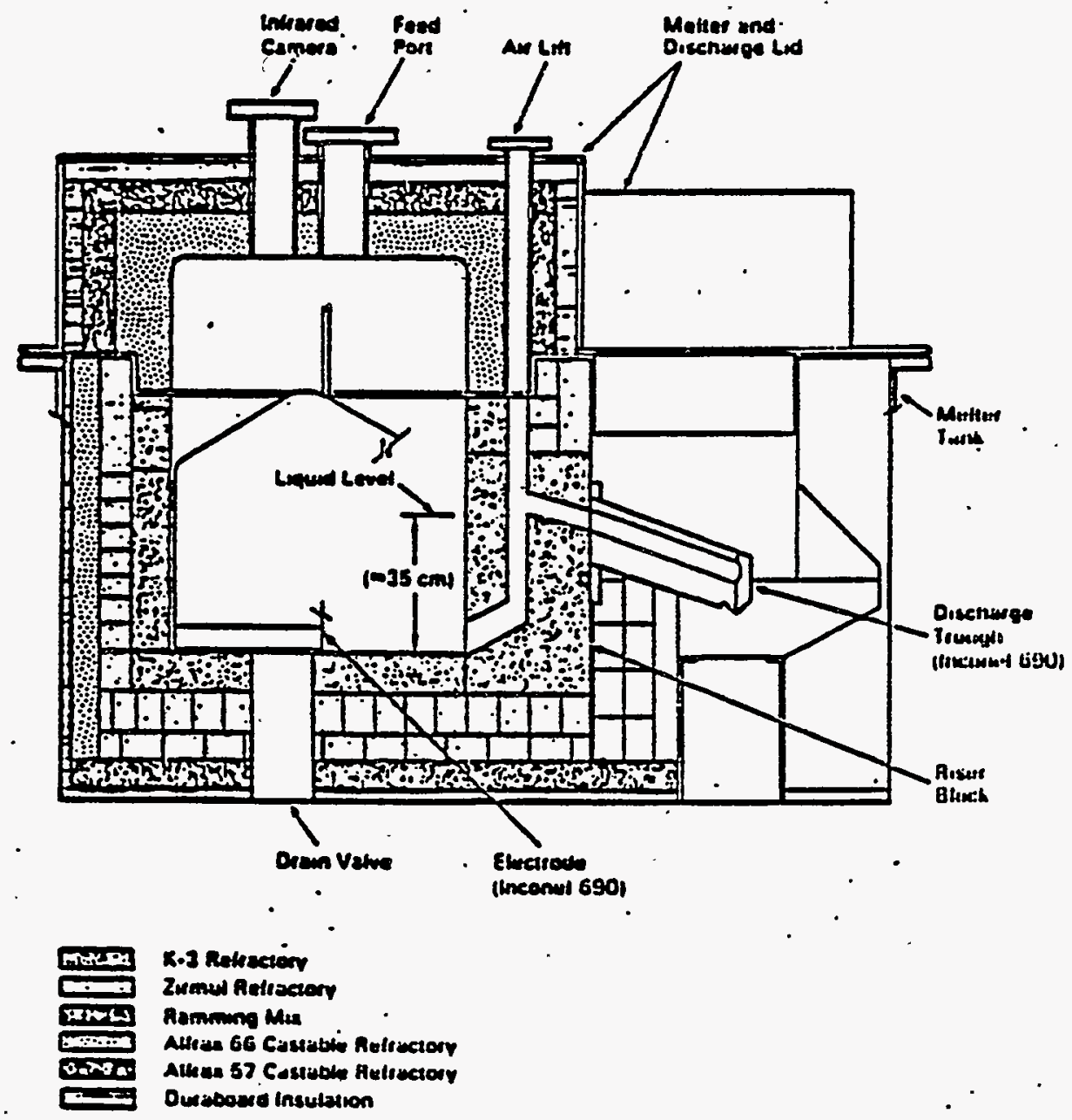

FIGURE 4.5-5. The Pilot-Scale Ceramic Melter HWVP-89-IVJ0010100B

4.5.4.2.1 Results of Engineering-Scale Experiment HWVP-11 (Ref. 4.5-1). The primary objectives of the engineering-scale melter experiment, HWVP-11, were to evaluate processing characteristics of two candidate slurries, select a method of glass former addition, and evaluate the quality of the product glass. During the five-day experiment, two slurry compositions were evaluated at average and maximum feeding rates. The first melter feed consisted of the HWVP feed and frit. The second melter feed consisted of the HWVP feed and glass formers consisting of one-third frit and two-thirds unreacted chemicals (Table 4.5-7). 


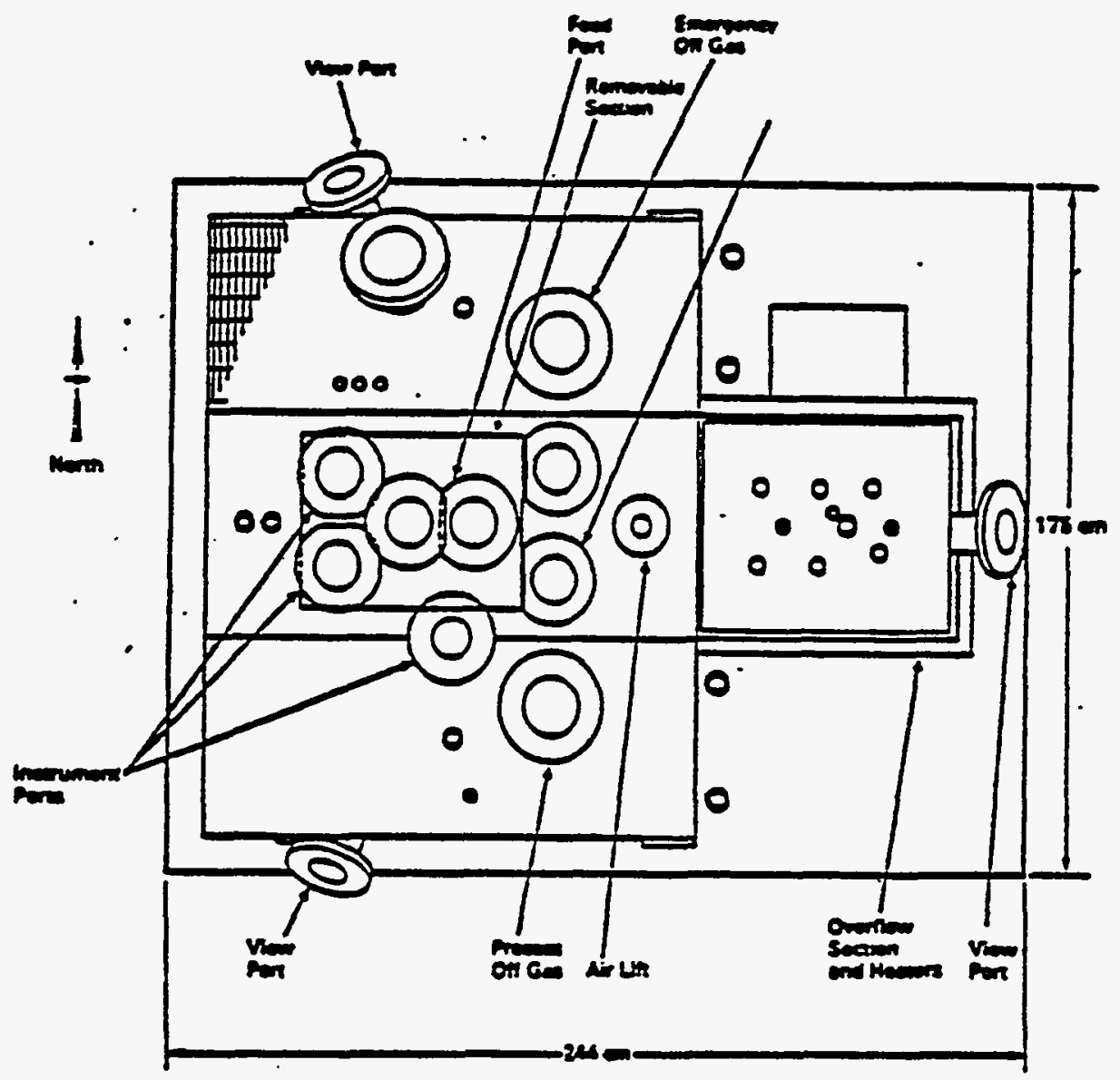

FIGURE 4.5-6. Instrument Locations for HWVP-15

HWVP-89-IVJ0010100B

Average rates are those rates that can be maintained indefinitely within the following constraints: 1) the cold-cap coverage is not to exceed $80 \%$ of the glass surface, 2) off-gas venting is to be stable with minimal surges, and 3) glass, plenum, electrode, and off-gas temperatures are to be stable over time. Processing at maximum rates would achieve cold-cap coverages of up to $95 \%$ with stable glass, plenum, electrode, and off-gas teriperatures. 0ff-gas venting would be expected to have more active surging events. To evaluate the processing characteristics of the slurries, the cold-cap thickness, spreading ability of the slurries on the glass melt, flexibility of the cold cap, venting behavior, and time required for the cold cap to melt into the-bulk glass once feeding stopped were evaluated. 
TABLE 4.5-4. Details of the Melter Runs: HWVP-11, $-12,-13$, and -15

\begin{tabular}{|c|c|c|c|c|}
\hline Details & $\begin{array}{l}\text { LWNP-11 (a) } \\
\text { HBCH-85-1 }\end{array}$ & $\begin{array}{l}\text { HWVP-12(a) } \\
\text { PSCM-22 }\end{array}$ & $\underset{\mathrm{HBCH}}{\mathrm{HWVP}-13(\mathrm{a})}$ & $\begin{array}{l}\text { INP }-15(\mathrm{a}) \\
\mathrm{PSCM}-23\end{array}$ \\
\hline $\begin{array}{l}\text { Date of Test } \\
\text { Scale . } \\
\text { Test Length, } h \\
\text { Total Feed Processed, L (gal) } \\
\text { Approx. Gl ass Produced, kg (ibs) }\end{array}$ & $\begin{array}{l}4 / 85 \\
\text { Engineering } \\
119 \\
1,094(289) \\
421(926)\end{array}$ & $\begin{array}{l}7 / 85 \\
\text { P110t } \\
384 \\
15,950(4,214) \\
6,131(13,488)\end{array}$ & $\begin{array}{l}4 / 86 \\
\text { Engineering } \\
149 \\
2,243(593) \\
1,093(2,404)\end{array}$ & $\begin{array}{l}6 / 88 \\
\text { Pil ot } \\
351 \\
15,000(3,960) \\
7,450(16,390)\end{array}$ \\
\hline
\end{tabular}

(a) Dual nomenclatures are used on melter run tests. HWVP-XX indicates the run was performed for the HWVP program and was numerically the $x \dot{x}$ test in the series. The parallel set of nomenclature specifies the melter system that the run was made on (PSCM - Pllot Scaie Ceranic Melter, HBCH - High Bay Ceramic Melter) followed by the year the run was made and a series of numbers for the equipment run on the year specified, such as $\mathrm{HBCM}-85-1$, which is al so HWVP-11.

Experimental results are summarized in Table 4.5-8. The waste + frit feed slurry case was processed for $72 \mathrm{~h}$. The first $24 \mathrm{~h}$ of feeding to the melter allowed the melter to equilibrate from an idling mode to an operating mode. Results of only the final $48 \mathrm{~h}$ of the waste + frit case are relevant.

Melter operating conditions were similar during both phases of the experiment. The operating bulk glass temperature was 2100 to $2190^{\circ} \mathrm{F}$ (1150 to $1200^{\circ} \mathrm{C}$ ) for the majority of the experiment. The $20^{\circ} \mathrm{C}$ higher average off-gas temperature for the waste +. frit + salts case was indicative of the lower processing rates achieved with this slurry composition. Both feeds pumped well with no feed-related problems. The glass melt was stable throughout the experiment because no foaming of the melt occurred. The ferrous-to-ferric ratio of the glass melt was 0.04 during the first three days, when the waste + frit siurry was processed. Although below the pre-run target range of 0.1 to 0.3 , the melt was sufficientiy reduced to prevent any reboil occurrences. The ferrous-toferric ratio over the last two days of the experiment steadily rose to a range of approximately 0.2 to 0.3 . 
TABLE 4.5-5. Simulated Waste Fraction of Melter Feed STurry(a) - HWVP (Ref. 4.5-1)

\begin{tabular}{|c|c|c|c|c|}
\hline Compound (b) & $\begin{array}{c}\text { Concentration } \\
(g / L)\end{array}$ & $\begin{array}{l}\text { Assumed } \\
\text { Oxide }\end{array}$ & $\begin{array}{c}\text { Concentration } \\
(g / L)\end{array}$ & $\begin{array}{l}\text { Glass } \\
\text { (wt\%) }\end{array}$ \\
\hline $\begin{array}{l}\mathrm{Fe}(\mathrm{OH})_{3} \\
\mathrm{Na}_{2} \mathrm{HOOO}_{4} \cdot 2 \mathrm{H}_{2} \mathrm{O} \\
\mathrm{NaNO}_{3} \\
\mathrm{Cr}(\mathrm{OH})_{3} \\
\mathrm{NaOH}\end{array}$ & $\begin{array}{c}59.5 \\
26.3 \\
13.4 \\
7.21 \\
3.58\end{array}$ & $\begin{array}{l}\mathrm{Fe}_{2} \mathrm{O}_{3} \\
\mathrm{Al}_{2} \mathrm{O}_{3} \\
\mathrm{Na}_{2} \mathrm{O} \\
\mathrm{Cr}_{2} \mathrm{O}_{3} \\
\mathrm{ZrO}_{2}\end{array}$ & $\begin{array}{r}44.4 \\
17.2 \\
10.7 \\
5.3 \\
2.4\end{array}$ & $\begin{array}{r}11.10 \\
4.30 \\
2.68 \\
1.33 \\
0.60\end{array}$ \\
\hline $\begin{array}{l}\mathrm{Na}_{2} \mathrm{C}_{2} \mathrm{O}_{4}(\mathrm{C}) \\
\mathrm{Zr}(\mathrm{OH})_{4} \\
\mathrm{SiO}_{2} \\
\mathrm{Ni}(\mathrm{OH})_{2} \\
\mathrm{Na}_{2} \mathrm{SO}_{4}\end{array}$ & $\begin{array}{l}3.37 \\
3.11 \\
3.00 \\
3.00 \\
2.32\end{array}$ & $\begin{array}{l}\mathrm{SiO}_{2} \\
\mathrm{NiO}^{2} \\
\mathrm{SO}_{3} \\
\mathrm{La}_{2} \mathrm{O}_{3} \\
\mathrm{MoO}_{3}\end{array}$. & $\begin{array}{l}3.0 \\
2.4 \\
1.5 \\
2.2 \\
1.2\end{array}$ & $\begin{array}{l}0.75 \\
0.60 \\
0.38 \\
0.55 \\
0.30\end{array}$ \\
\hline $\begin{array}{l}\mathrm{LaF}_{3} \\
\mathrm{Na}_{2} \mathrm{MOO}_{4} \cdot 2 \mathrm{H}_{2} \mathrm{O} \\
\mathrm{Nd}(\mathrm{OH})_{3} \\
\mathrm{CsOH} \\
\mathrm{Ce}(\mathrm{OH})_{3}\end{array}$ & $\begin{array}{l}2.16 \\
2.00 \\
1.84 \\
1.05 \\
0.79\end{array}$ & $\begin{array}{l}\mathrm{Nd}_{2} \mathrm{O}_{3} \\
\mathrm{Cs}_{2} \mathrm{O} \\
\mathrm{CeO}_{2} \\
\mathrm{CuO} \\
\mathrm{MnO}_{2}\end{array}$ & $\begin{array}{l}2.1 \\
1.0 \\
0.7 \\
0.5 \\
0.7\end{array}$ & $\begin{array}{l}0.53 \\
0.25 \\
0.18 \\
0.16 \\
0.18\end{array}$ \\
\hline $\begin{array}{l}\mathrm{Cu}(\mathrm{OH})_{2} \\
\mathrm{Mn}(\mathrm{OH})_{2} \\
\mathrm{BaSO}_{4} \\
\mathrm{NaF}_{3} \\
\mathrm{Sr}(\mathrm{OH})_{2}\end{array}$ & $\begin{array}{l}0.74 \\
0.74 \\
0.63 \\
0.58 \\
0.47\end{array}$ & $\begin{array}{l}\mathrm{BaO} \\
\mathrm{F}^{-} \\
\mathrm{SrO} \\
\mathrm{Pr}_{6} \mathrm{O}_{11} \\
\mathrm{MgO}\end{array}$ & $\begin{array}{l}0.4 \\
1.2 \\
0.4 \\
0.4 \\
0.3\end{array}$ & $\begin{array}{l}0.10 \\
0.30 \\
0.10 \\
0.10 \\
0.08\end{array}$ \\
\hline $\begin{array}{l}\mathrm{Pr}(\mathrm{OH})_{3} \\
\mathrm{La}(\mathrm{OH})_{3} . \\
\mathrm{NaF} \\
\mathrm{Mg}(\mathrm{OH})_{2} \\
\mathrm{CaF}_{2}\end{array}$ & $\begin{array}{l}0.47 \\
0.47 \\
0.47 \\
0.41 \\
0.42\end{array}$ & $\begin{array}{l}\mathrm{CaO} \\
\mathrm{Y}_{2} \mathrm{O}_{3} \\
\mathrm{Sm}_{2} \mathrm{O}_{3} \\
\mathrm{TOC}^{-} \\
\mathrm{I}^{-}\end{array}$ & $\begin{array}{l}0.3 \\
0.2 \\
0.2 \\
0.6 \\
0.04\end{array}$ & $\begin{array}{l}0.08 \\
0.05 \\
0.05 \\
0.15 \\
0.01\end{array}$ \\
\hline $\begin{array}{l}\mathrm{Y}(\mathrm{OH})_{3} \\
\mathrm{Sm}(\mathrm{OH})_{3} \\
\mathrm{NaI} \\
\text { Subtotals }\end{array}$ & $\begin{array}{c}0.26 \\
0.21 \\
0.05 \\
138.56 \mathrm{~g} / \mathrm{L}\end{array}$ & & $\overline{99.4} \mathrm{~g} / \mathrm{L}$ & $24.9 \%$ \\
\hline
\end{tabular}

(a) Basis: $400 \mathrm{~g}$ oxide/L slurry, $25 \mathrm{wt} \%$ waste oxide loading.

(b) Prior to reaction with formic acid.

(c) TOC substitute. 
TABLE 4.5-6. HWVP-15 Melter Feed Composition HLWP-89-IVJ0010100B

\begin{tabular}{|c|c|c|c|c|}
\hline $\begin{array}{c}\text { Chemicals Used(a) } \\
\text { In Makeup }\end{array}$ & $\begin{array}{c}\text { Concentration, } \\
(\mathrm{g} / \mathrm{L})\end{array}$ & $\begin{array}{l}\text { Assumed State } \\
\text { After Reaction }\end{array}$ & $\begin{array}{c}\text { Concentration, } \\
(g / L)\end{array}$ & $\begin{array}{c}\text { Glass } \\
\text { Concentration, wtoss) }\end{array}$ \\
\hline 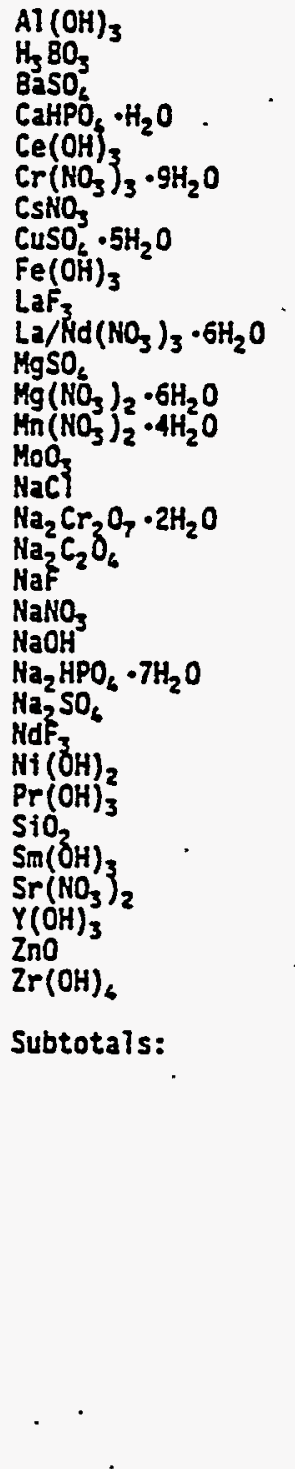 & $\begin{array}{r}18.11 \\
0.23 \\
0.80 \\
1.21 \\
0.87 \\
2.06 \\
1.09 \\
2.47 \\
49.31 \\
1.97 \\
17.25 \\
1.23 \\
0.30 \\
2.27 \\
1.58 \\
0.63 \\
0.53 \\
13.95 \\
0.79 \\
19.58 \\
10.46 \\
0.10 \\
0.65 \\
2.02 \\
3.76 \\
0.59 \\
5.26 \\
0.30 \\
1.07 \\
0.33 \\
2.50 \\
25.51 \\
188.8 \mathrm{~g} / \mathrm{L} \\
188.8 \mathrm{~g} \\
\text { HH-39-4 Frit } \\
\text { Composition (d) } \\
\end{array}$ & 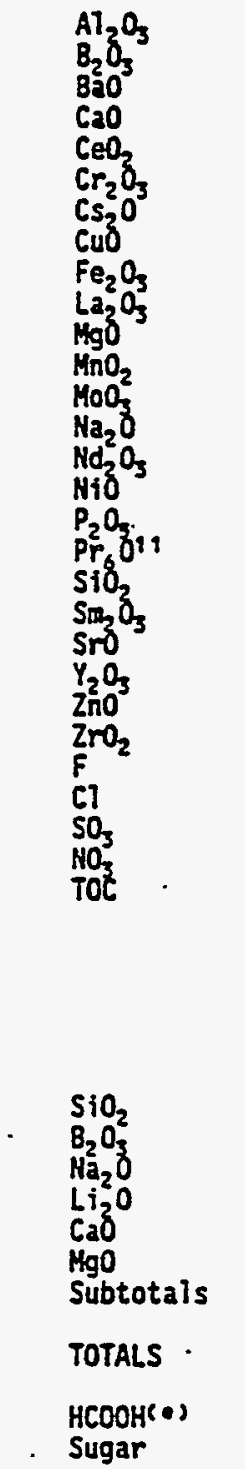 & $\begin{array}{r}11.84 \\
0.13 \\
0.53 \\
0.39 \\
0.79 \\
0.66 \\
0.79 \\
0.79 \\
36.85 \\
6.44 \\
0.46 \\
0.79 \\
1.58 \\
23.03 \\
3.35 \\
3.03 \\
0.53 \\
0.53 \\
5.26 \\
0.26 \\
0.53 \\
0.26 \\
2.50 \\
19.74 \\
1.50 \\
0.38 \\
2.25 \\
24.80(\mathrm{c}) \\
2.50(\mathrm{c})\end{array}$ & $\begin{array}{r}2.36 \\
0.03 \\
0.10 \\
0.08 \\
0.16 \\
0.13 \\
0.16 \\
0.16 \\
7.36 \\
1.29 \\
0.09 \\
0.16 \\
0.31 \\
4.60 \\
0.67 \\
0.61 \\
0.10 \\
0.10 \\
1.05 \\
0.05 \\
0.10 \\
0.05 \\
0.50 \\
3.94 \\
0.30 \\
0.08 \\
0.45 \\
. .- \\
.-\end{array}$ \\
\hline
\end{tabular}

(a) Prior to formic acid treatment.

(b) Values assume no volatility losses.

(c) Value is not included in subtotal values.

(d) Size distribution of frit was $-80 /+200$ mesh with a maximum of 10 wt\% -200 mesh.

(e) Value given is for a 90 wt\% solution of $\mathrm{HCOOH}$.

(f) Value includes 90 wt\% $\mathrm{HCOOH}$-added with frit, equivalent to 1 wt\% of frit added, or $4.2 \mathrm{~g} / \mathrm{L}$. 
TABLE 4.5-7. Glass-Forming Fraction in Melter Feed Slurry - HWVP (Ref. 4.5-1)

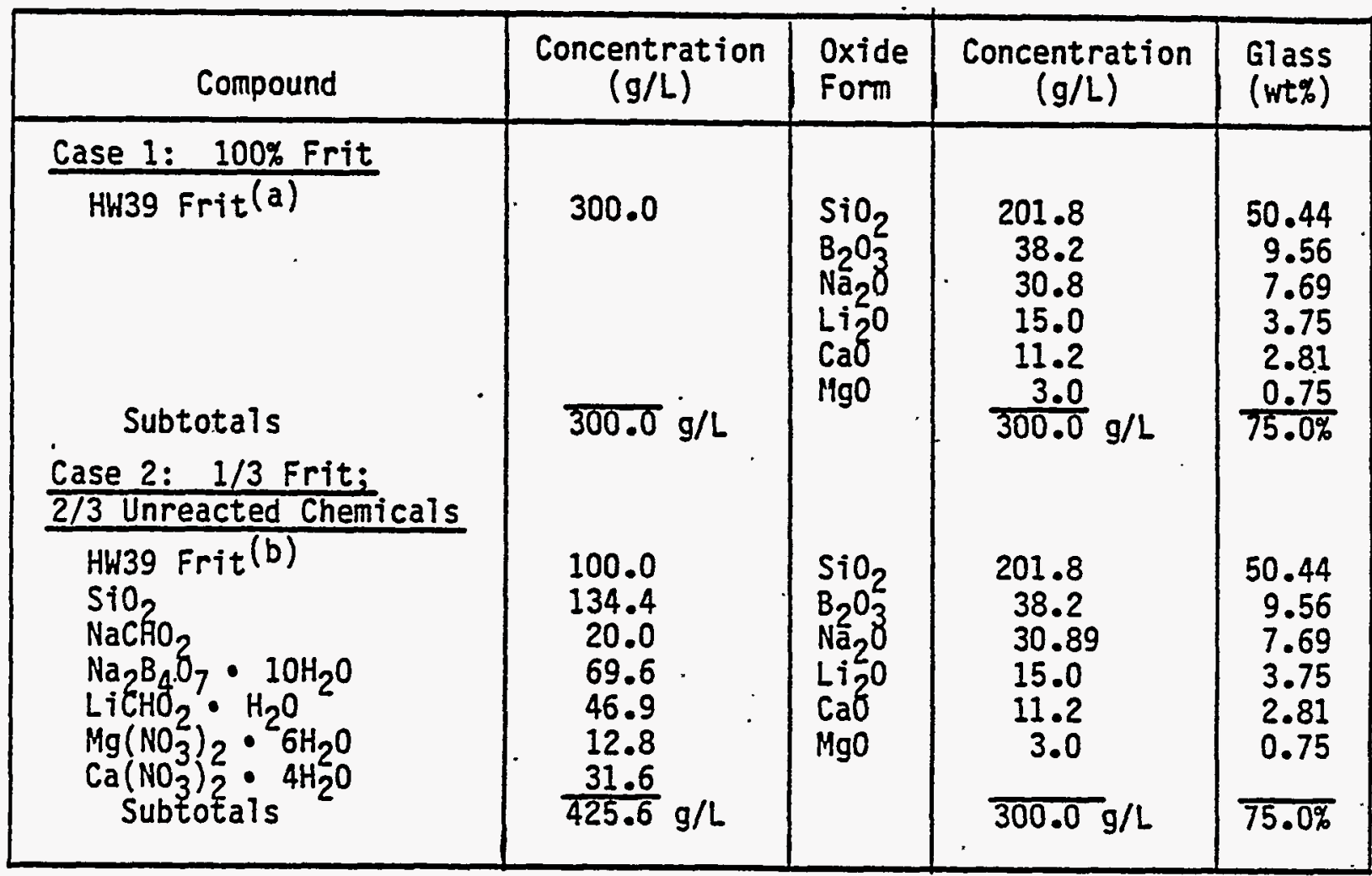

(a) HW39 frit size distribution as follows: $1 / 3$ to be $-80+20$ mesh

(b) HW39 frit size distribution as follows: $-80+200$ mesh.

TABLE 4.5-8. Summary Data of HBCM Experiment - HWVP (Ref. 4.5-1)

\begin{tabular}{|l|c|c|}
\hline \multicolumn{1}{|c|}{ Summary Item } & Waste + Frit & Waste + Frit + Salts \\
\hline Test Period (h) & 71.6 & 47.75 \\
On-Line Efficiency (\%) & 91 & 100 \\
Slurry Oxide Loading $(\mathrm{g} / \mathrm{L})$ & 396 & 365 \\
Total Slurry Processed $(\mathrm{L})$ & 687. & 407 \\
Est. Glass Produced $(\mathrm{kg})$ & 272 & 149 \\
Avg. Feed Rate (L/h) & 10.5 \\
Avg. Bulk Glass Temperature $\left({ }^{\circ} \mathrm{C}\right)$ & $1150-1200$ & 8.5 \\
Avg. Off-Gas Temperature $\left({ }^{\circ} \mathrm{C}\right)$ & 425 & $1150-1200$ \\
(measured at Venturi) & & 445 \\
\hline
\end{tabular}

(a) Based on actual feeding time and total slurry processed. 
The overall performance of the waste + frit slurry was very good, with feed rates up to $14 \mathrm{~L} / \mathrm{h}\left(56 \mathrm{~L} / \mathrm{h}-\mathrm{m}^{2}\right)$ for most of the two-day period. The cold cap was very flexible, and numerous vents were visible in and around the cold cap. This indicated that decomposition gases could readily escape from within and beneath the cold cap. The cold cap was 2.5 to $5 \mathrm{~cm}$ thick. The cold-cap coverage during feeding was 50 to $80 \%$ of the melt surface.

Processing the waste + frit + salts slurry resulted in substantially lower feeding rates. The design feed rate was only $8 \mathrm{~L} / \mathrm{h}\left(32 \mathrm{~L} / \mathrm{h}-\mathrm{m}^{2}\right)$. This rate was maintained over a 12-h period with a cold-cap coverage that approached 100\%. The cold cap produced by this feed tended to be thicker and more rigid. At 2.5 to $7.5 \mathrm{~cm}$ thick, the cap displayed very little flexibility or venting action. Cold-cap coverage ranged from $70 \%$ to as high as $100 \%$ for short periods. Due to lack of visible venting, the cold cap was presumed porous and therefore more insulating, resulting in lower heat transfer rates. The insulating properties of the thick cold cap seemed to limit the feed rate, contributing to the overall poor performance of this slurry composition.

Giass samples obtained during the five-day experiment were evaluated for viscosity, electrical conductivity, and composition. The viscosity and electrical-conductivity curves as functions of temperature were very close to laboratory results. The TIOOP temperature of the melter glass was $2000^{\circ} \mathrm{F}$ $\left(1095^{\circ} \mathrm{C}\right)$, compared to $2060^{\circ} \mathrm{F}\left(1124^{\circ} \mathrm{C}\right)$ in the laboratory glass. The slopes of the melter and laboratory glass viscosity curves were similar, but the curves were offset approximately $30^{\circ} \mathrm{C}$ lower. An electrical conductivity value of. 0.30 (ohm-cm $^{-1}$ was obtained for both the melter and the laboratory glasses at a temperature of $2100^{\circ} \mathrm{F}\left(1150^{\circ} \mathrm{C}\right)$. The conductivity-versus-temperature curves were nearly identical.

4.5.4.2.2 Results of Pilot-Scale Experiment HHVP-12 (Ref. 4.5-1). The major objective of the PSCM experiment was to evaluate the processing characteristics of the HWVP feed and glass compositions on a pilot scale under longterm operating conditions. The processing evaluation was similar to the HBCM experiment in identifying cold-cap thickness, spreading ability of the slurry, and cold-cap renting and flexibility.

The experiment was divided into three segments. During the first part of the experiment, the feed slurry was processed at a ferrous-to-ferric ratio of 0.1. Laboratory tests had determined that $3.5 \mathrm{~g} / \mathrm{L}$ of sugar should be added to the feed slurry to achieve this state of redox. Once steady state was achieved (72 $\mathrm{h}$ were allowed), the slurry was tested in the melter for an additional $120 \mathrm{~h}$ to obtain feeding rate and off-gas system performance data. At the end of this period, the feeding was interrupted to allow changeover to feeding slurry without the added sugar reductant. Eight days of testing were conducted 
to evaluate the processing characteristics without the added reductant; specifically, this testing was done to ascertain whether the melt would remain stable or reboil would occur at various processing rates (design maximum and overfeeding). Performance evaluations of off-gas equipment were continued during this period.

A summary of the experiment is provided in Table 4.5.9. The periods of testing using slurry without sugar and with sugar added are shown separately. It is obvious from the data that the slurry was processed at a higher rate when sugar was not present in the melter feed.

The operational control parameters of the experiment are plotted in Figures 4.5-7 and 4.5-8. The plenum temperature operated between 390 and $750^{\circ} \mathrm{F}$ $\left(200\right.$ and $\left.400^{\circ} \mathrm{C}\right)$ throughout the test period. The changes in temperature correspond to changes in melt surface coverage. The average glass temperature was maintained within operational constraints for the majority of the experiment. For short periods, the indicated temperature surpassed $2190^{\circ} \mathrm{F}\left(1200^{\circ} \mathrm{C}\right)$; however, these temperatures do not appear in the averaged data plotted in Figures 4.5-7 and 4.5-8. Values for the average bulk glass temperature and electrode power throughout the experiment were unsteady. This unsteadiness was due to the Inconel 690 crystal settling boat that was placed near the thermowell and electrode foot on the melt tank floor before the experiment. Once processing began and the electrode current was increased, partial shorting of

TABLE 4.5-9. Summary Data of PSCM Experiment - HWVP (Ref. 4.5-1)

\begin{tabular}{|c|c|c|}
\hline \multirow[b]{2}{*}{ Item } & \multicolumn{2}{|c|}{ Test Period } \\
\hline & Slurry with Sugar & Slurry Without Sugar \\
\hline $\begin{array}{l}\text { Test Period (h) } \\
\text { On-Line Efficiency }(\%) \\
\text { Slurry Oxide Loading }(\mathrm{g} / \mathrm{L}) \\
\text { Total Slurry Processed }(\mathrm{L}) \\
\text { Est. Glass Produced }(\mathrm{kg}) \\
\text { Design Feed Rate }\left[\mathrm{L} / \mathrm{h}\left(\mathrm{L} / \mathrm{H}^{\circ} \mathrm{m}^{2}\right)\right] \\
\text { Max. Feed Rate }\left[\mathrm{L} / \mathrm{h}\left(\mathrm{L} / \mathrm{h} \cdot \mathrm{m}^{2}\right)\right] \\
\text { Ferrous-to-Ferric Ratio } \\
\text { Feed Slurry } 0.104 \\
\text { Glass } 0.160\end{array}$ & $\begin{array}{l}186 \\
99 . \\
389 \\
6737 \\
2621 \\
37(51) \\
41(56) \\
\\
0.002 \\
0.015\end{array}$ & $\begin{array}{c}198 \\
99 \\
381 \\
9213 \\
3510 \\
45(61) \\
53(72)\end{array}$ \\
\hline
\end{tabular}

(a) Based on reported total slurry processed and slurry oxide loading values. 


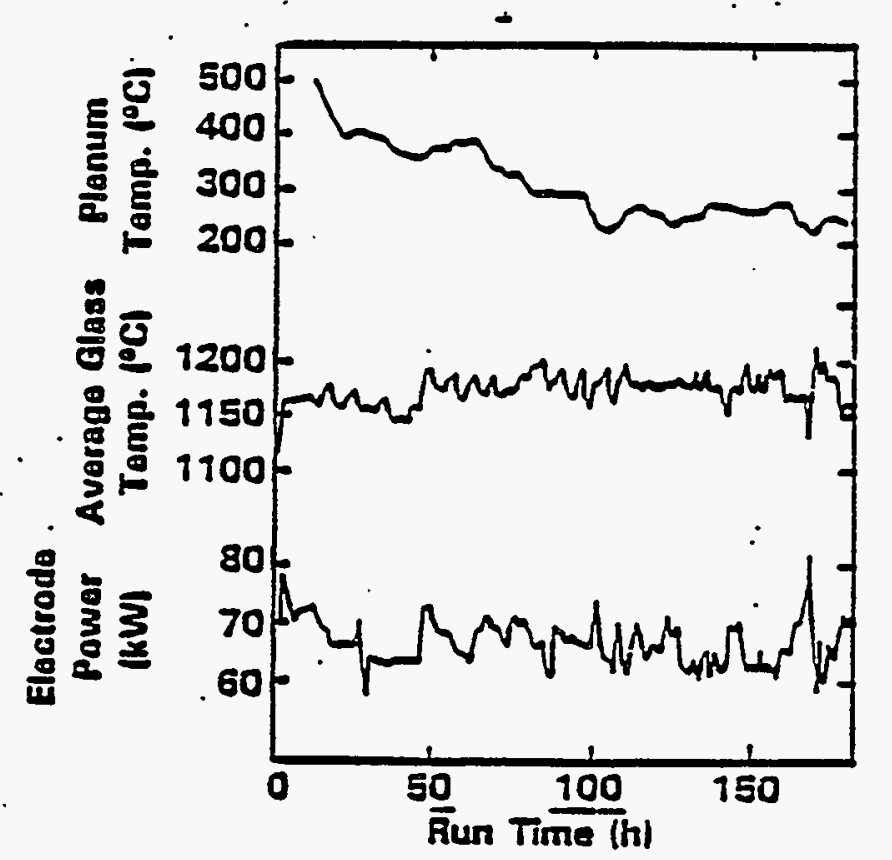

FIGURE 4.5-7. Operational Control Parameters for the First $200 \mathrm{~h}$ of the PSCM Experiment - HWVP (Ref. 4.5-1)

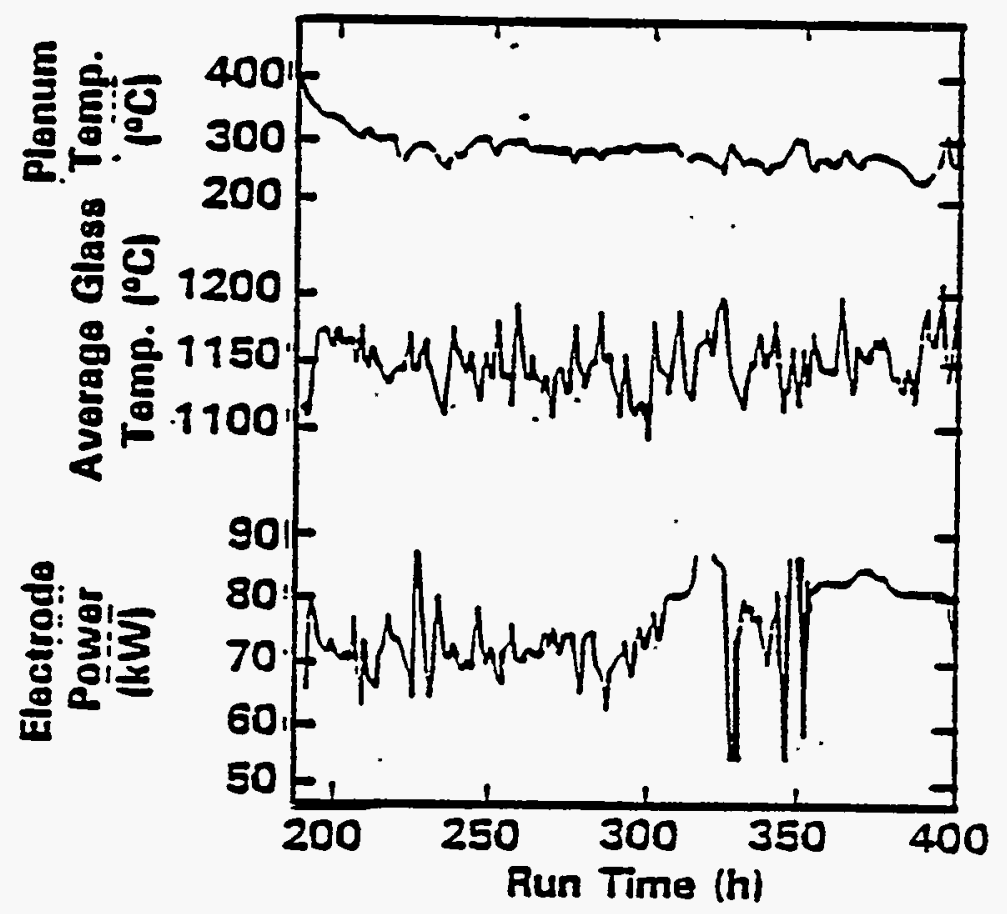

FIGURE 4.5-8. Operational Control Parameters for the Final $200 \mathrm{~h}$ of the PSCM Experiment - HWVP (Ref. 4.5-1) 
the current apparently occurred. As a result, the electrode power readings fluctuated and required constant adjustment. It is also theorized that localized heating of the glass in the area of the thermowell occurred, resulting in high-temperature indications that were not representative of the bulk of the glass.

Achieving steady state within the melter took three days. Following startup, a design feed rate was established at $37 . \mathrm{L} / \mathrm{h}\left(51 \mathrm{~L} / \mathrm{h} \cdot \mathrm{m}^{2}\right)$ and maintained for $120 \mathrm{~h}$. Feed rates greater than $40 \mathrm{~L} / \mathrm{h}$ were maintained during this time for periods of 6 to $12 \mathrm{~h}$. However, these rates could not be maintained based upon the operating constraints. The maximum feed rate was established at $41 \mathrm{~L} / \mathrm{h}\left(56 \mathrm{~L} / \mathrm{h}-\mathrm{m}^{2}\right)$ during the final $18 \mathrm{~h}$ before switchover to the feed slurry containing no sugar. Cold-cap thickness ranged from 4.0 to $6.0 \mathrm{~cm}$ for the design-rate period and from 5.0 to $6.5 \mathrm{~cm}$ for the maximum-feed-rate period.

After $186 \mathrm{~h}$ of operation, feed to the melter was stopped and the cold cap was allowed to melt. The feed tank was recharged with slurry feed that did not contain sugar. This slurry was processed for $198 \mathrm{~h}$, including an 18-h restart period to re-establish steady-state conditions. The average feed rate during the startup period was $36 \mathrm{~L} / \mathrm{h}$. A design feed rate of $45 \mathrm{~L} / \mathrm{h}\left(62 \mathrm{~L} / \mathrm{h}-\mathrm{m}^{2}\right)$ was sustained for $96 \mathrm{~h}$. The maximum rate established and maintained was $53 \mathrm{~L} / \mathrm{h}$ (73 $L / h-m^{2}$ ) over a 78-h period. Processing characteristics for the feed with and without sugar were similar except for achievable processing rates, where.the feed rate without sugar was $22 \%$ to $29 \%$ higher. The cold cap was very thin and flexible. Vents were numerous, and the glass surface near the cold cap was active, even vigorous at times.

Results of the HBCM experiment indicated that a design feed rate of $48 \mathrm{~L} / \mathrm{h}-\mathrm{m}^{2}$ was possible. A design rate of $51 \mathrm{~L} / \mathrm{h}-\mathrm{m}^{2}$ was reactied with the feed containing sugar. Therefore, the HBCM (which processed a slurry containing sugar) and PSCM experiments showed good agreement in the processing rate of the simulated feed. The glass meit was stable during the entire experiment, even under only slightly reducing conditions. Even though no sugar was added to the feed during the second half of the experiment, the ferrous-to-ferric ratio remained greater than zero. The formating step used in feed preparation, along with formic acid added with the frit-addition step, provided sufficient carbon to maintain the slurry composition in a reducing condition. Based upon melter stability and the higher processing rates obtained without sugar, a minimal ferrous-to-ferric ratio (1ess than 0.1 ) is desired.

4.5.4.2.3 Results of Engineering-Scale Equipment HWVP-13 (Ref. 4.5-2). The primary objective was to determine the effect of solids oxide loading on the processability of the simulated melter feed slurry, with the goal of determining the optimal solids level in the feed. Three oxide loadings were tested. 
The target oxide 7 oadings were 400, 500, and $650 \mathrm{~g} \mathrm{TO} / \mathrm{L}$ : The actuai loadings tested were: 415,515 , and $654 \mathrm{~g}$ TO/L, equivalent to 35,41 , and $50 \mathrm{wt} \%$ solids, respectively. Design and maximum feed rates were determined for each slurry.

The 415. g TO/L.segment achieved average design and maximum feed rates of $17.3 \mathrm{~L} / \mathrm{h}\left(69 \mathrm{~L} / \mathrm{h} \cdot \mathrm{m}^{2}\right)$ and $18.9 \mathrm{~L} / \mathrm{h}\left(76 \mathrm{~L} / \mathrm{h} \cdot \mathrm{m}^{2}\right)$, respectively; the $515 \mathrm{~g} \mathrm{TO} / \mathrm{L}$ segment achieved rates of $16.9 \mathrm{~L} / \mathrm{h}\left(68 \mathrm{~L} / \mathrm{h} \cdot \mathrm{m}^{2}\right)$ and $18.0 \mathrm{~L} / \mathrm{h}\left(7 \mathrm{R} / \mathrm{h} \cdot \mathrm{m}^{2}\right)$, respectively; and the $654 \mathrm{~g}$ TO/L segment achieved rates of $11.2 \mathrm{~L} / \mathrm{h}$ $\left(44.8 \mathrm{~L} / \mathrm{h} \cdot \mathrm{m}^{2}\right)$ and $13.4 \mathrm{~L} / \mathrm{h}\left(53.6 \mathrm{~L} / \mathrm{h} \cdot \mathrm{m}^{2}\right)$, respectively. Feed rate data taken during the $654 \mathrm{~g}$ TO/L segment were erratic in comparison with the two previous segments. This inconsistency was due to a change in the method used to determine feed rate. The method was changed from measuring the actual feed delivery to measuring feed tank dropout, which is less precise. This change was made when the larger feedline was installed and the sampling valve had to be removed in order to decrease the number of restrictions.

Processing characteristics of the three feed concentrations were similar, with average processing rates higher than experienced during the FY $1985 \mathrm{HBCM}$ experiment, HWVP-11. Table 4.5-10 compares the feed and glass production rates obtained during HWVP-13 with HWVP FY 1985 results. Process rates established during HWVP-11 were lower than in the other experiments. This decrease was due to the inciusion of sugar in the feed. Nonradioactive testing during FY 1984 and FY 1985 demonstrated that the use of sugar as a reductant resulted in lower processing rates. The HWVP-13 process rates achieved at a slurry oxide loading $415 \mathrm{~g} / \mathrm{L}$ do agree within $15 \%$ with rates achieved in the FY 1985 pilot-scale ceramic melter test, HWVP-12, for the period of HWVP-12 when sugar was not added to the feed. The fact that the $\mathrm{HBCM}$ and PSCM process rates can be scaled just about 1:1 based on glass surface area is evidence that the conclusions drawn from the HBCM melter tests are unaffected by the smaller size of the HBCM.

Both the 415 and $515 \mathrm{~g}$ TO/L feeds generated relatively thin cold caps (2 to $5 \mathrm{~cm}$ ) and exhibited desirable flexing and venting traits. However, the $654 \mathrm{~g}$ TO/L feed had a tendency to build a relatively thicker cap (3 to $6 \mathrm{~cm}$ ) with considerably less venting and flexing activity. Although cold-cap coverage for the most concentrated slurry was adequate in the HBCM, the traits exhibited by the cold cap indicated that in a larger melter, with more glass surface to cover, the $654 \mathrm{~g}$ TO/L slurry may not be able to provide complete coverage. 
TABLE 4.5-10. Comparison of Processing Rates Obtained During HWVP Melter Testing with NCAW-HWVP

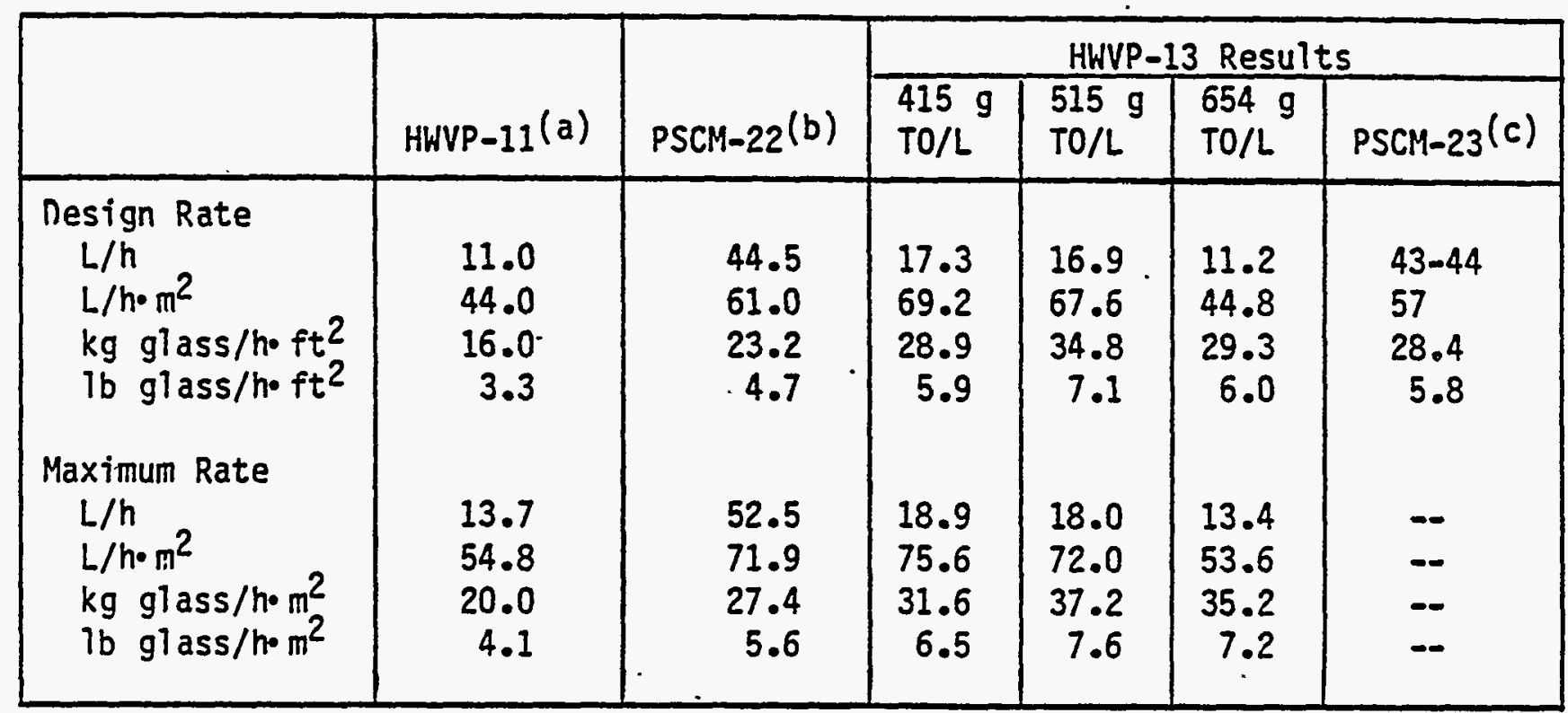

(a) Data reported are from the test segment that used frit as the sole glassformer source. Average slurry oxide concentration was $365 \mathrm{~g} / \mathrm{L}$.

(b) Data reported are from the test segment when sugar are not added to the feed slurry. Average siurry oxide concentration was $380 \mathrm{~g} / \mathrm{L}$.

(c) Data reported from the test used frit as the glass-former source. Average slurry oxide concentration was $500 \mathrm{~g} / \mathrm{L}$.

A major objective of this experiment was the evaluation of the processing characteristics of the simulated melter feed slurry as a function of oxide loading. Data from the three sections of the experiment were evaluated to determine optimal oxide loading for maximum glass production rate. Figure 4.5-9 presents the feed rate as a function of feed concentration. A significant drop in the slurry processing rate occurs as the feed concentration exceeds $515 \mathrm{~g} \mathrm{TO} / \mathrm{L}$. The drop in feed rate from 415 to $515 \mathrm{~g} \mathrm{TO} / \mathrm{L}$ is small in comparison. The increase in solids loading is felt to be the prime cause of the drop in feed rate with increasing oxide loading over $515 \mathrm{~g} \mathrm{TO} / \mathrm{L}$. It is hypothesized that there are two competing control mechanisms that determine the optimal solids loading in the slurry to maximize processing rates. At low solids loading, the processing rate is dominated by the rate that water can be evaporated from the slurry pool on the cold cap. At higher solids loading, the processing rate is governed by the rate at which the cold cap can be melted into the glass batch. Therefore, as solids 


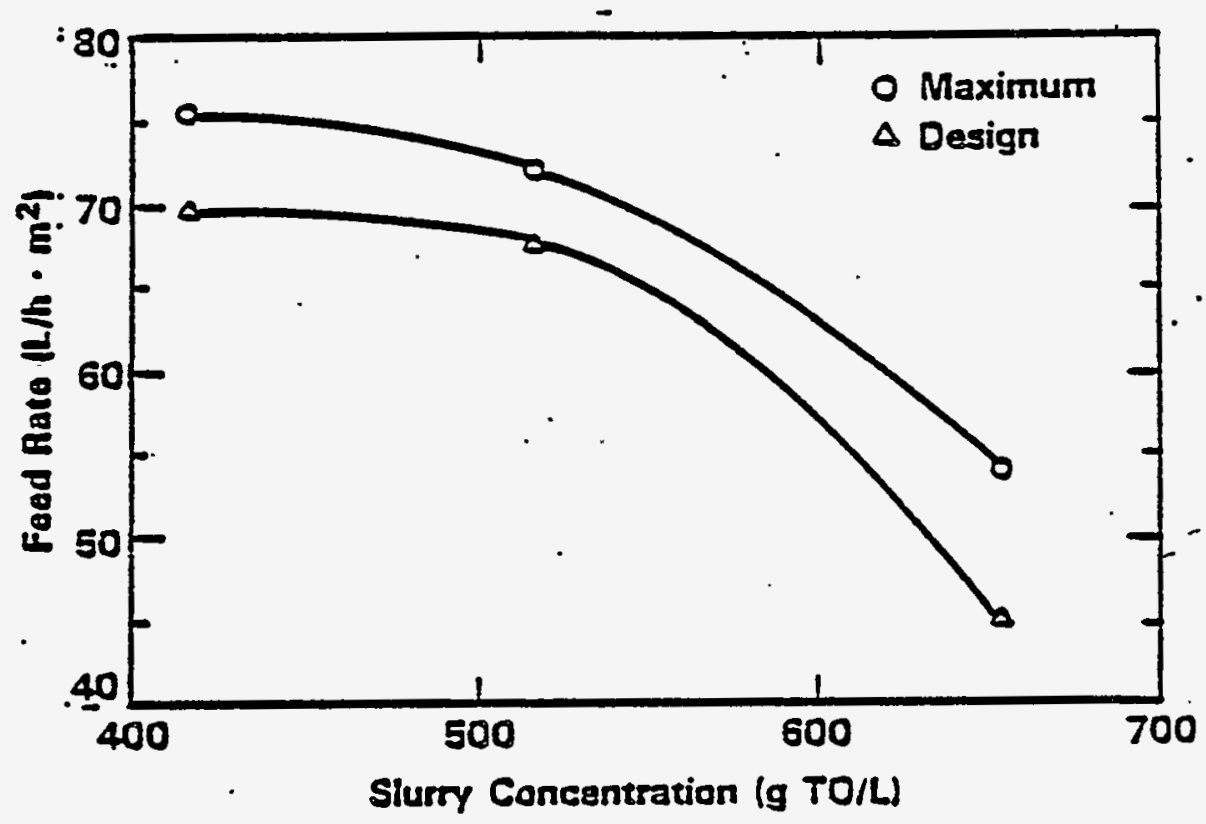

FIGURE 4.5-9. Effect of Feed Concentration on lielter Process Rate for HWVP-13

loading is increased (and water loading decreases), the processing rate will increase until a solids loading is reached in which cold-cap melting assumes control of the processing rate.

The effects of both water loading and solids loading on processing rate are shown in Figures 4.5-10 and 4.5-11, respectiveiy. Figure 4.5-10 shows that feed rate increased with increasing water loading. The dramatic drop in feed rate with decreasing water loading was due to the increased solids loading, as shown in Figure 4.5-11, expressed as feed rate versus slurry total wt\% solids. It is evident that increasing the solids loading from 41 wt\% to almost 50 wt\% caused a. marked drop in feed rate.

The SRL made a similar study. in the SRL slurry-fed minimelter (Ref. 4.5-3). A study of the effect of increasing solids loading from 30 to 50 wi\% is shown with the HWVP data in Figure 4.5-12. The HWVP data showed a definite drop in glass production rate with increasing. solids loading. The SRL slurry compositions (TDS-131 and TDSF-131) experienced increasing glass production throughout the solids loading range tested. However, the SRL researchers 


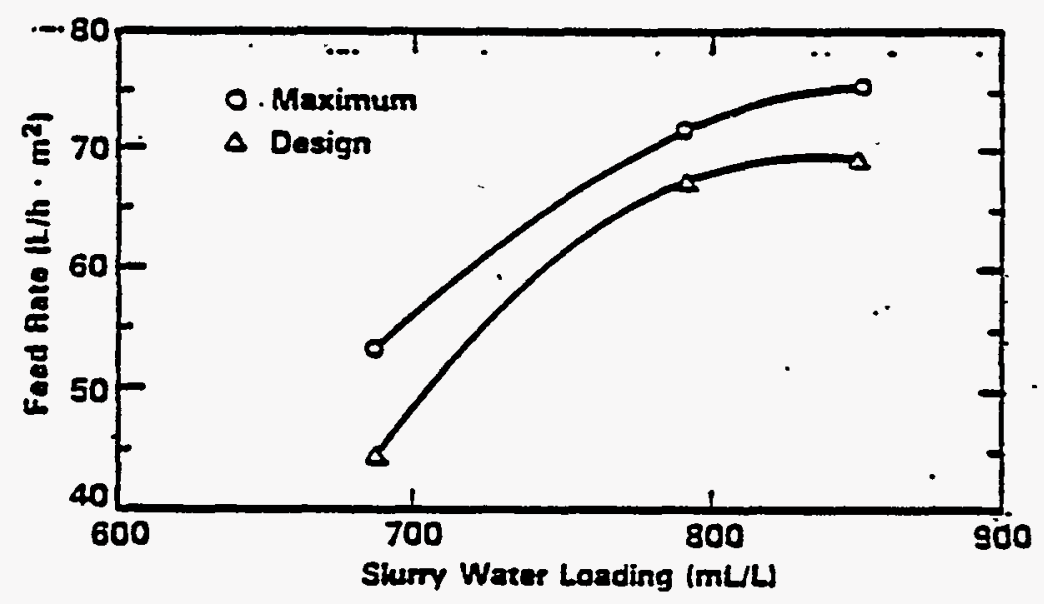

FIGURE 4.5-10. Effect of Hater Loading on Melter

Process Rate for HWVP-13

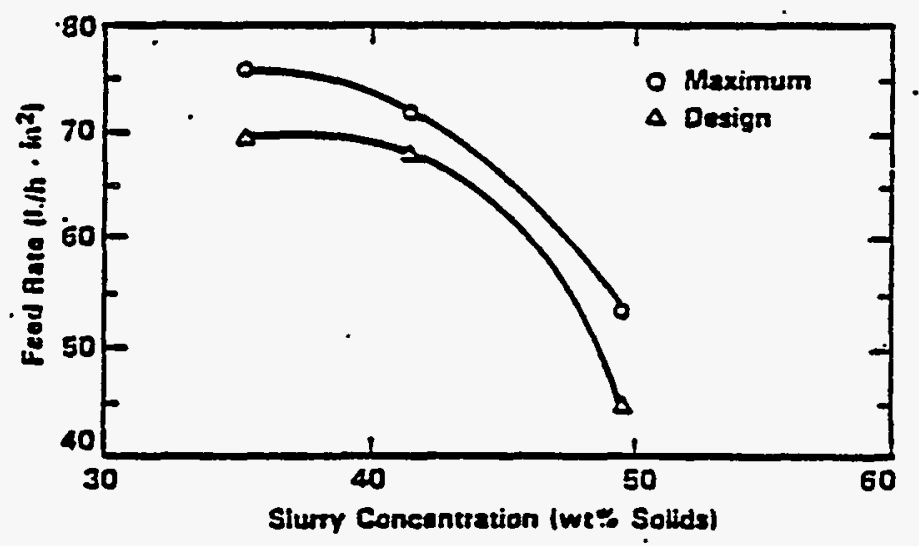

FIGURE 4.5-11. Effect of STurry Total wt\% Solids on Melter Process Rate for HWVP-13

did note that, based on visual observations of such phenomena as cold-cap bridging and slurry flooding conditions, the rate at which the cold-cap melted into the glass melt became rate limiting at approximately $50 \mathrm{wt} \%$ solids. Although the rate of water removal and the rate of cold-cap fluxing determine the point of optimal solids loading, differences in the slurry compositions (i.e., differences in the extent of formic acid treatment, frit compositions, and waste compositions) seem to affect the point of optimal solids loading. 


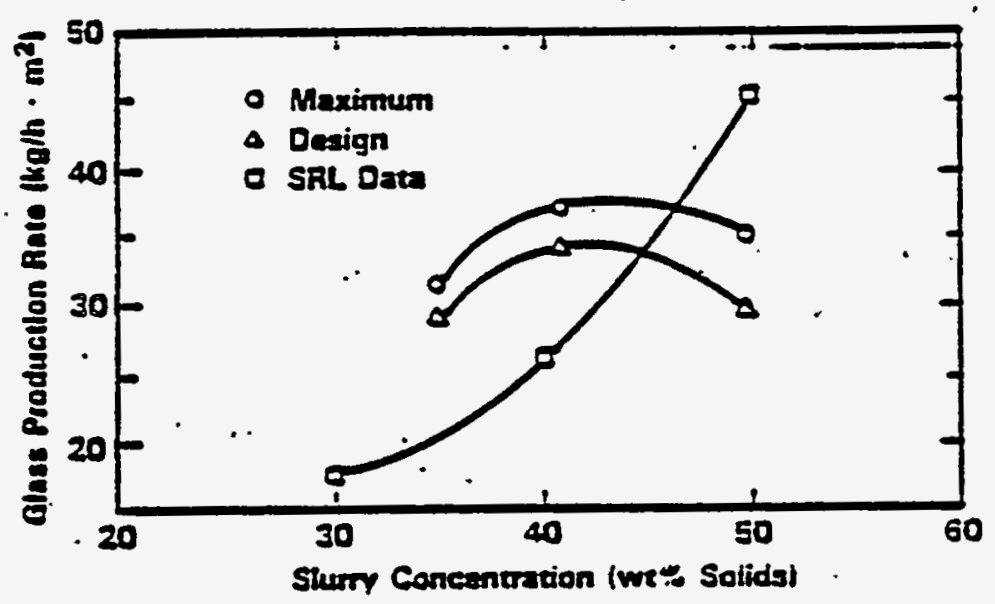

FIGURE 4.5-12. Comparison of HWVP and SRL Studies of the Effect of Solids Loading on Glass Production Rate

An optimal solids loading is predictable based on the results of the experiment. Figure 4.5-13 shows the glass production rate as a function of the feed concentration. The maximum glass production rate can be obtained at an oxide loading of between 500 and $550 \mathrm{~g}$ TO/L. Design and maximum giass production rates of approximately $34.5 \mathrm{~kg} / \mathrm{h} \cdot \mathrm{m}^{2}\left(7 \mathrm{lb} / \mathrm{h} \cdot \mathrm{ft}^{2}\right)$ and $37.2 \mathrm{~kg} / \mathrm{h} \cdot \mathrm{m}^{2}\left(7.6 \mathrm{lb} / \mathrm{h} \cdot \mathrm{ft}^{2}\right)$ : respectively, can be achieved with the reference HWVP NCAW melter feed composition. This corresponds to a water evaporation rate of 750 to $800 \mathrm{~mL} / \mathrm{L}$ of slurry ( 0.75 to 0.8 gal water/gal slurry) and a solids loading of 40 to 45 wt\%. Based on these results, a nominal oxide loading of approximately $500 \mathrm{~g} T 0 / \mathrm{L}$ was

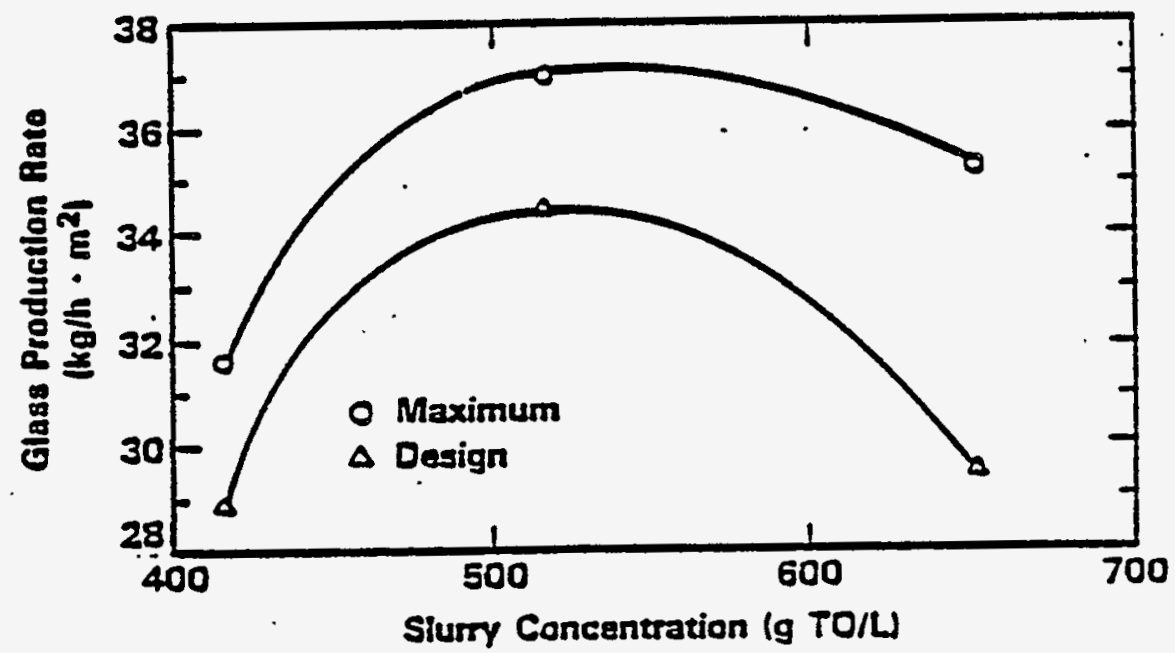

FIGURE 4.5-13. . Optimal Glass Production Rate as a Function of Melter Feed Concentration for HWVP-13 
used for HWVP-14. Processing characteristics were found to be acceptable at this oxide loading and very similar to the characteristics determined with the current reference oxide loading of $400 \mathrm{~g}$ TO/L.

4.5.4.2.4 Results of Pilot-Scale Experiment HWV-15 (R. W. Goles et al., Hanford Waste Vitrification Program Pilot-Scale Ceramic Melter Test 23.

HWVP-89-IVJ0010100B, Pacific Northwest Laboratory, Richland, Washington (1988). The primary objective of the test for melter processing was to establish and maintain steady-state operating conditions in the melter and evaluate the nominal processing characteristics of the simulated melter feed. The glass pouring characteristics of the PSCH pour through as a function of bulk glass and overflow section temperatures and pour rate were evaluated. A melter feed rate was established such that the cold cap coverage was nominally $-80 \%$ of the melter. surface area. During testing, the melter cold cap coverage ranged from 60 to $80 \%$; it rose to $90 \%$ for a brief period.

The major PSCM operating parameters are given in the process flowsheets for each period of the test (see Tables 4.5-11 through 4.5-13). Figures 4.5-14 through 4.5-27 show data plots for the entire feeding portion of HWVP-15. Feed to the melter was started on June 6,1988 at 1100 and continued for $351 \mathrm{~h}$ until June 21,1988 , at 0200 . The feed rate to the melter was consistent at 43 to $44 \mathrm{~L} / \mathrm{h}\left[57 \mathrm{l} / \mathrm{h} \mathrm{m} \mathrm{m}^{2}\left(1.4 \mathrm{lb} / \mathrm{h}^{\circ} \mathrm{ft}^{2}\right)\right]$. Including downtime periods when feed was not being fed to the melter, the average feed rate for the entire test was just over $41 \mathrm{l} / \mathrm{h}$. Approximately 15,000 L of melter feed were processed producing approximately $77450 \mathrm{~kg}(16,390 \mathrm{lb})$ of glass at a glass production rate of $28.4 \mathrm{~kg} / \mathrm{h} \cdot \mathrm{m}^{2}$ $\left(5.8 \mathrm{lb} / \mathrm{ho} \mathrm{ft}^{2}\right)$. Average glass and plenum temperatures reached steady-state. values after about $35 \mathrm{~h}$ of operation. With the exception of short periods of downtime, due chiefly to occasions of feed pump failure and feed nozzle plugging, the PSCM operation was very stable. On-stream efficiency was excellent--better than $98 \%$.

4.5.4.2.4.1 cold cap Conditions. Throughout the test the cold cap characteristics remained consistent. Initially, during the first $8 \mathrm{~h}$ of startup some degassing of the glass inventory occurred. This was expected, given the initial oxidized condition of the glass batch. The degassing resulted in a light foam accumulation forming over the open glass surface. It dispersed as melting of the HWVP glass gradually displaced the original glass tank contents.

The processing conditions produced by the current melter feed composition were very good. The slurry spread over the glass and cold cap easily without any signs of accumulation. The cold cap coverage of the glass surface ranged from between 60 and $80 \%$. For short periods (e.g., $<4 \mathrm{~h}$ ) the cold cap coverage grew as large as $90 \%$. The cold cap remained flexible throughout the run period. Venting was routinely observed, and the cap thickness appeared to remain consistent at 
TABLE 4.5-11. PSCM Process flowsheet---Period One HHVP-89-IVJ0010100B

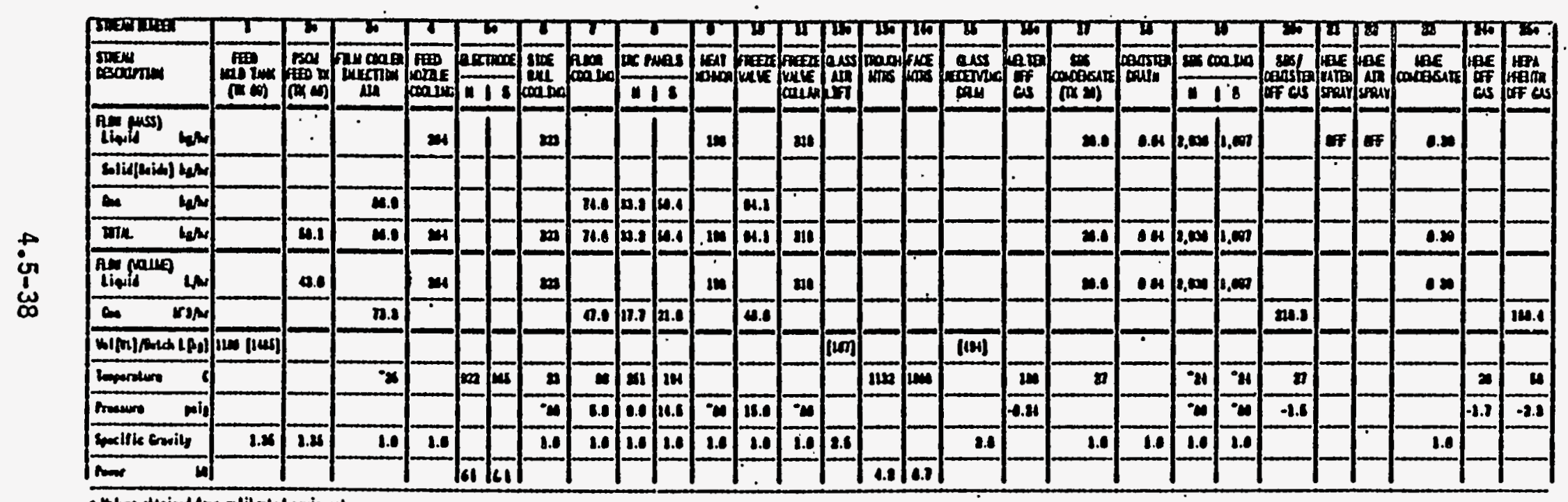

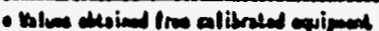


TABLE 4.5-12. PSCM-23 Process Flowsheet--Period Two HWVP-89-IVJ0010100B

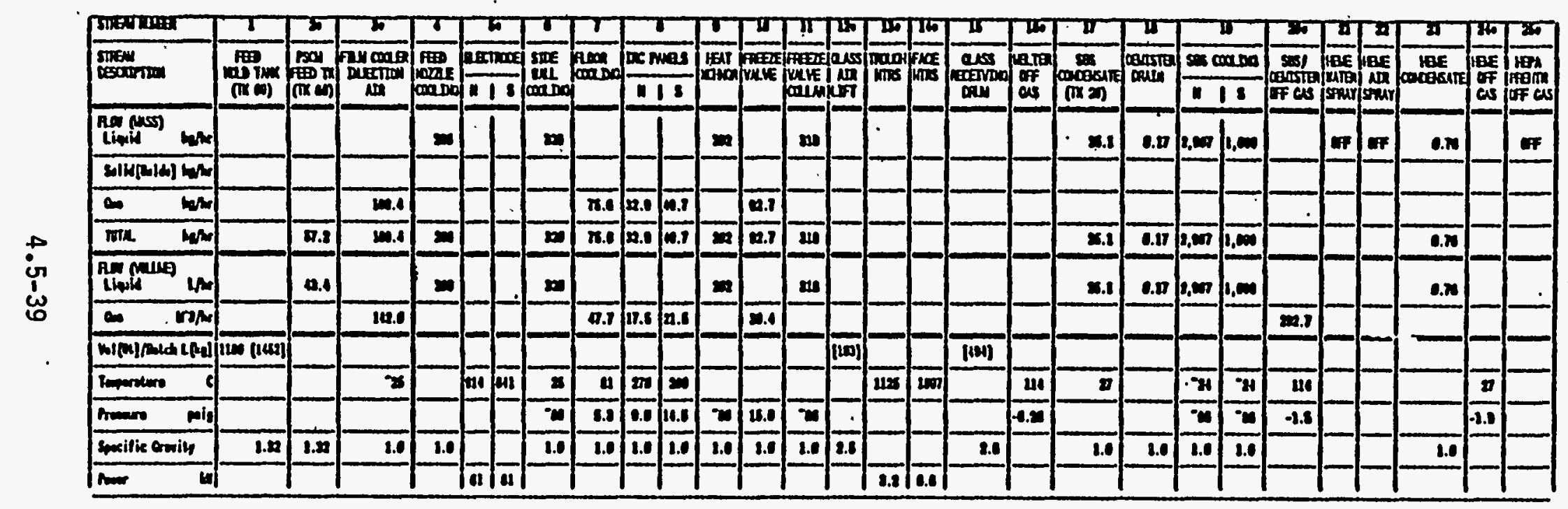


TABLE 4.5-13. PSCM-23 Process Flowsheet--Period Three HWV-89 IVJ0010100B

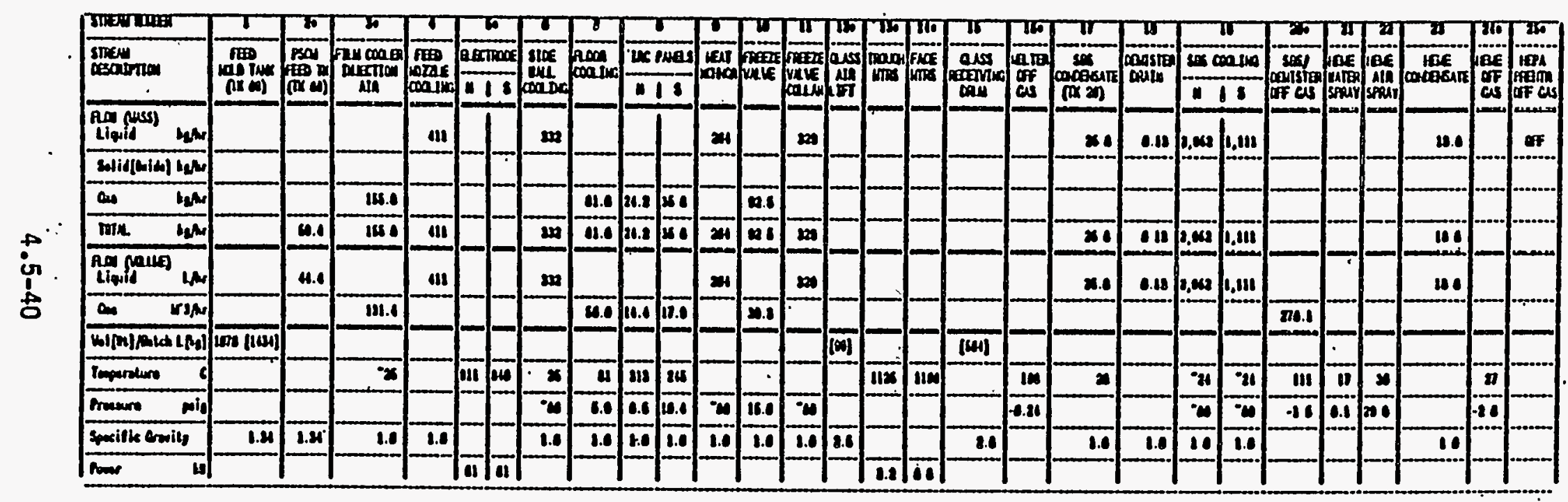




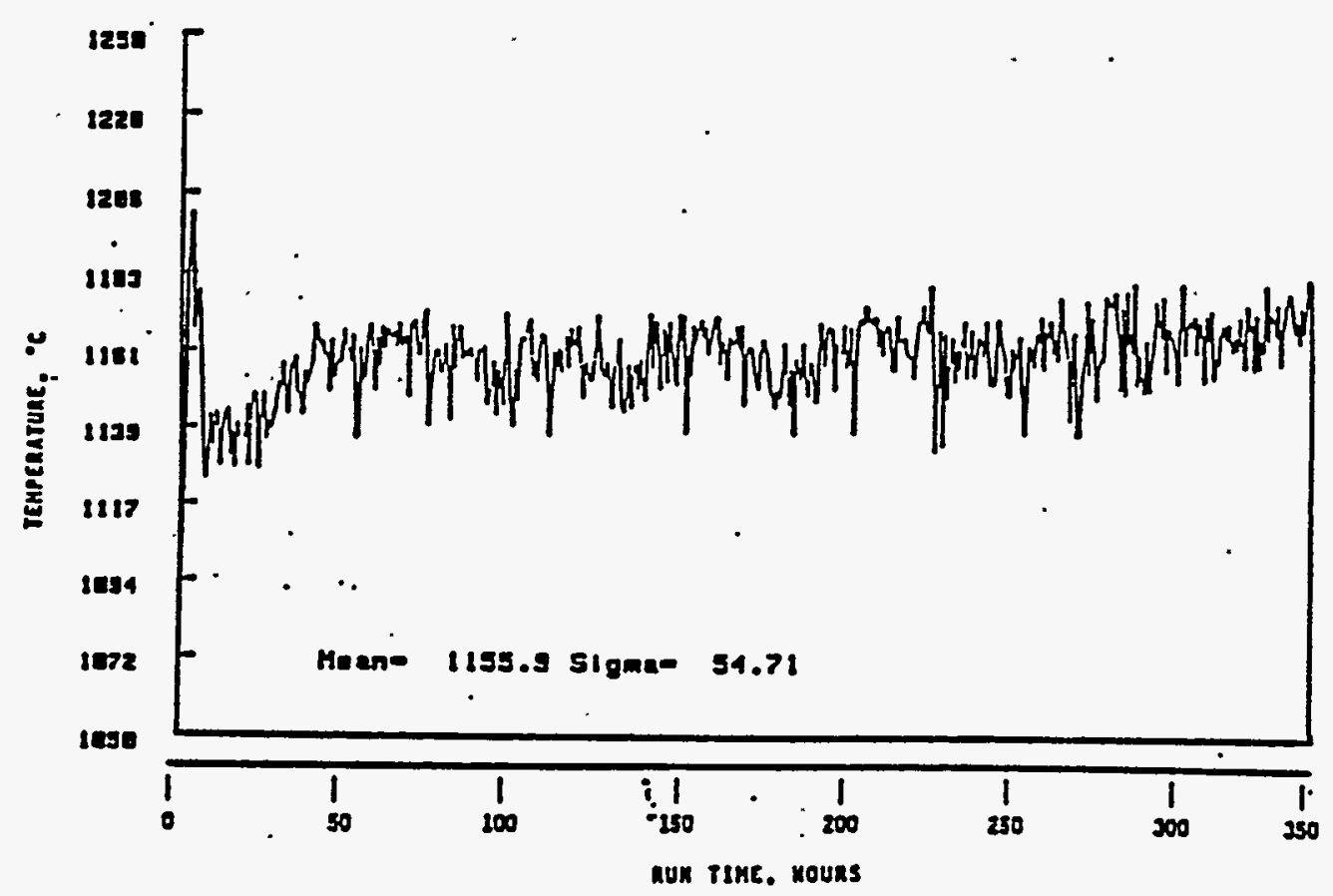

FIGURE 4.5-14. PSCM Average Bulk Glass Temperature

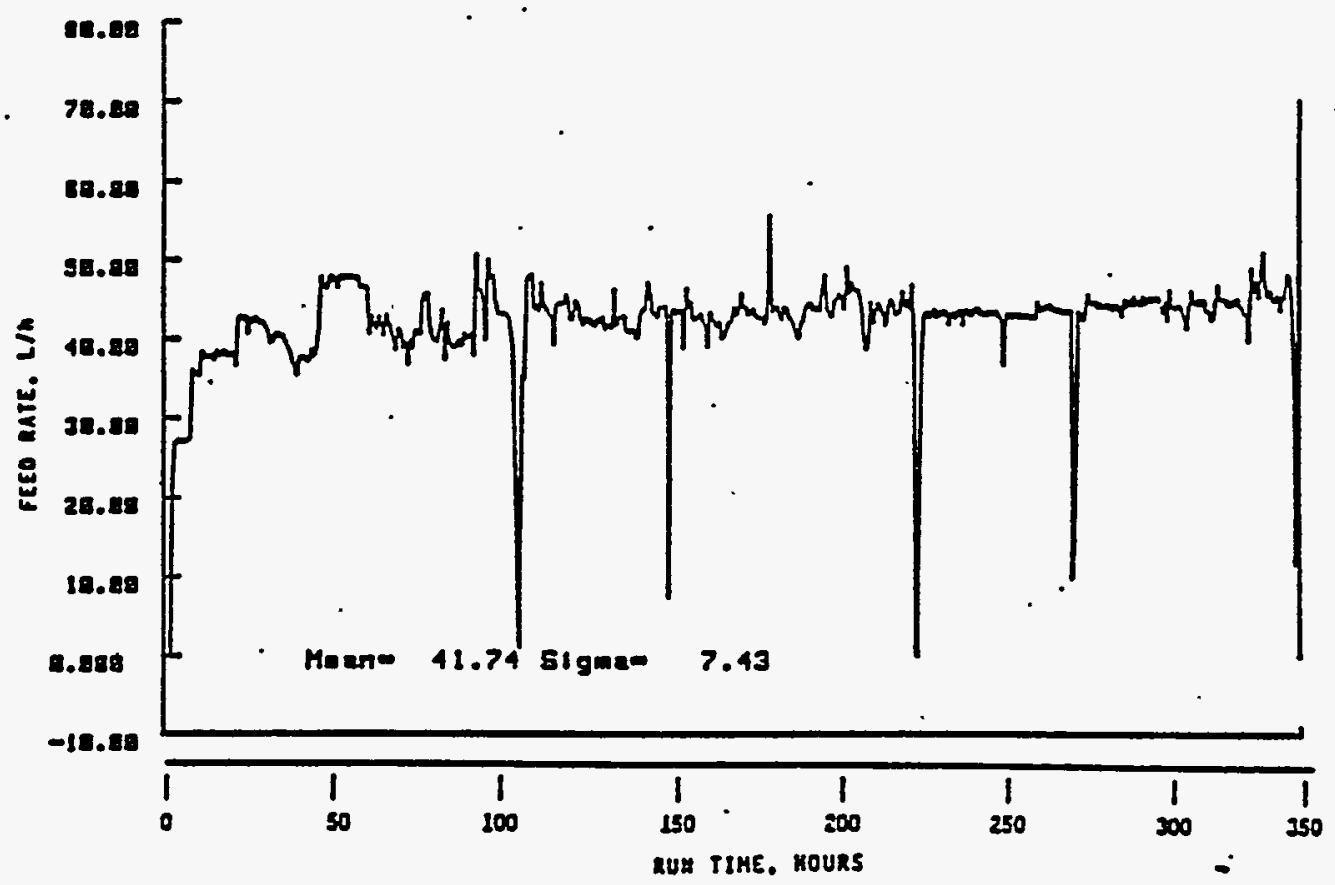

FIGURE 4.5-15. PSCM Average Melter Feed Rate 


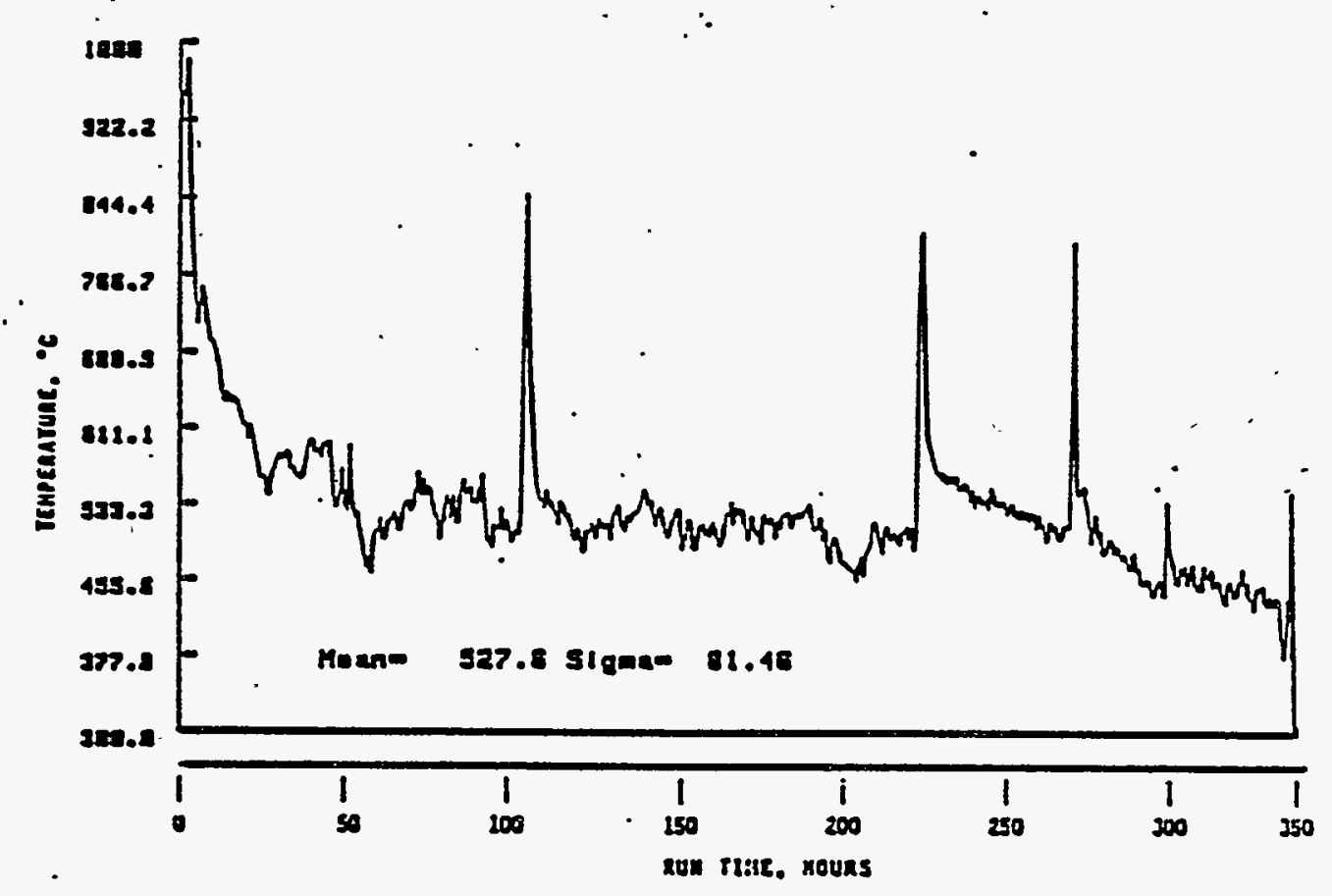

FIGURE 4.5-16. PSCM P.Tenum Temperature

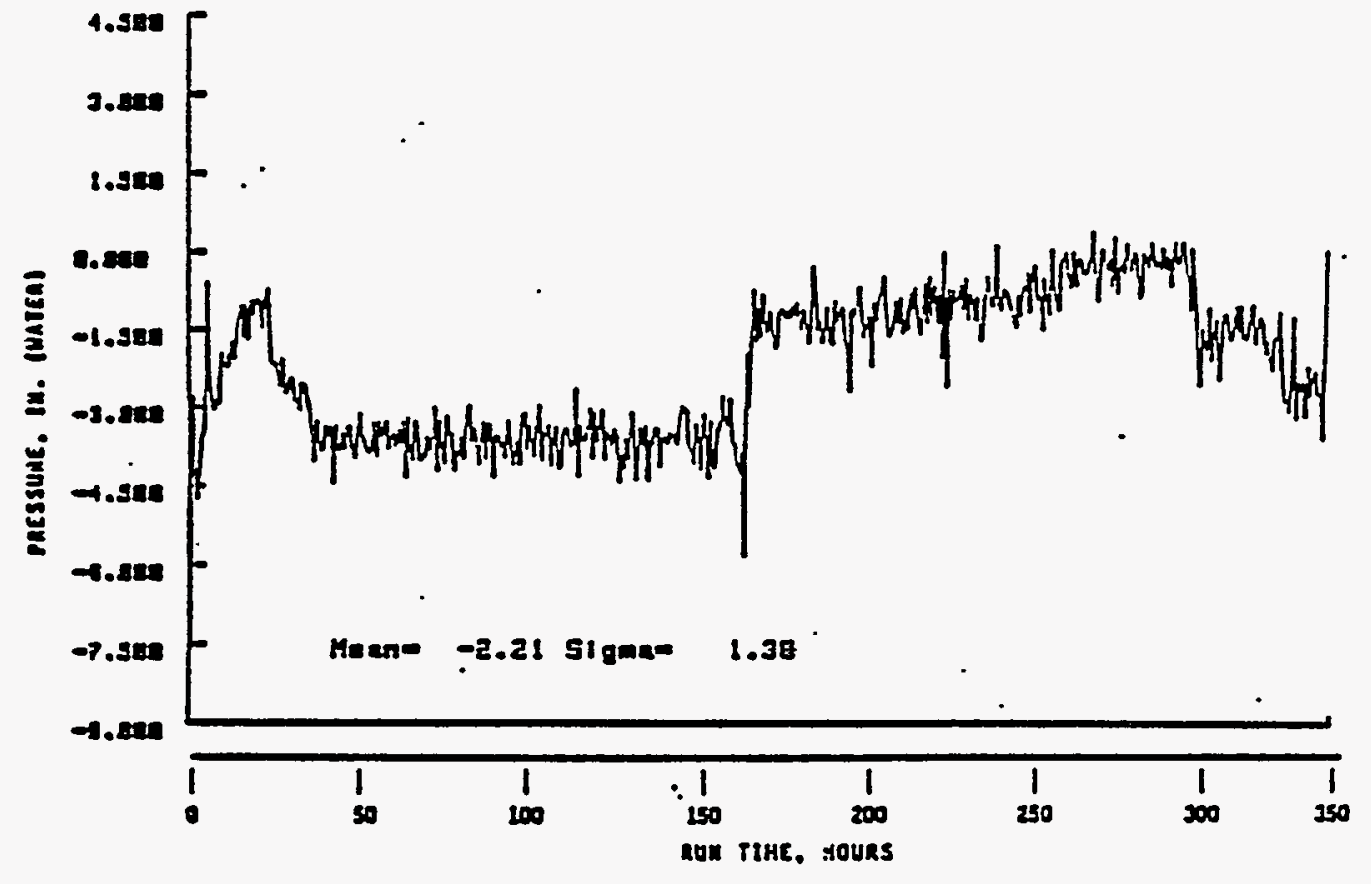

FIGURE 4.5-17. PSCM PI enum Pressure 


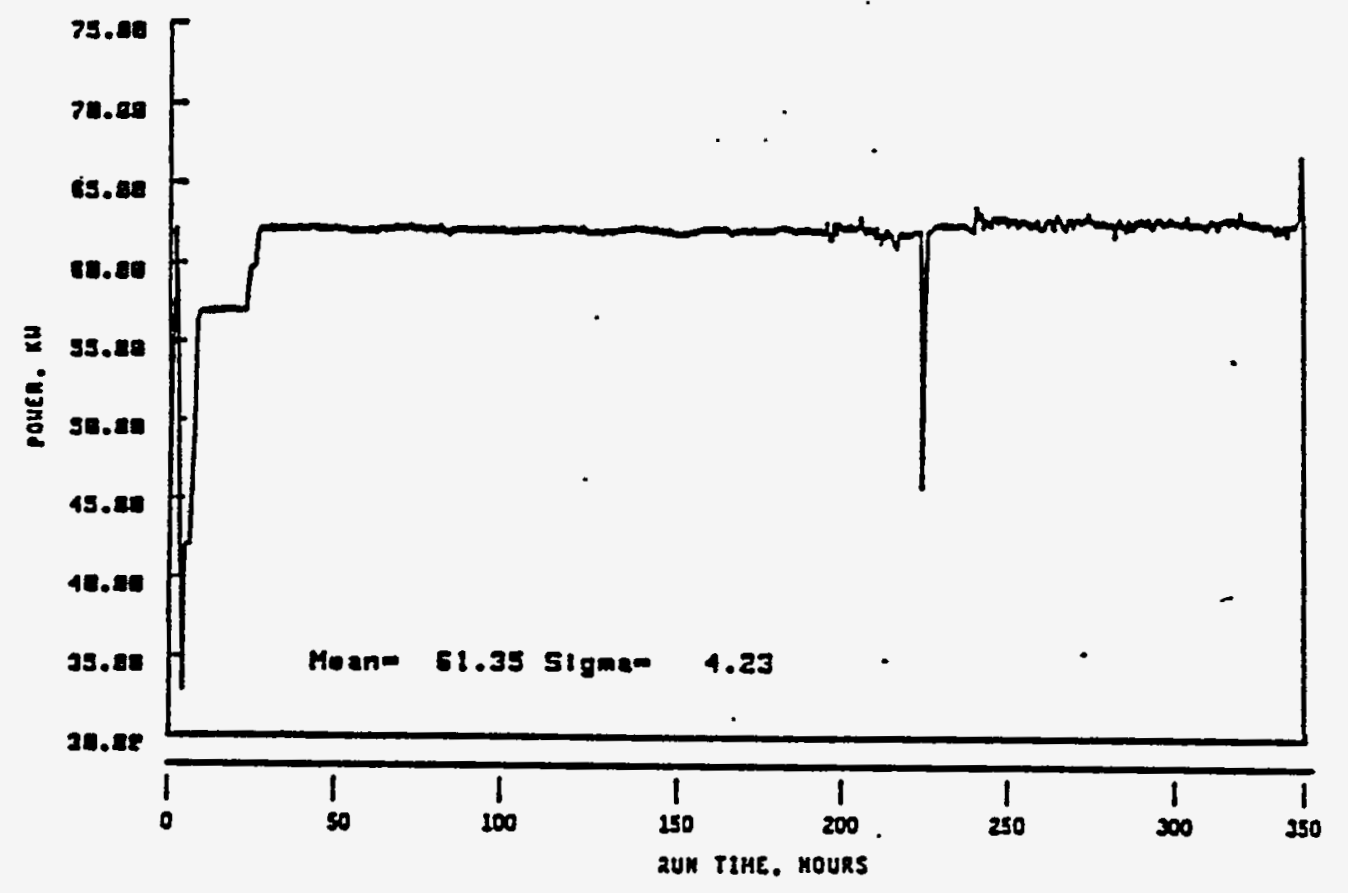

FIGURE 4.5-18. PSCM Electrode Power

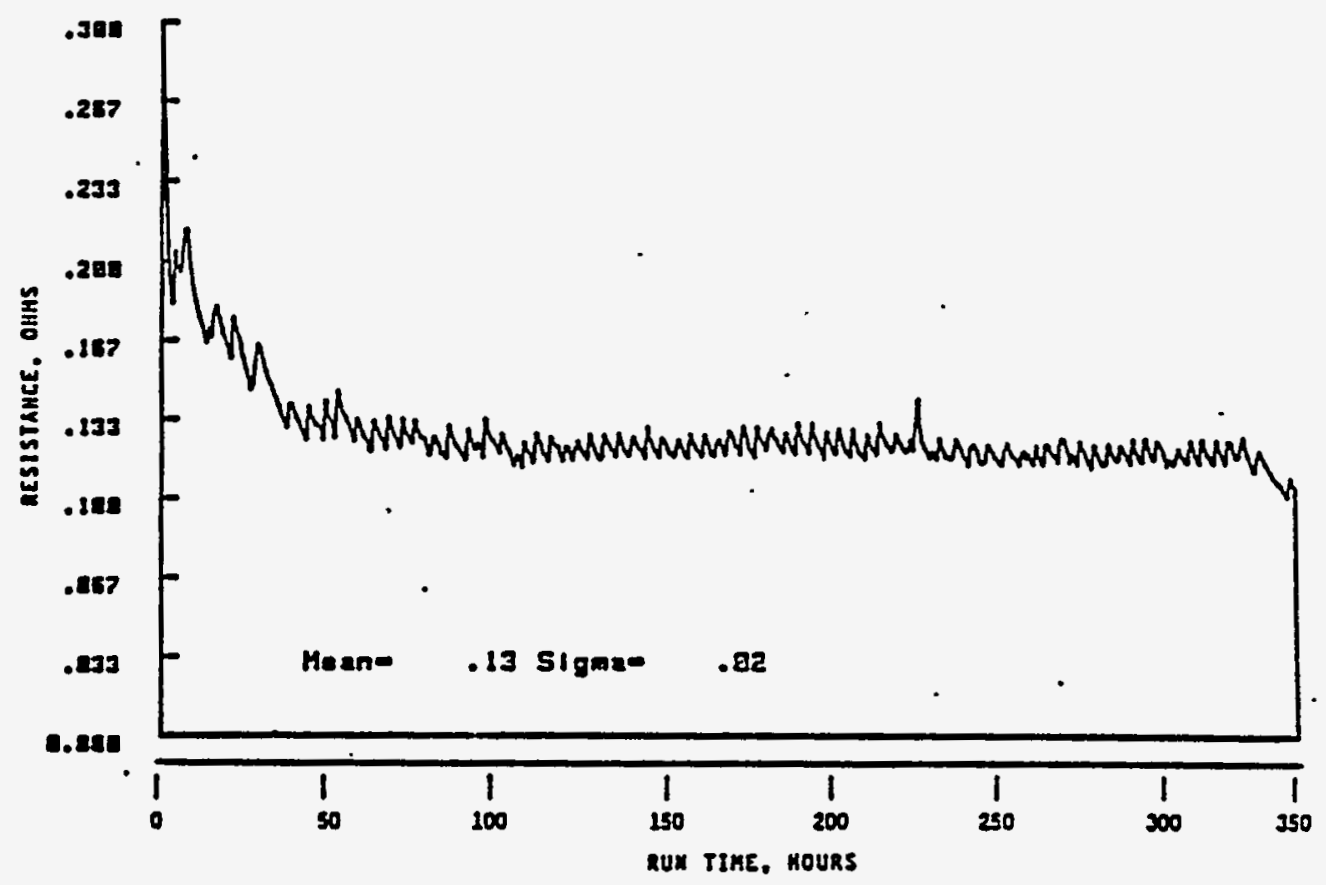

FIGURE 4.5-19. PSCM Electrode Resistance 


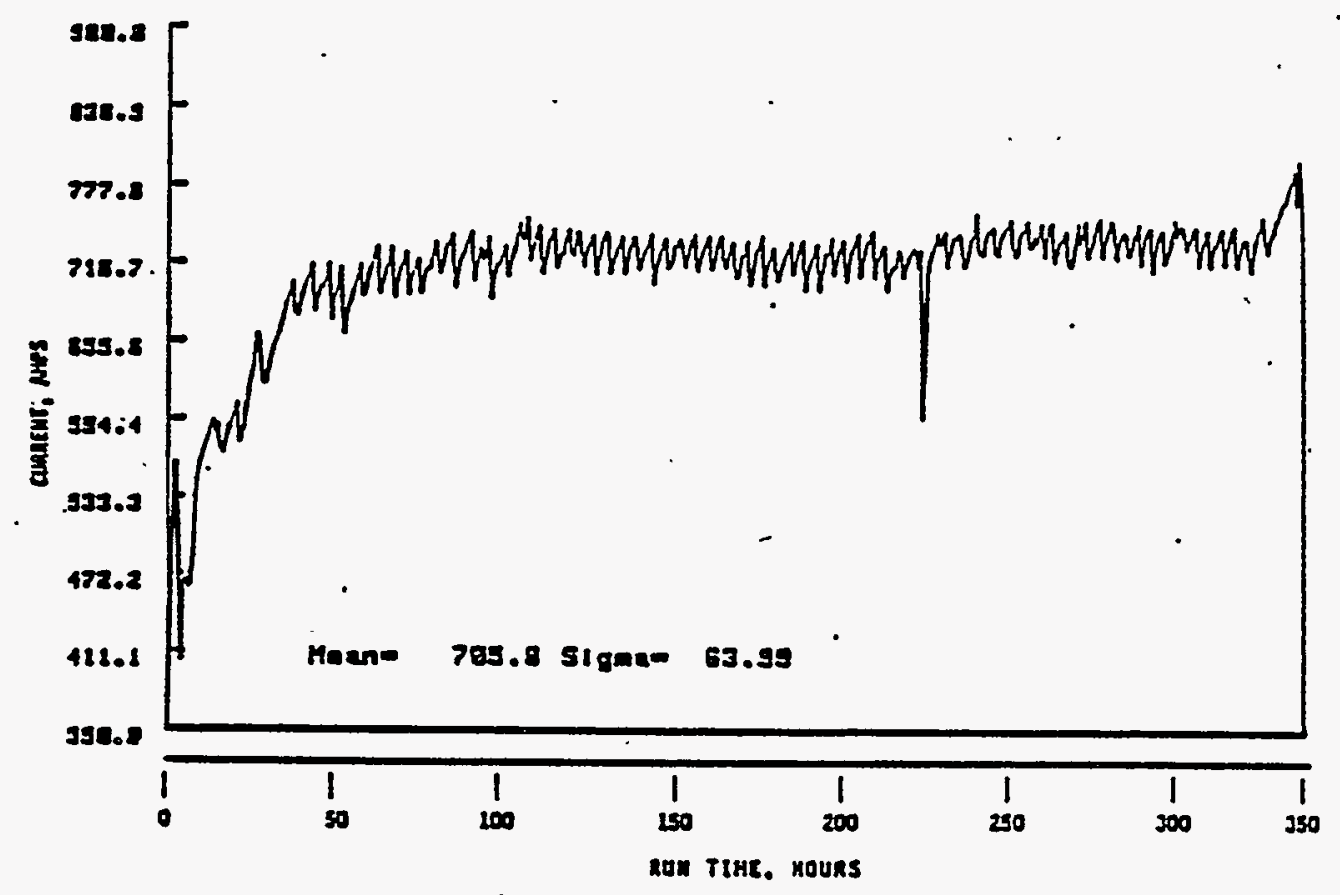

FIGURE 4.5-20. PSCM Electrode Current

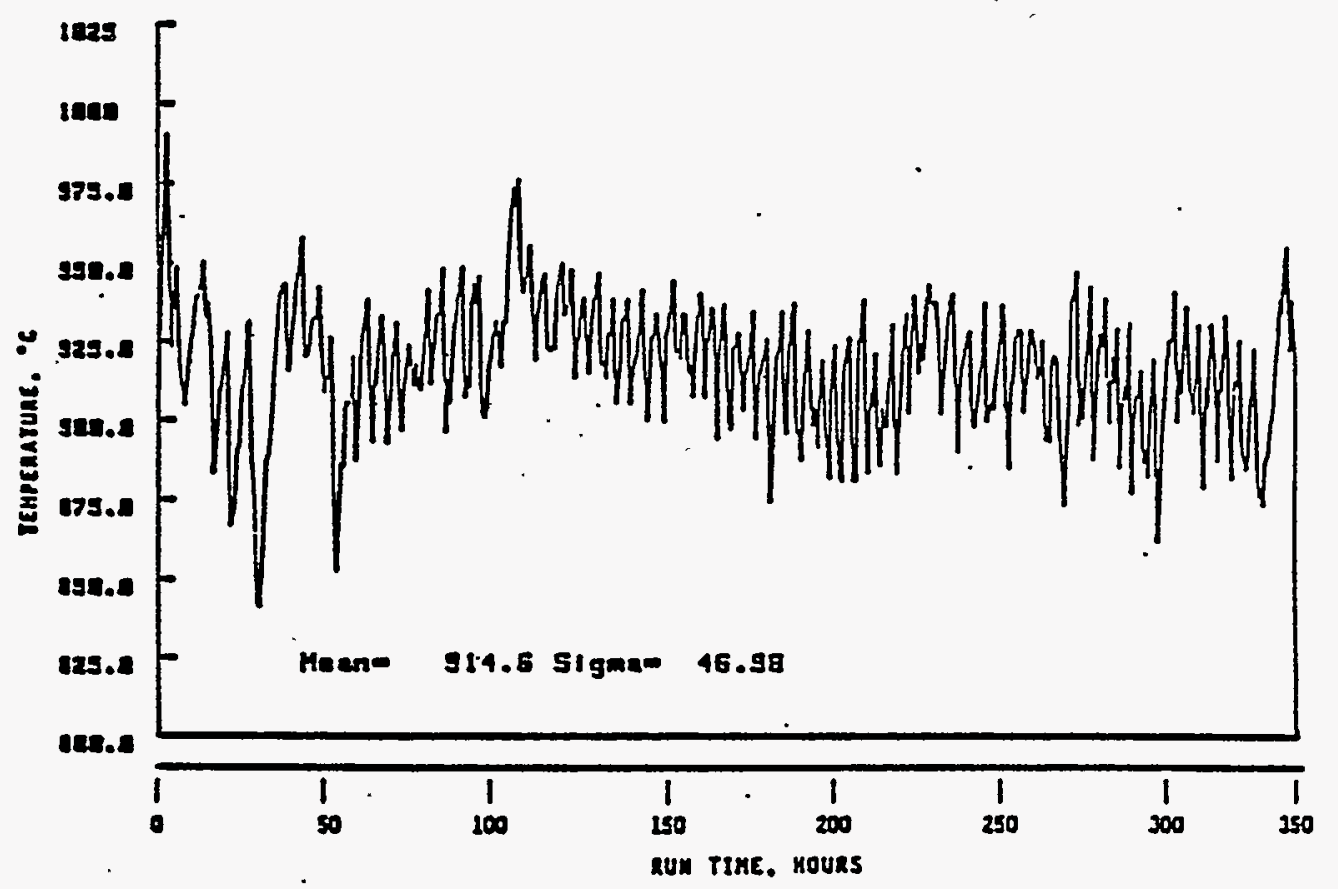

FIGURE 4.5-21. PSCM North Electrode Temperature 


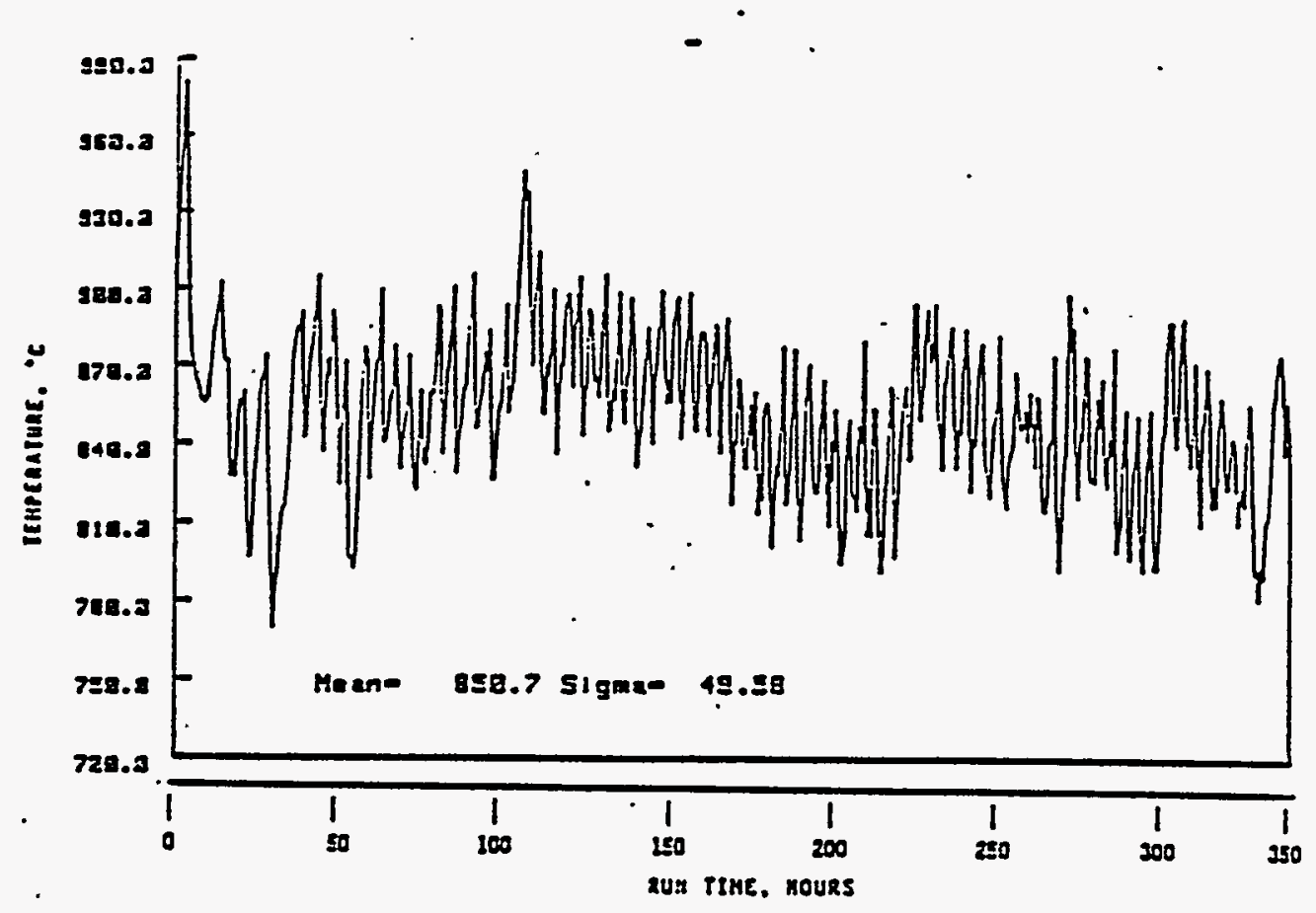

FIGURE 4.5-22. PSCM South Electrode Temperature

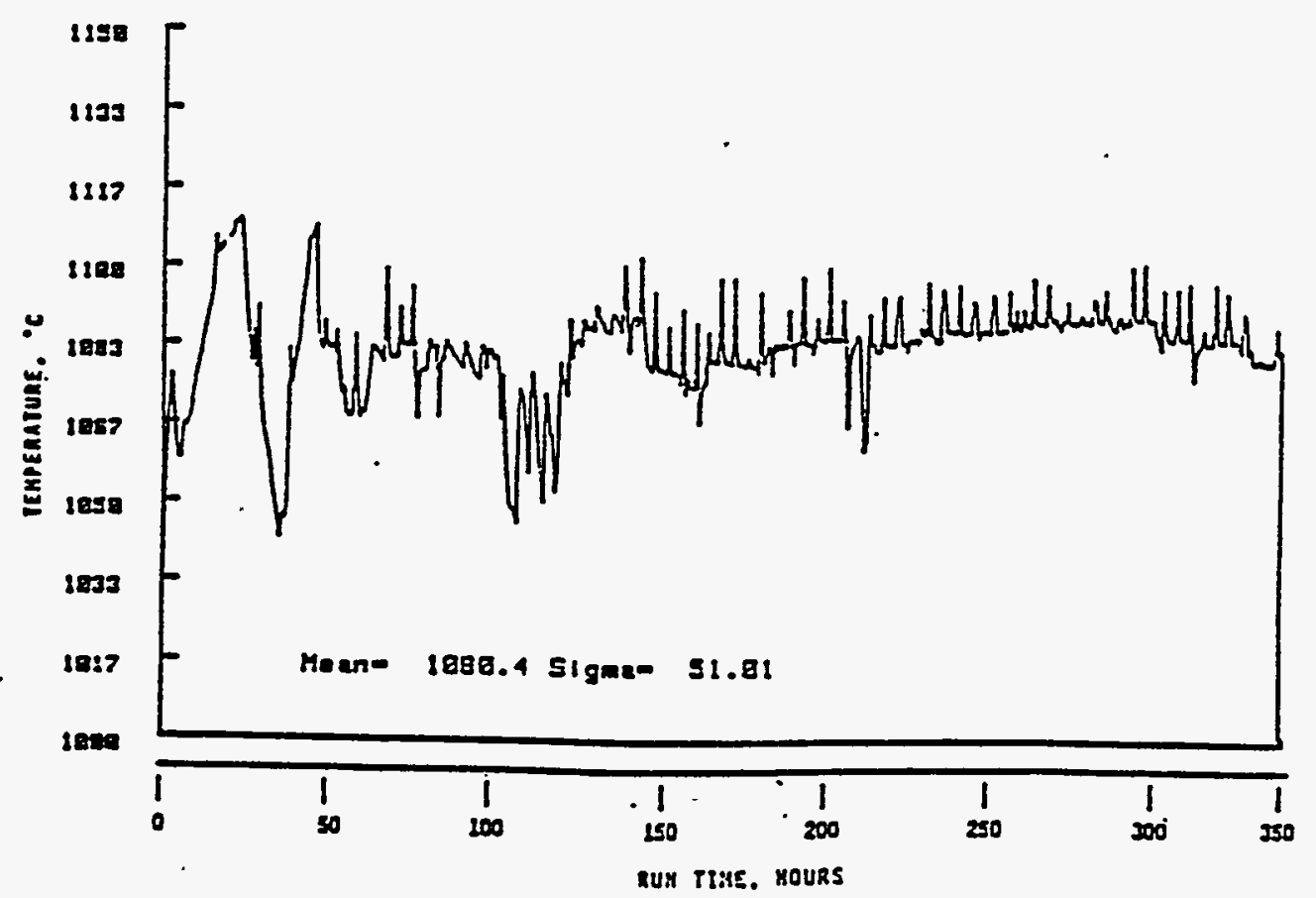

FIGURE 4.5-23. PSCM Glass Discharge Trough Block Temperature 


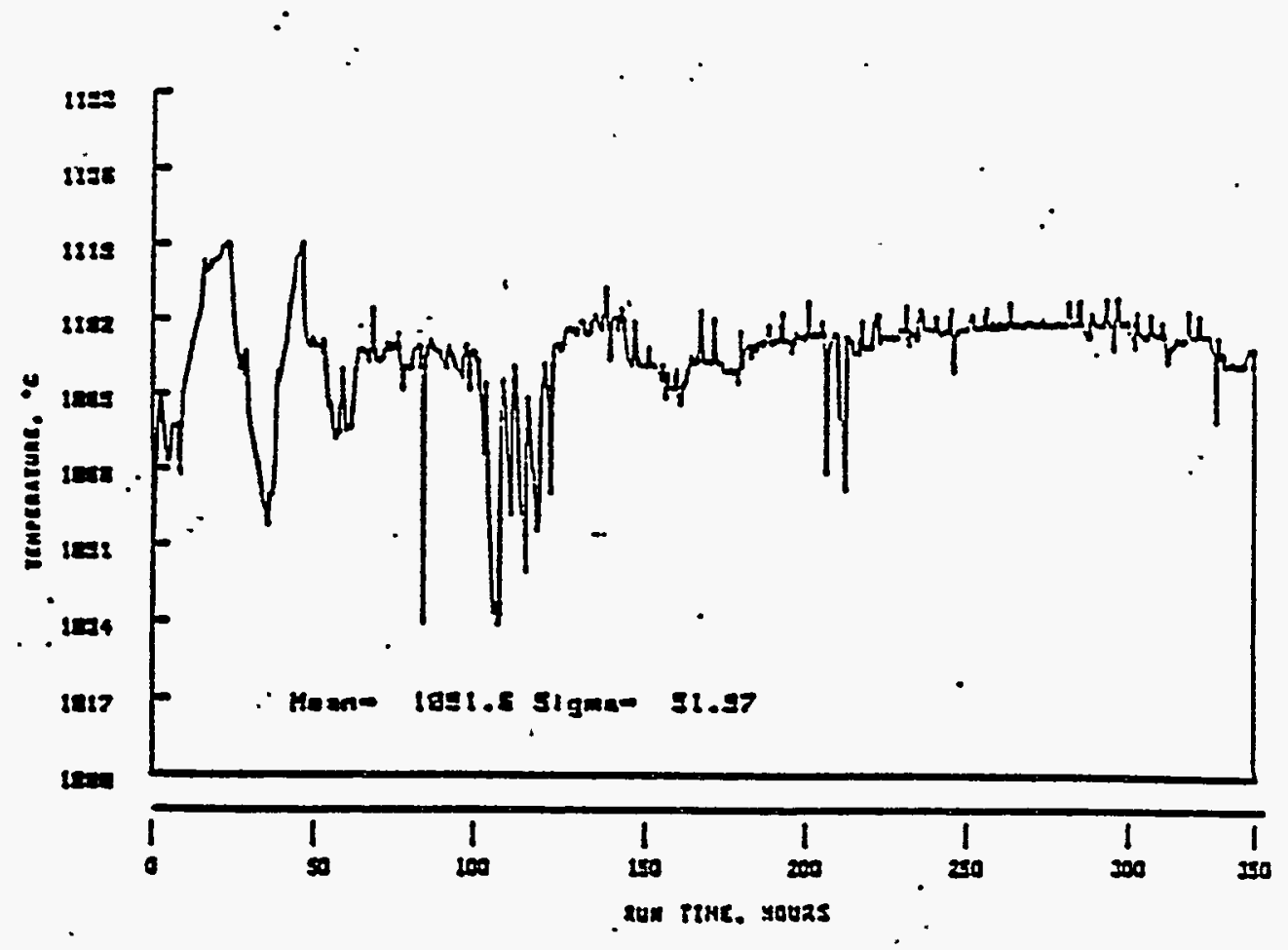

FIGURE 4.5-24. PSCM GIass Discharge Face Area Temperature

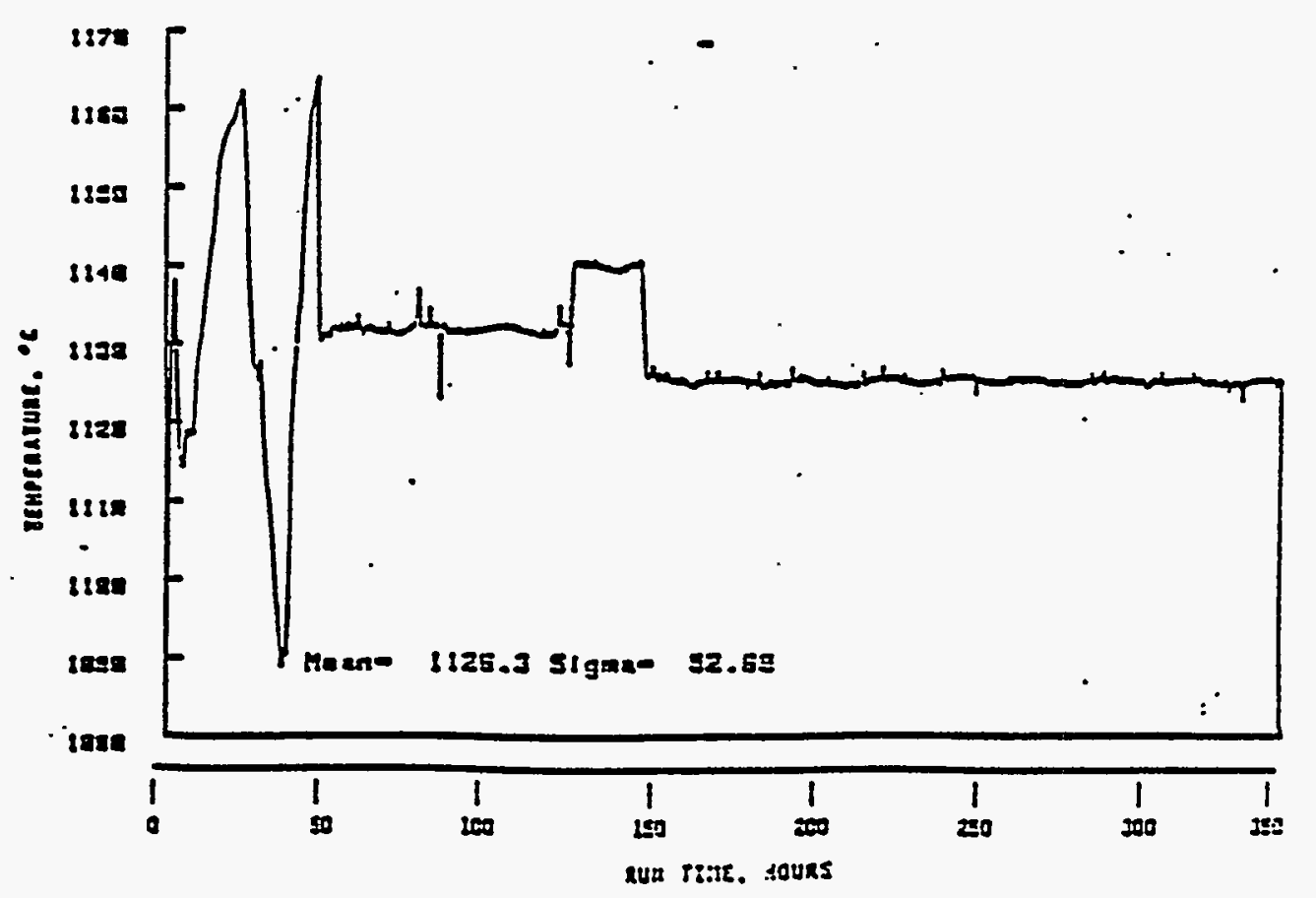

FIGURE 4.5-25. PSCM GIass Discharge Trough Area Temperature

\section{$4.5-46$}




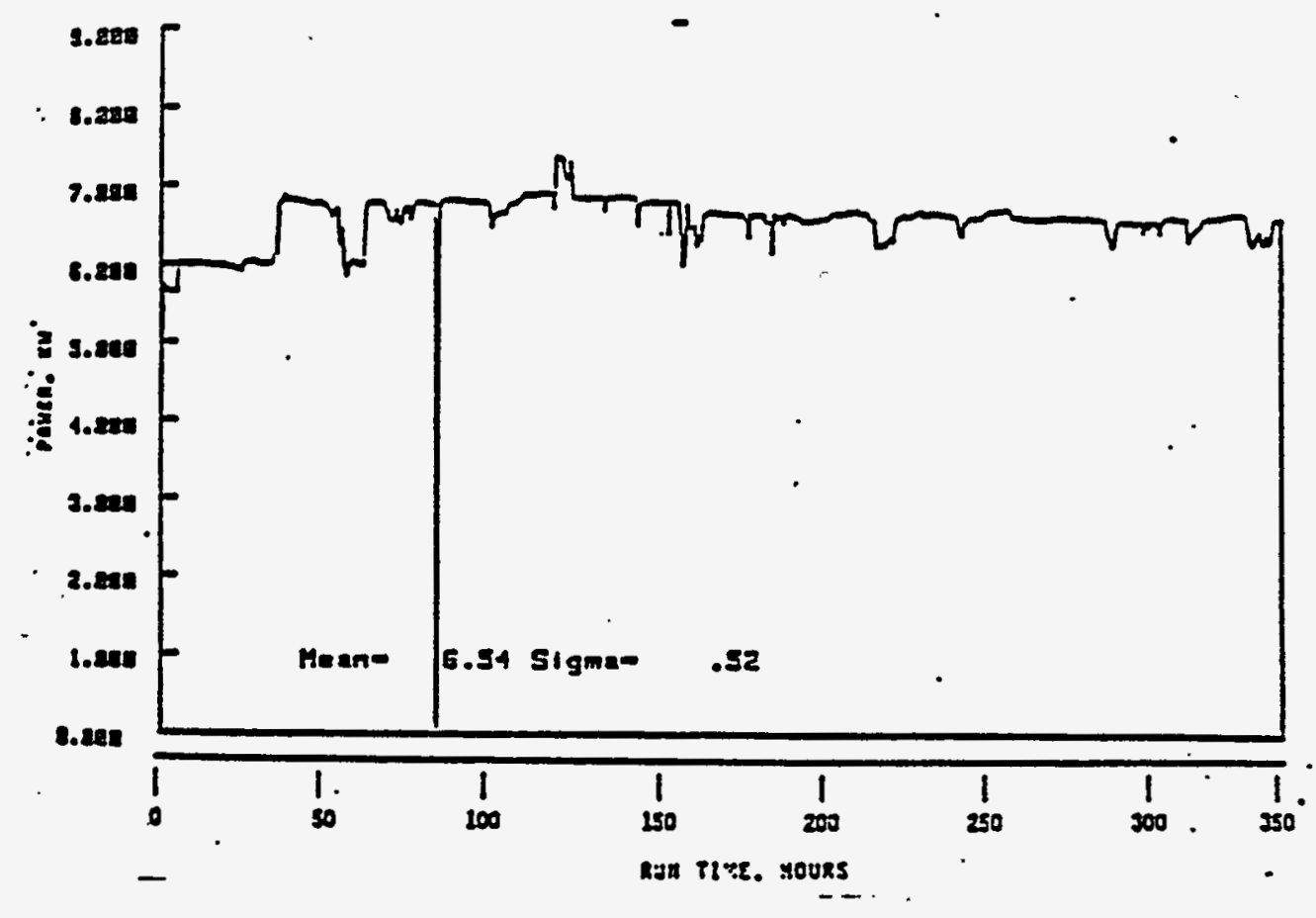

FIGURE 4.5-26. PSCM Glass Discharge Face Heater Power

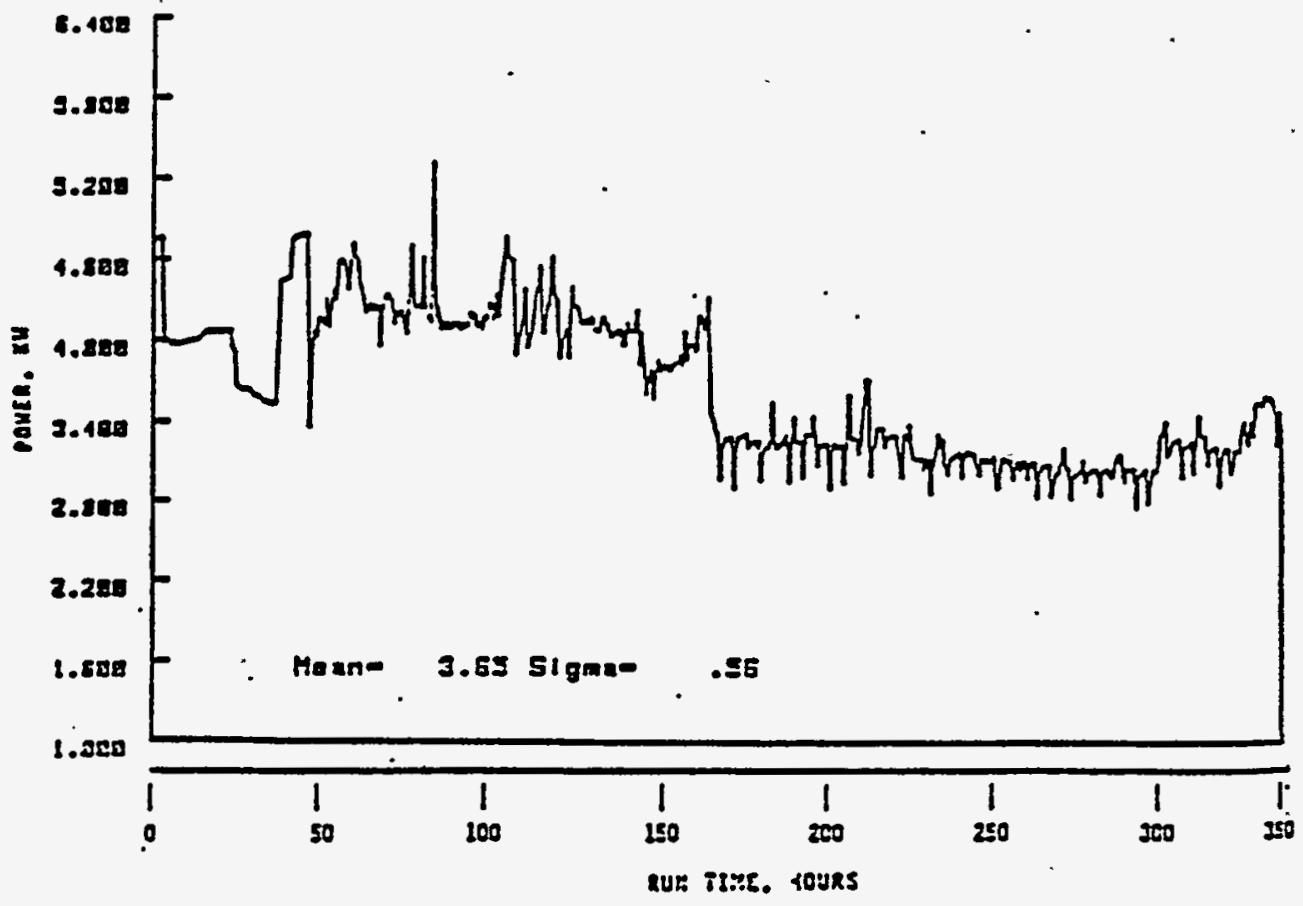

FIGURE 4.5-27. PSCM Glass Discharge Trough Heater Power 
about 2 to $5 \mathrm{~cm}$. The cold cap was judged to be equal in processability to the previous HWVP tests in which NCAW-based melter feeds were processed. At the termination of the feeding portion of HWVP-15, the cold cap melted into. the glass quickly (i.e., $<30 \mathrm{~min}$ ), and no refractory or molten salt accumulation were observed to be present.

4.5.4.2.4.2 Process Rate Evaluation. The average melter feed rates given in Tables 4.5-11 through 4.5-13 were for the feeding portion of the test. Normalizing these rates by the PSCM surface area, the PSCM processed at between 56 to $58 \mathrm{~L} / \mathrm{h} \cdot \mathrm{m}^{2}\left(-1.4 \mathrm{gal} / \mathrm{h} \cdot \mathrm{ft} \mathrm{t}^{2}\right)$ for the duration of the test. These rates are quite comparable to the PSCM-22 rates (Ref. 4:5-1). During HWVP-12, nominal rates of $51 \mathrm{~L} / \mathrm{h} \cdot \mathrm{m}^{2}$ (formated with. $3.5 \mathrm{~g} / \mathrm{L}$ sugar added) to $62 \mathrm{~L} / \mathrm{h} \cdot \mathrm{m}^{2}$ (formated feed without sugar added) were achieved. Although HWVP-15 rates were $7 \%$ lower than the higher HWWP -12 value (case for no sugar added), they are in excess of the design basis value of $45 \mathrm{l} / \mathrm{h} \cdot \mathrm{m}^{2}$ used for the HWVP meiter and are very close to the design maximum value of $601 / \mathrm{h} \cdot \mathrm{m}^{2}$.

These process values also compare quite favorably to rates achieved in the PSCM under other vitrification programs and by other test systems (Figure 4.5-28). During the recent WVDP melter test, SF-10, nominal rates of about $36 \mathrm{~L} / \mathrm{h} \mathrm{m}^{2}$ were achieved; cold cap coverage of the glass surface was estimated to be 80 to $.95 \%$. (a)

Comparisons to previous PNL and SRL test results are also favorable. Based on FY 1987 tests in the scale-glass melter (SGM-6 and -7), (b) glass production rates have been estimated to range from 190 to $205 \mathrm{lb} / \mathrm{h}$ for slurry processing rates of 45 to $54^{\circ} \mathrm{gal} / \mathrm{h}$ (reported values were extrapolated for the case of a $27 \mathrm{ft}^{2}$ glass surface area for use in Figure 4.5-28), equivalent to 1.7 to $2 \mathrm{gal} / \mathrm{h} \mathrm{ft}^{2}$. Given that the SGM utilizes lid heating to boost production rate, the nomalized production rates are comparable to nonboosted production in the PSCM.

Based on the processing characteristics of the melter feed, and rates achieved in past PSCM tests and by other. programs, the HW39-4 glass composition can be judged to be acceptable.

4.5.4.2.4.3 Glass Product Samples. Thin sections were cut and polished - from the glass bars (taken from melter pours) and a cold cap sample. The optical

\footnotetext{
(a) Personal communications with G. J. Sevigny (PNL staff who witnessed the SF-10 run), August 16, 1988.

(b) P. D. Guidatti et al., Summary of Campaigns. SGM-7 and SGM-7 of the DWPF Scale Giass Melter. DPST-87-532, Savannah River Laboratory, Aiken, South Carolina (1987).
} 


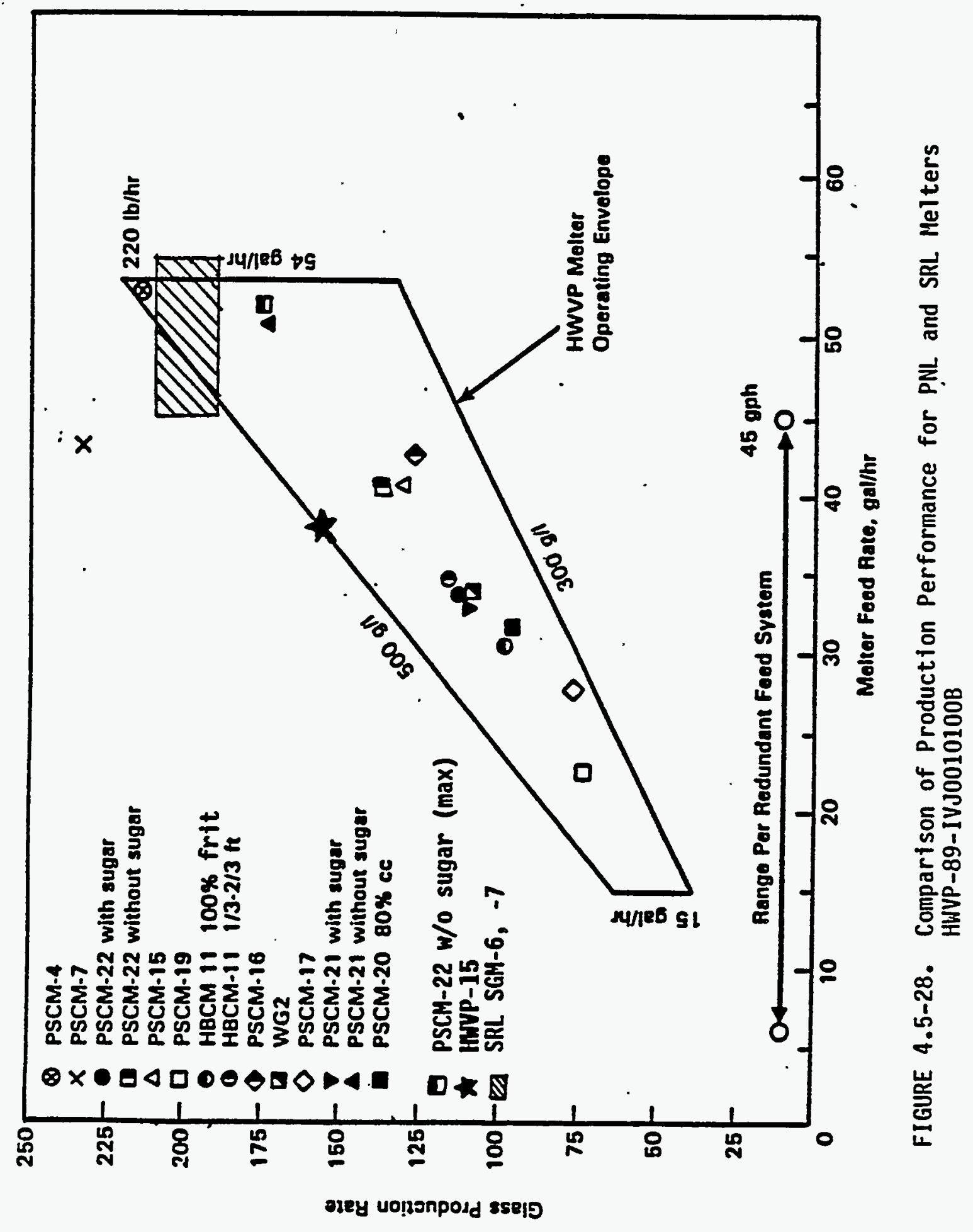


analysis at 630X magnification found no detectable crystalline phases in the glass bar samples. The lack of any observable crystalline phases compared to HWVP-12 glass samples is due to the $\mathrm{Cr}_{2} \mathrm{O}_{3}$ concentration in the HH39-4 glass composition ( -0.13 . wt\%) being below the solubility limit of -0.5 wt\% typical of these glasses. Glass from the HWVP-12 melter test had a significant amount of $\mathrm{Fe}-\mathrm{Cr}$ spinal due to the high $\mathrm{Cr}_{2} \mathrm{O}_{3}$ concentration in the glass ( $\left.-3 \mathrm{wt} \%\right)$.

The cold cap sample received did not provide a total cross-section of the cold cap and the molten glass underneath. The sample provided from the HWVP-15 test did have a small section with part of the cold cap/glass interface intact. The thin section of this part of the cold cap sample was observed optically up to 630X magnification. The crystalline material present appeared to be calcined but not yet melted feed with no observable segregation of the feed components.

The viscosity and electrical conductivity of the HWVP-15 glass was measured using glass taken from the top of a canister and the melter overflow section during a pour. The compositions of these two samples were found to be essentially the same and very close to the target.

The viscosity curves for both the laboratory version and the PSCM-23 glass are presented in Figure 4.5-29. Both viscosities and T100Ps are within experimental error of each other $\left( \pm 10^{\circ} \mathrm{C}\right)$. The el ectrical conductivity curves for both the laboratory version and the HWVP-15 glass are presented in Figure 4.5-30. Both electrical conductivities and E1150s are within experimental error of each other $\left( \pm 0.02 \mathrm{ohm}^{-1} \mathrm{cn}^{-1}\right)$.

The phase behavior was evaluated of thin sections of quenched and heattreated glass. The gross devitrification behavior of the HW39-4 glass was evaluated by subjecting the glass to a $900 \%$ C 3 -day isothermal anneal and a simulated canister heat-treatment. In the quenched and isothermal heat-treated glass, the only crystalline phases present were the oxide and metallic phases of inoble metal ( $R u, R h$, and $P d$ ), which were expected due to the negligible solubility of the noble metals. In the simulated canister heat-treated glass, small amounts of nickel-iron-chrome spinel crystals ( $\mathrm{Ni}, \mathrm{Fe})(\mathrm{Fe}, \mathrm{Cr})_{2} \mathrm{O}_{4}$, were al so observed (estimated $\leq 5 \mathrm{wt} \%$ ). As subsequently indicated, no crystalline phases were observed in the HWVP-153 melter glass, and there was no indication of sludge (crystalline phase) formation in the melter when the melter bottom was physically probed after the run. At this time no product specifications exist on the amount of crystallinity that may exist in the. production canisters transported to a federally licensed repository. Based on these evaluations, the phase behavior of the HW39-4 is judged acceptable. 


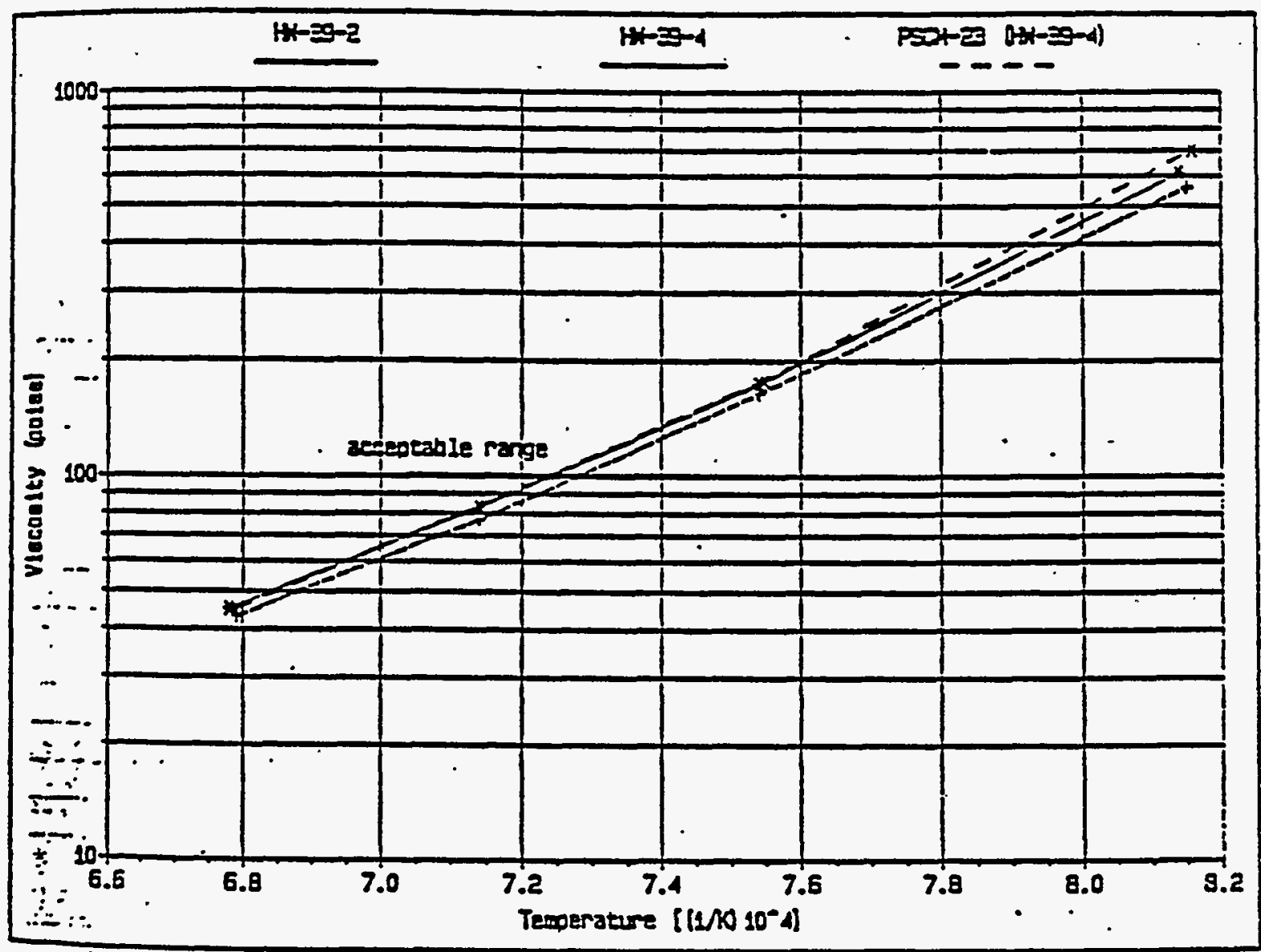

FIGURE '4.5-29. Viscosity Curves for HWVP Glasses HWI39-2, HW39-4, and PSCri-23 (HW39-4)

To evaluate if the HW39-4 frit composition could be produced commercially, the melting behavior of the frit alone was evaluated. Carbonate and oxide components of the frit were found to melt very well at $1150^{\circ} \mathrm{C}$. Therefore, commercial frit producers should have no problem producing this frit composition.

The HW39-4 laboratory glass was tested for 7 and 28 days using MCC -1 and MCC-3 leaching procedures. In the 7- and 28-day MCC-1 test, the normalized B releases for the HW39-4 and HW39-2 glasses were found to be similar, with slightly higher releases from HW39-4 in the 28-day teșt. Both of.these glasses were below the proposed tuff geologic repository B limit of $28 \mathrm{~g} / \mathrm{m}^{2}$ for a 28 -day period. In the 7-day MCC-3 tests, the normalized $B$ release from $H W 39-4$ was - 5 times higher than the normalized $B$ release from HW39-2. In the 28-day MCC-3 tests the normalized $B$ release was -8 times higher. The reason for this 


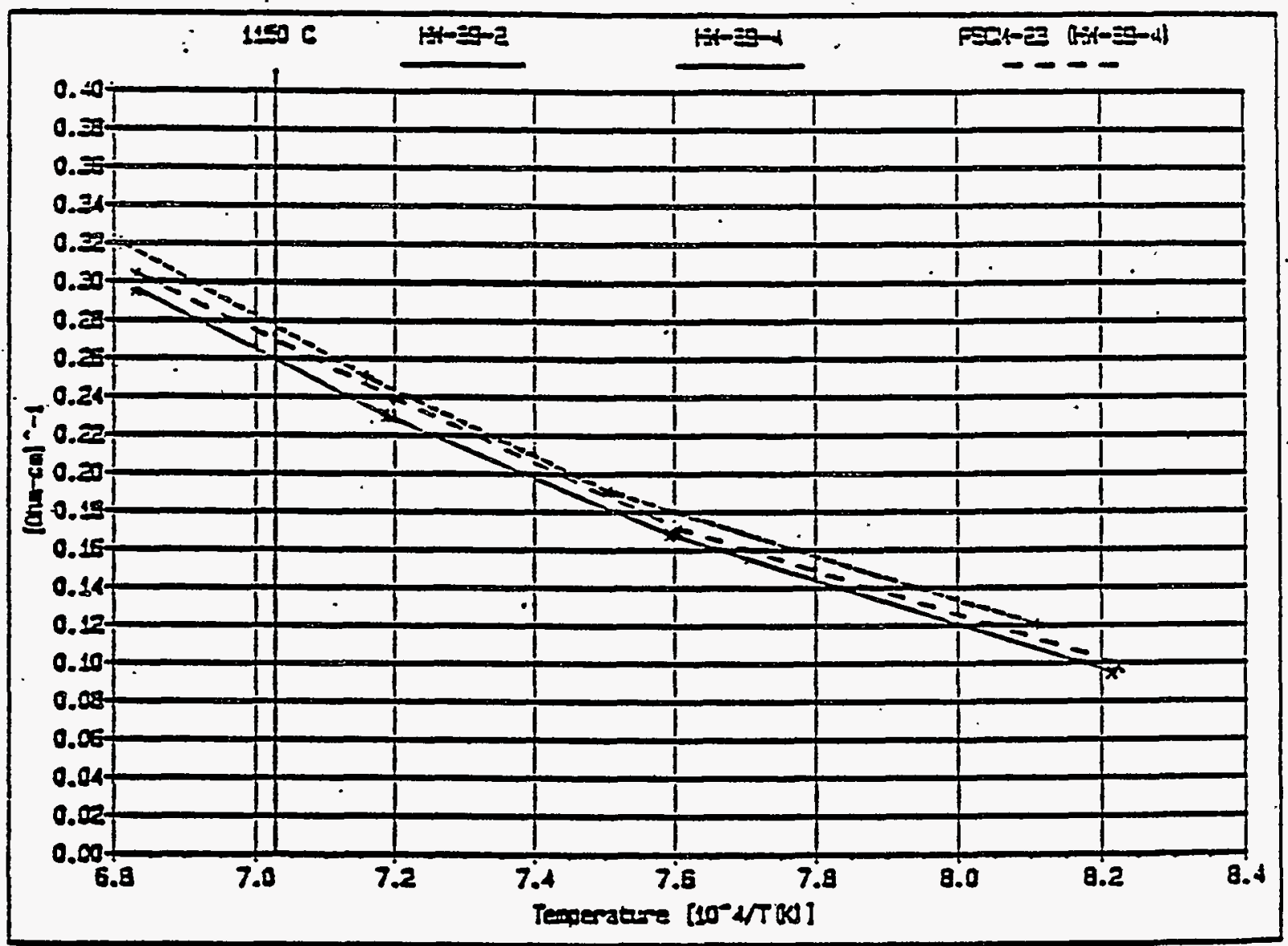

FIGURE 4.5-30. ETectrical Conductivity Curves for HWVP Glasses HW39-2, HW39-4, and PSCM-23 (HW39-4)

significant increase of glass dissolution under MCC-3 conditions is not clear. The final $\mathrm{pH}$ for the HW39-4 leachant was slightly lower than for HH39-2; generally, the higher the $\mathrm{pH}$ the greater the dissolution of the glass. The differences in the two glass composition do not suggest any large change indurability. Calculating the free energies of hydration for the two glasses using a DWPF model indicated that the HW39-4 glass should be more durable than the HW-39-2 glass.

4.5 -4.2.4.4 Melter Feeding. The HWV-15 test consisted of approximately 15 days of melter feeding. During this time, simulated HWV melter feed was processed under nominal conditions. A summary of the wt\% total oxide in the melter feed is presented in Figure 4.5-31. (The last two data points in Figure 4.5-31 are low due to process test equipment failure, not related to 


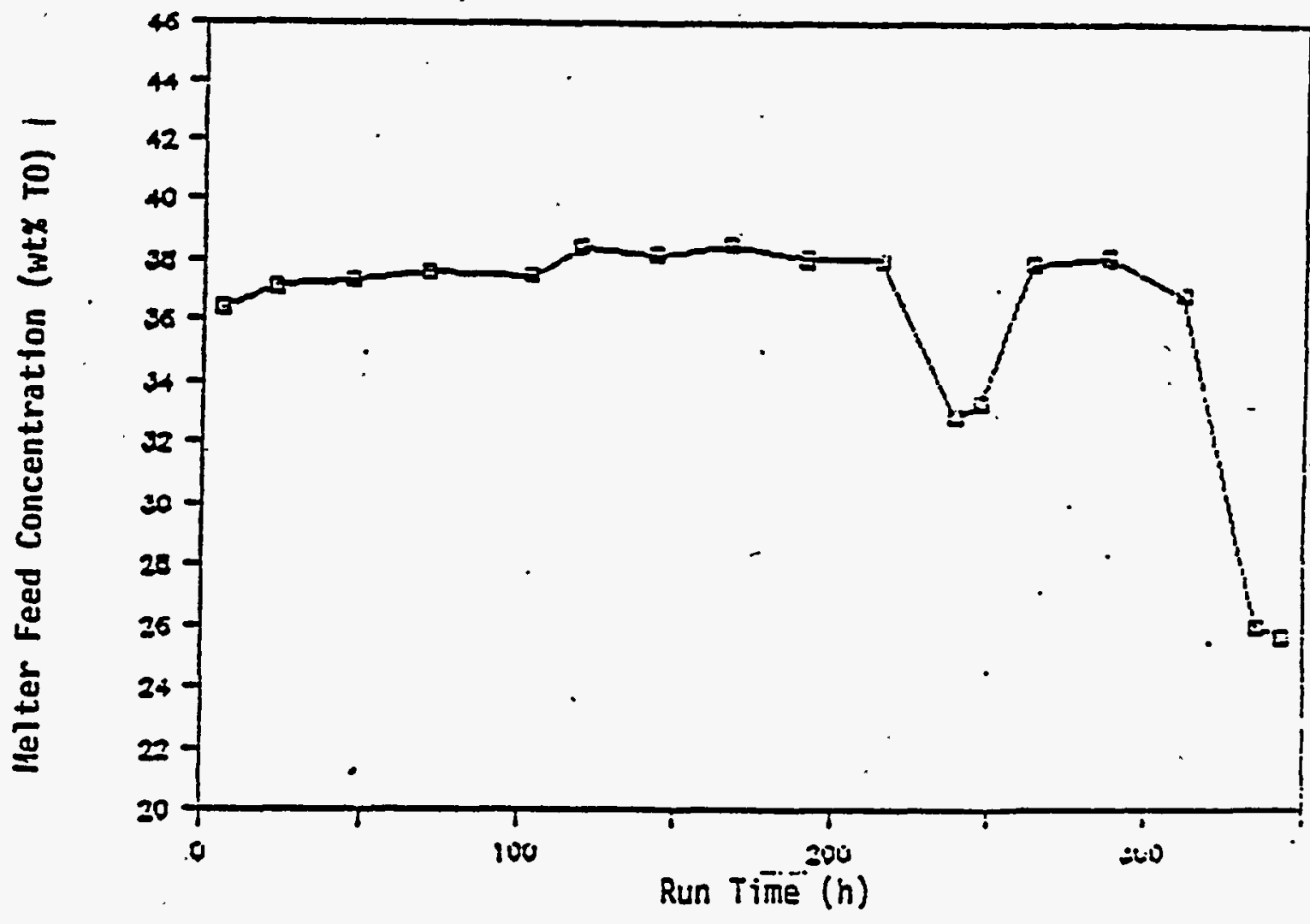

FIGURE 5.4-31. Total 0xide Concentration of PSCM-23 Melter Feed. Samples HWVP-89-IVJ0010100B

melter feed system.) The results of compositional analyses performed on five typical melter feed samples taken during the test are presented in Table 4.5-14. In general, the composition of the melter feed was consistent throughout the test and approximated the target composition for a majority of the individual feed components. A total of five samples taken during the glass pours were also sent for compositional analysis. The results of these analyses, as well as $\mathrm{Fe}^{+2} / \mathrm{Fe}^{+3}$ determinations, are presented in Table 4.5-15. Again, the steady-state composition of glass during the test was consistent and approximated the target composition.

The primary feed pump for the HWVP-15 test was a Moyno progressive cavity pump. In previous PSCM tests, the Moyno has been used as a backup for the ADS and has been operated for periods of weeks without failure. During the HWVP-15 test, however, excessive erosion between the stator and the rotor caused the pump to fail on two occasions. Initially, the Moyno was equipped with a butyl rubber stator. After approximately $73 \mathrm{~h}$ of operation, the pump was unable to deliver 
TABLE 4.5-14. Composition of Melter Feed Samples Taken During the HWVP-15 Test HWVP-89-IVJ0010100B

\begin{tabular}{|c|c|c|c|c|c|c|c|c|}
\hline Oxide & \multicolumn{5}{|c|}{ Individual Sample Conditions $(g / L)^{(e)}$} & Average & $\begin{array}{l}\text { Standard } \\
\text { Deviation }\end{array}$ & Target \\
\hline 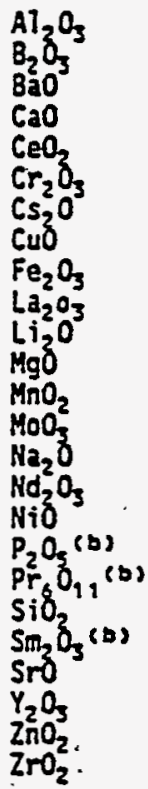 & $\begin{array}{r}11.64 \\
48.62 \\
0.49 \\
4.21 \\
0.61 \\
0.67 \\
0.81 \\
0.74 \\
32.31 \\
6.06 \\
17.33 \\
3.95 \\
0.85 \\
1.50 \\
53.92 \\
2.68 \\
2.75 \\
0.53 \\
0.53 \\
252.42 \\
0.26 \\
0.52 \\
0.27 \\
2.32 \\
18.37\end{array}$ & $\begin{array}{r}12.07 \\
50.23 \\
0.50 \\
4.32 \\
0.68 \\
0.69 \\
0.84 \\
0.75 \\
33.17 \\
6.27 \\
17.78 \\
4.13 \\
0.89 \\
1.56 \\
53.78 \\
3.14 \\
2.85 \\
0.53 \\
0.53 \\
260.98 \\
0.26 \\
0.53 \\
0.28 \\
2.38 \\
18.51\end{array}$ & $\begin{array}{r}12.38 \\
51.20 \\
0.52 \\
4.43 \\
0.70 \\
0.70 \\
0.83 \\
0.81 \\
34.03 \\
6.38 \\
18.21 \\
4.21 \\
0.89 \\
1.59 \\
55.40 \\
2.99 \\
2.96 \\
0.53 \\
0.53 \\
275.95 \\
0.26 \\
0.53 \\
0.28 \\
2.44 \\
18.91\end{array}$ & $\begin{array}{r}12.83 \\
53.13 \\
0.54 \\
4.56 \\
0.70 \\
0.72 \\
0.85 \\
0.79 \\
35.17 \\
6.53 \\
18.97 \\
4.31 \\
0.92 \\
1.64 \\
56.21 \\
3.09 \\
2.98 \\
0.53 \\
0.53 \\
275.95 \\
0.26 \\
0.56 \\
0.29 \\
2.51 \\
19.45\end{array}$ & $\begin{array}{r}12.87 \\
50.56 \\
0.52 \\
4.46 \\
0.74 \\
0.72 \\
0.85 \\
0.78 \\
34.60 \\
6.39 \\
17.91 \\
4.25 \\
0.92 \\
1.61 \\
55.40 \\
2.85 \\
2.95 \\
0.53 \\
0.53 \\
269.53 \\
0.26 \\
0.54 \\
0.28 \\
2.49 \\
19.05\end{array}$ & $\begin{array}{r}12.36 \\
50.75 \\
0.52 \\
4.40 \\
-0.69 \\
0.70 \\
0.83 \\
0.77 \\
33.86 \\
6.33 \\
18.04 \\
4.17 \\
0.89 \\
1.58 \\
54.94 \\
2.95 \\
2.90 \\
0.53 \\
0.53 \\
266.97 \\
0.26 \\
0.54 \\
0.28 \\
2.43 \\
18.86\end{array}$ & $\begin{array}{l}0.46 \\
1.46 \\
0.02 \\
0.12 \\
0.04 \\
0.02 \\
0.02 \\
0.03 \\
1.02 \\
0.16 \\
0.54 \\
0.13 \\
0.02 \\
0.05 \\
0.94 \\
0.17 \\
0.09 \\
0.00 \\
0.00 \\
9.12 \\
0.00 \\
0.01 \\
0.01 \\
0.07 \\
0.39\end{array}$ & $\begin{array}{r}11.84 \\
52.63 \\
0.53 \\
4.14 \\
0.79 \\
0.66 \\
0.79 \\
0.79 \\
36.85 \\
6.44 \\
18.75 \\
4.21 \\
0.79 \\
1.58 \\
56.78 \\
3.35 \\
3.03 \\
0.53 \\
0.53 \\
267.76 \\
0.26 \\
0.53 \\
0.26 \\
2.50 \\
19.74\end{array}$ \\
\hline $\begin{array}{l}\mathrm{Cl} \\
\mathrm{F} \\
\mathrm{SO}_{6} \\
\mathrm{NO}_{3}\end{array}$ & $\begin{array}{r}0.58 \\
1.23 \\
0.98 \\
35 \\
\end{array}$ & $\begin{array}{r}0.59 \\
1.33 \\
0.98 \\
36 \\
\end{array}$ & $\begin{array}{r}0.55 \\
0.61 \\
1.00 \\
37 \\
\end{array}$ & $\begin{array}{r}0.54 \\
1.22 \\
0.99 \\
37 \\
\end{array}$ & $\begin{array}{r}0.55 \\
1.16 \\
1.00 \\
37 \\
\end{array}$ & $\begin{array}{r}0.56 \\
1.11 \\
0.99 \\
36.4 \\
\end{array}$ & $\begin{array}{l}0.02 \\
0.26 \\
0.01 \\
0.8 \\
\end{array}$ & $\begin{array}{r}0.38 \\
1.50 \\
2.70 \\
35.0 \\
\end{array}$ \\
\hline Total(e) & 478.6 & 496.3 & 518.4 & 515.9 & 507.9 & 503.4 & 14.6 : & $50.6(d)$ \\
\hline
\end{tabular}

(a) Samples were collected after $23,71,119,167$, and $263 \mathrm{~h}$ of peration.

(b). Analyses did not include these compounds. values reported are target values.

(c) Total oxide concentration value was determined by oxide burn.

(d) Concentration of $\mathrm{NO}_{3}$ is not included in total oxide value.

the required feed rate while operating at full speed. The pump was removed from service and the stator was replaced with one made of Viton. Once placed back online, the Moyno operated for approximateiy $102 \mathrm{~h}$ before failing. The Moyno failed due to erosion of the stator material. During periods of the test when the Moyno was out of service, the ADS pump was used. . This pump operated well during $176 h$ of operation with no incidence of plugging in the pump chamber being observed.

The majority of downtime during the test was associated with plugs in the feed delivery systen (see Table 4.5-16). There appeared to be a tendency for frit to accumulate in the feedline just above the feed nozzle. On the average, 
TABLE 4.5-15. Composition of Melter Glass Samples Taken During the HWVP-15 Test HWVP-89-IVJ0010100B

\begin{tabular}{|c|c|c|c|c|c|c|c|c|c|}
\hline Oxide & \multicolumn{5}{|c|}{ Individual Sample Compositions $(\mathrm{g} / \mathrm{L})^{(s)}$} & Average & $\begin{array}{l}\text { Standard } \\
\text { Deviation }\end{array}$ & Average & Target \\
\hline 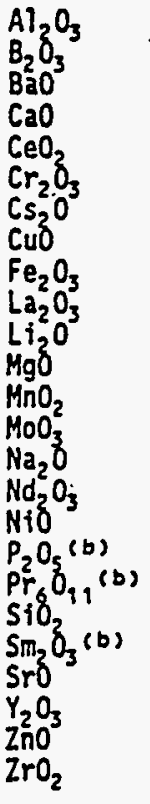 & $\begin{array}{r}2.69 \\
9.98 \\
0.09 \\
1.12 \\
0.15 \\
0.15 \\
0.16 \\
0.13 \\
7.03 \\
1.13 \\
3.48 \\
0.86 \\
0.17 \\
0.28 \\
9.92 \\
0.53 \\
0.52 \\
0.10 \\
0.10 \\
52.80 \\
0.05 \\
0.09 \\
0.05 \\
0.43 \\
3.08 \\
\end{array}$ & $\begin{array}{r}2.52 \\
9.94 \\
0.10 \\
0.90 \\
0.16 \\
0.16 \\
0.17 \\
0.15 \\
6.74 \\
1.26 \\
3.52 \\
0.83 \\
0.18 \\
0.31 \\
10.20 \\
0.60 \\
0.58 \\
0.10 \\
0.10 \\
52.40 \\
0.05 \\
0.10 \\
0.06 \\
0.48 \\
3.56 \\
\end{array}$ & $\begin{array}{r}2.52 \\
10.00 \\
0.10 \\
0.87 \\
0.15 \\
0.16 \\
0.16 \\
0.15 \\
6.71 \\
1.26 \\
3.54 \\
0.82 \\
0.17 \\
0.31 \\
10.20 \\
0.60 \\
0.58 \\
0.10 \\
0.10 \\
52.40 \\
0.05 \\
0.10 \\
0.06 \\
0.48 \\
3.62 \\
\end{array}$ & $\begin{array}{r}2.64 \\
9.74 \\
0.11 \\
0.87 \\
0.17 \\
0.17 \\
0.18 \\
0.16 \\
7.01 \\
1.33 \\
3.45 \\
0.82 \\
0.19 \\
0.32 \\
10.40 \\
0.61 \\
0.60 \\
0.10 \\
0.10 \\
51.20 \\
0.05 \\
0.11 \\
0.06 \\
0.51 \\
3.82 \\
\end{array}$ & $\begin{array}{r}2.55 \\
9.90 \\
0.10 \\
0.88 \\
0.17 \\
0.16 \\
0.16 \\
0.15 \\
6.78 \\
1.29 \\
3.44 \\
0.83 \\
0.18 \\
0.30 \\
10.30 \\
0.56 \\
0.60 \\
0.10 \\
0.10 \\
52.30 \\
0.05 \\
0.11 \\
0.06 \\
0.49 \\
3.76 \\
\end{array}$ & $\begin{array}{r}2.58 \\
9.91 \\
0.10 \\
0.93 \\
0.16 \\
0.16 \\
0.17 \\
0.15 \\
6.85 \\
1.25 \\
3.49 \\
0.83 \\
0.18 \\
0.30 \\
10.20 \\
0.58 \\
0.58 \\
0.10 \\
0.10 \\
52.22 \\
0.05 \\
0.10 \\
0.05 \\
0.48 \\
3.57 \\
\end{array}$ & $\begin{array}{l}0.07 \\
0.09 \\
0.01 \\
0.10 \\
0.01 \\
0.01 \\
0.01 \\
0.01 \\
0.14 \\
0.07 \\
0.04 \\
0.02 \\
0.01 \\
0.02 \\
0.16 \\
0.03 \\
0.03 \\
0.00 \\
0.00 \\
0.54 \\
0.00 \\
0.01 \\
0.00 \\
0.03 \\
0.26 \\
\end{array}$ & $\begin{array}{r}2.69 \\
10.34 \\
0.10 \\
0.97 \\
0.17 \\
0.16 \\
0.17 \\
0.15 \\
7.15 \\
1.31 \\
3.64 \\
0.87 \\
0.18 \\
0.32 \\
10.64 \\
0.61 \\
0.60 \\
0.10 \\
0.10 \\
54.45 \\
0.05 \\
0.11 \\
0.06 \\
0.50 \\
3.72 \\
\end{array}$ & $\begin{array}{r}2.36 \\
10.53 \\
0.10 \\
0.83 \\
0.16 \\
0.13 \\
0.16 \\
0.16 \\
7.36 \\
1.29 \\
3.75 \\
0.84 \\
0.16 \\
0.31 \\
11.35 \\
0.67 \\
0.61 \\
0.10 \\
0.10 \\
53.55 \\
0.05 \\
0.10 \\
0.05 \\
0.50 \\
3.94\end{array}$ \\
\hline Total & 95.09 & 95.15 & 95.20 & 94.69 & 95.33 & 95.09 & 0.22 & 99.16 & 99.16 \\
\hline $\mathrm{Fe}^{+2} / \mathrm{Fe}^{+3}$ & 0.045 & 0.045 & 0.055 & 0.049 & 0.056 & 0.050 & 0.005 & & \\
\hline
\end{tabular}

(a) Samples were collected after $72,142,216,287$, and $334 \mathrm{~h}$ of operation.

(b) Analyses did not include these compounds. Values reported are target values.

these accumulations occurred a little more than once per 24-h period and were generally removed by flushing the feedline with water. However, there were occasions when the feed pump had to be stopped and the feedline or the feed nozzle had to be manually cleared to remove the obstruction.

4.5.4.3 Reference Feed Variability. Due to the nonhomogeneous nature of the slurry stream and possible variations in front-end treatment processes, the composition of the reference feed entering the HWVP will vary during the processing life of the plant. The HWVP will be required to adequately adjust either the melter feed composition or the operational constraints of the process to generate an acceptable product. Technology development has been initiated to document the effects of reference feed variability on melter processing characteristics and glass product quality. Results of nonradioactive ceramic melter tests conducted in support of this issue are discussed in this section. 


\section{TABLE 4.5-16. Summary of HWVP Feeding Interruptions HWVP-89-IVJ0010100B}

\begin{tabular}{|c|c|c|c|}
\hline Dese & Iime oft & Iimen & eroblesuccuse \\
\hline $6 / 08 / 80$ & 1333 & 1337 & Peed stoppage (IIne plunged). \\
\hline 6/09/08 & 1130 & 1136 & Feed stoppage. \\
\hline $6 / 10 / 80^{\circ}$ & 0729 & MA & feed stoppege. \\
\hline 6/10/48 & 0800 & 0020 & Feed stoppege. \\
\hline $6 / 10 / 88$ & 1300 & MA & Feed stopped momentarily. \\
\hline $6 / 10 / 80$ & 1330 & 1338 & Beed line plugged. \\
\hline $6 / 10 / 20$ & 2000 & M & Feed off. \\
\hline $6 / 10 / 00$ & 2110 & ma & feed oft. \\
\hline $6 / 10 / 28$ & 2185 & ux & 65 inutes: \\
\hline $6 / 10 / 08$ & 2163 & MA & $=0$ \\
\hline & & 2215 & feed on. \\
\hline 8/11/as & & 0030 & \\
\hline $6 / 12 / 88$ & 2040 & 2055 & $\begin{array}{l}\text { feed line plugged (bulldep of trit at the } \\
\text { r- Junction ot the feed nozzle). }\end{array}$ \\
\hline $6 / 14 / 00$ & 1500 & & Feed IIne plugged up. \\
\hline 6/16/08 & 0127 & $\mathbf{M}$ & lost teed. \\
\hline
\end{tabular}

Feed IIIm was tluthed to the miter and out sho bull valve fwith the

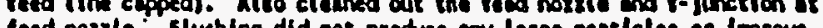

sultched to the ADS pusp from the Hoyno.

Air presaure to phep chmber was Increased for 3 aln to flush fend IIne, then returned pressure to 7.5 palg.

feed on and off for 425 ain. Blme pluse are suspected so pressure uas Increased pressure to feed chaber to 15 peig untll plus cleared.

Increased air pressure to $15 \mathrm{pel}$ ig and scrled unter tluch but nelther method cloared the lime. A polfod plug of feed was fand in the $Y$-junction at the teed nozzle. The feed nozzle was also cleaned out.

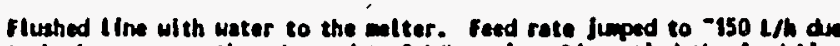
to buck pressure, then dropped to $0 \mathrm{~L} / \mathrm{h}$ agaln. Dlementled the feed line

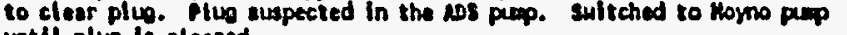

Moyno pupp uns turned off. Makino nolses.

Turned on 108 again. Feed rate ehot 4 over 100, then plugaed up again. LInes dicmantled to ctear plup.

Iried to start feod with AOS pup. Feed rate stert elimbed to over 100, then stopped.

Morno on and pumping feed to miter.

ADS teed purp beck in use.

sultched to Hoyno, lime still plugged. Clamed out feed lime sectlon between purp and melter. A bulldep in tlme near valve inear teod nozzle) was cleared out. Sultched beck to ADS pemp.

Flushed with water and an increased feed rate for a feu minutes.

Flushed the feed llne. 
TABLE 4.5-16. Summary of HWVP Feeding Interruptions (contd)

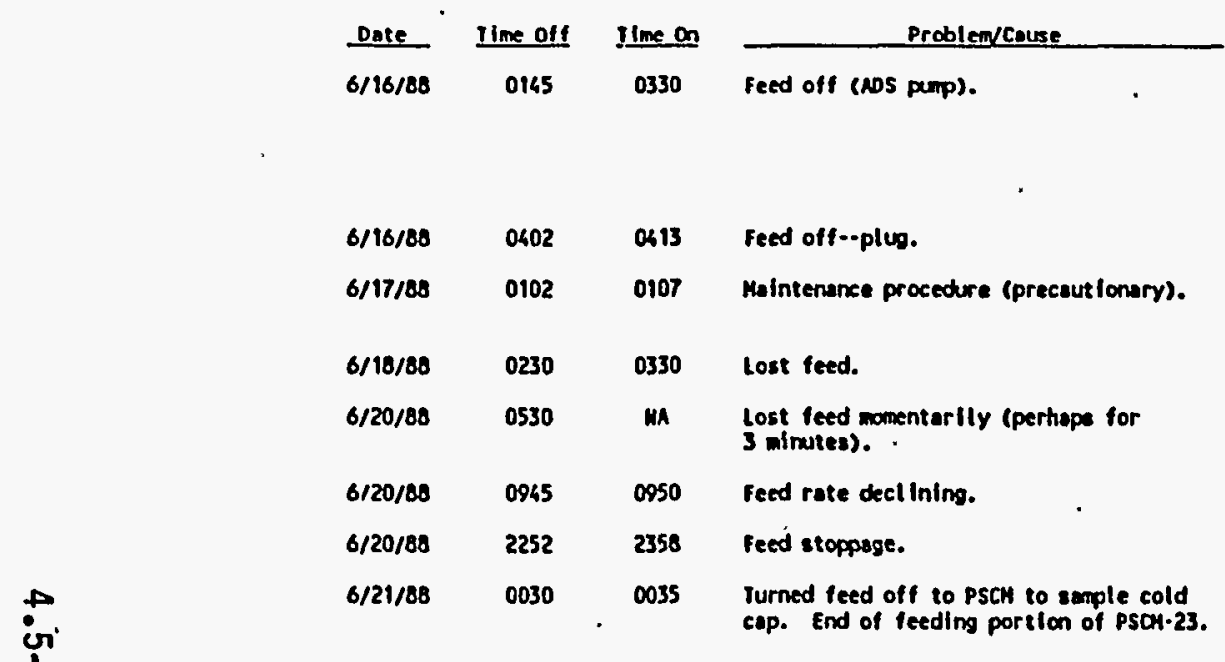

Responseccomments

Switched to Moyno. Deacheaded, tripped the breaker. Flustied both pumps, tried to flush feed line. Iried to rem nozzle, with rod, unsuccessful. Removed feed nozzle ind weed o drill to remove the plug. Hooked the teed line back up and found it uas plugged. Forced water

switched to Hoyro pump.

geroke line to inlet of feed perpo and added mater fluch for approximately 5 min.

feed nozzle was replaced. Insulated feed nozzle us plugged solid.

Moyno purp surned off. AOS pump plped in and tirned on. Lost flow on NoS. Moyno on line.

suitched back to NOS pump. 
4.5.4.3.1 Background. During FY 1986, statistically-designed scoping studies were conducted by the Waste Development subtask of the HWVP to establish the effects of reference feed compositional variability on current HWVP reference glass (HH39) properties.(a)

These studies: have identified the various elements within the NCAH reference feed that significantly affect the physical properties of the glass. Laboratory crucible tests were performed to establish the effects of independently varying the proportions. (wt\%) of $\mathrm{Na}_{2} \mathrm{O}, \mathrm{Fe}_{2} \mathrm{O}_{3}, \mathrm{Al}_{2} \mathrm{O}_{3}, \mathrm{Al}_{2} \mathrm{O}_{3}, \mathrm{SiO}_{2}, \mathrm{Cr}_{2} \mathrm{O}_{3}, \mathrm{ZrO}_{2}$ ? and $\mathrm{RE}_{2} \mathrm{O}_{3}$ on glass properties. Melt viscosity, electrical conductivity, phase behavior, and leach rate were determined for each melt. Laboratory test compositions were selected statistically to provide the required information with the fewest number of melts. Experimental data was used to generate predictive linear models for glass properties as a function of composition.

4.5.4.3.2 Resuits of Melter Tests. A 150-h engineering-scale experiment, HWVP-14, was conducted in the high-bay ceramic melter during FY 1986. The test was designed to address reference feed variability by evaluating the processing characteristics of three melter feed compositions. Compositions were selected for testing based on trends established as a result of aging waste tank samples obtained during FY 1985 and FY 1986 and the results of scoping studies performed by the Waste Form Deyelopment subtask. The scoping studies identified high-Na, low-Fe, and high-Zr compositions as having a propensity for affecting melter operation. Processing characteristics evaluated for each melter feed composition. included cold-cap characteristics (flexibility, thickness, venting ability, and coverage), formation of a secondary phase on the glass surface, melter feed rheology, and processing rate.

The three melter feed compositions selected: for testing during HWVP-14 were a high-Na case (13.2 $\mathrm{wt}^{\mathrm{N}} \mathrm{Na}_{2} \mathrm{O}$ in glass), a low-iron case (5.5 wt\% $\mathrm{Fe}_{2} \mathrm{O}_{3}$ in glass), and a high- $\mathrm{Zr}$ case ( $10.0 \mathrm{wt \%} \mathrm{ZrO}_{2}$ in glass). Target compositions for these feeds are presented in Table 4.5-17.

During HWVP-14, approximately $2500 \mathrm{~L}$ of simulated HLH melter feed was processed, generating almost $1150 \mathrm{~kg}$ of glass. A processing summary of the test, by segment, is presented in Table 4.5-18.

In comparison with previous HWVP melter experiments (HWVP-11, HWVP-12, and HWVP-13), the processing characteristics of HWVP-14 melter feeds were acceptable. Cold cap coverage, thickness, flexibility, and venting exhibited by the three melter feeds were essentially identical to similar characteristics

(a) S. 0. Bates and W. M. Bowen, Report on Composition Variability Testing Conducted for the HWVP, Interim Milestone HWVP-86-V1122C, Pacific Northwest Laboratory, Richland, Washington (1986). 
TABLE 4.5-17. Melter Feed Compositions Tested During HWVP-14

\begin{tabular}{|c|c|c|c|}
\hline $\begin{array}{l}\text { Assumed } \\
\text { Oxide }\end{array}$ & $\begin{array}{l}\text { High } \\
\text { Sodium }\end{array}$ & Low Iron & $\begin{array}{c}\text { High } \\
\text { Zirconium }\end{array}$ \\
\hline $\begin{array}{l}\mathrm{Al}_{2} \mathrm{O}_{3} \\
\mathrm{BaSO}_{4} \\
\mathrm{CaO} \\
\mathrm{CeO}_{2} \\
\mathrm{Cr}_{2} \mathrm{O}_{3}\end{array}$ & $\begin{array}{l}4.00 \\
0.10 \\
2.88 \\
0.17 \\
0.11\end{array}$ & $\begin{array}{l}6.66 \\
0.16 \\
2.93 \\
0.28 \\
0.19\end{array}$ & $\begin{array}{l}2.79 \\
0.16 \\
2.86 \\
0.12 \\
0.08\end{array}$ \\
\hline $\begin{array}{l}\mathrm{Cs}_{2} \mathrm{O} \\
\mathrm{CuO} \\
\mathrm{Fe}_{2} \mathrm{O}_{3} \\
\mathrm{MgO} \\
\mathrm{MnO}_{2}\end{array}$ & $\begin{array}{r}0.23 \\
0.14 \\
10.30 \\
0.82 \\
0.17\end{array}$ & $\begin{array}{l}0.38 \\
0.24 \\
5.50 \\
0.87 \\
0.28\end{array}$ & $\begin{array}{l}0.16 \\
0.10 \\
7.20 \\
0.80 \\
0.12\end{array}$ \\
\hline $\begin{array}{l}\mathrm{MoO}_{3} \\
\mathrm{Na}_{2} \mathrm{O} \\
\mathrm{NiO} \text { ('a) } \\
\mathrm{Pr}_{6} \mathrm{O}_{11} \text { (a) } \\
\mathrm{SiO}_{2}\end{array}$ & $\begin{array}{r}0.28 \\
13.20 \\
0.55 \\
0.10 \\
51.14\end{array}$ & $\begin{array}{r}0.47 \\
11.85 \\
0.82 \\
0.16 \\
51.61\end{array}$ & $\begin{array}{r}0.12 \\
9.44 \\
0.39 \\
0.07 \\
50.93\end{array}$ \\
\hline $\begin{array}{l}\mathrm{Sm}_{2} \mathrm{O}_{3}(\mathrm{a}) \\
\mathrm{SrO} \\
\mathrm{Y}_{2} \mathrm{O}_{3}(\mathrm{a}) \\
\mathrm{ZrO}_{2} \\
\mathrm{La}_{2} \mathrm{O}_{3} \\
\mathrm{Nd}_{2} \mathrm{O}_{3}\end{array}$ & $\begin{array}{l}0.04 \\
0.10 \\
0.04 \\
0.55 \\
0.51 \\
0.49\end{array}$ & $\begin{array}{l}0.07 \\
0.16 \\
0.07 \\
0.92 \\
0.85 \\
0.92\end{array}$ & $\begin{array}{r}0.02 \\
0.07 \\
0.02 \\
10.00 \\
0.36 \\
0.34\end{array}$ \\
\hline $\begin{array}{l}\mathrm{F}-(\mathrm{a}) \\
\mathrm{SO}_{3}(\mathrm{a}) \\
\mathrm{B}_{2} \mathrm{O}_{3} \\
\mathrm{Li}_{2} \mathrm{O} \\
\mathrm{NO}_{3}\end{array}$ & $\begin{array}{l}0.28 \\
0.35 \\
9.56 \\
3.75 \\
4.99\end{array}$ & $\begin{array}{l}0.47 \\
0.59 \\
9.56 \\
3.75 \\
3.77\end{array}$ & $\begin{array}{l}0.20 \\
0.25 \\
9.56 \\
3.75 \\
1.58\end{array}$ \\
\hline
\end{tabular}

(a) Not analyzed for; value given is target value. 
TABLE 4.5-18. Processing Sumnary for HWVP-14

\begin{tabular}{|l|c|c|c|c|}
\hline \multicolumn{1}{|c|}{ Segment } & $\begin{array}{c}\text { Duration } \\
(\mathrm{h})\end{array}$ & $\begin{array}{c}\text { Liters } \\
\text { Processed }\end{array}$ & $\begin{array}{c}\text { Feed Rate } \\
(\mathrm{L} / \mathrm{h})\end{array}$ & $\begin{array}{c}\text { Feed Rate } \\
\left(\mathrm{L} / \mathrm{h} \cdot \mathrm{m}^{2}\right)\end{array}$ \\
\hline High Sodium & 62 & 1090 & 22.3 & 89.2 \\
Low Iron & 71 & 1170 & 15.3 & 61.2 \\
High Zirconium & 15 & 250 & 20.1 & 80.4 \\
\hline
\end{tabular}

observed in previous HWVP meiter tests. During HWVP-14, cold cap coverage was slowly increased to approximately $80 \%$. and the associated feed rate was maintained. No effort was made to increase the feed rate to maintain the $80 \%$ coverage. Instead, the emphasis was to allow the melter to cycle without interference and maintain a constant feed rate.

For the high-Na and high-Zr segments of the test, feed rates established were higher than experienced during HWVP-13 for the $500 \mathrm{~g}$ TO/L feed, maximum feed rate. For the low-Fe segment, the feed rate maintained was only $10 \%$ lower than the nominal rate for the $500 \mathrm{~g}$ TO/L segment of HWVP-13 and approximated the current reference maximum fed rate $\left(60 \mathrm{~L} / \mathrm{h} \mathrm{m}^{2}\right)$. Average cold cap coverage was 58\% for the high-Na segment, $68 \%$ for the low-Fe segment, and $77 \%$ for the high-Zr segment.

Due to the shortened duration of the high $\mathrm{Zr}$ segment, the feed rate reported in Table 4.5-18 may be questionable. During this segment, only a $56 \%$ to $65 \%$ turnover of glass had been reached when the test was terminated. Based on the fact that the feed rate was reduced substantially during the final $3 \mathrm{~h}$ of the segment, the actual steady-state feed rate may not have been achieved. It appears that as the composition of the melter glass began to approximate the high-Zr composition; the ability of the system to process at the high initial rate diminished. At approximately $12 \mathrm{~h}$ into the segment, the cold cap increased in thickness from $2.5 \mathrm{~cm}$ to $6.4 \mathrm{~cm}$, decreasing flexibility and venting. Reductions in feed rate were necessary to relieve this condition. Actual feed rates needed to maintain stable operation were more in the range of 15 to $17 \mathrm{~L} / \mathrm{h}\left(60\right.$ to $\left.70 \mathrm{~L} / \mathrm{h} \mathrm{m^{2 }}\right)$.

The three melter feeds processed during HWVP-14 had $\mathrm{Cr}_{2} \mathrm{O}_{3}$ concentrations that were approximately an order of magnitude lower than the current reference composition ( $<0.2 \mathrm{wt} \% \mathrm{Cr}_{2} \mathrm{O}_{3}$ in glass). This was done to prevent a chromecontaining phase from forming in the glass. Optical microscopic evaluation of thin sections of the glasses produced from the three HWVP-1.4 melter feeds found no chrome-containing phases. 
4.5.4.4 Formation and Settling of Chromite Spinel Crystal. Extensive chromite spinel formation has been observed in glasses produced during HWVP melter tests conducted prior to HWVP-14. The chrome oxide concentration in the melter feeds processed during these tests was the reference value of $1.33 \mathrm{wt} \%$. At this level, the solubility limit for chrome oxide in HW39 glass was exceeded by approximately $166 \%$. These tests confirmed laboratory results and showed that the spinel crystals formed and agglomerated in the cold cap region during processing. Experiments with spinel crystal formation and settling during HWVP melter experiments is outlined in this section.

4.5.4.4.1 Background. Chromite spinel crystal formation was first .observed during HW39-1 reference glass development work. Reference glass compositions were batched in the laboratory from oxide compounds and melted in a crucible furnace. Optical examination of thin sections revealed detectable crystallinity in the as-melted and heat-treated glass samples. The crystal phase present in the laboratory glasses was identified as chromic spinel ( $\mathrm{FeCr}_{2} \mathrm{O}_{3}$ ) using scanning electron microscopy/energy-dispersive $x$-ray (SEM/EDX). The average size of the crystals was $8 \mu \mathrm{m}$. A second $\mathrm{Cr}$ phase was observed in laboratory produced glasses that had been exposed to temperatures near or above $2282^{\circ} \mathrm{F}\left(1250^{\circ} \mathrm{C}\right)$. This phase was identified as hexagonal platelets of $\mathrm{Cr}_{2} \mathrm{O}_{3}$. As expected, the formation of crystal phases in HW39-1 glass was due to the fact that the $\mathrm{Cr}_{2} \mathrm{O}_{3}$ reference concentration was in excess of solubility limits.

4 5.4.4.2 Melter Tests. Melter feeds containing the reference concentration of chrome oxide (1.33 wt\% $\mathrm{Cr}_{2} \mathrm{O}_{3}$ in glass) were processed during HWVP-11, HWVP-12, and HWVP-13. Spinel crystal formation was observed in glass samples collected during each of these experiments.

4.5.4.4.2.1 HWVP-11. Selected glass samples taken during HWVP-11 batch pours were thin-sectioned, polished, and examined optically and by SEM/EDX. Analyses revealed that chromic spinel crystals were present in the glass in approximately the same volume percent as. found in laboratory glasses ( 1 to 4 vol\%). Individual spinel crystals ranged in size from $5 \mu \mathrm{m}$ to $20 \mu \mathrm{m}$. Cold cap samples taken during the run showed that the crystals formed and agglomerated in this region. The average size of the agglomerations was approximately $50 \mu \mathrm{m}$. Because of the short duration of the test and the limited number of feed and glass samples analyzed, no attempt was made to determine if. crystal settling had occurred during the experiment.

4.5.4.4.2.2 HWVP-12. The extent of chromite and spinel formation and settling was studied using glass samples and mass balance calculations. Glass samples were obtained from the settling boat, bulk glass tank samples and overflow product glass. 
An Inconel 690 glass collection boat was placed on the melter floor prior to the test. The boat had two chambers. The first chamber was recovered after eight days of testing. The second chamber could not be covered at the end of the experiment because of a failed guide rod, and the data was lost. A crosssection sample of the boat glass was obtained and examined optically and by SEM/EDX analysis. The top $2 \mathrm{~cm}$ of the glass sample had only a very few agglomerated crystals. This glass had a $\mathrm{Cr}_{2} \mathrm{O}_{3}$ content of $0.52 \mathrm{wt} \%$, which is approximately the solubility limit of $\mathrm{Cr}_{2} \mathrm{O}_{3}$ in HW39 glass. The $\mathrm{Cr}_{2} \mathrm{O}_{3}$ concentration in the bottom $2.5 \mathrm{~cm}$ of the sample was $18.3 \mathrm{wt} \%$. The crystal phase was estimated to be 19 vol\%. The crystals were again agglomerated and had crystal diameters ip to $80 \mu \mathrm{m}$.

The bulk tank glass samples provided a vertical core of the tank glass composition. the samples contained a significant amount of crystalline material. In all but the bottom $1.8 \mathrm{~cm}$ of the core, the amount and types of crystalline material resembled the phases observed in the output glass. The bottom $1.8 \mathrm{~cm}$ of the core contained a settled layer of material of much greater density than that of the upper portion of the core.

Evaluation of the day-to-day feed and glass analyses indicated that although the average feed content of $\mathrm{Cr}_{2} \mathrm{O}_{3}$ was $1.30 \mathrm{wt}$, the average glass $\mathrm{Cr}_{2} \mathrm{O}_{3}$ content was only 1.18 wt\%. Of this $9.1 \%$ difference, analytical error was estimated to account for approximately $4 \%$. Therefore, approximately $5 \%$, or $4.6 \mathrm{~kg}$, of the $\mathrm{Cr}_{2} \mathrm{O}_{3}$ introduced during the run remained in the melter. Assuming a 19 vol\% of crystals, based upon the boat analyses, the sludge thickness formed during the experiment would be approximately $1 \mathrm{~cm}$.

Mass balance, melter core samples, and settling boat analyses indicate that a measurable amount of settling of chrome spinels occurred during melter processing of the HWVP composition. It is not known whether the layer will reach a steady-state thickness resulting from melter convection currents or continue to accumulate over time. Based on the measured and calculated thicknesses as spinels, settling can be expected to continue in stagnant regions. In the well-mixed areas of the tank, the extent of settling cannot. be quantified without further study. Should settling continue under long-term processing conditions, the operational life of the melter could be unacceptably shortened.

4.5.4.4.2.3 HWVP-13. A stainless steel glass collection boat $(4.5 \mathrm{~cm}$ by $4.5 \mathrm{~cm}$ dia.) was placed on the floor of the HBCM at the start of the HWVP-13 test. The top of the boat was open during the test to allow the collection of any settling crystalline phases. At the end of the run, the boat was removed from the melter. The boat was sectioned vertically in the laboratory to determine the amount of settling that occurred during the test. 
Crystalline material was found throughout the glass in the boat. Near the top of the boat, the hexagonal chromic oxide $\left(\mathrm{Cr}_{2} \mathrm{O}_{3}\right)$ crystals were the predominant phase, with few spinel crystals present. This crystal type has been observed in previous melter tests and is associated with operating conditions where the glass temperature approaches or exceeds $2190^{\circ} \mathrm{F}\left(1200^{\circ} \mathrm{C}\right)$. Individual hexagonal crystals were 50 to $100 \mu \mathrm{m}$ in diameter. Agglomerates of these crystals as large as $300 \mu \mathrm{m}$ across were more common nearer the bottom of the boat. Also, the gross amount of crystals increased nearer the bottom of the boat. In this region, crystals were predominantly agglomerated chromite spinel crystals. Although no distinct interface of a "settled layer" was observed, the increase in the amount of crystalline material toward the bottom of the boat indicates that some settling was occurring in the boat during the experiment.

During HWVP-13, giass samples were taken from each batch pour during the run. FolTowing completion of the run, samples were taken from the cold cap and me1t cavity. As was expected, the glass product for HWVP-13 was very similar to the glass produced during melter experiments in FY 1985 (Ref. 4.5-1).

Glass pour samples were examined qualitatively. Visually, the glass appeared identical to glasses produced during HWVP-12. Large chromite spinel crystal agglomerations were numerous and easily distinguishable.

The cold-cap sample was examined optically and by SEM/EDX. Results of analyses showed that the cold cap was approximately 50 vol\% crystalline in nature. The overall composition of the cold cap (both the crystalline and the vitreous phases) was the same as the reference composition. The crystalline phase was a $\mathrm{Ca}-\mathrm{Fe}-\mathrm{Cr}$ silicate (a member of the pyroxene crystal family). Coldcap analyses of previous melter runs have not detected the pyroxene crystal phase. Its presence in the HWVP-13 cold-cap sample cannot be explained at this time. The pyroxenes have been shown to occur in HW39 glass when the glass is within a temperature range of 1060 to $2005^{\circ} \mathrm{F}\left(570\right.$ to $775^{\circ} \mathrm{C}$ ) for periods greater than $10 \mathrm{~h}(4.5-7)$. At $1650^{\circ} \mathrm{F}\left(900^{\circ} \mathrm{C}\right)$ the pyroxenes are melted into the glass. Although the crystals did not seen to impact processing and they have no longterm effects, their presence was not predicted based on previous experience.

A sample of the glass remaining in the melter cavity at the completion of HWVP-13 was obtained using a core sampler. The bottom of the core sample was found to contain a greater concentration of hexagonal crystals of $\mathrm{Cr}_{2} \mathrm{O}_{3}$ (relative to the bulk glass), individual cubic crystals of.chromite spinels, and large (up to $10 \mathrm{~mm}$ dia) agglomerations containing both hexagonal and spinel crystals. No pyroxene crystals were observed in the sample. This layer containing the high density of crystal phases, was approximately 4 to $6 \mathrm{~cm}$ thick and was larger than the settled layer observed in the settling boat. The amount of crystalline material in the core sample was much greater than that 
observed in the settling boat. The core would be expected to have sampled the entire settled layer on the floor of the melt tank. This sample would have included any settled material that was present prior to the start of the HWVP-13 experiment, as well as material deposited during HWVP-13.

4.5.4.4.2.4 HWVP-14. The $\mathrm{Cr}_{2} \mathrm{O}_{3}$ concentration in the three feeds processed during HWVP-14 and $\mathrm{Cr}_{2} \mathrm{O}_{3}$ concentrations were lower than 0.2 wt\%. The low $\mathrm{Cr}_{2} \mathrm{O}_{3}$ concentrations were intended to prevent a chrome-containing phase from forming in the glass. Opticat microscopic evaluation of thin sections of the glasses produced from the three feeds used in HWVP-14 found no chromecontaining phases. These results confirm that if the $\mathrm{Cr}_{2} \mathrm{O}_{3}$ content of the updated NCAW waste is reduced to approximately 0.2 wt\%, chrome crystalline phase settling will no longer be a problem.

4.5.4.4.2.5 HuVP-15. The optical analysis of PSCM-23 melter glass found no detectable crystalline phases in the glass. The lack of any observable crystalline phases compared to HWVP-12 glass samples is due to the $\mathrm{Cr}_{2} \mathrm{O}_{3}$ concentration in the HW39-4 glass composition ( $0.13 \mathrm{wt} \%)$ being below the solubility limit of -0.5 wt\% typical of these glasses. Glass from the HWVP -12 melter test had a significant amount of $\mathrm{Fe}-\mathrm{Cr}$ spinal due to the high $\mathrm{Cr}_{2} \mathrm{O}_{3}$ concentration in the glass $(-1.3 \mathrm{wt} \%)$. The cold cap sample provided from the HWVP-I5 test did have a small section with part of the cold cap/glass interface intact. There was crystalline material present which appeared to be calcinedbut-not-yet-melted feed with no observable segregation of the feed components.

4.5.4.5 Redox State of Melter Glass. (a) The redox state of nuclear waste glasses has been identified as an important parameter affecting processing in a joule-heated melter. Previous laboratory and melter testing has demonstrated that glass has a tendency to foam if oxidizing conditions exist in the glass melt. Generation of a foan layer on the surface of the glass creates a barrier to heat transfer between the cold cap and the glass and thereby limits processing efficiency. To prevent foaming, the glass melt is maintained in a siightiy reduced condition. The reference method for quantifying the redox state of melter glass is measurement of the ferrous-to-ferric ratio $\left(\mathrm{Fe}^{+2} / \mathrm{Fe}^{+3}\right)$.

4.5.4.5.1 Background. Previous experience at PNL has indicated that a ferrous-to-ferric ratio of 0.005 to 0.3 ensures a stable melt. If required, reducing agents are added to the feed slurry to adjust the redox state. The upper limit of ferrous-to-ferric ratio reflects the fact that under excessively reducing conditions, stable metals, in particular noble metals, will form in

(a) S. 0. Bates and W. M. Bowen, Report on Composition Variability Testing Conducted for the HWVP, Interim Milestone HWVP-85-V1122C, Pacific Northwest Laboratory (1986). 
the glass. These metals have the potential of settling on the melter fioor, forming a highly conductive layer, and shorting the melter electrodes.

Typically, additional reductant has been included in the preparation of melter feed to increase the ferrous-to-ferric ratio about 0.1 . During the course of HWVP melter testing, it has been shown that formic acid treatment of melter feed is sufficient to maintain reducing conditions in the glass melt. Experience with controlling the redox state of melter glass during HWVP testing is discussed in this section.

4.5.4.5.2 Melter Tests. During the course of HWVP melter testing, preparation of simulated HLW (reference feed) has included the addition of formic acid. This pretreatment has been incorporated in the HWVP flowsheet to improve the rheology of the feed stream. It has subsequently been shown that the formating step introduces sufficient reductant to maintain a reducing condition in the glass melt. Foaming has not been observed during any of the HWVP melter tests performed to date.

4.5.4.5.2.1 HWVP-11. The current reference feed composition was first processed in HWVP-11. During this and all subsequent tests, the preparation of reference feed included the addition of formic acid $(9.2 \mathrm{~g} / \mathrm{L})$. For HWWP-11, reference feed was batched using technical grade chemicals. The feed was then heated to between 194 and $203^{\circ} \mathrm{F}\left(90\right.$ and $95^{\circ} \mathrm{C}$ ), and formic acid was added.

Prior to the melter experiment, laboratory tests on simulated feeds prepared with laboratory chemicals indicated that approximately $6 \mathrm{~g} / \mathrm{L}$ sugar should be added to both the $100 \%$ frit feed and the $1 / 3$ frit--2/3 unreacted chemical feed to achieve a ferrous-to-ferric ratio in the range of 0.1 to 0.3 . To confim these results, laboratory tests using a bottom-heated crucible technique were repeated using samples of actual melter feed. These tests indicated that $3 \mathrm{~g} / \mathrm{L}$ and $4.5 \mathrm{~g} / \mathrm{h}$ sugar should be added to the $100 \%$ frit and to the $1 / 3$ frit-$2 / 3$ unreacted chemical feeds, respectively, for the desired redox response.

Selected glass samples taken during the run were analyzed for ferrous-toferric ratio. The steady-state ferrous-to-ferric ratio for the $100 \%$ frit segment of the test was approximately 0.04 . Although this value was outside the desired range, the redox state of the glass melt was sufficiently reducing to prevent foaming. The redox response of the melter glass during the $1 / 3$ frit-$2 / 3$ unreacted chemical segment rose from 0.04 to 0.26 . A steady-state value for ferrous-to-ferric ratio was not determined, because the redox potential was still increasing at the end of the run.

4.5.4.5.2.2 HWVP-12. This experiment was conducted to verify the processing characteristics of HWVP reference melter feed with glass formers added 
as $100 \%$ frit. The test was separated into two segments. Meiter feed processed during the test was identical for both segments with the exception of sugar $\cdots$ addition. During the first segment, $3.5 \mathrm{~g} / \mathrm{L}$ of sugar was added to the feed. Melter feed target ferrous-to-ferpic ratios for the two segments were 0.1 and 0.0 , respectively. The amount of sugar needed to produce the desired redox response was determined in the laboratory. Melter feed preparation for this test was similar to HWVP-11 with the exception of a heat treatment sequence following acid addition. The reference feed was heated from approximately 195 to $220^{\circ} \mathrm{F}\left(90^{\circ} \mathrm{C}\right.$ to $\left.100^{\circ} \mathrm{C}\right)$. This temperature was maintained for $2 \mathrm{~h}$ to ensure that all chemical reactions had reached equilibrium.

The average ferrous-to-ferric ratio determined from glass sampies taken during the first segment of the run was 0.16 . For the second segment, the average value was 0.015 .

An objective of the test was to evaluate the processing characteristics of the melter under oxidizing conditions. It was anticipated that removing the sugar from the feed would generate an oxidizing glass in the melter. Ferrousto-ferric ratios of the glass during the second segment of the test never fell below 0.01 . the formating step used during preparation of the reference feed introduced sufficient TOC to maintain a reducing glass in the melter. Based on the stability of the glass melt and the higher processing rates obtained during the second segment of the test, it was determined that additional reductant was no longer desirable (Section 4.5 .4 ).

4.5.4.5.2.3 HWVP-13. Melter feed was prepared in a manner similar to previous HWVP tests. A single batch of feed, with a target total oxide loading of $550 \mathrm{~g}$ TO/L was prepared. the formic acid additional sequence was conducted using the procedure followed during HWVP-12 with the amount of formic acid adjusted to reflect the increased total oxide concentration. Finally, the melter feed was diluted to the desired total oxide concentrations. Sugar was not included in any of the melter feeds.

Selected glass samples taken during each segmient of the test were analyzed for ferrous-to-ferric ratio. The results of these analyses showed that the ferrous-to-ferric ratio was $<0.01$ over the duration of the experiment. $\therefore$. Because no foaming incidents were observed during the run, it was assumed that the glass melt was maintained. in a reducing condition. Currently, there are no methods for identifying or quantifying an oxidizing melt.

4.5.4.5.2.4 HWVP-14. During HWVP-14, melter feeds with varying concentrations of referenced feed components. Were processed. Because the relative concentrations of species thought to be involved in the reaction with formic acid varied, the amount of formic acid used in the pretreatment sequence was 
adjusted to reflect the composition of each reference feed batch. Melter feed for each segment of the test was prepared separately. No additional reductant (sugar) was included in the preparation of these feeds.

For each segment of the test, a single sample was analyzed for redox potential. The results showed that the ferrous-to-ferric ratio was $<0.002$ for the high-Na melter feed, $<0.002$ for the $10 w-F e$ feed, and 0.011 for the high- $\mathrm{Zr}$ feed.

The high value for ferrous-to-ferric ratio for the high-Zr feed may have been due to the procedure followed during the formic acid treatment. Because of the small reference feed batch needed for each segment and the increased inefficiency of the preparation equipment, the heat treatment sequence of feed makeup was not accomplished. Also, zirconium hydroxide used in the simulated HLW was added to the reference feed batch following completion of the formic acid addition due to a late shipment of the chemical. The reference feed was batched [excluding the majority of the $\mathrm{Zr}(\mathrm{OH})_{4}$ ], and the temperature raised to approximately $205^{\circ} \mathrm{F}\left(95^{\circ} \mathrm{C}\right)$. Formic acid was added, and an attempt was made to raise the temperature to $212^{\circ} \mathrm{F}\left(100^{\circ} \mathrm{C}\right)$. Maximum temperature actually achieved was around $207^{\circ} \mathrm{F}\left(97^{\circ} \mathrm{C}\right)$, because of fouling on the steam coils in the feed makeup tank. Solids had built up on the upper coils during the batching of the high-Na and low-Fe feeds and thus reduced the heat transfer efficiency. The buildup of solids was attributed to the fact that the volume of the three feed batches was not sufficient to cover the upper coils. Solids were deposited on the hot surfaces of the coils during the formic acid addition and heat treatment procedures. Thus, the formic reactions may not have reached equilibrium and may have affected the redox potential of the melter feed.

As was the case in all previous HWVP melter experiments, no foaming incidents were observed during HWVP-14. The lower reporting limits for ferrousto-ferric ratio from this test were due to increased familiarity with the analytical procedure. No changes were made in the analytical methods used to determine ferrous-to-ferric ratio between HWVP-13 and HWVP-14.

The actual ferrous-to-ferric ratio needed to prevent forming in the melter has not been established for HWVP feeds. The values of ferrous-to-ferric ratios of glasses from HWVP-13 and HWVP-14 were below detection limits for the analytical method. At this time, no method has been identified for determining an oxidizing condition in the glass. Formic acid treatment of the reference feed has successfully been used to prevent foaming during all HWVP melter tests. The inclusion of additional reductant (sugar) in the feed stream has been shown to be unnecessary under normal conditions. 
4.5 4.5.2.5 uwiv-15: Effect of Nitrate on Melter Feed Redox Adjustment. See discussion in Section 4.3.4.3.3.

4.5.4.6 Glass Discharge System Performance for HWVP-15 Testing HWVP-89-IVJ0010100B. The glass discharge system consists. of a riser block, a trough and a discharge nozzle. The riser is monolithic monofrax $K-3$ block with a vertical riser for airlifting. The trough is an Inconel-690 block with a 2-in. hole drilled in to transport the glass over to the discharge nozzle. At the end of the trough is a machined pouring tip in the. shape of a "V." The trough also has a metal dam to prevent glass from migrating from the melting cavity or the joint between the riser block. and the trough block to the discharge nozzle. The trough is sloped down $20^{\circ}, 15^{\circ}$ more than in the previous PSCM design, so the trough would drain residual glass quickly from the trough. The discharge nozzle is an 8-in. pipe nozzle extending through the melter floor shell. The nozzle was connected to a 55-gal drum about $8 \mathrm{ft}$ below the glass pouring tip. Within the connection section, a 10.8-cm-1.D. ring was placed to simulate the opening in the reference HWVP canister. The overflow trough used during HWVP-15 is shown in Figure 4.5-32.

During HWVP-15, glass was periodically airlifted from the melter into the 55-gal drums. The quality of the glass stream associated with the new pour trough and pour tip was assessed by the ability of the glass stream to pour through the center of the ring placed above the opening of the receiving drum. The amount of deflection was determined visually and compared with the glass pouring rate. The glass pour rate was determined by a load cell underneath the receiving drum and the change in the resistance of the glass in the melt cavity. Three Type $K$ thermocouples, one each located in the trough section, the face section, and imbedded in the trough block were used to monitor the discharge section temperature. The nominal temperature of the trough block was established at about $1100^{\circ} \mathrm{C}$ during most of the experiment as shown in Table 4.5-19. The overflow temperature was maintained constant so that it would not be a variable in the glass pouring tests. The air flow rate for the airlift was also monitored during the glass pour to establish a relationship between the air flow rate, the submergence, and the glass pouring rate.

The calculated glass pouring rates using the PSCM glass level were adjusted for the glass produced during the pour, but the overall glass rates were lower than the glass pouring rates calculated using the drum scale. The differences are thought to be caused by errors in estimating the glass resistance and the glass volume of the meit tank. Overall, the glass pouring rates gave consistent values about $20 \%$ lower than the scale readings. The calculated glass pouring rates are shown in Table 4.5-19. 


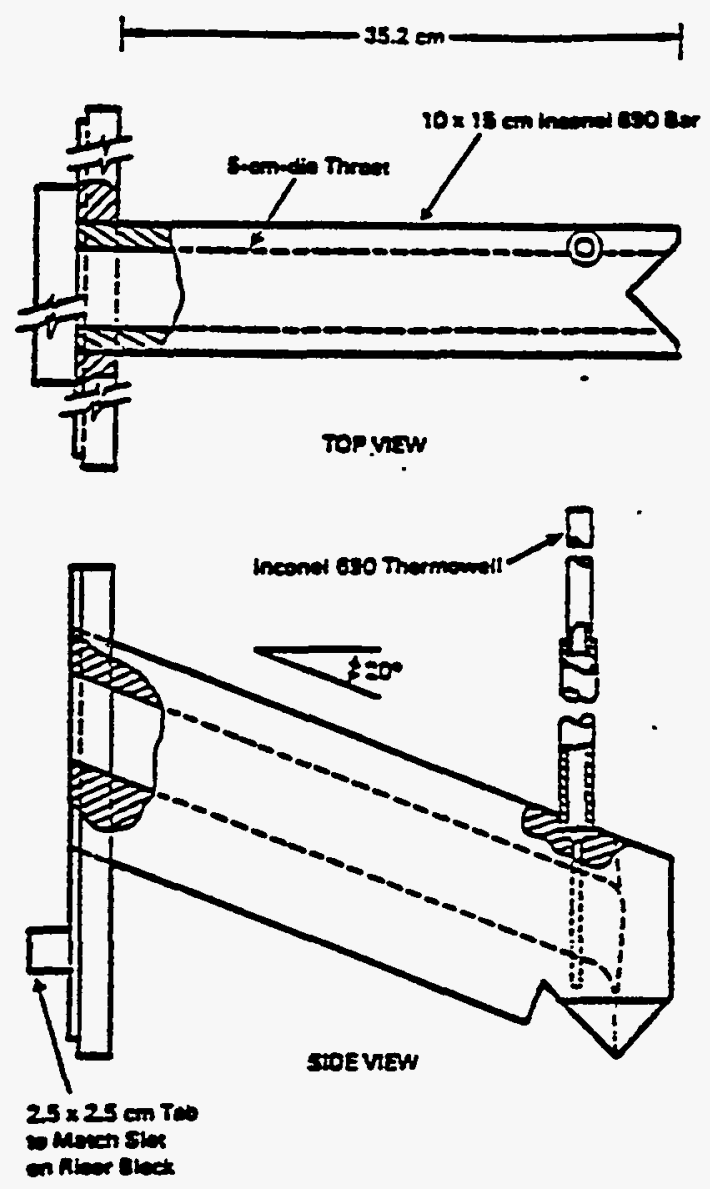

FIGURE 4.5-32. PSCM Modified Overflow Trough HWVP-89-IVJ0010100B

The glass pour rate varied during each glass pour period because of he change in submergence of the airlift with time. An airlift glass flow rate is based on the air flow rate, the submergence, the fluid channel size, and fluid viscosity. The channel size was fixed and the fluid viscosity was held fairly constant, so the glass flow rate was a function of the air flow rate and the submergence. The actual submergence of the airlift was not measured because the glass level sensors corroded after the first few days of the experiment. A pseudo submergence was calculated based on maximum glass resistance measured during the test and the glass resistance at the time of a pour. The accuracy of the air flow rates was about $\pm 20 \%$. The results of the data shown in Table 4.5-19 show the rapid decrease in glass flow rate with submergence. The data fit typical airlift fluid flow rates, which decrease exponentially with submergence. No correlation of air flow rate with glass flow rate could be 
- TABLE 4.5-19. HWVP-15 Glass Pouring Data HWVP-89-IVJ0010100B

\begin{tabular}{|c|c|c|c|c|c|c|c|c|c|}
\hline Day & Iime & $\begin{array}{l}\text { Ave.: } \\
\text { Glass } \\
\text { Temp. } \\
\text {-c. } \\
\end{array}$ & $\begin{array}{c}\text { Glass }(a) \\
\text { Tank } \\
\text { Res. } \\
n \\
\end{array}$ & $\begin{array}{c}\text { Air Fiow, } \\
\text { cth } \\
\end{array}$ & $\begin{array}{c}\text { Cardinal } \\
\text { Scale, } \\
\text { ka }\end{array}$ & $\begin{array}{c}\text { Stream } \\
\text { Deriect, } \\
\text { in. } \\
\end{array}$ & $\begin{array}{l}\text { Trough } \\
\text { Block } \\
\text { Teap., } \\
\\
\end{array}$ & $\begin{array}{c}\text { Measured (b) } \\
\text { Giass } \\
\text { Pouring } \\
\text { Rate kg/h }\end{array}$ & $\begin{array}{c}\text { Calculated (c) } \\
\text { Glass } \\
\text { Pouring } \\
\text { Rate. } \mathrm{kg} / \mathrm{h} \\
\end{array}$ \\
\hline \multirow[t]{7}{*}{$6 / 15$} & $11: 00$ & 1,163 & 0.1166 & 4 & 96 & & 1,683 & & \\
\hline & $11: 05$ & 1,158 & 0.118 & & 103 & & 1,086 & 84 & 105 \\
\hline & $11: 10$ & 1,156 & 0.1222 & & 145 & & 1,095 & 504 & 309 \\
\hline & $11: 17$ & 1,154 & 0.1253 & & 172 & & 1,098 & 231 & 159 \\
\hline & $11: 22$ & 1,149 & 0.1274 & & 187 & & 1,097 & 180 & .147 \\
\hline & $11: 28$ & 1,136 & 0.1292 & $\cdot$ & 203 & & 1.098 & 160 & 104 \\
\hline & & & & & OVERALL & 1 & & 229 & 177 \\
\hline \multirow[t]{6}{*}{$6 / 15$} & $14: 54$ & 1,158 & 0.1185 & 4 & 196 & - & 1,067 & & \\
\hline & $15: 00$ & 1,163 & 0.1215 & & 217 & & 1,080 & 210 & 184 \\
\hline & $15: 11$ & 1.162 & 0.1288 & & 266 & & 1,096 & 267 & 240 \\
\hline & $15: 24$ & 1,172 & 0.1325 & & 295 & & 1,096 & 134 & 100 \\
\hline & $15: 36$ & 1,171 & 0.1331 & & 299 & & 1.096 & 120 & 99 \\
\hline & & & & & OVERALL & 0 & & 193 & 166 \\
\hline \multirow[t]{7}{*}{$6 / 15$} & $19: 55$ & $1: 163$ & 0.118 & 4 & 298 & & 1,083 & & \\
\hline & $20: 00$ & 1,159 & 0.123 & & 330 & & 1,094 & 384 & 368 \\
\hline & 20:05 & 1,151 & 0.1262 & 4 & 357 & & 1,098 & 324 & 227 \\
\hline & $.20: 10$ & 1,156 & 0.1288 & & 372 & & 1,099 & 180 & 180 \\
\hline & $20: 15$ & 11,148 & 0.1308 & & 386 & & 1,099 & 168 & 136 \\
\hline & $20: 21$ & 1,139 & 0.1316 & & 398 & & 1.095 & 120 & 46 \\
\hline & & & & & OVERALL & & & 231 & 201 \\
\hline \multirow[t]{10}{*}{$6 / 16$} & $00: 25$ & 1,155 & 0.1205 & 1 & 417 & & 1,093 & & \\
\hline & $00: 30$ & 1,167 & 0.1212 & 1 & 425 & & 1,093 & 96 & 52 \\
\hline & $00: 35$ & 1,163 & 0.19218 & 1 & 432 & & 1,093 & 84 & 45 \\
\hline & $00: 40$ & 1,161 & $0 . i 224$ & 1 & 437 & & 1,093 & 60 & 44 \\
\hline & $00: 50$ & 1,161 & 0.1239 & 1.5 & 451 & MA & 1,094 & 84 & 56 \\
\hline & $00: 55$ & 1,160 & 0.1241 & 1.5 & 457 & & $.1,094$ & 72 & 16 \\
\hline & $01: 00$ & 1,155 & 0.1245 & 2 & 463 & & 1,094 & 72 & 30 \\
\hline & $01: 20$ & 1,169 & 0.1255 & 2 & 487 & & 1,094 & 72 & 24 \\
\hline & $01: 30$ & 1,157 & 0.1263 & 2 & 500 & & 1.095 & 78 & 31 \\
\hline & & & & & OVERALL & & & 77 & 55 \\
\hline \multirow[t]{5}{*}{$6 / 16$} & 07:32 & & 0.116 & 2.5 & 0 & & 1,085 & & \\
\hline & $07: 39$ & & 0.119 & $2: 5$ & 77 & & 1,093 & 660 & 162 \\
\hline & 07:44 & & 0.1196 & 1.5 & 94 & & 1,092 & 204 & 45 \\
\hline & 07:50 & & 0.121 & 0 & 102 & & 1.092 & 80 & 86 \\
\hline & & & & & OVERALL & 0.5 & & 340 & 110. \\
\hline
\end{tabular}

(a) Giass Tank Resistance measured in onas.

(b) Based on receiving drum scale weight readings.

(c) Based on glass tank electrical resistance readings. 


\section{TABLE 4.5-19. HWVP-15 Glass Pouring Data (contd)}

\begin{tabular}{|c|c|c|c|c|c|c|c|c|c|}
\hline Day & Iine & $\begin{array}{r}\text { Ave. } \\
\text { Glass } \\
\text { Temp. } \\
0 \\
\end{array}$ & $\begin{array}{c}\text { Glass(a) } \\
\text { Tank } \\
\text { Res. } \\
\Omega \\
\end{array}$ & $\begin{array}{l}\text { Air Flow, } \\
\text { cfh }\end{array}$ & $\begin{array}{c}\text { Cardinal } \\
\text { Scale, } \\
\mathrm{kg}\end{array}$ & $\begin{array}{c}\text { Stream } \\
\text { Oeflect, } \\
\text { in. } \\
\end{array}$ & $\begin{array}{l}\text { Trough } \\
\text { Block } \\
\text { Temp. , } \\
\end{array}$ & $\begin{array}{l}\text { Heasured }(b) \\
\text { Glass } \\
\text { Pouring } \\
\text { Rate, } \mathrm{kg} / \mathrm{h} \\
\end{array}$ & $\begin{array}{c}\text { Calculated (c) } \\
\text { Glass } \\
\text { Pouring } \\
\text { Rate_ka/h } \\
\end{array}$ \\
\hline \multirow[t]{9}{*}{$6 / 16$} & $09: 34$ & & 0.1164 & & 81 & & 1,086 & & \\
\hline & $09: 42$ & & 0.12 & 2.5 & 118 & & 1,094 & 278 & 170 \\
\hline & $09: 45$ & & 0.1205 & 1.5 & 128 & & 1,094 & 200 & 61 \\
\hline & $09: 50$ & & 0.1214 & 1.5 & 139 & . & 1,095 & 132 & 66 \\
\hline & $09: 55$ & & 0.1218 & 1.5 & 144 & & 1,095 & 60 & 30 \\
\hline & $10: 00$ & & 0.1244 & 2.5 & 152 & & 1,097 & 96 & 186 \\
\hline & $10: 15$ & & $0.1258^{\circ}$ & 2.5 & 188 & & 1,098 & 144 & 38 \\
\hline & $10: 25$ & & 0.1261 & 0 & 198 & & 1,097 & 60 & 14 \\
\hline & & & & & OVERALL & 0.5 & & 138 & 88 \\
\hline \multirow[t]{6}{*}{$6 / 16$} & $14: 35$ & 1,165 & 0.1156 & 2.5 & 198 & & 1,089 & & \\
\hline & $14: 43$ & 1,162 & 0.1186 & 2.5 & 221 & & 1,093 & 173 & 143 \\
\hline & $14: 50$ & 1,156 & 0.1212 & 2.5 & 244 & & 1,097 & 197 & 138 \\
\hline & $14: 55$ & 1,163 & 0.1213 & 1.5 & 248 & & 1,092 & 48 & 9 \\
\hline & $15: 10$ & 1,160 & 0.1232 & 2.5 & 269 & & 1.096 & 84 & 50 \\
\hline & & & & & OVERALL & 1 & & 122 & 93 \\
\hline \multirow[t]{7}{*}{$6 / 16$} & 19:35 & 1,162 & 0.1134 & 2.5 & 303 & & 1,086 & & \\
\hline & $19: 40$ & 1,168 & 0.1155 & 2.5 & 321 & & 1,092 & 215 & 162 \\
\hline & $19: 46$ & 1,167 & 0.1184 & 2.5 & 343 & & 1,096 & 220 & 183 \\
\hline & $19: 50$ & 1,173 & 0.1195 & 2.5 & 351 & & 1,097 & 120 & 102 \\
\hline & $19: 55$ & 1,173 & 0.1211 & 2.5 & 364 & & 1,098 & 156 & 117 \\
\hline & $20: 00$ & 1,158 & 0.1221 & 1.5 & 371 & & 1.097 & .84 & 73 \\
\hline & & & & & OVERALL & 1 & & 163 & 141 \\
\hline \multirow[t]{7}{*}{$6 / 17$} & $11: 25$ & & 0.1139 & NA & 134 & & 1,088 & & \\
\hline & $11: 31$ & & 0.1153 & MA & 149 & & 1,089 & 150 & 91 \\
\hline & $11: 37$ & & 0.1165 & NA & 156 & & 1,091 & 70 & 77 \\
\hline & $11: 46$ & & 0.12 & NA & 183 & & 1,096 & 180 & 147 \\
\hline & $12: 02$ & & 0.1227 & NA & 212 & & 1,098 & 109 & 65 \\
\hline & $12: 05$ & & 0.123 & MA & 217 & - & 1.099 & 100 & 36 \\
\hline & & & $\cdot$ & & OVERALL & 2 & & 125 & 100 \\
\hline \multirow[t]{5}{*}{$6 / 17$} & $15: 36$ & 1,155 & 0.1176 & 2.5 & 232 & & 1,092 & & \\
\hline & $15: 59$ & 1,154 & 0.1197 & 2.5 & 264 & & 1,096 & 83 & 42 \\
\hline & $16: 05$ & 1,153 & 0.1238 & 2.5 & 295 & & 1,102 & 310 & 249 \\
\hline & $16: 10$ & 1,147 & 0.1232 & 2.5 & 301 & & 1.096 & 72 & -40 \\
\hline & & & & & OVERALL & $-!$ & & 122 & 72 \\
\hline
\end{tabular}


TABLE 4.5.19. HWVP-15 Glass Pouring Data (contd)

\begin{tabular}{|c|c|c|c|c|c|c|c|c|c|}
\hline Day & Iine & $\begin{array}{l}\text { Ave. } \\
\text { Glass } \\
\text { Temp. } \\
\end{array}$ & $\begin{array}{c}\text { Giass }(a) \\
\text { Tank } \\
\text { Res. } \\
\Omega \\
\end{array}$ & $\begin{array}{c}\text { Air Flow, } \\
\text { Cfh }\end{array}$ & $\begin{array}{c}\text { Cardinal } \\
\text { Scale, } \\
\text { ka }\end{array}$ & $\begin{array}{c}\text { Stream } \\
\text { Deflect, } \\
\text { in. }\end{array}$ & $\begin{array}{l}\text { Trough } \\
\text { 8lock } \\
\text { Temp.., } \\
\end{array}$ & $\begin{array}{c}\text { Heasured (b) } \\
\text { Glass } \\
\text { Pouring } \\
\text { Rata. ka/h }\end{array}$ & $\begin{array}{c}\text { Calculated (c) } \\
\text { Glass } \\
\text { Pouring } \\
\text { Rate, ka/h } \\
\end{array}$ \\
\hline \multirow[t]{9}{*}{$6: 17$} & $18: 40$ & 1,159 & 0.1146 & 2.5 & 300 & -1 & $-1,089$ & & \\
\hline & $18: 45$ & 1,160 & 0.1171 & 1.5 & 332 & & 1,095 & 384 & 190 \\
\hline & i8:50 & 1,172 & 0.1188 & .1 .5 & 348 & & 1,099 & 192 & 127 \\
\hline & 19:55 & 1,173 & 0.1203 & 1.5 & 360 & & 1,099 & 144 & 111 \\
\hline & $19: 00$ & 1,159 & 0.122 & 1.5 & 369 & & 1,100 & 108 & . 124 \\
\hline & $19: 05$ & 1,156 & 0.1225 & 1.5 & 378 & & 1,099 & 108 & 37 \\
\hline & $19: 13$ & 1,167 & 0.124 & 1.5 & 389 & & 1,098 & 83 & 69 \\
\hline & $19: 23$ & 1,175 & 0.1244 & 1.5 & 400 & & 1.097 & 66 & 17 \\
\hline & & & & & OVERALL & 0 & & 140 & 101 \\
\hline \multirow[t]{6}{*}{$6 / 78$} & $05: 15$ & 1,164 & 0.1199 & 1.5 & 56 & & 1,100 & & \\
\hline & $05: 20$ & 1,163 & 0.1214 & 1.5 & 69 & & 1,101 & 156 & 110 \\
\hline & $05: 25$ & 1,172 & 0.1228 & 1.5 & 80 & & 1,102 & 132 & 101 \\
\hline & $05: 30$ & 1,164 & 0.1241 & 1.5 & 91 & & 1,101 & 132 & 93 \\
\hline & $05: 35$ & 1,166 & 0.1248 & 1.5 & 98 & & 1.100 & 84 & 50 \\
\hline & & & & & OYERALL & $?$ & & 126 & 95 \\
\hline \multirow[t]{5}{*}{$\cdot 6 / 18$} & $09: 40$ & 1,169 & 0.118 & 2.5 & 142 & & 1,098 & & \\
\hline & $09: 46$. & 1,176 & 0.123 & 2.5 . & 173 & & 1,103 & 310 & 307 \\
\hline & $09: 50$ & 1,174 & 0.124 & 2.5 & 186 & & 1,104 & 195 & 89. \\
\hline & $09: 56$ & 1,165 & 0.126 & 1.5 & 195 & & 1.099 & 90 & 118 \\
\hline & & & - & & OVERALL & $?$ & & 199 & 189 \\
\hline \multirow[t]{2}{*}{$6 / 18$} & $13: 57$ & & & 1.5 & 211 & - & & & \\
\hline & $14: 38$ & & & 1.5 & 305 & & & & 133 \\
\hline
\end{tabular}


obtained at low submergences because of the accuracy of the data. The data show that the reference glass pouring rate of $5001 \mathrm{~b} / \mathrm{h}$ is achievable with a submergence of 0.95 with an airflow rate of $2 \mathrm{cfh}$ or a submergence of 0.92 and air flow rate of $4 \mathrm{cfh}$.

The ring used to assess the quality of the glass pouring stream was only used during part of the run. The major characteristics of each pour are shown in Table 4.5-19. The ring was placed approximately $5 \mathrm{ft}$ below the pouring tip, which is the approximate distance between the pour tip and canister opening in the HWVP reference design. The ring was centered underneath the glass discharge spout visually with each changeout of the receiving drum. As a result, some misalignment did occur. The glass stream was observed to deflect back underneath the trough at high glass flowrates ( $i . e_{.},>500 \mathrm{lb} / \mathrm{h}$ ). The magnitude was sufficient to cause the glass stream to miss the opening in the ring and strike the ring surface. Glass flow rates of about $500 \mathrm{lb} / \mathrm{h}(225 \mathrm{~kg} / \mathrm{h})$ caused the glass stream to deflect back underneath the trough a maximum of 1.0 in. (as observed at the pour ring), and glass pour rates of $300 \mathrm{lb} / \mathrm{h}(135 \mathrm{~kg} / \mathrm{h})$ caused a glass stream deflection of less than 0.5 in. Higher glass flow rates were achieved, but could not be maintained long enough to estimate a glass flow rate. Maintaining the high flow rates would have caused an interruption in the experiment because the glass stream would strike the ring, causing an obstruction in the glass discharge port. Glass flow rates in excess of $500 \mathrm{lb} / \mathrm{h}$ could occur in the HWVP melter due to high air. flow rates to the airlift or off normal melter operations such as. a severely over fed melter.

Sampling of the glass stream just below the pour tip caused glass fibers to contact and stick to the side of the glass discharge nozzle. Sampling at the higher glass flow rates made it much more difficuit to keep the glass from overflowing the sample boat and contacting the sides of the discharge nozzle. The deposits left on the side of the discharge nozzle caused pouring problems because the deposits protruded into the discharge nozzle. During routine glass pouring, the glass stream hit the protrusion and caused a large deflection of the glass stream. The glass deposits were only able to be removed manually during drum changes. Glass sampling was judged to be the major cause of glass built up in the discharge pipe.

The tendency of the glass stream to deflect underneath the trough was very similar to the physical model tests performed by Sevigny and. Peters (a) is shown

(a) G. J. Sevigny and R. D. Peters, Evaluation of Glass Pour Stream Behavior Using Simulated Fluids. HWVP-87-V110307, Pacific Northwest Laboratory, Richland, Washington (1987). 
in Figure 4.5-33. The results indicate that the physical modeling tests are applicable to actual glass pouring tests and that pouring rates above $500 \mathrm{ib} / \mathrm{h}$ $(230 \mathrm{~kg} / \mathrm{h})$ witl cause a stream to be deflected about 1 in. The glass pouring rates should be less than $500 \mathrm{lb} / \mathrm{h}$ to minimize the glass stream deflection.

The HWVP-15 giass pouring tests also showed that a $20^{\circ}$ down-sloped troughi. wijl continue to pour a stream of glass for 3 min after the airlift air is turned off. After $3 \mathrm{~min}$, the glass stream breaks up into droplets. These results also match the results of physical modeling tests. (a) The formation of droplets as opposed to stringing of the glass is a function of the glass viscosity, and therefore the glass temperature, at the pouring tip. The drips appeared to stop less than 15 min after the airlift was turned off.

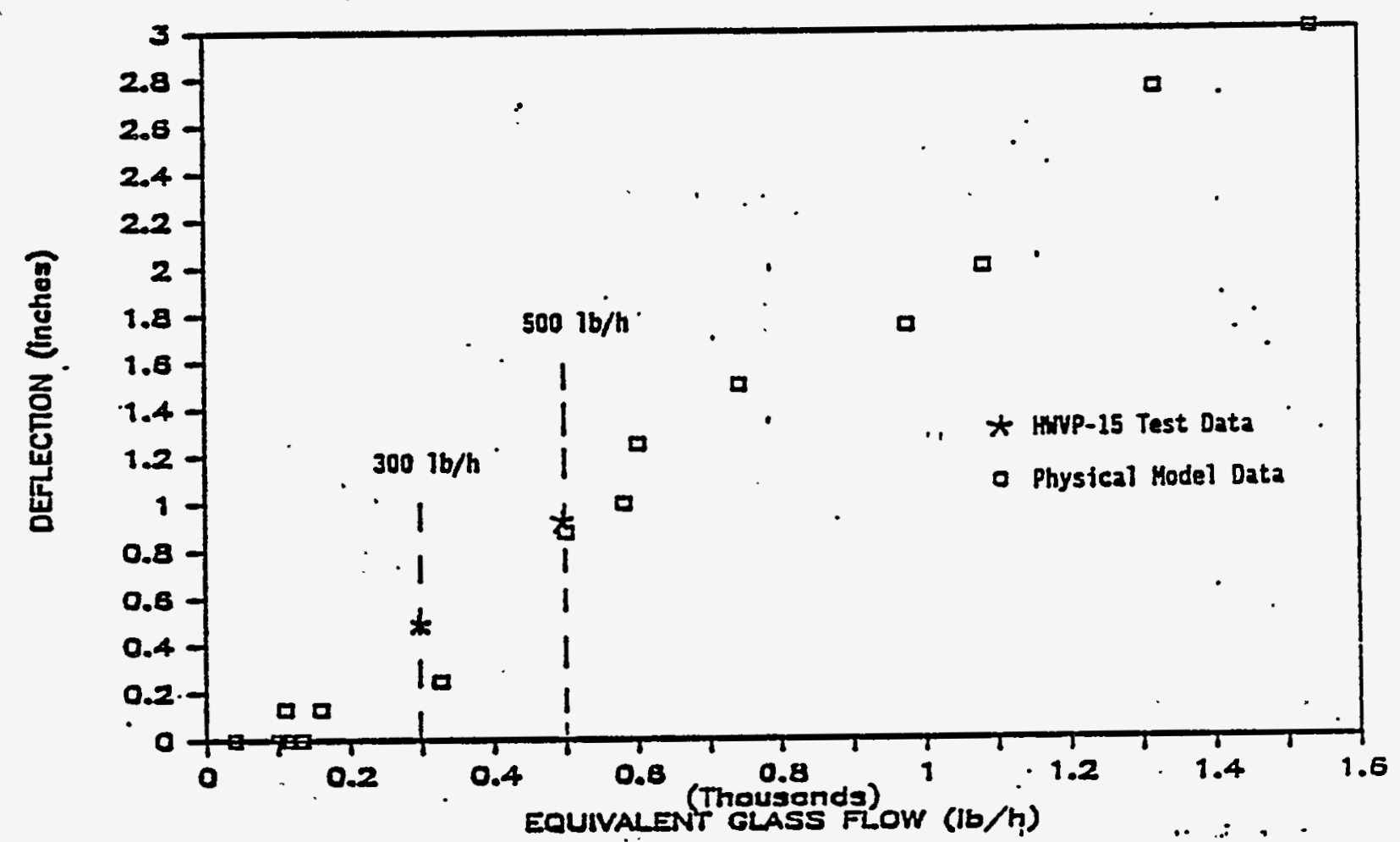

FIGURE 4.5-33. HWVP-15 and Physical Model Test Comparison Data HWVP-89-IVJ0010100B

(a) G. J. Sevigny and R. D. Peters, Evaluation of Glass Pour Stream Behavior Using Simulated Fluids. HWVP-87-V110307, Pacific Northwest Laboratory, Richland, Hashington (1987). 


\section{REFERENCES}

4.5-1 J. M. Perez and R. R. Nakaoka, "Vitrification Testing of Simulated. . High-Level Radioactive Waste at Hanford," PNL-SA-13360, Waste Manage-. ment 1986 Symposium, Pacific Northwest Laboratory, Richland, Washington (March 1986).

4.5-2 F. D. Richardson and J.H.E. Jeffes, J. Iron Steel Inst., Vol. 160, p. 261 (1948).

4.5-3 L. S. Darker and R. W. Gurry, Physical Chemistry of Metals, McGrawHill, New York (1953).

4.5-4 Rockwell Hanford Operations, Nonradioactive Liquid-Fed Ceramic Melter Testing for Fiscal Year 1986, RHO-RE-CR-17 P / HWVP-86-HLVID (November 17, 1986).

4.5-5 E. I. du Pont de Nemours 1982, cited on p. 4-137 from RHO-RE-CR-17, p. 4-16.

4.5-6 J. Halker, "The Amateur Scientist," Scientific American, 4(4):401-407 (1984). 



\subsection{MELTER OFF GAS (System 14)}

Steam, gases, and aerosols are generated from the liquid-fed ceramic melter (LFCM) during feed slurry processing in producing a glass product. This meiter off gas (MOG) effluent requires processing to remove toxic/hazardous aerosols (particulates) and gases. An effluent is produced that conforms to applicable requirements after it is combined with the vessel vent off gas and the canyon ventilation air for final filtration and exhaust from the plant. The HWVP MOG treatment system was reconfigured in FY 1988 to include the following: film cooler (FC), submerged bed scrubber (SBS), demister (DM), high-efficiency mist eliminator (HEME) filters, iodine sorber (IS), and NOx removal by selective catalytic destruction as shown in Figure 4.6-1 (demister not shown). This system replaces the previous reference MOG treatment system, Figure $4.6-2$, which served the same purposes but contained many process equipment components. similar to DWPF, such as an ejector venturi quencher, a gas scrubbing column (GC), and a steam atomized scrubber (SAS)/ condenser. The previous reference system al so contained a gaseous $\mathrm{RuO}_{4}$ sorber, which was removed. It was determined that no gaseous $R u$ exists downstream of the melter under the current reference HWVP process conditions. The Ru as $\mathrm{RuO}_{2}$ behaves as a semivolatile material.

Much of the technical information from the previous reference MOG treatment system configuration is retained in the Manual. This information aids in understanding the MOG process/chemistry, and provides a context for understanding DWPF and early HWVP process data still helpful in process design. However, data for the previous reference MOG treatment design may not be applicable to the current configuration. Process equipment component performance may be affected by the operation of the preceeding process equipment.

A dual nomenclature is subsequently used to identify HWVP melter test runs performed by PNL. HWVP-XX, where $X X$ is a sequence number, is the nomenclature identifying a melter run as one related to HWVP. The PSCM-XX or $H B C M-Y Y-X X$ nomenclature identifies the melter that the run was performed on, followed by a unique sequence number. HWVP run HWVP-11 corresponds to HBCM-85-1; HWVP-12 to PSCM-22; and HWVP-15 to PSCM-23.

\subsubsection{Function}

The purpose of the melter off gas (MOG) system is to remove radioactive, hazardous, and particulate material from the melter off gas. The MOG system also removes water from the MOG. The MOG system decontaminates the meiter off gas so that, when mixed with the vessel vent system (VVS) and cell ventilation off gases, the total HWVP. gaseous effluent, after sand filtration, complies with the emissions limits of RHO-MA-139(a) for an uncontrolled area and with other applicable standards and guidelines. (a) Rockwell Environmental Protection Manuall RHO-MA-139, Rockwe11 Hanford 


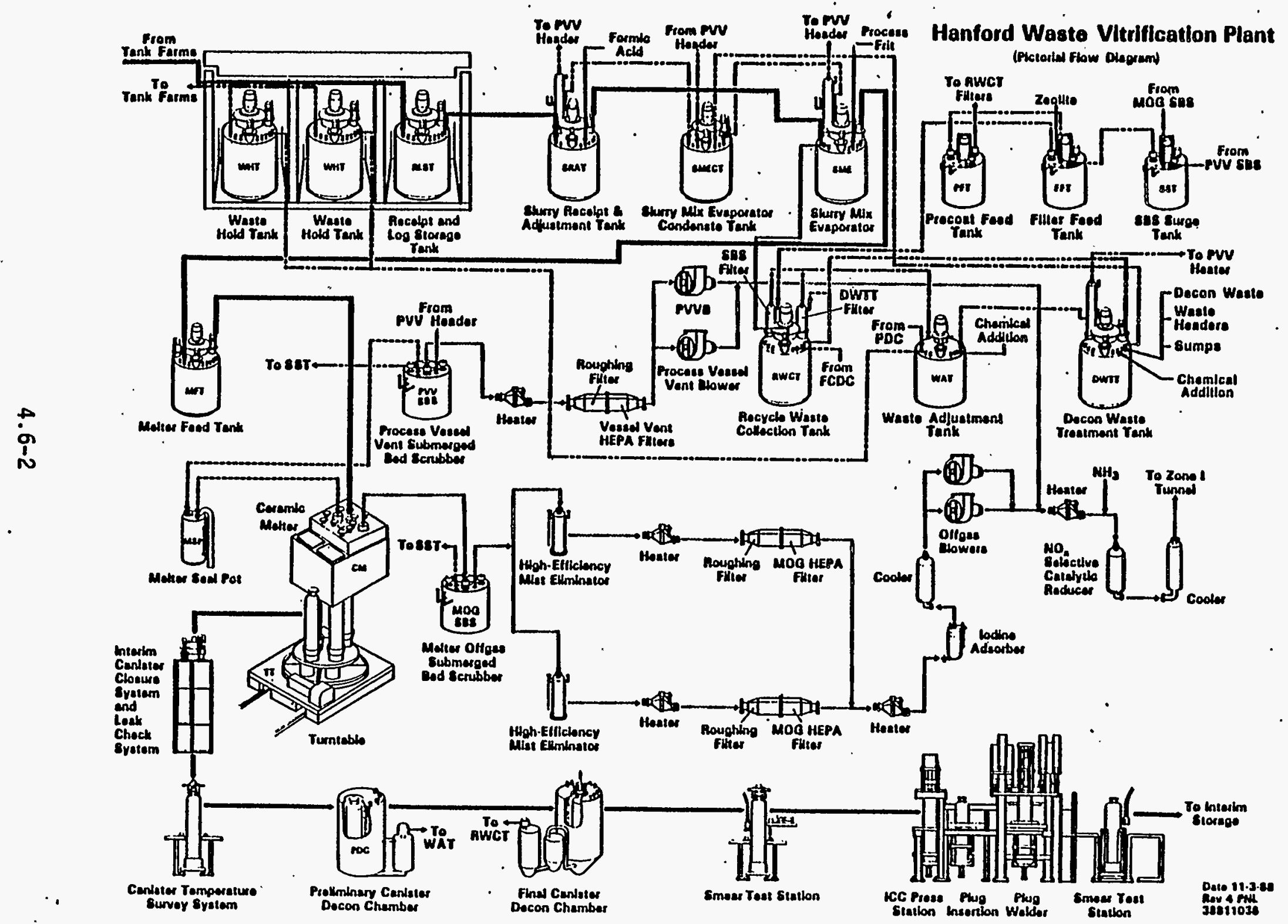

FIGURE 4.6-1. HWVP Melter Off-Gas Treatment System 


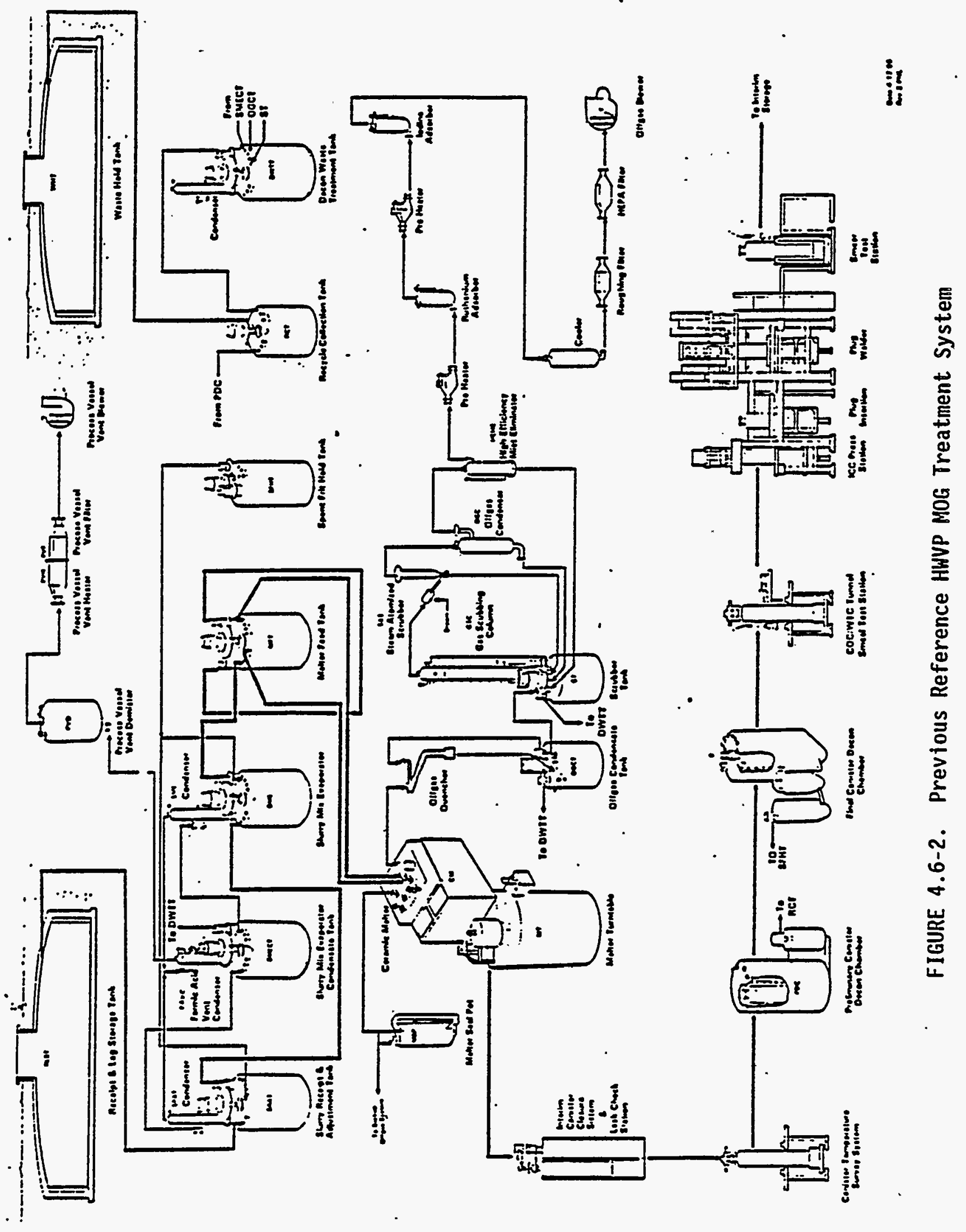




\subsubsection{Operationa7-Requirements}

The general operational requirements of the MOG system are provided in Table 4.6-1.

\subsubsection{Process Chemistry}

The MOG system removes hazardous materials from the melter off gas before release to the building exhaust tunnel. The off gas may be characterized as noncondensibles, particulates, semivolatiles, and water vapor.

- Noncondensibles are gases that do not condense at HWVP MOG system temperatures. Noncondensible materials may be selectively sorbed in aqueous solutions and on solid particulates. Noncondensible compounds include $\mathrm{CO}_{x}, \mathrm{H}_{2}, \mathrm{NO}_{x}, \mathrm{SO}_{x}, \mathrm{O}_{2}, \mathrm{~N}_{2}, \mathrm{H}_{2}$, hydrogen halides, and elemental halides. Noncondensibles are generated primarily from mielter feed reactions and air influx to the melter.

TABLE 4.6-1. Melter Off-Gas System Operational Requirements - HWVP

- Receive and treat MOG such that the gaseous effluent at the stack conforms to RHO-MA-139(a) and all other applicable standards and guidelines

- be able to handle a $7 X$ pressure surge from the melter without blowing the seal pot to the cell or backup off-gas system

- maintain treated exhaust gas temperature below $150^{\circ} \mathrm{F}\left(65^{\circ} \mathrm{C}\right)$ at the point of discharge

- maintain treated exhaust humidity low enough to assure that there is no condensation in the building ventilation system

- maintain MOG composition below $70 \%$ of composite lower explosive limit (LEL), defined in Table 4.6-2

- provide adequate redundancy and backup that continuous MOG treatment can be supplied to the melter

- batch transfer contents of the submerged bed scrubber (SBS) to the transuranic process waste handling system at a rate up to $100 \mathrm{gpm}$. Cool contents of SBS to $104^{\circ} \mathrm{F}\left(40^{\circ} \mathrm{C}\right)$

- provide adequate instrumentation and controls to monitor process performance, status, and safety.

(a) Rockwell Environmental Protection Manual, RHO-MA-139, Rockwell Hanford Operations, Richland, Hashington. 
TABLE 4.6:2. Calculation of Composite Lower Explosive Limit (E.I. du Pont de Nemours \& Company, "Basic Data Report - DHPF-S7udge Plant 200-S Area," DPSP 80-133, SRP)

$$
\begin{aligned}
& \text { Composite LEL }=\frac{100}{\left(\left[\mathrm{H}_{2}\right] / \mathrm{LH}_{2}\right)+([\mathrm{CO}] / \mathrm{LCO})} \\
& \text { where }\left[\mathrm{H}_{2}\right] \cdot=\frac{\mathrm{vol}_{\mathrm{C}} \mathrm{H}_{2} \times 100}{\mathrm{v} 01 \% \mathrm{H}_{2}+\mathrm{v}_{0} 7 \% \mathrm{CO}} \\
& {[\mathrm{CO}]=100-\left[\mathrm{H}_{2}\right]} \\
& \mathrm{LH}_{2}=\mathrm{LEL} \text { for } \mathrm{H}_{2} \text { in air (4.1 vol\%). } \\
& \text { LCO } \quad \text { LEL for CO in air (12.5 vol\%) }
\end{aligned}
$$

- Particulates are solid particles (aerosols) generated primarily from entrainment of dried/partialiy calcined melter feed.

- Semivolatiles are chemical compounds that vaporize from the melt surface and then change phase back to a solid (aerosols) through. cooling or chemical reaction. Compounds of elements regarded as semivolatile include $\mathrm{Ru}, \mathrm{Cs}, \mathrm{B}$, Se, Tc, Sb, and Te. The extent to which many of these elements are semivolatile depends on the chemical form and operating conditions. There are also alkali halides in the MOG which behave similar to semivolatiles.

- Hater vapor is water that is generated from feed evaporation, melter chemical reactions, and inclusion with air in-leakage.

Components of the MOG are identified generically by the classifications above as a matter of convenience and to highlight characteristics of interest. In practice, the properties of an element or compound depend on the chemical form of the element and the environment to which it is exposed. For example, $\mathrm{HCl}$ is a volatile. However, $\mathrm{NaCl}$ may be considered a particulate or semivolatile, depending on the classifier's judgment. Another example, Ru, is generated from the melter as particulate $\mathrm{RuO}_{2}$ and gaseous $\mathrm{RuO}_{4}$; however, $\mathrm{Ru}$ is considered a semivolatile because the $\mathrm{RuO}_{4}$ converts to $501 \mathrm{id}^{\mathrm{RuO}} \mathrm{O}_{2}$ in the MOG system. The chemistry of off-gas generation of the melter is described in Section 4.5.3.

Operating principles and associated chemistry of the major pieces of MOG treatment process equipment are subsequentiy provided.

$$
4.6-5
$$


4.6.3.1 Film Cooler. An air-driven film cooler forms the plenum exhaust port in the lid of the melter. The function of the film cooler; shown in Figure 4.6-3, is to maintain a clear and unobstructed pipe between the melter and the quench scrubber. Air is injected through radial slots to cool the melter exhaust stream below the softening point of off-gas particulates $\left(350^{\circ} \mathrm{C}\right)$, salts/oxjdes, and to increase the off-gas stream velocities. The off-gas stream velocities are maintained above $50 \mathrm{ft} / \mathrm{s}$ to minimize particulate deposition.

No significant chemical reactions have been determined. to take place in the film cooler. Reactions could proceed between the meiter outlet (FC inlet) and the SBS if the kinetics were rapid ( -1 to $3 \mathrm{~s}$ transit time). The only reactions that would proceed are those to achieve a chemical equilibrium after exiting the melter. Any chemical reactions may be affected by the temperture decrease to $130^{\circ} \mathrm{C}$ from approximately 300 to $1000^{\circ} \mathrm{C}$ in the $\mathrm{FC}$ or induction of air (including $\mathrm{O}_{2}$ ) into the MOG stream.

The primary mechanisms for preventing solids buildup in the pipe between the melter and SBS is cooling solids (glass, salts, and oxides) below the softening point of the solids to prevent sticking to pipe walls and rapid7y transporting the solids in turbulent flow at low concentration to the SBS. Turbulence inhibits. solids settling in and impacting the pipe.

Inspection of the MOG piping between the test melter and quencher at SRL during testing indicated there can be solids buildup at right angle pipe bend locations where solids momentum in the pipe gas cause the solids to impact the pipe wall.

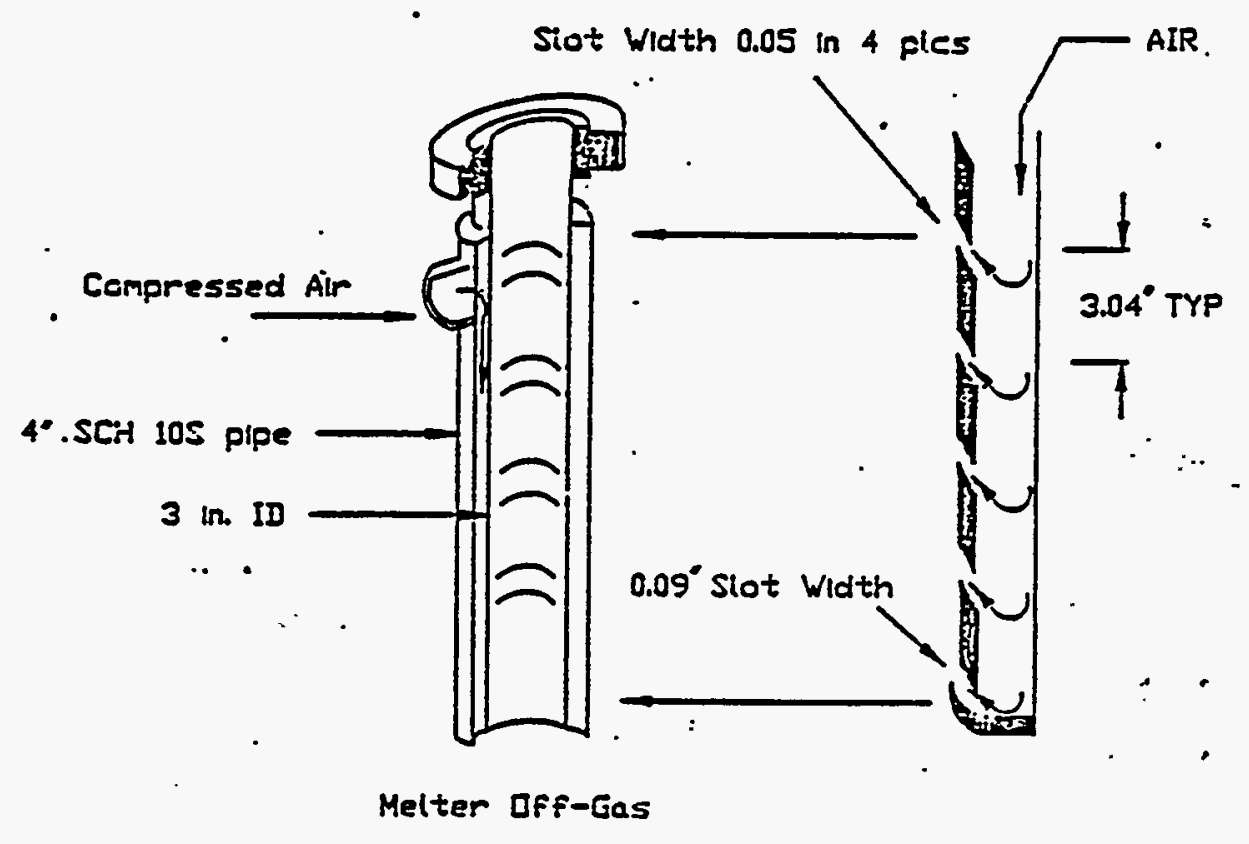

FIGURE 4.6-3. PSCM Film Cooler Schematic HWVP-89-IVJ0010100B 
4.6.3.2 Submerged Bed Scrubber. The SBS is a packed bed submerged in a vessel in which the meiter off gas enters the bottom of the bed. The gas buoyancy causes the SBS fluid to circulate through the bed. This recirculating fluid transfers heat from the hot melter exhaust and provides for gas scrubbing and cleaning of the bed. These processes are schematicaily illustrated in Figure 4.6-4. In operation, the process exhaust is concurrentiy contacted by the scrubbing liquor in the SBS bed where steam is condensed and the scrubbing fluid is heated. The accumulated condensate continuously overfiows into a collection tank. The outer portion of the vessel is fitted with cooling coils to remove the heat. Buoyancy effects maintain the fluid recirculation, so no external pump is needed. The pressure drop through the bed is high, being established by the submergence of the inlet pipe.

The SBS serves three functions. Water is removed by cooling the MOG below the water dew point (condensation). The HWVP-15 melter test run data indicated that the amount of water removed from the MOG could be accurately determined by humidity equilibrium relationships. Solid particulates (aerosols) are removed by impaction, interception, or Brownian movement, which causes the aerosols or coagulated aerosols to impact the water collection media. Finally, gases are removed by sorption in the water scrubbing media. The SBS is a poor sorber of NOx in low gaseous concentrations in the HWVP MOG as shown in the PNL HWVP-12 and -15 melter testing, -1\% absorption. The SBS is a also a poor sorber for $\mathrm{CO}_{x}$ with negligible sorption. The SBS has moderate sorption efficiency for suifur $\left(\mathrm{SO}_{\mathrm{x}}\right)$ and halide gases from the melter except for I. The MOG has not been characterized to the extent that the species containing $\mathrm{C}, \mathrm{N}, \mathrm{S}$, and halides are well known. However, it is expected that the species and associated chemical reactions in the -SBS for the HWVP feed can be characterized as follows:

$\mathrm{CO}_{\mathrm{x}}\left(\mathrm{CO}_{2} / \mathrm{CO}_{2} \approx 5\right.$ to $\left.15 / 1\right)$ : negligible sorption

$\mathrm{NO}_{x}$ ( $\mathrm{NO} / \mathrm{NO}_{2} \approx 4 / 1$; ratio varies with time and conditions): About $1 \%$ sorption; absorption mechanism complex and not fully characterized

$\mathrm{SO}_{x}$ (projected primarily SO) ${ }_{3}: \mathrm{SO}_{3}+\mathrm{H}_{2} \mathrm{O}_{2} \mathrm{H}_{2} \mathrm{SO}_{4}$

Halides (gaseous halide projected to be primarily hydrogen halides except for iodine, which is thought to be elemental)

$\mathrm{HCl}+\mathrm{H}_{2} \mathrm{O} \rightarrow \mathrm{H}^{+}+\mathrm{Cl}^{-}+\mathrm{H}_{2} \mathrm{O}$

$\mathrm{H}^{+}+\mathrm{Cl}^{-}+\mathrm{NaOH}$ (hydrolized alkali or alkaline earth oxides) $\rightarrow \mathrm{H}_{2} \mathrm{O}+\mathrm{NaCl}$.

4.6.3.3 Demister. Scrub solution carryover from an SBS can be quite large. under upset conditions. A chevron demisting device reduces the liquid phase aerosolized loading of the SBS process exhaust stream. The principle method for removing droplets from the exhaust stream is by causing the droplets to impact on corrugated plates. The impaction method of droplet removal works well for droplets larger than $3 \mu \mathrm{m}$ but not on submicron droplets. The chevron demister shown in Figure 4.6-5 was located at the outlet of the SBS in the PNL HWVP-1.5 melter run to collect the larger fluid droplets entrained in the SBS outlet gas stream. 


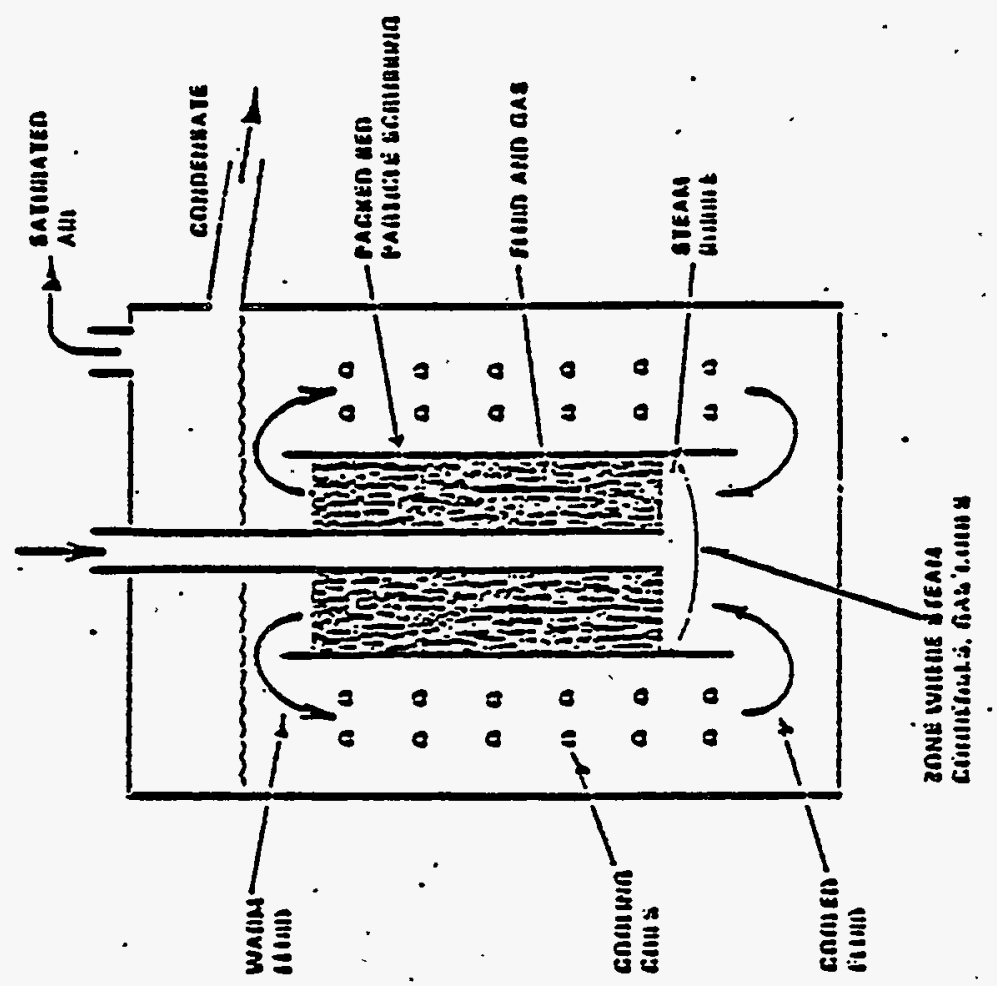

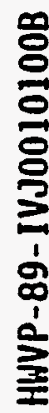

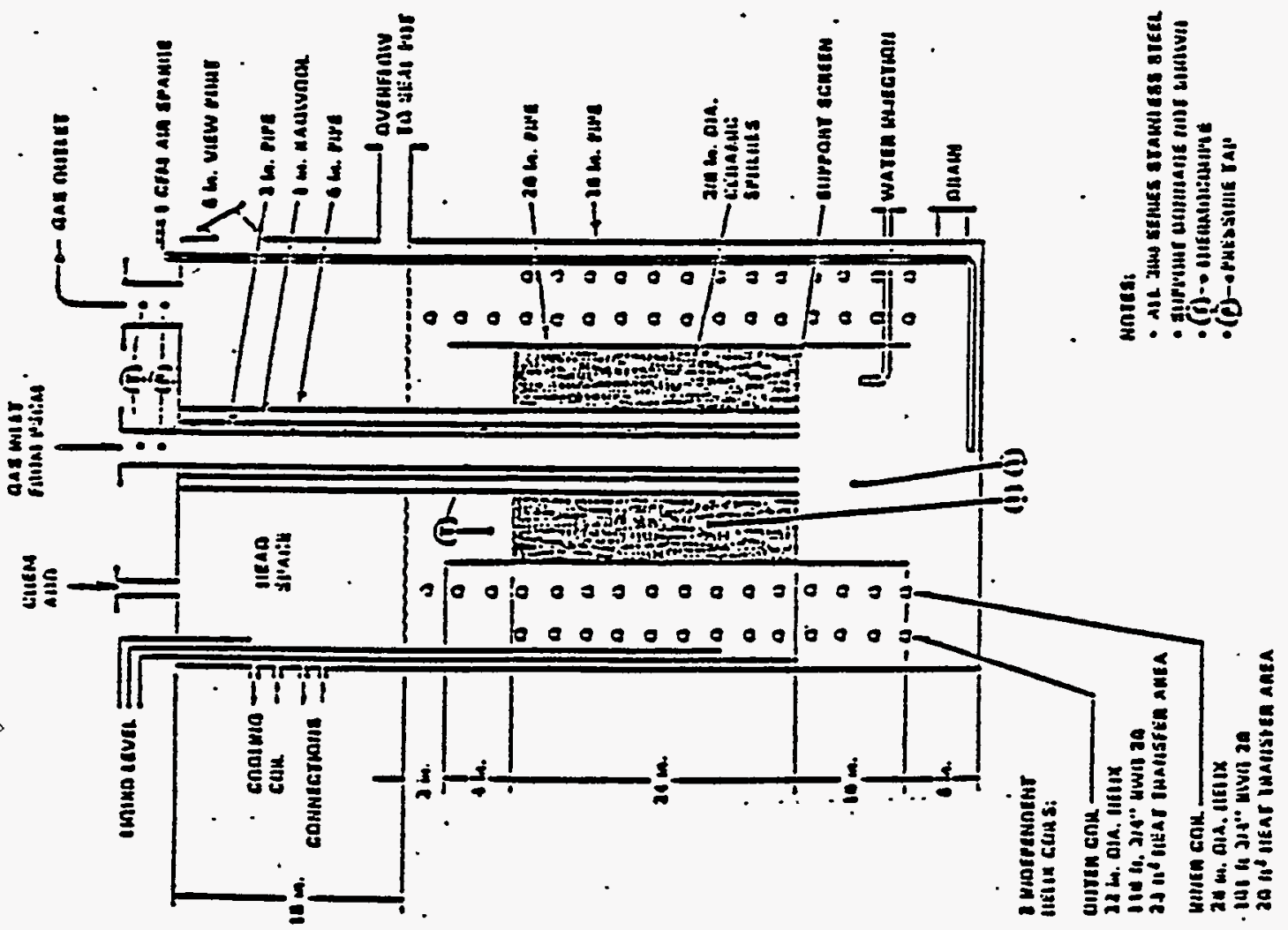




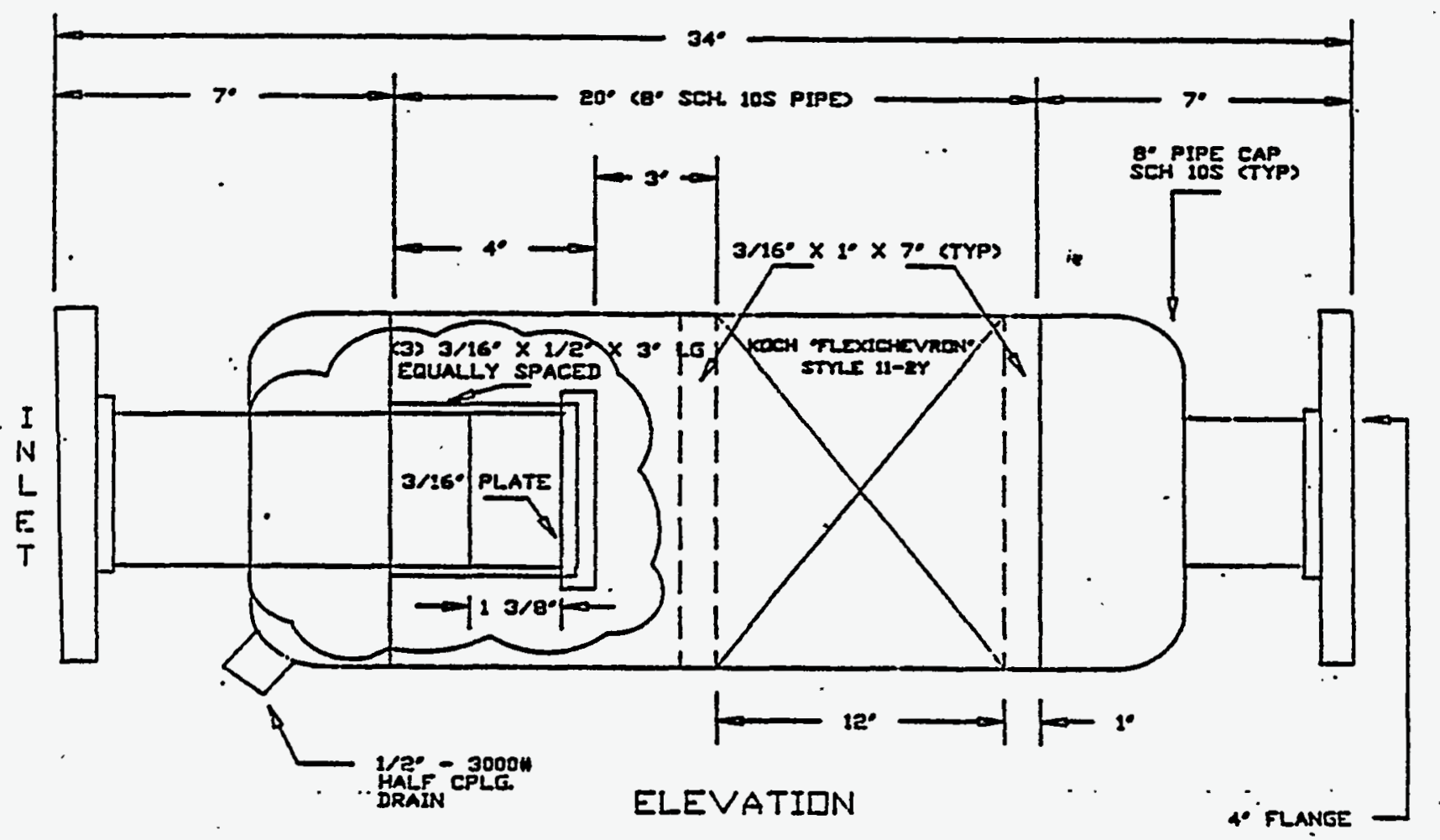

FIGURE 4.6-5. PSCM Chevron Demister Schematic HWVP-89-IVJ0010100B

4.6.3.4 Quencher (Ejector Venturi; Nonreference System). The quencher primarily condenses and cools water from the meiter off gas. The quencher al so acts as a scrubber removing larger $(>1 \mathrm{~m})$ particulates from the MOG and provides some vacuum for the melter. A high-pressure spray nozzie atomizes scrub liquid into droplets that $\operatorname{cool}$ the MOG, leading to water condensation. Particulate collection is achieved by impaction of the particle by a larger, faster-moving water drop and retention or capture of the particle by the water drop followed by removal or separation of the water drop containing the particle from the air or gas stream. Condensation of steam on particles increases the particle diameter, which aids in removal. Because of the short contact time and elevated temperature, sorption of soluble off gases such as halides, sulfur oxide, and nitrogen oxides is negligible.

The primary chemical reactions occurring in the quencher are expected to be partial dissolution of soluble oxides, such as $\mathrm{Na}_{2} \mathrm{O}$, entrained from the feed. The solutions containing the dissolved oxides may be neutralized by sorbed $\mathrm{NO}_{\mathrm{x}}$ from the melter off gas.

4.6.3.5 Gas Scrubbing Column (Nonreference System). The gas scrubbing column (GCS) is intended for removal of $\mathrm{NO}_{X}$ and acid halogen gases by aqueous absorption. Gases to be removed by the GSC include $\mathrm{NO}_{x}, \mathrm{RuO}_{4}, \mathrm{HCl}, \mathrm{SO}_{x}, \mathrm{HF}$ and elemental halides. The GSC may also remove some aerosol solids via impaction of the aerosols with liquid, although this is a secondary benefit and has low efficiency. $\mathrm{NO}_{x}$ and/or acid gas absorption is controlled by 
gas-phase reactions and liquid phase equilibrium conditions rather than mass transfer Timitations. Therefore, absorption efficiency will be a weak function of liquid-to-gas flow rate, assuming the liquid phase is kept lean in concentration and operating temperature. Reviews by Peters (Ref. 4.6-1) indicate that $\mathrm{NO}_{\mathrm{X}}$ scrubbing efficiencies for absorbers are from $50 \%$ to $90 \%$ across a broad range of operating conditions.

The predominant reactive gases entering the GSC are likely to be NO and $\mathrm{NO}_{2}$ - The principal chemical reactions involving these compounds are oxidation of $\mathrm{NO}$ and absorption of $\mathrm{NO}_{2}$ by water to form nitric acid:

$$
\begin{gathered}
2 \mathrm{NO}+\mathrm{O}_{2} \rightarrow 2 \mathrm{NO}_{2} \\
\mathrm{NO}_{2}+1 / 3 \mathrm{H}_{2} \mathrm{O} \rightarrow 2 / 3 \mathrm{HNO}_{3}+1 / 3 \mathrm{NO}
\end{gathered}
$$

Additionally, the acid gases $\mathrm{HCl}$ and HF are expected to be absorbed to form their respective aqueous species. The sorbed acids will likely react with available hydrolized alkali or alkal ine earth oxides to form salt and water simitar to the SBS.

4.6.3.6 Steam Atomized Scrubber (Nonreference System). The steam-aspirated wet scrubber (hydrosonic scrubber) is effective in reducing the concentration of submicron particles compared to other, more complex devices. Particulate scrubbing is accomplished by injecting a liquid stream into the wake region of an expanding supersonic free jet. Rapid acceleration of the liquid phase results in complete atomization. Fragmentation and acceleration of the liquid phase and the resulting high relative velocity created between the expanding jet flow and the entrained off-gas flow, result in efficient particulate scrubbing. Scrubbed particles are then effectively grown by agglomeration and separated from the gas phase by inertia. No significant chemical reactions are anticipated to occur in the SAS. Contact time is very brief.

4.6.3.7 Condenser (Nonreference System). The condenser, which follows the SAS, is intended to remove water vapor from the off-gas stream. The steam is condensed on tubing surfaces that are chilled with flowing cooling water. Because the process stream is primarily noncondensible (air), the unit actually functions as a dehumidifier. The presence of noncondensible gas results in a relatively low heat transfer coefficient, so the equipment design will require a correspondingly larger surface area. No significant chemical reactions occur in the condenser.

In the condenser, submicron particulates may form nucleating sites for condensation. Thus, condensation may cause the growth of particulates which could assist in their removal in the HEME.

4.6.3.8 High-Efficiency Mist Eliminator. The combined effect of the SBS and demister (D) upon the process exhaust is to quench the off-gas stream and to 
remove large diameter $(>1 \mathrm{~m})$ condensed phase aerosols by impaction. The HEME is utilized as a high-efficiency filtration device designed to remove the aerosolized matter penetrating the previous, 10w-efficiency MOG system components. The HEME has a higher efficiency for submicron particle removal because its main method for removing particulate is by Brownian diffusion and direct interception. HEME fiber (depth) filters were originally developed to remove acid or caustic fumes; they were commercially available with either fiberglass or polypropylene batt. Like HEPA filters, these devices can efficiently remove airborne submicron matter. But unlike HEPAs, they can be operated wet, allawing simultaneous removal of both Tiquid and solid aerosols. Since HEMEs can be operated wet, a continuous water spray has often been employed to wash down and cleanse filter elements of accumulated debris, thus extending the service life of the filter. The HEME, used during HWVP-15, was configured as shown in Figure 4.6-6 so that it can be irrigated and drained.

The HEME is a low to medium efficiency acid gas sorption device as used in the HWVP MOG treatment under suitable conditions. The HEME provides large gas/liquid contact surface on the wetted filter media. With suitable design, the contact time is sufficient to absorb soluble gas with efficiency similar to that of the SBS.

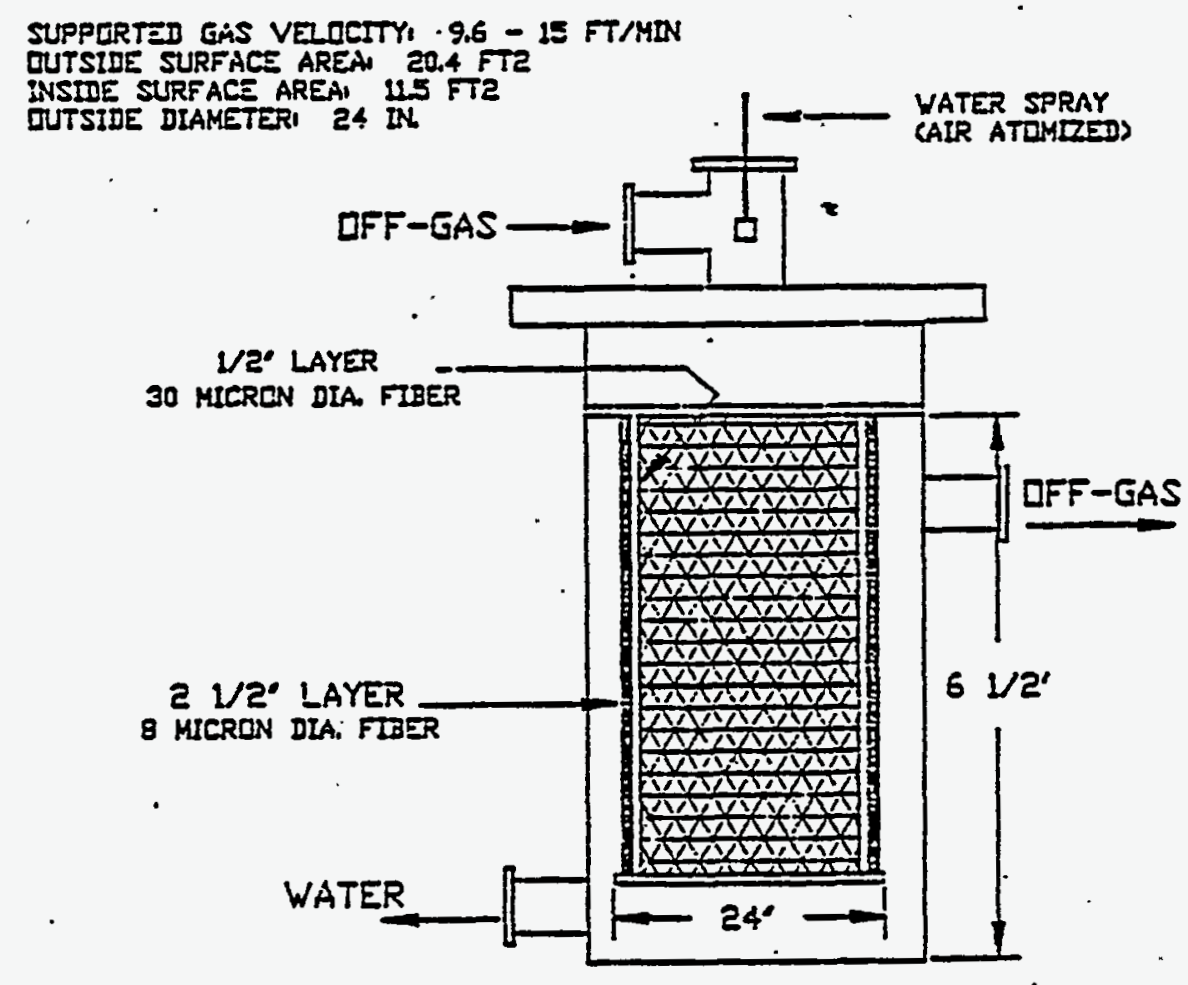

FIGURE 4.6-6. PSCM High-Efficiency Mist Eliminator Schematic HWVP-81-IVJ0010100B 
4.6.3.9 Iodine Adsorber. Gaseous iodine emitted from a waste glass melter is thought to be in the form of diatomic I. For the HWVP system, the proposed removal method. uses silver-loaded sol id substrates such as mordenite, zeolite, and silica. Iodine is removed from the gas phase through heterogeneous chemical reaction with silver substituted into the solid structure. The mechanism or kinetics of the reaction are not understood, but the end product is likely to be silver iodide (Ref. 4.6-2). The major reaction is. expected to be combination of silver with $I_{2}$ at an elevated temperature to form AgI.

4.6.3.10. Roughing and HEPA Filters. The roughing filter is designed to -retain dust generated by upstream sorption beds: used to el iminate gaseous forms of Ru and/or I. It can be purchased in varying grades of efficiency to remove submicron particulates. It consequently provides varying MOG particulate decontamination but provides for increased HEPA operating iffe.

High-efficiency particulate air filters remove solid aerosols primarily through Brownian diffusion of the aerosols to the surface of filter fibers, where they attach. Of all the filtration components, HEPA filters are the most aggressive toward submicron capture. With the use of submicron particulate removal devices before the HEPA filters (hydrosonic scrubber and/or HEME), it is anticipated that a majority of the melter-emitted aerosols will be removed by the time the gas reaches these final filters. Their inclusion in an off-gas system is necessary to ensure thorough decontamination before discharge of the gas to the stack and extend HEPA filter operating life.

\begin{abstract}
4.6.3.11 NO $\times$ Selective Catalytic Reduction HWVP-87-V110305B. Selective catalytic reduction. (SCR) of $\mathrm{NO}_{x}$ utilizes $\mathrm{NH}_{3}$ and an appropriate catalyst to selectively reduce $\mathrm{NO}_{x}$ to $\mathrm{N}_{z}$. In addition to this primary task, the catalyst must also. be capable of converting excess $\mathrm{NH}_{3}$ to $\mathrm{N}_{2}$ and minimizing competing reactions than can produce an undesirable effiuent such as $\mathrm{N}_{2} \mathrm{O}$. A variety of catalysts have been used in the SCR.(a) Most of these catalysts are quite efficient ( $>90 \%$ conversion), and essentially all are proprietary. Hydrogen zeolite has enjoyed great success as a SCR catalyst in oxygen-rich $\left(0_{2}>10 \%\right)$ process streams. It is efficient for reducing $\mathrm{NO}_{x}$ components, has a very wide operating temperature range $\left(300^{\circ} \mathrm{C}\right.$ to $\left.750^{\circ} \mathrm{C}\right)$, is not poisoned by sulfur or iodine compounds, is not significantly affected by high off-gas water loadings, and produces very little $\mathrm{N}_{2} \mathrm{O}$ byproduct. Hydrogen zeol ite al so efficiently catalyze $\mathrm{NH}_{3}$ reduction to $\mathrm{N}_{2}$; however, process water loading has been observed to impact the conversion efficiency of this reaction. In comparative tests, hydrogen zeolite have been found to meet or exceed the performance of several metal-based SCR catalysts in oxygen-rich $\left(\mathrm{O}_{2}>10 \%\right)$ process streams.
\end{abstract}

(a) J. R. Kiovsky, P. B. Koradia, and C. T. Lim, "Evaluation of a New Zeolytic Catalyst for $\mathrm{NO}_{x}$ Reduction with $\mathrm{NH}_{3}$." I\&EC Product Research and Development, Vol. 19 (1988). 
The apparent effectiveness of hydrogen zeolite as an SCR catalyst has led to several pilot-scale tests designed to further evaluate the applicability of the SCR technology to $\mathrm{NO}_{\mathrm{x}}$ emission abatement in nuclear process streams. The Idaho National Engineering Laboratory (INEL) applied this technology to a simulated waste calciner exhaust stream. (a) Greater than $99 \%$ abatement efficiency was obtained for both $\mathrm{NO}$ and $\mathrm{NO}_{2}$ in the temperature range of $340^{\circ} \mathrm{C}$ to $440^{\circ} \mathrm{C}$ using a $\mathrm{NH}_{3} / \mathrm{NO}_{x}$ ratio of $1.3^{2}$. Using the design criteria established at INEL, the National Lead Corporation (NLCO) constructed an SCR emission abatement plant to contro] $N_{x}$ tail gas emissions by uranium dissolution and purification processes. (b) Nôx abatement efficiencies $>99 \%$ were demonstrated for wet $\left(46^{\circ} \mathrm{C}\right.$ dew point) process streams containing up to $0.5 \% \mathrm{NO}_{x}(33 \% \mathrm{NO})$. Exxon Nuclear al so applied the hydrogen zeolite SCR technology to its uranium dissolver off-gas stream $\left(2.5 \%, \mathrm{NO}_{x}, 65 \% \mathrm{H}_{2} \mathrm{O}\right)$ and obtained $\mathrm{NO}_{\mathrm{x}}$ destruction efficiencies that exceeded $99 \%$. (c)

Although the above samples illustrate the usefulness of (hydrogen -zeo1ite) SCR methods for dealing with high $\mathrm{NO}_{x}$. concentrations, the technique has also been successfully applied to process streams with $10 \mathrm{~W}(500 \mathrm{ppm}) \mathrm{NO}_{\mathrm{X}}$ Concentrations. Thomas examined the suitability of hydrogen zeolite as an SCR catalyst for removal of $\mathrm{NO}_{X}$ in simulated fossil fuel plant exhausts $(500 \mathrm{ppm}$ $\mathrm{NO}, 3000 \mathrm{ppm} \mathrm{SO}, 12 \% \mathrm{CO}_{2}$, and air with $35^{\circ} \mathrm{C}$ dew point). (a) The study showed that NO could be selectively reduced to below $7 \mathrm{ppm}$ before competing reactions with $\mathrm{SO}_{2}$ limited the reduction process. The potential for using this technology for simultaneous $\mathrm{SO}_{2}$ recovery as ammonium bisulfate and sulfate was also demonstrated. Norton has recently developed and patented a natural hydrogen zeolite catalyst that is highly specific for $\mathrm{NO}_{\mathrm{x}}$ and exhibits negligible $\mathrm{SO}_{2}$ activity--a highly desirable property for industrial power plant operations. This catalyst is currentiy being successfully used to reduce power plant boiler emissions of $\mathrm{NO}_{x}(500 \mathrm{ppm})$ at a fossil fuel facility in Nurenburg, Germany. (d)

\subsubsection{Technology Development}

Melter off-gas treatment technology has been developed at PNL, SRL, and WVDP. The HWVP MOG treatment system performance is primarily based on experience developed in PSCM testing at PNL.

(a) T. R. Thomas and D. H. Munger, An Evaluation of $\mathrm{NO} \times$ Abatement by $\mathrm{NH}_{3}$ Over Hydrogen Mordinite For Nuclear Fuel Reprocessing Plants. ICP-1133, Idaho National Engineering Laboratory, Idaho Fal7s, Idaho (1978).

(b) N. R. Leist, The Design and Operation of a Pilot Unit for NO Destruction With Ammonia and a Synthetic Mordinite Catalyst. NCLO-I139, National Lead Corporation, Ohio (1975.)

(c) E. B. Mays and M. R. Schwab, "El imination of $\mathrm{NO}_{X}$ Fumes." Chemical Engineering, February 17, 1975, pp. 112 (1975).

(d) Private technical communication from S. M. Turner, Product Manager, Norton Chemical Process Products Division, Norton Corporation (1987). 
No significant development data are currentily available from WVDP with which to compare the HWVP development data. The MOG treatment system for DHPF is different from the HWVP system. Since process performance is sensitive to equipment type and configuration, the DWPF data is of limited use for HWVP design and analyses.

To assess the reference HWVP MOG treatment system for HWVP design application, the MOG treatment results for HWVP MOG process testing (HWVP-11, HWVP-12, and HWVP-15) were evaluated in context with WVDP and DWPF MOG treatment system studies performed at PNL (PSCM Test Nos. 1, 3, 4, 7, 9, 15, 16, 19, and 22, Appendix C). To determine characteristic MOG treatment system decontamination factors for HWVP application, the test run feed compositions, run conditions, particie size determinations/compositions, and equipment element decontamination factors were evaluated. Decontamination factors characteristic of a remoteiy, well-operated production plant, are identified in Table 4.6-3 The selected decontamination factors were weighted toward system performances observed in HWVP tests HWVP-1I and HWVP-12. Runs for West Valley process development, which are expected to be more typical of a remotely operated plant process using an MOG treatment configuration similar to the HWVP, were also considered heavily for off-gas treatment (HEME size increased between HWVP-15 and Hest Valley test runs). In HWVP-15 testing, the process operating conditions were so conservative and well controlled that the results were much better than expected in the HWVP. . For elements not shown in Table 4.6-3, the contamination factors should be used for chemically similar analogs. The decontamination factors are based on 7 imited data and will be updated as more test data becomes available and the associated chemistry is better defined. Also, it must be recognized that the decontamination factors vary as process conditions change.

4.6.4.1 Melter Emissions. Exhaust gas characteristics of liquid-fed melters. have been studied at PNL since the inception of the LFCM process. Many tests were conducted in support of the DWPF, the West Valley vitrification facility (West Valley Support Project, WVSP) and HWVP. Table 4.6-4 summarizes PSCM tests from these three programs, showing the PSCM process operating parameters. Table 4.6-4 includes only. DWPF tests that did not use 7 id heating for. melting rate boosting, similar to the HWVP. Nominal feed compositions for the tests are shown in Appendix C. For the HWVP, DWPF, and West Valley PSCM melter tests, the PSCM system testing decontamination information is summarized in Appendix C.

4.6.4.1.1 Particulates (Aerosols). Melter tests generally produce aerosol-size distributions that are bimodal (Table 4.6-5). This suggests that the overall aerosol distribution comprises two independent components, each having its own characteristic size distribution. Gross compositional dissimilarities between the discrete size fractions shown in Table 4.6-6 support this argument. The submicron-sized fraction shown in this table for LFCM-7 (DWPF) and HWVP-15 contain 12\% and $46 \%$, respectively, of the total sample mass and possesses the major amount of semivolatile matter of the sample. The mechanism responsible for the small-diameter component (semivolatile of the overall distribution is probably a volatilization/condensation process that occurs within the melter plenum. The compositions of 
TABLE 4.6-3. Hanford Waste Vitrification Plant Nominal Decontamination Factors

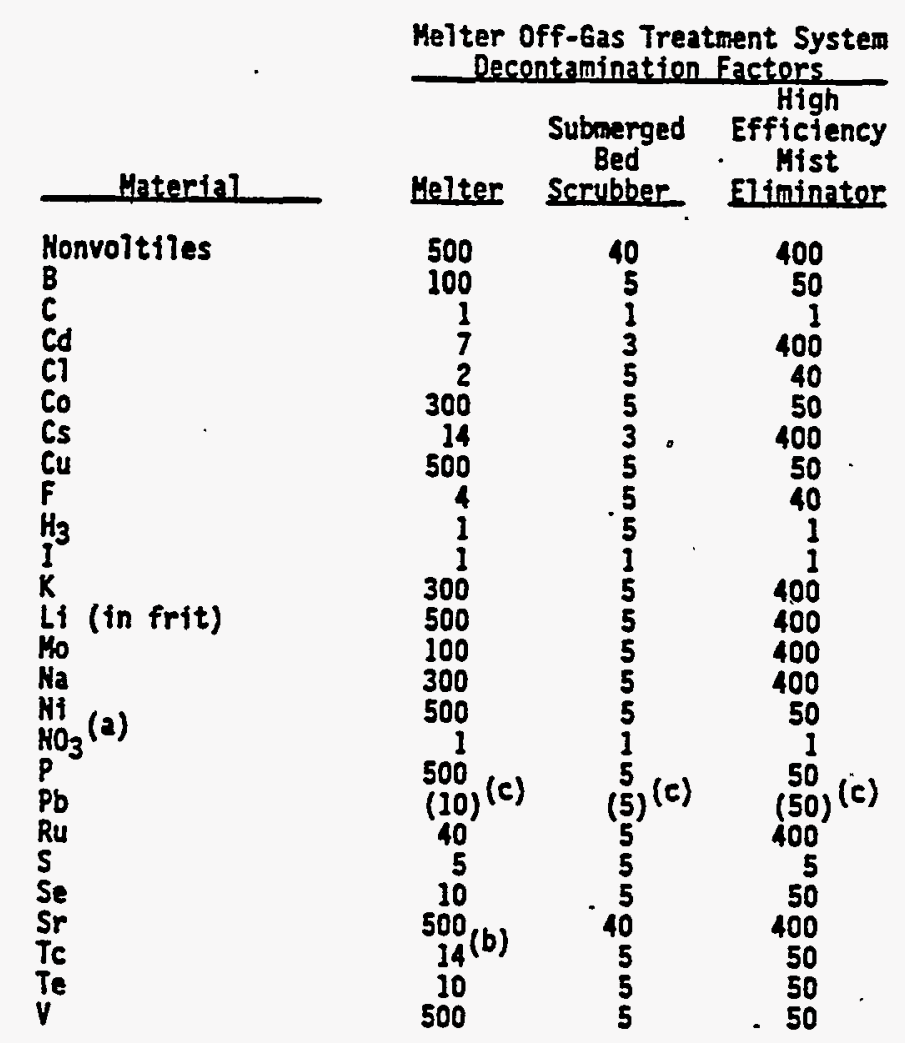

(a) Conversion of nitrate to $\mathrm{HO}_{x}$ is $-\mathbf{7 5 \%}$. Traces of

ammonia in $\mathrm{HOG}$ ( $<2 \%$ of nitrogen in $\mathrm{HO}_{3}$ ).

(b) SRL data (verbal communication from $G$. E. Stegen

to D. E. Larson, 1/25/89).

(c) Projected based on chemical properties.

the large-sized fractions are very similar to those of the slurry feed, as shown in Table 4.6-7. Consequently, the Targe-diameter component of the bimodal distribution is most certainly associated with a gross entrainment mechanism:

Since a major melter loss mechanism associated with the radiologically important semivolatiles is also associated with submicron aerosol emission, the elemental makeup of this size fraction is of particular interest.

Table 4.6-8 gives representative submicron particulate compositional data collected during the PSCM-4 experiment. If a material balance of this submicron matter is established by assuming an oxide form for all elements except for a stoichiometric quantity of $\mathrm{Na}$, which is associated with the $\mathrm{Cl}$ in the sample, $99 \%$ of the matter present can be accounted for. It should be noted that while the submicron sample fraction is quite rich in semivolatiles, it is essentially salt ( 83 wt\% $\mathrm{NaCl}$ ). 
TABLE 4.6-4, Pilot-Scale Ceramic Melter Operating Condittons(a) HWVP-85-V1143A, HWVP-86-V1124A, HWVP-89-IVJ0010100B, $7 \mathrm{H} 35-85-23$

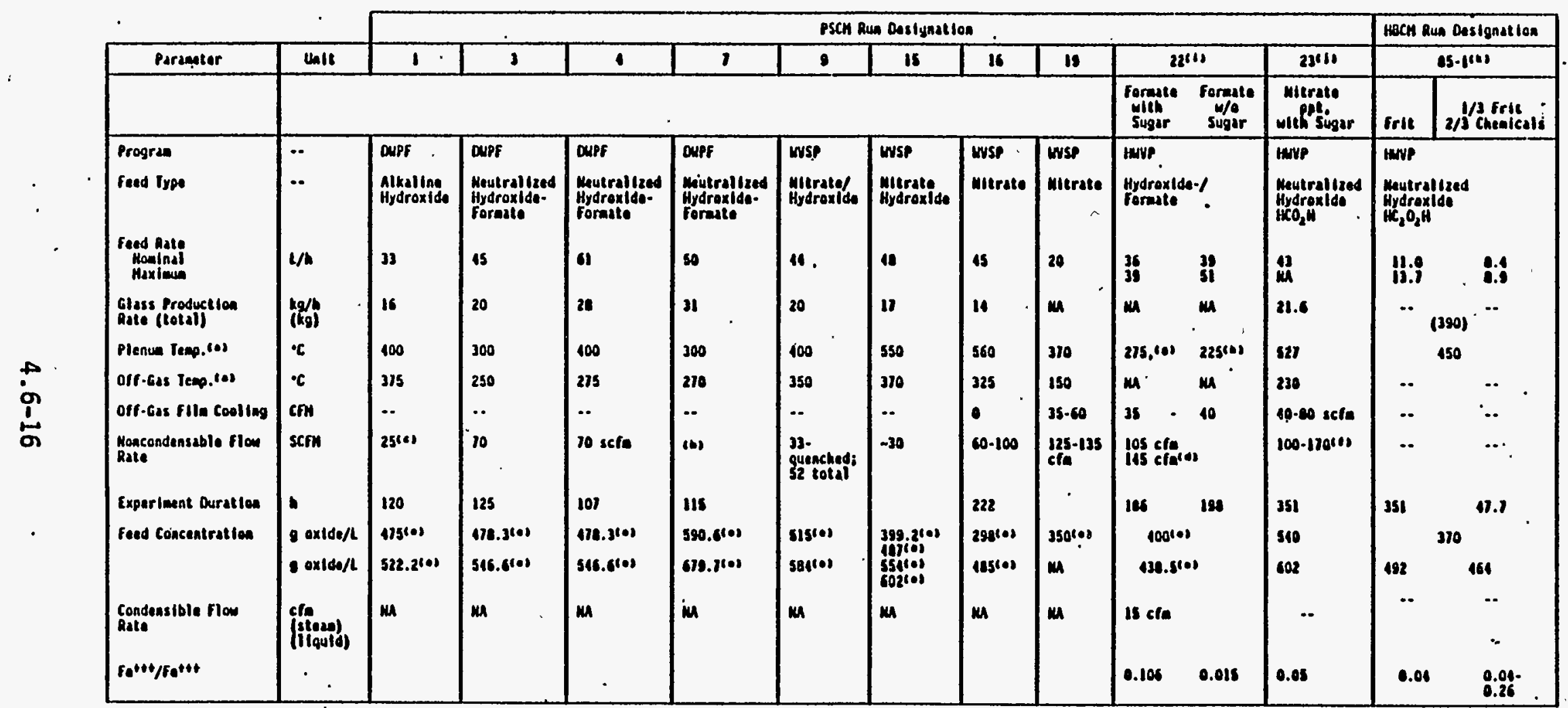

\footnotetext{
(8) Averaged aver course of rua.

Excludes

do 10 CF eifter vecuin control alr injected between EVS and columa.

8) Desiga lavol.

9) haninal fred rato.

1) Run dostgnatleas: iwup-12.

(k) Run deslganation: Murp-is.
} 
TABLE 4.6-5. Size Distribution of Aerosols in PSCM Exhaust Gas

Ref. 4.6-3, HWVP-89-1VJ0010100B

\begin{tabular}{|c|l|l|l|r|r|}
\hline \multirow{2}{*}{$\begin{array}{c}\text { PNL } \\
\text { Experiment } \\
\text { No. }\end{array}$} & \multicolumn{4}{|c|}{ Average wt\% Versus Cut Point } \\
\cline { 3 - 6 } & Feed Type & $16 \mu \mathrm{m}$ & $6 \mu \mathrm{m}$ & $1 \mu \mathrm{m}$ & $<1 \mu \mathrm{m}$ \\
\hline LFCM-7 & Formate & 76.7 & 2.8 & 8.5 & 11.9 \\
PSCM-4 & Formate & $(\mathrm{a})$ & 0.9 & 3.6. & 95.6 \\
PSCM-5 & Formate & 13.5 & 3.9 & 20.2 & 62.2 \\
PSCM-6 & Formate & 46.1 & 0.5 & 12.7 & 40.7 \\
PSCM-7 & Formate & 7.5 & 3.2 & 9.4 & 79.9 \\
PSCM-8 & Formate & 44.0 & 7.3 & 19.6 & 29.1 \\
PSCM-9 & Nitrate & 8.2 & 2.1 & 16.3 & 73.7 \\
PSCM-15. & Nitrate/hydroxide & 44.7 & 9.8 & 22.4 & 23.1 \\
PSCM-23 & Formate/sugar. & 29 & 5.2 & 18.8 & 46.4 \\
\hline
\end{tabular}

(a) Dashes indicate data below detection limit.

A comparison of the average gross melter DFs obtained from the melter tests conducted at. PNL indicates that, regardless of feed type, when a melter is underfed because of experimental design or system limitations, extremely. high aerosol DFs result. Conversely, experiments punctuated by melter overfeeding have, in general, exhibited the poorest off-gas emission performance. In between these two extremes lies the majority of melter tests conducted at PNL, where feeding rates were carefully ramped to produce stable steady-state operating conditions that matched feeding and glass production rates at $-80 \%$ cold-cap coverage. Table 4.6-9 compares emission data obtained from LFCM tests conducted under all three of these operating conditions: underfeeding, steady state, and overfeeding.

Air-sparge-induced glass convection has also been used to boost LFCM steady-state processing rates. The results obtained from the 1 imited tests con-ducted indicate that, at worst, a slight lowering of melter DF may result from increases in gross entrainment. These losses are, however, readily removed by the first-stage scrubber. The overall DF across the melter and quench scrubber has not been found to be significantly affected by forced-convective feed rate boosting techniques.

The consistency of melter DFs during the PSCM HWVP test (HWVP-12) indicates that the sugar redox supplement feed component has no significant influence upon melter aerosol emission. Similarly, melter off-gas decontamination performance was not significantly affected by the substitution of chemical glass former for two-thirds of the frit in the HWVP-11 feed stream. The variability in HWVP-11 data is, however, large enough that small effects could be masked, but no large impact upon melter performance was observed from this substitution. 
TABLE 4.6-6. Elemental Size Distribution Across the Cyclonic Sampling System - HWVP (Ref. 4.6-3) HWVP-89-1VJ0010100B

\begin{tabular}{|c|c|c|c|c|c|c|c|c|}
\hline \multirow[b]{3}{*}{ Element } & \multicolumn{8}{|c|}{ Average wt\% Versus Cut Point } \\
\hline & \multicolumn{2}{|c|}{$16 \mu n$} & \multicolumn{2}{|c|}{$6 \mu \mathrm{m}$} & \multicolumn{2}{|c|}{$11 \mathrm{mon}$} & \multicolumn{2}{|c|}{$<1 \mu m$} \\
\hline & LFCM-1 & HWVP-15 & LFCH-1. & HWVP-15 & LFCH-I & HWVP-15 & LFCM-1 & HWVP-15 \\
\hline $\begin{array}{l}A 7 \\
B \\
\mathrm{Ba} \\
\mathrm{Ca} \\
\mathrm{Cd} \\
\mathrm{Ce} \\
\mathrm{Cl} \\
\mathrm{Co} \\
\mathrm{Cr} \\
\mathrm{Cs} \\
\mathrm{Cu} \\
\mathrm{F} \\
\mathrm{Fe} \\
\mathrm{K} \\
\mathrm{La} \\
\mathrm{Li} \\
\mathrm{Mg} \\
\mathrm{Mn} \\
\mathrm{Mo} \\
N \\
\mathrm{Na} \\
\mathrm{Nd} \\
\mathrm{Ni} \\
\mathrm{P} \\
\mathrm{Pb} \\
\mathrm{S} \\
\mathrm{Sb} \\
\mathrm{Se} \\
\mathrm{Si} \\
\mathrm{Sr} \\
\mathrm{Te} \\
\mathrm{Ti} \\
\mathrm{V} \\
\mathrm{Y} \\
\mathrm{Zn} \\
\mathrm{Zr}\end{array}$ & $\begin{array}{c}96.2 \\
87.8 \\
89 \\
77.7 \\
10.7 \\
92.1 \\
-. \\
-- \\
46.4 \\
7.5 \\
82.6 \\
-- \\
77.3 \\
9- \\
91.9 \\
83.2 \\
91.5 \\
89.4 \\
77.5 \\
-- \\
68.8 \\
93.4 \\
-. \\
-. \\
0 . \\
-- \\
100.0 \\
56.9 \\
92.0 \\
77.6 \\
5.5 \\
91.2 \\
0- \\
-- \\
0- \\
91.6\end{array}$ & $\begin{array}{c}56 \\
58.1 \\
7.2 \\
50 \\
4.5 \\
64 \\
16 \\
5.2 \\
35 \\
6.8 \\
16 \\
20 \\
54 \\
3.4 \\
64 \\
7.6 \\
50 \\
52 . \\
12 \\
100 \\
11 \\
62 \\
38 \\
8.7 \\
9.5 \\
13 \\
\because- \\
-. \\
59 \\
57 \\
\cdots \\
50 \\
6.1 \\
59 \\
54 \\
54\end{array}$ & $\begin{array}{l}0.9 \\
1.8 \\
5.8 \\
2.7 \\
0.8 \\
0 \\
-. \\
-0 \\
21.7 \\
0 \\
4.9 \\
-0 \\
2.6 \\
-- \\
1.5 \\
1.5 \\
1.6 \\
6.4 \\
5.6 \\
-- \\
1.7 \\
0 . \\
-- \\
-0 \\
-0 \\
0 \\
0 \\
1.9 \\
1.8 \\
2.8 \\
0.4 \\
1.8 \\
-- \\
0- \\
-- \\
1.6 .\end{array}$ & $\begin{array}{c}11 \\
7.6 \\
12 \\
8.8 \\
0 \\
13 \\
2.9 \\
20 \\
7.5 \\
2.2 \\
2.5 \\
7.5 \\
11 \\
1.9 \\
11 \\
1.8 \\
11 \\
9.9 \\
3.1 \\
0 \\
2.6 \\
10 \\
2.4 \\
4.3 \\
0 \\
3.5 \\
0- \\
0- \\
12 \\
10 \\
-9 \\
9.9 \\
6.9 \\
10 \\
8.4 \\
10\end{array}$ & 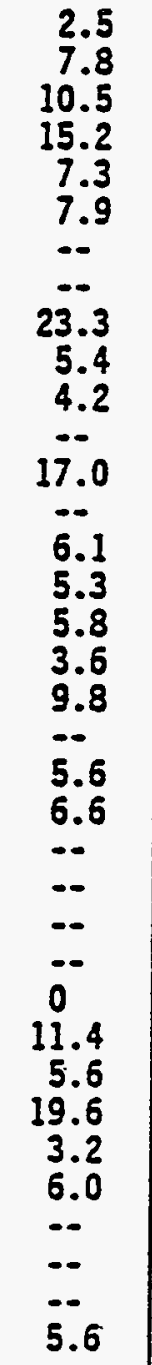 & $\begin{array}{c}26 \\
23 \\
14 \\
22 \\
4.2 \\
13 \\
14 / \\
3.9 \\
21 \\
15 \\
6.1 \\
16 \\
27 \\
6.7 . \\
21 \\
7.1 \\
21 \\
25 \\
13 \\
0 \\
9.2 \\
23 \\
4.2 \\
10 \\
10 \\
15 \\
-. \\
-9 \\
14 \\
24 \\
18 \\
18 \\
10 \\
24 \\
18 \\
26\end{array}$ & $\begin{array}{c}0.4 \\
2.6 \\
0 \\
4.4 \\
81.2 \\
0 \\
-- \\
-- \\
8.6 \\
87.1 \\
8.3 \\
-- \\
3.1 \\
-- \\
0.5 \\
10.0 \\
1.1 \\
0.6 \\
7.1 \\
-- \\
23.9 \\
0 \\
--. \\
-- \\
-- \\
-- \\
0 \\
29.8 \\
0.6 \\
0 \\
90.9 \\
1.0 \\
0- \\
-. \\
-- \\
1.2\end{array}$ & $\begin{array}{c}7 \\
12 \\
3.7 \\
19 \\
91 \\
9.8 \\
67 \\
71 \\
37 \\
76 \\
75 \\
56 \\
7.9 \\
88 \\
4.1 \\
83 \\
19 \\
13 \\
73 \\
0 \\
77 \\
4.6 \\
55 \\
76 \\
80 \\
68 \\
-- \\
-- \\
15 \\
8.4 \\
-- \\
22 \\
77 \\
6.3 \\
20 \\
10\end{array}$ \\
\hline
\end{tabular}


TABLE 4.6-7. Composition of $16-\mu$ Cyclonic Sample Fraction (LFCM-7) - HWVP (Ref. 4.6-3)

\begin{tabular}{|c|c|c|}
\hline & \multicolumn{2}{|c|}{ Weight Percent } \\
\hline Elemental Oxides(a) & $16 \mu \mathrm{m}$ & Feed \\
\hline $\begin{array}{l}\mathrm{Al}_{2} \mathrm{O}_{3} \\
\mathrm{~B}_{2} \mathrm{O}_{3} \\
\mathrm{CaO}^{2} \\
\mathrm{Fe}_{2} \mathrm{O}_{3} \\
\mathrm{La}_{2} \mathrm{O}_{3} \\
\mathrm{LiO}_{2} \\
\mathrm{MgO}^{2} \\
\mathrm{MnO} \\
\mathrm{Na}_{2} \mathrm{O} \\
\mathrm{SiO}_{2} \\
\mathrm{TiO}_{2} \\
\mathrm{ZrO}^{2}\end{array}$ & $\begin{array}{r}3.4 \\
9.0 \\
1.6 \\
14.4 \\
0.3 \\
3.5 \\
1.1 \\
3.2 \\
13.0 \\
38.0 \\
0.7 \\
0.3\end{array}$ & $\begin{array}{r}5.1 \\
10.5 \\
1.7 \\
12.7 \\
0.4 \\
4.1 \\
1.4 \\
2.9 \\
13.6 \\
45.6 \\
0.7 \\
0.4\end{array}$ \\
\hline
\end{tabular}

(a) Assumed oxide forms.

TABLE 4.6-8. Submicron Particulate Composition (PSCM-4) - HWVP (Ref. 4.6-3)

\begin{tabular}{|c|c|c|c|c|}
\hline Element & $\begin{array}{c}\text { Elementa] } \\
(w t \%)\end{array}$ & $\begin{array}{l}\text { Assumed } \\
\text { Form }\end{array}$ & $\begin{array}{l}\text { Compound } \\
(w t \%)\end{array}$ & $\begin{array}{c}\text { Feed } \\
\text { Composition }(\%)\end{array}$ \\
\hline $\begin{array}{l}\mathrm{AT} \\
\mathrm{B} \\
\mathrm{Ca} \\
\mathrm{Cd} \\
\mathrm{CT} \\
\mathrm{Cs} \\
\mathrm{Cu} \\
\mathrm{Fe} \\
\mathrm{K} \\
\mathrm{Li} \\
\mathrm{Mg} \\
\mathrm{Mn} \\
\mathrm{Na} \\
\mathrm{Ni} \\
\mathrm{Pb} \\
\mathrm{Si} \\
\mathrm{Te} . \\
\mathrm{Zn} \\
\text { Total }\end{array}$ & $\begin{array}{c}0.04 \\
0.07 \\
0.14 \\
0.55 \\
55.0 \\
2.1 \\
0.06 \\
0.29 \\
0.36 \\
1.1 \\
0.02 \\
0.08 \\
33.7 \\
\\
0.03 \\
0.04 \\
0.66 \\
0.56 \\
0.02\end{array}$ & 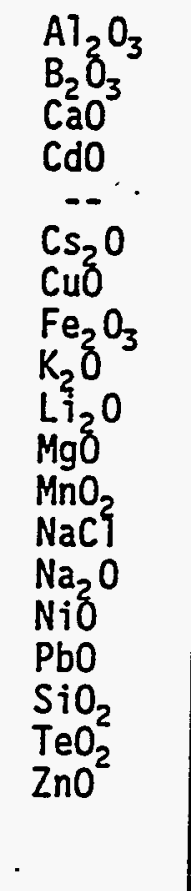 & $\begin{array}{l}0.8 \\
0.24 \\
0.20 \\
0.63 \\
-. \\
2.2 \\
0.09 \\
0.41 \\
0.43 \\
2.4 \\
0.03 \\
0.13 \\
83.0 \\
6.7 \\
0.04 \\
0.05 \\
1.4 \\
0.71 \\
0.02 \\
\\
99.8\end{array}$ & $\begin{array}{c}4.95 \\
9.86 \\
1.66 \\
0.006 \\
0.4 \\
0.044 \\
-. . \\
13.69 \\
-.- \\
3.98 \\
1.29 \\
3.25 \\
-. \\
13.88 \\
0.76 \\
-. \\
44.47 \\
0.006 \\
-.\end{array}$ \\
\hline
\end{tabular}


TABLE 4.6̈-9. Emission Data from LFCM Tests Under Various Conditions - HWVP (Ref. 4.6-4)

\begin{tabular}{|c|c|c|c|}
\hline & \multicolumn{3}{|c|}{ Melter DF } \\
\hline Element & Underfed & $\begin{array}{c}\text { Steady State } \\
\text { (PSCM-6) }\end{array}$ & $\begin{array}{l}\text { Overfed } \\
\text { (LFCM-7) }\end{array}$ \\
\hline $\begin{array}{l}\mathrm{Al} \\
\mathrm{B} \\
\mathrm{Ca} \\
\mathrm{Cd} \\
\mathrm{Cl}\end{array}$ & $\begin{array}{c}3,500 \\
44 \\
67 \\
--(a) \\
--\end{array}$ & $\begin{array}{r}22,000 \\
100 \\
1,200 \\
9.9 \\
2.9\end{array}$ & $\begin{array}{r}190 \\
75 \\
62 \\
8.0 \\
--\end{array}$ \\
\hline $\begin{array}{l}\mathrm{Cs} \\
\mathrm{Fe} \\
\mathrm{La} \\
\mathrm{Li} \\
\mathrm{Mg}\end{array}$ & $\begin{array}{r}330 \\
3,300 \\
3,100 \\
2,400 \\
2,600\end{array}$ & $\begin{array}{r}14 \\
1,800 \\
2,100 \\
1,300 \\
7,800\end{array}$ & $\begin{array}{r}12 \\
69 \\
-- \\
89 \\
120\end{array}$ \\
\hline $\begin{array}{l}\mathrm{Mn} \\
\mathrm{Na} \\
\mathrm{Nd} \\
\mathrm{Ni} \\
\mathrm{Ru}\end{array}$ & $\begin{array}{r}4,500 \\
1,500 \\
3,300 \\
4,200 \\
3.1\end{array}$ & $\begin{array}{r}1,800 \\
300 \\
2,500 \\
1,100 \\
.\end{array}$ & $\begin{array}{l}76 \\
60 \\
-- \\
-- \\
16\end{array}$ \\
\hline $\begin{array}{l}S \\
\text { Sb } \\
\text { Se } \\
\text { Si } \\
\text { Sr }\end{array}$ & $\begin{array}{r}\cdots \\
12,000^{-\cdots} \\
2,900\end{array}$ & $\begin{array}{r}5.5 \\
\cdots \\
13,000 \\
1,800\end{array}$ & $\begin{array}{r}-- \\
67 \\
1 \\
120 \\
55\end{array}$ \\
\hline $\begin{array}{l}\text { Te } \\
\text { Ti. } \\
\text { Zr }\end{array}$ & $\begin{array}{r}-- \\
4,700 \\
1,700 \\
\end{array}$ & $\begin{array}{r}3.0 \\
5,900 \\
22,000 \\
\end{array}$ & $\begin{array}{r}5.6 \\
120 \\
--. \\
\end{array}$ \\
\hline Total & 1,900 & 800 & 120 \\
\hline
\end{tabular}

(a) Dashes indicate data below detection limit.

As a point of comparison, it appears that the particulate sizes generated at SRL in LFCM testing (Figure-4.6-7) are moderately larger than those generated using the PSCM (Table 4.6-5). This difference would probably result in somewhat improved off-gas system decontamination performance for equivalent circumstances.

Because the loss mechanism associated with nonvolatile feed components is gross feed entrainment, it may be expected that the melter performance for 


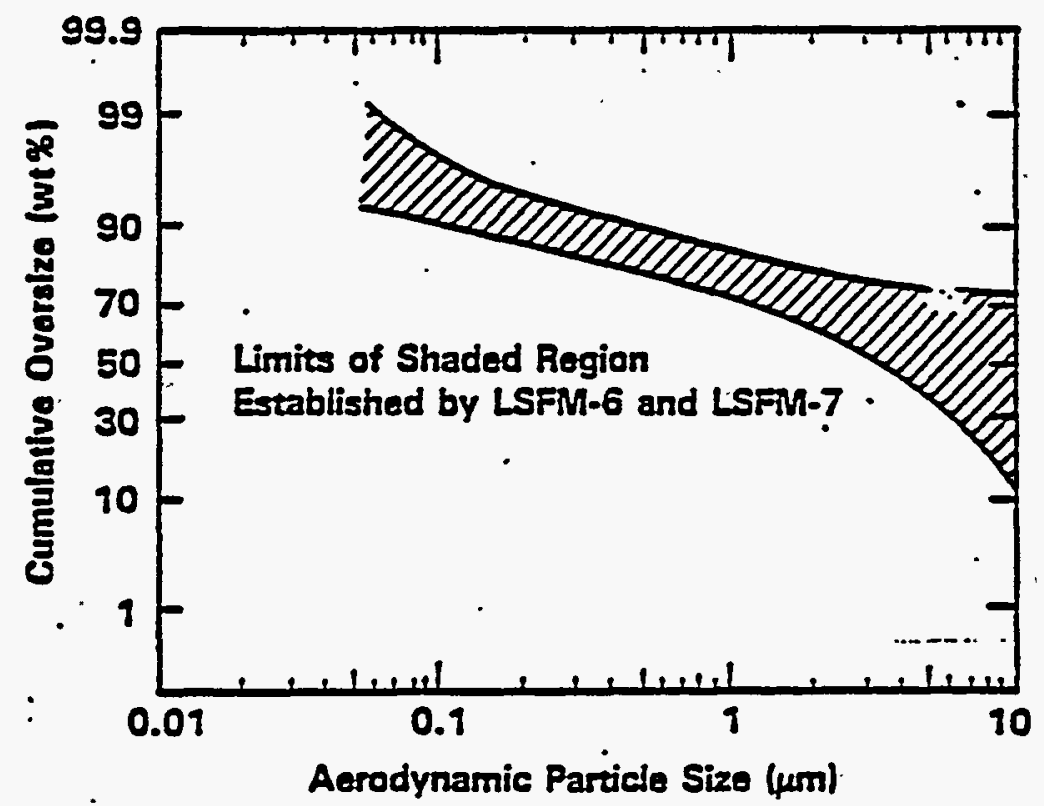

FIGURE 4.6-7. Aerosol Distribution of Slurry-Fed Off Gas (W. P. Colven, DWPF Off-Gas System, Technical Exchange with SRL, June 15-19, 1983)

nonvolatile species should not change for HWVP feed. This is not what actua17y occurs. The differences between observed DWPF and HWVP results are believed to be associated with gross feed properties such as the distribution of feed components between solution and slurry, the physical nature of insoluble feed components that were used in making up the slurry, and the approach used in operating the meiter.

Variations in the chemical forms employed and the physical methods used during feed preparation may influence nonvolatile effluent melter performance. Vapor pressure differences among the various possible chemical compounds that can be found in a melter can also affect melter DFs. The DF values of representative aerosol feed components appearing in HWVP-12 are in good agreement with results obtained from the HWVP-11 melter effluent characterization studies (HWVP-11 DF $=430$, HWVP-12 DF $=330$ ). (See Appendix C for average aerosol and individual element DFs.)

Aerosol decontamination factors for HWVP tests HWVP-12 and -15 are shown in Table 4.6-10. There is a significant difference in the average melter aerosol decontamination factors by a factor of -5 (HWVP-12 DF $=330$ versus HWVP-I5 DF $=1500$, average). This difference is attributed to the difference in testing techniques. In HWVP-12 the feed composition was changed three times; the feed rate seven times (testing nominal and maximum feeding), and there were scheduled and unscheduled feeding downtimes of 7.5 and $5.0 \mathrm{~h}$ respectively over the $427-h$ test period (resulting in a $98.8 \%$ melter feeding operating efficiency based on nonscheduled outages). In HWVP-15, there were no feed rate or composition changes. The melter was operated with a cold cap 
TABLE 4.6-10. HWUP-15 Decontamination Factors for Melter Aerosol, HWVP-89-IVJ0010100B

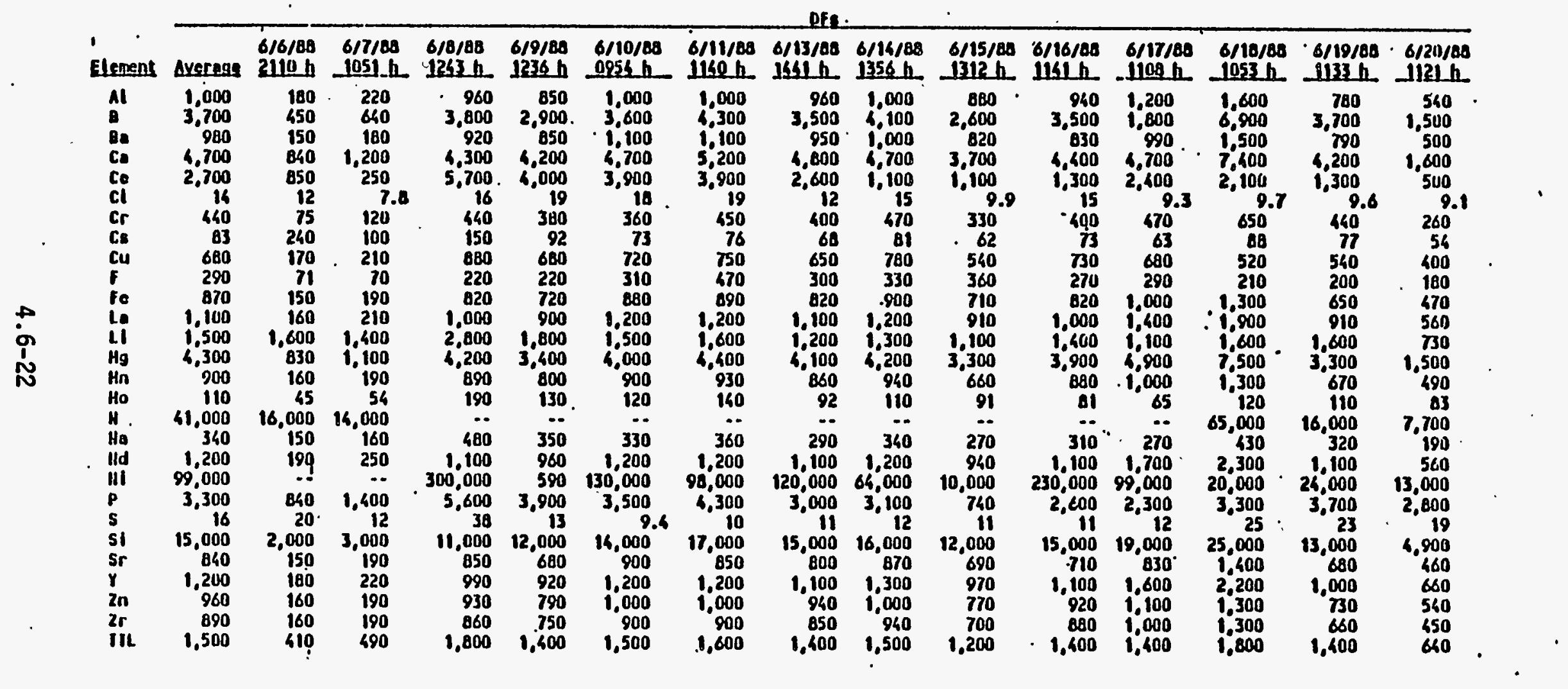


coverage of 60 to $80 \%$ throughout the melter feeding period. There were several pump failures and nozzle pluggages, which resulted in a $98 \%$ melter feeding operating efficiency. It is felt that the significant differences in run aerosol decontamination factors was caused by the unsteady operations in HWVP-12, which are expected to be more characteristic of plant operations. During feed rate ramp-up over the first 2.5 days of HWV-15 melter feeding, it can be seen from Table 4.6-10 that the total average aerosol decontamination factors (410 and 490) are rè atively close to those experienced in HWVP-15 testing and other PSCM and HBCM data shown in Appendix C.

\subsection{Semivolatiles. LFCM processing of simulated high-level} liquid waste (HLLW) slurries generates gaseous as well as condensed-phase effluent losses. Because of the large number of chemical components that can be formed, losses of volatile and semivolatile feed component elements can and usually do involve both gaseous and aerosol escape mechanisms. Nonvolatile losses, on the other hand, are strictly associated with an aerosol transport mechanism. The size distribution of aerosols responsible for a particular feed component loss is, however, dependent upon the dominant mechanism responsible for the aerosolization process. For the semivolatiles, volatilization quickly followed by reaction and/or condensation is responsible for the submicron nature of the aerosols associated with these elements.

Because volatile and semivolatile feed components possess at least two;. and possibly three independent loss mechanisms (entrainment, volatilization/ condensation and/or volatilization), elements possessing at least some degree of volatility would be expected to exhibit much lower melter DFs than corresponding nonvolatile feed components, as the process results illustrate. The lowest melter DFs are associated with elements that can form volatile and/or semivolatile compounds at operating melter temperatures.

The volatility of Ru can be quite high under strongly oxidizing conditions. Ruthenium volatility is effectively suppressed by the formic acid (reducing agent) in the HWVP reference feed (HWVP-12 Ru DF $=42$ ). This effect has also been observed during LFCM processing of reduced DWPF and WVSP feed streams. Although Ru aerosol emission is the predominant melter loss mechanism associated with processing of reduced feeds, gaseous Ru losses cannot be totally discounted because of the low elemental detection sensitivity associated with this element. Preliminary off-gas data generated by PNL's Radioactive Liquid-Fed Ceramic Melter (RLFCM) have indicated the presence of volatilized ${ }^{106} \mathrm{Ru}$ during the processing of a reduced, radioactive WVSP feed. The $R u$ DF recorded during HWVP- 12 is quite consistent with previous PSCM results obtained using a reduced WVSP feed stream. However, HWVP Ru effluent data are not totally consistent with previous PSCM-DWPF testing results because of the much higher formic acid loading in the SRL feed stream. The SRL feed stream was so highly reduced in those tests that the semivolatile nature of Ru was totally masked. Melter dropout of Ru was the most important loss mechanism for feed-component metallic Ru during those tests. In WVDP and HWVP PSCM testing with Ru, the Ru behaved.as a fully condensed semivolatile downstream of the melter based on the similarity between DFs for Cs, Mo, 
and $\mathrm{Ru}$ in the quench scrubber and subsequent MOG treatment equipment. PNL. has not observed volatile $R u$ in off-gas samples downstream of the quench scrubber.

The Tow melter DF for CS (DF = 14) indicated in HWVP-12 is consistent with previous test results obtained during PSCM processing of formatted SRL feeds. Formated feeds are effective in promoting the Cs volatilization/ condensation process in the melter plenum and, as a resuit, have been responsible for the lowest recorded Cs OFs measured at PNL. Consistentiy low melter. Cs DFs have been associated with the formate feed reductant; although the presence of the formate anion does not guarantee greatly enhanced Cs emission rates. This formate feed loading or reducing power of the feed also influences melter loss rates. A $30 \%$ increase in formic acid feed loading in the HWUP-12 run resulted in a factor of 7 decrease in average meiter CS DF when compared with HWVP-11 where sugar was also used. In HWVP-15 where the reductant concentration used (formic acid and sugar) was much higher (by a factor of -2) than in HWVP-12, the Cs decontamination factor was higher than in. HWVP-12 by a factor of 7 . However, in HWVP-15 the nitrate (oxidant) content in the feed was much higher. Cesium melter emission chemistry affecting $D F$ is not fully understood.

The PNL tests providing most of the semivolatile element behavior data are those that utilized feed with high levels of nitrate $(>2 M)$ in the WVSP testing. Nitrates in waste streams can increase the volatility of ruthenium during calcination and vitrification. Pilot-scale melter WVSP experiments identified in this regard are PSCM-9, -15 , and -16 . The key potential semivolatile or volatile fission products considered are: Ru, I, CS, Tc, Sb, Se, $T e$, and $S r$. The radioelement TC was represented by the nonradioactive homolog $\mathrm{Hn}_{\mathrm{n}}$. The principal issue in surveying these data is whether or not these elements are behaving as gases (volatiles) or aerosols (particles or nonvolatiles). Limited data have also been produced for semivolatile element behavior during HWVP runs HWVP-12, HWVP-15, and HWVP-11 (Appendix C).

The PSCM-9 results (Table 4.6-11) show that $I$, Ru, and Se are readily entrained or volatilized from the melter cold cap as evidenced by low DFs. Iodine appeared to behave as a gas during PSCM-9; the form most likely is $I_{2}$. Selenium penetrated all of the cyclone collectors and was captured in the condensate. In addition, Se has a Tow scrubber DF, meaning low removal efficiency. This implies that $\mathrm{Se}$ is gaseous in the melter off gas. Ruthenjum is mostiy collected in the submicron fraction of the cycione train, but very little was found in the condensate. This suggests that Ru is predominantly a submicron aerosol. Additionaliy, the primary. scrubber quite effectively removed Ru from the melter off gas, which would not be expected were Ru predominantly gaseous. The elements $\mathrm{CS}, \mathrm{Mn} ; \mathrm{Sb}, \mathrm{Te}$, and $\mathrm{Sr}$ had fairly high melter and scrubber DFs and were all nearly completely collected in the aerosol-collection cyclone samplers. This evidence indicates that $\mathrm{Cs}, \mathrm{Mn}$, $\mathrm{Sb}, \mathrm{Te}$, and $\mathrm{Sr}$ are aerosols rather than volatiles as they exit the melter. 
TABLE 4.6-11. WVSP(a) Semivolatile Element Decontamination Factor Results, PSCM-9 (D. E. Larson et al.,. "HWVP Process Off-Gas decontamination Factors," HWVP-85-V1143 A, February 1986)

\begin{tabular}{|c|c|c|c|c|c|c|c|c|c|}
\hline & \multicolumn{9}{|c|}{ Time-Averaged Decontamination Factors } \\
\hline & Ru & I & Cs & & & Sb & $\mathrm{Se}$ & $\mathrm{Te}$ & sr \\
\hline \multirow[t]{2}{*}{$\begin{array}{l}\text { Melter } \\
\text { Primary scrubber }\end{array}$} & 20 & $\begin{array}{l}1 \\
1.5\end{array}$ & $\begin{array}{r}14 \\
7\end{array}$ & & & $\begin{array}{r}470 \\
10\end{array}$ & $\frac{1}{2}$ & $\begin{array}{l}25 \\
10\end{array}$ & $\begin{array}{r}2200 \\
\text { (a) }\end{array}$ \\
\hline & \multicolumn{9}{|c|}{$\begin{array}{c}\text { Element Distribution (wt\%) Across } \\
\text { Cyclonic Size Fractions, Untreated } \\
\text { MeTter Off Gas }\end{array}$} \\
\hline Cut Size $(\mu \mathrm{m})$ & Ru & Cs & & $\mathrm{Mn}$ & $\mathrm{Sb}$ & & Se & $\mathrm{Te}$ & Sr \\
\hline $\begin{array}{c}16 \\
6 \\
1 \\
<1 \\
\text { Condensate }\end{array}$ & $\begin{array}{r}6 \\
1 \\
16 \\
65 \\
12\end{array}$ & $\begin{array}{r}1 \\
1 \\
10 \\
\cdot 88 \\
-\end{array}$ & & $\begin{array}{r}42 \\
4 \\
45 \\
5 \\
4\end{array}$ & $\begin{array}{r}8 \\
3 \\
17 \\
72 \\
--\end{array}$ & & $\begin{array}{l}-- \\
-- \\
-- \\
6 \\
94\end{array}$ & $\begin{array}{l}-- \\
-- \\
16 \\
84 \\
--\end{array}$ & $\begin{array}{r}14 \\
7 \\
21 \\
49 \\
9\end{array}$ \\
\hline
\end{tabular}

(a) Dashes, --, indicate data below detection limit.

The PSCM-15 results (Table 4.6-12) are qualitatively similar to the PSCM-9 results. Selenium is completely volatilized from the melter but shows a higher DF through the submerged bed scrubber (SBS) than in PSCM-9's ejector/venturi scrubber (EVS). Additional7y, the melter DF for Ru was much higher in PSCM-15 than in PSCM-9, but the primary scrubbers had approximately the same DF for the two tests. The HEME DFs provide insight as to the state of airborne elements. The fairly high OFs (greater than 50) for $\mathrm{Ru}, \mathrm{Cs}$, Se, and $\mathrm{Sr}$ indicate that these elements are essentially aerosols at this stage of the off-gas system. The low measured DF from Mn through the HEME is probably related to its nearly complete removal in the SBS. The high DF for Mn through the SBS is a consequence of its large particle size distribution as indicated by the particle size analysis. The $16-\mu \mathrm{m}$ stage collected $60 \%$ of the Mn.

The PSCM-16 results (Table 4.6-13) generally. support the implications of PSCM-9 and -15. Again, Se is volatilized completely; the high DFs through the SBS and HEME indicate that aerosols are the predominant form. Ruthenium exhibited high DFs through the metter and primary scrubber.

(a) WVSP - West Valley Support Project. 
TABLE 4.6-12. WVSP Semivolatile Element Decontamination Factor Results, PSCM-15 (D. E. Larson et al., "HWVP Process Off-Gas Decontamination Factors," HWVP-85-V1143 A, February 1986)

\begin{tabular}{|c|c|c|c|c|c|c|c|}
\hline & \multicolumn{7}{|c|}{ Time Averaged Decontamination Factors } \\
\hline & Ru & Cs & Mn & Sb & $\mathrm{Se}$ & Te & Sr \\
\hline $\begin{array}{l}\text { Melter } \\
\text { Primary serubber } \\
\text { HEME }\end{array}$ & $\begin{array}{l}10 \\
20(a) \\
220\end{array}$ & $\begin{array}{l}50(a) \\
6 \\
54\end{array}$ & $\begin{array}{r}400 \\
7,000 \\
14\end{array}$ & $\begin{array}{r}370 \\
13 \\
--\end{array}$ & $\frac{1}{21}$ & $\begin{array}{l}50(a) \\
6 \\
--\end{array}$ & $\begin{array}{l}100(a) \\
--(b) \\
77\end{array}$ \\
\hline$\cdot$ & \multicolumn{7}{|c|}{$\begin{array}{l}\text { Elemental Distribution (wt\%) Across Cyclonic } \\
\text { Size Fractions, Untreated Melter Off Gas }\end{array}$} \\
\hline Cut Size, & Ru & Cs & Mn & & & $\mathrm{Se}$ & $\mathrm{Te}$ \\
\hline $\begin{array}{r}16 \\
6 \\
1 \\
<1\end{array}$ & $\begin{array}{c}13 \\
5 \\
22 \\
61\end{array}$ & $\begin{array}{r}7 \\
4 \\
22 \\
67\end{array}$ & $\begin{array}{r}59 \\
15 \\
26 \\
0\end{array}$ & & & $\begin{array}{l}37 \\
12 \\
34 \\
17\end{array}$ & $\begin{array}{r}0 \\
6 \\
\cdot \quad 35 \\
59\end{array}$ \\
\hline
\end{tabular}

(a) These elements exhibited wide variations in DFs according to replicate measurements made at different times. The values given are conservative selections from the measured ranges, which are as follows:

\begin{tabular}{|c|c|}
\hline Melter & Scrubber \\
\hline $\begin{array}{l}\text { Cs, } 34-100 \\
\mathrm{Te}, 46-1700 \\
\mathrm{Sr}\end{array}$ & $\begin{array}{l}M n, 1-30,000 \\
R u, 6-210\end{array}$ \\
\hline
\end{tabular}

(b) Dashes indicate data below detection limit.

TABLE 4.6-13. WVSP Semivolatile Element Decontamination Factor Results, PSCM-16 (D. E. Larson et a7., "HWVP Process Off-Gas Decontamination Factors," HWVP-85-V1143 A, February 1986)

\begin{tabular}{|l|c|c|c|c|c|c|}
\cline { 2 - 7 } \multicolumn{1}{c|}{} & \multicolumn{5}{c|}{ Time-Averaged Decontamination Factors } \\
\cline { 2 - 7 } \multicolumn{1}{c|}{} & $\mathrm{Ru}$ & $\mathrm{CS}$ & $\mathrm{Mn}$ & $\mathrm{Se}$ & $\mathrm{Te}$ & $\mathrm{Sr}$ \\
\hline Melter & -- & 59 & 970 & 1.5 & 21 & 240 \\
Primary scrubber (SBS) & 4200 & 10 & 42 & 19 & 700 & 1300 \\
HEME & -- & -- & 10 & 420 & -- & -- \\
\hline
\end{tabular}


Results for. HWVP melter testing (HWVP-11, HWVP-12, HWVP-15) in Table 4.6-14 provide additional data on elements that have semivolatile characteristics but tend to. be more volatile. These results complement the WVSP testing results where common data exists. In addition, Table 4.6-6 implies that the following elements may have a partial tendency to volatilize based on a size distribution analysis: $\mathrm{Cd}, \mathrm{Co}, \mathrm{Cu}, \mathrm{K}, \mathrm{Li}, \mathrm{Mo}, \mathrm{Na}, \mathrm{Ni}, \mathrm{Pb}$, and $\mathrm{V}$. However, the measured decontamination factors in Appendix $C$ from the melter do not support that the volatilization is significant. Table 4.6-14 also provides the volatility of a number of elements that have a significant volatile portion exiting the melter. Based on HWVP melter test data, halides and sulphur have a significant volatility from the melter and continue to exhibit volatile properties in the MOG treatment system.

In summary, the PNL liquid-fed melter tests indicate that, of the potential volatile radionuclides, only $I$-and Se behave predominately as gases in untreated melter off gas. Upon cooling in a primary scrubber, Se tends to be collected as if it were an aerosol. Iodine will likely remain as gaseous $I_{2}$ in melter off-gas systems. Ruthenium was highly volatilized from the melter in one test (50\%, PSCM-9), but its behavior through the primary scrubber and through the fiberglass filter (HEME) was indicative of an aerosol. The other potential volatile elements ( $\mathrm{C}, \mathrm{Mn}, \mathrm{Sb}, \mathrm{Se}, \mathrm{Te}$, and $\mathrm{Sr}$ ) behaved essentially as aerosols. The chemistry of semivolatile materials in the vitrification process has not been studied extensively except to measure the elemental decontamination factors. The low DFs of the semivolatiles relative to the nonvolatiles suggest that a high vapor pressure of the oxide or metal causes the material to volatilize. Subsequent decontamination and materials properties suggest that the volatiles condense on cold. surfaces, on other particulates, and by themselves to form small particies $(<1 \mu \mathrm{m})$ or to coat equipment surfaces.

Ruthenium is a special case, in which the oxide is oxidized to a gaseous compound $\left(\mathrm{RuO}_{2}+\mathrm{O}_{2} \rightarrow \mathrm{RuO}_{4}\right)$. Depending on environmental conditions, equipment, surface conditions, and temperature, the $\mathrm{RuO}_{4}$ is easily reduced to the solid dioxide form. Data for the HWVP and SRL processes described in Appen$\operatorname{dix} C$, where conditions in the melter are reducing, show $2.5 \%$ to $3 \%$ of the Ru being volatilized to a gas, as indicated by the low decontamination factor. Subsequent DFs on the off-gas systems and sample collections indicate that essentially all of the gaseous Ru compounds decompose to the dioxide in the meiter vapor space or off-gàs outlet and subsequently behave as particulates.

4.6.4.1.3 Volatiles. Most elements generaliy regarded as volatile, including $\mathrm{C}, \mathrm{Cl}, \mathrm{F}, \mathrm{I}, \mathrm{H}, \mathrm{N}$, and $\mathrm{S}$, escape from the melter with a decontamination factor of $<2$. Except for the halides and sulfur, the halides may be in the form of semivolatile alkali halides or gases. Sulfur is likely associated with gaseous $\mathrm{SO}_{x}$ and also solids not yet characterized. The other volatiles behave as gases. 
TABLE 4.6-14. HWVP Semivolatile and Volat1le Decontamination Factor Results HWVP-12, HWVP-15, HWVP-11 HWVP-89-IVJ0010100B, HWVP-86-V1124A 7H35-85-23

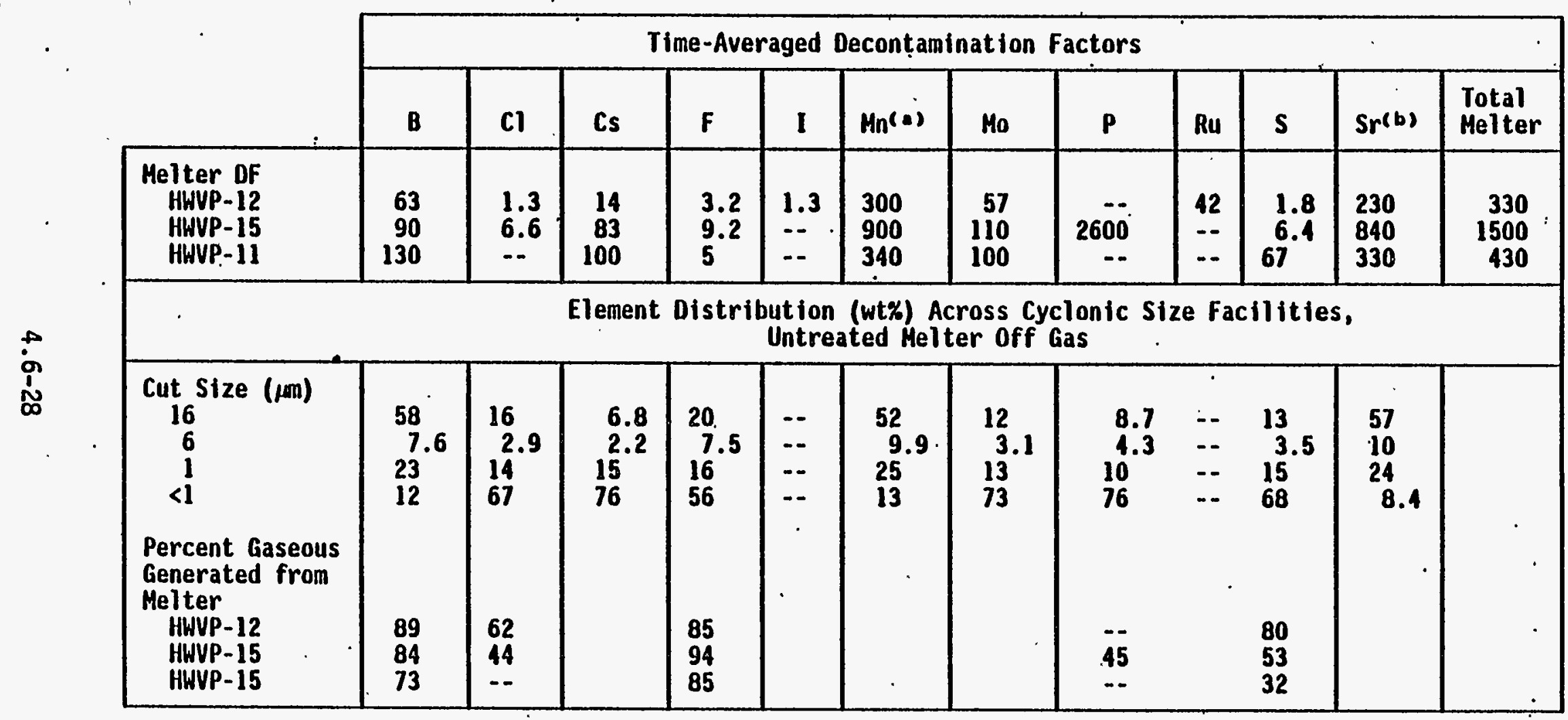

(a) Chemical analogue for Tc.

(b) Particulate. 
The composition and nature of melter-generated gas emissions are strong functions of feed composition. Both the elemental and chemical natures of the feed components are important in establishing relative proportions of the various gaseous byproducts produced during LFCM feed processing. This importance is illustrated by the behavior of carbonaceous reductants in the feed. When formic acid is used in LFCM feeds, flammability hazards associated with $\mathrm{H}_{2}$ and $\mathrm{CO}$ in the quenched melter exhaust are process concerns, although in HWVP- 12 and HWVP-15 the $\mathrm{H}_{2}$ and $\mathrm{CO}$ concentrations were well below the flammability limits. Other operational parameters, such as plenum temperature and melter in-leakage, can also be used to influence melter exhaust-gas composition. The DWPF process utilizes both of these parameters to oxidize combustibles before they are conveyed into the off-gas system.

The composition of the melter off-gas in HWVP-15 testing is shown in Tabie 4.6-15. For the simulated HWVP melter feed used during the HWVP-15 test, $\mathrm{CO}_{2}$, and $\mathrm{NO}_{X}$ are the major noncondensible $\left(-25^{\circ} \mathrm{C}\right)$ gases produced by the vitrification process. For a quenched off-gas fiow rate of $-110 \mathrm{scfm}$ and a steady-state feeding rate of $43 \mathrm{~L} / \mathrm{h}$, the MOG concentrations of these effluent gases were nominally 0.64 v01\% and 0.18 vol\%, respectively. The combustible gases $\mathrm{CO}$ and $\mathrm{H}_{2}$ were also detected, but at much lower concentrations:

$<0.10 \mathrm{v} 01 \%$ and 0.01 v01\%, respectively. These concentrations are well below the lower flammability limits of these combustible gases of 4.65 vol\% for $\mathrm{H}_{2}$ and 15.5 vol\% for $\mathrm{CO}$. Even without the benefit of film cooler dilution, offgas concentrations of these gases were not found to approach the lower flammability 7 imit at the $43 \mathrm{~L} / \mathrm{h}$ feeding rate. In the plenum and prior to the SBS, steam is the primary factor that eliminates the possibility of $\mathrm{H}_{2}$ and $\mathrm{CO}$ combustion. The dilution caused by air inleakage and the film cooler injection ensure against any possibility for auto-ignition downstream of the SBS. In the worse case (and quite unrealistic) scenario of no inleakage and no air injection, $\mathrm{Ar}, \mathrm{N}_{2}, \mathrm{O}_{2}$, and. $-5 \%$ of the $\mathrm{CO}_{2}$ would be eliminated. This would result in just 1 vol\% $\mathrm{H}_{2}$ and $<10$ vol\% $\mathrm{CO}$, both values still well below the lower flammability limits.

Table 4.6-15 summarizes the results obtained from mass spectrometric analysis of the quenched melter exhaust with and without film cooler air injection. The lack of $\mathrm{SO}_{x}$ results in this data does not mean that volatility losses for sulfur are small; rather, it is a reflection of the fact that $\mathrm{SO}_{2}$ production is not thermodynamically favored when plenum temperatures are $<600^{\circ} \mathrm{C}$ (Ref.. 4.6-3). $\mathrm{SO}_{3}$ is a reactive condensible gas which is effectively removed during the quenching process.

TABLE 4.6-15. Melter Off-Gas Composition HWVP-89-IV10010100B

\begin{tabular}{|c|c|c|c|c|c|c|c|c|c|c|}
\hline \multirow{2}{*}{$\begin{array}{c}\text { Sample } \\
\text { Date/Time }\end{array}$} & \multirow{2}{*}{$\begin{array}{c}\text { MOG Flow } \\
\text { (scfm) }\end{array}$} & \multicolumn{10}{|c|}{ Mole \% } \\
\cline { 3 - 13 } & $\mathrm{H}_{2}$ & $\mathrm{Ar}$ & $\mathrm{H}_{2}$ & $\mathrm{O}_{2}$ & $\mathrm{CO}$ & $\mathrm{CO}_{2}$ & $\mathrm{NO}_{x}$ & $\mathrm{SO}_{\mathrm{x}}$ & $\mathrm{CH}_{4}$ \\
\hline $6 / 10$ & 110 & 0.01 & 0.92 & 77.0 & 21.2 & $<0.10$ & 0.64 & 0.18 & $<0.01$ & $<0.01$ \\
$6 / 20$ & 70 & 0.13 & 0.90 & 75.5 & 20.4 & $<0.10$ & 2.51 & 0.47 & $<0.01$ & $<0.01$ \\
\hline
\end{tabular}


The time-dependent behavior of process emissions of $\mathrm{NO}_{x}, \mathrm{CO}$, and $\mathrm{CO}_{2}$ were followed in real time with specific gas analyzers during HWVP-15. Because steady-state feeding conditions were maintained throughout most phases of testing, the process exhaust concentrations of these gases were quite invariant throughout the test. They were perturbed only by planned changes in film cooler injection rates, i.e., MOG flow rate. Figure 4.6-8 illustrates the temporal behavior of these off-gas effluent gases.

Condensible gases are also generated during $L F C M$ processing. $B, C], F$, $P$, and $S$ feed components are all volatilized to some extent during LFCM processing; however, the volatile species. invoived are efficiently removed (physicaliy and/or chemicaliy) by the aqueous off-gas system quencher--in this case SBS. The percentage of effluent losses due to gas phase escape for each of these volatile elements is summarized in Table 4.6-16. These data demonstrate that essentially all he $B$ and $F$ and most of the $C T, P$, and $S$ exhausted to the SBS are in the gas phase. In Table 4.6-17 the percent volatility data for HWVP-15 are compared with similar data collected during the previous two HWVP melter tests.

Nitrogen and $C$ have no appreciable glass solubility, should be evolved quantitatively from the melter as volatile oxides. Although this is ostensively true for $\mathrm{C}, \mathrm{NO}_{2}$ releases during the present test can only account for $-75 \%$ of the $N$ fed to the meiter. Since condensed phase nitrates represent less than $1 \%$ of off-gas system nitrogen, there are apparently undetected chemical pathiways of melter nitrogen loss. The effort to identify al ternate nitrogen-bearing effluent led to the detection of $\mathrm{NH}_{4}^{*}$ of off-gas condensate solutions at ten times the concentrations expected from feed compositional data. Although the quantities of $\mathrm{NH}_{3}$ effluent detected are only $-5 \%$ of the nitrogen evolved during processing, it opens up the possibility that $\mathrm{NO}_{3}$ reduction to $\mathrm{N}_{2}$ may be occurring. If true, this would explain the inabijity to achieve a nitrogen mass balance in the present test and could also. explain similar results obtained by SRL during past LSFM melter tests. (a)

The effect of plenum lid heaters upon the melter exhaust composition is illustrated in Figure 4.6-9, which characterizes results from a PNL melter test. This test employed $100 \mathrm{~h}$ of radiant-7id-heating boosting, followed by $20 \mathrm{~h}$ of unboosted operation. The high plenum temperatures associated with Tid heating have a definite controlling influence on the combustible gases $C O$ and $\mathrm{H}_{2}$ and are not generated smoothly or continuously even under the most controlled operational conditions. This behavior is due to the variable, nonuniform way in which melter feed is dried, oxidized, and melted during the iquid feeding process. Large variations in gas generation rates usually occur when dammed-up liquid feed Tying atop an insulating layer of dry feed (the cold cap) abruptly flows out upon a hot glass surface. The liquid quickly flashes off this hot surface, producing a flow pulse composed of

(a) K. R. Crow, Summary of Campaigns SGM-4 and SGM-5 of the DWPF Scale GIaSS Melter. DPST-87-247, Savannah River Laboratory, Aiken, South Carolina (1986). 


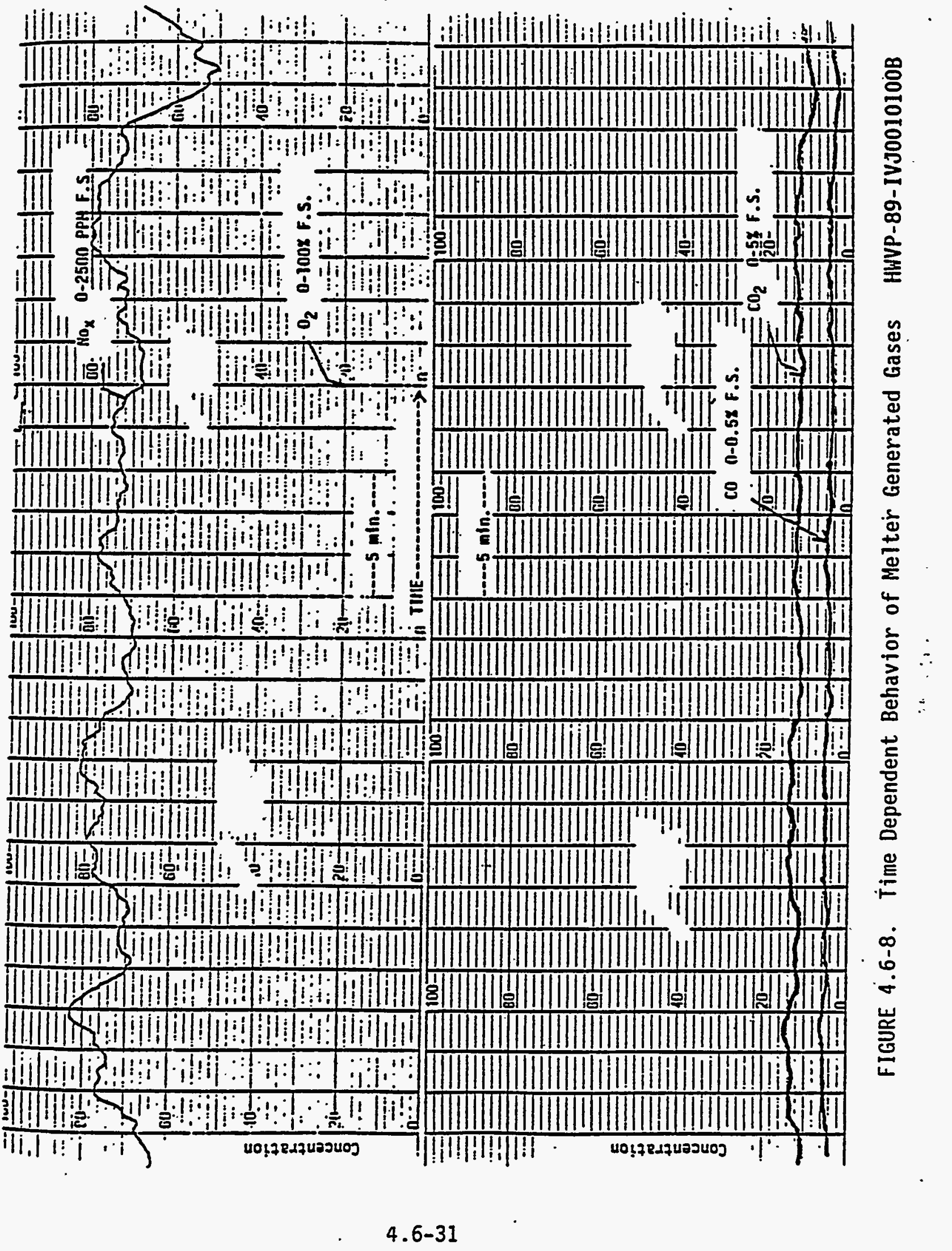


TABLE 4.6-16. . Volatile Melter Effiuent Losses HWVP-89-IVJ0010100B

\begin{tabular}{|c|c|c|c|c|c|}
\cline { 2 - 6 } \multicolumn{1}{c|}{} & \multicolumn{5}{c|}{ \% Losses Due to Gaseous Escape } \\
\hline Day & B & C1 & F & P & S \\
\hline 6 & 51 & $\ddots 11$ & 72 & 75 & 32 \\
7 & 59 & 33 & 86 & 12 & 23 \\
8 & 89 & 52 & 96 & 22 & 75 \\
9 & 85 & 52 & 96 & -- & 47 \\
10 & 87 & 43 & 97 & -- & 41 \\
11 & 92 & 63 & 99 & -- & 44 \\
13 & 88 & 45 & 97 & 12 & 56 \\
14 & 93 & 73 & 98 & -- & 59 \\
15 & 88 & 52 & 98 & 25 & 60 \\
16 & 88 & 52 & 96 & 70 & 51 \\
17 & 80 & 41 & 97 & -- & 63 \\
18 & 94 & 39 & 95 & -- & 54 \\
19 & 90 & 49 & 95 & 55 & 72 \\
20 & 94 & $(15)$ & 98 & -- & 66 \\
21 & 96 & 56 & 95 & 38 & 25 \\
22 & 85 & 61 & 95 & -- & 12 \\
23 & 82 & 19 & 83 & -- & 78 \\
Avg. & $84 \pm 15$ & $44 \pm 37$ & $94 \pm 7$ & $45 \pm 53$ & $53 \pm 28$ \\
\hline
\end{tabular}

TABLE 4.6-17. Percent Volatije Melter Effluent Losses HWVP-89-IVJ0010100B

\begin{tabular}{|c|c|c|c|}
\cline { 2 - 4 } \multicolumn{1}{c|}{} & \multicolumn{3}{c|}{$\%$ Loss by Volatility } \\
\hline \multirow{3}{*}{ Element } & $\begin{array}{l}\text { HWVP-15/ } \\
\text { PSCM-23 }\end{array}$ & $\begin{array}{c}\text { HWVP-12/ } \\
\text { PSCM-22 }\end{array}$ & $\begin{array}{c}\text { HWVP-11/ } \\
\text { HB85-1 }\end{array}$ \\
\hline B & 60 & 89 & 73 \\
C7 & 23 & 62 & -- \\
F & 17 & 85 & 85 \\
S & 6.6 & 80 & 32 \\
\hline
\end{tabular}




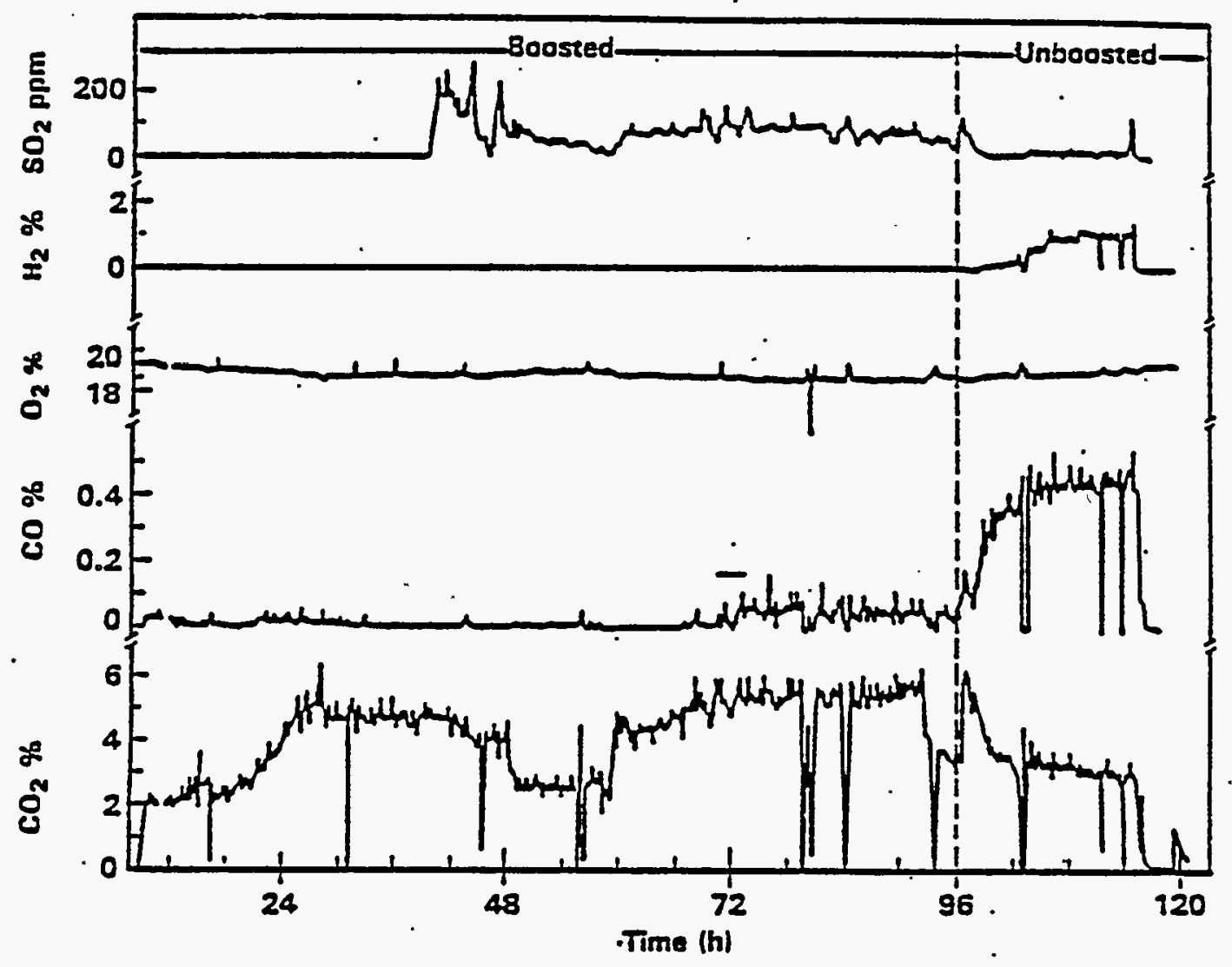

FIGURE 4.6-9. Melter Exhaust Gas Composition of 100-H Boosted, 20-H Unboosted Test (PSCM-6) - HWVP (Ref. 4.6-4).

steam and volatile decomposition/reaction products. The frequency and/or extent of these excursions are related to the physical properties of the feed which, in turn, are composition-dependent. Figures 4.6-10 and 4.6-11 illustrate the behavior of some of the more important melter-generated gases that accompany flow surges. The frequency and magnitude of these surges are positive indicators of melter system instabilities, which are most often associated with erratic excessive feeding. One of the instabilities is reboil, which is caused by glass redox changes and involves rapid evolution of oxygen.

The correlation between the emission rates of noncondensible gases and steam flow surges suggests a prompt evolution. of combustible gases from the cold cap. Figures $4 \cdot 6-12$ and $4 \cdot 6-13$ portray the time-dependent compositional behavior of the melter exhaust streams upon feed interruption or termination. With the exception of $\mathrm{SO}_{2}$, none of the melter-generated gases increased in 


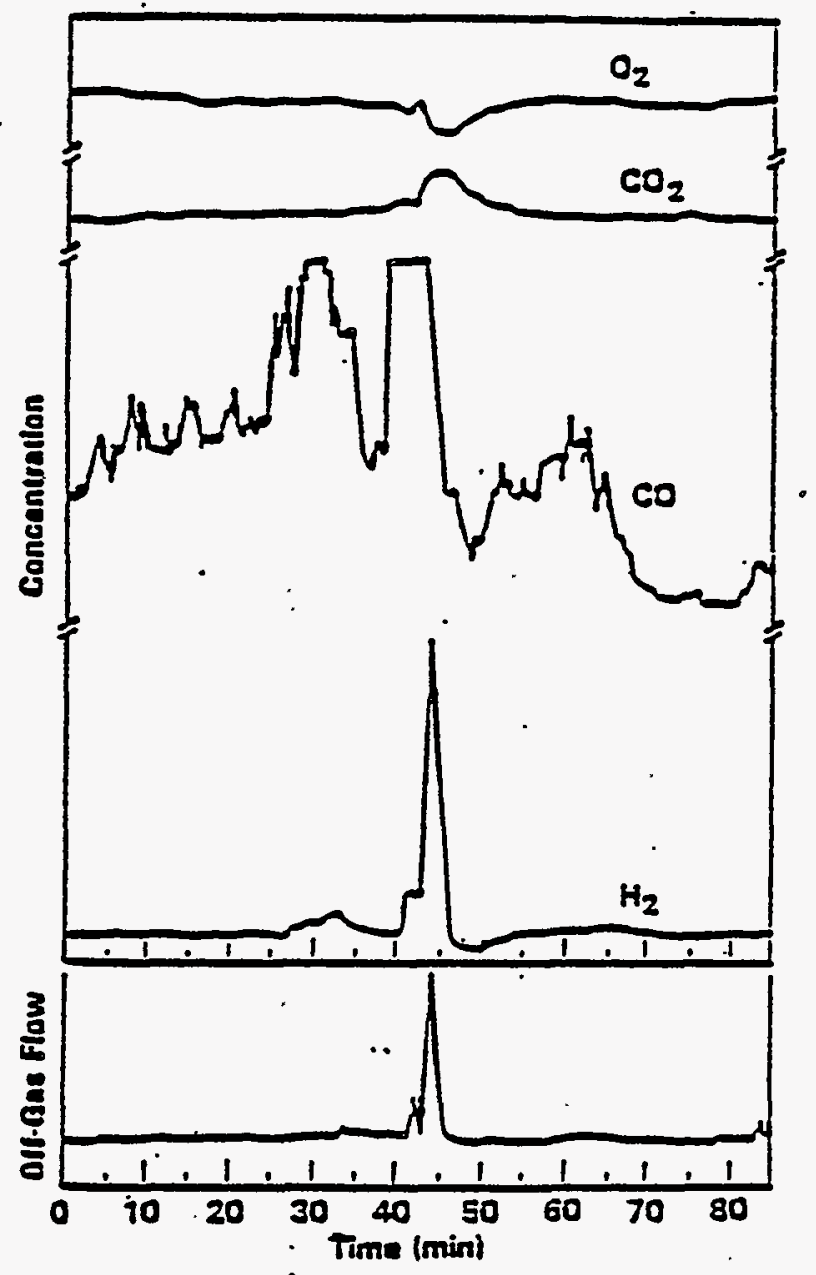

FIGURE 4.6-10. Compositional Behavior of Noncondensible Melter Exhaust Gases Accompanying a Flow Surge. (Maximum extent of the surge event flow: $3 X ; H 2<$ $3.5 \% ; \mathrm{CO} \gg 0.5 \% ; \mathrm{CO}_{2}-15 \% ; \mathrm{C}_{2}-17 \%$.) - HWVP (Ref. 4.6-4)

concentration when feeding was terminated. Consequently, a dry cold cap has not been observed to produce combustibility hazards above those that already exist during normal liquid feeding.

Feed components that have the greatest influence on melter exhaust gas composition are traditionally chemical additives used in fuel processing $\left(\mathrm{NO}_{3}-, \mathrm{SO}_{4}=\right.$ ) or in waste feed conditioning (organics). Because these elements all possess several volatile oxides, the exhaust conditions will vary depending on the nature of the feed and plenum temperature. Table 4.6-18 generalizes exhaust conditions based upon PNL observations involving these parameters. Table 4.6-19 shows the effect on melter off-gas composition when formic acid is added to the feed. 

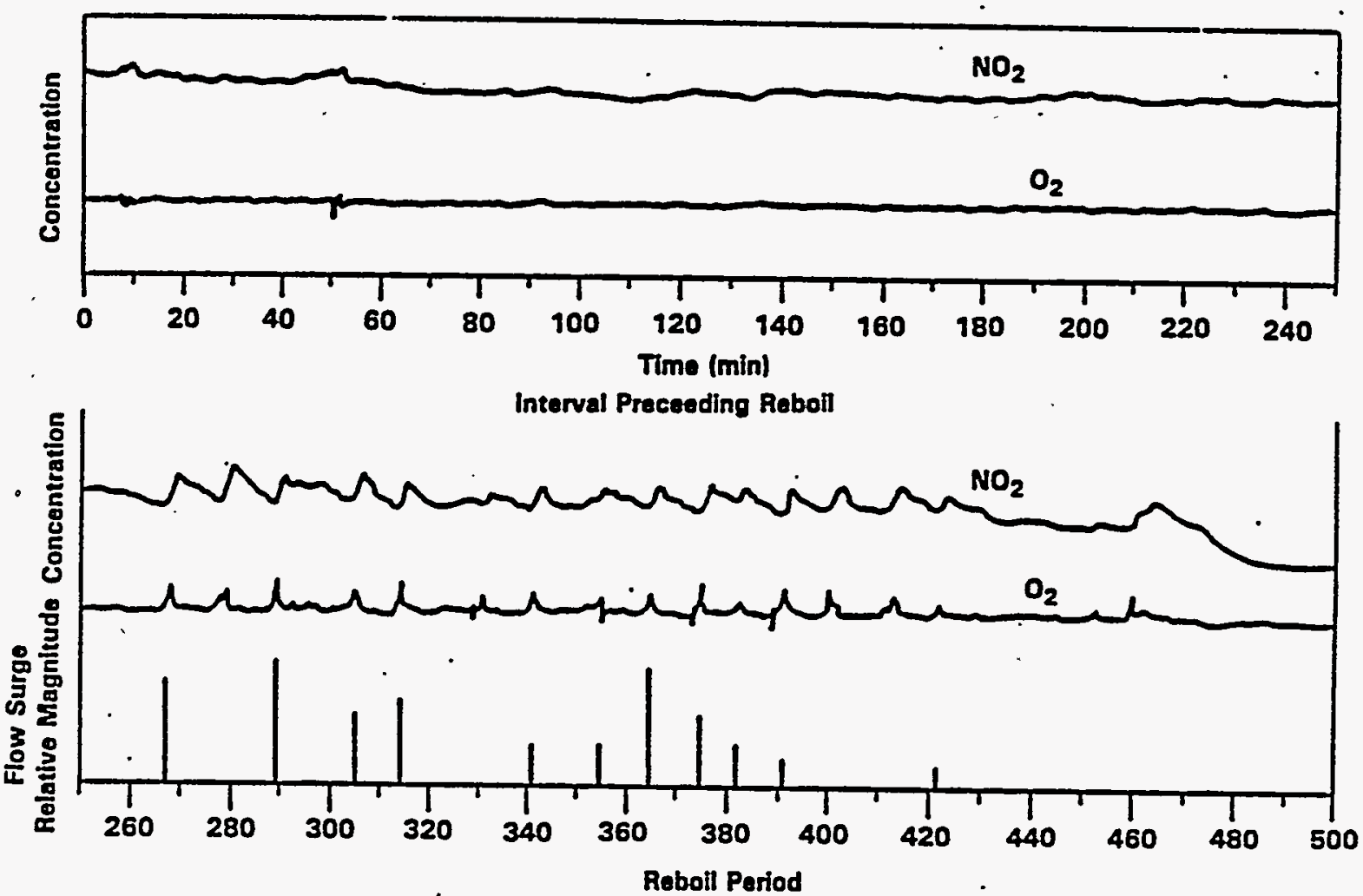

FIGURE 4.6-11. Noncondensible Off-Gas Composition Preceding and During Melter Reboil - HWVP (Ref. 4.6-4)

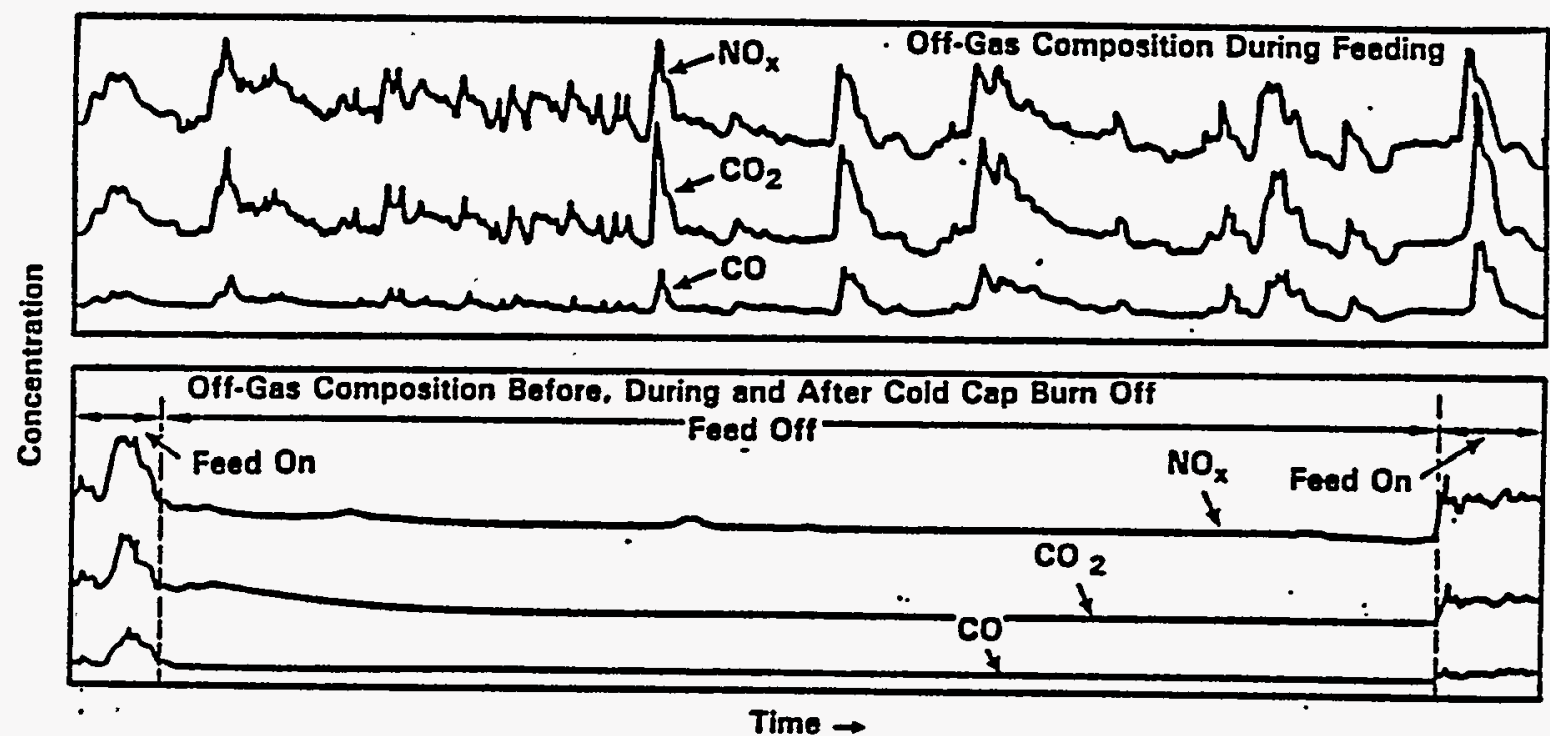

FIGURE 4.6-12. Compositional Behavior of Exhaust Stream Feed Interruption - HWVP. (Ref. 4.6-4) 


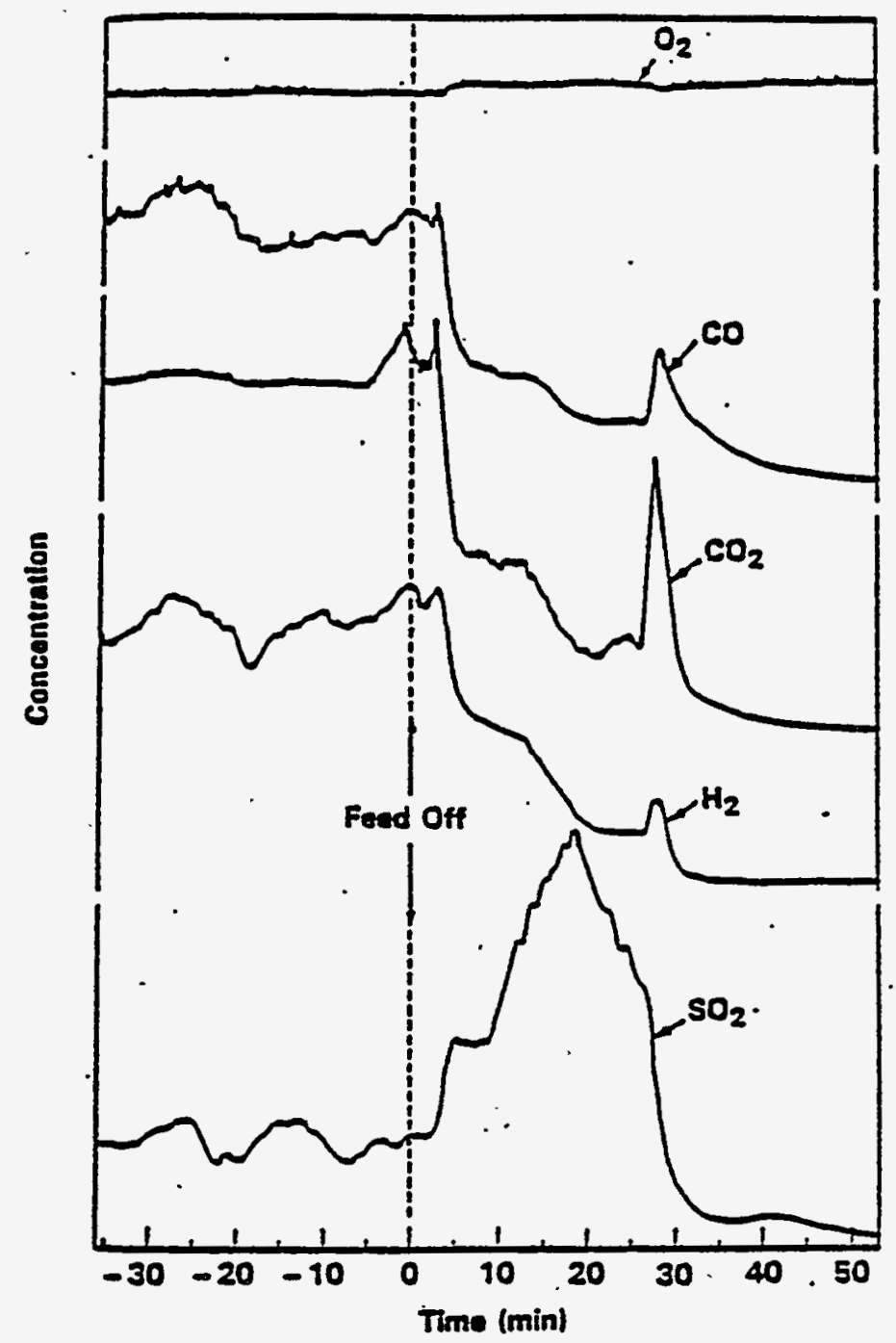

FIGURE 4.6-13. Melter Off-Gas Compositional Behavior Associated With Feed Termination. (The $t=30$ min compositional spike is due to the injection of a small quantity of liquid feed.) - HWVP (Ref. 4.6-4)

LFCM processing of feeds containing the formate anion presents the concern of producing significant concentrations of $\mathrm{H}_{2}$ and $\mathrm{CO}$. Because of its low flammability .l imit $(-4.0 \%)$, hydrogen generation can produce safetyrelated processing problems. PNL meiter tests involving DHPF formated feeds have shown the nominal relative prodyction rates of $\mathrm{CO}_{2}, \mathrm{H}_{2}$, and $\mathrm{CO}$ to be about $1,0.5$, and 0.1 , respectively. (a) However, application of lid heat

(a) E.I. du Pont de Nemours \& Company, "Basic Data Report - OWPF-Sludge Plant, SRP 200-S Area," DPSP 80-133, SRP. 
TABLE 4.6-18. Qualitative Relationship Between LFCM Feed Types and Presence of Exhaust-Gas Constituents - HWVP

(Ref. 4.6-4)

\begin{tabular}{|l|c|l|l|l|l|}
\cline { 2 - 6 } \multicolumn{1}{c|}{} & Temperature & $\mathrm{NO}_{2} / \mathrm{NO}(\mathrm{a})$ & $\mathrm{CO}_{2} / \mathrm{CO}$ & $\mathrm{H}_{2}$ & $\mathrm{SO}_{2}(b)$ \\
\hline $\begin{array}{l}\text { Nitrate } \\
\text { Refractory organics }\end{array}$ & $\mathrm{LOW}$ & $\infty$ & $--(\mathrm{c})$ & -- & $\mathrm{No}$ \\
$\begin{array}{l}\text { Formate. } \\
\text { Formate } \\
\text { Nitrate/refractory } \\
\text { organic }\end{array}$ & $\mathrm{LOW}$ & -- & 10 & $\mathrm{No}$ & $\mathrm{No}$ \\
& $\mathrm{High}$ & -- & $<3$ & $\mathrm{Yes}$ & $\mathrm{No}$ \\
\hline
\end{tabular}

(a) Time-dependent behabvior converts $\mathrm{NO}$ to $\mathrm{NO}_{2}$.

(b) $\mathrm{SO}_{2}$ emissions have never been measured directly.

(c) Dashes indicate data below detection limit.

TABLE 4.6-19. Melter-Generated Off-Gas Components (formate) - HWVP (Ref. 4.6-3)

\begin{tabular}{|c|c|c|c|c|c|c|c|c|c|c|}
\hline \multirow[b]{3}{*}{ Experiment } & \multirow{3}{*}{$\begin{array}{c}\text { Melter } \\
\text { In-Leakage } \\
\text { (scfm) }\end{array}$} & \multicolumn{9}{|c|}{ Molar \% } \\
\hline & & \multicolumn{3}{|c|}{$\mathrm{CO}_{2}$} & \multicolumn{3}{|c|}{ CO } & \multicolumn{3}{|c|}{$\mathrm{H}_{2}$} \\
\hline & & High & Avg & Low & High & Avg & Low & High & Avg & Low \\
\hline $\begin{array}{l}\text { PSCM-3(a) } \\
\text { LFCH-7 } \\
\text { PSCM-4 } \\
\text { PSCH-5 } \\
\text { PSCM-6 } \\
\text { PSCM-7 } \\
\text { PSCM-8 } \\
\text { PSCM-23 }\end{array}$ & $\begin{array}{l}20 \\
90 \\
20 \\
30 \\
30 \\
12(c) \\
14 \\
70(d) \\
120(d)\end{array}$ & $\begin{array}{l}2.9 \\
2.2 \\
4.4 \\
6.5 \\
6.5 \\
8.0 \\
9.3 \\
. . \\
. .\end{array}$ & $\begin{array}{l}1.3 \\
0.74 \\
2.9 \\
2.8 \\
41 \\
5.0 \\
6.1 \\
0.64 \\
2.51\end{array}$ & $\begin{array}{l}0.26 \\
0.03 \\
1.5 \\
2.0 \\
2.0 \\
1.5 \\
1.2 \\
. . \\
. .\end{array}$ & $\begin{array}{l}1.3 \\
0.44 \\
0.75 \\
0.90 \\
0.60 \\
1.2 \\
0.8 \\
\ldots \\
. .\end{array}$ & $\begin{array}{r}0.40 \\
0.13 \\
0.44 \\
0.35 \\
0.09 \\
0.75 \\
0.16 \\
<0.10 \\
<0.10\end{array}$ & $\begin{array}{l}0.04 \\
0.002 \\
0.20 \\
0.10 \\
0.005 \\
0.10 \\
<0.005 \\
. .- \\
. .\end{array}$ & $\begin{array}{l}1.11 \\
0.63 \\
1.3 \\
1.8 \\
1.2 \\
3.5 \\
\mathrm{NA} \\
\ldots- \\
.-\end{array}$ & $\begin{array}{l}\text { NA(b) } \\
0.54 \\
1.1 \\
0.80 \\
\text { NA } \\
1.9 \\
\text { NA } \\
0.01 \\
0.13\end{array}$ & $\begin{array}{c}0.17 \\
0.40 \\
0.94 \\
0.10 \\
0.05 \\
0.30 \\
\mathrm{NA} \\
.- \\
. .\end{array}$ \\
\hline
\end{tabular}

(a) Sample stream diluted -2.5 times.

(b) NA = not available

(c) Off-gas dilution was used.

(d) Air flow at film cooler outlets. 
effectively eliminates $\mathrm{H}_{2}$ and $\mathrm{CO}$ through plenum oxidation. The relative production ratios of $\mathrm{CO}_{2}, \mathrm{H}_{2}$, and $\mathrm{CO}$ observed in HVWP-12 and HWVP-15 were 1 , 0.1 , and $<0.1$ and $1,0.05$, and $<0.1$, respectively. The presence of highly oxidizing $\mathrm{NO}_{x}$ gases in the melter exhaust may be responsible for reducing the event flow: three times $\left(\mathrm{H}_{2}<3.5 \%\right.$; $\mathrm{CO} \gg 0.5 \% ; \mathrm{CO}_{2}-15 \% ; \mathrm{O}_{2}-17 \%$ ) (Ref. 4.6-4) the net off-gas yield of hydrogen produced by HWVP reference feed. Whatever the cause, $\mathrm{CO}_{2}$ normalized $\mathrm{H}_{2}$ off-gas concentrations were lower during the processing of HWVP feed than they were on the average during SRL feed processing.

The data collected by the differential sampler during HWVP-12 testing clearly showed that melter gas-phase losses to the off-gas system are only significant for $B, C, N, S$, and the halogens, all of which readity form volatile acidic gases. Appendix $C$ summarizes the DFs of each of these off-gas effluents that were exhausted in the gaseous state from the various off-gas system components listed. The volatility data demonstrate that the presence of feed component sugar has little effect on melter volatility losses. Indeed, the formate component of the feed alone was fully capable of maintaining the reducing conditions within the melter, as is clearly illustrated by the absence of Ru volatility. Glass redox state was also not significantly affected by the removal of feed component sugar; this also indicates the dominating influence of the formate reductant in HWVP-12 feed.

The HWVP data in Table 4.6-14 illustrate the propensity of the halogen feed components to evolve from the meiter in the gaseous state. Gaseous halogens have the ability to penetrate all of the off-gas processing equipment that were studied. This fact is especially important for iodine because of the long-lived ${ }^{129}$ I isotope.

The volatility data were not strongly influenced by feed changes that resulted when chemical glass formers were substituted for two-thirds of the frit used during the previous two days of processing in HWVP-11.

The melter emission rates for the halogens followed during HWVP-12 and HWVP-15 (CT, F, and I) were without exception quite high. Moreover, the loss mechanism for these group VII elements was predominantly associated with gas phase emissions. Fluorine exhibited the highest average DF of 3.2 for HWVP-12 and 9.2 for HWVP-15, followed by chlorine and iodine, which both exhibited average DFs of 1.3 in HWVP-12 and and 6.6 for $\mathrm{Cl}$ in HWVP-15. It should also be noted that, unlike fluorine and chiorine, chemicaliy combined iodine in aerosol matter was never detected in off-gas samples; consequently, the total iodine DFs for HWVP-12 may be lower than indicated in Appendix $C$ if undetected aerosol iodine was present.

Like the halogens, sulfur exhibits a very low average melter. DF of 1.8 in HWVP-12 and 6.4 in HWVP-15. The higher-formic-acid feed loading may have been responsible for promoted higher volatile loss rates of sulfur than occurred in HWVP-11 (DF = 67). With such a low DF, very little if any sulfur was accumulating within the melter as a separate insoluble sulfate phase. 
The exhaust gases generated by an operating LFCM can be used to monitor melter processing conditions. For instance, $\mathrm{NO}_{x}$ and/or $\mathrm{CO}_{x}$ concentrations can be used to monitor feed processing conditions. The ratio of the oxides of carbon, if present, can be used to assess the oxidizing power of the liquid feed. The nitrogen oxide ratio $\mathrm{NO}_{2} / \mathrm{NO}$, on the other hand, has been found to be useful in assessing the redox conditions of the melter glass. In addition, oxygen monitoring of the melter exhaust can diagnose and alarm foaming and/or meiter reboil conditions. The temporal behavior of major exhaust-gas components can be a good indicator of melter processing stability.

4.6.4.1.4 Id7ing. Because of the high $\left(-1000^{\circ} \mathrm{C}\right)$ plenum temperatures associated with idling joule-heated ceramic melters, volatilization losses of radiologically important glass components during these periods could overwhelmingly influence the overall melter source term. The compositions of two different types of deposits formed in the process off-gas line during meiter idling appear in Table 4.6-20. The data in this tabie verify the importance of the volatilization loss mechanism for the semivolatiles. In order to determine the overall importance of this meiter loss mechanism for the semivolatiles, LFCM elemental emission rates were monitored during and after a 10-day meiter test for SRL (DWPF). Emission monitoring after the test continued well beyond the time required for the melter to achieve thermal equilibrium. The only radiologically important elements to exhibit idling emission rates comparable to those occurring during the test were the semivolatiles. The emission behavior of Cs appearing in Figure 4.6-14 represents a worst-case condition for all elements exhibiting significant emission rates during melter idling. The dashed line indicates the time at which melter feeding was terminated. The peak in emission rate that lies to the right of this dashed line is due in part to burnoff of plenum deposits formed during the preceding liquid-fed melter test. The important point is that melter emission rates during idling never exceed the nominal rates occurring during normal LFCM feed processing.

Experiments have also been conducted to establish whether idling emissions could be suppressed or reduced by control of plenum temperature and, consequently, glass surface temperature and viscosity (Figure 4.6-15). Temperature control was maintained through use of plenum water sprays, which cooled but did not disturb the surface of the melter glass poor. This study was initiated immediately after a $120-h$ liquid-fed melter test. With a $42-\mathrm{L} / \mathrm{h}$ water-spraying rate and the melter under automatic control to maintain approximately constant bulk tank temperatures, the melter glass surface was cooled to the point that it formed a continuous, nonconvective layer above the bulk melter glass pool (with plenum at 280C). When the spray rate was decreased to $27 \mathrm{~L} / \mathrm{h}$, the surface temperatures increased and the viscosity decreased significantly. In addition, convective mixing opened vents in the glass surface that migrated at random across the glass pool. However, plenum temperatures were not high enough to melt feed deposits that formed on the melter walls and 1id during the preceding PSCM-5 experiment. Finally, the cooling spray was terminated and the melter was allowed to idle, which slowly brought the melter plenum up to $1560^{\circ} \mathrm{F}\left(850^{\circ} \mathrm{C}\right)$. 
TABLE 4:6-20. Melter Idling Deposits - HWVP (Ref: 4.6-3)

\begin{tabular}{|c|c|c|c|}
\hline Oxides & $\begin{array}{l}\text { Gray Deposits } \\
\text { (wt\%) }\end{array}$ & $\begin{array}{l}\text { White Deposits } \\
\text { (wt\%) }\end{array}$ & $\begin{array}{l}\text { GTass } \\
\text { (wt\%) }\end{array}$ \\
\hline $\begin{array}{l}\mathrm{Al}_{2} \mathrm{O}_{3} \\
\mathrm{~B}_{2} \mathrm{O}_{3} \\
\mathrm{CaO}_{3} \\
\mathrm{CdO} \\
\mathrm{Cr}_{2} \mathrm{O}_{3}\end{array}$ & $\begin{array}{c}1.2 \\
14.2 \\
0.22 \\
0.02 \\
0.57\end{array}$ & $\begin{array}{l}0.11 \\
1.6 \\
0.46 \\
0.02 \\
0.58\end{array}$ & $\begin{array}{l}3.7 \\
10.0 \\
1.2 \\
0.009 \\
0.02\end{array}$ \\
\hline $\begin{array}{l}\mathrm{Cs}_{2} \mathrm{O} \\
\mathrm{Fe}_{2} \mathrm{O}_{3} \\
\mathrm{~K}_{2} \mathrm{O} \\
\mathrm{LI}_{2} \mathrm{O} \\
\mathrm{MgO}\end{array}$ & $\begin{array}{l}3.7 \\
0.10 \\
0.79 \\
1.92 \\
0.05\end{array}$ & $\begin{array}{l}8.3 \\
0.17 \\
0.85 \\
2.6 \\
0.05\end{array}$ & $\begin{array}{c}0.05 \\
14.8 \\
.8 .8 \\
4.4 \\
1.4\end{array}$ \\
\hline $\begin{array}{l}\mathrm{HnO}_{2} \\
\mathrm{Na}_{2} \mathrm{O} \\
\mathrm{NiO} \\
\mathrm{RuO}_{2} \\
\mathrm{Sb}_{2} \mathrm{O}_{3}\end{array}$ & $\begin{array}{l}0.05 \\
31.0 \\
0.25 \\
0.82 \\
0.01\end{array}$ & $\begin{array}{c}0.05 \\
31.0 \\
0.02 \\
2.1 \\
0.01\end{array}$ & $\begin{array}{c}3.9 \\
15.7 \\
1.2 \\
0.01 \\
0.02\end{array}$ \\
\hline $\begin{array}{l}\mathrm{SiO}_{2} \\
\mathrm{SrO}^{2} \\
\mathrm{TeO}_{2} \\
\mathrm{TiO}^{2} \\
\mathrm{ZnO}\end{array}$ & $\begin{array}{l}0.02 \\
0.005 \\
0.70 \\
0.01 \\
0.02\end{array}$ & $\begin{array}{l}0.47 \\
0.005 \\
0.70 \\
0.01 \\
0.02\end{array}$ & $\begin{array}{l}45.1 \\
0.02 \\
0.002 \\
0.8 \\
0.008\end{array}$ \\
\hline
\end{tabular}

(a) Used in sample preparation.

The results obtained from these plenum samples are graphically summarized in Figure 4.6-14, which characterizes the emission rates of the semivolatile elements under various idling conditions (temperature) employed during this test. These data indicate that emission rates of all semivolatile elements decreased as a function of time after the completion of PSCM-5 at a $42-\mathrm{L} / \mathrm{h}$ water-spraying rate. Reducing the cooling spray rate to $27 \mathrm{~L} / \mathrm{h}$ increased both plenum temperature and semivolatile emission rates; however, an equilibrated plenum temperature was not achieved during the brief $24-h$ period of reduced spraying.

Termination of the water-cooling spray increased the plenum temperature steadily to the point where plenum surface deposits, formed during PSCM-5, began to melt and "burn" away. The dramatic peaking of emission rates of the semivolatile elements occurred during this period. The emission characteristics under these plenum warmup conditions are very similar to those observed during the previous melter idling test. 


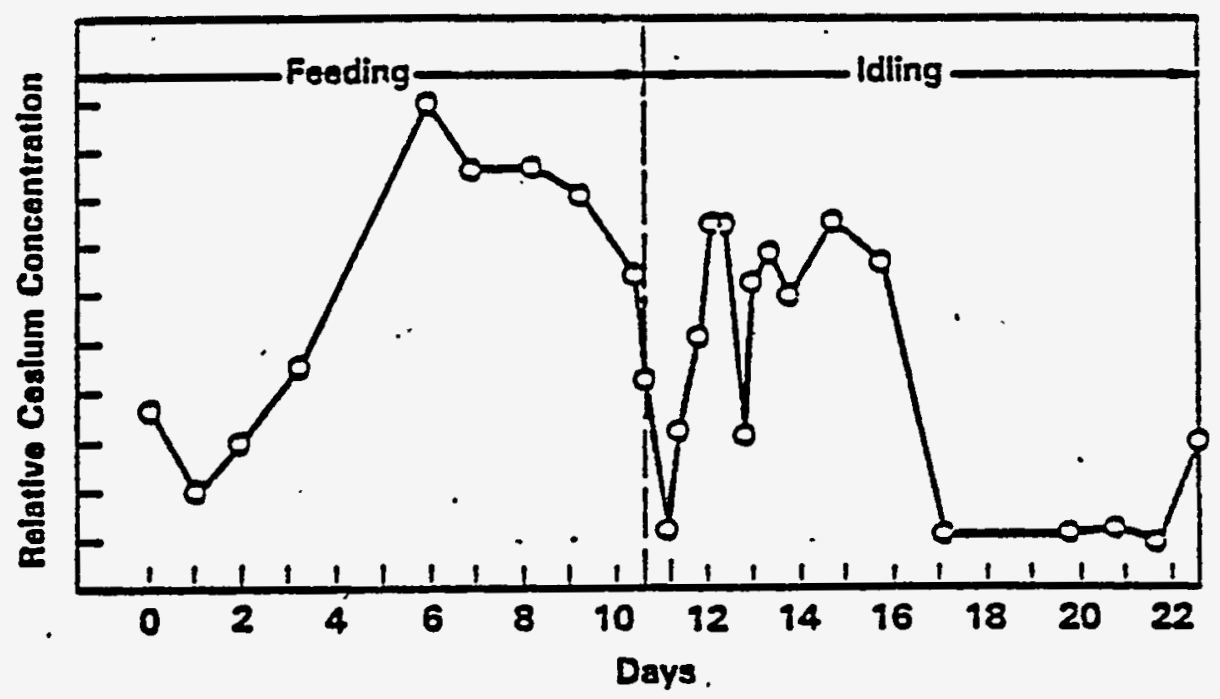

FIGURE 4.6-14. Time Distribution of Cesium Emission - HWVP (Ref. 4.6-4)

In HWVP-15, the off-gas evolution rates of all melter generated volatiles were quite uniform throughout most phases of feed processing. The initiation of melter idling, however, affected emission rates of these volatile effluents in differing ways. Nitrogen and carbon emission rates decrease immediately upon cessation of melter feeding and, essentially, cease once the melter cold cap has burned away (Ref. 4.6-3). The data collected during the present test support this fact, as is clearly shown in Figure 4.6-16.

Sulfur effluent behavior is somewhat like that of nitrogen and carbon when melter feeding is terminated, but unlike carbon and nitrogen, melter sulfur emission rates will begin to increase and level off as the melter plenum temperture increases and stabilizes (Ref. 4.6-3). These low-level sulfur idiling emissions persist as the sulfates thermally decompose and react with plenum $\mathrm{O}_{2}$ at $-990^{\circ} \mathrm{C}$ to produce $\mathrm{SO}_{\mathrm{x}}$ effluent. Glass evolution of sulfur may also be a contributor to this chronic $\mathrm{SO}_{x}$ emission source; however, long-term studies need to be conducted to verify this assumption. HWVP-15 sulfur effluent behavior is totally consistent with this model, as is clearly illustrated in Figure 4.6-16.

Boron, $\mathrm{Cl}$, and $\mathrm{F}$ behave quite similarly in that their volatile emission rates steadily decrease once idling has been initiated. However, $B$ gaseous emission rates decrease much more quickly than those associated with $C$. and $F$. This is quite reasonable as the rimary $B$ volatile during processing is boric acid, which cannot be formed under melter idling conditions. Since other volatile oxides of boron have higher boiling points and condense before being carried out into the off-gas system, gaseous boron emissions should drop off quickly as the melter heats up and the plenum dries out. The 


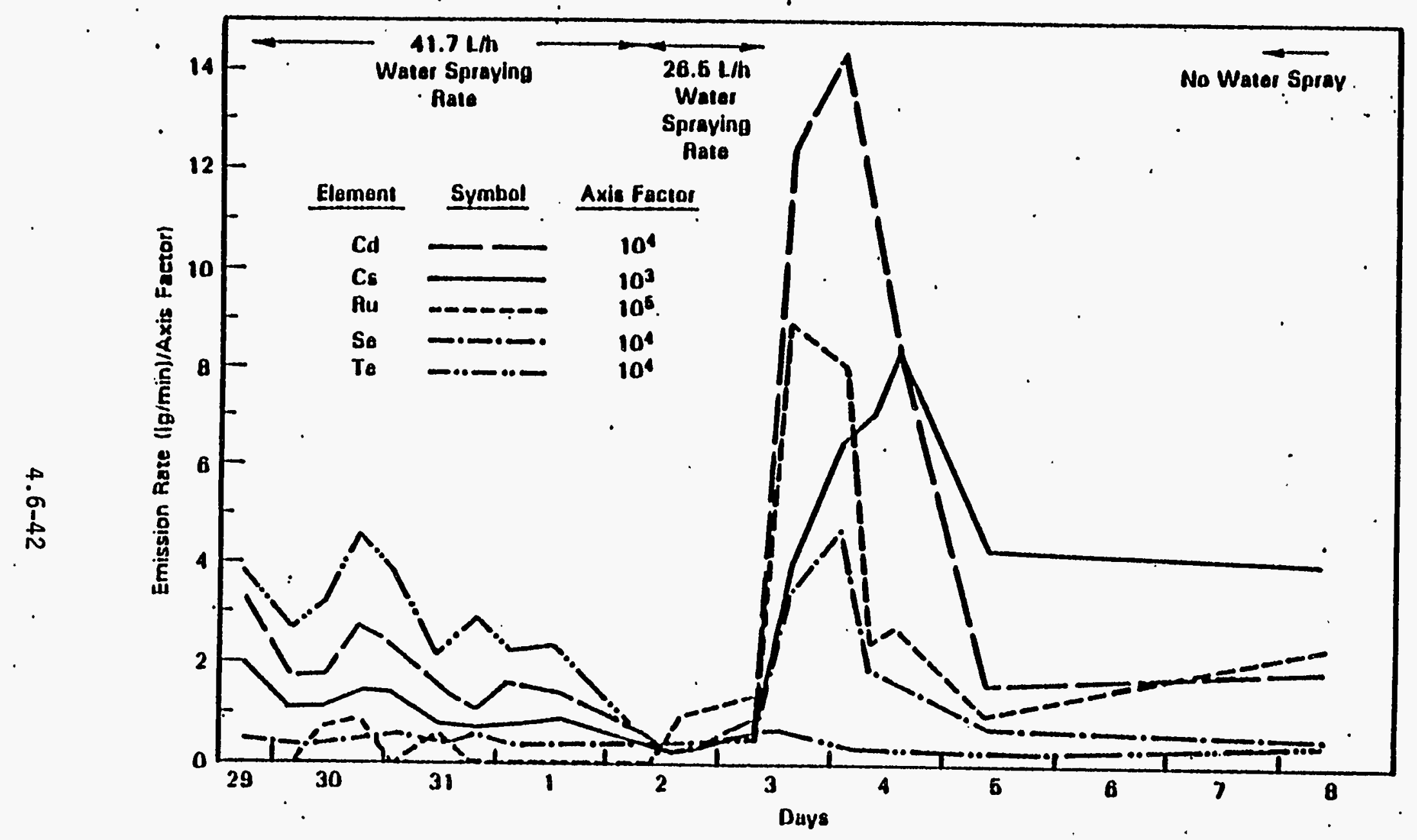
FIGURE 4.6-15. Emission Rates of Semivolatile Elements During Melter Idling - HWWP
(Ref. 4.6-3) 


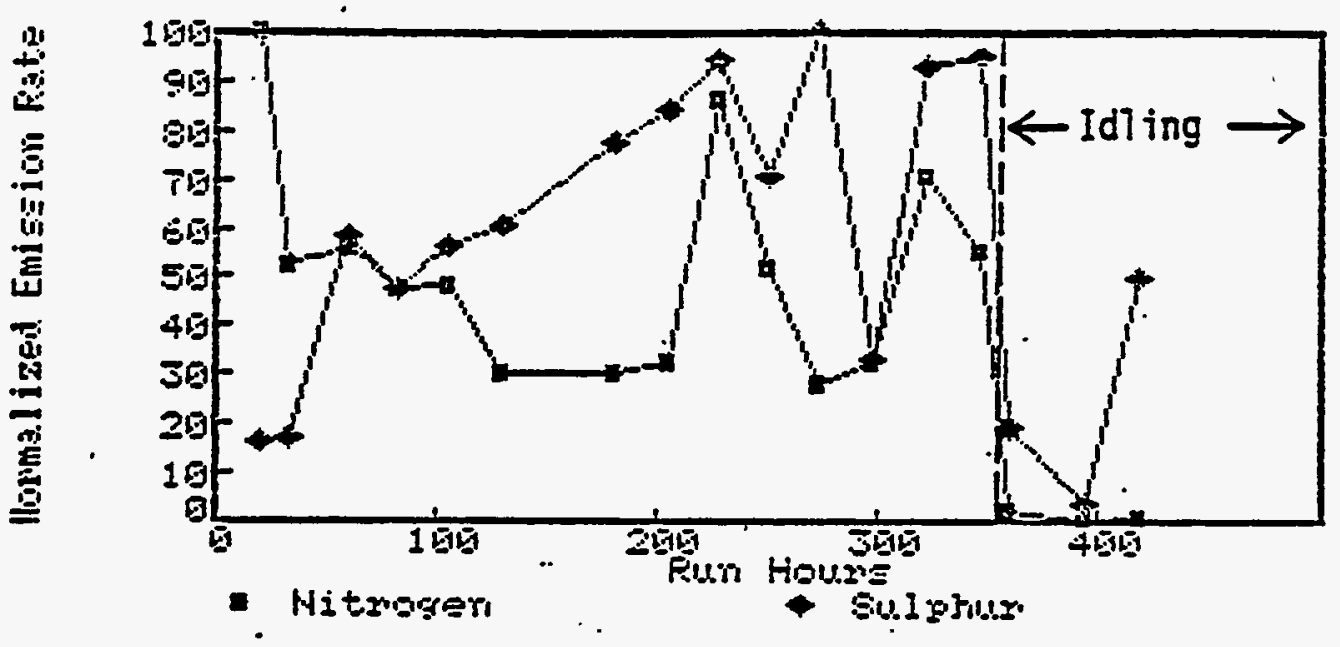

FIGURE 4.6-16. Emission Characteristics of Nitrogen and Sulfur HWVP-89-IVJ0010100B

volatile emission characteristics of these gaseous effluents throughout all phases of HWVP-15 testing are summarized in Figure 4.6-17.

Although there are significant differences in the idling emission rate characteristics of the previously described volatile effluents, the proportion of total Tosses due to gaseous escape remains constant for most of them for at least 2 days idling, as shown in Table 4.6-16. Table 4.6-16 al so shows the importance of thermal decomposition upon $\mathrm{SO}_{\mathrm{x}}$ emission rates.

Apart from the classic volatiles discussed above, other gaseous effluents were a7so observed during HWVP-15. Silicon volatility was strongly indicated by meiter sampies collected during the initial stages of idiing. The volatile species involved was most assuredly $\mathrm{SiF}_{6}$ as the sample also contained large quantities of $\mathrm{F}$. However, $\mathrm{SiF}_{6}$ may have not been the primary off-gas effluent in. that HF effluent interactions with the sampler's aerosol glass filter may have volatilized the $S$ that was subsequentiy collected and detected in the sampler's condensate fraction. In either case, the chemical behavior of $F$ was apparently altered during some part of the first day of idling to have produced this unique and previously unobserved result.

A particle-size anaysis of melter idling emission was also conducted 2 days after feed processing was terminated. Since plenum feed deposits had been melted away by that time, very little entrained matter $(>>1 \mu \mathrm{m})$ was expected in the meiter exhaust. This was indeed found to be the case; $>80 \%$ of the collected aerosol matter was collected on the final cyclonic collection stage $(<1 \mathrm{rm})$ as shown in Table 4.6-21. 


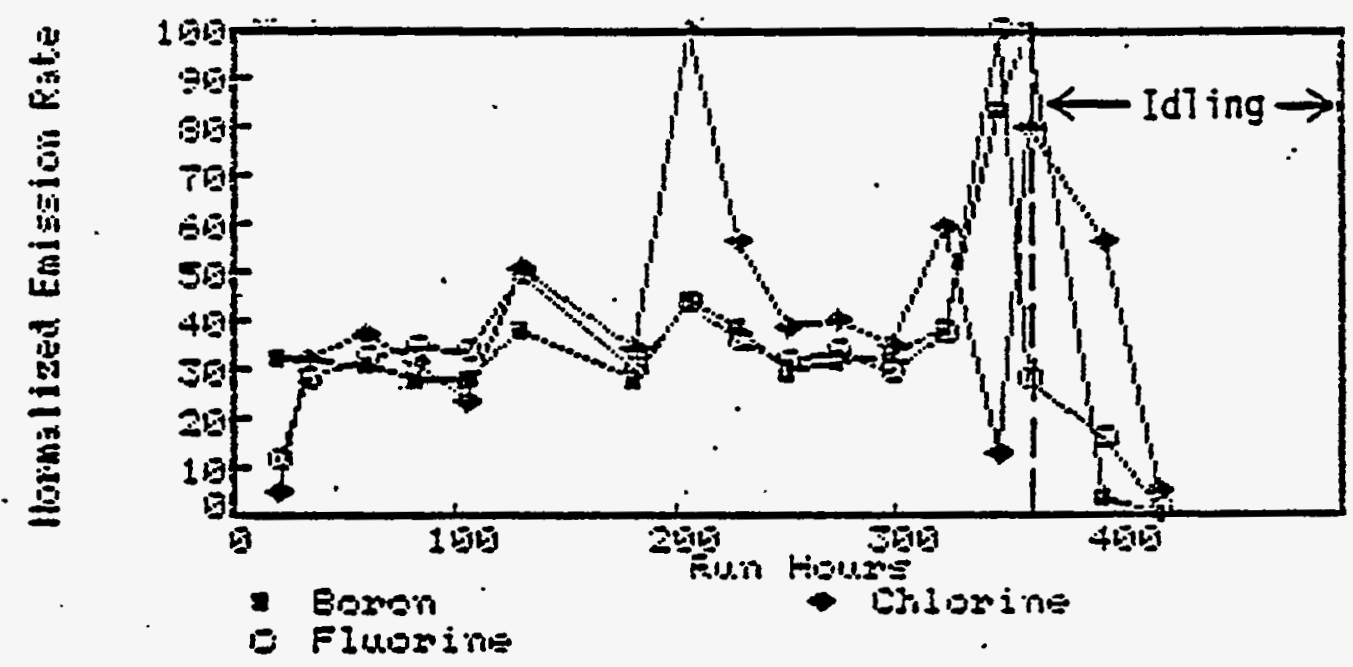

FIGURE 4.6-17. Emission Characteristics of Boron, Chlorine, and FTuorine HWVP-IVJO010100B

TABLE 4.6-21.. Size Distribution of Melter Aerosols HWVP-IVJ0010100B

\begin{tabular}{|c|c|c|c|c|}
\hline Date & $16 \mu \mathrm{m}^{(a)}$ & $6 \mu \mathrm{m}^{(a)}$ & $1 \mu \mathrm{m}^{(2)}$ & $<1 \mu \mathrm{m}$ \\
\hline $6 / 08 / 88$ & 35.2 & 5.1 & 18.1 & 41.6 \\
$6 / 14 / 88$ & 23.5 & 4.4 & 17.5 & 54.6 \\
$6 / 18 / 88$ & 30.0 & 6.1 & 20.9 & 43.0 \\
Average & 29.6 & 5.2 & 18.8 & 46.4 \\
$6 / 22 / 88(b)$ & 18.6 & -- &.- & 81.4 \\
\hline
\end{tabular}

(a) Cutoff equivalent diameter to next greater indicated cutoff equivalent diameter.

(b) Idling sample.

4.6.4.1.5 Process Upset. There are two conditions that may be termed process upsets for the off-gas system: large off-gas generation surges and foaming.

The melter is normally controlled at a slight vacuum (about $5-$ in. $\mathrm{H}_{2} \mathrm{O}$ ) to improve containment of radionuclides. Pressurization of the melter is undesirable because of the potential for releasing contamination to the cell, and also because an abrupt increase in melter pressure may force glass out of the melter discharge at an excessive rate. Normal melter operation involves periods of surges that occur when a pool of aqueous slurry on the cold cap flows quickly onto the giass melt. Also, several abnormal mechanisms may lead to melter pressurization, including off-gas line or equipment blockage, 
excessive feed.rate, loss of off-gas blowers, steam explosion, and combustible explosion. These mechanisms must be addressed. for system safety, but the surge event is a normal glass melting phenomenon and should be accommodated in the design.

The frequency and magnitude of surge events have been correlated by SRL from data collected during. a 63-day run on their liquid slurry-fed melter (LSFM). Using an exponential statistical model, the surge distribution data was extrapolated to allow prediction of the frequency of large surge events (Figure 4.6-18). As shown on the curve, surges greater than seven times the normal off-gas flow rate (7X) were predicted to occur once every 200 days, and surges greater than $10 X$ would be expected only once every 17 years. SRL chose to design the DWPF me7ter for a surge magnitude of seven times the normal off-gas flow rate. There is not sufficient PSCM data for HWVP operations to assess surge (pressurization) magnitudes and frequencies.

Cold-cap characteristics largely determine the amount of aqueous slurry that may pool on the surface, creating a surge potential. As such, surge -distributions such as the one developed by SRL are specific to the feed composition, melter geometry, and feed rate employed, and should be used cautiously for general design applications. The shape of the distribution would probably be similar for most melter conditions.

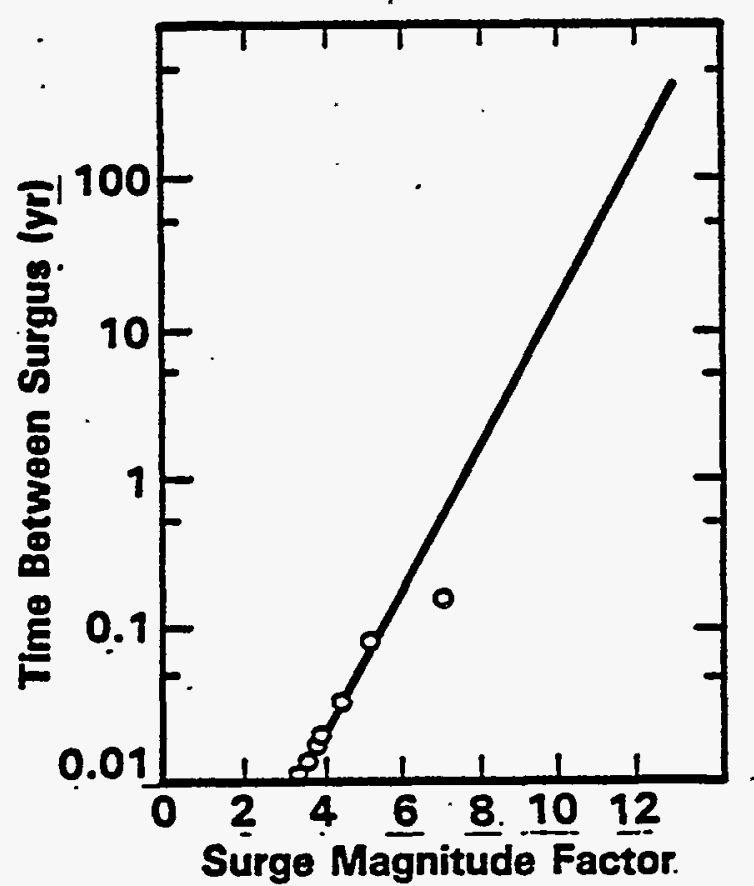

FIGURE 4.6-18. Off-Gas Surges in Savannah River Laboratory LSFM - DWPF (Ref. 4.6-4) 
The off-gas flow rates of two liquid-fed melters have been examined for over a year as part of the SRL-DHPF.melter development program at PNL. During this period of study, two separate feed formulations have been used, and a variety of melter operational running conditions have been employed. The results of these studies have shown that both feed composition and melter feeding rates have a predominant influence on the stability of melter off-gas flow rate.

The effect of feed composition on melter flow rate behavior is related to the physical ability of the feed components to form a structurally sound insulating layer. (cold cap) between the incoming liquid feed and the hot glass surface. As portions of the insulating cold cap become calcined, structural coltapse occurs, bringing dammed-up 1 iquid feed into contact with the extremely hot glass surface. This contact results in the flashing off of the water component (and volatile reaction products) of the feed, producing a flow pulse or an off-gas surge. The magnitude and extent of these surges are naturaliy dependent on the amount of liquid feed present on the cold cap that is delivered to the hot glass surface. Consequently, an erratic flow rate from the melter exhaust is often indicative of an unstable, overfed operational condition. Exhaust flow rate patterns associated with stable and unstable melter operations are illustrated in Figure 4.6-19.

4:6.4.2. File Cooler. The filmcooler is a slotted pipe that uses a gas such as air or steam to cool the melter off gas to prevent particulate deposits from sticking and fusing to the melter off gas line. Off-gas line deposits would eventually plug the off-gas 7 ine if they were allowed to build up and fuse together. Air is easy to use and provides a steady flow condition in the entire off-gas train. Steam has a slightly better cooling ability down to $400^{\circ} \mathrm{C}$ and can be removed from the off-gas train in the primary scrubber. However, if the steam condenses in the film cooler before it enters the off-. gas line, plugging of the off-gas line can increase because the water droplets collect the off-gas particulate and create deposits. Which cannot be removed by the turbulent air flow.

The primary off-gas liine should have a minimum gas velocity of $51 \mathrm{ft} / \mathrm{s}$ based on the total gas flow during idling or operation. DWPF testing indicated that to minimize the deposition on the off-gas line, the off-gas velocity in the pipe between the melter and the scrubber should be greater than $50 \mathrm{ft} / \mathrm{s}$ : Recent tests at PNL have shown that a higher velocity of $60 \mathrm{ft} / \mathrm{s}$ may work even better. To handle the additional cooling load, DWPF adds 80 psig steam to the film cooler to help cool the off gas without increasing the noncondensibie gas flow through the entire off-gas system. However, in a report by $W$. P. Colven (DPST-83-809), an air-to-steam ratio of 2 caused water droplets to form on the slots of the film cooler. . This is not a desirable condition because the water droplets will collect particulate from the off gas, which will dry from time to time and cause off-gas line plugs. Even at higher air-to-steam ratios the air is always near the saturation temperature. 


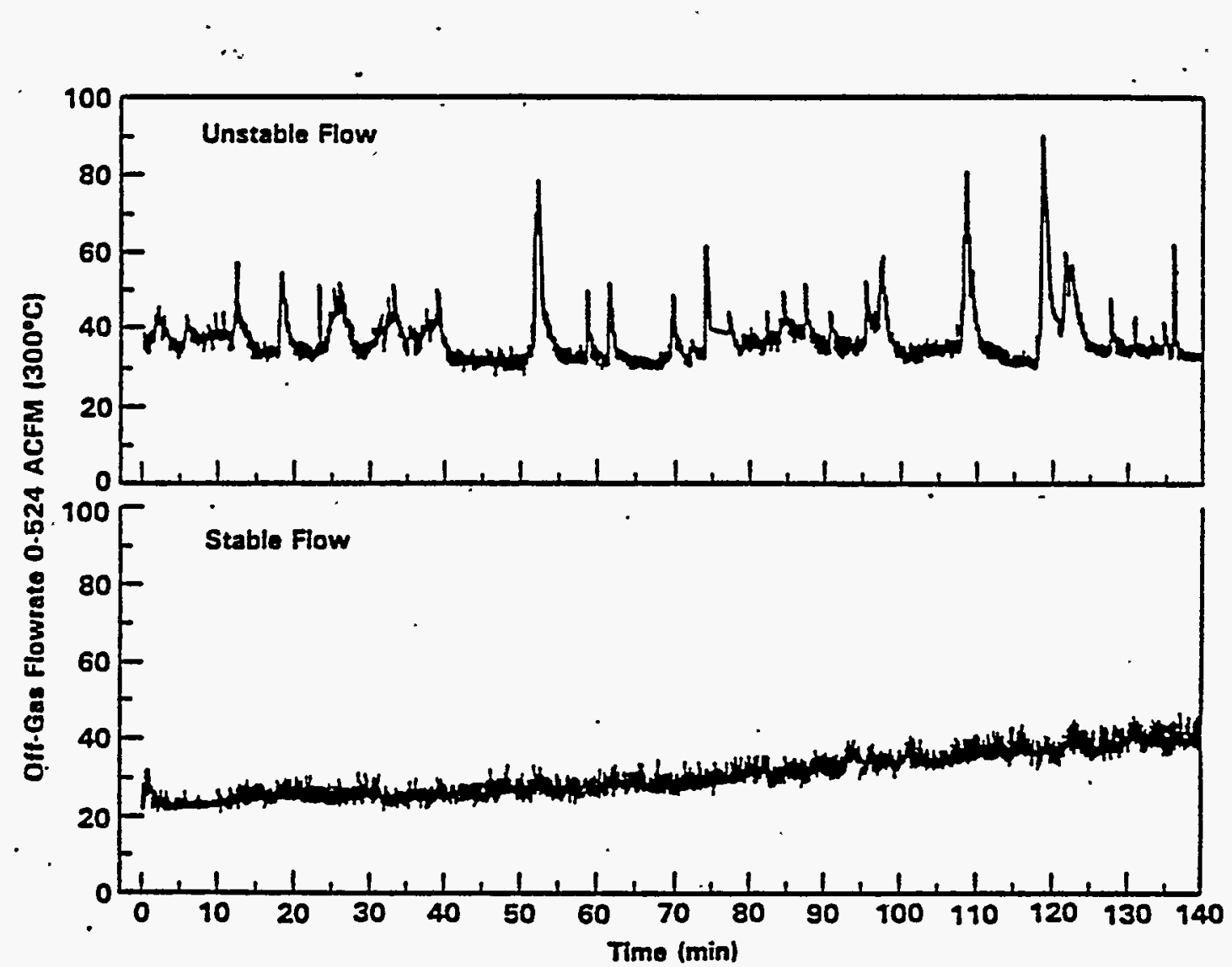

FIGURE 4.6-19. Typical Off-Gas Flow Rate Behavioral Patterns Associated with Liquid-Fed Melters - HWVP

(Ref. 4.6-3)

The minimum film cooler off-gas temperature should be $270^{\circ} \mathrm{F}\left(135^{\circ} \mathrm{C}\right.$ to prevent any condensation of concentrated acid solution in the pipe before the SBS. The maximum off-gas temperature exiting the film cooler should be $6600^{\circ} \mathrm{F}$ $\left(350^{\circ} \mathrm{C}\right)$ to prevent the melting and solidification of particulate deposits such as $\mathrm{NaBF}_{4}$ and giass (softening point $-490^{\circ} \mathrm{C}$ ) on the inside of the off-gas line.

The back-up film cooler should normally operate with an air purge back toward the melter. Steam should not be used in place of the purge air to prevent any possibility of condensing water in the film cooler during normal operation.

In HWVP-15 (HWVP-89-IVJ0010100B), the film cooler maintained off-gas system velocities above $45 \mathrm{ft} / \mathrm{s}$ in an insulated gradual radius 3 in. schedule 40 off-gas line (jumper) joining the film cooler to the SBS. Three off-gas system flow rates were used during HWVP-15 to study the impact of superficial face velocity on off-gas system component performance. These flow rates were established by controling film cooler air injection rates. 
The air injection rate to the film cooler. during the first 7 days of the experiment averaged 40 scfm. The melter plenum temperature was $500^{\circ} \mathrm{C}$ and the air inleakage rate was about 80 scfm. These conditions resulted in a total noncondensible off-gas flow rate of $110 \mathrm{scfm}$ entering the quench scrubber at a temperature of about $180^{\circ} \mathrm{C}$. Based on an average feed rate during this experiment of $43 \mathrm{~L} / \mathrm{h}$, the actual gas velocity (i.e., combined condensible and noncondensible flows) in the off-gas line was about $75 \mathrm{ft} / \mathrm{s}$ during the first 7 days. The jumper (at mid-point) skin temperature was $190^{\circ} \mathrm{C}$, and the meiter off-gas inlet temperature to the SBS was $230^{\circ} \mathrm{C}$.

During the next 9 days (days 7 to 16) the average film cooler air flow rate was adjusted to $85 \mathrm{sCfm}$, and the SBS inlet temperature dropped to near $100^{\circ} \mathrm{C}$. The increased air injection. rate resulted in a total off-gas flow rate was of 170 scfin which corresponded to an gas velocity of $90 \mathrm{ft} / \mathrm{s}$ in the melter-SBS off-gas jumper: The melter off-gas inlet temperature to the SBS. decreased to about $140^{\circ} \mathrm{C}$.

Feed processing was terminated on day 15 of the test to conduct melter idling tests. During the idling portion of the test, the melter vacuum was reduced and film cooler air injection was decreased to $40 \mathrm{scfm}$. This resulted in a total off-gas flow of $100 \mathrm{scfm}$ and an off-gas jumper velocity of $46 \mathrm{ft} / \mathrm{s}$. The film cooler air. flow and the low melter vacuum kept the offgas jumper skin temperature below $100^{\circ} \mathrm{C}$; the melter plenum temperature was. about $1000^{\circ} \mathrm{C}$.

No off-gas line blockages developed during the 15 days of HWVP-15 processing. However, some particulate deposition did occur within the off-gas jumper as revealed by post-test inspections. Two thin layers of 7 ight deposits, one white and one brown, with a combined thickness of 0.125 in. were observed. The deposit found adhering to the jumper wall was white, which is usually indicative of condensed salts collected during idling conditions. The outer deposit that overlaid the white wall accumulations had a definite brownish (iron) color, which is typical of calcined feed matter. The 0.125-in. thick deposits occurred from the top of the film cooler flange to a point a few feet downstream. The deposit thickness decreased to about a 0.03 in. after the last bend in the off-gas line about $15 \mathrm{ft}$ from the melter. Only a slight dusting of calcine material was found in the vertical inlet section above the SBS, except for one deposit near the top of the SBS. This deposit was similar to damp sand and could be scraped off easily, but would not be removed by the normal gas flow. The sandy deposit was believed to be due to the low temperatures in that the region of the off-gas line (near $100^{\circ} \mathrm{C}$ ). that occurred during part of the HWVP-15 experiment. Based on this resuit, the off-gas temperature be maintained above $130^{\circ} \mathrm{C}$ to ensure moisture condensation does not occur in the off-gas line jumper between the melter and the SBS.

The composition of the brown-colored accumulation was indeed found to be chemically similar to the feed, as is shown in Table 4.6-22; this deposit, however, was also found to be compositionalily enriched in the semi-volatile elements ( $C s$, Mo and the halogens) and depleted in frit components. ( $\mathrm{Si}, \mathrm{B}$, $\mathrm{Li}, \mathrm{Ca}$, and $\mathrm{Mg})$. As such, a fraction of the material would be expected to be 
TABLE 4.6-22. Comparison Between Compositions of Off-Gas Jumper Deposits and the Glass (brown colored) HWVP-89-IVJ0010100B

\begin{tabular}{|c|c|c|}
\hline Oxide & $\begin{array}{l}\text { Pipe Deposit } \\
\text { wt\% }\end{array}$ & $\begin{array}{c}\text { G7ass } \\
\text { Wt\% }\end{array}$ \\
\hline 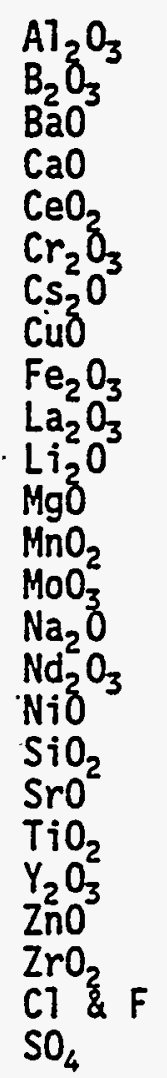 & $\begin{array}{c}4.50 \\
9.40 \\
0.24 \\
0.29 \\
0.28 \\
0.40 \\
1.10 \\
0.24 \\
13.8 \\
2.30 \\
0.74 \\
0.31 \\
0.36 \\
1.30 \\
12.2 \\
0.93 \\
1.15 \\
5.80 \\
0.23 \\
0.05 \\
0.09 \\
0.93 \\
7.78 \\
12.0 \\
5.1\end{array}$ & $\begin{array}{c}2.7 \\
10.0 \\
0.09 \\
1.1 \\
0.15 \\
0.15 \\
0.16 \\
0.13 \\
7.0 \\
1.1 \\
3.5 \\
0.86 \\
0.17 \\
0.28 \\
9.9 \\
0.53 \\
0.52 \\
52.8 \\
0.09 \\
0.08 \\
0.05 \\
0.43 \\
3.1 \\
0.60 \\
1.0\end{array}$ \\
\hline
\end{tabular}

water soluble. Should water spray cleanout techniques be considered, the spray action should strip away all the deposits, soluble and insoluble. In addition, this type of deposit is not expected to result in extensive accumulations. This is because both types of deposits were friable and loosely bound to the jumper. Since this type of material should be easily stripped away by the turbulent shearing action of the gas stream, it is unlikely that these deposits could rapidly grow into an off-gas line blockage.

Because of the low entrainment and the high melter DFs achieved during the HWVP-15 test, it is difficult to say how much the film cooler had to do with the off-gas $i$ ine conditions found. Similar off-gas conditions have been observed at the conclusion of comparable melter tests where no off-gas film cooler was used. There is no doubt that film cooler technology helps. 
maintain and open-off-gas line and that such devices form a necessary part of melter off-gas systems; however, HWVP-15 results do not demonstrate these facts.

4.6.4.3 Submerged Bed Scrubber (HWVP-89-IVJ0010100B). The SBS is a packed bed submerged in a vessel in which melter off gas enters the bottom of the bed. The gas buoyancy causes the SBS f7uid to circulate through the bed. This recirculating fluid transfers heat from the hot melter exhaust and provides for gas scrubbing and cleaning of the bed. In operation, the process exhaust is concurrently contacted by the scrubbing liquor in the SBS bed where stean is condensed and the scrubbing fluid is heated. The accumulated condensate continuously overflows ințo a collection tank. . The outer portion of the vessel is fitted with cooling coils to remove heat. Buoyancy effects maintained the fluid recirculation, so no external pump is needed. Not requiring a pump is a significant operational advantage because the scrubbing liquor is abrasive and usually corrosive. The pressure drop through the bed is high, being established by the submergence of the intet pipe. 
4.6.4.3.1 Parameters Influencing the Aerosol Capture Performance of the Submerged Bed Scrubber [C. M. Riecker and P. A. Scott, Parameters Influencing the Aerosol Capture Performance of the Submerged-Bed Scrubber. PNL-6035, Pacific Northwest Laboratory, Richland, Washington (1987)]. The SBS performance was characterized and methods to improve the aerosol capture efficiency by modifying the operating procedure or the design was studied. A partial factorial experimental matrix was completed to determine the main effects of aerosol solubility, inlet off-gas temperature, inlet off-gas flow rate, steamto-air ratio, bed diameter and packing diameter on the particulate removal. efficiency of the SBS. Several additional experiments were conducted to measure the influence of the inlet aerosol concentration and scrubbing-water concentration on aerosol-removal performance. All of the investigated parameters significantly influenced the performance of the SBS except for the inlet temperature, which had little effect over the $60^{\circ}$ to $100^{\circ} \mathrm{C}$ range investigated.

An important parameter influencing aerosol collection efficiency is the diameter of the airborne particulates. Several gas-cleaning devices characteristically exhibit a minimum collection efficiency for particles between 0.1 and $1.0 \mu \mathrm{m}$. For the SBS, the minimum was shown to be between 0.3 and $0.7 \mu \mathrm{m}$. Thus, all tests in this study were limited to that size range.

Only six parameters were varied in the partial factorial matrix and are listed in Table 4.6-23. Three levels of the off-gas flow rate and steam-to-air ratio were investigated. The other four parameters were limited to two levels.

TABLE 4.6-23: Values for Experimental Parameters (Ref. 4.6-9)

\begin{tabular}{|c|c|c|c|}
\hline Parameters & \multicolumn{3}{|c|}{ Levels } \\
\hline Superficial gas flow rate $(\mathrm{m} / \mathrm{s})$ & 0.48 & 0.34 & 0.21 \\
Steam/air (std $\mathrm{m}^{3} / \mathrm{h} /$ std $\mathrm{m}^{3} / \mathrm{h}$ ) & 0.0 & 0.33 & 0.50 \\
Inlet off-gas temperature $\left({ }^{\circ} \mathrm{C}\right)$ & 60 & 100 & \\
Bed diameter (m) & 0.5 & 0.5 & \\
Packing size (cm) & 0.3 & 1.0 & \\
Aerosol species & $\mathrm{Nacl}$ & $\mathrm{TiO}_{2}$ & \\
Concentration (particles/cc) & 1000 & & \\
Size distribution ( $\mu \mathrm{m})$ & $0.3-0.7$ & & \\
Packing depth (in.) & 0.55 & $\cdot$ & \\
Scrubbing solution temperature ( $\left.{ }^{\circ} \mathrm{C}\right)$ & 20 & & \\
Scrubbing solution concentration & 0 & & \\
(g captured aerosol/cc) & & & \\
\hline
\end{tabular}


An overflow Tine maintained the water level approximately $0.3 \mathrm{~m}$ above the top of the packing. Makeup water was added as necessary during operations, which caused the off gas to strip water from the reservoir. Manual adjustment of the water flow rate to the two cooling coils maintained the scrubbing water. temperature at $20^{\circ} \mathrm{C}$.

In the experiments involving $\mathrm{NaCl}$, it was found that re-entrainment losses predominated over penetration losses. As a result, all of the experiments involving sodium chloride aerosols were dropped from the statistical analysis, leaving a total of 69 experiments conducted with titanium dioxide. A linear regression on the data identified seven experiments which were influential in determining the model. These experiments were found to be very different than the other 62 experiments and will be.treated separately. Performing a linear regression on the remaining 62 titanium dioxide experiments resulted in the following model:

$$
\log (D F)=B_{0}+B_{1} F+B_{2} \alpha+B_{3} D+B_{4} P+B_{5} C+B_{6} F \cdot \alpha+\beta_{7} \alpha \cdot D
$$

where $\mathrm{DF}=$ decontamination factor, dimensionless

$F=$ superficial velocity, $\mathrm{m} / \mathrm{s}$

$\alpha=$ volumetric steam-to-ąir ratio, dimensionless .

$D=$ bed diameter, $m$

$P$ = packing diameter, $c m$

$C=$ inlet aerosol concentration, particles/cc

$B_{i}=$ coefficient

The coefficients for each term can be found in Table 4.6-24. This model fits the data very we11, accounting for $84 \%$ of the variation in the data. The F-test probability that all the coefficients in Equation 4.6-1 are equal to zero is less than 0.0001 ( $p<0.0001)$. All of the main effects investigated, except the inlet temperature, were determined to be significant. Two interaction terms, $F \cdot \alpha$ and $\alpha \cdot D$, were also found to be highly significant. The log of the DF is used to transform the data so that the residual errors follow a normal distribution (Ref. 4.6-5).

4.6.4.3.2 SimuTation of Important Compounds in LFCM off Gas. Radioactive cesium and ruthenium aerosols are the particulates that must be removed from LFCM off gas. Therefore, it is desirable to choose the primary scrubber on the basis of its ability to remove these compounds. Cesium usually leaves the melter in the form of oxides, chlorides and/or nitrates, -depending on the composition of the feed. These compounds should behave like their sodium analogs, since sodium and. cesium are in the same group of the periodic table. 
TABLE 4.6-24. Parameter Estimates (Ref. 4.6-9)

\begin{tabular}{|c|c|l|l|}
\hline Coefficient & $\begin{array}{c}\text { Coefficient } \\
\text { Estimate }\end{array}$ & $\begin{array}{c}\text { Standard } \\
\text { Error }\end{array}$ & $\begin{array}{c}\text { Probability of } \\
\text { Coefficient }=0\end{array}$ \\
\hline$\beta_{0}$ & 1.53 & 0.146 & 0.0001 \\
$\beta_{9}$ & -0.734 & 0.0920 & 0.0001 \\
$\beta_{2}$ & -1.12 & 0.477 & 0.0222 \\
$\beta_{3}$ & -1.93 & 0.200 & 0.0001 \\
$\beta_{4}$ & 0.120 & 0.0290 & 0.0001 \\
$\beta_{5}$ & 0.000196 & 0.0000918 & 0.0369 \\
$\beta_{6}$ & -1.80 & 0.464 & 0.0003 \\
$\beta_{7}$ & 3.96 & 1.08 & 0.0006 \\
\hline
\end{tabular}

The wettability of an aerosol is probably the most important characteristic, next to particle diameter, in determining the efficiency at which it will be removed from the off gas. For this reason it was felt that $\mathrm{NaCl}$ could be used to represent all of the cesium compounds, since the cesium compounds of interest are all highly soluble in water. Ruthenium aerosols are usually found as oxides which are insoluble in water. Titanium dioxide was used to simulate ruthenium dioxide, since both are insoluble in water and are relatively close together in the periodic table.

One experiment was repeated several times under the same experimental conditions but with different compounds in the aerosol generator. This experiment was used to demonstrate the ability of sodium chloride and titanium dioxide to simulate cesium and ruthenium compounds, respectively. A $0.5-\mathrm{m}$ bed filled with $0.36 \mathrm{~m}$ of $0.3-\mathrm{cm}$ packing was used. The off-gas flow rate was maintained at $127 \mathrm{std} \mathrm{m}^{3} / \mathrm{h}$. Once the inlet concentration was set at 1000 particles/cc, the on-line analysis was switched to the outlet sample port. An outlet particle distribution was measured when steady state had been achieved. The aerosol generator was then shut off, and a new outlet particle distribution was measured. The second measurement provided information as to how many of the aerosols coming out of the SBS actually penetrated the SBS and how many were entrained from the scrubbing solution by the vigorous agitation induced by bubbles bursting at the surface of the aqueous pool in the SBS.

Several important conclusions are drawn from the results, which are shown in Table 4.6-25. First, it appears that the outlet aerosol concentration is the same regardless of whether or not the aerosol generator is on when comparing the results of the three soluble compounds $\left(\mathrm{NaCl}, \mathrm{CsCl}\right.$ and $\left.\mathrm{CsNO}_{3}\right)$. This result suggests that there are no soluble aerosols penetrating the SBS and that the particles in the outlet stream are being re-entrained from the scrubbing 
TABLE 4.6-25: Influence of Aerosol on SBS Performance (Ref. 4.6-9)

\begin{tabular}{|c|c|c|c|c|c|c|}
\hline Number & Aeros01 & $\begin{array}{c}\text { Grams/3.0 L } \\
\text { Purified } \\
\text { Water }\end{array}$ & $\begin{array}{c}\text { Inlet Conc. } \\
\text { Particles/cc }\end{array}$ & $\begin{array}{l}\text { Outlet Conc. } \\
\text { Particles/cc }\end{array}$ & $\begin{array}{c}\text { Re-Entrained(a) } \\
\text { Particles/cc }\end{array}$ & $\begin{array}{c}\text { Mass } \\
\text { DF }\end{array}$ \\
\hline 108 & $\mathrm{NaCl}$ & 30 & 1097 & 38 & 48 & 26.7 \\
109 & $\mathrm{CsCl}$ & 50 & 1056 & 45 & 52 & 20.0 \\
110. & $\mathrm{CsNO}_{3}$ & 57 & 1092 & 56 & 55 & 18.4 \\
111 & $\mathrm{THO}_{2}$ & 50 & 1088 & 167 & 54 & 5.6 \\
112 & $\mathrm{RuO}_{2}$ & 100 & 787 & 207 & 54 & 3.9 \\
\hline
\end{tabular}

(a) Measured outlet with aerosol generator off.

solution. These results imply that sodium can be used to simulate cesium, although there are not many meaningful tests that can be performed with $\mathrm{NaCl}$ because the capture efficiency is limited by re-entrainment. This theory implies that there exists an upper limit on the obtainable mass of that is controlled by the amount of material being re-entrained. These results differ from the HWVP-15 test-results.

Aerosols in the outlet stream can. follow one of two paths through the SBS. Aerosols can remain in the off gas as it passes through the SBS. An aerosol can also be re-entrained after being captured. As the bubbles break through the surface of the aqueous pool, small droplets of scrubbing solution are sheared off and carried away by the off gas. As the scrubbing solution evaporates, any residual material will be left behind in the form of an aerosol. For the experiments conducted with soluble aerosols, the re-entrainment term dominates the penetration term, making it impossible to determine anything about the influence of various parameters on the removal of soluble particles. The captured aerosol concentration in these experiments was actually insignificant, but the optical sizing equipment could not distinguish between a sodium chloride aerosol and a silica aerosol. The SBS was filled with fresh process water, but the impurities present in the water and the resuspension of residual material in the SBS, as well as attrition of the packing, resulted in a high enough concentration of material in the scrubbing solution to produce submicron aerosols. This phenomenon suggests that efforts to improve efficiency should be directed toward reducing re-entrainment, as opposed to improving the initial capture of these soluble compounds.

The insoluble aerosols did not show the same trend. The outlet concentration during the experiment was much higher than the re-entrainment concentration measured after the experiment for both titanium and ruthenium dioxides. This result implies that there is significant penetration of insoluble aerosols through the SBS. There was not enough $\mathrm{RuO}_{2}$ available to achieve the concentration in the aerosol generator necessary to produce an inlet concentration 
of 1000 particles/cc. It is still apparent that Ru behaves reasonably like Ti, and was therefore replaced by $\mathrm{TiO}_{2}$ in all experiments. Even though re-entrainment contributes significantly to the exit mass flow rate, the penetration term dominates the total exit mass flow rate to the extent that the influence of various parameters on scrubbing performance can be accurately measured for insoluble aerosols.

4.6.4.3.3 Inlet Aerosol Concentration. The previously described experiment suggested that all of the incoming soluble aerosols were being captured, so a second experiment involving sodium chloride aerosols was conducted to further investigate this result. A 0.4-m-diameter bed was filled to a depth of $0.5 \mathrm{~m}$ with $1-\mathrm{cm}$ ceramic spheres. The off-gas flow rate was maintained at 51 std $\mathrm{m}^{3} / \mathrm{h}$ and an inlet temperature of $100^{\circ} \mathrm{C}$. The scrubbing solution was maintained at $20^{\circ} \mathrm{C}$. The inlet aerosol concentration was then varied from 500 particles/cc to 27,000 particles/cc. Figure 4.6-20 shows that the scrubbing performance increases with increasing inlet concentration. Also shown is the outlet concentration versus inlet concentration. The outlet concentration appears to be independent of the inlet concentration, having an average value of approximately 30 particles/cc. This result confirms the hypothesis that scrubbing performance of soluble aerosols is re-entrainment limited.

A similar experiment was not conducted for titanium dioxide, but the linear regression performed on the $\mathrm{TiO}_{2}$ experiments showed that the coefficient for the concentration term in the model was highly significant $(p=0.04)$. The scrubbing performance also increased with inlet concentration for insoluble yet the effect was not nearly as pronounced. The predicted influence of inlet concentration on performance is shown in Figure 4.6-20 for $\mathrm{TiO}_{2}$ aerosols based on Equation 4.6-1. The model is extrapolating out to a region where there are no data to complete the titanium dioxide curve shown in Figure $4.6-20$. Therefore, this curve should be used with caution. .

4.6.4.3.4 Humidity. As the off gas cools upon leaving the melter, the Cs and Ru compounds condense, forming submicron aerosols (Ref. 4.6-6). One approach to increasing the capture performance would be to shift the size range of these particles. This objective can be achieved by adding steam to the off gas. As the off gas is cooled, the water vapor will begin to condense on nuclides before undergoing homogeneous nucleation; thus, the steam should tend to condense on the aerosols present in the off gas, causing the particles to grow in size and making them easier to capture. This process may also improve the ability of insolubile aerosols to be captured, because they will become "pre-wetted." Several experiments were conducted using titanium dioxide aerosols to test this theory. A $0.5-\mathrm{m}$-diameter bed filled with $0.55 \mathrm{~m}$ of $1-\mathrm{cm}$ ceramic spheres was used in the SBS. The gas contained 1000 particles/cc of titanium dioxide aerosols in the $0.3-\mu \mathrm{m}$ to $0.7-\mu \mathrm{m}$ size range and was maintained at an inlet temperature of $100^{\circ} \mathrm{C}$. Again, the scrubbing solution was held at 


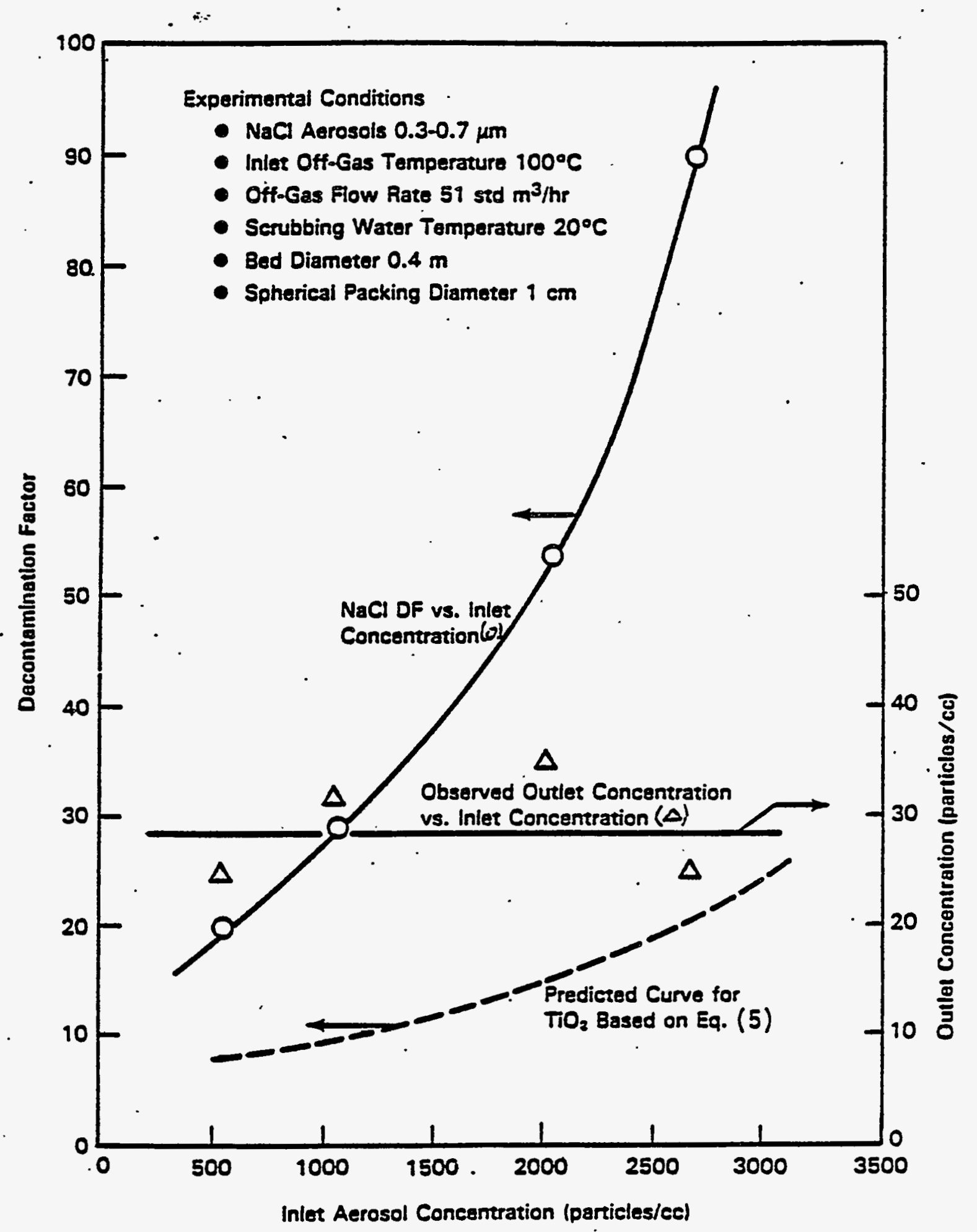

FIGURE 4.6-20. Influence of Inlet Concentration on SBS Performance (Ref. 4.6-9) 
$20^{\circ} \mathrm{C}$. The volumetric steam-to-air ratio was varied from 0 to 0.5 while the . superficial air velocity ranged from 0.14 to $0.48 \mathrm{~m} / \mathrm{s}$.

Figure 4.6-21 shows the family of curves relating the influence of the steam-to-air ratio on SBS performance as a function of the superficial air velocity. There was a significant increase in the scrubbing performance when steam was first added to the off gas. Increasing the ratio from 0.33 to 0.5 showed a modest increase in performance. The scrubbing performance decreases as the superficial velocity increases. Aerosols in the submicron size range should be captured predominantiy by interception and Brownian motion. The former capture mechanism is independent of flow rate, while the latter results in higher capture efficiencies at. lower flow rates.

Re-entrainment is another parameter influencing the shape of these curves that was not considered. As seen in Table 4.6-25 the re-entrained aerosol concentration can be a significant portion of the aerosol concentration leaving

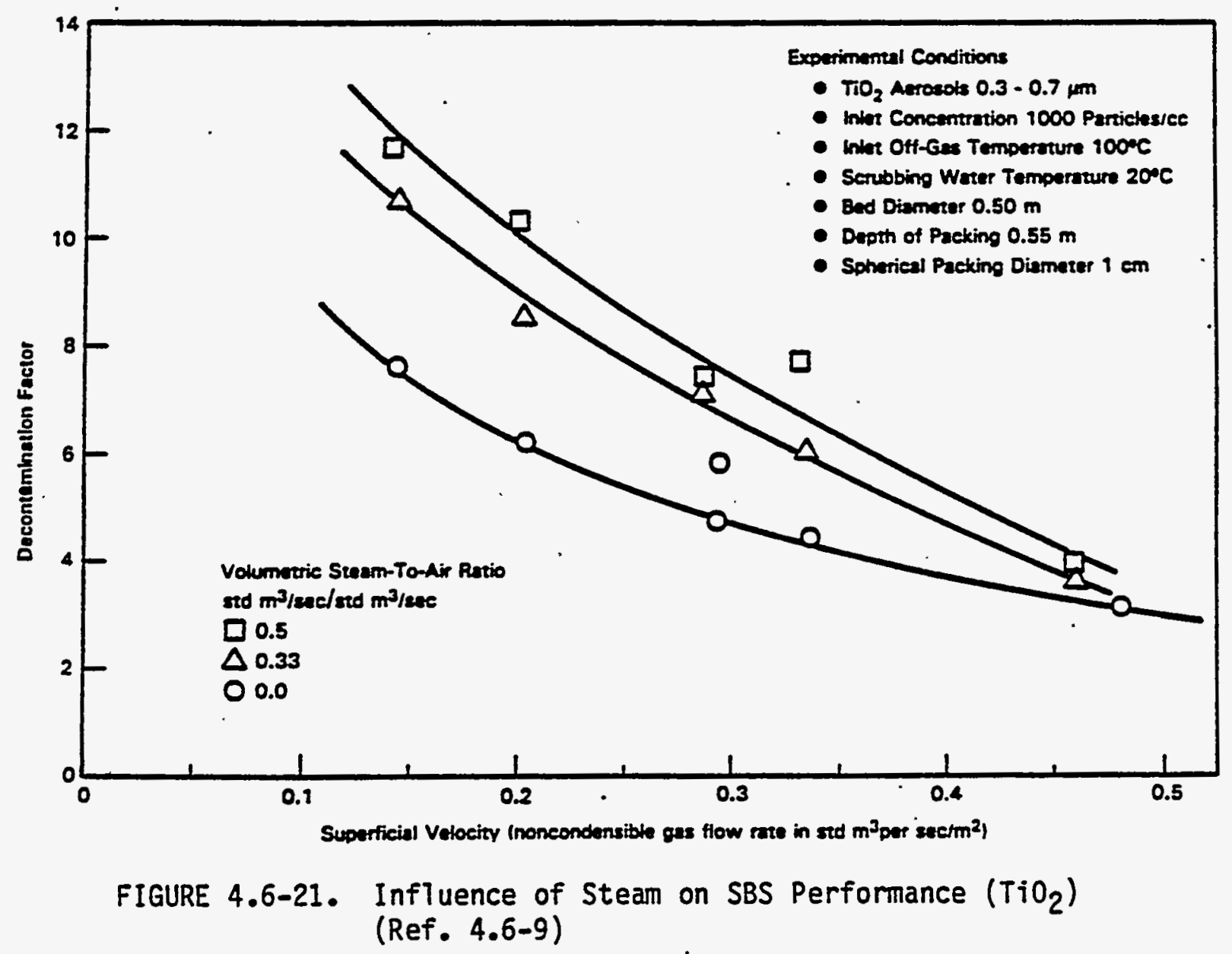


the SBS. The degree of re-entrainment depends on the superficial air velocity; the higher the velocity, the more material will be re-entrained. The decrease - in the mass DF at higher velocities is probably due more to increases in the re-entrainment than to increases in the penetration term. This phenomenon tends to lower the right-hand portion of the curves in Figure 4.6-21. At the highest velocity, the presence of steam appears to have little influence on the scrubbing performance. It is possible that the residence time is reduced sufficiently, at this velocity, that. full advantage cannot be taken of the condensing steam. It is more likely, however, that re-entrainment is so high that: any improvements that are due to steam are completely hidden by the dominance of the term due to re-entrainment.

The same set of experiments was repeated using $\mathrm{NaCl}$ aerosols. The results are shown in Figure 4.6-22. In this case, no consistent trend relating scrubbing performance to superficial velocity can be found. The random pattern is observed because the DF is limited by re-entrainment for soluble aerosols. The varied data reflect the sporadic nature of the re-entrainment mechanism. The inlet mass flow rate is very high compared to the outlet mass flow rate, so small changes in the re-entrainment concentration result in large changes in the inlet/outlet ratio. Although no trend can be found in the data, the experiments do show that the mass DF for the soluble sodium chloride is generally an order of magnitude higher than the corresponding DFs for insoluble titanium . dioxide aerosols.

4.6.4.3.5 Bed Diameter. No special attempt was made to ensure that the off gas was being evenly distributed across the inlet of the packing. Visual observation through $0.1-m$ view ports in the lid of the SBS (located directly above the packing) showed that the frothing was more vigorous next to the gas inlet pipe. It was difficult to quantify the nonuniformity of the gas distribution as the bed was not visible below the liquid level. To vary the bed diameter, a sleeve was designed to fit inside the original $0.5-m$-diameter bed, reducing the diameter to $0.4 \mathrm{~m}$. This sleeve changed the cross-sectional area from $0.172 \mathrm{~m}^{2}$ to $0.099 \mathrm{~m}^{2}$. The cross-sectional areas have been corrected for the area occupied by the downcomer assembly $(0.17 \mathrm{~m} 0.0$.). Experiments were then conducted in which four different bed configurations were compared at various superficial air velocities. Both bed diameters were investigated using $1-\mathrm{cm}$ and $0.3-\mathrm{cm}$ ceramic packing.

If the gas is distributed evenly across the packing for two different bed diameters containing the same packing, the performance should be the same as long as the volumetric flow rates are adjusted such that the velocities through the beds are equal. Any difference in performance between equivalent experiments can be attributed to inlet distribution problems. 


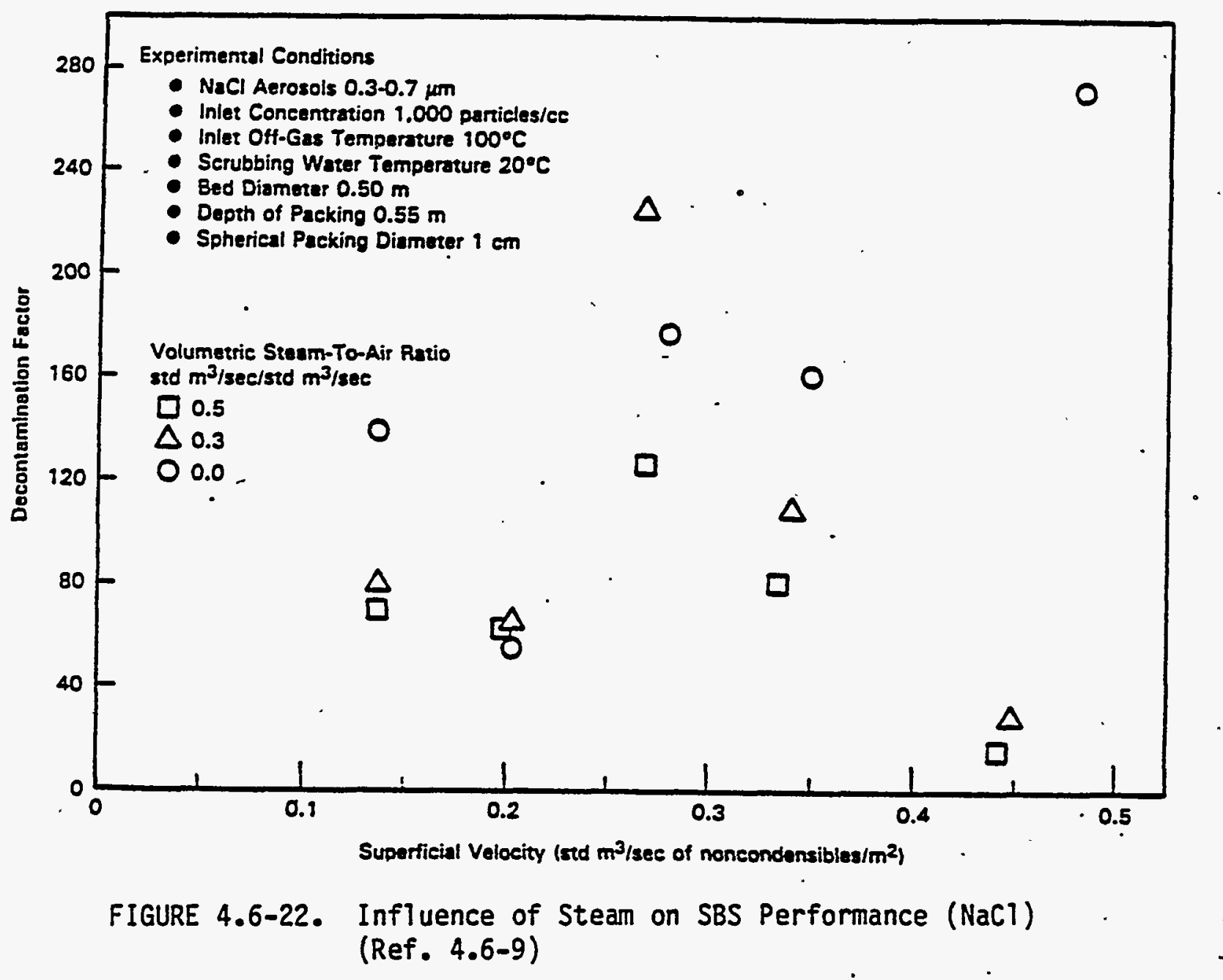

The results shown in figure 4.6-23 suggest that both packing size and bed diameter influence the scrubbing performance. The small-diameter bed outperformed the larger bed regardless of which packing was used. These results indicate a gas distribution problem. If the gas distribution is poor, the actual flow rate through the bed will be higher than expected. The higher flow rate lowers the mass DF by increasing both the exit mass flow rate due to penetration and re-entrainment. The penetration term increases because there is less time for the aerosols to migrate to the collecting medium through Brownian motion. The re-entrainment term increases because of the extra kinetic energy associated with the higher flow rate. Gas distribution problems probably exist with the small-diameter bed as well, at low flow rates. This explanation may account for the sudden decrease in performance at low velocities for the $0.4-m$ bed containing 1-cm packing. Under these conditions, the gas is probably channeling up through the packing close to the inlet pipe, where the void fraction is nighest. 


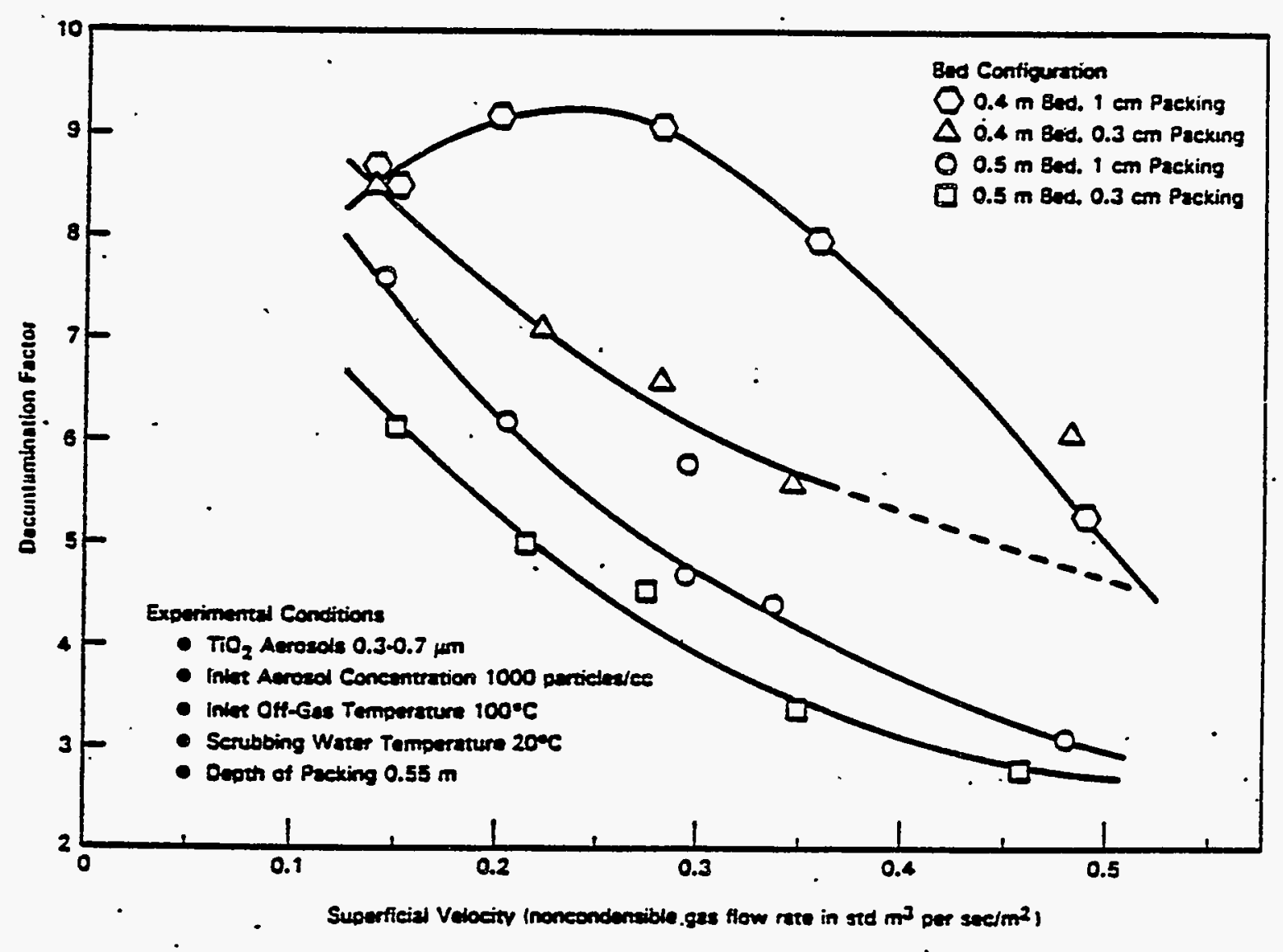

FIGURE 4.6-23. Influence of Bed Diameter on SBS Performance (Ref 4.6-9)

Figure 4.6-23 includes only conditions that do not involve steam. The model derived from a linear regression of the data shows that there is a significant two-way interaction between the bed diameter and steam-to-air ratio. Figure 4.6-24 shows the predicted interaction between the bed diameter and steam-to-air ratio for a given set of experimental conditions. The small bed should have a better gas distribution at equal superficial velocities, because the gas does not have to travel as far radially before it starts up the bed. A more uniform distribution should lead to larger DFs, since it will result in lower bed velocities, which enhances the aerosol capture mechanism due to Brownian motion. At a superficial velocity of $0.30 \mathrm{~m} / \mathrm{s}$ and a steam-to-air ratio of zero, the predicted performance decreases as the bed diameter increases. This result can be easily explained by the preceding argument if one accepts the assumption that the gas distribution is better in the smaller bed; the gas does not have as far to travel radially before starting up through the bed, and lower bed velocities result. As steam is added, the total volumetric flow rate increases while the superficial velocity of noncondensible 


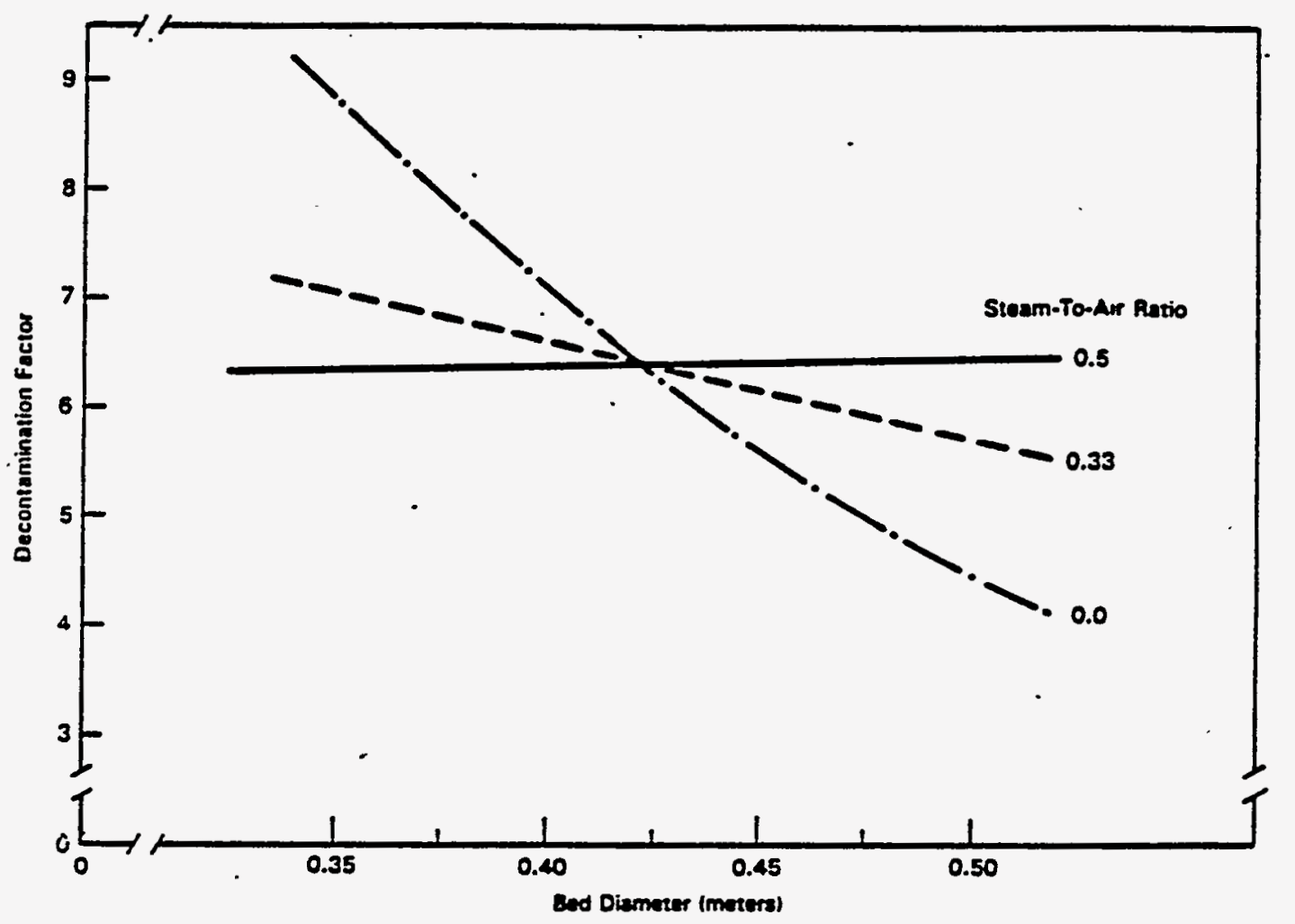

FIGURE 4.6-24. Predicted Interaction Between Bed Diameter and Steam-to-Air Ratio at a Superficial Velocity of $0.3 \mathrm{~m} / \mathrm{s}$ (Ref. $4.6-9$ )

gases remains the same. The steam will increase the size of the gas bubble under the packing, resulting in better gas distribution as well as larger DFs. As the gas distribution becomes more complete, the performance of the two beds should become equal. The predicted DFs do in fact become equal, as evidenced by the horizontal line, once the steam-to-air ratio reaches 0.5 .

4.6.4.3.6 Packing Size. Air-cleaning devices generally exhibit a minimum collection efficiency at a given aerosol diameter. This minimum is typically in the 0.1 to 1.0-micron range. Figure 4.6-25 shows that it occurs at approximately $0.5 \mu \mathrm{m}$ for the SBS. The interception capture mechanism plays a major role in aerosol removal in this region of minimum efficiency. The collection efficiency by interception can be improved by increasing the ratio of the aerosol particle diameter to the packing diameter (Ref. 4.6-7). Therefore, according to theory, the $0.3-\mathrm{cm}$ packing should work better than the $1-\mathrm{cm}$ packing. As seen in Figure 4.6-23, this is not the case. For a given bed diameter, the $1-\mathrm{cm}$ packing resulted in a larger DF. 


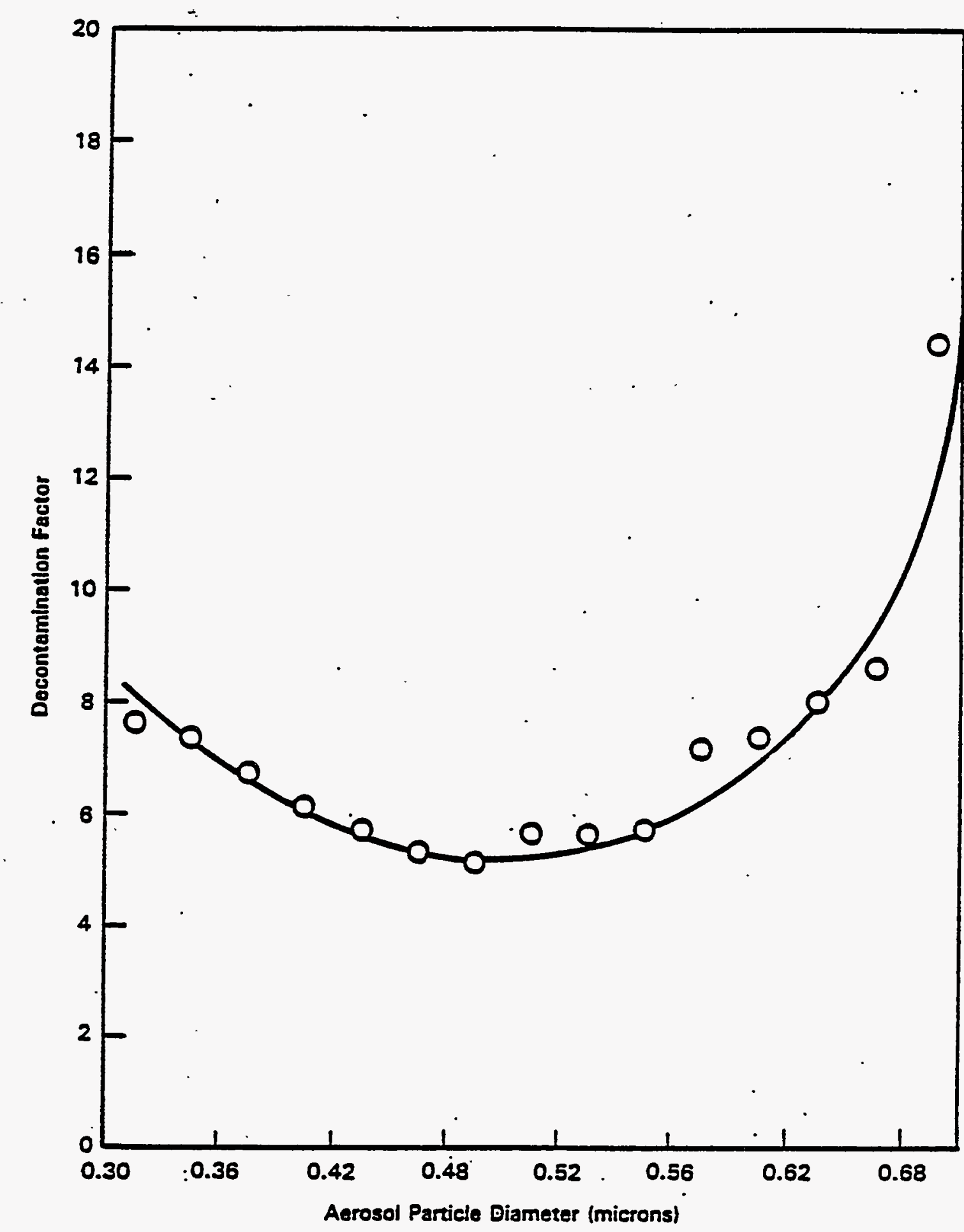

FIGURE 4.6-25. Collection Efficiency as a Function of Particle Diameter (Ref. 4.6-9) 
A small-scale plexiglass model of the SBS was constructed in an attempt to detect any significant differences in the flow pattern through the two different packing sizes. As expected, the smaller packing led to better. inlet gas distribution, but the flow patterns through the two beds were quite different. Bubbles remained discrete in the large packing, while channels containing a continuous gas phase formed in the small packing. The residence time in the bed was probably much shorter in the small packing than for the rising bubbles observed in the 1-cm packing, and this shorter residence time could explain the decrease in performance. Although the interception capture mechanism may improve with smaller packing, it is not the only capture mechanism at work. Removal by Browrian diffusion is very important for the aerosol size range investigated. The Brownian motion capture mechanism will become more effective at longer residence times. Thus, any increase in performance resulting from capture by interception in the bed containing small packing was more than offset by the decrease in the effectiveness of the Brownian motion capture mechanism.

4 6.4.3.7 Inlet Temperature. It was expected that the inlet temperature of the off gas should have an effect on scrubber performance. The maximum inlet temperature was limited to $100^{\circ} \mathrm{C}$ because of limitations on the building steam supply and the size of the heat exchanger used. A lower temperature of $60^{\circ} \mathrm{C}$ was chosen, as temperatures below $60^{\circ} \mathrm{C}$ were unachievable at steam-to-dir ratios of 0.5 without cooling of the off gas. The operating range of $60^{\circ}$ to $100^{\circ} \mathrm{C}$ was very small and not representative of melter off gas $\left(200^{\circ}\right.$ to $\left.400^{\circ} \mathrm{C}\right)$ but was included as a parameter in case temperature effects were significant enough to influence scrubbing performance even for small changes in the inlet temperature. Increased temperatures increase aerosol movement. Since some external force is necessary to drive an aerosol from a streamline to a collecting surface, any increase in movement should result in higher capture efficiencies. If there were no external driving forces, aerosols would only be removed by interception.

Figure 4.6-26 shows the results from several experiments repeated for inlet temperatures of $60^{\circ}$ and $100^{\circ} \mathrm{C}$ using a $0.5-\mathrm{m}$-diameter bed filled with 0.55 $\mathrm{m}$ of $0.3-\mathrm{cm}$ ceramic. spheres. No detectable influence of inlet temperature on aerosol scrubbing performance is indicated for the range investigated.

The inlet temperature probably has little influence on the scrubbing performance for the range of temperatures investigated as a result of the rapid quenching occurring once the off gas enters the bed. As can be seen in Figure 4.6-27, the off-gas cools very quickly. as it passes through the bed. The inlet temperature measured at the bottom of the bed in the axial thermowell varied constantly with the pulsing of the off-gas flow rate but was approximately $60^{\circ} \mathrm{C}$ colder than the inlet temperature measured by a thermocouple 


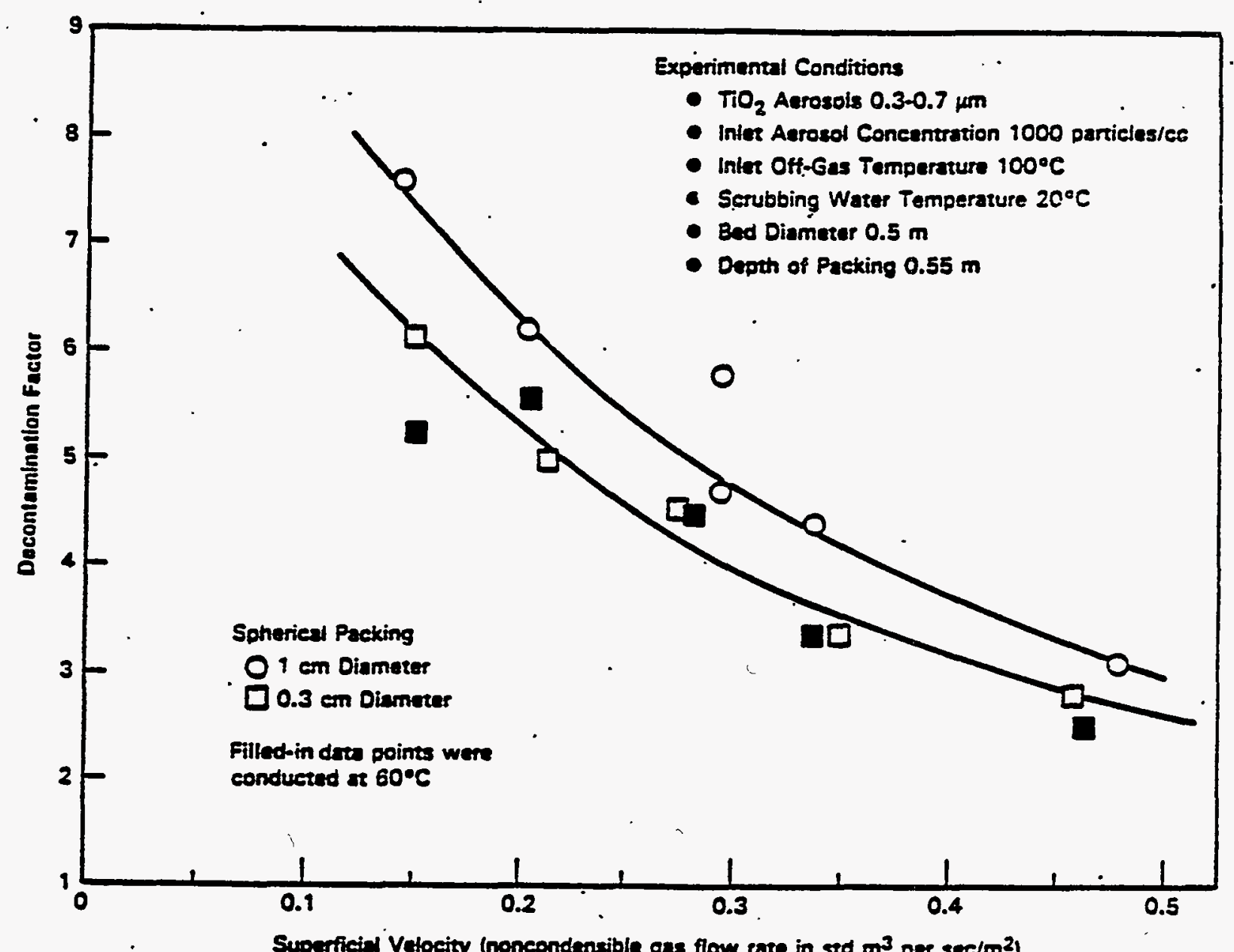

FIGURE 4.6-26. Influence of Packing Size on SBS Performance (Ref. 4.6-9)

located directly in the path of the off gas. There was little difference in the axial temperature profile between inlet temperatures of $60^{\circ}$ and $100^{\circ} \mathrm{C}$, which is probably one of the reasons that the inlet temperature did not seem to affect the performance.

The axial temperature profile does not, however, represent the only important temperature influencing the aerosol capture performance. While the axial temperature is probably a good indication of the gross movement of the aerosols in the bubble, the radial temperature profile within the bubble is more important in determining the net movement. The slope of the temperature gradient is in part determined by the inlet temperature and the temperature of the scrubbing solution. The gas is hottest at the center of the bubble and cools down to temperatures approaching that of the scrubbing solution at the gas-liquid 


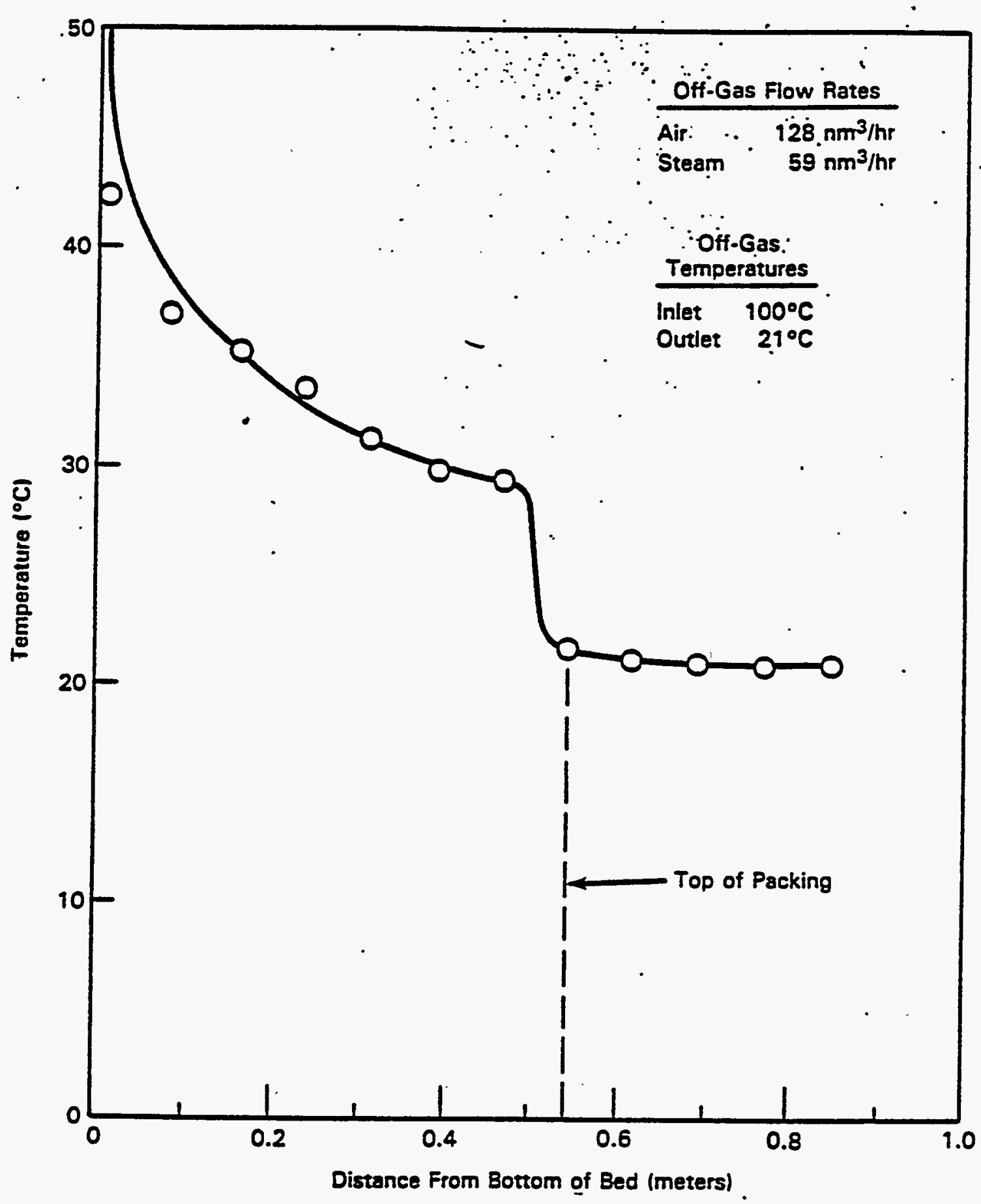

FIGURE 4.6-27. Typical Axial Bed Temperature Profile (Ref. 4.6-9) 
interface. Aerosol scrubbing efficiencies should be increased, if the inlet conditions can be raised sufficiently to establish a temperature gradient inside the bubble. Thermophoresis increases the particulate movement down the temperature gradient, forcing the aerosols towards the gas-liquid interface. This effect will probably not become significant until the temperature difference between the center of the bubble and the gas-1iquid interface is closer to $400^{\circ} \mathrm{C}$ than to $80^{\circ} \mathrm{C}$.

A higher inlet temperature is desirable, because it would allow greater stean-to-air ratios without the off gas becoming saturated. Several effects would be combined to help capture aerosols.

4.6.4.3.8 Effect of Sub-Dew-Point Inlet Conditions. A linear regression was performed on the original 69 experiments using $\mathrm{TiO}_{2}$. An inspection of the model revealed that it was severely influenced by a handful of experiments; the five tests having the highest DFs. The dew points for steam-to-air ratios of 0.33 and 0.5 are approximatel.y $65^{\circ}$ and $71^{\circ} \mathrm{C}$, respectively. All five of the experiments with high. DFs had two characteristics in common: 1) they had steam-to-air ratios of 0.33 or 0.5 , and 2) the inlet temperatures were $60^{\circ} \mathrm{C}$. The inlet conditions of these experiments were such that the off gas was entering the SBS below its dew-point temperature, so some condensation must have been occurring in the downcomer. A complete list of the sub-dew-point experiments, as well as their predicted DFs using Equation $4.6-1$ is shown in Table 4.6-26.

The overall results of all of the seven runs suggest that the inlet temperature will have little influence on the scrubbing perfornance until. it drops below the dew point of the off gas. Whether the temperature of the gas entering the SBSS is above or below the dew point probably determines where the steam

TABLE 4.6-26. Experiments Conducted at Inlet Temperatures Below the Dew Point (Ref. 4.6-9)

\begin{tabular}{|c|c|c|c|c|c|}
\hline $\begin{array}{c}\text { Run } \\
\text { No. }\end{array}$ & $\begin{array}{c}\text { Superficial } \\
\text { VeTocity } \\
(\mathrm{m} / \mathrm{s})\end{array}$ & $\begin{array}{c}\text { Inlet } \\
\text { Temperature } \\
\left({ }^{\circ} \mathrm{C}\right)\end{array}$ & $\begin{array}{c}\text { Steam/Air } \\
\text { Ratio }\end{array}$ & $\begin{array}{c}\text { Actual } \\
\text { DF }\end{array}$ & $\begin{array}{c}\text { Predicted } \\
\text { DF }\end{array}$ \\
\hline 5 & 0.18 & 62.9 & 0.42 & 39.9 & 9.8 \\
6 & 0.20 & 59.2 & 0.34 & 58.8 & 8.0 \\
24 & 0.34 & 59.4 & 0.34 & 15.9 & 5.4 \\
33 & 0.21 & 60.3 & 0.48 & 43.2 & 7.3 \\
36 & 0.46 & 58.0 & 0.34 & 4.1 & 2.5 \\
71 & 0.46 & 58.3 & 0.34 & 8.4 & 3.9 \\
77 & 0.35 & 64.0 & 0.49 & 43.3 & 5.3 \\
\hline
\end{tabular}


will condense. If the off gas is already below the dew point before entering the SBS, some condensation of steam must have occurred. In this situation, the steam will condense on the aerosols, making them larger and "pre-wetted." These developments will improve the capturability of the aerosols. If the inlet temperature is above the dew point, the steam will not condense until the off gas has contacted the scrubbing solution. At this point, the steam will preferentially condense at the gas-liquid interface and not on the aerosols. Although this action results in Stephan flow towards the interface, as mentioned before, it is obviously not as effective as when steam condenses on the aerosols themselves.

If the flow rate is slow enough, and the steam-to-air ratio high enough, it is possible to force steam condensation on the aerosols even when the inlet condition is above the dew point. Run \#44 fits this description and happens to have the highest DF (11.7) of any of the experiments conducted at inlet conditions above the dew point. These results point out the importance of controlling when and where the steam condensation occurs when operating an SBS. A significant improvement can be obtained if the off gas contains condensible gases and can be cooled below the dew point before it enters the SBS.

4.6.4.3.9 Re-Entrainment. An experiment was conducted in which the SBS was operated at severe inlet conditions (high inlet temperature and gas flow rate) for 24 hours to determine whether re-entrainment was a function of time. The results of this experiment are plotted in Figure 4.6-28. As can be seen, the outlet concentration did not change with time, maintaining a nearly constant value of 19 particles/cc. Those particles coming out of the SBS represent re-entrained particles since the aerosol generator was not used, so the only aerosols entering the SBS would be those already present in the room air. The data do not indicate any effect, over time, from re-entrainment, so experiments can be conducted in groups without confounding the data.

The origins of the particles composing the outlet concentration shown in Figure 4.6-28 are not known for certain. The particles detected by the CSAS leaving the SBS probably come from re-entrained material present in the scrubbing solution, water droplets that do not completely evaporate before entering the CSAS (operated at inlet temperatures around $80^{\circ} \mathrm{C}$ ), aerosols present in the room air that penetrate the SBS and/or material flaking off of the walls of the carbon steel sample lines. Inductively coupled plasma (ICP) analysis of the scrubbing water after a typical experiment indicated that the individual concentration of any one element was not very high. The. total concentration of impurities was around $0.05 \mathrm{~g} / \mathrm{L}$. This concentration implies that the original scrubbing solution droplet entrained in the exit off gas would have to have been approximately 10 to $20 \mu \mathrm{m}$ in diameter to result in an aerosol in the size 


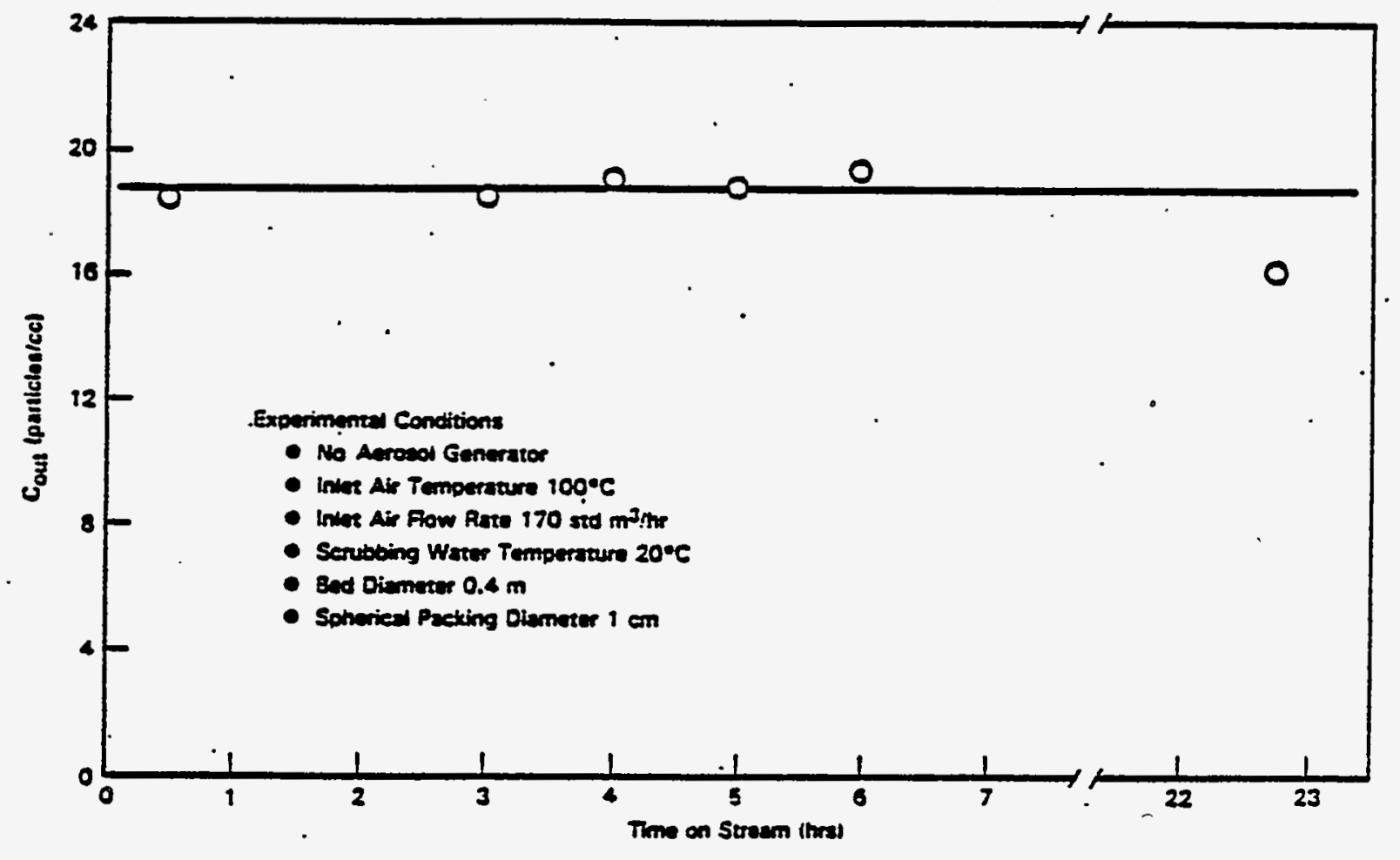

FIGURE 4.6-28. Outlet Concentration Due to Re-Entrainment as a Function of Time (Ref. 4.6-9)

range of the detector $(0.3$ to $0.7 \mu \mathrm{m})$ once the water had evaporated. Entrainment of droplets of this size is quite possible under the operating conditions of this study.

Influence of Scrubbing-Solution Concentration on Re-Entrainment. The infiuence of scrubbing-solution concentration on performance was investigated by adding either sodium chloride or titanium dioxide to the scrubbing solution while drawing room air through the SBS. The outlet concentration was monitored using the CSAS. One experiment was repeated using both sodium chloride and titanium dioxide to determine the difference between soluble and insoluble materials. The results are displayed in Figure 4.6-29.

The SBS was filled with fresh process water at the start of each experiment; yet the initial outlet concentration was approximately three times higher in the experiment with sodium chloride than in the experiment with titanium dioxide. The curves shown in Figure 4.6-29 have been corrected for this difference in initial concentrations, which are considered background noise. 


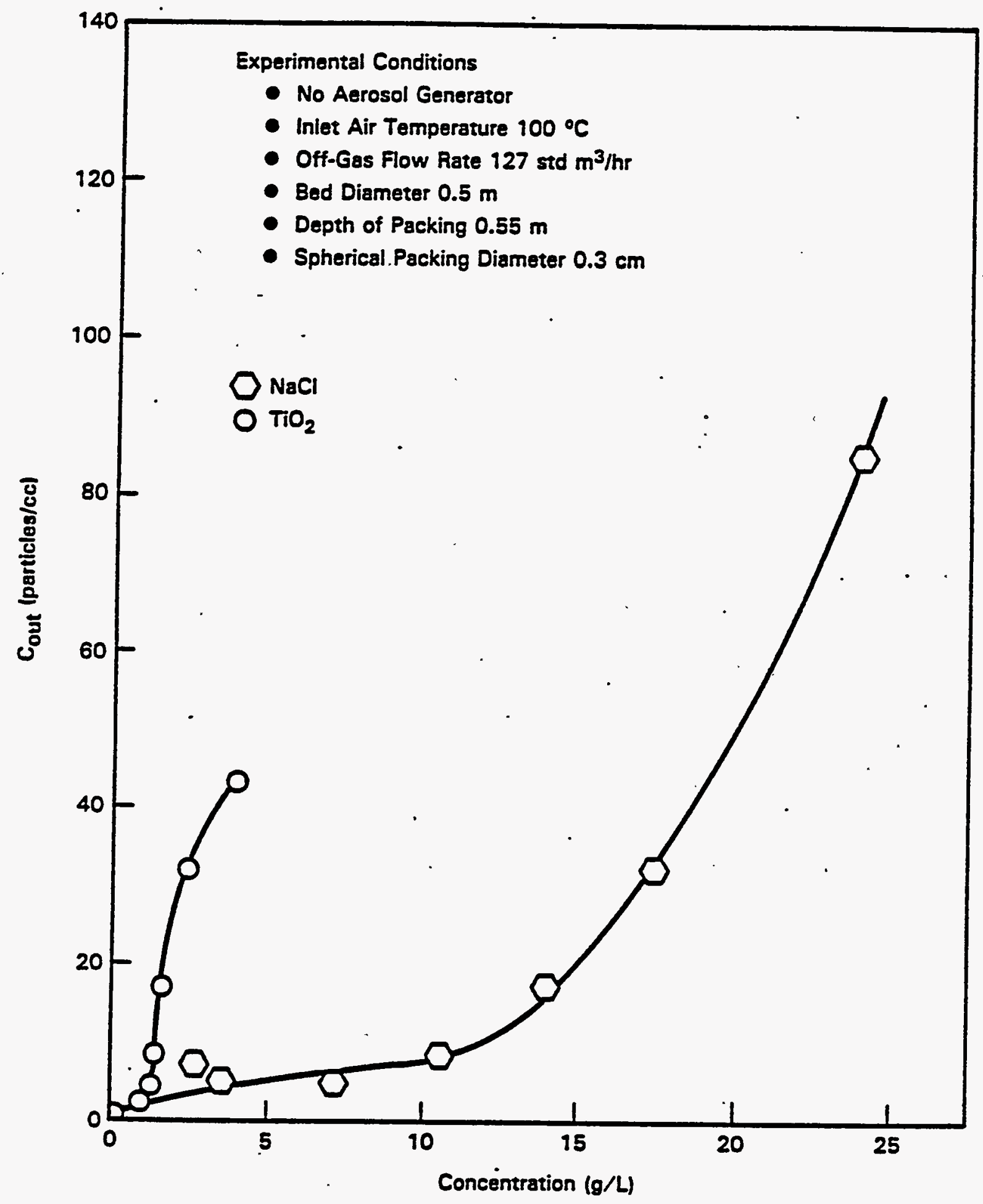
FIGURE 4.6-29. Effect of Scrubbing-Solution Concentration on Re-Entrainment
(Ref. 4.6-9.) 
The curve for $\mathrm{TiO}_{2}$ climbs much more rapidly than the corresponding curve for $\mathrm{NaCl}$. This behavior is consistent with the nature of the two chemical species. The titanium dioxide exists in the scrubbing solution as discrete particles, even at low concentrations. When a water droplet is entrained in the exit off gas, either there is a titanium dioxide particle in the droplet or there is not. If there is a particle, it should be large enough to be detected. This claim is based on the-size distribution data for titanium dioxide suspended in the scrubbing solution, shown in Figure 4.6-30. Sodium chloride aerosols, on the other hand, will show a slower formation rate of $0.3-$ to $0.7-4 \mathrm{~m}$ particles as its concentration increases in the scrubbing solution because it is distributed throughout the water as molecules, not as particles. The question of whether or not a "detectable" particle was formed depended on whether or not a titanium dioxide particle was present in the droplet in the first place. With. NaCl, there will be material in the droplet, but the question is whether the droplet. is large enough and/or the $\mathrm{NaCl}$ concentration high enough to produce a "detectable $e^{\text {a }}$ particle once the water has evaporated. The number of droplets and the original size distribution produced are probably insensitive to the captured aerosol concentration on the scrubbing solution. However, the size distribution of sodium chloride aerosols generated after the water has evaporated will slowly shift towards larger particles as the concentration increases. Above a certain concentration, a significant

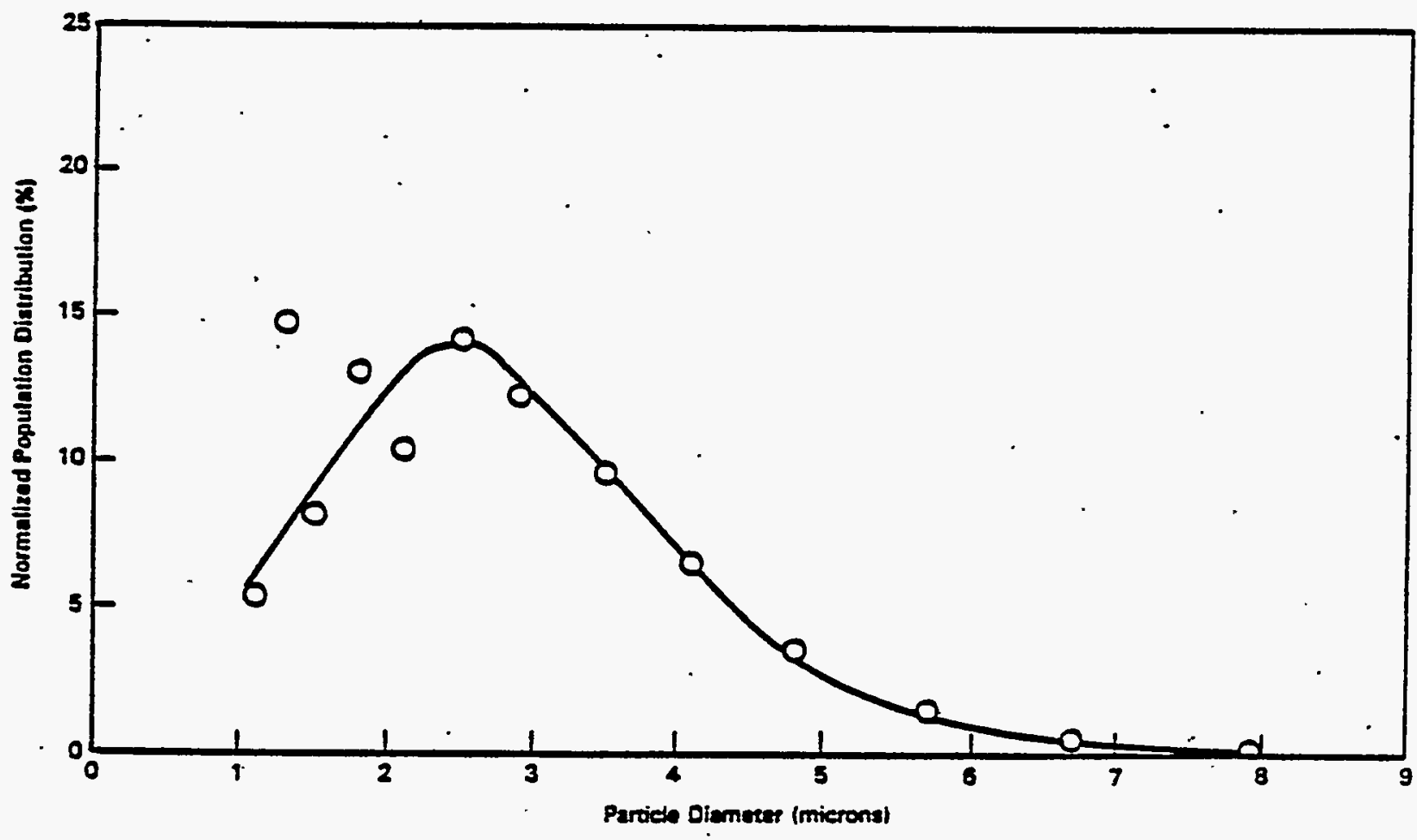

FIGURE 4.6-30 Particle Size Distribution of $\mathrm{TiO}_{2}$ Suspended in the Scrubbing Water (after adding $-36 \mathrm{~kg} \mathrm{TiO}_{2}$ to $650 \mathrm{~L} \mathrm{H}_{2} \mathrm{O}$ )
(Ref. 4.6-9) 
portion of the resulting sodium chloride aerosols will be between 0.3 and $0.7 \mu \mathrm{m}$. This point appears to occur at a $\mathrm{NaCl}$ concentration in the scrubbing liquor of approximately $15 \mathrm{~g} / \mathrm{L}$.

There is a limit as to how much insoluble material can remain suspended in the scrubbing solution for a given rate of agitation. During the $\mathrm{TiO}_{2}$ experiment, the suspended-solids concentration only increased from 2.3 to $3.8 \mathrm{~g} / \mathrm{L}$ as the amount of additional $\mathrm{TiO}_{2}$ increased from 16.2 to $36 \mathrm{~kg}$. Better than $90 \%$ of the $\mathrm{TiO}_{2}$ did not remain suspended, suggesting that the suspended-solids concentrations investigated cover the range of concentrations likely to be encountered during long-term operation.

Influence of Velocity on Re-Entrainment. The off-gas velocity was varied at the end of the two previous experiments to determine the influence of velocity on re-entrainment. The results are shown in Figure 4.6-31. The curve for sodium chloride demonstrates an exponential-type increase with velocity, while the curve for titanium dioxide is closer to being linear. If the increase in the re-entrained aerosol concentration with velocity was merely a result of more droplets being formed, then both curves should exhibit the same shape. The fact that the curve for sodium chloride increases faster than the curve for titanium dioxide implies that the size distribution of the droplets formed by bursting bubbles increases towards larger particles at higher flow rates. The increased importance of re-entrainment at higher velocities is one of the reasons why scrubbing performance decreases with increasing velocity. It is important to design an SBS such that the superficial velocities are as low as reasonably possible. Lower flow rates also increase the effectiveness of the Brownian motion capture mechanism.

Influence of Defoamers on Re-Entrainment. Adding $36 \mathrm{~kg}$ of $\mathrm{TiO}_{2}$ to the scrubbing solution only increased the outlet concentration a little more than twice its level at the start of the experiment (before the correction for background noise was made). While these numbers may seem small, they severely limit the performance of the SBS. At an inlet concentration of 1000 particles/cc, the mass DF is approximately 20 for insoluble aerosols at high aerosol concentrations in the scrubbing solution, assuming that all of the particles entering the SBS are initially captured. Any aerosols leaving as particles penetrating the SBS will lower the DF even more. As previously mentioned, the DF for soluble aerosols is almost always limited by re-entrainment. It is for this reason that efforts were directed to limit re-entrainment. One approach investigated was to lower the surface tension of the scrubbing solution, thus making it easier for the bubbles to break the surface of the scrubbing water. There should then be less potential energy stored in the gas within the bubble when it finally breaks, making it more difficult to form droplets that can become re-entrained. A defoamer supplied by Dow Corning (DB-110A) was added to the scrubbing solution after adding $16.2 \mathrm{~kg}$ of salt to the scrubbing solution. The effect of the defoamer on the outlet concentration is shown in Figure 4.6-32. After 50 grams (less than two ounces) was added to the approximately 650 liters of salt solution, the outlet concentration dropped below the background level observed at the start of the experiment. The addition of more defoamer did little to improve the outlet concentration. 


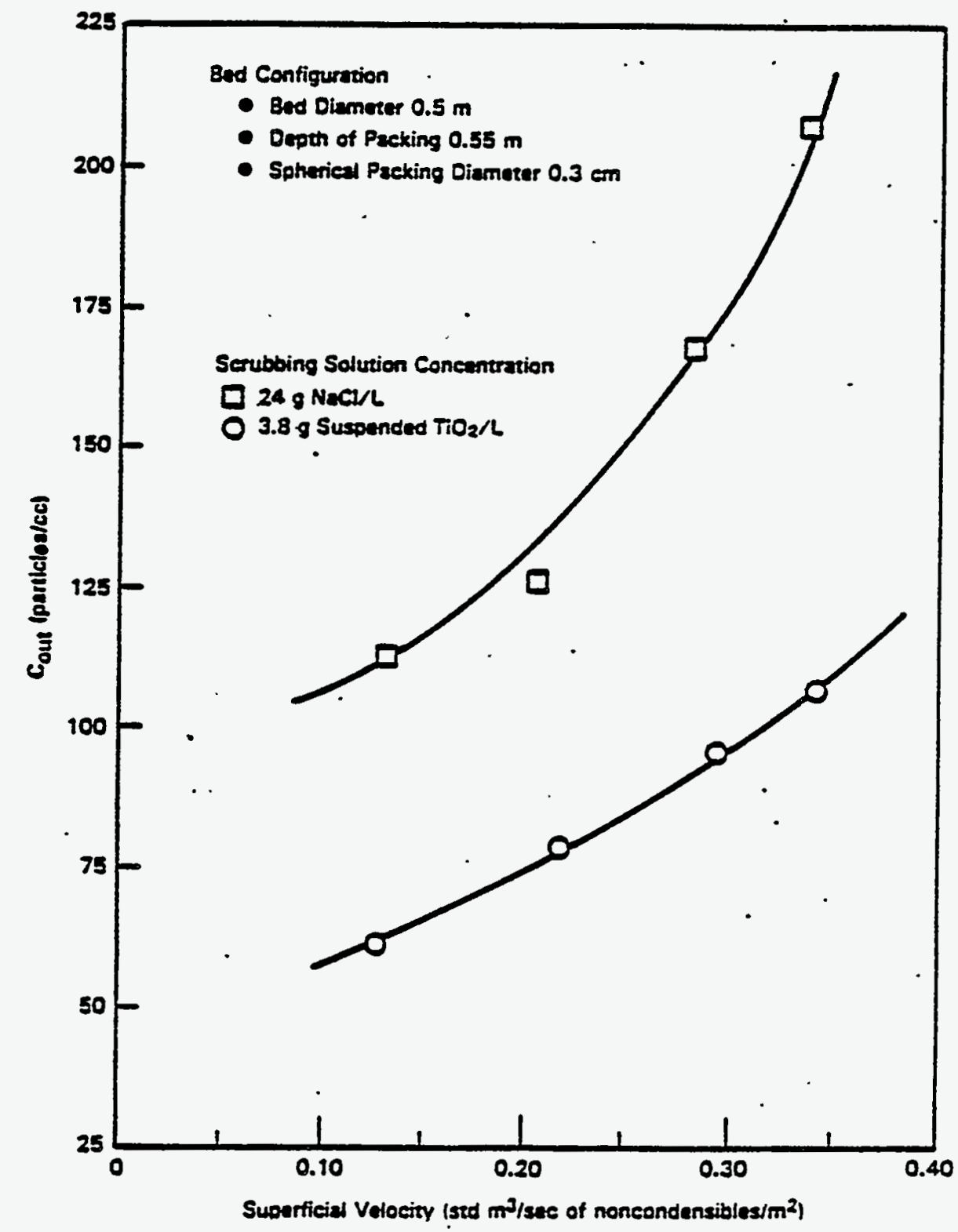

FIGURE 4.6-31. Effect of Gas Velocity on Re-Entrainment (Ref. 4.6-9)

A possible explänation has been extended as to the defoamer's effectiveness; but this hypothesis has not been proven, nor has the defoamer been tested under industrial conditions. It is sufficient to say that there does appear to be a practical way to limit re-entrainment, even for concentrated scrubbing . solutions. It may also be possible to improve the initial capture of insoluble 


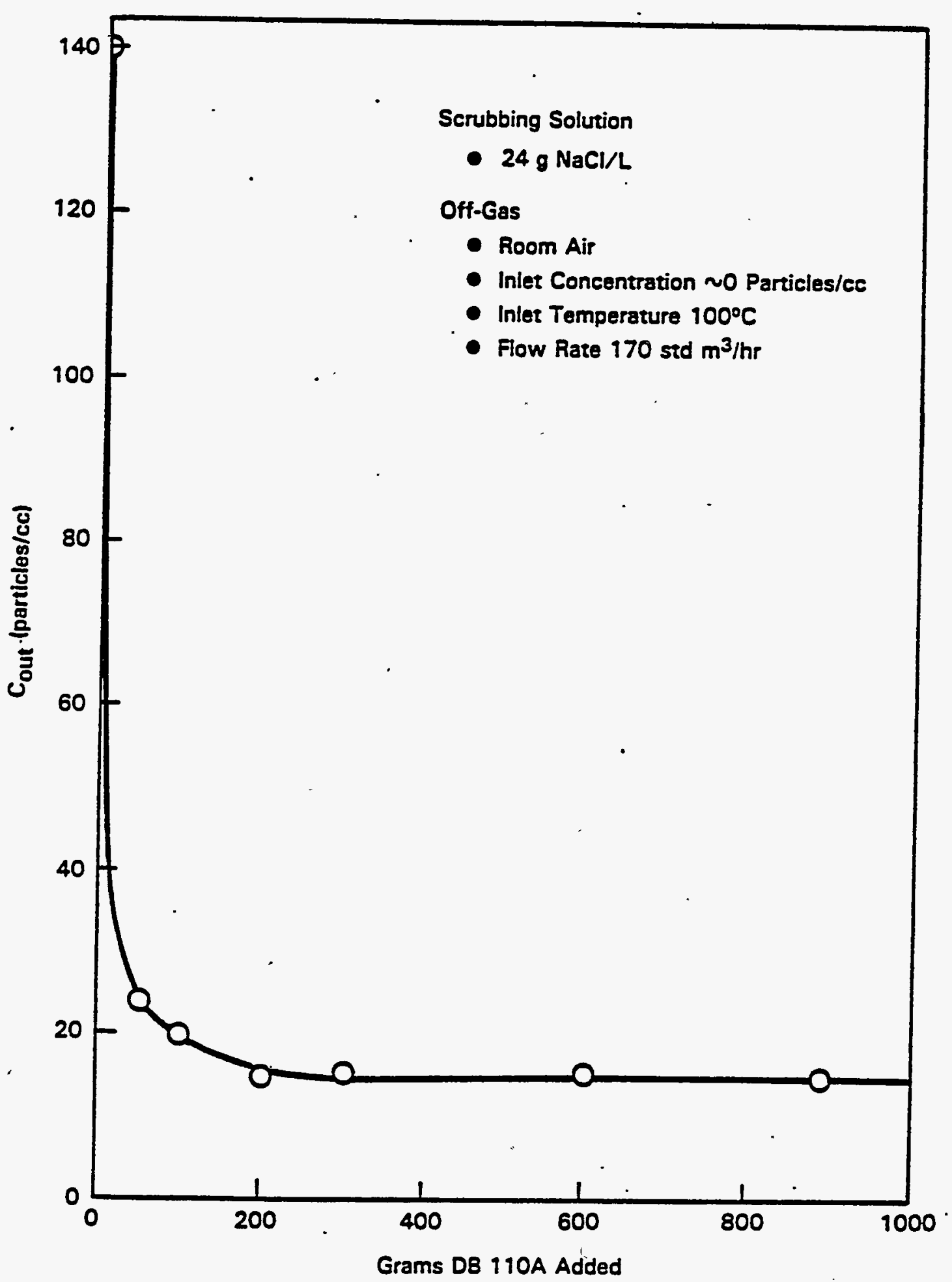

FIGURE 4.6-32. Effect of Dow Corning Defoamer DB-110A on Re-Entrainment (Ref. 4.6-9) 
aerosols using a surfactant. The surfactant should increase the wettability of the insoluble material, making it easier for the aerosols to penetrate the gasliquid interface (Ref. 4.6-8). 
4.6.4.3.10 HWVP SBS Development (HWVP-89-IVJ0010100B). The SBS was evaluated in the HWVP-15 MOB tretment system test for HWVP application.

\subsection{Physical Properties and Operating Conditions. At} $110 \mathrm{scfm}$, the pressure drop through the bed was 34 in. WC with a 31 in. WC submergence. This average pressure drop increased to 37 in. WC when the noncondensible off-gas flow rate was increased to $170 \mathrm{scfm}$. It has been hypothesized by Ruecker and Scott (Ref. 4.6-9) that unsteady-state surging through the SBS bed would occur. This surging Hould continue until a stable gas bubble developed beneath the distribution plate. Such a phenomenon could hamper lining out the entire melter to blower vacuum system if sensitive automatic vacuum control is used. This might necessitate starting the vacuum system on manual setpoint control until the system has stabilized. At the start of operations no significant pressure fluctuations were observed.

The composition of the SBS scrubbing liquor at steady state is summarized in Table 4.6-27 along with the average melter feed composition. The $\mathrm{pH}$ of the SBS scrub solution achieved a steady value of 4 . The acidity of the solution was due to absorption of acid gas effluents, primarily NO $\mathrm{N}_{x}$, generated by the meiter. The $\mathrm{NO}_{3}^{-}$anion is found to be the major soluble component in SBS supernatant solutions. Other major ionic components in SBS solutions are associated with $\mathrm{B}, \mathrm{Na}$, and $\mathrm{Cs}$. Frit and calcine are found to be responsible for most of the insoluble elements found in SBS solutions (Fe, Si, and $\mathrm{Na}$ ). The buildup of selected elements in the SBS supernate are plotted versus time in Figures 4.6-33 and 4.6-34.

Examination of Figures $4.6-33$ and 4.6-34 show significant differences between the concentration build-up curves of soluble, insoluble, and total elements in the SBS supernate. The SBS concentrations of essentially all insoluble elements are found to increase rapidly in an almost stepwise fashion during the first days of feed processing. The SBS concentrations recorded for the soluble components, however, follow an exponential rise, which is in accord with a theoretical stirred tank model shown in Figure 4.6-35. The theoretical prediction was based on an average steady-state concentration in the supernate, the overflow rate, the overflow concentration, and the volume of solution in the SBS as given by the following equation.

$$
\text { SBS Concentration }=C_{1}-C_{q} \cdot e^{-f\left(C_{f} / V \cdot t\right)}
$$

where $\begin{aligned} c_{p} & =\text { steady state concentration } \\ t & =\text { time } \\ f & =\text { overflow rate } \\ C_{f} & =\text { overflow concentration } \\ V & =\text { volume of SBS. }\end{aligned}$ 
TABLE 4.6-27. Composition of SBS Solution HWVP-89-IVJ0010100B

\begin{tabular}{|c|c|c|c|c|c|c|}
\hline Element & $\begin{array}{l}\text { Wt\% } \\
\text { Total }\end{array}$ & $\begin{array}{l}\text { Wt\% } \\
\text { PPT }\end{array}$ & $\begin{array}{c}\text { Ht\% } \\
\text { Supernate }\end{array}$ & $\begin{array}{l}\text { Total } \\
(\mathrm{mg} / \mathrm{L})\end{array}$ & $\begin{array}{l}\text { Feed } \\
\text { Average }(g / L)\end{array}$ & $\begin{array}{c}\text { Melter } \\
\text { DF }\end{array}$ \\
\hline $\begin{array}{l}\mathrm{AT} \\
\mathrm{Ba} \\
\mathrm{B} \\
\mathrm{Ca} \\
\mathrm{Ce} \\
\mathrm{Cr} \\
\mathrm{Cs} \\
\mathrm{Cu} \\
\mathrm{F} \\
\mathrm{Fe} \\
\mathrm{K} \\
\mathrm{La} \\
\mathrm{Li} \\
\mathrm{Mg} \\
\mathrm{Mn} \\
\mathrm{Mo} \\
\mathrm{Na} \\
\mathrm{Nd} \\
\mathrm{Ni} \\
\mathrm{P} \\
\mathrm{SO} \\
\mathrm{Si} \\
\mathrm{Sr} \\
\mathrm{Ti} \\
\mathrm{Zn} \\
\mathrm{Zr} \\
\mathrm{Cl}\end{array}$ & $\begin{array}{r}2.03 \\
0.11 \\
4.83 \\
0.33 \\
0.42 \\
0.21 \\
0.00 \\
0.18 \\
20.69 \\
5.77 \\
0.19 \\
0.95 \\
0.25 \\
0.50 \\
0.15 \\
0.43 \\
7.68 \\
0.68 \\
0.61 \\
0.14 \\
10.66 \\
2.67 \\
0.10 \\
0.13 \\
0.47 \\
3.64 \\
11.48\end{array}$ & $\begin{array}{r}3.44 \\
0.74 \\
1.10 \\
1.77 \\
2.91 \\
0.95 \\
0.00 \\
0.58 \\
0.00 \\
33.77 \\
0.00 \\
6.63 \\
0.46 \\
2.90 \\
0.52 \\
2.27 \\
18.00 \\
4.79 \\
3.19 \\
0.00 \\
0.00 \\
9.44 \\
0.62 \\
0.80 \\
0.84 \\
4.26 \\
0.00\end{array}$ & $\begin{array}{r}1.79 \\
0.00 \\
5.45 \\
0.10 \\
0.00 \\
0.08 \\
0.00 \\
0.11 \\
24.14 \\
1.10 \\
0.22 \\
0.00 \\
0.22 \\
0.10 \\
0.08 \\
0.12 \\
5.95 \\
0.00 \\
0.18 \\
0.17 \\
12.44 \\
1.54 \\
0.02 \\
0.02 \\
0.41 \\
3.53 \\
13.39\end{array}$ & $\begin{array}{r}32 \\
2 \\
77 \\
5 \\
7 \\
3 \\
12 \\
3 \\
330 \\
92 \\
3 \\
15 \\
4 \\
8 \\
2 \\
7 \\
122 \\
11 \\
10 \\
2 \\
170 \\
43 \\
2 \\
2 \\
8 \\
58 \\
183 \\
\end{array}$ & $\begin{array}{c}6.79 \\
0.48 \\
16.5 \\
3.26 \\
0.57 \\
0.49 \\
0.8 \\
0.63 \\
1.2 \\
24.6 \\
\text { NA } \\
5.57 \\
8.81 \\
2.6 \\
0.58 \\
1.09 \\
41.7 \\
2.65 \\
2.34 \\
0.4 \\
0.99 \\
129 \\
0.47 \\
0.01 \\
2.02 \\
14.4 \\
0.54 \\
\end{array}$ & $\begin{array}{r}338 \\
446 \\
314 \\
979 \\
138 \\
227 \\
77 \\
346 \\
-\quad 46 \\
431 \\
N A \\
595 \\
3054 \\
519 \\
400 \\
234 \\
500 \\
392 \\
374 \\
247 \\
8 \\
4868 \\
453 \\
8 \\
428 \\
400 \\
4 \\
\end{array}$ \\
\hline & & & & & 305.5 & 275 \\
\hline
\end{tabular}

Consequent7y, it appears that the sampling of the SBS for insoluble matter was not representative of bulk average conditions within the tank. However, the suspended SBS solids concentrations in the samples collected were much higher $(2 X)$ than off-gas effluent sampling results would predict. Since SBS samples were extracted toward the bottom of the tank, the above results indicate the that the SBS is not a uniformly mixed tank for suspended solids. It does not necessarily follow from this observation that significant settling of insolubles is occurring; however, it does not preclude it.

4.6.4.3.10.2 Quenching And Steam Collection. During HWVP-15, the SBS operated under maximum cooling conditions, which maintained the buik temperature of the scrubbing liquid below $30^{\circ} \mathrm{C}$ under all off-gas flow rate 


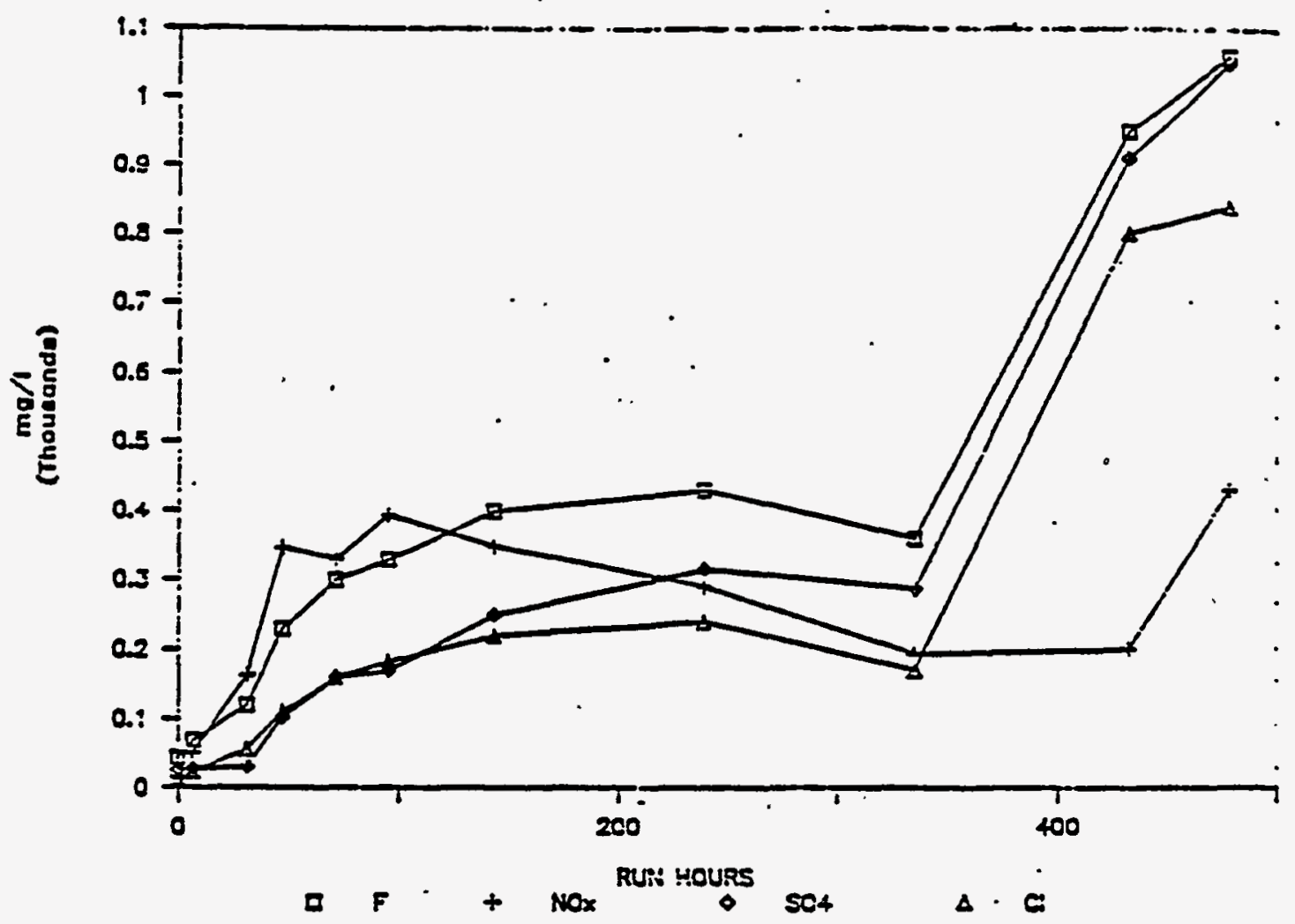

FIGURE 4.6-33. SBS Concentration Buildup of Anions HWVP-89-IVJ0010100B

conditions as shown in Figures 4.6-36 and 4.6-37. The SBS collected water at a rate of $26 \mathrm{~L} / \mathrm{h}$ while the melter was being fed $42 \mathrm{~L} / \mathrm{h}$ of feed. Since 1 liter of feed contains about $0.77 \mathrm{~L}$ of water (i.e., the water feed rate to the meiter was $32 \mathrm{~L} / \mathrm{h}$ ), data indicate the SBS collected $84 \%$ of the steam generated during steady-state processing conditions. The chevron demister collected a negligible amount of water under normal operation and the HEME collected only about $1 \mathrm{~L} / \mathrm{h}$. Calculations indicate the off-gas stream could carry out a maximum of $6 \mathrm{~L} / \mathrm{h}$ at the higher concondensible air flow rates tested, and off-gas sampling equipment confirmed that the noncondensible gas leaving the SBS was indeed saturated. The saturated air accounts for the remainder of the process steam generated during steady-state feeding conditions; therefore, a water balance across the SBS has been achieved using the operational data collected during HWVP-15 test.

The quenching capability of the SBS was evaluated under steady-state operations during the first 7 days of the test. The cooling water used in the SBS cooling coils was measured to have an inlet temperature of $15^{\circ} \mathrm{C}$, an outlet temperature of $24^{\circ} \mathrm{C}$, and water flow rate of about $25 \mathrm{gpm}$. The inlet and outlet gas temperatures were $190^{\circ} \mathrm{C}$ and $28^{\circ} \mathrm{C}$, respectively, during this same period. An overall heat transfer coefficient for the cooling coils was calculated to be $300 \mathrm{Btu} / \mathrm{h} \cdot \mathrm{ft}^{2} \cdot \cdot \mathrm{F}$. 


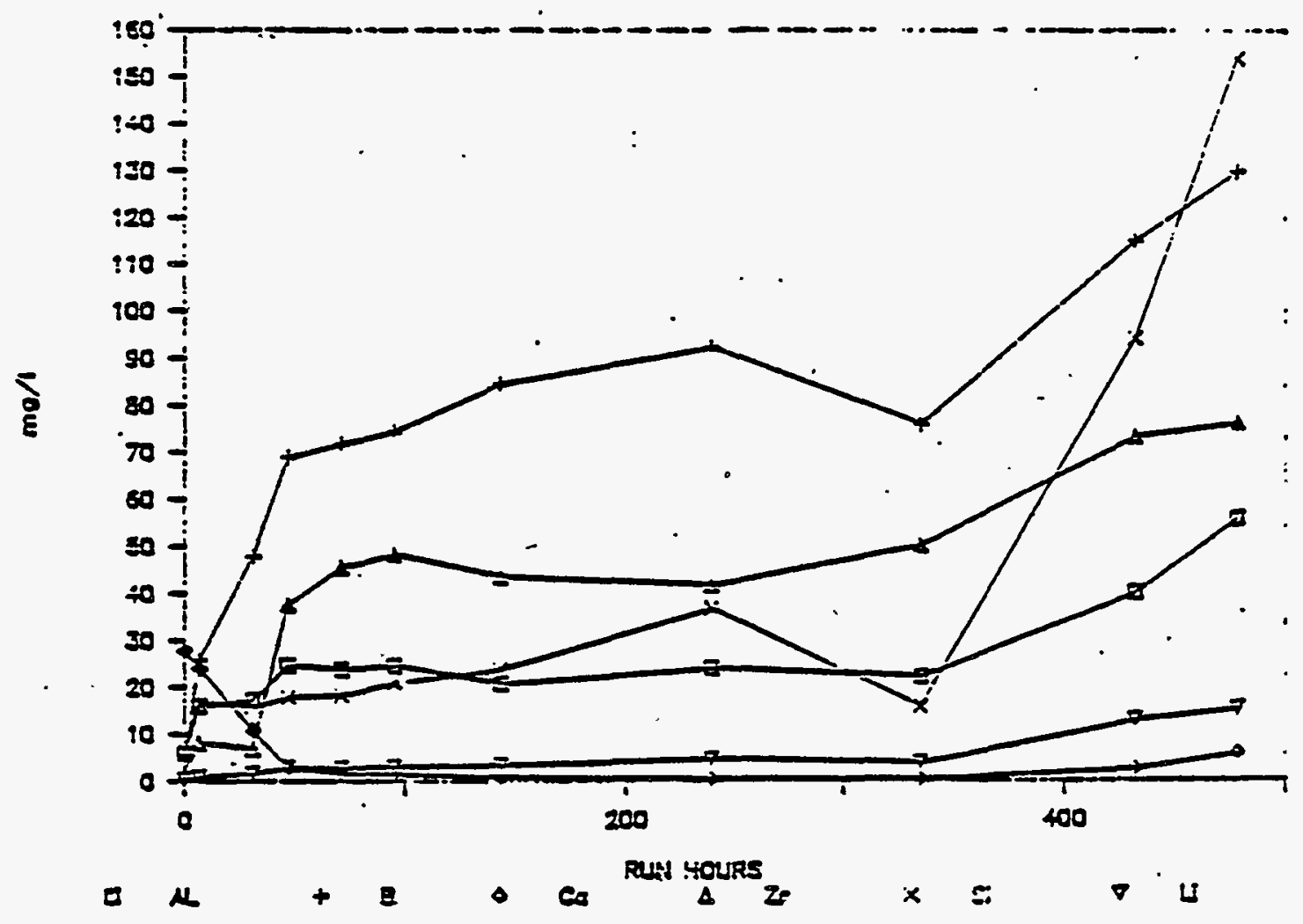

FIGURE 4.6-34. SBS Concentration Buildup of Cations. HWVP-89-IVJ0010100B

Typical heat transfer coefficients for heat transfer from warm water to cold with slight agitation are given as 100 to $400 \mathrm{Btu} / \mathrm{h} \cdot \mathrm{ft}^{2} \cdot{ }^{\circ} \mathrm{F}$ by engineering handbooks. This compares very well with the calculated value. A heat transfer coefficient of $150 \mathrm{Btu} / \mathrm{h} \cdot \mathrm{ft}^{2} \cdot{ }^{\circ} \mathrm{F}$ appears prudent for design as a conservative value that would allow for some particulate build-up on the coils.

4.6.4.3.10.3 Gas Scrubbing Performance. Using the nitrate content of the feed HWVP-15, the measured steady-state composition and condensation rate of the SBS and assuming $100 \% \mathrm{NO}_{3}$ to $\mathrm{NO}_{x}$ conversion, the average, steady-state $\mathrm{NO}_{x}$ scrubbing efficiency of the SBS has been estimated to be -1 vol\%. This result is in agreement with packed column data collected during the HWVP-12 test and confirms the strong dependence of aqueous scrubbing techniques upon inlet $\mathrm{NO}_{x}$ concentrations.

Since aqueous scrubbing kinetics is much greater for $\mathrm{NO}_{2}$ than for $\mathrm{NO}$, a high $\mathrm{NO} / \mathrm{NO}_{2}$ ratio at the SBS inlet may have al so contributed to the poor scrubbing performance of the SBS. A nitrogen oxide ratio of 2 was measured downstream of the HEME with an on-7ine chemi-luminescent $\mathrm{NO}_{\dot{x}}$ analyzer. Since NO is rapidly converted to $\mathrm{NO}_{2}$ at room temperatures and the SBS apparently did very little $\mathrm{NO}_{2}$ scrubbing, the SBS inlet $\mathrm{NO} / \mathrm{NO}_{2}$ ratio must have been. significantly greater than 2. Using a combined off-gas transit and sample 


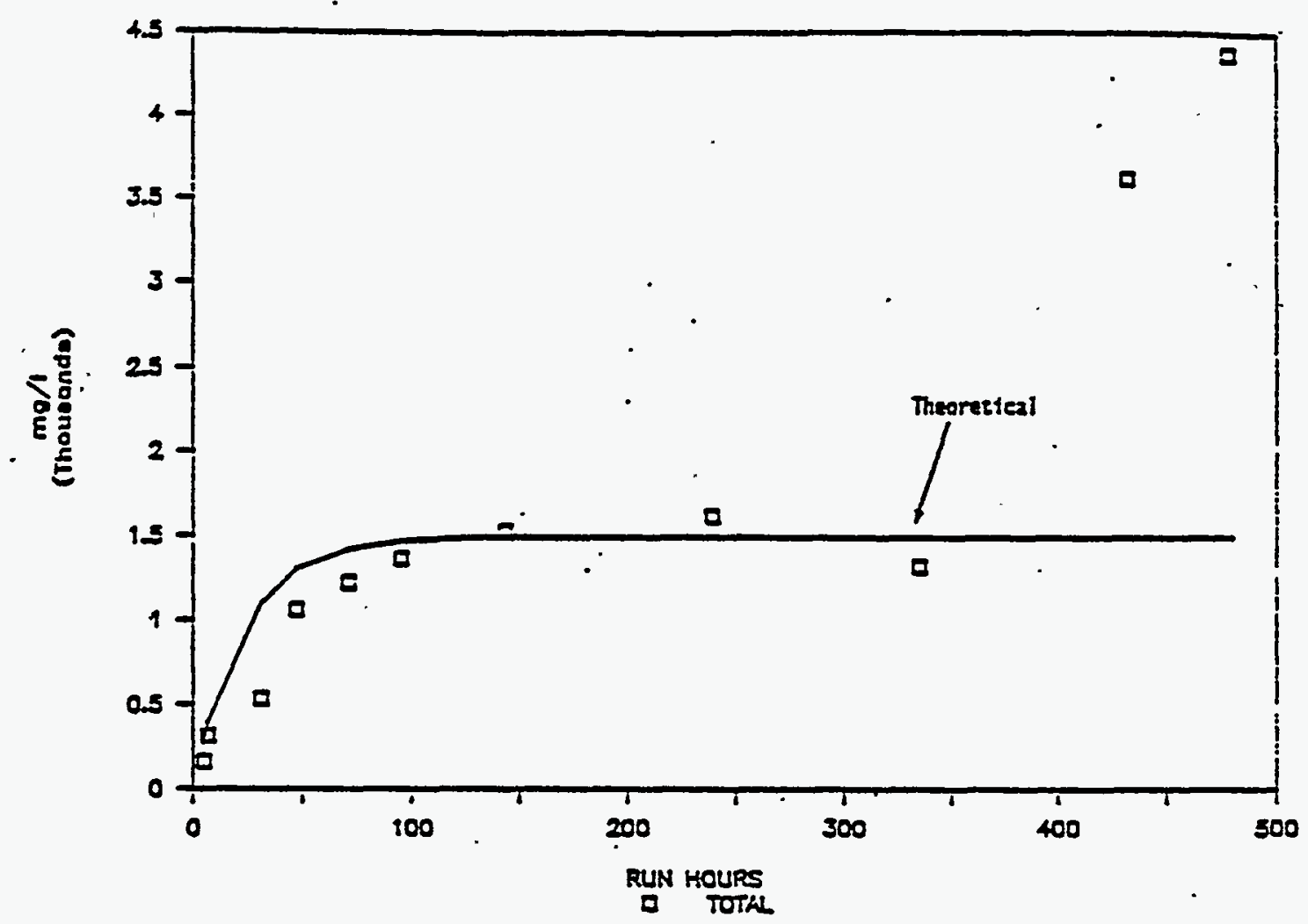

FIGURE 4.6-35. . Total Elemental Concentration Buildup in SBS Versus Theoretical Prediction HWVP-89-IVJ0010100B

stream hold-up time of $>30 \mathrm{~s}$ and the kinetic equations developed by Thomas and Munger, (a) the nitrogen oxide ratio at the SBS inlet is estimated to be $>4$, assuming little or no $\mathrm{NO}_{2}$ removal by the SBS and HEME.

SBS scrubbing performance for condensible volatile gas phase effluent is summarized in Table 4.6-28. Although the data scatter is quite large, SBS scrubbing efficiency for $\mathrm{B}, \mathrm{Cl}$, and $\mathrm{F}$ appears to be functionally dependent on off-gas fl.ow rate and, possibly, moisture loading. The DFs for all three effluent elements decreased markedly, on the average, when the off-gas flow rate was increased from $110 \mathrm{scfm}$ to $170 \mathrm{scfm}(6 / 13 / 88)$. These elemental DFs increased again when the solids loading of the feed dropped during the last two days of processing. A further increase in these DFs subsequently occurred when off-gas flow rate was reduced to $90 \mathrm{scfm}(6 / 21 / 88)$ when the melter idling campaign was initiated. Since gas contacting would be facilitated by both increased steam loading and reduced flow, the observed trends are at least consistent with a fairly simple, intuitive model.

(a) T. R. Thomas and D. H. Munger. 1978. An Evaluation of NO Abatement by $\mathrm{NH}_{3}$ Over Hydrogen Mordinite for Nuclear Fuel Reprocessing Plants. ICP-133, Idaho National Engineering Laboratory, Idaho Fal1s, Idaho. 


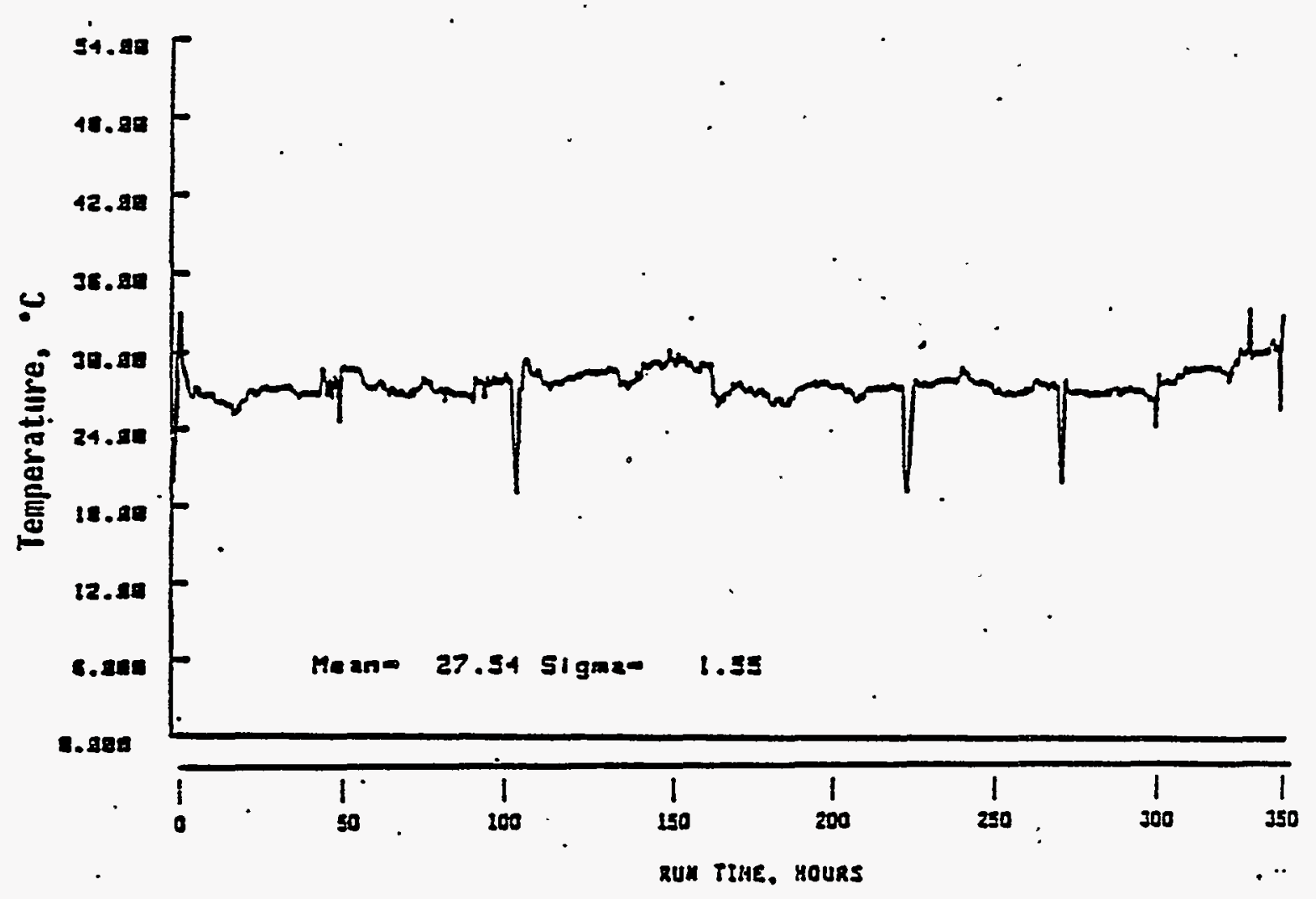

FIGURE 4.6-36. SBS Bed Temperature 2 Feet Below Surface HWVP-89-IVJ0010100B

The effect of off-gas flow rate upon gas scrubbing efficiency of the SBS was also evaluated from scrubbing solution concentration data. Figures 4.6-33 and 4.6-34 illustrate the time-dependent buildup of SBS effluent. Since most of these soluble anions have, to some extent, gaseous precursors, the time-dependent behavior of these ions can be used to track collection efficiency. As mentioned previously, the concentration increases recorded for all soluble anions follow theoretical homogeneous stirred tank predictions; consequently, no changes in gas scrubbing efficiency due to increased off-gas flow rate (bed residence time) is indicated by the concentration trend data. However, because of the limited and variable nature of the concentration data that are available, changes in scrubbing efficiencies would have to be quite large to be noticeable. As previously shown in Table 4.6-14, essentially all the boron and fluorine and most of the chlorine, phosphorous, and sulphur exhausted to the SBS are in the gas phase. Table 4.6-28 further illustrates that the SBS can significantly interact and remove a significant fraction of this effluent. The nature of the residual effluent exhausted by the SBS has al so been determined, as sumnarized in Table 4.6-29. The data in this table indicate that al though the SBS partially removes volatile effluent elements, it does not change the physical characteristics of these effluents. Consequently, $\mathrm{B}, \mathrm{Cl}, \mathrm{F}$, and $\mathrm{P}$ are primarily carried over to the HEME as gas phase effluents. 


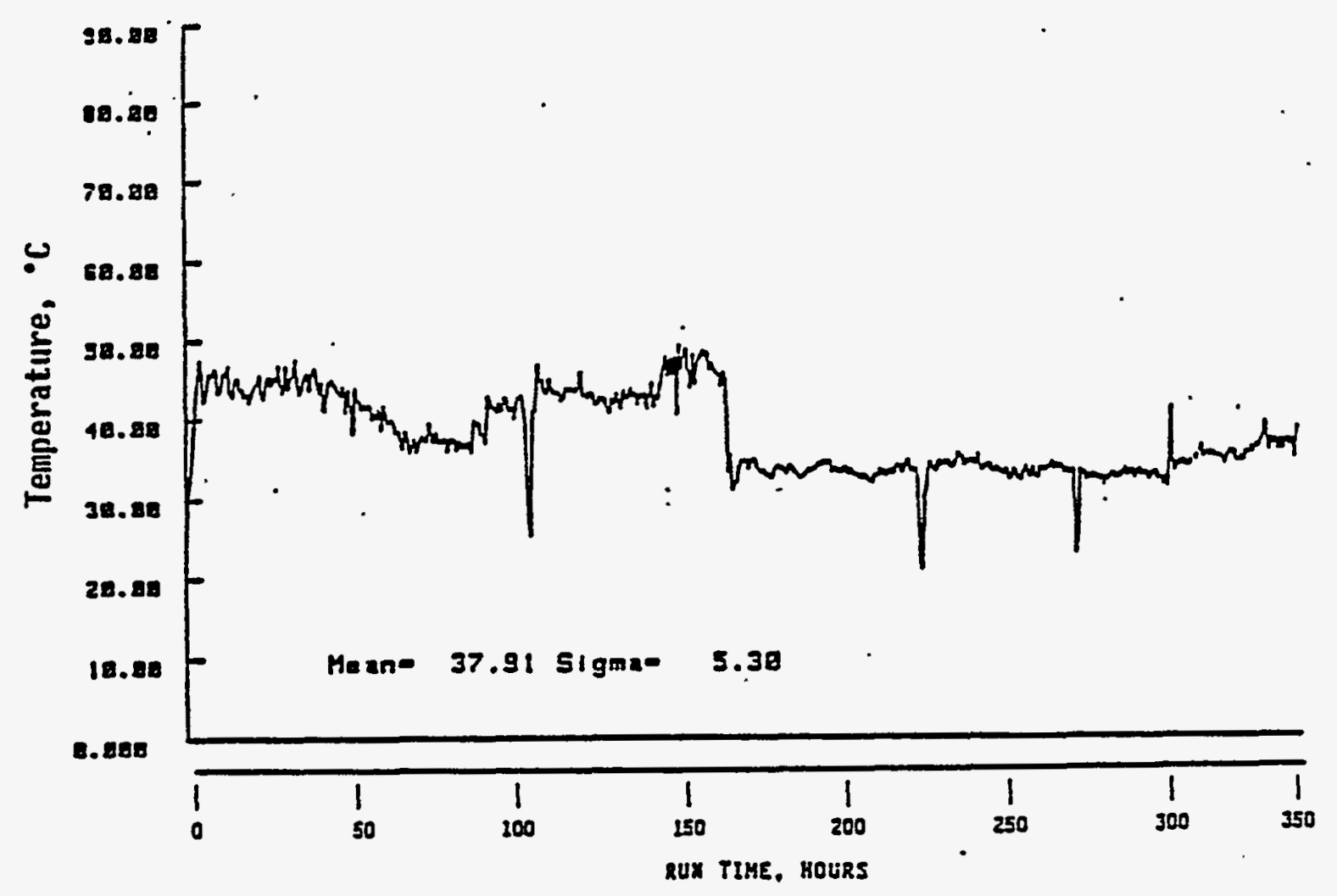

FIGURE 4.6-37. SBS Bed Temperature 4 Feet Below Surface HWVP-89-IVJ0010100B

4.6.4.3.9.4 Aerosol Scrubbing Efficiency. The SBS is designed to remove airborne particulate matter from the process exhaust. The efficiency of this device is strongly dependent on the size distribution of aerosols with which it is interacting.

Table 4.6-6 details the manner in which melter particulate matter was distributed across the cyclonic size fractions. During processing only $35 \%$ of the particulate mass leaving the melter was in a size range $(>1 \mu \mathrm{m})$ for which SBS efficiency is high, and only 20\% of the airborne mass was in this range during idling. The average steady-state off-gas concentration of particulate matter $(-100 \mu \mathrm{g} / \mathrm{L})$ was very low throughout most of the test due to the extremely high melter mass DF achieved. Because of these unfavorable off-gas conditions, only low to moderate SBS DFs would be predicted during steady-state processing and idling conditions.

Mass DFs are used as measure of overall SBS performance. A summary of SBS aerosol DFs is given in Table 4.6-30. If the first 2 days are excluded. from consideration because of me1ter instabilities previously described, SBS mass DFs are fairly consistent and are found to be low, as expected. Previous comparable melter tests (PSCM-19 and PSCM-21) have achieved SBS mass DFs 5 times greater than was observed in the present test. However, the previous 
TABLE 4.6-28. SBS Gaseous Decontamination Factors HWVP-89-IVU0010100B

\begin{tabular}{|c|c|c|c|c|c|c|c|c|c|c|c|c|c|c|c|}
\hline Element & $\begin{array}{l}6 / 6 / 80 \\
2110 \mathrm{~h}\end{array}$ & $\begin{array}{l}6 / 7 / 80 \\
1054 \mathrm{~h}\end{array}$ & $\begin{array}{l}6 / 8 / 88 \\
1216 \mathrm{~h}\end{array}$ & $\begin{array}{l}6 / 9 / 80 \\
1239 \\
h\end{array}$ & $\begin{array}{l}6 / 10 / 48 \\
0956 \mathrm{~h}\end{array}$ & $\begin{array}{l}6 / 11 / 88 \\
1116 \mathrm{~h}\end{array}$ & $\begin{array}{l}\text { G/14/88 } \\
\text { 1351 h }\end{array}$ & $\begin{array}{l}6 / 15 / 88 \\
1311 \text { h }\end{array}$ & $\begin{array}{l}6 / 16 / 88 \\
1113 \mathrm{~h}\end{array}$ & $\begin{array}{l}6 / 17 / 88 \\
1109 h\end{array}$ & $\begin{array}{l}6 / \mathrm{iB} / 80 \\
1055 \mathrm{~h}\end{array}$ & $\begin{array}{l}6 / 19 / 88 \\
1135 \mathrm{~h}\end{array}$ & $\begin{array}{l}6 / 20 / 88 \\
1132 \mathrm{~h}\end{array}$ & $\begin{array}{l}0 / 21 / 80 \\
0216^{\prime}\end{array}$ & $\begin{array}{l}\text { 6/22//88 } \\
1114 \mathrm{~h}\end{array}$ \\
\hline $\begin{array}{l}B \\
C 1 \\
f \\
p \\
S\end{array}$ & $\begin{array}{r}54 \\
7.1 \\
320 \\
4.4 \\
6.6\end{array}$ & $\begin{array}{l}51 \\
18 \\
71 \\
1.9\end{array}$ & $\begin{array}{c}18 \\
71.9 \\
7 . \\
7.5\end{array}$ & $\begin{array}{c}17 \\
6.2 \\
11 \\
120\end{array}$ & $\begin{array}{l}14 \\
3.8 \\
36 \\
27\end{array}$ & $\begin{array}{l}16 \\
5.1 \\
12 \\
33\end{array}$ & $\begin{array}{c}1.8 \\
2.8 \\
3 \\
37\end{array}$ & $\begin{array}{c}12 \\
6.3 \\
16 \\
1 . \\
830\end{array}$ & $\begin{array}{l}2.6 \\
1.3 \\
1.9 \\
\therefore \\
\therefore\end{array}$ & $\begin{array}{c}2.9 \\
1.9 \\
5.1 \\
05\end{array}$ & $\begin{array}{c}4.7 \\
2.7 \\
5.7 \\
25\end{array}$ & $\begin{array}{l}22 \\
12 \\
31\end{array}$ & $\begin{array}{l}13 \\
-. \\
25 \\
-- \\
53\end{array}$ & $\begin{array}{r}89 \\
19 \\
29 \\
-\ddot{230}\end{array}$ & $\begin{array}{l}11 \\
14 \\
51 \\
14\end{array}$ \\
\hline
\end{tabular}


TABLE 4.6-29. Volatile SBS Effluent Losses HWVP-89-IVJ0010100B

\begin{tabular}{|c|c|c|c|c|c|}
\cline { 2 - 6 } \multicolumn{1}{c|}{} & \multicolumn{5}{c|}{ \% Losses Due to Gaseous Escape } \\
\hline Day & B & C1 & F & P & S \\
\hline 6 & 93 & 18 & 60 & -- & 42 \\
7 & 69 & 30 & 91 & 74 & 5.7 \\
8 & 75 & 28 & 83 & -- & 51 \\
9 & 74 & 39 & 89 & -- & 1.3 \\
10 & 77 & 35 & 89 & 43 & 17 \\
11 & 80 & 44 & 81 & -- & 21 \\
14 & 95 & 72 & 98 & 95 & 13 \\
15 & 78 & 85 & 93 & -- & 3.4 \\
16 & 84 & 85 & 99 & -- & -- \\
17 & 84 & 64 & 92 & 86 & 10 \\
18 & 84 & 47 & 89 & 91 & 17 \\
19 & 76 & 63 & 92 & -- & -- \\
20 & 85 & 52 & 95 & 87 & 14 \\
21 & 89 & 17 & 83 & -- & -- \\
22 & 71 & 14 & 88 & -- & 1.3 \\
23 & 78 & 21 & 93 & -- & 81 \\
24 & 74 & 16 & 91 & -- & 2 \\
& $81 \pm 9$ & $51 \pm 42$ & $88 \pm 11$ & $79 \pm 24$ & $18 \pm 87$ \\
\hline
\end{tabular}

experiments did not achieve the stable steady-state operating conditions that distinguish HWVP-15. Indeed, melter stability was so low for. the previous tests that entrainment losses overwhelmingly influenced the melter source and the value of the meiter aerosol mass DF. Coincidentally, the average melter DFs for the previous tests were as much lower than these of HWVP-15 as their SBS DFs were higher--a factor of 5 . Thus, variable off-gas conditions rather than changing performance characteristics, are responsible for the differences in SBS efficiencies noted above. The SBS DFs are consistent with parametric tests performed in 1987 (Ref. 4.6-9) as shown in Figure 4.6-38.

The effect of off-gas conditions on SBS performance is clearly illustrated by the behavior of the SBS during first two days of testing. The melter was relatively unstable until steady-state conditions were established on or about the third day of the test. The first two days of test were characterized by high melter aerosol emission (entrainment) rates and correspond-. ing low melter DFs. During this same period, the SBS exhibited mass DFs that were as much as a factor of 10 higher than was achieved during steady-state operations. The factor responsible for the enhanced initial performance behavior of the SBS was high meiter entrainment during startup. These data illustrate that the SBS can act as an off-gas shock absorber by efficiently responding to increases in off-gas aerosol loadings caused by process upsets. A similar but more dramatic example of this behavior was observed during the 


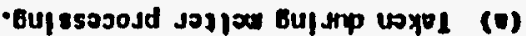

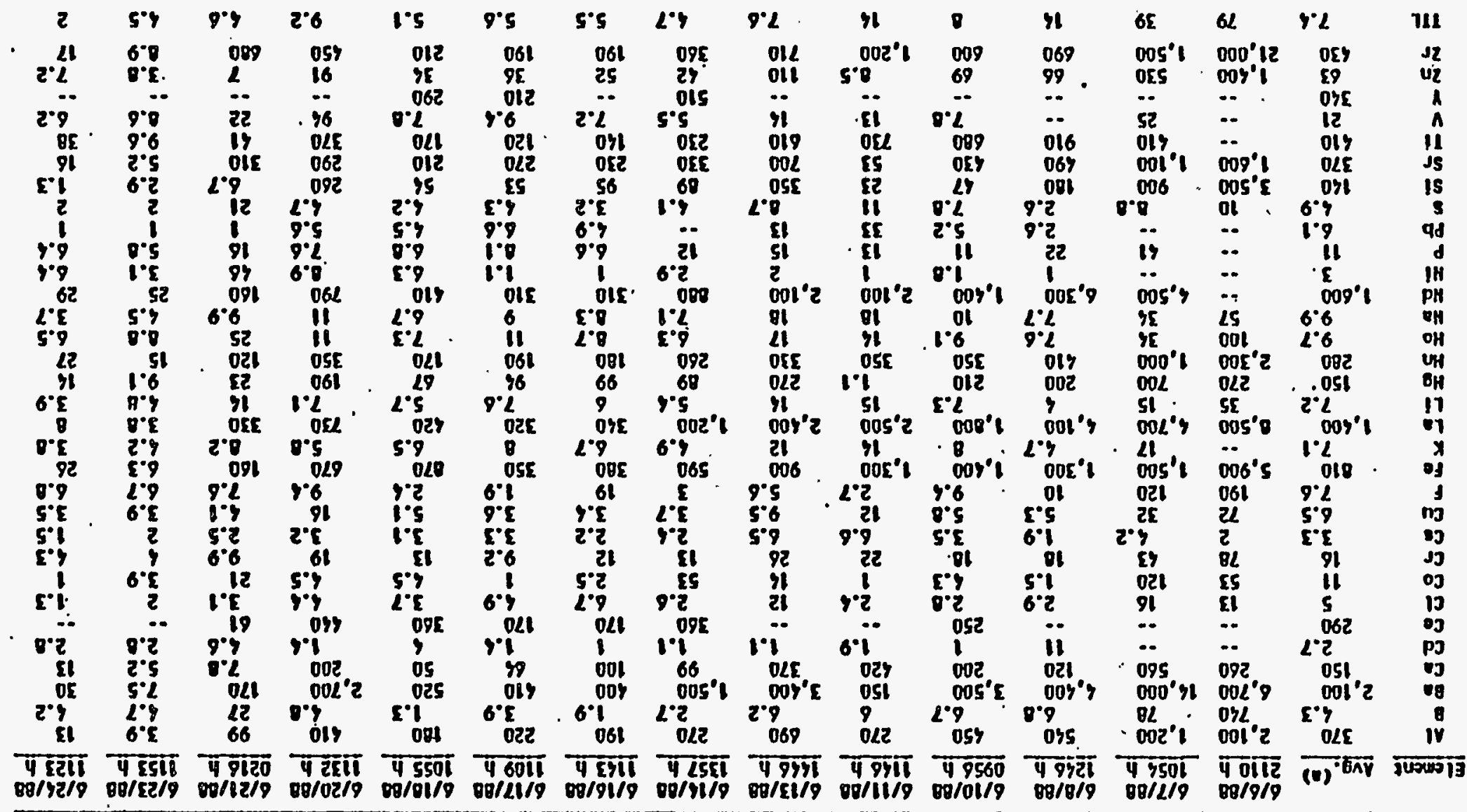




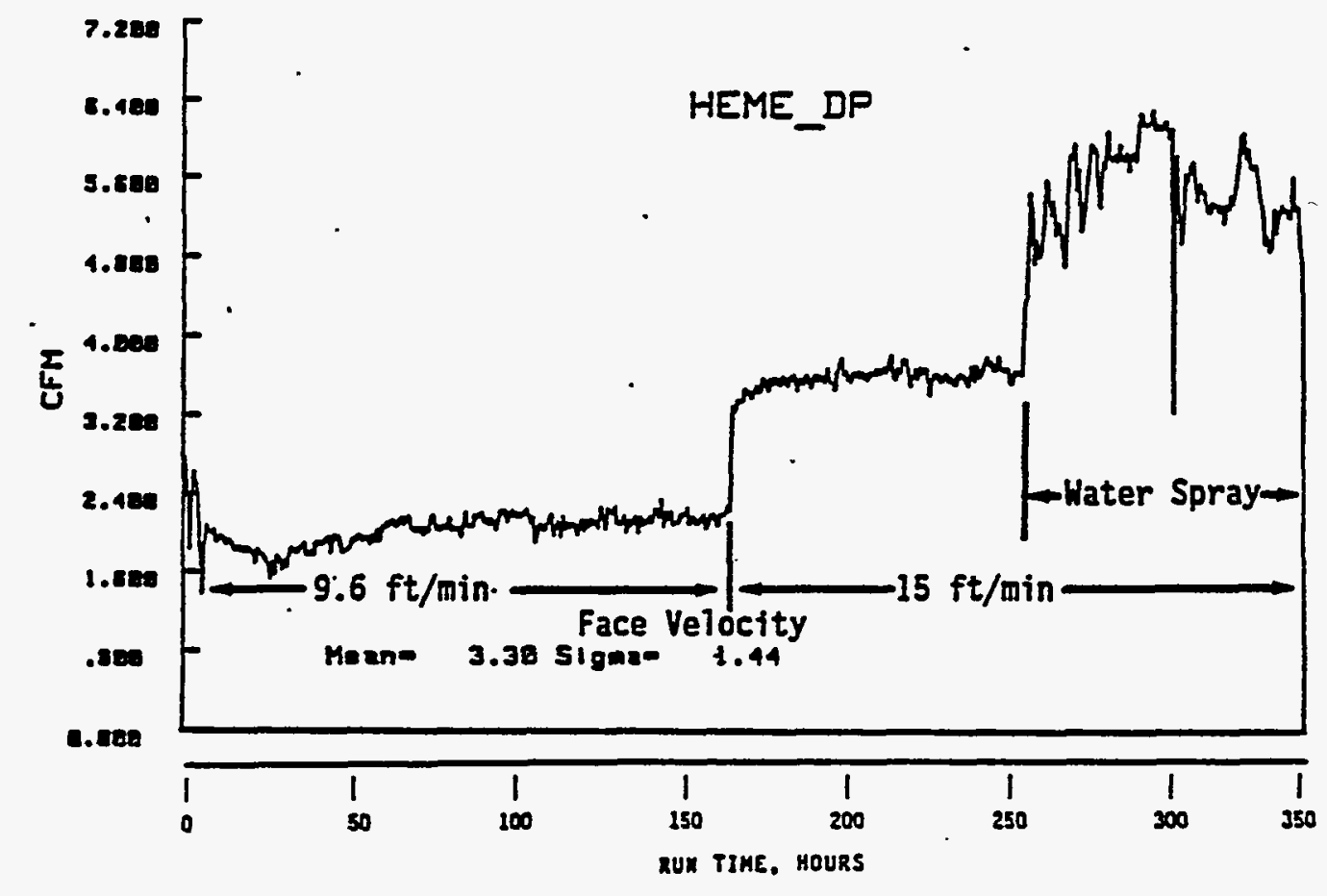

FIGURE 4.6-38. SBS Decontamination Factors Versus Gas Velocity HWVP-89-IVU0010100B

PSCM-21 test. Hide swings in melter DFs occurring before, during, and after a process upset were found to be compensated for by opposing changes in SBS . performance such that the overall DF remained essentialiy constant.

The aerosol scrubbing performance of the SBS for individual feed component effluents are tabulated in Table 4.6-30. This data overall is comparable to results obtained from previous quench scrubber performance tests SBS and Ejector Venturi Scrubber (EVS) alike. A common characteristic of all low-efficiency scrubbers is that aerosol effluent can be broken down into two groups; non-volatile and semi-volatile. Quench scrubber DFs for nonvolatile effluents are typically $>300$, while semi-volatile effluents have DFs $<50$. The spread of DFs within a given group is a manifestation of the differences in chemical properties of the effluents which determines their relative proportioning between groups.

Cesium is an effluent whose off-gas system losses are totally dominated by its semi-volatile nature. Consequently process - upsets that increase mass DFs rarely affect Cs melter DFs or off-gas concentration of this effluent, as is clearly shown in Table 4.6-10 for the first two days of the HWVP-15 test. Since the melter $C s$ source is not sensitive to process operating conditions, SBS performance for this effluent is also quite invariant, as shown in Table 4.6-30. This would not be true for classic non-volatiles since processing conditions would directly affect melter DF, which would in turn affect off-gas loadings and.SBS performance. However, most process effluents 
possess intermediate properties that are responsibie for the broad range in observed DFs and the variable responses to operational changes. Since HWVP-15 melter effluent is not dominated by either entrainment or volatilization, the members of the non-volatile and semi-volatile groupings are easy to identify. With few exceptions, these same groups can also be identified in the resuits obtained from past EVS and SBS characterizations efforts. Just as with mass DFs, differences in magnitude reflect deviations only in operational conditions, not variable performance characteristics.

Influence of off-Gas Flow Rate. The effect of off-gas flow rate upon SBS performance is insignificant for the flow range tested. The SBS effluent emission rate data appears to definitely relate increases in effluent concentrations to increased flow rate; however, melter off-gas loadings also went up during this period. The SBS DF data fails to show any consistent pattern that can be linked to off-gas flow conditions. Thus, even though a case could be made for specific effluents, a generalized correlation does not appear. to exist between SBS performance and off-gas system flow rate, at least in the range of 110 to $170 \mathrm{scfm}$, which corresponds to face velocity range of 60 to $90 \mathrm{ft} / \mathrm{min}$ at the center of the bed.

Influence of IdTing. The SBS performance responses to idling fall into esisentially two groups: semi-volatiles and non-volatiles. For the nonvolatile feed components, SBS DFs drop significantly; as shown in

Table 4.6-30. On the other hand, semi-volatile DFs remain essentially the same or decrease slowiy with time. The performance behavior of the SBS is understandable on the basis of the changing off-gas conditions resulting from the idling mode. When feeding is terminated and gross plenum deposits have melted, non-volatile off-gas loadings decrease to very low levels. The hot idling melter, however, continues to evolve semi-volatiles from both plenum and glass surfaces. The observed changes in SBS performance accompanying idling can be totally ascribed to concentration effects. It should be noted that even though non-yolatile SBS effluent DFs become quite small during idling, the SBS effluent concentrations of all non-volatiles are a factor 5 to 10 less during idling than under processing conditions. SBS effluent concentrations of semi-volatiles during idling are, at worst, no greater than conditions existing during processing and are.significantly iess for most cases.

Influence of SBS Fluid Entrainment. Because the operation of the SBS produces significant entrainment of the SBS scrubbing liquor that is, to some extent, carried over into the off-gas system, SBS performance could very well be influenced by the reentrainment of previously removed effluent matter. Examination of the time-dependent SBS effluent off-gas conceritrations reveals that when the melter source is turned down, as occurs for nonvolatiles during idling, the SBS effluent off-gas concentrations of these feed components also decrease. Moreover, the SBS exhaust concentrations of the semi-volatiles, whose emission persist but decrease during idling, also decrease in a corresponding way. This is found to be true for both soluble as well as.insoluble matter. Consequently, the effluent matter being exhausted from the SBS is airborne material that simply and directly penetrates the device, and the contributions from re-entrainment are found to be 
insignificant. This fact is also. confirmed by calculation based upon scrubbing liquor steady-state composition, water carryover measurements, and observed off-gas effluent concentrations.

Influence of Aerosol Size. A comparison of average off-gas condition entering and exiting the SBS is an effective way to demonstrate the functional dependence of SBS efficiency on off-gas aerosol characteristics. Previous melter data has shown that $-50 \%$ of the aerosol mass leaving the melter was $>1 \mathrm{~mm}$. A multi-stage cascade impactor was used to classify SBS aerosols sizes from $5 \mathrm{\mu m}$ to $<0.25 \mathrm{\mu m}$ in nine discreet steps. The aerosols exiting the SBS were always found to be exclusively submicron, independent of HWVP-15 process or off-gas operating conditions. Figure 4.6-39 is a picture of the aerosol deposits collected on consecutive impactor stages (5 $\mathrm{\mu m}$ to $0.25 \mu \mathrm{m}$ : left to right and top to bottom). The aerosol deposits, which form white jet patterns (lines) on the stainless steel collector stages, are present only on the last four stages. This absence of deposits on the large diameter. collection stages illustrate how very efficient the SBS is for removing large diameter (entrained) airborne particulate matter.

4.6.4.3.10.5 Total Performance. Since only a very few feed components are lost to the off-gas processing system in the gaseous state, essentially a17 the aerosol performance values 7 isted in Table 4.6-30 al so represent total SBS DFs for these elements. Notable exceptions to this statement are: $B, C T, F, N, P$ and $S$. Total performance values for these gaseous effluents have been directly derived from off-gas sampling data. The results are summarized in Table 4.6-31. Because these effluents are largely gaseous, SBS total DFs will be strongly influenced by gas phase removal efficiency. This is especially true for boron and fluorine effluents which are $>80 \%$ gaseous. For these elements the same performance trend linking SBS efficiency with off-gas flow rate and steam loading is apparent in the total DF data. The total DFs for chlorine do not demonstrate this trend to any appreciable extent due to the influence of condensed phase $C 7$ which apparently is not similarly affected. Overall the magnitudes of these total DFs are very reasonable given the physical nature of these. effluents, and they are quite comparable to previous quench scrubber performance measurements made during HWVP-12, as is illustrated in Table 4.6-32

4.6.4.4 Chevron Demister. The chevron demister, which is located down stream of the SBS, is primarily designed to control SBS water mist carry over into the HEME. The performance of this device was monitored throughout the HWV - 15 test by recording water collection rates. Since chevron plates remove water mainly by impingement, this demister is capable of efficiently removing only large entrained droplets. During the first days of HWVP-15, the chevron demister collected water at a very high rate- -5 to $10 \mathrm{~L} / \mathrm{h}$. Visual observation confirmed that the SBS was very turbulent, with large gas bubbles splashing water up the top of the SBS vessel where the exhaust port 

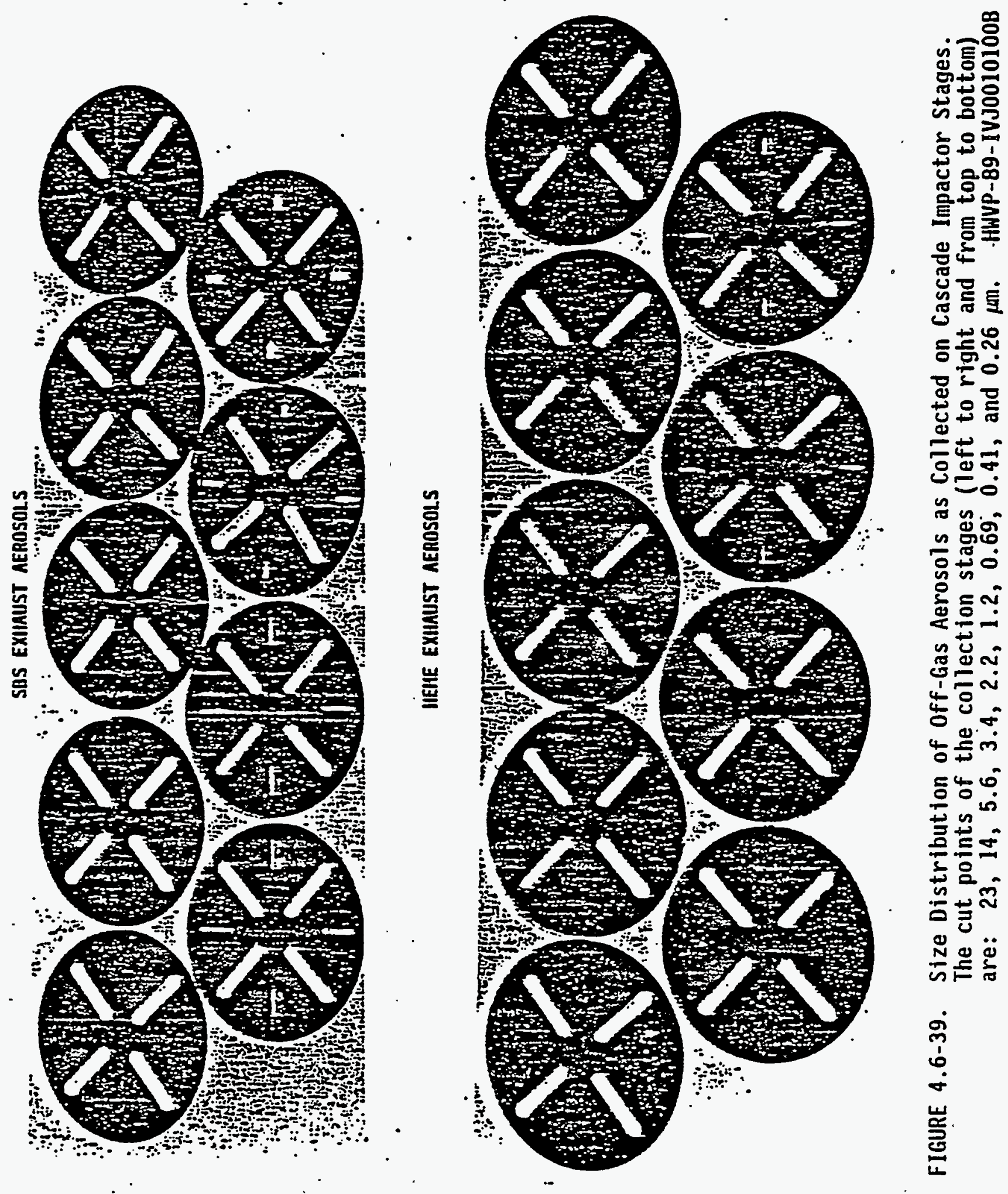
TABLE 4.6-31. SBS Total Decontamination Factors HWVP-89-IVJ0010100B

\begin{tabular}{|c|c|c|c|c|c|c|c|c|c|c|c|c|c|}
\hline Element & Avg. & $\begin{array}{l}6 / 6 / 88 \\
2110 \mathrm{~h}\end{array}$ & $\begin{array}{l}6 / 7 / 88 \\
1054 \mathrm{~h}\end{array}$ & $\begin{array}{l}6 / 8 / 88 \\
1246 \mathrm{~h}\end{array}$ & $\begin{array}{l}6 / 10 / 88 \\
.0956 \mathrm{~h}\end{array}$ & $\begin{array}{l}6 / 11 / 88 \\
1146 \mathrm{~h}\end{array}$ & $\begin{array}{l}6 / 14 / 88 \\
1357 \mathrm{~h}\end{array}$ & $\begin{array}{l}6 / 16 / 88 \\
1143 \mathrm{~h}\end{array}$ & $\begin{array}{l}6 / 17 / 88 \\
1109 \mathrm{~h} .\end{array}$ & $\begin{array}{l}6 / 18 / 88 \\
1055 \mathrm{~h}\end{array}$ & $\begin{array}{l}6 / 20 / 88 \\
1132 \mathrm{~h}\end{array}$ & $\begin{array}{l}6 / 21 / 88 \\
0216 \mathrm{~h} .\end{array}$ & $\begin{array}{l}6 / 23 / 88 \\
1153 \mathrm{~h}\end{array}$ \\
\hline $\begin{array}{l}B \\
C 1 \\
F \\
P \\
S\end{array}$ & $\begin{array}{r}7.1 \\
3.0 \\
16 \\
.8 .6 \\
8.7\end{array}$ & $\begin{array}{r}99 \\
12 \\
270 \\
5.9 \\
8.7\end{array}$ & $\begin{array}{l}59 \\
16 \\
78 \\
12 \\
11\end{array}$ & $\begin{array}{c}15 \\
4.3 \\
38 \\
28 \\
5.1\end{array}$ & $\begin{array}{c}12 \\
3.1 \\
33 \\
6.5 \\
11\end{array}$ & $\begin{array}{l}14 \\
3.6 \\
34 \\
13 \\
16\end{array}$ & $\begin{array}{l}1.9 \\
2.7 \\
3 \\
1 \\
8.6\end{array}$ & $\begin{array}{c}2.5 \\
2.2 \\
5 \\
22 \\
6.5\end{array}$ & $\begin{array}{l}3.0 \\
3.0 \\
4.8 \\
1.1 \\
10\end{array}$ & $\begin{array}{l}3.6 \\
3.2 \\
5.4 \\
1.7 \\
7.7\end{array}$ & $\begin{array}{l}11 \\
2.5 \\
24 \\
1 \\
12\end{array}$ & $\begin{array}{l}82 \\
5.9 \\
26 \\
26 \\
27\end{array}$ & $\begin{array}{l}1.1 \\
2.0 \\
2.9 \\
5.8 \\
1.7\end{array}$ \\
\hline
\end{tabular}


TABLE 4.6-32. Comparative Quench Scrubber Decontamination

Factors for Volatile Off-Gas Effluent

HWVP-89-IVJ0010100B

\begin{tabular}{|c|c|c|c|c|c|}
\hline \multirow{2}{*}{$\begin{array}{c}\text { Melter } \\
\text { Test }\end{array}$} & \multicolumn{5}{|c|}{ Total Quench Scrubber DF } \\
\cline { 2 - 6 } & B & C1 & F & P & S \\
\hline HWVP-15 & 7.1 & 3.0 & 16 & 8.6 & 8.7 \\
HWVP-12 & 11 & 6.2 & 14 & -- & 4.3 \\
\hline
\end{tabular}

is located. It is believed that this vigorous splashing was created by an inadequate initial water level in the SBS, which caused erratic two-phase flow leaving the bed. The turbulent operating condition subsided early in the test as condensed steam produced and maintained overflow conditions in the SBS tank. Calm, stable SBS operations persisted throughout the remainder of the test with commensurately lower water collection rates by the chevron demister.

Under steady-state processing conditions and with the SBS operating in a stable overflowing condition at $80^{\circ} \mathrm{F}\left(27^{\circ} \mathrm{C}\right)$ which is the same as the SBS outlet temperature, the average water collection rate of the chevron was $0.1 \mathrm{~L} / \mathrm{h}$. The composition of the fluid collected was predictably found to be very similar to the SBS scrubbing liquor as shown in Table 4.6-33. The fluid collected from the chevron was higher in sulfates, nitrates, and other gaseous compounds. The enrichment is caused by the additional contact time of a small quantity of water draining from the cheuron. The actual quantity of gas removed from the off gas is very small. The quantity of mist penetrating the chevron demister was estimated from the water run off from the downstream HEME. At an $110 \mathrm{scfm}$ off-gas flow rate the demister water penetration rate was estimated to be $1 \mathrm{~L} / \mathrm{h}$. The functional dependence of fluid collection upon off-gas flow rate is shown in Table 4.6-34. These data show that SBS f7uid entrainment losses did increase with off-gas flow rate, but even at high flow conditions the chevron removed only a small fraction of thetotal water content of the process exhaust. From the above, it is clear that under stable steady-state processing conditions the chevron demister does very little ( $\leq 10 \%)$ to reduce water carryover into the downstream HEME; however, the demister has also been clearly shown to be quite beneficial should SBS operations become turbulent. 
TABLE 4.6-33. Comparison of Compositions of Cherron Demister and SBS Overflow Solutions HWVP-89-IVJO010100B

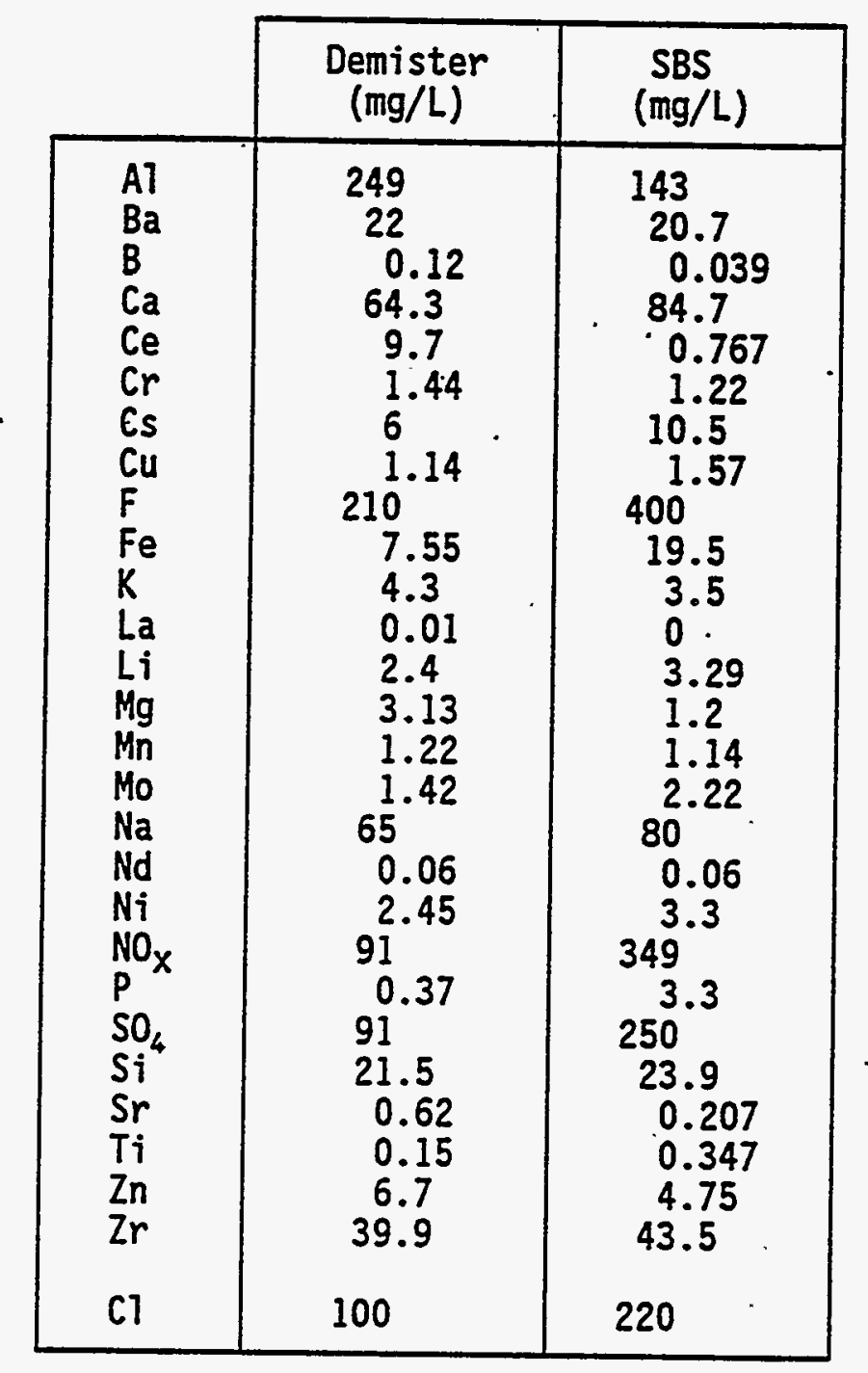

TABLE 4.6-34. Chevron Demister Hater Collection Rates HWVP-89-IVJ0010100B

\begin{tabular}{|c|c|}
\hline $\begin{array}{c}\text { Airflow Rates } \\
(\mathrm{cfm})\end{array}$ & $\begin{array}{c}\text { Water Collection Rate } \\
(\mathrm{L} / \mathrm{h})\end{array}$ \\
\hline 110 & 0.04 \\
170 & 0.1 \\
\hline
\end{tabular}


4.6.4.5 Ejector Venturi Scrubber (EVS) - Monreference. Industrial experience with the EVS is extensive. The scrubber has been in use since the late 1950s. The EVS has proven reliable even in service applications here the gas to be ' cleaned is corrosive or erosive. The most vuinerable component of the scrubber is the spray nozzle. There is limited operating experience with the EVS as applied to LFCM off-gas treatment. Two scaled-down melters have been operated at PNL using this type of scrubber.:

The aerosol. scrubbing performance of the EVS is not very sensitive to the off-gas flow rate as long as the desjgn limits of the box separator are not exceeded if a box separator is used. (a) Excessive flow rates cause contaminated water droplets to be blown through the separator. Conversely, if the flow rate is too low, the droplets will not have enough inertia for the separator to be effective. The most important variables influencing the collection efficiency of the EVS are the water droplet size distribution and concentration. The size distribution is predominately controlled by the scrubbing water pressure at the spray nozzle. The concentration of water droplets is determined by the scrubbing water pressure, the size of the spray nozzle, and the off-gas flow rate. In general, higher water pressures result in smaller droplets and a higher overall droplet concentration, which tends to improve the aerosol capture performance.

The pressure drop across the EVS is a function of off-gas flow rate, the EVS inlet size, the spray nozzle size, and the water pressure at the spray nozzle. The EVS is capable of inducing gas flow under certain operating conditions. The pressure drop or draft, as the case may be; versus the water. and off-gas flow rate is listed in Table 4.6-35.

The size distribution of aerosols entering the HIVP EVS is expected to be similar to those of Table 4.6-5. A substantial mass of aerosols is in the $1 \mu \mathrm{m}-$ and-less size range. Figure 4.6-40 shows the theoretical scrubbing efficiency as a function of particle size for an EVS under the conditions shown. The predicted performance is for treatment of a dry gas. The plot shows that efficiency for particles $1 \mu \mathrm{m}$ in diameter is $80 \%$ or less. Measured scrubbing efficiencies of the EVS for particulates on PSCM runs 7, 8, 9, and 22 are 9, 54,6 , and 3.7. The differences in scrubbing efficiencies probably reflect the effects of differences in particle size distribution (shown in Table 4.6-5) on scrubbing efficiency. Steam in the MOG, as it condenses to water, tends to enlarge the effective size of aerosols, thereby increasing their capture. Goles and Sevigny (Ref. 4.6-3) have shown that the DF through an EvS treating melter exhaust increases with the ratio of steam to noncondensible gas. The

(a) C. M. Rueker, "Evaluation of the Pilot-Scale Ceramic Melter Off-Gas System," HWVP-86-V1122 D, Pacific. Northwest Laboratory, Richland, Washington (final letter report, February 1987). 
TABLE 4.6-35. Gas Handling Capacities--Type 7014 Systems with Large Nozzles [Ametek Catalog Technical Supplement 7S, from C. M. Rueker, "Evaluation of the Pilot-Scale Ceramic Melter Off-Gas System," HWVP-86-V1122, PNL (February 1978)]

\begin{tabular}{|c|c|c|c|c|c|c|c|}
\hline \multirow{3}{*}{ 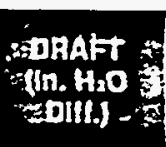 } & \multirow{3}{*}{$\begin{array}{l}\text { SWATEA } \\
\text { HRESSURE } \\
\text { (polpsig) }\end{array}$} & \multicolumn{5}{|c|}{ 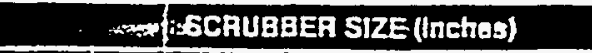 } & \multirow{2}{*}{$\frac{1}{12}$} \\
\hline & & 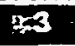 & $=4$ & 28 & 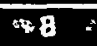 & 210 & \\
\hline & & \multicolumn{6}{|c|}{ AAPAqIIIES (clm alr at Vlowing Eonditions) } \\
\hline $\begin{array}{c}\cdots \\
\text { (Pressure } \\
\text { Drop) }\end{array}$ & $\begin{array}{r}60 \\
80 \\
.100\end{array}$ & $\begin{array}{l}68 \\
79 \\
88\end{array}$ & $\begin{array}{l}143 \\
183 \\
180\end{array}$ & $\begin{array}{l}370 \\
420 \\
465\end{array}$ & $\begin{array}{l}625 \\
710 \\
790\end{array}$ & $\begin{array}{l}1010 \\
1170 \\
1290\end{array}$ & $\begin{array}{l}2000 \\
2250 \\
2430\end{array}$ \\
\hline $\begin{array}{c}1 / 2 " \\
\text { (Preasure } \\
\text { Drop) }\end{array}$ & $\begin{array}{r}40 \\
60 \\
80 \\
100\end{array}$ & $\begin{array}{l}54 \\
65 \\
78 \\
85\end{array}$ & $\begin{array}{l}112 \\
135 \\
157 \\
175\end{array}$ & $\begin{array}{l}290 \\
350 \\
405 \\
450\end{array}$ & $\begin{array}{l}490 \\
595 \\
690 \\
770\end{array}$ & $\begin{array}{r}800 \\
970 \\
1120 \\
1240\end{array}$ & $\begin{array}{r}1550 \\
1910 \\
2170 \\
2350\end{array}$ \\
\hline $\begin{array}{c}\text { ZERO } \\
\text { ORAFT }\end{array}$ & $\begin{array}{r}20 \\
40 \\
60 \\
80 \\
100 \\
\end{array}$ & $\begin{array}{l}29 \\
50 \\
62 \\
72 \\
83\end{array}$ & $\begin{array}{r}60 \\
102 \\
127 \\
150 \\
169\end{array}$ & $\begin{array}{l}153 \\
260 \\
330 \\
390 \\
435\end{array}$ & $\begin{array}{l}260 \\
440 \\
560 \\
660 \\
740\end{array}$ & $\begin{array}{r}420 \\
740 \\
820 \\
1080 \\
1200\end{array}$ & $\begin{array}{r}970 \\
1410 \\
1810 \\
2080 \\
2280\end{array}$ \\
\hline $1 / 4 *$ & $\begin{array}{r}20 \\
40 \\
60 \\
80 \\
100\end{array}$ & $\begin{array}{l}25 \\
46 \\
60 \\
71 \\
81\end{array}$ & $\begin{array}{r}52 \\
95 \\
124 \\
148 \\
166\end{array}$ & $\begin{array}{r}\cdot 135 \\
245 \\
315 \\
380 \\
430\end{array}$ & $\begin{array}{l}210 \\
415 . \\
540 \\
645 \\
725\end{array}$ & $\begin{array}{r}350 \\
680 \\
880 \\
1050 \\
1180\end{array}$ & $\begin{array}{r}850 \\
1340 \\
1750 \\
2030 \\
2240\end{array}$ \\
\hline $1 / 2 "$ & $\begin{array}{r}20 \\
40 \\
60 \\
80 \\
100\end{array}$ & $\begin{array}{l}20 \\
43 \\
58 \\
70 \\
80\end{array}$ & $\begin{array}{r}43 \\
90 \\
119 \\
145 \\
163\end{array}$ & $\begin{array}{l}105 \\
250 \\
305 \\
375 \\
420\end{array}$ & $\begin{array}{l}190 \\
380 \\
520 \\
635 \\
720\end{array}$ & $\begin{array}{r}300 \\
630 \\
850 \\
1030 \\
1160\end{array}$ & $\begin{array}{r}700 \\
1250 \\
1700 \\
2000 \\
2200\end{array}$ \\
\hline$\varphi^{\prime \prime}$ & $\begin{array}{r}20 \\
40 \\
60 \\
80 \\
100\end{array}$ & $\begin{array}{l}17 \\
40 \\
58 \\
68 \\
78\end{array}$ & $\begin{array}{r}38 \\
84 \\
115 \\
142 \\
181\end{array}$ & $\begin{array}{r}95 \\
215 \\
295 \\
365 \\
415\end{array}$ & $\begin{array}{l}150 \\
360 \\
500 \\
620 \\
595\end{array}$ & $\begin{array}{r}260 \\
590 \\
820 \\
1010 \\
1150\end{array}$ & $\begin{array}{r}600 \\
1180 \\
1650 \\
1950 \\
2160\end{array}$ \\
\hline 10 & $\begin{array}{r}20 \\
40 \\
60 \\
80 \\
100\end{array}$ & $\begin{array}{l}13 \\
38 \\
53 \\
68 \\
77\end{array}$ & $\begin{array}{r}30 \\
80 \\
110 \\
139 \\
158\end{array}$ & $\begin{array}{l}75 \\
205 \\
285 \\
380 \\
410\end{array}$ & $\begin{array}{l}125 \\
345 \\
480 \\
605 \\
680\end{array}$ & $\begin{array}{r}200 \\
560 \\
780 \\
580 \\
1120\end{array}$ & $\begin{array}{l}500 \\
1100 \\
1600 \\
1900 \\
2110\end{array}$ \\
\hline $1 \frac{1 / 2}{}$ & $\begin{array}{r}40 \\
60 \\
80 \\
100 \\
\end{array}$ & $\begin{array}{l}34 \\
49 \\
63 \\
74\end{array}$ & $\begin{array}{c}71 \\
101 \\
132 \\
152\end{array}$ & $\begin{array}{l}185 \\
265 \\
340 \\
395\end{array}$ & $\begin{array}{l}310 \\
445 \\
575 \\
660\end{array}$ & $\begin{array}{r}500 \\
725 \\
940 \\
1080\end{array}$ & $\begin{array}{r}950 \\
1480 \\
1810 \\
2040\end{array}$ \\
\hline$\dot{2}$ & $\begin{array}{r}40 \\
60 \\
80 \\
100\end{array}$ & $\begin{array}{l}30 \\
45 \\
60 \\
71\end{array}$ & $\begin{array}{c}62 \\
94 \\
128 \\
146\end{array}$ & $\begin{array}{l}160 \\
245 \\
325 \\
380 \\
\end{array}$ & $\begin{array}{l}270 \\
110 \\
545 \\
640\end{array}$ & $\begin{array}{r}440 \\
675 \\
895 \\
1040\end{array}$ & $\begin{array}{r}810 \\
1360 \\
1720 \\
1960\end{array}$ \\
\hline 3⿻ & $\begin{array}{r}40 \\
60 \\
80 \\
100\end{array}$ & $\begin{array}{l}21 \\
38 \\
54 \\
64\end{array}$ & $\begin{array}{r}46 \\
81 \\
113 \\
134\end{array}$ & $\begin{array}{l}120 \\
210 \\
295 \\
350\end{array}$ & $\begin{array}{l}190 \\
350 \\
495 \\
590\end{array}$ & $\begin{array}{l}320 \\
560 \\
800 \\
960\end{array}$ & $\begin{array}{r}570 \\
1120 \\
1520 \\
1780\end{array}$ \\
\hline & . & TIVE & IOUID $\mathrm{F}$ & W (gpi & - & & \\
\hline $\begin{array}{l}\text { NOZZLE } \\
\text { FLOW }\end{array}$ & $\begin{array}{r}20 \\
40 \\
60 \\
80 \\
100\end{array}$ & $\begin{array}{l}3.4 \\
4.8 \\
5.8 \\
6.8 \\
7.8\end{array}$ & $\begin{array}{c}6.0 \\
8.5 \\
10 \\
12 \\
13\end{array}$ & $\begin{array}{l}16 \\
24 \\
29 \\
34 \\
39\end{array}$ & $\begin{array}{l}26 \\
38 \\
48 \\
54 \\
60\end{array}$ & $\begin{array}{l}42 \\
60 \\
72 \\
83 \\
93\end{array}$ & $\begin{array}{r}61 \\
86 \\
108 \\
128 \\
137\end{array}$ \\
\hline
\end{tabular}




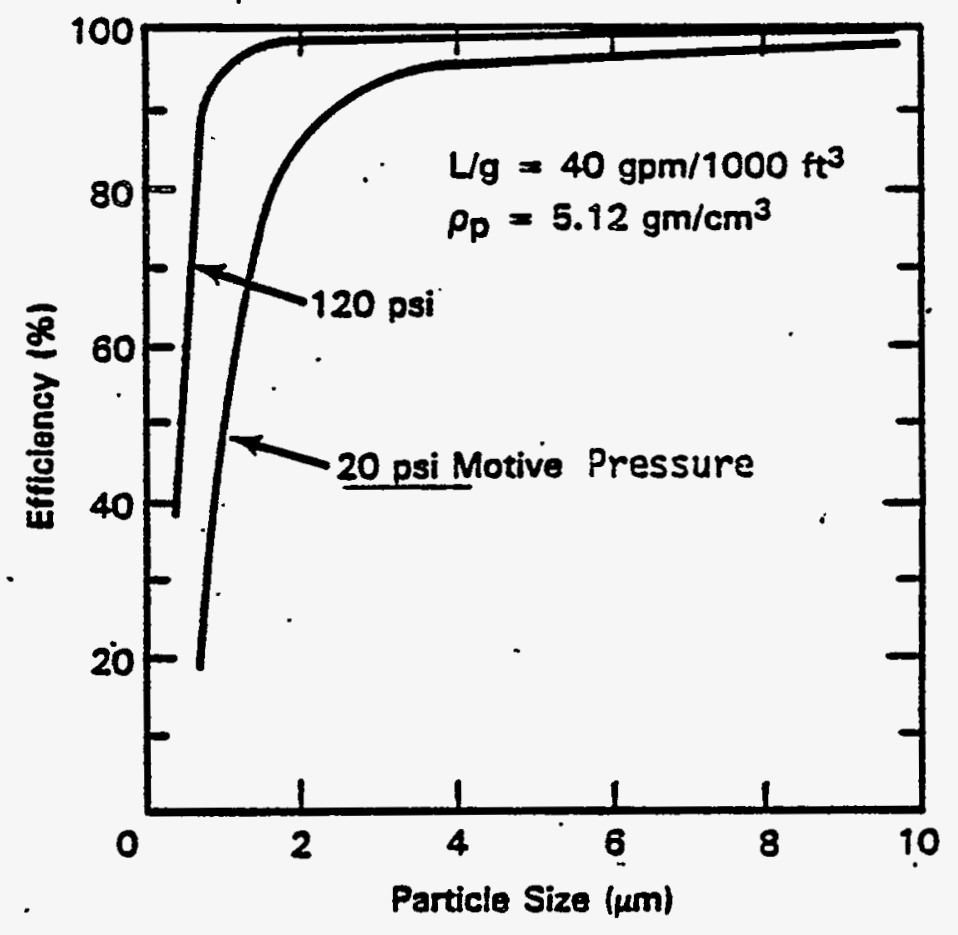

FIGURE 4.6-40. Theoretical Collection Efficiency for a 12-in. Ejector Venturi Scrubber (Ref. 4.6-10)

reverse of this phenomenon, together with the high air flow rate in HWVP-12, is the likely cause for the low particulate scrubbing efficiency. Size distributions of aerosols emitted from a scrubber during two melter tests are indicated in Figure 4.6-41, which shows that these aerosols are predominantiy less than $1 \mathrm{\mu m}$ in diameter. The relationship between motive water pressure, gas volume being handled by the scrubber, and aerosol collection efficiency is presented in Figures 4.6-42 and 4.6-43. These two plots are based on theoretical performance, rather than measured data. Measurements are needed to determine the performance of the EVS; however, these relationships serve as an indication of the effect of operating conditions. The scrubbing efficiency decreases with decreasing nozzle pressure (constant liquid to gas ratio), and decreases with increasing gas flow through the scrubber (constant nozzle pressure).

An EVS is a low-efficiency scrubber designed to quench the melter exhaust and to remove large-diameter $(>1 \mathrm{\mu m})$ aerosols. As a result, EVS elemental DFs should be direct measures of the mass mean diameters of the aerosols responsible for individual feed component losses. For instance, feed components that are volatilized and quickly converted by reaction and/or condensation to predominantly submicron aerosols would be expected to exhibit low EVS DFs; this is 


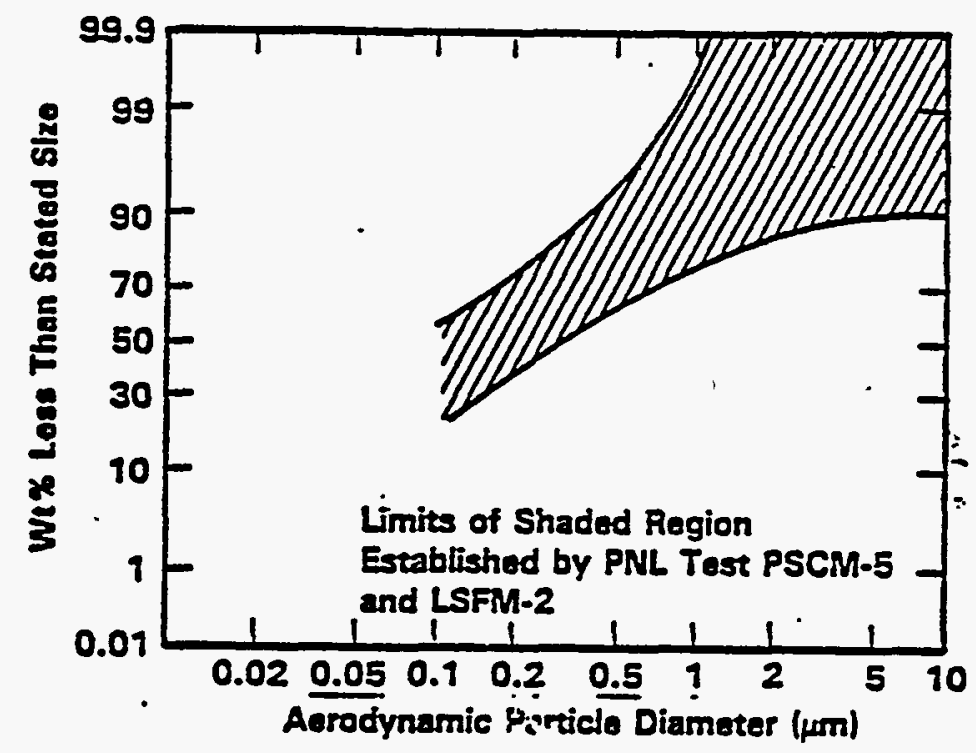

FIGURE 4.6.41. Aerosol Distribution of Quenched Melter Off-Gas DWPF

what is observed in HWVP-12 for the semivolatiles: Cs, $\mathrm{Li}, \mathrm{Na}$, and Ru. On the other hand, nonvolatiles whose escape mechanism is based solely on gross feed entrainment would be expected to exhibit much higher DFs. Such is indeed the case, as is clearly shown by the DF results obtained for $\mathrm{Ba}, \mathrm{Ca}, \mathrm{Fe}, \mathrm{La}, \mathrm{Nd}$, $\mathrm{Sr}$, etc. The overall aerosol DF of the EVS will consequently be a reflection of the overal1 mass median diameter of melter generated aerosols. Large

overall EVS DFS will result only if the gross feed entrainment process is a dominating aerosol-generating mechanism.

Since the EVS is not designed to be an efficient gas scrubber due to short residence times, gaseous effluent DFs would also be expected to be low. This is found to be true, as the EVS data for B, CT, F, and $S$ clearly show, for the HWVP-12 run. The absence of EVS iodine DF data is a reflection of special analytical difficulties associated with the detection of this element. Although iodine performance data beyond the melter are lacking, there is no reason to believe that its off-gas behavior is any less penetrating than the other halogens that are more easily detected and quantified.

Gaseous Ru emissions are important only in highly oxidizing feeds. Under these conditions, more than 90\% of the Ru lost from the LFCM is in. the gaseous state. However, quench scrubber DFs for gaseous Ru are still quite high. No evidence for Ru gaseous penetration of quench scrubbers (either SBS or EVS) has been found in PNL studies. Using the analytical detection limit associated with gaseous samples generated during LFCM processing of oxidizing feed, the quench scrubber DF for gaseous $R u$ has been estimated at 400 . This lower limit to $\mathrm{Ru}$ DF assumes low concentrations of $\mathrm{Ru}$ in the scrub liquor. If $\mathrm{Ru}$ concentrations build up in a highly acidic, nitrated solution, Ru revolatilization may occur. This is an important consideration if evaporative concentration of the scrub liquor is part of the recycle process. Gaseous evolution of halogens 


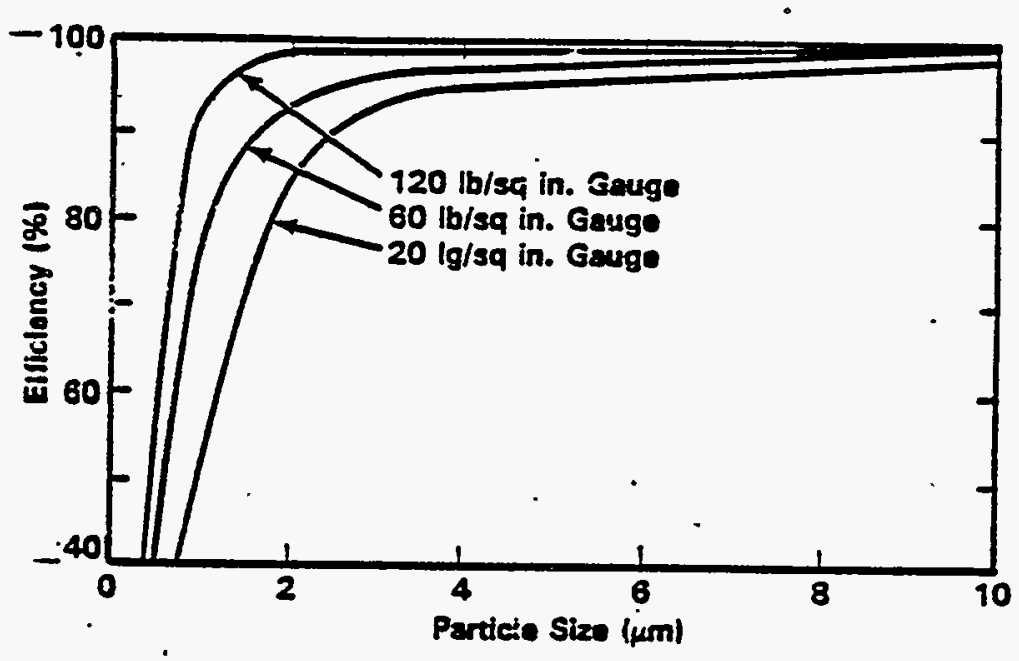

FIGURE. 4.6-42. Family of Theoretical Coilection Efficiency Curves at Constant Liquid/Gas Ratio and Various Motive Pressures

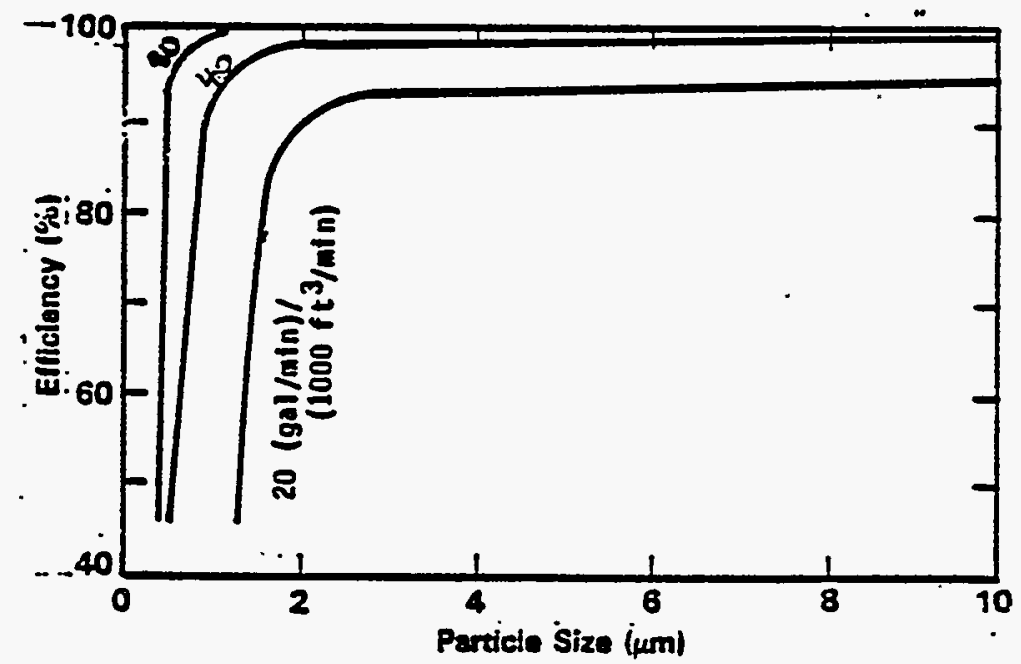

FIGURE 4.6-43. Family of Theoretical Collection Efficiency Curves at Constant Motive Pressure and Various Liquid/Gas Ratios 
may occur in LFCMs irrespective of the redox condition of the feed. The processing of oxidizing feed will strongly promote elemental losses of these elements. In particular, complete melter volatilization of iodine as $I_{2}$ in the feed is expected under these conditions.

Although data on quench scrubber DFs for $I_{2}$ are limited, the study that was conducted on an oxidizing WVNS feed (PSCM-9) suggests a very minimal scrubbing efficiency ( $D F=-1$ ) for this gaseous effluent. Consequently, if the ${ }^{129}$ I content of LFCM feed requires control, very little credit can be given to the quench scrubber if $\mathrm{I}_{2}$ is strongly evolved during LFCM processing.

The average EVS aerosol DF of 3.7 in HWVP-12 is somewhat lower than has been achieved previously. However; unlike the previous tests, HWVP-12 did employ a film cooler. Because HWVP-12 used a noncondensible gas (air) as the film cooler sweep fluid, a large process effluent dilution resulted upstream of the EVS, and may have reduced contacting and resultant scrubbing efficiency. Steam collapse of the melter effluent exhaust during EVS quenching as also significantiy reduced or eliminated by film cooler operations, which may have contributed to the overall degradation in EVS performance. .

The S\&K EVS was employed during PSCM-22 to detepmine the performance capabilities under actual melter operating.conditions. (a) The average inlet offgas temperature over the two-week period in which samples were collected was $410^{\circ} \mathrm{F}\left(212^{\circ} \mathrm{C}\right)$. The inlet aerosol concentration was consistently around $0.3 \mathrm{mg}$ per standard liter of noncondensible off gas. The off gas entering the EVS consisted of approximately 100 scfm of air (40 scfm from the film cooler and $70 \mathrm{scfm}$ from inleakage) and 25 scfm of steam. The EVS operating conditions during the 11 sample periods are summarized in Table 4.6-36. There is an increase in collection efficiency as the inlet concentration increases, as demonstrated in Figure 4.6-44. This result is consistent with the anticipated relationship between inlet aerosol loading and capture performance. Figure 4.6-44 also shows that the off-gas flow rate had little influence on the observed DF, as expected.

The EVS is also used to cool the off gas down to temperatures around $85^{\circ} \mathrm{F}$ $\left(30^{\circ} \mathrm{C}\right)$. The results from HWVP-12 1 isted in Table 4.6-36 suggest that the EVS had little trouble quenching the off gas from temperatures slightly. above $390^{\circ} \mathrm{F}$ $\left(200^{\circ} \mathrm{C}\right)$ down to $85^{\circ} \mathrm{F}\left(30^{\circ} \mathrm{C}\right)$. The EVS therefore meets the two requirements of a primary scrubber: 1) it is capable of removing the larger aerosols to help increase the life of the high-efficiency filters downstream and 2) it can adequately quench the off gas. One advantage of the EVS is that the aerosol

(a) C. M. Rueker, "Evaluation of the PSCM MOG System," PNL (February 1987). 
TABLE 4.6-36. Average Operating Conditions for the EVS During HWVP-12 EVS: 6" SS Schutte \& Koerting 7014 Ejector Venturi - HWVP (C. M. Rueker, "Evaluation of the PSCM MOG System," PNL, February. 1987)

\begin{tabular}{|c|c|c|c|c|c|c|c|}
\hline $\begin{array}{c}\text { Sample } \\
\text { Period }\end{array}$ & $\begin{array}{c}\text { Inl et } \\
\text { Temp. } \\
\left({ }^{\circ} \mathrm{C}\right) .\end{array}$ & $\begin{array}{c}\text { Outlet } \\
\text { Temp. } \\
\left({ }^{\circ} \mathrm{C}\right)\end{array}$ & $\begin{array}{c}\text { Air Flow } \\
\text { Rate } \\
\text { (scfm) }\end{array}$ & $\begin{array}{c}\text { Steam Flow } \\
\text { Rate } \\
\text { (scfm) }\end{array}$ & $\begin{array}{c}\text { Inlet } \\
\text { Conc. } \\
\text { (mg/std }\end{array}$ & $\begin{array}{c}\text { Water FYow } \\
\text { Rate } \\
\text { (gpm) }\end{array}$ & $\begin{array}{c}\text { Mass } \\
\text { OF }\end{array}$ \\
\hline 1 & 223 & 30 & 111 & 22.6 & 0.30 & 28 & 3.34 \\
2 & 219 & 30 & 88 & 20.2 & 0.29 & 28 & 3.43 \\
3 & 206 & 29 & 97 & 20.4 & 0.28 & 28 & 3.73 \\
4 & 216 & 30 & 93 & 20.9 & 0.26 & 26 & 3.52 \\
5 & 205 & 30 & 94 & 21.4 & 0.32 & .26 & 4.37 \\
6 & 198 & 30 & 110 & 26.9 & 0.23 & 24 & 3.27 \\
7 & 214 & 30 & 114 & 27.1 & 0.31 & 26 & 3.85 \\
8 & 203 & 30 & 100 & 23.1 & 0.31 & 26 & 3.86 \\
9 & 231 & 31 & 109 & 32.3 & 0.37 & 26 & 4.42 \\
10 & 222 & 28 & 124 & 24.9 & 0.27 & 28. & 3.28 \\
11 & 194 & 28 & 119 & 17.8 & 0.30 & 31 & 1.80 \\
Avg & 212 & 30 & 105 & 23.4 & 0.29 & 27 & 3.5 \\
\hline
\end{tabular}

removal efficiency is relatively insensitive to variations in the off-gas flow rate. This characteristic is very important for LFCM applications, because the off gas will periodically surge.

Re-entrainment can play a significant role in decreasing the capture performance for submicron particles. The EVS operates with the scrubbing solution in a recycle mode. The captured aerosol concentration in the scrubbing solution continues to build up over time when operated in this manner. Previously captured.aerosols may be reatomized by the scrubbing solution spray nozzle. Any submicron droplets produced by the spray nozzle stand the chance of not interacting with other droplets, thus avoiding agglomeration. These submicron droplets will not be disengaged by the box separator and will exit the EVS with the scrubbed gas. A certain amount of either just-captured or previously captured material will be present inside the droplet. When the water evaporates, a small solid aerosol will be formed, thus lowering the overall efficiency. Scrubbing solution droplets of approximately $20 \mathrm{\mu m}$ can lead to $0.3-\mu \mathrm{m}$ solid aerosols from materials present in the scrubbing solution at impurity concentrations as low as $0.05 \mathrm{~g} / \mathrm{L}$. 


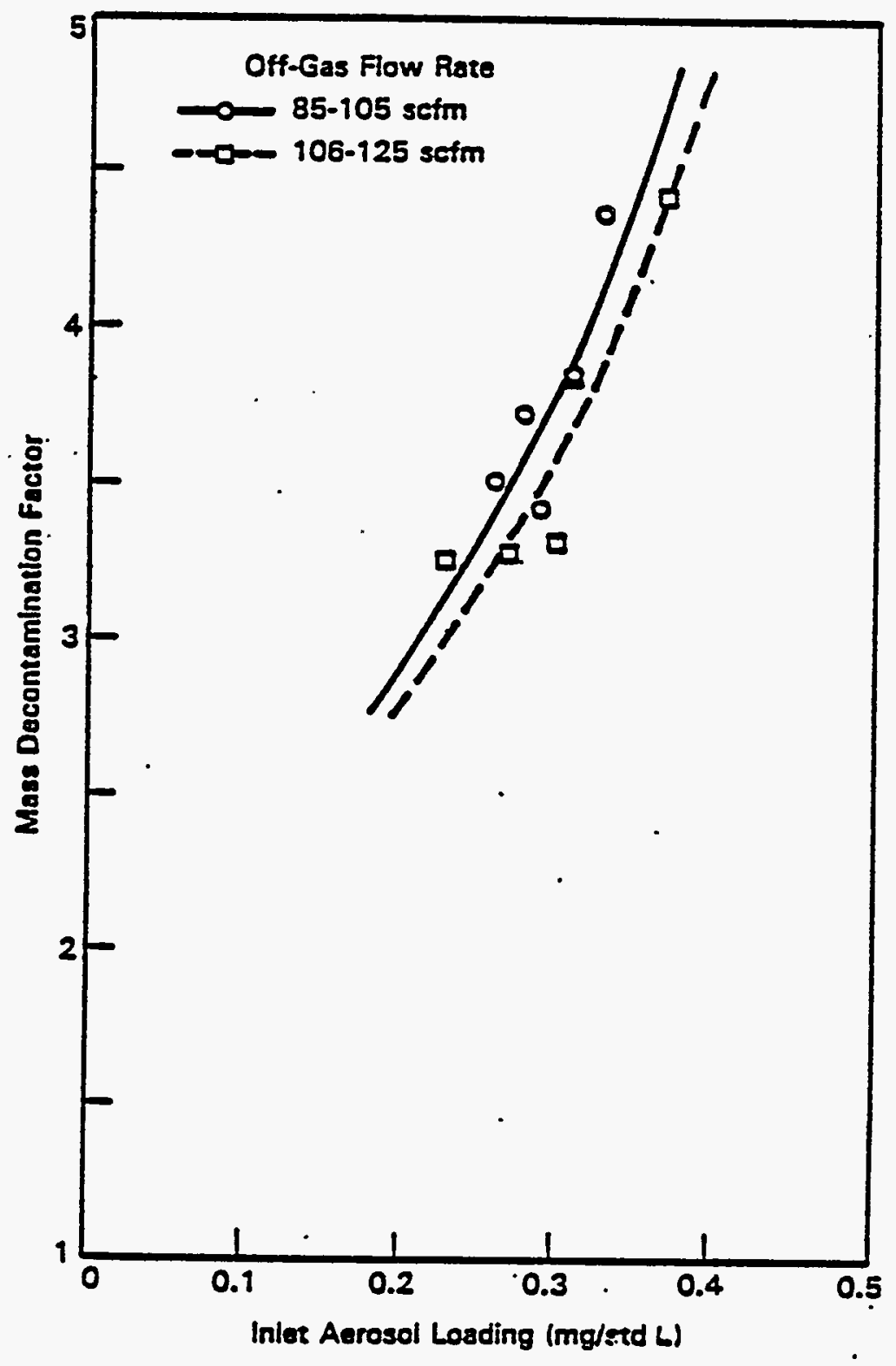

FIGURE 4.6-44. Relationship Between Inlet Aerosol Concentration and Aerosol Capture Efficiency for the EVS - HWVP (C. M. Rueker, "Evaluation of the PSCM MOG System," PNL, February 1987) 
4.6.4.6 Gas Scrubbing Column (Nonreference). Absorption columns have been used in commercial industry and in remote radioactive applications at Hanford for decades. There is, however, limited experience with gas absorption columns in vitrification systems. PNL has operated a nonradioactive LFCM off-gas system during brief (5-day) test runs. The system inciudes a structured-pack column, but because of the nature of the tests, the efficiency of the unit for removal of gases has not been fully characterized. Also, PNL has operated a dump-packed column in a radioactive vitrification facility, but its function in this application is particulate removal rather than gas absorption. PNL has encountered no significant operational difficulties using these columns.

Previously proposed HWVP designs, have indicated a bubble-cap column for $\mathrm{NO}_{x}$ absorption. However, with the shift to low-nitrate waste compositions, the incentive for using $\mathrm{NO}_{x}$ absorber is being reevaluated, especially the need for a large bubble-cap column as originaliy conceived. Concepts being considered include packed beds (structured or dump-type packings), perhaps with inner-bed cooling to remove exothermic reaction heat. In any case, these gas absorption devices capture aerosols via impaction mechanisms. Gas-phase pressure drops required in order to promote capture of submicron aerosols by impaction are generally on the order of 30 to 100 in. H.G. The $\mathrm{NO}_{x}$ absorption devices have pressure drops of 10 to 30 in. H.G. and, therefore, are not expected to effectively remove the submicron emissions from the EVS. This expectation is corroborated by the nonvolatile and semivolatile effluent data for HIVP-12. .

The performance of the PSCM system packed tower for the volatile effluents $C 1, F$, and $S$ ) is low, as the DF data for HWVP-12 illustrate. Although $\mathrm{NO}_{x}$ scrubbing efficiency for the packed tower is not available from HWVP melter test results, very low efficiencies were recorded during a previous WVNS test in which pure water was used as the scrubbing liquor. The column was not being operated under conditions conducive to efficient gas absorption, as evidenced by test results.

Aqueous column absorption of acid gases have been and continue to be extensively used in industrial applications and have undergone a great amount of technical analysis. Based on a review of $\mathrm{NO}_{\mathrm{x}}$ scrubbing by aqueous solutions, the following conclusions can be made:

- Nitrogen oxides are difficult to remove by aqueous scrubbing, particularly at low concentrations. Very few tests have demonstrated more than $90 \%$ removal of $\mathrm{NO}_{\mathrm{x}}$, with most reported results ranging from $20 \%$ to $70 \%$ removal (Ref. $4.6-1$ ).

- The mechanisms that lead to $\mathrm{NO}_{x}$ absorption are complex and not yet fully understood. A satisfactory model for predicting absorption may have to include up to eight mechanisms. 
- The design of nitric acid plants is certainly an established technology, and design calculations have apparently been sufficient to guide the design of $\mathrm{NO}_{\mathrm{x}}$ absorption towers. The fact that the complexities in the mechanisms have not prevented adequate designs is attributed to two factors. First, considerable empiricism has no doubt been used in design, and second, at high NO concentrations, one or two mechanisms control the absorption rate. It should be noted that nitric acid plants have a tail gas problem with residual $\mathrm{NO}_{x}$ that is not absorbed in the acid towers. This problem is similar to that arising from waste solidification.

- Sodium hydroxide solutions are not appreciably better than water or dilute acid at removing $\mathrm{NO}_{x}$ (Ref. 4.6-1).

- Experimental test data are needed to develop an adequate design for a $\mathrm{NO}_{x}$ scrubber. While models for $\mathrm{NO}_{x}$ absorption are available, the state of the technology is not far enough advanced to permit confident design of an absorber based solely on theory. The required experimental data could come from experience with similar equipment or from bench-scale laboratory tests. Recently introduced structured packings, such as wire gauze and chevron baffles, may offer significant advantages over traditional dump-packings in the capture of $\mathrm{NO}_{\mathrm{x}}$ fumes at low but troublesome concentrations. Such low concentrations may be encountered in the LFCM off-gas system.

The primary source of nitrogen oxide resulting from the LFCM process is the melter. The quantity of $\mathrm{NO}_{x}$ emitted depends on the waste $\mathrm{NO}_{3}$-concentrations treated and on the kind of acid destruction process used. In the melter, nitric acid is vaporized or converted to $\mathrm{NO}_{x}$ and nitrate salts are converted to NO $x$. Analyses of off gas from melters operated at PNL show that when the slurry feed contains reductants, such as formic acid, the nitric acid/nitrate salt reaction products are $\mathrm{NO}$ and $\mathrm{NO}_{2}$. However, if the feed and plenum atmospheres are oxidizing, only $\mathrm{NO}_{2}$ will be present. Because of its low vapor pressure, any $\mathrm{HNO}_{3}$ evolved will condense in the wet aerosol-scrubbing equipment, but $\mathrm{NO}_{x}$ gases will not necessarily be captured by devices such as the EVS and SBS because these are not specifically designed for gas contacting.

The $\mathrm{NO}_{x}$ column currently installed in the pilot-scale off-gas system is a 153-in. column constructed of 12-in. schedule 40 pipe (304L stainless steel). The bed is packed with Glitch Gempak $4 A$, which is a structured packing made from corrugated/perforated stainless steel plates. The actual depth of packing is $76 \mathrm{in}$. Above the packing is a liquid distributor designed by Glitch to evenly distribute water across the packing for flow rates ranging from 1 to $10 \mathrm{gpm}$. The column is designed to operate in a countercurrent fashion with the off gas flowing up through the packing. A demister is located in the top of 
the column to disengage entrained water droplets from the existing off gas. The mist eliminator is fabricated of 304 stainless steel and has a density of $9 \mathrm{lb} / \mathrm{ft}^{3}$.

The average column operating conditions during the HWVP-12 sample periods is summarized in Table 4.6-37. The off-gas and water flow rates during this interval indicate that the column was indeed operating in an acceptable mode from a gas/liquid contacting standpoint. The pressure drop across the $\mathrm{NO}_{x}$ column was $5^{\prime \prime} \mathrm{H}_{2} \mathrm{O}$ throughout HWP-12. Some limited particulate information was obtained that indicated that the. mass particulate DF for the $\mathrm{NO}_{x}$ column is essentially one; i.e., no aerosols are captured by the column. This result is to be expected because of the nature of the fundamental aerosol capture mechanisms, the geometry of the column, and the size distribution of the entering aerosols.

The $\mathrm{NO}_{x}$ concentrations listed in Table 4.6-37 were measured at the exit of the off-gas treatment system using an on-line $\mathrm{NO}_{x}$ analyzer. These concentrations represent the exit $\mathrm{NO}_{x}$ column concentration except for sample periods 9 through 11 that were diluted by the motive air injected at the HSS, which is downstream of the column but upstream from the $\mathrm{NO}_{x}$ analyzer. At one point during HWWP-12, the $\mathrm{NO}_{x}$ column was valved out of the off-gas system for a short period and then valved back in. This cycle was repeated several times. No measurable changes in the final $\mathrm{NO}_{x}$ concentration, as determined by the $\mathrm{NO}_{x}$ analyzer, were observed. These results imply that the absorption column removed little to no $\mathrm{NO}_{x}$.

The removal efficiency for $\mathrm{NO}_{2}$, as a function of the partial pressure of $\mathrm{NO}_{2}$, is given by Counce (Ref. 4.6-i1) based on the work of Peters (Ref. 4.6-1). using a three-plate bubble-cap column operated at room temperatures. The water flow rate was $5.0 \times 10^{-6} \mathrm{~m}^{3} / \mathrm{s}$ and the gas flow rate $5.9 \mathrm{~m}^{3} / \mathrm{s}$. The results are produced in Figure 4.6-45. The conversion of $\mathrm{NO}_{2}$ drops off rapidly as the partial pressure of $\mathrm{NO}_{2}$ decreases. The $\mathrm{NO}_{x}$ concentration at the column inlet was approximately $450 \mathrm{ppm}$, or a partial pressure of $0.00045 \mathrm{~atm}$, assuming that the absorption column did not remave any $\mathrm{NO}_{x}$. The exit $\mathrm{NO} / \mathrm{NO}_{2}$ ratio was approximately 0.8 throughout the sampling periods. The $N O / N O_{x}$ ratio should be high at the exit of the column because $\mathrm{NO}_{2}$ is absorbed much quicker than NO. Because the total $\mathrm{NO}_{x}$ concentration appears to be unchanged by the absorption column, it is safe to assume that the ratio is approximately 0.8 going into the column. This conclusion implies that the actual $\mathrm{NO}_{2}$ partial pressure entering the absorption column was approximately $0.0001 \mathrm{~atm}$, which is orders of magnitudes below the range of the data reported in Figure 4.6-45 $(0.01 \mathrm{~atm})$. It is safe to conclude that the expected removal of $\mathrm{NO}_{x}$ will be exceptionaliy low for the PSCM column based on this information. In fact, changes in the $\mathrm{NO}_{x}$ concentration were not detectable. 
TABLE 4.6-37. Average Operating Conditions for the $\mathrm{NO}_{x}$ Column During HWWP-12 - HWVP [C. M. Rueker, "Evaluation of the PSCM MOG System," Pacific Northwest Laboratory (February 1987)]

\begin{tabular}{|c|c|c|c|c|c|c|c|c|}
\hline $\begin{array}{l}\text { Sample } \\
\text { Period }\end{array}$ & $\begin{array}{c}\text { Off-Gas } \\
\text { Flow Rate } \\
\text { (scfm) }\end{array}$ & $\begin{array}{l}\text { Inlet Gas } \\
\text { Temp. } \\
\left({ }^{\circ} \mathrm{C}\right)\end{array}$ & $\begin{array}{l}\text { Outlet Gạs } \\
\text { Temp. } \\
\left({ }^{\circ} \mathrm{C}\right)\end{array}$ & $\begin{array}{c}\text { Water } \\
\text { Flow Rate } \\
\text { (gpm) }\end{array}$ & $\begin{array}{c}\text { Inlet Water } \\
\text { Temp. } \\
\left({ }^{\circ} \mathrm{C}\right)\end{array}$ & $\begin{array}{l}\text { Outlet } \\
\mathrm{NO}_{x} \\
\text { Conc. } \\
\text { (ppm) }\end{array}$ & $\frac{N O}{N_{x}}$ & $\begin{array}{c}\text { Mlass } \\
\text { DF }\end{array}$ \\
\hline $\begin{array}{r}1 \\
2 \\
3 \\
4 \\
5 \\
6 \\
7 \\
8 \\
9 \\
10 \\
11\end{array}$ & $\begin{array}{r}160 \\
180 \\
180 \\
180 \\
175 \\
155 \\
140 \\
125 \\
\sim 200 \\
-200 \\
-200\end{array}$ & $\begin{array}{l}29.9 \\
29.5 \\
29.4 \\
29.9 \\
29.8 \\
30.4 \\
29.9 \\
30.1 \\
31.1 \\
28.2 \\
28.3\end{array}$ & $\begin{array}{l}26.7 \\
26.8 \\
27.2 \\
27.2 \\
27.6 \\
26.8 \\
30.0 \\
26.9 \\
27.2 \\
25.9 \\
24.9\end{array}$ & $\begin{array}{l}5.3 \\
5.3 \\
5.3 \\
5.2 \\
5.2 \\
5.3 \\
5.2 \\
5.3 \\
5.2 . \\
5.3 \\
5.3 .\end{array}$ & $\begin{array}{l}26.6 \\
26.7 \\
27.2 \\
27.2 . \\
27.6 \\
26.7 \\
30.0 \\
26.6 \\
27.2 \\
25.8 \\
24.8\end{array}$ & $\begin{array}{l}510 \\
440 \\
430 \\
430 \\
460 \\
670 \\
540 \\
550 \\
250(a) \\
180(a) \\
320(a)\end{array}$ & $\begin{array}{l}0.77 \\
0.81 \\
0.87 \\
0.81 \\
0.80 \\
0.72 \\
0.68 \\
0.81 \\
0.77 \\
0.80 \\
0.85\end{array}$ & $\begin{array}{c}<1.2 \\
<1.3 \\
- \\
- \\
- \\
- \\
- \\
- \\
- \\
- \\
-\end{array}$ \\
\hline
\end{tabular}

(a) These concentrations have been diluted by injection air used by the HSS. Actual column outlet concentrations are higher. 


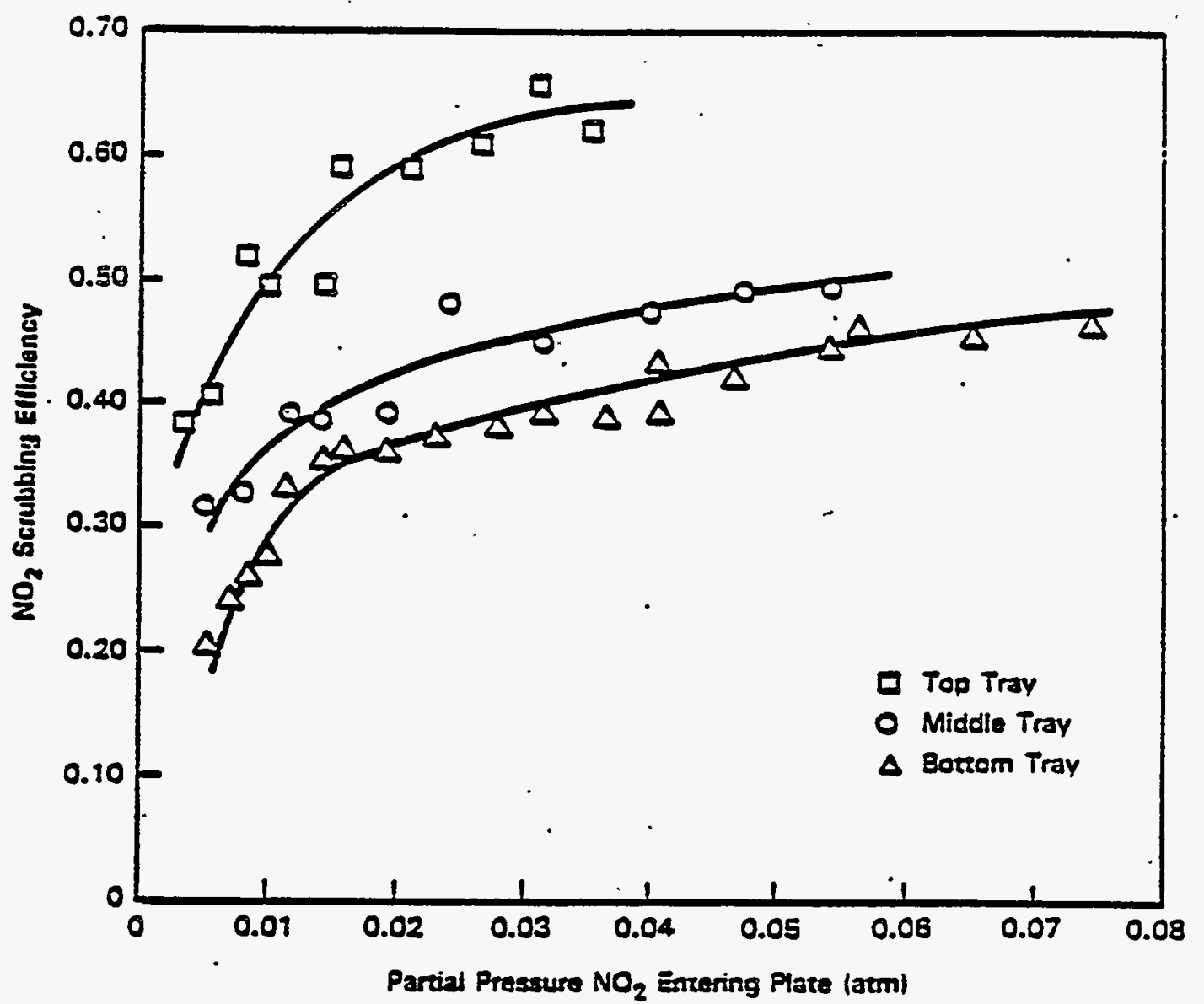

FIGURE. 4.6-45. Effect of $\mathrm{NO}_{2}$ Inlet Concentration on Plate Absorption Efficiencies in a Bubble-Cap Column - HWVP (Ref. 4.6-11)

4.6.4.7 Steam Atomized Scrubber (SAS) - Nonreference. The SAS has been used on a large commercial scale for about 15 years. Its original application was removal of submicron dust effluent from metal smelting furnaces, although it is presently used in numerous applications involving submicron aerosol pollution control. Commercial units are usually very large compared to the size needed for LFCM off-gas systems. The most sensitive components on the SAS are the small-diameter nozzles for steam and water injection, and it is important to keep these from becoming clogged with debris.

The effect of particle size on collection efficiency of the hydrosonic scrubber (HHS) has been studied (Ref. 4.6-12). Figure 4.6-46 gives some results and shows that removal efficiency remains high (90\%) even for $0.1-m$ particles. 


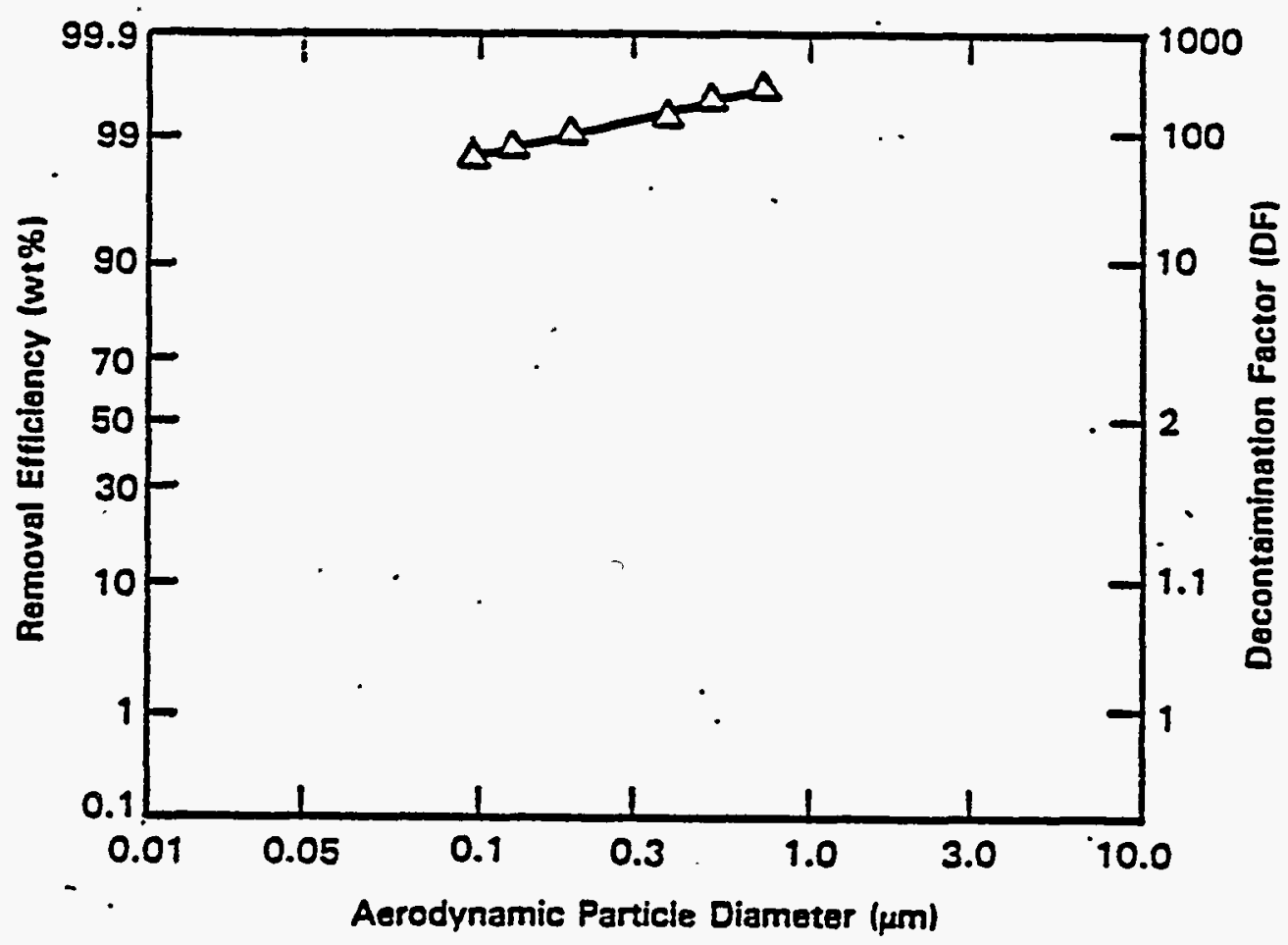

FIGURE 4.6-46. Particle Size Versus Decontamination Factor for Hydrosonic Scrubber - HWVP (Ref. 4.6-12)

The PSCM HSS was designed by the Lone Star Steel company to accommodate a gas flow not exceeding approximately 200 acfm of total exit off gas. Design inlet gas flow conditions for normal operation were taken to be $100 \mathrm{acfm}$, including moisture of saturation for temperture between 95 and $140^{\circ} \mathrm{F}(40$ and $60^{\circ} \mathrm{C}$ ). The ejector air was taken to be $30 \mathrm{scfm}$ using compressed air at about 50 psig and $70^{\circ} \mathrm{F}\left(21^{\circ} \mathrm{C}\right)$. The HSS was used in the off-gas system only during the last few days of HWVP-12. The operating conditions and resulting DFs are listed in Table 4.6-38. The scrubbing performance increased with successive samples. The same trend is not observed with any of the other variables. The operating conditions for sample periods 9 and 10 are very similar, as are the resulting DFs.

The higher DF for sample period 11 is probably a direct. result of the higher inlet concentration. This scrubber may be re-entrainment limited. In other words, the outlet aerosol concentration of the HSS depends more on the ability of the cyclone to remove the agglomerated droplets than on the inlet concentration and the number of particles not being captured by water drop1ets. Therefore, the DF should increase with increasing inlet aerosol concentration. Lone Star Steel Company shares the same opinion that the outlet concentration is independent of the inlet concentration. The brochure for the 
TABLE 4.6-38. Average Operating Conditions for the HSS During HWVP-12 (C. M. Rueker, "Evaluation of PSCM MOG System," HWVP86-V11220, Pacific Northwest Laboratory, 1987)

\begin{tabular}{|c|c|c|c|c|c|c|c|c|}
\hline $\begin{array}{c}\text { Sample } \\
\text { Period }\end{array}$ & $\begin{array}{c}\text { Inlet } \\
\text { Temp. } \\
\left({ }^{\circ} \mathrm{C}\right)\end{array}$ & $\begin{array}{c}\text { Outlet } \\
\text { Temp. } \\
\left({ }^{\circ} \mathrm{C}\right)\end{array}$ & $\begin{array}{c}\text { Off-Gas } \\
\text { Rate } \\
(\text { scfm) }\end{array}$ & $\begin{array}{c}\text { Air } \\
\text { Inject } \\
\text { Rate } \\
\text { (scfm) }\end{array}$ & $\begin{array}{c}\text { Water } \\
\text { Spray } \\
\text { Rate } \\
(\text { gpm) }\end{array}$ & $\begin{array}{c}\text { Pressure } \\
\text { Orop } \\
\left.\text { (in } \mathrm{H}_{2} \text { O) }\right)\end{array}$ & $\begin{array}{c}\text { Inlet } \\
\text { Conc. }\end{array}$ & $\begin{array}{c}\text { Mass } \\
\text { DF }\end{array}$ \\
\hline 9 & 27.2 & 26.7 & 250 & 20 & 3.8 & -21.3 & 0.084 & 4.0 \\
10 & 25.9 & 25.7 & 260. & 20 & 3.8 & -22.6 & 0.083 \\
11 & 24.9 & 25.3 & 230. & 20 & 3.8. & -20.8 & 0.165 & 15 \\
\hline
\end{tabular}

HSS shows some performance data, and only the exit concentration is given for this reason. Performance data for several industrial applications is reported in Figure 4.6-47. The outlet concentrations reported are in grains per std cubic feet. These values need to be multiplied by 2.3 to convert to $\mathrm{mg}$ per liter. The data shown in Figure 4.6-47 is for the SuperSub Hydro-Sonic system. The Air Ejector Drive unit in the PSCM off-gas system is not exactly the same. The PSCM HHS should perform better than the SuperSub, which it does as seen from the HWVP-12 data points also shown in Figure 4.6-47.

The performance of the HSS will increase with increasing driving force (inject air or steam) and water spray rate as long as the design limits of the cyclone are not exceeded. A point will be reached where the flow rate will exceed that for which the cyclone was designed, and droplets containing captured material will begin to penetrate the cyclone. Thus, any improvements in the initial capture of aerosols by .water droplets will be offset by the increase in the number of droplets penetrating the cyclone. The HSS was operated at the upper end of its designed operating range during. HWVP-12. In 1ight of this fact, it is doubtful that increases in performance can be achieved by increasing the compressed-air flow rate. Some improvements can probably be obtained by using steam instead of air as the driving fluid and by increasing the water spray rate.

The water scrub solution was recirculated during HWVP-12. The previously captured material could become re-entrained. after being atomized by the spray nozzle. Thus, improvements may also be realized by using clean water instead of recirculated water. The manufacturer claims that re-entrainment is not a problem for insoluble aerosols and that the recycle solution can contain up to 15\% dissolved solids before significant re-entrainment starts to occur. This clain may hold for typical industrial applications, but probably not for HLH 


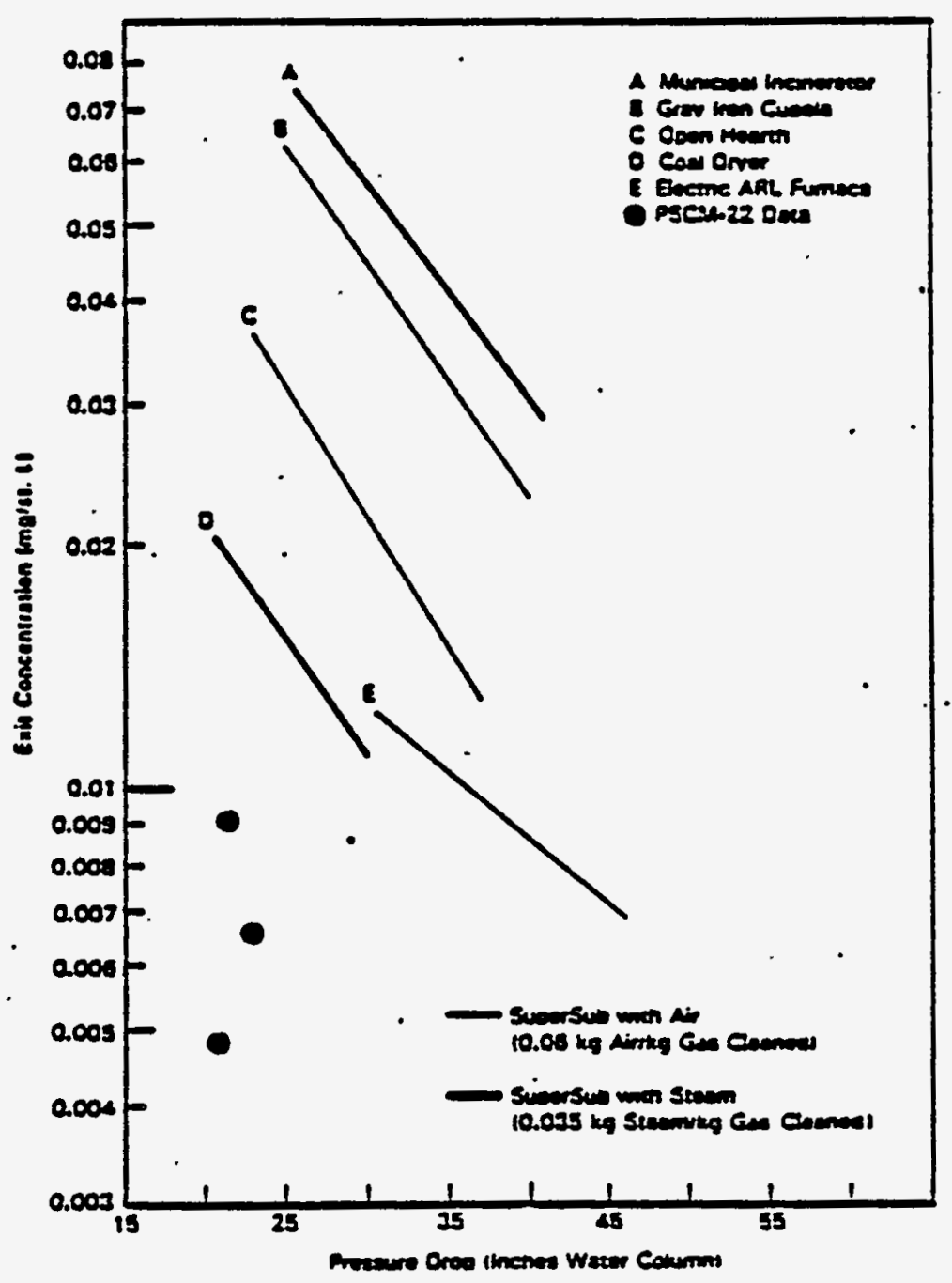

FIGURE 4-6-47. Outlet Concentrations from the SuperSub Scrubber as a Function of Pressure Loss for Several Industrial. Applications (from Hydro-Sonic brochure, reported in C. M. Rueker, "Evaluation of PSCM MOG System," HWVP-86-V11220, Pacific Northwest Laboratory, 1987)

processing. The inlet aerosol concentrations encountered in HLW processing are much lower than those for typical HSS processes. Some information is available for a slightly different hydrosonic system. This information has been reproduced in Figure 4.6-48 from a Hydrosonic brochure. Exit concentrations for a tandem nozzle system are given for both recirculated scrubbing solution and once-through water. The particulate DF increases from 11.8 to 16.7 by not recirculating the water. Differences between the two modes of operation will probably be more pronounced for HLH processing applications as a result of the 


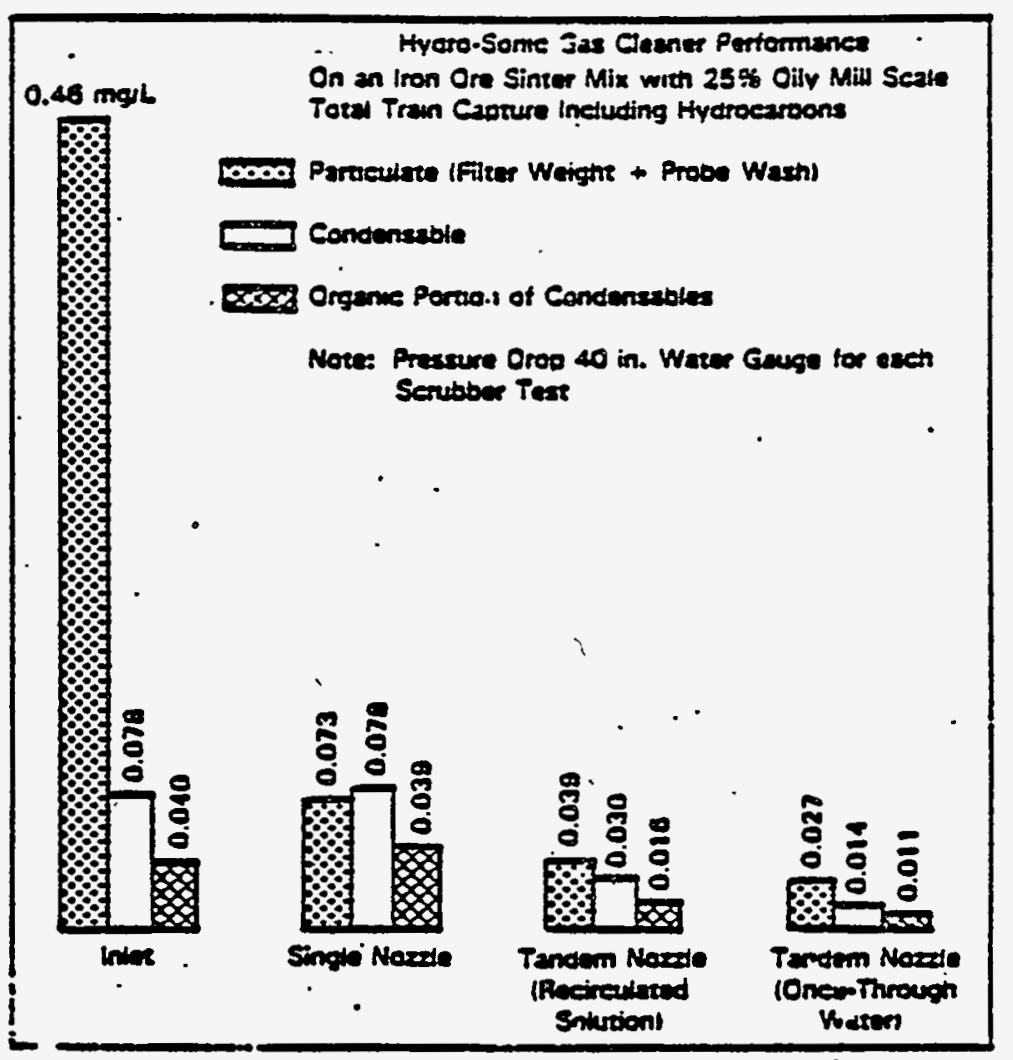

FIGURE 4.6-48. Outiet Concentrations for a Hydrosonic Gas Cleaner for Recycled and Once-Through Water Operation Modes (from Hydro-Sonic brochure), reported in C. M. Rueker, "Evaluation of PSCM MOG System," HWVP-86-V11220, Pacific Northwest Laboratory, 1987).

10w inlet aerosol concentrations. Re-entrainment can easily be plotted against captured aerosol concentration in the recycled scrub solution and would be useful in determining acceptable recycle rates.

LFCM off-gas testing of hydrosonic scrubbers has been conducted by SRL(a). SRL off-gas design provides for two cascaded hydrosonic devices directly downstream of the LFCM ejector venturi quench scrubber. Consequently, the LFCM scrubbing performance data associated with this system involve the tandem, cascaded system, which is designed to meet a DWPF-required DF of 50 for Cs aerosols. PNL perfomance data were obtained from a single unit located downstream of the LFCM quench scrubber. Representative data obtained from both laboratories are given in Table 4.6-39. Interlaboratory comparison of single-stage

(a) W. P. Colven, "DWPF Off-Gas System," technical exchange with SRL, June 1519, 1983. 
TABLE 4.6-39. Hydrosonic Decontamination. Factors (W. P. Colven, "DWPF Off-Gas System," technical exchange with. SRL, June $15-19,1987$ )

\begin{tabular}{|c|c|c|c|}
\hline \multirow{2}{*}{ ETement } & \multicolumn{2}{|c|}{ SRL } & PNL \\
\cline { 2 - 4 } & Cascaded & Single & \\
\hline $\mathrm{Al}$ & $(\mathrm{a})$ & -- & -- \\
$\mathrm{B}$ & & -- & 23 \\
$\mathrm{Ba}$ & -- & -- & 4.7 \\
$\mathrm{Ca}$ & -- & -- & 1.3 \\
$\mathrm{Cr}$ & -- & -- & 6.6 \\
$\mathrm{Cs}$ & 61 & 7.2 & 4.9 \\
$\mathrm{Fe}$ & -- & -- & 9.2 \\
$\mathrm{Li}$ & -- & -- & 6.1 \\
$\mathrm{Mg}$ & -- & - & 1 \\
$\mathrm{Mn}$ & 25 & 38.6 & 17 \\
$\mathrm{Na}$ & 61 & 8.9 & 6.1 \\
$\mathrm{Sr}$ & 3 & 5.2 & 5 \\
$\mathrm{Zr}$ & -- & -- & 3.2 \\
Total & 47 & 9.0 & 1.2 \\
\hline
\end{tabular}

(a) Dashes indicate data below detection limit.

hydrosonic DFs agree quite well. However, the important comparison to be made is between single- and dual-stage operational performance data. The efficiency of the first scrubber does not impair or degrade the Cs DF or the total DF of the second. Indeed, the first unit appears to slightly improve the performance of the second for both the CS DF and the total DF.

The aerosol DF performance of the hydrosonic scrubber used during the last two days of HWVP-12 testing was 4.1 and 5.5 for the two measurements made. The DF data obtained from samples collected on July 31 are somewhat higher than the results collected during the WVSP run PSCM-19, where the DF was 2.5. The increase in hydrosonic performance (aerosol DF $=15$ ) on August 1 illustrates the ability of this device to respond to higher aerosol loadings resulting from decreased performance of the melter and EVS. The combined overall DF across the melter EVS and Hydro-Sonic Scrubber was essentially constant $\left(5.9 \times 10^{3}\right.$, $5.6 \times 10^{3}$, and $5.6 \times 10^{3}$ ) during the period of hydrosonic testing, even though significant melter and EVS performance changes did occur.

Scrubber performance tests (Ref. 4.6-12) were conducted for inlet process gas temperatures of 95 to $120^{\circ} \mathrm{F}\left(35\right.$ to $50^{\circ} \mathrm{C}$ ) and aerosol loadings ranging from 3.4 to $794 \mathrm{mg} / \mathrm{m}^{3}$ dry gas. Scrubber water injection rates were maintained in 
excess of the design condition of $0.35 \mathrm{~kg}$ water $/ \mathrm{kg}$ process gas based on previ- . ous performance tests. Removal efficiencies, expressed as DF (where DF = $\mathrm{mg}$ aerosol injected/mg aerosol discharged) are summarized in Table 4.6-40.

For tests conducted with both aerosol generators operating, the gas stream DF increased as water injection. rate and separator swirl velocity were increased. Separator swirl velocity was controlled by an adjustable vane located at the inlet to the separator. Gas stream decontamination was effectively increased fron a of of 250 to 690 for a threefold increase in water injection rate.

The effect of increased water injection is not surprising. Calculations indicate that with particles 3 to $5 \mu \mathrm{m}$ and larger, particle size has a minimal effect on the measured and theoretical scrubbing efficiency. Increased water injection probably serves to improve overall collection efficiency by improving coverage. Because the transverse shear imposed by the jet on the fluid is

TABLE 4.6-40. Performance Test Results of Single-Stage, Air-Aspirated Scrubber (Ref. 4.6-12)

\begin{tabular}{|c|c|c|c|c|}
\hline $\begin{array}{c}\text { Inlet } \\
\text { Concentration } \\
\left(\mathrm{mg} / \mathrm{m}^{3} \text { dry gas }\right)\end{array}$ & $\begin{array}{c}\text { Ejector Air/ } \\
\text { Process Air. } \\
(\mathrm{kg} / \mathrm{kg})\end{array}$ & $\begin{array}{c}\text { Ejector Water/ } \\
\text { Process Air } \\
(\mathrm{kg} / \mathrm{kg})\end{array}$ & DF & $\begin{array}{c}\text { Aerosol Generator } \\
\text { Case }(\mathrm{a})\end{array}$ \\
\hline 27.4 & 0.28 & 0.52 & 25 & 1 \\
3.4 & 0.57 & 2.44 & 17 & 1 \\
514 & 0.58 & 1.02 & 250 & 2 \\
604 & 0.58 & 2.03 & 333 & 2 \\
636 & 0.58 & 3.18 & 690 & 2 \\
667 & 0.54 & 0.77 & 500 & 3 \\
794 & 0.47 & 2.57 & 333 & 2 \\
245 & 0.57 & 2.44 & 200 & 2 \\
\hline
\end{tabular}

(a) Case numbers are as follows:

1 - HPG aerosol generator only; mean particle size is $0.3 \mu \mathrm{m}$ aerodynamic diameter.

2 - HPG and coarse dust feeder.

3 - Coarse dust feeder only. 
constant, increasing the water rate' results in penetration of the jet by the liquid phase, thereby improving coverage. Increased coverage results in improved scrubber efficiency--an effect that has been studied extensively. (a)

An increased air injection rate did not result in improved collection efficiency. This effect was attributed to the performance aspects of the supersonic free jet. In fact, high air injection rates should decrease efficiency, since re-entrainment losses are increased.

. Mass overall DF values were lowest when the HPG aerosol generator was used. The aerosol produced by this device is predominantily submicron. Measured fractional collection efficiencies show that the most penetrating particle size is less than $0.1 \mathrm{\mu m}$ aerodynamic diameter. This fact was verified by theoretical calculations, which show that the separation for particles in this size range is controlled by diffusional effects. A comparison between measured data from these tests and data from Nankani $(b)$ is shown in Figure 4.6-49.

Scrubber pressure drop was found to have been low compared to other types of high-efficiency venturi scrubbers. Overall scrubber pressure drop ranged from 2.9 to $5.8 \mathrm{~cm}$ of water.

Scanning electron microscope studies indicate that the scrubber emits particles on the order of 0.1 to $0.5 \mu \mathrm{m}$ in diameter.

4.6.4.8 Condenser. Condensers have been used in nuclear applications at Hanford and elsewhere or many years. The condenser functions primarily to remove water vapor from the off-gas stream through condensation. Suitable design will enable it to also remove water condensate entrainment from the steam atomizer scrubber and condenser. The biggest concerns are with corrosion of the vessel or tubing and with fouling of the tubing with. corrosion products and entrained debris so that the required heat transfer rate is reduced. For the HWVP, these concerns can be avoided by proper materials selection and by designing a means to wash down tube surfaces as needed.

(a) W. P. Colven, "DWPF Off-Gas System," Technical Exchange with SRL, June 1519, 1983.

(b) F. D. Nankani, "Trip, Conference Report - HWVP/DWPF Technical Exchange Meeting--STurry Feed Preparation and Melter Feed system," 65651TCR86-002, Rockwell Hanford Operations, Richland, Washington (January 1, 1980). 


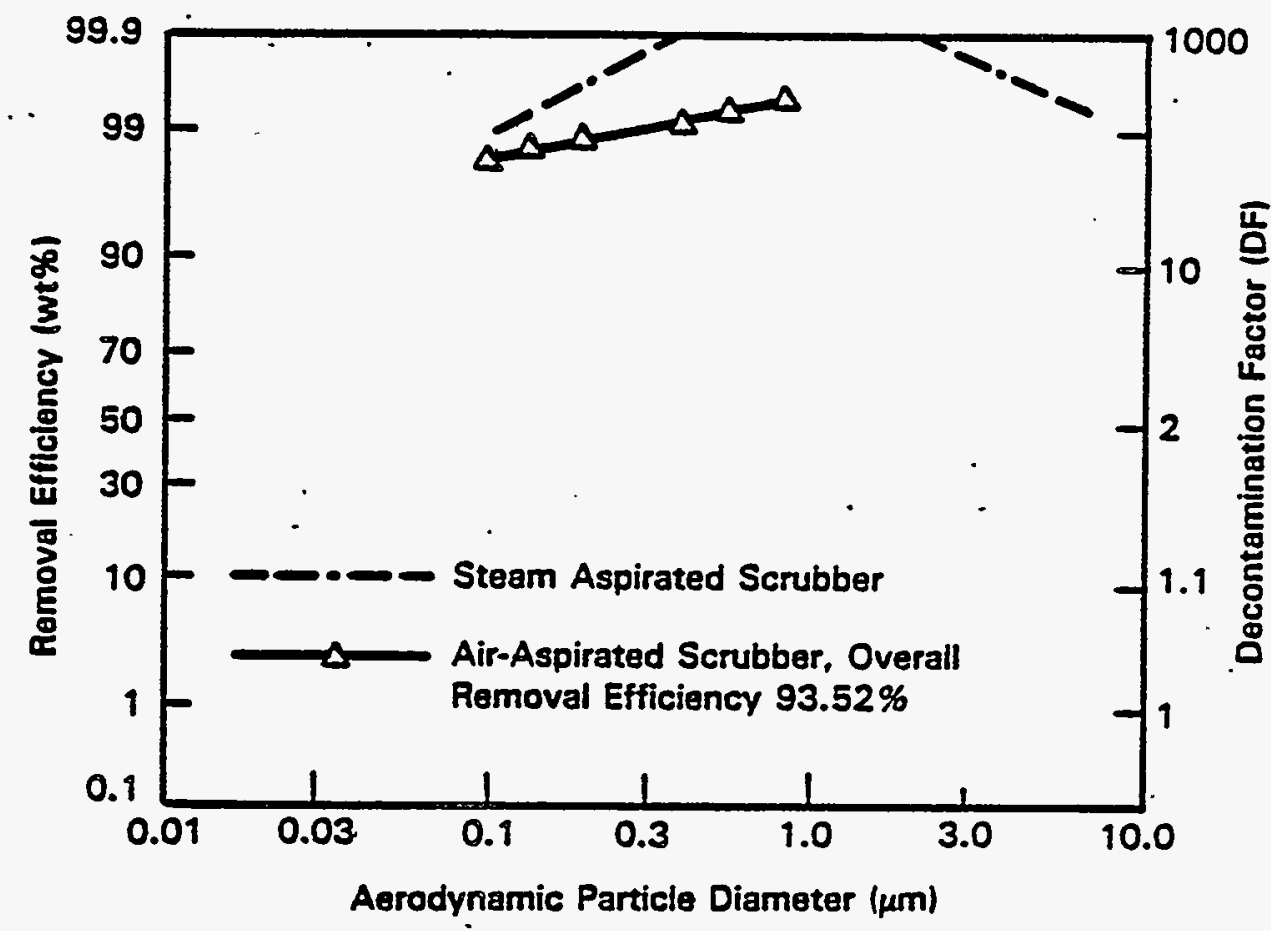

FIGURE 4.6-49. Comparison of Scrubber Performance (Ref. 4.6-12)

The condenser is not considered to be an off-gas particulate or gas decontamination device, nor is it allowed any OF credit in the off-gas systern performance evaluations. However, it might be expected that gaseous radionuclides such as Ru, should they penetrate this far in the off-gas system, would condense out at this stage. Several cases are cited (Ref. 4.6-13) where high Ru OFs are obtained for condensers. However, in these cases, the condenser is treating the effluent from dissolvers or waste calciners directly. Also, it is felt that condensing liquid could use aerosols as the nucleating sites, thus increasing the particulate size. These larger particulates could be more effectively removed by the HEME. The condenser has not been tested for off-gas systen operation use during PSCM runs.

4.6.4.9 High-Efficiency Mist Eliminator. Washable filters have been used industrially for about 15 years, primarily for capture of soluble aerosols such as mists or fumes. A typical application is removal of hydrochloric or sulfuric acid fumes. Their use with regard to LFCM effluent has been 1 imited to nonradioactive pilot-scale tests that have been performed at SRL WVDP and PNL. In LFCM service, it is expected that a significant fraction of the particulate entering the HEME will be insoluble, so service life is uncertain. In the DWPF and HWVP schemes, the HEME is located downstream of the hydrosonic scrubber or submerged bed scrubber, respectively, thus serves as a highly efficient demister. A. HEME was operated with continuous washdown for 63 days during LFCM 
pillot tests at SRL. At PNL, shorter-term tests have been conducted, usually with intermittent washdown. Excessive pressure drops have not been experienced in operating the HEMEs at either laboratory.

Furrer et al. (Ref. 4.6-14) examined HEME fiberglass filter performance on cleanup of aerosols from simulated dissolver off gas. Figure 4.6-50 shows their measurements of droplet size versus decontamination factor. The particle sizes on this plot are $>1 \mathrm{\mu m}$, and the indicated DFs are very large $\left(10^{3}\right.$ to $10^{6}$ for 1.5- to 6-jm aerosols). The DF-versus-size trend flattens out as the smaller particle sizes are approached, suggesting that capture efficiency may not severely degrade in the submicron regime. PNL tests support this assertion. Measured overall mass DFs for a polypropylene fiber HEME (installed in the PSCM-MOG system) are about 15 and 16. For certain elements a very high aerosol DF is reported, but the confidence in these data is low. The size distribution of airborne particulate leaving the PSCM-installed HEME was measured during run PSCM-15 using an aerosol spectrometer; Figure 4.6-51 shows number, surface, and volume size distributions with mean diameters of 0.22 , 0.27 , and $>0.31 \mu \mathrm{m}$, respectively. The HEME is very effective on aerosols in the $\geq 0.3-\mu m$ size range.

The performance of the HEME versus operating conditions can be stated in general terms. The filter elements obtained from vendors are rated. for a maximum air flow rate and pressure drop. Any increases in flow or pressure could damage the filter or could result in penetration of aerosols and thus

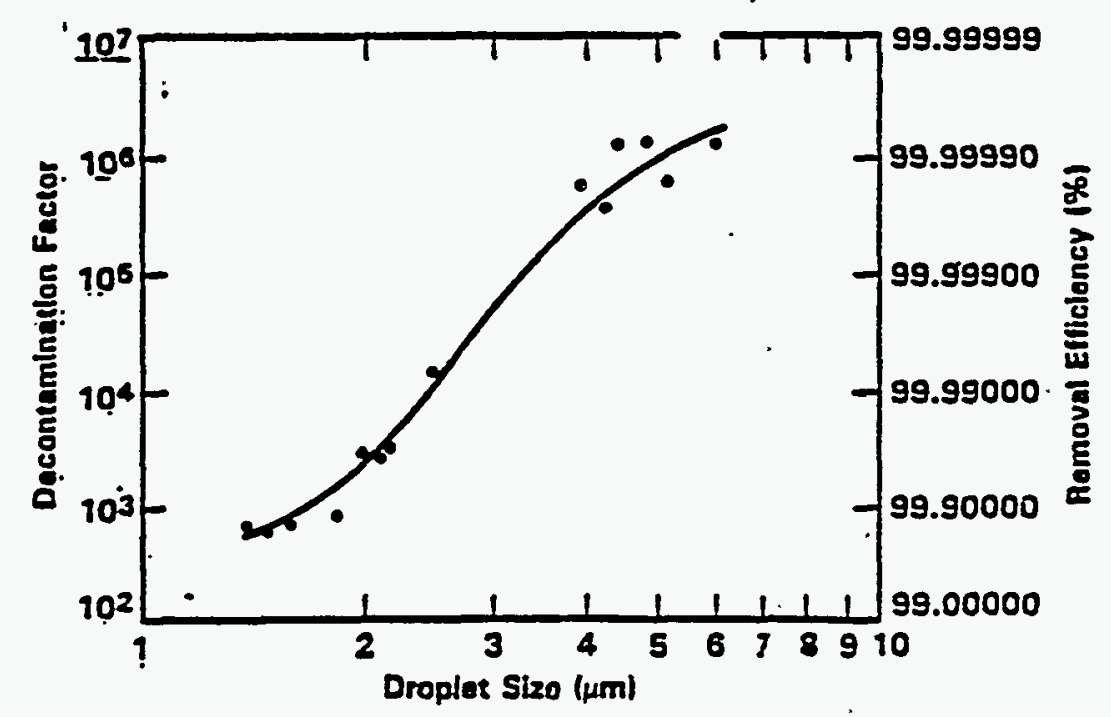

FIGURE 4.6-50. Decontamination Factor as a Function of Droplet Size for a High-Efficiency Mist Eliminator (Ref. 4.6-14) 


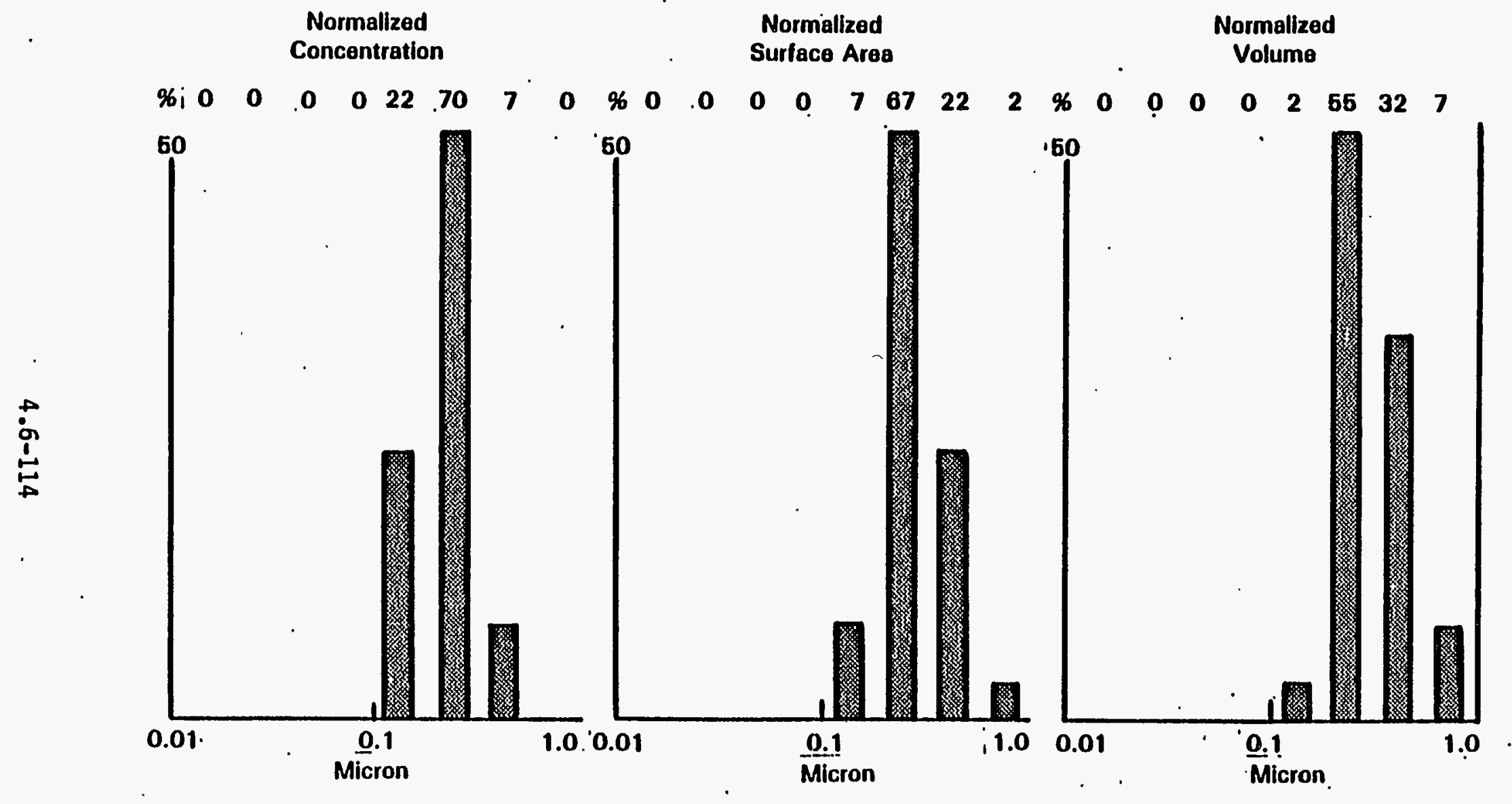

FIGURE 4.6-51. Number, Area, and Volume Distributions of Aerosols Exiting the HighEfficiency Mist Eliminator During PSCM-15 (D. E. Larson et al., "HWVP-Process Off-Gas Decontamination Factors," HWVP-85-V1143 $A$, 
loss of efficiency. In principle, reductions in flow below the design limit result in increased performance since the collection mechanism is based on diffusion and lower flow means longer residence time. The main virtues of employing HEMEs are that they are passive, renewable, and highly efficient. However, because the main purpose of a HEME in LFCM applications is to remove semivolatile (Cs) submicron aerosols, a great deal of attention must be given to HEME off-gas operating conditions.

4.6.4.9.1 HWVP-12 Test Results. The HEME in the pilot-scale off-gas system, before HWVP-12, is a 3-in.-thick cylindrical filter with an outside diameter of 12 in. and a length of 24 in. The filter was purchased from Koch Engineering Company and is composed of 8- to. 10- $\mu \mathrm{m}-\mathrm{di}$ ameter fiberglass fibers. The collection efficiency for submicron aerosols increases. as the particle-diameter-to-fiber-diameter ratio increases.

A schematic of the filter/housing is shown in Figure 4.6-52. The inlet gas enters through the top of the filter housing. The off gas flows from the inside of the filter cartridge to the outside. A water spray nozzle is located on the centerline near the top of the filter element. The water spray is used to flush the filter of captured aerosols, increasing the life of the filter. The spray can be used continuously or periodically, depending on which mode of operation produces the best aerosol collection efficiencies.

The pressure drop across the HEME is a function of the off-gas flow rate, particulate loading, the water spray rate, the packing material and the fiber packing density. The pressure drop across the HEME during HWVP-12 is shown in Figure 4.6-53. The pressure drop was stable at approximately $10 \mathrm{in}$. of water column during the period in which the water spray was not used. The pressure drop steadily increased once the water spray was started. A properly sized HEME should operate at a pressure drop of 7 in.

The operating conditions for the HEME during HWVP-12 and the corresponding DFs are given in Table 4.6-41. Mass DFs could not be calculated for the first two sample periods because outlet off-gas samples were unavailable. The HEME inlet conditions during sampling periods 3 through 5 were very consistent. The resulting DFs for these sampling periods are essentially the same, approximately 15.5, demonstrating the reproducibility of the off-gas sampling procedure.

Due to sizing problems, it was not easy to investigate the influence of water spray on the aerosol capture performance. The HElIE was originally sized before the film cooler was added to the PSCM. The injection air system for controlling the melter vacuum was also added, increasing the off-gas flow rate through the HEME from a previous value of $50 \mathrm{acfm}$, for which the HEME was designed, to approximately 175 acfm during HWVP-12. The existing HEME is 


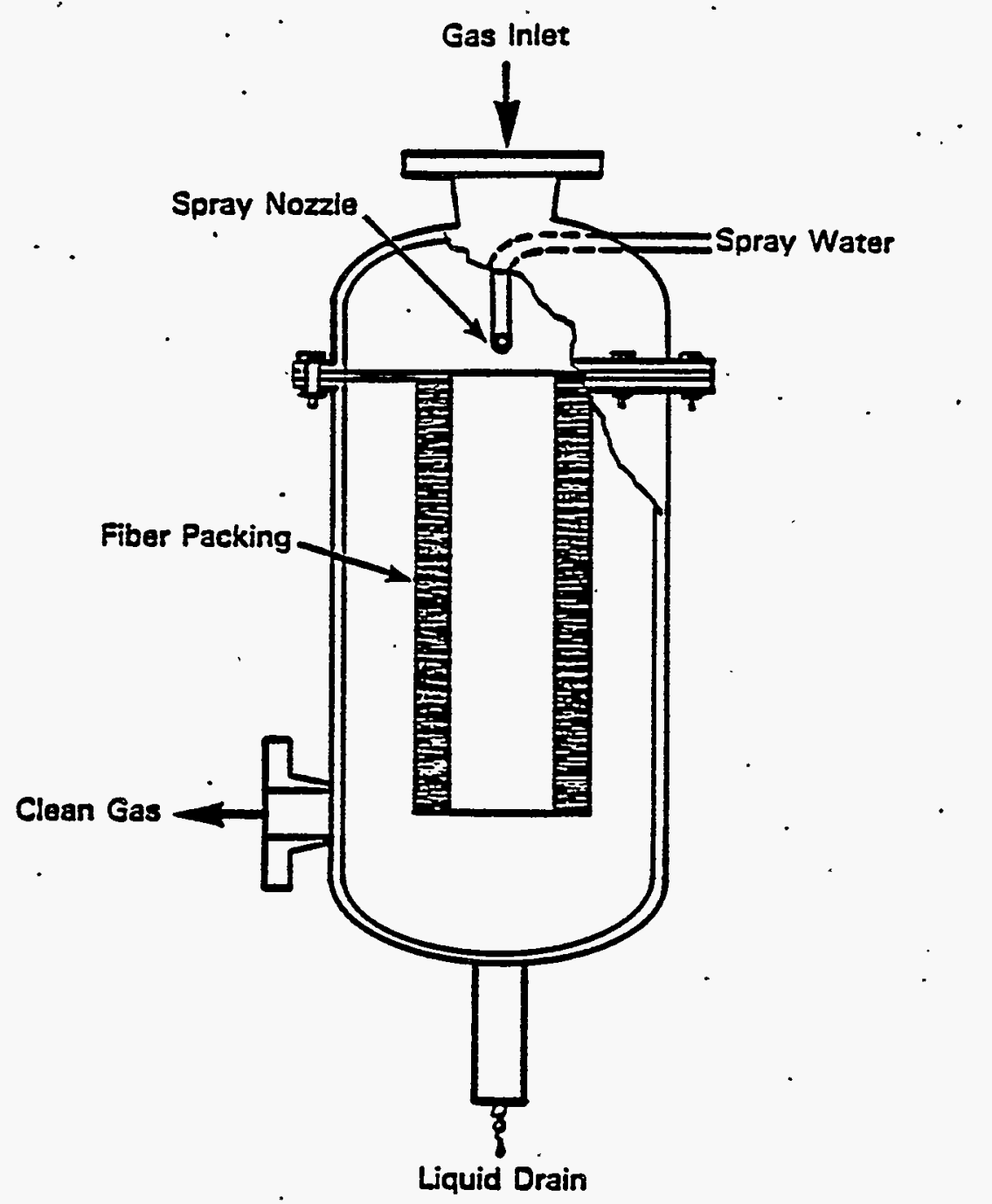

FIGURE 4.6-52. Cross-Sectional View of the High-Efficiency Mist Eliminator (PSCM HEME used for HWVP-12 test)

therefore well undersized for the existing application. A properly sized filter should have a face velocity of $15 \mathrm{ft} / \mathrm{min}$ based on the 1 og mean diameter. The face velocity for the PSCM filter, based on an off-gas flow rate of $1.75 \mathrm{acfm}$, is approximately $42 \mathrm{ft} / \mathrm{min}$. This face velocity is at the extreme end of the operating range. A representative from Koch was surprised to find that our DFs were as high as they were under the operating conditions encountered during HWVP-12. Because the filter was undersized, the influence of the water spray on scrubbing performance cannot be fairly judged. 


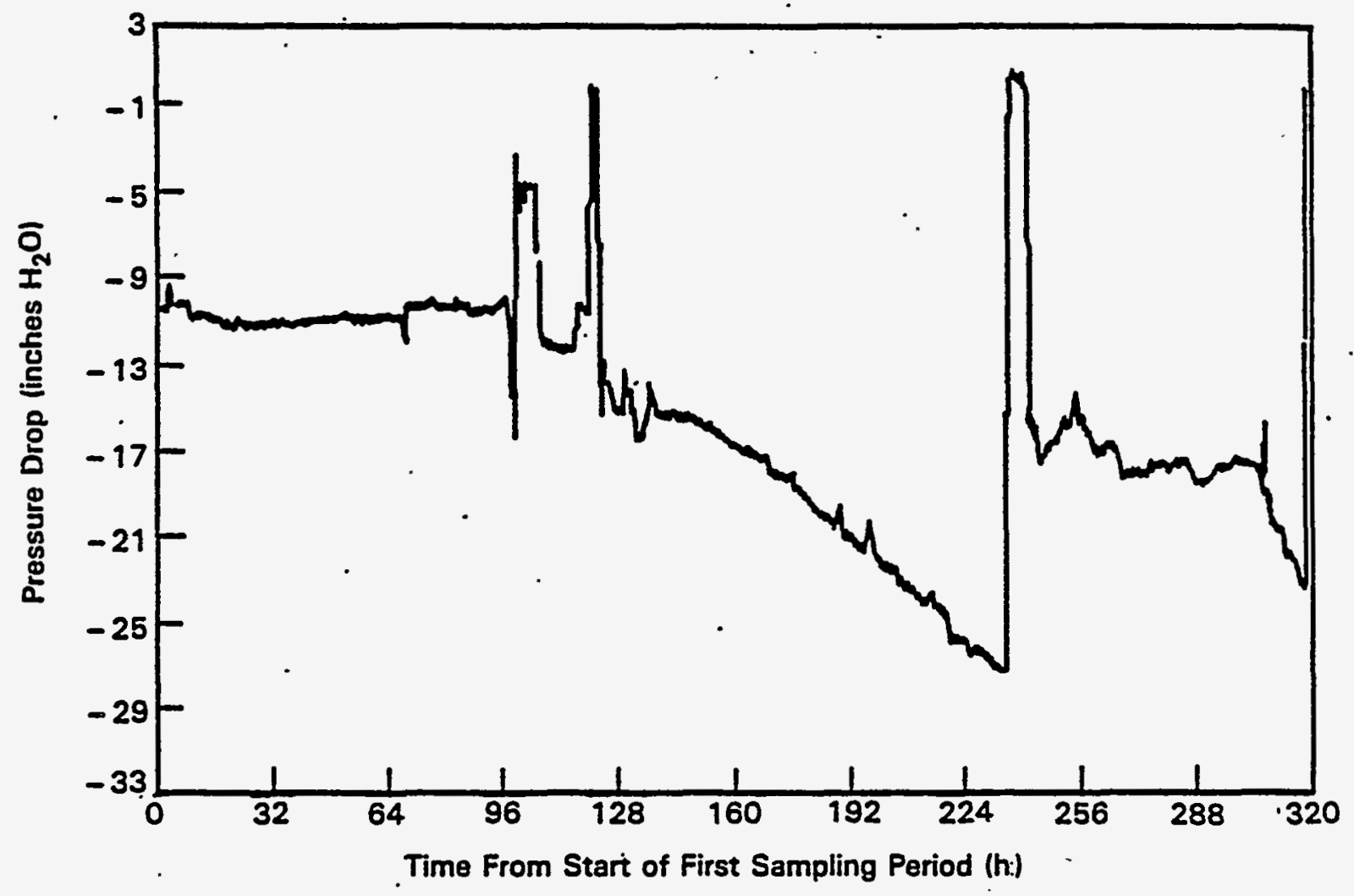

FIGURE 4.6-53. Measured Pressure Drop Across the HEME - HWVP

The DF first increased when the water spray was started but decreased pressure drop increased. As the spray was started, the gas flow rate through the filter decreased because of the accompanying increase in the pressure drop across the filter. The lower gas flow rate should have increased the collection efficiency because of the nature of the inlet aerosol distribution and classical aerosol capture mechanisms. More than likely, the HEME did not drain properly due to the high off-gas flow rates involved. The gas flow probably forced the water to migrate through the filter, carrying previously captured aerosols with it. The contaminated water was then likely re-entrained in the off gas from the exit surface of the filter element. This result is a consequence of the filter being undersized, thus it is inappropriate to make conclusions concerning the influence of water spray on filter performance from the data of HWVP-12.

The HSS was used upstream of the HEME during sampling periods 9 through 11, which explains the decrease in the inlet aerosol concentration. The offgas flow rate was also much higher as compressed air was used as the driving 
TABLE 4.6-41. Average Operating Conditions for the HEME During HWVP-12 - HWVP

\begin{tabular}{|c|l|c|c|c|c|c|c|}
\hline $\begin{array}{c}\text { Sample } \\
\text { Period }\end{array}$ & $\begin{array}{c}\text { Inlet } \\
\text { Temp. } \\
\left({ }^{\circ} \mathrm{C}\right)\end{array}$ & $\begin{array}{c}\text { Pressure } \\
\text { Orop } \\
\text { (in. H, }\end{array}$ & $\begin{array}{c}\text { Air Flow } \\
\text { Rate } \\
\text { (scfm) }\end{array}$ & $\begin{array}{c}\text { Water } \\
\text { Spray } \\
\text { Rate } \\
\text { (gph) }\end{array}$ & $\begin{array}{c}\text { Inlet } \\
\text { Conc. } \\
\text { (mg/L) }\end{array}$ & Mass DF & $\begin{array}{c}\text { HSS Used } \\
\text { Upstream }\end{array}$ \\
\hline 1 & 26.2 & 10.4 & 160 & 0 & 0.09 & - & No \\
2 & 26.2 & 11.1 & 180 & 0 & 0.084 & -- & No \\
3 & 26.4. & 11.0 & 180 & 0 & 0.075 & 15 & No \\
4 & 26.6 & 11.1 & 180 & 0 & 0.074 & 16 & No \\
5 & 26.8 & 10.9 & 175 & 0 & 0.074 & 16 & No \\
6 & 26.2 & 15.4 & 155 & 16 & 0.069 & 16 & No \\
7 & 29.3 & 17.8 & 140 & 17 & 0.081 & 22 & No \\
8 & 26.3 & 21.2 & 125 & 17 & 0.080 & 12 & No \\
9 & 26.7 & 18.0 & 250 & 0 & 0.021 & 14 & Yes \\
10 & 25.7 & 17.4 & 260 & 0 & 0.015 & 14 & Yes \\
11 & 25.3 & 22.3 & 230 & 0 & 0.011 & 20 & Yes \\
\hline
\end{tabular}

-- Mass DFs not obtained. .

force for the HSS. The inlet and outlet concentrations were so low for these last three sampling periods that small errors in the sampling procedure can cause significant errors in the DF. The actual amount of material collected to determine the outlet concentration for the last period was $1.4 \mathrm{mg}$. These $1 \mathrm{ow}$ concentrations make it difficult to characterize the downstream filters during melter operation; thus it is more appropriate and convenient to study these filters independently.

Koch Engineering Company claims that all particles greater than $3 \mu \mathrm{m}$ should be captured for a properly designed HEME. Particles less than $3 \mu \mathrm{m}$ are collected at a $95 \%$ efficiency rate (DF of 20). The experimental results from HWVP-12 ( $D F=15)$ are close to this expected value. The HEME performed exceptionally well during HWVP-12 considering the unit is undersized.

The aerosol DF values listed for HWVP-12 testing are a factor of -3 below engineering expectations. It is believed that some degree of solution breaching of the filter is responsible for the deficient HEME performance during that test. Much higher DFs have been observed at PNL, Cs DF $=50$, but only under 
conditions not allowing solution penetration. Table 4.6-42 compares performance data collected under both wet and dry conditions, where solution with dissolved salts penetrated the medium (wet) and nonsolution penetrating conditions (dry).

Because a HEME is an aerosol scrubber, HEME DFs for gases should be 1 unless reaction with or adsorption on filter fibers occurs. The data for the HWVP HWVP-12 indicate that one or both of these mechanisms are active for $\mathrm{Cl}$ and $F$.

The Savannah River Laboratory routinely uses a spray wash with their HEME in LFCM off-gas processing applications. The performance of their HEME during the 90-day LFCM test is included in Table 4.6-42 for comparison. These SRL DFs. are not necessarily directly comparable to the PNL. data, in that two cascaded hydrosonic scrubbers were used to pretreat the off-gas stream before HEME filtration. Because hydrosonic scrubber operation is based upon altering increasing) the aerosol size distributions, the pretreatment step could serve to increase effective HEME DFs and could be responsible for the differences in the laboratory data. However, the two sets of data do provide a good general sense of the usefulness of HEMEs for dealing with LFCM submicron aerosols.

Semivolatile penetration of HEMEs through aqueous solution transport is convincingly illustrated by examining the re-entrained matter collected downstream of the wet filtering media. Although filter loadings preclude statis-. tical size analysis of the aerosols collected, one thing is clear: essentially all of the collected matter is large; i.e., greater than $1 \mu \mathrm{m}$.

Particulate matter collected under. dry conditions is submicron. In all cases, it is found that the Cs and Se in the samples are associated with large, rod-like fibers. These fibers are crystals that have grown from solutions that are concentrated through the evaporative process on the downstream side of the HEME. The performance of a HEME in an LFCM off-gas system is impaired under these operating conditions, in which solution is allowed to penetrate the collection medium.

Wet operation with HEMEs can be effectively accomplished, however, if the HEME is washed by design. Filters can be continuously washed or irrigated countercurrent to the flow. Though operation may increase the pressure drop across the device, it is fully capable of preventing solution penetration of the filter. The once-through wash water, of course, would create another waste stream that would have to be dealt with. 
TABLE 4.6-42. HEME Aerosol Decontamination Factors - HWVP (Ref. 4.6-4)

\begin{tabular}{|c|c|c|c|}
\hline \multirow[b]{2}{*}{ Element } & \multicolumn{2}{|c|}{ PNL } & \multirow[b]{2}{*}{ SRL } \\
\hline & Dry & Wet & \\
\hline $\begin{array}{l}\mathrm{Al} \\
\mathrm{B} \\
\mathrm{Ba} \\
\mathrm{Ca} \\
\mathrm{Cr}\end{array}$ & $\begin{array}{r}(a) \\
120 \\
3 \\
5 \\
36\end{array}$ & $\begin{array}{l}10 \\
42 \\
15 \\
14 \\
11\end{array}$ & $\begin{array}{l}-- \\
- \\
- \\
--\end{array}$ \\
\hline Cs & 54. & 1.2 & 111 \\
\hline $\mathrm{Cu}$ & 2 & - & $\cdots$ \\
\hline Fe & 9 & 18 & - \\
\hline$K$ & 28 & $\bar{I}$ & - \\
\hline La & -- & 17 & $\cdots$ \\
\hline Li & 37 & 11 & - \\
\hline $\mathrm{Mg}$ & 19 & - & $-\infty$ \\
\hline Mn & $=$ & 14 & 33 \\
\hline Mo & 25 & $\cdots$ & -- \\
\hline N & 50 & $\cdots$ & $\cdots$ \\
\hline $\mathrm{Na}$ & 47 & 12 & 221 \\
\hline $\mathrm{Nd}$ & - & - & - \\
\hline $\mathrm{Ni}$ & 3 & 5 & \\
\hline P & 47 & $\because$ & - \\
\hline Ru & - & 8.1 & -- \\
\hline$S$ & 53 & -- & - \\
\hline Se & -- & 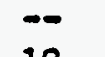 & - \\
\hline Si & $-\infty$ & 18 & -- \\
\hline $\begin{array}{l}S r \\
T i\end{array}$ & -- & $\begin{array}{l}14 \\
--\end{array}$ & - \\
\hline $\mathrm{Zn}$ & 5 & -- & \\
\hline $\mathrm{Zr}$ & - & 24 & - \\
\hline Total & 15 & 2 & 39 \\
\hline
\end{tabular}

(a) Dashes indicate data below detection limit. 
HEME aerosol off-gas performance, when the HEME was not used in conjunction with the hydrosonic scrubber, was relatively consistent and reproducible throughout HWVP-12. The average DF measured throughout this period of testing was 16 , which is a factor of three improvement over PNL test results in PSCM$19,-20$, and -21 . However, this $D F$ value is still at least a factor of three below engineering design expectations; i.e., $\mathrm{DF}=50 . \cdot$ As indicated, solution breaching of the fitter followed by subsequent re-entrainment of soluble effluent is responsible for HEME performance deterioration.

Evidence for solution penetration of the filter is provided by the chemical composition of the matter penetrating the HEME element. The fact that the low-flow-rate HEME water. spray, which was initiated in HWVP-12 on July 24 , had no observable impact upon HEME $D F$ is consistent with this penetration mechanism if it is recognized that water mist carryover from the packed tower was probably much greater than that introduced by the HEME spray nozzle. The rate of mist carryover or the degree of HEME wetting. may also affect the degree to which performance is reduced.

The use of a hydrosonic scrubber upstream of the HEME during the last two days of testing in HWVP-12 reduced the size of the off-gas samples downstream of the HEME to the point that gravimetric or gross overall DFs could not be reliably determined. However, individual elemental HEME DFs were not found to be significantly affected by hydrosonic pretreatment of the off-gas stream. Consequently, overall HEME DFs could not have been influenced to any great extent by hydrosonic scrubber operation.

The CS HEME DFs recorded during HWVP-12 were a factor of -3 higher than has been observed during previous. PSCM testing. These values are fairly consistent and are apparently unaffected by the use of the upstream hydrosonic scrubber during the last two days of HWVP-12 operation.

In the HWVP application, the device would be operated dry with periodic backwashing to remove collected aerosols. However, many of the aerosols are not soluble, and thus are not amenable to washing. Testing of glass pack filters in the SRL TNX facility during their liquid-fed melter runs has shown that an insoluble iron spinel collects on the fibers. 
- 4.6:4.9.2 HWVP-15 Test Results. A new and larger size HEME was procured for use in HWVP-15 testing. The HEME design specifications and operating conditions are given in Tabie 4.6-43.

4.6.4.9.2.1 Physical Properties and Operating Conditions. The HEME was operated at two off-gas fTow rates ( 110 and $170 \mathrm{scfm}$ ) without an auxitiary water spray. The water inlet rates to the HEME under these conditions were established by SBS mist carryover which averaged $1 \mathrm{l} / \mathrm{h}$. The pressure drop and corresponding gas face velocity data collected during this non-spray period are graphically displayed in Figure 4.6-54. The temperature is plotted in Figure 4.6-55. These data plots clearly show the significant impact that off-gas water loading can have upon HEME pressure drop. The $15 \mathrm{~L} / \mathrm{h}$ spray rate increased the average pressure drop across the HEME by more than 50\%. However, off-gas flow and water loadings were the only factors that affected HEME pressure drop throughout HWVP-15. To put HWVP-15 HEME operating conditions in perspective, the total HEME water inlet rate with the spray was 30 times. that recommended by DWPF ( $50 \mathrm{mg} / \mathrm{scfm}$ ); without the spray, it was only a factor of 2 greater than recommended.

TABLE 4.6-43. HEME Design Specifications and Operating Conditions Used in HWVP-15 HWVP-89-IVJ0010100B

\begin{tabular}{|c|c|}
\hline \multicolumn{2}{|c|}{ HEME Design Specifications } \\
\hline $\begin{array}{l}\text { Outside Surface Area } \\
\text { Inside Surface Area } \\
\text { Outside Diameter } \\
\text { Packing Thickness/Fiber Diameter } \\
\text { Inside Layer } \\
\text { Outside Layer } \\
\text { Height } \\
\text { Efficiency for Particles >I jm }\end{array}$ & $\begin{array}{l}20.4 \mathrm{ft}^{2} \\
11.5 \mathrm{ft}^{2} \\
24 \mathrm{in} . \\
0.5 \mathrm{in} . / 30 \mathrm{\mu m} \\
2.5 \mathrm{in} . / 8 \mathrm{\mu m} \\
6.5 \mathrm{ft} . \\
99.9 \%\end{array}$ \\
\hline \multicolumn{2}{|c|}{ HEME Operating Conditions } \\
\hline $\begin{array}{l}\text { Gas Temperature } \\
\text { Gas Superficial } \\
\text { Velocity } \\
\text { Gas Flow Rate } \\
\text { Gas Pressure } \\
\text { Gas Density } \\
\text { Water Content } \\
\text { With Hater Spray off } \\
\text { With Hater Spray On }\end{array}$ & $\begin{array}{l}26{ }^{\circ} \mathrm{C} \\
9.6-15.2 \mathrm{ft} / \mathrm{min} \\
7.4-12 \mathrm{lb} / \mathrm{min} \\
0.9 \mathrm{~atm} \\
0.067-0.07 \mathrm{~Tb} / \mathrm{ft}^{3} \\
0.002-0.004 \mathrm{lb} \text { water } / 1 \mathrm{~b} \\
\text { dry air } \\
0.03-0.05 \mathrm{lb} \text { water } / 7 \mathrm{~b} \\
\text { dry air }\end{array}$ \\
\hline
\end{tabular}




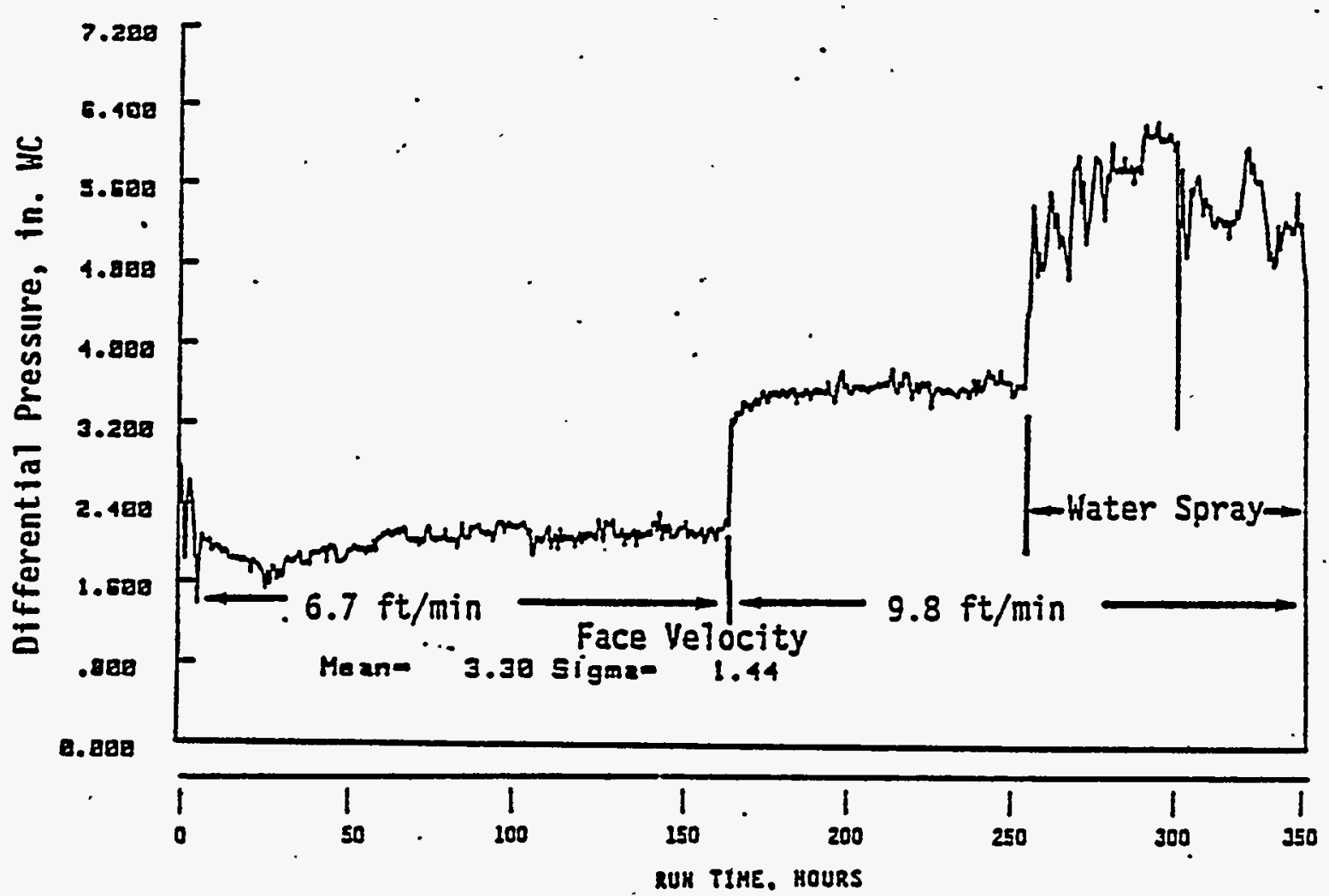

FIGURE 4.6-54. HEME Differential Pressure and Face Velocity HWVP-89-IVJ0010100B

The water collection characteristics of the HEME are graphically displayed in Figures 4.6-56 and 4.6-57. The data in Figure 4.6-56 show that condensate did not drain from the HEME for about a day after the test was initiated, which indicates that the glass fiber bed has about a $20-L$ hold-up capacity. The composition of the fluid that finaliy drained from the HEME during the experiment is shown in Table 4.6-44. The sample at run hour 239 is typical of fluid drained from the HEME when the water spray was not used, and the sample at run hour 335 is typical of fluid drained when the water spray was on. The last sample of HEME solution was taken after all the idling was completed. When the water spray was not on, the $\mathrm{pH}$ of the solution was about 1, which is much lower than the fluid collected from the SBS. The lower $\mathrm{pH}$ value is attributed to the longer contact time of the mist with the gas, which contains an average of $2000 \mathrm{ppm}$ of $\mathrm{NO}_{\mathrm{x}}$ and the other acid gases. When the water spray was used, the $\mathrm{pH}$ of the HEME drain solution increased to above 2 (Figure 4.6-58). This result indicates that the HEME was collecting about the same amount of gas but that the concentration was being diluted by a factor of about 15. The particulate concentrations were al so dilute by a factor around 15 when the water spray was turned on. This indicates there is little if any buildup of particulate in the HEME during HWVP-15. 


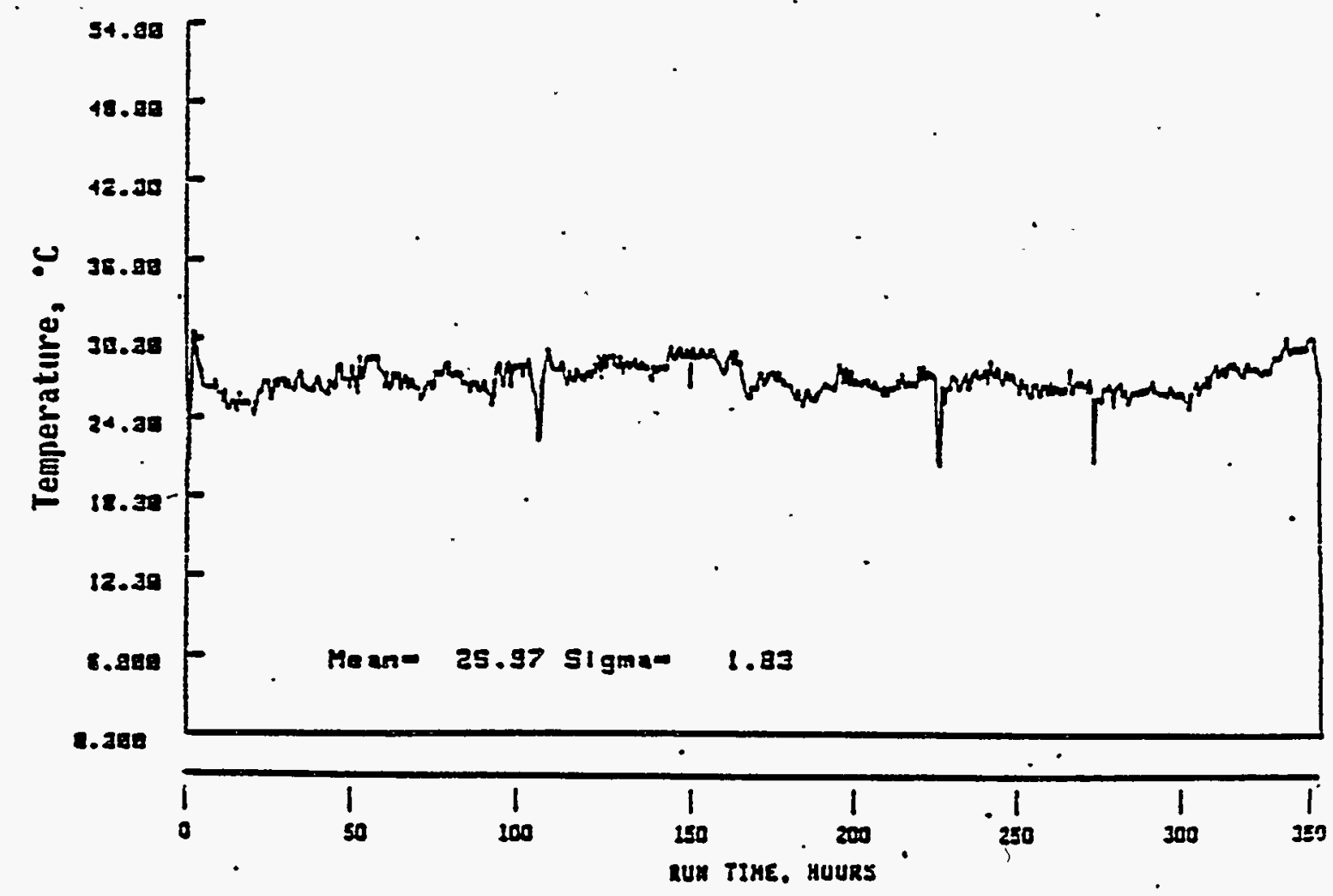

FIGURE 4.6-55. Inlet Temperature to the HEME HWVP-89-IVJ0010100B

4.6.4.9.2.2 Gas Scrubbing Performance. The HEME. is a high-efficiency aerosol removal device; however, when operated wet; the fiber bed provides a huge surface area over which the adsorbed water and reactive process gases are in contact. Consequently, the bed can also act as a gas scrubber for the acid gases of N, F, Cl, P, and $S$. Using the nitrate content of the feed, the measured steady-state composition and drain rate of the HEME and assuming $100 \% \mathrm{NO}_{3}^{-}$to $\mathrm{NO}_{x}$ melter conversion, the average, steady-state $\mathrm{NO}_{x}$ scrubbing efficiency of the HEME was found to be -1\%--the same as that of the SBS. Moreover this removal efficiency was not affected by the large (15X) increase in HEME irrigation rate produced by the auxiliary water spray. Apparentiy, the kinetics. of $\mathrm{NO}_{x}$ removal are being limited by a high $\mathrm{NO} / \mathrm{NO}_{2}$ ratio $\left(\mathrm{NO} / \mathrm{NO}_{2} \approx 2\right)$ and a low partial pressure of $\mathrm{NO}_{2}$.

HEME removal efficiencies for condensible gaseous effluents are summarized in Table 4.6-45. The scatter in these data is a reflection of analytical uncertainties associated with limited sample size. However, the data clearly show that the irrigated HEMEs are capable of interacting and removing gas phase effluent to a significant extent. The lack of available data precludes any assessment of the influence of flow rate upon HEME gas phase scrubbing efficiency. However, HEME aerosol removal efficiency is so high, 


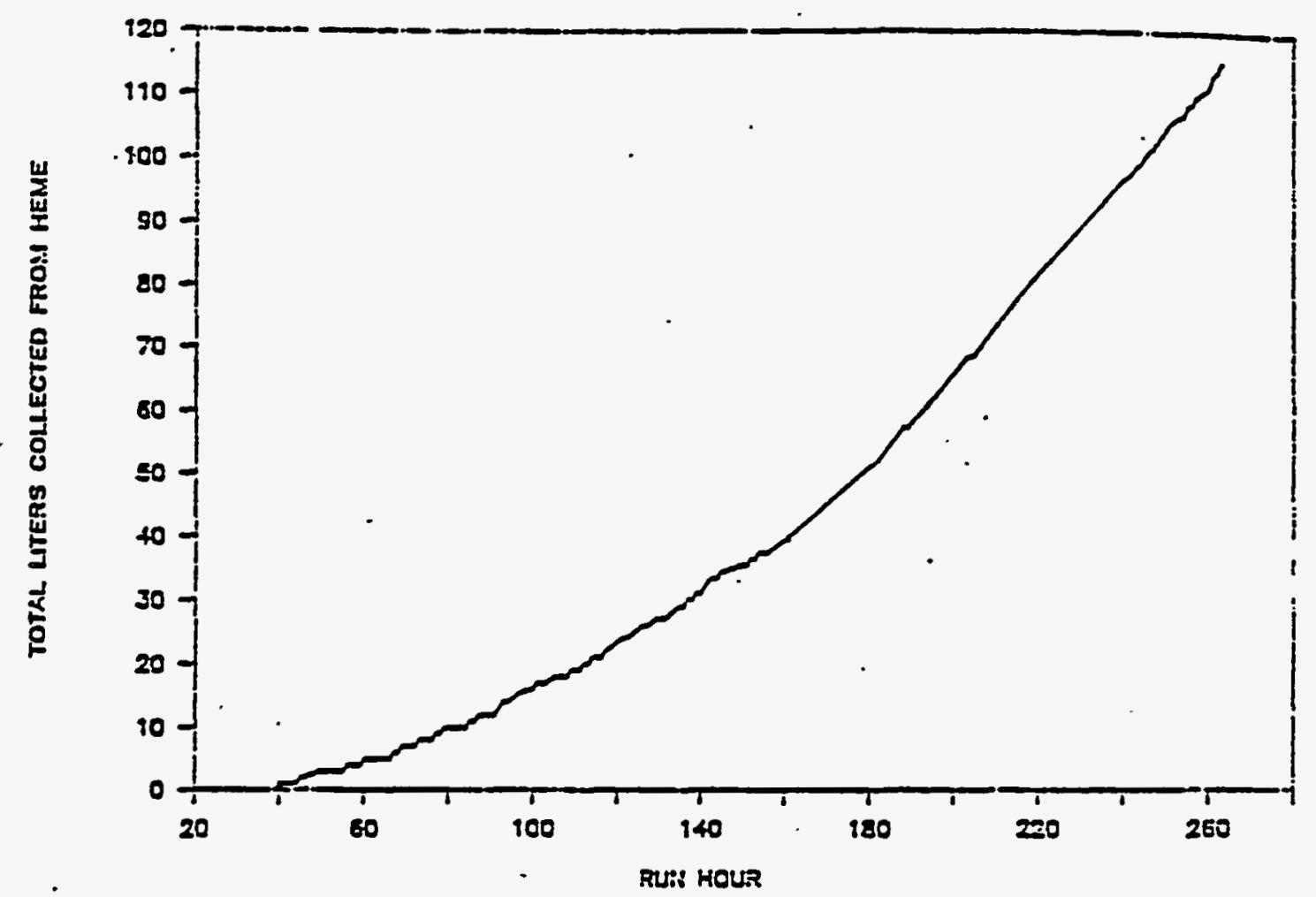

FIGURE 4.6-56. Water Collected from HEME When No Spray Was Used HWVP-89-IVJ0010100B

as discussed in the next section, that all traces of condensed phase material containing $\mathrm{B}, \mathrm{Cl}, \mathrm{F}$, and $\mathrm{S}$ are removed from the HEME process exhaust, as shown in Table 4.6-46. The characteristics of the gaseous volatiles exiting the HEME have not been altered.

4.6.4.9.2.3 Aerosol Scrubbing Efficiency. As discussed previous $7 y$, the primary purpose of the HEME off-gas component is to efficiently remove airborne condensed-phase effluent to extend the service life of downstream HEPA filters. The performance of the HEME, unlike the SBS and chevron demister, is not i imited by aerosol effluent size characteristics nor the physical state of the effiuent. The size distribution of particulate matter at the HEME inlet was determined through use of a cascade impactor, described previously. Aerosol deposits on successive impactor collection stages unequivocally demonstrate the submicron nature of the particulate effluent matter with which the HEME has to interact. This same result was obtained under al1 HWVP-15 operating conditions. Since chevron demisters exhibit relatively high removal efficiencies for mist droplets $>3 \mathrm{~mm}$, the water mist aerosols transmitted to the HEME are presumed to possess diameters $\leq 3 \mu \mathrm{m}$. Consequently, the average effluent characteristics of off-gas aerosols incident upon the HEME during HWVP-15 are found to be composed almost entirely of submicron particulate matter and tiny $(<3 \mu \mathrm{m})$ water aerosols. 


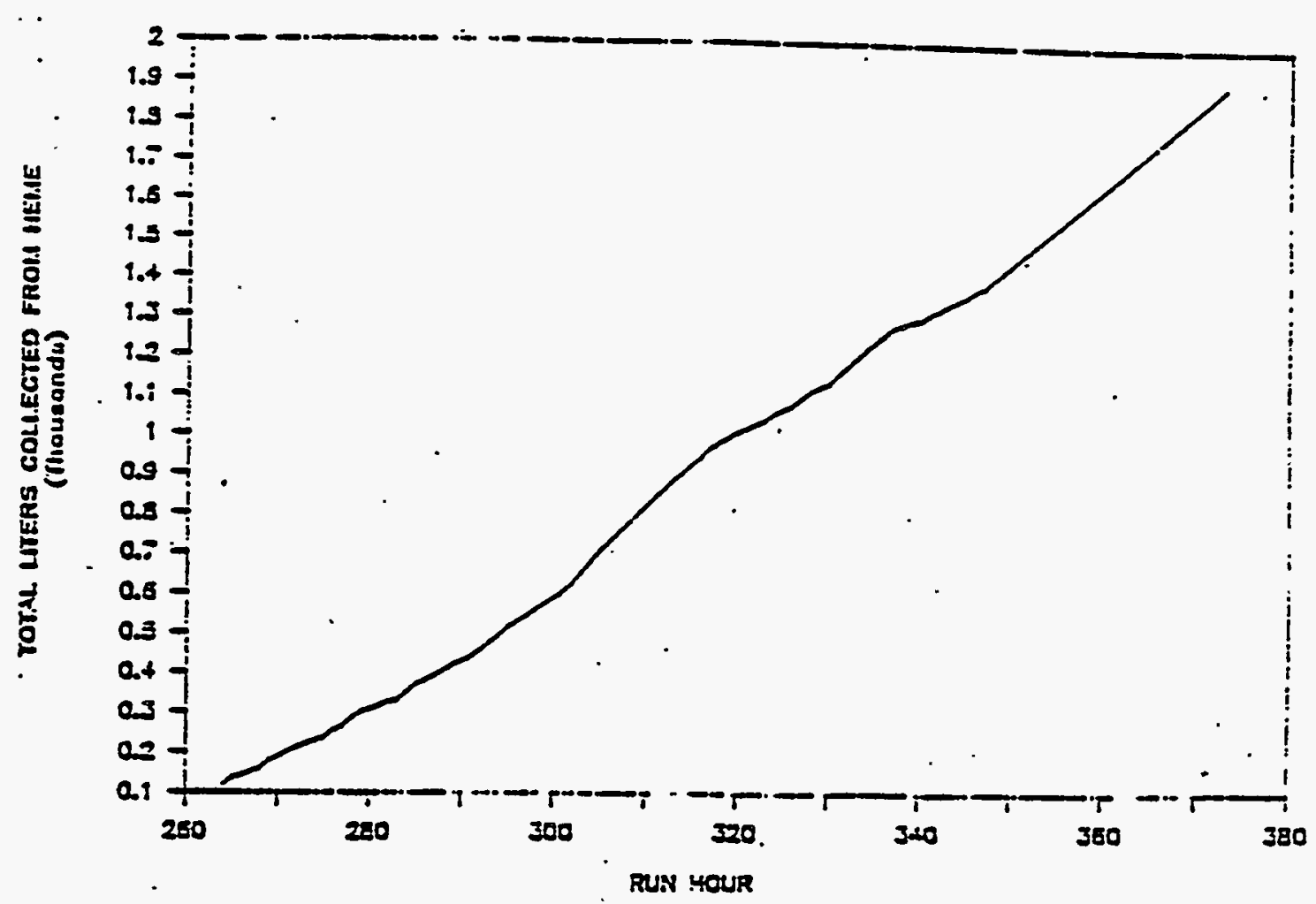

FIGURE 4.6-57. Hater Collected from HEME When Spray Was Used (15 L/h spray) HWVP-89-IVJ0010100B

The number of HEME aerosol mass. DFs derived from HWVP-15 data are significantly less than for the other off-gas devices characterized during this test due to minimum acceptabie sample size. Daily aerosol samples were collected over $-20 \mathrm{~h}$ periods before and after all major off-gas components. Even though HEME samples were collected at maximum possible flow rates for these sampling periods, the collected aerosol samples were massless, i.e., no detectable filter weight change. Consequently, daily samples were combined for chemical analysis. In addition to this, samples collected with the cascade impactor could not be used for performance measurements due to unacceptable impaction stage sample losses. A sumnary of HEME mass DFs are presented in Table 4.6-47 along with similar data obtained from the melter and SBS.

The data in this table reveal that very high HEME DFs were recorded throughout all phases of HWVP-15 testing. The dearth and variability of these data makes it difficult to identify trends. Thus, it is not justifiable to conclude that HEME mass. DFs increased during water spraying, al though individual test results may suggest this. It is also tempting to infer that HEME performance increases during idling, but this conclusion would be based on a single measurement. What can be said is that overall HEME DFs during HWVP-15 were $\geq 400$. This value is in agreement with radioactive measurements 
TABLE 4.6-44. Elemental Concentration of HEME Liquid Drain Stream HWVP-89-IVJ0010100B

\begin{tabular}{|l|c|c|c|c|}
\multicolumn{1}{c|}{} & \multicolumn{5}{|c|}{ Concentration, ppm } \\
\cline { 2 - 5 } Element & at $191 \mathrm{~h}$ & at $293 \mathrm{~h}$ & at $405 \mathrm{~h}$ & at $431 \mathrm{~h}$ \\
\hline $\mathrm{Al}$ & 201 & 384 & 8.47 & 14.5 \\
$\mathrm{~B}$ & 86.1 & 597 & 36.0 & 46.9 \\
$\mathrm{Ca}$ & 3,111 & 639 & 29.8 & 39.6 \\
$\mathrm{Cr}$ & 4.35 & 13.7 & 0.23 & 0.46 \\
$\mathrm{Cu}$ & 2.42 & 14.3 & 0.60 & 1.05 \\
$\mathrm{Fe}$ & 17.7 & 36.0 & 0.59 & 0.86 \\
$\mathrm{~K}$ & 47 & 144 & 5.6 & 8.6 \\
$\mathrm{Li}$ & 8.61 & 65.0 & 2.75 & 4.01 \\
$\mathrm{Mg}$ & 108 & 236 & 10.4 & 15.6 \\
$\mathrm{Mn}$ & 1.56 & 2.84 & 0.04 & 0.07 \\
$\mathrm{Ho}$ & 7.63 & 80.2 & 3.89 & 5.72 \\
$\mathrm{Na}$ & 580 & 2,510 & 93 & 163 \\
$\mathrm{Ni}$ & 1.25 & 3.99 & 0.11 & 19 \\
$\mathrm{Si}$ & 27.6 & 106 & 67.9 & 79 \\
$\mathrm{Sr}$ & 1.42 & 2.49 & 0.13 &.- \\
$\mathrm{Ti}$ & 0.33 & 1.07 & 0.02 & 0.04 \\
$\mathrm{Zn}$ & 0.02 & 14.3 & 0.18 & 0.30 \\
$\mathrm{Zr}$ & 0.46 & 5.05 & 0.23 & 0.67 \\
$\mathrm{Cs}$ & 37.5 & 251 & 12.3 & 22.4 \\
$\mathrm{~F}$ & 26 & 605 & 88 & 98 \\
$\mathrm{Cl}$ & 210 & 1,920 & 120 & 190 \\
$\mathrm{NO}$ & 10,000 & 36,900 & 1,110 & 1,440 \\
$\mathrm{SO}$ & 180 & 10,300 & 60 & 90 \\
\hline
\end{tabular}

made at the Belgium PAMELA facility. (a) The PSCM-23 data is significantly higher (10X) than has been achieved at SRL during similar melter tests, (b) but the off-gas systems are quite different. Uni ike the PAMELA and the HWVP ACD design, the SRL off-gas system uses a high-efficiency scrubbing stage before HEME filtration occurs. The additional scrubbing stage reduces HEME inlet aerosol concentration by more than a factor of 30 . Since HEME influent conditions are so dramatically different for the SRL design, further intercomparisons of HWVP-15 and SRL HEME performance data are not justifiable and wiTl not be made.

(a) Stehle, M. Karlsrhue Nuclear Research Center, Federal Republic of Germany, private communications.

(b) W. P. Colven, Off-Gas System Data Summary for the Ninth Run of the Large Slurry-Fed Melter. DPST-83-809, Savannah River Laboratory, Aiken, South Carolina. 


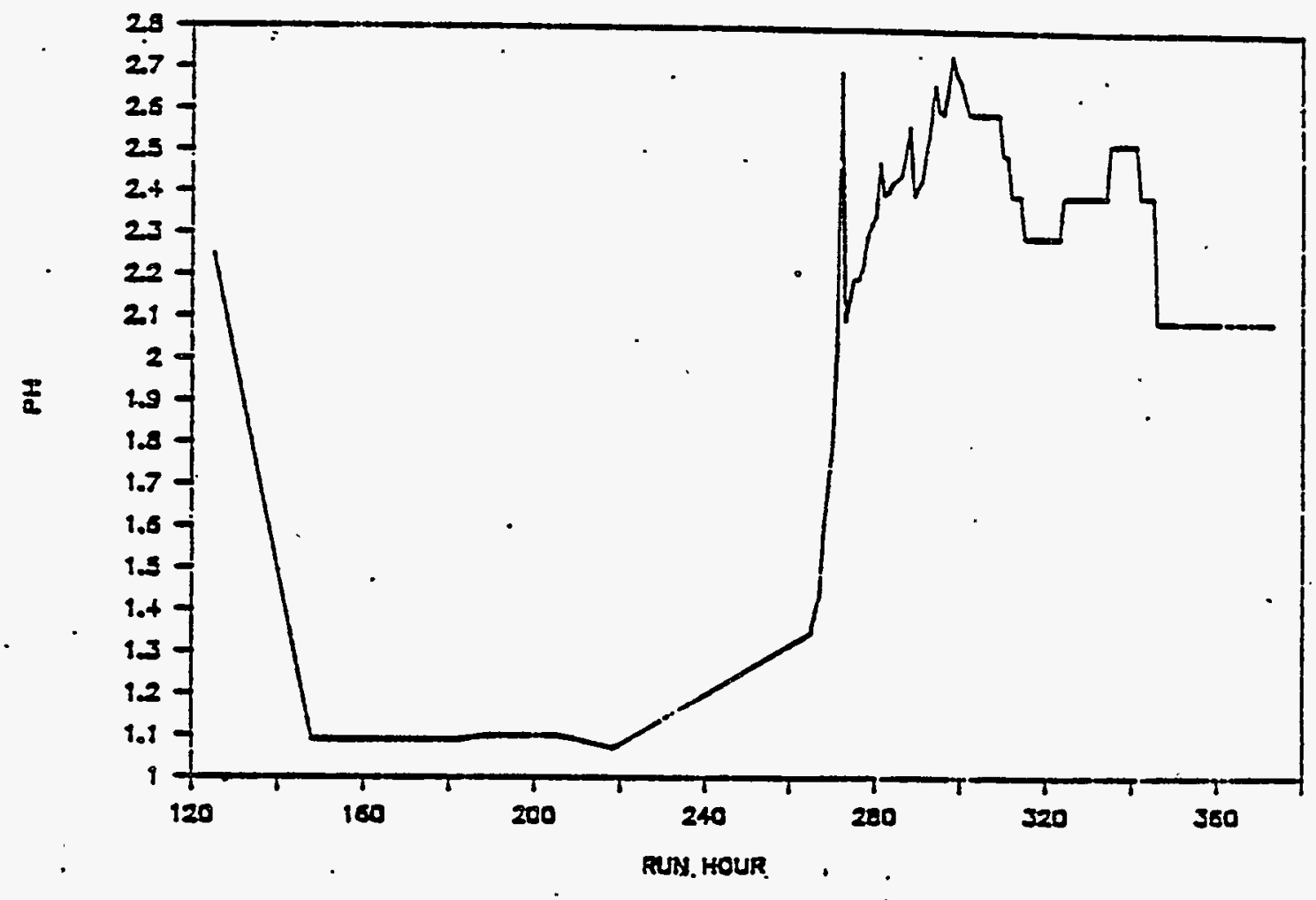

FIGURE 4.6-58. $\mathrm{PH}$ of HEME FTuid HWVP-89-IVJ0010100B

TABLE 4.6-45. Gaseous HEME Decontamination Factors HWVP-89-IVJ0010100B

\begin{tabular}{|c|c|c|c|c|}
\cline { 2 - 5 } \multicolumn{1}{c|}{} & \multicolumn{4}{|c|}{ HEME Gaseous DFs } \\
\hline & $6 / 6 / 88$ & $6 / 9 / 88$ & $6 / 17 / 88$ & $6 / 21 / 88$ \\
Element & $2110 \mathrm{~h}$ & $1240 \mathrm{~h}$ & $1110 \mathrm{~h}$ & $0217 \mathrm{~h}$ \\
\hline B & 6.5 & 57 & 260 & 29 \\
C7 & 19 & 19 & 96 & 66 \\
F & 4.2 & 75 & 40 & 18 \\
P & 1 & -- & -- & -- \\
S & 2.5 & 4.4 & -- & - \\
\hline
\end{tabular}


TABLE 6.4-46. . HEME Effluent Losses for Condensib7e Gas Phase Effluent HHVP-89-IVJ0010100B

\begin{tabular}{|c|c|c|c|c|c|}
\hline & \multicolumn{4}{|c|}{ \% Losses Due to Gaseous Escape } \\
\hline Day & B & CT & F & P & S \\
\hline 6 & -- & 99 & 100 & -- & 100 \\
9 & 91 & 72 & 85 & -- & 99 \\
13 & -- & 88 & 100 & -- & -- \\
17 & -- & 99 & 100 & -- & -- \\
21 & 100 & 98 & 100 & -- & -- \\
\hline
\end{tabular}

TABLE 4-6-47. Melter and Off-Gas Component Aerosol Mass Decontamination Factors HWVP-89-IVJ0010100B

\begin{tabular}{|c|c|c|c|c|c|c|}
\hline \multirow{2}{*}{$\begin{array}{r}\text { Mo/ } \\
\text { Day } \\
\end{array}$} & \multirow{2}{*}{$\begin{array}{c}\text { Mejter } \\
\text { Condition }\end{array}$} & \multirow{2}{*}{$\begin{array}{l}\text { MOG Flow, } \\
\text { scfm }\end{array}$} & \multirow{2}{*}{$\begin{array}{c}\text { HEME Spray, } \\
\text { L/h } \\
\end{array}$} & \multicolumn{3}{|c|}{ DF } \\
\hline & & & & Melter & $\underline{S B S}$ & HEME \\
\hline $6 / 6$ & Processing & 110 & 0 & 410 & 79 & \\
\hline $6 / 7$ & Processing. & 110 & 0 & $490^{\circ}$ & 39 & 1700 \\
\hline $6 / 8$ & Procéssing & 110 & 0 & 1800 & 14 & \\
\hline $6 / 9$ & Processing & 110 & 0 & 1400 & 7.6 & \\
\hline $6 / 10$ & Processing & 110 & 0 & 1500 & 8.0 & 340 \\
\hline $6 / 11$ & Processing & 110 & 0 & 31600 & 14 & 2400 \\
\hline $6 / 12$ & Processing & 110 & 0 & .1000 & 14 & 2400 \\
\hline $6 / 13$ & Processing & 170 & 0 & 1400 & 7.6 & 780 \\
\hline $6 / 14$ & Processing & 170 & 0 & 1500 & 4.7 & \\
\hline $6 / 15$ & Processing & 170 & 0 & 1200 & -- & -- \\
\hline $6 / 16$ & Processing & 170 & 0 & 1400 & 5.5 & -. \\
\hline $6 / 17$ & Processing & 170 & 15 & 1400 & 5.6 . & 1700 \\
\hline $6 / 18$ & Processing & 170 & 15 & 1800 & 5.1, & \\
\hline $6 / 19$ & Processing & 170 & 15 & 1400 & -- & 1500 \\
\hline $6 / 20$ & Processing & 170 & 15 & 640 & 9.2 & \\
\hline $6 / 21$ & Idling. & 90 & 0 & -- & 4.67 & \\
\hline $6 / 22$ & Id]ing & 90 & 0 & -- & -- & \\
\hline $6 / 23$ & Idling & 90 & 0 & -- & 4.5 & 7500 \\
\hline $6 / 24$ & IdTing & 90 & 0 & -- & & (100 \\
\hline $6 / 25$ & Idling & 90 & 0 & -- & 2.0 & \\
\hline $6 / 26$ & Idling & 90 & 0 & $\cdots$ & & \\
\hline Aver & Steady Stat & Processing & & 1500 & 7.4 & 1400 \\
\hline
\end{tabular}


HEME parametric tests were also. performed at PNL in FY 1987 and FY 1988 prior to the HWVP-15 to examine the decontamination abilities of the HEME under various operating conditions. The effect of water loading and off-gas flow rate were of primary interest and can be compared to HWVP-15 results. The variabie ranges in the parametric tests were as follows:

$\begin{array}{ll}\frac{\text { Variable }}{\text { Air Flow }} & \frac{\text { Range }}{50-250 \mathrm{scfm}} \\ \text { Water Spray } & 0-500 \mathrm{~mL} / \mathrm{min} \\ \text { Inlet Temperature } & 20-70 . \mathrm{C}\end{array}$

Based on a statistical examination of the data it was determined that the variability in the DF data were dependent on the magnitude of the DFs. In the discussion that follows, statistical significance is defined at the $95 \%$ confidence level. The resuits of the tests performed at room temperature are shown in Figures 4.6-59 and 4.6-60. Aerosols of $\mathrm{NaCl}$ and $\mathrm{TiO}_{2}$ were used for tests. The tests results shown in Figure 4.6-59 indicate the water spray rate did have a significant effect on the DF. The results showed that a water spray rate of about $50 \mathrm{~mL} / \mathrm{min}$. provided a better DF than the high water spray rate or no water spray. The water spray rates used during the PSCM experiment would be most comparable to the $50 \mathrm{~mL} / \mathrm{min}$ water flow rate. The . parametric and melter test results indicate the water loading in the off-gas

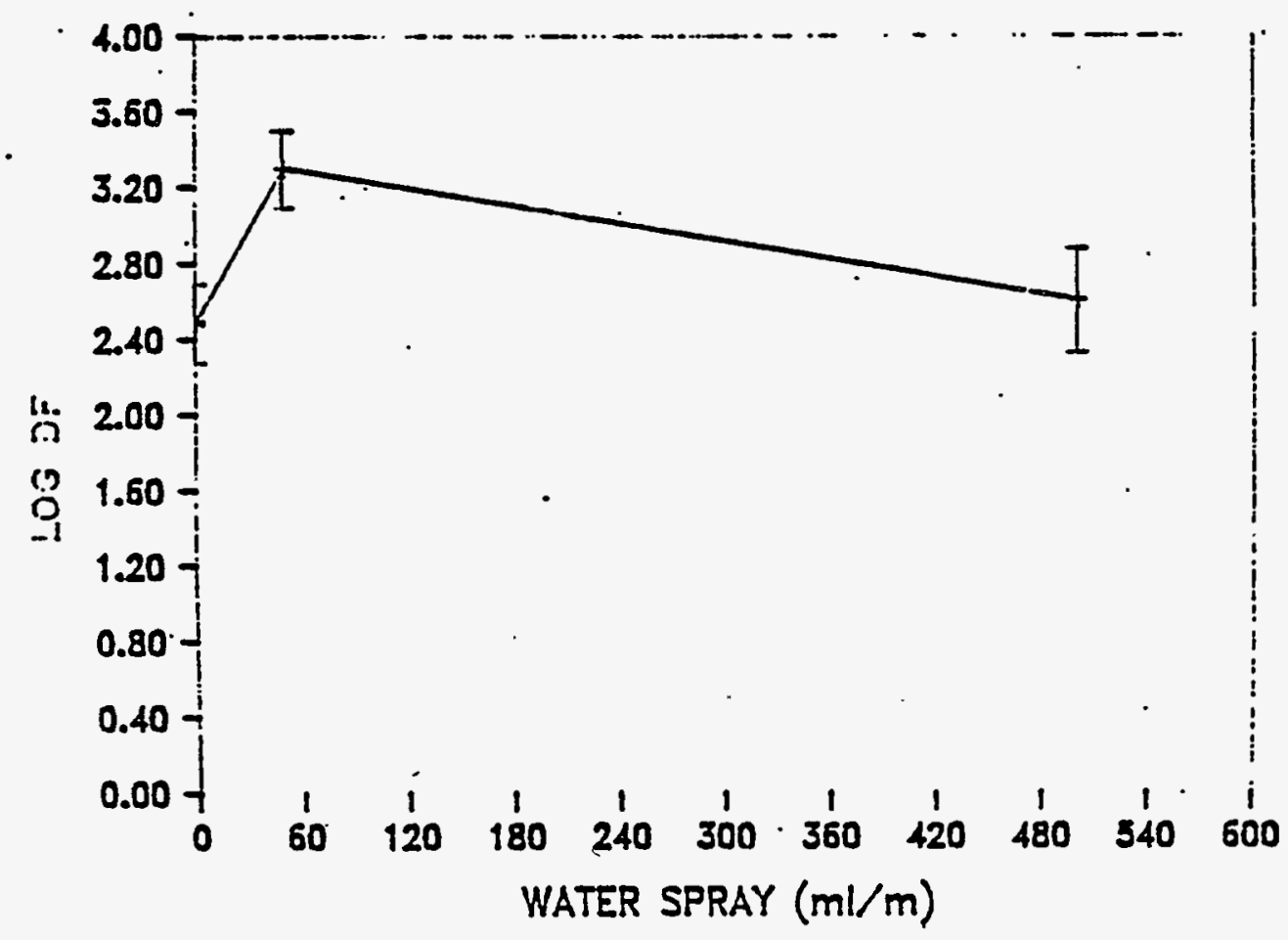

FIGURE 4-6-59. Effect of Inlet Water Spray on HEME Performance HWVP-89-IVJ0010100B 


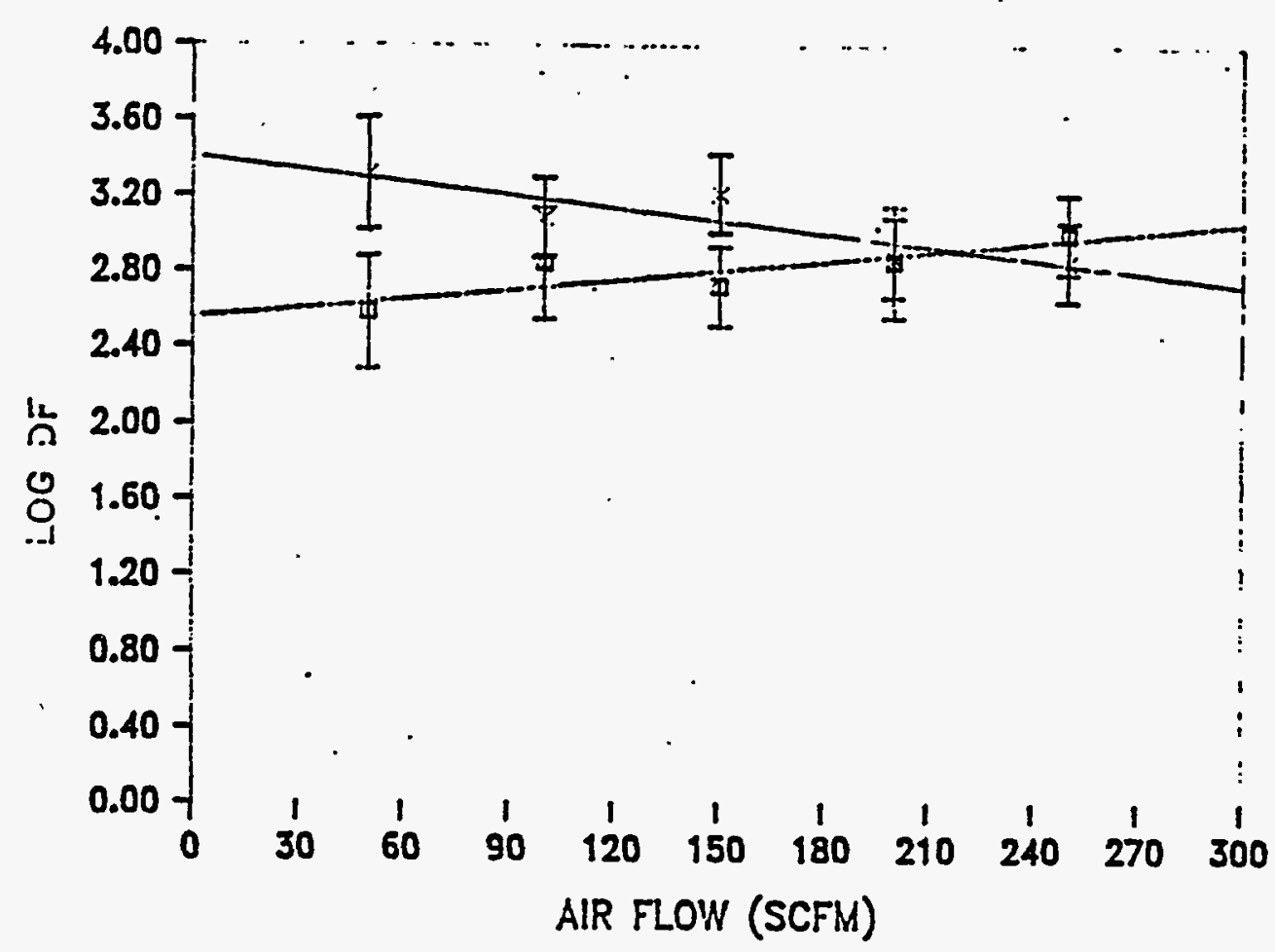

FIGURE 4.6-60. Effect of Air Flow on HEME Performance HWVP-89-IVJ0010100B

stream entering the HWVP HEME should be within the range used during PSCM-23. Significantly higher or lower rates would provide a decrease in performance.

The parametric test results also show that for the ranges tested, the gas flow. rate did not have a significant effect on the DF (Figure 4.6-60). This is in agreement with HWVP-15 test results (see Table 4.6-47). The test data is also supported by literature data (Figure 4.6-61). Figure 4.6-61 shows the relationship between the superficial gas velocity, pressure drop and collection efficiency. For the pressure drop range observed during HWVP-15 of 2 to 4 in. WC the collection efficiency varies less than $1 \%$. This low variability is well within the parametric and HWVP-15 test data variability. The commercial data compared the changes in pressure drop versus efficiency (see Figure 4.6-61).

The aerosol scrubbing performance of the HEME for individual effluent elements is presented in Table 4.6-48. Like the mass DFs discussed above, HEME elemental DFs are consistently high, but also quite variable. With few exceptions, the highest HEME DFs occurred at the beginning of the test when the filter was free of effluents. Most DFs decreased and leveled out at quite acceptable values by the middle of the test. Since most of the semivolatiles behaved in this manner and since these elements are major components of the sub-micron particulate matter being transmitted to the HEME as 


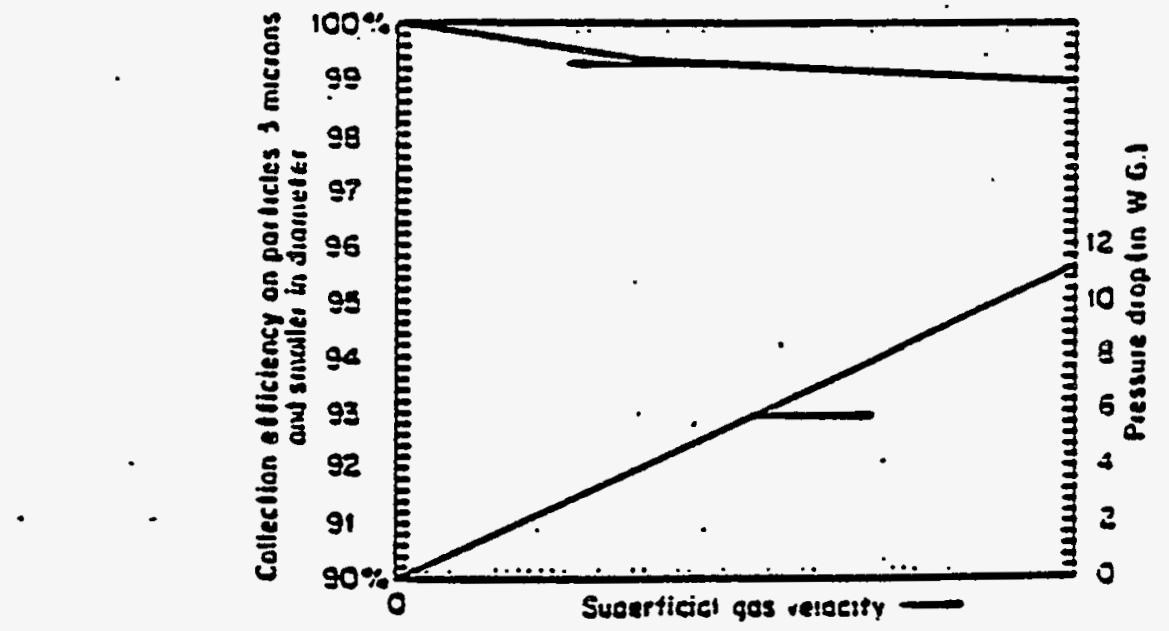

FIGURE 4.6-61. Collection Efficiency and Pressure Drop of a Fiber - Mist Eliminator as a Function of Gas Velocity Through Fiber Packing (Perry and Chilton 1973 cited in HWVP-89-IVJ0010100B)

shown preyiously, this trend is probably real. Assuming that all HEME surfaces were passivated midway through the test, essentiaily all important effluent elements exhibited DF. $>200$ : This conclusion is in agreement with experimental data collected both at the Japanese PNC facility and at the Belgium PAMELA plant. The low HEME performance values for Al, $\mathrm{Fe}$, and $\mathrm{Si}$ are believed to result from the filter's fiber glass material, which contributes to HEME exhaust concentrations of these elements.

The HEME performance values measured during HWWP-15 do not compare well with data obtained from the previous HWVP-12 test. Present performance values are at least an order of magnitude greater than was achieved during HWVP-12. Superficial face velocity was the only significant operating condition that differed in the two tests. The face velocity used during HWVP-15 was 6 to $10 \mathrm{ft} /$ min a factor of 4 to 8 smaller than previous conditions. It is postulated that the low HWVP-12 DFs resulted from reentrainment of previousiy captured effluents that penetrated the filter element by solution transport. Apparentiy, this supposition was correct; there was no indication that such an effect was occurring during HWVP-15 as evidenced by the comparatively high DFs achieved. The contrasting results obtained during these sequential tests emphasize the need to over-design the size of process HEMEs so as to compensate for any subsequent increases in off-gas' system (inleakage) flow.

Definitive assessments concerning the effects of off-gas flow, off-gas moisture loading, and idling upon HEME performance cannot be made due to the variable nature of the limited data available. However, all of the data taken together do illustrate that extremely high HEME DFs are achievable under all the conditions tested during HWVP-15. 
TABLE 4.6-48. Individual Element Decontamination Factors for HEME Aerosol HWVP-89-IVJ0010100B

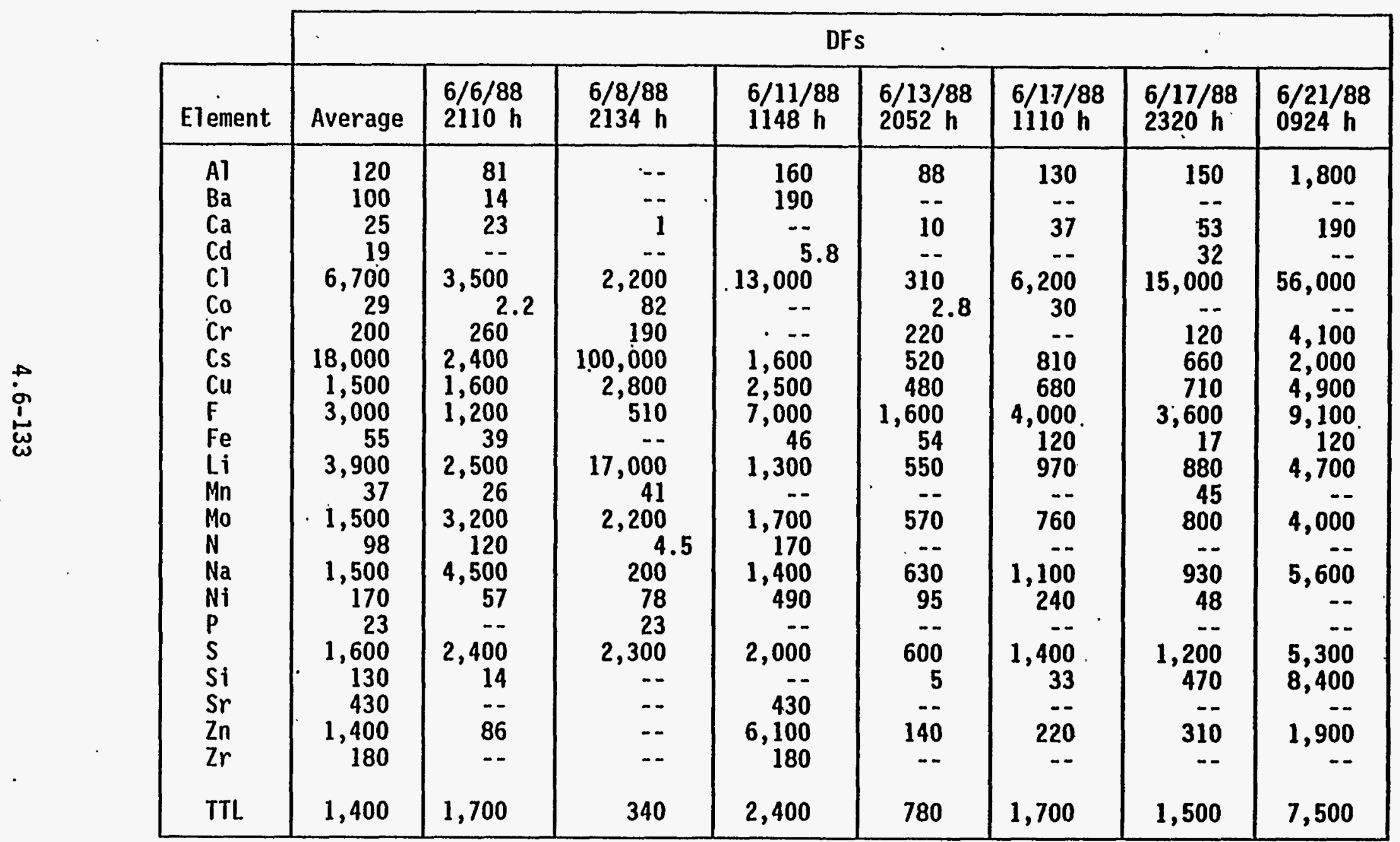


4.6.4.9.2.4 Total DFs. Total performance calculations need to be performed for $B, C 7$; F, P, and $S$ since these elements are present in both gaseous and condensed. phase process effiuents. Table 4.6-49 summarizes the results of these calculations. Because most of the mass of these effluents is carried by gaseous compounds, gaseous interactions will 1 imit and determine HEME DFs for these elements. The data in Table 4.6-49 confirm earlier observations that HEMEs exhibit significant gas phase effluent removal efficiency. Moreover, the magnitude of these DFs are at least as great as corresponding SBS DFs previously discussed.

TABLE 4.6-49. HEME Total Decontamination Factors HWVP-89-IVJ0010100B

\begin{tabular}{|c|c|c|c|c|c|}
\hline Element & $\begin{array}{l}6 / 6 / 88 \\
2110 \mathrm{~h}\end{array}$ & $\begin{array}{l}6 / 9 / 88 \\
1240 \mathrm{~h}\end{array}$ & $\begin{array}{l}6 / 11 / 88 \\
1148 \mathrm{~h}\end{array}$ & $\begin{array}{l}6 / 17 / 88 \\
1100 \mathrm{~h}\end{array}$ & $\begin{array}{l}6 / 21 / 88 \\
027 \mathrm{~h}\end{array}$ \\
\hline $\begin{array}{l}B \\
C 7 \\
F \\
P \\
S\end{array}$ & $\begin{array}{l}8.7 \\
65 \\
4.9 \\
1 \\
6.6\end{array}$ & $\begin{array}{c}68 \\
38 \\
72 \\
7.9 \\
38\end{array}$ & $\begin{array}{c}71 \\
17 \\
69 \\
-- \\
2500\end{array}$ & $\begin{array}{r}310 \\
170 \\
45 \\
-- \\
1600\end{array}$ & $\begin{array}{r}35 \\
400 \\
22 \\
-- \\
2300\end{array}$ \\
\hline
\end{tabular}


4.6.4.10 Ruthenium Adsorber - Nonreference. The function of the ruthenium sorber is to reduce concentrations of gas-phase Ru in the melter off gas.

4.6.4.10.1 Properties of Gaseous Ruthenium Effluents. (a) A significant. fraction of the total RU lost to LFCM off-gas systems during vitrification can be attributable to a gas-phase loss mechanism. This mechanism occurs only under strongly oxidizing conditions within the melter (Ref. 4.6-15). As an . example, simulated neutralized SRL reference waste was found to produced a melter glass and associated plenum conditions that were very conducive to gaseous Ru generation and high resultant off-gas system losses. With the introduction of formic acid to the SRL waste stream flow sheet, gaseous Ru effluent losses ceased, and overall Ru melter releases were difficult to measure (Ref. 4.6-15). The strong functional dependence of Ru volatility on the oxidizing conditions has also been observed and characterized during waste calcination (Ref. 4.6-16, -17,-18). However, significantly different volatile species of ruthenium are generated by these somewhat similar high-temperature immobilization processes. These differences affect off-gas processing requi rements.

There are three major forms or classes ruthenium compounds that are postulated in the literature to be responsible for the ruthenium volatility produced by high-temperature processes (Ref. $4.6-16,-17,-18,-19$ ). These are:

- ruthenium tetraoxide

- ruthenium nitrosyl compounds

- ruthenium fluoride and/or oxy-fluoride compounds

The relative importance of these potentially gaseous effluents depends most directly on waste composition and temperature. Under the thermal conditions normally associated with vitrification, the formation of ruthenium tetraoxide is apparently thermodynamically favored over formation of gaseous nitrosyl compounds, whereas the reverse is true for fluidized bed calcining conditions. Moreover, the instability of Ru04 and the kinetics for its conversion to $\mathrm{RuO}_{2}$ can be used to explain the apparent nonpenetrating nature of gaseous Ru in LFCM off-gas processing systems (Ref. 4.6-20). At PNL, no gasphase Ru has been detected downstream of LFCM quench scrubbers (DF>100). The persistence of gaseous Ru in the exhaust of fluidized bed calciners suggests that other, very different volatile forms of Ru (ritrosyl compounds) are being. generated (Ref. 4.6-20).

(a) R. W. Goles and C. M. Andersen, HWVP Melter Off-Gas System Evaluation, HWVP-87-V110305A, Pacific Northwest Laboratory, Richland, WA (May 1987). 
Similarly, fluorine in calciner waste feed streams has been shown to dramatically increase fluidized bed volatility losses, prompting speculation that gaseous fluoro complexes of ruthenium may be responsible (Ref. 4.6-19). Analogous affects have not been observed accompanying the vitrification of fluoride-bearing waste under either oxidizing or reducing conditions. $(a, b)$ Consequently, it appears that the empirical bases for establishing calcination process exhaust requirements are quite different from those associated with vitrification. With this conclusion, it is difficult to justify the need for a gaseous Ru sorption bed in LFCM applications.

Recognition and acceptance of these differences prompted operators of the Pamela Plant in Mol, Belgium, to eliminate ruthenium sorption beds from their LFCM's off-gas processing system (Ref 4.6-20). The Pamela Plant has since processed radioactive waste containing $64 \mathrm{kgs}$ of ruthenium and have demonstrated that gaseous ruthenium is not a persistent off-gas effluent that requires special processing conditions or equipment (b).

The Pamela Plant experiences are very important in evaluating the processing needs of the HWVP MOG system. Fron a volatility standpoint, the low enriched waste concentrate (LEHC) processed at the Pamela Vitrification Plant represents a worst-case situation. The waste was highly nitrated $\left(2 \mathrm{M} \mathrm{HNO}_{3}\right)$, contained significant quantities of fluorine $(2.7 \mathrm{~g} / \mathrm{L})$, and it was very oxidizing (no organic additives). Consequently, all proposed gaseous forms of ruthenium could in principle be generated by this feed during vitrification. Apparently, only the unstable $\mathrm{RuO}_{4}$ was actually. produced, and it had no direct impact on off-gas processing needs.

The HWWP waste is also nitrated, contains significant fluoride concentrations, but is not strongly oxidizing because of the formic acid feed stream additive. However, organic feed additives have been shown to dramatically suppress all forms of Ru volatility associated with high-temperature solidification processes (Ref. 4.5-16,-17,-18). Consequently, specialized Ru sorption devices are less justifiable for HWVP than they are for the Pamela facility.

Experience suggests that the HWVP process would produce very little gaseous $R u$, and very little of this would remain gaseous for lang. Consequentiy, the $R \dot{u}$ sorption bed in the reference HWVP MOG system would not be expected to contribute significantly to melter off-gas decontamination.

(a) R. K. Nakaoka. Pilot-Scale Ceramic Melter Test Run Summary HWVP-12/ PSCM-22. HWVP-86-V1124A, Pacific Northwest Laboratory, Richland, Washington (1985).

(b) M. Stehle. Karlsrhue Nuclear Research Center, Federal Republic of Germany, Private Communications. 
4.6.4.10.2 Methods for Removal of Ruthenium from Gas Streams. Hansen et a1. (Ref. 4.6-21) performed early work on Ru sorption onto silica gel and obtained DFs of 1000. Newby and Barnes (Ref. 4.6-22) evaluated a number of Ru adsorber materials for a fluidized-bed system, which calcined $6 \mathrm{MHNO}_{3}$ waste solutions. Silica gel, hydrous zirconium oxide, and ferric oxide were found to provide DFs of 1000 or greater. Silica gel was selected for use because of its regenerability and low-temperature operability.

Klein et al. (Ref. 4.6-23) studied volatilization and gas phase removal of Ru during calcination of nitric acid solutions. In a series of experiments, Ru was introduced to the gas stream' in different ways, as shown in Figure 4.5-62. The $\mathrm{RuO}_{4}$ generator utilizes a reaction of $\mathrm{RuCl}_{3}$ with $\mathrm{KIO}_{4}$ in a sulfuric acid solvent to produce $\mathrm{RuO}_{4}$ gas. When $\mathrm{RuO}_{4}$ is mixed with $\mathrm{NO}_{x}$ vapors from the calciner (Case 3), it was determined that a gas phase reaction occurs between $\mathrm{RuO}_{4}$ and $\mathrm{NO}_{x}$ to form a less volatile compound (perhaps a Ru nitrosyl complex).

When $\mathrm{RuO}_{4}$ in dry air was fed to a silica gel sorber (Case 1), a DF of greater than 1000 was obtained, with a silica gel absorption capacity of $1 \mathrm{mg}$ $\mathrm{Ru} / \mathrm{g}$ sorbent. The bed temperature was $20^{\circ} \mathrm{C}$ and the inlet $\mathrm{RuO}_{4}$ concentration was $00 \mathrm{mg} / \mathrm{m}^{3}$. The absorption capacity was found to increase linearly with gaseous $\mathrm{RuO}_{4}$ concentration and decrease with adsorption temperature, thus following the Arrhenius model with a heat of adsorption equal to $29 \mathrm{~kJ} / \mathrm{mole}$.

Cases I and II RuQ 4 With Dry or Morst Alr

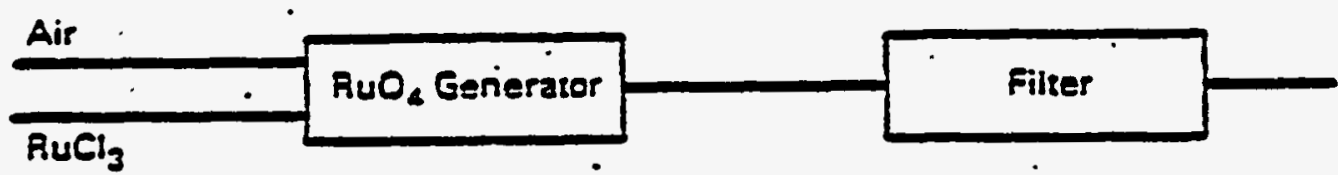

Case III RuQ. Fad at Outlet of Caleiner and Mixed Wirh NOX

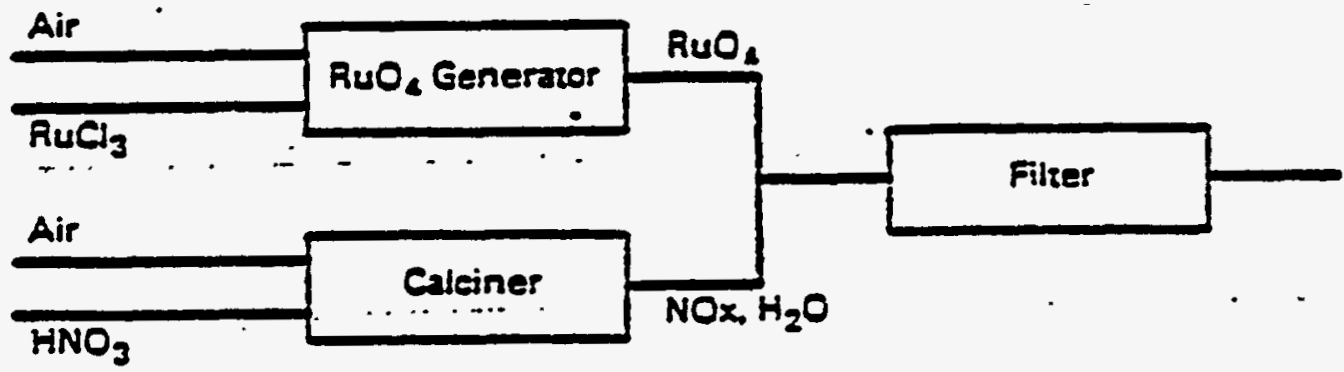

FIGURE 4.6-62. Description of the Experimental System Used by Klein et al. (Ref. 4.6-18) 
Adsorption of $\mathrm{RuO}_{4}$ on silica gel in a moist carrier gas (Case 2) was much ess efficient than in the dry gas. Dew points from 15 to $80^{\circ} \mathrm{C}$ were studied. (The adsorbent bed must work at a.temperature higher than the dew point to avoid condensation.) The combined influences of higher bed temperature 122 to $212^{\circ} \mathrm{F}$ (50 to $100^{\circ} \mathrm{C}$ ) and competition of adsorption sites between $\mathrm{RuO}_{4}$ and $\mathrm{H}_{2} \mathrm{O}$ resulted in rapid bed saturation and a DF which fell to 1.0 after a brief operating period.

When $\mathrm{RuO}_{4}$ was mixed with calciner emissions ( $\mathrm{NO}_{x}$ and $\mathrm{H}_{2} \mathrm{O}$, see Case 3 ), OFs higher than 100 were obtained when the bed was held at $212^{\circ} \mathrm{F}\left(100^{\circ} \mathrm{C}\right)$. No bed saturation was observed during the test.

In another set of experiments, Klein et al. (Ref. 4.6-23) studied calcination of $3.5 \mathrm{M}$ nitric acid containing ruthenium nitrosyl nitrate $\left[\mathrm{RuNO}\left(\mathrm{NO}_{3}\right) \times \mathrm{OH}_{3}\right.$ ] spiked to $50 \mathrm{mg} / \mathrm{L}$. It was found that adsorbers did not work when placed after a condenser which treated calciner effiuents; evidently only Ru aerosols were present at the condenser discharge. Adsorbents performed only when placed directly at the calciner exit. Two types of silica gel, two types of molecular sieves, and $\mathrm{SiO}_{2} / \mathrm{Al}_{2} \mathrm{O}_{3}$ with ferric-oxide/chromium oxide deposits were tested. For all adsorbents, similar DFs were found, in the range of 10 to 100 . Capacities were not determined because none of the beds were saturated. The molecular sieve materials (Zeolon $900 \mathrm{H}$ and UC13X) were more resistant to water condensation than the silica gels. Klein et al. stated that on the basis of their tests, the molecular sieve materials are preferable to the silica gels for Ru adsorption. Several catalysts were tested by klein et al. for removal of volatile ruthenium: metal oxides on a Si/Al support; Zeolon $900 \mathrm{H}$ impregnated with $\mathrm{RuO}_{2}, \mathrm{Fe}_{2} \mathrm{O}_{3}$, or $\mathrm{Cr}_{2} \mathrm{O}_{3}$; and various commercial catalysts. The optimal bed temperature was $570^{\circ} \mathrm{F}\left(300^{\circ} \mathrm{C}\right)$ for most catalysts. DFs were in the range of 2 to 10 for metal oxide and Zeolon $900 \mathrm{H}$ catalysts, and 10 to 100 for the commercial catalysts.

The early work reported by Newby and Barnes (Ref. 4.6-22) showed that silica gel is effective for ruthenium capture under conditions where its gas concentration is high $\left(\geq 1 \mathrm{mg} / \mathrm{m}^{3}\right)$ and the gas stream is dry. Once loaded, silica gel beds have a tendency to desorb Ru when subjected to process gas with reduced Ru concentration. These conditions would occur, for example, during down-time periods or during process feed fluctuations. The loss of Ru is attributed to desorption of physisorbed species, perhaps RuO 4 . Additionally, the DF performance of silica gel is found by these researchers to suffer markedly at $\mathrm{Ru}$ concentrations of less than $0.5 \mathrm{mg} / \mathrm{m}^{3}$.

Screening tests on alternative capture media have been performed using transition metal catalysts. The intent is catalysis of the reaction of $\mathrm{RuO}_{4}$ to the more stable, solid form, $\mathrm{RuO}_{2}$. In separate tests, Cain and Yewer (Ref. 4.6-24) studied oxides of $\mathrm{Fe}, \mathrm{Ni}, \mathrm{V}, \mathrm{Cr}, \mathrm{Cu}, \mathrm{Zn}, \mathrm{Mo}, \mathrm{Co}$, and $\mathrm{lin}$ doped 
individually onto alumina supports and also silicated iron oxide, and Ru metal on alumina support. A packed bed $5.8 \mathrm{~cm}$ in diameter by $50 \mathrm{~cm}$ long was operated at $660^{\circ} \mathrm{F}\left(350^{\circ} \mathrm{C}\right)$ for the tests. A calciner pot was used to volatilize Ru at $750^{\circ} \mathrm{F}\left(400^{\circ} \mathrm{C}\right.$ ) from a solution of $10 \mathrm{mg} / \mathrm{L} \mathrm{Ru}$ (as a nitrosyl/ruthenium complex) and $8 M$ nitric acid. The most promising catalysts were zinc oxide, Ru metal, nickel (II) oxide, and chromium (III) oxide on alumina supports. Decontamination factors for Ru ranged from 400 to 2500 for these candidates and suitable retention characteristics were indicated. Because of the preliminary nature of Cain and Yewer's study, it appears that further investigation is needed before these materials can be deployed in LFCM off-gas systems.

Extensive work on adsorption of volatile ruthenium has been reported by Newby and Barnes (Ref. 4.6-22). Their objective was identification of the best sorbent or removing Ru from calciner off gas. On a laboratory scale, they produced a gas stream by volatilizing a nitric acid solution at $750^{\circ} \mathrm{F}\left(400^{\circ} \mathrm{C}\right)$ that contained either ruthenium nitrate or trichloride. The off gas contained about $3 \% \mathrm{NO}_{\mathrm{X}}$. The two most promising sorbents were silica gel and ferric oxide.

Silica gel beds operating at just above the dew point gave DFs ranging from 100 up to 3000 . The DF rapidly falls as the sorption bed reaches its capacity, which is found to be about $130 \mathrm{~g}$ Ru/cubic ft of 12 to 40 mesh silica if the superficial vapor velocity is held to $0.4 \mathrm{ft} / \mathrm{s}$ or less. Increasing the velocity to $0.7 \mathrm{ft} / \mathrm{s}$ dramatically lowers the capacity to $0.08 \mathrm{~g} /$ cubic $\mathrm{ft}$. Doubling the column height from 26 to 52 in. Was found to raise the DF by a factor of 10 .

Another sorbent found effective by Newby and Barnes is ferric oxide. The sorption capacity and DF performance is comparable to or greater than that of silica gel. To be effective, the bed must be operated in a temperature range between 570 and $1020^{\circ} \mathrm{F}\left(300\right.$ and $\left.550^{\circ} \mathrm{C}\right)$. In Newby and Barnes' work, most of the data were collected at $750^{\circ} \mathrm{F}\left(400^{\circ} \mathrm{C}\right)$. Increasing the bed superficial velocity from 0.4 to $1.3 \mathrm{ft} / \mathrm{s}$ lowered the bed capacity from. 136 to $0.15 \mathrm{~g} \mathrm{Ru} /$ cubic ft. As with the silica gel bed, doubling the column height increased the DF by a factor of 10 .

4.6.4.11 lodine Adsorber. The design function of this MOG component device is to remove gaseous forms of iodine. 
4.6.4.11.1 Properties of Gaseous Iodine Effluents. (a) Liquid-Fed Ceramic Meiter (LFCII) processing conditions can produce a variety of I compounds that possess significant vapor pressures at off-gas processing temperatures. Some of the more important of these volatile chemical species are

- elementar iodine

- organic iodine

- acids and oxy-acids of iodine

The PNL melter tests conducted with both oxidizing and reducing feeds have demonstrated that the vitrification process has little capacity for retention of $I$ and the halogens in general. $(b, c)$ Moreover, these same LFCII tests have shown melters to be strong generators of gaseous I. This behavior is mirrored in other high-temperature solidification processes as well (Ref. 4.6-19, 4.6-25). Uni ike their effect on Ru, reductive (organic) waste stream additives do little to suppress I volatility; indeed, formic acid pretreatment of PUREXsimulated waste has been found to enhance I volatility losses during pot calcination (Ref. 4.6-19). Consequently, the HWVP MOG system will most certainly have to deal with gaseous iodine effluents.

The impact of gaseous iodine on off-gas system performance will depend on the chemical species of gaseous iodine produced and their relative magnitudes. The inorganic acids of iodine, and the halogens in general, should be easily removed by aqueous gas scrubbing techniques because they are reactive and exhibit low, concentration-dependent vapor pressures above solutions in.which they are dissolved. However, aqueous solutions of HI are not particularly stable because the iodide anion is readily reduced to its elemental state by oxidizing agents such as dissolved oxygen. Consequently, overall scrubbing efficiency for HI will depend on scrub solution chemistry and steady-state concentration. The effects of these parameters on I off-gas partial pressure could not be empirically. established from HWVP-12 data because continuous purging of the scrub liquor occurred throughout the test. However, under full recycle conditions the scrub liquor will become acidic and oxidizing due to melter $\mathrm{NO}_{\mathrm{x}}$ emissions. Both of these conditions will act to 1 imit scrubber performance through the formation of volatile compounds: $\mathrm{HI}$ and $\mathrm{I}_{2}$ respectively.

(a) R. W. Goles and C. M. Anderson, HWVP Melter Off-Gas System Evaluation. HIVP-87-V110305A, Pacific Northwest Laboratory, Richland, Washington (May 1987).

(b) R. K. Nakaoka, Pilot-Scale Ceramic Melter Test Run Summary HWVP-12/ PSCM-22, HWVP-86-VI124A, Pacific Northwest Laboratory, Richland, Washington (1985).

(c) J. Carre11, West Valley Waste Vitrification Demonstration PSCM-9 Run Summary, Pacific Northwest Laboratory, Richland, Washington. 
Elemental iodine, on the other hand, is not easily removed by aqueous media unless the scrub liquor, by design, contains reactive components designed to convert iodine to an anionic form (Ref. 4.6-26). Elemental effluent I has been identified in all PNL melter tests that have processed iodide-bearing feeds including HWVP-12. $(a, b)$ Consequently, a finite vapor pressure of elemental iodine should be expected in the HWVP MOG system. The magnitude of this partial pressure is difficult to predict because it depends on melter production rates of elemental I and. the steady-state concentration of this effluent in aqueous scrub liquors.

The off-gas behavior of organically bound jodine is very dependent on the specific I compounds produced and their relative magnitudes. If nonpolar volatile compounds of I are produced, they will easily penetrate all MOG components except for the I sorption bed. The fact that organic additives can increase I volatility losses in high-temperature solidification processes (Ref. 4.6-19) demonstrates the potential importance of volatile, organically bound I effluent to off-gas processing needs. Little information is available concerning the specific forms of organic I that are formed during the vitrification process..

Gaseous-phase I will challenge the HWWP MOG processing system. The magnitude of the challenge cannot be established from available data that is pertinent to the HWVP process. The fact that off-gas system components can themselves become significant sources of gas-phase iodine independent of the melter source itself has been demonstrated recently by a controlled experiment conducted at the Pamela Plant in Mol, Belgium. (c) In this test, $131_{\text {I }}$ was introduced into a single batch of feed, which was subsequently vitrified. The step function injection of I into Pamela's off-gas processing system produced protracted plant emissions of gaseous ${ }^{131_{I}}$ over a 6 -week period. Because the LEWC feed processed at Mol is very oxidizing, the major form of effluent I produced was most certainly $I_{2}$. Because $I_{2}$ has also been observed to be generated by the HWVP-12 simulation of the HWVP process, the buildup and subsequent off-gas exhaust bleedout of gaseous iodine appears likely to be pertinent to the HWVP PTant design. The only active MOG component that can effectively and verifiably deal with this source is the I sorption bed.

(a) R. K. Nakaoka, Pilot-Scale Ceramic Melter Test Run Summary HWVP-12/ PSCM-22, HWVP-86-V1124A, Pacific Northwest Laboratory, Richland, Washington (1985).

(b) J. R. Carrel1, West Valley Waste Vitrification Demonstration PSCH-9 Run Summary, Pacific Northwest Laboratory, Richland, Washington.

(c) M. Stehle, Karlsrhue Nuclear Research Center, Federal Republic of Germany, Private Communication. 
4.6.4.11.2 Methods for Removal of Iodine from Gas Stream. There is no information on the use of silver mordenite I adsorbers for either calcination or vitrifiction processes. Experience with I adsorbers has been largely in the context of dissolver off gas. It is this stage of the fuel reprocessing cycle in which nearly all the I is volatilized. A significant anount of laboratoryscale work, has been performed on silver-loaded.solid substrates. Silver zeolite is found to be effective at very low I concentrations. Silver mordenite has an advantage over the zeolite in that it is acid resistant. Another alternative is amorphous silica impregnated with $\mathrm{AgNO}_{3}$. This acid-resistant material was developed in Germany, and very high DFs are obtained with it for I removal.

The effectiveness of either of these candidate sorbents is uncertain for the conditions of the HWVP off-gas system. The selection of the best material and reliable predictions of performance will require laboratory screening and performance tests under conditions relevant to the HWVP.

Iodine has been found to be almost totally volatilized during LFCM processing of oxidized as well as reducing feeds. The HIVP feed stream utilized during HWVP-12 was no exception to this rule. Because of the analytical limitations associated with iodine detection, melter-generated iodine effluent was difficult to follow beyond the off-gas quench scrubber during HWVP-12. However, gas-phase $C l$ and $F$ were found to easily penetrate all off-gas processing equipment (EVS, packed tower, hydrosonic and HEME) during that test. Consequently, it is only prudent to expect that gas-phase I was also able to penetrate these devices to some undetermined extent.

From the standpoint of volatile I recovery, the differences between calciner/vitrification effluents and dissolver effiuents are:

- dissolver off gas is likely to be more concentrated in I than calciner/vitrification off gas

- dissolver off gas may contain methyl iodide $\left(\mathrm{CH}_{3} \mathrm{I}\right)$ as well as $\mathrm{I}_{2}$, whereas calciner/vitrification off gas is likely to contain only $I_{2}$ because of the instability of other species at the high temperature of solidification processes.

Holladay (4.6-26) and Burger and Scheele (Ref. 4.6-27) have extensively reviewed the literature on removal of iodine from off gases, specifically these processes: Iodox wet scrubbing (hyperazeotropic $\mathrm{HNO}_{3}$ ), mercuric nitrate-nitric acid wet scrubbing, sorption on charcoal, metal-exchanged zeolites, sorption on $\mathrm{AgNO}_{3}$-impregnated silicic acid, sorption on $\mathrm{Ag}$ - and $\mathrm{Pb}$-exchanged mordenites, and sorption on macroreticular resins. Specific wet scrubbing for iodine may not be practical for most LFCII off-gas systems because of process complexities, 
the need for special reagents, and copious liquid effluent generation. Thus, the solid sorption techniques will be emphasized.

Holladay's review describes activated charcoal as an effective sorbent for $I_{2}$ capture over a wide range of $I_{2}$ gas concentrations, from as $l o w$ as $10^{-3} \mathrm{~g}$ $\mathrm{I}_{2} / \mathrm{m}^{3}$ up to $10^{3} \mathrm{mg} \mathrm{I} \mathrm{I}_{2} / \mathrm{m}^{3}$. Some of the disadvantages of charcoal are: it can ignite at temperatures of $390^{\circ} \mathrm{F}\left(200^{\circ} \mathrm{C}\right)$, it desorbs iodine at high temperatures, and it is deleteriously affected by $\mathrm{NO}_{x}$ gases (with possible formation of explosive compounds.). Though macroreticulär resins such as Amberlite XAD-4 have been shown to be effective in removing $I_{2}$, they, like charcoal, can readily release $I_{2}$, are combustible, and also have questionable radiation stability.

Silver-exchanged zeolites $(A g X)$ have been found effective for $I_{2}$ capture from off gases. Holladay (Ref. 4.6-26) describes work by Staples in which $I_{2}$ adsorption capacity decreased in the presence of $2 \% \mathrm{NO}_{2}$. Experimental work indicates that loading capacities for AgX range from 6 to $140 \mathrm{mg} \mathrm{I} / \mathrm{g}$ of sorbent, and DFs range from 102 to 105. Typical operating conditions were 10 to $500 \mathrm{mg} \mathrm{I} \mathrm{I}_{2} / \mathrm{m}^{3}$ inlet gas concentration, $0 \%$ to $2 \%$ relative humidity, and feed gas temperatures of 121 to $390^{\circ} \mathrm{F}\left(100\right.$ to $\left.200^{\circ} \mathrm{C}\right)$. The negative effect on absorption capacity experienced when AgX was subjected to $2 \% \mathrm{NO}_{2}$ may preclude this sorbent material or. use in systems with significant $\mathrm{NO}_{2}$ concentrations. However, an attractive feature of the AgX sorbent is its ability to remove $\mathrm{I}_{2}$ from the gases to as $10 \mathrm{w}$ as $10^{-10} \mathrm{mg} \mathrm{I}_{2} / \mathrm{m}^{3}$.

Another silver-loaded substrate is mordenite (AgZ), which is prepared from the synthetic sodium mordenite Zeolon and is more resistant to acidic environments than is AgX. When heated in the presence of $\mathrm{H}_{2}$, reduced silver is formed on the catalyst and the material is then designated Agz. AgZ demonstrates higher loading capacity than AgZ (Ref. 4.6-24).

Holladay's (Ref. 4.6-26) review of work by Slansky indicates that AgZ is superior to AgX because of greater acid stability, higher loading capacity, and higher removal efficiency. Testing with mordenite doped with reduced silver (obtained by $\mathrm{H}_{2}$ pretreatment) is sumarized as follows. With a simulated dissolver off-gas stream of $6 \% \mathrm{H}_{2} \mathrm{O}, 2 \% \mathrm{NO}_{2}$, and $2 \%$ NO and a bed temperature of $50^{\circ} \mathrm{C}, \mathrm{I}_{2}$ DFs of $10^{3}$ and $10^{4}$ were reported at loading capacities of about $120 \mathrm{mg}$ $I_{2} / g$ sorbent ( $60 \%$ theoretical capacity). In these tests, a 2-in.-diameter $x$ 6 -in.-deep bed was used with a superficial gas velocity of $0.8 \mathrm{ft} / \mathrm{s}$. Burger and Scheele (Ref. 4.6-27) report that the DF decreases when the $\mathrm{I}_{2}$ loading exceeds $30 \%$ to $40 \%$ of the theoretical capacity, which is $200 \mathrm{mg} \mathrm{I} / \mathrm{g} \mathrm{AgZ}$.

Amorphous silica impregnated with AgN03 was developed in the FRG and has been known by the commercial name of $A C-6120$. The material is used much like AgZ or AgX and contains 7 to $12 \mathrm{wt} \%$ silver. Beds can be operated at 110 to 
$160^{\circ} \mathrm{C}$. Burger and Scheele (Ref. 4.6-27) cite work by Furrer, Kaempfer, and Wilhelm in which DFs greater than $10^{4}$ were obtained. Iodine loadings of $95 \%$ silver utilization were achieved; $60 \%$ silver utilization was achieved before DFs dropped below $10^{5}$. The process is compatible with $\mathrm{NO}_{x}$ in the off gas.

- Holladay (Ref. 4.6-26) also reports on experience with $A C-6120$ at the Karisruhe Reprocessing Plant. A bed with $26 \mathrm{~kg}$ of $7 \% \mathrm{Ag}$ was used with a dissolver off-gas flow rate of $148 \mathrm{~m}^{3} / \mathrm{h}$, giving a bed residence time of about 1 s at a temperature of $265^{\circ} \mathrm{F}\left(130^{\circ} \mathrm{C}\right)$. The average $\mathrm{NO}_{x}$ concentration was less than $2 \%$, with peaks of up to $20 \%$. Based on 129 I analysis, the DF ranged from 10,000 to 20,000 over 120 days of service life. At the end of the operation, a total of bout $1.3 \mathrm{~kg}$ of $\mathrm{I}_{2}$ was sorbed, which corresponds to a $60 \%$ utilization of the sorbed bed capacity. .

4.6.4.12 Filters. HEPA filters have been used in nuclear applications for decades. If properly deployed, reliable performance can be expected for submicron-sized aerosol removal. HEPA filters are vulnerable to moist air (dew-point conditions), pressure surges in excess of 10 in. W.g., and temperatures over $200^{\circ} \mathrm{F}\left(90^{\circ} \mathrm{C}\right)$. It is expected that the filters will efficiently remove aerosols.

The principal submicron capture mechanism in the HEPA filter is brownian diffusion. Filtration efficiency varies strongly with particle size and is a minimum for sizes around 0.4 to $0.7 \mu \mathrm{m}$ (Ref. 4.6-28). Table 4.6-50 (Ref. 4.6-29) shows penetration ersus particle size through a bank of HEPA filters in series. The OF (inverse of penetration) does not drop sharply as particles progress from one stage to the next, a consequence of the controlling diffusion mechanism.

TABLE 4.6-50. Fractional Penetration(a) of Dry-Process Polydisperse Aerosol Through Various HEPA Filter Stages (Ref. 4.6-29)

\begin{tabular}{|c|c|c|c|}
\hline $\begin{array}{c}\text { Particle Size } \\
\text { Range }(\mu \mathrm{m})\end{array}$ & $\begin{array}{c}\text { Reference Fractional } \\
\text { Distribution }\end{array}$ & HEPA 1, $\times 10^{-6}$ & HEPA 2, $\times 10^{-6}$ \\
\hline$<0.12$ & 0.0001 & $36 \pm 36$ & $200 \pm 220$ \\
$0.12-0.22$ & 0.002 & $54 \pm 50$ & $82 \pm 31$ \\
$0.22-0.44$ & 0.038 & $71 \pm 59$ & $92 \pm 24$ \\
$0.44-0.96$ & 0.10 & $64 \pm 57$ & $126 \pm 82$ \\
$0.96-1.54$ & 0.86 & $39 \pm 33$ & $24 \pm 19$ \\
$>1.54$ & $30 \pm 30$ & $4.2 \pm 2$ \\
\hline
\end{tabular}

(a) DF is the inverse of these fractional penetrations. 
Elder et al. (Ref. 4.6-30) have performed in-place tests on tandem HEPA filters in large system $(20,000 \mathrm{cfm})$. They used a sonic nozzle generator that produced a stream of particles with 0.27 to $0.04 \mu \mathrm{m}$ median diameter. The first stage of the HEPA filters exhibited DFs on the order of $8 \times 10^{3}$ to $5 \times 10^{4}$. The second stage had DFs of between $5 \times 10^{3}$ and $2 \times 10^{4}$. The combined DF for the tanden system was $10^{8}$. The scatter in the data did not permit Elder and his colleagues to evaluate DF versus particle size; however, the data did indicate a diminishing DF below $0.15 \mu \mathrm{m}$. The results of Gonzales and of Elder are in overall agreement: very high particulate DFs are expected from tandem HEPA filters.

4.6.4.12.1 HWVP-15 HEPA Filter Performance. A HEPA filter assembly was included in the MOG treatment system for HWVP-15.

4.6.4.12.1.1 Physical Properties and Operating Conditions. The HWVP-15 HEPA filter was used for only the first 7 days of the test due to the pressure drop associated with the HEPA's preheater. As a result, the HEPA accumulated very little aerosol, and no change in pressure drop occurred during this period. HEPA operating parameters during the test, such as the air flow rate, pressure drop, and inlet temperature, are graphically displayed in Figures 4.6-63 through 4.6-65, respectively. These data are invariably normal and are of little use in predicting the service life of the HEPA underlong-term projected exposure.

4.6-4.12.1.2 Influent Conditions and Service Life. The need for prefilters and the loading capacity of HEPA filters are determined by the nature and composition of aerosol effluents to be treated by HEPA filtration. A multistage cascade impactor was used to classify the sizes of HEME effluent (HEPA influent) aerosols from $5 \mu \mathrm{m}$ to $<0.25 \mu \mathrm{m}$ in nine discreet steps. The aerosols exiting the HEME were always found to be exclusively submicron, independent of HWVP-15 process or off-gas operating conditions.

Although the size distribution of particulate matter incident upon the HEPA during HWVP-15 is compatible with a long service life, loading rates and/or exposure criteria will establish the operational life of the HEPA. The mass loading of the HEPA influent (HEME. effluent) stream was determined under all process and off-gas operating conditions; it was never found to be greater than $0.02 \mu \mathrm{g} / \mathrm{L}$.

4.6.4.13. Technetium Volatility. The chemistry of Tc in high-temperature solidification processes is found to be quite similar to that of Ru (Ref. 4.6-19, Ref. 4.6-31). This element can be volatilized as either a heptaoxide or oxy-acid. The volatile oxide melts at $120^{\circ} \mathrm{C}$, boils at $310^{\circ} \mathrm{C}$, and exerts a vapor pressure of 0.1 Torr at $100^{\circ} \mathrm{C}$. Consequently, volatilization of technetium during vitrification can be appreciable. Indeed, technetium was 


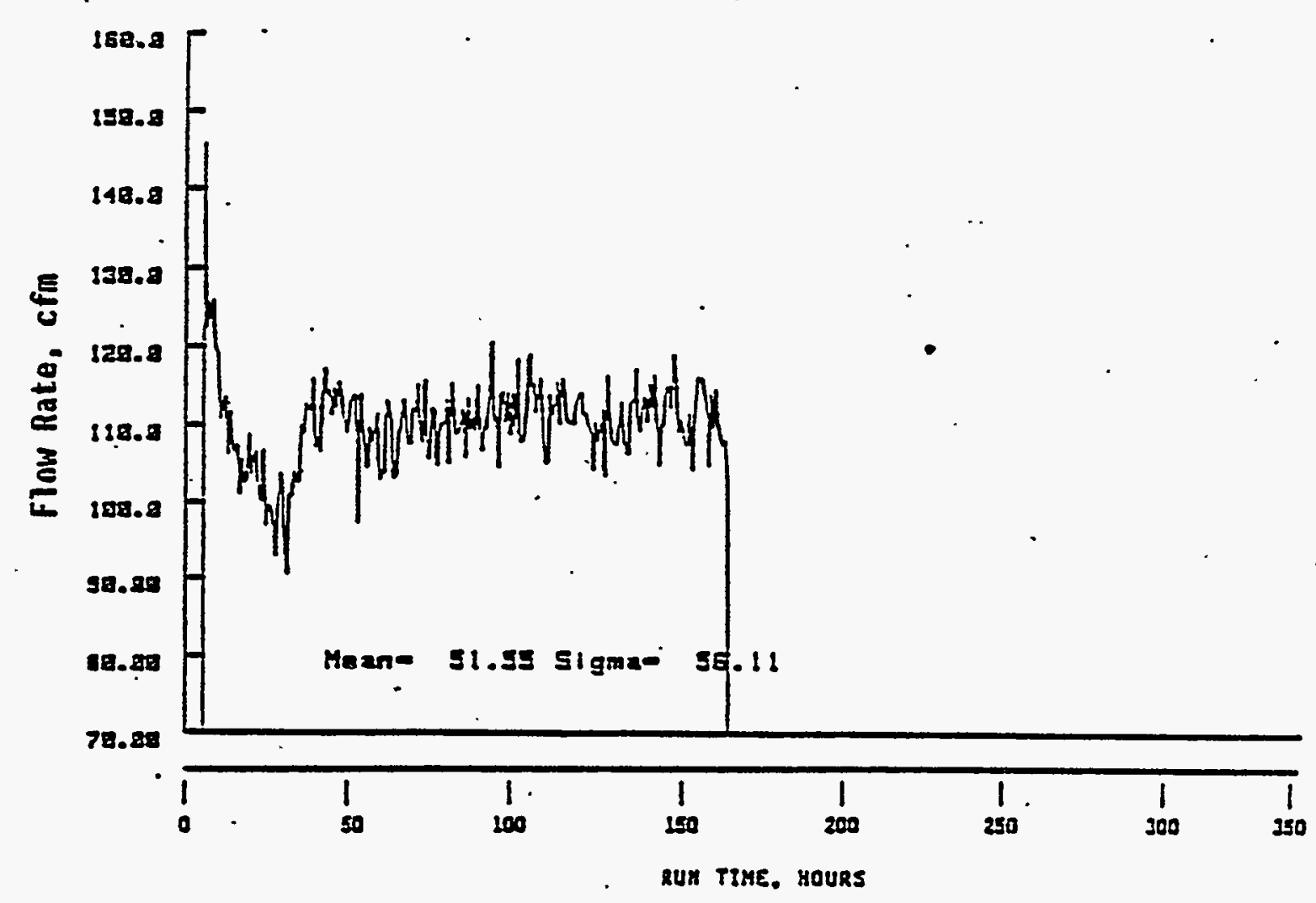

FIGURE 4.6-63. Air Flow Rates Through HEPA Filter HWVP-89-IVJ0010100B

found to be the most penetrating of the effluents generated at the Pameia Vitrification Plant. (a) This fact suggests some degree of gas-phase transport of Tc effluent through the plants off-gas system.

However, the LEWC waste processed at the Pamela Vitrification Plant was highly oxidizing, which is conducive as well as necessary for forming the +7 oxidation state of TC that is characteristic of all its volatile compounds. Reductant added to calciner feed has been shown to significantly reduce $T c$ volatility as one might expect (Ref. $4 \cdot 6-19$ ). Because the reference HWVP process utilizes a formated feed stream, no significant Tc volatility is expected to accompany vitrification. This expectation has not been verified experimentally at PNL because TC has no stable isotopes. Because Tc is adjacent to $\mathrm{Ru}$ in the same transition series of the periodic table, the chemical behavior of these elements should be strongly linked.

(a) M. Stehle, Karlsrhue Nuclear Research Center, Federal Republic of Germany, Private Communication. 


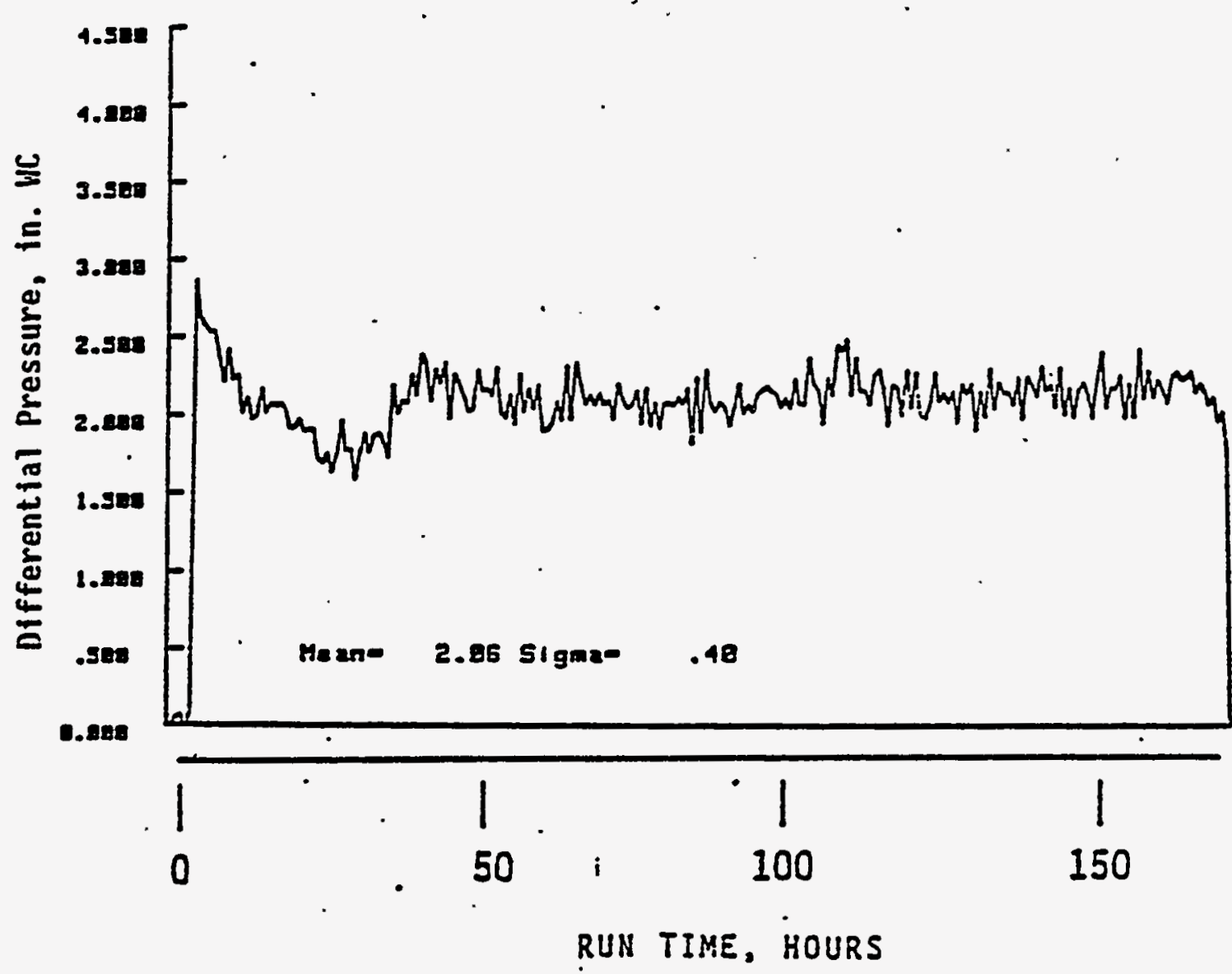

FIGURE 4.6-64. Pressure Drop Across HEPA Filter Housing HWVP-89-IVJ0010100B

4.6.4.14 Effect of Redox on Melter Emissions. A study was (a) conducted to investigate correlations between the redox state ( $\mathrm{Fe}^{++} / \mathrm{Fe}^{+++}$of $\mathrm{LFCM}$ glasses and the nature and magnitude of melter effluent losses. Major emphasis was on the evaluation of the loss mechanisms and individual DFs associated with ruthenium, cesium, and iodine as a function of glass redox controlled through organic feed loading.

A variation in glass redox was made by adding sugar as a reductant in the feed slurry. The effluents generated during liquid-fed mini-melter (LFMM) processing of these feeds were characterized to establish a correlation of emission to feed reductant additions. Four experiments were conducted in the LFMM to determine the relationship between melter emission characteristics and the corresponding redox of the glass produced. The melter decontamination

(a) S. J. Jette, Effect of Glass Redox on Melter Off-Gas Composition. HWVP-88-V110306B, Pacific Northwest Laboratory, Richland, Washington (1988). 


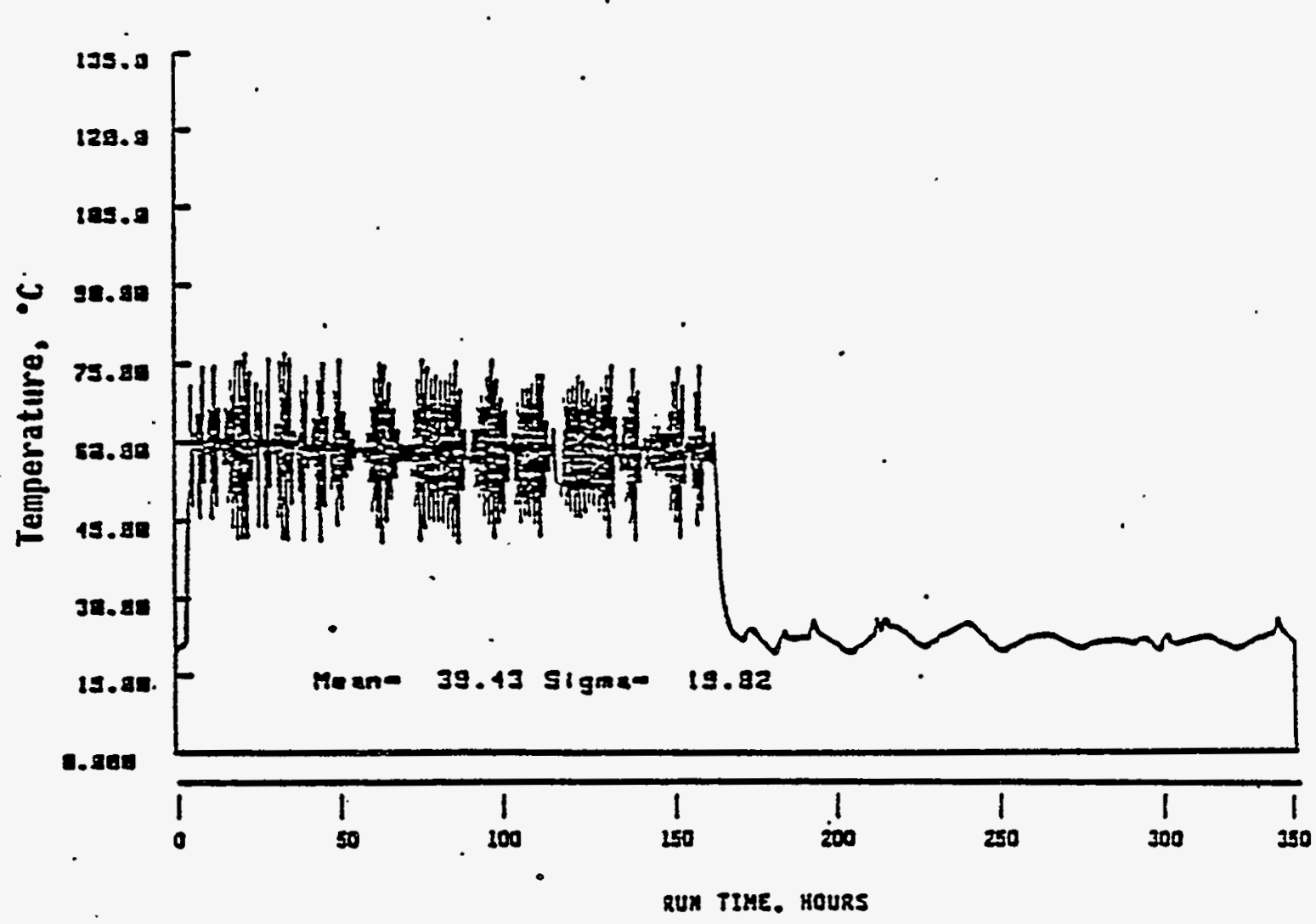

FIGURE 4.6-65. Inlet Temperature to HEPA Filter HWVP-89-0010100B

factors for melter feed cations were determined. The absolute of values calculated for the LFMM are specific for the mini-melter system and are not representative of large-scale performance values; however, performance variability should be independent of process scale.

The LFM is continously fed with a peristalic pump into an Inconel 625 crucible. The LFMM is externally resistance heated; it maintained the bulk glass at about $1120^{\circ} \mathrm{C}$. The glass surface area was $29 \mathrm{~cm}^{2}$ and the volume was about $300 \mathrm{~cm}^{3}$. The upper glass layer was 850 to $1000^{\circ} \mathrm{C}$, and cold cap coverage was 75 to $80 \%$. The melter plenum temperature was about $950^{\circ} \mathrm{F}\left(510^{\circ} \mathrm{C}\right)$ and was closed. The melter and intervals experienced significant corrosion during testing.

The off-gas system consisted of a melter exhaust line, a particulate filter, a condenser, a condensate flask, a series of three gas washig bottles, 
a catalyst bed, a fourth gas washing bottle, a gas drying tube, and a vacuum pump. The components were assembled in the order listed here. Effluent gases were directed into an exhaust line mounted on top of the LFMM plenum and attached directly to a Gelman 2220 filter housing. A Gelman Type AE glass fiber filter was used in the filter housing. The tubing from the plenum and the filter housing were maintained above $300^{\circ} \mathrm{F}\left(150^{\circ} \mathrm{C}\right)$ using an electrical resistant heat tape.

The experimentws were conducted using NCAW'84 10w-chromium reference waste made up to provide the glass composition. Shown in Table 4.6-51. SRL 131 glass was used as the initial glass charge to the melter. The initial test proved the system to be operable under the range of parameters necessary for off-gas characterization. A cold cap. Was produced using feed rates comparable to those , that would be required for one melter turnover in 6 to $8 \mathrm{~h}$ operation ( 80 to $120 \mathrm{~g}$ of glass). The cold cap was visually monitored through a quartz window installed in the top of the plenum. The vacuum system was able to draw 4 slpm of air into the system via leaks in the melter system. This inleakage acted as a carrier gas through the off-gas system.

Tabie 4.6-52 summarizes the experiment parameters: grams sugar per liter of feed slurry, total run times, glass turnover, and the target and actual $\mathrm{Fe}^{+2} / \mathrm{Fe}^{+3}$ values. The amount of glass required for a turnover was estimated to be $800 \mathrm{~g}$. The results indicate that turnover was achieved in all but the first experiment.

Crucible melts of the liquid slurry indicated that the $\mathrm{Fe}^{+2} / \mathrm{Fe}^{+3}$ value of glass for feed slurry without sugar would be approximately 0.3 . The anticipated $\mathrm{Fe}^{+2} / \mathrm{Fe}^{+3}$ value of 0.03 was not achieved in either Experiment 1 or Experiment 2. The 0.24 value of Experiment 1 was initially thought to be due to lack of glass production turnover within the LFMM. The 0.19 redox of Experiment 2 was still higher than the anticipated 0.03 value. The high value attained in Experiment 2 was attributed to the chemical interaction of the Inconel crucible with the molten glass. A high rate of corrosion on the Inconel-625 crucible and outlet tube indicated that the molten glass was reacting chemically with the Inconel-625. Examination of the glass in the LFMM indicated that noble metals were precipitating from the melter glass. It is postulated that the noble metal precipitate catalyzed the Inconel-625 corrosion.

Experiment 3 shows an increase in redox value to 0.34 using $6 \mathrm{~g}$ of sugar per liter; the target value was 0.3 . Thus the redox ratio in the LFMM is a function of reductant in the feed, regardless of the chemical action of the Inconel crucible. The sugar loading of $6 \mathrm{~g}$ in Experiment 3 was decreased to $3.5 \mathrm{~g}$ in Experiment 4 . Based on crucible melts, the redox value would be expected to drop. However, the redox value increased. This inconsistency may 
TABLE 4.6-51. Composition of the HWVP NCAM'84 (Low Chromium) Reference Waste, Substituted Waste, (a) and Glass (HW39-2) at a 25 wt\% Oxides Haste Loading HWVP-88-VI103068

\begin{tabular}{|c|c|c|c|c|c|c|}
\hline oxide & $\begin{array}{l}\text { Normalized } \\
\text { Waste } \\
\text { (wt: Oxide) }\end{array}$ & $\begin{array}{l}\text { Substituted } \\
\text { Haste } \\
\text { (wtz oxide) }\end{array}$ & $\begin{array}{l}\text { Substituted } \\
\text { Waste Nor. } \\
\text { (wt: oxide) }\end{array}$ & $\begin{array}{l}\text { Substituted } \\
\text { Waste Nor: } \\
\text { (wt: oxide) }\end{array}$ & $\begin{array}{l}\text { HW-39 Frit } \\
\text { (Wtz oxide) }\end{array}$ & $\begin{array}{l}\text { HW-39 Glass } \\
\text { (wt\% oxide) }\end{array}$ \\
\hline \multirow[t]{2}{*}{ 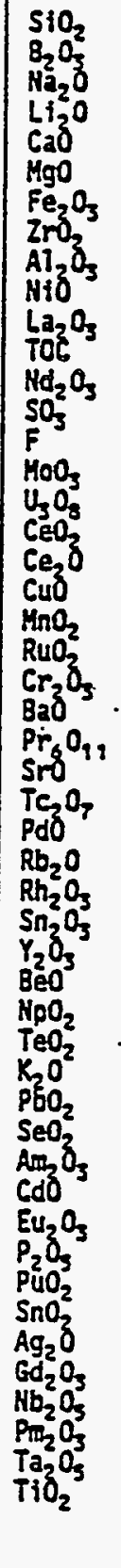 } & $\begin{array}{l}3.09 \\
0.01 \\
11.1 \\
0.00 \\
.0 .31 \\
0.25 \\
48.3 \\
2.5 \\
17.9 \\
2.47 \\
2.29 \\
0.62 \\
1.79 \\
1.54 \\
1.24 \\
1.24 \\
0.82 \\
0.62 \\
0.62 \\
0.62 \\
0.62 \\
0.62 \\
0.56 \\
0.43 \\
0.37 \\
0.37 \\
0.37 \\
0.19 \\
0.25 \\
0.19 \\
0.19 \\
0.19 \\
0.06 \\
0.12 \\
0.12 \\
0.00 \\
0.00 \\
0.03 \\
0.02 \\
0.02 \\
0.02 \\
0.02 \\
0.02 \\
0.02 \\
0.01 \\
0.01 \\
0.01 \\
0.01 \\
0.01 \\
0.01 \\
\end{array}$ & 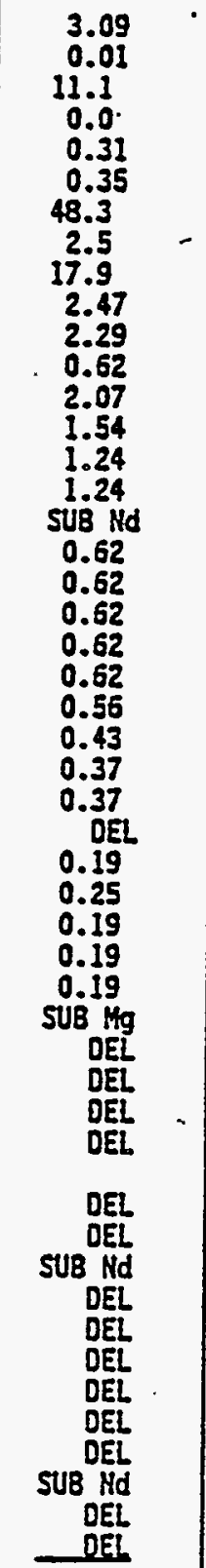 & 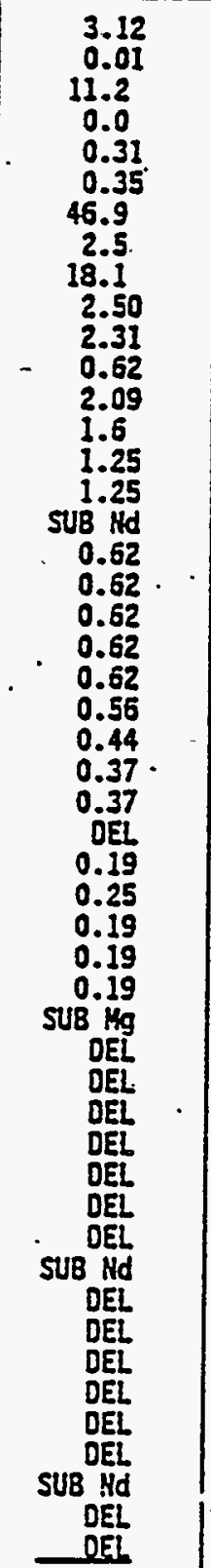 & 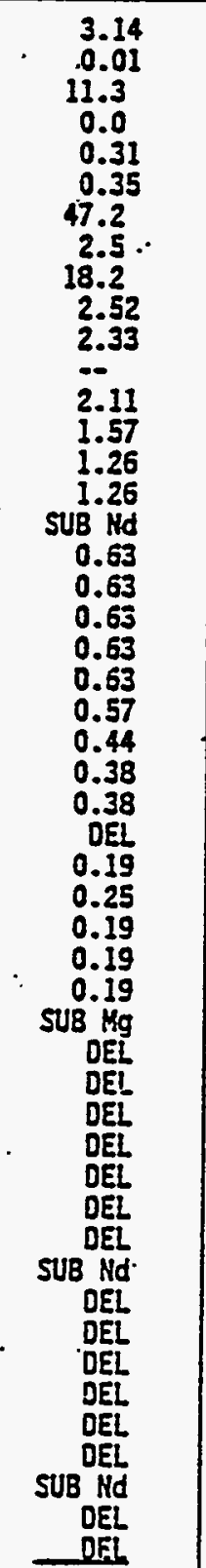 & $\begin{array}{r}67.25 \\
12.75 \\
10.25 \\
5.00 \\
3.75 \\
1.00\end{array}$ & $\begin{array}{r}51.22 \\
9.56 \\
10.52 \\
3.75 \\
2.89 \\
0.84 \\
11.79 \\
0.63 \\
4.56 \\
0.63 \\
0.58 \\
0.00 \\
0.53 \\
0.39 \\
0.31 \\
0.31 \\
0.16 \\
0.16 \\
0.16 \\
0.16 \\
0.16 \\
0.14 \\
0.11 \\
0.09 \\
0.09 \\
0.05 \\
0.06 \\
0.05 \\
0.05 \\
0.05\end{array}$ \\
\hline & 100.8 & 98.869 & 100.0 & 100.0 & 100.0 & 100.0 \\
\hline
\end{tabular}

(a) Substituted waste does not contain all components of estimated actual waste composition. Limited substitution is made of chemically similar elements 
TABLE 4.6-52. Surmary of 1987 LFMM Experimental Runs

HWVP-88-V110306B

\begin{tabular}{|c|c|c|c|c|c|}
\hline Experiment & $\begin{array}{c}\text { Grams Sugar } \\
\text { Per Liter } \\
\text { of Feed }\end{array}$ & $\begin{array}{c}\text { Total } \\
\text { Run Time }\end{array}$ & $\begin{array}{c}\text { Glass } \\
\text { Turnover }\end{array}$ & $\begin{array}{c}\text { Target } \\
\text { Fe }^{+2} / \mathrm{Fe}^{+3} \\
\text { Values }\end{array}$ & $\begin{array}{c}\text { Actual } \\
\mathrm{Fe}^{+2} / \mathrm{Fe}^{+3} \\
\text { Values }\end{array}$ \\
\hline 1 & 0.0 & $7 \mathrm{~h}$ & 0.8 & 0.03 & 0.24 \\
2 & 0.0 & $8 \mathrm{~h} 45 \mathrm{~min}$ & 1.1 & 0.3 & 0.188 \\
3 & 6.0 & $8 \mathrm{~h} 50 \mathrm{~min}$ & 1.1 & 0.30 & 0.34 \\
4 & 3.5 & $7 \mathrm{~h} 45 \mathrm{~min}$ & 1.1 & 0.15 & 0.47 \\
\hline
\end{tabular}

The elemental DF values are given in Table 4.6-53 with the experiments listed according to increasing sugar loading. The DF values vary, but there are no distinct trends of increasing or decreasing DF values except for iodine. The DF data demonstrate that the presence of sugar in the feed as a redundant has little effect on the LFMM off-gas effluent.

The majority of DF values for the LFMP are two to three times less than DF values achieved in HWVP-12. These lower DF values are the result of a higher rate of loss to the off-gas system in the form of particulate. However, the magnitude of these results are not as important as are the relative trends since laboratory tests are not representative of large-scale operations. The cesium DF observed in.LFMM testing is similar to DFs observed for strontium and other classic nonvolatiles in the LFMM. The similarity exhibited between these DF values (i.e., 50 compared with 80 ) also indicate the major loss mechanism from the LFMM may be entrainment rather than volatility.

The DF value for iodine increased from 4.2 to 7.8 when sugar loading increased from 0.0 to $3.5 \mathrm{~g}$ sugar/L and from 7.8 to 17 when sugar loading increased from 3.5 to $6 \mathrm{~g}$ sugar/L. This rise may be partially due to the nature of the system itself because there is a slight rise from Experiment 1 to Experiment 2 (from 2.3 to 4.2 ) where there is no sugar loading in either case. However, the overall increase indicates that an increase in reductant loading will decrease the amount of iodine lost to the off-gas system.

Table 4.6-54 shows the percent distribution of iodine in the major off-gas system components. Experiment 1 presents results that are somewhat inconsistent with the results from Experiment 2, which had the same operating parameters. The composition of the glass charge used to prime the LFMM in Experiment 1 differed from that of HW39-2. The LFMM was brought up to temperature several times with this glass charge present to test the components of the LFMM 
TABLE 4.6-53. Elemental DF Values for the Sugar Loadings in the Four Experiments HWVP-88-V110306B

\begin{tabular}{|c|c|c|c|c|}
\hline Element & $\begin{array}{l}\text { Experiment } 1 \\
0.0 \mathrm{~g} \mathrm{Sugar} / \mathrm{L}_{3} \\
0.24-\mathrm{Fe}^{2} / \mathrm{Fe}_{3}\end{array}$ & $\begin{array}{l}\text { Experiment } 2 \\
0.0 \mathrm{~g} \text { sugar } / \mathrm{h} \\
0.19=\mathrm{Fe}^{+2} / \mathrm{Fe}_{3}\end{array}$ & $\begin{array}{l}\text { Experiment } 4 \\
3.5 \mathrm{~g} \text { sugar } / \mathrm{L} \\
0.47=\mathrm{Fe}^{2} / \mathrm{Fe}\end{array}$ & $\begin{array}{l}\text { Experiment } 3 \\
6.0 \mathrm{~g} \text { sugar } / \mathrm{L} \\
0.34=\mathrm{Fe}^{+\frac{1}{2}} / \mathrm{Fe}^{+}\end{array}$ \\
\hline $\begin{array}{l}\mathrm{Al} \\
\mathrm{B} \\
\mathrm{Ba} \\
\mathrm{Ca} \\
\mathrm{Ce} \\
\mathrm{Cr} \\
\mathrm{Cs} \\
\mathrm{Cu} \\
\mathrm{Fe} \\
\mathrm{I} \\
\mathrm{La} \\
\mathrm{Li} \\
\mathrm{Mg} \\
\mathrm{Mn} . \\
\mathrm{Mo} \\
\mathrm{Na} \\
\mathrm{Nd} \\
\mathrm{Ni} \\
\mathrm{Ru} \\
\mathrm{Si} \\
\mathrm{Sr} \\
\mathrm{Ti} \\
\mathrm{Y} \\
\text { Total(a) } \\
\text { Mass }\end{array}$ & $\begin{array}{c}120 \\
150 \\
56 \\
890 \\
93 \\
65 \\
62 \\
83 \\
66 \\
2.3 \\
79 \\
3200 \\
560 \\
78 \\
57 \\
3.3 \\
170 \\
250000 \\
63 \\
2300 \\
65 \\
170 \\
-- \\
--\end{array}$ & $\begin{array}{c}57 \\
120 \\
52 \\
690 \\
75 \\
46 \\
43 \\
66 \\
51 \\
4.2 \\
74 \\
1400 \\
380 \\
55 \\
33 \\
3.3 \\
130 \\
59 \\
52 \\
1400 \\
55 \\
150 \\
70 \\
200 \\
20\end{array}$ & $\begin{array}{r}89 \\
150 \\
79 \\
780 \\
110 \\
70 \\
47 \\
93 \\
76 \\
7.8 \\
120 \\
1100 \\
450 \\
76 \\
46 \\
2.8 \\
200 \\
86 \\
71 \\
1600 \\
88 \\
180 \\
120 \\
220\end{array}$ & $\begin{array}{r}86 \\
160 \\
77 \\
810 \\
110 \\
71 \\
54 \\
74 \\
78 \\
17 \\
120 \\
1900 \\
430 \\
76 \\
50 \\
1.2 \\
210 \\
200 \\
71 \\
1500 \\
91 \\
27 \\
110 \\
210\end{array}$ \\
\hline
\end{tabular}

(a) DF value for the total mass was calculated using the mass of the particulate on the off-gas filter and the mass in the feed slurry.

operation. The composition of the glass charge and the extended period of exposure of the molten glass to the Inconel-625 crucible could have impact on the off-gas results for-Experiment 1 .

If the results of Experiment 1 are neglected, it can be seen that over $89 \%$ of the iodine lost to the off-gas system is in a volatile state. Of that volatile fraction, two-thirds was condensible at $14^{\circ} \mathrm{C}$. An increase in the sugar loading did not result in an increase of iodine in the volatile fraction. 
TABLE 4.6-54. Distribution of Idone in the. Off-Gas Components HWVP-88-V110306B

\begin{tabular}{|l|c|c|c|c|c|}
\hline Loading (g/L) & $\begin{array}{c}\text { Particulate } \\
\text { Filter }\end{array}$ & $\begin{array}{c}\text { Condensate } \\
\text { and Condenser } \\
\text { Rinse }\end{array}$ & $\begin{array}{c}\text { Sum in } \\
\text { Gas Washing } \\
\text { Bottles }\end{array}$ & Total & $\begin{array}{c}\text { Percent } \\
\text { Volatile }\end{array}$ \\
\hline $\begin{array}{l}0.0 \mathrm{~g} \\
\text { (Experiment 1) }\end{array}$ & 51.00 & 17.36 & 31.64 & 100.00 & 49.0 \\
$0.0 \mathrm{~g}$ & 6.62 & 76.64 & 16.74 & 100.00 & 93.38 \\
$\begin{array}{l}\text { (Experiment 2) } \\
\text { 3.5 g }\end{array}$ & 10.90 & 63.57 & 25.53 & 100.00 & 89.10 \\
$\begin{array}{l}\text { (Experiment 4) } \\
\text { (Exg g }\end{array}$ & 7.39. & 87.64 & 4.97 & 100.00 & 92.61 \\
\hline
\end{tabular}

In Experiment 4 , at $3.5 \mathrm{~g}$ per liter sugar loading, I was found in the fourth scrub bottle beyond the converter. However, only $1 \%$ of the total I penetrated the system. The other experiments showed no penetration beyond the third gas scrubbing bottle. It was necessary to maintain a higher flow rate through the off-gas system near the completion of Experiments 3 and 4 to-maintain a vacuum at the plenum. The small carry over of iodine may be attributable to the increased gas flow rate.

The Ru was always collected as particulate and was not present in condenser rinse solutions or other gas washing solutions. There were no experimental results to indicate the generation of gaseous Ru from the LFMM.

The following conclusions resulted from this study:

- The variation of reducing potential in a highly reduced HW39-2 glass has little effect on the off-gas DF values for most feed components with the exception of $I$.

- The amount of I lost to the off-gas system decreases as the reductant loading is increased. This is shown by an increase in iodine DF values as the sugar is increased. An I DF correlation with measured redox could not be identified.

- The I losses were mainiy volatile forms ( $-92 \%)$ that were easily condensed or scrubbed out of the off-gas system. An increase in sugar reductant loading did not cause a noticeable increase in percent of I in the melter off-gas volatile fraction versus the particulate. 
- Ruthenium and CS OF values were independent of reductant sugar loading and glass redox value. Neither Ru nor Cs were observed as .. gaseous effiuent in any of the tests.

- The redox values established in the present LFMM tests were not the same redox values achieved in other LFCMs with the same feed. The glass redox values produced by the LFMM may have been influenced by unexpected chemical interactions of the Inconei-625 crucible with the molten glass.

\section{REFERENCES}

4.6-1 M. S. Peters, Principles and Processes for Removing Nitrogen Oxides from Gases. CO0-1015, Engineering experiment Station, University of Illionis, Urbana, Illionis (August 31, 1955).

4.6-2 W. J. Bjorkland, Defense Waste Vitrification Studies During FY 1980, PNL-3818, Pacific Northwest Laboratory, Richland, Washington (August 1981).

4.6-3 R. W. Goles and G. J. Sevigny., Off-Gas Characteristics of Defense Waste Vitrification Using Liquid-Fed Joule-Heated Ceramic Melters, PNL-4819, Pacific Northwest Laboratory, Richland, Washington (September 1983).

4.6-4 P. A. Scott et al., Technology of Off-Gas Treatment for Liquid-Fed Ceramic Meiters, PNL-5446, Pacific Northwest Laboratory, Richland, Washington (May 1985).

4.6-5 B. 0. Ostle and R. W. Mensing, Statistics in Research, The Iowa State University Press, Aimes, Iowa (1982).

4.6-6 P. S. Scott, R. H. Goles, and R. D. Peters, Technology of Off-Gas. Treatment for Liquid-Fed Ceramic Melters, PNL-5446, Pacific Northwest Laboratory, Richland, Washington (1985).

4.6-7 W. C. Hinds, Aerosol Technology: Properties, Behavior, and Measurement of Airborne Particles, John Wiley and Sons, New York (1982).

4.6-8 Y. Goldshmid and S. Calvert, "Small Particle Collection Supported by Liquid Drops," AIChE J. 9:352 (1963).

4.6-9 C. M. Ruecker and P. A. Scott, Parameters Influencing the Aerosol Capture Performance of the Submerged-Bed Scrubber, PNL-6035, Pacific Northwest Laboratory, Richland, Washington (1987). 
4.6-10 L. S. Harris, "Fume Scrubbing with the Ejector Venturi System," Chemical Engineering Progress \#4, 62, 55 (1966).

4.6-11 R. M. Counce, Nitrogen Oxide Absorption into Hater and Dilute Nitric Acid in an Engineering-Scale Sieve-Plate Column--Description of a Mathematical Model and Comparison with Experimental Data, ORNL-5438, Oak Ridge National Laboratory, Oak Ridge, Tennessee (1978).

4.6-12 G. T. Wright, "Effect Particulate S̀crubber for Glass Melter Off-Gas," in Scientific Basis for NucTear Waste Management VI Symposium Held November 1982 in Boston, Massachusetts, USA, D. G. Brookens, ed..

4.6-13 Internationál Atomic Energy Agency, "Control of Semivolatile Radionuclides in Gaseous Effluents at Nuclear Facilities," Technical Report Series No. 220, International Atomic. Energy Agency, Vienna, Italy (1982).

4.6-14 Furrer et al. "Results of Cleaning Dissolver Off-Gas in the Passat Prototype Dissolver Off-Gas Filter System." Proceedings of 16th DOE Nuclear Air Cleaning Conference, U.S. Department of Energy, Washingtion, D.C., CONF-801038, Vol. 1 (1980).

4.6-15 R. W. Goles and G. J. Sevigny, "Off-Gas Characteristics of.Liquid-Fed Joule Heated Ceramic Melters," Proceedings of the 17th DOE Nuclear Air Cleaning Conference, U.S. Department of Energy, Washington, D.C. (1983).

4.6-16 J. D. Cristian, "Process Behaviour and Control of Ruthenium and Cesium," Controlling Airborne Effluents from Fuel Cycle Plants (Proc. ANS-AIChE Topical Meeting Sun Valley, 1986), American Nuclear Society, Hinsdale, Illinois (1976).

4.6-17 B. J. Newby and V. H. Barnes, Volatile Ruthenium Removal from Calciner Off-Gas Using Solid Sorbents. ICP-1078, Allied Chemical Cororation, Idaho Falls, Idaho (1975).

4.6-18 M. Klein, C. Weyers, and W. R. A. Goossens, "Behavior of Ruthenium, Cesium and Antimony in High Temperature Processes for Waste Conditioning." Radioactive Waste Management and the Nuclear Fuel Cycle $6(3-4): 255-276(1985)$. 
4.6-19 S. J. Rimshaw, F. N. Case, and J. A. Tompkins, Volatility of Ruthenium-106, Technetium-99 and Iodine-129, and the Evolution of Nitrogen Oxide Compounds During the Calcination of High-Level, Radioactive Nitric Acid Waste, ORNL-5562, Oak Ridge National Laboratory, Oak Ridge; Tennessee (1980)。

4.6-20 M. Klein, C. Heyers, and W. R. A. Gossens, "Volatilization and Trapping of Ruthenium in High Temperature Processes," In Proceedings of the 17th DOE Nuclear air Cleaning Conference, U.S. Department of Energy, Hashington, D.C. (1983).

4:6-21 D. A. Hanson, B. J. Newby; and K. L. Rohde, The Adsorption of Ruthenium from Nitric Acid-Air Mixtures, IDO-14458, Phillips Petroleum Co., Idaho Falls, Idaho.

4.6-22 B. Newby and V. H. Barnes, Volatile Ruthenium Removal from Calciner Off-Gas Using Solid Sorbents. ICP-1078, Allied Chemical Cororation, Idaho Falls, Idaho (1975).

4.6-23 M. Klein et al., "Volatilization et trappage du ruthenium lous de la calcination de solutions nitriques," in Proceedings of seminar on The Testing and Operation of Off-Gas Cleaning Systems at Nuclear Facjlities, KarTsruhe, FRG, May 3-7, 1982, IAEA-SR-72/03, International Atọmic Energy Agency (1982).

4.6-24 P. W. Cain and K. C: Yewer, "Volatile Ruthenuium Trapping on Silica Gel and Solid Catalyst," in 18th DOE Nuclear Airborne Waste Management and Air Cleaning Conference, CONF-840806, U.S. Department of Energy, Washington, D.C.

4.6-25 J. Furrer, R. Kaempffer, A. Linek, and A. Merz, "Results of Cleaning Dissolver Off-Gas in the Passat Prototype Dissolver Off-Gas Filter System," In Proceedings of the 16th DOE Nuclear Air Cleaning Conference, San Diego, 1980, U.S. Department of Energy, Washington, D.C. $(1980)$.

4.6-26 D. H. Holladay, A Literature Survey: Methods for the Removal of Iodine Species from Off-Gases and Liquid Waste Streams of Nuclear Power and Fuel Reprocessing Plants with Emphasis on Solid. Sorbents. ORNL/ TM-6350, Oak Ridge Nationat Laboratory, Oak Ridge, Tennessee (1979).

4.6-27 L. L. Burger and R. D. Scheele, The Status of Radioiodine Control for Nuclear Fuel Reprocessing Plants, PNL-4689, Pacific Northwest Laboratory, Richland, Washington (1983). 
: 4.6-28 Fullwood and liendoza, "HEPA Filter, Appendix A," in Status Report on the EPRI Fuel Cycle Accident Risk Assessment, EPRI NP-1128, Electrical Power Research Institute, Palo Also, California (1979).

4.6-29 Gonzales et al., Performance of Multiple HEPA Filters Against Plutonium Aerosols," LA-6546, Los Alamos Scientific Laboratory, Los Alamos, New Mexico (1976).

4.6-30 J. C. Edler et a. In-Place Testing of Tandem HEPA Filter Stages Using Fluorescent Aerosols, LA-UR-80-2863, Los Alamos Scientific Laboratory, Los Alamo, New Mexico (1980).

4.6-31 H. Lammertz, E. Merz, and S. T. Halazovich, "Technetium Volatilization During HLLW Vitrification," Scientific Basis for Nuclear Waste

Management, Vol. VIII, pp. 823-329 (1985). 



\subsection{EQUIPMENT CONSTRUCTION MATERIALS}

\subsubsection{Function}

Construction materials must be selected for process equipment fabrication. These materials must be chemically and physically compatible with process streams and conditions, and they must satisfy design requirements for the process equipment given in the HWVP Functional Design Criteria (FDC). (a)

\subsubsection{Operational 'Requirements}

The FDC imposes certain functional design requirements on materials used in the construction of remote process equipment. The minimum service life for remote process equipment for the HWVP is as follows:.

- 40 years for nonreplaceable equipment

- 20 years for replaceable compionents.

Exceptions to these requirements will be made where necessary. For instance, the design life for the melter is 3 years. For certain replaceable melter components, however, expected service life is less than 3 years. Also, for the feed preparation and off-gas treatment areas, the process vessels, aithough replaceable, are to be designed for a 40-year life, if practicable.

Based upon the DHPF materials selection criteria (Ref. 4.7-1), the following materials selection criteria were proposed for the HWVP: (b)

- Design the HWVP for a minimum of hands-on maintenance.

- Design radioactive process cell operations to be controlled remotely from outside the cell.

- Design all major equipment to be removable from cells for repair, replacement, or disposal.

- Design piping connections with gasketed connections rather than field welds to facilitate their remote installation and removal, a7though gasketed connections may make equipment especially sensitive to pitting and crevice corrosion.

(a) D. A. Clapp, Hanford Waste Vitrification Plant Functional Design Criteria, SD-HWV-FDC-001, Rockwe11 Hanford Operations, Richland, Washington (1986)

(b) M. R. Elmore, Preliminary Evaluation of Materials Selection for the Hanford Waste Vitrification PTant. HWVP-86-VI135A, Pacific Northwest Laboratory, Richland, Washington (July 1986). 
- Design service life for most major equipment to be 20 years, except for the melter which is 3 years, and 5 years for easily replaced equipment. [The HHVP Functional Design Criteria gives the design basis for process components and equipment as 20 years for replaceable items, 40 years for nonreplaceable items, and 3 years for the melter. However, designing equipment for a 20-year lifetime may not be practicable for all components.]

- Minimize the number of alloys used to maximize interchangeability: and to maintain quality control in installation and field repairs.

- Avoid the use of chemical corrosion inhibitors, which may tend to increase the amount of waste that eventually must be processed for storage and disposal.

In designing to these criteria, materials with acceptable corrosion resistance, erosion resistance, strength, and compatibility must be identified. Ease of fabrication, availability of materials, and costs are additional important considerations in the selection of materials for the HWVP.

The basis and results of the DHPF materials selection effort have been reviewed. (a) Acceptance criteria for DWPF corrosion testing was established as a basis for evaluating the results. A uniform corrosion rate of 5 mpy was chosen as a pass/fail criterion. The decision for 5 mpy was, according to DHPF staff, arbitrary but based on typical constraints used in other chemical process industries with added conservatism because of the unique application at the-DWPF. Additionally, materials were rejected if there was any evidence of localized corrosion, such as pitting, crevice corrosion, and galvanic corrosion.

\subsubsection{Corrosion/Erosion Chemistry}

Corrosion is defined (Ref. 4.7-2) as "the destructive attack of a metal by chemical or electrochemical reaction with its environment. Deterioration by physical causes is not called corrosion, but is described as erosion, galling, or wear. In some instances, chemical attack accompanies physical deterioration as described by the terms: corrosion-erosion, corrosive wear, or fretting corrosion."

Corrosion of metal is a chemical oxidation process that must be coupled with a reduction process. The corrosion process can also be described as electrochemical since electrons are transferred between reacting chemicals. For example.

(a) M. R. Elmore, Preliminary Evaluation of Materials Selection for the Hanford Haste Vitrification Plant. HWVP-86-V1135A, Pacific Northwest Laboratory, Richland, Washington (1986). 
Chemical Reaction:

Oxidation (anodic reaction):

$\mathrm{Zn}+2 \mathrm{H}^{+}+2 \mathrm{Cl}^{-} \rightarrow \mathrm{Zn}^{+2}+2 \mathrm{Cl}^{-}+\mathrm{H}_{2}+$

Reduction (carthodic reaction): $\mathrm{2H}^{+}+2 \mathrm{e} \rightarrow \mathrm{H}_{2}+$

The major source of the chemical changes involved in the corrosion of a metal is its environment. Some of the more common environmental variables that are significant to the HWVP are

- Oxygen and 0xidizers - For many metals, increased oxygen and/or oxidizer concentration with all other conditions remaining constant results in an increased corrosion rate. However, some metals exhibit an active/passive transition. For such a material, the corrosion rate in a solution or siurry may increase up to a point with increased oxidizer concentration. But upon further addition of oxidizing agents, the corrosion rate may decrease by several orders of magnitude as the metal surface is passivated by the solution. Since, with the addition of oxidizers, the corrosion rate of a metal may increase, may not be affected, or may exhibit very complex behavior, it is necessary to fully understand the characteristics of an alloy and the particular environment to which it is to be exposed.

- Velocity - The effects of velocity on corrosion rate are also complex. They depend on the characteristics of the metal and the environment to which it is exposed. For corrosion processes that are controlled by activation polarization, agitation and velocity generaliy have no effect on the corrosion rate of the metal. If the corrosion process is under diffusion control, then agitation increases the corrosion rate. Some metals owe their corrosion resistance to the formation of massive bulk protective films on their surfaces. These films are generally much less tenacious than passivating films, and when exposed to extremely high corrosive velocities, removal of the films can occur. This removal, erosion/ corrosion, then usually results in much higher corrosion rates. S7urries containing abrasive particles, such as HWVP frit, also scour the surface of these protective films, thereby increasing their apparent erosion/corrosion rates. However, although a distinction is often obscure, siurry abrasion is actualiy a combination of erosion and abrasion.

- Temperature - Increased temperature increases the rate of almost all chemical reactions, including most corrosion processes. Corrosion behavior where corrosion rate increases very rapid7y. or exponentially with increased temperature is frequentiy observed, depending on the rate-controlling step of the corrosion mechanism.

- Corrosive Concentration - Corrosion behavior varies widely with concentration of corrosive components. Many materials that exhibit passivity effects are only negligibly affected by wide changes in corrosive concentrations. Other materials show similar behavior except at high corrosive concentrations, when corrosion rate may increase sharply. Another common behavior of metals corroding in 
acid solutions is an initial increase in corrosion rate with acid concentrations as the amount of hydrogen ion increases. The maximum rate reached by this initial increase may be followed by a decreasing corrosion rate with increasing concentration. This decrease is due to decreased acid ionization at high acid concentrations.

- Galvanic Coupling - In complex process streams and piping systems, different metals are frequently in contact with each other and the corrosive solution. Such a condition can result in the increased corrosion of one or more of the metals due to increased flow of a gaivanic corroding current between the dissimilar metals. The consequences of this occurrence are complex, depending on the relative surface areas of the anodic and cathodic materials, the magnitude of the differential of their respective potentials in the corroding solution, etc.

Metallurgical aspects must also be considered in the selection of materials of construction. These aspects include composition, structure, effects of impurities, heat treatment, effects of physical forming, welding, etc. These factors are addressed at least to a limited extent in the design of corrosion tests to preclude unanticipated failures of plant equipment.

- Uniform Corrosion is a general attack over large areas of a metal surface. It can be wet or dry, chemical or electrochemical. Uniform corrosion is the easiest form of corrosion to detect and measure, and unexpected failures can usualiy be avoided by regular inspection.

- Galvanic Corrosion may occur when two different metals in contact are exposed to a conducting solution. A difference in electrical potential serves as the driving force to pass current through the corrodent, resulting in corrosion of the less noble or more active metal. For the DWPF, the reference alloy for pump impellers (Special Pump AlToy) had to be replaced after testing showed severe attack by mercury in the waste on the copper-containing alloy. The selected replacement alloy is Stellite, an erosion-resistant alloy without copper. (a)

- Erosion Corrosion is the form of attack that occurs when movement of a corrodent over a metal surface increases the rate of mechanical wear and corrosion. The role of erosion is usually attributed to the removal of protective surface films or adherent corrosion products. Erosion corrosion is frequently seen on pump impellers, agitators, and piping, particularly at bends and elbows. Fastmoving slurries containing hard particles, such as the HWVP feed slurry and frit slurries, are also likely to cause erosion of equipment and components.

(a) Telecon with Dennis Bickford, SRL, about current status of SRL's materials evaluation program for DWPF. Savannah River Laboratory, Aiken, South Carolina (April 14, 1986). 
- Crevice Corrosion occurs when the chemical environment in a crevice becomes quite different from the conditions on a nearby open surface. A more aggressive environment may develop and cause local corrosion in the crevice. Crevice corrosion is usually a result of one or more of the following conditions in the crevice: changes in acidity, lack of oxygen, buildup of a detrimental ion species, or depletion of an inhibitor. Crevices will be a common problem in the HWVP because of the required gasketed fittings. Some materials are more susceptible than others and must be considered in selecting alloys.

- Pitting Corrosion is the formation of holes in an otherwise relatively unattacked surface. The shape of a pit is often responsible for its continued growth for the same reasons mentioned under crevice corrosion. The initiation of pitting is usualiy a slow process (sometimes taking months or years to become visible). But once initiated, pitting can proceed rapidiy and may result in sudden unexpected failures of the equipment. Based on experience, pitting may be of particular concern because of the chemical nature of the HWVP feed. For example, species that may be present in very low concentrations in the bulk fiuid, such as halides, sulfates, etc., may be concentrated in pits. In fact, the selection of $\mathrm{C}-276$ for the DWPF was primarily due to its apparent pitting resistance in the DWPF solutions. [Since pitting initiation can be a slow process, there is some concern at PNL as to whether the DWPF tests were conducted long enough to evaluate the long-term pitting resistance of the $\mathrm{C}-276$.

- Stress corrosion is the cracking of a metal alloy that results from the combined action of a tensile stress and a corrodent. Cracking can follow either intergranular or transgranular paths. One combination that is familiar to the nuclear industry, and must be considered for the HWVP, is $304-L$ stainless steel used in contact with solutions containing even minute concentrations of chloride.

Many other forms of corrosion (corrosion fatigue, intergranular attack, sulphidation, parting, fretting corrosion, embrittlement, etc.) are also possible under various conditions. The possibility of localized corrosion (particularly stress corrosion cracking and pitting) should be considered whenever a material is selected. These forms of corrosion are much more likely to occur and result in failure when the rate of uniform corrosion is low. This emphasizes the need to recognize the various forms of corrosion and the seriousness of localized corrosion when selecting materials for the HWVP. Verification testing of selected materials is extremely important to provide input to the design of any new plant or piece of equipment. This is especially true for the HWVP because of the unique process and special requirements. 


\subsubsection{Iechnology Develooment}

Descriptions, results, and conclusions of materials evaluation studies for the HWVP are presented in this section. Studies conducted at PNL include preliminary screening tests, follow-on corrosion studies, erosion/corrosion studies, an evaluation of the impact of recycling TRU-containing waste, tests for the HOG system and melter materials, and a cost evaluation. DWPF studies relevant to selection of HWVP materials for feed preparation and off-gas processing are also reported.

\subsubsection{Background. Materials selection activities for the DUPF have served} as the basis for much of the HWVP materials evaluation effort. Because of similarities in plant equipment designs and waste ( $p$ lant feed) compositions, SRL-developed guidel ines for selecting materials and laboratory corrosion testing experience are referred to extensively as a basis for the HWVP materials selection process. Differences in the HWVP feed compositions and processing conditions have been identified that necessitate independent verification of the suitability of candidate materials of construction for HWVP process equipment. Mercury is present in DWPF sludge and not in the HWVP slurry. There is a much higher fluoride concentration in the HWVP feed compared with the DWPF feed (a) ( $-400 \mathrm{ppm}$ for the more dilute HHVP feed versus -60 ppm for the DWPF feed. However, when comparing the two feeds at similar solids concentrations, the effective difference in fluoride levels based on similar solids concentrations is about $3000 \mathrm{ppm}$ for HWVP versus $60 \mathrm{ppm}$ for DWPF). Another important consideration is the potential impact of waste stream recycling on materials requirements for the HWVP. The HWVP feed specification has a much broader envelope of component concentrations than the DWPF feed specification, which may unfavorably impact materials performance. These differences have influenced much of the testing effort for the HWVP materials selection activities.

The HWVP materials evaluation activity was established to select and verify the performance of suitable materials for the HWVP remote process equipment and process piping. The approach for this activity has been to 1) review DWPF and other relevant materials selection studies, and 2) cpnduct necessary verification testing as a basis for recommending materials. (b)

A preliminary materials selection review was conducted in FY 1986. (b) This study reviewed expected waste stream compositions and process conditions and evaluated DWPF materials selection studies for applicability to HWVP. From information available at that time regarding HWVP feed composition and processing conditions, a preliminary list of reference materials was proposed

(a) M. R. Elmore, Preliminary Evaluation of Materials Selection for the HWVP. HWVP-86-V1135A, Pacific Northwest Laboratory, Richland, Wastington (1986)

(b) M. R. Elmore, Test PIan for Materials Selection Program: HWVP Equipment Cost Comparison and Continued Materials Testing Requirements. HWVP-88-V110305A, Pacific Northwest Laboratory, Richland, Washington (1988). 
and initial screening tests were outlined. The materials selected for initial tests were based on both SRL testing and on recommendations of alloy suppliers. The list of initial materials consisted of 304-L stainless steel, Carpenter Alloy $20 \mathrm{Cb}-3$, three Hastelloy alloys (C-276, C-22, and G-3), two titanium alloys (Ti Grade 7 and Beta-C Ti), and ALLCORR.

A reference feed composition for the HWVP was specified, based on limited tank farm characterization and on various PUREX and waste treatment simulations. 'Using that feed specification and a projected HWVP process flowsheet, test solution compositions were developed for accelerated laboratory corrosion tests to prepare an initial ranking of the selected alloys. Laboratory tests were conducted in FY 1987 as an initial performance evaluation of those first materials. (a) Some of the alloys, 304-L SS and the two titanium alloys, were eliminated from further testing because of unsatisfactory performance, high unjform corrosion rates, and localized attack.

- Hastelloy G-3 was el iminated because of its similar composition and performances to two other Hastelloy alloys selected for further testing. Those selected for follow-on testing included Alloy $20 \mathrm{Cb}-3$, Hastelloy C-276, Hastelloy $C-22$, and ALLCORR. Alloy 20 was retained in anticipation that a more economical material may be suitable for HWVP than the Hastelloy C-276 selected for DWPF. Hastelloy $\mathrm{C}-22$, showing similar performance to C-276, was retained because better fabrication properties were reported for it compared. with C-276. ALLCORR was included because of SRL results where C-276 had questionable performance under simulated off-gas quencher testing.

Follow-on testing conducted in FY 1987 indicated that the materials were subject to uniform corrosion but at different corrosion rates. Under those conditions used for the corrosion tests, the alloys showed no evidence of localized corrosion in the test solutions. Performance of the alloys in these preliminary tests was such that the more highly alloyed materials, which are also generally more expensive, were generally the more corrosion resistant ones. Two candidate materials became the focus for further work, A7loy 20 and C-276. C-276 appeared to be more corrosion resistant to test solutions than the Alloy 20; however, the Alloy 20 was thought to be significantiy less expensive than the C-276. ALLCORR was eliminated when test results showed it to be potentially less corrosion resistant than the Hastelloys. Also, availability of the material may be a problem according to information from SRL. Hastelloy C-22 was dropped because of its similar behavior to $\mathrm{C}-276$, and since $\mathrm{C}-276$ is the reference material for much of the DWPF equipment.

Another series of scoping tests was conducted to study the erosive effects of the waste and frit slurries to be encountered in the HWVP. Slurry abrasivity tests were conducted in accordance with the ASTM G-75 procedure on samples of Alloy -20, C-276, and Stellite-6. The Stellite exhibited a much higher abrasive wear resistance than either of the other two materials

(a) M. R. Elmore, Materials Selection for the Hanford Haste Vitrification P1ant - FY 1987 Scouting Tests. HWVP-87-V110304A, Pacific Northwest Laboratory, Richland, Washington (1987). 
(approximately 10: to 20 times higher). The $\mathrm{C}-276$ was only slightly more wear resistant than the Alloy 20. Results of these tests were reported in FY 1987. (a)

After preliminary testing in FY 1987, an approach was taken to evaluate the relative costs of materials and to eventually determine whether Alloy 20, a less expensive alloy than the C-276 specified for DWPF, could be used for the HWVP. This pian is described in the FY 1988 Letter of Instruction. (b). Preliminary cost comparisons for process equipment fabricated from corrosionresistant alloys indicate that the initial cost penalty for. specifying a more corrosion-resistant material over a lesser one can be significant. Specifying ATloy C-276 over AlToy 20 . for DWPF equipment resuTted in an apparent fabricated cost increase by a factor of 2 . Other sources indicate similar results. The high cost of corrosion-resistant materials and the potentially high cost of faited components reflects the need for proper verification testing to avoid either under- or overdesign of equipment. Caution is justified in the selection of materials for the HWVP, given the unique materials seTection criteria for the plant, uncertainties in stream compositions and processing conditions, and lack of specific information on the corrosion resistance of potential materials under actual plant conditions.

\subsubsection{PNL Materials Tests.}

4.7.4.2.1 Preliminary Materials Screening Tests for Feed Preparation and Off-Gas Tanks. [M. R. Elmore, Materials Selection for the Hanford Waste Vitrification PTant - FY 1987 Scouting Tests. HWVP-87-V110304A, Pacific Northwest Laboratory, Richland, Hashington (1987)]. Laboratory screening tests were performed to evaluate materials for equipment construction in process areas that would be in contact with corrosive aqueous solutions, specifically the feed preparation and off-gas equipment. Laboratory testing included two phases:

- Conduct preliminary. scoping tests with all the initial candidate materials. Results of these scoping tests were used to identify a limited number of the initial candidates that are suitable for further testing. Scoping tests included standard immersed coupon tests and potentiodynamic electrochemical tests.

- Perform additional testing on materials selected from the initial list. Testing included longer-term immersion tests with simulated feed preparation solutions and simulated off-gas condensate solutions.

(a) M. R. Elmore, Materials Selection for the Hanford Waste Vitrification Plant - FY 1987 Scouting Tests. HWVP-87-V110304A, Pacific Northwest Laboratory, Richiand, Washington (1987).

(b) M. R. Elmore, Preliminary Evaluation of Materials Selection for the HWVP. HWVP-86-V1135A, Pacific Northwest Laboratory, Richland, Washington (1986): 
Where possible, standard methods were used or adapted for the materials testing. These methods included procedures for standard laboratory immersion tests, potentiodynamic corrosion tests, and erosion/corrosion (siurry abrasion) tests. These methods are common for all HWVP materials testing performed, described in subsequent sections. .

4.7.4.2.1.1 Immersion Corrosion Testing. This section describes the methods used for preparing the test solutions, preparing metal specimens for the laboratory immersion corrosion tests, conducting the immersion tests, removing corrosion products from the specimens after a test has been completed, and for evaluating the corrosion damage that has occurred. Methods used for the immersion corrosion tests are based upon standard ASTM procedures (e.g. ASTM-G-1-81, ASTM-G-31-72).

\subsection{1 Solution Compositions And Makeup. A variety of solution} compositions were used for the immersion tests. For the preliminary scoping tests, a solution composition was derived from an evaluation of the reference feed and an analysis of the expected process conditions, including provisions for waste and condensate recycle in the plant. Only a few of the constituents of the HWVP feed contribute significantly to corrosion of the candidate materials, including chloride, fluoride, sulfate, nitrate, and formate, particularly in acidic environments. Other possible components that may contribute to corrosion to a lesser extent include certain transition metal . ions. The effects of these minor components were not included in the scope of the FY 1987 tests.

Test durations were initially limited to a few days to facilitate the evaluation of several initial candidate materials. Therefore, a concentrated solution consisting of the corrosive components was used to accelerate the corrosion rates and produce measurable weight losses from the test coupons. The composition of the pretiminary scoping test solution is shown in Table 4.7-1. Each of the anion components was added in its acid form, resulting in an initial $\mathrm{pH}$ of -2 for this solution.

At the completion of the scoping tests, the reference feed was reevaluated along with the original assumptions made about the expected processing conditions. Appropriate changes were made to the test solution compositions for subsequent testing. Two types of test solutions were identified for follow-on immersion testing; one that simulated solutions expected to be encountered in the feed preparation area such as the SRAT or SME, and the other that simulated potential off-gas condensate solutions. The composition of the feed preparation and off-gas condensate simulant solutions are also shown in Table 4.7-1. Two acid concentrations were selected for each of the two solutions types. For the feed preparation solutions, pHs of 2 and 4 were chosen. (Normal pH endpoint after formating the HWVP. feed should be close to 4.) Solutions for each $\mathrm{pH}$ were prepared by adding the components in predetermined combinations of acids and sodium salts. The actual components used to make up the simulated feed preparation solutions are also shown in Table 4.7-1. 
TABLE 4.7-1... Compositions of Solutions Used For FY 1987 Corrosion Tests HWVP-87-V110304A

\begin{tabular}{|c|c|c|c|c|c|c|}
\hline \multirow[b]{2}{*}{ Component } & \multicolumn{2}{|c|}{$\begin{array}{l}\text { Prel iminary } \\
\text { Scoping Tests } \\
\text { Solution(a) }\end{array}$} & \multicolumn{2}{|c|}{$\begin{array}{l}\text { Simulated Feed } \\
\text { Preparation Solution }\end{array}$} & \multicolumn{2}{|c|}{$\begin{array}{l}\text { Simulated Off-Gas } \\
\text { Condensate Solution }\end{array}$} \\
\hline & $\begin{array}{c}\text { Cone, } \\
\text { ppm }\end{array}$ & $\begin{array}{c}\text { Added } \\
\text { As: }\end{array}$ & $\begin{array}{c}\text { Conc, } \\
\text { ppnin }\end{array}$ & Added As: & $\begin{array}{c}\text { Conc, } \\
\text { ppm }\end{array}$ & Added As: \\
\hline $\begin{array}{l}\mathrm{Cl}^{-} \\
\mathrm{F}^{-} \\
\mathrm{SO}_{4}^{-} \\
\mathrm{NO}_{3}^{-} \\
\mathrm{COOH}^{-}\end{array}$ & $\begin{array}{r}1000 \\
5000 \\
10000 \\
1000 \\
10000\end{array}$ & $\begin{array}{l}\mathrm{HCT} \\
\mathrm{HF} \\
\mathrm{H}_{2} \mathrm{SO}_{4} \\
\mathrm{HNO}_{3} \\
\mathrm{HCOOH}\end{array}$ & $\begin{array}{r}1000 \\
5000 \\
5000 \\
12000 \\
16000\end{array}$ & $\begin{array}{l}\mathrm{HCl}(b) \mathrm{NaCl}(c) \\
\mathrm{HF}(b) \mathrm{NaF}^{(c)} \\
\mathrm{Na}_{2} \mathrm{SO}_{4} \\
\mathrm{NaNO}_{3} \\
\mathrm{HCOOH}\end{array}$ & $\begin{array}{r}1500 \\
7000 \\
7000 \\
17000 \\
0\end{array}$ & $\begin{array}{l}\mathrm{HCl}(d) \mathrm{NaCl}(e) \\
\mathrm{HF}(d) \mathrm{NaF}(e) \\
\mathrm{H}_{2} \mathrm{SO}_{4}(d) \mathrm{Na}_{2} \mathrm{SO}_{4}(e) \\
\mathrm{HNO}_{3}\end{array}$ \\
\hline
\end{tabular}

(a) Solution $\mathrm{pH}-2$

(b) Solution $\mathrm{pH}-2$

(c) Solution $\mathrm{pH}-4$

(d) Solution $\mathrm{pH}-1$

(e) Solution $\mathrm{pH}-2$

For the off-gas condensate solutions, the selected pHs were 1 and 2 , based on expected more acidic conditions for the melter off-gas condensate. The primary difference in compositions between the simulated feed preparation solutions and the simulated off-gas condensate solutions is the presence of significant quantities of formic acid in the feed preparation solutions. The majority of the. formic acjd is destroyed in the melter and therefore does not collect in the off-gas condensate to significant concentrations. The actual solution components used to prepare the simulated off-gas condensate solutions are given in Tabie 4.7-1.

In addition to the solution-based tests as described above, a number of immersed coupon tests were conducted using simulated HWVP feed slurries. The simulated HWWP feed slurry, identified as HWS-7, came from a large lot previously used for other HWVP work (Ref. 4.7-3). Its composition is shown in Table 4.7-2. Two series of tests were run with the slurry; one test immersed the coupons in boiling unformated slurry, and another used boiling formated siurry. Formating was accomplished according to previousiy estabi ished procedures -- slow addition of formic acid to the slurry at $-95^{\circ} \mathrm{C}$ to an endpoint of $\mathrm{pH} 4$ then holding the slurry at temperature for $2 \mathrm{~h}$.

\subsection{2 Immersion Test Equipment And Procedures. The apparatus} used for the immersion testing was very similar to that recommended by ASTM G-31-72 (Ref. 4.7-4). It consisted of a 3-L resin kettle fitted with a condenser, coupon hanger, and thermocouple. The kettle was heated with a heating mantle controlled by a thermocouple and controller. Figure 4.7-1 shows the test apparatus used for the immersion testing of the metal coupons, 1 in. $x 2$ in. $x 1 / 16$ in. with a hole punched near one end. 
TABLE 4.7-2. Composition of Simulated HWVP Feed, HWS-7 HWVP-87-V110304A

\begin{tabular}{|c|c|}
\hline Compound & $\begin{array}{c}\text { Concentration, } \\
g / L\end{array}$ \\
\hline 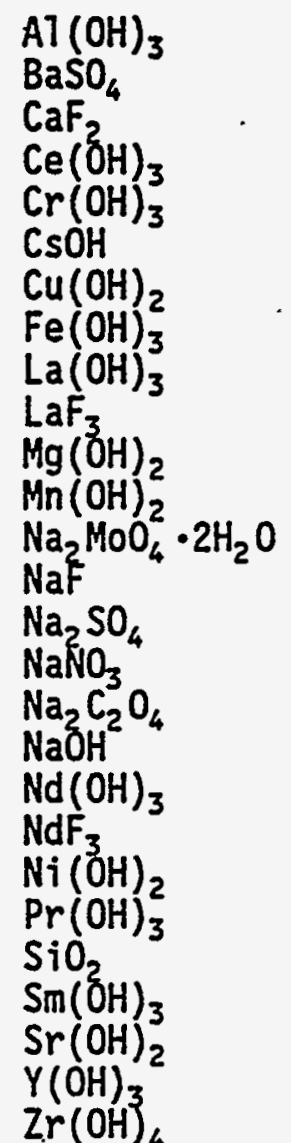 & $\begin{array}{r}39.13 \\
0.94 \\
0.63 \\
1.17 \\
10.72 \\
1.57 \\
1.10 \\
88.44 \\
0.70 \\
3.21 \\
0.63 \\
1.10 \\
2.97 \\
2.74 \\
3.44 \\
19.96 \\
5.01 \\
5.32 \\
0.70 \\
0.86 \\
4.46 \\
0.70 \\
4.46 \\
0.31 \\
0.70 \\
0.39 \\
4.62\end{array}$ \\
\hline
\end{tabular}

Source: (Ref. 4.7-3)

A fluoropolymer (Tefion) coating for the resin kettle was used to protect the glassware from potential fluoride attack

Throughout the tests, the kettles were monitored to ensure temperature control and to check for indications of other problems. Fest durations ranged from 4 to 8 days for the prel iminary scoping tests, and from 14 to 28 days for succeeding tests. The coupons were removed from the kettles after a specified time, cleaned, and weighed. The extent of corrosion of the materials was determined by first visualiy inspecting the coupons for evidence of localized corrosion, then determining uniform corrosion rates by weight loss. 


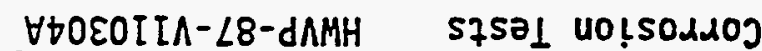

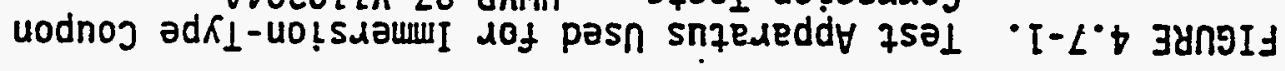

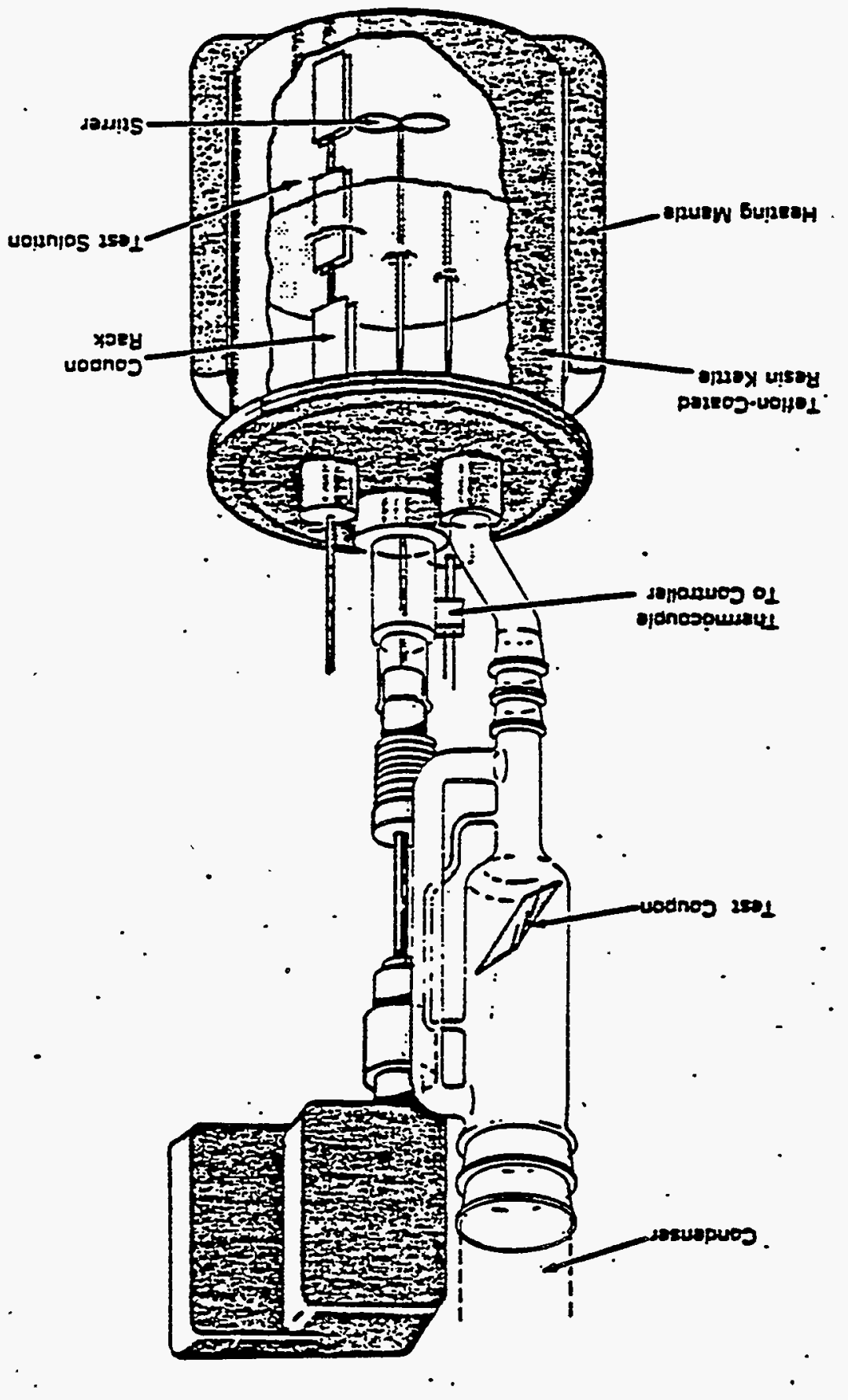


4.7.4.2.1.2 Electrochemical Testing. Aqueous corrosion of metals is generalty due to electrochemical phenomena. Standard electrochemical tests. have been developed that are useful for rapidly comparing the resistance of metals to certain types of localized corrosion, such as pitting, which otherwise" may not be evident in immersion tests (Ref. 4.7-5). Potentiodynamic testing is a method to accelerate the electrochemical corrosion of a sample by artificially impressing a much higher potential on the specimen than the material would experience due to its chemical potential in regular immersion testing.

4.7.4.2.1.2.1 Solution Compositions and Makeup. The solution used for the electrochemical tests was the same as that described above in Section 4.7.4.2.1.1.1.

4.7.4.2.1.2.2 Electrochemical Test Apparatus and Procedures. Prior to polishing each specimen and starting a test, the test vessel was filled with solution, and the temperature was stabilized at the setpoint for the test. Once the temperature was stabilized, the specimen holder was placed in the kettle. The electrodes were then connected to the potentiostat (PAR Model $350 \mathrm{~A}$ ), and after the system stabilized, the open circuit potential for the specimen was recorded. Materials evaluated in the electrochemical tests were the same as those for the immersion tests (Table 4.7-3). The specimens used for the electrochemical tests were 1/2-in.-diameter discs. The test apparatus for electrochemical testing was similar to the one used for immersion testing.

A pitting scan was then run on each of the materials at various temperatures to investigate for sensitivity to pitting or crevicing that the immersion tests might not have detected. For the PAR potentiostat, a pitting scan is performed by programming into the instrument the desired starting and endpoints and the scan rate. As the scan is started, the corrosion current versus potential is recorded by the instrument. The resulting plot of the potential-current function is indicative of the tendency of the material to undergo pitting.

4.7.4.2.1.3 Erosion/Corrosion Testing. Erosion is defined as the progressive loss of original material from a solid surface due to mechanical action between that surface and a fluid, a multicomponent fluid, or impinging liquid or solid particles. In certain instances, abrasion is identified as a subset of the overall process of erosion (slurry abrasion). In these cases, abrasion is defined as wear due to exposure of equipment to a moving slurry of hard particles.

4.7.4.2.1.3.1 S7urry Compositions and Makeup. Two typical slurries were selected for the abrasion tests. One was a siurry containing HWVP frit, formic acid, and water. The other slurry contained simulated HWVP feed (HWS-7), frit, formic acid, and water. The compositions of these slurries is shown in Table 4.7-4. Formic acid is known to leach components from the frit with time, which could alter the abrasivity of the frit particles, as well as change the corrosiveness of the slurry. (As formic acid reacts with the glass frit, the solution $\mathrm{pH}$ increases.) For these reasons, the slurries were made up just prior to each test. 
TABLE 4.7-3. Compositions of Candidate Alloys For FY 1987 Corrosion Tests HWVP-87-V110304A

\begin{tabular}{|c|c|c|c|c|c|}
\hline & \multicolumn{5}{|c|}{ Alloy Composition (wt\%) } \\
\hline Material & $\mathrm{Fe}$ & $\mathrm{Ni}$ & $\mathrm{Cr}$ & Ti & Other \\
\hline $304-L$ SS & BAL & $8-10$ & $18-20$ & & $M_{n}<2.0$, si $<1.0, c<0.03$ \\
\hline Al Toy $20 \mathrm{Cb}-3$ & BAL & $32-35$ & $19-21$ & & $\begin{array}{l}\text { Mo } 2-3 \text {, Cu } 3-4, C b+T a<1.0, \\
\text { Mn }<2.0 \text {, Si }<1.0, C<0.06\end{array}$ \\
\hline Hastelloy C-276 & $4-7$ & BAL & $14-17$ & & $\begin{array}{l}C_{0}<2.5, M o 15-17, W 3-4.5, \\
M n<1.0, C<0.01\end{array}$ \\
\hline Hastel 1 oy C-22 & $2-6$ & BAL & $20-23$ & & $\begin{array}{l}\text { Co }<2.5 \text {, Mo } 12-15, \text { W 2-4, } \\
M_{n}<0.5, C<0.01\end{array}$ \\
\hline Hastel7oy G-3 & $18-21$ & BAL & $21-24$ & & $\begin{array}{l}\text { Co }<2.5, \text { Mo 5-8, } W<1.0, \\
\text { Mn } 1-2, C<0.05\end{array}$ \\
\hline ALLCORR & $\because-$ & BAL & $30-32$ & & Mo $10, W 2.0$, Ti 0.25, Al 0.2 \\
\hline Grade $7 \mathrm{Ti}$ & & & 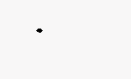 & BAL & Pd $0.12-0.25$ \\
\hline Beta-C Ti & & & & BAL & $\begin{array}{l}\text { A1 } 3-4, \text { i } 7-9 \text {, Cr 5-7, } \\
\text { Mo } 3-5, \text { Zr 3-5 }\end{array}$ \\
\hline
\end{tabular}

Source: Manufacturer Data Sheets-

$$
\begin{aligned}
& \text { Hastelloys - Cabot Corp. } \\
& \text { Alloy } 20 \text { - Carpenter Technology } \\
& \text { ALLCORR - Teledyne Allvac } \\
& \text { Ti Alloys - RMI Company } \\
& 304-L \text { - United States Steel Corp. }
\end{aligned}
$$

4.7.4.2.1.3.2 Erosion/Corrosion Test Apparatus and Procedure. The procedure for evaluating the abrasion resistance of the candidate materials to the selected slurries was adapted from ASTM G-75-82, Test Method For Slurry Abrasivity By Miller Number (Ref. 4.7-6): This test method determines the abrasivity of a slurry and assigns a relative index (Miller Number) that can be used to compare the effects of different slurries on the wear of slurry handling equipment. Three materials were selected for initial HWVP abrasion tests: Alloy $20 \mathrm{Cb}-3$, Hastell oy $C=276$, and Stellite-6. Figure 4.7-2 shows a sketch of the wear specimens with dimensions, as recommended by the ASTM procedure.

The test apparatus, shown in Figure 4.7-3, imparts a horizontal reciprocating motion to the test specimen moving in a siurry contained in a rectangular pan. Each of the specimen holders was loaded with extra weight to increase the wear rates of the specimens.. The standard test length was 
TABLE 4.7-4. Compositions of Abrasion Test S7urries HWVP-87-V110304A

\begin{tabular}{|c|c|c|}
\hline Slurry & Component & Concentration, wt \% \\
\hline Frit/ $/ \mathrm{HCOOH} / \mathrm{H}_{2} \mathrm{O}$ & $\begin{array}{l}\text { Frit }(H H-39)(a) \\
\text { HCOOH } \\
\text { Hater }\end{array}$ & $\begin{array}{l}60 \\
-1 \\
\text { BAL }\end{array}$ \\
\hline $\begin{array}{l}\text { Simulated HWVP Feed/ } \\
\text { Frit/ } / \mathrm{HCOOH} / \mathrm{H}_{2} \mathrm{O}\end{array}$ & $\begin{array}{l}\text { HWVP Feed (HHS-7) } \\
\text { Frit (HH-39) } \\
\text { HCOOH } \\
\text { Water }\end{array}$ & $\begin{array}{l}-11 \\
-33 \\
-1 \\
B A L\end{array}(\mathrm{pH}-4)$ \\
\hline
\end{tabular}

(a) HW-39 Particle Size and Chemical Composition:

\begin{tabular}{|c|c|c|}
\hline $\begin{array}{l}\text { Particle Size: } \\
\text { Composition: }\end{array}$ & $\begin{array}{l}-80 /+ \\
\text { Oxide }\end{array}$ & Wesh \\
\hline & $\begin{array}{l}\mathrm{SiO}_{2} \\
\mathrm{~B}_{2} \mathrm{O}_{3} \\
\mathrm{Na}_{2} \mathrm{O} \\
\mathrm{Li}_{2} \mathrm{O} \\
\mathrm{CaO} \\
\mathrm{MgO}\end{array}$ & $\begin{array}{r}67.3 \\
12.7 \\
10.3 \\
5.0 \\
3.7 \\
1.0\end{array}$ \\
\hline
\end{tabular}

Source: (Ref. 4.7-3)
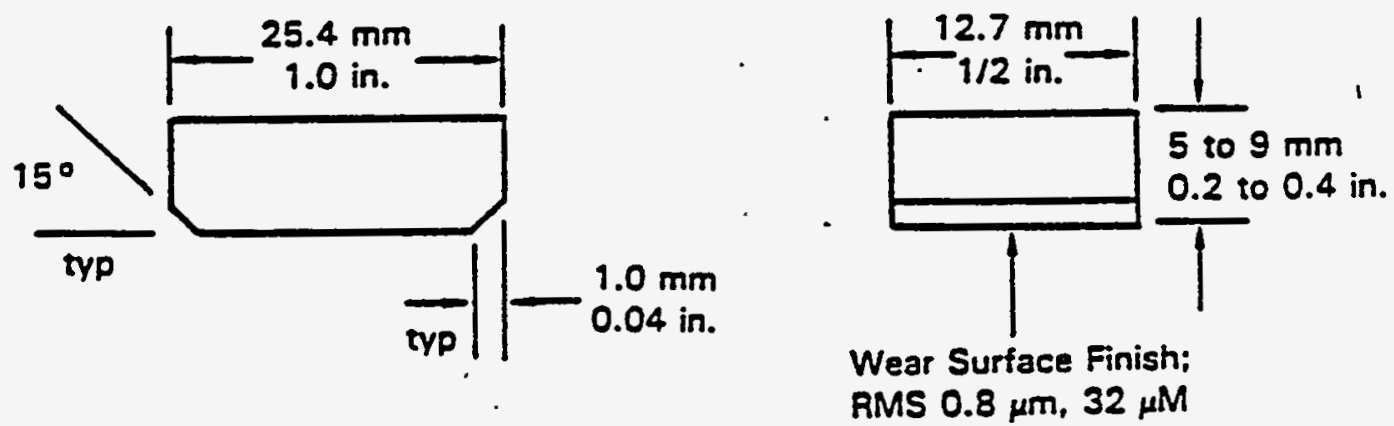

FIGURE 4.7-2. Sketch of Test Specimens Used in the Abrasive Slurry Tests HWVP-87-V110304A 

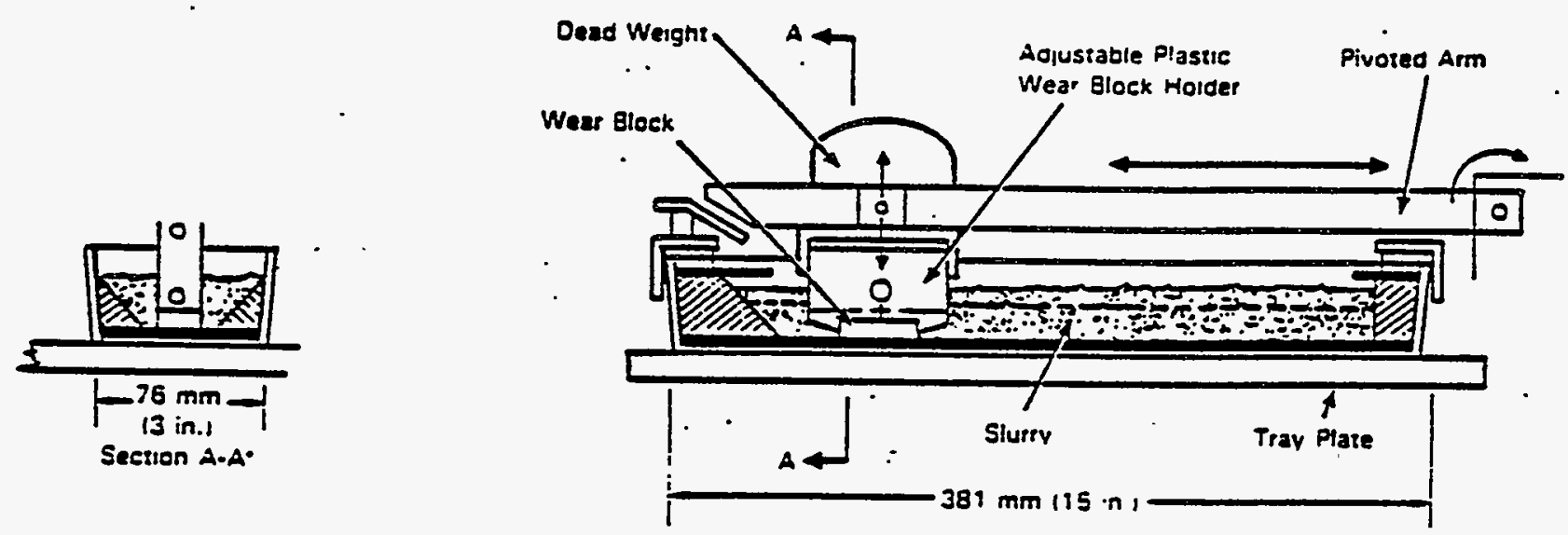

FIGURE 4.7-3. Sketch of ASTM Abrasive S7urry Testing Machine HWVP-87-V110304A

$16 \mathrm{~h}$. The test specimen was removed at $4-h$ intervals, cleaned, dried, and weighed. The mass loss recorded for the specimen during the test corresponds to the material's wear resistance to the abrasive slurries.

4.7.4.2.1.4 Results of Preliminary Scoping Studies. This section discusses the results of the two types of corrosion tests that were conducted during the preliminary phase of the FY 1987 testing. Initial immersion coupon tests were first.performed to rank candidate materials by apparent corrosion resistance, followed by a series of electrochemical tests performed specifically to evaluate the material's' resistance to pitting or crevice attack (localized corrosion).

4.7.4.2.1.4.1 Initial Immersion Coupon Tests. Coupons were placed in the test apparatus to expose them to the condensate, to the vapor space, half-submerged at the interface, and fully submerged in the boiling solution. Duplicate tests were run for each alloy. Test durations varied for these initial tests. All tests were run for at least 4 days. Tests on some of the more corrosion-resistant alloys were continued for 8 days when inspection after 4 days showed little or no visible attack. Those alloys tested for 4. days included the 304-L, titanium alloys, and the Alloy 20 . The other materials were tested for the 8-day period. Calculated corrosion rates in all cases were normalized to mils per year. Although the results are presented in mils per year, it must be remembered that the corrosion rates are to be used only as a means of comparing and ranking the different alloys. The rates do not reflect expected corrosion rates of the materials in service. Actual corrosion rates cannot be accurately predicted from these types of accelerated tests.

Uniform corrosion rates were calculated for each coupon, and the materials were ranked accordingly. (Corrosion rates generally varied between the vapor space and submerged coupons, so uniform corrosion rates are not as meaningful for the interface sampies. In most instances the corrosion rate for the interface samples fell between those of the vapor space and submerged 
coupons, which supports the observation that attack was, in general, uniform corrosion.) Results of the preliminary scoping tests are given in

Table 4.7-5 in terms of the calculated uniform corrosion rates.

After testing all the materials, it was found that all but two alloys exhibited uniform attack. The exceptions were the titanium alloys, Beta-C and $\mathrm{Gr}-7$. The Beta-C alloy showed very severe attack, apparently intergranular, over the entire submerged coupon, and below the liquid surface on the interface sample. The attack on the Gr-T titanium alloy was much different. For the Gr-7 alloy, the corrosion appeared only at the interface in a thin "knife-line" attack. It is not uncommon for materials to show more severe corrosion at a liquid/gas interface, usually attributable to a mass transport phenomenon, but this occurrence was particularly striking. The fully submerged coupon of the GR-7 titanium alloy had a relatively low corrosion loss.

A statistical analysis of the data was performed to determine a level of uncertainty for the calculated corrosion rates. From this statistical analysis, the estimate of the standard deviation (SD) for the replicate tests was found to be 1.57 mils per year. This SD would indicate that differences in corrosion rates of less than a few mils per year (e.g. <5 mpy) between alloys are not very significant. This uncertainty estimate is a composite SD for the tests, including variations due to specimen differences, test variations, and measurement variability. An estimate was made of measurement variability and found to be $-0.004 \mathrm{mils}$ per year, insignificant in the total uncertainty. Therefore, the specimen differences and test variations comprise the majority of uncertainty in the calculated corrosion rates. The analysis of the corrosion rates did reveal that the corrosion rates for the $G-3$ and ALLCORR were

- significantiy higher than the $\mathrm{C}-276$ or $\mathrm{C}-22$. There appeared to be no difference between the ALLCORR and the G-3; nor was there any difference

TABLE 4.7:5. Corrosion Rates For Preliminary Scoping Tests(a) HWVP-87-V110304A

\begin{tabular}{|c|c|c|c|c|}
\hline \multirow[b]{2}{*}{ Material } & \multicolumn{4}{|c|}{ Corrosion Rates, Hils per year } \\
\hline & Condensate & Vapor Space & Interface & Submerged \\
\hline $\begin{array}{l}304-L \text { SS } \\
\text { Ti Beta-C(b) } \\
\text { Ti Gr-7(b) } \\
\text { Alloy } 20 \text { Cb-3 } \\
\text { Hastalloy C-276 } \\
\text { Hasta7loy C-22 } \\
\text { Hastalloy G-3 } \\
\text { LLCORR }\end{array}$ & $\begin{array}{l}0.4 \\
0 \\
8.6 \\
1.0 \\
0 \\
0 \\
0 \\
0\end{array}$ & $\begin{array}{l}0.2 \\
1.4 \\
1.2 \\
1.2 \\
0.1 \\
0.1 \\
0.1 \\
0.2\end{array}$ & $\begin{array}{r}59.0 \\
-550 \\
-\therefore- \\
26.2 \\
4.6 \\
3.3 \\
8.0 \\
9.3\end{array}$ & $\begin{array}{r}100.4 \\
-775 \\
29.8 \\
31.9 \\
.3 .9 \\
2.9 \\
9.0 \\
7.2\end{array}$ \\
\hline
\end{tabular}

(a) Solution Temerature: $-130^{\circ} \mathrm{C}$, Solution $\mathrm{pH}$ : -2 . Corrosion rates given are averages of duplicate coupons for each test, except as oterwise indicated.

(b) Duplicate tets were not performed. 
any difference between the $6-276$ and $c-22$ corrosion rates. The results of this analysis can be represented by ranking the candidate alloys according to corrosion rate by the following:

$$
\text { 304-L, Ti alloys } \gg>\text { Alloy } 20>\text { G-3, ALLCORR > C-22, C-276 }
$$

After the initial immersion tests were completed, the candidate materials were divided into two groups based on relative corrosion resistance. Group one consisted of both titanium alloys and the 304-L stainless steel, which had comparatively high corrosion rates. The second group, consisting of the remaining materials (Alloy 20, the Hastelloys, and ALLCORR), exhibited reasonably similar corrosion responses. Based on responses to the initial immersion tests, group one materials would be unsuitable for further consideration as candidate materials of construction.

A brief series of immersion tests with simulated welded coupons was conducted to evaluate potential corrosion of heat-affected zones on some of the materials. Coupons of Alloy 20, C-276, and C-22 were subjected to a gas tungsten arc weld (GTAW) beam, producing a heat-affected band across the specimen. Immersion tests using the same solution and conditions as before were then performed, and the heat-affected zones were examined for local attack. No localized attack was visible on the coupons after the tests. - Uniform corrosion rates were determined in Table 4.7-6. Corrosion rates for the materials at each location are nearly identical to the corresponding ones in the earlier tests with unwelded coupons.

4.7.4.2.1.4.2 Electrochemical Tests. A series of electrochemical tests were conducted using a potentiostat to quickly evaluate the materials for susceptibility to pitting. The procedure used for these tests was described in. Section 4.7.4.2.1.2.2. After each pitting scan was completed, the results were automatically plotted by the potentiostat on a graph of potential versus corrosion current. Since the potential for pitting can be a function of temperature, tests were conducted at temperatures ranging from room temperature to $-90^{\circ} \mathrm{C}$. Figure $4.7-4$ shows a plot of the pitting scan for ALLCORR as a function of temperature, which was typical for most of the materials. The

TABLE 4.7-6. Corrosion Rates for Simulated Welded Coupons(a) HWVP-87-V110304A

\begin{tabular}{|l|c|c|c|c|}
\cline { 2 - 5 } \multicolumn{1}{c|}{} & \multicolumn{4}{c|}{ Corrosion Rates mils per year } \\
\hline Material & Condensate & Vapor Space & Interface & Submerged \\
\hline Alloy 20 Cb-3 & 0.1 & & & \\
Hastalloy C-276 & 0 & 0.6 & 22.7 & 44.7 \\
Hastal7oy C-22 & 0.1 & 0.2 & 3.3 & 2.9 \\
\hline
\end{tabular}

(a) Solution Temperature: $-103^{\circ} \mathrm{C}$, Solution $\mathrm{pH}:-2$.

Corrosion rates are for single coupon tests, not duplicates. 


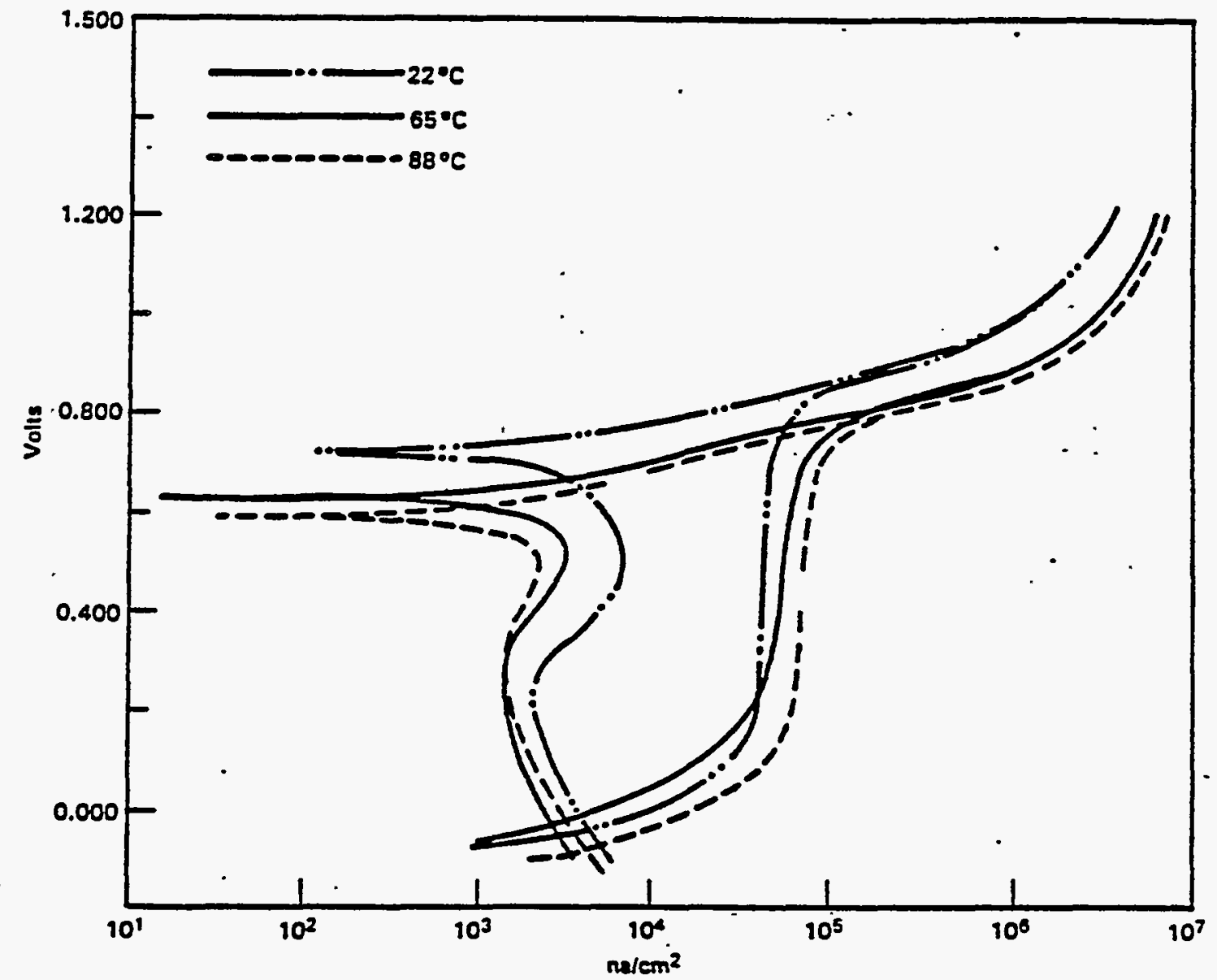

FIGURE 4.7-4. Pitting Scan for ALLCORR in Scoping Study Test Solution at $22^{\circ} \mathrm{C}, 65^{\circ} \mathrm{C}$, and $88^{\circ} \mathrm{C}$. The graph indicates a shift toward higher corrosion currents with increasing temperature, but shows no evidence of pitting susceptibility. HWVP-87-V110304A

effect of increasing the solution temperature was to shift the corrosion current to higher values for a given potential, but no particular susceptibility to pitting or crevice attack was evident in these tests.

4.7.4.2.1.5 Results of Follow-On Corrosion Studies. Once the initial immersion tests and electrochemical tests were completed, a decision was made about which materials to el iminate from further testing. As a result of the tests, the 304-L and titanium alloys were dropped due to poor relative performance. At that point, the remaining materials were: Alloy $20 \mathrm{Cb}-3$, Haste17 oy C-276, Haste17 oy C-22, Hastelloy G-3, and ALLCORR. Additional eliminations were made following discussions with Rockwell personnel.

The Alloy 20 was retained because it was the original reference material for both DWPF and HWVP designs. Also, al though it had a higher corrosion rate than the Hastelloys, it is a significantly less expensive alloy, and may 
yet prove to be a cost effective choice. The Hastelloys all had very similar corrosion responses. However, to simplify follow-on testing, it was decided to drop the C-22 and G-3, and proceed with the Hastelloy C-276. The $6-276$ was picked over the other two because of the depth of experience with this material in various industries and in particular by DuPont for DWPF. The ALLCORR was atso retained because of DuPont experience, indicating that it may outperform the $\mathrm{C}-276$ in off-gas condensate solutions. Therefore, these three materials: Alloy $20 \mathrm{Cb}-3$; Hastelloy $\mathrm{C}-276$, and ALLCORR were selected for the follow-on tests.

For the follow-on studies, several test solutions were used, as described earlier, simulating feed preparation solutions and slurries and off-gas condensate solutions. Four test stands had been assembled and used for the preliminary immersion tests. Because of availability of the fourth test stand, one additional alloy was added to the list of materials. Hastelloy C-22 was selected partly because this alloy is beginning to replace $\mathrm{C}-276$ in industry as a more easily fabricated and more corrosion-resistant alloy. Results of the follow-on tests are presented in the following sections.

4.7.4.2.1.5.1 Tests in Simulated Feed Preparation Solution. Two solutions were used for testing in simulated feed preparation solutions. One solution had a $\mathrm{pH}-2$, and the other a $\mathrm{pH}-4$. The results of these tests, averages of duplicate coupons, are given in Table 4.7-7. As might be expected, the corrosion rates were generally higher at the lower $\mathrm{pH}$. An exception was the Alloy 20, which had a much lower corrosion rate at the lower $\mathrm{pH}$. The reason for this is not yet understood. However, after exposure to the solutions with formic acid, the Alloy 20 coupons had a copper: colored layer on their surfaces. This layer, which appeared to be metallic copper (the alloy contains about $4 \mathrm{wt} \%$ copper), may tend to partially protect the surface under highly reducing conditions. Surface analyses were not performed to determine the composition of the coatings.

TABLE 4.7-7. Corrosion Rates for Coupons in Simulated Feed Preparation Solutions(a) (HWVP-87-V110304A)

\begin{tabular}{|l|c|c|}
\cline { 2 - 3 } \multicolumn{1}{c|}{} & \multicolumn{2}{c|}{$\begin{array}{c}\text { Corrosion Rates, } \\
\text { mils per year }\end{array}$} \\
\hline Material & $\mathrm{pH}-2$ & $\mathrm{pH}-4$ \\
\hline Alloy & 48.0 & 85.0 \\
Hastalloy C-276 & 68.2 & 12.2 \\
Hastalloy C-22 & 15.1 & 12.2 \\
ALLCORR & 8.6 & 4.7 \\
\hline
\end{tabular}

(a) Corrosion rates shown are averages of duplicate coupons for each test. 
4.7.4.2.1.5.2 Tests in Simulated HWVP. Feed S7urry. A limited volume of HWS-7 slurry was available for these tests, so duplicate tests were not conducted for each material. Results of the immersion corrosion tests in slurries of unformated and formated simulated HWVP feed are shown in Table 4.7-8. No.statistically significant corrosion rate was detected for the materials in either slurry, most likely due to the lower solution concentrations of corrosives. (Concentrations of the corrosive components, such as fluorides and chlorides, were much less in the siurry tests, since the composition of the slurry was based on the reference HWVP feed composition.)

4.7.4.2.1.5.3 Tests in Simulated Off-Gas Condensate Solution. Results of the simulated off-gas condensate solution corrosion tests are presented in Table 4.7-9. Prior to testing, it was expected that these corrosion rates might be higher than in the simulated feed preparation solution tests because of the higher halide concentrations and higher acidity. However, the actual results were opposite. The higher corrosion rates occurred in the feed preparation solutions. The primary difference in compositions of the solutions is the absence of formic acid in the off-gas condensate solutions. Formic acid is known to be very aggressive in many environments and probably accounts for the comparatively higher corrosion rates in the feed preparation solutions than in the off-gas condensate solutions. The results of the offgas condensate solution tests were also consistent between the $2 \mathrm{pH}^{\prime} \mathrm{s}$, with the higher corrosion rates occurring in the lower $\mathrm{pH}$ solution, al though the differences are not significant.

TABLE 4.7-8. Corrosion Rates for Coupons in Simulated Feed Siurries(a) HWVP-87-Vi10304A

\begin{tabular}{|l|c|c|}
\cline { 2 - 3 } \multicolumn{1}{c|}{} & \multicolumn{2}{c|}{$\begin{array}{c}\text { Corrosion Rates, } \\
\text { mils per year }\end{array}$} \\
\hline Material & Unformated & Formated \\
\hline Alloy 20 Cb-3 & 0 & 0 \\
Hastalloy C-276 & 0 & 0.1 \\
(INCO) & 0 & 0 \\
Hastalloy C-22 & 0 & 0 \\
\hline ALLCORR & 0 & 0 \\
\hline
\end{tabular}

(a) Corrosion rates are for single coupon tests not duplicates. 
TABLE 4.7-9. Coupons Corrosion Rates in Simulated Off-Gas Condensate Solutions(a). HHVP-87-V110304A

\begin{tabular}{|l|c|c|}
\cline { 2 - 3 } \multicolumn{1}{c|}{} & \multicolumn{2}{c|}{$\begin{array}{c}\text { Corrosion Rates, } \\
\text { mils per year }\end{array}$} \\
\hline Material & $\mathrm{pH}-1$ & $\mathrm{pH}-2$ \\
\hline Alloy 20 Cb-3 & & \\
Hasta]10y C-276 & 2.7 & 3.4 \\
Hastal7oy C-22 & 3.5 & 5.2 \\
ALLCORR & 1.3 & 1.8 \\
\hline
\end{tabular}

(a) Corrosion rates shown are averages of duplicate coupons for each test.

4.7.4.2.1.6 Resuits of Erosion/Corrosion Studies. Table 4.7-10 gives the calculated wear rates for the test materials in both slurries. These values are averages of duplicate tests. Again there was very good agreement of results between the duplicate tests.

STurries containing just frit/acid/water were much more abrasive to a 11 materials than the slurry of simulated HWVP feed/frit/acid/water (approximately three times higher). This observation indicates that the solids in the HWVP feed simulant cushion the abrasive effects of the hard angular frit particles. The corrosion tests conducted in the HWVP feed slurry showed that the HWVP feed itself was not very corrosive and so does not contribute to the wear of the alloys in the abrasion tests.

TABLE 4.7-10. Wear Rates of A77oy in Abrasive S7urry Tests HWVP-87.-V110304A

\begin{tabular}{|l|c|c|}
\cline { 2 - 3 } \multicolumn{1}{c|}{} & \multicolumn{2}{|c|}{ Hear Rates, mils per year } \\
\hline Material & STurry A(a) & STurry $B^{(b)}$ \\
\hline Alloy 20 Cb-3 & & \\
Hastalloy C-276 & 2100 & 700 \\
Stellite-6 & 1400 & 500 \\
& 100 & 30 \\
\hline
\end{tabular}

(a) Slurry A - frit/formic acid/water

(b) Slurry B - simulated HWVP feed/frit/formic acid/water 
Stellite exhibited a much higher abrasive wear resistance than either of the other two materials (approximately 10 to 20 times higher). The $6-276$ was only slightly more wear resistant than the Alloy 20.

\subsection{Conclusions of PNL Materials Tests.}

\subsection{1 General Conclusions of Materials Evaluation Studies.}

- The Hastelloys and ALLCORR provide similar performance under most of the conditions tested. The Alloy 20 generally experienced higher corrosion rates than the Hastelloys or ALLCORR, but may be competitive with the others when evaluated in terms of costeffectiveness.

\subsection{2.1.7.2 Conclusions of Prel iminary Scoping Studies.}

- Of the eight starting candidate materials, three were eliminated (304-L, Ti Beta-C, and Ti Grade-7) because of poor performance.

- Of the five remaining alloys, two others were initially el iminated (Hastalloy C-22 and Hastalloy G-3) because of similar metallurgy and similar initial results to the Hastelloy $\mathrm{C}-276$. C-22 was later included.

- No difference in corrosion was seen among corresponding unwelded and simulated welded coupons of A7loy $20, C-276$, and $\mathrm{C}-22$.

\subsection{3 Conclusions of Follow-On Corrosion Studies.}

- All the materials were corrosion resistant to boiling simulated slurries of unformated and formated HWVP feed. No measurable weight loss was detected after 30-day tests.

- Corrosion rates for all the materials were significantly higher in simulated feed preparation solutions than in the HWVP feed slurries. This difference was expected because component concentrations in the simulated solutions were much higher in order to accelerate the corrosion rates. The lower corrosion rates using the simulated HWVP feed slurries also indicates that other components in the HWVP feed, such as transition metal ions, do not have a strong effect on. the corrosiveness of the solutions.

- Corrosion rates for $\mathrm{C}-276, \mathrm{C}-22$, and ALLCORR increased going from $\mathrm{pH} 4$ to $\mathrm{pH} 2$ feed prep solution, as expected. However, the Alloy 20 behavior was the opposite; duplicate tests agreed very closely. This behavior has not yet been explained. The copper and/or iron contents of the alloy may be partially responsible since these are the major compositional differences between the Alloy 20 and the other a!lloys. 
- ALLCORR had the lowest calculated corrosion rate in the simulated feed preparation solutions. However, the actual uncertainties associated with the corrosion rates are not accurately known, and as a result, the differences in corrosion rates among the C-276, C-22, and ALLCORR may not be statistically significant.

\subsection{4 Conclusion of Erosion/Corrosion Studies.}

- The slurry containing only frit/acid/water was more abrasive than the slurry composed of simulated HiWP feed/frit/acid/water, approximately three times more abrasive in these tests. This result indicates that the simulated HWVP feed acts to cushion the test mate-rials and minimize the abrasion resulting from the hard angular frit particles. It also indicates that potential corrosion of the materials from the HWVP feed followed by rapid abrasion of the corrosion products is not significant.

- Based on the average weight loss from the wear blocks, Stellite 6 exhibited a much higher abrasive wear resistance to each of the slurries than either the C-276 or Alloy 20 .

- The Hastelloy C-276 was only slightly more abrasion resistant than the Alloy 20.

4.7.4.2.2 Impacts of Recycling TRU-Containing Haste [M. R. Elmore, FY 1988 HWVP Materials . Selection Testing: TRU-Recycle Impacts on Equioment Fabrication Materials. -HWVP-88-V110305B, Pacific Northwest Laboratory, Richland, Hashington (September 1988)]. Laboratory corrosion tests were conducted to evaluate the impacts of the proposed recycling of TRU-containing process waste on materials requirements for the HWVP process equipment. The reference conceptual design (RCD) TRU-recycle process involves combining TRUcontaining wastes in the Decontamination Waste Treatment Tank (DWTT), concentration of the wastes by boiling the DWTT contents, and recycling the TRU-containing bottoms back into the feed preparation system. This method of recycle would also concentrate halides, sulfates, and nitrates in certain process streams, which could impact corrosion of related equipment.

Simulations of the HWVP TRU-recycle process were performed by WHC using the Heat and Material Balance Computer Program (HMBCP) to determine flowsheet compositions at various stages of processing. Based on these simulations, the most severe corrosion conditions exist in the SME and the DWTT, where concentration of the respective streams are accomplished by boiling. The HMBCP simulations calculated that concentrations of chlorides, fluorides, and nitrates could increase by factors of $40,1.25$, and 4 , respectively. Laboratory immersion-type corrosion tests were conducted with simulated feed slurry and waste recycle solutions using the principal candidate materials, $\mathrm{C}-276$ and Alloy 20.

Two candidate materials were tested, Carpenter AT7oy 20 and Haynes Hastelloy C-276. Several types of coupons were evaluated, including standard flat coupons to determine uniform corrosion. rate, coupons with crevice washers to evaluate sensitivity to crevice corrosion, $U$-bend specimens to 
check for susceptibility to stress corrosion cracking, weld specimens to. evaluate corrosion of weld zones and heat-affected zones, and coupons partially submerged during the test to look for localized interfacial corrosion. The U-bend coupons were prepared by butt welding two coupons together, then bending and welding the ends together to stress the weld area. Figure 4.7-5 shows sketches of the various types of coupons used for the laboratory tests. The U-bend coupons were eventualiy used for the interfacial specimens as wel1, since the welded stressed area was submerged below the liquid level. A test matrix graphically representing this plan is shown in Figure 4.7-6.

4.7.4.2.2.1 Test Equipment. The test equipment used for the laboratory corrosion tests, shown in Figure 4.7-7, consists of a Teflon-coated kettle and lid, a water-cooied condenser for reflux boiling of the test solution, a
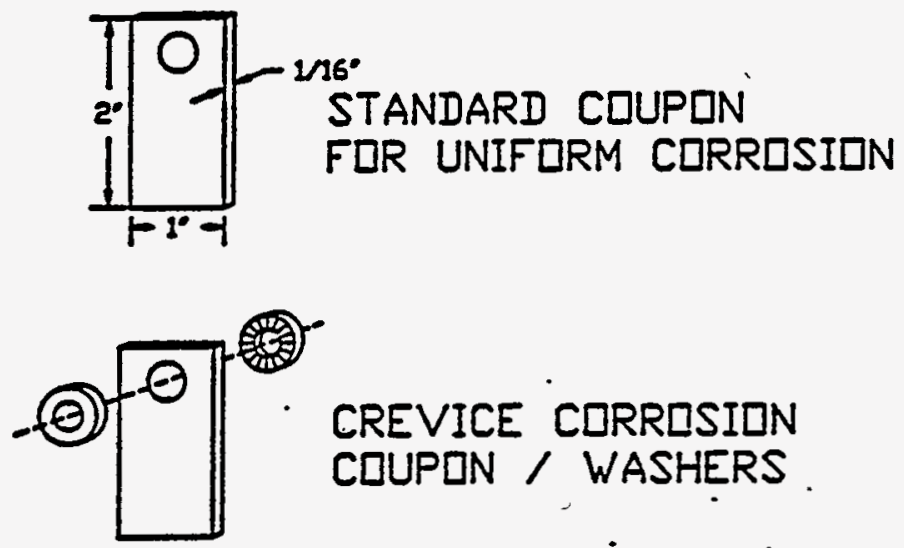

CREVICE CORRISIDN CLUPON / WASHERS .

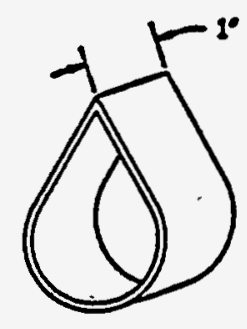

-TEARDRDP'-SHAPED

U-BEND COUPON FOR

STRESS CORROSION CRACKING STUDIES

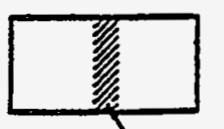

BDTTDM VIEW OF U-BEND SHDWING WELD ZDNE

— VELD AFFECTED ZONE

FIGURE 4.7-5. Sketches of the Types of Corrosion Coupons Used for the FY 1988 HWWP TRU-Recycle Corrosion Testing, Inciuding Standard Coupons, Crevice Corrosion Coupons, and Helded U-Bend Coupons HWVP-88-V110305B 


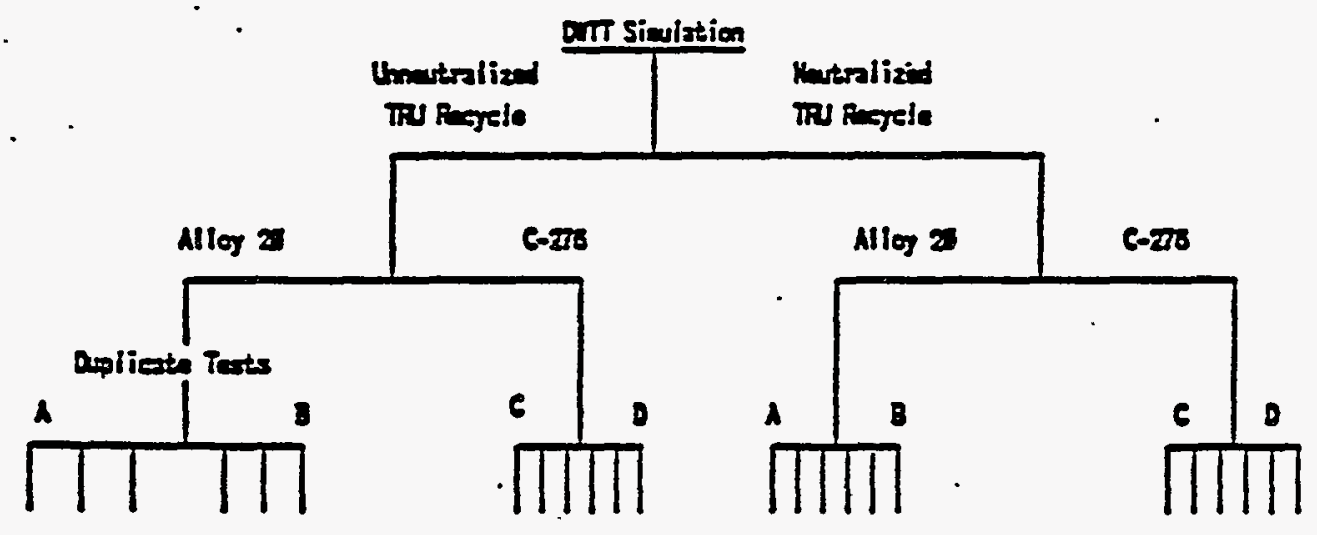

LB 0 Sib

kE?:

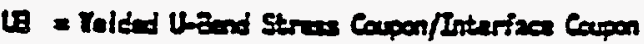

C a corvice Corrosion Coupon

Sub a suberged Stantard Com

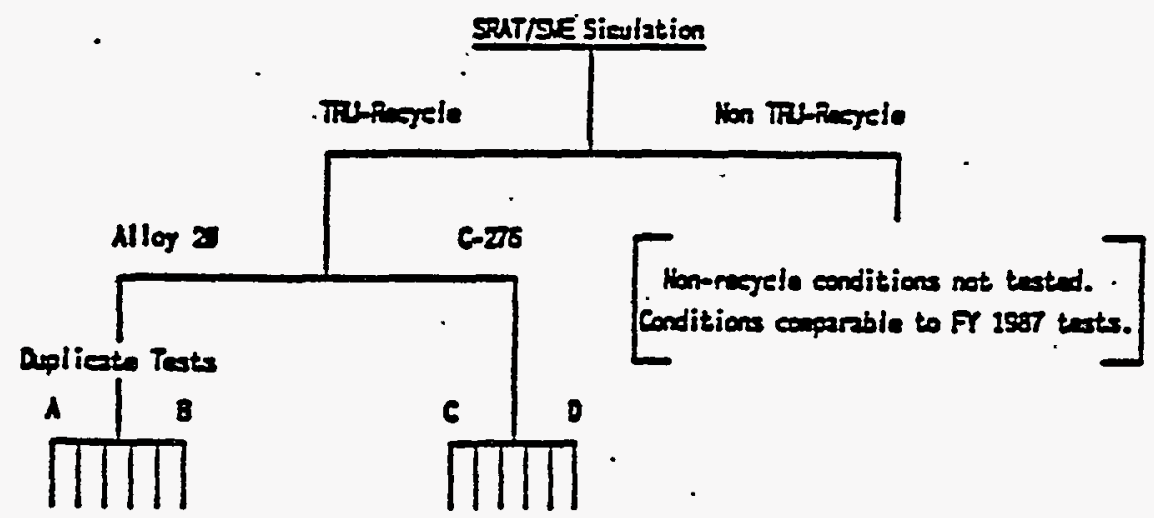

FIGURE 4.7-6. Test Schematic Showing Test Solutions, TRU-Recyclẹ Versus Nonrecycle Conditions, Test Materials, and Number and Types of Coupons HWVP-88-V110305B 


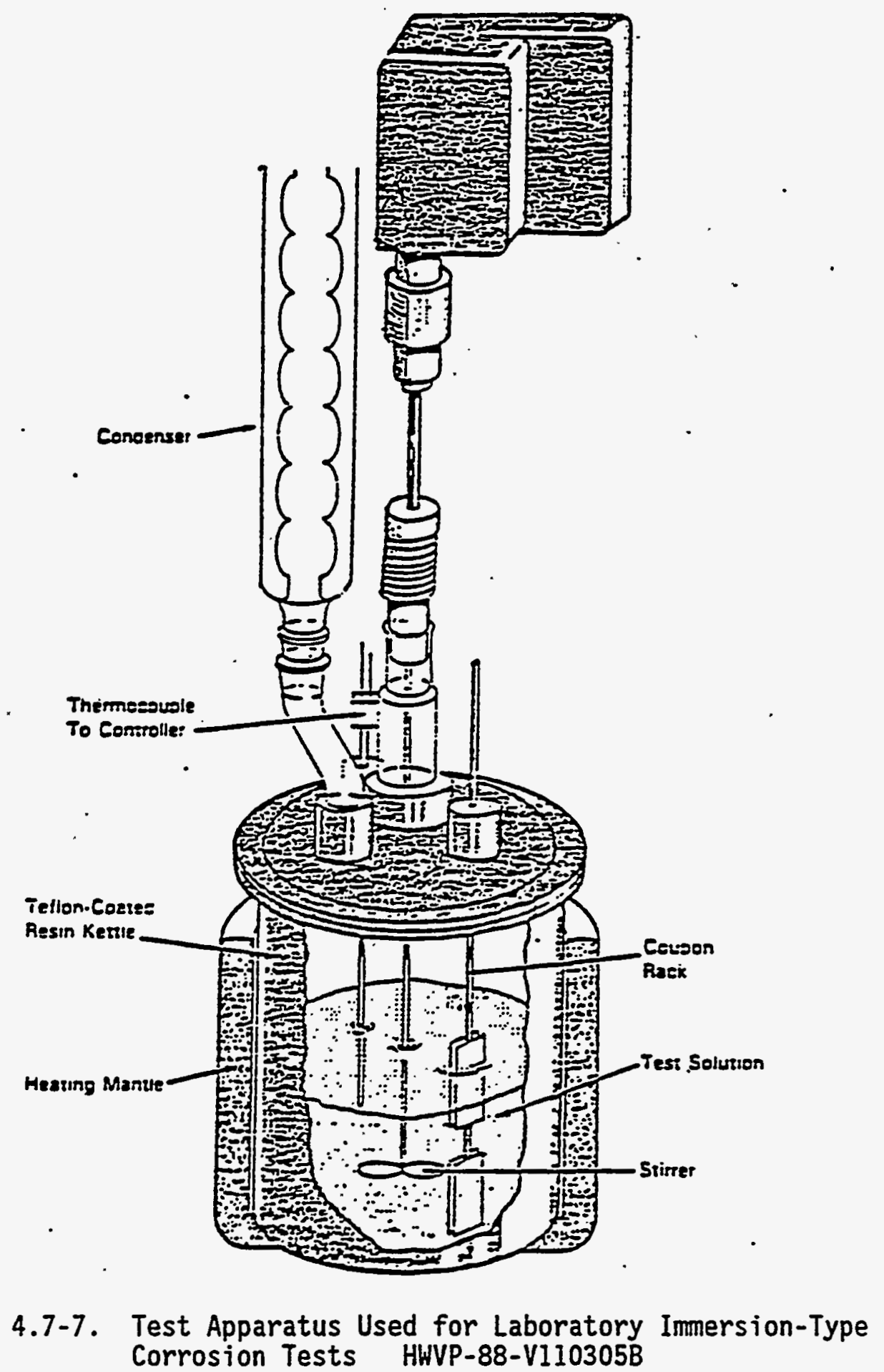

FIGURE 4.7-7. Test Apparatus Used for Laboratory Immersion-Type Corrosion Tests HWVP-88-V110305B 
Teflon-coated mechanical stirrer for agitation, a. thermocouple/heater for temperature control, and a Teflon-coated specimen hanger to suspend the coupons in the test solution. (a)

4.7.4.2.2.2 Test Procedure. The testing procedure used for the laboratory corrosion testing, based on ASTM G-31 "Immersjon Corrosion Testing", (Ref. 4.7-4), is described in Section 4.7.4.1.1.2. (a) Crevice washers were affixed to the crevice corrosion coupons. The coupons were then suspended in the vessel, and the corrosion test was conducted at the prescribed conditions (time, temperature, agitation). The planned exposure time was 2 weeks, the temperature was the boiling point of the test solution $\left(-100^{\circ} \mathrm{C}\right)$, and agitation (used only with the SME slurry tests) sufficient to produce visible mixing of the slurry.

4.7.4.2.2.3 Test Results. The first set of tests involved in un-neutralized DWTT simulant solution. The DWTT simulant, composition shown in Table 4.7-11, was prepared by adding the anion acids together and adjusting the final volume with deionized water. After the solution was prepared, its $\mathrm{pH}$ was measured, less than 1. A $\mathrm{pH}$ this low is outside the usual working range for a $\mathrm{pH}$ meter. The reading may not be accurate, but it is an indication of the conditions present in this solution. The test vessels were then assembled and duplicate tests were conducted.

Shortly after the tests began, brown $\mathrm{NO}_{x}$ fumes were noted rising into the condensers of the vessels containing the Alloy 20 specimens. This condition had not been observed in previous tests. After approximately $1 \mathrm{~h}$ from start the coupons were inspected through the lid of the vessel. Rapid gas evolution was occurring at the surface of the coupons, and all the coupons were noticeably thinner. At less than $2 \mathrm{~h}$ from the start the Alloy 20 coupons were completely dissolved, and the test was stopped. The C-276 coupons were inspected at the same times. Aithough corrosion of the specimens was

TABLE 4.7-11. Composition of DWTT Simulant Solution HWVP-88-VI10305B

\begin{tabular}{|l|c|c|}
\hline $\begin{array}{c}\text { Anion } \\
\text { Component }\end{array}$ & $\begin{array}{c}\text { Concentration } \\
\text { (ppm) }\end{array}$ & Added as \\
\hline $\mathrm{F}^{-}$ & 3,000 & $\mathrm{HF}$ \\
$\mathrm{Cl}^{-}$ & 80,000 & $\mathrm{HCl}$ \\
$\mathrm{SO}_{4}^{-}$ & 1,000 & $\mathrm{H}_{2} \mathrm{SO}_{4}$ \\
$\mathrm{NO}_{3}^{-}$ & 55,000 & $\mathrm{HNO}_{3}$ \\
\hline
\end{tabular}

(a) M. R. Elmore, Materials Selection for the HWVP - FY 1987 Scouting Tests. HWVP-87-V110304A, Pacific Northwest Laboratory, Richland, Washington (1987). 
visible, which would mean an extremely high corrosion rate, it was decided to continue the test for a few days with frequent monitoring of the samples. After 4 days the C-276 tests were a7so ended with visibly severe corrosion of the specimens. Results from these tests were dramatically different than those from corresponding fests previously conducted with an off-gas condensate simulant solution. (a) Information available at the time those tests were conducted led to a solution composition shown in Table 4.7-1. This composition is in fact similar to the non-recycle composition calculated for the DWTT by the HMBCP simulations performed during FY 1988. Corrosion rates for AlToy 20 and INCO C-276 in the FY 1987 off-gas condensate simulant are given in Table 4.7-9 for comparison. Corrosion rates for the materials in the unneutralized DWTT simulant are listed in Table 4.7-12.

Tests were then conducted similar to the ones completed but with a neutralized DHTT simulant. The solution had the same anion concentrations as the previous DWTT simulant, but was prepared with a mixture of acids and sodium salts to give a resulting $\mathrm{pH}$ of -4 . The composition of this solution is shown in Table 4.7-13.

The neutralized DWTT tests were run at boiling $\left(-100^{\circ} \mathrm{C}\right)$ for two weeks. Corrosion of both materials was significant but far less than in the previous test. The Alloy 20 specimens also showed pitting, particularly in the area of the crevice washers. Uniform corrosion rates for Alloy 20 and C-276 in the neutralized DWTT simulant are given in Table 4.7-14.

The next tests were conducted using the feed slurry simulant prepared for the PSCM-23 melter run. The feed components received from various vendors were blended, concentrated to $-150 \mathrm{~g} / \mathrm{L}$, and formated to a $\mathrm{pH}$ of about 4. A sample of this formated feed slurry prior to frit addition was then

TABLE 4.7-12. Corrosion Rates for Materials in Unneutralized (pH<1) DWTT Simulant for Anticipated TRU-Recycle Conditions (a) HHVP-88-V110305B

\begin{tabular}{|l|c|}
\hline Material & $\begin{array}{l}\text { Corrosion Rates } \\
\text { (mils per year) }\end{array}$ \\
\hline C-276 & 690 \\
Alloy 20 & $10^{5(\mathrm{~b})}$ \\
\hline
\end{tabular}

(a) Established by HHC flowsheet calculations.

(b) Alloy 20 coupons completely dissolved in this solution in less than $2 \mathrm{~h}$ at boiling.

(a) M. R. Elmore, Materials Selection for the HWWP - FY 1987 Scouting Tests. HWVP-87-V11304A, Pacific Northwest Laboratory, Richland, Washington (1987). 
TABLE 4.7-13. Composition of Neutralized DWTT Simulant Solution HHV.P-88-V110305B

\begin{tabular}{|l|c|l|}
\hline $\begin{array}{c}\text { Anion } \\
\text { Component }\end{array}$ & $\begin{array}{c}\text { Concentration } \\
\text { (ppm) }\end{array}$ & Added as \\
\hline $\mathrm{F}^{-}$ & 3,000 & $\mathrm{NaF}$ \\
$\mathrm{Cl}_{-}^{-}$ & 80,000 & $\mathrm{NaCl}$ \\
$\mathrm{SO}_{4}=$ & 1,000 & $\mathrm{H}_{2} \mathrm{SO}_{4}$ \\
$\mathrm{NO}_{3}^{-}$ & 55,000 & $\mathrm{NaNO}_{3}$ \\
\hline
\end{tabular}

TABLE 4.7-14. Corrosion Rates for Materials in Neutralized (pH-4) DWTT Simulant for Anticipated TRU-Recycle Conditions(a) HWVP-88-V110305B

\begin{tabular}{|c|c|}
\hline Material & $\begin{array}{c}\text { Corrosion Rates } \\
\text { (mils per year) }\end{array}$ \\
\hline C-276 & \\
Alloy 20 & 2.3 \\
& 7.8 \\
\hline
\end{tabular}

(a) Established by HHC flowsheet calculations.

taken for the corrosion testing. The feed slurry was chemically adjusted prior to the tests to simulate TRU-recycle concentration of the halides and sulfate. The nitrate level was already high due to the off-specification feed received from the vendor $(34,500 \mathrm{ppm}$ rather than $25,000 \mathrm{ppm}$ target value), so nitrate concentration was not adjusted. Selected anion concentrations in the TRU-recycle adjusted slurry is given in Table 4.7-15. Judging from the results of these and other tests the elevated nitrate concentration is probably not significant to corrosion of the materials.

The slurry tests were agitated and run at boiling $\left(-102^{\circ} \mathrm{C}\right)$ for two weeks. No visible corrosion was apparent on specimens of either Alloy 20 or C-276. Height loss measurements showed only very minor corrosion of either material. Because of the low corrosion rates, and because the high nitrate concentration in the feed slurry would not permit an accurate simulation of non-TRU-recycle conditions, corresponding non-recycle tests with the slurry were not conducted. Resuits from FY 1987 tests with formated feed slurry compare closeTy with these results. Uniform corrosion rates for the 1987 tests are given in Table 4.7-8. Corresponding uniform corrosion rates for the recycle slurry tests are given in Table 4.7-16. 
TABLE 4.7-15. Composition of the Feed Slurry Simulant Chemically Adjusted to Simulate TRU-Recycle Conditions HWVP-88-V110305B

\begin{tabular}{|c|c|c|}
\hline Component & $\begin{array}{c}\text { Concentration } \\
\text { (ppm) }\end{array}$ & Added as \\
\hline & $\vdots$ & \\
Formated STurry & (see Appendix B) & (Used As Rec'd.) \\
$\mathrm{FaF}^{-}$ & 2,500 & $\mathrm{NaF}$ \\
$\mathrm{Cl}^{-}$ & 20,000 & $\mathrm{NaCl}^{-}$ \\
$\mathrm{SO}_{4}^{-}$ & 2,500 & $\mathrm{Na}_{2} \mathrm{SO}_{4}$ \\
$\mathrm{NO}_{3}^{-}$ & 34,500 & (No Adjustment) \\
\hline
\end{tabular}

TABLE 4.7-16. Corrosion Rates for Materials in Simulated Feed Slurry Under Anticipated TRU-Recycle Conditions(a) HWVP-88-V110305B

\begin{tabular}{|l|c|c|}
\cline { 2 - 3 } \multicolumn{1}{c|}{} & \multicolumn{2}{c|}{ Corrosion Rates (mils per year) } \\
\hline Material & Standard Coupon & Crevice Coupon \\
\hline C-276 & 0.004 & 0.01 \\
A77oy 20 & 0.02 & 0.02 \\
\hline
\end{tabular}

(a) . FY 1988 tests with HW39-4 slurry formated to $\mathrm{pH} \sim 4$.

Corrosion rates observed during the above tests are supported by results of comparable tests conducted by Savannah River Laboratory for the DWPF. (a) Table 4.7-17 compares results of similar laboratory corrosion tests conducted for the DWPF materials selection and HWVP materials selection efforts. All the DHPF test solutions and slurries included mercury, while none of the HWVP test solutions to date did. Mercury, particularly mercury-chloride, has been reported by DWPF to cause pitting in the Alloy 20 . Other differences between the data sets include concentrations of nitrates and fluorides (higher in some instances in the HWVP tests), and the presence of $\mathrm{I}^{-}$in the DWPF tests. The effect of $\mathrm{I}^{-}$on corrosion of these materials is uncertain, but is not expected to have much impact on corrosion.

(a) D. B. Bickford, DWPF Corrosion Testing Data Base. DPST-85-956-TL, E. I. du Pont de Nemours and Company, Savannah River Laboratory, Aiken, South Carolina (1985). 
Corrosion rates shown in TabTe 4,7-17 indicate similar trends in corrosion response of the two materials exposed to similar conditions. Feed slurry (SRAT/SME) tests resulted in essentialiy the same corrosion rates for each material between DWPF and HWVP tests. In the second data set, DWPF offgas condensate solution tests at $\mathrm{pH} 1.6$ show corrosion rates bracketed by comparable results of HWVP DHTT solution tests at $\mathrm{pH}<1$ and $\mathrm{pH}-4$. . The DWPF solution composition was concentrated for preliminary accelerated corrosion tests. The HHVP solution composition represented the TRU-recycle conditions. The third set of data, comparing corrosion rates at $\mathrm{pH}-1$ and 2 for less concentrated solutions, also shows close correlation. In this case the DWPF test solution was to have represented more realistic conditions for longerterm tests, while the HWVP solution is more representative of anticipated non-recycle conditions.

\subsection{Test Conclusions.}

- Corrosion tests conducted with an unneutralized (pH<1) DWTT simulant solution incorporating TRU-recycle conditions showed unacceptably high corrosion rates for both Alloy 20 and $\mathrm{C}-276$.

- By neutralizing the DWTT solution to pH-4, uniform corrosion of the materials was decreased significantly. No localized corrosion of the C-276 was evident at these conditions. However, some pitting/crevice corrosion was present on the Alloy 20 specimens.

- TRU-recycle has no significant effect on either material's corrosion resistance to simulated feed slurries at $\mathrm{pH}-4$ when comparing results of these tests with those of previous similar tests using slurry simulating non-recycle conditions. Although Alloy 20 specimens experienced slightly higher corrosion rates than Hastelloy C-276, either material would be considered acceptable based on the preliminary acceptance criteria of less than 5 mils per year uniform corrosion and no localized corrosion.

- Test results show good correlation with similar tests conducted by Savannah River Laboratory for the DWPF materials selection effort.

4.7.4.2.3 Materials Screening Tests for Melter Off-Gas System and Submerged Bed Scrubber. [R. W. Goles et al Hanford Waste Vitrification Program, Pilot Scale Ceramic Melter Test Number 23. HWVP-89-IVJ0010100B, Pacific Northwest Laboratory, Richland, Washington (1989)]. Metal coupons were installed on racks into the PSCM melter plenum and the submerged bed scrubber (SBS). The materials selected for the preliminary tests are shown in Table 4.7-18. The melter plenum coupons were used to evaluate corrosion resistance in conditions similar to those experienced near the inlet of the off-gas line and by other equipment installed in the melter plenum (IR-TV, thermowells, dip tubes, etc.). With the exception of the C-276, the materials for the melter plenum test were selected for high-temperature corrosion resistance. The $\mathrm{C}-276$ was included as a comparison with other corrosion 
TABLE 4.7-17. Comparison of DWPF and HWVP Corrosion Test Results HWVP-88-V110305B

\begin{tabular}{|c|c|c|c|c|c|c|c|}
\hline \multicolumn{4}{|c|}{ DWPF } & \multicolumn{4}{|c|}{ HWVP } \\
\hline \multicolumn{2}{|c|}{ Solution } & \multicolumn{2}{|c|}{ Corrosion Rates } & \multicolumn{2}{|c|}{ Solution } & \multicolumn{2}{|c|}{ Coorrosion Rates } \\
\hline SRAT/SME & Composition & Alloy 20. & $C-276$ & SME & Composition & Alloy 20 & C-276 \\
\hline $\begin{array}{l}\mathrm{pH}=6 \\
95-100^{\circ} \mathrm{C}\end{array}$ & $\begin{array}{l}\mathrm{Cl}^{-} 20000 \mathrm{ppm} \\
\mathrm{F}^{-} \quad 2300 \\
\mathrm{I}^{-} \quad 300 \\
\mathrm{SO}^{2}=1400 \\
\mathrm{Hg}^{+} 10000-56000\end{array}$ & $0.1-0.2$ & $0.1-0.5$ & $\begin{array}{l}\mathrm{pH}=4 \\
100^{\circ} \mathrm{C}\end{array}$ & $\begin{array}{l}\mathrm{Cl}^{-} \quad 20000 \mathrm{ppm} \\
\mathrm{F}^{-}=2500 \\
\mathrm{SO}_{4}=2500 \\
\mathrm{NO}_{3}^{-}=34500\end{array}$ & 0.02 & $.004-.01$ \\
\hline \multicolumn{2}{|c|}{ Solution } & \multicolumn{2}{|c|}{ Corrosion Rates } & \multicolumn{2}{|c|}{ Solution } & \multicolumn{2}{|c|}{ Corrosion Rates } \\
\hline OGCT & Composition & Alloy 20 & $C-276$ & DWTT & Composition & Alloy 20 & $C-276$ \\
\hline $\begin{array}{l}\mathrm{pH}=1.6 \\
90^{\circ} \mathrm{C}\end{array}$ & $\begin{array}{l}\mathrm{Cl}^{-} 20000 \mathrm{ppm} \\
\mathrm{F}^{-} \quad 2300 \\
\mathrm{I}^{-} \quad 300 \\
\mathrm{SO}_{4}=1400 \\
\mathrm{NO}_{3}^{-} 1000 \\
\mathrm{Hg}^{+} \quad 4500\end{array}$ & $25-200$ & $17-30$ & $\begin{array}{l}\mathrm{pH}=<1 \\
100^{\circ} \mathrm{C} \\
\mathrm{pH}=4\end{array}$ & $\begin{array}{l}\mathrm{Cl}^{-} \quad 80000 \mathrm{ppm} \\
\mathrm{F}^{-}=3000 \\
\mathrm{SO}_{4}=1000 \\
\mathrm{NO}_{3}^{-} 55000\end{array}$ & $\begin{array}{l}\text { Dissolved } \\
7.8\end{array}$ & $\begin{array}{l}690 \\
2.3\end{array}$ \\
\hline \multicolumn{2}{|c|}{ Solution } & \multicolumn{2}{|c|}{ Corrosion Rates } & \multicolumn{2}{|c|}{ Solution } & \multicolumn{2}{|c|}{ Corrosion Rates } \\
\hline OGCT & Composition & Alloy 20 & $C-276$ & DWTT & Composition & Alloy 20 & $C-276$ \\
\hline $\begin{array}{l}\mathrm{pH}=1.6,2.2 \\
95-100^{\circ} \mathrm{C}\end{array}$ & $\begin{array}{l}\mathrm{Cl}^{-} \quad 2500 \mathrm{ppm} \\
\mathrm{F}^{-} \quad 300 \\
\mathrm{I}^{-}=30 \\
\mathrm{SO}_{4}=800 \\
\mathrm{NO}_{3}^{-} 1000 \\
\mathrm{Hg}^{7} 1000\end{array}$ & $0.1-2.4$ & $1-2$ & $\begin{array}{l}\mathrm{pH}=1,2 \\
100^{\circ} \mathrm{C}\end{array}$ & $\begin{array}{l}\mathrm{Cl}^{-} \quad 1500 \mathrm{ppm} \\
\mathrm{F}^{-} \quad 7000 \\
\mathrm{SO}_{4}=7000 \\
\mathrm{NO}_{3}^{-}=17000\end{array}$ & $2.7-3.4$ & $3.5-5.2$ \\
\hline
\end{tabular}


TABLE 4.7-18. Materials Selected for the PSCM-23 Materials

Evaluation Tests HWVP-89-IVJ0010100B

\begin{tabular}{|c|c|}
\hline \multicolumn{2}{|c|}{ Coupon Location. } \\
\hline Melter P1enum & Submerged Bed Scrubber \\
\hline $\begin{array}{l}\text { Inconel } 690 \\
\text { Incöloy } 825 \\
\text { Haynes } 214 \\
\text { Haynes } 556 \\
\text { Hastelloy C-276 }\end{array}$ & $\begin{array}{l}\text { Hastelloy C-276 } \\
\text { Carpenter A1loy } 20 \mathrm{Cb}-3 \\
\text { 304L Stainless Steel }\end{array}$ \\
\hline
\end{tabular}

tests under the HWVP materials evaluation activity. Selected melter plenum coupons were exposed to feeding-only conditions, to combined feeding and idling periods, or to idling-only exposure.

The SBS testing assessed corrosion resistance to the atmosphere above the SBS solution and to recirculating solution in the SBS. The coupons used in the SBS test represent the range of materials that have been evaluated for resistance to aqueous corrosion conditions in the HWVP. SBS coupons were installed in the SBS prior to the start of the run and removed following completion of the run. .

The coupons used for these tests were comparable to coupons used for other. HHVP corrosion studies. The coupons were rectangular ( 1 in. $x 2$ in. $x$ $-1 / 16$ in.) with a hole drilled near one end for hanging. The installation and retrieval schedule for the coupons installed in the PSCM plenum and the SBS is shown in Table 4.7-19. The coupon numbers correspond to the same numbered coupons in Tables 4.7-20 and 4.7-21.

The specimens were observed in the "as-removed" condition for general eyaluation. The surface deposits and corrosion products were then removed to evaluate the samples' conditions. The specimens were then repetitively cleaned in 50 wt\% solution of $\mathrm{HCl}$ and evaluated for corrosion. Localized corrosion was evaluated by visual observation of the coupons using a $10 \mathrm{X}$ magnifying eyepiece.

The corrosion rates of coupons exposed to the various melter plenum conditions, along with the initial dimensions of the coupons, weight losses, alloy densities, and exposure times that were used in the calculation of corrosion rate, are tabulated in Table 4.7-20. Similar information for the SBS coupons is presented in Table 4.7-21.

4.7.4.2.3.1 Melter Plenum Corrosion Tests. The coupons exposed to melter feeding-only conditions resulted in measurable but slight corrosion, in general showing only tenths of a mil per year. Corrosion rates during idling-only periods were significantly higher, ranging from a few mils per year to tens of mils per year. The combined feeding and idling samples, 
TABLE 4.7-19. - Coupon Exposure Schedule for PSCM-23 Materials Evaluation Tests HWVP-89-IVJ0010100B

\begin{tabular}{|c|c|c|c|c|c|c|}
\hline Material & Location & Coupon & $\begin{array}{c}\text { Date } \\
\text { Installed }\end{array}$ & $\begin{array}{l}\text { Date } \\
\text { Removed }\end{array}$ & $\begin{array}{l}\text { Exposure } \\
\text { Time (h) }\end{array}$ & $\begin{array}{l}\text { Approx. } \\
\text { Temp. }\left({ }^{\circ} \mathrm{C}\right)\end{array}$ \\
\hline Inconel 690 & $\begin{array}{l}\text { PSCM } \\
\text { PSCM } \\
\text { PSCM }\end{array}$ & $\begin{array}{l}1 \\
2 \\
2(a) \\
3\end{array}$ & $\begin{array}{l}6-06-88 \\
6-06-88 \\
6-29-88 \\
6-29-88\end{array}$ & $\begin{array}{l}6-21-88 \\
6-21-88 \\
7-18-88 \\
7-18-88\end{array}$ & $\begin{array}{l}360 \\
360 \\
450 \\
450\end{array}$ & $\begin{array}{r}500 \\
500 \\
1000 \\
1000\end{array}$ \\
\hline Incoloy 825 & $\begin{array}{l}\text { PSCM } \\
\text { PSCM } \\
\text { PSCM }\end{array}$ & $\begin{array}{l}4 \\
5 \\
5(a) \\
6\end{array}$ & $\begin{array}{l}6-06-88 \\
6-06-88 \\
6-29-88 \\
6-29-88\end{array}$ & $\begin{array}{l}6-21-88 \\
6-21-88 \\
7-18-88 \\
7-18-88\end{array}$ & $\begin{array}{l}360 \\
360 \\
450 \\
450\end{array}$ & $\begin{array}{r}500 \\
500 \\
1000 \\
1000\end{array}$ \\
\hline Haynes 214 & $\begin{array}{l}\text { PSCM } \\
\text { PSCM } \\
\text { PSCM }\end{array}$ & $\begin{array}{l}7 \\
8 \\
8 \\
9\end{array}$ & $\begin{array}{l}6-06-88 \\
6-06-88 \\
6-29-88 \\
6-29-88\end{array}$ & $\begin{array}{l}6-21-88 \\
6-21-88 \\
7-18-88 \\
7-18-88\end{array}$ & $\begin{array}{l}360 \\
360 \\
450 \\
450\end{array}$ & $\begin{array}{r}500 \\
500 \\
1000 \\
1000\end{array}$ \\
\hline Haynes 556 & $\begin{array}{l}\text { PSCM } \\
\text { PSCM }\end{array}$ & $\begin{array}{l}10 \\
10(a) \\
11\end{array}$ & $\begin{array}{l}6-06-88 \\
6-29-88 \\
6-29-88\end{array}$ & $\begin{array}{l}6-21-88 \\
7-18-88 \\
7-18-88\end{array}$ & $\begin{array}{l}360 \\
450 \\
450\end{array}$ & $\begin{array}{r}500 \\
1000 \\
1000\end{array}$ \\
\hline $\begin{array}{c}\text { Hasta11oy } \\
\text { C-276 }\end{array}$ & $\begin{array}{l}\text { PSCM } \\
\text { SBS-vapor } \\
\text { SBS-sol'n }\end{array}$ & $\begin{array}{l}12 \\
13 \\
14\end{array}$ & $\begin{array}{l}6-06-88 \\
6-03-88 \\
6-03-88\end{array}$ & $\begin{array}{l}6-21-88 \\
6-29-88 \\
6-29-88\end{array}$ & $\begin{array}{l}360 \\
550 \\
550\end{array}$ & $\begin{array}{r}500 \\
30 \\
25\end{array}$ \\
\hline Alloy $20 \mathrm{Cb}-3$ & $\begin{array}{l}\text { SBS-vapor } \\
\text { SBS-sol'n }\end{array}$ & $\begin{array}{l}15 \\
16\end{array}$ & $\begin{array}{l}6-03-88 \\
6-03-88\end{array}$ & $\begin{array}{l}6-29-88 \\
6-29-88\end{array}$ & $\begin{array}{l}550 \\
550\end{array}$ & $\begin{array}{l}30 \\
25\end{array}$ \\
\hline $304 L$ SS & $\begin{array}{l}\text { SBS-vapor } \\
\text { SBS-sol'n }\end{array}$ & $\begin{array}{l}17 \\
18\end{array}$ & $\begin{array}{l}6-03-88 \\
6-03-88\end{array}$ & $\begin{array}{l}6-29-88 \\
6-29-88\end{array}$ & $\begin{array}{l}550 \\
550\end{array}$ & $\begin{array}{l}30 \\
25\end{array}$ \\
\hline
\end{tabular}

(a) Coupons were exposed to feeding conditions then reinstalled in the plenum during idling period without cleaning to measure weight loss. 
TABLE 4.7-20.-- Materials, Conditions, and Corrosion Data for Plenum Coupons HWVP-89-IVJ0010100B

\begin{tabular}{|c|c|c|c|c|c|c|}
\hline Material & Density & Condition & Coupon & $\begin{array}{l}\text { Surface } \\
\text { Area }\left(\mathrm{cm}^{2}\right)\end{array}$ & $\begin{array}{l}\text { Height } \\
\text { Loss (g) }\end{array}$ & $\begin{array}{l}\text { Corrosion } \\
\text { Rate (mpy) }\end{array}$ \\
\hline Inconel 690 & 8.19 & $\begin{array}{l}\text { Feed Only } \\
\text { Feed/Idle } \\
\text { Idle Onily }\end{array}$ & $\begin{array}{l}1 \\
2 \\
3\end{array}$ & $\begin{array}{l}26.9665 \\
26.937 \\
26.917\end{array}$ & $\begin{array}{l}0.003 \\
0.246 \\
0.500\end{array}$ & $\begin{array}{l}0.1 \\
4.7 \\
17.4\end{array}$ \\
\hline Incoloy 825 & 8.14 & $\begin{array}{l}\text { Feed Only } \\
\text { Feed/Idle } \\
\text { Idle Onily }\end{array}$ & $\begin{array}{l}4 \\
5 \\
6\end{array}$ & $\begin{array}{l}26.542 \\
26.622 \\
26.358\end{array}$ & $\begin{array}{l}0.004 \\
0.265 \\
0.222\end{array}$ & $\begin{array}{l}0.2 \\
5.2 \\
7.9\end{array}$ \\
\hline Hạynes 214 & 8.05 & $\begin{array}{l}\text { Feed Only } \\
\text { Feed/Idle } \\
\text { Idle Only }\end{array}$ & $\begin{array}{l}7 \\
8 \\
9\end{array}$ & $\begin{array}{l}26.689 \\
26.665 \\
26.654\end{array}$ & $\begin{array}{l}0.013 \\
0.130 \\
0.031\end{array}$ & $\begin{array}{l}0.6 \\
2.6 \\
1.1\end{array}$ \\
\hline Haynes 556 & 8.23 & $\begin{array}{l}\text { Feed/Idle } \\
\text { Idle Onily }\end{array}$ & $\begin{array}{l}10 \\
11\end{array}$ & $\begin{array}{l}25.966 \\
25.707\end{array}$ & $\begin{array}{l}0.584 \\
1.01\end{array}$ & $\begin{array}{l}11.6 \\
36.6\end{array}$ \\
\hline $\begin{array}{c}\text { Hastalloy- } \\
C-276\end{array}$ & 8.89 & Feed Oniy & 12 & 27.589 & 0.012 & 0.5 \\
\hline
\end{tabular}

TABLE 4.7-21. Corrosion Data for Coupons from the SBS Material - Evaluation Test HWVP-89-IVJ0010100B

\begin{tabular}{|c|l|l|c|c|c|c|}
\hline Material & Density & Condition & Coupon & $\begin{array}{c}\text { Surface } \\
\text { Area }\left(\mathrm{cm}^{2}\right)\end{array}$ & $\begin{array}{c}\text { Weight } \\
\text { Loss }(\mathrm{g})\end{array}$ & $\begin{array}{c}\text { Corrosion } \\
\text { Rate }(\mathrm{mpy})\end{array}$ \\
\hline Hasta11 oy- & \multirow{2}{*}{8.89} & Vapor & 13 & 27.809 & 0.0008 & 0.02 \\
C-276 & & Submerged & 14 & 27.524 & 0.0003 & 0.008 \\
A110y 20 Cb-3 & \multirow{2}{*}{8.08} & Vapor & 15 & 28.076 & 0.0014 & 0.04 \\
& & Submerged & 16 & 28.114 & 0.0006 & 0.017 \\
304L SS & \multirow{2}{*}{7.90} & Vapor & 17 & 27.039 & 0.0010 & 0.03 \\
& & Submerged & 18 & 27.119 & 0.0003 & 0.009 \\
\hline
\end{tabular}

expected to show the most severe corrosion (as seen on the Haynes 214 samples), actualiy ranged in between the feeding and idling rates for the other materials. It is postulated that a protective surface was established on those samples, except for the Haynes 214 alloy, during the lower-temperature feeding periods that helped protect the samples from the higher temperatures at melter idling conditions. Pitting was not evident on any of the samples. However, the surfaces of most of the samples were quite rough, apparently due to uneven corrosion rates over different areas of the samples. A nonuniform 
oxide layer, or possibly some splattering of the samples may account for. the rough surface after the samples were cleaned to remove the corrosion products. The corrosion of the samples can generally be classified as uniform.

The INCO materials (Inconel 690 and Incoloy 825) and the Haynes 214 appear resistant to both feeding and idling conditions. They would apparently be suitable preliminary candidates for plenum and off-gas 7 ine service.

4.7.4.2.3.2 Submerged Bed Scrubber Corrosion Tests. The SBS coupons showed very little corrosion during the melter run. Differences in the vapor space and submerged corrosion rates were measurable, tenths of a' mil per year in the vapor space compared with hundredths of a mil per year in the solution. The low temperatures of the scrub solution and the vapor space above that solution facilitate minimizing the corrosion. Additionally, the pH of the scrubbing solution remained above -4 throughout the run, indicating that the solution never became very concentrated in the corrosive components of the off gas (halides and sulfur oxides).

Any of the three materials would appear adequate for the SBS service. This conclusion is supported by the fact that the SBS is made of stainiess stee] and has shown little if any corrosion. It is probable that more corrosive conditions could exist elsewhere in the SBS other than where the coupons were located for this test. The inlet pipe, for example, is exposed to humid gases at high temperatures relative to the rest of the SBS. A region probably exists in the lower portion of that pipe where the vapor could condense and possibly trap corrosive components. This environment could be significantly more corrosive than either the scrubber solution or the vapor space above the solution.

4.7.4.3 Cost Evaluation of Using A7T oy 20 and C-276 for Equipment Fabrication. [M. R. Elmore, Test Plan for Materials Selection Program: HWVP Equipment Cost Comparison and Continued Materials Testing Requirements.

HWVP-88-V110305A, Pacific Northwest Laboratory, Richland, Washington, (1988)]. The objectives of this study were to evaluate the relative costs of HWVP process equipment fabricated from Alloy 20 and C-276.

The materials cost differential for equipment fabricated from Alloy 20 or C-276 appears to be small. It is estimated that the cost of Alloy 20 may be about equal to, perhaps as much as $20 \%$ less than, the cost of $C-276$ for certain equipment items. This figure depends on the complexity of the equipment, extent of fabrication and inspection requirements, and the price of the raw materials. Raw material costs can vary with size of the order, requirements for non-standard plate thickness, etc. Specific examples and discussions with fabricators are presented.

4.7.4.3.1 Materials and Fabrication Direct Costs. The raw material prices for alloys increase significantly with increased corrosion resistance. Actual metal prices depend heavily on the quantities ordered, the dimensions of plate or other form purchased (non-standard plate thickness used for certain DWPF applications created significant cost penalties), the specifications for composition and heat treatment of the alloy, and the material 
availability. However, suppliers and fabricators contacted indicated that with 304-L stainless as a base, the cost of Alloy 20 would currently be about 3 to 5 times higher than the stainless, and Hastelloy $C-276$ would range from about the same as Alloy 20 to possibly twice the cost of Alloy 20. Figures varied widely, depending on prior experiences of the fabricators.

Table 4.7-22 gives estimates of materials costs supplied by various

fabricators.

These same fabricators were asked about the relative difficulty of fabricating equipment with either Alloy 20 or C-276. The majority of those asked indicated that there was essentially no difference in difficulty between the two materials. Neither material is considered easy to work with; both materials are susceptible to weld cracking if proper welding procedures are not followed. But with strict adherence to established procedures, most agree that either material can be routinely fabricated, and neither is sig-. nificantly more difficult to use.

TABLE 4.7-22. Estimates of Equipment Fabrication Material Costs HWVP-88-V110305A

\begin{tabular}{|l|c|c|}
\cline { 2 - 3 } \multicolumn{1}{c|}{} & \multicolumn{2}{c|}{ Raw Material Cost Factors $(304 L=1)^{(a)}$} \\
\hline Fabricator & Alloy 20 & $6-276^{\circ}$ \\
\hline Brighton Corporation & 3 & \\
CBI Services, Inc. (b) & 4 & 4 \\
Mitternight Boiler Works(b) & 5 & 5 \\
Lightnin Mixers & 3 & 10 \\
Nooter Corporation & 5 & 5 \\
Offenhauser Company & 4 & 8 \\
Philadelphia Mixers(b) & 5 & 5 \\
\hline
\end{tabular}

(a) The raw materials cost factor $(304-L=.1)$ is essentially $\$ 1 / 7 b$, at the time of this study. Estimated 304-L material costs for a large fabrication, such as one of the process tanks, were close to $\$ 1 / 1 \mathrm{~b}$. However, -prices vary considerably depending on several factors, as described in the preceding discussion, so that numbers shown are more accurately cost multipliers than actual dollars per pound.

(b) These fabricators have produced equipment for the DWPF and have relevant experience with the construction of equipment for this type of facility. However, this does not appear to have significantly affected the estimated costs of the materials involved compared to other suppliers. 
One exception came from Mitternight Boiler Horks. (a) Mitternight fabricated the condensers for the DWPF process vessels. Mitternight commented that they would rather work with the C-276 than the Alloy 20 . Based on their experience, Alloy 20 is more sensitive to hot cracking than is the C-276; in their view, this cracking results in a higher percentage of rework or repair:

Another comment, from CBI services, was that $C-276$ can be more difficult to machine than Alloy 20 if not done correctly. (b) C-276 will work harden very rapidiy, such that low feed rates or dull tools can make machining $C-276$ difficult. According to CBI and others, anticipating this condition and using correct feed rates, sharp cutting tools, etc. minimizes the work hardening problem with the $\mathrm{C}-276$.

Based on information from CBI Services, the fabricator supplying the DHPF process vessels, the material costs were roughly $40 \%$ of the fabricated cost of the vessel. (b) For estimating purposes, a fabricated vessel cost of $-\$ 1,000,000$ was assumed; good information about the actual cost of materials is not readily available, and market prices fluctuate rapidly. Total amount, dimensions, and specifications of plate, pipe, etc., used in the fabrication; materials certifications; and so forth complicate the material cost factor.

The costs associated with very tight fabrication tolerances were originally anticipated to contribute significantly to the costs of equipment. CBI Services and Mitternight indicated that with the proper equipment and facilities available, fabricating equipment to the tighter tolerances was really no more difficult than to achieve more standard tolerances. It was also indicated that the costs of establishing the facilities and necessary equipment were not reflected in the final equipment costs. Therefore, the impact of tolerances on overall fabricated costs, and thereby the fraction of fabricated costs due to the materials costs, is expected to be insignificant or very small.

An estimate of expected difference in material costs appears to be a savings of about 0 to $50 \%$ with the Alloy 20 over $C-276$. With material costs being $-40 \%$ of the fabricated cost for one of the process tanks, the savings then becomes 0 to $20 \%$ of the vessel cost using Alloy 20 , or from 0 to $-\$ 200,000$ using the $\$ 1,000,000$ estimate described earlier. Fabrication costs for other types of equipment, such as pumps and agitators, are expected to be quite different from those of the process vessels. So the materials fraction of the cost for those items is also expected to differ from the example given above.

(a) M. R. Elmore, Telecon with Fred A. Green, Mitternight Boiler Works, on fabricated costs of DWPF equipment. HWVP/PRMC-H010964, Pacific Northwest Laboratory, Richland, Washington (1988).

(b) M. R. Elmore, Telecon with Bruce Fabert, CBI Services, Inc., on fabricated costs of DWPF equipment. HWVP.PRMC-H010905, Pacific Northwest Laboratory, Richland, Washington (1988). 
4.7.4.3.2 Indirect Materials Selection and Equipment Cost Factors. Requirements for the equipment imposed by the Functional Design Criteria for the HWVP (a) also impact the costs of HWVP equipment. The requirement is that "where practicable, replaceable vitrification system process components and equipment shall be designed for a 20-year life and non-replaceable components and equipment shall be designed for a 40-year life." In addition, "vitrification system components that may credibly have an operational life shorter than the facility life shall be designed to be remotely replaceable." This requirement results in standard remote flanged connections to permit remote assemb7y and disassembiy of the equipment. These fianged consections produce conditions favorable to crevice corrosion, requiring materials that are resistant to this form of localized attack. .

Because of the difficulty of detecting corrosion of the equipment once in operation, selected materials of construction must be very resistant to both localizied attack and uniform corrosion under anticipated process. conditions. DWPF criteria for an acceptable alloy were that test results show no indication of localized corrosion and a uniform corrosion rate of less than 5 mils per year. These requirements are generally much tighter than those experienced in other chemical process industries, and expensive alloys are usually required to satisfy them. However, because of the consequences of equipment failure, these are probably reasonable criteria for the HWVP equipment as well. Exceptions will undoubtediy have to be made for some equipment; a 20-year life-may not be achievabie, or at least not cost effective. This criterion must be considered carefuily, as it will significantly impact the selection of materials of construction for the HWVP equipment.

\subsection{Cost Evaluation Conclusions.}

- The extent of the fabricated cost savings for equipment made from Alloy 20 versus C-276 can be expected to vary considerabiy, ranging from perhaps zero to $-20 \%$ depending on the complexity of the equipment being made.

- The raw material cost of Alloy 20 is less than that of C-276, but estimates of the cost savings with A7loy 20 given by suppliers and fabricators varied from 0 to $-50 \%$. Actual bulk costs depend heavily on quantity, dimensions, and alloy specifications.

- The cost of fabricated process equipment for the HWVP will be strongly influenced by the following: HWVP functional design criteria, materials performance specifications (corrosion and abrasion resistance), and fabrication and inspection requirements.

(a) D. A. Clapp, Hanford Haste Vitrification Plant Functional Design Criteria. SD-HHV-FDC-001, Rev. 1. Rockwell Hanford Operations, Richland, Washington (1985). 
- Although potential cost differences exist between Alloy 20 and C-276, the suitability of either for HWVP process equipment has not been conclusively established. Material compatibility hinges upon identifying and evaluating the significant corrosive and erosive environments to be encountered in the HWVP, and evaluating the impacts of current uncertainties in HWVP feed composition and in the process flowsheet.

\subsubsection{Me]ter Materials Evaluation (Ref. 4.7-7)}

The pilot-scale ceramic melter (PSCM) was shut down in September 1985 to be rebuilt. The PSCM had operated since April 1978 for a variety of highlevel waste calcine and slurry feed vitrification test programs. The melter construction materials were examined for corrosion, erosion, and structural integrity.

The original melter tank, first used in April 1978, was $71 \mathrm{~cm}$ wide by $117 \mathrm{~cm}$ long, which is a surface area (excluding electrodes) of $0.76 \mathrm{~m}^{2}$. The glass volume was $240^{\circ} \mathrm{L}$, and the tank could be tipped to transfer glass out of the melt cavity. The melter construction utilized Inconel 690 and fused-cast chrome-alumina (Monofax K-3®) block construction in areas in contact with glass for their excellent resistance to corrosion. Because the K-3 has a relatively high thermal conductivity, it was backed by zirconia-alumina paving blocks and other low-conductivity ceramic materials. Between November 1979 and November 1980, the CFCM refractories were replaced and some modifications were made to the feed and off-gas system for use of the melter in direct slurry feeding studies. At this point, the meiter was renamed the PSCM and could no longer be coupled to the calciner.

4.7.4.4.1 PSCM Operating History. The PSCM operated from Apri1 1978 through September 1985 with one major rebuild and rebricking in 1979-1980. Since 1980, there have been several shutdowns during which the 7 id, electrodes, or other components have been modified. The operational and shutdown periods from 1978 to 1985 are briefly described emphasizing changes made to the melter from experience gained during operation. Table 4.7-23 gives a brief chronology of the PSCM.experiments and shutdowns from 1978 to 1985.

\subsection{Operational Period 1 (April 1978-October 1978). At the end} of the initial testing, the melter was shut down for about six months for inspection and repair (Ref. 4.7-8). Some widening of the block-to-block refractory joints had occurred on the melter tank walls and the square corners of the discharge throat showed some rounding. No corrosion was detected on the electrodes. The lid was modified to improve the feed nozzle area corrosion resistance by adding a cooling collar to the feed inlet.

During the shutdown, an Inconel 690 liner was added to the underflow discharge throat to prevent further corrosion in this area. In addition, feet were welded onto the electrodes to increase the power density on the

Monofax $\mathrm{K}-3$ is a tradename of Carborundum/Sohio Engineered Materials, Refractories Division, Keasbey, New Jersey. 
TABLE 4.7-23. Operational History of PSCM PNL-6259

\begin{tabular}{|c|c|c|c|}
\hline Run ID $\neq$ & Date & Years & Comments ' \\
\hline Startup & $4 / 24 / 78$ & 0 & Mark-1 lid installed. \\
\hline CFCH -1 & $5 / 8 / 78$ & -- & \\
\hline CFCM-2 & $5 / 34 / 78$ & $\cdots$ & · \\
\hline CFCH -3 & $6 / 1 / 78$ & -- & \\
\hline CFCH -4 & $6 / 26 / 78$ & $\cdots$ & . \\
\hline CFCH -5 & $9 / 20-30 / 78$ & $\cdots$ & First multiday test. \\
\hline Shutdown & $10 / 24 / 78$ & 0.5 & Mark-1 lid removed. \\
\hline Startup & $4 / 13 / 79$ & -- & $\begin{array}{l}\text { Mark-II lid installed, electrode feet added, throat } \\
\text { liner installed. }\end{array}$ \\
\hline CFCH-6 & $4 / 18-27 / 79$ & - & \\
\hline СЕСН-7 & $6 / 4-30 / 79$ & $\cdots$ & \\
\hline CFCH $=8$ & $11 / 5-9 / 79$ & $\cdots$ & \\
\hline Shutdown & $11 / 30 / 79$ & 1.13 & $\begin{array}{l}\text { Mark-II Iid removed, CFCH tests produced } 61,500 \mathrm{~kg} \\
\text { of glass in } 1266 \mathrm{~h} \text { of operation. }\end{array}$ \\
\hline Startup & $11 / 28 / 80$ & $\cdots$ & $\begin{array}{l}\text { Mark-111 lid installed, refractories replaced, } \\
\text { electrode bus changed. }\end{array}$ \\
\hline PSCH-1 & $12 / 12-19 / 80$ & $\cdots$ & $\begin{array}{l}\text { First liquid. slurry test, TOSM-131 with coal, } \\
220 \mathrm{~kg} \text { of glass produced. }\end{array}$ \\
\hline PSCH-2 & $3 / 23-27 / 81$ & $\cdots$ & $\begin{array}{l}\text { Propane boost, TDSH=131 with c0al, } 2872 \mathrm{~kg} \text { of glass } \\
\text { produced. }\end{array}$ \\
\hline PSCM-3 & $7 / 19-24 / 81$ & $\because$ & TDSF-131 with formate, $2400 \mathrm{~kg}$ of glass produced. \\
\hline Shutdown & $7 / 28 / 81$ & 1.80 & Total glass produced $=7292 \mathrm{~kg}$. \\
\hline Startup & $11 / .14 / 81$ & $\cdots$ & Mark-IV lid installed. \\
\hline PSCH-4 & $12 / 7-11 / 81$ & $\cdots$ & TDSF-131 with formate, $2709 \mathrm{~kg}$ of glass produced. \\
\hline PSCH-5 & $1 / 25-31 / 82$ & -- & $\begin{array}{l}\text { Lid heating, TOSF-131 with formate, } 3338 \mathrm{~kg} \text { of } \\
\text { glass produced. }\end{array}$ \\
\hline PSCM-6 & $3 / 21-26 / 82$ & -- & $\begin{array}{l}\text { Lid heating, TDSF-165 with formate, } 40 \% \text { solids, } \\
4125 \mathrm{~kg} \text { of glass produced. }\end{array}$ \\
\hline PSCH-7 & $5 / 17-21 / 82$ & -- & $\begin{array}{l}\text { DWPF-165 with formate, } 50 \% \text { solids, } 2750 \mathrm{~kg} \text { of glass } \\
\text { produced. }\end{array}$ \\
\hline PSCM-8 & $6 / 14-24 / 82$ & -- & $\begin{array}{l}\text { Lid heating, high A1-165 with formate, } 7630 \mathrm{~kg} \text { of } \\
\text { glass produced. }\end{array}$ \\
\hline Shutdown & $6 / 24 / 82$ & 2.41 & $\begin{array}{l}\text { End of SRL program support, } 27,844 \mathrm{~kg} \text { of glass } \\
\text { produced. }\end{array}$ \\
\hline
\end{tabular}


TABLE 4.7-23. Operational History of PSCM (contd)

\begin{tabular}{|c|c|c|c|}
\hline Run ID * & Date & Years & Comments \\
\hline Startup & $7 / 24 / 82$ & $\cdots$ & \\
\hline PSCM-9 & $8 / 2 \cdot 5 / 82$ & -- & WV-131S, about $2238 \mathrm{~kg}$ of glass produced. \\
\hline PSCM-10 & $8 / 82$ & $\cdots$ & $\begin{array}{l}\text { WV-131S, HWVP instrument test, about } 72 \mathrm{~h} \text {, about } \\
900 \mathrm{~kg} \text { of glass produced. }\end{array}$ \\
\hline PSCM-11 & $11 / 15-19 / 82$ & -- & NCAW/frit-82-10, $220 \mathrm{~kg}$ of glass produced, HWNP-5. \\
\hline PSCM-12 & $12 / 21 / 82$ & -- & $\begin{array}{l}\text { Nonfeed reboil test for } 17 \mathrm{~h} \text {, fed for } 11 \mathrm{~h}, 43 \mathrm{~kg} \\
\text { of glass produced, HWWP-6 NCAW/82-10 frit. }\end{array}$ \\
\hline PSCM-13 & $1 / 17-19 / 83$ & $\cdots$ & HWVP-7, $48 \mathrm{~h}$, NCAW/82-10, $182 \mathrm{~kg}$ of glass produced. \\
\hline PSCM-14 & $\begin{array}{l}3 / 24,25 \\
28-31 / 83\end{array}$ & $\cdots$ & $\begin{array}{l}\text { WW dry fed test, } 4400 \mathrm{~kg} \text { of glass produced, WV } \\
\text { washed sludge at } 30 \mathrm{wt} \% \text {. }\end{array}$ \\
\hline PSCH-15 & $5 / 17-26 / 83$ & -- & $\begin{array}{l}\text { WV Hydrox, waste at } 30 . \mathrm{wt} \%, 3650 \mathrm{~kg} \text { of glass } \\
\text { produced. }\end{array}$ \\
\hline PSCH-16 & $\begin{array}{l}8 / 22-29,31 \\
9 / 1 / 83\end{array}$ & $\cdots$ & $\begin{array}{l}\text { WV nitric acid waste at } 30 \mathrm{wt} \%, 3000 \mathrm{~kg} \text { of } \\
\text { glass produced. }\end{array}$ \\
\hline PSCM-17 & $9 / 26-30 / 83$ & $\cdots$ & HWYP, CAW, $694 \mathrm{~kg}$ of glass produced. \\
\hline PSCH-XX & $7 / 9-10 / 84$ & -- & $\begin{array}{l}\text { MCC test, filled } 361 / 4-\text { scale cans with } \\
\text { SRL-TDSF- } 165 \text { glass, dry fed, } 3500 \mathrm{~kg} \text { of glass } \\
\text { produced. }\end{array}$ \\
\hline PSCM-18 & $8 / 1 / 84$ & -- & $\begin{array}{l}\text { W short test to test off-gas equipment, } 300 \mathrm{~kg} \\
\text { of glass produced. }\end{array}$ \\
\hline $\begin{array}{l}\text { PSCM-19/ } \\
\text { I9E }\end{array}$ & $\begin{array}{l}8 / 21-31 \\
9 / 1 \\
19-21 / 84\end{array}$ & $\cdots$ & $\begin{array}{l}\text { WV with zeolite ( } 30 \mathrm{CV}) \text {, chemical glass formers, } \\
0.5 \text { moles nitric acid, } 2870 \mathrm{~kg} \text { of glass produced. }\end{array}$ \\
\hline PSCH-20 & $4 / 1-10 / 85$ & -. & $\begin{array}{l}8 \text { FRG canister filled; } \# 8 \text { feed used, } 240 \mathrm{~h} \text { of } \\
\text { operation, } 2000 \mathrm{~kg} \text { of glass produced. }\end{array}$ \\
\hline PSCM-21 & $5 / 31-6 / 11 / 85$ & -- & $\begin{array}{l}\text { WV-205 feed, } 296 \mathrm{~h} \text { of operation, } 3170 \mathrm{~kg} \text { of glass } \\
\text { produced. }\end{array}$ \\
\hline PSCM-22 & $7 / 15-8 / 2 / 85$ & - & $\begin{array}{l}\text { HW-39 glass composition, } 101 / 2-s c a l e \text { canisters } \\
\text { filled for SRL, } 427 \mathrm{~h} \text { of operation, } 6800 \mathrm{~kg} \text { of } \\
\text { glass produced. }\end{array}$ \\
\hline Undesignated & $9 / 11-12 / 85$ & -- & $\begin{array}{l}2 \text { FRG canisters filled, } 400 \mathrm{~kg} \text { SRL } 131 \text { frit/calcine } \\
\text { (dry féd), } 30 \mathrm{~h} \text { of operation. }\end{array}$ \\
\hline Shutdown & $9 / 13 / 85$ & -- & $34,367 \mathrm{~kg}$ of glass produced since last shutdown. \\
\hline
\end{tabular}

SUMMARY

Total operating time $=5.55$ years $=48,700 \mathrm{~h}$.

Total liquid feeding time $=0.40$ years $=142$ days $=3410 \mathrm{~h}$.

Total glass produced $=119,500 \mathrm{~kg}=262,9007 \mathrm{~b}$.

Glass produced from liquid-fed operation $=57,600 \mathrm{~kg}=126,750 \mathrm{lb}$. 
floor of the melter. This change was intended to improve glass circulation and limit the sludge accumulation on the melter floor. A detailed description of these modifications with sketches and photographs is provided in Ref. 4.7-8.

4.7.4.4.1.2 Operational Period 2 (Apri7 1979-November 1979). Following an eight-month operating period in which $51,000 \mathrm{~kg}$ of glass was produced, the melter was shut down and examined (Ref. 4.7-8). Significant corrosion had occurred to the lid refractory and feed nozzle area, viewports, and tank refractory. There was no measurable corrosion to the melter fioor or the overflow section. The electrodes showed minor corrosion. The outer corners of the feet and back edges were still sharp, but the front vertical edges showed a slight rounding. Lẹs than $1 \%$ of each electrode mass was missing.

The tank refractory corrosion was serious and required the replacement of the exposed layers of $\mathrm{K}-3$ and zirconia-alumina brick. The horizontal configuration of the K-3 brick al Towed attack at the horizontal joints between the brick. Gas bubbles caused "upward drilling" into the bottom face of the upper brick. Although some glass penetrated the $K-3$, no corrosion could be detected on the zirconia-alumina or Alfrax backup ceramics. The slab cooters between the tank and the overflow section successfully prevented glass migration into the overfiow section of the melter. The zirconiaalumina brick above the $K-3$ was badly spalled, apparently due to thermal cycling and contact with glass foam or feed material splatter.

The Inconel 690 underflow discharge throat 7 iner was severely attacked; approximately $10 \%$ of its mass was lost. In spite of the throat liner, corrosion occurred to the K-3 riser block by upward drilling of trapped gas bubbles between the liner and the brick.

The rebuild of the melter (Ref. 4.7-9) sought to correct many of the problems noted. above: One of the most significant changes was that the bottom row of K-3 bricks was placed vertically so that there were no horizontal joints beneath the glass surface. The bricks were also cemented together with K-3 mortar. The melter tank interior dimensions were changed to $69 \mathrm{~cm}$ by $117 \mathrm{~cm}$, resulting in a melter surface area of $0.73 \mathrm{~m}^{2}$ and a glass holdup volume of $255 \mathrm{~L}$. The riser section was fabricated from a. single monolithic $\mathrm{K}-3$ block with a 30 upward sloping discharge throat entrance.

A new lid was installed that provided additional plenum space above the tank and better under-lid insulation to minimize lid corrosion. The electrodes were modified with wedge-shaped feet to prevent sludge accumulation on the electrode feet and to direct some of the electrical current flow away from the tank walls toward the center and floor of the tank.

\subsection{Operational Period 3 (November 1980-July 1981). During} this period of operation, direct slurry feeding of the melter was used for the first time. Three melter experiments were made, producing $7300 \mathrm{~kg}$ of glass. At the end of the third run, the melter was shut down for inspection and to install a new lid (Ref. 4.7-9). Little corrosion of the tank ceramics or electrodes was noted. 
During the shutdown from July to November 1981, a new lid (Mark IV) was constructed and installed. The new lid increased the idling freeboard above the glass level from $37 \mathrm{~cm}$ to $117 \mathrm{~cm}$ and allowed two banks of electrical radiant heaters positioned horizontally in the plenum space to be installed. The new 7 id was also equipped with two microwave penetrations in the top for studies on microwave startup and feed rate boosting. Because of the taller lid, the electrodes and tank were modified for side entry of the electrode bus. connections.

At the same time, the electrode feet fillets were removed, leaving the original $5 \mathrm{~cm} \times 15 \mathrm{~cm}$ feet at the bottom of the electrodes. The electrode bus connections were modified, as shown in Figure 4.7-8, so that electrical connections could be made through the sides of the melter box instead of through the lid.

4.7.4.4.1.4 Operational Period 4 (November 1981-July 1982). Following the completion of the PSCM-8 run, the melter was drained and inspected (Ref. 4.7-10). Little glass or sludge remained in the melter, but a significant number of metallic nodules, resulting from processing glass under excessive reducing conditions, were removed from the floor. The throat block and other refractories were still in excellent condition. On the riser block face, a hairline crack ran vertically from the centerline of the throat, but no enlargement was seen anywhere along the crack.

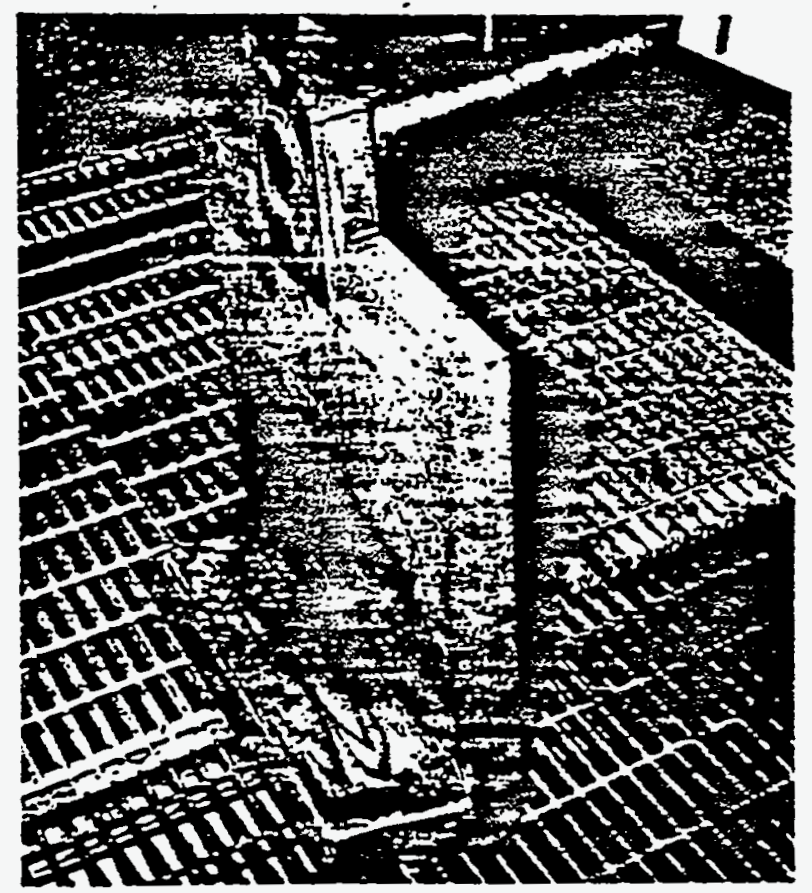

FIGURE 4.7-8. Electrodes Modified for Side Bus Entry PNL-6259 
The electrodes showed some corrosion in the portion exposed to plenum vapors. Damage included spalling and pitting. The off-gas port exhibited severe pitting. The spray coating of $80 \% \mathrm{Ni} / 20 \% \mathrm{Cr}$ applied on the previous shutdown was not effective in preventing attack.

The melter was reassembled without major modifications after a brief one-month shutdown. Only the heater units on the freeze valve were replaced.

4.7.4.4.1.5 Qperational Period 5 (Auqust 1982-September 1985). At its shutdown in September 1985, the PSCM had been in service for nearly 5 years since its refurbishment in 1980. The melter performed well over this extended period, producing over $34,000 \mathrm{~kg}$ of glass. By mid-1985, however, there were several indications that the PSCM was experiencing problems resulting from this long period of operation. Visual inspection through the microwave ports revealed that the electrodes were approaching failure. In addition, a portion of the lid refractory had falien into the melter and the tip of the pour trough was deteriorated, causing glass meit pouring problems.

These conditions did not require the immediate cessation of testing. However, a decision was made in mid-1985 to drain and inspect the melter and make needed repairs. Damaged and corroded components were repaired or replaced to ensure that the PSCM would be available for planned testing over the next 3 to 5 years.

\subsection{Materials Inspection. The melter was drained and inspected} in September 1985; however, the accumulation of sludge prevented unassisted draining. An air lance was used to clean the drain hole area on the side of the melter tank to initiate glass flow. A 2- to 5-cm-thick layer of sludge and glass remained on the floor of the melter after the glass had drained. No metal nodules of the type seen in previous shutdowns were noted. Significant corrosion had occurred to the melter walls, lid, and electrodes; and the pour trough required replacement.

4.7.4.4.2.1 Electrodes. Aithough the general condition of the electrode faces and feet appeared good, large vertical cracks had formed in the electrodes and significant corrosion was evident on the back sides of both electrodes (next to the wal1) near the glass operating level. Figure 4.7-9 shows the condition of the electrodes as removed from the meiter. In addition, the accumulation of material behind the electrodes, possibiy corrosion oxides, had pushed the electrodes away from the tank walls, causing failure of many- of the bus weld connections at the top of the electrodes. Figure 4.7-10 compares the melter tank and electrodes at the July 1982 shutdown with the September 1985 shutdown.

Sand blasting removed the corrosion products and exposed the severe corrosion that had occurred to the electrodes. "(The electrodes are shown again in Figure 4.7-11 after sand blasting.) The most severe corrosion can be seen at the bus connections and on the rear of the electrodes at the glass interface level (approximately at the electrode midpoints). The vertical cracks penetrated the electrode body. The electrode thickness was less than $3 \mathrm{~cm}$ in the area of the crack. 


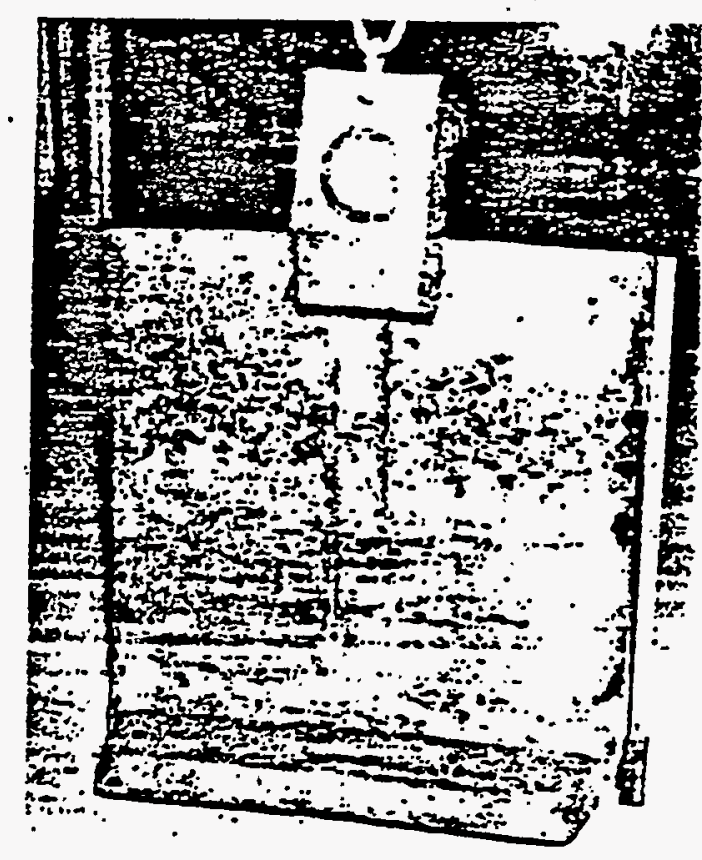

a) North - Front

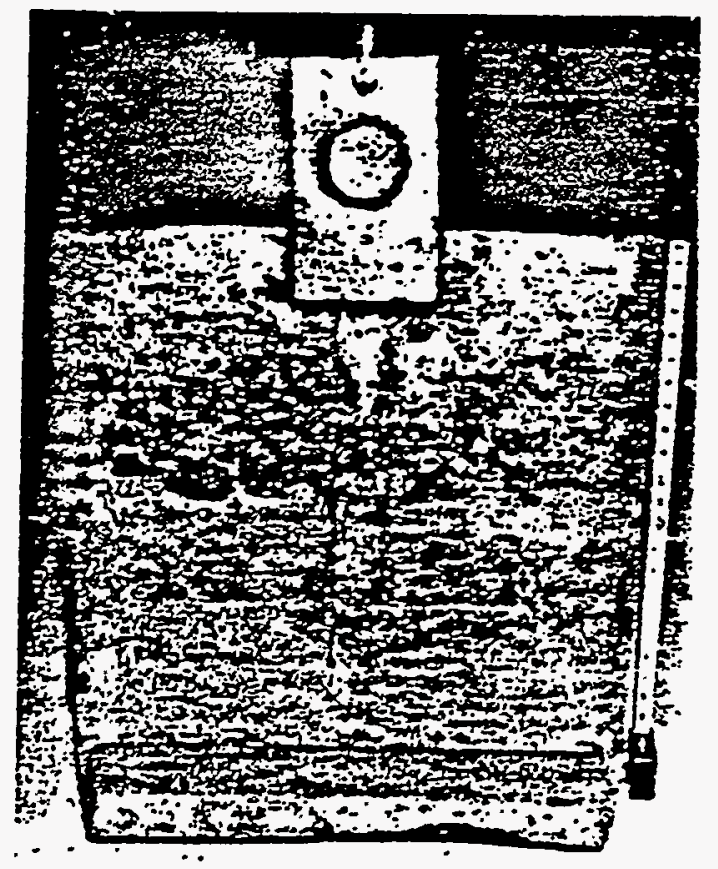

a) South - Front

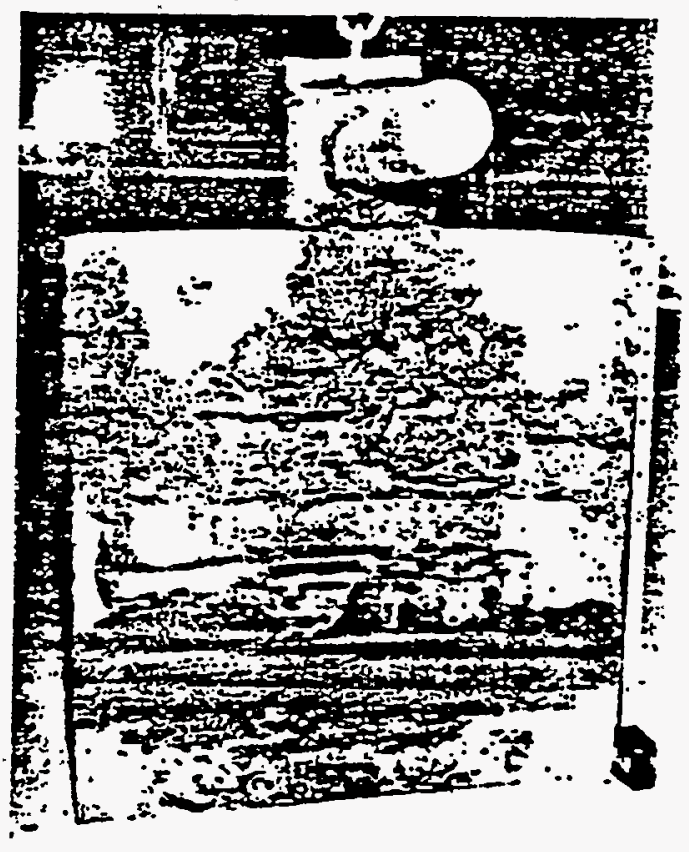

b) North - Back

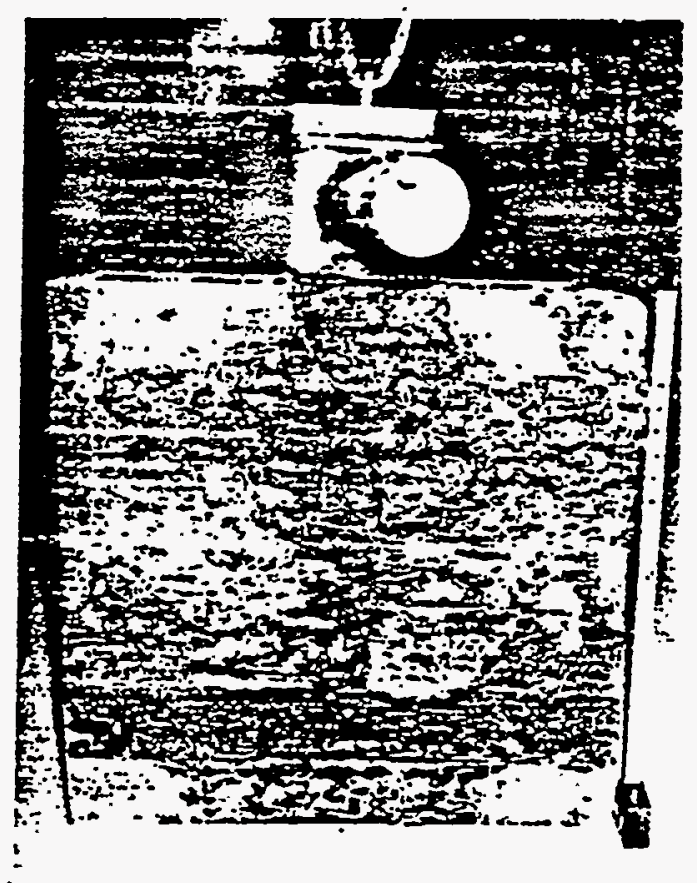

b) South - Black

FIGURE 4.7-9. Condition of Electrodes as Removed from the PSCM During the 1985 Inspection PNL-6259 


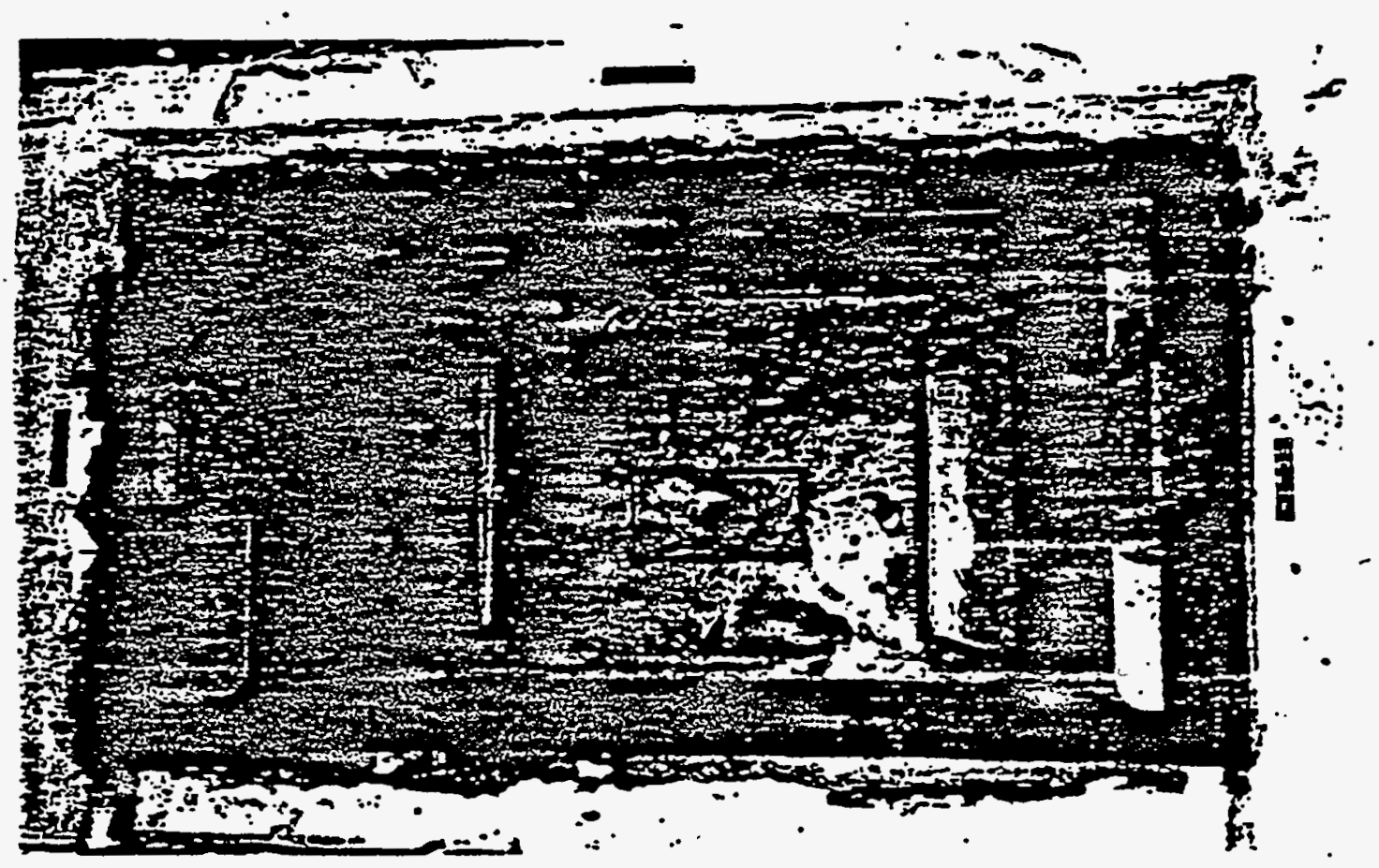

a) After 1982 Shutdown

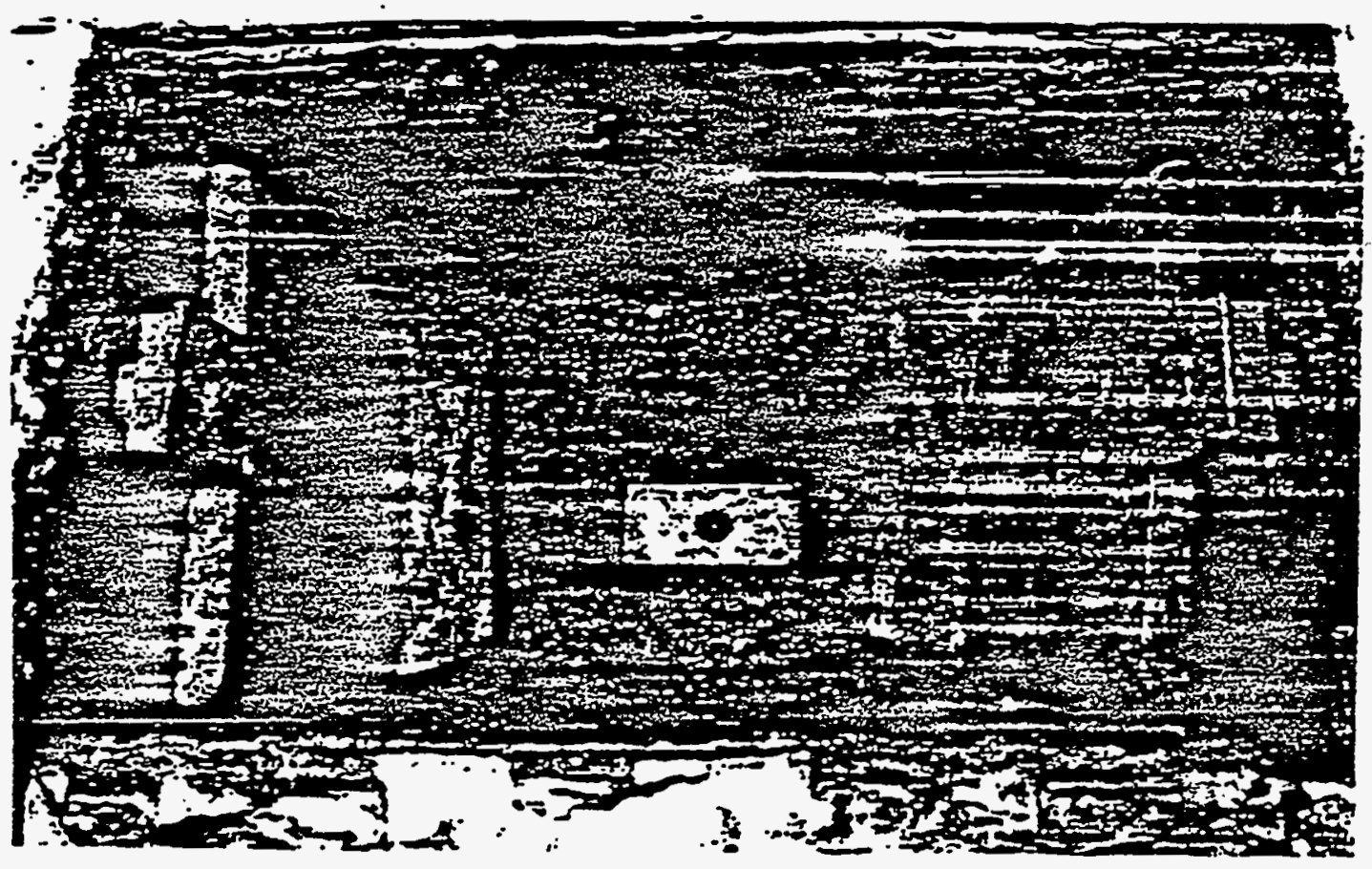

b) After 1985 Shutdown

FIGURE 4.7-10. Appearance of Melter Tank After 1982 Shutdown and After 1985 Shutdown PNL 6259 


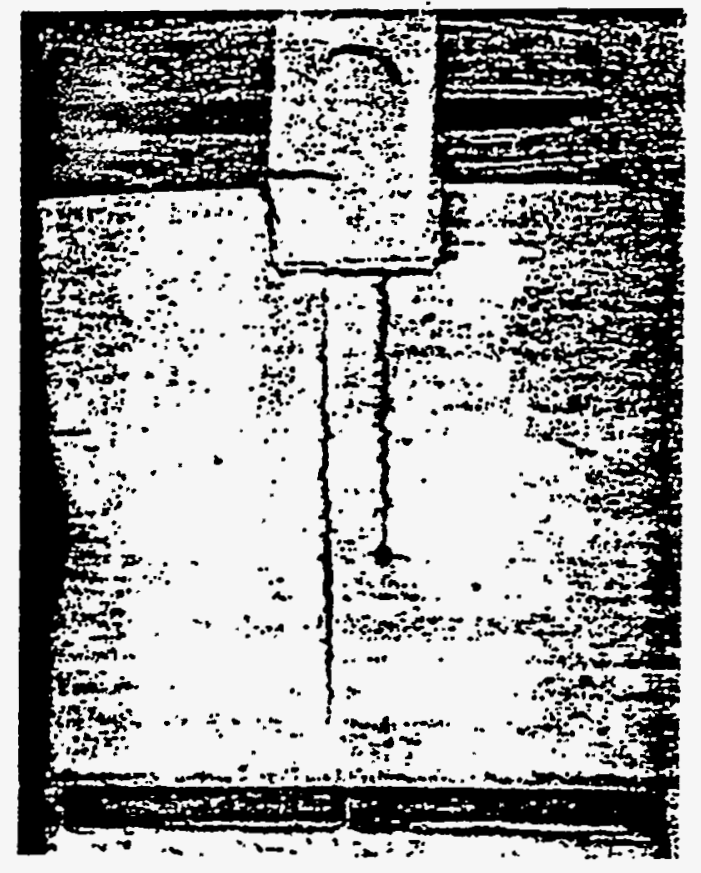

a) North - Front

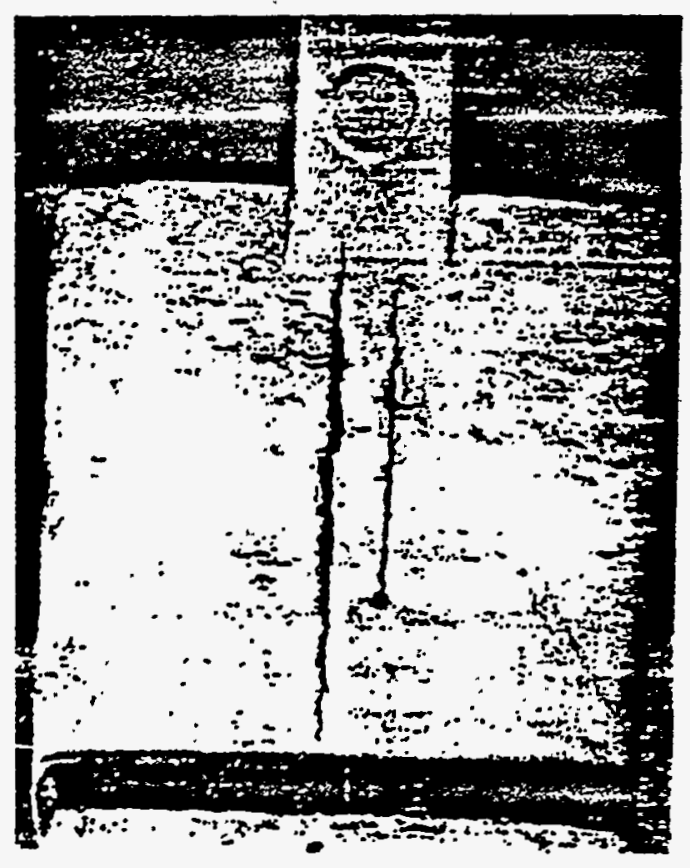

a) South - Front

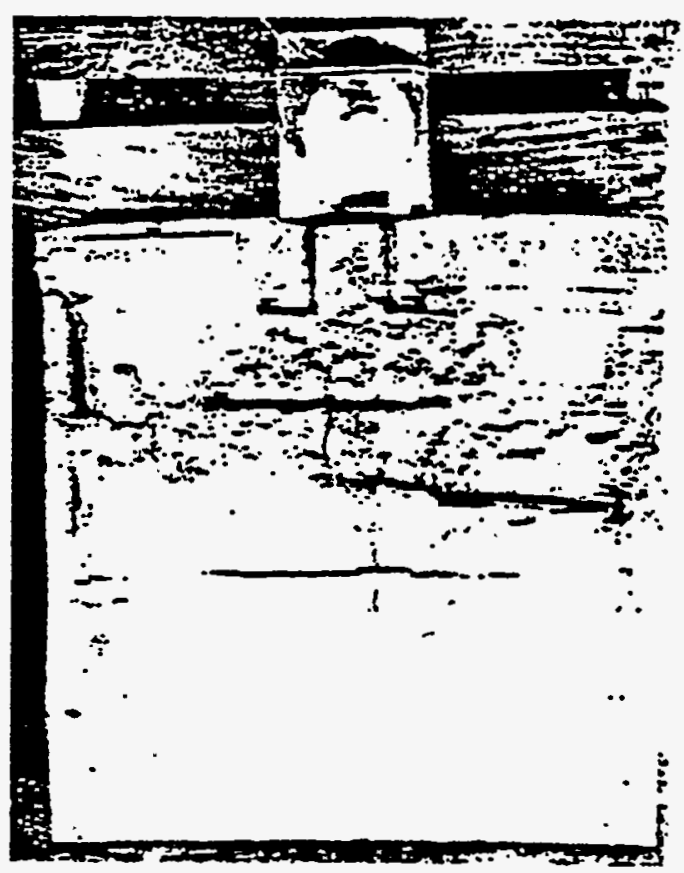

b) North - Back

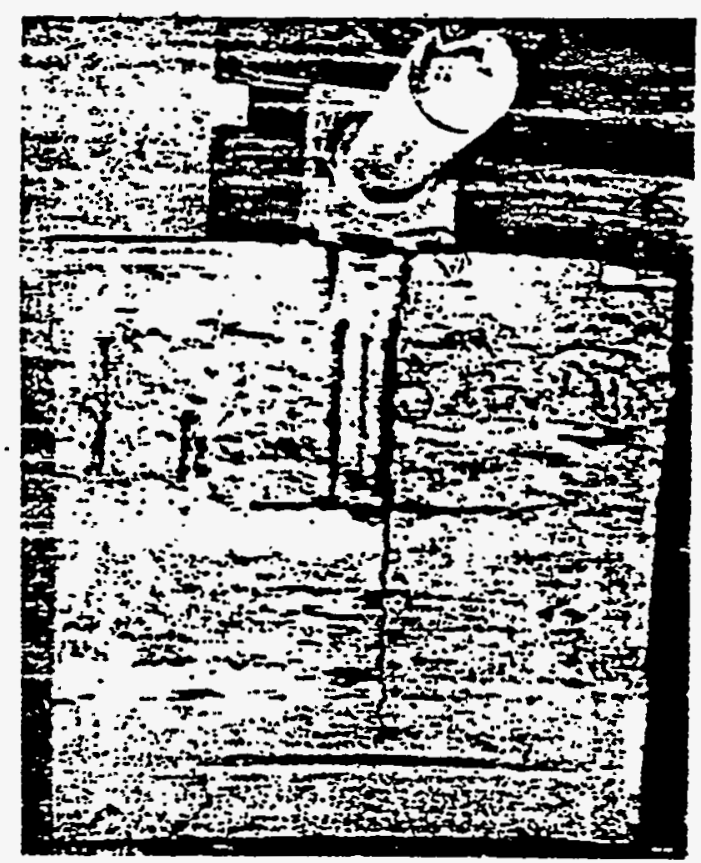

b) South - Back

FIGURE 4.7-11. Electrodes After Sand Blasting PNL-6259 
A close-up of the front of the south electrode foot shows significant pitting (Figure 4.7-12). The condition of the north electrode was similar to that of the south electrode with slightly higher corrosion at the bus connection. The north and south electrodes weighed $187 \mathrm{~kg}$ and $174 \mathrm{~kg}$, respectively, after sand blasting. This compares with $195 \mathrm{~kg}$ and $193 \mathrm{~kg}$ when the electrodes were installed in october $1981(62,000 \mathrm{~kg}$ of glass was produced in 47 months). The total weight decreased by $6.8 \%$ since the electrodes were last modified and installed in November 1981. This compares with a $0.4 \%$ decrease in weight between November 1980 and July 1981 (7300 $\mathrm{kg}$ of glass was produced in 8 months).

Previous corrosion studies of Inconel 690 in meiter environments have indicated very good corrosion resistance under reducing conditions. PNL laboratory tests on a wide assortment of glasses indicated static corrosion rates of 0 to $15 \mathrm{~m} /$ day as shown in Table 4.7-24 (Ref. 4.7-11).

Inconel electrode corrosion data from other development melters confirm the favorable laboratory corrosion resistance of Inconel 690. The SRP Smal7 cylindrical meiter (SCM) was examined in 1982 and showed excellent electrode corrosion resistance. However, portions of the melter constructed from Inconel 690 above the melt line experienced severe corrosion (Ref. 4.7-12). The SRP lairge slurry-fed melter (LSFM) was shit down and examined in 1984 after two years of operation at 1100 to $1150^{\circ} \mathrm{C}$ (Ref. 4.7-13). The largest decrease in electrode thickness was $0.6 \mathrm{~cm}(8 \mu \mathrm{m} /$ day $)$ near the top of the

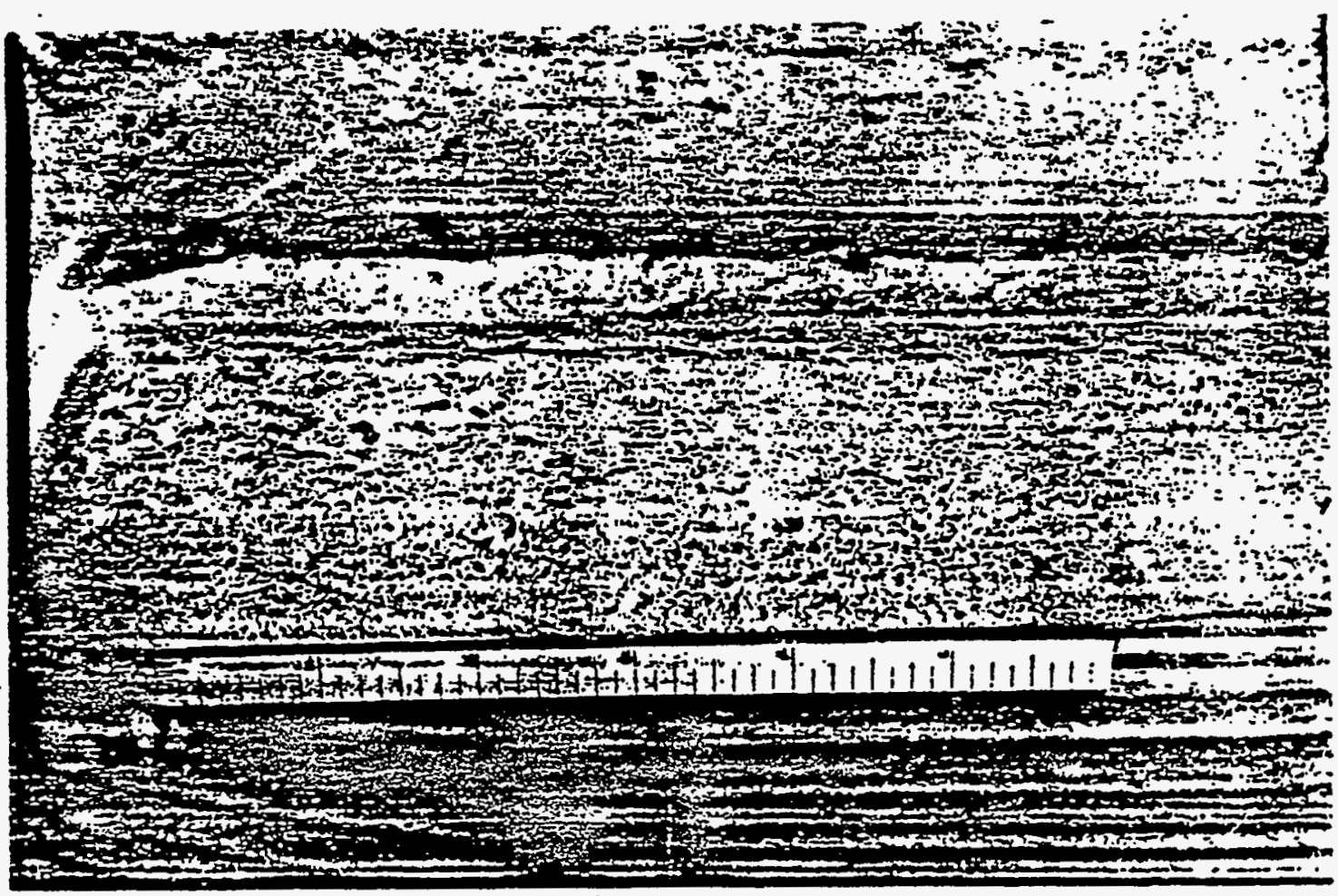

FIGURE 4.7-12. Front View of the South Electrode PNL-6259 
TABLE 4.7-24. Comparative Static Corrosion Rates of Candidate Electrode Materials PNL-6259

\begin{tabular}{|c|c|c|c|c|c|c|}
\hline \multirow[b]{3}{*}{ Material } & \multicolumn{6}{|c|}{ Corrosion Rate $(\mu \mathrm{m} / \mathrm{day})(a)$} \\
\hline & \multicolumn{2}{|c|}{$\begin{array}{c}\text { Static Testing } \\
\text { at } 1050^{\circ} \mathrm{C}\end{array}$} & \multicolumn{2}{|c|}{$\begin{array}{l}\text { Static Testing } \\
\text { at } 1050^{\circ} \mathrm{C}\end{array}$} & \multicolumn{2}{|c|}{$\begin{array}{c}\text { Powered at } \\
0.78 \mathrm{~A} / \mathrm{cm}^{2}\left(1050^{\circ} \mathrm{C}\right)\end{array}$} \\
\hline & $\begin{array}{l}\text { Flux } \\
\text { Line }\end{array}$ & Submerged & $\begin{array}{l}\text { Flux } \\
\text { Line }\end{array}$ & Submerged & $\begin{array}{l}\text { Flux } \\
\text { Line }\end{array}$ & Submerged \\
\hline $\begin{array}{l}\text { Inconel } 690 \\
\text { Inconel } 601 \\
\text { Tin oxide } \\
304-L\end{array}$ & $\begin{array}{l}0 \text { to } 15 \\
4 \text { to } 18 \\
5 \text { to } 15 \\
9 \text { to } 58\end{array}$ & $\begin{array}{l}0 \text { to } 5 \\
0 \text { to } 15 \\
2 \text { to } 9 \\
0 \text { to } 69\end{array}$ & 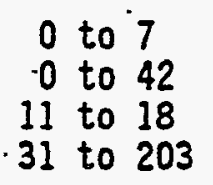 & $\begin{array}{ll}0 & \text { to } 7 \\
0 & \text { to } 33 \\
0 & \text { to } 15 \\
9 & \text { to } 100\end{array}$ & $\begin{array}{c}4 \text { to } 11 \\
18 \\
-- \\
90\end{array}$ & $\begin{array}{c}0 \text { to } 9 \\
18 \\
- \\
90\end{array}$ \\
\hline
\end{tabular}

(a) Ranges measured for six different glașs compositions in seven-day static tests.

electrodes. A corrosion rate of $29 \mu \mathrm{m} /$ day was seen on Idaho National Engineering Laboratory (INEL) melter electrodes after 18 weeks at 1000 to $1100^{\circ} \mathrm{C}$ (Ref. 4.7-14). However, the glass contained significant calcium fluoride. While none of these electrode corrosion data show the severe attack experienced in the PSCM, many accounts indicated significant corrosion of exposed Inconel 690 surfaces in the plenum areas.

Barnes and Larson (Ref. 4.7-15) found a maximum corrosion rate of $3 \mu \mathrm{m} /$ day for the electrodes in the PSCM in 1980 after three years of operation. While the submerged electrodes experienced little corrosion, the Inconel materials in the plenum showed severe corrosion due to halides and sulfates in the feed stream (Ref. 4.7-8). This corrosion by oxidizing materials may have application to the corrosion experienced at the rear of the PSCM electrodes.

Table 4.7-25 gives the results of corrosion product analyses on samples taken around the PSCM electrodes during the 1985 rebuild. Corrosion products removed from below the south electrode bus bar show much higher $\mathrm{Fe}$ and $\mathrm{Mn}$ to $\mathrm{Cr}$ ratios than Incone7 690 . Corrosion product samples from both electrodes showed $\mathrm{Ni}$ and $\mathrm{Cr}$ levels significantly below Inconel 690. The $\mathrm{F}, \mathrm{Cl}$, and $\mathrm{S}$ levels in the corrosion products were below $0.2 \%$ in all but the north electrode corrosion sample, which was $0.5 \%$. The $\mathrm{F}, \mathrm{Cl}$, and $\mathrm{S}$ levels were close to the concentrations of these elements in the sludge removed from the melter floor. Although these analyses are indicative of corrosion, they do not give strong evidence of a particular corrosion mechanism. Unfortunately, most of the corrosion material was sand blasted from the backs of the electrodes before samples were taken and these analyses are inconclusive. 
TABLE 4.7-25. Analysis of Electrode Corrosion Products PNL-6259

\begin{tabular}{|c|c|c|c|c|c|c|c|c|c|c|}
\hline \multirow{2}{*}{$\begin{array}{l}\text { Sample } \\
\text { Locations }\end{array}$} & \multicolumn{10}{|c|}{ Concentrations (\%) } \\
\hline & A1 & $\mathrm{Cr}$ & $\mathrm{Fe}$ & Mn & Ni & $\mathrm{Na}$ & Si & $F$ & $C 1$ & $\mathbf{S}$ \\
\hline $\begin{array}{l}\text { Sludge tank } \\
\text { bottom }\end{array}$ & 4.23 & 8.48 & 8.54 & 0.75 & 1.82 & 7.80 & 15.80 & 0.04 & 0.16 & 0.02 \\
\hline $\begin{array}{l}\text { South } \\
\text { electrode } \\
\text { ( } 5 \text { cn below } \\
\text { bus bar) }\end{array}$ & 4.98 & 2.12 & 21.00 & 4.96 & 6.72 & 4.91 & $\begin{array}{l}7.55 \\
.\end{array}$ & 0.03 & 0.06 & 0.54 \\
\hline $\begin{array}{l}\text { North } \\
\text { electrode } \\
\text { bus bar }\end{array}$ & 2.51 & 21.60 & 10.30 & 2.15 & 7.72 & 3.81 & 7.80 & 0.01 & 0.03 & 0.20 \\
\hline Inconel 690 & 0.20 & 30.00 & 9.40 & 0.14 & 60.00 & $\cdots$ & 0.13 & -- & $\cdots$ & -- \\
\hline
\end{tabular}

A possible mechanism for the severe corrosion seen at the rear of the electrodes is suggested by the appearance of the electrodes after sand blasting. As the electrodes were pushed away from the walls, the mechanical stress (and possibiy heating and cooling cycles) opened small cracks at the cooling channel welds on the back of the electrodes and breached the vertical holes drilled for weight factor and specific gravity measurements. The cooler stagnant area behind the electrodes allowed an accumulation of oxidizing salts, especially at the melt line, which accelerated the attack of the Inconel 690.

4.7.4.4.2.2 Lid Shel7 and Refractory. As can be seen in Figure 4.7-13, a portion of the 1 id refractory material above the overflow section had fallen into the melter tank. This photograph shows exposed Inconel hangers on the west wall of the upside-down 7id. Lack of support for this section of refractory is credited with its failure. In the previous lid design, the west wall extended over the melter tank with no support from below. The Inconel 690 hangers failed to hold the 1 id ceramic to the shell and part of the 7 id fell into the melter tank. This problem was addressed by using ceramic hangers in the new lid design.

4.7.4.4.2.3 Melter Tank Refractory. The K-3 brick on the melter walls showed some corrosion consistent with the 5-year operating 7 ife of the melter refractory. Figure 4.7-14 shows that the K-3 brick was attacked both above and below the glass line. East to west wall measurements taken in 1980, 1981 , and 1985 showed erosion/corrosion of the wal7s and indicated that the walls had shifted east with reference to the melter tank flanges. Figure 4.7-15 shows the east and west wall profiles at a point $53 \mathrm{~cm}$ south of the north wall $(5 \mathrm{~cm}$ north of the tank centerline). The same figure also shows the total corrosion at the same location when the east and west wall measurements are combined. These measurements indicate the most severe 

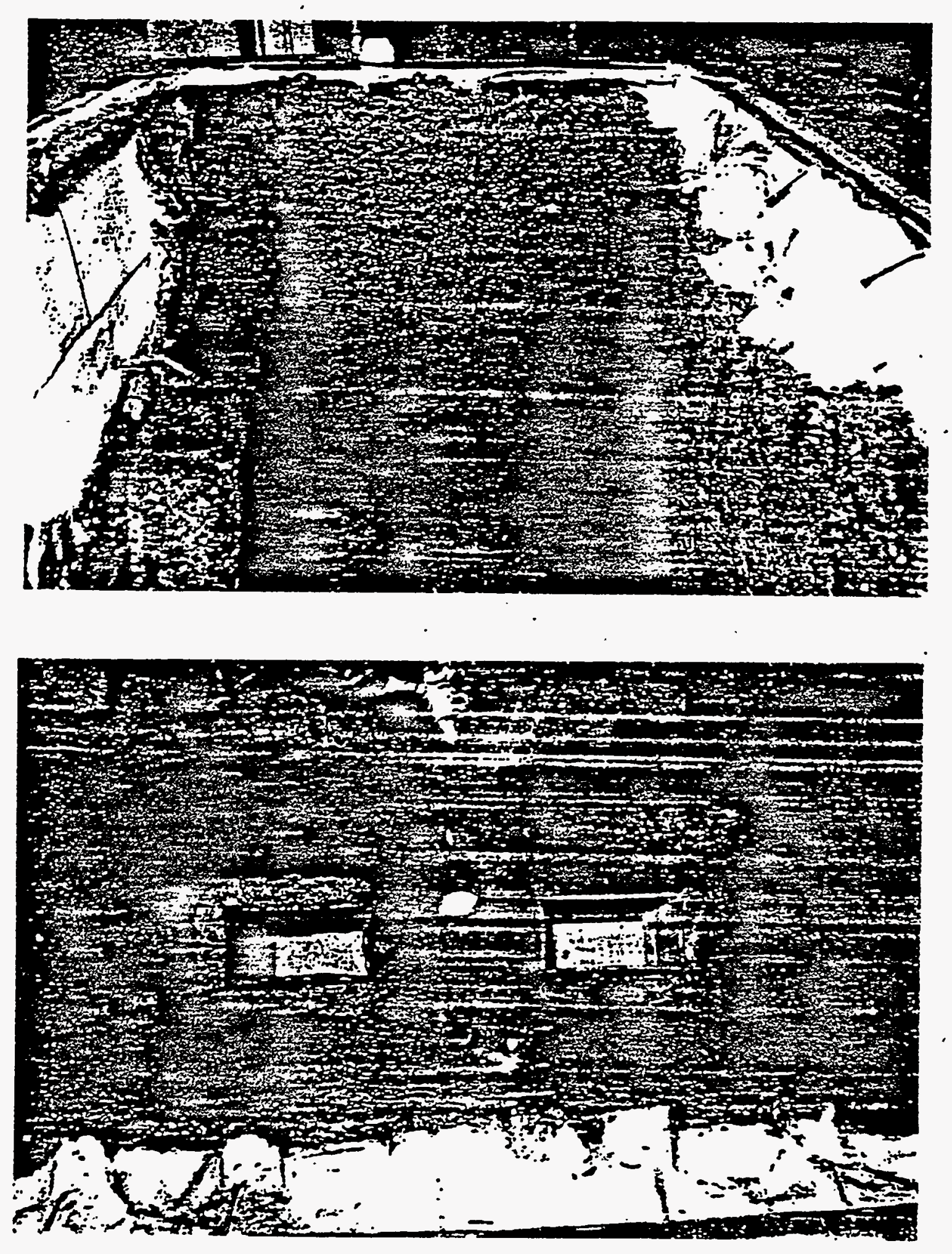

FIGURE 4.7-13. Lid Refractory PNL-6259 


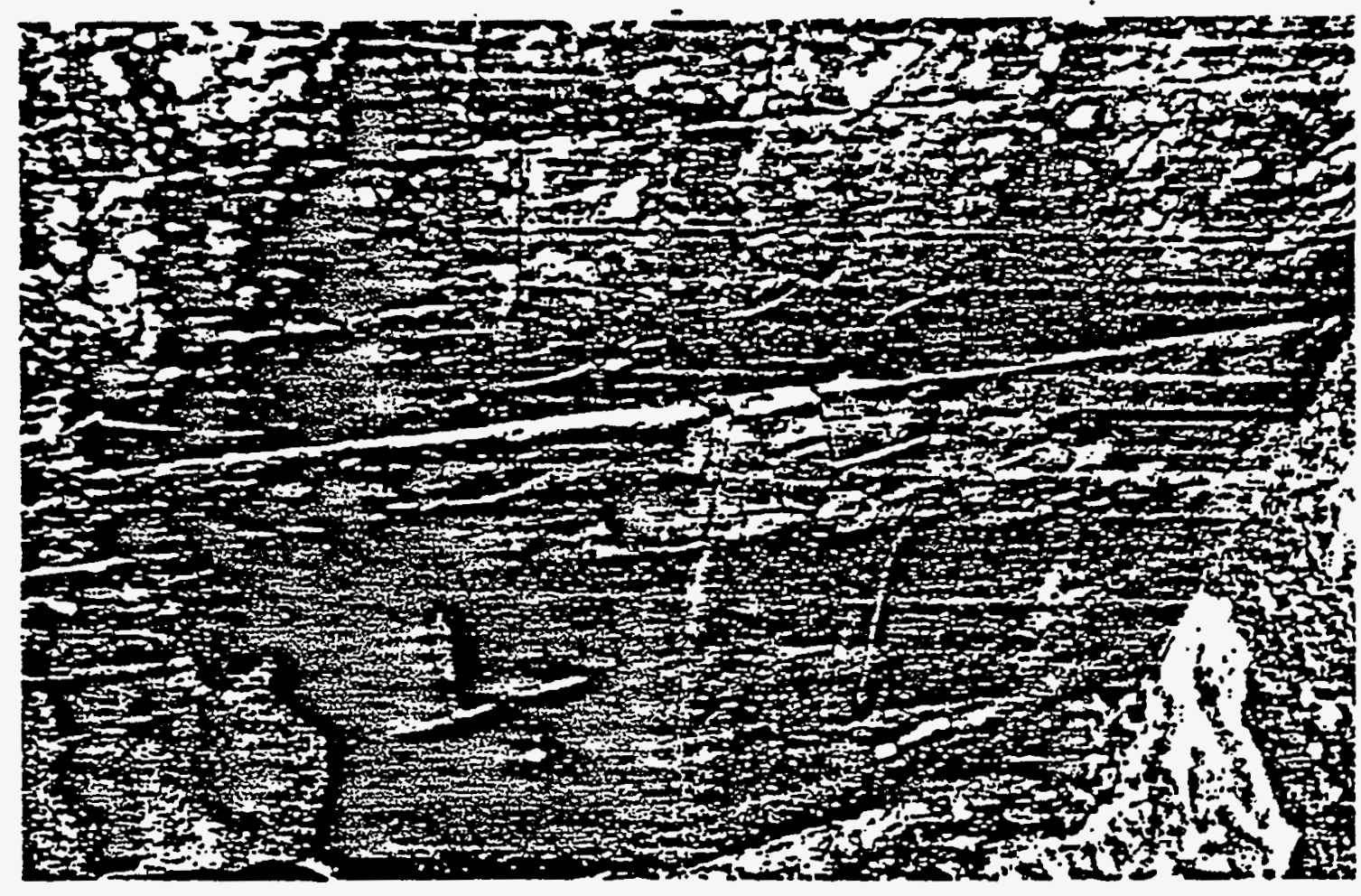

FIGURE 4.7-14. East Wall of Melter Tank PNL 6259

corrosion of the brick occurred 25 to $30 \mathrm{~cm}$ above the melter floor. Figure 4.7-16 shows the total change of the east and west walls at six locations along the melter tank. The north-south locations of the measurement points are given in Table 4.7-26. These measurements show that the corrosion was more pronounced at the center of the tank than on the ends near the electrodes.

Measurements of individual bottom row K-3 brick confirmed that 0.8 to $1.5 \mathrm{~cm}$ of material had corroded fram the east and west walls in a band 10 to $20 \mathrm{~cm}$ high centered about $30 \mathrm{~cm}$ above the melter floor. Thus, the maximum wall corrosion occurred about $10 \mathrm{~cm}$ below the nominal $40-\mathrm{cm}$ glass operating level. Corrosion of the walls was most severe just below the glass surface where the largest convection currents are present due to convective heat transfer to the cold cap.

The $\mathrm{K}-3$ refractory corrosion rates have been measured by a number of investigators (Ref. 4.7-11) in commercial and defense glass. Between $1050^{\circ} \mathrm{C}$ and $1150^{\circ} \mathrm{C}$, the static corrosion rates were generally between 10 and $20 \mathrm{~m} /$ day at the melt line and less than $10 \mathrm{~m} /$ day below the glass surface. The PSCM K-3 corrosion rate in the 1600 days of operation since the PSCM was last rebricked in 1979-1980 was 4 to $8 \mathrm{~mm} /$ day based on the wall and individual block measurements. This indicates that the PSCM K-3 corrosion resistance was satisfactory and within expected performance limits. 

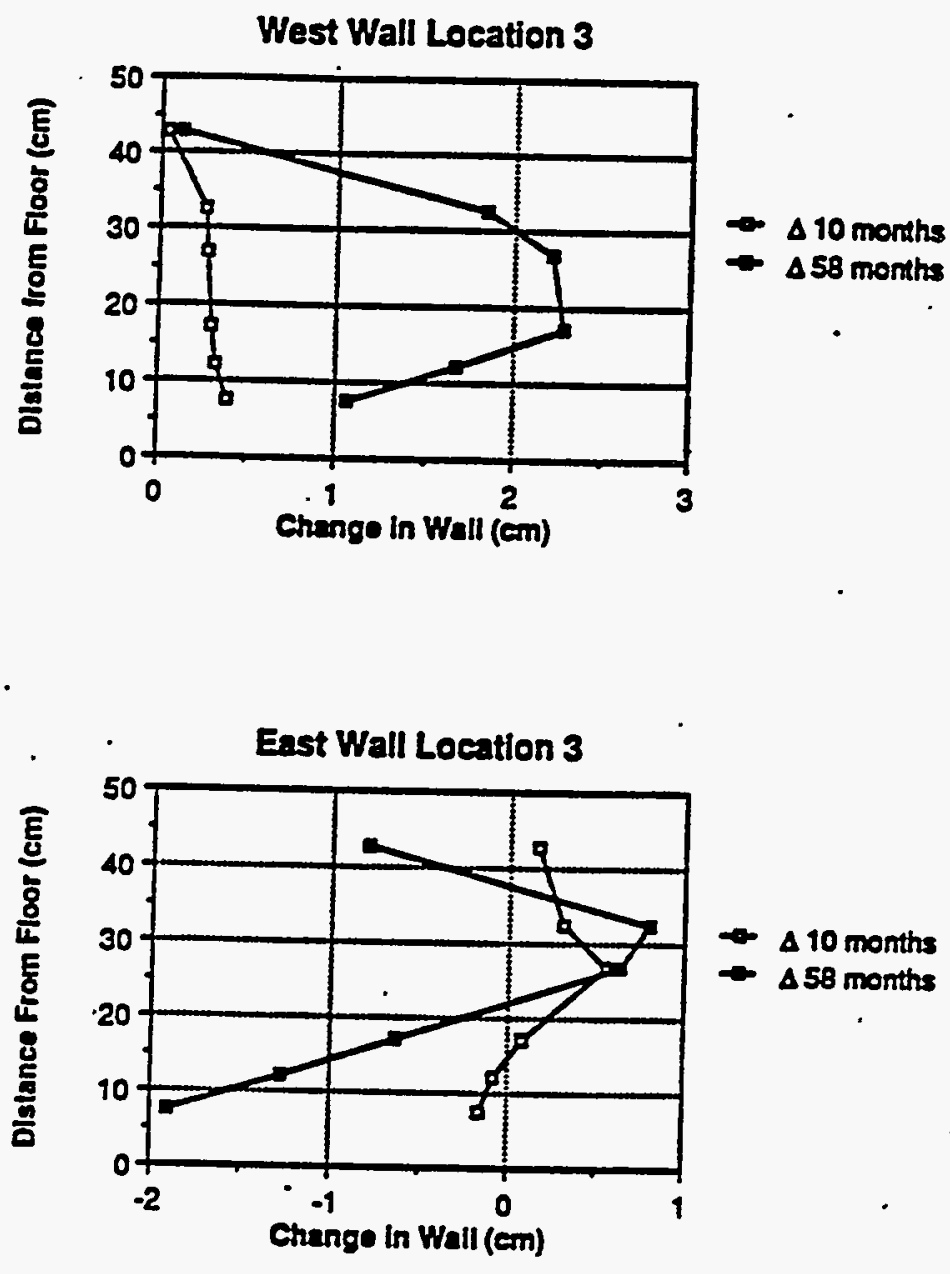

$\triangle 10$ months

- $\Delta 58$ months
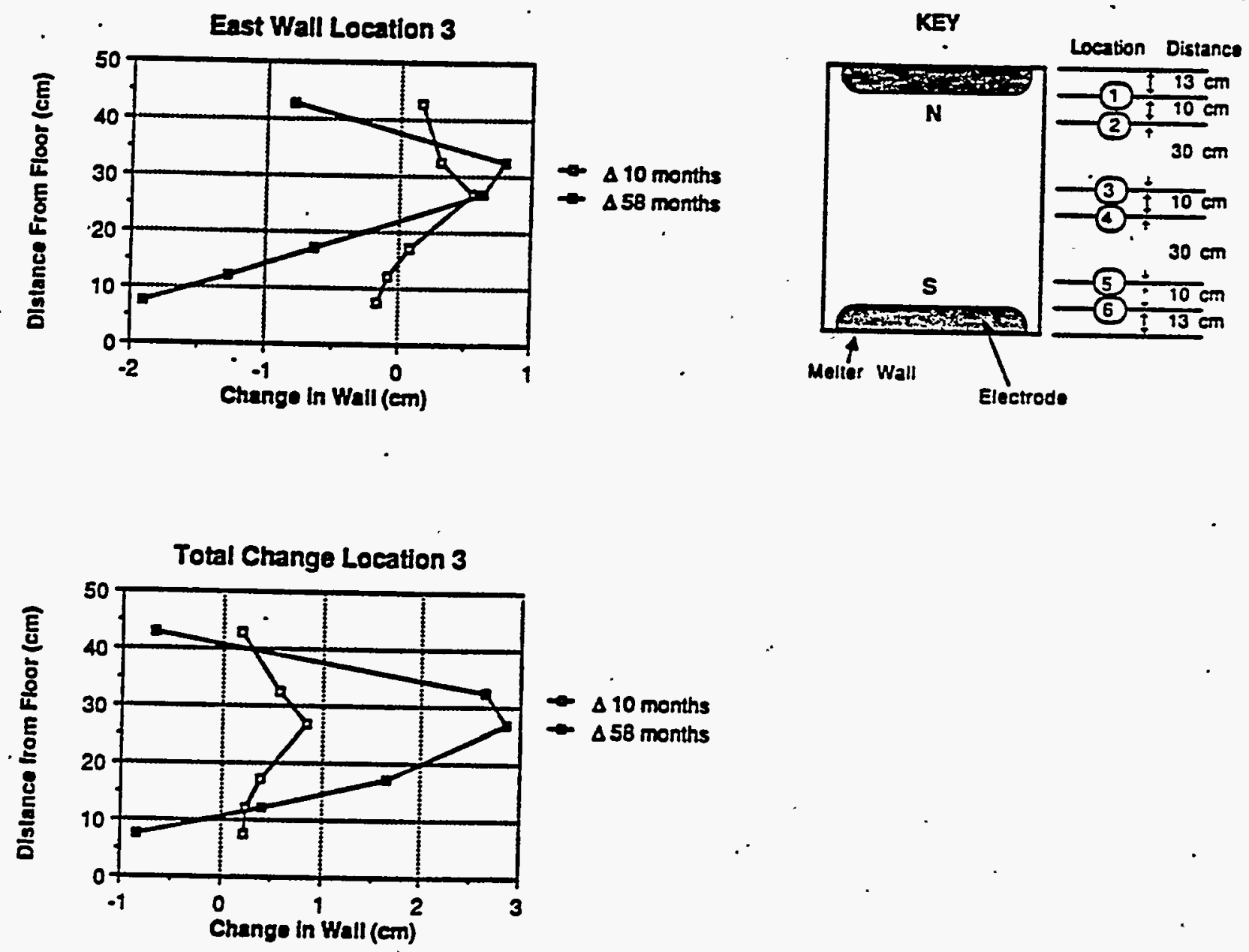

FIGURE 4.7--15. Changes in Melter Wall Measurements PNL-6259 
Total Change Location 1

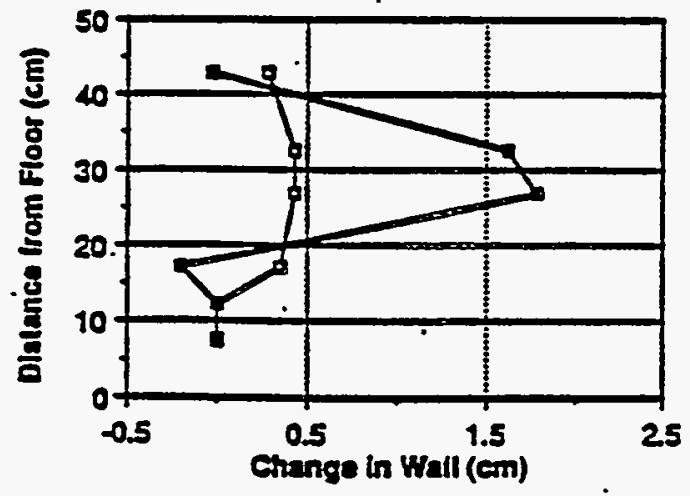

$\rightarrow \Delta 10$ months

$-\Delta 58$ months

Total Change Location 2

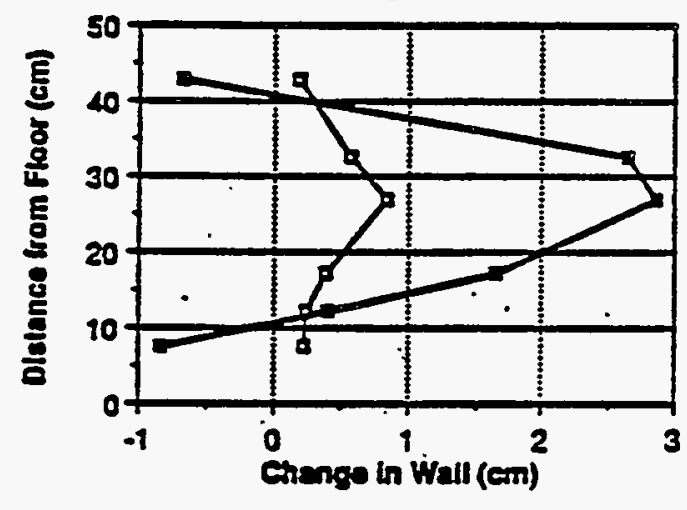

- $\triangle 10$ months - $\Delta 58$ months

Total Change Location 3

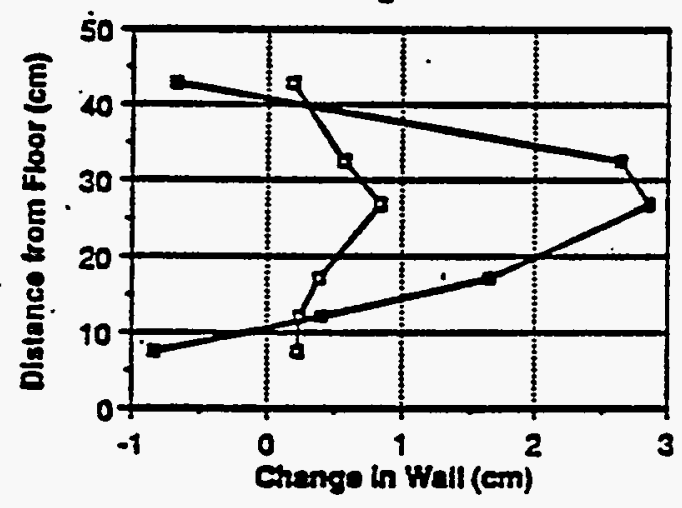

Total Change Location 4
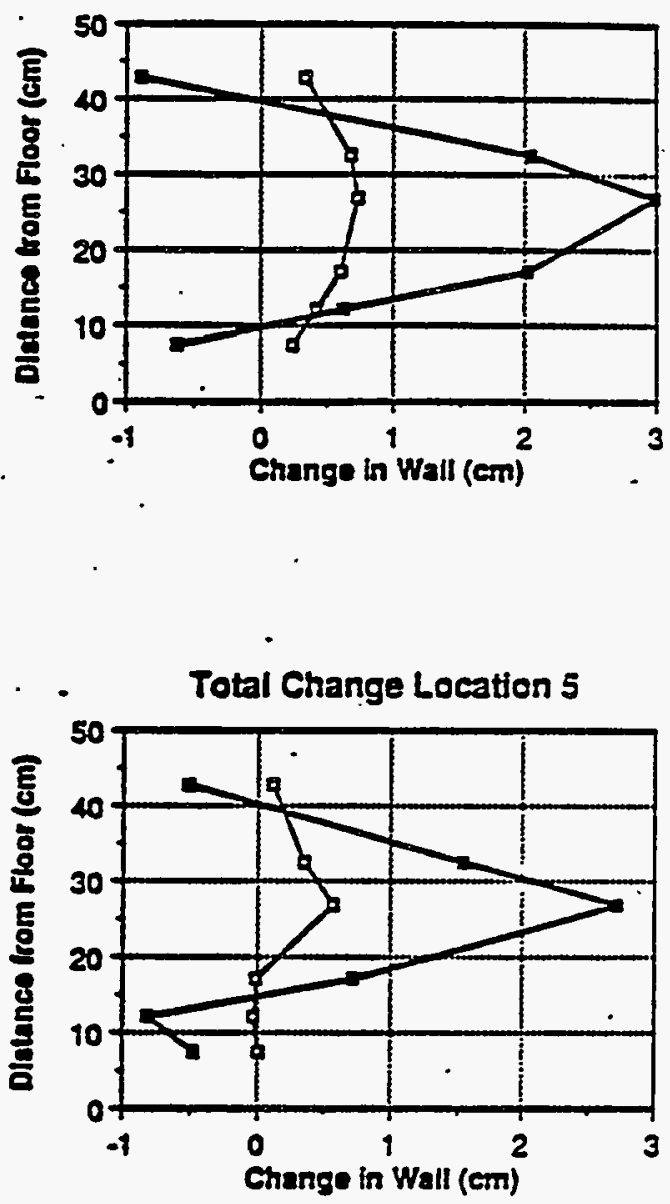

Total Change Location 6

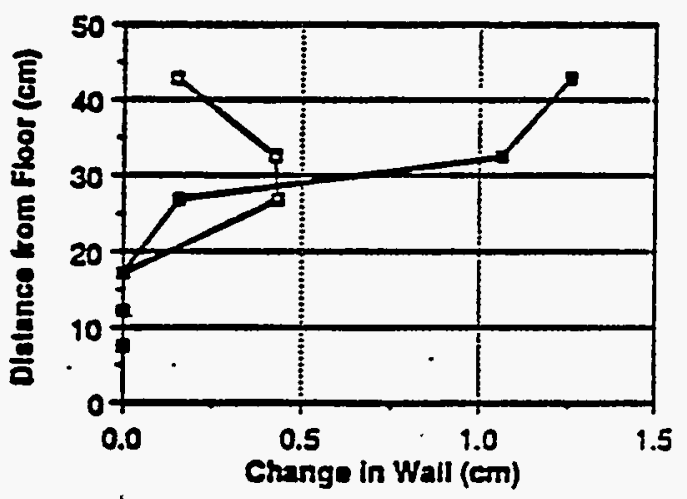

FIGURE 4.7-16. Total Change in Melter Wall Measurements PNL-6259 
TABLE 4.7-26. Reference Points for Wall Corrosion Measurements PNL-6259

\begin{tabular}{|c|c|c|}
\hline & $\begin{array}{c}\text { Distance from } \\
\text { North Wall (cm) }\end{array}$ & $\begin{array}{c}\text { Distance from } \\
\text { South Wall (cm) }\end{array}$ \\
\hline 1 & 13 & 103 \\
2 & 23 & 93 \\
3 & 53 & 63 \\
4 & 63 & 53 \\
5 & 93 & 23 \\
6 & 103 & 13 \\
\hline
\end{tabular}

(a) See Figure 4.7-16 for locations.

Some glass penetrated the K-3 brick layer, especially on the west wall. The zirconia-alumina brick was not attacked and prevented the glass from penetrating further.

The meiter K-3 floor brick also required replacement, although corrosion was less severe there than on the walls. Measurements of the degree of corrosion on the floor were not possible because the sludge was removed from the floor by chipping. The refractory materials beneath the K-3 brick were in good condition, although glass had penetrated the $\mathrm{K}-3$ layer in the freeze valve area.

4.7.4.4.2.4 Riser Block. Width measurements indicated that the riser block was subjected to the same erosion/corrosion as the rest of the east and west walls (Figure 4.7-17). The riser block also exhibited a $1.3-\mathrm{cm}$ concave band about $10 \mathrm{~cm}$ below the glass level approximately $15 \mathrm{~cm}$ high. Figure 4.7-18 shows the throat entrance as it appeared in the 1982 shutdown and after the riser block was removed in 1985. The throat entrance widened from an original $5.0 \mathrm{~cm}$, to $6.4 \mathrm{~cm}$ in 1982 , and to $7.4 \mathrm{~cm}$ in 1985. The throat entrance was considerabiy wider at the bottom when removed in 1985 . Although there was no indication of upward drilling by gas bubbles on the upper surface of the throat Figure 4.7-18 shows that the throat entrance also grew vertical1y by about $1.5 \mathrm{~cm}$.

4.7.4.4.2.5 Overflow Trough. The Inconel tip on the pour trough was removed in June 1985 because of corrosion. The main K-3 portion of the pour trough was in good condition, although there was fracturing of the trough at the overflow face. The entire trough was removed to replace the pour tip. Figure 4.1-19 compares the trough as it appeared in the 1985 shutdown with its "as-installed" appearance.

4.7.4.5 DWPF Studies [M. R. E]more, Preliminary Eva]uation of Materials Selection for the Hanford Waste Vitrification Plant. HWVP-88-V1135A, Pacific Northwest Laboratory, Richland, Washington (1986)]. The initial approach to DWPF materials selection was to select $304 \mathrm{~L}$ stainless steel as a reference material, then perform tests to verify the suitability of this selection. 


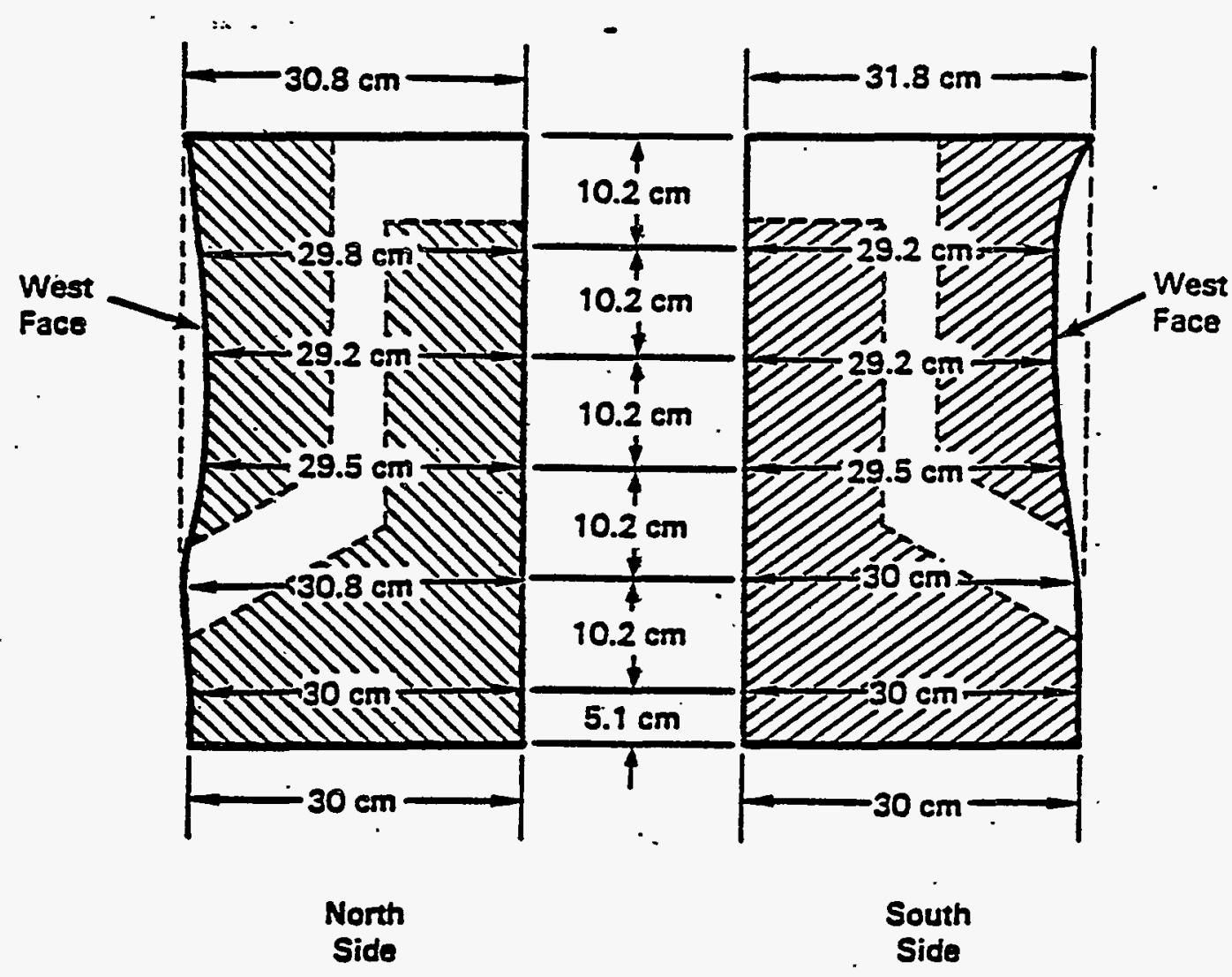

FIGURE 4.7-17. Riser BTock Measurements PNL-6259

Preliminary testing showed that $304 \mathrm{~L}$ stainless steel would not be suitable for the DWPF slurry treatment and off-gas treatment equipment. A more corrosion-resistant stainless steel, Ailoy 20, was then chosen as the next reference material for the DWPF. Preliminary tests indicated that the Alloy 20 would be an acceptable choice. Alloy 20 was then found to be unsuitable due to the presence of $\mathrm{Hg}$ and $\mathrm{Hg}$ compounds in the feed and offgas systems, which caused severe intergranular attack and pitting of the alloy. For this reason, Alloy C-276 was selected to replace Alloy 20 because of its demonstrated resistance to the $\mathrm{Hg}$-induced corrosion.

Additional SRL testing indicated that the C-276 may not be satisfactory for the off-gas quencher. An alternative material (ALLCORR) with additional resistance to pitting has been selected for the quencher; $\mathrm{C}-276$ is the backup. Inconel 690 has been selected by SRL for the melter's metal components and off-gas line to the quencher. As long as temperatures are maintained above the dewpoint Inconel 690 appears satisfactory, but SRL personne] still have some reservations about this alloy. 

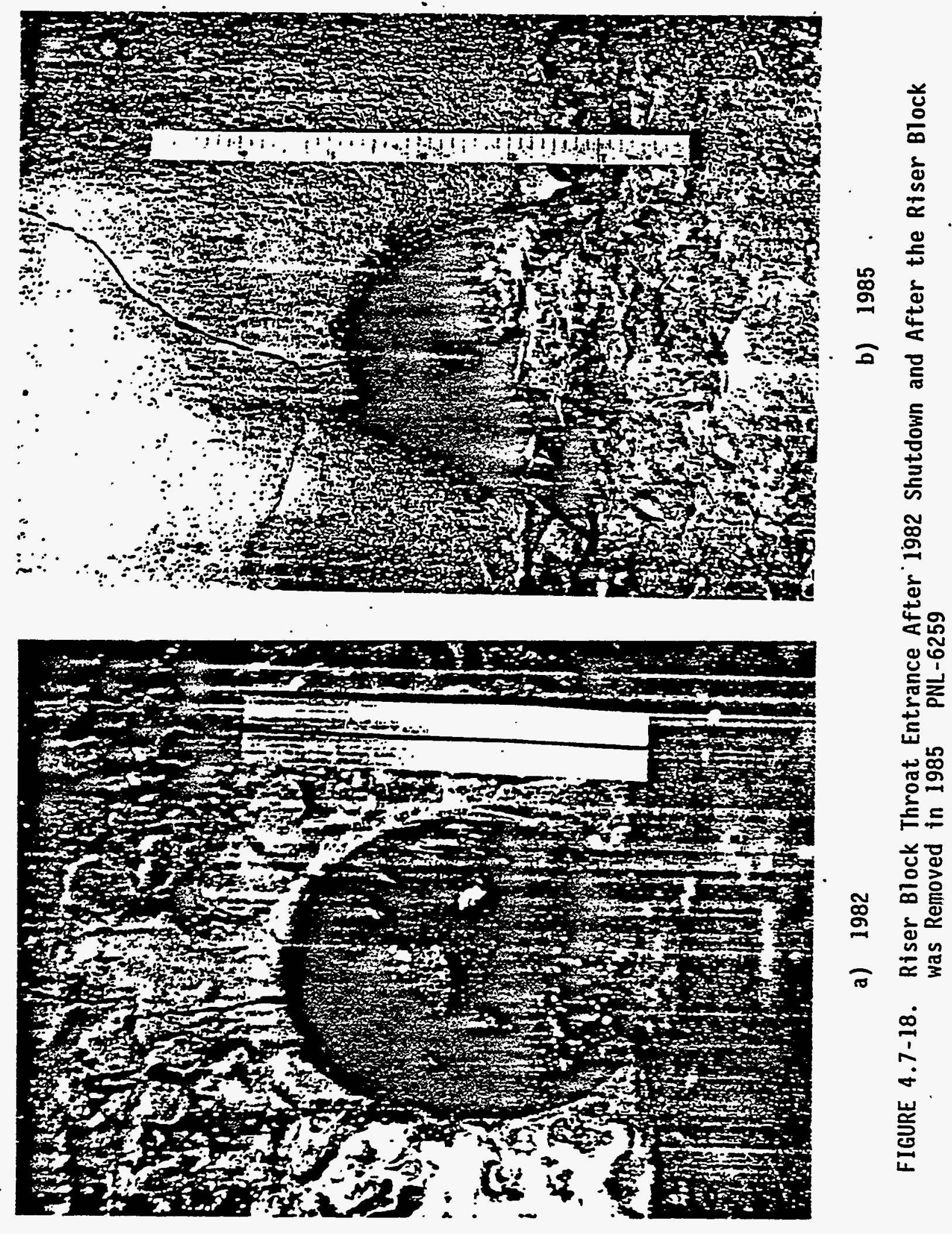

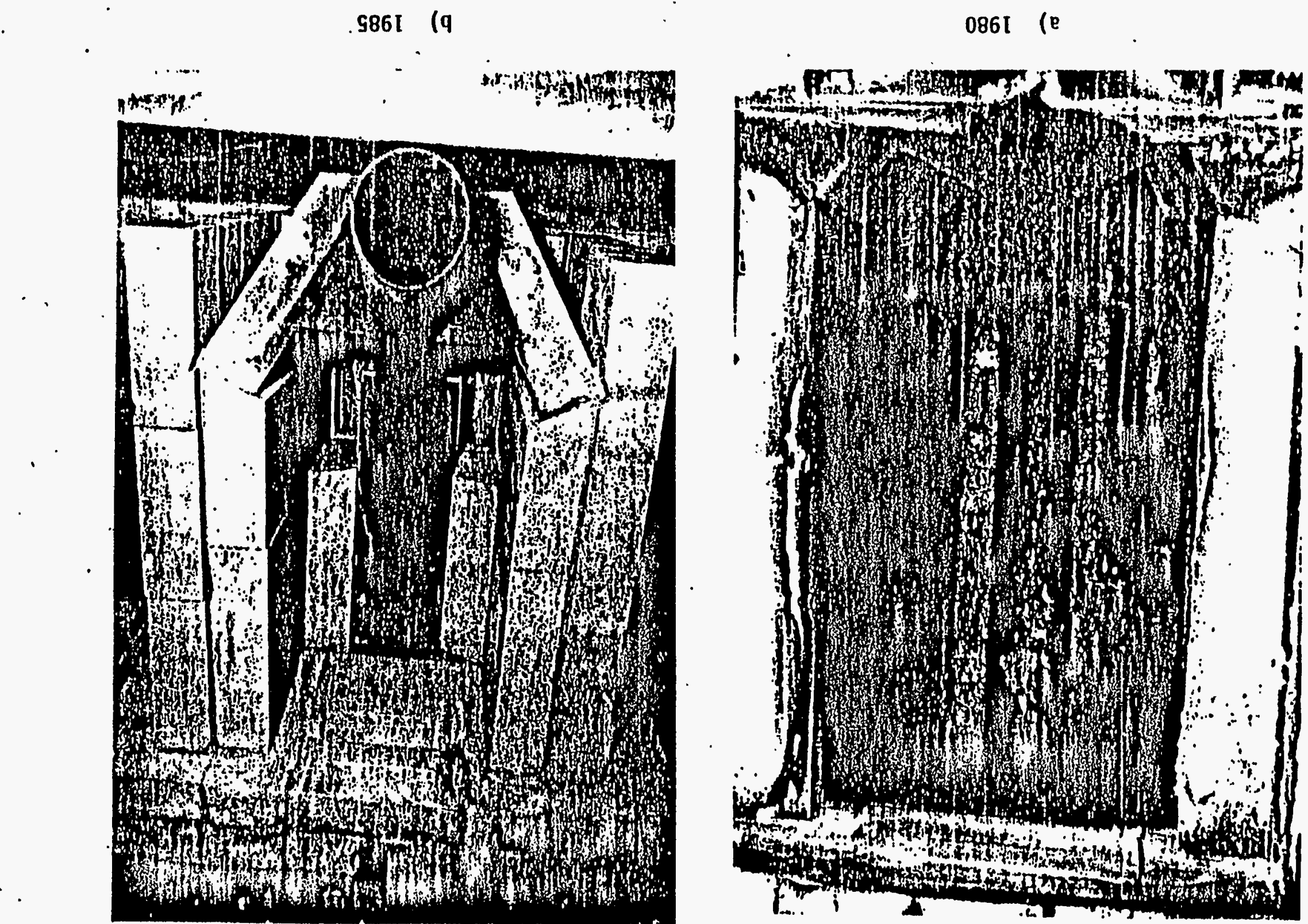
4.7.4.5.1 Feed Preparation. In Savannah River's review of materials requirements for the feed preparation system (the SRAT, SME, and MFT), particular consideration was given to the criteria to minimize the number of alloys used and to maximize interchangeability of equipment. In doing so, it was decided to construct the SRAT, SME, and MFT out of the same materials and make the tank designs identical. This will maximize interchangeability of the equipment, but it means that the materials of construction for the tanks and components must be resistant to the worst-case corrosion and erosion/ corrosion conditions that may exist at some point in those components of the feed preparation system. Genera]. DHPF conditions for preliminary scouting tests and later verification tests for the SRAT, SME, and off-gas equipment, including time, temperature, and $\mathrm{pH}$, were determined from pilot-scale operations (Ref. 4.7-1). Conditions determined for the scouting and verification tests are shown in Table 4.7-27. Due to the higher solids concentration in the SME and MFT, and particularly because of the addition of glass frit, the abrasion or erosion resistance of the agitators and pump impeliers is an additional concern.

Several reference materials were initially selected by SRL, followed by short tests to provide a relative ranking of the alloys and determine the modes of attack. Tests were run for one to two weeks at higher-thananticipated concentrations, under submerged, vapor space and condensing conditions. According to Bickford the concentrations selected for the preliminary testing were arrived at iteratively by questioning people about the expected composition and process conditions, and estimating the stream compositions throughout the process. (a)

TABLE 4.7-27. Chosen Conditions for SRL Preliminary and Verification Tests HWVP-86-V1135A

\begin{tabular}{|l|c|c|c|c|c|c|}
\cline { 2 - 7 } \multicolumn{1}{c|}{} & \multicolumn{2}{c|}{ SRAT(a) } & \multicolumn{2}{c|}{ SME(a) } & \multicolumn{2}{c|}{ Off-Gas(b) } \\
\cline { 2 - 7 } \multicolumn{1}{c|}{} & Pre. & Ver. & Pre. & Ver. & Pre. & Ver. \\
\hline C1, ppm & 20000 & 3800 & 20000 & 3800 & 20000 & 2500 \\
$\mathrm{~F}, \mathrm{ppm}$ & 2300 & 400 & 2300 & 400 & 2300 & 300 \\
$\mathrm{SO}_{4}, \mathrm{ppm}$ & 300 & 60 & 300 & 60 & 1400 & 800 \\
$\mathrm{NO}_{3}, \mathrm{ppm}$ & -- & -- & -- & -- & 0 & 0,6000 \\
$\mathrm{Hg}, \mathrm{ppm}$ & 28000 & 10600 & 10000 & 10600 & 4500 & 1000 \\
$\mathrm{pH}$ & 4,6 & $3.2,6$ & 4,6 & $3.2,6$ & $1.6,6$ & $2.2,6.9,12$ \\
Temp., $\cdot \mathrm{F}$ & $\mathrm{Boi1}$ & $\mathrm{Boi1}$ & .203 & 203 & 104,194 & $104,140,194$ \\
\hline
\end{tabular}

(a) $\mathrm{pH}$ adjusted with formic acid.

(b) $\mathrm{pH}$ adjusted with sulfuric acid.

Source: (Ref. 4.7-1)

(a) Telecon with D. F. Bickford, SRL, about current status of SRL's materials evaluation program for DWPF. Savannah River Laboratory, Aiken, South Carolina (April 14, 1986). 
Alloy 20 (Carpenter 20Cb-3) was selected as the reference material for the DWPF for all process vessels operating below $300^{\circ} \mathrm{C}$ in the melter feed preparation and melter off-gas areas. This selection was primarily based on this alloy being the feast expensive and most readily available al7oy with good resistance to chloride-induced stress corrosion cracking. Inconel 690 was selected as the reference melter material based upon demonstrated oxidation and suifidation resistance in engineering melter tests (Ref. 4.7-1).

A backup material was determined to be necessary for the feed preparation and off-gas equipment because of the concern that the relatively high copper content of the Al7oy 20 (3.5\%) might result in accelerated attack due to the high $\mathrm{Hg}$ content of the DWPF waste. The greatest uncertainties involved the interactions between formic acid, halides, $\mathrm{Hg}$ and abrasion in the feed preparation equipment, and corrosion effects of $\mathrm{Hg}$ and $\mathrm{Hg}$ compounds in the melter off gas. Additional alloys were further tested by SRL for both feed preparation and off-gas equipment applications. Of the alloys tested, highly alloyed Hastelloy $\mathrm{C}-276$ was the only alloy with good resistance to both general and localized attack. C-276 was then selected as the new reference material for these process zones.

Two estimates of costs were performed for the DHPF: a "currept appraisal of costs" in 1983 (a) and a cost-at-completion estimate in 1985. (b) Cost estimates for individual equipment items, including feed preparation equipment, are provided in the reports. In the 1983 appraisal of costs the reference material for much of the feed preparation equipment was Alloy 20 . For the 1985 estimate, the reference material was changed to Alloy $C-276$. The price increased for most of the equipment items, as indicated by selected equipment items shown in Table 4.7-28, are primarily attributabie to the higher material and slightly higher fabrication costs of the $C-276$. Another portion of the cost increase may also be attributable to closer tolerances specified for some of the equipment. The average price increase for an item fabricated from $\mathrm{C}-276$ versus Alloy 20 is about twofold. This price difference is similar to published information on installed costs for corrosionresistant piping (Ref. 4.7-16) shown in Table 4.7-29. For similar installations of a 500-ft-long complex piping system of different diameter Schedule 40 pipe, the cost ratios for Alloy C-276 to Alloy 20 ranged from 1.45 to 2.05. Information from Cabot Corporation gave a slightly higher bulk material cost ratio for A] loy C-276 to Alloy 20 for 1984 and 1985 . Ratios ranged from 2.4 to 2.8. (c) The fabrication costs, however, represent a significant portion of the total costs and are nearly equal for C-276 and Alloy 20 , which would lower the corresponding fabricated cost ratio to about 2 , in line with the preceding. estimates.

(a) "DWPF Summary Base Estimate Current Appraisal of Cost, 12/83." E.I. duPont de Nemours and Company, Savannah River Plant, Aiken, South Carolina (1983).

(b) "DWPF Summary Base Estimate Cost at Completion, 5/85." E.I. du Pont de Nemours and Company, Savannah River Plant, Aiken, South Carolina (1985).

(c) Telecon with Larry Tuff, Cabot Corporation, regarding fabricated equipment costs using corrosion-resistant alloys. Cabot Corporation, Anaheim, Virginia. 
TABLE 4.7-28. DWPF Cost Estimates for Selected Process Equipment HWVP-86-V1135A

\begin{tabular}{|l|c|c|c|}
\cline { 2 - 4 } \multicolumn{1}{c|}{} & $\begin{array}{c}1983 \text { Estimate(a) } \\
\text { (ATloy 20) }\end{array}$ & $\begin{array}{c}1985 \text { Estimate(b) } \\
\text { (Alloy C-276) }\end{array}$ & $\begin{array}{c}\text { Cost Ratio(c) } \\
\text { (C-276/A71oy 20) }\end{array}$ \\
\hline SHE Tank & $\$ 565,000$ & $\$ 1,066,796$ & 1.89 \\
SRAT Tank & 565,000 & $1,066,931$ & 1.89 \\
SRAT Agitator & 78,125 & 151,598 & 1.94 \\
RAT Condenser & 93,600 & 197,139 & 2.11 \\
\hline
\end{tabular}

(a) 1983 Current Appraisal of Cost estimated based on using Alloy 20 inciudes fabrication costs.

(b) 1985 Cost at Completion estimate based on using C-276 - includes fabrication costs.

(c) Cost Ratio does not account for inflation from 1983 to 1985.

TABLE 4.7-29. Installed Costs of Corrosion-Resistant Piping(a) HWVP-86-V1135A

\begin{tabular}{|l|c|c|c|}
\cline { 2 - 4 } \multicolumn{1}{c|}{} & $\begin{array}{c}\text { Alloy 20, } \\
\text { Sch. 40 }\end{array}$ & $\begin{array}{c}\text { Alloy C-276, } \\
\text { Sch. 40 }\end{array}$ & $\begin{array}{c}\text { Cost Ratio } \\
\text { C-276/A77oy 20 }\end{array}$ \\
\hline & & & \\
2-in.-dia. pipe & $\$ 37,537$ & $\$ 76,875$ & 2.05 \\
4-in.-dia. pipe & 100,904 & 180.173 & 1.79 \\
6-in.-dia. pipe & 189.746 & 275,644 & 1.45 \\
\hline
\end{tabular}

(a) Installed costs include costs of piping, flanges, fittings, hangers, etc. and fabrication and installation labor for a typical 500-ft-long complex piping system.

Source: (Ref. 4.7-16)

The cost increase resulting from specifying $\mathrm{C}-276$ rather than the less expensive but also less corrosion resistant Alioy 20 is a significant factor in the facility costs. Information extracted from the 1985 CAC shows that the major equipment items for the DWPF fabricated from C-276, including primarily tanks, pumps, agitators, and condensers, were expected to total about $\$ 11$ million. This figure includes only the fabricated material costs, and does not inciude field installation, piping, and other smaller items. Using the cost ratio of 2 described above, the cost increase going from Alloy 20 to $\mathrm{C}-276$ would be about $\$ 5.5$ million. Savannah River. determined that this cost penalty was necessary to provide satisfactory corrosion resistance for the specified DWPF process equipment when exposed to their anticipated operating environment. 
Since the time of the testing described above, additional. SRL results of longer term tests have shown local attack on the $6-276$ when exposed to low $\mathrm{pH}$ solutions and high temperature. The only alloy tested to date without localized attack under those test conditions was ALLCORR, which is a relatively new alloy with little operating experience. ALLCORR has since been selected for specific applications such as the off-gas quencher (Ref. 4.7-17).

4.7.4.5.2 Off Gas Processing. Varying amounts of volatile and entrained species pass into the off-gas collection and treatment equipment during vitrification of the waste. As the hot off gas is quenched and scrubbed much of the volatile and entrained material is removed from the off-gas stream. This results in an acidic aqueous solution of sulfates, halides, nitrates and other chemical species.

Savannah River Laboratory had some pilot-scale melter tests performed by PNL around 1982-83. Critical operating conditions for further off-gas corrosion tests were based on results of the pilot-scale tests. Examination of test materials revealed that Inconel 690 was not locally attacked where temperatures remained above the dewpoint. However, severe pitting was seen after relatively short times due to dewpoint corrosion, as in portions of the off-gas quencher. Therefore, the quencher became an area of special study. As mentioned above, ALLCORR was the only alloy tested, for applications, such as for the quencher, that resisted pitting, crevice corrosion or other types of local attack. ALLCORR has been designated as the reference material for the off-gas quencher, with $C-276$ as a backup. (a) Inconel 690 . is still the reference material for the off-gas line leading to the quencher, although there are apparently still some problems with the Inconel 690.

The phenomerion of acid dewpoint corrosion in off-gas treatment equipment and duct work is well documented in the literature (Ref. 4.7-18 and 4.7-19). Studies have identified several factors that contribute to corrosion in this situation: chemical environment, scale formation, operating conditions and temperature, etc. Combinations of laboratory and field tests have shown that severe corrosion of gas-treatment equipment is generally related to the presence of acid gases and/or halides. Of all materials tested, generally only the highly alloyed nickel-based alloys and. in some cases titanium alloys exhibit good corrosion resistance. In closed-7oop systems, where plant process water is recycled, this recycling can lead to 10- to 35-fold increases in chemical concentrations in scrubber makeup water, for example, leading to extremely corrosive conditions in a scrubber (Ref. 4.7-19). Lower nickelbased alloys and stainless steels proved unacceptable for this type of application due to excessive general corrosion, pitting, and crevice corrosion.

(a) Telecomi with D. F. Bickford, SRL, about SRL's materials evaluation program for DWPF. Savannah River Laboratory, Aiken South Carolina (November 7, 1985). 


\section{REFERENCES}

4.7-1 D. F. Bickford and R. A. Corbett, Material Selection for the Defense Waste Processing. Facility." In Conference Proceedings on the International Conference on Corrosion of Nickel-Base AlToys, American Society for Metals, Metals Park, Ohio (1984).

4.7-2 H. H. Uhi ig (1971).

4.7-3 R. K. Farnsworth, C. M. Ruecker, J. M. Perez, Jr., H. T. Blair, and G. T. Thornton, Feed Process Variability Testing for Fiscal Year 1986. RHO-RE-CR-16P/HHVP-V1123C, Pacific Northwest Laboratory, Richi and, Washington (1986).

4.7-4 ASTM-G-31-72, "Standard Practice for Laboratory Immersion Corrosion Testing for Metals." 1985 Annual Book of Standards Section 3 Metals Test Methods and Analytical Procedures, American Society of Testing and Materials, Philadelphia, Pennsylvania.

4.7-5 ASTM-G-5-82, "Standard Reference Method for Making Potentiostatic and Potentiodynamic Anodic Polarization Measurements." 1985 Annual Book of Standards Section 3 - Metals Test Methods and Analytical Procedures, American Society of Testing and Materials, Phitadelphia, Pennsylvania.

4.7-6 ASTM-G-75-82, . "Test Method for S1urry Abrasivity by Miller Number." 1985 Annual Book of Standards Section 3 - Metals Test Methods and Analytical Procedures, American Society of Testing and Materials, Philadelphia, Pennsylvania.

4.7-7 S. S. Koegler, Pilot-Scale Ceramic Melter 1985-1985 Rebuild. PNL-6259, Pacific Northwest Laboratory, Richland, Washington (1987.).

4.7-8 R. D. Dierks et al., Investigation of Corrosion Experienced in a Spray Calciner/Ceramic Melter Vitrification System. PNL-3406, Pacific Northwest Laboratory, Richland, Washington (1980).

4.7-9 W. J. Bjorklund, Defense Waste Vitrification Studies During FY 1981. PNL-4366, Pacific Northwest Laboratory, Rich7and, Washington (1982).

4.7-10 L. J. Ethridge, Savannah River Plant Defense Waste Vitrification Studies During FY-1982. PNL-4834,. Pacific Northwest Laboratory, Richland, Washington.

4.7:-11 R. A. Brouns and W. L. Partain, Joule-Heated Nuclear Haste Glass Melter Design Development at Pacific Northwest Laboratory. PNL-5997, Pacific Northwest Laboratory, Richland, Washington (1986).

4.7-12 T. L. Allen, D. C. Iverson, and M. J. Plodinec, History of the Small Cylindrical Melter. DP-1676, E.I. du Pont de Nemours \& Company, Inc., Savannah River Laboratory, Aiken, South Carolina (1985). 
4.7-13 D. C. Iverson and D.F. Bickford, "Evaluation of Materials Performance. in a Large-Scale Glass Melter After Years of Vitrifying Simulated SRP. Defense Waste." Materials Research Society Proceedings, Vol: 44 , pp. $839-845$ (1985).

4.7-14 D. Gombert and M. Y. Pong, Operation of a Laboratory-Scale Glass Melter to Vitrify ICCP Zirconia Calcine. ENICO-1058, Exxon Nuclear.

4.7-15 S. M. Barnes and D. E. Lasson, Materials and Design Experience in a STurry-Fed Electric Melter. PNL-3959, Pacific Northwest Laboratory, Richland, Washington (1981).

4.7-16 J. Yamartino, "Installed Costs of Corrosion-Resistant Piping -1978." Chemical Engineering, MCGraw-Hi11, Inc., New York (1978).

4.7-17 R. A. Corbett, D: E. Bickford, and W. S. Morrison, Corrosion Evaluation of A7loys for Nuclear Haste Processing. DP-MS-85-161, E. I. du Pont de Nemours and Company, Hilmington, Del aware, and Savannah River Laboratory, Aiken, South Carolina (1986).

4.7-18 D. C. Agarwa T, F. G. Hodge, and I. J. Storey, "Combating Dewpoint Corrosion with High-Performance $\mathrm{Ni}$-Cr-Mo-Type Alloys." In Dewpoint Corrosion, Published by E7l is Horwood Limited, Chichester, England (1985).

4.7-19. C. Dene, "Corrosion and Erosion of Outlet Ducts." ECS UPDATE, Winter 1985-86, No. 3, Environmental Control Systems Department, Electric Power Research Institute, Palo Alto, California (1985). 


\subsubsection{Function}

The purpose of the vessel vent system (VVS) is. to collect and decontaminate ventilation gases from process and waste tanks, decontamination chambers, and any connected reserved capacity vent sources in the hot cells and tank vaults. Decontaminated vent gas is discharged to the HVAC vent tunnel. The VVS is designed to decontaminate vessel ventilation-gases so that, when mixed with the cell ventilation and treated melter off gases, the total HWWP effluent, after sand filtration, complies with the emissions limits of RHO-MA-139(a) for an uncontrolled area.

(a) Environmental Protection Manual, RHO-MA-139, RHO (May 8, 1978). 



\subsection{RADIOACTIVE PROCESS WASTE COLLECTION AND TREATHENT (System 20)}

\subsubsection{Function}

The primary purpose of the radioactive process waste collection and treatment (RPWCT) system is. to receive radioactive wastes from the HWVP systems, segregate TRU wastes concentrate and recycle TRU wastes to feed receipt, chemically treat the radioactive wastes to tank farm requirements, and return the non-TRU wastes to the tank farm through a hoid tank (WHT). 
4.10 CANISTER HANDLING AND INSPECTION (System 23)

\subsubsection{Function}

The purposes of the canister handling and inspection system (System 23) are to transport canisters between and within cells and provide. inspection of the filled canister in two tunnels and in the weld test cell. 



\subsubsection{Function}

The purposes of the canister closure system, are to provide a temporary (inner canister) closure and a final (plug) welded closure in the melter cell and weld test cell, respectively. An inner canister closure station (ICCS) provides for temporary closure, leak testing, and a temperature check on canisters. The ICCS receives canisters from and returns them to the remote handling melter cell crane.

A plug welder presses down the inner canister plug, places and inspects a final weld plug in its place, and then performs a weld of the plug to the canister. The plug welder receives canisters from and returns them to the remote handling system weld test cell cranes. 



\subsubsection{Function}

The purpose of preliminary canister decontamination is to remove looselyadhered contaminates from the outside surface of each canister.

The purpose of final decontamination is to reduce the smearable radioactive surface contamination on canisters to a releasable level. These levels are set by 49 CFR 173.433 and are presentiy as follows:

1. Alpha-200 disintegrations/min/100 $\mathrm{cm}^{2}$
2. Beta/Gamma - 2200 disintegrations/min/100 $\mathrm{cm}^{2}$.

The entire external surface must meet this criteria. 



\subsubsection{Function}

The function of the Interim Canister Storage Building is to serve as a storage location for canisters of vitrified waste. The facilities will receive and store canisters filled with the vitrified product that have been sealed, decontaminated, and characterized; remove the radioactive decay heat generated by the canisters by air ventilation that is high-efficiency particulate air (HEPA) filtered before discharge; and house support systems and electrical distribution system components, required for the building and its equipment. 
4.14 CANISTER LOADOUT (System 19)

\subsubsection{Function}

The canister loadout system receives closed and inspected canisters from .the interim canister storage system. It also receives canister transport casks, and loads the canisters from interim storage into the transport casks. The system prepares the casks for shipment. 


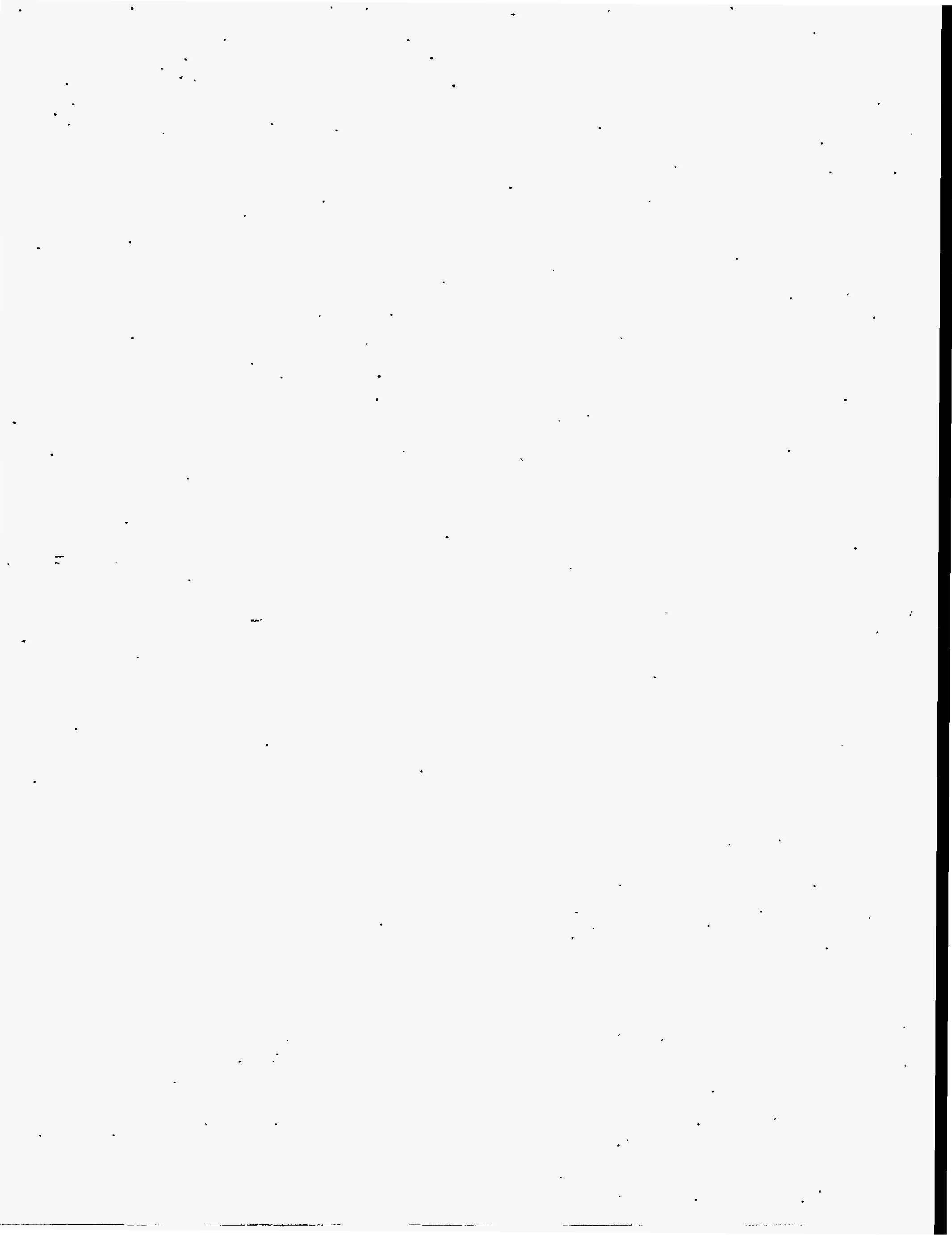




\subsection{CHEMICAL MAKEUP AND TRANSFER (Systems 54 and 58)}

\subsubsection{Function}

The purpose of the frit receipt and make-up system (System 54 is to receive, convey, condition, and slurry dry glass frit into a water suspension consisting of $60 \mathrm{wt} \%$ total solids. Dilute formic acid is added to improve the siurry suspension and pumping characteristics. Frit slurry is then transferred to the Vitrification Building where it is used for either of two purposes:

1. Frit transferred to the process frit slurry feed tank is transferred in 2600-gal batches to feed preparation operations in the chemical processing cell.

2. Frit transferred to the decontamination frit slurry feed tank is transferred in 74-gal batches where it is diluted and used for. canister decontamination.

The jurpose of the chemical receipt, make-up and distribution system (System 58) receives liquid and dry chemicals in bulk quantities; provides safe bulk storage of these chemicals to ensure inventory requirements; prepares these chemicals for use in process, equipment decontamination, and/or waste processing use; and distributes these prepared chemical solutions to the systems that require them. The functional requirements include sampling of raw materials and solutions. Requirements for storage of chemical solutions include tank venting requirements to ensure that chemical storage does not cause any potential safety hazard. 

4.16 HWVP VENTILATION

\section{$4 \cdot 16-1$}



4.17 EQUIPMENT DECONTAMINATION AND DECOMMISSIONING

4.17-1 

SECTION 5.0

PROCESS EQUIPMENT ENGINEERING 



\section{CONTENTS}

5.1 TANKS/AGITATION

5.2 HEAT TRANSFER

5-1

5-1 

The process equipment engineering section provides engineering principles and sample calculations for process equipment engineering analyses. Analytical methods are provided with suitable content to perform engineering analyses of process equipment design performance. HWVP equipment engineering analyses are provided as examples to demonstrate the application of these methods.

\subsection{TANKS/AGITATION}

\subsection{HEAT TRANSFER}

Heat transfer analytic methods are presented for the following process equipment:

$\begin{array}{ll}\text { - } \text { process tanks } & (5.2 .1) \\ \text { - condensers } & (5.2 .2) \\ \text { - melter off-gas heaters } & (5.2 .3) \\ \text { - quencher } & (5.2 .4) \\ \text { - gas scrubbing column } & (5.2 .5) \\ \text { - off-gas cooler } & (5.2 .6) \\ \text { - canister } & (5.2 .7) \\ \text { - film cooler } & (5.2 .8) .\end{array}$

\subsubsection{Process Tanks}

The process tanks considered for heat transfer are the canyon tanks and remote tanks including the SRAT, SME, DWTT, MFT, OGCT, ST, and RLST.

Techniques used to perform equipment analyses for heat transfer are presented in this section. The equations and references used for the heat transfer analyses are presented and defined. Then a sample calculation is also presented. The heat transfer situations analyzed include the following: 
Agitated tank with helical coil-

- concentration

- heating

(5.2.1.1)

- cooling

$(5.2 .1 .2)$

$(5.2 .1 .3)$

- Decay Heat Removal (5.2.1.4).

\subsubsection{Concentration}

The following analysis is for boiling in an agitated tank with an isothermal heating medium (steam) such as the SRAT, SME, and DWTT (coil-intank).

\subsection{Design Equations.}

$Q^{\prime}=$ boiling heat transfer rate

$=m_{S}^{\prime} \Delta H_{S}$, heating rate from steam

$=U_{C} A_{H C}\left(T_{S}-t_{t}\right)$ heat transfer rate through coil

$=m_{v}^{\prime} \Delta H_{v}+U_{t} A_{t}\left(t_{t}-t_{c 1}\right)-V_{t} g^{\prime}$ heat loss from tank: vapor +.walls decay heat

5.2.1.1.2 SME and SRAT.

$Q^{\prime}=$ boiling heat transfer rate, Btu/h

$=2.81 \times 10^{6} \mathrm{Btu} / \mathrm{h}$

$m_{s}^{\prime}=$ heating steam flow rate, $1 \mathrm{~b} / \mathrm{h}$

$=3174 \mathrm{lb} / \mathrm{h}=6.34 \mathrm{gpm}$

$\Delta H_{S}=$ heating steam enthalpy of vaporization, Btu/lb

$=887 \mathrm{Btu} / \mathrm{lb}$ - $103 \mathrm{psia}(88.3 \mathrm{psig}$ )

$U_{c}=$ overall coil heat transfer coefficient, Btu/h-ft${ }^{2}{ }^{\circ} \mathrm{F}$

$=80 \mathrm{Btu} / \mathrm{h}-\mathrm{ft} \mathrm{t}^{2}-{ }^{\circ} \mathrm{F}$, DWPF Design, Ref. (37)

$=160 \mathrm{Btu} / \mathrm{h}-\mathrm{ft} \mathrm{t}^{\circ}{ }^{\circ} \mathrm{F}$, DWPF Test, Ref. (37)

$=70 \mathrm{Btu} / \mathrm{h}-\mathrm{ft} \mathrm{t}^{\circ}-^{\circ} \mathrm{F}$, Hanford Design, Ref.

$A_{H C}=$ heating coil heat transfer area, $\mathrm{ft}^{2}$

$=306 \mathrm{ft}^{2}$

$T_{s}=$ heating steam temperature, ${ }^{\circ} \mathrm{F}$

$=330^{\circ} \mathrm{F}$ @ 103 psia (88.3 psig) 


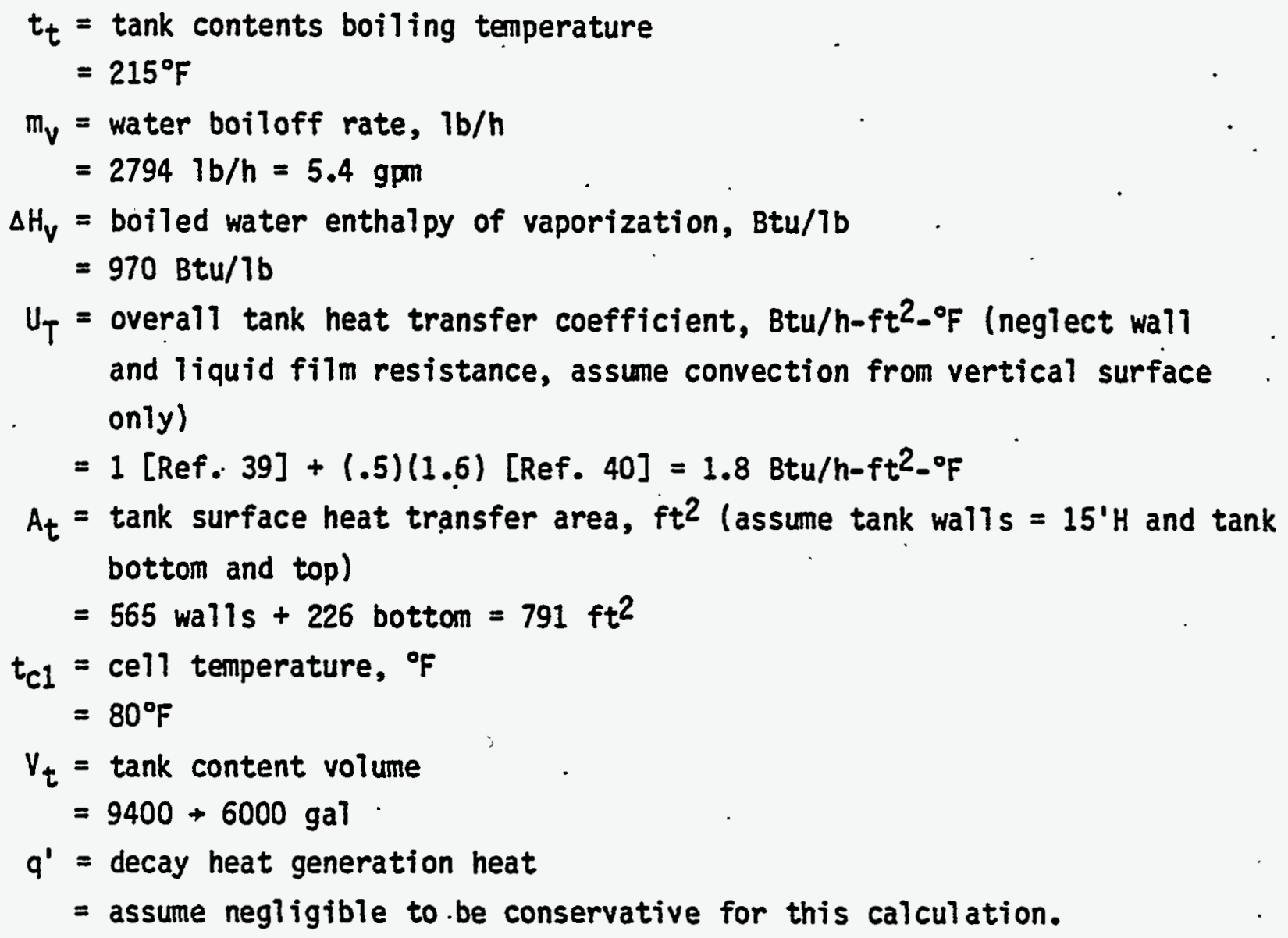

$$
\begin{aligned}
& U_{c} A_{H C}\left(T_{s}-t_{t}\right)=\left(\frac{80 \mathrm{Btu}}{\mathrm{h}-\mathrm{ft}^{2}-\mathrm{F}}\right)\left(306 \mathrm{ft}^{2}\right)(330-215 \mathrm{~F}) . \\
&=2,815,200 \mathrm{Btu} / \mathrm{h} \\
& Q^{\prime}=\left(\frac{1.8 \mathrm{Btu}}{\mathrm{h}-\mathrm{ft}^{2}-\mathrm{F}}\right)\left(791 \mathrm{ft}^{2}\right)(215-80 \mathrm{~F}) \\
&=192,213 \mathrm{Btu} / \mathrm{h} \\
& U_{t} A_{t}\left(t_{t}-t_{c 1}\right) \\
& V_{t} q^{\prime}=\text { Assume negligible for this calculation. } \\
& m_{v}^{\prime}=\left[Q^{\prime}-U_{t} A_{t}\left(t_{t}-t_{c 1}\right)\right] / \Delta H_{v} \\
&=[2,815,200-192,213 \mathrm{Btu} / \mathrm{h}] /(970 \mathrm{Btu} / 7 \mathrm{~b}-\mathrm{F})
\end{aligned}
$$


$=2704 \mathrm{lb} / \mathrm{h}=5.4 \mathrm{gpm}$

$$
\begin{aligned}
m_{s}^{\prime} & =(2,815,200 \mathrm{Btu} / \mathrm{h})(887 \mathrm{Btu} / 7 \mathrm{~b}-\mathrm{F}) \\
& =3174 \mathrm{~Tb} / \mathrm{h}=6.34 \mathrm{gpm}
\end{aligned}
$$

Time to boil-off a given volume, $V$

$\checkmark=$ gallons boiled off

$\theta=$ time to boit" off $V$, min

$\theta=V /(5.4 \mathrm{gpm})$.

\subsubsection{Heating}

The following analysis is for heating the contents of an agitated tank with an isothermal heating medium (steam) such as the SRAT, SME, and DWTT (coil-in-tank).

\subsection{Design Equations.}

$Q^{\prime}=$ heating heat transfer rate

$=m_{S}^{\prime} \Delta H_{S}$, heating rate from steam

$=U_{C} A_{H C}\left(T_{S}-t_{t}\right)$, heat transfer rate through coil

$=m_{t} c_{p} \frac{d t_{t}}{d \theta}+v_{t} A_{t}\left(t_{t}-t_{c 1}\right)$.

Heat/time to heat tank contents and loss to cell

For plant application, this situation applies only when heating tank contents to boiling or $95^{\circ} \mathrm{C}\left(203^{\circ} \mathrm{F}\right)$ for formic acid addition from a tank contents temperature of $50^{\circ} \mathrm{C}\left(122^{\circ} \mathrm{F}\right)$.

For this calculation, the heat required to heat vessel in-leakage air is negi igible. To make this calculation conservative, the decay heat generation as a heating source is also neglected. 
To solve the above equation easily for heating time, it is necessary to neglect the heat loss term from the tank to the cell. Calculations for concentration and cooling show that this heat loss can range from 192,000 Btu/h for concentration to $44,000 \mathrm{Btu} / \mathrm{h}$ for c00ling. The overall heat transfer rate is similar to that for concentration, 2,800,000 Btu/h. Thus, the heat loss from the tank would only be $47 \%$ of the heat used. To allow for heat loss to the cell, the heating time determined by neglecting tank heat loss to the cell will be multiplied by 1.07. For time cycle studies it is assumed the time required to heat to $203^{\circ} \mathrm{F}\left(95^{\circ} \mathrm{C}\right)$ is the same as heating to boiling.

Time to heat batch, Ref. (41)

$$
\theta=1.07 \frac{m_{t} C_{p t}}{U_{H C} A_{H C}} \ln \frac{T_{s}-t_{t 1}}{T_{s}-t_{t 2}}
$$

Initial Heat Transfer and Steam Use

$$
Q_{1}^{\prime}=m_{s 1}^{\prime} \Delta H_{s}=U_{c} A_{H C}\left(T_{s}-t_{t 1}\right)
$$

Final Heat Transfer and Steam Use

$$
\begin{aligned}
Q_{2}^{\prime}=m_{s_{2}}^{\prime} & \Delta H_{s}=U_{c} A_{H C} \cdot\left(T_{s}-t_{t 2}\right) \\
\theta= & \text { time to heat tank contents from } 122^{\circ} \mathrm{F}\left(50^{\circ} \mathrm{C}\right) \text { to boiling } 215^{\circ} \mathrm{F} \\
& \left(102^{\circ} \mathrm{C}\right), \mathrm{h} \\
= & \text { mass of liquid in tank, ib } \\
m_{t}= & 9400 \text { gal }(8.34 \mathrm{lb} / g a 1)(1.2)=94.0751 \mathrm{~b} \\
C_{p t}= & \text { specific heat of tank contents (assume same as water, high), } \\
& \text { Btu/lb- }{ }^{\circ} \mathrm{F} \\
= & 1 \text { Btu/lb- }{ }^{\circ} \mathrm{F} \\
U_{H C}= & \text { overall heat transfer coefficient of coil, Btu/lb- }{ }^{\circ} \mathrm{F}-\mathrm{ft}^{2} \\
= & 150 \mathrm{Btu} / \mathrm{h}-\mathrm{ft}^{2}-\mathrm{F} \text { implied in Ref: (37) (This is only slightly lower } \\
& \text { than boiling.) } \\
= & 50 \text { Btu/h- } \mathrm{ft}^{2}-{ }^{\circ} \mathrm{F}, \text { Ref. (38) }
\end{aligned}
$$




$$
\begin{aligned}
& =70 \mathrm{Btu} / \mathrm{h}-\mathrm{ft} \mathrm{t}^{2}-{ }^{\circ} \mathrm{F} \text { Use } \\
& A_{h}=\text { coil heating heat transfer surface area, } \mathrm{ft}^{2} \\
& =306 \mathrm{ft}^{2} \\
& T_{s}=\text { steam temperature o } 103 \text { psia } \\
& =330^{\circ} \mathrm{F} \\
& t_{t 1}=\text { initial tank contents temperature, }{ }^{\circ} \mathrm{F} \\
& =122^{\circ} \mathrm{F} \\
& t_{t 2}=\text { final tank contents temperature, }{ }^{\circ} \mathrm{F} \\
& =215^{\circ} \mathrm{F} \\
& Q_{1}, Q_{2}=\text { initial and final heat transfer rate, Btu/h } \\
& m_{s 1}, m_{s 2}=\text { Initial and final steam flow rate, } 1 \mathrm{~b} / \mathrm{h} \\
& \theta=\frac{(1.07)(94,075 \mathrm{lb})(1 \mathrm{Btu} / 7 \mathrm{~b} F)}{\left(\frac{70 \mathrm{Btu}}{h-\mathrm{ft}^{2}-\mathrm{F}}\right)\left(306 \mathrm{ft}^{2}\right)} \ln \frac{330-122 \mathrm{~F}}{330-215 \mathrm{~F}} \\
& =2.78 \mathrm{~h}=167 \mathrm{~min} \\
& Q_{1}^{\prime}=\left(\frac{70 B t u}{h-f t^{2}-F}\right)\left(306 \mathrm{ft}^{2}\right)(330-122 \mathrm{~F}) \\
& =4,455,000 \mathrm{Btu} / \mathrm{h} \text {. } \\
& m_{1}^{\prime}=(4,455,000 \mathrm{Btu} / \mathrm{h}) /(887 \mathrm{Btu} / \mathrm{Tb}) \\
& =5023 \mathrm{lb} / \mathrm{h}=10.0 \mathrm{gpm} \\
& Q_{1}^{\prime}=\left(\frac{70 \mathrm{Btu}}{h-\mathrm{ft}^{2}}\right)\left(306 \mathrm{ft}^{2}\right)(330-215 \mathrm{~F})^{\circ} \\
& =2,463,000 \mathrm{Btu} / \mathrm{h} \\
& m_{1}^{\prime}=(2,463,000 \mathrm{Btu} / \mathrm{h}) /(887 \mathrm{Btu} / \mathrm{Tb}) \\
& =2777 \mathrm{lb} / \mathrm{h}=5.54 \mathrm{gpm}
\end{aligned}
$$




\subsubsection{Cooling}

The following analysis is for cooling the contents of an agitated tank with a nonisothermal cooling medium (water) such SRAT, SME, and DWTT (coil-in-tank).

\subsection{Design Equations.}

$Q^{-}=$Heat transfer rate

$=m_{W} C_{p W}\left(t_{W 2}-t_{W 7}\right)$ Heat increase rate of cooling water

$=U_{c C} A_{C C}\left(t_{t}-t_{W}\right) \quad$ Heat transfer rate through coil

$=-m_{t} C_{p t} \frac{d T}{d t}$. Heat decrease rate of tank contents

- U $U_{T}\left(t_{t}-t_{c 1}\right) \quad$ Heat lost from tank through tank walls

$+v_{t} g^{-}$

Heat added to tank contents through decay heat generation

For plant application, this situation applies only when cooling tank contents after boiling $\left(215^{\circ} \mathrm{F}\right)$ to transfer temperature $\left(122^{\circ} \mathrm{F}\right)$. Tank contents are generally about $6000 \mathrm{gal}$ in volume after concentration.

For this calculation the heat removal required to $c 001$ the air in-leakage is neglected. To. make the calculation conservative; the heat loss from the tank to the cell is neglected.

To make this series of equations easily soluble for cooling time, it is convenient to neglect the tank contents heat generation term. Calculations for cooling indicate this term is $\langle 117,000 \mathrm{Btu} / \mathrm{h}$, which is expected to be a small fraction of the cooling load.

Time to Coor Batch (Ref. 41)

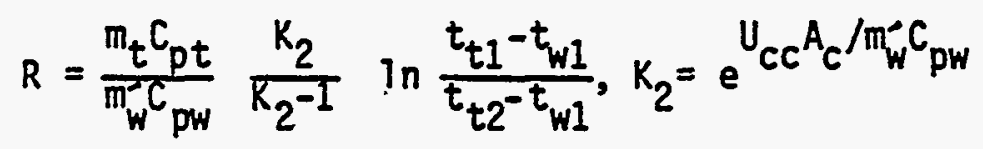

Initial heat transfer and water use

$$
Q_{I}=m_{w} c_{p w}\left(t_{w 2}-t_{w 1}\right)_{1}=U_{c} A_{c c}\left(t_{w 1}-t_{t 1}\right)
$$


Final heat transfer and water use

$$
Q_{2}^{-}=m_{w} c_{p W}\left(t_{W 2}-t_{W 1}\right)_{E}=U_{c} \text { ACC }\left(t_{w 2}-t_{t 2}\right)
$$

$\theta=$ time to cool tank contents from boiling $215^{\circ} \mathrm{F}$ to $122^{\circ} \mathrm{F}, \mathrm{h}$

$$
\mathrm{m}_{t}=\text { weight of water in the tank, } 1 \mathrm{~b}
$$$$
=5800 \mathrm{gal}(8.34 \mathrm{lb} / \mathrm{gal})(1.3)=62,884 \mathrm{~Tb}
$$

$C_{p t}=$ specific heat of tank contents, Btu/Tb- ${ }^{\circ} \mathrm{F}$

$=1 \mathrm{Btu} / 1 \mathrm{~b}-{ }^{\circ} \mathrm{F}$ (assume same as water)

$\pi_{w}=$ cooling water flow rate, $1 \mathrm{~b} / \mathrm{h}$

$=60,000 \mathrm{lb} / \mathrm{h}$ (120 gpm)

$C_{p w}=$ specific heat of cooling water, Btu/lb

$=1$ Btu/1b

$U_{c c}=$ overall heat transfer coefficient, Btu/lb-h-ft ${ }^{2}$

$=150 \mathrm{Btu} / \mathrm{lb}-h-f t^{2}$, Ref. 1.c

$=40 . B t u / 1 b-h-f t^{2}$, Ref. 2.a, Ref. 6.a

$A_{c}=$ cooling coil heat transfer area, $\mathrm{ft}^{2}$

$=127 \mathrm{ft}^{2}$

$t_{t 1}=$ tank contents initial, temperature, ${ }^{\circ} \mathrm{F}$

$=215^{\circ} \mathrm{F}$

$t_{t 2}=$ tank contents final temperature

$=122^{\circ} \mathrm{F}$

$t_{W I}=$ cooling water initial temperature, ${ }^{\circ} \mathrm{F}$

$=70^{\circ} \mathrm{F}$

$t_{w 2}=$ cooling water final temperature, ${ }^{\circ} \mathrm{F}$ 
To perform this calculation, either the cooling water flow rate or a $\Delta T$ profile has to be established. Assume the water flow rate $=m_{w}=120 \mathrm{gpn}$ (10 fps in 2 in. Sch 40 pipe) $=60,000 \mathrm{lb} / \mathrm{h}$.

$$
\begin{aligned}
K_{2} & =e^{\left(40 \mathrm{Btu} / \mathrm{h}-\mathrm{ft}^{2}-{ }^{\circ} \mathrm{F}\right)\left(127 \mathrm{ft}^{2}\right) /(60,000 \mathrm{ib} / \mathrm{h})\left(1 \mathrm{Btu} /{ }^{\circ} \mathrm{F}-\mathrm{Ib}\right)} \\
& =1.088 \\
e & =\frac{(62,884 \mathrm{lb})\left(1 \mathrm{Btu} / \mathrm{lb}-\mathrm{O}^{\circ} \mathrm{F}\right)}{(60,000 \mathrm{lb} / \mathrm{h})(1 \mathrm{Btu} / \mathrm{Tb}-0 \mathrm{~F})} \frac{1.088}{1.088-1} \text { in } \frac{215-70}{122-70} \\
& =13.29 \mathrm{~h}=797 \mathrm{~min}
\end{aligned}
$$

Initial

$$
\begin{aligned}
Q^{-} & =\left(\frac{40 \mathrm{Btu}}{\mathrm{h}-\mathrm{ft}^{2}-0 \mathrm{~F}}\right)\left(127 \mathrm{ft}^{2}\right)\left(215-70^{\circ} \mathrm{F}\right) \\
& =736,600 \mathrm{Btu} / \mathrm{h} \\
t_{W 2} & =82^{\circ} \mathrm{F}
\end{aligned}
$$

Fina?

$$
\begin{aligned}
Q^{-} & =\left(\frac{40 \mathrm{Btu}}{\mathrm{h}-\mathrm{ft}^{2}-0 \mathrm{~F}}\right)\left(127 \mathrm{ft}^{2}\right)\left(122-70^{\circ} \mathrm{F}\right) \\
& =264,160 \mathrm{Btu} / \mathrm{h} \\
& =74.4^{\circ} \mathrm{F}
\end{aligned}
$$

\subsubsection{Decay Heat Removal}

The following analysis is for steady-state decay heat removal from an agitated tank with cooling water such as any canyon tank.

\subsection{Design Equations}

$Q^{-}=$rate of cooling heat removal by water

$=m^{-}{ }_{C W} C_{P W}\left(t_{w O}-t_{W i}\right)$ cooling rate of water

$=U_{c} A_{c c}\left(t_{W}-t_{t}\right)$ cooling rate through coil

$=v_{t} q_{t}^{e}-U_{t} A_{t}\left(t_{t}-t_{A}\right)-m_{a} C_{p a}\left(t_{t}-t_{A}\right)$

Net heat lost rate from tank to cooling coil. 
SME and SRAT

$Q^{-}=$rate of cooling heat removal by water, Btu/h

$\mathrm{m}_{\mathrm{Cw}}=$ cooling water flow rate, $1 \mathrm{~b} / \mathrm{h}$

$C_{p w}=$ cooling water heat capacity, Btu/7b- ${ }^{\circ} F$

$=1 \mathrm{Btu} / 7 \mathrm{~b}-{ }^{\circ} \mathrm{F}$

$t_{\text {wo }}=$ cooling water temperature out

$=80^{\circ} \mathrm{F}$ (assume)

$t_{\text {wi }}=$ cooling water temperature iniet

$=70^{\circ} \mathrm{F}$

$U_{c}=$ overall heat transfer coefficient for cooling, Btu/h-ft ${ }^{2}-{ }^{\circ} \mathrm{F}$

$=150 \mathrm{Btu} / \mathrm{h}-\mathrm{ft} \mathrm{t}^{\circ}{ }^{\circ} \mathrm{F}$, Ref. (37)

$=40 \mathrm{Btu} / \mathrm{h}-\mathrm{ft} \mathrm{t}^{\circ} \mathrm{\circ}^{\circ} \mathrm{F}$, Ref. (38)

AcC $=$ cooling coil area

$=127 \mathrm{ft}^{2}$ calculated from $\$ 752197$

$\hbar_{w}=$ cooling water temperature, use average

$=\frac{t_{w O}-t_{w i}}{2}=\frac{80+70}{2} F=75 F$

$t_{t}=$ tank contents temperature, cooling design

$=95^{\circ} \mathrm{F}\left(35^{\circ} \mathrm{C}\right), 122^{\circ} \mathrm{F}\left(50^{\circ} \mathrm{C}\right.$ is maximum pumping temperature $)$

$V_{t}=$ maximum tank contents volume, gai

a 9400 gallons

$q^{-}=$decay heat generation from tank volume contents; for design use maximun HWVP feed concentration heat generation, 0.38 watts/gal

(Appendix B, Table B.2) concentrated from $19 \mathrm{~g} \mathrm{WO} / \mathrm{L}$ to $190 \mathrm{~g} \mathrm{WO} / \mathrm{L}$

or a factor of 10 .

$=0.38 \mathrm{w} /$ gal $(10)=3.8 \mathrm{w} /$ gal $=13 \mathrm{Btu} / \mathrm{h}-\mathrm{gal}$. 


$$
\begin{aligned}
& U_{t}=\text { overall heat transfer coefficient from tank, Btu/h-ft }{ }^{2}{ }^{\circ} \mathrm{F} \text {. For } \\
& =h_{c}+h_{r} \text {, connective }+ \text { radiative heat transfer coefficients. To } \\
& =0.7[\operatorname{Ref} .(39)]+0.5(1.3)[\operatorname{Ref} .(40)]= \\
& =1.35 \mathrm{Btu} / \mathrm{h}-\mathrm{ft} \mathrm{t}^{2}-{ }^{\circ} \mathrm{F} \\
& A_{t}=\text { tank surface area, } \mathrm{ft}^{2} \\
& =\pi\left(12^{-}\right)\left(15^{\circ}\right)+2 \pi 12^{-2} / 4=791 \mathrm{ft}^{2} \\
& t_{A}=t_{C W}=\text { cell air and well temperature, }{ }^{\circ} \mathrm{F} \\
& =80^{\circ} \mathrm{F} \\
& m_{a}=\text { air in-leakage rate, } 1 b / h \\
& C_{p a}=\text { air specific heat, Btu/7b- }{ }^{\circ} \mathrm{F} \\
& =0.25 \mathrm{Btu} / 7 \mathrm{~b}-{ }^{\circ} \mathrm{F} \text { (neglect water content since } 0.01 \mathrm{lb} \\
& \left.\mathrm{H}_{2} \mathrm{O} / 1 \mathrm{~b} \text { air } 80^{\circ} \mathrm{F}, 40 \% \mathrm{RH}\right) \\
& \text { At } t_{t}=122^{\circ} \mathrm{F}\left(50^{\circ} \mathrm{C}\right) \\
& \begin{aligned}
m_{a} C_{p a}\left(t_{t}-t_{A}\right) & =\left(96 \frac{1 b}{h}\right)\left(\frac{0.25 \mathrm{Btu}}{1 \mathrm{~b}-\mathrm{F}}\right)(122-80 \mathrm{~F}) \\
& =1008 \mathrm{Btu} / \mathrm{h}
\end{aligned} \\
& \begin{aligned}
U_{t} A_{t}\left(t_{t}-t_{A}\right) & =\left(\frac{1.35 \mathrm{Btu}}{\mathrm{h}-\mathrm{ft}^{2}-\mathrm{F}}\right)\left(791 \mathrm{ft}^{2}\right)(122 \mathrm{~F}-80 \mathrm{~F}) \\
& =44,850 \mathrm{Btu} / \mathrm{h}
\end{aligned} \\
& v_{t} q_{t}=(9000 \mathrm{gal})(13 \mathrm{Btu} / \mathrm{h}-\mathrm{gal}) \\
& =117,000 \mathrm{Btu} / \mathrm{h} \\
& U_{c} A_{c c}\left(t_{w}-t_{t}\right)=\left(\frac{40 \mathrm{Btu}}{h-\mathrm{ft}^{2}-F}\right)\left(127 \mathrm{ft}^{2}\right)(122-75 \mathrm{~F}) \\
& =238,760 \mathrm{Btu} / \mathrm{h}
\end{aligned}
$$
this coefficient assume that the liquid and metal resistances are $122^{\circ} \mathrm{F}$; cell air and wall temperature $=80^{\circ} \mathrm{F}$; tank emissivity $=0.5$ 


$$
\begin{aligned}
& \text { - } Q^{-}=238,760 \mathrm{Btu} / \mathrm{h} \\
& m_{C W}^{\prime}=\frac{Q^{-}}{C_{p W}\left(t_{w 0^{-t}}{ }_{w i}\right)}=\frac{238,760 \mathrm{Btu} / \mathrm{hr}}{\left(\frac{1 \mathrm{Btu}}{1 \mathrm{D}-\mathrm{F}}\right)(80-70 \mathrm{~F})} \\
& =23,876 \frac{\mathrm{lb}}{\mathrm{h}}=398 \frac{\mathrm{lb}}{\mathrm{mTn}}=48 \mathrm{gpm}
\end{aligned}
$$

For minimum water use assume that water effluent comes to equilibrium with tank temperature

$$
m_{C W}=\frac{71,142 \mathrm{Btu} / \mathrm{h}}{\left(\frac{1 B t u}{T b-F}\right)(122-70 \mathrm{~F})}=1,368 \frac{1 \mathrm{~b}}{\mathrm{~h}}=2.7 \mathrm{gpm}
$$


SECTION 6.0

SAFETY

Future Inclusion . 


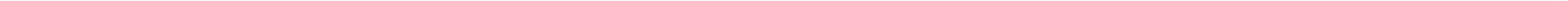




\section{SECTION 7.0 \\ WASTE FORM QUALIFICATION}

Future Inclusion 

SECTION 8.0

QUALITY ASSURANCE 

This document represents a summary of development work, physical properties data, and design information applicable to the Hanford Waste Vitrification Plant (HWVP). There are numerous sources of supporting information involving Department of Energy (DOE) contractors and non-DOE-related organizations such as EPRI, the IAEA, universities, etc.

There are no specific Quality assurance (QA) requirements for treatment of development data related to process technology and design at this time. Contractors, DOE Laboratories, and Engineering Technology centers engaged in DOE programs are responsible for the quality of their activities and are directed by DOE Order 5700.6A to apply quality assurance requirements on a selective basis depending on the complexity, consequences of failure, significance to success and content of contractual documents. In the nuclear area, the national consensus standard ANSI/ASME NQA-1 has been adopted as the preferred standard for QA. For work conducted by non-DOE-related funded organizations with QA programs, there is no single standard that has been used as the basis for the QA requirements. Furthermore, in some instances it is expected that work has been referenced by this document for which there was no formal QA program established at the time the work was conducted.

A QA Waste Acceptance Working Group has been formed to prepare specifications and $Q A$ requirements for the waste form producers. This group has the responsibility for determining the basic requirements for QA programs and their application to the waste acceptance process. In addition, the group will provide guidance for treatment of unique information or data that was obtained without an established program: One aspect of this work is to prepare a procedure for acceptance of technical information that must meet specific QA requirements through a peer review process. Details of the acceptance procedure are under review and should be available at a later date.

In compiling this document, there has been no formal evaluation of the QA program or lack thereof associated with each referenced work. Therefore, prior to using any information contained in this report for process, equipment, or facility design, an evaluation of the significance of the data to the success of the design should be made. Depending on this evaluation, it may be necessary to review the specific QA program and its implementation prior to relying on the information in the design process. 



\section{APPENDIX A}

HWVP PROCESS STREAM CHEMICAL COMPOSITIONS

AND PROPERTIES 



\section{APPENDIX A}

\section{HWVP PROCESS STREAM CHEMICAL COMPOSITIONS AND PROPERTIES}

The chemical compositions of HWVP process streams used for development studies are presented in this section. ATso, some data on basic properties of chemicals are included.

\section{A.1 HWVP PROCESS STREAM COMPOSITIONS}

The HWVP process streams chemical compositions, techniques used to prepare the synthetic siurries and methods employed to measure their properties are presented.

\section{A.1.1 NCAH-84 High Chrome (a)}

The dilute HWVP feed ( -19 WO/L) was prepared by diluting concentrated simulated HWVP Feed batch. HWS6 (157 $\mathrm{g}$ HO/L). HWS6 was prepared using the procedure described in Table A-1. The target and analyzed compositions of HWS6 on an oxide basis are presented in Table A-2. Analyzed chemical compositions of HWS6 slurries used in the development studies are presented in Tables $\mathrm{A}-3$ and $\mathrm{A}-4$.

The concentrates were all prepared from the dilute HWS6 feed. The 100 and $125 \mathrm{~g} \mathrm{WO} / \mathrm{L}$ concentrates were prepared by direct evaporation. The formated $100 \mathrm{~g} \mathrm{WO} / \mathrm{L}$ concentrates were prepared by addition of formic acid at $0.046,0.092,0.138$, and $0.184 \mathrm{~g}$ formic acid/g WO; these additions are factors of $0.5,1.0,1.5$, and 2 times the reference formic acid addition rate of $0.092 \mathrm{~g}$ formic acid/g wo. The formate concentrates were refluxed for $2 \mathrm{~h}$ and evaporated to the desired concentration. The formated $125 \mathrm{~g} \mathrm{WO} / \mathrm{L}$ slurry was formated, refluxed, and evaporated as before. The 151 and $198 \mathrm{~g} \mathrm{WO} / \mathrm{L}$ slurries were prepared by concentrating $2 L$ of dilute feed to $850 \mathrm{~mL}$, adding $1150 \mathrm{~mL}$ of difute feed, concentrating to $850 \mathrm{~mL}$, and repeating this process until the desired concentration level was reached. The $151 \mathrm{~g}$ WO/L slurry using the reference formic acid addition was formated using the procedure described before.

Four concentrates containing frit were made for characterization. Dry $-80 /+200$ mesh HW39 frit was added to the formated 100 and $125 \mathrm{~g} \mathrm{WO} \mathrm{L}$ slurries to make formated $100 \mathrm{~g} \mathrm{WO} / \mathrm{L}+$ unformated $300 \mathrm{~g}$ frit/L and $125 \mathrm{~g} \mathrm{WO} / \mathrm{L}+$ unformated $275 \mathrm{~g}$ frit/L slurries, respectively. After frit addition, the volume

(a) Memorandum from R. D. Scheele to D. E. Larson, "Report on HWVP Feed and Concentrates," Pacific Northwest Laboratory, Richland, Washington (JuTy 10, 1986). 
TABLE A-1. HWS6 Makeup.

The following quantities were added to $15,293.7 \mathrm{~g}$ of $10.3 \mathrm{wt} \% \mathrm{Fe}(\mathrm{OH})_{3}$ slurry. Two groups of chemicals were prepared and then added together to make up HWS-6. Group 1 was added to $500 \mathrm{~mL}$ of $\mathrm{H}_{2} \mathrm{O}$ and homogenized with an electric, variable-speed homogenizer. The Group $1^{2}$ chemicals frequently form cl umps, since they do not dissolve; they must therefore be homogenized into a slurry before addition to the waste simulation. Group 2 chemicals are all added, dry, $t$ a common beaker, transferred to the $\mathrm{Fe}(\mathrm{OH})_{3}$, and blended. The Group 1 chemicals are then added.

\begin{tabular}{|c|c|}
\hline \multirow[b]{2}{*}{ Compound } & Group 1 Chemicals \\
\hline & Amount Added (g) \\
\hline $\begin{array}{l}\mathrm{Cr}(\mathrm{OH})_{3} \\
\mathrm{Ni}(\mathrm{OH})_{2} \\
\mathrm{Cu}(\mathrm{OH})_{2} \\
\mathrm{NaNO}_{3}\end{array}$ & $\begin{array}{r}190.9 \\
79.4 \\
19.6 \\
355.4\end{array}$ \\
\hline \multirow[b]{2}{*}{ Compound } & Group 2 Chemicals \\
\hline & Amount Added (g) \\
\hline 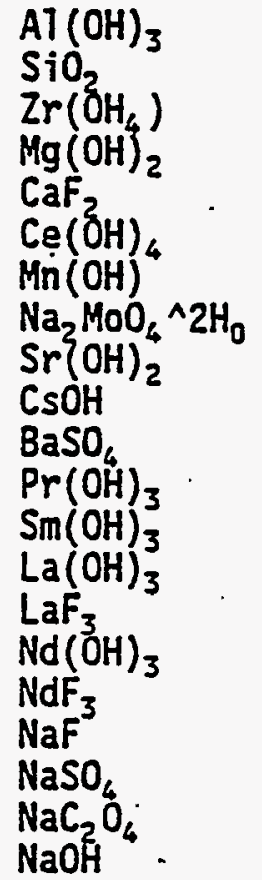 & $\begin{aligned} 696.3 \\
64.3 \\
122.7 \\
11.1 \\
8.3 \\
\left.44.0 \text { (as } \mathrm{CeO}_{2} 36.38 \mathrm{~g}\right) \\
19.6 \\
53.0 \\
24.2 \\
39.7 \\
16.8 \\
12.6 \\
5.6 \\
19.3 \\
57.1 \\
55.2 \\
15.3 \\
16.8 \\
61.3 \\
89.2 \\
79.4\end{aligned}$ \\
\hline
\end{tabular}


TABLE A-2. Composition of Simulated HWVP Feed Batch HWS6(a)

\begin{tabular}{|c|c|c|c|}
\hline Component & $\begin{array}{c}\text { Target } \\
\text { Amount (wt\%) }\end{array}$ & $\begin{array}{c}\text { Analyzed } \\
\text { Amount (wt\%) }\end{array}$ & Deviation (\%) \\
\hline $\begin{array}{l}\mathrm{Al}_{2} \mathrm{O}_{3} \\
\mathrm{~B}_{2} \mathrm{O}_{3} \\
\mathrm{CaO} \\
\mathrm{CeO} \\
\mathrm{Cr}_{2} \mathrm{O}_{3} \\
\mathrm{CuO} \\
\mathrm{Fe}_{2} \mathrm{O}_{3} \\
\mathrm{La}_{2} \mathrm{O}_{3} \\
\mathrm{Li}_{2} \mathrm{O}^{2} \\
\mathrm{MgO} \mathrm{MnO}_{2} \\
\mathrm{MoO}_{3} \\
\mathrm{Na}_{2} \mathrm{O} \\
\mathrm{Nd}_{2} \mathrm{O}_{3} \\
\mathrm{NiO}_{3} \\
\mathrm{SiO}_{2} \\
\mathrm{SrO}^{2} \\
\mathrm{TiO}_{2} \\
\mathrm{ZrO}_{2}\end{array}$ & $\begin{array}{r}17.2 \\
0.0 \\
0.3 \\
0.7 \\
5.3 \\
0.6 \\
44.4 \\
2.2 \\
0.0 \\
0.3 \\
0.7 \\
1.2 \\
10.7 \\
2.1 \\
2.4 \\
3.0 \\
0.4 \\
0.0 \\
2.4\end{array}$ & $\begin{array}{c}17.1 \\
0.4 \\
0.4 \\
0.5 \\
5.5 \\
0.6 \\
40.9 \\
2.2 \\
f .03 \\
0.3 \\
0.7 \\
1.1 \\
10.2 \\
2.4 \\
2.3 \\
2.9 \\
0.4 \\
0.03 \\
2.6\end{array}$ & $\begin{array}{c}99 \\
\text { Contaminant } \\
133 \\
71 \\
104 \\
0 \\
92 \\
0 \\
\text { Contaminant } \\
0 \\
0 \\
92 \\
95 \\
114 \\
96 \\
97 \\
0 \\
\text { Contaminant. } \\
108\end{array}$ \\
\hline
\end{tabular}

(a) Letter from J. E. Minor to R. N. Gurley, February 7, 1986, Hanford Waste Management Program Monthly Report - January 1986." H. J. Blair, Feed Processing, Pacific Northwest Laboratory, Richland, Hashington.

was reduced by evaporation to the desired level. The formated $100 \mathrm{~g} \mathrm{HO} / \mathrm{L}+$ formated $300 \mathrm{~g}$ frit/L was prepared by addition of formic acid $10.01 \mathrm{~g}$ formic $\mathrm{acid} / \mathrm{g}$ frit) to the $100 \mathrm{~g} \mathrm{WO} / \mathrm{L}+$ unformated $300 \mathrm{~g}$ frit/L s7urry and refluxing for $2 \mathrm{~h}$. The formated $125 \mathrm{~g}$ WO/L + formated $375 \mathrm{~g}$ frit/L s7urry was prepared by adding formic acid at the reference formic acid addition level for frit $(0.01 \mathrm{~g}$ formic acid/g frit), refluxing for $2 \mathrm{~h}$, and adding frit.

Four frit slurries in water were made for characterization. The frit s7urries were 10 or $60 \mathrm{wt} \%$ frit and were formated at $0.01 \mathrm{~g}$ formic acid $/ \mathrm{g}$ frit or $0.1 \mathrm{~g}$ formic/g slurry. The solids settling rate for these four siurries was rapid and created sampling problems, especially for the $10 \mathrm{wt} \%$ frit slurries.

One observation of special note was that after concentration to $200 \mathrm{~g}$ $W O / L$, solids began to accumulate on the sides of the vessel and on the agitator shaft. Thus, it is believed that $200 \mathrm{~g} \mathrm{WO} / \mathrm{L}$ is the maximum concentration to which the HWVP feed can be concentrated before being treated with formic acid to improve the slurry's physical properties. 


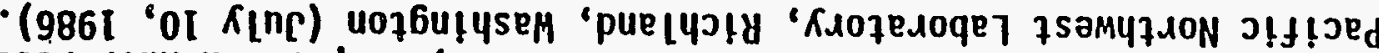

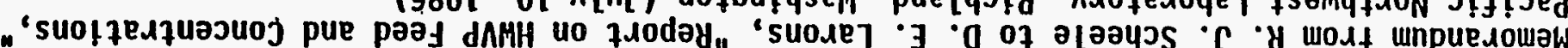

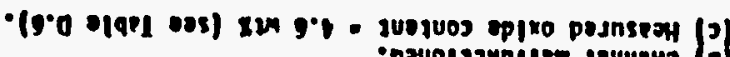
- pavolisunjira peuveys (q

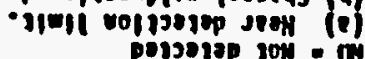

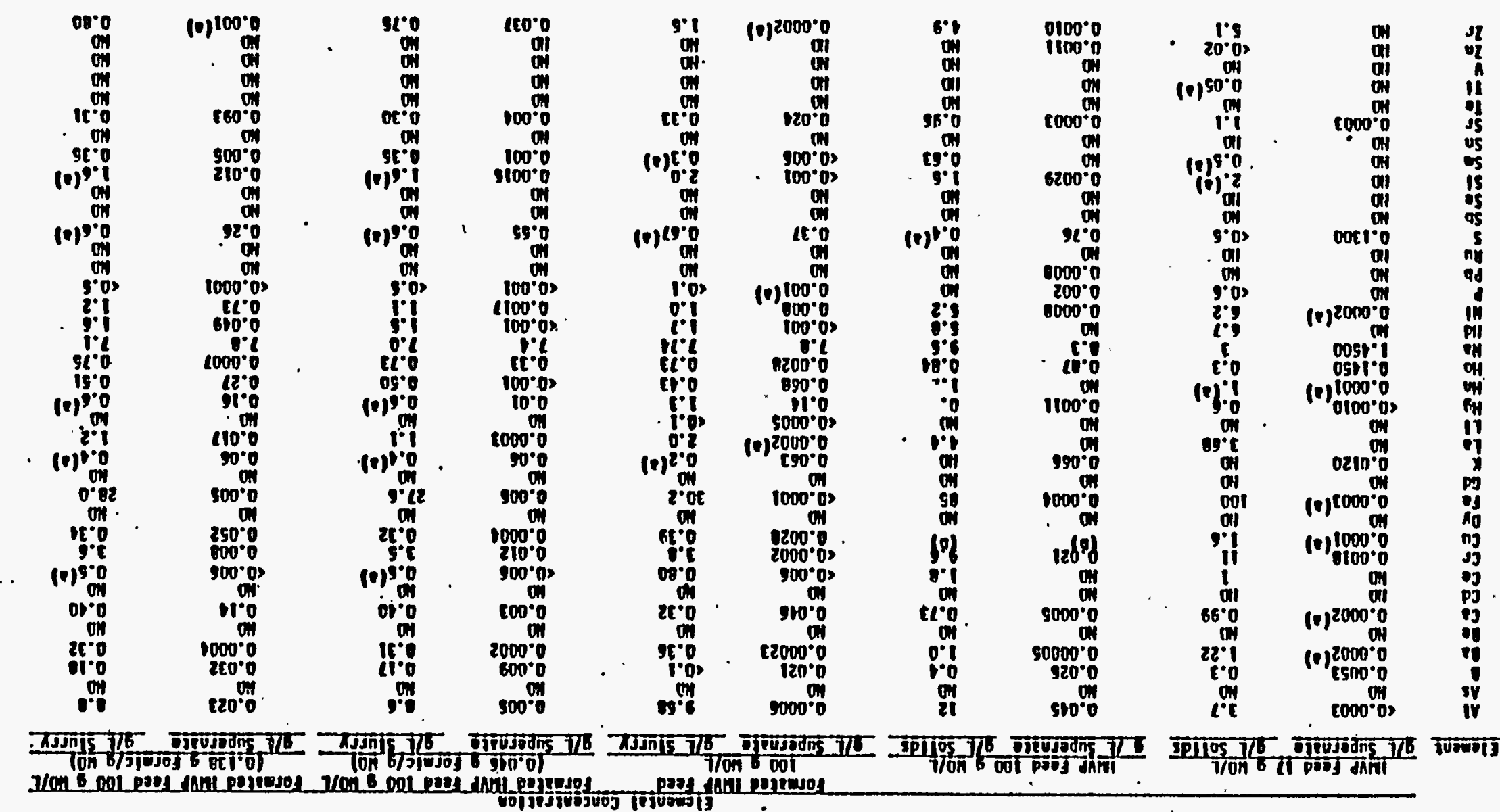

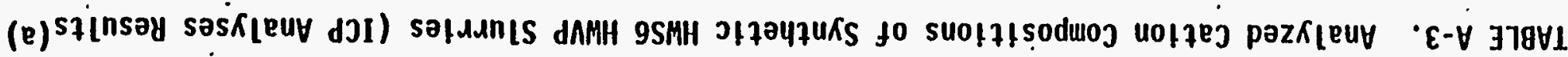


TABLE A-3. (contd)

Elenental Concentration

\begin{tabular}{|c|c|c|c|}
\hline $\begin{array}{l}\text { HeTEer Feed } \\
\text { formated } 125 \mathrm{~g} \mathrm{HO/L}+ \\
375 \mathrm{~g} \text { frit/l }\end{array}$ & $\begin{array}{c}\text { formated IMVP Feed } \\
151 \text { g } \mathrm{HO} / \mathrm{L}\end{array}$ & $\begin{array}{l}\text { IHYP Feed } \\
198 \mathrm{~g} \text { HO/L }\end{array}$ & $\begin{array}{l}\text { FrTE STurry } \\
\text { Formated } 60 \text { wts frit } \\
\text { 0.01 9 Formic Acid }\end{array}$ \\
\hline
\end{tabular}

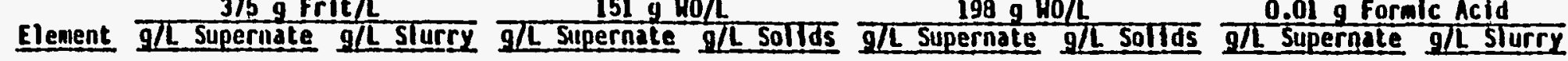

紊

\begin{tabular}{|c|c|c|c|c|}
\hline 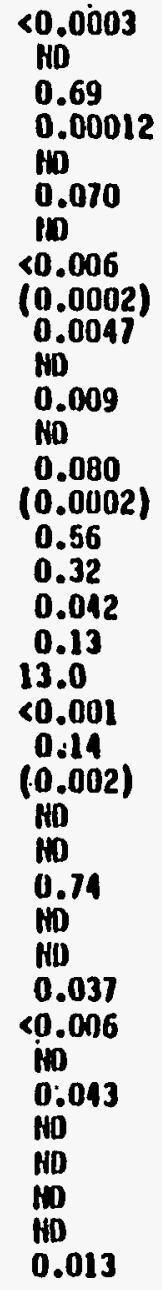 & $\begin{array}{c}22.0 \\
100 \\
17.5 \\
0.49 \\
110 \\
14.4 \\
100 \\
1.8 \\
6.4 \\
0.59 \\
100 \\
50.3 \\
100 \\
10.3) \\
2.6 \\
20.1 \\
4.5 \\
0.87 \\
1.4 \\
50.2 \\
3.0 \\
2.0 \\
60.1 \\
100 \\
100 \\
12.4 \\
100 \\
100 \\
265 \\
(0.48) \\
100 \\
0.47 \\
100 \\
110 \\
100 \\
100 \\
3.0\end{array}$ & 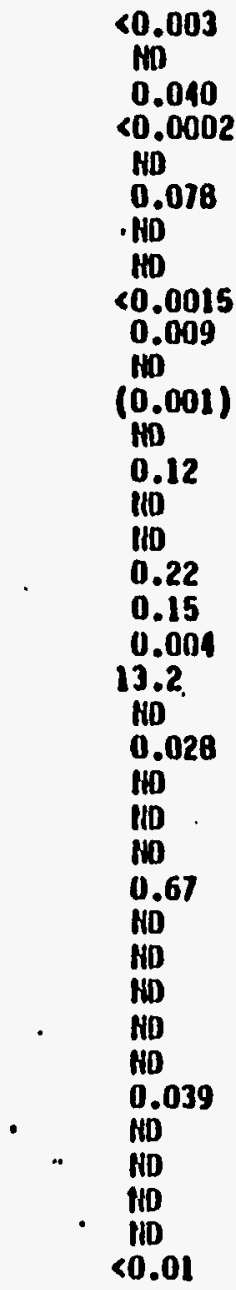 & 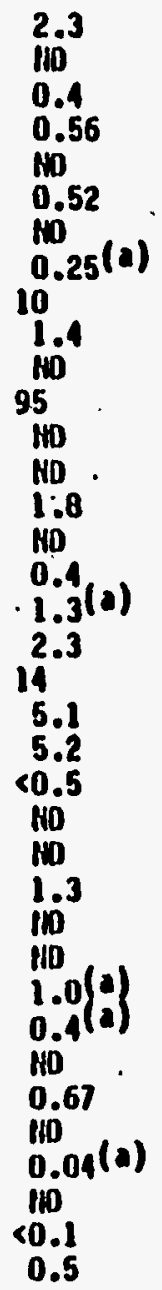 & 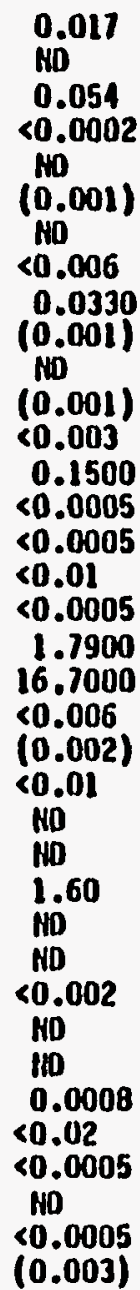 \\
\hline
\end{tabular}

\begin{tabular}{|c|c|}
\hline 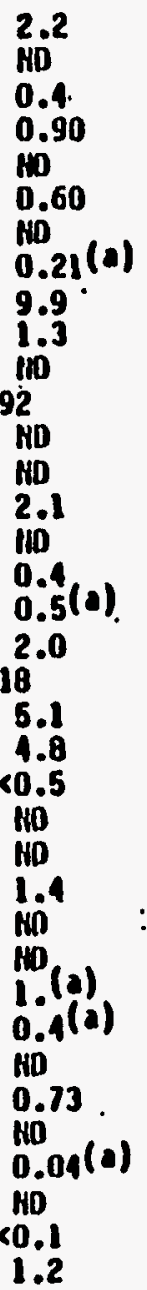 & 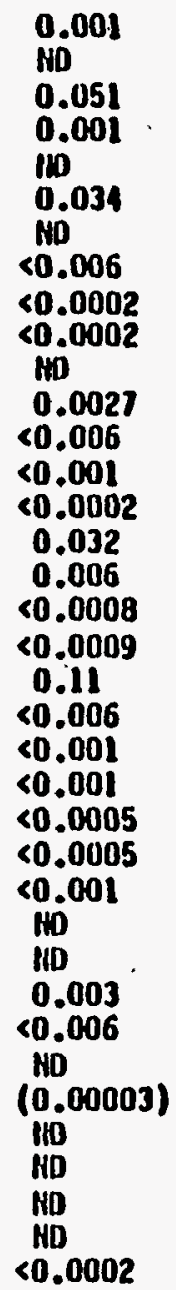 \\
\hline
\end{tabular}

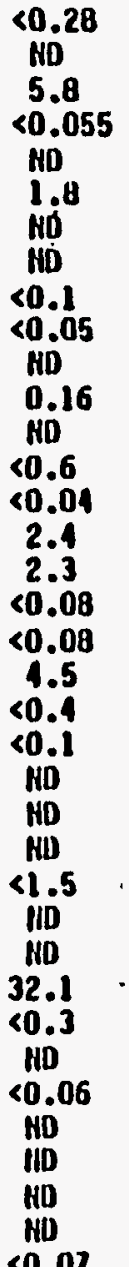



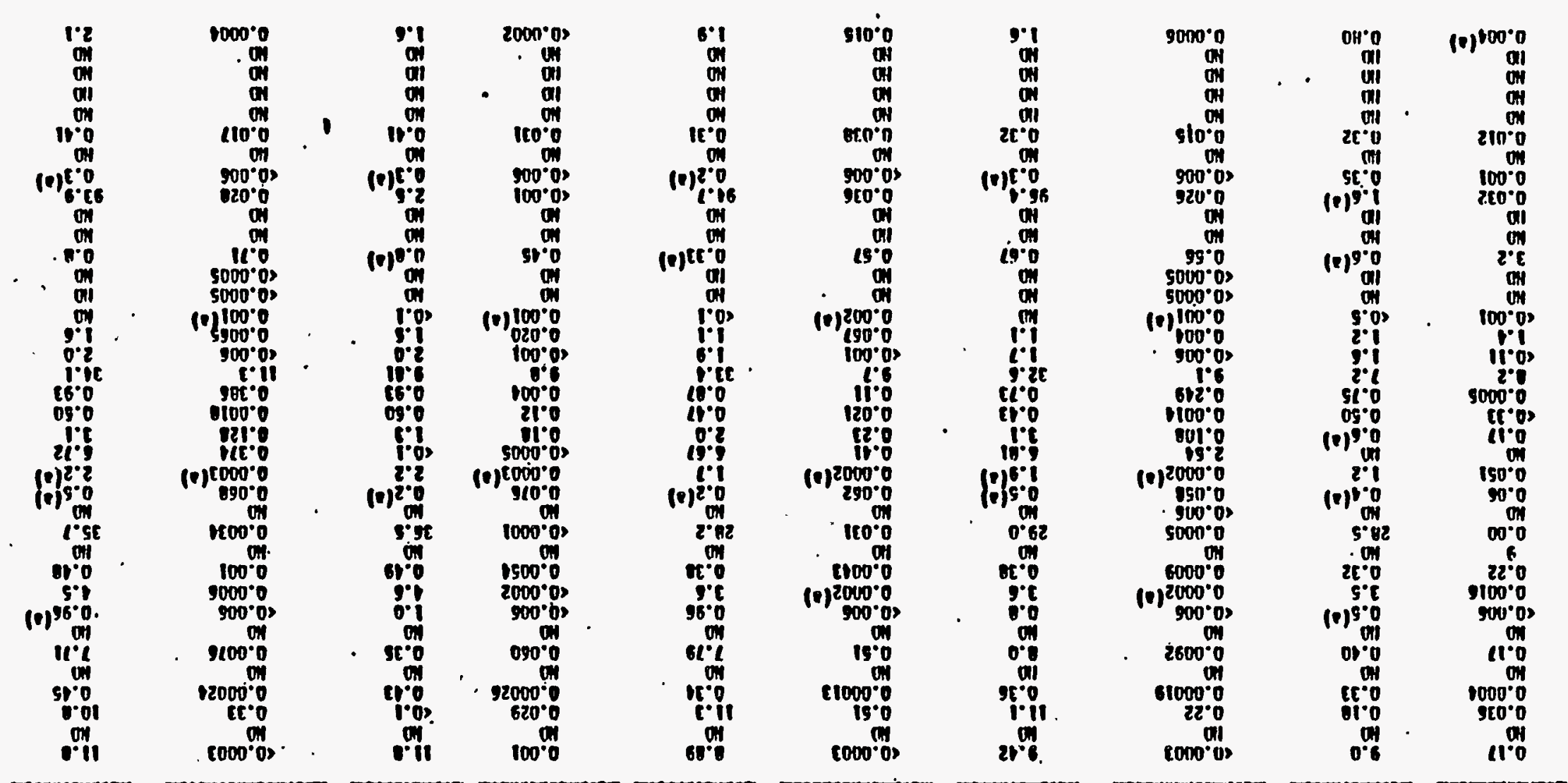

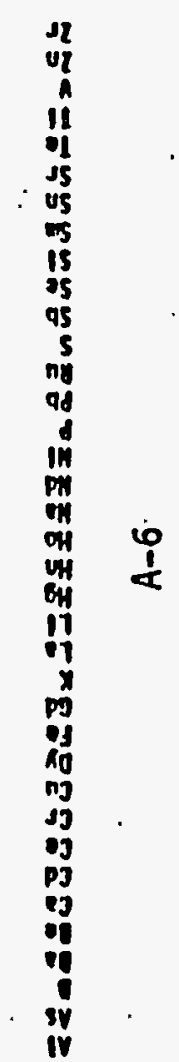

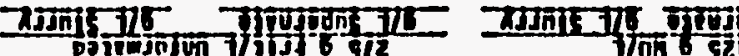

- T/On sel postumos

poes dAll Dossunsos

poseresos t/on on

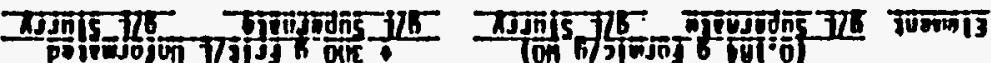


TABLE A-4. Analyzed Anion Compositions of Synthetic HWS6 HWVP Slurries

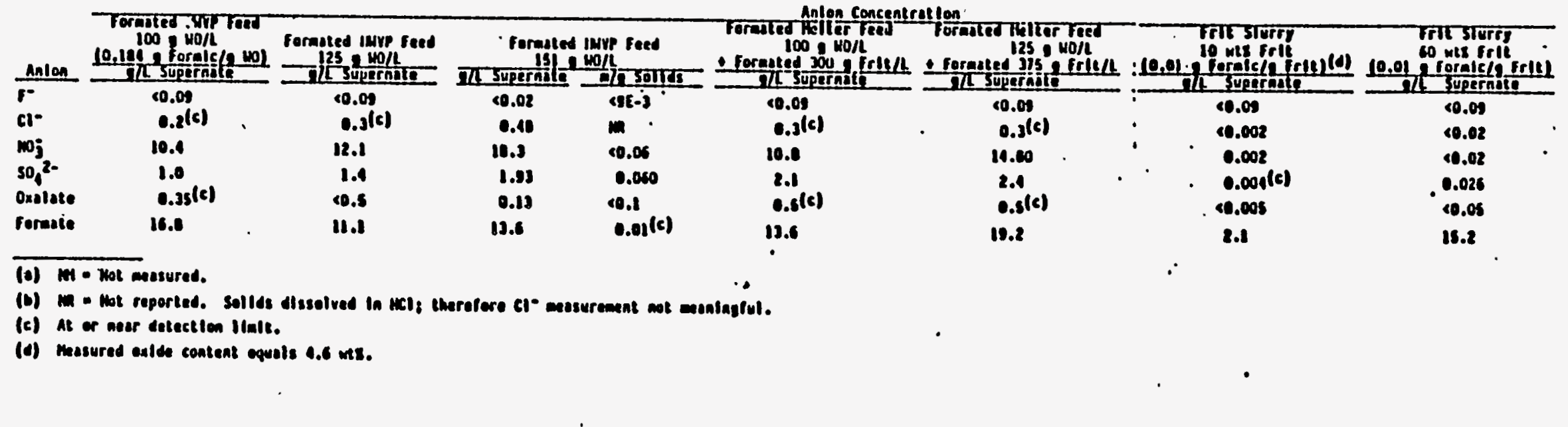

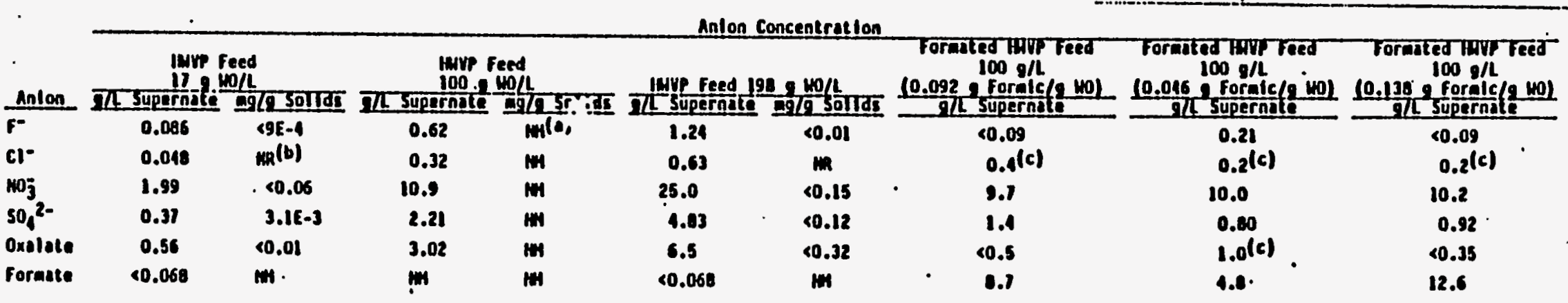

(a) in - Mot messured.

(b) in - Hot reported. Sollds dissolved In HCl: therefore Cl- messurement not meaninglul.

(c) At or near detection Ilait.

(d) Heasured oxlde content equals $4.6 \mathrm{~ms}$. 
A correlation was developed for converting: slurry concentrations expressed as $\mathrm{g}$ WO/g slurry to $\mathrm{g}$ TO/g slurry and of projecting a WO/L slurry from the $\mathrm{g} \mathrm{WO} / \mathrm{g}$ slurry. Data from past studies were plotted to provide an empirical conversion factor. The results are! presented in Figures 4.3-60 and A-1. These plots have proven accurate and consistent, even for the synthetic B-P1ant feed prepared by Rockwe 17 by a different process.

Rockwe11 provided PNL with about $20 \mathrm{~L}$ of synthetic B-P1ant feed that was prepared by dissolving all the chemicals representing the waste components in the nitric acid. The solution was then neutralized with sodium hydroxide and digested. At PNL, the supernatant was decanted and the residual solid was washed with $15 \cdot t i m e s$ its volume of deionized water. The wash supernatant was decanted. The residual slurry is believed to be representative of HWVP feed. It had a concentration of $34.2 \mathrm{~g} \mathrm{WO} / \mathrm{L}$, which is more than the $19 \mathrm{~g} \mathrm{WO} / \mathrm{L}$ projected for the HWVP feed.

\section{A.1.2 HWS6 and B PI ant Synthetic Feed Rheology}

Rheograms were produced by the viscometer from a sample of this washed synthetic B-PIant feed and from a sample of HWS-6 that was diluted to $34.2 \mathrm{HO} / \mathrm{L}$. The washed synthetic B-Plant feed appears to be a Bingham fiuid, and the HWS6 is pseudoplastic and has no yield stress. Solids settle out of the diTute HWS6, but the washed synthetic B-PIant feed appears to be a colloidal suspension. These results are significant in that the dilute concentration range of the waste feed, before concentration, the laboratory simulation does not duplicate some synthetic B-PTant feed properties.

\section{A.1.3 HWWP Development STurry Compositions}

The compositions of the HWVP reference feeds used in various laboratory studies and provided in Tables $A-5, A-6, A-7$, and $A-8$.

\section{A.2 ANALYTICAL TECHNIQUES}

This section describes the analytical techniques that were used to measure various chemical, rheological, and physical properties of the slurries, centrifuged solids, and supernates.

Inductively coupled plasma (ICP) atomic emission spectroscopy and ion chromatography (IC) were used to determine the elemental and anion contents of the supernate and solids. The IC and the standard eluant were used to measure chioride, fluoride, nitrate, sulfate, and oxalate in the supernate and centrifuged solids dissolved in $\mathrm{HCl}$. For formate determination, $0.005 \mathrm{M}$ sodium borate was used as the IC eluant. The solids and slurries were dissolved by adding the solids and slurries to $75 \mathrm{~mL}$ of $3.6 \mathrm{M} \mathrm{HCT}$, boiling for 3 to 5 minutes and then diluting to $1 \mathrm{M} \mathrm{HCl}$; chloride thus could not be determined for the solids. The $\mathrm{pH}$ was measured using a calibrated $\mathrm{pH}$ electrode. Alkalinity was measured by adding $0.20 \mathrm{~mL}$ of sample to $100 \mathrm{~mL}$ of deionized 


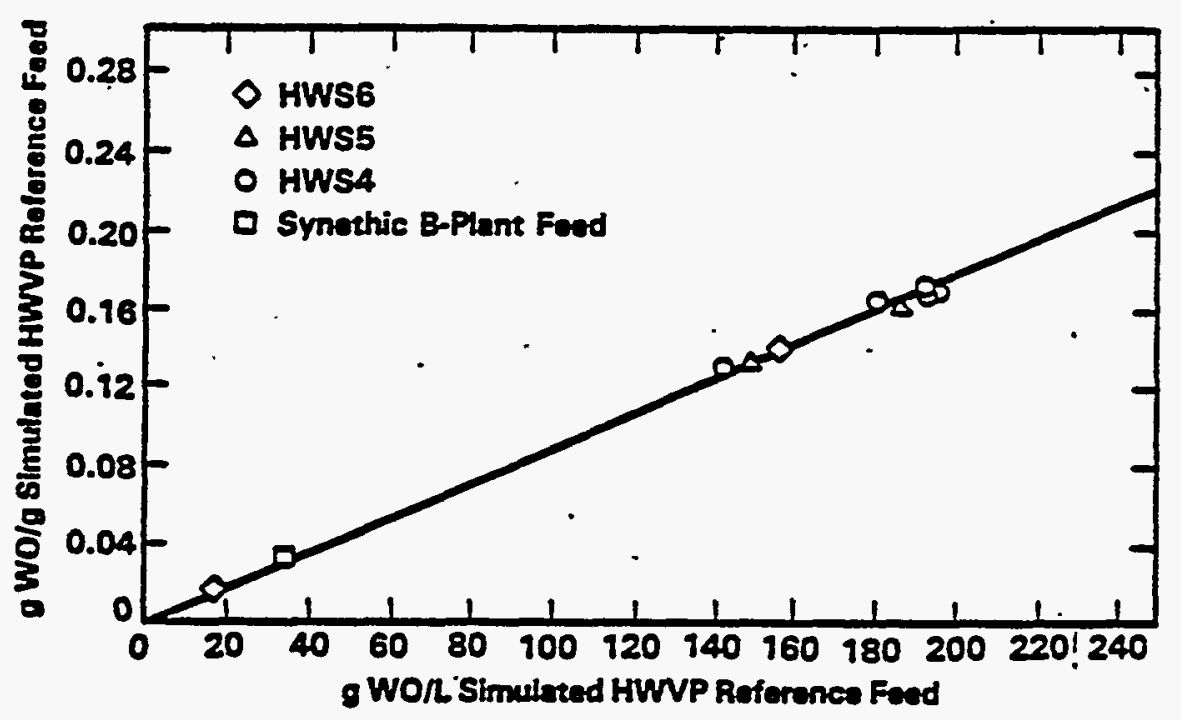

FIGURE A-1. Projecting $g$ WO/g Feed from Measured $g$ WO/L Feed (J. E. Minor to R. M. Gurley, February. 7, 1986, in "Hanford Waste Management Program Monthiy Report - January 1986," PNL)

(DI) water and titrating to a pH of 4.3 using $0.02 \mathrm{M} \mathrm{HCl}$. Solids from the dilute feed also were chemically analyzed using x-ray diffraction.

The volume percentage of the centrifuged solids was determined by centrifuging a weighed amount of sample in a weighed graduated centrifuge cone for $-2 h$ in a laboratory centrufige. The supernate was decanted, and the weight of the centrifuged solids was measured; the density of these solids was calculated by dividing the solids' weight by the solids' volume as measured by the cone graduations. The density of the supernate was measured using a weighed volumetric fiask. The weight percentage of soluble solids, insoluble solids, and total solids was determined by drying a weighed amount of sample at $.95^{\circ} \mathrm{C}$ for $5 \mathrm{~h}$ and at $120^{\circ} \mathrm{C}$ for $16 \mathrm{~h}$. Oxide content was measured by heating the dried sample at $1000^{\circ} \mathrm{C}$ for $16 \mathrm{~h}$. The. solids settling behavior was determined by measuring the height of the solids/liquid interface as the solids settled from the slurry in a graduated cylinder.

The apparent viscosities and yield stresses of the siurries were measured using a Haake Rotovisco viscometer; for a description of the principle of operation, see McCarthy, Chan, and Lokken (Ref. A-I). No method development for measuring the apparent viscosities at 50 and $95^{\circ} \mathrm{C}$ was done because of insufficient time available. The procedure used to obtain room temperature rheograms was used, with the exception that the viscometer rotor and cup and the siurry were preheated to 120 to $200^{\circ} \mathrm{F}\left(50\right.$ to $\left.95^{\circ} \mathrm{C}\right)$. While obtaining the rheogram, water can evaporate from the slurry, particularly at $200^{\circ} \mathrm{F}$ $\left(95^{\circ} \mathrm{C}\right)$. The boiling point was measured using a calibrated digital thermometer and thermocouple. The particle sizes were determined using (HIAC) instrumental particle analysis for particles 1.5 to $67.5 \mathrm{~mm}$. 
TABLE A-5. Compositions of Simulated HWWP Reference Feed Batch HWS7 (NCAW-84, high chromium) and NCAW 86 Feed Batch HWS9 (G. T. Thornton, HWVP-87-V110203C, 1987)

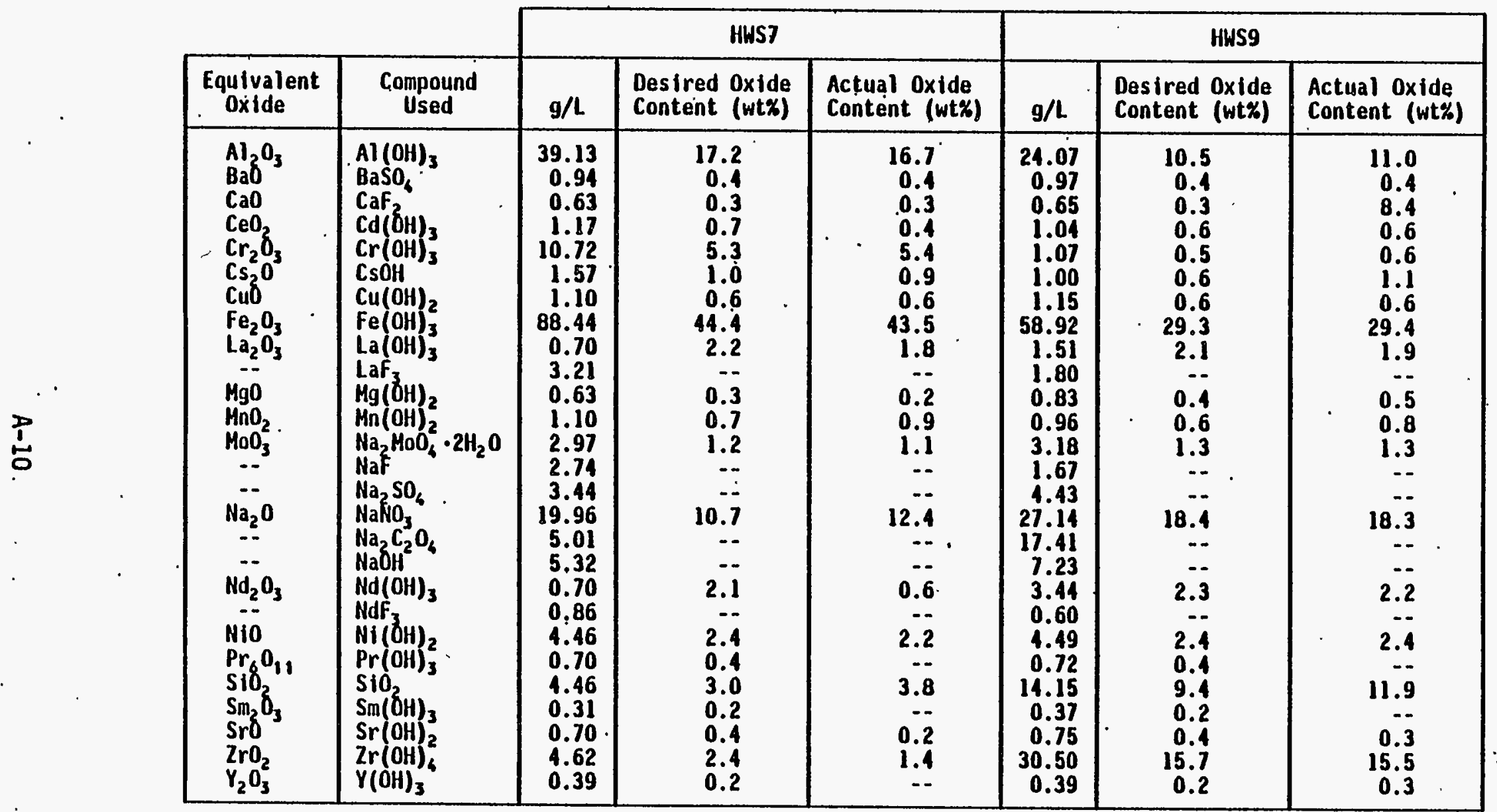

NOTE: The sources of the chemicals used in the simulant preparation were the same for all components in both batches, except the $\mathrm{NdF}_{3}$ source. The difference in $\mathrm{NdF}_{3}$ source was not considered significant since $\mathrm{Nd}_{2} \mathrm{O}_{3}$, which results from the oxidation of $\mathrm{NdF}_{3}$, represents only $0.39 \mathrm{wt} \%$ of the waste oxides in HWS9. It is important to note that the same source of ferric hydroxide [ $\mathrm{Fe}(\mathrm{OH}) 3$ ] was used to prepare both HWS7 and HWS9. Several scoping studies on ferric hydroxide slurry behavior have shown that $\mathrm{Fe}(\mathrm{OH})_{3}$ slurries originating from different vendors and vendor lots have significantiy different rheological properties. These studies have also shown that ferric hydroxide has a greater impact on simulated HWVP feed rheology than any other single component. 
TABLE A-6. Nominal Equivalent Oxide Composition of HWVP 84 (NCAW-84, high chromium) Feed and the Simulation Used for Glass and Meiter Feed Development (HWS4, HWS5)

\begin{tabular}{|c|c|c|c|c|}
\hline Oxide & $\begin{array}{l}\text { As Received } \\
\text { (kg/MTU) }\end{array}$ & $\begin{array}{c}\text { Normalized } \\
\text { Waste } \\
\text { (wt\% Oxide) }\end{array}$ & $\begin{array}{l}\text { Simulated } \\
\text { Haste } \\
\text { (wt\% Oxide) }\end{array}$ & $\begin{array}{c}\text { Simulated Haste } \\
\text { (Normalized wt\% } \\
\text { Oxide) }\end{array}$ \\
\hline $\begin{array}{l}\mathrm{Al}_{2} \mathrm{O}_{3} \\
\mathrm{Na}_{2} \mathrm{O} \\
\mathrm{Fe}_{2} \mathrm{O}_{3} \\
\mathrm{SiO}_{2} \\
\mathrm{Cr}_{2} \mathrm{O}_{3}\end{array}$ & $\begin{array}{l}2.9 \\
1.8 \\
7.5 \\
0.5 \\
0.9\end{array}$ & $\begin{array}{r}17.0 \\
10.5 \\
44.0 \\
2.9 \\
5.3\end{array}$ & $\begin{array}{r}17.0 \\
10.5 \\
44.0 \\
2.9 \\
5.3\end{array}$ & $\begin{array}{r}17.2 \\
10.7 \\
44.4 \\
3.0 \\
5.3\end{array}$ \\
\hline $\begin{array}{l}\mathrm{NiO} \\
\mathrm{ZrO}_{2} \\
\mathrm{MgO}^{2} \\
\mathrm{CaO} \\
\mathrm{La}_{2} \mathrm{O}_{3}\end{array}$ & $\begin{array}{r}0.4 \\
0.4 \\
<0.1 \\
0.1 \\
0.4\end{array}$ & $\begin{array}{l}2.3 \\
2.3 \\
0.2 \\
0.3 \\
2.2\end{array}$ & $\begin{array}{l}2.3 \\
2.3 \\
0.3 \\
0.3 \\
2.2\end{array}$ & $\begin{array}{l}2.4 \\
2.4 \\
0.3 \\
0.3 \\
2.2\end{array}$ \\
\hline $\begin{array}{l}\mathrm{Nd}_{2} \mathrm{O}_{3} \\
\mathrm{~F}^{-} \\
\mathrm{SO}_{4}-2 \\
\mathrm{~B}_{2} \mathrm{O}_{3} \\
\mathrm{Li}_{2} \mathrm{O}\end{array}$ & $\begin{array}{r}0.3 \\
0.2 \\
0.3 \\
<0.1 \\
<0.1\end{array}$ & $\begin{array}{l}1.7 \\
1.2 \\
1.8 \\
0.0 \\
0.0\end{array}$ & $\begin{array}{r}2.1 \\
1.2 \\
1.8 \\
0.0 \\
0.0\end{array}$ & $\begin{array}{l}2.1 \\
1.2 \\
1.8 \\
0.0 \\
0.0\end{array}$ \\
\hline $\begin{array}{l}\mathrm{CeO} 2 \\
\mathrm{TOC}^{2} \text { ( ) } \\
\mathrm{U}_{3} \mathrm{O}_{8} \\
\mathrm{PuO}_{2} \\
\mathrm{NpO}_{2}\end{array}$ & $\begin{array}{r}0.1 \\
0.1 \\
0.1 \\
<0.1 \\
<0.1\end{array}$ & $\begin{array}{r}0.6 \\
0.6 \\
0.6 \\
<0.1 \\
0.1\end{array}$ & $\begin{array}{l}0.7 \\
0.6 \\
\text { Sub } N d^{(b)} \\
\text { Sub } C e^{(b)} \\
\text { Sub } C e^{(b)}\end{array}$ & $\begin{array}{ll} & 0.7 \\
& 0.6 \\
\text { Sub } & N d^{(b)} \\
\text { Sub } C e^{(b)} \\
\text { Sub } C e^{(b)}\end{array}$ \\
\hline $\begin{array}{l}\mathrm{Am}_{2} \mathrm{O}_{3} \\
\mathrm{CuO} \\
\mathrm{MnO}_{2}\end{array}$ & $\begin{array}{r}<0.1 \\
0.1 \\
0.1\end{array}$ & $\begin{array}{r}<0.1 \\
0.6 \\
0.6\end{array}$ & $\begin{array}{c}\text { Sub } \operatorname{Nd}(b) \\
0.6 \\
0.7\end{array}$ & $\begin{array}{c}\text { Sub } N d(b) \\
0.6 \\
0.7\end{array}$ \\
\hline
\end{tabular}

(a) Total organic carbon.

(b) Substituted on a molar basis. 
TABLE A-6. (contd)

\begin{tabular}{|c|c|c|c|c|}
\hline Oxide & $\begin{array}{l}\text { As Received } \\
\text { (kg/MTU) }\end{array}$ & $\begin{array}{l}\text { Normalized } \\
\text { Haste } \\
\text { (wt\% Oxide) }\end{array}$ & $\begin{array}{c}\text { Simulated } \\
\text { Waste } \\
\text { (wt\% Oxide) }\end{array}$ & $\begin{array}{l}\text { Simulated Waste } \\
\text { (Normalized wt\% } \\
\text { Oxide) }\end{array}$ \\
\hline 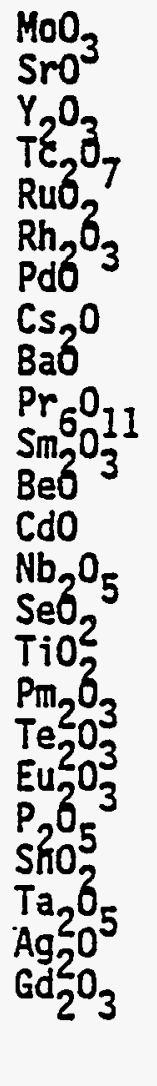 & $\begin{array}{c}0.1 \\
0.1 \\
<0.1 \\
0.1 \\
0.1 \\
<0.1 \\
<0.1 \\
0.1 \\
0.1 \\
0.1 \\
<0.1 \\
<0.1 \\
<0.1 \\
<0.1 \\
<0.1 \\
<0.1 . \\
<0.1 \\
<0.1 \\
<0.1 \\
<0.1 \\
<0.1 \\
<0.1 \\
<0.1 . \\
<0.1 \\
17.06\end{array}$ & $\begin{array}{r}1.2 \\
0.4 \\
0.2 \\
0.4 \\
0.6 \\
0.2 \\
0.2 \\
0.6 \\
0.4 \\
0.4 \\
0.2 \\
0.1 \\
<0.1 \\
<0.1 \\
<0.1 \\
<0.1 \\
0.1 \\
0.1 \\
<0.1 \\
0.2 \\
<0.1 \\
<0.1 \\
<0.1 \\
<0.1 \\
< \\
00.00\end{array}$ & 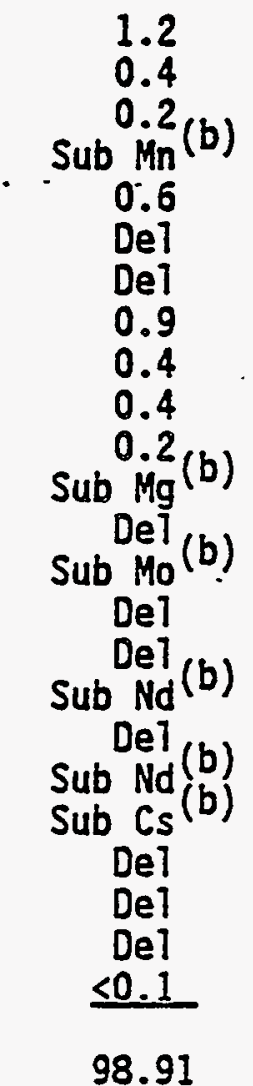 & 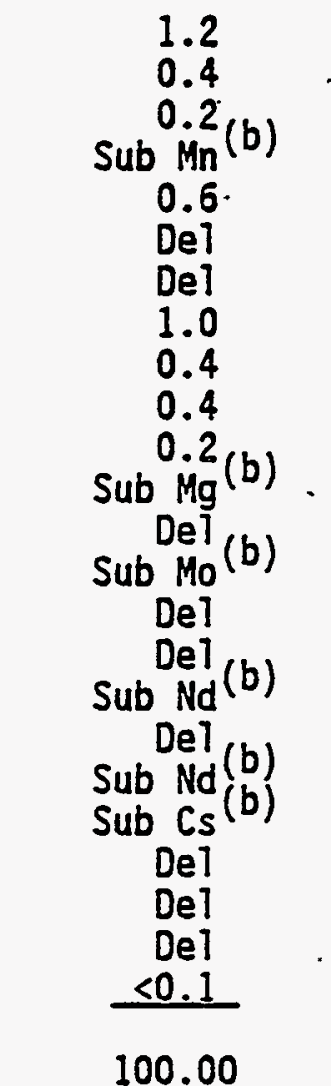 \\
\hline
\end{tabular}

(a) Total organic carbon.

(b) Substituted on a molar basis.

The heat capacities were measured using differential scanning calorimetry and hermetically sealed sample pans capable of containing 2 atm to prevent water loss. Gold pans were used for the basic samples and aluminum pans for the formated samples.

To measure the "resuspendability" of solids settled from HWVP feed, concentrates, and frit feed slurries, the shear strengths of the settled solids were measured. The shear strength was measured by submerging a $0.975-\mathrm{cm}-$ diameter by $0.975-\mathrm{cm}$-high shear vane into the settled solids of the' sample. The solids settled for 2 days before their shear strength was measured. The shear vane was submerged gently to prevent disturbing the solids as much as possible. The shear strength was measured using a Brookfield viscometer at 
TABLE A-7.. Composition of Simulated HWVP (NCAW-84) Reference Feed Batch HWS6

\begin{tabular}{|c|c|c|c|c|}
\hline $\begin{array}{l}\text { Compound } \\
\text { Used }\end{array}$ & $\begin{array}{c}\text { Concentration } \\
(\mathrm{g} / \mathrm{L})\end{array}$ & $\begin{array}{l}\text { Equivalent } \\
\text { 0xide }\end{array}$ & $\begin{array}{c}\text { Desired } \\
\text { Oxide Content } \\
\text { (wt\%) }\end{array}$ & $\begin{array}{l}\text { Average } \\
\text { Analytical } \\
\text { Result (a) } \\
\text { (wt\%) }\end{array}$ \\
\hline 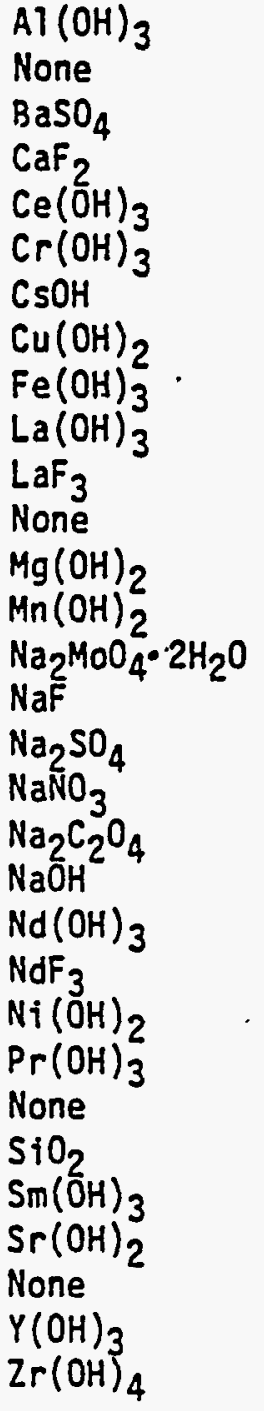 & $\begin{array}{c}39.13 \\
-. \\
0.94 \\
0.63 \\
1.17 \\
10.72 \\
1.57 \\
1.10 \\
88.44 \\
0.70 \\
3.21 \\
-. \\
0.63 \\
1.10 \\
2.97 \\
2.74 \\
3.44 \\
19.96 \\
5.01 \\
5.32 \\
0.70 \\
0.86 \\
4.46 \\
0.70 \\
0 . \\
4.46 \\
0.31 \\
0.70 \\
-. \\
0.39 \\
4.62\end{array}$ & 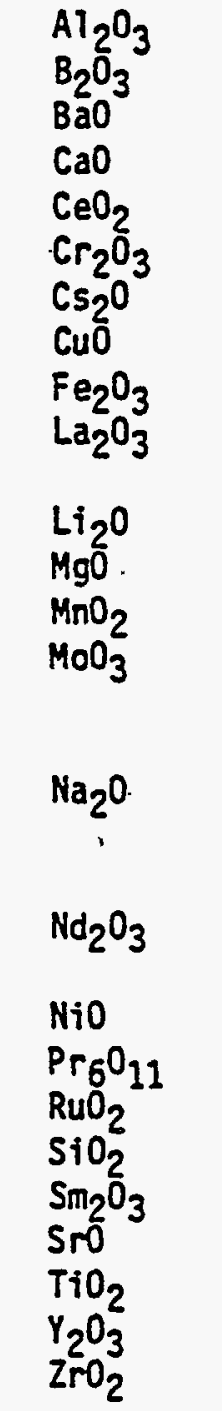 & $\begin{array}{r}17.2 \\
0.0 \\
0.4 \\
0.3 \\
0.7 \\
5.3 \\
1.0 \\
0.6 \\
44.4 \\
2.2 \\
\\
0.0 \\
0.3 \\
0.7 \\
1.2 \\
\\
\\
10.7 \\
\\
2.1 \\
\\
2.4 \\
0.4 \\
0.6 \\
3.0 \\
0.2 \\
0.4 \\
0.0 \\
0.2 \\
2.4\end{array}$ & $\begin{array}{c}17.1 \\
0.4 \\
0.4 \\
0.4 \\
0.5 \\
5.5 \\
9.0 \text { (b) } \\
0.6 \\
40.9 \\
2.2 \\
0.3 \\
0.3 \\
0.7 \\
1.1 \\
\\
10.2 \\
\\
\\
2.4 \\
\\
2.3 \\
\text { (b) } \\
\text { (b) } \\
2.9 \\
\text { (b) } \\
0.4 \\
0.03 \\
\text { (b) } \\
2.6\end{array}$ \\
\hline
\end{tabular}

(a) Normalized to $157 \mathrm{~g} \mathrm{WO} / \mathrm{L}$.

(b) No analysis. 
TABBLE A-8. Composition of Simulated HWVP (NCAW-84) Reference Feed Batch HWS7 (G. T. Thornton, HWVP-87-V110203C, 1987)

\begin{tabular}{|c|c|c|c|}
\hline Compound & $\begin{array}{c}\text { Concentration } \\
(\mathrm{g} / \mathrm{h})\end{array}$ & $\begin{array}{l}\text { Equivalent } \\
\text { Oxide }\end{array}$ & $\begin{array}{l}\text { Desired Oxide } \\
\text { Content (wty) }\end{array}$ \\
\hline $\begin{array}{l}\mathrm{Al}(\mathrm{OH})_{3} \\
\mathrm{BaSO}_{4} \\
\mathrm{CaF}_{2} \\
\mathrm{Ce}(\mathrm{OH})_{3} \\
\mathrm{Cr}(\mathrm{OH})_{3}\end{array}$ & $\begin{array}{r}39.13 \\
0.94 \\
0.63 \\
1.17 \\
10.72\end{array}$ & $\begin{array}{l}\mathrm{Al}_{2} \mathrm{O}_{3} \\
\mathrm{BaO}^{3} \\
\mathrm{CaO} \\
\mathrm{CeO}_{2} \\
\mathrm{Cr}_{2} \mathrm{O}_{3} .\end{array}$ & $\begin{array}{r}17.2 \\
0.4 \\
0.3 \\
0.7 \\
.5 .3\end{array}$ \\
\hline $\begin{array}{l}\mathrm{CsOH} \\
\mathrm{Cu}(\mathrm{OH})_{2} \\
\mathrm{Fe}(\mathrm{OH})_{3} \\
\mathrm{La}(\mathrm{OH})_{3} \\
\mathrm{LaF}_{3}\end{array}$ & $\begin{array}{r}-\quad 1.57 \\
1.10 \\
: \quad 88.44 \\
0.70 \\
3.21\end{array}$ & $\begin{array}{l}\mathrm{Cs}_{2} \mathrm{O} \\
\mathrm{CuO}_{2} \\
\mathrm{Fe}_{2} \mathrm{O}_{3} \\
\mathrm{La}_{2} \mathrm{O}_{3}\end{array}$ & $\begin{array}{r}1.0 \\
0.6 \\
44.4 \\
2.2\end{array}$ \\
\hline $\begin{array}{l}\mathrm{Mg}(\mathrm{OH})_{2} \\
\mathrm{Mn}(\mathrm{OH})_{2} \\
\mathrm{Na}_{2} \mathrm{MOO}_{4} \cdot 2 \mathrm{H}_{2} \mathrm{O} \\
\mathrm{NaF} \mathrm{Na}_{2} \mathrm{SO}_{4}\end{array}$ & $\begin{array}{l}0.63 \\
1.10 \\
2.97 \\
2.74 \\
3.44\end{array}$ & $\begin{array}{l}\mathrm{MgO} \\
\mathrm{MnO}_{2} \\
\mathrm{MoO}_{3}\end{array}$ & $\begin{array}{l}0.3 \\
0.7 \\
1.2\end{array}$ \\
\hline $\mathrm{NaNO}_{3}$ & $\begin{array}{r}19.96 \\
3.44\end{array}$ & $\mathrm{Na}_{2} \mathrm{O}$ & 10.7 \\
\hline $\begin{array}{l}\mathrm{NaNO}_{3}^{-} \\
\mathrm{Na}_{2} \mathrm{C}_{2} \mathrm{O}_{4} \\
\mathrm{NaOH}\end{array}$ & $\begin{array}{r}19.96 \\
5.01 \\
5.32\end{array}$ & $\mathrm{Na}_{2} \mathrm{O}$ & 10.7 \\
\hline $\begin{array}{l}\mathrm{Nd}(\mathrm{OH})_{3} \\
\mathrm{NdF}_{3}\end{array}$ & $\begin{array}{l}0.70 \\
0.86\end{array}$ & & \\
\hline $\begin{array}{l}\mathrm{Ni}(\mathrm{OH})_{2} \\
\mathrm{Pr}(\mathrm{OH})^{2} \\
\mathrm{SiO}_{2}\end{array}$ & $\begin{array}{l}4.46 \\
0.70 \\
4.46\end{array}$ & $\begin{array}{l}\mathrm{NiO} \\
\mathrm{Pr}_{6} \mathrm{O}_{11} \\
\mathrm{SiO}_{2}\end{array}$ & $\begin{array}{l}2.4 \\
0.4 \\
3.0\end{array}$ \\
\hline $\begin{array}{l}\mathrm{Sm}(\mathrm{OH})_{3} \\
\mathrm{Sr}(\mathrm{OH})_{2} \\
\mathrm{Y}(\mathrm{OH})_{3} \\
\mathrm{Zr}(\mathrm{OH})_{4}\end{array}$ & $\begin{array}{l}0.31 \\
0.70 \\
0.39 \\
4.62\end{array}$ & $\begin{array}{l}\mathrm{Sm}_{2} \mathrm{O}_{3} \\
\mathrm{SrO}_{2} \\
\mathrm{Y}_{2} \mathrm{O}_{3} \\
\mathrm{ZrO}_{2}\end{array}$ & $\begin{array}{l}0.2 \\
0.4 \\
0.2 \\
2.4\end{array}$ \\
\hline
\end{tabular}


$0.3 \mathrm{rpm}$ for all samples except for the $192 \mathrm{~g} \mathrm{WO} / \mathrm{L}$ and formated 60 wt\% frit (0.01 formic acid/g. frit) samples, which were done at $0.5 \mathrm{rpm}$. All samples were measured as prepared, with the- exception of the $17 \mathrm{~g} \mathrm{WO} / \mathrm{L}$ sample; the supernate was removed to accommodate the length of the shear vane.

\section{A.3 CHEMICAL COMPOUND PHYSICAL PROPERTIES}

The physical properties of chemical compounds in the HWVP process are provided in Table A-9.

\section{REFERENCE}

A-1 D. McCarthy, M. K. C. Chan, and R. 0. Lokken, Rheological Evaluation of Pretreated Cladding Removal Haste, PNL-5584, Pacific Northwest Laboratory, Richland, Hashington (1986). 
- TABLE A-9. Physical Properties of Feed and Reaction Products - DWPF (E.I. du Pont de Nemours and Co., Apri1 1985, "Basic Data Report - DWPF - Sludge Plant - SRP, 200-S Area," DPSP $80-1033$, SRP)

\begin{tabular}{|c|c|c|c|c|}
\hline Compound & $\begin{array}{l}\text { Moleculap } \\
\text { Neight }\end{array}$ & $1 b / f^{3}(a)$ & Vapor Pressure(b) & Heat Capacity(e) \\
\hline $\mathrm{Ag}$ & 107.88 & $655.49(20)$ & $\begin{array}{l}\text { a: } 5.2283 E+00 \\
\text { b: }-1.2583 E+04 \\
\text { c: }-7.8425 E+01\end{array}$ & 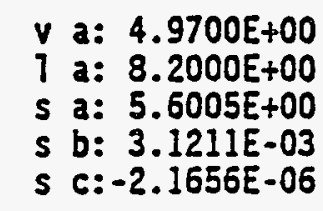 \\
\hline $\mathrm{AgNO}_{3}$ & 169.89 & 271.70 (19) & - & $\begin{array}{l}1 \text { a: } 3.0200 E+01 \\
s \text { a: } 2.2832 E+01 \\
\text { s b: } 1.2500 E-02\end{array}$ \\
\hline AgOH & 124.89 & $312.16(20)$ & & $\begin{array}{l}s \text { a: } 9.7600 E-02 \\
s \text { b: } 1.6467 E-05\end{array}$ \\
\hline $\mathrm{Ag}_{2} \mathrm{O}$ & 231.76 & $445.92(17)$ & & $\begin{array}{l}\text { s a: } 1.4260 E+01 \\
\text { s b: } 9.0000 E-03 \\
\text { s c: }-2.0000 E-06\end{array}$ \\
\hline $\mathrm{AT}(\mathrm{OH})_{3}$ & 77.99 & $151.04(20)$ & & $\begin{array}{l}\text { s a: } 2.1008 E+01 \\
\text { s b: } 5.0150 E-02\end{array}$ \\
\hline $\mathrm{Ba}\left(\mathrm{NO}_{3}\right)_{2}$ & $\begin{array}{l}101.94 \\
261.38\end{array}$ & $\begin{array}{l}249: 72(20) \\
202.47(23)\end{array}$ & $\begin{array}{l}\text { a: } 7.7801 E+00 \\
\text { b: }-2.8868 E+04 \\
\text { c: }-1.8231 E+02\end{array}$ & $\begin{array}{ll}1 & \text { a: } 3.3000 E+01 \\
\text { s a: } 1.7073 E+01 \\
\text { s b: } 2.1474 E-02 \\
\text { s c: }-5.0632 E-06 \\
\text { s a: } 3.9800 E+01 .\end{array}$ \\
\hline $\mathrm{BaCl}_{2}$ & 208.27 & $240.67(20)$ & & s a: $1.7001 E+01$ \\
\hline $\mathrm{BaO}$ & 153.36 & $357.10(20)$ & & $\begin{array}{ll}i & a: 9.1000 E-02 \\
\text { s } & a: 6.8617 \mathrm{E}-02 \\
\text { s b: } 1.5330 \mathrm{E}-04 \\
\text { s c: }-1.8231 \mathrm{E}-07\end{array}$ \\
\hline $\mathrm{BaSO}_{4}$ & 233.42 & 280.87 (15) & & $\begin{array}{l}s \text { a: } 2.4352 E+01 \\
\text { s b: } 1.6190 E-02 \\
s \text { c: }-1.8141 E-06\end{array}$ \\
\hline
\end{tabular}

(a) Temperature in ${ }^{\circ} C$ shown in parentheses.

(b) Vapor pressure data provided as the non-zero constants to fit the Antoine equation ${ }^{\log 10}(\dot{p})=a+b /(t+c)$," where $p$ is pressure in atm, and $t$ is in $k$.

(c) Heat capacity data provided as non-zero constants for the relationship "Ht Cap $=a+b t+c t t, "$ where heat capacity is in PCU/1b-mole-degree-C, and $t$ is in ${ }^{\circ} \mathrm{C}$. 
TABLE A-9. (contd)

\begin{tabular}{|c|c|c|c|c|}
\hline Compound & $\begin{array}{l}\text { Molecular } \\
\text { Weight }\end{array}$ & $1 b / f^{3}(a)$ & Vapor Pressure(b) & Heat Capacity(c) \\
\hline $\mathrm{B}_{2} \mathrm{O}_{3}$ & 69.64 & $115.49(20)$ & $\cdot$ & 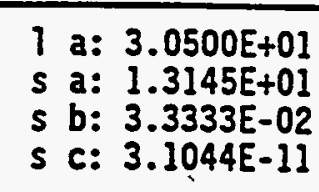 \\
\hline $\mathrm{Ca}(\mathrm{COOH})_{2}$ & 130.12 & 125.76. (20) & & 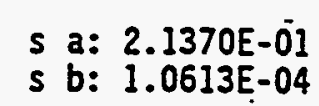 \\
\hline $\mathrm{Ca}(\mathrm{OH})_{2}$ & 74.10 & $137.85(20)$ & - & $S$ a: $2.1400 E+01$ \\
\hline Carbon & 12.01 & $141.09(20)$ & $\begin{array}{l}\text { a: } 9.2970 E+00 \\
\text { b: }-4.8772 E+04 \\
\text { c: } 1.4585 E+02\end{array}$ & 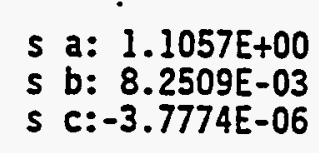 \\
\hline $\mathrm{CaCO}_{3}$ & 100.09 & $182.87(20)$ & & $\begin{array}{ll}s & a: \\
s & 1.8556 E+01 \\
s & b: 2083 E-02 \\
s & c:-6.8309 E-06\end{array}$ \\
\hline $\mathrm{CaCO}_{3}(\mathrm{C}-14)$ & 102.09 & $182.87(20)$ & $\cdot$ & $\begin{array}{l}\text { s a: } 1.8800 E-01 \\
\text { s b: } 2.4737 E-04 \\
\text { s c: }-1.0388 E-07\end{array}$ \\
\hline $\mathrm{CaC}_{2} \mathrm{O}_{4}$ & 128.10 & $137.84(4)$ & & $\begin{array}{l}\text { s a: } 1.6360 E-01 \\
\text { s b: } 1.0153 E-04\end{array}$ \\
\hline $\mathrm{CaF}_{2}$ & 78.08 & $198.48(20)$ & . & $\begin{array}{lll}1 & \text { a: } & 3.0580 E-01 \\
\text { s a: } & 1.5700 E+01 \\
\text { s b: } 2.1774 E-03 \\
\text { s c: } 1.0532 E-06\end{array}$ \\
\hline $\mathrm{CaO}$ & 56.08 & $207.21(20)$ & & $\begin{array}{l}s \text { a: } 9.5522 E+00 \\
s \text { b: } 8.4429 E-03 \\
s \text { c: }-2.7515 E-06\end{array}$ \\
\hline $\mathrm{CaSO}_{4}$ & 136.14 & $184.75(20)$ & & $\begin{array}{l}\text { s a: } 2.1421 \mathrm{E}+01 \\
\text { s b: } 2.9516 \mathrm{E}-02 \\
\text { s c: }-4.5026 \mathrm{E}-06\end{array}$ \\
\hline
\end{tabular}

(a) Temperature in ${ }^{\circ} C$ shown in parentheses.

(b) Vapor pressure data provided as the non-zero constants to fit the Antoine equation "Log10 $(p)=a+b /(t+c)$," where $p$ is pressure in $a t m$, and $t$ is in $K$.

(c) Heat capacity data provided as non-zero constants for the relationship "Ht Cap $=a+b t+c t t$, "where heat capacity is in PCU/Ib-mole-degree-c, and $t$ is in $\cdot c$. 
TABLE A-9. (contd)

\begin{tabular}{|c|c|c|c|c|}
\hline Compound & $\begin{array}{l}\text { Molecular } \\
\text { Weight }\end{array}$ & $.7 \mathrm{~b} / \mathrm{ft}^{3}(0)$ & Vapor Pressure ${ }^{(b)}$ & Heat Capacity(c) \\
\hline$C a_{3}\left(\mathrm{PO}_{4}\right)_{2}$ & 310.20 & $195.98(20)$ & & $\begin{array}{l}s \text { a: } 1.6960 E-01 \\
s \text { b: } 1.0460 E-04\end{array}$ \\
\hline $\mathrm{CO}(\mathrm{COOH})_{2}$ & 148.98 & $132.91(22)$ & & $\begin{array}{l}s \text { a: } 1.8460 E-01 \\
s \text { b: } 9.8067 E-05\end{array}$ \\
\hline $\mathrm{CO}(\mathrm{OH})_{2}$ & 92.95 & 224.56 (15) & & $\begin{array}{l}s \text { a: } 1.9960 E-01 \\
s \text { b: } 7.5400 E-05\end{array}$ \\
\hline $\mathrm{CO}(\mathrm{OH})_{3}$ & 109.96 & $278.43(20)$ & & $\begin{array}{l}s \text { a: } 2.2630 \mathrm{E}-01 \\
\mathrm{~s} \text { b: } 7.6067 \mathrm{E}-05\end{array}$ \\
\hline $\mathrm{COO}$ & 74.94 & $354.51(20)$ & & 1 a: $1.5500 E+01$ \\
\hline $\mathrm{Cr}(\mathrm{COOH})_{3}$ & 187.05 & $187.20(20)$ & & s a: $6.7400 \mathrm{E}+01$ \\
\hline $\mathrm{Cr}(\mathrm{OH})_{3}$ & 103.03 & $230.99(20)$ & . & $\begin{array}{l}s \text { a: } 2.3680 E-01 \\
s \text { b: } 6.6067 E-05\end{array}$ \\
\hline $\mathrm{Cr}_{2} \mathrm{O}_{3}$ & 152.02 & $325.18(20)$ & & $\begin{array}{l}s \text { a: } 2.7001 E+01 \\
s \text { b: } 4.0201 E-03\end{array}$ \\
\hline CsC1 & 168.36 & $248.96(20)$ & $\begin{array}{l}\text { a: } 5.4591 E+00 \\
\text { b: }-8.5237 E+03 \\
c:-1.8337 E-02\end{array}$ & $\begin{array}{l}\text { I a: } 1.1456 E-01 \\
\text { i b: }-7.3171 E-06 \\
\text { s a: } 1.1701 E+01 \\
s \text { b: } 4.1754 E-03\end{array}$ \\
\hline $\mathrm{CsCOOH}$ & 177.93 & $187.29(20)$ & & $\begin{array}{l}s \text { a: } 1.8900 \mathrm{E}-01 \\
s \text { b: } 1.5067 \mathrm{E}-05\end{array}$ \\
\hline $\mathrm{CsNO}_{3}$ & 194.92 & 230.18 (28) & & $\begin{array}{l}s \text { a: } 1.0070 E-01 \\
s \text { b: } 1.6800 E-05\end{array}$ \\
\hline $\mathrm{Cs}_{2} \mathrm{O}$ & 281.81 & $265.32(20)$ & & $\begin{array}{ll}l \text { a: } & 2.2000 E+01 \\
s \text { a: } & 6.4000 E-02 \\
s \text { b: } & 1.9000 E-05\end{array}$ \\
\hline $\mathrm{Cu}(\mathrm{COOH})_{2}$ & 153.61 & $114.31(20)$ & & \\
\hline $\mathrm{Cu}(\mathrm{OH})_{2}$ & 97.59 & $210.26(20)$ & & $\begin{array}{l}s: 1.8940 E-01 \\
s \text { b: } 4.3138 E-05\end{array}$ \\
\hline
\end{tabular}

(a) Temperature in ' $C$ shown in parentheses.

(b) Vapor pressure data provided as the non-zero constants to fit the Antoine equation "Log10 $(p)=a+b /(t+c)$," where $p$ is pressure in $a t m$, and $t$ is in $K$.

(c) Heat capacity data provided as non-zero constants for the relationship "Ht Cap $=a+b t+c t t, "$ where heat capacity is in PCU/lb-mole-degree-C, and $t$ is in ${ }^{\circ} \mathrm{C}$. 
TABLE A-9. (contd)

\begin{tabular}{|c|c|c|c|c|}
\hline Compound & $\begin{array}{l}\text { Molecular } \\
\text { Weight }\end{array}$ & $1 b / f t^{3}(a)$ & Vapor Pressure(b) & Heat Capacity(c) \\
\hline CuO & 79.57 & $\begin{array}{l}399.55(20) \\
50.82(-195)\end{array}$ & $\begin{array}{l}\text { a: } 8.1054 E+00 \\
\text { b: }-1.9810 E+02 \\
c:-1.8057 E+01\end{array}$ & 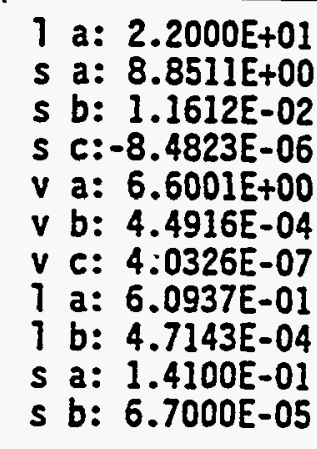 \\
\hline $\mathrm{CO}_{2}$ & 44.01 & $68.74(-37)$ & $\begin{array}{l}\text { a: } 6.1963 E+00 \\
\text { b: }-1.0953 E+03 \\
\text { c: }-1.8185 E+01\end{array}$ & $\begin{array}{lll}v & a: 7.7187 E+00 \\
v & b: 1.2472 E-02 \\
v & c:-7.0708 E-06 \\
l & a: 5.8979 E-01 \\
l & b: 7.8917 E-03 \\
l & c: 9.5952 E-05 \\
\text { s a: } & 1.2400 E-01\end{array}$ \\
\hline $\mathrm{CO}_{2}(\mathrm{C}-14)$ & 46.01 & $68.74(-37)$ & $\begin{array}{l}\text { a: } 6.1963 E+00 \\
\text { b: }-1.0953 E+03 \\
c:-1.8185 E+01\end{array}$ & 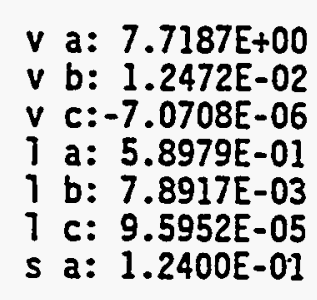 \\
\hline $\mathrm{Fe}(\mathrm{OH})_{3}$ & 106.87 & $243.48(20)$ & & $\begin{array}{l}s \text { a: } 5.5100 E-02 \\
s \text { b: } 2.1940 E-04\end{array}$ \\
\hline $\mathrm{FeO}$ & 71.85 & $355.85(20)$ & & $\begin{array}{l}\text { s a: } 1.1883 E+01 \\
\text { s b: } 4.1733 E-03 \\
\text { s c c: }-1.3750 E-06\end{array}$ \\
\hline $\mathrm{Fe}_{2} \mathrm{O}_{3}$ & 159.70 & $827.12(20)$ & & $\begin{array}{ll}\text { s } & a: 2.3043 E+01 \\
\text { s } & b: 3.0077 E-02 \\
\text { s } & c:-9.5089 E-06 \\
\text { s b: } & 4.6667 \mathrm{E}-05\end{array}$ \\
\hline
\end{tabular}

(a) Temperature in ${ }^{\circ} \mathrm{C}$ shown in parentheses.

(b) Vapor pressure data provided as the non-zero constants to fit the Antoine equation $" \log 10(p)=a+b /(t+c)$," where $p$ is pressure in atm, and $t$ is in $K$.

(c) Heat capacity data provided as non-zero constants for the relationship "Ht Cap $=a+b t+c t t, "$ where heat capacity is in PCU/lb-mole-degree-C, and $t$ is in $\cdot C$. 
TABLE. A-9. ' (contd)

\begin{tabular}{|c|c|c|c|c|}
\hline Compound & $\begin{array}{l}\text { Molecular } \\
\text { Weight }\end{array}$ & $7 b / f^{3}(a)$ & Vapor Pressure ${ }^{(b)}$ & Heat Capacity $(c)$ \\
\hline Group $A(d)$ & 98.37 & $462.23(20)$ & & s a: $6.0000 E-02$ \\
\hline Group $B(e)$ & 122.97 & 413.93. (20) & . & $\begin{array}{l}s \text { a: } 5.5000 E-02 \\
s \text { b: } 3.3333 E-05\end{array}$ \\
\hline $\mathrm{Hg}$ & 200.61 & $845.68(20)$ & $\begin{array}{l}\text { a: } 4.8256 E+00 \\
\text { b: }-2.9794 E+03 \\
c:-1.2737 E+01\end{array}$ & $\begin{array}{lll}\text { y a: } & 4.9700 E+00 \\
\text { i a : } & 6.6100 E+00 \\
\text { s a: } & 3.5587 \mathrm{E}-02 \\
\text { s b: } & 1.1216 \mathrm{E}-04 \\
\text { s c: } & 2.4979 \mathrm{E}-07\end{array}$ \\
\hline $\mathrm{Hg}\left(\mathrm{NO}_{3}\right)_{2}$ & 324.59 & $274.69(20)$ & & $\begin{array}{l}s \text { a: } 9.9500 \mathrm{E}-02 \\
s \text { b: } 1.7600 \mathrm{E}-05\end{array}$ \\
\hline $\mathrm{HgCl}_{2}$ & 271.52 & $345.86(20)$ & $\begin{array}{l}\text { a: } 5.7340 E+00 \\
b:-2.8773 E+03 \\
c:-7.5359 E+01\end{array}$ & $\begin{array}{ll}s & a: 2.0592 E+01 \\
\text { s } & b:-1.9339 E-02 \\
\text { s c } & \text { : } 1.5625 E-05\end{array}$ \\
\hline Hgo & 216.61 & $695.29(20)$ & & $\mathrm{s}$ a: $1.1500 \mathrm{E}+01$ \\
\hline HCT & 36.47 & $74.10(-85)$ & $\begin{array}{l}\text { a: } 3.5934 E+00 \\
\text { b: }-5.3299 E+02 \\
c:-4.0025 E+01\end{array}$ & $\begin{array}{l}v \text { a: } 6.6999 \mathrm{E}+00 \\
v \text { b: }-5.7884 \mathrm{E}-04 \\
v \text { c: } 6.7057 \mathrm{E}-07\end{array}$ \\
\hline $\mathrm{HCOOH}$ & 46.03 & 76.15 (20) & $\begin{array}{l}\text { a: } 2.8202 E+00 \\
b:-6.7307 E+02 \\
c:-1.3509 E+02\end{array}$ & $\begin{array}{l}v \text { a: } 2.3500 E-01 \\
1 \text { a: } 5.1300 E-01 \\
s \text { a: } 4.3000 E-01 \\
s \text { b: } \cdot 1.9545 E-03\end{array}$ \\
\hline
\end{tabular}
(a) Temperature in ${ }^{\circ} \mathrm{C}$ shown in parentheses.
(b) Vapor pressure data provided as the non-zero constants to fit the Antoine equation " $\log 10(p)=a+b /(t+c), "$ where $p$ is pressure in atm, and $t$ is in' $K$.
(c) Heat capacity data provided as non-zero constants for the relationship "Ht Cap $=a+b t+c t t$," where heat capacity is in PCU/7b-mole-degree-c, and $t$ is in ${ }^{\circ} \mathrm{c}$.
(d) Cd, Mo, Rb, Se, Tc, Te.
(e) Ag, Am, Ce, Cm, Co, Cr, Ev, La, Nb, Nd, Np, Pm, Pr, Sb, Sm, Sn, Tb, Tl, $\mathrm{Zr}$. 
TABLE A-9. (contd) .

\begin{tabular}{|c|c|c|c|c|}
\hline Compound & $\begin{array}{l}\text { Molecular } \\
\text { Weight }\end{array}$ & $\mathrm{lb} / \mathrm{ft}^{3}(\mathrm{a})$ & Vapor Pressure(b) & Heat Capacity(c) \\
\hline $\mathrm{HF}$ & 20.01 & $61.67(14)$ & $\begin{array}{l}\text { a: } 4.8002 E+00 \\
\text { b:-1.4756E+03 } \\
\text { c: } 1.4730 E+01\end{array}$ & $\begin{array}{l}\text { v a: } 6.9999 \mathrm{E}+00 \\
\text { v b: }-3.4699 \mathrm{E}-04 \\
\text { v c: } 8.7500 \mathrm{E}-07\end{array}$ \\
\hline $\mathrm{HNO}_{3}$ & 63.02 & $93.75(20)$ & $\begin{array}{l}\text { a: } 4.8881 E-01 \\
\text { b: }-5.0679 E+01 \\
\dot{c}:-2.3533 E+02\end{array}$ & $\begin{array}{l}\text { s a: } 1.2706 E+01 \\
s \text { b: } 2.1229 \mathrm{E}-02 \\
\text { s c:-1.1708E-05 }\end{array}$ \\
\hline $\mathrm{H}_{2}$ & 2.02 & $4.43(-253)$ & $\begin{array}{l}\text { a: } 3.0930 E+00 \\
\text { b: }-6.9270 E+01 \\
\text { c: } 1.7456 E+00\end{array}$ & $\begin{array}{l}v \text { a: } 6.6201 E+00 \\
v \text { b: } 8.9307 E-04\end{array}$ \\
\hline $\mathrm{H}_{2} \mathrm{C}_{2} \mathrm{O}_{4}$ & 90.03 & $103.20(19)$ & $\begin{array}{l}\text { a: } 9.3419 E+00 \\
b:-4.7268 E+03 \\
\text { c: }-5.1700 E-03\end{array}$ & $\begin{array}{l}\text { s a: } 2.5900 \mathrm{E}-01 \\
\mathrm{~s} \text { b: } 7.6000 \mathrm{E}-04\end{array}$ \\
\hline $\mathrm{H}_{2} \mathrm{O}$ & 18.02 & $62.43(4)$ & 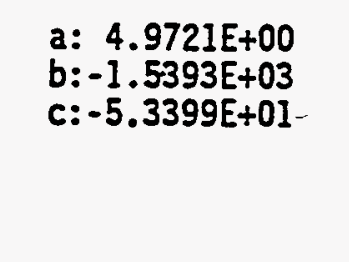 & $\begin{array}{lll}v & a: & 4.6359 E-01 \\
v & b: 5.0097 E-05 \\
v & c: 7.3967 E-08 \\
l & a: 1.0080 E+00 \\
1 & b:-4.1862 E-04 \\
l & c: 4.1462 E-06\end{array}$ \\
\hline $\mathrm{H}_{2} \cdot \mathrm{SO}_{4}$ & 98.08 & $114.27(18)$ & & $\begin{array}{l}\text { s a: } 4.1820 E+01 \\
\text { s b: }-4.5890 E-02 \\
\text { s c: } 4.3588 E-05\end{array}$ \\
\hline$I_{2}$ & .253 .84 & $307.77(20)$ & $\begin{array}{l}\text { a: } 3.0620 E+00 \\
\text { b: }-9.1143 E+02 \\
c:-1.5848 E+02\end{array}$ & $\begin{array}{lll}v & a: & 9.0000 E+00 \\
\text { s a: } & 4.1193 E-02 \\
\text { s b: } & 2.1236 E-05 \\
\text { s c: } & 2.0525 E-06\end{array}$ \\
\hline $\mathrm{KMnO}_{4}$ & 158.03 & $168.74(20)$ & & $s$ a: $2.8000 E+01$ \\
\hline $\mathrm{KNO}_{3}$ & 101.10 & 131.73 (11) & . & $\begin{array}{lll}\text { l a: } & 2.9500 E+01 \\
\text { s a: } & 2.0426 E+01 \\
\text { s b: } & 3.9099 E-02 \\
\text { s c: } & 1.2207 E-04\end{array}$ \\
\hline $\mathrm{K}_{2} \mathrm{O}$ & & 94.19 & $144.84(20)$ & $\begin{array}{l}s \text { a: } 1.7160 E-01 \\
s \text { b: } 4.2207 E-04\end{array}$ \\
\hline
\end{tabular}

(a) Temperature in ${ }^{\circ} \mathrm{C}$ shown in parentheses.

(b) Vapor pressure data provided as the non-zero constants to fit the Antoine equation $\log 10(p)=a+b /(t+c)$," where $p$ is pressure in atm, and $t$ is in $K$.

(c) Heat capacity data provided as non-zero constants for the relationship "Ht Cap = $a+b t+c t t, "$ where heat capacity is in PCU/1b-mole-degree-c, and $t$ is in $\cdot c$. 
TABLE A-9. (contd)

\begin{tabular}{|c|c|c|c|c|}
\hline Compound & $\begin{array}{l}\text { Molecular } \\
\text { Weight }\end{array}$ & $7 b / f^{3}(a)$ & Vapor Pressure(b) & Heat Capacity(c) \\
\hline $\mathrm{La}_{2} \mathrm{O}_{3}$ & 325.82 & 406.41 (15) & & 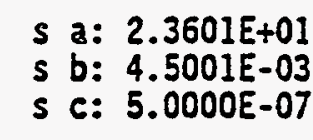 \\
\hline $\mathrm{Li}_{2} \mathrm{O}$ & 29.88 & $125.64(25)$ & & $\begin{array}{l}1 \text { a: } 2.1000 E+01 \\
\text { s a: } 4.3100 E-01 \\
\text { s b: } 1.8000 E-04\end{array}$ \\
\hline $\mathrm{Mg}(\mathrm{COOH})_{2}$ & 114.35 & $88.65(20)$ & . & $\begin{array}{l}s \text { a: } 2.4020 E-01 \\
s \text { b: } 1.1240 E-04\end{array}$ \\
\hline $\mathrm{Mg}(\mathrm{OH})_{2}$ & 58.34 & $147.33(20)$ & & s a: $1.8200 \mathrm{E}+01$ \\
\hline MgO & 40.32 & $227.81(20)$ & & $\begin{array}{l}\text { s a: } 8.0606 E+00 \\
\text { s b: } 5.4676 E-03 \\
s \text { c: }-1.5713 E-06\end{array}$ \\
\hline $\mathrm{Mn}(\mathrm{COOH})_{2}$ & 144.98 & 121.93. (20) & & $\begin{array}{l}s \text { a: } 1.9130 E-01 \\
\text { s b: } 9.6667 E-05\end{array}$ \\
\hline $\mathrm{Mn}\left(\mathrm{NO}_{3}\right)_{2}$ & 178.37 & $113.62(20)$ & & $\begin{array}{l}s \text { a: } 1.7140 E-01 \\
s \text { b: } 5.7667 E-05\end{array}$ \\
\hline $\mathrm{Mn}(\mathrm{OH})_{2}$ & 88.95 & $203.40(13)$ & & $\begin{array}{l}s \text { a: } 2.1120 E-01 \\
s \text { b: } 7.2067 E-05\end{array}$ \\
\hline Mno & 70.93 & $340.86(20)$ & & $\begin{array}{l}l \text { a: } 1.3500 E+01 \\
\text { s a: } 1.1695 E+01 \\
\text { s b: } 1.6488 E-02 \\
s \text { c: }-3.6199 E-06\end{array}$ \\
\hline $\mathrm{MnO}_{2}$ & 86.93 & $313.69(20)$ & & $\begin{array}{l}\text { s a: } 1.1711 \mathrm{E}+01 \\
\text { s b: } 3.1775 \mathrm{E}-02 \\
\text { s c: }-2.9700 \mathrm{E}-05\end{array}$ \\
\hline
\end{tabular}

(a) Temperature in ${ }^{\circ} C$ shown in parentheses.

(b) Vapor pressure data provided as the non-zero constants to fit the Antoine equation $" \log 10(p)=a+b /(t+c)$," where $p$ is pressure in $a t m$, and $t$ is in $k$.

(c) Heat capacity data provided as non-zero constants for the relationship "Ht Cap = a + bt $+\mathrm{ctt,"} \mathrm{where} \mathrm{heat} \mathrm{capacity} \mathrm{is} \mathrm{in} \mathrm{PCU/7b-mole-degree-C,}$ and $t$ is in ${ }^{\circ} \mathrm{C}$. 
TABLE A-9. (contd)

\begin{tabular}{|c|c|c|c|c|}
\hline Compound & $\begin{array}{l}\text { Moiecular } \\
\text { Weight }\end{array}$ & $1 \mathrm{~b} / \mathrm{ft}^{3}(\mathrm{~s})$ & Vapor Pressure $(b)$ & Heat Capacity(c) \\
\hline $\mathrm{HoO}_{2}$ & 127.94 & $403.92(20)$ & & $\begin{array}{l}\text { s a: } 1.8102 E+01 \\
\text { s b: } 1.3836 E-02 \\
\text { s c: }-3.1644 E-06\end{array}$ \\
\hline $\mathrm{Na}(\mathrm{HgO}(\mathrm{OH}))$ & 256.59 & $412.97(20)$ & & $\begin{array}{l}s \text { a: } 8.7500 E-02 \\
s \text { b: } 2.6200 E-05\end{array}$ \\
\hline $\mathrm{NaAg}(\mathrm{OH})_{2}$ & 164.88 & $312.00(1000)$ & & $\begin{array}{l}s \text { a: } 1.1601 E+01 \\
s \text { b: } 8.7912 E-03\end{array}$ \\
\hline $\mathrm{NaAl}_{(\mathrm{OH})_{4}}$ & 117.00 & $124.00(20)$ & - & $\begin{array}{l}s \text { a:: } 1.7073 E+01 \\
s \text { b: } 2.1474 E-02 \\
s \text { c: }-5.0632 E-06\end{array}$ \\
\hline $\mathrm{NaBO}_{2}$ & 65.81 & $153.82(20)$ & & $\begin{array}{l}\text { s a: } 1.5403 E+01 \\
\text { s b: } 2.1738 E-02 \\
\text { s c: }-2.1433 E-06\end{array}$ \\
\hline $\mathrm{NaCl}$ & 58.45 & $135.04(20)$ & $\begin{array}{l}\text { a: } 5.0803 E+00 \\
\text { b: }-8.4237 E+03 \\
\text { c: }-8.0044 E+01\end{array}$ & $\begin{array}{lll}l & \text { a: } & 1.5900 E+01 \\
\text { s a: } & 1.1790 E+01 \\
\text { s b: } & 1.2494 E-03 \\
\text { s c } & \text { c: } 3.1172 E-06\end{array}$ \\
\hline $\mathrm{NaCOOH}$ & 68.01 & $.119 .77(20)$ & & $\begin{array}{l}s \text { a: } 2.5570 E-01 \\
s \text { b: } 1.4107 E-04\end{array}$ \\
\hline $\mathrm{NaF}$ & 42.00 & $174.18(20)$ & $\begin{array}{l}\text { a: } 5.8112 E+00 \\
b:-1.0994 E+04 \\
c:-8.5351 E+01\end{array}$ & $\begin{array}{l}\text { s a: } 1.0401 E+01 \\
\text { s b: } 5.0601 E-03 \\
\text { s c: }-2.0489 E-06\end{array}$ \\
\hline $\mathrm{NaI}$ & 149.92 & $228.87(0)$ & $\begin{array}{l}a: 4.8993 E+00 \\
b:-7.1054 E+03 \\
c:-1.2688 E+02\end{array}$ & $\begin{array}{l}\text { s a: } 1.2500 E+01 \\
\text { s b: }-1.5069 \mathrm{E}-03 \\
\text { s c: } 4.5499 \mathrm{E}-06\end{array}$ \\
\hline $\mathrm{NaNO}_{2}$ & 69.01 & $135.35(0)$ & & $\begin{array}{l}\text { s a: } 2.3010 \mathrm{E}-01 \\
\text { s b: }\end{array}$ \\
\hline $\mathrm{NaNO}_{3}$ & 85.01 & $140.87(20)$ & & $\begin{array}{l}1 \text { a: } 3.7200 E+01 \\
\text { s a: } 1.9569 E+01 \\
s \text { b: } 5.8065 E-02\end{array}$ \\
\hline
\end{tabular}

(a) Temperature in ${ }^{\circ} \mathrm{C}$ shown in parentheses.

(b) Vapor pressure data provided as the non-zero constants to fit the Antoine equation "Log10 $(p)=a+b /(t+c), "$ where $p$ is pressure in $a t m$, and $t$ is in $K$.

(c) Heat capacity data provided as non-zero constants for the relationship "Ht Cap $=a+b t+c t t$," where heat capacity is in PCU/lb-mole-degree- $C$, and $t$ is in ${ }^{\circ} \mathrm{C}$. 
TABLE A-9. (contd)

\begin{tabular}{|c|c|c|c|c|}
\hline Compound & $\begin{array}{l}\text { Molecular } \\
\text { Weight }\end{array}$ & $1 b / f^{3}(a)$ & Vapor Pressure(b) & Heat Capacity(c) \\
\hline $\mathrm{NaOH}$ & 40.00 & $132.94(20)$ & $\begin{array}{l}a: 4.5747 E+00 \\
b:-7.5654 E+03\end{array}$ & $\begin{array}{l}s \text { a: } 3.2300 E-01 \\
s \text { b: } 1.4473 E-04\end{array}$ \\
\hline$\cdot \mathrm{Na}_{2} \mathrm{~B}_{6} \mathrm{O}_{7}$ & 201.27 & $147.73(20)$ & & s a: $4.7900 E+01$ \\
\hline $\mathrm{Na}_{2} \mathrm{CrO}_{4}$ & 162.00 & $169.95(20)$ & - & s a: $2.8000 E+01$ \\
\hline $\mathrm{Na}_{2} \mathrm{CO}_{3}$ & $\begin{array}{c}106.00 \\
:\end{array}$ & $158.09^{\circ}(20)$ & & $\begin{array}{l}1 \text { a: } 3.4807 E-02 \\
.1 \text { b: } 1.0120 E-05 \\
\text { s a: } 2.8900 E+01\end{array}$ \\
\hline $\mathrm{Na}_{2} \mathrm{CO}_{3}(\mathrm{C}-14)$ & 108.00 & $158.09(20)$ & & $\begin{array}{ll}1 & \text { a: } 3.4807 E-02 \\
1 & \text { b: } 1.0120 E-05 \\
\text { s a: } 2.8900 E+01\end{array}$ \\
\hline $\mathrm{Na}_{2} \mathrm{C}_{2} \mathrm{O}_{4}$ & 134.01 & $146.09(20)$ & & $\begin{array}{l}s \text { a: } 2.0850 E-01 \\
s \text { b: } 1.3713 E-04\end{array}$ \\
\hline $\mathrm{Na}_{2} \mathrm{HOO}_{6}$ & 205.92 & $204.77(20)$ & & $\begin{array}{l}\text { s a: } 1.8102 E+01 \\
\text { s b: } 1.3336 E-02 \\
\text { s c: }-3.1644 E-06\end{array}$ \\
\hline $\mathrm{Na}_{2} \mathrm{O}$ & 61.99 & $141.68(20)$ & & $\begin{array}{l}1 \text { a: } 2.2000 E+01 \\
\text { s a: } 2.7700 E-01 \\
\text { s b: } 8.8000 E-05\end{array}$ \\
\hline $\mathrm{Na}_{2} \mathrm{PuO}_{2}(\mathrm{OH})_{4}$ & 385.01 & $369.96(20)$ & - & $\begin{array}{l}s \text { a: } 1.3120 E-01 \\
s \text { b: } 5.1400 E-05\end{array}$ \\
\hline $\mathrm{Na}_{2} \mathrm{RhO}_{4}$ & 212.88 & $187.29(20)$ & . & $\begin{array}{l}s \text { a: } 1.4470 E-01 \\
s \text { b: } 6.9800 E-05\end{array}$ \\
\hline $\mathrm{Na}_{2} \mathrm{RuO}_{4}$ & 211.05 & $187.29(20)$ & & $\begin{array}{l}\text { s a: } 1.4440 E-01 \\
\text { s b: } 6.7133 E-05\end{array}$ \\
\hline $\mathrm{Na}_{2} \mathrm{SiO}_{3}$ & 122.05 & $163.84(10)$ & & $\begin{array}{l}s \text { a: } 1.1585 E+01 \\
\text { s b: } 5.8536 E-03 \\
\text { s c: } 3.6344 E-12\end{array}$ \\
\hline
\end{tabular}

(a) Temperature in ${ }^{\circ} C$ shown in parentheses.

(b) Vapor pressure data provided as the non-zero constants to fit the Antoine equation $" \log 10(p)=a+b /(t+c)$," where $p$ is pressure in $a t m$, and $t$ is in $k$.

(c) Heat capacity data provided as non-zero constants for the relationship "Ht Cap = a + bt + ctt," where heat capacity is in PCU/7b-mole-degree-C, and $t$ is in ${ }^{\circ} C$. 
TABLE A-9. (contd)

\begin{tabular}{|c|c|c|c|c|}
\hline Compound & $\begin{array}{l}\text { Molecular } \\
\text { Weight }\end{array}$ & $\mathrm{lb} / \mathrm{ft}^{3}(a)$ & Vapor Pressure( $b)$ & Heat Capacity(c) \\
\hline $\mathrm{Na}_{2} \mathrm{SO}_{4}$ & 142.05 & $168.39(20)$ & & s a: $3.2800 E+01$ \\
\hline $\mathrm{Na}_{3} \mathrm{PO}_{4}$ & 163.97 & 158.34 (18) & & s a: $2.2100 E+01$ \\
\hline $\mathrm{Ni}(\mathrm{COOH})_{2}$. & 148.72 & $134.47(20)$ & & $\begin{array}{l}s \text { a: } 1.8550 E-01 \\
s \text { b: } 1.1667 E-04\end{array}$ \\
\hline $\mathrm{Ni}(\mathrm{OH})_{2}$ & 92.71 & $272.19(20)$ & - & $\begin{array}{l}\text { s a: } 2.0110 E-01 \\
\text { s b: } 1.0513 E-04\end{array}$ \\
\hline Nio & 74.69 & $464.98(20)$ & & $\begin{array}{l}\text { s a: }: 1.1300 E+01 \\
\text { s b: } 2.0000 E-03\end{array}$ \\
\hline $\mathrm{NH}_{4} \mathrm{NO}_{3}$ & 30.05 & $103.64(20)$ & & $s$ a: $3.1800 E+01$ \\
\hline NO & 30.01 & $79.22(-150)$ & $\begin{array}{l}\text { a: } 3.8150 E+00 \\
b:-2.9084 E+02 \\
c:-4.5214 E+01\end{array}$ & $\begin{array}{lll}v & a: & 6.2897 E+00 \\
v & b: & 8.8153 E-04 \\
v & c:-6.3233 E-08 \\
1 & a: 5.0721 E+00 \\
1 & b: & 2.8472 E-02\end{array}$ \\
\hline $\mathrm{NO}_{2}$ & 46.01 & $90.38(20)$ & $\begin{array}{l}\text { a: } 5.9329 E+00 \\
b:-1.7459 E+03 \\
c:-1.5084 E-02\end{array}$ & $\begin{array}{lll}v & \text { a: } & 8.8263 E+00 \\
v & b: & 9.3931 E-03 \\
\text { v c c: }-5.4583 E-06 \\
1 \\
\text { a: } 3.5912 E-01 \\
1 & b: 4.2159 E-04\end{array}$ \\
\hline $\mathrm{N}_{2}$ & 28.02 & $\begin{array}{l}64.05(-253) \\
50.44(-196)\end{array}$ & $\begin{array}{l}\text { a: } 3.1161 E+00 \\
\text { b: }-1.9655 E+02 \\
c:-1.4275 E+01\end{array}$ & 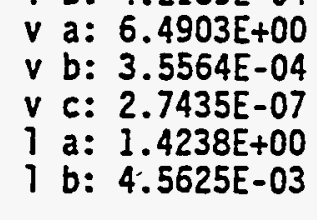 \\
\hline $\mathrm{O}_{2}$ & 82.00 & $\begin{array}{l}71.17(-188) \\
89.03(-253)\end{array}$ & $\begin{array}{l}\text { a: } 3.8101 E+00 \\
b:-3.1857 E+02 \\
c:-6.4376 E+00\end{array}$ & $\begin{array}{ll}v & a: 6.1549 E+00 \\
v & b: 1.1023 E-03 \\
v & c:-9.4125 E-08 \\
v & a: 3.9434 \mathrm{E}-01 \\
1 & b:-2.9197 \mathrm{E}-06\end{array}$ \\
\hline $\mathrm{PbCO}_{3}$ & 267.22 & $412.04(20)$ & & s a: $2.1100 E+01$ \\
\hline
\end{tabular}

(a) Temperature in ${ }^{\circ} \mathrm{C}$ shown in parentheses.

(b) Vapor pressure data provided as the non-zero constants to fit the Antoine equation "Log10 $(p)=a+b /(t+c)$," where $p$ is pressure in $a t m$, and $t$ is in $K$.

(c) Heat capacity data provided as non-zero constants for the relationship "Ht Cap $=a+b t+c t t$," where heat capacity is in PCU/lb-mole-degree-c, and $t$ is in ${ }^{\circ} C$. 
TABLE A-9. (contd)

\begin{tabular}{|c|c|c|c|c|}
\hline Compound & $\begin{array}{l}\text { Molecular } \\
\text { Weight }\end{array}$ & $7 b / f^{3}(a)$ & Vapor Pressure(b) & Heat Capacity(c) \\
\hline $\mathrm{PbO}$ & 223.21 & $594.94(20)$ & $\begin{array}{l}\text { a: } 6.2669 E+00 \\
\text { b: }-1.0527 E+04 \\
c:-6.5372 E+01\end{array}$ & $\begin{array}{l}\text { v a: } 8.1000 E+00 \\
\text { l a: } 1.4600 E+01 \\
\text { s a: } 1.0332 E+01 \\
\text { s b: } 1.1062 E-02 \\
\text { s c: }-2.7233 E-05\end{array}$ \\
\hline $\mathrm{PbS}$ & 239.27 & $468.25(20)$ & $\begin{array}{l}\text { a: } 5.8872 E+00 \\
\text { b: }-7.6870 E+03 \\
c:-2.4845 E+02\end{array}$ & $\begin{array}{l}s \text { a: } 1.1630 E+01 \\
s \text { b: } 3.3338 E-03\end{array}$ \\
\hline $\mathrm{PbSO}_{4}$. & 303.27 & $386.97(20)$ & & s a: $2.6400 E+01$ \\
\hline $\mathrm{Pd}\left(\mathrm{NO}_{3}\right)_{2}$ & 230.72 & $\begin{array}{l}749.16(20)^{\circ} \\
562.20(20)\end{array}$ & & $\begin{array}{lll}1 & \text { a: } & 9.0000 E+00 \\
s & \text { a: } & 5.4101 E+00 \\
s & b: & 6.4583 E-04 \\
s & c: & 8.3354 E-07 \\
s & a: & 1.3270 E-014 \\
s & b: & 3.4467 E-05\end{array}$ \\
\hline $\mathrm{Pd}(\mathrm{OH})_{2}$ & 140.72 & $387.07(20)$ & & $\begin{array}{l}s \text { a: } 1.3390 E-01 \\
s \text { b: } 2.9000 E-05\end{array}$ \\
\hline Pdo & 122.70 & $543.14(20)$ & - & 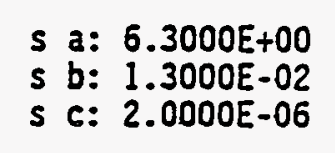 \\
\hline $\mathrm{Pu}(\mathrm{COOH})_{4}$ & 419.13 & $374.58(20)$ & - & $\begin{array}{l}s \text { a: } 1.1790 E-01 \\
s \text { b: } 5.7733 E-05\end{array}$ \\
\hline $\mathrm{PuO}_{2}$ & 274.00 & $715.42(20)$ & & $\begin{array}{ll}l & a: 2.0500 E+01 \\
\text { s a: } & 1.3615 E+01 \\
\text { s b: } & 1.2875 E-02 \\
s & c:-5.5506 E-06\end{array}$ \\
\hline Rh & 102.91 & $780.38(20)$ & & $\begin{array}{l}1 \text { a: } 9.0000 E+00 \\
s \text { a: } 5.4000 E+00\end{array}$ \\
\hline $\mathrm{RhO}_{2}$ & 134.90 & $435.12(20)$ & & $S$ a: 8.7600 E-02 \\
\hline & & & & \\
\hline
\end{tabular}

(a) Temperature in ${ }^{\circ} C$ shown in parentheses.

(b) Vapor pressure data provided as the non-zero constants to fit the Antoine equation " $\log 10(p)=a+b /(t+c)$, " where $p$ is pressure in $a t m$, and $t$ is in $K$.

(c) Heat capacity data provided as non-zero constants for the relationship "Ht Cap $=a+b t+c t t, "$ where heat capacity is in PCU/lb-mole-degree- $c$,
and $t$ is in $c$. 
TABLE A-9. (contd)

\begin{tabular}{|c|c|c|c|c|}
\hline Compound & $\begin{array}{l}\text { Molecular } \\
\text { Height }\end{array}$ & $\mathrm{lb} / \mathrm{ft}^{3}(\mathrm{a})$ & Vapor Pressure ${ }^{(b)}$ & Heat Capacity(e) \\
\hline $\mathrm{RuO}_{2}$ & 133.07 & $435.12(20)$ & & $\begin{array}{l}\text { s a: } 1.2400 E+01 \\
s \text { b: } 6.0000 E-03\end{array}$ \\
\hline $\mathrm{RuO}_{4}$ & 165.70 & $360.22(100)$ & & $\begin{array}{l}\text { I a: } 3.3000 E+01 \\
\text { s a: } 2.0000 E+01\end{array}$ \\
\hline $\mathrm{SiO}_{2}$ & 60.06 & $143.55(20)$ & $\begin{array}{l}\text { a: } 7.9725 E+00 \\
\text { b: }-2.0675 E+04 \\
\text { c: } 9.3084 E+01\end{array}$ & $\begin{array}{l}l \text { a: } 2.0000 E+01 \\
\text { s a: } 9.6363 \mathrm{E}+00 \\
\text { s b: } 1.7343 \mathrm{E}-02 \\
\text { s c: }-6.2682 \mathrm{E}-06\end{array}$ \\
\hline $\mathrm{Sr}(\mathrm{COOH})_{2}$ & 177.66 & $168.08(20)$ & & $\begin{array}{l}\text { s a: } 1.5520 E-01 \\
\text { s b: } 6.5800 E-05\end{array}$ \\
\hline $\operatorname{Sr}\left(\mathrm{NO}_{3}\right)_{2}$ & 211.65 & $186.42(20)$ & & $\begin{array}{l}\text { s a: } 2.2857 E-01 \\
\text { s b: } 4.2806 E-04 \\
\text { s c: }-1.8484 E-07\end{array}$ \\
\hline $\mathrm{Sr}(\mathrm{OH})_{2}$ & 121.65 & $226.31(20)$ & & $\begin{array}{l}\text { s a: } 1.5320 E-01 \\
s \text { b: } 3.3533 E-05\end{array}$ \\
\hline $\mathrm{SrCO}_{3}$ & 147.64 & $230.93(20)$ & & $s$ a: $2.1800 E+01$ \\
\hline Sro & 103.63 & $293.35(20)$ & . & $\begin{array}{l}s \text { a: } 9.9000 E-02 \\
s \text { b: } 5.0000 E-05\end{array}$ \\
\hline $\mathrm{SO}_{2}$ & 64.06 & $\begin{array}{c}86.66(20) \\
.\end{array}$ & $\begin{array}{l}\text { a: } 3.7965 E-01 \\
\text { b:-3.6739E+01 } \\
\text { c: }-1.6638 E+02\end{array}$ & $\begin{array}{lll}v & a: & 8.4916 E+00 \\
v & b: 5: 0011 E-03 \\
v & c:-8.3000 E-07 \\
i & a: 2.9925 E-01 \\
1 & b: & 4.1250 E-04 \\
s & a: & 2.2900 E-01\end{array}$ \\
\hline $\mathrm{SO}_{3}$ & 80.06 & $19.82(20)$ & $\begin{array}{l}\text { a: } 8.4432 E+00 \\
\text { c: } 7.2675 \mathrm{E}+02\end{array}$ & $\begin{array}{ll}v & a: 1.1991 E+01 \\
v & b: 1.7503 E-02 \\
v & c:-9.3750 E-06 \\
i & a: 3.3520 E-01\end{array}$ \\
\hline
\end{tabular}

(a) Temperature in ${ }^{\circ} \mathrm{C}$ shown in parentheses.

(b) Vapor pressure data provided as the non-zero constants to fit the Antoine equation $" \log 10(p)=a+b /(t+c)$," where $p$ is pressure in atm, and $t$ is in $k$

(c) Heat capacity data provided as non-zero constants for the relationship "Ht Cap = a + bt + ctt," where heat capacity is in PCU/1b-mole-degree-C, and $t$ is in ${ }^{\circ} \mathrm{C}$. 
TABLE A-9. (contd)

\begin{tabular}{|c|c|c|c|c|}
\hline Compound & $\begin{array}{l}\text { Molecular } \\
\text { Weight }\end{array}$ & $\cdot 1 b / f^{3}(a)$ & Vapor Pressure(b) & Heat Capacity(c) \\
\hline $\mathrm{ThO}_{2}$ & 264.12 & $604.79(20)$ & & $\begin{array}{l}s \text { a: } 1.5600 E+01 \\
s \text { b: } 3.0006 E-03 \\
s \text { c: } 2.0000 E-06\end{array}$ \\
\hline $\mathrm{TiO}_{2}$ & 79.90 & $262.21(20)$ & & $\begin{array}{l}1 \text { a: } 2.1400 E+01 \\
s \text { a: } 1.3249 E+01 \\
\text { s b: } 4.7232 E-03 \\
s \text { c: } 7.2332 E-06\end{array}$ \\
\hline Tritium & 3.02 & $62.43(4)$ & $\begin{array}{l}\text { a: } 4.9721 E+00 \\
\text { b: }-1.5398 E+03 \\
\text { c: }-5.3399 E+01\end{array}$ & $\begin{array}{lll}v & a: 8.3200 E+00 \\
v & b: 7.3204 E-04 \\
v & c: 1.3400 E-06 \\
& \text { a: } 1.2200 E+01 \\
1 & b: 8.0000 E-03\end{array}$ \\
\hline $\mathrm{UO}_{2}(\mathrm{COOH})_{2}$ & 360.06 & 230.37 (19) & & $\begin{array}{l}s \text { a: } 9.4400 E-02 \\
s \text { b: } 5.4600 E-05\end{array}$ \\
\hline $\mathrm{UO}_{2}(\mathrm{OH})_{2}$ & 304.04 & $369.96(20)$ & & $\begin{array}{l}s \text { a: } 8.2300 E-02 \\
s \text { b: } 3.9667 \mathrm{E}-05\end{array}$ \\
\hline $\mathrm{U}_{3} \mathrm{O}_{8}$ & 842.21 & $456.25(20)$ & & s a: $7.1000 E-02$ \\
\hline$Y(\mathrm{COOH})_{3}$ & 223.96 & $137.29(20)$ & & $\begin{array}{l}s \text { a: } 1.7240 E-01 \\
s \text { b: } 7.8867 E-05\end{array}$ \\
\hline $\mathrm{Y}\left(\mathrm{NO}_{3}\right)_{3}$ & 274.92 & $167.44(20)$ & & $\begin{array}{l}s \text { a: } 1.5570 E-01 \\
s \text { b: } 4.3800 E-05\end{array}$ \\
\hline$Y(\mathrm{OH})_{3}$ & 139.93 & $218.51(20)$ & & $\begin{array}{l}s \text { a: } 1.8000 E-01 \\
s \text { b: } 4.4800 E-05\end{array}$ \\
\hline$Y_{2}\left(\mathrm{CO}_{3}\right)_{3}$ & 357.87 & $218.51(20)$ & & $\begin{array}{l}\text { S a: } 1.2090 \mathrm{E}-01 \\
\text { s b: } 6.0133 \mathrm{E}-05\end{array}$ \\
\hline $\mathrm{Y}_{2} \mathrm{O}_{3}$ & 225.81 & $312.76(20)$ & & $\begin{array}{l}s \text { a: } 1.1200 E-01 \\
s \text { b: } 6.0000 E-05\end{array}$ \\
\hline Zeolite & 999.90 & $168.16(20)$ & & $s$ a: $2.6500 E-01$ \\
\hline
\end{tabular}

(a) Temperature in $C \mathcal{C}$ shown in parentheses.

(b) Vapor pressure data provided as the non-zero constants to fit the Antoine equation "Log10 $(p)=a+b /(t+c)$," where $p$ is pressure in $a t m$, and $t$ is in $K$

(c) Heat capacity data provided as non-zero constants for the relationship "Ht Cap $=a+b t+c t t$," where heat capacity is in PCU/1b-mole-degree-C, and $t$ is in $\cdot c$. 
TABLE A-9. (contd)

\begin{tabular}{|c|c|c|c|c|}
\hline Compound & $\begin{array}{l}\text { Molecular } \\
\text { Weight }\end{array}$ & $7 \mathrm{~b} / \mathrm{ft}^{3(a)}$. & Vapor Pressure(b) & Heat Capacity(c) \\
\hline $\mathrm{Zn}(\mathrm{COOH})_{2}$ & 155.42 & $147.83(20)$ & & $\begin{array}{l}s \text { a: } 1.7770 E-01 \\
s \text { b: } 8.1733 E-05\end{array}$ \\
\hline $\mathrm{Zn}(\mathrm{OH})_{2}$ & 99.40 & $190.59(20)$ & & $\begin{array}{l}S \text { a: } 1.8780 E-01 \\
s \text { b: } 5.1400 E-05\end{array}$ \\
\hline $\mathrm{ZnO}$ & 81.38 & $341.40(20)$ & & $\begin{array}{l}s \text { a: } 8.9536 E+00 \\
s \text { b: } 6.5884 E-03 \\
s \text { c: }-2.4768 E-06\end{array}$ \\
\hline $\mathrm{ZrO}_{2}$ & 123.22 & $357.63(20)$ & & $\begin{array}{l}\text { s a: } 1.1238 E+01 \\
\text { s b: } 1.6760 \mathrm{E}-02 \\
\text { s c: }-3.1351 \mathrm{I}-06\end{array}$ \\
\hline
\end{tabular}

(a) Temperatures in $C$ shown in parentheses.

(b) Vapor pressure data provided as the non-zero constants to fit the Antoine equation "Log10 $(p)=a+b /(t+c)$," where $p$ is pressure in $a t m$, and $t$ is in $K$.

(c) Heat capacity data provided as non-zero constants for the relationship "Ht Cap = a + bt + ctt," where heat capacity is in PCU/lb-mole-degree- $c$, and $t$ is in $C$. 



\section{APPENDIX B}

GLASS ELECTRICAL CONDUCTIVITY CONSTRAINTS 



\section{GLASS ELECTRICAL CONDUCTIV.ITY CONSTRAINTS}

\section{GLASS ELECTRICAL CONDUCTIVITY' CONSTRAINTS (a)}

The electrical conductivity constraints for the expanded B-Plant Immobilization Pilot Plant (BIPP) melter were calculated by estimating the resistance through the glass between the electrode pairs. The lower conductivity is based on data collected on the BIPP physical model, and the high conductivity limit is derived from an engineering estimate of the lowest credible meiter resistance. The conductivity range should be 1 imited to 0.18 $0.5 \mathrm{ohm}-\mathrm{Cm}^{-1}$ at $1150^{\circ} \mathrm{C}$. This range is also compatible with the Hest Valley melter and the reference design. HWVP. melter.

The expanded BIPP melter is assumed to have a glass surface area of $27 \mathrm{ft}^{2}\left(2.5 \mathrm{~m}^{2}\right)$ and depth of $2.17 \mathrm{ft}(26 \mathrm{in.})$. The electrode height assumptions were 10 in. for the upper electrode and 8 in. for the lower electrode; the two electrodes are 8 in. apart. The maximum power requirements were assumed to be $400 \mathrm{kH}$ for the upper electrode circuit and $300 \mathrm{~kW}$ for the lower electrode system.

The electrical resistance for the melter was estimated by assuming that the current would flow in a zone as shown in Figure B.1. This is believed to be the largest conduction zone feasible for an electrode circuit. Using the equation

$$
R=\alpha \times L \times \frac{1}{W} \times \frac{1}{D} \times F g
$$

where $R=$ resistance

$\alpha=$ resistivity

$L=$ melter length

$W=$ melter width

$D=$ melter depth

$\mathrm{Fg}=$ geometric shape factor

and the shape factors calculated from the conduction zone assumptions, the electrical resistance of the expanded BIPP melter can be estimated. The shape factors based on the conduction zone assumption and those measured from the physical model are listed in Table B.I

The acceptable range of glass conductivities was determined by using a maximum electrode current density criteria of $1 \mathrm{amp} / \mathrm{cm}^{2}$ to set the highest

(a) Memo from M. S. Hanson to J. E. Minor, "December 1984 Monthiy Report HWVP Task V-02," Pacific Northwest Laboratory, Richland, Washington (January 8, 1985). 


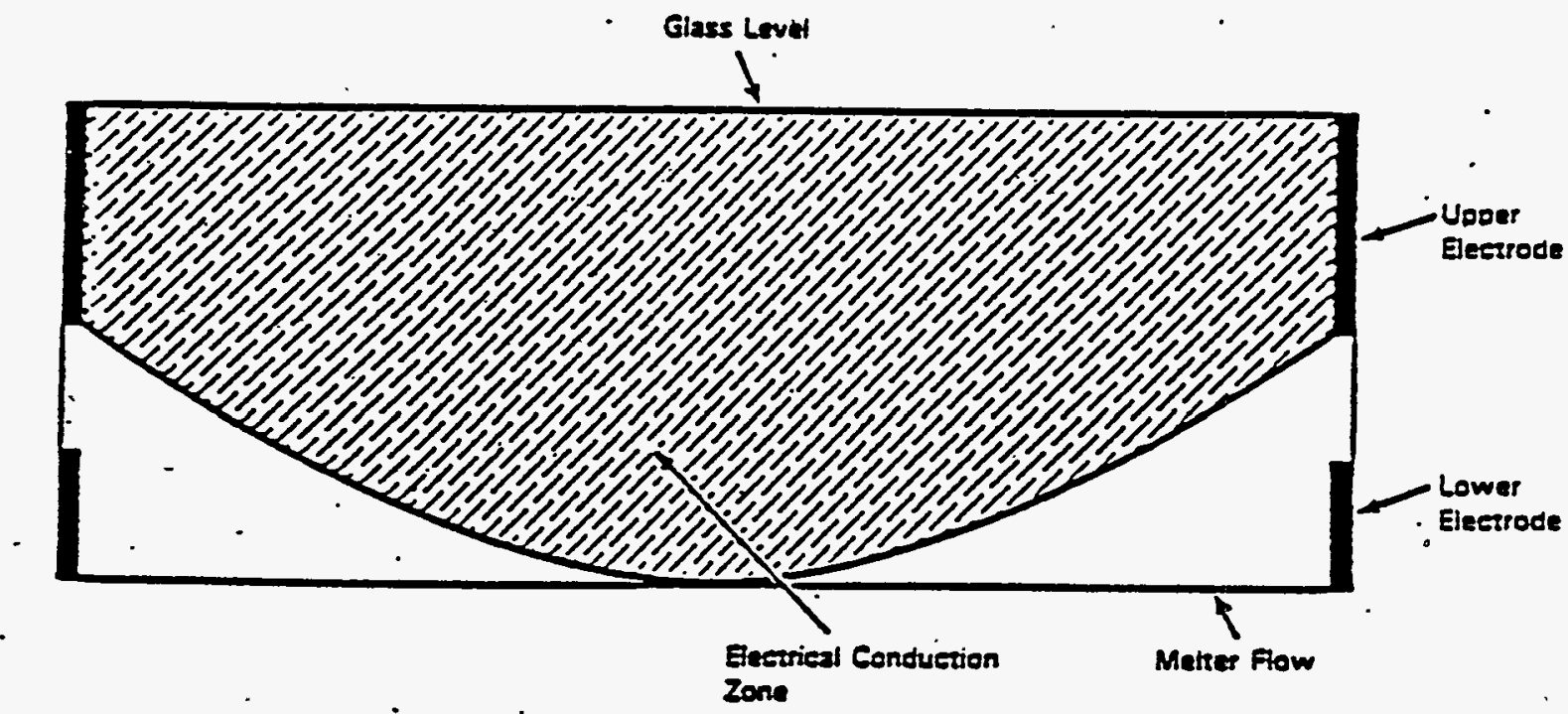

FIGURE B.1. Conduction. Zone Assumption for Lowest Credible Melter Resistance Calculation

TABLE B.1. Geometric Shape Factors for the Expanded BIPP Melter

\begin{tabular}{|l|c|cc|}
\cline { 2 - 4 } \multicolumn{1}{c|}{} & \multirow{2}{*}{$\begin{array}{c}\text { Lowest } \\
\text { Estimate }\end{array}$} & \multicolumn{2}{|c|}{ Physical Model } \\
\cline { 3 - 4 } & E 100\% Power & @ 50\% Power \\
\hline Upper Electrode & 1.29 & 1.4 & 1.4 \\
Lower Electrode & 1.34 & $\cdots-8$ & 1.8 \\
\hline
\end{tabular}

conductivity and a maximum electrode voltage drop of $250 v$ to establish thelowest acceptable conductivity. The melter electrical responses to these criteria are summarized in Table B.2. From the data presented in Table B.2 for cases 1 through 4 , it is clear that glass conductivities much greater than 0.5 (ohm-cm) ${ }^{-1}$ will produce electrode current densities in excess of the $1 \mathrm{~A} / \mathrm{cm}^{2}$ criteria. Cases 5 and 6 indicate that electrical conductivities less than 0.18 (ohm-cm) ${ }^{-1}$ will result in electrode potentials greater than the 25 volt limit. 
TABLE B.2. Melter Electrical Responses

\begin{tabular}{|c|c|c|c|c|c|c|}
\hline & \multicolumn{6}{|c|}{ Trial Cases } \\
\hline & 1 & 2 & 3 & 4 & 5 & 6 \\
\hline $\begin{array}{l}\text { Electrode Pair } \\
\text { Shape Factor } \\
\text { Maximum Power (kW) } \\
\text { Glass Conductivity } \\
\text { (ohm-cm) }\end{array}$ & $\begin{array}{r}\text { Upper } \\
1.29 \\
400 \\
0.5\end{array}$ & $\begin{array}{r}\text { Lower } \\
1.34 \\
300 \\
0.5\end{array}$ & $\begin{array}{r}\text { Upper } \\
1.29 \\
400 \\
.1\end{array}$ & $\begin{array}{r}\text { Lower } \\
1.34 \\
300 \\
1\end{array}$ & $\begin{array}{r}\text { Upper } \\
1.4 \\
400 \\
0.18\end{array}$ & $\begin{array}{r}\text { Lower } \\
1.8 \\
300 \\
0.17\end{array}$ \\
\hline $\begin{array}{l}\text { Meiter Resistance (ohm) } \\
\text { Electrode Current (amps) } \\
\text { Electrode Potential } \\
\text { Drop (volts) }\end{array}$ & $\begin{array}{r}0.052 \\
2771 \\
144\end{array}$ & $\begin{array}{r}0.052 \\
2355 \\
127\end{array}$ & $\begin{array}{r}0.026 \\
3918 \\
102\end{array}$ & $\begin{array}{r}0.027 \\
3330 \\
90\end{array}$ & $\begin{array}{r}0.016 \\
1600 \\
250\end{array}$ & $\begin{array}{r}0.21 \\
1200 \\
250\end{array}$ \\
\hline $\begin{array}{l}\text { Electrode Current } \\
\text { Density }\left(\mathrm{A} / \mathrm{cm}^{2}\right)\end{array}$ & 0.80 & 0.84 & 1.13 & 1.20 & 0.46 & 0.43 \\
\hline
\end{tabular}

B.3. 



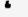

$\cdot$ $\cdot$

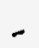

PNL MELTER OFF-GAS TREATMENT DEVELOPMENT DATA

$\therefore$ 
.

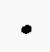

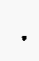

•

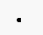

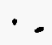

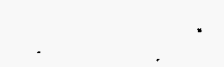

I

1

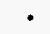

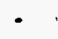

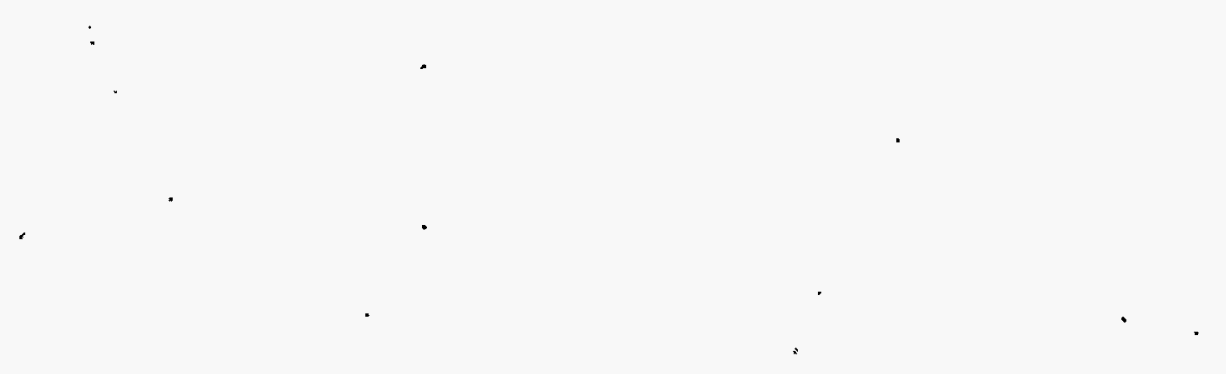

.

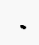




\section{PNL MELTER OFF-GAS TREATMENT DEVELOPMENT DATA}

The tables in Appendix $C$ present melter feed composition operating conditions and MOG treatment system decontamination factor data from pilotscale ceramic melter (PSCM) and high-bay ceramic melter (HBCM) testing. These data are relevant to development of the HWVP process off-gas treatment system. The information in this appendix is identified in the table index below.

Table No.

Table Title

C-1 Liquid-Fed Ceramic Melter Test Operating Conditions

C-2 : Pilot-Scale Ceramic Melter Run-23 (HWVP-15) - Hanford Waste Vitrification Plant Process Off-Gas Decontamination Factors

C-3 Pilot-Scale Ceramic Melter Run 22 (HWVP-12) - Hanford Waste Vitrification Plant Process Off-Gas Decontamination Factors

C-4 High-Bay Ceramic Melter Run 85-1 (HWVP-11) - Hanford Waste Vitrification Plant Process Off-Gas Decontamination Factors

C-5 Pilot-Scale Ceramic Melter Run Summary - Defense Waste Processing Facility Process Off-Gas Decontamination Factors

C-6 Pilot-Scale Ceramic Run Summary - West Valley Support Program Process Off-Gas Decontamination Factors

C-7 Composition of Simulated Hanford Waste Vitrification Plant PSCM Melter Feed Slurry (PSCM-23/HWVP-15)

C-8 Composition of Simulated Hanford Waste Vitrification Plant PSCM Melter Feed Slurry (PSCM-22/HHVP-12)

C-9 Composition of Simulated Hanford Waste Vitrification Plant HBCM Melter Feed Slurry (HBCM-11/HBCM-85-1)

C-10 Composition of Simulated Defense Waste Processing Facility PSCM Melter Feed Slurry and Glass

C-11 Composition of Simulated West Valley Support Program PSCM Melter Feed STurry

A - PSCM-9

B - PSCM-15

C - PSCM-16

D - PSCM-19 
TABLE C-1. Liquid-Fed Ceramic Melter Test Operating Conditions(a) HWVP 85-V1143A, HWVP-86-V1124A, HWVP-89-IVJ0010100B, 7H35-85-23

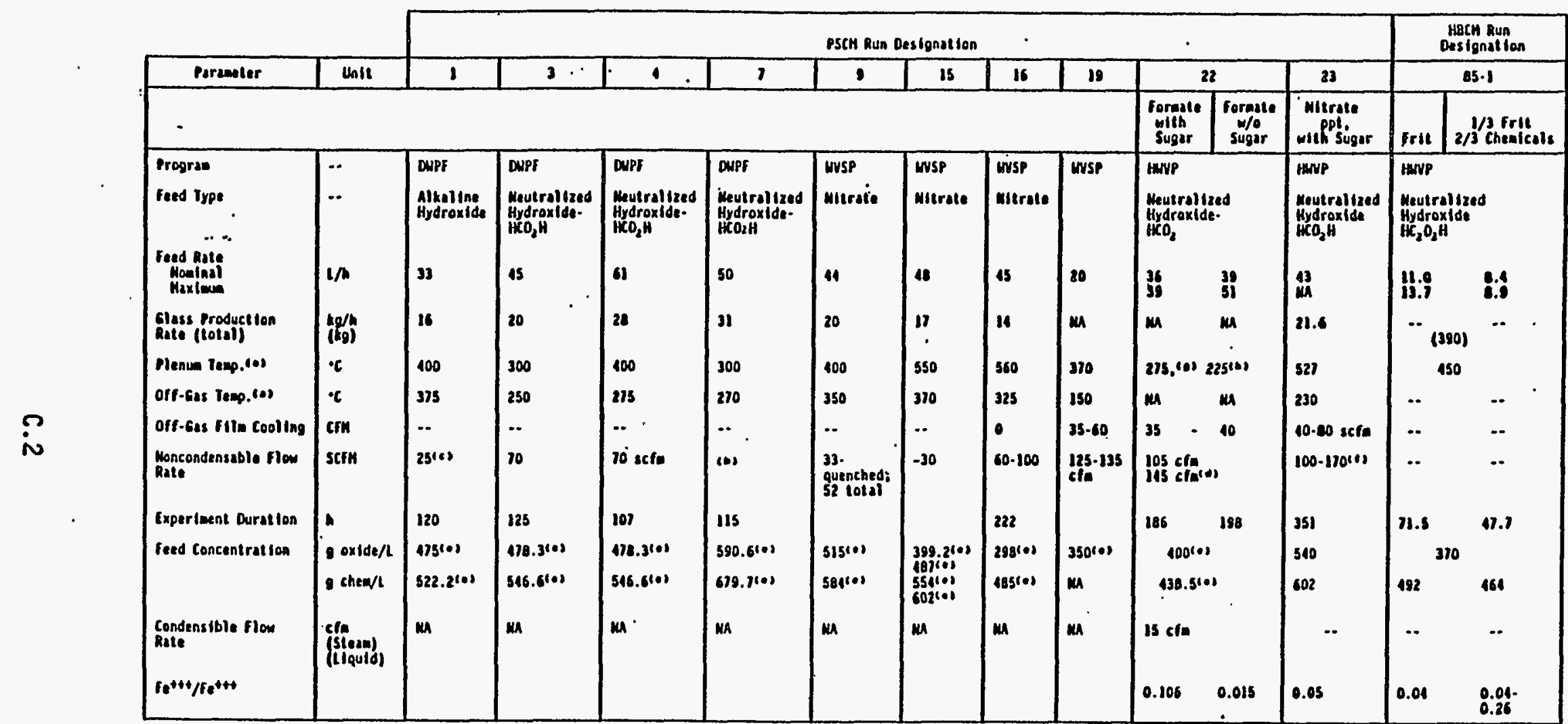

(a) Aversged over course of run.

(c) Ixcludes Inlestune.

(d) 10 Cill welter vacuia control alr Injected between Evs and colvan.

8. Design level.

(h) Haxinut leed rate. 
TABLE C-2. Pilot-Scale Ceramic Melter Run-23 (HWVP-15) -Hanford Waste. Vitrification Plant Process Off-Gas Decontamination Factors HWVP-IVJ0010100B

\begin{tabular}{|c|c|c|c|c|c|c|c|c|c|c|}
\hline & & & & & High & & igh-Effi & iency Mi & Eliminat & \\
\hline & Class & Element & Melter & $\begin{array}{l}\text { Bed } \\
\text { Scrubber }\end{array}$ & $\begin{array}{l}\text { Mist } \\
\text { Eliminator }\end{array}$ & $\begin{array}{l}6 / 6 / 88 \\
2110 h\end{array}$ & $\begin{array}{l}6 / 9 / 88 \\
1240 \mathrm{~h}\end{array}$ & $\begin{array}{l}6 / 11 / 88 \\
1148 \mathrm{~h}\end{array}$ & $\begin{array}{l}6 / 17 / 88 \\
1100 \mathrm{~h}\end{array}$ & $\begin{array}{l}6 / 21 / 88 \\
0127 \mathrm{~h}\end{array}$ \\
\hline$?$ & $\begin{array}{c}\begin{array}{c}\text { Nonvolatile } \\
\text { and } \\
\text { Semivolatile }\end{array} \\
\text {. }\end{array}$ & $\begin{array}{l}\mathrm{Al} \\
\mathrm{Ba} \\
\mathrm{Ca} \\
\mathrm{Cd} \\
\mathrm{Ce} \\
\mathrm{Co} \\
\mathrm{Cr} \\
\mathrm{Cs} \\
\mathrm{Cu} \\
\mathrm{Fe} \\
\mathrm{K} \\
\mathrm{La} \\
\mathrm{LI} \\
\mathrm{Mg} \\
\mathrm{Mn} \\
\mathrm{Mo} \\
\mathrm{Na} \\
\mathrm{Nd} \\
\mathrm{Ni} \\
\mathrm{Pb} \\
\mathrm{Si} \\
\mathrm{Sr} \\
\mathrm{Ti} \\
\mathrm{V} \\
\mathrm{Y} \\
\mathrm{Zn} \\
\mathrm{Zr} \\
\mathrm{THL}\end{array}$ & $\begin{array}{r}1,000 \\
980 \\
4,700 \\
7- \\
2,700 \\
-- \\
440 \\
83 \\
680 \\
870 \\
-2 \\
1,100 \\
1,500 \\
4,300 \\
900 \\
110 \\
340 \\
1,200 \\
99,000 \\
-- \\
15,000 \\
840 \\
-- \\
1,200 \\
960 \\
890 \\
1,600\end{array}$ & $\begin{array}{c}370 \\
2,100 \\
150 \\
2.7 \\
290 \\
11 \\
16 \\
3.3 \\
6.5 \\
810 \\
7.1 \\
1,400 \\
7.2 \\
150 \\
280 \\
9.7 \\
9.9 \\
1,600 \\
3 \\
6.1 \\
140 \\
370 \\
410 \\
21 \\
340 \\
63 \\
430 \\
7.4\end{array}$ & $\begin{array}{r}120 \\
100 \\
25 \\
19 \\
-- \\
29 \\
200 \\
18,000 \\
1,500 \\
55 \\
-- \\
-- \\
3,900 \\
-- \\
37 \\
1,500 \\
1,500 \\
-- \\
170 \\
-- \\
130 \\
430 \\
\cdots \\
\cdots \\
-- \\
1,400 \\
180 \\
1,400\end{array}$ & & & $\cdot$ & . & \\
\hline . & Volatile & $\begin{array}{l}B \\
C 1 \\
F \\
P \\
S\end{array}$ & $\begin{array}{r}390 \\
6.6 \\
9.2 \\
2,600 \\
6.4\end{array}$ & $\begin{array}{c}7.1 \\
3.0 \\
16 \\
8.6 \\
8.7\end{array}$ & $\begin{array}{l}-- \\
- \\
-- \\
--\end{array}$ & $\begin{array}{c}8.7 \\
65 \\
4.9 \\
1 \\
6.6\end{array}$ & $\begin{array}{c}68 \\
38 \\
72 \\
7.9 \\
39\end{array}$ & $\begin{array}{r}71 \\
17 \\
69 \\
-0 \\
2500\end{array}$ & $\begin{array}{r}310 \\
170 \\
45 \\
-3 \\
1600\end{array}$ & $\begin{array}{r}35 \\
400 \\
22 \\
-- \\
2300\end{array}$ \\
\hline
\end{tabular}


- TABLE C-3. Pilot-Scale Ceramic Melter Run 22 - Hanford Haste Vitrification P1 ant-Process Off-Gas Decontamination Factors HWVP-86-V1124A

\begin{tabular}{|c|c|c|c|c|c|c|c|}
\hline \multicolumn{2}{|c|}{ Component } & \multirow{2}{*}{ Melter } & \multirow{2}{*}{$\begin{array}{l}\text { Eject/ } \\
\text { Vent } \\
\text { Scrubber } \\
\end{array}$} & \multirow{2}{*}{$\begin{array}{l}\text { Packed } \\
\text { Tower }\end{array}$} & \multirow[b]{2}{*}{$\begin{array}{l}\text { Hydrosonic } \\
\text { Scrubber }\end{array}$} & \multicolumn{2}{|c|}{ Mist Eliminator } \\
\hline Class & E7ement & & & & & w/HSS (a) & W/O HSS \\
\hline $\begin{array}{c}\text { Monvolattle } \\
.\end{array}$ & $\begin{array}{l}\text { Total } \\
\text { AI } \\
\mathrm{Ba} \\
\mathrm{Ca} \\
\mathrm{Ce} \\
\mathrm{Cr} . \\
\mathrm{Cu} \\
\mathrm{Fe} \\
\mathrm{La} \\
\mathrm{LI} \\
\mathrm{Hg} \\
\mathrm{Mn} \\
\mathrm{Ha} \\
\mathrm{Hd} \\
\mathrm{Mf} \\
\mathrm{SI} \\
\mathrm{Sr} \\
\mathrm{Tr} \\
\mathrm{Zn} \\
\mathrm{Zr}\end{array}$ & $\begin{array}{l}330 \pm 14 \% \\
750 \\
190 \\
730 \\
450 \\
180 \\
250 \\
260 \\
610 \\
500 \\
630 \\
300 \\
260 \\
290 \\
2100 \\
780 \\
230 \\
250 \\
160 \\
420\end{array}$ & $\begin{array}{l}3.7 \pm 117 \\
32 \\
290 \\
160 \\
14 \\
14.2 \\
7.2 \\
92 \\
440 \\
2.6 \\
94 \\
220 \\
2.1 \cdot \\
17 \\
3.7 \\
59 \\
260 \\
970 \\
19 \\
670\end{array}$ & $\begin{array}{l}7.4 \\
1.3 \\
1.2 \\
\\
1.3 \\
3.5 \\
13^{\circ}\end{array}$ & $\begin{array}{l}4.8 \\
4.5 \\
7.3 \\
5.9 \\
\\
5.3 \\
7.3 \\
61 \\
5 \\
5 \\
1.2 \\
5.5 \\
5 \\
\\
6.1 \\
1.1 \\
11 \\
18 \\
1.4 \\
8.8\end{array}$ & $\begin{array}{l}16 \pm 20 \% \\
10 \\
8.3 \\
3 \\
14 \\
16 \\
53 \\
19 \\
1 \\
47 \\
16 \\
66 \\
5.4 \\
55 \\
3.4 \\
32\end{array}$ & $\begin{array}{c}9.7 \\
\\
20 \\
16 \\
18 \\
18 \\
18 \\
4.9 \\
20 \\
55 \\
8.9 \\
11 \\
5.5 \\
3.4\end{array}$ \\
\hline Senivolatile & $\begin{array}{l}\text { Total } \\
\text { B } \\
\text { Cs } \\
\text { Mo } \\
\text { Ru }\end{array}$ & $\begin{array}{l}63 \\
14 \\
57 \\
42\end{array}$ & $\begin{array}{l}11 \\
1.4 \\
1.6 \\
1.4\end{array}$ & $\begin{array}{l}1.9 \\
1.2\end{array}$ & $\begin{array}{l}6.2 \\
4.3 \\
4.8 \\
4.8\end{array}$ & $\begin{array}{l}9.0 \\
18 \\
19 \\
43\end{array}$ & $\begin{array}{l}3.4 \\
21 \\
19 \\
20\end{array}$ \\
\hline Volatile & $\begin{array}{l}\text { Total } \\
C \\
C I \\
F \\
H \\
I \\
N \\
S\end{array}$ & $\begin{array}{c}1.3 \\
3.2 \\
1 \\
1.3 . \\
<94 \\
1.8\end{array}$ & $\begin{array}{c}6.2 \\
14 \\
1 \\
1 \\
4.3\end{array}$ & $\begin{array}{l}1 \\
1.8 \\
1 \\
<5 \\
1.2\end{array}$ & $\begin{array}{l}4.9 \\
3.5 \\
1 \\
1 \\
2.3\end{array}$ & $\begin{array}{l}15 \\
6.6\end{array}$ & $\begin{array}{l}11 \\
5.0 \\
3.5 \\
47\end{array}$ \\
\hline
\end{tabular}

(a). HSS = hydrosonic scrubber. 
TABLE C-4. High-Bay Ceramic Melter Run 85-1. (HWVP-11). - Hanford Waste Vitrification Plant Off-Gas Decontamination Factors HWVP-88-V1124 A

\begin{tabular}{|c|c|c|c|c|c|c|c|c|}
\hline \multirow[b]{3}{*}{ ID } & \multirow[b]{3}{*}{ Average } & \multicolumn{7}{|c|}{ Decontamination Factors } \\
\hline & & \multicolumn{4}{|c|}{$100 \%$ Frit } & \multicolumn{3}{|c|}{$1 / 3$ Frit / $2 / 3$ Chemicals } \\
\hline & & $\begin{array}{l}4 / 18 / 85 \\
0906 \mathrm{~h}\end{array}$ & $\begin{array}{l}4 / 18 / 85 \\
1624^{h} \mathrm{~h}\end{array}$ & $\begin{array}{l}4 / 19 / 85 \\
0914 \mathrm{~h}\end{array}$ & $\begin{array}{l}4 / 19 / 85 \\
1534 \mathrm{~h}\end{array}$ & $\begin{array}{l}4 / 21 / 85 \\
0837 \mathrm{~h}\end{array}$ & $\begin{array}{l}4 / 21 / 85 \\
2154 \mathrm{~h}\end{array}$ & $\begin{array}{l}4 / 22 / 85 \\
0954 . h\end{array}$ \\
\hline $\begin{array}{l}\mathrm{AT} \\
\mathrm{B} \\
\mathrm{Ba} \\
\mathrm{Ca} \\
\mathrm{Ce} \\
\mathrm{Cr} \\
\mathrm{Cs} \\
\mathrm{Cu} \\
\mathrm{F} \\
\mathrm{Fe} \\
\mathrm{La} \\
\mathrm{Li} \\
\mathrm{Mg} \\
\mathrm{Mn} \\
\mathrm{Mo} \\
\mathrm{Na} \\
\mathrm{Nd} \\
\mathrm{Ni} \\
\mathrm{S} \\
\mathrm{Si} \\
\mathrm{Sr} \\
\mathrm{Ti} \\
\mathrm{Zr} \\
\mathrm{TTL}\end{array}$ & $\begin{array}{r}2200 \\
130 \\
290 \\
650 \\
530 \\
260 \\
100 \\
290 \\
5 \\
310 \\
730 \\
690 \\
700 \\
340 \\
100 \\
350 \\
300 \\
8100 \\
67 \\
850 \\
330 \\
740 \\
620 \\
430\end{array}$ & $\begin{array}{r}590 \\
120 \\
81 \\
290 \\
140 \\
61 \\
78 \\
77 \\
67 \\
77 \\
190 \\
320 \\
270 \\
110 \\
41 \\
160 \\
77 \\
5200 \\
54 \\
360 \\
87 \\
270 \\
210 \\
220\end{array}$ & $\begin{array}{r}1400 \\
140 \\
120 \\
530 \\
260 \\
100 \\
210 \\
120 \\
7.4 \\
130 \\
320 \\
510 \\
490 \\
170 \\
61 \\
240 \\
130 \\
7400 \\
65 \\
620 \\
130 \\
430 \\
320 \\
340\end{array}$ & $\begin{array}{r}1800 \\
160 \\
230 \\
860 \\
770 \\
200 \\
50 \\
220 \\
3.9 \\
260 \\
630 \\
760 \\
930 \\
220 \\
83 \\
370 \\
280 \\
3800 \\
86 \\
970 \\
270 \\
1100 \\
500 \\
470\end{array}$ & $\begin{array}{r}3000 \\
170 \\
280 \\
1100 \\
690 \\
250 \\
66 \\
320 \\
5.3 \\
510 \\
300 \\
800 \\
1700 \\
1200 \\
430 \\
110 \\
470 \\
330 \\
1800 \\
99 \\
130 \\
310 \\
680 \\
760 \\
590\end{array}$ & $\begin{array}{r}4600 \\
140 \\
640 \\
890 \\
1000 \\
600 \\
110 \\
650 \\
3.6 \\
700 \\
1600 \\
720 \\
1000 \\
820 \\
170 \\
570 \\
630 \\
-7 \\
56 \\
130 \\
750 \\
1000 \\
1200 \\
580\end{array}$ & $\begin{array}{r}2300 \\
110 \\
320 \\
490 \\
490 \\
330 \\
92 \\
320 \\
4.2 \\
330 \\
820 \\
380 \\
510 \\
390 \\
130 \\
320 \\
330 \\
6600 \\
53 \\
690 \\
370 \\
3100 \\
720 \\
400\end{array}$ & $\begin{array}{r}2000 \\
110 \\
330 \\
420 \\
320 \\
310 \\
320 \\
330 \\
330 \\
350 \\
360 \\
760 \\
390 \\
600 \\
260 \\
130 \\
350 \\
390 \\
\quad-0 \\
55 \\
680 \\
390 \\
370 \\
540 \\
640 \\
390\end{array}$ \\
\hline & \multicolumn{7}{|c|}{ \% Gas Phase Melter Loss } \\
\hline & & \multicolumn{4}{|c|}{$100 \%$ Frit } & \multicolumn{3}{|c|}{ 1/3 Frit / 2/3 Chemical } \\
\hline \multicolumn{2}{|c|}{ Element } & $\begin{array}{l}4 / 18 / 85 \\
0900 \mathrm{~h}\end{array}$ & $\begin{array}{l}4 / 18 / 85 \\
1600 \mathrm{~h}\end{array}$ & $\begin{array}{l}4 / 19 / 85 \\
0900 \mathrm{~h}\end{array}$ & $\begin{array}{l}4 / 91 / 85 \\
1600 \mathrm{~h}\end{array}$ & $\begin{array}{l}4 / 21 / 85 \\
0900 \mathrm{~h}\end{array}$ & $\begin{array}{l}4 / 21 / 85 \\
2200 \mathrm{~h}\end{array}$ & $\begin{array}{l}4 / 22 / 85 \\
1000 \mathrm{~h}\end{array}$ \\
\hline \multicolumn{2}{|c|}{$\begin{array}{l}B \\
F \\
S\end{array}$} & $\begin{array}{r}62 \\
, \quad 79 \\
<100\end{array}$ & $\begin{array}{r}69 \\
72 \\
<100\end{array}$ & $\begin{array}{l}78 \\
92 \\
19\end{array}$ & $\begin{array}{l}81 \\
90 \\
22\end{array}$ & $\begin{array}{l}79 \\
94 \\
47\end{array}$ & $\begin{array}{l}71 \\
84 \\
41\end{array}$ & $\begin{array}{r}71 \\
<100 \\
34\end{array}$ \\
\hline
\end{tabular}


TABLE C-5. Pilot-Scale Ceramic Melter Run Summary - Defense Waste Processing Facility Process Off-Gas Decontamination Factors HWVP-85-V1143A

\begin{tabular}{|c|c|c|c|c|c|c|}
\hline \multicolumn{2}{|c|}{ Component } & \multicolumn{4}{|c|}{ Melter } & \multirow{2}{*}{$\begin{array}{r}\begin{array}{r}\text { Ejector/ } \\
\text { Venturi } \\
\text { Scrubber }\end{array} \\
7\end{array}$} \\
\hline Class & Element & 1 & 3 & 4 & 7 & \\
\hline $\begin{array}{l}\text { Semivolatile } \\
\text { Volatile } \\
\text { Total }\end{array}$ & $\begin{array}{l}\text { Total } \\
\text { Al } \\
\text { Ca } \\
\text { Fe } \\
\text { La } \\
\text { id } \\
\text { Hg } \\
\text { Mr } \\
\text { Na } \\
\text { Nd } \\
\text { Ni } \\
\text { Si } \\
\text { Sr } \\
\text { Ti } \\
\text { Zr } \\
\text { Cr } \\
\text { Cu } \\
\text { Pb } \\
\text { Zn } \\
\text { Total } \\
\text { B } \\
\text { Cd } \\
\text { CS } \\
\text { Ru } \\
\text { Sb } \\
\text { Se } \\
\text { Te } \\
\text { S } \\
\text { F }\end{array}$ & \begin{tabular}{|c|c|c}
$1,140(a)$ \\
11,000 \\
1,840 \\
3,800 \\
-- \\
1,900 \\
9,000 \\
5,700 \\
$: 830$ \\
-- \\
1,500 \\
15,000 \\
7,400 \\
-- \\
- \\
- \\
-- \\
- \\
-- \\
210 \\
190 \\
51 \\
32 \\
-- \\
-- \\
170 \\
3.1 \\
-- \\
-- \\
1,100 \\
\end{tabular} & $\begin{array}{c}980(a) \\
6,000 \\
200 \\
1,600 \\
-\infty \\
2,600 \\
8,200 \\
3,300 \\
900 \\
-\infty \\
9,400 \\
3,000 \\
640 \\
4,100 \\
-- \\
-- \\
-- \\
- \\
-- \\
200 \\
-- \\
3.8 \\
-- \\
-- \\
-- \\
32 \\
4 \\
-- \\
\end{array}$ & $\begin{array}{c}720 \\
23,000 \\
230 \\
2,000 \\
-- \\
3,200 \\
-\infty \\
2,100 \\
180 \\
-- \\
1,400 \\
9,200 \\
250 \\
8,700 \\
5,000 \\
\cdot \\
-- \\
-- \\
-- \\
-- \\
230 \\
9.2 \\
16 \\
-- \\
-- \\
-- \\
3.1 \\
5 \\
-- \\
490 \\
16\end{array}$ & $\begin{array}{r}1,240 \\
26,000 \\
210 \\
28,000 \\
3,600 \\
1,100 \\
11,000 \\
3,700 \\
290 \\
4,100 \\
3,100 \\
8,700 \\
4,200 \\
15,000 \\
9,400 \\
\\
-- \\
-- \\
-- \\
- \\
210 \\
6.5 \\
13 \\
-= \\
710 \\
40 \\
24 \\
6.4 \\
2.9 \\
-- \\
1,200 \\
\end{array}$ & $\begin{array}{c}11 \\
81 \\
90 \\
260 \\
52 \\
23 \\
-0 \\
470 \\
20 \\
140 \\
120 \\
180 \\
9.1 \\
13 \\
36 \\
\\
32 \\
20 \\
12 \\
23 \\
\\
5.2 \\
19 \\
18 \\
-9 \\
23 \\
7.9 \\
14 \\
-- \\
7.7 \\
11 \\
9\end{array}$ \\
\hline
\end{tabular}

(a) Single measurement. 
TABLE C-6. Pilot-Scale Ceramic Run Summary - Hest Valley Support Program Process Off-Gas Decontamination Factors HWWP-85-V1143A

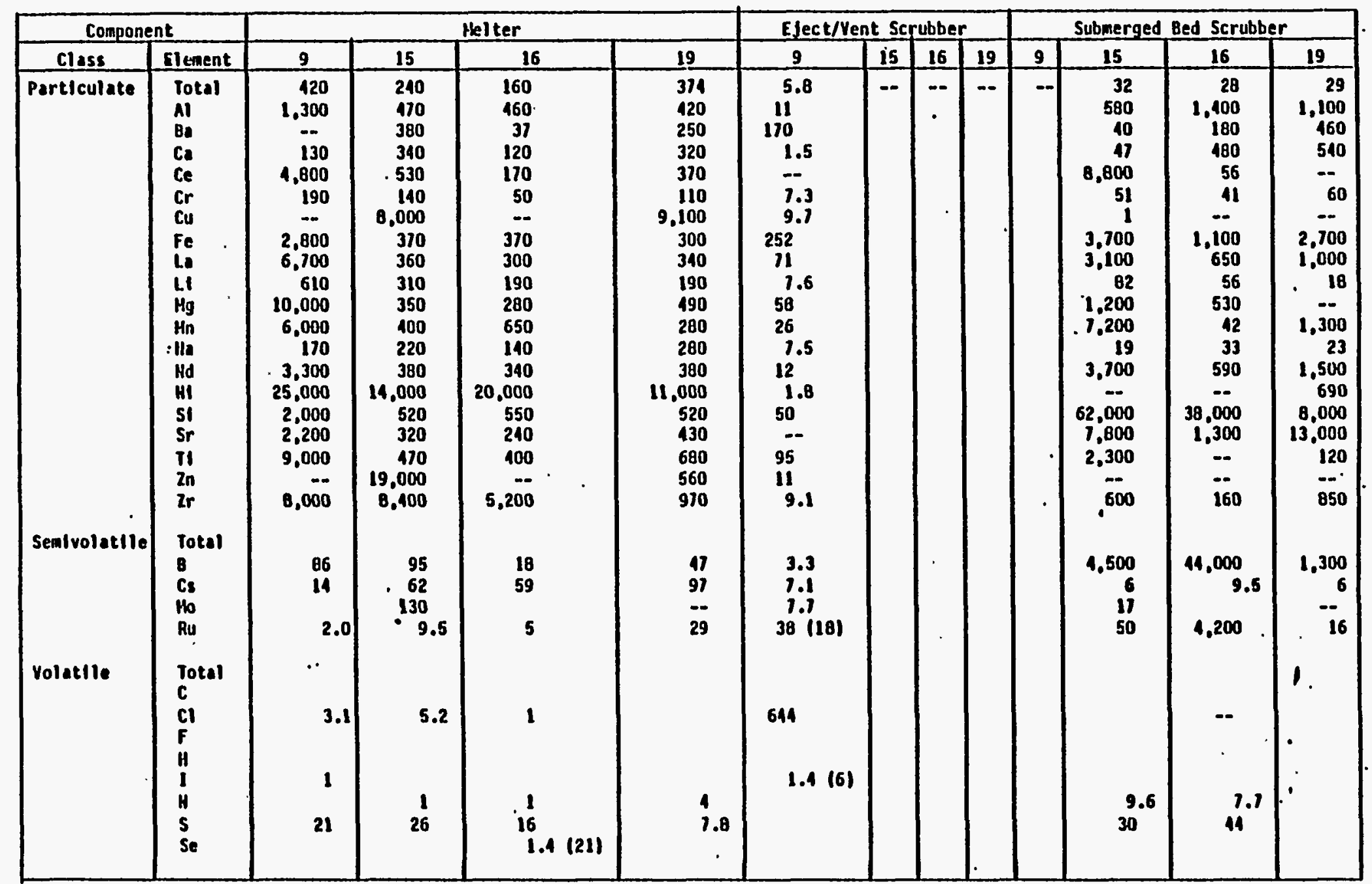




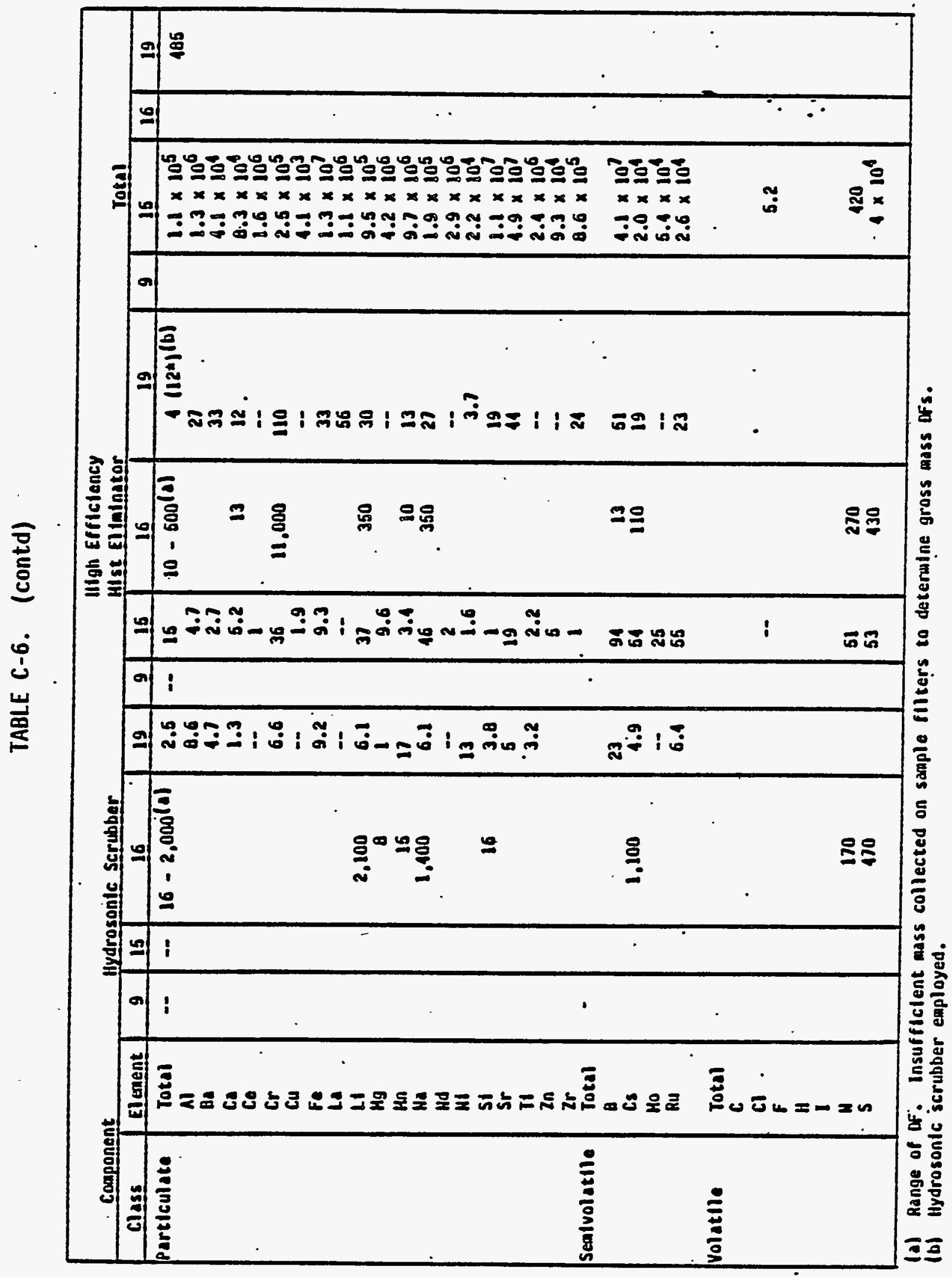


TABLE C-7. Composition of -Simulated Hanford Waste Vitrification P7ant PSCM PSCM Me1ter Feed Slurry (PSCM-23/HWVP-15) HWVP-89-IVJ0010100B

\begin{tabular}{|c|c|c|c|c|}
\hline $\begin{array}{c}\text { Chemicals Used( } \bullet) \\
\text { in Makeup }\end{array}$ & $\begin{array}{c}\text { Concentration } \\
(\mathrm{g} / \mathrm{L})\end{array}$ & $\begin{array}{l}\text { Assumed State } \\
\text { After Reaction }\end{array}$ & $\begin{array}{c}\text { Concentration } \\
(\mathrm{g} / \mathrm{L})\end{array}$ & $\begin{array}{c}\text { Glass } \\
\text { Concentration } \\
(w t \%)(b)\end{array}$ \\
\hline 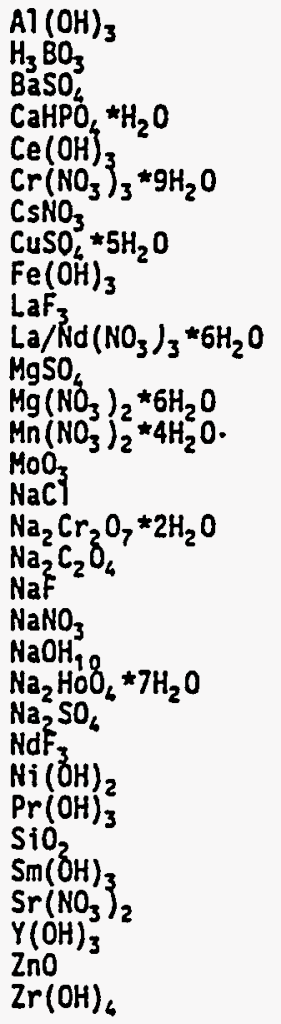 & $\begin{array}{r}18.11 \\
0.23 \\
0.80 \\
1.21 \\
0.87 \\
2.06 \\
1.09 \\
2.47 \\
49.31 \\
1.97 \\
17.25 \\
1.23 \\
0.30 \\
2.27 \\
1.58 \\
0.63 \\
0.53 \\
13.95 \\
0.79 \\
19.58 \\
10.46 \\
0.10 \\
0.65 \\
2.02 \\
3.76 \\
0.59 \\
5.26 \\
0.30 \\
1.07 \\
0.33 \\
2.50 \\
25.51\end{array}$ & 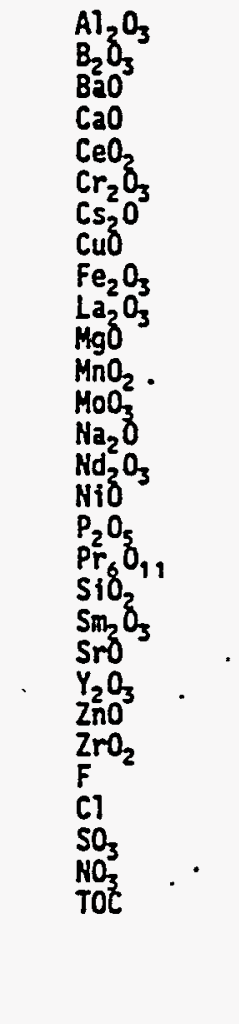 & $\begin{array}{c}11.84 \\
0.13 \\
0.53 \\
0.39 \\
0.79 \\
0.66 \\
0.79 \\
0.79 \\
36.85 \\
6.44 \\
0.46 \\
0.79 \\
1.58 \\
23.03 \\
3.35 \\
3.03 \\
0.53 \\
0.53 \\
5.26 \\
0.26 \\
0.53 \\
0.26 \\
2.50 \\
19.74 \\
1.50 \\
0.38 \\
2.25 \\
24.80(c) \\
2.50(c) \\
.\end{array}$ & $\begin{array}{l}2.36 \\
0.03 \\
0.10 \\
0.08 \\
0.16 \\
0.13 \\
0.16 \\
0.16 \\
7.36 \\
1.29 \\
0.09 \\
0.16 \\
0.31 \\
4.60 \\
0.67 \\
0.61 \\
0.10 \\
0.10 \\
1.05 \\
0.05 \\
. .10 \\
0.05 \\
0.50 \\
3.94 \\
0.30 \\
0.08 \\
0.45 \\
.- \\
-.\end{array}$ \\
\hline \multirow[t]{5}{*}{ Subtotoal } & $\begin{array}{c}188.8 \mathrm{~g} / \mathrm{L} \\
\text { HW39-4 Fri } \\
\text { Comoosition(o) }\end{array}$ & & $125.2 \mathrm{~g} / \mathrm{L}$ & $25.0 \mathrm{wt \%}$ \\
\hline & & $\begin{array}{l}\mathrm{SiO}_{2} \\
\mathrm{~B}_{2} \mathrm{O}_{3} \\
\mathrm{Na}_{2} \mathrm{O} \\
\mathrm{Li}_{2} \mathrm{O} \\
\mathrm{CaO}^{2} \\
\mathrm{MgO}\end{array}$ & $\begin{array}{r}262.50 \\
52.50 \\
33.75 \\
18.75 \\
3.75 \\
3.75 \\
\end{array}$ & $\begin{array}{r}52.50 \\
10.50 \\
6.75 \\
3.75 \\
0.75 \\
0.75 \\
\end{array}$ \\
\hline & & Subtotals & $375.0 \mathrm{~g} / \mathrm{L}$ & $75.0 \mathrm{wt} \%$ \\
\hline & & TOTALS . & $500.2 \mathrm{~g} / \mathrm{L}$ & $100.0 \mathrm{wt \%}$ \\
\hline & $\begin{array}{c}\text { Reductant } \\
\text { Added }\end{array}$ & $\begin{array}{l}\mathrm{HCOOH}(\bullet) \\
\text { Sugar }\end{array}$ & $\begin{array}{l}23.2 \mathrm{~g} / \mathrm{L}(\mathrm{f}) \\
10.0 \mathrm{~g} / \mathrm{L}\end{array}$ & \\
\hline
\end{tabular}
(a) Prior to formic acid treatment.
(b) Values assume no volatility losses.
(c) Value is not included in subtotal values.
(d) Size distribution of frit was $-80 /+200$ mesh with a maximum of $10 \mathrm{wt} \%-200$ mesh.
(e) Value given is for a $90 \mathrm{wt} \%$ solution of $\mathrm{HCOOH}$.
(f) Value includes $90 \mathrm{wt \%} \mathrm{HCOOH}$ added with frit, equivalent to I wt\% of frit added, or $4.2 \mathrm{~g} / \mathrm{L}$. 
TABLE C-8. Composition of Simulated Hanford Haste Vitrification Plant PSCM Mèiter Feed S7urry(a) (PSCM-22/HWVP-12) HWVP-86-V1124A

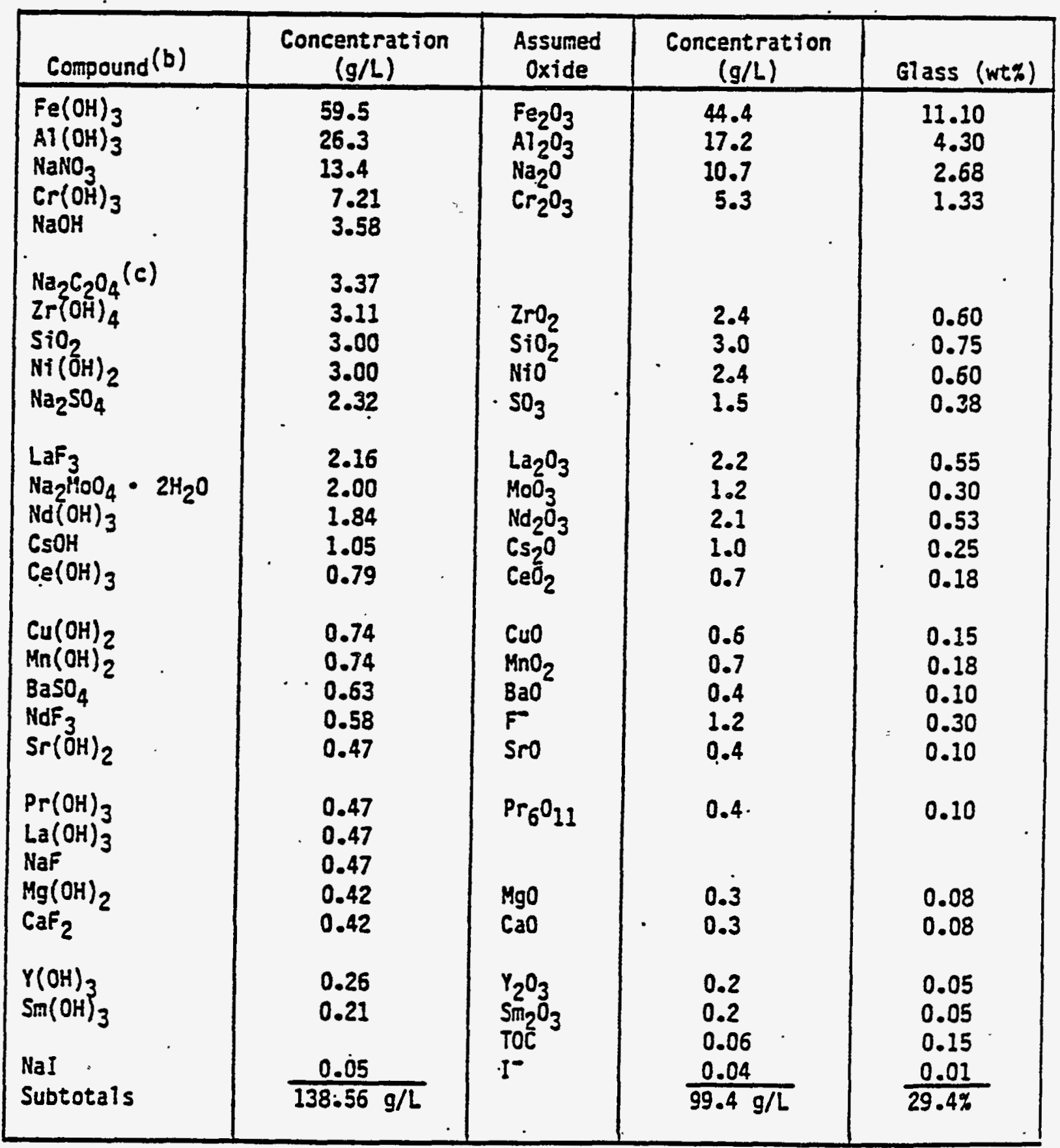


TABLE C-8. (contd)

\begin{tabular}{|c|c|c|c|c|}
\hline Compound (b) & $\begin{array}{c}\text { Concentration } \\
(g / L)\end{array}$ & $\begin{array}{c}\text { Assumed } \\
\text { Oxide }\end{array}$ & $\begin{array}{c}\text { Concențration } \\
(\mathrm{g} / \mathrm{L})\end{array}$ & Glass (wt\%) \\
\hline $\begin{array}{l}\text { HW39 Frit (d) } \\
\text { Subtotals }\end{array}$ & $\overline{300.0 \mathrm{~g} / \mathrm{L}}$ & $\begin{array}{l}\mathrm{SiO}_{2} \\
\mathrm{~B}_{2} \mathrm{O}_{3} \\
\mathrm{Na}_{2} \mathrm{O} \\
\mathrm{Li}_{2} \mathrm{O} \\
\mathrm{CaO} \\
\mathrm{MgO}\end{array}$ & $\begin{array}{c}201.8 \\
38.2 \\
30.8 \\
15.0 \\
11.2 \\
3.0 \\
300.0 \mathrm{~g} / \mathrm{L}\end{array}$ & $\begin{array}{c}50.44 \\
9.56 \\
7.69 \\
3.75 \\
2.81 \\
0.75 \\
75.0 \text { wt\% }\end{array}$ \\
\hline Totals & $\overline{438.5 \mathrm{~g} / \mathrm{L}}$ & & $\overline{400.0 \mathrm{~g} / \mathrm{L}}$ & $\overline{100.0 \mathrm{wtq}}$ \\
\hline
\end{tabular}

Reductants: $12.2 \mathrm{~g} / \mathrm{L}$ formic acid, 3.5 to $0 \mathrm{~g} / \mathrm{L}$ sugar.

(a) Basis: $400 \mathrm{~g}$ oxide/L slurry, $25 \mathrm{wt} \%$ waste oxide loading.

(b) Before reaction with formic acid.

(c) Total Organic Carbon (TOC) substitute.

(d) HW-39 frit size distribution as follows: $1 / 3$ to be $-80+200$ mesh

$2 / 3$ to be -200 mesh. 
TABLE C-9. Composition of Simulated Hanford Waste Vitrification Plant HBCM Helter Feed STurry (HBCM-11/HBCM-85-1)(a) 7H35-85-23

\begin{tabular}{|c|c|c|c|c|}
\hline \multicolumn{5}{|c|}{ HWVP Feed in Melter Feed STurry } \\
\hline Compound & $\begin{array}{c}\text { Cancentration } \\
(\mathrm{g} / \mathrm{L})\end{array}$ & $\begin{array}{l}\text { Assumed } \\
\text { Oxide }\end{array}$ & $\begin{array}{c}\text { Concentraton } \\
(g / L)\end{array}$ & $\begin{array}{l}\text { Glass } \\
\text { (wt\%) }\end{array}$ \\
\hline 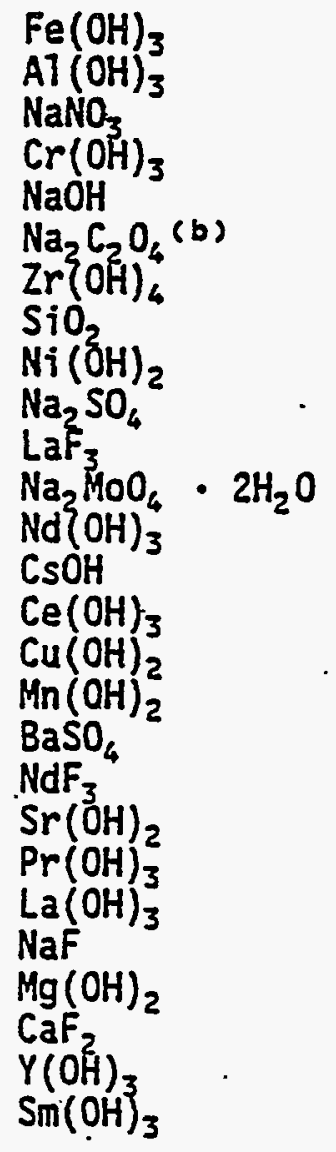 & $\begin{array}{c}59.5 \\
26.3 \\
13.4 \\
7.21 \\
3.58 \\
3.37 \\
3.11 \\
3.00 \\
3.00 \\
2.32 \\
2.16 \\
2.00 \\
1.84 \\
1.05 \\
0.79 \\
0.74 \\
0.74 \\
0.63 \\
0.58 \\
0.47 \\
0.47 \\
0.47 \\
0.47 \\
0.42 \\
0.42 \\
0.26\end{array}$ & 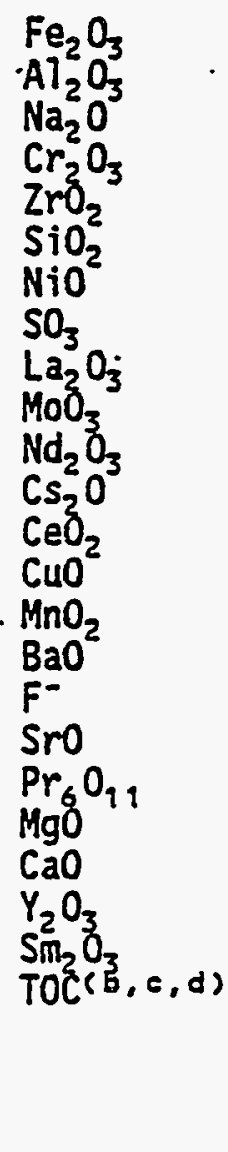 & $\begin{array}{l}44.4 \\
17.2 \\
10.7 \\
5.3 \\
2.4 \\
3.0 \\
2.4 \\
1.5 \\
2.2 \\
1.2 \\
2.1 \\
1.0 \\
0.7 \\
0.6 \\
0.7 \\
0.4 \\
1.2 \\
0.4 \\
0.4 \\
0.3 \\
0.3 \\
0.2 \\
0.2 \\
0.6\end{array}$ & $\begin{array}{l}11.10 \\
4.30 \\
2.68 \\
1.33 \\
0.60 \\
0.75 \\
0.60 \\
0.38 \\
0.55 \\
0.30 \\
0.53 \\
0.25 \\
0.18 \\
0.15 \\
0.18 \\
0.10 \\
0.30 \\
0.10 \\
0.10 \\
0.08 \\
0.08 \\
0.05 \\
0.05 \\
0.15\end{array}$ \\
\hline Subtotal & $138.51 \mathrm{~g} / \mathrm{L}$ & & $99.6 \mathrm{~g} / \mathrm{L}$ & $24.89 \%$ \\
\hline
\end{tabular}

(a) Basis: $400 \mathrm{~g}$ oxide/L slurry, 25 wt\% waste oxide loading (365 g oxide/7iter slurry measured).

(b) TOC substitute.

(TOC = Total Organic Carbon)

(c) $90 \mathrm{wt \%}$ formic acid added $=8.2 \mathrm{~mL} / \mathrm{L}$ of melter feed $(0.092 \mathrm{HCOOH} /$ $g$ HO, $0.2 M$ formic acid).

Note: $\mathrm{pH}$ of melter feed:

$$
\begin{array}{ll}
100 \% \text { frit: } & \\
1 / 3 \text { frit } / 2 / 3 \text { chemicals: } & 8.8
\end{array}
$$

(d) Sugar additions
$100 \%$ frit:
1/3 frit/2/3 chemical:
$3.5 \mathrm{~g} / \mathrm{L}$ melter slurry
$4.5 \mathrm{~g} / \mathrm{L}$ melter slurry 
TABLE C-9. (contd)

\begin{tabular}{|c|c|c|c|c|}
\hline \multicolumn{5}{|c|}{ Glass-Forming Fraction in Melter Feed Slurry } \\
\hline \multicolumn{5}{|c|}{ Case 1: 100\% Frit } \\
\hline Compound & $\begin{array}{c}\text { Concentration } \\
(\mathrm{g} / \mathrm{L})\end{array}$ & $\begin{array}{l}\text { Assumed } \\
\text { Formed }\end{array}$ & $\begin{array}{c}\text { Concentraton } \\
(g / L)\end{array}$ & $\begin{array}{l}\text { Glass } \\
\text { (wt\%) }\end{array}$ \\
\hline HH39 Frit(a) & 300.0 & $\begin{array}{l}\mathrm{SiO}_{2} \\
\mathrm{~B}_{2} \mathrm{O}_{3} \\
\mathrm{Na}_{2} \mathrm{O} \\
\mathrm{Li}_{2} \mathrm{O} \\
\mathrm{CaO}\end{array}$ & $\begin{array}{r}201.8 \\
38.2 \\
30.8 \\
15.0 \\
11.2\end{array}$ & $\begin{array}{r}50.44 \\
9.56 \\
7.69 \\
3.75 \\
2.81\end{array}$ \\
\hline Subtotals & 300.0 & & 300.0 & .75 .0 \\
\hline \multicolumn{5}{|c|}{ Case 2: 1/3 Frit: $2 / 3$ Unreacted Chemicals } \\
\hline $\begin{array}{l}\mathrm{HW} 39 \mathrm{Frit}(b) \\
\mathrm{SiO}_{2} \\
\mathrm{NaCHO}_{2} \\
\mathrm{Na}_{2} \mathrm{~B}_{4} \mathrm{O}_{7} \cdot 1 \mathrm{OH}_{2} \mathrm{O} \\
\mathrm{LiCHO} \cdot \mathrm{H}_{2} \mathrm{O} \\
\mathrm{Mg}\left(\mathrm{NO}_{3}\right)_{2} \cdot 6 \mathrm{H}_{2} \mathrm{O} \\
\mathrm{Ca}\left(\mathrm{NO}_{3}\right)_{2} \cdot 4 \mathrm{H}_{2} \mathrm{O}\end{array}$ & $\begin{array}{r}100.0 \\
134.4 \\
20.0 \\
69.9 \\
46.9 \\
12.8 \\
31.6 \\
\end{array}$ & $\begin{array}{l}\mathrm{SiO}_{2} \\
\mathrm{~B}_{2} \mathrm{O}_{3} \\
\mathrm{Na}_{2} \mathrm{O} \\
\mathrm{Li}_{2} \mathrm{O} \\
\mathrm{CaO} \\
\mathrm{MgO}\end{array}$ & $\begin{array}{r}201.8 \\
38.2 \\
30.8 \\
15.0 \\
11.2 \\
3.0\end{array}$ & $\begin{array}{r}50.44 \\
9.56 \\
7.69 \\
3.75 \\
2.81 \\
0.75 \\
\end{array}$ \\
\hline Subtotals & .425 .6 & & 300.0 & 75.0 \\
\hline
\end{tabular}

(a) HW39 frit size distribution as follows: $1 / 3$ to be $-80+200$ mesh

(b) HW39 frit size distribution as follows: $\begin{aligned} & 2 / 3 \text { to be }-200 \\ & -80+200 \text { mesh. }\end{aligned}$ 
TABLE C-10. Composition of Simulated Defense Waste Processing Facility - PSCM Meiter Feed STurry and Glass

HWVP-85-V1143A

\begin{tabular}{|c|c|c|c|c|c|c|c|c|c|}
\hline \multicolumn{4}{|c|}{ Waste Slurry Composition } & \multicolumn{6}{|c|}{ Typtcal Slurry and Glass Oxide Composition (a) } \\
\hline \multicolumn{2}{|c|}{ Alkaline Waste } & \multicolumn{2}{|c|}{ Acid Waste } & \multicolumn{5}{|c|}{ Equivalent oxide Concentration $(g / L)$} & \multirow{2}{*}{$\begin{array}{c}\text { Final Glass } \\
\text { Composition } \\
\text { (wtz) }\end{array}$} \\
\hline Compound & $\begin{array}{l}\text { Cone. } \\
(g / L)\end{array}$ & Compound & $\begin{array}{l}\text { Cone. } \\
(\mathrm{g} / \mathrm{L})\end{array}$ & Oxide & $\begin{array}{l}\text { Waste } \\
\text { S7udge } \\
\end{array}$ & $\begin{array}{l}\text { Frit- } \\
131(b)\end{array}$ & Zeolite $(c)$ & Total & \\
\hline 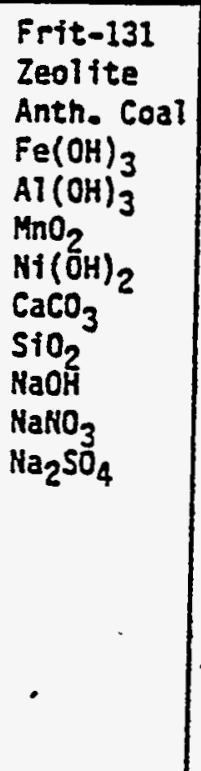 & $\begin{array}{c}338.0 \\
14.7 \\
3.30 \\
90.9 \\
21.0 \\
19.5 \\
10.4 \\
8.90 \\
5.84 \\
4.93 \\
2.01 \\
0.73\end{array}$ & $\begin{array}{l}\text { Frit-131 } \\
\text { Zeolite } \\
\mathrm{HCHO} \\
\mathrm{Fe}(\mathrm{OH})_{3} \\
\mathrm{Al}(\mathrm{OH})_{3} \\
\mathrm{Mn}\left(\mathrm{CHO}_{2}\right)_{2} \\
\mathrm{Mi}\left(\mathrm{CHO}_{2}\right)_{2} \\
\mathrm{Ca}\left(\mathrm{CHO}_{2}\right)_{2} \\
\mathrm{SiO}_{2} \\
\mathrm{MaCHO}_{2} \\
\mathrm{NaHO}_{2} \\
\mathrm{Na}_{2} \mathrm{SO}_{4}\end{array}$ & $\begin{array}{r}341.3 \\
9.9 \\
18.0 \\
81.2 \\
34.2 \\
28.2 \\
8.3 \\
16.7 \\
15.6 \\
8.42 \\
2.01 \\
0.72\end{array}$ & $\begin{array}{l}\mathrm{Fe}_{2} \mathrm{O}_{3} \\
\mathrm{Al}_{2} \mathrm{O}_{3} \\
\mathrm{MnO} \\
\mathrm{MiO} \\
\mathrm{CaO} \\
\mathrm{SiO}_{2} \\
\mathrm{Ha}_{2} \mathrm{O} \\
\mathrm{Ma}_{2} \mathrm{SO}_{4} \\
\mathrm{~B}_{2} \mathrm{O}_{3} \\
\mathrm{Li}_{2} \mathrm{O} \\
\mathrm{MgO}^{2} \\
\mathrm{THO}_{2} \\
\mathrm{La}_{2} \mathrm{O}_{3} \\
\mathrm{ZrO}_{2} \\
\mathrm{Total}^{2}\end{array}$ & $\begin{array}{r}60.7 \\
22.3 \\
13.8 \\
4.1 \\
7.2 \\
15.6 \\
\because \quad 4.6 \\
\\
0.7\end{array}$ & $\begin{array}{r}197.6 \\
60.4 \\
50.2 \\
19.4 \\
6.8 \\
3.4 \\
1.7 \\
1.7 \\
341.2\end{array}$ & $\begin{array}{l}1.9 \\
1.1^{\circ} \\
4.7 \\
0.2\end{array}$ & \begin{tabular}{|r|}
60.7 \\
24.2 \\
-13.8 \\
4.1 \\
8.3 \\
219.9 \\
\\
65.2 \\
0.7 \\
50.2 \\
19.4 \\
6.8 \\
3.4 \\
1.7 \\
1.7 \\
480.1 \\
\end{tabular} & $\begin{array}{r}12.7 \\
5.1 \\
2.9 \\
0.8 \\
1.7 \\
45.6 \\
\\
13.5 \\
0.1 \\
10.5 \\
4.1 \\
1.4 \\
0.7 \\
0.4 \\
0.4 \\
100.0\end{array}$ \\
\hline
\end{tabular}

(a) Feed slurry content $=0.48 \mathrm{~kg} / \mathrm{L}$.

(b) Frit-131 composition (-200 mesh).

(c). Zeolite composition: Linde Ionsiv IE-95.

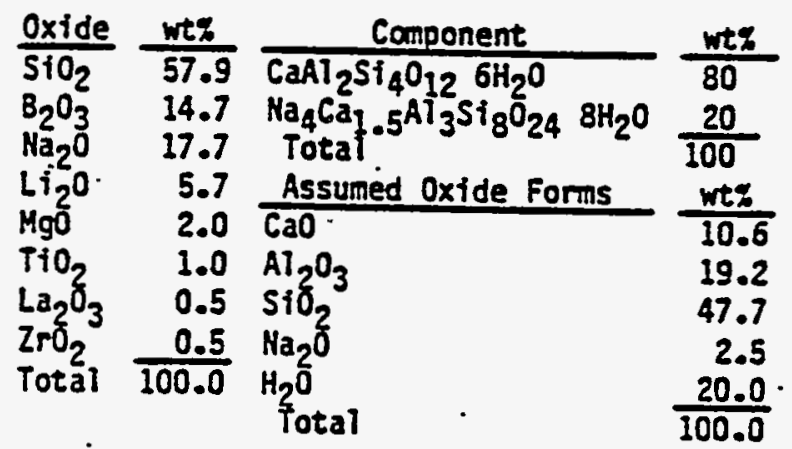


TABLE C-11A. Composition of Simulated West Valley Support Program PSCM Meiter Feed Slurry - PSCM-9 HWVP-85-VI143A

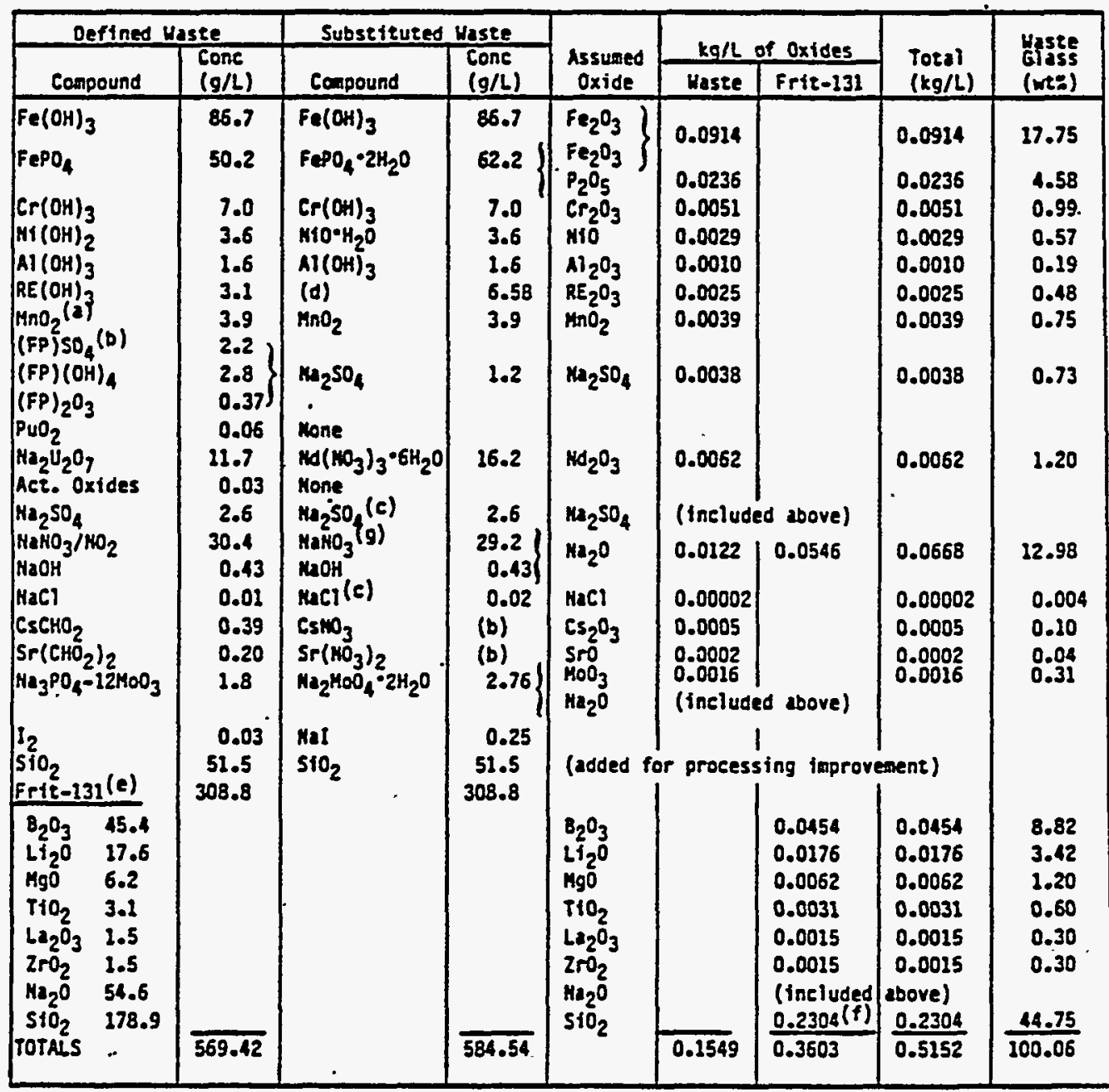

(a) $\mathrm{MnO}_{2}(-200 \mathrm{mesh})$.

(b) FP = Fisston product analogs/substitutes are added to the feed tank as a separate batch in the following concentration $(g / L)$. NOTE: Flousheet value is given in [ I If it is different from feed composition, or known.

$$
\begin{array}{lll}
S r=0.20 & C d=0.033 & {[?]} \\
C s=0.424 & S=0.071 & {[0.0024]} \\
R u=0.059 & I=0.25 & {[0.031]} \\
T e=0.05[?] & S b=0.12 & {[0.0002]} \\
Y=0.20[?] & &
\end{array}
$$

(c) Chloride and sulfate levels are likely to be dictared by tapurities in the $\mathrm{Fe}(\mathrm{OH})_{3}$.

(f) Includes $0.1789 \mathrm{~kg} / \mathrm{L} \mathrm{SiO}_{2}$ from Frit-131 and $0.0515 \mathrm{~kg} / \mathrm{L} \mathrm{SiO}_{2}$ added for process inprovement. (d) Rare Earth Mitrate Mix (6.58 g RE nitrate aix/L). Mominal oxide composition:

$\begin{array}{ll}\mathrm{CeO}=48 \% & \mathrm{Sm}_{2} \mathrm{O}_{3}=38 \\ \mathrm{La}_{2} \mathrm{O}_{3}=248 & \mathrm{Gd}_{2} \mathrm{O}_{3}=28 \\ \mathrm{MO}_{2} \mathrm{O}_{3}=178 & \mathrm{Y}_{2} \mathrm{O}_{3}=0.28 \\ \mathrm{Pr}_{5} \mathrm{O}_{11}=58 & \mathrm{aisc.}=0.88\end{array}$

(e) 200 mesh Frit-131

\begin{tabular}{l} 
wt \\
\hline 57.9 \\
14.7 \\
17.7 \\
5.7 \\
2.0 \\
1.0 \\
0.5 \\
0.5 \\
\hline 100.0
\end{tabular}

(g) $\mathrm{KaHO}_{3}$ amount reduced to account for ha added with $\mathrm{Ha}_{2} \mathrm{SO}_{4}$ and $\mathrm{Ha}_{2} \mathrm{HOO}_{4} \cdot 2 \mathrm{H}_{2} \mathrm{O}$. 
TABLE-C-11B. Composition of Simulated West Valley Support Program PSCM. Melter Feed S7urry - PSCM-15 HWVP-85-V1143A

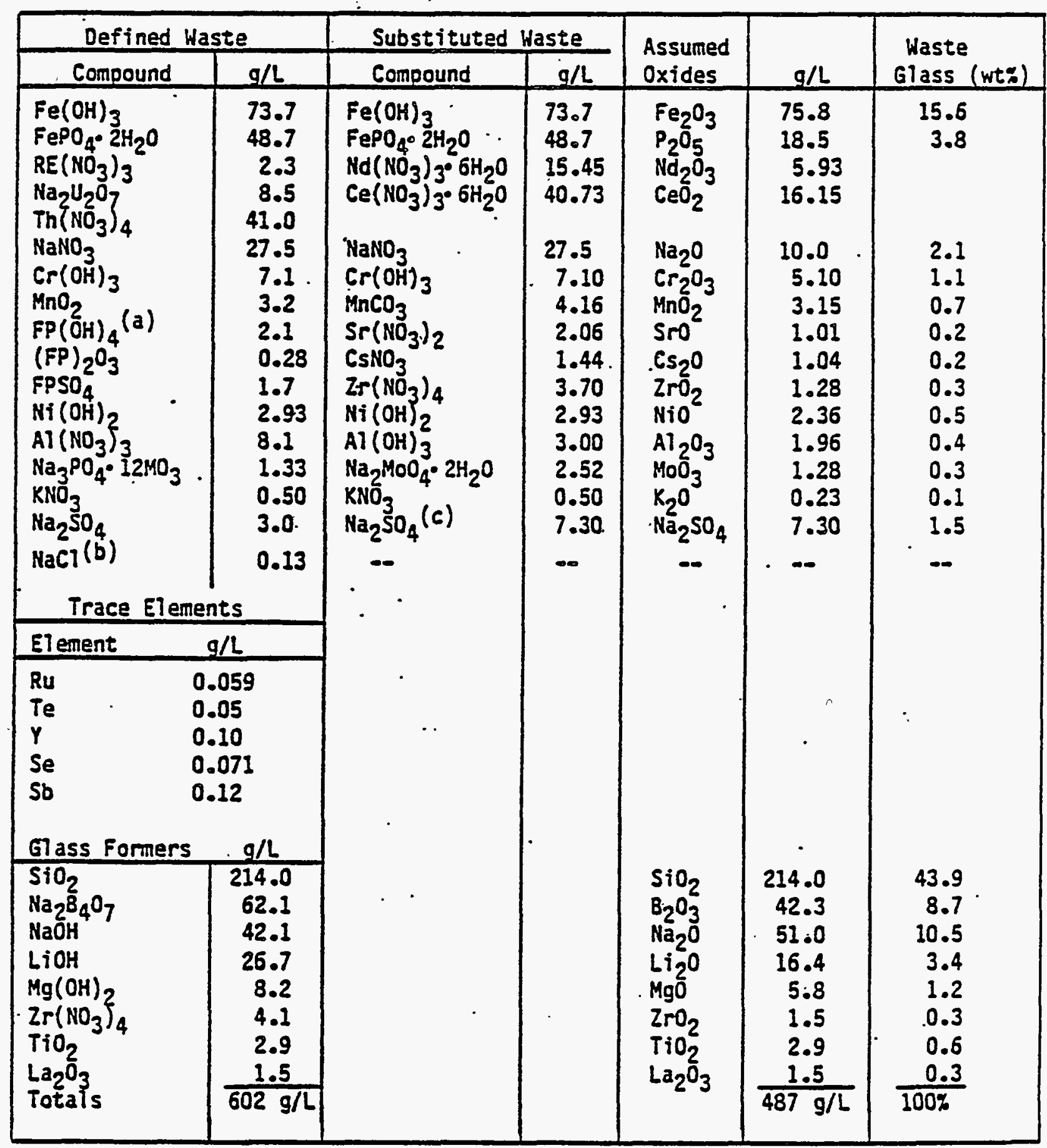

(a) FP denotes fission product.

(b) Chloride levels will be dictated by impurities in the $\mathrm{Fe}(\mathrm{OH})_{3}$.

(c) Sodium sulfate level is $50 \%$ higher than expected level that can be accomodated by glass and is to provide data on sulfate sait accumulation in the melter. 
TABLE 11C. Composition of Simulated Hest Valley Support Program PSCM Me7ter Feed S1urry - PSCM-16 HWVP-85-V1143A

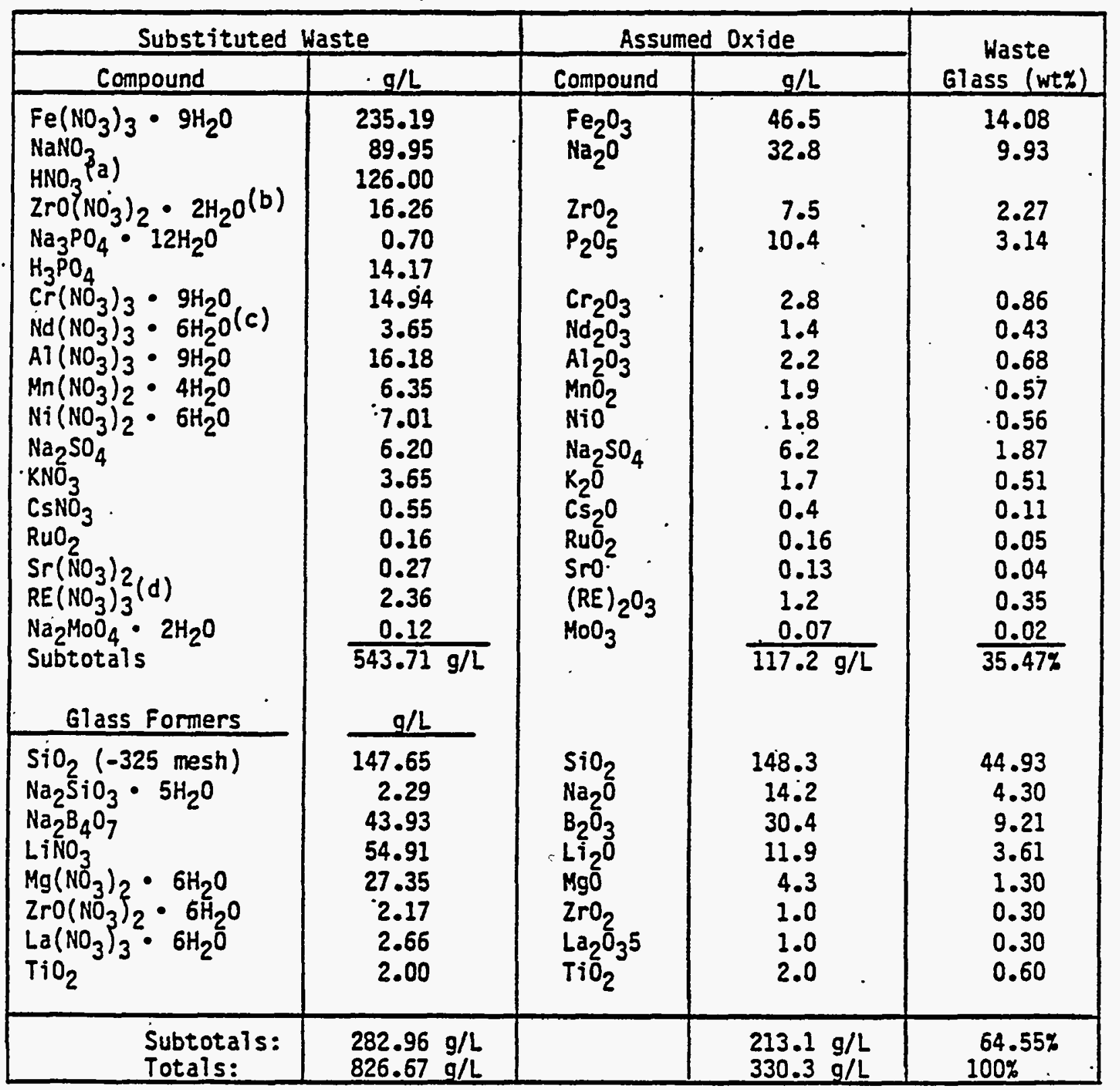

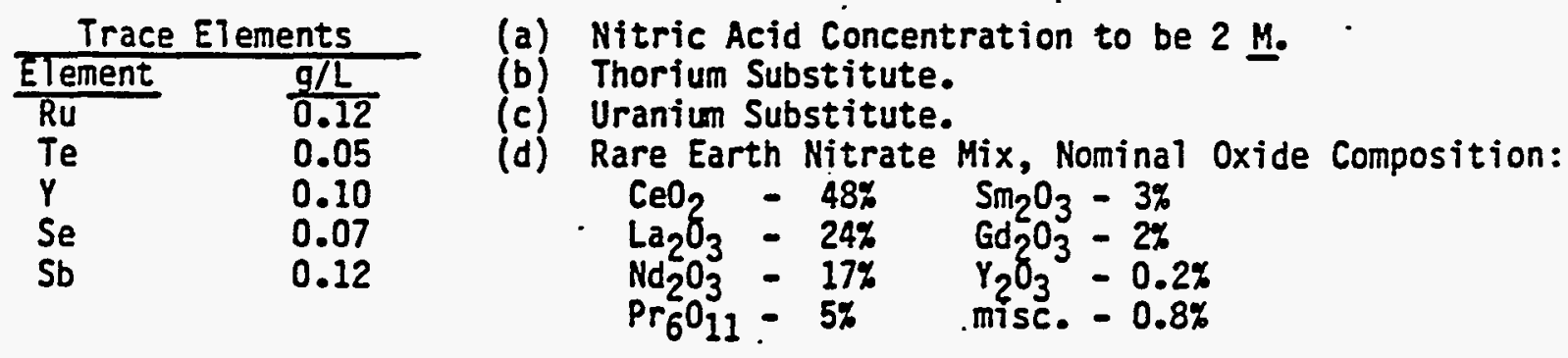


TABLE 11D. Composition of Simulated West Valley Support Program PSCM Melter Feed S7urry - PSCM-19 HWVP-85-V1143A

\begin{tabular}{|c|c|c|c|c|c|c|}
\hline \multicolumn{2}{|c|}{ Substituted Waste } & \multicolumn{2}{|c|}{ Assumed Oxide } & \multicolumn{3}{|c|}{ Final Glass } \\
\hline Compound & $g / L$ & Compound & $g / L$ & Oxide & $g / L$ & wex \\
\hline $\begin{array}{l}\mathrm{Fe}\left(\mathrm{NO}_{3}\right)_{3} \cdot 9 \mathrm{H}_{2} \mathrm{O} \\
\mathrm{NaNO} \mathrm{H}_{3} \\
\mathrm{Al}\left(\mathrm{NO}_{3}\right)_{3} \cdot 9 \mathrm{H}_{2} \mathrm{O} \\
\mathrm{Cr}\left(\mathrm{NO}_{3}\right)_{3} \cdot 6 \mathrm{H}_{2} \mathrm{O} \\
\mathrm{Ni}\left(\mathrm{NO}_{3}\right)_{2} \cdot 6 \mathrm{H}_{2} \mathrm{O}\end{array}$ & $\begin{array}{r}158.0 \\
8.9 \\
14.7 \\
12.5 \\
6.1\end{array}$ & $\begin{array}{l}\mathrm{Fe}_{2} \mathrm{O}_{3} \\
\mathrm{Na}_{2} \mathrm{O} \\
\mathrm{Al}_{2} \mathrm{O}_{3} \\
\mathrm{Cr}_{2} \mathrm{O}_{3} \\
\mathrm{MiO}\end{array}$ & $\begin{array}{l}4.51 \\
3.64 \\
2.00 \\
2.38 \\
1.58\end{array}$ & $\begin{array}{l}\mathrm{SiO}_{2} \\
\mathrm{Na}_{2} \mathrm{O} \\
\mathrm{B}_{2} \mathrm{O}_{3} \\
\mathrm{Fe}_{2} \mathrm{O}_{3} \\
\mathrm{RE}_{2} \mathrm{O}_{3}\end{array}$ & $\begin{array}{r}156.4 \\
52.8 \\
44.4 \\
43.0 \\
10.2\end{array}$ & $\begin{array}{r}44.7 \\
15.1 \\
12.7 \\
12.3 \\
2.9\end{array}$ \\
\hline $\begin{array}{l}\mathrm{Ce}\left(\mathrm{NO}_{3}\right)_{3} \cdot 9 \mathrm{H}_{2} \mathrm{O} \\
\mathrm{Rare} \text { Earth } \\
\mathrm{KNO}_{3} \\
\mathrm{CsNO} \\
\mathrm{Mn}\left(\mathrm{NO}_{3}\right)_{2} \cdot 4 \mathrm{H}_{2} \mathrm{O}\end{array}$ & $\begin{array}{c}14.6 \\
1.7 \\
0.60 \\
0.48 \\
4.9:\end{array}$ & $\begin{array}{l}\mathrm{RE}_{2} \mathrm{O}_{3} \\
\mathrm{CeO}_{2} \\
\mathrm{~K}_{2} \mathrm{O}^{2} \\
\mathrm{Cs}_{2} \mathrm{O} \\
\mathrm{MnO}_{2}\end{array}$ & $\begin{array}{r}10.26 \\
0.60 \\
0.28 \\
0.35 \\
1.68\end{array}$ & $\begin{array}{l}\mathrm{CeO}_{2} \\
\mathrm{Al}_{2} \mathrm{O}_{3} \\
\mathrm{CaO} \\
\mathrm{P}_{2} \mathrm{O}_{5} \\
\mathrm{Cr}_{2} \mathrm{O}_{3}\end{array}$ & $\begin{array}{c}0.6 \\
8.4 \\
10.5 \\
9.1 \\
2.38\end{array}$ & $\begin{array}{l}0.17 \\
2.4 \\
3.0 \\
2.6 \\
0.68\end{array}$ \\
\hline $\begin{array}{l}\mathrm{ZrO}\left(\mathrm{NO}_{3}\right)_{2} \cdot 2 \mathrm{H}_{2} \mathrm{O} \\
\mathrm{NaCl} \\
\mathrm{Ba}\left(\mathrm{NO}_{3}\right)_{2} \\
\mathrm{FePO}_{4} \cdot{ }^{2} \mathrm{H}_{2} \mathrm{O} \\
\mathrm{Na}_{2} \mathrm{SO}_{4}\end{array}$ & $\begin{array}{c}14.7 \\
0.34 \\
0.36 \\
24.1 \\
0.87\end{array}$ & $\begin{array}{l}\mathrm{ZrO}_{2} \\
-\mathrm{BaO}^{2} \\
\mathrm{P}_{2} \mathrm{O}_{5} \\
\mathrm{SO}_{3}\end{array}$ & $\begin{array}{l}5.88 \\
-- \\
0.21 \\
9.14 \\
0.49\end{array}$ & $\begin{array}{l}\mathrm{ZrO}_{2} \\
\mathrm{MnO}_{2} \\
\mathrm{NiO}^{2} \\
\mathrm{Cs}_{2} \mathrm{O} \\
\mathrm{K}_{2} \mathrm{O}\end{array}$ & $\begin{array}{l}5.88 \\
1.72 \\
1.58 \\
0.35 \\
0.60\end{array}$ & $\begin{array}{l}1.68 \\
0.49 \\
0.45 \\
0.10 \\
0.17\end{array}$ \\
\hline $\begin{array}{l}\mathrm{RuO}_{2} \\
\mathrm{Y}_{2} \mathrm{O}_{3} \\
\mathrm{Sr}^{2}\left(\mathrm{NO}_{3}\right)_{2} \\
\quad \text { Subtotals }\end{array}$ & $\begin{array}{l}0.28 \\
0.07 \\
0.22 \\
263.4\end{array}$ & $\begin{array}{l}\mathrm{RuO}_{2} \\
\mathrm{Y}_{2} \mathrm{O}_{3} \\
\mathrm{SrO}^{2}\end{array}$ & $\begin{array}{l}0.28 \\
0.07 \\
0.11 \\
80.5\end{array}$ & $\begin{array}{l}\mathrm{BaO} \\
\mathrm{SO}_{3} \\
\mathrm{RuO}_{2} \\
\mathrm{Y}_{2} \mathrm{O}_{3} \\
\mathrm{SrO}^{2} \\
\mathrm{TiO}_{2} \\
\mathrm{MgO}^{2}\end{array}$ & $\begin{array}{c}0.35 \\
0.70 \\
0.28 \\
0.07 \\
0.10 \\
0.10 \\
0.35 \\
349.9\end{array}$ & $\begin{array}{c}0.10 \\
0.20 \\
0.08 \\
0.02 \\
0.03 \\
0.03 \\
0.10 \\
100.0\end{array}$ \\
\hline
\end{tabular}


TABLE 11D. (contd)

\begin{tabular}{|c|c|c|c|}
\hline \multicolumn{2}{|c|}{ Substituted Waste } & \multicolumn{2}{|c|}{ Assumed Oxide } \\
\hline Compound & $g / L$ & Compound & $g / L$ \\
\hline & Zeolite & & \\
\hline $\begin{array}{l}\mathrm{SiO}_{2} \\
\mathrm{Al}_{2} \mathrm{O}_{3} \\
\mathrm{Na}_{2} \mathrm{O} \\
\mathrm{Fe}_{2} \mathrm{O}_{3} \\
\mathrm{CaO} \\
\mathrm{SO}_{3} \\
\mathrm{~K}_{2} \mathrm{O} \\
\mathrm{BaO} \\
\mathrm{MgO} \mathrm{TiO}_{2} \\
\mathrm{H}_{2} \mathrm{O}^{2}\end{array}$ & $\begin{array}{r} \\
\\
24.1 \\
6.5 \\
1.3 \\
1.4 \\
1.4 \\
1.5 \\
0.2 \\
0.3 \\
0 \quad 0.1 \\
0.4 \\
0.1 \\
4.5 \\
40.4\end{array}$ & $\begin{array}{l}\mathrm{SiO}_{2} \\
\mathrm{Al}_{2} \mathrm{O}_{3} \\
\mathrm{Na}_{2} \mathrm{O} \\
\mathrm{Fe}_{2} \mathrm{O}_{3} \\
\mathrm{CaO} \\
\mathrm{SO}_{3} \\
\mathrm{~K}_{2} \mathrm{O} \\
\mathrm{BaO} \\
\mathrm{MgO} \mathrm{TiO}_{2}\end{array}$ & $\begin{array}{r}24.1 \\
6.5 \\
1.3 \\
1.4 \\
1.5 \\
0.2 \\
0.3 \\
0.1 \\
0.4 \\
.1 \\
35.9\end{array}$ \\
\hline & Glass Formers & Additive & - \\
\hline 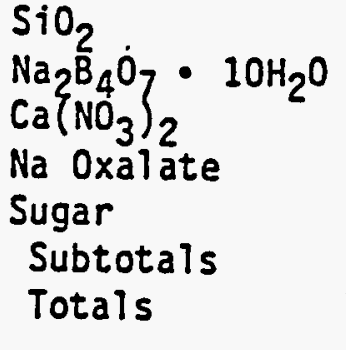 & $\begin{array}{l}132.3 \\
128.2^{(b)} \\
26.3 \\
56.0 \\
\frac{(b)}{342.8} \\
\frac{346.6}{6}\end{array}$ & $\begin{array}{l}\mathrm{SiO}_{2} \\
\mathrm{~B}_{2} \mathrm{O}_{3} \\
\mathrm{CaO}^{2} \\
\mathrm{Na}_{2} \mathrm{O}\end{array}$ & $\begin{array}{c}132.3 \\
44.6(a) \\
9.0 \\
47.7 \\
\frac{-.}{233.6} \\
\frac{350.0}{}\end{array}$ \\
\hline
\end{tabular}

(a) Assumes a 5\% loss of $B$ due to volatility.

(b) Sugar concentrations of $0.42,57$, and $76 \mathrm{~g} / \mathrm{L}$ were used. 



\section{APPENDIX D}

NOX EMISSION ABATEMENT TECHNOLOGIES 
APPENDIX D

\section{NOX EMISSION ABATEMENT TECHNOLOGIES $(a)$}

In the liquid-fed ceramic melter (LFCM) vitrification process, all feed component nitrogen is lost to the process exhaust. (b) Since Hanford Waste Vitrification Plant (HWVP) feed component nitrogen will be almost entirely composed of $\mathrm{NO}_{3}^{-}$and $\mathrm{NO}_{2}^{-}$anions, process emissions of nitrogen will be composed primarily of the gaseous effluents $\mathrm{NO}_{2}$ and $\mathrm{NO}$, or $\mathrm{NO}_{x}$ for short. The relative proportion to which each of the $\mathrm{NO}_{\mathrm{x}}$ components is produced depends on how oxidizing the process is.. Without organic feed reductants, $\mathrm{NO}_{2}$ emissions will predominate. As the carbon loading of LFCM feeds increase, the importance of NO emissions will also increase. For the HWVP reference feed composition, a low average $\mathrm{NO}_{x}$ oxidation state (high $\mathrm{NO} / \mathrm{NO}_{2}$ ) would be predicted. This prediction was confirmed during a recent cold simulation of the HWVP process $(c)$ (PSCM-22) where $80 \%$ of the $\mathrm{NO}_{x}$ evolved was found to be NO.

Although NO is not a noxious environmental pollutant, it is quickly converted to $\mathrm{NO}_{2}$, which is. As a result, process emission limits for nitrogen oxides are based upon the magnitude of. $\mathrm{NO}_{x}$ concentrations independent of composition. For HWVP, $\mathrm{NO}_{x}$ emissions may be high enough, depending upon the nitrogen feed loading, to require impiementation of $\mathrm{NO}_{x}$ emission control technology. This appendix summarizes and compares applicable $\mathrm{NO}_{x}$ emission abatement technologies so that alternatives can be evaluated for ${ }^{\mathrm{N}} \mathrm{O}_{x}$ emission control for the HWVP.

\section{D.1 NO $x$ CONTROL TECHNOLOGIES}

Although plant emission limits are independent of $\mathrm{NO}_{\mathrm{NO}}$ ratios, the average oxidation state of $\mathrm{NO}_{x}$ is quite important in evaluating technical alternatives for emission abatement. Nitrogen dioxide is much more reactive with an aqueous media than is NO; consequently, wet scrubbing strategies are strongly dependent upon the characteristics of the $\mathrm{NO}_{\mathrm{x}}$ source term. Dry $\mathrm{NO}_{\mathrm{x}}$ abatement technologies, on the other hand, are much less sensitive to $\mathrm{NO}^{-\mathrm{NO}_{2}}$

(a) R. W. Goles, NO Emission Abatement Technologies. HWVP-87-V110305B, Pacific Northwest Laboratory, Richland, Washington (September 1987).

(b) R. W. Goles, HWVP Melter Off-Gas System Evaluation. HWVP-87-V1210305A, Pacific Northwest Laboratory, Richland, Hashington (1987).

(c) R. K. Nakaoka, Pilot-Scale Ceramic Melter Test Run Summary HWVP-121 PSCM-22. HWVP-86-V1124A, Pacific Northwest Laboratory, Richland, Hashington (1985). 
ratios but are limited by a variety of other processing conditions. Since the wet- and dry-based technologies are so dissimilar, each will be discussed separately.

\section{D.1.1 Wet Treatment Methods}

Conventional aqueous $\mathrm{NO}_{x}$ scrubbing techniques are limited by low concentrations, high $\mathrm{NO}_{2} \mathrm{NO}_{2}$ ratios, and by the fundamental chemist gy, governing $\mathrm{NO}_{2}$ absorption (Ref. D-1). AIT three limitations apply to HWVP. (a) For an atmospheric-pressure nonrecycle water scrubber, maximum expected removal efficiency for $\mathrm{NO}_{2}$ at low concentrations ( $\$ 1000 \mathrm{ppm}$ ) has been projected to be $60 \%$ (Ref. D-1). This $\mathrm{NO}_{x}$ scrubbing efficiency $\left(\mathrm{NO}_{2} / \mathrm{NO}_{x}=1\right)$ would be dramatically reduced if significant NO was present (as is the case for HWVP) or if the scrubbing liquor was recycled. The limitations to conventional wet scrubbing efficiencies can, however, be overcome to some extent through physical and chemical process design modification.

For a fixed scrubber design, NOx scrubbing efficiency increases with increasing effluent concentration. Therefore, process exhaust recycle to offgas film coolers, which is currently being evaluated by Fluor, would act to enhance wet $\mathrm{NO}_{x}$ scrubbing efficiency if the column was located downstream of the recycle extraction point. Since $\mathrm{NO}_{x}$ concentrations would only be increased by a factor of 2 (HWP-RCD) by recycle, scrubbing efficiency would not be significantly improved by this off-gas system modification alone; however, recycle would have a definite impact upon equipment sizing.

Combining adsorption methods with wet scrubbing techniques is yet another way of overcoming concentration limitations to scrubbing. Since absorption is considered a dry removal process, it is discussed in more detail in the following section.

To overcome the NO limitation to wet $\mathrm{NO}_{x}$ scrubbing efficiencies, NO can be converted to $\mathrm{NO}_{2}$. The oxidation-absorption technique (Ref. D-2) is a method by which $\mathrm{NO}$ is converted to $\mathrm{NO}_{2}$ in the process exhaust prior to liquid contacting. Ozone $\left(\mathrm{O}_{3}\right)$ and chlorine dioxide $\left(\mathrm{ClO}_{2}\right)$ are common oxidants that have been successfully used for this purpose. The absorption-oxidation method (Ref. D-2) is similar to the previous tectinique, but liquid-phase reactions between an aqueous oxidant $\left(\mathrm{H}_{2} \mathrm{O}_{2}, \mathrm{MnO}_{4}^{-}\right)$and $\mathrm{NO}_{(a q)}$ are used. Because of low NO solubility, much longer gas-liquid contact times are required for this latter technique. Consequently, large absorbers with high liquid-to-gas ratios $\left(\mathrm{L} / \mathrm{G}=15 \mathrm{~L} / \mathrm{Nm}^{3}\right.$ ) and 1 ow superficial velocities ( 1 to $3 \mathrm{~m} / \mathrm{s}$ ) are required to

(a) R. W. Goles, HWVP Melter Off-Gas System Evaluation. HWVP-87-V1210305A, Pacific Northwest Laboratory, Richland, Washington (1987). 
support it. ${ }^{N O} x$ removal efficiencies of $85 \%$ to $90 \%$ (DF 10) have been demonstrated by both of these chemically modified scrubbing techniques.

The basic chemistry governing aqueous $\mathrm{NO}_{\mathrm{x}}$ absorption can also be modified by adding complexing agents to the scrubbing liquor that catalyze the $\mathrm{NO}_{4}-\mathrm{H}_{2} \mathrm{O}$ absorption process. Ferrous ethylene dianine tetraacetic acid (Fe ${ }^{2+}$ EDTA) has been successfully used to increase scrubbing efficiencies for both $\mathrm{NO}$ and $\mathrm{NO}_{2}$ without the use of expensive oxidants (Ref. D-2). Like the absorptionoxidation method, this technique requires an absorber with a large $L / G$ ratio and low superficial gas velocities if NO is to be directly sorbed. However, prior gas-phase oxidation can significantly reduce the required size of the liquid-gas contactor. This oxidation-complexation technique for $\mathrm{NO}_{\mathrm{x}}$ removal has been evaluated in fossil fuel power plant flue gas applications, with demonstrated scrubbing efficiencies of $\sim 90 \%$ (Ref. D-2).

From the above discussion, it is apparent that wet scrubbing techniques can be effectively utilized in reducing $\mathrm{NO}_{\mathrm{x}}$ emissions. These methods have been successfully applied to combustion gases that exhibit $\mathrm{NO}_{\mathrm{x}}$ compositions (500 ppm) similar to those projected for the HWVP process. With proper design of the $\mathrm{NO}_{x}$ absorber and application of chemical methods to enhance absorption kinetics, wet scrubbing techniques could be used to reduce HWVP $\mathrm{NO}_{x}$ process effluent by $>60 \%$ should emission abatement become necessary. A comparison of wet scrubbing approaches is presented in Table D-1. 
TABLE 0 -1. Characteristics of $\mathrm{NO}_{x}$ Technologies

\begin{tabular}{|c|c|c|}
\hline $\begin{array}{l}\text { Abatement } \\
\text { Téchnology }\end{array}$ & Advantages & Disadvantages \\
\hline$\frac{\text { Wet Trea bnent }}{\cdot}$ & $\begin{array}{l}\text { Mul ti-purpose } \\
\text { Simple, developed }\end{array}$ & Waste generator, inefficient, costly \\
\hline $\begin{array}{l}\text { Water } \\
\text { scrubber }\end{array}$ & Simple & $\begin{array}{l}\text { Extremely large equipment } \\
\text { required }\end{array}$ \\
\hline $\begin{array}{l}\text { Oxidation- } \\
\text { Absorption }\end{array}$ & $\begin{array}{l}\text { Decrease equip. size } \\
\text { requirements, more } \\
\text { efficient }\end{array}$ & $\begin{array}{l}\text { Gas-phase oxidants required, increased } \\
\text { waste probl ems, more compl ex. }\end{array}$ \\
\hline $\begin{array}{l}\text { Absorption- } \\
\text { Oxidation }\end{array}$ & $\begin{array}{l}\text { Increased scrub } \\
\text { efficiency }\end{array}$ & $\begin{array}{l}\text { Extremely large equip. required, } \\
\text { increased waste, expensive oxidants. }\end{array}$ \\
\hline $\begin{array}{l}\text { Oxidation- } \\
\text { Complexation }\end{array}$ & $\begin{array}{l}\text { High efficiency, } \\
\text { reduced equipment size }\end{array}$ & $\begin{array}{l}\text { Increased waste, costly oxidants, } \\
\text { complex process }\end{array}$ \\
\hline$\frac{\text { Ory Reducing }}{\text { Methods }}$ & $\begin{array}{l}\text { High efficiency, } \\
\text { simpie, no waste, } \\
\text { well developed. }\end{array}$ & $\begin{array}{l}\text { Requires reductant, aerosol } \\
\text { sensitive, high temperatures, } \\
\mathrm{NO}_{x} \text { specific }\end{array}$ \\
\hline Ṣ́R & $\begin{array}{l}\text { Hell establ ished, } \\
\text { efficient, safe }\end{array}$ & $\begin{array}{l}\text { Requires } \mathrm{NH}_{3} \text {, requires temperature } \\
\text { control, } \mathrm{NH}_{3} \text { and } \mathrm{N}_{2} \mathrm{O} \text { potential effluents }\end{array}$ \\
\hline NCR & Efficient & $\begin{array}{l}\text { High fuel use, costly, } \mathrm{O}_{2} \text { depleted. } \\
\text { streams oniy }\end{array}$ \\
\hline SNR & Extremeiy simpie & $\begin{array}{l}\text { Low efficiency, not well developed, very } \\
\text { high temp, tight temp control required }\end{array}$ \\
\hline Other Dry & . & \\
\hline Adsorption & Efficient & $\begin{array}{l}\text { Large equipment requirements, high } \\
\text { energy, compl ex, waste generator }\end{array}$ \\
\hline Radiation & $\begin{array}{l}\text { Simple, no service } \\
\text { requirements, no } \\
\text { aqueous wastes, } \\
\text { remote, compatible } \\
\text { with existing } \\
\text { equipment }\end{array}$ & $\begin{array}{l}\text { Extremely large radioactive source } \\
\text { required, may require chenical } \\
\text { additives }\end{array}$ \\
\hline
\end{tabular}




\section{D.1.2 Dry Treatment Methods}

As the name implies, dry $\mathrm{NO}_{x}$ treatment methods do not require aqueous scrubbing support and do not generate a condensed-phase waste stream. Indeed, the main virtue associated with most dry technologies is that they eliminate the pollution problem rather than transforming it. For a variety of reasons, including simplicity, economy, and compatibility, dry denitrification methods have been extensively developed for the purpose of supporting effluent control at fossit fuel power plants. This is especially true in Japan. All dry denitrification processes can be placed into essentially five categories. These categories are:

- selective catalytic reduction (SCR)

- nonselective catalytic reduction (NCR)

- selective noncatalytic reduction (SNR)

- adsorption

- radiation

The advantages of the $\mathrm{NO}_{x}$ abatement methods associated with each of these groups is discussed as they apply to the HWVP processing needs.

D.1.2.1 Selective Catalytic Reduction (SCR). Thịs technology utilizes $\mathrm{NH}_{3}$ and an appropriate catalyst to selectively reduce $\mathrm{NO}_{x}$ to $\mathrm{N}_{2}$. In addition. to this primary task, the catalyst must also be capable of converting excess $\mathrm{NH}_{3}$ to $\mathrm{N}_{2}$ and minimizing competing reactions that can produce undesirable effluent such as $\mathrm{N}_{2} \mathrm{O}$. A variety of catalysts have been used to support SCR (Ref. D-3); most of these catalysts are quite efficient $(>90 \%)$ and essentially all are proprietary. Metal-based catalysts (noble and nonnoble) have been used extensively in the denitrification of oxygen depleted flue gases. However, these catalysts, in general, have quite narrow operating temperature ranges that are limited at the $10 \mathrm{~W}$ end by $\mathrm{NH}_{4} \mathrm{NO}_{3}$ formation and at the upper end by competing oxygen reactions, which consume reductant and further increase reactor temperatures (Ref. D-4). Nevertheless, several of these metal-based SCR systems have been examined in nuclear process applications involving high- $\mathrm{O}_{2}(20 \%)$ process stream conditions. Bruggeman (Ref. D-5) evaluated $\mathrm{Fe}_{2} \mathrm{O}_{3}-\mathrm{Cr}_{2} \mathrm{O}_{3}-\mathrm{C}$ and $\mathrm{Pd}-\mathrm{Al}_{2} \mathrm{O}_{3}$ as SCR catalysts under simulated reprocessing conditions. Both catalysts lacked required efficiency. Titanium, which also has been evaluated under oxidizing conditions, has been found to be an effective but difficult to use SCR catalyst that can produce significant.quantities of $\mathrm{N} 20$ effluent (Ref. D-6).

Natural and synthetic zeolites also have been evaluated as potential SCR catalysts (Ref. D-3, D-4, D-5, D-6). Sodium zeolites have been satisfactorily used for $\mathrm{NO}_{2}$ reduction but were found to be ineffective for NO. A platinum zeolite has been found to actually catalyze the conversion of $\mathrm{NH}_{3}$ to $\mathrm{NO}_{x}$, 
making it totally unsuitabie as a $\mathrm{NH}_{3}$-based SCR catalyst. Hydrogen zeolite, on the other hand, has enjoyed great success as a SCR catalyst in oxygen-rich $\left(\mathrm{O}_{2}>10 \%\right)$ process streams. It is efficient for reducing both $\mathrm{NO}_{x}$ components, has a very wide operating temperature range $\left(300^{\circ} \mathrm{C}\right.$ to $\left.750^{\circ} \mathrm{C}\right)$, is not poisoned by sulfur or iodine compounds, is not significantly affected by high off-gas water loadings, and produces very little $\mathrm{N}_{2} \mathrm{O}$ by-product. Hydrogen zeolites also efficiently catalyze $\mathrm{NH}_{3}$ reduction to $\mathrm{N}_{2}$; however, process water loading. has been observed to impact the conversion efficiency of this reaction. In comparative tests, hydrogen zeolites have been found to meet or exceed the performance of several metal-based SCR catalysts in oxygen-rich $\left(0_{2}>10 \%\right)$ process streans.

The apparent effectiveness of hydrogen zeolites as an SCR catalyst has led to several pilot-scale tests designed to further evaluate the applicability of the SCR technology to $\mathrm{NO}_{x}$ emission abatement in nuclear process streams. The Idaho National Engineering Laboratory (INEL) applied this technology to a simulated waste calciner exhaust stream (Ref. D-8). Greater than 99\% abatement efficiency was obtained for both $\mathrm{NO}$ and $\mathrm{NO}_{2}$ in the temperature range of $340^{\circ} \mathrm{C}$ to $440^{\circ} \mathrm{C}$ using a $\mathrm{NH}_{3} / \mathrm{NO}_{\mathrm{x}}$ ratio of 1.3. Using the design criteria established at INEL, the National Lead Corporation constructed an SCR emission abatement plant to control $\mathrm{NO}_{x}$ tail gas emissions generated by uranium dissolution and purification processes (Ref. D-7). NO ${ }_{x}$ abatement efficiencies $>99 \%$ were dẹmonstrated for wet $\left(46^{\circ} \mathrm{C}\right.$ dew point) process streams containing up to $0.5 \% \mathrm{NO}_{\mathrm{X}}$ ( $30 \% \mathrm{NO}$ ). EXXON nuclear also applied the hydrogen zeolite SCR technology to its uranium dissolver off-gas stream $\left(2.5 \% \mathrm{NO}_{x}, 65 \% \mathrm{H}_{2} \mathrm{O}\right)$ - and obtained $\mathrm{NO}_{x}$ destruction efficiencies that exceeded $99 \%$ (Ref. D-4)?

Although the above examples illustrate the usefulness of (hydrogen zeolite) SCR methods for dealing with high $\mathrm{NO}_{x}$ concentrations, the technique has also been successfully applied to process streams with low (500 ppm) $\mathrm{NO}_{x}$ concentrations. Thomas examined the suitability of hydrogen zeolite as an SCR catalyst for removal of $\mathrm{NO}_{x}$ in simulated fossil fuel plant exhausts (500 ppm NO, $3000 \mathrm{ppm} \mathrm{SO}, 12 \% \mathrm{CO}_{2}$, and air with a $35^{\circ} \mathrm{C}$ dew point) (Ref. D-4). The study showed that NO could be selectively reduced to below 7 ppr before competing reactions with $\mathrm{SO}_{2}$ limited the reduction process; however, the potential for using this technology for simultaneous $\mathrm{SO}_{2}$ recovery as ammonium bisulfate and sulfate was also demonstrated. Norton has recently developed and patented a natural hydrogen zeolite catalyst that is highly specific for $\mathrm{NO}_{x}$ and exhibits negligible $\mathrm{SO}_{2}$ activity-a highly desirable property for industrial power plant operations. This catalyst is currently being successfully used to reduce power plant boiler emissions of $\mathrm{NO}_{x}(500 \mathrm{ppm})$ at a fossil fuel
facility in Nurenburg, Germany.

(a) S. M. Turner, Porduct Manager, Norton Chenical Process Products Div., Norton Corp. Private Technical Communication (1987). 
Selective catalytic reduction techniques for $\mathrm{NO}_{x}$ destruction have been successfully demonstrated in small-, pilot-, and large-scale applications under a variety of processing conditions. The method is highly efficient $(>90 \%)$, is applicable to a wide range of $\mathrm{NO}_{x}(500$ to $30,000 \mathrm{ppm})$ and $\mathrm{O}_{2}(2$ to $20 \%)$ concentrations, and it eliminates a pollution problem without creating a waste stream. Minimal temperature control constraints $\left(\mathrm{T}>250^{\circ} \mathrm{C}\right)$ can easily mitigate safety concerns regarding the potential production of ammonium nitrate salts. Since hydrogen zeolite catalysts have a very wide operating temperature range $\left(325^{\circ} \mathrm{C}\right.$ to $750^{\circ} \mathrm{C}$ ) and are normally controlled at $-400^{\circ} \mathrm{C}$, maintaining catalytic reactor temperatures above $250^{\circ} \mathrm{C}$ is a trivial process control task. Selective catalytic reduction methods for $\mathrm{NO}_{x}$ reduction have been shown to be effective and versatile as well as safe; furthermore, this technology is compatible and. directly applicable to the HWNP process should $\mathrm{NO}_{\mathrm{x}}$ emission abatement be required.

D.1.2.2 Nonselective Catalytic Reduction (NCR). This process utilizes a fuel or reducing gas in combination with a catalyst to promote the reduction of all oxidizing agents in the treated process exhaust stream. Since $\mathrm{O}_{2}$ is consumed preferentially by this nonselective method, all process oxygen has to be consumed before $\mathrm{NO}_{x}$ can be reduced (Ref. D-2). Due to the exothermic nature of the combustion process, catalytic burnup limits the application of the NCR technology to oxygen depleted $\left(\mathrm{O}_{2}<3 \%\right)$ process streams (Ref. D-4). This method of $\mathrm{NO}_{\mathrm{x}}$ destruction is clearly incompatible with reference HWVP process conditions and, consequently, will not be discussed further.

D.1.2.3 Selective Noncatalytic Reduction (SNC). This themal denitrification process utilizes $\mathrm{NH}_{3}$ and high temperatures $\left(1000^{\circ} \mathrm{C}\right)$ to selectively reduce No to $\mathrm{N}_{2}$. The efficiency of this technology is expected to be $<70 \%$ (Ref. D-9). Although SNC is simple in comparison to other wet and dry denitrification processes, its application, in practice, can be quite difficult. This difficulty is due to the fact that SNC reduction efficiency is highly temperature dependent. If operating conditions vary from the narrow temperature range required (which is $\mathrm{NH}_{3}$ /NO dependent), additional NO effluent will be produced or unreacted $\mathrm{NH}_{3}$ will be discharged. Selective noncatalytic reduction has been exclusively applied to oxygen-depleted $\left(0_{2}<5 \%\right)$ process streams (flue gases) (Ref. D-2), and thus the effect of high $(-20 \%)$ oxygen concentrations upon potential competing reactions ( $\mathrm{NO}_{2}, \mathrm{NO}$ production) and upon denitrification efficiency in general has not been established. The applicability of SNC to the HWVP process is doubtfu?.

0.1.2.4 Adsorption. The dry adsorption process is based upon a catalytically active sorption bed that not only physically removes $\mathrm{NO}_{x}$ from the process stream but also efficiently converts the NO component to the easily (wet) scrubbed $\mathrm{NO}_{2}$ species. Typically, two beds are utilized to support a continuous denitrification process. The beds are cyclically employed so that one bed is 
always being loaded while the other is being regenerated. The highly concentrated $\mathrm{NO}_{2}$ strean produced during regeneration is usually recovered (at high efficiency.) with conventional scrubbing equipment. The PuraSiv-N molecular sieye process developed by Union Carbide has been successfully applied to the nitric acid plant tai] gas enissions ( $-3000 \mathrm{ppm})$ with reported $\mathrm{NO}_{x}$ recovery efficiencies of $>90 \%$ (a) Application of this process would be quite useful in overcoming concentration and chemical (NO) limitations to wet scrubbing techniques previously discussed if $\mathrm{HNO}_{3}$ recovery is considered useful and desirable. Othemwise the adsorption system will add significant complexities and waste handling problems to the process. This technology is compatible with the HWVP process, but it may not be economically practical since it is not a stand alone system and must be supported by a NO $x$ removal method that could be used to mitigate the process emission problem directly.

0.1.2.5 Radiation. Extensive investigations have been conducted evaluating the effectiveness of using ionizing radiation for the destruction of $\mathrm{NO}_{x}$ and $\mathrm{SO}_{2}$ compounds (Ref. D-2). Again, most of this work has been directed at developing more efficient and cost effective methods for eliminating fiue gas pollutants generated by fossil fuel power plants. Due to the nature of the industry for which these methods are being developed, the source of ionizing radiation used in essentially all of these evaluations is an high-energy electron beam.

The radiation method of pollution abatement is based upon the chemical transformation of the complex pollutants into simpler innocuous compounds that can be emitted into the environment or easily removed from the process exhaust. The mechanisms responsible for these chemical transformations are quite complex and composition dependent. In general, the processes of importance in radiation chemistry include fonization, the formation of excited electronic states, the transfer. of excitation energy between molecules, molecular dissociation, electron capture, neutralization, and radical reactions. The relative importance of each of these processes is dependent upon the chemical reactants present. Consequentiy, chemical additives can and have been used to control the composition and yield of radiolytic products.

If typical flue gases are exposed to Mrad doses of ionizing radiation, 290\% of the $\mathrm{NO}_{x}$ present will be radiolytically converted to $\mathrm{N}_{2}$ and other condensed phase compounds, for example $\mathrm{HNO}_{3}$ (Ref. D-10). Since the nature of the condensed phase radiolytic products of $\mathrm{NO}_{x}$ are in general easily removed by conventional flue gas treatment systems, application of ionizing radiation can eliminate the need for specialized and costly $\mathrm{NO}_{x}$ (and $\mathrm{SO}_{2}$ ) emission abatement equipment. A $10,000 \mathrm{Nm}^{3} / \mathrm{h}$ pilot plant using this technology has been built by

(a) L. L. Fornoff, Union Carbide Corporation, Material Systems Division, 270 Park Ave., New York, Priyate communications. 
the Ebara Manufacturing Corp. to treat $\mathrm{NO}_{\mathrm{x}}$ and $\mathrm{SO}_{2}$ emissions generated by an iron ore sintering plant operated by Nippon Steel Corporation (Ref. D-11). The only active effluent removal component in the system was an electrostatic precipitator. Nevertheless, demonstrated removal efficiencies of $95 \%$ and $85 \%$ were achieved for $\mathrm{NO}_{x}$ and $\mathrm{SO}_{2}$, respectively. Ebara, supported by the U.S. Department of energy, is currently applying this radiolytic $\mathrm{NO}_{x}$ and $\mathrm{SO}_{2}$ abatement technology to a fossil fuel power plant operated by Indianapolis Power and Light (Ref. D-12).

In gases, the radiolytic chemical reactions observed are found to be independent of the type and energy of the ionizing radiation used. In addition, the magnitude of the effects in a particular system is solely determined by the total energy absorbed -- the dose. Consequentiy, passive radioactive sources $\left({ }^{137} \mathrm{Cs}\right)$ can effectively replace the complex, high-energy scanning electron source used almost exclusively in flue gas denitrification investigations. The required source strength of an isotopic irradiator would, admittedly, be exceedingly high ( $>M C i$ ), but high-intensity $137 \mathrm{Cs}$ sources are available at Hanford that could be readily used to support this application. Since the irradiation source need only catalyze selected radiolytic reactions to remove $\mathrm{NO}_{x}$ effluent, source strength requirements of this approach could be significantly reduced by controlling off-gas chemistry. The radiolytic $\mathrm{NO}_{x}$ destruction technology is compatible with HWVP design, and its application is, in principle, simple as well as straightforward. Whether this technology is practical or not is a question that requires further study. A comparison of dry scrubbing techniques is presented in Table D-1.

\section{D.2 COMPARISON OF WET AND DRY EFFLUENT ABATEMENT TECHNOLOGIES}

$\mathrm{NO}_{\mathrm{x}}$ abatement technologies have been examined for the purpose of identifying alternative off-gas treatment methods that are appiicable to the HWVP process should plant emissions need to be controlled. A summary of the process characteristics of the various scrubbing technologies is presented in Table D-1. Denitrification processes can be separated into two distinct categories, wet or dry, depending upon whether or not $\mathrm{NO}_{\mathrm{x}}$ is absorbed into an aqueous solution. Dry methods for $\mathrm{NO}_{\mathrm{x}}$ removal are general ly superior to wet technologies. The advantages (Ref. D-2) of the dry $\mathrm{NO}_{x}$ technologies over wet scrubbing techniques for 1 ow to intermediate $\mathrm{NO}_{x}$ concentrations $(500$ to. $30,000 \mathrm{ppm}$ ) can be generalized as follows: :

- higher $\mathrm{NO}_{\mathrm{x}}$ removal efficiencies (>90\%)

- no secondary waste stream generated

- simpler systems with few process requirements 
- lower capital investment and operating costs

- more-extensive large-scale proven applications.

Dry $\mathrm{NO}_{X}$ abatement system disadvantages are

- sensitivity to off-gas aerosol loadings

- control of consumption of $\mathrm{NH}_{3}$ reductant may. be required

- high $\left(400^{\circ} \mathrm{C}\right)$ reactor temperatures may be required

- potential for $\mathrm{NH}_{4} \mathrm{NO}_{3}$ formation.

The first and last areas of concern can be easily mitigated by proper positioning of the catalytic bed and by controiling its temperature, respectively. The remaining disadvantages are associated with the operating conditions (costs) of some of the dry technologies themselves, which have been previously.established to be advantageous over wet techniques. Thus, there is no serious impediment to the application of compatible dry $\mathrm{NO}_{x}$ removal technologies to the HHVP process.

of the applicable dry technologies, only SCR using a hydrogen zeolite catalyst can be considered an established technology. Idaho National Engineering Laboratory js planning to apply SCR technology to its waste calciner facility (WCF). (a) A pilot plant is currently being built to establish the design criteria for full-scale application. The Hest Valley Nuclear Demonstration Project (WVDP) is also evaluating the SCR technology as a cost effective replacement for its off-gas wet (Absorption-0xidation type) scrubber. (b) During FY 1988 a commercial pilot-scale SCR unit will be evaluated against WVDP wet scrubber performance under actual LFCM processing conditions. The data obtained in both of these applications will be quite useful and directly applicable to the HWVP process.

The only other dry technology that has had limited large-scale applications compatible with the HWW process is the radiation destruction method. In principle, this $\mathrm{NO}_{\mathrm{x}}$ abatement technology could applied to the HWVP process without impacting the off-gas system design. This capability is due to the fact that high energy $\gamma$-ray emitters $\left({ }^{137} \mathrm{Cs}\right.$ ) are capable of penetrating and establishing a high-radiation field within, for instance, pipes. Consequentiy, external radiators located about the periphery of an off-gas jumper can be used to deliver a radiation dose to the process exhaust. If the dose is delivered between the ejector venturi scrubber (EVS) and the high-efficiency mist eliminator (HEME), and efficient radiolytic destruction of $\mathrm{NO}_{x}$ occurs, the HEME

(a) T. R. Thomas, Idaho National Engineering Laboratory, Idaho Falls, Idaho, private communication.

(b) D. D. Daruwalla, West Valley Demonstration Project, West Valley, New York, private technical communication. 
will remove (demist \& filter) all the nonvolatile chemical remriants of the $\mathrm{NO}_{x}$ effluent. Since this method uses existing off-gas equipment to eliminate radiolytic byproducts, $N O_{x}$ destruction can be achieved in principle by $a$. passive external add-on device whose operation is transparent to melter off-gas processing system. Unfortunately, essentially all the developmental work on radiolytic destruction of $\mathrm{NO}_{x}$ has been conducted on flue gases that are not similar to the reference HWVP process stream. The impact of composition differences upon radiolytic products is difficult to predict. However, this technology deserves to be considered if process emissions of $\mathrm{NO}_{x}$ become a future concern because it is an ideal remote emission-abatement tool.

Unlike dry $\mathrm{NO}_{\mathrm{x}}$ scrubbing methods, the wet techniques are not specific to NO , so they may support the process in more than one way. The major advantages to wet scrubbing methods include

- multi-purpose scrubbing ( $\mathrm{NO}_{x}, \mathrm{~F}^{-}$, etc)

- insensitivity to off-gas aerosol loadings

- back-up quenching capabilities.

On the other hand, wet system disadvantages include

- complexity resulting from $\mathrm{NO}_{x}$ insolubility

- waste formation

- high capital and operating expenses

- only moderate $\mathrm{NO}_{\mathrm{x}}$ removal $(-70 \%)$.

Wet scrubbing of low concentrations of $\mathrm{NO}_{x}$ is justifiable only if the technology is needed to eliminate other process effluents. Expensive chemical additives would probably be necessary to provide efficient $\mathrm{NO}_{\mathrm{x}}$ scrubbing for reasonably sized absorption equipment. On the other hand, some scrubbing approaches (absorption-oxidation) may not be compatible with other off-gas processing objectives. ( $I_{2}$ retention). Since specialized chemical recovery and/or regeneration equipment or processes could also be required to support the chemical optimization of $\mathrm{NO}_{x}$ removal, the best approach to wet scrubbing (absorption-oxidation, oxidation-absorption, absorption-reduction, etc.) is difficult to predict without conducting a thorough economic and technical analysis of the process involved. For HWVP, process compatibility and economics are major factors that will influence the potential applicability of the wet scrubbing technologies if $\mathrm{NO}_{x}$ abatement is needed.

In summary, both wet and dry effluent abatement technologies have been examined for the purpose of identifying alternatives for HWVP $\mathrm{NO}_{\mathrm{x}}$ emission control should it be required. Dry techniques are efficient processes (>90\%), that have been developed and applied to process streams similar to those associated with HWVP. The wet technologies become quite complex when applied 
to low concentrations of $\mathrm{NO}_{x}$ but are capable, in principle, of reducing $\mathrm{NO}_{\mathrm{x}}$. concentrations by. $-70 \%$. Process compatibility, waste stream generation, and capital equipment and operating costs are major factors that will influence the applicability of wet methods for low level (500 ppm) $\mathrm{NO}_{x}$ removal.

\section{REFERENCES}

D-1. R. M. Counce, "The Theory and Practice of Nitrogen Oxide Absorption." Proceedings of the 18th DOE Nuclear Airborne Waste Management and Air Cleaning Conference, Department of Energy, Washington, D. C. (1984).

D-2 H. L. Fausett, Technical Assessment of NO Removal Processes for Utility Applications. EPRI AF-568, Electric Power Research Institute, Pạlo A7to, California (1977).

D-3 J. R. Kiovsky, P. B. Koradia, and C. T. Lim, "Evaluation of a New Zeolytic Catalyst For $\mathrm{NO}_{x}$ Reduction with $\mathrm{NH}_{3 .}:$ I\&EC Product Research \& Development (19) 218 (1980).

D-4 T. R. Thomas and D. H. Munger, An Evaluation of $\mathrm{NO}_{x}$ Abatement By $\mathrm{NH}_{3}$ Over Hydrogen Mordinite For Nuclear Fuel Reprocessing P1ants. ICP-1133, Idaho National Engineering Laboratory, Idaho Falls, Idaho (1978). .

D-5 A. Bruggeman, L. Meynendonckx; and $W$. R. A. Goossens, "Elimination Of $\mathrm{NO}_{x}$ By Selective Reduction With $\mathrm{NH}_{3}{ }^{\circ}$ " Proceedings of the 15th DOE Air Cleaning Conference, Department of Energy, Washington D.C. (1981).

D-6 S. Hattori, Y. Kobayashi, Y. Katoh, Y. Takinoto, and M. Kunikata, "NO Removal From Nuclear Fuel Reprocessing Plants Off Gas By Catalytic Reduction with $\mathrm{NH}_{3}$." Proceedings of the 18th DOE Nuclear Airborne Waste Management and Air cleaning Conference, Department of Energy, Washington, D. C. (1984).

D-7 N. R. Leist, The Design and Operation of a Pilot Unit for NO Destruction with Anmonia and a Synthetic Mordinite Catalyst, NCLO-1139, National Lead Corporation, Ohio (1975).

D-8 E. B. Mays and M. R. Schwab, "Elimination of $\mathrm{NO}_{x}$ Fumes." Chemical Engineering, February 17, 1975, pp 112.

D-9 L. J. Muzio, J. K. Arand, K. L. Maloney, Noncatalytic NO Removal with Ammonia, EPRI FP-735, Energy Research Institute, Palo Alto California (1978). 
D-10 D. J. Helfritch, and P. L. Feldman, "Flue Gas $\mathrm{SO}_{2} / \mathrm{NO}_{x}$ Control By Combination of Dry Scrubber and Electron Beam." Radiat Phys Chem (24) 129-143 (1984).

D-11 K. Kawamura and V. H. Shui, "Pilot Plant Experiences in Electron-beam Treatment of Iron-Ore Sintering Flue Gas and Its Application To Coal Boiler Flue Gas Cleanup." Radiat Phys Chem (24) 129-143 (1984).

D-12 D. Fishlock, "IAEA's Acid Rain Solution: Radiation." New Technology Heek, Vol 1, No. 14, August 31, 1987. 

APPENDIX E

\section{MATERIAL BALANCE TABLES}





\section{APPENDIX E}

\section{MATERIAL BALANCE TABLES}

The HWVP and Material Balance Computer Program block flow diagram is shown in Figure E-1. Each process stream is identified with a number in Table E.1. These process stream identification numbers provide traceability to the material balance calculations shown in Table E-2. The various streams and units for the material and heat balance calculations are identified in the table. 


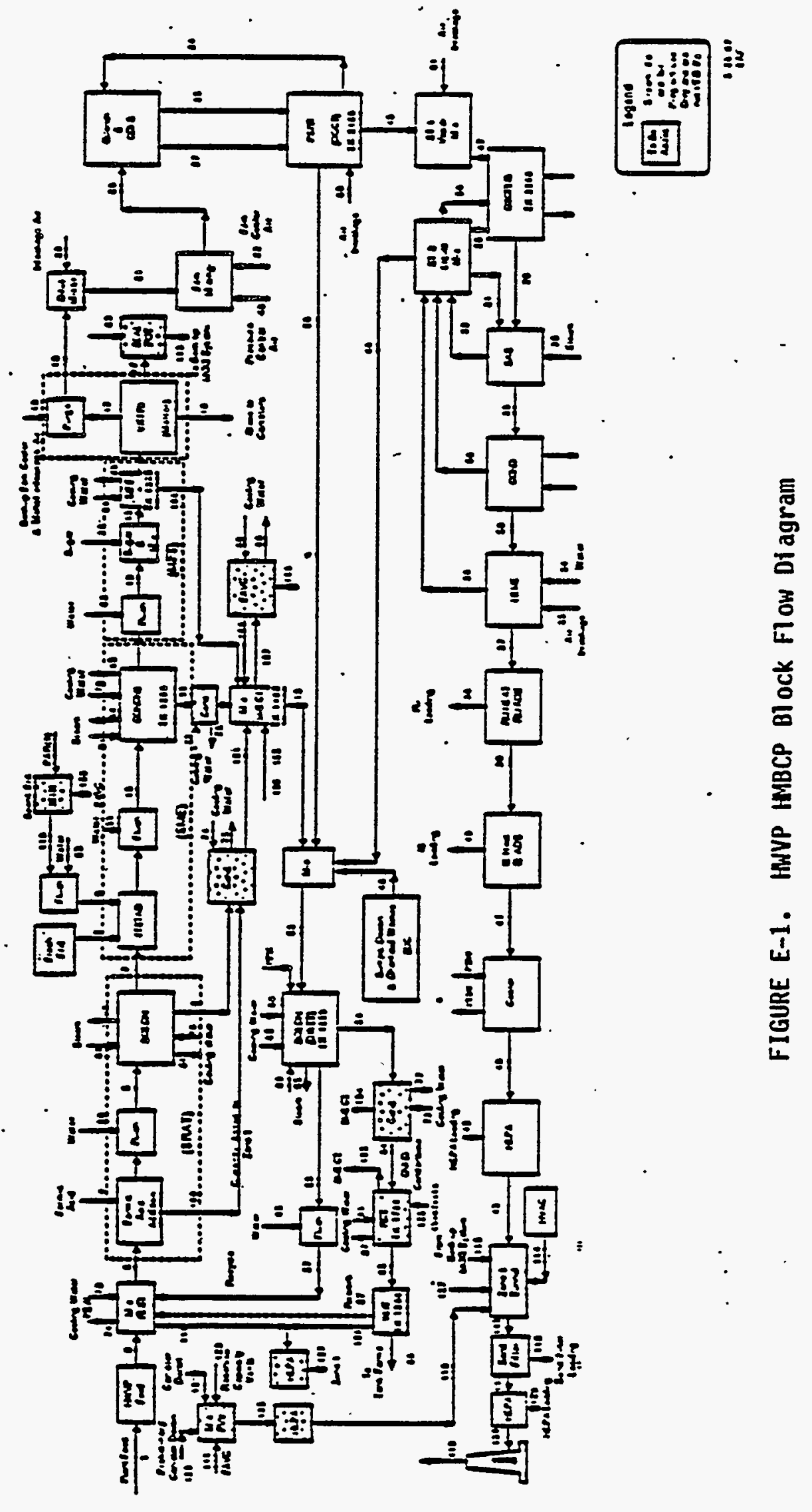

E-2 
TABLE E-1.

\begin{tabular}{|c|c|c|c|}
\hline STREAM & DESCRIPTION & (maximum st & streams $=150$ \\
\hline $\begin{array}{r}1 \\
2 \\
3 \\
4 \\
5 \\
6 \\
7 \\
8 \\
9 \\
10 \\
11 \\
12 \\
13 \\
14 \\
15 \\
16 \\
17 \\
18 \\
19 \\
\\
20 \\
21 \\
22 \\
23 \\
24 \\
25 \\
26 \\
27 \\
28 \\
29 \\
30 \\
31 \\
32 \\
33 \\
34 \\
35 \\
36 \\
37 \\
38\end{array}$ & $\begin{array}{l}\text { NCAH/RLST } \\
\text { FEED FROM RLST } \\
\text { FEED TO SRAT } \\
\text { FORMIC ACID TO SRAT } \\
\text { SRAT COPOSITION } \\
\text { SRAT CONDENSATE TO SMECT } \\
\text { FEED TO SME } \\
\text { FRESH FRIT TO SME } \\
\text { SPENT FRIT TO SME } \\
\text { SME COMPOSITION. } \\
\text { SME CONDENSATE TO SMECT } \\
\text { SLURRY TO MFT } \\
\text { ACCUMULATION FROM SMECT } \\
\text { SUGAR TO MFT } \\
\text { SLURRY TO MELTER } \\
\text { GLASS TO CANISTER } \\
\text { MELTER OFF GAS } \\
\text { MELTER INLEAK AIR AND BACKUP FILM COOLER } \\
\text { OFF GAS AND INLEAK AIR AND BACKUP FILM } \\
\text { COOLER } \\
\text { DILUTION AIR } \\
\text { OFF-GAS-TO-FILM COOLER } \\
\text { AIR-TO-FILM COOLER } \\
\text { OFF GAS TO QUENCH } \\
\text { SOLUTION TO QUENCH } \\
\text { CONDENSATE FROM QUENCH } \\
\text { ACCUMULATION FROM OGCT } \\
\text { OFF GAS FROM QUENCH } \\
\text { RICH SOLUTION FROM SCRUB } \\
\text { OFF GAS FROM SCRUB } \\
\text { STEAM TO SAS } \\
\text { LEAN SOLUTION TO SAS } \\
\text { RICH SOLUTION FROM SAS } \\
\text { OFF GAS FROM SAS } \\
\text { HEME WASH WATER } \\
\text { INLEAK AIR TO HEME } \\
\text { SOLUTION FROM HEME } \\
\text { OFF GAS FROM HEME } \\
\text { RUTHENIUM LOADING } \\
\text { OFI }\end{array}$ & - & $i$ \\
\hline
\end{tabular}


TABLE- E-1. (contd)

\begin{tabular}{|c|c|c|}
\hline STREAM & DESCRIPTION & (maximum streams $=150$ \\
\hline $\begin{array}{l}39 \\
40 \\
41 \\
42 \\
43 \\
44 \\
45 \\
46 \\
47 \\
48 \\
49 \\
50 \\
51 \\
52 \\
53 \\
54 \\
55 \\
55 \\
57 \\
58 \\
59 \\
60 \\
61 \\
62 \\
63 \\
64 \\
65 \\
66 \\
67 \\
68 \\
69 \\
70 \\
71 \\
72 \\
73 \\
74 \\
75 \\
76 \\
77\end{array}$ & $\begin{array}{l}\text { OFF GAS FROM RUTHENIUM PH/AD } \\
\text { IODINE LOADING } \\
\text { OFF GAS FROM IODINE PH/AD } \\
\text { HEPA LOADING } \\
\text { OFF GAS FROM HEPA } \\
\text { ACGUMULATION FROM SCTI } \\
\text { OFF GAS TO SCT2 } \\
\text { SUMPS, DECON, AND CHEMICAL WASTES } \\
\text { OFF GAS TO SCRUB } \\
\text { PRESSURE CONTROL AIR TO FILM COOLER } \\
\text { OFF GAS FROM COOLER } \\
\text { FLUSH WATER TO SRAT } \\
\text { FLUSH WATER TO SME } \\
\text { FLUSH WATER TO MFT } \\
\text { DWTT COMPOSITION } \\
\text { CONDENSATE FROM DWTT } \\
\text { BOTTOMS FROM DWTT } \\
\text { LEAN SOLUTION TO SCRUB } \\
\text { RECYCLE FROM DWTT } \\
\text { CONDENSATE FROM CONDENSER } \\
\text { OFF GAS FROM CONDENSER } \\
\text { INLEAK AIR TO OGCT } \\
\text { INLEAK AIR TO ST } \\
\text { OWTT BOTTOMS WATER FLUSH } \\
\text { SPENT FRIT WATER FLUSH } \\
\text { OVERHEAD CONDENSATE } \\
\text { RCT OISCHARGE } \\
\text { LIQUID WASTE TO TANK FARMS } \\
\text { LIQUID WASTE REWORK } \\
\text { COOLING WATER TO FAVC } \\
\text { COOLING WATER FROM FAVC } \\
\text { COOLING WATER TO RLST } \\
\text { COOLING WATER TO SRAT COND } \\
\text { COOLING WATER TO SME COND } \\
\text { COOLING WATER TO DWTT COND } \\
\text { COOLING WATER FROM RLST } \\
\text { COOLING WATER FROM SRAT COND } \\
\text { COOLING WATER FROM SME COND } \\
\text { COOLING WATER FROM DWTT COND }\end{array}$ & - \\
\hline
\end{tabular}


TABLE E-1. '(contd)

\begin{tabular}{|c|c|c|}
\hline STREAM & DESCRİPTION & (maximum streams $=150$ \\
\hline $\begin{array}{l}78 \\
79 \\
80 \\
81 \\
82 \\
83 \\
84 \\
85 \\
86 \\
87 \\
88 \\
89 \\
90 \\
91 \\
92 \\
93 \\
94 \\
95 \\
100 \\
101 \\
102 \\
103 \\
104 \\
105 \\
106 \\
107 \\
108 \\
109 \\
110 \\
111 \\
112 \\
113 \\
114 \\
115 \\
116 \\
117 \\
118 \\
119 \\
120\end{array}$ & $\begin{array}{l}\text { COOLING WATER TO SRAT TANK } \\
\text { COOLING WATER TO SME TANK } \\
\text { COOLING WATER TO MFT TANK } \\
\text { COOLING WATER TO RCT TANK } \\
\text { COOLING WATER TO DWTT TANK } \\
\text { AIR INLEAKAGE TO SEAL POT } \\
\text { COOLING WATER FROM SRAT TANK } \\
\text { COOLING WATER FROM SME TANK } \\
\text { COOLING WATER FROM MFT TANK } \\
\text { COOLING WATER FROM RCT TANK } \\
\text { COOLING WATER FROM DWTT TANK } \\
\text { FEED TO MELTER } \\
\text { STEAM TO SRAT } \\
\text { STEAM TO SME } \\
\text { STEAM TO DWTT } \\
\text { STEAM FROM SRAT } \\
\text { STEAM FROM SME } \\
\text { STEAM FROM DWTT } \\
\text { FORMIC ACID OFF GAS } \\
\text { SRAT CONDENSATE OFF GAS } \\
\text { SPENT FRIT OFF GAS } \\
\text { SME CONDENSATE OFF GAS } \\
\text { DWTT CONDENSATE OFF GAS } \\
\text { RCT OFF GAS } \\
\text { MFT OFF GAS } \\
\text { SMECT OFF GAS } \\
\text { FAVC TO SMECT } \\
\text { RLST - WHT OFF GAS } \\
\text { RLST OFF GAS } \\
\text { FAVC TO PVV SYSTEM } \\
\text { PVV TO ZONE I TUNNEL } \\
\text { SEAL POT TO BACKUP MOG SYSTEM } \\
\text { HVAC } \\
\text { TO SAND FILTER } \\
\text { SAND FILTER LOADING } \\
\text { OFF GAS FROM SAND FILTER } \\
\text { STACK DISCHARGE } \\
\text { SPENT FRIT } \\
\text { PRELIMINARY CANISTER DECON }\end{array}$ & $\cdot$ \\
\hline
\end{tabular}


TABLE E-1. (contd)

\begin{tabular}{|l|l|l|}
\hline STREAM & \multicolumn{1}{|c|}{ DESCRIPTION } & (maximum streams = 150 \\
\hline 121 & CANISTER DECON & \\
122 & RESERVED CAPABILITY VENTS & \\
123 & CONDENSATE TO SMECT FROM SRAT & \\
124 & CONDENSATE TO SMECT FROM SME & \\
125 & VESSEL VENT & \\
126 & WASTE HOLDING TANK (WHT) VENT & \\
127 & RLST/WHT VENT & \\
128 & CHEMICALS TO WHT . & \\
129 & SAND FILTER HEPA LOADING & \\
130 & OFF GAS FROM SAND FILTER HEPA & \\
& & \\
149 & STACK CONCENTRATION LIMITS & \\
150 & RATIO OF STACK CURIES TO CONCEN. LIMITS & \\
\hline
\end{tabular}


TABLE E-2. Preliminary Material Balance Calculations

$8: 44: 18$

coq. fat of trustres.out FILE

11-งแแ-ตร

\begin{tabular}{|c|c|c|c|c|c|c|c|c|}
\hline $\begin{array}{l}\text { STREAM RUMBER } \\
\text { FLUDR STREAH KUKBER } \\
\text { STREAM } \\
\text { DESCRIPTIOK }\end{array}$ & $\begin{array}{c}43 \\
238 \\
\text { OFFEAS Fi } \\
\text { HEPA }\end{array}$ & $\begin{array}{l}112 \\
112 \\
\text { Fil PUV }\end{array}$ & $\begin{array}{l}114 \\
114 \\
\text { wins }\end{array}$ & $\begin{array}{l}115 \\
115 \\
\text { T0 SAMO } \\
\text { FILTERS }\end{array}$ & $\begin{array}{l}117 \\
117 \\
\text { OFFEA Fri } \\
\text { SAMD FII }\end{array}$ & $\begin{array}{l}118 \\
118 \\
\text { siact o15 } \\
\text { ufi/al }\end{array}$ & $\begin{array}{l}149 \\
\text { conc tint } \\
\text { uCi/nl }\end{array}$ & $\begin{array}{l}\text { I5I } \\
\text { STAG: LIK } \\
\text { RATIO }\end{array}$ \\
\hline $\mathrm{bs} / \mathrm{hr}$ ) & 2.15 & & & & 2.43 & $3 !$ & & \\
\hline OA (gps) & i & & & & $i$ & i & & \\
\hline Don (acfa) & 7.13HE+12: & & & 1.17 & & $+\infty 5:$ & & \\
\hline 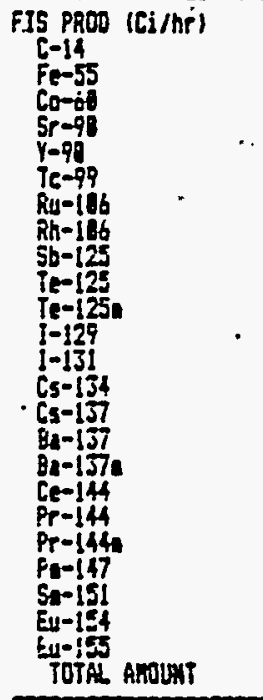 & 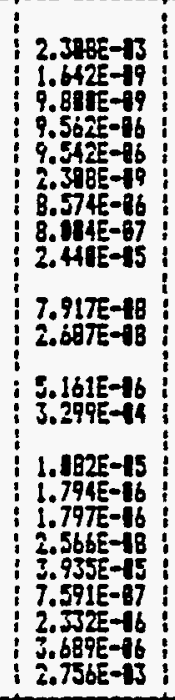 & 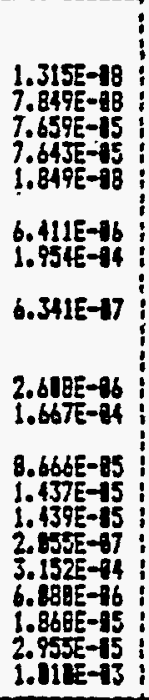 & 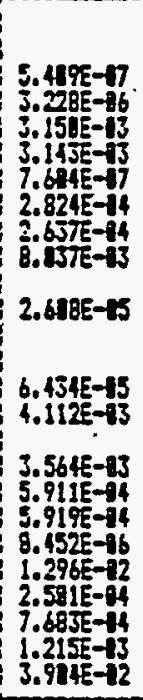 & 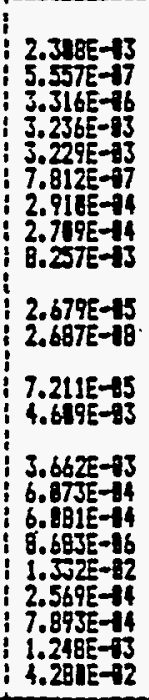 & 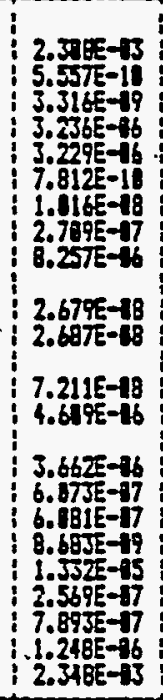 & 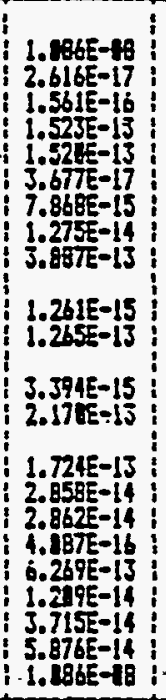 & 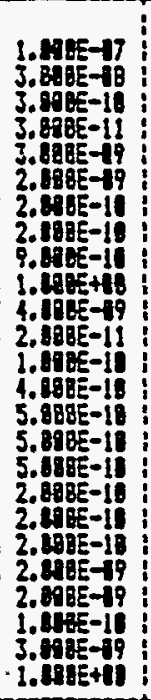 & 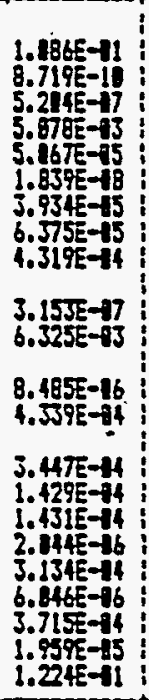 \\
\hline 234 & is & & 7 & & & & & $-1=$ \\
\hline 235 & 4 & $13:$ & -11 & 11 & -14 & $-22:$ & 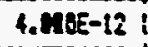 & 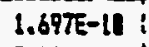 \\
\hline 250 & 1.8 & & & & & -21 & -12 & \\
\hline 238 & 17.6 & $12 i$ & -16 & & & $-28 \vdots$ & 3. & 4. \\
\hline-237 & 111 & $18:$ & $-I B$ & 18 & -11. & .19 & & \\
\hline-238 & & & $-A B$ & & -11 & -19 & -14 & 1.2 \\
\hline-259 & & $49:$ & 1.5 & 1. & 10 & $18:$ & 14 & Modert \\
\hline-248 & 1.5 & $19 i$ & -18 & 18 & $-11:$ & 18 & 6.1 & 4.1 \\
\hline-241 & : $4.8985-19$ & $3.917 E-18$ & 1E-16 & 1.6 & $1.655 E-19$ & $7.798 E-17:$ & $=-12$ & $=-10$ \\
\hline-242 & + & $14:$ & 12 & & 15 & -22 & & $2000=11$ \\
\hline-211 & 1. & -16 & -15 & & $-18:$ & -15 & -13 & $=-12$ \\
\hline 672 & $+\infty$ & 1 & & & & $1.247 E-18:$ & 1.09EE- & $1 .<975-77$ \\
\hline$-24 j$ & i & 8 & 88 & 8 & -11 & 19 & -13 & 96 \\
\hline-242 & & & & & & $2.575 E-17$ & 4.19 & $0.43 \pi E-96:$ \\
\hline-244 & 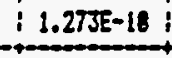 & $-89:$ & $=-88$ & 18 & -11 & 2.8 & -13 & $\infty$ \\
\hline OTAL & & & & & & $2.388 E-43$ & & 1.J3JE-11 \\
\hline ii (Watt/hr) & & & & & & & & \\
\hline
\end{tabular}


TABLE E-2. (contd)

วิเวืม:

Pad.iat if STRMS.QUT Fi:LE

i

\begin{tabular}{|c|c|c|c|c|c|c|c|c|c|}
\hline 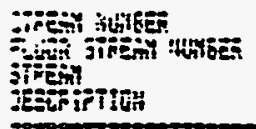 & 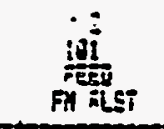 & 竎 & 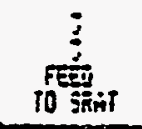 & chast & 溜 & 跑 & 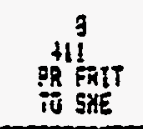 & 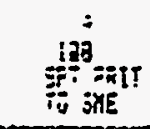 & 洋 \\
\hline Fos idbs/Ari & i $1.127 z+23$ & i $6.224 E+91$ & 1.16GE+R3 & i. i. $162 E+13$ & : $3.02 \pi E+i 2$ & : J.liietis & 1.1.6de $+\sqrt{2}$ & : $1.1 \%$ & $\therefore \equiv 10 \mathrm{E}+2 \sqrt{2}$ \\
\hline D. & i B. I3HE+A & 1. 2TSE-91 & $2.23+E+98$ & $12.28 \mathrm{EE}+9 \mathrm{~A}$ & $1.7+45+39$ & $0.2265-41$ & $1.5+75-11$ & ; A DFiE-A! & $\therefore 604=-1$ \\
\hline Dy ixfo & $\because$ & $i$ & 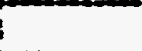 & $i$ & 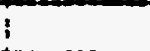 & 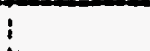 & ; & i & $\because "$ \\
\hline 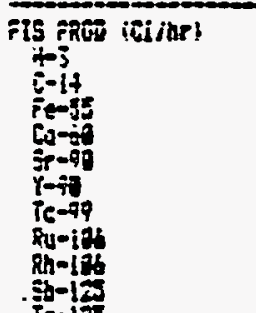 & 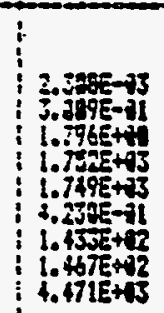 & 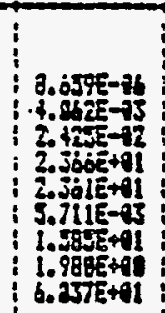 & 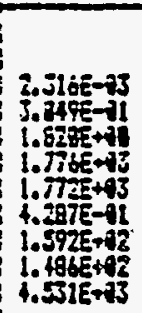 & 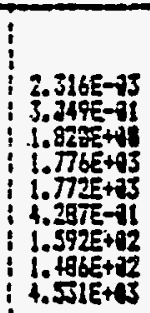 & 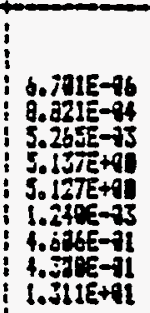 & 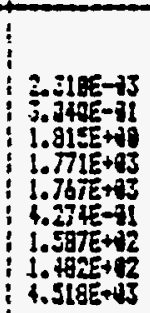 & & 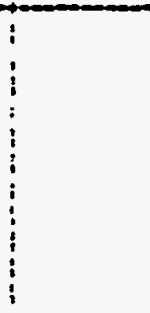 & 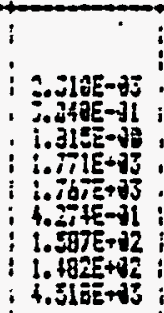 \\
\hline 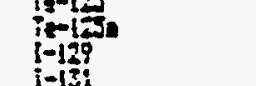 & $\begin{array}{l}\text { l. } 251 E+11 \\
\text { s.i.15E- }\end{array}$ & 1. $2959 E-11$ & 1. $13925+21$ & $\frac{1.478 E+41}{5.395 E-75}$ & 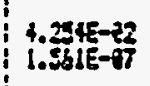 & 1. $5 .+56=+31$ & & $\vdots$ & : i.tgoge-31 \\
\hline 等 & 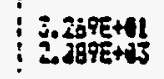 & 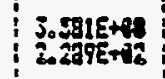 & j.. & $\begin{array}{l}3.077 E+91 \\
3.019 E+13\end{array}$ & $\begin{array}{l}\text { 1. } 2498-718 \\
\text { 3. }\end{array}$ & 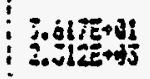 & & : & 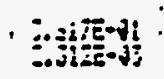 \\
\hline 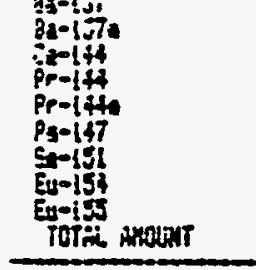 & 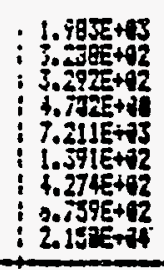 & 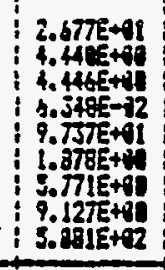 & 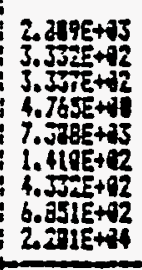 & 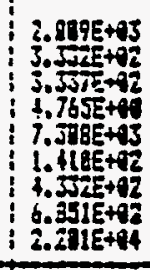 & 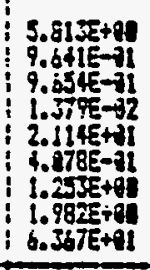 & 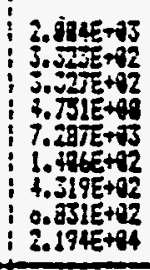 & & $\vdots$ & 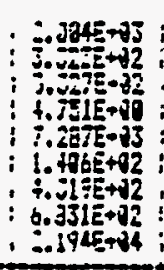 \\
\hline 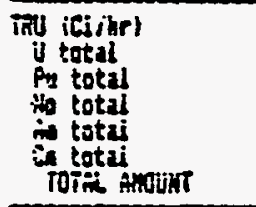 & 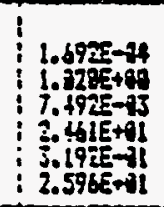 & 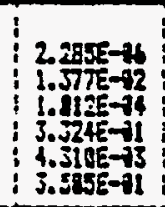 & $\begin{array}{l}1.715 E-24 \\
1.3515+01 \\
1.595-73 \\
2.1955-41 \\
3.255-11 \\
3.051 E+11\end{array}$ & 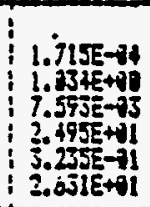 & 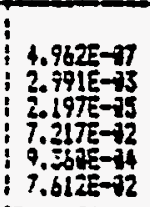 & 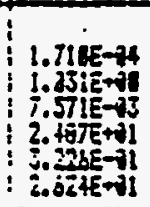 & & 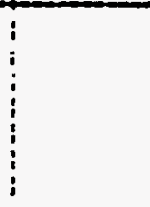 & 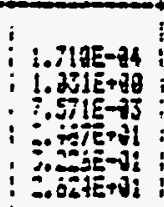 \\
\hline-241 & $2.459 E+11$ & $3.528 E-11$ & $2 .+92 E+41$ & $2.1725+11$ & $7.2185-72$ & 2. & & ; & 2. $245 E+21$ \\
\hline (Ci i $h r)$ & i $2.1505+96$ & I. $584 E+92$ & $2.208 E+74$ & $2.2038+94$ & $6.574 E+91$ & 2. $197 \mathrm{E}+\sqrt{4}$ & & : & $23297 E+84$ \\
\hline iT. astt/hr: & : S.a1FE+91 & : 1. & 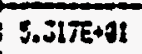 & S.317E+91 & 3E-11 & S.301E+91 & & i & SZiE-Al \\
\hline
\end{tabular}


TABLE E-2. (contd)

\begin{tabular}{|c|c|c|c|c|c|c|c|c|c|}
\hline 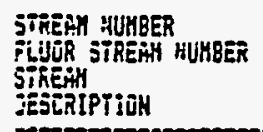 & $\begin{array}{l}11 \\
\text { site cono } \\
\text { To shent }\end{array}$ & 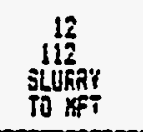 & $\begin{array}{l}13 \\
141 \\
\text { Stiect } \\
0+12\end{array}$ & $\begin{array}{l}15 \\
114 \\
\text { SLïRRY } \\
\text { To KELIER }\end{array}$ & $\begin{array}{l}\text { lo } \\
\text { Gings in } \\
\text { Ginisits }\end{array}$ & 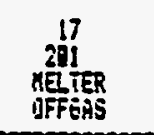 & 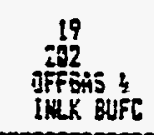 & 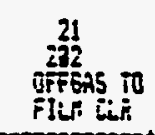 & û́n \\
\hline ôl ilaginr) & i $2.434 E+32 ;$ & $3.998 E+32$ & $1.136 \overline{0}+03$ & : 3.898E+72 : & $9.965 E+31$ & $3 E+32$; & +82 & 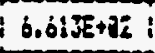 & 1 \\
\hline oi loppl & ; $4.8 a 1 E-11:$ & 5. 238E-1: & $2.2325+4$ & $3.238 E-91$ & $7.1109 E-82$ & 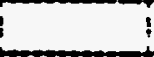 & & & 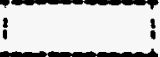 \\
\hline OH icins & 1 & & $i$ & 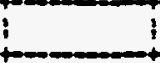 & & $1.478 E+12 Z$ & i.5JHE+ & Nat: & $+92:$ \\
\hline 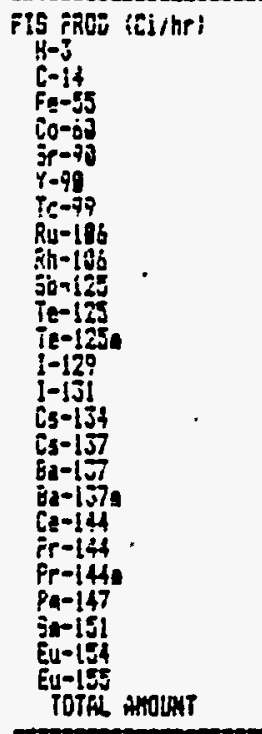 & 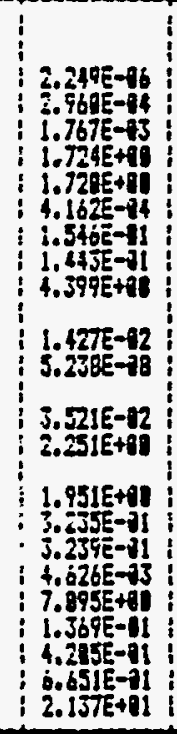 & 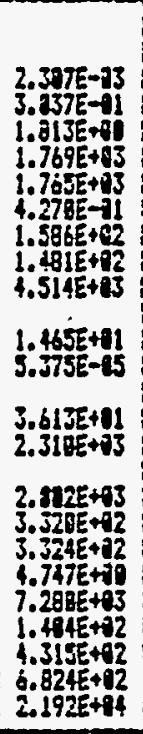 & 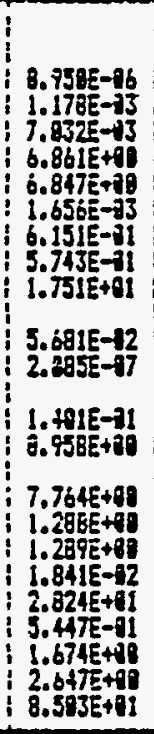 & 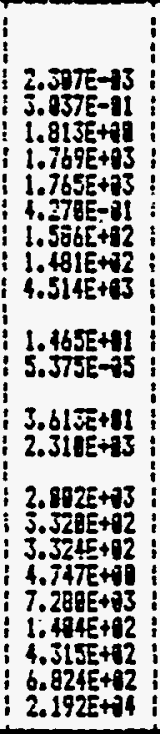 & 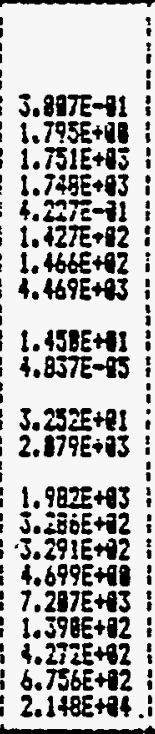 & 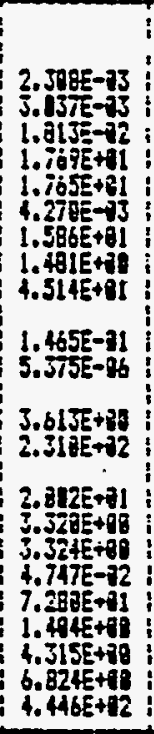 & 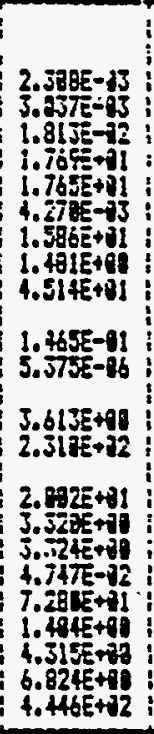 & 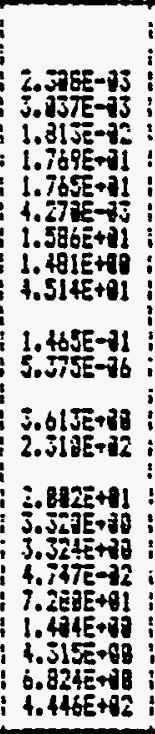 & 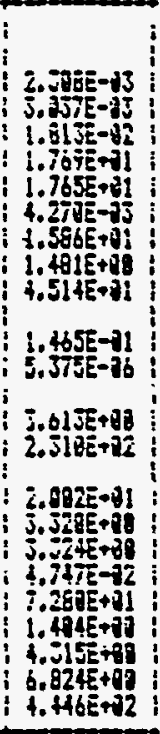 \\
\hline 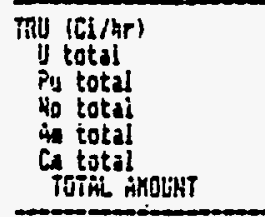 & $\begin{array}{l}1.665 E-17 \\
1.14 E-13 \\
7.372 E-86 \\
2.42 E E-32 \\
3.141 E-84 \\
2.554 E-32 \\
\end{array}$ & $\begin{array}{l}1.778 E-14 \\
1.2385+98 \\
7.564 \mathrm{E}-13 \\
2.405 \mathrm{E}+11 \\
3.223 \mathrm{E}-11 \\
2.021 \mathrm{E}+91 \\
\end{array}$ & $\begin{array}{l}6.62 \pi \mathrm{E}-97 \\
3.997 \mathrm{E}-33 \\
3.934 \mathrm{E}-75 \\
9.635 \mathrm{E}-27 \\
9.652 \\
1.258 \mathrm{E}-33 \\
1.017 \mathrm{E}-11 \\
\end{array}$ & $\begin{array}{l}1.709 E-14 \\
1.238 E+16 \\
7.564 E-23 \\
2.465 E+91 \\
3.223 E-31 \\
2.623 E+11 \\
\end{array}$ & 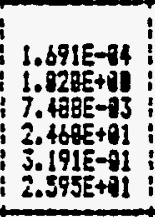 & $\begin{array}{l}1.778 E-96 \\
1.2385-12 \\
7.5645-85 \\
2.485 E-91 \\
3.225 \mathrm{E}-3 \mathrm{~J}\end{array}$ & 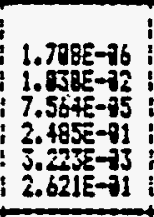 & 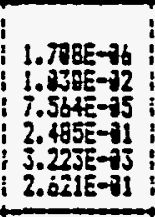 & $\begin{array}{l}1.799 E-96 \\
1.259 E-72 \\
3.564 E-75 \\
2.465 E-11 \\
3.25 \mathrm{E}-13 \\
2.021 \mathrm{E}-11 \\
\end{array}$ \\
\hline$-2+1$ & $2.419 E-72$ & $2.4655+91$ & 9. $6 E 9 E-92$ & $2.483 E+21$ & 2. $458 E+91$ & $2.483 E-11$ & $2.493 E-11$ & $E-2 !$ & Z. FENE-11 \\
\hline THL (Ci/hP) & 6 & 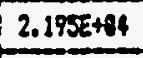 & 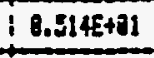 & 6. & $2=0$ & 04 & 061 & & 81 \\
\hline EhT ithtt/hr) & & & & & & & 31 & & \\
\hline
\end{tabular}


TABLE E-2. (contd)

\begin{tabular}{|c|c|c|c|c|c|c|c|c|c|}
\hline 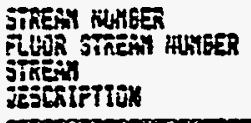 & 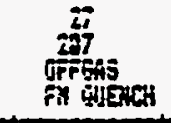 & 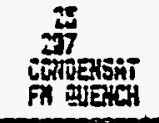 & 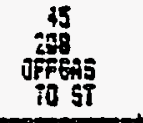 & 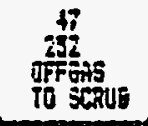 & 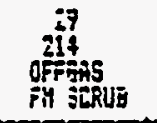 & 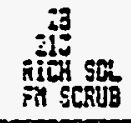 & 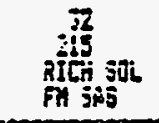 & 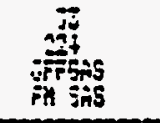 & 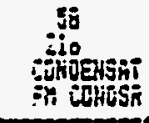 \\
\hline Cis ilssikrl & i 1 & 5.97 & 95 & $1 . \sqrt{552}+43$ & 1. SIBE+A3 : & 1.6DEET+A4t & $7.761 E+13$ & i.ingse+is i & t.7|JE-11 \\
\hline rath igan & i & 1.2085+92i & 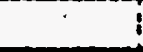 & & i & S. ATRE+ It & I $1.5555 E+11$ & & $i_{1}+1+15-12$ \\
\hline Las iscini & i J.t55e+12 : & & $12 ;$ & $3.842 E+12$ & Sol62E+12 : & & $i$ & 4.4TE+32: & \\
\hline 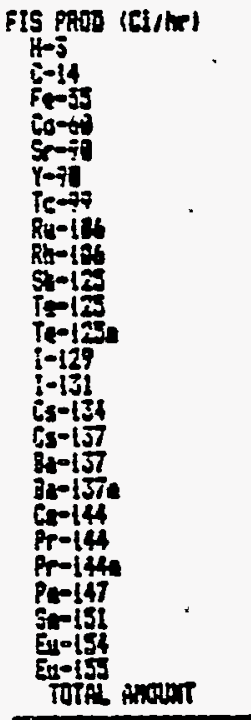 & 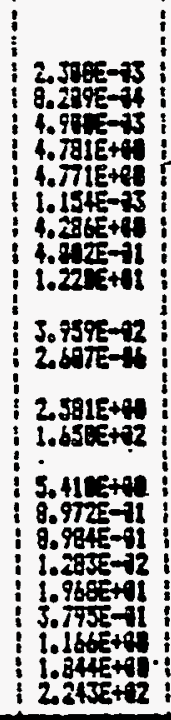 & 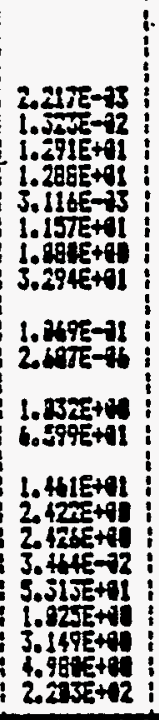 & 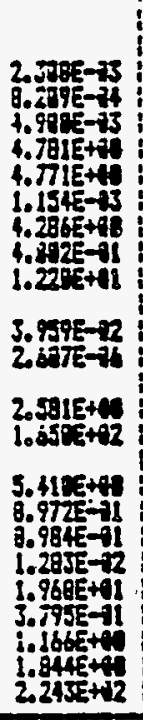 & 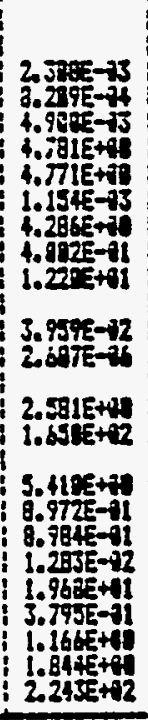 & 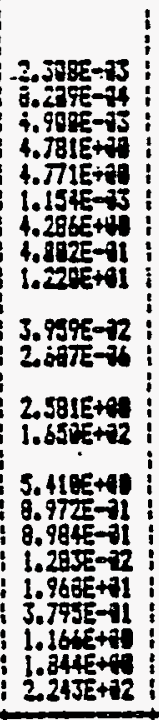 & & 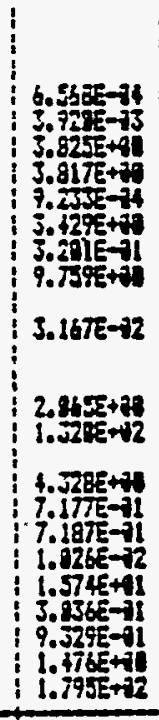 & 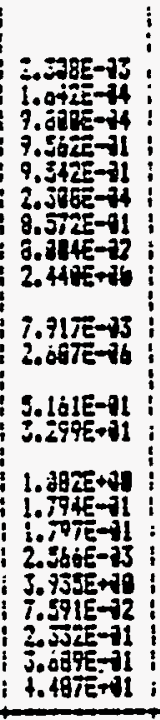 & \\
\hline 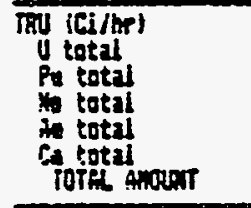 & $\begin{array}{l}2.793 \mathrm{E}-13 \\
2.014 \mathrm{E}-\mathrm{A} \\
6.716 \mathrm{E}-\mathrm{T} \\
0.711 \mathrm{E}-\mathrm{1} \\
7.984 \mathrm{E}-12\end{array}$ & 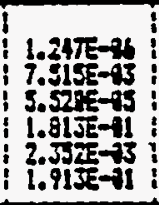 & $\begin{array}{l}4.6185-7 \\
2.7854-23 \\
2.844 E-75 \\
6.7165-12 \\
8.7115-4 \\
7.0045-72\end{array}$ & $\begin{array}{l}4.618 E-17 \\
2.793 E-35 \\
2.244 E-15 \\
6.716 E-72 \\
8.711 E-74 \\
7.284 E-72\end{array}$ & $\begin{array}{l}4.6185-17 \\
2.785 E-13 \\
3.0445-23 \\
6.7165-72 \\
8.711 E-74 \\
7.294 E-72\end{array}$ & & 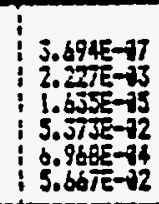 & 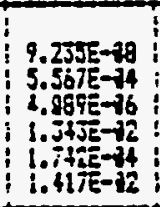 & \\
\hline in-23i & : b.71:5-12 & 1.912z-11 & $E-72$ & : $6.711 E-12$ & 6.71:x-12 : & & $13.3695-72$ & $1.392 z-12$ & \\
\hline TOTAL (Ciinr) & +12 & 92 & $2.244 E+12$ & $E+12$ & $E+e r$ & & 1.8 & $4.468 E+11$ & \\
\hline tor & & & & & & & & & \\
\hline
\end{tabular}


TABLE E-2. (contd)

\begin{tabular}{|c|c|c|c|c|c|c|c|c|c|}
\hline 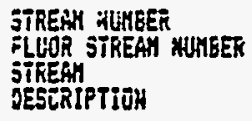 & 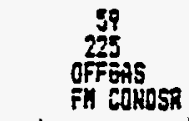 & $\begin{array}{l}36 \\
217 \\
504 \\
\text { Fin HEME }\end{array}$ & $\begin{array}{l}\frac{37}{279} \\
\text { OFFAS io } \\
\text { FH HERE }\end{array}$ & $\begin{array}{l}38 \\
\text { RutritenIUn } \\
\text { LQAOIHS }\end{array}$ & 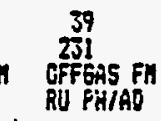 & 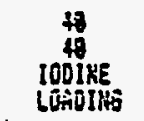 & 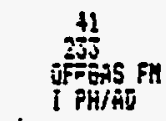 & $\begin{array}{c}19 \\
334 \\
\text { offois }\end{array}$ & Loming \\
\hline an & 11 & & & & & & & & \\
\hline i & $i$ & $: 5$ & & & 1 & i & $i$ & ! & \\
\hline 严 & 14.4 & & 5.5 & & 7. & & i : & 16. & \\
\hline 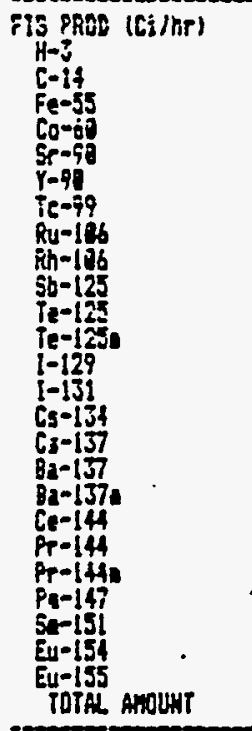 & 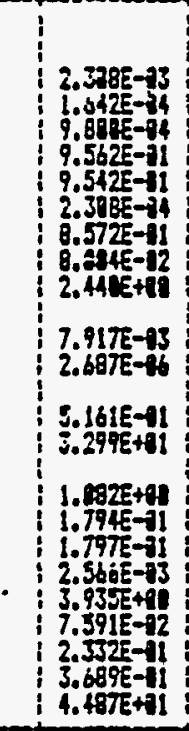 & $\begin{array}{l}4.645 E-11 \\
2.966 \mathrm{E}+11 \\
9.73 \mathrm{EE}-11 \\
1.615 \mathrm{E}-11 \\
1.61 \mathrm{E}-11 \\
2.39 \mathrm{EE}-13 \\
3.542 \mathrm{E}+11 \\
6.033 \mathrm{E}-12 \\
2.099 \mathrm{E}-11 \\
3.52 \mathrm{EE}-11 \\
4.03 \mathrm{BE}+11\end{array}$ & 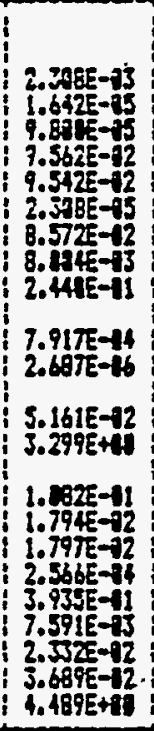 & 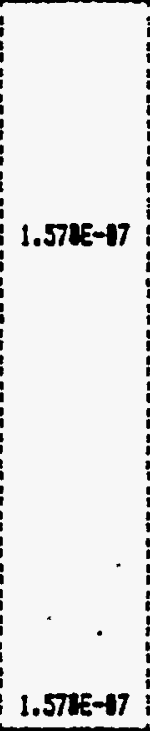 & 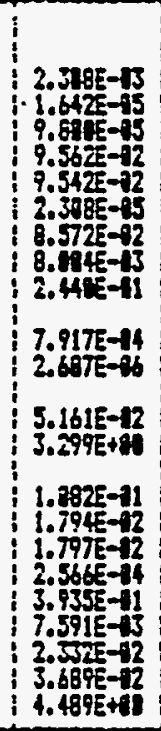 & 20 & 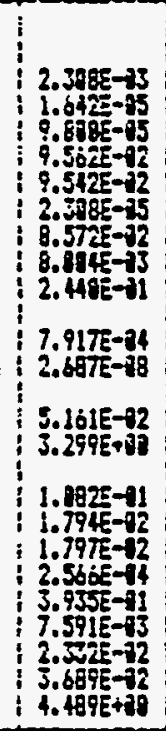 & 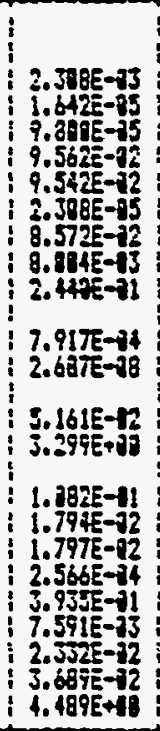 & 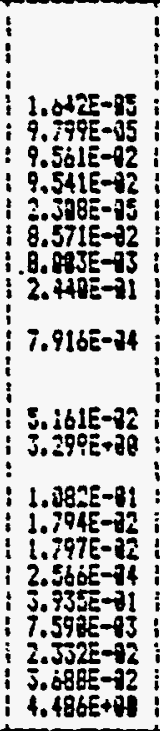 \\
\hline $\begin{array}{l}\text { if total } \\
\text { Pu total } \\
\text { No total } \\
\text { A cotal } \\
\text { Ca total } \\
\text { iota moun? }\end{array}$ & $\begin{array}{l}3.567 E-94 \\
4.189 \mathrm{E}-16 \\
1.34 \mathrm{JE}-02 \\
1.742 \mathrm{z}-94\end{array}$ & $\begin{array}{l}5.010 E-94 \\
3.68 E \overline{1} \\
1.239-16 \\
1.569-92 \\
1.275 E-12\end{array}$ & $\begin{array}{l}9.235 E-19 \\
5.567 E-15 \\
4.1895-17 \\
1.3475-13 \\
1.742 E-15\end{array}$ & & $\begin{array}{l}9.235 \mathrm{E}-19 \\
5.357 \mathrm{E}-15 \\
4.099 \mathrm{E}-17 \\
1.34 \mathrm{JE}-13 \\
1.742 \mathrm{E}-15\end{array}$ & & 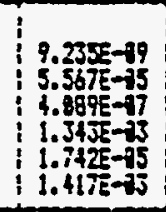 & $\begin{array}{l}9.235 E-99 \\
5.55 E-49 \\
4.296-15 \\
1.345--73 \\
1.742-95\end{array}$ & 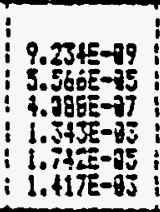 \\
\hline 276 & + & & & & 1 & & $\infty$ & 78 & 11 \\
\hline TAL & 11 & & & 17 & 14 & & 14 & & \\
\hline - & & & & & & & & & \\
\hline
\end{tabular}


TABLE E-2. (contd)

\begin{tabular}{|c|c|c|c|c|c|c|c|c|}
\hline 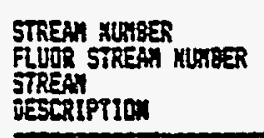 & 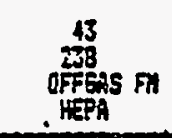 & 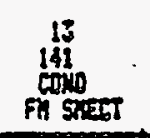 & $\frac{26}{\frac{36}{30 \operatorname{com}}}$ & $\begin{array}{l}4 \\
219 \\
\text { Ant } 5 T\end{array}$ & $\begin{array}{l}46 \\
151 \\
5405 \\
0\end{array}$ & contr & $\begin{array}{c}54 \\
145 \\
\text { cong } \\
\text { Fin } 01 \pi \pi \\
\end{array}$ & 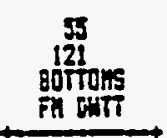 \\
\hline Dis ilbsitrel & 2018 & 231 & 1. $355 E+92$ & 3.9 & $3.5151+92$ & 1. & $\mathbf{B}$ & $6.221 E+02$ \\
\hline (10) (epp) & $i$ & $2.53 x+10 !$ & $2.673 E-31$ & $7.774-11$ & 7.8115oll & $13.9752+19$ & $3.898 E+4$ & $1.2312-11$ \\
\hline Fon (acfe) & : 7.254E+12: & ; & & $:$ & & $i$ & 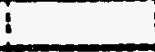 & 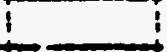 \\
\hline 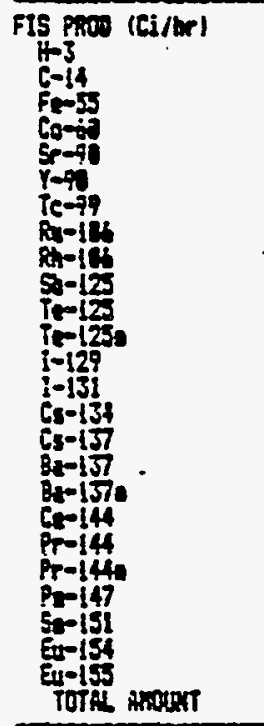 & $\begin{array}{l}1.7945-19 \\
1.7975-16 \\
2.565-18 \\
3.935 E-15 \\
7.5915-17 \\
2.354 E-16 \\
3.6595-16 \\
2.756 E-13\end{array}$ & 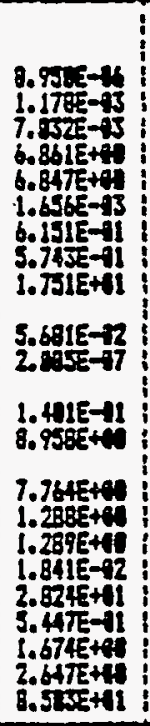 & 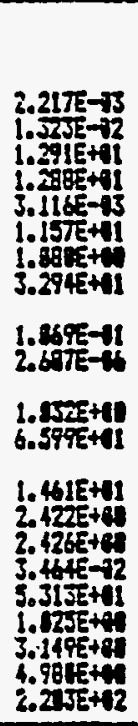 & 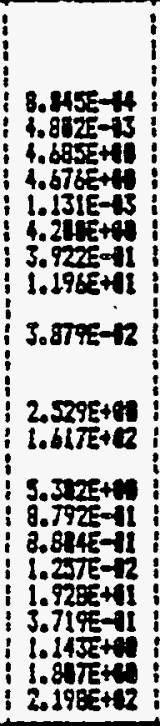 & & 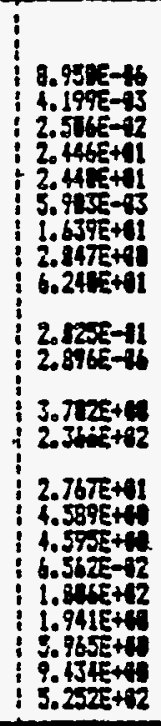 & 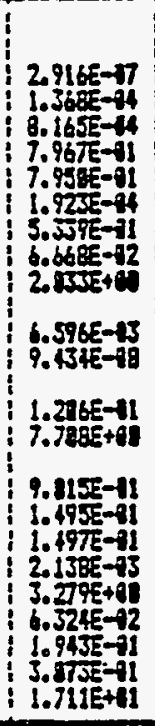 & 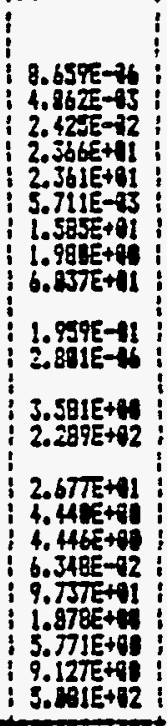 \\
\hline 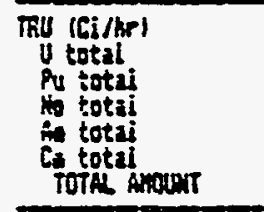 & $\begin{array}{l}9.245 E-13 \\
5.367 E-19 \\
4.389 E-11 \\
1.313 E-27 \\
1.742 \pm-19 \\
1.417 E-17\end{array}$ & $\begin{array}{l}6.627 E-17 \\
3.995 E-13 \\
2.9315-95 \\
9.6395-92 \\
1.75 \mathrm{E}-93 \\
1.017 \mathrm{E}-91\end{array}$ & $\begin{array}{l}1.247 E-91 \\
7.315 E-35 \\
5.515-75 \\
1.815 E-91 \\
2.3525-13 \\
1.913 E-11\end{array}$ & $\begin{array}{l}4.525 E-17 \\
2.728 E-13 \\
2.815-95 \\
6.552-12 \\
6.525-12 \\
6.942 E-12 \\
\end{array}$ & & 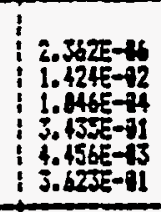 & $\begin{array}{l}7.6955-98 \\
4.6385-44 \\
3.497 E-96 \\
1.119 E-82 \\
1.4525-44 \\
1.180 \mathrm{E}-72\end{array}$ & $\begin{array}{l}2.285 E-96 \\
1.375-96 \\
1.812 E-96 \\
3.324 E-31 \\
4.315-93 \\
3.535 E-91\end{array}$ \\
\hline $20-24 !$ & $1.3122-17$ & P. S2YE-12 & $1.81 z-11$ & $6.576 E-12$ & & $3.4352-91$ & -12 & $3.3285-91$ \\
\hline TOTA (Cl/hr) & $2 \pi$ & +4 & $2215 x+12$ & 2.199E+12 & & $5.255 x+82$ & $i .71$ & +28 \\
\hline t/hri & & & & & & & $\sqrt{2}$ & $E+6$ \\
\hline
\end{tabular}


TABLE E-2. (contd)

$=: 34181$

EHE.ISH.FH OF STRHS. DUT FILE

$10-i b 4-97$

\begin{tabular}{|c|c|c|c|c|c|c|c|c|c|}
\hline 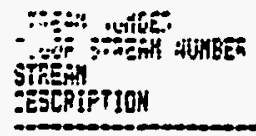 & $\begin{array}{c}\vdots \\
\vdots \\
\text { HCAM/RL }\end{array}$ & 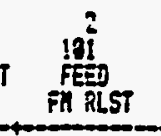 & 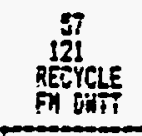 & I0 & 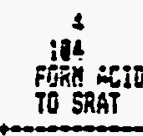 & 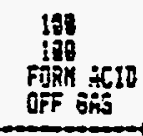 & 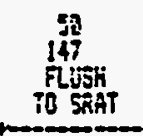 & 竞: & is \\
\hline 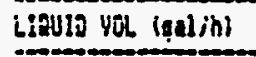 & i & $1.299 E+12$ & $? .2$ & i. $35=25+12$ & 4. $257 E-81$ & & $.3+5+8$ & 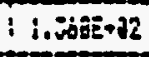 & SE \\
\hline Dge voL (atth) & 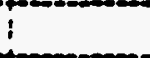 & $!$ & & 1 & i & 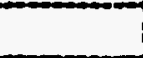 & ; & 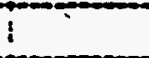 & \\
\hline TAL NASS IIb/hi & ! & $\because 1.1203 E+93$ & $6.221 E+11$ & $1.1665+93$ & $4.258 E+18$ & & i. isFE+11 & i i.jE8E+45 & E. $627 E-92$ \\
\hline FER ISTEAM $(1 \mathrm{~b} / \mathrm{h})$ & +40 & 1 1. $3665+02$ & $5.621 E+61$ & $1.125 E+23$ & $4.25 E E-01$ & & 1.:33E-7! & $1.15 \pi+43$ & $2665+92$ \\
\hline 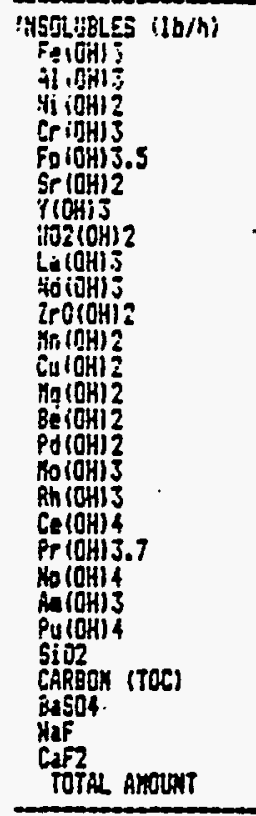 & 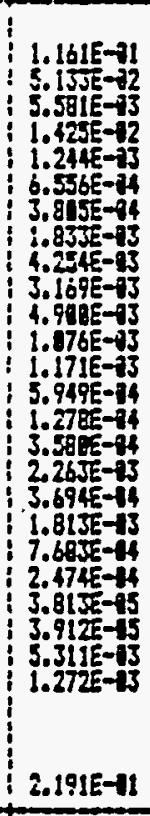 & 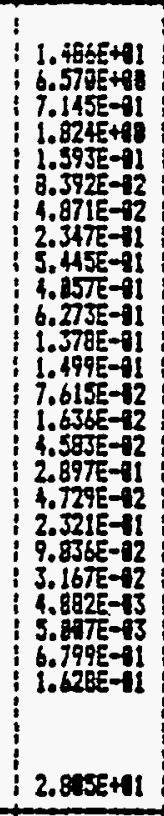 & 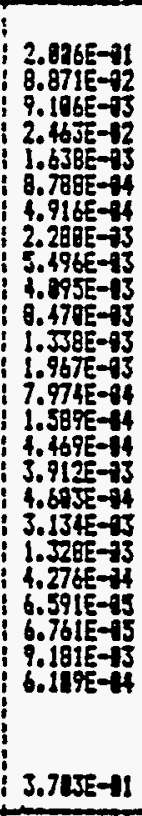 & 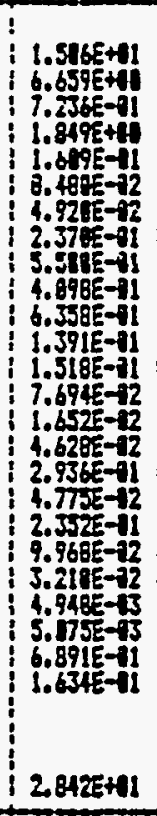 & & & & 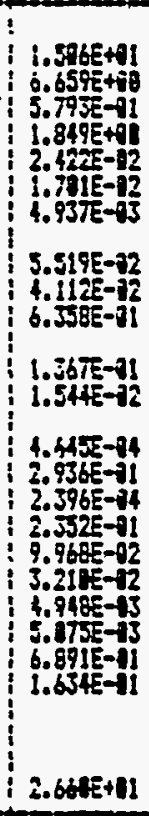 & 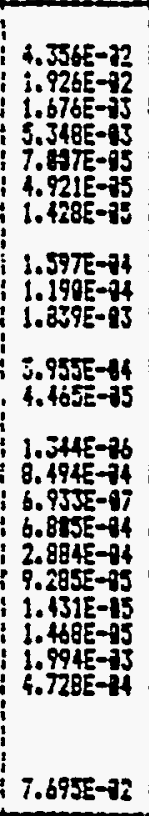 \\
\hline 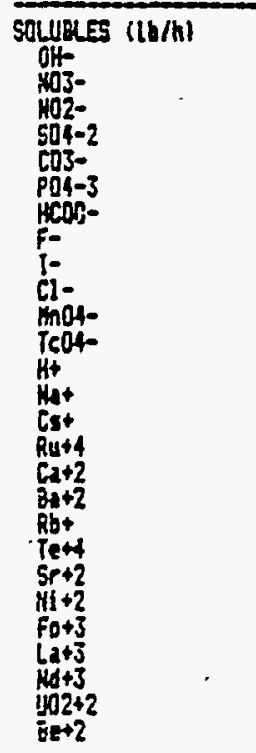 & 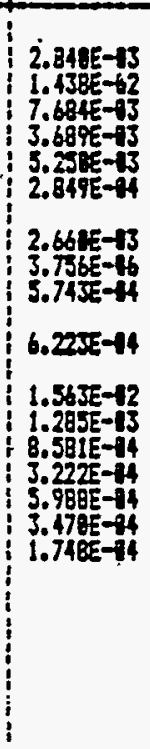 & 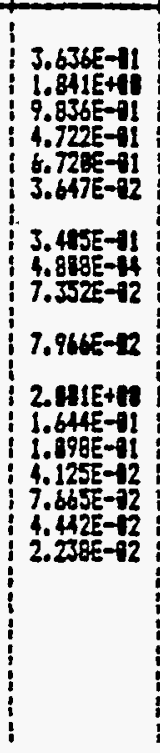 & 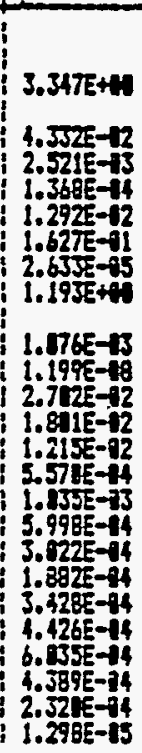 & 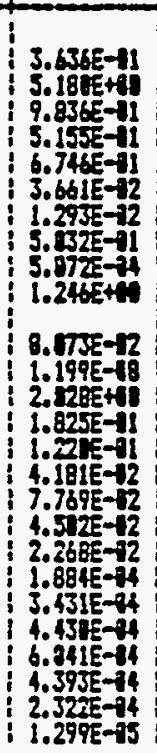 & & & & 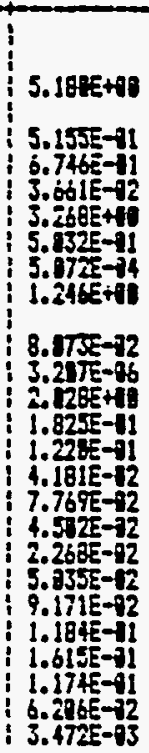 & 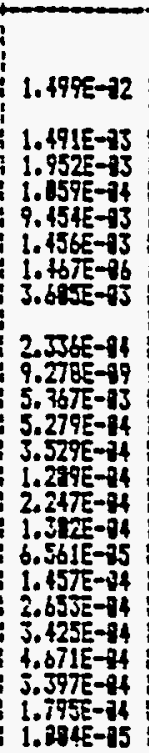 \\
\hline
\end{tabular}


TABLE E-2. (contd)

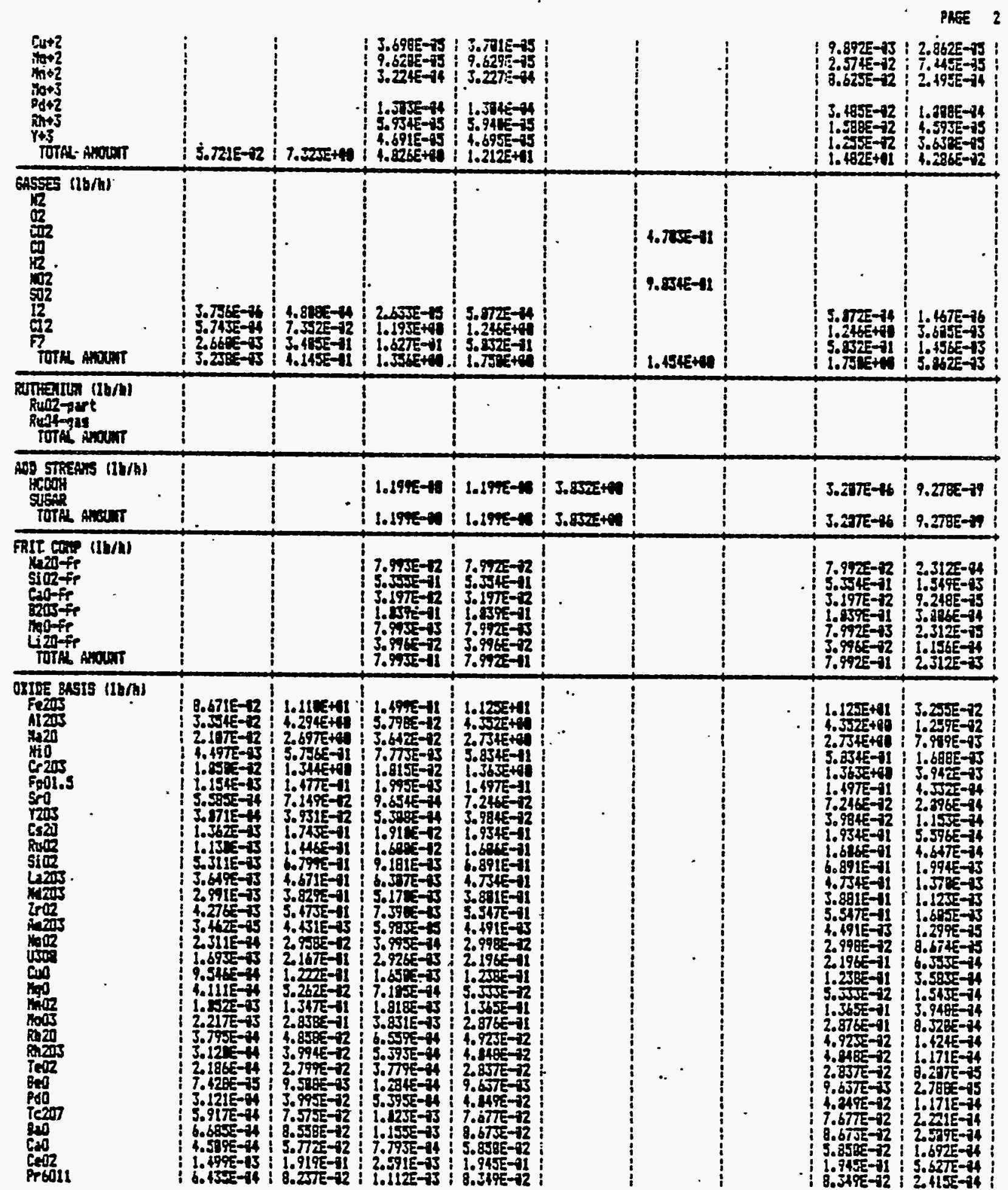


TABLE E-2. (contd).

PASE 3

\begin{tabular}{|c|c|c|c|c|c|c|c|c|c|}
\hline $\begin{array}{l}\text { PuOZ } \\
\text { TOTAL AHOUNT }\end{array}$ & $\begin{array}{l}3.45 \mathrm{EE}-15 \\
1.68 \mathrm{EE}-81\end{array}$ & $\begin{array}{r}4.425 \mathrm{E}-23 \\
2.417 \mathrm{E}+01 \\
\end{array}$ & $\begin{array}{l}5.972 E-75 \\
3.572 E-71\end{array}$ & $\begin{array}{l}4.493 E-03 \\
2.453 E+01\end{array}$ & & $!$ & $!$ & $\mid \begin{array}{l}4.495 E-93 \\
2.45 J E+11\end{array}$ & $\begin{array}{l}1.297 \mathrm{E}-75 \\
7.097 \mathrm{E}-12\end{array}$ \\
\hline IURIES & $1.682 E+72$ & $2.155 E+44$ & $5.084 E+92$ & $2.2035+14$ & & $2.3785-13$ & 1 & $2.215 E+04$ & $6.574 E+11$ \\
\hline Lest Ean (natts) & 4. $1706-91$ & $5.211 E+11$ & $1.2665+91$ & $5.31 \pi t+11$ & & $6.156 E-77$ & $i$ & I $5.31 T E+11$ & | 1.538E-71 : \\
\hline TERPEATURE $\left({ }^{\prime} F\right]$ & i & $1.250 E+22$ & $1.220 E+12$ & $1.260 E+12$ & $7.791+1$ & 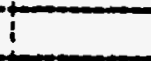 & $7.77 x+41$ & $1.20 x+9$ & $\mid 1.229=+12$ \\
\hline PRESSURE (osia) & $i$ & 1 & 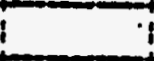 & & 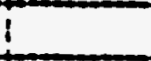 & 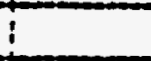 & 1 & $!$ & 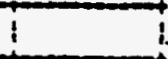 \\
\hline SLLIDS (ut 1 ) & 1 & $3.196 E+8$ & $9.6575+11$ & $3.557 \mathrm{E}+11$ & 9.nate+11 & 1 & 1 & I. $398 E+11$ & $1.421 E-12$ \\
\hline DERITIT ' $(16 /(t 3)$ & $i$ & $6.4465+11$ & $6.4315+11$ & $6.446 E+11$ & $7.515 E+11$ & $i$ & $6.241 E+11$ & 6. $15 E E+11$ & $6.166 E+11$ \\
\hline VISCOSITY (ep) & 1 & S.899E-11 & 6.036E-11: & 5.897E-11: & & 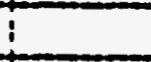 & $9.319 E-11$ & $6.066 E-91$ & 6. $256 E-71$ \\
\hline WOL VEIGT & 1 & $1.844 E+11$ & $1.921 E+11$ & $1.848 E+11$ & 3.791E+e1 & $i$ & 1.819E+ & $1.846 E+91$ & $1.834 E+01$ \\
\hline (Btw/hr) & $i$ & $i$ & $3.121 E+15$ & $3.525 E+25$ & & 1 & $!$ & $3.125 E+15$ & $8.7465+92$ \\
\hline ExTHALPY (Btu/he) & 1 & I S.116E+4 & $2.524 E+23$ & $5.386 E+14$ & & 1 & 4.611E-11 & $5.10 \pi+4$ & $3.87 x+44$ \\
\hline LATEMT KEAT (BtU/IS) & 1 & 1 & 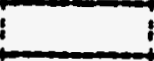 & 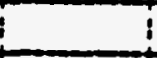 & 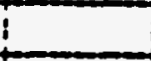 & 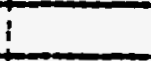 & 1 & $!$ & $1.124 E+13$ \\
\hline KEAT CAP (Btu/Ib'f) & 1 & $9.978 E-11$ & 9.97TE-11: & $9.9785-11$ & & 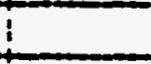 & $9.9695-21$ & : $9.977 E-11$ & $9.977 \mathrm{E}-91$ \\
\hline BATCH Th (hr) & $i$ & $2.5486+12$ & $2.548 E+12$ & $2.5485+12$ & $2.5485+92$ & 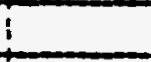 & $2,548 E+12$ & $2.548 E+72$ & $2.548 E+22$ \\
\hline BATTH PREP Th (hr) & 1 & $3.4352+91$ & $3.0725-11$ & & $6.27 n e+91$ & & $5.751 E-12$ & 1 & $4.449 E+11$ \\
\hline BATCH VOLX (sal) & 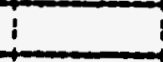 & $3.261 E+14$ & $1.843 E+03$ & $3.446 E+14$ & $1.079 E+12$ & & $3.450 E+12$ & $3.465 E+44$ & i 20666 E+4 \\
\hline CAMISTERS //batl & $i$ & $\because$ & 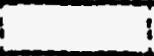 & & 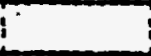 & 1 & 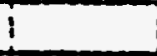 & + & $!$ \\
\hline
\end{tabular}


TABLE E-2. (contd)

\begin{tabular}{|c|c|c|c|c|c|c|c|c|c|}
\hline 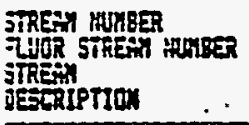 & 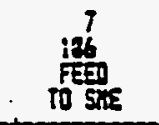 & T⿱艹 & 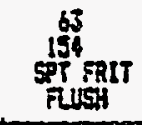 & 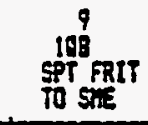 & 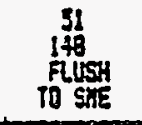 & $\operatorname{lig}_{\substack{\text { sine } \\
\text { contost }}}$ & 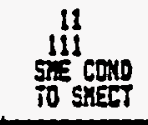 & $\begin{array}{l}52 \\
149 \\
1054 \\
10 \text { int }\end{array}$ & $\begin{array}{l}17 \\
112 \\
\text { SilliRY } \\
\text { To ifi }\end{array}$ \\
\hline OIID vol (qalih) & 3. & $9.281 E+29$ & $1.3916-01$ & 1. $1.314 E+32$ & 5. $8595-11$ & +91 & $2.916 E+91$ & 2. $3945-91$ & 31 \\
\hline Hon vol (12ethi) & $i$ & : & 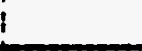 & 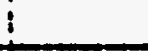 & ! & $i$ & & & $i$ \\
\hline JThL MASS (lb/h) & J.171E+e2 & $1.164+62$ & 1. Bepe+96 & $-1.122 x+12$ & $4.899 E+40$ & I $5.5085+92$ & $2.434 E+42$ & $2.497 E+21$ & 3. $6995+02$ \\
\hline ARR/STEA (Ib/h) & $2.3495+18$ & $4.6525+11$ & $1.886 E+4$ & $1.249 E+12$ & $4.8995+6$ & $E+12$ & +2 & $2.497 E+39$ & 1.7 \\
\hline 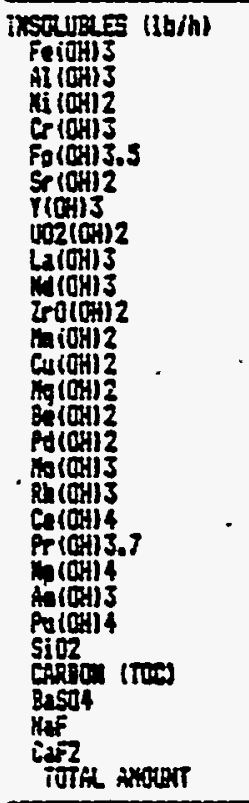 & 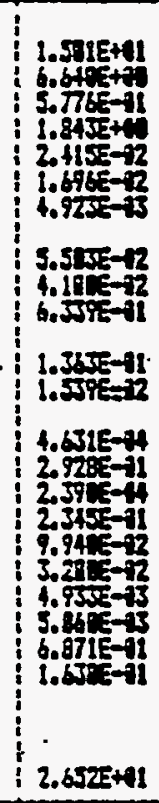 & $\cdot$ & 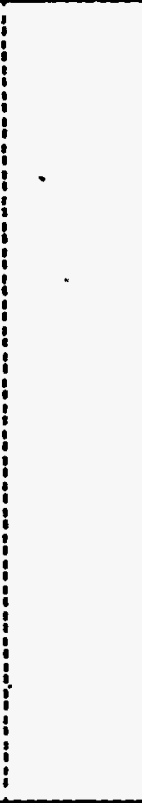 & 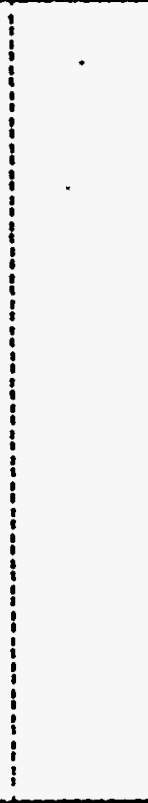 & & 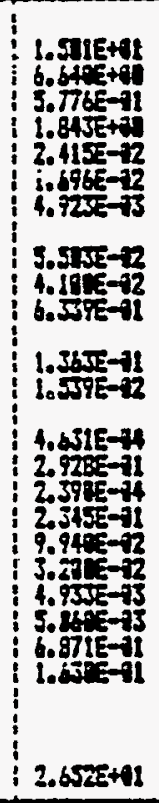 & 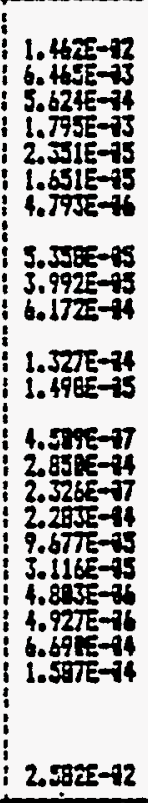 & . & 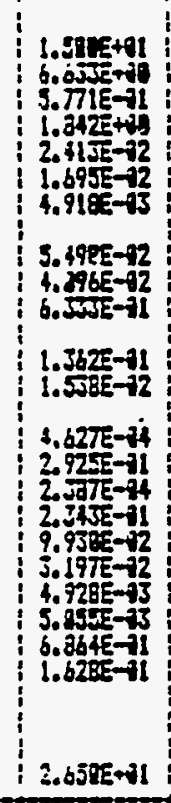 \\
\hline 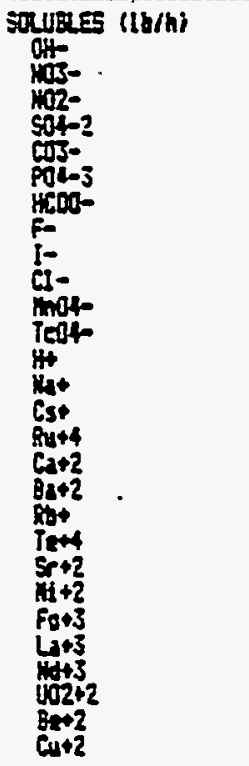 & 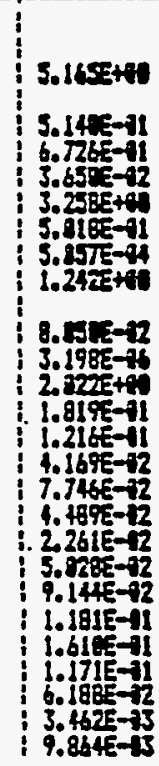 & $6.954 E-11$ & & 5.2TE-R2 & 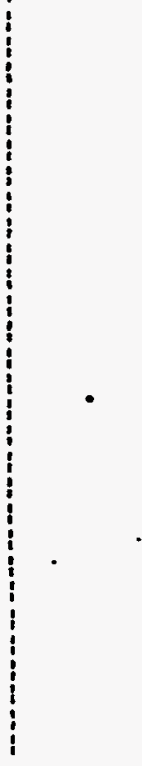 & 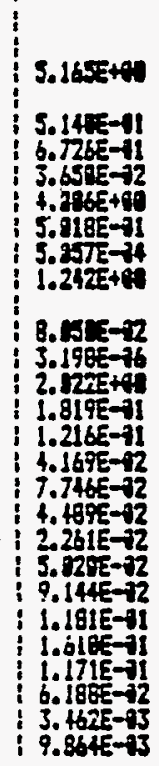 & 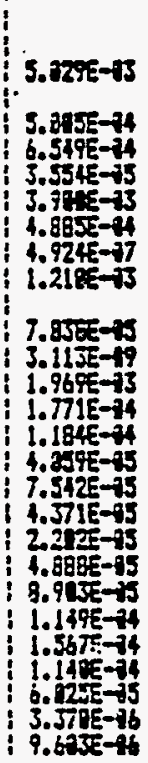 & & 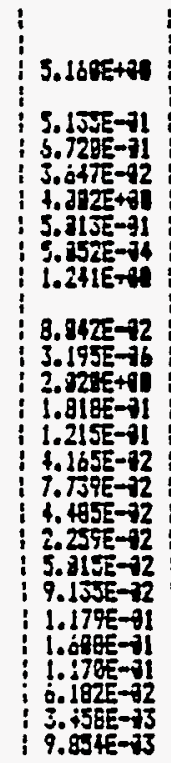 \\
\hline
\end{tabular}


TABLE E-2. (contd)

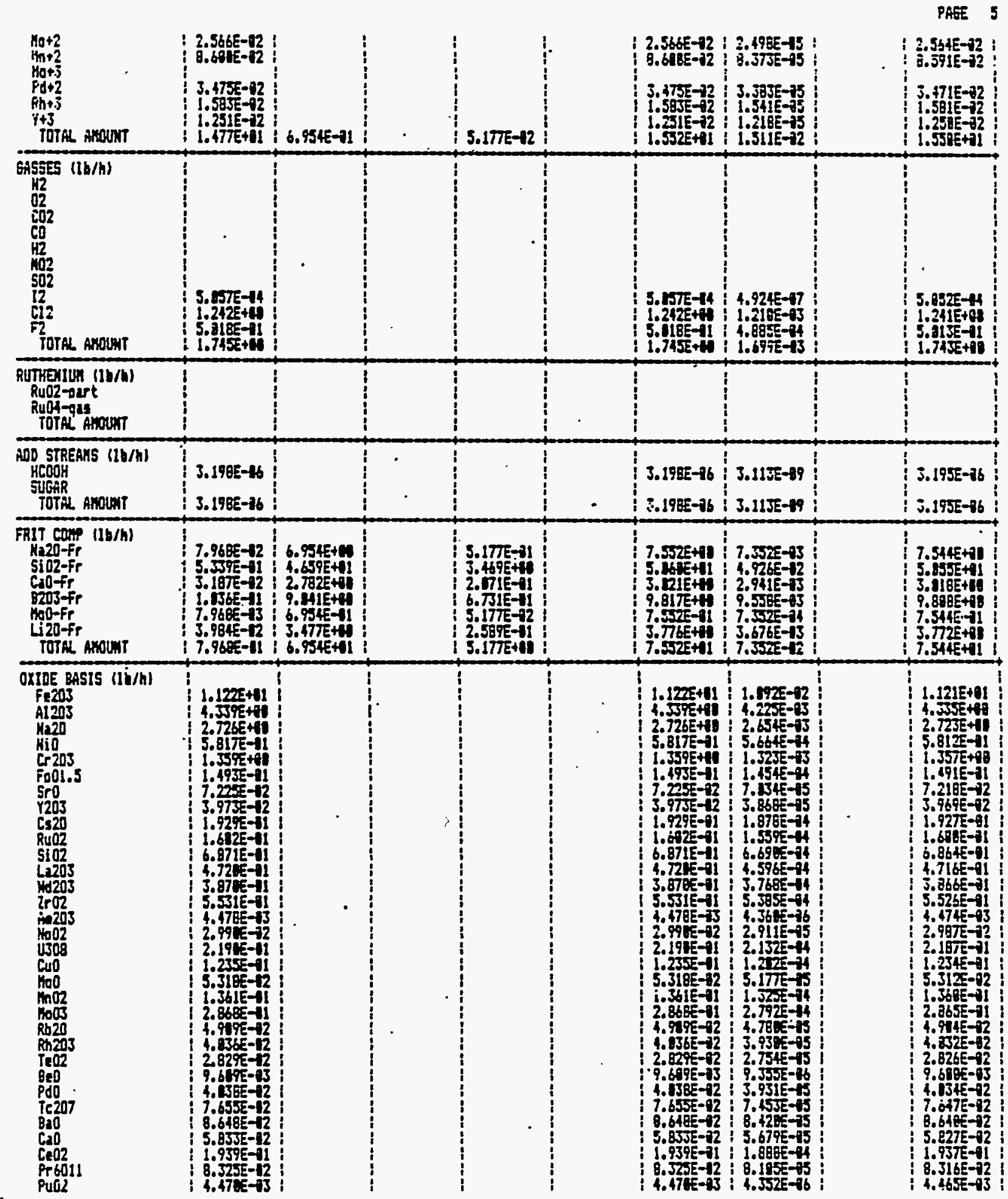


TABLE E-2. (contd).

PAEE 6

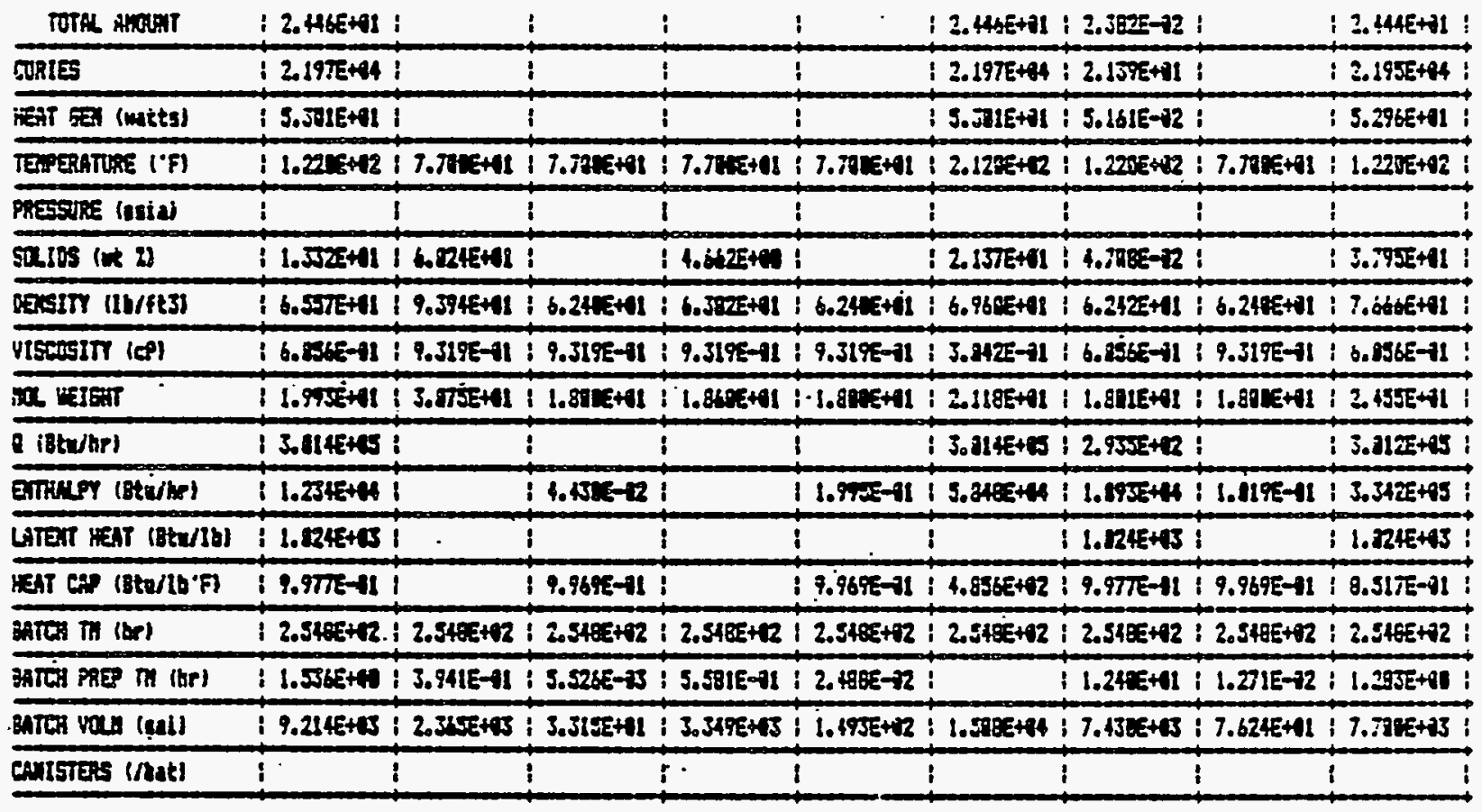


TABLE E-2. (contd.)

PAEE 1

\begin{tabular}{|c|c|c|c|c|c|c|c|c|c|}
\hline $\begin{array}{l}\text { STREAM NUHBER } \\
\text { FLUPR STIEEM HUMBER } \\
\text { STREAM } \\
\text { DESCRIPTION }\end{array}$ & $\begin{array}{c}13 \\
141 \\
\text { Snitet } \\
6+11\end{array}$ & $\begin{array}{l}14 \\
169 \\
\text { SUGAR } \\
10 \text { IIf }\end{array}$ & $\begin{array}{l}\text { Is } \\
\text { lif } \\
\text { gutURRY } \\
\text { io HEITER }\end{array}$ & $\begin{array}{l}16 \\
52 \\
\text { GLAs5 To } \\
\text { CANIStER }\end{array}$ & 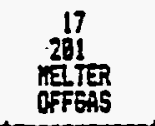 & $\begin{array}{l}18 \\
\text { 2H: } \\
\text { NEIER } \\
\text { IMK BUFE }\end{array}$ & $\begin{array}{l}19 \\
212 \\
\text { offGis \& } \\
\text { IHK BUTE }\end{array}$ & $\begin{array}{c}28 \\
\text { DILITIOK } \\
\text { AIR }\end{array}$ & $\begin{array}{l}21 \\
292 \\
\text { ofFons To } \\
\text { FILH GLR }\end{array}$ \\
\hline Liqu10 val (qal/h) & $|1.538 E+12|$ & & | 3.222E+11 & 4.264E+41: & 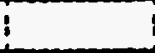 & 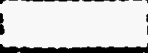 & 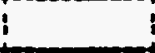 & & 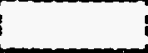 \\
\hline VAPOR KUL (acfh) & 1 & & $i$ & i & 8.869E+13 & $1.235 E+94$ & $2.12 E E+14$ & & $2.1292+94$ \\
\hline JOTAL WSS $(1 \mathrm{~b} / \mathrm{h})$ & $1.1065+13$ & & 3.199E+12 & $9.965 E+11$ & $2.5935+02$ & $4.521 E+02$ & $6.613 E+12$ & & $6.613 E+92$ \\
\hline HATER/STEHA $(1 \mathrm{~b} / \mathrm{hl}$ & I.196E+13 : & & $1.9272+12$ & & $1.98+15+92$ & $2.1375+21$ & $2.84 z+92$ & & $2.832 E+92$ \\
\hline 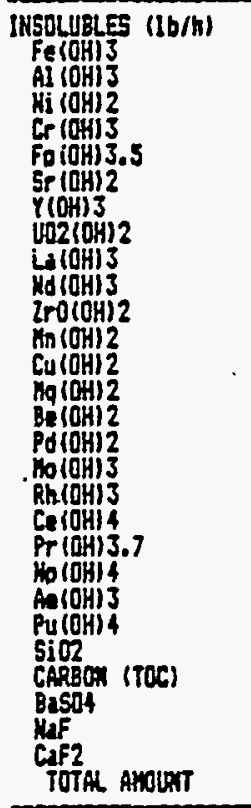 & 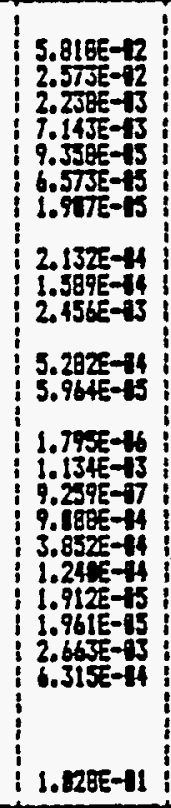 & & 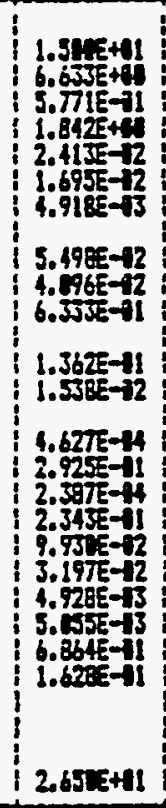 & 列 & $6.8445-23$ & & $\begin{array}{l}6.864 E-13 \\
6.864 E-13\end{array}$ & & $\begin{array}{l}6 \\
6.8645-23 \\
6.8645-13 \\
6\end{array}$ \\
\hline 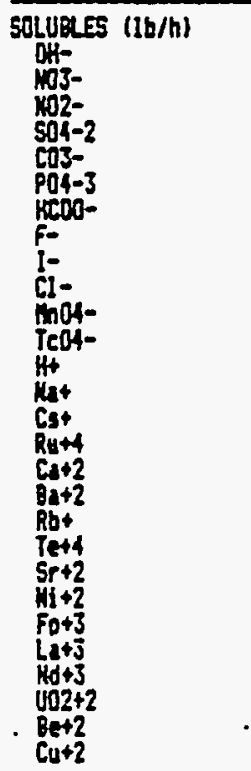 & 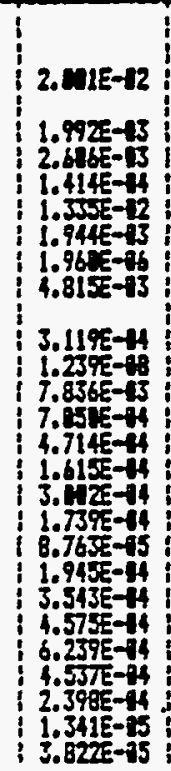 & . & 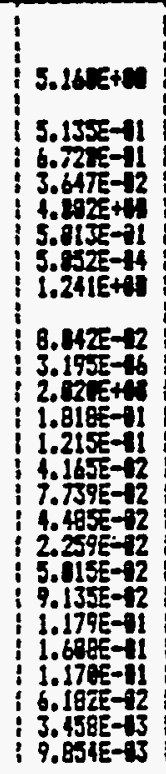 & $\begin{array}{l}4.622 E-11 \\
3.342 E-11 \\
4.547 E-14 \\
.\end{array}$ & . & 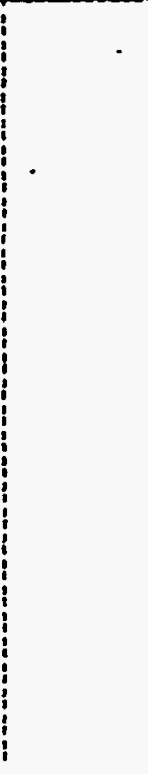 & 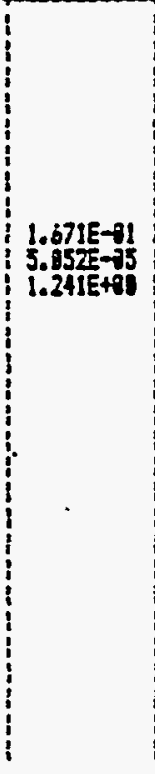 & & $\begin{array}{c}. \\
1.671 E-11 \\
5.852 E-75 \\
1.241 E+11\end{array}$ \\
\hline
\end{tabular}


TABLE E-2. (contd).

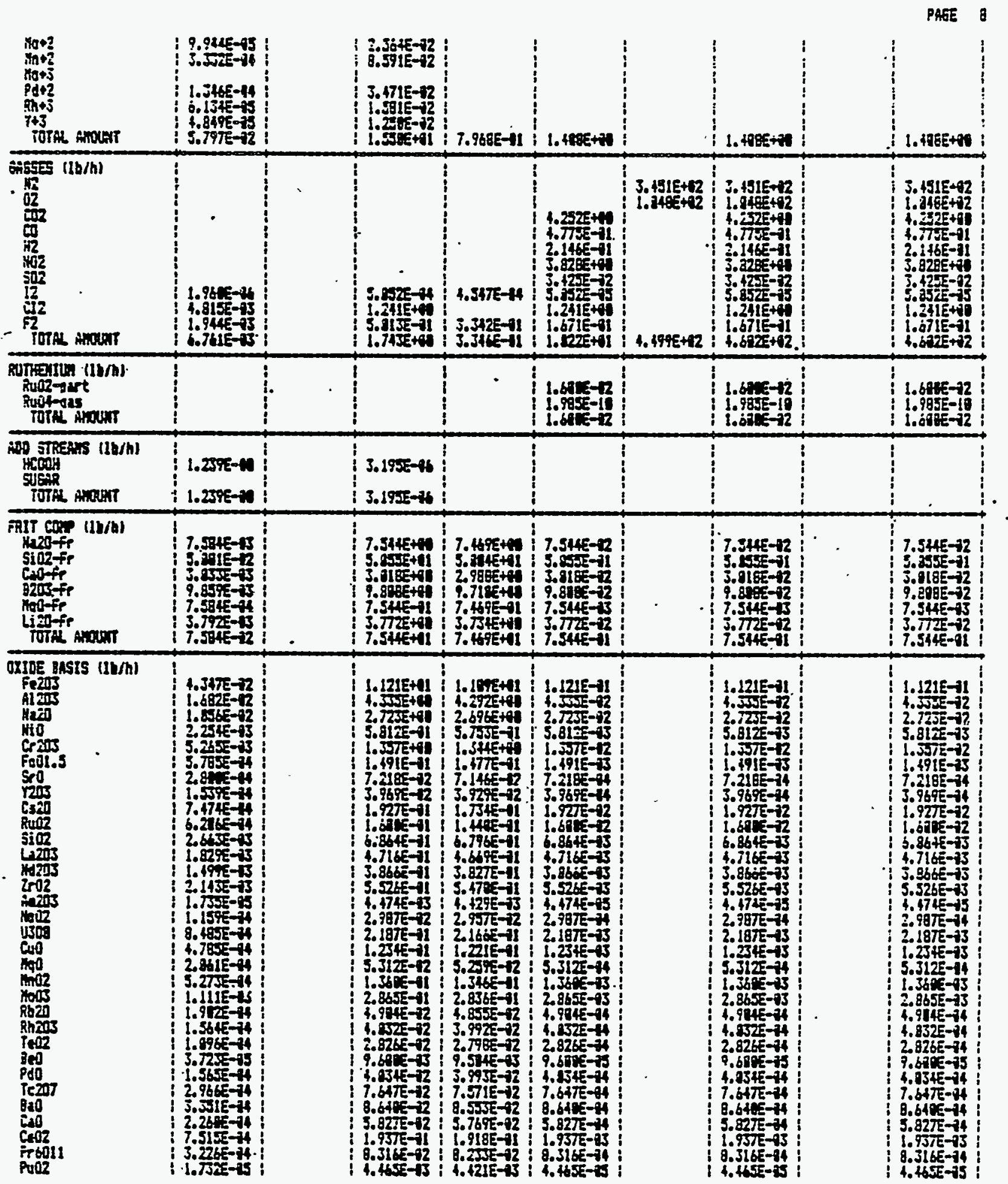


TABLE E-2. (contd)

PASE ?

\begin{tabular}{|c|c|c|c|c|c|c|c|c|}
\hline TOTAL AHOUNT & ; $9.4785-92:$ & & $2.444 E+91:$ & $2.416 E+11\}$ & $2.761 E-81:$ & & | 2.761E-21 : & $2.761 E-11$ \\
\hline OURIEE & $8.514 E+81:$ & & $2.195 E+14$ & $2.15 t \leq+94$ & $4.449 E+92$ & & $4.449+12$ & 1 4. $449 E+12$ \\
\hline HEAT GEY (wtts) & 2.824E-31 i & & $5.2968+11$ & 3.206E+81 & 9.8AE-11: & & 1 9. $550 E-11:$ & 9.85:E-21 \\
\hline TEPPERATURE ('F) & $1.220 E+12$ & & $1.2245+12$ & $1.198 E+93$ & $5.7285+02:$ & $5.720 E+92$ & i $5.72 \pi E+02:$ & 3. $7245+72$ \\
\hline PRESSURE (OSiA) & $i$ & & 1 & 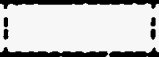 & $1.411 E+11$ : & 1.411E+1 & I.411E+1! ! & I $1.411 E+11$ \\
\hline soLids int II & $2.144 E-12$ : & & i $3.795 E+11$ & & 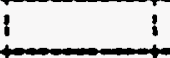 & 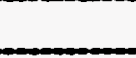 & 1 & 1 \\
\hline iEHSITY $(1 \mathrm{~b} / \mathrm{ft} 3)$ & I $6.1835+11$ : & & 17.666E+11 : & & $2.35 \% 5-12$ ! & $3.6 \operatorname{sic}-72$ & | 3.118E-22 | & $3.11 \mathrm{BE}-12$ \\
\hline Utscosity (ep) & | $6.8565-11$ & & I 6. ESKE-11 : & & $1.628 E-92$ : & $2.8 \times 1 E-2$ & $2.1605-72$ i & $2.188 E-92$ \\
\hline MoL VEIGUT & $1.80 * 5+11$ : & $\dot{-}$ & $2.455 E+91$ & $6.5735+41$ & $1.341 E+11:$ & 2.876E+91 & $: 2.425+11 !$ & $2.42 E+11$ \\
\hline (Btu/hr) & | $1.1685+93$; & & | 3.812E+15 | & & 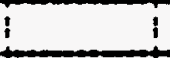 & 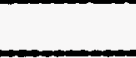 & $i$ & $i$ \\
\hline ENTHALPY (Btu/hr) & $4.96665+44$ & & $3.342 E+95$ & & $4.6985+14$ & $5.6065+44$ & $1.2315+15$ : & i. $1.23 x+15$ \\
\hline LATEHT HEAT (BtU/IS) & $i$ & & $i$ & 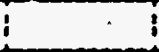 & 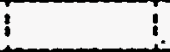 & 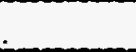 & $i$ & $i$ \\
\hline KEAT CAP (BRU/L'F) & 19.97TE-11: & & B.517E-11 & & ; $4.771 E-11$ : & 2.5L7E-11 & | $3.2555-11$ ! & $\begin{array}{r}3.259 E-71 \\
\end{array}$ \\
\hline BATEH Th (br) & $2.549 E+12$ & $2.548 E+12$ & $2.548 E+12$ & $2.548 E+02$ & 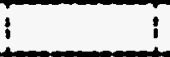 & 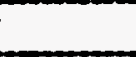 & 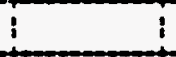 & $i$ \\
\hline BATCH PREP In (hr) & ; $5.6818+14:$ & S.ARE-11 & 1 & $2.346 E+12:$ & 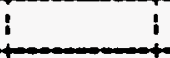 & 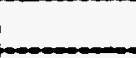 & $i$ & 1 \\
\hline BATCH VOLI (nal) & 3.thifets i & - & i.7RE+13 & i.887E+e3 ; & 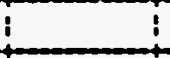 & 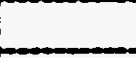 & $i$ & 1 \\
\hline CANISTERS (/bat) & i & 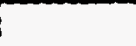 & 1 & $6.98 C E+4$ & $i$ & 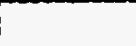 & i & $i$ \\
\hline
\end{tabular}


TABLE E-2. (contd)

PAGE ID

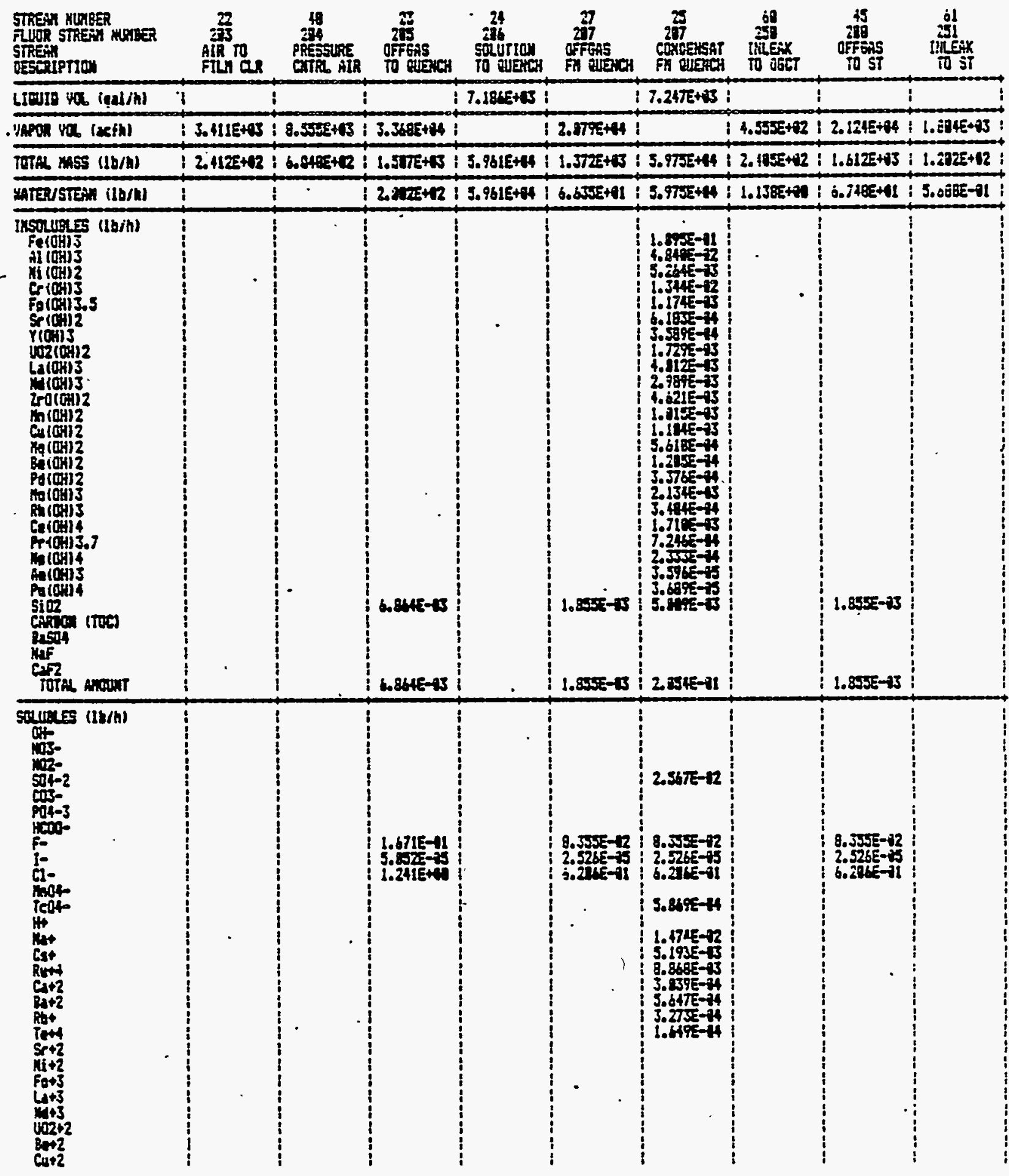


TABLE E-2. (contd)

\begin{tabular}{|c|c|c|c|c|c|c|c|c|c|}
\hline 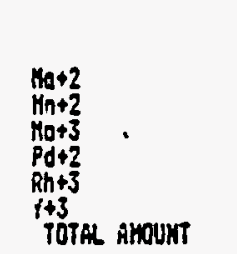 & & & : & & 7.042E-11 & $\begin{array}{l}7.6965-91 \\
1\end{array}$ & & 7.042E-31: & PAGE \\
\hline 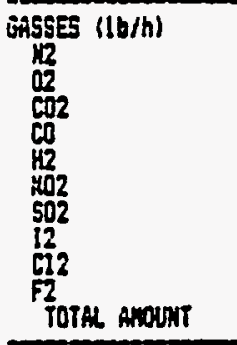 & $\begin{array}{l}1.85 E E+12 \\
5.619 E+11 \\
2.412 E+12\end{array}$ & $\begin{array}{l}\text { 4. 339E+12 } \\
1.495+12 \\
\\
\text { D.MHEE+12 }\end{array}$ & 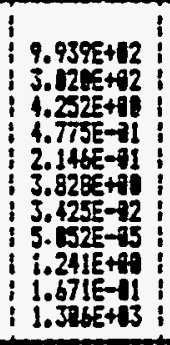 & & 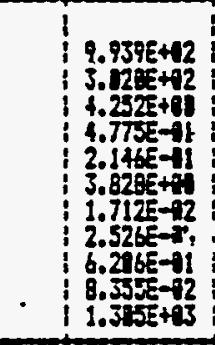 & $\begin{array}{l}0.5265-15 \\
6.205-11 \\
8.355 E-12 \\
7.2425-11 \\
\end{array}$ & $\begin{array}{l}1.836 E+22 \\
5.577 E+11 \\
2.393 E+12\end{array}$ & 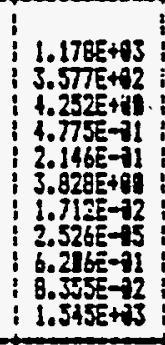 & $\begin{array}{l}9.176 E+01 \\
2.796 E+01 \\
1.197 E+22 \\
\end{array}$ \\
\hline 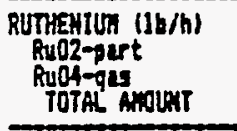 & & & $\begin{array}{l}1.67 y E-92 \\
1.965 E-10 \\
1.69 E-12\end{array}$ & & $\begin{array}{l}4.3 \\
1.9 \\
4.3\end{array}$ & & - & $\begin{array}{l}E-13 \\
-13 \\
-13\end{array}$ & \\
\hline $\begin{array}{l}\text { ADg STREAMS }(1 \mathrm{~h} / \mathrm{h}) \\
\text { HCOOH } \\
\text { SUGAR } \\
\text { TOPAL AMOUNT }\end{array}$ & 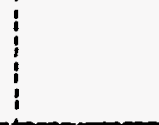 & & 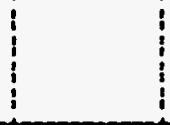 & & 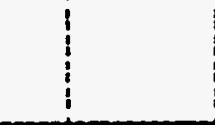 & & & 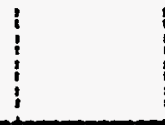 & \\
\hline 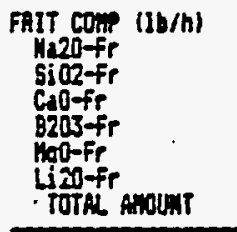 & 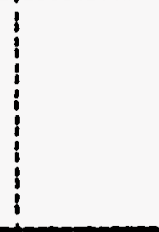 & • & $\begin{array}{l}7.544-12 \\
5.055-11 \\
3.01 E-22 \\
9.810 E-72 \\
7.544 E-23 \\
3.772 E-12 \\
7.544 E-11\end{array}$ & & $\begin{array}{l}2.109 E-12 \\
1.360 E-11 \\
8.156 E-13 \\
2.651 E-12 \\
2.139 E-13 \\
1.129 E-12 \\
2.139 E-11\end{array}$ & 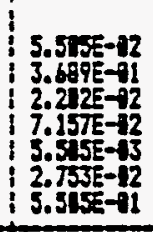 & & $\begin{array}{l}2.039 E-12 \\
1.360 E-01 \\
3.156 E-13 \\
2.651 E-72 \\
2.1395-75 \\
1.020 E-02 \\
2.239 E-11 \\
\end{array}$ & \\
\hline 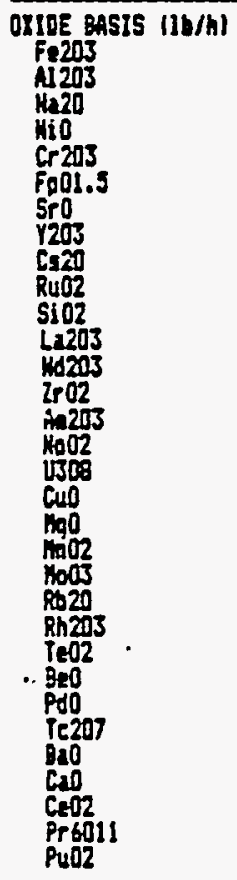 & $\begin{array}{l} \\
\\
\end{array}$ & & 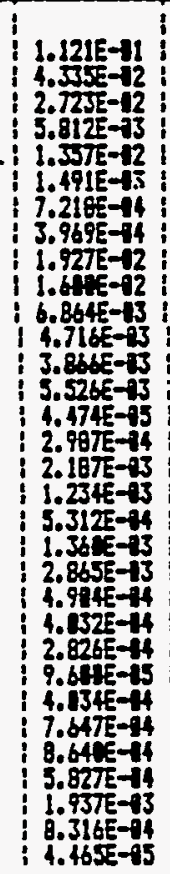 & & 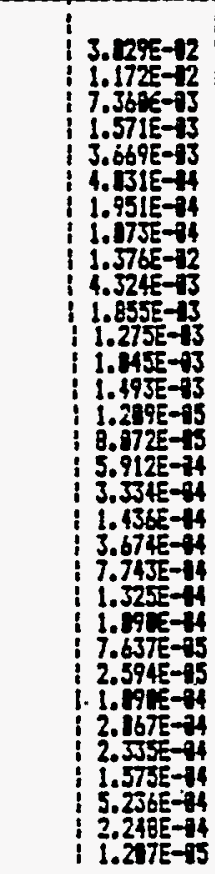 & 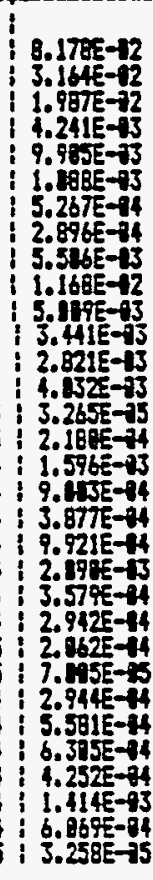 & • & 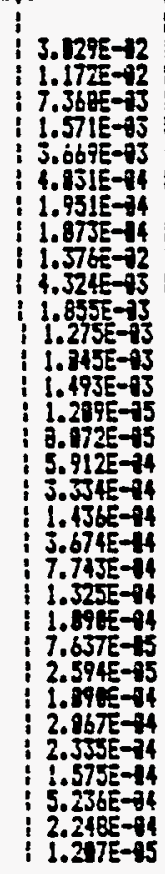 & \\
\hline
\end{tabular}


TABLE E-2. (contd)

\begin{tabular}{|c|c|c|c|c|c|c|c|c|}
\hline Tota P̣mont & i & $!$ & | 2.361E-11 ! & : $8.318 E-92$ & : $1.729 E-71$ & & ; 9.318E- 22 ; & \\
\hline CURTES & $\therefore$ & ; & i $4.449 E+92:$ & $2.244 E+12$ & $2.2055+02$ & & | $2.244 E+12$ & $i$ \\
\hline :FAT GES (matts) & $i \quad$ & $\mathbf{i}$ & | 9.2315-11: & $4.2945-71$ & 1 4.756E-91 & & : $4.694 F-11:$ & 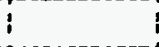 \\
\hline JERERATUEE $(\cdot F)$ & 1.70xe+1 & : $7.395 \mathrm{E}+11$ & $3.264 E+12: 1.041 E+42$ & $1.345 E=72$ & $1.045 E \div 72$ & $1.043 E+12$ & $2: 1.345 E+02$ & $1.243 E+92$ \\
\hline PRESSURE (Asia) & I. 1.11E+91 & 1. 11Lt+k1 & I. IIIEA+1: & $1.424 E+01$ & & $1.424 E+1$ & 1 : 1.1245:31 : & I 1.40RE+II \\
\hline $\sec$ ios int $y$ & 1 & $i$ & $i$ & $i$ & $2.524 E-13$ & & i & 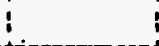 \\
\hline Denstr (1sift3) & : $7.4 \pi T-22$ & : T.*HJE-12 & | 4.173E-72 : 6. 225E+11 & 6.59Ee-12 & $6.1655+11$ & : $5.22 \pi \mathrm{E}-11$ & 1 | 7. $58 \mathrm{EE}-12$ & 6. $\sin 1 E-92$ \\
\hline Viscositr (ep) & $11.79=-12$ & $1.791=-12$ & I 2.01TE-12:7.412E-11 & 1:.712z-72 & i 7. $119 E-11$ : & $i$ & $1.7305-32$ & 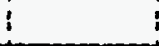 \\
\hline Wor veleit & i $2.884 E+11$ & I $3884 E+11$ & $2.6725+91: 1.825+91$ & $2.8455+11$ & $1.8 k z+41$ & $2.8765+91$ & $1: 2.814 E+11$ & 2.37iEt+1 \\
\hline I Eluikr) & 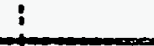 & 1 & i-5.1955+4 ! & i-2.525e+6s & : 2.J10x++25: & & i-2.5255E+45 & $\vdots$ \\
\hline Bnthupl (Btw/kr) & 1 & $\vdots$ & | $1.23 x+6 \mid 1.359 E+66$ & $9.139 E+13$ & $1.6265+46$ & & 1.1255+4 & 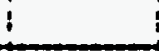 \\
\hline Latean bett (Bka/lb) & $i$ & $\vdots$ & $i$ & $1.254 E+13$ & $1.1345+23$ & & $\vdots$ & $i$ \\
\hline Har CAs (Btw/b'P & $2418=-11$ & $2418 E-11$ & 2.785E-11:9.967E-91 & $2.531 E-91$ & $9.968 \mathrm{E}-91$ & $!$ & $1.2 .5175-11$ & $\vdots$ \\
\hline BATEH In (hr) & $!$ & $i$ & $i$ & i & 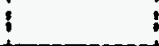 & ; & $i$ & $i$ \\
\hline 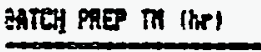 & $i$ & $i$ & $\vdots$ & 1 & $i$ & $i$ & $!$ & $i$ \\
\hline sates ves igall & $i$ & $i$ & $1^{\circ}$ & $i$ & $i$ & : & $i$ & $i$ \\
\hline CaMistzes (/but) & $i$ & $i$ & $\vdots$ & $i$. & $i$ & i & i & i \\
\hline
\end{tabular}




\begin{tabular}{|c|c|c|c|c|c|c|c|c|c|}
\hline $\begin{array}{l}\text { STREAM FUHEER } \\
\text { FLUOR STREAH } \\
\text { STREAMBER } \\
\text { JESCRIPTIOK }\end{array}$ & $\begin{array}{l}47 \\
252 \\
\text { OFFEAS } \\
\text { TO StrRU: }\end{array}$ & $\begin{array}{l}56 \\
2\rfloor 2 \\
\text { LEAH SAL } \\
\text { To scRuB }\end{array}$ & $\begin{array}{c}29 \\
214 \\
\text { offFAs } \\
\text { Fh STRUB }\end{array}$ & $\begin{array}{l}28 \\
213 \\
\text { RICH SQ } \\
\text { FH SCRt }\end{array}$ & $\begin{array}{l}31 \\
218 \\
10 \\
\end{array}$ & $\begin{array}{l}39 \\
223 \\
\text { STEAH } \\
\text { To SAS } \\
\end{array}$ & $\begin{array}{l}215 \\
\text { RICH SOL } \\
\text { Fit 5A5 }\end{array}$ & $\begin{array}{r}33 \\
274 \\
\text { OFFEAS } \\
\text { FH SAS } \\
\end{array}$ & $\begin{array}{l}58 \\
216 \\
\text { conofyisht } \\
\text { Fin comosn } \\
\end{array}$ \\
\hline Lievido //u (qai/h) & i & $i .917 E+13$ & & $1.924 E+13$ & $8.984 E+12$ & & 9.327E+212 & & $5.647 E+01$; \\
\hline VAPOR YOL (acih) & $2.355 E+4$ & & $3.108 E+12$ & & & $9.896 E+12$ & $!$ & $2.067 E+14$ & $i$ \\
\hline TOTAL KASS $(1 \mathrm{~b} / \mathrm{h})$ & $1 . \sqrt{35 E+23}$ & 1.6AnE+24 & $1.6768+43$ & $1.616 E+94$ & $7.475 E+13$ & $3.322 x+i 2$ & $7.761 E+13$ & $1.7225+13$ & $4.7135+91$ \\
\hline WATER/STEAH $(\mathrm{lb} / \mathrm{h})$ & 6. BesE+11 & 1.6PE+41: & $1.414 E+11$ & $1.625 E+14$ & $7.475 E+23$ & $3.3221+42$ & 1 $7.761 E+13$ & $6.8865+01$ & $4.713 E+01$ \\
\hline 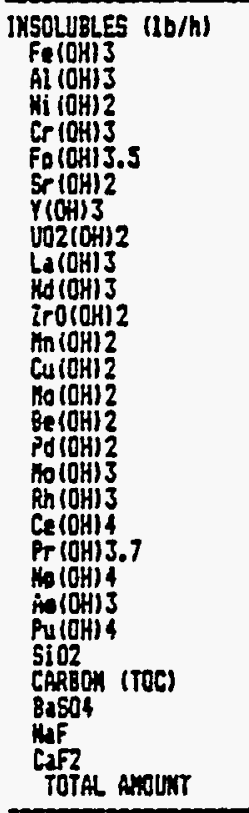 & $\begin{array}{l}1.255 E-13 \\
1.855 E-13 \\
1.23\end{array}$ & 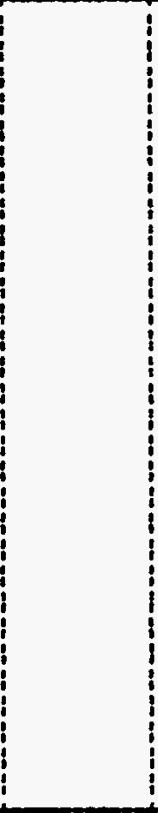 & $\begin{array}{r}. \\
1.855 E-13 . \\
1.855 E-13 \\
\end{array}$ & 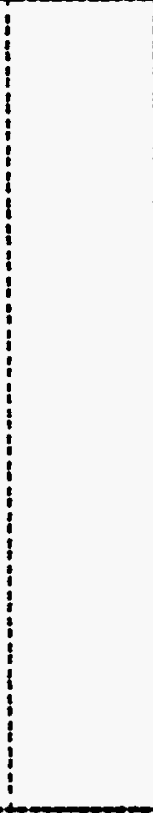 & , & \begin{tabular}{|l}
4 \\
$\vdots$ \\
$\vdots$ \\
$\vdots$ \\
$\vdots$
\end{tabular} & 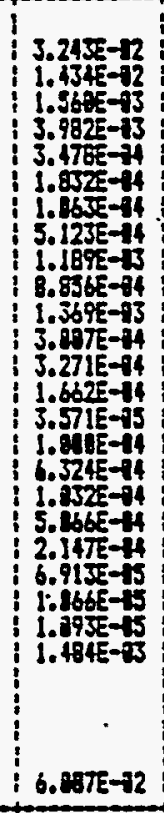 & 3.71EE-14 & . \\
\hline 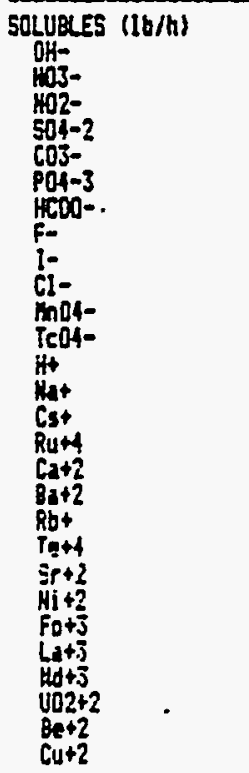 & 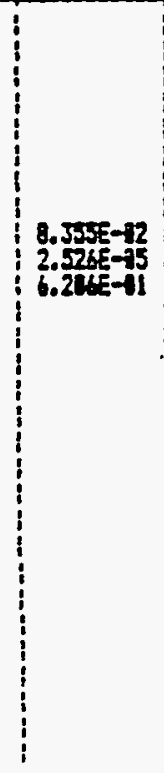 & 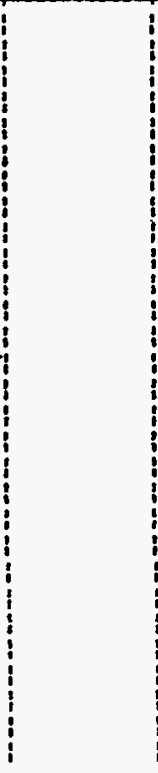 & $\begin{array}{l}\text { 8. } 355 E-44 \\
2.526 E-15 \\
1.231 E-T_{1}\end{array}$ & $\begin{array}{l}3.44 \mathrm{EE}+1 \\
1.711 E-12 \\
8.271 E-12 \\
6.062 E-11\end{array}$ & & $\begin{array}{l}\vdots \\
\vdots \\
\vdots \\
\vdots\end{array}$ & 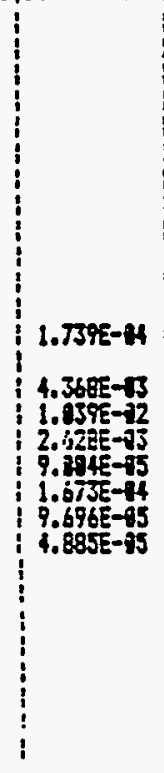 & $\begin{array}{l}\text { 8. } 355-94 \\
2.326-24 \\
1.241 E-92\end{array}$ & 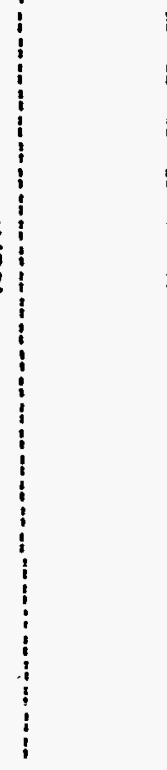 \\
\hline
\end{tabular}


TABLE E-2. (contd)

pinse 14

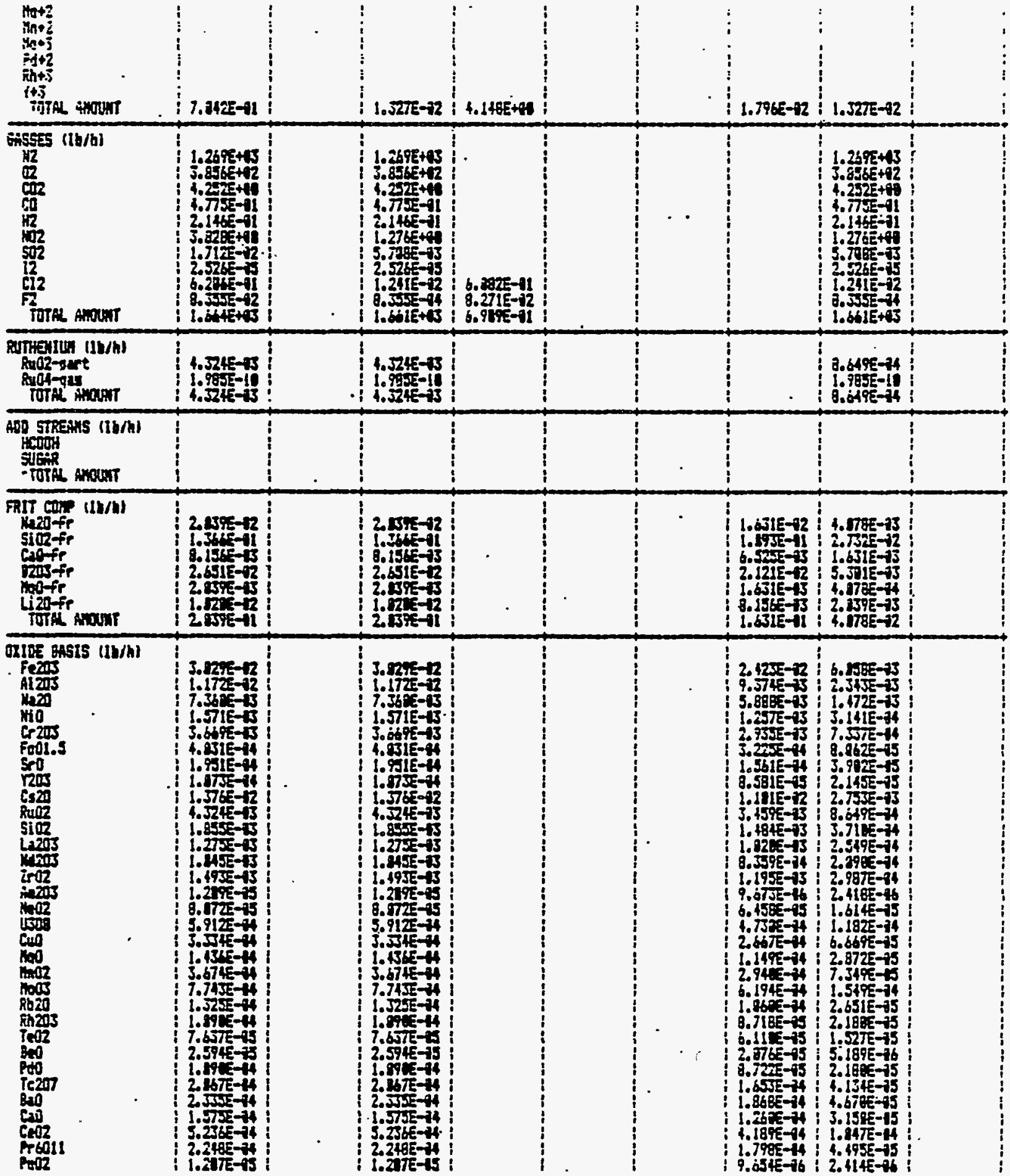




\begin{tabular}{|c|c|c|c|c|c|c|c|c|}
\hline TOTA AMOH: & ; 8.31E5- 12 ; & & $8.3185-12$; & & 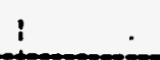 & : & $6.654 E-12: 1.664 E-12$ & \\
\hline CURIES & $2.244 E+22$ & & $2.244 E+12$ & & $i$ & $i$ & 1 $1.795 E+02: 4.488 E+01$ & \\
\hline HEAT GEH ImattsI & $4.2945-11$ & & $4.294 E-91$ & & 1 & 1 & $3.435 E-21: 8.58 \pi E-92$ & \\
\hline TEXPERATURE $(\cdot F)$ & I. $435+12$ & S.EANE+QI & $5.2 A n E+61:$ & $5.497 E+11$ & 5.14RE+O! & J.65EE+92 & 9.284E+11:9.284E+11 & 5.82aE+91 \\
\hline FRESSURE IAsia) & $1.4125+11$ & & $1.387 E+11$ & & $i$ & $1.650=2+12$ & i $1.3585+11$ & \\
\hline Solios (ut i) & $i$ & & 1 & $2.584 E-12$ & & + & I.111E-T3 : & 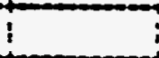 \\
\hline DEtsITY (1bift3) & $7.515 E-12$ & 6.24 EN+11 & | $5.388 E+11 \mid$ & $6.2425+11$ & $6.221 E+11$ & $3.356 E-11$ & 6.221E+11: 6.44FE-72 & $6.248 E+91$ \\
\hline VISCOSITY (eP) & 1. TJTE-12 & $1.252 E+11$ & $1.6955-12$ & $1.1835+91$ & $1.2525+98$ & $1.2925-12$ & 1.943E-11:1.721E-12 & $1.252 E+98$ \\
\hline MIL VEIEHT & | 2.818E+ +1 | & 1.BALE+11 & i $2.8665+41:$ & $1.80 n E+11$ & $1.898 E+91$ & $1.840+11$ & 1. BtIE+11:2.822E+11 & 1. BttE+1 : \\
\hline S IBtu/hrt & $|-2.375 t+15|$ & & I-8.291E+44: & 0.MIE+14 & 1 & 1 & 6.797E+4 & \\
\hline ETruhlpy (Btw/hr) & 1.j85E+4 ! & $-4.3465+45$ & i-1.A19E+4 & $-3.5222+15$ & $-2.112 E+95$ & $4.575 E+44$ & $1.229 E+15: 6.810 E+15$ & $-1.268 E+13$ \\
\hline LATEMT HEAT (8to/lb) & i & & $1.264 E+13$ & $1.262 x+13$ & & $i$ & $1.41 E+13: 1.44 E+13$ & \\
\hline (IEAT $\operatorname{cat}($ Btu/lb'F) & : $2.512 E-11:$ & 1.MIE+10 & $2.4265-11:$ & $9.995 \mathrm{E}-11$ & I.MIE+ & $4.682 E-11$ & \begin{tabular}{|c|c|}
$9.966 E-11$ & $2.58 R E-01$ \\
\end{tabular} & 1.VIIE+in \\
\hline BATCH Th (hP) & i & & $i$ & & 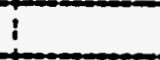 & $i$ & $i$ & 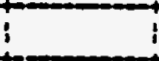 \\
\hline BATCH PREP II (hr) & $i$ & - & $i$ & & 1 & i & 1 & 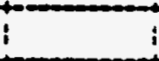 \\
\hline BATCH VOLX (ạa) & $i$ & & 1 & & 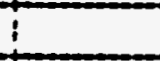 & 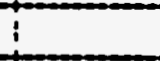 & 1 & 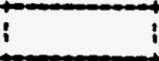 \\
\hline CAHISTERS (/bat) & i & & $i$ & & $i$ & + & $i$ & 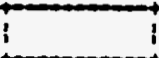 \\
\hline
\end{tabular}


TABLE E-2.. (contd)

pase 16

\begin{tabular}{|c|c|c|c|c|c|c|c|c|c|}
\hline 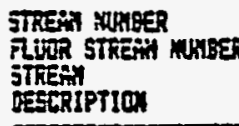 & $\begin{array}{l}\frac{59}{228} \\
\text { offents } \\
\text { Fil conos }\end{array}$ & 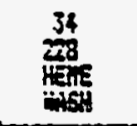 & 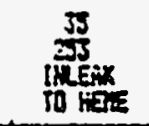 & Fin & 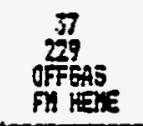 & $\begin{array}{l}\text { 羿 } \\
\text { RUThentun } \\
\text { LOADInS }\end{array}$ & 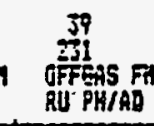 & 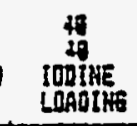 & $\begin{array}{c}\frac{11}{235} \\
\text { offFons in } \\
\text { I PHint }\end{array}$ \\
\hline Imolis va (ga/m) & $:$ & 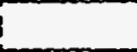 & $\mathbf{i}$ & 3.1 & & $i$ & $i$ & $\vdots$ & $!$ \\
\hline SPOR var (acfh) & $20655+04$ & & I $7.6785+13$ & & $3.35: z+94$ & & $4.056 E+24$ & . & $5.629 E-24$ \\
\hline ToTa mass itb/h) & $1.675 x+23$ & $2,6565+10$ & :4.84PE+12 & $2.711 E+10$ & $2.156 E+23$ & 1.38 & $2.156 E+13$ & : 2.501E-35 & $2.156 E+13$ \\
\hline ALE/STEM (Ib/h) & 1. JTSE+A1 & $2.0365+91$ & 2.2.25E+4 & i $2.656 E+\infty 1$ & I 1.60IE+ & 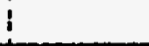 & $1.691 E+41$ & $i$ & ! !.sate-alt \\
\hline 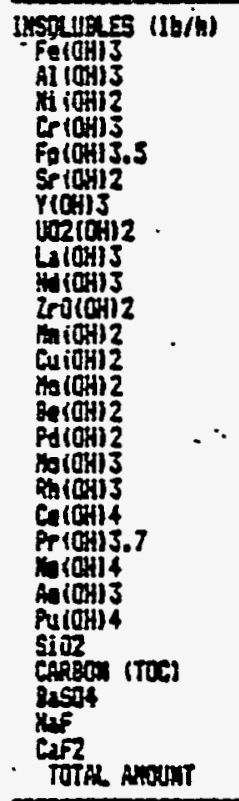 & 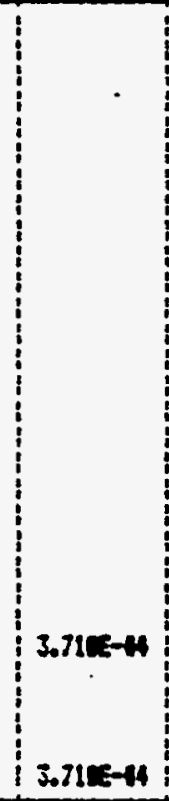 & & 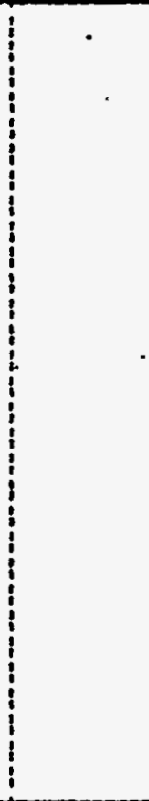 & 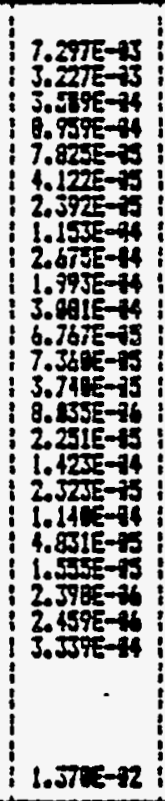 & 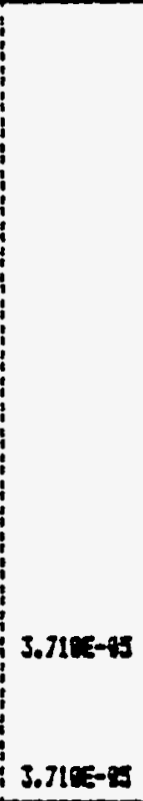 & & $\begin{array}{l} \\
3.716=-25 \\
3.718 c-25\end{array}$ & 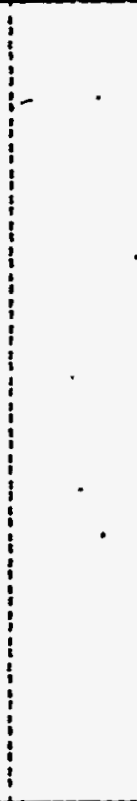 & $\begin{array}{c} \\
\text { 3.71xE-25 } \\
\text { 5.71RE-75 }\end{array}$ \\
\hline 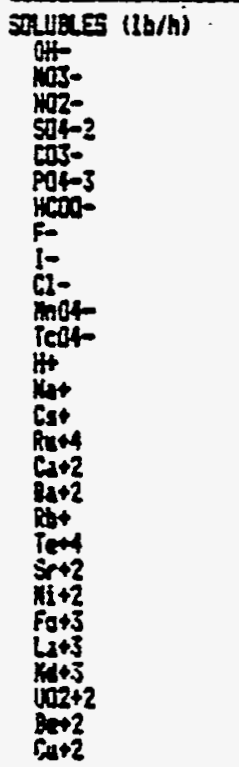 & $\begin{array}{l}8.35 \mathrm{E}-14 \\
2.5265-35 \\
1.241 \mathrm{E}-72\end{array}$ & & . & 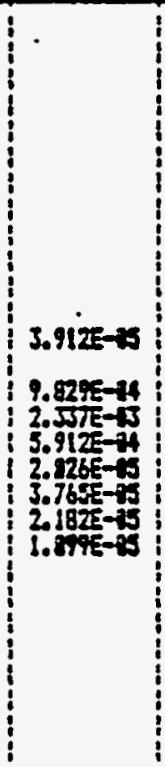 & $\begin{array}{l}. \\
\text { 8. } 55 E-44 \\
2.526 E-15 \\
1.211 E-12\end{array}$ & & $\begin{array}{l}0 \\
\text { 9.35SE-H } \\
2.526 E-75 \\
1.241 E-72\end{array}$ & $\begin{array}{l}2.501 E-15 \\
. \\
.\end{array}$ & $\begin{array}{l}3 \\
9.355 E-24 \\
2.5265-77 \\
1.241 E-72\end{array}$ \\
\hline
\end{tabular}


TABLE E-2. (contd)

PASE 17

\begin{tabular}{|c|c|c|c|c|c|c|c|c|}
\hline $\begin{array}{l}\text { not2 } \\
m i+2 \\
n o+3 \\
P d+2 \\
R h+3 \\
1+3 \\
\text { Totm Amoun }\end{array}$ & $\begin{array}{l} \\
\vdots \\
1\end{array}$ & 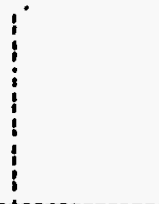 & 4.241E-A3 & $1.32 \pi-2$ & & 1.32TE-12 & $2.501 E-95$ & \begin{tabular}{|l}
$1.3255-72$ \\
1
\end{tabular} \\
\hline 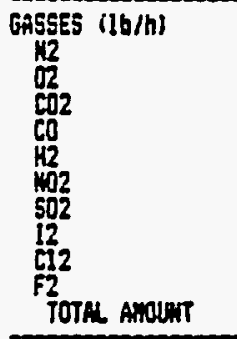 & 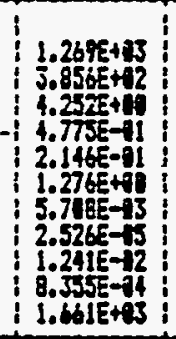 & $\begin{array}{l}3.671 E+92 \\
1.115 E+12 \\
4.787 E+92\end{array}$ & 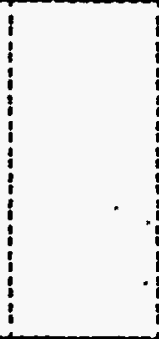 & 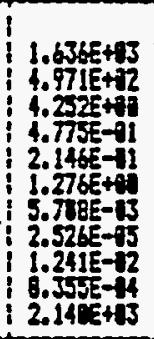 & & 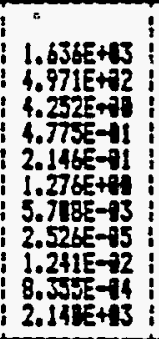 & $\begin{array}{l}- \\
2.501 E-25 \\
2.531 E-15\end{array}$ & 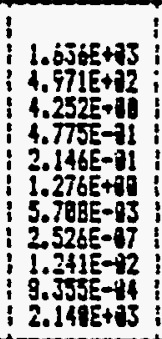 \\
\hline 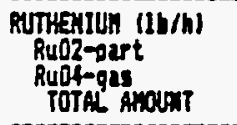 & $\begin{array}{l}8.649 E-14 \\
1.985 E-10 \\
8.649 E-94\end{array}$ & 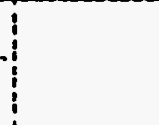 & ! & $\begin{array}{l}1.9855-10 \\
8.645 E-95\end{array}$ & $\begin{array}{l}1.965 E-19 \\
1.965 E-10\end{array}$ & $\begin{array}{l}8.649 E-15 \\
1.965 E-12 \\
8.6475-15\end{array}$ & & $\begin{array}{l}8.905 E-12 \\
8.047 E-15\end{array}$ \\
\hline 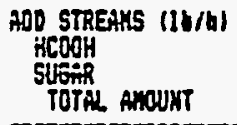 & 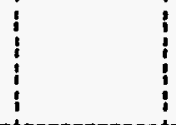 & 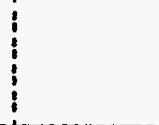 & 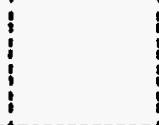 & 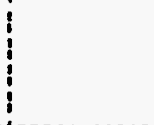 & 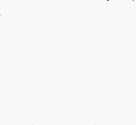 & 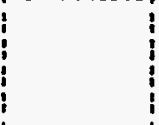 & & \\
\hline 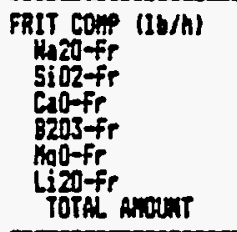 & \begin{tabular}{|l|}
$4.078 c-13$ \\
$2.73 z E-12$ \\
$1.631 E-13$ \\
$5.311 E-13$ \\
$4.078 E-44$ \\
$2.039 E-33$ \\
$4.178 E-42$
\end{tabular} & 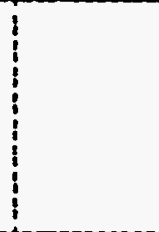 & $\begin{array}{l}3.67 \mathrm{E}-13 \\
2.45 \mathrm{E}-12 \\
1.46 \mathrm{E}-13 \\
4.71 \mathrm{E}-13 \\
3.67 \mathrm{E}-14 \\
1.835 \mathrm{E}-13 \\
3.67 \mathrm{E}-12\end{array}$ & $\begin{array}{l}4.578 E-14 \\
2.732 E-13 \\
1.631 E-14 \\
3.311 E-4 \\
4.37 E E-25 \\
2.035 E-41 \\
4.078 E-13\end{array}$ & & $\begin{array}{l}4.078 E-14 \\
2.752 E-13 \\
1.031 E-14 \\
5.351 E-24 \\
4.078 E-95 \\
2.0355-41 \\
4.078 E-23\end{array}$ & & $\begin{array}{l}4.178 E-14 \\
2.732 E-15 \\
1.0315-74 \\
5.3915-14 \\
4.378 E-15 \\
2.2395-14 \\
4.878 E-13\end{array}$ \\
\hline 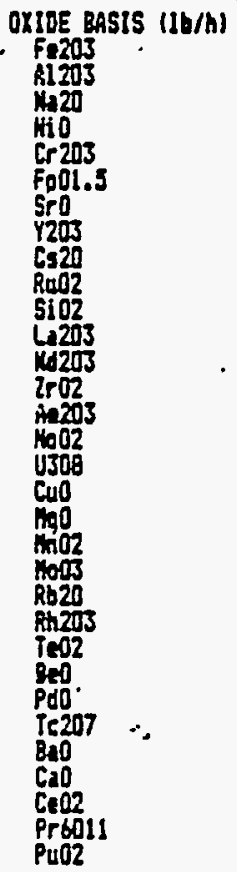 & 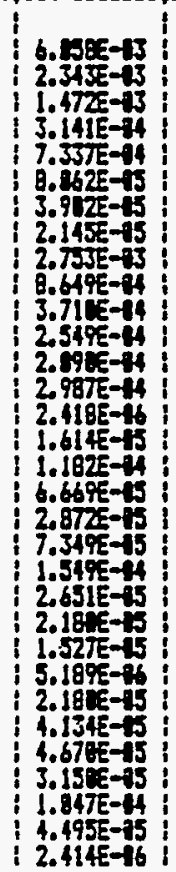 & 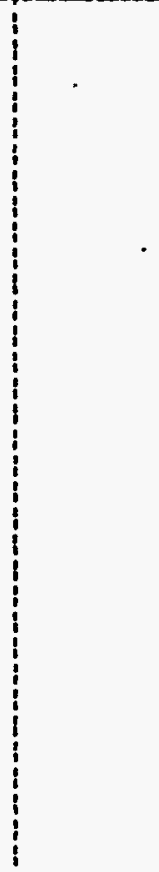 & 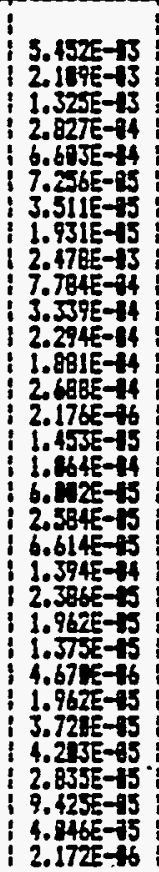 & 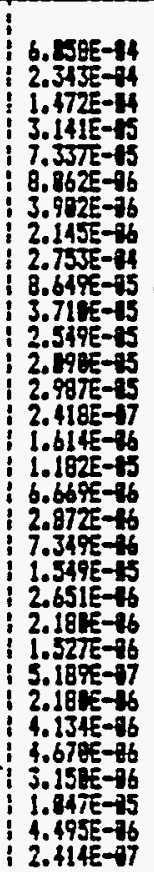 & 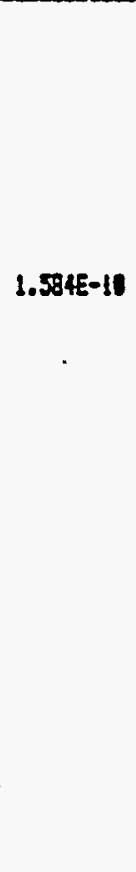 & 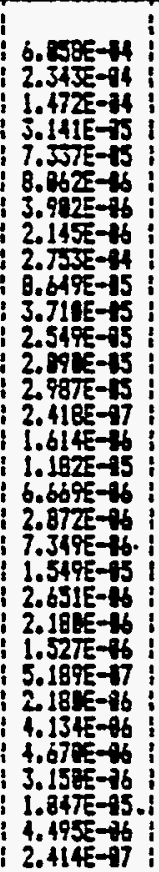 & & 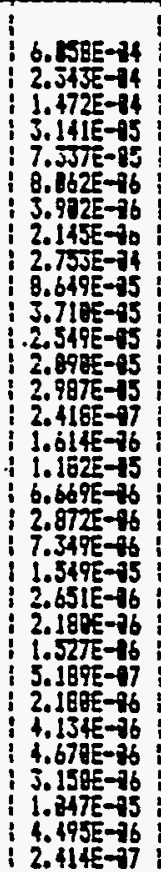 \\
\hline
\end{tabular}


TABLE E-2. (contd)

\begin{tabular}{|c|c|c|c|c|c|c|c|c|c|}
\hline rota Amour & : 1. gàte-12 & & i & : $1.49 \pi E-12$ & 1.604E-2S: & ;.584E-10 : & $1.8545-93$ & & ; 1.60ite-13 : \\
\hline FIRIES & if.4885+91 & & $!$ & i $4.2345+61$ & $4.29 \mathrm{eg}+4 \mathrm{a}$ & $1.576-27$ & | $1.4986+9$ & 2.563E-76 & I t.496E-81: \\
\hline KEAT GEX (mattsi & 8.591E- & & $i$ & $1 . \sqrt{695-12}$ & $8.588 E-23$ & 9.3ETE-12 & $8.58 B E-73$ & $1.3515-79$ & ; \&.538E-33 : \\
\hline TENERATURE ('P) & i S.9nes+11 & : 7.j2RE+11 & 1 $6.98=5+11$ & i $6.8075+1$ & i S.816est : & & $2.1725+02$ & & i $3.292 E+02$ : \\
\hline PREssure (naid) & $1.5255+11$ & & 1 1.25JE+11 & $i$ & 1. LJTE+A1 : & & $1.1595+11$ & & | $1.8925+91$ | \\
\hline selios int 4 & 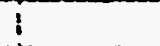 & i. & $i$ & i 2.0 Noten & 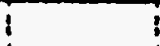 & ; & 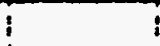 & $i$ & $i$ \\
\hline Dexsitn (1)/ft3) & i $6.2828-12$ & & 6. $641 E-72$ & I $6.3605+11$ & S. So491E-12: & & $4.627 E-92$ & i & $3.842 E-92$ \\
\hline ytscostT $\left(0^{\circ}\right)$ & $1.6915-12$ & : $9.319 E-11$ & : $1.7355-28$ & i $1.4205+20$ & $1.694 E-12$ & & $2.2955-12$ & $\cdot$ & : $2.297 E-92:$ \\
\hline ha intent & $2.8405+11$ & $1.8 n E+Q 1$ & $2.9765+11$ & $\because 1.826 E+11$ & $2.978 \mathrm{c}+01$ & $1.331 E+92$ & $2.97 \times 6+91$ & 1. $6695-42$ & i 2.artie+al : \\
\hline Q (Atu/he) & i-t.858E+44 & & 1 & $\dot{.}$ & $\vdots$ & 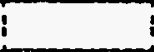 & $8.396 E+94$ & $i$ & : $4.7195+04:$ \\
\hline Entmest (Atu/br) & $i-1.895+4$ & 1. BAFE-11 & $1-4.415+12$ & $i-2.5752+41$ & -1.414E+4 & & T. $66 \pi+94$ & $i$ & $1.1918+15$ \\
\hline LATENT KEAT (Btw!Ib) & i & $i$ & 1 & $i$ & $!$ & 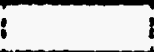 & 1 & $i$ & $i$ \\
\hline IEAT CAP $\left(8 t w / 1 b^{\circ} f\right)$ & $2.1205-11$ & $9.969 E_{-11}$ & $2.1245-11$ & $9.975 E-41$ & $2.4228-91$ & & $3.4845-11$ & 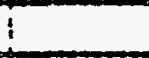 & B.SLIE-91 \\
\hline sarea in (ter) & $i$ & $i$ & $i$ & $i$ & 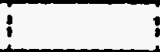 & 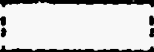 & $i$ & $i$ & $i$ \\
\hline BATEA PiES Th (hr) & 1 & $i$ & $i$ & 1 & 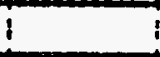 & $\cdot 1$ & $i$ & $i$ & $i$ \\
\hline aAtCh Hen (a) & $i$ & 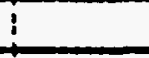 & $i$ & $i$ & $i$ & 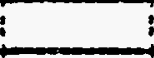 & : & i & 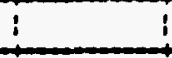 \\
\hline CantsTens i/hat] & ! & $i$ & $i$ & 1 & $!$ & ; & ! & ? & $i$ \\
\hline
\end{tabular}


TABLE E-2. (contd.) -

PAEE 19

\begin{tabular}{|c|c|c|c|c|c|c|c|c|c|}
\hline $\begin{array}{l}\text { STREAX KUHBER } \\
\text { FUUOR STREAH HUABER } \\
\text { STREAH } \\
\text { OESCRIPTIOY }\end{array}$ & $\begin{array}{l}29 \\
234 \\
\text { OFFEA FR } \\
\text { COLLER }\end{array}$ & $\begin{array}{c}12 \\
12 \\
\text { KEEPA } \\
\text { LOADIHE }\end{array}$ & $\underset{\text { OFFGA }}{\stackrel{43}{258}}$ & 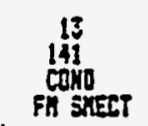 & $\begin{array}{c}26 \\
239 \\
\text { ficcux }\end{array}$ & $\begin{array}{l}41 \\
219 \\
\text { Accoun } \\
\text { fit St }\end{array}$ & $\begin{array}{l}16 \\
151 \\
\text { sinis } \\
0 \mathrm{at}\end{array}$ & confosit & 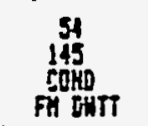 \\
\hline LSQUIS YOL (qui/h) & 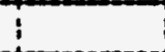 & 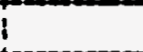 & $i$ & $1.338 E+12$ & $1.684 E+91$ & $4.664 E+11$ & $4.24 E+11$ & $2.384 E+32$ & $2.3555+12$ \\
\hline VAPOR VOL (acth) & $4.1315+14$ & & ; 4.219E+14 : & & $i$ & i & i & 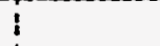 & \\
\hline TOTAL MASS $(\mathrm{lb} / \mathrm{h})$ & $2.156 E+93$ & $5.741 E-23$ & $2.156 E+13$ & $1.146 E+13$ & $1.5555+12$ & $3.9765+12$ & 3.515E+92 & $1.9065+43$ & $1.724 E+13$ \\
\hline YATER/STEAY (IB/h) & $1.6 \| 1 E+01$ & & I $1.611 E+11:$ & $1.116 E+13$ & $1.53 \mathrm{BE}+12$ & $3.892 E+12$ & $3.575 E+12$ & 1 1.879E+i3 & $1.924 E+23$ \\
\hline 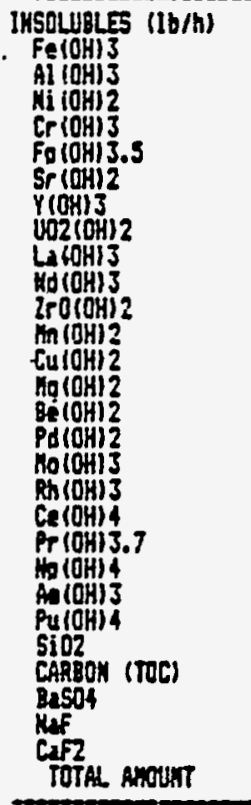 & 3.71CE-Is & 3.JIIE-1S & . & 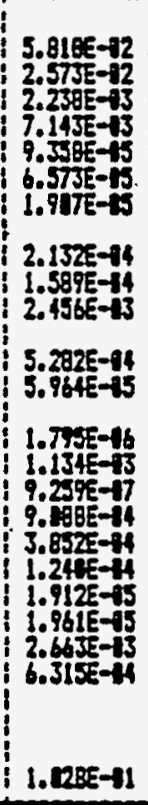 & 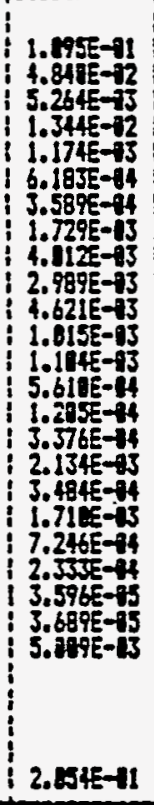 & 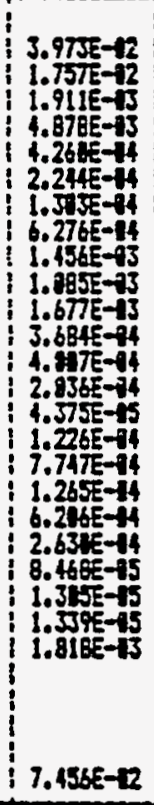 & & 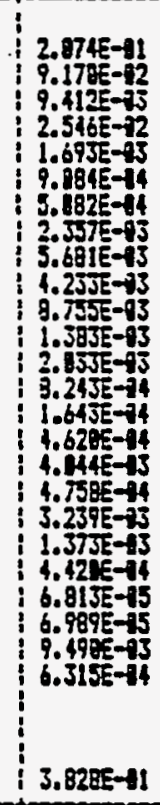 & 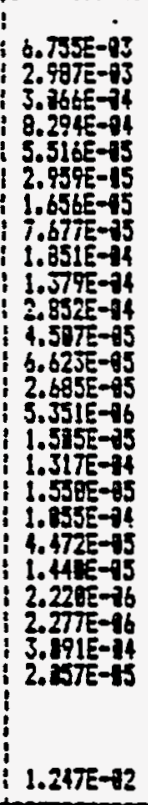 \\
\hline 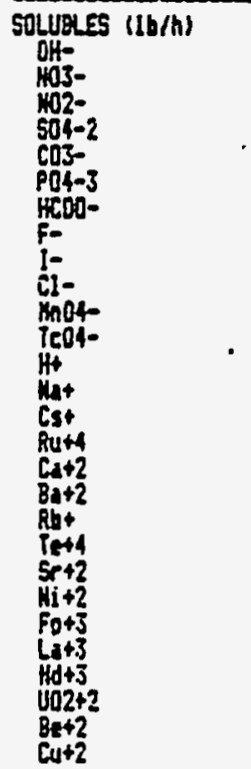 & $\begin{array}{l} \\
8.355 E-14 \\
2.526 E-7 \\
1.261 E-12\end{array}$ & & $\begin{array}{c}0.355 E-94 \\
2.526 E-77 \\
1.2315-12\end{array}$ & 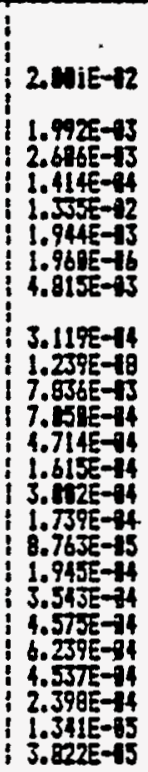 & 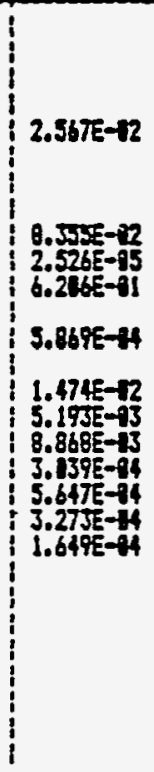 & 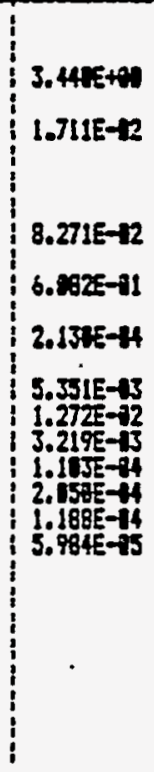 & • & 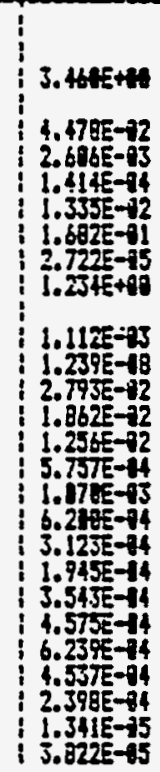 & 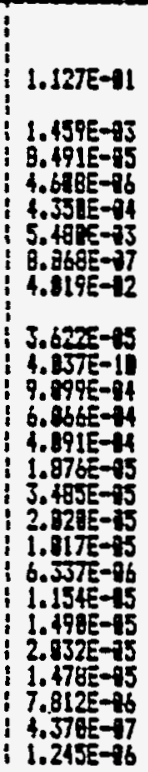 \\
\hline
\end{tabular}


TABLE E-2. (contd)

PASE 21

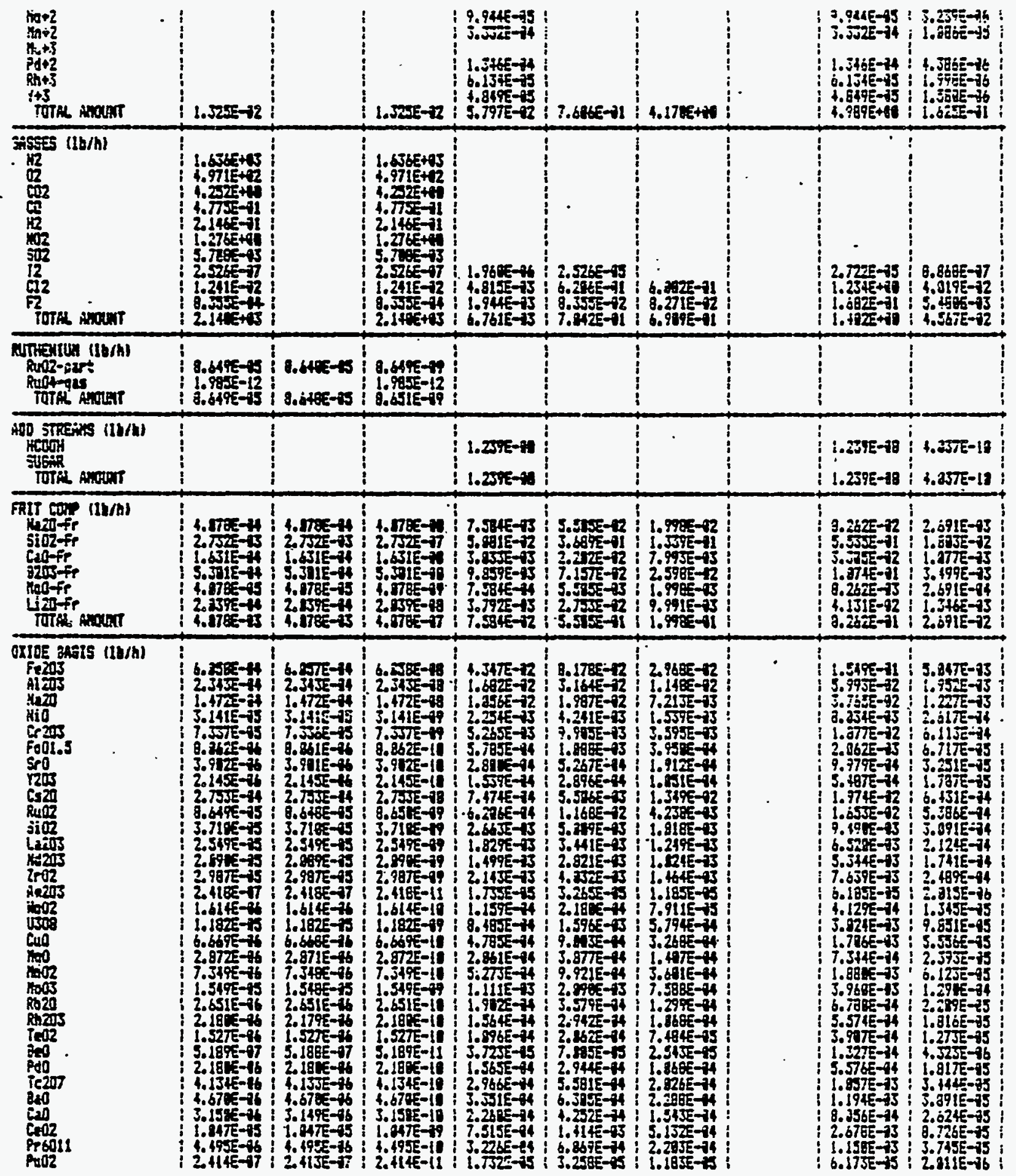


TABLE E-2. (contd)

PAEE 21

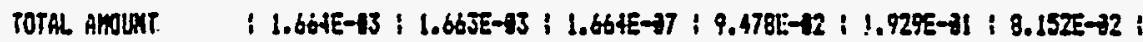

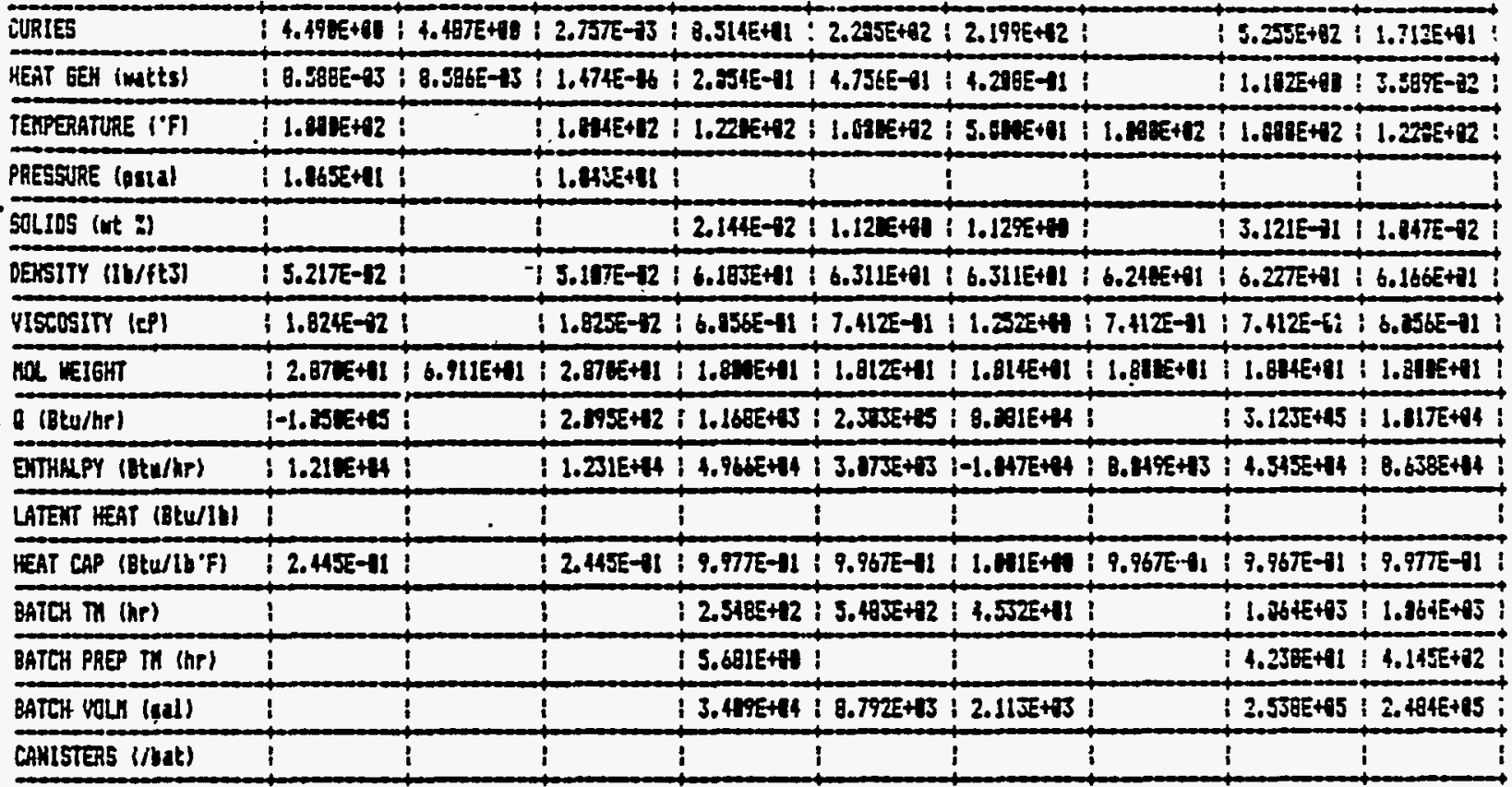


TABLE E-2. (contd)

PAGE 22

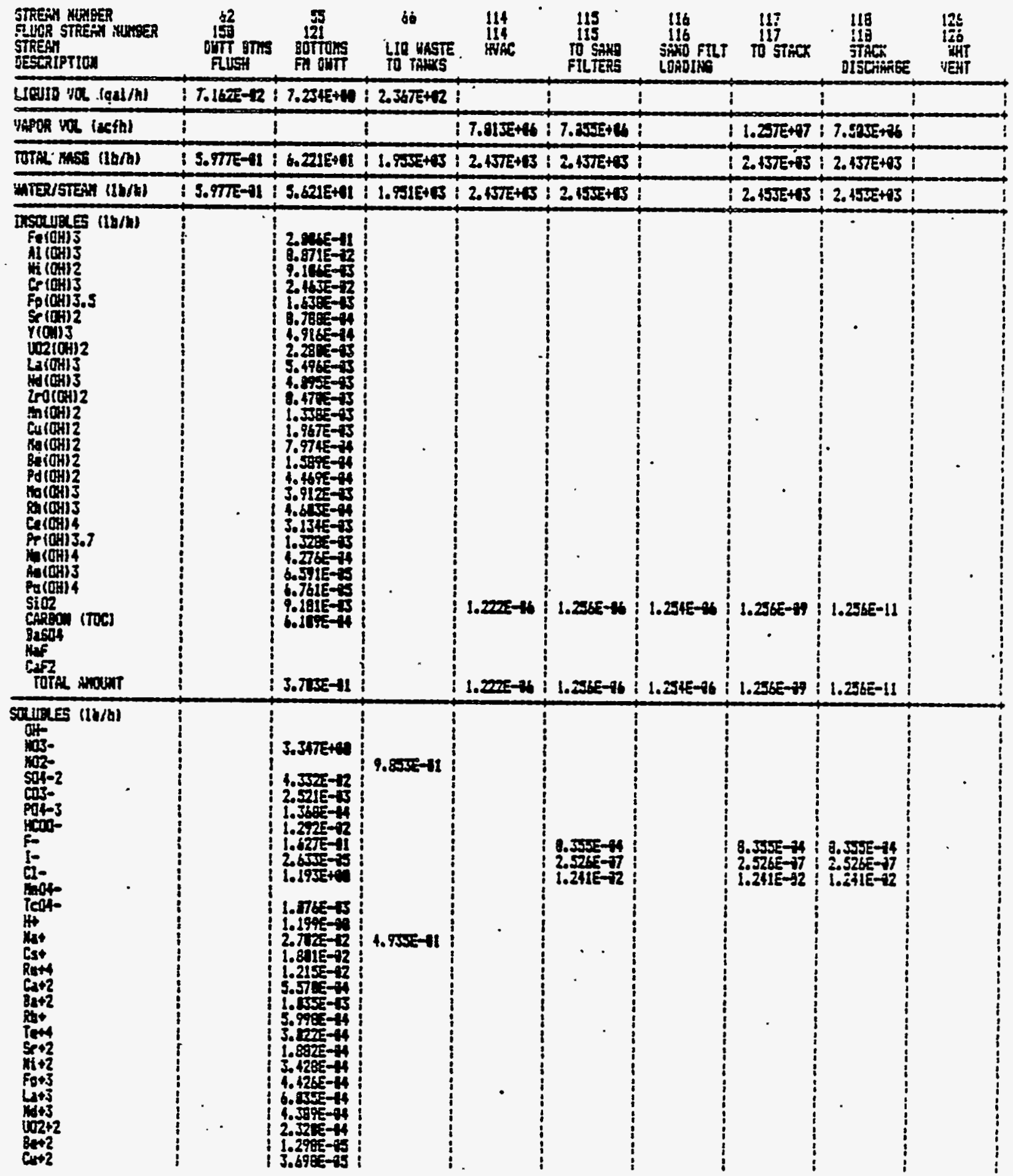


TABLE E-2. (contd)

\begin{tabular}{|c|c|c|c|c|c|c|c|c|c|}
\hline 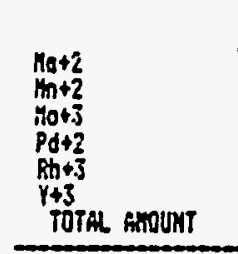 & $:$ & \begin{tabular}{|l|}
$9.620 E-35$ \\
$3.224 \pm-84$ \\
$1.3235-14$ \\
$5.934 E-15$ \\
$4.691 E-15$ \\
$4.826 E+15$
\end{tabular} & $1.477 E+1$ & 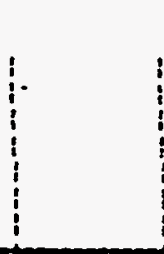 & $1.325 E-92$ & & $1.325 E-12$ & 1.325E-12 & PASE \\
\hline 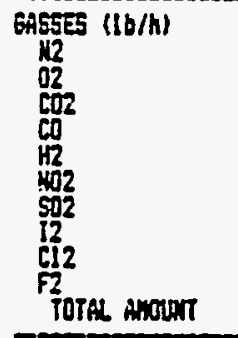 & 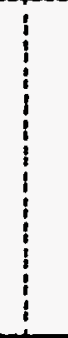 & $\begin{array}{l} \\
2.655 E-25 \\
1.195 E+4 \\
1.62 \pi 5-11 \\
1.3556+1\end{array}$ & & $\begin{array}{l}3.9325+13 \\
1.1945+15 \\
5.1265+15\end{array}$ & 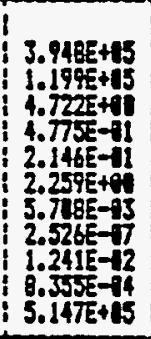 & & $\begin{array}{l}3.946 E+15 \\
1.195 E+15 \\
4.722 E+13 \\
4.775 E-11 \\
2.146 E-11 \\
2.259 E+91 \\
5.715 E-93 \\
3.526 E-17 \\
1.241 E-92 \\
8.355 E-44 \\
3.147 E+15\end{array}$ & 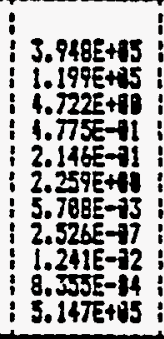 & \\
\hline $\begin{array}{l}\text { RUTHEIIUn }(1 \mathrm{~b} / \mathrm{h}) \\
\text { Ru02 } \rightarrow \text { art } \\
\text { RuOA-gas } \\
\text { TOTAL HownT } \\
\end{array}$ & 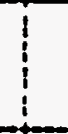 & 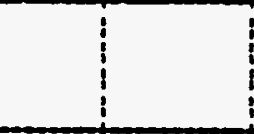 & & 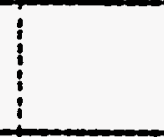 & $\begin{array}{l}12 \\
-89 \\
\end{array}$ & $\begin{array}{l}8.641 E-49 \\
8.6415-19\end{array}$ & 65E-12 & $\begin{array}{l}8.649 E-14 \\
1.985 E-12 \\
2.071 E-12\end{array}$ & \\
\hline $\begin{array}{l}\text { ADO STREAMS }(\mathrm{db} / \mathrm{hl} \\
\text { HCOOH } \\
\text { SUGAR } \\
\text { TOTAL AHOUnT }\end{array}$ & 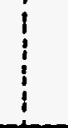 & $\begin{array}{l}1.199 E-18 \\
1.199 E-19\end{array}$ & & & & & & & \\
\hline 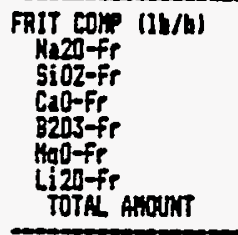 & & 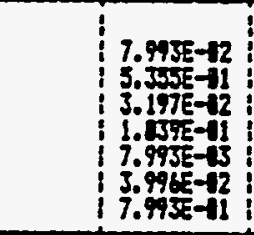 & $\cdot$ & & $\begin{array}{l}4.178 E-18 \\
2.732 E-17 \\
1.631 E-79 \\
5.371 E-98 \\
4.078 E-19 \\
2.239 E-18 \\
4.178 E-17\end{array}$ & $\begin{array}{l}4.074 E-18 \\
2.731 E-17 \\
1.635-18 \\
3.2965-18 \\
4.174 E-19 . \\
2.037 E-18 \\
4.174 E-17\end{array}$ & $\begin{array}{l}4.07 E E-11 \\
2.3325-10 \\
1.631 E-11 \\
5.311 E-11 \\
4.0765-12 \\
2.039 E-11 \\
4.178 E-10\end{array}$ & \begin{tabular}{|l|}
$4.07 E E-13$ \\
$2.7325-12$ \\
$1.631 E-13$ \\
$5.391 E-13$ \\
$4.176 E-14$ \\
$2.135 E-13$ \\
$4.078 E-12$
\end{tabular} & \\
\hline 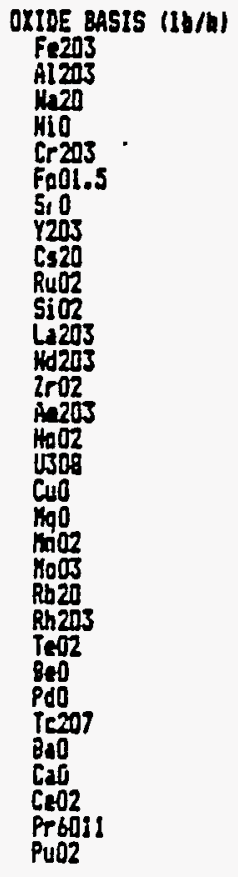 & & 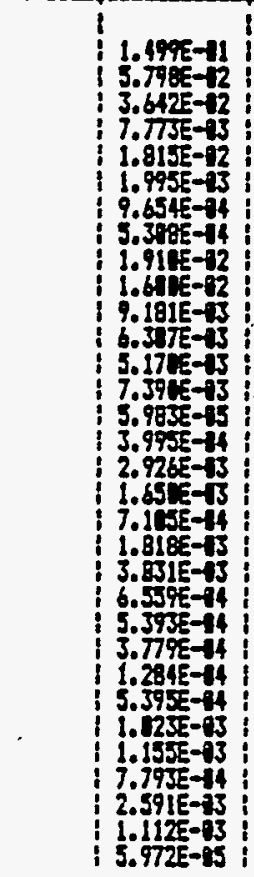 & 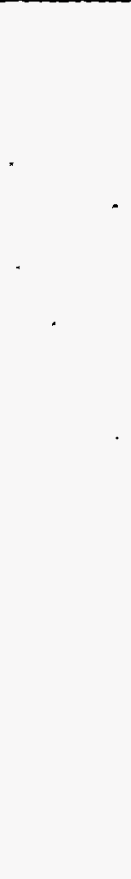 & 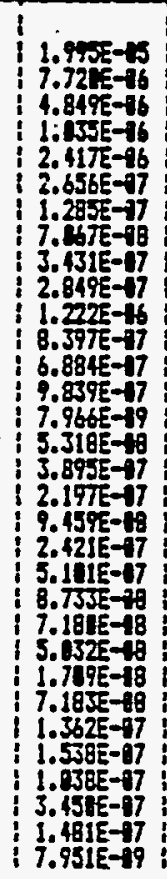 & 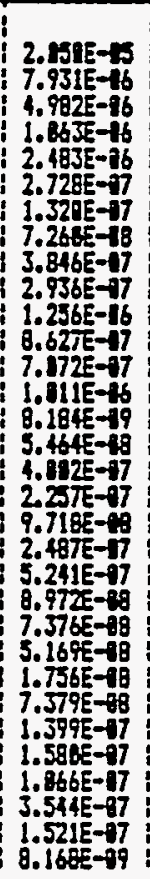 & 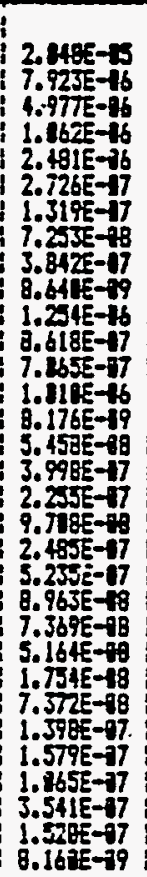 & 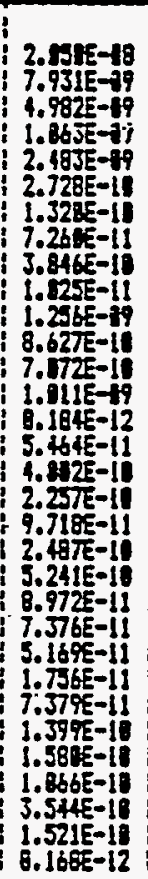 & 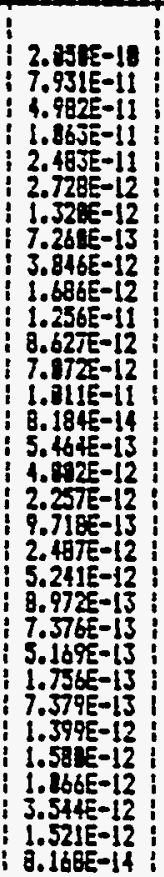 & \\
\hline
\end{tabular}


TABLE E-2. (contd)

9 Af5e 24

i $3.57 a-11$ :

; 4.J5IE-75:4.474E-75:4.44IE-85:4.445E-38:4.461E-18 :

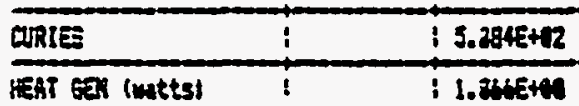

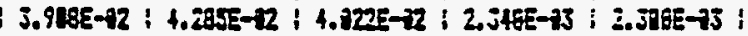

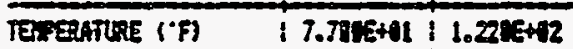

PRESTSRE casial $i \quad i \quad i$

Solits (we I) i

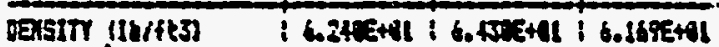

visanitr (e⿻) i $9.319 E-41$ i $6.0065-11$

nat. velent

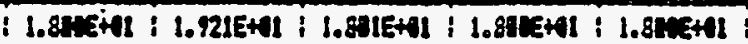

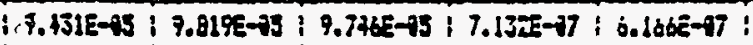

(atular) i J.221Eth :

\begin{tabular}{|c|c|c|c|c|c|c|c|}
\hline ! & ; & \multicolumn{2}{|c|}{ | 2.tsis+12 ! } & \multicolumn{2}{|c|}{ |-9.576E+16 ! } & i & ; \\
\hline 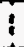 & ! & ! & i & ; & 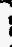 & i & $i$ \\
\hline 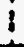 & $:$ & : & i & i & 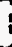 & 1 & i \\
\hline 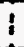 & i & ! & $i$ & $\mathbf{i}$ & 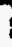 & i & ! \\
\hline$i$ & : & i & i & i & 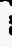 & $i$ & $i$ \\
\hline 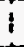 & : & i & i & I & 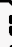 & i & 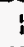 \\
\hline i & a & i & i & i & 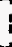 & • & $i$ \\
\hline 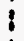 & $i$ & i & 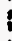 & i & & : & $i$ \\
\hline
\end{tabular}

| 1.244E+12 : 1.24E+12 :

EITHAPY (Ita/he)

: 2.4395-92 | 2.524E+T :

LATET HEAT IItU/II)

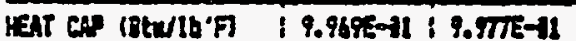

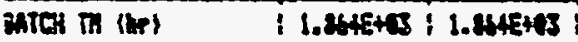

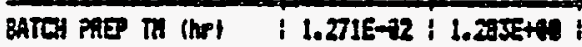

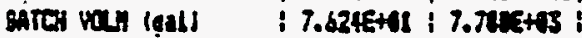

Canistess (ihat) : :


TABLE E-2. (contd)

\begin{tabular}{|c|c|}
\hline $\begin{array}{l}\text { STRES NUWEER } \\
\text { FLUOR STRESH HUMEER } \\
\text { STREAM } \\
\text { JESCRIPTION }\end{array}$ & $\begin{array}{l}128 \\
128 \\
\text { CKLELCALS } \\
\text { TO WHT }\end{array}$ \\
\hline LIRUID Va (gal/h) & $3.355 E+10$ \\
\hline YAPOR VOL laefh) & $\mathbf{i}$ \\
\hline TOTAL MASS $(\mathrm{lb} / \mathrm{h})$ & $i$ \\
\hline YATER/STESH $(1 \mathrm{~b} / \mathrm{h})$ & $2 . \sqrt{3} E+11$ \\
\hline 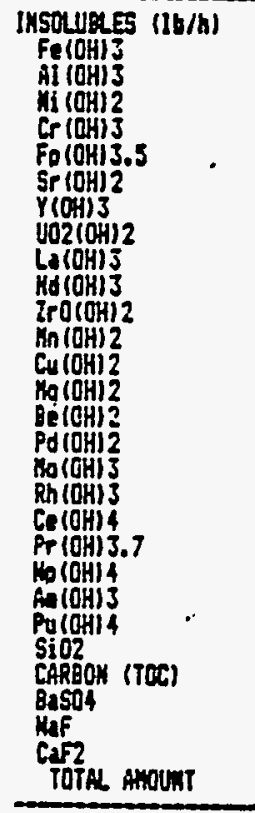 & 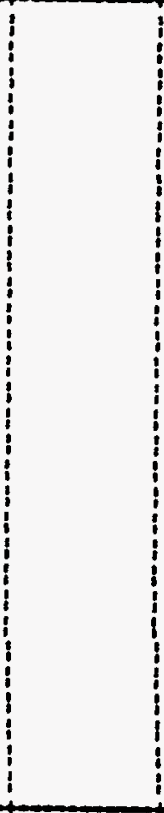 \\
\hline 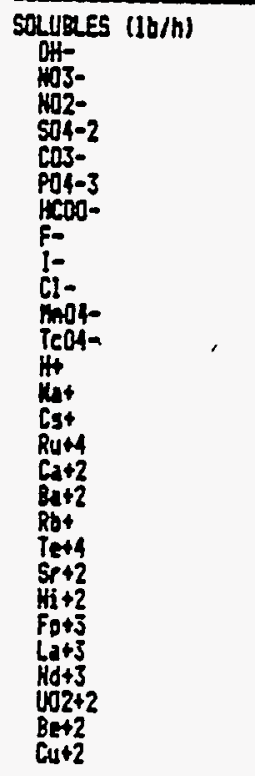 & $\begin{array}{l}9.855 E-11 \\
4.926 E-11\end{array}$ \\
\hline
\end{tabular}


TABLE E-2. (contd) .

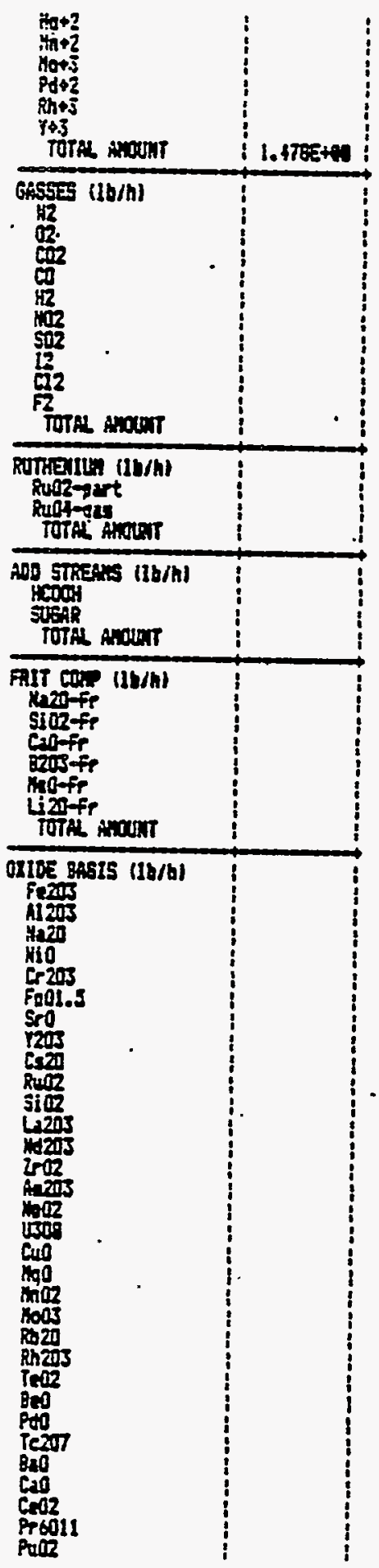

PAGE 26 
TABLE E-2. (contd)

PABE 27

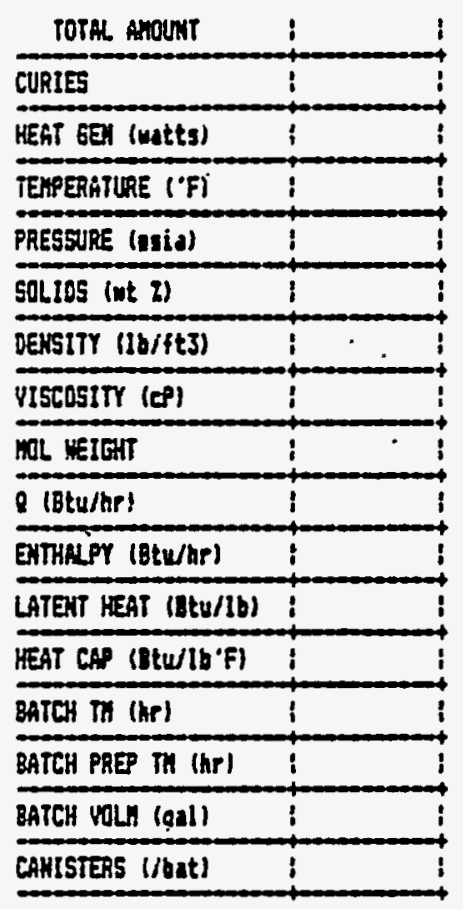

?. 
